\title{
Efficiënte preventie en compensatie van catastroferisico's : het voorbeeld van schade door kernongevallen
}

Citation for published version (APA):

Vanden Borre, T. (2001). Efficiënte preventie en compensatie van catastroferisico's : het voorbeeld van schade door kernongevallen. [Doctoral Thesis, Maastricht University]. Intersentia Uitgevers. https://doi.org/10.26481/dis.20010629tb

Document status and date:

Published: 01/01/2001

DOI:

10.26481/dis.20010629tb

Document Version:

Publisher's PDF, also known as Version of record

Please check the document version of this publication:

- A submitted manuscript is the version of the article upon submission and before peer-review. There can be important differences between the submitted version and the official published version of record.

People interested in the research are advised to contact the author for the final version of the publication, or visit the DOI to the publisher's website.

- The final author version and the galley proof are versions of the publication after peer review.

- The final published version features the final layout of the paper including the volume, issue and page numbers.

Link to publication

\footnotetext{
General rights rights.

- You may freely distribute the URL identifying the publication in the public portal. please follow below link for the End User Agreement:

www.umlib.nl/taverne-license

Take down policy

If you believe that this document breaches copyright please contact us at:

repository@maastrichtuniversity.nl

providing details and we will investigate your claim.
}

Copyright and moral rights for the publications made accessible in the public portal are retained by the authors and/or other copyright owners and it is a condition of accessing publications that users recognise and abide by the legal requirements associated with these

- Users may download and print one copy of any publication from the public portal for the purpose of private study or research.

- You may not further distribute the material or use it for any profit-making activity or commercial gain

If the publication is distributed under the terms of Article $25 \mathrm{fa}$ of the Dutch Copyright Act, indicated by the "Taverne" license above, 
EFFICIËNTE PREVENTIE EN COMPENSATIE VAN

CATASTROFERISICO'S -

HET VOORBEELD VAN SCHADE

DOOR KERNONGEVALLEN 
Van dit proefschrift verschijnt een handelseditie in de reeks Energie en Recht bij Intersentia Uitgevers onder ISBN 90-5095-174-0. 


\title{
VERDEDIGING
}

\section{Efficiënte preventie en compensatie van catastroferisico's - het voorbeeld van schade door kernongevallen}

\author{
PROEFSCHRIFT
}

ter verkrijging van de graad van doctor aan de Universiteit Maastricht, op gezag van de Rector Magnificus, Prof. Dr. A.C. Nieuwenhuijzen Kruseman volgens het besluit van het College van Decanen, in het openbaar te verdedigen op vrijdag 29 juni 2001 om 12.00 uur

door

Tom Vanden Borre 


\section{Promotor:}

Prof. dr. M.G. Faure, LL.M.

\section{Beoordelingscommissie:}

Prof. mr. drs. G.E. van Maanen (voorzitter)

Prof. dr. K. Deketelaere (Katholieke Universiteit Leuven)

Prof. mr. G.R. de Groot (Universiteit Maastricht)

Dit onderzoek werd gefinancierd door en is het resultaat van een samerwerking tussen het Maastrichts Instituut voor Transnationaal Rechtswttenschappelijk Onderzoek (METRO, Universiteit Maastricht) en het Sttdiecentrum voor Kernenergie (Mol, België). 
"Atomic power can cure as well as kill. It can fertilize and enrich a region as well as devastate it. It can widen man's horizon as well as force him back into the cave".

Alvin M. Weinberg 
Het onderzoek werd afgesloten op 1 oktober 2000. Met wijzigingen na die datum werd enkel rekening gehouden in de mate van het mogelijke. 


\section{DANKWOORD}

Het schrijven van een proefschrift is bij uitstek een individuele aangelegenheid: ontelbare uren werden doorgebracht in de bibliotheek, achter de kopieermachine en - vooral - achter het computerscherm. En toch zou dit werk nooit zijn voltooid zonder de stcun van verschillende mensen. In zekere zin kan het schrijven van een proefschrift worden vergeleken met de voorbereiding op de Olympische Spelen. Bijvoorbeeld voor rwermmen en atletiek is het telkens de individuele atlect die cen prestatie dient neer te zetten, maar die prestatic is er enkel gekomen dankzij de inzet van een groep mensen die zich achter de atleet hebben geschaard en die hem of haar ten volle hebben gesteund, en dit zowel op professioneel vlak als op persoonlijk vlak.

In de eerste plaats wens ik de instellingen te bedanken die dit onderzoek hebben mogelijk gemaakt en gefinancierd. Voorliggend boek is het resultaat van een samenwerking tussen het Studiecentrum voor Kernenergie te Mol (België) en de Universiteit Maastricht. Zonder de financiële en didactische steun van beide instellingen was het materieel onmogelijk geweest om dit onderzoek uit te voeren. Eén van de belangrijkste elementen hierbij was ongetwijfeld de uitstekende bibliotheek van het SCK/VITO waar ik documenten heb gevonden uit de jaren vijftig die aan de basis liggen van dit onderzoek. Vooral dankzij Dominique Vanpée heb ik heel wat bronnen kunnen ontsluiten. Tegelijk boud het SCK mij de gelegenheid om als jurist samen te werken met een aantal technisch geschoolde mensen. De inzichten die zij mij bijbrachten zijn van groot belang gewcest bij het verdere onderzoek. Heel in het bijzonder wens ik de heer Roland Carchon te bedanken voor de leerrijke samenwerking en de heer Charles De Raedt voor het nalezen van de inleiding. Tenslotte wens ik ook Ludo Veuchelen, Diane Schepers, Ann Verledens en Peter Vermaerche tc bedanken voor hun steun.

Aan de Universiteit Maastricht heb ik steeds steun gevonden bij een aantal collega's/vrienden. De gezellige lunches en leuke babbels met Martien van Dam en Monica Claes zullen me steeds bijblijven. Overigens was de aangename sfeer binnen METRO (Maastrichts Europees Instituut voor Transnationaal Rechtswetenschappelijk Onderzoek) ook steeds een bijzondere stimulans: er werd steevast hard gewerkt, wat af en toe 's avonds werd bekroond in een of ander Maastrichts restaurant. Ook de zachte dwang van Petra Vrancken om deel te nemen aan de jaaruitstappen van METRO kwamen de goede sfeer zeker ten goede. In de laatste rechte lijn van het proefschrift heb ik tenslotte ontzettend veel hulp gekregen van het METRO-secretariaat: Marina Jodogne heeft me feilloos door een aantal administratieve beslommeringen heen geloodst; Marjo Mullers heeft het (monniken)werk op zich genomen om het boek camera-ready aan de drukker af te leveren. De opmaak van dit boek is uitsluitend aan haar inspanningen (zelfs in het weekend) te danken.

In tweede instantie heeft een aantal mensen mij geholpen om ruime toegang te verkrijgen tot bronnen die eveneens belangrijk zijn geweest voor het onderzoek. Een bijzonder woord van dank gaat hierbij uit naar de heer Vital Verbraeken, directeur van SYBAN, en naar Omer Brown (Harmon, Wilmot \& Brown, Washington), die aan de basis lagen van mijn onderzoek in de Verenigde Staten en die heel wat deuren hebben geopend. Wat de contacten met de nucleaire sector betrefit, wens ik de heer Alec Vanden Abeele en de heer Marc Beyens van Tractebel, de heer Danny Van Welkenhuyzen (EMANI), mevrouw Julia Schwartz (NEA) en de heer Sebastiaan Reitsma (Swiss $\mathrm{Re}$ ), te bedanken voor het feit dat ze me te woord hebben gestaan en voor de informatie die me ter beschikking werd gesteld. Bijkomend wens ik ook Erik Hanenburg (Universiteit Amsterdam) te bedanken omdat ik via hem toegang kreeg tot de bibliotheek van het Institut für Völkerrecht (Göttingen) en voor de contacten met prof. Norbert Pelzer. Wat de documenten inzake verzekeringen betreft, richt mijn dank zich tot prof. em. Hubert Claassens die me de toegang heeft ver- 
gemakkelijkt tot de - uitstekende - bibliotheek van de KBC-Bank te Leuven. Tenslotte richt mijn dank zich heel in het bijzonder tot mevrouw Zehnhoff, die me een onschatbare verzameling boeken inzake het Duitse kemenergierecht heeft geschonken.

Ik had ook een aantal mensen waar ik steeds op kon rekenen om even van gedachten te wisselen. Hier wens ik dr. Nathalie Horbach te bedanken voor haar bereidheid en voor de tijd die we aan de telefoon hebben doorgebracht om te discussiëren over het nucleaire aansprakelijkheidsrecht. Ze heeft ook een aanzienlijk stuk van de drukproeven van het boek nagelezen. Mijn bijzondere dank richt zich hier eveneens tot Olaf Bonotto. In universitaire middens kon ik steevast rekenen op een ruime welwillendheid van Dr. Caroline Van Schoubroeck (KU Leuven), prof. C.C. van Dam (Universiteit Amsterdam) en prof. T. Hartlief (Universiteit Maastricht).

Naast het schrijven van dit proefschrift, heb ik steeds gewerkt als bedrijfsjurist; deze combinatie was niet altijd even eenvoudig. De laatste rechte lijn naar het einde van mijn proefschrift werd vergemakkelijkt doordat mijn toenmalige werkgever, Biffa Waste Services België, toestemde in een loopbaanonderbreking van zes maanden. Deze toestemming heb ik in hoofdzaak te danken aan de steun en het vertrouwen van dr. Carl Malbrain. Aansluitend hierbij werd ik gedurende mijn loopbaanonderbreking bij Biffa vervangen door mr. Cathy Van Vyvc (Stibbe); haar inspanningen en inzet hebben lieten toe dat ik me ten volle op mijn proefschrift kon concentreren. Ik wens ook mijn nieuwe werkgever, Deloitte\&Touche, te bedanken voor de tijd die ik heb kunnen vrijmaken voor de verdediging van mijn proefschrift.

Tenslotte is een inspanning als het schrijven van een proefschrift onmogelijk zonder een goede coach. Mijn promotor, prof. dr. Michael Faure heeft mij op ongeëvenaarde wijze begeleid en gesteund; met een nooit aflatende inzet heeft hij het gchele boek - tot tweemaal toe - volledig doorgenomen; met telkens weer rake opmerkingen heeft hij een sterke hand in het slagen van deze promotie.

Het doorzetten tot het beëindigen van dit proefschrift was ook onmogelijk geweest zonder de steun van mijn familie die ook een aantal offers heeft moeten brengen. Doordat ik vaak in het weekend heb gewerkt was ik veel minder beschikbaar waardoor vooral mijn zus misschien nict de steun kreeg die ze verdiende. Op het praktische vlak dank ik uiteraard ook mijn beide ouders, die me altijd hebben gesteund. Een bijzondere dank gaat hierbij uit naar mijn moeder die me vele uren werk heeft bespaard na een crash van mijn computer en die met een engelengeduld de drukproeven van dit boek hecft helpen nalezen

De persoon die mc het meest heeft moeten missen is zonder twijfel mijn echtgenote, Marie. Ons verhaal is in feite nauw verbonden met dit proefschrift aangezien we elkaar hebben leren kennen op het SCK te Mol en aangczien we in Maastricht zijn getrouwd. Hoewel de redactie van het procfschrift langer hecf aangesleept dan gepland is ze me blijven steunen, en is ze blijven geloven in het welslagen van dit proefschrift toen bij mij de twijfel toesloeg. Zonder overdrijven kan worden gezegd dat achter dit procfschrift de steun schuilgaat van mijn echtgenote. Toen de spreekwoordelijke laatste loodjes zwaar begonnen te wegen werd mijn motivatie bijzonder gestimulcerd door de nakende geboorte van ons zoontje.

Bij wijze van slot wil ik dit boek opdragen aan wijlen mijn peter en meter; ik heb veel geleerd van hun inzet en levensvisie.

Tom Vanden Borrc

Leuven, april 2001 


\section{AFKORTINGENLIJST}

ABACC

AIDN

Amvb

ANI

ARAB

ART

AVB-polis

AVP-polis

BA

BEF

BS

BTR

BW

CERCLA

CFR

CLC-Verdrag

CRISTAL

DM

DOE

EMANI

ENO
Agence Brasilo-Argentine de Comptabilité et de Controle des matières nucléaires

Association Internationale de Droit Nucléaire

Algemene Maatregel van Bestuur

American Nuclear Insurers

Algemeen Reglement op de Arbeidsbescherming

Alternative Risk Transfer

Polis Aansprakelijkheidsverzekering voor Bedrijven

Polis Aansprakelijkheidsverzekering voor Particulieren

Burgerlijke Aansprakelijkheid

Belgische frank

Belgisch Staatsblad

Bijzondere Trekkingsrechten (van het Internationaal Muntfonds)

Burgerlijk Wetboek

Comprehensive Environmental Response, Compensation and Liability Act

Code of Federal Regulations

Convention on Civil Liability for Oil Pollution Damage

Contract Regarding an Interim Supplement to Tanker Liability for Oil Pollution

Deutsche Mark

Department of Energy

European Mutual Association for Nuclear Insurance

Extraordinary Nuclear Occurrence 
ERDA Energy Research and Development Administration

ERICAM Environmental Risk Intemalisation through Capital Market

EU

FANC

HNS-Verdrag

HR

IAEA

Ibs

ICHM

ICRP

IGA

IMO

INLA

IOPC-Fonds

IPR

KB

Kew

KwH

MAELU

MAERP

MARPOL

MAS

MAV-polis
Europese Unie

Federaal Agentschap voor Nucleaire Controle

Convention on Liability and Compensation for Damage in Connection with the Carriage of Hazardous and Noxious Substances at Sea

Hoge Raad

International Atomic Energy Agency

Interimwet Bodemsanering

Interuniversitaire Commissie voor de Herziening van het Milieurccht in het Vlaamse Gewest

International Commission for Radiation Protection

International Group Agreement

International Maritime Organisation

International Nuclear Law Association

International Oil Pollution Compensation Fund

Internationaal Privaatrecht

Koninklijk Besluit

Kermencrgiewet (Nederland)

Kilowatt-uur

Mutual Atomic Energy Liability Underwriters

Mutual Atomic Energy Reinsurance Pool

International Convention for the Prevention of Oil Pollution

Milieuaansprakelijkheid Samenwerkingsverband

Milieuaansprakelijkheidsverzekering 


$\begin{array}{ll}\text { MINA-Fonds } & \text { Fonds voor Preventie en Sanering inzake Leefmilieu en Natuur } \\ \text { MED } & \text { Manhattan Engineer District } \\ \text { MSV } & \text { Milieuschadeverzekering } \\ \text { NBW } & \text { Nederlandse) Nieuw Burgerlijk Wetboek } \\ \text { NEA } & \text { Nuclear Energy Agency } \\ \text { NEIL } & \text { Nuclear Electric Insurance Limited } \\ \text { NELIA } & \text { Nuclear Energy Liability Insurance Association } \\ \text { NEPIA } & \text { Nuclear Energy Propcrty Insurance Association } \\ \text { NIRAS } & \text { Nationale Instelling voor Radioactief Afval en verrijkte Splijtstoffen } \\ \text { NLG } & \text { Nederlandse gulden } \\ \text { NML } & \text { Nuclear Mutual Limited } \\ \text { NRC } & \text { Nuclear Regulatory Commission } \\ \text { OPSO } & \text { Organisatie voor Economische Samenwerking en Ontwikkeling } \\ & \end{array}$

OPANAL Organismo para la Proscripción de las Amas Nucleares en la América Latina PB Publicatieblad van de Europese Gemeenschap

P\&I Club

Protection and Indeminty Club

PLATO

Pollution Liability Agreement among Tank Owners

SCK

Studiecentrum voor Kernenergie

SFP-Polis

Secondary Financial Protection polis

Stb.

Staatsblad (Nederland)

SYBAN

Syndicat Belge des Assurances Nucléaires

TMI

Three Mile Island

TOVALOP

Tanker Owners Voluntary Agreement Conccming Liability for Oil Pollution 
Trb.

USAEC

UNAEC

UNCLOS

UNO

UNSCEAR

VLAREM

VN

VROM

VS

VT Sv

WABM

WAKO

WAM

Waot

Wbb

WbSV

$\mathrm{Wm}$

WMS

WvK
Tractatenblad

United States Atomic Energy Commission

United Nations Atomic Energy Commission

United Nations Convention on the Law of the Sea

United Nations Organisation

United Nations Scientific Committee on the Effects of Atomic Radiation

Vlaams Reglement inzake Milieuvergunningen

Verenigde Naties

(Nederlandse) Ministerie van Volkshuisvesting, Ruimtelijke Ordening en Milieubeheer

Verenigde Staten

Voorlopige Titel van het (Belgische) Wetboek Strafvordering

Wet Algemene Bepalingen Milieuhygiëne

Wet Aansprakelijkheid voor Kernongevallen

Wet Aansprakelijkheidsverzekering Motorrijtuigen

Wet Aansprakelijkheid Olietankschepen

Wet bodembescherming

Wetboek Strafvordering

Wet Milieubeheer

Wet Milieugevaarlijke Stoffen

Wetboek van Koophandel (Nederland) 


\section{BEKNOPTE INHOUDSTAFEL}

PROLOOG: HET NUCLEAIRE TIJDPERK IN VOGELVLUCHT

INLEIDING

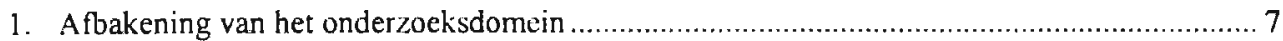

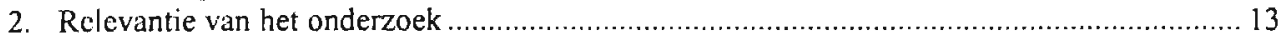

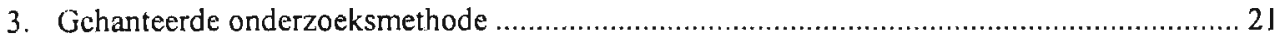

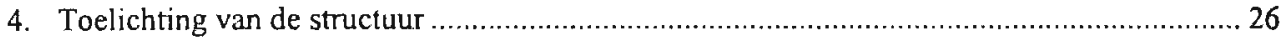

\section{DEEL 1. ANALYSE VAN HET CIVIELRECHTELIJKE (NUCLEAIRE)} AANSPRAKELIJKHEIDSRECHT

\section{Hoofdstuk 1}

Toepassing van het civielrechtelijke aansprakelijkheidsrecht op milieuschade

1. Het civielrechtelijke aansprakelijkheidsrecht in het Burgerlijk Wetboek in België en Nederland.

2. De aansprakelijkhcidsgrondslag bij milieuschade .................................................. 51

3. Het aansprakelijkheidsrecht tegenover andere vergoedingsmechanismen ......................... 71

4. Conclusie

\section{Hoofdstuk 2}

Ontstaan en overzicht van het internationale en nationale kernenergierecht

1. Ontstaan van de internationale samenwerking inzake het gebruik van kernenergie

2. Overzicht van de internationale Verdragen inzake civielrechtelijke aansprakelijkheid voor kernongevallen en aanverwante Verdragen

3. Ontstaan van het Belgische kemenergierecht

4. Ontstaan van het Nederlandse kemenergierecht

5. Conclusie.

\section{Hoofdstuk 3}

Toepassingsgebied van de nucleaire aansprakelijkheidswetgeving

1. Toepassingsgebied van het Verdrag van Parijs van 29 juli 1960

2. Toepassingsgebied van de Belgische wet van 22 juli 1985 betreffende de wettelijke aansprakelijkheid op het gebied van de kemenergie.

3. Toepassingsgebied van de Nederlandse Wet Aansprakelijkheid Kernongevallen van 26 juni 1991 (WAKO)

4. Conclusie

\section{Hoofdstuk 4}

Basisprincipes van de nucleaire aansprakelijkheidswetgeving

1. Risicoaansprakelijkheid 
2. Kanalisatie van aansprakelijkheid.

3. Beperking van de aansprakelijkheid van de exploitant van een kerninstallatie................... 312

4. Verplichte dekking var de aansprakelijkheid van de exploitant .......................................356

5. Exclusieve bevoegdheid van één rechtbank per land

\section{Hoofdstuk 5 \\ Verzekeringen.}

1. Historische schets van het ontstaan van verzekeringen.

2. Definiëring en wezenlijke bestanddelen van de verzekeringsovereenkomst......................385

3. Onderscheid tussen verschillende soorten verzekeringen .......................................... 388

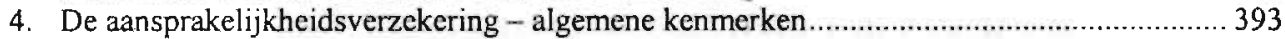

5. Dekking van de aansprakelijkheid in de tijd .............................................................. 402

\section{Hoofdstuk 6}

Verzekering van het nucleaire risico

1. Het nucleaire risico vanuit het oogpunt van de verzekeringsindustrie.

2. De nucleaire verzekeringspools

3 De Belgische Nucleaire verzekeringspool: Syndicat Belge des Assurances Nucléaires (SYBAN)

4. Verenigbaarheid van de (nucleaire) verzekeringspools met het Europese concurrentierecht

5. Conclusie

\section{Hoofdstuk 11}

Dekking van catastroferisico's

1. Dekking van milieuschade via de klassieke verzekeringsmarkt .................................... 561

2. Alternatieve compensatiemechanismen voor de dekking van milieuschade....................... 571

3. Twee voorstellen ter zake van de dekking van het nucleaire risico ................................... 599

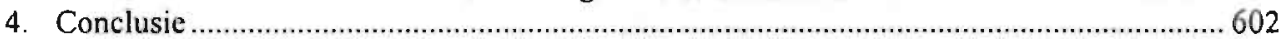

\section{Hoofdstuk 12}

Aaansprakelijkheid voor schade door olieverontreiniging op zee

1. Ontstaan van de mariticme aansprikclijkheidswetgeving.....

2. Het Verdrag inzake de Civielrechtelijke aansprakelijkheid voor olieverontreiniging op zee van 29 november 1969.

3. Het Verdrag tot oprichting van een Intemationaal Fonds voor vergoeding van schade door verontreiniging door olie van 18 december 1971 .

4. De vrijwillige compensaticmechanismen: TOVALOP en CRISTAL

5. De Protection and Indemnity Clubs

6. Conclusie 


\section{Hoofdstuk 13}

Aansprakelijkheid en verzekering van het nucleaire risico in de

Verenigde Staten.

1. Beknopt overzicht van het Amerikaanse nucleaire dansprakelijkheidsrecht

2. De Price-Anderson Act.

3. Verzekering van het nucleaire risico in de Verenigde Staten.

4. Conclusie

DEEL 4. CONCLUSIES EN AANBEVELINGEN

\section{Hoofdstuk 14}

Conclusies uit de juridische analyse

1. Voor wat betreft het nucleaire aansprakelijkheidsrecht

2. Voor wat betreft het algemene milieuaansprakelijkheidsrecht.

\section{Hoofdstuk 15}

Rechtseconomische conclusies.

1. Rechtseconomisch model van het kernongevallenrecht

2. Normatieve rechtseconomische analyse van de rechtsvergelijkende inzichten.

3. Conclusie

\section{Hoofdstuk 16}

Naar een verbeterd model inzake compensatie van schade door

kernongevallen

1. Uitgangspunten

2. Invoering van een vijftrapssysteem

3. Beperkte mogelijkheid om de eigen schade te verzekeren, met "decontaminatiedekking" 


\section{INHOUDSTAFEL}

DANKWOORD

BEKNOPTE INHOUDSOPGAVE

INHOUDSOPGAVE

PROLOOG: HET NUCLEAIRE TIJDPERK IN VOGELVLUCHT

INLEIDING.

1. Afbakening van het onderzoeksdomein

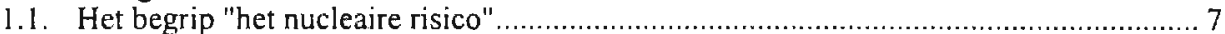

1.2. Proliferatic van kemwapens - safeguards en security ........................................ 8

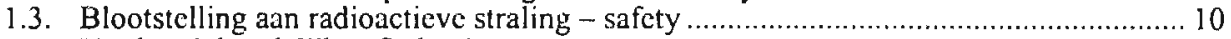

1.4. Verdere inhoudclijke afbakening ................................................................. 11

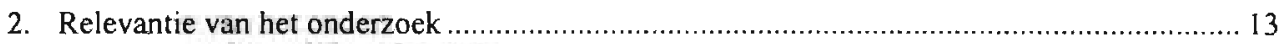

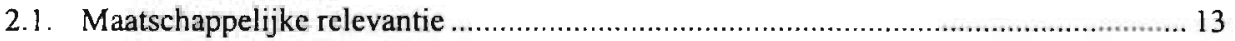

2.1.1. Groeiende nood aan energie ..................................................................... 13

2.1.2. De invloed van de energievoorziening op milieuvervuiling ............................ 15

2.1.2.1. Problemen bij het aanwenden van fossiele brandstoffen .................. 15

2.1.2.2. Problemen bij het aanwenden van kernenergie................................... 17

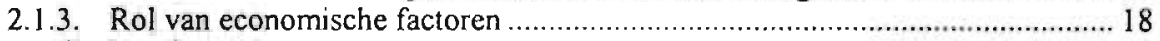

2.2. Juridische relevantie ............................................................................. 19

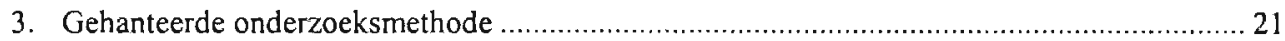

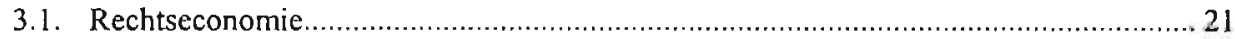

3.1.1. Verwantschap tussen economie en recht .................................................. 2]

3.1.2. Verschil tussen "Old" en "New" Law and Economics ..................................22 22

3.1.3. Bijzondere benadering in het aansprakelijkheidsrecht .................................. 23

3.1.4. Voordelen van de rechtseconomie .......................................................... 24

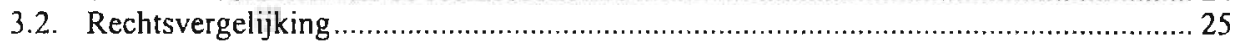

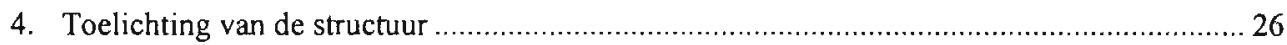

DEEL 1. ANALYSE VAN HET CIVIELRECHTELIJKE (NUCLEAIRE) AANSPRAKELIJKHEIDSRECHT

\section{Hoofdstuk 1}

Toepassing van het civielrechtelijke aansprakelijkheidsrecht op milieuschade

1. Het civielrechtelijke aansprakelijkheidsrecht in het Burgerlijk Wetboek in

België en Nederland.

1.1. Totstandkoming en gelding van de code Napoléon in België en Nederland................... 34

1.2. De centrale positie van de fout in de code napoléon........................................... 36 
1.3. Foutaansprakelijkheid in het Belgische en het Nederlandse BW.......................... 39

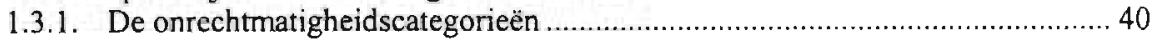

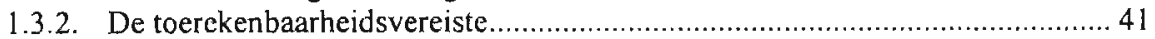

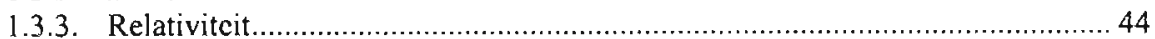

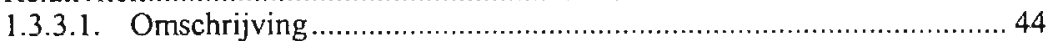

1.3.3.2. Relativiteit versus causaliteit .................................................... 45

1.3.3.3 Toepassing inzake milicuaansprakelijkheid voor bodemvervuiling naar Nederlands recht ...................................... 47

1.4. Conclusie

2. De aansprakelijkheidsgrondslag bij milieuschade .................................................. 51

2.1. Foutaansprakelijkheid voor milieuschade in het Burgerlijk Wetboek ..................... 51

2.1.1. Op basis van het Bclgische BW ................................................................ 51

2.1.2 Op basis van het Nederlandse BW ..................................................... 53

2.2. Risicoaansprakelijkheid in het Burgerlijk Wetboek ........................................... 57

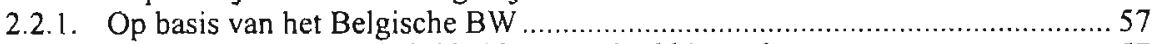

2.2.1.1. De aansprakelijkheid voor gebrekkige zaken ............................ 57

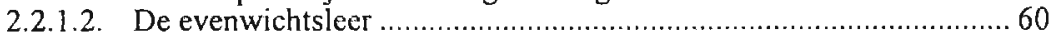

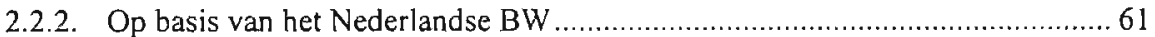

2.2.2.1 Het Nederlandse oud BW .................................................. 61

2.2.2.2. De wijzigingen aan het Nederlandse NBW .............................. 63

2.3. Aansprakelijkheid voor milieuschade buiten het Burgerlijk Wetboek....................... 67

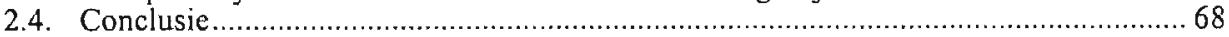

3. Het aansprakelijkheidsrecht tegenover andere vergoedingsmechanismen ........................ 71

3.1. Invloed van verzekeringen op het aansprakelijkheidsrecht.................................. 72

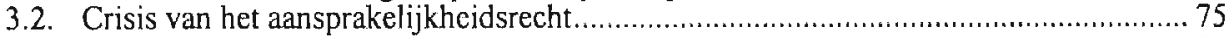

3.3. Voor- en nadelen van de verschillende mechanismen ........................................ 78

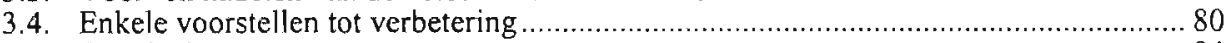

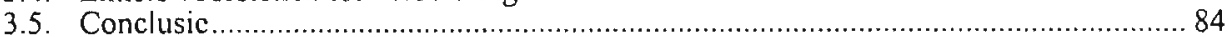

4. Conclusie

\section{Hoofdstuk 2}

Ontstaan en overzicht van het internationale en nationale kernenergierecht

1. Ontstaan van de internationale samenwerking inzake het gebruik van kemenergie .............89

1.1. Verspreiding van kennis en technologie mits controle ....................................... 90

1.2. Internationale organisaties in het kernenergierecht ............................................ 93

1.2.1. International Atomic Energy Agency (IAEA) ...................................... 94

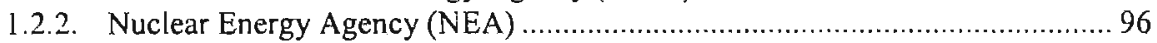

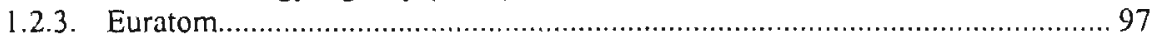

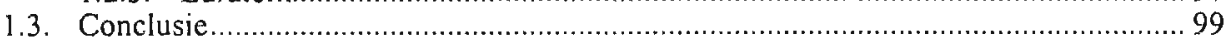

2. Overzicht van de internationale Verdragen inzake civielrechtelijke aansprakelijkheid voor kernongevallen en aanverwante Verdragen

2.1. De nucleaire (aansprakelijkheids)verdragen van de eerste generatie ......................... 101

2.1.1. Ontstaan van de Verdragen inzake nucleaire aansprakelijkheid ................... 102

2.1.2. De Verdragen inzake de civielrechtelijke aansprakelijkheid voor

kernongevallen in vaste kerninstallaties.

2.1.2.1. Het regime uitgewerkt door de NEA.

2.1.2.2. Het regime uitgewerkt door het IAEA: het Verdrag van Wenen van 21 mei 1963 
2.1.3. Verdragen inzake de civielrechtelijke aansprakelijkheid voor

kemongevallen bij maritiem transport

2.1.3.1. Het Verdrag van Brussel van 25 mei 1962 inzake de

aansprakelijkheid van exploitanten van nucleaire schepen

2.1.3.2. Het Verdrag van Brussel van 17 december 1971 inzake de wettelijke aansprakelijkheid op het gebied van zeevervoer van nucleaire stoffen.

2.2. Internationaal kemenergierecht na Tsjemobyl: de Verdragen van de tweede generatie.

2.2.1. Nieuwe thema's van de Verdragen van de tweede generatie ........................... 119

2.2.1.1. Vroegtijdige kennisgeving en assistentie bij kemongevallen ......... 119

2.2.1.2. Nucleaire veiligheid.

2.2.2. Het verbeteren van de reeds bestaande nucleaire aansprakelijkheids

regimes.

2.2.2.1. Het koppelen van beide regimes door het Gemeenschappelijk

Protocol van 21 september 1988 .

2.2.2.2. De inhoudelijke wijzigingen: twee nieuwe Verdragen

2.2.2.3. De revisie van het Verdrag van Parijs

2.3. Conclusie

3. Ontstaan van het Belgische kernenergierecht

3.1. De rol van Belgisch-Kongo voor de ontwikkeling van kemenergie in België............. I41

3.2. Overzicht van het Belgische kemenergierecht ................................................... 143

3.3. Ontstaan van de Belgische nucleaire aansprakelijkheidswetgeving ...................... 145

3.3.1. De wet betreffende de burgerlijke aansprakelijkheid van het

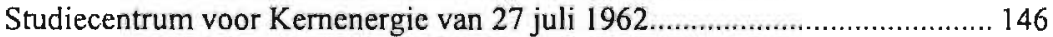

3.3.1.1. Klassieke aansprakelijkheidsregels............................................ 147

3.3.1.2. Verplichte verzekering tot een bepaald bedrag........................... 148

3.3.1.3. Subrogatie annex rechtstreekse vordering van het slachtoffer......... 149

3.3.1.4. Rol van de Belgische Staat ..................................................... 151

3.3.1.5. Exclusieve bevoegdheid van de rechtbank van Brussel.................... 152

3.3.1.6. Vonnis van de correctionele rechtbank van Turnhout van 14 februari 1969

3.3.1.7. Conclusie omtrent de wet van 1962 inzake de burgerlijke aansprakelijkheid van het SCK....

3.3.2. Wet betreffende de wettelijke aansprakelijkheid op het gebied van

kernenergie van 18 juli 1966, houdende vaststelling van bepaalde maatregelen tot onmiddellijke toepassing van het Verdrag van Parijs

en van het toegevoegd Protocol

3.3.3. Wet van 22 juli 1985 betreffende de wettelijke aansprakelijkheid op het

gebied van kemenergie.

3.4. Invloed van de Staatshervorming op het Belgische kernenergierecht..................... 16]

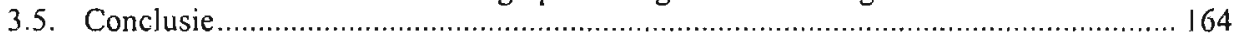

4. Ontstaan van het Nederlandse kemenergierecht .................................................. 165

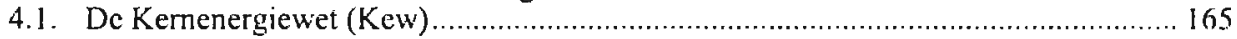

4.1.1. De oorspronkelijke Kernenergiewet................................................. 165

4.1.2. Wijziging op het punt van de ongevallenbestrijding ............................. 167

4.2. Overzicht van de Nederlandse nucleaire civielrechtelijke

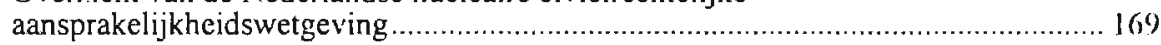

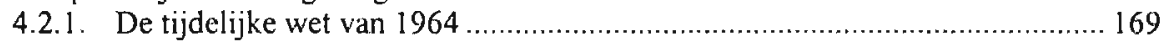

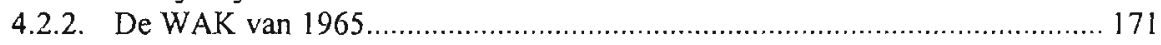

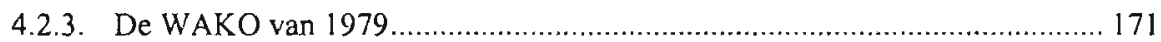

5. Conclusie 


\section{Hoofdstuk 3}

Toepassingsgebied van de nucleaire aansprakelijkheidswetgeving

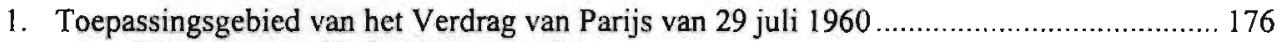

1.1. Toepassingsgebied ratione materiae ...................................................................... 176

1.1.1. Het begrip "kernongeval" in het Verdrag van Parijs .................................. 176

1.1.1.1. Definitie van het Verdrag van Parijs............................................ 176

1.1.1.2. Twee aanknopingspunten: feit of schade ..................................... 176

1.1.1.3. Plotselinge gebeurtenis......................................................... 179

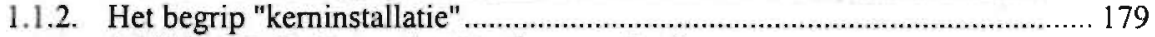

1.1.2.1. Definitie van het Verdrag van Parijs........................................ 180

1.1.2.2. Berging van radioactief afval .............................................. 182

1.1.2.3. Beperkingen voortvloeiend uit het Aanvullend Verdrag

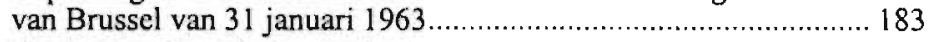

1.1.3. Kwalificatie als een uitzonderingsregime ....................................... 184

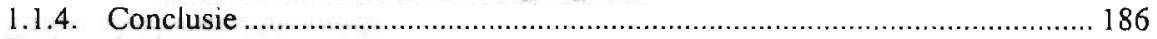

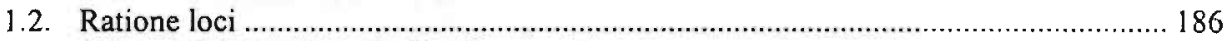

1.2.1.. Het Verdrag van Parijs ...................................................................... 180

1.2.2. Het Aanvullend Verdrag van Brussel van 31 januari $1963 \ldots \ldots \ldots \ldots \ldots \ldots \ldots \ldots . .188$

1.2.3. De gevolgen van het Gemeenschappelijk Protocol van 1988....................... 190

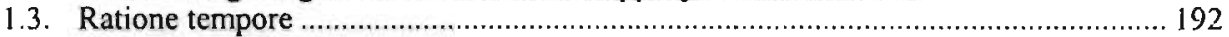

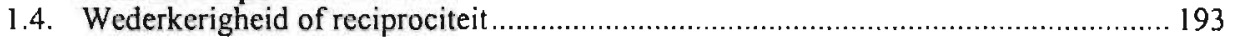

2. Toepassingsgebied van de Belgische wet van 22 juli 1985 betreffende de wettelijke aansprakelijkheid op het gebied van de kemenergic.

2.1. Ratione materiae: het begrip "kerninstallatie" .

2.2. Ratione loci

2.3. Wederkerigheid

3. Toepassingsgebied van de Nederlandse Wet Aansprakelijkheid Kernongevallen van 26 juni 1991 (WAKO)

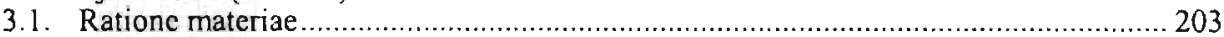

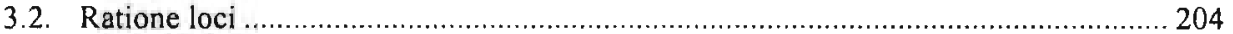

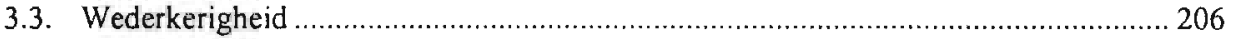

4. Conclusie

\section{Hoofdstuk 4}

Basisprincipes van de nucleaire aansprakelijkheidswetgeving

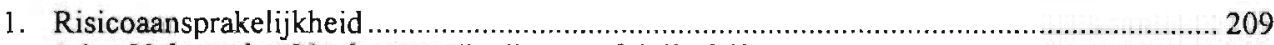

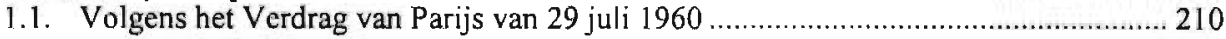

1.1.1. Artikel 3 van het Verdrag van Parijs .................................................. 210

1.1.2. Beroep op overmacht - uitsluitingsgronden .......................................... 211

1. 1.3. Uitgestrektheid van de aansprakelijkheid van de exploitant ....................... 214

1.1.3.1. Eigen schade van de exploitant................................................. 214

1.1.3.2. Aansprakelijkheid bij transport van nucleair materiaal ................... 215

1.1.3.3. Aansprakelijkheid van andere personen?.................................. 216

1.1.3.4. De tussenkomst van een stelsel van sociale zekerheid...................... 218

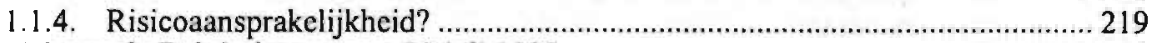

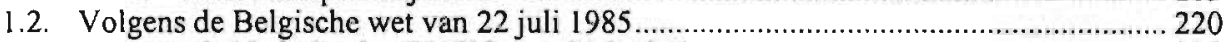

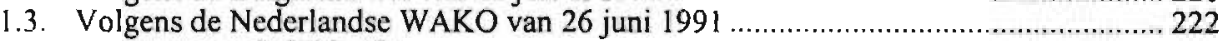

1.4. Risicoaansprakelijkheid naar toekomstig recht....................................................... 224

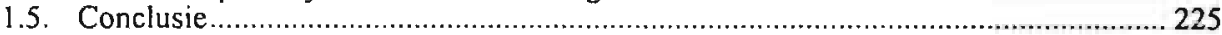




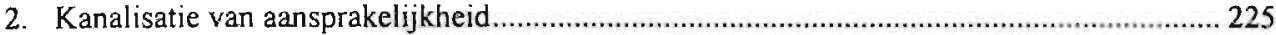

2.1. Ontstaan van de juridische constructie "kanalisatie van aansprakelijkheid" ...............2227

2.1.1. Ontstaan van het Amerikaanse nucleaire aansprakelijkheidsrecht.

2.1.1.1. De Atomic Energy Act van 1946

2.1.1.2. De Atomic Energy Act van 1954: het einde

van het overheidsmonopolie.

2.1.2. Preliminary Report on Financial Protection against Atomic Hazards

(het Voorlopig Rapport).

2.1.3. International Problems of Financial Protection against the Nuclear Risk

(Harvard Rapport).

2.1.3.1. Argumenten van de Amerikaanse nucleaire toeleverings-

industrie om een eventuele aansprakelijkheid af te wijzen

2.1.3.2. Onderzoek naar privaatrechtelijke beschermingsmechanismen....... 239

2. l.3.3. Geheel van maatregelen noodzakelijk om afdoende

bescherming te bieden

2.1.3.4. De exoneratie van aansprakelijkheid van leveranciers ................... 243

2.1.4. Conclusie.

2.2. Kanalisatie van aansprakelijkheid in het kernenergierecht

2.2.1. Verschil tussen economische en juridische kanalisatie van aansprakelijkheid

2.2.2. Ratio legis volgens de Exposé des Motifs bij het Verdrag van Parijs

2.2.3. Definitie van het begrip "kanalisatie van aansprakelijkheid" in het internationale kernenergierecht....

2.2.4. Strekking van de kanalisatie van aansprakelijkheid zoals voorzien in het Verdrag van Parijs.

2.2.4.I. Eerste visie: de leveranciers zijn zowel immuun tegen vorderingen van de exploitant ingevolge de door hem betaalde schadevergoeding als gevolg van de door hem geleden eigenschade

2.2.4.2. Tweede visie: leveranciers zijn niet immuun tegen vorderingen

2.2.4.3. Analyse.

van de exploitant ingevolge de eigen schade van de exploitant...... 255

2.2.5. Kanalisatie van aansprakelijkheid in het Belgische en Nederlandse kemenergierecht.

2.2.6. Weerstand tegen de kanalisatie van aansprakelijkheid in het kernenergierecht.

2.2.6.1. Bij de onderhandelingen van het Verdrag van Parijs en bij

het Verdrag van Wenen ....

2.2.6.2. Bij de invoering van de Verdragen in het nationale

kemenergierecht

2.2.6.3. Conclusie

2.2.7. Exclusicve en/of exhaustieve karakter van het nucleairc aansprakslijkheidsrecht

2.2.8. Belang van IPR-regels voor de kanalisatie van aansprakelijkheid ............... 268

2.2.8.1. Het belang van IPR-regels in de zaak van de Amoco Cadiz........... 269

2.2.8.2. Het "Amoco Cadiz-scenario" in het nucleaire aansprakelijkheidsrecht ......................................................... 272

2.2.8.3. Belang van de IPR-regels in het Harvard Rapport........................... 274

2.2.8.4. Conclusic

2.2.9. De rol van de kanalisatie van aansprakelijkheid bij de (mocizame) onderhandelingen voorafgaand aan het Verdrag inzake Bijkomende Compensatie van 1997

2.2.9.1. Eerste beperking: behoud van de economische kanalisatie in de Price-Anderson Act 
2.2.9.2. Tweede beperking: behoud van de kanalisatie van aansprakelijkheid in de internationale nucleaire aansprakelijkheidsverdragen

2.2.9.3. Oplossing: VS treden toe via de "grandfather clause" .................... 284

2.2.9.4. Conclusie

2.2.10. Belang van de kanalisatie van aansprakelijkheid naar de exploitant van een keminstallatie voor Europese nucleaire leveranciers ............................. 286

2.2.11. Conclusie

2.3. Kanalisatie van ansprakelijkheid buiten het kemenergierecht ..............................291

2.3.1. Kanalisatie van aansprakelijkheid volgens naar Belgisch recht .................... 292

2.3.1.1. Kanalisatie van aansprakelijkheid versus risicoaansprakelijkheid... 292

2.3.1.2. Gebruik van de term kanalisatie door de Interuniversitaire

Commissie tot Herziening van het Milieurecht in het

Vlaamse Gewest.

2.3.2. Omschrijving van "kanalisatie van aansprakelijkheid" in het

Nederlandse recht.

2.3.2.1. Kanalisatie in het kader van artikel 6:175 NBW ........................ 297

2.3.2.2. Merites van een poging tot verduidelijking ................................. 300

2.3.3. Gevolgen voor de dogmatiek inzake (risico)aansprakelijkheid.....................302

2.4. Afbakening van het begrip "kanalisatie van aansprakelijkheid" ............................. 304

2.4.1. Wezenlijke kenmerken van de kanalisatie van aansprakelijkheid ................. 304

2.4.2. Mogelijke verschijningsvormen van de "kanalisatie van aansprakelijkheid".. 306

2.5 Conclusie.

3. Beperking van de aansprakelijkheid van de exploitant van een kerninstallatie

3.1. Beperking van het bedrag van de aansprakelijkheid

3.1.1. Volgens het NEA-regime

3.1.1.1. Ratio legis.

3.1.1.2. Analyse van de bepalingen van het Verdrag van Parijs

3.1.1.3. Verband met de overheidstussenkomst ex Aanvullend

Verdrag van Brussel

3.1.2. Volgens de Belgische wet van 22 juli 1985

3.1.2.1. De aansprakelijkheidsbeperking in de oorspronkelijke wet van 22 juli 1985

3.1.2.2. De aansprakelijkheidsbeperking volgens de gewijzigde wet....

3.1.3. Volgens de Nederlandse WAKO

3.1.4. De beperking van het bedrag van de aansprakelijkheid naar toekomstig recht ......

3.1.4.1. Relevante bepalingen in het Protocol van het Verdrag van Wenen

3.1.4.2. Relevante bepalingen in het Verdrag inzake Bijkomende

Compensatic...

3.1.4.3. De voorstellen in het kader van de revisic van het Verdrag van Parijs.

3.1.5. Vergelijking van de bedragen in een aantal landen ................................. 335

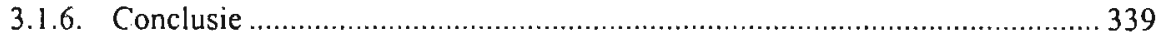

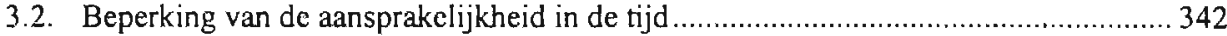

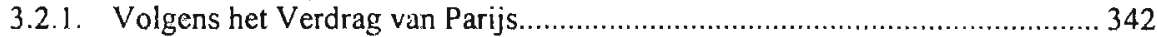

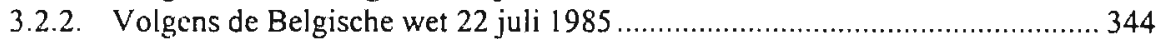

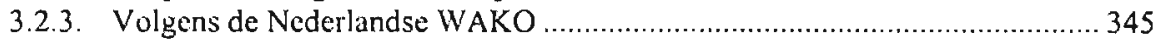

3.2.3.1. Termijn voor het instellen van ecn vordering ............................... 346

3.2.3.2. Procesrechtelijke bepalingen ter zake van de afwikkeling van schadegevallen ............................................................... 348

3.2.4. De beperking van de aansprakelijkheid in de tijd naar toekomstig recht ....... 350

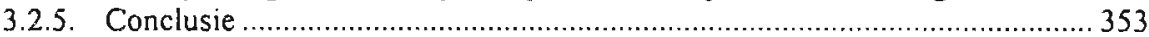

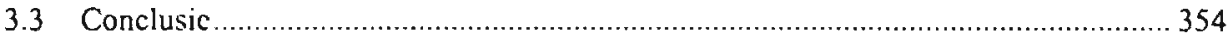


4. Verplichte dekking van de aansprakelijkheid van de exploitant ....................................... 356

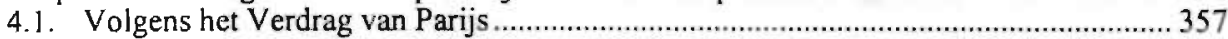

4.1.1. Verplichte dekking van de aansprakelijkheid: het congruentievereiste........... 357

4.1.2. Rol van het congruentievereiste in de discussie omtrent de toelaatbaarheid van de onbeperkte aansprakelijkheid in het Verdrag van Parijs................... 359

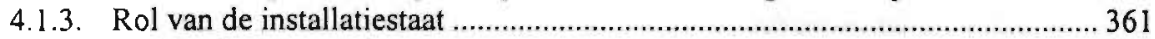

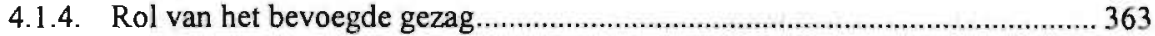

4. I.5. Dekking per installatie of per kernongeval ?............................................... 364

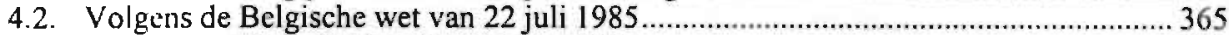

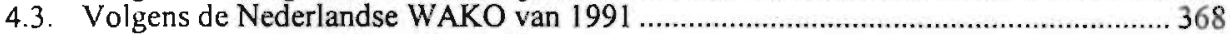

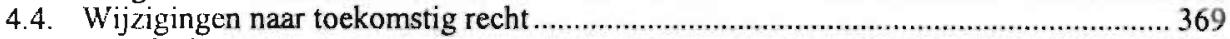

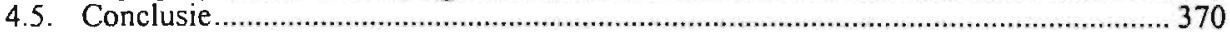

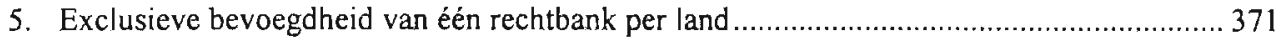

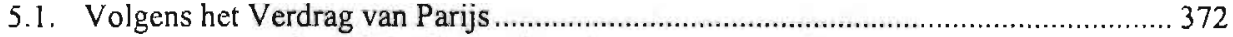

5.1.1. Bevoegde rechtbank en erkenning van een vonnis.................................... 372

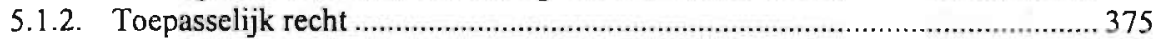

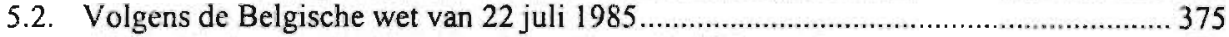

5.2.1. De bevoegdheid overeenkomstig artikel 26 van de wet ............................. 376

5.2.2. Invloed van een mogelijke strafrechtelijke vordering overeenkomstig het

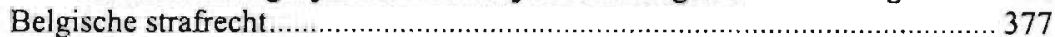

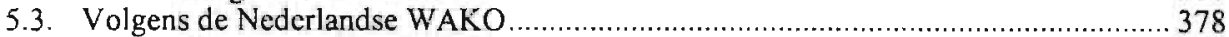

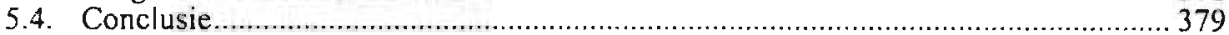

\section{Hoofdstuk 5}

Verzekeringen.

1. Historische schets van het ontstaan van verzekeringen ......................................................... 381

2. Definiëring en wezenlijke bestanddelen van de verzekeringsovereenkomst...................... 385

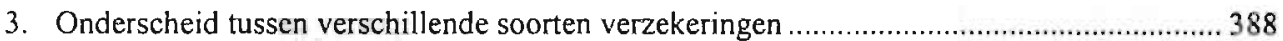

3.1. Privé en sociale verzekeringen ........................................................................ 388

3.2. Verzekering tegen premie en onderlinge verzekering .......................................... 389

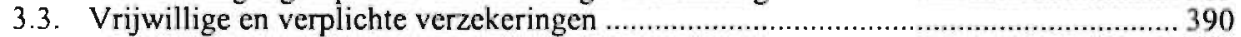

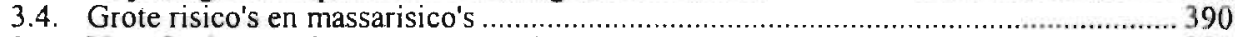

3.5. Verzekering, medeverzekering en herverzekering ............................................... 391

4. De aansprakelijkheidsverzckering - algemene kenmerken ......................................... 393

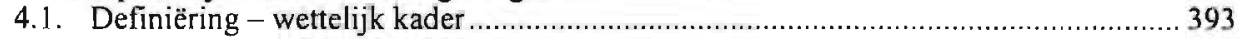

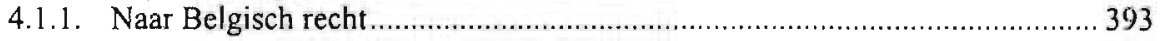

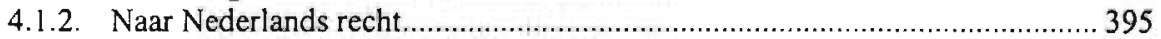

4.2. Voomaamste elementen in aansprakelijkheidsverzekering ...................................395

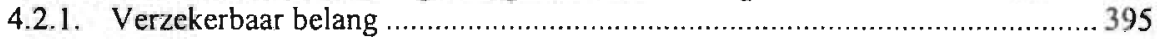

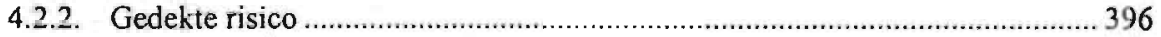

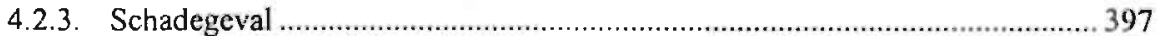

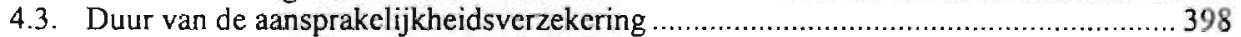

4.4. Overige relevante bepalingen in de Belgische wet op de landverzekerings-

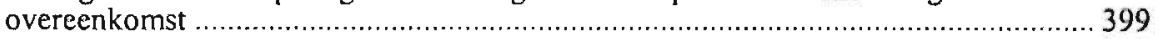

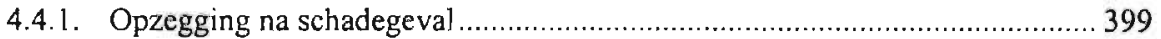

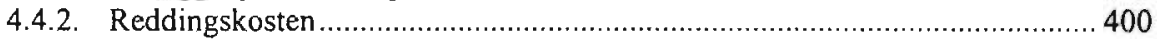

4.4.3. Dekking van interesten en (gerechts)kosten............................................ 401 


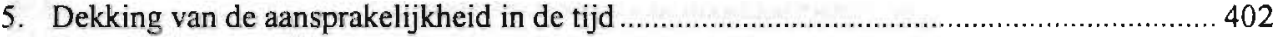

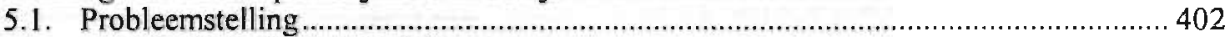

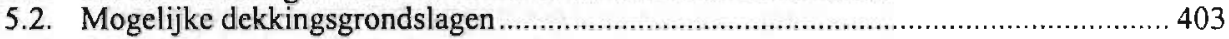

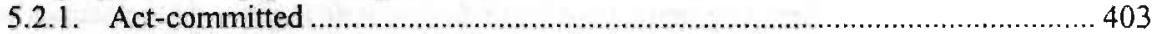

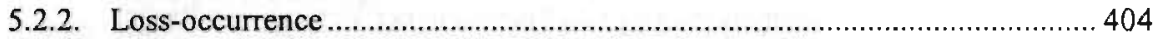

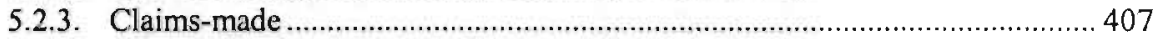

5.3. Dekking in de tijd volgens de Belgische wet op de landverzekeringsovereenkomst ... 409

5.3.1. Noodzaak tot wijziging van de wet op de landverzekeringsovereenkomst: van act-committed naar loss-occurrence ..................................................... 410

5.3.2. Strekking van inloop- en narisico in de gewijzigde wet............................... 412

5.3.2.1. Interpretatie van het in- en narisico in het licht van het dwingende karakter van de wet

5.3.2.2. Onopgeloste vragen onder de nieuwe wet op de

landverzekeringsovereenkomst.

5.3.2.3. Ter illustratie: een kernongeval

5.4. Dekking in de tijd onder de Nederlandse AVB-, AVP- en MAS-polis

5.5. Conclusie

\section{Hoofdstuk 6}

Verzekering van het nucleaire risico

1. Het nucleaire risico vanuit het oogpunt van de verzekeringsindustrie

1.1. Specifieke kenmerken van het nucleaire risico

1.2. Oplossing van de bijzondere problemen

1.2.1. Aanpassen van bestaande verzekeringspolissen en creëren van nieuwe polissen

1.2.2. Creatie van verzekeringspools

1.2.3. Tot stand komen van bijzondere wetgeving

2. De nucleaire verzekeringspools

2.1. Ontstaan

2.2. Definiëring van een nucleaire verzekeringspool of van een syndicaat

2.3. Werking van de pools

2.4. Kenmerken van de nucleaire verzekeringspools

2.5. Verleende dekking.....

3 De Belgische Nucleaire verzekeringspool: Syndicat Belge des Assurances

Nucléaires (SYBAN)

3.1. De oprichting van SYBAN

3.2. Toetredingsmodaliteiten en werking van SYBAN

3.3. De aansprakelijkheidsverzekeringspolis van de exploitant van cen kerninstallatic .... 438

3.4. Eigenschadeverzekering van de exploitanten....

3.5. Positie van SYBAN op het einde van de jaren negentig....

4. Verenigbaarheid van de (nucleaire) verzekeringspools met het Europese concurrentierecht

4.1. Het Europese concurrentierecht

4.1.1. Artikel 81, lid 1: kartelverbod (ex artikel 85)

4.1.2. Artikel 81, lid 2: sanctic.

4.1.3. Artikel 81, lid 3: ontheffing

4.1.4. Artikel 82: misbruik van machtspositie (ex artikel 86)

4.2. Europees concurrentierecht toegepast op de verzekeringssector ............................445

4.3. Gemeenschappelijke dekking van bepaalde risico's ........................................ 448

4.3.1. Volgens de Vrijstellingsverordening inzake verzekeringen ......................... 448 
4.3.2. Visie van de Commissie ten aanzien van verzekeringspools:

de zaak van de P\&I Clubs

4.3.3. Algemene elementen van het EG-beleid .................................................... 455

4.3.4. De toekomst van het EG-beleid ............................................................ 457

4.4. De nucleaire verzekeringspools en het EG-concurrenticrecht ............................... 460

4.4.1. Reactie van enkele exploitanten van een kerninstallatic op de monopoliepositie van de nucleaire verzekeringspools.

4.4.2. Houding van de Europese Commissie ten aanzien van de nucleaire verzekeringspools

5. Conclusie

DEEL 2. RECHTSECONOMISCHE ANALYSE

\section{Hoofdstuk 7}

Inleiding rechtseconomie.

1. Historische ontwikkeling van de rechtseconomie

2. Verschillende concepten zoals gehanteerd in de rechtseconomie

2.1. Homo economicus.

2.2. Efficiëntie.

2.2.2. Het Kaldor-Hicks criterium.

3. Uitgangspunten van de economische analyse van het ongevallenrecht

4. Twee grondleggers: Guido Calabresi en Ronald Coase

4.1. Guido Calabresi

4.2. Het Coase-theorema

\section{Hoofdstuk 8}

Het rechtseconomische model van het ongevallenrecht

1. De Learned Hand-formule

2. Rechtseconomisch model van het aansprakelijkheidsrecht ......................................4 489

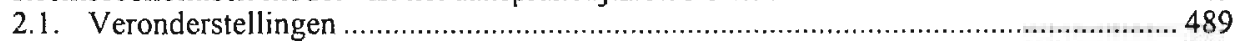

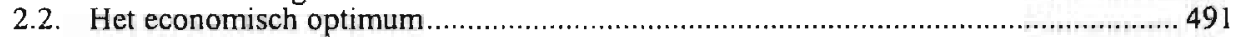

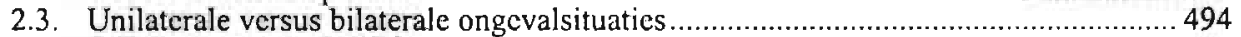

2.4. Efficiënte aansprakelijkheidsregels bij unilaterale ongevallen ................................ 494

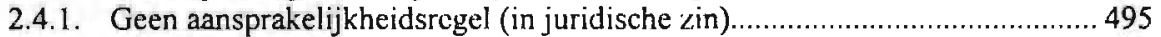

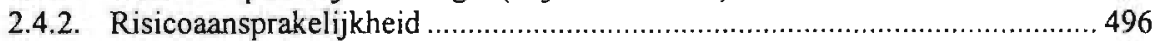

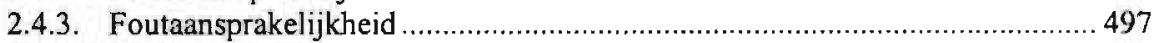

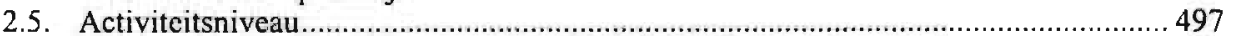

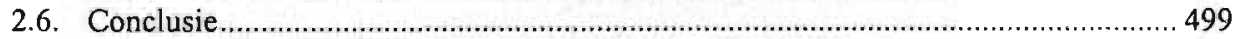

3. De invloed van informatieproblemen - het model verfijnd .......................................5 500

3.1. Problemen bij het bepalen van de fout .......................................................... 501

3.2. Problemen bij causaliteitsonzekerheid................................................................... 502

3.3. Problemen bij onzekerheid over de schadeomvang ................................................. 505

3.3.1. Schatting van de schade door de rechtbank ................................................505

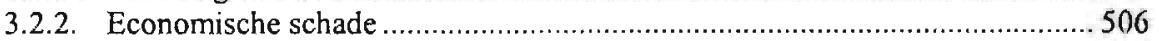

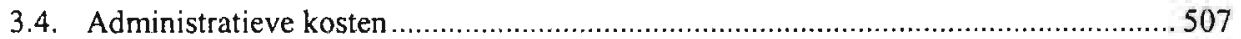

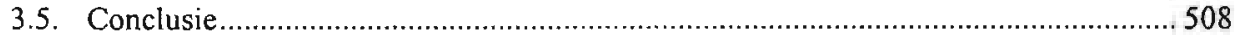




\section{Hoofdstuk 9}

Rechtseconomische analyse van verzekeringen

1. Hoofdlijnen van de cconomische risicotheorie ....................................................... 5 I 1

1.1. Verschillende houdingen ten aanzien van risico ................................................. 511

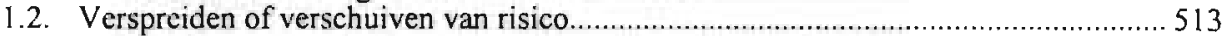

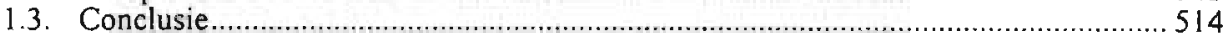

2. Economische analyse van verzekering.................................................................. 514

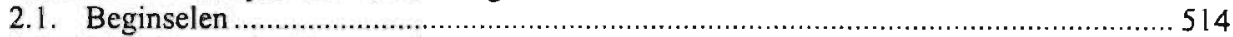

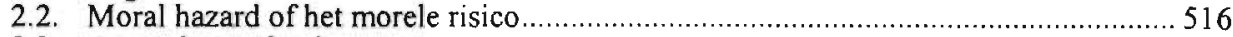

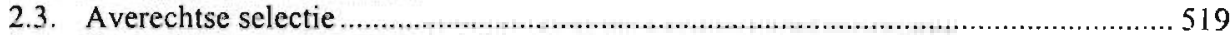

2.4. De invloed van de aansprakelijkheidsverzekering op de maatschappelijke welvaart .. 522

2.4.1. Onder een regime van risicoaansprakelijkheid.................................. 522

2.4.2. Onder een regime van foutaansprakelijkheid ..................................... 522

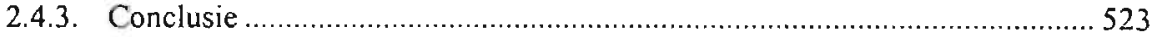

2.5. Economische gevolgen van onvoldoende concurrentie op de verzekeringsmarkt ....... 524

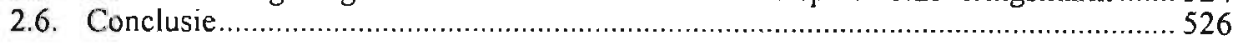

3. Economische analyse van een verplichte verzckering ....................................... 526

3.1. Verplichte aansprakelijkheidsverzekering en de maatschappelijke welvaart............. 527

3.2. Verplichte verzekering als antwoord op mogelijke insolventic van de dader............. 528

3.3. Verplichte verzekering als antwoord op een informatieasymmetrie ......................... 532

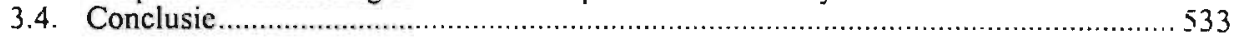

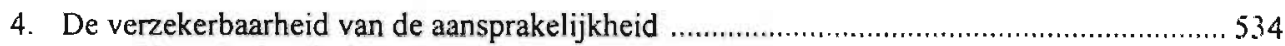

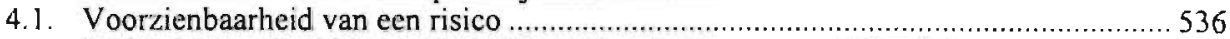

4.2. Invloed van gebrekkige statistische gegevens op de verzekerbaarheid........................557

4.3. Elementen die kunnen leiden tot onverzekerbaarheid ...................................... 540

4.3.1. Moreel risico en averechtse selectie....................................................... 541

4.3.2. Retroactieve aansprakelijkheid ..................................................... 542

4.3.3. Onzekcre causaliteit ....................................................................... 543

4.4. Invloed van de dekkingsgrondslag op de verzekerbaarheid.................................... 545

4.5. Beperking van de aansprakelijkheid als remedie tegen onverzekerbaarheid?............ 548

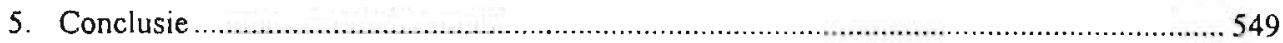

\section{Hoofdstuk 10}

Economische analyse van veiligheidsregulering ...................................... 551

1. Verklaringen voor overheidsregulering ........................................................................... 55 I

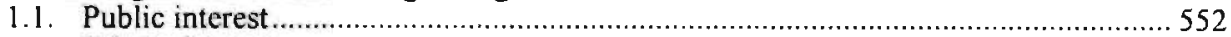

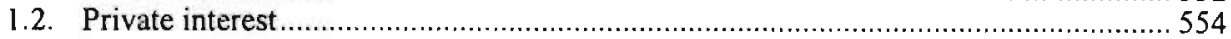

2. Veiligheidsregulering en het aansprakelijkheidsrecht.................................................... 556

2.1. Gevallen waar het gebruik van veiligheidsregulering nuttig kan zijn ....................... 556

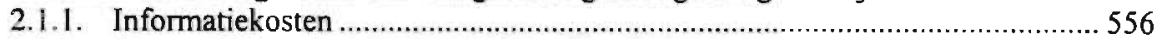

2.1.2. Onmogelijkheid om alle schade te vergoeden...............................................56

2.1.3. Gebrekkige dreiging uitgaande van de aansprakelijkheidsvordering ...............557

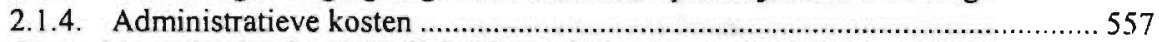

2.2. Gecombineerd gebruik van veiligheidsregulering en aansprakelijkheidsrecht ............557 


\section{Hoofdstuk 11}

Dekking van catastroferisico's

1. Dekking van milieuschade via de klassieke verzekeringsmarkt .................................. 561

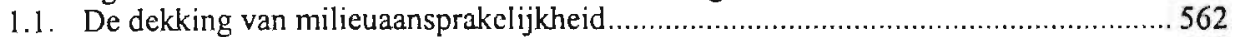

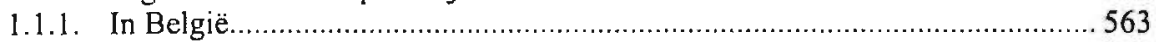

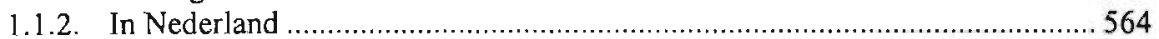

1.2. Directe verzekering ten behoeve van derden ................................................. 568

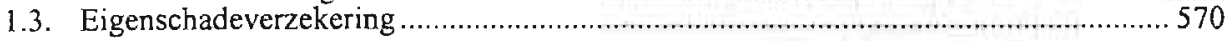

2. Alternatieve compensatiemechanismen voor de dekking van milieuschade ...................... 571

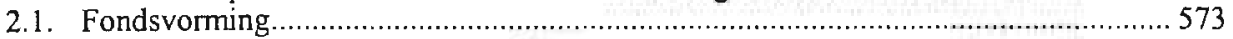

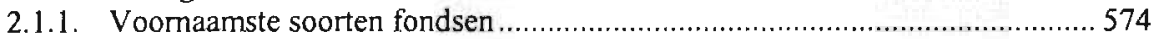

2.1.2. De voorstellen van de Commissie Bocken ............................................... 577

2.1.3. Het Nederlandse Fonds Luchtverontreiniging..................................... 580

2.1.4. De toekomst: naar een algemeen milieuschadefonds? .............................582

2.1.5. Fonds ten aanzien van andere compensatiemechanismen ...........................5 584

2.1.5.1. Invloed van collectieve compensatiemechanismen op de

preventie van ongevallen......................................................... 584

2.1.5.2. Schadefonds versus aansprakelijkheidsverzekering ..................... 586

2.1.5.3. First party verzekering en directe verzekering.............................. 588

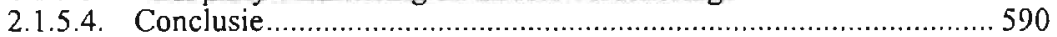

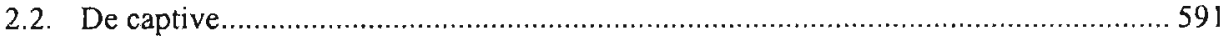

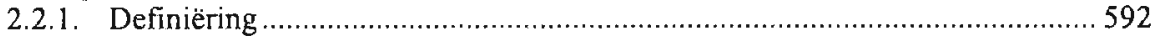

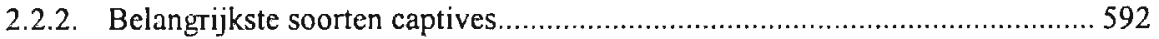

2.2.2.1. De herverzekeringscaptive ............................................... 592

2.2.2.2. De directe verzekeringscaptive............................................. 593

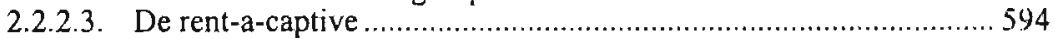

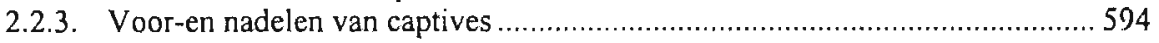

2.2.4. Impact op de traditionele verzekeringsmarkt ......................................... 596

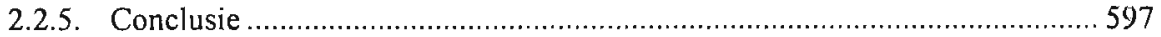

2.3. Dekking van natuurrampen via de kapitaalmarkt .......................................... 597

3. Twee voorstellen ter zake van de dekking van het nucleaire risico ............................... 599

3.1. Environmental Risk Internalisation through Capital Market (ERICAM) ................. 599

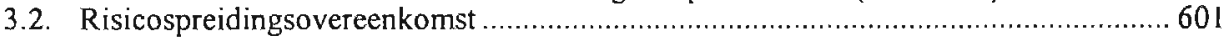

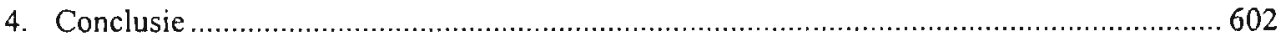

\section{Hoofdstuk 12}

Aaansprakelijkheid voor schade door olieverontreiniging op zee

1. Ontstaan van de maritieme aansprakelijkheidswetgeving.

2. Het Verdrag inzake de Civielrechtelijke aansprakelijkheid voor

olieverontreiniging op zee van 29 november 1969

2.1. Tot stand komen van het Verdrag en van de wijzigingen

2.2. Territoriaal toepassingsgebied

2.3. Basisprincipes van de wetgeving inzake de aansprakelijkheid voor

schade door olieverontreiniging op zee....

2.3.1. Risicoaansprakelijkheid

2.3.2. Kanalisatie van aansprakelijkheid

2.3.2.1. Volgens het Verdrag

2.3.2.2. Volgens de Belgische wet. 
2.3.2.3. Volgens de Nederlandse wet .....................................................6 618

2.3.3. Beperking van de aansprakelijkheid ........................................................619

2.3.4. Verplichte verzekering van de aansprakelijkheid.......................................621

2.3.5. Procesrechtelijke bepalingen .............................................................. 621

3. Het Verdrag tot oprichting van een Internationaal Fonds voor vergoeding van

schade door verontreiniging door olie van 18 december 1971

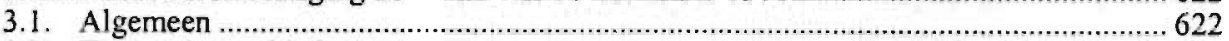

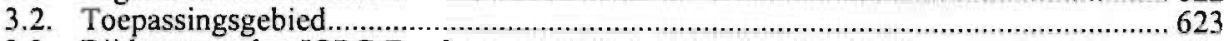

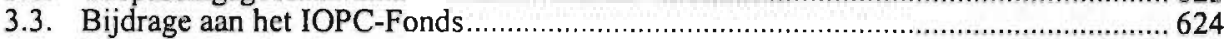

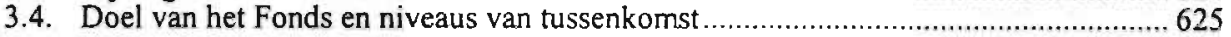

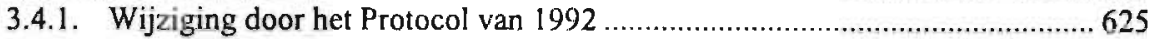

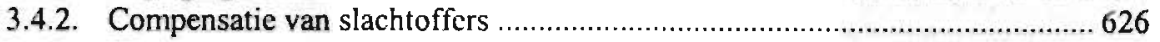

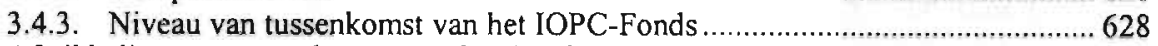

3.5. Afwikkeling van procedures tegen het Fonds................................................ 629

4. De vrijwillige compensatiemechanismen: TOVALOP en CRISTAL ..............................6 630

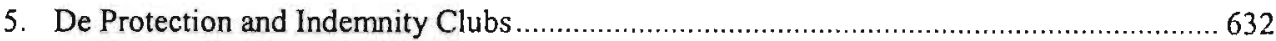

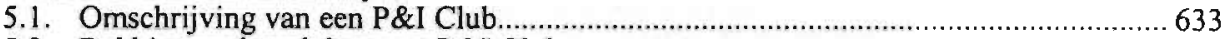

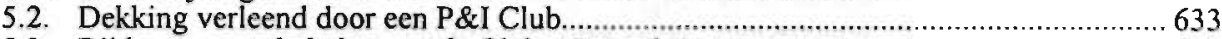

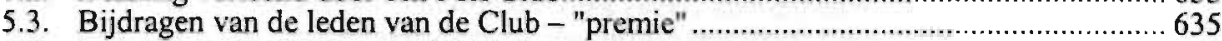

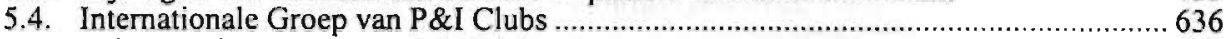

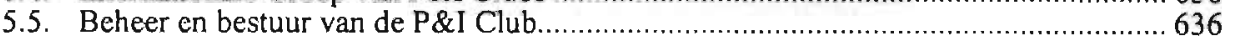

6. Conclusie.

\section{Hoofdstuk 13}

\section{Aansprakelijkheid en verzekering van het nucleaire risico in de} Verenigde Staten

1. Beknopt overzicht van het Amerikaanse nucleaire aansprakelijkheidsrecht.....................639

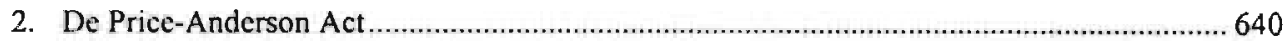

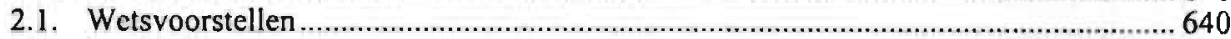

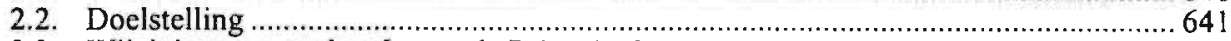

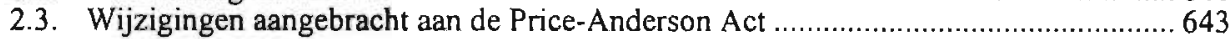

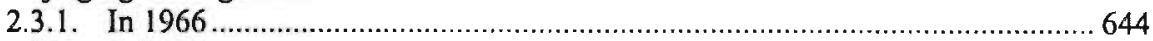

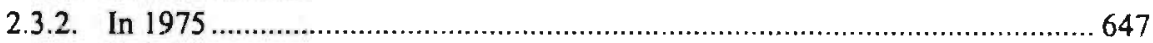

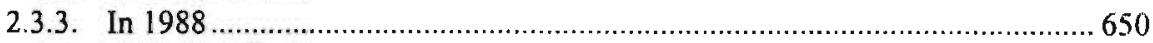

2.4. Voornaamste bepalingen van de Price-Anderson Act anno 2000...........................653

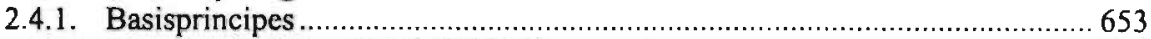

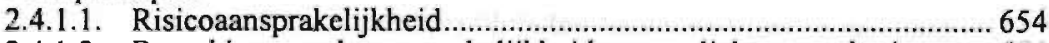

2.4.1.2. Beperking van de aansprakelijkheid en verplichte verzekering .......654 65

2.4.1.3. Economische kanalisatie ........................................................... 656

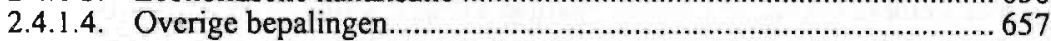

2.4.2. De Nuclear Regulatory Commission (NRC) ............................................6. 658

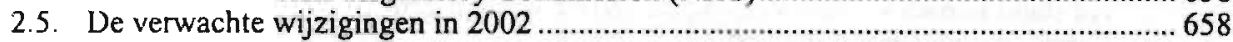

3. Verzekering van het nucleaire risico in de Verenigde Staten...........................................6 660

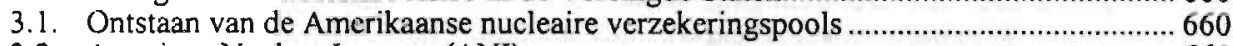

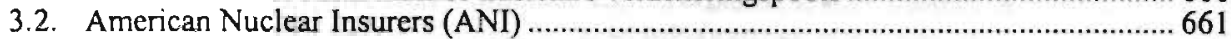

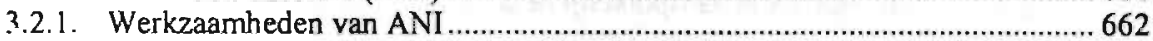

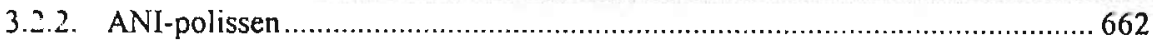




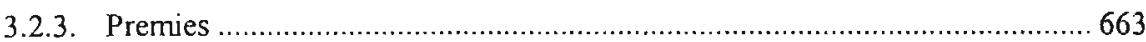

3.2.4. Tussenkomst van ANI ingevolge Three Mile Island ................................... 665

3.3. Nuclear Electric Insurance Limited (NEIL) en Nuclear Mutual Limited (NML) ........667

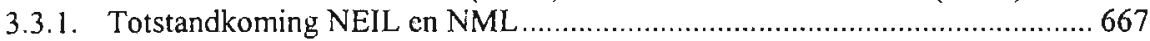

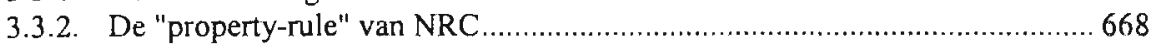

3.3.3. Op de markt beschikbare dekking ................................................................6 668

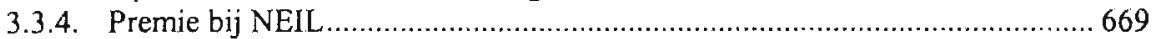

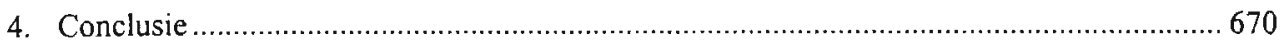

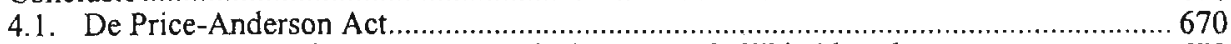

4.2. Vergelijking met het Europese nucleaire aansprakelijkheidsrecht..............................672

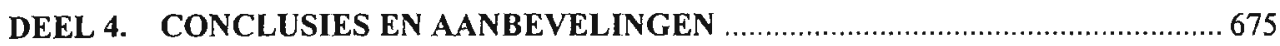

\section{Hoofdstuk 14 \\ Conclusies uit de juridische analyse}

1. Voor wat betreft het nucleaire aansprakelijkheidsrecht .................................................677

1.1. De basisprincipes van het nucleaire aansprakelijkheidsrecht ...................................677

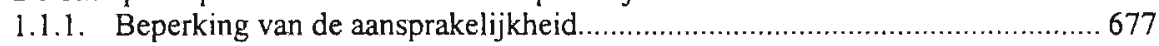

1.1.2. Verplichte dekking van de aansprakelijkheid................................................679 679

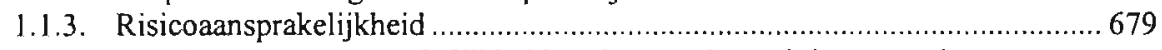

1.1.4. Kanalisatie van aansprakelijkheidsrecht naar de exploitant van de

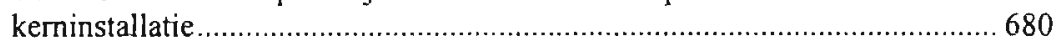

1.1.5. Exclusieve bevoegdheid van één rechter per land .......................................680

1.2. Inschrijven van tijdelijke principes in het internationale

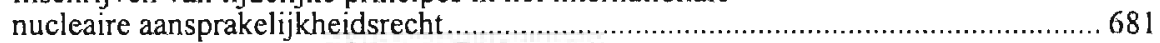

1.3. Organisatie van de nucleaire verzekeringsmarkt ...............................................68

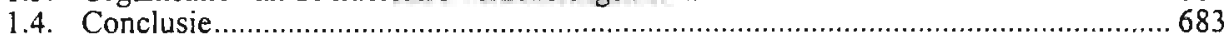

2. Voor wat betreft het algemene milieuaansprakelijkheidsrecht......................................... 684

\section{Hoofdstuk 15}

\section{Rechtseconomische conclusies}

1. Rechtseconomisch model van het kernongevallenrecht ..................................................687

1.1. De basisprincipes van het nucleaire aansprakelijkheidsrecht .......................................687

1.1.1. Risicoaansprakelijkheid versus bescherming van slachtoffers van een kernongeval

1.1.2. Beperking van de aansprakelijkheid van de exploitant van de kerninstallatie en ter beschikking stellen van openbare middelen.

1.1.2.1. Beperking van de aansprakelijkheid van de exploitant.......

1.1.2.2. Ter beschikking stellen van openbare fondsen ..

1.1.3. Juridische kanalisatie van aansprakelijkheid naar de exploitant van een kerninstallatie.....

1.1.3.1. Invloed van de kanalisatie van aansprakelijkheid op de toepassing van het Coase-theorema.

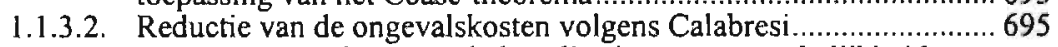

1.1.3.3. Functie en gevolgen van de kanalisatie van aansprakelijkheid

1.1.3.4. Conclusie.

1.1.4. Verplicht stellen van de aansprakelijkheidsverzekering................................. 701

1.1.5. Eén exclusief bevoegde rechtbank per land ................................................ 702 
1.1.6. Nut van veiligheidsregulering ............................................................. 703

1.2. Het toekomstige nucleaire aansprakelijkheidsrecht ……....................................... 704

1.3. Economische analyse van de verzekering van het nucleaire risico ............................. 705

1.3.1. Verzekerbaarheid van het nucleaire risico ………….................................. 705

1.3.2. Gebrekkige concurrentie op de nucleaire verzekeringsmarkt.......................... 706

1.3.3. Tailor-made polis .................................................................................. 709

1.4. Verklaring van het huidige nucleaire aansprakelijkheidsrecht ................................. 710

1.4.1. Vanuit een Public Interest benadering …………..................................... 710

1.4.2. Vanuit een Private Interest benadering ……….......................................... 711

2. Normatieve rechtseconomische analyse van de rechtsvergelijkende inzichten....................713

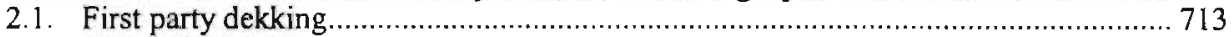

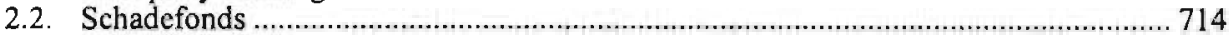

2.3. Collectieve compensatiemechanismen van de exploitanten …….............................. 716

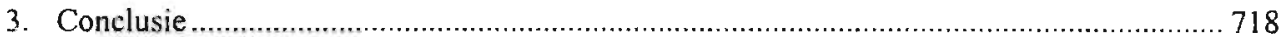

\section{Hoofdstuk 16}

Naar een verbeterd model inzake compensatie van schade door

kernongevallen

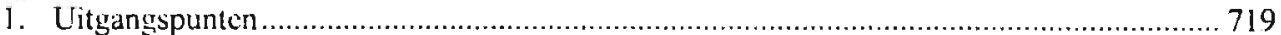

1.1. Regionaal Verdrag met duur van telkens 10 jaar ................................................... 719

1.2. Beschikbaarheid van bedragen: snel en gespreid in de tijd.................................... 719

1.3. Onafhankelijk regulerend orgaan ........................................................................ 720

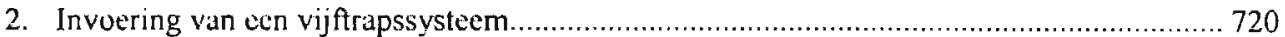

2.1. Eerste trap: onbeperkte aansprakelijkheid met beperkte verzekeringsplicht............... 721

22 Tweedc trap: collectieve aansprakelijkheid van de exploitanten ................................ 722

23. Derde trap: de verschillende landen als herver $/$ ckeraar ........................................... 723

2.4. Vierde trap: Nucleair Schadefonds .................................................................. 723

2.5. Vijfde trap: Voluntary Liability Agreement of Nuclear Operators and Suppliers (VLANOS)

3. Beperkte mogelijkheid om de eigen schade te verzekeren, met

"decontaminatiedekking"

SUMMARY

TREFWOORDENREGISTER

LITERATUUR

CURRICULUM VITAE 


\section{PROLOOG}

\section{HET NUCLEAIRE TIJDPERK IN VOGELVLUCHT}

Op 26 februari 1896 stond Henri Becquerel voor een raadsel. Nadat hij cen paar dagen eerder een doos uraniumzout op een gesloten doos met fotografische platen had geplaatst, stelde hij vast dat de platen waren aangetast door een onbekende straling, waarvan de effecten vergelijkbaar waren met die van de X-stralen die een jaar eerder door Röntgen waren ontdekt. Uit nader onderzoek leidde Becquerel af dat deze aantasting enkel het gevolg kon zijn van de straling van het uranium. $\mathrm{Hij}$ had het bestaan ontdekt van onstabiele kernen en dus van de natuurlijke radioactiviteit.

Marie Curie begon deze straling te bestuderen en zocht naar andere lichamen die een soortgelijke straling hadden. In 1898 slaagde zij erin om samen met haar man Pierre, radium en polonium af te scheiden van uraniumerts. Henri Becquerel en Marie Curie stelden vervolgens vast dat wanneer radium in contact kwam met de menselijke huid, dit leidde tot een verbranding van de opperhuid, die slechts zichtbaar was enkele dagen na de bestraling. Later werd radium gebruikt voor de behandeling van huidaandoeningen en voor de behandeling van bepaalde gevallen van kanker. Voor dit pionierswerk op het gebied van stralingsverschijnselen, kregen Becquerel en Pierre en Marie Curie in 1903 de Nobelprijs voor natuurkunde.

In 1905 publiceerde Albert Einstein de resultaten van zijn onderzoek over beperkte relativiteit: wanneer een lichaam in rust een verhoging van energie krijgt, gedraagt dat lichaam zich alsof zijn massa zou zijn toegenomen. De geleerden kwamen tot de vaststelling dat er een equivalentie bestaat tussen de absorptie van energie en de toename van massa': wanneer de massa van een lichaam afneemt, komt een bepaalde hoeveclheid encrgie vrij. Of nog: materie zet zich om in energie en energie zet zich om in materie.

De praktische toepassing van deze ontdekking liet evenwel nog een dertigtal jaar op zich wachten. Gedurende deze periode werd het neutron ontdekt en bekwam men meer gegevens over de structuur en het gewicht der kernen ${ }^{2}$.

In 1934 ontdekten Frédéric en Irène Joliot-Curie de kunstmatige radioactiviteit. Hierdoor werd de mens in de mogelijkheid gesteld om kemen te produceren die niet in de natuur voorkomen. Momenteel bestaan ongeveer 2.000 onstabiele kernen. Deze ontdekking leidde niet alleen tot de productie van radio-isotopen, maar legde tegelijk de basis voor de ontdekking, een paar jaar later, van de fissie of splitsing van kernen. De ontdekking van de kunstmatige radioactiviteit betekende meteen de start van de nucleaire geneeskunde en van de moleculaire biologie.

Gillon, L., De kwestie kernenergie, Standaard Uitgeverij, 1986, 76.

Een atuom is samengesteld uit een kem die wordt omgeven door één of meerdere elektronen. De kern van het atoom wordt gevormd door protonen en neutronen (samen de "nucleonen" genoemd). De protonen zijn positief geladen en hebben nagenoeg dezelfde massa als die van de neutronen, die elcktrisch neutraal zijn. In zijn normale toestand is het atoom elektrisch neutraal hetgeen betekent dat de positieve lading van de kem (door de protonen) gelijk dient te zijn aan het aantal elektronen. Kemen die te veel protonen of te veel neutronen bevatten, worden onstabiele kernen genoemd. Dorgelijke onstabiele kernen vertonen steeds de tendens om te evolueren naar cen stabiele toestand; hierbij stoot de kem bepaalde deeltjes uit. Deze desintegraties gaan gepaard met het uitzenden van ioniserende straling. Dit verschijnsel wordt radioactiviteit genoemd (zie o.m. Gillon, L., "De kwestie kemenergie", l.c., 68 e.v.). 
In 1939 kwamen de wetenschappers tot de slotsom dat structuurwijzigingen van kernen in feite beantwoorden aan massavariaties die op basis van Einsteins relativiteitstheorie, konden worden geïnterpreteerd als energievariaties. Stilaan begonnen Frédéric Joliot, Enrico Fermi, en Pierre en Marie Curie een link te leggen tussen deze verschillende fenomenen. Zij stelden namelijk vast dat bij splitsing van bepaalde kemen enorme hoeveelheden energie vrijkomen. Wanneer een neutron (neutraal geladen deeltje van een atoom) wordt afgevuurd op een zware kem (dit betekent een kern met een hoge massa) ontstaan twee kernen (zgn. fissieproducten) met meestal een ongelijke massa, alsook twee tot drie vrije neutronen ${ }^{3}$. Dit fenomeen noemt men kernsplijting of fissie.

Met de ontdekking van de relativiteitstheorie, had Einstein dus niets anders gedaan dan de basis gelegd voor de ontwikkeling van kemenergie. Indien een zware kem wordt gesplitst, neemt de massa van deze kern af; hierdoor komt een aanzienlijke hoeveelheid energie vrij ${ }^{4}$. Indien bijvoorbeeld één gram uranium 235 wordt gesplitst, komt $22.700 \mathrm{kWh}$ vrij; dit beantwoordt aan de hoeveelheid elektrische energie die jaarlijks per gemiddeld huisgezin in België wordt verbruikt.

In het interbellum waarschuwde Einstein er reeds voor dat kemenergie wel eens voor niet vreedzame - militair-politieke - doeleinden zou kunnen worden gcbruikt ${ }^{5}$. Op 6 en 9 augustus 1945 bleek inderdaad de enorme kracht van een nucleaire explosie: bij de atoombonmen op Hiroshima en Nagasaki vielen respectievelijk 78.000 en 27.000 onmiddellijke slachtoffers.

De eigenlijke start van het nucleaire tijdperk ${ }^{6}$ situeert zich eveneens in het interbellum. In Stagg Field (Chicago, USA) slaagde Fermi er op 2 december 1942 in om voor het eerst een kemreactie tot stand te brengen waarbij op gecontroleerde wijze kemenergie vrijkwam.

De eerste elektrische energie van nucleaire oorsprong werd in 1951 geproduceerd in de Verenigde Staten; de eerste kemcentrales waren operationcel rond 1955: Obninsk in de voormalige SovjetUnie, Shipping-Port in de Verenigde Staten. Calder Hall in Groot-Brittannië en Marcoule in Frankrijk. Dit betekende evenwel niet dat meteen en massaal werd overgegaan tot de bouw van kemcentrales overal ter wereld. Om diverse redenen liet de aanwending van kemenergie, als energicbron die de elektriciteitsbehoefte van grote delen van de bevolking zou dekken, nog twee decennia op zich wachten.

Een eerste belangrijke reden waarom het massale gebruik van kemenergie als energiebron op zich liet wachten, was het risico van militair gebruik van kernenergie. Zeker gedurende de Koude Oorlog eisten de grootmachten de nodige garanties eisten van een land waamaar nucleaire technologie werd geëxporteerd. Landen die kemenergie wensten te gebruiken, dienden eerst toe te tre-

3 Gillon, L., Le nucléaire en question, Duculot, 1986, 80.

4 Wanneer een zware kem wordt gesplitst, is de totale massa van de twee fissieproducten plus de twee tot drie neutronen kleiner dan de massa van de zware kem plus de neutron die de fissie heeft veroorzaakt: er is dus een verlies van massa, of met andere woorden een toename van energie.

Leclereq, J., L'ère nucléaire: le monde des centrales nucléaires, Hachette, 1986, 56.

Wanneer sprake is van "het nucleaire tijdperk", wordt in eerste instantie gedacht aan de grote elektriciteitproducerende kemcentrales. De ontwikkeling van kemenergie heeft zich in de loop der jaren evenwel niet beperkt tot de productie van elektriciteit. Alom bekend zijn de toepassingen in de geneeskunde en dit zowel bij het stellen van diagnose bij diverse aandoeningen, als bij de behandeling van bijvoorbeeld kanker. Maar kernenergie wordt ook via de meest verscheiden toepassingen gebruikt in de industrie, bijvoorbeeld voor de controle van lasnaden, voor het opsporen van microscopisch kleine scheurtjes in metaal, voor het meten van de dikte van materialen, of nog voor het meten van de vochtigheid van de grond. Zie bijvoorbeeld Jaumotte, A., "Introduction and Historical Summary", paper gepresenteerd op de jaarlijkse Conferentie van de Belgian Nuclear Society (BNS) van 1-3 juni 1995 NonEnergetic Applications of Nuclear Science: Medical - Environmental - Industrial. 
den tot de voomaamste internationale Verdragen die garandeerden dat het gebruikte materiaal en de overgedragen kennis, niet voor militaire doeleinden zou worden aangewend.

In tweede instantie waren in het midden van de twintigste eeuw vooral petroleum maar ook steenkool de voornaamste bronnen van energie. Zolang deze natuurlijke olie- en steenkoolreserves op peil bleven, bestond er geen reden om zich toe te leggen op de productie van elektriciteit via andere encrgiebronnen.

Gedurende de jaren '70 veroorzaakte de Yom Kippour oorlog een aanzienlijke stijging van de petroleumprijs. Zeker na de beslissing van de landen van de OPEC (Organisation of Oil Exporting Countries) om de prijs per vat olie te verdrievoudigen, werd koortsachtig gezocht naar andere en vooral goedkopere energiebronnen.

De resultaten van het werk van Albert Einstein, Frédéric Joliot, Enrico Fermi en Pierre en Marie Curie dienden zich aan als ideale oplossing. Heel snel vermenigvuldigden zich de onderzoeken in het domein van de nucleaire energie in de hoop het ideale type reactor te ontdekken. Tedereen was ervan overtuigd dat een beslissende vooruitgang in het onderzock en de massale productie van kerncentrales voor de nabije toekomst was. Nochtans is tot vandaag nooit één ideaal type reactor "gevonden"; wereldwijd bestaan verschillende types reactoren met elk hun eigen kenmerken.

Andere energiebronnen zoals zonne- en hydro-energie werden weliswaar aangewend, maar deze dienen zich evenmin aan als ideale oplossing. Afgezien van het risico op nict-vreedzaam gebruik, leek kernenergie meerdere voordelen te bieden: kernenergie zou niet alleen goedkoop zijn, bovendien levert uranium zoveel energie dat de natuurlijke voorraden quasi niet uit te putten zijn. Overal ter wereld werden midden in de jaren zeventig kerncentrales gebouwd. Door de oliecrisis en de ongelijke verdeling van de natuurlijke olie-, gas- en steenkoolvoorraden besefte een groot aantal westerse landen hoe afhankelijk zij waren van andere landen en werd duidelijk welke gevolgen de oliecrisis kon hebben op de westerse economieën. De zoektocht naar een andere energiebron kreeg hierdoor een strategische dimensie: hoe meer een land op min of meer zelfstandige manier zou instaan voor zijn energievoorziening, hoe beperkter de gevolgen zouden zijn van een politieke of economische crisis in het land van waaruit olie of gas worden geïmporteerd.

Een groot aantal landen nam bijgevolg de beslissing om kerncentrales te bouwen. Van het in 1993 totale aantal operationele kerncentrales werd $34,7 \%$ operationeel gedurende de jaren zeventig en nog eens $34,4 \%$ in de eerste helft van de jaren tachtig ${ }^{3}$. Dit betekent dat voor de ruime meerderheid van deze kerncentrales de beslissing om een beroep te doen op kernenergie werd genomen gedurende de zeventiger jaren. De oliecrisis heeft dus een duidelijke impact gehad op de beslissing om op vrij grote schaal kerncentrales te bouwen ${ }^{8}$.

Cijfers afgeleid uit Nuclear News, september 1993, 43 e.v.

Weliswaar verschilt het aandeel waarvoor landen cen beroep doen op kemenergie ter dekking van hun elektriciteitsbehoeftes sterk van land tot land. Volgende cijfers geven het aandeel weer van het gebruik van kernenergie in de totale elektriciteitsproductie van een land per april 2000: Frankrijk: 75\%; Litouwen: $73 \%$; België: $57 \%$; Slovakije: $47 \%$; Bulgarije: $47 \%$; Zweden: $46 \%$; Oekraîne: $43 \%$; Japan: $24 \%$; Zwitserland: 36\%; Duitsland: 31\%; Spanje: 3 I\%; Verenigd Koninkrijk: 28\%; Verenigde Staten: 19\%; Nederland: $4 \%$ (deze opsomming van het aantal landen dat een beroep doet op kemenergie is niet volledig, maar wordt enkel weergegeven bij wijze van voorbeeld) (bron: IAEA Bulletin, 2000, vol. 42, $\mathrm{n}^{\circ}$ 2,62). 
Ook het groeiende besef dat olie, gas en steenkool een nadelige invloed hadden op het milieu, vergrootte de nood aan een andere energiebron. Zeker in het licht van de - in bepaalde landen explosieve -- bevolkingsgroei groeide de vraag naar energie op spectaculaire wijze.

Het gevolg van de geschetste factoren is dat, sinds het midden van de jaren zeventig, een groot aantal landen een beroep doet op kernenergie om tegemoet te komen aan de steeds groeiende vraag naar energie. Net zoals het toenemend gebruik van bijvoorbecld petroleum leidde tot milieurampen als de Torrey Canyon, Amoco Cadiz en de Exxon Valdez, steeg ook het risico van een kemongeval naarmate meer kerncentrales in gebruik werden genomen.

Op 28 maart 1979 vond in Thr'e' Mile Island (Harrisburg, Pennsylvania. VS) een ongeval plaats met zwarc beschadiging van de reactorkern. Het was het eerste emstigc ongeval in de burgerlijke nucleaire industric. De gevolgen voor de gezondheid bleven beperkt: volgens officiële gegevens ontving één persoon cen dosis van $86 \mathrm{mrem}^{9}$, wat evenveel is als de straling dic men krijgt bij het nemen van twee röntgenopnames. Niettegenstaande de gevolgen van het ongeval te Three Mile Island beperkt bleven tot het reactorgebouw hebben de omvang, de complexiteit en de kosten van het ongeval zelts de meest pessimistische voorspellingen van vóór 1979 overtroffen ${ }^{\text {iD }}$. De verzekeraar heeft een aantal vorderingen buiten de rechtbank tocgekend door mecr dan 40 miljoen dollar uit te keren aan derden. Bovendien werden naar aanleiding van het ongeval verschillende rechtszaken aangespannen die ook nog in 2000 verder aansleepten ${ }^{11}$ 1?.

Op 26 april 1986 vond in Tsjernobyl - een stadje van 50.000 inwoners midden in de Oekraïne een zwaar ongeval plaats waarbij een aanzienlijke hoeveelheid radioactiviteit in de atmosfeer werd geloosd. Reactor 4 van Tsjernobyl, die voor onderhoud moest worden stilgelegd in het begin van de namiddag, draaide op half-vermogen. Om een elektrische proefneming uit te voeren, schakelden de operatoren verschillende veiligheids- en automatische stillegsystemen van de reactor uit. Door verkeerde manipulaties van de operatoren en een verkeerd concept van de stillegsystemen van de reactor sloeg de reactor op hol zonder dat de stillegsystemen tijdig konden ingrijpen: de reactor bereikte een vermogen gelijk aan 400 maal zijn normaal vermogen en ontplofte ${ }^{13}$. Alle

Hier moet er reeds op gewezen worden dat ook de natuur radioactiviteit uitstraalt; de jaarlijkse dosis die de mens door deze natuurlijke bestraling ontvangt, bedraagt 150 tot 250 mrem per jaar (Gillon, L., "De kwestie kemenergie", l.c., 210). Hildebrand, J.E., "The Three Mile Island unit 2 recovery: a decade of challenge", Recovery operations in the event of a nuclear accident or radiological emergency, IAFA, Vienna, 1990, 65-77.

" Brown, Q., "Litigation persists from the 1979 Three Miles Island Accident", Nuclear Law Bulletin, vol. 57, 1996, 67-69; Quattrochi, J.L., "The Price-Anderson Act in the New Millennium. An Insurer's Perspective", in "Nuclear Inter Jura 1999", AIDN/NLA, Washington, 1999, 251.

12 Cfr. infra, hootdstuk 13.

13 De Tsjernobyl-reactor is een grafiet-reactor; een type dat in het westen nauwelijks wordt gebruikt. Grafiet is een zgn. moderator: het vertraagt de snelheid van de neutronen zodat de kemreactie kan plaatshebben. Zonder moderator vindt geen kemreactie plaats omdat de verschillende neutronen met een te hoge snelheid op de atomen worden afgevuurd. Terwijl in Tsjernobyl grafiet wordt gebruikt als moderator, wordt in de meeste centrales van westerse makelij water als moderator gebruikt. Zowel bij de grafietreactoren van het Tsjernobyl-type als bij de westerse pressurized water en boiling water reactoren (PWR en BWR-reactoren) wordt water evenwel als koelmiddel gebruikt. Dit kan leiden tot een probleem bij de grafietreactoren indien het water wegvloeit of verdampt uit de reactor. Indien bijvoorbeeld door een lek het water uit de reactor ontsnapt bij een PWR-reactor, valt weliswaar het koelmiddel weg, maar doordat het water ook dienst doet als moderator, valt de kemreactie ogenblikkelijk stil (neutronen hebben een te grote snelheid om een kernreactie te kunnen opwekken). Het probleem bij grafietreactoren is dat wanneer het water uit de reactor wegvloeit of verdampt, deze geen koelmiddel meer heeft terwijl de moderator - grafiet - nog steeds aanwezig is en de kernreactie blijft plaatshebben. Indien een grafietreactor geen koelmiddel meer heeft, is met andere woorden een bijkomende manipu- 
voorziene barrières om de fissieproducten te behouden werden verbroken: de grafietmoderator en het uranium vatten vuur en aanzienlijke hoeveelheden fissieproducten evenals plutonium en uranium werden in de atmosfeer geloosd. Een deel van de vrijgekomen radioactiviteit kwam terecht in de onmiddellijke omgeving van de reactor; een ander deel werd in de vorm van een radioactieve wolk, tot op duizenden kilometers vervoerd ${ }^{14}$.

Nagenoeg alle landen van Europa werden getroffen door de gevolgen van de radioactieve neerslag. De televisiebeelden schokten de gehele wereld. Ruwe schattingen spreken van 8.000 doden; officiële cijfers spreken van 43 slachtoffers. Tsjernobyl komt nog gercgeld in het nieuws, mat berichten hetzij over de gebrekkige staat van de sarcofaag, hetzij met de mogelijke gevolgrn van het ongeval op mens en milieu, tot ver buiten de gren $e^{2}$ van Oekraïne ${ }^{15}$.

Ook op het einde van de twintigste eeuw bleek wat de gevolgen konden zijn van een kemongeval: op 30 september 1999 vond een kernongeval plats in Tokaimura (Japan). Ook hier liep de schade in de vele miljarden.

Kernsplijting en haar mogelijke gevolgen op mens en milieu blijven omgeven door een sluier van mysteries, waardoor het vreedzaam (en militair) gebruik ervan leiden tot een grote belangstelling in de publieke opinie ${ }^{16}$. Deze belangstelling is minstens ten dele de uiting van de angst van de bevolking voor het fenomeen kernenergie. $\mathrm{Na}$ TMI en Tsjernobyl ${ }^{17}$ is de toenemende oppositie tegen nucleaire energie-opwekking opvallend. Zo steeg na Three Mile Island de tcgenstand in Harrisburg tegen de bouw van nieuwe nucleaire installaties van $26 \%$ naar $42 \%{ }^{18}$. Het hoeft geen verder betoog dat het ongeval in Tsjernobyl deze negatieve houding enkel heeft versterkt: na het ongeval kondigden verschillende landen een moratorium af op de bouw van - zelfs reeds in aanbouw zijnde - kemcentrales.

Specifick wat Tsjemobyl betreft, kwam daarbij het probleem dat de schade die in andere landen werd geleden niet door de voormalige Sovjet-Unie werd vergoed omdat dit land geen lid was van de internationale verdragen inzake de civielrechtelijke aansprakelijkheid voor kemongevallen.

latie van de controicstaven nodig: enkel wanneer deze in de reactor worden gebracht (of wañneet de brandstofstaven uit de reactor worden verwijderd), zal de kemreactie stilvallen. De combinatie van waterkoeling en grafietmoderatie, zoals bij de reactoren van het Tsjernobyl-type, wordt beschouwd als inherent gevaarlijk. Voor een meer gedetailleerde beschrijving van de omstandigheden van het ongeval, leze men o.m. Gillon, L., "De kwestie kernenergie", l.c., 212 e.v. Gillon, L., L'Atome et l'Homme, Editions Racine, Bruxelles, 1995.

Zo bijvoorbeeld: "Still a risk 10 years after the explosion", Financial Times, 7 december 1995; "Petroleumlicht in Tsjernobyl", NRC Handelsblad, 21 maart 1996; "Le taux de leucémie infantile a augmenté en Grèce après Chernobyl", Le Monde, 31 juli 1996.

Zie hierover o.m. X., "Public Understanding and Nuclear Energy", IAEA Bulletin, 2/1990, 5 e.v.

17 Over de gevolgen van Tsjernobyl: Ilyin, L.A. en Pavlovskij, O.A., "Radiological Conseguences of the Chemobyl Accident in the Soviet Union and measures taken to mitigate their impact", LAEA Bulletin, 4/1987, 17-24; X., "Radiation levels: WHO reports on Chemobyl", IAEA Bulletin, Autumn 1986, 27 39; X., "Response, to Chemobyl", IAEA Bulletin, Summer 1986, 61-65; X., "The International Chemobyl Project", IAEA Bulletin, 2/1991, 4-13; X., "One decade after Chernobyl: the basis for decisions", IAEA Bulletin, 3/1996; X. Tchernobyl. Dix ans déjà. Impact radiologique et sanitaire, AEN, OECD, Paris, 1996.

18 Mc Cormick, N.J., "Changes in the nuclear power industry after TMI", Progress in Nuclear Energy, 1982, Vol. 10, 247; Melber, B.D., "The impact of TMI upon the public acceptance of nuclear power"," Progress in Nuclear Energy, 1982, Vol. 10,387-398. 



\section{INLEIDING}

In dit boek wordt onderzocht hoe de aansprakelijkheid voor schade door catastroferisico's op efficiënte wijze kan worden geregeld en op welke wijze kan worden voorzien in een compensatiesysteem. Over het algemeen wordt een catastroferisico beschouwd als een risico dat een groot aantal slachtoffers kan treffen en dat de insolventie van de aansprakelijke tot gevolg kan hebben ${ }^{\text {' }}$ ${ }^{2}$; vanuit economisch en verzekeringsoogpunt kan een catastroferisico worden omschreven als een risico met lage probabiliteit en een hoge verwachte schade ${ }^{3}$. In het kader van dit onderzoek wordt met een "catastroferisico" dus niet gerefereerd naar de schade door een natuurramp, maar naar schade veroorzaakt door (hoog)technologische en gevaarlijke activiteiten zoals de productie van kernenergie en het vervoer van olie over zee. Als voorbeeld van een dergelijk catastroferisico staat in dit onderzoek met name de schade veroorzaakt door kernongevallen centraal.

Deze inleiding licht de keuze van het onderzoeksonderwerp toe, motiveert de keuze voor de gehanteerde onderzoeksmethode en geeft uitleg bij de structuur van dit boek. In eerste instantie wordt, door het afbakenen van het onderzoeksdomein, aangegeven wat het precieze voorwerp is van het gevoerde onderzoek $(\$ 1)$. Vervolgens wordt de maatschappelijke relevantie van het gevoerde onderzoek toegelicht $(\$ 2)$. Hier wordt nagegaan in welke mate de kans op kernongevallen reëel is en wordt de relevantie geschetst van wetenschappelijk juridisch onderzoek op het vlak van de aansprakelijkheid voor schade veroorzaakt door catastroferisico's, c.q. kemongevallen. Paragraaf 3 van deze inleiding geeft toelichting bij de gehanteerde wetenschappelijke methode, Tenslotte wordt uitleg gegeven bij de structuur van dit bock $(\S 4)$.

\section{AFBAKENING VAN HET ONDERZOEKSDOMIEIN}

Het aanwenden van kemenergie schept meerdere risico's die schade kunnen veroorzaken en tot aansprakelijkhcid kunnen leiden, zodat dient te worden aangegeven wat wordt verstaan onder het begrip "nucleaire risico" ( $\$ 1.1)$. In tweede instantie wordt tocgelicht welke elementen al dan niet in het onderzoek worden betrokken $(\S 1.2)$.

\subsection{Het begrip "het nucleaire risico"}

Voor een goed begrip van het voorwerp van het gevoerde onderzoek, is het in de cerste plaats van belang dat duidelijkheid bestaat over de inhoud van het begrip "nucleair risico" ${ }^{4}$. Het gebruik van kernenergie creëert immers meerdere gevaren die niet los van elkaar kunnen worden gezien. Bovendien werd voor elk van deze gevaren een specifieke wetgeving in het leven geroepen zodat een afbakening van het begrip "nuclcair risico" het inzicht kan vergroten omtrent de manier waarop deze verschillende regels elkaar kunnen beïnvloeden.

Verhoeven, J., "Une réparation communautaire ou internationale des catastrophes? Conclusions", in La réparation des dommages catastrophiques: les risques technologiques majeurs en droit international et en droit communautaire, Travaux des XIlles Joumées d'études juridiques Jean Dabin, Bruxelles, Bruylant, 1990, 460.

2 Zie hierover met name Cousy, H., "Over de verzekering van het onverzekerbare", in Liber Amicorum Prof. Dr. Roger Blanpain, Die Keure, Brugge, 1998, 695 e.v.

3 Zeckhauser, R. "19th Annual lecture of the Geneva Association. Insurance and Catastrophes", The Geneva Papers on Risk and Insurance, vol. 21, $\mathrm{n}^{\circ} 78,1996,3$.

4 Het risico van kemongevallen wordt vaak aangegeven met de term "nucleaire risico"; zic bijvoorbeeld het boek Faure, M. (red.), Aansprakelijkheid voor het nucleaire risico, Maklu, Antwerpen Apeldoom, 1993, 236. 
Vanaf de eerste gecontroleerde kettingreactie werd onze samenleving geconfronteerd met twee grote titdagingen ${ }^{5}$ : ten eerste aan de verleiding te weerstaan om kernenergie aan te wenden voor oorlogsdoeleinden en ten tweede de uitdaging om kernenergie op een voor de mensheid verantwoorde, en vooral veilige manier te exploiteren. Veilig betekent zowel dat de bevolking dient te worden beschermd tegen de gevaren van ioniserende straling als dat kernongevallen dienen te worden vermeden. Grosso modo wordt het nucleaire risico in volgende aspecten onderverdeeld ${ }^{6}$ :

- Safety: heeft betrekking op de veiligheid van kemcentrales en transport en beoogt de bescherming van de bevolking tegen de gevaren voortkomend uit ioniserende straling;

- Safeguards: garandeert dat kemenergie voor vreedzame doeleinden wordt aangewend;

- Security: hiermee wordt bedoeld de bescherming van radioactief materiaal tegen terroristische en misdadige acties.

De grens tussen deze drie aspecten is soms mocilijk te trekken; er kan worden gesproken van een interactie tussen safety, security en safeguards. Wat deze verschillende termen inhouden, wordt hieronder weergegeven. Hierbij wordt bewust vastgehouden aan de Engelse terminologie aangezien in het Vederlands de temen "safety" en "security" worden vertaald door "veiligheid" terwijl, zoals uit de bespreking van de Engelse termen zal blijken, de inhoud van deze begrippen duidelijk verschilt.

\subsection{Proliferatie van kernwapens - safeguards en security}

Het gebruik van kernwapens in Hiroschima en Nagasaki had aangetoond tot welke verwoesting de militaire toepassing van kemenergie kon leiden. Vastberaden om de wereldvrede te promoten, stelde de Verenigde Naties zich als doel te vermijden dat ooit nog (kern)wapens zouden worden gebruikt $^{7}$. Met het oog hicrop werd in 1956 het Internationaal Atoomagentschap (International Atomic Energy Agenc'y of het IAEA) opgericht ${ }^{8}$. Dit Agentschap heeft als voomaamste doelstelling ervoor te zorgen dat kemenergie de vrede, de gezondheid en de welvaart in de hele wereld

Blix, H., "The dual challenge of a nuclear age", IAEA Bulletin, 1/1993, 33.

Vanden Borre. T. en Carchon, R., "Garantir la non-prolifération des armes nucléaires. 50 ans d’atomes pour la paix", Bulletin de Dröt Nucléaire, 1996, n57, 26 e.v. (eveneens verschenen in het Engels onder de titel: "Preventing the Proliferation of Nuclear Weapons: 50 years of Atoms for Peace", Nuclear Law Bulletin, 1996, $\mathrm{n}^{\circ} 57,23$ e.v.).

Het op 26 juni 1945 goedgekeurde Charter van de Verenigde Naties begint als volgt: "We, the people of the United Nations, determined to save succeeding generations from the scourge of war, which twice in our lifetime has brought untold sorrow to mankind...".

Zie hicrover o.m. McKnight, A., Atomic safeguards. A study in international verification, UNTAR, New York, 1971; Scheinman, L. The International Atomic Energy Agency and World Nuclear Order, Resources for the Future, 1987; Kooymans, P.H., "The peaceful application of nuclear power and the non-proliferation system", X., Proliferation and the safeguarding of the peaccful application of nuclear power, Koninklijk Instituut van Ingenieurs Kerntechniek, The Hague. Symposium, 8 december 1976; Rainaud, J.M., L'Agence Internationale de l'Energie Atomique, Colin, Paris, 1953, 21 e.v.; Fischer, G., "L'Agence Internationale de l'Energie Atomique", Annuaire Français de Droit International, 1956, 616 e.v.; Lamm, V., The Utilization of Nuclear Energy and International Law, Akadémiai Kiađó, Budapest 1984, 62 e.v. 
bevordert 9 . Het IAEA beschikt over de bevoegdheid om matregelen te nemen teneinde de verspreiding of proliferatie van kemwapens tegen te gaan ${ }^{10}$.

Een onderscheid wordt gemaakt tussen verticale en horizontale proliferatie. Horizontale proliferatie betekent een uitbreiding van het aantal landen dat over kernwapens beschikt. Er is sprake van een verticale proliferatie indien een land dat over kernwapens beschikt meer kemwapens produceert en/of wanneer deze kernwapens een grotere kracht hebben ". De verspreiding van kernwapens wordt tegengegaan, zowel door middel van de werkzaamheden van het Internationaal Atoomagentschap als door een aantal internationale Verdragen die op een bepaalde manier het militaire gebruik van kernwapens beperken.

Met het oog op het tegengaan van de - zowel horizontale als verticale - proliferatie van kernwapens, heeft het IAEA een safeguardssysteem ${ }^{12}$ ontwikkeld, waarbij inspecteurs van het Atoomagentschap ter plaatse controles uitvoeren in diverse nucleaire installaties. Met het oog op het uitvoeren van deze controles sluit het IAEA zgn. garantieakkoorden af met verschillende landen ${ }^{13}$ ${ }^{14}$. Meer in het algemeen wordt de term "garanties" gebruikt om de activiteit van het IAEA aan te duiden wannecr het agentschap zijn bevoegdheden uitoefent om te garanderen dat nucleaire installaties en nucleair miteriaal niet worden aangewend om kernwapens te produceren.

De betrachting om het militaire gebruik van kernenergie tegen te gaan, heeft zich eveneens geuit in de totstandkoming van meerdere internationale Verdragen die het gebruik van kernwapens hebben beperkt. Bedoeld worden met name de Verdragen betreffende de demilitarisatie van de res communis $^{15}$, betreffende de verspreiding van kernwapens ${ }^{16}$, betreffende nucleaire ontwapening ${ }^{17}$

Artikel 11 van het Statuut van het IAEA. Cfr. infra, in $\$ 1.2 .1$ van hoofdstuk 2.

Volgens artikel Il.A.5 heeft het agentschap onder meer als taak maatregelen uit te werken en toe te passen die garanderen dat splijtstoffen, diensten, uitrusting, installaties en inlichtingen die door het. agentschap zijn verstrekt, niet voor militaire doeleinden worden aangewend.

Er zijn vijf officiële kemwapenstaten: China, Frankrijk, het Verenigd Koninkrijk, de voormalige Sovjet-Unie en de Verenigde Staten. Krachtens artikel IX.3 van het non-proliferatieverdrag is een officielle kernwapenstaat: elk land dat voor 1 januari 1967 een kernwapen heeft geproduceerd of tot ontploffing heeft gebracht. Daarnaast zijn er đrie de facto kernwapenstaten, met name Israël, Indië en Pakistan. In het Frans wordt de term "système de garanties" gehanteerd.

13 Bovendien is in verschillende landen een bijkomend safeguards-systeem van toepassing. Zo worden krachtens artikel 81 Euratom inspecties uitgevoerd in de verschillende Euratom Lidstaten (zie hierover: Errera, J., Simon, E., Van der Meulen, J. en Vernaeve, L. Euratom. Analyse et Commentaires du Traité, Librairie Encyclopédique, Bruxelles, 1958 en Pirotte, O., Girerd, P., Marsal, P. en Morson, S., Trente ans d 'expérience Euratom. La naissance d'une Europe nucléaire, Bruxelles. Bruylant, 1988). Ook tussen Braziliê en Argentinie is een Verdrag van kracht dat bijkomende inspecties invoert. Het gaat om het Verdrag van 18 juli 1991 tussen Braziliê en Argentinie inzake het exclusief vreedzaam gebruik van kemenergie (INFCIRC/395, november I991). Het door dit Verdrag in het leven geroepen organisme, het ABACC (Agence Brasilo-Argentine de Comptabilité et de Contrôle đes matières nucléaires) heeft eveneens inspectiebevoegdheden. Zowel Euratom als het ABACC hebben overeenkomsteri met het LAEA afgesloten om de onderlinge controles op elkaar af te stemmen.

Per 31 december 1999 waren 224 safeguards akkoorden van kracht in 140 landen (IAEA, Wenen, Year Report 1999, 90; dit jaarrapport van het IAEA is beschikbaar op de website van het IAEA: http://www.iaea.org).

Het Antarticaverdrag van 1 december 1959, het Ruimteverdrag van 27 januari 1967, het Verdrag inzake het Marine milieu van 11 februari 1971 en het Maanverdrag van 18 december 1979.

Het non-proliferatieverdrag van 1 juli 1968, het Verdrag op het verbod van kemwapens in LatijnsAmerika (Verdrag van Tlatelolco) van 14 februari 1967, het Verdrag over de kernwapenvrije zone in de Stille Zuidzee (Verdrag van Rarotonga) van 6 augustus 1985, het Verdrag inzake de kernwapenvrije zone in Zuid-oost Azië van 15 december 1995 (Verdrag van Bangkok) en het Verdrag inzake de Afri- 
en betreffende het verbod op kemproeven ${ }^{18}{ }^{19}$. Een van de belangrijkste Verdragen in deze materie is het Non-Proliferatieverdrag van $1968^{20}$ dat midden 1999 door 187 Staten was ondertekend $^{21}$. Dankzij dit Verdrag bleef de horizontale proliferatic van kemwapens beperkt. Het bestrijden van de verticale proliferatie was minder succesvol hoewel, zowel omwille van economische als politieke redenen, sinds het begin van de jaren negentig ook op dat vlak vorderingen werden geboekt $^{22}$.

Een deelaspect van de safeguards betreft de zogenaamde fysieke bescherming van kernmateriaal $^{23}$, wat hierboven reeds werd aangegeven met de term "security". Hiermee wordt de bescherming van nucleair materiaal en van nucleaire installaties tegen acties van onbevoegde personen of groeperingen bedoeld ${ }^{24}$. De link met safeguards is duidelijk aangezien een van de doelstellingen hiervan precies is het voorkomen van verspreiden van kernwapens door terroristische acties of sabotage.

\subsection{Blootstelling aan radioactieve straling - safety}

Het hoofddoel van de veiligheid met betrekking tot het gebruik van kernenergie is de bescherming van de bevolking tegen radioactieve straling. Dit behelst zowel de veiligheid in nucleaire installaties ter preventie van een kernongeval, het veilig omgaan met en opbergen van radioactief afval, als het nemen van afdoende veiligheidsmaatregelen tijdens transport. Ook hier is in de praktijk de scheidingslijn tussen deze verschillende deelaspecten slechts moeilijk te trekken: indien bijvoorbeeld terroristen een kemwapen zouden ontvreemden en tot ontploffing zouden willen brengen, leidt dit zowel tot een probleem inzake security en safeguards als inzake safety.

kaanse kernwapenvrije zone van II april 1996 (Verdrag van Pelindaba). Informatie over en de tekst van deze Verdragen is terug te vinden op het internet en dan met name op de wcbsite van de OPANAL (http://www.opanal.org).

De Strategic Arms Limitation Talks die leidden tot SALT I in 1972 en tot SALT II in 1979; in de jaren tachtig werden de gesprekken hervat onder de benaming START (Strategic Arms Reduction Talks). Op 7 december 1987 bereikten de presidenten Reagan en Gorbachov een akkoord betreffende het INFVerdrag; tenslotte werden op 31 juli 1991 en op 3 januari 1993 de START I en START II Verdragen ondertekend.

De Partial Test Ban Treaty van 1963, de Treshold Test Ban Treaty van 1974, de Peaceful Nuclear Explosions Treaty van 1976 en tenslotte de Comprehensive Test Ban Treaty van 1996.

Voor meer details over deze Verdragen: zie The United Nations and Nuclear Non-Proliferation, United Nations Blue Books Series, New York, vol. 3, 1995.

Verdrag houdende niet verspreiding van kernwapens. Voor een analyse van het non-poliferatieverdrag zelf, zie o.m. Fischer, G., La non-prolifération des armes nucléaires, Paris, Pichon et Durand-Auzias, 1969, 225-240; Domsdorf, E.P.M.W., Internationaal Aloomenergierecht. De beirokkenheid van Nederland bij meer dan 100 verdragen, W.E.J. Tjecnk Willink, Zwolle, 1993, 895-1015; Scheinman, L., "The non-proliferation Treaty: on the road to 1995", LAEA Bulletin, november 1992, 33-40; Goldblatt, J., Twenty years of the non-proliferation Treaty. Implementation and Prospects, International Peace Research Institute, Oslo, 1990; Herron, L.W., "Le point de vue d'un juriste sur les garanties et la non-proliferation", AIEA Bulletin, 1982/3, vol. 24, 32-38. Bron: website van het IAEA op 28 november 2000 (http://www.iaea.org). Vanden Borre, $T$. en Carchon, R., "Garantir la non-prolifération des armes nucléaires. 50 ans d'atomes pour la paix", o.c., 53.

Van toepassing is hier het Verdrag betreffende de Fysieke Beveiliging van Kemmateriaal, ondertekend op 3 maart 1980 te New York. Belgie heeft dit Verdrag geratificeerd bij wet van 24 juli 1984; in Nederland werd het Verdrag goedgekeurd bij wet van 17 december 1987 (Sib., 1987, 640). Het Verdrag is in de Lidstaten van Euratom in werking vanaf 6 oktober 1991 (B.S., 27 februari 1992, 4117) (Domsdorf, E.P.M.W., "Intemationaal Atoomenergierecht", l.c., 1210). 
Het opstellen, afdwingen en controleren van veiligheidsmaatregelen komt in de eerste plaats toe aan de nationale autoriteiten. Nochtans bestaat ook de noodzaak om het nucleaire veiligheidsaspect internationaal te benaderen en te normeren. In dit kader wordt gesproken van een "international nuclear safety culture" ${ }^{\prime 25}$. Het stijgend belang van een dergelijke veiligheidscultuur vloeit rechtstreeks voort uit de ongevallen in Tsjernobyl en Three Mile Island. In de mate waarin de nucleaire veiligheidsregulering erin slaagt een kernongeval te voorkomen, is de hierop betrekking hebbende wetgeving van belang in het kader van dit onderzoek.

Indien in dit proefschrift wordt gesproken van "het nucleaire risico", wordt daarmee enkel de kans bedoeld dat zich een kemongeval voordoet. Er wordt geen aandacht besteed aan de hierboven aangehaalde aspecten safeguards en security. Het aspect "safety" zal in zekere mate aan bod komen omdat met name de regelgeving inzake de bescherming tegen ioniserende straling een invloed hecft op de preventie van kernongevallen en de mogelijke schade aan de omgeving.

In dit onderzoek wordt enkel stilgestaan bij schade voortvloeiend uit het vreedraam gebruik van kemencrgic, en dan met name bij schade veroorzaakt door keminstallaties die worden ingeschakeld bij de productie van elektriciteit. Schade door militair gebruik (hetzij via kernwapens, het $/$ ij via atoomproeven) en schade veroorzaakt door andere vreedzame tocpassingen van kernencrgic (zoals schade veroorzaakt door medische toepassingen ${ }^{26}$ ) worden als dusdanig niet aan de orde gesteld. Vandaar wordt in dit proefschrift de aandacht toegespitst op de aansprakelijkheid en verzekering voor schade veroorzaakt door commerciële elektriciteitsproducerende keminstallaties.

Andere juridische aspecten en gevaren van het gebruik van kernenergie zoals de berging van radioactief afval, de ontmanteling van keminstallaties en het transport van kemmateriaal komen in dit onderzoek niet aan bod.

\subsection{Verdere inhoudelijke afbakening}

Voor een goed begrip van dit proefschrift, dient te worden verduidelijkt wat wordt verstaan onder het begrip "schade", althans in het kader van het gevoerde onderzoek.

Onder schade wordt verstaan de aantasting die een exploitant van een keminstallatie veroorzaakt tengevolge van een kernongeval (schade aan goederen, personen en schade aan het milieu). Er wordt van uitgegaan dat deze aantasting in geld kan worden uitgedrukt - zelfs indien dit nadeel het overlijden van een persoon betreft of schade aan "het milieu" sensu lato (bijvoorbeeld de zee) - en dat de door een kernongeval veroorzaakte kosten zijn gekend ${ }^{27}$.

Blix, H., "The dual challenge of a nuclear age", o.c., 38; Gonzalez, A.J., "Towards an International Regime on Radiation and Nuclear Safety", LAEA Bulletin, 1998/2, 2-4; Barraclough, I. en Camino, A., "Safety Culture. Keys for Sustaining Progress", IAEA Bulletin, 1998/2, 27-30.

Zie bijvoorbeeld Vanden Borre, T., "Liability for medical isotopes used in radiotherapy", in Nuclear Inter Jura'95, AIDN/INLA Helsinki, 1995, 215-272; Deprimoz, J., "Risques liés à la production et aux utilisations industrielles et medicales des radioisotopes", in Le Droit Nucléaire: $d u$ XX a ${ }^{\circ}$ XXI siècle. Nuclear Inter Jura '97, AIDN/INLA, Tours, Société de Législation Comparée, Paris, 1997, 337-350. Het is een fictie te stellen dat door het betalen van een bepaalde som geld, het leed veroorzaakt door het overlijden van een persoon kan worden weggenomen. Maar deze fictie is inherent aan het (aansprakelijkheids-)recht en niet aan het kemenergierecht. Deze problematiek wordt in het kader van dit onderzoek niet aan de orde gesteld. 
In een Europese context wordt inderdaad gewerkt aan economische modellen die voorspellen en berekenen welke schade een kernongeval veroorzaakt ${ }^{28}{ }^{29}$. Hierbij wordt onder meer rekening gehouden met het type reactor, de weersomstandigheden en dergelijke meer. Aan deze modellen, die bij uitstek het onderzoeksterrein vormen van econometristen en ingenieurs, wordt in dit boek verder geen aandacht besteed.

Dit proefschrift is een juridisch onderzoek naar de civielrechtelijke aansprakelijkheid bij kemongevallen en naar de verzekering van dergelijke ongevallen. De strafrechtelijke aansprakelijkheid voor dergelijke ongevallen, wordt niet behandeld. De aandacht zal centraal worden gericht op de basisprincipes van de nucleaire aansprakelijkheidswetgeving, zoals ingevoerd door een aantal internationale Verdragen. Zoals zal blijken, worden deze principes ook gehanteerd in andere Verdragen, c.q. in andere takken van het civiele aansprakelijkheidsrecht. De conclusies met betrekking tot de analyse van de aansprakelijkheid voor schade door kemongevallen zullen met andere woorden ook ten dele gelden voor de aansprakelijkheid voor andere catastroferisico's.

Een aantal aan het civiele aansprakelijkheidsrecht verwante problemen worden in dit onderzoek niét behandeld. Met name de causaliteitsproblematiek, de invulling van het schadebegrip en de vorderingsrechten voor zuivere ecologische schade komen in dit onderzoek als dusdanig niet aan bod. Over deze problemen is reeds een aantal proefschriften verschenen ${ }^{30}$. Ter zake van causaliteit en de invulling van het schadebegrip werd ook recent nog bijkomend onderzoek verricht ${ }^{31}$. Aan de causaliteitsproblematiek en het begrip schade wordt in dit boek evenwel incidenteel aandacht besteed in de rechtseconomische analyse: onzekerheid met betrekking tot de causaliteit en de schade hebben namelijk een aanzienlijke invloed op de maatschappelijke kosten van een ongeval. Enkel in die context zullen deze problemen aan de orde worden gesteld.

Het onderzoek is evenwel niet beperkt tot de aansprakelijkheidsproblematick en compensatie van schade door kernongevalien. Zoals de titel van het boek aangeeft, wordt de aansprakelijkheid voor het nucleaire risico als voorbeeld genomen, maar heeft het onderzoek ook betrekking op andere zogenaamde catastroferisico's. Met name de aansprakelijkheid en compensatie van milieurampen en zware industriële ongevallen komen eveneens aan bod (dekking via de klassieke verzeke-

Zo werd in samenwerking met de Europese Commissie de COSYMA-code uitgebouwd. COSYMA is het acroniem voor Code System MARIA. MARIA is het acroniem voor "Methods for Assessing the Radiological Impact of Accidents". Zie hierover onder meer Govaerts, P. "Economische aspecten van emstige nucleaire ongevallen", in Faure, M. (red.), Aansprakelijkheid voor het nucleaire risico, Maklu, Antwerpen-Apeldoorm, 1993, 177-207; van Wonderen, E., van der Steen, J. en Haasemann, I., Nuclear Science and Technology. COSYMA: Users Intercomparison Exercise, European Commission, EUR 15108, 1994; Cosyma, A new Programme package for accident consequence assessment, European Commission, 1990; Prault, D. en Desaignes, B., "L'évaluation de l'impact économique des situations post-accidentelles: présentation et analyse du modele Cosyma", Rapport n²16, CEPN, juni 1993. Ook daarbuiten wordt gewerkt aan modellen die berekenen hoe groot de schade is die een gegeven activiteit tocbrengt aan het milieu. Zic bijvoorbeeld Pething, R. (ed.), Valuing the Environment Methodological and Measurement Issues, Kluwer Academic Publishers, Dordrecht, 1994. Akkermans, A.J., Proportionele aansprakelijkheid bij onzeker causaal verband. Een rechtsvergelijkend onderzoek naar wenselijkheid, grondslagen en afgrenzing van aansprakelijkheid a rato van veroorzakingswaarschijnlijkheid, Deventer, Tjeenk Willink, Zwolle, 1997; Van, A.J., Onzekerheid over daderschap en causaliteit, Gouda Quint, Amhem, 1995; Carette, A., Herstel van en vergoeding voor aantastingen aan niet-toegeëigende milieubestanddelen, Intersentia, Antwerpen, Groningen, 1997. Akkermans, A., Faure, M. en Hartlief, T., Proportionele Aansprakelijkheid, Boom Juridische Uitgevers, Den Haag, 2000; Kottenhagen-Edzes, P.A. (red.), Immateriële schade: tendensen en wensen, Intersentia, Antwerpen-Groningen, 2000. 
ringsınarkt, fondsvorming, captives, ...). Zonder op dit punt een exclusief overzicht te willen geven, wordt in dit boek aandacht besteed aan enkele actuele tendensen terzake.

Volledigheidshalve wordt erop gewezen dat in de loop van het onderzoek verschillende cijfers zullen worden gehanteerd, teneinde het in de verschillende landen beschikbare schadevergoedingsbedrag te kunnen vergelijken. Een dergelijke vergelijking ligt niet meteen voor de hand, in de eerste plaats door het feit dat de nucleaire aansprakelijkheidsverdragen zelf bedragen invoeren gebaseerd op de - dagelijks schommelende - bijzondere trekkingsrechten (BTR) van het Internationaal Muntfonds. In de tweede plaats moet ook rekening worden gehouden met de koersschommelingen tussen de verschillende munten. Om toch een adequate vergelijking van de bedragen mogelijk te maken, werd er in dit onderzoek voor gekozen om alle bedragen uit te drukken in euro, en om een vaste omrekeningskoers te hanteren voor de munten buiten de eurozone ${ }^{32}$.

De vraag rijst vervolgens in welke mate het zinvol is om deze problematiek op juridischwetenschappelijke wijze te benaderen.

\section{RELEVANTIE VAN HET ONDERZOEK}

Het is zinvol om onderzoek te verrichten naar de aansprakelijkheid, verzekering en compensatie van schade veroorzaakt door kernongevallen indien blijkt dat hetzij aan deze vorm van elektriciteitsopwekking, hetzij aan elektriciteitsopwekking in het algemeen, hetzij aan bepaalde bedrijfsactiviteiten buiten de sfeer van de energieopwekking, milieurisico's verbonden zijn die ecn aanzienlijke schade kunnen veroorzaken (maatschappelijke relevantie, $\S 2.1$ ) waarop noch het aansprakelijkheidsrecht, noch de traditionele verzekeringstechnieken een antwoord kunnen bieden (juridische relevantie, $\S 2.2$ ).

\subsection{Maatschappelijke relevantie}

Hieronder wordt eerst stilgestaan bij de oorzaak van de groeiende vraag naar energie en wordt een idee gegeven van de groeiende nood aan energie (\$2.1.1). Vervolgens wordt aan de orde gesteld welke risico's zijn verbonden aan de verschillende vormen van elektriciteitsopwekking (\$2.1.2). Zoals zal blijken uit paragraaf 2.1.3, liggen naast de milieufactoren ook andere, met name economische factoren aan de basis van de beslissing van een land met betrekking tot de keuze van het aanwenden van een gegeven vorm van elektriciteitsopwekking.

\subsubsection{Groeiende nood aan energie ${ }^{33}$}

De laatste 100 jaar is de wereldbevolking verdrievoudigd; nog steeds stijgt het bevolkingsaantal met 90 miljoen per jaar ${ }^{34}$. In dezelfde periode groeide de wereldeconomie met cen factor 20 , steeg de consumptie van fossiele brandstoffen met een factor 30 en nam de industriële productie toe

32 De verschillende omrekeningen zijn gebeurd op basis van de koersen op 2 augustus 2000: 1 SDR $=$ 1,431050 euro $=1,309550$ USD (bron: Website van het Intemationaal Monetair Fonds, www.imf.org) Zie over de elektriciteitsbehoeftes en de verschillende energiebronnen: X., "World electricity generation, nuclear power and oil markets", Special Report, IAEA Bulletin, 1/1990, 31-37. 
met een factor 50. De meeste van deze stijgingen deden zich bovendien voor gedurende de laatste veertig jaar, waarin de wereldbevolking meer dan verdubbelde ${ }^{35}$.

Deze groei - van zowel de bevolking, de productie als de consumptie - heeft zich zeer verspreid voorgedaan, zowel in tijd als in plaats. De bevolkingsgroei zette zich in de jaren negentig vooral door in de ontwikkelingslanden, terwijl de groei van productic en consumptic zich voordced in de geïndustrialiseerde landen. De ongelijke verdeling van de economische groei en de bevolkingsgroei blijkt uit het feit dat de geïndustrialiseerde landen, die slechts één vierde van de wereldbevolking vertegenwoordigen, ongeveer $80 \%$ van 's werelds grondstoffen verbruiken ${ }^{36}$. Ook in de nabije toekomst (gedurende de komende 20 tot 50 jaar) zal deze groeitendens zich doorzetten. Terwijl in 1995 de jaarlijkse economische output 20 triljoen dollar bedroeg, wordt verwacht dat dezc output in $2030 \mathrm{zal}$ tocnemen met een factor 3,5 tot 69 triljoen dollar ${ }^{37}$.

Door de steeds groeiende wereldbevolking stijgt de jaarlijkse vraag naar energie. Dit is vooreerst het geval in het Westen, dat zich reeds in de jaren vijftig op de productie van kemenergie heeft toegelegd. Voor heel wat landen betreft het echter een optie die slechts recent ${ }^{38}{ }^{39}$ - door de steeds groeiende vraag naar elektriciteit - ernstig in overweging werd of wordt genomen.

Vastgesteld dient te worden dat heel wat landen de stijgende vraag zullen dekken door de productie van kernenergie. Einde 2000 waren wereldwijd 433 reactoren in gebruik, en waren 37 reactoren in aanbouw ${ }^{40}$. De steeds stijgende vraag naar elektriciteit heeft er dan ook toe geleid dat niet alleen geïndustrialiseerde landen, maar ook (semi-)ontwikkelingslanden elektriciteit wensen te produceren door middel van kemenergie. Opvallend is vooral dat bepaalde van deze landen nochtans voldoende potentieel bezitten om een beroep te doen op alternatieve energievormen ${ }^{41}$ ter dekking van hun elektriciteitsbehoeftes. Uitgerekend in de landen waar de grootste bevolkingsexplosie te verwachten valt, zullen deze behoeftes nagenoeg even explosief stijgen.

Hocwel de landen van het Gemenebest van Onafhankelijke Staten (GOS) over reusachtige hoeveelheden olie, gas, en steenkool beschikken, opteert het overgrote deel van hen toch voor de productic van kernenergie om hun respectievelijke elektriciteitsbehoeftes te dekken ${ }^{42}$. Een even forse stijging van het energieverbruik valt eveneens te verwachten in Azië en in de landen van de Stille Occaan. In 1992 leverde kernenergie in die landen 12\% van de totale elektriciteitsproductie $^{43}$. Zeker wat Azië betreft dat $60 \%$ van de wereldbevolking huisvest, zal de vraag naar energie drastisch stijgen. Einde 1998 was $16 \%$ van de totale elektriciteitsproductie in de wereld van

Stanners, D. en Bourdeau, Ph., (ed.), "The Dobris Assessment", l.c., 12.

Ibidem.

Ibidem, 13.

Bijvoorbecld: de Republiek Tsjechië nam in 1985 een eerste kerninstallatie in gebruik; Brazilië deed dat in 1987; Mcxicu's eerste reactor was uperationeel in 1990; China nam twee reactoren in gebruik in 1993 en einde 1994 (bron: Nuclear News, september 1993). Naar de toekomst toe heeft China nog 7 reactoren gepland; de Tsjechische Republiek 2 reactoren; India en Rusland elk 3 reactoren (bron: IAEA Bulletin, vol. $42, \mathrm{n}^{\circ} 2,2000,62$ ).

Dit uit zich o.m. in het feit dat de sterkste stijging van het gebruik van kemenergie zich situeert in de periode 1980-1985 (bron: Les centrales nucléaires dans le monde, AEN, Paris, 1993). IAEA Rulletin, vol. $42, \mathrm{n}^{\circ} 2,2000,62$.

Bijvoorbceld via windturbines, stuwdammen e.d.m.

Zie hicrover o.m. Sumenov, B.A., Dastidar, P. en Bennett, L.L., "Electricity supply in Central and Eastem liuropean Countries: the role of nuclear energy", IAEA Bulletin, 1/1993, 4.

Fascy, J. en Molina, P., "Regional cooperation in Asia and the Pacific: energy, electricity, and nuclear power planning", IAEA Bullein, 4/1993, 10. 
nucleaire oorsprong; het aantal geproduceerde $\mathrm{KwH}$ door kemenergic bedroeg méér dan de totale elektriciteitsproductie (van eender welk oorsprong) veertig jaar eerder ${ }^{4.4}$.

Deze gegevens tonen duidelijk aan hoe actueel het in het Brundtland-rapport aan de orde gestelde spanningsveld tussen milieu en ontwikkeling is: enerzijds dient onze maatschappij te worden behoed voor een milieuramp en -vervuiling maar anderzijds leidt de te verwachten bevolkingsgroei tot steeds groeiende energie- en elektriciteitsbehoeftes ${ }^{45}$.

De steeds groeiende wereldbevolking zal in toenemende mate het milieu onder druk zetten en aldus de economische groei in de weg staan. Nochtans is de economische output in meerdere opzichten uiterst afhankelijk van het milieu. Ten eerste is het milieu de energiebron en primaire bron voor wat betreft de productie van verschillende goederen. Daarnaast vormt het milieu de plaats waar emissies plaatsvinden en waar het door productie en consumptie veroorzaakte afval wordt achtergelaten. En ten derde levert het milieu een aantal basisvoorwaarden voor menselijk en economisch leven (bijvoorbeeld een stabiel klimaat). De capaciteit van het milieu om energiebronnen te leveren en om emissies en afval te absorberen, is uiteraard beperkt. Een ecosysteem kan dus slechts een gelimiteerde impact verdragen, zonder hierbij definitieve schade op te lopen.

\subsubsection{De invloed van de energievoorziening op milieuvervuiling ${ }^{46}$}

Het is niet de bedoeling om in het kader van dit proefschrift uitgebreid aandacht te besteden aan de respectievelijke voor- en nadelen van verschillende soorten van energie-opwekking. Hieronder worden pro memorie kort enkele nadelen geschetst van het gebruik van fossiele brandstoffen en van kernenergie.

IAEA Press Release, $P R$ 1999/04, 29 april 1999.

De Brundlandt-commissie heeft duidelijk aangetoond dat er een verband bestaat tussen milieu-, economische en sociale factoren: "Until recently, the planet was a large world in which human activities and their effects were neatly compartmentalised within nations, within sectors (energy, agriculture, trade) and within broad areas of concem (environmental, ecunomic, social). These compartments have begun to dissolve. This applies in particular to the global 'crises' that have seized public concern, particularly over the last decade. These are not seperate crises: an environmental crisis, a development crisis, an cnergy crisis. They are all one." (Our Common Future, 1987, 4). De resultaten van de Brundtland Commissie werden later opgenomen in de verklaring van Rio (1992); zie o.m. Deketelaerc, K., "Het juridisch kader inzake duurzame ontwikkeling in Belgiè", in Faure, M. en Deketclaer, K., (red.), lus Commune en Milieurecht. Actualia in het Milieurecht in België en Nederland, Intersentia, Antwerpen-Groningen, 1997, 94 e.v.; Sands, Ph., Principles of Intemational Environmental l.aw. Manchester University Press, 1995, 45 e.v.; Tonnaer, F.C., Handboek van het Nederlands Milieurecht, Lemma, Utrecht, 1994, 74

Aangaande deze problematiek wordt heel wat wetenschappelijk onderzoek verricht, teneinde over betrouwbare en objectieve gegevens te beschikken over de milieu-impact van het aanwenden van verschillende energiebronnen. Het hoger vermelde Europe's Environment. The Dobris Assessment (zic voetnoot 22) bevat uiterst waardevolle gegevens terzake. Het betreft een rapport dat werd samengesteld door de European Environment Task Force (EC DG XI en Phare), in samenwerking met heel wat internationale organisaties, onder meer de Wereldgezondheidsorganisatie (WHO) en de UN Environment Programme (UNEP). Een ander initiatief is het DECADES project (evencens in samenwerking met meerdere internationale organisaties waaronder het IAEA, de UNEP en de BIRD) dat als doel heeft een computermodel op te stellen dat technische, economische, ecologische en sanitaire aspecten incorporeert. Dit model moet de gebruiker in de mogelijkheid stellen de beslissing inzake de elektriciteitsproductie te nemen op basis van correcte en volledige gegevens. Zie Bertel; E., "Electricité, santé et environnement: le projet DECADES", AIEA Bulletin, 2/1995, 2-6. 


\subsubsection{Problemen bij het aanwenden van fossiele brandstoffen}

De aanwending van fossiele brandstoffen creëert in verschillende productiestadia ${ }^{47}$ milieuproblemen ${ }^{48}$. Bij het verbranden van fossiele brandstoffen komen naast kooldioxide of koolzuurgas $\left(\mathrm{CO}_{2}\right)$, zwaveldioxide $\left(\mathrm{SO}_{2}\right)$ en stikstofoxide $\left(\mathrm{NO}_{\mathrm{x}}\right)$ ook zware metalen en radionucliden vrij. Koolzuurgas draagt bij tot het broeikaseffect, terwijl zwaveldioxide en stikstofoxide zure regen veroorzaken ${ }^{49}$. Het verbruik van fossiele brandstoffen is de grootste oorzaak van menselijke atmosferische emissies van zwaveldioxide en stikstofoxide. In 20 Europese landen werd 95\% van de $\mathrm{SO}_{2}$-uitstoot en $97 \%$ van de $\mathrm{NO}_{\mathrm{x}}$-uitstoot veroorzaakt door de verbranding van fossicle brandstoffen $^{\text {so. }}$. Vaste fossiele brandstof (steenkool en hout) is de grootste vervuiler; gas is de kleinste vervuiler en bij olie vormen de potentiële ongevallen bij transport het grootste probleem ${ }^{51}$. De landen van centraal en Oost-Europa vormen de regio waar het grootste aandeel fossiele brandstof gebruikt wordt $t^{52}$; Japan, China en India zijn de grootste $\mathrm{CO}_{2}$-vervuilers ter wereld ${ }^{53}$.

Gezien deze stijging der elektriciteitsbehoeftes, kan worden verwacht dat de doorgedreven aanwending van fossiele brandstoffen een aanzienlijke stijging van de $\mathrm{CO}_{2}, \mathrm{SO}_{2}$ en $\mathrm{NO}_{\mathrm{x}}$-uitstoot zal teweegbrengen ${ }^{54}$. Indien het Westen zich bijvoorbeeld beperkt tot het aanwenden van aardolie, wordt het voor zijn oliebevoorrading meer en meer afhankelijk van het Midden-Oosten. Studies hebben uitgewezen dat met het huidige potentieel aan kerncentrales, en de blijvende stijging van de energiebehoeftes, het Westen in het jaar 2005 voor maar liefst de helft van zijn bevoorrading afhankelijk zal zijn van import uit het - politiek onstabiele - Midden-Oosten ${ }^{55}$.

Het aanwenden van fossiele brandstof vervuilt bijgevolg voomamelijk de atmosfeer, hetgeen leidt tot zure regen en bijdraagt tot het broeikaseffect. Atmosferische vervuiling is een graduele vervuiling: dc hoeveelheid schadelijke gassen zwelt gestaag aan en brengt langzaam maar zeker het milicu emstige schade toe. Daarenboven kan ook de productie van elektriciteit op basis van fossicle brandstoffen leiden tot zware ongevallen, c.q. milieurampen (Amoco Cadiz, Exxon Valdez, Erika, ...).

Het Verdrag inzake klimaatsverandering getuigt van de internationale wil om de uitstoot van de broeikasgassen te beperken ${ }^{56}$; deze wil kreeg in hoofdzaak vorm in het Kyoto Protocol van

Zowel het aanleggen van een mijn, het ontginnen ervan, het verwerken tot bruikbare grondstof, het verbranden en de berging van afval leiden tot aantasting van het milieu.

Door middel van de zgn. Life Cycle Analysis kan de gehele impact van het aanwenden van i.c. een fossiele brandstof worden nagegaan, dit wil zeggen vanaf het ontginnen van die brandstof tot en met de berging ervan als afval ("assessment from cradle to grave").

Stanners, D. en Bourdeau, Ph., (ed.), "The Dobris Assessment", l.c., 400.

Ibidem, 401.

De zwaarste ongevallen die in de laatste tien jaar het maritieme milieu aantastten, waren ongevallen met olietankers (ibidem, 403).

Semenov, B.A., Dastidar, P. en Bennett, L.L., "Electricity supply in Central and Eastern European Countries: the role of nuclear energy", o.c., 3 .

Zie Hu, C. en Woite, G., "Nuclear power development in Asia", IAEA Bulletin, 4/1993, 4.

Iansiti, E. en Nichaus, F., "Impact of energy production on atmospheric concentration of greenhouse gases", IAEA Bulletin, 2/1989, 12 e.v. 
$1997^{57}$. De discussie met betrekking tot de bijdrage van energiebronnen tot het broeikaseffect stond overigens hoog op de agenda van de Klimaatconferentie te Den Haag in november $2000^{58}$.

\subsubsection{Problemen bij het aanwenden van kernenergie}

Naast de door het gebruik van fossiele brandstoffen veroorzaakte vervuiling, kan worden nagegaan wat de vervuiling is, veroorzaakt door de civiele nucleaire industrie.

Een rapport van de United Nations Scientific Committee on the Effects of Atomic Radiation (UNSCEAR) stelt dat de gewone bedrijvigheid van alle keminstallaties samen, niet of nauwelijks bijdraagt tot de globale blootstelling aan radioactieve straling ${ }^{59}$. Deze hele nucleaire bedrijvigheid is verantwoordelijk voor eenzelfde dosis straling als de blootstelling gedurende enkele dagen aan natuurlijke stralingsbronnen ${ }^{60}$.

Volgens de UNSCEAR is vooral het militair gebruik van kernenergie verantwoordelijk voor de grootste stralingsdosis veroorzaakt door menselijke activiteiten. De door de UNO uitgevoerde studie toont aan dat er een duidelijk verschil is tussen de gevolgen van vreedzaam en van militair gebruik van kernenergie.

Radioactiviteit wordt enkel met de nucleaire industrie geassocieerd. Nochtans is radioactiviteit even oud als ons heelal: "alle materie" werd gecreëerd door een combinatie van kemreacties en radioactiviteit ${ }^{61}$. Vandaar dat van de meer dan 5000 bekende verschillende atomen, er $95 \%$ radioactief zijn ${ }^{62}$. Nagenoeg elk element en elke omgeving op onze planeet zijn zowel radioactief als van nature uit blootgesteld aan radioactieve straling. De radioactieve uitstoot van de vreedzame nucleaire industrie is volgens wetenschappers te verwaarlozen in verhouding tot de natuurlijke uitstoot en de uitstoot van conventionele industrieën ${ }^{63}$.

Het vervuilingsprobleem met betrekking tot kemenergie stelt zich op twee gebieden: het risico dat een kemongeval zich voordoet en het probleem van het nucleair afval. Hoe veilig de kemcentrales in het Westen ook worden geacht, toch moet rekening worden gehouden met het feit dat cen kernongeval zich eveneens in het Westen kan voordoen en dat de gevolgen van een ernstig kernongeval in het Oosten ook in het Westen zware schade kan veroorzaken. Tsjernobyl heeft ge-

Zie hierover o.m. Rogner, H.-H., "Kyoto's flexible mechanisms and nuclear power. Rethinking the options", LAEA Bulletin, vol. 42, $\mathrm{n}^{\circ} 2,2000,25-30$; Spadaro, J.V., Langlois, L. en Hamilton, B., "Greenhouse gas emissions of electricity gencration chains. Assessing the Difference, IAEA Bulletin, vol. 42, $n^{\circ}$ 2, 2000, 19-24; Kagramanian, V., Kononov, S. en Rogner, H.-H., "Climate Change driving forces. Nuclear energy and the latest IPCC emission scenarios", IAEA Bulletin, vol. 42, $n^{\circ} 2,2000,31$ 35.

58 Zie hierover 0.m. X., "Inside the Greenhouse Debate. Energy Issues set to Rise on Global Warming Agenda", LAEA Bulletin, vol. $n^{\circ} 4,2000,2-5$; Vanheusden, B., "Het federale plan inzake duurzame ontwikkeling: de impact op het Belgisch bedrijfsleven via productnormen, verhandelbare emissierechten en milieuheffingen", in Deketelaere, K. en Deketelaere, M. (ed.), Jaarboek Milieurecht 2000, Brugge, Die Keure, 2001, 221-222. González, A.J., "Global levels of radiation exposure: latest international findings", IAEA Bulletin, 4/1993, 49 .

6. Ibidem.

ol Zie hierover bijvoorbeełd: Flakus, F.N., "Les rayonnement sous leur vrai jour: les risques doivent être mieux compris", AIEA Bulletin, 2/1995, 7-13.

62 Baxter, M.S., "Environmental radioactivity: a perspective on industrial contributions", IAEA Bulletin, 2/1993, 33.

63 González, A.J., "Global levels of radiation exposure: latest international findings", o.c., 49. 
noegzaam aangetoond wat de gevolgen kunnen zijn van een radioactieve omgevingsbesmetting. In ieder geval zijn storingen in een keminstallatie niet uit te sluiten: in 1999 werden aan het IAEA 14 incidenten, 3 ernstige incidenten en één ongeval gemeld (Tokaimura) ${ }^{64}$.

Inzake afval kunnen vooral de gevaren en problemen verbonden aan de berging van hoogradioactief afval ${ }^{65}$ ernstige problemen opleveren voor mens en milieu. Het gebruik van kernenergie kan bijgevolg zowel een graduele als een accidentele schade veroorzaken ${ }^{66}$.

\subsubsection{Rol van economische factoren}

Nochtans bepalen niet enkel deze milieufactoren de keuze van een land voor een bepaalde (combinatie van) energiebron(nen) teneinde de toenemende vraag naar energie te kunnen dekken.

De hoofdreden waarom heel wat landen de nucleaire optie kiezen, lijkt vooral te maken te hebben met het feit dat met uiterst weinig uranium aanzienlijke hoeveelheden energie kunnen worden opgewekt. Traditioncel wordt kemenergic, met name in de nucleaire sector zelf, beschouwd als een goedkope vorm van energieopwekking ${ }^{67}$.

Ook andere factoren zoals de beschikbuarheid en de kostprijs van de brandstoffen evenals de financieringsmogelijkheden en de politicke situatie zijn van doorslaggevende betekenis ${ }^{\text {is }}$. De meeste landen kiezen voor een combinatie van verschillende bronnen om al te bruuske verandcringen in vraag en aanbod op te vangen. Elektriciteitsproducenten trachten immers een regelmatige bevoonading te garanderen tegen een stabiele prijs. Een diversificatie van encrgicbronnen strekt ertue het aanbod te handhaven en de elektriciteitsprijs te stabiliseren. Ook economische en strategische factoren spelen een duidelijke rol bij de keuze om voor het dekken van de elkktriciteitsbehoeftes op een bepaalde encrgiebron een beroep te doen ${ }^{69}$.

Concluderend kan worden gesteld dat door de te verwachten toename van de wereldbevolking de vraag naar energie zal toenemen. Hoewel op nationaal en internationaal niveau aanzienlijke inspanningen worden geleverd ter bevordering van energie-efficiëntie, zal de vraag naar energie blijven stijgen. Een aantal landen doet hiervoor in mindere of meerdere mate een beroep op kernenergie. Het is niet de opzet noch de ambitie van dit proefschrift om te oordelen in hoeverre de keuze voor kemenergie een correcte en/of verantwoorde keuze is. De nucleaire industrie zal nog een rol van betekenis blijven spelen in onze moderne maatschappij omdat einde 2000 wereldwijd

Annual Report 1999, LAEA, Wenen, 116. De begrippen "incident", "ernstige incident" en "ongeval", zijn opgebouwd volgens een Nuclear event scale van het IAEA.

Voomamelijk het bergen van de spent fuel (gebruikte brandstofelementen) en, na het verstrijken van de levensduur van de reactor, het afval dat voortkomt uit de ontmanteling van de primaire kring van de reactor. Voor een vrij pessimistische benadering van het nucleaire risico, zie o.m. Zwartboek aver het Nucleaire Tijdperk, Greenpeace, 1990, 379.

Zie bijvoorbeeld Jones, P.M.S. en Woite, G, "Cost of nuclear and conventional baseload electricity generation", IAEA Bulletin, 3/1990, 18 e.v.; Rogner, H.-H., "Economic competitiveness of nuclear power. Moving Targets", IAEA Bulletin, vol. 42, $n^{\circ} 2,2000,36-42$. Davies, L.M., et Boothroyd, A.D., "L'énergie nucléaire: option toujours valable", AIEA Bulletin, 2/1995, 14 .

Zic met name voor wat Europa betreft: "Groenboek: op weg naar een Europese strategie voor een continue energievoorziening", Com (2000) 769 final, 29 november 2000; X., The Security of Energy Supply. The European Commission's Green Paper Stimulates Debate", IAEA Bulletin, vol. 42, $\mathrm{n}^{\circ} 4$, $2000,6-8$. 
nog 438 centrales operationeel waren en er nog 31 kerncentrales in aanbouw waren ${ }^{70}$. Dit betekent dat tenminste tot 2050 kerncentrales operationeel zullen zijn - en dit in de veronderstelling dat in de tussentijd geen nieuwe kemcentrales meer worden gebouwd. Na de uitbating van deze kerninstallaties, dienen zij te worden ontmanteld, waama delen daarvan als hoogradioactief afval dienen te worden opgeborgen. Het risico dat zich een kemongeval voordoet zal dus nog geruime tijd bestaan.

De kans op aanzienlijke (milieu)schade bestaat ook bij het aanwenden van een andere energiebron: de verschillende bestaande vormen van energieopwekking hebben elk een aanzienlijke impact op het milieu ${ }^{71}$. Tenzij massaal andere, alternatieve energiebronnen zullen worden aangewend, zal de groeiende vraag naar elektriciteit het milieu blijven belasten, en dit ongeacht of een land hoofdzakelijk kemenergie dan wel petroleum zal aanwenden. Elke keuze die een land maakt, zal bijgevolg potentieel tot een milieuschade kunnen leiden ${ }^{72}$.

Abstractie makend van de schade die specifiek door kernongevallen wordt veroorzaakt, en onafhankelijk van de gevolgen van de groeiende wereldbevolking en de daaraan gckoppelde nood aan energie, zullen ook verschillende industrieên gevaarlijke activiteiten (blijven) ontwikkelen bijvoorbeeld de chemische industrie - waarbij eveneens een potentieel aanzienlijke schade kan worden veroorzaakt (Bhopal, Seveso, ...) ${ }^{73}$. Het is dan ook zinvol om niet enkel aandacht te besteden aan de preventie en compensatie van schade door kernongevallen, maar eveneens aan de preventie en compensatic van schade door analoge catastroferisico's. De bevindingen van dit proefschrift zullen dus ook relevant zijn buiten de problematiek van de aansprakelijkheid voor het nuclcaire risico.

\subsection{Juridische relevantie}

Het uitgangspunt van de juridische analyse van dit onderzoek is de vaststelling dat de kans dat een kcrnongeval plaatsheeft waarbij aanzienlijke schade wordt veroorzaakt, niet kan worden uitgesloten. De resultaten van het gevoerde onderzoek zullen toelaten de wijzigingen te evalueren die het internationale kemenergierecht heeft ondergaan in de 15 jaar na het ongeval in Tsjernobyl.

In de periode 1986-1997 kende het internationale kemenergierecht inderdaad een aanzienlijke evolutie. Deze evolutie schijnt erop te wijzen dat het internationale kemenergierecht door het ongeval te Tsjernobyl zwaar werd op de proef gesteld ${ }^{74}$ en dat het ongeval de redactie en het ondertekenen van nieuwe internationale afspraken in een stroomversnelling bracht. De belangrijkste wijzigingen waren de adoptie van nieuwe Conventies inzake vroegtijdige kennisgeving en

7. Press Release 2001/7, "Nuclear Power Statistics for 2000", LAEA, Wenen.

1 Ook het Brundtland-rapport stelde met zoveel woorden dat zowel het gebruik van hemieuwbare als van niet-hermieuwbare brandstoffen kan leiden tot milieuproblemen (Gedrukte Stukken, Kamer, 1996-1997, nr. 834/1, 2).

Over deze keuze, zie bijvoorbeeld Bertel, E. en Van de Vate, J., "Nuclear energy and the environmental debate: the context of choices", IAEA Bulletin, 4/1995, 2 e.v.

Over de mogelijke kosten van industrièle ongevallen, zie met name Smets, $H$., "Le coût des pollutions accidentelles", in La réparation des dommages catastrophiques. Les risques technologiques majeurs en droit international et en droit communautaire, Travaux des XIIlles Joumées d'études juridiques Jean Dabin, Bruxelles, Bruylant, 1990, 23-46.

Het ongeval creěerde inderdaad de indruk dat de bestaande mechanismen niet of onvoldoende hadden gefunctioneerd. Zie o.m. Cameron, P.D., "Legislative consequences of the Chernobyl Accident", $\mathrm{Nu}$ clear Inter Jura '87, INLA, Antwerpen, 20-24 September 1987, C.2; Strohl, P. "Chemobyl et le problème des obligations internationales relatives aux accidents nucléaires", Revue de Politique Etrangère, $1987, \mathrm{n}^{\circ} 4$. 
het verlenen van assistentie bij kernongevallen ${ }^{75}$; de koppeling van het werkingsveld van de twee nucleaire aansprakelijkheidsverdragen in $1988^{i 6}$; de ondertekening van de Nuclear Safety Convention ${ }^{77}$ in 1994. Van groot belang in het kader van dit proefschrift zijn uiteraard de twee nieuwe nucleaire dansprakelijkheidsverdragen die op 12 septcmber 1997 werden opengesteld ter ondertekening: het Verdrag inzake Bijkomende Fondsvorming en het Protocol aan het Verdrag van Wenen. Deze wijzigingen doen het vermoeden rijzen dat de wetgeving vóór het ongeval in Tsjernobyl een aantal tekortkomingen vertoonde. De vraag rijst uiteraard hoe ingrijpend deze wijzigingen zijn en of het huidige systeem van aansprakelijkheid en verzekering er op afdoende wijze in slaagt alle uit een kemongeval veroorzaakte schade te vergoeden.

In de tweede plaats is het interessant om de aansprakelijkheid en verzekering van het nuclcaire risico juridisch te benaderen omwille van de complexiteit van de problematiek, met name door de wisselwerking tussen beperkte aansprakelijkheid, verplichte verzekering, beperkte beschikbaarheid van verzekeringsdekking op de markt, de organisatie van de nucleaire verzekeringspools en de invloed van veiligheidsregulering. Hoewel een aantal problemen die in dit proefschrift aan de orde worden gesteld reeds in mindere of meerdere mate het voorwerp hebben uitgemaakt van een juridische analyse, menen wij dat de combinatie van deze problemen nog niet op juridisch wetenschappelijke wijze werd bestudeerd. Dit is meteen een van de redenen waarom werd geopteerd voor de rechtseconomie als onderzoeksmethode: dankzij de economische analyse van het kernongevallenrecht wordt de problematiek op multidisciplinaire wijze benaderd. Wanneer activiteiten of inrichtingen een zware schade veroorzaken, leidt dit tot een ingewikkeld aansprakelijkheidsvraagstuk waarbij niet enkel het aansprakelijkheidsrecht, maar ook het procesrecht, milieurecht en verzekeringsrecht aan de orde zijn. Door de techniciteit van bijvoorbeeld productieprocédés zal de jurist dienen te worden bijgestaan door specialisten, bijvoorbeeld voor het begroten van de schade of het vaststellen van de medische causaliteit. Deze vaststelling geldt overigens ook voor andere zogenaamde "catastroferisico's".

De complexiteit van grote schadegevallen roept inderdaad een aantal interessante juridische problemen op waarvan de oplossing niet meteen voor de hand ligt. Massaschade veroorzaakt schade aan honderden of duizenden slachtoffers en dit terwijl slechts beperkte bedragen beschikbaar zijn; massaschade kan zijn veroorzaakt door verschillende daders, zodat het voor een slachtoffer moeilijk wordt om uit te maken wie nu precies aansprakelijk is voor de door hem geleden schade; bij grensoverschrijdende schade is het voor een "buitenlands" slachtoffer vaak niet evident te procederen in een vreemd land; de grootte van de schade uit een emstig ongeval kan het vermogen van de veroorzaker of dat van diens verzekeraar te boven gaan, waardoor de schade die niet wordt vergoed ten laste valt van de gemeenschap of van het slachtoffer; ...

Volgens sommige auteurs is het aansprakelijkheidsrecht traag en duur en bevat het vele valkuilen. De vraag rijst of dit inderdaad zo is, en in welke mate andere mechanismen beter in staat zijn om aan deze vermeende tekortkomingen tegemoet te komen.

Verdragen van Wenen van 26 september 1986 inzake vroegtijdige kennisgeving van een kernongeva! en inzake het verlenen van dringende assistentie bij kernongeval. Reeds vóór het ongeval te Tsjemobyl had het LAEA hierover een aantal aanbevelingen opgesteld; door Tsjemobyl was plots de politieke wil aanwezig deze aanbevelingen om te zetten in juridische verplichtingen. Gemeenschappelijk Protocol van 21 september 1988 met betrekking tot de toepassing van het Verdrag van Wenen en het Verdrag van Parijs (voor een bespreking: cfr. infra, in hoofdstuk 2). Cavalcanti en O. Jankowitsch op het Nuclear Inter Jura '95, "Nuclear Law as a Source of Confidence", Helsinki, 3-7 September 1995. 
Een aantal van de hierboven kort aangehaalde problemen laat zich zeer sterk voelen bij de aansprakelijkheid voor schade uit kemongevallen. Zeker in het nucleaire aansprakelijkheidsrecht rijst de vraag naar de invloed van verzekeringen en andere collectieve compensatiemechanismen op de individuele verantwoordelijkheid van al diegenen die een invloed hebben op het ongevallenrisico.

Los van de problematiek van de nucleaire elektriciteitsopwekking, kan het onderwerp van dit proefschrift evenzeer worden toegepast op alle maatschappelijke activiteiten waarbij ernstige schade kan worden veroorzaakt. Vandaar raakt het gekozen onderwerp van dit proefschrift een uitermate actueel thema aan en zullen de resultaten ervan in principe ook kunnen worden toegepast bij schade veroorzaakt door andere catastroferisico's.

In de volgende paragraaf wordt de gehanteerde onderzoeksmethode besproken en vervolgens wordt de structuur van het onderzoek toegelicht $(\S 4)$.

\section{GEHANTEERDE ONDERZOEKSMETHODE}

De resultaten van dit onderzoek zijn het resultaat van een rechtseconomisch onderzoek enerzijds (§ 3.1) en van een internationaal en rechtsvergelijkend onderzoek anderzijds ( $\$ 3.2$ ). De reden waarom voor deze methodes werd gekozen, wordt hieronder uiteengezet.

\subsection{Rechtseconomie}

De keuze voor de rechtseconomie als onderzoeksmethode is vrij voor de hand liggend, gelet op de verwantschap tussen economie en recht. Hieronder wordt zowel deze verwantschap besproken (\$3.1.1) als de evolutie die de rechtseconomie heeft ondergaan (\$3.1.2). Aangezien in dit proefschrift de civielrechtelijke aansprakelijkheid cen centrale plaats inneemt, zal ook worden aangegeven hoc in de rechtseconomie het aansprakelijkheidsvraagstuk op een bijzondere wijze wordt benaderd $(\$ 3.1 .3)$. Uit deze elementen zullen de voordelen blijken van de cconomische analyse van het recht ( $\$ 3.1 .4$ ). Het is trouwens niet de bedoeling om in dit proefschrift uitgebreid de kritiek op de rechtseconomie te weerleggen omdat dit ons te ver zou afleiden van het docl van het gevoerde onderzoek.

\subsubsection{Verwantschap tussen economie en recht}

In dit onderzoek neemt de economische analyse van het recht een bijzondere positie in. Uitgangspunt hierbij is de verwantschap die bestaat tussen economie en recht: beiden zijn sociale wetenschappen die verband houden met menselijke gedragingen. Terwijl de economie bestudeert hoe in een gegeven maatschappij een optimale verdeling van schaarse middelen kan worden bercikt ${ }^{78}$, beoogt het recht een ordening te bewerkstelligen tussen de conflicterende belangen van diverse individuen ${ }^{79}$. Zowel het recht als de cconomie hebben dus betrekking op menselijke keuzes, elk bekeken vanuit een verschillende invalshoek. Terwijl de economie beoordeelt hoe een keuze kan worden gemaakt tussen - per definitie - schaarse middelen, stuurt het recht evenzeer menselijke keuzes, maar dan bijvoorbeeld vanuit rechtvaardigheids- of billijkheidsoogpunt. Doordat het recht bijvoorbeeld een snelheidsbeperking oplegt, heeft het een invloed op menselijke keuzes: degene die de beperking overtreedt, weet dat hij zich blootstelt aan mogelijke sancties. Degene die geen sanctie wenst op te lopen, zal zich derhalve aan de snelheidsbeperking houden, ook al zou hij

Vandewalle, G. en Van den Broeck, J., Algemene Economie, Kluwer, Antwerpen/Brussel, 1987, I e.v. Pitlo, A., Gerver, P. e.a., Het Systeem van het Nederlandse privaatrecht, Tweede druk, Gouda Quint, Amhem, 1990, l e.v. 
misschien liever wat harder rijden. Aldus tracht het recht prikkels te geven aan de verschillende rechtssubjecten.

De rechtseconomic vertrekt van de economie als gedragswetenschap, en "beoogt rechtsregels en rechtsinstellingen vanuit het mensbeeld van de economist en met diens gereedschap te beschrijven en te verklaren" ${ }^{80}$. Op basis van begrippen die traditioneel in de micro-economie thuishoren, verklaart en evalueert de rechtseconoom het recht ${ }^{81}$. De rechtseconomie onderscheidt zich als een wetenschappelijke discipline doordat zij de gegeven rechtsregel evalueert en aan de hand van economische begrippen bestudeert of de regel het gewenste effect ressorteert. Al naargelang van het voorwerp van de analyse van de rechtseconoom, wordt een onderscheid gemaakt tussen "oude" en "nieuwe" rechtseconomie.

\subsubsection{Verschil tussen "Old" en "New" Law and Economics}

Het economische begrippenapparaat wordt gehanteerd in materies waar een menselijk handelen zich afspeelt buiten een "markt" senso stricto ${ }^{82}$, hetgeen vanuit een klassieke juridische benadering vaak niet evident is.

Dat het niet gebruikelijk is om economische beginselen toe te passen op de meest diverse rechtstakken, blijkt uit het feit dat de econoom en de jurist een verschillend uitgangspunt hanteren bij hun analyse. Een rechtseconoom zal ex ante de gevolgen van een rechtsrcgel onderzoeken; hij zal als het ware een prognose kunnen maken over de effecten van rechtsregel ${ }^{8.3}$. Een jurist zal daarentegen ex post denken: hoe dient een rechtsregel in een gegeven situatie te worden toegepast?

Bij de interpretatie van een juridisch concept of begrip, zal een jurist een beroep doen op voorhanden zijnde wettelijke bepalingen en, bij afwezigheid daarvan, op empirische gegevens. Hij zal nagaan of zich in het verleden reeds analoge problemen hebben voorgedaan en zo ja, of de oplossing daarvan enige houvast kan bieden voor het voorliggende interpretatieprobleem. Economen daarentegen baseren zich op wiskundige modellen en theorieën die een verklaring bieden voor bepaalde gedragingen; vervolgens worden gegevens uit de praktijk toegevoegd om na te gaan of deze modellen in staat zijn het gedrag te verklaren en te voorspellen. Precies de afwczighcid van kwantificeerbare gegevens in het recht heeft geleid tot de toenemende belangstelling in het recht vanwege een aantal economen ${ }^{84}$. Op basis van economische concepten als welvaartmaximalisatie en efficiëntie, helpt de rechtseconomie bij het objectiveren en invullen van vage juridische begrippen als rechtvaardigheid, redelijkheid en billijkheid.

In dit boek vormt het aansprakelijkheidsrecht het voorwerp van een economische analyse; indien de term "rechtseconomie" wordt gehanteerd, wordt hiermee de nieuwe rechtseconomische analyse bedoeld. Dit impliceert meteen dat in dit onderzoek geen aandacht wordt besteed aan economische criteria op basis waarvan de schade van een (kem)ongeval kan worden berekend. Er wordt in

Mackaay, E., "Het recht bezien door de bril van een economist. Een gestyleerd overzicht van de rechtseconomie", Rechisgeleerd Magazijn Themis, $n^{\circ}$ 9, november 1988, 412. Van den Bergh, R., "Wat is rechtseconomie?", Hondius, E.H., Schippers, J.J. en Siegers, J.J., Rechiseconomie en Recht. Een kennismaking met een rechtsgebied in opkomst, W.E.J. Tjeenk Willink, Zwolle, 1991, 10-11. Van den Bergh, R. en Heremans, D., "Recht en Economie", Tijdschrift voor Economie en Management, 1987, 139-164. Cooter, R. en Ulen, T., Law and Economics, Scott, Foresman and Company, Illinois, 1988, 9. 
dit onderzoek uitgegaan van de veronderstelling dat de grootte van de schade is gekend en dus reeds is berekend.

\subsubsection{Bijzondere benadering in het aansprakelijkheidsrecht}

Net zoals bij de rechtseconomische benadering in het algemeen, valt ook in de economische analyse van het ongevallenrecht de verschillende benadering op van de rechtseconoom en de klassicke jurist.

Vanuit een klassieke invalshoek wordt gesteld dat slachtoffers dienen te worden beschermd ${ }^{85}$, dat het redelijk en billijk is dat de door een slachtoffer geleden schade wordt vergoed ${ }^{86}$. In deze visie dient het recht enkel tussen te komen nadat schade werd veroorzaakt. De rol van het recht beperkt zich dan ook tot het bepalen van de voorwaarden waaronder de schadeveroorzaker de schadelijder dient schadeloos te stellen. De verschuiving van de schade die per definitie initieel door het slachtoffer wordt geleden, is voor een econoom een neutrale operatie die op zich niet zal bijdragen tot een verhoging van de maatschappelijke welvaart ${ }^{87}$. Uiteraard kan de compensatie niet worden losgekoppeld van de preventic van schade: enkel wanneer een dader weet dat hij de door hem veroorzaakte schade zal moeten vergoeden, zal hij een prikkel hebben om deze schade niet te veroorzaken. Vanuit een klassieke juridische hoek is het aansprakelijkheidsrecht het middel om het docl - compensatie van slachtoffers - te bereiken; vanuit rechtseconomische optiek daarentegen is deze vergoedende functie van het aansprakelijkheidsrecht een middel om een minimalisering van de maatschappelijke kosten van ongevallen te bewerkstelligen.

Vanuit rechtseconomische hoek wordt ervan uitgegaan dat het recht prikkels geeft aan partijen waardoor hun gedrag wordt beînvloed; aldus wordt eerder de nadruk gelegd op de preventie van ongevallen. Eerder dan de vraag te stellen hoe een gegeven schade dient te worden vergoed, gaat de rechtseconoom uit van het gegeven dat elk ongeval maatschappelijke kosten veroorzaakt die dienen te worden geminimaliseerd. Immers, wanneer de maatschappelijke kosten van ongevallen zo laag mogelijk worden gehouden, zal de maatschappelijke welvaart verhogen. Het is bijgevolg niet omdat een rechtseconoom zich baseert op economische begrippen zoals efficiëntie dat de rechtseconomie minder zou zijn begaan met slachtofferbescherming, of dat de rechtseconomie minder "billijk" zou zijn dan "het recht". Wordt een potentieel slachtoffer niet beter beschermd door uit te gaan van de preventieve werking van het aansprakelijkheidsrecht, dan door het zoeken naar rechtsregels die een eerlijke of billijke schadevergoeding garanderen?

De in dit onderzoek gehanteerde rechtseconomische analyse ziet de problematiek in een bredere context dan de slachtoffer-dader verhouding. De rechtseconomische analyse van het ongevallenrecht impliceert dat ook andere verhoudingen in aanmerking worden genomen; zelden zal een on-

Zie bijvoorbecld Kruithof, R., "Do buitencontractuele aansprakeijkheid van en voor geesteszieken", Recueil Générale des Assurances et des Responsabilités, 1980, 10179, nr. 16; Simoens, D., "Hoofdlijnen in de evolutie van het aansprakelijkheidsreeht", Rechiskundig Weekblad, 1980-1981, 1981; Van Oevelen, A.. "Enige bedenkingen van een jurist bij de economische analyse van het aansprakelijkheidsrecht". in Van den Bergh, R., (ed.), Verslagboek Eerste Werkvergadering Recht en Economie, Antwerpen, Handelshogeschool, 1986, 25; Van Schellen, J., "De onvoorzichtige consument", Tijdschrift voor Consumentenrecht, 1987, 15.

Zo heeft Bocken het over "schadevergoedingsrecht" (Bocken, H., "Aansprakelijkheid voor milieuschade", Rechtskundig Weekblad, 1987-1988, 1280).

87 Faure, M., "Rechtseconomie en privaatrecht: kunnen rechtsregels bijdragen tot de reductic van ongevalskosten?", in Hondius, E.H., Schippers, J.J. en Siegers, J.J., Rechtseconomie en Recht. Een kennismaking met een rechtsgebied in opkomst, W.E.J. Tjeenk Willink, Zwolle, 1991, 51. 
geval gevolgen hebben voor slechts twee actoren. Zo worden bij een min of meer emstig verkeersongeval ook de ver/ckering, de politie en uitcindelijk misschien zelfs de rechtbank betrokken bij het ongeval. De vraag die hierbij vanuit rechtseconomische hoek wordt gesteld, is hoe de maatschappelijke kosten ${ }^{48}$ van cen dergelijk ongeval kunnen worden geminimaliseerd en hoe het recht hiertoe kan bijdragen. Niet alleen het aansprakelijk stellen van een bepaalde persoon kan leiden tot een efficiënte prikkel tot het aanwenden van zorg. Ook veiligheidsmaatregelen zullen cen invloed hebben op de ongevalskosten. Het wekt daarom weinig verwondering dat alle elementen dic een invloed (kunnen) hebben op de maatschappelijke kosten van ongevallen en op de prikkel tot het vermijden van schadeverwekkend gedrag, in de economische analyse van het ongevallenrecht worden betrokticn.

Een bijzondere plaats wordt hierbij ingenomen door verzekeringen omdat een verzekeringsdekking de prikkel tot het aanwenden van zorg kan aantasten. De rechtseconomische analyse van verzekeringen gaat na hoe verzekeringen de maatschappelijke welvaart kunnen verhogen, waarbij de potentiële schadeveroorzaker een prikkel blijft hebben om voldoende zorg aan te wenden.

Op basis van deze elementen wordt een rechtseconomisch model uitgebouwd ${ }^{89}$ dat de maatschappelijke kosten van een kemongeval minimaliseert, de klemtoon legt op preventie en voorziet in de integrale vergoeding van de schade veroorzaakt door een kernongeval c.q. door een catastroferisico. Deze rechtseconomische benadering biedt een aantal voordelen die hieronder worden uiteengezet.

\subsubsection{Voordelen van de rechtseconomie}

In de eerste plaats laat een rechtseconomische benadering toe om een effectiviteitsonderzoek te doen. Dit betekent dat wordt nagegaan in welke mate de door de regelgever vooropgestelde doelstellingen ook effectief (zullen) worden bereikt, wat de eventuele neveneffecten zijn van een bepaalde rechtsregel en hoe mogelijke onvolkomenheden kunnen worden verholpen. Indien bijvoorbeeld een wet pretendeert slachtoffers van een verkeersongeval of van een kcmongeval te beschermen, dan kan via een rechtseconomische analyse worden aangetoond tot op welke hoogte dit doel ook daadwerkelijk wordt bereikt ${ }^{90}$. Dankzij de rechtseconomische analyse kan het recht aldus kritisch worden benaderd, terwijl de traditionele literatuur veelal (te) beschrijvend te werk gaat.

De rechtseconomische analyse laat vervolgens toe te komen tot preciezere, beter te kwantificeren conclusies in vergelijking met klassieke juridische argumenten zoals rechtvaardigheid. Het is vreemd vast te stellen dat rechtseconomie vanuit een bepaalde hoek argwanend wordt bekcken, eerder dan te aanvaarden dat de rechtseconomie een gegeven juridisch concept van een degelijke

Bij de rechtseconomische analyse worden de "globale kosten van het aansprakelijkheidsrecht" in rekening gebracht (Faure, M. en Van den Bergh, R., Objectieve Aansprakelijkheid, Verplichle Verzekering en Veiligheidsregulering, Antwerpen, Maklu, 1989, 18; hiema gectieerd als "Objectieve Aansprakelijkheid").

Nochtans is het niet de ambitie van dit boek om zelf wiskundige formules en tabellen naar voren te schuiven op basis waarvan de wetgeving inzake de civielrechtelijke aansprakelijkheid bij kernongevallen kan worden verklaard. Dit is eerder het werk van economen en econometristen.

Zo toont $V$ an den Bergh aan dat in het verkeersrecht de goed bedoelde intentie om de ongemotoriseerde weggebruiker te beschermen, niet heeft geleid tot het gewenste resultaat: Van den Bergh, R., "Automatische vergoeding van schade geleden door zwakke verkeersdeelnemers: een rechtseconomische kritiek", in Faure, M. en Hartlief, T. (red.), Verkeersaansprakelijkheid in België en Nederland, Intersentia, Antwerpen-Groningen, 1998, 27 e.v. 
onderbouw kan voorzien. In de mate waarin de rechtseconomie erin slaagt een juridisch klassiek concept via een economisch rationeel begrippenapparaat te verklaren, kan het misschien meehelpen om de toepassing van dat concept te verbeteren en de strekking ervan uit te leggen. Op deze wijze biedt de rechtseconomie een referentiekader aan waarbinnen in het licht van economische efficiëntie op wetenschappelijk verantwoorde wijze kan worden nagedacht over preventie en compensatie van schade door ongevallen. Hier dient te worden benadrukt dat in vele gevallen de jurist tot precies dezelfde conclusies komt als de rechtseconoom omdat eerstgenoemde, soms zonder dat zelf te beseffen, toepassing maakt van een klassiek economisch concept.

Een derde voordeel van de rechtseconomische analyse van het (ongevallen)recht is dat de bestudeerde problematiek vanuit een ex ante uitgangspunt wordt benaderd, dat met andere woorden wordt bekeken hoe het recht kan bijdragen tot de preventie van ongevallen en hoe het recht erin kan slagen de maatschappelijke kosten van ongevallen te minimaliseren.

Tenslotte wordt door de combinatie van juridische en economische inzichten multidisciplinair onderzoek verricht hetgeen impliceert dat de op het einde van het onderzoek naar voor geschoven conclusies niet zouden zijn bereikt, had het onderzoek zich beperkt tot een zuiver juridische analyse. Door een rechtseconomische analyse wordt het puur juridische verlaten en wordt een brede waaier aan elementen die een invloed kunnen hebben op de prikkelwerking van rechtsregels, in de analyse betrokken. Vandaar werd gekozen voor de economische analyse van het recht vanuit de overtuiging dat een dergelijke analyse bijkomende en waardevolle inzichten kan verschaffen in het onderzoek naar efficiënte preventie en compensatie van schade door catastroferisico's, c.q. kernongevallen. De titel van dit boek verwijst dan ook uitdrukkelijk naar de rechtseconomie.

Hicrbij wordt bewust niet stilgestaan bij de discussie ontrent het nut en de wairde van de rechtseconomie als wetenschappelijke methode omdat deze discussie reeds grotendeels elders is gevoerd en omdat het niet binnen de ambitie van dit proefschrift valt om in deze discussie te tre$\operatorname{den}^{21}$. Bovenvermelde voordelen van de rechtseconomische analyse, vormen een voldoende reden om deze analyse toe te passen op de problematick van de aansprakelijkheid voor schade uit kernongevallen en andere catastroferisico's.

\subsection{Rechtsvergelijking}

De rechtseconomische analyse wordt verder verrijkt met rechtsvergelijkend onderzoek. De conclusies zijn in ruime mate gebaseerd op rechtsvergelijkende inzichten; er wordt zowel gekeken naar het kemenergierecht in een aantal landen, naar de dekking van catastroferisico's, als naar de wetgeving inzake aansprakelijkheid voor schade door olieverontreiniging op zee. Een dergelijke benadering zal ons inderdaad toelaten om te vergelijken en het goede te behouden ${ }^{92}$.

De rechtsvergelijkende aanpak blijkt in de eerste plaats uit de parallel tussen Belgisch en Nederlands recht die nagenoeg over de gehele lijn wordt doorgetrokken, en dit zowel bij de analyse van het gemene aansprakelijkheidsrecht, van het milieuaansprakelijkheidsrecht, van het nucleairc aunsprakelijkhcidsrecht, als bij de wijze waarop deze aansprakelijkheden in beide landen worden ge-

91

Voor een uitstekend onderzoek naar de waarde van de rechtseconomie, zie De Geest, G., Economische analyse van het contracten- en quasi-contractenrecht. Een onderzoek naar de wetenschappelijke waarde van de rechtseconomie, diss., Maklu, Antwerpen, Apeldoom, 1994.

92 De Groot, G.R., Vergelijkt alles en behoudt het goede. Beschouwingen over onderwijs en onderzoek op het gebied van rechtsvergelijking, oratie universiteit Maastricht, 5 oktober 1989, Kluwer, Deventer, 1989. 
dekt. De keuze voor deze twee rechtsgebieden ligt in de eerste plaats voor de hand gelet op het feit dat het onderzoek is gevoerd vanuit de Universiteit Maastricht door een "Belgisch geschoold" jurist. Maar de vergelijking tussen België en Nederland is ook interessant gelet op de historische en juridische banden (Napoleontisch Burgerlijk Wetboek) ${ }^{93}$. Bovendien is deze vergelijking interessant met name voor wat betreft de studie van de aansprakelijkheid voor het nucleaire risico aangezien Nederland slechts voor $4 \%$ van zijn elektriciteitsvoorziening een beroep doet op kernenergie, terwijl in België kernenergie 57\% levert van de totale elektriciteitsproductie ${ }^{94}$. Een aantal van de Belgische kerncentrales bevindt zich overigens in Doel (bij Antwerpen) zodat bij een grensoverschrijdend kernongeval in Doel, Nederland in alle waarschijnlijkheid als eerste zal zijn getroffen.

Het rechtsvergelijkende aspect gaat evenwel verder dan de vergelijking tussen België en Nederland. Zo wordt een vergelijking gemaakt met het Amerikaanse nucleaire aansprakclijkheidsrecht omdat de Europese toepasselijke Verdragen - waarop de Belgische en Nederlandse wetgeving zijn gebaseerd - zijn geïnspireerd op de wetgeving in de Vercnigde Staten ${ }^{95}$. In een aantal gevallen zal sporadisch en fragmentarisch naar het nucleairc aansprakelijkheidsrecht van andere landen worden gekeken. De bedoeling hiervan is om opvallende elementen van het kernenergicrecht van een gegeven land aan de orde te stellen.

In derde instantie wordt de rechtsvergelijkende analyse verruimd tot de dekking van catastroferisico's. Zowel de dekking via de verzekeringsmarkt als een aantal alternatieve compensatiemechanismen zullen aan bod komen. Ook hier worden het Belgische en het Nederlandse recht naast elkuar geplaatst.

Tenslotte wordt het internationale milieurecht in de rechtseconomische analyse betrokken. Hierbij wordt onderzocht in welke mate de aansprakelijkheid en dekking van het nucleaire risico kunnen worden vergelcken met de aansprakelijkheid en dekking van schade door olieverontreiniging op zee. Gekeken wordt of de aanpak in die tak van het milieurecht zinvol is en of bepaalde elementen daarvan desgevallend kunnen worden toegepast op de schade veroorzaakt door kernongevallen.

Volledigheidshalve dient erop te worden gewezen dat de resultaten van de rechtsvergelijkende analyse op het einde van het boek zullen worden gecombineerd met de inzichten vanuit de rechtseconomische analyse. In dit onderzoek wordt dus de rechtseconomische benadering gecombincerd met de juridische analyse van leerstukken en begrippen uit het kernenergie- en het milieurecht. Beide methodes zullen elkaar bijgevolg in belangrijke mate aanvullen.

\section{TOELICHTING VAN DE STRUICTUUR}

Uit de bespreking van de gehanteerde onderzoeksmethode is reeds gebleken dat het gevoerde onderzoek op drie pijlers steunt, namelijk het aansprakelijkheidsrecht, het verzekeringsrecht en

Beide rechtsgebieden stammen uit de Romeinse rechtsfamilie (Zweigert, K. en Kobtz, H., An Introduction to Comparative Law, Clarendon Press, Oxford, 1992, 103). Grensoverschrijdende milieuproblemen: uitdagingen voor de nationale en internationale rechtsorde, Intersentia, Antwerpen-Groningen, 1998, 443 e.v. Cfr. infra, in hoofdstuk 13. 
het milieuaansprakelijkheidsrecht. Deze pijlers zullen in de verschillende delen van het onderzoek en telkens vanuit een andere gezichtshoek aan de orde worden gesteld.

Dit boek bevat vier delen die zijn samengesteld uit verschillende hoofdstukken. Deze delen sluiten uiteraard aan bij de opbouw van het boek en bij de gehanteerde en hoger geschetste onderzoeksmethodes. In een cerste deel wordt de nucleaire aansprakelijkheidswetgeving juridisch geanalyseerd. Het tweede deel bevat de rechtseconomische analyse van aansprakelijkheid en verzekering. In deel 3 worden verschillende andere compensatiemechanismen besproken. Daar wordt met name aandacht besteed aan de dekking van catastroferisico's in het algemeen en wordt de vergelijking gemaakt met de Price-Anderson Act in de Verenigde Staten en met de wetgeving ter zake van de aansprakelijkheid voor schade door olieverontreiniging op zee. In deel 4 tenslotte worden een aantal conclusies en aanbevelingen van het gevoerde onderzoek geformuleerd.

In deel 1 worden de wetgeving inzake de civielrechtelijke aansprakelijkheid voor kernongevallen en de verzekering van het nucleaire risico geanalyseerd.

Hoofdstuk 1 onderzoekt in welke mate het Belgische en Nederlandse civielrechtelijke aansprakelijkheidsrecht met elkaar kunnen worden vergeleken en past het aansprakelijkheidsrecht toe op milieuschade. Voor de verdere analyse is het namelijk van groot belang dat duidelijkheid bestaat over een aantal begrippen die in het kader van dit onderzoek een belangrijke plaats innemen. In het tweede hoofdstuk wordt het ontstaan van het kernenergierecht sensu lato toegelicht, waarbij zowel het internationale als het hierop geïnspireerde nationale Belgische en Nederlandse kernenergierecht worden belicht. Hierbij wordt een overzicht gegeven van de internationale Verdragen inzake de civielrechtelijke aansprakelijkheid voor kernongevallen, waarbij zowel de in de jaren zestig tot stand gekomen Verdragen als de wijzigingen van deze Verdragen tengevolge van het ongeval van Tsjernobyl worden weergegeven. Op basis van dit overzicht zullen ook het Belgische en het Nederlandse kernenergierecht worden besproken. Door eerst het ontstaan van het internationale kernenergierecht te bestuderen, wordt meteen duidelijk hoe het Belgische en het Nederlandse kemenergierecht daaruit zijn ontstaan.

In hoofdstuk 3 wordt het toepassingsgebied besproken van zowel het Verdrag van Parijs inzake de civielrechtelijke aansprakelijkheid voor kernongevallen, als van de Belgische en Nederlandse uitvoeringswet. Hierbij wordt de vraag beantwoord of deze wetgeving van toepassing is op alle ongevallen met radioactieve stoffen en wat precies met de term "kernongeval" wordt bedoeld. Tegelijk wordt het toepassingsgebied ratione loci aan de orde gesteld, waarbij wordt gekeken welke wetgeving van toepassing is indien de plaats van het ongeval verschilt van de plaats (het land) waar de schade wordt geleden.

In het vierde hoofdstuk worden de basisprincipes van de nucleaire aansprakelijkheidswetgeving besproken. Daarbij zal in ruime mate aandacht worden geschonken aan de juridische instrumenten waarover een slachtoffer van een kemongeval de lege lata in België en in Nederland beschikt, voor de compensatie van de tengevolge van een kernongeval geleden schade. Hierbij zal overigens regelmatig worden verwezen naar het nucleaire aansprakelijkheidsrecht van andere landen, in de mate waarin deze wetgeving zich duidelijk onderscheidt van de in de Verdragen neergelegde principes of in de mate waarin het dece principes op een andere manicr invult. Er dient op te worden gewezen dat bij de juridische analyse van de basisprincipes ook telkens aandacht zal worden besteed aan het Protocol van het Verdrag van Wenen en het Verdrag inzake Bijkomende Compensatie van 1997 en aan de lopende besprekingen voor de revisie van het Verdrag van Parijs van 29 juli 1960 . 
Vervolgens worden ook verzekeringen betrokken bij de juridische analyse. Hoofdstuk 5 bespreekt het fenomeen verzekeringen, het ontstaan ervan en besteedt uiteraard aandacht aan de aansprakelijkheidsverzekering en aan verschillende soorten verzekeringspolissen en -technieken waarbij milieuschade wordt gedekt. Bijkomende aandacht zal uitgaan naar de problemen van de dekking van de aansprakelijkheid in de tijd.

In hoofdstuk 6 wordt onderzocht hoe het nucleaire risico wordt verzekerd. Hier zal de aandacht zich richten tot het ontstaan van de nuclcaire verzekeringspools, de werking en de kenmerken van dergelijke pools. Als voorbeeld van de analyse zal de Belgische nucleaire verzekeringspool ( $S_{1}$ indicat Belge des Assurance's Nucléaires of SYBAN) worden genomen. Nadien wordt onderzocht in welke mate deze pools verenigbaar zijn met het Europese concurrentierecht.

$\mathrm{Na}$ de juridische analyse wordt in deel 2 de rechtseconomie geintroduceerd. Hierbij wordt in hoofdstuk 7 geschetst wat rechtscconomie precics inhoudt en wordt de lezer vertrouwd gemaakt met de verderop gehanteerde begrippen en concepten, waarbij het begrip "efficiëntie" een bijzondere plauts inneemt. Ook worden de doelstellingen en de uitgangspunten van de economische analyse van het ongevallenrecht verduidelijkt. Deze uitgangspunten zijn van wezenlijk belang voor een goed begrip van de verdere analyse ondat een aantal hypothesen waarop het rechtseconomisch model is gebaseerd naar voren worden geschoven. In hoofdstuk 8 wordt het rechtseconomisch model van het ongevallenrecht uiteen gezet, onder meer on te bestuderen onder welke voorwaarden fout- of risicoaansprakelijkheid leiden tot het aanwenden van optimale zorg en wat de invloed is van het activiteitsniveau op het ongevalsrisico.

Hoofdstuk 9 bespreekt de rechtseconomische analyse van verzekeringen, wadr wordt gekeken in welke mate een risico een invloed uitocfent op het gedrag van de ongevalspartijen. Aan de hand van de mogelijke houdingen ten aanzien van een risico, wordt bekeken in welke situaties de combinatie van verzekeringen met (fout- of risico-)aansprakelijkheid leidt tot cen verhoging van de maatschappelijke welvaart. Vanuit rechtseconomische hoek wordt onderzocht of het economisch linvol is om een aansprakelijkheidswer/ekering verplicht te stellen en wat het welvaartverlies is, veruor/aakt door een gebrek aan concurrentie op de verzekeringsmarkt. Tegelijk wordt de problematiek van de verzekerbaarheid van een risico vanuit rechtseconomische hoek belicht. In hoofdstuk 10 wordt nagegaan in welke gevallen veiligheidsregulering in combinatie met aansprakelijkheid, de maatschappelijke welvaart kan verhogen.

In het derde deel van dit boek worden enkele andere compensatiemechanismen in de analyse betrokken. Hoofdstuk 1 I besteedt met name aandacht aan de dekking van een aantal catastroferisico's buiten het kemenergicrecht. Zowel de klussieke mechanismen die een beroep docn op de verzekeringsmarkt als een aantal alternatieve mechanismen zoals fondsen en captives, worden bestudecrd. Nadien wordt in hoofdstuk 12 de vergelijking gemaakt met de wetgeving en de dekking betreffende de aansprakelijkheid voor schade door olieverontreiniging op zec. Een vergelijking met het nucleaire risico ligt voor de hand omdat voor beide problemen wetgeving van kracht is, gebascerd op dezclfde principes, namelijk risicoaansprakelijkheid, kanalisatie van aansprakelijkheid, beperking van de aansprakelijkheid en verplichte verzekering van deze aansprakelijkheid.

In hoofdstuk 1.3 wordt de aansprakelijkheid en de verzekering van het nucleaire risico in de Verenigde Staten besproken. Het is inderdaad de moeite waard om de in dat land geldende nucleaire civielrechtelijke aansprakelijkheidsregels en de daaraan verbonden dekking tc analyseren omdat, zoals zal blijken uit de bespreking van het ontstaan van het kemenergierecht, het Europese nucleaire aansprakelijkheidsrecht tot stand is gekomen onder invloed van de Verenigde Staten. Bovendien zijn de Verenigde Staten niet toegetreden tot het Verdrag van Parijs van 1960 waar 
België en Nederland wel lid van zijn. De vergelijking van zowel de aansprakelijkheidsregels als de dekkingsmogelijkheden met een land dat geen lid is van de internationaal van kracht zijnde Verdragen, zal nuttige inzichten verschaffen bij de beoordeling van de merites of tekortkomingen van het op het Verdrag van Parijs gebaseerde compensatiesysteem.

De kennis die aldus in de eerste drie delen van het onderzoek is verworven, wordt in het laatste deel op normatieve rechtseconomische wijze benaderd. De gehanteerde begrippen van het nucleaire en het milieuaansprakelijkheidsrecht zullen hier op hun merites worden beoordeeld. In deel 4 van dit boek worden inderdaad enkele conclusies en aanbevelingen geformuleerd. In hoofdstuk 14 worden de conclusies aangegeven van de juridische analyse van het nucleaire aansprakelijkheidsrecht.

In hoofdstuk 15 worden enkele normatieve rechtseconomische conclusies getrokken uit het onderzoek. Er wordt nagegaan wat het gevolg is van een stelsel van risicoaansprakelijkheid ${ }^{96}$, waarom voor deze vorm werd gekozen en of deze keuze ook rechtseconomisch verantwoord is. Daarmee samenhangend wordt de beperking van de aansprakelijkheid van een exploitant van een keminstallatie behandeld en de gevolgen daarvan op de prikkels die uitgaan van een aansprakelijkheidsvordering. Hier zullen vraagtekens worden geplaatst bij de combinatie en de band tussen verplichte aansprakelijkheidsverzekering, de beperkte beschikbaarheid van verzekering op de markt en de beperking van de aansprakelijkheid van een nucleaire exploitant. Vervolgens zal aandacht worden besteed aan de vraag wat het nut is van veiligheidsmaatregelen indien reeds aansprakelijkheidsregelen en verzekeringsdekking voorhanden zijn. Ook de inzichten vanuit de rechtsvergelijkende analyse zullen in dat hoofdstuk worden benaderd vanuit rechtseconomische hoek.

Op basis van deze inzichten, wordt in hoofdstuk 16 een verbeterd model voor de compensatie van schade door kernongevallen uitgebouwd. Deze aanbevelingen zullen de klemtoon leggen op een optimale preventie en efficiënte compensatie van de door een kemongeval veroorzaakte schade. In de mate waarin de aansprakelijkheid voor schade uit andere catastroferisico's via analoge mechanismen en principes wordt geregeld, zullen deze conclusies en aanbevelingen ook kunnen worden gehanteerd voor andere catastroferisico's. 



\section{DEEL 1}

\section{ANALYSE VAN HET CIVIELRECHTELIJKE (NUCLEAIRE) AANSPRAKELIJKHEIDSRECHT}

In het eerste deel van dit proefschrift wordt het extracontractucle civiclrechtelijke aansprakelijkheidsrecht voor schade ontstaan door (kern)ongevallen besproken. Voor de goede orde wordt erop gewezen dat met het begrip "aansprakelijkheidsrecht" het civielrechtelijke cxtracontractuele aansprakelijkhcidsrecht wordt bedoeld. Centraal in dit onderzock staat de positie van slachtoffers van een kemongeval: deze slachtoffers zijn derden ten overstaan van de exploitant en bijgevolg gaat onze aandacht primair uit naar het extracontractuele aansprakelijkheidsrecht. In een aantal gevallen zal echter ook aandacht worden bestced aan de contractuele relatie tussen de exploitant en diens leveranciers; in een dergelijk geval zal duidelijk worden aangegeven dat het ecn contractuele relatie betreft. De strafrechtelijke aansprakelijkheid komt in dit onderzoek als dusdanig niet aan bod.

De in dit deel gevoerde analyse beperkt zich niet tot de positicfrechtelijke analyse, maar doet op geregelde tijdstippen recds een aantal normatieve uitspraken. De juridische analyse vormt bijgevolg een eerste aanzet tot de normaticve analyse en de conclusies en aanbevelingen. Deze conclusies worden in het vierde deel van dit boek aan de orde gesteld.

In dit deel wordt in eerste instantie aandacht besteed aan het gemene extracontractuele aansprakelijkheidsrecht en aan de rol van de daarin opgenomen aansprakelijkheidsgrondslagen bij de aansprakelijkheid voor milieuschade. Vervolgens zal de aandacht uitgaan naar het nucleaire civielrechtelijke aansprakelijkheidsrecht. Uit de verdere analyse zal blijken dat het nucleaire aansprakelijkheidsrecht een regime van risicoaansprakelijkheid hanteert, terwijl in het gemene aansprakelijkheidsrecht nog steeds de "fout" een centrale positie inneemt ${ }^{1}$. Er zal worden onderzocht waarom in het kemenergierecht werd afgeweken van deze foutstandaard. Zo kan meer bepaald de vraag worden beantwoord in welke mate het nucleaire aansprakelijkheidsrecht voortbouwt op het begrippenarsenaal en de inzichten van het gemene aansprakelijkheidsrecht, dan wel in welke mate het nucleaire aansprakelijkheidsrecht hiervan afwijkt.

Een onderzoek dat in hoofdzaak betrekking heeft op de civielrechtelijke aansprakelijkheid zal uiteraard ook in ruime mate de verzekering van deze aansprakelijkheid in de analyse betrekken; in dit deel wordt dan ook aandacht besteed aan de verzekeringsproblematiek. Naar analogie met de bespreking van het aansprakelijkheidsrecht waar zowel het gemene als het nucleaire aansprakelijkheidsrecht aan de orde komen, wordt eveneens aandacht besteed aan verzekeringen in het algemeen en aan de verzekering van het nucleaire risico. Gelet op het voorwerp van dit onderzoek, zal de aansprakelijkheidsverzekering centraal staan.

De positicfrechtelijke analyse van het nucleaire civielrechtelijke aansprakelijkheidsrecht veronderstelt bijgevolg dat vicr thema's worden besproken: het gemene extracontractuele aansprakelijkheidsrecht, de aansprakelijkheid van de exploitant van een keminstallatie in het kemenergierecht, de (aansprakelijkheids)verzekering in het algemeen en de verzekering voor het nucleaire risico. Dcze thema's worden in dit deel van het onderzoek in 6 hoofdstukken aan de orde gesteld. Bij elk van deze thema's wordt zowel aandacht besteed aan het Belgische en het Nederlandse recht.

Dit begrip wordt verderop toegelicht, cfr. infra in $\S 1.3$ van dit hoofidstuk. 
In het eerste hoofdstuk worden enkele begrippen toegelicht die in het Belgische en Nederlandse civiele aansprakelijkheidsrecht worden gehanteerd en wordt onderzocht in welke mate het extracontractuele aansprakelijkheidsrecht kan wordt toegepast op de ansprakelijkheid voor milieuschade. Nadien wordt het ontstaan van het kemenergierecht besproken en wordt een overzicht gegeven van de internationale Verdragen inzake de civielrechtelijke aansprakelijkheid voor kernongevallen (hoofdstuk 2). Hoofdstuk 3 bespreekt het toepassingsgebied van deze Verdragen en van de overeenstemmende wetgeving in België en in Nederland. De basisprincipes van het nucleaire aansprakelijkheidsrecht worden in hoofdstuk 4 uiteengezet.

In het vijfde hoofdstuk wordt aandacht besteed aan verzekeringen in het algemeen en aan de aansprakelijkheidsverzekering in het bijzonder. De verzekering van het nucleaire risico wordt besproken in hoofdstuk 6. 


\section{HOOFDSTUK 1}

\section{TOEPASSING VAN HET CIVIELRECHTELIJKE AANSPRAKELIJKHEIDSRECHT OP MILIEUSCHADE}

In dit hoofdstuk wordt hoofdzakelijk aandacht besteed aan het civielrechtelijke aansprakelijkheidsrecht voor milieuschade, zoals neergelegd in het Belgische en het Nederlandse BW. Op deze wijze kan duidelijkheid worden gecreëerd over de inhoud van bepaalde begrippen die frequent zullen worden gebruikt, kunnen mogelijke valkuilen van de rechtsvergelijkende invalshoek worden ontweken, kan de vradg worden beantwoord of het extracontractuele aansprakelijkheidsrecht geschikt is voor de vergoeding van milieuschade en kan tenslotte aandacht worden besteed aan de rol van het aansprakelijkheidsrecht ten overstaan van andere vergoedingsmechanismen.

In eerste instantic is het voor de verdere analyse van dit onderzock van belang dat duidelijkheid bestaat omtrent een aantal fundamentele bcgrippen zoals risicoaansprakelijkhcid en objectieve aansprakelijkheid, of tenminste dat wordt toegelicht wat onder deze begrippen wordt verstaan bij de verdere analyse van dit proefschrift. Een analyse omtrent de inhoud van deze begrippen zal ook van nut zijn bij de vergelijking tussen het Belgische en Nederlandse nucleaire aansprakelijkheidsrecht, die als een rode draad door de volgende hoofdstukken loopt. Het is bekend dat in België wordt gesproken van de "foutaansprakelijkheid", terwijl Nederland het begrip "schuldaansprakelijkheid" hanteert. Voorzichtigheidshalve is het dus aangewezen om eerst na te gaan of de begrippen en de inzichten die in beide aansprakelijkheidsstelsels worden gehantecrd überhaupt vergelijkbaar zijn. Tenslotte kan door de studie van het begrip "fout" of "schuld" in het gemene aansprakelijkheidsrecht worden nagegaan hoe het nucleaire aansprakelijkheidsrecht zich verhoudt tot de basisprincipes van een rechtstak die is gebaseerd op het Burgerlijk Wetboek van 1804'. Door te onderzoeken welke de rol is van de fout in het gemene aansprakelijkheidsrecht, kan in een later stadium worden nagegaan in hoeverre de principes uit het nucleairc aansprakelijkheidsrecht vernieuwend waren.

Hieronder wordt in $\S$ I aandacht besteed aan het onrechtmatige daadsrccht in Bclgië en Nederland. Daar worden zowel de totstandkoming van Burgerlijk Wetboek, als de uitgangspunten van de code Napoléon besproken. Tegelijk wordt aangegeven in welke mate het Belgische en het Nederlandse aansprakelijkheidsrecht vergelijkbaar zijn. In de tweede paragraaf wordt de rol bestudeerd van het Burgerlijk Wetboek ter zake van de aansprakelijkheid voor milieuschade. Hier wordt met name de vraag beantwoord welke juridische grondslugen in het Belgische en Nederlandse Burgerlijk Wetboek voorhanden zijn voor de aansprakelijkheid voor milieuschade. De positie van het aansprakelijkheidsrecht tegenover andere vergoedingsmechanismen wordt in $\S 3$ aan de orde gesteld. De bevindingen van dit hoofdstuk worden weergegeven in de conclusie (§4).

\section{HeT CIVIELRECHTELIJKE AANSPRAKELIJKHEIDSRECHT IN HET BURGERLIJK WETBOEK IN BELGIË EN NEDERLAND}

In deze paragraaf wordt aandacht besteed aan het gemene civielrechtelijke aansprakelijkheidsrecht, zoals neergelegd in het Belgische en Nederlandse Burgerlijk Wetboek. De analyse blijft beperkt tot respectievelijk artikel $1382 \mathrm{BW}$ en artikel 6:162 NBW. Het is de bedoeling om aan te

Hoewel Nederland is overgegaan tot de introductie van een Nieuw Burgerlijk Wetboek; geldt deze stelling zowel voor Belgie als voor Nederland: in het begin van de negentiende eeuw waren in beide landen nagenoeg identieke wetboeken van kracht (cfr. infra, §1.1). 
geven in welke mate de vergelijking tussen de Belgische foutaansprakelijkheid en de Nederlandse schuldaansprakelijkheid gerechtvaardigd is. Het zou te ver voeren om in het kader van dit onderzoek uitgebreid het Belgische en het Nederlandse civiele aansprakelijkheidsrecht te vergelijken; het gaat erom om in deze paragraaf te toetsen of de in beide landen gehanteerde terminologie "compatibel" is.

Hieronder wordt eerst de totstandkoming en de gelding van het Burgerlijk Wetboek in Belgie en Nederland belicht $(\$ 1.1)$. Het is immers interessant om kort stil te staan bij de invloed die de code Napoléon van 1804 heeft gehad in twee landen die ooit één geheel hebben gevormd, waar gedurende korte tijd een identicke versie van het BW is van kracht gewecst on die net vóór de start van het derde millennium elk nog steeds over een Burgerlijk Wetboek beschikken. Vervolgens wordt de centrale positie van de fout in de code Napoléon belicht (§ 1.2). Daarop volgend wordt getoctst hoe de foutaansprakelijkheid in het Belgische en het Nederlandse BW worden geformuleerd en wordt gekeken in welke mate deze aansprakelijkheid gelijklopend is (\$1.3). Dit zal toelaten om beide rechtsstelsels op correcte wijze met elkaar te kunnen vergelijken. In welke mate deze vergelijking gerechtvaardigd is, zal in de conclusie worden uiteengezet (§ 1.4).

\subsection{Torstandkoming en gelding van de code Napoléon in België en Nederland}

De Frunse Revolutie maakte een einde aan het Oostenrijkse bewind in België: door het Verdrag van Campo-Formio (1795) zag Jozef II af van iedere aanspraak op de zuidelijke Nederlanden. Het graafschap Vluanderen, het hertogdom Brabant en het prinsbisdom Luik verdwenen; in de plaats kwamen negen departementen die bij Frankrijk werden ingelijfd ${ }^{2}$. Hierdoor werden op het grondgebied van het latere België de liranse wetten en de napolcontische codes van kracht ${ }^{3}$.

De Republiek der Verenigde Nederlanden, die aanvankelijk als een vazalkoninkrijk weld beschouwd, werd slechts in 1810 formeel ingelijfd bij Frankrijk. Op 1 mei 1809 was nochtans het Wetboek ingerigt voor het Koningrijk Holland ingevoerd; door de inlijving in Frankrijk werd dit wetboek vanaf 1811 afgeschaft en vervangen door de Franse codes (waaronder de Code Civil) ${ }^{4}$. Bijgevolg was in België en Nederland aan het begin van de negentiende eeuw eenzelfde wetboek van kracht - een wetboek met daarin onder meer de regels terzake van de aansprakelijkheid bij schade veroorzaakt aan derden.

Nadat Napoléon was verslagen, werden Belgiê en Nederland uitgeroepen tot het Koninkrijk der Nederlanden onder Willem I. Zoals elk koninkrijk in die tijd zijn eigen national gecodificeerd

Zie voor een uitgebreide geschiedenis: Carson, P., Het fraaie gelaal van Vlaanderen, Lannoo, Tielt, 1995.

Na zijn staatsgreep op 9 november 1799, wilde Napoléon het nodige houvast bieden aan de streken waarover hij regeerde, hetgeen hij onder meer wenste te verwezenlijken door de invoering van een stel wetboeken met algemene gelding (Van Caenegem, R.C., Geschiedkundige inleiding tot het privaatrecht, Story Scientia, 1985, 5). In augustus 1800 richtte hij daarom een vierkoppige commissie van juristen op die in amper vier maanden tijd het ontwerp van de code civil had geschreven. De commissie bestond uit Portalis (expert op het juridisch-technische vlak), Tronchet (advocaat en kenner van het gewoonterecht), Maleville (kenner van het Romeinse recht) en Bigot de Préameneu (lid van de Assemblée Législative in 1791). Naast deze vier personen hebben ook Naopléon Bonaparte zelf en Cambacérès een aanzienlijke invloed uitgeoefend op de code civil (Poughon, J-M., "Le Code Civil", Que sais$j e$, Presses Universitaires de France, tweede uitgave, 1995, 12 e.v.). Tussen 5 maart 1803 en 21 maart 1804 werd een reeks van 36 wetten gesternd die op 21 maart 1804 werden gebundeld tot de Code Civil des Français.

Het "Wetboek ingerigt voor het Koningrijk Holland" bouwde voort op de Code Civil en bevatte deels inheems recht (Van Caenegem, R.C., "Geschiedkundige inleiding tot het privaatrecht", I.c., 163). 
recht hoorde te hebben, wilde ook het nieuwe koninkrijk haar eigen codes invoeren. Deze codes werden voorbereid door de "Commissie tot de Nationale Wetgeving"s , die in 1829 haar ontwerp voor de afkondiging van vier wetboeken - waaronder het Burgerlijk Wetboek - klaar had. Deze wetboeken zouden op 1 februari 1831 van kracht worden. Door de Belgische onafhankelijkheid zijn deze wetboeken evenwel nooit ingevoerd en bleven de napoleontische wetboeken van kracht $t^{6}$.

Gehed in de gecst van die tijd, wilde ook het onafhankelijke Belgische koninkrijk haar eigen nationale codes uitvaardigen. Een eigen Belgisch Burgerlijk Wetboek is evenwel nooit tot stand gekomen. Totnogtoe werd het Belgische BW, inzake civiclrechtelijke aansprakelijkheid, slechts tweemaal formeel gewijzigd. In 1935 werd een titel IVbis toegcroegd betreffende de vergoeding van schade door abnormalen veroor/aakt (artikel 1386bis BW) ${ }^{7}$; in 1977 werd een lichte wijziging aangebracht aan de aansprakelijkhcid voor ouders voor schade veroor zaakt door hun minderjarige kinderen ${ }^{8}$. Hiet op het BW gebaseerde civiele aansprakelijkheidsrecht is voomamelijk onder invloed van de rechtspraak en van de opkomst van ver/ckeringen, sterk geëvolucerd ${ }^{9}$.

Nederland van zijn kant voerde in 1838 toch een eigen Burgerlijk Wetboek in dat grotendeels was gebascerd op de Franse Code Civil en op de inzichten van de Commissie tot de Nationale Wetgeving. Na de tweede wereldoorlog kreeg Meijers de opdracht een nieuw ontwerp Burgerlijk Wetboek op te stellen. Het ontwerp van Meijers bevatte cen Inleidende Titel en Negen Bocken waarvan hij er vicr heeft voltooid. Boek 1 (Personen- en Familierecht) is in werking getreden in 1970); Boek 2 (Rechtspersonen) op 26 juli 1976; Boek 8 (Transportrecht) trad in 1991 in werking; de boeken 3 (Vermogensrecht in het algemeen), 5 (Zakelijke rechten), 6 (Verbintenissen in het algemeen) en bepaalde titels van Boek 7 (Bijzondere Overeenkomsten) zijn in 1992 van kracht geworden. Tenslotte werden per 1 februari 1995 een aantal wijzigingen aangebracht aan de Boeken 3,6 en $8^{10}$. Voornamelijk deze laatste wijziging betekende ecn aanzienlijke verandering in het Nederlandse civielrechtelijke aansprakelijkheidsrecht zoals neergelegd in het Burgerlijk Wethoek.

Uit bovenstaande elementen blijkt dat het Belgische en het Nederlandse burgerlijk recht, het aansprakelijkheidsrecht inbegrepen, initieel waren gebaseerd op nagenoeg identieke wetteksten. Aangezien in dit onderzoek het Belgische en het Nederlandse nucleaire aansprakelijkheidsrecht naast elkaar worden geplaatst, is het van belang om in het achterhoofd te houden dat de wetteksten inzake het civielrechtelijke aansprakelijkheidsrecht waarop beide rechtsstelsels zijn gebaseerd, zeer sterk op elkaar geleken. Toch zal ook rekening moeten worden gehouden met de verschillen die beide rechtsstelsels, sinds hun totstandkoming onder invloed van de rechtspraak en door de invoering van het Nieuw Burgerlijk Wetboek in Nederland, ondergingen.

5 De werkzaamheden in de Commissie hebben inderdaad vrij lang geduurd, deels door tegenstellingen tussen Noord en Zuid en deels door tegenstellingen, binnen de Conmissie, tussen de Nederlander Johan Melchior Kemper en de Belg Pierre Thomas Nicolaĩ.

Zie o.m. Milo, J.M., Het rechtsvergelijkende argument in de ontwikkeling van het Nederlandse vermogensrecht 1838-1940: aansprakelijkheid voor zaken, artikel 2014, publiek domein en de relativiteit van de onrechtmatige daad, diss., Intersentia, Antwerpen-Groningen, 1997, 29 e.v.

Ingevoegd bij wet van 16 april 1935 (B.S. 18 april 1935).

Gewijzigd bij wet van 6 juli 1977 (B.S., 2 augustus 1977).

Cfr. infra.

Wet van 30 november 1994 tot aanvulling van de Boeken 3, 6 en 8 van het Burgerlijk Wetboek met regels betreffende de aansprakelijkheid voor gevaarlijke stoffen en verontreiniging van. lucht, water of bodem, Stb. 1994, 646. 
Vooraleer de analyse van het civiele aansprakelijkheidsrecht naar Belgisch en Nederlands recht wordt aangevat, zal hieronder worden stilgestaan bij het uitgangspunt van het Napoleontische aansprakelijkheidsrecht. Dit: is nuttig voor een goed begrip van de basisbegrippen die in paragraaf 1.3 worden besproken.

\subsection{De centrale positie van de fout in de code Napoléon}

Uit de evolutie van het aansprakelijkheidsdenken door de eeuwen heen, blijkt dat het begrip "fout" in het Burgerlijk Wetboek van Napoléon een centrale positic inneemt" .

Essentieel in het op het Franse recht gebaseerde aansprakelijkheidsrecht is het dubbel onderscheid tussen de civiele of burgerrechtelijke en strafrechtelijke aansprakelijkheid enerzijds en tussen de contractuele en extracontractuele aansprakelijkheid anderzijds. Deze systematische benadering van de code civil kwam tot stand onder invloed van Jean Domat ${ }^{12}$ wiens ideeën voortbouwden op de inzichten van Gratianus en dus op het canonieke recht ${ }^{13}$. In het canonieke recht werd belang gehecht aan de intentie waarmee iemand schade berokkende aan een ander: indien iemand onopzettelijk schade berokkende diende hij daarvoor niet te worden gestraft; het louter compenseren van de geleden schade volstond. Zich hierop inspirerende stelde Domat dat ook schade voortkomende uit onvoorzichtigheid, slordigheid of nalatigheid aanleiding diende te geven tot compensatie $^{\mathrm{IH}}$.

De strafrechtelijke vordering kan enkel worden gebaseerd op een beperkte lijst van inbreuken, terwijl de civiele aansprakelijkheid rust op het algemeen schadevergoedingsbeginsel, dat enkel schade die is veroorzaakt door een fout aanleiding geeft tot compensatic ${ }^{15}$. Door de strakke scheiding tussen de publieke - strafrechtelijke - en de private - civiele - aansprakelijkheid wordt in het civiele aansprakelijkheidsrecht de vergoeding van schade in beginsel los gezien van het element straf. Enkel indien een gegeven schade ook leidt tot een verstoring van de sociale orde, kan

Het is niet de bedoeling om in het kader van dit proefschrift een uitgebreid overzicht te geven van de geschiedenis van het aansprakelijkheidsrecht; verwezen kan worden naar o.m. Mazeaud, H. \& L., et Tunc, A., Traité théorique et pratique de la responsabilité délictuelle et contractuelle, tome $\mathrm{I}, 6^{\circ}$ édition, Montchrétien, Paris, 1932, 1-99 (hierna geciteerd als "Traité"); Leçons de droit civil, tome II, Montchréstien, Paris, 1969, 309-346; Tunc, A., La responsabilité civile, Economica, Paris, 1981, 51 e.v. (hierna gecitecrd als "Responsabilité civile"); Viney, G., Traité de Droit Civil. Les Obligations. La responsabilité: conditions, LGDJ, Paris, 1982, 4-18 (hiema geciteerd als "La Responsabilité"); Hartkamp, A.S., Asser's handleiding tot de beoefening van het Nederlands Burgerlijk recht. Verbintenissenrecht. Deel III, De verbintenis uil de wel, 10de druk, Tjeenk Willink, Zwolle, 1998, 5 e.v. (hierna geciteerd als: Asser-Hartkamp, "Verbintenissen III").

Jean Domat, de in 1696 overleden aanhanger van de Franse school van het natuurrecht, had in zijn boek Les lois civiles dans leur ordre naturel het Romeinse recht gesystematiseerd en geordend. Zo stelde hij dat drie soorten fouten aanleiding konden geven tot schade: ten eerste de fout die tegelijkertijd een delict uitmaakt, ten tweede die fout die voortkomt uit de niet naleving van eerder gemaakte afspraken en ten derde de fout die weliswaar geen delict is, maar die voortkomt uit onvoorzichtigheid, slordigheid of nalatigheid (Mazeaud en Tunc, "Traité", l.c., 46 en "Leçons de droit civil", l.c., 317). Domat beklemtoonde overigens de algemene draagwijdte van nalatigheid of onvoorzichtigheid; de teksten die hij hieromtrent had geschreven, zouden later door de redacteuren van het napoleontisch Burgerlijk Wetboek als basis worden gebruikt voor de artikelen 1382 en 1383 (Tunc, A., "Responsabilité civile", l.c., 55).

Gratianus is de grondlegger van het canonieke recht; hij was een monnik die te Bologna theologie doceerde en die zich toespitste op de studie van het kerkelijk recht (Van Caenegem, R.C. "Geschiedkundige inleiding tot het privaatrecht", l.c., 66). 
de dader zowel civielrechtelijk als strafrechtclijk worden aansprakclijk gesteld. In een dergelijk geval behoort het tot de taak van de gemeenschap, om primair in hoofde van de opsporings- en vervolgingsambtenaren en vervolgens door de strafrechter de orde te herstellen.

Hieruit kan ook worden afgeleid dat de bedoeling van het civiele aansprakelijkheidsrecht onder de code Napoléon niet lag in de bestraffing van de schadeveroorzaker ${ }^{16}$. Het strafrecht is gericht op het straffen van de dader; het aansprakelijkheidsrecht is eerder gericht op de compensatie van de geleden schade ${ }^{17}$ of, vanuit een rechtseconomische optiek, op de preventie van ongevallen, c.q. schade. Het element straf zal in principe enkel dan een rol spelen indien de civielrechtelijke fout ook een strafrechtelijk verwijtbare gedraging uitmaakt.

Het foutbegrip is dus niet sinds jaar cn dag onlosmakelijk met het aansprakelijkheidsrecht verbonden, maar werd onder invloed van de herontdekking van het Romeinse recht, van het canonieke recht en van de maatschappelijke opvattingen van de achttiende eeuw naar voren geschoven als hoeksteen van het napoleontische aansprakelijkheidsrecht ${ }^{18}$. De code civil van Napoléon Bonaparte was dus een synthese van oud én nieuw: zowel het traditionele Franse gewoonterecht, de ideeën van de belangrijke rechtsgeleerden uit die tijd en de innovaties van de Franse Revolutie vormden de bronnen waarop de autcurs van het Burgerlijk Wetboek zich hebben gebaseerd ${ }^{19}$.

De individuele vrijheid van cenieder, was in het ideeëngoed van de Franse Revolutie dermate belangrijk, dat wanneer icmand in het uitoefenen van zijn vrijheid schade berokkende aan een ander, deze schade enkel diende te worden vergoed indien aan de dader een fout kon worden aangewreven. Er werd gevrecsd dat ecn aansprakclijkheid buiten fout een te zware last zou zijn voor de opkomende industrieën en dus de vooruitgang zou belemmeren ${ }^{20}$. Onder invloed van het liberalisme en individualisme die in de Franse Revolutie een vruchtbare voedingsbodem hadden gevonden, werden de intrinsieke kwaliteiten van elk individu, die naar eigen oordeel kon handelen, geprezen. Kan geen fout worden aangetoond, dan worden de economische gevolgen van de schade gedragen door het slachtoffer, zonder dat deze de schade kan afwentelen op een andere persoon. De individuele vrijheid van elkeen zou immers worden belemmerd indien ook schade die niet door een fout was veroorzaakt, zou moeten worden vergoed. Er werd vanuit gegaan dat wanneer iemand schade leed, zulks een speling was van het noodlot en dat eenieder zelf de tegenslagen verwerkt die hij te verduren krijgt. De hieruit ontstane schade kon dus niet naar andere individuen worden verschoven; zonder goede reden diende de schade ten laste te blijven van de gelaedeerde $^{21}$. De ontwikkeling van de industrie - waar de gehele gemeenschap de vruchten vāi zou plukken - mocht niet worden belemmerd door een te zware aansprakelijkheid. De foutaansprakelijkheid ondersteunde in zekere zin de opkomst van het kapitalisme ${ }^{22}$.

Ook in die zin Hartlief, $\mathrm{T}$, leder draagt zijn eigen schade. Enige opmerkingen over de fundamenten van en ontwikkelingen in het aansprakelijkheidsrecht, oratie, Kluwer, Deventer, 1997, 17 (hierna geciteerd als "leder draagt zijn eigen schade"). Asser-Hartkamp, "Verbintenissen III", I.c., 8.

is Van Dunné, J.M., Verbintenissenrecht. Onrechtmatige daad. Overige Verbintenissen. Deel 2, Kluwer, Deventer, derde druk, 1997, 338 (hiema geciteerd als "Verbintenissenrecht 2"). Van Caenegem, R.C. "Geschiedkundige inleiding tot het privaatrecht", l.c., 7 e.v.

20 Zweigert, K. en Kotz, H., An Introduction to Comparative Law, Clarendon Press, Oxford, $2^{\circ}$ druk, 1987,688 .

21 Het beginsel dat ieder zijn eigen schade draagt, kan inderdaad worden beschouwd als een normatief uitgangspunt (Hartlief, T., "Ieder draagt zijn eigen schade", l.c., 24). 316. 
Het civieliechtelijke aansprakelijkheidsrecht kreeg in de codes van Napoléon een algemeen en universeel karakter. Dit blijkt uit de algemene draagwijdte die aan de civielrechtelijke aansprakelijkheid wordt gegeven - in tegenstelling tot de casuïstische benadering onder het Romeinse recht. De in het $\mathrm{BW}$ neergelegde abstracte regels kunnen worden toegepast op een oneindig aantal analoge situaties, ongeacht waar een schade is tot stand gekomen en ongeacht het geslacht, de religie of de nationaliteit van dader en slachtoffer. Het biedt met andere woorden een algemeen kader waarnaar steeds kan worden teruggegrepen. In dit universele kader, neemt de foutaansprakelijkheid van artikel 1382 (1401 voor Nederland) cen centrale positie in.

Het negentiende eeuwse aansprakelijkheidsrecht kan dan ook als volgt worden geparafraseerd: "of er is een fout en dus volledige vergoeding, of er is niets waarmee het aansprakelijkheidsrecht zich in te laten heeft" ${ }^{23}$. Inzake aansprakelijkheid is het laten liggen van de schade de regel (wem es triff, dem trifft es), een verliesverschuiving de uitzondering ${ }^{24}$. Door een aansprakelijkheidsvordering wordt de last, aanvankelijk gedragen door het slachtoffer, maar veroorzaakt door andermans foutieve gedraging, verplaatst naar de auteur van deze fout ${ }^{25}$.

De fout kan zowel negatief (geen aansprakelijkheid zonder fout) als positief (elke fout geeft aanleiding tot aansprakelijkheid) worden omschreven. De negatieve omschrijving van de fout moet worden gezien in het licht van de ten tijde van de Franse Revolutie gepropageerde vrijheid van elkeen. De aansprakelijkheid werd inderdaad beperkt tot die gevallen waar door een ander een fout werd begaan ${ }^{26}$. De positieve omschrijving van de foutvereiste gaf uiting aan een rechtvaardigheidsgevoel en een belangenafweging: indien iemand schade leed tengevolge van de fout van een ander, vereist de rechtvaardigheid dat bij de afweging van de belangen van het onschuldig slachtoffer enerzijds en van de dader anderzijds, de belangen van het slachtoffer primeren ${ }^{27}$. Het was dus in de ogen van de redacteuren van de code civil niet meer dan rechtvaardig een verschil te maken tussen een foutieve en niet-foutieve gedraging.

Opvallend is dat nauwelijks vijf artikelen van de Code Civil aandacht besteden aan de vergoeding van ongevalsschade: de artikelen 1382 tot en met 1386 (in Nederland artikel 1401 e.v. oud BW). Deze artikelen blinken echter uit in beknoptheid en bondigheid en houden al bijna twee eeuwen stand: niettegenstaande de verregaande en dramatische wijzigingen die de maatschappij heeft ondergaan, blijven ook vandaag de artikelen 1382 en volgende in België en - zij het in licht gewijzigde versie - de artikelen 6:162 NBW in Nederland het uitgangspunt van het civiele aansprakelijkheidsrecht. Door de hoge kwaliteit van deze bepalingen, vormen ze de basis waarop rechtspraak en rechtsleer een theorie inzake de civielrechtelijke aansprakelijkheid opbouwden en verfijnden ${ }^{28}$.

Simoens, D., "Hoofdlijnen in de evolutie van het aansprakelijkheidsrecht", o.c., 1968.

De Page, Traité, II, Bruxelles, Bruylant, 1965, nr. 935; Van Gerven, W., "De invloed van verzekering op het verbintenissenrecht", Rechtskundig Weekblad, 1962-63, 777.

Meteen moet erop gewezen worden dat schadevergoeding niet betekent dat de schade ongedaan gemaakt wordt, maar enkel dat de economische last ervan kan teruggekoppeld worden naar de "dader". Of zoals Schäfer het stelt: "ein Schaden, der einmal eingetreten ist, mag sich gering halten lassen - aus der Welt sehaffen läßt er sich nicht mehr. Er muß unweigerlich von irgendjemandem getragen werden. Die Frage ist nur, von wem. Das und nichts anderes ist die Grundfrage, die eine gesellschaftliche Schadenverteilungsordnung zu lösen hat" (Schäfer, D., Soziale Schäden, Soziale Kosten und Soziale Sicherung, Berlijn, 1972, 160).

Simoens, D., "Hoofdlijnen in de evolutie van het aansprakelijkheidsrecht", o.c., 1966-1967.

Simoens, D., "Hoofdlijnen in de evolutie van het aansprakelijkheidsrecht", o.c., 1967.

Zie de inleiding van Henri Capitant bij het magistrale werk van Mazeaud en Tunc: Traité théorique et pratique de la responsabilité délictuelle et contractuelle: "Ils sont écrits sur le roc, et supportent encore 
Zowel het Belgische als het Nederlandse Burgerlijk Wetboek gaan dus terug op de code civil de Napoléon. Gedurende de negentiende eeuw waren in Belgiê en Nederland sterk analoge - en op bepaalde punten zelfs identieke - wetten van kracht op het vlak van de civielrechtelijke aansprakelijkheid. Maar in tegenstelling tot in België is het Nederlandse Burgerlijk Wetboek, ook ter zake van de civielrechtelijke aansprakelijkheid, reeds formeel gewijzigd. Vandaar is het nict zonder gevaar om beide systemen zonder meer met elkaar te verglijken, zonder voorafgaandelijk te hebben vastgesteld dat er voldoende gemeenschappelijke aanknopingspunten zijn.

\subsection{Foutaansprakelijkheid in het Belgische en het Nederlandse BW}

De vergelijking van de tekst van artikel 1382 van het Belgische $\mathrm{BW}$ en artikel 6:162 van het Nederlandse BW, doet op het eerste gezicht vermoeden dat er tussen beide rechtsstelsels een aantal aanzienlijke verschillen bestaat inzake de civielrechtelijke aansprakelijkheid.

Artike] 1382 van het Belgische BW luidt:

"Elke daad van de mens, waardoor aan een ander schade wordt veroorzaakt, verplicht degene door wiens schuld de schade is ontstaan, deze te vergocden".

Artikel 6:162 BW huidt als volgt ${ }^{29}$ :

"1. Hij die jegens een ander een onrechtmatige daad plecgt, wclke aan hem kan worden toegerekend is verplicht de schade die de ander dientengevolge lijdt, te vergoeden.

2. Als onrechtmatige daad worden aangemerkt een inbreuk op een recht en een doen of nalaten in strijd met een wettelijke plicht of met hetgeen volgens ongeschreven recht in het maatschappelijk verkeer betaamt, een en ander behoudens de aanwezigheid van een rechtvaardigingsgrond.

Een onrechtmatige daad kan aan de dader worden toegerekend, indien zij te wijten is aan zijn schuld of aan een oorzaak welke krachtens de wet of de in het verkeer geldende opvattingen voor zijn rekening komt".

Hierbij kan worden opgemerkt dat in België over het algemeen de term foutaansprakelijkheid wordt gehanteerd, hoewel de tekst van artikel $1382 \mathrm{BW}$ het uitdrukkelijk heeft over "schuld" ${ }^{30}$.

sans faiblir l'énorme contruction que les tribunaux et la doctrine ont édifiée sur eux. (...) S'il est vrai que les proverbes soient la sagessie des nations, on peut dire que ces textes sont des proverbes juridiques, car ils résument la sagesse de la tradition juridique et restent jeune (...)".

Een voor de Belgische jurist niet-onbelangrijk - zij het praktisch - verschil in het Nederlandse NBW ten opzichte van de op de napoleontische codes geinspireerde wetboeken (zoals het Belgische $\mathrm{BW}$ ), betreft de nummering. Daar waar het Belgische $\mathrm{BW}$ in beginsel nog steeds uitgaat van een doorlopende nummering, wordt onder het Nederlandse NBW de doorlopende nummering slechts aangehouden per Boek. Aldus komt men tot artikel 1 van Boek 2, artikel I van Boek 3 enz., hetgeen wordt aangehaald als artikel 2:1, artikel 3:1, waarbij het eerste cijfer staat voor het desbetreffende Boek van het NBW en het tweede voor het artikel zelf. De bcpalingen inzake de civielrechtelijke aansprakelijkheid van het NBW zijn terug te vinden vanaf artikel 162 van Boek 6, met andere woorden artikel 6:162 e.v.

Zie over de dubbele betekenis van het schuld/fout-begrip in het leerstuk van de onrechtmatige daad onder meer: Nieuwenhuis, J.H., "De tuinman en de dood", Rechtsgeleerd Magazijn Themis, 1989, 193201; KJaassen, C.J.M., Risicoaansprakelijkheid. De afdelingen 6.3.2 en 6.3.3 NBW' alsmede ari. 31 
Anderzijds baseren Belgische Franstalige auteurs zich op de Franstalige tekst van het BW, waar sprake is van "une faute", hetgeen over het algemeen wordt vertaald als een "fout", eerder dan "schuld".

De tekstuele vergelijking van beide artikelen lijkt aan te geven dat tussen het Belgische en het Nederlandse civielrechtelijke aansprakelijkheidsrecht op een drietal punten aanzienlijk van elkaar verschillen. In de eerste plaats vermeldt het Nederlandse BW verschillende onrechtmatigheidscategorieën, wat niet het geval is voor het Belgische BW. In tweede instantie wordt in het Nederlandse BW gerefereerd aan de toerekenbaarheid en tenslotte wordt via de zinsnede jegens een ander in lid I van artikel 6:162 de relativiteitsvereiste verwoord. Als dusdanig is deze vereiste niet bekend in het Belgische civielrechtelijke aansprakelijkheidsrecht. Deze drie verschillen worden hieronder aan de orde gesteld.

\subsubsection{De onrechtmatigheidscategorieèn}

In artikcl 6:162, tweede lid NBW worden uitdrukkelijk drie vormen van onrechtmatigheid onderscheiden: een inbreuk op een recht, cen doen of nalaten in strijd met een wettelijke plicht of een doen of nalaten in strijd met hetgeen volgens ongeschreven recht in het maatschappelijke verkeer betaami ${ }^{31}$.

Naar Belgisch recht worden de verschillende vormen van onrechtmatigheid als dusdanig niet in de wet zelf opgesomd maar wordt, op basis van de rechtspraak, tot een quasi analoog resultaat gekomen: er is sprake van een onrechtmatige daad bij inbreuk op een welbepaald gebod of verbod of bij een inbreuk op de zorgvuldigheidsnorm. Deze kan worden omschreven als de norm die in het maatschappelijke verkeer door een redelijk en voorzichtig persoon gcplaatst in dezelfue omstandigheden, wordt in acht genomen ${ }^{32}$.

Artikel 6:162 NBW vermeldt daarnaast nog een derde onrechtmatigheidscategorie, namelijk de inbreuk op een (subjectief) recht. Toch is, naar geldend Nederlands recht, een inbreuk op een subjectief recht op zich evenwel niet zonder meer voldoende om te besluiten tot onrechtmatigheid. Eun inbreuk op een subjectief recht geldt slechts als een vermoeden van de overtreding van een norm ${ }^{33}$. Maar over de criteria op basis waarvan tot onrechtmatigheid kan worden besloten, bestaat discussie $\mathrm{i}^{34}$. Over het algemcen wordt aanvaard dat met de schending van een exclusief

Wegenverkeersrecht, Zwolle, Tjeenk Willink, 1991, 202; Van Maanen, G.E., Onrechtmatige Daad: Aspekten van de ontwikkeling en struktuur van een omstreden leerstuk, diss., Deventer, Kluwer, 1986, 192 e.v.; Van Maanen, G.E., Spier, J. en Sterck, C.H.W.M., "Van schuld naar risico. Enkele opmerkingen over ontwikkelingen in het aansprakelijkheidsrecht", in Raaijmakers, M., Van Rooij, R. en Spier, J., (red.), Aansprakelijkheden, Deventer, Kluwer, 1990, 68 e.v. (hierna geciteerd als "Van schuld naar risico").

Gesproken wordt van een "gelaagde structuur" (Hartlief, T. en Van Maanen, G.E., "Hoe werkt de onrechtmatige daad? Of het paard van de professor en andere aangrijpende verhalen", Ars Aequi Cahiers Privaatrecht, deel 5, Amhem, 1995, l.c., 18).

Vandenberghe H., Van Quickenborne, M. en Wynant, L., "Overzicht van rechtspraak (1985-1993). Aansprakelijkheid uit onrechtmatige daad", Tijdschrift voor Privaatrecht, 1995, 1172.

Schut, G.H.A., Onrechtmatige Daad, W.E.J. Tjeenk Willink, Zwolle $5^{\text {de }}$ druk, 1997, 58. Sieburgh daarentegen verdedigt de stelling dat een beperkt inbreukbegrip een zelfstandige plaats dient te hebben in het privaatrecht (Sieburgh, C.H., "Wat is rechtsinbreuk?", Nederlands Jurisienblad, 1997, 628-635). Voor een handig overzicht van deze verschillende criteria zie Spier J., Hartlief, T., Van Maanen G.E. en Vriesendorp, R.D., "Verbintenissen", l.c., 31-36. 
recht meteen ook de onrechtmatigheid van de gedraging vaststaat; maar in een groot aantal gevallen zal cen bijkomende toctsing aan het zorgvuldigheidscriterium vereist zijn ${ }^{35}$.

In de Belgische rechtsleer bestaat evenmin eensgezindheid over de vraag of een inbreuk op een recht kan worden beschouwd als een zelfstandige onrechtmatigheidscategorie. De meerderheid van de rechtsleer ${ }^{36}$ verwerpt de stelling dat de inbreuk op een recht als een zelfstandige onrechtmatigheidscategorie kan worden beschouwd. De reden waarom bijvoorbeeld Cornelis de inbreuk op een recht als zelfstandige onrechtmatigheidscategorie verwerpt, is omdat hij van oordeel is dat een inbreuk op een recht niet automatisch betekent dat ook de zorgvuldigheidsnorm werd overtre$\mathrm{den}^{37}$. Ook bijvoorbeeld Vandenberghe is genuanceerd in die zin dat wordt gesproken van een rechtstreekse inbreuk op een subjectief recht ${ }^{38}$. Recent heeft Bocken, onder verwijzing naar het Nederlandse recht, deze discussie nieuw leven ingeblazen ${ }^{39}$. Hij stelt als uitgangspunt dat de draagwijdte van de subjectieve rechten sterk uiteenloopt ${ }^{40}$ : in een aantal gevallen kennen subjectieve rechten exclusieve rechten toe; in andere gevallen worden deze rechten met andere gedeeld. Op basis hiervan verdedigt Bocken de stelling dat een inbreuk op een exclusief subjectief recht voldoende maar niet noodzakelijk is om onrechtmatigheid vast te stellen ${ }^{41}$.

De discussie over de zelfstandigheid van de onrechtmatigheidscategorie "inbreuk op een recht" is uitermate relevant met betrekking tot de vraag of er een subjectief recht op een gezond leefmilieu bestaat. Daarop wordt in de volgende paragraaf teruggekomen.

De onrechtmatigheidscategorie "handelen of nalaten in strijd met een wettelijke plicht" levert de minste problemen op, aangenomen dat de desbetreffende wettekst voldoende duidelijk is omtrent de inhoud en de strekking van deze plicht.

\subsubsection{De toerekenbaarheidsvereiste}

In het Belgische recht wordt geen formcel onderscheid gemaakt tussen onrechtmatigheid en toerekening ${ }^{42}$. Naar Belgisch recht wordt in het algemeen de toerekenbaarheid beschouwd als een

Kottenhagen-Edzes, P.A., Onrechtmatige Daad en Milieu, diss., Gouda Quint, Amhem, 1992, 155; Van Dam, C.C., Zorgvuldigheidsnorm en Aansprakelijkheid. Een rechisvergelijkend onderzoek naar plaats, inhoud en functie van de zorgvuldigheidsnorm bij de aansprakelijkheid voor letsel-en zaakschade, diss., Kluwer, Deventer, 1989, 74 en 95 (hierma geciteerd als "Zorgvuldigheidsnorm en Aansprakelijkheid"), Spier J., Hartlief, T., Van Maanen G.E. en Vriesendorp, R.D., Verbinienissen wit de wet en schadevergoeding, Kluwer, Deventer, 1997, 36; Schut, G.A., "Onrechtmatige Daad", I.c., 59. Comelis, L., Beginselen wan het Belgische buitencontractuele aansprakelijkheidsrecht. De onrechimatige daad, Maklu, ced.samsom, Antwerpen, 1988, 146-151; Dabin, I., "Les thèses du Procureur Général Leclercq en matière de responsabilité civile", Revue Générale des Assurances et des Responsabilités, 1933, nr. 1315; De Page, H., "Traité II", l.c., 923-927; Mazeaud H. en Tunc, A., "Traité", l.c., 464. Comelis, L., "Beginselen", l.c., 149.

Vandenberghe H., Van Quickenbome, M. en Wynant, L., "Overzicht van rechtspraak (1985-1993)", o.c., 1167.

Bocken, H., "Nog iets over inbreuk op recht?", in Liber Amicorum Walter van Gerven, Kluwer, Deurne, $2000,183-202$.

Ook in die zin: Spier J., Hartlief, T., Van Maanen G.E. en Vriesendorp, R.D., "Verbintenissen", l.c., 29. Bocken volgt hier met name de visie van Sieburgh, C.H., "Wat is rechtsinbreuk?", o.c., 630.

Bocken, H., "Nog iets over inbreuk op recht?", o.c., 193.

Van Dam, C.C., Aansprakelijkheidsrecht. Een grensoverschrijdend handboek, Boom Juridische uitgevers, Den Haag, 2000, 51. 
bestanddcel van de foutvereiste ${ }^{43}$ : zowel in het geval waarbij personen de controle over hun handelingen verliezen, als bij het bestaan van een rechtvaardigingsgrond ${ }^{44} 45$, zal worden geoordeeld dat niet is voldaan aan de toerekenbaarheidsverciste en dat de betrokkene bijgevolg geen fout hecft begaan. Ook het Belgische Hof van Cassatie oordeelt dat een overtreding van ecn wettelijke bepaling een fout uitmaakt, op voorwaarde dat deze aan de dader kan worden toegerekend ${ }^{46}$. Uit het klassicke foutconcept zoals dat in het algemeen in België wordt gehanteerd ${ }^{47}$, wordt dus zowel ecn subjectief als een objectief clement afgeleid. De fout verwijst zowel naar de objectieve verwijtbaarheid van de gedraging (schuld in ruime zin) als naar de subjectieve verwijtbaarhaid van de dader (schuld in enge zin). Het objectieve element bestaat uit een onrechtmatige handeling, tcrwijl het subjectieve element bestaat in de toerekenbaarheid ervan aan de dader. Volgens Cornelis bestaat de fout uit drie elementen: de toerekeningsvatbaarheid ${ }^{48}$, de miskenning van een algemene zorgvuldigheidsnorm en de voorspelbaarheid van de schade ${ }^{49}$.

In Nederland werd het schuldbegrip zoals verwoord in artikel 1401 oud $B W^{50}$, eveneens op verschillende wijze uitgelegd ${ }^{51}$. Zo werd al dan niet een onderscheid gemaakt tussen onrechtnatig-

Comelis, L., Beginselen van het Belgische buitencontractuele aansprakelijkheidsrecht. De onrechtmatige daad, Maklu, ced.samson, Antwerpen, 1989, 22 (hierna geciteerd als "Beginselen").

De rechtvaardigingsgrond in het civielrechtelijke aansprakelijkheidsrecht leunt naar Belgisch recht nauw aan bij het strafrecht; zo komen onder meer wettelijke zelfverdediging, noodtoestand, dwang, bevel van de wet of van de overheid en onoverkomelijke dwaling in aanmerking als rechtvaardigingsgrond in het civielrechtelijke aansprakelijkheidsrecht. Zie over deze rechtvaardigingsgronden o.m. Cornelis, L., "Beginselen", l.c., 29 e.v.; Vandenberghe, H., Van Quickenborne, M. en Wynant, L., "Overzicht van rechtspraak (1985-1993)", o.c., 1269 e.v.; Van Ommeslaghe, P. en Cornelis, L., "Les faits justificatifs dans le droit belge de la responsabilité aquilienne, In memoriam Jean Limpens, Antwerpen, Kluwer, 1987, 265 e.v.

Terecht wijst Cornelis op het onderscheid dat dient te worden gemaakt tussen de notie rechtvaardigingsgrond en een vreemde oorzaak (Comelis, L., "Beginselen", l.c., 27 en 40). De vaststelling dat in een gegeven situatie sprake is van een vreemde oorzaak, doet op zich geen afbreuk aan de fout van de dader, maar zal de conclusie rechtvaardigen dat geen causale relatie bestaat tussen diens fout en de schade.

Hof van Cassatie, 22 september 1988, Arresten van het Hof van Cassatie, 1988-89, 941.

Vandenberghe, H., Van Quickenborne, M. en Hamelinck, P., "Aansprakelijkheid uit onrechtmatige daad (1964-1978)", Tijdschrift voor privaatrecht, 1980, 1146; Vandenberghe, H., Van Quickenborne, M., Geelen, K. en Decoster, S., "Overzicht van rechtspraak (1979-1984). Aansprakelijkheid voor onrechtmatige daad", Tijdschrift voor Privaatrecht, 1987, 1263.

Vandenberghe e.a. hebben het over "toerekenbaarheid" (Vandenberghe, H., Van Quickenbome, M. en Wynant, L., "Overzicht van rechtspraak (1985-1993)", o.c., 1122 e.v).

Comelis, L., "Beginselen", l.c., 21 e.v.

Een opmerkelijk verschil tussen artikel 1382 van het Belgische BW en artikel 1401 van het oude Nederlandse BW, bestond erin dat in Nederland de term "onrechtmatig" was toegevoegd aan de vertaling uit het Frans. Blijkbaar wilde de Nederlandse wetgever beklemtonen dat enkel een onrechtmatige daad aanleiding kon geven tot schadevergoeding en werd aldus getracht een beperking aan te brengen aan artikel 1401. Uit onderzoek blijkt dat evenwel dat de toevoeging van de notie "onrechtmatige" niet heeft geleid tot een dergelijke beperking (Van Maanen, G.E., "Onrechtmatige Daad", l.c., 14 en 176). In de juridische literatuur in Nederland is inderdaad heel wat geschreven omtrent de invulling die gedurende de negentiende eeuw werd gegeven aan artikel $1401 \mathrm{BW}$ en de al dan niet zelfstandige betekenis van artikel 1402 BW. Zie hierover o.m. Schut, G.H.A., "Onrechtmatige Daad", l.c., 37 e.v.; Asser-Hartkamp, "Verbintenissen III", l.c., 77 e.v.; Van Dunné, J.M., "Verbintenissenrecht 2", l.c., 126 c.v.; Van Maanen, G.E., "Onrechtmatige Daad", l.c., 152; Van Maanen, G.E., "De mythe rond het arrest Lindenbaum-Cohen (31 januari 1919)", Recht en Kritiek, 1983, 51-87; Van Maanen, G.E., "Onrechtmatige Daad tussen BW en NBW. Overeenkomsten en verschillen in de wettelijke struktuur van de artt. 1401 en $1402 \mathrm{BW} 1838$ en art. 6.3.1.1 NBW", Groninger opmerkingen en mededelingen. Magazijn voor Leerstellige Rechtsvergelijking op Historische Grondslag, II, 1985, 156. 
heid en schuld en werd het begrip schuld in objectieve of in subjectieve zin gehanteerd. Bij de redactie van het NBW, heeft de Nederlandse wetgever zich in ruime mate laten inspireren door de uitspraak in de zaak Lindenbaum-Cohen ${ }^{52}$. . Uit de tekst van art. 6:162 NBW $^{54}$, waar het tweede lid verwijst naar de onrechtmatigheid en het derde lid naar de toerekenbaarheid blijkt dat een formeel onderscheid wordt gemaakt tussen onrechtmatigheid en toerekening ${ }^{55}$. Schuld wordt er gehanteerd in de beperkte betekenis van verwijtbaarheid ${ }^{56}$.

Van Dam heeft kritiek geleverd op de formulering van lid 3, omdat hij vreest dat de term toerekening onder het NBW derelfde dubbelzinnige functie zou krijgen als de term schuld in het oude $\mathrm{BW}^{57}$. Ook andere auteurs stellen de functie van het begrip "schuld", zoals geformuleerd in artikel $6: 162$, lid 3 in vraag ${ }^{58}$.

In feitc wordt het begrip "fout" in België gehantecrd in dezelfde zin als het begrip schuld in ruime zin in Nederland, namelijk een tocrekenbare onrechtmatige gedraging. Ook het voortreffelijk onderzock van van Dam heeft aangetoond dat deze verschillende begrippen teruy te voeren zijn tot verschillen in formele vercisten (met name "fout" in België en "onrechtmatigheid" en "toerekening" in Nederland) $)^{59}$. De structuur van artikel 6:162 NBW leunt inderdaad meer aan bij het Frans recht, dan op het cerste gezicht kan worden vermoed ${ }^{610}$. In beide landen is uiteindelijk van belang of de zorgvildigheidsnorm al dan niet werd geschonden; materieel bestaan tussen beide svstemen aldus geen aanzienlijke verschillen ${ }^{\text {t }}$ o? .

Hoge Raad, 31 januari 1919, Nederlandse Jurispradentie, 1919, 161. Deze zaak kan als volgt worden samengeval. Cohen, ex-werknemer van de drukkerij van Lindenbaum, richte een eigen drukkerij op waarbij hij een werknemer van zijn voormalige werkgever ertoe overhaalde inlichtingen te verstrekken betreffende uitgaande offertes. Lindenbaum beweerde dat hij hierdoor verschillende bestellingen had gemist en hij daagde Cohen voor de rechtbank. Aangezien in die tijd de feiten niet onder de toenmalige strafwet vielen en er aldus geen wet was geschonden, kwalificeerde de Hoge Raad de handelingen van Cohen wel degeiijk als onrechtmatig. Zie hierover onder meer Spier J., Hartlief, T., Van Maanen G.E. en Vriesendorp, R.D., "Verbintenissen", l.c., 21; Van Dunné, J.M., "Verbintenissenrecht 2", l.c., 124 e.v. Dit artikel van het Nederlandse Nieuw BW bouwt voort op artikel 1401 van het oude BW (AsserHartkamp, "Verbinterissen III", l.c., 77-78). Over de toerekening, zic Sieburgh, C.H., Toerekening van een onrechimatige daad, Kluwer, Deventer, 2000, 5 e.v.

Hartlief, T. en Van Maanen, G.E., "Hoe werkt de onrechtmatige dasd?", l.c., 53; Spier J., Hartlief, T., Van Maanen G.E. en Vriesendorp, R.D., "Verbintenissen", l.c., 15.

Hiermee wordt bedoeld dat, in de categorie van strijdigheid met een wettelijke plicht, zowel het gedrag als de persoon worden getoest: niet alleen deze strijdigheid zelf, maar bovendien de onachtzaamheid van de dader moet worden bewezen (Van Dam, C.C., "Zorgvuldigheidsnorm en Aansprakelijkheid", l.c., 86-87). Spier J., Hartlief, T., Van Maanen G.E. en Vriesendorp, R.D., "Verbintenissen", l.c., 65.

Van Dam, C.C., "Zorgvuldigheidsnorm en Aansprakelijkheid", l.c., 94.

Van Dam, C.C., "Aansprakelijkheidsrecht", l.c., 164.

Van Dam, C.C., "Zorgvuldigheidsnorm en Aansprakelijkheid", l.c., 94.

Van Dam heeft verschillende elementen ontwikkeld die van belang zijn bij de vraag of een persoon in een gegeven situatie zorgvuldig heeft gehandeld: de aard en de omvang van de schade; de waarschijnlijkheid dat deze schade zich zal voordoen; de aard van de gedraging; de bezwaarlijkheid, in termen van kosten, tijd en moeite voor het nemen van voorzorgsmaatregelen (Van Dam, C.C., "Zorgvuldigheidsnorm en Aansprakelijkheid", l.c., 110-132). 


\subsubsection{Relativiteit}

Hieronder wordt eerst weergegeven wat onder de relativiteitsleer wordt bcgrepen ( $\S$ 1.3.3.1), wordt vervolgens toegelicht hoe de relativiteit zich verhoudt tot de causaliteit ( $\$$ 1.3.3.2). Tenslotte wordt aangetoond dat de relativiteitseis zoals die in Nederland wordt gehanteerd, ook een invloed heeft op gevallen van milieuaansprakelijkheid bij bodemverontreiniging ( $\$ 1.3 .3 .3)$.

\subsubsection{Omschrijving}

Zoals aangegeven neemt de zorgvuldigheidsnorm een centrale rol in in het aansprakelijkheidsrecht en zal een fout die in een oorzakelijk verband staat tot de schade, aanleiding geven tot aansprakelijkheid.

In Nederland is evenwel een bijkomende zorgvuldigheidstoetsing vereist. Niettegenstaande het tweede lid van dit artikel 6:162 NBW de indruk wekt dat de inbreuk op een subjectief recht meteen zou leiden tot een onrechtmatige daad, wordt vrij algemeen aanvaard dat ook moet worden getoetst of werd gehandeld in strijd met de maatschappelijke zorgvuldigheid ${ }^{6.3}$.

Deze problematiek heeft te maken met de in Nederland en Duitsland aanvaarde relativiteitsleer (ook bekend als de Schutznorm-theorie of de normbestemmingsleer) ${ }^{64}$ : enkel wanneer de norm ertoe strekt het belang van de benadeelde te beschermen, zal schadevergoeding worden toegekend.

In Nederland werd de relativiteitsleer geïntroduceerd door van Gelein Vitringa ${ }^{\text {tis }}$ en in 1928 voor het eerst door de Hoge Raad aanvaard ${ }^{66}$. Zeker sinds het brandstichtingarrest van $1930^{67}$ hanteert de Hoge Raad het principe dat onrechtmatigheid tegenover één bepaalde persoon niet meteen betekent dat tegelijk onrechtmatig wordt gehandeld tegenover eenieder die schade heeft gele$\operatorname{den}^{6 / 8}$. Nadat anvankelijk op deze theorie kritiek werd geleverd ${ }^{69}$, wordt de relativiteitsleer in Nederland vrij algemeen aanvaard ${ }^{70}$. Na de genoemde arresten, werd deze leer expressis verbis

In verband hienmee wordt in Nederland de bepaling van artikel 6:162 onder vuur genomen Met name door Van Dam, C.C., "Zorgvuldigheidsnorm en Aansprakelijkheid", l.c., 191-192; hierin bijgetreden door Van Dunné, J.M., "Verbintenissenrecht 2", l.c., 192-193.

In Duitsland wordt de relativiteitsleer verwoord in § 823 BGB: "(1) Wer vorsătzlich oder fahrlässig das Leben, den Körper, die Gesundheit, die Freiheit, das Eigentum oder ein sonstiges Recht eines anderen widerrechtlich verletzt, ist dernm anderen zum Ersatze des daraus entstchenden Schadens verpflichtet. (2) Die gleiche Verpflichtung trifft denjenigen, weicher gegen ein den Schutz eines anderen bezweckendes Gesetz verstößt. Ist nach dem Inhalte des Gesetzes ein VerstoB gegen dieses auch ohne Verschulden moglich, so tritt die Ersatzpflicht nur im Falle des Verschuldens ein". van Gelein Vitringa, J., "Openbaarheid van den weg en burgerlijk recht", Rechtsgeleerd Magazijn Themis, 1919, 23-50. Zie hierover Van Maanen, G.E., "Onrechtmatige Daad", l.c., 196 e.v. Hoge Raad, Marchant d'Asembourg/Staat, 25 mei 1928, Nederlandse Jurisprudentie, 1928, 1688.

67 Hoge Raad, Vonk brandstichting, 24 januari 1930, Nederlandse Jurisprudentie, 1930, 299. Hier dient te worden aangestipt dat de relativiteitsleer aldus werd toegepast op de onrechtmatigheidscategorie "doen of nalaten in strijd met cen wettelijke plicht".

Met name door Scholten en Meijers en later door Van Dunné; Meijers schreef bijvoorbeeld: "Een beperking der aansprakelijkheid door na te gaan wier belangen de norm beoogt te schermen, past alleen bij sommige, publiekrechtelijke wettelijke voorschriften" (Meijers, Nederlandse Jurisprudentie, 1937, 899). Schut, G.H.A., "Onrechtmatige daad", l.c., 41 e.v. 
opgenomen in het NBW, met name in artikel 6:163 (juncto art. 6:162, lid $1^{71}$ ): "Geen verplichting tot schadevergoeding bestaat, wanneer de geschonden norm niet strekt tot bescherming tegen de schade zoals de benadeelde die heeft geleden". Met andere woorden: de handeling moet jegens de eiser onrechtmatig zijn ${ }^{72}$. De relativiteitsleer is niet beperkt tot één onrechtmatigheidscategorie, maar kan worden toegepast op de verschillende onrechtmatigheidscategorieën.

De wettelijke neerslag van de relativiteit in artikel 6:163 NBW heeft bijgevolg geleid tot een uitbreiding van het toepassingsgebied van de relativiteitsleer ${ }^{73}$. Volgens Hartlief is de relativiteitseis voornamelijk van belang bij de wetsovertreding aangezien bij de inbreuk op een recht enkel de titularis van dat recht een vordering kan instellen en aangezien de maatschappelijke zorgvuldigheid "bijna per definitie een gericht beschermingsbereik heeft" ${ }^{14}$. Over het algemeen wordt aangenomen dat artikel 6:163 een dubbele functie heeft: ten eerste dient het gedrag jegens een ander onrechtmatig te zijn; en ten tweede dient tegelijk de door de benadeelde geleden schade onder het beschermingsbereik van de geschonden norm te vallen ${ }^{75}$.

Volgens van Dunné is de relativiteitsleer een verkeerd toegepaste Duitse theoric, in die zin dat $\varnothing$ 823 , lid 2 BGB betrekking heeft op de inbreuk op een subjectief recht ${ }^{76}$. Zeker sinds de aanvaarding van de Hoge Raad van de toerekening naar redelijkheid als causaliteitsgrondslag in $1970^{77}$ zou er geen nood meer zijn aan een Schutznorm, aldus van Dunne ${ }^{78}{ }^{79}$. Dit brengt ons bij het verband tussen relativiteit en causaliteit.

\subsubsection{Relativiteit versus causaliteit}

Over het algemeen wordt de relativiteitstheorie noch in België, noch in Frankrijk aanvaard ${ }^{80}$ : zodra een fout wordt begaan die in een causale relatie staat tot de schade, zal de auteur van de: schade tot schadevergoeding gehouden zijn. Nochtans betekent deze afwijzing niet dat in België

7 Met name de bepaling: "Hij die jegens een ander een onrechtmatige daad pleegt ..." (eigen cursivering).

Schut, G.H.A., "Onrechtmatige Daad", l.c., 42.

Van Dam, C.C., "Zorgvuldigheidsnorm en Aansprakelijkheid", l.c., 80-81. Van Dam wijst er overigens op dat de wet dusdanig is geformuleerd dat sprake is van een relativiteitsvermoeden; het is aan de veroorzaker om de afwezigheid van relativiteit te bewijzen. Hartlief, T., "leder draagt zijn eigen schade", I.c. 46.

75 Van Maanen, G.E., "De relativiteit als onlosmakelijk bestanddeel van de onrechtmatigheidsvraag", in Miscellanea. Jurisconsulto vero Dedicata, Van Dunné-bundel, 1997, 262; Spier J., Hartlief, T., Van Maanen G.E. en Vriesendorp, R.D., "Verbintenissen", l.c., 57. Van Dunné, J.M., "Verbintenissenrecht 2", l.c., 208.

Hoge Raad, 20 maart 1970. Nederlandse Jurisprudentie, 1970, 251 (Waterwingebied). Voorheen werd in Nederland uitgegaan van de adequatietheorie (Hoge Raad, 3 fcbruari 1927, Nederlandse Jurisprudentie, 1927, 626 (Haagsche Post) en Hoge Raad, 28 februari 1929, Nederlandse Jurisprudentie, 1929, 905 (Intercueros)). Verderop wordt teruggekomen op het causaliteitsvraagstuk.

Van Dunné, J.M., "Verbintenissenrecht 2", l.c., 208.

79 In het midden van de jaren negentig werd over het nut van de relativiteitsvereiste een vinnige discussie gevoerd tussen Van Maanen en Van Dunné. Zie Van Maanen, G.E., "Kroniek van het vermogensrecht", Nederlands Juristenblad, 1995, 338-346, als kritiek op Van Dunnés visie op de 30-september arresten in NJB, 1994, 1330 e.v. Van Maanen, G.E., "De relativiteit als onlosmakelijk bestanddeel van de onrechtmatigheidsuraag", o.c., 260 en 267.

Comelis is het niet eens met deze stelling: hij ziet zowel in de aansprakelijkheid van de ouders voor schade veroorzaakt door hun kinderen (art. 1384, lid 2 BW), als in de aansprakelijkheid van onderwijzers en ambachtslui (art. 1384, lid $4 \mathrm{BW}$ ) een toepassing van de relativiteitsleer, in die zin dat enkel derden op deze bepalingen een beroep kunnen doen. De ouders of de ambachtslui zelf kunnen op deze bepaling geen beroep doen (Comelis, L., "Beginselen", l.c., 309 en 336). 
en Nederland analoge gevallen systematisch tot verschillende resultaten leiden. Eerder reeds verdedigden tegenstanders van de relativiteitsleer dat tot eenzelfde resultaat kan worden gekomen door een correcte toepassing van de causaliteitstheorie ${ }^{81}$.

Terwijl in Nederland een gegeven vordering zal worden afgewezen omdat de geschonden norm niet strekte tot bescherming van de belangen van de klager, zal in België dezelfde vordering veelal worden afgewezen wegens het ontbreken van een causale relatie tussen de fout en de scha$\mathrm{de}^{82}$. Zoals bekend wordt in België, bij het beoordelen van de causaliteitsvraag, de equivalentieleer gehanteerd. Deze leer impliceert dat de dader wordt aansprakelijk gesteld zodra de schade zich niet zou hebben voorgedaan bij afwezigheid van fout ${ }^{83}$. Omgekeerd kan de rechter een op een fout gebaseerde schadevordering afwijzen indien de schade ook zou zijn ontstaan zonder de fout $^{84}$. Hoewel in België en Frankrijk kritiek wordt geleverd op de relativiteitsleer omdat deze vaag zou zijn, blijkt dat de equivalentieleer en de beoordeling van de noodzakelijke causale relatie, even vaag zijn ${ }^{85}$. Door de vereiste causaliteit tussen de geschonden norm en de schade, wordt in het Franse, en in zekere mate ook in het Belgische systeem de relativiteit als het ware op indirecte wijze aangenomen ${ }^{86}$. In zekere zin verwijzen zowel de causaliteit als de relativiteit naar de voorzienbaarheid van de schade ${ }^{87}$.

Hier ligt dan ook de essentie van de gehele discussie: zowel de causaliteit als de relativiteit zijn leerstukken die ertoe strekken te vermijden dat de aansprakelijkheid in een concrete situatie te ver zou worden doorgetrokken. Op dit punt zijn van Maanen en van Dunné het overigens met elkaar eens: de onrechtmatigheidsvraag ex artikel 6:162 BW valt steeds terug te leiden naar een concrete vraag $^{88}$. Het meningsverschil tussen beide hoogleraren slaat op de wijze waarop dit dient te gebeuren $^{89}$.

Naar Belgisch recht zal de beperking van de aansprakelijkheid eerder worden bereikt via de causaliteitsvraag, terwijl in Nederland in mindere of meerdere mate een beroep zal worden gedaan op de relativiteitseis. Het is hierbij zeer de vraag of het ene criterium minder aanleiding geeft tot discussie dan het andere.

" Zo onder meer Wolfsbergen. A., "Reactie op Telders", Weekblad voor Privaatrecht, Notariaat en Registratie, 1929, 3115-3116.

82 In Nederland heeft de causaliteitsvraag vooral nog een functie bij de schending van wettelijke gedragsnormen (Hartlief, T. en Van Maanen, G.E., "Hoe werkt de onrechtmatige daad?", l.c., 16).

83 Vandenberghe H., Van Quickenbome, M. en Wynant, L., "Overzicht van rechtspraak (1985-1993)", o.c., 1452.

Hof van Cassatic 13 februari 1987, Arresten van het Hof van Cassatie, 1986-87; Hof van Cassatie, 2 september 1986, Arresten van het Hof van Cassatie, 1986-87, 9. Philippe, D.-M., "La théorie de la relativité aquilienne", in Mélanges Roger O. Dalcq. Responsabilités et Assurances, Larcier, Bruxelles, 1994, 484-485.

Van Dam, C.C., "Zorgvuldigheidsnorm en Aansprakelijkheid", I.c., 96.

Schamps, G., La mise en danger: Un concept fondateur d'un principe général de responsabilité. Analyse de droit comparé, Bruylant, L.G.D.J., Brussel, 1998, 939 (hierna geciteerd als "La mise en danger").

Van Maanen, G.E., "De relativiteit als onlosmakelijk bestanddeel van de onrechtmatigheidsvraag", o.c., 270 .

Hierbij is Van Maanen de mening toegedaan dat de toepassing van de Schutznorm-lecr in sommige gevallen leidt tot een zinniger oplossing dan een correctie via de schuld of causaliteit (Van Maanen, G.E., "De relativiteit als onlosmakelijk bestanddecl van de onrechtmatigheidsvraag", o.c., 268). 


\subsubsection{Toepassing inzake milieuaansprakelijkheid voor bodemvervuiling naar Nederlands recht}

Het interessante van de relativiteitsleer in het kader van dit proefschrift, ligt erin dat deze leer in het begin van de negentiger jaren in Nederland opnieuw volop in de aandacht is gekomen in het kader van milieuaansprakelijkheid voor bodemvervuiling. Voor een goed begrip van deze problematiek, dienen een aantal belangrijke arresten te worden besproken die in deze materie door de Hoge Raad werden geveld.

Inzake aansprakelijkheid voor bodemvervuiling en meer in het bijzonder het verhaalsrecht van de overheid, is in Nederland met name artikel 75 van de Wet Bodembescherming (Wbb) ${ }^{90}$ van belang ${ }^{91}$. Krachtens artikel $75 \mathrm{Wbb}$ eerste lid, kan de Staat de kosten van onderzoek en sanering die te haren laste vallen, verhalen op degene door wiens onrechtmatige daad de verontreiniging of aantasting van de bodem in het betrokken geval is veroorzaakt en die deswege of anderszins buiten overeenkomst jegens enige overheid krachtens burgerlijk recht aansprakelijk is voor de gevolgen daarvan. Een eerste belangrijke vaststelling in dit verband is dat dit wetsartikel slechts verwijst naar de op basis van het privaatrecht bestaande aansprakelijkheidsgronden ${ }^{92}$. De onrechtmatigheid dient dus te worden vastgesteld op basis van de gebruikelijke criteria ex artikel 6:162 NBW. Ten tweede wordt met de zinsnede "anderszins buiten overeenkomst (...) krachtens burgerlijk recht aansprakelijk" aangegeven dat de overheid eveneens over een verhaalsrecht beschikt bij risicoaansprakelijkheid ${ }^{93}$.

De relativiteitseis impliceert dat enkel degenen die door de overtreden bepaling worden beschermd aanspraak kunnen maken op schadevergoeding ${ }^{94}$. Indien een eis bijvoorbeeld is gebaseerd op het overtreden van de milieuvergunning zal worden gekeken in welke mate inspraak bij de vergunningverlening is mogelijk geweest; is er inspraak geweest, dan kan dit een indicatie vormen dat de belangen van derden inderdaad door de desbetreffende bepaling worden beschermd ${ }^{95}$. Logischerwijze vlocit uit bovenstaande bepaling voort dat een essentieel belang toekomt aan de vraag wanneer iemand jegens de overheid onrechtmatig handelde. In een eerste belangrijk arrest besliste de Hoge Raad dat verontreiniging van de bodem onrechtmatig is jegens de Staat ${ }^{6}$ omdat de milieubelangen van de Staat op ontoelaatbare wijze werden opgeofferd aan de eigen bedrijfs-

Wet van 10 mei 1994, Stb., 331.

De Wbb werd voorafgegaan door artikel 21 van de Nederlandse Interimwet Bodemsanering (Wet van 29 december 1982, Stb., 763) die voorzag in een directie financiering door de Staat (met bijdrageplicht van de gemeenten), de mogelijkheid tot het instellen van heffingen voor bepaalde bedrijfstakken en het kostenverhaal op de daadwerkelijke (onrechtmatige) veroorzaker. Zic hierover Bauw, E., Buitencontractuele aansprakelijkheid bij bodemverontreiniging, diss., Kluwer, Deventer, 1994, 250 e.v.

Van Acht, R.J.J. en Bauw, E., Milieuprivaatrecht, W.E.J. Tjeenk Willink, Zwolle, tweede druk, 1996, 138.

Tonnacr, F.P.C.L., Handboek van het Nederlands Milieurecht, Lemma, Utrecht, 1994, 960 (hierna geciteerd als "Handbock Nederlands Milieurecht").

Van Acht, R.J.J. en Bauw, E., "Milieuprivaatrecht", l.c., 39.

Rus-Van der Velde, M., "Onrechtmatige daad en vergunning", in Koeman, N.S.J., Ouwerkerk, W.J. cn Van Dunné, J.M. (red.), "Civielrechtelijke aansprakelijkheid voor milieuschade", l.c., 106.

Hoge Raad, 14 april 1989, Rechtspraak van de Week, 1989, nr. 107 (Benckiser/Staat), Kwartaalbericht Nieuw BW, 1989, 123 e.v. met noot Van Maanen, G.E. en Hartlief, T. Het Duitse bedrijf Benckiser, dat begin dat jaren tachtig manieren vond om af te geraken van het door hen geproduceerd chemisch afvalgips, had deze afvalstoffen afgegeven aan een Nederlands bedrijf (Bos Bouwstoffen), zonder voorafgaand onderzoek te verrichten aangaande de definitieve bestemming van het afval en dit terwijl er duidelijke aanwijzingen bestonden dat Bos op onverantwoorde wijze met het afval zou omgaan (Bos heeft het afval inderdaad op verschillende plaatsen in Nederland gestort). 
belangen. Het storten van het afvalgips was onrechtmatig jegens de Staat aangezien Benckiser de milieubelangen van de Staat op ontoelaatbare wijze had opgeofferd aan haar eigen belangen ${ }^{97}$.

In de zaak Staat $/$ an Amersfoor ${ }^{9 s}$ besliste de Hoge Raad dat de overheid enkel een beroep kon doen op artikel 21 Ibs indien is voldaan aan alle vereisten van artikel 6:162 NBW. Dit impliceert dat de veroorzaker slechts onrechtmatig handelde jegens de overheid indien het voor de veroorzaker duidelijk was of duidelijk behoorde te zijn dat de overheid zich het belang van de bodemsanering zou aantrekken. Pas vanaf dat moment diende het voor de veroorzaker duidelijk te zijn dat hij de overheid in haar belang zou treffen en ontstond een zorgplicht ten overstaan van die overheid $^{99}$. Aldus formuleerde de Hoge Raad een algemeen abstract criterium voor het bepalen van de datum vanaf wanneer de overheid zich het belang van de bodemsanering zou aantrekken. Deze uitspraak stelde de overheid voor een probleem aangezien de bedoeling van artikcl $21 \mathrm{lbs}$ crin bestond om de relativiteitseis opzij te schuiven ${ }^{100}$ terwijl de Hoge Raad in het arrest Van Amersfoort integendecl deze relativitcit, minstens ten dele, bevestigde.

In de daarop volgende arresten Akzo Resins en Van Wijngaarden preciseerde de Hoge Raad ${ }^{101}$ dat het pas vanaf het midden van de jaren zeventig voor ondememers duidelijk was (of duidelijk hoorde te zijn) dat de overheid tot concrete actie inzake bodemsanering zou overgaan. De vereiste duidelijkheid voor ondememers die in het verleden hun eigen bedrijfsterrein hebben verontreinigd, bestond volgens de Hoge Raad vanaf 1 januari 1975.

In drie belangrijke arresten gewezen op 30 september 1994 - met name Shell-Gouderak, Solvay Duphar en Fasson ${ }^{102}$ - ging de Hoge Raad een stap verder ${ }^{103}$ door te preciseren dat deze datum eveneens geldt voor het storten of ter stort afgeven van afvalstoffen. De Shell-Guuderak-/aak als voorbeeld nemend, achtte het Hof van Amsterdam ${ }^{104}$ (nadien aanhangig gemaakt voor de Hoge Raad) weliswaar bewezen dat de verontreiniging grotendeels was veroorzaakt door onzorgvuldig handelen van Duphar, maar stond het daarentegen niet vast dat Duphar reeds vóór 1969 wist of kon weten dat de overheid zou overgaan tot sanering van de stortplaats in kwestie. Daarenboven oordeelde het Hof dat de relativiteitsvereiste niet alleen geldt voor verontreiniging van het eigen bedrijfsterrein, maar eveneens voor andere gevallen van bodemverontreiniging. Ook de Hoge Raad was van oordeel dat voor andere terreinen dan het eigen bedrijfsterrein het Van Amersfoortarrest diende te worden gevolgd. Aangezien het belang niet van aard verschilt naargelang het gaat om een eigen terrein van de vervuiler of om een terrein van icmand andcrs, is ook voor deze

Tonnaer, F.P.C.L., "Handboek Nederlands Milieurecht", l.c., 962-963.

Hoge Rad, 9 februari 1990, Nederlandse Jurispndentie, 1991, 462 (Staat/Van Amersfoort).

Van Acht, R.J.J. en Bauw, E., "Milieuprivaatrecht", l.c., 139.

In het memorie van antwoord van de Minister van Volksgezondheid en Milieuhygiëne lezen we het volgende: "... om iedere twijfel betreffende de mogelijkheid van verhaal door het Rijk te voorkomen, in artikel $21(\ldots)$ een specifiek verhaalsrecht van het Rijk was opgenomen, ongeacht het antwoord op de vraag jegens wie de onrechtmatige daad is gepleegd" (Memorie van Antwoord, Eerste Kamer, $1982-1983,16.821$, nr. 30b, 4).

Hoge Raad, 24 april 1992, nr. 14.746 (Staa/Akzo Resins) en Hoge Raad, 24 april 1992, nr. 14.490 (StaatVan Wijngaarden), Tijdschrift voor Milieuaansprakelijkheid, 1992/4, 140 e.v. Zie hierover o.m. Drupsteen, Th.G., "Relativiteit per 1 januari 1975", Nederlands Juristenblad, 1992, afl. 25, 786-791.

Respectievelijk nrs. 15.308, 15.314 en 15.315; gepubliceerd in Rechrspraak van de Week, 1994/29, nr. 185-187.

Zie o.m. Van Maanen, G.E., "Bodemsanering na Duphar, Fasson en Gouderak", Aansprakelijkheid en Verzekering, 1994/6, 139-143; Van Dunné, "Wie sterk is mag dom zijn", Nederlands Juristenblad, 1994, 1329-1338.

Hof Amsterdam; 17 december 1992, Tijischrift voor Milieuaunsprakelijkheid, 1993, nr. 4, 107, met noot Van Dunné. 
andere terreinen vóór I januari 1975 niet aan de relativiteitsvereiste voldaan. Verder bevestigt de Hoge Raad het Van Amersfoort-arrest door erop te wijzen dat artikel 21 lbs draait rond de vraag of sprake is van onrechtmatigheid in de zin van artikel 1401 oud BW doordat is gehandeld in strijd met hetgeen volgens ongeschreven recht betaamt. Indien de vervuiler een belang van een ander schendt waarop hij niet hoefde bedacht te zijn, dan is niet voldaan aan de relativiteitseis; bijgevolg heeft de vervuiler niet onrechtmatig gehandeld jegens die ander, aldus de Hoge Raad.

De genoemde arresten hebben volgens van Maanen duidelijkheid geschapen doordat, buiten de theoretische gevallen van strijdigheid met de wet of inbreuk op een subjectief recht, de saneringskosten voor gevallen waar de vervuiling dateert van vóór 1 januari 1975 niet verhaalbaar zijn op de toenmalige veroorzaker, tenzij de vervuiler wist of moest weten dat zijn handelswijze tot verontreiniging zou leiden ${ }^{105}$. Al deze kosten vallen bijgevolg in principe ten laste van de gemeenschap, die heeft geprofiteerd van de economische groei die aan de basis ligt van de bodemverontreiniging, aldus nog steeds de Hoge Raad. Het moge duidelijk zijn dat tengevolge deze arresten, de gedaagde bedrijven vrijuit gingen.

De uit de 30-september arresten voortvloeiende leer, heeft in de Nederlandse literatuur aanleiding gegeven tot talrijke discussies. Zo onder meer van de kant van van Dunné die betoogt dat de oplossing uit de arresten in strijd is met artikel $6: 163 \mathrm{BW}^{106}{ }^{107}$. Stceds volgens van Dunné heeft de Hoge Raad in deze arresten "op opzienbare wijze" het relativiteitsvereiste ondergebracht bij de onsechtmatigheid van de handeling, waardoor beide criteria éćn geheel vormen ${ }^{108}$ en is de Hoge Raad tekortgeschoten in haar motiveringsverplichting ${ }^{\text {(119 }}$. Van Dunné pleit dan ook vurig voor de afschafling van het leerstuk van de relativiteit.

Inmiddels is artikel 21 Ibs vervangen door artikel $75 \mathrm{Wbb}$ dat -... zij het in ecn beperkt aantal gevallen - de relativiteitsvereiste opzij schuift. Artikel 75, vijfde lid Wbb biedt de Nederlandse Staat de mogelijkheid om de saneringskosten, waarvan de vervuiling die craan ten grondslag ligt dateert van vóór 1975 , onder twee voorwaarden te verhalen. Deze voorwaarden ${ }^{110}$ zijn evenwel dermate strikt dat de Staat slechts in uitzonderlijke gevallen de kosten cal kunnen verhalen ${ }^{\prime \prime}$. Met

105 Van Maanen, G.E., "Bodemsanering na Duphar, Fasson en Gouderak", o.c., 143; zie ook Bauw, E., "Buitencontractuele aansprakelijkheid bij bodemverontreiniging", l.c., 282 e.v.

106 Ten eerste omdat dit artikel geen voorzienbaarheid van de schade van de benadeelde vereist en ten tweede ondat het aan de gedaagde partij toekomt om te bewijzen dat niet is voldaan aan de relativiteitsvereiste (Van Dunné, noot onder de arresten in het Tijdschrift voor Milieuaansprakelijkheid, 1994, 166 en Van Dunné, J.M., "Verbintenissenrecht 2", I.c., 218). De discussie met betrekking tot de voor. zienbaarheid van de schade vloeit voort uit een overweging van de Hoge Raad die stelt dat het een geval betreft "waarin de ander ten gevolge van dit onrechtmatige gedrag een schade lijdt welke de dader niet had voorzien en niet behoefde te voorzien" (overweging 3.8.5, in fine).

Zie evenwel ook de discussie tussen Spier en Snijders: Snijders, H.J., "Aansprakelijkheidsrecht na Gouderak en Spier", Weekblad voor Privaatrecht, Notariaat en Registratie, 1995, nr. 6180 en 6181; en reactie van Spier, J., "De macht van het toeval", Weekblad voor Privaatrecht, Notariaat en Registratie, 1995, nr. 6205, 847. Van Dunné, J.M., "Verbintenissenrecht 2", l.c., 212.

Smale, L.J. en Van Dunné, J.M., "Aansprakelijkheid voor milieuschade en financięle zekerheid naar huidig recht: knelpunten en gerealiseerde oplossingen. Nederlands recht", Wiggers-Rust, L.F. en Deketelaere, K., (red.), Aansprakelijkheid voor milieuschade en financiële zekerheid. Een vergelijking van Nederlands, Belgisch en Europees recht, Die Keure, Vermande, Lelystad, 1998, 26.

Deze kunnen als volgt worden geresumeerd: vereist is dat de veroorzaker de aan de stoffen verbonden emstige gevaren kende of behoorde te kennen en dat de veroorzaker zich emstig verwijtbaar niet van de verontreinigende gedragingen heeft onthouden.

11. De voorwaarden onder artikel $75 \mathrm{Wbb}$ zijn volgens Van Dunné niet eens zo strikt, gelet op de sterke objectivering van het schuldbegrip en de zware eisen die de rechtspraak in verschillende gevallen op- 
andere woorden: op basis van art. $75,5^{\circ}$ lid Bww kan slechts in een zeer beperkt aantal gevallen de relativiteitseis opzij worden geschoven. In een minderheid van gevallen zal bodemvervuiling daterend van vóór 1975 onrechtmatig zijn jegens de Staat.

Bovenstaande elementen geven aan dat de discussie in verband met een aantal concepten zoals die worden gebruikt en omschreven in het onrechtmatige daadsrecht (i.c. de relativiteitsleer toegepast op de aansprakelijkheid voor bodemverontreiniging) geenszins theoretische discussies zijn, maar integendeel een belangrijke maatschappelijke en economische impact kunnen hebben.

\subsection{Conclusie}

Het Belgische en het Nederlandse civielrechtelijke aansprakelijkheidsrecht, die in het begin van de negentiende eeuw op hetzelfde wetboek waren gebaseerd, zijn formeel en op het eerste gezicht ver uit elkaar gegroeid. Opvallend hierbij is dat het Belgische aansprakelijkheidsrecht zijn banden met het Franse recht heeft behouden, terwijl in het Nederlandse recht veeleer een invloed van het Duitse recht (bijvoorbeeld via de relativiteitsleer) is te merken.

Dit betekent evenwel niet dat beide rechtsstelsels niet meer met elkaar zijn te vergelijken. Vaak zal, via andere wegen en andere begrippen, een analoog resultaat worden bereikt: in tegenstelling tot in Nederland, staat de tocrekeningsvereiste niet met zoveel woorden in het Belgische BW, en toch dient ook in België een fout aan de dader kunnen worden toegerekend; inzake de: onrechmatigheidsvereiste, wordt in beide landen een beroep gedaan op de zorgvuldigheidsnorm; voor wat betreft het verhinderen van een overdreven aansprakelijkheid, wordt in Belgiê een beroep gedaan op de causaliteitsleer en in Nederland op de relativiteitsleer. In beide rechtsstelsels wordt bijgevolg ook rekening gehouden met de voorzienbaarheid van de schade. Opvallend is vooral dat bepaalde begrippen zoals schuld en causaliteit in beide landen een andere invulling krijgen, maar dat anderzijds deze verschillen niet dermate onoverbrugbaar zijn dat een vergelijking tussen het Nederlandse en het Belgische nucleaire civiele aansprakelijkheidsrecht, in het verdere onderzoek, onmogelijk zou zijn.

Rechtsvergelijkend onderzoek heeft inderdaad uitgewezen dat het Franse privaatrecht - en een groot decl van de Belgische rechtsleer - ook van belang is voor de invulling van het Nederlandse $\mathrm{BW}^{112}$. Bovendien sluit Boek 6 NBW inhoudelijk vrij nauw aan bij het oude Nederlandse BW waardoor in deze materic ook het "oude recht" nog van groot belang is voor het geldende Nederlandse civielrechtelijke aansprakelijkheidsrecht ${ }^{13}$. Opvallend is ook dat de formele wijziging van het civielrechtelijke aansprakelijkheidsrecht in Nederland niet heeft belet dat ook na de invoering van het NBW discussies zijn blijven bestaan. In beide landen blijven meningsverschillen bestaan over de inhoud van bepaalde begrippen, wat de dynamiek van het civiele aansprakelijkheidsrecht zeker ten goede komt.

Er kan dan ook worden aangenomen dat het uitgangspunt van de code Napoléon voor beide rechtsstelsels nog steeds geldig is: in principe draagt eenieder zijn eigen schade, tenzij een fout in hoofde van een ander kan worden bewezen en dczc aan de aangesprokenen kan worden toegewezen. Het uitgangspunt van cen op de napoleontische code gebaseerde civielrechtelijke aansprake-

legt. Aldus wordt vrijwel alles ernstig verwijtbaar (Van Dunné, J.M., "Verbintenissenrecht 2", l.c., $561)$.

Milo, J.M., "Het rechtsvergelijkende argument in de ontwikkeling van het Nederlandse vermogensrecht 1838-1940", l.c., 37. 
lijkheid houdt in dat ieder zijn eigen schade draagt en dat enkel na bewijs van bijzondere omstandigheden, een verhaal kan worden uitgeoefend tegen een ander ${ }^{114}$. Een dergelijke bijzondere omstandigheid onder het Belgische en Nederlandse BW, is in de regel het bestaan van een fout, namelijk een inbreuk op een juridisch gesanctioneerde, al dan niet geschreven gedragsnorm of een inbreuk op de zorgvuldigheidsnorm.

Samenvattend kan worden gesteld dat, zowel naar Belgisch als naar Nederlands recht, een persoon onrechtmatig handelt wanneer hij een inbreuk pleegt op een juridisch gesanctioneerde, al dan niet geschreven, gedragsnorm (inbreuk op een gebod of een verbod), of wanneer hij een inbreuk pleegt op de zorgvuldigheidsnorm. Ook onachtzaamheid of onvoorzichtigheid kunnen dus aanleiding geven tot de plicht om schadevergoeding uit te betalen. Tegelijk wordt de fout van een persoon in abstracto getoetst aan de zorgvuldigheidsnorm, waardoor het de voorkeur verdient om deze fout te ontdoen van enig moreel of verwijtbaar element. De notie schuld zal enkel worden gebruikt in enge zin, namelijk de verwijtbaarheid van de dader. In dit onderzoek worden bijgevolg de noties fout en foutaansprakelijkheid gehanteerd.

De analyse in deze paragraaf heeft ook aangetoond dat de discussie omtrent de verschillende begrippen maatschappelijk en economisch bijzonder relevant kunnen zijn. Tengevolge van de 30september arresten van de Hoge Raad dient de Nederlandse Staat in een aantal gevallen op te draaien voor de kosten van bodemsanering. Meteen is hiermec ook sprake van de aansprakelijkheid voor milieuschade. Dit thema wordt hieronder verder besproken.

\section{DE AANSPRAKELIJKHEIDSGRONDSI.AG BIJ MILIEUSCHADE}

Nadat is duidelijk geworden dat het Nederlandse en het Belgische civielrechtelijke aansprakelijkheidsrecht zonder onoverkomelijke problemen met elkaar kunnen worden vergeleken, rijst veivolgens de vraag naar de toepasselijkheid van de bepalingen van het Burgerlijk Wetboek op gevallen waarbij zich milieuschade voordoet ${ }^{115}$. Hieronder wordt de vraag aan de orde gesteld of het Burgerlijk Wetboek een nuttig instrument is ter zake van de aansprakelijkheid voor milieuschade. In eerste instantie wordt onderzocht of foutaansprakelijkheid en risicoaansprakelijkheid in het BW nuttige instrumenten zijn bij de aansprakelijkheid voor milieuschade (respectievelijk $\S 2.1$ en $\S 2.2$ ). Nadien wordt in $\$ 2.3$ een beknopt overzicht gegeven van enkele vormen vinn risicoaansprakelijkheid buiten het Burgerlijk Wetboek. De conclusie van dit hoofdstuk wordt gebundeld in $\S 2.4$.

\subsection{Foutaansprakelijkheid voor milieuschade in het Burgerlijk Wetboek}

Hieronder wordt zowel voor wat betreft het Belgische (\$2.1.1) als het Nederlandse Burgerlijk Wetboek (\$2.1.2) de vraag beantwoord of de klassieke foutaansprakelijkheid een voldoende grondslag biedt bij de aansprakelijkheid voor milieuschade.

\subsubsection{Op basis van het Belgische BW}

Hoewel het in het Belgische BW neergelegde civiele aansprakelijkheidsrecht formeel nog dateert van 1804, neemt de foutaansprakelijkheid toch een belangrijke positie in bij een aansprakelijk-

It Zie hicrover Van Gerven, W., "De invloed van verzekeringen op het verbintenissenrecht", o.c., 778. Hiermec bedoelen we zowel schade aan het milieu zelf (door emissie) als schade ontstaan via het milieu (zie hierover: Van Acht, R.J.J. en Bauw, E., "Milieuprivaatrecht", l.c., 26 e.v.; en Kottenhagen. Edzes, P.A., "Onrechtmatige Daad en milieu", l.c., 21 e.v.).
} 
heidsvordering ingevolge milieuschade. Reeds in 1979 wees Bocken erop dat artikel 1382 van het BW een belangrijk instrument is voor de rechter om milieuverstoring tegen te gaan ${ }^{116}$. Traditioneel worden naar Belgisch recht twee onrechtmatigheidscategorieën onderscheiden: de inbreuk op een gebod over verbod en de inbreuk op de zorgvuldigheidsnorm.

Vooraleer verder wordt ingegaan op deze twee categorieën, wordt even aandacht besteed aan de meest omstreden categorie, namelijk de inbreuk op een subjectief recht. Deze categorie is uitermate relevant ter zake van de aansprakelijkhcid voor milieuschade. Immers indien wordt aanvaard dat een inbreuk op een subjectief recht automatisch betekent dat onrechtmatig werd gehandeld, dan opent dit nieuwe perspectieven in de discussie rond de vraag of uit het huidige recht een subjectief recht op een gezond leefmilieu kan worden afgeleid. In het proefschrift van Carette wordt hieraan uitgebreid aandacht besteed ${ }^{117}$. Zij is de mening toegedaan dat een inbreuk op een recht een aanvullende toetsing aan de zorgvuldigheidsnorm vereist ${ }^{118}$, en maakt dus geen onderscheid al naargelang de precieze inhoud van het subjectieve recht. Hoe dan ook wordt naar geldend Belgisch recht niet aanvaard dat de schending van een subjectief recht een juridische grondslag vormt ter zake van de aansprakelijkheid voor milieuschade. Slechts enkele rechterlijke uitspraken in kort geding lijken in die richting te gaan; rechtspraakonderzoek heeft echter aangetoond dat bij de uitspraken ten gronde slechts zelden wordt gebruik gemaakt van het subjectief recht op cen gezond leefmilieu ${ }^{119}$.

Zoals hoger aangegeven, wordt naar Belgisch recht een fout aangenomen zodra cen wettelijke of reglementaire bepaling wordt overtreden ${ }^{i 20}$. Hier dient te worden herinnerd aan het feit dat de relativiteitsvereiste in Belgiẻ niet wordt gesteld ${ }^{121}$. Toegepast op het milieurecht, betckent dit dat indien bijvoorbeeld een strafrechtelijk gesanctioneerde inbreuk wordt gepleegd of wanneer de door de vergunningverlenende overheid opgelegde milieuvoorschriften met de voeten worden getreden, een fout zal worden aanvaard. Meteen is duidelijk dat naarmate het milieurecht preciezcre normen bevat en bijkomende activiteiten of inrichtingen onderwerpt aan een vergunningsplicht, het foutcriterium aan belang zal winnen bij de aansprakelijkheid voor milieuschade ${ }^{122}$. Tegelijk zal de bruikbaarheid van het foutcriterium ter zake van de aansprakelijkheid voor milieuschade in bclangrijke mate afhangen van de precieze strekking van betrokken bepaling, c.q. van de interpretatie die aan deze bepaling wordt gegeven.

Bocken, H., Het aansprakelijkheidsrechi als sanctie tegen verstoring van het leefmilieu, diss., Brussel Bruylant, 1979, 427 (hierna geciteerd als "Het aansprakelijkheidsrecht als sanctie").

Carette, A., Herstel van en vergoeding voor aantasting aan niet-loegeëigende milieubestanddelen, diss., Intersentia, Antwerpen, 1997, 531-599.

Hierin volgt Carette de visie van Comelis (Carette, A., "Herstel van en vergoeding voor aantasting aan niet-toegeéigende milieubestanddelen", l.c., 534).

Carette, A., "Herstel van en vergoeding voor aantasting aan niet-toegeeigende milieubestanddelen", l.c., 589 .

Bocken, H., "Aansprakelijkheid voor milieuschade", Rechtskundig Weekblad, 1987-1988, 1269; Bocken, H., Ryckbost, D. en Deloddere, S., Voorontwerp Decreet Milieubeleid, Interuniversitaire Commissie tot Herziening van het Milieurecht in het Vlaamse Gewest, Die Keure, Brugge, 1995, 861-862 (hiema geciteerd ats "Voorontwerp Decreet Milieubeleid"); Coenraets, Ph., Les responsabilite's en matiere d'environnement, Kluwer, 1997/1, 29-30; Comelis, L., "Beginselen", l.c., 60 e.v.; Faure, M. en Deketelaere, K., "Environmental Law in Belgium", in Koeman, N.S.J. (ed.), Environmental Law in Europe, Kluwer Law Intemational, Den Haag 1999, 84; Van Oevelen, A., "Objectieve aansprakelijkheid voor schade veroorzaakt door milieuverontreiniging. volgcns het Belgische recht", in Risicoaansprakelijkheid voor Milieuschade, W.E.J. Tjeenk Willink, Zwolle, 1992, 84.

122 Bocken, H., "Het aansprakelijkheidsrecht als sanctie", l.c., 38.

Bocken, H., Ryckbost, D. en Deloddere, S., "Voorontwerp Decrect Milieubeleid", l.c., 862. 
Omgekeerd biedt het naleven van alle wettelijke en reglementaire bepalingen evenwel geen garantie om niet aansprakelijk te worclen gesteld voor eventueel ontstane schade ${ }^{123}$. Zelfs indien de exploitant de milieuvergunning respecteert en binnen de wettelijk opgelegde emissienormen blijit, kan een exploitant aansprakelijk worden gesteld indien de rechter van oordeel is dat de exploitant de zorgvuldigheidsnorm niet heeft nageleefd.

Ook dient te worden benadrukt dat met name een overtreding van een wettclijke of reglementaire bcpaling in cen causale relatie dient te staan tot de schade. Indien bijvoorbeeld een exploitant van cen inrichting voor de opslag en overslag van afvalstoffen een inbreuk pleegt op de op hem toepasselijke sectorale milieuvoorwaarden inzake het aanbrengen van een paneel met inlichtingen over de exploitant zelf ${ }^{24}$, dan zal hij niet op basis van deze overtreding kunnen worden aansprakelijk gesteld voor schade door geluidsoverlast of stofhinder.

Net zoals bij het leerstuk van de onrechtmatige daad in het algemeen, is ook de zorgvuldigheidsnorm van belang bij de aansprakelijkheid voor milicuschade ${ }^{125}$. Ook hier wordt de gocde huisvader als critcrium gehantecrd: heeft de verwecrder gehandeld zoals een redelijk en voorzichtig persoon in dezelfde onslandigheden zou hebben gedaan? Het bewijs van het schenden van een corgvuldigheidsnom $/$ al vaak niet makkelijk zjjn ${ }^{i 2 n}$. Het louter ontstaan van een hinder of schade is geen voldoende reden on te besluiten tot de overtreding van de zorgvuldigheidsnom. De centrale vraag hierbij is welke hinder aanvaardbaar wordt geacht en welke niet.

Bij milieuschade is de kans reëel dat zich, bij de beoordeling van de zorgvuldigheidsnorm, voor de rechtbank een technische discussie zal ontwikkelen. Artikel 7 van VLAREM II hanteert hierbij als criterium de best beschikbare techniek ${ }^{127}$. Dit leidt ertoe dat een exploitant kan aansprakelijk worden gesteld indien zou blijken dat hij onvoldoende op de hoogte is van de stand der techniek, of indien hij deze verkeerd zou toepassen. De genomen veiligheidsmaatregelen, de informatieplicht en de waarschuwingsplicht kunnen elementen zijn in de appreciatie van de rechter bij het bepalen of de zorgvuldigheidsnorm al dan niet werd geschonden. Over het algemeen wordt aangenomen dat een zorgplicht, zoals bijvoorbeeld opgenomen in artikel 22 van het Vlaamse milieu-

Bocken, H., "Het aansprakelijkheidsrecht als sanctie", l.c., 39; Deketelaere, M., "Milieuaansprakelijkheid. Burgerrechtelijke aansprakelijkheid voor milieuschade, strafrechtelijke aansprakelijkheid voor milieumisdrijven, administratieve sancties en veiligheidsmaatregelen, en verzekering van milieuschade", in Milieurecht in Belgię. Status Questionis Anno 1997, Die Keure, 1997, 682.

Artikel 5.2.1.5, $\S 1$ van VLAREM II bepaalt aan de ingang van de inrichting cen uithangbord moet hangen met daarop onder meer telefoonnummers van de exploitant, de brandweer etc. Deketelaere, M., "Deel VII. Milicu en burgerlijk aansprakelijkheidsrecht", in Deketelacre, K. (ed.), Handboek Milieurecht, Brugge, Die Keure, 2001, 1163. Zie uitvoerig Bocken, H., "Het aansprakelijkheidsrecht als sanctie", l.c., 39 e.v.

Zie hierover o.m. Bocken, H. en De Saegher, T., "Aansprakelijkheid en financiële zekerheden na VLAREM II", Tijdschrift voor Milieurecht, 1993, 83; Billiet, C., "BAT et BATNEEC: quelques faits et réflexions", Aménagement-Envrionnement, 1995/2, $71-77$. 
vergunningsdecreet $^{128}{ }^{129}$, weinig toevoegt met het oog op een mogelijke aansprakelijkheid ex artikel $1382 \mathrm{BW}^{130}$.

Toch moet voor ogen worden gehouden dat de foutaansprakelijkheid geen wondermiddel is op basis waarvan aansprakelijkheid voor eender welke milieuschade zonder meer kan worden aangenomen. In heel wat gevallen zal het slachtoffer toch een aanzienlijke bewijslast moeten dragen: vooral het bewijs van de fout en van het causaal verband tussen een fout en de schade kunnen soms moeilijk zijn ${ }^{131}$. Toch aanvaardt het Hof van Cassatie een vrij ruime interpretatie van het begrip "causaliteit". Op basis van de equivalentieleer wordt in beginsel elke oorzaak van de schade in aanmerking genomen ${ }^{132}$.

\subsubsection{Op basis van het Yederlandse $B W$}

Hoger werd reeds aangegeven dat naar huidig Nederlands recht artikel 6:162 NBW de basis vormt van het Nederlandsc foutaansprakelijkheidsrecht. Onderzocht dient te worden of de verschillende in dit wetsartikel aangegeven onrechtmatigheidscategorieën als grondslag kunnen dienen bij de aansprakelijkheid voor milieuschade ${ }^{133}$.

Het eerste criterium dat uitdrukkelijk in artikel 6:162 BW wordt aangegeven is de inbreuk op een subjectief recht. Zoals hoger aangegeven geldt een inbreuk op een subjectief recht slechts als een vermoeden van de overtreding van een norm en is een bijkomende toetsing aan het zorgvuldigheidscritcrium vereist.

In dit kader wordt voornamelijk gedacht aan een inbreuk op het eigendomsrecht; maar ook andere zakclijke en persoonlijke rechten zoals het erfpachtrecht of het huurrecht komen in aanmerking voor de toepassing van de onrechmatigheidscategorie "inbreuk op een rccht" ex artikel 6:162 $\mathrm{NBW}^{1.4}$. In dit verband wordt ook gesproken van het burenrecht ${ }^{135}$; het betreft immers hinder veroorzaakt door cen naburig erf. Van belang zijn de artikelen 5:37. 5:38 en 5:39 van het

Deze bepaling legt aan de exploitant van een vergunningsplichtige inrichting de plicht op om de nodige maatregelen te nemen om schade en hinderen te voorkomen.

Een analoge zorgplichtbepaling is opgenomen in artikel 1.la van de Nederlandse Wet Milieubeheer. Zie hierover Drupsteen, Th.G. en Koeman, N.S.J. (red.), Wet Milieubeheer. Tekst \& Commentaar, Kluwer, Deventer, 1996, 15; Michiels, F.C.M.A., De wet milieubeheer, W.E.J. Tjeenk Willink, Zwolle, tweede druk. 1994, 6-7.

Zie hierover Carette. A, "Op zoek naar de inhoud en de draagwijdte van BAT(NEEC)", Tijdschrift wor Milieurecht, 1996, 310-328.

13i Cónracts, Ph., "Les responsabilités en matiere d'environnement", l.c., 32; Deketelaere, K., "De voorstellen van de Interuniversitaire Commissie tot Herziening van het Milieurecht in het Vlaamse Gewest inzake de aansprakelijkheid voor milieuschade", in Deketelaere, M. (red.), Recente Ontwikkelingen inzake de aansprakelijkheid voor milieuschade, Milieurechtstandpunten 3. Brugge, Die Keure, 1993, 77. Zie hierover o.m. Bocken, H., "Het aansprakelijkheidsrecht als sanctie", l.c., 112 e.v.; Bocken, H., "Enkele hoofdthema's van de causaliteitsproblematiek", Tijdschrift voor Belgisch Burgerlijk Recht, 1988, 268-296; Bocken, H., "Actuele problemen inzake het oorzakelijk verband", Recht halen uit Aansprakelijkheid, Postuniversitaire cyclus Willy Delva, Mys en Breesch, Gent, 1993, 81-121; Faure, M., "(G)een schijn van kans", l.c., 26-28.

Zie uitgebreid Hulst, E.H., Grondslagen van milieu-aansprakelijkheid, diss., Gouda Quint, Amhem, 1993, 10 e.v.

Tonnaer, F.P.C.L., "Handboek Nederlands Milieurecht", l.c., 920; Van Acht, R.J.J. en Bauw, E., "Milieuprivaatrecht", I.c., 36.

Zie hierover Van Acht, R.J.J., Burenrecht, Kluwer, Deventer, 1990, 320 e.v. 
$\mathrm{NBW}^{136}$. De twee laatstgenoemde artikelen hebben betrekking op hinder door aflopend water en door een wijziging van de waterloop, terwijl artikel 5:37 kan worden gehanteerd bij hinder zoals door het verspreiden van rumoer, trillingen, stank, rook of gassen, door het onthouden van licht of lucht of door het ontnemen van steun. Uiteraard heeft vooral de hinder door rumoer, trillingen, stank, rook of gassen een duidelijke band met gevallen van milieuhinder en mogelijks milieuaansprakelijkheid $^{137}$.

Maar doordat de artikelen 5:37 en 5:39 NBW het ondubbelzinnig hebben over een hinder die op basis van artikel 6:162 NBW onrechtmatig is, neemt het burenrecht in Nederland slechts een beperkte plaats in bij de aansprakelijkheid voor milieuschade. Met name van Dunné pleit voor het gebruik van het burenrecht als aansprakelijkheidsgrondslag naar Frans en Belgisch model omdat een slachtoffer dat deze grondslag hanteert "geen last heeft van klassieke vereisten van onrechtmatige daad" en omdat deze grondslag doorgaans wordt beschouwd als een vorm van risicoaansprakelijkheid ${ }^{138}{ }^{139}$. Het Nederlandse NBW legt evenwel zoals aangegeven het verband tussen een vordering ex artikel 5:37 of 5:39 NBW en de regels inzake onrechtmatige daad. Deze artikelen bieden dus geen afzonderlijk toetsingscriterium, maar moeten integendeel worden getoetst aan het onrechtmatige daadsrecht ${ }^{140}$.

Net zoals dat het geval is in het Belgische BW, kan de onrechtmatigheidscategorie in strijd met een wettelijke plicht een grondslag vormen voor de aansprakelijkheid voor milieuschade ${ }^{141}{ }^{142}$. Ook al geldt naar Nederlands recht dat een gedraging die het milieu aantast een schending kan uitmaken van een milieunorm, toch wordt over het algemeen aangenomen dat het schenden van een wettelijke plicht niet zonder meer impliceert dat tegelijk onrechtmatig werd gehandeld ${ }^{143}$. De schending van een wettelijke plicht zal automatisch als onrechtmatig worden beschouwd indien het concrete regels betreft, zoals bij verordeningen en vergunningen ${ }^{144}$. In het andere geval zal de overtreding van de wettelijke plicht slechts worden beschouwd als één element dat, samen met

Artikel 5:37 BW luidt: "De eigenaar van een erf mag niet in een mate of op een wijze die volgens artikel 6:162 onrechtmatig is, aan eigenaars van andere erven hinder toebrengen zoals door het verspreiden van rumoer, trillingen, stank, rook of gassen, door het onthouden van licht of lucht of door het ontnemen van steun". Artikel 5:38: "Lagere erven moeten het water ontvangen dat van hoger gelegen erven van nature afloopt". Artikel 5:39 BW: "De eigenaar van een erf mag niet in een mate of op een wijze die volgens artikel 6:162 onrechtmatig is, aan eigenaars van andere erven schaude toebrengen door wijziging te brengen in de loop, de hoeveelheid of de hoedanigheid van over zijn erf stromend water of van het grondwater, dan wel door gebruik van water dat zich op zijn erf bevindt en in operı gemeenschap staat met het water op eens anders erf". Tonnaer, F.P.C.L., "Handboek Nederlands Milieurecht", I.c., 938.

Van Dunné, J.M., "Verbintenissenrecht 2", l.c., 500-501. Over het burenrecht naar Belgisch recht, zie verderop $\$ 2.2 .1 .2$ van dit hoofdstuk.

Tonnaer, F.P.C.L., "Handboek Nederlands Milieurecht", l.c., 938.

Zie uitgebreid Braams, W., Th., "Over de rol van schuld bij milieu-aansprakelijkheid", in Koeman, N.S.J., Ouwerkerk, W.J. en Van Dunné, J.M. (red.), Civielrechtelijke aansprakelijkheid voor milieuschade, Vereniging voor Milieurecht, W.E.J. Tjeenk Willink, Zwolle, 1989, 46-78. Het onderzoek van Kottenhagen-Edzes heeft overigens uitgewezen dat hei civiele foutaansprakelijkheidsrecht niet alleen een middel is in handen van individuen wiens persoonlijk belang is geschaad, maar ook een middel kan zijn ter behartiging van algemene milieubelangen (Kottenhagen-Edzes, P.A., "Onrechtmatige Daad en Milieu", l.c., 97-152).

Kottenhagen-Edzes, P.A., "Onrechtmatige Daad en Milieu", l.c., 157; Van Acht, R.J.J. en Bauw, E., "Milieuprivaatrecht", l.c., 38. een directe relatie tussen de inbreuk en de schadeveroorzakende gedraging (Van Maanen, G.E., Spier, J. en Sterk, C.H.W.M., "Van schuld naar risico", o.c., 76). 
andere elementen, in het aansprakelijkheidsvraagstuk zal worden betrokken ${ }^{145}$. Specifiek met betrekking tot een milieuvergunning oordeelde de Hoge Raad in de zaak Van Dam/Beukeboom ${ }^{146}$ dat aan de vergunningsvoorschriften een soortgelijke betekenis moet worden toegekend als aan door de centrale of lokale wetgever vastgestelde gedragnormen, waarvan de schending in beginsel een onrechtmatige daad oplevert.

Volledigheidshalve moet ook hier worden gewezen op de discussie in verband met de relativiteitsvereiste. In een recente publicatie wees Koeman erop dat de relativiteitsvereiste ertoe leidt dat niet icdereen zomaar een aansprakelijkhcidsvordering kan indienen indien sprake is van schending van een wettelijke plicht ${ }^{147}$. Het is zcer de vraag of hiermee de situatie sterk verschilt van bijvoorbeeld het Belgische recht; ook naar Belgisch recht zal hot "doorschieten" van een aansprakelijkheidsvordering worden beperkt, maar dan eerder op grond van het ontbreken van causaliteit.

De derde categorie die in artikel 6:162 NBW wordt aangegeven, is een gedraging in strijd met hetgeen volgens ongeschreven recht in het maatschappelijk verkeer betaamt; hier is met andere woorden de vraag aan de orde of de zorgvuldigheidsnorm al dan niet werd geschonden. Over het algemeen wordt aangenomen dat handelen in strijd met het ongeschreven recht als onrechtmatig zal worden gekwalificeerd ${ }^{148}$. Deze onrechtmatigheidscategorie vervult als het ware een vangnetfunctie $^{149}$, omdat het aan een brede groep van slachtoffers van milieuschade een juridische grondslag biedt voor gevallen waar bijvoorbeeld (nog) geen concrete juridische milieunomen van kracht zijn. Specifiek in verband met milieuhinder zijn de overwegingen van het hierboven reeds aangehaalde arrest Van Dam/Beukeboom interessant. De Hoge Raad stelde:

"Voorzover zodanige maximaal toegelaten geluidsniveaus niet bij een wettelijk voorschrift of in de voorwaarden van de hinderwetvergunning zijn voorzien, is overschrijding ervan niet zonder meer een onrechtmatige daad jegens degenen die daar hinder van ondervinden, maar zal de onrechtmatigheid van de hinder mede afhangen van: a. de mate en frequentie van de overschrijdingen, b. de omvang van de hinder die degene die in rechte over de overschrijding klaagt, ervan ondervindt en c. de offers die ermee gemoeid zijn om overschrijdingen te voorkomen".

Als elementen bij het bepalen van de zorgvuldigheidsnorm in het kader van milieuschade, zijn met name een aantal plichten in hoofde van degene die bepaalde gevaarlijke activiteiten uitvoert van belang: waarschuwingsplicht, informatieplicht, onderhoudsplicht en de plicht tot het nemen van voldoende veiligheidsmaatregelen ${ }^{150}$. De rechter zal dienen over te gaan tot een afweging van de verschillende in het geding betrokken belangen. Een mooi voorbeeld in dat verband is de Franse Kalimijnen-zaak ${ }^{151}$ waar de Hoge Raad de belangen van de bovenstroomse gebruiker (Mines de Potasse D'Alsace) afwoog tegen de belangen van de benedenstroomse gebruikers

Kottenhagen-Edzes, P.A., "Onrechtmatige Daad en Milieu", l.c., 158.

HR, 9 januari 1981, Nederlandse Jurisprudentie, 1981, 227. Zie hierover o.m. Van Acht, R.J.J, en Bauw, E., "Milieuprivaatrecht", I.c., 278-279; Tonnaer, F.P.C.L., "Handboek Nederlands Milieurecht", l.c. 922 .

Koeman, N.S.J., "Environmental Law in the Netherlands", in Koeman, N.S.J. (ed.), Environmental Law in Europe. Kluwer Law International. Den Haag, 1999, 436.

Van Maanen, G.E., Spier, J. en Sterk, C.H.W.M., "Van schuld naar risico", o.c., 77; Van Maanen, G.L., "Onrechtmatige Daad", l.c., 219.

lonnaer, F.P.C.L., "Handboek Nederlands Milieurceht", l.c., 925.

Van Acht, R.J.J. en Bauw, E., "Milicuprivaatrecht", l.c., 58.

Hoge Raad, 23 september 1988, Ncderlandse Jurisprudentie, 1989, 743. In deze zaak leden Nederlandse tuinders schade door de afvalzouten in de Rijn, afkomstig van het Franse Mines de Potasse D'Alsace. 
(Nederlandse tuinders). Een bijzonder belang kwam toe aan de belangen van de tuinders aangezien benedenstroomse gebruikers in beginsel mogen verwachten dat de rivier niet door omvangrijke lozingen bovenmatig wordt verontreinigd.

Tenslotte geldt ook naar Nederlands recht de stelling dat het naleven van de milieuvergunning en de verschillende wettelijke en reglementaire bepalingen geen garantie biedt om niet aansprakelijk te worden gesteld. In dit verband oordeelde de Hoge Raad dat hinder die in het algemeen niet moet worden geduld, niet plotseling wél moet worden geduld omdat de persoon die de hinder veroorzaakt over een hinderwetvergunning beschikt ${ }^{152}$.

\subsection{Risicoaansprakelijkheid in het Burgerlijk Wetboek}

Uit de totstandkoming van het BW bleek de centrale positie van het foutbegrip in het Burgerlijk Wetboek. Nochtans dient te worden vastgesteld dat reeds in de code civil van 1804 enkele nuanceringen werden aangebracht aan de foutvereiste. Minstens één nuancering is in het kader van dit proefschrift van belang teneinde te kunnen inschatten of en in welke mate de aansprakelijkheid van de exploitant van een kerninstallatie afwijkt van het gemeenrechtelijke aansprakelijkheidsrecht zoals neergelegd in het BW en teneinde de begrippen van het nucleaire aansprakelijkheidsrecht te kunnen situeren ten overstaan van het gemeenrechtelijke begrippenarsenaal. Hieronder wordt hoofdzakelijk de aansprakelijkheid voor (gebrekkige) zaken aan de orde gesteld. Zoals uit de analyse zal blijken, vormt deze vorm van aansprakelijkheid een belangrijke grondslag ter zake van de aansprakelijkheid voor milieuschade. Daarenboven werd het Nederlandse BW op dit vlak in 1995 ingrijpend gewijzigd. Zowel het Belgische $(\S 2.2 .1)$ als het Nederlandse BW (§ 2.2.2) komen hieronder aan de orde.

\subsubsection{Op basis van het Belgische BW}

Voor wat betreft de in het Belgische Burgerlijk Wetboek voorziene gevallen van risicoaansprakelijkheid voor milieuschade, zijn voornamelijk twee bepalingen relevant. In eerste instantie dient aandacht te worden geschonken aan artikel 1384, lid 1, dat voorzict in de aansprakelijkheid voor schade veroorzaakt door gcbrekkige zaken $(\$ 2.2 .1 .1)$. Daarenboven dient ook te worden stilgestaan bij artikel $544 \mathrm{BW}$ op basis waarvan de evenwichtslecr werd ontwikkeld (\$2.2.1.2).

\subsubsection{De aansprakelijkheid voor gebrekkige zaken}

Met betrekking tot de aansprakelijkheid voor zaken, bepaalt artikel 1384, lid 1 van het Belgische BW dat men niet alleen aansprakelijk is voor de schade die men veroorzaakt door zijn eigen daad, maar ook voor schade die veroorzaakt wordt door de daad (...) van zaken die men onder zijn bewaring heeft. Hoewel hierover niets is terug te vinden in de voorbereidende werken van het BW, is uit dit artikel door de rechtspraak een algemeen aansprakelijkheidsbeginsel ten laste van 
de bewaarder van de zaak afgeleid ${ }^{153}$ : wanneer een zaak gebrekkig is, dan kan de bewaarder van deze zaak hiervoor worden aansprakelijk gesteld ${ }^{154}$.

De stelling dat uit artikel 1384 BW een algemeen beginsel inzake aansprakelijkheid voor gebrekkige zaken kan worden afgeleid, werd niet alleen in België maar ook in Frankrijk ${ }^{155}$ aanvaard. Het Belgische recht stelt evenwel de bewaarder van de zaak alleen dan aansprakelijk indien een gebrek in de zaak kan worden aangetoond ${ }^{156}$, hetgeen niet het geval is in het Franse recht ${ }^{157} 158$.

Zeer in het algemeen kan een gebrek ${ }^{159}$ worden gedefinieerd als een abnormaal gebrek van de zaak, van aard om schade aan derden te berokkenen ${ }^{160161}$. De rechter zal dus dienen na te gaan of het kenmerk van de zaak als een normale dan wel als een abnormale gesteldheid van de zaak dient te worden beschouwd; bovendien moet het gebrek inherent of intrinsiek aan de zaak zijn ${ }^{162}$. Uit het loutere feit dat een zuak schade heeft veroorzaakt, kan niet worden afgeleid dat de zaak behept is met een gebrek ${ }^{103}$ 164: een abnormale gedraging of een abnormale plaats van de zaak volstaat niet om het gebrek in de zaak te bewijzen ${ }^{165}$.

Cassatie, 26 mei 1904, Pasicrisie, 1904, I, 246. Zie Comelis, L., "Beginselen". l.c., 457; Comelis, L., "Extra-contractuele aansprakelijkheid voor zaken. Het gebrek van de zaak en de causaliteitsbeoordeling", Tijdschrift voor Privaatrech, 1984, 299-327; Vandenberghe, H., Van Quickenborne, M. en Wynant, L., "Overzicht van rechtspraak (1985-1993)", o.c., 1280.

En dit naar analogie met artikel 1386 BW (ter zake van de aansprakelijkheid voor schade veroorzaakt door een gebouw). Hof van Cassatie Fr. 11 juni 1896, Sirey, 1897, I, 17.

Het Franse Hof van Cassatie is deze stelling niet gevolgd: Hof van Cassatie fr., 16 november 1920, Dalloz, 1920, I, 169.

Terecht wijst Comelis erop dat hiermee de verwijzing naar de fout in zekere zin behouden blijft (Cornelis, L., "Beginselen", l.c., 508).

Dalcq en Schamps betreuren deze interpretatie en staan een interpretatie voor naar Frans model (Dalcq, R.O., "Las responsabilités de l'entreprise: de la faute au risque", in Les Assurances de l'Entreprise, Bruxelles Bruylant, vol. I, 1988, 10-11; Schamps, G., "La mise en danger", l.c., 663-664). Voor een invulling van de begrippen "bewaarder" en "zaak", zie onder meer Vandenberghe, H., Van Quickenborne, M. en Wynant, L., "Overzicht van rechtspraak (1985-1993)", o.c., 1290. Hof van Cassatie, 23 september 1971, Pasicrisie, 1872, I, 80, nadien meermaals bevestigd.

Voor een overzicht van rechtspraak in deze materie, zie Dubuisson, B., "Développements récents concernant les reponsabilités du fait des choses (choses, aninaux, bâtiments), Revue Générale des Assurances et des Responsabilités, 1997, $n^{\circ} 12729$ en Dalcq, R.O. en Schamps, G., "Examen de jurisprudence (1987 à 1993), La responsabilité délictuelle et quasi-délictuelle", Revue Critique de Jurisprudence Belge, 1995,625 e.v.

Hof van Cassatie 11 december 1986, Arresten van het Hof van Cassatie, 1986-87, 486; Cornelis, L., "Beginselen", l.c., 478; Comelis, L., "Extra-contractuele aansprakelijkheid voor zaken. Het gebrek van de zaak en de causaliteitsbeoordeling", o.c., 305-306; Vandenberghe, H., Van Quickenborne, M. en Wynant, L., "Overzicht van rechtspraak (1979-1984)", o.c., 1397.

Bijvoorbeeld Luik, 27 juni 1988, Revue Générale des Assurances et des Responsabilités, 1992, nг. 12.009.

Dit in tegenstelling tot het Franse recht, waar het volstaat te bewijzen dat de zaak schade heeft veroorzaakt (Vandenberghe, H., Van Quickenborne, M. en Wynant, L., "Overzicht van rechtspraak (19851993)", o.c., 1282). 
Bovenstaande algemene definiëring ten spijt, dient te worden vastgesteld dat het in bepaalde gevallen zeer moeilijk te voorspellen valt of een rechtbank zal aanvaarden dat een bepaald kenmerk van de zaak al dan niet een gebrek uitmaakt ${ }^{166}$.

Omtrent de kwalificatie van de aansprakelijkheid ex artikel 1384, lid l bestuat geen eensgezindheid: Vandenberghe en Bocken hebben het over een vermoeden iuris et de iure ${ }^{167}{ }^{168}$; Cornelis spreekt van een aansprakelijkheid van rechtswcge ${ }^{169}$. Volgens Schamps is sprake van een vermoeden van causaliteit tussen de schade en de veronderstelde fout van de burgerrechtelijk aansprakelijke persoon: zij heeft het dan ook over een vermoeden van aansprakelijkheid eerder dan van een vermoeden van fout ${ }^{170}$.

Artikel 1384 , lid $1 \mathrm{BW}$ werd reeds meerdere malen tocgepast terzake van de aansprakelijkheid voor milieuschade ${ }^{171}$, vooral in gevallen van accidentele milieuverontreiniging waar de oorzaak ligt in technische onvolkomenheden van installaties en machines ${ }^{172}$. Zo is er rechtspraak die artikel 1384, lid $1 \mathrm{BW}$ toepast bij het breken van een leiding, op voorwaarde echter dat kan worden bewezen dat de oorzaak van de gesprongen leiding ligt bij een gebrek van de leiding ${ }^{173}$.

De aansprakclijkheid voor gebrekkige zaken wordt eveneens toegepast bij niet-accidentele verontreiniging van bodem of water ${ }^{174}$. De aanwezigheid van olie in de bodem ${ }^{175}$ heeft aanleiding gegeven tot de toepassing van artikel 1384, lid $1 \mathrm{BW}^{176}$. Met name is hierbij van belang dat de aanwezigheid van een vrecmd voorwerp of een vreemde stof in een groter geheel, ertoe kan lei-

In het ene geval aanvaardt het Hof van Cassatic een olievlek op de vloer van een grootwarenhuis als een gebrek (Hof van Cassatie, 22 november 1985, Arresten van het Hof van Cassatie, 1985-86, 420), terwijl het Hof in een ander geval oordeelt dat een kers voor de kousenafdeling van een grootwarenhuis niet impliceert dat de staat van de vloer abnormaal was (Hof van Cassatie, 26 juni 1986, Rechtskundig Weekblad, 1986-87, 2021) (Voorbeeld ontleend aan Vandenberghe, H., Van Quickenbome, M. en Wynant, L., "Overzicht van rechtspraak (1985-1993)", o.c., 1314-1315).

Vandenberghe, H., Van Quickenbome, M. en Wynant, L., "Overzicht van rechtspraak (1985-1993)", o.c., 1332.

Bocken heeft het over een "onomstootbaar vermoeden van fout" (Bocken, H., "Het aansprakelijkheidsrecht als sanctie", l.c., 256).

Comelis, L., "Beginselen", l.c., 507.

Schamps, G., "La mise en danger", I.c., 597.

Zie uitgebreid de voorstellen van de Interuniversitaire Commissie tot Herziening van het Milieurecht in het Vlaams Gewest: Bocken, H., Ryckbost, D. en Deloddere, S., "Aansprakelijkheid en Financiële zekerheden", "Voorontwerp Decreet Milieubeleid", l.c., 835 e.v. en m.b.t. artikel 1384, lid 1 BW in het bijzonder: 869 e.v.; zie ook o.m. Coenraets $\mathrm{Ph}$., "Responsabilité du fait des choses et responsabilités objectives en droit de l'environnement", Revue Générale des Assurances el des Responsabilités, 1993, $n^{\circ}$ 12.213; Coenraets, Ph., Les Responsabilités en matière d'environnement, Kluwer, 1997/1.0, 33; Deketelaere, M., "Burgertechtelijke aansprakelijkheid voor milieuschade, strafrechtelijke aansprakelijkheid voor milieumisdrijven, administratieve sancties en veiligheidsmaatregelen en verzekering van milieuschade", in Milieurecht in België. Status Questionis Anno 1997, Die Keure, 1997, 671 e.v.

Bocken, H., "Het aansprakelijkheidsrecht als sanctie", l.c., 260 e.v.; Bocken, H., Ryckbost, D. en Deloddere, S., "Voorontwerp Decreet Milieubeleid", l.c., 870; Deketelaere M., "Deel IV. Milieu en burgerlijk aansprakelijkheidsrecht", in Deketelaere, K., "Handboek Milieurecht", l.c., 1168. Bergen, 18 november 1975, Pasicrisie, 1976, II, 136.

Bocken, H., Ryckbost, D. en Deloddere, S., "Voorontwerp Decreet Milieubeleid", l.c., 870.

Rb. Kh. Sint-Niklaas, 2 december 1958, Rechtskundig Weekblad, 1959-1960, 1904.

Bocken, "Milieuwetgeving en onroerende goederen. Aansprakelijkheid voor de kosten van bodemsanering", Tijdschrift voor Privaatrecht, 1992, 37 e.v.; Coenraets, Ph., "Les responsabilités en matière d'environnement", l.c. $38-39$. 
den dat het geheel gebrekkig zal worden ${ }^{177}$. Dit zal voormamelijk zo zijn indien het vreemde voorwerp daadwerkelijk een deel van de zaak is geworden ${ }^{178}$.

Door de vereiste dat het een abnormaal kenmerk van de zaak betreft, wordt echter het toepassingsgebied van deze wetsbepaling sterk beperkt op het vlak van de aansprakelijkheid voor milieuschade. Het is immers een normaal gegeven dat bijvoorbeeld het gebruik van machines een bepaalde emissie (geluid, stof etc.) veroorzaken ${ }^{179}$.

Volledigheidshalve wordt erop gewezen dat de richtlijn productaansprakelijkheid ${ }^{180}$ niet wordt beschouwd als een middel ter zake van de aansprakelijkheid voor milieuschade ${ }^{181}$ : met name de verschillende bevrijdingsgronden waarover de producent beschikt en de vereiste van schade in de privésfeer staan de toepassing van deze grondslag in de weg.

\subsubsection{De evenwichtsleer}

In België wordt aanvaard dat artikel $544 \mathrm{BW}^{182}$ en de daaruit afgeleide evenwichtsleer een juridische grondslag vormt die van belang kan zijn bij bepaalde vormen van milieuschade ${ }^{183}$. De\%e leer

Bocken, H., Ryckbost, D. en Deloddere, S., "Voorontwerp Decreet Milieubeleid", l.c., 870.

Cornelis, L., "Extra-contractuele aansprakelijkheid voor zaken. Het gebrek van de zaak en de causaliteitsbeoordeling", o.c., 318.

Bocken, H., "Het aansprakelijkheidsrecht als sanctie", t.c., 258; Van Oevelen, A., "Objectieve aansprakelijkheid voor schade veroorzaakt door milieuverontreiniging, volgens het Belgische recht", o.c., 98; Schamps, G., "La mise en danger", l.c. 659-660.

Zie o.m. Comelis, L., "Aansprakelijkheid voor gevaarlijke produkten", Rechtshundig Weckblat, 19871988, 1139-1 159; Cousy, H., Produkienaansprakelijkheid, Veiligheit en Verzekering, Maklu, Antwerpen-Apeldoom, 1988; Cousy, H., "L'adaptation du droit belge à la directive sur la responsabilité du fait des produits défectueux", Les Assurances de l'Entreprise, vol. I, 1988, 93-139; Dalcq, R.O., "Le risque des produits et des services", Les Assurances de l'Entreprise, vol. II, 1993, 215-280; Dommering-Van Rongen, L., Produktenaansprakelijkheid. Een nieuwe Europese privaatrechtelijke regeling vergeleken met de produktenaansprakelijkheid in de Verenigde Staten, Kluwer, Deventer, 1991; Fallon, M., "L'adaptation de la responsabilité du fait des produits à la directive européenne du 25 juillet $1985^{\prime \prime}, R e-$ vue Générale des Assurances et des Responsabilités, 1987, n 11245; Fallon, M., "La loi du 25 fëvrier 1991 relative à la repsonsabilité du fait des produits défectueux". Journal des Tribunaux, 1991, 465473; Fagnart, J.L., "La responsabilite du fait des produits à l'approche du Grand Marché", Droit des Affaires, 1990, n० 17, 9-40; Faure, M. en Van Buggenhout, W., "Produktenaansprakelijkheid. De Europese richtlijn: harmonisatic cn consumentenbescherming?", Rechtskundig Weekblad, 1987-1988, 1 e.v.; Kelly, P. en Attree, R., European Product Liability, London Butterworths, 1992; Knottenbelt, J., Hoofdstukken produktaansprakelijkheid: buitencontractuele aansprakelijkheid van de producent van een gebrekkig produki voor persoonschade, Tjeenk Willink. Zwolle, 1991.

Van Oevelen, A., "Objectieve aansprakelijkheid voor schade veroorzaakt door milieuverontreiniging, volgens het Belgische recht", o.c., 102.

Artikel 544 BW luidt: "Eigendom is het recht om op de meest volstrekte wijze van een zaak het genot te hebben en daarover te beschikken, mits men er geen gebruik van maakt dat strijdig is met de wetten of verordeningen".

Zie hierover: Bocken, H., Het aansprakelijkheidsrecht als sanctie, l.c., 267 e.v.; Bocken, H., "Aansprakelijkheid voor milieuschade: een nieuw en belangrijk milieurisico", in Morrens, P. (red.), Milieurecht voor bedrijfsleiders en hun adviseurs, Mys en Breesch, Gent, 1993, 70; Comelis; L., "Beginselen", I.c., 670-714; Hanotiau, M., "La responsabilité en matière de troubles de voisinage", Bulletin des Assurances, 1981, 365; Chandelle, J.M., "La réparation du dommage en matière de troubles de voisinage", Annales de la Faculté de Droit de Liège, 1980, 85-126; Deketelaere, M., "Burgerrechtelijke aansprakelijkheid voor milieuschade, strafrechtelijke aansprakelijkheid voor milieumisdrijven, administratieve sancties en veiligheidsmaatregelen, en verzekering van milieuschade", o.c., 685-686. 
vloeit voort uit de kanaal- en schoorsteen arresten ${ }^{184}$ en stelt dat de eigenaar van een onroerend goed, die door een niet foutief handelen het evenwicht verstoort tussen naburige eigendommen, door aan een naburige eigenaar een stoornis op te leggen die de maat van de gewone buurschapsnadelen overschrijdt, gehouden is tot een passende compensatie. De evenwichtsleer wordt niet alleen toegepast ten voordele van eigenaars, maar ook van huurders, vruchtgebruikers etc. van een onroerend goed die te lijden hebben onder abnormale burenhinder ${ }^{185}$.

Indien een eigenaar van een onroerend goed het evenwicht verbreekt met een naburige eigendom, dan zal hij ertoe gehouden zijn dit evenwicht te herstellen door het betalen van een passende vergoeding ${ }^{186}$. Opmerkelijk is vooral dat de benadeelde geen fout hoeft te bewijzen en dat de bevrijdingsmogelijkheden van de eigenaar beperkt zijn. Anderzijds dient wel een gedraging in hoofde van de verweerder te worden bewezen ${ }^{187}$. Deze gedraging wordt ruim opgevat in die zin dat zowel een doen als een nalaten in aanmerking komen.

De aansprakelijkheid die uit artikel 544 BW wordt afgeleid, wordt door Bocken gekwalificeerd als een aansprakelijkheid voor "rechtmatige daad" ${ }^{188}$; Cornelis wijst erop dat deze aansprakelijkheidsregel een specifieke toepassing is van het algemene rechtsbeginsel dat rechtsmisbruik verbiedt $^{189}$.

De evenwichtsleer werd reeds toegepast bij bepaalde gevallen van milieuverstoring zoals hinder door stof en slijk ${ }^{190}$ en geluidshinder door het nachtelijk lawaai van vrachtwagens ${ }^{19}$.

\subsubsection{Op basis van het Nederlandse BW}

Het onderzoek van het Nederlandse recht inzake de ansprakelijkheid voor gebrekkige zaken gebeurt in eerste instantie door de analyse van de bepalingen van het oude BW (\$ 2.2.2.1). In tweede instantie wordt een overzicht gegeven van de wijzigingen die in 1995 aan het NBW werden aangebracht $(\S 2.2 .2 .2)$.

\subsubsection{Het Nederlandse oud BW}

De evenknie van artikel 1384, lid 1 van het Belgische BW, was terug te vinden in artikel 1403, eerste lid van het Nederlandse oud BW. Omtrent de precieze strekking van dit artikel, bestond

\footnotetext{
184 Hof van Cassatie, 6 april 1960, Pasicrisie, 1960, I. 920.

185 Hof van Cassatie, 10 januari 1974, Arresten van het Hof van Cassalie, 1974, 520. Zie onder meer Renard, $\bar{C}$., "Le dynamisme de la théorie des troubles de voisinage: le cas du locataire", Revue Critique de Jurisprudence Belge. 1975, 360-369; Comelis, L., "Beginselen", l.c., 678.

Over het algemeen wordt ervan uitgegaan dat het op basis vân deze juridische grondslag niet mogelijk is om een bevel of verbod op te leggen om de hinder te beperken. Geoordeeld wordt dat het in de evenwichtsleer een foutloze activiteit betreft en dat men bijgevolg niet kan verbieden wat niet onrechtmatig is (Bocken, H., Het aansprakelijkheidsrecht als sanctie, l.c., 294 e.v.; Bocken,, H., "Aansprakelijkheid voor milieuschade: een nieuw en belangrijk milieurisico", o.c., 71-72; ook in die zin Comelis, L., "Beginselen", I.c., 694).

Comelis, L., "Beginselen", l.c., 672.

188 Deze term komt van Bocken, onder meer in "Van fout naar risico", o.c., 343 en Bocken, H., Ryckbost, D. en Deloddere, S., "Voorontwerp Decreet Milieubeleid", l.c., 868.

Comelis, L., "Beginselen", l.c., 699.

Hof van Cassatie, 26 mei 1983, Rechlskundig Weekblad, 1983-84, 1133.

Vred. Kraainem, 4 december 1981, geciteerd in Bocken, H., Ryckbost, D. en Deloddere, S., "Voorontwerp Decreet Milieubeleid", l.c., 869.
} 
geen eensgezindheid. Rechtspraak en rechtsleer waren het hierover grondig met elkaar oneens. Meermaals reikten verschillende auteurs argumenten aan die de rechtspraak dienden toe te laten on uit dit artikel een risicoaansprakelijkheid voor schade veroorzaakt door zaken af te leiden ${ }^{192}$.

Typcrend in dat verband is het acetyleen-cylinder-arrest van $1933^{193}$ waar de Hoge Raad overwoog dat het strijdig was met de zorgvuldigheid om als professioneel een cilinder te verhuren zonder zich ervan vergewist te hebben dat het om een deugdelijke cilinder gaat. In zekere zin betreft deze uitspraak een productaansprakelijkheid avant la lettre ${ }^{194}$. Bekend is inmiddels ook het Natronloog-arrest ${ }^{195}$ waaruit over het algemeen een waarschuwingsplicht wordt afgeleid ten aanzien van gevaarlijke stoffen die men in zijn bezit heeft en waarvan men de gevaarlijke kenmerken niet kent ${ }^{196}$. Ook later volgden uitspraken inzake de invulling van de zorgvuldigheidsnorm bij gevaarsituaties. Een schoolvoorbeeld hiervan is het Kelderluik-arrest waar de Hoge Raad een aantal criteria ontwikkelde op basis waarvan kan worden vastgesteld of veiligheidsmaatregelen al dan niet dienden te worden genomen ${ }^{197}$. Deze arresten tonen aan dat de Hoge Raad langzaam en uiterst voorzichtig afweek van de foutvereiste en via allerlei constructies zoals het foutof schuldvermoeden, aanleunde bij een risicoaansprakelijkheid.

$\mathrm{Na}$ het vinylacetaat-arrest ${ }^{198}$ rees in de rechtsleer twijfel over de visie van de Hoge Raad; zij oordeelde namelijk in deze zaak dat naar toen geldend Nederlands recht er geen rechtsregel voorhanden was op basis waarvan iemand dic een gevaarlijke zaak onder zich heeft aansprakelijk kon worden gesteld wanneer dat gevaar zich verwezenlijkt. Dit arrest wordt door sommige auteurs gezien als een bevestiging van een reeds meer dan een eeuw vaststaande rechtspraak, namelijk dat in het kader van artikel 1403, eerste lid oud BW, geen plaats zou zijn voor risicoaansprakelijkheid, noch voor omkering van de bewijslast ${ }^{199}$. Deze visie wordt in het geheel niet bijgetreden

Asser-Hartkamp, "Verbintenissen III", l.c., 156 e.v

Hoge Raad, 6 april 1933, Nederlandse Jurisprudentie, 1933, 881 (Acetyleen). In deze zaak had een fabrikant van acetyleen cilinders van een onbekende een dergelijke cilinder gekocht en deze vervolgens verhuurd. Door een probleem in de vulmassa ontplofte de cilinder en raakte de zoon van de huurder gewond. De fabrikant werd hiervoor aansprakelijk gesteld. Van Maanen, G.E., "Van schuld naar risico?", o.c., 123; Van Dunné spreekt van een verkapte risicoaansprakelijkheid (Van Dunné, J.M., "Verbintenissenrecht 2", l.c., 355). Hoge Raad, 8 januari 1982, Nederlandse Jurisprudentie, 614 (Natronloog). In deze zaak werd een plastic zak - met daarin een emmer met een onbekendc substantie - afgegeven aan een vuilnisman. Door omstandigheden kwam de substantie in het oog van de man terecht die er een blijvend letstel aan overhield.

In die zin: Van Maanen, G.E., "Van schuld naar risico", o.c., 126; Van Dunné, J.M., "Verbintenissenrecht $2^{\prime \prime}$, l.c., 393.

Hoge Raad, 5 november 1965, Nederlandse Jurisprudentie, 1966, 136 (Kelderluik). Een bediende van Coca-Cola die een café bevoorraadde liet een kelderluik openstaan dat zich vlakbij de toiletten bevond. Eén van de cafébezoekers is vervolgens door het keldergat gevallen en was gewond. De Hoge. Raad overwoog: "... daarbij dient te worden gelet niet alleen op de mate van waarschijnlijkheid waarmee de nict-inachtneming van de vereiste oplettendheid en voorzichtigheid kan worden verwacht, maar ook op de hoegrootheid van de kans dat daaruit ongevallen ontstaan, op de emst die de gevolgen daarvan kunnen hebben en op de mate van bezwaarlijkheid van te nemen veiligheidsmaatregelen".

Hoge Raad, 22 juni 1979, Nederlandse Jurisprudentie, 1979, 535 (Vinylacetaat of Van der LeeBroere). Na een kettingbotsing in de dichte mist, vatte de vrachtwagen van Broere, die met vinylacetaat was geladen vlam, waardoor Van der Lee schade leed. Van der Lee vorderde schadevergoeding aan Broere uit hoofde van diens hoedanigheid als bewaarder van een gevaarlijke zaak.

O.m. Sterk, C.H.W.M., Verhoogd gevaar in het aansprakelijkheidsrecht. Een rechtsvergelijkend onderzoek naar aansprakelijkheid voor zaken, stoffen en motorrijtuigen, diss., Kluwer, Breda, 1994, 181 (hiema geciteerd als "Verhoogd gevaar"); ook Van Maanen schijnt deze mening te delen, al geeft hij toe dat niet onverkort wordt vastgehouden aan artikel 1401 (Van Maanen, G.E., "Van schuld naar risico?", o.c., 116 en II0). 
door van Dunné voor wie het vinylacetaat-arrest een "misleading case" is en die de mening is toegedaan dat uit artikel 1403, lid 1 een omkering van de bewijslast of zelfs een risicoaansprakelijkheid kon worden afgeleid ${ }^{200}$.

\subsubsection{De wijzigingen aan het Nederlandse NBW}

Onder het Nederlandse NBW is een regeling uitgewerkt waar een onderscheid wordt gemaakt tussen aansprakelijkheid voor gebrekkige roerende zaken (art. 6:173), aansprakelijkheid voor opstallen (art. 6:174) en productaansprakelijkheid (art. 6:185). In 1995 werden drie kwalitatieve aansprakelijkheden toegevoegd aan het $\mathrm{BW}^{201}$, met name de aansprakelijkheid voor gevaarlijke stoffen (art. 6:175), de aansprakelijkheid voor de exploitant van een stortplaats (art. 6:176) en de aansprakelijkheid van de exploitant van een boorgat (art. 6:177). Hieronder zal enkel aandacht worden besteed aan de aansprakelijkheid voor gebrekkige roerende zaken en de aansprakelijkheid voor gevaarlijke stoffen. De regeling inzake productaansprakelijkheid, de aansprakelijkheid van de exploitant van een stortplaats en een boorgat wordt aan de orde gesteld bij de bespreking van de kanalisatie van aansprakelijkheid ${ }^{202}$.

Hieronder worden eerst een aantal elementen aangegeven die hebben geleid tot de wijzigingen van 1995 (a). Nadien worden respectievelijk de bepalingen van artikel 6:173 inzake de aansprakelijkheid voor gebrekkige roerende zaken besproken (b) en van artikel 6:175 inzake de aansprakelijkheid yoor gevaarlijke stoffen (c).

\section{a. Elementen die hebben geleid tot de wijzigingen van 1995}

Het is interessant te wij.zen op een aantal clementen van de Memorie van Toelichting. De op 1 februari 1995 van kracht geworden kwalitatieve dansprakelijkheden waren onder meer ingegeven vanuit de vaststelling dat het Nederlandse recht, in vergelijking met andere landen, minder te bieden zou hebben aan hen die schade hebben geleden door verontreiniging van het milieu, hetgeen als een "gemis" werd ervaren ${ }^{203}$. Als voorbeelden worden hierbij gegeven de algemene aansprakelijkheid voor zaken in Frankrijk en de algemene aansprakelijkheid voor gebrekkige zaken in België (terwijl een dergelijke algemene aansprakelijkheid voor zaken in Nederland niet voorhanden is); ook werd gerefereerd aan de mogelijkheden die in België en Frankrijk bestaan op het vlak van het burenrecht ${ }^{204}$.

Aan de ingevoerde aansprakelijkheden ligt eenzelfde idee ten grondslag, namelijk dat het gaat om bronnen van verhoogd gevaar en dat, indien dit gevaar zich verwezenlijkt, de slachtoffers hun bescherming dienen te vinden in de aansprakelijkheid van degene die voor het uit deze bron voortvloeiende gevaar moet worden verantwoordelijk geacht ${ }^{205}$.

De Memorie van Toelichting stelt verderop dat in een reeks bepalingen de risicoaansprakelijkheden zijn gekanaliseerd "in dier voege dat in beginsel ter zake van één gebeurtenis niet op nneer

201 Van Dunné, J.M., "Verbintenissenrecht 2", l.c., 393

Wet van 30 november 1994 tot aanvulling van de Boeken 3, 6 en 8 van het Burgerlijk Wetbock met regels betreffende de aansprakelijkheid voor gevaarlijke stoffen en verontreiniging van lucht, water of bodem (Stb., 1994, 887). Met name in de tweede paragraaf van hoofdstuk 4 (Basisprincipes van de nucleaire aansprakelijkheidswetgeving). Tweede Kamer, vergaderjaar 1988-1989, 21 202, nr. 3, Memorie van Toelichting, 3. Zie hierboven, $\$ 2.2 .1 .2$.

Tweede Kamer, vergaderjaar 1988-1989, 21 202, nr 3. Memorie van Toelichting, 8.
} 
personen tegelijk een risicoaansprakelijkheid rust" ${ }^{206}$. Verderop in dit boek wordt uitgebreider aandacht besteed aan de precieze inhoud van het begrip "kanalisatie van aansprakelijkheid"207.

\section{b. De aansprakelijkheid voor schade veroorzaakt door roerende zaken ex artikel 6:173 BW}

De aansprakelijkheid voor gebrekkige (roerende) zaken naar geldend Nederlands recht is, zoals gezegd, neergelegd in artikel 6:173 NBW. Ingevolge dit artikel is de bezitter van een roerende zaak waarvan bekend is dat zij, zo zij niet voldoet aan de eisen die men in de gegeven ornstandigheden aan de zaak mag stellen, een bijzonder gevaar oplevert, aansprakelijk wannecr dit gevaar zich verwezenlijkt. De Nederlandse regeling veronderstelt dat de zaak gebrekkig ${ }^{208}$ is, hoewel deze term niet als dusdanig in de wettekst is terug te vinden. Een zaak is gebrekkig wannecr het niet voldoet aan de eisen die men in de gegeven omstandigheden aan de zaak mag stellen en daardoor een bijzonder gevaar oplevert. Met "bijzonder" wordt het onderscheid beklemtoond met een algemeen gevaar dat aan het gebruik van een zaak is verbonden (zo wordt het risico om in water te verdrinken als een algemeen risico beschouwd). Artikel 6:173 is niet van toepassing op algemene gevaren. Net zoals dat het geval is in Belgiê, is de notie "gebrekkig" naar Nederlands civielrechtelijk aansprakelijkheidsrecht omstreden ${ }^{209}$; de notie "bijzonder gevaar" doet immers sterk denken aan het criterium van het abnormaal kenmerk van de zaak naar Belgisch recht ${ }^{210}$.

De aansprakelijkheid inzake gebrekkige roerende zaken wordt over het algemeen beschouwd als een risicoaansprakelijkheid ${ }^{211}$. Maar artikel 6:173, eerste lid in fine bevat een hoogst eigenaardige en inmiddels zwaar onder vuur genomen tenzij-formule ${ }^{212}$ :

"... tenzij aansprakelijkheid op grond van de vorige afdeling zou hebben ontbroken indien hij dit gevaar op het tijdstip van het ontstaan daarvan zou hebben gekend".

Anders geformuleerd luidt het dat de bezitter vrijuit gaat indien hij uit hoofde van art. 6:162 niet aansprakelijk zou zijn, had hij op het moment van het ontstaan van de schade het gevaar gekend. De persoon die aansprakelijk wordt geacht, kan derhalve een beroep doen op dezelfde verweermiddelen als deze onder artikel $6: 162^{213}$ : hij kan een rechtvaardigingsgrond ${ }^{214}$, afwezigheid van relativiteit of overmacht inroepen. Onderstreept dient te worden dat de aansprakelijke persoon hierop enkel een beroep kan doen indien hij het gevaar op het tijdstip van het ontstaan van de

Tweede Kamer, vergaderjaar 1988-1989, 21 202, nr. 3, Memorie yan Toelichting, 8.

Zie $\$ 2.3 .2$ van hoofdstuk 4 .

Een gebrek wordt over het algemeen gedefinieerd als een intrinsick gebrek of een abnormaal kenmerk van de zaak, of het hebben van een eigenschap die de zaak niet behoort te hebben (Klaassen, C.J.M., "Risicoaansprakelijkheid", l.c., 95; Schut, G.H.A., "Onrechtmatige Daad", l.c., 120; Spier J., Hartlief, T., Van Maanen G.E. en Vriesendorp, R.D., "Vesbintenissenrecht 2", l.c., 86).

Zie bijvoorbeeld de kritiek van Van Dunné, J.M., "Verbintenissenrecht 2", l.c., 399 e.v.

Nochtans dient te worden gewezen op een aantal in het oog springende verschillen tussen beide rechisstelsels. Naar Nederlands recht is de bezitter aansprakelijk, tenwijl in België de bewaarder van de zaak aansprakelijk is. Bovendien is de aansprakelijkheid op basis van artikel 6:173 beperkt tot roerende zaken, ierwijl 1384, eerste lid BW cok van toepassing is op onroerende zaken.

Zo bijvoorbeeld Sterk, C.H.W.M., "Verhoogd gevaar", l.c., 182.

De discussie beperkt zich in Nederland evenwel niet tot de tenzij-formule en het begrip "gebrek". Ook het feit dat enkel de bezitter van de roerende zaak aansprakelijk is, wordt bekritiseerd. Hier blijkt het nochtans te gaan om een bewuste keuze van de Nederlandse wetgever: de bezitter is voor de benadeclde het makkelijkst te vinden en is tegelijk de meest aangewezen persoon om zich te verzekeren (Schut, G.H.A., "Onrechmatige Daad", l.c., 121).

Spier J., Hartlief, T., Van Maanen G.E. en Vriesendorp, R.D., "Verbintenissen", l.c., 89.

Artikel 6:162, tweede lid in fine luidt immers: "een en ander behoudens de aanwezigheid van een rechtvaardigingsgrond". 
schade zou hebben gekend. Het lag in de bedoeling van de Nederlandse wetgever om via deze bepaling aan te tonen dat de aansprakelijkheid diende te worden begrensd ${ }^{215}$; zoncler de tenzijregel werd de aansprakelijkheid te ruim geacht.

Critici wijzen erop dat door deze tenzij-formule geen sprake meer is van risicoaansprakelijkheid, maar van een weerlegbaar foutvermoeden ${ }^{216}$. Indien het gedrag van de betrokkene in aanmerking komt als bevrijdingsgrond, blijft volgens Comelis van een risicoaansprakelijkheid weinig over ${ }^{217}$. Aldus is niet langer sprake van een kwalitatieve, maar van een persoonlijke aansprakelijkheid, hetgeen de originele bedoeling van de ontwerpers zou zijn geweest ${ }^{218}$.

Inzake milieuaansprakelijkheid wordt artikel $6: 173 \mathrm{BW}$ voornamelijk gebruikt bij milieuschade ontstaan tengevolge van lekkende vaten of gebrekkige machines ${ }^{219}$. Meteen rijst de vraag naar het verschil tussen deze regeling en de aansprakelijkheid op basis van artikel 6:175.

\section{c. De aansprakelijkheid voor schade veroorzaakt door gevaarlijke stoffen ex artikel 6:175 BW}

Een belangrijk verschil bestaat erin dat artikel 6:173 betrekking heeft op zaken en artikel 6:175 op stoffen. Aan het begrip stoffen wordt een veel ruimere betekenis toegekend dan aan het begrip $z_{\text {aken }}{ }^{220}$. Volgens artikel $3: 2 \mathrm{BW}$ is een zaak een voor menselijke beheersing vatbaar stoffelijk object. Hoewel een stof aan deze omschrijving kan beantwoorden en een stof zelfs kan deel uitmaken van een zaak, is een stof veel ruimer: immers, een stof kan zowel een vaste stof zijn als een vloeistof of een gas. Hierbij vallen zowel grondstoffen, hulpstoffen, halffabrikaten, eindproducten en afvalstoffen onder het toepassingsgebied van artikel $6: 175 \mathrm{BW}^{221}$. Volgens de Memorie van $A$ twoord ${ }^{222}$ vallen ook radioactieve stoffen onder het toepassingsgebied van artikel 6:175, op voorwaarde evenwel dat zij niet vallen onder het Verdrag van Parijs inzake de civielrechtelijke aansprakelijkheid bij kemongevallen.

Naast het begrip "stof", bevat artikel 6:175 volgende elementen ${ }^{223}$ : stof waarvan bekend is dat zij zodanige eigenschappen heeft, dat zij cen bijzonder gevaar van ernstige aard oplevert voor personen en zaken 224 . Voor wat betreft de kwalificatie "bijzonder gevaar van ernstige aard", geeft de laatste zin van artikel 6:175 aan dat in ieder geval sprake is van een bijzonder gevaar indien de stof ontplofbaar, oxyderend, ontvlambaar, licht ontvlambaar of zeer licht ontvlambaar, dan wel giftig of zeer giftig is volgens de criteria en methoden vastgesteld krachtens artikel 34, derde lid

\footnotetext{
215. Van Dunné, J.M., "Verbintenissenrecht 2", l.c., 402, Schut, G.H.A., "Onrechtmatige Daad", l.c., 19.

216 Comelis, L., "De aansprakelijkheid voor gebrekkige zaken in Belgie en Nederland (art. 6.3.2.5 NBW)", Rechtgeleerd Magazijn Themis, 1987, 177 e.v.; Van Maanen, G.E., Kwarlaalbericht NBW, 1988,24 e.v.

Comelis, L., "De aansprakelijkheid voor gebrekkige zaken in België en Nederland (art. 6.3.2.5 NBW)", o.c., 177.

Van Dunné, J.M., "Verbintenissenrecht 2", l.c., 400.

Van Acht, R.J.J. en Bauw, E., "Milieuprivaatrecht", l.c., 91-92.

Dit blijkt duidelijk uit onder meer de voorbereidende werken (Tweede Kamer, vergaderjaar 1988-1989, 21 202, nr, 3, Memorie van Toelichting, 13).

Van Acht, R.J.J. en Bauw, E., "Milieuprivaatrecht", l.c., 74; Schut, G.H.A., "Onrechtmatige Daad", l.c., 122 .

Tweede kamer, vergaderjaar 1988-1989, 21 202, nr. 6, Memorie van Antwoord, 17.

Zie hierover Spier, J. en Sterk, C.H.W.M., Aansprakelijkheid voor gevaarlijke stoffen. Gevaarlijke stoffen, stortplaatsen, boorgaten en vervoer van gevaarlijke stoffen, Kluwer, Deventer, 1995, 45-46.

De bekendheid heeft dus betrekking op de uit de stof voortvloeiende gevaren en dus niet op de bekendheid of voorzienbaarheid van de schade.
} 
van de Wet Milieugevaarlijke Stoffen (WMS) ${ }^{225}$. De verwijzing naar de Wet Milieugevaarlijke stoffen ten spijt, wordt artikel 6:175 primair niet beschouwd als een regel die inzake milieuaarisprakelijkheid frequent kan worden toegepast ${ }^{226}$. Deze wetsbepaling heeft hoofdzakelijk tot doel om personen en zaken te beschermen tegen schade veroorzaakt door gevaarlijke stoffen. Gevallen van milieuschade of -overlast die niet door gevaarlijke stoffen zijn veroorzaakt, kunnen niet via deze bepaling leiden tot aansprakelijkheid.

In hoofde van artikel 6:175 $\mathrm{BW}$, eerste lid rust een risicoaansprakelijkheid op de bedrijfsmatige gebruiker of bezitter ${ }^{227}$. Het tweede lid legt de aansprakelijkheid bij de "bewaarder die er zijn bedrijf van maakt zodanige stoffen te bewaren". Met bewaarder wordt gelijkgesteld de vervoerder, expediteur, stuwadoor, bewaarder of soortgelijke ondernemer die de stof ten vervoer of uit hoofde van een met het vervoer samenhangende overeenkomst in ontvangst heeft genomen. Hier wordt gesproken van een kanalisatie van de aansprakelijkheid naar de bewaarder ${ }^{22}$. De aansprakelijkheid van de bewaarder strekt zich uit tot de periode dat hij de zaak onder zijn bewaring heeft. Op deze wijze wordt de aansprakelijkheid gelegd bij degene bij wie de stof was op het moment waarop de schade werd veroorzaakt ${ }^{229}$.

De in het NBW ingevoerde risicoaansprakelijkheid is evenwel niet absoluut in die zin dat artikel 6:178 BW een aantal bevrijdende omstandigheden bevat ${ }^{230}$. Deze omstandigheden worden door de wet exclusief en expliciet voorbehouden voor de aansprakelijkheid voor gevaarlijke stoffen, stortplaatsen en boorgaten. Volgens Spier zijn de bevrijdende omstandigheden dan ook, weze het tot op zekere hoogte, analoog aan de regeling op basis van de eerder besproken tenzij-formule ${ }^{23 !}$.

Volledigheidshalve dient ook te worden gewezen op de visie van Braams die stelt dat de risicoaansprakelijkheid voor gevaarlijke stoffen in wezen een aansprakelijkheid is gebaseerd op de klassieke foutaansprakelijkheid, maar met een bevredigender bewijsregeling. Uit de vaststelling dat het stelsel een gevaarscriterium hanteert en dat het gevaar een relatief begrip is dat afhangt van de omstandigheden, leidt Braams af dat de regeling in concrete gevallen geen zekerheid biedt over de vraag of er in beginsel aansprakelijkheid is ${ }^{232}$. Braams raadde de Nederlandse wetgever dan ook aan om de notic "gevaar" niet over te nemen, maar om (blijvend) een beroep te doen op de zorgvuldigheidsnorm. Deze visie werd door de wetgever en over het algemeen in de litera-

Overeenkomstig artikel 6:175, zesde lid BW kan een stof die als zodanig is aangewezen bij $A M v B$ (Algemene Maatregel van Bestuur), worden geacht een bijzonder gevaar van emstige aard op te leveren. In december 1994 werd een dergelijke AmvB uitgevaardigd (Uitvoeringsbesluit aansprakelijkheid gevaarlijke stoffen en milieuverontreiniging van 15 december 1994, Stb., 1994, 888). Hulst, E.H., "Grondslagen van milieu-aansprakelijkheid", l.c., 17; Van Acht, R.J.J. en Bauw, E., "Milieuprivaatrecht", l.c., 75; Smale, L.J. en Van Dunné, J.M., "Aansprakelijkheid voor milieuschade en financiële zekerheid naar huidig recht: knelpunten en gerealiseerde oplossingen. Nederlands recht", Wiggers-Rust, L.F. en Deketelaere, K., (red.), "Aansprakelijkheid voor milieuschade", l.c., 49. In het oorspronkelijke wetsontwerp werd de gebruiker aansprakelijk gesteld en had dit artikel ook worden toegepast voor schade door gebrekkige zaken uit de privé-sfeer. Spier, J. en Sterk, C.H.W.M., "Aansprakelijkheid voor gevaarlijke stoffen,", l.c., 52; Scharmps heeft het over "le système de canalisation segmentée" (Schamps, G., "La mise en danger", l.c., 189). Tweede Kamer, vergaderjaar 1988-1989, 2I 202, nr. 3, Memorie van Toelichting, 9.

O.m. bij schade veroorzaakt door gewapend conflict, burgeroorlog en natuurrampen.

Spier J., Hartlief, T., Van Maanen G.E. en Vriesendorp, R.D., "Verbintenissen", l.c., 102.

Braams, W. Th., Buitencontractuele Aansprakelikheid voor gevaarlijke stoffen. Rechtsvergelijkende beschouwingen naar aanleiding van het wetsvoorstel ter aanvulling van de boeken 3, 6 en 8 van het Nieuw BW met regels betreffende de aansprakelijkheid voor gevaarlijke stoffen en verontreiniging van lucht, water of bodem, Kluwer, Deventer, 1989, 23. 
tuur $^{233}$ verworpen. Volgens de Nederlandse wetgever is geen sprake van een terugkoppeling naar artikel 6:162 "omdat voor de aansprakelijkheid zelfs geen bepaalde gedraging van de aangesprokene, die als een onrechtmatige daad zou kunnen worden beschouwd, is vereist" ${ }^{234}$. De visie van Braams is volgens de Nederlandse wetgever dan ook ingegeven door de leer die stelt dat wanneer aan de zorgvuldigheidsnorm zulke hoge eisen worden gesteld dat daaraan redelijkerwijze niet kan worden voldaan, het resultaat vergelijkbaar is aan een regime van risicoaansprakelijkheid ${ }^{235}$.

\subsection{Aansprakelijkheid voor milieuschade buiten het Burgerlijk Wethoek}

Naast een aantal artikelen binnen het Burgerlijk Wetboek, reiken ook een aantal bijzondere wetten een juridische grondslag aan voor de aansprakelijkheid voor milieuschade. De wetgever is voor bepaalde risico's tussenbeide gekomen en heeft een specifieke regeling in het leven geroepen.

In een aantal gevallen kaderde de tussenkomst van de - internationale of Europese en nationale wetgever in de risico's ontstaan door het gebruik van nieuwe technologische toepassingen: de uitvinding van het vliegtuig, de ontwikkeling van de ruimtevaart, het vreedzaam gebruik van kernenergie, enzovoort.

De tussenkomst van de wetgever inzake milieuaansprakelijkheid heeft soms ook te maken met bepaalde ongevallen die de publieke opinie beroerden: het Verdrag inzake de aansprakelijkheid voor olieverontreiniging op zee van 1969 was een direct gevolg van het ongeval met de Torrey Canyon in $1967^{236}$; de Seveso I richtlijn van $1982^{237}$ werd uitgevaardigd naar aanleiding van een ongeval in Seveso (Italië) in 1976; de Verdragen van september 1986 inzake vroegtijdige kennisgeving en assistentie bij kemongevallen waren een antwoord op de ramp in Tsjernobyl, enkele maanden eerder ${ }^{238}$.

Hoewel deze wetten, zoals gezegd, vaak te beschouwen zijn als een vertaling van de verontwaardigde publieke opinie naar aanleiding van een bepaald ongeval of voorval ${ }^{239}$, blijken zij een aantal gemeenschappclijke kenmerken te vertonen ${ }^{24 t !}$.

O.m. door Klaassen, C.I.M., "Risicoaansprakelijkheid", l.c., 121 e.v. en 227 e.v.; Van Maanen, G.E., "Aansprakelijkheid voor schade door gevaarlijke stoffen en verontreiniging van lucht, water of bodem", Weekblad voor Privaatrecht. Notariaat en Registratie, 1990, 5946, 75; Sterk, C.H.W.M., "De aansprakelijkheid voor gevaarlijke stoffen en afvalstoffen", Weekblad voor Privaatrecht, Notariaat en Registratie, 5991, 73 e.v. en 5992, 89 e.v.; Spier, J. en Sterk, C.H.W.M., "Aansprakelijkheid voor gevaarlijke stoffen", l.c., 10 e.v.

Tweede Kamer, vergaderiaar 1988-1989, 21 202, nr. 6, Memorie van Antwoord, 14.

Tweede Kamer, vergaderjaar 1988-1989, 21 202, nr. 6, Memorie van Antwoord, 15.

Dit Verdrag wordt verderop besproken in hoofdstuk 12.

Richtlijn 82/501/EEG, $P B$ L 230, 1982; later gewijzigd door de Seveso II-richtlijn: Richtlijn 96/82/EG, $P B$ L 10, 1997. Zie hierover bijwoorbeeld Seerden, $\mathrm{R}$ en Van Eekeren, J., "Industriële ongevallen: (on)gelukkig geregeld ?! Een beschouwing over (de collisie van) Nederlandse, Europese en intemationale rechtsregels inzake het voorkomen en bestrijden van (zware) industriële ongevallen met gevolgen voor het milieu", in Deketelaere, K., Faure, M. en Verhoosel, G., Grensoverschrijdende milieuproblemen: uitdagingen voor de nationale in internationale rechtsorde, intersentia, Antwerpen, Apeldoom, 1998, 333 e.v.

Dit fenomeen is niet eigen aan het civiele aansprakelijkheidsrecht. Zo is de justitie- en politiehervorming in België, zoals van start gegaan in 1999, het gevolg van "de affaire Dutroux"; vooral diens kortstondige ontsnapping in april 1998, bracht een ware inflatie van wetgevende initiatieven op gang. 
Een constante van bijzondere wetten inzake de civiele aansprakelijkheid, bestaat erin dat telkens een regime van risicoaansprakelijkheid wordt gehanteerd ${ }^{241}$. Eerder dan uit te gaan van een algemene "risicoaansprakelijkheidsregel" voor al deze gevaren en/of activiteiten, werd voor al deze specifieke risico's afzonderlijk een (soort van) risicoaansprakelijkheid geïntroduceerd. Uit de verschillende wetgeving valt niet eenduidig af te leiden of één welbepaalde grondslag heeft geleid tot de invoering van de risicoaansprakelijkheid; deze wetten zijn fragmentarisch en casuïstisch ${ }^{24}$.

De bijzondere aansprakelijkheidswetten bevatten ook nog andere gemeenschappelijke kenmerken. Zo wordt de schade vaak beperkt tot een gegeven bedrag, wordt de schade vergoed mits het afhouden van een vrijstelling of franchise, wordt de termijn waarbinnen een vordcring tot schadevergoeding kan worden ingediend beperkt, en wordt de aansprakelijke verplicht zich te verzekeren ${ }^{24.3}$. Dezc kenmerken - of een aantal daarvan - zijn bijvoorbecld terug te vinden in de productaansprakelijkheidswetgeving, in de wetgeving inzake de aansprakelijkheid voor schade door olicverontreiniging op zee en in het nucleaire aansprakelijkheidsrecht. Het is opvallend dat de hier genoemde wetgeving van internationalal-rechtelijke oorsprong is ${ }^{2+4}$.

De inflatie van nationale en internationale regelgeving is niet enkel terug te vinden in het civicle aansprakelijkheidsrecht, maar ook in het milieurecht in het algemeen. Met name de Europese Unie heeft regels uitgewerkt onder meer inzake de beoordeling van milieu-effecten, het transport van afval, de uitbating van stortplaatsen, de verantwoordelijkheid van producenten van afval $\mathrm{etc}^{245}$.

\subsection{Conclusie}

Een vergelijking van de verschillende in het BW (en in bijzondere wetten) voorziene aansprakelijkheidsregimes ter zake van de aansprakelijkhoid voor milieuschade, leert in de cerste plaats dat de klassieke foutuansprakelijkheid nog steeds een belangrijke positie inneemt. Deze positie hangt nauw samen met de in het bredere milieurecht opgelegde normen en verplichtingen: met name een overschrijding van die norm of verplichting kan leiden tot aansprakelijkheid. Zonder deze milieunormen zou de foutaansprakclijkheid nict deze plaats innemen in het milieuaansprakelijkheidsrecht.

Bocken, H., "Van fout naar risico", o.c., 373-374.

Deze risicoaansprakelijkheden - net zoals deze voorzien in het BW - worden beschouwd als toepassingen vin de risicoleer (Faure, M. en Van den Bergh, R., "Objectieve aansprakelijkheid", l.c., 181). Zo wordt de afwijkende regeling inzake kemongevallen verdedigd op basis van de "omvang en complexiteit van het risico" (Bocken, H., "Van fout naar risico", o.c., 394). Omdat een bepaalde persoon een risicovolle activiteit start, wordt het niet meer dan billijk geacht dat hij ook de lasten ervan voor zijn rekening neemt.

Comslis, L., "Beginselen", l.c., 571-572.

Het verplicht stellen van de verzekering zou een slachtolfer compensatie garanderen, zelfs bij insolvabiliteit van de verantwoordelijke van de risicovolle activiteit ( Tunc, A., "La responsabilité civile", l.c., 75).

De productaansprakelijkheidswetgeving is gebascerd op de Europese richtlijn van 25 juli 1985 ( $P B$ L210/29 van 7 augustus 1985); de wetgeving irzake de aansprakelijkheid voot schade doot olieveronireiniging op zee is gebaseerd op de CLC-Conventie van 29 november 1969 (cfr. infra hoofdstuk 12) en het nucleaire aansprakelijkheidsrecht is gebaseerd op het Verdrag van Parijs van 29 juli 1960 en het Verdrag van Wenen van 31 januari 1963 (cfr. infra: hoofdstukken 3 en 4).

Voor een volledig overzicht zie bijvgorbeeld Krämer, L, EEC Treaty and Environmental Protection, London, Sweet \& Maxwell, 1997; Krămer, L., Focus on European Environmental Law, London, Sweet \& Maxwell, 1998. 
Voor wat betreft de vergelijking tussen het Belgische en Nederlandse aansprakelijkheidsrecht, is een opvallend verschil terug te vinden in de in Nederland in het BW ingevoerde algemene aansprakelijkheid voor gevaarlijke zaken enerzijds en in de in België aanvaarde evenwichtsleer. Op zich kan een algemene aansprakelijkheidsregel ter zake van gevaarlijke activiteiten, naar het voorbeeld van de algemene foutaansprakelijkheidsregel, zinvol zijn, toch moet worden gewezen op de beperkingen en discussies van artikel 6:175 van het Nederlandse BW. Uit het overzicht van de aansprakelijkheidsregels valt dus niet in algemene termen af te leiden dat een Belgisch slachtoffer van milieuschade zich in een minder gunstige positie bevindt ten opzichte van een Nederlands slachtoffer, of omgekeerd.

Wat daarentegen wel kan worden gezegd, is dat in beide landen discussie bestaat over de precieze kwalificatie van de juridische grondslag voor de aansprakelijkheid voor milieuschade. Dat een tussenkomst van de wetgever geen garantie is voor duidelijkheid, is bijvoorbeeld aangetoond door de vragen rond de tenzij-formule van artikel 6:173 van het Nederlandse NBW.

Uit bovenstaand overzicht van het civiele aansprakelijkheidsrecht, valt een tendens af te leiden op basis waarvan meer en meer wordt afgeweken van de klassieke foutaansprakelijkheid, ten voordele van een regime van risicoaansprakelijkheid. Deze tendens geldt evenzeer voor de rechtspraak als voor de wetgeving en doet zich op nationaal en internationaal vlak voor. Verschillende onderzoeken in dat verband hebben gewezen op een zekere uitbreiding van het aansprakelijkheidsrecht $^{246}$. Vooral de bekommernis van de rechtbanken om slachtoffers en consumenten te beschermen, heeft hiertoe bijgedragen. In bepaalde gevallen valt de grens tussen foutaansprakelijkheid en risicoaansprakelijkheid nog zeer moeilijk te trekken ${ }^{247}$.

Voor wat betreft de kwalificatie van de aansprakelijkheidsgrondslag ter zake van de aansprakelijkheid voor milieuschade, kan worden geconcludeerd dat deze aansprakelijkheidsgrondslag allemninst duidelijk is. Rechtspraak en rechtsleer hanteren verschillende begrippen, zoals aansprakelijkheidsvermoeden, foutvermoeden, onweerlegbaar vermoeden ${ }^{248}$, aansprakelijkheid van rechtswege, risicoaansprakelijkheid, objectieve aansprakelijkheid ${ }^{249}$, risicoaansprakelijkheid met correctie via de tenzij-formule. Het is niet evident om uit al deze begrippen het juiste aankno-

Spier, J., De maalstroom van het aansprakelijkheidsrecht, Houthoff-lezing, maan 1992; Rogers, W.V.H., Spier, J. en Vincy, G., "Preliminary Observations", in Spier, J., The Limits of Liability. Keeping the Floodgates Shut, Kluwer Law Intemational, Den Haag, 1996, 1-2; Bolt, A.T. en Spier, J., De witdijende reikwijdte van de aansprakelijkheid uit onrechimatige daad, W.E.J. Tjeenk Willink, Zwolle, 1996, 365 (hiema gecitecrd als: "De uitdijende reikwijdte, preadvies"). Betlem, G., "It's no use crying over spilt chemicals. House of Lords, Cambridge Water Co. V. Eastern Counties ple and Hoge Raad, 30 September 1994, Netherlands State v. Shell", Maastricht Journal of European and Comparative Law, 1995, vol. 2, $n^{\circ} 3,297-298$.

Vansweevelt wijst op de inconsistentie van dit begrip. Immers, in de eigenlijke betekenis van het woord impliceert een vermoeden dat een bewijs van het tegendeel is toegelaten (Vansweevelt, $\mathrm{T}$., "Onderzoek naar de grondslag en de begrenzing van de aansprakelijkheid voor dieren", Rechtskundig Weekblad, 1985-1986, 2190).

Door een deel van de Belgische doctrine wordt met name een onderscheid gemaakt tussen objectieve aansprakelijkheid en risicoaansprakelijkheid (Bocken, H., "Van fout van risico", o.c., 331; hierin gevolgd door Van Oevelen, A., "Objectieve aansprakelijkheid voor schade veroorzaakt door milieuverontreiniging volgens het Belgische recht", in "Risico-aansprakelijkheid voor milieuschade", l.c., 86). Anderen beschouwen risicoaansprakelijkheid en objectieve aansprakelijkheid dan weer als synoniemen (Faure, M. en Van den Bergh, R., "Objectieve aansprakelijkheid", l.c., 170). Hierop wordt later teruggekomen, bij de bespreking van de kanalisatie van aansprakelijkheid. 
pingspunt te kiezen en daaruit de juiste conclusie te trekken omtrent de precieze bewijslast van het slachtoffer en de bevrijdingsmogelijkheden van de dader ${ }^{250}$.

Deze onduidelijkheden doen heel wat vragen rijzen. Bestaat er een verschil tussen risicoaansprakelijkheid en objectieve aansprakelijkheid? Waar ligt de grens tussen een wettelijk vermoeden en risicoaansprakelijkheid, zeker wanneer dit vermoeden onomkeerbaar is ${ }^{251}$ ? Verzwakt de tenzijformule in het Nederlandse BW de risicoaansprakelijkheid tot een aansprakelijkheidsvermoeden? Deze onduidelijkheid blijft evenwel niet bepcrkt tot de op het BW gebaseerde aansprakelijkheidsregimes, maar werkt ook door in de in bijzondere wetten neergelegde aansprakelijkheidsregimes. Zo wordt bijvoorbeeld art. 29 bis van de Belgische WAM-wet ${ }^{252}$ beschouwd als een aansprakelijkheidsverzekering ${ }^{253}$, als een wettelijke persoonsverzekering met indemnitair karakter ${ }^{254}$ of als een autonome verbintenis ${ }^{255}$ en een objectieve aansprakelijkheid ${ }^{256}$.

Zelfs voor specialisten is het dus geen sinecure om het precicze onderscheid te onderkennen tussen foutaansprakelijkheid en risicoaansprakelijkheid ${ }^{257}$. Het antwoord op deze vragen heeft nochtans een directe invloed op de bewijslast van het slachtoffer, c.q. de bevrijdingsmogclijkheden van de dader.

Als uitersten in het brede spectrum van aansprakelijkheden, lijkt zich aan de ene kant de klassieke foutaansprakelijkheid te bevinden en aan de andere kant de absolute aansprakelijkheid ${ }^{258}{ }^{259}$. Alle

Ook in die zin Cousy, H., "Enkele beschouwingen over de systematiek van de stelsels van foutloze aansprakelijkhuid", in Liber Amicorum Jacques Putzeys. Etudes de Droit des Transports, Bruxelles, Bruylant, 1996, 38 e.v.

251 Qok in die zin: Van Dunné, J.M., "Verbintenissenrecht 2", 348 en 356.

"Wut van 21 november 1989 op de verplichte aansprakelijkheidsverzekering voor motorrijtuigen (B.S., 8 december 1989). Het eerste lid van dit artikel luidt: "Bij een verkeersongeval waarbij een motorijtuig betrokken is, wordt (...) alle schade veroorzaakt aan elk slachtoffer of zijn rechthebbenden en voortvloeicnd uit lichamelijke letsels of het overlijden, vergoed door de verzekeraar die de aansprakelijkheid dekt van de cigenaar, de bestuurder of de houder van het voertuig (...)". Enkel slachtofiers die een onverschoonbare fout hebben begaan, kunnen zich niet op deze bepaling beroepen. Onder een onverschoonbare fout wordt verstaan: "de opzettelijke fout van uitzonderlijke ernst, waardoor degene die ze heeft begaan zonder geldige reden wordt blootgesteld aan een gevaar waarvan hij zich niet bewust had moeten zijn" (art. 29bis, \$1, 6० WAM-wet).

Fagnart, J.-L., "I.'indemnisation des victimes d'accidents de la circulation après la réforme baclíe du 30 mars 1994, Revue Générale des Assurances et des Responsabilités, 1994, nr. 12388, nr. 20; Dalcq, R.O., "L'indennisation des dommages corporels des pietons et des cyclistes", Journal des Tribunaux, $1.994,665-672$. Bocken, H. en Geerts, L., "De vergoeding van lctsclschade en schade door overlijden bij verkeersongevallen in het Belgisch recht", Tijdschrift voor Privaatrecht, 1996, 1250-1255; Simoens, D., "De nieuwe verkeersongevallenwet: contouren van een genereus vergoedingsprincipe", Tijdschrift voor Belgisch Burgerlijk Recht, 1997, 54-57; Simoens, D., "De gewijzigde vergoedingsregel ten voordele van voetgangers, fietsers en passagiers", Rechtskundig Weekblad, 1995-1996, 219.

Schoorens, G., "Verkeersongevallen met 'zwakke weggebruikers': het nieuwe vergoedingssysteem van art. 29bis WAM-wet. Het kwalificatieproblecm", Revue Générale des Assurances et des Responsabilités, 1995, nr. 12443, nr. 8. Comelis, L., "De objectieve aansprakelijkheid voor motorrijtuigen", Rechtskundig Weekblad, 1998$1999,535$. Faure, M. en Hartlief, T., "Towards an Expending Enterprise Liability in Europe?", Maastricht Journal of European and Comparative Law, 1996, vol. 3, 247. dader zich zelfs niet kan bevrijden door het inroepen overmacht, noch van enig ander verweermiddel. Het is onzeker of deze vorm van aansprakelijkheid überhaupt in enige wettekst is terug te vinden. 
andere vormen van aansprakelijkheid situeren zich ergens tussen beide in. In stijgende lijn van strengheid van aansprakelijkheid (en dus van tegemoetkoming aan de bewijslast van een slachtoffer) kunnen worden beschouwd het foutvermoeden, het vermoeden van aansprakelijkheid ${ }^{260}{ }^{261}$ en de aansprakelijkheid van rechtswege.

De essentie van de discussie met betrekking tot de aansprakelijkheidsgrondslag ligt in feite bij de verschillende bevrijdingsmogelijkheden en overmachtsgronden die de aangesprokene kan inroe:pen: naarmate deze laatste meer mogelijkheden heeft om aan aansprakelijkheid te ontsnappen, zal er sprake zijn van een minder streng aansprakelijkheidsregime. Ook de precieze verdeling van de bewijslast is hierbij van belang: is het aan de eiser om te bewijzen dat de verweerder een fout heeft begaan, of is het aan de verweerder om te bewijzen dat hij geen fout heeft begaan? De beoordeling van de aansprakelijkheid in een gegeven situatie zal dus nict kunnen ontsnappen aan een analyse van de gevallen van bevrijding en overmacht die in een gegeven situatie aan de aangesprokenen worden toegestaan evenals van de bewijslastverdeling. Bij de analyse van de aansprakelijkheid van de exploitant van een kerninstallatie zal bijgevolg rekening dienen te worden gehouden met de verschillende bevrijdingsmogelijkheden, overmachtsgronden en bewijslastverdeling.

Nadat een overzicht werd gegeven van het civiele aansprakelijkheidsrecht in het algemeen en van de mate waarin het Burgerlijk Wetboek als juridische grondslag kan dienen ter zake van de aansprakelijkheid voor milieuschade, is het in het kader van dit onderzoek van belang om stil te staan bij (de invloed van) andere compensaticmechanismen dan het aansprakelijkheidsrecht.

\section{HET AANSPRAKELIJKHEIDSRECHT TEGENOVER ANDERE VERGOEDINGSMECHANISMEN}

Een eenmaal ontstane schade is vaak het begin van een lang verhaal waar niet enkel het aansprakelijkheidsrecht van belang is. Degene die de schade lijdt zal trachten deze schade geheel of gedeeltelijk door te schuiven naar een ander ${ }^{262}$. Maar de schade kan evenwel enkel worden doorgeschoven indien daarvoor een goede reden bestaat ${ }^{263}$. Naast het aansprakelijkheidsrecht kunnen ook een first party verzekering (of eigenschadeverzekering) en een sociale zekerheidsdekking en/of sociale verzekering een goede reden bieden om de schade te verschuiven ${ }^{264}$. Deze vaststelling is relevant in het kader van dit onderzoek aangezien, enerzijds, de exploitant van een kemin-

Risicoaansprakelijkheid mag niet worden verward met absolute aansprakelijkheid zoals bijvoorbeeld Vranken dat doet (Vranken, J.B.M., "Zorgvuldigheidsnorm en aansprakelijkheid voor bodemverontreiniging uit het verleden", Weekblad voor Privaatrecht, Notariaat en Regisiratie, 1990, 5953-55. Zie ook de reactie daarop: Van Dunné, J.M., "Een kamikaze-aktie op de Rotte. De visie van Vranken op de aansprakelijkheid uit artikel $1401 \mathrm{BW}$, in het bijzonder bij bodemvervuiling uit het verleden", Weekblad voor Privaatrecht, Notariaat en Registratie, 1990, 5976). Het verschil tussen beide bestaat erin dat bij een aansprakelijkheidsvermoeden niet enkei de fout, maar ook de causaliteit wordt vermoed.

Deze term wordt verworpen door Vansweevelt (Vansweevelt, T., "Onderzoek naar de grondslag en de begrenzing van de aansprakelijkheid voor dieren", o.c., 2193).

Van Gerven, W., "De invloed van de verzekering op het verbintenissenrecht", o.c., 777; Simoens, D., "Hoofdlijnen in de evolutie van het aansprakelijkheidsrecht", o.c., 1964; Hartlief, T. en Tjittes, R.P.J.L., Aansprakelijkheid en Verzekering, Kluwer, $2^{\text {de }}$ druk, 1999.

Hartlief, T., "leder draagt zijn eigen schade", l.c., 11 .

Gepreciseerd dient te worden dat het belang van elk van deze vergoedingssystemen varieert al naargelang de soort schade. Het is evident dat sociale verzekeringen in de eerste plaats gericht zijn op de personenschade. Private verzekeringen zullen in eerste instantie van belang zijn bij schade aan goederen en andere vermogensschade. Het aansprakelijkheidsrecht daarentegen za! eerder op de voorgrond treden bij deze schade die niet of niet volledig door de andere systemen wordt of kan worden gedekt. 
stallatie ertoe is gehouden om een aansprakelijkheidsverzekering af te sluiten en anderzijds omdat in België en Nederland minstens een deel van de letselschade veroorzaakt door een kernongeval zal worden vergoed via het stelsel van sociale zekerheid.

Meteen rijst de vraag naar de wisselwerking tussen deze verschillende compensatiemechanismen $^{26.5}$. In $\$ 3.1$ wordt de wisselwerking besproken tussen aansprakelijkheid en verzekering. Vervolgens wordt de vraag beantwoord of het aansprakelijkheidsrecht, onder meer onder invloed van verzekering, zich al dan niet in een crisis bevindt ( $\$ 3.2$ ). Vervolgens worden de voor- en nadelen van de verschillende compensatiesystemen aan de orde gesteld ( $\$ 3.3$ ). In $\S 3.4$ worden enkele voorstellen van verschillende auteurs besproken, die allen trachten tegemoet te komen aan bepaalde tckortkomingen van met name het aansprakelijkheidsrecht. Tenslotte worden de bevindingen van de analyse gebundeld in $\S 3.5$.

\subsection{Invloed van verzekeringen op het aansprakelijkheidsrecht ${ }^{266}$}

Meerdere onderzoeken wijzen op het toenemend beroep op het aansprakelijkheidsrecht ${ }^{267}$; bij deze onderzoeken is telkens de verzekering en de verzekerbaarheid van de toenemende aansprakelijkheid een belangrijk thema. Er is reeds veel geschreven over de invloed van verzekeringen op het aansprakelijkheidsrecht. De vraag naar oorzaak en gevolg relatic van aansprakelijkheid en verzekering (heeft een toenemende aansprakelijkheid geleid tot het succes van verzekeringen of hebben daarentegen verzekeringen geleid tot het succes van het aansprakelijkheidsrecht?) is moeilijk cenduidig te beantwoorden ${ }^{268}$.

Het feit dat de beschikbaarheid van een ver zckeringsdekking leidt tot cen intensiever gebruik van vergocdingsmochanismen, kan op zich geen aanleiding geven tot ongerustheid. Enkel wanneer deze mechanismen bepaalde wijzigingen ondergaan zoals enerzijds een beperking van het beschermingsbereik van de sociale zekerheid en anderzijds een inhoudelijke evolutie van het aansprakelijkheidsrecht, kunnen problemen ontstaan. Zo wordt vooral gevreesd dat een toenemend

In deze paragraaf worden hoofdzakelijk de klassieke compensatiemechanismen besproken. In hoofdstuk 11 worden enkele altematieve compensatiemechanismen aan de orde gesteld. Zie ook Faure, M.G., "The Influence of Insurance on Liability Issues", in McGee, A. en Heusel, W. (ed.). The Law and Praciice of Insurance in the Single European Markel, Bundesanzeiger, Keulen, 1995, 190-195; Hartlief, T. en Tjittes, R.P.J.L., "Verzekering en aansprakelijkheid", I.c., 21-23. Faure, M.G. en Hartlief, T., Verzekering en de groeiende aansprakelijkheidslast. Een juridisch, gezondheidskundig en economisch onderzoek naar ontwikkelingen met betrekking tot de aansprakclijkheidslast en de consequenties voor verzekeraars naar aanleiding van de werkgeversaansprakelijkheid voor bedrijfsongevallen en beroepsziekten, Kluwer, Deventer, 1995, (hierna geciteerd als "Verzekering en de grociende aansprakelijkheidslast"); Bolt, A.T. en Spier, J., "De uitdijende reikwijdte, preadvies", l.c., 7 e.v. 174-183; Dekkers, R., "Aansprakelijkheid en verzekering", Rechtskundig Weekblad, 1970-1971, 1545 e.v.; Tunc, A., "Responsabilité civile et assurance", Hommage à René Dekkers, Bruxelles, Bruylant, 1982, 343; Simoens, D., "Hoofdlijnen in de evolutic van het aansprakelijkheidsrecht", o.c., 2025 e.v.; Simoens, D., "Ongevallenrecht: grensgebieden van aansprakelijkheid, verzekering, en sociale zekerheid", Tijdschrift voor Privaatrecht, 1984, 421; Gill, M., "The expansion of liability and the role of insurance. Who is the chicken?", The International Journal of Insurance Law, 1999, $27-40$. 
aantal vorderingen de verzekerbaarheid in het gedrang zou kunnen brengen ${ }^{269}$ dat zich analoge problemen zouden voordoen als in de Verenigde $\operatorname{Staten}^{270}$.

In het algemeen wordt aangenomen dat het aansprakelijkheidsrecht tot ontwikkeling is kunnen komen dankzij de ontwikkeling en de opkomst van de aansprakelijkheidverzekering ${ }^{271}$. Dit is zowel tot uiting gekomen in de rechtspraak als in de wetgeving.

Een mooi voorbecld van de invloed van verzekeringen op het aansprakelijkheidsvraagstuk, is de door van Gcrvens aangehaalde uitspraak van het Deense Hooggerechtshof, waiar de aansprakelijkheid werd gelegd bij die partij die beschikte over een schadever zekering ${ }^{372}$. Deze rechterlijke uitspraak is beïnvloed door de beschikbaarheid van ecn verzckeringsdekking, eerder dan tc zoeken naar degene die aan de oor zaak ligt van het schadegeval. Dergelijke voorbeelden van rechterlijke uitspraken blijven een uitzondering. Het uitgangspunt van het aansprakelijkheidsrecht is en blijft dat enkel een fout kan aanleiding geven tot aansprakelijkheid. De stelling dat het aansprakelijkhcidsrecht is geëvolucerd van cen faute oblige naar een assurance oblige ${ }^{273}$ kan niet worden bijgetreden. Hicrbij zou bepalend zijn wie van bcide partijen (slachtoffer of dader) over cen verzekeringsdekking beschikt om tot aansprakelijkheid te besluiten ${ }^{274}$. Een aansprakelijkheidsverzekering dekt de aansprakelijkheid, maar creëert de niet $^{275} 276$.

Bolt, A.T. en Spier, J., "De uitdijende reikwijdte, preadvies", l.c., 116 e.v.

Faure, M., "Over beschermde slachtofiers, vrijgevige rechters en zuchtende verzekeraars", Nederlands Juristenblad, 1995, 1227 e.v.; Hazzen, O.A. en Spier, J., "Amerikaanse toestanden en de nieuwe aansprakelijkheidsverzekering voor bedrijven", Nederlands Juristenblad, 1996, 45 e.v:; Spier, J., "De (on)verzekerbaarheid van ansprakelijkheden", in Miscellanea Jurisconsulto vero Dedicata (Van Dunné-bundel), Deventer, 1997, 405 e.v.

Cousy, H., "Over aansprakelijkheidsrecht en verzekering: living together apart?", in Liber Amicorum Walter van Gerven, Kluwer, 2000, 207. Sommigen zijn van oordecl dat door de opkomst van allerlei soorten verzekeringsdekkingen de fundamenten van het aansprakelijkheidsrecht worden bedreigd. Zie met name Tunc, A., "Les problèmes contemporains de la responsabilité civile délictuelle", Revue Internationale de Droit Comparé, 1967, 759.

Van Gerven, W., "De invloed van verzekeringen op het verbintenissenrecht", o.c., 777. De feiten in deze zaak waren als volgt: een bakkersgast was met zijn fiets in het uitstalraam van een bakkerij gereden. De vraag was aan de orde wie hiervoor aansprakelijk was. Het Deerise Hof oordeelde dat niet de bakkersgast (noch diens werkgever) aansprakelijk waren, omdat de bakker beschikte over een schadeverzekering voor de schade aan het uitstalraam.

Simoens, D., "Hoofdlijnen in de cvolutie van het aansprakelijkheidssrecht", o.c., 2025 e.v; Simoens, D., "Ongevallenrecht: grensgebieden van aansprakelijkheid, verzekering, en sociale zekerheid", o.c., 421; Van Gerven, W., "De invloed van verzekeringen op het verbintenissenrecht", o.c., 782-783.

Een aantal auteurs is van oordeel dat bepaalde interpretaties van het aansprakelijkheidsrecht er nooit waren gekomen indien de "dader" niet zou beschikken over eer verzekeringsdekking. Zo zou de Franse. rechtspraak aan artikel 1384, lid I BW nooit de algemene strekking hebben toegekend zoals wij die. vandaag kennen, indien de aansprakelijke zich hiervoor niet zou hebben kunnen verzekeren (Tunc, $A$., "Responsabilité civile et assurance", o.c., 346; Markesinis, B., "La perversion des notions de responsabilité civile délictuelle par la pratique de l'assurance", Revue Internationale de Droit Comparé, 1983, 301 e.v.).

Zo heeft de Nederlandse Hoge Raad in de zaak Eef Kamerbeek geoordeeld dat het onrechtmatige daadsrecht geen verplichting met zich meebrengt om een verzekeringsdekking af te sluiten voor die gevallen waarin men aansprakelijk kan worden gesteld (Hoge Raad, 14 februari 1969, Nederlands Juristenblad, 1969, 189). In deze zaak had de eiser tevergeefs aangevoerd dat het niet onderschrijven van een aansprakelijkheidsverzekering onzorgvuldig zou zijn.

Hartlief, T., "Ieder draagt zijn eigen schade", l.c., 36; Hartlief, T. en Tjittes, R.P.J.L., "Verzekering en Aansprakelijkheid", l.c., 21 e.v. 
Een wisselwerking tussen aansprakelijkheid en verzekering kan daarentegen wel worden onderkend in de wetgeving ${ }^{27}$. Een groot aantal bijzondere wetten, bijvoorbeeld inzake milieurecht, verplicht de exploitant om diens aansprakelijkheid te verzekeren. Ook de evolutic naar vormen van objectieve of risicoaansprakelijkheid is nauw verbonden met.de ontwikkeling van de aansprakelijkheidsversekering ${ }^{278}$.

Het gevaar van een te verregaande wisselwerking is duidelijk ${ }^{279}$. De verleiding kan immers bestaan om de hoogte van de aansprakelijkheid en de soorten schade die in aanmerking worden genomen, in mindere of meerdere mate te laten afhangen van de inhoud van de toepasselijke verzekeringspolis ${ }^{280}$.

De ingreep van verzekeringen op het aansprakelijkheidsvraagstuk wordt treffend geïllustreerd door de interpretatie van het begrip "betrokken bij een verkeersongeval" onder artikcl 29-bis van de Bclgische WAM-wet ${ }^{231}$. Geoordeeld wordt dat geen rekening dient te worden gehouden met enige inbreuk op de wegcode omdat op deze wijze het foutcriterium opnieuw zou worden ingevoerd $^{282}$, hetgeen uitdrukkelijk door de wetgever zou zijn uitgesloten. Het gevolg hiervan is dat zelfs indien een fietser tegen een geparkcerde wagen rijdt, de aansprakelijkhcidsverzekering van de bestuurder dient tussen te komen ${ }^{283}$. Nochtans blijkt dat een dergelijke automatische vergocdingsplicht leidt tot een aantal perverse effecten ${ }^{284}$.

Ook de verzekeringen zelf hebben een belangrijke evolutie ondergaan ${ }^{285}$ : in functie van de vraag op de markt, worden nieuwe dekkingen aangeboden (bijvoorbeeld de dekking voor milieuschade).

Het aansprakelijkheidsrecht wordt echter niet enkel geconfronteerd met andere takken van het privaatrecht. De complexiteit van de regelgeving is dermate toegenomen dat ook de invloed van publiekrechtelijke regels niet mag uit het oog worden verloren. We denken hier met name aan veiligheidsrcgulering (in het verkeers- en milieurecht) en aan de regelgeving inzake vergunningverlening in hot milieurecht. In dit verband pleit Bergkamp voor een gebalanceerd gebruik van publiek en privaat recht in het milieurecht (Bergkamp, L., De Vervuiler Betaalt Dubbel: over de Verhouding tussen Privaat en Publiek Milieurecht, oratie, Intersentia, Antwerpen, 1998, 91 e.v.).

Markesinis, B., "La perversion des notions de responsabilité civile délictuelle par la pratique de l'assurance", o.c., 301 .

Volgens een aantal auteurs krijgt, door de directe koppeling tussen aansprakelijkheid en verzekering, het schadevergoedingsrecht langzaam maar zeker vorm. Zie Dalcq, R.O., "Sécurité, assurance et solidarité", in Responsabilité et réparation des dommagres, êd. Jeune barreau, 1983, 327 e.v.; Fagnart, J.L., "Recherches sur le droit de la réparation", in Mélanges Roger O. Dalcq. Responsabilités et Assurances, Larcier, Bruxelles, 1994, 136. Jorgensen, S., "The Decline and Fall of the Law of Torts", The American Journal of Comparative Law, 1970, vol. 18,48 .

Zie hierover Claassens, H. en Van Schoubroeck, C., "Praktische ervaring met de Belgische schadevergoedingsregeling voor zwakke weggebruikers in de autoverzekering", in Faure, M. en Hartlief, T. (red.), Verkeersaansprakelijkheid in België en Nederland, Intersentia, Antwerpen-Groningen, 1998, 79-111; Decroïs, A., "De vergoeding van de zwakke weggebruikers (art. 29 bis WAM-wet)", Rechtskundig Weekblad, 2000-2001, 1257-1267.

Claassens, H. en Van Schoubroeck, C., "Praktische ervaring met de Belgische schadevergoedingsregeling voor zwakke weggebruikers in de autoverzekering", "Verkeersaansprakelijkheid in Belgie en Nederland", l.c., 91

Pol. Rb. Kortrijk, 14 oktober 1998 en Pol. Rb. Brugge, 9 november 1998, Tijdschrift voor Belgisch Handelsrecht, 1999, 218-221, met noot Van Schoubroeck, C.

Van den Bergh, R., "Automatische vergoeding van schade geleden door zwakke verkeersdeclnemers: een rechtseconomische kritiek", in Faure, M. en Hartlief, T., Verkeersaansprakelijkheid in Belgie en Nederland, Intersentia, Antwerpen, Groningen, 1998, 48 e.v. Gompel, Story Scientia, Kluwer, Deurne, 1998, 129-155. 
Tegelijk zal een slachtoffer veelal over een directe vordering tegen de verzekeraar beschikken. Hierdoor wordt het slachtoffer in feite gedirigeerd naar een verzekeraar ${ }^{286}$. Daamaast leidt bijvoorbeeld een rechtsbijstandverzekering ertoe dat slachtoffers een extra prikkel krijgen om een vordering in te dienen, in die zin dat bij afwezigheid van een rechtsbijstandsdekking, bepaalde vorderingen waarschijnlijk niet zouden worden ingediend ${ }^{287}$.

Naast de intrede van de (aansprakelijkheids)verzekeringen, wijzigde ook het ontstaan van de zogenaamde sociale risico's het wezen van de civiele aansprakelijkheid; het gaat met name om schadevergoeding die gebaseerd is op solidariteit en waarvan uitkering geschiedt zonder aanknoping met een aansprakelijk gestelde persoon. Het doel van deze sociale zekerheid bestaat erin de verzekerden een minimum van middelen te garanderen indien zij worden getroffen door werkongeval, ziekte, etc. Alhoewel het sociale zekerheidsrecht vandaag duidelijk wordt onderscheiden van de civiele aansprakelijkheid, stamt de sociale zekerheid oorspronkelijk uit een systeem van aansprakelijkheidsverzekering. De eerste wetgeving met betrekking tot de bescherming van de werknemers was duidelijk gebaseerd op de civiele aansprakelijkheid ${ }^{288}$. Het grote probleem van het hedendaagse aansprakelijkheid is de moeilijkheid om de grenzen en de wisselwerking vast te leggen tussen het aansprakelijkheidsrecht en de beschikbare collectieve voorzieningen ter vergoeding van de geleden schade ${ }^{283}$.

Het is intussen bijna een gemeenplaats geworden om te stellen dat het aansprakelijkheidsrecht zich in een crisis bevindt ${ }^{290}$ en dat het aansprakelijkheidsrecht traag en duur is ${ }^{291}$. Met name verzekeraars onderschrijven deze stelling ${ }^{292}$ door te wijzen op de gevolgen van deze crisis op het vlak van de (on)verzekerbaarheid. De elementen die bepalend zijn voor de verzekerbaarheid van een gegeven risico worden besproken bij de rechtseconomische analyse van verzekeringen ${ }^{293}$. Hieronder worden enkele elementen belicht waarvan wordt aangenomen dat zij een invloed hebben op het aansprakelijkheidsrecht.

\subsection{Crisis van het aansprakelijkheidsrecht}

Nadat een aantal bijdragen in de literatuur weren op ecn aanzienlijke toename van het aantal aansprakelijkheidsvorderingen in de Verenigde Staten ${ }^{244}$, werd de vraag gesteld of ook in het Belgische en Nederlandse aansprakelijkheidsrecht een analoge tendens waameembaar was. Hoe-

Simoens, D., "Ongevallenrecht: grensgebieden van aansprakelijkheid, verzekering, en sociale zekerheid", $0, c, 425$. Faure, M.G. en Hartlief. T., "Verzekering en de groeiende aansprakelijkheidslast", l.c., 78-79; Hartlief, T. en Tjittes, R.P.J.L., "Verzekering en Aansprakelijkheid", l.c., hoofdstuk 6.

Tunc, A., "Responsabilité civile", l.c., 28.

Tunc, A., "Responsabilité civile", l.c., 108.

Zie onder meer Tunc, A., "Responsabilité civile et assurance", o.c., 346; Markesinis, B., "La perversion des notions de responsabilité civile délictuélle par la pratique de l'assurance", o.c., 301 e.v.; Viney, G., "Responsabilité", l.c., 23.

Onder meer: Priest, G., "The Invention of Enterprise Liability: A Critical History of the Intellectual Foundations of Modern Tort Law", Journal of Legal Studies, 1985, 461; Tunc, A., "Où va la responsabilité civile aux Etats-Unis?", Revue Internationale de Droit Comparé, 1989, 7; Schirmeister, F.C., Amerikaanse toestanden in het schadevergoedingsrecht? De vergoeding van letselschade in de Verenigde Staten, Koninklijke Vermande, Lelystad, 1996, 437-531.
} 
wel over het algemeen deze vraag ontkennend kan worden beantwoord, moet toch op een aantal elementen worden gewezen ${ }^{295}$.

Uit bovenstaand overzicht van het civiele aansprakelijkheidsrecht is reeds gebleken dat in het aansprakelijkheidsrecht in het algemeen, en evenzeer op het vlak van de milieuaansprakelijkheid, een tendens is vast te stellen van foutaansprakelijkheid naar risicoaansprakelijkheid. Het is evenwel zeer de vraag of deze tendens leidt tot een effectieve vorzwaring van de aansprakelijkheidslast. De aansprakelijkheidsgrondslag is immer slechts één element bij de beoordeling van de aansprakelijkheid.

Reeds meermaals is gewezen op bepaalde tekortkomingen van het aansprakelijkheidsrecht en de aansprakelijkheidsverzekering ${ }^{296}$. Het probleem waarmee het aansprakelijkheidsrecht heeft te kampen, is dat twee essentiële criteria onder zware druk komen te staan: in een aantal gevallen is zowel het bewijs van de schade als van de causaliteit problematisch. Meer en meer worden inderdaad verschillende soorten schade, waaronder ecologische schade ${ }^{297}$, schade door de aantasting van de zelfredzaamheid, sluipende schade etc., onderscheiden ${ }^{298}$. In Nederland is bijvoorbeeld een stijging vastgesteld van de bedragen die werden toegekend ter zake van immateriële schade ${ }^{299} 300$.

In bepaalde gevallen van milieuaansprakelijkheid ${ }^{301}$ zal er bijvoorbeeld ook een lange tijd verlopen tussen een voorval en de manifestatie van de schade: in cen dergelijk geval zal het causaliteitsbewijs geen sinecure blijken ${ }^{302}$. De genoemde problemen van het aansprakclijkheidsrecht, sleuren als het ware de aansprakelijkheidsverzekering met zich mee: indien een lange tijd verstrijkt tussen een voorval en het zich manifesteren van de schade, rijst het probleem van de dekking van de aansprakelijkheid in de tijd. Tegelijk kan ook de rechterlijke beslissing ter zake van de causaliteitsonzekerheid leiden tot problemen voor aansprakelijkheidsvcrzckeraars. Ecn inmiddels bekend voorbeeld is de Nederlandse DES-zaak die heeft geleid tot een ware inflatie van vorderingen $^{303}$ en wordt beschouwd als "een van de meest sprekende voorbeelden van het uitdijend aansprakelijkheidsrecht" ${ }^{1304}$. Onderzoek heeft inderdaad uitgewezen dat vooral het afwentelen

Bolt, A.T. en Spier, J., "De uitdijende reikwijdte- preadvies", l.c.; Faure, M.G. cn Hartlief, T., "Verzckering en de groeiende aansprakelijkheidslast", I.c.; Faure, M. en Hartlief, T., "Towards an Expending Enterprise Liability in Europe?", o.c., 235 e.v.

Voor een bondig overzicht, zie bijvoorbeeld Cousy, $\mathrm{H}$., "Over aansprakelijkheidsrecht en verzekering: living together apart?", in Liber Amicorum Walter van Gerven, l.c., 212 e.v,

Zie hierover Bocken, H., "Compensation of Ecological Damage in Belgium", in Wetterstein, P. (ed.), Harm to the Environment: the right 10 Compensation and the assessment of Damages, Oxford, Clarendon Priss, 1997, 143-158.

Simoens, D., Buitencontractuele aansprakelijkheid, Deel $\llbracket \mathrm{l}$, Schade en schadeloosstelling, Story Scientia, 1999, 255 e.v. Faure, M.G. en Hartlief, T., "Verzekering en de groeiende aansprakelijkheidslast", l.c., 33-37. Zie hierover ook de verschillende bijdragen in Kottenhagen-Edzes, P. (red.), Immateriële schade: tendensen en wensen, Boekenreeks lus Commune, nr. 33, Intersentia, Antwerpen, Apeldoom, 2000, 184.

Over de problemen van het milieuaansprakelijkheidsrecht zie Deketelaere, M., "Deel VII. Milicu en burgerlijk aansprakelijkheidsrecht" in Handboek Milieurecht", l.c., 1176-1192. Meer en meer wordt dan ook gepleit voor het aannemen van een proportionele of altematieve causaliteit. Zie met name Akkermans, A.J., "Proportionele Aansprakelijkheid", l.c., Van Dunné, J.M., Causaliteitsproblemen in het milieu-aansprakelijkheidsrecht; alternatieve causaliteit en res ipsa loquitur", Tijdschrift voor Milieuaansprakelijkheid, 1999-4, 119-125 en 1999-5, 145-157. Kort na het arrest waren reeds meer dan 20.000 vorderingen ingediend (Wansink, J.H., "Het DESarrest in het perspecticf van verzekerbare slachtofferbescherming", Aansprakelijkheid \& Verzekering, 1993, 10). 
van retroactieve aansprakelijkheid (onvoorzienbare risico's) en van causaliteitsonzekerheid op de bedrijfswereld, tot een aanzienlijke uitbreiding van de aansprakelijkheidslast kan leiden ${ }^{305}$.

Volledigheidshalve wordt aangegeven dat ook een stijging in de toegekende bedragen en in het aantal personen dat een vordering kan inleiden, zal leiden tot een verhoging van de aansprakelijkheidslast. Onderzoek in Nederland heeft uitgewezen dat een stijging van de door verzekeraars uitgekeerde bedragen kan worden vastgesteld ${ }^{306}$. Nochtans lijken Europese rechtssystemen niet geneigd om over te gaan tot het toekennen van punitive damages ${ }^{307}$.

De vraag of het aansprakelijkheidsrecht zich in een crisis bevindt, hangt slechts ten dele af van de ontwikkelingen van het aansprakelijkheidsrecht. Ook andere factoren dienen in rekening te worden gebracht. Als belangrijkste factoren kunnen hier worden onderscheiden: het stelsel van sociale zekerheid en factoren die drempelverlagend werken op de bereidheid om vorderingen in te diencn (willingness to claim).

Een belangrijke factor is de mate waarin een sociaal zekerheidsstelsel voorhanden is. Een dergelijk stelsel zal namelijk instaan voor de compensatie van met name letselschade. Een stelsel van sociale zekerheid is in die optiek een vergoedingsmechanisme dat voor een deel in de plaats kan treden van het aansprakelijkheidsrecht: een breed systeem van sociale zekerheid zal tot gevolg hebben dat er minder een beroep wordt gedaan op het aansprakelijkheidsrecht ter compensatie van de geleden letselschade. Omgekeerd zal, bij afwezigheid of bij de afbouw van sociale zekerheid, het slachtoffer trachten via het aansprakelijkheidsrecht een vergoeding te bekomen van letselschade. De mate waarin het aansprakelijkheidsrecht tussenkomt ter compensatie van letselschade hangt dus in eerste instantie af van de mate waarin het sociale zekerheidssysteem dekking verleent. Daarnaast zal de rol van het aansprakelijkheidsrecht ter zake van letselschade in belangrijke mate worden beïnvloed door de vraag of voor de uitgekeerde bedragen een regresrecht openstaat tegen de veroorzaker ${ }^{308}$.

Een bijkomende factor wordt gevonnd door verschillende factoren die bepalend zijn voor de willingness to $\mathrm{claim}^{309}$. De bereidheid tot het indienen van vorderingen zal in belangrijke mate afhangen van een aantal juridische elementen. Hiermee bedoelen we in hoofdzaak de mogelijkheden ter zake van het indienen van collectieve vorderingen. Hierbij valt te denken aan artikel 3:305 $\mathrm{a}$ en b van het Nederlandse BW ${ }^{310}$ en aan de Belgische wet van 12 januari 1993 betreffende een

Faure, M.G. en Hartlief, T., "Verzekering en de groeiende aansprakelijkheidslast", l.c., 22-27.

Bolt, A.T. en Spier, J., "De uitdijende reikwijdte- preadvies", l.c., 10 e.v.

Faure, M. en Hartlief, T., "Towards an Expending Enterprise Liability in Europe?", o.c., 267.

Bijzonder in dat verband is de Nederlandse tijdelijke regeling verhaalsrechten, verwoord in artikel $6.197 \mathrm{BW}$ dat een beperking bevat van de mogelijkheid om regres uit te ocfenen. Als algemeen beginsel houdt deze regeling in dat regresnemers die onder het oude recht over een verhaalsmogelijkheid beschikten, deze onder het nieuwe BW behouden. Aldus staat in beginsel geen regresrecht open ter zake van de "nieuwe" gevallen van risicoaansprakelijkheid, met name voor de hierboven besproken aansprakelijkheid voor gevaarlijke zaken. Zie in dat verband Hartlief, T. en Tjittes, R.P.J.L., "Verzekering en Aansprakelijkheid", l.c., 98-106; Van Maanen, G.E. en Römers, P., "De tijdelijke regeling verhaalsrechten, verhaalsmogelijkheden voor verzekeraars en uitkeringsinstanties", Ars Aequi, Nijmegen, 1994; Spier J., Hartlief, T., Van Maanen G.E. en Vriesendorp, R.D., "Verbintenissen", l.c., 232-236. Bolt, A.T. en Spier, J., "De uitdijende reikwijdte- preadvies", l.c., 42-43.

Artikel $3: 305$ a BW luidt: "1. Een stichting of vereniging met volledige rechtsbevoegdheid kan een rechtsvordering instellen die strekt tot bescherming van gelijksoortige belangen van andere personen, voorzover zij deze belangen ingevolge haar statuten behartigt. 2 . Een rechtspersoon als bedoeld in lid l is niet ontvankelijk, indien hij in de gegeven onstandigheden onvoldoende heeft getracht het gevorderde door het voeren van overleg met de gedaagde te bereiken $(\ldots)^{\prime \prime}$. Zie hierover onder meer Van 
vorderingsrecht inzake de bescherming van het leefmilieu ${ }^{311}$. Deze bereidheid hangt ook af van de beschikbaarheid van een rechtsbijstandspolis: beschikt het slachtoffer over een rechtsbijstanddekking, dan zal zijn drempel om een proces aan te spannen, bijzonder laag zijn. De willingness to claim hangt tenslotte ook af van de organisatie van de advocatenpraktijk en van de mogelijkheid om de advocatenkosten terug te vorderen van de verliezende partij etc. Zo lijkt in bepaalde gevallen zelfs te worden gekozen voor het Amerikaanse recht omwille van de wijze van organisatie van de advocatenpraktijk. Van de niet juridische elementen die eveneens een invloed hebben op de willingness to claim, vermelden we hier de invloed van de media en van allerlei belangengroeperingen $^{312}$.

In deze paragraaf is vooral naar voren gekomen dat niet enkel elementen van het aansprakelijkheidsrecht zelf bepalen of deze rechtstak zich in een crisis bevinden, maar evenzeer elementen buiten het aansprakelijkheidsrecht. Tegelijk is duidelijk geworden dat verschillende compensatiemechanismen voorhanden zijn, waarvan het aansprakelijkheidsrecht er slechts één is. De voor- en nadelen van de verschillende mechanismen worden hieronder kort aan de orde gesteld.

\subsection{Voor-en nadelen van de verschillende mechanismen}

Is er geen goede reden voor de verschuiving van de schade voorhanden, dan blijft de schade bij degene die ze heeft geleden: the loss lies where it falls ${ }^{313}$, ofwel: "ieder draagt zijn eigen schade" 14 31:. Zoals recds aangegeven, zijn or meerdere manieren om deze schade af te wentelen: het aansprakelijkheidsrecht, een first party verzekering (of eigenschadeverzekering) en een systeem sociale zekerheidsdekking en/of sociale verzekering.

De basis van het aansprakelijkheidsrecht bestaat erin dat schade die initieel door een persoon wordt gedragen, op grond van een regel van het aansprakelijkheidsrecht, wordt afgewenteld op een andere persoon. Deze andere persoon heeft een fout begaan of is bijvoorbeeld exploitant van een vergunningsplichtige inrichting die schade aan derden heeft veroorzaakt. Het grote voordeel van het aansprakelijkheidsrecht bestaat erin dat in principe alle geleden schade voor vergoeding in aanmerking komt ${ }^{316}$. Of zoals Hartlief het treffend verwoordt: "Wie in de prijzen van het aan-

Acht, R.J.J. en Bauw, E., "Milieuprivaatrecht", l.c., 240; Frenk, N., Kollektieve akties in het privaatrecht, diss, Kluwer, Deventer, 1994.

B.S., 19 februari 1993; zie o.m. Carette, A., "Wet betreffende een vorderingsrecht inzake bescherming leefmilieu", Rechtskundig Weekblad, 1992-1993, 1392-1400; Carette, A., "Herstel van en vergoeding voor aantasting aan niet-toegeeigende milieubestanddelen", l.c., 138 e.v.; Van Hecke, S., "Drie jaar vorderingsrecht inzake bescherming leefmilieu": analyse van de eerste rechtspraak", Tijdschrift voor Milieurecht, 1996, 2-18.

Hartlief, T., "Ieder draagt zijn eigen schade", l.c., 37-38; Faure, M.G. en Hartlief, T., "Verzekering en de groeiende aansprakelijkheidslast", l.c., 74.

Van Gerven, W, "De invloed van de verzekering op het verbintenissenrecht", o.c., 777; Simoens, D., "Hoofdlijnen in de evolutie van het aansprakelijkheidsrecht", o.c., 1964. Hartlief, T., "leder draagt zijn eigen schade", l.c., 24.

315 Spier trekt deze stelling in twijfel (Spier, J., Een nieuwe dagerand voor het aansprakelijkheidsrecht?, Rede uitgesproken bij het afscheid van het ambt van gewoon hoogleraar in het privaatrecht aan de Katholieke Universiteit Brabant op vrijdag 26 maart 1999, W.E.J. Tjeenk Willink, Deventer, 1999, 1). Ook Huls twijfelt hieraan en stelt dat het uitgangspunt nu luidt: "Pech moet weg" (Huls, N.J.H., Recht in de risicomaatschappij, Delft University Press, Delft 1997, 12-13). ing the Floodgates Shut", l.c., 2. Specifiek met betrekking tot het Belgische recht zie Van Oevelen, A, "La modération de la réparation du dommage dans le droit belge de la responsabilité civile extracontractuelle", in Spier, J., The Limits of Liability. Keeping the Floodgates Shut, Kluwer Law Intemational, Den Haag, 1996, 65-74. 
sprakelijkheidsrecht valt, krijgt in beginsel zijn volledige vermogensschade vergoed" ${ }^{317}$. In die optiek valt het aansprakelijkheidsrecht dan ook te beschouwen als een luxesysteem ${ }^{318}$.

Het voordeel van de private verzekering en de sociale zekerheid bestaat erin dat niét wordt gezocht naar de oorzaak van de schade; deze oorzaak is in beginsel irrelevant. Het louter optreden van de schade is een voldoende reden tot het verschuiven van de schade. Deze mechanismen kunnen dan ook worden beschouwd als een laagdrempelig systeem. Indien bijvoorbeeld iemand in slaap valt achter het stuur van de wagen, tegen een boom rijdt en hierdoor twee weken werkonbekwaam is, dan zal het sociale zekerheidsstelsel automatisch tussenkomen voor wat betreft het inkomensverlies ingevolge de werkonbekwaamheid. Indien de betrokkene daarenboven een eigenschadeverzekering heeft voor zijn wagen en een bijkomende hospitalisatieverzekering, dan zullen eveneens de herstellingskosten van de wagen en (een deel van) de ziektekosten niet voor rekening van het slachtoffer vallen. Precies hetzelfde geldt indien, in bovenstaand voorbeeld, de chauffeur niet tegen een boom, maar tegen een andere wagen aanrijdt.

Slechts zodra een bepaalde schade niet of niet geheel door een van deze twee vergoedingsmechanismen wordt vergoed, zal een beroep op het aansprakelijkheidsrecht aan de orde zijn. Het is het laatste hulpmiddel of een randverschijnsel ${ }^{319}$. Dit brengt ons meteen bij een belangrijk nadeel van het aansprakelijkheidsrecht. Dit mechanisme zal slechts dan soelaas bieden indien het slachtoffer erin slaagt om te bewijzen dat een bepaalde aansprakelijkheidsregel van toepassing is (bijvoorbeeld door te bewijzen dat een persoon een bepaalde hoedanigheid bezit of een onrechtmatige daad heeft gepleegd). Tegelijk kan de eigen schuld van het slachtoffer een belangrijke rol spelen, hetzij bij het aanvaarden van de aansprakelijkheid van een derde, hetzij bij het bepalen van de schadeomvang. Vandaar kan het aansprakelijkheidsrecht worden gezien als een hoogdrempelig systeem, om in de terminologie van Hartlief te blijven.

Een private verzekering en de sociale zekerheid hebben daarentegen als nadeel dat, in tegenstelling tot het aansprakelijkheidsrecht, veclal slechts een beperkt bedrag wordt vergoed (bijvoorbeeld bij een brandverzekering), zelts indien de daadwerkelijk geleden schade hoger ligt dan dat beperkte bedrag. Hetzelfde geldt voor de sociale zckerheid en voor sociale verzekeringen, waar bijvoorbeeld de tussenkomst ingevolge inkomensderving eveneens is beperkt.

Hiermee is niet gezegd dat deze systemen losstaan van elkaar, wel integendeel: zo worden de tekortkomingen van het aansprakelijkheidsrecht opgevangen door de andere compensatiemechanismen $^{320}$. Maar het probleem hierbij is dat de kenmerken van de verschillende mechanismen vervagen en de kenmerken van het ene systeem aan het andere worden toebedeeld: van het aansprakelijkheidsrecht wordt verwacht dat geen rekening meer wordt gehouden met de oorzaak van de schade (kenmerk van verzekering) en van verzekeringen wordt verwacht dat ze de volledige schade vergoeden (kenmerk van het aansprakelijkheidsrecht), of "the best of both worlds" ${ }^{1321}$.

Om tegemoet te komen aan de tekortkomingen van het aansprakelijkheidsrecht, werden reeds meerdere voorstellen geformuleerd, en dit op verschillende terreinen van het ongevallenrecht

Hartlief, T., "Ieder draagt zijn eigen schade", l.c., 28.

Hartlief, T., "Ieder draagt zijn eigen schade", l.c., 29.

Hartlief, T., "leder draagt zijn eigen schade", l.c., 29.

Hartict, T., "leder draagt zijn eigen schade", l.c., 13.

Hartlief, T., "leder draagt zijn eigen schade", l.c., 56-57.
} 
(verkeersaansprakelijkheid, milieuaansprakelijkheid ${ }^{322}$, etc.). Zo is vaak gepleit voor de creatie van allerlei fondsen ${ }^{323}$, voor de invoering van een nieuwe aansprakelijkheidsregeling, voor een beperking van de aansprakelijkheid, hetzij in de vestigingsfase, hetzij in omvang, etc ${ }^{324}$. Een aantal van deze voorstellen wordt hieronder aan de orde gesteld.

\subsection{Enkele voorstellen tot verbetering}

Ideeën en voorstellen die trachten tegemoet te komen aan de problemen van het aansprakelijkheidsrecht, zijn niet nieuw en zijn - zeker initieel - niet uitsluitend gericht op de aansprakelijkheid voor milieuschade.

Zo werd in het begin van de jaren zeventig in Nieuw-Zeeland de Accident Compensation Commission opgericht. Deze Commissie beheert drie fondsen en heeft als taak de vergoeding van slachtoffers van ongevallen en de preventie van ongevallen. Een eerste fonds heeft betrckking op de accidentele lichamelijke schade en beroepszickten van werknemers (inclusief zelfstandigen). Het fonds wordt gefinancierd door een belasting die de werkgever dient te betalen op de uitbetaalde lonen of door de werknemer, op basis van diens inkomen. Een tweede fonds dekt alle slachtoffers van verkeersongevallen in Nieuw-Zeeland. De bijdragen aan het fonds komen uit een bescheiden jaarlijkse belasting op motorrijtuigen. Het derde fonds tenslotte, gefinancierd door middelen uit de schatkist, staat in voor gepensioneerden en bezoekers. De twee laatstgenoemde fondsen zijn subsidiair aan het eerste: indien een gepensioneerde het slachtoffer wordt van een verkcersongeval, zal diens schade die onder het fonds wordt gedekt, worden vergoed door het ecrste fonds ${ }^{325}$. Vandaar speelt het aansprakelijkheidsrecht in Nieuw-Zeeland geen rol meer voor slachtoffers van ongevallen of van beroepsziekten. Sterker nog: aansprakelijkhcidsvorderingen voor dergelijke schade werden afgeschaft ${ }^{326}$.

Deels in dezclfde richting gingen de voorstellen van de Britse "Royal Commission on Civil Liability and Compensation for Personal Injury" of de Pearson-Commissie ${ }^{327}$. Hoewel de foutaansprakelijkheid als basis diende te worden behouden, stelde de commissie voor om bijvoorbeeld inzake ongevallen met motorrijtuigen, via een no-fault compensation system een beroep te doen op een fonds ${ }^{328}$.

De discussie met betrekking tot de rol van het aansprakelijkheidsrecht en de verhouding tot andere compensatiemechanismen, die initieel vooral werd gevoerd naar aanleiding van letselschade bij

322

Ook Carette besluit haar voorteffelijk onderzoek met de vaststelling dat het huidige recht ongeschikt is om aantastingen aan niet-toegeëigende milieubestanddelen te herstellen of te vergoeden (Carette, $A$., "Herstel van en vergoeding voor aantasting aan niet-tocgcëigende milieubestanddelen", l.c., 603). Bocken, H., "Rechtstreekse verzekeringen ten behoeve van derden en andere wisseloplossingen voor aansprakelijkheid en aansprakelijkheidsverzekering. Een typologie", in Liber Amicorum René Van Gompel, Story Scientia, Kluwer, Deumc, 1998, 25 e.v.; Faurc, M.G. en Hartlicf, T., "Een schadefonds als altematief voor aansprakelijkheid en verzekering?", Rechtsgeleerd Magazijn Thenis, 1998/7, 211 e.v.

Voor meer details, zie Tunc, A., "Responsabilité civile", l.c., 79 e.v.

Markesinis, B.S. en Deakin, S.F., "Tort Law", l.c., 277.

Deze commissie werd in Groot-Brittannië opgericht naar aanleiding van de problemen met thalidomide, een geneesmiddel dat, indien het werd ingenomen door zwangere vrouwen, in een aantal gevallen leidde tot afwijkingen bij kinderen. Deze commissie werd opgericht in 1973 en kwam met haar conclusies in 1978 .

Schamps, G., "La mise en danger", l.c., 522. 
ongevallen (verkeersongevallen, medische aansprakelijkheid etc.), heeft bijkomende aandacht gekregen in het kader van gevallen van milieuaansprakelijkheid.

In dit verband zijn onder meer de voorstellen van de Interuniversitaire Commissie tot Herziening van het Milieurecht in het Vlaamse Gewest (Commissie Bocken) ${ }^{329}$ en de Nederlandse voorstellen inzake de oprichting van een Fonds voor Milieuschade interessant. Deze voorstellen, net zoals de voorstellen van verschillende auteurs, bepleiten nagenoeg allemaal een (algemeen) regime van risicoaansprakelijkheid voor milieuschade en/of gevaarlijke activiteiten, gekoppeld aan de oprichting van een Fonds ${ }^{330}$.

De invoering van een regime van risicoaansprakelijkheid ter zake van milieuschade, wordt steevast beschouwd als een invulling van het beginsel "de vervuiler betaalt" ${ }^{331}$, dat leidt tot de internalisering van de kosten ${ }^{332}$. De evolutie naar risicoaansprakelijkheid voor milieuschade is reeds duidelijk gebleken uit de verschillende bijzondere wetgevingen. Ook naar toekomstig Europees recht lijkt deze trend te worden doorgezet: in het Europese Witboek betreffende milieuaansprakelijkheid ${ }^{33}$ gaat de Europese Commissie uit van een regime van risicoaansprakelijkheid voor gevaarlijke activiteiten. Enkel voor wat betreft schade veroorzaakt aan de biodiversiteit door een niet-gevaarlijke activiteit zou de foutaansprakelijkheid worden behouden. Als verweermiddelen worden aanvaard: overmacht, bijdrage tot de schade door of toestemming van de eisende partij en de betrokkenheid van een derde partij. Opmerkelijk is dat in het Witboek nog geen uitspraak wordt gedaan of de stand der techniek en het ontwikkelingsrisico als verweermiddelen zullen worden aanvaard. Tegelijk blijft het Witboek vaag over de bewijslast. Weliswaar wordt aangegeven dat een communautaire regeling zou moeten voorzien in een verlichting van de bewijslast, maar de precieze strekking van de bewijslast moet in een later stadium worden gepreciseerd ${ }^{334}$.

Opmerkelijk is tenslotte dat hoewel reeds vrij veel rond deze problematiek is verschenen, het thema inzake de verhouding tussen verzekering en de groeiende aansprakelijkheid, nog steeds actueel is. In het preadvies van Bolt en Spier worden bijvoorbeeld als mogelijke oplossingen onder meer een beperking van de aansprakelijkheid door limitering of door het beperken van de schadesoorten, verplichte verzekeringen, fondsen en first party verzekeringen genoemd ${ }^{335}$. Ook in een onderzoek naar de aansprakelijkheid van werkgevers voor bedrijfsongevallen en beroepsziekten, worden de voor- en nadelen van deze opties naast elkaar geplaatst ${ }^{336}$.

Opvallend was ook het pleidooi van Bloembergen die reeds in 1965 pleitte voor een afschaffing van de aansprakelijkheid uit onrechtmatige daad, voorzover de schade niet opzettclijk werd veroorzaakt. In diens visie moeten verzekeringen aan de kant van de schadeveroorzaker worden

Bocken, H., Ryckbost, D. en Deloddere, S., "Herstel van schade door milieuverontreiniging", deel 9 in "Voorontwerp Decreet Milieubeleid", I.c., 1995.

Deze voorstellen worden afzonderlijk besproken in hoofdstuk 11 .

Hulst, E.H., "Grondslagen van milieu-aansprakelijkheid", l.c., 479.

Carette, A, "Herstel van en vergoeding voor aantasting aan niet-toegeëigende milieubestanddelen", l.c. 489 .

Wiboek betreffende milieuaansprakelijkheid, Commissie van de Europese Gemeenschappen, Brussel, 9 februari 2000, COM(2000)66 def. Zie hierover Rehbinder, E., "Towards a Community Environmental Liability Regime: the Commission's White Paper on Environmental Liability", Environmental Liability, vol. 8, $n^{\circ} 3,2000,85-90$; Rice, P., "From Lugano to Brussels via Árhus: Environmental Liability White Paper Published", Environmental Liability, vol. 2, 2000, 39-45.

"Witboek betreffende milicuaansprakelijkheid", l.c., 18.

Bolt, A.T. en Spier, J., "De uitdijende reikwijdte-preadvies", l.c., 394.

Faure, M.G. en Hartlief, T., "Verzekering en de groeiende aansprakelijkheidslast", l.c. 
vervangen door voorzieningen aan de kant van het slachtoffer ${ }^{337}$. Ook Hartlief pleitte - veel rccenter - voor het terugtreden, tot op zekere hoogte - van het aansprakelijkheidsrecht en voor de (her)introductie van andere mechanismen. Indien bijvoorbeeld in bijkomende mate een beroep wordt gedaan op private schadeverzekering, zou dit meer dan nu het geval is, benadrukken dat in beginsel ieder zijn eigen schade draagt ${ }^{338}$.

Toch blijkt uit bovenstaande analyse dat totnogtoe de aandacht zich hoofdzakelijk heeft gericht tot het aansprakelijkheidsregime (foutaansprakelijkheid of risicoaansprakelijkheid) en slechts in beperkte mate tot de gevallen van overmacht, de verweermiddelen en de bewijslastverdeling. Nochtans zijn het vooral deze elementen die een doorslaggevende invloed hebben op de mogelijkheid tot bewijzen dan wel afwijzen van aansprakelijkheid.

Een onderzoek dat wel aandacht besteed aan de elementen overmacht, verweermiddelen en bewijslast, is het proefschrift van Schamps. Uitgangspunt van dit voortreffelijke onderzoek is de afwezigheid, in België en Frankrijk, van een algemene aansprakelijkheidsregel die kann worden toegepast op de verwezenlijking van bepaalde risico's en de daaruit voortvloeiende problemen waarmee slachtoffers worden geconfronteerd ter vergoeding van de door hen geleden schade ${ }^{339}$.

Schamps pleit voor een kanalisatie van (risico)aansprakelijkheid naar de exploitant van de gevaarlijke activiteit ${ }^{340}{ }^{341}$. De kanalisatie van ansprakelijkheid zou meerdere voordelen bieden: de aansprakelijke is makkelijk te identificeren en vermijdt een dubbele verzekeringsdekking ${ }^{342}$. De exploitant is degene die het beste is geplaatst om het risico te beheersen, beschikt over alle noodzakelijke know-how; vandaar dient de aansprakelijkheid te worden gekanaliseerd naar de exploitant en bijvoorbeeld niet naar de houder of bezitter van gevaarlijke stoffen, aldus Schamps ${ }^{343}$. Teneinde de vergoeding van slachtoffers niet in het gedrang te brengen, mag de aansprakelijkheid van de exploitant niet worden beperkt ${ }^{344}$.

In het door Schamps vooropgestelde regime, wordt de causaliteitsvereiste aan de kant geschoven om plaats te maken voor de relativiteitsvereiste. Hicrdoor zou de bewijslast niet bij het slachtoffer liggen, in die zin dat het belang waarop het slachtoffer zich beroept, is vervat in de beschermingsfeer van de wet ${ }^{345}$. Zij verwijst voor haar stelling naar het Nederlandse recht, waar sinds het wa-

Bloembergen, A.T., "Naar een nieuw ongevallenrecht", l.c., 25-26.

Hartlief, T., "Ieder đraagt zijn eigen schade", l.c., 74-76.

Schamps, G., "La mise en danger", l.c., 843.

Schamps, G., "La mise en danger", l.c., 921 e.v.

Het door Schamps voorgestelde regime is enkel van toepassing op schade aan de gezondheid, de fysische of psychische integriteit van een persoon, en schade aan het milieu. Noch schade aan goederen, noch economische schade vallen onder het voorgestelde regime (Schamps, G., "La mise en danger", l.c., 944).

Schamps, G., "La mise en danger", l.c., $921-922$.

Desgevallend kan de exploitant een regresrecht uitoefenen tegen onderaannemers die de schade zouden hebben veroorzaakt. Eventueel kunnen ook deze onderaannemers zelf vallen onder het toepassingsgebied van de algemene regel, indien ook zij een bijzonder gevaarlijke activiteit uitvocren (Schamps, $G$., "La mise en danger", l.c., 929).

Het zou onbillijk zijn om cen bepaalde gevaarlijke activiteit toe te laten waarbij een deel van de geleden schade ten laste valt van het slachtoffer. Ze verzet zich ertegen dat de beschikbaarheid van een verzekeringsdekking op de markt de hoogte van de aansprakelijkheid bepaalt. Indien de exploitant niet in staat is het slachtoffer volledig te vergoeden, zal hij de exploitatie van zijn onderneming dienen stop te zetten en zal de ondememing desgevallend worden gesloten (Schamps, G., "La mise en danger", l.c., 930 e.v.).

Schamps, G., "La mise en danger", l.c., 939. 
terwingebied-arrest van $1970^{346}$ toepassing wordt gemaakt van leer van de toerekening naar redelijkheid ${ }^{347}$, die later werd gecodificeerd in artikel $6: 98 \mathrm{NBW}^{348}$. Enkel die schade waarvan kan worden aangetoond dat zij is verbonden met de verwezenlijking van een bepaald risico, dient in aanmerking te worden genomen ${ }^{349}$. Het is hierbij niet de bedoeling om aan de relativiteitsleer aan algemene gelding te geven; zij dient enkel te worden toegepast op dic schade die het gevolg is van een specifiek risico en dus niet op eender welke schade veroorzaakt gedurende de uitbating van een onderneming. Aldus wordt, steeds volgens Schamps, de nadruk gelegd op de ratio van de desbetreffende rechtsregel ${ }^{350}$.

Verder pleit Schamps voor een zeer strikte toepassing van de klassieke gevallen van overmacht: voor een slachtoffer is het niet van belang of de schade rechtstreeks voortvloeit uit de exploitatie, dan wel uit een externe gebeurtenis die een dergelijke schade slechts heeft kunnen veroorzaken dan door de aanwezigheid van de gevaarlijke activiteit ${ }^{351}$. Enkel deze elementen die onvermijdelijk, vreemd aan de exploitatie en vreemd zijn aan de gevaren van de exploitatie, kunnen worden beschouwd als een geval van overmacht. Vandaar dienen de overmachtsgronden telkens te worden omschreven in specifieke rechtsregels en dit in functie van de gevaren van de desbetreffende activiteit, zoals dat het geval is in Nederland, waar artikel 6:178 BW de overmachtgronden vermeldt die enkel van toepassing zijn op de gebruiker van een gevaarlijke stof, de exploitant van een stortplaats en de exploitant van een boorgat ${ }^{352}$. Daarenboven kan in de visie van Schamps het ontwikkelingsrisico ${ }^{353}$ niet in aanmerking worden genomen als overmachtsgrond. Dit ligt, volgens dezelfde auteur, volledige in de lijn met het steeds stijgende belang van het voorzorgsbeginsel zoals ingeschreven in het EG-Verdrag ${ }^{354}$. Ingeval toch sprake zou zijn van een overmachtsituatie, dient het slachtoffer schadevergoeding te bekomen van een garantiefonds ${ }^{355}$.

346 Hoge Raad, 20 maart 1970, Nederlandse Jurisprudentie, 42. Bij een ongeval met eun vrachtwagen stroomde een grote hoeveelheid olie weg, waardoor een waterwingebied werd vervuild. Aldus dienden aanzienlijke kosten te worden gemaakt teneinde de schade te beperken. De vraag was aan de orde of deze schade voorzienbaar was en er een causaal verband bestond tussen het ongeval en de schade. De Hoge Raad oordeelde dat de "schade terzake van de waterwinning hier te lande niet een zo uitzonderlijke vorm van schade t.g.v. een dergelijk ongeluk is, noch in een zo ver verwijderd verband daarmee staat, dat die schade naar redelijkheid niet - als veroorzaakt door het ongeval - ten laste zou mogen worden gebracht van degene, die krachtens de wet de aansprakelijkheid voor de gevolgen van het ongeluk draagt".

347 Volgens Lankhorst dient de theorie van de toerekening naar redelijkheid te worden beschouwd als cen toepassing avant la lettre van de relativiteitsvereiste (Lankhorst, G.H., De relativiteit van onrechtmatige daad, Kluwer, Deventer, 1992, 151-152).

Dit wetsartikel luidt: "Voor vergoeding komst slechts in aanmerking schade die in zodanig verband staat met de gebeurtenis waarop de aansprakelijkheid van de schuldenaar berust, dat zij hem, mede gezien de aard van de aansprakelijkheid en van de schade, als een gevolg van deze gebeurtenis kan worden toegerekend".

Schamps, G., "La mise en danger", l.c., 940.

Schamps, G., "La mise en danger", l.c., 943.

Schamps, G., "La mise en danger", l.c., 947.

Schamps, G., "La mise en danger", l.c., 854 en 948.

Voor de definiëring van deze term sluit Schamps aan bij Lambert-Faivie en Fagnart en niet bij de bredere definiëring die bij Vansweevelt is terug te vinden. In de visie van Vansweevelt vallen ook deze risico's onder het begrip ontwikkelingsrisico, waarvan de wetenschappelijke of technische kennis op het moment van het in verkeer brengen niet toelaat om deze helemaal uit te sluiten. Zie o.m. Vansweevelt, T., "Les risques de développement", Les Assurances de l'Entreprise, Brussel, Bruylant, $1993,317$. 358; Lambert-Faivre, Y., noot onder Cass. Fr., 9 juli 1996, D., 1996, 613-614; Lambert-Faivre, Y., Risques el assurances des entreprises, Dalloz, Paris, $3^{\mathrm{C}}$ ed., 1991, 631-632.

Schamps, G., "La mise en danger", l.c., 948. 
Tensiotte pleit Schamps voor de invoering van een weerlegbaar vermoeden en aldus van de omkering van de bewijslast ${ }^{350}$. Aan de bewijsproblematiek wordt verder tegemoet gekomen doordat de exploitant door de rechter kan worden verplicht om het slachtoffer toegang te verlenen tot de informatie aangaande het specifieke gevaar van de activiteit ${ }^{357}$.

\subsection{Conclusie}

Hét ideale compensatiemechanisme lijkt (nog?) niet te bestaan. Een slachtoffer van een bepaalde schade zal meestal de keuze hebben om een aansprakelijkheidsvordering al dan niet op te starten. In dit geval zal hij wel voor ogen moeten houden dat het aansprakelijkheidsrecht als compensatiesysteem vele valkuilen bevat en als een hoogdrempelig systeem kan worden beschouwd. Worden de valkuilen overwonnen, dan kan in principe alle schade worden vergoed.

Een dergelijke luxe wordt niet geboden door een verzekeringsdekking, noch door een stelsel van sociale zekerheid waar de tussenkomst van de verzekeraar veelal is beperkt tot een bepaald bedrag. Daar staat tegenover dat de toegang tot de verzekeraar en tot de instantie die sociale bijdragen uitkeert, zeker in gevallen waar het slachtoffer over een rechtstreekse vordering beschikt, vaak minder problematisch is dan de toegang tot het aansprakelijkheidsrecht. In zekere zin lijkt het erop dat een slachtoffer de keuze heeft: ofwel lang wachten op een onzekere maar eventueel voldoende vergoeding, ofwel genoegen nemen met een snelle maar onvolledige uitkcring.

Ten tijde van de redactie van de code civil werd de stelling aanvaard dat de schade in principe een speling was van het noodlot en dat enkel door de fout van een ander deze schade kon worden verschoven. De opvatting bij de aanvang van de eenentwintigste eeuw is volgens sommige auteurs geheel anders: degenen die door cen ongeval worden getroffen mogen niet aan hun lot worden overgelaten ${ }^{358}$; hun schade dient te worden vergoed, los van een eventuele aansprakelijkheidsvraag.

In de loop der jaren hebben de verschillende compensatiemechanismen elkaar wederzijds beïnvloed. Zo heeft de aansprakelijkheidsverzekering bepaalde vorderingen mogelijk gemaakt; toch blijft de oorzaak-gevolg relatie tussen het succes van de aansprakelijkheidsverzekering en de opgang van het aansprakelijkheidsrecht een moeilijk op te lossen vraagstuk. Het succes van verzekeringen heeft er in bepaalde gevallen toe geleid dat in hoofde van slachtoffers de perceptie werd gecreěerd dat - zoals dat in de regel het geval is bij een stelsel van sociale zekerheid en bij een first party insurance - de loutere beschikbaarheid van een dekking en het zich voordoen van een schade steevast zal leiden tot vergoeding van de geleden schade. Dit is echter niet het geval bij aansprakelijkheidsverzekeringen waar het aansprakelijkheidsvraagstuk onverkort aan de orde is.

Onder invloed van de wijzigingen die het verzekeringsrecht inmiddels heeft ondergaan, wordt een schadegeval vaak enkel afgewikkeld tussen het slachtoffer en de aansprakelijkheidsverzekeraar van de "dader". Ook dit kan de indruk versterken dat het aansprakelijkheidsrecht in een concreet schadegeval niet relevant is. Nochtans zal de verzekeraar over het algemeen slechts tussenkomen in:overre de aansprakelijkheid van de verzekeringsnemer is komen vast te staan en zal nadien het

Hier verwijst Scharnps onder mecr naar de res ipsa loquitur regel (ofwel "de zaak spreekt voor zich") zoals van toepassing in het Engelse recht en naar artikel 177 van het Nederlandse Wetboek van Burgerlijke Rechtsvordering (Schamps, G., "La mise en danger", l.c., 959).

Schamps, G., "La mise en danger", l.c., 960.

358

Bloembergen, A.T., "Naar een nieuw ongevallenrecht", l.c., 8. 
aansprakclijkheidsrecht mogelijks nog een rol spelen zo de verzekeraar een regresrecht wenst uit te oefenen ${ }^{339}$. In heel wat gevallen zal de tussenkomst van de verzekeraar beperkt zijn, waardoor het aansprakelijkheidsrecht ook een rol kan spelen voor het deel van de schade dat niet is verzekerd.

De maatschappij is sinds 1804 minder individualistisch en meer collectief geworden, in die zin dat voor de vergoeding van bepaalde schade of kosten, in een modeme samenleving, cen beroep kan worden gedaan op collectieve mechanismen, terwijl slachtoffers van een bepaalde schade in de 19de eeuw, bij gebrek aan dergelijke mechanismen, op zichzelf waren aangewezen. In de welvaartstaat voelt een persoon die een schade lijdt tengevolge van de daden van een ander, zich gerechtigd om de dader te vervolgen en een schadevergoeding te bekomen ${ }^{360}$. Blijkbaar is de bereidheid van slachtoffers om een geleden schade te dragen, gedaald. Sociologische factoren waaronder het verzwakken van de familiale en religieuze banden zouden hieraan mede ten grondslag liggen ${ }^{361}$. De opkomst van verzekering heeft bij de burger blijkbaar de illusie gecreëerd dat een bepaalde schade sowieso zal worden vergoed; door wie en op welke basis schijnt ter zake niet dienend te zijn. Terwijl slachtoffers in het verleden er eerder toe geneigd waren een bepaalde schade toe te schrijven aan het noodlot, overheerst in de huidige maatschappij de tendens om een schade toe te schrijven aan een ander. Dit komt bijvoorbeeld tot uiting in de steeds stijgende vraag naar verzekeringsdekking bij natuurrampen ${ }^{362}$.

Vaststaat dat het laatste woord nog niet is gezegd over de verhouding tussen de verschillende compensatiemechanismen, de noodzaak aan nieuwe rechtsregels etc.

Verschillende onderzoeken hebben gewezen op een zekere verzwaring van de aansprakelijkheid, maar vooralsnog zijn er geen redenen om aan te nemen dat het Belgische en Nederlandse aansprakelijkheidsrecht zich in een crisis zouden bevinden. Wel is gebleken dat ook elementen buiten het aansprakelijkheidsrecht een belangrijke invloed kunnen hebben op de uiteindelijke aansprakelijkheid. Hierbij denken we vooral aan de willingness to claim en aan procesrechtelijke aspecten van een aansprakelijkheidsvordering.

Vele voorstellen met betrekking tot de aansprakelijkheid voor milieuschade voorzien in de invoering van een regime van risicoaansprakelijkheid, gekoppeld aan de creatie van een fonds en/of de beperking van de aansprakelijkheid. Totnogtoe werd echter weinig aandacht besteed aan de bevrijdingsmogelijkheden, de gevallen van overmacht en de bewijslast. Een stap in de goede richting zijn de voorstellen van Schamps. Toch blijft het zo dat ook voor een aantal andere klassieke valkuilen van de aansprakelijkheid geen oplossing wordt geboden. We denken hier met name aan de vraag wie een vordering kan instellen, procesrechtelijke aspecten bij massaschade en de begroting van de schade.

Het is overigens opvallend dat de bekommernis om te komen tot gebalanceerd aansprakelijkheidsrecht voornamelijk voortvloeit uit de betrachting om de door slachtoffers geleden letselschade te vergoeden. Andere vormen van schade worden daaraan ondergeschikt geacht. Dit bleek met name ook uit het preadvies van Bolt en Spier, die vaststelden dat in de ogen van de Hoge

Zie hierover verschillende bijdragen in van Boom, W.H., Hartlief, T. en Spier, J., Regresrechten. Afschaffen, handhaven of uitbreiden?, W.E.J. Tjeenk Willink, Deventer, 1996, 165.

Tunc, A., "Les problèmes contemporains de la responsabilité civile délictuelle", Revue Internationale de Droit Comparé, 1967, 758.

Markesinis, B.S. en Deakin, S.F., "Tort Law", l.c., 2.

Zie hierover de verschillende bijdragen in Cousy, H. en Claassens, H., Natuurrampen en Verzekering, Verslagboek van de Negende Leuvense Verzekeringsdagen, Maklu, Antwerpen-Apeldoorn, 1995. 
Raad de letselschade een aparte status inneemt en van een hogere orde is dan milieuschade ${ }^{363}$. Ook de voorstellen van Schamps hebben enkel betrekking op de compensatie van letselschade.

\section{Conclusie}

Het uitgangspunt van het op de code Napoléon gebaseerde civiele aansprakelijkheidsrecht is onveranderd: in principe draagt iedereen zijn eigen schade, tenzij er een goede reden bestaat om deze schade te verschuiven. Weliswaar heeft een aantal bijzondere wetten nieuwe redenen tot schadeverschuiving gegeven, toch blijft dit uitgangspunt onverkort van kracht. Ook de opkomst en het succes van andere compensatiemechanismen, zoals verzekering en een stelsel van sociale zekerheid, doen hieraan geen afbreuk. Zij creëren enkel de illusie dat het uitgangspunt werd gewijzigd.

De nuanceringen aan de foutvereiste en de daaraan gegeven interpretatie, evenals de via bijzondere wetten ingevoerde vormen van risicoaansprakelijkheid hebben gemeen dat emaar werd gestreefd de positie van slachtoffers te verbeteren. Dit streven heeft evenwel geen goede diensten bewezen aan de coherentic van de civielrechtelijke aansprakelijkheid. Er bestaat onduidelijkheid omtrent een groot aantal begrippen, het onderscheid tussen de begrippen en de precieze draagwijdte daarvan ${ }^{364}$. Bij wijze van voorbeeld rijst de vraag of er een onderscheid kan worden gemaakt tussen risicoaansprakelijkheid en objectieve aansprakelijkheid en wat het verschil is tussen een objectieve aansprakelijkheid en een aansprakelijkheid gebaseerd op een onomkeerbaar aansprakelijkheidsvermoeden of een aansprakelijkheid van rechtswege. Een merkwaardige vaststelling bij het overzicht van het aansprakelijkheidsrecht, is dat de enige noemenswaardige wijziging ter zake van milieuschade erin bestaat dat over het algemeen wordt gekozen voor een stelsel van risicoaansprakelijkheid in plaats van foutaansprakelijkheid. Een coherente visie op de bevrijdingsgronden, de omkering van de bewijslast en de toegelaten gevallen van overmacht, is hierbij niet aanwezig. Tegelijk is, ter zake van milieuschade, relatief weinig aandacht besteed aan processuele moeilijkheden en aan problemen inzake de berekening van de schade.

Ook de door de nationale en internationale wetgever - die verschillende aansprakelijkheidsmechanismen hebben gecreëerd waarbij in mindere of meerdere mate wordt afgeweken van de klassieke foutaansprakelijkheid - gehanteerde terminologie is allerminst eenduidig te noemen. De verschillende aansprakelijkheden lijken niet alleen een huis met vele kamers ${ }^{365}$, maar veeleer een doolhof ${ }^{366}$.

Uit het in dit hoofdstuk geboden overzicht blijkt dat het aanduiden van het relevante aanknopingspunt bij een gegeven aansprakelijkheidsvraagstuk, op basis van het Belgische en Nederlandse Burgerlijk Wetbock, in een aantal gevallen bijzonder moeilijk is ${ }^{367}$. Gewaarschuwd dient te worden voor een verkeerd of overlappend gebruik van een aantal in dit kader relevante termen. Aangezien in dit onderzoek in belangrijke mate wordt gebruik gemaakt van begrippen die hierop voortbouwen, dient duidelijkheid te bestaan omtrent de precieze inhoud van deze begrippen.

Boit, A.T. en Spier, J., "De uitdijende reikwijdte, preadvies", l.c., 264.

Cousy, H., "Enkele beschouwingen over de systematiek van de stelsels van foutloze aansprakelijkheid", in "Liber Amicorum Jacques Putzeys", l.c., 38-39.

Bocken, H., "Van fout naar risico", o.c., 331.

Cornelis, L., "Beginselen", l.c., 357.

Hoewel deze conclusie hier enkel naar voren wordt geschoven voor wat betreft de Belgische en Nederlandse rechtsorde, zal deze conclusie, minstens ten dele, evenzeer gelden voor een aantal andere rechtsstelsels. 
Het begrip schuld zoals dat in de gewone omgangstaal wordt gebruikt, lijkt meer dan het begrip "fout", te appelleren aan de morele verwijtbaarheid van de specificke, in de civiele aansprakelijkheidsvordering ter discussie staande, gedraging. Comelis wijst er terecht op dat het begrip fout niét op een moreel verwijt stoelt ${ }^{368}$. Hiermee wordt bedoeld dat de gedraging van de aangesprokene op abstracte wijze wordt getoetst aan het criterium van de goede huisvader eerder dan aan de persoon van de aangesprokene en diens kwaliteiten en tekortkomingen. De centrale toetssteen in het leerstuk van de onrechtmatige daad is het gedrag van de aangesprokene ten overstaan van het gedrag van een normaal en voorzichtig persoon die zich in dezelfde omstandigheden bevindt. Dit is een abstracte toetsing. Vandaar geeft het begrip "fout" minder aanleiding tot verwarring dan het begrip "schuld", in die zin dat de term schuld in de Nederlandse taal onwillekeurig moreel, quasiintentioneel is geklcurd. Dit is niet of in veel mindere mate het geval voor de term "fout". De term "fout" is immers niets anders dan de objectieve verwijtbaarheid van de gedraging (het begrip schuld in ruime zin) en geeft aldus aan dat hiermee de gedraging wordt bedocld en niet de subjectieve verwijtbaarheid van de dader (begrip schuld in enge zin). Hiermede deels van Maanen volgend $^{369}$ wensen wij aldus volgend onderscheid te maken:

- foutaansprakelijkheid betekent elke vorm van aansprakelijkheid voor eigen fouten ${ }^{370}$;

- risicoaansprakelijkheid is een aansprakelijkheid op grond van andere criteria dan de fout. Degene wiens aansprakelijkheid in het gedrang komt, kan zich niet bevrijden door te bewijzen dat hij geen fout heeft begaan.

Een belangrijke factor die zowel de door de rechtspraak gegeven interpretaties heeft mogelijk gemaakt, als de door de wetgever ingevoerde risicoaansprakelijkheden, is het ontstaan van verzekeringen. Zeker bij een stelsel van sociale zekerheid, maar ook onder invloed van de aansprakelijkheidsverzekering, wordt de indruk gewekt dat in bepaalde gevallen ecn aansprakelijkheidsrecht niet meer van belang is.

Het is overigens zeer de vraag of de verschillen tussen risicoaansprakelijkheid en foutaansprakelijkheid wel zo strak kunnen worden aangehouden. Ligt in de meerderheid van de aansprakelijkheidsvorderingen (onafhankelijk van de vraag of deze vordering is gebaseerd op een regime van foutaansprakelijkheid dan wel op een regime van risicoaansprakelijkheid) niet een bepaald tekortschieten aan de basis van de aansprakelijkheid ${ }^{371}$ ? Zodra een dergelijk tekortschieten, in een causale relatie tot de schade kan worden aannemelijk gemaakt, zal het aansprakelijkheidsrecht een voldoende reden geven om de schade af te wentelen op een ander aan wie de tekortkoming kan worden toegerekend, hetzij omwille van een persoonlijk tekortschieten, hetzij omwille van een tekortschieten uit hoofde van een hoedanigheid (exploitant van een vergunningsplichtige inrichting, bewaarder van een gevaarlijk product, ...).

In dit hoofdstuk werd ook aangetoond dat het Belgische en Nederlandse civiele aansprakelijkheidsrecht nog in grote lijnen overstemmen, wat de vergelijking doorheen de volgende hoofdstukken zal vergemakkelijken. Op het eerste gezicht lijken met name de bepalingen van de Belgische en het Nederlandse BW een aantal verschillen te vertonen, maar deze verschillen zijn in belangrijke mate terug te voeren tot verschillende terminologie. Inhoudelijk worden via andere concepten en begrippen vaak analoge resultaten bereikt.

Comelis, L., "Beginselen", l.c., 34.

$\mathrm{Hij}$ heeft het over schuldaansprakelijkheid, waar wij het over foutaansprakelijkheid hebben (Van Maanen, G.E., "Van schuld naar risico", o.c., 71).

Zoals hoger aangegeven, geven wij de voorkeur aan de notie "fout" eerder dan aan de notie schuld aangezien een "fout" geen moreel oordecl omvat.

371

Hartlief, T., "leder draagt zijn eigen schade", l.c., 26; Klaassen, C.J.M., "Risicoaansprakelijkheid en foutaansprakelijkheid, twee woorden, één gedachte?", Op recht, Zwolle, 1996, 137 e.v. 
Het gemene aansprakelijkheidsrecht biedt in een aantal gevallen een voldoende grondslag voor de aansprakelijkheid voor milieuschade. Het Belgische en Nederlandse BW bieden zowel een juridische grondslag op basis van de klassieke foutaansprakelijkheid als op basis van risicoaansprakelijkheid. Toch lijden beide stelsels aan belangrijke tekortkomingen die bijvoorbeeld te maken hebben met discussies omtrent de begrippen "gebrek" en "bijzonder gevaar".

Specifiek in het kader van milieuschade wordt risicoaansprakelijkheid vaak gekoppeld aan de creatie van een fonds. De merites van deze voorstellen kunnen echter niet alleen worden beoordeeld op basis van deze analyse. Een aantal compensatiemechanismen ter zake van milieuschade wordt in hoofdstuk 11 aan de orde gesteld.

In het volgende hoofdstuk wordt het ontstaan van de nucleaire wetgeving besproken en wordt een overzicht gegeven van het internationale kemenergierecht. 


\section{HOOFDSTIK 2}

\section{ONTSTAAN EN OVERZICHT VAN HET INTERNATIONALE EN NATIONALE KERNENERGIERECHT}

In het vorige hoofdstuk werd aandacht bosteed aan het gemeenrechtelijke civiele aansprakelijkheidsrecht; meer in het bijzonder werd aangegeven in welke mate de civielrechtclijke aansprakelijkhcid als grondslag kan dienen voor de compensatie van de schade aan het milieu. Aangezien het onderzoek in dit proefschrift is gericht op de analyse van de aansprakelijkheid voor kemongevallen, wordt vervolgens een overzicht gegeven van de relevante wetgeving op het gebied van kernenergic. In dit hoofdstuk wordt het ontstaan bestudeerd van het kernenergierecht, waaruit zal blijken dat het intemationale en nationale kernenergierecht moeilijk los van elkaar kunnen worden gezien. Tegelijk wordt een overzicht gegeven van de belangrijkste Verdragen en van de belangrijkste wetten in België en Nederland op het gebied van kemenergie.

Vooraleer het ontstaan van het kemenergierecht wordt bestudeerd, wordt even stil gestaan bij de keuze van de term "kernenergierecht". In dit onderzoek wordt ervoor geopteerd om de term "kernenergierecht" te gebruiken eerder dan "atoomenergierecht". Er kunnen meerdere soorten ioniserende stralingen worden onderscheiden: $\alpha, \beta$, en $\gamma$-stralen. $\alpha$ en $\gamma$-stralen komen rechtstreeks voort uit de nucleus, terwijl $\beta$-stralen in principe voortkomen uit de elektronen van een kem. Omdat $\beta$-stralen voortkomen uit elektronen wordt soms de stelling verdedigd dat deze straling niet valt onder het begrip kernenergie. In deze visie zou de term "kernenergierecht" nauwkeuriger zijn dan "atoomenergierecht"'. Nochtans is het vrijkomen van deze elektronen - en dus van $\beta$-stralen - het gevolg van een fenomeen dat zich in de nucleus afspeelt. Met andere woorden: alle energie komt hetzij rechtstreeks, hetzij onrechtstreeks uit de kern van een atoom. Daarom verdient het de voorkeur om voor de term kemenergie of energie van nucleaire oorsprong te opteren ${ }^{2}$. Vandaar zal in dit proefschrift steeds over "kemenergierecht" of "nucleair recht" worden gesproken.

In dit hoofdstuk wordt in eerste instantie aangegeven hoe de internationale samenwerking inzake kemenergie is tot stand gekomen $(\S 1)$. Vervolgens wordt een overzicht gegeven van het internationale kernenergierecht $(\S 2)$ en van het nationale kernenergierecht in België $(\S 3)$ en Nederland $(\S 4)$. Tenslotte worden enkele conclusies getrokken uit de analyse (§5).

\section{ONTSTAAN VAN DE INTERNATIONALE SAMENWERKING INZAKE HET GEBRUIK VAN KERN- E.NERGIE}

In de eerste paragraaf wordt aandacht besteed aan het ontstaan van (internationale) regels op het terrein van het nucleaire risico in de brede betekenis van het woord. Hierbij wordt nagegaan hoe de samenwerking inzakc het gebruik van kernenergie langzaam is op gang gekomen en kan worden samengevat als "verspreiding van kennis mits controle" ( $\$ 1.1$ ). Deze samenwerking voorzag niet alleen in een aantal materieelrechtelijke regels, maar creëerde tegelijk een institutioneel en organisatorisch kader waarbinnen deze samenwerking vorm kreeg. Op deze wijze ontstonden

Met name Domsdorf verkiest de term "atoomenergierecht" (Domsdorf, E.P.M.W., "Internationaal atoomenergierecht", l.c., 291 e.v.).

Ook in die zin: Matthijs, $\mathrm{J}$, "Aansprakelijkheid bij toepassing van kernenergie tot vreedzame doeleinden", Rechiskundig Weekblad, 1962, 113, voetnoot 2bis. Over deze discussie, zie ook Lamm, V., "The utilization of nuclear energy and intemational law", l.c., 19-20. 
verschillende internationale organisaties waarvan de voomaamste in $\S 1.2$ aan de orde worden gesteld. In $\S 1.3$ tenslotte worden enkele conclusies getrokken over het ontstaan van de internationale samenwerking inzake het gebruik van kernenergie.

\subsection{Verspreiding van kennis en technologie mits controle}

Vóór de tweede wereldoorlog was het gebruik van radioactiviteit voornamelijk beperkt tot medische toepassingen ( $x$-stralen en radium). Teneinde diegenen te beschermen die blootstonden aan de hieruit voortkomende straling, werd een aantal regels opgesteld inzake stralingsbescherming. Vrij vroeg reeds richtte een groep wetenschappers de International Commission for Radiation Protection (ICRP) ${ }^{3}$ op, die vanaf 1934 de eerste normen inzake stralingsbescherming opstelde ${ }^{4}$. Deze normen waren niet meer dan aanbevelingen die, naarmate de kennis over de schadelijke gevolgen van kernenergie voor de gezondheid van de mens toenam, in de loop der jaren meermaals zouden worden aangepast.

Op het einde van de dertiger jaren werd het gebruik van kernenergie meer en meer gericht op de militaire toepassing ervan. Onder invloed van de tweede wereldoorlog ging de aandacht van het wetenschappelijk onderzoek voomamelijk uit naar de ontwikkeling van de atoombom. Het is in dit kader typerend dat, voor wat de Verenigde Staten betreft, het Manhattan Engineer District (MED) ${ }^{5}$ waar zich het onderzoek naar de ontwikkeling van de atoombom concentreerde, deel uitmaakte van het Ministerie van Oorlog ${ }^{6}$. De hiermee gepaard gaande geheimhouding verhinderde nagenoeg iedere transfer van nucleaire kennis en materiaal.

Nog tijdens de oorlog werden afspraken gemaakt die kunnen worden beschouwd als de aanzet van de non-proliferatie politiek ${ }^{7}$ : de akkoorden van Quebec van 19 augustus 1943 en de DrieMogendheden-Verklaring van 15 november $1945^{8}$. Volgens deze Verklaring diende te worden verhinderd dat kernenergie voor destructieve doeleinden zou worden gebruikt, en mocht het toekomstig gebruik van kernenergie enkel vredelievende en humanitaire doeleinden dienen. Aansluitend hierbij richtten de VS, Canada en het Verenigd Koninkrijk de Combined Develop-

De belangrijkste taak van het ICRP bestaat in het vaststellen, door middel van richtlijnen en aanbevelingen, van de fundamentele principes inzake stralingsbescherming. Het doel hiervan is bijstand te geven aan intemationale en nationale bevoegde instanties en organisaties alsook aan het personeel van nucleaire installaties bij hun belcid om de gevolgen van ioniserende straling zovecl mogelijk te beperken. De aanbevelingen van de ICRP worden gepubliceerd in series die periodiek worden herzien. De ICRP, die een privatrechtelijke vereniging is van wetenschappers, werkt zeer nauw samen met de in 1955 opgerichte United Naiions Scientific Committee on the Effects of Atomic Radiation (UNSCEAR). Hoewel de ICRP een privaatrechtelijke organisatie is die geen juridisch bindende nonmen kan uitschrijven, geniet de ICRP een enorm gezag (Pelzer, N., "The nature and scope of intemational cooperation in connection with the peaceful uses of nuclear energy and its limits - an assessment", o.c., 39).

Rainaud, J.M., "Lé Uroit nucléaire", Que snis-je?, Presses Universitaires de France, 1994, 6.

The Manhatian Project. Making the Atomic Bomb, United States Department of Energy, Energy History Series, september 1994, 13.

Smyth, H.D., Atomic energy for military purposes. The official report on the Development of the Atomic Bomb under the auspices of the U.S. Goversment, Princeton, 1946, 45-54.

Domsdorf, E.P.M.W., "Intemationaal Atoomenergierecht", l.c., 285.

Tussen de Verenigde Staten van Amerika, het Verenigd Koninkrijk en Canada.

"We are, however, prepared to share (...) detailed information coneeming the practical industrial application of atomic energy just as soon as effective enforceable safeguards against its use for destruetive purposes can be devised" (Drie-Mogendheden-Verklaring, paragraaf 6, United Nations Treaty Series, (947, $\left.\mathrm{n}^{\circ} 26\right)$. 
ment Agency op, die een belangrijke rol zou spelen bij de bevoorrading van ruwe grondstoffen (uranium).

Tussen 1945 en 1955 werden verschillende initiatieven genomen met tot doel het ongecontroleerd verspreiden van nucleaire kennis en materiaal te voorkomen; dit zowel op nationaal-Amerikaans als op internationaal vlak ${ }^{10}$.

In de Verenigde Staten werd in 1946 de Atomic Energy Act of de wet Mac Mahon gestemd ". Deze wet legde een verbod op tot de verspreiding van nucleaire kennis, technologie en materiaal. Tegelijk vielen alle vragen in verband met kernenergie onder de exclusieve verantwoordelijkheid van de Atomic Energy Commission (USAEC) wiens gegevens werden beschermd door het militair geheim ${ }^{12}{ }^{13}$. De filosofie van de Mac Mahon wet hield in feite in, dat zolang geen internationale controle bestond inzake het vreedzame gebruik van kemenergie, internationale samenwerking in principe onmogelijk was. Toch heeft de Mac Mahon wet niet belet dat de Amerikaanse private sector werd betrokken bij het gebruik van kernenergie en dat in de periode 1945-1956 verschillende bilaterale akkoorden werden afgesloten. Een aantal van deze akkoorden had betrekking op de aankoop van nucleaire grondstoffen door de VS (hoofdzakelijk de invoer van uranium); anderzijds werden ook akkoorden gesloten die ertoe strekten om private investeerders aan te trekken.

Aangezien de VS zelf niet beschikten over de natuurlijke grondstoffen nodig voor de ontwikkeling van de nucleaire activiteiten, dienden deze grondstoffen te worden ingevoerd. In die zin waren de bilaterale akkoorden een noodzaak in de Amerikaanse bevoorradingspolitiek ${ }^{14}$. De Verenigde Staten waren voor de bevoorrading van grondstoffen (met name uranium) inderdaad in zeer belangrijke mate afhankelijk van een aantal andere landen. Zuid-Afrika, België en Australië waren echter enkel bereid om grondstoffen aan te leveren op voorwaarde dat zij toegang kregen tot de Amerikaanse technologie en knowhow ${ }^{15}$. In dit verband werden overeenkomsten afgesloten op basis waarvan nagenoeg alle in Zuid-Afrika, Congo en Australië gedolven uraniumerts aan de door de VS gecontroleerde Combined Development Agency werd verkocht ${ }^{16}$ en waar de exportlanden een beperkte toegang werd verleend tot nucleaire kennis. Toch is gebleken dat, zeker wat België betreft, de VS slechts in zeer beperkte mate haar verbintenissen zijn nagekomen, zodat van internationale uitwisseling van gegevens alsnog geen sprake was ${ }^{17}$.

10 Vanden Borre, T. en Carchon, R., "Preventing the Proliferation of Nuclear Weapons: 50 years of Atoms for Peace", o.c., 24 e.v.; Carchon, R., "De non-proliferatie van kemwapens en internationale controles", o.c., 14 e.v. In hoofdstuk 13 wordt het Amerikaanse kernenergierecht meer in detail bestudeerd.

Pascal, M. (ed.), Droit Nucléaire, CEA, Paris, Eyrolles, 1979, 12-13.

Voor meer details over het beleid van de USAEC en haar functies, zie Mazuzan, G.T. en Walker, J.S., Controlling the Atom. The Beginnings of Nuclear Regulation 1946-1962, University of California Press, 1984, Los Angeles, 1-31.

Zie hierover Pelzer, N., "The nature and scope of international co-operation in connection with the peaceful uses of nuclear energy and its limits - an assessment", Nuclear Law Bulletin, vol. 27, 1981, 26.

Fischer, G., L'énergie atomique et les Etats-Unis. Droit interne et droit international, Pichon et Durand-Auzias, Parijs, 1957, 252-253 (hierna geciteerd als "L'énergie atomique et les Etats-Unis"). Arangio-Ruiz, G., "Some International Legal Problems of the Civil Uses of Nuclear Energy", Recueil des Cours, Académie de Droit International, 1962, tome 107 de la Collection, A.W. Sijthoff, Leiden, 1963,32 .

Pas vanaf 1955 was echt sprake van een uitwisseling van gegevens. Zie verderop, bij de bespreking van het ontstaan van het Beigische kernenergierecht, en dan met name § 3.1. 
De bezorgdheid om de ongecontroleerde verspreiding van nucleaire kennis tegen te gaan was niet uitsluitend een Amerikaanse, maar ook een intemationale bezorgdheid. De bezorgdheid van de internationale gemeenschap omtrent het verdere gebruik van atoomwapens kwam met name tot uiting in het kader van de UNO. De eerste Resolutie van de Algemene Vergadering van de UNO installeerde de UN Atomic Energy Commission (UNAEC). Deze commissie had als taak na te gaan welke de mogelijkheden waren om de bestaande kernwapens te elimineren, om het uitwisselen van wetenschappelijke informatie te bevorderen en om de controle van het vreedzaam gebruik van kemenergic te garanderen ${ }^{18}$.

In juni 1946 stelde Bernard Baruch, de Amerikaanse vertegenwoordiger van de UNAEC, de oprichting voor van de International Atomic Development Authority die het exclusief recht zou hebben om ten eerste, onderzock te doen inzake nucleaire explosies en die, ten tweede, als enige het recht zou krijgen om splijtbaar materiaal te produceren en te bezitten; elke andere nucleaire activiteit zou slechts worden toegelaten mits toestemming en controle van de "Authority". De Verenigde Staten en de voormalige Sovjet-Unie kwamen niet tot een akkoord, voonnamelijk omdat geen overeenstemming kon worden bereikt omtrent het tijdstip waarop de kemwapens dienden te worden overgedragen of vernietigd ${ }^{19}$. De VS waren enkel bereid hun bestaande kernwapens te ontmantelen nadat de Authority operationeel zou zijn. De Sovjets daarentegen - bij monde van hun delegatieleider Gromyko - stelden dat controlemaatregelen slechts konden worden ingesteld indien eerst de kemwapens werden vernietigd ${ }^{20}$. De meningsverschillen bleken niet te overbruggen en de UNAEC hield in juli 1949 haar laatste bijeenkomst. Niet toevallig raakte in september van dat jaar bekend dat ook de Sovjet-Unie over een kembom beschikte ${ }^{21}$. In 1953 slaagde Sovjet-Unie er ook in een waterstofbom te ontwikkelen.

Doordat de Verenigde Staten niet meer als enigen beschikten over nucleaire kennis en technologie, was het van kracht zijnde overheidsmonopolie vanuit commercieel oogpunt zinloos geworden. In het begin van de jaren vijftig steeg de vraag naar vredelievende toepassingen van kernenergie, in hoofdzaak op het vlak van de productie van elektriciteit. Deze vraag kwam in belangrijke mate van verschillende West-Europese landen die een beroep wensten te doen op Amerikaanse kennis en die Amerikaanse technologie wensten aan te kopen. Voor de Amerikaanse nucleaire industrie was Europa een belangrijke nieuwe markt ${ }^{22}$. Vandaar namen de VS de leiding in de initiatieven rond de oprichting van een internationaal controleorgaan ter zake van de verspreiding van nucleaire kennis en materiaal.

Op 8 november 1953 sprak de Amerikaanse president Eisenhower de Algemene Vergadering van de UNO toe met zijn bekende Atoms for Peace-speech. Hierbij stelde hij de oprichting voor van

Kocymans, P.H., "The peaceful applications of nuclear power and the non-proliferation system", X., Proliferation and the safeguarding of the peaceful application of nuclear power, Koninklijk Instituut van Ingenieurs Kerntechniek, Den Haag, Symposium van 8 december, 1976; Scheinman, L., The International Atomic Energy Agency and World Nuclear Order, Resources for the Future, 1987.

Daamaast kon de Sovjet-Unie geen genoegen nemen met het uit het Baruch-plan voortvloeiende monopolic van de International Atomic Development Authority (Häfele, W., "Die historische Entwicklung der friedlichen Nützung der Kernenergie", in Kaiser, K. en Lindemann, B. (herausg.), Kernenergie und Internationale Politik, R. Oldenbourg Verlag, München, 1975, 44).

The Manhattan Project, 56; Pelzer, N., "The present state of research carried out by the English speaking section of the Centre for Studies and Research", in The hazards arising out of the peaceful use of nuclear energy, Centre for Studies and Research in International Law and International Relations, Hague Academy of International Law, Kluwer Academic Publishers, Dordrecht, 1993, 222. een aanzienlijke verticale proliferatie van kemwapens (over dit begrip: zie $\$ 1.2$ van de inleiding). 
een intemationaal agentschap voor kemenergie dat de vreedzame toepassingen van kemenergie zou bevorderen en dat ter zake over de nodige controlebevoegdheden zou beschikken. Dit initiatief leidde rechtstreeks tot de oprichting van het International Atomic Energy Agency (IAEA).

Aansluitend hierbij werd in de Verenigde Staten in 1954 de Atomic Energy Act gewijzigd, die een einde maakte aan het Amerikaanse overheidsmonopolie. De combinatie van de opheffing van het overheidsmonopolie en het totstandkomen van internationale garanties betekende dat voor de Amerikaanse nucleaire industrie de weg naar internationale expansie open $\operatorname{lag}^{23}$.

Naarmate de klemtoon van het gebruik van kemenergie zich toespitste op vredelievende toepassingen, werd het voor de private sector mogelijk om een actievere rol te gaan spelen op het vlak van de ontwikkeling van kemenergie - het militaire gebruik van kemenergie zou een prerogatief blijven van de overheid. Fischer heeft erop gewezen dat dit niet eigen is aan het gebruik van kemenergie ${ }^{24}$ : in de luchtvaartsector werden luchtvaartmotoren aanvankelijk voor militair gebruik gefabriceerd door de overheid. Slechts op het moment waarop ook vliegtuigen voor vreedzaam gebruik werden gebouwd, kon de private industrie haar activiteiten ten volle ontplooien. Hetzelfde geldt in grote lijnen voor de nucleaire industrie. Naarmate kernenergie meer voor vredelievende doeleinden werd aangewend, evolueerde het juridische kader van een overheidsmonopolie en de daaraan gekoppelde geheimhouding naar het toelaten van private initiatieven mits een (gecontroleerde) samenwerking. De controle had voornamelijk tot doel te garanderen dat kernenergie enkel voor vreedzame doeleinden zou worden aangewend. Dankzij de samenwerking werd een internationale uitwisseling van gegevens mogelijk. Een sleutelpositie werd hierin bekleed door drie internationale organisaties: het Internationaal Atoomagentschap (IAEA), het Nuclear Energy Agency (NEA) - binnen het kader van de OESO - en Euratom.

\subsection{Internationale organisaties in het kernenergierecht ${ }^{25}$}

Zowel het Internationaal Atoomagentschap (Intemational Atomic Energy Agency), de Nuclear Energy Agency als Euratom kunnen worden beschouwd als de belangrijkste internationale organisaties in het kemenergierecht omdat hun taak er primair in bestaat om te voorzien in een wetenschappelijke onderbouw voor regels inzake de bescherming van de volksgezondheid bij het gebruik van kernenergie en inzake de veiligheid van keminstallaties ${ }^{26}$. Het ligt niet in onze bedoeling om hier een volledig en uitgebreid overzicht te geven van de verschillende internationale organisaties met specifieke bevoegdheid in het kernenergierecht ${ }^{27}$. In het kader van dit proef-

In hêt licht van de Koude Oorlog was het overigens logisch dat de landen van West-Europa zich tot de VS richtten en niet tot de andere kernmogendheid, de voormalige Sovjet-Unie.

Fischer, G., "L'énergie atomique et les Etats-Unis", l.c., 90.

Voor een overzicht van de verschillende organisaties, zie bijvoorbeeld Arangio-Ruiz, G., "Some International Legal Problems of the Civil Uses of Nuclear Energy", o.c., 519 e.v.; Pelzer, N., "The present state of research carried out by the English speaking section of the Centre for Studies and Research", o.c. 225 c.v.; Ungerer. W., "Die Rolle internationaler Organisationen bei der Verhinderung mißbrăuchlicher Verwendung der Kemenergie", in Kaiser, $\mathrm{K}$. en Lindemann, B. (herausg.), Kernenergie und Internationale Politik, R. Oldenbourg Verlag, München, 1975, 161 e.v.; Deketelaere, K., De Cock, K., Deridder, L. en Verhoosel, G., Handboek Energierecht, Reeks Energie \& Recht, Intersentia, Antwerpen, Groningen, 2001, 173 e.v. Reyners, P. en Lellouche, E., "Regulation and control by international organisations in the context of a nuclear accident: the International Atomic Energy Agency and the OECD Nuclear Energy Agency", o.c., 2.

Over deze verschillende organisaties, zie o.m. Reyners, P. en Lellouche, "Regulation and Control by Intemational Organisations in the Context of a Nuclear Accident: the International Atomic Energy Agency and the OECD Nuclear Energy Agency", in Cameron, P., Hancher, L. en Kühn, W., Nuclear 
schrift wordt volstaan met een beknopt overzicht van de bevoegdheden van de drie belangrijkste organisaties. Hieronder wordt besproken welke de taken en bevoegdheden zijn van het Internationaal Atoomagentschap ( $\S 1.2 .1)$, de Nuclear Energy Agency $(\S 1.2 .2)$ en Euratom $(\S 1.2 .3)$.

\subsubsection{International Atomic Energy Agency (IAEA) ${ }^{28}$}

Het IAEA met zetel te Wenen is een organisatie opgericht in de schoot van de UNO. Nochtans is het IAEA geen gespecialiseerde organisatie zoals de ILO (International Labour Organisation) of de WHO (World Health Organisation), maar functioneert zij juridisch onafhankelijk. Gezien de specifieke aan het IAEA verleende taken, werkt zij nauw samen met de UNO, meer bepaald met de UNO-Veiligheidsraad ${ }^{29}$.

Het IAEA heeft zowel een promotie- als een controlerende taak. Dit blijkt uit artikel III van haar statuut $^{36}$. Het IAEA heeft als taak (o.m.):

"het stimuleren en bevorderen van wetenschappelijk onderzoek en de ontwikkeling en toepassing van atoomenergie voor vreedzaam gebruik over de gehele wereld; het vaststellen en toepassen van waarborgen teneinde te verzekeren dat splijtstoffen en andere materialen (...) niet worden aangewend ten behoeve van enig militair doel".

De rol van het IAEA als promotor van de vredelievende tocpassingen van kernenergie komt onder meer tot uiting in het feit dat het IAEA technische en wetenschappelijke assistentie verleent aan minder ontwikkelde landen. Geoordeeld wordt dat de gebrekkige ontwikkeling van de nucleaire technologie van een land kan worden beschouwd als een beperking van de vooruitgang van dat land. Hierbij wordt dan vooral gerefereerd aan het gebruik van kemenergie in de medische sector en in de landbouw. Tegelijk moedigt het IAEA de uitwisseling aan van wetenschappelijke gegevens met betrekking tot het vreedzaam gebruik van kernenergie; regelmatig worden symposia gehouden waarvan de resultaten ter beschikking worden gesteld van de IAEA-leden. Parallel hiermee verricht het IAEA, in samenwerking met onderzoeksinstituten overal ter wereld, wetenschappelijk onderzoek aangaande diverse aspecten van het vreedzaam gebruik van kemenergie. Daarenboven bevat de door haar uitgegeven IAEA Bulletin - Bulletin de l'AIEA artikelen vanuit weten-

Energy Law after Chernobyl, Graham \& Trotman, London, International Bar Association, 1988, 1-17; Strohi, P. "Chemobyl et le problème des obligations internationales relatives aux accidents nucléaires", Revue de Politique Etrangère, $1986, \mathrm{n}^{\circ} 4$.

Zic o.m. El Baradei, M., Nwogugu, E. en Rames, J, "International law and nuclear energy: Overview of the legal framework", IAEA Bulletin, 3/1995, 16-25; Rainaud, J.M. L'Agence Internationale de I'Energie Atomique, Colin, Paris, 1953, 21 e.v.; Fischer, G., "L'Agence Internationale de l'Energic Atomique", Annuaire Français de Droit International, 1956, 616 e.v.; Lamm, V., "The utilization of nucleair energy and international law", l.c., 44 c.v.; Street, H. en Frame, F.R., Law relating to nuclear energy, London, Butterworths, 1966, 123 e.v.; Domsdorf, E.P.M.W., "Internationaal Atoomenergierecht", l.c., 450 e.v.; Reyners, P. en Lellouche, E., "Regulation and control by international organisations in the context of a nuclear accident: the International Atomic Energy Agency and the OECD Nuclear Energy Agency", o.c., 4 e.v.

Pelzer, N., "The present state of research carried out by the English speaking section of the Centre for Studies and Research", o.c., 232-233. op 20 juli 1957. Ook Belgiê en Nederland zijn lid van het LAEA. 
schappelijke en juridische invalshoek ${ }^{31}$, wordt onder haar auspiciën een groot aantal boeken uitgegeven en organiseert zij internationale conferenties.

De controlerende taak van het IAEA strekt ertoe om, in die landen die een beroep doen op het IAEA voor assistentie en voor landen die bijvoorbeeld zijn toegetreden tot het Non-Proliferatieverdrag, te controleren of kernenergie niet voor militaire doeleinden wordt aangewend. Op dit vlak beschikt het IAEA over verregaande bevoegdheden ${ }^{32}$ zoals het uitvoeren van inspecties, het nemen van monsters etc. Tegelijk schakelt het IAEA, indien noodzakelijk, de VN-Veiligheidsraad in bij overtredingen van het Non-Proliferatieverdrag ${ }^{33}$.

Op juridisch vlak draagt het IAEA bij tot het opstellen van regels inzake de bescherming van de gezondheid (stralingsbescherming), en nucleaire veiligheid. Traditioneel wordt nucleaire veiligheid beschouwd als een strikt nationale bevoegdheid. De activiteiten van het IAEA op dit vlak strekken er enkel toe om veiligheidsrichtlijnen uit te werken die door de verschillende staten als referentic kunnen worden gebruikt ${ }^{34}$. Onderstreept dient te worden dat het IAEA, louter op basis van haar statuut, inderdaad geen juridisch dwingende juridische normen kan uitvaardigen en dat het IAEA niet over de bevoegdheid beschikt om bindende beslissingen te nemen in naam van haar leden $^{35}$. Heel vaak beperkt haar rol zich tot het uitvaardigen van richtlijnen en aanbevelingen ${ }^{36}$. Toch worden, met name inzake stralingsbescherming, deze richtlijnen bijna universeel aanvaard en omgezet in nationale regelgeving. Tegelijk speelt het IAEA een zeer belangrijke rol bij de totstandkoming van verschillende Verdragen inzake kemenergierecht. Bijgevolg kan de rol van het IAEA voor het internationale kemenergierecht mocilijk worden onderschat.

Specifiek met betrekking tot de aansprakelijkheid voor kernongevallen, kwam een aantal zeer belangrijke Verdragen tot stand onder auspiciën van het IAEA: het Verdrag van Wenen van 21 mei 1963 inzake de civielrechtelijke aansprakelijkheid voor kernongevallen, het Gemeenschappelijk Protocol van 21 september 1988, het Protocol van het Verdrag van Wenen van 12 september 1997 en het Verdrag inzake Bijkomende Compensatie eveneens van 12 september 1997. Deze Verdragen worden verderop in dit onderzoek geanalyseerd.

De integrale tekst van de recente nummers van dit tijdschrift is beschikbaar op het Intemet: http://www.iaea.org/worldatom.

32 Opgemerkt dient te worden dat de juridische grondslag van deze bevoegdheid is terug te vinden in het Statuut van het IAEA, in het Non-Proliferatieverdrag (of een ander Verdrag terzake van de beperking op het gebruik van kernwapens) en in een overeenkomst die het IAEA telkens sluit met de desbetreffende Staat. Zie uitgebreider: Vanden Borre, T. en Carchon, R, "Garantir la non-prolifération des armes nucléaires. 50 ans d'atomes pour la paix", o.c., 31 e.v.

Zo stemde de Veiligheidsraad op 3 april 1991 resolutie 687 waarbij aan het LAEA uitgebreide bevoegdheden werden tocgekend om in Irak installaties en sites te inspecteren. Zie hierover van Leeuwen, M., "Nuclear Proliferation in the Middle-East", in van Leeuwen, M. (ed.), The Future of the International Nuclear Non-Proliferation Regime, Martinus Nijhoff Publishers, Dordrecht, 1995, 125153; Thom, L., "IAEA Nuclear Inspections in Iraq", IAEA Bulletin, 1/1992, 16-24. Zo werden veiligheidsnormen uitgevaardigd inzake transport, opslag en berging van radioactief afval, het omgaan met radio-isotopen en de veilige werking van kerninstallaties. Van belang zijn vooral het Agency's Nuclear Safety Standards Programme (NUSS) en de Safety Series.

Strohl, P., "Bilan des recherches de la section de langue française", in Les risques résultant de l'utilisation pacifique de l'énergie nucléaire, Académie de Droit International de La Haye, 1993, 37. De bevoegdheden van het LAEA ter zake van de safeguards vormen een belangrijke nuance op deze stelling. Maar de bevoegdheden waarover het IAEA ter zake beschikt zijn terug te vinden in de verschillende overeenkomsten die het Agentschap afsluit met de verschillende staten. 


\subsubsection{Nuclear Energy Agency (NEA)}

Een tweede belangrijke internationale organisatie die actief is op het vlak van kemenergie, is de Nuclear Energy Agency. Deze organisatie functioneert in het kader van de Organisatie voor Economische Samenwerking en Ontwikkeling (OESO) en heette vroeger het Europees Agentschap voor Atoomenergie; sinds de toetreding van Japan tot de OESO, werd de naam op 20 april 1972 omgevormd tot het Agentschap voor Kemenergie van de OESO, of in het kort het Agentschap voor kernenergie ("Nuclear Energy Agency" of "Agence de l'Energie Nucléaire"). Behalve alle Europese OESO-leden ${ }^{37}$ zijn ook Australië, Canada, Japan, Zuid-Korea, Mexico en de Verenigde Staten lid van de NEA.

Volgens artikel 8 van haar statuut is de voomaamste taak van de NEA het promoten van de samenwerking tussen de regeringen van de leden, teneinde kemenergie te ontwikkelen als een veilige, ecologisch aanvaardbare en rendabele energiebron. Heel wat werk wordt verricht ter harmonisering van nationale regulering ${ }^{38}$, meer bepaald op het gebied van de veiligheid van kerninstallaties, de bescherming van mens en milieu tegen de gevaren uit ioniserende straling, het beleid inzake radioactief afval en nucleaire aansprakelijkheid en verzekering. Zo kwamen het Verdrag van Parijs van 29 juli 1960 inzake civiele aansprakelijkheid op gebied van kemenergie en het Aanvullend Verdrag van Brussel van 31 januari 1963 tot stand in het kader van deze organisatie. Tegelijk heeft de NEA - beperkte - bevoegdheden inzake safeguards en heeft het in het verleden een voomame rol gespeeld bij verschillende internationale samenwerkingsverbanden zoals Eurochemic en het Halden-Project ${ }^{39}$. Van belang is uiteraard ook de nauwe samenwerking tussen de NEA en het IAEA, voomamelijk op het vlak van stralingsbescherming ${ }^{40}$.

In de schoot van de NEA komt ook een groot aantal publicaties tot stand op het vlak van het kernenergierecht. Vooral van belang in dit verband is de publicatie van het zesmaandelijkse tijdschrift Bulletin de Droit Nucléaire - Nuclear Law Bulletin. Dat tijdschrift bevat niet enkel artikelen over specifieke onderwerpen op het terrein van het kernenergierecht, maar geeft telkens ook een overzicht van de wijzigingen van de interne wetgeving van de verschillende NEA-leden en van de totstandkoming of wijziging van multilaterale of bilaterale overeenkomsten. De tekst zelf van deze wetten en Verdragen worden gewoontegetrouw opgenomen in een bijlage van de Nuclear Law Bulletin ${ }^{4 !}$.

Opmerkelijk is overigens dat in het kader van de werkzaamheden van de NEA een specifieke rechtbank werd opgericht. Door de "Convention on the Establishment of a Security Control in the Ficld of Nuclear Energy" van 1957, werd het European Nuclear Energy Tribunal opgericht. Dit is

Belgič, Oostenrijk, Denemarken, Frankrijk, Duitsland, Griekenland, LJsland, Ierland, Italië, Luxemburg, Nederland, Noorwegen, Portugal, Spanje, Zweden, het Verenigd Koninkrijk en Finland (bron: Liability and Compensation for Nuclear Damage. An international overview, OECD, NEA, 1994 (hierna geciteerd als "Liability and Compensation for Nuclear Damage").

38 Reyners, P. en Lellouche, E., "Regulation and control by intemational organisations in the context of a nuclear accident: the Internationa! Atomic Energy Agency and the OECD Nuclear Energy Agency", o.c., 6 e.v.

39 Stein, R.M., "The European Nuclear Energy Agency", Nuclear Law for a Developing World, Legal Series $n^{\circ} 5$, IAEA, Vienna, 1969, 23 e.v.; de becommentarieerde teksten van de overeenkomsten inzake Eurochemic en het. Halden-project zijn terug te vinden bij Hädrich, H., Europaische Atomverträge. Kommentar, Nomos, Baden-Baden, 1966, 219 e.v.

40 Zie hierover Shapar, H., "L'Agence pour l'energie nucléaire de l'OCDE: nouvelles orientations", AIEA Bulletin, vol. 25, $n^{\circ} 1,1983,23-25$.

4! Nagenoeg aile nummers van de Nuclear Law Bulletin kunnen on-line worden geraadpleegd op het Internet (www.nea.fr/html/law/nlb). 
een van de NEA onafhankelijke rechtbank, die onder meer bevoegd is om geschillen te beslechten inzake de interpretatie van het Verdrag van Parijs van 1960 en het Aanvullend Verdrag van Brussel van $1963^{42}$

\subsubsection{Euratom}

De hoofdtaak van Euratom bestaat er volgens art 1, lid 2 van het Euratom-Verdrag ${ }^{43}$ in:

"door het scheppen van de voorwaarden noodzakelijk voor de snelle totstandkoming en groei van de industrie op het gebied van kemencrgie, bij te dragen tot de verhoging van de levensstandaard in de lidstaten en de ontwikkeling van betrekkingen met andere landen".

De voomaamste deeltaken van Euratom zijn het bevorderen van onderzoek en verspreiden van kennis, het vaststellen van uniforme veiligheidsnormen ter bescherming van de bevolking en de werknemers (safety), het waarborgen dat kemmaterialen niet voor andere doeleinden worden aangewend dan waarvoor zij bestemd zijn (safeguards) en het tot stand brengen met andere landen en met internationale organisaties, van alle betrekkingen die de vooruitgang in het vreedzame gebruik van kemenergie kunnen bevorderen.

De Euratom-organen zijn dezelfde als de organen van de EU en de EGKS (Europese Gemeenschap voor Kolen en Staal). In de Raad van ministers wordt de COREPER (Comité des Représentants Permanents), voor het nemen van beslissingen op basis van het Euratom-verdrag, bijgestaan door een groep atoomdeskundigen; de Commissie van haar kant wordt bijgestaan door een technisch-wetenschappelijk comité met raadgevende functic.

Het Euratom-beleid is van groot belang op het vlak van stralingsbescherming, het verwerven van kernmaterial en inzake safeguards. Euratom hecft inderdaad meerdere richtlijnen uitgewerkt inzake diverse aspecten van stralingsbescherming ${ }^{44}$ : vooral van belang hierbij is de algemene bescherming van de bevolking en de werknemers uit de nucleaire sector ${ }^{45} 46$ en in het bijzonder de

X., "Liability and Compensation for Nuclear Damage", l.c., 51; Stein, R.M., "The European Nuclear Energy Agency", o.c., 31-32.

Een uitgebreide bespreking van de bepalingen van het Euratom-Verdrag is onder meer terug te vinden bij Eirera, Simon en Vemaeve, Le traité Euratom, 311; Pirntte, O., Girerd, P., Marsal, P. en Morson, S., Trenté añs d' expérience Euratom. La naissance d'une Europe nucléaire, Bruxclles, Bruylant, 1988; Street, H. en Frame, F.R, "Law relating to nucleair energy", l.c, 144 e.v.; Domsdorf, E.P.M.W., "Internationaal Atoomenergierecht", l.c., 542 e.v.; Sünner, H. en Pfanner, K., Der gewerbliche Rechusschuiz in Euratomvertrag, Carl Heymanns Verlag, München, 1958, 197.

Voor enkele beschouwingen bij de stralingsbeschermingswetgeving, zie Boustany, $\mathrm{K}$, "Reflection on the Development of Nuclear Law", Nuclear Law Bulletin, vol. 51, 1993, 7-25; Lochard, J. en Grenery. Boehler, M-C., "Les bases éthiques et juridisues du principe d'optimisation de la radioprotection", Bulletin de Droil Nucléaire, vol. 52, 1993, 9-28.

Op dit vlak is met name van belang: Richtlijn 96/29/Euratom van de Raad van 13 mei 1996 tot vaststelling van de basisnormen voor de bescherming van de gezondheid der bevolking en der werkers tegen de aan ioniserende straling verbonden gevaren (PB, L 159 van 29 juni 1996). Deze richtlijn vervangt Richtlijn 80/836/Euratom van 15 juli 1980 houdende wijziging van de richtlijnen tot vaststelling van de basisnormen voor de bescherming van de gezondheid der bevolking en der werknemers tegen de aan ioniserende straling verbonden gevaren (PB, L. 246/1, van 17.9.1980). Artikel 56 van richtijin $96 / 29$ trekt met ingang van 13 mei 2000 de eerdere basisrichtlijnen ter zake in. De nieuwe richtlijn is op bepaalde punten uitgebreid in die zin dat bijvoorbeeld ook voorzieningen zijn opgenomen voor de blootstelling aan natuurlijke radioactiviteit op de werkplek. Zie hierover Lecomte, J.F., "La nouvelle: 
te nemen maatregelen bij grensoverschrijdend transport van radioactief materiaal ${ }^{47}$. Ook hier geldt - net zoals dat het geval is voor het IAEA - dat dit beleid in grote mate wordt beïnvloed door de door het ICRP ${ }^{48}$ opgestelde aanbevelingen.

In het verleden is discussie ontstaan omtrent de mogelijkheid van lidstaten om strengere normen uit te vaardigen inzake stralingsbescherming dan deze voorzien in Richtlijn 80/836/Euratom van 15 juli 1980. Met name België had strengere normen uitgevaardigd dan de normen die waren voorgeschreven door de richtlijn en werd hiervoor door de Commissie voor het Europees Hof gedaagd $^{49}$. Volgens de Commissie bracht het Belgische beleid de eenheidsmarkt in het gedrang. Het Europees Hof stelde echter België in het gelijk omdat de richtlijn enkel minimumnormen vastlegt en zich niet verzet tegen de mogelijkheid voor een lidstaat om strengere normen uit te vaardigen $^{50}$. De momenteel geldende kaderrichtlijn inzake stralingsbescherming, richtlijn 96/29, is in dit verband duidelijker en onderschrijft de visie zoals die eerder door het Europees Hof werd verdedigd: de in de richtlijn vastgelegde normen zijn basisnormen; het is een lidstaat toegelaten om hiervan af te wijken mits de Commissie en de andere lidstaten daarvan worden in kennis gesteld ${ }^{5 !}$.

Volledigheidshalve dient te worden aangestipt dat ook andere takken van het EG-recht van belang kunnen zijn voor het kernenergierecht: zo is de MER-richtlijn ook van toepassing op kerncentrales en andere kemreactoren ${ }^{52}$.

Euratom is voor de verschillende lidstaten van kapitaal belang voor wat betreft het verwerven van kernmateriaal. Het Euratom-Verdrag bevat in dit verband een aantal zeer specifieke bepalingen op basis warvan exploitanten van een keminstallatie gelegen in een Lidstaat enkel kernmateriaal kunnen verwerven mits daartoe specifieke procedures worden gevolgd. In dit verband heeft Euratom contracten afgesloten met verschillende landen ${ }^{53}$.

Directive Communautaire sur le normes de base en matière de radioprotection", in Le droit nucléaire: du XXe au XXIe siècle. Nuclear Inter Jura '97, Société de Législation Comparée, AIDN/INLA, Paris, 1998, 155-161; Nocera, F., Boehler, M.C. e.a., "Radiation Protection Legislation in the European Union: the Imperative of Uniformity, related initiatives and problems", in Nuclear Inter Jura "99, INLA/AIDN, Washington, 1999, 55-75; Courades, J-M., "The New 96/29/Euratom Directive on Basic Safety Standards for the Protection of Workers and the General Public Against lonising Radiation, Nuclear Law Bulletin, vol. 58, 1996, 49-53. Zie hierover Deketelacre, K. e.a., "Handboek Energierecht", l.c., 183-194.

Richtlijn $92 / 3$ van de Raad van 3 februari 1992 betreffende toezicht en controle op de overbrenging van radioactieve afvalstofien tussen Lidstaten, en naar en vanuit de Gemeenschap $(P B, L$ 35/24 van 12.02.1992). Verordening 1493/93/Euratom van de Raad van 8 juni 1993, betreffende de overbrenging van radioactieve stoffen tussen lidstaten van de Europese Gemeenschap ( $P B, \mathrm{~L} 148$, van 19 juni 1993). Cfr. supra, in \$ 1.1 van dit hoofdstuk.

Arrest van het Europees Hof van 25 november 1992, zaak C-376/90 Commissie tegen Belgie, in beperkte vorm weergegeven in Nuclear Law Bulletin, vol. 53, 1994, 48.

Zic hierover Lennartz, R., "La protection sanitaire contre les rayonnements ionisants et la Cour de Justice des Communautés Européennes", Bulletin de Droit Nucléaire, vol. 53, 1994, 9-21. Artikel 54 van de hierboven vermelde richtlijn 96/29.

52 Bijlage 1 , sub 2 van de Richtlijn van de Raad betreftende de milieu-effectbeoordeling van bepaalde openbare en particuliere projecten van 27 juni $1985,85 / 337 / \mathrm{EEG} /, P B$ nr. L $175 / 5,5$ juli 1985 . Gewijzigd door richtlijn 97/1 1/EG van de Raad van 3 maart 1997 tot wijziging van Richtlijn 85/337/EEG betreffende de milieu-effectbeoordeling van bepaalde openbare en particuliere projecten, $P B \mathrm{nr}$. L 73/5, 14 maart 1997. 
Tenslotte beschikt Euratom over vergaande bevoegdheden op het vlak van safeguards ${ }^{54}$. Euratom heeft eigen inspecteurs die inspecties verrichten in kerninstallaties van de Euratom lidstaten ${ }^{55}$. Indien inbreuken worden vastgesteld, kan de Commissie overeenkomstig artikel 83 van het Verdrag bepaalde sancties opleggen aan personen of ondernemingen.

\subsection{Conclusie}

Het gebruik van Little Boy en Fat Man heeft een aanzienlijke invloed gehad op de ontwikkeling van het kemenergierecht: de twee atoombommen hebben inderdaad initieel het ontstaan van het internationale kernenergierecht in de weg gestaan. Om te vermijden dat ook andere landen of de private industrie een kernwapen zouden kunnen produceren, was het Amerikaanse beleid van in het begin gericht op geheimhouding van kennis en materiaal; samenwerking was enkel mogelijk mits controle op overdracht van kennis en technologie. Aanvankelijk kreeg deze controle gestalte in de vorm van een Amerikaans overheidsmonopolie - wat elke internationale samenwerking verhinderde aangezien de VS een feitelijk monopolie hadden. Het nieuwe feitelijke gegeven dat ook de Sovjet-Unie over een kernwapen beschikte, leidde tot een "internationalisering" van dit beleid. Terwijl aanvankelijk nationale-Amerikaanse samenwerking mogelijk was door een systeem van nationale controle werd internationale uitwisseling van gegevens mogelijk door een systeem van internationale controle.

Het spreekt voor zich dat deze internationale controle te maken heeft met de verschillende aan het gebruik van kernenergie verbonden gevaren. Toch was de aandacht initicel, in het licht van de Koude Oorlog, voornamelijk gericht op het verhinderen dat kernenergie voor militaire doeleinden zou worden gebruikt (aspect "safeguards" van het nucleaire risico). Nadien zou de klemtoon meer en meer komen te liggen op de elementen safety en security.

De oprichting van het IAEA en de opheffing van het Amerikaanse overheidsmonopolic door de wijziging van de Atomic Energy Act van 1954, gaf de Amerikaanse nucleaire industrie aanzienlijke commerciële mogelijkheden, met name in Europa ${ }^{{ }^{5}}$. Dit blijkt bijvoorbeeld uit de nauwe samenwerking tussen de VS en Euratom ${ }^{57}$. Reeds in november 1958 werd een samenwerkingsakkoord tussen beide partners ondertekend. Voor de VS betekende dit akkoord een helangrijke commerciële doorbraak voor haar kemenergic-industrie ${ }^{58}$. Ook het in 1968 afgesloten Non-

Ook op dit vlak wordt nauw samengewerkt met het LAEA; de modaliteiten hiervan werden in 1972 vastgesteld in een overeenkomst: Overeenkomst van 20 en 22 september 1972 tussen hel Koninikrijk Belgie, het Koninkrijk Denemarken, de Duitse Bondsrepubliek, lerland, de Republiek ltalie, het GrootHertogdom Luxemburg, het Koninkrijk der Nederlanden, de Europese Gemeenschap voor Atoomenergie, en het Internationaal Agentschap voor Atoomenergie, bij toepassing van de paragrafen 1 en 4 . van artikel 3 van het Verdrag houdende de non-proliferatie van kemwapens, B.S., 20 november 1975 , 14688. Zie hierover Vanden Borre, T. en Carchon, R, "Garantir la non-prolifération des armes nucléaires. 50 ans d'atomes pour la paix", o.c., 46-48.

Deze bevoegdheden zijn terug te vinden in hoofdstuk VII "Veiligheidscontrole" van het EuratomVerdrag.

Hetzelide geldt uiteraard voor de Sovjet-Unie, wiens commercieel beleid zich hoofdzakelijk op OostEuropa richtte.

Zie hierover bijvoorbeeld Freeman, A.V., "The development of international co-operation in the peaceful use of a tomic energy", American Journal of International Law, vol. 54, 1960, 384 e.v.

Hăfele, W., "Die historische Entwicklung der friedlichen Nützung der Kernenergie", o.c., 52-53. 
Proliferatieverdrag was een zeer belangrijk element in de uitvoer van nucleaire technologie en materiaal van de VS naar Europa ${ }^{59}$.

Na de oprichting van het Internationaal Atoomagentschap (IAEA), met als taak om het vredelievende gebruik van kemenergie te garanderen en om dit gebruik te bevorderen, kon de commerciële uitbouw van de kemenergic-industrie van start gaan. Nucleaire handel werd mogelijk, op voorwaarde dat garanties werden gegeven dat kernenergie enkel voor vredelievende doeleinden werd aangewend; op deze wijze werd het beleid inzake vredelievende toepassingen een belangrijk element in de beperking van de horizontale proliferatie van kernwapens. In de periode van de oprichting van het IAEA, werden ook de NEA en Euratom opgericht.

Een gemeenschappelijk element in de bevocgdheden van de NEA en het IAEA is dat hun werkzaamheden niet leiden tot de redactie van dwingende juridische bepalingen. Over het algemeen hebben de regels die bijvoorbeeld het IAEA uitvaardigt hooguit het karakter van een aanbeveling. Het staat de verschillende landen vrij om deze aanbevelingen al dan niet op te volgen. Een land dat nalaat om deze normen om te zetten in nationale wetgeving zal hiervoor dus in beginsel niet aansprakelijk kunnen worden gesteld. Precies dit gebrek aan juridisch dwingende kracht - "soft law" - bij belangrijke delen van het kernenergierecht is in de literatuur reeds meermaals onder vuur genomen ${ }^{60}$.

De wetgeving van Euratom is voor een groot deel wél dwingend. Dit geldt uiteraard in de eerste plaats voor de door Euratom uitgevaardigde Verordeningen, die rechtstreeks toepasselijk zijn in de interne rechtsorde van de lidstaten. Daamaast is vooral van belang dat een groot deel van de Euratom-wetgeving bestaat uit richtlijnen. Deze zijn zoals bekend bindend voor de verschillende lidstaten: zij zijn verplicht om deze om te zetten in de nationale rechtsorde. Sinds de arresten Francovich, Brasserie en Factortame kan een Lidstaat zelfs aansprakelijk worden gesteld voor schade die particulieren leiden als gevolg van een schending van het gemeenschapsrecht ${ }^{61}$. Het is aannemelijk om ervan uit te gaan dat - uiteraard voorzover aan de voorwaarden van de "Francovich-rechtspraak" is voldaan ${ }^{2}$ - eenzelfde redenering kan worden gevolgd voor wat betreft Euratom richtlijnen.

Een uitermate belangrijk element is de nauwe samenwerking tussen het IAEA, de NEA en Euratom. Deze samenwerking is niet verwonderlijk aangezien hun taak in belangrijke mate gericht is

Zie hierover Kraemer, J.R., "NPT and AFC - Building Blocks for Confidence and Predictability in Nuclear Trade", in Nuclear Inter Jura '95, AIDN/INL.A, Helsinki, 1995, 452-471.

Zie bijvoorbeeld Boustany, $\mathrm{K}$., "Le développement de la normativité nucléaire ou l'art de l'évasion juridique", Bulletin de Droit Nucléaire, $n^{\circ} 61,1998,43$ e.\%.

Zie hicrover van Gerven, W, "Non-contractual Liability of Member States, Community Institutions and Individuals for Breaches of Community Law with a View to a Common Law for Europe", Maastricht Journal of European and Comparative Law, 1994, afl. 1, 6-4I; van Gerven, W., "Bridging the unbridgeable: community and national tort laws after Francovich and Brasserie", International and Comparative Law Quarterly, vol. 45 1996, 507-544; van Gerven, W., "The ECJ's Recent Case-Law in the Field of Tort Liability; Towards a European lus Commune? ", in Jansen, R., Koster, D., van Zutphen, R. (ed.), European Ambitions of the National Judiciary, Kluwer Law International, Den Haag, 1997. 91-110; Gilliams, H., "Horizontale werking van richtlijnen: dogma's en realiteit", in Liber Amiconum Walter van Gerven, Kluwer, Deventer, 2000, 223-245; Zie ook Van Darn, C.C., "Aansprakelijkheidsrecht", l.c., 150-157.

Deze voorwaarden zijn: de geschonden gemeenschapsmaatregel moet rechten toekennen aan particulieren, het moet gaan on eerı gekwalificeerde schending van deze gemeenschapsregel en er moet een direct causaal verband bestaan tussen de schending en de door de particulier geleden schade. 
op het verrichten van wetenschappelijk onderzoek naar de gevaren van het gebruik van kernenergie en naar de omzetting van de resultaten van dit onderzoek in juridische regelgeving.

De verschillende besproken internationale organisaties hebben een determinerende rol gespeeld in de ontwikkeling van het kernenergierecht. Hun oprichting leidde tot controlemechanismen die dienden te garanderen dat kernenergie enkel voor vredelievende doeleinden zou worden aangewend. Inmiddels is gebleken dat zij er inderdaad zijn in geslaagd om de horizontale proliferatie van kernwapens te beperken ${ }^{63}$. Tegelijk is door de inspanningen van deze organisaties inmiddels een aanzienlijk geheel van regels tot stand gekomen die, via tussenkomst van de nationale wetgever, afdwingbaar zijn in de interne rechtsorde van verschillende landen. Zeker inzake stralingsbescherming is sprake van een verregaande harmonisering van de wetgeving.

Hieronder wordt een overzicht gegeven van de verschillende Verdragen die onder invloed van deze organisaties zijn tot stand gekomen. De aandacht gaat hierbij vooral uit naar die Verdragen die in het kader van dit onderzoek relevant zijn en die bepalingen bevatten inzake de civielrechtelijke aansprakelijkheid voor kernongevallen.

\section{OVERZICHT VAN DE INTERNATIONALE VERDRAGEN INZAKE, CIVIELRECHTELIJKE AANSPRA- KELIJKHEID VOOR KERNONGEVALLEN EN AANVERWANTE VERDRAGEN}

In deze paragraaf wordt een overzicht gegeven van de internationale Verdragen inzake de civielrechtelijke aansprakelijkheid voor het nucleaire risico en van een aantal aanverwante Verdragen. Hiermee worden de Verdragen bedoeld die betrekking hebben op de nucleaire veiligheid; deze hebben als dusdanig geen direct verband met de civielrechtelijke aansprakelijkheid bij kemongevallen, maar zij trachten bij te dragen tot de preventie van kemongevallen. In onze visie, hierin bijgetreden door de rechtseconomische analyse, is preventie immers een van de basisdoelstellingen van het aansprakelijkheidsrecht. Tegelijk besteedt de rechtseconomische analyse aandacht aan de wisselwerking tussen aansprakelijkheid, verzekering en veiligheidsregulering ${ }^{64}$. Vandaar beperkt dit overzicht zich niet tot de Verdragen inzake de civielrechtelijke aansprakelijkheid voor kemongevallen, maar wordt ook een overzicht gegeven van de Verdragen in $7 a k e$ nucleaire veiligheid.

In dit overzicht van de internationale Verdragen wordt een onderscheid gemaakt tussen de Verdragen van de cerste generatie $(\$ 2.1)$ en deze van de tweede generatie (\$2.2). De Verdragen van de eerste generatie zijn deze die tot stand zijn gekomen bij de start van de nucleaire civiele industrie (begin van de jaren zestig), met name de Verdragen inzake de civiele aansprakelijkheid voor kernongevallen. De Verdragen van de tweede generatie zijn de Verdragen die tot stand zijn gekomen naar aanleiding van het kernongeval in Tsjernobyl. De conclusie van de eerste twee paragrafen, wordt weergegeven in $\S 2.3$.

\subsection{De nucleaire (aansprakelijkheids)verdragen van de eerste generatie}

De intemationale nucleaire verdragen van de eerste generatie vallen onder to verdelen in twee groepen: de Verdragen inzake de civielrechtelijke aansprakelijkheid voor een kernongevai in een vaste kerninstallatie en de Verdragen inzake de civielrechtelijke aansprakelijkheid voor een kern-

\footnotetext{
63 Vanden Borre, T. en Carchon, R, "Preventing the Proliferation of Nuclear Weapons: 50 Years of Atoms for Peace", o.c., 47.

64

Zie met name Faure, M. en Van den Berghe, R., "Objectieve Aansprakelijkheid", L.c., 257 e.v.; zie ook in deel 2 van dit boek.
} 
ongeval bij maritiem transport van nucleaire stoffen of materialen ${ }^{65}$. In dit onderzoek staan vooral de Verdragen inzake kemongevallen in vaste kerninstallaties centraal.

Het toepassingsgebied van deze Verdragen, evenals de grote basisprincipes komen respectievelijk in de hoofdstukken 3 en 4 aan bod; hieronder wordt stilgestaan bij de achtergronden en beweegredenen van het ontstaan van deze Verdragen $(\$ 2.1 .1)$ en wordt een overzicht gegeven van de Verdragen inzake de civielrechtelijke aansprakelijkheid voor schade uit kernongevallen in vaste kerninstallaties $(\S 2.1 .2)$ en voor schade uit kernongevallen bij maritiem transport van nucleair materiaal (\$2.1.3).

\subsubsection{Ontstaan van de Verdragen inzake nucleaire aansprakelijkheid}

In landen die een beroep wensten te doen op kernenergie, ontstond in het midden van de jaren vijftig, begin de jaren zestig de eerste nationale regelgeving inzake aansprakelijkheid en schadevergoeding bij kernongevallen. De eerste Belgische wet was de wet op de civielrechtelijke aansprakelijkheid van het SCK (1962) en de eerste Nederlandse wet ter zake, was de Kew van $1963^{66}$. Ook in andere landen kwam nationale regelgeving tot stand. Koploper waren de Verenigde Staten die in 1957 de Price Anderson Act afkondigden ${ }^{67}$, hierbij gevolgd door Duitsland (Atomgesetz van 1959) ${ }^{68}$.

Door de evolutie van het kernenergierecht van geheimhouding naar samenwerking, drong zich een harmonisatie op van de verschillende nationale wetten ${ }^{69}$. Tegelijk dienden regels te worden uitgewerkt betreffende de grensoverschrijdende gevolgen van een kernongeval, zowel bij een kernongeval in een vaste kerninstallatie, als bij een kernongeval gedurende het transport van nucleaire stoffen. Internationale regelgeving diende tegemoet te komen aan mogelijke problemen van intemationaal-privaatrechtelijke aard zoals toepasselijke wetgeving, bevoegde rechtbank, uitvoering van rechterlijke uitspraken eic. In het licht hiervan startten vanaf het midden van de jaren vijftig onderhandelingen met het oog op het afsluiten van een intemationaal Verdrag.

In december 1958 stelde de Directeur-Generaal van het IAEA een panel van experten aan dat het IAEA diende te adviseren omtrent de problemen in verband met de civielrechtelijke aansprakelijkheid voor kernongevallen. Dit team van experten kwam driemaal bijeen in 1959, hetgeen resulteerde in een IAEA-ontwerpverdrag dat ter goedkeuring aan de verschillende leden van de Verenigde Naties werd gestuurd ${ }^{20}$.

Toch heeft een aantal landen de uitkomst van de onderhandelingen in de schoot van het IAEA niet afgewacht om zelf reeds een ander Verdrag te sluiten. In het kader van de NEA mondden de

Het transport van nucleaire materialen over de weg, valt in principe onder hetzelfde regime als ongevallen in een vaste kerninstallatic. Cfr. infra, onder $\S 1.1 .3$ van hoofdstuk 4. Zie verderop dit hoofdstuk, respectievelijk in paragrafen 3 en 4.

Zie hierover o.m. Vanden Borre T., "Dekking van het nucleaire risico op nationaalrechtelijke basis of via internationale Verdragen: de Verenigde Staten versus Europa", in Faure, M., Deketelaere, K. en Verhoosel, G., (red.), "Grensoverschrijdende milieuproblemen", l.c., 450 e.v. en de daar geciteerde literatuur. Zie ook verderop, in hoofdstuk 13 van dit boek.

Zie hierover de verschillende bijdragen in Pelzer, N., (herausg.), Deutsches Atomenergierecht im internationalen Rahmen, Nomos, Baden-Baden, 1992, 293.

"Nuclear Liability and Compensation for Nuclear Damage", I.c., 41.

International Conference on Civil Liability for Nuclear Damage, Vienna, 29 April - 19 May 1963, "Official Records", IAEA Legal Series $N^{\circ}$ 2, LAEA, Wenen, 1964, STUPUB/54, 65 (hierna geciteerd als "Official Records Vienna Convention"). 
onderhandelingen uit in de totstandkoming van twee Verdragen inzake de civielrechtelijke aansprakelijkheid bij kernongevallen: het Verdrag van Parijs van 29 juli 1960, het Verdrag van Brussel van 31 januari 1963: "Verdrag tot aanvulling van het Verdrag van Parijs van 29 juli 1960 inzake de wettelijke aansprakelijkheid op het gebied van kernenergie" ${ }^{51}$. Beide Verdragen zijn totstandgekomen in het kader van de Organisatie voor Economische Samenwerking en Ontwikkeling (OESO), meer bepaald onder auspiciën van het European Nuclear Energy Agency (ENEA). Beide Verdragen zijn op hun beurt reeds aangevuld door enkele Aanvullende Protocollen $^{72}$. Basistekst blijft echter het Verdrag van Parijs; wanneer daarnaar wordt verwezen, wordt dus de gecoördineerde tekst bedoeld waarin zowel het Aanvullend Verdrag als de Aanvullende Protocollen zijn opgenomen.

Parallel aan de onderhandelingen van het Verdrag van Parijs, werden in de schoot van het IAEA onderhandelingen gevoerd met het oog op het ondertekenen van een analoog Verdrag als het Verdrag van Parijs. Nadat verschillende opmerkingen werden gemaakt op het eerder genoemde IAEA-ontwerpverdrag, werd in februari 1961 een Intergouvemementeel Comité opgericht dat de ondertekening van het Verdrag verder diende voor te bereiden. Opvallend hierbij is dat zowel landen die reeds het Verdrag van Parijs hadden ondertekend of later zouden ondertekenen, als de Verenigde Staten, die noch het Verdrag van Parijs, noch het Verdrag van Wenen zouden ondertekenen, in dit Comitê waren vertegenwoordigd.

Op 14 en 15 maart 1963 werd onderzocht in welke mate de inhoud van het reeds ondertekende Verdrag van Parijs en het ontwerp Verdrag van Wenen gelijklopend was en werd nagegaan in welke mate een toenadering tussen deze Verdragen mogelijk was. De verschillen bleken echter groter dan verwacht en de standpunten tussen de Lidstaten van het Parijse Verdrag en van het Weense Verdrag konden niet worden verzoend. Hoewel beide Verdragen dezelfde basisprincipes hanteren $^{73}$, gaf het Verdrag van Parijs aan een harmonisatie van de wetgeving van de verschillende leden te betrachten, terwijl het Verdrag van Wenen zich ertoe beperkte een minimumkader te creëren waaraan een nucleair civielrechtelijk aansprakelijkheidsregime diende te voldoen. Dit blijkt bijvoorbeeld uit het feit dat het bedrag van de beperkte aansprakelijkheid in het Weense Verdrag een stuk lager is dan in het Parijse Verdrag en uit het feit dat het Verdrag van Wenen geen enkele bepaling bevat inzake de doorvoer van nucleaire stoffen die de doorvoerstaat toelaat de aansprakelijke exploitant een gelijkwaardig aansprakelijkheidsniveau op te leggen als de eigen exploitanten ${ }^{74}$. Uiteindelijk werd op 21 mei 1963 in de schoot van het International Atomic Energy Agency (IAEA) het Verdrag van Wenen ondertekend.

Dit Verdrag bepaalt de Verdragen waarvoor de exploitant aunsprakelijk kan gesteld worden voigens een indeling van het totale beschikbare schadevergoedingsbedrag in drie schijven (efr. infra). Zie o.m. Lagorce, M., "The Brussels Supplementary Convention and its Joint Intergovemmental Security Fund", in Nuclear Law for a Developing World, IAEA, Vienna, Legal Series n 5, 1969, 143-148. Zie hierover o.m. Lagorce, M., "Bilan et perspectives de la Convention de Paris et de la Convention complémentaire de Bruxelles après les Protocoles de 1982", Nuclear Third Party Liability. Status and Prospects, Munich Symposium, Paris, 1985, 24-42.

Beide Verdragen gaan uit van een risicoaansprakelijkheid, kanaliseren de aansprakelijkheid naar de exploitant, beperken đeze aansprakelijkheid zowel in bedrag als in de tijd, verplichterı de expiloitant zijn aansprakelijkheid te verzekeren, maken de reehter van slechts één. Staat bevoegd om kennis te nemen van een vordering uit een kernongeval, en bevatten cerı non-discriminatic clausule.

Voor een vergelijking van beide Verdragen, zie Lagoree, M., "Etude comparative des Conventions OCDE et AIEA sur la responsabilité civile dans le domaine de l'énergie nucléaire", in Puget, H. (éd.), Aspects du droit de lénergie atomique, Centre national de la recherche scientifique, Paris, 1967, 93102. 
In feite is het Verdrag van Wenen universeler en mondialer gericht dan het Verdrag van Parijs. Dit blijkt uit het feit dat het Parijse Verdrag tot stand kwam in de schoot van de OESO (in die tijd nog de Organisatie voor Europese Samenwerking \& Ontwikkeling), terwijl het Weense Verdrag tot stand kwam in de schoot van het IAEA, dat ressorteert onder de UNO. Het Verdrag van Wenen beperkte zich niet tot de landen die kernenergie aanwendden, maar riep alle landen op om dit Verdrag te ondertekenen, aangezien zich in om het even welk land schade zou kunnen voordoen voortvloeiend uit een kernongeval ${ }^{75}$. Maar het universele karakter van het Verdrag van Wenen, bleek ook meteen haar achillespees te zijn ${ }^{76}$ : zij is slechts 14 jaar na haar ondertekening van kracht geworden ${ }^{77}$ en ook haar doelstelling bleek vrij vaag te zijn.

Als gevolg hiervan, waren in oktober 2000 slechts 32 landen (waarvan de meerderheid geen keminstallaties heeft) lid van het Verdrag van Wenen, hetgeen gering is, gelet op zijn universeel karakter $^{78}$. Daar staat tegenover dat, eveneens in oktober 2000, 14 Europese landen lid waren van het Verdrag van Parijs. Van de 15 Euratom-lidstaten waren enkel Ierland, Oostenrijk en Luxemburg, die geen eigen nucleaire activiteiten hadden, niet toegetreden tot het Verdrag van Parijs ${ }^{79}$.

Het was overigens initieel de bedoeling dat het Verdrag van Parijs een specifiek regime zou creëren, enkel van toepassing in de landen van de OESO, terwijl het Weense Verdrag een algemeen regime in het leven zou roepen, waartoe ook de leden van het Verdrag van Parijs konden toetre$\operatorname{den}^{80}$. Uiteindelijk waren de lidstaten van het Verdrag van Parijs weinig enthousiast om tegelijkertijd lid te worden van het Verdrag van Wenen: begin 2000 was geen enkel land dat lid was van het Verdrag van Parijs, eveneens lid van het Verdrag van Wenen ${ }^{81}$. Aldus kwamen twee afzonderlijke regimes inzake de civielrechtelijke aansprakelijkheid voor kernongevallen tot stand ${ }^{82}$. Dit had voor gevolg dat het werkingsveld van het Verdrag van Wenen en dat van Parijs op geen

Official Records Vienna Convention, 67.

Ook in die zin: Piérard, J.P., Responsabilité civile. Energie atomique êt droit comparé, Centre universitaire de druit comparé, Bruxelles, Bruylant, 1963, 465 (hierna geciteerd als "Energie atomique").

Nochtans waren slechts vijf ratificaties nodig opdat het Verdrag in werking zou treden.

Op de website van het LAEA kan worden nagegaan welke landen zijn toegetreden tot de verschillende verdragen ( $w$ ww.iaea.org).

Daamaast zijn twee niet-Euratom lidstaten toegetreden tot het Verdrag van Parijs, namelijk Zwitserland en Turkije.

"Nuclear Liability and Compensation for Nuclear Damage", l.c., 44.

Weliswaar hadden Spanje en het Verenigd Koninkrijk respectievelijk op 6 september 1963 en op 11 november 1964 het Verdrag van Wenen ondertekend, maar dit Verdrag is door geen van beide landen geratificeerd.

Beide Verdragen bevatten echter bepalingen over de relatie tussen beide regimes. Overeenkomstig artikel 16 van het Verdrag van Wenen, heeft een slachtoffer geen recht op schadevergoeding op grond van het Verdrag indien het reeds schadevergoeding heeft ontvangen op basis van een ander internationaal Verdrag inzake civielrechtelijke aansprakelijkheid bij kernongevallen. Artikel 17 van het Verdrag van Wenen stelt dat het Verdrag geen afbreuk doet aan de toepassing van andere internationale Verdragen in dezelfde materie. Het gaat hier om een duidelijke venwijzing naar het Verdrag van Parijs in het Aanvullend Verdrag van Brussel. Beide laatstgenoernde Verdragen dienden uiteraard ook bepalirgen te bevatten aangaande de relatie met het Verdrag van Wenen. Doō de leden van het Verdrag van Parijs werd op 28 januari 1964 een Aanvullend Protocol ondertekend dat de relatie regelde met het Verdrag van Wenen. De Preambule van het Aanvullend Protocol refereert aan artikel 17 van het Verdrag van Wenen en stelt dat de ondertekenende Staten elk mogelijk conflict tussen beide Verdragen wensen te vermijden, om de Partijen indien zij dat wensen, toe te laten lid te worden van beide Verdragen. Zie hierover Von Busekist, O., "Haftungsprobleme im Verhäitnis zwischen Vertragsstaten des Pariser und des Wiener Atomhaftungsübereinkommens", in Pelzer, N., (herausg.), Friedliche Kernenergienutzung und Staatsgrenzen in Mitteleuropa, Nomos, Baden-Baden, 1987, 273. 
enkele wijze aan elkaar was - en is - gekoppeld ${ }^{83}$. Tot na het ongeval in Tsjernobyl hadden zowel het Verdrag van Parijs als dat van Wenen hun eigen territoriaal werkingsveld waardoor in feite twee afzonderlijke regimes werden gecreëerd die niet met elkaar in verbinding stonden.

Hieronder worden eerst de Verdragen inzake de civielrechtelijke aansprakelijkheid voor kernongevallen in vaste nucleaire installaties besproken (\$2.1.2). In $\$ 2.1 .3$ worden de Verdragen inzake de civielrechtelijke nucleaire aansprakelijkheid bij maritiem transport aan de orde gesteld.

\subsubsection{De Verdragen inzake de civielrechtelijke aansprakelijkheid voor kernongevallen in vaste kerninstallaties}

De Verdragen van de eerste generatie inzake de civielrechtelijke aansprakelijkheid voor kernongevallen die zich voordoen in vaste kerninstallaties kunnen, wat hun ontstaan betreft, worden opgedeeld in het regime dat werd uitgewerkt door de NEA enerzijds $(\$ 2.1 .2 .1)$ en dat uitgewerkt door het IAEA anderzijds $(\S 2.1 .2 .2)$.

\subsubsection{Het regime uitgewerkt door de NEA}

Het door de NEA uitgewerkte regime, bestaat op haar beurt uit twee Verdragen: het "basisverdrag" van Parijs van 29 juli 1960 en het Aanvullend Verdrag van Brussel van 31 januari 1963.

In oktober 2000 waren de volgende 14 landen lid van het Verdrag van Parijs en de Protocollen.

Von Busekist, O., "Le Protocole Commun relatif à l'application de la Convention de Vienne et de la Convention de Paris: Une passerelle entre les deux Conventions sur la responsabilité civile pour fes dommages nucléaires", Bulletin de Droit Nucléaire, nr. 43, juni 1989, 16. 


\section{Partijen bij het Verdrag van Parijs van 29 juli 1960}

\begin{tabular}{|c|c|c|c|}
\hline & \multicolumn{3}{|c|}{ Datum van toetreding of ratificatie } \\
\hline & Verdrag van Parijs & Protocol van 1964 & Protocol van 1982 \\
\hline In werking op & 1 april 1968 & I april 1968 & 7 oktober 1988 \\
\hline België & 3 augustus 1966 & 3 augustus 1966 & 9 september 1985 \\
\hline Denemarken & 4 september 1974 & 4 september $19 \overline{74}$ & 16 mei 1989 \\
\hline Duitsland & 30 september 1975 & 30 september 1975 & 25 september 1985 \\
\hline Finland & 16 juni 1972 & 16 juni 1972 & 22 december 1989 \\
\hline Frankrijk & 9 maart 1966 & 9 maart 1966 & 9 juli 1990 \\
\hline Griekenland & 12 mei 1970 & 12 mei 1970 & 30 mei 1988 \\
\hline Italië & 17 september 1975 & 17 september 1975 & 28 juni 1985 \\
\hline Nederland & 28 december 1979 & 28 december 1979 & 1 augustus 1991 \\
\hline Noorwegen & 2 juli 1973 & 2 juli 1973 & 3 juni 1986 \\
\hline Portugal & 29 september 1977 & 29 september 1977 & 28 mei 1984 \\
\hline Spanje & 31 oktober 1961 & 30 april 1965 & 7 oktober 1988 \\
\hline Turkije & 10 oktober 1961 & 5 april 1968 & 21 januari 1986 \\
\hline Verenigd Koninkrijk & 23 februari 1966 & 23 februari 1966 & 19 augustus 1985 \\
\hline Zweden & 1 april 1968 & 1 april 1968 & 8 maart 1983 \\
\hline
\end{tabular}

Essentieel is dat het Verdrag van Parijs uitsluitend betrekking heeft op vorderingen van individuele personen ${ }^{84}$; het voorziet in privaatrechtelijke mogelijkheden voor het terugvorderen van de geleden schade van de nucleaire exploitant die onder het Verdrag aansprakelijk is. Het Verdrag van Parijs introduceert inderdaad een aantal juridische principes (risicoaansprakelijkheid, kanalisatie van aansprakelijkheid, beperking van de aansprakelijkheid, ...) die in het inteme nucleaire aansprakelijkheidsrecht van de verschillende Staten dienen te worden opgenomen. De verschillende Verdragsluitende Staten hebben dan ook de in het Verdrag neergelegde principes via een nationale wet ingevoerd in de nationale rechtsorde - hoewel het Verdrag zelf hicrtoe geen expliciete verplichting bevat ${ }^{85}$. Voomamelijk op het vlak van de opvolging van deze nationale

84 Horbach, N.L.J.T., "Lacunea of International Nuclear Liability Agreements", in Horbach, N.L.J.T., Contemporary Developments in Nuclear Energy Law. Harmonising Legislation in CEEC/NIS, Kluwer Law Intemational, Den Haag, Boston, 1999, 45.

85 Volgens bepaalde auteurs zijn de bepalingen van het Verdrag voldoende duidelijk zodat zij "direct effect" hebben voor particulieren die op basis van het Verdrag kunnen worden aansprakelijk gesteld (Nguyen Quoc, D., Daillier, P. en Pellet, P., Droit International Public, $5^{\circ}$ druk, LGDJ, Parijs, 1994, 752). 
wetgeving en de communicatie naar andere Verdragsluitende Staten, speelt de NEA een belangrijke rol.

Uit de Exposé des Motifs ${ }^{85}$ bij het Verdrag valt af te leiden waarom de Verdragspartijen het opportuun, en zelfs noodzakelijk achtten om de wettelijke aansprakelijkheid van een exploitant te onderwerpen aan cen bijzonder regime.

De noodzaak een afzonderlijke regeling tot stand te brengen volgde volgens de Verdragspartners in de eerste plaats uit de vaststelling dat onder het (toen) geldende recht de exploitanten van kerninstallaties onbeperkt aansprakelijk zouden zijn, terwijl een onbeperkte financiële dekking onmogelijk kon worden verkregen ${ }^{87}$. Ten tweede wilde men vermijden dat al diegenen die betrokken zijn bij de bouw van een keminstallatie eveneens onbeperkt aansprakelijk zouden kunnen worden gesteld. Tegelijk meenden de Verdragsluitende Staten dat de aansprakelijkheid voor schade uit een kernongeval beperkt diende te worden.

Hiertegenover stond dat een dergelijke beperking van de aansprakelijkheid niet tot gevolg mocht hebben dat slachtoffers in de kou bleven staan. Het Verdrag heeft als het ware het midden gezocht. tussen het Förderungszweck en het Schutzzweck zoals dat vaak in de Duitse rechtsleer wordt genoemd ${ }^{88}$ : enerzijds kon kernenergie de welvaart verhogen en mocht de ontwikkeling ervan niet worden belemmerd door een potentieel zeer hoge schadelast; anderzijds dienden slachtoffers te worden beschermd tegen de gevolgen van schade veroorzaakt door een kemongeval. Maar indien de toegekende schadevergoeding te hoog zou zijn, dan kon dit de toekomst van de nucleaire sector in het gedrang brengen. Met andere woorden, zo luidde de filosofie, schadevergoeding voor het slachtoffer van een kernongeval was aanvaardbaar, zolang dit de groei van de nucleaire sector niet belenmerde ${ }^{89}$.

Tenslotte werd een internationale aanpak noodzakelijk geacht omdat volgens de Verdragsstaten de speciale regeling van de wettelijke aansprakelijkheid voor alle West-Europese landen zoveel mogelijk op gelijke beginselen diende te berusten en omdat de omvang van een kernongeval internationale samenwerking tussen nationale verzekeringspools noodzakelijk maakte, met name door co-assurantie en herverzekering ${ }^{90}$.

Het Verdrag van Parijs werd in de loop der jaren aangepast door twee Protocollen. Het Protocol bij het Verdrag van Parijs van 28 januari 1964 bracht een zekere harmonisatie tot stand met de bepalingen van het Verdrag van Wenen. Het Protocol van 16 november 1982 had tot doel de

${ }^{86}$ Dit Exposé geldt als officiecel commentaar bij het Verdrag. Een Engelse en Franse versie vindt men in de door de OESO uitgegeven tekst van het Verdrag van Parijs; voor een Nederlandse vertaling, zie bijvoorbeeld Tractatenblad, 1964, 175, 49 e.v.

"Lcs experts sont, pour la plupart, enclins à estimer que la probabilité d'une catastrophe due à l'énergie nucléaire est extrêmement faible, mais, si minime que soit le risque, un accident reste possible qui pourrait causer des dommages considérables. Les charges financières très lourdes que pourrait entraîner cette responsabilité illimitée risqueraient de compromettre sérieusement le développement de l'industrie nucléaire" (Exposé des Motifs, punt 2).

Voomamelijk bij Fischerhof, Deutsches Atomgesetz und Strahlenschutrecht, Baden-Baden, 1962, 144 e.v.

Zie ook: Bauer, R, "Les projets de l'OECD et de l'Euratom relatifs à une convention sur la responsabilité civile dans le domaine de l'énergie atomique", Puget, H. (red.), Aspects du droit de l'énergie atomique, Parijs, 1965, 6.

Exposé des Motifs, nr. 3. 
herziening van de beschikbare bedragen, de harmonisatie van de wetgeving van de verschillende Verdragsstaten te versterken en het aanbrengen van enkele redactionele aanpassingen ${ }^{9 !}$.

Reeds bij de adoptie van het Verdrag van Parijs beseften de verschillende Verdragsstaten dat het bedrag van de aansprakelijkheid van de exploitant ontoereikend was om alle uit een kernongeval voortvloeiende schade te kunnen vergoeden. Geoordeeld werd dat de Staat op ad hoc basis diende tussen te komen ingeval de bedragen beschikbaar op basis van het Verdrag van Parijs, onvoldoende zouden blijken ${ }^{92}$. Later groeide toch de consensus dat, naar het voorbeeld van de uniforme regelen van het Verdrag van Parijs, het wenselijk zou zijn dat ook deze Staatstussenkomst op uniforme wijze zou worden geregeld ${ }^{93}$.

De noodzaak om te voorzien in een tussenkomst van de Staat, zou overigens zijn ingegeven door buitenlandse leveranciers van de Westerse exploitanten van een kerninstallatie. Deze leveranciers waren bevreesd dat door de beperking van de aansprakelijkheid van de exploitant onder het Verdrag van Parijs, zij toch nog aansprakelijk zouden kunnen worden gesteld ${ }^{94}$. In die zin zou dus eerder de druk van de leveranciers dan wel het belang van slachtoffers aan de bron liggen van de adoptie van het Aanvullend Verdrag van Brussel ${ }^{95}$. De regeringen van de exporterende landen gingen zelfs zover om leveringen door hun leveranciers te stoppen, tenzij in bijkomende middelen werd voorzien. Dit zou in het bijzonder het geval zijn geweest tussen de landen van Euratom en de $\mathrm{VS}^{96}$.

Het Verdrag kwam tot stand in overleg met de NEA, hoewel de 6 originele Euratom-lidstaten in feite het initiatief hadden genomen ${ }^{97}$. Dit Verdrag vormt een aanvulling op het Verdrag van Parijs en is in wcrking getreden op 4 december 1974 . Het betreft een Verdrag met accessoir karakter ${ }^{98}$ in die zin dat het krachtens artikel 1 onderworpen is aan de bepalingen van het Verdrag van Parijs.

Ook het Aanvullend Verdrag van Brussel werd aangepast door het Protocol van 16 november 1982; hierbij werden de bijzondere hogere trekkingsrechten bepaald en werden de vergoedingsschijven verhoogd.

In oktober 2000 waren de volgende 11 landen lid van het Aanvullend Verdrag van Brussel en de protocollen.

Lagorce, M., "Bilan et analyse critique de la Convention de Paris et de la Convention Complémentaire de Bruxelles après les Protocoles de 1982", o.c., 25. Bette, A., Didier, J.M., Fomasier, R., Stein, R.M., La Réparation des Dommages Nucléaires en Europe. Régime instauré par la Convention de Bruxelles du 31 janvier 1963, Brussel, 1965, 10. lbidem. Arangio-Ruiz, G., "Some International Legal Problems of the Civil Uses of Nuclear Energy", Revit des Cours, Académie de Droit International, 1962, toure 107 de la collection, A.W. Sijthoff, Leiden, $1963,599$.

Doeker, G. en Gehring, T., "Private or International Liability for Transnational Environmental Damagc - the precedent of conventional liability regimes", Journal of Environmental Law, vol.2, $\pi^{\circ} 1,1990$, 10.

Arangio-Ruiz, G., "Some Intemational Legal Problems of the Civil Uses of Nuclear Energy", o.c., 599.

Zie hierover Domsdorf, E.P.M.W., "Internationaal Atoomenergierecht", l.c., 745. 


\section{Partijen bij het Aanvullend Verdrag van Brussel van 31 januari 1963}

\begin{tabular}{|c|c|c|}
\hline & \multicolumn{2}{|c|}{ Datum van toetreding of ratificatie } \\
\hline & $\begin{array}{l}\text { Verdrag van Brussel en } \\
\text { Protocol van } 1964\end{array}$ & Protocol van 1982 \\
\hline In werking op & 4 december 1974 & 1 augustus 1991 \\
\hline België & 20 augustus 1985 & 20 augustus 1985 \\
\hline Denemarken & 4 september 1974 & 10 mei 1989 \\
\hline Duitsland & 1 oktober 1975 & 25 september 1985 \\
\hline Finland & 14 januari 1977 & 15 januari 1990 \\
\hline Frankrijk & 30 maart 1966 & 11 juli 1990 \\
\hline Italiề & 3 februari 1976 & 14 juni 1985 \\
\hline Nederland & 28 september 1979 & 1 augustus 1991 \\
\hline Noorwegen & 7 juli $197 \overline{3}$ & 13 mei 1986 \\
\hline Spanje & 27 juli 1966 & 29 september 1988 \\
\hline Verenigd Koninkrijk & 24 maart 1966 & 8 augustus 1985 \\
\hline Zweden & 3 april 1968 & 22 maart 1983 \\
\hline
\end{tabular}

Behalve Portugal, Griekenland en Turkije, zijn alle partijen van het Verdrag van Parijs eveneens partij bij het Aanvullend Verdrag van Brussel.

Het Aanvullend Verdrug van Brussel voorziet in bijkomende middelen indien de aansprakelijkheidsdekking van de exploitant, zōals voorzien in het Verdrag van Parijs, ontocreikend zou zijn. Het Brusselse Verdrag voorziet in twee additionele schijven, namelijk een schijf die wordt betaald door de Staat waar de kerninstallatie is gelegen en een schijf die wordt gefinancierd door alle Verdragsstaten.

Artikel 3 van het Aanvullend Verdrag van Brussel verplicht de Verdragsluitende Staten om "ervoor zorg te dragen" dat de schade uit een kernongeval wordt vergoed tot een bedrag van 300 miljoen Bijzondere Trekkingsrechten (BTR) of 429,31 miljoen euro per ongeval. Dit bedrag wordi samengesteld uit de volgende schijven:

- een eerste schijf van minimum 5 miljoen BTR ten laste van de aansprakelijke exploitant;

- een tweede schijf tussen dit bedrag en 175 miljoen BTR ten laste van de Stáat op wiens grondgebied de installatie van de aansprakelijke exploitant is gelegen;

- een derde schijf tussen 175 miljoen BTR en 300 miljoen BTR ten laste van de Verdragsluitende Staten a ruto van het BNP en het thermisch vermogen van de reactoren ${ }^{99}$. 
Het Aanvullend Verdrag van Brussel laat de verschillende Verdragsluitende Partijen vrij te kiezen uit twee systemen om het vooropgestelde minimum schadevergoedingsbedrag samen te stellen (artikel 3, c van het Verdrag). Ofwel wordt het bedrag der aansprakelijkheid vastgesteld op 300 miljoen bijzondere trekkingsrechten. Dit bedrag wordt samengesteld uit enerzijds het bedrag dat de exploitant verkregen hceft via verzekering of financiële zekerheid; en anderzijds worden bovenop dit bedrag aan de exploitant openbare middelen ter beschikking gesteld ter dekking van zijn aansprakelijkheid. Ofwcl wordt het maximumbedrag der aansprakelijkheid vastgelegd op een niveau waarvoor de exploitant op de verzekeringsmarkt dekking kan vinden; bovenop dit bedrag worden tot 300 miljoen bijzondere trekkingsrechten beschikbaar gesteld. Deze openbare middelen worden dan door de Staat rechtstreeks ter beschikking gesteld aan de slachtoffers.

In het eerste geval dienen de openbare middelen dus rechtstreeks ter dekking van de aansprakelijkheid van de exploitant; in het tweede geval daarentegen wordt het totale schadevergoedingsbedrag opgesplitst in verschillende schijven, waarvan de aansprakelijkheid er één is.

Het belang van het Aanvullend Verdrag van Brussel is bijgevolg dat het voorziet in een financiële tussenkomst uit de openbare middelen van de Staat waar het kernongeval zich heeft voorgedaanen bijgevolg een soort van aansprakelijkheid van de Staat invoert in het regime van het Verdrag van Parijs ${ }^{100}$ - én in een solidaire bijdrage van de verschillende Verdragsluitende Staten ${ }^{101}$. Hiermee is ook het voornaamste verschil aangetoond tussen het Verdrag van Parijs en het Aanvullend Verdrag van Brussel. Het Verdrag van Parijs voorziet in een aantal regels die in het nationale privaatrecht dienen te worden omgezet, terwijl het Aanvullende Verdrag van Brussel in essentie de onderlinge relaties regelt tussen de verschillende Verdragsluitende Staten ingeval de onder het Verdrag van Parijs beschikbare vergoeding ontoereikend blijkt te zijn ${ }^{102}$. Hierbij moet voor ogen worden gehouden dat een verdragsluitende Staat niet kan worden verplicht om de openbare middelen ter beschikking te stellen zolang er nog middelen beschikbaar zijn uit de eerste schijf; indien met andere woorden de aansprakelijkheidsdekking van de exploitant van de kerninstallatie nog niet is uitgeput ${ }^{103}$.

Hier dient dan ook te worden onderstreept dat het Aanvullend Verdrag van Brussel geen enkele wijziging aanbrengt aan de principes van het Verdrag van Parijs (risicoaansprakelijkheid, kanalisatie etc.). Volgens artikel 1 van het Aanvullend Verdrag van Brussel is het immers onderworpen aan de bepalingen van het Verdrag van Parijs.

Op basis van deze bijkomende publieke fondsen, verleent artikel 8 van dit Verdrag aan cenieder die aanspraak kan maken op schadevergoeding, het recht op volledige vergoeding van de geleden schade overeenkomstig het nationale recht. Uit de redactie van artikel 8 van het Aanvullend Verdrag van Brussel blijkt evenwel dat dit recht op volledige schadevergoeding enkel geldt in zoverre

$50 \%$ op grondslag van de verhouding tussen het BNP tegen lopende prijzen van elke Partij enerzijds, en het gezamenlijk bedrag van het BNP tegen lopende prijzen van alle Partijen anderzijds, zoals deze cijfers voor het jaar voorafgaan, worden afgeleid uit de statistieken gepubliceerd door de OESO;

$50 \%$ op de grondslag van de verhouding tussen het thermisch vermogen van de reactoren die zich op het grondgebied van elke Partij bevinden enerzijds, en het gezamenlijk thermisch vermogen van de reactoren die zich op het grondgebied van alle Partijen bevinden anderzijds. Horbach, N.L.J.T., "Lacunea of International Nuclear Liability Agreements", in Horbach, N.L.J.T., "Contemporary Developments in Nuclear Energy Law", l.c., 49.

101 Zie hierover Lagorce, M., "The Brussels Supplementary Convention and its Joint Intergovernmental Security Fund", o.c., 143 e.v. rope", l.c., 63.

Artikel 9, $\mathrm{c}$ van het Aanvullend Verdrag van Brussel. 
de totale schade niet hoger is dan de op basis van het Verdrag van Parijs en van Brussel beschikbare bedragen: indien de totale schade hoger is dan 300 miljoen BTR, kan elke Partij maatstaven vaststellen met het oog op een billijke vergoeding van de geleden schade.

Tenslotte moet worden gewezen op het belang van de gekozen terminologie: op basis van het Aanvullend Verdrag van Brussel verbinden de Verdragsstaten zich ertoe om bepaalde bedragen ter beschikking te stellen. Nergens in het Verdrag wordt gesproken van een internationale aansprakelijkheid van de Staat; het lijkt inderdaad een bewuste keuze te zijn geweest om geen directe bepalingen in dit verband in te voeren. De financiële tussenkomst van de verschillende Verdragsstaten zou verband houden met hun hoedanigheid als vergunningverlenende Staat ${ }^{104}$.

\subsubsection{Het regime uitgewerkt door het LAEA: het Verdrag van Wenen van 21 mei $1963^{105}$}

Het Verdrag van Wenen staat open ter ondertekening voor alle leden van de Verenigde Naties. Toch heeft het slechts een beperkt succes gekend: zo duurde het tot 1977 eer het in werking trad en telde het Verdrag, ten tijde van het ongeval in Tsjemobyl, 10 leden waarvan er slechts twee nucleaire activiteiten hadden ${ }^{106}$. In oktober 2000 waren de volgende 32 landen toegetreden tot het Verdrag van Wenen.

Doeker, G. en Gehring. T., "Private or Intemational Liability for Transnational Environmental Damage - the precedent of conventional liability regimes", o.c., 12.

Voor een bespreking van dit Verdrag, zic o.m.: Domsdorf, E.P.M.W., "Internationaal Atoomenergierecht", l.c., 763 e.v.; Martinez Favini, J., "Application de la Convention de Vienne et mise en pratique au niveau mondial des principes de la responsabilité civile en matière nucléaire", in Nuclear Accidents. Liabilities and Guaraniees, OECD-NEA, 1993, 43-59.

"Nuclear Liability and Compensation for Nuclear Damage", l.c., 57
} 


\section{Partijen bij het Verdrag van Wenen van 21 mei 1963}

(in werking op 12 november 1977)

\begin{tabular}{|c|c|}
\hline Land & Datum van in werking treden \\
\hline Argentinië & 12 november 1977 \\
\hline Armenië & 24 november 1993 \\
\hline Bolivië & 12 november 1977 \\
\hline Bosnië-Herzegovina & 1 maart 1992 \\
\hline Brazilië & 26 juni 1993 \\
\hline Bulgarije & 24 november 1994 \\
\hline Chili & 23 februari 1990 \\
\hline Croatië & 8 oktober 1991 \\
\hline Cuba & 12 november 1977 \\
\hline Egypte & 12 november 1977 \\
\hline Estland & 9 augustus 1994 \\
\hline Filippijnen & 12 november 1977 \\
\hline Hongarije & 28 oktober 1989 \\
\hline Joegoslavië & 12 november 1977 \\
\hline Kameroen & 12 november 1977 \\
\hline Letland & 15 juni 1995 \\
\hline Libanon & 17 juli 1997 \\
\hline Litouwen & 15 december 1992 \\
\hline Mexico & 25 juli 1989 \\
\hline Niger & 24 oktober 1979 \\
\hline Peru & 26 november 1980 \\
\hline Polen & 23 april 1990 \\
\hline Republiek Moldavië & 7 augustus 1998 \\
\hline Republiek Tsjechië & 24 juni 1994 \\
\hline Roemenië & 29 maart 1993 \\
\hline Slovakije & 7 juni 1995 \\
\hline Slovenië & 25 juni 1991 \\
\hline Trinidad-Tobago & 12 november 1977 \\
\hline Ukraïne & 20 december 1996 \\
\hline Uruguay & 13 juli 1999 \\
\hline Voorm. Joegosl. Rep. Macedonië & 8 september 1991 \\
\hline Wit-Rusland & 9 mei 1998 \\
\hline
\end{tabular}

Uit dit overzicht blijkt dat in de jaren negentig een twintigtal landen lid is geworden van het Verdrag, maar dat dese toename in belangrijke mate is toe tc schrijven aan het uiteenvallen van 
het voormalige Oostblok ${ }^{107}$. Het Verdrag van Wenen is inderdaad geratificeerd door maar liefst 18 landen uit het voormalige Oostblok. Meer dan de helft van de leden van het Verdrag van Wenen zijn dus landen uit Oost-Europa. De grootste afwezige blijft voorlopig de Russische Federatie, dat het Verdrag weliswaar heeft ondertekend op 6 mei 1996, maar dat nog steeds wacht met de ratificatie ervan ${ }^{10 s}$.

Eerder werd reeds aangestipt dat het Verdrag van Wenen dezelfde basisbeginselen hanteert als het Verdrag van Parijs. Het meest opmerkelijke verschil tussen beide Verdragen is dat het Verdrag van Wenen in een lagere aansprakelijkheidslimiet voorziet dan het Verdrag van Parijs. Krachtens artikel 5, lid 1 van het Verdrag van Wenen mag de aansprakelijkheid van de exploitant van een kerninstallatie niet lager zijn dan 5 miljoen USD. Dit terwijl de minimale aansprakelijkheid onder het Verdrag van Parijs 19,64 miljoen dollar bedraagt ${ }^{109} 110$.

Tegelijk is in het Verdrag van Wenen, in tegenstelling tot het regime uitgewerkt door de NEA, slechts indirect sprake van de financiële tussenkomst van de Staat: enkel ingeval de door de exploitant gestelde financiële zekerheid ontoereikend is om het gehele bedrag van diens aansprakelijkheid te dekken, zal de Staat ertoe gehouden zijn om tussen te komen tot maximaal het bedrag waarvoor de exploitant aansprakelijk is ${ }^{11 !}$. Hier ligt meteen het voornaamste verschil tussen de nucleaire aansprakelijkheidsregimes van de eerste generatie: het regime van de NEA (Verdrag van Parijs en Aanvullend Verdrag van Brussel) omvat een financiële tussenkomst van de Staat, hetgeen niet het geval is onder het regime van het IAEA (Verdrag van Wenen). Hier kan worden

Het is overigens zeer de vraag of de toetreding van be voormalige Oostbloklanden is ingegeven door de bekommemis orn aan slachtoffers van een kemongeval afủoende garanties to bieden inzake preventic en schadevergoeding, dan wel door andere overwegingen. De mogelijkheid orn nucleaire technologie aan te kopen wordt vaak afhankelijk gesteld van het toetreden tot het internationale kemenergierecht. Slechts een beperkt aantal landen in de wereld beschikt over de technologie en kennis, noodzakelijk voor de bouw van kemcentrales. Indien een bepaald land bijgevolg kemenergie wenst aan te wenden ter dekking van haar elektriciteitsbehoeften, zal dat land zich moeten richten tot een gering aantal leveranciers. Deze hebben zich verenigd in de Nuclear Suppliers Group zzie hierover Carchon. $\mathrm{R}$. De non-proliferatie van kernwapens en internationale conirole, SCK/CEN, NN-3605, 1995, 3637), met tot doel te garanderen dat de export van nucleaire technologie en nucleair materiaal steeds vergezeld gaat met het onderschrijven, door de bestemmeling, van de voornaamste intemationale nucleaire Verdragen (waaronder in eerste instantie het Non-Proliferatieverdrag, maar ook het Verdrag van Wenen). Deze problematiek is zeer actueel in verband met landen van het voormalige Oostblok de westerse leveranciers zijn slechts bereid nucleair material te leveren indien het land van bestemming lid is van bovenvermelde Verdragen - hetgeen verklaart waarom een aanzienlijk aantal landen van het voormalige Oostblok in de loop van de jaren negentig het Verdrag van Wenen heeft ondertekend.

Voor een uitstekend overzicht van de wetgeving inzake nucleaire aansprakelijkheid in de landen van het voormalige Oostblok, zie verschillende bijdragen in Horbach, N.L.J.T., "Contemporary Developments in Nuclear Energy Law", I.c. In augustus 2000 was de waarde van 1 BTR $=1,30955$ USD; de minimumlimiet krachtens het Verdrag van Parijs bedraagt 15 miljoen BTR.

De vergelijking tussen de beschikbare bedragen onder beide regimes wordt bemocilijkt aangezien het Verdrag van Wenen het aansprakelijkheidsbedrag in dollar vermeldt, terwijl het Verdrag van Parijs werkt via de Bijzondere Trekkingsrechten van het IMF. Het Protocol van het Verdrag van Wenen varr 1997 verandert deze situatie en hanteert eveneens de BTR.

Artikel VII van het Verdrag van Wenen. Zie ook Official Records Vienna Convention, 81. 
gesproken van een asymmetrie tussen beide regimes die door sommigen als een van de grootste tekortkomingen van het Verdrag van Wenen wordt beschouwd ${ }^{112}$.

Voor het overige zijn grotendeels dezelfde principes terug te vinden als in het Verdrag van Parijs. Toch biedt het Verdrag van Wenen op bepaalde punten aanzienlijk minder bescherming dan het Verdrag van Parijs. Zo bestaat onder het Verdrag van Wenen het risico dat in welbepaalde gevallen ${ }^{113}$ de uitvoering van een rechterlijke uitspraak bekomen in een andere Verdragsstaat, zal worden aangevochten, terwijl het Verdrag van Parijs bepaalt dat een vonnis dat uitvoerbaar is krachtens het recht van de rechtsprekende rechtbank, eveneens uitvoerbaar is op het grondgebied van elke andere Verdragsluitende Staat ${ }^{114}$. Dit element toont eens te meer aan dat het universele karakter van het Verdrag van Wenen ook duidelijke nadelen heeft. De erkenning van een buitenlands vonnis wordt zeer moeilijk naarmate meer landen met verschillende culturele achtergrond tot het Verdrag toetreden.

$\mathrm{Na}$ het ongeval in Tsjernobyl gingen de Verdragsluitende Partijen van beide Verdragen rond de tafel zitten om conflicten tussen beide regimes te vermijden en om de andere naar aanleiding van het ongeval vastgestelde tekortkomingen het hoofd te bieden. Dit wordt verderop aan de orde gesteld, bij de bespreking van het Gemeenschappelijk Protocol van $1988^{115}$. In deze paragraaf werden de verdragen besproken inzake de civielrechtelijke aansprakelijkheid voor ongevallen in vaste kerninstallaties. Een ander deel van de verdragen van de eerste generatie had betrekking op het transport van nucleair materiaal over de zee.

\subsubsection{Verdragen inzake de civielrechtelijke aansprakelijkheid voor kernongevallen bij maritiem transport ${ }^{116}$}

De civielrechtelijke nucleaire aansprakelijkheid bij transport wordt zowel geregeld in het Verdrag van Parijs van 1960 als in het Verdrag van Wenen van 1963. Beide Verdragen bepalen in grote lijnen dat wanneer zich bij vervoer van nucleaire stoffen een kemongeval voordoet buiten de kerninstallatie, de exploitant van wie de nucleaire stoffen afkomstig zijn of de exploitant-bestemmeling van deze stoffen, aansprakelijk is overeenkomstig het Verdrag van Parijs of Wenen ${ }^{17}$. Maar bij kernongevallen op zee kunnen zich problemen voordoen, hetzij omdat het Verdrag van Parijs of het Verdrag van Wenen niet van toepassing is (met name bij nucleaire schepen), hetzij omdat conflicten tussen het kemenergierecht en het zeerecht niet zijn uit te sluiten (met name bij transport van nucleaire stoffen). Om mogelijke conflicten te vermijden werd voor beide hypotheses een afzonderlijk Verdrag opgesteld, namelijk het Verdrag van 25 mei 1962 voor wat betreft nucleaire schepen $(\$ 2.1 .3 .1)$ en het Verdrag van 17 december 1971 voor wat betreft het maritiem transport van nucleaire stoffen $(\$ 2.1 .3 .2)$.

Met name door Horbach, N.L.J.T., "Lacunea of International Nuclear Liability Agreements", in Horbach, N.L.J.T., "Contemporary Developments in Nuclear Energy Law", l.c., 53.

Met name indien de uitspraak werd verkregen via fraude, indien de veroordeelde geen eerlijke kans heeft gekregen om zijn zaak naar voren te brenger of indien de uitspraak strijdig is met de openbare orde ("openbare orde" is een eigen vrije vertaling van de tekst van het Verdrag; deze heeft het over strijdigheid met de "public policy" en de "fundamental standards of justice") (artikel XII van het Verdrag van Wenen). Artikel 13, d) van het Verdrag van Parijs. Cfr. infra, in $\$ 2.2 .2 .1$.

In hoofdstuk 5 wordt de nucleaire civielrechtelijke aansprakelijkheid bij vervoer verder besproken. Voor een analyse van het Belgische strafrechtelijke nucleaire aansprakelijkheidsrecht bij vervoer, zie Spriet, B., "De strafrechtelijke aansprakelijkheid voor het transport van nucleait materiaal naar Belgisch recht", in Faure, M., "Aansprakelijkheid voor het nucleaire risico", I.c., 89-118. 


\subsubsection{Het Verdrag van Brussel van 25 mei 1962 inzake de aansprakelijkheid van exploitanten van nucleaire schepen ${ }^{118}$}

Nucleaire schepen vallen niet onder het toepassingsgebied van het Verdrag van Parijs: volgens artikel 1 a (ii) van het Verdrag van Parijs vallen reactoren die deel uitmaken van ecn vervoermiddel niet onder het Verdrag.

Daarom diende een afzonderlijk Verdrag te worden opgesteld voor wat betreft de aansprakelijkheid van nucleaire schepen ${ }^{19}$. In dit kader kwam het Verdrag van Brussel van 25 mei 1962 tot stand. Het verschilt van de andere Verdragen inzake nucleairc civielrechtelijke aansprakelijkheid doordat het niet is tot stand gekomen onder auspiciën van het IAEA of van de NEA, maar wel in het kader van de International Maritime Organisation (IMO).

Het Verdrag is van toepassing op een nucleair ongeval dat zich voordoet tengevolge van de splijtstoffen van, of de radioactieve producten of afval geproduceerd in nucleaire schepen varende onder de vlag van een Verdragsstaat. Slechts vier landen zijn lid van dit Verdrag: Nederland ${ }^{120}$, Portugal, Zaïre en Malaga ${ }^{121}$; het Verdrag was in oktober 2000 nog steeds niet in werking getreden.

Meerdere redenen liggen ten grondslag aan de terughoudendheid van Staten om dit Verdrag te ondertekenen. Ten eerste zijn er nauwelijks nucleaire commerciële schepen in de omvaart. Indien een nucleair schip een haven wil binnenvaren, worden in beginsel specifieke overeenkomsten opgesteld tussen de haven-Staat en de vlagstaat. Bovendien is het Verdrag van toepassing op nucleaire schepen, terwijl de landen met een aanzienlijke nucleaire militaire vloot geen lid wensen te worden ${ }^{122}$

De grote principes van dit Verdrag zijn dezelfde als de principes neergelegd in het Verdrag van Parijs en Wenen. Wel zijn de aansprakelijkheidsbedragen onder dit maritieme Verdrag een stuk lager ${ }^{123}$ en kan een slachtoffer kiezen of hij zijn vordering instelt bij de rechter van de vlagstaat dan wel bij de rechter van het land waar de schade werd geleden.

118 Zie hierover uitgebreid Arangio-Ruiz, G., "Some International Legal Problems of the Civil Uses of Nuclear Energy", o.c., 601.

119 Hieronder wordt verstaan ieder schip dat is uitgerust met een nucleaire krachtinstallatie (artikel I, I van het Verdrag). Onder "nucleaire krachtinstallatie" wordt verstaan iedere installatie ter opwekking van energie waarin een kemreactor wordt gebruikt of bestemd is te worden gebruikt als krachtbron, hetzij voor de voortboweging van het schip, hetzij voor cnig ander doel (artikel I, 9 van het Verdrag). Nederland heeft dit Verdrag verder uitgewerkt in de Wet aansprakelijkheid exploitanten nucleaire schepen (Wans) van 24 oktober 1973, Staatsblad, 536; de tekst van het Verdrag. zie Tractatenblad, 1968 , пг. 90.

121 "Nuclear Liability and Compensation for Nuclcar Damage", l.c., 61; Tonnacr, F.P.C.L., "Handboek Nedcrlands Milieurecht", I.c., 264 en 1287; Domsdorf, E.P.M.W., "Internationaal Atoomenergierecht", l.c., 802 e.v.

122 "Nuclear Liability and Compensation for Nuclear Damage", l.c., 61.

123 De Nederlandse wet aansprakelijkheid exploitanten nucleaire schepen (Wans) voorzict in een aansprakelijkheidslimiet van 100 miljoen gulden, terwijl de WAKO een limiet voorschrijft van 750 miljocn gulden. 


\subsubsection{Het Verdrag van Brussel van 17 december 1971 inzake de wettelijke aansprakelijkheid op het gebied van zeevervoer van nucleaire stoffen ${ }^{124}$}

Artikel 6 b) van het Verdrag van Parijs laat onverlet de toepassing van internationale overeenkomsten op het gebied van vervoer. Bijgevolg beschikt een slachtoffer van een kemongeval dat heeft plaatsgevonden naar aanleiding van een maritiem transport van nucleaire stoffen, over twee mogelijke vorderingen: één tegen de vervoerder op basis van het maritieme recht ${ }^{125}$ en één tegen de aansprakelijke nucleaire exploitant ingevolge het Verdrag van Parijs ${ }^{126}$. Indien tijdens het vervoer een ongeval plaatsheeft met nucleaire stoffen waarvoor een exploitant aansprakelijk is overeenkonnstig het Parijse of Weense Verdrag en indien de vlagstaat lid is van een maritiem Verdrag, kunnen twee regimes van kracht zijn: het "nucleaire" en het "maritieme" regime ${ }^{127}$.

Dit kon leiden tot problemen op het vlak van de aansprakelijkheidsvordering. Bovendien werd het feit dat de bedragen waarvoor de eigenaar van het schip aansprakelijk kon worden gesteld hoger lagen dan deze in de Verdragen van Parijs en Wenen, als problematisch beschouwd. Een mogelijk conflict tussen het zeerecht en het kemenergierecht zou kunnen rijzen indien de eigenaar van een zeeschip een regresvordering zou instellen tegen de exploitant van een kerninstallatie en dit voor een hoger bedrag dan het bedrag waarvoor de exploitant onder de nucleaire verdragen aansprakelijk kan worden gesteld. Eigenaars van zeeschepen waren in die omstandigheden enkel bereid om nucleair materiaal te vervoeren indien zij van de exploitant van de kerninstallatie een onbeperkte garantie kregen voor de schade uit een kernongeval bij maritiem transport; de verzekeraars van de exploitant achtten het evenwel onmogelijk om een dergelijke garantie aan te bieden ${ }^{128}$.

Door deze onzekerheid weigerden verzekeringsmaatschappijen dekking te verlenen voor zeetransport van nucleaire stoffen. Teneinde de onzekerheid weg te nemen, hebben de NEA, het IAEA en de IMO het Verdrag inzake civiele aansprakelijkheid op het gebied van zeevervoer van nucleaire stoffen opgesteld. Het werd van kracht op 15 juli 1975 en telde einde 199314 leden ${ }^{129} 130$.

Het Verdrag van Brussel stelt de exploitant van een nucleaire installatie exclusief aansprakelijk voor schade door een nucleair ongeval dat zich voordoet tijdens maritiem vervoer van nucleaire

Voor de tekst van het Verdrag, zie Tractatenblad, 1974, 199. Voor een bespreking van de bepalingen van dit Verdrag, zie Strohl, P., "La Convention de 1971 relative à la responsabilité civile dans le domaine du transport maritime de matières nucléaires", Annuaire Français de Droit International, 1972, $755-760$.

Hierbij werd met name gedacht aan het Verdrag van Brussel van 23 september 1910 tot het vaststellen van enige eenvormige regelen betreffende aanvaring, het Verdrag van Brussel van 25 augustus 1924 ter vaststelling van enige eenvormige regelen betreffende het cognossement, het Verdrag van Brussel van 25 augustus 1924 en van 10 oktober 1957 betreffende de beperking van de aansprakelijkheid van eigenaren van zeeschepen.

Lagorce, M., "Le Transport de Matières Nueléaires sous le Régime de la Convention de Bruxelles de 197I", 1975, 63; Veuchelen, L., "De civielrechtelijke aansprakelijkheid voor kernongevallen naar Belgisch recht", in Faure, M., "Aansprakelijkheid voor het nucleaire risico", I.c., 41. Zie over de wisselwerking tussen het kemenergierecht en het zeerecht: Von Welck, S., "La troisième Conférence des Nations Unies sur le droit de la mer et l'utilisation de l'énergie nucléaire", Bulletin de Droit Nucléaire, $\mathrm{n}^{\circ} 15,1975,70-79$. Van Gijn, S.H., "Liability and Insurance Aspects of Intermational Transport of Nuclear Materials", in "Nuclear Third Party Liability and Insurance", l.c., 186.

"Nuclear Liability and Compensation for Nuclear Damage", l.c., 60; Tonnaer, F.P.C.L., "Handboek Nederlands Milieurecht", I.c., 264; Domsdorf, E.P.M.W., "Internationaal Atoomenergierecht", l.c., 804 e.v. 1991, 148). 
stoffen. Indien de exploitant van de kerninstallatie aansprakelijk is krachtens het Parijse of Weense Verdrag, of krachtens een nationale wet, ontheft artikel 1 van het Verdrag van Brussel elke persoon van de aansprakelijkheid die krachtens een internationale overeenkomst of een nationale wet betreffende zeevervoer op hem zou rusten. Aldus vestigt het Verdrag van Brussel van 1971 de primauteit van het kemenergierecht op het zeerecht ${ }^{131}$. Volledigheidshalve moet worden gewezen op artikel 4, d van het Verdrag van Parijs en artikel II.2 van het Verdrag van Wenen, die de mogelijkheid bieden om in het nationale recht een bepaling op te nemen dat, onder bepaalde voorwaarden, de vervoerder in plaats van de exploitant zal aansprakelijk zijn.

\subsection{Internationaal kernenergierecht na Tsjernobyl: de Verdragen van de tweede generatic}

De internationale nucleaire aansprakelijkheidsverdragen van de eerste generatie zijn in eenzelfde periode tot stand gekomen en werden, zeker tot aan het ongeval in Tsjemobyl, niet gewijzigd. De enige wijziging aan de eerste generatie nucleaire aansprakelijkheidsverdragen, was het Protocol van 1964 dat het regime van het Verdrag van Parijs wijzigde. Het Protocol van 1982 is pas in werking getreden in 1988 voor wat betreft het Verdrag van Parijs en in 1991 voor wat betreft het Aanvullend Verdrag van Brussel.

Over het algemeen wordt aangenomen dat het ongeval in Tsjernobyl het ecrste zware kemongeval was warbij schade aan derden werd veroor $\angle$ iakt ${ }^{132}$. Meteen na het Tsjernobyl ongeval besloot het IAEA cen aantal maatrcgelen te nemen teneinde een herhaling van een dergelijk ongeval to vermijden ${ }^{\text {iss }}$. Doordat grensoverschrijdende radioactiviteit in de atmosfeer werd verspreid, rezen vanuit intemationaalrechtelijke hoek vragen omtrent de informatieplicht van landen, het al dan niet bestaan van een plicht tot bijstand en uiteraard ook de uit een kernongeval voortvlociende schadevergoedingsplicht ${ }^{134}$.

Een eventuele schadevergoeding kon niet worden verkregen op basis van het Verdray van Wenen, aangezien noch de voormalige USSR, noch enig ander Europees land lid was van het Verdrag van Wenen ${ }^{135}$. Zelfs indien de USSR lid was geweest van het Verdrug van Wenen, konden de WestEuropese landen geen beroep doen op dit Verdrag, aangezien zij lid waren (en zijn) van het Verdrag van Parijs en aangezien, ten tijde van het ongeval, geen koppeling bestond tussen de territoriale werking van beide Verdragen. Ook waren de kansen om schadevergoeding te bekomen via

Deprimoz, J., "Régime juridique des Assurances contre les Risques Nucléaires", Editions du JurisChasseur, Fasc. 55, 1995/5, 17.

Voor een gedetaillecrd overzicht van de oorzaken en de radiologische gevolgen van het ongeval in Tsjemobyl, zie X., Chernobyl. Dix ans déjà. Impact radiologique et sanitaire, Evaluation établie par le Comité de protection radiologique et de sante publique de l'AEN, OECD-AEN, november 1995, 118; over de gevolgen van het ongeval, zie ook het themanummer van de IAEA-Bulletin: X., "One decade after Chemobyl: the basis for decisions", IAEA Bulletin, 3/1996, 14-23; X., "Post-Chemobyl scientific perspectives: Reports on topics addressed at technical sessions of the International Conference convened in Vienna 10 years after the Chernobyl accident", IAEA Bulletin, 3/1996, 24-47.

Voor een overzicht, zie Egan, J.R., "Preventing another Chernobyl: codes, practices and the role of new technology", in Cameron, P., Hancher, L., Kühn, W. (ed.), Nuclear Energy Law after Chernobyl, Graham and Trotman, 1988, 159-177.

Meer in detail, zie Sands, Ph., (ed.), Chernobyl: Law and Communication, Grotius Publications Limited, Cambridge, 1988, 5.

135

Over de juridische situatie ten tijde van het ongeval in Tsjemobyl: Joirysch, A. en Supataeva, O., "Compensation for damage caused by the Chernobyl accident", Nuclear Accidents. Liabilities and Guarantees, OECD, Paris, 1993, 70-79 en Joirysch, A. en Supataeva, O., "The problem of the Russian Legislation on Liability for Nuclear Damage", Nuclear Accidents. Liabilities and Guarantees, OECD, Paris, 1993, 80-91. 
het (toenmalige) intemationale recht ${ }^{136}$, via het international privaatrecht $t^{137}$, of om de USSR als Staat aansprakelijk te stellen ${ }^{138}$ voor het ongeval, vrij gering ${ }^{139}$. Vandaar werd, voorzover bekend, geen formele aanvraag tot schadevergoeding ingediend voor buiten de Sovjet-Unie geleden schade. Wel werd in de toenmalige Sovjet-Unie een wet goedgekeurd op basis waarvan vergoedingen werden uitgekeerd voor de aldaar geleden schade. Na het uiteenvallen van de Sovjet-Unie hebben de verschillende deelrepublieken dit beleid verder gezet en werden de bedragen ter compensatie van letselschade en zaakschade zelfs nog verhoogd ${ }^{140}$.

Sowieso was de Sovjet-Unie van oordeel dat de in West-Europa gemeten radioactiviteit ${ }^{141}$ voortkwam van de Westerse kerncentrales (en niet van het ongeval in Tsjernobyl) en dat de schade die in West-Europa werd geleden voortkwam uit de preventieve maatregelen die de verschillende landen hadden genomen ${ }^{142}$. Hiermee had de Sovjet-Unie twee essentiële problemen van het internationale nucleaire aansprakelijkheidsrecht aangeraakt: de moeilijkheid om een causaal verband te bewijzen tussen een ongeval en de geleden schade enerzijds en de invulling van het begrip "schade" anderzijds. Het kernongeval van Tsjernobyl had duidelijk gemaakt dat milieuschade, economische schade en kosten van preventieve maatregelen op basis van de nucleaire civielrechtelijke aansprakelijkheidsverdragen niet als "schade" konden worden gekwalificeerd en dat sowieso de onder deze Verdragen beschikbare bedragen veel te laag waren om alle schade te kunnen vergoeden ${ }^{143}$. Tsjernobyl had aangetoond dat, zelfs bij toepassing van de internationale Verdragen, de geleden schade slechts in zeer beperkte mate zou worden vergoed. Indien de internationale Verdragen van toepassing waren geweest, zou er evenwel geen onenigheid hebben bestaan omtrent de bevoegde rechtbank en het toepasselijke recht ${ }^{144}$.

Kiss, A, "L'accident de Tchernobyl et ses conséquences au point de vue du droit international", Annuaire Français de Droit International, 1986, 139-152.

Zie hierover Jessurun D'Oliviera, M.U., "IPR en Tsjemobyl. Privaatrechtelijke aansprakelijkheid voor grensoverschrijdende kemrampen", Nederlands Juristenblad, afl. 42, 1986, 1331-1334 en Kapteyn, P., "Vergoeding schade Tsjernobyl. Volkenrechtelijke Aspecten", Nederlands Juristenblad, afl. 42, 1986, 1329.

Zie hierover onder meer Barton, J., "After Chemobyl: Liability for Nuclear Accidents Under Intemational Law", Columbia Journal of Transboundary Law, 1988, 25(3), 653-654; Boyle, A.E., "Nuclear Energy and Intemational Law: An Environmental Perspective", British Yearbook of International Law, 1989, vol. $60,296$.

Over de toepassing van het recht van de Sovjet-Unie, zie Brodecki, Z., "The Polish-Soviet Disputes arising from the Chemobyl Accident - A hypothetical legal analysis", in La réparation des dommages catastrophiques. Les risques technologiques majeurs en droit international et en droit communautaire, Travaux des XIIles Joumées d'études Jean Dabin, Bruxelles, Bruylant, 1990, 249 e.v.

Bochler, M.C., "Reflections on Liability and Radiological or Nuclear Accidents: the accidents at Goiania, Forbach, Three Mile Island and Chemobyl", Nuclear Law Bulletin, $n^{\circ} 59,1997,23$. Welke bedragen ook daadwerkelijk op basis van deze wetten werden uitgekeerd, is onduidelijk.

Onderzoek na het ongeval heeft aangetoond dat nagenoeg het ganse grondgebied van West-Europa in mindere of meerdere mate radioactief werd besmet door de uit Tsjemobyl afkomstige radioactieve wolk (X., "Chernobyl. Dix ans déjà. Impact radiologique et sanitaire", I.c., 35 e.v.). Een overzicht van de gemeten radioactiviteit voor een aantal landen is terug te vinden in X., "Radiation levels: WHO reports on Chernobyl", met aansluitend "National Reports", in IAEA Bulletin, autumn 1986, 27 e.v. Pelzer, N., "La responsabilité civile dans le domaine nucléaire au lendemain de l'accident de Chernobyl", Bulletin de Droit Nucléaire, 1987, $\mathrm{n}^{\circ} 39,71-72$.

143 Horbach, N.L.J.T., "Liability versus Responsability under International Law", I.c., 265-272.

14 Pelzer, N., "Intemationales Atomrecht im Wandel - Auf dem Wege zu einer Nuklearen Sicherheitskonvention und zur Verbesserung des internationalen Atomhaftungsrecht", in Jahrbuch des Umwelt- und Technikrechts, Decker's Verlag, Heidelberg, 1994, 661. 
Het beperkte aantal landen dat ten tijde van het ongeval lid was van het Verdrag van Wenen - dat toch een uitgesproken universele roeping had - en de mogelijke problemen die zich zelfs bij toepassing van dit Verdrag (of van het Verdrag van Parijs) zouden hebben gesteld, toonden de noodzaak aan van een hervorming van het internationale kernenergierecht. Deze hervorming diende zowel te garanderen dat de risico's van het gebruik van kemenergie tot een aanvaardbaar minimum zouden worden teruggebracht en dat slachtoffers van een kernongeval konden rekenen op een snelle en volledige schadevergoeding ${ }^{145}$.

Vrij snel na Tsjernobyl kwam een aantal initiatieven op gang met tot doel de effectiviteit van de bestaande regimes te verbeteren ${ }^{146}$. De betrachting om het kernenergierecht uit het "pre-Tsjernobyl tijdperk" te verbeteren bleek uit het feit dat regelgeving tot stand werd gebracht in materies waar tot dan toe elke verdragstekst ontbrak en uit de wil om de bestaande aansprakelijkheidsregimes te verbeteren en om zoveel mogelijk landen aan te moedigen om tot deze Verdragen toe te treden. Deze verschillende thema's worden hieronder besproken. Hierbij worden in eerste instantie de nieuwe thema's bestudeerd $(\$ 2.2 .1)$. Vervolgens wordt aandacht besteed aan de verbeteringen aan de bestaande nucleaire aansprakelijkheidsregimes onder het Verdrag van Wenen en van Parijs (\$2.2.2).

\subsubsection{Nieuwe thema's van de Verdragen van de tweede generatie}

De "nieuwe thema's" die door de internationale gemeenschap na het ongeval in Tsjernobyl op de agenda werden geplaatst, betroffen in de eerste plaats maatregelen inzake de vroegtijdige kennisgeving en assistentie bij kernongevallen (\$ 2.2.1.1). In tweede instantie ging de aandacht uit naar verschillende manieren om de nucleaire veiligheid te verhogen $(\$ 2.2 .1 .2)$.

\subsubsection{Troegtijdige kennisgeving en assistentie bij kernongevallen}

Ten gevolge van het ongeval in Tsjernobyl kwamen in een record tempo (namelijk in vier weken $t_{i j d} \mathrm{~d}^{147}$ ) twee Verdragen tot stand die uitermate snel werden geratificeerd ${ }^{148}$. Op 26 september 1986 werden het Verdrag inzake vroegtijdige kennisgeving bij kernongevallen en het Verdrag inzake assistentie bij kernongevallen voor ondertekening opengesteld ${ }^{149}$; de Verdragen traden in

us Handl, G., "Transboundary Nuclear Accidents: the Post-Chemobyl Multilateral Legislative Agenda", Ecology Law Quarterly, vol. 15:203, 1988, 203-204.

146. Pelzer, N., "Concepts of Nuclear Liability Revisited: A Post-Chemobyl Assessment of the Paris and the Vienna Conventions", in Cameron, P., Hancher, L. en Külnn, W., Nuclear Energy Law after Chernobyl, Graham and Trotman, London-Dordrecht, 1988, 103.

16? Zie hierover Adede, A.O., The IAEA Notification and Assistance Conventions in Case of a Nuclear Accident. Landmarks in the Multilateral Treaty-Making Process, Graham and Trotman, LondonDordrecht, 1987, xix.

148 Voor een bespreking van deze Verdragen, zie onder meer Cameron, P., "The Vienna Conventions on early notification and assistance", in Cameron, P., Hancher, L. en Kühn, W., Nuclear Energy Law after Chernobyl, Graham and Trotman, London-Dordrecht, 1988, 19-32; Domsdorf, E.P.M.W., "Intemtationaal Atoomenergierecht", l.c., 1212-1233; Glaize, G., "Cadre Général des Conventions internationales relatives à la Notification des Incidents ou Accidents et à l'Assistance Mutuelle en cas d'Accident Nucléaire", in Nuclear Inter Jura '87, AIDN/INLA, Antweryen, 1987, C.23 e.v.; Politi, M., "International and Civil Liability for Nuclear Damage: Some Recent Developments of State Practice", in "La réparation des dommages catastrophiques", l.c., 323 e.v.; Flakus, F.N. en Johnson, L.D., "Binding Agreements for Nuelear Safety: the global legal framework", $I A E A$ Bulletin, vol. 40/2, 1998, 21 e.v.

Volledigheidshalve dient erop te worden gewezen dat voordien reeds algemene richtlijnen voorhanden waren ter zake van melding bij kernongevallen (met name de INFCIRC/310 van januari 1984 en de INFCIRC/321 van januari 1985) 
werking respectievelijk op 27 oktober 1986 en op 26 februari 1987. Hoewel deze Verdragen als dusdanig geen directe band hebben met de civiele nucleaire aansprakelijkheidswetgeving zijn deze Verdragen toch van belang in de mate waarin het nemen van snelle en adequate maatregelen onmiddellijk na een kernongeval een aanzienlijke invloed heeft op de gevolgen en de kosten daarvan.

Het Verdrag inzake vroegtijdige kennisgeving ${ }^{150}$ is volgens artikel 1 van toepassing op ${ }^{151}$ :

"elk ongeval waarbij installaties of werkzaamheden van een Staat die Partij is bij dit Verdrag, of van personen of rechtspersonen die onder zijn rechtsmacht of toezicht vallen (...) zijn betrokken en waarbij een radioactieve stof vrijkomt of waarschijnlijk vrijkomt, hetgeen heeft geleid of kan leiden tot een internationale grensoverschrijdende uitstoot die voor een andere Staat belangrijk kan zijn met betrekking tot de beveiliging tegen vrijgekomen radioactieve stoffen".

Het tweede lid van artikel 1 geeft vervolgens een op het eerste gezicht brede definitie van "installaties en werkzaamheden". Ook installaties voor de behandeling en opslag van radioactief afval vallen onder het Verdrag, evenals iedere installatie voor de vervaardiging, het gebruik, de opslag, de verwijdering en het vervoer van radio-isotopen voor agrarische, industriële en medische doeleinden, alsmede doeleinden op het gebied van de wetenschap en het wetenschappelijk onderzoek. Daarentegen is het Verdrag niet van toepassing op ongevallen die het gevolg zijn van militaire activiteiten.

Opvallend is verder dat het Verdrag geen definitie geeft van het begrip "kernongeval". Het is zeer de vraag of zonder meer kan worden verweyen naar de definities van het Verdrag van Parijs of

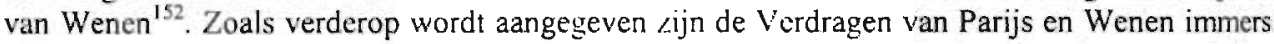
niet van tocpassing op ongevallen met radio-isotopen, terwijl het Verdrag inzake vroegtijdige kennisgeving daar wel op van toepassing is. Dit laatste Verdrag spreekt immers van "elk ongeval", terwijl het Verdrag van Parijs het heeft over een kemongeval.

Indien zich een ongeval voordoet, dient een lid van het Verdrag rechtstreeks, of door middel van het IAEA de Staten te waarschuwen die worden getroffen of kunnen worden getroffen door de gevolgen van het ongeval. Dezc informaticplicht is vrij ruim en behelst o.m. tijdstip, plaats en aard van het ongeval, de algemene kenmerken van de vrijgekomen stoffen en het voorspelde gedrag van die stoffen ${ }^{153}$. Bovendien is niet vereist dat een (buur)land daadwerkelijk wordt getroffen; het is voldoende dat een land mogelijkerwijze te maken krijgt met de uit een andere Verdragsstaat afkomstige radioactieve uitstoot.

Een van de discussiepunten bij de redactie van het Verdrag was de vraag of objectieve criteria dienden te worden opgesteld om te bepalen wanneer een uitstoot "belangrijk" kan zijn. Dit criterium is van groot belang aangezien het bepaalt of een Staat op wiens grondgebeid een ongeval plaatsheeft, gehouden is informatie te verschaffen. Dergelijke objectieve criteria werden niet opgesteld en bijgevolg is het de Staat waar het ongeval plaatsheeft die bepaalt of de vrijgekomen

In oktober 2000 hadden $\$ 6$ landen, waaronder Belgie, Nederland, Frankrijk, Duitsland en de Verenigde Staten het Verdrag ondertekend (Bron: website van het LAEA op 11 oktober 2000: www.iaea.or). De tekst van het Verdrag werd gepubliceerd in Trb., 1986, 125 en 164. 
radioactieve stoffen zullen leiden tot een transnationale uitstoot, of deze uitstoot voor de buurlanden belangrijk kan zijn.

Volgens artikel 3 kunnen Verdragsstaten ook kennisgeven bij kernongevallen die niet onder het Verdrag vallen. Verder laat het Verdrag de leden vrij om bi- of multilaterale overeenkomsten af te sluiten voor materies die onder het Verdrag vallen. Meerdere Staten hebben van deze gelegenheid gebruik gemaakt ${ }^{154}$. Uit deze bepaling blijkt dat het Verdrag een beroep doet op de goede wil van de Verdragspartijen teneinde de toepassing van dit Verdrag zo ruim mogelijk te maken. Zo heeft het Verenigd Koninkrijk te kennen gegeven dat het IAEA en de buurlanden zullen worden verwittigd indien zich een ongeval heef voorgedaan in een militaire installatie ${ }^{155}$.

Het Verdrag geeft tenslotte aan dat bij onenigheid tussen twee Staten betreffende de interpretatie of de toepassing ervan, het geschil kan worden voorgelegd aan het Internationaal Gerechtshof of aan een arbitragecommissie ${ }^{156}$.

Het tweede Verdrag dat eveneens kort na het ongeval van Tsjernobyl is tot stand gekomen, is het Verdrag inzake het verlenen van bijstand ${ }^{157}{ }^{158}$. Onder dit Verdrag zullen de partijen samenwerken, met tot doel (art. 1):

"de onmiddellijke bijstand in geval van een nucleair ongeval of een calamiteit met radioactieve stoffen te vergemakkelijken, teneinde de gevolgen daarvan zoveel mogelijk te verzachten en leven, goederen en het milieu te beschermen tegen de gevolgen van de vrijgekomen radioactieve stoffen".

Indien een kernongeval plaatsheeft, kan een Partij van het Verdrag de andere leden vragen bijstand te verlenen. De Partij die om bijstand verzoekt, is overigens niet noodzakelijk de Partij op wiens grondgebied het ongeval heeft plaatsgehad. Alle Staten die door een kemongeval worden getroffen, zijn gerechtigd om bijstand te verzocken. Een Staat die een verzoek om bijstand heeft ontvangen, moet onmiddellijk beslissen of het de gevraagde bijstand kan verlenen, in welke vorm en onder welke voorwaarden dat kan.

Nergens worden de Verdragspartijen evenwel verplicht bijstand te geven of te aanvaarden, hetgeen bij kemongevallen nochtans fundamenteel kan zijn ${ }^{159}$. Anderzijds is het begrip "bijstand" breed geformuleerd zodat ook medische hulp en tijdelijke relocatie van de bevolking naar het grondgebied van een andere Verdragsstaat mogelijk is.

Wat de aansprakelijkheid betreft, behandelt artikel 10 zowel schade veroorzaakt door als schade veroorzaakt aan de bijstandverlenende Staat. Deze kan niet aansprakelijk gesteld worden voor op het grondgebied van de verzoekende Staat veroorzaakte dood of letsels aan personen, schade aan

Zo werd een bilaterale overeenkomst afgesloten tussen Belgie en Nederland op 14 maart 1987 (zie Domsdorf, E.P.M.W., "Internationaal Atoomenergierecht", l.c., 1219); ook Euratom heeft maatregelen genomen die verder bouwen op dit Verdrag: Beschikking 87/600 Euratom van 14 december 1987, $P B$, L 371, 30 december 1987.

Cameron, P. "The Vienna Conventions on early notification and assistance", 0.c. 26.

Zie artikel 11 van het Verdrag inzake vroegtijdige kennisgeving.

De tekst van het Verdrag werd gepubliccerd in Tractatenblad, 1986, $126 \mathrm{en} 165$.

In oktober 2000 hadden 82 landen, waaronder Belgié, Nederland, Frankrijk, Duitsland en de Verenigde. Staten het Verdrag ondertekend (Bron: website van het LAEA op 11 oktober 2000: www.iaca.or).

Pelzer, N., "The impact of the Chemobyl accident on International Nuclear Energy Law", Archiv des Völkerrechts, 1987, 25, 303. 
of verlies van goederen of schade aan milieu, tenzij indien deze schade opzettelijk werd veroorzaakt. Omgekeerd zal de bijstandontvangende Staat de bijstandverlenende Staat schadeloos stellen, tenzij sprake is van opzet. Staten kunnen evenwel in hun national recht afwijkende regelen opnemen (art. 10, $2^{\circ} \mathrm{lid}$ ). Het is van belang te onderstrepen dat volgens artikel 10, derde lid deze bepalingen geen afbreuk doen aan de bepalingen van de Verdragen van Parijs en Wenen.

Net zoals dat het geval is bij het Verdrag inzake vroegtijdige kennisgeving, voorziet ook het Verdrag inzake assistentie in de mogelijkheid tot samenwerking op bi- of multilaterale basis.

Het Verdrag inzake assistentie werd in oktober 1987 voor het eerst toegepast op vraag van Brazilië. In Goiânia had een instituut gespecialiseerd in radiotherapie één van haar machines gedeeltelijk ontmanteld; toch kwam een deel ervan, een Cesium-137 bron, terecht bij een schroothandelaar wiens manipulatie van het "schroot" mede aan de basis lag van een verspreiding van de Cesium in de stad ${ }^{160}$. Tengevolge hiervan stierven vier personen en werden meer dan 200 mensen radioactief besmet ${ }^{16 !}$. Brazilië vroeg het IAEA om assistentic; zowel het IAEA ais verschillende leden van het Verdrag stuurden mensen en materiaal ter plaatse ${ }^{162}$.

Net als het Verdrag inzake vroegtijdige kennisgeving, doet het Verdrag inzake assistentie in ruime mate een beroep op de goede wil van de Verdragpartijen. Dit blijkt uit het feit dat onder het Verdrag inzake vroegtijdige kennisgeving de invulling van het begrip "belangrijk" wordt overgelaten aan de Staat waar het ongeval plaatshad en uit het feit dat onder het Verdrag inzake bijstandverlening een Staat niet verplicht is om bijstand te vragen en de Staat die om bijstand wordt verzocht, niet verplicht is om deze bijstand te verlenen. Vandaar rijst de vraag of deze Verdragen niet eerder moeten worden beschouwd als intentieverklaringen, dan wel als duidelijk afdwingbare internationaal-rechtelijke verplichtingen ${ }^{163}$.

Naast de vroegtijdige kennisgeving en het verlenen van assistentie bij kemongevallen, was de nucleaire veiligheid een belangrijk nieuw thema van de nucleaire Verdragen van de tweede generatie.

\subsubsection{Nucleaire veiligheid}

De "post Tsjernobyl inspanningen" met betrekking tot het verhogen van de nucleaire veiligheid hebben geleid tot de adoptie van een Verdrag inzake Nucleaire Veiligheid (a) en tot een Gemeenschappelijk Verdrag inzake de Veiligheid van het Beheer van gebruikte Splijtstoffen en Radioactief Afval (b). Aansluitend werd ook getracht om een gedragscode voor het civiele gebruik van kemenergie in te voeren (c).

X., "Radiation sources: lessons from Goiâna", IAEA Bulletin, 4/1988, 10-17; X., "Four die in cesium accident in Brazil", Nuclear News, december 1997, 86-87.

IAEA Newsbriefs, 25 November 1987.

Zie Cameron, P., "The Vienna Conventions on early notification and assistance", o.c., 29.

Pelzer beschouwt de Verdragen als een noodzakelijke maar slechts eerste stap in de goede richting: Pelzer, N., "The impact of the Chemobyl accident on International Nuclear Energy Law", Archiv des Völkerrechts, 1987, 25, 306. 


\section{a. Het Verdrag van Wenen inzake Nucleaire Veiligheid van 17 juni $1994^{164}$}

Kort na het ongeval van Tsjernobyl onderstreepte het IAEA de noodzaak tot een grotere samenwerking op het gebied van nucleaire veiligheid ${ }^{165}$. Aangezien nucleaire veiligheid bij uitstek een materie is die ressorteert onder de bevoegdheid van elke individuele Staat., lag een internationale samenwerking op dit vlak niet meteen voor de hand ${ }^{166}$.

Dit betekent echter niet dat er voorheen geen intemationale normen bestonden inzake nucleaire veiligheid. Via de ontwikkeling van het Nuclear Safety Standards-Programme, of kortweg het NUSS-Programma, had het IAEA reeds internationale normen uitgevaardigd inzake nucleaire veiligheid. Hoewel de in dit kader tot stand gekomen NUSS-Codes slechts aanbevelingen zijn, zijn deze toch van belang geweest bij het ontwikkelen van de internationale veiligheidsregulering en bij de controle daarvan. Gespecialiseerde teams van het IAEA (ook wel OSART, of Operational Safety Review Team genoemd) hadden tot taak om in de verschillende landen de nucleaire veiligheid van kerninstallaties te onderzoeken ${ }^{167}$.

In 1990 werd een belangrijk initiatief genomen door de EG-lidstaten; een initiatief dat zou leiden tot een bijdrage van het IAEA aan de UNO-Conferentie van Rio over milieu en ontwikkeling ${ }^{168}$.

Het Verdrag inzake Nucleaire Veiligheid werd uiteindelijk aangenomen in Wenen op 17 juni 1994 en werd opengesteld voor ondertekening op 20 september 1994; op 24 oktober 1996 trad dit Verdrag in werking. Midden 2000 waren 53 landen (waaronder Belgie ${ }^{169}$ en Nederland ${ }^{170 ~}{ }^{171}$ ) toegetreden tot het Verdrag ${ }^{172} 173$.

Zis hierover met name; Jankowitsch, O. "Convention on Nuclear Safety: Status, Structure and contents", in Nuclear Inter Jura "95, AIDN/INLA, Helsinki, 1995, 687-690; Jankowitsch, O., "La Convention sur la Sûreté nucléaire", Bulletin de Droit Nucléaire, $n^{\circ}$ 54, december 1994, 9-23; Jankowitsch, O. en Flakus. F.-N., "La Convention internationale sur la Sûreté Nucléaire marque une étape en droit", AIEA Bulletin, 3/1994, 36-40; Pelzer, N., "Intemationales Atomtecht im Wandel - Auf dem Wege zu einer Nuklearen Sicherheitskonvention und zur Verbesserung des internationalen Atomhaftungsiecht", in Jahrbuch des Umwelt- und Technikrechts, Decker's Verlag, Heidelberg, 1994, 639-681; Stoiber, C., "Convention on Nuclear Sāety", in Nuclear Inter .hira '95, AIDN/INL A, Helsinki, 1995, 655-669. Beslissing dd. 21 mei 1986, GOV/OR.649.

Hetzelfde geldt voor het hiermee verwante thema van de fysieke bescherming van kemmateriasl.

Zie hierover meer in detail: Pelzer, $\mathrm{N}$., "Internationales Atomrecht im Wandel - Auf dem Wege zu einer Nuklearen Sicherheitskonvention und zur Verbesserung des internationalen Atomhaftungsrecht". o.c., 649; Handl, G., "Transboundary Nuclear Accidents: the Post-Chemobyl Multilateral Legislative Agenda", o.c., 214 e.v.

Jankowitsch, O., "La Convention sur la Sûreté Nucléaire", o.c., 10.

Wet houdende instemming met het Verdrag inzake nucleaire veiligheid, gedaan te Wenen op 20 septernber 1994, B.S., 22 augustus 1997, 21485. Voor Belgiê trad het Verdrag in werking op 13 april 1997.

Brief van de Minister van Buitenlandse Zaken van 26 augustus 1996, Staten-Generaal, Vergaderjaar $1995-1996,24833, \mathrm{nr} .315$ en 1. Voor Nederland trad het Verdrag in werking op 13 januari 1997.

Doordat het Euratom-Verdrag geen bepalingen bevat omirent nucleaire veiligheid en doordat het Verdrag inzake Nucleaire Veiligheid de nadruk legt op de rol van elke individuele Staat, ontstond in de Euratom-lidstaten discussie omtrent de bevoegdheid van de Commissie om al dan niet tol dit Verdrag toe te treden. Zie hierover Pinel, C., "La Convention sur lá sûreté nucléaire adoptée le 17 juin 1994: amélioration ou détérioration de la règle de droit? La confiance en question", in "Nuclear inter Jura '95", l.c., 671-677.

Bron: website van het LAEA op 28 juni 2000. 
Het Verdrag is van toepassing op de veiligheid van kerninstallaties. Hieronder wordt verstaan elke op het land gelegen civiele kerncentrale (artikel 2). Ook installaties voor de opslag en de behandeling van radioactief afval die zich op dezelfde site bevinden en die direct verbonden zijn aan de exploitatie van kemcentrales, zijn keminstallaties in de zin van het Verdrag. Het Verdrag is bijgevolg niet van toepassing op installaties betreffende de definitieve berging van radioactief afval.

Het Verdrag bevat drie doelstellingen: een algemene doelstelling inzake nucleaire veiligheid, een doelstelling met betrekking tot stralingsbescherming en een doelstelling betreffende technische veiligheid.

De algemene doelstelling komt tot uiting in artikel 7 dat elke Lidstaat verplicht een wettelijk en reglementair kader te creëren om de veiligheid van kerncentrales te waarborgen. Dit impliceert dat een Staat ertoe is gehouden om te voorzien in een systeem van vergunningen, om inspecties naar de veiligheid van kerncentrales uit te voeren, etc.

Inzake stralingsbescherming dient absolute voorrang te worden gegeven aan veiligheid en wordt de blootstelling aan straling beoordeeld aan de hand van het ALARA-principe ${ }^{174}$. Deze twee elementen impliceren dat voldoende middelen (financiële middelen zowel als "human resources") moeten worden ter beschikking gesteld van een overheidsorgaan dat de nucleaire veiligheid controleert en handhaaft en dat veiligheidsprocedures (quality assurance and quality control) en noodplannen dienen te worden opgesteld en geïmplementeerd.

De technische veiligheid van installaties moet worden geëvalueerd zowel bij de keuze van de site, bij het ontwerp en de bouw als bij de exploitatie van de kemcentrale.

Het Verdrag bevestigt de verantwoordelijkheid van elke Staat bij het opstellen van nationale regels, bijvoorbeeld wat betreft het verlenen van een vergunning, het opstellen van adequate veiligheidsregulering en het inspecteren van de installaties. Vandaar is elke Verdragsstaat ertoe gehouden om in zijn interne recht afdoende maatregelen te voorzien (zowel materieelrechtelijk als institutioneel) om dit Verdrag uit te voeren, dient het periodiek aan het IAEA een nationaal rapport over te maken met daarin een overzicht van de implementatie van het Verdrag en dient elke Verdragsstaat te participeren bij driejaarlijkse bijeenkomsten ("peer reviews") betreffende de veiligheid van kerninstallaties ${ }^{175}{ }^{176}$. Het is de bedocling van het Verdrag om een dialoog tussen de Verdragsstaten op gang te brengen inzake de verbetering van de nucleaire veiligheid ${ }^{179}$. Door-

Tegelijkertijd werd het Nuclear Protocol ontwikkeld in het kader van de Energy Charter Treaty. Zie hierover Horbach, N.L.J.T., "Nuclear Protocol of the Energy Charter Treaty", Journal of Energy and Natural Resources Law, vol. 13, $\mathrm{n}^{\circ} 3,1995,163$ e.v

174 Zonder evenwel dit principe intemationaal-rechtelijk afdwingbaar te maken (Lindemann, C., "Die Nukleare Sicherheitskonvention - Bestätigung deutschen und Fortschreibung intenationalen Rechts?", in Pelzer, N., (herausg.), Newes Atomenergierecht - Internationale und nationale EntwickJungen, Nomos, Baden-Baden, 1995, 80). Jankowitsch, O., "La Convention sur la sûreté nucléaire", o.c., 17; Stoiber, C., "The Convention on Nuclear Safety: an Introduction", in "Nuclear Inter Jura "95", l.c., 659; Stoiber, C., "International Convention in Nuclear Safety: National Reporting as the Key to Effective Implementation", in Horbach, N.L.J.T., "Contemparary Developments in Nuclear Energy Law", l.c., 101. De eerste peer review heeft plaatsgehad in april 1999 (IAEA Newsbriefs, vol. 14, $\mathrm{N}^{\circ} 2$ (83), april/mei 1999).

177 Stoiber, C., "The Peer Review Process of the Nuclear Safety Convention", in Pelzer, N., (herausg.), Neues Atomenergierecht - Internationale und nationale Entwicklungen, Nomos, Baden-Baden, 1995 , $4 i$. 
dat het Verdrag vaag blijft omtrent de details van de periodieke samenkomsten en de precieze vorm en inhoud van de rapporten, wordt geoordeeld dat het Verdrag meteen de nodige soepelheid biedt voor een dynamische uitwisseling van gegevens en een dialoog tussen de verschillende leden van het Verdrag ${ }^{178}$.

Van belang is dat het Verdrag inzake Nucleaire Veiligheid geen gedetailleerde veiligheidsmaatregelen omvat: er is bewust gekozen voor de "incentive-approach"179; hiermee wordt bedoeld dat het Verdrag de Verdragsstaten aanmoedigt om in de interne wetgeving de nodige veiligheidsmaatregelen te voorzien. Het Verdrag bevat echter geen dwingende bepalingen die enerzijds een Staat ertoe kunnen aansporen om bij eventuele laattijdigheid toch een rapport af te leveren en die anderzijds kunnen nagaan in welke mate de inhoud van deze rapporten een waarheidsgetrouw beeld geeft van genomen maatregelen en van de effectiviteit van de uitgevoerde controles ${ }^{180}$. Door de afwezigheid van sancties in het Verdrag en door de "incentive aproach" kunnen de nodige vragen worden gesteld omtrent de juridische waarde ervan ${ }^{181}$. Blijkbaar is het bijzonder moeilijk om te komen tot internationale afdwingbare afspraken in een materie die traditioneel tot de (politionele) bevoegdheid van elk individueel land behoort. Een aantal auteurs is echter van mening dat precies de periodieke bijcenkomsten een uitstekende gelegenheid bieden voor de verschillende landen om te bewijzen dat zij de verdragsbepalingen wel degelijk naleven ${ }^{182}$.

\section{b. Het Gemeenschappelijk Verdrag inzake de Veiligheid van het Beheer van gebruikte Splijtstoffen en Radioactief Afval van 1 september 1997}

Uitgaande van het Verdrag inzake Nucleaire Veiligheid startten onderhandelingen met betrekking tot het beheer van radioactief afval. Deze hebben, op de diplomatieke conferentie van 1 tot 5 september 1997, geleid tot de adoptie van de "Joint Convention on the Safety of Spent Fuel Management and on the Safety of Radioactive Waste Management"183. Dit Verdrag is in werking getreden op 18 juni 2001, nadat 25 landen, waaronder 15 die een operationele kerninstallatic op

Schäfer, A., "Die Nukleare Sicherheitskonvention mit den Augen eines Naturwissenschaftlers gesehen", in Pelzer, N, (herausg.), Neues Atomenergierecht - Internationale und nationale Entwick. lungen, Nomos, Baden-Baden, 1995, 38-39.

Stoiber, C., "The Convention on Nuclear Safety: an Introduction", in "Nuclear Law as Source of Confidence", l.c., 657; Stoiber, C., "International Convention in Nuclear Safely: National Reporting as the Key to Effective Implementation", in Horbach, N.L.J.T., "Contemporary Developments in Nuclear Energy Law", l.c., 99-100.

Dit lijkt een bewuste keuze te zijn geweest van de onderhandelaars: doordat Staten niet meteen worden gesanctioneerd bij niet naleving van de Verdragsbcpalingen worden landen aangemoedigd on dit Verdrag te onderschrijven (Stoiber, C., "The Peer Review Process of the Nuclear Safety Convention", in Pelzer, N., "Neues A tomenergierecht", l.c., 42).

Boustany, K., "Le développement de la normativité nucléaire ou l'art de l'évasion juridique", o.c., 43.

Pelzer, N., "Internationales Atomrecht im Wandel - Auf dem Wege zu einer Nuklearen Sicherheitskonvention und zur Verbesserung des internationalen Atomhaftungsrecht", o.c., 655-656.

Zie over dit Verdrag o.m. Cameron, P., "Joint Convention on the Safety of Spent Fuel Management and on the Safety of Radioactive Waste Management", in Horbach, N.L.J.T., "Contemporary Developments in Nuclear Energy Law", l.c., 117 e.v.; De Kageneck, A., "La Convention Commune sur la Sûreté de la Gestion du Combustible usé et sur la Sûreté de la gestion des Déchets Radioactifs: Champ d'Application et Contexte conventionnel existant", in Le droit nucléaire: du XXe au XXle: sciècle. Nuclear Inter Jura '97, Société de Législation Comparée, AIDN/INLA, Paris, 1998, 509 e.v.; Iankowitsch; O., "La Convention Commune sur la sûreté de la gestion du combustible usé et sur la sûreté de la gestion des déchets radioactifs", in Le droit muclénire: du XXe au XXle sciècle. Nuclear Inter Jura '97, Société de Législation Comparée, AIDN/INLA, Paris, 1998, 539 e.v.; Tonhauser, W., "The Joint Convention on the Safety of the Spent fuel Management and on the Safety of Radioactive Waste Management", in Le droit nucléaire: du XXe au XXIe sciècle. Nuclear Inter Jura '97, Société de Législation Comparée, AIDN/INLA, Paris, 1998, 535 e.v. 
hun grondgebied hebben, het Verdrag hadden geratificeerd. In juni 2001 waren de volgende landen lid van het Verdrag: Argentinië, Bulgarije, Canada, Denemarken, Finland, Frankrijk, Duitsland, Griekenland, Hongarije, Terland, Kroatië, Letland, Marokko, Nederland, Noorwegen, Polen, Roemenië, Slovakije, Slovenië, Spanje, Tsjechische Republiek, Ukraïne, Verenigd Koninkrijk, Zweden, Zwitserland ${ }^{184}$.

In principe is het Gemeenschappelijke Verdrag van toepassing op kembrandstof, behalve in twee gevallen: zowel het transport van splijtstoffen buiten de site als splijtstoffen die worden opgewerkt, vallen niet onder het Verdrag.

Bij de onderhandelingen voor de totstandkoming van dit Verdrag, bestond discussie omtrent het toepassingsgebied: bepaalde landen wensten niet dat gebruikte splijtstoffen onder het toepassingsgebied zouden vallen. De discussie vond zijn oorsprong in het feit dat deze landen de volledige vrijheid wensten te behouden omtrent hun beleid van de splijtstoffencyclus ${ }^{185}$. Landen als Frankrijk en China doen, voor wat betreft het invullen van hun nood aan kernbrandstof, een beroep op de opwerking van gebruikte splijtstoffen. Hierbij wordt splijtstof vervoerd naar een opwerkingsinstallatie waarbij het nog bruikbare uranium of plutonium wordt gescheiden van de niet bruikbare componenten. Van de bruikbare delen wordt nieuwe splijtstof, en dus nieuwe brandstof voor de kernreactor gemaakt ${ }^{186}$.

De beslissing om gebruikte kembrandstof al dan niet te laten opwerken is een beleidsvraag: elk land maakt individueel uit of het al dan niet cen beroep doet op opwerking. De gevolgen hiervan voor de discussie omtrent het toepassingsgebied van het Gemeenschappelijk Verdrag zijn duidelijk: indien geen beroep wordt gedaan op opwerking, zullen de gebruikte splijtstoffen worden beschouwd en behandeld als radioactief afval; indien wel voor opwerking wordt geopteerd, worden de gebruikte splijtstoffen beschouwd als grondstof voor de productie van nieuwe splijtstoffen. In dit laatste geval zouden splijtstoffen dus niet onder een internationaal Verdrag betreffende radioaclief afvalbehecr ressorteren.

Het beheer van splijtstoffen omvat alle activiteiten met betrekking tot het verladen en de tussenopslag van gebruikte splijtstoffen, met uitzondering evenwel van transporten buiten de site. $A$ contrario vloeit hieruit voort dat het transport van splijtstoffen van een installatie naar een andere, binnen één enkele site gelegen installatie, wel onder het toepassingsgebied valt van het Gemeenschappelijke Verdrag. De Verdragsluitende Staten achtten het onnodig om "externe transporten" aan het bijzondere regime van het Verdrag te onderwerpen, aangezien daar reeds voldoende internationale normen op van toepassing zijn.

Ook de splijtstoffen die zich in een opwerkingsfabriek bevinden en die het voorwerp uitmaken van opwerkingsactiviteiten, vallen niet onder de bepalingen van het Gemeenschappelijke Ver-

184

135

186

Belgie en de Verenigde Staien hebben dit Verdrag weliswaar getekend, maar nog niet geratificeerd (IAEA Newsbriefs, vol. 14, n² (83), april/mei 1999).

Splijistoffen vamen de brandstof van een kerneactor: het zijn de uranium- of plutoniumstaven in het hart van de reactor, die de kernreactie op gang brengen. Vandaar wordt de spiljtstofeyclus ook de brandstofeyclus genoemd. Zie hierover Gillon, L., "De Kwestic Kemenergie", lc., 100.

Gillon, L.s "De Kwestie Kernenergie", I.c., 114. 
drag. Hieruit volgt dat het overladen en de tussenopslag van splijtstoffen, zelfs met het oog op opwerking, wél onder het Verdrag valt ${ }^{187}$.

Een ander belangrijk element bij de bespreking van het toepassingsgebied van het Gemeenschappelijke Verdrag bestaat erin dat het Verdrag in principe niet van toepassing is op radioactief afval en splijtstoffen van militaire oorsprong. Zodra deze evenwel definitief worden gebruikt in civiele programma's en exclusief in dat kader worden aangewend, vallen radioactief afval en splijtstoffen van militaire oorsprong automatisch onder het toepassingsgebied van het Gemeenschappelijke Verdrag.

Anderzijds is het toepassingsgebied van het Gemeenschappelijke Verdrag zonder meer ruim, aangezien radioactief afval in zijn verschillende vormen (vloeibaar, gas en vast) onder het Verdrag valt.

Inhoudelijk hanteert het Gemeenschappelijke Verdrag dezelfde principes als het hierboven besproken Verdrag inzake Nucleaire Veiligheid: via periodieke nationale rapporten en periodieke bijeenkomsten wordt getracht een veiligheidscultuur voor nucleaire installaties in het leven te roepen. Toch is de relatie tussen beide Verdragen opzettelijk vaag gehouden omdat werd geoordeeld dat dit aan bod kan komen bij het uitwerken van de procedure van de periodieke bijeenkomsten.

Het Verdrag beoogt in artikel 1 (ii) onder meer te verzekeren:

"... that during all stages of spent fuel and radioactive waste management there are effective defences against potential hazards so that individuals, society and the environment are protected from harmful effects of ionising radiation, now and in the future, in such a way the needs and aspirations of the present generation are met without compromising the ability of future generations to meet their needs and aspirations".

Principes en beginselen die reeds lang in het milieurecht zijn gekend zoals het ALARA-principe, duurzame ontwikkeling en de bescherming van de volgende generaties worden via de beide Verdragen formeel ingevoerd in het internationale kernenergierecht. Het feit dat op verschillende plaatsen in het Verdrag uitdrukkelijk wordt verwezen naar milieurechtelijke beginselen, kan worden beschouwd als een niet onbelangrijke verwezenlijking van het Gemeenschappelijke Ver$\mathrm{drag}^{188}$. Eenzelfde milieurechtelijke benadering is afwezig bij de nucleaire aansprakelijkheidsverdragen.

\section{c. Gedragscode voor het civiele gebruik van kernenergie}

Aansluitend bij de bespreking van het Verdrag inzake Nucleaire Veiligheid en bij het Gemeenschappelijke Verdrag inzake de Veiligheid van het Beheer van gebruikte Splijtstoffen en Radioactief Afval, dient kort de aandacht te worden gevestigd op een initiatief vanuit de nucleaire sector die een gedragscode wenst in te voeren voor het civiele gebruik van kemenergie. De band tussen

De Kageneck, A., "Lāa Convention Commune sur la Sûreté de la Gestion du Combustible usé et sur la Sûreté de la gestion des Déchets Radioactifs: Champ d'Application et Contexte conventionnel existant", in "Nuclear Inter Jura '97", l.c., 515. Law", l.c., 126. 
dit initiatief en de hierboven besproken Verdragen is gelegen in het feit dat beide wensen bij te dragen tot het creëren van een nucleaire veiligheidscultuur ${ }^{189}$.

Voorstanders van de gedragscode ("Rules of good conduct" of "Règles de bonne conduite") gaan ervan uit dat het positieve recht niet in staat is het hoofd te bieden aan het nucleaire risico in de brede zin van het woord ${ }^{190}$. Een dergelijke code moet zijn geïnspireerd door ethische overwegingen $^{191}$ en moet worden aanvaard door eenieder die verantwoordelijkheid draagt in de verschillende etappes van de diverse toepassingen van kernenergie. De gedragscode voor het civiele gebruik van kernenergie moet worden gezien als een coherent geheel van aanbevelingen en richtlijnen, gebaseerd op de professionele ervaring van de sector zelf, en op de verantwooderlijkheidszin en de geest tot innovatie van deze professionelen ${ }^{192}$.

Tot dusver werd een ontwerpcode opgesteld die algemene richtlijnen bevat inzake technische en wetenschappelijke kwaliteit, de nood aan energie, stralingsbescherming, nucleaire veiligheid, milieubescherming, beheer van radioactief afval, informatie en consultatie van het publiek, nonproliferatie en internationale samenwerking. De discussie omtrent het nut van deze code, de manier waarop deze code moet worden onderschreven en de compatibiliteit ervan met het positieve recht, is nog volop aan de gang. Tegenstanders van deze code zijn van oordeel dat de nucleaire sector sowieso reeds is onderworpen aan zeer gedetailleerde veiligheidsregels en dat de code mogelijkerwijze leidt tot verwarring met de bepalingen van met name het Verdrag inzake Nucleaire Veiligheid ${ }^{193}$.

\subsubsection{Het verbeteren van de reeds bestaande nucleaire aansprakelijkheidsregimes}

Het ongeval in Tsjernobyl leidde niet enkel tot internationale afspraken over nieuwe thema's zoals vroegtijdige kennisgeving en nucleaire veiligheid, ook werd de betrouwbaarheid van de bestaande nucleaire aansprakelijkheidsregimes in vraag gesteld. De onderhandelingen met betrekking tot dit laatste thema hebben inmiddels geleid tot een drievoudige aanpassing van deze regimes. Zo werd in eerste instantie het werkingsveld van het Verdrag van Parijs en van het Verdrag van Wenen aan elkaar gekoppeld. Dit is gebeurd door de totstandkoming van het Gemeenschappelijk Protocol van 1988 ( $\$ 2.2 .2 .1$ ). Vervolgens werd gedurende tien jaar onderhandeld over een inhoudelijke verbetering van het Verdrag van Wenen, hetgeen in 1997 resulteerde in twee nieuwe Verdragen (\$ 2.2.2.2). Tenslotte dient ook aandacht te worden besteed aan werkzaamheden voor de revisie van het Verdrag vañ Parijs ( $\$ 2.2 .2 .3$ ).

Zie hierover o.m. Barraclough, I. en Carnino, A., "Safety culture. Keys for sustaining progress", IAEA Bulletin, vol. 40/2, 1998, 27-30.

Strohl, P., "Règles de bonne conduite pour les utilisations civiles de l'énergie nucléaire", "Nuclear Inter Jura '95", l.c., 778-792.

191 Strohl, P. en Derché, B., "Project on standards on good behaviour for the civilian nuclear industry", AIDN/INLA, Nuclear Inter Jura '93, "Nuclear energy and sustainable development. The rule of law", Rio de Janeiro, 12-17 September 1993, VI.2.4: Strohl, P., "Code de bonne conduite pour les utilisations pacifiques de l'énergie nucléaire", L'option nucléaire. L'éthique et le droit, conferentie 12-13 mei 1994, Tunis, 286-302. Strohl, P., "Règles de bonne conduite pour les utilisations civiles de l'énergie nucléaire", in "Nuclear Inter Jura "95", l.c., 4. 


\subsubsection{Het koppelen van beide regimes door het Gemeenschappelijk Protocol van 21 septem- ber 1988}

Vóór het ongeval van Tsjernobyl functioneerden de Verdragen van Parijs en Wenen, gelet op hun eigen territoriaal toepassingsgebied, volledig geïsoleerd van elkaar: een Verdragsstaat van het Verdrag van Parijs is geen Verdragsstaat van het Verdrag van Wenen en vice versa.

Om die reden is geen van deze Verdragen van toepassing op de schade uit een kernongeval geleden op het grondgebied van een Staat die lid is van het andere regime. De Verdragen zijn evenmin van toepassing op een kernongeval dat zich heeft voorgedaan op het grondgebied van een Staat die lid is van het andere regime (bij transport). Bij kemongevallen en schade uit kernongevallen geleden in volle zee, kunnen beide Verdragen toepassing vinden ${ }^{194}$.

Een belangrijk element bij het totstandkomen van het Gemeenschappelijk Protocol is het feit dat reeds lang vóór het ongeval in Tsjemobyl werd getracht om beide regimes aan elkaar te koppelen. Zoals hoger aangegeven was het bij de onderhandelingen voorafgaand aan het ondertekenen van het Verdrag van Wenen de bedoeling dat de partijen van het Verdrag van Parijs eveneens zouden toetreden tot het Verdrag van Wenen. Door de aanzienlijke verschillen tussen beide regimes is evenwel geen enkele partij van het Verdrag van Parijs eveneens partij bij het Verdrag van Wenen.

Door het ongeval in Tsjemobyl werd de noodzaak duidelijk om één geüniformiseerd systeem tot stand te brengen en raakten de onderhandelingen met het oog op een territoriale aansluiting van beide verdragen in een stroomverșnelling. Bij de onderhandelingen van een Verdrag waarbij de beide nucleaire aansprakelijkheidsregimes op elkaar zouden worden afgestemd, werd zowel de mogelijkheid onderzocht om één Verdrag tot stand te brengen, als de mogelijkheid om beide Verdragen te laten verder bestaan.

Indien zou worden geopteerd voor één Verdrag, dan had dit kunnen impliceren hetzij dat een geheel nieuw Verdrag zou worden gecreëerd, hetzij dat het Verdrag van Parijs zou worden opgeheven ten voordele van het Verdrag van Wenen, hetzij dat het Verdrag van Wenen zou worden opgeheven ten voordele van het Verdrag van Parijs.

De mogelijkheid om de twee regimes te behouden impliceerde ofwel dat alle lidstaten van het Verdrag van Parijs het Verdrag van Wenen zouden ratificeren, ofwel dat het territoriale werkingsveld van beide Verdragen zou worden uitgebreid, ofwel dat een brug zou worden gecreêerd tussen beide regimes.

Uiteindelijk werd besloten om niet te raken aan de bestaande Verdragen en om, in de vorm van een Gemeenschappelijk Protocol, een brug te slaan tussen beide Verdragen ${ }^{195}$. De territoriale werking van beide Verdragen wordt aan elkaar verbonden zodat het er bij grensoverschrijdende schade in principe niet toe doet of een Staat op wiens grondgebied het kemongeval plaatsheeft, Partij is bij het Verdrag van Wenen, dan wel bij het Verdrag van Parijs. Voortaan worden Ver-

\footnotetext{
194 Von Busekist, O., "Le Protocole Commun relatif à l'upplication de la Convention de Vienne et de: la Convention de Paris: Une passerelle entre les deux Conventions sur la responsabilité civile pour les domnages nucléaires", Bulletin de Droit nucleaire, nr. 43, juni 1989, 17.

105

Zic in detail Von Busekist, $\mathrm{O}$., "Haftungsprobleme im Verhälmis zwischen Vertragsstaaten des Pariser und des Wiener Atomhaftungsübereinkommens", in Pelzer, N., "Friedliche Kemenergienutzung und Statsgrenzen in Mitteleuropa", l.c., 282 e.v.
} 
dragspartijen bij het Verdrag van Parijs niet meer behandeld als niet-verdragspartijen van het Verdrag van Wenen, en omgekeerd 196197.

Benadrukt dient te worden dat het Gemeenschappelijk Protocol, voor wat betreft het NEAregime, enkel verwijst naar het Verdrag van Parijs en niet naar het Aanvullend Verdrag van Brussel en bijgevolg enkel een koppeling maakt tussen het territoriale werkingsveld van het Verdrag van Parijs en het Verdrag van Wenen ${ }^{198}$. Voor wat betreft de in het Aanvullend Verdrag van Brussel voorziene fondsen, blijven de bepalingen van het Aanvullend Verdrag toepassing vinden. Dit impliceert dat schade geleden in een niet-Verdragsstaat niet kan worden vergoed door middel van de publieke fondsen als voorzien in het Aanvullend Verdrag van Brussel. Doordat meer vorderingen worden toegelaten in de eerste schijf, spreekt het voor zich dat de tweede schijf sneller zal worden aangesproken en dat de Verdragsstaten van het Aanvullend Verdrag sneller een beroep zullen moeten doen op hun openbare middelen ${ }^{199}$.

Het leidt weinig twijfel dat de koppeling van twee ten dele asymmetrische regimes zal leiden tot de nodige problemen ${ }^{200}$. Op basis van het non-discriminatiebeginsel - dat zowel in het Verdrag van Parijs als het Verdrag van Wenen, als in het Gemeenschappelijk Protocol is opgenomen ${ }^{201}$ mag, voor wat betreft de verdeling van de sommen beschikbaar uit de aansprakelijkheidsverzekering van de aansprakelijke exploitant, geen onderscheid worden gemaakt naar nationaliteit en woonplaats van het slachtoffer van een kemongeval. In de hypothese waarin een kernongeval plaatsvindt in een lidstaat van het Verdrag van Parijs en waarbij eveneens schade wordt veroorzaakt in een lidstaat van het Verdrag van Wenen en ervan uitgaande dat voor deze beide landen eveneens het Gemeenschappelijk Protocol toepasselijk is, lijkt een zekere discriminatie evenwel bijna niet uit te sluiten:

- ofwel wordt de som beschikbaar uit de eerste schijf uitsluitend gebruikt om de slachtoffers te vergoeden van een land dat lid is van het Verdrag van Wenen en worden de sommen in de twee daarop volgende schijven uitsluitend gebruikt voor de slachtoffers van een land dat lid is van

Pelzer, N., "Inadequacies in the Civil Liability Regime evident after the Chernobyl Accident: the Response in the Joint Protocol of 1988", in Nuclear Accidents. Liabilities and Guarantees, Helsinki symposium, LAEA-NEA, Paris, 1983, 162; Von Busekist, O., "Le Protocole Commun relatif à l'application de la Convention de Vienne et de la Convention de Paris: Une passerelle entre les deux Conventions sur la responsabilité civile pour les dommages nucléaires", o.c., 16.

Bij de bespreking van het territoriale toepassingsgebied van het Verdrag van Parijs, in $\S 1.2 .3$ van hoofdstuk 3, worden de bepalingen van het Gemeerischappelijk Protocol geanalysecrd.

Dit is een bewuste keuze geweest van de onderhandelaars. Bij de totstandkoming van het Gemeenschappelijk Protocol hadden nochtans mecrdere voorstellen tot voorwerp om expliciet de bepalingen van het Aanvullend Verdrag van Brussel veilig te stellen. Uiteindelijk is beslist hierover niets in te voeren in het Gemeenschappelijk Protocol omdat het Weense Verdragen-Verdrag voldoende houvast zou bieden bij interpretatieproblemen of bij uit de versehillende verdragen voortvloeiende tegenstrjjige verplichtingen (Von Busekist, O., "Le Protocole Commun relatif à l'application de la Convention de Vienne et de la Convention de Paris: Une passerelle entre les deux Conventions sur la responsabilité civile pour les dommages nucléaires", o.c., 27 en 30 ).

Pelzer, N., "Internationales Atomreeht im Wandel - Auf dem Wege zu einer Nuklearen Sicherheitskonvention und zur Verbesserung des internationalen Atomhaftungsrecht", o.c., 667-668; Reyners, P. en Von Busekist, O., "The Joint Protocol Relating to the Application of the Vienna and the Paris Conventions - One Step towards the Necessary Modernisation of the International Nuclear Civil Liability Regime", in Nuclear Inter Jura '89, AIDN/INLA, 1989, II-69.

In \$ 2.1.2.2 werd aangegeven wat met deze asymmetrie wordt bedoeld: het feit dat onder het regime van de NEA wél is voorzien van een Staatstussenkomst (via het Aanvullend Verdrag van Brussel), hetgeen niet het geval is bij het door het IAEA uitgewerkte nucleaire aansprakelijkheidsregime. Respectievelijk in artikel 14 van het Verdrag van Parijs, artikel XIII van het Verdrag van Wenen en artikel IV van het Gemeenschappelijk Protocel. 
het NEA-regime (deze sommen worden dan uitgekeerd onder het Aanvullend Verdrag van Brussel). In dit geval is sprake van een discriminatie van de onderdanen van het Verdrag van Parijs $^{202}$;

- ofwel wordt de som beschikbaar in de eerste schijf proportioneel verdeeld tussen slachtoffers van beide regimes, en krijgen de slachtoffers van een land dat lid is van het Verdrag van Parijs daar bovenop een bedrag uit de twee volgende schijven. In dit geval zullen de slachtoffers van een land dat lid is van het Verdrag van Wenen de facto worden gediscrimineerd.

Het Gemeenschappelijk Protocol kampt niet alleen met inhoudelijke problemen. Ook het uiterst geringe enthousiasme van de leden van het Verdrag van Parijs, om toe te treden tot het Gemeenschappelijk Protocol, hypothekeert het bereiken van het beoogde doel. Zolang het aantal leden van het Verdrag van Wenen geografisch ver uiteen blijft liggen en zolang het Verdrag van Wenen niet wordt gemoderniseerd, zullen de leden van het Verdrag van Parijs niet geneigd zijn om het Gemeenschappelijk Protocol te onderschrijven. Die modemisering heeft niet enkel betrekking op een betere juridische omschrijving van het schadebegrip, maar ook op het herzien van de bedragen waarvoor de exploitant aansprakelijk is: het heeft immers weinig zin om door een uitbreiding van het territoriale toepassingsgebied een groter aantal vorderingen toe te laten, zonder de beschikbare schadevergoedingsbedragen te verhogen ${ }^{203}$.

Vandaar wekt het weinig verbazing dat zolang hieraan niet is tegemoet gekomen, het enthousiasme om het Gemeenschappelijk Protocol te ratificeren, gering is ${ }^{204}$. Midden 2000 telde het Gemeenschappelijk Protocol 21 leden waaronder slechts 6 leden van het Verdrag van Parijs ${ }^{205}$.

\subsubsection{De inhoudelijke wijzigingen: twee nieuwe Verdragen}

Meteen na het ongeval in Tsjemobyl werd op de Algemene Vergadering van het IAEA de noodzak benadrukt om het toenmalige nucleaire aansprakelijkheidsregime te herzien en om een nieuw Verdrag op te stellen waarin de beginselen zouden worden vastgelegd van een "intemational liability for nuclear damage under the law of State responsibility concerning international claims against States" ${ }^{206}$. Hierbij aansluitend werd in 1988 een resolutie aangenomen ${ }^{207}$ waarbij werd opgeroepen om een werkgroep in te stellen met als taak om alle aspecten van aansprakelijkheid voor schade uit een kemongeval te onderzoeken, inclusief de vraag naar internationale aansprakelijkheid ${ }^{208}{ }^{209}$. De eigenlijke werkzaamheden voor de revisie van het Verdrag van Wenen

202 Bovendien kan het zijn dat een land enkel lid is van het Verdrag van Parijs en niet van het Aanvullend Verdrag van Brussel, waardoor de discriminatie nog wordt versterkt.

Ook in die zin Strohl, P.,"Bilan de Recherches de la Section de langue française du Centre d'étude et de recherche de l'Académie", in X., Les Risques Résultant de l'Utilisation Pacifique de l'Energie Nucléal. $r e$, Académie de droit international de La Haye, Centre d'étude et de recherche de droit international et de relations internationales, Kluwer Academic Publishers, Dordrecht, 1993, 156. Het Gemeenschappelijk Protocol trad in werking op 27 april 1992.

Met name Denemarken, Finland, Italic, Nederland, Noorwegen en Zweden. Bron: website van het IAEA (www iaea.or) op 28 juni 2000.

Toespraak door de Directeur-Generaal van het IAEA: "The Question of Liability for Damage resulting from a Nuclear Accident", IAEA Doc., GOV/2306, 22 mei 1987.

IAEA Doc., GC(XXXII)/Res/49].

Zie hierover Boulanenkov, V. en Brands, B., "Nuclear Liability: Status and Prospects", IAEA Bulletin, 4/1988, 9; De la Fayette, L., "Vers un nouveau régime de responsabilité de l'Etat visant les activités nucléaires", Bulletin de Droit Nucléaire, $\mathrm{n}^{\circ} 50,1992,7-39$.

Voor een overzicht van de argumenten pro en contra zie Reyners, P., "Civil Liability versus State Liability in case of a Nuclear Incident - Some Thoughts inspired by the Vienna Convention Revision Exercise", in AIDN/INLA, Nuclear Inter Jura '9! , Bath., "Nuclear Law and Nuclear Energy for the Fu- 
werden evenwel slechts aangevat nadat een akkoord was bereikt over het Gemeenschappelijk Protocol ${ }^{210}$.

In februari 1989 werd de Working Group on Liability for Nuclear Damage opgericht. De werkgroep, die tweemaal is bijeen gekomen, heeft een aantal onderwerpen besproken, waaronder de verhouding tussen een systeem van civielrechtelijke aansprakelijkheid en van staatsaansprakelijkheid. In een rapport dat de werkgroep einde 1989 aan de Board of Governors van het IAEA overhandigde, werd aanbevolen om het mandaat uit te breiden tot verbetcringen aan het nucleaire civiele aansprakelijkheidsrecht ${ }^{211}$.

De aanbeveling werd gevolgd en in februari 1990 werd de Standing Committee on Liability for Nuclear Damage in het leven geroepen. De vervanging van de Working Group in het Standing Committee resulteerde meteen in een uitbreiding van de taken: naast de internationale aansprakelijkheid van de Staat, diende ook de civielrechtelijke aansprakelijkheid en de verhouding tussen beide te worden bestudeerd. De werkzaamheden van de Standing Committee hadden betrekking op drie onderwerpen: de revisie van het Verdrag van Wenen, bijkomende fondsvorming en de verhouding tussen staatsaansprakelijkheid en civielrechtelijke aansprakelijkheid ${ }^{212}$.

In feite werd de aanvankelijkc idee om de nucleaire aansprakelijkheidsverdragen van de eerste generatie te herzien via de introductie van een internationale aansprakelijkheid van de Staat, verlaten ten voordele van een wijziging van het Verdrag van Wenen. Gevreesd werd onder meer dat onderhandelingen over een maximalistische wijziging (hiermee wordt bedoeld zowel inhoudelijke wijzigingen wat betreft de civielrechtelijke aansprakelijkheid als de introductie van de internationale aansprakelijkheid van de Staat) te veel tijd in beslag zouden nemen en dat een te verregaande wijziging ertoe zou leiden dat slechts een gering aantal landen met het herziene Verdrag zou instemmen ${ }^{213}{ }^{214}$. De idee van de invoering van een internationale aansprakelijkheid werd dan ook verlaten om de andere inhoudelijke hervormingen aan de bestaande regimes niet al te zeer te vertragen $^{215}$.

ture", 1991, 239 e.v. en Handl, G., "Towards a Global System of Compensation for Transboundary Nuclear Damage: Reflexions on the Interrelationship of Civil and International State Liability", Niclear Accidenis. Liabilities and Guarantees, OECD, Paris, 1993, 498 e.v. De lá Fayette, L., "Nuclear Liability Revisited", Review of European Community and International Environmental Law, 1992, vol. 1, $0^{\circ} 4,443-452$. "Liability and Compensation for Nuclear Damage", l.c. 121.

"Liability and Compensation for Nuclear Damage", l.c., 122.

Lamm, V., "Status of the Revision of the Vienna Convention", Nuclear Accidents. Liabilities and Guarantees, OECD, Paris, 1993, 178; Reyners, P., "Le Régime Intemational de Responsabilité civile Nucléaire. Prespectives d'évolution", in L'option Nucléaire. L'Ethique et le Droit, Colloqium mei 1994, Société Française d'Energie Nucléaire, 1994, 267.

Bovendien werd gevreesd dat het werk van het IAEA zou interfereren met de werkzaamheden van de International Law Commission ter zake van het ontwikkelen van staatsaansprakelijkheid voor gevaarlijke activiteiten (Boulanenkov, V. en Brands, B., "Nuclear Liability: Status and Prospects", o.c., 9). Voor een uitstekende analyse van de werkzaamheden van de ILC, zie Horbach, N.L.J.T., Liability versus Responsibility under International Law. Defending strict State Responsibility for Transboundary Damage, Amsterdam, 1996.

215 Het leidt weinig twijfel dat de mocizame discussies omtrent de aansprakelijkheid van de Staat, het werk van de Standing Committee heeft vertraagd. (Horbach, N.L.J.T., "Lacunea of International Nuclear Liability Agreements", in Horbach, N.L.J.T., "Contemporary Developments in Nuclear Energy Law", l.c., 59). 
Er werden dus verschillende thema's besproken. De belangrijkste thema's zijn de uitbreiding van het geografische toepassingsgebied, het optrekken van de aansprakelijkheidslimiet van de exploitant, het verlengen van de termijn waarbinnen een vordering kan worden ingediend, en het uitbreiden van het begrip "schade" waardoor ook schade aan het milieu, preventieve maatregelen en winstverlies onder het Verdrag zouden worden gedekt ${ }^{216}$.

Bijkomend waren de verschillende experten van oordeel dat een wijziging van het Verdrag van Wenen alleen niet voldoende zou zijn om tegemoet te komen aan de belangen van slachtoffers van een kernongeval. Deze belangen zouden enkel worden gediend indien, naast deze inhoudelijke wijziging, ook zou worden voorzien in een internationaal fonds dat schadevergoeding zou toelaten bovenop de bedragen beschikbaar door de aansprakelijkheidsverzekering van de exploitant van de keminstallatie ${ }^{27}$. Een systeem van bijkomende fondsvorming zou aanzienlijk hogere bedragen kunnen genereren. Een verregaande bescherming van de nucleaire sector zoals dat het geval was in de beginjaren van de bestaande Conventies, was volgens Lopuski niet langer verantwoord ${ }^{218}$.

Tijdens de onderhandelingen bestond vrij snel eensgezindheid over de noodzaak om te voorzien in bijkomende fondsvorming of compensatie; maar het is niet eenvoudig gebleken om een akkoord te bereiken over de wijze waarop deze bijkomende compensatie gestalte zou krijgen, laat staan over de verdeelsleutel van de bijdragen tot deze bijkomende compensatie.

In de eerste plaats diende overeenstemming te bestaan over de wijze waarop de bijkomende fondsvorming vorm zou krijgen. Zo werd voorgesteld de Bijkomende Fondsvorming te incorporeren in het gewijzigde Verdrag van Wenen; ofwel diende de Bijkomende Fondsvorming gestalte te krijgen in de vorm van een afzonderlijk Verdrag dat het Verdrag van Wenen (en desgevallend ook het Verdrag van Parijs) zou aanvullen; tenslotte werd ook voorgesteld een geheel afzonderlijke Conventie in het leven te roepen die zowel de bestaande Verdragen als de nationale wetgeving (zelfs van niet-Verdragsluitende Staten) zou aanvullen. Dit laatste voorstel werd door de Amerikanen geïntroduceerd en staat bekend als de "Umbrella Convention", of "Paraplu-Verdrag"2.19.

De twee voornaamste voorstellen inzake bijkomende Fondsvorming heten respectievelijk de Pool-draft en de Levy-draft.

Volgens de levy-draft diende de nucleaire industrie in de verschillende Verdragsluitende Staten een collectieve bijdrage te leveren. Onder dit systeem diende de exploitant in fondsen te voorzien tot op een bepaald niveau. Als tweede trap diende de Staat tussen te komen; een derde deel diende te worden vergoed, gemeenschappelijk door de verschillende exploitanten en het vierde deel van

"Liability and Compensation for Nuclear Damage", 1.., 123.

Lamm, V., "Le Protocole d'amendement de la Convention de Vienne de 1963", Bulleiin de Droit Nucléaire, $n^{\circ}$ 61, 1998, 9; Reyners, P., "Modernisation du régime de responsabilité civile pour les dommages nucléaires: révision de la Convention de Vienne et nouvelle Convention sur la réparation complémentaire des dommages nuciéaires", Revue Générale de Droit International Public, 1998/3, $758-759$.

In X., "Outlook on International Nuclear liability, o.c., 8; ook Lopuski, J., "Civil liability for nuclear damage: selected questions connected with the revision of the Vienna Convention", Nuclear Accidents. Liabilities and Guarantees, Helsinki symposium, OECD, 1993, 181-216.

De uiteindelijke tekst van het goedgekeurde Verdrag wijkt op cen aantal punten af van de tekst van de umbrella-draft, maar toch bevat het er onmiskenbaar de sporen van (Brown, O.F., II, "Recent Developments from the Perspective of the United States", in Horbach, N.I.J.T. (ed.), "Contemporary Developments in Nuclear Energy Law", l.c., 485-486). 
het schadevergoedingsbedrag zou worden betaaid met de opbrengsten van een door de exploitanten te betalen heffing. Deze heffing zou variëren al naargelang het type en de capaciteit van de kerninstallaties. De tegenstanders van dit systeem oordeelden dat een dergelijk systeem in de praktijk niet haalbaar zou zijn, gelet op het grote verschil in veiligheid tussen de keminstallaties van de verschillende landen. De exploitanten van "veilige" kerninstallaties waren met andere woorden niet bereid om bijdragen te leveren voor minder veilige kerninstallaties ${ }^{220}$.

Volgens de pool-draft diende de aansprakelijkheid van de exploitant te worden vastgesteld op een hoger niveau dan de bedragen voorzien in het Verdrag van Parijs en het Verdrag van Wenen. Voor de bedragen waarvoor geen dekking kan worden verkregen op de verzekeringsmarkt, zouden exploitanten een beroep kunnen doen op de Staat of zouden zij kunnen participeren in een risicopool. Van belang is dat de voorstellen die in dit kader werden gelanceerd, in belangrijke mate waren geïnspireerd op het Amerikaanse systeem onder de Price-Anderson Act ${ }^{22 I}$, en dat de exploitanten bereid waren hierop in te gaan, op voorwaarde dat een poolingsysteem op vrijwillige basis zou worden gecreěerd 222 .

Het pool-systeem zou impliceren dat bepaalde exploitanten niet tot een dergelijke pool zouden worden toegelaten. Voor bepaalde delegaties bij de onderhandelingen werd dit beschouwd als een voordeel, aangezien op deze wijze landen zouden worden aangezet om de veiligheidsmaatregelen te verscherpen; andere delegaties waren van oordeel dat dit ertoe zou leiden dat slechts een zeer beperkt aantal landen tot het systeem van bijkomende compensatie zou kunnen toetreden ${ }^{223}$. Tegelijk kon geen eensgezindheid worden bereikt over de vraag op welke wijze deze gemeenschappelijke bijdragen van de exploitanten dienden te worden georganiseerd: door middel van een verplicht internationaal fonds dat door het IAEA zou worden beheerd, dan wel door aan de exploitanten de vrijheid te laten om al dan niet deel te nemen aan een poolingovereenkomst met andere exploitanten ${ }^{224}$.

Zowel de pool-draft als de levy-draft gingen dus uit van een collectieve bijdrage van de exploitanten; na verschillende jaren van onderhandelingen bleek evenwel dat het onmogelijk zou zijn om hierover een brede consensus te bereiken. Bijgevolg werd ervoor geopteerd dat de bijkomende fondsvorming, naar het voorbeeld van het Aanvullend Verdrag van Brussel, zou bestaan uit publieke fondsen.

De onderhandelingen hebben uiteindelijk in september 1997 tot een resultaat geleid, waarbij uitsluitend wijzigingen werden aangebracht aan de civielrechtelijke aansprakelijkheid zoals die eerder bestond; er werd geen internationale aansprakelijkheid van de Staat ingevoerd. Op de diplomatieke conferentie van 8 tot 12 september 1997 werden twee nieuwe Verdragen opengesteld ter ondertekening: het Protocol aan het Verdrag van Wenen en het Verdrag inzake Bijkomende Compensatie.

Het Protocol ter wijziging van het Verdrag van Wenen brengt een aantal wijzigingen aan aan de tekst van het Verdrag van Wenen van 1963 en voegt er een aantal nieuwe artikelen aan toe. De voornaamste wijzigingen hebben betrekking op het geografische toepassingsgebied, het begrip

"Liability and Compensation for Nuclear Damage", l.c., 123.

Strohl, P., "Bilan des recherches de la section de langue française", o.c., 158.

Delpirou, D., "La contribution de l'industrie au financement complémentaire du risque nucléaire. Le point de vue commun de deux organisations d'exploitants: OPEN et I'UNIPEDE", in Nuclear Accidents. Liabilities and Guarantees, OECD-NEA, 1993, 464-470. 
nucleaire schade, en de aansprakelijkheidslimiet van de exploitant van een kerninstallatie ${ }^{225}$. Het Protocol treedt in werking drie maanden na het neerleggen van het vijfde instrument van ratificatie, ondertekening of goedkeuring ${ }^{226}$. Eens het in werking zal zijn getreden, dient naar het Protocol en het Verdrag van Wenen te worden verwezen als het "Verdrag van Wenen van 1997 inzake. de Civielrechtelijke Aansprakelijkheid voor Kernongevallen" 227.

Het Verdrag inzake Bijkomende Compensatie stelt zich tot doel om een wereldwijd aansprakelijkheidsregime in het leven te roepen om de uit de regimes van het Verdrag van Parijs en het Verdrag van Wenen voortvloeiende maatregelen te verbeteren en aan te vullen via een verhoging van de beschikbare schadevergoeding bij een kernongeval. De verhoging van de schadevergoeding wordt bereikt via een verzwaarde aansprakelijkheid van de exploitant van een kerninstallatie en via het ter beschikking stellen van publieke fondsen. Het Verdrag kan worden ondertekend door een Staat die hetzij lid is van een van de bestaande internationale nucleaire aansprakelijkheidsregimes, hetzij verklaart dat haar interne wetgeving voldoet aan de bepalingen die zijn weergegeven in de bijlage van het Verdrag. Dit is meteen een bijzonder kenmerk van het Verdrag inzake Bijkomende Compensatie: het is een onafhankelijk Verdrag ${ }^{228}$ dat - anders dan het Aanvullend Verdrag van Brussel dat enkel openstaat ter ondertekening voor landen die eveneens lid zijn van het Verdrag van Parijs - volledig losstaat van het NEA- of het IAEA-regime.

De enige voorwaarde die wordt gesteld is, dat een land dat een kerninstallatie op zijn grondgebied heeft, enkel tot het Verdrag inzake Bijkomende Compensatie kan toetreden indien het eveneens is toegetreden tot het Verdrag inzake Nucleaire Veiligheid. Het Verdrag inzake Bijkomende Compensatie zal in werking treden op de negentigste dag volgend op de dag waarop ten minste 5 landen met een minimum geïnstalleerde nucleaire capaciteit van 400.000 eenheden een instrument van ratificatie of aanvaarding hebben neergelegd. Meteen is duidelijk dat enkel wanneer enkele van de meest genucleariseerde landen zullen toetreden, het Verdrag in werking zal treden.

Het succes van de nucleaire aansprakelijkheidsverdragen van de tweede generatie zal dus grotendeels afhangen van de mate waarin nucleaire landen zullen toetreden tot het herziene Verdrag van Wenen en tot het Verdrag inzake Bijkomende Compensatie ${ }^{229}$. In oktober 2000 hadden 14 landen het Protocol van het Verdrag van Wenen ondertekend; 13 landen waren toegetreden tot het Verdrag inzake Bijkomende Compensatie ${ }^{230}$. Maar slechts twee landen hadden de Verdragen geratificeerd (met name Roemenië en Marokko), waardoor de Verdragen van de tweede generatie nog niet in werking waren getreden en waardoor de vraag kan worden gesteld of zij spoedig in wer-

225. Zo blijkt overigens uit de Preambule van het Protocol: "Considering that it is desirable to amend the Vienna Convention on Civil Liability for Nuclear Damage of 21st May 1963, to provide for broader scope, increased amount of liability of the operator of a nuclear installation and enhanced means for securing adequate and equitable compensation".

Artikel 21 van het Protocol

Artikel $18,2^{\circ}$ van het Protocol.

Zo ook Horbach, N.L.J.T., "Lacunea of International Nuelear Lisbility Agreements", in Horbach, N.L.J.T., "Contemporary Developments in Nuclear Energy Law", l.c. 69.

Schwartz, J., "Diplomatic Conference convened to adopt a Protocol to amend the Vienna Convention on Civil Liability for Nuclear Damage and to adopt a Convention on Supplementary Compensation for Nuclear Damage", in "Nuclear Inter Jura '97", l.c., 429. Ook in die zin Brodecki, Z., "The Polish-Soviet Disputes arising from the Chernobyl Accident - A hypothetical legal analysis", in "La Réparation des Dommages Catastrophiques", l.c., 260.

Bron: website van het IAEA op 28 juni 2000. 
king zullen treden ${ }^{231}$. De geringe belangstelling van verschillende landen om toe te treden tot deze verdragen, wordt hier en daar zwaar onder vuur genomen ${ }^{232}$.

Aangezien een goed begrip van deze nucleaire aansprakelijkheidsverdragen van de tweede generatie inzicht vereist in de beginselen van de verdragen van de eerste generatie, zullen de bepalingen van het Protocol van 1997 en het Verdrag inzake Bijkomende Compensatie worden besproken in hoofdstuk 4, namelijk bij de bespreking van de basisprincipes van het nucleaire aansprakelijkheidsrecht. Telkens zal worden aangegeven op welke punten de Verdragen van 1997 afwijken van de Verdragen van de eerste generatie.

\subsubsection{De revisie van het Verdrag van Parijs}

Ingevolge de wijzigingen aan het Verdrag van Wenen, rijst uiteraard de vraag nuar de impact hiervan op het Verdrag van Parijs. In 1998 zijn inderdaad in de schoot van de NEA de werkzaamheden gestart voor de revisie van het Verdrag van Parijs.

De revisie van het Verdrag van Parijs heeft een dubbel doel. Ten eerste zal emaar worden gestreefd om de bepalingen van het Verdrag van Parijs af te stemmen met deze van het gewijzigde Verdrag van Wenen. Aangezien het Verdrag van Wenen werd gemoderniseerd vereist cen transparant internationaal nucleair aansprakelijkheidsrecht eveneens de modernisering van het Verdrag van Parijs ${ }^{233}$. Met name de koppeling van beide regimes via het Gemeenschappelijk Protocol vereist dat beide Verdragen zo nauw mogelijk op elkaar aansluiten.

Ten tweede zal worden onderzocht in welke mate het herziene Verdrag van Parijs en het herziene Aanvullend Verdrag van Brussel compatibel zijn met het Verdrag inzake Bijkomende Compensa$t^{2} \mathrm{e}^{234}$. De voornaamste thema's bij de onderhandelingen voor de revisie van het Verdrag van Parijs zijn: het optrekken van de aansprakelijkheidslimiet, de uitbreiding van het geografisch toepassingsgebied, de invulling van het begrip "schade" en het wijzigen van de wederkerigheidsbepaling 235236 .

Het is van belang erop te wijzen dat in het kader van de NEA ook de revisie van het Aanvullend Verdrag van Brussel atan de orde is. Er wordt aan gedacht om de tweede schijf van het Verdrag van Brussel (tussenkomst van de installatiestaat) onder te brengen in het Verdrag van Parijs. Eén

Al moet worden benadrukt dat de toetreding tot deze Verdragen niet allesbepalend is in die zin dat ook een afdoende nationale regeling aan slachtoffers een ruime bescherming kan bieden (Vanden Borre $T$, "Dekking van het nucleaire risieo op nationaalrechtelijke basis of via internationale Verdragen: de Verenigde Staten versus Europa", in Faure, M., Deketelaere, K. en Verhoosel, G., (red.), "Grensoverschrijdende milicuproblemen", l.c., 484). Het feit dat meer dan 10 jagr na het ongeval in Tsjemobyl verschillende landen nog geen eigen wetgeving inzake nucleaire aansprakelijkheid hebben opgesteld, wordt door Boustany beschouwd als fundamenteel strijdig met een rechtsstaat Boustany, K., "Le développement de la normativité nucléaire ou l'art de l'évasion juridiçue", a.c., 44.

Horbach, N.L.J.T., "Lacunea of International Nuclcar Liability Agreements", in Horbach, N.L.I.T., "Contemporary Developments in Nuclear Energy Law", l.c., 77. NEA, Note by the Secretariat, Proposed Revision of the Mandate of the Group of Governmental Experts on third party liability in the field of nuclear energy, Room Document $N^{\circ} I, 1999,4$. Summary Record of the meeting held in Paris, 21-22 october 1999, NEA/SEN/LEG(99)3, 6. Rustand, $\mathrm{H}_{\text {n, " }}$ Paris Convention on Third Party Liability in the field of Nuclear Energy. Progress report on negotiations to revise the Convention", in "Reform of Civil Nuclear Liability", International Symposium, Budapest, OECD, Paris, 2000, 142 e.v. 
van de voorstellen die begin 2000 ter tafel lag, was om de derde schijf van het Aanvullend Verdrag van Brussel te vervangen door een verplicht pooling systeem van de exploitanten ${ }^{237}$.

Het ligt in de bedoeling van de onderhandelaars om de discussies af te ronden tegen het einde van 2001 of uiterlijk in 2002. Aangezien de onderhandelingen nog volop aan de gang zijn, is het niet eenvoudig om reeds enig inzicht te verkrijgen in de voortgang van de onderhandelingen. Toch zullen in het verdere onderzoek, in de mate waarin de beschikbare bronnen dit toclaten, ook de voorstellen worden besproken die in het kader van de revisie van het Verdrag van Parijs ter tafel liggen.

\subsection{Conclusie}

Uit bovenstaand overzicht van de intemationale Verdragen die in het kader van dit onderzoek relevant zijn, kunnen conclusies worden getrokken in verband met de tijd die nodig is om nieuwe Verdragen in het leven te roepen, in verband met de inhoudelijke aspecten van de Verdragen van de eerste en de tweede generatie en tenslotte in verband met de naast elkaar bestaande nucleaire aansprakelijkheidsregimes.

Blijkbaar is het niet makkelijk om een overeenkomst te bereiken over een Verdrag inzake de aansprakelijkheid voor schade uit kernongevallen: het heeft ongeveer drie decennia geduurd eer de Verdragen van de eerste generatie (Verdrag van Parijs van 1960 en Verdrag van Wenen 1963) werden aangevuld door de Verdragen van de tweede generatie ${ }^{238}$. Het ongeval in Tsjernobyl heeft als effect gehad dat een Verdrag inzake onderlinge bijstand en een Verdrag inzake vroegtijdige melding in een recordtempo zijn tot stand gekomen en dat ook de onderhandelingen inzake de toenadering tussen beide regimes in een stroomversnelling terechtkwamen - hetgeen heeft geleid tot het Gemeenschappelijk Protocol van 1988. Verder vormde Tsjernobyl de aanleiding tot twee Verdragen inzake Nucleaire Veiligheid - waarvan er één betrekking heeft op de delicate kwestie van het beheer van radioactief afval en gebruikte splijtstoffen - en tot twee Verdragen waarvan wordt verwacht dat zij het internationale nucleaire aansprakelijkheidsrecht modemiseren. Toch moet worden vastgesteld dat de onderhandelingen van het Protocol van het Verdrag van Wenen en van het Verdrag inzake Bijkomende Compensatie ruim tien jaar hebben aangesleept en slechts 11 jaar na het ongeval van Tsjernobyl werden opengesteld ter ondertekening. Bovendien is het twijfelachtig of deze wijzigingen ooit in werking zullen treden.

Bij een inhoudelijke analyse van de verschillende verdragen valt het in de ecrste pluats op dat de Verdragen van de eerste generatic uitsluitend betrekking hadden op de civielrechtelijke aansprakelijkheid bij kemongevallen (hetzij bij vaste kerninstallaties, hetzij bij mariticm transport). Des: $V$ crdragen bevatten daarentegen geen bepalingen inzake de internationale aansprakelijkheid van Staten bij schade door grensoverschrijdende kernongevallen; een poging om hierasn verandering te brengen bij het Protocol van het Verdrag van Wenen of het Verdrag inzake Bijkomende Compensatic is mislukt. De nucleaire aansprakelijkheidsverdragen hebben dus enkel geleid tot een

\footnotetext{
237 Summary Report, Ninth Meeting of the Contracting Parties to revise the Paris Convention, Room Document $n^{\circ} 40,2000,3$; Report, Eight Meeting of the Contracting Parties to revise the Paris Convention, $N E A / L E G / C P P C(2000) 15,10$.

De enige wijziging aan de Verdragen van de eerste generatie die vóór het ongeval in Tsjemobyl in werking is getreden, is het Protocol van 1964 aan het NEA-regime (Verdrag van Parijs én Aanvullend Verdrag van Brussel). Zo hadden de aanslepende onderhandelingen inzake het Protocol van 1982 en inzake de territoriale binding van beide regimes blijkbaar een duwtje in de rug van Tsjemobyl nodig.
} 
zekere harmonisatie van het nucleaire privaatrecht van verschillende landen ${ }^{239}$. Hiermee is evenwel niet gezegd dat in de "pre-Tsjernobyl periode" geen aandacht werd besteed aan de andere elementen van het nucleaire risico: in $1968 \mathrm{kwam}$ het non-proliferatieverdrag tot stand en reeds in 1959 vaardigde Euratom een eerste richtlijn uit inzake stralingsbescherming.

Pas bij de Verdragen van de tweede generatie werd een verdrag opgesteld inzake nucleaire veiligheid. Via het Verdrag inzake Nucleaire Veiligheid van 1994 wordt getracht om een nucleaire veiligheidscultuur te creëren en bij te dragen tot de preventie van kernongevallen. Blijkbaar willen de regeringen van de verschillende landen ook meer en meer de duidelijke band tussen veiligheid, preventie en aansprakelijkheid benadrukken; dit blijkt met name uit het feit dat een land dat over keminstallaties beschikt slechts tot het Verdrag inzake Bijkomende Compensatie van september 1997 wordt toegelaten, indien het ook is toegetreden tot het Verdrag inzake Nucleaire Veiligheid.

Toch moet worden vastgesteld dat de nieuwe juridische instrumenten van de tweede generatie de Verdragen inzake onderlinge assistentie en vroegtijdige kennisgeving en het Verdrag inzake Nucleaire Veiligheid - nauwelijks concrete of dwingende juridische bepalingen bevatten: de verschillende landen zijn er in essentie toe gehouden om bepaalde informatie te verschaften of zij kunnen worden gevraagd om bijstand te verlenen; van enige bijstandsplicht is evenwel geen sprake. Over de controle op de juistheid van de verstrekte informatie en de opvolging daarvan is nauwelijks iets geregeld. In die optick wekt het weinig verwondering dat het Verdrag inzake Nucleaire Veiligheid en het gemeenschappelijk Verdrag inzake de Veiligheid van het Beheer van gebruikte splijtstoffen en Radioactief Afval relatief snel in werking zijn getreden. Hiermee is meteen de vraag gesteld naar de juridische draagwijdte van het internationale kemenergierecht.

In het internationale recht rijst in het algemeen de vraag naar de afdwingbaarheid van de regels neergelegd in de verschillende verdragen en naar de mate waarin Staten kunnen worden aansprakelijk gesteld wanneer zij hun intemationale verbintenissen niet nakomen ${ }^{240}{ }^{241}$. Specifiek met betrekking tot het kernenergierecht geldt dat het internationale kemenergierecht voor een groot deel bestaat uit niet dwingende juridische bepalingen ${ }^{242}$ : het IAEA, noch de NEA hebben de bevoegdheid om dergelijke bepalingen uit te vaardigen. Ook de afdwingbaarheid van de in hun schoot tot stand gekomen Verdragen is gering. Daarom wordt aan het internationale kernenergie-

Alle "eerste" verdragen inzake bepaalde vormen van milieuaansprakelijkheid hebben overigens betrekking op een internationaal geregeld systeem van civielrechtelijke aansprakelijkheid en niet op de internationaalrechtelijke aansprakelijkheid van staten (Doeker, $G$. en Gehring. T., "Private or International Liability for Transnational Envircnmental Damage - the precedent of conventional liability regimes", o.c., 16).

Net zoals dit het geval is in het Belgische en Nederlandse contractenrecht, dienen geldig afgesloten verdragen te worden nageleefd (pacta sunt servanda), en te goeder trouw te worden uitgevoerd - zoals angegeven in artikel 26 van het Weense Verdragenverdrag van 1969 (Zie hierover Nguyen Quoc, D., Daillier, P. en Pellet, P., Droit International Public, $5^{\circ}$ druk, LGDJ, Parijs, 1994, 216). In het internationale recht worden de overeenkomsten (verdragen) afgesloten door versehillende Staten, zodat de plicht om het verdrag na te komen in de regel enkel op de Staat en haar verschillende organen rust (Carreau, D., Droit International, Pedone, $6^{\circ}$ druk, Parijs, 1999, 148). Indien een Staat de verdragsbepalingen heeft geschonden, is een sanctie mogelijk: in principe leidt een schending van een internationale verbintenis tot de verplichting om deze schending te herstellen (Cogen, M., Handboek Internationaal recht, Mys \& Breesch, Gent, 1998, 102) en kan de intemationale aansprakelijkheid van de auteur in het gedrang worden gebracht (Carreau, D., "Droit International", l.c., 429).

242 Zie met betrekking tot nuclear safety: Herrero de la Fuente, A., "The legal force of international rules relating to nuclear risks" ${ }_{x}$ Nuclear Law Bulletin, vol. 30, 1982, 47-59. 
recht verweten te zeer uit soft law te bestaan ${ }^{243}$. De enige dwingende juridische bepalingen zijn terug te vinden inzake nucleaire aansprakelijkheid en inzake non-proliferatie ${ }^{244}$. Pelzer stelt in dit verband dat het internationale recht moet worden beschouwd als een "imperfect legal order"245. Voor de lidstaten van Euratom ligt de situatie enigszins anders, gelet op de mogelijke aansprakelijkheid van een lidstaat bij schending van het gemeenschapsrecht. De Verdragen van de tweede generatie hebben weinig veranderd aan de beperkte juridische dwingende kracht van het internationale kemenergierecht. Bijgevolg is het zeer de vraag of de Verdragen van de tweede generatie daadwerkelijk hebben geleid tot een fundamentele wijziging, c.q. verbetering van het internationale kernenergierecht. Specifiek inzake nucleaire aansprakelijkheid, verdedigt Boustany de stelling dat de principes inzake nucleaire aansprakelijkheid dermate zijn aanvaard dat een gewoonterechtelijke norm is ontstaan op basis waarvan een internationaal-rechtelijke plicht bestaat om te voldoen aan de eisen van een gedegen systeem van civielrechtelijke nucleaire aansprakelijkheid ${ }^{246}$ 247.

Een derde element dat bij dit overzicht in het oog springt, is het naast elkaar bestaan van twee verschillende regimes inzake nucleaire aansprakelijkheid. Er hebben steeds twee internationale nucleaire aansprakelijkheidsregimes bestaan: een universeel regime van het Internationaal Atoomagentschap (IAEA) te Wenen en een regionaal regime van Kernenergie-Agentschap van de OESO (NEA) te Parijs. Het grote inhoudelijke verschil tussen beide regimes, die overigens dezelfde basisbeginselen hanteren, bestaat erin dat in het NEA-regime de totale schadevergoeding die voor een slachtoffer beschikbaar is, uit meerdere schijven bestaat. Het Aanvullend Verdrag van Brussel voert inderdaad, bovenop de eerste schijf van de aansprakelijkheid van de exploitant van de kerninstallatie overeenkomstig het Verdrag van Parijs, een tweede schijf en een derde schijf in; beide schijven bestaan uit overheidsmiddelen: respectievelijk middelen ter beschikking gesteld door de installatiestaat en middelen van de verschillende Verdragspartijen.

Het antwoord op de vraag waarom een dergelijke solidariteit uitgerekend aanwezig is in het NEAregime, is blijkbaar te vinden in de regionale samenhang tussen de leden van het Verdrag van Parijs: het zijn hoofdzakelijk Euratom-lidstaten, die samen met enkele buurlanden lid zijn van het Verdrag van Parijs. Gelet op de culturele en socio-economische gelijkenis, en de gelijkwaardige technische kwaliteit van de keminstallaties, was een solidaire bijdrage tussen deze verschillende landen reeds mogelijk in 1963, bij het afsluiten van het Aanvullend Verdrag van Brussel. Blijkbaar heerste toen reeds vertrouwen in de wederzijdse veiligheid van de kerninstallaties - de bevoegdheden en inspanningen van Euratom ter zake, zullen daar wellicht niet vreemd aan zijin geweest.

Een analoge socio-economische gelijkenis is in veel mindere mate aanwezig tussen de landen van het Verdrag van Wenen. Vandaar dat een eerste stap in de richting van een solidariteit pas veel

Boustany, K., "Le développernent de la normativité nucléaire ou l'art de l'évasion juridique", $0 . c ., 43$ e.v.

Ook in die zin Strohl, P., "Chemobyl et le problème des obligations internationales relatives aux accidents nucléaires", o.c., C.57.

Pelzer, N., "The present state of research carried out by the English speaking section of the Centre for Studies and Research", o.c., 294.

Boustany, K., "Le développement de la normativité nucléaire ou l'art de l'évasion juridique", o.c., 57.

De mate watarin inderdaad kan worden gesproken van een internationaalrechtelijke: gewoonteregel en de mate waarin een Staat kan worden aansprakelijk gesteld indien het haar verplichtingen uit het internationale kemenergierecht niet zou nakomen is een discussic waarop in het kader van dit proefschrift niet verder wordt ingegaan. Onze aandacht richt zich immers primair op de civielrechtelijke aansprakelijkheid voor kernongevallen. 
later is gezet - met name in het Verdrag inzake Bijkomende Compensatie -waarvan de inwerkingtreding nog vele jaren op zich kan laten wachten.

Zowel de geografische spreiding van de landen van het IAEA-regime, als de hieruit noodzakelijkerwijze voortvloeiende socio-economische verschillen, verklaren meteen waarom beide regimes worden in stand gehouden. Opvallend is dat zowel ten tijde van het afsluiten van het Verdrag van Wenen als op latere tijdstippen is getracht beide regimes beter op elkaar af te stemmen, of zelfs in elkaar te doen opgaan. Totnogtoe is men er enkel in gelukt om beide regimes aan elkaar te koppelen door middel van het Gemeenschappelijk Protocol van 1988. Blijkbaar zullen de kansen op een daadwerkelijke toenadering slechts reëel worden wanneer het IAEA-regime eenzelfde "bescherming" biedt als het NEA-regime wat betreft de Staatsinterventic, de hoogte van de aansprakelijkheid van de exploitant van een kerninstallatie en de veiligheid van de keminstallaties. Uiteraard rijst de vraag of de twee regimes per se volledig moeten worden geïntegreerd. Het lijkt voor de hand liggend dat een beter regionaal regime haar voordelen niet uit handen wenst te geven aan een universeel regime dat aan slachtoffers van kernongeval minder te bieden heeft.

Hiermee is misschien zelfs het nut aangetoond van regionale Verdragen inzake nucleaire aansprakelijkheid of ruimer, inzake kernenergierecht. Het is makkelijker om in kleinere groep tot een consensus te komen aangaande de hoogte van de aansprakelijkheid etc. Uiteraard heeft regionalisme ook duidelijke nadelen: het heeft geen zin verschillende eilanden te creëren die op geen enkele manier met elkaar in verbinding zijn. Het lijkt dan ook dat de huidige situatie waarbij regionalisme via het Gemeenschappelijk Protocol wordt overbrugd, een stap is in de goede richting.

Toch is het naast elkaar bestaan van verschillende regimes niet eigen aan de nucleaire aansprakelijkheidsverdragen. Ook inzake het garanderen van het vreedzaam gebruik van kernenergie, bestaat het mondiale safeguards-systeem van het IAEA naast de regionale systemen van Euratom, ABACC (Argentinië en Brazilië) en OPANAL (Latijns-Amerika) ${ }^{248}$ en lijkt de wisselwerking tussen deze regionale systemen enerzijds en het overkoepelende mondiale systeem anderzijds, goed te functioneren. In zekere zin zou, indien het IAEA waakt over een algemene uniformiteit van het internationale kemenergierecht, een systeem van regionale bevoegde instanties kunnen worden beschouwd als een toepassing van het subsidiariteitsbeginsel in het kernenergierecht. Zo zou Euratom, vertrekkende van het Verdrag inzake onderlinge bijstand, een richtlijn kunnen uitvaardigen waarbij de vage beginselen van deze verdragen verder worden geconcretiseerd en vervolgens worden omgezet in dwingende juridische regelgeving. Hetzelfde geldt voor de nucleaire aansprakelijkheidsverdragen: niets belet dat Euratom een richtlijn inzake de aansprakelijkheid voor kernongevallen zou uitvaardigen, waarbij dan een aantal principes van het Verdrag inzake Bijkomende Compensatie zouden worden opgenomen of waarin, meer in het algemeen, de regeling van het Verdrag van Parijs verder zou worden uitgewerkt.

In de huidige context is het opvallend dat enkel de nucleaire Verdragen die vage beginselen propageren snel worden ondertekend en van kracht worden. De Verdragen die wel juridische verplichtingen met zich mee brengen worden slechts moeizaam geratificeerd en zullen misschien nooit in deze vorm in werking treden. Het enthousiasme van Staten om toe te treden tot de nucleaire Verdragen is dus omgekeerd evenredig met de mate waarin deze verdragen juridische verplichtingen opleggen. Dit geldt voor de Verdragen van de eerste generatie (het Verdrag van Wenen) en naar alle waarschijnlijkheid ook voor deze van de tweede generatie. Misschien valt de 
terughoudendheid te verklaren doordat het uiteindelijke resultaat van de verdragsonderhandelingen, als grootste gemene deler, voor sommige landen veel te ver lijkt te gaan en voor andere landen niet ver genoeg.

Los van deze discussie, is het voor het vervolg van dit onderzoek vooral van belang dat op basis van de nucleaire Verdragen van de eerste generatie, de verschillende landen van het NEA-regime (en grotendeels ook van het IAEA-regime) de in de verdragen aangegeven principes hebben opgenomen in hun nationale wetgeving. De Verdragen hebben in dat opzicht dan ook een belangrijke verdienste op het vlak van de harmonisering van de wetgeving. Of en in welke mate de nucleaire aansprakelijkheidsverdragen het ontstaan van het Belgische en Nederlandse kemenergierecht hebben beïnvloed, wordt in de volgende paragrafen aan de orde gesteld.

Hieronder eerst wordt aandacht besteed aan het ontstaan van het kernenergierecht in België $(\S 3)$ en Nederland ( $(4)$. Zowel de materieelrechtelijke bepalingen als het institutionele kader worden hierbij aan de orde gesteld. Deze analyse is noodzakelijk omdat vanaf het volgende hoofdstuk steeds de bepalingen van zowel de Verdragen als van het Belgische en Nederlandse kernenergierecht in de analyse worden betrokken. Het ligt voor de hand om in het overzicht van deze rechtssystemen die aspecten te bespreken die van belang zullen zijn voor de verdere analyse in dit proefschrift.

\section{ONTSTAAN YAN HET BELgische KERNENERGIERECHT}

Het ontstaan van het Belgische kernenergierecht kan niet worden losgezien van de bijzondere positie van België in de ontwikkeling en het gebruik van kernenergie: via haar Kongolese kolonie had België namelijk toegang had tot unieke uraniumertsen. De rol van Belgisch-Kongo in de ontwikkeling van kernenergie in België wordt in $\S 3.1$ besproken. Nadien wordt in grote lijnen de totstandkoming van het "algemene" Belgische kernenergierecht ${ }^{249}$ geschetst ( $\$ 3.2$ ). De nadruk zal daarbij liggen op de wetgeving inzake stralingsbescherming. De eerste wetten inzake nucleaire aansprakelijkheid worden in $\S 3.3$ aan de orde gesteld. De invloed van de Belgische staatshervorming (federalisering) op het kemenergierecht wordt in $\$ 3.4$ besproken. De conclusie van de in deze paragraaf gevoerde analyse wordt weergegeven in $\S 3.5$.

\subsection{De rol van Belgisch-Kongo voor de ontwikkeling van kernenergie in België}

Een belangrijke factor in de ontwikkeling van het kemenergieprogramma van België bestond in de ontdekking in Katanga (Belgisch-Kongo) van aanzienlijke hoeveclheden uraniumerts met een uitzonderlijke concentratie uranium. Vanaf 1921 begon Union Minière de exploitatie van de mines du Haut-Katanga; tot 1936 zou een totale hoeveelheid van 5.700 ton uranium worden ontgonnen. De ontgonnen ertsen bleven deels ter plaatse en werden deels naar België (Olen) getransporteerd $^{250}$.

Door het uitbreken van de Tweede Wereldoorlog bestond het risico dat Hitler de hand zou kunnen leggen op de Belgische uraniumvoorraden. Vóór 10 mei 1940 slaagde Union Minière erin om ongeveer 1.000 ton ruw uraniumerts dat in België aanwezig was, te verschepen naar de Verenigde

\footnotetext{
249

Hiermee wordt bedoeld dat deel van het kemenergierecht dat geen deel uitmaakt van het nucleaire aansprakelijkheidsrecht.

250

Gillon, L., "L'approvisionnement en uranium", L'énergie Nucléaire en Europe': des Originus à Luratom, Actes de joumées d'études de Louvain-la-Neuve, 18-19 november 1991; Vandenberghe, $\mathrm{H}$, Kernenergie in België, SCK/CEN, ENE.RA95xx, april 1995 (niet gepubliceerd), 12.
} 
Staten en naar het Verenigd Koninkrijk. Ook de in Kongo aanwezige voortaden werden naar de VS gestuurd ${ }^{25 !}$.

Aldus waren de Kongolese uraniumvoorraden voor de Verenigde Staten en het Verenigd Koninkrijk van belang en ontstond cen samenwerking tussen België enerzijds en de Verenigde Staten en het Verenigd Koninkrijk anderzijds ${ }^{252}$. Deze samenwerking werd juridisch vastgelegd door middel van commerciële contracten inzake de aankoop van uranium. Daamaast ontstonden in de periode 1944 en 1956 tussen België, de VS en het VK de eerste bi- en tripartite Verdragen inzake het gebruik van kemenergie.

Een eerste Verdrag tussen de Verenigde Staten van Amerika, het Verenigd Koninkrijk en Belgiëdat uiteraard diende geheim te blijven - werd in de vorn van een Memorandum of Understanding afgesloten op 26 september 1944. Hoewel de bewoordingen van het "Verdrag" vaag waren opgesteld, verleende België aan de VS en het VK een optie voor de aankoop van uranium en verbonden de VS en het VK er zich anderzijds toe om België toegang te verlenen tot de kennis inzake het gebruik van kemenergie voor commerciële doeleinden ${ }^{253}$. België bevond zich dus in een bevoorrechte positie omdat het, als enige niet grootmacht, toegang zou krijgen tot de kennis inzake kernenergie.

Maar in 1946 stemde het Amerikaanse Congres de Atomic Energy Act, die een strikte geheimhouding van nucleaire kennis en materiaal invoerde ${ }^{254}$. België eiste compensaties tengevolge van het nucleaire embargo en kreeg die, na enig aandringen, in de vorm van een heffing per kilogram geexporteerd uraniumerts ${ }^{255}$ : in 1951 stonden de VS een heffingstoeslag toe voor de leveringen tot aan het einde van het Memorandum in 1956. Deze extra fondsen zouden worden aangewend voor de financiering van het Belgisch nucleair onderzoeksprogramma ${ }^{256}$. Maar nog steeds kreeg België geen toegang tot nucleaire kennis.

Pas gedurende de onderhandelingen voor de hernieuwing van het Memorandum van 1944 in het midden van de jaren vijftig ${ }^{257}$, werd daadwerkelijk tegemoet gekomen aan de Belgische eisen en kregen Belgische wetenschappers en industriëlen opleiding in Britse en Amerikaanse labo's; een tiental mensen kreeg zelfs een opleiding bij de USAEC. De gewijzigde Amerikaanse houding dient ongetwijfeld te worden gezien in het licht van de versoepeling van de geheimhouding rond civiele toepassingen van kernenergie, ten voordele van een gecontroleerde internationale samen-

25) Gillon, L., "L'approvisionnement en uranium", o.c.; zie uitvoerig: Vandenberghe, H., "Kernenergie in België", l.c., 10 e.v.

252 Buch, P., Mund, E. en Vanderlinden, J., "Aux origines de l'effort nucleaire belge", in Govaerts, P., Jaumotte, A. en Vanderlinden, J. (ed.), Un demi-sciècle de nucléaire en Belgique. Témoignages, Belgian Nuclear Society, Presses Universitaires Européennes, 1994, 22.

Zie hierover Helmreich, J.E., "The Uranium Negotiations of 1944" in Le Congo Belge durant la seconde Guère Mondiale, Brussels, Royal Academy for Overseas Studies, 1983, 253-283; Helnreich, J.E., "Belgium, Britain, the United States and Uranium, 1952-1959", Studia Diplomatica, $n^{\circ}$ 3, 1990 , 27-81.

Zie over deze wet o.m. Fischer, G., L'Energie atomique el les Etats Unis. Droit Interne et droit International, Paris, Durand-Auzias, 1957, 87 e.v.; zie eveneens hoofdstuk 13.

256 Helmreich, J.E., "Belgium, Britain, the United States and Uranium, 1952-1959", o.c., 27-81. Government of Belgium, getekend op 15 juni 1955. 
werking. De gewijzigde houding bleek uit de Price-Anderson Act van 1957 en het reeds aangehaalde "Atoms for Peace" programma van president Eisenhower ${ }^{258}$.

Het is interessant aan te stippen dat de eerste Belgische wetgeving inzake civiele aansprakelijkheid bij kernongevallen rechtstreeks is verbonden aan de start van het Studiecentrum voor Kernenergie (SCK) en dat de start van het SCK op zijn beurt een gevolg was van bovenvermelde overeenkomsten en dan met name wat betreft de heffingen op het uraniumerts. Uit de opbrengst ervan werd in 1951 te $\mathrm{Mol}$ het Studiecentrum voor Toepassingen in de Kernenergie (STK) - het latere SCK - opgericht ${ }^{259}$. Hiermee was België het eerste Westerse land buiten de traditionele grootmachten dat vreedzame nucleaire activiteiten ging (en kon) ontplooien. Vanaf het moment echter waarop kemenergie werd aangewend, drong de noodzaak zich op om de burger daadwerkelijk te beschermen tegen het hiermee gepaard gaande nucleaire risico, in de meest brede zin van het woord. Op deze wijze ontstond het Belgische kernenergierecht.

\subsection{Overzicht van het Belgische kernenergierecht ${ }^{260}$}

In navolging van de wetgeving van de grootmachten werd in België een wetgevend kader gecreeerd teneinde zowel de veiligheid van de Staat als de veiligheid van de bevolking en van de werknemers tegen de gevaren van kemenergie te garanderen en teneinde een regeling te treffen inzake de aansprakelijkheid bij kemongevallen.

De regels met betrekking tot de fysieke bescherming van kemmateriaal en inzake safeguards vallen onder de regelgeving inzake de bescherming van de veiligheid van de Staat. Het Verdrag inzake de externe beveiliging van kernmateriaal werd goedgekeurd bij wet van 24 juli $1984^{2 n 1}$; het Verdrag werd door België bekrachtigd op 6 september 1991, met ingang van 6 oktober 1991 . Tegelijk voegde de wet van 17 april $1986^{262}$ een aantal nieuwe bepalingen toe aan het Strafwetboek ${ }^{263}$. Voor wat betreft de controle op de aanwending van nucleair materiaal voor vrcedzame doeleinden, is België lid van het Non-Proliferatie Verdrag en uiteraard van Euratom. Uit dien hoofde werd in april 1973 tussen het IAEA, Euratom en de niet kernwapenstaten van Euratom, een internationale overeenkomst afgesloten ${ }^{264} 265$. In het bijzonder wat de taken van het IAEA

Cfr. supra, § l. I van dit hoofdstuk.

Cfr. infra, $\$ 2.3 .1$ bij de bespreking van de wet op de civielrechtelijke aansprakelijkheid van het SCK. Het is niet de bedoeling om hier een volledig overzicht te geven van alle wetgeving en van alle controle-instanties die terzake bevoegd zijn. Hier wordt volstaan met een beeld van de voornaamste regels inzake veiligheid die, zoals we later zullen zien, ook hun relevantie hebben op het vlak van de prikkels op het gedrag van de exploitant. Voor een volledig beeld van de nucleaire wetgeving, kan worden verwezen naar de door de NEA uitgegeven losbladige recks Nuclear Legislation.

B.S., 27 februari 1992.

B.S., 14 augustus 1986.

Met name een Afdeling ITbis aan het hoofdstuk I inzake diefstal en afpersing "Diefstal en afpersing van kermmateriaal" (artikelen 477-477 sexies Sw), cen hoofdstuk Ibis "Externe beveiliging van kernmateriaal" (artikel 488bis Sw). Beide hoofdstukken behoren tot Titel 9 van het Sw inzake misdaden en wanbedrijven tegen eigendonmen. Verder werden ook de artikelen 331 bis en $487 \mathrm{bis}$ ingevoerd in het Belgische Strafwetboek.

Wet van 14 maart 1975 betreffende goedkeuring van het Verdrag inzake de niet verspreiding van kernwapens, B.S., 20 november 1975, 14680; Overeenkomst tussen het Koninkrijk Belgiẻ, het Koninkrijk Denemarken, de Bondsrepubliek Duitsland, lerland, de Italiaanse Republiek, het Groothertogdom Luxemburg, het Koninkrijk der Nederlanden, de Europese Gemeenschap voor Atoomenergie en de Internationale Organisatie voor Atoomenergie ter uitvoering van artikel III, de leden 1 en 4 van het Verdrag inzake de niet verspreiding van kernwapens, B.S., 20 november 1975, 14688.

Over de samenwerking tussen Euratom en het IAEA, zie o.m. Gijssels; J., "L'accord entre Euratom et I'AIEA en application du Traité de non-prolifération des armes nucléaires", Annuaire Français de 
betreft, werden bij wet van 20 juli 1978 de nodige schikkingen getroffen om de inspecteurs van het IAEA toe te laten hun inspectie- en verificatiewerkzaamheden uit te voeren ${ }^{266}$.

De belangrijkste wet inzake stralingsbescherming is de wet van 29 maart $1958^{267}$ ter bescherming van de bevolking tegen de uit ioniserende stralingen ${ }^{268}$ voortspruitende gevaren, uitgevoerd door het KB van 28 februari 1963 houdende Algemeen Reglement op de bescherming van de bevolking en van de werknemers tegen de gevaren van ioniserende stralen en het KB van 11 mei 1971 houdende Militair Reglement. Zowel de wet zelf als de K'B's bevatten een zeer technische materie waarin onder meer is opgenomen: zeer gedetailleerde veiligheidsvoorschriften waaraan nucleaire installaties dienen te voldoen, limietdoses waaraan verschillende categorieën mensen (werknemers, bevolking, ...) mogen worden blootgesteld, evenals een brede waaier van controlevoorschriften (onder meer medisch toezicht van de werknemers van een nucleaire installatie, toegangsbeveiliging, ...), voorschriften inzake vervoer van nucleair materiaal enzovoort. Het toezicht van het Algemeen Reglement is in handen van de Dienst voor Bescherming tegen Ioniserende Stralingen (DBIS), dat deel uitmaakt van het Ministerie van Volksgezondheid en Leefmili$\mathrm{eu}^{209}$. Voor de vergunningsaanvragen voor kerninstallaties werkt zij nauw samen met de Dienst vor Technische V'eiligheid van Nucleaire Installaties (DTVNI).

Voor een groot deel is de wet van 1958, althans in theorie, vervangen door een andere wet. Op 15 april 1994 werd de wet betreffende de bescherming van de bevolking en van het leefmilieu tegen de uit ioniserende stralingen voortspruitende gevaren en betreffende het Federaal Agentschap voor Nucleaire Controle (FANC) goedgekeurd ${ }^{270}$.

Het FANC is belast met een algemene taak van toezicht en controle en met het begeleiden van de inspecteurs van het IAEA wanneer deze hun controlewerkzaamheden uitvoeren. Het FANC zal aldus de taken overnemen van de Dienst voor Bescherming tegen Ioniserende Straling (DBIS). De wet voor/iet dat de leden van de controledienst van het FANC worden bekleed met de hoedanigheid van officier van gerechtelijke politie, hulpofficier van de Procureur des Konings. Daarnaast heeft het FANC ook een algemene opdracht om wetenschappelijke en technische documentatie op het gebied van nucleaire veiligheid samen te stellen en om neutrale en objectieve informa-

Droit International, 1972, 837-863; Thorstensen, S. en Chitumbo, K., "Safeguards in the European Union: the New Partnership Approach", IAEA Bulletin, No 1, 1995, 25-28; Vanden Borre, T. en Carchon, R., "Preventing the Proliferation of Nuclear Weapons: 50 Years of Atoms for Peace", o.c., 43. Wet houdende geêigende beschikkingen teneinde de Internationale Organisatie voor Atoomenergie toe te laten inspectie- en verificatiewerkzaamheden door te voeren op Belgisch grondgebied, in uitvoering van het Internationaal akkoord van 5 april 1973 bij toepassing der $\S \S$ l en 4 van artikel III van het Verdrag van 1 juli 1968 inzake de niet-verspreiding van kernwapens (B.S., 17 oktober 1978 ). B.S., 30 april 1958, uitgevoerd bij $\mathrm{KB}$ van 28 februari 1963 houdende algemeen reglement op de bescherming van de bevolking en van de werknemers tegen het gevaar van de ioniserende stralingen (B.S., 16 mei 1963). Artikel twee van de wet luidt: "De Koning met uitsluiting van de gemeenteoverheid is gemachtigd, aan de invoer, het produceren, het vervaardigen, het onder zich houden, de doorvoer, het vervoer, het te koop aanbieden, het verkopen, het onder bezwarende voorwaarden of kosteloos afstaan, de verdeling en het gebruik met commercieel, industrieel, wetenschappelijk, medisch of enig ander oogmerk, van apparaten of stoffen, die ioniserende stralingen kunnen verspreiden voorwaarden te verbinden die de bescherming van de gezondheid van de bevolking en van het leefmilieu tot doel hebben. Hij kan eveneens, met dit doel, de verwijdering en de afvoer van radioactieve stoffen reglementeren". Zie hierover Deketelaere, K. e.a., "Handboek energierecht", l.c., 196-198. Ioniserende stralingen worden gedefinieerd als: "stralingen die, op hun doortocht, de stof al dan niet rechtstreeks ioniseren" (artikel I van de wet van 29 maart 1958). Deze dienst is eveneens bevoegd inzake te toekennen van vergunningen en het voorbereiden van nieuwe regelgeving inzake stralingsbescherming. B.S., 29 juli 1994, 19537. 
tie op nucleair gebied te verspreiden. Artikel 54 van de wet op het FANC laat de inwerkingtreding evenwel afhangen van een KB. Einde 2000 was de wet evenwel slechts fragmentarisch van kracht geworden $^{271}$, waardoor nog steeds een aantal bepalingen van de wet van 1958 van kracht zijn: artikel 52 van de wet op het FANC dat de wet van 1958 opheft, is immers nog steeds niet in werking getreden. Het Algemeen Reglement blijft van kracht zolang het niet is opgeheven of gewijzigd krachtens de wet op het FANC. Met name de bepalingen inzake vervoer werden reeds anzienlijk gewijzigd bij het KB van 2 oktober 1997. Eens de wet op het FANC volledig in werking zal zijn getreden, wordt bijgevolg de wet van 14 april 1994 de nieuwe kaderwet inzake de bescherming van de bevolking tegen de gevaren voortkomende uit ioniserende straling.

Tenslotte heeft België bij wet van 26 november 1996 beslist dat het Verdrag inzake nucleaire veiligheid van Wenen, volledige uitwerking zal hebben ${ }^{272}$.

Het kernenergierecht bestaat evenwel niet alleen uit de regelgeving inzake stralingsbescherming en daaraan gekoppeld het nodige toezicht en controle, maar ook uit de regelgeving inzake civielrechtelijke aansprakelijkheid voor kernongevallen. De ecrste regels inzake de civiele aansprakelijkheid voor kernongevallen kwamen pas in 1962 tot stand, namelijk op het moment waarop het SCK de BR 3-reactor ${ }^{273}$ in gebruik nam. Het is duidelijk dat in het kader van dit procfschrift vooral aandacht zal worden besteed aan de nucleairc aansprakelijkheidswetgeving. Het ontstaan van deze wetgeving wordt hieronder besproken.

\subsection{Ontstaan van de Belgische nucleaire aansprakelijkheidswetgeving}

Totnogtoe zijn in dit kader in België vier wetten tot stand gekomen: de wet van 27 juli 1962 betreffende de burgerlijke aansprakelijkheid van het Studiecentrum voor Kernenergie, de wet van 9 augustus 1963 tot vaststelling van de aansprakelijkheid van de exploitant van een atoomschip $^{274}$, de wet betreffende de wettelijke aansprakelijkheid op het gebied van kemenergie van 18

$27 \mathrm{Bij}$ KB van 17 september 1996 tot gedeeltelijke inwwerkingstelling van de wet van 15 april 1994 betreffende de bescherming van de bevolking en van het leefmilieu tegen de uit ioniserende stralingen voortspruitende gevaren en betreffende het Federaal Agentschap voor Nucleaire Controle (B.S., 4 maart 1997) werden de artikelen 1, 2, 35, 36, 38, 40, 42 en 48 in werking gesteld; bij KB van 2 oktober 1997 tot wijziging van het koninklijk besluit van 28 februari 1963 houdende algemeen reglement op de bescherming van de bevolking en van de werknemers tegen het gevaar van de ioniserende stralingen en tot gedeeltelijke inwerkingstelling van de wet van 15 april 1994 betreffende de bescherming van de bevolking en van het leefmilieu tegen de uit ioniserende stralingen voortspruitende gevaren en betreffende het Federaal Agentschap voor Nucleaire Controle (B.S., 23 oktober 1997) werden de artikelen 3 en 49 in werking gesteld, althans wat de uitvoer betreft. Het KB van 13 maart 1998 tot verdere gedeeltelijke inwerkingstelling van de wet van 15 april 1994 betreffende de bescherming van de bevolking en van het leefmilieu tegen de uit ioniserende stralingen voortspruitende gevaren en betreffende het Federaal Agentschap voor Nucleaire Controle (B.S., 16 april 1998) heeft de artikelen 12, 32, 33, 34, 39, 41, $43,44,45,46$ en 47 in werking gesteld per 1 januari 1998.

Wet van 26 november 1996 houdende instemming met het Verdrag inzake nucleaire veiligheid, gedaan te Wenen op 20 september 1994 (B.S., 22 augustus 1997). Hierop wordt verder teruggekomen in hoofdstuk 3.

"BR" staat voor Belgian Reactor. Het betrof een vermogensreactor, in tegenstelling tot de BR-1 en BR2, die onderzoeksreactoren zijn. Zie hierover Vandenberghe, H., "Kemenergie in Belgię", l.c., 33 e.v.

B.S., 8 oktober 1963. 
juli 1966, en de wet van 22 juli 1985 betreffende de wettelijke aansprakelijkheid op het gebied van kernenergie ${ }^{275276}$.

Hierna wordt vooral aandacht besteed aan de wet van 1962 betreffende de burgerlijke aansprakelijkheid van het SCK omdat deze een aantal merkwaardige elementen bevat ( $\$ 3.3 .1$ ). Nadien komt de totstandkoming aan bod van de wet van 1966 (\$3.3.2) en van de wet van 1985 ( $\$ 3.3 .3$ ). De inhoudelijke analyse van de wet van 22 julj 1985 zal volgen vanaf hoofdstuk 3 .

\subsubsection{De wet betreffende de burgerlijke aansprakelijkheid van het Studiecentrum voor Kernenergie van 27 juli $1962^{277}$}

De eerste Belgische wetgeving op het terrein van de civiele aansprakelijkheid van kemenergie had, zoals eerder aangehaald, betrekking op de oprichting van het Studiecentrum voor Kernenergie te $\mathrm{Mol}^{278}$. Op 9 april 1952 werd het Studiecentrum voor Toepassingen van de Kernenergie (STK) opgericht. Het betrof een vereniging zonder winstoogmerk met als taak het verrichten van wetenschappelijk onderzoek inzake kernenergie ${ }^{279}$. De eerste Belgische reactor (BR 1) was operationeel in 1956; een jaar later werd het statuut van het STK gewijzigd om op die manier behalve financiering vanwege de overheid, ook particuliere financiering toe te laten: het STK werd SCK/CEN (Studiecentrum voor Kernenergie/Centre d'Etude de l'Energie Nucléaire) ${ }^{280}$.

Bij gebrek aan wettelijke maatregelen kon één van de reactoren van het SCK onmogelijk in werking worden gesteld. In het contract tussen het SCK en haar Amerikaanse leverancier, diende het SCK, overeenkomstig de hold harmless-clausule, haar leverancier te vrijwaren tegen alle vorderingen van derden die schade zouden lijden tengevolge van de uitbating van de reactor en van het materiaal, inclusief de splijtstoffen ${ }^{281}$. Bovendien was het SCK er contractueel toe gehouden om een verzekeringsdekking of een garantie vanwege de Belgische Staat te bekomen; dere dekking of garantic zou de Amerikaanse leverancier de zekerheid geven dat het SCK hem ook daadwerkelijk zou vrijwaren. De wet had dus zowel tot doel het SCK toe te laten om bij de Amerikaanse leverancier de nodige splijtstoffen aan te schaffen als te garanderen dat slachtoffers compensatie zouden krijgen indien zij schade hadden geleden na een ongeval op het SCK.

In meerdere opzichten is de wet van 1962 een unicum te noemen. Eerst en vooral was deze wet van tijdelijke aard, in afwachting van een definitieve regeling inzake de aansprakelijkheid voor

275 Het spreekt voor zich dat de wet van 1962 door deze van 1966 is opgeheven, net zoals de wet van 1966 door de wet van 1985 is opgeheven.

276 In dit kader wordt niet stilgestaan bij de wet van 9 augustus 1963 tot vaststelling van de aansprakelijkheid van de exploitant van een atoomschip. Hoewel het officieel om een gelegenheidswet ging, biedt deze wet nog steeds het kader voor verdere regels inzake de aansprakelijkheid van de exploitant van een stoomschip (Faure, M. en Van den Bergh, R., Objectieve aansprakelijkheid", l.c., 173). Voor meer details, zie Bonte, E., "Aansprakelijkheidsbeperking der eigenaars en exploitanten van konventionele en kernenergetische schepen", Rechiskundig Weekblad, 1963-64, 145-182. B.S., 7 augustus 1962 .

278 Veuchelen, L., "De civielrechtelijke aansprakelijkheid voor kernongevallen naar Belgisch recht", in Faure, M. (red.), o.c., 1993, 37.

279 Over de geschiedenis van het SCK/CEN, zie o.m. Planquart, J., "Histoire du Centre d'étude de l'énergie nucléaire - SCK/CEN", in Govaerts, P., Jaumotte, A. en Vanderlinden, J. (ed.), Un demi-scièle de mucléaire en Belgique. Témoignages, Belgian Nuclear Society, Presses universitaire européennes, Bruxelles, 1994, 201-297.

280 Daar waar het STK een vzw was, werd het SCK-CEN een Instelling van Openbaar Nut (IO.N.).

281 Reygaerts, M., "Le droit nucléaire belge", Puget, H., Aspects du droit de l'énergie alomique, tome II, Editions du centre national de la recherehe scientifique, Paris, 1967, 267. 
schade door kernongevallen. Deze definitieve regeling bestond in 1962 slechts op papier omdat het Verdrag van Parijs van 29 juli 1960 nog niet in werking was getreden en omdat België nog niet de nodige maatregelen had genomen voor de invoering van het Verdrag van Parijs in de Belgische rechtsorde. De wet diende als "overbrugging" totdat het Verdrag van Parijs zou zijn omgezet in Belgisch recht en was bijgevolg tijdelijk. Daarnaast was deze wet enkel van toepassing op het SCK en niet op andere exploitanten van kerninstallaties.

Meerdere inhoudelijke elementen van de wet zijn de moeite om nader toe te lichten. Ten eerste het feit dat de wet was gebaseerd op de klassieke foutaansprakelijkheid (\$3.3.1.1). Vervolgens de verplichte verzekering van het SCK (\$ 3.3.1.2), de subrogatie en de daaraan gekoppelde rechtstreekse vordering van het slachtoffer tegen de verzekeraar of garant van het SCK (§3.3.1.3). Opmerkelijk zijn eveneens de rol van de Staat bij een eventueel schadegeval (\$ 3.3.1.4) en de exclusieve bevoegdheid van de Brusselse rechter ( $\$ 3.3 .1 .5)$. Verder wordt ook een vonnis besproken van de correctionele rechtbank van Turnhout van 1969, naar aanleiding van een kernongeval op het SCK (§ 3.3.1.6). Hoewel de beginselen van de wet op het SCK (deels) kunnen worden gerekend tot de basisprincipes van het nucleaire aansprakelijkheidsrecht, waarvan de analyse plaatsvindt in hoofdstuk 4, worden een aantal daarvan toch reeds hier aan de orde gesteld omdat, zoals zal blijken uit de conclusie van deze paragraaf, de wet van 1962 inzake de burgerlijke aansprakelijkheid van het SCK deze principes in een bijzondere context hanteerde $(\$ 3.3 .1 .7)$.

\subsubsection{Klassieke aansprakelijkheidsregels}

In het oog springend is vooral dat de wet uitging van het gemeenrechtelijke regime van foutaansprakelijkheid ingeval derden schade leden tengevolge van de nucleaire activiteiten van het SCK. Artikel 2 van de wet van 1962 liet er geen twijfel over bestaan dat het SCK enkel kon worden aansprakelijk gesteld "wanneer het wegens onrechtmatige daad aansprakelijk is". De wet op het SCK voerde dus geen eigen aansprakelijkheidsregel in, maar verwees naar het gemeenrechtelijke, op een fout gebaseerde aansprakelijkheidsrecht.

Het behoud van het regime van foutaansprakelijkheid was op zich een vreemde zaak aangezien het op dat moment reeds tot stand gekomen Verdrag van Parijs van 1960 een regime van risicoaansprakelijkheid introduceerde ${ }^{282}$. Het is dan ook niet verwonderlijk dat behoud van het foutaansprakelijkheidsregime, zowel in de voorbereidende commissievergaderingen als tijdens de parlementaire bespreking van de wet, het voorwerp was van discussie. Principieel werd gesteld dat door het behoud van de foutaansprakelijkheid, het slachtoffer zou worden geconfronteerd met een te zware bewijslast. Daarop werd geantwoord dat een onvolmaakte wet toch beter was dan niets, en dat om redenen van hoogdringendheid ieder verder uitstel diende te worden vermeden ${ }^{283}$. Opvallend is de opmerking van de Minister van Economische Zaken en Energie in de Kamer:

282 Eerder waren met name in het luchtvaartrecht ook reeds andere Verdragen tot stand gekemen die net beginsel van risicoaansprakelijkheid hanteerden én invoerden in Belgisch recht, te weten het Verdrag van Rome van 29 mei 1933 (goedgekeurd bij wet van 11 september 1936, B.S. 14 februari 1937) en het Verdrag van Rome van 7 oktober 1952. Zie hierover Kirkpatrick, R., "La responsabilité objective en matière d'accidents d'aviation et de roulage", Revie Générale des Assurances et des Responsabilités, 1933, 1341; Clerens, A., "Burgerrechtelijke aansprakelijkheid inzake schade aan derden op het aardoppervlak toegebracht door luchtvaartuigen. De Verdragen van Rome van 1933 en 1952", Rechtskundig Weekblad, 1958-59, 1377-1414; Faure, M. en Van den Bergh, R., "Objectieve Aansprakelijkheid," l.c., 260 e.v.; Cleton, R., "Aansprakelijkheid en schadevergoeding als nasleep van luchtvaartongevallen", Nederlands Juristenblad, 1993, afl. 17, 621-629.

Parlementaire Bescheiden, Kamer, GZ/1961-1962, $n^{\circ} 349 / 3,4$. 
"Ik zou er willen op wijzen dat dit instrument (de BR 3) een zeer aanzienlijk aantal miljoenen heeft gekost en dat het hoog tijd wordt dat het zou worden benut.

Ofwel laat men de reactor nog één of twee jaren onbenut en gebruikt men die tijd om een wetgeving op touw te zetten (...); ofwel stelt men zich op het praktische standpunt en keurt men dit ontwerp van wet goed"284.

Ook vanuit de rechtsleer werd zware kritiek geuit op het behoud van de gemeenrechtelijke aansprakelijkheid $^{285}$. Toch is de wet goedgekeurd omdat deze snel zou worden vervangen door een wet die het Verdrag van Parijs van 29 juli 1960 uitvoerde en die een regime van risicoaansprakelijkheid introduceerde ${ }^{286}$. De definitieve wet zou ook op andere nucleaire exploitanten van toepassing zijn en dus niet enkel op het SCK.

Van belang is ook dat uit artikel 3, § I van de wet op het SCK voortvloeide dat de wet enkel van toepassing was voor de in België geleden schade. De Raad van State wees erop dat hierdoor de vreemde leveranciers niet geheel gerustgesteld konden zijn, bij gebrek aan verzekering voor de schade die buiten het Belgische grondgebied werd geleden. De Regering was daarentegen van oordeel dat aan de leveranciers reeds voldoening werd geschonken, doordat de Koning, overeenkomstig artikel $3 \S 2$ van de wet, de toepassing ervan kon uitbreiden tot schade geleden buiten het Belgische grondgebied ${ }^{287}$.

\subsubsection{Verplichte verzekering tot een bepaald bedrag}

Het SCK was verplicht verzekeringscontracten af te sluiten of persoonlijke zekerheden te verstrekken om de betaling te waarborgen van de schadeloosstelling die aan de getroffenen is verschuldigd. Deze verzekeringsplicht gold zowel indien het SCK uit onrechtmatige daad schade had berokkend (art. 2), als ingeval een derde uit onrechtmatige daad een kernongeval had veroorzaakt (art. 3). Deze laatste bepaling is van belang omdat de wet, eveneens in afwijking van de bepalingen van het Verdrag van Parijs, althans op het eerste gezicht de kanalisatie van aansprakelijkheid niét invoerde.

Maar doordat het SCK verplicht was zich te verzekeren tegen de door een derde veroorzaakte schade, leek dit regime verdacht veel op de kanalisatie van aansprakelijkheid of op een vorm van risicoaansprakelijkheid. Niet alleen het SCK, maar ook een derde kon inderdaad een kemongeval veroorzaken. Het SCK werd verplicht om zich eveneens te verzekeren "telkens wanneer iemand wegens onrechtmatige daad aansprakelijk is voor in België geleden schade", op voorwaarde dat de schade veroorzaakt werd door stoffen waarvan het SCK bezitter was, die ervan voortkwamen of die het SCK tot bestemming hadden ${ }^{288}$. Het SCK was dus verplicht zich te verzekeren voor

284 Parlementaire Handelingen, Kamer, GZ1961-1962, Vergadering van 12 juli 1962, 48-49.

285: Matthijs, J., "Aansprakelijkheid bij toepassing van kemenergic tot vreedzame doeleinden", o.c, 125.

286 "Onderhavige wet is bestemd om binnen een betrekkelijk korte termijn te worden vervangen door internationale overeenkomsten uitgewerkt in OESO en Euratom-verband. Ze is dus voorlopig (...) maar onontbeerlijk aangezien ze het Studiecentrum voor Kenenergie moet toelaten haar normale activiteiten voort te zetten" (Parlementaire Bescheiden, Senaat, GZ/1961-1962, Memorie van Toelichting, nr. 118, 11-12).

Parlementaire Bescheiden, Senaat, GZ/1961-1962, Memorie van Toelichting, nr. 118, 4.

Het volgende voorbeeld werd hierbij gegeven: stel dat een gewone voetganger door zijn schuld en op de openbare weg, de vemieling veroorzaakt van een vrachtwagen, geladen met nucleair materiaal dat aan het Centrum toebehoort (Parlementaire Stukken, Memorie van Toelichting, Senaat, GZ/1961-1962, $\left.n^{\circ} 118,7\right)$. 
andermans aansprakelijkheid, indien deze derde door een onrechtmatige daad in combinatie met stoffen die een band hadden met het SCK, een (kem)ongeval had veroorzaakt. De bedoeling hiervan was "voorecrst (...) om de vreemde leverancier gerust te stellen"289, maar ook om de belangen van een slachtoffer te waarborgen: indien bijvoorbeeld een auto-ongeval zou zijn veroorzaakt door de bestuurder van de wagen, dan zou het slachtoffer het risico lopen dat zijn schade niet wordt vergoed wegens insolventie van de bestuurder, aldus de redenering.

Vanuit zuiver juridisch oogpunt was het SCK evenwel niet aansprakelijk voor de door een derde veroorzaakte schade; het was enkel verplicht zich hiervoor te verzekeren. Op zich leidt de verplichting om zich te verzekeren voor andermans aansprakelijkheid niet tot een kanalisatie van aansprakelijkheid; hier kan hooguit worden gesproken van een soort van economische kanalisatie van aansprakelijkheid. Een "zuivere" vorm van kanalisatie van aansprakelijkheid veronderstelt immers dat een persoon die op basis van het gemene aansprakelijkheidsrecht aansprakelijk zou zijn, wordt geexxonereerd ${ }^{290}$, hetgeen in casu niet het geval was. Anderzijds kan de verzekering zoals voorzien in de wet van 1962 worden beschouwd als een soort economische kanalisatie omdat de verzekeraar het aansprakelijkheidsrisico draagt en niet de juridisch aansprakelijke per$\operatorname{soon}^{291}$.

Deze regeling impliceerde dat indien een derde een ongeval veroorzaakte, in principe deze derde (en niet het SCK) aansprakelijk was, maar dat de verzekeraar van het SCK deze schade diende te vergoeden. Vandaar bestond de enige verplichting van het SCK onder de wet van 1962 erin om aan slachtoffers te garanderen dat er een verzekeringsdekking beschikbaar was ten belope van het wettelijk voorziene bedrag ${ }^{292} 293$.

Het SCK was verplicht zich te verzekeren voor een bedrag van 500 miljoen frank (artikel 9), een bedrag dat was ingegeven door de toenmalige capaciteiten van de verzekeringsmarkt ${ }^{294}$. Teneinde rekening te houden met mogelijke evoluties op dat vlak, werd in artikel 15 de mogelijkheid ingeschreven om dit bedrag bij KB te wijzigen.

\subsubsection{Subrogatie annex rechtstreckse vordering i'an het slachtoffer}

De regeling onder de wet van 1962 inzake de civielrechtelijke aansprakelijkheid van het SCK inzake verzekeringen, dient samen te worden gelezen met artikel 4 van dezelfde wet:

\footnotetext{
289

Parlementaire Stukken, Memorie van Toelichting, Senaat, GZ/1961-1962, $\mathrm{n}^{\circ} 118,6$.

Eerder hebben we dit de beschermende werking of de wettelijke exoneratie ten aanzien van de schadeveroorzaker genoemd (Vanden Borte, T., "Kanalisatie van aansprakelijkheid", o.c., 358), Zie ook in § 2.4 van hoofdstuk 4.

291 Mosthaf, H.D., "Wirtschaftlich oder rechtlich kanalisieren? Eine Streitfrage der Kemhaftung", Versichenungsrecht, maart 1967, Heft 9, 197.

29

Bonotto, O. en Vanden Borre, T., "Problèmes de compétence judiciaire dans les procédures de droit pénal relatives aux accidents nucléaires. Les principes de droit pénal et l'article 13 de la Convention de Paris", Le droit nucléaire: du XXe au XXIe Sciècle. Nuclear Inter Jura '97, Société de Législation Comparée, Paris, 1998, 470. Zie ook verderop, de bespreking van het vonnis van de correctionele rechtbank van Turnhout van 1969 (\$2.3.1.6).

Dit bleek overigens ook uit de bespreking van het wetsontwerp in de Senaat, waar werd gesteld dat: "On demande simplement au parlement de rendre obligatoire l'assurance couvrant lá reponsabilité existant pour les accidents dont il s'agit" (Parlementaire Handelingen, Senaat, GZ/1961-1962, Vergadering van 12 april 1962,1083 ).

Parlementaire Handelingen, Senaat, GZ/1961-1962, Vergadering van 12 april 1962, 1083.
} 
"De verzekeraars en de persoonlijke zekerheden zijn gesubrogeerd in de verplichting van het Centrum of van de derde verantwoordelijke de bij de artikelen 2 en 3 bedoelde schade, in de mate van de overeenkomsten welke zij krachtens de beide artikelen met het Centrum hebben gesloten, te herstellen".

Volgens de Memorie van Toelichting heeft de subrogatie tot praktisch gevolg dat het verhaal van het slachtoffer tegen de foutieve dader van de schade wordt afgeschaft ${ }^{295}$; doordat de aansprakelijkheidsverzekering van het SCK de schade zal vergoeden, zal het voor het slachtoffer onnodig zijn om een tweede rechtsvordering in te stellen. Het afschaffen van de vordering tegen de dader werd ook noodzakelijk geacht om te vermijden dat de verzekeraar van de derde de schade zou moeten vergoeden ${ }^{296}$. In de hypothese waarbij een kernongeval zou zijn veroorzaakt door een automobilist (bijvoorbeeld bij nucleaire stoffen afkomstig van het SCK), zou diens verzekeraar en niet die van het SCK gehouden zijn de schade te vergoeden. Dit zou meteen een stijging van de premies van de autoverzekeringen tot gevolg hebben ${ }^{297}$.

Toch is de bepaling inzake subrogatie uit de wet van het SCK vreemd te noemen. In het algemeen kan een subrogatie worden gedefinieerd als de juridische constructie op basis waarvan een derde in de rechtspositie treedt van de oorspronkelijke schuldeiser. Het komt er in feite op neer dat een derde de schuld ovemeemt van een schuldenaar; aldus is de initiële schuldeiser geen schuldeiser meer $^{298}$. Eens de schuld van een ander is betaald, kan de betaler (de gesubrogeerde) in de rechten van de oorspronkelijke schuldeiser (de subrogant) worden geplaatst ${ }^{299}$. Vandaar is de bepaling van de wet van 1962 vreemd, aangezien sprake is van een subrogatie in de plicht tot herstel van de schade. Het lijkt er bijna op alsof de wetgever heeft willen aangeven dat enkel de verzekeraar van het SCK kon worden verplicht om schadevergoeding uit te betalen. Hierover vinden we overigens steun in andere bepalingen van het oorspronkelijke wetsontwerp, met name inzake de rechtstreekse vordering van het slachtoffer. De wet voorzag dus niet in de subrogatie in een recht, maar in een plicht $^{300}$.

Volgens artikel 17 van de wet van 1962 inzake de burgerlijke aansprakelijkheid van het SCK, beschikte het slachtoffer over een rechtstreekse vordering tegen de verzekeraars en de persoonlijke zekerheden van het SCK en tegen de Staat. Opvallend is vooral het feit dat in een eerdere versie van het wetsontwerp het slachtoffer over een rechtstreekse vordering beschikte, met uitzondering van elke andere burgerlijke vordering (artikel 13 van het ontwerp) ${ }^{301}$. Zonder de minste twijfel was het de bedoeling van de wetgever om, weze het in verkapte vorm, de kanalisatie van aansprakelijkheid in te voeren. De Raad van State had immers opmerkingen bij deze bepaling omdat deze aan het slachtoffer het recht ontzegt om tegen de fouticve dader op te treden ${ }^{302}$. Ten-

Er werd geoordeeld dat dit de zekerheid gaf dat slachtoffers steeds volledig zullen worden vergoed (Parlementaire Stukken, Memorie van Toelichting, Senaat, GZ/1961-1962, $n^{\circ} 118,11$ ).

Parlementaire Stukken, Memorie van Toelichting, Senaat, GZ/1961-1962, $\mathrm{n}^{\circ} 118,11$. Parlementaire Siukken, Memorie van Toelichting, Senaat, GZ/1961-1962, n 118, 11.

Bocken, H., Cursus Verbintenissenrecht, Rijksuniversiteit Gent, 1988, 213.

Kruithof, R., De Ly, F, Bocken, H. en De Temmerman, B., "Verbintenissen. Overzicht van rechtspraak 1981-1992", Tijdschrift voor Privaatrecht, 1994, 699.

Op een andere plaats voorzag de wet op het SCK wel degelijk in een duidelijk subrogatierecht. Volgens artikel 12 in fine treedt de Staat in de rechten en vorderingen van de getroffene bij het in gebreke blijven van de waarborgen. Deze bepaling moet worden gezien in het licht van de rol van de Staat indien hetzij niet alle schade was gedekt door verzekering, hetzij indien het SCK er niet was in geslaagd on een verzekeringsdekking aan te schaffen.

Onze cursivering.

Parlementaire Stukken, Memoric van Toelichting, Senaat, GZ/1961-1962, $n^{\circ} 118,4-5$. 
gevolge van deze opmerking heeft de regering artikel 13 van het ontwerp vervangen door de bepaling inzake subrogatie ${ }^{303}$.

Het lijkt er bijgevolg sterk op dat de bepaling inzake subrogatie in de wet op het SCK, die in feite een vervanging was van een eerdere bepaling met het oog op het beperken van de vorderingen waarover een slachtoffer van een kernongeval op het SCK beschikte, in feite neerkwam op een vorm van economische kanalisatie ${ }^{304}$.

\subsubsection{Rol van de Belgische Staat}

Op basis van de wet op de civielrechtelijke aansprakelijkheid van het SCK, speelde de Belgische Staat een belangrijke rol bij de compensatie van de geleden schade, en dit zowel indien het bedrag van de verzekering (500 miljoen BEF) ontoereikend was als indien het SCK er om welke reden ook niet zou zijn in geslaagd om een verzekeringsdekking te kopen.

Overeenkomstig artikel 11 was de Staat verplicht dat gedeelte van de schade te herstellen dat het door het SCK verzekerde bedrag van 500 miljoen BEF overtrof ${ }^{305}$. De Staat was er dus toe gehouden de schade van een kernongeval op het SCK te dekken, behalve voor wat betreft een eerste schijf van 500 miljoen BEF.

De Raad van State vond dit een vreemde situatie, en wees erop dat andere landen zich beperkten tot cen aanvullende maar gedeeltelijke schadeloosstelling. In antwoord hierop stelde de regering dat andere landen het principe van objectieve aansprakelijkheid hadden ingevoerd, terwijl België het hield bij de traditionele regels van wettelijke aansprakelijkheid die een volledige schadeloosstelling beogen ${ }^{306}$. Als tegenhanger van het vasthouden aan de foutaansprakelijkheid was het totale schadevergoedingsbedrag onder het toepassingsgebied van de wet van 1962 onbeperkt. De regering vond de Staatstussenkomst normaal, aangezien de Staat zelf, door het bevorderen van de ontwikkeling van kernenergie, aandeel had in het scheppen van het risico ${ }^{307}$.

Artikel 12 van de wet van 1962 bepaalde dat, in de hypothese waarin het SCK in gebreke zou blijven om de waarborgen te verschaffen, de Staat ook deze schade diende te vergoeden. Indien het SCK in gebreke zou zijn gebleven om haar aansprakelijkheid te verzekeren, was de Staat met andere worden verplicht om alle schade te vergoeden, zelfs de schade uit de cerste schijf van

Parlementaire Stukken, Memorie van Toelichting, Senaat, GZ/1961-1962, $\mathrm{n}^{\circ} 118,5$.

Eerder verdedigde Reygaerts de stelling dat, hoewel het principe van de kanalisatie van aansprakelijk. heid niet in de wet van 1962 was opgenomen, deze toch tot een analoog resultaat leidde omwille van de rechtstreekse vordering van het slachtoffer tegen de verzekeraar, c.q. de Staat (Reygaerts, M., "Le droit nucléaire beige", o.c., 269). Deze stelling moet worden genuanceerd. Het is immers niet omdat een slachtoffer beschikt over een rechtstreckse vordering tegen een verzekeraar, dat meteen andere rechtsgronden waarop het slachtoffer zich desgevallend zou kunnen baseren, buiten werking worden gesteld. Precies dat laatste element is̄ immers éen van de wezenlijke kenmerken van de zogenaamde juridische kanalisatic van aansprakelijkheid; zic verder bij de bespreking van kanalisatie van aansprakelijkheid, in hoofdstuk 4. De wet op het SCK hanteerde in feite een stelsel van economische kanalisatie, maar dan wel via de regeling inzake subrogatie en inzake de rol van de Belgisch Staat.

Opvallend hierbij is dat de tekst van artikel 11 het had over de schade veroorzaakt door een "ramp". Volgens de Memorie van Toelichting is een ramp het enig gebeuren dat één of meer schadegevallen veroorzaakt (Parlementaire Stukken, Senaat, Memorie van Toelichting, GZ1196!-1962, $\mathrm{n}^{\circ} 118,10-11$ ). Parlementaire Stukken, Senaat, Memorie van Toelichting, GZ/1961-1962, $\mathrm{n}^{\circ} 118,9$.

Parlementaire Stukken, Senaat, Memorie van Toelichting, GZ/1961-1962, n 118, 10 
500 miljoen BEF. De wet van 1962 op de aansprakelijkheid van het SCK voorzag bijgevolg in een integrale financiële dekking van nucleaire schade ${ }^{308}$.

Vooral opvallend in zowel artikel 11 als in artikel 12, is dat de verplichting om alle schade te vergoeden rustte op de Staat met uitsluiting van elk ander persoon ${ }^{309}$. Uit de voorbereidende werken van de wet valt niet meteen op te maken wat de bedoeling was van deze bepaling. Toch is de strekking van deze zinsnede duidelijk: indien het SCK in gebreke zou zijn gebleven om zich te verzekeren, was enkel de Staat ertoe gehouden om de schade vergoeden. Ook deze bepaling doet sterk denken aan een (vorm van) kanalisatie van aansprakelijkheid en verklaart waarom de leveranciers van het SCK zich voldoende beschermd achtten. Immers, zelfs indien het SCK niet zou zijn verzekerd, konden de leveranciers er, op basis van de Belgische wet op de civielrechtelijke aansprakelijkheid van het SCK, niet toe worden verplicht om de schade uit een kernongeval te vergoeden.

Zoals verderop zal blijken bij de bespreking van de kanalisatie van aansprakelijkheid, is dit een vorm van economische kanalisatie, naar het voorbeeld van de Amerikaanse Price-Anderson Act: het gemene aansprakelijkheidsrecht wordt intact gelaten, maar de verzekeringsdekking van de exploitant (of in casu de Staat) zal instaan voor de compensatie van de geleden schade. Met andere woorden: zelfs indien de leverancier zou worden aansprakelijk gesteld, dan nog was niet zijn verzekeraar, maar hetzij de verzekeraar van het SCK, hetzij de Belgische Staat ertoe gehouden om de geleden schade te vergoeden.

Indien de Staat of de verzekeraar van het SCK schadevergoeding hadden uitgekeerd, beschikten zij slechts in een zeer beperkte mate over een regresrecht. Volgens artikel 5 , tweede lid van de wet op het SCK kon enkel een regresrecht worden uitgeoefend bij zware schuld; bovendien kon dit regres enkel worden uitgeoefend tegen de persoon die de schade heeft veroorzaakt en niet tegen zijn verzekeraar, noch tegen zijn meester of aangestelde. Wel beschikte de Staat, zoals hoger reeds aangegeven, over een subrogatierecht. Dit recht was echter beperkt in die zin dat het enkel sloeg op de hypothese waar de verzekering van het SCK (500 miljoen BEF) om welke reden ook niet zou zijn tussengekomen. Een analoge bepaling was niet terug te vinden in artikel 11 dat de hypothese dekt waarin de schade hoger was dan de 500 miljoen BEF. Bijgevolg was het subrogatierecht van de Belgische Staat, zoals voorzien in artikel 12, beperkt tot maximaal 500 miljoen BEF.

\subsubsection{Exclusieve bevoegdheid van de rechtbank van Brussel}

Tot slot voerde de wet een afwijking in op de klassieke gerechtelijke procedureregels. Artikel 16 stelde dat uitsluitend de rechtbank van eerste aanleg van Brussel, zetelend in burgerlijke zaken, bevoegd was om kennis te nemen van de vorderingen gebaseerd op deze wet. Ter motivering wees de minister op het feit dat dit de eenheid van het gerechtelijk onderzoek ten goede kwam en dat dit bovendien in overeenstemming was met de internationale verdragen die de bevoegdheid van één rechtbank per land voorschrijven ${ }^{310}$. Vooral dit laatste argument wekt verwondering aangezien inzake de aard der aansprakelijkheid België - door het behoud van de foutaansprakelijkheid - afweek van het reeds ondertekende Verdrag van Parijs.

Ook in die zin: Reygaerts, M., "Le droit nucléaire belge", o.c., 276.

Onze cursivering.

Parlementaire Stukken, Kamer, GZ/1961-1962, n³49/3, 5. 
De hoofdreden waarom de minister van Justitie opteerde voor de bevoegdheid van één enkele rechtbank hield verband met de waarborg van de Staat boven het bedrag van een half miljard $\mathrm{BEF}$. De minister stelde dat wanneer een ongeval slachtoffers zou maken in meerdere arrondissementen, verschillende rechtbanken waar slachtoffers zich aanmelden zouden moeten uitmaken of de aansprakelijkheidslimiet al dan niet werd overschreden. In dat geval zou men, steeds volgens de Minister, toch de procedures moeten samenvoegen ofwel zouden de verslagen van de ene rechtbank naar de andere moeten worden verstuurd, met alle tijdverlies van dien. Bovendien zou. in dat geval het risico te groot zijn dat de rechtbanken verschillende vonnissen zouden vellen ${ }^{311}$.

De invoering van de exclusieve bevoegdheidsregeling stuitte in de Senaat op aanzienlijk verzet. Terecht stelde een aantal sceptici dat de bevoegdheidsregeling inzake burgerrechtelijke vorderingen niet zou verhinderen dat op basis van de regels inzake strafrechtelijke bevoegdheid toch meerdere rechtbanken bevoegd zouden zijn, waardoor de doelstelling van deze regel teniet zou worden gedaan. Toch werd het principe van één exclusief bevoegde rechter, zetelend in civiele zaken, goedgekeurd.

Nadat uiteindelijk werd beslist om één enkele rechtbank bevoegd te maken, diende te worden aangegeven welke rechtbank exclusief bevoegd zou zijn. Die van Turnhout, Brussel of van een andere $\mathrm{stad}^{312}$.

In de stemming in de Senaat werd geoordeeld dat de keuze voor de rechtbank van Brussel gerechtvaardigd was aangezien Brussel over een tweetalig rechtsapparaat beschikt. Bovendien waarborgde de Staat de schadeloosstelling der slachtoffers en beschikte het slachtoffer over een rechtstreekse vordering tegen de verzekeraars die hun zetel hadden in Brussel en niet te Turnhout $^{313}$. Deze argumenten waren onvoldoende om een aantal parlementsleden te overtuigen. $\mathrm{Zij}$ waren van oordeel dat de eenheid van rechtspraak niet kon worden bereikt aangezien de correctionele rechtbanken bevoegd bleven om uitspraak te doen over een eventuele strafrechtelijke vordering. In antwoord hierop ontkende de Minister niet dat zich hier een conflict kon voordoen maar dat de eenheid in rechtspraak ook aan de belangen van de slachtoffers tegemoet kwam waardoor deze er geen belang bij hadden om zich burgerlijke partij te stellen ${ }^{314}$. Blijkbaar slaagde de Minister erin om een meerderheid te overtuigen: de exclusieve bevoegdheid van de Brusselse rechter werd goedgekeurd.

De praktijk heeft evenwel geleerd dat het laatstgenoemde argument van de minister niet overtuigend was. Nadat een kemongeval had plaatsgevonden op het SCK, bleek enkele jaren later dat eventuele slachtoffers, niettegenstaande de bevoegdheid van de Brusselse rechter, zich inderdaad steunden op de bepalingen van het Strafwetboek en het Wetboek van Strafvordering, om een vordering bij een andere dan de Brusselse rechter aanhangig te maken. Een slachtoffer van een ongeval van het SCK leidde inderdaad een vordering in bij de rechtbank in Tumhout én de rechtbank heeft zich bovendien bevoegd verklaard. De door de wet beoogde eenheid van rechtspraak kwam hierdoor minstens ten dele in gedrang. Dit vonnis wordt hieronder besproken, omdat de uitspraak ook relevant kan zijn voor de vigerende wet op de civielrechtelijke aansprakelijkheid voor kernongevallen.

312 Parlementaire Handelingen, Kamer, GZ/1961-1962, Vergadering van 12 juli 1962, 51.

Er werd inderdaad een amendement ingediend op basis waarvan de rechtbank van Tumhout exclusief bevoegd was, omdat het in de opinie van de indiener van het amendement logisch ware geweest dat de rechtbank van de plaats waar het SCK is gelegen, bevoegd zou zijn geweest (Parlementaire Stukken, Kamer, GZ/1961-1962, n³49/5, 1).

Parlementaire Handelingen, Kamer, GZ/1961-1962, Vergadering van 12 juli 1962, 51

Parlementaire Handelingen, Kamer, GZ/1961-1962, Vergadering van 12 juli 1962, 52.
} 


\subsubsection{Vonnis van de correctionele rechtbank van Turnhout van 14 februari $1969^{315}$}

Op 30 december 1965 werd een werknemer van het SCK blootgesteld aan een aanzienlijke dosis radioactieve straling, waardoor hij zijn linker been verloor. Zowel de werknemer in kwestie als het Openbaar Ministerie leidden een vordering in voor de correctionele rechtbank te Turnhout en dus niet voor de Brusselse civiele rechter, zoals voorzien in artikel 16 van de wet van 1962 inzake de burgerlijke aansprakelijkheid van het SCK. Drie collega's van het slachtoffer werden samen met het SCK, als burgerrechtelijk aansprakelijke, vervolgd wegens het door gebrek aan voorzichtigheid of voorzorg toebrengen van onopzettelijke slagen en verwondingen ${ }^{316} 317$ omdat uit een naar aanleiding van het ongeval opgesteld rapport bleek dat de veiligheidsmaatregelen niet voldoende waren gerespecteerd.

Om eventuele conflicten te kunnen beoordelen tussen het algemene straf(proces)recht enerzijds en de bepaling inzake de exclusieve bevoegdheid van de rechtbank van Brussel zoals neergelegd in artikel 16 van de wet inzake de burgerlijke aansprakelijkheid van het SCK anderzijds, besteedde de rechter in eerste instantie aandacht aan de bevoegdheid in strafzaken.

Naar Belgisch recht wordt de strafrechtelijke bevoegdheid ratione loci bepaald in functie van de procureur des Konings en de onderzoeksrechter die ter plaatse bevoegd zijn om resp. de strafvordering in te stellen en het gerechtelijk onderzoek te leiden (art. 23, 24, 62bis Sv). Zijn aldus gelijkelijk bevoegd: de rechtbank van de plaats waar het misdrijf werd gepleegd (forum delicti commissi), de rechtbank van de plaats waar de verdachte verblijft (forum domicilii) en de rechtbank van de plaats waar de verdachte kan worden aangetroffen (forum deprehensionis) ${ }^{318}$. Deze bevoegdheidsregels in strafzaken zijn van openbare orde ${ }^{319}$. Aangezien de Procureur des Konings meende dat er voldoende gronden waren om de superieuren van het slachtoffer te vervolgen wegens een inbreuk op het strafrecht, werd bijgevolg de rechtbank van Turnhout (gelegen in het gerechtelijke arrondissement waar zich ook het SCK bevindt) bevoegd geacht voor wat betreft de strafvordering.

Gelet op het eerder besproken artikel 16 van de wet van 1962 inzake de burgerlijke aansprakelijkheid van het SCK, rijst vervolgens de vraag of de strafrechter dan ook meteen bevoegd werd voor

Corr. Rb. Tumhout, 14 februari 1969, n० A 24/66n G n ${ }^{\circ} 277$, inzake J. tegen L. e.a. en SCK, deels gepubliceerd in Nuclear Law Bulletin, 1996, vol. 3, 22-24. Reeds besproken in Bonotto, O. en Vanden Borre, T., "Problèmes de compétence judiciaire dans les procédures de droit pénal relatives aux accidents nucléaires. Les principes de droit pénal et l'article 13 de la Convention de Paris", in "Nuclear Inter Jura '97", l.c., 469 e.v.

Zoals voorzien in de artikelen $418-420$ van het Belgische strafwetboek.

317 In de eerste plaats rees in deze casus een conflict ratione tempore. In de periode tussen het ongeval en het vonnis werd de wet van 1962 inzake de burgerlijke aansprakelijkheid van het SCK vervangen door de wet van 18 juli 1966. Deze laatste wet bevatte geen bepalingen betreffende vroeger antstane situaties en bovendien blijkt de bevoegdheidsattributie specifiek te zijn aan beide wetten, zodat geen toepassing kan worden gemaaki van de algemeen geldende principes van terugwerkende kracht of onmiddellijke toepasbaarheid van wettelijke bepalingen inzake loutere rechtspleging op reeds ontstane situaties (De Page, H., Traité, Tome l, nr. 231-bis, 1962, Bruxelles, Bruylant). De rechter oordeelde terecht dat $\mathrm{op}$ basis van het non-retroactiviteitsbeginsel van artikel 2 van het B.W., de wet van 1966 niet van toepassing was op het ogenblik dat het ongeval zich voordeed: bij toepassing van artikel $2 \mathrm{~B}$.W. was de wet van 1962 toepasselijk. Over het territoriale toepassingsgebied van het Belgische strafrecht, zie Bosly, H.D. en Vandermeersch, D., Droit de la procédure pénale, $2^{\circ}$ druk, Brugge, Die Keure, 2000, 53 e.v.

Van den Wijngaert, C., Strafrecht en Sirafprocesrecht in hoofdlijnen, Maklu, Antwerpen-Apeldoom, 1999,507 e.v. 
wat betreft de civiele vordering tot schadevergoeding vanwege het slachtoffer. Artikel 4 van Voorlopige Titel van het Wetboek van Strafvordering bepaalt namelijk dat de burgerlijke rechtsvordering tezelfdertijd en voor dezelfde rechter kan worden vervolgd als de strafvordering. Dit is precies wat in casu is gebeurd: nadat het Openbaar Ministerie de verdachten had gedagvaard voor de rechtbank in Turnhout, heeft het slachtoffer zich voor wat haar burgerlijke vordering betreft, eveneens gericht tot de correctionele rechtbank van Turnhout. Het spreekt voor zich dat de verweerders de bevoegdheid van de rechtbank op burgerlijk vlak betwistten, zich hierbij ten dele steunend op de inmiddels van kracht geworden wet inzake de civielrechtelijke aansprakelijkheid voor kernongevallen van 18 juli 1966.

De rechtbank ging over tot een vergelijking tussen het toepassingsgebied van de wet van 1962 en dat van de wet van $1966^{320}$. Artikel 2 van de wet van 1962 stelde uitdrukkelijk dat het SCK in staat moest zijn om de betaling te waarborgen van de schadeloosstelling die aan de getroffenen is verschuldigd, telkens wanneer het wegens onrechtmatige daad aansprakelijk was voor schade die voortvloeit uit of veroorzaakt wordt door radioactieve eigenschappen. De wet strekte er dus in de eerste plaats toe om slachtoffers van kemongevallen te garanderen dat het SCK in staat zou zijn de opgelopen schade te vergoeden door middel van een systeem van verplichte verzekering; indien de schade hoger zou zijn dan het bedrag van de verplichte verzekering, was de Staat verplicht om tussenbeide te komen.

Het verschil met de wet van 1966 blijkt overduidelijk wanneer de bepalingen inzake de exclusieve bevoegdheid van de Brusselse rechtbank naast elkaar werden gelegd. Nicttegenstaande beide wetten deze laatste rechtbank bevoegd verklaren, spreekt artikel 16 van de wet van 1962 over "de op deze wet gegronde vorderingen"; terwijl artikel 10 van de wet van 1966 het heeft over "vorderingen gebaseerd op het Verdrag van Parijs".

Hieruit volgt dat de bevoegdheidsattributie aan de Brusselse rechter onder beide wetten totaal verschillend was. Onder de wet van 1962 was deze enkel bevoegd indien het SCK niet de nodige fondsen zou hebben gehad; terwijl de rechtbank van Brussel krachtens de wet van 1960 bevoegd was voor een vordering gebaseerd op het Verdrag van Parijs, dus telkens wanneer een burgerlijke eis in schadevergoeding tengevolge van een kemongeval werd ingesteld. In het vonnis stelde de Tumhoutse rechter trouwens dat uit de wet van 1962:

\begin{abstract}
"blijkt dat geen enkele afbreuk werd gedaan aan onze algemene principes inzake verantwoordelijkheid in het algemeen, doch dat enkel aan het Studiecentrum voor Kernenergie opgelegd werd zekerheden te verschaffen betreffende verbintenissen, voortspnuitende uit een aquiliaanse verantwoordelijkheid, hetzij delictueel, hetzij quasidelictueel zoals voorzien in de artikelen $1382 \mathrm{~B}$.W. en volgende en dit in haren hoofde en in hoofde van derden" ${ }^{121}$.
\end{abstract}

Nochtans blijkt uit de discussies in het Parlement ter voorbcreiding op de wet op het SCK dat men dezelfde bevoegdheidsattributie voor ogen had als in het toen reeds ondertekende Verdrag van Parijs; er werd zelfs uitdrukkelijk naar verwezen. Een strikte interpretatie van de tekst van de wet toont echter een geheel ander beeld. Enkel inclien de vordering van het slachtoffer ertoe strekte het SCK te veroordelen omdat zij haar verzekeringsplicht niet nakwam, was de rechtbank van. Brussel bevoegd, althans wat de civiele vordering van het slachtoffer betreft. 
De rechtbank heeft de beklaagde (de verantwoordelijke ingenieur) en het SCK, als civielrechtelijke aansprakelijke, strafrechtelijk veroordeeld. Uit de omstandigheden bleek dat experimenten waren uitgevoerd terwijl nog water in de reactorkuip aanwezig was en dit terwijl de veiligheidsvoorschriften nochtans bepaalden dat dergelijke experimenten dienden te geschieden met een lege reactorkuip. De rechtbank oordeelde dat het niet-naleven van de veiligheidsmaatregelen ten gevolge van een vergissing of van een beoordelingsfout een gebrek aan voorzorg en voorzichtigheid uitmaakt in de zin van art. 418-420 SW.

Van belang voor de huidige analyse is dat de rechtbank zich bevoegd verklaarde om kennis te nemen van de burgerlijke vordering en dat deze ontvankelijk werd verklaard ${ }^{322}$, en dit niettegenstaande de exclusieve bevoegdheidsattributie ten voordele van de Brusselse rechtbank in de wet op de civiele aansprakelijkheid van het SCK.

Verderop zal worden onderzocht of het onder de bevoegdheidsattributie van de vigerende wet inzake de civielrechtelijke aansprakelijkheid voor kemongevallen eveneens mogelijk is dat een strafrechtelijke vordering wordt ingeleid voor een andere rechtbank dan de rechtbank die exclusief bevoegd is om te oordelen over de civiele vordering gebaseerd op cen kemongeval ${ }^{323}$. Heel vaak zal een slachtoffer immers ertoe geneigd zijn om naast burgerlijke vorderingen inzake ongevallen met nucleaire stoffen, ook een strafvordering in te stellen ${ }^{324}$.

\subsubsection{Conclusie omtrent de wet van 1962 inzake de burgerlijke aansprakelijkheid van het $S C K$}

De wet inzake de burgerlijke aansprakelijkheid van het SCK is op zijn minst merkwaardig te noemen. De analyse van de wet, die door het vonnis van de correctionele rechtbank van Tumhout is bevestigd, leidt tot de conclusie dat de enige verplichting die voor het SCK uit de wet voortvloeide, erin bestond zich te verzekeren tot een bedrag van 500 miljoen BEF. Voor het overige werd verwezen naar het gemene aansprakelijkheidsrecht.

Tegelijk nam de wet bepaalde basisbeginselen van het Verdrag van Parijs over, terwijl andere basisbeginselen niét werden overgenomen. Zo werd bijvoorbeeld beslist dat slechts één enkele rechtbank bevoegd was, maar anderzijds werd geopteerd voor een regime van foutaansprakelijkheid (terwijl het Verdrag van Parijs een regime van risicoaansprakelijkheid invoert). Voomamelijk deze twee elementen hebben aanleiding gegeven tot heel wat discussie tijdens de parlementaire voorbereiding

Daarnaast is het belangrijk vast te stellen dat indien de door het SCK afgesloten verzekering ontoereikend zou zijn geweest, de Belgische Staat, zonder enige limiet, de vorderingen tot schadevergoeding diende te betalen. Op die manier werd inderdaad alle schade uit een kernongeval op het SCK vergoed. Indien het tot een zwaar kemongeval was gekomen op het SCK ten tijde dat de wet van 1962 van kracht was, dan zou het grootste deel van de schadevergoeding ten laste zijn gevallen van de Belgische Staat. Uiteraard was dit, vanuit het standpunt van het slachtoffer, een uiterst voordelige regeling. Op zich was het, zeker in de jaren vijftig en zestig (en in een groot

322 De civielrechtelijke eis werd weliswaar ongegrond verklaard omdat het een arbeidsongeval betrof.

323 Cfr. infra, $\$ 5.2$ van hoofdstuk 4 .

324 Zie de bespreking van de strafrechtelijke vordering naar aanleiding van de ongevallen in Goiania en

Forbach: Bochler, M.C., "Reflections on Liability and Radiological or Nuclear Accidents: the accidents at Goiania, Forbach, Three Mile Island and Chemobyl", Nuclear Law Bulletin, n 59, 1997, 15 17. 
aantal landen ook vandaag nog) niet ongebruikelijk dat de Staat een groot deel van de schade voor haar rekening nam. Ook bijvoorbeeld onder de Price-Anderson Act van 1957 viel het grootste deel van de schade ten laste van de Amerikaanse overheid. Het was vooral opmerkelijk dat onder de wet van 1962 de tussenkomst van de Belgische Staat onbeperkt was én dat de Staat, bij uitsluiting van elk ander persoon verplicht was deze schade te vergoeden.

Doordat het SCK verplicht was om zich te verzekeren voor andermans aansprakelijkheid paste de wet op het SCK in feite het systeem toe van de Amerikaanse Price-Anderson Act. Ook daar wordt het gemene aansprakelijkheidsrecht ongemoeid gelaten, maar dekt de verzekering van de exploitant ook de aansprakelijkheid van andere actoren (zgn. umbrella-dekking) ${ }^{325}$. Het systeem van de Price-Anderson Act kan worden beschouwd als een vorm van economische kanalisatic van aansprakelijkheid. Dus voerde ook de wet op het SCK deze economische kanalisatie in.

Uit de voorbereidende werken van de wet blijkt ontegensprekelijk de bekommernis om de Amerikaanse leveranciers van het SCK van alle aansprakelijkheid te ontheffen. De meest geëigende weg ware de invoering geweest van de juridische kanalisatie van aansprakelijkheid ${ }^{326}$, hetgeen niét is geschied in de wet van 1962. Het gemene aansprakelijkheidsrecht werd immers intact gelaten. De Amerikaanse leverancier(s) van de BR-3 mocten zich dus op andere wijze "veilig" hebben gevoeld: ofwel waren zij van oordeel voldoende te zijn beschermd door de subrogatieregeling, annex directe vordering van het slachtoffer tegen de verzekeraar of tegen de Staat, ofwel bood de algehele schadevergoedingsplicht van de Belgische Staat hen voldoende bescherming.

Naar onze mening is het weinig waarschijnlijk dat de Amerikaanse juristen, die onderzoek hadden laten uitvoeren naar het Europese aansprakelijkheidsrecht (inclusief het Belgische, het Nederlandse en het Franse aansprakelijkheidsrecht) ${ }^{327}$ niet hebben geweten dat de subrogatieregeling annex directe vordering tegen de verzekeraar of de Staat, niet noodzakelijk andere gemeenrechtelijke vorderingen uitsloot. Dit laat vermoeden dat in de ogen van de Amerikaanse leveranciers, de verplichte, onbeperkte en exclusieve tussenkomst van de Belgische Staat voldoende bescherming bood.

3.3.2. Wet betreffende de wettelijke aansprakelijkheid op het gebied van kernenergie van 18 juli 1966, houdende vaststelling van bepaalde maatregelen tot onmiddellijke toepassing van het Verdrag van Parijs en van het toegevoegd Protocol ${ }^{328}$

De wet van 1966 introduceerde de bepalingen van het Verdrag van Parijs van 29 juli 1960 en van het Aanvullend Verdrag van Brussel van 31 januari 1963 - beide tot stand gekomen in het kader van de OESO - in het Belgische recht ${ }^{320}$.

\footnotetext{
3 Vanden Borre T., "Dekking van het nucleaire risico op nationaalrechtelijke basis of via internationale Verdragen: de Verenigde Staten versus Europa", o.c., 450 e.v. Zie ook verderop in hoofdstuk 13. Eerder hebben we reeds aangetoond dat kanalisatie inderdaad in de Verdragen werd ingeschreven onder druk van de Amerikaanse kernenergie-industrie die wilde vermijden aansprakelijk te worden gesteld voor kemongevallen in Europa (Vanden Borrc, T., "Kanalisatie van aansprakelijkheid", o.c., 347 en 370; Vanden Borre, T., "Channelling of Liability", o.c., 13 e.v.; zie ook verder bij de bespreking van kanalisatie van aansprakelijkheid, in hoofdstuk 4). Protection against Nuclear Risk, Harvard Law School, 1959. Dit onderzoek wordt in $\S 2$ van hoofdstuk 4 verder besproken. 
Het doel van deze wet was dubbel. Doordat rond die tijd meerdere bedrijven activiteiten wensten te ontplooien op het vlak van de productie van kernenergie, diende de wet van 1962 die, zoals hoger aangegeven, enkel van toepassing was op het SCK, te worden vervangen door een wet die van toepassing zou zijn op alle Belgische exploitanten van een kerninstallatie. Bovendien dienden maatregelen te worden genomen om het Verdrag van Parijs uit te voeren.

Niettegenstaande het feit dat deze wet is opgeheven bij wet van 22 juli 1985, zijn de in 1966 gë̈ntroduceerde principes ook nu nog van kracht. De bespreking van de wet van 18 juli 1966 valt dus grotendeels samen met de analyse van de wet van 1985.

Toch lijkt het aangewezen om kort hier stil te staan bij de verschillen tussen de wet van 18 juli 1966 en de allereerste nucleaire aansprakelijkheidswet, namelijk de hoger besproken wet van 1962 inzake de burgerlijke aansprakelijkheid van het SCK. Twee verschillen tussen beide genoemde werten zijn van groot belang: enerzijds de beperking van de aansprakelijkheid en anderzijds de afschaffing van de tussenkomst van de Belgische Staat.

Artikel 2. van de wet van 1966 verklaart een aantal artikelen van het Verdrag van Parijs onmiddellijk van toepassing. Onder de artikelen die aldus in België van toepassing werden, bevonden zich de artikelen van het Verdrag van Parijs, die een risicoaansprakelijkheid en de kanalisatie van die aansprakelijkheid naar de exploitant van de kerninstallatie invoerden ${ }^{330}$ en die de exploitant verplichtten om een verzekeringsdekking te nemen tot het bedrag waarvoor hij aansprakelijk was ${ }^{33 !}$. De invoering van het objectieve aansprakelijkheidsregime leidde inderdaad tot een dubbele beperking van de aansprakelijkheid: zowel in tijd als in bedrag. Een slachtoffer beschikte over een termijn van 10 jaar om een vordering in te stellen op basis van deze wet. Het bedrag van de aansprakelijkheid van de exploitant werd beperkt tot een bedrag van 500 miljoen BEF; hetzelfde bedrag, dus waarvoor het SCK onder de wet van 1962 een verzekeringsdekking diende te nemen. Geoordeeld werd dat het bij onbeperkte aansprakelijkheid voor een exploitant onmogelijk zou zijn het nucleaire risico te verzekeren ${ }^{332} 333$.

De wet van 1966 verschilde van de wet van 1962 inzake de burgerlijke aansprakelijkheid van het SCK voornamelijk door deze beperking van de aansprakelijkheid, gekoppeld aan de invoering van een regime van risicoaansprakelijkheid en aan de juridische kanalisatie van aansprakelijkheid. $E_{r}$ is immers een groot verschil tussen het opleggen van een verzekeringsplicht tot een bepaald bedrag enerzijds en anderzijds het beperken van de aansprakelijkheid, met een verzekeringsplicht tot het bedrag van de beperkte aansprakelijkheid. Onder de wet van 1966 werd, in navolging van het Verdrag van Parijs, de totale beschikbare schadevergoeding beperkt, terwijl onder de wet van 1962 inzake de burgerlijke aansprakelijkheid van het SCK, alle geleden schade kon worden vergoed (alle schade groter dan 500 miljoen BEF diende immers door de Staat te worden bijgepast).

Artikel 14 van de wet van 18 juli 1966, heef de wet van 1962 inzake de civielrechtelijke aansprakelijkheid van het SCK opgeheven. De wet is op 23 augustus 1966 in werking getreden.

Ook op dat vlak: werd gesteld dat de objectieve aansprakelijkheid enkel rust op de exploitant en dat geen enkele vordering mag worden ingesteld tegen een persoon die diensten, materialen, of uitrusting heeft verstrekt ter gelegenheid van de bouw of het onderhoud van de keminstallatie (Parlementaire Stukken, Mernorie van Toelichting, Senaat, GZ 1965-1966, 122, 2).

Aansluitend bij de verzekeringsplicht, legde de wet van 1966 de verplichting op in hoofde van de exploitant om voorafgaandelijk een erkenning aan te vragen als exploitant; deze erkenning wordt verleend nadat de aanvrager bewezen heeft een aansprakelijkheidsverzekering voor het voorziene bedrag te hebben afgesloten (artikelen 3 en 4). Parlementaire Stukken, Memorie van Toelichting, Senaat, GZ/1965-1966, 122, 3.

333 Precies eenzelfde redenering lag aan de basis van de invoering van de beperkte aansprakelijkheid in het Verdrag van Parijs (cfr. infra, in hoofdstuk 4). 
Dit brengt ons bij een tweede belangrijk verschil tussen de wet van 1966 en de wet van 1962: de tussenkomst van de Belgische Staat. De wet van 18 juli 1966 geeft enkel uitvoering aan de bepalingen van het Verdrag van Parijs en niét aan de bepalingen van het Aanvullend Verdrag van Brussel. De regels inzake de tussenkomst van de Staat zijn inderdaad enkel terug te vinden in het Aanvullend Verdrag van Brussel van 1963. De wet van 18 juli 1966 rept met geen woord over het aanvullende Verdrag en voert op geen enkele wijze enige vorm van staatstussenkomst in - en dit niettegenstaande dit Verdrag bij wet van 1 augustus 1966 werd goedgekeurd ${ }^{334}$. Het Aanvullend Verdrag van Brussel van 1963, dat in werking trad op 4 december 1974, zou slechts bij wet van 22 juli 1985 in de Belgische rechtsorde worden omgezet.

Daarnaast vertoont de wet van 1966 opvallende gelijkenissen met de bepalingen van de wet van 1962. Ook de wet van 1966 kende aan het slachtoffer een rechtstreekse vordering toe tegen de verzekeraar en voor een vordering gebaseerd op deze wet, is exclusief de Brusselse rechter bevoegd.

Tenslotte dient te worden aangestipt dat beide wetten in een gelijke sfeer zijn tot stand gekomen. Net zoals dat het geval was voor de wet op het SCK, werd tijdens de voorbereidende werkzaamheden van de wet van 1966 meermaals gewezen op de hoogdringendheid van het wetsontwerp: de kerncentrale van Chooz diende immers in gebruik te worden genomen ${ }^{335}$.

In deze paragraaf wordt niet verder stilgestaan bij deze wet, aangezien de bepalingen ervan grotendeels zijn overgenomen door de wet van 22 juli 1985 . De totstandkoming van deze wet wordt hieronder besproken.

\subsubsection{Wet van 22 juli 1985 betreffende de wettelijke aansprakelijkheid op het gebied van kernenergie $^{336}$}

Deze wet vervangt de wet van 18 juli 1966 die, zoals hierboven besproken, zich beperkte tot de toepassingsmaatregelen van het Verdrag van Parijs. Vóór de wet van 1985 waren in België de toepassingsmaatregelen voor het Aanvullend Verdrag van Brussel, het Protocol tot wijziging van 1964 en voor de op 16 november 1982 te Parijs ondertekende Protocollen nog niet in werking. De wet van 22 juli 1985 had dus tot doel deze leemte in de wetgeving aan te vullen door deze Verdragen om te zetten in Belgisch recht ${ }^{337} 338$

Doordat deze wet ook uitvoering gaf aan het Aanvullend Verdrag van Brussel, werd ook (opnieuw) een stelsel ingevoerd van Staatstussenkomst. Onder de oorspronkelijke versie van de wet van 1985 was de Belgische Staat verplicht tussen te komen in de tweede schijf (tussen 4 en 9 miljard BEF).

$\mathrm{Na}$ het ongeval in Tsjernobyl werden verschillende pogingen ondernomen om de wet te wijzigen, met name inzake de beperking van de aansprakelijkheid van de exploitant. Overeenkomstig artikel 7 van de wet van 22 juli 1985 was de exploitant aansprakelijk tot 4 miljard BEF ( 99 miljoen

\footnotetext{
33

Wet van 1 augustus 1966 houdende goedkeuring van Internationale Akten (B.S., 23 augustus 1966).

Parlementaire Stukken, Senaat, Commissieverslag, 26 mei 1966, 2; Parlementaire Handelingen, Senaat, GZ/1965-1966, Vergadering van 22 juni 1966, 1416.

B.S., 31 augustus 1985 .

Memorie van Toelichting, Parlementaire Stukken, Senaat, GZ/1983-1984, 593, N 1, 2.

De Verdragen zelf werden goedgekeurd bij wet van 3 juli 1985 houdende goedkeuring van Internationale Akten (B.S., 8 februari 1986).
} 
euro). De eerste en meest opvallende poging strekte ertoe om de beperking van de aansprakelijkheid van de exploitant op te heffen ${ }^{339}$, gekoppeld aan een verzekeringsplicht tot 500 miljard BEF. Volgens de indieners van dit wetsvoorstel was het "onduldbaar" dat de aansprakelijkheid van de exploitant beperkt was tot een "overigens belachelijk laag maximumbedrag" ${ }^{134}$. Een tweede poging tot wijziging van de wet op de nucleaire aansprakelijkheid had tot doel de aansprakelijkheid van de exploitant op te trekken tot een bedrag van 9,1 miljard BEF en om de Belgische Staat in (zeer) aanzienlijke mate aansprakelijk te stellen voor de schade die bepaalde drempels te boven ging ${ }^{341}$. Bij de bespreking van de beperking van de aansprakelijkheid van de exploitant van een kerninstallatie wordt hierop verder teruggekomen ${ }^{342}$.

Deze twee wetsvoorstellen zijn echter nooit wet geworden. Uiteindelijk werd de wet van 22 juli 1985 pas gewijzigd bij wet van 11 juli $2000^{343}$. De wijziging, die in werking is getreden op 1 januari 2001, heeft betrekking op de beperking van de aansprakelijkheid van de exploitant van een kerninstallatie, in die zin dat het bedrag waarvoor de exploitant aansprakelijk is, werd opgetrokken van 4 miljard BEF naar 12 miljard BEF (van 99 miljoen euro naar 297 miljoen euro) ${ }^{344}$. Opvallend hierbij is wel dat de tussenkomst van de Belgische Staat werd afgeschaf ${ }^{345}$; het totale schadevergoedingsbedrag in België bedraagt dus 18,5 miljard BEF - namelijk 12 miljard BEF van de verzekeringsdekking van de exploitant en 6,5 miljard via de derde schijf zoals voorzien in het Aanvullend Verdrag van Brussel.

De wet van 22 juli 1985 zoals gewijzigd in 2000 , bevat dus de basisprincipes van het Belgische civielrechtelijke nucleaire aansprakelijkheidsrecht. Deze principes worden in hoofdstuk 4 per thema besproken.

Net als het Verdrag van Parijs, behandelt deze wet enkel de aansprakelijkheid en de dekking bij een kemongeval. Deze wet is inderdaad slechts een deel van de gehele Belgische nucleaire wetgeving $^{346} 347$, met als voomaamste doel de schadeloosstelling van derden bij een ongeval in een kerninstallatie ${ }^{345}$. Als dusdanig dient deze wet te worden gezien als een aanvulling van de wet van 29 maart 1958 betreffende de bescherming van de bevolking tegen de uit ioniserende straling voortspruitende gevaren en haar uitvoeringsbesluiten.

339 Zowel de beperking in bedrag als de beperking in de tijd zouden, volgens het ingediende voorstel, worden opgeheven.

346 Toelichting, Voorstel van wet tot wijziging van de wet van 22 juli 1985 betreffende de wettelijke aansprakelijkheid op het gebied van kemenergie, Parlementaire Stukken, Senaat, GZ/1986-1987, $\mathrm{N}^{2}$ $402 / 1,4$.

Toelichting, Wetsvoorstel tot wijziging van de wet van 22 juli 1985 betreffende de wettelijke aansprakelijkheid op het gebied van kernenergie, Parlementaire Stukken, Senaat, BZ/1988, No 4l6/1, 4-5. Zie $\$ 3.1 .2$ van hoofdstuk 4 .

B.S., 4 oktober 2000.

Zie hierover Vanden Borre, T., "Recente ontwikkelingen in het nucleaire aansprakelijkheidsrecht: innovatic of renovatie?", Milieu- en Energierecht, 2001-1, 25-49.

Volgens de Staatssecretaris voor Energie en Duurzame Ontwikkeling is het niet aan te raden dat de Staat bijspringt voor vergoeding van schade ten gevolge van een privé-activiteit (Verslag, 24 mei 2000, Parlementaire Stukken, GZ/1999-2000, 560/002, 6).

Met de term "nucleaire wetgeving" bedoel ik alle regelen die betrekking hebben op nucleaire activititen sensu lato; het betreft niet enkel de regels die aan de exploitanten bepaalde verplichtingen opleggen of die de burgers besehermen, maar alle bepalingen die op welke wijze dan ook eender welk facet van de nucleaire activiteit in globo (dus ook inzake transport, ontmanteling, afval, enz.) betreffen. lingen betreffende de bescherming van de bevolking en van de werknemers tegen het gevaar van ioniserende stralingen, ...". 
Specifiek voor wat België betreft, dient ook rekening te worden gehouden met de regelgeving inzake de staatshervorming. Aangezien de staatshervorming op cen aantal punten een belangrijke invloed heeft op het kemenergierecht, wordt deze problematiek hicronder aan de orde gesteld.

\subsection{Invloed van de Staatshervorming op het Belgische kernenergierecht}

De invloed van de staatshervorming op het Belgische kernenergierecht, is van belang in de mate waarin een deel van het kernenergierecht duidelijk thuishoort in het milieurecht en in de mate waarin een keminstallatie zowel nucleaire als niet nucleaire risico's creëert.

De vraag rijst in het algemeen of de Gewesten over een bevoegdheid beschikken inzake nietnucleaire risico's van nucleaire bedrijven. Meer in het bijzonder dient de vraag te worden beantwoord of de regionale milieuwetgeving ook op nucleaire installaties kan worden van toepassing verklaard.

Het principe zelf van de federalisering van België is terug te vinden in de Grondwet. Zo luidt artikel 1 van de Grondwet: "België is een federale Staat, samengesteld uit Gemeenschappen en Gewesten". De respectievelijke bevoegdheden van de Staat, de Gemeenschappen en de Gewesten zijn neergelegd in de bijzondere wet tot hervorming der instellingen van 8 augustus $1980^{349}$. Deze wet werd door de latere fasen van de staatshervorming meermaals gewijzigd ${ }^{350} 35 \mathrm{I}$.

Op basis van artikel $6, \S 1, \mathrm{II}, 1^{\circ}$ van de bijzondere wet tot hervorming der instellingen zijn de Gewesten (onder meer) bevoegd voor de bescherming van het leefmilieu, onder meer die van de bodem, de ondergrond, het water en de lucht tegen verontreiniging en auntasting, alsmede de strijd tegen de geluidshinder. De federale overheid is daarentegen bevoegd voor (...) de bescherming tegen ioniserende stralingen, met inbegrip van het radioactief afval ${ }^{352}$.

De Gewesten zijn eveneens bevoegd voor wat betreft de gewestelijke aspecten van de energic ${ }^{353}$. De federale overheid blijft evenwel bevoegd voor de aangelegenheden die wegens hun technische en economische ondeelbaarheid een gelijke behandeling op nationaal vlak behoeven, te weten (...) de kernbrandstofcyclus ${ }^{354}$. Met deze bepaling wordt de exclusieve federale bevoegdheid inzake

\section{$349 \quad$ B.S., 15 augustus 1980 .}

350 Door de Wet van 8 augustus 1988 tot wijziging van de wet van 8 augustus 1980 tot hervorming der instellingen (B.S., 13 augustus 1988); bijzondere wet tot vervollediging van de federale staatsstructuur van 16 juli 1993 (B.S., 20 juli 1993). Deze wijzigingen werden van kracht op 30 juli 1993. In het kader van dit proefschrift wordt enkel de bevoegdheidsverdeling inzake leefmilieu en energiebeleid onderzocht. De overige bevoegdheden van Staat, Gemeenschappen en Gewesten worden hierbij niet aan de orde gisteld.

Deze laatste bepaling impliceert dat de wet van 29 maart 1958 betreffende de bescherming van de bevolking tegen ioniserende straling en het uitvoeringsbesluit van 28 februari 1963 een federale bevoegdheid blijft (Toelichting, Parlementaire Stukken, Senaat, 1992-93, nr. 558/l, 21. Verklaring van de Minister van Institutionele Hervormingen in de bevoegde kamercommissie, Parlementaire Handelingen, Kamer, 1988, nr. 516/6, 72).

353 Artikel $6, \S 1$, Vll van bijzondere wet tot hervorming der instellingen.

3.4 Met het begrip "kembrandstofcyclus" wordt volgens het Arbitragehof bedoeld alle bewerkingen vanaf de extractie van het uraniumerts tot de definitieve opruiming van radioactieve afvalstoffen (Arbitragehof, 24 mei 1988, nr. 54, B.S., 11 juni 1988, 6.B.6.). Worden dus bedoeld: de ontginning van uraniumerts, de omzetting ervan tot uraniumhexafluoride, de verrijking, de omzetting tot uraniumdioxide, de aanmaak van splijtstofelementen, het gebruik ervan in de kernreactor, de koeling en het transport, de opwerking, de opslag van het afval, de herwinning van splijtstof en de aanmaak van splijtbaar plutonium (Gillon, L., "De kwestie kernenergie", l.c., 100). 
kernenergie bevestigd ${ }^{355}$. Artikel $6, \S 1$, VII, f bevestigt overigens de gewestelijke onbevoegdheid ${ }^{356}$ : de Gewesten zijn bevoegd voor de gewestelijke aspecten van de energie en in ieder geval "de nieuwe energiebronnen, met uitzondering van deze die verband houden met de kernenergie".

Een belangrijke vraag die in dit verband rijst, is of de kernbrandstofcyclus enkel van de gewestelijke bevoegdheid is uitgesloten in het kader van het energiebeleid, dan wel of de Gewesten evenmin bevoegd zijn om de randvoorwaarden van milieubeleid te bepalen waarbinnen de kernbrandstofcyclus kan functioneren ${ }^{357}$.

Over het algemeen wordt aangenomen dat artikel $6, \S 1$, VII, tweede lid, b) van de bijzondere wet tot hervorming der instellingen er toe strekt, de nationale bevoegdheid te bevestigen voor het beheer of medebeheer van de ondernemingen en instellingen die werkzaam zijn in de brandstofcyclus, zoals het NIRAS en het $\mathrm{SCK}^{358}$. Op zichzelf genomen betekent dit dus nict dat de Gewesten geen bevoegdheid zouden bezitten voor wat betreft milieuaspecten van kemenergie. Zo kan een milieu-effectenstudie worden opgelegd in het kader van een bouwvergunning voor nucleaire installaties, zij het beperkt tot de doelstelling van stedenbouw en ruimtelijke ordening ${ }^{359}$ en zijn de Gewesten bevoegd voor het toekennen van een lozingsvergunning betreffende het koelwater, omdat lozingen van het koelwater een niet-radioactieve lozing is ${ }^{360}$.

Bij het beoordelen van deze aspecten mogen de Gewesten nochtans enkel rekening houden met overwegingen "die verband houden met de bescherming van het leefmilieu en niet met overwegingen die verband houden met bescherming tegen ioniserende stralingen" ${ }^{361}$. Zo stelt het Arbitragehof dat het Gewest haar bevoegdheid inzake stedenbouw en ruimtelijke ordening niet mag opvatten op een zodanige wijze dat het voor de Staat niet doenbaar zou zijn om een doeltreffend beleid te voeren in de aangelegenheden die tot zijn bevoegdheid behore ${ }^{362}{ }^{363}$. In dezelfde lijn was eerder de Raad van State van oordeel dat de Gewesten niet noodzakelijk bevoegd zijn zodra

Lavrysen, L., "De bevoegdheidsverdeling tussen Staat en Gewesten inzake leefmilieu na de tweede fase van de Staatshervorming 1988-1989", De bevoegdheden inzake milieubeheer, Story Scientia, Gent, 1990, 117; Theunis, J., "Deel IV. Milieu en Staatsrecht", in Deketelaere, K. (ed.), "Handboek nilieurecht", l.c., 339 e.v. Deridder, L., "Deel 7. Energiebeleid", in van Haegendoren, G. en Seutin, B. (ed.), De bevoegdheidsverdeling in het federale Belgie, Die Keure, Brugge, $2000,47$.

Lavrysen, L. De ontwikkeling van het Europese, Belgische en Vlaamse milieurecht in een wijzigende institutionele context. Onderzoek naar de ontwikkeling van het milieurecht vanuit een publiekrechtelijke invalshoek, Kluwer, Antwerpen, 1998, 235. Lavrysen, L., "De bevoegdheidsverdeling tussen Staat en Gewesten inzake leefmilieu na de tweede fase van de Staatshervorming 1988-1989", o.c., 122. Arbitragehof, nr. $57 / 95,12$ juli 1995 , B.S. 1 september 1995 , B.6.

Parlementaire Handelingen, 28 juli 1988, 1388.

Toelichting, Parlementaire Stukken, Senaat, 1992-93, nr. 558/1, 21.

Arbitragehof, 24 mei 1988, nr. 54, B.S., 11 juni 1988, 6.B.12.c in fine.

Hier dient te worden opgemerkt dat het arrest werd geveld op basis van de ongewijzigde wet tot hervorming der instellingen, met name de versie van 1980. Ondertussen is, zoals gezegd, deze wet reets meermaals gewijzigd waarbij werd verduidelijkt dat de federale wetgever exclusief bevoegd is voor de kembrandstofcyclus (De Sadelecr, N., "Les transferts de compétences aux entités fédérées: l'environnement, l'agriculture et le pénal", Administration Publique, 1994, 184). Nochtans hebben de gewijzigde bepalingen geen daadwerkelijke wijziging der bevoegdheden tot gevolg (Lavrysen, L., "De bevoegdheidsverdeling tussen Staat en Gewesten inzake leefmilieu na de tweede fase van de Statshervorming 1988-1989", o.c., 80 e.v.; Theunis, J., "Bevoegdheden en bevoegdheidsgrenzen inzake leefmilieu: een stand van zaken", in Deketelaere, K. (red.), Milieurecht in Belgiê. Status Questionis Anno 1997, Die Keure, Brugge, 1997, 66). 
het begrip "leefmilicu" te berde kan worden gebracht ${ }^{304}$. Hiermee wordt min of meer gerefereerd aan het proportionaliteits-, evenredigheids- en redelijkheidsbeginsel ${ }^{365}$.

Anderzijds lag het volgens het Arbitragehof niet in de bedoeling van de bijzondere wetgever om de bescherming tegen ioniserende straling die gedeeltelijk ook de leefmilieubescherming omvat, op het vlak van het vergunningstelsel, te splitsen over verscheidene overheden. Het geheel van belangen waarmee rekening dient te worden gehouden met het oog op de bescherming tegen ioniserende straling, maakt de exclusieve federale bevoegdheid ondeelbaar ${ }^{365}$. Aangezien het Gewest niet bevoegd is om vergunningen toe te kennen voor de exploitatie van kerninstallaties, kan het dus ook de procedure ervan niet bepalen, al was het maar van één van de elementen ervan ${ }^{367}$. Zo kan de gewestelijke overheid geen milieuvergunning opleggen voor boringen met het oog op het opslaan van nucleair afval ${ }^{368}$.

Zowel de gewestelijke bevoegdheid inzake leefmilieu als inzake energiebeleid kent dus beperkingen die verband houden met nucleaire installaties en/of toepassingen. Met betrekking tot leefmilieu blijft de federale overheid bevoegd inzake de bescherming tegen ioniserende stralingen met inbegrip het radioactief afval; met betrekking tot encrgiebeleid blijft de federale overheid bevoegd voor de kembrandstofcyclus aangezien dit een aangelegenheid betreft die wegens haar technische en economische ondeelbaarheid een gelijke behandeling op nationaal vlak behoeft. Anders gezegd bevindt de exclusieve nationale bevocgdheid inzake de bescherming tegen ioniserende stralingen zich voor wat betreft de bescherming van het leefmilieu in een spanningsveld met de eveneens exclusieve gewestelijke bevoegdheid ter zake. Immers: ioniserende stralingen kunnen leiden tot een verontreiniging van water, lucht en bodem. De bescherming van deze laatste is een regionale materie.

Als vuistregel kan het volgende worden gesteld: zodra een materie betrekking heeft op de bescherming van ioniserende stralen, is de federale overheid exclusief bevoegd tot het nemen van maatregelen, ongeacht het feit of de emissies van radio-isotopen voortkomen uit nucleaire of nietnucleaire installaties ${ }^{369}$. Omgekecrd zijn de Gewesten bevoegd inzake niet-radioactieve risico's zelfs indien deze risico's voortkomen uit nucleaire activiteiten. Net als alle andere sectoren, is inderdaad ook de nucleaire sector onderworpen aan de gewestelijke reglementering ${ }^{370}$, bijvoorbeeld het gewestelijke milieurecht. Een voorbeeld kan dit verduidelijken.

Indien zich in een in Vlaanderen gelegen keminstallatie een probleem voordoet inzake bodemvervuiling en -sanering, zal het bodemsaneringsdecreet ${ }^{371}$ kunnen worden toegepast, tenzij zou blijken dat de bodem radioactief besmet zou zijn. Blijkt op een nucleaire site de bodemverontreiniging te zijn vcroorzaakt door een lekkende dieseltank, dan hebben we te maken met een "conventionele niet-nucleaire milieuverontreiniging" en dan zal het bodemsaneringsdecreet

R.v. St., Afd. Wetg., advies van 23 juni 1983 uver een vourstel van decreet houdende regeling van de milieu-effectrapportering, Gedr. St., Vlaamse Raad, 1981-1982, nr. 139/2, 3.

Orban de Xivry, E., "Jurisprudence de la Cour d'Arbitrage et droit de l'environnement", De bevoegdheden inzake Milieubeheer, Story Scientia, Gent, 1990, 258.

Arbitragehof, nr. 54, 24 mei 1988, B.S., 11 juni 1988, 6.B.11. en 6.B.10.

Arbitragehof, arrest nr. 54, B.S., 11 juni $1988,6 . B .10$.

Arbitragehof, nr. 47/95, 12 juli 1995, B.S., 1 septcmber 1995, B. 13.2

De Sadeleer, $N$., "La répartition des compétences en matière d'environnement: les apports de la loi spéciale du 16 juillet 1993 visant à achever la structure fédérale de l'Etat", Milieubeleid in he't federale België anno 1993, Belgische Vereniging voor Milicurecht, Story Scientia, Gent, 1994, 26.

Deridder, L., "Deel 7. Energiebeleid", o.c., 48.

Decreet van 22 februari 1995 betreffende de bodemsanering, gewijzigd door het Decreet van 28 mei 1998 (B.S., 25 juli 1998). 
toepassing vinden; het tegendeel zal waar zijn indien de verontreiniging werd veroorzaakt door een tank waarin zich radioactief lozingswater bevond. In het laatste geval zal, gelet op haar exclusieve bevoegdheid ter zake van de bescherming tegen ioniserende straling, alleen de federale overheid bevoegd zijn en zullen de drempelwaarden en limietdoses van het ARAB toepassing vinden. Het spreekt voor zich dat nooit van tevoren zal kunnen worden bepaald of een gegeven verontreiniging al dan niet van radioactieve aard is. Enig overleg tussen de verschillende bevoegde overheidsinstanties is bijgevolg vereist ${ }^{372}$.

\subsection{Conclusie}

De ontwikkeling van het Belgische kernenergierecht is nauw verbonden met het ontstaan van het Studiecentrum voor Kemenergie (SCK/CEN) te Mol. Belangrijk hierbij is dat de fondsen waarmee het SCK werd opgericht, direct voortvloeien uit heffingen die voornamelijk door de VS werden betaald uit de uraniumvoorraden uit voormalig Belgisch Congo.

Een belangrijk deel van het Belgische kemenergierecht is ontstaan op het einde van de jaren vijftig en bij het begin van de jaren zestig. Vooral van belang zijn de wet van 29 maart 1958 ter bescherming van de gevaren uit ioniserende straling en de wetten inzake nucleaire aansprakelijkheid. De wet van $1958 \mathrm{zal}$ worden vervangen wanneer de wet van 15 april 1994 in werking zal treden. Het in werking treden van deze wet zal het Federaal Agentschap voor Nucleaire Controle toelaten ten volle haar werkzaamheden uit te oefenen. Toch bestaat onduidelijkheid over de precieze taakverdeling tussen het FANC enerzijds en het SCK en NIRAS anderzijds.

De eerste Belgische nucleaire aansprakelijkheidswet was van tijdelijke aard en had enkel betrekking op het SCK. Deze wet was gunstig voor slachtoffers van een ongeval op het SCK in die zin dat alle schade werd vergoed, hetzij door het SCK (of diens verzekeraar), hetzij door de Belgische Staat. Anderzijds diende het slachtoffer een fout te kunnen bewijzen in hoofde van het SCK. Doordat de wet geen wijzigingen aanbracht aan het gemeenrechtelijke aansprakelijkheidsregime, maar het SCK ook verplichtte zich te verzekeren voor andermans aansprakelijkheid, was dit stelsel nauw verwant met de Amerikaanse Price-Anderson $\mathrm{Act}^{373}$.

De wet op de civielrechtelijke aansprakelijkheid van het SCK werd in 1966 vervangen; hierbij werden de bepalingen van het Verdrag van Parijs ingevoerd in het Belgische recht. Dit betekende dat de economische kanalisatie werd vervangen door de juridische kanalisatie van aansprakelijkheid naar de exploitant van een kerninstallatie. Meteen werd ook een einde gesteld aan het voor slachtoffers van een kernongeval uitermate gunstige regime zoals van kracht onder de wet van 1962. Voortaan werd de aansprakelijkheid beperkt. Doordat de Belgische Staat financieel niei

Een dergelijk overleg is overigens binnen het Belgische federale model perfect mogelijk. Door het Belgische duale federalisme (namelijk de splitsing in Gemeenschappen en Gewesten) is een strakke scheiding en onafhankelijkheid van bevoegdheden tussen de versehillende beleidsniveaus onmogelijk. Het accent ligt dus eerder op complementariteit en samenwerking dan op de scheiding en de autoriomie van de respectievelijke bevoegdheden (Alen, A., België: een tweeledig en centrifugaal federalisme, Ministerie van Buitenlandse Zaken, Buitenlandse handel en Ontwikkelingssamenwerking, Brussel, 1990, 21; Alen, A. en Peters, P., "België op zoek naar een coüperatief federaal staatsmodel. Over dê samenwerking tussen de Staat, de Gemeenschappen en de Gewesten na de derde staatshervorming ${ }^{n}$, Tijdschrift voor Belgisch Publiekrecht, 1989, 344-345). Zie hierover meer in detail Moerenhout, R. th Smets, J., De samenwerking tussen de federale Staat, de Gemeenschappen en de Gewesten, Kluwer, Deume, 1994, 42 e.v.; Moerenhout, R., "De samenwerking tussen de federale Staat, de Gemeenschappen en de Gewesten - recente ontwikkelingen", Tijdschrift voor Belgisch Publiekrecht, 1996, 271 -283. 
meer bijdroeg, betekende dit ook dat het totale beschikbare schadevergoedingsbedrag werd beperkt tot 500 miljoen BEF. Pas door de wet van 22 juli 1985 werd ook het Aanvullend Verdrag van Brussel omgezet in het Belgische recht en werd de bijdrage van de Staat opnieuw geïntroduceerd. Vanaf 1 januari 2001 is deze Staatsbijdrage in de tweede schijf van het Aanvullend Verdrag van Brussel, afgeschaft. De Belgische Staat zal enkel nog kunnen worden verplicht om bij te dragen in de derde schijf van het Verdrag.

Tenslotte dient in het Belgische kemenergierecht, dat grosso modo een federale materie is, in gevallen waar sprake is van niet nucleaire "conventionele milieurisico's" eveneens rekening te worden gehouden met de respectievelijke gewestelijke milieuwetgevingen.

$\mathrm{Na}$ de bespreking van het ontstaan van het Belgische kernenergierecht, zal in $\S 4$ het ontstaan en de ontwikkeling van het Nederlandse kernenergierecht aan de orde worden gesteld.

\section{ONTSTAAN VAN HET NEDERLANDSE KERNENERGIERECHT}

Nederland is toegetreden tot de voornaamste Verdragen inzake het civiele gebruik van kernener$\mathrm{gie}^{374}$. Tegelijk is Nederland lid van Euratom en van het IAEA en is het toegetreden tot het NonProliferatieverdrag, het Verdrag inzake fysieke beveiliging van kemmateriaal ${ }^{375}$ en het Verdrag inzake Nucleaire Veiligheid ${ }^{376}$.

De Nederlandse "basiswet" inzake de gevaren verbonden aan het gebruik van kernenergie is de Kemenergiewet. Die wordt hieronder besproken in $\$ 4.1$. Vervolgens wordt een overzicht gegeven van de Nederlandse wetgeving inzake civielrechtelijke aansprakelijkheid voor kemongevallen $(\S 4.2)$.

\subsection{De Kernenergiewet (Kew)}

De Nederlandse Kew dient in twee delen te worden besproken, aangczien deze wet in 1994 aanzienlijk werd gewijzigd. Vandaar wordt eerst aandacht besteed aan de oorspronkelijke kew van 1963 (\$ 4.1.1) en vervolgens aan de wijzigingen van 1994 (\$ 4.1.2).

\subsubsection{De oorspronkelijke Kernenergiewet}

Op 21 februari $1963 \mathrm{kwam}$ in Nederland de wet houdende regelen met betrekking tot de vrijmaking van kemenergie en de aanwending van radioactieve stoffen en ioniserende stralen uitzendende toestellen ${ }^{377}$, beter bekend als de Kemenergiewet (Kew), tot stand. Deze wet beoogt volgens de considerans de "bevordering van een goede ontwikkeling op het gebied van de vrijmaking van kemenergie en de aanwending van radioactieve stoffen en ioniserende stralen uitzendende toestellen, zomede ter bescherming tegen de hieraan verbonden gevaren". Primair strekte deze

\footnotetext{
374 Een overzicht van de verschillende Verdragen inzake kernenergierecht waar Nederland bij betrokken is, kan worden teruggevonden bij Domsdorf, E.P.M.W., "Internationaal Atoomenergierecht", \&c. Wet van 17 december 1987, Stb., 1987, 640 .

376 Goedkeuring via brief van de Minister van Buitenlandse Zaken (Staten-Generaal, Vergaderjaar 1995 1996, 24.833, Nr. 325 en 1). Zie ook Tracutenblad, 1996, nr. 315. Het Verdrag is in Nederland in werking getreden op 13 januari 1997 .

Sib., 1963/82.
} 
wet ertoe de volksgezondheid te beschermen tegen de gevaren voortkomend uit ioniserende stralen, maar geleidelijk aan heeft deze wet zich ook ontwikkeld tot een natuurbeschermingswet ${ }^{378}$.

In haar geheel is de wet slechts in werking getreden op 1 januari 1970, met uitzondering van hoofdstuk II Kew, dat in werking trad op 27 maart 1963. Hoofdstuk II behandelt de advisering aan de regering; door de vervroegde inwerkingtreding van deze bepalingen konden deze adviesorganen reeds worden opgericht en hun werkzaamheden aanvatten. Voor de nog niet in werking getreden bepalingen, diende een beroep te worden gedaan op de bestaande wetgeving: inrichtingen waar splijtstoffen werden vervaardigd vielen onder de Hinderwet en de bescherming van de werknemers binnen dergelijke inrichting vielen onder het Veiligheidsbesluit ioniserende stralen, gebaseerd op de Veiligheidswet van 1934; de import, export, productie en het gebruik van radioactieve stoffen werd geregeld door de Warenwet van 1935; wat betreft het gebruik van gevaarlijke apparaten diende de Wet op de gevaarlijke werktuigen van 1952 te worden gerespecteerd ${ }^{379}$.

Net zoals de Belgische wet van 29 maart 1958 betreffende bescherming van de bevolking tegen de uit ioniserende stralingen voortspruitende gevaren, is de Nederlandse Kew een kaderwet; voor de verdere uitwerking van de Kew zijn amvb's en ministeriële beschikkingen nodig. Inzake vergunningverlening zijn drie amvb's van belang: het Besluit kerninstallaties, splijtstoffen en ert$\operatorname{sen}^{380}$, het Besluit stralenbescherming Kew ${ }^{381}$ en het Besluit vervoer splijtstoffen, ertsen en radioactieve stoffen $^{382}$. De Kew is bijgevolg de wet die de uit het Euratom-verdrag voortvloeiende verplichtingen inzake de bescherning van de bevolking tegen ioniserende straling invoert in de Nederlandse rechtsorde.

De Kemenergiewet is ook de basiswet waarin de vergunningsplicht is opgenomen ter zake van nucleaire activiteiten ${ }^{383}$. In verband met de vergunningverlening is de openbare voorbereidingsprocedure van toepassing zoals voorzien in afdeling 3.4 van de Algemene Wet Bestuursrecht ${ }^{354}$. Deze procedure is speciaal geschreven voor ingewikkelde besluiten waar veel belanghebbenden bij zijn betrokken ${ }^{385}$.

De Kernenergiewet is reeds meermaals gewijzigd ${ }^{386}$. Eén van de belangrijkste wijzigingen betrof de aanpassingen op het vlak van de ongevallenbestrijding. Bij deze wijziging wordt hieronder even stilgestaan.

Tonnaer, F.P.C.L., "Handboek Nederlands Milieurecht", I.c., 1279.

Alexander, W., "La législation nucléaire aux Pays-Bas", in Puget, H. (éd.), Aspects du droit de l'énergie atomique, Tome II, Editions du centre national de la recherche scientifique, Paris, 1967, 347356.

Besluit van 4 september 1969, Stb., 403, nadien meermaals gewijzigd.

Besluit van 10 september 1986, Stb. 465, nadien meermaals gewijzigd.

Besluit van 3 september 1987, Stb. 403, nadien meermaals gewijzigd.

Zie artikel 15 van de Kernenergiewet.

Wet van 4 juni 1992 houdende algemene regels van bestuursrecht (Stb. 315), inmiddels meermaals gewijzigd.

Heldeweg, M., Hertoghs, M. en Seerden, R., "Besluitvorming rond de lokalisatie van kerncentrales", in Faure, M. (red.), "Aansprakelijkheid voor het nucleaire risico", l.c., 131.

Ook recent werd de wet gewijzigd: op 25 mei 2000 werd het wetsvoorstel aangenomen tot Wijziging van de Kernenergiewet. Deze wijziging strekte er voornamelijk toe om de Kemenergiewet aan te passen aan Richtlijn 96/29/Euratom tot vaststelling van de basisnormen voor de bescherming tegen stralingsgevaar. Zie Tweede Kamer, Vergaderjaar 1999-2000, 26.992, nr. 3, Memorie van Toelichting. 


\subsubsection{Wijziging op het punt van de ongevallenbestrijding}

Een opvallende wijziging aan de Kew werd aangebracht door de toevoeging, in 1994, van een nieuw hoofdstuk $\mathrm{VI}^{38 \%}$. Rechtstreekse aanleiding tot deze wijziging was het feit dat het overheidsoptreden tijdens het ongeval van Tsjernobyl diende te worden geïmproviseerd bij gebrek aan afdoende regelgeving terzake ${ }^{388}$. Op initiatief van de minister van Volkshuisvesting, Ruimtelijke Ordening en Milieubeheer (VROM) werd begin 1987 gestart met het project Kernongevallenbestrijding. Op 13 februari 1989 werd de Nota Kernongevallenbestrijding ${ }^{389}$ en het Nationaal Plan voor de Kernongevallenbestrijding (NPK) aan de Tweede Kamer der Staten-Generaal aangeboden $^{330}$. De nota bevat de beleidsvisie met betrekking tot de opzet en organisatie van de kemongevallenbestrijding. Het suggereerde een aantal verbeteringen aan de bestaande regelgeving; deze verbeteringen werden vervolgens in wetteljjke vorm gegoten en vormen het voorwerp van de wijziging aan de Kew.

De wetswijziging heeft een viervoudig doel. In de eerste plaats beoogt de wetswijziging duidelijkheid te scheppen inzake de bestuurlijke coördinatie van ongevallen met een stralingsrisico voor mens en milieu. Daarnaast wil de wijziging de onduidelijkheid opheffen met betrekking tot de vraag of de strafbaarstelling van overtredingen van sommige getroffen maatregelen ter beperking van het stralingsgevaar wel gebaseerd kon worden op de Kew. Ten derde voert de wet de EG-richtlijn uit betreffende de informatie van de bevolking over de bij stralingsgevaar toepasselijke matregelen ter bescherming van de gezondheid ${ }^{391}$. Ten slotte kadert de wijziging in de vereenvoudiging van het vergunningenstelsel.

Uitgangspunt van de Nederlandse kernongevallenbestrijding is de indeling in categorie A- en Bobjecten. Teneinde duidelijkheid te scheppen in de coördinerende taken bij kernongevallenbestrijding, is het niveau van bestuurlijke coördinatie afhankelijk gesteld van de potentiële gevolgen van een kemongeval. Bij categorie A-objecten kunnen de gevolgen van een kemongeval gevolgen hebben voor het gehele land, hetgeen de inschakeling van de rijksoverheid vereist in verband met de afstemming met de autoriteiten van de buurlanden ${ }^{392}$; bij categorie B-objecten evenwel blijven de gevolgen van een ongeval beperkt tot de gemeente waar het ongeval heeft plaatsgevonden en bijgevolg ligt de bestuurlijke coördinatie in dat geval bij de burgemeester. Categorie A-objecten zijn kerncentrales en ruimtevaartuigen of vervoermiddelen die door kemenergie worden aangedreven. Categorie B-objecten zijn inrichtingen voor uraniumverrijking, inrichtingen voor verwerking en opslag van radioactieve stoffen of splijtstoffen, inrichtingen waar radioactieve stoffen of ioniserende stralen uitzendende toestellen worden vervaardigd of gebruikt en toestellen waarin zich splijtstoffen, ertsen, radioactieve stoffen of ioniserende straling uitzendende stoffen bevinden en vervoermiddelen waarin zich splijtstoffen, ertsen, radioactieve stoffen of ioniserende stralen uitzendende toestellen bevinden (art. 38, c en d).

Zoals hierboven reeds kort werd aangegeven, werd de bestuurlijke coördinatie bij categorie Aobjecten op rijksniveau vastgelegd. De desbetreffende ministers hebben de bevoegdheid gekregen

Wet van 4 februari 1994 tot wijziging van de Kemenergiewet op het punt van de ongevallenbestrijding en andere zaken, Sib. 1994, 95; deze wet trad in werking op 23 februari 1994.

Kernongevallenbestrijding. Tweede Kamer, 1988-1989, 21 015, nr. 2, 5.

Ibidem.

Zie de brief van de minister van de VROM aan de voorzitter van de Tweede-Kamer der Staten Generaal, Stb., 1988-1989, 2.1015 , nr. 1.

Richtlijn van 27 november 1989, 89/618/Euratom, PB, L 357/31.

Hier zijn de Verdragen inzake vroegtijdige kennisgeving van belang; cfr. supra, in $\$ 2.2 .1 .1$. van dit hoofdstuk.
} 
om de nodige maatregelen te treffen, hetgeen een afwijking is van het systeem van de Rampenwet $^{393}$, daar deze wet in een decentrale opzet van de rampenbestrijding voorziet ${ }^{394}$. Dit terwijl er voor categorie B-objecten geen reden bestaat om af te wijken van het decentrale systeem van de Rampenwet.

Opmerkelijk is het artikel 39 dat stelt dat ieder die weet of redelijkerwijs kan vermoeden dat zich een ongeval voordoet met een categorie A- of B-object verplicht is dit terstond te melden aan de burgemeester van de gemeente waar hij zich bevindt. Deze laatste rapporteert deze melding "onverwijld" aan de minister van de VROM. Om er zeker van te zijn dat deze verplichting ook geldt voor de exploitant van een Niederlandse kemcentrale, werd tevens een derde lid opgenomen in artikel 39 op basis waarvan de burgemeester de exploitant om alle informatie kan verzoeken ${ }^{395}$.

Op basis van artikel 46 kan de minister van de VROM zelf de nodige maatregelen treffen om de gevolgen van een kernongeval zoveel mogelijk te beperken of ongedaan te maken ${ }^{396}$; tegelijk kan hij de exploitant daartoe verplichten. De maatregelen kunnen onderverdeeld worden in beschermende en medische maatregelen, maatregelen betreffende de landbouw en voedselvoorziening, en maatregelen betreffende de waterhuishouding en drinkwatervoorziening. In het kader van dit onderzoek is hier met name de vraag relevant of de zogenaamde preventieve maatregelen die door de Nederlandse overheid in het kader van de Kemenergiewet worden genomen, al dan niet onder het schadebegrip vallen zoals bepaald in het Verdrag van Parijs. Daar wordt later op teruggekomen.

De wijziging aan de Kew bevat ook interessante bepalingen met betrekking tot schadevergoeding. Op basis van artikel $49 \mathrm{e}$ kan vergoeding worden bekomen voor maatregelschade bij een ongeval met een B-object, voorzover de schade niet via burgerrechtelijke weg is of kan worden verhaald en voorzover in de vergoeding van de schade niet op andere wijze is of kan worden voorzien. Het is duidelijk de bedoeling geweest van de wetgever om de toepassing van artikel $49 \mathrm{e}$ te beperken. Ten eerste wegens de strikte formulering van artikel $49 \mathrm{e}$, eerste lid en ten tweede door het subsidiaire karakter ervan.

De beperkte toepassing van artikel 49e blijkt in de eerste plaats uit de strikte bewoordingen ervan: aan degene die door een naar aanleiding van een ongeval met een categorie B-object opgelegde maatregel "rechtstreeks en onmiddellijk" schade heeft geleden "die redelijkerwijs niet of niet geheel te zijnen laste behoort te blijven, kan (...) een naar billijkheid te bepalen schadevergoeding worden toegekend". Er dient bijgevolg sprake te zijn van een stringent causaal verband tussen de getroffen maatregel en de schade. Na het ongeval in Tsjernobyl werd bijvoorbeeld een spinazicverbod uitgevaardigd; de spinazietelers kregen hiervoor een vergoeding. Ondanks de voorlichting door de overheid waarin gezegd werd dat andere groenten zonder gevaar voor de volksgezondheid konden worden geconsumeerd, kende ook de verkoop van andere verse groenten een forse daling. De schade van de andere telers wordt echter niet beschouwd als zijnde het rechtstreekse en onmiddellijke gevolg van het spinazieverbod. Daamaast gaat het in artikel $49 \mathrm{e}$ om schade die redelijkerwijs niet of niet geheel ten laste van belanghebbende dient te blijven: enkel schade die gelet op de aard van het bedrijf als abnormaal dient te worden beschouwd, kan voor vergoeding in aanmerking komen. In de wet is sprake van een "naar billijkheid te bepalen schadevergoeding". Met deze zinsnede wordt aangesloten bij de artikelen $15.20,15.25$ en 15.26 van de Wet Milieube-

Wet 26 februari 1985, Stb. 88, in werking getreden op 1 maart 1985, meermaals gewijzigd.

Memorie van Toelichting, Tweede Kamer, 1992-1993, 23 053, nr. 3, 3.

Memorie van Toelichting, Tweede Kamer, 1992-1993, 23 053, nr. 3, 14.

Hierbij dient hij zoveel mogelijk overleg te plegen met de betrokken burgemeester. 
heer $(\mathrm{Wm})^{397}$; het betreft een louter redactionele overeenstemming die inhoudelijk geen gevolgen heeft $^{398}$.

Het subsidiaire karakter blijkt uit het feit dat dit artikel enkel in overweging kan worden genomen indien compensatie niet op andere wijze - hetzij op basis van de WAKO, hetzij op basis van het $\mathrm{BW}$, hetzij op basis van artikel 49e, lid 2 - kan worden verkregen. Volgens de Memorie van Toelichting is de aansprakelijkheid voor ongevallen met categorie A-objecten geheel geregeld in het Verdrag van Parijs en in de WAKO ${ }^{399}$. Bepaalde ongevallen met categorie B-objecten zullen ook onder het Verdrag en de WAKO vallen. Indien schade door een ongeval met een categorie Bobject niet onder de verdragsregeling valt, dient eerst te worden nagegaan of de gelaedeerden een actie kunnen instellen op basis van Boek 6, titel 3 BW. Is dit niet het geval, dan kan desgevallend een beroep op artikel $49 \mathrm{e}$ Kew worden overwogen. Voorts wordt door het tweede lid van artikel $49 \mathrm{e}$ de mogelijkheid geboden dat het bevoegde gezag dat naar aanleiding van een kernongeval algemene regels uitvaardigt, tevens regels stelt waarbij categorieën van gevallen worden aangewezen die voor schadevergoeding in aanmerking komen. Er is als het ware sprake van een cascade-vergoedingsregeling: eerst dient te worden nagegaan of de WAKO van toepassing is; is dat niet het geval, dan kan Boek 6 titel 3 als rechtsgrond dienen; biedt dit evenmin soelaas, dan is vergoeding misschien via een andere weg voorzien, zijnde dat het bevoegde orgaan dat de maatregelen heeft genomen die tot schade aanleiding hebben gegeven, een regeling instelt. Pas indien geen van deze regels compensatie toelaten, kan een beroep worden gedaan op artikel $49 \mathrm{e}$, lid 1 Kew.

\subsection{Overzicht van de Nederlandse nucleaire civielrechtelijke aansprakelijkheidswetgeving}

Nederland heeft tot op heden drie wetten uitgevaardigd betreffende de civielrechtelijke aansprakelijkheid voor kernongevallen. De eerste wet was een voorlopige wet van 1964. Deze werd vervangen door de Wet Aansprakelijkheid Kernongevallen van 1965; deze werd op zijn beurt vervangen door de in 1979 tot stand gekomen WAKO (Wet Aansprakelijkheid voor Kernongevallen). Deze drie wetten worden hieronder kort aan de orde gesteld.

\subsubsection{De tijdelijke wet van 1964}

Voór de inwerkingtreding van de eigenlijke Nederlandse nucleaire civiele aansprakelijkheidswet van 1965 werd in het Nederlandse Parlement een tijdelijke wet goedgekeurd die het mogelijk moest maken dat met het ontwerp en de bouw van de centrale in Dodewaard kon worden aangevangen.

De Memorie van Toelichting van deze voorlopige wet van 1964 is interessant. Daaruit blijkt immers dat deze wet snel diende te worden genomen, zoniet riskeerde de geplande bouw van een 50 Megawatt kerncentrale in het gedrang te komen. Het contract dat het Nederlandse SEP NV (Samenwerkende Elektriciteitsproductiebedrijven) hiertoe had afgesloten met een Zwitsers filiaal van het Amerikaanse General Electric, bevatte namelijk een clausule dat de werkzaamheden van het project konden worden beëindigd indien vóór 2 april 1964 in Nederland hetzij het Verdrag van Parijs nog niet in werking zou zijn, hetzij Nederland nog geen analoge nationale regeling in zijn

\footnotetext{
39

Artikel 15.20 bevindt zich onder titel 15.4 "Vergoeding van kosten en schade"; de artikelen 15.25 en 15.26 hebben betrekking op het Fonds Luehtverontreiniging (titel 15.5). Zowel artikel 15.20, lid 1 in fine Wm, als artikel 15.26, eerste lid Wm spreken van een schadevergoeding in billijkheid.

Memorie van Toelichting, Tweede Kamer, 1992-1993, 23 053, nr. 3, 7, onderaan.
} 
wetgeving zou hebben opgenomen. Aldus was het noodzakelijk dat de Nederlandse regering ten opzichte van de leverancier de verplichting aanging om hem te vrijwaren tegen de geldelijke gevolgen van diens aansprakelijkheid. Deze condities moesten worden gezien als "het gevolg van de in de Verenigde Staten gevolgde rechtspraktijk ${ }^{\prime 400}$. De situatie was dus precies dezelfde als in Belgiê: ook daar werd een tijdelijke wet aangenomen teneinde het mogelijk te maken de BR3reactor in werking te stellen ${ }^{401}$.

Maar in plaats van een wet aan te nemen die zeer specifiek van toepassing zou zijn op de kerninstallatie van Dodewaard, beperkte het Nederlandse Parlement zich tot het wijzigen van de rijksmiddelenbegroting; de wet voegde artikel 71 a toe aan de rijksmiddelenbegroting, met als titel:

vrijwaring van de leverancier van het ontwerp van de eerste in Nederland te bouwen kernenergiecentrale tegen de geldelijke gevolgen van wettelijke aansprakelijkheid voor kernongevallen ${ }^{402}$.

Het toegevoegde artikel 71 a werd ingedeeld in het algemeen beheer van afdeling V: industrialisatie en energievoorziening. In dezelfde afdeling was onder meer voorzien: bijdrage in de kosten van het Reactor-Centrum Nederland (RCN) en een bijdrage in het kader van Euratomverplichtingen van Nederland (resp. artikel 67 en 68). In tegenstelling tot de twee laatstgenoemde artikelen van de rijksmiddelenbegroting, voorzag het toegevoegde artikel 7la evenwel niet in een "toegestaan bedrag". Het vreemde hierbij is dat er blijkbaar geen bepaling werd aangenomen door het Nederlandse Parlement op basis waarvan de Nederlandse Staat zich ertoe verbond de gevolgen van de aansprakelijkheid van de leverancier op zich te nemen. De wijze waarop de vrijwaring is ingeschreven in de rijksmiddelenbegroting van 1964 impliceert eigenlijk dat de Nederlandse Staat ten voordele van de Amerikaanse leverancier een in bedrag onbeperkte garantie heeft gesteld ${ }^{403}$.

Het inschrijven van een vrijwaringsverbintenis in de wet op de rijksmiddelenbegroting is in feite een manier om de economische kanalisatie in te voeren. De wetgever wilde met deze wet niets anders dan het verlenen van een garantie aan de leverancier dat hij niet financieel zou moeten opdraaien voor de schade veroorzaakt door een kernongeval ${ }^{404}$; de leverancier werd inderdaad gevrijwaard tegen een mogelijke aansprakelijkheid. Doordat de Nederlandse wetgever geen enkele bijkomende bepaling toevoegde, dienden bijgevolg voor het overige de gemeenrechtelijke aansprakelijkheidsbepalingen te worden toegepast, hetgeen er op neer zou zijn gekomen dat de foutaansprakelijkheid onverkort gold. Dit toont in feite vrij goed aan wat een economische kanalisatie eigenlijk inhoudt: het betreft het verschuiven van de economische last van een bepaalde aansprakelijkheid. Aan deze aansprakelijkheid zelf wordt niet geraakt.

De geest waarin dit artikel tot stand is gekomen, is vrij merkwaardig: er werd gesteld dat een ongeval in het toenmalige stadium weinig waarschijnlijk was, aangezien de wet betrekking had op het ontwerp van de kemcentrale; het risico was slechts te verwachten wanneer de reactor in be-

\footnotetext{
400 Memorie van Toelichting, zitting 1963-1964, 7622, nr. 3.

40! Wet betreffende de burgeriijke a.ansprakelijkheid van het Studiecentrum voor kemenergie van 27 juli 1962, cfi. supra.

402 Wet van 1 augustus 1964 houdende wijziging van hoofdstuk XIII der rijksbegroting voor het dienstjar 1964, Stb. $1964,316$.

403 In de tijd was deze verbintenis wel beperkt in die zin dat het een artikel betrof van de rijksmiddelenbegroting van 1964. Voor de daaropvolgende jaren kon dus in principe geen beroep meer worden gejaan op deze bepaling. Voorzover bekend werd van deze bepaling inderdaad geen gebruik gemaakt. 
drijf zou worden gesteld, hetgeen pas in 1967 kon worden verwacht en tegen die tijd, zo werd gesteld, zal het Verdrag van Parijs van kracht zijn ${ }^{405}$.

"Indien zich echter voordien onverhoopt een kemongeval mocht voordoen, dan zal, wil de leverancier kunnen worden aangesproken, toch eerst diens schuld moeten worden aangetoond, terwijl juist het noodzakelijke bewijs van schuld bij een ongeval in een kerninstallatic uitermate moeilijk te leveren zal zijn. Dat de leverancier desondanks staat op de (...) garantie, is een gevolg van de in de Verenigde Staten gevolgde rechtspraktijk" ${ }^{106}$.

Indien deze wet wordt vergeleken met de Belgische wet van 1962, dan is de eerste opvallende gelijkenis dat beide het regime van foutaansprakelijkheid hanteerden: de Belgische wet expressis verbis en de Nederlandse impliciet. Daarnatast voorzagen beide wetten in een systeem van economische kanalisatie van aansprakelijkheid, zij het dat die op verschillende wijze werd ingevoerd. In Belgie werd een afzonderlijke wet inzake de civielrechtelijke aansprakelijkheid in het leven geroepen met daarin opgenomen de onbeperkte tussenkomst van de Belgische Staat, terwijl in Nederland de economische kanalisatie in de Nederlandse rechtsorde werd geïntroduceerd via een artikel van de rijksmiddelenbegroting.

\subsubsection{De WAK van 1965}

De Wet Aansprakelijkheid Kernongevallen (WAK) werd door het Nederlandse Parlement goedgekeurd op 27 oktober $1965^{407}$.

Deze wet bevatte geen bijzonderheden en introduceerde de door het Verdrag van Parijs gehuldigde principes: kanalisatie van de aansprakelijkheid naar de exploitant van de kerninstallatie, beperking van diens aansprakelijkheid tot een bedrag van 430 miljoen gulden, verplichte verzekering, verjaringstermijn van 10 jaar en exclusieve bevoegdheid van de arrondissementsrechtbank van's Gravenhage. Op deze principes wordt later uitvoerig teruggekomen.

Deze wet gaf enkel uitvoering aan de bepalingen van het Verdrag van Parijs; het is wachten tot de invoering van de WAKO van 1979 voor de uitvoering van de bepalingen van het Aanvullend Verdrag van Brussel.

\subsubsection{De WAKO van 1979}

Op 17 maart 1979 ratificeerde Nederland het Verdrag van Parijs en het Aanvullend Verdrag van Brussel $^{408}$. In plaats van de WAK kwam de Wet op de Aansprakelijkheid voor Kemongevallen $(\text { WAKO })^{409}$.

De WAKO werd ingrijpend gewijzigd in 1991. Vooral opvallend was dat de tussenkomst van de Nederlandse Staat werd opgetrokken tot 5 miljard gulden; ook in dezclfde wet werd de aansprakelijkheid van de exploitant van de kerninstallatie gebracht op 500 miljoen gulden. De/e wijzigingen waren een direct gevolg van het ongeval in Tsjernobyl.

Zitting 1963-1964, Nota naar aanleiding van het verslag dd. 17 juni 1964, 7.622, nr. 5, 2.

Zitting 1963-1964, Nota naar aanleiding van het verslag dd. 17 juni 1964, Sib, 7622, nr. 5, 2.

Stb. $1965,546$.

Deze ratificatie trad in werking op 28 december 1979.

Wet van 17 maart 1979, Stb., 1979, 225. 
Volledigheidshalve wordt erop gewezen dat bij Besluit van 14 november 1997, het bedrag van de aansprakelijkheid van de exploitant werd opgetrokken tot 750 miljoen gulden ${ }^{410}$. Zoals reeds aangegeven zullen de inhoudelijke bepalingen van het nucleaire civiele aansprakelijkheidsrecht in de hoofdstukken 3 en 4 worden geanalyseerd.

\section{Conclusie}

In de vorige paragrafen werd het ontstaan bestudeerd van het internationale en van het Belgische en Nederlandse kernenergierecht. Tegelijk werd een overzicht gegeven van de belangrijkste verdragen en wetten met betrekking tot het nucleaire risico.

Van in het begin is het kernenergierecht beïnvloed door de mogelijke militaire toepassingen van kernenergie. Elke vorm van samenwerking is steeds gepaard gegaan met een vorm van controle. Toen de samenwerking hoofdzakelijk plaatsvond tussen de Amerikaanse overheid en de Amerikaanse privé-industrie, werd die controle uitgevoerd door de Amerikaanse Atomic Energy Commission. Naarmate de samenwerking grensoverschrijdende vormen aannam, werd deze taak overgenomen door een internationaal orgaan (het IAEA). Deze controles hadden niet alleen betrekking op het civiele gebruik van kernenergie (safeguards), maar ook op het beperken van de gevolgen van ioniserende straling op de bevolking en op werknemers (safety).

Van groot belang voor het internationale kernenergierecht, zijn de taken en bevoegdheden van drie internationale organisaties: het Internationaal Atoomagentschap van Wenen, het Energieagentschap van de OESO en Euratom. Nochtans kan enkel Euratom juridisch dwingende maatregelen opleggen aan de verschillende lidstaten. De afdwingbaarheid van de verschillende internationale Verdragen is overigens de achillespees van het internationale kemenergierecht. Van belang in het kader van dit onderzoek is toch de vaststelling dat de regelgeving inzake de civiele aansprakelijkheid voor kemongevallen tot de meest dwingende bepalingen behoort van het internationale kernenergierecht.

Het kernenergierecht is inderdaad uitgesproken internationaal van aard. Deze internationale dimensie is makkelijk te verklaren, ten eerste door de inspanningen op internationaal vlak om te verhinderen dat kemenergie ook voor militaire doeleinden wordt aangewend. Ten twecde vereist het aanwenden van kemenergie dat men beschikt over een aanzienlijke technologische uitrusting, over de juiste knowhow en over voldoende financiële middelen. Een dergelijke uitwisseling van wetenschappelijke kennis en financiële ondersteuning worden bevorderd door middel van internationale samenwcrking ${ }^{411}$. Tenslotte zou met name de veiligheidsregulering weinig zinvol zijn indien door de verschillende landen verschillende standaarden zouden worden gehanteerd. De internationale dimensie van het kernenergierecht uit zich bijgevolg vrij sterk in de harmonisatic van de wetgeving in het algemeen en de inspanningen die de verschillende internationale organisaties ter zake leveren. Bijvoorbeeld inzake veiligheidsregulering worden de richtlijnen van de ICRP gevolgd door het IAEA en door Euratom. In de meeste landen die een beroep doen op kernenergie, en zeker in België en Nederland, heeft zich een parallelle nationale wetgeving ont-

410 Besluit houdende vcrhoging van het maximumbedrag van de aansprakelijkheid, bedoeld in artikel 5 , tweede lid van de Wet aansprakelijkheid kernongevallen (Staatsblad, 1997, 577). De WAKO bevat inderdaad de mogelijkheid om het bedrag waarvoor de exploitant aansprakelijk is, te verhogen bij algemene maatregel van Bestuur. Eerder was dit bedrag, bij Besluit van 14 december 1993 (Staaisbiad, 1993, 702), gebracht op 625 miljoen gulden.

4 Dit is met name het geval in de Euratom-lidstaten waar de Europese Commissic uitgebreide financiele steun biedt voor bepaalde pilootprojecten. Zo loopt in Belgie, op het SCK, een pilootproject betreffende de ontmanteling van een kerninstallatic. 
wikkeld die de internationaal-rechtelijke verplichtingen omzet in de nationale rechtsorde: de verschillende wetten die in België en Nederland werden aangenomen, zijn het gevolg van een internationale regelgeving. Wat België betreft implementeert de wet van 29 maart 1958 (die volledig zal worden vervangen door de wet van 15 april 1994) de Euratom-verplichtingen en is de wet van 22 juli 1985 de uitvoering van het Verdrag van Parijs van 1960 inzake de wettelijke aansprakelijkheid op het gebied van kemenergie. In Nederland voert de kemenergiewet ${ }^{412}$ de Euratom-verplichtingen uit; terwijl de $\mathrm{WAKO}^{413}$ het Verdrag van Parijs uitvoert.

Teruggrijpend naar de in de inleiding aangehaalde kwalificatie van het nucleaire risico, zien we dus dat het intemationale kernenergierecht juridische instrumenten in de Belgische en Nederlandse rechtsorde heeft geïntroduceerd met betrekking tot elk van die aspecten:

- inzake safeguards zijn België en Nederland niet alleen een Euratom-lidstaat, maar bovendien zijn zij partij bij het Non-Proliferatieverdrag van 1969 en hebben zij in hoedanigheid van nietkernwapenstaat de eerder genoemde overeenkomst tussen Euratom en het IAEA ondertekend; - inzake safety zijn de Euratomverplichtingen en het Verdrag van Parijs van 29 juli 1960 inzake de wettelijke aansprakelijkheid op het gebied van kernenergie relevant; België en Nederland zijn lid van dit Verdrag en hebben dit Verdrag, middels een eigen wet inzake de civielrechtelijke aansprakelijkheid voor kernongevallen, omgezet in de respectievelijke rechtsorde;

- inzake security hebben beide landen de Conventie van New York en Wenen van 3 maart 1980 inzake de fysieke bescherming van kernmateriaal getekend en geratificeerd ${ }^{414}$.

Het kernenergierecht heeft bijgevolg een geheel aan regels gecreëerd dat het hoofd biedt aan de verschillende risico's verbonden aan het aanwenden van kernenergie. Zowel geheimhouding, veiligheidswoorschriften, schadevergoeding als aanzienlijk zware strafsancties komen hierbij aan de orde. Als dusdanig ligt een brede waaier van akten, besluiten en wetten aan de basis van het kemenergierecht ${ }^{415}$ : het betreft zowel specifieke wetgeving ${ }^{416}$ als de oprichting van (semi-)publickrechtelijke rechtspersonen, als de goedkeuring van internationale verdragen. Doordat de verschillende internationale afspraken telkens worden omgezet in nationale regelgeving, kunnen geen algemene uitspraken worden gedaan over hét kernenergierecht; steeds zal moeten worden gckeken naar het nationale kernenergierecht van de verschillende landen.

In het internationale kemenergierecht werd een onderscheid gemaakt tussen de Verdragen van de eerste en die van de tweede generatic. De "demarcatielijn" was het ongeval in Tsjemobyl. Dit ongeval was een stimulans voor het kemenergicrecht in de mate waarin het heeft geleid tot internationale afspraken omtrent nieuwe thema's: onderlinge bijstand, vroegtijdige kennisgeving en

Wet van 21 februari 1963, Stb. 82; het doel van deze wet is het bevorderen van een goede ontwikkeling op het gebied van de vrijmaking van kemenergie en de aanwending van radioactieve stoffen en ioniserende straling uitzendende toestellen alsook de bescherming tegen de hieraan verbonden gevaren (zie hierover o.m. Tonnaer, F.P.C.L., "Handboek Nederlands Milieurecht", l.c., 1279 e.v.).

413 Wet aansprakelijkheid voor Kernongevallen, wet 17 maart 1979, Stb. 225, gewijzigd in 1991, zie verder.

Voor Belgiê: wet van 24 juli 1984 houdende ratificatie van de Conventie van 3 maart 1980 inzake de bescherming van kernmateriaal, B.S., 27 februari 1992, 4117. In Belgie is de Conventie sinds 6 oktober 1991 in werking. In Nederland werd deze conventie goedgekeurd bij wet van 17 december 1987 (Stb. 1987,640 ) en trad zij op 8 februari 1987 in werking.

Reygaerts, M., "Le droit nucléaire belge", o.c., 263; Matthijs, J., "Aansprakelijkheid bij toepassing van kemenergie tot vreedzame doeleinden", o.c., 115; Dopchie, H., "La Réglementation nucléaire en Belgique", in, Govaerts, P., Jaumotte, A. en Vanderlinden, J., Un demi-siècle de nucléaire en Belgique. Témoignages, Belgian Nuclear Society, Presses Universitaires Européennes, Bruxelles, 1994, 301-352. Bijvoorbeeld ter bescherming van de werknemers van de nucleaire sector en ter bescherming van de bevolking tegen de uit ioniserende straling voortspruitende gevaren. 
nucleaire veiligheid. Tegelijk werden ook de nucleaire aansprakelijkheidsverdragen aan een revisic onderworpen. Dit revisieproces is slechts gedeeltelijk teneinde, in die zin dat de revisie van het Verdrag van Parijs in 2000 nog lang nict was afgerond.

Het is overigens zeer de vraag of de nucleaire aansprakelijkheidsverdragen van de tweede generatie (Verdrag inzake Bijkomende Compensatie en het Protocol van het Verdrag van Wenen van 12 september 1997) veel toevoegen aan het internationale kernenergierecht en of zij spoedig in werking zullen treden. De overige Verdragen van de tweede generatie zijn zodanig algemeen dat hieruit geen verplichtingen kunnen worden afgeleid. Of het ongeval van Tsjemobyl heef geleid tot een werkelijke breuk met het verleden, is zeer twijfelachtig ${ }^{417}$; wat wel met zekerheid kan worden gezegd, is dat het ongeval enkele thema's op de politieke en diplomatieke agenda heeft geplaatst.

De invloed van het ongeval in Tsjernobyl is, wat het nationale Belgische kernenergierecht betreft, niet meteen waameembaar. Weliswaar werd in 1994 een wet goedgekeurd inzake de gevaren voortspruitend uit ioniserende straling en is het de bedoeling dat hiermee de wet van 1958 wordt vervangen, maar in oktober 2000 was deze wet slechts zeer partieel in werking getreden. Ook de wet op de nucleaire aansprakelijkheid werd niet gewijzigd naar aanleiding van het ongeval in Tsjernobyl, waarschijnlijk omdat de wet als "nieuw" werd beschouwd: deze wet was op het moment van het ongeval in Tsjernobyl inderdaad nog geen jaar van kracht. Na twee mislukte pogingen om de wet van 22 juli 1985 op de civiele aansprakelijkheid voor kernongevallen te wijzigen, namelijk in 1986 en 1988, werd de wet gewijzigd bij wet van 11 juli 2000.

In Nederland daarentegen kan tot op zekere hoogte wél worden gesproken van een duidelijke wijziging na het ongeval in Tsjernobyl. In 1991 werd de WAKO ingrijpend gewijzigd door de invoering van de Staatsbijdrage van 5 miljard gulden ${ }^{418}$. In 1994 werd de Kemenergiewet aanzienlijk uitgebreid.

Het loutere feit dat een wet in de loop der jaren al dan niet is gewijzigd, kan bezwaarlijk als criterium worden gebruikt om deze wet op haar inhoudelijke merites te beoordelen. In het vorige hoofdstuk werd aangetoond dat de bepalingen inzake de civielrechtelijke aansprakclijkheid als basis kunnen dienen voor aansprakelijkheid voor milieuschade - weze het met bepaalde beperkingen. Het feit dat de Belgische wet inzake nucleaire aansprakelijkheid na 15 jaar werd gewijzigd en de Nederlandse wet na 11 jaar, is dus op zich van weinig betekenis.

Om een precies beeld te kunnen krijgen van deze wijzigingen, is een analyse vereist van de inhoudelijke bepalingen van het Verdrag van Parijs en van de Belgische en Nederlandse nucleaire aansprakelijkheidswetgeving. Deze analyse wordt hieronder aangevat. In hoofdstuk 3 wordt het toepassingsgebied van het nucleaire aansprakelijkheidsrecht besproken; in hoofdstuk 4 worden de grote basisprincipes van deze wetgeving bestudeerd.

\footnotetext{
417 Vanden Borre, T., "Recente ontwikkelingen in het nucleaire aansprakelijkheidsrecht: innovatie of renovatie?", Milieu- en Energierecht, 2001. landen zijn toegetreden, het Verdrag van Parijs, nog steeds niet is gewijzigd.
} 


\section{HOOFDSTUK 3}

\section{TOEPASSINGSGEBIED VAN DE NUCLEAIRE AANSPRAKELIJKHEIDSWETGEVING}

In dit hoofdstuk wordt onderzocht in welke gevallen het Verdrag van Parijs en de Belgische en Nederlandse uitvoeringswet toepassing vinden. Het belang van een correcte omschrijving van het tocpassingsgebied kan moeilijk worden onderschat omdat, zoals zal blijken, de nucleaire aansprakelijkheidswetgeving een uitzonderingsregime in het leven roept. Enkel wanneer is voldaan aan de toepassingsvoorwaarden zullen de basisprincipes van deze uitzonderingsregeling, die in het volgende hoofdstuk worden besproken, kunnen worden ingeroepen.

Het toepassingsgebied van een wet of van een Verdrag omvat twee componenten. Ten eerste moet worden nagegaan in welke gevallen de regelgeving van toepassing is, i.c. moet de vraag worden beantwoord of de nucleaire aansprakelijkheidswetgeving van toepassing is op alle ongevallen met radioactieve stoffen (toepassing ratione materiae). Dit impliceert dat wordt nagegaan hoe een "kernongeval" en een "keminstallatie" worden gedefinieerd op basis van het nucleaire aansprakelijkheidsrecht. Daamaast moet ook worden onderzocht op welk territorium of welke territoria deze bijzondere regelgeving van toepassing is (toepassingsgebied ratione loci). Zeker wanneer de plaats van het ongeval verschilt van de plaats waai de schade wordt geleden, en wanneer het ene land geen lid is van het Verdrag van Parijs en het andere wel, is het belang van het toepassingsgebied ratione loci duidelijk. Aan het toepassingsgebied ratione tempore wordt enkel aandacht besteed bij de bespreking van het Verdrag van Parijs en niet bij de bespreking van de Belgische wet, noch van de Nederlandse Wet op de aansprakelijkheid van kemongevallen (WAKO). Het is namelijk zo dat zich in de regel geen tijdsconflicten kunnen voordoen betreffende de toepassing van het nucleaire aansprakelijkheidsrecht in de tijd.

Hieronder wordt eerst het toepassingsgebied van het internationale nucleaire aansprakelijkheidsrecht, en dan met name van het Verdrag van Parijs besproken $(\$ 1)$. In dit onderzoek staat niet enkel het Verdrag van Parijs centraal, maar het gehele NEA-regime, en dus ook het Aanvullend Verdrag van Brussel van 31 januari 1963. Ook het toepassingsgebied van dit verdrag dient dus aan bod te komen. Maar de bepalingen van het Aanvullend Verdrag van Brussel steunen wat betreft de inhoudelijke bepalingen (ratione materiae) nagenocg volledig op het Verdrag van Parijs en zoals reeds aangegeven brengt het Aanvullend Verdrag van Brussel gecn enkele wijziging aan aan het Verdrag van Parijs'. Om die reden wordt het toepassingsgebicd van het Aanvullend Verdrag van Brussel niet als afzonderlijke paragraaf opgenomen in de analyse. Twee aspecten van het Aanvullend Verdrag van Brussel die mede bepalend zijn voor het toepassingsgebied van het Verdrag van Parijs, zullen respectievelijk worden besproken bij de uiteenzetting over het begrip kerninstallatie en bij de analyse van het territoriale toepassingsgebied.

In $\$ 2$ wordt het toepassingsgebied van de Belgische wet van 22 juli 1985 en in $\$ 3$ het toepassingsgebied van de WAKO geanalyseerd. Dit is trouwens de indeling die van hier af aan wordt gehanteerd, met name bij de bespreking, in het volgende hoofdstuk, van de basisprincipes van de nucleaire aansprakelijkheidswetgeving. Ook daar zal dezelfde indeling telkens terugkomen. De voonaamste elementen van het toepassingsgebied worden samengevat in paragraaf 4 .

Cfr. supra, $\$ 2.1 .2 .1$ van hoofdstuk 2 . 


\title{
1. Toepassingsgebied van het Verdrag van Parijs van 29 juli 1960
}

Vooraleer de analyse van het toepassingsgebied van het Verdrag van Parijs wordt aangevat, is het van groot belang te onderstrepen dat het verdrag enkel betrekking heeft op de aansprakelijkheid tegenover derden. Dit blijkt niet met zoveel woorden uit de toepassingsbepalingen van het verdrag, maar volgt uit artikel 3 op basis waarvan de exploitant niet aansprakelijk is voor de schade aan de kerninstallatie zelf. Ook de Engelse titel van het verdrag laat hierover weinig twijfel bestaan: Convention on third party liability in the field of nuclear energy. Het verdrag heeft dus betrekking, op de extracontractuele aansprakelijkheid van de exploitant van een kerninstallatie. Hierop wordt teruggekomen in het volgende hoofdstuk.

Bij de analyse van het toepassingsgebied van het Verdrag van Parijs inzake de wettelijke aansprakelijkheid op het gebied van kemenergic, wordt zowel het inhoudelijke toepassingsgebied (ratione materiac, $\$ 1.1$ ), het territoriale toepassingsgebied (ratione loci, $\$ 1.2$ ) als de toepassing in de tijd (ratione tempore, $\$ 1.3$ ) aan de orde gesteld. Tenslotte wordt ook aandacht besteed aan de wedcrkerigheidsbepaling zoals die in het Verdrug is opgenomen (\$1.4).

\subsection{Toepassingsgebied ratione materiae}

In essentie luidt artikel 3 van het Verdrag van Parijs van 29 juli 1960 dat de exploitant van een kerninstallatie aansprakelijk is voor de schade uit een kernongeval. Deze bepaling geeft aan dat bij de afbakening van het inhoudelijke toepassingsgebied van het Verdrag een centrale betekenis toekomt aan de begrippen "kemongeval" en "kerninstallatie". Deze twee begrippen worden hieronder achtereenvolgens geanalyseerd, respectievelijk in $\$ 1.1 .1$ en $\$ 1.1 .2$. Vervolgens wordt ook aangegeven dat het in het Verdrag van Parijs ingestelde regime een uitzonderingsregime betreft (\$ 1.1.3). De belangrijkste elementen van het toepassingsgebied ratione materiae worden samengevat in $\S 1.1 .4$.

\subsubsection{Het begrip "kernongeval" in het Verdrag van Parijs}

Het begrip kernongeval zal worden toegelicht door in eerste instantie de definitie van dit begrip in het Verdrag van Parijs weer te geven $(\$ 1.1 .1 .1)$. Op basis van deze definitie worden vervolgens de in de definitie aangereikte aanknopingspunten aan de orde gesteld ( $\S$ 1.1.1.2) en zal worden aangetoond dat volgens de bepalingen van het verdrag geen plotselinge gebeurtenis is vereist om een bepaald feit als een kemongeval te kwalificeren (\$ $\$ 1.1 .1 .3$ ).

\subsubsection{Definitie van het Verdrag van Parijs}

Artikel 1, a), i) van het Verdrag van Parijs definieert een kernongeval als volgt:

\begin{abstract}
"een schadebrengend feit of een opeenvolging van zulke feiten met dezelfde oorzaak, mits dat feit of die opeenvolging van feiten of enige daardoor veroorzaakte schade voortkomt uit of het gevolg is van radioactieve eigenschappen of een combinatie van radioactieve eigenschappen met giftige, explosieve of andere gevaarlijke eigenschappen van splijtstoffen of radioactieve producten of afvalstoffen, dan wel voortkomt uit of het gevolg is van ioniserende straling afkomstig van enige andere stralingsbron die zich in een kerninstallatie bevindt".
\end{abstract}

Uit deze definitie blijkt dat sprake is van een kernongeval indien zich een schade heeft voorgedaan waarvan de schade zelf of het feit dat de schade heeft veroorzaakt, in verband staat met 
radioactieve eigenschappen van splijtstoffen, radioactieve producten of afvalstoffen of met de ioniserende straling van een andere stralingsbron in de kerninstallatie. Uit deze laatste zinsnede kan op het eerste gezicht een onderscheid worden afgeleid naargelang de schade het gevolg is van hetzij de radioactieve eigenschappen van splijtstoffen, radioactieve producten of afvalstoffen, hetzij van enige andere stralingsbron die zich in een keminstallatie bevindt. Nochtans blijkt dit onderscheid alleen te bestaan in de Nederlandse versie van de Verdragstekst; in de officiële Franse en Engelse tekst ${ }^{2}$ is enkel sprake van radioactieve eigenschappen van splijtstoffen, radioactieve producten of afvalstoffen. Waarschijnlijk wil de laatste zinsnede van de Nederlandse tekst benadrukken dat bijvoorbeeld ook ongevallen met radio-isotopen die zich nog in de keminstallatie bevinden, als een kernongeval zijn te beschouwen. Zoals verderop zal worden toegelicht is dit sowieso het geval en is deze verduidelijking overbodig. Hierbij aansluitend verwijzen de officiële Franse en Engelse definitie van kemongeval nergens naar een keminstallatie, hetgeen wel het geval is in de Nederlandse tekst. Hoe deze zinsnede in de Nederlandse tekst van het Verdrag is terechtgekomen, is niet meteen duidelijk.

De definitie geeft twee aanknopingspunten: het feit of de schade moeten verband houden met de verschillende gevaarlijke eigenschappen van radioactieve stoffen.

\subsubsection{Twee aanknopingspunten: feit of schade}

In de regel is het voldoende dat een gegeven feit of een gegeven schade voortkomen uit de gevaarlijke eigenschappen (waarvan radioactiviteit er één is) van splijtstoffen, radioactieve producten of afvalstoffen. Dankzij deze aanknopingspunten, kan worden gesteld dat zodra het feit of de schade ${ }^{3}$ nucleair is, er sprake is van een kemongeval zoals gedefinieerd in het Verdrag van Parijs.

In een aantal gevallen zal het evenwel niet makkelijk zijn om uit te maken of een bepaald ongeval al dan niet als een kernongeval dient te worden beschouwd, omdat het met name niet evident zal zijn om te oordelen of een feit en een schade al dan niet nucleair zijn. Radioactiviteit is kleurloos en reukloos; bijgevolg is het mogelijk dat in bepaalde gevallen de kwalificatie van een bepaalde schade als "nucleaire schade" moeilijk zal zijn, zeker wanneer een lange tijd verloopt tussen een vrijgekomen straling en de manifestatie van de schade.

In andere gevallen zal het niet meteen mogelijk zijn om uit te maken of een feit al dan niet van nucleaire oorsprong is. Indien geen nucleaire schade werd berokkend zal cen ongeval of een feit immers lijken op een conventioneel ongeval, terwijl het misschien toch als een kernongeval zoals gedefinieerd in het Verdrag van Parijs moet worden gekwalificeerd. Met andere woorden, de oorzaak van een kemongeval zal van belang zijn zodra de schade niet nucleair is. Dit zal bijvoorbeeld het geval zijn bij een explosie in het reactorgebouw (dit is een conventioneel feit), waarbij een deel van het gebouw wordt weggeblazen. In deze hypothese zal de oorzaak van het conventionele feit bepalen of al dan niet sprake is van een kernongeval. Het is immers perfect mogelijk dat de explosie is veroorzaakt door springstoffen die zich in het gebouw bevonden en niet door de explosieve eigenschappen van het nucleair materiaal; indien hierdoor enkel conventionele schade

De Engelse tekst luidt: "a nuclear incident means any occurrence or succession of occurrences having the same origin which causes damage, provided that such occurrence or succession of occurrences or any of the damage caused, arises out of or results from the radioactive properties, or a combination of radioactive properties with toxic, explosive, or other hazardous properties of nuclear fuel or radioactive products or waste or with any of them".

Hierbij moet ook voor ogen worden gehouden dat het Verdrag geen definitie geeft van de notic "scha$\mathrm{de}^{n}$. Welke schade precies is gedekt, wordt overgelaten aan het op het ongeval toepasselijke nationale recht (artikel 11 van het Verdrag van Parijs). 
wordt veroorzaakt, zal geen sprake zijn van een kemongeval. Is de explosie daarentegen het gevolg van de explosieve eigenschappen van zich in de kerninstallatie bevindend radioactief materiaal, dan zal wel degelijk sprake zijn van een kernongeval - en dit ongeacht of er enkel conventionele schade is veroorzaakt. Hetzelfde geldt bijvoorbeeld bij een brand: zodra een brand is veroorzaakt door de gevaarlijke eigenschappen van radioactief materiaal is er sprake van een kernongeval, zelfs indien enkel conventionele schade werd veroorzaakt. Hetzelfde kan worden gezegd van een transport van nucleair materiaal: indien dat transport bijvoorbeeld over de weg plaatsvindt en de vrachtwagen die met deze stoffen is geladen in aanrijding komt met een voertuig waarbij enkel conventionele schade wordt veroorzaakt, dan kan dit ongeval op basis van het Verdrag van Parijs niet worden beschouwd als een kernongeval.

Doordat de definitie spreekt van radioactieve of giftige, explosieve of andere gevaarlijke eigenschappen, hoeft niet noodzakelijk radioactiviteit te zijn vrijgekomen om van een kernongeval te kunnen spreken. Radioactiviteit is immers slechts één gevaarlijke eigenschap van radioacticve stoffen. Bepaalde radioactieve stoffen zijn giftig zodat het vrijkomen van giftige stoffen als een nucleair feit dient te worden beschouwd. Dit kan bijvoorbeeld het geval zijn indien koelwater zou worden geloosd waarin nog schadelijke producten aanwezig zijn.

Uit deze analyse kan ook worden afgeleid dat niet vereist is dat het kernongeval zich voordoet in een kerninstallatie. Dit toont aan dat een ongeval tijdens een transport van nucleair materiaal in bepaalde gevallen zal worden beschouwd als een kemongeval. Tegelijk is hiermee aangegeven dat de verwijzing, in de Nederlandse tekst van de definitie, naar het begrip "kerninstallatie" aanleiding kan geven tot verwarring ${ }^{4}$. Van belang is de vaststelling dat de toepassing van het Verdrag van Parijs niet vereist dat een kernongeval plaatsheeft in een kerninstallatie.

Hieruit volgt dat het Verdrag van Parijs een vrij ruime definitie hanteert van het begrip "kemongeval"; een schade hoeft niet nucleair te zijn om onder het Verdrag te vallen. Tot eenzelfde conclusie wordt gekomen bij analyse van het Verdrag van Wenen. Nochtans lijkt de definitie van een kernongeval in het Verdrag van Wenen beperkter. Artikel I, 1, I definieert een kernongeval als een feit of opeenvolging van feiten met eenzelfde oorzaak die nucleaire schade veroorzaakt. Maar door de definiëring van het begrip "nucleaire schade" waarbij ook schade wordt bedoeld die voortvloeit uit of het gevolg is van radioactiviteit, wordt tot een analoog resultaat gekomen, zij het via een omweg?

$4 \quad$ Uit de verwijzing naar een "keminstallatie" zou kunnen worden afgeleid dat enkel ongevallen in ecn kerninstallatie als een kernongeval kunnen worden beschouwd.

\$ De Engelse tekst spreekt van een "nuclear incident" waarmee wordt bedoeld dat ook kleinere ongevallen die schade veroorzaken aan derden kernongevallen kunnen zijn waarop het Verdrag van toepassing is ("Nuclear Liability and Compensation for Nuclear Damage", l.c., 46). Deze nuance is niet terug th vinden in de Franse of Nederlandse tekst van het Verdrag; daar is sprake van respectievelijk een "actident" en "ongeval".

$6 \quad$ Het Verdrag van Wenen van 1963 definieert nucleaire schade als volgt: "(i) loss of life, any personal injury or any loss of, or damage to, property which arises out of or results from the radioactive properties or a combination of radioactive properties with toxic, explosive or other hazardous properties of nuclear fuel or radioactive products or waste in, or of nuclear material coming from, originating in, or sent to, a nuclear installation; (ii) any other loss or damage so arising or resulting if and to the extent that the law of the competent court so provides; and (iii) if the law of the Installation State so provides, loss of life, any personal injury or any loss of, or damage to, property which arises out of or results from other ionizing radiation emitted by any other source of radiation inside a nuclear installation".

De voorbereidende werken van het Verdrag stellen in dat verband dat elke schade te wijten aan de giftigheid, warmte of aan een explosie zal worden vergoed op basis van het Verdrag, op voorwaarde 


\subsubsection{Plotselinge gebeurtenis}

Verder moet de vraag worden beantwoord of enkel een plotselinge gebeurtenis in aanmerking komt (accidentele vervuiling) dan wel of ook het gedurende een zekere tijd vrijkomen van radioactiviteit (graduele vervuiling) onder de definitie "kernongeval" is onder te brengen.

De tekst van de definitie heeft het enkel over "feiten"; er wordt niet gesproken van een plotselinge gebeurtenis. Dit doet vermoeden dat op basis van het Verdrag van Parijs, zowel een accidentele als een graduele verontreiniging van of met nucleaire stoffen is te beschouwen als een feit en dus als een kernongeval.

Het Exposé des Motifs bevestigt deze visie: de uitstoot van radioactiviteit die zich gedurende een bepaalde periode voordoet, is te beschouwen als een kernongeval indien de oorzaak van de uitstoot terug te brengen is tot één fenomeen, zelfs indien er een onderbreking is geweest in de radioactieve uitstoot ${ }^{s}$. Deze visie werd ook naar voren geschoven in het Forum-rapport dat stelt dat graduele nucleaire vervuiling aanleiding moet geven tot dezelfde schadevergoeding als schade voortkomend uit een in de tijd duidelijk identificeerbaar incident ${ }^{9}$.

Opdat sprake is van een kernongeval in de zin van het Verdrag van Parijs, is dus geen plotselinge gebeurtenis vereist; een langdurige blootstelling aan vrijgekomen radioactiviteit of aan andere gevaarlijke eigenschappen van kernmateriaal is te kwalificeren als een kernongeval.

Samenvattend kan worden gesteld dat het regime dat door het Verdrag van Parijs wordt ingesteld, van toepassing is zodra het feit dat aanleiding gaf tot de schade of de schade zelf nucleair zijn, dit wil zeggen het gevolg zijn van één van de gevaarlijke eigenschappen van radioactieve stoffen. Het Verdrag van Parijs vereist niet dat er sprake zou zijn van een plotselinge gebeurtenis, noch dat radioactiviteit is vrijgekomen.

\subsubsection{Het begrip "kerninstallatie"}

Een tweede belangrijk element in de analyse van het toepassingsgebied van het Verdrag van Parijs, is het begrip "keminstallatie". Het begrip "keminstallatie" zal worden verduidelijkt door in eerste instantie aan te geven welke definitie het Verdrag van Parijs hanteert $(\$ 1.1 .2 .1)$. In $\S$ I.1.2.2 wordt de vraag beantwoord of ook installaties voor de berging van radioactief afval onder het toepassingsgebied vallen van het Verdrag. Vervolgens worden twee uit het Aanvullend Verdrag van Brussel voortvloeiende beperkingen aan de orde gesteld (§ 1.1.2.3).

uiteraard dat deze voortkomt uit de radioactieve eigenschappen van nucleaire stoffen (Official Records Vienna Convention, nr. 34).

Exposé des Motifs, nr. 8, $2^{\circ}$ paragraaf. De gecoördineerde tekst van de Exposé des Motifs (ố de: Memorie van Toelichting) is terug te vinden op de website van het NEA (http/www.nea.fr).

$X$, International problems of financial protection against nuclear risk. A Forum-report, Study under the Auspices of the Harvard Law School and Atomic Industrial Forum Inc., New York, 1959, (hiema geciteerd als "Forum-rapport"), 46. Het Forum-rapport is een studie die aan de Harvard Law School werd uitgevoerd in opdracht van de Amerikaanse nucleaire tocleveringsindustrie. In bijlage van het Rapport is de ontwerptekst opgenomen van het Verdrag van Parijs en het kan in die zin worden gebruikt bij de interpretatie van het Verdrag zelf. Het Forum-rapport zelf wordt in detail bestudeerd bij de bespreking van de kanalisatie van aansprakelijkheid ( $\$ 2$ van hoofdstuk 4). 


\subsubsection{Definitie van het Verdrag van Parijs}

Artikel 1, a), ii) van het Verdrag van Parijs definieert een "kerninstallatie" hoofúzakelijk als een kemreactor. Worden evenwel niet gekwalificeerd als kerninstallatie:

- reactoren die deel uitmaken van een vervoermiddel;

- fabrieken voor de vervaardiging of behandeling van nucleaire stoffen ${ }^{10}$;

- fabrieken voor de scheiding van isotopen van splijtstoffen ${ }^{11}$;

- fabrieken voor het opwerken van bestraalde splijtstoffen;

- inrichtingen voor de opslag van nucleaire stoffen, met uitzondering van de opslag die verband houdt met het vervoer van die stoffen;

- andere door de Bestuurscommissie van het OESO-Agentschap voor Kernenergie aan te wijzen installaties waarin zich splijtstoffen of radioactieve producten of afvalstoffen bevinden.

Het betreft dus een negatieve definitie: indien een kernongeval plaatsheeft in een kernreactor zal eerst moeten worden nagegaan of het ongeval zich heeft voorgedaan in éen van bovenvermelde fabrieken of inrichtingen. Is dit het geval, dan is het verdrag niet van toepassing.

De risico's in deze inrichtingen worden niet beschouwd als zijnde van uitzonderlijke aard en bijgevolg vallen zij onder het gemeenrechtelijk aansprakelijkheidsregime. Bepaalde stoffen met een lage radioactiviteit vertegenwoordigen een gering risico. Niet alle activiteiten waar toepassing wordt gemaakt van kernenergie vallen onder het Verdrag van Parijs; niet-uitzonderlijke risico's, waarvoor in het gemeen recht een afdoende regeling bestaat, vallen buiten de werkingssfeer van het Verdrag.

Ongevallen met radio-isotopen bij medische toepassingen in ziekenhuizen vallen bijvoorbeeld buiten de werkingssfeer van het Verdrag: het gaat om laagradioactieve stoffen die bovendien worden aangewend buiten een reactor. Radio-isotopen die voor medische, commerciële, landbouwkundige, industriële of wetenschappelijke doeleinden worden aangewend, vallen buiten het Verdrag, zodra zij voor deze doeleinden worden aangewend ${ }^{12}$. Zolang deze isotopen zich evenwel in een kerninstallatie bevinden en daar een kernongeval zouden veroorzaken ingevolge hun gevaarlijke eigenschappen, zal het Verdrag wel degelijk van toepassing zijn ${ }^{13}{ }^{14}$.

Nucleaire stoffen zijn splijtstoffen met uitzondering van natuurlijk uranium en verarmd uranium, en radioactieve producten of afvalstoffen.

Splijtstoffen worden gedefinieerd ais "splijtbaar materiaal in de vorm van uraniummutaal en legeringen of chemische verbindingen daarvan (met inbegrip van natuurlijk uranium) en plutoniummetaal en legeringen of chemische verbindingen daarvan".

Dit blijkt uit de definiëring van het begrip "radioactieve producten en afvalstoffen": "alle radioactieve stoffen verkregen of radioactief geworden door blootstelling aan bestraling verband houdende met de produetie of het gebruik van splijtstoffen, met uitzondering van splijtstoffen en zich buiten een kerninstallatie bevindende radioactieve isotopen die het laatste stadium van vervaardiging hebben bereikt en kunnen worden gebruikt voor industriële, commerciële, landbouwkundige, medische, wetenschappelijke of onderwijskundige doeleinden" (artikel $1, a$, iv, van het Verdrag van Parijs). Exposé des Motifs, nr. 10.

Op een bepaald moment zal er een "omslagpunt" zijn waarop deze radio-isotopen uit de kerninstallatie worden verwijderd en buiten het toepassingsgebied van het Verdrag komen te vallen. Dit omslagpunt is van kapitaal belang aangezien het bepalend zal zijn of het uitzonderingsregime van het Verdrag dan wel het gemeenrechtelijke aansprakelijkheidsregime toepassing zal vinden. Indien deze radio-isotopen uit de reactor werden verwijderd, werden verpakt conform de geldende veiligheidsregels en afzonderlijk werden opgeslagen zal het Verdrag van Parijs geen toepassing meer vinden. Dit impliceert dan ook 
Niet elk incident met radioactieve stoffen kan dus worden beschouwd als een kernongeval. Zo vinden bijvoorbeeld in de nucleaire diensten van ziekenhuizen isotopenonderzoeken en radiotherapeutische bestraling plaats waar via medische isotopen een bepaalde diagnose kan worden gesteld of ziekte kan worden bestreden. Een incident in die afdeling wordt niét beschouwd als een kernongeval en bijgevolg zal het slachtoffer een beroep kunnen doen op de gemeenrechtelijke aansprakelijkheidsregeling, waaronder de regels inzake productaansprakelijkheid ${ }^{15}$.

Meer in het algemeen valt uit de voorbereidende werken af te leiden dat een installatie met geringe radioactieve straling, in de regel niet als een keminstallatie wordt beschouwd ${ }^{16}$. Zo zijn installaties voor het ontginnen of het opslaan van natuurlijk of verarmd uranium geen keminstallaties. Hetzelfde geldt voor installaties waarin slechts een geringe hoeveelheid splijtbaar materiaal aanwezig is, zoals onderzoekslaboratoria. Deeltjesversnellers of cyclotrons vallen evenmin binnen het toepassingsgebied. Tenslotte vallen installaties waar uraniumzout buiten de nucleaire industrie wordt aangewend, eveneens buiten het toepassingsgebied ${ }^{17}$.

Nochtans is ook de omschrijving van een kerninstallatie als "een kernreactor" te ruim. De nucleaire aansprakelijkheidswetgeving is niet zonder meer van toepassing op alle reactoren. Zo worden met reactoren enkel diegene bedoeld die geen deel uitmaken van een transportmiddel; reactoren die als aanstuwing worden gebruikt in boten of vliegtuigen, vallen niet onder het Verdrag ${ }^{18}$. Ook kernfusie valt niet onder het Verdrag ${ }^{19}$.

Verder moet worden gewezen op een interpretatie van de Bestuurscommissie van de NEA op basis waarvan ook een kerninstallatie die zich in de ontmantelingsfase bevindt, als een keminstallatie dient te worden beschouwd ${ }^{20}$.

Teneinde rekening te kunnen houden met tockomstige ontwikkelingen en nieuwe activiteiten inzake het gebruik van kernenergie, kan de Bestuurscommissie van het NEA ook andere installaties waarin zich splijtstoffen of radioactieve producten of afvalstoffen bevinden, beschouwen als een keminstallatie 21 . Ook met betrekking tot het begrip "splijtstoffen" kan de Bestuurscommissic ander splijtbaar materiaal dan die aangegeven in de definitie, aanwijzen als splijtstoffen. Omge-

dat deze stofion niet noodzakelijkerwijze de site van de keminstallatie hebben verlaten opdat het gemeenrechtelijke aansprakelijkheidsregime van toepassing zou zijn.

Fagnart stelt dat producten uit de nucleaire sector niet vallen onder de productaansprakelijkheidswetgeving (Fagnart, J.L., Produktaansprakelijkheid en productveiligheid, Studienamiddag georganiseerd door Fabrimetal op 18 mei 1995, deel 1, 14). Dit is onvoldoende genuanceerd. De nucleaire aansprakelijkheidswetgeving wordt door artikel 14 van de richtlijn productaansprakelijkheid enkel buiten werking gesteld in gevallen waar het Verdrag van Parijs van toepassing is. Uit het toepassingsgebied van dit Verdrag blijkt dat medische isotopen niet onder het begrip radioactieve stoffen vallen (artikel 1, a), iv) Verdrag van Parijs). Bijgevolg zal in bepaalde gevallen de productaansprakelijkheidswetgeving wel degelijk kunnen worden toegepast op ongevallen met medische isotopen. Zie daarover Vanden Borre,

T., "Liability for isotopes used in radiotherapy", "Nuclear Inter Jura '95", l.c., 21 5-272.

Exposé des Morifs, nr. 9.

Exposé des Motifs, nr. 9.

Exposé des Motifs, nr. 11.

Exposé des Motifs, nr. 12.

Interpretatie van de Bestuurscommissie van 28 april $1987 \mathrm{NE} / \mathrm{M} /(87)$, gepubliceerd in Paris Convention. Decisions, Recommendations, Interpretations, Parijs, NEA, 1990, 6.

Exposé des Motifs, nr. 13. 
keerd kan de Bestuurscommissie ook, wanneer de geringe risico's dit rechtvaardigen, kerninstal. laties, splijtstoffen of splijtbare stoffen uitsluiten van het toepassingsgebied van het Verdrag ${ }^{22}$.

Tot slot is het Verdrag van Parijs eveneens van toepassing bij het vervoer van nucleaire stoffen. Bij Protocol van 28 januari 1964 werd ook het vervoer van nucleaire stoffen opgenomen in het toepassingsgebied ratione materiae ${ }^{23}$. Tijdens het vervoer van nucleaire stoffen is de exploitant aansprakelijk voor schade buiten zijn installatie waarbij nucleaire stoffen betrokken zijn die voor hem bestemd zijn of dic uit zijn installatie afkomstig zijn. Zelfs al doet het incident zich voor buiten de reactor, dan nog zal de exploitant aansprakelijk zijn.

\subsubsection{Berging van radioactief afval}

Het Verdrag van Parijs bevat geen specifieke bepalingen omtrent de langetermijnaansprakelijkheid inzake de gevaren verbonden aan de definitieve opslag van hoogradioactief afval ${ }^{24}$. Aangezien afvalstoffen vervat zitten in de definitie van nucleaire stoffen, werd ervan uitgegaan dat het Verdrag van Parijs eveneens van toepassing was op installaties voor de berging van radioactief afval. In een beslissing van de Bestuurscommissie van de NEA is aangenomen dat in de operationele of preclosure fase van definitieve opslag van radioactief afval, dergelijke installatie wel degelijk onder het Verdrag van Parijs valt, tot de installatie is gevuld en afgesloten ${ }^{25}$. Maar de beslissing betrof enkel de pre-sluitingsfase van een opslagplaats voor radioactief afval; hiermee is door de NEA geen enkele uitspraak gedaan over de toepassing van het Verdrag van Parijs in de post-sluitingsfase ${ }^{26}$.

Het leidt weinig twijfel dat de toepassing van het Verdrag van Parijs op installaties voor de definitieve berging van radioactief afval, zal leiden tot een aantal juridische problemen. Eén van deze problemen heeft te maken met de beperking van de aansprakelijkheid van de exploitant in de tijd. Overeenkomstig artikel 8 van het Verdrag van Parijs, dient een vordering tot schadevergoeding te worden ingesteld binnen de tien jaar na de datum van het ongeval. Specifiek wat betreft de installaties voor de geologische berging van radioactief afval, zal de datum van het ongeval moeilijk kunnen worden vastgesteld. Een tweede probleem betreft de verwijzing naar de exploitant van de kerninstallatie. Die wordt aangewezen door het bevoegde gezag met tot doel duidelijk aan te geven wie aansprakelijk is voor een kemongeval en wie verplicht is om deze aansprakelijkheid te dekken. Het is evenwel zeer de vraag of een onderneming gedurende verschillende duizenden jaren als exploitant van een kerninstallatie zal kunnen worden beschouwd. Het lijkt in deze optick weinig waarschijnlijk dat de verzekeringssector in staat of bereid zal zijn deze dekking gedurende al die tijd in stand te houden. Een van de opties bestaat erin om de aansprakelijkheid voor installaties voor de geologische berging van radioactief afval na een zekere tijd toe te vertrouwen aan de Staat ${ }^{27}$

Artikel 1 (b) van het Verdrag.

Artikel 4 van het Verdrag.

Hoogradioactief afval is afval met een zeer hoge radioactiviteit of met een zeer lange halveringstijo (vaak verschillende duizenden jaren), dat via zogenaamde geologische berging zal worden opgeborgen. Zie hierover Weet jij wat er in België met radioactieve afvalstoffen gebeurt?, brochure NIRAS/ONDRAF, 1993.

Beslissing van 11 april 1984, NE/M(84), gepubliceerd in Paris Convention. Decisions, Recommendations, Interpretations, Parijs, NEA, 1990, 6.

X., "Questions soulevées par l'application des Conventions sur la responsabilité civile nucléaire aux installations d'évacuation des déchets radioactifs", Bulletin de Droit Nucléaire, $\mathrm{n}^{\circ}$ 55, juni 1995, 20. Ibidem, 21. 
Op dit moment worden in het kader van de NEA besprekingen gevoerd ter voorbereiding van een Verdrag inzake de aansprakelijkheid inzake radioactief afvall ${ }^{28}$. Dit Verdrag zal meer dan waarschijnlijk ook bepalingen bevatten ten aanzien van de langetermijnaansprakelijkheid voor hoog radioactief afval.

\subsubsection{Beperkingen voortvloeiend uit het Aanvullend Verdrag van Brussel van 31 januari 1963}

De analyse van het begrip "kerninstallatie" zoals gedefinieerd in het Vordrag van Parijs, moet voor de landen die eveneens lid zijn van het Aanvullend Verdrag van Brussel - waironder Belgic̈ en Nederland - worden gezien in samenhang nnet de overeenstemmende bepalingen van het Aanvullend Verdrag van Brussel van 31 januari 1963. Uit artikel 2 (a) (i) van dit Verdrag volgt dat het begrip kerninstallatie is onderworpen aan twee beperkingen.

De eerste beperking houdt in dat het Verdrag enkel van toepassing is op voorwaarde dat de installatie van de aansprakelijke exploitant gesitueerd is binnen het territorium van een van de Verdragsstaten van het Aanvullend Verdrag. In het vorige hoofdstuk werd aangetoond dat op basis van het Aanvullend Verdrag twee schijven bestaande uit openbare middelen worden ter beschikking gesteld: één schijf van de installatiestaat en één schijf gebaseerd op de solidariteit van de verdragsstaten. In die optiek is het niet verwonderlijk dat openbare middelen in principe enkel ter beschikking worden gesteld aan slachtoffers van wie het land analoge verplichtingen op zich heeft genomen op basis van het Aanvullend Verdrag van Brussel. De sommen die de Verdragsstaten uit de eigen openbare middelen ter beschikking stellen, kunnen enkel worden aangewend voor kernongevallen in installaties op het grondgebied van een Verdragsstaat omdat geen wederkerigheid ${ }^{29}$ bestaat in de landen die geen lid zijn van het Verdrag ${ }^{30}$.

De tweede beperking houdt in dat het aansprakelijkheidsregime enkel van toepassing is op installaties voor vreedzaam gebruik van kernenergie. Artikel 2, a), i) van het Aanvullend Verdrag van Brussel stelt dat de regeling van het Verdrag enkel van toepassing is op:

"schade waarvoor krachtens het Verdrag van Parijs de aansprakelijkheid berust bij de exploitant van een kerninstallatie voor vreedzaam gebruik, gelegen op het grondgebied van een Partij en vermeld op de lijst die overeenkomstig artikel 13 wordt opgesteld en bijgehouden".

Aangezien het technisch te moeilijk leek om tijdens de onderhandelingen voorafgaand aan de ondertekening van het Verdrag een precieze definitie te geven van het begrip "vreedzaam gebruik", werd geopteerd voor het opstellen van een lijst, overeenkomstig artikel 13 van het Verdrag van Brussel. Elke Partij bij het Verdrag dient ervoor te zorgen dat alle kerninstallaties voor vreedzaam gebruik op deze lijst voorkomen; deze lijst dient te worden neergelegd bij de Belgische regering, die fungeert als depositaris van het Aanvullend Verdrag van Brussel.

Een Verdrag inzake de nucleaire veiligheid van radioactief afval, is wel reeds tot stand gekomen, met name de "Joint Convention on the Safety of Spent Fuel Management and on the Safety of Radioactive Waste Management" (cfr. supra, in hoofdstuk 2, \$2.2.1.2).

Over dit begrip, cfr. infra, $\$ 1.4$ van dit hoofdstuk.

Bette, A., Didier, J.M., Fomasier, R. en Stein, R.M., "La Réparation des Dommages Nucléaires en Europe", l.c., 20. 
Op zich worden militaire installaties niet vermeld in het Verdrag van Parijs - evenmin in het Verdrag van Wenen. Door de afwezigheid van enige expliciete bepaling dienaangaande ${ }^{31}$ bestaat tussen de Parijse verdragspartijen geen eensgezindheid met betrekking tot de vraag of militaire installaties al dan niet onder het toepassingsveld van het Verdrag van Parijs vallen ${ }^{32}$. Het is niet omdat het Aanvullend Verdrag van Brussel enkel van toepassing is op kerninstallaties voor vreedzaam gebruik, dat daarom meteen ook het Verdrag van Parijs enkel daarop van toepassing zou zijn: het is perfect mogelijk dat de aansprakelijkheid van een exploitant (gebaseerd op het Verdrag van Parijs) zowel geldt ten aanzien van militaire als van civiele keminstallaties, terwijl de aanwending van de openbare middelen onder het Aanvullend Verdrag van Brussel enkel van toepassing wordt verklaard op kerninstallaties voor vreedzaam gebruik.

Bepaalde Staten oordeelden dat militaire installaties onder het Verdrag van Parijs vallen, omdat zij niet expliciet werden uitgesloten. Andere Partijen verzetten zich tegen het feit dat militaire installaties onderworpen zouden worden aan het privaatrecht of aan een aansprakelijkheidsregime $^{33}$. Uiteindelijk werd de volgende oplossing uitgewerkt. Als bijlage bij het Aanvullend Verdrag van Brussel is een verklaring opgenomen op basis waarvan de verschillende leden "ernaar zullen streven" om ten aanzien van niet op de lijst voorkomende kerninstallaties een soortgelijke regeling te treffen als de onder het Verdrag ressorterende kerninstallaties. Voor militaire installaties zou met andere woorden een gelijkwaardige schadevergoedingsregeling dienen te gelden als voor civiele kerninstallaties ${ }^{34}$. Toch kunnen vragen worden gesteld bij de juridische waarde van deze bepaling, in die zin dat de verschillende landen enkel "ernaar moeten streven" om een gelijkaardig regime in stand te houden voor militaire installaties. Van enige resultaatsverbintenis is geen sprake. Dit neemt niet weg dat een ongeval in een militaire installatie, mogelijkerwijs de aansprakelijkheid van de installatiestaat in het gedrang zal brengen, aangezien militaire installaties in de regel door de Staat worden uitgebaat.

Eenzelfde discussie heef plaats (gehad) met betrekking tot de interpretatie van het Verdrag van Wenen. Ook daar bevat de definitie van kerninstallatie geen aanwijzing of daarmee enkel installaties voor vreedzame doeleinden worden bedoeld. Artikel 3 van de uiteindelijk goedgekeurde tekst van het Protocol van het Verdrag van Wenen voegt een artikel I B toe aan het Verdrag waarbij uitdrukkelijk wordt vermeld dat het Verdrag niet van toepassing is op kerninstallaties voor nietvreedzame doeleinden.

\subsubsection{Kwalificatie als een uitzonderingsregime}

Hierboven werd besproken wat overeenkomstig het Verdrag van Parijs dient te worden verstaan onder een kemongeval en een kerninstallatie. Van belang bij de afbakening van het toepassingsgebied, is het feit dat het door het Verdrag van Parijs (en ook dat van Wenen ${ }^{35}$ ) ingestelde regime, een uitzonderingsregime betreft. De voorbereidende werken bevestigen dat het Verdrag van Parijs:

De Preambule van het Verdrag van Parijs heeft het enkel over het gebruik van kernenergie voor vreedzame doeleinden.

Bette, A., Didier, J.M., Fomasier, R. en Stein, R.M., "La Réparation des Dommages Nucléaires en Europe", l.c., 20.

"Nuclear Liability and Compensation for Nuclear Damage", l.c., 124.

Bette, A., Didier, J.M., Fornasier, R. en Stein, R.M., "La Réparation des Dommages Nucléaires en Europe", l.c., 24 e.v.

Zoals blijkt uit de Official Records Vienna Convention, nr. 33. 
"provides an exceptional régime and its scope is limited to risks of an exceptional character for which common law rules and practice are not suitable. Whenever risks, even those associated with nuclear activities, can properly be dealt with through existing legal processes, they are left outside the scope if the Convention" ${ }^{36}$.

Het lijdt weinig twijfel dat het Verdrag van Parijs van 1960 - en ook het Verdrag van Wenen van 1963 - een uitzonderingsregime instellen. Dit blijkt voomamelijk uit het feit dat via de introductie van de (juridische) kanalisatie van aansprakelijkheid het gemeenrechtelijke aansprakelijkheidsrecht buiten werking wordt gesteld: de toepassing van het Verdrag van Parijs brengt immers met zich mee dat andere rechtsgronden waarop een slachtoffer zich zou kunnen baseren, niet meer kunnen worden ingeroepen ${ }^{37}$.

Het uitzonderingsregime dient dan ook restrictief te worden geïnterpreteerd: enkel in die gevallen waar het toepassen van het bijzondere regime gerechtvaardigd is, zal het Verdrag van Parijs toepassing vinden. Het gaat dus niet op om, inzake de civieirechtelijke aansprakelijkheid, de juridische gevolgen van alle nucleaire activiteiten te onttrekken aan het gemene recht; het is niet omdat in een gegeven schadegeval radioactieve stoffen zijn betrokken, dat daarom meteen het Verdrag van Parijs toepassing zal vinden. Zoals aangegeven is niet elk ongeval in een kerninstallatie te beschouwen als een kernongeval; tegelijk is niet elk ongeval met radioactieve stoffen een kernongeval in de zin van het Verdrag van Parijs.

Het Verdrag zelf geeft overigens aan dat de bepalingen ervan strikt dienen te worden geïnterpreteerd: indien de schade is veroorzaakt door een kemongeval en door een niet onder het Verdrag vallend vrijkomen van ioniserende straling, wordt de gemeenrechtelijke aansprakelijkheid met betrekking tot dit vrijkomen geheel intact gelaten ${ }^{38}$. In gevallen waarin bij eenzelfde schade een onderscheid kan worden gemaakt tussen een deel van de schade dat voortkomt uit het kernongeval en het deel dat voortkomt uit het conventionele ongeval, ; al dus enerzijds het bijzondere verdragsrechtelijke regime dienen te worden toegepast en anderzijds het gemeenrechtelijke aansprakelijkheidsregime. Concreet zal dit ook betekenen dat decls de nucleaire verzekeringspools zullen dienen tussen te komen en deels de conventioncle verzekeringsdekkingen, voorzover uiteraard voor het betrokken niet nucleaire risico in een verzekeringsdekking werd voorzien.

Uit de hierboven geciteerde bepaling van de Exposé des Motifs blijkt ook dat, wanneer het Verdrag geen toepassing vindt, het gewone civielrechtelijke aansprakelijkheidsrecht zal moeten worden toegepast ${ }^{39}$. Het is bijgevolg niet omdat het Verdrag niet van toepassing is, dat de exploitant niet aansprakelijk zal zijn; hij zal niet op basis van het Verdrag van Parijs kunnen worden aansprakelijk gesteld. Desgevallend zal dienen te worden onderzocht of diens aansprakelijkhcid niet in het gedrang komt als bewaarder van een gebrekkige zaak (artikel 1384, ecrste lid van het Belgische $\mathrm{BW}$ ); uit eerdere analyse bleek bijvoorbeeld dat wat Nederland betreft, artikel 6:175 NBW mogelijks toepassing kan vinden ${ }^{40}$. Bij grensoverschrijdende schade waarop het Verdrag niet van toepassing is, zal het intemationaal privaatrecht toepassing vinden ${ }^{4}$. Tegelijk zal ook dienen te

Exposé des Motifs, nr. 7.

Cfr. infra in hoofdstuk 4.

Artikel 3, b) van het Verdrag van Parijs.

Eenzelfde redenering is terug te vinden in de voorbereidende werken van het Verdrag van Wenen, zie bijvoorbeeld Official Records Vienna Convention, nr. 34.

Cfr. supra, hoofdstuk $1, \S 2.2 .2 .2$, c.

In een groot aantal landen voorziet het intemationaal privaatrecht in een forum indien schade werd geleden of schade werd veroorzaakt op haar grondgebied. Voor België en Nederland is hier met name 
worden onderzocht of in een dergelijk geval andere actoren dan de exploitant kunnen worden aansprakelijk gesteld, eveneens op basis van het gemene aansprakelijkheidsrecht.

\subsubsection{Conclusie}

De belangrijkste elementen wat betreft het materiële toepassingsgebied van het Verdrag van Parijs, kunnen als volgt worden samengevat. Het Verdrag is van toepassing op de door het gebruik van kemenergie gecreëerde uitzonderingsrisico's, dat wil zeggen in de eerste plaats op de grote commerciële kernreactoren die gebruikt worden voor de productie van elektriciteit. Het vervoer van nucleair materiaal van en naar deze reactoren, valt eveneens onder het Verdrag. Het is duidelijk de bedoeling geweest van de Verdragspartijen om niet uitzonderlijke risico's in verband met kemenergie, uit te sluiten van het toepassingsgebied en bijgevolg te onderwerpen aan het gemene aansprakelijkheidsrecht. Daarom zijn zeker niet alle ongevallen met radioactieve stoffen, noch alle ongevallen in een kerninstallatie te beschouwen als kernongevallen. Telkens dient de definitie van het Verdrag van Parijs te worden geanalyseerd.

Toch is de definitie van het Verdrag van Parijs vrij ruim omdat van een kernongeval sprake is zodra de schade of het feit dat de schade heeft veroorzaakt van nucleaire aard is. Er hoeft dus niet noodzakelijk radioactiviteit zijn vrijgekomen om van een kemongeval te kunnen spreken. Er is evenmin een plotselinge gebeurtenis vereist. Het Verdrag van Parijs zou dus kunnen worden toegepast indien bijvoorbeeld een langdurige en continue blootstelling aan radioactieve straling schade veroorzaakt.

Volledigheidshalve wordt gewezen op een mogelijk interpretatieprobleem ingevolge een gebrekkige afstemming in de Verdragen van het NEA-regime: het Aanvullend Verdrag van Brussel is onmiskenbaar enkel van toepassing op kernreactoren voor vreedzaam gebruik, terwijl een tekstuele lezing van het Verdrag van Parijs niet tot dezelfde conclusie leidt. Ook inhoudelijk kan worden gewezen op een verschil tussen beide Verdragen, in die zin dat het Verdrag van Parijs betrekking heeft op de aansprakelijkheid van de exploitant van de keminstallatie, terwijl het Aanvullend Verdrag van Brussel betrekking heeft op vergoeding van de schade door middel van publieke fondsen.

\subsection{Ratione loci}

Op basis van de analyse van het materiële toepassingsgebied van het nucleaire aansprakelijkheidsrecht werd besproken op welk type ongevallen het bijzondere regime van toepassing is. Gelet op de mogelijke grensoverschrijdende gevolgen van een kernongeval, rijst de vraag waar dit Verdrag precies van toepassing is. Wat betreft het territoriale toepassingsgebied van het NEAregime, wordt hieronder niet enkel het Verdrag van Parijs van 29 juli 1960 besproken ( $\$ 1.2 .1$ ), maar ook het Aanvullend Verdrag van Brussel van 31 januari 1963 (\$ 1.2.2). Tenslotte moet ook worden bekeken wat de gevolgen zijn van de adoptie van het Gemeenschappelijk Protocol van 1988 op het territoriale toepassingsgebied $(\$ 1.2 .3)$.

\subsubsection{Het Verdrag van Parijs}

Het territoriale toepassingsgebied van het Verdrag van Parijs wordt in artikel 2 als volgt omschreven:

van belang: het Europees Verdrag betreffende de rechterlijke bevoegdheid en de tenuitvoerlegging van beslissingen in burgerlijke en handelszaken van 27 september 1968. 
"Dit Verdrag is, tenzij de wetgeving van de Verdragsluitende Staat op wier grondgebied de kerninstallatie van de aansprakelijke exploitant is gelegen anders bepaalt, niet van toepassing op kernongevallen welke zich voordoen op het grondgebied van een niet-Verdragsluitende Staat, noch op schade op zodanig grondgebied geleden $(\ldots)^{\prime \prime}$.

Een kernongeval op het grondgebied van een Staat die geen Partij is bij het Verdrag, en de aldaar geleden schade, vallen dus niet onder dit Verdrag, tenzij de nationale wet van de aansprakelijke exploitant anders bepaalt. Aan de verschillende Verdragsluitende Staten wordt met andere woorden de mogelijkheid gegeven om een ruimer territoriaal toepassingsgebied in hun nationale wetgeving in te schrijven.

Opvallend bij deze omschrijving is vooral dat zij negatief is geformuleerd, in die zin dat zij enkel zegt waarop zij niet van toepassing is ${ }^{42}$. Het eerste deel van de omschrijving is makkelijk te begrijpen: indien zich een kernongeval voordoet in een land dat geen lid is van het Verdrag van Parijs, zal het Verdrag niet van toepassing zijn. Het tweede deel van de omschrijving dient in die zin te worden begrepen dat indien zich een kernongeval voordoet in een land van het Verdrag van Parijs, clke schade die is geleden buiten het territorium van de leden van het Verdrag, in beginsel zal zijn uitgesloten. De territoriale beperking heeft tot gevolg dat de onder het Verdrag beschikbare (beperkte) bedragen ten voordele van slachtoffers van een kernongeval, niet over een te groot aantal landen moeten worden gespreid; de territoriale beperking hangt dus in zekere zin samen met de beperkte aansprakelijkheid van de exploitant van een kerninstallatie ${ }^{43}$.

Hoewel de Verdragstekst hiervan geen melding maakt, vallen ook de territoriale wateren onder het begrip "grondgebied"44. Ingevolge een aanbeveling van de NEA van 1968, zal het Verdrag eveneens van toepassing zijn op kernongevallen die zich voordoen in volle zee en op schade geleden in volle zee, zodra de exploitant is onderworpen aan de bepalingen van het Verdrag van Parijs ${ }^{45}$.

In een tweede aanbeveling raadde het Comité de Verdragsstaten aan om in hun interne wetgeving het toepassingsgebied van het Verdrag uit te breiden tot schade geleden in een Verdragsstaat of schade geleden in volle zee of op een schip dat ingeschreven is bij een verdragsluitende partij, zelfs indien het ongeval werd veroorzaakt in een niet-Verdragsluitende Staat ${ }^{46}$. De bedoeling van deze uitbreiding is om aan te geven dat het Verdrag van toepassing is op elke schade die wordt geleden binnen het territorium van de Verdragsstaten van het Verdrag van Parijs, en dit ongeacht

\footnotetext{
42 Merk op dat het Verdrag van Wenen - merkwaardig genoeg - geen enkel artikel bevat met betrekking tot de omschrijving van het territoriale toepassingsgebied. Toch wordt ervan uitgegaan dat schade geleden in een niet-Verdragsstaat, niet onder het Verdrag valt, zelfs indien het kernongeval heeft plaatsgehad op het grondgebied van een land van het Verdrag van Wenen (X., "Champ d'Application des Conventions Nucléaires", Bulletin de Droit Nucléaire, $\left.n^{\circ} 5,1970,26\right)$.

Met dien verstande dat indien bepaalde slachtoffers worden uitgesloten van de onder het Verdrag beschikbare schadevergoeding, zulks mogelijks strijdig is met algemene internationaalrechtelijke beginselen (Pelzer, N., "On modernising the Paris Convention", Nuclear Law Bulletin, $\mathrm{n}^{\circ}$ 12, 1973, 52 e.v.; Pelzer, N., "Inadequacies in the Civil Liability Regime evident after the Chemobyl Accident: The Response in the Joint Protocol of 1988", in "Liabilities and Guarantees", l.c., 166).

4s Exposé des Motifs, nr. 7.

45 Aanbeveling van de Bestuurscommissie van 25 april 1968, NE/M(68)1, gepubliceerd in Paris Convention. Decisions, Recommendations, Interpretations, Parijs, NEA, 1990, 9.

Aanbeveling van 22 april 1971, NE/M(71), 17113, gepubliceerd in Paris Convention. Decisions, Recommendations, Interpretations, Parijs, NEA, 1990, 9.
} 
de plaats van het ongeva $\left.\right|^{47}$ - en dit uiteraard enkel in zoverre een exploitant van een van de verdragsstaten aansprakelijk is; onder het Verdrag van Parijs zal enkel bij transport van nucleaire stoffen een exploitant aansprakelijk kunnen zijn voor schade die wordt geleden op het grondgebied van cen niet-Verdragsluitende Staat. De verschillende leden van het Verdrag van Parijs beschikken dus over de mogelijkheid het toepassingsgebied van het Verdrag uit te breiden ${ }^{43}$. Zoals verder zal blijken, hebben onder meer België en Nederland van deze mogelijkheid gebruik gemaakt.

Het enige geval waarin het land waarin een kernongeval plaatsvindt, zal verschillen van het land van de aansprakelijke exploitant, is een ongeval bij vervoer van nucleaire stoffen. In dit geval zal aansprakelijk zijn de exploitant waarvan de stoffen afkomstig zijn of de exploitant naar wie de stoffen worden vervoerd. Het Verdrag stelt dat het aan de twee exploitanten toekomt om via een schriftelijke overeenkomst uit te maken op welk moment de aansprakelijkheid door de andere exploitant zal worden overgenomen ${ }^{49}$.

Uit bovenstaande analyse volgt dat bij een kernongeval in België, dat niet alleen schade veroorzaakt in de buurlanden, maar ook in Bulgarije - dat geen lid is van het Verdrag van Parijs - de in Bulgarije veroorzaakte schade in principe niet onder het Verdrag zal vallen. Zoals aangegeven betekent de niet-toepasselijkheid van het Verdrag van Parijs echter niet dat i.c. het Bulgarse slachtoffer geen recht zou hebben op schadevergoeding. ${ }^{50}$. Hij zal bijvoorbeeld een beroep kunnen doen op de rechtsgronden van het Bulgaarse gemeenrechtelijke aansprakelijkheidsrecht. Het valt niet uit te sluiten dat in deze hypothese ook andere personen dan de exploitant kunnen worden aangesproken. Hiermee is uiteraard niet gezegd dat de schade van de Bulgaarse slachtoffers die een andere rechtsgrond vinden orn hun vordering in te dienen, meteen ook zal worden gecompenseerd. De doeltreffendheid van de ingediende vordering zal in belangrijke mate afhangen van de afdwingbaarheid van de rechterlijke uitspraak en van het feit of de exploitant bijvoorbeeld in Bulgarije over goederen beschikt.

\subsubsection{Het Aanvullend Verdrag van Brussel van 31 januari 1963}

Het Aanvullend Verdrag van Brussel is van toepassing op voorwaarde dat het een kemongeval betreft op grond waarvan een exploitant aansprakelijk is overeenkomstig de bepalingen van het Verdrag van Parijs en indien de rechtbank van een Verdragsstaat van het Verdrag van Parijs bevoegd is ${ }^{5 !}$.

De basisregel met betrekking tot het territoriale toepassingsgebied wordt verwoord in artikel 2 a): De regeling van het Aanvullend Verdrag is van toepassing op schade door kernongevallen, met uitzondering van die welke zich hebben voorgedaan op het grondgebied van een niet Verdragsstaat - dit uiteraard op voorwaarde dat de exploitant aansprakelijk is overeenkomstig de bepalingen van het Verdrag van Parijs. Omgekeerd is het Aanvullend Verdrag van Brussel niet van toe-

"Liability and Compensation for Nuclear Damage", l.c., 47.

De Verdragsluitende Staten kunnen het toepassingsgebied uitbreiden ofwel op kernongevallen in een Verdragsstaāt waarbij schade buiten een Verdragsstaat wordt geleden, ofwel op schade in een Verdragsstaat voor een kernongeval in een niet-Verdragsstaat, ofwel op een ongeval én op schade in cen niet-Verdragsstaat. De Bestuurscommissie raadt evenwel aan om voor de tweede optie te kiezen, aangezien dit de harmonisatie in de verschillende landen kan versterken en aangezien dit ook de interpretatie is zoals ze onder het Verdrag van Wenen wordt aangehouden.

Zie artikel 4 van het Verdrag.

Cfr. supra, in § 1.1.3 van dit hoofdstuk.

"Nuclear Liability and Compensation for Nuclear Damage", l.c., 53-54. 
passing op kernongevallen die zich volledig hebben voorgedaan op het grondgebied van een nietVerdragsstaat. Dit impliceert dat geen bijkomende schadevergoedingsschijven van het Brusselse Verdrag beschikbaar zullen zijn indien het een kernongeval in een niet-Verdragsstaat betreft. en dit ongeacht de plaats waar de schade is geleden ${ }^{52}$. Zelfs indien de schade dus is geleden in een land dat wél lid is van het Aanvullend Verdrag van Brussel, dan nog zal dit Verdrag geen toepassing vinden.

Daarnaast bevat het Aanvullend Verdrag van Brussel een aantal toepassingsvoorwaarden die verband houden met de plaats waar de schade is geleden, de aard van de schade en de nationaliteit van het slachtoffer. Op deze wijze maakt het verdrag gebruik van de in artikel 15 van het Verdrag van Parijs geboden mogelijkheid om bijzondere voorwaarden op te leggen ten aanzien van het ter beschikking stellen van openbare middelen ${ }^{53} 54$ : is de schade geleden op het grondgebied van een verdragspartij, dan is het Verdrag van toepassing, ongeacht de nationaliteit van het slachtoffer. $A$ contrario volgt hieruit dat schade gelcden in een niet-Verdragsstaat, niét vait onder de bepalingen van het Aanvullend Verdrag van Brussel. Is de schade daarentegen geleden op of boven volle zee, dan zal een onderdaan van een niet-Verdragsstaat het Aanvullend Verdrag van Brussel slechts kunnen inroepen indien het schip of het vliegtuig waar zich de schade heeft voorgedaan, is ingeschreven in een Verdragsstaat ${ }^{55}$.

Er moet ook op worden gewezen dat het Aanvullend Verdrag van Brussel veel minder soepelheid biedt aan de Verdragsstaten om het territoriale toepassingsgebied uit te breiden. Een dergelijke uitbreiding is vrij makkelijk in het Vcrdrag van Parijs omdat uitdrukkelijk in de mogelijkheid wordt voorzien dat het nationale recht afwijkt van de bepaling inzake het territoriale toepassingsgebied. Een analoge soepelheid bestaat niet in het Aanvullend Verdrag van Brussel. Staten die de toepassing willen uitbreiden, hebben daarvoor namelijk de toestemming nodig van de andere Verdragsstaten. Artikel 14, b van het Aanvullend Verdrag van Brussel bepaalt dat de door een partij van het Verdrag van Parijs genomen maatregelen inzake het ter beschikking stellen van openbare middelen, slechts tegen een andere partij kunnen worden ingeroepen voorzover deze daarmee heeft ingestemd. Op zich is deze bepaling begrijpelijk in die zin dat de Verdragsstaten niet willen dat zomaar een uitbreiding wordt aangebracht aan hun verplichting om openbare middelen ter beschikking te stellen. Anderzijds komt dit de hanteerbaarheid van het gehele systeem niet ten goede: indien een bepaalde Verdragsstaat een uitbreiding heeft opgenomen in de interne wetgeving, dan zal deze uitbreiding enkel "tegenstelbaar" zijn ten aanzien van deze Staten die dit uitdrukkelijk hebben aanvaard.

Samenvattend betekent dit dat indien een kernongeval heeft plaatsgehad in een Verdragsstaat, de bijkomende schijven van het Aanvullend Verdrag van Brussel enkel ter beschikking staan van de andere Verdragsstaten. Slachtoffers van een land dat bijvoorbeeld enkel lid is van het Verdrag van Parijs, zullen geen beroep kunnen doen op deze bijkomende schijven, maar enkel op de aansprakelijkheidsverzekering van de exploitant. Heeft het kernongeval plaatsgehad in een nietVerdragsstaat, dan is het Verdrag niet van toepassing, zelfs niet voor de schade die in de Verdragsstaten is geleden. Ook hier geldt dat indien het land van de installatiestaat lid is van het

Bette, A., Didier, J.M., Fornasier, R. en Stein, R.M., "La Réparation des Dommages Nucléaires en Europe", l.c., 30 .

Cfr. infra, $\$ 1.4$ bij de bespreking van de wederkerigheid.

Lagorce, M., "The Brussels Supplementary Convention and its Joint Intergovemmental Security Fund", o.c., 145.

Voor meer details, zie Bette, A., Didier, J.M., Fornasier, R. en Stein, R.M., "La Réparation des Dommages Nucléaires en Europe", l.c., 31-32. 
Verdrag van Parijs, enkel een beroep zal kunnen worden gedaan op de aansprakelijkheidsverzekering van de exploitant.

Hiermee is aangetoond welke de gevolgen kunnen zijn van de beperkte territoriale werking van het Verdrag. De bepalingen van het Verdrag van Parijs inzake de territoriale werking moeten ondertussen worden gezien in samenhang met het Gemeenschappelijk Protocol van 1988, waardoor in een aantal gevallen de territoriale toepassing van het Verdrag van Parijs wordt uitgebreid tot landen van het Verdrag van Wenen.

\subsubsection{De gevolgen van het Gemeenschappelijk Protocol van $1988^{56}$}

Het hierboven uitgewerkte voorbeeld van de in Bulgarije geleden schade, heeft de beperking aangetoond van de territoriale werking van de twee naast elkaar bestaande nucleaire aansprakehijkheidsregimes. Pas na het ongeval in Tsjemobyl werd de noodzaak ingezien om het werkingsveld van beide Verdragen aan elkaar te koppelen.

Het is de bedoeling dat het Gemeenschappelijk Protocol de problemen inzake het territoriale werkingsveld van de Verdragen het hoofd biedt ${ }^{57}$. De territoriale werking van beide verdragsregimes wordt geïntegreerd, zodat het er bij grensoverschrijdende schade in principe niet toe doet of een Staat op wiens grondgebied het kernongeval plaatsheeft, Partij is bij het Verdrag van Wenen, dan wel bij het Verdrag van Parijs ${ }^{5 s}$. Voortaan worden Verdragspartijen bij het Verdrag van Parijs dus niet meer behandeld als niet-verdragspartijen van het Verdrag van Wenen, en omgekeerd ${ }^{59}$.

De uitbreiding van het territoriale toepassingsgebied van het Verdrag van Parijs, heeft echter ook gevolgen voor de leden van het Aanvullend Verdrag van Brussel ${ }^{60}$. Doordat meer slachtoffers aanspraak kunnen maken op schadevergoeding op basis van het Verdrag van Parijs, zal de financiële zekerheid van de exploitant sneller zijn uitgeput en zullen de Verdragsstaten er sneller toe gehouden zijn om de openbare middelen, bepaald in het Aanvullend Verdrag van Brussel, ter beschikking te stellen ${ }^{61}$. Maar juridisch stelt het Brusselse Verdrag dat een uitbreiding enkel geldt ten aanzien van die landen die daarvoor hun toestemming hebben gegeven. Aan dit probleem is tegemoet gekomen door cen aanbeveling van het bestuurscomité van de NEA waarin de Verdragsstaten van het Aanvullend Verdrag van Brussel zich akkoord verklaren met een vroegere

Het totstandkomen van het Protocol werd reeds besproken in hoofdstuk 2, onder paragraaf 2.2.2.1. Pelzer, N., "Inadequacies in the Civil Liability Regime evident after the Chemobyl Accident: The Response in the Joint Protocol of $1988^{\prime \prime}$, o.c., 162.

Artikel II van het Gemeenschappelijk Protocol bepaalt hierbij het volgende. De exploitant van een keminstallatie gelegen op het grondgebied van een Partij bij het Verdrag van Wenen, is overeenkornstig dat Verdrag aansprakelijk voor alle kernschade geleden op het grondgebied van een Partij zowel bij het Verdrag van Parijs als bij dit Protocol. De exploitant van een kerninstallatie gelegen op het grondgebied van een Partij bij het Verdrag van Parijs, is overeenkomstig dat Verdrag aansprakelijk voor kemschade geleden op het grondgebied van een Partij bij zowel het Verdrag van Wenen als bij dit Protocol.

Von Busekist, O., "Le Protocole Commun relatif à l'application de la Convention de Vienne et de la Convention de Paris: Une passerelle entre Jes deux Conventions sur la responsabilité civile pour les dommages nucléaires", o.c., I6.

Strikt juridisch gezien maakt het Gemeenschappelijk Protocol enkel een verbinding tussen het Verdrag van Parijs en het Verdrag van Wenen, en dus niet tussen het NEA-regime en het LAEA-regime, wat impliceert dat het Gemeenschappelijk Protocol geen betrekking heeft op de bepalingen van het Aanvullend Verdrag van Brussel.

Zie hierover "Nuclear Liability and Compensation for Nuclear Damage", l.c., 97. 
mobilisatie van openbare middelen ingevolge de territoriale uitbreiding van het Gemeenschappelijk Protocol $^{62}$.

In het Gemeenschappelijk Protocol is voorzien in een aantal conflictregels die moeten uitmaken welk Verdrag van toepassing zal zijn op een concreet schadegeval. Op een kernongeval is ofwel het Verdrag van Parijs, ofwel het Verdrag van Wenen van tocpassing, telkens met uitsluiting van het andere Verdrag. Aanknopingspunt is de Staat op wiens territorium de kerninstallatie is gelegen waar het kernongeval zich heeft voorgedaan ${ }^{63}$.

Bij vervoer van nucleair materiaal zal het Verdrag van tocpassing zijn van het land waarin de kerninstallatie is gelegen van de exploitant die aansprakelijk is, hetzij overeenkomstig het Verdrag van Parijs, hetzij overeenkomstig het Verdrag van Wenen ${ }^{64}$.

Het Gemeenschappelijk Protocol stelt, net als de Verdragen van Parijs en Wenen, een discriminatieverbod in: de bepalingen van het Verdrag van Wenen en die van het Verdrag van Parijs moeten op dezelfde wijze toegepast worden voor onderdanen van een "Parijse" als voor onderdanen van een "Weense" Staat ${ }^{65}$.

Van groot belang is uiteraard de toepasselijke wetgeving, dangezien die bepalend zal zijn voor het bedrag waarvoor de exploitant aansprakelijk zal zijn. Ter zake geldt de regel dat de exploitant aansprakelijk zal zijn overeenkomstig het Verdrag waarvan de Staat waar diens installatie is gelegen, lid is ${ }^{66}$. Het maximumbedrag van de aansprakelijkheid van de exploitant wordt bijgevolg bepaald door de wetgeving van de Staat waar de installatie is gelegen.

Over het algemeen worden bovenstaande beginselen van het Gemeenschappelijk Protocol beschouwd als een adequaat instrument waarbij het territoriale werkingsveld van de Verdragen van Parijs en van Wenen aan elkaar worden gekoppeld ${ }^{67}$. Maar tegelijk zal dit instrument enkel zijn degelijkheid kunnen bewijzen indien een voldoende aantal landen de verschillende Verdragen onderschrijft en is het Gemeenschappelijk Protocol niet meer dan een eerste stap van cen verdere evolutie ${ }^{68}$.

In hoofdstuk twee werd reeds aangegeven dat slechts een gering aantal landen het Gemeenschappelijk Protocol heeft geratificeerd. De voomaamste tekortkoming ter verklaring van de geringe belangstelling om het Gemeenschappelijk Protocol te ratificeren, heeft te maken met het beperkte bedrag waarvoor de exploitant van een kerninstallatie aansprakclijk is. Het feit dat de minimumaansprakelijkheid van het Verdrag van Wenen 4 keer lager is dan het bedrag bepaald in het Verdrag van Parijs, verklaart grotendeels de terughoudendheid van de landen van het Verdrag

Recommendation of the Council on the Application of the Brussels Supplementary Convention in the Field of Nuclear Liability, 26-27 november 1992, C(92)// 66/Final, NEA, Parijs.

63

Artikel III, 2 van het Gerneenschappelijk Protocol.

Artikel III, 3 van het Gemeenschappelijk Protocol.

Artikel IV van het Gemeenschappelijk Protocol.

Reyners, P. en Van Busekist, O., "The Joint Protocol Relating to the Application of the Vienna and the Paris Conventions - One Step towards the Necessary Modernisation of the International Nuclear Civil Liability Regime", in "Nuclear Inter Jura '89, l.c., II-67.

Pelzer, N., "Inadequacies in the Civil Liability Regime evident after the Chemobyl Accident: The Response in the Joint Protocol of 1988", in "Liabilities and Guarantees", l.c., 164.

Reyners, P. en Von Busekist, O., "The Joint Protocol Relating to the Application of the Vienna and the Paris Conventions - One Step towards the Necessary Modernisation of the International Nuclear Civil Liability Regime", in "Nuclear Inter Jura '89", l.c., II-64. 
van Parijs om tot het Gemeenschappelijk Protocol toe te treden. Voor landen met een hoge aansprakelijkheid en een hoge: Staatstussenkomst brengt een toetreding tot het Gemeenschappelijk Protocol in hoofdzaak nadelen mee in die zin dat de beschikbare bedragen over een groter aantal slachtoffers moeten worden verdeeld. De voordelen voor de eigen onderdanen zijn beperkt tot de toegang tot de sowieso veel geringere bedragen van de andere verdragsstaten.

Tenslotte kan de terughoudendheid van de landen van het Verdrag van Parijs eveneens worden verklaard door de geringe "geografische dekking" van het Verdrag van Wenen, al dient wat dit latste betreft te worden vastgesteld dat de laatste jaren een aanzienlijke inspanning werd gedaan om de landen van het voormalige Oostblok ertoe aan te zetten om het Verdrag van Wenen te ondertekenen ${ }^{6 !}$.

\subsection{Ratione tempore}

Inzake nucleaire aansprakelijkheid kan het toepassingsgebied in de tijd op twee wijzen worden geïnterpreteerd. Ten eerste vanaf welk moment het Verdrag geldt en ten tweede vanaf welk moment de exploitant over een aansprakelijkheidsdekking dient te beschikken. Aan deze twee aspecten wordt hieronder aandacht besteed.

Het Verdrag van Parijs is van kracht geworden in $1971^{70} 71$. Het was oorspronkelijk van kracht voor een periode van 10 jaar. Vanaf 1981 is het van kracht, telkens voor een periode van vijf jaar, tenminste voor die Partijen die het Verdrag niet hebben opgezegd. Dit betekent dat het Verdrag om de vijf jaar stilzwijgend wordt verlengd, telkens voor een periode van vijf jaar.

E.en ander aspect betreffende het toepassingsgebied ratione tempore heeft betrekking op het begin en einde van de aansprakelijkheid van de exploitant overeenkomstig het Verdrag van Parijs. Het is bijvoorbeeld niet omdat de reactor definitief wordt stilgelegd, dat alle gevaar geweken is. Anderzijds zou het onredelijk zijn om vanaf de start van de bouw van de reactor reeds over een uitgebreide verzekeringsdekking te moeten beschikken; op dat moment is het nucleaire risico immers nog niet aanwezig.

Het Verdrag zelf bevat geen expliciete bepalingen betreffende de aansprakelijkheid ratione tempore van de exploitant. Toch kan uit de bepalingen inzake de erkenning worden afgeleid vanaf welk moment en tot wanneer de exploitant aansprakelijk zal zijn. Als exploitant wordt beschouwd de persoon die door de bevoegde autoriteiten als dusdanig is aangewezen of erkend ${ }^{72}$. Zo is het perfect mogelijk dat bijvoorbeeld gedurende de initiële testperiode van een reactor, de leverancier van de uitbater van de keminstallatie als exploitant zal worden beschouwd ${ }^{73}$.

Cfr. supra in 3 2.1.2.2. van hoofdstuk 2.

Volgens artikel 19. b) treedt het Verdrag in werking zodra ten minste vijf ondertekenende Regeringen hun acte van bekrachtiging hebben neergelegd (zie "Liability and Compensation for Nuclear Damage", l.c. 45). Voor elk land dat na die daturn het Verdrag ondertekent, treedi het in werking op de dag van de neerlegging van haar akte van bekrachtiging.

Merk op dat het Verdrag in de mogelijkheid voorziet het Verdrag op te zeggen (artikel 20), mits het respecteren van een opzegternijn van twasli maanden.

Artikel 1, a, vi van het Verdrag van Parijs. Deze erkenning wordt slechts toegekend indien de exploitant bewijst dat hij een voldoende financiële zekerheid heeft gesteld (zie verderop, bij de bespreking van de dekking van de aansprakelijkheid van de exploitant in $\$ 4$ van hoofdstuk 4).

Exposé des Motifs, 39. 
Er kan van worden uitgegaan dat via het systeem van de erkenning van een exploitant, duidelijk wordt wanneer de aansprakelijkheid van de exploitant op grond van het Verdrag van Parijs aanvangt en eindigt. Aangezien de erkenning slechts wordt verleend nadat aan de verzekeringsplicht is voldaan en aangezien deze dekking nodig is om enige nucleaire activiteit uit te oefenen, bepaalt de erkenning de aanvang en het einde van de aansprakelijkheid van de exploitant op grond van het Verdrag van Parijs. In samenspraak met zijn verzekeraar en met de bevoegde overheid zal worden bepaald vanaf wanneer en tot wanneer een nucleair risico aanwezig is. Er kan worden aangenomen dat een dekking voor de nucleaire aansprakelijkheid is vereist zodra de reactor kritisch is of kan worden, dat wil zeggen zodra de splijtstoffen in de keminstallatie worden binnengebracht ${ }^{74}$. Vanaf dat moment kan zich immers een ongeval voordoen waarbij radioactieve straling vrijkomt en waarbij schade aan derden wordt berokkend.

Tenslotte rijst de vraag naar het tijdstip tot wanneer het Verdrag van Parijs van toepassing zal zijn, c.q. tot wanneer een aansprakelijkheidsdekking overeenkomstig het Verdrag dient te worden in stand gehouden. In een interpretatie oordeelde de Bestuurscommissie van de NEA dat het Verdrag van Parijs ook kerninstallaties omvat die zich in de ontmantelingsfase bevinden ${ }^{75}$. Nochtans werd beslist dat de Verdragsstaten onder bepaalde voorwaarden de kerninstallatie die wordt ontmanteld, mogen uitsluiten van de toepassing van het Verdrag ${ }^{76}$.

Doet zich toch een schade voor buiten de duur van de erkenning, dan zal dit betekenen dat de exploitant niet kan worden aansprakelijk gesteld op grond van het Verdrag van Parijs; in dat geval is geen sprake van een uitzonderlijk risico en is er geen reden waarom het in het Verdrag neergelegde uitzonderingsregime zou worden toegepast. Het gemeenrechtelijke aansprakelijkheidsrecht zal bijgevolg kunnen worden toegepast.

\subsection{Wederkerigheid of reciprociteit}

Wederkerigheid is in feite de toepassing van het algemene privaatrechtelijke contractenrecht op het intemationale verdragsrecht. Een land dat toetreedt tot een internationaal verdrag aanvaardt hierdoor in de regel de in dat Verdrag opgenomen wederzijdse verbintenissen ${ }^{77}$; bovendien geldt het Verdrag in principe slechts voor de verschillende Verdragsstaten. Dit betekent dat de voordelen van een bepaald Verdrag enkel kunnen worden ingeroepen door een land dat eveneens lid is van dat Verdrag. Er kan in dit verband worden gesproken van een soort "algemene wederkerigheid". Hierboven kwam deze wederkerigheid reeds aan de orde, bijvoorbeeld bij de bespreking van het Aanvullend Verdrag van Brussel ${ }^{78}$ : enkel die landen die zelf openbare middelen ter be-

\footnotetext{
Steun voor deze stelling is terug te vinden in het Aanvullend Verdrag van Brussel dat de Verdragsstaten verplicht om de datum mee te delen waarop de reactor voor het eerst kritisch is geworden (artikel 13, d van het Aanvullend Verdrag van Brussel).

Interpretatie van 28 april 1987, NE/M(87)1, gepubliceerd in Paris Convention. Decisions, Recommendations, Interpretations, Parijs, NEA, 1990, 6.

Beslissing van 20 april 1990, NE/M(90)1, gepubliceerd in Paris Convention. Decisions. Recommendations, Interpretations, Parijs. NEA, 1990, 8. Deze voonwarden zijn de volgende: de activiteiten van de keminstallatie moeten definitief zijn gestopt en hierbij moeten zowel alle splijtstoffen, alle radioactief materiaal als het gedurende de activiteiten geproduceerde afval, zijn verwijderd; de installatie moet onder controle blijven van de nationaal bevoegde autoriteit; de maatregelen opgelegd door de bevoegde autoriteit om de verspreiding van radioactiviteit tegen te gaan, moeten behouden blijven; de installatie mag geen radionucliden bevatten die bepaalde activiteitslimieten te boven gaar.

Nguyen Quoc, D., Pallier, P. en Pellet, A., "Droit international public", l.c., 221; Carreau, D., "Droit International", l.c., 422 .

Cfr. supra, $\$ 1.2 .2$ van dit hoofdstuk.
} 
schikking stellen en dus lid zijn van het Verdrag, kunnen een beroep doen op de openbare middelen die op basis van het Verdrag worden gegenereerd.

In het Verdrag van Parijs van 1960 inzake de wettelijke aansprakelijkheid op het gebied van kernenergie wordt een bijzondere invulling gegeven aan de wederkerigheidsregel. Op basis van artikel 15 a) van het Verdrag van Parijs kan een Verdragsstaat die maatregelen treffen die hij nodig acht voor een verhoging van de in het Verdrag opgenomen bedragen der schadevergoeding. Volgens artikel 15, b) van het Verdrag van Parijs kunnen Staten bijzondere voorwaarden opleggen die afwijken van het Verdrag, voorzover bij de schadevergoeding openbare middelen zijn betrokken en de schadevergoeding meer bedraagt dan 5 miljoen BTR.

De wederkerigheid hangt nauw samen met de vrijheid waarover de Verdragsluitende Staten beschikken om het bedrag te bepalen waarvoor de exploitant aansprakelijk is. Zoals verderop zal worden toegelicht, bestaan er tussen de landen van het NEA-regime aanzienlijke verschillen in de beschikbare bedragen.

De "wederkerigheid" of "reciprociteit" in het Verdrag van Parijs impliceert dat bepaalde voordelen, eigen aan het nationale kemenergierecht, worden voorbehouden aan de schade die op het eigen grondgebied is geleden, tenzij in het land van het slachtoffer eenzelfde of een analoge regeling voorhanden is. Blijkbaar is artikel 15 in extremis aan de verdragstekst toegevoegd op vraag van enkele landen die later het Aanvullend Verdrag van Brussel zouden ondertekenen ${ }^{79}$. Mede om deze reden is de interpretatie van de wederkerigheidsbepaling allesbehalve eenvoudig; de voorbereidende werken bieden in ieder geval weinig houvast. Er wordt volstaan met aan te geven dat, gelet op de mogelijke grensoverschrijdende gevolgen van een kemongeval, het aangewezen is dat "persons on one side of a frontier should be no less well protected than persons on the other si$\mathrm{de}^{n 80}$, dat de bijzondere voorwaarden die de Staat gerechtigd is te nemen, niet moeten worden toegepast zonder discriminatie tussen de verschillende slachtoffers en dat de wijze waarop een Staat voorziet in bijkomende schadevergoeding, volledig aan de Staat zelf wordt overgelaten ${ }^{81}$. Uit deze bepaling wordt afgeleid dat het Verdrag van Parijs een wederkerige bescherming wil bieden aan slachtoffers binnen de verdragsluitende Staten en dat aan deze bescherming beperkingen kunnen worden aangebracht ${ }^{82}$, voorzover die niet wederkerig zijn.

De wederkerigheid onder het Verdrag van Parijs impliceert dat een land gerechtigd is om onder twee strikte voorwaarden en ondanks het non-discriminatiebeginsel zoals verwoord in artikel 14 van het Verdrag, toch een zekere discriminatie in te voeren. Enerzijds dienen bij de schadevergoeding openbare middelen te zijn betrokken en anderzijds dient de schadevergoeding meer te bedragen dan de 5 miljoen BTR. Uit de tekst kan worden afgeleid dat het twee cumulaticve voorwaarden betreft.

Doordat het Verdrag van Parijs in de wederkerigheidsbepaling verwijst naar het Aanvullend Verdrag van Brussel, moeten uiteraard ook de bepalingen van dit Verdrag worden onderzocht. Uit artikel 3, e) van het Aanvullend Verdrag van Brussel blijkt dat de mogelijkheden om deze weder-

Bette, A., Didier, J.M., Fornasier, R. en Stein, R.M., "La Réparation des Dommages Nucléaires en Europe", l.c., 44-45.

Exposé des Motifs, nr. 3; in het Frans luidt de tekst: "soient protégés aussi bien d'un côté de la frontière que l'autre" (onze cursivering).

Expose des Motifs, nr. 62.

12 Feldmann, F.J., "Reciprocity within the Framework of Nuclear Civil Liability Law", in Pelzer, N. (ed), International Harmonisation in the Field of Nuclear Energy Law, Nuclear Inter Jura '85, Nomos, Baden Baden, 1986, 311. 
kerigheid in te roepen, worden beperkt. Overeenkomstig dit artikel verplichten de Verdragsstaten er zich toe om geen gebruik te maken van de wederkerigheidsbepaling van het Verdrag van $\mathrm{Pa}$ rijs, noch voor de schadevergoeding uitgekeerd op basis van de eerste schijf van de schadevergoeding, noch voor de buiten de in het Verdrag vastgestelde schadevergoeding uitgekeerd op basis van openbare middelen in de tweede en derde schijf. Daarenboven bepaalt artikel $14 \mathrm{c}$ ) van het Brusselse Verdrag dat een Partij voorzieningen kan treffen buiten het kader van het Verdrag van Parijs en van het Aanvullend Verdrag van Brussel, mits deze geen verdere verplichtingen voor andere Partijen meebrengen ten aanzien van de door deze Partijen ter beschikking te stellen openbare middelen.

De combinatie van de lezing van artikel 15 van het Verdrag van Parijs, met de artikelen 3, e) en 14 van het Aanvullend Verdrag van Brussel, maken een goed begrip van het begrip wederkerigheid er niet eenvoudiger op. Noch de voorbereidende werken, noch de literatuur bieden overigens enig houvast. Indien voor ogen wordt gehouden dat het Aanvullend Verdrag van Brussel ertoe strckt om op basis van een internationale solidariteit openbare middelen ter beschikking te stellen bovenop de financiële zckerheid van de exploitant van een kerninstallatie, dan kan de wederkerigheid als volgt worden begrepen. De wederkerigheidsvereiste wil verhinderen dat landen die zelf nauwelijks of geen openbare middelen ter beschikking stellen, toch een beroep kunnen doen op (aanzienlijke) openbare middelen van de installatiestaat (tweede schijf) of gezamenlijk van de andere verdragsstaten (derde schijf). De wederkerigheidsbepaling laat toe om buitenlandse slachtoffers $^{83}$ tot op zekere hoogte de toegang tot de openbare middelen te ontzeggen en dus te discrimineren, tenzij in hun interne wetgeving een analoge regeling voorhanden is.

De belangrijkste elementen met betrekking tot de toepassing van de wederkerigheid zijn dus dat ze enkel kan worden toegepast ten aanzien van openbare middelen en dat sowieso een minimumdrempel (van hetzij 5 miljoen BTR, hetzij 300 miljoen BTR) wordt in acht genomen. Aangezien in het NEA-regime niet alle landen van het Verdrag van Parijs eveneens lid zijn van het Aanvullend Verdrag van Brussel, wordt de wederkerigheidsbepaling verschillend toegepast. Dat is de strekking van artikel 3, e) van het Brusselse Verdrag. 'Ten aanzien van niet-Verdragspartijen van het Aanvullend Verdrag van Brussel mag wederkerigheid worden ingeroepen zodra de beschikbare middelen 5 miljoen BTR overtreffen; ten aanzien van andere Verdragspartijen, mag de wederkerigheid slechts worden ingeroepen zodra de beschikbare middelen meer bedragen dan 300 miljoen BTR. Het wekt dan ook weinig verwondering dat precies de landen waar (relatief) hoge bedragen beschikbaar zijn, een wederkerigheidsbepaling in hun interne recht hebben opgenomen ${ }^{84}$.

Vooral Duitsland heeft een vrij verregaande wederkerigheidsbepaling in haar intern kemenergierecht opgenomen, en wel in verschillende hypothesen. De reden waarom uitgerekend Duitsland een dergelijkc bepaling heeft opgenomen, ligt voor de hand: als enige lid van het Verdrag van Parijs, heeft het een onbeperkte aansprakelijkheid van de exploitant van een kcrninstallatic inge$v^{v e r d}{ }^{85} 86$. Deze aansprakelijkheid is daarentegen wél beperkt ten aanzien van buiten Duitsland

Hiermee wordt bedoeld slachtoffers die in een ander land dan de installatiestaat schade hebben geleden.

Strohl, P., "Bilan des recherches de la section de langue française", o.c., 151.

$\$ 31$ (1) van het Duitse Atomgesetz.

Van belang hierbij is dat het Duitse nucleairc aansprakelijkheidsrecht de onbeperkte aansprakelijkheid koppelt aan een verplichte verzekeringsdekking tot 500 miljoen DM $(\$ 13$, Abs. 3 van het Duitse Atomgesetz). Dit bedrag bestaat uit twee lagen: een ecrste laag van 200 miljoen DM wordt gedekt door de aansprakelijkheidsverzekering van de exploitant; de tweede laag wordt gedekt in het kader van een akkoord tussen de verschillende Duitse exploitanten van cen kerninstallatie. Naast de aanwending van 
geleden schade, tenzij het land waar deze schade is geleden "im Verhältnis zur Bundesrepublik Deutschland eine (...) nach Art, Ausma $\beta$ und Höhe gleichwertige Regelung sichergestellt hat". Is niet voorzien in een gelijkaardige regeling, dan is de aansprakelijkheid beperkt tot 300 miljoen BTR ten aanzien van andere leden van het NEA-regime en tot 15 miljoen BTR ten aanzien van andere staten ${ }^{87}$.

Eenzelfde wederkerighcidseis is opgenomen inzake overmacht: principieel is de exploitant van een in Duitsland gelegen kerninstallatie aansprakelijk bij overmacht ${ }^{88}$, zij het tot een beperk bedrag. Maar ten aanzien van in het buitenland geleden schade, zal de Duitse exploitant enkel aansprakelijk zijn bij overmacht indien in dat land in een gelijkaardige regeling werd voorzien ${ }^{89}$.

Het meest delicate probleem ligt in de beoordeling van het feit of de regeling in het land waar de schade is geleden al dan niet als gelijkaardig aan de Duitse regeling kan worden beschouwd. Het is bijvoorbeeld onduidelijk wat wordt bedoeld met een gelijkaardige regeling inzake de onbeperkte aansprakelijkheid. Naar alle waarschijnlijkheid wordt hiermee bedoeld dat ook in het land van het slachtoffer de exploitant onbeperkt aansprakelijk moet zijn tegenover in Duitsland geleden schade. Toch lijkt dit een weinig genuanceerde visie. Het is immers perfect mogelijk dat in een bepaald land het totale beschikbare schadevergoedingsbedrag (combinatie van de aansprakelijkheidsdekking van de exploitant en de staatstussenkomst) veel hoger ligt dan de in Duitsland beschikbare bedragen. In Nederland bijvoorbeeld is de aansprakelijkheid van de exploitant weliswaar beperkt, maar is voorzien in een staatstussenkomst van 5 miljard gulden. Toch zal de strikte toepassing van de wederkerigheidsvereiste naar Duits recht ertoe leiden dat het maximumbedrag waarop Nederlandse slachtoffers - ingevolge een kernongeval waarvoor een Duitse exploitant aansprakelijk is - een beroep kunnen doen, beperkt is tot 300 miljoen BTR. De Duitse wederkerigheidsbepaling is dus ongenuanceerd; er zou minstens een vergelijking moeten worden gemaakt met de in het land van het slachtoffer beschikbare bedragen ${ }^{90}$.

Een strikte interpretatie van artikel 15, b) van het Verdrag van Parijs waarbij de wederkerigheidsvereiste enkel kan worden gesteld met betrekking tot het aanwenden van openbare middelen, leidt tot de conclusie dat de in het Duitse kernenergierecht voorziene wederkerigheid minstens ten dele

private middelen, is eveneens voorzien in een Staatsgarantie ("Freistellungsverpflichtung") voor alle bedragen hoger dan 500 miljoen DM tot maximaal I miljard DM ( $\$ 34$ Abs. van het Duitse Atomgesetz). Ingeval de exploitant niet kan voldoen aan diens verplichting om de eerste 500 miljoen DM te betalen, zal de Duitse Staat instaan voor het gehele bedrag van 1 miljard DM. Het in Duitsland totaal beschikbare schadevergoedingsbedrag bestaat dus uit drie schijven: een eerste schijf van 200 miljocn DM van de aansprakelijkheidsverzekering van de exploitant zelf; een tweede schijf van 300 miljoen DM van de verschillende Duitse exploitanten van een keminstallatie; en tenslotte een schijf van 500 miljoen DM van overheidstussenkomst. Voor alle schade boven 1 miljard DM die niet is gedekt, is de exploitant aansprakelijk, al is hij niet verplicht zich hiervoor te verzekeren.

\$ 31, Abs. 2 van het Duitse Atomgesetz.

$\S 25$, Abs. 3 van het Duitse Atomgesetz verklaart artikel 9 van het Verdrag van Parijs niet van toepassing: "Die Bestimmungen des Artikels 9 des Pariser Übereinkommens über den Haftungsausschlu $\beta$ bei Schăden, die auf nuklearen Ereignissen beruhen, die unmittelbar auf Handlungen eines bewaffneten Konfliktes, von Feindseligkeiten, eines Bürgerkrieges, eines Aufstandes oder auf eine schwere Naturkatastrophe außergewöhnlicher Art zurürckzufüren sind, sind nicht anzuwenden". Feldmann, F.J., "Reciprocity within the Framework of Nuclear Civil Liability Law", o.c., 316.

Pelzer, N., "Überlegungen zur Novellierung des atomrechtlichen Haftungs- und Deckungsrechts in den 90 er Jahren", in Lukes, R., Reformiberlegugen zum Atomrecht, Carl Heymans Verlag, Keulen, 1991. 490. 
in strijd is met de Verdragsbepalingen ${ }^{91}$ : de Duitse wederkerigheidsbepaling lijkt niet in alle gevallen uitsluitend betrekking te hebben op de onder het Aanvullend Verdrag van Brussel omschreven openbare middelen.

Bovendien is bij de bepaling van de wederkerigheid de loutere verwijzing naar bedragen als criterium te eenzijdig: ook de inhoud van juridische concepten in het aansprakelijkheidsrecht kan van land tot land aanzienlijk verschillen. Indien bijvoorbeeld een land enerzijds de aansprakelijkheid van de exploitant beperkt, maar anderzijds causaliteit makkelijker aanvaardt dan in het Duitse recht, dan wordt de beoordeling van een gelijkaardige regeling bijzonder moeilijk.

Hoewel het op zich begrijpelijk is dat landen die aanzienlijke openbare middelen ter beschikking stellen een wederkerigheidsvereiste invoeren, toch zal het niet makkelijk zijn om dit vereiste in de praktijk toe te passen.

Volledigheidshalve dient erop te worden gewezen dat de wederkerigheidsvereiste het voorwerp uitmaakt van de onderhandelingen voor de revisie van het Verdrag van Parijs. Met narne Duitsland heeft voorgesteld om artikel 15 van het Verdrag te verduidelijken ${ }^{92}$. Volgens het ingediende voorstel zou, zodra het ter beschikking gestelde bedrag hoger is dan het in het Verdrag bepaalde minimum, de wederkerigheid niet enkel van toepassing zijn op de openbare middelen, maar eveneens op de private middelen van de exploitant. Dit zou de verschillende landen moeten aansporen on in de interne wetgeving te voorzien in een zo hoog mogelijke compensatie. Blijkbaar werd inmiddels aanvaard om het wederkerigheidsbeginsel in die zin uit te breiden ${ }^{93}$. Over de precieze formulering van deze uitbreiding wordt nog onderhandeld.

Uit de bespreking van het toepassingsgebied van het Verdrag van Parijs, is gebleken dat met: name de wisselwerking tussen het Verdrag van Parijs en het Aanvullend Verdrag van Brussel tot problemen aanleiding kan geven. Anderzijds geeft het Verdrag van Parijs aan de Verdragsstaten op bepaalde punten de vrijheid om verder te gaan dan de verdragsbepalingen zelf. In de twee volgende paragrafen worden respectievelijk het toepassingsgebied van de Belgische en van de Nederlandse wet besproken.

\section{TOEPASSingsgebied VAN DE BELGISCHE WET VAN 22 JULI 1985 BETREFFENDE de WETTE- LIJKE AANSPRAKELIJKHEID OP HET GEBIED VAN DE KERNENERGIE}

De bespreking van het toepassingsgebied van de Belgische civielrechtelijke nucleaire aansprakelijkheidswet wordt opgesplitst in drie delen. In eerste instantie wordt aangegeven wat onder het begrip "kerninstallatie" wordt verstaan $(\$ 2.1)$. Vervolgens wordt het territoriale toepassingsgebied aan de orde gesteld $(\$ 2.2)$ en tenslotte wordt onderzocht of de Belgische wet een wederkerigheidsbepaling bevat $(\$ 2.3)$. Het spreekt voor zich dat op deze aspecten alleen wordt ingegaan voorzover de Belgische regeling afwijkt van de bepalingen van het Verdrag van Parijs.

9. Ook Domsdorf heeft gewezen op problemen in verband met de toepassing van de wederkerigheid onder het Duitse kemenergierecht (Domsdorf, E.P.M.W., "Intemationaal Atoomenergierecht", l.c., 729-732).

92 Contracting Parties to the Paris Convention on Third Party Liability in the Field of Nuclear Energy, "The Principle of Reciprocity as an Incentive for increasing national Compensation amounts beyond the Mandatory minimum amount", NEA/LEG/CPPC(99)6.

Report, Eighth Meeting of the Contracting Parties to revise the Paris Convention, $N E A / L E G / C P P C(2000) 15,9$. 


\title{
2.1. Ratione materiae: het begrip "kerninstallatie"
}

Voor de begrippen kemongeval, splijtstoffen, radioactieve producten of afvalstoffen en nucleaire stoffen verwijst de wet expliciet naar de definities zoals die zijn opgenomen in het Verdrag van Parijs. Voor het begrip "kerninstallatie" echter gaat de wet verder dan een verwijzing. Volgens artikel 1, e) van de wet van 22 juli 1985 is een keminstallatie:

\begin{abstract}
"het begrip zoals het is omschreven in artikel I van het Verdrag van Parijs, met inbegrip van elke installatie die bestemd is voor de evacuatie van nucleaire stoffen gedurende de fase die aan de sluiting van de installatie voorafgaat, met dien verstande dat elke entiteit een kerninstallatie vormt in de zin van de wet".
\end{abstract}

De zinsnede "met inbegrip van ..." was niet opgenomen in het oorspronkelijke wetsontwerp en is het gevolg van een amendement van de Regering ${ }^{94}$. Deze was van oordeel dat uit de definitie van het begrip "keminstallatie" overeenkomstig het Verdrag van Parijs niet duidelijk blijkt dat elke reactor, fabriek of inrichting een entiteit vormt waarvoor een exploitant verplicht is een verzekering af te sluiten. Volgens de Regering bestond daarenboven twijfell of inrichtingen voor de verwijdering van radioactieve afvalstoffen konden worden gekwalificeerd als een kerninstallatie in de zin van het Verdrag ${ }^{95}$. Er kunnen vraagtekens worden geplaatst bij het feit dat de Belgische wetgever een eigen interpretatie invoert. De bevoegdheid om het Verdrag van Parijs te interpreteren komt immers alleen toe aan de Bestuurscommissie van de NEA. Het Verdrag zelf laat overigens niet uitdrukkelijk toe dat Verdragspartijen zouden afwijken van de in artikel 1 van het Verdrag neerlegde definities. Een dergelijke afwijkingsmogelijkheid is daarentegen wel uitdrukkelijk opgenomen ten aanzien van het territoriale toepassingsgebied. Zeker indien de NEA op latere datum een interpretatie naar voren schuift die anders is dan die van de Belgische wetgever, dan zal de Belgische wet op dat punt strijdig zijn met de verdragsbepalingen. Het ware dus eenvoudiger geweest om de toevoeging in artikel 1, e van de wet weg te laten en om ook voor de invulling van het begrip "kerninstallatie" te verwijzen naar het Verdrag van Parijs.

Met betrekking tot de vraag of de ontmanteling van kerninstallaties onder de wet valt, stelde de minister dat ontmanteling van een keminstallatie niet onder het Verdrag, noch onder het toepassingsgebied van de wet viel ${ }^{96}$. Nochtans vallen, zoals hoger aangegeven, volgens een interpretatie van het Bestuurscomité voor Kernenergie van de OESO kerninstallaties in fase van ontmanteling wel degelijk onder het Verdrag. ${ }^{97}$.

Overeenkomstig de oorspronkelijke versie van artikel 4 konden meerdere kerncentrales echter als één enkele kerninstallatie worden beschouwd: keminstallaties die door eenzelfde exploitant werden uitgebaat, alsook enige andere installatic op dit terrein waar zich radioactieve stoffen bevinden konden door de Koning als één kerninstallatie worden beschouwd ${ }^{98}$. In dat geval was het bedrag van de verzekering die door de exploitant moest worden gesloten, gelijk aan de som wan de bedragen voor iedere installatie afzonderlijk genomen. Deze bepaling had nict tot doel dat de Koning een te verzekeren bedrag oplegde dat kleiner was dan de som van de bedragen voor iedere

Parlementaire Stukken, Senaat, GZ 1984-1985, 593/2, 1.

Parlementaire Stukken, Senaat, GZ 1984-1985, 593/3, 21.

Parlementaire Stukken, Senaat, GZ/1983-1984, 593/3, 18.

Cfr. supra, \$1.1.2.1. van dit hoofdstuk.

Ook één of meer niet-nucleaire installaties die samen met een keminstallatie op hetzelfde terrein met een gemeenschappelijk doel worden geëxploiteerd konden als één keminstallatie worden beschouwd. 
installatie afzonderlijk. Het betrof een technische groepering van verschillende installaties op één enkel terrein, die niet leidde tot een juridische groepering van de risico's $\mathrm{s}^{99}$.

Artikel 4 van de wet van 22 juli 1985 werd echter vervangen bij wet van 11 juli 2000. Voortaan worden meerdere kerninstallaties die zich op dezelfde vestigingsplaats bevinden en die door eenzelfde exploitant worden uitgebaat, beschouwd als één enkele kerninstallatie. De bevoegdheidsdelegatie naar de Koning om meerdere op eenzelfde site gelegen keminstallaties als één keminstallatie te kwalificeren, is dus opgeheven. De verschillende kerninstallaties van Electrabel die zich op eenzelfde site bevinden, worden dus voortaan automatisch als één kerninstallatie beschouwd. Volgens de Belgische wetgever worden hierdoor aan verzekeraars en exploitanten, ruimere onderhandelingsmogelijkheden geboden ${ }^{100}$. Tegelijk wordt gesteld dat de kans zo gering is dat een ongeval plaatsheeft in twee op dezelfde plaats gelegen keminstallaties, dat hiermee geen rekening wordt gehouden ${ }^{101}$.

Tenslotte moet worden aangestipt dat in de Belgische nucleaire aansprakelijkheidswet niet expressis verbis wordt gesproken over vreedzaam of militair gebruik van keminstallaties; wel bepaalt artikel 5 dat de exploitant van een kerninstallatic aansprakelijk is overeenkomstig de bepalingen van het Verdrag van Parijs, van het Aanvullend Verdrag en van de wet. Er kan dus van worden uit gegaan dat de Belgische inderdaad enkel op kerninstallaties voor vreedzaam gebruik van toepassing is.

\subsection{Ratione loci}

Volgens artikel $2, \S 1$ is de wet van toepassing op schade ontstaan uit een kemongeval waarvoor de aansprakelijkheid berust bij de exploitant van een kerninstallatie, gelegen op het Belgische grondgebied, op voorwaarde dat het ongeval zich heeft voorgedaan op het grondgebied van een der Verdragsluitende Staten of niet-verdragsluitende Staten, in volle zee of daarboven, en dat de schade geleden is op het grondgebied van een der Verdragsluitende Staten, hetzij in volle zee of daarboven aan boord van een schip of een luchtvaartuig ingeschreven op het grondgebied van een dezer staten, hetzij in volle zee of daarboven, door een onderdaan een dezer Staten ${ }^{102}$. De Koning kan via een Ministerieel Besluit de toepassing van de wet uitbreiden tot schade ontstaan uit een kemongeval als bedoeld in paragraaf 1 , en geleden door een onderdaan van een verdragsluitende Staat op het grondgebied van een niet-verdragsluitende Staat.

Eenvoudiger weergegeven, kan worden gesteld dat de Belgische wet van toepassing is:

1. op een kemongeval:

- waarbij de aansprakelijkheid berust bij de exploitant van een kerninstallatie, gelegen op het Belgische grondgebied;

- dat zich heeft voorgedaan op het grondgebied van een Verdragsluitende of van een niet Verdragsluitende Staat;

Parlementaire Stukken, Senaat, GZ, 1983-1984, 593/3, 31.

Memorie van Toelichting, 3 april 2000, Parlementaire Stukken, GZ/1999-2000, 560/001, 4.

Verslag, 24 mei 2000, Parlementaire Stukken, GZ/1999-2000, 560/002, 4.

Op voorwaarde dat voldaan is aan artikel 2, a), ii), 3, van het Aanvullend Verdrag. Het gaat met name om schade geleden op het grondgebied van een Partij, of in volle zee of daarboven, aan boord van een schip of een luchtvaartuig ingeschreven op het grondgebied van een Partij, of in volle zee of daarboven, door een onderdaan van een Partij, onder voorwaarde dat, indien het schade aan een schip of een luchtvaartuig betreft, dit schip of luchtvaartuig op het grondgebied van een Partij is ingeschreven, mits de rechters van een Partij bevoegd zijn overeenkomstig het Verdrag van Parijs. 
2. op schade geleden:

- ofwel op het grondgebied van een Verdragsluitende Strat;

- ofwel, in volle zee of daarboven, aan boord van een schip of vliegtuig ingeschreven in een Verdragsluitende Staat;

- ofwel, in volle zee of daarboven, door een onderdaan van een Verdragsluitende Staat, op voorwaarde dat, indien het schade aan een schip of een vliegtuig betreft, de boot of het vliegtuig zijn ingeschreven in een Verdragsluitende Staat.

De Belgische wet heeft dus gebruik gemaakt van de in artikel 2 van het Verdrag van Parijs ingeschreven mogelijkheid om het toepassingsgebied van de wet uit te breiden: de wet is met name ook van toepassing op ongevallen die zich in een niet-Verdragsluitende Staat hebben voorgedaan. Hieruit volgt dat de Belgische wet van toepassing is, ongeacht de plaats waar het ongeval zich voordoet ${ }^{103}$; het doet er niet toe of het ongeval zich heeft voorgedaan in een buurland (lid van het Verdrag van Parijs), dan wel in een niet-Verdragsluitende Staat. Deze bepaling is duidelijk een verruiming van de toepassingssfecr van het Verdrag van Parijs, aangezien dit de kernongevallen die zich voordoen op het grondgebied van niet-Verdragsluitende Staten, in beginsel uitsluit. Dit kan via onderstaande tabel worden verduidelijkt.

TERRITORIAAL TOEPASSINGSGEBIED VAN DE BELGISCHE WET VAN 22 JULI 1985

\begin{tabular}{|l|c|c|c|}
\hline \multicolumn{1}{|c|}{ Ongeval in } & \multicolumn{3}{|c|}{ Schade in } \\
\cline { 2 - 4 } & België & Verdragsstaat & Niet-Verdragsstaat \\
\hline België & $\mathrm{Ja}$ & $\mathrm{Ja}$ & Neen \\
\hline Verdragsstaat & $\mathrm{Ja}$ & $\mathrm{Ja}$ & Neen \\
\hline Niet-Verdragsstaat & $\mathrm{Ja}$ & $\mathrm{Ja}$ & Neen \\
\hline
\end{tabular}

In de meest eenvoudige hypothese is de wet van toepassing indien er zich bijvoorbeeld een kernongeval voordoet in België waardoor in België, Nederland en Frankrijk schade wordt geleden. Het meest opvallende aan deze wettelijke bepaling, is dat zelfs indien het ongeval is veroorzaakt in een niet-Verdragsstaat, de in België én Nederland geleden schade onder het toepassingsgebied van de Belgische wet valt - uiteraard steeds ervan uitgaande dat een exploitant van een in Belgiê gelegen keminstallatie aansprakelijk is voor het ongeval. De schade geleden in een nietVerdragsstaat valt daarentegen nooit onder het toepassingsgebied van de Belgische wet, zelfs niet indien het kernongeval in België heeft plaatsgchad, noch wanneer de exploitant van een in Belgiê gelegen kerninstallatie hiervoor aansprakelijk zou zijn. cation de la législation belge sur la responsabilité civile nucléaire", Bulletin de Droil Nucléaire, N0 37. 1986,64 . 
Inzake de toepasselijkheid van het Verdrag van Parijs verschaft de Belgische wet op de nucleaire ansprakelijkheid met andere woorden meerdere aanknopingspunten. Het moet in de eerste plaats gaan om een kernongeval waarvan de aansprakelijkheid berust bij een Belgische exploitant. Daarnaast is van belang de plaats waar de schade wordt geleden; om binnen het toepassingsveld van de wet te vallen dient de schade geleden te zijn op het grondgebied van een Partij van het Verdrag van Parijs.

Vanuit een strikte interpretatie van de wet zou een persoon die geen onderdaan is van een van de Verdragsluitende Staten en die in de buurt woont van een Belgische kerncentrale waar zich een ongeval heeft voorgedaan, geen recht hebben op schadevergoeding. Nochtans stelde de Minister dat deze persoon wel degelijk recht heeft op schadevergoeding ${ }^{104}$. Indien een persoon schadevergoeding wordt geweigerd op basis van zijn nationaliteit, wordt het in het Verdrag ingeschreven non-discriminatiebeginsel geschonden. Het lag inderdaad in de bedoeling van de Verdragsluitende Partijen om de slachtoffers van een kernongeval te vergoeden, ongeacht hun nationaliteit of woonplaats. Zelfs een toerist die schade lijdt tengevolge van een kernongeval in een land waarmee hij verder geen enkele band heeft, kan het Verdrag inroepen. Zijn kortstondig verblijf op het grondgebied van de ongevalsstaat is een voldoende aanknopingspunt.

Maar in de omgekeerde situatie, waarin bijvoorbeeld een Belg in een niet-Verdragsluitende Staat verblijft en daar schade lijdt tengevolge een kernongeval waarvoor een Belgische exploitant aansprakelijk is, zal de Belgische niét van toepassing zijn. In deze hypothese is de letselschade van de persoon in kwestie niet gedekt; de schade aan in België (of in een ander Verdragsluitende Staat) gelegen goederen is daarentegen wel gedekt. Om hieraan tegemoet te komen, bepaalt lid 2 van artikel 2 van de wet dat de Koning bij een in Ministerraad overlegd besluit de toepassing van titel I van de wet ${ }^{105}$ kan uitbreiden tot schade ontstaan uit een kernongeval geieden door een onderdaan van een Verdragsluitende Staat op het grondgebied van een niet-Verdragsluitende Staat. Van deze mogelijkheid werd nog geen gebruik gemaakt. Overigens lijkt het niet de bedoeling te zijn geweest om op basis van deze bepaling een ad hocregeling uit te werken, dit wil zeggen nadat zich een kernongeval heeft voorgedaan ${ }^{106}$.

Tenslotte bepaalt artikel 34 van de wet van 22 juli 1985 dat de Regering kan besluiten om de vergoeding te haren laste te nemen van schade geleden op Belgisch grondgebied en veroorzaakt door een kemongeval "waarvoor de aansprakelijkheid berust bij een exploitant van een kerninstallatie gelegen op het grondgebied van een niet-verdragsluitende Staat", wanneer het slachtoffer in die Staat geen vergoeding voor zijn schade kan verkrijgen. Volgens de Memorie van Toelichting gaat het om in België geleden schade die niet is gedekt door het Aanvullend Verdrag. Het zou volgens de voorbereidende werken van de wet gaan om schade die is gedekt door het Verdrag van Parijs, maar niet door het Aanvullend Verdrag van Brussel, dus om schade waarvoor een exploitant van een Verdragsstaat van het Verdrag van Parijs aansprakelijk is maar wiens land geen partij is bij het Aanvullend Verdrag van Brussel ${ }^{107}$. Ook in het verslag van de bevoegde kamercommissie bevestigt de Minister dat artikel 34 die gevallen betreft waar het Aanvullend Verdrag van Brussel niet van toepassing is en waar er dus geen derde trap van vergoedingssysteem voorhanden is ${ }^{108}$. In de praktijk zou deze bepaling dus enkel kunnen worden toegepast op de drie landen die

Parlementaire Stukken, Senaat, GZ 1983-1984, 593/3, 26.

Titel I heeft betrekking op maatregelen tot toepassing van het Verdrag van Parijs en van het Aanvullend Verdrag van Brussel.

In de kamercommissie stelde de Minister dat het niet de bedoeling was om aan sommige bepalingen terugwerkende kracht te verlenen (Verslag, Parlementaire Sukken, GZ/1983-1984, 593/3, 26). 
wel lid zijn van het Verdrag van Parijs, maar niet van het Aanvullend Verdrag van Brussel (Portugal, Griekenland en Turkije) ${ }^{109}$.

\subsection{Wederkerigheid}

Uit de hierboven gevoerde analyse van de wederkerigheidsbepaling in het NEA-regime, is gebleken dat wederkerigheid verband houdt met de ter beschikking gestelde openbare middelen. Ook België is lid van het Aanvullend Verdrag van Brussel en is er dus toe gehouden de bepalingen van dit Verdrag in haar interne wetgeving in te voeren.

Artikel 19 van de Belgische wet van 22 juli 1985 heeft betrekking op dat deel van de schade dat op basis van het Aanvullend Verdrag uit de openbare middelen wordt betaald. Volgens dit artikel zal, wanneer de totale schade groter is dan de aansprakelijkheidslimiet van de exploitant, het gedeelte van de schade dat groter is, worden vergoed met openbare middelen, overeenkomstig artikel 3, b, ii) en iii) (...) van het Aanvullend Verdrag van Brussel. Zowel de tussenkomst vân België in de tweede schijf-onder de oorspronkelijke wet van 22 juli 1985 - als van de verschillende Verdragsluitende Staten in de derde schijf zijn dus geviseerd.

Op zich maakt de wet geen onderscheid tussen slachtoffers uit een Verdragsstaat en slachtoffers uit een niet-Verdragsstaat. Uit het tocpassingsgebied van het Aanvullend Verdrag van Brussel is echter gebleken dat het Verdrag niet van toepassing is op schade geleden in een nietVerdragspartij. Die landen uit het NEA-regime die enkel zijn toegetreden tot het Verdrag van Parijs ${ }^{10}$, kunnen dus geen beroep doen op artikel 19 van de Belgische wet, maar enkel op de eerste schijf, namelijk de aansprakelijkheidsverzekering van de exploitant van de keminstallatie $^{111}$. Op basis van de toepassingsvoorwaarden volgt dus een zekere beperking van de inroepbaarheid van de openbare middelen ex artikel 19. Maar de Belgische wet van 22 juli 1985 bevat geen expliciete bepaling inzake wederkerigheid.

Nochtans bepaalde artikel 2 van het oorspronkelijke wetsontwerp dat voor advies naar de Raad van State werd gezonden, in een uitdrukkelijke wederkerigheidsbepaling ${ }^{1 / 2}$. Zoals hierboven aangegeven, wordt in de wet een uitbreiding voorzien op het territoriale toepassingsgebied; in de oorspronkelijke versie was deze uitbreiding enkel van toepassing "voorzover de nationale wetgeving van de verdragsluitende Staat op wiens grondgebied de schade wordt geleden, in dezelfde uitbreiding voorziet". Op aangeven van de Raad van State is deze bepaling uit de wet gehaald, omdat dit verplichtingen zou meebrengen voor de andere verdragsluitende $\operatorname{Staten}^{113} 114$.

Toch moet worden aangegeven dat sowieso een wcderkerigheidsbepaling, indien die in de Belgische wet zou zijn opgenomen, niet toepasbaar zou zijn geweest, gelet op de bcperkte beschikbare bedragen. Zoals aangegeven moet bij de toepassing van de wederkerigheid rekening worden

109

110

111 Dit wordt bevestigd door de voorbereidende werken. Zie met name Memorie van Toelichting, Parlementaire Stukken, 1983-1984, 593/1, 12.

112

113

114

Zie $\$ 2.1 .2 .1$ van hoofdstuk 2 .

Met name Portugal, Griekenland en Turkije.

Ook in het Commissieverslag was de wederkerigheid aan de orde, bijvoorbeeld met betrekking tot de vraag of Belgie langere termijnen zou moeten invoeren binnen dewelke een slachtoffer een vordering kan instellen (Parlementaire Sitkken, Senaat, G2/1983-1984, 593/3, 20).

Advies van de Raad van State, Parlementaire Stukken, 1983-1984, 593/1, 39.

Artikel $14, c$ ) van het Aanvullend Verdrag van Brussel bepaalt dat Staten regelingen kunnen treffer buiten het Verdrag van Parijs, voorzover die geen bijkomende verplichtingen met zich meebrengen voor de andere Partijen ten aanzien van de ter beschikking te stellen openbare middelen. 
gehouden met de in de Verdragen neergelegde drempels. Het is landen enkel toegestaan om een wederkerigheidsbepaling in te voeren indien de totale beschikbare middelen de 300 miljoen BTR overtreffen ten aanzien van Verdragsstaten van het Aanvullend Verdrag van Brussel, of de 5 miljoen BTR ten aanzien van Staten die enkel zijn toegetreden tot het Verdrag van Parijs. Slechts sinds de wijziging van de Belgische nucleaire aansprakelijkheidswet bij wet van 11 juli 2000, stijgt het in België beschikbare schadevergoedingsbedrag uit boven deze limiet: door de wijziging bedraagt het totale bedrag inderdaad 18,5 miljard BEF. In het verleden kon de wederkerigheidsbepaling juridisch gezien dus niet worden toegepast: het totale beschikbare bedrag bedroeg immers 15,6 miljard BEF, ofwel 300 miljoen BTR.

Concluderend kan worclen gesteld dat de Belgische wet inzake de wettelijke aansprakelijkheid op het gebied van de kernenergie geen wederkerigheidsbepaling bevat en dat dit tot vóor de wijziging van de nucleaire aansprakelijkheidswet ook niet toepasbaar zou zijn geweest.

\section{Toepassingsgebied VAN de NeDERL.ANDSE Wet Aansprakeli.JKHEId KeRNongevallen VAN 26 JUNI 1991 (WAKO)}

Net zoals de Belgische wet van 22 juli 1985, bevat ook de Nederlandse wet een bijzonderheid met betrekking tot het begrip "keminstallaties". Het toepassingsgebied ratione materiae wordt besproken in $\$ 3.1$. Nadien wordt het territoriale toepassingsgebied bestudeerd $(\$ 3.2)$ en tenslotte wordt nagegaan of de Nederlandse WAKO een bepaling bevat inzake wederkerigheid $(\S 3.3)$.

\subsection{Ratione materiae}

Volgens artikel 1.1 WAKO wordt wat betreft de begrippen kemongeval, kerninstallatie, nucleaire stoffen, exploitant en schade, verwezen naar de definities van het Verdrag van Parijs.

Deze loutere verwijzing, die zeker het voordeel biedt van een correcte toepassing van de definities in het Nederlandse recht, roept toch vragen op met betrekking tot de draagwijdte van de beslissingen en interpretaties van de NEA ${ }^{115}$. Zo rijst de vraag of de verwijzing meteen impliceert dat ook alle beslissingen en interpretaties van de Bestuurscommissie ten aanzien van deze begrippen, mee worden "overgenomen" in het Nederlandse kernenergierecht. Deze zijn met name van belang bij de invulling van het begrip keminstallatie en bij de afbakening van het territoriale toepassingsgebied.

Inzake het begrip "keminstallatie" besliste de NEA dat een installatie voor de berging van radioactief afval gedurende de operationele fase onder de bepalingen van het Verdrag van Parijs valt $^{116}$. Tegelijk vallen volgens een interpretatie van de NEA-Bestuurscommissie keminstallaties in fase van ontmanteling onder het Verdrag. De vraag rijst of de verwijzing in de WAKO naar de definities van het Verdrag van Parijs voldoende is opdat de beslissingen en de interpretaties ook als geldend Nederlands recht kunnen worden beschouwd.

Artikel 16 van het Verdrag van Parijs bepaalt dat de besluiten van de Bestuurscommissie worden genomen in onderlinge toestemming tussen de leden die de Verdragsluitende Staten vertegenwoordigen. Hierbij wordt geen onderscheid gemaakt tussen aanbevelingen en beslissingen. Het

Het spreekt voor zich dat deze vragen evenzeer rijzen voor de toepassing van de Belgische wet.

Cfr. supra, $\$ 1.1 .2 .2$. 
Statuut van de NEA ${ }^{117}$ geeft evenmin uitsluitsel. Daarin wordt enkel bevestigd dat de Bestuurscommissie ${ }^{118}$ beslissingen en interpretaties mag geven en dat beslissingen "which are binding on Goveriments and which are taken by the Steering Committee within the powers conferred upon it shall commit only those countries which have accepted them" ${ }^{\text {II9 }}$. De beslissingen en interpretaties zullen dus enkel gelden in Nederland, voorzover Nederland deze heeft aanvaard. In de regel is het voldoende dat een verklaring in die zin wordt afgegeven aan de NEA. Uit de gepubliceerde beslissingen en interpretaties kan niet worden afgeleid of Nederland daarmee heeft ingestemd.

Artikel 16 van de WAKO stelt dat het Verdrag van Parijs en de hoofdstukken I, II en V van de wet ${ }^{120}$ ook van toepassing zijn op de in Nederland gelegen kerninstallaties die niet zijn vermeld in de lijst als bedoeld in artikel 13 van het Aanvullend Verdrag van Brussel. Dit leidt ertoe dat de Nederlandse WAKO eveneens van toepassing is op keminstallaties voor militair gebruik. De Nederlandse wetgever is immers van oordeel dat ook militaire installaties onder het Verdrag van Parijs vallen $^{121}$. Op dit punt verschilt de WAKO van de Belgische wet van 22 juli 1985 die enkel van toepassing is op kerninstallaties voor vreedzaam gebruik. Hierboven werd reeds gewezen op de onduidelijkheid met betrekking tot de vraag of militaire kerninstallaties al dan niet onder het Verdrag van Parijs vallen ${ }^{122}$. Enkel met betrekking tot het Aanvullend Verdrag van Brussel bestaat duidelijkheid in die zin dat het van toepassing is op kerninstallaties voor vreedzaam gebruik. Vandaar heeft de toepassing van de WAKO op militaire kerninstallaties enkel betrekking op de aansprakelijkheid van de exploitant en niet op de door de Nederlandse Staat ter beschikking gestelde bedragen uit de tweede schijf van het Verdrag van Brussel ${ }^{123}$.

Aangezien Nederland geen keminstallaties voor militair gebruik heeft, zal deze uitbreiding in de praktijk weinig gevolgen hebben. Volgens de Tweede Kamer impliceert de uitbreiding dat de WAKO van toepassing zal zijn op de Amerikaanse kernwapens die in het kader van de NAVO op het Nederlandse grondgebied zijn opgeslagen ${ }^{124}$. Deze visie strookt niet met onze eerdere analyse van het toepassingsgebied van het Verdrag van Parijs. Kernwapens bevatten plutoniummaterial en vallen dus onder het begrip "nucleaire stoffen". Inrichtingen voor de opslag van nucleaire stoffen vallen niet onder de definitie van een keminstallatie; de opslag van kernwapens valt dan ook buiten het toepassingsgebied van het Verdrag.

\subsection{Ratione loci}

Artikel 15, eerste lid van de WAKO bepaalt dat de in artikel 2 van het Verdrag van Parijs genoemde beperkingen van de werkingssfeer niet van toepassing zijn op de aansprakelijkheid van een exploitant van een in Nederland gelegen kerninstallatie voor schade die op het grondgebied van Nederland is geleden of die het gevolg is van een kernongeval dat zich op dat grondgebied

Het Statuut werd aangenomen bij beslissing van 20 december 1957 door de Raad van de Organisatie voor Europese Economische Samenwerking en werd sindsdien meermaals gewijzigd. Het Statuut ken worden geraadpleegd op de website van de NEA: http:/www.nea.fr.

De Bestuurscommissic is samengesteld uit vertegenwoordigers van alle Regeringen die deelnemen in de desbetreffende beslissing (artikel 9 van het Statuut van de OECD Nuclear Energy Agency). Artikel 11, d van het Statuut van de OECD Nuclear Energy Agency.

Deze hebben betrekking op respectievelijk de begripsbepalingen, de uitvoering van het Verdrag van Parijs en Procesrecht.

Memorie van Toelichting, Tweede Kamer, zitting 1975-1976, 13 928, nr. 5, 33.

Cfr. supra, \$1.1.2.

Memorie van Toelichting, Tweede Kamer, zitting 1975-1976, 13 928, nr. 5, 25.

Memorie van Toelichting, Tweede Kamer, zitting 1975-1976, 13 928, nr. 5, 33. 
heeft voorgedaan. De beperkingen waarnaar de WAKO verwijst, hebben betrekking op kemongevallen die zich voordoen in een niet-Verdragsstaat en schade geleden in een niet-Verdragsstaat.

Het toepassingsgebied van de WAKO is bijgevolg ruimer dan het Verdrag van Parijs, aangezien, in de hypothese waarin een kernongeval heeft plaatsgevonden in Nederland, ook schade op het grondgebied van een niet-Verdragsstaat, onder de wet valt. Maar de verruiming van het toepassingsgebied zoals die in de WAKO is aangegeven, is niet absoluut ${ }^{125}$. In de hypothese waarin zich in een niet-Verdragsstaat een kernongeval voordoet waarvoor een Nederlandse exploitant aansprakelijk is, is de WAKO enkel van toepassing voor schade geleden op het Nederlandse grondgebied. De WAKO gaat dus niet zover om ook de schade die in de laatstgenoemde hypothese zou zijn veroorzaakt aan andere Verdragsstaten, op te nemen in het territoriale werkingsveld. Vandaar heeft Nederland de aanbeveling van de NEA niet in zijn geheel gevolgd ${ }^{126}$.

Zodra zich in Nederland een kernongeval heeft voorgedaan waarvoor de exploitant van een in Nederland gelegen keminstallatic aansprakelijk is, dan is de WAKO van toepassing, ongeachl de plaats waar de schade is geleden. Onderstaande tabel kan een en ander verduidelijken.

\section{TERRITORIAAL TOEPASSINGSGEBIED VAN DE NEDERLANDSE WAKO}

\begin{tabular}{|l|c|c|c|}
\hline \multirow{2}{*}{ Ongeval in } & \multicolumn{3}{|c|}{ Schade in } \\
\cline { 2 - 4 } & Nederland & Verdragsstaat & Niet-Verdragsstaat \\
\hline Nederland & Ja & Ja & Ja \\
\hline Verdragsstaat & Ja & Ja & Neen \\
\hline Niet-Verdragsstaat & Ja & Neen & Neen \\
\hline
\end{tabular}

Betreffende het territoriale toepassingsgebied verschilt de Nederlandse WAKO van de Belgische wet van 1985 omdat Nederland lid is van het Gemeenschappelijk Protocol. Hierdoor worden landen die het Verdrag van Wenen en het Gemeenschappelijk Protocol hebben ondertekend en geratificeerd, eveneens als Verdragspartijen beschouwd. Dit heeft als concreet gevolg dat in bovenstaande tabel de landen van het Verdrag van Wenen die eveneens lid zijn van het Gemeenschappelijk Protocol als Verdragsstaten worden beschouwd.

De WAKO geeft evenwel nergens aan of ook kemongevallen op volle zee of daarboven en ongevallen in de territoriale wateren, onder het toepassingsgebied vallen. Wat de territoriale wateren

Domsdorf, E.P.M.W., "Internationaal Atoomenergierecht", l.c., 693.

Memorie van Toelichting, Tweede Kamer, zitting 1975-1976, 13 928, nr. 5, 32. 
betreft, kan ervan worden uitgegaan dat het klassieke volkenrechtelijke begrip "grondgebied"127, waarin ook de territoriale wateren zijn vervat, kan worden toegepast. Met betrekking tot de volle zee, is de situatie onduidelijk.

Tenslotte moet worden gewezen op artikel 15.2 van de WAKO waarin wordt aangegeven dat, wat de aansprakelijkheid betreft van de exploitant van een in Nederland gelegen kerninstallatie, bij algemene maatregel van bestuur artikel 2 van het Verdrag van Parijs nog verder kan worden uitgebreid.

\subsection{Wederkerigheid}

Artikel 18.1 van de WAKO voorziet in een Staatstussenkomst van 5 miljard gulden (ongeveer 92 miljard BEF of 2,27 miljard euro). Deze bepaling, die werd ingevoerd ingevolge de in 1991 aangebrachte wijzigingen, kan zonder enige twijfel worden beschouwd als een van de meest spectaculaire veranderingen ten overstaan van de WAKO van $1979^{128}$. Doordat de Nederlandse Staat in aanzienlijke mate tussenkomt, wekt het geen verwondering dat de Nederlandse WAKO een wederkerigheidsbepaling bevat. Artikel 18.4 WAKO stelt dat de beschikbaarstelling van openbare middelen enkel van toepassing is ten overstaan van landen die eveneens partij rijn bij het Verdrag van Brussel en waar ten tijde van het kernongeval een regeling van kracht is die naar aard, toepassingsgebied en bedrag gelijkwaardig is aan de door de WAKO vooropgestelde regeling.

Tijdens de parlementaire voorbereiding werd door een van de fracties de vraag gesteld of door het hoge bedrag van de Nederlandse staatstussenkomst de financiële dekking bij kemongevallen in Nederland ecn stuk hoger ligt dan in Duitsland. Het antwoord op deze vraag luidde - geheel terecht - dat dit niet helcmaal duidelijk is ${ }^{129}$, aangezicn vragen bestaan omtrent de gevolgen van de onbeperkte aansprakelijkheid in de Duitse wetgeving: de wederkerigheid wordt in Duitsland zonder meer toegepast op de onbeperkte aansprakelijkheid, terwijl de WAKO zich beperkt tot het ter beschikking stellen van openbare middelen ${ }^{130}{ }^{131}$. Door de hoge tussenkomst van de Nederlandse Staat, werd overigens gesteld dat bij een kernongeval in Duitsland waarbij ook in Nederland schade zou worden geleden, de Nederlandse slachtoffers een beroep zouden kunnen doen op de Duitse Statstussenkomst van 1 miljard $D M^{132}$.

Het grote verschil tussen de Duitse en de Nederlandse wederkerigheidsvereiste bestaat er inderdaad in dat de Nederlandse wederkerigheidseis uitsluitend betrekking heeft op het bedrag dat de Nederlandse Staat ter beschikking stelt, terwijl de Duitse wederkerigheidseis, zowel met betrekking tot overmacht als met betrekking tot de onbeperkte aansprakelijkheid, te ongenuanceerd is

Volgens artikel 23 van het Verdrag van Parijs, is het Verơrag van toepassing op het grondgebied van het moederland van de Verdragsluitende Staten. Met moederland werd bedoeld het land zonder de kolonies waarover dat land beschikte ten tijde van het ondertekenen van het Verdrag. Van Maanen, G.E., "De civielrechtelijke aansprakelijkheid voor kernongevalicn naar Nederlands recht", in Faure, M., (red.), "Aansprakelijkheid voor het nucleaire risico", l.c., 24. Ook in die zin: Domsdorf, E.P.M.W., "Intemational Atoomenergierecht", l.c., 731. Nota naar aanleiding van het Eindverslag, Tweede Kamer, vergaderjaar 1988-1989, 20 374, nr. 9, 1 e.v.

Zie ook het uitgewerkte voorbceld bij de bespreking van de wederkerigheid onder het Verdrag ven Parijs (cfr. supra, $\$ 1.4$ van dit hoofdstuk). Memorie van Antwoord, Tweede Kamer, vergaderjaar 1988-1989, 20 374, nr. 6, 11: "Aangenoment mag worden dat met de regeling van onbeperktc aansprakelijkheid in de Bondsrepubliek en de Nederlandse garantie (...) voldaan wordt aan de eis van reciprociteit die in beide wetgevingen wordt gesteld". 
geformuleerd ${ }^{133}$. Doordat Nederland de wederkerigheid enkel koppelt aan de openbare middelen en doordat ook het totale beschikbare schadevergoedingsbedrag hoger ligt dan 300 miljoen BTR is voldaan aan de voorwaarden die artikel 15, b) van het Verdrag van Parijs ter zake stelt.

of Nederland hierdoor ontsnapt aan het risico dat Duitsland de wederkerigheidseis ook ten aanzien van Nederland zal inroepen, blijft onduidelijk ingevolge het ongenuanceerde karakter van de Duitse wederkerigheidsbepaling. Nederland kan de wederkerigheidsbepaling daarentegen wel inrocpen ten overstaan van in België geleden schade. Slechts voor het deel dat het in België beschikbare bedrag van 300 miljoen BTR te boven gaat, zal de wederkerigheid niet kunnen worden toegepast. Met andere woorden: voor de in België geleden schade kan hooguit tot 136 miljoen gulden een beroep worden gedaan op artikel 18.1 van de WAKO ${ }^{134}$.

Toch blijven ook hier de bezwaren tegen praktische toepasbaarheid wan de wederkerigheidsbepaling behouden.

\section{Conclusie.}

De meest voorkomende hypothese waar het Verdrag van Parijs van toepassing zal zijn, is een kernongeval zoals Tsjernobyl - een ongeval in een kerninstallatie - en een ongeval tijdens het vervoer van stoffen van en naar een exploitant wiens land lid is van het Verdrag. Toch is het toepassingsgebied van het Verdrag van Parijs tegelijk ruim en beperkt. Het toepassingsgebied is ruim omdat het in principe voldoende is dat het feit of de schade voortkomt uit de gevaarlijke eigenschappen van radioactieve stoffen, omdat niet noodzakelijk een vrijkomen van radioactiviteit is vereist en omdat evenmin een plotselinge gebeurtenis is vereist. Het toepassingsgebied is daarentegen beperkt in die zin dat bepaalde fabrieken of inrichtingen niet onder het Verdrag vallen, net zomin als bepaalde radioactieve stoffen (zoals medische isotopen in ziekenhuizen).

Het feit dat niet zomaar elk feit of ongeval ingevolge het gebruik van radioactieve stoffen leidt tot de toepassing van het nucleaire aansprakelijkheidsrecht, is niet verwonderlijk aangezien het Verdrag van Parijs een uitzonderingsregime invoert. Dit regime kan inderdaad ook vanuit juridisch oogpunt als bijzonder worden beschouwd omdat het gemenc aansprakelijkheidsrecht buiten werking wordt gesteld ${ }^{135}$. In gevallen waar de risico's ingevolge het gebruik van kemenergie beperkt zijn, zal het gemene aansprakelijkheidsrecht van kracht blijven.

Het Verdrag van Parijs laat een bepaalde vrijheid aan de verschillende Verdragsluitende Staten ten aanzien van het territoriale toepassingsgebied. Zowel België als Nederland hebben van deze mogelijkheid gebruik genaakt. Het Verdrag van Parijs is enkel van toepassing op een kernongeval dat zich heeft voorgedaan op het grondgebied van een verdragsluitende Staat en op de aldaar geleden schade. De Belgische en de Nederlandse wet verschillen dus op twee punten: in tegenstelling tot de Belgische wet van 22 juli 1985 die van toepassing is ongeacht de plaats van het onge$\mathrm{val}$, is de plaats van het ongeval wel degelijk van belang onder de Nederlandse WAKO. Bovendien valt schade in ccn nict-Verdragsstaat tengevolge van een kernongeval in Nederland wel onder de WAKO, terwijl de analoge situatie niet onder de Belgische wet zou vallen.

\footnotetext{
[3]

13. Cfr. supra, $\$ 1.4$ van dit hoofdstuk.

Namelijk het verschil tussen de 15,6 miljard BEF (zijnde de limiet van 300 miljoen BTR) en 18,1 miljard BEF (het totale beschikbare bedrag na de wijziging van de Belgische wet van 11 juli 2000), zijnde 2,5 miljard BEF, of 136 miljoen gulden (61,9 miljoen euro).

Daar wordt later op teruggekomen. Zie $\$ 2$ van hoofdstuk 4 .
} 
Eenzelfde vrijheid is niet met zoveel woorden gegeven ten aanzien van het materiële toepassingsgebied. Indien een land in de nationale wetgeving een eigen interpretatie naar voren schuift zoals de Belgische wetgever heeft gedaan - dan is de kans reëel dat hiermee afbreuk wordt gedaan aan de bevoegdheid van de NEA om aanbevelingen, beslissingen en interpretaties te geven inzake de Verdragen van het NEA-regime.

Een specifiek probleem met betrekking tot de beoordeling van de Verdragen van het NEA-regime heeft betrekking op een aantal onduidelijkheden ingevolge de wisselwerking tussen het Verdrag van Parijs en het Aanvullend Verdrag van Brussel. In de analyse werden verschillen vastgesteld in het territoriale toepassingsgebied en met betrekking tot de vraag of ook kerninstallaties voor vreedzaam gebruik onder het NEA-regime vallen.

Via de analyse van het Belgische en Nederlandse nucleaire aansprakelijkheidsrecht, is gebleken dat de toepassing van de verschillende Verdragen tot complexe situaties én tot aanzienlijke verschillen aanleiding kan geven. Doordat Nederland lid is van het Gemeenschappelijk Protocol van 1988, zullen Nederlandse slachtoffers van een kernongeval in Hongarije - dat lid is van het Verdrag van Wenen en van het Gemeenschappelijk Protocol - een beroep kunnen doen op de bepalingen van het Verdrag van Wenen. Doordat België niet is aangesloten bij het Gemeenschappelijk Protocol, zullen Belgische slachtoffers geen beroep kunnen doen op het Verdrag van Wenen.

In de vorige hoofdstukken werd een overzicht gegeven van het gemeenrechtelijke civiele aansprakelijkheidsrecht (hoofdstuk 1), werd het ontstaan van het kemenergierecht toegelicht en werd een overzicht gegeven van de internationale Verdragen inzake nucleaire civielrechtelijke aansprakelijkheid (hoofdstuk 2). Nu in dit hoofdstuk ook het toepassingsgebied van deze Verdrag is verduidelijkt, zullen in hoofdstuk 4 de basisprincipes van het nucleaire aansprakelijkheidsiecht aan de orde worden gesteld. 


\section{HOOFDSTUK 4}

\section{BASISPRINCIPES VAN DE NUCLEAIRE AANSPRAKELIJKHEIDSWETGEVING}

In de vorige hoofdstukken werd het civielrechtelijke aansprakelijkheidsrecht aan de orde gesteld, werd een overzicht gegeven van het kemenergierecht en werd het toepassingsgebied van het nucleaire aansprakelijkheidsrecht bestudeerd. In dit hoofdstuk worden de basisprincipes van de nucleaire aansprakelijkheidswetgeving geanalyseerd.

In eerste instantie wordt aandacht besteed aan de invoering van de risicoaansprakelijkheid ( $\$ 1$ ). Nadien wordt geanalyseerd wat dient te worden verstaan onder de "kanalisatie van aansprakelijkheid" ( $(2)$; dit is een van de meest opmerkelijke basisprincipes van het nucleaire aansprakelijkheidsrecht. Vervolgens worden achtereenvolgens de beperking van het bedrag van de aansprakelijkheid en de beperking van de aansprakelijkheid in de tijd $(\S 3)$ aan de orde gesteld. In $\$ 4$ worden de Verdragsbepalingen bestudeerd inzake de verplichting tot het verzekeren van de aansprakelijkheid. Tenslotte worden de procesrechtelijke bepalingen van het Verdrag toegelicht, met name inzake de exclusieve bevoegdheid van één rechter per land $(\$ 5)$. Zoals zal worden aangetoond houden deze verschillende principes nauw verband met elkaar en vormen zij één samenhangend systeem dat werd ingevoerd door het Verdrag van Parijs van 29 juli 1960 - en dat later werd overgenomen door het Verdrag van Wenen van 21 mei 1963.

De wijze waarop deze verschillende principes zullen worden besproken, is identiek. Telkens zal zowel worden onderzocht hoe en waarom het principe werd ingeschreven in het Verdrag van Parijs, als de wijze waarop dit principe vervolgens in de Belgische wet van 22 juli 1985 en in de Nederlandse WAKO van 26 juni 1991 werd omgezet. De analyse beperkt zich echter niet tot de bepalingen van het Verdrag van Parijs zelf; er zal ook worden gekeken in welke mate de aan de gang zijnde besprekingen inzake de revisie van het Verdrag van Parijs voorzien dat wijzigingen zullen worden aangebracht aan de verschillende basisprincipes.

Daamaast zal ook vaak worden gekeken naar de corresponderende bepaling in het Verdrag van Wenen. Hoewel het niet in onze bedoeling ligt om beide Verdragen op systematische wijze met elkaar te vergelijken, zal het naast elkaar plaatsen van beide regimes een aantal interessante elementen opleveren voor de verdere analyse. Tenslotte zal ook aandacht worden besteed aan de wijkigingen die aan het nucleaire aansprakelijkheidsrecht werden aangebracht door de Verdragen van 12 september 1997 (Protocol van het Verdrag van Wenen en Verdrag inzake Bijkomende ('ompensatie'); hoewel deze wijzigingen nog niet in werking zijn getreden, is het toch interessant te analyseren wat deze wijzigingen precies inhouden en waarom deze zijn tot stand gekomen.

\section{RISICOAANSPRAKELIJKHEID}

De basisbeginselen van het nucleaire civiele aansprakelijkheidsrecht worden in dit hoofdstuk telkens bestudeerd volgens het Verdrag van Parijs (\$1.1), volgens de Belgische wet van 22 juli 1985 ( $\$ 1.2)$ en volgens de Nederlandse WAKO van 1991 (\$ 1.3). Ook zal worden onderzocht of de nucleaire aansprakelijkheidsverdragen van 1997 wijzigingen hebben aangebracht aan het principe van de risicoaansprakelijkheid en in welke mate dit thema aan de orde is bij de onderhandelingen inzake de revisie van het Verdrag van Parijs. Deze twee elementen worden gebun-

Cfr. supra, in $\$ 2.2 .2 .2$ van hoofdstuk 2 . 
deld bij de bespreking van de risicoaansprakelijkheid naar toekomstig recht $(\S 1.4)$. De bevindingen van de analyse worden samengevat in de conclusie $(\S 1.5)$. Deze indeling zal grosso modo in het gehele hoofdstuk worden aangehouden.

\subsection{Volgens het Verdrag van Parijs van 29 juli 1960}

Aangezien het in onze bedoeling ligt om na te gaan welk type van aansprakelijkheid door het Verdrag wordt gehanteerd, wordt de bespreking van de risicoaansprakelijkheid opgesplitst in een aantal onderdelen. Zo wordt in eerste instantie artikel 3 van het Verdrag, dat de risicoaansprakelijkheid invoert, besproken $(\S 1.1 .1)$. Vervolgens wordt nagegaan in welke gevallen de exploitant zich kan beroepen op overmacht $(\S 1.1 .2)$. De uitgestrektheid van de risicoaansprakelijkheid van de exploitant wordt aan de orde gesteld in $\$ 1.1 .3$. Nadien zal de vraag worden beantwoord of het Verdrag daadwerkelijk een regime van risicoaansprakelijkheid invoert (\$1.1.4).

\subsubsection{Artikel 3 van het Verdrag van Parijs}

In het algemeen wordt inzake gevaarlijke activiteiten risicoaansprakelijkheid ingevoerd in gevallen waar het niet meer dan rechtvaardig is dat de persoon die een risico creëert er ook de gevolgen van draagt. Over het algemeen is dit de exploitant van deze gevaarlijke activiteiten; hij heeft de feitelijke controle en is dus beter in staat om preventieve maatregelen te treffen en om cen verzekeringsdekking te nemen ${ }^{2}$. Risicoaansprakelijkheid wordt in deze context dan ook beschouwd als een toepassing van het principe "de vervuiler betaalt", dat op zijn beurt een vertaling is van de vereiste van de intemalisatie van kosten of van negatieve externe effecten ${ }^{3}$. Blijkbaar is de risicoaansprakelijkheid zoals ingevoerd in het Verdrag van Parijs geïnspireerd door de risicoleer: doordat de cxploitant van een kerninstallatie - alleen reeds door zijn activiteit - een risico creêert, wordt hij aansprakelijk gesteld voor de uit deze activiteiten voortvloeiende schade ${ }^{4}$. De door een kernongeval veroorzaakte schade werd door juristen op het einde van de jaren vijftig beschouwd als een klassiek voorbeeld van de risicoleer: indien wordt aanvaard dat een bepaald risico in het leven wordt geroepen, dan dienen slachtoffers te worden vergoed door degene die de kerninstallatie exploiteert en er voordeel uit haalt ${ }^{5}$.

Artikel 3 van het Verdrag van Parijs stelt de exploitant van een kerninstallatie aansprakelijk voor de door hem veroorzaakte schade, hetzij aan personen, hetzij aan goederen of vermogen, op voorwaarde dat wordt bewezen dat de schade is veroorzaakt door het kernongeval dat zich heeft voorgedaan in die kerninstallatie of waarbij nucleaire stoffen zijn betrokken die uit de installatie afkomstig zijn ${ }^{6}$ ?

2 "I iability and Compensation for Nuclear Damage", l.c., 19-20.

3 Bergkamp, L., "De vervuiler betaalt dubbel", l.c., 30 e.v

4 Camier, M.-C., Responsabilité et Assurance du Risque Aromique dans les Droits Européens, Centre français de droit comparé, Paris, 1960, 71-72.

5 Von Caemmerer, E., "La Responsabilité du fait des Choses inanimées et le Risque Atomique", in Puget, H. (ed.), Aspects du droit Atomique, Centre français de droit comparé, Tome I, 25.

Het Vurdrag voorzict niet in bijkomende bepalingen met betrekking tot de invulling van het begrip "schade". Welke schade al dan niet voor vergoeding in aanmerking komt (indirecte schade, schade aan het milieu, ...), wordt overgelaten aan het op het schadegeval toepasselijke recht. Artikel 11 van het Verdrag van Parijs bepaalt dat de aard, vorm en omvang van de schadevergoeding, alsmede de billijke verdeling ervan, wordt geregeld door de nationale wet die op het kernongeval van toepassing is. Indien schade aanleiding gceft tot de aansprakelijkheid van meer dan én exploitant, zijn de exploitanten hoofdelijk en ieder voor het geheel aansprakelijk (artikel 5, d van het Verdrag van Parijs). In geen 
Deze definitie refereert niet aan een fout in hoofde van de exploitant of in hoofde van enige andere persoon; hieruit blijkt dat het de bedoeling was van de Verdragspartijen om de exploitant van een keminstallatie aansprakelijk te stellen, buiten elk bewijs van fout om. De invoering van risicoaansprakelijkheid lag volgens de Verdragspartijen in de lijn van de wettelijke evolutie en van de evolutie in de rechtspraak in West-Europa waarbij in hoofde van degenen die een gevaarlijke activiteit uitoefenen, een vermoeden van aansprakelijkheid wordt gecreëerd ${ }^{8}$ : gelet op de gevaren verbonden aan het gebruik van kernenergie en gelet op de moeilijkheden om een fout te bewijzen in hoofde van de exploitant, werd geopteerd voor de introductie van risicoaansprakelijkheid in het nucleaire aansprakelijkheidsrecht ${ }^{9}$.

In de voorbereidende werken van het Verdrag van Parijs, wordt de aansprakelijkheid van de exploitant gekwalificeerd als cen absolute aansprakelijkheid ${ }^{10}$. In de Verdragstekst van het Verdrag van Parijs zelf wordt dit evenwel nergens met zoveel woorden geëxpliciteerd. Artikel IV van het Verdrag van Wenen daarentegen hanteert wel uitdrukkelijk de term absolute aansprakelijkheid" $^{11}$. De vraag rijst dus of het Verdrag van Parijs een regime invoert van risicoaansprakelijkheid, dan wel van absolute aansprakelijkheid ${ }^{12}$. Onder absolute aansprakelijkheid wordt immers verstaan een aansprakelijkheid waar nauwelijks of geen beroep kan worden gedaan op overmacht ${ }^{13}$.

Hieronder zal worden bestudeerd in welke mate het Verdrag van Parijs toelaat dat de exploitant zich op overmacht beroept $(\S 1.1 .2)$ en tot waar de aansprakelijkheid van de exploitant zich uitstrekt $(\S 1.1 .3)$. Dit zal toelaten om in een $\S 1.1 .4$ te beciordelen of sprake is van risicoaansprakelijkheid dan wel van absolute aansprakelijkheid.

\subsubsection{Beroep op overmacht - uitsluitingsgronden}

Artikel 9 van het Verdrag van Parijs stelt dat de exploitant niet aansprakelijk is voor schade veroorzaakt door een kernongeval dat rechtstreeks te wijten is aan een gewapend conflict, vijandelijkheden, burgeroorlog, opstand of, tenzij de wetgeving van cen Verdragsluitende Staat op wier grondgebied de kerninstallatie is gelegen het tegendeel bepaalt, een ernstige natuurramp van uitzonderlijke aard $^{14}$.

geval echter zal een exploitant meer moeten betalen dan het bedrag waarvoor hij maximaal kan worden aansprakelijk gesteld. De beperking van de aansprakelijkheid van de exploitant, is een ander basisprincipe van de nucleaire aansprakelijkheidswetgeving. Dit wordt besproken in paragraaf 3.

Voor een rechtsvergelijkende analyse van de wetgeving inzake gevaarlijke activiteiten zie Horbach, N.L.J.T., "Liability versus Responsibility under International Law", l.c., 109-224.

Exposé des Motifs, 37.

Exposé des Motifs, 37 en 57.

Artikel IV.1 van het Verdrag van Wenen luidt: "The liability of the operator for nuclear damage under this Convention shall be absolute".

Goldie, L.F.E., "Liability for damage and the progressive development of intemational law", International and Comparative Law Quarterly, vol. 14, 1965, 1215; Boyle, A.E., "Nuclear energy and international law: an environmental perspective", o.c., 302.

is In ieder geval kan absolute aansprakelijkheid worden beschouwd als een striktere ansprakelijkheidsvorm dan risicoaansprakelijkheid (Goldie, L.F.E., "Liability for damage and the progressive development of international law", o.c., 1215-1216).

Een nagenoeg identieke bepaling is terug te vinden in artikel IV.3 van het Verdrag van Wenen: "(a) No liability under this Convention shall attach to an operator for nuclear damage caused by a nuclear incident directly due to an act of armed conflict, hostilities, civil war or insurrection. (b) Except in so far as 
De enige exoneraties warop de exploitant van een kerninstallatie zich kan beroepen, zijn bijgevolg bepaalde onlusten van internationale of van politieke aard of ernstige natuurrampen van uitzonderlijke aard die rechtstreeks het kernongeval hebben veroorzaakt. Hieruit leiden de Verdragspartijen af dat de aansprakelijkheid van de exploitant van een kerninstallatie verder gaat dan een risicoaansprakelijkheid aangezien de klassieke overmachtsituaties niet door de exploitant kunnen worden ingeroepen; derhalve wordt diens aansprakelijkheid beschouwd als een absolute aansprakelijkheid ${ }^{15}$.

Uit de voorbereidende werken valt af te leiden dat de Verdragspartijen van het Verdrag van Parijs belang hechtten aan de zinsnede "rechtstreeks te wijten aan" en op deze wijze een restrictieve visie van het begrip overmacht hanteerden. Uitsluitend gebeurtenissen van intemationale en politieke aard en zware natuurrampen "which are catastrophic and completely unforeseeable", kunnen als overmacht worden aanzien ${ }^{16}$. Hieruit blijkt dat de exploitant geenszins automatisch een beroep kan doen op overmacht om aan aansprakelijkheid te ontsnappen. De exploitant zal aansprakelijk zijn voor schade die onrechtstreeks is veroorzaakt door de genoemde gevallen van overmacht, evenals door andere, niet in de lijst opgenomen klassieke gevallen van overmacht.

De centrale vraag hierbij is uiteraard wat wordt verstaan onder "volledig onvoorzienbaar" en "rechtstreeks te wijten aan". Er dient te worden vastgesteld dat eveneens onder het gemeenrechtelijke overmachtsbegrip belang wordt gehecht aan het onvoorzienbare en onweerstaanbare karakter van een gegeven gebeurtenis ${ }^{17}$. Het Exposé des Motifs van het Verdrag van Parijs refereert op dit punt aan de mogelijkheid om voorzorgsmaatregelen te nemen ${ }^{18}$. Indien het kernongeval bijgevolg kon worden vermeden door het nemen van voorzorgsmaatregelen, zal de exploitant zich niet op overmacht kunnen beroepen, zelfs niet bij burgeroorlog, opstand, etc. Deze bepaling lijkt een verzwaarde voorzorgsplicht te creëren in hoofde van een exploitant van een kerninstallatie; deze zal alle redelijke maatregelen moeten nemen om te verhinderen dat door een opstand of een gewapend conflict een kernongeval kan ontstaan ${ }^{19}$.

Opvallend in de lijst van overmachtsbepalingen in het Verdrag is de afwezigheid van terrorisme en sabotage, twee klassieke gevallen van overmacht. Aangezien het onmiskenbaar de bedoeling was van de Verdragspartijen om verder te gaan dan een klassieke "risicoaansprakelijkheid", dienen de uitsluitingsgronden waarop de exploitant zich kan baseren, beperkend te worden uitgelegd. In deze optiek zal de exploitant wel degelijk aansprakelijk kunnen worden gesteld indien het kernongeval werd veroorzaakt door een daad van terrorisme of sabotage, of door een gemeenrechtelijk geval van overmacht zoals noodtoestand. Het Exposé des Motifs stelt overigens dat geen andere uitsluitingen zijn tocgelaten dan deze opgenomen in artikel 9 van het Verdrag van Parijs ${ }^{20}$. Het lijkt overigens een bewuste keuze van de Verdragspartijen te zijn geweest om sabotage en terrorisme niet in de overmachtgronden op te nemen; dit benadrukt eens te meer de voorzorgsmatregelen die cen exploitant van een kerninstallatic dient in acht te nemen.

the law of the Installation State may provide to the contrary, the operator shall not be liable for nuclear damage caused by a nuclear incident due to a grave natural disaster of an exceptional character". Exposé des Motifs, 57. Eenzelfde redenering is terug te vinden in de voorbereidende werken van het Verdrag van Wenen: Official Records Vienna Convention, 56. Exposé des Motifs. 57.

Zowel in het Belgische als in het Nederlandse aansprakelijkheidsrecht wordt de vergelijking gemaakt met het strafrechtelijke overmachtsbegrip. Zic o.m. Cornelis, L., "Beginselen", l.c., 27; Spier, J., Hartlief, T., Van Maanen, G.E. en Vriesendorp, R.D., "Verbintenissen", I.c., 17. "In so far as any precautions can be taken, those in charge of a nuclear installation are in a position to take them, whereas potential victims have no ways of protecting themselves" (Exposé des Motifs, 57). "Liability and Compensation for Nuclear Damage", l.c., 23. Exposé des Morifis, 57. 
Specifiek met betrekking tot natuurrampen, biedt het Verdrag de mogelijkheid dat Verdragsstaten de exploitanten ook kunnen aansprakelijk stellen voor zware natuumampen van uitzonderlijke aard. België en Nederland hebben van deze mogelijkheid gebruik gemaakt. Duitsland is nog verder gegaan, door de exploitant de mogelijkheid te ontnemen om zich op de uitsluitingsgronden als voorzien in artikel 9 van het Verdrag van Parijs te kunnen beroepen ${ }^{21}$ - hiertoe had Duitsland, net als Oostenrijk, een voorbehoud gemaakt met betrekking tot de toepassing van artikel 9. Gewezen dient te worden op de formulering in het Verdrag inzake natuurrampen: er wordt gesproken van een "ernstige natuurramp van uitzonderlijke aard". Door de formulering heeft men blijkbaar willen benadrukken dat de exploitant aansprakelijk zal zijn voor natuurrampen van nietuitzonderlijke aard. Doordat de Belgische en de Nederlandse exploitant ook aansprakelijk zijn voor natuurrampen van uitzonderlijke aard, is deze discussie hier niet aan de orde.

Een belangrijk instrument bij het beoordelen van de verschillende gevallen van overmacht waarop de exploitant zich desgevallend kan beroepen is ongetwijfeld het Verdrag inzake Nucleaire Veiligheid van $1994^{22}$; dit Verdrag verplicht een Staat om te voorzien in regels betreffende de planning en de bouw van kerninstallaties. Op basis hiervan zal de exploitant bijvoorbeeld versterkte prikkeldraad aanbrengen en andere veiligheidsmechanismen installeren om te vermijden dat een burgeroorlog een kemongeval kan veroorzaken, dat onbevoegden zich toegang tot de installatie kunnen verschaffen, etc. Indien een Staat, in uitvoering van haar verplichtingen van het Verdrag inzake Nucleaire Veiligheid, in haar intern recht hiertoe de nodige maatregelen heeft genomen, en indien zou blijken dat de exploitant deze bepalingen niet heeft nageleefd, kan dit tot de conclusie leiden dat de exploitant geen overmacht kan inroepen ${ }^{23}$. Het is immers in de eerste plaats de exploitant zelf, die door het uitbaten van een kerninstallatie, cen verhoogd risico creëert op aanzienlijke schade. Het is daarom aan hem om, in overleg met de toezichthoudende overheid, de nodige voorzorgsmaatregelen te nemen teneinde enkele klassieke gevallen van overmacht het hoofd te kunnen bieden. Enkel indien er toch een kemongeval heeft plaatsgevonden niettegenstaande deze voorzorgsmaatregelen, zal het ongeval rechtstreeks te wijten zijn aan bijvoorbeeld een burgeroorlog en zal de exploitant zich kunnen berocpen op de overmachtsgronden die in het Verdrag van Parijs zijn opgenomen.

Volledigheidshalve moet erop worden gewezen dat indien de exploitant overmacht kan inroepen, het gemene aansprakelijkheidsrecht toepassing zal vinden "and those responsible may therefore be sued as ordinary tortfeasors"24. Vandaar zal desgevallend enige andere persoon, op andere juridische gronden kunnen worden aansprakelijk gesteld - op voorwaarde uiteraard dat voor de overnacht niet geldt ten aanzien van deze persoon.

Concluderend kan worden gesteld dat de exploitant zich uitsluitend kan beroepen op die gevallen van overmacht die in het Verdrag van Parijs zijn weergegeven. Meer nog dan de invoering van een regime van risicoaansprakelijkheid, lijkt de beperking van de gemeenrechtelijke overmachtsgronden te zijn gegrond op de risicoleer. Het is immers de exploitant van de kerninstallatie, die door zijn activiteit het risico creëert op een aanzienlijke schade, bij bijvoorbeeld natuurrampen: door zijn activiteit zal de schade door een overstroming of een aardbeving groter zijn dan bij

\footnotetext{
Zie $\$ 25 \mathrm{Abs}$. 3 van het Duitse Atomgesetz, zoals reeds besproken inzake wederkerigheid onder het Verdrag van Parijs ( $\$ 1.4$ van het vorige hoofdstuk). Cfr. supra, in hoofdstuk $2, \S 2.2 .1 .2$.

Dit uiteraard onverminderd de aansprakelijkheid van de Staat om de uitvoering van de door haar opgelegde maatregelen ook te controleren en om haar internationaalrechtelijke verbintenissen na te komen. Nochtans werd hogerop reeds gewezen op het feit dat een groot deel van het internationale kemenergierecht, zeker inzake safety, als soft law dient te worden beschouwd. 
afwezigheid van een keminstallatie. De exploitant kan zijn aansprakelijkheid niet afwenden don te bewijzen dat hij geen fout heeft begaan, dat een derde een fout heeft begaan of dat een vreemde oorzaak aan de basis van het kernongeval ligt ${ }^{25}$ - enkel de in het Verdrag opgesomde gevallen van overmacht zullen bevrijdend werken.

\subsubsection{Uitgestrektheid van de aansprakelijkheid van de exploitant}

Aansluitend bij de bespreking van de overmachtgronden waarop de exploitant een beroep kan doen, moet worden onderzocht hoe ver diens aansprakelijkheid zich uitstrekt. Hieronder word eerst aangegeven dat de aansprakelijkheid op basis van het Verdrag van Parijs geen betrekking heeft op de eigenschade van de exploitant $(\$ 1.1 .3 .1)$. Nadien wordt besproken in welke mate de exploitant aansprakelijk is tijdens het transport van kemmateriaal $(\$ 1.1 .3 .2)$. Vervolgens wordt de vraag beantwoord of de aansprakelijkheid die door het Verdrag van Parijs wordt ingevoerd enkel geldt ten aanzien van de exploitant, dan wel evenzeer kan worden toegepast op andere personen $(\$ 1.1 .3 .3)$. Tenslotte: zal ook worden besproken welke bepalingen het Verdrag van Parijs voorziet ter zake van het sociale zekerheidsstelsel dat in een gegeven land van kracht is $(\$ 1.1 .3 .4)$.

\subsubsection{Eigenschiil' van de exploitant}

Voorzover als nodig moet worden benadrukt dat het Verdrag van Parijs enkel betrekking heeft op de asnsprakelijkheid tegenover derden. Ten aanzien van de eigen goederen kan de exploitant onmogelijk "aansprakelijk" worden gesteld: aansprakelijkheid veronderstelt immers een duidelijk onderscheiden schuldenaar en schuldeiser (resp. dader en slachtoffer). Het staat de exploitant uiteraard vrij om diens eigenschade al dan niet te verzekeren ${ }^{26}$.

De uitsluiting van aansprakelijkheid voor eigenschade is ook een logisch gevolg van het feit dat het Verdrag van Parijs een uit/ronderingsregime in het leven roept voor een uitzonderlijk risico ${ }^{27}$. Het risico van kemongevallen is uitzonderlijk in de relatie tot schade van derden en niet tot do eigenschade van de exploitant.

Artikel 3, a) van het Verdrag van Parijs benadrukt dat de exploitant niet aansprakelijk is voor de schade aan de kerninstallatie zelf en aan andere kerninstallaties, zelfs in aanbouw, op het terrein noch voor schade aan goederen die zich op het terrein bevinden en worden gebruikt of bestemd zijn te worden gebruikt in verband met een van die installaties. A contrario vloeit hieruit voort da de exploitant wel aansprakelijk is voor goederen dic zich op het terrein van de keminstallatie bevinden, maar die niet in verband met de keminstallatie worden gebruikt.

Als cigenschade van de exploitant wordt beschouwd zaken die door de exploitant, in verband mo de keminstallatie. in bewaring worden gehouden of waarover hij feitelijke controle heeft ${ }^{28}$. Vour namelijk wanneer andere ondememingen bijvoorbeeld onderhoudswerken komen uitvoeren ar de kerninstallatie, waarbij goederen van de onderaannemer op de site worden achtergelaten, be

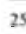

Sirohl. P., "Bilan de recherches de la section de langue française", o.c., 139-140.

Zie hierover meer in hoofdstuk 6 waar de verzekering van het nucleaire risico aan de orde word gesteld.

Suontausta. $T$., "L'exelusion de la responsabilité en cas ce qui concement les dommages à l'installation elle-même et aux biens qui se trouvent sur le site de cette installation", Nuclear Inter Jura "73 AIDN/INLA, Karlsruhe, 1973, 79 e.v.

Exposé des Motifs. 51 . 
staat de kans dat deze goederen zullen worden beschouwd als goiederen die in verband met de keminstallatie worden gebruikt, en waarvoor de exploitant dus niet aansprakelijk is op grond van het Verdrag van Parijs. Desgevallend kan de aansprakelijkheid van de exploitant in het gedrang komen op andere juridische gronden.

Daamaast is de exploitant evenmin op grond van het Verdrag van Parijs aansprakelijk voor schade aan het vervoermiddel waarmee nucleaire stoffen werden vervoerd. Tunnels, elektrische kabels, spoorlijnen etc. worden niet beschouwd als een vervoermiddel ${ }^{29}$. Voor de daaraan veroorzaakte schade is de exploitant wel degelijk aansprakelijk op grond van het Verdrag van Parijs.

Tenslotte geven de voorbereidende werken uitdrukkelijk aan dat het Verdrag de uit contractuele afspraken voortvlociende rechten op schadevergoeding, onverlet laat ${ }^{30}$. Zo kan in bovenstaand voorbeeld een onderaannemer perfect contractueel bedingen dat de exploitant wel degelijk aansprakelijk zal zijn voor de schade aan goederen die in verband met de keminstallatie worden gebruikt - met dien verstande dat voor wat betreft de vergoeding van deze schade geen gebruik kan worden gemaakt van de onder het Verdrag voorziene aansprakelijkheidsverzekering van de exploitant.

\subsubsection{Aansprakelijkheid bij transport van nucleair materiaal ${ }^{3 \mathrm{i}}$}

Bij een kernongeval bij transport, moet eveneens worden gezocht naar een aansprakelijke persoon. Dit kan zowel de exploitant zijn van wie de vervoerde nucleaire stoffen afkomstig zijn, de exploitant voor wie deze stoffen bestemd zijn, als de vervoerder zelf. In het transportrecht zal in de regel de vervoerder aansprakelijk zijn voor de schade ingevolge het transport. Maar hierbij rijzen twee problemen. Ten eerste kan de vervoerder niet worden geacht een professioneel te zijn inzake het verpakken en beschermen van kemmateriaal; bovendien dekt de transportverzekering in de regel enkel de waarde van de vervoerde goederen (een contractuele aansprakelijkheid in plaats van de extracontractuele aansprakelijkheid). Daarenboven is de aansprakelijkheid van de vervoerder doorgaans wettelijk of contractueel beperkt.

Overeenkomstig artikel 4, a) van het Verdrag van Parijs zal de exploitant-verzender aansprakelijk zijn, tot op het moment waarop deze aansprakelijkheid, ingevolge uitdrukkelijke bepalingen van een schriftelijke overeenkomst, is overgenomen door de exploitant-bestemmeling ${ }^{32}$. Omgekeerd zal de exploitant-bestemmeling aansprakelijk zijn nadat de aansprakelijkheid door hem is overgenomen ingevolge de bedoelde overeenkomst ${ }^{3}$. Bijgevolg zal het doorgaans de exploitant van een kerninstallatie zijn die kan worden aansprakelijk gesteld voor schade veroorzaakt door transport van kemmateriaal.

Tenslotte geeft artikel 4, d) de Verdragsluitende Staten de mogelijkheid om in hun interne wetgeving te bepalen dat de vervoerder in plaats van de exploitant zal aansprakelijk zijn overeenkomstig het Verdrag.

\section{Exposé des Motifs, 51.}

Exposé des Motifs, 53.

Deze bepaling is van toepassing op eender welke vorm van transport ( $E$ rapose des $M o l i f s, 49$, in fine).

Indien hierover geen uitdrukkelijke sehriftelijke afspraken werden gemaakt, zal de exploitantverzender aansprakelijk zijn tot op het moment waarop de exploitant de stoffen heeft overgenomen (artikel 4, a), ii) van het Verdrag van Parijs).

Het Verdrag voorziet dat in de hypothese waarin de stoffen worden vervoerd naar een nietVerdragsstaat, de exploitant-verzender aansprakelijk is tot aan het uitladen van de stoffen (artikel 4, a), iv) van het Verdrag van Parijs). 
Deze bepalingen nemen niet weg dat bij schade veroorzaakt door een kernongeval bij transport, twee vorderingen mogelijk zijn: één tegen de exploitant op grond van het Verdrag van Parijs en één tegen de vervoerder op grond van het internationaal vervoerrecht. Indien de exploitant zelf instaat voor het transport, kan hij dus ook op grond van het internationaal vervoerrecht aansprakelijk zijn. Dit mag er evenwel niet toe leiden dat zijn aansprakelijkheid onder het Verdrag van Parijs wordt verminderd of gewijzigd ${ }^{34}$. Indien de exploitant niet zelf instaat voor het transport, zal de persoon die aansprakelijk wordt gesteld op basis van een internationaal Verdrag, over een regresrecht beschikken tegenover de aansprakelijke exploitant - met dien verstande dat het bedrag van de aansprakelijkheid van de exploitant niet kan worden overschreden.

\subsubsection{Aansprakelijkheid van andere personen?}

Uit bovenstaande analyse is gebleken dat op basis van de bepalingen van het Verdrag van Parijs, de exploitant van een keminstallatie aansprakelijk is voor de schade uit een kemongeval, zelfs indien hem geen fout kan worden verweten. In de praktijk is het evenwel denkbaar dat niet de fout van de exploitant maar de fout van enige andere persoon aan de basis van het kemongeval zal liggen. De vraag rijst bijgevolg welke de invloed is van de fout van anderen op de aansprakelijkheid van de exploitant.

Een eerste opvallend element is dat de voorbereidende werken van het Verdrag van Parjis er weinig twijfel over laten bestaan dat indien het kemongeval is veroorzaakt door de fout van cen leverancier van de exploitant of door een gebrek in het ontwerp van de installatie, de slachtoffers van het kemongeval niet beschikken over een vordering tegen deze leveranciers ${ }^{35}$. Deze bepaling dient te worden gelezen in samenhang met artikel 6, b van het Verdrag van Parijs op basis waarvan niemand anders dan de exploitant aansprakelijk kan worden gesteld voor de schade uit een kernongeval. Dit brengt ons meteen bij de "kanalisatie van aansprakelijkheid" naar de exploitant: Zoals verderop zal worden aangetoond, is het in het Verdrag van Parijs neergelegde aansprakelijkheidssysteem een exclusief en exhaustief systeem, in die zin dat de aansprakelijkheid van andere personen dan de exploitant, op andere juridische gronden, is uitgesloten ${ }^{36}$. De fout van de leveranciers van de exploitant zal bijgevolg geen enkele invloed hebben op de extracontractuele aansprakelijkheid van de exploitant tegenover de slachtoffers van het kernongeval.

De exploitant kan bijgevolg tegenover derden niet aan aansprakelijkheid ontsnappen, zelfs niet indien hij erin zou slagen een fout te bewijzen in hoofde van zijn leverancier. Hetzelfde geldt voor fouten van bijvoorbeeld een bezoeker van de site of, bij transport, van een verkeersdeelnemer. Stel bijvoorbeeld dat kernmateriaal wordt vervoerd over de weg en dat een personenwagen door het rode licht rijdt. Deze komt in aanrijding met het nucleaire transport en hierdoor vindt een kernongeval plaats. In dit geval heeft de chauffeur van de wagen een civielrechtelijke fout begaan, maar toch zal deze fout geen afbrcuk doen aan de aansprakelijkheid van de exploitant. Meer nog: de chauffeur die het kernongeval heeft veroorzaakt zal door slachtoffers van een kernongeval niet kunnen worden aangesproken, noch op basis van de bepalingen van het Verdrag van Parijs, noch op enige andere rechtsgrond. De slachtoffers kunnen hun vordering uitsluitend baseren op het Verdrag van Parijs, en kunnen deze vordering enkel instellen tegen de exploitant (of diens verzekeraar).

34

35

36

Exposé des Motifs, 49.

Exposé des Motifs, 39-41.

Cfr. infra, § 2.2.4 van hoofdstuk 4; zie ook eerder Vanden Borre T., "Transplantatie van kanalisatic van aansprakelijkheid van het kemenergierecht naar het milieu(aansprakelijkheids)recht: een goede of een gebrekkige zaak?", in Faure, M. en Deketelaere, K., (red.), "lus Commune en Milieurecht", l.c., 343-344. 
Uit de weinige beschikbare literatuur betreffende de totstandkoming van het Verdrag van Parijs valt af te leiden waarom de fout van de derde geen exoneratiemogelijkheid creëert in hoofde van de exploitant. Er werd blijkbaar van uit gegaan dat er geen causale relatie bestaat tussen het verkeersongeval en het kernongeval, maar dat het kernongeval daarentegen wel degelijk in relatie staat tot de risicovolle activiteiten van de exploitant ${ }^{37}$. De uitbating van de kerninstallatie creëert dermate aanzienlijke risico's dat zelfs indien de fout van de derde het ongeval veroorzatakt, er nog steeds een causale relatie bestaat tussen de activiteiten van de exploitant en het kemongeval ${ }^{38}$ : de door de exploitant te nemen veiligheidsmaatregelen mocten zelfs voorkomen dat bij fout van een derde een kemongeval kan plaatshebben. Deze redenering sluit in feite aan bij de reden waarom de exploitant van een kerninstallatie slechts in bijzondere gevallen een beroep kan doen op overmacht.

Eenzelfde redenering werd aangehouden ter zake van de fout van het slachtoffer. Ook dit is geen voldoende reden om de exploitant te bevrijden van aansprakelijkheid. Bij de bespreking van het Verdrag van Parijs werd wel de mogelijkheid naar voren geschoven dat, ingeval een fout van het slachtoffer zelf tot het kernongeval heeft geleid, de voor dat slachtoffer beschikbare schadevergoeding zou worden verminderd ${ }^{39}$. In het Verdrag van Parijs is hierover niets terug te vinden ${ }^{40}$. Wel werd via het Protocol van 1982 verduidelijkt dat het Verdrag van Parijs geen afbreuk doet aan de aansprakelijkheid van natuurlijke personen voor eigenschade van de exploitant of voor schade veroorzaakt door overmacht én welke het gevolg is van een handelen of nalaten van die natuurlijke persoon met het opzet om schade te berokkenen (artikel 6, c, i, 1 van het Verdrag van Parijs) $)^{41}$. Daarenboven voorziet het Verdrag in een regresrecht van de exploitant tegen een derde die opzettelijk schade heeft berokkend (artikel 6, f, i van het Verdrag van Parijs).

Uit artikel 6 , c blijkt overigens dat enkel natuurlijke personen kunnen worden aansprakelijk gesteld; de voorbereidende werken laten er geen twijfel over bestaan dat i.c. de regel van de respondeat superior buiten werking wordt gesteld ${ }^{42}$. Met andere woorden kan de werkgever van de persoon die opzettelijk schade berokkent, niet worden aansprakelijk gesteld.

Als tweede reden waarom de fout van een derde niet leidt tot de exoneratie van de exploitant, werd aangehaald dat het doel van het Verdrag van Parijs erin bestaat slachtoffers te beschermen. Indien de exploitant zou zijn bevrijd van aansprakelijkheid ingevolge de fout van een derde, dan zou elke vordering die door slachtoffers zou worden ingesteld tegen andere personen dan de exploitant, zinloos zijn ${ }^{43}$ : deze andere personen zullen immers niet over voldoende financiêle middelen beschikken om de geleden schade te vergoeden.

De aansprakelijkheid van de exploitant van een kerninstallatie overeenkomstig het Verdrag van Parijs is dus vrij verregaand: zelfs indien het kernongeval is veroorzaakt door bepaalde gevallen

Camier, M.-C., "Responsabilité et Assurance du Risque Atomique", l.c., 87.

Ibidem.

Camier, M.-C., "Responsabilité et Assurance du Risque Atomique", l.c., 88.

Artikel IV, 2 van het Verdrag van Wenen van Wenen daarentegen bepaalt dat een opzettelijke fout van het slachtoffer de exploitant geheel of gedeeltelijk ontheft van aansprakelijkheid tegenover het slachtoffer.

" Deze bepaling lijkt te zijn gebaseerd op artikcl IV, 7, a van het Verdrag van Wenen: "Nothing in this Convention shall affect the liability of any individual for nuclear damage for which the operator, by virtue of paragraph 3 or 5 of this Article, is not liable under this Convention and which that individual caused by an act or an omission done with the intent to cause damage".

Exposé des Motifs, 41

Aldus Camier (Camier, M.-C., "Responsabilité et Assurance du Risque Atomique", l.c., 87). 
van overmacht, door de leverancier van de exploitant, door de fout van een derde of door een fout van een slachtoffer, toch zal dit niet volstaan om hem te ontheffen van aansprakelijkheid.

\subsubsection{De tussenkomst van een stelsel van sociale zekerheid}

De uitgestrektheid van de aansprakelijkheid van de exploitant wordt tenslotte ook beïnvloed door het in een gegeven land aanwezige stelsel van sociale zekerheid. In heel wat geïndustrialiseerde landen is immers een stelsel aanwezig dat instaat voor bepaalde medische kosten, dat een bepaald inkomen garandeert aan zieke werknemers etc. In de mate waarin dergelijke stelsels vergoedingen verrichten ingevolge een kernongeval, en een regres uitoefenen op de exploitant, wordt ook op dit punt de aansprakelijkheid van de exploitant beïnvloed.

Artikel 6, h van het Verdrag van Parijs voorziet in dat verband dat indien in een land een ziektekostenvcrzekering, sociale zekerheid, arbeidsongevallen- of beroepsziekteverzekering aanwezig is, de aanspraken van rechthebbenden van dit systeem - en desgevallend de regresrechten - wor. den geregeld volgens de wet van de Verdragsluitende Staat ${ }^{44}$.

In de meeste landen die lid zijn van het Verdrag van Parijs is een sociaal zekerheidssysteem in voege. Op basis van dit systeem zal een slachtoffer dat door een kernongeval is getroffen, een beroep kunnen doen op de regeling inzake beroepsziekten en arbeidsongevallen. De auteurs van het Verdrag van Parijs hebben ervoor geopteerd om de voordelen van een dergelijk systeem te behouden $^{45}$. De wetgeving van het land wiens sociale zekerheidsstelsel een uitkering heeft verricht zal bijgevolg bepalen of dit stelsel tussenkomt bij een kernongeval en zo ja binnen welke grenzen en in welke mate een regres tegen de exploitant van de keminstallatie openstaat. Onderzock heeft uitgewezen dat geen enkel algemeen systeem van sociale zekerheid de schade uit een kernongeval uitsluit van haar werkingsveld ${ }^{46}$, maar dat aanzienlijke verschillen bestaan terzake van de mogelijkheid om voor de uitgekeerde bedragen een regresrecht uit te oefenen tegen de exploitant van de kerninstallatie. Deprimoz onderscheidt twee grote systemen: het systeem van subrogatie waar de uitkeringsinstantie in de rechten treedt van het slachtoffer en aldus over eenpartieel of geheel - regresrecht beschikt en het systeem van imputatie waar geen mogelijkheid tot regres bestaat ${ }^{47}$.

Voorstanders van een systeem van imputatie stellen dat het weinig zin heeft orm een regres uit te oefenen, omdat dergelijke vordering inefficiënt en zeer duur zijn. Volgens voorstanders van een systeem van subrogatie daarentegen zou het afschaffen van een regres neerkomen op een uitholling van de aansprakelijkheid van de exploitant ter zake van persoonsschade.

De bepalingen van het Verdrag van Parijs inzake de vergoeding van persoonsschade of letselschade via een stelsel van sociale zekerheid, kunnen in de praktijk tot heel wat problemen aanleiding geven. Encr/ijds zal de op een gegeven schadegeval toepasselijke wet de lex fora zijn (de wet van het land van de kerninstallatic waar het ongeval zich heeft voorgedaan), maar anderzijds verwijst het Verdrag inzake sociale zekerheid naar het recht van elke afzonderlijke lidstaat. Dit impliceert dat niettegenstaande het algemene discriminatieverbod van artikel 14 van het Verdrag,

Zie hierover Camier, M.-C., "Responsabilité et Assurance du Risque Atomique", l.c., 136-138. Exposé des Motifs, 53.

Deprimoz, J., "Relations des exploitants ct de leurs assureurs avec les organismes de protection sociale au cours des procédures d'indemisation des domnages aux personnes", in "Nuclear Inter Jura ' $93^{\prime \prime}$, l. ., Il. $5.3-5$ e.v.

lbidem. 
de Verdragsluitende Staten ervoor hebben geopteerd om ter zake van de sociale zekerheid de ongelijkheid te handhaven ${ }^{48}$.

Dit leidt tot het vreemde gevolg dat indien het land van de aansprakelijke exploitant een systeem hanteert van imputatie, hij niet zal kunnen ontsnappen aan het regres van het sociaal zekerheidsstelsel uit een land dat een systeem van regres hanteert. Het is zeer de vraag of dit niet leidt tot een onaanvaardbare discriminatie van de inwoners van het land van de exploitant. Samen met Deprimoz kan derhalve worden gepleit voor een voorafgaandelijke regeling van mogelijke problemen op dit vlak ${ }^{49}$.

\subsubsection{Risicoaansprakelijkheid?}

Op grond van artikel 3 van het Verdrag van Parijs kan worden aangenomen dat zodra iemand letselschade lijdt, dan wel zaakschade - behalve de eigen goederen van de exploitant, of de goederen die op de site in verband met de kerninstallatie worden gebruikt - deze volgende zaken zal dienen te bewijzen: het bestaan van de schade, het bestaan van een kernongeval, het causaal verband tussen beide en het bewijs dat de gedaagde de hoedanigheid bezit van exploitant (van de kerninstallatie in kwestie). Er kan dus worden gesproken van een aansprakelijkheid van rechtswege, waarbij het bewijs van deze vier elementen volstaat opdat de exploitant kan worden aansprakelijk gesteld: het gedrag van de exploitant is immers irrelevant. Anders gezegd: de aansprakelijkheid bestaat zodra de vier elementen zijn bewezen ${ }^{50}$

De exploitant zal zich bijgevolg niet kunnen bevrijden door te bewijzen dat hij geen fout heeft gemaakt, of dat hij alle veiligheidsmaatregelen heeft nageleefd; het gedrag van de exploitant is volkomen irrelevant bij het beoordelen van diens aansprakelijkheid. Ook het bewijs dat het ongeval door een derde of door het slachtoffer zelf is veroorzaakt, is niet dienend. Een persoon die wenst te ontsnappen aan een tegen hem ingestelde vordering voor schade uit een kemongeval, zal moeten bewijzen hetzij dat geen schade werd veroorzaakt, hetzij dat er geen kemongeval heeft plaatsgevonden, hetzij dat er geen causale relatie bestaat tussen het kernongeval en de schade, hetzij dat hij geen exploitant is, c.q. niet de exploitant is van de keminstallatie waar het ongeval werd veroorzaakt, hetzij dat hij zich in een van de in het Verdrag opgesomde restrictieve gevallen van overmacht bevindt.

Uit bovenstaande analyse blijkt dat de Verdragspartijen bij het Verdrag van Parijs onmiskenbaar een risicoaansprakelijkheid op het oog hadden die strenger was dan de "gewone" risicouansprakelijkheid, in die zin dat de exploitant geen beroep kan doen op cnkele klassieke overmachtgronden. Maar doordat hij nog steeds een beroep kan doen op een aantal "strengere" gevallen van overmacht, is zijn aansprakelijkheid niet geheel absoluut. Anderzijds is vooral opmerkelijk dat de aansprakelijkheid van andere personen, behoudens bij overmacht, op andere juridische gronden, is uitgesloten. In feite kan dus eerder worden gesproken van een semi-absolute maar exclusicve aansprakelijkheid van de exploitant ${ }^{5 t}$. Een aantal auteurs omschrijft de aansprakelijkheid van de

\footnotetext{
48

Deprimoz, J., "Relations des exploitants et de leurs assureurs avec les organismes de protection sociale: au cours des procédures d'indemisation des dommages aux personnes", o.c., 11.5.3-16.

Deprimoz, J., "Relations des exploitants et de leurs assureurs avec les organismes de protection sociale au cours des procédures d'indemisation des dommages aux personnes", o.c., 11.5.3-18. Dit is de omschrijving die Comelis geeft aan aansprakelijkheid van rechtswege (Cornelis, L., "Beginselen", l.c. 618).

Ook Boyle stelt dat de aansprakelijkheid van de exploitant van een keminstallatie onder het internationale kemenergierecht ergens het midden houdt tussen de absolute aansprakelijkheid zoals ter zake. de aansprakelijkheidswetgeving voor de schade veroorzaakt door ruimtetuigen (Ruimte-aansprakelijk-
} 
exploitant toch als absolute aansprakelijkheid en brengt deze in verband met de kanalisatie van aansprakelijkheid ${ }^{52}$ : elke uitzondering op de aansprakelijkheid van de exploitant zou immers met zich meebrengen dat andere personen dan de exploitant, op basis van het gemene aansprakelijkheidsrecht, kunnen worden aansprakelijk gesteld ${ }^{53}$.

Hiermee komt de bespreking van de risicoaansprakelijkheid onder het internationale kernenergierecht dicht in de buurt van de bespreking van de kanalisatie van aansprakelijkheid naar de exploitant. Dit begrip wordt in paragraaf 2 aan de orde gesteld. Hieronder wordt eerst besproken op welke wijze de risicoaansprakelijkheid van het kernenergierecht werd ingevoerd in de Belgische en de Nederlandse rechtsorde.

\subsection{Volge'ns de Belgische wet van 22 juli 1985}

Artikel 5 van de wet van 22 juli 1985 bepaalt dat de exploitant van een kerninstallatie overeenkomstig de bepalingen van het Verdrag van Parijs, van het Aanvullend Protocol en van deze wet, aansprakelijk is voor de door een kernongeval veroorzaakte schade.

De invoering van de risicoaansprakelijkheid werd in de voorbereidende werkzaamheden gezien als het hoofdobjectief van het Verdrag van Parijs ${ }^{54}$. Doordat het slachtoffer wordt ontslaan van de plicht tevens een fout in hoofde van de exploitant van een keminstallatie te bewijzen, werd geoordeeld dat het slachtoffer in een veel comfortabelere positic zit dan in het gemeenrechtelijk aansprakelijkheidsregime.

Volgens de Memorie van Toelichting vloeit uit de wettelijke aansprakelijkheid voort dat geen enkele vordering kan worden ingesteld tegen een andere persoon en dat elk verhaal van de exploitant is uitgesloten ${ }^{55}$. Volgens de Raad van State leidt de risicoaansprakelijkheid ertoe dat alle vorderingen moeten worden gericht tegen de ene exploitant, met uitsluiting van alle andere personen $^{56}$. Ook in de Senaatscommissie verklaarde de minister dat het gevolg van deze risicoaansprakelijkheid erin bestaat dat een slachtoffer niet meer over de mogelijkheid beschikt om te kiezen tussen deze bijzondere wet en het gemene recht en dat het evenmin mogelijk is om de vergoeding bekomen op grond van de bijzondere wet aan te vullen door een beroep te doen op het gemene recht $^{57}$. Hier werden duidelijk de begrippen risicoaansprakelijkheid en kanalisatie van aansprakelijkheid met elkaar verward ${ }^{5 s}$.

Artikel 3 bepaalt dat de exploitant aansprakelijk is totdat de keminstallatie volledig is gesloten. De Koning bepaalt, met inachtneming van criteria die hij zelf vaststelt, bij een in Ministerraad overlegd besluit, de datum waarop de sluiting van iedere kerncentrale geacht wordt vast te staan.

heidsverdrag van 1972) en de risicoaansprakelijkheid zoals onder de Verdragen inzake aansprakelijkheid voor olieverontreiniging op zee (CLC-Conventie van 1969) (Boyle, A.E., "Nuclear energy and international law: an environmental perspective", o.c., 303).

Goldie, L.F.E., "Liability for damage and the progressive development of international law", oc.. 1216.

Doeker, G. en Gehring, T., "Private or International Liability for Transnational Environmental Damage - the precedent of conventional liability regimes", o.c., 9.

Memorie van Toelichting, Parlementaire Stukken, Senaat, GZ/1983-1984, 593/1, 2.

Memorie van Toelichting, Parlementaire Stukken, Senaat, GZ/1983-1984, 593/1, 7.

Advies Raad van State, Parlementaire Stukken, Senaat, GZ/1983-1984, 593/1, 32.

Verslag namens de commissie voor economische aangelegenheden, Parlementaire Stukken, GZ/1983$1984,593 / 3,32$.

Cfr. infra in $\$ 2$ bij de bespreking van de kanalisatie van aansprakelijkheid. 
Het doel van deze bepaling is dat een exploitant aansprakelijk blijft zolang er besmettingsgevaar is en dat duidelijk wordt aangegeven dat de aansprakelijkheid van de exploitant loopt tot aan de definitieve sluiting van de kerninstallatie ${ }^{59}$. In de Senaatscommissie benadrukte de Minister dat het onmogelijk is ecn alomvattende definitie te geven voor de term "sluiting", of om zelfs maar een lijst op te stellen met de opsomming van de mogelijke gevallen van sluiting. Het zou in eenieders belang zijn om in elk geval afzonderlijk te onderzoeken of het besmettingsgevaar nog anwezig is of niet ${ }^{60}$.

De Belgische wetgever heeft van de in artikel 9 van het Verdrag van Parijs geboden mogelijkheid gebruikt gemaakt om de exploitant aansprakelijk te stellen voor kernongevallen veroorzaakt door een natuurramp van uitzonderlijke aard. Blijkbaar was de wetgever van oordeel dat de exoneratic van de exploitant ingeval van natuurramp, strijdig was met het in de wet voorziene regime van risicoaansprakclijkheid ${ }^{61}$. Toch is een klein verschil vast te stellen tussen de tekst van het Verdrag van Parijs en de tekst van de wet: de wet het heeft over een natuurramp van uitzonderlijke aard, terwijl het Verdrag van Parijs het heeft over een "ernstige natuurramp van uitzonderlijke aard".

In de Senaatscommissie werd de vraag gesteld waarom inzake overmacht, geen bepalingen werden voorzien inzake sabotage of terrorisme, waarbij werd voorgestcld om de daaruit voortvloeiende schade te laten vergoeden door een speciaal daartoe opgericht Rampenfonds ${ }^{62}$. Het is evenwel niet duidelijk waarom aan deze vraag geen verder gevolg gegeven.

Artikel 6 van de wet van 22 juli 1985 sluit de schade aan de keminstallatie en aan goederen die op het terrein worden gebruikt in verband met deze installatie uit; hicrmee moet worden belet dat de aansprakelijkheid van de exploitant grotendeels zou worden opgeslorpt door de schade aan de kerninstallatie $z$ elf ${ }^{63}$. Verder wordt verduidelijkt dat de exploitant niet aansprakclijk zal zijn voor gehuurde nucleaire stoffen en producten die door klanten van de kerninstallatie worden aangeboden voor bestraling of bewerking. De exploitant behoudt evenwel de mogelijkheid om contractueel in een verhaal te voorzien, zonder dat dit verhaal de wettelijke aansprakelijkhcid mag aantas$\operatorname{ten}^{64}$.

Volgens de Belgische wet is de exploitant echter wél aansprakelijk voor schade veroorzaakt aan het vervoermiddel (artikel $6,2^{\circ}$ van de wet).

Artikel 21 stelt dat gerechtigden op een stelsel van sociale zekerheid of vergoeding van arbcidsongevallen of beroepsziekten, zelfs bij kemongeval, aan dat stelsel onderworpen blijven. De Memorie van Toelichting laat er weinig twijfel over bestaan dat dit artikel zowel van toepassing is op aangestelden van de exploitant als op andere arbeiders tewerkgesteld door de exploitant ${ }^{65}$. Dit artikel is dus niet alleen van toepassing op werknemers van de exploitant ${ }^{66}$. De verwijzing naar het begrip werknemer in de voorbereidende werken kan inderdaad leiden tot enige verwarring

Parlemeniaire Stukken, Senaat, GZ 1983-1984, 593/2, 2.

Parlementaire Stukken, Senaat, GZ 1983-1984, 593/3, 29

Conruyt, H. en Rivalet, F., "Champ d'application de la Législation Belge sur la Responsabilitć (.ivile Nucléaire", o.c., 66 .

Verslag namens de commissie voor economische aangelegenheden, Parlementaire Stukken, GZ/1983$1984,593 / 3,27$.

Memorie van Toelichting, Senaat, Parlementaire Stukken, GZ'1983-1984, 593/1, 7.

Memorie van Toelichting, Senaat, Parlementaire Stukken, G2/1983-1984, 593/1, 7.

Memorie van Toelichting, Parlementaire Stukken, Senaat, GZ/1983-1984, 593/1, 14.

A contrario: Veuchelen, L., "Civielrechtelijke aansprakelijkheid voor kemongevallen naar Belgisch recht", in Faure, M. (red.), "Aansprakelijkheid voor het nucleaire risico", l.c., 49. 
ondat dit doet vermoeden dat hiermee de werknemer van de exploitant wordt bedoeld. Dit hoeft echter niet noodzakelijk het geval te zijn: de verwijzing naar "de werknemer" is in feite gewoon overgenomen vanuit het sociaal zekerheidsrecht. De gerechtigde bij uitstek van een systeem van sociale zekerheid is immers een (ex-)werknemer. Artikel $21, \S 1$ wil enkel aangeven dat niet wordt geraakt aan het Belgische sociale zekerheidsstelsel, en dat dit stelsel onder invloed van het nucleaire aansprakelijkheidsrecht niet wordt uitgebreid, noch beperkt ${ }^{67}$. Concreet impliceert dit dat persoonsschade veelal in eerste instantie zal worden vergoed door tussenkomst van het stelsel van sociale zekerheid.

De vraag rijst vervolgens of het slachtoffer nog over een verhaalsrecht beschikt tegen de exploitant voor die schade die niet wordt vergoed door het sociale zekerheidsstelsel. Artikel $21,2^{\circ}$ lid stelt in dat verband dat de schade die niet is vergoed door het sociale zekerheidsstelsel in aanmerking komt voor vergoeding op basis van het nucleaire aansprakelijkheidsrecht, "voorzover deze gerechtigden een vordering naar gemeen recht kunnen instellen tegen de exploitant". Het begrip "vordering naar gemeen recht" vergt in deze context nadere toelichting. Het betekent geenszins een gemeenrechtelijke aansprakelijkheidsvordering ex artikel $1382 \mathrm{BW}$ e.v., noch een vordering gebaseerd op de wet van 22 juli 1985. Bedoeld wordt een vordering gebaseerd op de arbeidsongevallenwetgeving ${ }^{68}$.

De instanties die in dit kader een uitkering hebben verricht, beschikken tegen de exploitant, tegen zijn verzekeraar of tegen de Staat over "het verhaalsrecht (...) dat hun krachtens dic stelsels is toegekend"(artikel 21, $\S 3$ van de wet). Bovendien kan dit regresrecht in geen geval leiden tot cen overschrijding van de bedragen waarvoor de exploitant en de Staat aansprakelijk zijn. Van belang is vooral het feit dat de instellingen die een uitkering hebben verricht enkel over een verhaalsrecht beschikken indien de sociale zekerheidswetgeving dit toelaat.

Vermeldenswaard is tenslotte artikel 24 van de wet op basis waarvan het slachtoffer geen recht op schadevergoeding heeft indien het kemongeval opzettelijk door het slachtoffer werd veroorzakt.

\subsection{Volgens de Nederlandse WAKO yan 26 juni 1991}

Artikel 2 van de WAKO geeft uitvoering aan de bepalingen van het Verdrag van Parijs. De Nederlandse wetgever hanteerde bijgevolg een andere wetgevingstechniek dan de Belgische wetgever. Eerder dan alle bepalingen van het Verdrag over te nemen in een eigen nationale wet, werd voorzien in een artikel dat op algemene wijze de Verdragsbepalingen invoert in de Nederlandse rechtsorde ${ }^{70}$. De WAKO gecf aldus slechts een aanvullende regeling betreffende een aantal

Memorie van Toelichting, Parlementaire Stukken, Senaat, GZ/1983-1984, 593/1, 14.

Pariementaire Siukken, Senaat, GZ/1983-1984, 593/3, 52-53.

Bij een arbeidsongeval kunnen slachtoffers bij toepassing van artikel $46, \S 1$ van de wet op de arbeidsongevallen een vordering instelien tegen de werkgever die het arbeidsongeval opzettelijk heeft veroorzaakt of die opzettelijk een ongeval heeft veroorzaakt dat een arbeidsongeval tot gevolg heeft; tegen de werkgever wanneer het arbeidsongeval schade heeft veroorzaakt aan goederen van de werknemer, $\mathrm{l}$ gen de lasthebber of aangestelde van de werkgever die het arbeidsongeval opzettelijk heeft veroorzaakt; tegen andere personen dan de werkgever, zijn lasthebbers of aangestelden die aansprakelijk zijn voor het ongeval; tegen de werkgever, zijn lasthebbers of aangestelden indien het ongeval zich voordoet op weg van een naar het werk.

Memorie van Toelichting, Tweede Kamer, zitting 1975-1976, 13 928, nr. 5, 26. 
punten die niet in het Verdrag van Parijs zijn geregeld of waarbij het Verdrag aan de Verdragsluitende Staten een keuze heeft gelaten ${ }^{71}$.

In de WAKO van 17 maart 1979 waren geen afzonderlijke bepalingen opgenomen met betrekking tot overmacht. Bijgevolg was de exploitant van een in Nederland gelegen keminstallatie niet ansprakelijk indien het kernongeval was veroorzaakt door een emstige natuurramp van uitzonderlijke aard. Van de in het Verdrag geboden mogelijkheid om de exploitant in deze hypothese wel aansprakelijk te stellen, werd gebruikt gemaakt ter gelegenheid van de ingrijpende wijzigin* gen die in 1991 aan de WAKO werden aangebracht ${ }^{72}$.

De invoering van de aansprakelijkheid van de exploitant bij een ernstige natuurramp van uitzonderlijke aard, werd wenselijk geacht omdat enkele buurlanden van Nederland (waaronder Duitsland en België) een analoge regeling hadden. Daarnaast zou door de invoering van de aansprakelijkheid van de exploitant bij een natuurramp, worden voldaan aan de wederkerigheidseis ten aanzien van Duitsland ${ }^{73}$. Bovendien zou de aansprakelijkheid voor ernstige natuurrampen van uitzonderlijke aard perfect aansluiten bij de risicoaansprakelijkheid van het Verdrag van Parijs, in die zin dat door het exploiteren van een kerninstallatie ook risico's worden verhoogd die door van buiten komende oorzaken kunnen ontstaan ${ }^{74}$.

Vrij opvallend is dat meermaals en vanuit verschillende fracties werd gewezen op de onduidelijkheid met betrekking tot het begrip "ernstige natuurramp van uitzonderlijke aard". Zo werd onder meer de vraag gesteld of de schade uit een kemongeval veroorzaakt door demonstratieve acties, al dan niet onder de exoneratie viel. Het antwoord luidde dat voorzover de demonstratieve acties niet konden worden beschouwd als een burgeroorlog of opstand, de exploitant hiervoor wel degelijk aansprakelijk was ${ }^{75}$.

De WAKO bevat geen specifieke bepalingen inzake de hoofdelijke aansprakelijkheid van exploitanten of inzake regres. Door de algemene tocpasselijkheid van het Vurdrag van Parıjs, volstaat het on te verwijzen naar de bepalingen van het Verdrag.

Artikel 20 van de WAKO van 1991 bevat een bepaling ter zake van de toepasselijkheid van de sociale wetgeving op slachtoffers van het kernongeval. Dit artikel was overigens reeds opgenomen als artikel 30 van de WAKO van 1979 én als artikel $7,8^{\circ}$ van de wet van 27 oktober 1965 . In 1979 werd de redactie van dit artikel aangepast aan de inmiddels gewijzigde Nederlandse sociale wetten $^{76}$. De regeling komt erop neer dat slachtoffers hun schade inderdaad kunnen vergoeden via het stelsel van de sociale zekerheid. Ook hier geldt dat de overige bepalingen van het sociale zekerheidssysteem van kracht blijven. Maar uit onderzoek is gebleken dat het Nederlandse sociale zckerheidsstelsel in de regel elk regres uitsluit ${ }^{77}$.

Memorie van Toelichting. Tweede Kamer, zitting 1987-1988, 20 374, nr. 3, 1

Voor een vergelijking van de oude en de nieuwe WAKO, zie. Van Maanen, G.E., "De civielrechtelijke. aansprakelijkheid voor kernongevallen naar Nederlands recht", in Faure, M., (red.), "Aansprakelijkheid. voor het nucleaire risico", l.c., 20 e.v.

Memoric van Toelichting, Tweede Kamer, zitting 1987-1988, 20 374, nr. 3, 3. Zie ook hierboven, $\$ 1.4$ van hoofdstuk 3.

Nota naar aanleiding van het verslag, Tweede Kamer, zitting 1987-1988, $20374, \mathrm{nr} .9,3$.

Memorie van Antwoord, Tweede Kamer, zitting 1987-1988, 20 374, nr. 6, 5.

Memorie van Toelichting, Tweede Kamer, zitting 1975-1976, 13 928, nr. 5, 34-35.

Deprimoz, J., "Relations des exploitants et de leurs assureurs avec les organismes de protection sociale au cours des procédures d'indemisation des dommages aux personnes", o.c., II.5.3-11. 
Dit betekent dat de exploitanten van een Nederlandse kerninstallatie ten aanzien van slachtoffers onderworpen aan het Nederlandse stelsel van sociale zekerheid, enkel deze persoonsschade zullen dienen te vergoeden die niet wordt vergoed door dit stelsel. Daarenboven kan dit tot de nodige problemen leiden bij grensoverschrijdende schade uit een kernongeval. Het is onduidelijk wat het regime zal zijn van de vorderingen vanwege de instellingen die op basis van het Belgische sociale zekerheidsstelsel uitkeringen hebben vernicht. Het Verdrag van Parijs laat dit stelsel intact, maar het is niet uitgesloten dat bij toepassing van de lex for $a$ geen voorrang wordt verleend aan deze vorderingen. Vanuit het standpunt van het slachtoffer is deze situatie overigens niet meteen dramatisch: zijn schade werd immers vergoed. Vanuit het standpunt van de preventieve werking van het aansprakelijkheidsrecht impliceert dit dat niet alle kosten van het kernongeval worden geinternaliseerd ${ }^{78}$.

\subsection{Risicoaansprakelijkheid naar toekomstig recht}

Tot slot moet de vraag worden beantwoord of het Protocol van het Verdrag van Wenen en/of het Verdrag inzake Bijkomende Compensatie van september 1997 en de voorstellen voor de revisie van het Verdrag van Parijs wijzigingen aanbrengen aan het in het internationale nucleaire aansprakelijkheidsstelsel neergelegde beginsel van risicoaansprakelijkheid.

Het Verdrag inzake Bijkomende Compensatie is toegankelijk voor landen die zijn toegetreden tot het Verdrag inzake Nucleaire Veiligheid van 1994 en die hetzij zijn toegetreden tot het Verdrag van Parijs of Wenen, hetzij in hun interne wetgeving een aantal basisprincipes hebben opgenomen. De basisbeginselen waaraan de wetgeving dient te beantwoorden, zijn weergegeven in de annex van het Verdrag. Het wekt weinig verwondering dat onder meer is vereist dat de exploitant aansprakelijk is op basis van een regime van risicoaansprakelijkheid - het Verdrag zelf heeft het over de vereiste van een absolute aansprakelijkheid (artikel 3, $3^{\circ}$ van de Annex). Met betrekking tot overmacht, laat het Verdrag inzake Bijkomende Compensatie aan de Verdragsstaten de mogelijkheid om de exploitant toch aansprakelijk te stellen voor natuurrampen van uitzonderlijke aard. Hierboven werd reeds aangegeven dat een analoge bepaling is terug te vinden in het Verdrag van Parijs en dat België en Nederland van deze mogelijkheid hebben gebruik gemaakt.

Het Protocol van het Verdrag van Wenen brengt op zich geen wijziging aan aan de risicoaansprakelijkheid van de exploitant; wel wordt de positie van de exploitant in die zin verzwaard dat de nationale wetgeving niet meer kan voorzien in de exoneratie van zijn aansprakelijkheid bij natuurrampen van uitzonderlijke aard. Artikel 6, lid I wijzigt inderdaad artikel IV, lid 3 van het Verdrag van Wenen. Dit impliceert dat onder het IAEA-regime de exploitant ook aansprakelijk is voor de schade veroorzaakt door een natuurramp en dat de wetgeving van een land dat lid is van het Verdrag van Wenen hieromtrent geen uitzondering meer mag bevatten. Deze wijziging schijnt te zijn ingegeven door de technologische vooruitgang in het ontwerp en de bouw van keminstallaties? Deze zouden immers toelaten om een kerninstallatie te bouwen die voldoende stevig is om te weerstaan aan de kracht van een natuurramp.

In de huidige stand van zaken, ziet het er niet naar uit dat het Verdrag van Parijs op dit punt zal worden gewijzigd. Tenzij in de loop van de onderhandelingen nog andere voorstellen worden ingediend, lijkt het er dus op dat de mogelijkheid om een ernstige natuurramp als overmachtsgrond in te roepen, blijft behouden.

78

79
Zie verderop in de rechtseconomische analyse (deel 2).

Horbach, N.L.J.T., "Lacunae of International Nuclear Liability Agreements", in Horbach, N.L.J.T. (ed.), "Contemporary Developments in Nuclear Energy Law", l.c., 67. 


\subsection{Conclusie}

Het Verdrag van Parijs voert een regime in van risicoaansprakclijkheid in hoofde van de exploitant van een kerninstallatie. Deze vorm van risicoaansprakelijkheid gaat echter verder dan een aantal andere vormen van risicoaansprakelijkheid, waar de aansprakelijkc zich kan beroepen op de klassieke gevallen van overmacht of op een vreemde oorzaak. De aansprakelijkheid van de exploitant is dus vrij absoluut; geheel absoluut kan diens aansprakelijkheid niet worden genoemd, ondat bijvoorbeeld een burgeroorlog een geval van overmacht kan uitmaken. Vereist is wel dat de burgeroorlog rechtstreeks het kemongeval heeft veroorzaakt. Het zal aan de feitenrechter toekomen om dit te beoordelen.

De aansprakelijkheid van de exploitant strekt zich ook uit tot het transport van nucleair materiaal van en naar zijn site.

Ter zake van letselschade bevat het Verdrag van Parijs evenwel bepalingen die op procesrechtelijk vlak tot moeilijkheden aanleiding kunnen geven: het sociale zekerheidstelsel van elk land wordt intact gelaten en het recht van het land dat de uitkering heeft gedaan, zal bepalen of een regresrecht openstaat tegen de exploitant. Hicrmee zijn conflicten met het op het schadegeval toepasselijke recht niet uitgesloten. Op dit punt blijft de beoogde harmonisatie van het Verdrag van Parijs dus minstens ten dele achterwege.

Zowel de Nederlandse WAKO als de Belgische wet van 22 juli 1985 nemen de bepalingen van het Verdrag van Parijs over en maken gebruik van de mogelijkheid om de exploitant ook aansprakelijk te stellen indien een kernongeval wordt veroorzaakt door een ernstige natuumamp van uitzonderlijke aard.

\section{KANALISATIE VAN AANSPRAKELIJKHEID}

Een tweede basisprincipe van het nucleaire aansprakelijkheidsrecht is de kanalisatie van aansprakelijkheid naar de exploitant van een kerninstallatic. De term "kanalisatie van aansprakelijkheid" blijkt in de Europese rechtsorde te zijn geïntroduceerd via het internationale kernenergierecht; nadien werd dit begrip ook in andere rechtstakken, en in het bijzonder in het milieuaansprakelijkheidsrecht overgenomen ${ }^{80}$. Centraal in deze paragraaf staat de inhoud van de term "kanalisatie van aansprakelijkheid" in het nucleaire aansprakelijkheidsrecht en in het milicuaansprakelijkheidsrecht - al wordt incidenteel ook het gemene civielrechtelijke aansprakelijkheidsrecht aan de orde gesteld.

Aan de kanalisatie van aansprakelijkheid zal uitgebreid aandacht worden besteed omdat het, zoals zal blijken, kan leiden tot een verregaande ingreep in het gemene aansprakelijkheidsrecht. Daarenboven is de kanalisatie van aansprakelijkheid, hoewel totstandgekomen in het kemenergierecht rond 1959, een zeer actueel thema en dit zowel binnen het (intemationale) kemenergierecht als daarbuiten. In de jaren negentig kwam de kanalisatie van aansprakelijkheid naar de exploitant van een keminstallatie opnieuw in de belangstelling, onder meer door de val van de Berlijnse muur: de levering van westers nucleair materiaal aan de landen van het voormalige Oostblok werd belemmerd doordat deze landen niet waren toegetreden tot het Verdrag van Wenen en doordat de

Het gebruik van het begrip "kanalisatie van aansprakelijkheid" in het internationale recht, is niet alleen bekend van het nucleaire aansprakelijkheidsrecht, maar eveneens van de verdragen inzake de aansprakelijkheid voor schade door olieverontreiniging op zee (CLC-Verdrag van 1969). Cfr. infra, hoofdstuk 12. 
nucleaire wetgeving in die landen de aansprakelijkheid niet naar de exploitant van de kerninstallatie kanaliseerde. Ook bij de wijziging van de Oostenrijkse nucleaire aansprakelijkheidswet, die in 1999 van kracht werd, vormde de kanalisatie van aansprakelijkheid cen belangrijk thema.

De kanalisatie van aansprakelijkheid is ook actueel buiten het kernenergierecht, met name in het milicuaansprakelijkheidsrecht. In België heeft de Interuniversitaire Commissie tot Herziening van het Milieurecht in het Vlaamsc Gewest voorgesteld om de kanalisatie in te voeren met betrekking schade veroorzaakt door emissie; in Nederland werd de aansprakelijkheid gekanaliseerd via de invoering van enkele nicuwc kwalitatieve aansprakelijkheden in het NBW in 1995. Uit het onderzoek <al blijken dat kanalisatic overigens niet is beperkt tot het milieuaansprakelijkheidsrecht, maar evenzeer wordt gehanteerd bij verschillende aansprakelijkheidsvormen buiten het milieurecht.

Doordat kanalisatie van aansprakelijkheid ook in andere rechtstakken dan in het kernenergierechi wordt gebruikt, is het interessant om na te gaan welke de redenen waren om de aansprakelijkheid te kanaliseren naar de exploitant van cen kerninstallatie, en om te onderzoeken of dezelfde redenen kunnen worden ingeroepen om bijvoorbeeld in het milieurecht de aansprakelijkheid te kanaliseren naar een bepaalde persoon. Daarnaast zal worden aangetoond dat het gebruik van het begrip kanalisatie van aansprakelijkheid in het kernenergierecht en daarbuiten heeft geleid tot een begrippenvervuiling.

In eerste instantie wordt onderzocht hoe en in welke context de kanalisatie van aansprakelijkheid is ontstaan $(\S 2.1)$. Met name wordt de historische rol belicht die de Verenigde Staten hebben gespeeld bij de ontwikkeling van kernenergie kort na de Tweede Wereldoorlog. In tweede instantie wordt aandacht besteed aan de kanalisatie van aansprakelijkheid in het kernenergierecht $(\S 2.2)$. Hicrbij wordt zowel aandacht bestecd aan de Verdragsbepalingen, aan de omschrijving van kanalisatie in het Belgische en Nederlandse kemenergierecht, als aan de weerstand tegen de invoering van deze kanalisatie en aan de rol die de VS in dat kader hebben gespeeld. In $\S 2.3 \mathrm{zal}$ worden aangegeven dat ook buiten het kernenergierecht de aansprakelijkheid wordt gekanaliseerd naar bepaalde personen. Dankzij de vergelijking van de kanalisatie van aansprakelijkheid in en buiten het kemenergierecht, zal worden getracht om in $\S 2.4$ het begrip kanalisatie af te bakenen. In $\S 2.5$ tenslotte, worden enkele conclusies getrokken over het begrip "kanalisatie van aansprakelijkheid". 


\subsection{Ontstaan van de juridische constructie "kanalisatie van aansprakelijkheid" 81}

Het ontstaan van de term "kanalisatie van aansprakelijkheid", kan enkel worden verklaard tegen de achtergrond van het Amerikaanse monopolie bij de ontwikkeling van kemenergie in het begin van de jaren vijftig. Dit monopolie was wettelijk vastgesteld. Bijgevolg wordt in eerste instantie het ontstaan toegelicht van het Amerikaanse nucleaire aansprakelijkheidsrecht $\left(\begin{array}{l}\$ \\ \$\end{array} 2.1 .1\right)$. Vervolgens wordt aandacht besteed aan twee in opdracht van het Amerikaanse "Atomic Industrial Forum" geschreven documenten die aan de basis liggen van de kanalisatie van aansprakelijkheid, en an de basis van de nucleaire aansprakelijkheidswetgeving: ten eerste het Preliminary Report on Financial Protection against Atomic Hazards $(\$ 2.1 .2)$ en ten tweede het daarop voortbouwende International Problems of Financial Protection against Nuclear Risk ( $\$ 2.1 .3)$. Uit deze twee rapporten zal blijken dat kanalisatie van aansprakelijkheid werd ingevoerd samen met een aantal andere maatregelen. In $\$ 2.1 .4$ wordt aangegeven welke conclusies kunnen worden getrokken uit de analyse van deze rapporten.

\subsubsection{Ontstaan van het Amerikaanse nucleaire aansprakelijkheidsrecht ${ }^{82}$}

In deze paragraaf wordt chronologisch de totstandkoming geschetst van het Amerikaanse nucleaire aansprakelijkheidsrecht. De eerste Amerikaanse wet ter zake, de Atomic Energy Act van 1946, die een overheidsmonopolie invoerde voor het bezit en het beheer van kerninstallaties, wordt besproken in $\S 2.1 .1 .1$. Aan dit monopolie werd een einde gesteld door de wijzigingen die aan de Atomic Energy Act werden aangebracht in 1954 (\$ 2.1.1.2).

\subsubsection{De Atomic Energy Act van 1946}

De cerste kennismaking van de mensheid met het fenomeen kernenergie was van militaire aard, met name door de atoombommen op Hiroshima en op Nagasaki, respectievelijk op 6 en 9 augustus 1945. Deze bommen werden gemaakt in het kader van het in augustus 1942 opgerichte Manhattan Engineer District (MED), dat deel uitmaakte van het Ministerie van Oorlog ${ }^{83}$. De ontwik-

Zie meerdere bijdragen in het bock Albonetti, Belser e.a. Droit Nucléaire Européen, Presses universitaires de France, 1968, 268. (dit boek is de weergave van de verschillende bijdragen aan de conferentie gehouden te Parijs op 5 en 6 mei 1966). Zié in dit boek Fischerhof, H., "Essai d'une théorie juridique de la canalisation de la responsabilité sur l'exploitant d'une installation nueléaire", 111-!20 en Demoures. Y. "La responsabilité de l'exploitant nucléaire au regard de la réglementation française de la responsabilité civile", 121-132. En verder Fischerhof, H., "Das Problem einer dogmatischen Begründung der rechtlichen Kanalisienung der Haftung auf den Betrieber einer Kernanalage", Versicherungsrecht, 1966, 601 en Pelzer, N., "Die rechtliche Kanalisierung der Haftung auf den Inhaber einer Atomanlage - ein juristischer und wirtschaftlicher Fehigrift?", Versicherungsrecht, 1966, 1010; zie ook onze eerdere analyse: Vanden Borre T., "Transplantatic van kanalisatie van aansprakelijkheid van het kemenergierecht naar het milieu(aansprakelijkheids)recht: een goede of een gebrekkige zaak?", in Faure, M. en Deketelaere, K., (red.), "Ius Commune en Milieurecht", l.c., 331-382 en Vanden Borre, T., "Channelling of Liability: A Few Juridicial and Economic Views on an Inadequate Legal Construction", in Horbach, N.L.J.T. (ed.), "Contemporary Developments in Nuclear Energy Law", l.c., 13-39.

Hier kan ook worden verwezen naar de bespreking van het ontstaan van het kernenergierecht in hoofdstuk 2. Deze analyse sluit daar nauw op aan, met dien verstande dat in deze paragraaf de klemioon ligt op de wijze waarop de samenwerking met de VS contractueel werd geregeld, en uiteraard op de aansprakelijkheid bij ongevallen. Het huidige Amerikaanse nueleaire aansprakelijkheidsrecht, met name de Price-Anderson Act, wordt in hoofdstuk 13 aan de orde gesteld.

The Manhattan Project. Making the Atomic Bomb. United States Department of Energy, Energy History Series, september 1994, 13. Smyth, H.D., Atomic energy for military purposes. The official report 
keling van deze bommen vereiste evenwel enorme investeringen die niet enkel door de overheid konden worden gedragen. Daarom zocht het MED voor haar activiteiten industriële partners die de overheid hielpen bij de constructie en het beheer van de kerninstallaties. Deze privépartners van de overheid vroegen evenwel in ruil voor hun participatie dat zij schadeloos zouden worden gesteld omdat een verzekeringsdekking voor deze activiteiten niet beschikbaar was. Aan deze vraag werd tegemoet gekomen: de contracten met MED bevatten een hold harmless clausule op basis waarvan de contractanten gevrijwaard bleven tegen elk verlies, alle kosten of elke vordering of schade veroorzaakt in samenhang met de uitvoering van het contract ${ }^{84}$.

Na de tweede wereldoorlog, brak in de Verenigde Staten discussie los met betrekking tot de toekomst en het statuut van het Manhattan Project. Niet zozeer de bevoegdheden van het te creëren organisme vormden het voorwerp van de discussie, maar wel de vraag of militairen dan wel burgers controle zouden uitoefenen over het organisme, c.q. of militairen dan wel burgers de zeggenschap kregen over de verdere ontwikkeling van kemenergic.

Deze discussie - die niet los kan worden gezien van de besprekingen die na het einde van de tweede wereldoorlog hebben plaatsgehad tussen de VS en de Sovjet-Unie met betrekking tot de oprichting van een systeem van internationale controle op de verspreiding van kernmateriaal en nucleaire kennis ${ }^{85}$ - vond haar weerslag in twee wetsvoorstellen: enerzijds de May-Johnson Bill en anderzijds de McMahon Bill ${ }^{86}$. Het voorstel van May-Johnson van 3 oktober 1945 voorzag in een strikte militaire controle - en dus de facto in de voortzetting van het Manhattan Project in vredestijd. Het leger achtte een dergelijke strikte controle en de daarmee gepaard gaande strikte geheimhoudingsverplichtingen essentieel indien de Verenigde Staten hun voorsprong op het gebied van kemenergie wensten te behouden. Voor de meeste wetenschappers die aan de basis lagen van de ontwikkeling van de atoombom daarentegen was dit wetsontwerp onaanvaardbaar: de May-Johnson Bill bevestigde de militaire controle over de verdere ontwikkeling van kernenergie, hetgeen enkel aanvaardbaar was in oorlogstijd. De wetenschappers waren dan ook voorstander van een "civiele" controle, en van een grote internationale samenwerking in het domein van kernenergie. Een te strikte geheimhouding zou hun wetenschappelijke onafhankelijkheid in het gedrang kunnen brengen en zou aan de rest van de wereld de indruk kunnen geven dat de Verenigde Staten enkel waren geïnteresseerd in militaire toepassingen van kernenergie ${ }^{87}$.

on the Development of the Atomic Bomb under the auspices of the U.S. government, Princeton, 1946, 45-54.

84 Brown, O.F., II, "Legislative History of Govemment Indemnification Under the Price Anderson Ad", paper gepresenteerd voor The Price-Anderson Contractors Policy Issues Study, september 1984, 2-3. Cir. supra, in $\$ 1.1$ van hoofdstuk 2.

s6 Meteen na het einde van de tweede wereldoorlog rees de vraag welke houding de VS, gelet op hun voorsprong op het gebied van kemenergie, dienden in te nemen tegenover de internationale gemeenschap: dienden de gegevens te worden vrijgegeven of diende de grootste geheimhouding te worden bewaard? Niels Bohr was voorstander van een verregaande internationale samenwerking en volledige publiciteit van het MED. Deze visie stuitte evenwel op het veto van Roosevelt en Churchill die de Amerikaans-Britse voorsprong wensten te consolideren. De meeste wetenschappers steunden evenwel de idee van Bohr om een deel van de informatie van het MED vrij te geven. In hun visie zou de voorsprong van de VS binnen drie jaar na het einde van de tweede wereldoorlog zijn ingehaald en kon een bescherming tegen de ontwikkeling van zwaardere kernwapens enkel worden geboden door internationale afspraken met tot doel te vermijden dat bepaalde landen in het geheim zouden werken aan de ontwikkeling van hun eigen kernwapen. Deze visie kreeg uiteindelijk de vorm van een officieel Amerikaanse plan inzake internationale controle inzake kemenergie, het Baruch-plan (cfr. infra). 
De McMahon Bill daarentegen plaatsie de verdere ontwikkeling van kernenergie onder civiele controle. De visie van de wetenschappers heeft het uiteindelijk gehaald: de McMahon Bill werd als "Atomic Energy Act" goedgekeurd op I augustus 1946. Deze wet voorzag onder meer in de overdracht van bevoegdheden van het Amerikaanse leger aan de Atomic Energy Commission (USAEC) $)^{88}$, een vijfkoppige uit burgers samengestelde commissie. Bij het in werking treden van de McMahon Bill op 1 januari 1947 werd het MED opgevolgd door de Amerikaanse USAEC ${ }^{89}$. Via deze overdracht van bevoegdheden aan een uit burgers samengestelde commissie, wensten de VS de rest van de wereld te overtuigen van hun vredelievende bedoelingen inzake de verdere ontwikkelingen op het gebied van kemenergie ${ }^{90}$.

Onder de Atomic Energy Act van 1946 werd de ontwikkeling van kernenergie weliswaar via de oprichting van de USAEC onder de controle van burgers geplaatst, toch bleef - zeker in het licht van de steeds toenemende spanningen tussen de VS en de voormalige Sovjet-Unie en het daaruit voortvloeiende begin van de koude oorlog - de nadruk liggen op strikte geheimhouding uit vrees dat ook andere landen zouden beschikken over de kennis en technologie inzake de productie van kernwapens. De Amerikaanse regering bevestigde inderdaad haar intentic om een strikte controle op nucleaire technologie te behouden en om kernenergie verder voor militaire doeleinden aan te wenden ${ }^{91}{ }^{92}$. Het basiskenmerk van de Atomic Energy Act van 1946 was dan ook dat de Amerikanse overheid een monopolie had over nucleaire technologie en kennis ${ }^{93}$; het was aan privéondernemingen absoluut verboden was om op eigen initiaiief commerciële nucleaire activiteiten te ontwikkelen. Op deze wijze werd het feitelijke monopolie van de VS inzake het gebruik van kernenergierecht, verankerd in een wet ${ }^{94}$.

Gelet op de enorme investeringen die met de ontwikkeling van kemenergie gepaard gingen, deed de Amerikaanse overheid uitgebreid beroep van private ondernemingen - hetgeen zij ook al had gedaan tijdens de oorlog. Belangrijk element hierbij is dat de contracten dic voorheen door de MED waren afgesloten met de industrie, door de USAEC werden "geërfd". De USAEC kreeg inderdaad de bevoegdheid om contracten af te sluiten met private ondernemingen met dien verstande dat de USAEC eigenaar bleef van al het splijtbaar materiaal en van de technologie die zich

Het betreft de Amerikaanse Atomic Energy Commission; deze mag niet worden verward met de UN Atomic Energy Commission, opgericht in 1946 in de schoot van de UNO-Veiligheidsraad (zie voor meer details: Kocymans, P.H., "The Peaceful Application of Nuclear Power and the Non-Proliferation System". Proliferation and the Safeguarding of the Peaceful Application of Nuclear Power, Koninklijk Instituut van Ingenieurs Kerntechniek. The Hague Symposium, 9 december 1976; Scheinman, L., The International Atomic Energy Agency and the World Nuclear Order, Resources for the Future, 1987; Vanden Borre, T. en Carchon, R., "Preventing the Proliferation of Nuclear Weapons: 50 Years of Atoms for Peace", o.c., 24 e.v.).

The Manhatian Project, 57.

Fischer, G., "Energic Atomique et les Etats-Unis", l.c., 247.

A Short History of Nuclear Regulation, 1946-1992, NRC, Internet: http://wwww.nrc.gov.

Nochtans werd ook gerefereerd naar de potentiêle vredelievende toepassingen van kemenergie. "Subject at all times to the paramount objective of assuring the common defense and security, the development and utilization of atomic energy shall, so far as practicable, be directed toward improving the public welfare, increasing the standard of living, strengthening free competition in private enterprise, and promoting world peace" ( $\$ 1$ (a) van de Atomic Energy Act van 1946).

Rockett, L. R., Financial Protection against Nuclear Hazards: Thirty Years Experience under the Price Anderson- $\mathrm{Act}$, The Legislative Drafting Research Fund of Columbia University, januari 1984, I-2 (hiena genoemd: Columbia Rapport).

Zie hicrover Hollis, E.L., "The New Law in General", A Forum Report. The New Atomic Energy Law. What it means to Industry, congres onder auspiciën van de Atomic Industrial Forum Inc., november 1954, New York, 2 (hiema geciteerd als: "The New Atomic Energy Law"). 
op Amerikaans grondgebied bevonden en dat in de samenwerking strikte geheimhoudingsverplichtingen dienden te worden in acht genomen.

De samenwerking tussen de USAEC en de industrie geschiedde op contractuele basis ${ }^{95}$, waarbij de Amerikaanse overheid - in hoofde van de USAEC - haar contractant en diens verzekeraars door middel van de hold harmless clausule vrijwaarde tegen aansprakelijkheid tegenover derden ingevolge schade voortvloeiend uit het gebruik van splijtbaar materiaal. De USAEC ontsloeg met andere woorden haar leveranciers van elke schadevergoedingsverplichting, zelfs tegenover derden, tengevolge van een kernongeval ${ }^{96}$. Alleen onder die voorwaarde waren de nucleaire bedrijven bereid contracten met de USAEC af te sluiten ${ }^{97}$. Dit kwam erop neer dat ingevolge deze contracten de gehele en exclusieve aansprakelijkheid voor schade uit een kernongeval in handen lag van de USAEC en dus van de Amerikaanse Staat.

Dit resulteerde in een voor de private industrie uitermate gunstig regime ${ }^{98}$ : niet zijzelf, maar de USAEC - en dus de Amerikaanse Staat - droeg alle aansprakelijkheid voor schade aan derden. Op deze wijze wilde men aan het publiek de zekerheid geven dat de uit nucleaire activiteiten voortvlociende schade zou worden vergoed: het slachtoffer stond niet alleen tegenover een solvabele schuldenaar, met name de Staat; tegelijk werd alle schade vergoed.

Niettegenstaande het onder de Atomic Energy Act van 1946 geldende overheidsmonopolie, heeft de wettelijke bevoegdheid van de USAEC om contracten af te sluiten met de private sector ertoe geleid dat de privé-industrie vanaf het begin van het nucleaire tijdperk een zeer belangrijke rol heeft gespeeld in de ontwikkeling van kernenergie ${ }^{99}$. Voor de ondernemingen waren de voordelen van een dergelijk systeem duidelijk: ze hadden toegang tot de kennis en technologie, zonder hierbij zware financiële risico's te lopen ${ }^{100}$. Tot in 1955 werd $95 \%$ van de totale uitgaven van de USAEC verricht door middel van contracten met de privésector ${ }^{101}$. De wisselwerking tussen openbare en private belangen kan worden gezien als een zeer belangrijk kenmerk van de activiteiten van de USAEC ${ }^{\mathrm{j} 02}$. De bedoeling van deze contractuele politiek bestond erin de industriële ontwikkeling van i.c. kernenergie te bevorderen.

Voor de overheid was de participatie van de private industrie meer dan welkom gelet op de vereiste gigantische investeringen. Voor de industrie betekende dit een uitgelezen opportuniteit om toegang te krijgen tot de nucleaire knowhow, zonder hierbij zware financiële risico's te lopen ${ }^{103}$ : dankzij de vrijwaringsclausule droeg de Amerikaans overheid immers nagenoeg alle aansprake-

Op deze wijze werd geiracht om het overheidsmonopolie te verzoenen met de regets inzake viji concurrentie (Fischer, G. "Energie Atomique et les Etats-Unis", l.c., 91). Een dergelijke vrijwaring is niks anders dan een (economische) kanalisatie van aansprakelijkheid. Over de begrippen econornisehe en juridisehe kanalisatie, cfr. infra, $\$ 2.2 .1$ van dit hoofdstuk. Fischerhof, H., "Essai d'une théorie juridique de la canalisation de la responsabilité sur l'exploitant d'une installation nucléaire", o.c., 112. Piérard, J.P., "Responsabilité civile. Risque Atomique", l.c., 271. Hollis, E.L., "The New Law in General", in "The new Atomic Energy Law", l.c., 2. Charlier, R.E., "Questions soulevées par l'évolution de la science atomique", Recueil des Cours, Académie de Droit International, 1957, tome 91 de la Collection, A.W. Sijthoff, Leiden, 1958, 219. Fischer, G., "Energie Atomique et les Etats-Unis", l.c., 87.

102 Fischer, G., "Energie Atomique et les Etats-Unis", l.c., 88.

103 Fischer, G., "Energie Atomique et les Etats-Unis", l.c., 107; Piérard, J.P., "Responsabilité civile. Energie atornique", l.c., 271 ; Rockett, L.R., Columbia Rapport, 1-2. 
lijkheid tegenover derden ${ }^{104}$. Een dergelijke bescherming werd beschouwd als een manier om de industrie de tijd te geven zich voor te bereiden op de werking van het marktmechanisme en de vrije concurrentie. De contractuele vrijwaring vanwege de Amerikaanse Staat werd van in het begin als tijdelijk aanzien; later zou de private industrie zelf haar verantwoordelijkheid dienen op te nemen ${ }^{105}$. Vanuit het standpunt van slachtoffers lijkt deze situatie op het eerste gezicht uiterst voordelig omdat uiteindelijk de Staat (onbeperkt) aansprakelijk was en er dus geen risico bestond van insolvabiliteit van de exploitant. Nochtans mag niet uit het oog worden verloren dat in die tijd nog steeds een fout diende te worden bewezen in hoofde van een agent of aangestelde van de Staat ${ }^{106}$.

Het Amerikaanse overheidsmonopolie heeft ongeveer negen jaar stand gehouden. In die periode hadden zich een aantal belangrijke gebeurtenissen voorgedaan waardoor de VS zich verplicht zagen hun strikte geheimhoudingsbeleid te wijzigen. Met name het feit dat ook de voormalige Sovjet-Unie sinds 1949 over een atoombom beschikte was hierbij een belangrijke factor: de VS waren niet langer de enige supermacht die over een atoombom beschikte, waardoor een van de uitgangspunten van de McMahon wet werden ondergraven. Het kwam er voor de VS op aan haar voorsprong te behouden, aangezien zowel de beperkte mogelijkheden van privé-ondernemingen om zelf nucleaire activiteiten op te starten, als de strikte geheimhouding verbonden aan de militaire toepassingen van kemenergie, een snelle ontwikkeling van vreedzame toepassingen van kernenergie in de weg stonden. Daarenboven waren de mogelijkheden op de Amerikaanse nucleaire markt eerder beperkt omdat het land zelf over reusachtige voorraden fossiele brandstoffen beschikte. De grote Amerikaanse nucleaire bedrijven wensten hun marktaandeel uit te breiden door zaken te doen met andere westerse landen voor wie de productie van elektriciteit door middel van kemenergie, bij afwezigheid van grote voorraden fossiele brandstoffen, een aantrekkelijk alternatief kon betekenen.

Samenwerking met andere landen bood daarnaast twee andere voordelen. Een dergelijke samenwerking inzake nieuwe commerciële toepassingen in het buitenland zou belangrijke en nieuwe wetenschappelijke informatie opleveren voor de Amerikaanse industrie. Op deze wijze kreeg de technologische know-how inzake het vreedzame gebruik van kcmenergie een belangrijke strategische dimensie: de supernacht die snel een uitgebreid civiel kemenergieprogramma zou ontwikkelen, zou haar leidende rol in de kemenergie-industrie kunnen bevestigen ${ }^{107}$. Op deze wijze werd de ontwikkeling van kernenergie voor vreedzaam gebruik een factor in de koude oorlog ${ }^{108}$. Ten tweede waren de VS voor de aanlevering van nucleaire brandstof voor een groot deel afhankelijk van andere landen; via samenwerking met andere landen zouden de VS toegang krijgen tot 's werelds uraniumvoorraden.

Het Amerikaanse overheidsmonopolie zou bijgevolg de nationale en internationale ontwikkcling van kernenergie kunnen belemmeren ${ }^{109}$. Uit de activiteiten van de USAEC zou gebleken zijn dat

104 Hennessey, J.F., "Indemnification of the US Atomic Energy Commission's Contractors against Liability for Nuclear Accidents", in Weinstein, J.L. (ed.), Progress in Nuclear Energy, Law and Administration, Vol. 3, Nuclear Liability, Oxford, Pergamon Press, 1962, 252.

${ }_{106}$ Fischer, G., "Energie Atomique et les Etats-Unis", l.c., 92, 109.

Zie hierover Murphy, A.W., "Principles of United States law governing Liability for Nuclear Accidents", in Mayda, J. (ed.), Atomic Energy and Law, School of Law, Puerio Rico, 1959, 121-122; Pićrard, J.P., "Responsabilité civile. Risque Atomique", l.c., 27l; Stason, E.B., Estep, S.D. en Pierce, W.J., Atoms and the Law, Ann Arbor, University of Michigan Law School, 1959, 725 e.v.

Fischer, G., "Energie Atomique et les Etats-Unis", l.c., 255.

Hollis, E., L., "The New Law in General", The New Alomic Energy Law, 2.

Zoals reeds aangegeven waren de Verenigde Staten, voor wat betreft de bevoorrading van grondstoffen (met name uranium), in zeer belangrijke mate afhankelijk van een aantal andere landen (cfr. supra, 
het gebruik van kernenergie voor de productie van elektriciteit inmiddels technisch en commercieel haalbaar was ${ }^{10}$. Om de Amerikaanse bedrijven via commerciële en civiele toepassingen van kernenergie volop de mogelijkheid te geven zich uit te breiden, diende het monopolie te worden opgeheven. De Atomic Energy Act van 1946 werd in die zin gewijzigd in 1954.

\subsubsection{De Atomic Energy Act van 1954: het einde van het overheidsmonopolie}

Een wijziging van de Atomic Energy Act van 1946 en van het overheidsmonopolie was noodzakelijk on eerı snelle groei van de nucleaire industrie mogelijk te kunnen maken ${ }^{111}$. De Atomic Energy Act van 1954 verklaarde uitdrukkelijk dat kernenergie zowel voor vredelievende als voor militaire doeleinden kan worden aangewend. Deze wet wilde bijdragen tot het algemeen welzijn, tot een gezamenlijke verdediging en veiligheid, tot de wereldvrede, tot een verhoogde levensstandaard en de Act beoogde tegelijk private concurrentie in de sector te stimuleren ${ }^{12}{ }^{113}$. Dankzij de nieuwe Atomic Energy Act konden privé-ondernemingen een groeiende rol spelen bij de ontwikkeling van kernenergie; bovendien werd een wetgevend kader gecreëerd waarbinnen het mogelijk werd om op het terrein van kernenergie samen te werken met andere landen. Een belangrijk gevolg van de Atomic Energy Act van 1954 was inderdaad dat de VS bilaterale samenwerkingsakkoorden sloten met voomamelijk West-Europese landen ${ }^{114}$.

Door de wet van 1954 werden ondernemingen dus aangemoedigd om kapitaal ter beschikking te stellen teneinde onderzoek en ontwikkeling van kemenergie mogelijk te maken. De Amerikanen konden hun wetenschappelijke voorsprong op het gebied van kemenergie enkel verdedigen mits een financiële injectie vanwege bedrijven die bereid waren te investeren op cen terrein waar enkel op lange termijn op winsten kon worden gerekend ${ }^{115}$. In het beginstadium droeg de Staat de kosten van onderzoek, maar geleidelijk zouden meer en meer ondernemingen investeren waardoor de financiële bijdrage van de Staat zou verminderen. Op lange termijn zouden de ondemeningen winst kunnen halen uit de vreedzame toepassingen van kemenergie; ook de belastingbetaler die de aanvankelijke kosten droeg, zou uiteindelijk kunnen genieten van de voordelen van breedschalige productie van kernenergie, aldus de redenering ${ }^{116}$.

$\S 1.1$ van hoofdstuk 2). Deze laatsten waren enkel bereid om grondstoffen aan te leveren op voorwaarde dat zij toegang kregen tot de Amerikaanse technologie en knowhow (Fischer, G., "Energie Atomique et les Etats-Unis", l.c., 252-253). Columbia Rapport, 1.

11 Zie hierover 0.m. Isenbergh, M., "La loi Américaine sur l'énergie atomique", in Puget, H., Aspects de droit de l'énergie atomique, tome II, Centre français de droit comparé, Paris, 1967, 279-288; Stcin, R.M., "La nouvelle Législation Américaine relative à la propriété privée des matières, nucléaires", in Puget, H., Aspects de droil de l'énergie atomique, tome II, Centre français de droit comparé, Paris, 1967, 288 e.v.; Murphy, A.W., "Third Party Liability of suppliers in intemational nucleat transactions", in Weinstein, J.L. (ed.), "Progress in Nuclear Energie", l.c., 166-186; Piérard, J.P., "Responsabilité civile. Risque Atomique ", l.c., 263-309. Section 1. Declaration. 42 USC 2011.

113 Onder de nieuwe Atomic Energy Act van $1954 \mathrm{kreeg}$ de AEC een drievoudige taak: het Amerikaanse kernwapenprogramma verder ontwikkelen, het vredelievende gebruik van kemenergie promoten en het. publiek beschermen tegen de gevaren veroorzaakt door commerciële kerninstallaties (A Short Hisson) of Nuclear Regulation, 1946-1992, NRC, Internet: http://www.nrc.gov).

It Fischer, G., "Energie Atomique et les Etats-Unis", l.c., 241 e.v.; Olson, L.K., "The existing Legal Framework in the United States", in Mayda, J. (ed.), Atomic Energy and Law, School of Law Puerto Rico, 1959, 164-165.

115 Borden, W.L., "Financing Future Development", in "The New Atomic Energy Law", l.c., 60.

116 Zie bijvoorbeeld Collins, D.L., What the Industry sees ahead, "The New Atomic Energy Law", l.c., 64. 
Ook privé-ondernemingen konden voortaan - onder strikte overheidscontrole en in nauwe samenwerking van de AEC - reactoren bouwen en bezitten "17: door middel van door de AEC verleende vergunningen konden ondernemingen voortaan nucleair materiaal aankopen, bezitten, en konden zij kerninstallaties bouwen en beheren.

Terwijl de samenwerking onder de Atomic Energy Act van 1946 plaatsvond op contractuele basis, kreeg de samenwerking met private ondernemingen na 1954 gestalte via licentieovereenkomsten met de USAEC ${ }^{118}$. Meteen werd ook het gunstige regime voor de industrie ongedaan gemaakt in die zin dat de aansprakclijkheid voor schade aan derden in de schoot werd gelegd van de industrie die de USAEC diende te vrijwaren. Onder deze nieuwe wet werd het gunstige aansprakelijkheidsregime dat bestond onder het staatsmonopolie dus omgekeerd: voortaan diende de vergunninghouder - de industrie - de USAEC te vrijwaren, en bijgevolg liep de industrie het risico om zonder enige beperking te mocten instaan voor de uit nucleaire activiteiten aan derden berokkende schade. Door de directe participatie van privé-ondernemingen onder het regime van de Atomic Energy Act van 1954, werden deze laatsten blootgesteld aan de gemeenrechtelijke aansprakelijkheidsvorderingen. Terwijl de Atomic Energy Act van 1954 de groei van de Amerikanse nucleaire industrie wilde stimuleren, remde de potentieel zware aansprakelijkheid het enthousiasme van de industrie om in kemenergie te investeren ${ }^{119}$.

Aangezien hierdoor de onontbeerlijke financiële steun van de industrie in het gedrang dreigde te komen, liet de atoomindustrie onderzoek verrichten naar mogelijkheden om de investeringen aan te moedigen en tezelfdertijd het publiek te beschermen tegen de schade uit kemongevallen. Van groot belang in dat verband was het Preliminary Report on Financial Protection against Atomic Hazards. De resultaten van dit onderzoek hebben een aanzienlijke invloed gehad op de wijzigingen die de Price-Anderson Act in 1957 heeft aangebracht aan de Atomic Energy Act ${ }^{120}$.

\subsubsection{Preliminary Report on Financial Protection against Atomic Hazards ${ }^{121}$ (het Voorlo- pig Rapport)}

Volgens de auteurs van het Voorlopig Rapport was het gebrek aan kennis en ervaring van het nucleaire risico een aanzienlijk probleem bij het inschatten van de aansprakelijkheid voor schade uit kernongevallen. Men wist weliswaar dat de schade afhankelijk zou zijn van de plaats van het ongeval, van het type reactor en van de meteorologische omstandigheden en men was er zich zelfs van bewust dat ook zonder letselschade de schade aanzienlijk kon zijn. De berekening van

\footnotetext{
117 Nochtans werd het overheidsmonopolie niet volledig afgeschaft aangezien de regering eigenaar bleef van het splijtbaar materiaal (Hollis, E.L., "The New Law in General", "The New Atomic Energy Law", l.c., 3).

118 Voor meer bijzonderheden hierover: Oulahan, C., "United States Atomic Energy Commission Licensing", in Weinstein, J.L. (ed.), Law and Administration, Pergamon Press, Oxford, 1962, 35-65.

119 Gautron, $R$, "La responsabilité civile et la protection financière en raison des risques atomiques aux Etats-Unis", in Puget. H., Aspects de droit de l'énergie alomique, tome II, Centre français de droit comparé, Paris, 1967, 61; Hébert, J., "Risque Nucléairc", Juris Classeur Responsahilité Civile, 1963, nr. 14; Piérard, J.P., "Responsabilité civile. Risque Atomique ", l.c., 273; Mohr, P.C., Die Kanalisierung der Haftung unter besondere Berücksichtigung des Atomrechts, Berlin, Walter de (iruyter \& CO, 1970, 85; Mazuzan, G.T. en Walker, J.S., "Controlling the Atom", l.c., 95.

Zie hierover in detail Mazuzan, G.T. en Walker, J.S., "Controlling the Atom", l.c., 104 e.v.

121 Uitgevoerd door A.W. Murphy en de Legislative Drafting Research Fund of Columbia University, maart 1956.
} 
de werkelijke grootte van de schade was in de jaren vijftig, bij gebrek aan ervaring en aan computers $^{122}$, uitermate moeilijk.

De gevaren uit het vreedzaam gebruik van kemenergie richtten zich volgens de auteurs van het Voorlopig Rapport tot verschillende groepen: de nucleaire industrie, de private verzekeraars, de overheid en de slachtoffers van een kernongeval.

Voor de nucleaire industrie - hiermee werden niet enkel de exploitanten bedoeld, maar iedereen die bij de bouw en het ontwerp van de installatie was betrokken - was het grootste probleem dat een aansprakelijkheidsvordering van derden ingevolge een kemongeval vele malen hoger zou liggen dan wat op de verzekeringsmarkt beschikbaar was ${ }^{123}{ }^{124}$. Meteen waren de mogelijkheden van een exploitant om zijn risico te spreiden beperkt tot de op de verzekeringsmarkt beschikbare bedragen en zou, voor dat deel van het risico dat niet door verzekering was gedekt, zijn gehele vermogen in het gedrang kunnen komen ${ }^{125}$. De terughoudendheid om te participeren in het Amerikaanse kernenergie programma viel ook te verklaren doordat kernenergie zich op dat moment in een experimenteel stadium bevond, zodat niet meteen duidelijk was of een investering snel zou renderen. Volgens de auteurs van het Voorlopig Rapport was het zwaarste probleem van de industrie dan ook de noodzaak om bijkomende bescherming te vinden tegen een aansprakelijkheidsvordering.

De verzekeringsindustrie kon onvoldoende dekking verschaffen doordat er op de markt onvoldoende verzekeringscapaciteit beschikbaar was en doordat, wegens gebrek aan gegevens inzake de probabiliteit van een kemongeval, de premie moeilijk kon worden berekend. Deze problemen stelden zich overigens zonder onderscheid al naargelang dekking zou worden geboden voor de aansprakelijkheid van de exploitant, dan wel wanneer particulieren een eigen dekking zouden wensen aan te kopen voor schade die niet door de exploitant werd vergoed ${ }^{126}$.

Op grond van de "undisputed fact that there is a vital national interest in the development of atomic power"127 werd het logisch geacht dat ook de overheid een rol te vervullen had. De overheid moest er encrzijds voor zorgen dat potentiële aansprakelijkheidsvorderingen de ontwikkeling van de industrie niet belemmerden maar anderzijds, zo werd betoogd, had de overheid ook als taak de gezondheid en de veiligheid van de bevolking te waarborgen. Een dergelijke waarborg impliceerde onder meer een intense samenwerking tussen de overheid en de industrie ${ }^{128}$.

De situatie van slachtoffers van een kernongeval werd door het Voorlopig Rapport precair geacht omdat het slachtoffer, op basis van het toenmalige aansprakelijkheidsrecht, in een aantal gevallen

Een inschatting van de gevolgen van een kemongeval gebeurt vanaf de jaren tachtig via computermodellen; in Europa wordt vooral gewerkt met COSYMA (Code System MARIA); MARIA betekent "Methods for Assessing the Radiological Impact of Accidents"). Zie hierover o.m. Govaerts, P., "Economische aspecten van emstige nucleaire ongevallen", in Faure, M. (red.), "Aansprakelijkheid voor hat nucleaire risico", i.c., 189 e.v. Voorlopig Rapport, 5.

124 Tegelijk bestond onzekerheid inzake de aansprakelijkheidsgrondslag: zo was het in die tijd nog anduidelijk of het algemene regime van foutaansprakelijkheid zou evolueren naar een risicoaansprakelijkheid (Stason, E.B., Estep, S.D. en Pierce, W.I., "Atoms and the Law", l.c, 772). Voorlopig Rapport, 11.

Voorlopig Rappori, 15

Voorlopig Rapport, 16.

128

"... teamwork between Government and industry (...) is the key to optimum progress, efficiency and economy in this area of atomic endeavour" (Voorlopig Rapport, 17). 
een fout zou moeten bewijzen, hetgeen onmogelijk zou zijn, en omwille van de capaciteitsproblemen van de verzekeringsmarkt. Om aan het eerste probleem tegemoet te komen was cen wetgevend ingrijpen noodzakelijk; voor wat het tweede probleem betreft, zou een en ander afhangen van de wil en bereidheid van het publiek om zich via eigen verzekeringsdekkingen (levensverzckering, schadeverzekering, ongevallenverzekering, sociale verzekering, ...) tegen het nucleaire risico te beschermen.

Uit de problemen waarmee de nucleaire industrie, de verzekeringsindustrie, de overheid en het publiek werden geconfronteerd, leidden de auteurs van het Voorlopig Rapport af dat privé-initiatieven onvoldoende zouden zijn en dat daarom de federale ovcrhcid op de een of andere manicr diende tussen te komen ${ }^{129}$.

Belangrijk hierbij was dat een dergelijk "overheidsprogramma" werd verantwoord door een gebrek aan kennis en ervaring met betrekking tot het nucleaire risico ${ }^{130}$. Het was van groot belang dat dit programma "pragmatic and responsive to changing needs" zou zijn ${ }^{131}$. Hoe dan ook diende een dergelijk programma te worden gesteund op twee basisvereisten: enerzijds zou aan de nucleaire industrie worden toegelaten om zichzelf te beschermen tegen een ongekende aansprakelijkheid en anderzijds diende het publiek afdoende te worden beschermd bij letsel- en zaakschade.

Een aansprakelijkheidsverzekering of andere financiële zekerheid was de meest geëigende weg voor de bescherming van de industrie. Maar zelfs indien een aansprakelijkheidsdekking beschikbaar zou zijn, dan hield dit volgens de auteurs van het rapport geen enkele garantie in naar de bescherming van het publiek. Vandaar diende de overheid erop toe te zien dat de exploitant adequate maatregelen heeft genomen ter compensatie van de door hem veroorzaakte schade. De exploitant diende vrij te worden gelaten om de aard van deze maatregelen (ver/ekeringsdekking, bankgarantie e.d.m.) zelf te bepalen. Hierbij aansluitend opperde het rapport de mogelijkheid om het verlenen van de vergunning afhankelijk te maken van het bewijs van een aansprakelijkheidsdekking. Gelet op de potentiële omvang van een kernongeval, konden slachtoffers evenwel nooit afdoende worden beschermd louter via een verzekering of financiële zekerheid vanwege de exploitant. Daarom diende de overheid, voor het deel van de schade dat de dekking van de exploitant te boven gaat, verplicht tussen te komen.

Voor wat betreft de mate waarin de overheid diende tussen te komen ${ }^{132}$, werd in eerste instantie aangegeven dat zij de private verzekeringsindustrie geen concurrentie mocht aandoen. De industrie diende zich dus slechts te verzekeren tot op het punt waar dekking via de nomale kanalen kon worden verkregen. Metcen werd eraan toegevoegd dat een eventuele beperking van de aansprakelijkheid ondenkbaar was zonder bijkomende schadevergoeding bovenop het bedrag van die aansprakelijkheid ${ }^{133}$. De schade die daarboven uitkomt, zou door de overheid moeten worden gedragen. Gesteld werd dat zolang de economie niet in gevaar werd gebracht, de overheid volledi-

\footnotetext{
129

130. Voorlopig Rapport, 23.

Bovendien lag het initiatief betreffende het aanwenden van kernenergie bij de overheid, en bijgevoly diende zij haar verantwoordelijkheid te nemen indien.de bevolking schade zou lijden ingevolge e.n dergelijk overheidsinitiatief (Voorlopig Rapport, 21 ).

132 Voorlopig Rapport, 24.

De tussenkomst kon overigens meerdere vormen aannemen: ofwel kon de overhcid optreden als herverzekeraar, ofwel kon de overheid zorgen voor een "excess insurance" bovenop de private verzekering, ofwel diende de exploitant dezelfde exoneratic te genieten als diens leverancicrs, ofwel diende de aansprakelijkheid wettelijk te worden beperkt (Voorlopig Rapport, 26-27).

133 Voorlopig Rapport, 26.
} 
ge compensatie zou moeten aanbieden; de auteurs van het Voorlopig Rapport waren dan ook voorstander van een onbeperkte overheidstussenkomst ${ }^{134}$.

Deze tussenkomst zou niet zozeer als een verzekering vanwege de overheid dienen te worden beschouwd, maar eerder als een indemnity. Het doel van het "Indemnity Programm" bestond erin te voorkomen dat privépartners zouden worden afgeschrikt door de dreiging van een enorme aansprakelijkheidsvordering ${ }^{135}$. In ruil voor de Indemnity diende de overheid geen premie aan te rekenen, aangezien elke premie toch arbitrair zou zijn ${ }^{136}$. De overheidstussenkomst kon volgens de auteurs van het Voorlopig Rapport worden verantwoord omwille van de verantwoordelijkheid die de overheid draagt tegenover slachtoffers en omdat de overheid belang had bij de groei van de Amerikaanse nucleaire industric ${ }^{137}$.

Concluderend stelde het Voorlopig Rapport dat de belangen van de industrie en het publiek konden worden verenigd door het bedrag waarvoor de exploitant dient in te staan te plafonneren en door te voorzien in overheidsmiddelen voor de compensatie van de overige schade. Uit het Yoorlopig Rapport vloeien dus twee principes voort die determinerend zijn gewcest in de ontwikkeling van het (internationale) kemenergierecht: de spreiding van het risico tussen de overheid en de industrie en de beperking van de aansprakelijkheid van de exploitant van de kerninstallatic tot het bedrag waarvoor de exploitant een verzekering of andere financiële zekerheid kon kopen op de markt.

Door de adoptie van de Price-Anderson Act van 1957 bleek dat een groot deel van de aanbevelingen van het Voorlopig Rapport door de Amerikaanse wetgever werden gevolgd ${ }^{138}$. De overheid stelde onder de Price-Anderson Act een bedrag ter beschikking zodra de exploitant het bewijs leverde dat hij over een financiële zekerheid beschikte van 60 miljoen dollar (het op dat momen maximaal verzekerbare of beschikbare bedrag). Ook het tijdelijke karakter van de overheidstussenkomst werd benadrukt doordat de Price-Anderson Act elke 10 jaar dient te worden hernieuwd $^{139}$. Het Amerikaanse Congres heeft de aanbevelingen van het Voorlopig Rapport niet gevolgd inzake de hoogte van de overheidstussenkomst: deze werd toch gelimiteerd op 500 mil-

134 Indien evenwel te veel kernongevallen zouden plaatsvinden, zou de economie worden bedreigd en zou een volledige compensatie onmogelijk worden. Uitgaande van de geringe probabiliteit, stelde het voorlopige rapport dat een volledige compensatie mogelijk zou zijn. Indien zich te veel kernongevalien zouden voordoen, kon daar eventueel op worden teruggekomen: "We can then re-examine whether the rapid development of peaceful atomic encrgy is worth the cost" (Voorlopig Rapport, 30).

Lowenstein, R., "Indemnification against liability for nuclear accidents in licensed atomic energy activities", in Weinstein, J.L. (ed.), Progress in Nuclear Energy Law and Administration, vol. 3, Nuclear Liability, Pergamon Press, Oxford, 1962, 238.

136 Voorlopig Rapport, 33.

137 Voorlopig Rapport, 32-33.

138 Cfr. infra, in hoofdstuk 13.

139 Ter gelegenheid van deze hemieuwingen werd de overheidstussenkomst geleidelijk afgebouwd; vanaf 1982 neemt de Amerikaanse Staat geen enkele financiële verplichting meer op zich bij een kemongeval, hetgeen sneller was dan verwacht. Met name de introductie van de retrospectieve premies tussen exploitanten, heeft hiertoe geleid (zie daarover Vanden Borre, T., "Dekking van het nucleaire risico op nationaalrechtelijke basis of via internationale Verdragen: de Verenigde Staten versus Europa", in Falre, M., Deketelaere, K. en Verhoosel, G., (red.), "Grensoverschrijdende milieuproblemen", l.c., 454. 455). 
joen dollar ${ }^{140}$. Dit neemt niet weg dat de Price-Anderson Act een gunstig klimaat heeft gecreëerd voor de nucleaire toeleveringsindustrie ${ }^{141}$.

Zoals de naam zelf reeds aangeeft was het hierboven besproken rapport slechts een voorlopig rapport. Hiermee werd niet bedoeld dat de resultaten naderhand nog dienden te worden geverifieerd, maar dat zij slechts een oplossing boden voor de terughoudendheid vanwege de Amerikaanse private industrie om in eigen land te investeren in de ontwikkeling van kernenergie ${ }^{142}$. Voor de oplossing van problemen bij internationale uitvoer van nucleair materiaal en kennis was bijkomend onderzoek noodzakelijk. De resultaten van een belangrijk deel van dat bijkomend onderzoek zijn neergelegd in het Harvard Rapport.

\subsubsection{International Problems of Financial Protection against the Nuclear Risk (Harvard Rapport)}

Uitgangspunt van deze studie, uitgevoerd door het Atomic Industrial Fonm, Inc, in samenwerking met de Harvard Law School ${ }^{145}$, was dat de Amerikaanse industrie een rol van betekenis kon spelen in de ontwikkeling van kemenergie in de gehele wereld. De internationale uitbouw van de Amerikaanse kemenergie industrie werd hierbij beschouwd als een zaak van algemeen belang; een samenwerking over de grenzen heen zou bovendien de commerciële belangen dienen van Amerikaanse leveranciers van kemmateriaal, zeker in een tijd waar kernenergie in de Verenigde Staten (nog) niet rendabel was ${ }^{144}$. In eigen land was de Amerikaanse industrie inmiddels afdoende beschermo via de Price-Anderson Act, maar in een internationale context waren de problemen complexer. Het gevaar bestond immers dat een kerninstallatie die werd ontworpen en gebouwd in een bepaald land, die is geleverd aan een ander land, schade veroorzaakt in dat land én in nog een derde land ${ }^{145}$. Een kernongeval kon er ook toe leiden dat de - Amerikaanse - bedrijven die onderdelen hadden geleverd aan de kernenergic-industric, aan aanzienlijke risico's zouden worden blootgesteld ${ }^{146}$. Dergelijke risico's konden volgens het rapport de snelle en veelbelovende ontwikkeling van kernenergie ernstig vertragen of zelfs verhinderen ${ }^{147}$.

Hieronder zal het Harvard Rapport worden geanalyseerd. Eerst worden de argumenten weergegeven die in het Harvard Rapport werden aangehaald om de aansprakelijkheid van de Amerikaanse nucleaire toeleveringsindustrie af te wijzen $(\$ 2.1 .3 .1$ ). Nadien wordt de vraag beantwoord of de Amerikaanse leveranciers zich volgens de auteurs van het Harvard Rapport afdoende konden

Het Congres was niet bereid om op voorhand reeds een ongelimiteerde verplichting op zich te nemen. Op het moment warop zelfs de 560 miljoen dollar niet zou volstaan, zou het Congres bijkomende maatregelen nemen (Lowenstein, R., "Indemnification against Liability for Nuclear Accidents in Licensed Atomic Energy Activities", in Weinstein, J.L. (ed.), "Progress in Nuclear Energy", l.c., 245. 246).

Stason, E.B., Estep, S.D. en Pierce, W.J., "Atoms and the Law", l.c., 572 en 780.

Het Voorlopig Rapport werd gepubliceerd in maart 1956, één jaar vóór de adoptie van de PriceAnderson Act; de resultaten van het Voorlopige Rapport werden aan de orde gesteld gedurende de parlementaire werkzaamheden bij de bespreking van de Price-Anderson Act (Hearings before the Jioint Committee on Atomic Energy, Congress of the US, 84th Congress, 2nd Session, 1956, 292 e.v.). International Problems of Financial Protection against Nuclear Risk. A study under the Auspices of Harvard Law School and Atomic Industrial Forum, Inc., New York, 1959, 95.

Harvard Rapport, 6-7.

Harvard Rapport, 5.

De centrale onderzoeksvraag in het rapport luidde: "How can this inhibition to atomic development best be removed consistently with the public's legitimate interest in safety and reasonable compensati-

on in the event of an accident?" (Harvard Rapport, 7)

Harvard Rapport, 7. 
beschermen op basis van privaatrechtelijke mechanismen $(\S 2.1 .3 .2)$. Vervolgens wordt een overzicht gegeven van de verschillende maatregelen die noodzakelijk werden geacht om een afdoende bescherming te bieden $(\xi 2.1 .3 .3$ ). Tenslotte wordt aangegeven welke regeling uiteindelijk werd naar voren geschoven met betrekking tot de exoneratie van de leveranciers $(\S 2.1 .3 .4)$.

\subsubsection{J. Argumenten van de Amerikaanse nucleaire toeleveringsindustrie om een eventuele aansprakelijkheid af te wijzen}

De auteurs van het rapport hadden de (aansprakelijkheids)wetgeving van een aantal Europese landen onderzocht en vastgesteld dat zowel de exploitant van een gevaarlijke activiteit of inrichting als diens leveranciers aansprakelijk konden worden gesteld buiten elk bewijs van fout ${ }^{145}$. Op basis van deze vaststelling was de Amerikaanse industrie niet bereid om zonder enige juridische bescherming goederen en diensten te leveren aan Europese kerninstallaties. In het Harvard Rapport werden drie argumenten aangedragen om de aansprakelijkheid van de leveranciers van een kerninstallatie af te wijzen: een procesrechtelijk, een redelijkheidsargument en een verzekeringstechnisch argument.

Bij een nucleair ongeval vreesden de leveranciers te worden gedagvaard in plaats van of samen met de exploitant van een kerninstallatie, zelfs indien hun rol was beperkt tot berekeningen of supervisies van bepaalde onderdelen van de reactor. Voor een slachtoffer van een kemongeval kon het immers aantrekkelijk zijn zoveel mogelijk bedrijven te dagvaarden ${ }^{149}$ : indien een van de bedrijven onvoldoende solvabel blijkt te zijn, kon het slachtoffer zich nog steeds tot andere bedrijven richten - bij voorkeur bedrijven met aanzienlijke eigen middelen. Zo zou het zeker voor Europese slachtoffers interessant zijn om Amerikaanse leveranciers in de VS te dagvaarden. Toch suggereerde het Harvard rapport dat in een dergelijk geval de kansen op succes vrij gering waren: op grond van de doctrine forum non conveniens werd de kans gering geacht dat een rechtbank een forum zou toekennen bij een vordering tegen een Amerikaanse moedermaatschappij wier dochteronderneming bij de bouw van een kerninstallatie was betrokken. Indien de Amerikaanse rechtbank zich toch bevoegd zou verklaren, was de kans reëel dat deze niet het Amerikaanse recht, maar wel het recht van de Staat van het ongeval zou toepassen ${ }^{150}$. Geen enkel bedrijf dat op de een of andere manier heeft meegeholpen aan de bouw van de kerncentrale was bijgevolg absoluut immuun voor mogelijke aansprakelijkheidsvorderingen. Dit kon, volgens de auteurs van het Harvard Rapport, aanleiding geven tot aanzienlijke juridische problemen ${ }^{151}$ en tot langdurige processen.

Ten tweede zou het volgens het Harvard Rapport onredelijk zijn de leveranciers aansprakelijk to stellen omdat zij na het leveren van goederen en diensten de controle verliezen over deze goe-

149 Het rapport stelt uitdrukkelijk dat bovenop de extracontractuele aansprakelijkheidsvordering, een leverancier ook contractueel aansprakelijk kan worden gesteld indien de door hem geleverde goederen of diensten gebrekkig blijken te zijn (Harward Rapport, 11). Zie ook verder bij de bespreking van de strekking van de kanalisatie van aansprakelijkheid in $\$ 2.2 .4$, met name betreffende de vraag of kanalisatie enkel de extracontractuele aansprakelijkheid betreft, dan wel ook de contractuele aansprakelijkheid van leveranciers uitsluit.

Harvard Rapport, 27-30. Toch bleven de auteurs van het rapport zeer voorzichtig en stelden zij dai op basis van de geringe ervaring met soortgelijke vorderingen, geen precieze uitspraken konden wordel gedaan.

Is Voomamelijk problemen van internationaal privaatrechtelijke aard: bevoegde rechter, toepasselijk recht en afdwingbaarheid van buitenlandse vonnissen in de VS. Tegelijk bestond het risico dat een slachtoffer door middel van forum-shopping de wetgeving van de installatiestaat zou trachten te ontwijken (Harvard' Rappori, 33, e.v.). 
deren en diensten ${ }^{152}$. Wat goed is ontworpen, kan gevaarlijk worden indien het slecht wordi geëxploiteerd ${ }^{153}$. De exploitant zou dus beter in staat zijn het risico te controleren dan de verschillende leveranciers. Het zou met name onredelijk zijn om de leverancier van een (klein) onderdeel van een kerninstallatie aansprakelijk te stellen voor alle door een kernongeval veroorzaakte schade.

Tenslotte werd een verzekeringsargument aangehaald om de aansprakelijkheid van de leveranciers af te wijzen. Het werd zinloos geacht om zowel de leverancier als de exploitant te verplichten zich te verzekeren tegen de aansprakelijkheid tegenover derden. Indien daarentegen alle aansprakelijkheid zou worden geconcentreerd bij de exploitant van de kerninstallatie konden piramidale verzekeringskosten worden vermeden ${ }^{154}$. Hiermee wordt bedoeld dat indien elke leverancier een aparte verzekeringspolis zou nemen ter dekking van eenzelfde risico, dit tot onevenredig hoge premies zou leiden.

Op basis van bovenvermelde argumenten, werd het onredelijk geacht dat de Amerikaanse leveranciers zouden worden aansprakelijk gesteld voor een kemongeval in een Europese kerninstallatie die gedeeltelijk met Amerikaanse kennis en technologie was gebouwd. Vervolgens werd onderzocht hoe deze aansprakelijkheid kon worden vermeden. Hierbij werd in de eerste plaats onderzocht of het privaatrecht voldoende bescherming bood.

\subsubsection{Onderzoek naar privaatrechtelijke beschermingsmechanismen}

De auteurs van het Harvard Rapport hebben, onder meer op basis van de analyse van het aansprakelijkheidsrecht van enkele Europese landen, onderzocht welke privaatrechtelijke mogelijkheden de leveranciers ter beschikking hadden om zich tegen een aansprakelijkheidsvordering ingevolge een kernongeval te beschermen. De belangrijkste van deze mogelijkheden waren cen aansprakelijkheidsverzekering, het splitsen van de ondememing en het inlassen van exoneratieclausules.

Een aansprakelijkheidsverzekering kon de leveranciers enkel voldoende bescherming bieden in de mate waarin een dergelijke dekking beschikbaar was tegen een redelijke premie. Op dat ogenblik was het nog niet duidelijk of verzekeringsmaatschappijen bereid waren om een dekking te verlenen. Bovendien kon, gelet op de potentiële omvang van de schade bij een kernongeval, een aansprakelijkheidsverzekering enkel afdoende bescherming bieden indien de aansprakelijkheid zou worden beperkt ${ }^{155}$ is6.

152 Een bijzonder element bij de discussie omtrent het regresrecht betrof de positie van subleveranciers. Uiteraard kan de rol van een leverancier van de exploitant van een keminstallatic zeer beperkt zijn; daar waar bepaalde leveranciers zallen instaan voor de productie van het reactorvat, zullen andere leveranciers slechts zeer kleine onderdeien leveren, zoals een pomp of een onderdeel van een ander produet. Sommige producenten zullen daarom een aanzienlijke rol spelen bij de bouw van de keminstallatie, terwijl anderen misschien niet weten dat hun product als onderdeel van een ander product dat in een keminstallatie zal worden gebruikt (Murphy, A.W., "Third Party Liability of Suppliers in International Nuclear Transactions", in Weinstein, J.L. (ed.), "Progress in Nuclear Energy", l.c., 167).

153 Harvard Rapport, 52

154 Harvard Rapport, 57; Pelzer, N., "Channelling: Concept and Policy under the Paris and the Vienna Conventions", o.c., 9. Precies dezelfde redenering vinden we dan ook terug in het Exposé des Motifs, nr. 18.

155

Harvard Rapport, 39.

Meteen pleitten de auteurs voor een concentratie van de aansprakelijkheid bij de exploitant, wiens aansprakelijkheidsverzekering zowel zijn eigen aansprakelijkheid zou dekken als de aansprakelijkheid van de leveranciers. Door de concentratie van aansprakelijkheid bij de exploitant zouden de verzekeringskosten worden teruggedrongen (Harvard Rapport, 57). 
Vervolgens werd onderzocht of het oprichten van een dochteronderneming de moedermaatschappij kon vrijwaren tegen aansprakelijkheidsvorderingen. Deze vorderingen worden vaak beperkt tot de dochterondememing waardoor het vermogen van de moederonderneming geen gevaar zou lopen. Een buitenlandse dochteronderneming zou nict kunnen worden gedagvaard bij de zetel van de Amerikaanse moederondememing en bovendien zouden in vele gevallen buitenlandse vonnissen tegen een Amerikaanse moederondememing niet kunnen worden afgedwongen in de VS ${ }^{157}$. Ook deze techniek kon echter volgens de auteurs van het rapport de leveranciers geen afdoende bescherming bieden. Indien zou blijken dat de activiteiten van de moederonderneming op enigerlei wijze hebben bijgedragen tot de schade, zou zij toch kunnen worden aansprakelijk gesteld.

Het onderzoek van de Harvard Law School richtte zich uitgebreid tot de vraag of een contractuele clausule - de hold-harmless clausule - de beoogde bescherming kon bieden. Deze clausule wordt ook economische kanalisatie ${ }^{158}$ genoemd omdat de beneficiaris van een dergelijke clausule enkel wordt gevrijwaard tegen de financiële gevolgen van een aansprakelijkheidsvordering. De holdharmless clausule verhindert niet dat de leverancier wordt gedagvaard maar zorgt ervoor dat de financiële last van de aansprakclijkheid uiteindelijk door de exploitant wordt gedragen. Volgens het Harvard Rapport zouden evenwel een aantal Europese rechtsstelsels een dergelijke clausule buiten werking stellen indien zou blijken dat de schade werd veroorzaakt door de zware fout van de leverancier ${ }^{159}$. Bovendien konden onoverkomelijke praktische problemen het beschermend effect van de clausule teniet doen. Indien slachtoffers niet alle schade uit het kernongeval hebben kunnen terugvorderen van de exploitant omdat de totale schade de (beperkte) aansprakelijkheidsdekking van de exploitant te boven gaat, zouden slachtoffers zich vervolgens tot de leveranciers kunnen richten. Bij een ernstig kernongeval werd de kans op insolventie van de exploitant aanzienlijk geacht, waardoor de hold harmless clausule de facto werd uitgehold.

Geen van bovenstaande privaatrechtelijke mogelijkheden leek dus op afdoende wijze de Amerikaanse nucleaire industrie te beschermen. Vandaar werd de idee gelanceerd om de leverancier niet meer contractueel, maar ook wettelijk te beschermen, namelijk via tussenkomst van de wetgever in het land waar nucleaire technologie wordt ingevoerd ${ }^{160}$. Landen waar Amerikaanse goederen en diensten werden geimporteerd, dienden bijgevolg in hun wetgeving de nodige maatregelen te nemen om ervoor te zorgen dat slachtoffers juridisch niet over de mogelijkheid zouden beschikken om leveranciers van de exploitant aansprakelijk te stellen.

In het licht van de huidige analyse, richt onze aandacht - en ook deze van de auteurs van het Harvard Rapport - zich in de eerste plaats naar de regeling inzake de positie van de leveranciers. Het is evenwel van belang te benadrukken dat het rapport een geheel van maatregelen als ideale oplossing voorop stelde. Hieronder wordt eerst een overzicht gegeven van deze verschillende maatregclen $(\$ 2.1 .3 .3)$. Nadicn wordt de regeling bestudeerd met betrekking tot de exoneratie van de leveranciers $(\$ 2.1 .3 .4)$.

\footnotetext{
157 Harvard Rapport, 39.

158 Cfr. infra, $\$ 2.2 .1$.

159 Ook een eventuele contractuele exoneratie tussen leverancier en exploitant werd om dezelfde reden niet geheel sluitend geacht (Harvard Rapport, 43).

160 "Suppliers cannot adequately protect themselves against many of the risks of excessive liability inherent in atomic enterprises. Legislative or treaty action would seem to be called for" (Harvard Rapport. 44).
} 


\subsubsection{Geheel van maatregelen noodzakelijk om afdoende bescherming te bieden}

Doordat de geanalyseerde privaatrechtelijke beschermingsmechanismen niet de zekerheid boden dat de leverancier niet zou worden aansprakelijk gesteld voor de schade uit een kernongeval, bestond de meest adequate oplossing volgens het Harvard Rapport uit een twaalftal maatregelen $^{161}$. Zoals zal blijken, zijn deze principes later overgenomen zowel door het Verdrag van Parijs van 29 juli 1960 als door het Verdrag van Wenen van 21 mei 1963. Zonder de minste twijfel heeft het Harvard Rapport een aanzienlijke invloed gehad op de totstandkoming van beide Verdragen. Bijgevolg speelt dit rapport een belangrijke rol in de analyse van de (werkelijke) reden waarom bepaalde principes werden ingevoerd. In zekere zin kan het Harvard Rapport dus worden gezien als een niet onbelangrijk document bij de interpretatic van de voorbereidende werken van de genoemde Verdragen.

Hieronder wordt een overzicht gegeven van deze maatregelen en van de reden waarom deze werden ingevoerd.

a. Alle aansprakelijkheid dient te worden geconcentreerd bij de exploitant van de keminstallatie. Hij is beter dan de leverancier in staat om een verzekeringsdekking te kopen. Niet de leveranciers, maar wel de exploitant diende bijgevolg alle aansprakelijkheid te dragen bij een kernongeval.

b. Teneinde de bewijsproblemen van slachtoffers te verlichten, zijn exploitanten aansprakelijk buiten elk bewijs van fout om. Risicoaansprakelijkheid kan in redelijkheid niet worden opgelegd aan de leveranciers omdat, eens de goederen zijn geleverd, deze niet meer onder hun controle staan.

c. De aansprakelijkheid van de exploitant dient te worden beperkt tot het bedrag waarvoor hij financiële dekking kan krijgen (hetzij via verzekering, hetzij via een financiële garantie). Enkel via een aansprakelijkheidsbeperking kon de privé-industrie worden aangemoedigd om bij te dragen tot de ontwikkeling van kemenergie. Bovendien was deze beperking niet nieuw: met name inzake luchtvaart en zeerecht waren reeds beperkingen van aansprakelijkheid van kracht $^{162}$.

d. De exploitant mag zijn keminstallatie slechts opstarten indien hij als exploitant is erkend door het land waar de kerninstallatie is gelegen. Op deze wijze wordt de exploitant verplicht zich te houden aan de internationale veiligheidsmaatregelen en aan de veiligheidsmaatregelen van het land waar de kerninstallatie zich bevindt.

e. De exploitant moet de financiële zekerheid ter dekking van zijn aansprakelijkheid op allc tijdstippen hebben en in stand houden tot de kerninstallatie wordt gesloten. Dere financiële zekerheid beoogt uitsluitend de compensatie van slachtoffers; de kosicn verbonden aan deze procesvoering vallen buiten deze dekking.

f. Waar radioactieve stoffen of matcriaal worden vervoerd, zal de exploitant eveneens aansprakclijk zijn.

g. Enkel de rechtbanken van het land waar een kerninstallatie is gesitucerd, zijn exclusief bevoegd om de aansprakelijkheidsvorderingen uit een kernongeval te behandelen; hierdoor worden problemen inzake het afdwingen van vonnissen vermeden. Door een exclusief forum te creëren worden de proceskosten beperkt en stellen zich geen procedureproblemen. Ook andere 
staten moeten de exclusieve bevoegdheid van de rechtbank van de installatiestaat erkennen; een vonnis tot stand gekomen buiten deze staat zal in de installatiestaat niet worden erkend. Indien geen exclusieve bevoegdheid zou zijn voorzien, kan de gehele voorziene regeling immers worden omzeild ${ }^{163}$. Het is vooral op basis van dit argument dat de auteurs van het rapport pleitten voor het opstellen van een internationaal Verdrag.

h. Het recht van het land waar de kerninstallatie is gelegen, moet van toepassing zijn op alle materies inzake aansprakelijkheid voor schade uit een kernongeval. Hiermee wordt vermeden dat het "aansprakelijkheidsfonds", dat in bedrag is beperkt, meermaals door verschillende rechtbanken zou worden toegekend ${ }^{164}$.

i. De periode waarbinnen slachtoffers hun vordering kunnen indienen dient op uniforme wijze te worden beperkt, bij voorkeur tot tien jaar nadat het kernongeval heeft plaatsgehad. Bovendien beschikt een slachtoffer dat kennis heeft van zijn schade uit een kernongeval over een periode van twee jaar om zijn vordering in te dienen. De verschillende vorderingen moeten immers worden uitbetaald uit een beperkt fonds en in het belang van de meerderheid van de slachtoffers mag de periode niet te lang zijn. Hoe langer deze periode, hoe moeilijker het zou zijn de causaliteit vast te stellen $^{165}$. Een kortere periode heeft ook een gunstige invloed op de verzekeringspremies, waardoor een hogere limiet kan worden gesteld aan de aansprakelijkheid van de exploitant. De verjaringstermijn is vooral problematisch voor verzekeraars indien de polis is afgelopen; zolang de polis loopt moeten zij immers sowieso de nodige fondsen hebben. Opmerkelijk is dat ook wordt verwezen naar schade veroorzaakt door de normale operatie van een kerninstallatie; in een dergelijk geval zal de vervaltermijn beginnen lopen vanaf de laatste dag van de operatie ${ }^{166}$.

j. Indien de financiële zekerheid van de exploitant ontoereikend is, zal het beschikbare bedrag evenredig worden verdecld; schade door letsel of overlijden dient voorrang te krijgen.

k. Indien de financiële zekerheid van de exploitant onvoldoende is om alle schade te vergoeden, heeft het land waar de kerninstallatie is gelegen de plicht om door middel van publieke fondsen in bijkomende compensatie te voorzien. Volgens welk mechanisme deze compensatie dient te geschieden, moet worden vastgesteld in een internationale overeenkomst.

I. Elk land moet deze principes toepassen zonder enige discriminatie gebaseerd op nationaliteit, woonplaats of verblijfplaats.

Al deze maatregelen getuigen van een bepaalde redenering vanwege de auteurs van het Harvard Rapport. Volgens hen is het beter om aan slachtoffers een - beperkt - systeem aan te bieden dat een aantal garanties bevat ("Veiligheidsfonds"), onder meer inzake beschikbare bedragen, inzake procesvoering e.d.m. Het alternatief zou het gemene aansprakelijkheidsrecht zijn waar geen enkele garantie voorhanden zou zijn inzake beschikbaarheid van bedragen, versoepeling van procesvoering, etc. Van al de maatregelen die het Harvard Rapport naar voren schoof, is in het kader van dit onderzoek de concentratie van aansprakelijkheid bij de exploitant van de kerninstallatic cn de hieraan gekoppelde exoneratie van de leveranciers de belangrijkste maatregel. Deze wordt hieronder verder besproken. 


\subsubsection{De exoneratie van aansprakelijkheid van leveranciers}

Terwijl eventueel argumenten kunnen worden aanvaard voor wat betreft het concentreren van de aansprakelijkheid in hoofde van de exploitant van een kerninstallatie, is niet meteen duidelijk waarom dit dient gepaard te gaan met de exoneratie van de aansprakelijkheid van de leverancier van deze installatie. Het is daarom interessant na te gaan welke argumenten en oplossingen hiervoor in het Harvard Rapport naar voren werden geschoven.

De vrees van de leveranciers was vooral dat - indien de aansprakelijkheid van de exploitant weliswaar beperkt, maar niet exclusief zou zijn, en indien de totale schade deze limieten zou overstijgen - slachtoffers zouden trachten aan te tonen dat het kernongeval is te wijten aan een gebrekkig ontwerp van de installatie of een gebrek in het toeleveringsmateriaal. Vooral het feit dat rechtbanken de neiging zouden hebben om sneller een fout te aanvaarden en om dus tegemoet te komen aan de bewijslast van slachtoffers, was volgens de auteurs problematisch ${ }^{167}$. Daarenboven bestond steeds het risico tot forum shopping: rechtbanken buiten de installatiestaat zouden niet noodzakelijkerwijze de bijzondere wetgeving van kracht in de installatiestaat, op basis waarvan de aansprakelijkheid wordt beperkt en de leverancier wordt beschermd, toepassen ${ }^{168}$.

In het Harvard Rapport werd de mogelijkheid gesuggereerd om ook voor internationale transacties het systeem van de Price-Anderson Act in te voeren (economische kanalisatie) ${ }^{169}$. Hierbij werd het gemene aansprakelijkheidsrecht intact gelaten, maar zou de verzekeringspolis van de exploitant ook de aansprakelijkheid dekken van alle mogelijke verweerders. Geredeneerd werd dat de exploitant een verzekeringsdekking kon nemen die zowel zijn aansprakelijkheid als deze van zijn leveranciers zou dekken ${ }^{170}$. Maar in dit geval zou het volgens de auteurs van het Harvard Rapport weinig zin hebben om andere personen nog aansprakelijk te stellen ${ }^{171}$. Dit zou enkel tot aanzienlijke proceskosten leiden.

Zelfs indien de leveranciers niet aansprakelijk konden worden gesteld, betekende dit, steeds volgens het Harvard Rapport, niet dat de leveranciers volledig zouden zijn geêxonereerd voor de gevolgen van hun handelen. Vanuit commercieel oogpunt hadden zij steeds voldoende reden ervoor te zorgen dat het door hen geleverde materiaal of de verstrekte diensten geen gebreken vertoonden. De leverancier wist dat één enkel ongeval te wijten aan gebreken aan zijn producten of diensten, het einde kon betekenen van zijn onderneming waardoor deze sowieso voldoende reden had om ervoor te zorgen dat zijn materiaal uitermate veilig zou zijn ${ }^{172}$. Zelfs indien de leveranciers nict aansprakelijk zouden zijn, zou op de markt voldoende vraag zijn naar veilig materiaal omdat de veiligheidsfactor van het gebruikte materiaal zou worden weerspicgeld in de verzekeringspremie die de exploitant dient te betalen. Een exploitant met een veiligere installatie zou dus minder verzekeringspremie dienen te betalen en zou daarom opteren voor het veiliger material $^{173}$.

167

Harvard Rapport, 56-57.

Harvard Rapport, 57.

Deze term wordt verderop tocgelicht, zie \$ 2.2.1

Dit was een duidelijke verwijzing naar de bepalingen van de Priee-Anderson Act, waar eenieder die wordt aansprakelijk gesteld, is gedekt door de verzekeringspolis van de exploitant (zgn. omrubusdekking). Cfr. infra, hoofdstuk 13.

"... the question who is formally liable loses much of its importance" (Harvard Rapport, 57).

"The fear of third party liability is thus not likely to add much motivation to the safety-mindedness of designers or manufacturers of nuclear equipment" (Harvard Rapport, 57).

Harvard Rapport, 57. 
De reden waarom volgens het Harvard Rapport de vordering tegen de leverancier kon worden afgeschaft, was dus dat door de aansprakelijkheidsverzekering (of andere financiële zekerheid) van de exploitant, de vraag naar de uiteindelijke aansprakelijkheid niet meer van belang zou zijn. De aansprakelijkheidsvordering van een derde tegen de leverancier kon maar best worden afgeschaft omdat dit anders zou leiden tot ingewikkelde en langdurige processen.

Het uitsluiten van extracontractuele vorderingen van slachtoffers van een kernongeval tegen de leveranciers van de exploitant van de kerninstallatie zou echter niet volstaan. Ook de (contractuele) vorderingen van de exploitant tegen de leveranciers dienden onmogelijk te worden gemaakt ${ }^{174}$.

Volgens het Harvard Rapport was het voor slachtoffers van een kernongeval voldoende dat de exploitant is verzekerd tot het beperkte bedrag van zijn aansprakelijkheid en bestaat er weinig reden om een deel van deze aansprakelijkheid naar andere personen door te schuiven. Zeker indien de exploitant en de leverancier onder eenzelfde polis zouden zijn gedekt, heeft een regresrecht tegen de leverancier weinig praktisch nut; dit zou neerkomen op een boekhoudkundige operatie van de verzekeraar, zo luidde de redenering ${ }^{175}$. Het regresrecht diende ook te worden afgeschaft om te vermijden dat de Staat, die tengevolge van een kemongeval eveneens een bepaalde schade zou hebben vergoed (met name in het kader van een sociaal zekerheidsstelsel), zou worden gesubrogeerd in de rechten van de exploitant: indien de exploitant over een regresrecht zou beschikken, zou de Staat in dat regresrecht worden gesubrogeerd ${ }^{176}$.

Volgens de auteurs van het Harvard Rapport bestonden er bijgevolg voldoende redenen om ervoor te zorgen dat schadevergoeding enkel kon worden bekomen van het "veiligheidsfonds" van de exploitant (met name diens aansprakelijkheidsverzekering of financiële zekerheid) en om alle vorderingen tegen de leveranciers van de exploitant - zowel vorderingen van derden als vorderingen van de leverancier zelf - onmogelijk te maken.

Hoe deze doelstelling kon worden bereikt, werd geanalyseerd in de paragraaf met als titel "Methods for Channelling all Third Party Tort Suits to the Operator ${ }^{n 177}$. Het is inderdaad in deze paragraaf van het Harvard Rapport, behorende tot de sectie "Liability of Suppliers" dat wordt gesproken van de kanalisatie van aansprakelijkheid naar de exploitant. Deze sectie valt op haar beurt onder het hoofdstuk: "Areas in which Government Action is Desirable". Een adequaat wetgevend ingrijpen was hier bijgevolg noodzakelijk.

Een dergelijk ingrijpen kon op verschillende wijzen gebeuren. Zo kon de wet het aantal verweerders beperken waartegen een slachtoffer zich kan keren. De auteurs van het Harvard Rapport stelden dat de leveranciers onvoldoende zouden worden beschermd wanneer een wet het aantal personen zou beperken dat door slachtoffers van een kemongeval kan worden aangesproken. Dit zou namelijk worden beschouwd als een procedureregel die door de rechter terzijde kon worden geschoven.

Indien daarentegen de wet van het land van het ongeval elke vordering tegen leveranciers zou afschaffen, dan zou dit niet zo makkelijk terzijde kunnen worden geschoven ${ }^{178}$. Het afschaffen vän

Zie hierover Murphy, A.W., "Third Party Liability of Suppliers in International Nuclear Transactions", in Weinstein, J.L. (cd.), "Progress in Nuclear Energy", l.c., 176.

Harvard Rapport, 57.

Harvard Rapport, 57-58.

Harvard Rapport, 58.

Volgens de auteurs van het Rapport was dit een "matter (...) of substance" (Harvard Rapport, 58).
} 
de vorderingen tegen de leverancier kon, steeds volgens het Harvard Rapport, worden verantwoord door het feit dat deze afschaffing kadert in een geheel van maatregelen dat de beschikbarheid garandeert van bepaalde fondsen.

Concluderend zou de eenvoudigste en meest effectieve oplossing er volgens het Harvard Rapport in bestaan dat alle rechtsvorderingen tegen de leveranciers zouden worden afgeschaft door wetgevend ingrijpen ${ }^{179}$. Door de nieuwe sociale en economische omstandigheden - onder meer veroor.zaakt door het vreedzaam gebruik van kemenergie - werd een dergelijke wetgevende ingreep noodzakelijk geacht; rechtsdogmatische bezwaren tegen de kanalisatie van aansprakelijkheid konden moeilijk worden aanvaard.

Het wekt dan ook weinig verwondering dat het Harvard Rapport aandrong op het afsluiten van een internationale overeenkomst ${ }^{180}$, waartoe zoveel mogelijk landen dienden toe te treden: hoe meer landen een dergelijk systeem zouden aanvaarden, hoe "veiliger" de leveranciers zouden worden ten aanzien van vorderingen van derden. Indien een land niet zou toetreden tot een ver$\mathrm{drag}$, of indien het in zijn interne wetgeving de vooropgestelde maatregelen niet had ingevoerd, dan zouden de leveranciers nog steeds kunnen worden gedagvaard in of door slachtoffers van dat land ${ }^{\text {is! }}$.

Toen het rapport werd geschreven, waren de onderhandelingen van het Verdrag van Parijs in volle gang. In bijlage van het Rapport is trouwens een ontwerptekst van het Verdrag opgenomen. Geredeneerd werd dat een uniform aansprakelijkheidssysteem, gebaseerd op internationale verplichtingen zowel de belangen zou dienen van de installatiestaat, van de staten waar de schade wordt geleden als van de staten die materiaal en diensten hebben geleverd ${ }^{182}$.

Nochtans suggereerde het Harvard Rapport dat het Verdrag van Parijs niet de ideale oplossing was omdat het slechts een regionaal verdrag is; het werd dan ook eerder gezien als een soort van tussenoplossing voor verdere internationale afspraken ${ }^{183}$, bij voorkeur in het kader van het IAEA $^{184}$. Zoals bekend werd 3 jaar na het Verdrag van Parijs ook het Verdrag van Wenen ondertekend. De basisprincipes van beide internationale nucleaire aansprakelijkheidsregimes, die in dit hoofdstuk worden besproken, zijn dan ook grotendeels gebaseerd op de twaalf maatregelen vooropgesteld door het Harvard Rapport.

Harvard Rapport, 59.

Dit was overigens niet alleen de mening van de auteurs van het Harvard Rapport, maar ook van de leden van de USAEC. Zie bijvoorbeeld de bijdrage van een lid van de USAEC in dat verband: Ferguson, E.E., "Liability for Nuclear Hazards: international Problems and Progress", in Mayda, J. (ed.), Atomic Energy and Law, School of Law, Puerto Rico, 1959, 140-149.

Harvard Rapport, 58.

Ferguson, E.E., "Liability for Nuclear Hazards: international Problems and Progress", in Mayda, J. (ed.), l.c., 141 .

"(...) a draft convention of regional scope which can serve on an interim basis as a partial groundwork for further intemational arrangements and national legislation, pending eventual conclusion of a worldwide agreement" (Harvard Rapport, 17).

it Ook Stason en Estep pleitten ervoor dat buitenlandse regeringen zouden voorzien in een aan de Amerikaanse Price-Anderson Act analoge bescherming voor de leveranciers (Stason, E.B., Estep, S.D. en Pierce, W.J., "Atoms and the Law", l.c., 780). Zie hierover ook Hardy, M.J.L. "Nuclear Liability: the general principles of law and further proposals", British Yearbook of International Law, 1960, 246. 


\subsubsection{Conclusie}

Het concept "kanalisatie van aansprakelijkheid" zoals die in het kernenergierecht wordt gehanteerd, is ontstaan als een contractuele vrijwaringsclausule. Deze vrijwaringsclausule werd aangewend in de contracten tussen de USAEC en private ondernemingen die nucleaire activiteiten wensten te ontwikkelen. De kanalisatie van aansprakelijkheid in het kemenergierecht stamt dus oorspronkelijk uit het contractenrecht ${ }^{185}$.

Via de vrijwaringselausule of hold harmless clause kon de industrie weliswaar worden aansprakelijk gesteld voor schade uit een kernongeval, maar de financiële gevolgen hiervan werden volledig door de overheid gedragen. Er werden met andere woorden contractuele afspraken gemaakt over de gevolgen van een eventuele aansprakelijkheid; de aansprakelijkheidsgronden zelf bleven onverminderd van kracht.

Door de Atomic Energy Act van 1954 werd de vrijwaringsclausule gewoon omgekeerd. Het was de industrie - de vergunninghouder - die voortaan de overheid diende te vrijwaren tegen mogelijke aanspraken van derden. Het resultaat was dat de investeringen in kernenergie vanwege de industrie, nagenoeg stilvielen.

Om hieraan tegemoet te komen, werd onderzoek verricht naar manieren om zowel de indusitric als het publiek te beschermen. Volgens het Voorlopige Rapport diende de overheid tijdelijk de financiële lasten over te nemen die op de industrie rustten ingevolge de mogelijke aansprakelijkheidsvorderingen van derden ${ }^{186}$. Dit principe werd overgenomen in de Price-Anderson Act van 1957. Het daarin opgenomen Indemnity Programm is in feite niets meer dan de inschrijving in een wet van de vrijwaringsclausules die eerder werden gebruikt in contracten tussen de overheid en de industrie: indien de schade een bepaald bedrag te boven ging, zou de overheid de industrie vrijwaren tegen de financiële gevolgen van deze aansprakelijkheid.

Door de afschaffing van het overheidsmonopolie op de ontwikkeling van kemenergie, ging ook de Europese markt open voor de Amerikaanse leveranciers. Dit impliceerde dat zij niet enkel wensten te worden beschermd tegen vorderingen in eigen land voor kemongevallen in de VS, maar ook tegen vorderingen voor schade uit kernongevallen in Europa. Het Harvard Rapport leidde tot de conclusie dat zowel vanuit procesrechtelijk, verzekerings- als vanuit redelijkheidsoogpunt er maatregelen dienden te worden genomen. De beste oplossing bestond erin om via cen internationaal verdrag elke vordering tegen de leveranciers onmogelijk te maken. Belangrijk hierbij is het feit dat de invoering van de kanalisatie van aansprakelijkheid naar de exploitant van de kerninstallatie kaderde in een geheel van maatregelen waaronder ook de beperking van de aansprakelijkheid en de exclusieve bevoegdheid van één rechter per land. Tegelijk stelde het Harvard Rapport dat zowel diende te worden ingegrepen in het extracontractuele aansprakelijkheidsrecht (relatie leverancier-derde) als in het contractuele aansprakelijkheidsrecht (relatic leverancierexploitant).

In internationale nucleaire transacties was meer nodig dan een bescherming tegen de financiêle gevolgen van aansprakelijkheid; volgens de auteurs van het Harvard Rapport dienden de leveranciers ook te worden beschermd tegen de aansprakelijkheid zelf. Uit de analyse is inderdaad geble-

Fischerhof, H., "Essai d'une théorie juridique de la eanalisation de la responsabilité d'une installation nucléaire", o.c., 112. 
ken dat in de ogen van de leveranciers de gewone contractuele vrijwaringsbedingen volstonden zolang de leveringen van de Amerikaanse industrie zich beperkten tot eigen land, maar dat voor internationale leveringen een wettelijke ingreep in het contractuele en extracontractuele aansprakelijkheidsrecht werd noodzakelijk geacht. Hoe deze ingreep en dus de kanalisatie van aansprakelijkheid uiteindelijk in het Verdrag van Parijs van 29 juli 1960 en in de Belgische en Nederlandse nucleaire aansprakelijkheidswetgeving is verwoord, wordt in onderstaande paragraaf besproken.

\subsection{Kanalisatie van aansprakelijkheid in het kernenergierecht}

In dit deel wordt de precieze inhoud toegelicht van de term kanalisatie van aansprakelijkheid in het kemenergierecht. Hier wordt in eerste instantie het klassieke onderscheid aangegeven tussen economische en juridische kanalisatie $(\$ 2.2 .1)$. Dit is een zeer belangrijk, hoewel zeker niet alomvattend, onderscheid dat een belangrijke positie inneemt bij de verdere analyse. In tweede instantie worden de redenen besproken waarom, volgens de Exposé des Motifs, in het Verdrag van Parijs de aansprakelijkheid werd gekanaliseerd naar de exploitant van de keminstallatie $(\$ 2.2 .2)$. Hier wordt dus in feite de vraag beantwoord of de redenen waarom de kanalisatie van aansprakelijkheid werd ingevoerd in het Verdrag van Parijs, vergelijkbaar zijn met de redenen die in het Harvard Rapport werden naar voren geschoven.

De bespreking van de eigenlijke betekenis van het begrip "kanalisatie van aansprakelijkheid" onder het Verdrag van Parijs, wordt opgesplitst in twee elementen. Ten eerste wordt de definitie van kanalisatie van aansprakelijkheid in het internationale kernenergierecht weergegeven (\$2.2.3). Doordat kanalisatie ook gevolgen heeft op de (regres)positie van de exploitant, wordt in tweede instantie onderzocht wat precies de strekking is van de kanalisatie van aansprakelijkheid onder het Verdrag van Parijs ( $\$ 2.2 .4$ ). Aansluitend hierbij wordt aangegeven hoe de kanalisatie is opgenomen in het Belgische en het Nederlandse nucleaire aansprakelijkheidsrecht $(\$ 2.2 .5)$.

Doordat de kanalisatie van aansprakelijkheid in feite een inbreuk betekent op het gemene aansprakelijkheidsrecht, is het niet verwonderlijk dat de invoering van dit principe tot weerstand heeft geleid en dit zowel op internationaal als op nationaal vlak. De precieze oorzaak van deze weerstand, wordt in $\$ 2.2 .6$ besproken. Zoals zal blijken heeft de weerstand tegen de kanalisatie ten dele te maken met de bedoeling van de verdragspartijen om, via het Verdrag van Parijs, een exclusief en exhaustief systeem in het leven te roepen. Dit betekent dat de schade die de in het Verdrag voorziene bedragen te boven gaat, niet op een andere basis voor vergoeding in aanmerking komt. De vraag of de kanalisatie van aansprakclijkheid naar de exploitant van een kerninstallatie inderdaad exclusief en exhaustief is, wordt in $\$ 2.2 .7$ beantwoord.

Het Harvard Rapport ging ervan uit dat een combinatie van maatregelen noodzakelijk was om de bescherming van de leveranciers te garanderen. In $\$ 2.2 .8$ zal worden aangetoond dat de IPRregels, zoals voorzien in het Harvard Rapport en uiteindelijk ook in het internationale nucleaire aansprakelijkheidsrecht, inderdaad onontbeerlijk zijn orm de kanalisatie van aansprakelijkheid sluitend te maken. Precies het belang van deze IPR-regels in samenhang met de kanalisatic van aansprakelijkheid waren belangrijke elementen bij de totstandkoming van het Verdrag inzake Bijkomende Compensatie van 12 september 1997. In $\$ 2.2 .9$ zal worden aangetoond dat de onderhandelingen van dit Verdrag ernstig werden bemoeilijkt door discussies met betrekking tot de kanalisatic van aansprakelijkheid en zal worden aangegeven waarom de VS, die tot voor kort geen van de nucleaire aansprakelijkheidsverdragen hadden ondertekend, het Verdrag inzake Bijkomende Compensatic als één van de eersten hebben ondertekend.

De rol die de kanalisatie van uansprakelijkheid heeft ingenomen bij de onderhandelingen van het Verdrag inzake Bijkomende Compensatie van 1997 toont reeds aan dat kanalisatie van aansprake- 
lijkheid nog steeds actueel is ten aanzien van Amerikaanse leveranciers. In $\S 2.2 .10$ zal worden aangetoond dat de kanalisatie van ansprakelijkheid in het intemationale kernenergierecht bij de aanvang van de éénentwintigste eeuw ook actueel is ten aanzien van de Europese nucleaire toeleveringsindustrie. De analyse van de kanalisatie van aansprakelijkheid wordt afgesloten met enkele conclusies $(\S 2.2 .11)$.

\subsubsection{Verschil tussen economische en juridische kanalisatie van aansprakelijkheid}

Traditioneel wordt een onderscheid gemaakt tussen economische of onrechtstreekse kanalisatie en juridische of rechtstreekse kanalisatie ${ }^{187}$.

Juridische kanalisatie betekent enerzijds dat slechts één enkele, welbepaalde persoon aansprakelijk is voor alle schade die wordt veroorzaakt uit een bepaalde activiteit of uit een bepaald feit, ook al liggen andere personen aan de oorzaak van de schade en anderzijds dat deze persoon slechts op één enkele juridische grond kan worden aangesproken. Hierbij is een vordering tegen andere personen juridisch onmogelijk, precies omwille van het feit dat de aansprakelijkheid algcheel bij één persoon is geconcentreerd.

Economische kanalisatie betekent dat de personen die de schade hebben veroorzaakt principieel aansprakelijk zijn en blijven, maar dat de uiteindelijke economische last van de schade door één welbepaalde persoon wordt gedragen. Andere personen dan diegenen naar wie de aansprakelijkheid econonisch wordt gekanaliseerd kunnen bijgevolg juridisch aansprakelijk worden gesteld, met dien verstande dat de sommen waartoe zij werden veroordeeld zullen worden gedekt door degene naar wie deze schade economisch wordt gekanaliseerd.

Het grote verschil tussen beide soorten kanalisatie is dat de juridische kanalisatie een deel van het gemene aansprakelijkheidsrecht buiten werking stelt. De aansprakelijkheid wordt op één enkele persoon geconcentreerd, hoewel op basis van het klassieke aansprakelijkheidsrecht ook andere personen aansprakelijk kunnen worden gesteld. Bij economische kanalisatie daarentegen wordt het gemene aansprakelijkheidsrecht intact gelaten.

Tot op zekere hoogte is het resultaat van beide vormen van kanalisatie evenwel hetzelfde, aangezien onder beide vormen degene naar wie de aansprakelijkheid wordt gekanaliseerd, uiteindelijk de economische gevolgen van de aansprakelijkheid zal dragen ${ }^{188}$. Dit wordt bijwoorbeeld aangetoond door de omnibus dekking onder de Price-Anderson Act in de Verenigde Staten: hocwel aan het aansprakelijkheidsrecht niet wordt geraakt, zal het uiteindelijk toch de exploitant (of diens verzekeraar) zijn die de economische last van de aansprakelijkheid zal dragen; ook onder

Cousy, H., "Een nieuwe vorm van schuldloze aansprakelijkheid - Aansprakelijkheid voor schade veroorzaakt door het vreedzaam gebruik van kemenergie", Jura Falconis, 1974-1975, 44; Dăuber, W., Haftung für gefahrliche Technologien. Das Beispiel Atomrecht, C.F. Müller Juristischer Verlag, Heidelberg, 1988, 125; Fischerhof, H., Deutsches Atomgesetz und Strahlenschutzrecht, Baden-Baden, 1962, 290; Hébert, J., "Nucléaire", Juris Classeur Responsabilité Civile fasc. 425-1, 1986, 1-40; Mohr, P.C., "Die Kanalisierung der Haftung unter besondere Berücksichtigung des Atomrechts", o.c., 128; Mosthaf, H.D., "Wirtschaftlich oder rechtlich kanalisieren? Eine Streitfrage der Kernhaftung", Versicherungsrecht, maart 1967, Heft 9, 167-202.

Bij economische kanalisatie zal dat veelal onrechtstreeks zijn, bij juridische kanalisatie zal de persoon naar wie de aansprakelijkheid wordt gekanaliseerd rechtstreeks aansprakelijk zijn. 
het stelsel van het Verdrag van Parijs en Wenen is het de exploitant van de keminstallatie (of diens verzekeraar) die de schade moet vergoeden ${ }^{189}$.

Indien economische kanalisatie wordt beschouwd als het verschuiven van de economische gevolgen van een aansprakelijkheid, dan kan ook verzekering worden beschouwd als een toepassing van de economische kanalisatie. Bij een verzekeringsdekking wordt het risico verschoven naar de verzekeraar ${ }^{190}$. Er kan worden geargumenteerd dat bij een aansprakelijkheidsverzekering de verzekeraar het aansprakelijkheidsrisico draagt en niet langer de juridisch aansprakelijke personen. Ook bij bedrijven wordt de verzekeringspremie doorberekend in de prijzen zodat elke aansprakelijkheid in hoofde van de bedrijven economisch wordt gekanaliseerd naar de consument ${ }^{191}$.

Maar de economische kanalisatie van verzekeringen kan niet op eenzelfde voet worden geplaatst als de kanalisatic van aansprakelijkheid in het kemenergierecht. Bij een ernstig schadegeval (kernongeval, milieuramp, ...), liggen mogelijks meerdere personen feitelijk aan de oorsprong van de schade. Eén enkel schadegeval kan dus aanleiding geven tot een kluwen van rechtsverhoudingen waarbij enerzijds meerdere personen zich in een contractuele keten bevinden en waarbij anderzijds een aantal andere personen geen contractuele band heeft ten overstaan van de zich in de keten bevindende personen ${ }^{192}{ }^{193}$. Er mag niet uit het oog worden verloren dat de onderliggende verhouding tussen de aansprakelijke en degene die de economische last van deze aansprakelijkheid draagt - de verzekeraar - van contractuele aard is: de plicht van deze laatste orn de (economische) last van een gegeven schade te dragen, is gebaseerd op de uit het verzekeringscontract voortvloeiende verbintenissen. Bij een juridische kanalisatie daarentegen bestaat in principe geen enkele contractuele band tussen dader en slachtoffer. Een - contractuele - economische kanalisatic dient daarom duidelijk te worden onderscheiden van de - extracontractuele - juridische kanalisatie ${ }^{194}$. Dit verklaart ook waarom in het algemeen zeer omzichtig dient te worden ongesprongen met het hanteren van het begrip "kanalisatie van aansprakelijkheid". Het risico bestaat immers dat de contractuele en de extracontractuele verbintenissen worden verward.

In ieder geval lijkt het ons correcter om te spreken van enerzijds een economische kanalisatie en anderzijds de juridische kanalisatie van aansprakelijkheid. Enkel deze laatste term grijpt namelijk in in het gemene aansprakelijkheidsrecht. Economische kanalisatie heeft enkel betrekking op de gevolgen van aansprakelijkheid (of van een financiële last, anders dan voortvloeiend uit aansprakelijkheid) ${ }^{195}$. In het kader van dit onderzoek zal telkens worden gesproken van kanalisatie van

189 Vanden Borre, T., "Dekking van het nucleaire risico op nationaalrechtelijke basis of via intemationale Verdragen: de Verenigde Staten versus Europa", in Faure, M., Deketelaere, K. en Verhoosel, G., (red.), "Grensoverschrijdende milieuproblemen", l.c., 451. Zie ook verderop, in hoofdstuk 13.

Hiermee is niet gezegd dat verzekering uitsluitend heeft tc maken met het verschuiven van een risico; bij de economische analyse van verzekeringen zal blijken dat met name risicospreiding één van de basiskenmerken van verzekering is (cfr. infra in hoofdstuk 9).

(9) Mosthaf, H.D., "Wirtschaftlich oder rechtlich kanalisieren? Eine Streitfrage der Kernhafung", o.c., 197 e.v.

${ }^{19} 2$ Of beter, waar de slachtoffers in de regel ten overstaan van de meerderheid van de zich in de keten bevindende personen enkel een contractuele band hebben met de laatste schakel van die keten (bijvoorbeeld bij de aankoop van een bepaald product).

i9s Dit kluwen zal nog ingewikkelder zijn bij ongevallen met een internationale dimensie zoals grensoverschrijdende schade of bij verschillende nationaliteit van dader en slachtoffer.

194 Mosthaf heeft het in deze over een daadwerkelijke kanalisatie (Mosthaf, H.D., "Wirtschaftlich oder rechtlich kanalisieren? Eine Streitfrage der Kemhaftung", o.c., 198).

Later wordt teruggekomen op de begrippenverwarring van de term kanalisatie, en dan met name het gebruik ervan buiten het kernenergierecht, cfr. infra, $\S 2.3$ van dit hoofdstuk. 
aansprakelijkheid; hiermee wordt de juridische kanalisatie bedoeld. Terwijl wordt verwezen naar de economische kanalisatie, zal dit uitdrukkelijk worden aangegeven.

Vooraleer de bepalingen van het Verdrag zelf te analyseren, wordt hieronder aangegeven waarom, volgens de ratio legis van het Verdrag van Parijs, de aansprakelijkheid werd gekanaliseerd naar de exploitant van de kerninstallatie.

\subsubsection{Ratio legis volgens de Exposé des Motifs bij het Verdrag van Parijs}

Het Exposé des Motifs van het Verdrag van Parijs benadrukt dat ingevolge de kanalisatie van aansprakelijkheid enkel de exploitant aansprakelijk is voor de door een kernongeval veroorzaakte schade $^{196}$. Van belang is ook dat daar meteen wordt aan toegevoegd dat het Verdrag enkel betrekking heeft op de civielrechtelijke aansprakelijkheid. Het blijkt niet de bedoeling van kanalisatie te zijn geweest om enige wijziging aan te brengen aan de regels inzake internationaal publiekrecht inzake de aansprakelijkheid van de Staat bij grensoverschrijdende schade.

Volgens het Exposé des Motifs hebben twee overwegingen geleid tot de invoering van de kanalisatie van aansprakelijkheid naar de exploitant van een keminstallatie. Ten eerste dienden ingewikkelde en langdurige rechtszaken te worden vermeden. Op deze wijze moest worden voorkomen dat verschillende personen op verschillende juridische grondslagen zouden worden gedagvaard in een vordering tot schadeloosstelling. Ten tweede zou de aansprakelijkheid van de leverancier vereisen dat al degenen die zijn betrokken bij de bouw van een keminstallatie, hiervoor een verzekeringsdekking zouden nemen, naast de aansprakelijkheidsverzekering van de exploitant, terwijl het niet eens zeker is dat deze verzekeringen verkrijgbaar of betaalbaar zijn ${ }^{197}$.

Nog steeds volgens het Exposé des Motifs was het essentieel dat bij een kemongeval geen acties kunnen worden ingeleid tegen andere personen dan de exploitant ${ }^{198}$. Hierbij werd vooral gedacht aan personen die diensten hadden verleend of materiaal of uitrusting hadden geleverd bij het opmaken van de plannen, bij de bouw, de constructie, het onderhoud of het herstel van de keminstallatie. De vrees bestond dat indien het kernongeval zou (kunnen) te wijten zijn aan een gebrek in het ontwerp van de installatie of aan gebrek aan geleverd materiaal, het slachtoffer de leverancier zou kunnen aanspreken op grond van de regeling inzake productaansprakelijkheid ${ }^{199}$.

De ratio legis van het Verdrag van Parijs neemt bijgevolg twee argumenten uit het Harvard Rapport over: zowel het procesrechtelijke als verzekeringsargument worden in de Exposé des Motifs uitdrukkelijk vermeld.

Artikel 1, a, vi van het Verdrag definieert de exploitant als de persoon die door het bevoegde gezag is aangewezen of erkend als exploitant van een keminstallatic. Het is bijgevolg mogelijk dat gedurende de testfase, wanneer de reactor wordt bestuurd door of onder leiding van een van de leveranciers, de leverancier zal worden aangewezen als exploitant onder toepassing van het Verdrag. Indien cen vordering wordt ingesteld, zal de rechter moeten nagaan wie door de bevoegde autoriteiten van de installatiestaat als exploitant is aangewezen (Exposé des Motifs, nr. 15). 


\subsubsection{Definitie van het begrip "kanalisatie van aansprakelijkheid" in het internationale kernenergierecht}

Tijdens de onderhandelingen van het Verdrag van Parijs, werden meerdere voorstellen gelanceerd om tegemoet te komen aan de vrees van Amerikaanse leveranciers van keminstallaties in Euro$\mathrm{pa}^{200}$. Het ene voorstel voorzag in de invoering van een stelsel van economische kanalisatie naar Amerikaans model; een ander voorstel voorzag in de invoering van een stelsel van juridische kanalisatie van aansprakelijkheid, waarbij vorderingen tegen de leverancier werden beperkt. Voomamelijk de Europese verzekeringsindustrie leek echter niet geneigd om polissen met een omnibusdekking (waarbij zowel de aansprakelijkheid van de exploitant als deze van zijn leveranciers werden gedekt) uit te schrijven ${ }^{201}$. De meerderheid van organisaties en delegaties die bij de onderhandelingen van het Verdrag van Parijs waren betrokken kozen blijkbaar vrij snel voor het afschaffen van de vordcringen tegen de leveranciers ${ }^{202}$.

De kanalisatie van aansprakelijkheid wordt als volgt gedefinieerd in artikel 6 van het Verdrag van Parijs:

"Het recht op vergoeding van schade ontstaan door een kernongeval kan slechts worden uitgeoefend tegen een exploitant die overeenkomstig dit Verdrag aansprakelijk is (...).

Tenzij in dit artikel anders is bepaald, is niemand anders aansprakelijk voor schade veroorzaakt door een kernongeval (...)".

In het Verdrag van Wenen wordt de kanalisatie van aansprakelijkheid als volgt verwoord:

"Except as otherwise provided in this Convention, no person other than the operator shall be liable for nuclear damage"203

De omschrijving van de kanalisatie van aansprakelijkheid houdt twee elementen in ${ }^{204}$. Ten cerste kan, indien zich een kernongeval voordoet zoals gedefinieerd in het Verdrag van Parijs of van Wenen, de exploitant alleen onder het Verdrag aansprakelijk worden gesteld en ten tweede is niemand anders dan de exploitant aansprakelijk voor schade uit een kemongeval.

Camier, M.-C., "Responsabilité et Assurance du Risque Atomique", l.c., 115-117.

Murphy, A.W., "Third Party Liability of Suppliers in International Nuclear Transactions", in Weinstein, J.L. (ed.), "Progress in Nuclear Energy", l.c., 180.

Ook de ontwerptekst van het Verdrag van Wenen voorzag in een systecm van cconomischc kanalisatic, hierbij uitdrukkelijk verwijzend naar de Amerikaanse Atomic Energy Act (Official Records Vienna Convention, 74-75).

Artikel II.5 van het Verdrag van Wenen van 1963.

Cousy, H., "Een nieuwe vorm van schuldloze aansprakelijkheid - Aansprakelijkheid voor schade veroorzaakt door het vreedzaam gebruik van kernenergie", o.c., 45 ; Pelzer, $\mathrm{N}$., "The present state of research carried out by the English speaking section", o.c., 276-277; Vanden Borre T., "Transplantatic van kanalisatie van aansprakelijkheid van het kernenergierecht naar het milieu(aansprakelijkheids)recht: een goede of een gebrekkige zaak?", in Faure, M. en Deketelaere, K., (red.), "lus Commune en Milieurecht", l.c., 343-344; Vanden Borre, T., "Channelling of Liability: A Few Juridicial and Economic Views on an Inadequate Legal Construction", in Horbach, N.L.J.T. (ed.), "Contemporary Developments in Nuclear Energy Law", l.c., 22. 
Dit betekent vooral dat het Verdrag van Parijs of het Verdrag van Wenen de enige rechtsgrond biedt waarop een slachtoffer zich kan beroepen ter vergoeding van de door hem geleden schade uit een kernongeval. Deze kanalisatie van aansprakelijkheid leidt ertoe dat elke andere aansprakelijkheidsgrond buiten werking wordt gesteld. Indien een slachtoffer schade lijdt ingevolge de activiteit of een inrichting waarvoor de aansprakelijkheid wordt gekanaliseerd, kan hij enkel en alleen de persoon naar wie deze aansprakelijkheid wordt gekanaliseerd (i.c. de exploitant van een kerninstallatie) aansprakelijk stellen. Kanalisatie in het kemenergierecht brengt het slachtoffer automatisch bij de exploitant terecht ${ }^{205}$ : enkel de exploitant kan worden aangesproken en hij kan enkel worden aangesproken op grond van de Verdragsbepalingen.

De kanalisatie der aansprakelijkheid leidt er in tweede instantie toe dat de exploitant van een kerninstallatie voor de bedragen die hij of zijn verzekeraar aan slachtoffers van een kernongeval heeft uitgekeerd, in beginsel niet beschikt over een regresvordering tegen zijn leveranciers ${ }^{206}$. Andere personen die hebben meegeholpen aan de bouw van de kerninstallatie kunnen niet worden aangesproken; een regresrecht kan slechts in een aantal welbepaalde gevallen worden uitgeoefend. Bovendien zal de exploitant, in de hypothese dat een andere persoon dan de exploitant of een van zijn werknemers of aangestelden het ongeval heeft veroorzaakt, in beginsel geen recht op verhaal hebben tegen degene die de facto het ongeval veroorzaakte. De kanalisatie van aansprakelijkheid zoals voorzien in het Verdrag van Parijs schakelt niet enkel de extracontractuele vorderingen uit tussen een slachtoffer en, bijvoorbeeld, een leverancier van de exploitant, maar het beperkt ook het regresrecht van de exploitant tegenover diens leverancier. Belangrijk is dus dat het Verdrag van Parijs en het Verdrag van Wenen de aansprakelijkheid juridisch kanaliseren naar de exploitant van de kerninstallatie. Op zich bieden de Verdragen niet de mogelijkheid om naar het voorbeeld van de Amerikaanse Price-Anderson Act een systeem van economische kanalisatie in te voeren.

Aan het principe van de kanalisatie van aansprakelijkheid naar de exploitant van een keminstallatic worden in het Verdrag van Parijs dric uitzonderingen aangebracht ${ }^{207}$. Ten eerste kent artikel 6, feen verhaalsrecht toe aan de exploitant indien het kernongeval werd veroorzaakt door een handelen of nalaten met het opzet schade te veroorzaken, op de persoon die met opzet heeft gehandeld of nagelaten heeft te handelen. Het is echter niet omdat dergelijk regresrecht werd toegekend, dat zomaar het gemeenrechtelijk regime opnieuw toepassing zal vinden. Het "Exposé des Motifs" stelt immers uitdrukkelijk dat hoe dan ook de regel respondeat superior buiten werking blijft ${ }^{208}$. Bijgevolg zal een persoon die met opzet schade heeft berokkend - hetzij door handelen, hetzij door nalaten te handelen - en die dit deed tijdens de uitvoering van zijn beroepswerkzaamheden, de enige persoon zijn die kan worden aangesproken. De exploitant zal zich, in tegenstelling tot het gemeenrechtelijke regime, niet tot de werkgever van die persoon kunnen richten.

Ten tweede zal de exploitant over een regresrecht beschikken indien dit uitdrukkelijk bij overeenkomst werd bepaald (artikel 6, f, ii van het Verdrag). Dit regresrecht kan uiteraard via subrogatie worden uitgeoefend door de verzekeraar of door degene die cen andere financiële zekerheid heeft gesteld.

205

Pelzer, N., "Channelling: Concept and Policy under the Paris and the Vienna Conventions", Joint CEC/LAEA/NEA Training Seminar on Nuclear Law, Bratislava, 30 augustus - 2 september 1994.

Deze regel vindt haar grondslag in het eerder aangehaalde verzekeringsargument: indien zowel leverancier als de exploitant zich voor eenzelfde risico zouden (moeten) verzekeren dan zou dit leiden tol een dubbele verzekeringsdekking.

In het Verdrag van Wenen werden analoge uitzonderingen opgenomen.

Exposé des Motifs, nr. 19. 
Ten derde is ook in een regresrecht voorzien ingeval van doorvoer van nucleaire stoffen. Volgens artikel 7 e) van het Verdrag van Parijs kan een Verdragsluitende Partij de doorvoer van nucleaire stoffen op haar grondgebied afhankelijk stellen van de voorwaarde dat het maximumbedrag warvoor de betrokken exploitant aansprakelijk is, wordt verhoogd tot op hetzelfde niveau als de aansprakelijkheid van de exploitant van het transitland. Indien een dergelijke doorvoer zou geschieden zonder de toestemming van deze laatste dan beschikt hij, ingeval de schade diens aansprakelijkheid overtreft, over een regresvordering tegen de vervoerder.

Er heeft evenwel steeds discussie bestaan over de interpretatie van artikel 6 van het Verdrag van Parijs - en van het corresponderende artikel in het Verdrag van Wenen. Ter discussie stond de vaag of de leveranciers van de exploitant, dankzij de kanalisatie van aansprakelijkheid, enkel immuun zijn tegen vorderingen van derden, dan wel of zij ook immuun zijn tegen vorderingen van de exploitant ter zake van de door hem geleden eigenschade. Deze problematiek wordt hieronder aan de orde gesteld.

\subsubsection{Strekking van de kanalisatie van aansprakelijkheid zoals voorzien in het Verdrag van Parijs}

Door de kanalisatie van aansprakelijkheid zoals voorzien in het Verdrag van Parijs is een leverancier immuun tegen een vordering van het slachtoffer van een kernongeval. Voor wat betreft de aansprakelijkheid van de leveranciers ten aanzien van de exploitant van de kerninstallatie, heeft in het kernenergierecht steeds onzekerheid bestaan over de interpretatie van het in het Verdrag van Parijs voorziene regresrecht. De kern van de discussie heeft betrekking op de vraag of de kanalisatic van aansprakelijkheid aan de exploitant de mogelijkheid ontneemt, c.q. beperkt om zijn eigenschade terug te vorderen van zijn leverancier(s). Met andere woorden: strekt de kanalisatie zich uit tot de vorderingen van de exploitant tegen zijn leveranciers voor wat betreft de schade aan de kerninstallatie, of heeft de kanalisatie van aansprakelijkheid enkel tot gevolg dat de exploitant slechts in beperkte gevallen regres mag uitoefenen voor de schadevergoeding die hij aan slachtoffers heeft uitbetaald ${ }^{20 \%}$ ?

Volgens artikel 6 van het Verdrag van Parijs beschikt de exploitant enkel over een regresrecht indien dit contractueel werd bepaald. Dit impliceert dat de exploitant de bedragen die hij aan derden heeft uitbetaald ingevolge zijn aansprakelijkheid naar aanleiding van een kernongeval, slechts kan terugvorderen van de leverancier, indien dit contractueel werd overeengekomen. Maar in het internationale kemenergierecht bestaat discussie over de vraag of dit ook betckent dat de exploitant de schade aan zijn eigen keminstallatie slechts kan terugvorderen van de leverancier indien dit contractueel werd overeengekomen.

Deze discussie is bepalend voor de omvang van de immuniteit van de leveranciers, en dus ook voor de omvang van de kanalisatie van aansprakelijkheid. Een volledige bescherming van de leveranciers zou impliceren dat niet alleen vorderingen van derden tegen de leverancier onmogelijk werden gemaakt, maar dat ook vorderingen van de exploitant tegen de leverancier zouden worden onmogelijk gemaakt ${ }^{210}$. Tijdens de onderhandelingen van het Verdrag van Parijs en het Verdrag van Wenen, bleek overeenstemming te bestaan over het feit dat leveranciers dienden te worden beschermd tegen vorderingen van slachtoffers van een kernongeval; grote onenigheid

Beyens, M., "Les dommages aux biens sur le site", in Reform of Civil Nuclear Liability, OECD, Puris, $2000,509$.

Murphy, A.W., "Third Party Liability of Suppliers in International Nuclear Transactions", in

Weinstein, J.L. (ed.), "Progress in Nuclear Energy", l.c., 166-186, 176. 
bestond evenwel over de mate waarin de leveranciers dienden te worden beschermd tegen de regresrechten waarover de exploitant overeenkomstig het gemene recht beschikt ${ }^{211}$.

Omdat de juiste strekking van dit regresrecht essentieel is bij beoordeling van de al dan niet absolute immuniteit van de leveranciers en bijgevolg bij de interpretatie van de omvang van de kanalisatie van aansprakelijkheid, wordt dit hieronder verder toegelicht. Overigens is de vraag naar de strekking van de kanalisatie van aansprakelijkheid actueel: deze problematiek maakt het voorwerp uit van de onderhandelingen inzake de revisie van het Verdrag van Parijs ${ }^{212}$.

Volgens Vedel zijn in de literatuur twee interpretaties terug te vinden ${ }^{213}$. De eerste visie stelt dat de leveranciers volledig immuun zijn voor vorderingen uit een kernongeval $(\$ 2.2 .4 .1)$. Volgens de tweede visie daarentegen kunnen de leveranciers wel degelijk worden aangesproken voor wat betreft de schade aan de installatie van de exploitant ( $\$ 2.2 .4 .2)$. De verschillende elementen van de analyse worden gebundeld in $\S 2.2 .4 .3$.

\subsubsection{Eerste visie: de leveranciers zijn zowel immuun tegen vorderingen van de exploitant ingevolge de door hem betaalde schadevergoeding als gevolg van de door hem geleden eigenschade}

Volgens een eerste interpretatie omvat artikel 6 van het Verdrag van Parijs zowel de extracontractuele aansprakelijkheid tegenover derden als de contractuele aansprakelijkheid in de relatie tussen de exploitant en de leverancier. Drie argumenten onderbouwen deze visie.

Zo wordt in de eerste plaats gesteld dat het feit dat een dergelijk onderscheid niet wordt gemaakt in de tekst van het Verdrag van Parijs, precies aangeeft dat de auteurs van het Verdrag van Parijs zowel de extracontractuele aansprakelijkheid tegenover derden als de contractuele aansprakelijkheid (voor eigenschade van de exploitant) beoogden. Artikel 6 van het Verdrag van Parijs luidt immers: "Het recht op vergoeding van schade ontstaan door een kernongeval kan slechts worden uitgeoefend tegen een exploitant", en dus niet tegen een leverancier, zelfs niet indien deze laatste schade veroorzaakt aan de eigen goederen exploitant of aan de goederen die zich op de site bevinden. Hieruit wordt afgeleid dat het beginsel van de kanalisatic van aansprakelijkheid, dat in zeer absolute termen is voorwoord, verhindert dat de contractuele aansprakelijkheid aan het gemene recht zou onderworpen zijn, zelfs bij eigenschade van de exploitant.

In de tweede plaats blijkt dat met name artikel $6, f$ ) in een regresrecht voorziet indien dit contractueel werd overeengekomen. $A$ contrario wordt hieruit afgeleid dat zowel de extracontractuele als de contractuele aansprakelijkheid worden gekanaliseerd naar de exploitant en dat de opstellers van het Verdrag terdege rekening hielden met de contractuele relaties tussen de exploitant en zijn leverancier. Indien het de bedoeling zou zijn geweest van de Verdragspartijen om de contractuele

211 Hébert, J., "Nucléaire", o.c., 31; Murphy, A.W., "Third Party Liability of Suppliers in Interiational Nuclear Transactions", in Weinstein, J.L. (ed.), "Progress in Nuclear Energy", l.c., 179.

212 De NEA heeft de rechtsonzekerheid in verband met de interpretatic van deze bepaling van het Verdrag van Parijs erkend. Note by the Secretariat, "On site property damage under the Paris-Convention", NEA/LEG/DOC (99) 4 .

Vedel, G., "Un problème difficile: la responsabilité des foumisseurs envers les exploítants d'installations nucléaires en cas de dommage nucleaire imputable au fait de ceux-ci", Cahiers Juridiques de l'électricité el de gaz, 1973, 249-263. 
ansprakelijkheid te ondenwerpen aan het gemene recht, dan was zulks expliciet vermeld in plaats van de kanalisatie van aansprakelijkheid in dergelijke absolute termen te formuleren ${ }^{21.4}$.

Bovendien zou, steeds volgens deze visie, een vordering van de exploitant tegen de leverancier in strijd zijn met één van de fundamentele basisprincipes van het Verdrag: dit wil namelijk de ontwikkeling van kemenergie niet belemmeren. Indien een vordering tegen de leverancier zou worden toegelaten, dan zou dit in strijd zijn met de bedoeling van de Verdragspartijen ${ }^{215}$.

Tenslotte wordt uit het feit dat de exploitant niet aansprakelijk is voor de schade aan zijn installatie, afgeleid dat de eigenschade van de exploitant op niemand kan worden verhaald ${ }^{216}$.

Deze visie impliceert dus dat het Verdrag van Parijs de exploitant zowel het regresrecht ontneemt ten aanzien van de schadevergoeding die hij - of zijn verzekeraar - aan derden heeft uitgekeerd, als ten aanzien van de schade aan de eigen installatie. Recent werd deze stelling overigens nog verdedigd door Wiwen-Nilson. Volgens deze auteur laten noch het Verdrag van Parijs, noch het Verdrag van Wenen toe dat vorderingen tegen leveranciers zouden worden ingediend ten aanzien van schade aan de installatie zelf, tenzij de leverancier schriftelijk heeft ingestemd met deze ansprakelijkheid ${ }^{217}$.

2.2.4.2. Tweede visie: leveranciers zijn niet immuun tegen vorderingen van de exploitant ingevolge de eigenschade van de exploitant

Volgens een tweede interpretatie is artikel 6 van het Verdrag uitsluitend van toepassing op de extracontractuele aansprakelijkheid tegenover derden en laat deze onverlet de contractuele aansprakelijkheid in de relatie tussen de exploitant en de leverancier. Ook deze visie wordt uitgebouwd in drie argumenten.

In de eerste plaats bestaat er geen aansprakelijkheid jegens derden ter zake van de eigenschade: de exploitant kan onmogelijk aansprakelijk zijn voor de door hem geleden schade en bijgevolg kan de kanalisatie onmogelijk betrekking hebben op de contractuele aansprakelijkheid in de relatie tussen de exploitant en zijn leverancier. Het argument dat de kanalisatie van aansprakelijkheid in absolute termen is verwoord, is gebaseerd op een foute interpretatie: de kanalisatie geldt immers enkel in zoverre de exploitant ingevolge het Verdrag van Parijs aansprakelijk is.

In de tweede plaats toont het regresrecht als voor 2 ien in artikel $6, \mathrm{f}$, ii) van het Verdrag van Parijs aan dat enkel sprake is van kanalisatie voor vorderingen ingesteld tegen de exploitant en niet van kanalisatie van vorderingen door de exploitant ingesteld.

Tenslotte wordt het gehele systeem zoals voorzien in het Verdrag van Parijs opgezet om een onbegrensd risico het hoofd te kunnen bieden; maar het nucleaire risico is enkel onbegrensd

\footnotetext{
214 Vedel, G., "Un problème difficile: la responsabilité des foumisseurs envers les cxploitants d'installations nucléaires en cas de dommage nucléaire imputable au fajt de ceux-ci", o.c., 255.

Ibidem, 255.

Beyens, M., "Les dommages aux biens sur le site", in "Reform of Civil Nuclear Liability", l.c., 51 l.

Wiwen-Nilsson, T., "Memorandum. Liability of Suppliers and Contractors for nuclear damage to onsite property under the Vienna Convention for Nuclear Damage 1963", NEA/LEG/DOC(S7)5.
} 
tegenover slachtoffers en niet in de (contractuele) relatie tussen exploitant en diens leveran$\operatorname{cier}(s)^{218}$.

\subsubsection{Analyse}

Op basis van de resultaten van de eerdere analyse in dit boek, kan enkel deze tweede visie worden bijgetreden. De gehele discussie is naar onze mening overigens zonder voorwerp. De verdedigers van de eerste visie gaan namelijk voorbij aan de inhoud van het begrip "regresrecht".

Een regresrecht is het recht waarover een persoon beschikt om een door hem uitbetaalde schadevergoeding of uitkering terug te vorderen van een andere persoon. Een regresrecht veronderstelt dus minstens drie verschillende partijen. Het regresrecht bestaat erin dat de initiële schuldenaar schuldeiser wordt in een andere rechtsverhouding en dit ten aanzien van de compensatie die hij heeft betaald aan de initiële schuldeiser ${ }^{219}$. Indien dus wordt gesproken van een regresrecht in het kader van het Verdrag van Parijs, dan kan dit alleen betrekking hebben op de schadevergoeding die de exploitant aan slachtoffers heeft uitbetaald. De discussie omtrent de strekking van het regresrecht van de exploitant is dus deels zonder voorwerp omdat er nooit sprake kan zijn van een regres indien de exploitant de schade van zijn eigen installatie wenst ten laste te leggen van zijn leverancier.

Ook het Verdrag van Parijs laat er weinig twijfel over bestaan dat de exploitant de eigenschade kan verhalen op zijn leverancier. Het is immers zo dat een contractuele vordering van de exploitant tegen een leverancier ingevolge de eigenschade aan de keminstallatie, duidelijk niet onder het toepassingsgebied van het Verdrag van Parijs valt ${ }^{220}$. Het zou dan ook onlogisch zijn dat het Verdrag enerzijds niet van toepassing is op de eigenschade van de exploitant, maar dat het anderzijds wel de contractucle aansprakelijkheid van de leverancier zou beperken ${ }^{22 !}$. Ook in het Harvard Rapport vinden we steun van deze redenering. Volgens het Harvard Rapport was de aansprakelijkheid van de leverancier tegenover de exploitant niet voorzien in ontweipverdragen of in de ontwerpen van wet ${ }^{222}$. Ook uit de voorbereidende werken van het Verdrag van Wenen blijkt dat het Verdrag niet van toepassing is op de eigenschade van de exploitant en dat het gemene aansprakelijkheidsrecht daarop van toepassing is ${ }^{223}$ : onder verwijzing naar artikel 3 van het Verdrag van Parijs, werd benadrukt dat schade aan de installatie niet onder het Verdrag valt en dat het de exploitant vrijstaat om zijn leverancier te dagvaarden op basis van de regels inzake productaansprakelijkheid ${ }^{224}$. Eens de exploitant de schade heeft vergoed, had de kanalisatie zijn rol gespeeld ${ }^{225}$.

218 Vedel, G., "Un problème difficile: la responsabilité des foumisseurs envers les exploitants d'installations nucléaires en cas de dommage nucléaire imputable zu fait de ceux-ci", o.c., 256.

Zie hierover onder meer Sinninghe Damst.,. W.A., Regres bij Onrechtmatige Daad, Koninklijke Ver. mande, Lelystad, 1999, 101, evenals versehillende bijdragen in Van Boom, W.H., Hartlief, T., Spiet, J., Regresrechien. Afschaffen, handhaven of uitbreiden, W.E.J. Tjeenk Willink, Deventer, 1996. Artikel 3 van het Verdrag van Parijs stelt uitdrukkelijk dat de exploitant niet aansprakelijk is voor de schade toegebracht aan de kerninstallatie zelf.

Het Exposé des Motifs bevestigt dit: "Where a right to compensation of damage exists by virtue of contractual arrangements, such right remains unaffected by the Convention" (Exposé des Motifs, 53). Harvard Rapport, 59. Ook in de conclusie van het rapport wordt gesteld dat "... the Convention will not apply to any liability of a supplier for damage to the operator's property" (Harvard Rapport, 81). 
Interessant in dit verband is een amendement ingediend gedurende de onderhandelingen van het Verdrag van Wenen; het strekte ertoe dat noch de exploitant, noch enige andere persoon aansprakelijk zou zijn voor schade aan de keminstallatie zelf ${ }^{226}$. Het amendement stuitte op heel wat kritiek omdat het veel verder ging dan het Verdrag zelf. In het kader hiervan werd beklemtoond dat de exploitant, voor eigenschade aan zijn installatie het recht diende te hebben om deze schade terug te vorderen van degene die deze schade had veroorzaakt ${ }^{227}$.

Het lag duidelijk in de bedoeling van de Verdragspartijen om de regresrechten waarover de exploitant beschikt overeenkomstig het gemene recht, voor wat betreft de door hem betaalde schadevergoeding aan derden, te beperken. Dit laat echter onverlet de contractuele verhoudingen die aan het gemene recht zijn onderworpen ${ }^{228}$. Het regresrecht als voorzien in artikel $6, f$, ii) van het Verdrag van Parijs heeft bijgevolg uitsluitend betrekking op de extracontractuele aansprakelijkheid van de exploitant: indien dit uitdrukkelijk bij contract wordt bepaald, dan kan de exploitant - of bij subrogatie diens verzekeraar - de sommen dic aan derden werden uitbetaald ingevolge een kemongeval, (al dan niet ten dele) terugvorderen van de leverancier.

Meer in het algemeen dient overigens te worden vastgesteld dat het nucleaire aansprakelijkheidsrecht het contractuele aansprakelijkheidsrecht intact laat. Met andere woorden: het nucleaire aansprakelijkheidsrecht kanaliseert enkel de extracontractuele aansprakelijkheidsvorderingen naar de exploitant en niet de contractuele vorderingen van de exploitant voor de schade aan zijn kerninstallatie. De leveranciers zijn dus niet geheel immuun tegen vorderingen: zij kunnen op basis van het gemene aansprakelijkheidsrecht worden aangesproken door de exploitant voor de aan zijn installatie veroorzaakte schade ${ }^{229}$.

$\mathrm{Na}$ de analyse van de kanalisatie van aansprakelijkheid in het Verdrag van Parijs, volgt hieronder een analyse van de wijze waarop de kanalisatie van aansprakelijkheid werd geintroduccerd in het Belgische en het Nederlandse kemenergierecht.

\subsubsection{Kanalisatie van aansprakelijkheid in het Belgische en Nederlandse kernenergierecht}

De Belgische wetgever heeft het begrip "kanalisatie van aansprakelijkheid" niet geëxpliciteerd in de wet van 22 juli 1985 inzake de wettelijke aansprakelijkheid op het gebied van de kernenergie. In de Memorie van Toelichting werd wel gewezen op de band tussen kanalisatie van aansprakelijkheid en risicoaansprakelijkheid: risicoaansprakelijkheid impliceert volgens de Belgische wetgever ten eerste dat de aansprakelijkheid losstaat van elke schuld en ten tweede dat deze aansprakelijkheid volledig ten laste valt van één persoon, te weten de exploitant van de kerninstallatie $e^{230}$. Toch werd tussen beide begrippen geen duidelijk onderscheid gemaakt.

Volledigheidshalve dient erop te worden gewezen dat de kanalisatie van aansprakelijkheid niet werd ingevoerd door de wet van 22 juli 1985; dit was namelijk reeds gebeurd bij de wet van 18 juli $1966^{231}$. In de Memorie van Toelichting bij deze laatste wet werd overigens gesproken van

Document CN-12/CW/1 No 66, Official Records Vienna Convention, 401.

Official Records Vienna Convention, 255.

Camier, M.-C., "Responsabilité et Assurance du Risque Atomique", l.c., 119.

Niets sluit uiteraard uit dat de exploitant en de leverancier contractueel bepaalde afspraken maken met betrekking tot vorderingen van de exploitant tegen diens leverancier ingevolge schade aan de kernin. stallatie.

Memorie van Toelichting, Parlementaire Stukken, Senaat, GZ/1983-1984, 593/1, 6.

Zoals eerder besproken onder $\$ 3.3 .2$ van hoofdstuk 2 . 
een "aansprakelijkheidsexclusiviteit" 232 . Er weze an herinnerd dat de wet van 1966 de kanalisatie van ansprakelijkheid bij hoogdringendheid had ingevoerd in de Belgische rechtsorde: onder druk van de leveranciers kon, zonder de kanalisatie, de kerncentrale van Chooz niet worden in gebruik genomen.

De Nederlandse WAKO geeft net als de Belgische wet geen specifieke definitie of omschrijving van het begrip kanalisatie van aansprakelijkheid. Hier wordt herinnerd aan het feit dat in Nederland de kanalisatie is ingevorerd in het kemenergierecht via een tijdelijke wet, en dan met name als deel van een begrotingswet ${ }^{233}$.

Toch waren de allereerste vormen van kanalisatie in het Belgische en Nederlandse kemenergicrecht economische kanalisatie. Onder de wet op de civiele aansprakelijkheid van het SCK, en de wet op de rijksmiddelenbegroting bleef het gemene aansprakelijkheidsrecht onverninderd van kracht; slechts de gevolgen van de aansprakelijkheid werden doorgeschoven naar de Staat. Pas op het moment waarop beide landen het Verdrag van Parijs in het nationale recht invoerden, deed de juridische kanalisatie haar intrede in het Belgische en Nederlandse kernenergierecht.

Indien zich bijgevolg in België of Nederland een kernongeval voordoet waarop respectievelijk de wet van 22 juli 1985 of de WAKO van toepassing is dan zal dit de enige rechtsgrond zijn waarop slachtoffers zich kunnen baseren en kunnen zij zich enkel tot de exploitant richten. De juridische grondslagen van aansprakelijkheid zoals vervat in het BW, het NBW, of enige andere wet worden precies door de toepassing van het nucleaire aansprakelijkheidsregime buiten werking gesteld.

Doordat het nucleaire aansprakelijkheidsrecht een vrij verregaande wijziging aanbrengt aan het gemene aansprakelijkheidsrecht, is de kanalisatie van aansprakelijkheid "traditioneel" een omstreden thema, zeker bij de invoering ervan in het nationale recht. De weerstand tegen de kanalisatie wordt in onderstaande paragraaf besproken.

\subsubsection{Weerstand tegen de kanalisatie van aansprakelijkheid in het kernenergierecht}

Op verschillende tijdstippen en in verschillende landen werd de kanalisatie van aansprakelijkheid niet zonder meer aanvaard en werd deze niet zonder slag of stoot in het nationale kernenergierecht ingevoerd. Reeds bij de onderhandelingen van het Verdrag van Parijs en het Verdrag van Wenen op het einde van de jaren vijftig en begin de jaren zestig, vormde de invoering van de kanalisatic van aansprakelijkheid het voorwerp van discussie $(\$ 2.2 .6 .1$ ). Ook de omvetting van de Verdragen in het nationale kemenergierecht heeft aanleiding gegeven tot vaak hevige discussies; uit $\$ 2.2 .6 .2$ zal blijken dat deze discussie ook in de jaren negentig niet is afgerond. In $\$ 2.2 .6 .3$ tenslotte worden de voornaamste elementen van de analyse gebundeld en gecombineerd met de inzichten van de eerdere analyse.

\subsubsection{Bij de onderhandelingen van het Verdrag van Parijs en bij het Verdrag van Wenen}

Zowel tijdens de onderhandelingen van het Verdrag van Parijs als van het Verdrag van Wenen, werd voorgesteld om in de Verdragen de economische kanalisatie, naar het model van de PriceAnderson Act, in te voeren. Het gemene aansprakelijkheidsrecht zou worden intact gelaten, en de aansprakelijkheidsverzekering van de exploitant van de kerninstallatie zou naast de eigen aansprakelijkheid, ook de aansprakelijkheid van andere mogelijke schadeveroorzakers dekken. 
Bij gebrek aan officiële rapporten over de onderhandelingen van het Verdrag van Parijs, is het niet makkelijk te achterhalen wat zich tijdens die onderhandelingen heeft afgespeeld. Toch kan een en ander worden afgeleid uit onderzoek van verschillende bronnen die dicht bij de onderhandelingen waren betrokken. Tijdens de onderhandelingen van het Verdrag van Parijs wilden de delegaties van Duitsland, Zwitserland en Oostenrijk een nuance aanbrengen aan de kanalisatie van aansprakelijkheid. Er werd voorgesteld te preciseren dat de nationale wet de aansprakelijkheid van andere personen intact kon laten, op voorwaarde dat deze aansprakelijkheid integraal zou zijn gedekt door de verzekering of financiële zekerheid van de exploitant ${ }^{234}$. Deze nuance werd uiteindelijk niet opgenomen in de tekst van het Verdrag, maar Duitsland, Oostenrijk en Griekenland hebben ten aanzien van de kanalisatie van aansprakelijkheid een voorbehoud geformuleerd $^{235}$. Deze drie landen hebben zich inderdaad het recht voorbehouden om "bij nationale wet te bepalen dat andere personen dan de exploitant aansprakelijk kunnen blijven voor door een kernongeval veroorzaakte schade, op voorwaarde dat deze personen voor hun aansprakelijkheid volledig zijn gedekt (...) door middel van door de exploitant verkregen verzekering of andere financiële zekerheid of door middel van openbare middelen". De reden waarom in het Verdrag van Parijs uiteindelijk werd gekozen voor de (juridische) kanalisatie van aansprakelijkheid eerder dan voor het Amerikaanse systeem, vloeit voort uit de positie van de Europese verzekeraars. Deze waren niet bereid of niet in staat om parapludekkingen, die zowel de aansprakelijkheid dekte van de exploitant als deze van de leveranciers, te verlenen ${ }^{236}$.

Uit de officiële voorbereidende werkzaamheden van het Verdrag van Wenen kan worden afgeleid dat ook tijdens de onderhandelingen van het Verdrag van Wenen, de invocring van kanalisatie van aansprakelijkheid het voorwerp vormde van discussie. In het oorspronkelijke ontwerp van het Verdrag $^{237}$ luidde artikel II als volgt:

"§5. Except as otherwise provided for in this Convention no person other than the operator shall be liable for nuclear damage.

$\S 6$. The law of the Installation State may determine that, in addition to the operator, other persons shall also be liable if:

a) the total liability of all persons thus liable for the same nuclear damage is limited so as not to exceed the limit of liability established in conformity with article IV;

b) the liability of all such persons is covered by the financial security maintained pursuant to article Vl".

Voortbouwend op het voorbehoud dat enkele landen hadden aangetekend tegen de kanalisatie van aansprakelijkheid onder het Verdrag van Parijs, voorzag paragraaf 6 van het ontwerp van het Verdrag van Wenen in een economische kanalisatie. In dit geval is de exploitant niet de enige persoon die juridisch aansprakelijk kan worden gesteld; uiteindelijk wordt de schade echter economisch naar hem gekanaliseerd aangezien zijn verzekeringsdekking ook de schade uit het kemongeval zal dienen te vergoeden waartoe een andere persoon is gehouden. Dit werd voorgesteld ondat de zuivere, juridische kanalisatie van aansprakelijkheid "may contradict traditional legal

\footnotetext{
3 Camicr, M.-C., "Responsabilité et Assurance du Risque Atomique", l.c., 117.

Zwitserland heeft uiteindelijk het Verdrag van Parijs niet ondertekend.

236 Murphy, A.W., "Third Party Liability of Suppliers in Intemational Nuclear Transactions", in Weinstein, J.L. (ed.), "Progress in Nuclear Energy", l.c., 180.

2

Dit ontwerp dateerde van oktober 1962; "Draft Convention on Minımum International Standards regarding Civil Liability for Nuclear Damage", Official Records Vienna Convention, 45.
} 
principles ${ }^{238}$; bovendien zou het een zekere flexibiliteit geven aan het Verdrag dat op deze wijze voor een groter aantal landen aanvaardbaar zou zijjn ${ }^{239}$.

Meerdere delegaties (waaronder de Belgische en de Nederlandse delegatie) bleken echter niet gewonnen voor een systeem van economische kanalisatie en dienden meerdere amendementen in om paragraaf 6 te schrappen ${ }^{240}$. De tegenstanders van de mogelijkheid om economische kanalisatie in het Verdrag te voorzien waren duidelijk in de meerderheid: paragraaf 6 werd geschrapt en het Verdrag van Wenen zou uitgaan van de juridische kanalisatie van aansprakelijkheid naar de exploitant van de kerninstallatie. Een land dat toetreedt tot het Verdrag zou niet de keuze hebben tussen economische kanalisatie en juridische kanalisatie van aansprakelijkheid.

Uit de bespreking van de wijze waarop de kanalisatie van aansprakelijkheid is ingeschreven in het Verdrag van Parijs, bleek dat de kanalisatie naast de beperking van de extracontractuele vorderingen ook ingrijpt in de contractuele vorderingen tussen de exploitant en zijn leverancier(s); het regresrecht van de exploitant wordt namelijk beperkt ${ }^{241}$. Ook dit regresrecht vormde het voorwerp van discussie bij de onderhandelingen van het Verdrag van Wenen.

De ontwerptekst van het Verdrag van Wenen voorzag, naar het voorbeeld van het Verdrag van Parijs, in cen regresrecht van de exploitant indien het kernongeval opzettelijk was veroorzaakt, indien het regresrecht contractueel was overeengekomen of bij de transit van een nucleair transport. Een volledige afschaffing van alle regresrechten kon moeilijk worden gerechtvaardigd ${ }^{242}$. Een groot aantal landen had echter problemen met het feit dat de exploitant enkel regres kon uitoefenen indien het ongeval opzettelijk werd veroorzaakt.

Veertien landen dienden daarom gezamenlijk een amendement in ${ }^{243}$ op basis waarvan een regresrecht zou openstaan tegen leveranciers van de kerninstallatie indien hen een fout zou kunnen worden verweten ${ }^{244}$. In de opinie van de indieners van dit amendement ging het te ver om enkel een regresrecht te voorzien indien het ongeval opzettelijk werd veroorzaakt; hun voorstel achtten ze aanvaardbaar omdat nog steeds een fout in hoofde van de leverancier diende te worden bewezen. De veertien plaatsten overigens vraagtekens bij de stelling dat zonder de juridische kanalisatie van aansprakelijkheid de verzekeringskosten zouden toenemen ${ }^{245}$. Zo zouden ook de leveranciers een verzekeringsdekking nemen en bovendien zou een exploitant die wist dat hij regres zou kunnen uitoefenen tegen zijn leveranciers, sneller geneigd zijn om aan slachtoffers een schadevergoeding uit te keren. Er was, steeds volgens de veertien, geen enkele reden waarom, in een verdrag dat hoofdzakelijk slachtoffers wil beschermen, economische argumenten belangrijker zouden zijn dan juridische ${ }^{246}$. Indien leveranciers wisten dat zij aansprakelijk kunnen worden

238

Official Records Vienna Convention, 74.

Official Records Vienna Convention, 229.

Official Records Vienna Convention, 228.

Cfr. supra, in \$2.2.3 van dit hoofdstuk.

Hardy, M.J.L. "Nuclear Liability: the general principles of law and further proposals", o.c., 247.

Amendement $\mathrm{CN}-12 / \mathrm{CW} / 92$ ingediend door Argentinië, Brazilie, Colombia, Griekenland, Filippijnen, Indonesiē, Iran, Libanon, Mexico, Marokko, Oostenrijk, Portugal, Spanje, Vietnam.

Het amendement luidde: "Operators shall have a right of recourse against any person who has manufactured materials or equipment for, or who has furnished materials, equipment or services in connection with the design, construction, repair or operation of a nuclear installation, or who has transported or stored nuclear material, for fault or such person".

Dit was, zoals aangetoond, een van de argumenten die zowel in het Harvard Rapport als in de Exposé des Motifs van het Verdrag van Parijs werd aangehaald om de invoering van de juridische kanalisatie van aansprakelijkheid te motiveren.

Official Records Vienna Convention, 294. 
gesteld voor de uit een kernongeval voortvloeiende schade, zouden zij meteen alle maatregelen nemen om ongevallen te vermijden ${ }^{247}$.

Het amendement van de veertien landen stuitte op hevige kritiek van andere landen die beklemtoonden dat indien het amendement zou worden aanvaard, de ontwikkeling van de kemenergieindustrie in het gedrang zou komen. Een aantal landen beschouwde dit zelfs als een breekpunt ${ }^{248}$. De stelling van een aantal ontwikkelingslanden dat enkel de landen met een eigen, sterk ontwikkelde kernenergie-industrie voorstander waren van de afschaffing van het regresrecht en dus enkel hun eigen industrie wilden beschermen, werd door de Engelse delegatie ontkend. Ei zou geen belangentegenstelling zijn tussen de meer ontwikkelde landen, als leverancier van kernmateriaal, en de ontwikkelingslanden ${ }^{249}$. Uiteindelijk werd het amendement verworpen ${ }^{250}$; ook onder het Verdrag van Wenen werd het regresrecht van de exploitant beperkt.

De weerstand tegen de kanalisatic van aansprakelijkheid in het kernenergicrecht beperkte zich niet tot de onderhandelingen van de nucleaire aansprakelijkheidsverdragen. Ook bij de invoering van de verdragsbepalingen in het nationale (kemenergie)recht ontstonden vaak discussies.

\subsubsection{Bij de invoering van de Verdragen in het nationale kernenergierecht}

Bij het invoeren van het Verdrag van Parijs in de nationale wetgeving, werd met name in Duitsland kritiek geleverd op de kanalisatic. Recent werd in Oostenrijk de nucleaire aansprakelijkheidswet gewijzigd; hierbij was de kritiek op de kanalisatie van aansprakelijkheid één van de belangrijkste elementen. In de paragraaf wordt stilgestaan bij deze kritiek.

In Duitsland werd fel tegen dit mechanisme van leer getrokken, met name door Fischerhof en Pelzer ${ }^{251}$. Niettegenstaande de samenhang en de logica van alle maatregelen die in het Harvard Rapport werden naar voren geschoven, uitten zij felle kritiek op de kanalisatie van aansprakelijkheid, met name omdat kanalisatie een slachtoffer van een kernongeval een aantal rechtsgronden voor een vordering tot schadeloosstelling ontneemt. In de literatuur werd daarom de vraag gesteld of een dergelijke (drastische) ingreep in het gemeenrechtelijke aansprakelijkheidsrecht wel gerechtvaardigd was $^{252}$

Official Records Vienua Convenlion, 296 en 300.

Een lid van de Nederlandse delegatie stelde dienaangaande: "The Committee's decision on the joint amendment would be decisive for the success or failure of the Conference" (Official Records Vienna Convention, 298).

Official Records Vienna Convention, 300.

Official Records Vienna Convention, 301.

Duitsland heeft lang geaarzeld om het Verdrag van Parijs to ondertekenen en het had zelfs voorbchoud gemaakt bij de juridische kanalisatie van aansprakelijkheid. Maar uiteindelijk wilde Duitsland de harmonisatie van het internationale kemenergierecht niet belenmeren, zie o.rn. Warrikoff, A., "Soll Deutschland die Pariser Atomhaftungskonvention ratifizieren?", Atomwirtschafl, maart 1965, 129-131. Dit voorbehoud werd door de industrie zwaar onder vuur genomen (Klarr, H., "Current Problems of Nuclear Insurance from the point of view of Industry", Insurance for Nuclear insiallations, IAEA, Wenen, 1979, Legal Series $n^{\circ}, 6,67$ e.v.).

Fischerhof verwoordt het als volgt: "(...) la canalisation juridique de la responsabilité sur l"exploitant de l'installation ne se justifie (...) que si la promotion de l'utilisation pacifique de l'énergie nucléaire sert les intérêts supérieurs de la collectivité de telle sorte que ce demier objectif ne puisse être attient de la même manière par d'autres moyens" (Fischerhof, H., "Essai d'une théorie juridique de la canalisation de la responsabilité d'une installation nucléaire", o.c., 118). 
Bovendien werd geopperd dat een dergelijke aantasting op de van kracht zijnde juridische principes wel eens kon uitdraaien op een desintegratie van de aansprakelijkheid in andere domeinen van het recht. Kanalisatie van aansprakelijkheid was volgens hen strijdig met de billijkheid ondat andere personen die mogelijkerwijze aansprakelijk zijn voor het ongeval, deze aansprakelijkheid konden ontlopen ${ }^{253}$. De concentratie van aansprakelijkheid zou de individuele aansprakelijkheid van verschillende personen aantasten en waardoor het "zu einer gewissen Sorglosigkeit fürht" ${ }^{\prime \prime 25}$. Fischerhof bekritiseerde kanalisatie vooral omdat deze rechtsfiguur niet op een theoretische grondslag zou steunen. Het is dus niet toevallig dat uitgerekend Duitsland een voorbehoud heeft geformuleerd bij het Verdrag van Parijs ten aanzien van de kanalisatie van aansprakelijkheid.

Binnen Europa komt een bijzondere plaats toe aan Oostenrijk, dankzij de nieuwe Atomhafpflicht. gesetz van 7 oktober $1998^{255}$. Deze heeft niet alleen een systeem van onbeperkte aansprakelijkheid ingevoerd, maar tegelijk werd de kanalisatie van aansprakelijkheid (zoals ingevoerd in de nucleaire aansprakelijkheidswet van 1964) afgeschaft ${ }^{256}$. De aanpassing van de nieuwe nucleaire aansprakelijkheidswet heeft in ruime mate betrekking op de kanalisatie van aansprakelijkheid.

Volgens de Oostenrijkse wetgever is de kanalisatie van aansprakelijkheid nadelig voor de positie van slachtoffers van kernongevallen en kan de exoneratie van de leveranciers van de exploitant bijdragen tot het verminderen van de vereiste zorgvuldigheid ${ }^{257}$. De wet wil dan ook komaf maken met de geprivilegieerde positie van de kernenergie-industrie ${ }^{258}$. Precies de kanalisatie van aansprakelijkheid in de internationale nucleaire aansprakelijkheidsverdragen is voor Oostenrijk overigens de belangrijkste reden waarom zij niet tot deze verdragen wenst toe te treden - noch tot deze van de eerste generatie, noch tot de verdragen van de tweede generatie. Artikel 16 van de wet stelt uitdrukkelijk dat de gemeenrechtelijke bepalingen van het Burgerlijk Wetboek volledig intact blijven en dat slachtoffers rechtstreeks een vordering kunnen instellen tegen personen die goederen of diensten hebben geleverd aan de exploitant van de kerninstallatie ${ }^{259}$.

Aansluitend bij de afschaffing van de kanalisatie van aansprakelijkheid, is de aansprakelijkheid onbeperkt - de exploitant van een in Oostenrijk gelegen kerninstallatie is wel verplicht om een aansprakelijkheidsverzekering af te sluiten voor een bedrag van 5,6 miljard Schilling per ongeval. Ook opmerkelijk is dat de wet een bijzondere definiëring geeft van het begrip "exploitant": volgens artikel $2,4^{\circ}$ is een exploitant degene die een vergunning heeft "and who continually realises or at any time could realise the profits thereof". Met deze bepaling wordt getracht een antwoord te

Pelzer, N., "Die rechtliche Kanalisierung der Haftung auf den Inhaber einer Atomanlage - ein juristischer und wirtschaftlicher Fehlgriff?", Versicherungsrecht, 1966, 1010. Ibidem, "In der Tat stellt die Radikallösung der Konvention einen Einbruch in das allgemeine zivilrechtliche Haftungsrecht dar, der in der Rechtsgeschichte ohne Beispiel ist".

255 De tekst van de wet werd gepubliceerd in de bijlagen van de Nuclear Law Bulletin, vol. 63, 1999. De wet is van kracht geworden op 1 januari 1999 (artikel 29, $\$ 1$ van de wet). Hierbij moet wel voor ogen worden gehouden dat Oostenrijk - in wiens hoofdstad de hoofdzetel is gevestigd van het IAEA - geen lid is van een van de nucleaire aansprakelijkheidsverdragen. Hinteregger, M., "La nouvelle loi autrichienne sur la responsabilité civile pour les dommages nucléaires", Bulletin de Droit Nucléaire, vol. 62, 1998, 28.

Gehr, W., "La question de la responsabilité exclusive - la réponse de l'Autriche", in Reform of Civil Nuclear Liability, International Symposium, OECD, Paris, 2000, 470; Posch, W., "New developments in the Law of Civil Liability for Nuclear Damage Spearheaded by Austria: from Privileges for the Nuclear Industry to a true Protection of Mankind and the Environment", Environmental Liability, 1999 , vol. 3,81 . kerninstallaties voor de productie van elektriciteit. 
bieden op de soms ingewikkelde structuren van grote ondernemingen ${ }^{260}$; de Oostenrijkse wetgever wil blijkbaar vermijden dat een moedermaatschappij zich verstopt achter éen van haar dochterondememingen en op deze wijze zou trachten (een deel van) haar aansprakelijkheid te ontlopen.

De nieuwe Oostenrijkse nucleaire aansprakelijkheidswet is alleen al door de opheffing van de kanalisatie van aansprakelijkheid en van de beperking van de aansprakelijkheid, vrij uniek te noemen. Het unieke karakter komt daarenboven naar voren in andere bepalingen van de wet: de exploitant kan geen overmacht inroepen zoals voorzien in het Verdrag van Parijs en het Verdrag van Wenen, het causaliteitsbewijs wordt versoepeld ter zake van letselschade ${ }^{261}$, ook schade aan het milieu en de kosten van preventieve maatregelen komen voor vergoeding in aanmerking ${ }^{262}$, en tenslotte wordt afgezien van de creatie van één exclusief bevoegde rechtbank.

Doordat Oostenrijk geen keminstallatie voor de productie van elektriciteit heeft, kunnen uiteraard vragen worden gesteld bij het nut van deze wet. Toch moet er in ecrste instantie op worden gewezen dat de Oostenrijkse wet ook van toepassing is op ongevallen met radio-isotopen, bijvoorbeeld in ziekenhuizen, al moet worden benadrukt dat deze ongevallen onder een ander regime vallen ${ }^{263}$. Het belang van de Oostenrijkse Atomhaftplichtgesetz van 1998 in het kader van dit onderzoek is vooral de discussie met betrekking tot de kanalisatie van aansprakelijkheid in het kernenergierecht: 40 jaar na de invoering van dit principe in het internationale nucleaire aansprakelijkheidsrecht, is de kanalisatie van aansprakelijkheid naar de exploitant van de kerninstallatie nog steeds een actueel en omstreden thema. Door het Oostenrijkse initiatief is het niet uitgesloten dat ook andere landen, en zeker landen die geen eigen keminstallaties hebben, dit principe (opnieuw) in vraag stellen. Zoals verderop zal blijken, was de kanalisatie van aansprakelijkheid ook een belangrijk thema tijdens de onderhandelingen van het Verdrag inzake Bijkomende Compensatie van 1997.

\subsubsection{Conclusie}

Hoewel de leverancier ingevolge de kanalisatie van de aansprakelijkheid naar de exploitant van een kerninstallatie, niet absoluut immuun is tegen aansprakelijkheidsvorderingen ${ }^{264}$ en hiermee

Hinteregger, M., "La nouvelle loi autrichienne sur la responsabilité civile pour les dommages nucléaires", o,c., 30

26! Artikel 12 van de Oostenrijkse wet voert een causaliteitsvermoeden in: zodra het slachtoffer kan aantonen dat er een sterke kans bestaat dat hij werd blootgesteld aan ioniserende straling, dan zal worden aangenomen dat zijn schade inderdaad door ioniserende straling werd veroorzaakt. Dit vermoeden kan worden weerlegd indien de verweerder kan aantonen dat er een sterke kans bestaat dat de schade niet door ioniserende straling werd veroorzaakt.

Zelfs zuiver ecologische schade zou voor vergoeding in aanmerking komen (Posch, W., "New developments in the Law of Civil Liability for Nuclear Damage Spearheaded by Austria: from Privileges for the Nuclear Industry to a true Protection of Mankind and the Environment", o.c., 82).

260 De Oostenrijkse wet hanteert ter zake een regime van foutaansprakelijkheid in hoofde van de houder van de radionucliden. Deze aansprakelijkheid is onbeperkt maar dient te zijn gedekt door een verzekering of andere financiële zekerheid. Enkel voor radionucliden met cen straling van meer dan 370 gigabecquerel bepaalt de wet een minimumbedrag waaraan deze dekking dient te voldoen (met name 56 miljoen shilling) per ongeval (artikelen 9 en 10 van de wet).

Hoewel sommige auteurs nog steeds aarzelen, zie bijvoorbeeld Krause-Ablaß, W.D., "Zuliefererhaftung trotz rechtlicher Kanalisierung?", in Pelzer, N. (ed.), Friedliche Kernenergienutzung und Staatsgrenzen in Mitteleuropa, Baden Baden, Nomos, 1987, 308-321. 
een bezwaar tegen de kanalisatie van aansprakelijkheid gedeeltelijk is ontkracht ${ }^{265}$, is het van belang vast te stellen dat in de Verdragen de leveranciers op dubbele wijze worden beschermd voor de uit een kemongeval voortvloeiende schade: de leverancier kan niet door een slachtoffer worden aangesproken en daarenboven kan de exploitant enkel een regresrecht uitoefenen indien dit bij contract is voorzien. Voorziet het contract hierover niets, dan zal de exploitant (of bij subrogatie diens verzekeraar) niet over een regresrecht beschikken voor wat betreft de aan slachtoffers uitbetaalde schadevergoeding ${ }^{266}$.

Voorstellen die met name door de Italiaanse delegatie werden ingediend, zowel bij de onderhandelingen van het Verdrag van Parijs als bij de onderhandelingen van het Verdrag van Wenen, waarbij het regres werd voorzien, behalve indien dit contractueel werd uitgesloten, hebben het niet gehaald. Dit doet vermoeden dat het economisch gewicht van de leveranciers de doorslag heeft gegeven ${ }^{267}$.

Daarnaast blijkt dat in de praktijk weinig is in huis gekomen van deze contractuele clausule: door de feitelijke monopoliepositie van de Amerikaanse nucleaire industrie, waren zij over het algemeen niet bereid om in de contracten met de Europese exploitanten een regresclausule in te lassen. Door hun monopolie bleef het regresrecht zoals voorzien in het Verdrag, dode letter, wat de immuniteit van de leveranciers enkel maar versterkt.

Uiteraard valt de strafrechtelijke aansprakelijkheid van de leverancier evenmin uit te sluiten. Vanuit zuiver juridisch oogpunt zijn zij dus inderdaad niet volledig immuun. De weerstand tegen de kanalisatie van aansprakelijkheid is in belangrijke mate gericht tegen de beperking van het regresrecht, dus tegen het tweede element van de kanalisatie zoals verwoord in het internationale kemenergierecht. Recent heeft Oostenrijk evenwel ook het eerste element van de kanalisatie in vraag gesteld.

Concluderend kan worden gesteld dat het centrale element bij de weerstand tegen de kanalisatie van aansprakelijkheid te maken heeft met de immuniteit van de leveranciers ten overstaan van slachtoffers van een kernongeval en ten overstaan van de beperkte mogelijkheid van een exploitant om regres in te stellen. In ieder geval zal de leverancier niet geheel immuun zijn: contractuele vorderingen vanwege de exploitant ten aanzien van schade aan de kerninstallatie en strafrechtelijke vorderingen ${ }^{268}$ blijven mogelijk.

Toch zijn hiermee niet alle vragen omtrent de omvang van de immuniteit van de leveranciers opgelost. Zo is het van belang om te weten tot op welk punt de rechtsgronden van het gemene aansprakelijkheidsrecht worden buiten werking gesteld. Deze vraag heeft betrekking op het exclusieve en/of exhaustieve karakter van het nucleaire aansprakelijkheidsrecht.

265 Om die reden zijn Pelzer en Fischerhof teruggekomen op hun eerdere kritiek op de kanalisatie van aansprakelijkheid. Zie Pelzer, N., "Die internationale Atomhafungsübereinkommen and das Deutsche Recht", Erstes Deutsches Atomrechts Symposium, Carl Heymans, München, 1972, 187; Fischerhof, H., "Deutsches Atomgesetz", l.c., 542.

266 Volledigheidshalve wordt benadrukt dat het Verdrag van Parijs wel degelijk in een regresrecht voorziet, ten aanzien van opzettelijk veroorzaakte schade en bij doorvoer van nucleaire stoffen. Hébert, J., "Nucléaire", o.c., 32.

Zie hierover Gnam, P., "Die nukleare Zulieferindustrie im Haftungsfreiraum der rechtlichen Kanailsierung", Drittes Deutsches Atomrechts Symposium, Carl Heymans Verlag, 1975, 240; Mosthaf, H.D., "Wirtschaftlich oder rechtlich kanalisieren?", o.c., 201. Dit werd ook benadrukt tijdens de voorbereidende werken van het Verdrag van Wenen (Official Records Vienna Convention, 83). 


\subsubsection{Exclusieve en/of exhaustieve karakter van het nucleaire aansprakelijkheidsrecht}

De vraag naar het exclusieve of exhaustieve karakter van het nucleaire aansprakelijkhcidsrecht heeft betrekking op de mogelijke vorderingen die een slachtoffer van een kernongeval zou kunnen instellen ten aanzien van schade die niét via het Verdrag van Parijs (of het Verdrag van Wenen) wordt gecompenseerd. Zo zou kunnen worden geredeneerd dat een bepaalde schade die niet voor vergoeding in aanmerking komt op basis van het Verdrag van Parijs, via een andere weg wél kan worden vergoed. Hier is met name de vraag aan de orde wie aansprakelijk is voor de schade uit een kemongeval wanneer diens aansprakelijkheid en de beschikbare schadevergoeding zijn "uitgeput". Is in dit geval de exploitant aansprakelijk buiten het kemenergierecht, of kan desgevallend een andere persoon, eveneens buiten de Verdragen van Parijs en Wenen, hicrvoor worden aansprakelijk gesteld?

Voor alle duidelijkheid dient te worden onderstreept dat de vraag naar het exclusieve en exhaustieve karakter van het nucleaire aansprakelijkheidsrecht enkel rijst in de hypothese waar de totale schade het beschikbare schadevergoedingsbedrag (waarvan in het NEA regime de aansprakelijkheid van de exploitant slechts de eerste schijf vormt) te boven gaat en waar bijgevolg een deel van de schade niet kan worden gecompenseerd. Een geheel andere situatie, die met het exhaustieve karakter van het nucleaire aansprakelijkheidsrecht geen uitstaans heeft, betreft de hypothese waar een ongeval niet onder het toepassingsgebied valt van het Verdrag van Parijs; in deze hypothese zal immers het gemene aansprakelijkheidsrecht kunnen worden toegepast en is de vraag naar het exclusieve karakter van de nucleaire aansprakelijkheid niet aan de orde.

Volgens artikel 3 van het Verdrag van Parijs is de exploitant, overeenkomstig het Verdrag aansprakelijk voor elke schade aan personen en elke schade aan goederen of vermogen, met uitzondering van schade aan de kerninstallatie zelf en goederen die zich op het terrein bevinden en die worden gebruikt in verband met een kerninstallatie. Eenzelfde bepaling is terug te vinden in het Verdrag van Wenen ${ }^{269}$. Wat precies onder schade dient te worden verstaan en de mate waarin deze schade wordt vergoed, wordt overgelaten aan het op de zaak toepasselijke recht ${ }^{270} 271$. De vraag of milieuschade al dan niet onder het begrip schade zal vallen, en via het kernenergierecht voor vergoeding in aanmerking komt, hangt dus af van het recht dat door de rechter wordt toegepast. Uit onderzoek is gebleken dat het recht van de meeste landen voorziet in de vergoeding van "nucleaire milieuschade", in zoverre deze schade direct in verband staat met de eigendom van een gegeven persoon ${ }^{272}$. De vraag rijst dus wie aansprakelijk kan worden gesteld voor andere schade dan deze die op basis van het toepasselijke recht wordt aanvaard, bijvoorbeeld voor bepaalde vomen van milieuschade.

Voor het antwoord op deze vraag kan in eerste instantie worden verwezen naar de verdragsbepalingen zelf. Volgens artikel 6, b van het Verdrag van Parijs is buiten de exploitant van een kem-

Artikel 2 van Verdrag van Wenen stelt de exploitunt aansprakelijk voor "nuclear damage". Deze term wordt gedefinicerd als "loss of life, any personal injury, and any loss of, or damage to, property" (artikel $!, 1, k)$.

Artikel 11 van het Verdrag van Parijs.

Artikel VIII van het Verdrag van Wenen bevat een analoge bepaling. Gelet op de verschillende concepten inzake civiclrechtelijke aansprakelijkheid in de verschillende landen, werd het niet haalbaar geacht hiervoor uniforme internationaalrechtelijke regels op te stellen; op deze wijze zou een rechter nooit worden verplicht om schadevergoeding toe te kennen voor een bepaalde soort schade die in zijn recht niet voor vergoeding in aanmerking komt (Official Records Vienna Convention, 71)

Gomez del Campo, J., "Report on Environmental Nuclear Damage", in Nuclear Inter Jura 1999, AIDN/INLA, Washington, 1999, 216. 
installatie niemand anders aansprakelijk voor schade veroorzaakt door een kernongeval ${ }^{273} 274$. Het Verdrag van Wenen voorziet in artikel II, 6 eveneens dat niemand aansprakelijk is ${ }^{275}$. De voor de huidige analyse relevante vraag is of hieruit mag worden afgeleid dat het aansprakelijkheidssysteem zoals neergelegd in het Verdrag van Parijs exclusief of exhaustief is.

Het Exposé des Motifs van het Verdrag van Parijs biedt weinig houvast voor de interpretatie van deze bepaling; uit de voorbereidende werken van het Verdrag van Wenen daarentegen valt af te leiden hoe en waarom deze bepaling in het Verdrag werd ingeschreven. In één van de eerste versies van de tekst van het Verdrag van Wenen was een dergelijke bepaling niet opgenomen. Artikel II, 6 van het Verdrag van Wenen blijkt in het Verdrag te zijn ingeschreven op suggestie van de Amerikaanse delegatie. Deze stelde voor om een paragraaf in de tekst op te nemen zodat zou worden gegarandeerd dat de schade uit een kernongeval die niet was gedekt door het Verdrag, niet via een andere weg kon worden gecompenseerd ${ }^{276}$. Indien voor een gegeven schade niemand aansprakelijk is onder het Verdrag, diende te worden vermeden dat hieruit zou worden afgeleid dat schadevergoeding kon worden bekomen buiten de verdragsbepalingen en op grond van het gemene recht. Dit voorstel is, weze het onder gewijzigde vorm, uiteindelijk in artikel II, 6 van het Verdrag van Wenen opgenomen ${ }^{277}$.

Het Verdrag van Parijs bevat bepalingen die zeer sterk lijken op deze in het Verdrag van Wenen. Dit laatste Verdrag stelt dat niemand aansprakelijk is ter zake van andere schade dan "nucleaire schade"; het Verdrag van Parijs daarentegen stelt dat, buiten de exploitant van de keminstallatie, niemand aansprakelijk is voor schade veroorzaakt door een kernongeval. Daarenboven verwijzen beide Verdragen, wat betreft de concrete afhandeling van de aansprakelijkheidsvordering, naar het op de zaak toepasselijke nationale recht. Hoewel in het gevoerde onderzoek geen gegevens konden worden gevonden met betrekking tot de precieze reden waarom artikel $6, b$ ) in het Verdrag van Parijs werd ingeschreven, kan op basis van de sterke gelijkenis met de verdragsbepalingen van het Verdrag van Wenen worden geconcludeerd dat ook de partijen van het Verdrag van Parijs wilden benadrukken dat het in het Verdrag neergelegde systeem een exclusief en exhaustief systeem was.

Opmerkelijk is dat het exhaustieve karakter van de aansprakelijkheid van de exploitant wordt aangehaald in een afzonderlijk verdragsartikel. Blijkbaar waren de verdragspartijen van mening dat de loutere omschrijving van de kanalisatie van aansprakelijkheid niet zou volstaan om tot eenzelfde conclusie te komen. Op dit vlak valt tussen de aansprakelijkheidsverdragen van beide regimes een verschil op te merken. Artikel II.5 van het Verdrag van Wenen, dat de kanalisatie van aansprakelijkheid invoert, bepaalt uitdrukkelijk dat niemand anders dan de exploitant aansprakelijk is en is dus reeds vrij duidelijk. Het overeenstemmende artikel van het Verdrag van Parijs laat daarentegen wel ruimte voor interpretatie. Artikel 6, a) van het Verdrag van Parijs stelt dat het recht op schadevergoeding slechts kan worden uitgeoefend "tegen een exploitant die over-

Onze cursivering. In de Engelse versie luidt dit: "no other person shall be liable"; de Franse tekst luid: "aucune autre personne n'est tenue de réparer un dommage".

Tegelijk stelt artikel $6, c_{3}$ ii, dat de exploitant niet buiten het Verdrag aansprakelijk is voor schade veroorzaakt door een kemongeval. Deze laatste bepaling werd toegevoegd aan het Verdrag van Parijs door het Protocol van 1982.

Artikel II, 6 van het Verdrag van Wenen luidt: "No person shall be liable for any loss or damage which is not nuclear damage pursuant to sub-paragraph $(\mathrm{k})$ of paragraph 1 of Article I but which could have been included as such pursuant to sub-paragraph (k) (ii) of that paragraph". Official Records Vienna Convention, 227-228.

277. Het voorstel luidde: "If under the second sentence of article I, paragraph 9, the law of the competent court does not include any other loss or damage as nuclear damage, no person shall be liable for such other loss or damage". 
eenkomstig dit Verdrag aansprakelijk is". Hieruit zou kunnen worden afgeleid dat zodra de exploitant niet aansprakelijk is volgens de verdragsbepalingen, niets zou beletten dat de exploitant op andere juridische gronden aansprakelijk kan worden gesteld. Hier voegt artikel 6, b wel degelijk iets toe aan de Verdragstekst: doordat het preciseert dat niemand anders aansprakelijk is voor schade veroorzaakt door een kernongeval, zal noch de exploitant zelf, nog een andere persoon aansprakelijk kunnen worden gesteld voor niet gedekte schade. De bepaling van artikel 6, b van het Verdrag van Parijs brengt bijgevolg wel degelijk een precisering aan aan artikel 6, a waarin de algemene "kanalisaticregel" is neergelegd. Dit is niet het geval voor artikel II, 6 van het Verdrag van Wenen, dat grotendeels een herhaling is van artikel II, 5 .

Het is dus onmiskenbaar de bedoeling geweest van de verdragspartijen van zowel het aansprakelijkheidsregime van de NEA als dat van het IAEA, om de vergoeding van schade uit een kernongeval exclusief en uitsluitend te laten verlopen via de juridische basis aangereikt door het Verdrag van Parijs of Wenen. Voor schade uit een kernongeval die de beschikbare bedragen te boven gaat, zou niemand aansprakelijk kunnen worden gesteld. In deze visie dient het nucleaire aansprakelijkheidsrecht te worden beschouwd als een lex specialis ten overstaan van het gemene aansprakelijkheidsrecht. Deze visie is ook vrij logisch omdat een niet exclusief en niet exhaustief systeem ertoe zou leiden dat de kanalisatie van aansprakelijkheid naar de exploitant van de keminstallatie virtueel dode letter is. Het nucleaire aansprakelijkheidsregime stelt uitdrukkelijk dat de exploitant enkel op basis van het Verdrag aansprakelijk is en dat daarbuiten niemand anders dan de exploitant aansprakelijk is.

Onder invloed van de uitbreiding van het aansprakelijkheidsrecht ${ }^{278}$ sinds de adoptie van de nucleaire aansprakelijkheidsverdragen, is het echter zeer de vraag of het exclusieve en exhaustieve karakter van het nucleaire aansprakelijkheidsrecht heeft weten stand te houden, bijvoorbeeld voor wat betreft milieuschade. Sinds de jaren zestig heeft het milieurecht zich inderdaad ontwikkeld tot een belangrijke rechtstak en zijn in het intemationale en nationale milieuaansprakelijkheidsrecht juridische grondslagen terug te vinden met betrekking tot milieuschade. In de mate waarin deze bijzondere wetten milieuschade door kemongevallen niet uitsluiten ${ }^{279}$, bestaat de kans dat de "exclusiviteit" van het nucleaire aansprakelijkheidsrecht wordt ondergraven. In een dergelijk geval staan twee lex speciales tegenover elkaar en is het niet ondenkbaar dat indien geen compensatie kan worden verkregen via de ene lex specialis (nucleaire aansprakelijkheid), compensatie voor milieuschade wel zou kunnen worden verkregen op basis van de andere lex specialis (milieusansprakelijkheid). Bovendien zal de juridische basis uit het milicuaansprakelijkheidsrecht van recentere datum zijn dan deze uit het nucleaire aansprakelijkheidsrecht, zodat een rechtbank hieruit een argument kan putten om het exhaustieve karakter van de aansprakelijkheid van de exploitant van een kerninstallatie terzijde te schuiven.

Hoewel de mogelijkheden om compensatie te bekomen voor zuivere milieuschade nog ecrder beperkt zijn, is het toch een element dat van groot belang kan zijn naarmate ook het milicuaansprakelijkheidsrecht verdere uitbreiding zou nemen. Indien bijvoorbeeld de initiatieven van de Europesc Commissie zouden leiden tot cen richtlijn inzake milieuaansprakelijkheid ${ }^{280}$, waarbij

Cfr. supra, hooidstuk 1 .

Dit is bijvoorbeeld het geval met het Verdrag van Lugano van 21 juni 1993: "Convention on civil liability for damage resulting from activities dangerous to the environment" van de Raad van Europa. Zie hierover o.m. Carette, A., "Herstel van en vergoeding voor aantasting aan niet-toegeëigende milieubestanddelen", l.c., 372 e.v.; Sturms, W.W., "Internationale ontwikkelingen met betrekking tot aansprakelijkheid voor milieuschade", Tijdschrift voor Milieuaansprakelijkheid, 1992/5, 157 e.v.

Zie met name het Witboek betreffende milieuaansprakelijkheid, $\operatorname{COM}(2000), 66$ def. 9 februari 2000, 17. 
een specifieke juridische grondslag wordt in het leven geroepen ten aanzien van milieuschade en waarbij nucleaire milieuschade niet wordt uitgesloten, dan kan dit een belangrijke juridische grondslag vormen voor de vergoeding van milieuschade uit een kernongeval die niet via het kernenergierecht kan worden vergoed. In ieder geval is het een onderwerp dat in werkgroepen van de nucleaire sector hoog op de agenda staat ${ }^{28 !}$.

Concluderend kan dan ook worden gesteld dat het door de Verdragen van Parijs en Wenen ingevoerde compensatieregime is bedoeld als een exhaustief systeem dat andere aansprakelijkheidsgronden buiten werking stelt: voor schade uit een kernongeval die de beschikbare bedragen te boven gaat, is niemand aansprakelijk. De aansprakelijkheid van de exploitant van een kerninstallatie is dus op basis van de Verdragen inzake civiele nucleaire aansprakelijkheid inderdaad exclusief en exhaustief te noemen. Maar hiermee is niet gezegd dat ook andere rechtstakken ter zake van de civielrechtelijke aansprakelijkheid dit exclusieve en exhaustieve karakter zullen "erkennen". Door de verschillende ontwikkelingen van het aansprakelijkheidsrecht is het namelijk onzeker of het nucleaire aansprakelijkheidsrecht, als lex specialis, niet in conflict kan komen met een andere lex specialis, met name inzake milieuaansprakelijkheid. Het is niet ondenkbaar dat zodra een dergelijke juridische basis beschikbaar is, een rechtbank de aansprakelijkheid voor milieuschade uit een kernongeval gaat toewijzen via een specifieke juridische bepaling, eerder dan via het Verdrag van Parijs.

De in deze paragraaf geschetste problematiek kan dus een belangrijke beperking betekenen van de toepasbaarheid van de kanalisatie van aansprakelijkheid. Hieronder zal worden aangetoond dat deze toepasbaarheid nog meer in het gedrang kan komen bij een grensoverschrijdend kemongeval.

\subsubsection{Belang van IPR-regels voor de kanalisatie van aansprakelijkheid}

Zoals aangegeven, stelde het Harvard Rapport een samenhangend systeem voor, waaronder bepaalde IPR-regels inzake bevoegde rechtbank en toepasselijk recht; deze regels zijn ook overgenomen in zowel het Verdrag van Parijs als het Verdrag van Wenen. Onder beide Verdragen is uitsluitend bevoegd de rechtbank van de Verdragsluitende Staat op wiens grondgebied het kernongeval heeft plaatsgevonden ${ }^{282}$; deze rechtbank zal de lex fora toepassen ${ }^{283}$. In deze paragraaf wordt gewezen op de relatic tussen IPR-regels en de kanalisatic van aansprakelijkheid en op het belang van deze relatie voor de samenhang van de verschillende principes van het nucleaire aansprakelijkheidsrecht.

Het invoeren van een systeem van kanalisatie van aansprakelijkheid, gebeurt via het nationale aansprakelijkheidsrecht. Deze kanalisatie geldt dan ook uiteraard binnen de limieten van het territoriale toepassingsgebied van de nucleaire aansprakelijkheidswet. Zolang de gevolgen van een kernongeval strikt beperkt blijven tot het grondgebied van een land dat de aansprakelijkheid kanaliseert naar de exploitant van de kerninstallatie, kunnen zich weinig IPR-problemen stellen. Geheel anders is de situatie waarbij een kernongeval ook grensoverschrijdende schade veroorzaakt in een land waar de aansprakelijkheid niét wordt gekanaliseerd, of wanneer andere internationale aanknopingspunten ertoe kunnen leiden dat een ander recht zou worden toegepast. In deze

De werkgroep "Liability and Insurance" van de International Nuclear Law Association buigt zich met name over dit thema. Zie hierover Gomez del Campo, J., "Report on Environmental Nuclear Damage", in "Nuclear Inter Jura 1999", l.c., 203-247. 
hypothese is het mogelijk dat de rechtbank van een land bevoegdheid opneemt en een wet toepast die de aansprakelijkheid niét kanaliseert naar de exploitant van de kerninstallatie. Als gevolg hiervan kunnen desgevallend ook andere personen dan de exploitant worden aansprakelijk gesteld. Op deze wijze zou in feite het gehele systeem van de kanalisatie van aansprakelijkheid kunnen worden ontweken.

In eerste instantie wordt het verband aangetoond van de relatie tussen IPR-regels en de kanalisatie van aansprakelijkheid inzake de civiele aansprakelijkheid voor olieverontreiniging op zee. Hoewel deze regelgeving een vergelijkbaar systeem hanteert van kanalisatie van aansprakelijkheid, werden Amerikaanse bedrijven toch in de VS gedagvaard voor een schadegeval in het buitenland. Het belang van de IPR-regels in de zaak van de Amoco-Cadiz, wordt aangetoond in $\$ 2.2 .8$. 1 . Vervolgens wordt onderzocht of deze hypothese zich ook zou kunnen voordoen in het nucleaire aansprakelijkheidsrecht ( $\$ 2.2 .8 .2$ ). Nadien wordt besproken of en in welke mate het Harvard Rapport belang hechtte aan de IPR-regels, en in welke mate het de verschillende hypothesen heeft voorzien $(\$ 2.2 .8 .3$ ). De bevindingen van de analyse worden gebundeld in $\$ 2.2 .8 .4$.

\subsubsection{Het belang van IPR-regels in de zaak van de Amoco Cadiz}

Bij de ramp met de Amoco Cadiz op 16 maart 1978 waren verschillende partijen betrokken. Het schip, gebouwd op de scheepswerf van het Spaanse Astilleros, was geregistreerd in Liberia en behoorde toe aan de Amoco Transport Company, een vennootschap naar Liberiaans recht met voornaamste activiteiten in Hamilton op de Bermudas. Het beheer van het schip zelf lag in handen van Amoco International Oil Company, een vennootschap uit Delaware met maatschappelijke zetel in Chicago (Illinois). Uiteindelijk bleken zowel Amoco Transport Company als Amoco International Oil Company te behoren tot eenzelfde groep, namelijk Standard Oil Company, met zetel te Chicago ${ }^{284}$

Op basis van de complexe structuur van de Amoco-groep en de verschillende personen die mogelijkerwijze waren betrokken bij het ongeval (als bouwer, ontwerper, ...) werden in de Verenigde Staten tegen verschillende verweerders vorderingen ingediend, zowel door de Franse regering, door een aantal gemeenten als door individuele slachtoffers.

Een van de redenen waarom de VS als forum werd gekozen heeft te maken met het feit dat dit land geen lid was van het CLC-Verdrag van $1969^{285}$. Dit Verdrag voorziet in sterk analoge principes als deze van het Verdrag van Parijs inzake de civielrechtelijke aansprakelijkheid voor kernongevallen, met name een beperking van de aansprakelijkheid, kanalisatie van aansprakelijkheid e.d.m. Precies met het oog op het omzeilen van deze beperking van de aansprakelijkheid en de kanalisatie van aansprakelijkheid naar de scheepscigenaar, werd forum gezocht in de $\mathrm{VS}^{286}$. Zo-

\footnotetext{
24 Lucchini, L., "Le procès de l'Amoco Cadiz: présent et voies du Futur", Annuaire Français de Droit International, 1985, 763; Scovazzi, T., "Industrial Accidents and the Veil of Transnational Corporations", in Francioni, F. en Scovazzi, T. (ed.), International Responsibility for Environmental Harm, Graham \& Trotman, London, 1991, 416.

235 Verdrag inzake de burgerlijke aansprakelijkheid voor schade veroorzaakt door verontreiniging door olie tot stand van 29 november 1969 (o.m. in Gold, E., Handbook on Marine Pollution, Arendal, Gard, 1985, 23-32). Dit Verdrag wordt besproken in hoofdstuk 12.

Ballarino, T., "La réparation des dommages catastrophiques. Problèmes de droit international privé", in La Réparation des dommages catastrophiques. Les risques technologiques majeurs en droit international et en droit communautaire, Travaux des XIIles Joumées d'étdues juridiques Jean Dabin, Bruxelles, Bruylant, 1990, 73; Murase, S., "Perspectives from International Economic Law on Transnational Environmental Issues", Recueil des Cours, Academy of International Law, Tome 253, Martinus Nijhoff
} 
wel Frankrijk (plaats van het ongeval) als Liberia (plaats waar het schip was geregistreerd) waren lid van het CLC-Verdrag en bijgevolg werd de jurisdictie van die twee landen vermeden. De bedoeling van de eisers was duidelijk: er werd enerzijds gezocht naar een rechtbank die bevoegdheid zou opnemen en die daarenboven het recht zou toepassen van een land waar geen beperking van aansprakelijkheid in voege was (i.c. Amerikaans recht) en waar ook andere personen dan de scheepseigenaar konden worden aansprakelijk gesteld.

De jurisdictic van de Amerikaanse rechtbank werd in 1984 aanvaard omdat het ongeval had plaatsgevonden in "navigable waters" 287 . Eerder reeds had ook de District Court zich, op basis van de "long-arm statute" van Illinois ${ }^{258}$ bevoegd verklaard in een aansprakelijkheidsvordering van Amoco Transport tegen Astilleros. De door Astilleros opgeworpen forum non conveniens ${ }^{289}$ werd door de rechtbank niet aanvaard. De rechtszaak was dermate complex dat de rechtbank het opportuun achtte om alle vorderingen in één rechtszaak en voor één enkele rechtbank te beslechten waarbij geen enkel ander forum meer of beter geschikt zou zijn om van de zaak kennis te nemen.

Voor wat betreft het toepasselijke recht oordeelde de rechtbank dat aangezien alle schade was geleden op Frans grondgebied "the substantive law would therefore have been French law if it had been proved different from that of the United States"; maar volgens de rechter was niet bewezen dat het Franse recht wezenlijk verschilde van het Amerikaanse recht en bijgevolg werd Amerikaans recht op deze zaak toegcpast ${ }^{2 \% 0}$. Daarenboven zou, zelfs indien Frans recht op deze zaak van toepassing zou zijn, het CLC-Verdrag niet kunnen verhinderen dat vorderingen werden ingediend tegen Standard Oil Company of tegen Amoco International Oil Company, aldus de rechtbank.

Op het vlak van de toewijzing van de aansprakelijkheid, stelde de Amerikaanse rechter vast dit Standard Oil Company direct of via dochterondernemingen $100 \%$ beslissingsrecht had in Amoco International Oil Company en in Amoco Transport Company; alle belangrijke beslissingen, waaronder het ontwerp, de bouw en het beheer van de Amoco Cadiz werden genomen door de moedermaatschappij of vereisten ten minste de goedkeuring van de moedermaatschappij.

Uiteindelijk oordeelde de Amerikaanse rechter dat Astilleros aansprakelijk was voor gebreken in het ontwerp en de bouw van het schip en dat verschillende vennootschappen van de Amoco groep aansprakelijk waren ingevolge gebrekkig onderhoud van het schip en gebrekkige opleiding van de bemanning.

Publishers, Den Haag, 1996, 377; Horbach, N.L.J.T., "Liability versus Responsibility under International Law", l.c., 291 e.v. Amoco Cadiz, US District Court, Northem District of Illinois, Eastern Division, 18 April 1984, $699 \mathrm{~F}$. 2d 909 (1983).

Op basis van deze bepaling valt iedereen, zelfs niet onderdanen of niet inwoners van de stat Illinois. die zaken doet binnen de staat, onder de jurisdictie van de rechtbanken van Illinois.

Dit is een regel die voomamelijk in common law landen wordt toegepast en die inhoudt dat een rechter kan weigeren om van een bepaalde zaak kennis te nemen omdat elders een meer geschikt forumbestaat. Over de toepassingsvercisten en bedenkingen hierbij, zie o.m. Herzog, P., "La théorie du forum non conveniens en droit anglo-américain: un aperçu", Revue Critique de Droit International Privé, 1976, 1-41; Prince, P., "Bhopal, Bougainville and Ok Tedi: Why Australia's forum non conveniens Approach is better", International and Conparative Law Quarterly, vol. 47, 1998. 573-598. 
De uitspraak in de zaak van de Amoco Cadiz heeft aangetoond dat in bepalde gevallen de rechtbank de toepassing van het vreemde recht (met name het recht van de plaats van het ongeval) opzij schuift en daarentegen de lex fora zal toepassen ${ }^{291}$ én dat door de techniek van "lifting the corporate veil ${ }^{1292}$ multinationale ondernemingen in een aantal gevallen zware risico's lopen om in een bepaald land aansprakelijk te worden gesteld voor de activiteiten van één van haar dochterondememingen elders in de wereld ${ }^{293}$.

De aansprakelijkheid van een buitenlandse moedermaatschappij werd eveneens in vraag gesteld naar aanleiding van het ongeval in Bhopal in 1984. Het ongeval zelf gebeurde bij Union Carbide India Ltd., een onderneming die voor $50,9 \%$ in handen was van Union Carbide Corporation (gevestigd te New York). Ook hier hebben de slachtoffers zich gericht tot de Amerikaanse moedermaatschappij en werden 145 vorderingen ingeleid voor een Amerikaanse rechtbank. In dit geval werd de forum non conveniens wél aanvaard ${ }^{294}$ en kwam de zaak uiteindelijk voor een rechtbank in India ${ }^{295}$. Hoewel deze rechtbank zich niet over het juridische vraagstuk naar de uiteindelijke ansprakelijkheid van Union Carbide Corporation heeft uitgesproken ${ }^{296}$, wordt deze zaak over het algemeen beschouwd als een impliciete bevestiging van een regel op basis waarvan de aansprakelijkheid van grote multinationale ondernemingen in het gedrang kan komen ingevolge gevaarlijke activiteiten van hun dochterondernemingen ${ }^{297}$. Amerikaanse bedrijven lopen dus het risico om in de VS te worden gedagvaard voor schade die deze bedrijven, of hun dochterondernemingen, in het buitenland hebben veroorzaakt ${ }^{298299}$.

In de rechtszaak naar aanleiding van het ongeval met de Amoco Cadiz werden de kanalisatie en de beperking van aansprakelijkheid succesvol ontweken. Hiermee werd duidelijk dat het invoeren wan de kanalisatie van aansprakelijkheid in het land waar zich mogelijkerwijze een ongeval of een schade voordoet, onvoldoende bescherming biedt aan degenen die via de kanalisatie immuniteit verkrijgen (ontwerpers, leveranciers etc). Anders gezegd: immuniteit in het land waar de schade is geleden of waar het ongeval heeft plaatsgevonden is niet noodzakelijk voldoende om aan een aantal personen immuniteit te verlenen. Leveranciers die onderdelen van gevaarlijke technologieen exporteren, lopen bijgevolg het risico aansprakelijk te worden gesteld voor een rechtbank én volgens cen toepasselijk recht dat niet meteen in verband staat met het land waarnaar de technologie werd uitgevoerd en dat de aansprakelijkheid niét kanaliseert, noch beperkt. Aangezien, in gevallen waar de ondernemingssluier kan worden doorbroken, deze stelling ook geldt voor schade

Ballarino, $T$, "La réparation des dommages catastrophiques. Problèmes de droit international privé", in "La Réparation des dommages catastrophiques", l.c., 71-72; Lowenfeld, A.F., "Intemational Litigation and the Quest for Reasonableness", o.c., 129 e.v. Hiena genoemd doorbreken van de ondememingssluier.

28 Zie o.m. Von Bar, C., "Environmental Damage in Private Intemational Law", Recueil des Cours, Academy of International Law, 1997, Tome 268, Martinus Nijhoff Publishers, Den Haag, 1999, 393; Jacobsen, D.A. en Yellen, J.D., "Oil Pollution: the 1984 London Protocols and the Amoco Cadiz", Journal of Maritime Law and Commerce, vol. 15, $n^{\circ} 4,1984,486$.

Von Bar, C., "Environmental Damage in Private International Law", o.c., 344-346.

Voor een kritiek, zie o.m. Prince, P., "Bhopal, Bougainville and Ok Tedi: Why Australia's forum non conveniens Approach is better", o.c., 577.

Er werd een overeenkomst bereikt waarbij Union Carbide Corporation 470 miljoen dollar betaalde.

Murase, S., "Perspectives from International Economic Law on Transnational Environmental Issues", o.c., 382; Scovazzi, T., "Industrial Accidents and the Veil of Transnational Corporations", o.c., 413.

Brown, O.F., II, "Recent Developments from the Perspective of the United States", in Horbach, N.L.J.T. (ed.), "Contemporary Developments in Nuclear Energy Law", l.c., 483.

Meer in het algemeen wordt in deze zaak de bevestiging gezien van een trend naar een strikte verplichting om geen schade te veroorzaken door gevaarlijke activiteiten (Horbach, N.L.J.T., Liability versus Responsibility under International Law, 1996, 287). 
veroorzaakt door dochterondememingen, geldt deze stelling a fortiori voor bedrijven die rechtstreeks aan het buitenland hebben geleverd ${ }^{300}$.

De reden wairom slachtoffers desgevallend zullen trachten om zich te richten tegen de moedermaatschappij van een onderneming die schade heeft veroorzaakt, ligt voor de hand: aangenomen kan worden dat de moedermaatschappij over aanzienlijke financiële middelen beschikt ${ }^{301}$. Bovendien vertonen slachtoffers in het algemeen de neiging om hun vordering in te leiden voor rechtbanken die een hogere schadevergoeding toekennen ${ }^{302}$. Toch dienen slachtoffers heel wat obstakels te overwinnen vooraleer hun vordering voor een buitenlandse rechter zal worden aanvaard. Het is dus niet gezegd dat indien de ondememingssluier kan worden doorbroken, de buitenlandse rechter bevoegdheid opneemt en zijn eigen recht - of een voor slachtoffers "gunstig recht" toepast, slachtoffers automatisch in een betere positie zouden verkeren. Immers, hoe ingewikkelder en internationaler een bepaalde zaak is, des te hoger de advocatenkosten en de administratieve kosten van een proces zullen zijn $^{303}$.

Het in het kader van dit proefschrift relevante punt bestaat erin dat indien de wetgeving van het land van de lex loci delicti de aansprakelijkheid naar een bepaalde persoon kanaliseert en/of de aansprakelijkheid van deze persoon beperkt, deze kanalisatie en/of beperking kunnen worden ontweken indien een buitenlandse rechter bevoegdheid opneemt en een wetgeving toepast die de aansprakelijkheid nièt kanaliseert en/of beperkt. In de Amoco Cadiz zaak werden de kanalisatie van aansprakelijkheid naar de scheepseigenaar en de beperking van de aansprakelijkheid inderdaad opzij geschoven ${ }^{304}$. De vraag rijst of deze conclusie mag worden doorgetrokken naar het nucleaire aansprakelijkheidsrecht.

\subsubsection{Het "Amoco Cadiz-scenario" in het nucleaire aansprakelijkheidsrecht}

Het is niet zonder gevaar om de conclusies met betrekking tot de wetgeving inzake aansprakelijkheid voor olieverontreiniging op zee zonder meer door te trekken naar de wetgeving inzake de

Specifiek wat betreft het doorbreken van de ondernemingssluier spreekt het voor zich dat het feit dat een dochtermaatschappij schade berokkent niet automatisch zal leiden tot de aansprakelijkheid van de elders gevestigde moedermaatschappij. Er dient aan heel wat voorwaarden te zijn voldaan vooraleer een moedermaatschappij kan worden aansprakelijk gesteld voor schade door gevaarlijke activiteiten van een van haar dochterondernemingen. Zo zal het loutere feit dat een onderneming de meerderheid der aandelen heeft van een andere onderneming op zich geen voldoende reden zijn. Uit de uitspraak van de Amoco Cadiz valt op te maken dat de rechter onderzocht heeft in welke mate Standard Oil Company effectief zeggenschap had over beslissingen inzake de aankoop van het schip. Het criterium van de effectieve zeggenschap is inderdaad belangrijker dan het bezit van de meerderheid der aandelen: cen bedrijf dat $51 \%$ van de aandelen van een andere ondememing bezit zal niet meer of niet minder aansprakelijk zijn dan wanneer het $100 \%$ van de aandelen in handen heeft. Wat telt is de daadwerkelijke zeggenschap, dit is beslissingsrecht of controle op de genomen beslissingen, binnen het bedrijf dat de schade heeft veroorzaakt. Uiteraard gaan eigendom en zeggenschap over het algemeen hand in hand.

McCaffrey, S.C., "Expediting the Provision of Compensation to Accident Victims", in Hândl, G. en Lutz, R.E., Transferring Hazardous Technologies and Substances. The International Legal Challenge, Graham \& Trotman, Martinus Nijhoff, London, 1989, 209.

Ballarino, T., "La réparation des dommages catastrophiques. Problèmes de droit international privé", in "La Reparation des dommages catastrophiques", l.c., 99.

Zowel voor, tijdens als na een dergelijk proces, worden slachtoffers geconfronteerd met aanzienlijke problemen. Zie hierover McCaffrey, S.C., "Expediting the Provision of Compensation to Accident Victims", o.c., 209. 
civielrechtelijke aansprakelijkheid voor kemongevallen. Zo is de kanalisatie van aansprakelijkheid naar de scheepseigenaar onder het CLC-Verdrag anders geformuleerd dan de kanalisatie van ansprakelijkheid naar de exploitant van een kerninstallatie onder het Verdrag van Parijs, onder meer doordat in het maritieme recht het regresrecht van de scheepseigenaar intact wordt gelaten ${ }^{305}$ 306. Toch bevat de kanalisatie in het maritieme recht ook regels ter zake van de uitsluiting van andere juridische grondslagen, c.q. van de aansprakelijkheid van andere personen dan de scheepseigenaar. Het is precies dit element dat de essentie uitmaakt van de kanalisatie van aansprakelijkheid in het kernenergierecht. Daarenboven is de situatie sterk vergelijkbaar omdat de VS niet zijn toegetreden, noch tot het CLC-Verdrag, noch tot het Verdrag van Parijs of het Verdrag van Wenen.

Naar analogie met de rechtszaak naar aanleiding van het ongeval met de Amoco Cadiz, zou een slachtoffer van een kernongeval in Europa de bouwer of de ontwerper van de Europese kerninstallatie in de Verenigde Staten kunnen dagvaarden ${ }^{307}$ en de toepassing kunnen vragen van de lex fora. Dit impliceert dat het risico bestaat dat een Amerikaanse rechter zich bevoegd zou verklaren en dat deze, door de gelijkenissen tussen het Europese en Amerikaanse nucleaire aansprakelijkheidsrecht, Amerikaans recht zou toepassen ${ }^{308}$. Precies op dit punt is de bescherming van de Amerikaanse leveranciers bepaald onzeker: doordat de VS niet zijn toegetreden tot de internationale nucleaire aansprakelijkheidsverdragen, kunnen de erin opgenomen verwijzingsregels geen toepassing vinden en kan worden getracht om de kanalisatie en de beperking van aansprakelijkheid te omzeilen.

Een Amerikaanse rechtbank zal niet zomaar bevoegdheid opnemen; het is evenmin zeker dat zomaar Amerikaans recht zal worden toegepast. Er moet in ieder geval een voldoende Amerikaanse aanknopingspunt voorhanden zijn. Met betrekking tot het gebruik van kemenergie in West-Europa, is de band met de VS niet ver te zoeken: voornamelijk Amerikaanse bedrijven hebben, zeker in de beginjaren, reactoren geleverd en ontwerpen gemaakt voor westerse kerninstallaties. Anders dan bij de Bhopal-zaak en bij de Amoco Cadiz, doen Amerikaanse nucleaire bedrijven niet noodzakelijk via dochterondernemingen zaken met Europese exploitanten van kerninstallaties: hier zal de ondernemingssluier niet moeten doorbroken worden en zal het "volstaan" om een andere wet toe te passen dan deze die de aansprakelijkheid kanaliseert of de leveranciers exonereert.

Het "Amoco Cadiz-scenario" is bijgevolg voor de Amerikaanse nucleaire sector niet noodzakelijk een fictie: de kans is reëel dat slachtoffers van een grensovcrschrijdend kernongeval, in een kern-

xis

Over de term kanalisatic in het maritieme recht, zie Rémond-Gouilloud, M., "The Future of the Compensation System established by International Convention", in De la Rue, C.M. (ed.), Liability for Damage to the Marine Environment, Lloyd's of London Press Ltd., 1993, 94 e.v.; Ballarino, T., "La réparation des dommages catastrophiques. Problèmes de droit international privé", in "La Réparation des dommages catastrophiques", l.c., 73-75.

Cfr. infra, in hoofdstuk 12 van dit boek.

Het is immers niet ondenkbeeldig dat de bouw en de constructie van een gevaarlijke installatie in vraag worden gesteld, zoals in de Bhopal zaak (zie hierover Nanda, V.P. en Bailey, B.C., "Nature and Scope of the Problem", in Händl, G. en Lutz, R.E., Transferring Hazardous Technologies and Substances. The International Legal Challenge, Graham \& Trotman, Martinus Nijhoff, London, 1989, 9).

Zoals bij de Amoco Cadiz zou de Amerikaanse rechter kunnen oordelen dat het Amerikaanse recht niet wezenlijk verschilt van de lex loci delicti - inzake beperking van de aansprakelijkheid, verplichte verzekering van aansprakelijkheid lopen het Amerikaanse en Europese systeem inderdaad grotendecls gelijk. Zie hierover Vanden Borre, $T$., "Dekking van het nucleaire risico op nationaalrechtelijke basis of via internationale Verdragen: de Verenigde Staten versus Europa", in Faure, M., Deketelaere, K. en Verhoosel, G., (red.), "Grensoverschrijdende milieuproblemen", l.c., 477-479. 
installatie waarbij Amerikaanse bedrijven bijvoorbeeld hebben ingestaan voor het onderhoud, zullen trachten om in de VS toepassing te vragen van het Amerikaanse recht waar de aansprakelijkheid niét juridisch wordt gekanaliseerd. Los van het feit dat misschien juridische vraagtekens kunnen worden geplaatst bij de uitspraak van de Amoco Cadiz, blijft de houding van een Amerikaanse juryrechtbank een belangrijke onbekende en betekent dit dus een niet te verwaarlozen risico.

De uit het Verdrag van Parijs voortvloeiende regels (met name de beperking van de aansprakelijkheid en de kanalisatie van aansprakelijkheid naar de exploitant) zouden dus terzijde kunnen worden geschoven ten voordele van het Amerikaanse aansprakelijkheidsrecht. Het feit dat met name de VS zelf niet zijn toegetreden tot het internationale nucleaire aansprakelijkheidsrecht, houdt een risico in voor de Amerikaanse industrie. Deze problematiek stelt zich uiteraard nie uitsluitend ten aanzien van de Verenigde Staten en de Amerikaanse leveranciers. Meer in het algemeen geldt voor het nucleaire aansprakelijkheidsrecht dat leveranciers enkel volledig beschermd zullen zijn indien zowel het land van de leverancier, het land waaraan wordt geleverd (zijnde het land waar de kerninstallatie is gelegen), als het land van het slachtoffer zijn toegetreden tot het internationale nucleaire aansprakelijkheidsrecht, én indien zij in hun interne wetgeving deze Verdragen hebben geïntroduceerd in het nationale recht ${ }^{309}$. Er bestaat bijgevolg wel degelijk een kans dat slachtoffers van een kernongeval wiens schade voor een (groot) deel niet werd vergoed, c.q. op basis van het nucleaire aansprakelijkheidsrecht niet voor vergoeding in aanmerking komt, zullen trachten om andere wegen te vinden om alsnog compensatie te bekomen.

Het "gesloten systeem" zoals bedacht door het Harvard Rapport kan met andere woorden worden omzeild indien niet alle landen waar een aanknopingspunt bestaat met het kemongeval zijn toegetreden tot het internationale nucleaire aansprakelijkheidsrecht, c.q. de basisprincipes van het Verdrag hebben ingevoerd in hun nationale wetgeving. De vraag rijst of en in welke mate de auteurs van het Harvard Rapport aan deze problematiek aandacht hebben besteed en hoe het komt dat anno 2000 de Amerikaanse leveranciers van de - hoofdzakelijk Europese - nucleaire industrie aan een niet te verwaarlozen risico worden blootgesteld.

\subsubsection{Belang van de IPR-regels in het Harvard Rapport}

De belangrijkste doelstelling van het Harvard Rapport bestond in het uitwerken van een juridisch regime dat de Amerikaanse nucleaire toeleveringsindustrie zou beschermen tegen vorderingen in de VS ingevolge kernongevallen in het buitenland. Zoals aangegeven werd precies om die reden voorgesteld om een geheel aan maatregelen ${ }^{310}$ in te voeren, waarvan de kanalisatie van aansprakelijkheid er één was. Via de verschillende maatregelen zoals voorgesteld in het Harvard Rapport werd een gesloten systeem opgebouwd dat ervoor moest zorgen dat elk kernongeval binnen dit gesloten systeem wordt behandeld. Zodra evenwel, in een internationale context, één land gcen deel uitmaakte van het systeem, kon dit gehele systeem op de helling worden gezet, zeker indien de onder het systeem beschikbare bedragen ontoereikend zouden zijn om alle schade te compenseren. Het wekt dan ook weinig verwondering dat de auteurs van het Harvard Rapport groot

Blanchard, P., "The Risk of Civil Nuclear Liability of Foreign Contractors in Central and Eastem Europe and the NIS", in Horbach, N.L.J.T. (ed.), "Contemporary Developments in Nuclear Energy Law", l.c., 532. 
voorstander waren van een mondiaal Verdrag in de schoot van het IAEA, eerder dan van regionale verdragen ${ }^{311}$.

Bij de bespreking van de mogelijkheid tot het indienen van vorderingen in de VS ingevolge een kernongeval in het buitenland valt de voorzichtigheid op van de auteurs van het Harvard Rapport. Enerzijds werd vastgesteld dat de Amerikaanse rechter niet makkelijk rechtsmacht zou aanvaarden op basis van de doctrine van de forum non conveniens en dat over het algemeen de kans reẹel. zou zijn dat de lex loci delicti zou worden toegepast, eerder dan de het recht van de zetel van de leverancier ${ }^{312}$. Anderzijds vonden de auteurs van het Harvard Rapport het te gevaarlijk, gelet op de discretionaire bevoegdheid van de rechter ter zake, om te vertrouwen op de forum non conveniens doctrine $\mathrm{e}^{313}{ }^{314}$ en om met zekerheid uitspraken te doen over het recht dat een Amerikaanse rechtbank desgevallend zou toepassen ${ }^{315}$. Door de onzekerheden in verband met de bevoegdheid van de rechtbank en met het recht dat zou worden toegepast, was een wetgevend ingrijpen noodzakelijk, hetzij via Verdrag, hetzij via nationale wetgeving ${ }^{316}$.

Als oplossing voor mogelijke procedurele problemen, stelde het Harvard Rapport volgende IPRregels voor: de rechtbank van de plaats van kerninstallatie zou exclusief bevoegd zijn, deze rechter zou het recht van het land van de plaats van de kerninstallatie toepassen en er diende een systeem te worden ingevoerd van erkenning van buitenlandse vonnissen ${ }^{317}$. Op deze wijze zou op een kemongeval in Europa het aansprakelijkheidsrecht van een Europees land van toepassing zijn.

Toch waren hiermee, steeds volgens het Harvard Rapport niet alle problemen van de baan, tenminste vanuit het oogpunt van de leveranciers. Hun positie kon in het gedrang komen indien bij een zeer zwaar kernongeval in Europa de beperkte bedragen van het Verdrag van Parijs ontoereikend zouden zijn, en indien geen bijkomende overheidstussenkomst beschikbaar was. In deze hypothese kon het wel eens zijn dat de Amerikaanse rechter zou weigeren om de beperkingen van het Verdrag van Parijs toe te passen, zeker indien een fout van een leverancier aan de basis lag van het kernongeval ${ }^{318}$. De lage limieten zoals die waren voorzien in het toenmalige ontwerp van het Verdrag van Parijs ${ }^{319}$ waren volgens de auteurs van het Rapport:

"... an open invitation for injured persons to sue suppliers in the United States or in other countries, not parties to the convention, in which suppliers may have assets" ${ }^{320}$.

Indien de landen die het Verdrag van Parijs zouden ondertekenen geen bijkomende schadevergoeding zouden ter beschikking stellen, kon volgens het Harvard Rapport op drie verschillende

Harvard Rappon, 80.

Harvard Rapport, 26.29

Harvard Rapport, 66.

De Amoco Cadiz zalak heeft aangetoond dat de discretionaire bevoegdheid van de Amerikaanse rechter terzake, inderdaad kan leiden tot het omzeilen van een systeem van kanalisatie van aansprakelijkheid, zelfs indien de kanalisatie van aansprakelijkheid onder het maritieme recht anders is geformuleerd dan in het kemenergierecht.

Harvard Rappori, 30.

Harvard Rapport, 38.

Harvard Rapport, 65-68; zie ook eerder, \$2.1.3.3.

Harvard Rapport, 84-85.

Het Harvard Rapport is verschenen in 1959, dus één jaar vóór de adoptie van het Verdrag van Parijs. De ontwerptekst van het Verdrag van Parijs dat zich in bijlage van het Harvard Rapport bevindt, heeft het over een aansprakelijkheid van 15 miljoen Europese rekeneenheden. Het is precies de limiet die later in het Verdrag van Parijs is opgenomen.

Harvard Rapport, 85. 
manieren worden tegemoet gekomen aan het risico van de leveranciers ${ }^{321}$. De eerste mogelijkheid zou erin bestaan om een Amerikaanse federale wet in te voeren op basis waarvan de schadevergoeding die in Amerikaanse rechtbanken zou worden aanvaard ter zake van een kernongeval in het buitenland, gelijk zou zijn aan het bedrag waarop het buitenlandse slachtoffer recht heeft op basis van de wetgeving in de installatiestaat. Aansluitend zou een bepaling kunnen worden ingevoerd op basis waarvan het recht van het land waar de schade is geleden, zou worden toegepast. Het werd evenwel niet mogelijk geacht om een dergelijke federale wet in te voeren omdat het zou getuigen van "international bad manners", omdat dit politiek onaanvaardbaar zou zijn ten opzichte van Amerikaanse slachtoffers en omdat dit ook tot de nodige grondwettelijke problemen zou kunnen leiden ${ }^{322}$.

De tweede mogelijkheid zou erin bestaan dat de VS zouden toetreden tot het Verdrag. Toetreding van de VS tot het internationaal nucleair aansprakelijkheidsrecht zou de bescherming van de leveranciers kunnen verbeteren, aldus het Harvard Rapport ${ }^{323}$. Maar op dit vlak was het probleem dat het Amerikaanse nucleaire aansprakelijkheidsrecht uitgaat van een systeem van economische kanalisatie en niet van de juridische kanalisatie zoals in het internationale kernenergierecht. Doordat de Price-Anderson Act echter een betere bescherming bood dan de Europese Verdragen, zouden de VS enkel tot deze Verdragen kunnen toetreden mits een voorbehoud zou worden gemaakt betreffende de kanalisatie van aansprakelijkheid, aldus het Harvard Rapport ${ }^{324}$. Toch was ook een toetreding met voorbehoud niet evident, onder meer omdat de VS nog nooit partij waren bij een internationaal verdrag dat de erkenning inhield van een buitenlands vonnis ${ }^{325}$.

De derde mogelijkheid was het afsluiten van governmental hold harmless agreements met de verschillende landen waarnaar nucleair materiaal werd geëxporteerd. Maar het Harvard Rapport had reeds aangetoond dat privaatrechtelijke mechanismen om de leveranciers te beschermen onvoldoende waren ${ }^{326}$.

Van belang voor de huidige analyse is vooral het feit dat het Harvard Rapport een combinatie heeft voorgesteld van materieelrechtelijke en procesrechtelijke bepalingen om zodoende het "Amoco Cadiz scenario" te vermijden. De Amerikaanse nucleaire industrie was inderdaad vooral beducht voor mogelijke gevolgen van bepaalde conflictregels, waarbij ener $\iota$ ijds een Amerikaanse rechtbank zich bevoegd zou verklaren voor elders geleden schade en waarbij niet de lex loci delicti maar wel de lex fora zou worden toegepast ${ }^{327}{ }^{328}$. De auteurs van het Harvard Rapport zijn

$\begin{array}{ll}321 & \text { Harvard Rapport, 84-87. } \\ 322 & \text { Hanard Rapport, 85. } \\ 323 & \text { Harvard Rapport, 86. } \\ 324 & \text { Harvard Rappor, 86. } \\ 325 & \text { Harvard Rapport, 87. } \\ 326 & \text { Cfr. supra, } \$ 2.1 .3 .2 .\end{array}$

Cfr. stupra, \$2 132.

Een deel van de problematiek heeft inderdaad betrekking op de regels van intemationaal privaatrecht, waarbij enerzijds de rechtsmacht of jurisdictie van een gegeven rechtbank en anderzijds de toepasselijke wetgeving twee essentiele vragen zijn. Uitgangspunt wat de rechtsmacht betreft, is dat elke Staat eenzijdig de regelen bepaalt van zowel de nationale als de intemationale jurisdictie van haar rechtbanken. Het gevolg hiervan is uiteraard dat in heel wat gevallen rechters in verschillende landen, op basis van hun eigen nationale procesrechtelijke bepalingen, bevoegd zullen zijn voor eenzelfde zaak. Dit biedt aan slachtoffers de mogelijkheid tot forwm shopping, tot het kiezen van de in hun ogen meest geschikte rechtbank. Specifiek wat het Anglo-Amerikaanse recht betreft, is de aanwezigheid van de verweerder op Amerikaans grondgebied een factor die tot de bevoegdheid van de Amerikaanse rechtbank leidt. Vaak zal uit de jurisdictie van een bepaalde rechter ook de toepassing voortvloeien van het eigen recht van de rechter (lex fora). Zie hierover o.m. Erauw, J., Beginselen van Internationaal Privalrecht, Story, Gent, 1985; Rigaux, F. en Fallon, M., Droit International Privé, Tome II, Droit positif 
bij de inschatting van de risico's bovendien uitermate voorzichtig geweest, en hebben oog gehad voor het "Amoco Cadiz scenario", zelfs indien dat - zeker op basis van het toenmalige aansprakelijkheidsrecht - een weinig waarschijnlijk scenario was.

Tegelijk hechtte het Harvard Rapport belang aan de noodzaak voor de VS om in bijkomende maatregelen te voorzien. De bezorgdheid van Amerikaanse industrie voor vorderingen uit het buitenland had in niet onbelangrijke: nnate te maken met de lage bedragen die op basis van het Verdrag van Parijs beschikbaar waren. Immers, het risico voor leveranciers om in de VS te woiden gedagvaard zou minimaal zijn indien sowieso alle schade uit een kernongeval in Europa reeds zou worden vergoed. Vandaar dienden bijkomende maatregelen te worden genomen teneinde deze tekortkomingen van het Verdrag van Parijs op te vangen.

Toch is blijkbaar iets fout gegaan met de opvolging van de drie hierboven besproken bijkomende maatregelen die de tekorten van het Verdrag van Parijs zouden moeten opvangen, in die zin dat de VS geen van deze drie maatregelen hebben uitgevoerd. De derde mogelijkheid (afsluiten van vrijwaringsakoorden) werd sowieso als onvoldoende beschouwd. Daamaast hebben de VS geen federale wet aanvaard, en waren de VS in 2000 nog steeds geen formeel lid van het internationale nucleaire aansprakelijkheidsrecht. In de volgende paragraaf wordt de terughoudendheid van de Amerikanen om tot de Verdragen toe te treden en met name om een federale aansprakelijkheidswet aan te nemen, verder toegelicht ${ }^{329}$.

\subsubsection{Conclusie}

Een aantal industriële ongevallen heeft ertoe geleid dat Amerikaanse bedrijven voorzichtiger zijn geworden om, in het algemeen, commerciële activiteiten te ontwikkelen ter zake van leveringen aan gevaarlijke industrieën en/of activiteiten, en om, in het bijzonder, onderdelen voor dergelijke industrieën of activiteiten naar het buitenland te exporteren. Het ongeval met de olietanker Amoco Cadiz en het gaslek van Bhopal hebben aangetoond dat de Amerikaanse bedrijven niet immuun zijn tegen vorderingen in eigen land en tegen de toepassing van het Amerikaans recht op vorderingen uit schade in het buitenland en dat, zoals bevestigd bij de Amoco-Cadiz, dergelijke vorderingen de aansprakelijkheid van deze bedrijven in het gedrang kunnen brengen. Onder meer door deze ontwikkelingen vreest de Amerikaanse nucleaire toeleveringsindustrie (als ontwerper, bouwer, leverancier van een onderdeel, ...) dat zij in de VS kan worden gedagvaard en aansprakelijk kan worden gesteld op grond van het Amerikaanse aansprakelijkheidsrecht, ook al kanaliseert het recht van het land van het slachtoffer de aansprakelijkheid naar de (Europese) exploitant van de keminstallatie.

Deze vaststelling impliceert echter niet dat zomaar elke leverancier (ook een niet-Amerikaanse leverancier) van nucleair materiaal het risico loopt te worden gedagvaard in een of ander exotisch land. De vordering moet ook goed gekozen zijn, zowel wat betreft het toepasselijke recht als wat betreft de kansen op uitvoering van een gunstige rechterlijke uitspraak. Vorderingen in de VS voor een kernongeval in Europa, in een keminstallatie die met Amerikaanse hulp werd gebouwd,

belge, Larcier, Bruxelles, 1993; Van Hecke, G. en Lenaerts, K., Internationaal Privaatrecht, Story, Gent, 1989, 33 .

Ook Gautron wees reeds op het risico dat een Amerikaanse leverancier door zijn eigen rechtbanken zou worden veroordeeld indien deze weigeren om het recht van de schadeverwekkende gebeurtenis toe te passen (Gautron, R., "La responsabilité du Constructeur de Centrales Nucléaires", in Puget, H., Aspects de droit de l'énergie atomique, tome II, Centre français de droit comparé, Paris, 1967, 118).

Zie verderop, bij de bespreking van de rol van de VS bij de totstandkoming van het Verdrag inzake Bijkomende Compensatie, $\S 2.2 .9$. 
lijken aan deze voorwaarden te voldoen. Het Amerikaanse aansprakelijkheidsrecht staat erom bekend om riante sommen toe te kennen aan slachtoffers - denk maar bijvoorbeeld aar de schadevergoeding van 6.000 miljard BEF, waartoe de tabaksindustrie werd veroordecld ${ }^{330}$ - en bovendien hebben de Amerikaanse leveranciers voldoende bezittingen in de VS om ook de uitvoering van een vonnis te kunnen garanderen.

De rechtszaak naar aanleiding van de zaak Amoco Cadiz heeft aangetoond dat de bescherming die wordt geboden door de kanalisatie van aansprakelijkheid in het maritieme recht, onvoldoende is indien niet alle landen die een aanknopingspunt hebben met de schade of met het ongeval, verwijzingsregels bevatten naar een recht dat de aansprakelijkheid wél kanaliseert en beperkt. Via de Amoco Cadiz werd duidelijk dat ook een onderneming die ogenschijnlijk niets met een concreet schadegeval heeft te maken, het risico loopt om te worden gedagvaard voor een schadegeval dat zich aan de andere kant van de wereld heeft afgespeeld - met name de moedermaatschappij van een onderneming die wel degelijk een band heeft met het schadegeval. Het succes van een dergelijke vordering in de VS, zal in ruime mate afhangen van het feit of de forum non conveniens doctrine door de rechtbank al dan niet wordt gevolgd ${ }^{331}$.

Aan dit Amoco Cadiz scenario is door de auteurs van het Harvard Rapport uitgebreid aandacht besteed. Precies om te vermijden dat bij een grensoverschrijdend kernongeval een andere wet zou worden toegepast dan de wet die de aansprakelijkheid kanaliseert naar de exploitant van een kerninstallatic, bevatte het gehele systeem van maatregelen van het Harvard Rapport ook regels inzake IPR. Bij een grensoverschrijdend kernongeval is de kanalisatie van aansprakelijkheid pas sluitend op voonwaarde dat alle landen met een mogelijk aanknopingspunt met het ongeval of met de schade, eveneens de aansprakelijkheid kanaliseren naar de exploitant van de kerninstallatie.

Het probleem voor de Amerikaanse leveranciers van de nucleaire industrie was/is niet noodzakelijk dat een andere rechter dan deze van de installatiestaat bevoegdheid opneemt, maar vooral dat een wet zou worden toegepast die de aansprakelijkheid niet naar één enkele persoon kanaliseert en die bijgevolg, voor wat betreft de schade uit een kernongeval, vorderingen tegen meerdere personen zou toelaten.

Doordat de in het Verdrag van Parijs beschikbare bedragen door de VS als te laag werden aanzien, achtten de auteurs van het Harvard Rapport evenwel de introductie van de verschillende maatregelen onvoldoende. Ook de VS zelf dienden bijkomende maatregelen te nemen, waarvan de toetreding tot het internationale nucleaire aansprakelijkheidsrecht nog het meest voor de hand lag. Maar deze bijkomende maatregelen werden nooit doorgevoerd.

Het belang van IPR-regels voor de kanalisatie van aansprakelijkheid in het kernenergierecht bestaat er dus in dat de bescherming die bij een grensoverschrijdend kernongeval aan leveranciers wordt geboden door de kanalisatie, slechts een voldoende effect heeft indien tegelijk wordt voorzien in verwijzingsregels die garanderen dat een wet wordt toegepast die de aansprakelijkheid kanaliseert naar de exploitant. De ideale situatie zou er voor leveranciers in bestaan dat alle landen ter wereld lid zijn van de internationale nucleaire aansprakelijkheidsverdragen en de verschillende daarin opgenomen principes in hun interne wetgeving hebben opgenomen. Deze IPR-regels

"Amerikannse tabaksindustrie in beroep tegen miljardenstraf", De Standaard, 17 juli 2000; "Boele Tabaksindustrie 340 miljard", NRC Handelsblad, 15 juli 2000.

331

Blijkbaar wordt de forum non conveniens meer en meer toegepast (Bunjes, H.J., "Praktische aspecten bij de behandeling van massaschades", in Massaschade. Vergt de behandeling van massale schade een bijzondere benadering?, Koninklijke Vermande, Lelystad, 1996, 16). 
dienen ervoor te zorgen dat enkel dat recht wordt toegepast dat de aansprakelijkheid kanaliseert naar de exploitant van de kerninstallatie waar het kernongeval zich heeft voorgedaan. De IPRregels zijn dus van belang omdat zij ertoe leiden dat het gehele systeem "gesloten blijtt"; anders gezegd dienen de IPR-regels te garanderen dat op een concreet schadegeval een recht zal worden toegepast dat de leveranciers beschermt, c.q. de aansprakelijkheid kanaliseert naar de exploitant van de kerninstallatic.

Toch is de invoering van de kanalisatie van aansprakelijkheid, vanuit het oogpunt van de leveranciers, enkel strikt noodzakelijk in "installatiestaten". Op zich is de kanalisatie van aansprakelijkheid geen conditio sine qua non in landen die geen kerninstallaties hebben en dus enkel het slachtoffer kunnen worden van een kernongeval in een bururstaat; het zal belangrijker zijn dat deze landen de verwijzingsregel hanteren waardoor de zaak wordt behandeld volgens het recht van de installatiestaat. Een afdoende bescherming zal inderdaad voorhanden zijn indien alle installatiestaten de aansprakelijkheid kanaliseren naar de exploitant en indien alle niet-installatiestaten een verwijzingsregel invoeren die garandeert dat het recht van de installatiestaat wordt toegepast. Het belang voor de leveranciers van de nucleaire industrie dat zoveel mogelijk landen toetreden tot het internationale nucleaire aansprakelijkheidsrecht ligt voor wat betreft de niet installatiestaten vooral in de verwijzingsregels.

Volledigheidshalve wordt benadrukt dat deze IPR-regels enkel van belang zijn bij een systeem van juridische kanalisatie van aansprakelijkheid. Bij een economische kanalisatie is het niet van belang dat een leverancier elders wordt gedagvaard en aansprakelijk gesteld, omdat deze aansprakelijkheid toch wordt gedekt via de aansprakelijkheidsverzekering of financiële zekerheid van de exploitant. Een systeem van economische kanalisatie zou dus de positie van de (Amerikaanse) leveranciers sterk kunnen vereenvoudigen. Dit kan een reden zijn waarom de Amerikanen vrede hadden kunnen nemen met de invoering van de economische kanalisatie in het Verdrag van Parijs en het Verdrag van Wenen ${ }^{332}$.

Door de beperkte toetreding van zowel niet-installatiestaten als van installatiestaten, bestaat ook in 2000 nog steeds het risico dat het Amoco-Cadiz scenario zich \%uu voordoen in het nucleaire aansprakelijkheidsrecht. Het feit dat de VS geen lid zijn het Verdrag van Parijs of het Verdrag van Wenen, en dus de aansprakelijkheid niet kanaliseren en evenmin de "juiste" verwijzingsregels hanteren, biedt bijgevolg perspectieven voor slachtoffers en vormt een risico voor leveranciers. Precies in dit licht dient de veranderde houding van de VS te worden gezien ten aanzien van het internationale nucleaire aansprakelijkheidsrecht. De VS hebben inderdaad het Verdrag inzake Bijkomende Compensatie van 12 september 1997 ondertekend; dit betekent dat hun beleid om buiten het intemationale nucleaire aansprakelijkheidsrecht te blijven, is gewijzigd. Omdat ook hier de kanalisatie van aansprakelijkheid een centrale rol heeft gespeeld, wordt deze problematiek hicronder aan de orde gesteld.

\subsubsection{De rol van de kanalisatie van aansprakelijkheid bij de (moeizame) onderhandelingen voorafgaand aan het Verdrag inzake Bijkomende Compensatie van 1997}

Uit de analyse van het belang van de IPR-regels voor de kanalisatic van aansprakelijkheid is gebleken dat zolang de VS de bevoegdheidsattributie en de toepasselijke wetgeving onder de nucleaire aansprakelijkheidsverdragen niet erkennen en zolang niet overal de kanalisatic van aansprakelijkheid is ingevoerd, Amerikaanse leveranciers kwetsbaar zullen blijven voor vorderingen

32

Uit de analyse in $\$ 2.2 .6 .1$ is inderdaad gebleken dat verschillende voorstellen werden gelanceerd om te opteren voor de economische kanalisatic, maar dat deze voorstellen het niet hebben gehaald. 
in eigen land, naar aanleiding van een kernongeval in het buitenland. Vanuit het standpunt van Amerikaanse leveranciers komt het er vooral op aan de garantie te hebben dat de Amerikaanse rechter - of een rechter in een ander land - een wet zal toepassen waar de aansprakelijkheid wél wordt gekanaliseerd naar de exploitant van de kerninstallatie. Dit verklaart de rol die de VS hebben gespeeld bij het totstandkomen van het Verdrag inzake Bijkomende Compensatie van 1997 en verklaart waarom de VS meteen tot dit Verdrag zijn toegetreden.

Het in september 1997 bereikte akkoord omtrent een Verdrag inzake Bijkomende Compensatie en het Protocol van het Verdrag van Wenen, heeft inderdaad geleid tot een wijziging in het Amerikaanse beleid ten aanzien van hun participatie in het internationale nucleaire aansprakelijkheidsrecht. Terwijl de VS vroeger uitdrukkelijk opereerden buiten het internationale kader, hebben de VS als een van de eerste landen het Verdrag inzake Bijkomende Compensatie ondertekend. De VS zijn enkel toegetreden tot het Verdrag inzake Bijkomende Compensatie omdat het een "alleenstaand" Verdrag is dat niet noodzakelijk vereist dat een lid van het Verdrag eveneens is toegetreden tot het Verdrag van Parijs of het Verdrag van Wenen ${ }^{333}$.

Toch liepen de onderhandelingen bij de totstandkoming van het Verdrag inzake Bijkomende Compensatie niet van een leien dakje omdat twee elementen met betrekking tot de kanalisatie van aansprakelijkheid de onderhandelingsmarges aanzienlijk beperkten. Ten eerste voorziet de nationale Amerikaanse nucleaire aansprakelijkheidswet, de Price-Anderson Act, niet in de kanalisatie van aansprakelijkheid naar de exploitant van de kerninstallatie en waren de VS niet bereid om de Price-Anderson Act te wijzigen. Deze problematiek wordt in $\S 2.2 .9 .1$ besproken. In tweede instantie leek het niet haalbaar om de economische kanalisatie in te schrijven in het Verdrag inzake Bijkomende Compensatic ( $\$ 2.2 .9 .2$ ). Uiteindelijk werd een oplossing gevonden die in $\S 2.2 .9 .3$ wordt besproken. In $\S 2.2 .9 .4$ tenslotte worden de bevindingen verder geanalyseerd.

\subsubsection{Eerste beperking: behoud van de economische kanalisatie in de Price-Anderson Act}

De wet die in de VS bepalend is bij de aansprakelijkheid voor schade uit een kemongeval, is de Atomic Energy Act, zoals gewijzigd door de Price-Anderson Act van 1957. Deze wet wordt in detail besproken in hoofdstuk 13 van dit boek. In deze paragraaf wordt met name aandacht besteed aan de bepaling inzake kanalisatie.

Eén van de basiskenmerken van de Price-Anderson Act is de "omnibus dekking" en daaraan gekoppeld het feit dat de Price-Anderson Act geen wijzigingen aanbrengt in het aansprakelijkheidsrecht van de versehillende staten ${ }^{334}$. Dit houdt in dat de aansprakelijkheidsverzekering van de exploitant van de keminstallatie niet enkel van toepassing is op de aansprakelijkheid van de exploitant, maar op elke person indemnified. Onder "person indemnified" dient volgens artikel 42 USCS $\$ 2014, t$ niet alleen te worden verstaan de persoon met wie een Indemnity Agreement is afgesloten of de persoon die is verplicht om een financiële zekerheid te stellen, maar ook elke andere persoon die voor het kernongeval aansprakelijk kan worden gesteld ${ }^{335}$. Hierdoor geniet elke persoon die tengevolge van een kernongeval aansprakelijk wordt gesteld voor de uit een kernongeval voortvloeiende schade van de aansprakelijkheidsverzekering van de exploitant in wiens installatie dat kernongeval plaatshad. Ook al heeft bijvoorbeeld een leverancier van de

333

334

335
Cfr. supra, § 2.2.2.2 van hoofdstuk 2 .

Lowenstein, R., "Indemnification against Liability for Nuclear Accidents in Licensed Atomic Energy Activities", in Weinstein, J.L. (ed.), "Progress in Nuclear Energy", l.c., 250.

Het is van belang erop te wijzen dat "person indemnified" dus niet het slachtoffer is van een kernongeval. Gautron wees reeds op de mogelijke verwarting van deze term: Gautron, R., "La responsabilité civile et la protection financière en raison des risques atomiques aux Etats-Unis", in Puget, H., l.c., 72. 
exploitant het kemongeval veroorzaakt en wordt hij hiervoor aansprakelijk gesteld, dan nog zal de aansprakelijkheidsverzekeraar van de exploitant tussenkomen. Op deze wijze kan bijvoorbeeld de bouwer van een vliegtuig dat een gebrek vertoont en dat neerstort op een keminstallatie, ook genieten van de verzekeringsdekking van de exploitant ${ }^{336}$. Dit is in feite wat de economische kanalisatie naar de exploitant wordt genoemd $\mathrm{g}^{337338}$

Onder het systeem van de omnibus-dekking doet het er bijgevolg niet toe wie uiteindelijk voor een rechtbank aansprakelijk wordt geacht voor een bepaalde schade. De economische gevolgen van deze aansprakelijkheid zullen steeds worden gedragen door de verzekeringsdekking van de exploitant van de kerninstallatie. Indien de initiële, door het Harvard Rapport aangehaalde reden om de kanalisatie van aansprakelijkheid in te voeren worden getoetst aan de situatie onder de Price-Anderson Act, dan blijkt op het eerste gezicht dat twee van deze doelstellingen zijn verwezenlijkt. Onder de omnibus-dekking is geen dubbele verzekering vereist en bovendien kunnen ook de proceskosten in de hand worden gehouden doordat partijen niet zullen trachten de aansprakelijkheid in elkaars schoenen te schuiven. Dat het omnibus systeem werkt, is bewezen naar aanleiding van het kernongeval van Three Mile Island, waar één advocatenkantoor alle gedaagden heeft verdedigd (zowel de exploitant van de kerninstallatie als de ontwerper en de constructeur) ${ }^{339}$.

Door deze omnibus dekking werd bij de invoering van de Price-Anderson Act in 1957 geen verdere aandacht besteed aan de kanalisatie van aansprakelijkheid in het Amerikaanse recht. Ter gelegenheid van de eerste wijziging van de Price-Anderson Act, in 1966, kwam de vraag of de Verenigde Staten de kanalisatie dienden in te voeren wél aan de orde ${ }^{340}$. Het is overigens niet verwonderlijk dat deze vraag uitgerekend toen op de agenda werd geplaatst, aangezien in 1966 de notie "Extraordinary Nuclear Occurrence" (kortweg ENO) werd ingevoerd in de Price-Anderson Act, hetgeen neerkomt op een regime van risicoaansprakelijkheid ${ }^{34 !}$. Hoewel er dus cen soort van risicoaansprakelijkheid werd ingevoerd, werd er toch voor gekozen om de aansprakelijkheid voor schade uit een kernongeval niet te kanaliseren naar de exploitant van de kerninstallatie. Dit zou een onnodige en ongeoorloofde inbreuk vormen op het traditionele aansprakelijkheidssysteem. Bovendien was via de economische kanalisatie reeds een analoge regeling voorhanden: hierdoor werden de administratieve kosten geminimaliseerd en wordt de economische last van de aansprakelijkheid geconcentreerd. Vandaar werd geoordeeld dat:

"An adequate system to protect both the general public and the industry can be established without introducing this drastic and novel principle ${ }^{1342}$.

Het grote verschil tussen het internationale en het Amerikaanse nucleaire aansprakelijkheidsrecht bestaat er dus in dat onder de Amerikaanse Price-Anderson Act het gemene aansprakelijkheidsrecht ongemoeid wordt gelaten, terwijl in Europa het Verdrag van Parijs en het Verdrag van

S. Rep. $N^{\circ} 296,85$ th Congress, $1^{\text {tte }}$ Session, 1957, 1818.

Over deze term, cfr. supra, $\$ 2.2 .1$ van dit hoofdstuk.

Brown, O.F., "Nuclear Liability Coverage Developments in the United States of America", in Nuclear Inter Jura '93, AIDN/NLA, Rio de Janeiro, 1993, 11.5.6-2; Shapar, H.K., "La législation relative à l'indemnisation des dommages nucléaires aux Etats-Unis", Bulletin de Droil Nucléaire, $n^{\circ} 15,1975$, 55.

Brown, O.F., II, "Recent Developments from the Perspcctive of the United States", in Horbach, N.L.J.T. (ed.), "Contemporary Developments in Nuclcar Energy Law", I.c., 481

Zie verderop in hoofdstuk 13.

Vanden Borre, T., "Dekking van het nucleaire risico op nationaalrechtelijkc basis of via internationale Verdragen: de Verenigde Staten versus Europa", in Faure, M., Deketelaere, K. en Verhoosel, G., (red.), "Grensoverschrijdende milieuproblemen", l.c., 453-454.

Hearings held before the Joint Committee of Atomic Energy, 1965, 89th Congress, 1st Session, 36-37. 
Wenen wel degelijk beperkingen aanbrengen aan het gemene civiele aansprakelijkheidsrecht. Precies omdat het Amerikaanse kemenergierecht de aansprakelijkheid niet juridisch kanaliseert naar één enkele persoon, zijn de Verenigde Staten niet toegetreden tot het Verdrag van Wenen, noch tot het Verdrag van Parijs.

Ook bij de onderhandelingen tijdens de revisie van het Verdrag van Wenen was deze problematiek van belang. De VS stonden voor de keuze ofwel om de situatie bij het oude te laten - met alle mogelijke gevolgen voor de positie van hun leveranciers - ofwel om toe te treden tot een gewijzigd Verdrag. Onder meer op basis van de mogelijke gevolgen van de Amoco Cadiz zaak werd er toch voor gekozen om toe treden tot het internationale nucleaire aansprakelijkheidsrecht.

Uiteraard diende een oplossing te worden gevonden voor het verschil tussen de economische kanalisatie in de VS en de juridische kanalisatie in het internationale nucleaire aansprakelijkheidsverdragen. De meest eenvoudige manier om de Amerikaanse industrie te beschermen, zou erin bestaan om ook de Price-Anderson Act te wijzigen door invoering van de juridische kanalisatie van aansprakelijkheid. Indien een Amerikaanse rechter toch bevoegdheid zou aanvaarden voor schade uit een kernongeval in Europa en indien deze Amerikaans recht zou toepassen, dan zou dit tot gevolg hebben dat de verwijzingsregels van het nucleaire aansprakelijkheidsrecht zouden gelden: in principe zou de Amerikaanse rechter de exclusieve bevoegdheid erkennen van de rechtbank van de installatiestaat en zou worden verwezen naar de lex loci delicti.

Maar voor de VS is het ondenkbaar om de Price-Anderson Act aan te passen door de introductie van de juridische kanalisatie van aansprakelijkheid; het lijkt niet haalbaar en niet in de lijn met het Amerikaanse recht om een federale wet te laten ingrijpen in het aansprakelijkheidsrecht van elke afzonderlijke Staat. De introductie van de kanalisatie van aansprakelijkheid naar de exploitant zou een "pre-empting of State tort law" vereisen, heigeen juridisch wel mogelijk is maar politiek nog steeds - onhaalbaar schijnt te zijn ${ }^{343}$. Dezelfde bezwaren als deze die in het Harvard Rapport werden aangehaald tegen de toetreding van de VS in de jaren zestig, waren dus grotendeels aan de orde bij de onderhandelingen van de revisie van het Verdrag van Wenen. Dit was dus een eerste belangrijke beperking bij de onderhandelingen. Er diende naar een andere oplossing te worden gezocht.

\subsubsection{Tweede beperking: behoud van de kanalisatie van aansprakelijkheid in de internationa- le micleaire aansprakelijkheidswerdragen}

Een tweede oplossing zou erin hebben bestaan om het internationale nucleaire aansprakelijkheidsrecht in die zin te wijzigen dat economische kanalisatie zou worden toegelaten. In dat geval beantwoordt immers het Amerikaanse nucleaire aansprakelijkheidsrecht aan het internationale nucleaire aansprakelijkheidsrecht en is voor de toetreding van de VS tot de Verdragen, geen wijziging van de Price-Anderson Act vereist.

Zoals gezegd bieden noch het Verdrag van Wenen, noch het Verdrag van Parijs de mogelijkheid om te kiezen voor hetzij economische kanalisatie, hetzij voor de juridische kanalisatie van aansprakelijkheid ${ }^{344}$. Nochtans werd de mogelijkheid om onder beide Verdragen ook de economische

Brown. Q.F., II, "Recent Developments from the Perspective of the United States", in Horbach. N.L.J.T. (ed.), "Contemporary Developments in Nuelear Energy Law", l.c., 479. 
kanalisatie toe te laten, wel degelijk besproken ${ }^{345}$. Hetzelfde geldt vooj de onderhandelingen van het Verdrag inzake Bijkomende Compensatie ven het Protocol van het Verdrag van Wenen.

In de loop van de revisie van het Verdrag van Wenen hebben de VS inderdaad voorgesteld om cen systeem van economische kanalisatie in te voeren; om met andere woorden te voorzien in een systeem dat analoge bepalingen bevat aan de Price-Anderson $\mathrm{Act}^{346}$. Aanvankelijk waren de VS zelfs voorstander van het toelaten van een alternatief gebruik van economische of juridische kanalisatie van aansprakelijkheid. Aan Verdragspartijen zou de mogelijkheid worden geboden om te kiezen voor hetzij de toepassing van de bepalingen van het Verdrag van Wenen, hetzij abstractie te maken van de kanalisatie van aansprakelijkheid naar de exploitant. Deze laatste optie zou worden onderworpen aan de voorwaarde dat in voldoende financiële bescherming zou worden voorzien, ongeachl de persoon die door de rechtbank zou worden aansprakelijk gesteld.

Een groot aantal landen bleek evenwel bezwaren te hebben tegen het feit dat bijvoorbeeld de kanalisatie van aansprakelijkheid zou worden afgeschaft ${ }^{347} 348$. Het invoeren van de economische kanalisatie zou leiden tot een aanzienlijk aantal rechtsvorderingen en bijgevolg tot dure proces$\operatorname{sen}^{349}$.

Bij de volgende samenkomst van de Standing Committee werd de vraag naar de invoering van de juridische dan wel economische kanalisatie definitief beantwoord. Het nieuwe Verdrag zou de juridische kanalisatie overnemen zoals verwoord in het Verdrag van Wenen. In de volgende bijeenkomsten van de Standing Committee werd dit concept niet echt meer in vraag gesteld. Blijkbaar was het voor de andere landen onbespreekbaar dat zou worden geraakt aan de kanalisatie van aansprakelijkheid naar de exploitant van een kerninstallatie; zelfs een keuze tussen economische of juridische kanalisatie bleek niet haalbaar. De reden waarom dit niet haalbaar was, is moeilijk te achterhalen. Toch lijkt het aannemelijk om ervan uit te gaan dat net als in de jaren vijftig, ook nu de Europese verzekeringspools zich blijven kanten tegen de economische kanalisatie. Daarenboven is een aantal West-Europese landen zelf leverancier van nucleair materiaal geworden en hebben zij dus meer belang bij de juridische kanalisatie ${ }^{350}$.

Aangezien het enerzijds niet haalbaar was om de Price-Anderson Act te wijzigen door de invoering van de juridische kanalisatie van aansprakelijkheid en aangezicn het evenmin haalbaar was om in de internationale Verdragen inzake nucleaire aansprakelijkheid de economische kanalisatie toe te laten, diende een andere oplossing te worden gevonden.

J.L. (ed.), "Progress in Nuclear Encrgy", l.c., 180). Deze nucleaire verzekeringspools worden in hoofdstuk 6 besproken. Cfr. supra, \$2.2.3 van dit hoofdstuk.

Proposal by the Delegation of the United States of America conceming Economic Channelling, Report of the Drafing Committee, IAEA, Wenen, 1992, 40.

Standing Committee on Liability for Nuclear Damage, 10th session, Wenen, 31 oktober -4 november 1994, SCNL/IOINF.4, 18 november 1994, 3.

Uit de discussie rond de kanalisatie van aansprakelijkheid blijkt dat, tijdens de onderhandelingen van de revisie van de verdragen. Greenpeace Intemational geen voorstander was van het behoud van de kanalisatic. Zo stelde Greenpeace voor om de kanalisatie af te schaffen door het wijzigen van de notie "exploitant": ook elke persoon die in zou staan voor de financiering of voor het leveren van gebrekkige onderdelen of het verstrekken van gebrekkige dienstverlening zou worden beschouwd als exploitant van een kerninstallatie (Greenpeace International, "Proposed Alternative to the LAEA. Draft Language", Report of the Drafting Committee, IAEA, Wenen, 1992, 82).

Standing Committee on Liability for Nuclear Damage, 10th session, Wenen, 31 oktober -4 november 1994, SCNL/10/INF.4, 18 november 1994, 9.

Zie verderop in $\$ 2.2 .10$. 


\subsubsection{Oplossing: VS treden toe via de "grandfather clause"}

Nadat in de onderhandelingen werd aanvaard dat de VS de Price-Anderson Act zouden wijzigen en dat de juridische kanalisatie onder de Verdragen van Parijs en Wenen zou behouden blijven, werd een oplossing uitgewerkt die zowel tegemoet kwam aan de Amerikaanse als aan de Europese belangen. Een oplossing werd gevonden in de vorm van de speciale formule die in het internationale recht de grandfather clause of de clause des droits acquis wordt genoemd ${ }^{351}$.

Principieel staat het Verdrag inzake Bijkomende Compensatie open ter ondertekening van lidstaten van het Verdrag van Parijs of van Wenen, of van landen wiens interne wetgeving voldoet aan de bepalingen zoals weergegeven in de Bijlage van het Verdrag ${ }^{352}$. De Bijlage die uit elf artikelen bestaat, verplicht een Verdragspartij die geen Verdragsstaat is bij het Verdrag van Parijs of van Wenen, om te verzekeren dat het nationale recht conform is aan de bepalingen van de Bijlage. Deze bepalingen nemen de grote basisprincipes van de internationale nucleaire aansprakelijkheidsregimes over, inclusief de juridische kanalisatie van aansprakelijkheid naar de exploitant van een kerninstallatie ${ }^{353}$.

Artikel 2.1 van de Bijlage bevat de grandfather-clause. Het stelt dat het nationale recht van een land wordt geacht in overeenstemming te zijn met (onder meer) de bepaling inzake kanalisatie van aansprakelijkheid indien de wetgeving van dat land op 1 januari 1995 bepalingen bevat die "require the indemnification of any person other than the operator liable for nuclear damage $(\ldots)^{\text {1354 }}$. Hoewel artikel 2.1 van de Bijlage niet expressis verbis verwijst naar de Verenigde Staten, is dit het enige land dat op 1 januari 1995 voldeed aan de in dat artikel gestelde voorwaarden. Geen enkel ander land zal zich op de grandfather-clausule kunnen beroepen ${ }^{355}$.

Deze grandfather-clausule laat de Verenigde Staten bijgevolg toe om tot het internationale nucleaire aansprakelijkheidsrecht toe te treden, zonder de verplichting op zich te nemen om de kanalisatie van aansprakelijkheid te moeten invoeren en dus zonder de Price-Anderson Act te moeten wijzigen $^{356}$. Tegelijk zijn de Europese leden van de Verdragen verzekerd van het feit dat enkel juridische kanalisatie is toegelaten.

Het grote belang voor de VS bestaat erin dat met name ook de procedureregels van het Verdrag van Wenen (en dat van Parijs) worden behouden. Door toe te treden tot dit Verdrag en de daaraan verbonden procedureregels zal de Amcrikaanse rechter gehouden zijn de Verdragsbepalingen toe te passen. Overeenkomstig artikel XIII van het Verdrag inzake Bijkomende Compensatie is exclusief bevoegd de rechtbank van de Verdragsstaat waar het kernongeval zich heeft voorgedaan.

Zeer in het algemeen stelt een grandfather clause bepaalde mensen of landen vrij om te voldoti aan bepaalde verplichtingen die uit een wet of een Verdrag voortvlocien. Artikel II van het Verdrag inzake Bijkomende Compensatic.

Met name in de artikelen 3.9 en 3.10 van de Bijlage van het Verdrag inzake Bijkomende Compensatie: "The right to compensation for nuclear damage may be exercised only against the operator liable (...). The operator shall incur no liability for damage caused by a nuclear incident outside the provisions of national law in accordance with this Convention".

Hiermee wordt duidelijk gerefereerd aan de omnibus-dekking zoals voorzien in de Price-Anderson Act.

McRae, B., "La Convention sur la réparation: sur la voie d'une régime mondial permettant de faire face à la responsabilité et à l'indemnisation des dommages nucléaires", Bulletin de Droit Nucléaire, $\mathrm{n}^{\circ} 61$, 1998, 38; Kremen, D., "Transboundary Damage. Carpe Solutionem", Nuclear Inter Jura 1999, AIDN/INLA, Washington, 1999, 275. 
Deze rechtszaak zal worden beoordeeld op grond van het recht van de bevoegde rcchtbank (artikel XIV). Dit betekent dat zodra een vordering in de VS zal worden ingespannen ingevolge een kernongeval in Europa, ook de procedureregels van het internationale nucleaire aansprakelijkheidsrecht zullen van toepassing zijn.

Zodra het Verdrag inzake Bijkomende Compensatie in werking zal zijn getreden, zullen de VS bijgevolg voor het eerst deel uitmaken van het internationale nucleaire aansprakelijkheidsrccht. Op procedureel vlak betekent dit dat een Amerikaanse leverancier in principe niet meer in de VS kan worden gedagvaard ingevolge een kemongeval in Europa.

\subsubsection{Conclusie}

Een reële inschatting van het risico naar aanleiding van de rechtszaak met de Amoco Cadiz, hebben de VS ertoe gebracht om actief deel te nemen aan de onderhandelingen bij de revisie van het Verdrag van Wenen en om vervolgens het Verdrag inzake Bijkomende Compensatic van 1997 te ondertekenen. Immers, zolang de VS niet waren toegetreden tot het internationale nucleaire aansprakelijkheidsrecht, bleven de Amerikaanse leveranciers in eigen land kwetsbaar voor vorderingen ingevolge een kernongeval in Europa. De onderhandelingen bij de revisie van het Verdrag van Wenen werden inderdaad aangegrepen als opportuniteit om dan toch een bijkomende beschermingsmaatregel zoals reeds voorgesteld door het Harvard Rapport, in te voeren: de toctreding van de VS tot het internationale nucleaire aansprakelijkheidsrccht.

Toch heeft deze toetreding heel wat voeten in de aarde gehad, omdat de VS vasthielden aan de economische kanalisatie zoals voortvloeiend uit de Price-Anderson Act en omdat anderzijds een aantal andere onderhandelingspartners vasthield aan de (juridische) kanalisatie van aansprakelijkheid. De uiteindelijke oplossing komt aan beide vereisten tegemoet en laat de VS via een achterpoort toe om de economische kanalisatie te behouden en laat de juridische kanalisatie in de Verdragen onaangeroerd. Hieruit blijkt dat de moeizame onderhandelingen van het Verdrag inzake Bijkomende Compensatie voor een belangrijk deel betrekking hadden op de kanalisatie van aansprakelijkheid.

Een aantal vragen blijft echter onopgelost. Zo rijst de vraag of personen die schade lijden in een land dat enkel lid is van het Verdrag van Wenen of van Parijs en niét van het Verdrag van 1997 , toch nog een vordering in de VS kunnen instellen ${ }^{357}$. Bovendien rijst de vraag of landen een voorbehoud kunnen maken ${ }^{358}$ ten aanzien van de grandfather-clause en wat de gevolgen daarvan

357 Zie nok McRae, B., "Nuclear Liability from the Perspective of the United States", in Nuclear Inter Jura 1999, AIDN/INLA, Washington, 301-302.

Artikel 19 van het Weense Verdragenverdrag van 1969 bevat het algemene beginsel dat elke Staat vrij is om een voorbehoud aan te tekenen: elke Staat die een Verdrag tekent, goedkeurt of ratificeert kan een voorbehoud maken, behalve indien het maken van reserves uitdrukkelijk door het desbetreffende Verdrag is verboden, indien het Verdrag slechts een beperkte vrijheid toelaat of indien het voorbehoud niet verenigbaar is met de doelstelling en de bedoeling van het Verdrag. Een voorbehoud wordt in artikel 2, d gedefinieerd als "a unilateral statement, however phrased or named, made by a State when signing, ratifying, accepting, approving or acceding to a treaty, whereby it purports to exclude or to modify the legal effect of certain provisions of the treaty in their application to that State". De tekst van het Weense Verdragenverdrag van 23 mei 1969 is onder meer gepubliceerd in Suy, E., Corpus Iuris Gentium. A Collection of Basic Texts on Modern Interstate Relations, Acco, Leuven, 1996, 99-120. Zie hierover o.m. Brownlie, l., Principles of Public International Law, Clarendon Press, Oxford, 5th edition, 1998, 614; Cogen, M., Handboek Internationaal recht, tweede uitgave, 1998, Mys \& Breesch, Gent, 393; Daillier, P. en Pellet, A., Droit International Public, Librairie Générale de Droit et de Jurisprudence, Paris, 1999, 179. 
zijn voor wat betreft de immuniteit van Amerikaanse leveranciers. Dit boek is echter geen onderzoek naar de immuniteit van Amerikaanse leveranciers en bijgevolg zal aan deze vragen geen verdere aandacht worden besteed. De analyse van de wijze waarop het Verdrag inzake Bijkomende Compensatie is tot stand gekomen en de achterliggende reden van het gewijzigde Amerikaanse beleid, hebben wel enkele interessante inzichten opgeleverd voor de verdere analyse in dit proefschrift.

Daarenboven is het zeer de vraag of het Verdrag inzake Bijkomende Compensatie ooit in werking zal treden; ook de nucleaire aansprakelijkheidsverdragen van de tweede generatie lijken dus niet te leiden tot een groot enthousiasme. En zolang dit Verdrag niet in werking is, blijft de toestand van de Amerikaanse leveranciers onzeker. Ook hier geldt de noodzaak dat zoveel mogelijk landen tot het Verdrag zullen toetreden. Om die reden drongen de VS aan op een Verdrag dat dermate aantrekkelijk zou zijn dat de meeste landen tot dat Verdrag zouden willen toetreden ${ }^{359}$. Een Verdrag zal, steeds volgens de VS, aantrekkelijk zijn indien het er \%owel in slaagt om te voorzien in een adequate compensatie voor slachtoffers als wanneer het de industrie toelaat om zich te ontwikkelen; deze ontwikkeling zou niet mogen worden geremd door onzekerheden op het vlak van de adnsprakelijkheid ${ }^{300}$. Volgens deze redenering is het voor slachtoffers van een kernongeval in de ccrste plaats van belang dat wordt geïnvesteerd in veiligc onderdelen en dienstverlening; indien er echter onzekcrheid bestaat inzake aansprakelijkhcid, dan zou de beschikbaarheid van dergelijke goederen en diensten in het gedrang kunnen komen. Deze onzekerheid kan enkel worden weggenomen door het opstellen van een internationaal nucleair aansprakelijkheidsregime waar zoveel mogelijk landen aan deelnemen ${ }^{301}$.

Uit bovenstaande analyse blijkt tenslotte eens te meer dat de VS een aanzienlijke invloed hebben uitgeoefend op het Verdrag inzake Bijkomende Compensatie en het Protocol van het Verdrag van Wenen, nadat zij ook al hun stempel hadden gedrukt op de nucleaire aansprakelijkheidsverdragen van de eerste generatie.

In deze paragraaf werd reeds gesuggereerd dat de Europese nucleaire industrie er niet voor te vinden was om de juridische kanalisatie van aansprakelijkheid op te geven ten voordele van de economische kanalisatie. In onderstaande paragraaf wordt toegelicht waarom ook de Europese nucleaire industrie belang heeft bij de juridische kanalisatie van aansprakelijkheid.

\subsubsection{Belang van de kanalisatie van aansprakelijkheid naar de exploitant van een kernin- stallatie voor Europese nucleaire leveranciers}

In het internationale kemenergierecht is het belang van de kanalisatie van aansprakelijkheid naar de exploitant van een keminstallatie niet meer beperkt tot de relatie tussen de Amerikaanse leveranciers enerzijds en Europese exploitanten anderzijds. Sinds de opheffing van het Amerikaanse monopolie op nucleaire know-how en nucleair materiaal, is een aantal Europese bedrijven ook zelf producent geworden van nucleair materiaal. Deze bedrijven hebben bijgevolg dezelfde belangen als de Amerikaanse nucleaire toeleveringsindustrie in het begin van de jaren vijftig: ook zij hameren op het belang van de kanalisatie van aansprakelijkheid naar de exploitant omdat

359 Mckae, B., "Nuclear Liability from the Perspective of the United States", in "Nuclear Inter Jura 1999", l.c., 297.

360 US Non-Paper on an Approach to Revising the Vienna Convention to attract Broad Adherence, Standing Committee on Liability for Nuclear Damage, 10th session, Wenen, 31 oktober -4 november 1994, SCNLIIO/INF.4, 18 november 1994, 102. 
zijzelf op die manier niet kunnen worden aansprakelijk gesteld voor de uit een kernongeval voortvloeiende schade.

Dit is een belangrijk element in de appreciatie van de verhouding tussen westerse leveranciers en landen van het voormalige Oostblok. Na de val van de Berlijnse muur ging een nicuwe markt open voor de Westerse (zijnde Amerikaanse en Europese) nuclcaire toeleveringsindustrie. Maar het probleem hierbij was dat slechts een zeer beperkt aantal landen van het voormalige Oostblok lid was van het Verdrag van Wenen of in hun interne recht een wetgeving had die de aansprakelijkheid kanaliseerde naar de exploitant van de kerninstallatie.

Nochtans was de situatie ten aanzien van het voormalige Oostblok landen bijzonder, in die zin dat na het ongeval in Tsjemobyl, westerse landen erop aandrongen dat de veiligheid van de kcrninstallaties in het Oostblok zou worden verbeterd. Tsjernobyl had aangetoond wat de gevolgen van een ernstig kernongeval konden zijn. Het verbeteren van de veiligheid kon evenwel enkel worden bereikt door middel van westerse technologie en kennis. Naar aanleiding van de Conferentie van Lissabon van 1992 verbonden de Verenigde Staten en een aantal andere Westerse regeringen zich ertoe om de veiligheid van reactoren van Sovjetmakelij te verbeteren ${ }^{362}$.

Zolang de tussenkomst van de Westerse bedrijven beperkt bleef tot het verrichten van algemene studies, werd geoordeeld dat ook de risico's zeer beperkt waren ${ }^{363}$. Indien westerse bedrijven evenwel echte bijstand verleenden (in de vorm van dienstverlening of levering van goederen) liepen zij het risico te worden aansprakelijk gesteld indien zich een kemongeval zou voordoen. Om aan het aansprakelijkheidsrisico tegemoet te komen werd een aantal bilaterale akkoorden getekend, bijvoorbeeld tussen de VS en Oekraïne en de Russische Federatie; dezc akkoorden bleken echter, vanuit het standpunt van de leveranciers, geen afdoende bescherming te bieden waardoor de meerderheid van Westerse leveranciers niet bereid was om mee te werken zonder betere bescherming tegen aansprakelijkheid ${ }^{364}$. Een andere tijdelijke oplossing bestond erin dat het land waarnaar de technologie werd uitgevoerd, zich garant zou stellen; maar ook hier bestonden twijfels over de daadwerkelijke financiële capacitciten van de landen van het voormalige $0_{0}$ stblok ${ }^{365}$. Het resultaat hiervan was dat de levering van materiaal dat de veiligheid van de Russische kerncentrales kon verbeteren, in het gedrang dreigde te komen ${ }^{366}$.

De inspanningen die Europese en Amerikaanse leveranciers vanaf de jaren negentig ondemamen om landen van het voormalige Oostblok ervan te overtuigen om toe: te treden ${ }^{367}$ tot het Verdrag

I6! In mei 1992 vond de Lisbon Co-ordinating Conference on Assistance to the Newly Independent States of the Former Soviet Union plaats, op basis waarvan een veiligheidsprogramma werd uitgewerkt. Aansluitend hierbij werd een fonds opgericht inzake bijstand bij nucleaire veiligheid. Het Nuclear Safety Account, in het leven geroepen in februari 1993, wordt beheerd door de European Bank for Reconstruction and Development (EBRD). Zie hierover Zahariev, K., "Nuclear Liability from the Perspective of the European Bank for Reconstruction and Development", in Nuclear Inter Jura 1999, AIDN/IN LA,

163 Washington, $1999,277-282$.

344 Eastem Europe", Nuclear Law Bulletin, $n^{\circ} 53,1994,37$.
Brown, O.F., "Bilateral Agreements with CEEC/NIS from the Perspective of the United States", in

365 Horbach, N.L.J.T. (ed.), "Contemporary Developments in Nuclear Energy Law", l.c., 492.

366 Eastem Europe", o.c., 40-41.
Brown, O.F., "Bilateral Agreements with CEEC/NIS from the Perspective of the United States", in

367 Horbach, N.L.J.T. (ed.), "Contemporary Developments in Nuclear Energy Law", l.c., 492.
Totnogtoe zijn hun inspanningen niet zonder succes gebleken: tussen 1990 en 1994 hebben niet minder dan zes voormalige Oostbloklanden Het Verdrag van Wenen ondertekend, namelijk Armenië, Estland, 
van Wenen zijn te vergelijken, of zijn ten minste ingegeven door dezelfde belangen, als de inspanningen van de VS om haar eigen leveranciers via het Harvard Rapport immuun te maken voor vorderingen in eigen land. Europese leveranciers van nucleair materiaal werisen niet in eigen land aansprakelijk te worden gesteld voor schade uit een kernongeval in Oost-Europa waarbij een kerninstallatie is betrokken waar zij goederen hebben geleverd of diensten hebben verstrekt. Om die reden drongen Europese leveranciers meer en meer aan op de toetreding van deze landen tot het Verdrag van Wenen. De bezorgdheid van deze leveranciers had inderdaad te maken met de vrees dat buitenlandse slachtoffers ertoe geneigd zullen zijn solvabele leveranciers van de keminstallatie te dagvaarden en te zoeken naar een rechtbank die rechtsmacht zal opnemen ${ }^{368}$. Europese en Amerikaanse leveranciers beperkten hun inspanningen evenwel niet tot het aandringen op toetreding tot het Verdrag van Wenen; er werd ook telkens nagegaan of, eens de toetreding tot het Verdrag een feit was, dit Verdrag wel op afdoende wijze in het interne recht werd omgezet. Opvallend is telkens dat de omzetting in het interne recht vaak de nodige tijd in beslag nam ${ }^{369} 370$.

Volledigheidshalve wordt erop gewezen dat de Europese leveranciers voldoende zouden worden beschermd door een stelsel van economische kanalisatie. Met name de Europese nucleaire verzekeraars lijken zich tegen een dergelijk systeem te verzetten.

Door de toetreding van de landen van het voormalige Oostblok tot het internationale nucleaire aansprakelijkheidsrecht, hopen westerse leveranciers immuun te zijn voor vorderingen die desgevallend tegen hen kunnen worden ingesteld. Toch blijkt ook hier het belang van een massale toetreding van landen tot de bestaande Verdragen. Er zijn immers verschillende scenario's denkbaar waarbij de uit deze Verdragen voortvloeiende principes, en dan met name de kanalisatic van de aansprakelijkheid naar de exploitant van de kerninstallatie en de beperking van diens aansprakelijkheid, kunnen worden omzeild.

Zo is het perfect mogelijk dat indien een kemongeval plaatsheeft in een land dat lid is van hot Verdrag van Wenen, waarbij eveneens schade wordt veroorzaakt in een land dat geen lid van dit Verdrag, slachtoffers in dit laatste land zullen trachten om op cen andere manier schadevergoeding te bekomen ${ }^{371}$. Stel bijvoorbeeld dat een kernongeval plaatsheeft in de republiek Tsjechië

de Tsjechische Republiek, Litouwen, Roemenie en Bulgarije en in 1996 is ook Rusland lid geworden van dit Verdrag. Hiermee zijn de problemen echter nog niet van de baan. Het is lang niet zeker of de exploitunten op de markt dekking zullen kunnen vinden voor hun aansprakelijkheid en of de exploitanten de premies zullen kunnen betalen. Zise "Outlook on Intemational Nuclear Liability", Nucleonics Week, 29 september 1994, 2.

Blanchard. P., "The Risk of Civil Nuclear Liability of Foreign Contractors in Central and Eastem Europe and the NIS", in Horbach, N.L.J.T. (ed.), "Contemporary Developments in Nuclear Energy. Law", l.c., 524 .

369 Zo ondertekende Hongarije het Verdrag van Wenen op 28 juli 1989, maar een nationale wet die de verdragsbepalingen op afdoende wijze in het Hongaarse recht integreerde, kwam pas tot stand in december 1999. Hetzelfde geldt voor Tsjechie (dat het Verdrag van Wenen ratificeerde in februari 1994 en waar de wet tot stand kwam in 1997) en voor Oekraïne (dat in 1996 toetrad tot het Verdrag van Wenen, maar dat einde 1999 nog steeds geen afdoende bepalingen in haar interne wetgeving had ingevoerd). Voor details zie Blanchard, P., "The Risk of Civil Nuclear Liability of Foreign Contractors in Central and Easterm Europe and the NIS", in Horbach, N.L.J.T. (ed.), "Contemporary Developments in Nuciear Energy Law", I.c, 534 e.v.

Vooĩ een uitstekend overzicht en bespreking van de wetgeving van deze landen, zie Horbach, N.L.JT. (ed.), "Nuclear Energy Law and Regulation in Central and Eastern Europe", in Horbach, N.L.J.T. (ed.), "Contemporary Developments in Nuclear Energy Law", l.c., 139 e.v. Zie ook Overview of Nuclear Legislation in Central and Eastern Europe and the NIS, OECD/NEA, Paris, 1998.

Leigh, W.J., "The Nuclear Liability Convention - the only World on Liability?", in Horbach, N.L.J.T. (ed.), "Contemporary Developments in Nuclear Energy Law", l.c., 513. 
(lid van het Verdrag van Wenen) waarbij eveneens schade wordt veroorzaakt in Belgiê (lid van het Verdrag van Parijs) ${ }^{372}$. In een dergelijk geval zal het voor slachtoffers in België aantrekkelijk zijn om te zoeken naar een aanknopingspunt met een land dat geen lid is van het Verdrag van Wenen. Een aanknopingspunt kan er bijvoorbeeld in bestaan dat wordt aangevoerd dat het ongeval is veroorzaakt door een gebrekkig onderdeel en gebrekkig onderhoud van een Frans bedrijf. Hoewel zowel Frankrijk als België lid zijn van het Verdrag van Parijs en bijgevolg de aansprakelijkheid kanaliseren naar de exploitant van een kerninstallatie, kan bijvoorbeeld worden getracht om in Frankrijk een forum te vinden en om het Franse gemeenrechtelijke aansprakelijkheidsrecht toe te passen.

Er zijn nog verschillende andere scenario's denkbaar waarbij de schade uit een kernongeval kan worden behandeld buiten de bestaande nucleaire aansprakelijkheidsverdragen, zelfs indien het land van de installatiestaat lid is van één van de verdragen of zelfs indien andere factoren de toepassing van het Verdrag van Wenen of het Verdrag van Parijs toelaten ${ }^{373}$. Het spreekt voor zich dat het succes van een aansprakelijkheidsvordering buiten de bestaande verdragen in belangrijke mate afhangt van de op de zaak toepasselijke regels van internationaal privaatrecht en van de regels inzake de erkenning van buitenlandse vonnissen ${ }^{374}$.

Het belang van de kanalisatie van aansprakelijkheid bij de aanvraag van de éénentwintigste eeuw bestaat erin dat de verschillende landen die nucleair materiaal en kennis exporteren, bondgenoot zijn geworden voor de introductie van een systeem dat de leveranciers beschermt. Ook de WestEuropese exportlanden hebben er belang bij dat zowel de kanalisatie van aansprakelijkheid als de IPR-regels in de wetgeving van de importlanden worden ingevoerd.

\subsubsection{Conclusie}

In het nucleaire aansprakelijkheidsrecht bestaan twee grote systemen van kanalisatie. In een eerste systeem ("economische kanalisatie") wordt niet geraakt aan het civiele aansprakelijkheidsrecht en zal eenieder door een slachtoffer van een kernongeval kunnen worden gedagvaard c.q. aansprakelijk worden gesteld, indien hiertoe aan alle wettelijke voorwaarden is voldaan. Toch zal de uiteindelijke last van deze aansprakelijkheid worden gedragen door degene naar wie de schade wordt gekanaliseerd. In de regel zal dit de aansprakelijkheidsverzekering van de exploitant van de kerninstallatie zijn. Onder een systeem van economische kanalisatie is het dus mogelijk dat de aansprakelijkheidsverzekering van de exploitant zal dienen tussen te komen, zelfs indien cen andere: persoon dan de exploitant werd aansprakelijk gesteld. Het tweede systeem ("juridische" of directe kanalisatie van aansprakelijkheid) grijpt wel degelijk in in het civielrechtelijke aansprakelijkheidsrecht in die zin dat het een aantal rechtsgronden, waarover een slachtoffer overeenkomstig het gemene recht beschikt ter compensatie van de door hem geleden schade, buiten werking stelt.

In de intemationale nucleaire aansprakelijkheidsverdragen - Verdrag van Parijs van 1960 en het Verdrag van Wenen van 1963 - werd het tweede systeem overgenomen. De ratio legis van de

Voor geen van deze landen is het Gemeenschappelijk Protocol van 1988 in werking.

Zie bijvoorbeeld een aantal scenario's uitgewerkt in Leigh, W.J., "The Nuclear Liability Convention the only World on Liability?", in Horbach, N.L.J.T. (ed.), "Contemporary Developments in Nuclear Energy Law", l.c., 509 e.v.

In Europa is met name het Europees Executieverdrag van 1968 van belang (Verdrag van Brussel van 27 september 1968 betreffende de rechterlijke bevoegdheid en de tenuitvoerleggingvan beslissingen in burgerlijke en handelszaken). Over de invloed van het Europees Executieverdrag op het nucleaire aansprakelijkheidsrecht zie Sands, Ph. en Galizzi, P., "The 1968 Brussels Convention and Liability for Nuclear Damage" in Reform of Civil Nuclear Liability, OECD, Paris, 2000, 475-506. 
introductie van dit systeem is een kopie van de argumenten van het Harvard Rapport: het vermijden van een dubbele verzekeringsdekking en van langdurige en ingewikkelde processen ${ }^{375}$. De historische rol die de Verenigde Staten hebben gespeeld bij de ontwikkeling van kernenergie en het juridische en vervolgens - tijdelijke - feitelijke monopolie dat daaruit is ontstaan, heeft dan ook sporen nagelaten in het kernenergierecht ${ }^{376}$. De kanalisatie van aansprakelijkheid is immers ontstaan als beschermingsmechanisme ten voordele van de Amerikaanse leveranciers.

De kanalisatie van aansprakelijkheid zoals verwoord in zowel het Verdrag van Parijs als het Verdrag van Wenen, bestaat uit twee elementen: zowel de extracontractuele vorderingen van een slachtoffer als de contractuele regresvorderingen van de exploitant zelf, zijn beperkt. Een derde kan enkel een vordering instellen tegen de exploitant en daarenboven kan niemand anders dan de exploitant aansprakelijk worden gesteld. Onder beide Verdragen is het de bedoeling geweest dat een exclusief systeem in het leven zou worden geroepen. Dit impliceert dat voor schade uit cen kernongeval die niet onder het Verdrag wordt gecompenseerd, niemand aansprakelijk is. In die optiek kan worden gesproken van een exclusieve aansprakelijkheid van de exploitant van cen kerninstallatie. Door de evolutie van het civielrechtelijke aansprakelijkheidsrecht is het echter onzeker of het nucleaire aansprakelijkheidsrecht nog steeds zal worden beschouwd als enige lex specialis, bijvoorbeeld ten aanzien van door een kernongeval veroorzaakte milieuschade. In de mate waarin een bijzondere rechtsgrond voorhanden is voor de aansprakelijkheid voor dergelijke schade, is een conflict tussen twee lex speciales niet uitgesloten.

Precies omdat, door de juridische kanalisatie van aansprakelijkheid naar de exploitant van de kerninstallatie, de leveranciers van de exploitant niet kunnen worden aansprakelijk gesteld heeft steeds weerstand bestaan tegen dit principe. Recent nog werd in Oostenrijk vanaf 1 januari 1999 de kanalisatie van aansprakelijkheid afgeschaft. Ook in de VS zelf, is via de Price-Anderson Act het systeem van de economische kanalisatie in voege.

Aansluitend hierbij is het vreemd te moeten vaststellen dat in de Verenigde Staten een adequaat systeem kan worden bereikt waarbij zowel de belangen van de industrie als de belangen van slachtoffers worden gediend, zonder hierbij de kanalisatie van aansprakelijkheid te moeten invoeren, terwijl voor een adequaat systeem in Europa de invoering van kanalisatie van aansprakelijkheid wel was vereist. Indien, zoals steeds wordt voorgehouden, kanalisatie van aansprakelijkheid inderdaad voordelig is voor slachtoffers, is het vreemd om vast te stellen dat de Amerikaanse Price-Anderson Act géén kanalisatie van aansprakelijkheid heeft ingevoerd in het Amerikaanse kemenergierecht en dat de Verenigde Staten niet zijn toegetreden tot een van de nucleaire aansprakelijkheidsverdragen $^{377}$.

De keuze om in de Verdragen van Parijs en Wenen het systeem te introduceren van de juridische kanalisatie van aansprakelijkheid, heeft tot gevolg dat ook maatregelen dienden te worden ingevoerd inzake IPR. Deze maatregelen dienden te garanderen dat bij een grensoverschrijdend kemongeval een recht zou worden toegepast dat de aansprakelijkheid kanaliseert naar de exploitant en dat uitsluitend de rechter in de installatiestaat bevoegdheid zou kunnen opnemen. De rechtszak naar aanleiding van het ongeval met de Amoco Cadiz heeft evenwel aangetoond dat met name het feit dat de VS niet waren toegetreden tot één van de internationale aansprakelijkheidsverdragen inzake olieverontreiniging op zee, een belangrijke tekortkoming vormde aan de bescherming. Ook

Cfr. supra, \$2.1.3.1.

Ook in die zin Hébert, J., "Nucléaire", o.c., 8-9.

Met deze nuance dat de Verenigde Staten als een van de eerste landen het Verdrag inzake Bijkomende Compensatie hebben ondertekend op 29 september 1997; in 2001 was het Verdrag evenwel nog steeds niet geratificeerd door de Verenigde Staten. 
het Harvard Rapport had erop gewezen dat door de beperkte beschikbare bedragen onder het Verdrag van Parijs de kans bestond dat slachtoffers zouden trachten om via andere wegen dan de bijzondere nucleaire aansprakelijkheidswetgeving volledige compensatie te bekomen. Mede hierdoor hebben de VS actief deelgenomen aan de onderhandelingen van het Verdrag inzake Bijkomende Compensatie van september 1997 en hebben zij als een van de eerste dat Verdrag andertekend. Vanuit het standpunt van de Amerikaanse leveranciers is het vooral belangrijk dat, zodra dit Verdrag in werking treedt, de Amerikaanse rechter op basis van de verwijzingsregels van het Verdrag inzake Bijkomende Compensatie, de exclusieve bevoegdheid zal erkennen van de rechtbank van de installatiestaat en dat ook het recht van dat land toepassing zal vinden.

Meteen is ook het belang aangetoond van de toetreding van een zo groot mogelijk aantal landen tot de nucleaire aansprakelijkheidsverdragen van zowel de ecrste als de tweede generatie. Als algemene regel kan worden gesteld dat de leveranciers pas volledig immuun zullen zijn voor vorderingen buiten de verdragen indien alle landen waarmee zij aanknopingspunten hebben of waar zij bezittingen hebben, tot de verdragen zijn toegetreden. Zolang dit niet het geval is, kan het voor slachtoffers van een kernongeval zinvol zijn om een forum en een toepasselijk recht te vinden buiten deze Verdragen. De geringe kans op een snelle inwerkingtreding van het Verdrag inzake Bijkomende Compensatie leidt er echter toe dat de positie van de Amerikaanse leveranciers nog geruime tijd onzeker zal zijn, dat zij met andere woorden nog steeds kwetsbaar zullen voor vorderingen in eigen land tengevolge van kemongevallen in installaties gebouwd met Amerikaanse kennis en technologie. Hetzelfde geldt ook voor de Europese leveranciers die inmiddels een belangrijke exporteur zijn geworden van nucleaire technologie en kennis.

Op zich kan uit de vaststelling dat de kanalisatie van aansprakelijkheid in het kemenergierecht is ingevoerd met het oog op de bescherming van de industrie nog geen enkele conclusie worden getrokken met betrekking tot de merites en tekortkomingen van de kanalisatie van aansprakelijkhcid. Het is immers principieel mogelijk om een systeem in het leven te roepen, dat zowel de belangen van slachtoffers als van de industrie zou dienen. Het is dan ook moeilijk om de kanalisatie van aansprakelijkheid te beoordelen zonder een objectief toetsingskader. Zoals reeds aangegeven in de inleiding van dit boek, werd in dit onderzoek geopteerd voor de rechtseconomie als toetsingskader. De beoordeling van de merites van de kanalisatie van aansprakelijkheid, zal plaatsvinden in hoofdstuk 15 van dit bock.

Nadat in paragraaf 2.2 de kanalisatie van aansprakelijkheid in het nucleaire aansprakelijkheidsrecht centraal stond, wordt in onderstaande paragraaf verder gegaan met de juridische analyse van de kanalisatie aansprakelijkheid buiten het kernenergierecht.

\subsection{Kanalisatie van aansprakelijkheid buiten het kernenergierecht}

In de bovenstaande paragrafen werd weergegeven hoe de kanalisatie van aansprakelijkheid is ontstaan, en werden diverse aspecten belicht van de kanalisatie van aansprakelijkheid in het kernenergierecht, met name de kanalisatie van aansprakelijkheid naar de exploitant van een keminstallatie. Op basis van deze analyse zal vervolgens worden aangetoond dat het begrip "kanalisatie van aansprakelijkheid" ook buiten het kernenergierecht en dan met name in het extracontractuele ansprakelijkheidsrecht wordt gehanteerd. De analyse van het gebruik van de term kanalisatie van ansprakelijkheid in het kernenergierecht enerzijds en in het (milieu)aansprakelijkheidsrecht anderzijds, zal ons toelaten om in de paragraaf 2.4 het begrip "kanalisatie" preciezer af te bakenen.

Bij wijze van voorbeeld zullen enkele wettelijke bepalingen uit het Belgische en uit het Nederlandse aansprakelijkheidsrecht worden aangehaald. Deze bespreking zal zich met name richten tot 
een aantal wettelijke bepalingen waar het begrip "kanalisatie van aansprakelijkheid" werd gehanteerd. Het ligt geenszins in onze bedoeling om op exhaustieve wijze een overzicht te geven van alle wettelijke bepalingen waarin de aansprakelijkhcid wordt gekanaliseerd of waarin het begrip kanalisatie wordt gehanteerd buiten het aansprakelijkheidsrecht. De bedoeling is om na te gaan welke de precieze inhoud is van dit begrip buiten het nucleaire aansprakelijkheidsrecht. Meer in het bijzonder willen we in deze paragraaf aantonen dat het begrip "kanalisatie van aansprakelijkheid" zoals dat wordt gebruikt in het milieurecht, een andere strekking heeft dan in het kernenergierecht, en dat totnogtoe nauwelijk aandacht werd besteed aan deze verschillen.

Hieronder zal worden aangegeven hoe kanalisatie van aansprakelijkheid buiten het kernenergierecht wordt omschreven in het Belgische recht ( $\$ 2.3 .1)$ en in het Nederlandse recht (\$2.3.2). De gevolgen van deze omschrijvingen op de dogmatiek inzake risicoaansprakelijkheid, worden in $\S 2.3 .3$ besproken. Deze inzichten zullen toelaten om in $\S 2.4$ het begrip "kanalisatie van aansprakelijkheid" verder af te bakenen.

\subsubsection{Kanalisatie van aansprakelijkheid volgens naar Belgisch recht}

De omschrijving van het begrip "kanalisatie van aansprakelijkheid" in het Belgische recht dient te worden geplaatst in het licht van de onduidelijkheid, in een deel van de Belgische doctrine, omtrent de begrippen kanalisatie van aansprakelijkheid en risicoaansprakelijkheid ${ }^{378}$. Hieronder zal eerst het verschil tussen beide begrippen worden uiteengezet $(\$ 2.3 .1 .1)$. In tweede instantie wordt onderzocht hoe het begrip kanalisatie wordt gebruikt door de Interuniversitaire Commissie tot Herziening van het Milieurecht in het Vlaamse Gewest (§ 2.3.1.2).

\subsubsection{Kanalisatie van aansprakelijkheid versus risicoaansprakelijkheid}

In een deel van de Belgische doctrine bestaat verwarring omtrent het begrip kanalisatie van aansprakelijkheid, en dan met name met betrekking tot de wederzijdse wisselwerking tussen kanalisatic van aansprakelijkheid en risicoaansprakelijkheid. Hct lijkt in bepaalde gevallen inderdaad niet makkelijk om de kanalisatie van aansprakelijkheid te plaatsen in het brede gamma van de van de klassieke fout afwijkende aansprakelijkheidsregimes. In deze paragraaf zal worden aangetoond dat kanalisatie van aansprakelijkheid niet hetzelfde is als risicoaansprakelijkheid, hoewel beide begrippen door de wetgever vaak samen worden geïntroduceerd.

Bocken brengt de verschillende van de fout afwijkende civiele aansprakelijkheden samen onder de noemer objectieve aansprakelijkheid ${ }^{379}$. Deze groep dient volgens Bocken vervolgens te worden onderverdeeld in twee groepen, namelijk risicoaansprakelijkheid en objectieve aansprakelijkheid voor eigen daad ${ }^{380}$. Als criterium voor het onderscheid tussen beide begrippen, geldt dat bij objectieve aansprakelijkheid voor eigen daad het slachtoffer nog steeds het bewijs dient te leveren van het causaal verband tussen de schade en de daad van de verweerder, terwijl een dergelijk bewijs bij risicoaansprakelijkheid niet meer zou moeten worden geleverd. Tegelijk worden vol-

Vanden Borre T., "Transplantatie van kanalisatie van aansprakelijkheid van het kernenergierecht naar het milieu(aansprakelijk-heids)recht: een goede of een gebrekkige zaak?", in Faure, M. en Deketelaere, K., (red.), "Lus Commune en Milieurecht", l.c., 352.

Bocken, H., "Van fout naar risico", o.c., 333 e.v. Hij wordt hierin onder meer gevolgd door Van Oevelen (Van Oevelen, A., "Objectieve aansprakelijkheid voor schade veroorzaakt door milieuverontreiniging volgens het Belgische recht", in "Risicoaansprakelijkheid voor Milieuschade", l.c., 87). ge overheidsdaad en de aansprakelijkheid voor bijzonder gevaarlijke activiteiten). 
gens deze visie kanalisatie van aansprakelijkheid en risicoaansprakelijkheid beschouwd als synoniemen.

Risicoaansprakelijkheid wijkt in deze visie nog meer af van de klassieke foutaansprakelijkheid en gaat verder dan objectieve aansprakelijkheid omdat het slachtoffer niet meer dient te bewijzen dat de schade werd veroorzakkt door de al dan niet foutieve gedraging van de verweerder: "De schade word juridisch naar een welbepaalde persoon gekanaliseerd omdat deze persoon zeggenschap heeft over (één van) de risicofactoren die bij het totstandkomen van de schade een rol hebben gespeeld $^{\text {1381 }}$. Bij risicoaansprakelijkheid moet niet worden bewezen dat de aansprakelijke rechtstreeks of onrechtstreeks de schade heeft veroorzaakt omdat de schade wordt gekanaliseerd naar één persoon ${ }^{382} 383$.

Kanalisatie van aansprakelijkheid staat dus los van elke causaliteit in die zin dat de aansprakelijke niet langer wordt geselecteerd op basis van feitelijke causaliteit ${ }^{384}$. Hiermee wordt bedoeld dat indien bijvoorbeeld het kernongeval door een leverancier van de exploitant werd veroorzaakt, de causaliteit tussen het gedrag van de leverancier en het kernongeval niet dient te worden vastgesteld. In zekere zin leidt de kanalisatie van aansprakelijkheid inderdaad tot een afzwakking van de causaliteitsvereiste $^{385}$ : er is niet meer vereist dat degene naar wie de aansprakelijkheid wordt gekanaliseerd daadwerkelijk en feitelijk de schade heeft veroorzaakt.

De indeling van Bocken gaat dus uit van een dubbele veronderstelling: enerzijds dat enkel in de gevallen die worden ondergebracht bij de risicoaansprakelijkheid de aansprakelijkheid wordt gekanaliseerd (en dat beide begrippen synoniemen zijn) en anderzijds dat kanalisatie uitsluitend mogelijk is bij risicoaansprakelijkheid (hiermee wordt een aansprakelijkheid zonder fout bedoeld).

Zoals verder zal blijken, betekent kanalisatie van aansprakelijkheid in de brede betekenis van het woord dat de aansprakelijkheid naar een bepaalde persoon wordt geleid of gedirigeerd. Toch blijken een aantal aansprakelijkheden die door Bocken onder de noemer "aansprakelijkheid voor rechtmatige daad" worden geplaatst, eveneens de aansprakelijkheid te kanaliseren. Alvast in de categorie van gevaarlijke activiteiten lijkt dit het geval te zijn: voor wat betreft de opslag van gas in situ wordt de aansprakelijkheid gekanaliseerd naar de houder van de exploitatievergunning; de schade terzake van het oppompen van grondwater respectievelijk van het vervoer van gasachtige producten wordt gekanaliseerd naar de exploitant van grondwaterwinningen, resp. de houder van de vervoersvergunning. Het "kanaliseren van aansprakelijkheid" kan dus niet als criterium worden weerhouden om een onderscheid te maken tussen risicoaansprakelijkheid en objectieve aansprakelijkheid voor eigen daad, tenminste voor de genoemde aansprakelijkheidsvormen. De aanspra-

311

Bocken, H., "Van fout naar risico", o.c., 373; Bocken, H., Ryckbost, D. en Deloddere, S., "Aansprakelijkheid en financiële zekerheden - Vergoeding van schade door het Vlaamse Gewest", in "Voorontwerp Decreet Milieubeleid", l.c., 869; Bocken, H., "Het aansprakelijkheidsrecht als sanctie", l.c., 315. Bocken, H., "Van fout naar risico", o.c., 373; Bocken, H., Ryckbost, D. en Deloddere, S., "Aansprakelijkheid en financiele zekerheden", in "Voorontwerp Decreet Milieubeleid", l.e., 888.

Volgens Faure en Van den Bergh dienen risicoaansprakelijkheid en objectieve aansprakelijkheid duidelijk te worden onderscheiden van de kanalisatie van aansprakelijkheid (Faure, M. en Van den Bergh, R., "Objectieve Aansprakelijkheid", l.c., 169).

Bocken, H., "Van fout naar risico", o.c., 373; Bocken, H., "Het proces zonder einde: aansprakelijkheid voor schade veroorzaakt door grondwaterwinning en bronbemaling", Tijdschrift voor Privaatrecht, $1995,1657$.

Faure, M. en Van den Bergh, R., "Objectieve Aansprakelijkheid", l.c., 169. 
kelijkheid wordt dus niet alleen gekanaliseerd bij de aansprakelijkheidsvormen die Bocken onderbrengt bij de risicoaansprakelijkheid.

Daarenboven dient te worden onderstreept dat het dirigeren van een aansprakelijkheid naar een bepaalde persoon in beginsel geen uitstaans heeft met de grondslag van deze aansprakelijkheid. Een gekanaliseerde aansprakelijkheid betekent dat een persoon wordt aangewezen die aansprakelijk is. Toch betekent dit niet dat deze persoon enkel kan worden aansprakelijk gesteld op basis van stelsel van risicoaansprakelijkheid. De vraag wie moet worden aansprakelijk gesteld, kan dus niet worden gelijkgeschakeld met de vraag op welke grondslag deze aansprakelijkheid is gebaseerd (fout, risico of vermoeden van aansprakelijkheid). Het feit dat een persoon wordt aangewezen als aansprakelijke persoon impliceert niet noodzakelijk dat deze persoon aansprakelijk is op basis van een fout, dan wel op basis van risicoaansprakelijkheid. De samenloopproblematick die door de kanalisatie wordt geregeld, staat dus los van de aansprakelijkheidsgrondslag, en bijgevolg kunnen beide begrippen niet als synoniemen worden aanzien. Doordat beide begrippen losstaan van elkaar, is in principe kanalisatie ook mogelijk bij foutaansprakelijkheid. Voorzover bekend bestaat er geen foutaansprakelijkheid die de aansprakelijkheid tegelijk kanaliseert, en bestaat er niet meteen een risicoaansprakelijkheid die de aansprakelijkheid niet kanaliseert, maar dit betekent niet dat deze combinatie niet zou kunnen worden gecreëerd. Het is dus gevaarlijk om op basis van een indeling van het geldende Belgische aansprakelijkheidsrecht dogmatische conclusies te trekken, i.c. inzake de begrippen kanalisatie van aansprakelijkheid en risicoaansprakelijkheid $^{386}$. De door Bocken ondernomen poging tot systematisering van de verschillende regimes is dus zeker verdienstelijk maar niet allesomvattend ${ }^{387}$.

Concluderend kan worden gesteld dat risicoaansprakelijkheid niet noodzakelijk hetzelfde is als het kanaliseren van de aansprakelijkheid naar een bepaalde persoon ${ }^{388}$. Sterker nog: beide begrippen hebben niet noodzakelijk iets met elkaar te maken. Kanalisatie heeft betrekking op de vraag welke personen kunnen worden aansprakelijk gesteld; dit staat in beginsel volledig los van de aansprakelijkheidsgrondslag. Niet alle vormen van risicoaansprakelijkheid vereisen dus noodzakelijkerwijze kanalisatie van aansprakelijkheid. Tegelijk is kanalisatie perfect mogelijk onder een regime van foutaansprakelijkheid. De indeling van de verschillende risicoaansprakelijkheden zoals die wordt gevolgd door een deel van de Belgische rechtsleer, is zeker op het vlak van het onderscheid tussen risicoaansprakelijkheid en objectieve aansprakelijkheid voor eigen daad niet langer houdbaar. Risicoaansprakelijkheid is namelijk geen synoniem voor de kanalisatie van aansprakelijkheid, maar staat daar in beginsel volledig los van.

Vervolgens wordt onderzocht hoe de term kanalisatie van aansprakelijkheid wordt gebruikt door de Interuniversitaire Commissic tot Herziening van het Milieurecht in het Vlaamse Gewest ${ }^{389}$. Deze Commissie heeft in 1995 namelijk belangrijke voorstellen gelanceerd voor de verbetering

Hierop wordt verder ingegaan bij de bespreking van de gevolgen op het dogmatisch denken rond risicoaansprakelijkheid (Cfr. infra, in $\$ 2.3 .3$ van dit hoofdstuk). Cousy, H., "Enkele beschouwingen over de systematiek van de stelsels van foutloze aansprakelijkheid", in "Liber Amicorum Jacques Putzeys", l.c., 39.

388 In zekere zin kan kanalisatie worden beschouwd als een kenmerk van de verschillende bekende vormen van risicoaansprakelijkheid (De Pue, E., "Hoofdstuk 4. Privaatrecht", in De Pue, E., Lavrysen, L. en Stryckers ${ }_{\sharp}$ P., Milieuzakboekje, editie 2000, Kluwer, Antwerpen, 2000, 818).

Deze Commissie is opgericht bij KB van 5 juli 1989 met als opdracht om een voorontwerp van kaderdecreet inzake milieuhygiëne uit te werken en aanbevelingen te formuleren om de doelmatigheid van het milieuhygiënerecht te vergroten. Op 20 februari 1995 werd het resultaat van de opmerkelijke werkzaamheden aan de Minister overhandigd. De Interuniversitaire Commissie was erin geslaagd om in een relatief kort tijdsbestek de aanzet te geven tot de codificatie van het Vlaamse milieuhygiênerecht en aldus de samenhang, de slagkracht en de efficiêntie van Vlaamse milieurecht te vergroten. 
van het Vlaamse milieurecht. Een aantal van deze voorstellen werd reeds in decreten gegoten ${ }^{390}$; op andere vlakken, zoals inzake milieuaansprakelijkheid, is een decretale tekst alsnog uitgebleven. Het is dus interessant om in het kader van dit proefschrift verder te onderzoeken of de terminologie zoals die wordt gehanteerd door de Interuniversitaire Commissie tot Herziening van het Milieurecht in het Vlaamse Gewest eveneens de begrippen risicoaansprakelijkheid en kanalisatie onder eenzelfde noemer plaatst.

\subsubsection{Gebruik van de term kanalisatie door de Interuniversitaire Commissie tot Herziening van het Milieurechi in het Vlaamse Gewest}

Op zich zijn de bepalingen van het Voorontwerp Decreet Milieubeleid inzake het herstel van schade door milieuverontreiniging duidelijk. Artikel 9.1.3 van het Voorontwerp bepaalt dat eenieder die door emissie schade of milieuverstoring veroorzaakt, hiervoor aansprakelijk is. Artikel 9.1.4 gaat hier verder op in en stelt dat indien de emissie uitgaat van een ingedeelde inrichting of het gevolg is van een ingedeelde activiteit, de aansprakelijkheid zal berusten op de exploitant van deze inrichting of activiteit.

Volgens de toelichting bij het Voorontwerp hanteren beide artikelen een aansprakelijkheid waarbij geen fout moet worden bewezen: deze aansprakelijkheid is niet afhankelijk van het bewijs dat de schade werd veroorzaakt door een al dan niet foutieve gedraging van de aansprakelijke ${ }^{3.1}$. Nochtans kan worden gediscussieerd of hier inderdaad een risicoaansprakelijkheid wordt ingevoerd: de tekst heeft het uitdrukkelijk over een schade door emissie. Het slachtoffer zal dus nog steeds moeten bewijzen dat een emissie heeft plaatsgevonden. Daarom verkiezen we om in deze context te spreken van een quasi-risicoaansprakelijkheid.

Toch bestaat een duidelijk verschil tussen beide artikelen: enkel artikel 9.1.4 dirigeert, dus kanaliseert de aansprakelijkheid naar een bepaalde persoon (exploitant van een vergunningsplichtige inrichting). Artikel 9.1 .3 bevat géén kanalisatie: er wordt volstaan met aan te geven dat eenieder aansprakelijk is voor schade door emissie. Nochtans wordt bij de artikelsgewijze bespreking gesteld dat ook artikel 9.1.3 de aansprakelijkheid kanaliseert ${ }^{392}$.

Het is duidelijk dat ook de Interuniversitaire Commissie de begrippen kanalisatie van aansprakelijkheid en risicoaansprakelijkheid als synoniemen beschouwt, hetgeen zoals hierboven reeds is aangegeven, niet correct is. Artikel 9.1.3 voert een algemene quasi-risicoaansprakelijkheid in voor schade door emissie, zonder deze aansprakelijkheid te kanaliseren naar een bepaalde persoon; artikel 9.1.4 voert een risicoaansprakelijkheid in én kanaliseert deze naar de exploitant van een vergunningsplichtige inrichting. Enkel ten aanzien van de exploitant van een vergunningsplichtige inrichting, voert het Voorontwerp een kanalisatie van aansprakelijkheid in. Doordat het onderscheid met risicoaansprakelijkheid niet wordt gemaakt, is het ook tevergeefs zoeken naar een motivatie naar de voordelen van de kanalisatie ten overstaan van een regime van risicoaansprakelijkheid zonder kanalisatie van aansprakelijkheid.

Zo zijn de bepalingen van de bodemsaneringsdecreet evenals de wijzigingen van het milieuvergunningsdecreet ten dele gebaseerd op de voorstellen van de ICHM.

Bocken, H., Ryckbost, D. en Deloddere, S., "Aansprakelijkheid en financiële zekerheden", in "Voorontwerp Decreet Milieubeleid", l.c., 888.

Bocken, H., Ryckbost, D. en Deloddere, S., "Aansprakelijkheid en financiële zekerheden", in "Voorontwerp Decreet Milieubeleid", l.c., 888. 
Overigens werd in 1998 in opdracht van de Vlaamse Minister van Leefmilieu onderzoek gedaan naar de "Opportuniteit en de haalbaarheid van een vernieuwd vergoedingssysteem voor milieuschade". Hierbij werden met name de bepalingen van het Voorontwerp Decreet Milieubeleid onderzocht. Ook in het kader van dit onderzoek werd gewaarschuwd voor een ongenuanceerd gebruik van het begrip "kanalisatie van aansprakelijkheid"393.

De vraag in welke mate het begrip "kanalisatie van aansprakelijkheid" zoals gehanteerd door de ICHM verschilt van de kanalisatie van aansprakelijkheid in het kernenergierecht, is vrij makkelijk te beantwoorden. In tegenstelling tot het Verdrag van Parijs, bevat het Voorontwerp geen bijkomende bepalingen die de kanalisatie aanscherpen. Het is duidelijk niet de bedoeling van het Voorontwerp om even ver te gaan als in het kernenergierecht: de voorgestelde tekst van het voorontwerp van decreet bevat géén bepaling die andere rechtsgronden buiten werking stelt of die het regresrecht van de exploitant beperkt. De huidige tekst bevat geen bepaling op basis waarvan slachtoffers zich uitsluitend tot de exploitant kunnen richten en op basis waarvan de exploitant slechts in uitzonderlijke gevallen een regresrecht zou kunnen uitoefenen. De Memorie van Toelichting zelf bevestigt immers dat de in artikel 9.1.4 uitgewerkte regel de artikelen 1382 en volgende van het Burgerlijk Wetboek niet buiten toepassing plaatst, maar aanvult ${ }^{394}$. De kanalisatie zoals voorzien in het Voorontwerp Decreet Milieubeleid, is bijgevolg een andere vorm dan de kanalisatie van aansprakelijkheid in het kernenergierecht.

De onduidelijkheid met betrekking tot het begrip "kanalisatie" is niet eigen aan de Belgische rechtsorde. Ook in Nederland blijkt niet meteen eenduidigheid te bestaan, al werden er reeds pogingen ondernomen om de gewenste duidelijkheid te creëren.

\subsubsection{Omschrijving van "kanalisatie van aansprakelijkheid" in het Nederlandse recht}

In het Nederlandse recht kwam de kanalisatie van aansprakelijkheid uitdrukkelijk aan de orde in het kader van de invoering van de aansprakelijkheid van gevaarlijke stoffen in het NBW. Omdat de Nederlandse wetgever in dat kader het begrip "kanalisatie" heeft gehanteerd, is het interessant na te gaan om welke reden zulks nuttig werd geacht en wat met deze term werd bedoeld c.q. beoogd. Deze vraag wordt beantwoord in $\S 2.3 .2 .1$. Nadien worden de merites besproken van cen poging tot systematisering van de verschillende door de Nederlandse wetgever gehanteerde begrippen $(\$ 2.3 .2 .2)$.

393 Deketelacre, K., Deketelaere, M. en Schutyser, F., "Onderzoek naar de opportuniteit en de haalbaarheid van een Vernieuwd Vergoedingssysteem voor Milieuschade", Instituut voor Milieu- en Energierecht, KUIL december 1998, 17-18; zie hierover Schutyser, F., "Aansprakelijkheid voor milieuschade en financiele zekerheid naar toekomstig recht: nieuwe oplossingen", in Deketelaere, $K$. en WiggersRust, L.F. (red.), Aansprakelijheid voor milieuschade en financielle zekerheid. Een vergelijking vain Nederlands, Belgisch en Europees recht, Die Keure, Vermande, Brugge, 1998, 133 e.v.: Schutyser, F., Deketelacre, $M$ en Deketelaere, K., "Onderzoek naar de opportuniteit en de haalbaarheid van een Vernieuwd Vergoedingssysteem voor Milieuschade", Milieu- en Energierecht, 1999, nr. 6-7, 146-174.

Bocken, H., Ryckbost, D. en Deloddere, S., "Aansprakelijkheid en financiële zekerheden", in "Voorontiwerp Decreet Milieubeleid", l.c., 886. Weliswar sluit de toepassing van artikel 9.1.4 de toepassing uit van artikel 9.1.3, maar dit heeft niet de invoering van kanalisatie van aansprakelijkheid tot gevolg. De in het voorontwerp aangehaalde regeling betreft twee aanknopingspunten van eenzelfide juridische grondslag die niet cumulatief kunnen worden toegepast, hetgeen betekent dat zodra een exploitant aansprakelijk wordt bevonden op grond van die regel, iemand die voldoet aan de omschrijving van artikel 9.1 .3 niet op die grond kan worden aansprakelijk gesteld. Desgevallend zal deze laatste op een andere juridische grond kunnen worden aansprakelijk gesteld. 


\subsubsection{Kanalisatie in het kader van artikel 6:175 NBW}

Naar aanleiding van de op 1 februari 1995 van kracht geworden wijzigingen in het NBW betreffende de aansprakelijkheid voor gevaarlijke stoffen en verontreiniging van lucht, water of bodem werden in het Nederlandse NBW drie nieuwe kwalitatieve aansprakelijkheden ingevoerd ${ }^{305} 3 \%$. De bepalingen die in het bijzonder onze aandacht wegdragen, zijn deze met betrekking tot de wijzigingen van Boek 6 (aansprakelijkheid voor gevaarlijke stoffen) ${ }^{397}$.

Ter gelegenheid van de invoering van deze kwalitatieve aansprakelijkheden werd de term kanalisatie van aansprakelijkheid gehanteerd. Volgens de Memorie van Toelichting wordt de risicoaansprakelijkheid gekanaliseerd "in dier voege dat in beginsel ter zake van één gebeurtenis niet op meerdere personen tegelijk een risicoaansprakelijkheid berust ${ }^{1398}$. Sommige auteurs suggereren dat kanalisatie uitdrukkelijk slechts om samenloop van risicoaansprakelijkheden gaat ${ }^{399}$. Het is hierbij onduidelijk of hiermee wordt gesuggereerd dat kanalisatic altijd in verband staat met risicoaansprakelijkheid, dan wel of wordt bedoeld dat de kanalisatie zoals ingevoerd door de wetswijziging is verbonden aan risicoaansprakelijkheid.

De Nederlandse wetgever heeft een onderscheid gemaakt tussen segmentering van aansprakelijkheid, klevende aansprakelijkheid en kanalisering van aansprakelijkheid ${ }^{400}$.

Een stelsel van gesegmenteerde aansprakelijkheid impliceert dat de aansprakelijkheid wordt gelegd op degene in wiens handen de stof zich bevond op het tijdstip dat de schade werd veroorzaakt. Aansprakelijk is degene die op het moment van de schadeveroorzakende gebeurtenis de meeste invloed op de stof kan uitoefenen ${ }^{401}$. Vanaf het moment waarop de stof wordt doorgegeven aan de volgende schakel binnen de ketting van verwerkers, bewerkers, verkopers etc., zal in principe een nieuwe "houder" voor deze stoffen aansprakelijk zijn. Bauw heeft het in casu over het adagium de aansprakelijkheid volgt de stof ${ }^{402}$.

Cfr. supra, in $\$ 2.2 .2 .2$ van hoofdstuk 1 .

Zie afdeling 6.3.2. BW inzake de aansprakelijkheid voor de beroeps- of bedrijîsmatige gebruikers of bewaarder van gevaarlijke stoffen (art. 6:175), voor de exploitant van een stortplaats (art. 6:176) en voor de exploitant van een boorgat (art. 6:177). Wetsontwerp 21 202, Vergaderjaar 1988-1989, Aanvulling van de Boeken 3, 6 en 8 Nieuw BW. Met deze wetswijziging wilde de Nederlandse wetgever onder meer uitwerking geven aan het Verdrag van Lugano inzake de burgerrechtelijke aansprakelijkheid voor milieuschade (Raad van Europa, 22 juni 1993). Zie hierover De Boer, J., "Risicoaansprakelijkheid voor gevaarlijke stoffen en milieuverontreiniging", Nederlands Juristenblad, 1993, 225. Tegelijk wilde Nederland een achterstand inhalen ten overstaan van landen zoals Belgiě, die een algemene aansprakelijkheidsregel hebben voor (gebrekkige) zaken (Memorie van Antwoord, Eerste Kamer, Vergaderjaar 1993-1994, $21202, \mathrm{nr} .99 \mathrm{a}, 5$ ).

Ook inzake de wijzigingen aangebracht in Boek 8 ter zake van transport (artikel 8: 623 NBW) wordt gesproken van kanalisering van de aansprakelijkheid (Memorie van Toelichting, Tweede Kamer, vergaderjaar 1988-1989, 21 202, nr. 3, 25).

Memorie van Toelichting, Tweede Kamer, vergaderjaar 1988-1989, 21 202, nr. 3, 8.

Spier, J. en Sterk, C.H.W.M., "Aansprakelijkheid voor gevaarlijke stoffen", l.c., 32.

Meteen dient erop te worden gewezen dat reeds omtrent deze terminologie op verschillende wijze wordt gehanteerd. Zo maakt Messer een onderscheid tussen kanalisatie met segmentatie en kanalisatic zonder segmentatie (Messer, E.A., Risicoaansprakelijkheid voor milieuverontreiniging in het $B W$, diss., Amhem, Gouda Quint, 1994, 221).

Van Acht, R.J.J en Bauw, E., "Milieuprivaatrecht", l.c., 71.

Bauw, E., "Buitencontractuele Aansprakelijkheid voor bodemverontreiniging", l.c., 186. 
Het tweede stelsel is dat van de klevende aansprakelijkheid: de persoon die de stof in het verkeer heeft gebracht blijft aansprakelijk voor de door deze stof veroorzaakt schade, zoals inzake de wetgeving inzake productaansprakelijkheid. Zelfs indien de stof op dat moment in handen is van een andere persoon, blijft de aansprakelijkheid als het ware kleven aan de persoon die de stof in het verkeer heeft gebracht.

Kanalisatie betekent dat voor één gebeurtenis de risicoaansprakelijkheid naar één enkele persoon wordt geleid ${ }^{403}$ en dat de aansprakelijkheid binnen één segment - zoveel mogelijk ${ }^{404}$ - rust op dezelfde makkelijk te traceren persoon ${ }^{405}$. Eenzelfde indeling is terug te vinden bij Bauw, die gesegmenteerde en gekanaliseerde aansprakelijkheid onderscheidt, waarbij hij klevende aansprakelijkheid ziet als een spiegelbeeld van de gesegmenteerde aansprakelijkheid ${ }^{406}$.

Het stelsel van de gesegmenteerde aansprakelijkheid wordt gehanteerd ter zake van de aansprakelijkheid voor gevaarlijke stoffen. In hoofde van artikel 6:175 $\mathrm{BW}$, eerste lid rust een risicoaansprakelijkheid op de bedrijfsmatige gebruiker of bezitter van gevaarlijke stoffen ${ }^{407}$. Het tweede lid legt de aansprakelijkheid bij de "bewaarder die er zijn bedrijf van maakt zodanige stoffen te bewaren". Met bewaarder wordt gelijkgesteld de vervoerder, expediteur, stuwadoor, bewaarder of soortgelijke ondernemer die de stof ten vervoer of uit hoofde van een met het vervoer samenhangende overeenkomst in ontvangst heeft genomen. Hier wordt gesproken van een kanalisatie van de aansprakelijkheid naar de bewaarder ${ }^{408}$. De aansprakelijkheid van de bewaarder strekt zich uit tot de periode dat hij de zaak onder zijn bewaring heeft. Op deze wijze wordt de aansprakelijkheid gelegd bij degene bij wie de stof was op het moment waarop de schade werd veroorzaakt ${ }^{409}$. De Nederlandse wetgever achtte het niet opportuun om inzake de aansprakelijkheid voor gevaarlijke stoffen een regime van klevende aansprakelijkheid in te voeren omwille van bezwaren uit het oogpunt van de verzekerbaarheid ${ }^{410}$. Door de segmentering van aansprakelijkheid wordt de verzekering gekoppeld aan een bepaalde locatie, waardoor het risico beter kan worden overzien $^{41 !}$. Bij klevende aansprakelijkheid daarentegen blijft een persoon aansprakelijk zelfs op het moment waarop hij alle feitelijke controle over een stof heeft verloren. Hieruit blijkt dat het verzekeringsaspect inzake de aansprakelijkheid voor gevaarlijke stoffen een belangrijke rol heeft gespeeld bij de wetswijziging ${ }^{42}$.

Memorie van Toelichting. Tweede Kamer, vergaderjaar 1988-1989, 21 202, nr. $3,8$.

Van Acht, R.J.J en Bauw, E., "Milieuprivaatrecht", l.c., 71

Van Maanen, G.E., "Aansprakelijkheid voor schade door gevaarlijke stoffen en verontreiniging van lucht, water of bodem", Weekblad voor Privaatrecht, Notariaat en Registratie, 1990, 5946, 57. Bauw, E., "Buitencontractuele Aansprakelijkheid voor bodemverontreiniging", l.c., 186.

Artikel 6: 175 NBW luidt: "Degene die in de uitoefening van zijn beroep of bedrijf een stof gebruikt of onder zich heeft, terwijl van deze stof bekend is dat zij een bijzonder gevaar van emstige aard voor personen of zaken oplevert, is aansprakelijk, wanneer dit gevaar zich verwezenlijkt".

Sp̣ier, J. en Sterk, C.H.W.M., "Aansprakelijkheid voor gevaarlijke stoffen", l.c, 52; Van Dunné, J.M. en Smale, L.J., "Aansprakelijkheid voor milieuschade en financięle zekerheid naar huidig recht: knelpunten en gerealiseerde oplossingen", o.c., 50; Schamps heeft het over "le système de canalisation segmenté" (Schamps, G., "La mise en danger", l.c., 189). Memorie van Toelichting, Tweede Kamer, vergaderjaar 1988-1989, 21 202, nr. 3, 9.

410 Memorie van Toelichting. Tweede Kamer, vergaderjaar 1988-1989, 21 202, nr. 3, 9-10; Spier, J. en Sterk, C.H.W.M., "Aansprakelijkheid voor gevaarlijke stoffen", l.c., 12-14.

411 Bauw, E., "Buitencontractuele Aansprakelijkheid voor bodemverontreiniging", l.c., 186; Sturms, W.W., "Internationale ontwikkelingen m.b.t. aansprakelijkheid voor milieuschade", in "Risicoaansprakelijkheid voor Milieuschade", l.c., 131.

Hartlief, T. en Tjittes, R.P.J.L., "Aansprakelijkheid en Verzekering", l.c., 25.
} 
Opvallend is overigens dat de Nederlandse wetgever zich bij de invoering van de kanalisatie van aansprakelijkheid grosso modo heeft laten leiden door dezelfde argumenten als deze aangehaald in het Harvard Rapport: het vermijden van samenloop (processueel argument) en het vermijden van een dubbele verzekeringsdekking ${ }^{413}$.

Uitgaande van de stelling dat kanalisatie niets meer is dan het dirigeren van een aansprakelijkheid naar een bepaalde categorie personen, c.q. personen die een bepaalde hoedanigheid bezitten, is ook het onderscheid dat door de Nederlandse wetgever wordt gemaakt niet eenduidig te noemen. Zowel in het stelsel van de gesegmenteerde aansprakelijkheid als van de klevende aansprakelijkheid, wordt de aansprakelijkheid immers gedirigeerd en dus gekanaliseerd, naar respectievelijk de houder van een stof en naar de invoerder van een product. Maar hiermee is een tweede element aangeraakt, dat voor de verdere analyse van belang kan zijn, met name de band tussen een kwalitatieve en een gekanaliseerde aansprakelijkheid. Dit wordt verder geanalyseerd bij de bespreking van de gevolgen voor de dogmatiek inzake risicoaansprakelijkheid ${ }^{44}$.

Hoewel in artikel 6:175 BW de aansprakelijkheid onmiskenbaar wordt geleid of gedirigeerd (of "gekanaliseerd") naar een bepaalde persoon, rijst de vraag naar het verschil tussen deze kanalisatic van aansprakelijkheid en de kanalisatie van aansprakelijkheid zoals gehanteerd in het kernenergierecht. Er zal sprake zijn van een kanalisatie in het Nederlandse (milieu)recht indien, conform de kanalisatie in het kernenergierecht, deze bepaling de toepassing van andere rechtsgronden buiten werking stelt. Uit de tekst van het BW valt reeds op te maken dat nergens met zoveel woorden wordt gesteld dat het recht op schadevergoeding enkel tegen één enkele persoon kan worden uitgeoefend. Artikel 6:175 BW laat slachtoffers toe om meerdere personen aan te spreken: het desbetreffende artikel biedt inderdaad meerdere aanknopingspunten (beroeps- of bedrijfsmatige gebruiker, bewaarder of leidingbeheerder) én raakt niet aan de eventuele toepassing van andere rechtsgronden. Dit was uitdrukkelijk de bedoeling van de wetgever. De benadeelde kan alle in aanmerking komende bepalingen en dus alle mogelijke juridische grondslagen, inroe$\operatorname{pen}^{415} 416$. Verschillende auteurs wezen reeds op de mogelijke parallelle toepassing van artikel 6:175 BW met andere bepalingen, hetzij inzake algemene onrechtmatige daad ${ }^{417}$, hetzij met ecn van de andere ingevoerde risicoaansprakelijkheden ${ }^{418}$.

Hieruit volgt dat het begrip "kanalisatie" zoals gehanteerd in het Nederlandse recht niet kan worden gelijkgesteld met de kanalisatie van aansprakelijkheid zoals gehanteerd in het internationale en nationale kemenergierecht. In Nederland wordt kanalisatie blijkbaar gehanteerd als een overkoepelende term om aan te geven dat de aansprakelijkheid naar een bepaalde persoon wordt gedirigeerd, zonder hierbij evenwel te raken aan het gemeenrechtelijke aansprakelijkheidsrecht. Ook van Maanen wees op het verschil tussen de kanalisatie van aansprakelijkheid zoals gehanteerd naar aanleiding van de wijziging van het Nederlandse BW met de kanalisatie van aan-

\footnotetext{
413

114 Cfr. supra, $\$ 2.1 .3$ van dit hoofdstuk.

114 Cfr. infra, \$2.3.3 van dit hoofdstuk.

\$15 Spier, J. en Sterk, C.H.W.M., "Aansprakelijkheid voor gevaarlijke stoffen", l.c, 56.

${ }_{16}$ In de Memorie van Toelichting wordt aangegeven dat het aan de rechter toekomt om de voor het slachtoffer meest gunstige bepaling toe te passen (Memorie van Toelichting, Tweede Kamer, vergaderjaar 1988-1989, 21 202, nr. 3,9).

$d 1 ?$

Van Maanen, G.E., "Aansprakelijkheid voor schade door gevaarlijke stoffen en verontreiniging van lucht, water of bodem", o.c., 57.

41

Zo kan de regeling inzake de aansprakelijkheid bij boorgaten (artikel 6:177) in samenloop worden gebracht met de regeling betreffende gevaarlijke zaken (artikel 6: 173) (Van Dunné, J.M. en Smale, L.J., "Aansprakelijkheid voor milieuschade en financiêle zekerheid naar huidig recht: knelpunten en gerealiseerde oplossingen", in "Aansprakelijkheid voor milieuschade en financiële zekerheid", l.c., 53).
} 
sprakelijkheid in het kernenergierecht ${ }^{419}$. Vandaar betreft de kanalisatie onder de Nederlandse wetgeving inzake aansprakelijkheid voor gevaarlijke stoffen minstens een andere vorm van kanalisatie dan deze onder het Verdrag van Parijs van 29 juli 1960. Tot eenzelfde conclusie werd gekomen na de analyse van de bepalingen van Voorontwerp Decreet Milieubeleid van de $\mathrm{ICHM}^{420}$.

Een opvallende gelijkenis tussen het Belgische en Nederlandse recht bestaat erin dat bij de verschillende vormen van risicoaansprakelijkheid in het Belgische en het Nederlandse civiele aansprakelijkheidsrecht de risicoaansprakelijkheid telkens wordt gecombineerd met de kanalisatie van aansprakelijkheid. Totnogtoe werd niet de vraag gesteld waarom een dergelijke koppeling zou zijn vereist of wat daarvan de voordelen zijn. Het is dan ook weinig verwonderlijk dat in beide landen evenmin duidelijkheid bestaat over de precieze inhoud van de term "kanalisatie van aansprakelijkheid". Uitgaande van de voorstellen van de Nederlandse wetgever, werd in de Nederlandse rechtsleer wel een poging ondemomen tot systematisering.

\subsubsection{Merites van een poging tot verduidelijking}

Een belangrijke poging tot verduidelijking van de verschillende begrippen werd ondernomen door Tjittes. Hij plaatst de segmentering, kanalisering en de klevende aansprakelijkheid onder de algemene noemer centralisering van aansprakelijkheid, hetgeen inhoudt dat de aansprakelijkheid naar een duidelijk aanwijsbare (rechts)persoon wordt geleid ${ }^{42 !}$. Volgens Tjittes vallen de drie "rechtsinstrumenten" (segmentatie, klevende aansprakelijkheid en kanalisering) onder de algemene noemer van de centralisering van aansprakelijkheid. Als voorbeeld van kanalisering haalt hij de aansprakelijkheid aan van de bedrijfsmatige gebruiker van een gebrekkige roerende zaak ex artikel 6:173, lid 1, juncto 181, lid 1.

Via de centralisering van aansprakelijkheid tracht de Nederlandse wetgever zowel de belangen van het slachtoffer als de belangen van de schadeveroorzaker te dienen ${ }^{422}$. Het slachtofferbeschermingsargument bestaat erin dat de aansprakelijkheid bij één enkele persoon berust waardoor voor het slachtoffer mocilijk te achterhalen samenloopsituaties worden vermeden. Het probleem bij milieuschade door gevaarlijke stoffen is immers dat deze stoffen het resultaat zijn van de bewerking van verschillende personen of bedrijven, waardoor het moeilijk wordt degene aan te duiden die aansprakelijk kan worden gesteld ${ }^{423}$. Met samenloop wordt in deze context dan ook de situatie bedoeld waarbij voor eenzelfde schadegeval meerdere personen op verschillende juridische bases kunnen worden aansprakelijk gesteld. Degene die wettelijk aansprakelijk wordt gesteld fungeert als het ware als aanspreekpunt voor het slachtoffer ${ }^{424}$; deze laatste hoeft zich niet te bekommeren om de (voornamelijk contractuele) verhoudingen tussen de verschillende personen.

Centralisering dient daarnaast ook de belangen van de schadeveroorzaker: door centralisering wordt het nemen van een dubbele verzekeringsdekking vermeden en worden dus geen onnodig

Van Maanen, G.E., "Aansprakelijkheid voor schade door gevaarlijke stoffen en verontreiniging van lucht, water of bodem", o.c., 57. Cfr. supra, in $\$ 2.3 .1 .2$ van dit hoofdstuk. 
zware lasten gelegd op het bedrijfsleven. Centralisering voorkomt in deze optiek de noodzaak om één risico meermaals te verzekeren ${ }^{425}$.

Tjittes vindt de benadering waarbij enkel bovenstaande overwegingen de grondslag vormen voor het invoeren van een centralisering van aansprakelijkheid, eenzijdig ${ }^{426}$. Hij bepleit een sterkere theoretische fundering van de centralisering van aansprakelijkheid waarbij ook elementen als de zeggenschap over de schadeveroorzakende gedraging, de mogelijkheid tot risicospreiding en de preventieve werking van het aansprakelijkheidsrecht moeten worden betrokken bij de vraag of een gegeven aansprakelijkheid al dan niet moet worden gecentraliseerd.

Hij wijst er voorts op dat de wetgever zich blijkbaar niet bewust is van het bestaan van twee tegengestelde vormen van centralisering, namelijk cumulatieve en exclusieve centralisering ${ }^{427}$. Exclusieve centralisering betekent dat voor een bepaalde schadeveroorzakende gebeurtenis één enkele persoon exclusief wordt aansprakelijk gesteld. Cumulatieve centralisering houdt in dat in een kluwen van rechtsverhoudingen één duidelijke centrale persoon naast andere personen, en op een verschillende juridische grondslag, mede aansprakelijk wordt gesteld ${ }^{428}$. Het is opvallend hoe zeer het door Tjittes gemaakte onderscheid tussen exclusieve en cumulatieve centralisering doet denken aan het onderscheid tussen juridische en economische kanalisatie ${ }^{429}$. Cumulatieve centralisering laat het gemene aansprakelijkheidsrecht onverkort gelden, net zoals dat het geval is bij economische kanalisatic. Exclusieve centralisering daarentegen stelt het gemene aansprakelijkheidsrecht wel degelijk buiten werking, net zoals dit het geval is bij juridische kanalisatic.

Vervolgens plaatst Tjittes de nodige vraagtekens bij de doelstelling die de Nederlandse wetgever beoogt te bereiken door de invoering van de centralisering van aansprakelijkheid. Zo stelt hij onder meer dat de slachtoffers over het algemeen worden bijgestaan door juridische deskundigen voor wie samenloopproblemen geen moeilijkheden mogen opleveren ${ }^{430}$. Aldus komt Tjittes tot de conclusie dat door het onderscheid tussen cumulatieve en exclusieve centralisering de centraliseringgedachte niet op eenduidige wijze in het $\mathrm{BW}$ is terug te vinden. Cumulatieve centralisering dient vooral de belangen van benadeelden, terwijl exclusieve centralisering eerder de belangen van de schadeveroorzaker dient ${ }^{431}$.

Het is zonder meer de verdienste geweest van Tjittes, te wijzen op het centrale element bij kanalisatie van aansprakelijkheid: kanalisatie van aansprakelijkheid biedt een oplossing bij samenloopproblemen. Het wijst een persoon aan die voor een bepaalde schade kan worden aansprakelijk gesteld; het dirigeert de aansprakelijkheid naar die persoon. Anderzijds wordt ook in het door Tjittes gemaakte onderscheid tussen kanalisatie, scgmenteren en klevende aansprakelijkheid, het begrip "kanalisatic" eerder ongenuanceerd gehanteerd ${ }^{432}$. Ook in cen stelsel van gesegmentecrde aansprakelijkheid is namelijk sprake van kanalisatie. Kanalisatie van aansprakelijkheid moet worden beschouwd als een synoniem van centralisering van aansprakelijkheid, en niet als een vorm van centralisering. Op zich is het begrip "centralisering" dus even vaag als het begrip "kana-

Memorie van Toelichting, Tweede Kamer, vergaderjaar 1988-1989, 21 202, nr. 3, 8.

Tjittes, R.P.J.L., "Centralisering van aansprakelijkheden", o.c., 279.

Ibidem.

Ibidem.

Cfr. supra, § 2.2.1

Tjittes, R.P.J.L., "Centralisering van aansprakelijkheden", o.c., 280.

Tjittes, R.P.J.L., "Centralisering van aansprakelijkheden", o.c., 281.

Samen met Hartlief heeft Tjittes het over een gekanaliseerde of gesegmentectde aansprakelijkheid (Hartlief, T. en Tjittes, R.P.J.L., "Aansprakelijkheid en Verzekering", I.c., 26).
} 
liseren", waarbij het zeer de vraag is of centraliseren een betere term zou zijn dan kanaliseren ${ }^{433}$. Het is dus niet meteen duidelijk wat de introductie van de term "centralisering" kan bijbrengen in de gehele discussie.

Voortbouwend op de inzichten die de analyse van de kanalisatic van aansprakelijkheid buiten het kernenergierecht heett opgeleverd, kan worden gewezen op de gevolgen van de genoemde onduidelijkheden op het dogmatisch denken rond risicoaansprakelijkheid.

\subsubsection{Gevolgen voor de dogmatiek inzake (risico)aansprakelijkheid}

Men kan niet om de vaststelling heen dat het inderdaad een vaste gewoonte lijkt te zijn van de nationale en intemationale wetgever om risicoaansprakelijkheid steeds naar een bepaalde persoon to dirigeren en om dus in één klap twee verschillende elementen te regelen: de aansprakelijkheidsgrondslag en de samenloopvraag. Telkens werd dus risicoaansprakelijkheid op eenzelfde lijn gcplaatst met kanalisatie van aansprakelijkheid, wat heeft geleid tot een verschraling van het dogmatisch denken. Dankzij het onderzoek van Tjittes is gebleken dat bij kanalisatie van aansprakelijkheid in essentie een uitspraak wordt gedaan naar mogelijke samenloop ${ }^{434}$. Het dirigeren van een aansprakelijkheid en dus een uitspraak omtrent samenloop, staat echter volledig los van de aansprakclijkheidsgrondslag.

Tegelijk kan worden vastgesteld dat bijvoorbeeld de nieuwe aansprakelijkheden in het Nederlands Burgerlijk Wetboek worden beschouwd als een "kwalitatieve aansprakelijkheid". Van Dam omschrijft een kwalitatieve aansprakelijkheid als een aansprakelijkheid op grond van een speciale relatie met een zaak of een persoon ${ }^{435}$. Hier kan een nieuw element aan de analyse worden toegevoegd: de band tussen kwalitatieve aansprakelijkheid, risicoaansprakelijkheid en kanalisatie van aunsprakelijkheid

Telkens wanneer een kwalitatieve aansprakelijkheid in het leven wordt geroepen, wordt in feite de samenloopproblematiek geregeld. De verschillende wettelijke bepalingen die risicoaansprakelijkheid $^{436}$ invoeren, bepalen tegelijk dat een gegeven hoedanigheid tot aansprakelijkheid zal leiden: het bezit van een vergunning, het invoeren van een product ${ }^{437}$, het bezit van een huis, het professioneel gebruik van een gevaarlijk product, ... Hiermee wordt onvermijdelijk de aansprakelijkheid geleid of gedirigeerd naar de bezitter, invoerder, gebruiker, etc. Deze vormen van risicoaansprakelijkheid zijn dus allemaal vormen van kwalitatieve aansprakelijkheid: de hoedanigheid van een persoon zal beslissend zijn. Het is precies deze kwalitatieve aansprakelijkheid die de kanalisatie van aansprakelijkheid impliceert: de persoon naar wie de aansprakelijkheid wordt

Zie ook eerder Vanden Borre T., "Transplantatie van kanalisatie van aansprakelijkheid van het kemenergierecht naar het milieu(aansprakelijkheids)recht: een goede of een gebrekkige zaak?", in Faure, M. en Deketelaere, K., (red.), "Ius Commune en Milieurecht", l.c., 371.

Ook Bocken had in zijn proefschrift onderkend dat het er bij kanalisatie van aansprakelijkheid op aan komt de persoon te identificeren die juridisch aansprakelijk is, met name in gevallen waar IPRproblemen de procesvoering bemoeilijken (Bocken, H., "Het aansprakelijkheidsrecht als sanctie", I.c., 314-315). Van Dam, C.C., "Aansprakelijkheidsrecht", l.c., 297.

Hierboven hebben we dit begrip omschreven als een van de foutaansprakelijkheid afwijkend aansprakelijkheidsregime (zie hoofdstuk 1).

Hier brengen we bijgevolg een nuance aan op onze eerdere stelling dat onder de productaansprakelijkheidsrichtlijn wel sprake is van risicoaansprakelijkheid maar niet van kanalisatie van aansprakelijkheid (Vanden Borre T., "Transplantatie van kanalisatie van aansprakelijkheid van het kernenergierecht naar het milieu(aansprakelijkheids)recht: een goede of een gebrekkige zaak?", in Faure, M. en Deketelaere, K., (red.), "Ius Commune en Milieurecht", l.c., 358). 
gekanaliseerd, is de persoon in wiens hoofde de kwalitatieve aansprakelijkheid is gevestigd (ouder, onderwijzer, werkgever, exploitant van een gevaarlijke activiteit, houder van gevaarlijke stoffen, ...). Er kan inderdaad worden geconcludeerd dat een gekwalificeerde aansprakelijkheid hetzelfde betekent als een gekanaliseerde aansprakelijkheid. Deze beide begrippen hebben echter niet noodzakelijk een risicoaansprakelijkheid tot gevolg.

Het is inderdaad mogelijk om risicoaansprakelijkheid te creëren zonder kanalisatie of zonder gekwalificeerde aansprakelijkheid ${ }^{438}$. Artikel 9.1.3 van Voorontwerp Decreet Milieubeleid is daar een voorbeeld van: eenieder die door een emissie schade of milieuverstoring veroorzaakt, is daarvoor aansprakelijk. Of dit effectief een risicoaansprakelijkheid inhoudt, is niet meteen zeker omdat de aansprakelijkheid afhangt van de emissie. Het relevante punt bestaat crin dat deze aansprakelijkheid niet naar een bepaalde categorie van personen wordt gedirigeerd. Een zuivere vorm van risicoaansprakelijkheid voor milieuschade, zonder kanalisatie zou luiden: "wie milieuschade veroorzaakt, is hiervoor aansprakelijk". Dit zou een zeer brede en algemene risicoaansprakelijkheid impliceren voor milieuschade; tegelijk wordt de aansprakelijkheid niet naar een persoon met een bepaalde hoedanigheid gedirigeerd en kan dus niet worden gesproken van een kanalisatie van aansprakelijkheid.

Het verschil tussen een risicoaansprakelijkheid met en zonder gekwalificeerde aansprakelijkheid bestaat erin dat bij een gekwalificecrdc aansprakclijkheid de aansprakelijkheid enkel rust op de persoon die de desbetreffende hoedanigheid bezit, c.q. op de persoon waamaar de aansprakelijkheid wordt gekanaliseerd. Anders gezegd: doordat een aansprakelijkheidsgrondslag wordt gekoppeld aan een persoon (of hocdanigheid), kan dic specifieke aansprakelijkheidsgrondslag enkel ten aanzien van die persoon worden toegepast.

Het feit dat de verschillende van kracht zijnde vormen van risicoaansprakelijkheid meteen ook deze aansprakelijkheid kanaliseren naar een bepaalde persoon, impliceert dat de risicoaansprakelijkheid enkel geldt ten aanzien van die welbepaalde persoon of groep van personen. Andere personen zullen op een andere juridische basis, desgevallend via de foutaansprakelijkheid, dienen te worden aangesproken. In die optiek zijn de verschillende vormen van risicoaansprakclijkheid zoals die onder het huidige recht bestaan, een vorm van beperkte risicoaansprakelijkhcid: enkel de personen wier hoedanigheid bepalend is, zijn aansprakelijk buiten de fout om.

Uit de ontkoppeling van het kanaliseren van de aansprakelijkheid (of kwalificeren van een aansprakelijkheid) en de aansprakelijkheidsgrondslag, volgt ook onmiskenbaar dat een gekwalificeerde of gekanaliseerde aansprakelijkheid evenzeer denkbaar is bij foutaansprakelijkheid. Een voorbeeld zou kunnen zijn: "De exploitant van een vergunningsplichtige inrichting die een fout heeft begaan, is hiervoor aansprakelijk". Een dergelijke aansprakelijkheid bcstaat, voorzover bekend, niet. Toch lijken zowel cen risicoaansprakelijkheid zonder kanalisatie als een foutaansprakelijkheid mét kanalisatie vanuit theoretisch en dogmatisch oogpunt mogelijk. Artikel 9.1.3 van het Vlaamse Voorontwerp Decreet Milieubeleid gaat aardig in de richting van een risicoaansprakelijkheid zonder kanalisatie.

De systematische koppeling tussen risicoaansprakelijkheid en de kanalisatie van aansprakelijkheid (of een kwalitatieve aansprakelijkheid), heeft in feite geleid tot een systematische beperking van de groep personen die kon worden aansprakelijk gesteld. Vandaar dat bijvoorbeeld ook het door Schamps geformuleerde voorstel om een algemene risicoaansprakelijkheid in te

138

Ook Van Dam spreekt volkomen terecht van een kwalitatieve risicoaansprakelijkheid en foutaansprakelijkheid (Van Dam, C.C., "Aansprakelijkheidsrecht", l.c., 297 e.v.). 
voeren voor gevaarlijke activiteiten strikt genomen géén algemene risicoaansprakelijkheid is ${ }^{439}$ : in haar voorstel wordt de aansprakelijkheid gekanaliseerd naar de exploitant.

Het verschil tussen risicoaansprakelijkheid en kanalisatie van aansprakelijkheid is blijkbaar uit het oog verloren doordat beide juridische begrippen in het hedendaagse aansprakelijkheidsrecht bijna altijd samen voorkomen. Het wekt dan ook weinig verwondering dat ook de succesvolle pogingen om het begrip kanalisatie te verduidelijken, beperkt zijn gebleven. In onderstaande paragraaf zal worden getracht om een duidelijkere begripsomschrijving van "kanalisatie van aansprakelijkheid" te introduceren.

\subsection{Afbakening van het begrip "kanalisatie van aansprakelijkheid"}

De kanalisatie van aansprakelijkheid in het kernenergierecht impliceert dat de aansprakelijkheid wordt gedirigeerd naar de exploitant van de kerninstallatie, dat de regresrechten van de exploitant worden beperkt en dat andere rechtsgronden buiten werking worden gesteld. De kanalisatic van aansprakelijkheid buiten het kemenergierecht houdt in dat de aansprakelijkheid weliswaar naar één persoon wordt gedirigeerd, maar dat de regresrechten en het gemene aansprakelijkheidsrecht ongemoeid worden gelaten. Het is dan ook zinvol om dit ruime begrip op preciezere wijze af te bakenen.

In deze paragraaf wordt aangegeven welke de wezenlijke kenmerken zijn van de kanalisatie van aansprakelijkheid $(\S 2.4 .1)$ en zal een overzicht worden gegeven van de verschillende mogelijke verschijningsvormen van de kanalisatie van aansprakelijkheid $(\S 2.4 .2)$.

\subsubsection{Wezenlijke kenmerken van de kanalisatie van aansprakelijkheid}

Het kanaliseren van de aansprakelijkheid moet worden gezien als een manier om processuele of samenloopproblemen het hoofd te bieden. Hiermee worden problemen bedoeld inzake de identificatie van de aansprakelijke persoon: vaak is moeilijk vast te stellen waar de oorzaak ligt van een bepaalde schade, en kunnen meerdere personen voor deze schade worden aansprakelijk gesteld. Een bepaalde gevaarlijke activiteit is het gevolg van een samengaan van activiteiten van verschillende actoren die elk (voor een deel) de schade kunnen veroorzaken.

Kanalisatie van aansprakelijkheid biedt een oplossing voor dit probleem door één persoon aan te wijzen die een bepaalde band of zeggenschap heeft over een van de risicofactoren die een rol hebben gespeeld bij het schadegeval ${ }^{440}$. Het slachtoffer hoeft niet te onderzoeken wie van de verschillende actoren daadwerkelijk aan de oorzaak ligt van de schade. Bij de kanalisatie van aansprakelijkheid in het kernenergierecht kan slechts één persoon worden aangesproken; in gevallen waar de aansprakelijkheid wordt gekanaliseerd buiten het kernenergierecht kunnen nog steeds meerdere personen worden aangesproken.

De essentie van een regime waarbij de aansprakelijkheid naar een bepaalde persoon wordt gekanalisecrd betreft de samenloopvraag: wijst de wet een persoon of een activiteit aan die geacht wordt aan de oorzaak van de schade te liggen? Anders gezegd: is voor de aansprakelijkheid een bepaalde hoedanigheid vereist? 
In zekere zin impliceert kanalisatie van aansprakelijkheid dat een feitelijk vermoeden wordt gecreëerd dat de schade door een bepaalde persoon is veroorzaakt. Bij schade door emissie zoals verwoord in artikel 9.1.4 van het Voorontwerp Decreet Milieubeleid, wordt vermoed dat de schade is veroorzaakt door de exploitant van een vergunningsplichtige inrichting; bij schade door gevaarlijke stoffen onder het Nederlandse NBW wordt de schade vermoed te zijn veroorzaakt door de beroepsmatige gebruiker van gevaarlijke stoffen. Of in casu daadwerkelijk kan worden gesproken van een feitelijk vermoeden wordt hier in het midden gelaten; van belang is dat een regime van kanalisatie van aansprakelijkheid een bijzonder aanspreekpunt creëert voor het slachtoffer en dat uitspraak wordt gedaan over mogelijke samenloopproblemen. Bij kanalisatie van aansprakelijkheid zal de wet een persoon aanduiden die door de benadeelde in een extracontractueel verband kan worden aangesproken voor een specifieke schade of voor schade uit een specifieke activiteit. Ook hier komt de band naar voren met het begrip "kwalitatieve aansprakelijkheid": de aansprakelijkheid wordt gekanaliseerd naar de persoon die een bepaalde hoedanigheid bekleedt. Inzake milieuaansprakelijkheid wordt de aansprakelijkheid over het algemeen gekanaliseerd naar die persoon die een bepaalde zeggenschap heeft over gevaarlijke activiteiten of producten.

Kanalisatie van aansprakelijkheid betekent dat een of meerdere aanknopingspunten worden gegeven ter zake van de persoon of de personen bij wie de aansprakelijkheid moet worden gelegd: de exploitant van een vergunningsplichtige inrichting, al dan niet samen met, de bewaarder van gevaarlijke stoffen, de producent van een gebrekkig product, ...

Het kanaliseren van aansprakelijkheid op zich betekent dan ook niets meer of niets minder dan dat de aansprakelijkheid in een gegeven schadegeval, via een wettelijke bepaling wordt gedirigeerd naar een bepaalde persoon. Dit houdt in dat, in een potentieel kluwen van rechtsverhoudingen, door de wetgever een welbepaalde persoon wordt aangeduid die - al naargelang de vorm van de kanalisatie - hetzij mogelijks, hetzij in ieder geval, hetzij als enige, hetzij samen met anderen aansprakelijk zal worden gesteld.

Hiermee hoeft de wetgever evenwel geen uitspraak te doen naar de mogelijke aansprakelijkheid van andere personen dan degene naar wie de aansprakelijkheid wordt gekanaliseerd. Kanalisatie van aansprakelijkheid hoeft daarom niet noodzakelijk andere rechtsgronden uit te sluiten. De wet kan de kanalisatie zowel op cumulatieve als op exclusieve wijze regelen. Indien het aanduiden van de aan te spreken persoon gepaard gaat met het beperken van het aantal aan te spreken personen, impliceert dit dat andere personen - die op basis van het gemene aansprakelijkheidsrecht zouden kunnen worden aangesproken - worden geëxonereerd; dat zij met andere woorden nict meer door derden kunnen worden aansprakelijk gesteld voor de geleden schade. Wordt het aantal personen daarentegen niet beperkt, dan is het effect dat als het ware een richtlijn wordt gegeven van de bij voorkeur aan te spreken persoon, naast andere personen die op basis van het gemene recht aansprakelijk zijn en blijven.

Essentieel bij de kanalisatie van aansprakelijkheid in het kemenergierecht is wat de beschermende werking of de wettelijke exoneratie ten aanzien van een potentiële schadeveroorzaker kan worden genoemd ${ }^{441}$.

Vanden Borre T., "Transplantatie van kanalisatie van aansprakelijkheid van het kemenergierecht naar het milieu(aansprakelijk-heids)recht: een goede of een gebrekkige zaak?", in Faure, M. en Deketelaere, K., (red.), "Ius Commune en Milieurecht", l.c., 358. 
Met wettelijke exoneratie wordt bedoeld dat door de kanalisatie een persoon die op basis van het gemene aansprakelijkheidsrecht aansprakelijk zou kunnen worden gesteld, via een wettelijke bepaling wordt geëxonereerd. Dit is bijvoorbeeld het geval voor de bouwer van een keminstallatie die door een slachtoffer van een kernongeval niet op extracontractuele - laat staan op contractuele - basis kan worden aangesproken. De leverancier wordt met andere woorden beschermd doordat de aansprakelijkheid wordt gekanaliseerd naar de exploitant van de keminstallatie. Hiermee grijpt de kanalisatie in in de externe, extracontractuele verhouding van slachtoffers ten overstaan van een keten van potentiële schuldenaars. Het maakt een aantal gemeenrechtelijke aansprakelijkheidsvorderingen van slachtoffers juridisch onmogelijk.

Via de beschermende werking van elke vorm van kanalisatie van aansprakelijkheid, wordt in zekere mate een beperking aangebracht aan de kring van personen die op de gegeven juridische grondslag kan worden aangesproken. Wordt de kanalisatie gekoppeld aan risicoaansprakelijkheid, dan kunnen enkel de personen naar wie de aansprakelijkheid wordt gekanaliseerd, op deze juridische grondslag worden aangesproken. Omdat risicoaansprakelijkheid systematisch wordt gekoppeld aan de kanalisatie van aansprakelijkheid, leidt kanalisatie in feite tot een beperkte hanteerbaarheid van de risicoaansprakelijkheid.

Hieruit blijkt eens te meer het gevaar om kanalisatie zomaar gelijk te stellen met risicoaansprakelijkheid. Kanalisatie op zich geeft geen enkele aanwijzing met betrekking tot de aansprakelijkhcidsgrondslag: het geeft niet an of in hoofde van degene naar wie de aansprakelijkheid wordt gekanaliseerd al dan niet een fout dient te worden bewezen. Zo is het ook mogelijk dat de wetgever een bepaalde samenloop verduidelijkt dan wel uitsluit bij een regime van foutaansprakelijkheid.

Indien de nucleaire aansprakelijkheidsverdragen zouden uitgaan van een regime van foutaansprakelijkheid, dan zou dit geen afbreuk doen aan de beperkende werking van de kanalisatie onder deze Verdragen. De vraag of de aansprakelijkheid al dan niet is gebaseerd op de klassicke fout, hoeft daarom geen verband te houden met de vraag of een slachtoffer meerdere dan wel eén enkele persoon kan aanspreken. Onder het gemene foutaansprakelijkheidsrecht wordt de aansprakelijkheid niet gekanaliseerd: daar wordt in abstracto weergegeven dat een schadevergoedingsverplichting bestaat in hoofde van degene die een fout heeft begaan. Dat kan bijgevolg eender wie zijn.

\subsubsection{Mogelijke verschijningsvormen van de "kanalisatie van aansprakelijkheid"}

Doordat kanalisatie in bepaalde gevallen wel andere rechtsgronden uitsluit en in andere gevallen geen afbreuk doet aan het gemene aansprakelijkheidsrecht, is duidelijk dat deze term een zecr brede waaier aan juridische verschijningsvormen dekt. Verduidelijking zal worden gegeven door de voorstellen van de Interuniversitaire Commissie tot Herziening van het Milieurecht in het Vlaamse Gewest en de bepaling van artikel 6:175 NBW te plaatsen tegenover de bepalingen van het Verdrag van Parijs van 29 juli 1960.

De bepaling op basis waarvan de exploitant van een inrichting aansprakelijk is voor schade veroorzaakt door emissie in art. 9.1.4 van het Voorontwerp Decreet Milieubeleid, is inderdaad cen vorm van kanalisatie van aansprakelijkheid omdat een uitspraak wordt gedaan inzake samenloop. De feitelijke oor zaak van een schade door emissie kan hetzij bij de exploitant van de vergunningsplichtige inrichting of activiteit liggen, maar kan net zo goed elders liggen, bijvoorbeeld in een gebrek in een onderdeel van de installatie. Teneinde het slachtoffer de noodzaak te besparen om de juiste aansprakelijke te identificeren, wordt de exploitant van een vergunningsplichtige activiteit uitgekozen als degene die dient te worden aangesproken. De aansprakelijkheid wordt naar de 
exploitant geleid. Hetzelfde kan worden gezegd van de aansprakelijkheid voor gevaarlijke stoffen ex artikel 6:175 NBW. Zo wordt de aansprakelijkheid in de eerste plaats gedirigeerd naar degene die de stof gebruikt of onder zich heeft. Maar ook de bewaarder of leidingbeheerder kunnen ingevolge hetzelfde artikel worden aansprakelijk gesteld; bovendien worden andere rechtsgronden niet buiten werking gesteld.

Bij de kanalisatie van aansprakelijkheid in het kernenergierecht wordt wel degelijk ingegrepen in het gemene aansprakelijkheidsrecht omdat bijkomende bepalingen de kanalisatie verstrakken, namelijk door het regresrecht van de persoon waarnaar de aansprakelijkheid wordt gekanaliseerd te beperken en door de overige rechtsgronden waarop een slachtoffer zich desgevallend zou kunnen beroepen, buiten werking te stellen.

Het moet daarom duidelijk worden gemaakt dat de kanalisatie van aansprakelijkheid in relatie staat met drie variabelen. Ten eerste het aantal personen naar wie de aansprakelijkheid wordt gekanaliseerd; ten tweede het al dan niet intact laten van de regresvorderingen van de persoon waamaar de aansprakelijkheid wordt gekanaliseerd (beperken van de contractuele aansprakelijkheid) en ten derde het al dan niet intact laten van de gemene aansprakelijkheidsrecht voor het slachtoffer van de schade (beperken van de extracontractuele aansprakelijkheid). De kanalisatie van aansprakelijkheid kan dus variëren volgens onderstaand model.

Theoretische verschijningsvormen van de kanalisatie van aansprakelijkheid

\begin{tabular}{|c|c|c|}
\hline $\begin{array}{l}\text { Aantal personen naar wie de } \\
\text { aansprakelijkheid wordt } \\
\text { gekanaliseerd }\end{array}$ & Gemeen recht intact & Regres mogelijk \\
\hline \multirow{4}{*}{ Naar I persoon } & $\operatorname{Necn}$ & Ncen \\
\hline & $\mathrm{Ja}$ & Neen \\
\hline & Neen & $\mathrm{Ja}$ \\
\hline & $\mathrm{Ja}$ & $\mathrm{Ja}$ \\
\hline \multirow{4}{*}{ Naar $>1$ persoon } & Neen & Neen \\
\hline & $\mathrm{Ja}$ & Neen \\
\hline & Neen & $\mathrm{Ja}$ \\
\hline & Ja & $\mathrm{Ja}$ \\
\hline
\end{tabular}

De theoretisch meest zuivere of strenge vorm van kanalisatie zal deze zijn waarbij slachtoffers zich slechts kunnen richten tot één enkele persoon, waarbij slachtoffers niet over de mogelijkheid beschikken om een andere persoon op enige andere rechtsgrond aan te spreken, en waarbij ten- 
slotte de persoon naar wie de aansprakelijkheid wordt gekanaliseerd over geen enkel regresrecht beschikt. Door toevoeging van de "variabelen" beperking van het regresrecht en buiten werking stellen van het gemene aansprakelijkheidsrecht, kan kanalisatie bijgevolg leiden tot een exclusieve aansprakelijkheid ${ }^{442}$. Hiermee wordt een aansprakelijkheid bedoeld waarbij slechts één enkele persoon op één enkele juridische grondslag voor een specifieke schade kan worden aansprakelijk gesteld, en waarbij deze over geen enkel regresrecht beschikt.

Hierbij moet ook worden duidelijk gemaakt dat het beperken van het regres en het buiten werking stellen van het aansprakelijkheidsiecht automatisch leiden tot het kanaliseren van de aansprakelijkheid. Indien iemands regresrecht wordt beperkt, betekent dit dat hij ook moet instaan voor de gevolgen van daden of activiteiten van anderen en dat de aansprakelijkheid voor schade veroorzaakt door deze anderen, automatisch naar hem wordt gedirigeerd. Hetzelfde geldt voor het buiten werking stellen van het gemene aansprakelijkheidsrecht.

Het spreekt voor zich dat dit een vereenvoudigd model is omdat afhankelijk van het aantal personen naar wie de aansprakelijkheid wordt gekanaliseerd en al naargelang het aantal personen waartegen regres kan worden uitgeoefend, nog meerdere opties beschikbaar zijn. Ook de reële regresmogelijkheid zal de "strengheid" van de kanalisatie bepalen ${ }^{443}$.

Uit bovenstaand overzicht kan worden afgeleid dat de kanalisatie zoals voorzien in het Nederlandse artikel 6:175 NBW te beschouwen is als één van de lichtste vormen van kanalisatie: de aansprakelijkheid wordt gekanaliseerd naar meerdere personen, en zowel de regresrechten van de "gekanaliseerde", als de gemeenrechtelijke vorderingen van het slachtoffer worden intact gelaten. De kanalisatie als voorzien in het Vlaamse Voorontwerp Decreet Milieubeleid is een iets "zwaardere" vorm van kanalisatie aangezien voor wat betreft emissies door vergunningsplichtige inrichtingen, er slechts één persoon is naar wie de aansprakelijkheid wordt gekanaliseerd.

Kanalisatie van aansprakelijkheid in het kernenergierecht is in het licht van bovenstaande elementen een zeer verregaande vorm van kanalisatie, omdat de aansprakelijkheid naar slechts één enkele persoon wordt gekanaliseerd en omdat het slachtoffer maar één enkele rechtsgrond ter beschikking heeft om compensatie te kunnen bekomen van de door hen geleden schade ${ }^{444}$. Voorstanders van de kanalisatie van aansprakelijkheid hebben overigens steeds gehamerd op het belang van het feit dat kanalisatie, om haar doel te bereiken, geen enkele uitzondering mag kennen ${ }^{445}$.

De in het maritieme recht voorziene kanalisatie van aansprakelijkheid gaat duidelijk minder ver, aangezien de regresrechten van de scheepseigenaar intact worden gelaten en orndat personen naasi de scheepseigenaar kunnen worden aangesproken ${ }^{46}$. In het maritieme recht geniet slechts een gering aantal potentiële schadeveroorzakers van de beschermende werking, terwijl niet wordt geraakt aan hun interne verhouding.

Zie ook "Liability and Compensation for Nuclear Damage", l.c., 24.

Met andere woorden de vraag of een regresrecht daadwerkelijk kan worden uitgeoefend, dan wel slechts een theoretische mogelijkheid is waarvan, ingevolge de machtspositie van de persoon wartegen regres zou kunnen worden uitgeoefend, in de praktijk geen gebruik kan worden gemaakt.

Theoretisch heeft de exploitant de mogelijkheid om regres uit te oefenen tegen de leveranciers, maar gelet op de monopoliepositie van de Amerikaanse leveranciers, werd de regresclausule slechts in uitzonderlijke gevallen in de contracten ingelast. Piérard, J.P., "Responsabilité civile. Energie atomique", l.c., 462. International Convention", in De la Rue, C.M. (ed.), Liability for Damage to the Marine Environment, Lloyd's of London, 1993, 94 e.v. Zie ook in hoofdstuk 12 van dit boek. 
Kanalisatie van aansprakelijkheid kan bijgevolg voorkomen onder een zeer groot aantal vormen waarbij de strengheid van de kanalisatie kan variëren. Gelet op deze vele mogelijkheden, heeft het weinig zin om voor elk van deze vormen een eigen benaming naar voren te schuiven. Wel draagt het de voorkeur weg om de term kanalisatic van aansprakelijkheid voor te behouden voor het dirigeren van een aansprakelijkheid naar een bepaalde persoon of naar een categorie van personen.

Het verdient ook de aanbeveling dat de wetgever, telkens wanneer hij gebruik wenst te maken van de kanalisatie van aansprakelijkheid, telkens de drie criteria voor ogen houdt én motiveert waarom hij voor een strengere dan wel voor een lichtere vorm kiest van de kanalisatie van aansprakelijkheid ${ }^{447}$. De wetgever dient zich bewust te zijn van de brede waaier van mogelijkheden waarover hij beschikt om de civielrechtelijke aansprakelijkheid aan een bepaalde persoon toe te wijzen. Onafhankelijk van deze toewijzing en de strengheid van de kanalisatie van aansprakelijkheid, kan hij deze nog eens combineren met een foutaansprakelijkheid dan wel met een regime van risicoaansprakelijkheid. De Belgische, noch de Nederlandse, noch de internationale wetgever ${ }^{448}$ lijken zich van deze uitgebreide mogelijkheden en hun gevolgen bewust te zijn ${ }^{449}$.

Bovenstaand overzicht moet worden gezien als een eerste poging tot verduidelijking van het begrip "kanalisatie van aansprakelijkheid". Er blijven vele vragen open. Bijkomend onderzoek is vereist naar de verschillende rechtstakken waarin sprake kan zijn van kanalisatie van aansprakelijkheid ${ }^{450}$. Bovendien is bijvoorbeeld onduidelijk of gevallen bestaan waar sprake is van kanalisatie van aansprakelijkheid onder een regime van foutaansprakelijkheid. Dit zijn vragen waarop in het kader van dit proefschrift niet verder kan worden ingegaan.

\subsection{Conclusie}

Kanalisatie van aansprakelijkheid is een begrip dat in essentie een uitspraak doet over samenloopproblemen: het kiest uit een grote groep personen die personen uit die op basis van cen specifieke juridische grondslag aansprakelijk kunnen worden gesteld.

Voorzover bekend werd de kanalisatic van aansprakelijkheid altijd gekoppeld aan risicoaansprakelijkheid. Er lijken dus op heden geen vormen te bestaan van risicoaansprakelijkheid die de aansprakelijkheid niet kanaliseren.

De term kanalisatie zelf lijkt voor het eerst in het nucleaire aansprakelijkheidsrecht te zijn gehanteerd. Kanalisatie van aansprakelijkheid is een juridisch begrip dat voortkomt uit de vrijwaringsclausule (hold harmless clause) waarmee de Amerikaanse overheid initieel de private sector liet

Het ware aangewezen dat bijvoorbeeld de Intcruniversitaire Commissie tot Herziening van het Milietirecht in het licht van deze elementen haar conclusies inzake de kanalisatie van ansprakelijkheid naar de exploitant zou verduidelijken. Artikel 6.1 van het Milieuschadeverdrag van de Raad van Europa kanaliseert de aansprakelijkheid naar de exploitant. Ook de Europese Commissie wil de aansprakelijkheid kanaliseren naar de persoon oie controle uitoefent over een activiteit (Witboek betreffende milicuaansprakelijkheid, COM(2000), 66 def. 9 februari $2000,20-21$ ).

Eerder heeft ook Cousy reeds gewezen op de gebrekkige systematiek van de verschillende fout afwijkende aansprakelijkheidsregimes (Cousy, H., "Enkele beschouwingen over de systematiek van de stelsels van foutloze aansprakelijkheid", in "Liber Amicorum Jacques Putzeys", l.c., 38).

Zo is in Duitsland reeds onderzoek gedaan naar de kanalisatie van ansprakelijkheid in het arbeidsrecht; (Mohr, P.C., "Die Kanalisierung der Haftung unter besondere Berüeksichtigung des Atomrechts", o.c., 128). 
participeren in de ontwikkeling van het gebruik van kernenergie. Via het Harvard Rapport werd deze vrijwaringsclausule in de vorm van een kanalisatie van aansprakelijkheid ingevoerd in het internationale nucleaire aansprakelijkheidsrecht. Maar blijkbaar werd in de loop der jaren uit het oog verloren dat de vrijwaringsclausule initieel als een tijdelijke clausule werd beschouwd zodat de private sector zich kon voorbereiden op de vrije markt. Doordat de kanalisatie van aansprakelijkheid werd ingevoerd via een Verdrag, werd meteen ook de gunstmaatregel uit de Amerikaanse contractuele politiek bestendigd.

In het internationale kernenergierecht worden twee vormen van kanalisatie onderscheiden: de economische kanalisatie en de juridische kanalisatie van aansprakelijkheid. De Amerikaanse Price-Anderson Act hanteert een systeem van economische kanalisatie; de internationale Verdragen gaan uit van een juridische kanalisatie van aansprakelijkheid waarbij zowel wordt ingegrepen in het extracontractuele aansprakelijkheidsrecht (uitsluiten van andere rechtsgronden) als in het contractuele aansprakelijkheidsrecht (regresrecht van de exploitant ten overstaan van zijn leveranciers).

Volgens het Harvard Rapport was de kanalisatie van aansprakelijkheid naar de exploitant van de kerninstallatie noodzakelijk om drie redenen. Door kanalisatie zou ten eerste een dubbele verzekeringsdekking worden vermeden. Indien zowel de exploitant als diens leverancier voor hetzelfde risico een verzekeringsdekking moeten nemen, zou dit resulteren in hogere verzekeringskosten zonder evenredig voordeel voor slachtoffers. Vervolgens wordt ook het beperken van de samenloop als een voordeel gezien omdat een slachtoffer eenvoudig kan achterhalen wie hij precies moet aanspreken bij een vordering tot schadevergoeding. Tenslotte zou het onredelijk zijn de leverancier van een klein onderdeel van de reactor aansprakelijk te stellen voor alle schade uit een kernongeval. Daarbij, zo werd geredeneerd, zou het voor slachtoffers weinig zin hebben om deze kleine bedrijven aan te spreken omdat deze sowieso onvoldoende middelen hebben om aan alle uit een kernongeval voortvloeiende vorderingen het hoofd te bieden. Op basis van deze argumenten, werd de kanalisatie van aansprakelijkheid ingeschreven in het Verdrag van Parijs van 29 juli 1960 en het Verdrag van Wenen van 21 mei 1963 inzake de civiele aansprakelijkheid bij kernongevallen: precies dezelfde redenen als deze aangegeven in het Harvard Rapport zijn terug te vinden in het Exposé des Motifs van het Verdrag van Parijs en bij de voorbereidende werken van het Verdrag van Wenen.

Het meest opvallende, en meteen vernieuwende element van de kanalisatie van aansprakelijkheid in het kernenergierecht, bestaat in de combinatie van het dirigeren van de aansprakelijkheid naar de exploitant van de keminstallatie met het beperken van diens regresrechten en het buiten werking stellen van het gemene aansprakelijkheidsrecht.

Van meet af aan werd erkend dat de kanalisatie van aansprakelijkheid zoals verwoord in het internationale kernenergierecht con drastische ingrcep was in het civiele aansprakelijkheidsrecht, alangezien dit leidt tot de immuniteit van de leveranciers van de exploitant van de kerninstallatic: anderzijds werd ook gewezen op de voordelen ervan. Voorstanders van de kanalisatie in het kernenergierecht benadrukken dat de afschaffing van de gemeenrechtelijke vorderingen bij cen kemongeval kadert in een geheel van matregelen dat zowel de belangen van de industrie als de belangen van de slachtoffers dient. De beschikbare aansprakelijkheidsdekking, die wcliswaar is beperkt, moet in deze optiek, samen met de andere maatregelen (zoals cxclusieve bevoegdheid van én rechter, toepasselijk recht e.d.m.), worden gezien als een garantiefonds voor slachtoffers. Bij afwezigheid van al deze matregelen zou ecn slachtoffer geen enkele garantic hebben dat welke som ook zou kunnen worden uitbetaald, aldus de redenering. Tegenstanders daarentegen blijwen bezwaren uiten tegen het afschaffen van de gemeenrechtelijke vorderingen. 
De discussie omtrent het nut, de merites en de tekortkomingen van de kanalisatie van aansprakelijkheid in het kemenergierecht, is nog steeds actueel. Getuige daarvan het feit dat Oostenrijk in 1999 de kanalisatie van aansprakelijkheid in het kernenergierecht heeft afgeschaft.

Het belang dat met name de VS hechten aan de bescherming van de nucleaire industric, is ook gebleken naar aanleiding van hun inspanningen bij de onderhandelingen van het Verdrag inzake Bijkomende Compensatie. Toen in de rechtszaken naar aanleiding van de ongevallen met de Amoco Cadiz en in Bhopal bleek dat Amerikaanse leveranciers kwetsbaar waren voor vorderingen in eigen land voor schade uit een schadegeval elders in de wereld, hebben de VS actief deelgenomen aan de onderhandelingen: gevreesd werd dat het Amoco Cadiz scenario zich ook zou kunnen voordoen in het kemenergierecht. Het resultaat zal zijn dat zodra het Verdrag inzake Bijkomende Compensatie in werking zal zijn getreden, de Amerikaanse rechter de zaak in principe zal doorverwijzen naar de rechtbank van de installatiestaat.

Het is vooralsnog onduidelijk of de nucleaire aansprakelijkheidsverdragen van de tweede generatie wel in werking zullen treden. Het gebrek aan enthousiasme van de verschillende landen om toe te treden tot één van de internationale nucleaire aansprakelijkheidsverdragen lijkt een bres te slaan in de bescherming van de nucleaire toeleveringsindustrie.

Volledigheidshalve dient erop te worden gewezen dat de vrees van de Amerikaanse industrie om buiten het nucleaire aansprakelijkheidsrecht te worden aansprakelijk gesteld in belangrijke mate verband houdt met hun stelling dat de onder de Verdragen van Parijs en Wenen beschikbare bedragen, dermate laag zijn dat de kans reëel is dat een groot deel van de schade niet voor vergoeding in aanmerking komt op basis van het nucleaire aansprakelijkheidsrecht. Het is inderdaad niet ondenkbeeldig dat slachtoffers zullen trachten om via andere wegen de niet vergoedbare schade alsnog vergoed te zien.

Ook buiten het nucleaire aansprakelijkheidsrecht wordt de term kanalisatie gehanteerd, maar het moet duidelijk zijn dat de kanalisatie van aansprakelijkheid in het nucleaire aansprakelijkheidsrecht $\mathrm{en}$ in het (milieu)aansprakelijkheidsrecht aanzienlijk van elkaar verschillen. Kanalisatie in het kernenergierecht gaat duidelijk een stuk verder ${ }^{451}$ : het beperkt de mogelijkheden van de slachtoffers om zich op een andere rechtsgrond te baseren enerzijds en anderzijds kan degene die wordt aansprakelijk gesteld slechts in een beperkt aantal gevallen een regresrecht uitoefenen.

Het gebruik van deze term buiten het kernenergierecht gaat echter vaak gepaard met heel wat verwarring; zo wordt risicoaansprakelijkheid in een deel van de Belgische doctrine ten onrechte beschouwd als een synoniem voor kanalisatie van aansprakelijkheid. Deze verwarring heeft voor een groot deel te maken met het feit dat in de praktijk risicoaansprakelijkheid en kanalisatie nagenoeg steeds samen voorkomen. Uit de analyse is evenwel gebleken dat de samenloopvraag dogmatisch duidelijk dient te worden onderscheiden van aansprakelijkheidsgrondslag.

Het kanaliseren van aansprakelijkheid betekent dan ook niets meer of niets minder dan dat de aansprakelijkheid in een gegeven schadegeval, via een wettelijke bepaling wordt gedirigeerd naar een bepaalde persoon. Dit houdt in dat in een potentieel kluwen van rechtsverhoudingen door de wetgever een welbepaalde persoon wordt aangeduid die - al naargelang van vorm van de kanalisatie - hetzij mogelijks, hetzij in ieder geval, hetzij als enige, hetzij samen met anderen aansprakelijk kan worden gesteld. tions", o.c., 3 . 
De "strengheid" van een bepaalde vorm van kanalisatie van aansprakelijkheid zal afhangen van drie factoren: het aantal personen naar wie de aansprakelijkheid wordt gekanaliseerd, het al dan niet intact laten van de regresvorderingen van de "gekanaliseerde" en het al dan niet intact laten van de gemene aansprakelijkheidsrecht voor slachtoffers van de schade.

Het feit dat de kanalisatie steeds wordt verbonden aan een aansprakelijkheidsgrondslag heeft in feite een beperking tot gevolg van de personen die zich op deze grondslag kunnen baseren. Bijgevolg heeft elke vorm van kanalisatie een beperkende werking; die vormen van kanalisatie waarbij eveneens worden ingegrepen in het gemene aansprakelijkheidsrecht (contractueel en extracontractueel) hebben daarenboven een beschermende of exonererende werking ten aanzien van andere potentiële gedaagden/daders. Teneinde absolute duidelijkheid te hebben bij de verschillende vormen van kanalisatie lijkt het aangewezen dat de wetgever, telkens wanneer hij gebruik wenst te maken van de kanalisatie van aansprakelijkheid, steeds de drie criteria voor ogen houdt én motiveert waarom hij voor een strengere dan wel voor een lichtere vorm kiest van de kanalisatie van aansprakelijkheid.

\section{BEPERKING VAN DE AANSPRAKELIJKHEID VAN DE EXPLOITANT VAN EEN KERNINSTALLATIE}

Het derde basisprincipe van het nucleaire aansprakelijkheidsrecht, naast de risicoaansprakelijkheid en de kanalisatie van aansprakelijkheid, is de beperking van de aansprakelijkheid van de exploitant van de kerninstallatie. Dit is een belangrijke afwijking van het gemene civiele aansprakelijkheidsrecht waar in principe degene die schade berokkent aan een ander, gehouden is tot compensatie van alle door een slachtoffer geleden schade.

In het algemeen omschrijtt de Vries de beperking van de aansprakelijkheid als de bevocgdheid van een schuldenaar om zich van zijn verplichting tot schadevergoeding te kwijten door betaling van een lager bedrag dan de werkelijk geleden schade ${ }^{452}$. Deze bevoegdheid impliceert in casu dat het slachtoffer van een kernongeval niet het recht heeft om van de exploitant van de kerninstallatie de compensatie te vorderen van alle door hem geleden schade. In deze paragraaf wordt onderzocht waarom de exploitant van een keminstallatie de bevoegdheid kreeg om slechts een deel van de schade uit een kernongeval te moeten compenseren.

De Verdragen van Parijs en Wenen beperken de aansprakelijkheid van de exploitant van een keminstallatic op dubbele wijze: zowel het bedrag van de aansprakelijkheid als de periode waarin hij aansprakelijk kan worden gesteld, werden gelimiteerd. Bij beide elementen van de beperking van aansprakelijkheid zal ook worden aangegeven in welke mate aan dit principe wijzigingen worden aangebracht door de nucleaire aansprakelijkheidsverdragen van de tweede generatie of door de lopende onderhandelingen voor de revisie van het Verdrag van Parijs.

In eerste instantic wordt de beperking van het bedrag van de aansprakelijkheid besproken ( $\$ 3.1)$ en in tweede instantie de beperking van de aansprakelijkheid in de tijd (\$3.2). De conclusies van deze analyse wordt weergegeven in $\$ 3.3$. kemongevallen naar Nederlands recht", in Faure, M. (red.), "Aansprakelijkheid voor het nucleaire risi$\operatorname{con}^{\prime \prime}$, l.c., 32 . 


\subsection{Beperking van het bedrag van de aansprakelijkheid}

De beperking van het bedrag waarvoor de exploitant kan worden aansprakelijk gesteld, wordt zowel besproken naar huidig als naar toekomstig recht. Eerst worden de bepalingen van het NEAregime (\$3.1.1), van de Belgische wet van 1985 (\$ 3.1.2) en van de WAKO (\$3.1.3) aan de orde gesteld; nadien wordt ook gekeken welke de wijzigingen zijn die mogelijkerwijze in de toekomst zullen worden aangebracht aan deze beperking van de aansprakelijkheid. In $\$ 3.1 .4$ worden met name de wijzigingen besproken ingevolge het Protocol van het Verdrag van Wenen en door het Verdrag inzake Bijkomende Compensatic van september 1997 en worden eveneens de voorstellen besproken die bij de revisie van het Verdrag van Parijs ter tafel liggen. In $\$ 3.1 .5$ wordt een overzicht gegeven van de verschillende bedragen die in een aantal landen en in het internationale nucleaire aansprakelijkheidsrecht beschikbaar zijn. Tenslotte worden in $\$ 3.1 .6$ enkele conclusies getrokken.

\subsubsection{Volgens bet NEA-regime}

In deze paragraaf wordt in ecrste instantie ingegaan op de ratio legis van de beperking van de aansprakelijkheid $(\S 3.1 .1 .1)$; in tweede instantie worden de verdragsbepalingen van het Verdrag van Parijs inzake de beperking van het bedrag van de aansprakelijkheid geanalyseerd (\$ 3.1.1.2). In $\$ 3.1 .1 .3$ tenslotte wordt het verband aangetoond met de bepalingen van het Aanvullend Verdrag van Brussel van 1963.

\subsubsection{Ratio legis}

De invoering van de beperking van de aansprakelijkheid heeft alles te maken met het feit dat kemenergie, bij de totstandkoming van de nucleaire aansprakelijkheidsverdragen op het einde van de jaren vijftig en het begin van de jaren zestig, nog in haar beginschoenen stond. In die periode bestond een grote vraag naar kemenergie, vooral met het oog op de steeds toenemende elektriciteitsbehoeftes. Er bestond nauwelijks discussie over de positieve bijdrage die kernenergie kon leveren tot de industriële en maatschappelijke vooruitgang. In de visie van die tijd was het dan ook in het belang van de samenleving en van de verschillende landen dat deze nieuwe energievorm zou worden ontwikkeld. Anderzijds werd ook gewezen op de gevaren die met het gebruik van kernenergie gepaard gingen en op de noodzaak om deze gevaren te remediëren ${ }^{453}$. Indien de exploitant van de keminstallatie met een te zware aansprakelijkheid zou worden belast, dan zou dit strijdig kunnen zijn met dit belang, aldus de redenering ${ }^{454}$. Kortom, een onbeperkte aansprakelijkheid kon de ontwikkeling van de kemenergie-industrie ernstig in het gedrang brengen. Er diende bijgevolg een oplossing te worden gevonden waarbij zowel aan het Förderungszweck als aan het Schutzzweck werd tegemoet gekomen ${ }^{455}$.

Dit blijkt overigens duidelijk uit een van de overwegingen uit de Exposé des Motifs ${ }^{456}{ }^{457}$ :

453

Pelzer, N., "The nature and scope of international co-operation in connection with the peaceful uses of nuclear energy and its limits - an assessment", o.c., 34 e.v.

Camier, M.-C., "Responsabilité ct Assurance du Risque Atomique", l.c., 92.

Deze termen zijn ontleend aan Pelzer, N., Begrenzle und unbegrenzte Haftung im deutschen Atomrecht, Nomos, Baden-Baden, 1982, 9; Pelzer, N., "Reformüberlegungen zur Ausgestaltung der atomrechtlichen Haftung", in Lukes, R. (herausg.), Sechstes Deutsches Atomrechts-Symposium, Carl Heymanns Verlag, Keulen, 1980, 411.

Ook de preambule van het Verdrag van Parijs van 29 juli 1960 bevat een bepaling die dit bevestigt: "Desirous of ensuring adequate compensation for persons who suffer damage caused by nuclear inci- 
"On the one hand, the public exposed must be ensured of adequate protection in the face of unknown dangers, both for legal and for psychological reasons, and, on the other hand, the growth of the nuclear industry should not be hindered by a burden of liability which could be intolerable in the case of an incident assuming catastrophic proportions and which could not be covered by conventional insurance".

De kern van de beperking van aansprakelijkheid in het kemenergierecht heeft inderdaad te maken met de beperkte mogelijkheden van de verzekeringsmarkt in de jaren vijftig ${ }^{458}{ }^{459}$. Het nucleaire risico werd en wordt beschouwd als een niet actuariecl risico dat sommen vereist die de capaciteit van de verzekeringsmarkt te boven gaan ${ }^{460} 461$. Volgens de Exposé des Motifs van het Verdrag van Parijs zou het voor de exploitant, zelfs met een beperking van de aansprakelijkheid, niet makkelijk zijn om een afdoende dekking te vinden ${ }^{462}$. De redenering was dat de middelen van de exploitant sowieso beperkt zijn tot de aansprakelijkheidsverzekering en de desgevallend daarbovenop beschikbare eigen middelen van de exploitant, maar dat een aansprakelijkheid die deze sommen te boven gaat, niet zou leiden tot een hogere schadevergoeding ${ }^{463}$. Een onbeperkte aansprakelijkheid zou niet meteen positieve gevolgen hebben voor slachtoffers: niemand heeft onbeperkte middelen en bijgevolg zou een onbeperkte aansprakelijkheid niet leiden tot een onbeperkte schadevergoeding ${ }^{464}$. Indien de exploitant volledig aansprakelijk zou zijn, zou er een aanzienlijk risico bestaan dat hij na een kernongeval failliet zou gaan, hetgeen ook voor slachtoffers zeer nadelig is ${ }^{465}$. In feite was de redenering dat een garantie op een beperkte schadevergoeding beter was dan de onzekerheden verbonden aan het gemeenrechtelijke stelsel. Een onbeperkte aansprakelijkheid zou weinig toevoegen aan de positic van slachtoffers omdat een onbeperkte aansprakelijkheid niet zou leiden tot een onbeperkte dekking ${ }^{466} 467$.

De opstellers van het Verdrag hebben blijkbaar drie uitgangspunten gehanteerd om het bedrag te bepalen waarvoor de exploitant kon worden aansprakelijk gesteld ${ }^{468}$. Het eerste uitgangspunt was dat de aansprakelijkheid van de exploitant nauw diende te zijn verbonden aan de op de markt

dents whilst taking the necessary steps to ensure that the development of nuclear energy for peaceful purposes is not hereby hindered".

Exposé des Motifs, 32. Dit stuk is overgenomen uit de oorspronkelijke Exposé des Motifs van 1960; naar aanleiding van de wijzigingen aan het Verdrag van Parijs, aangebracht door het Protocol van 1982, werd eveneens de Exposé des Motifs licht gewijzigd. Ook deze gewijzigde Exposé des Motifs bevat evenwel een analoge bepaling.

Strohl, P., "Bilan des recherches de la section de langue française", o.c., 141-142.

Zoals hoger weergegeven vloeit de beperking van de aansprakelijkheid van de exploitent voort uit de resultaten van het Voorlopig Rapport, dat uitging van het totaal gebrek aan kennis en ervaring inzake dekking van dergelijke risico's. Cfr. supra, \$2.1.2 van dit hoofdstuk.

Radetzki, M., "Limitation de la responsabilité civile nueléaire: causes, conséquences et perspectives", Bulletin de Droit Nucléaire, $\mathrm{n}^{\circ} 63,1999,12$.

Over de verzekerbaarheid van een risico cfr. infra, in $\$ 4$ van hoofdstuk 9.

Exposé des Motifs, 53.

Radetzki, M., "Limitation de la responsabilité civile nucléaire: causes, conséquences et perspectives", o.c., 11 .

"Liability and Compensation for Nuclear Damage", l.c., 25.

Camier, M.-C., "Responsabilité et Assurance du Risque Atomique", l.c., 92.

Breining, W., "Reform of liability in Nuclear Law (unlimited liability does not automatically create unlimited cover", Nuclear Law Bulletin, $\mathrm{n}^{\circ} 25,1980$, 76-79; Matthijs, J., "Aansprakelijkheid bij toepassing van kernenergie tot vreedzame doeleinden", o.c., 128.

Volgens sommige auteurs is de discussie met betrekking tot een beperkte dan wel onbeperkte aansprakelijkheid een politieke en geen juridische discussie (Pelzer, N., "The present state of research carried out by the English speaking section of the Centre for Studies and Research", o.c., 278). 
beschikbare verzekeringsdekking. Ten tweede zou worden voorzien in één enkele beperking; het werd onmogelijk geacht om per type installatie of locatic een afzonderlijke limiet vast te leggen. Tenslotte werd ervoor gekozen om geen onderscheid te maken naargelang het type schade (zaakof letselschade). Het werd onhaalbaar geacht om de sommen inzake letselschade te beperken ten voordele van sommen voor zaakschade ${ }^{469}$.

Vooral het eerste uitgangspunt heeft een doorslaggevende rol gespeeld. Dit valt af te leiden uit de Verdragstekst zelf, maar ook uit het Harvard Rapport, waar werd gesteld dat indien de privéindustrie deelneemt aan de nucleaire ontwikkeling, de aansprakelijkheid dient te worden beperkt tot het bedrag waarvoor op de verzekeringsmarkt dekking kan worden verkregen ${ }^{470}$ : volgens de auteurs van het Harvard Rapport kan een verzekeringsdekking, door de beperkte capaciteiten van de verzekeringsmarkt, slechts een beperkte bescherming bieden tegen rü̈neuze vorderingen, tenzij de aansprakelijkheid via aangepaste wetgeving in bedrag en in de tijd wordt beperkt ${ }^{471}$. Over het algemeen wordt het bedrag waarvoor de exploitant aansprakelijk is, inderdaad beperkt tot de bedragen die op de verzekeringsmarkt beschikbaar zijn ${ }^{472}$. Als criterium voor het bepalen van de aansprakelijkheidslimiet van de exploitant van een keminstallatie werd dus niet de mogelijke omvang van de schade genomen, maar wel de capaciteit van de verzekeringsmarkt. In feite komt het erop neer dat in het nucleaire aansprakelijkheidsrecht de aansprakelijkheidsproblematiek werd gekoppeld aan de verzekering eerder dan de verzekeringsproblematiek te koppelen aan de aansprakelijkheid ${ }^{473}$.

Toch werd bij de onderhandelingen even overwogen om in bepaalde gevallen te voorzien in een regime van onbeperkte aansprakelijkheid wanneer het kernongeval te wijten zou zijn aan de fout van de exploitant of van een van zijn werknemers. Uiteindelijk werd een dergelijke bepaling niet in het Verdrag ingeschreven omdat werd geoordeeld dat de begrippen nalatigheid en grove schuld moeilijk te omschrijven zijn en dat hieraan een te ruime betekenis zou worden toegekend ${ }^{474}$.

De reden waarom het bedrag van de aansprakelijkheid van de exploitant werd beperkt, was dan ook louter van economische aard ${ }^{475}$; er werd niet of nauwelijks gezocht naar juridische of rechtsdogmatische gronden ${ }^{476}$. Ook in de literatuur werd de beperking van de aansprakelijkheid noodzakelijk geacht teneinde de economische haalbaarheid van een activiteit nict in het gedrang te brengen. Of ook andere dan economische motieven hebben meegespeeld on de aansprakelijkheid te beperken is, althans voor wat betreft het Verdrag van Parijs, bij gebrek aan de officiële publicatie van voorbereidende werken, niet zeker. Wel werd door twee bronnen dicht bij de onderhandelingen aangegeven dat de beperking van de aansprakelijkheid reeds in andere rechtstakken be-

49 Een aantal voorstellen bevatte inderdaad bepalingen in die richting. Zo was er een Duits voorstel om bij overlijden 100.000 DM toe te kennen; voor wat betreft zaakschade zou de waarde van de zaak worden vergoed, vermeerderd met de kosten nodig om de zaak te beschermen tegen gevolgen van de radioactieve straling (Camier, M.-C., "Responsabilité et Assurance du Risque Atomique", l.c., 99).

Harvard Rappori, 45-50.

Harvard Rapport, $71-72$.

Pelzer, N, "The present state of research carried out by the English speaking section of the Centre for Studies and Resiearch", o.c., 281.

473 Moulaert, J., "De burgerlijke verantwoordelijkheid bij het gebruik voor vredesdoeleinden van de kemenergie", o.c., 1192.

474 "(...) onbeperkte aansprakelijkheid (zou) gemakkelijk tot rünering van de exploitanten kunnen leiden zonder dat zij wezenlijk tot vergoeding van de veroorzaakte schade zou bijdragen" (Exposé des Motifs, 55 ).

475 Hohlefelder, W., "Reconsideration of the Principle of the Nuclear Operator's Limitation of Liability", in Nuclear Third Party Liability and Insurance, AEN-OECD, Paris, 1985, 375.

Pelzer, N., "Begrenzte und unbegrenzte Haftung"', l.c., 13. 
stond ${ }^{477}$ en dat dit principe derhalve niet door het nucleaire aansprakelijkheidsrecht werd ingevoerd ${ }^{478}$. De beperking van het bedrag van de aansprakelijkheid tegenover derden zou overigens voor het eerst zijn voorgekomen in het Verdrag van Warschau van $1929^{479}$, al kunnen de eerste sporen van de beperking van aansprakelijkheid nog verder terug in de tijd worden getraceerd ${ }^{485}$. Ook in het Harvard Rapport werd aangegeven dat de beperking van de aansprakelijkheid onder meer reeds in voege was in het luchtvaartrecht en in het maritieme recht en dat een beperking van de aansprakelijkheid werd gehanteerd in gevallen waar een activiteit die van groot maatschappelijk nut kon zijn, de industrie voor aanzienlijke risico's plaatste ${ }^{481}$.

Vaak wordt ervan uitgegaan dat een beperking van de aansprakelijkheid de tegenhanger is van de betere bescherming van het slachtoffer dankzij het ingestelde regime van risicoaansprakelijkheid $^{482}$. De artikelsgewijze bespreking van het Verdrag van Wenen lijkt dit te bevestigen ${ }^{483}$. In welke mate de beperking van de aansprakelijkheid ook in het Verdrag van Parijs kan worden beschouwd als tegenhanger van het voordeel van een regime van risicoaansprakelijkheid, is niet meteen duidelijk bij gebrek aan specifieke bepalingen hierover in de Exposé des Motifs. Pelzer trekt de systematische koppeling tussen beide basisprincipes in twijfel ${ }^{484}$. Hij stelt dat de koppeling tussen risicoaansprakelijkheid en beperking van de aansprakelijkheid zich nergens op een algemene wijze heeft doorgezet en dat voldoende voorbeelden bekend zijn, ook in buitenlands recht, waar de aansprakelijkheid niet wordt beperkt bij risicoaansprakelijkheid ${ }^{485}$. Volgens Strohl moet de beperking van de aansprakelijkheid ten dele worden verklaard als tegenhanger van de kanalisatie van aansprakelijkheid ${ }^{486}$. Door de kanalisatie van aansprakelijkheid zoals geformuleerd in het Verdrag van Parijs en de hieruit voortvloeiende exclusieve aansprakelijkheid van de exploitant van de kerninstallatie, moet de exploitant immers ook instaan voor de aansprakelijkheid van bijvoorbeeld zijn leveranciers, wat een verzwaring van deze aansprakelijkheid tot gevolg heeft, aldus Strohl.

Hierbij werd met name verwezen naar de wetgeving inzake de aansprakelijkheid voor schade veroorzaakt door luchtvaartuigen: het Verdrag van Warschau van 12 oktober 1929 tot het brengen van eenheid in enige bepalingen inzake het internationaal luchtvervoer (B.S. 24 september 1936) en het Verdrag van Rome van 7 oktober 1952 betreffende de schade door buitenlandse luchtvaartuigen aan derden aan het aardoppervlak veroorzaakt (B.S., 27 september 1966). Zie hierover o.m. Naveau, J. en Godfroid, M., Précis de droit Aérien, Bruylant, Bruxelles, 1988, 183 e.v. en 285 e.v.; Faure, M. en Van den Bergh, R., "Objectieve Aansprakelijkheid", I.c., 260 e.v.; Matte, N.M., "Intemational Air Transport", International Encyclopaedia of Comparative Law, vol. XII, 6-3l e.v. Camier, M.-C., "Responsabilité et Assurance du Risque Atomique", l.c., 92; Moulaert, J., "De burgerlijke verantwoordelijkheid bij het gebruik voor vredesdoeleinden van de kemenergie", o.c., 1191. Ballarino, T., "La réparation des dommages catastrophiques. Problèmes de droit international privé", in "La réparation des dommages catastrophiques", l.c., 65.

Voor een historisch overzicht van de beperking van aansprakelijkheid, zie De Vries, F.J., "Wettelijke limitering van aansprakelijkheid", I.c., 5-8.

\section{Harvard Rappori, 45.}

Schamps, G., "La mise en danger", l.c., 744; Lambert-Faivre, Y., Risques et assurances des entreprises, Précis Dalioz, $3^{\circ}$ édition, 1991, 591; Faure, M. en Van den Bergh, R., "Objectieve Aansprakelijkheid", l.c., 339; Moulaert, J., "De burgerlijke verantwoordelijkheid bij het gebruik voor vredesdoeleinden van de kernenergie", o.c., 1192; Piérard, J.P., "Responsabilité civile. Energie atomique et droit comparé", l.c., 113; Warren, G.C., "Nuclear Damage under the 1997 Protocol: Conventional Thinking?", in Reform of Civil Nuclear Liability, OECD, Parijs, 2000, 90.

Official Records Vienna Convention, 78.

Pelzer, N., "Concepts of Nuclear Liability revisited: a Post-Chemobyl Assessment of the Paris and the Vienna Convention", in Cameron, P. Hancher, L. an Kühn, W. (ed.), "Nuclear Energy Law after Chernobyl", l.c., 108.

Pelzer, N., "Unbegrenzte Haftung", l.c., 33-34.

Strohl, P., "Bilan des recherches de la section de langue française", o.c., 142. 
Het is onmiskenbaar zo dat de risicoaansprakelijkheid en de kanalisatie van aansprakelijkheid naar de exploitant van een kerninstallatie leiden tot een verzwaring van de aansprakelijkheid in hoofde van de exploitant en dat de beperking van de aansprakelijkheid is ingevoerd om te vermijden dat deze verzwaarde aansprakelijkheid zou leiden tot het faillissement van de exploitant ${ }^{487}$. Bijgevolg kan worden verdedigd dat de beperking van de aansprakelijkheid inderdaad verband houdt met de economische gevolgen van de verzwaarde aansprakelijkheid in het nucleaire aansprakelijkheidsrecht. Het door het Verdrag van Parijs ingestelde regime van risicoaansprakelijkheid is evenwel slechts één element dat de aansprakelijkheid verzwaart; ook de kanalisatie van aansprakelijkheid, de beperkte regresrechten van de exploitant en de beperkte overmachtsgronden waarop de exploitant zich kan beroepen zijn van aard om de aansprakelijkheid van de exploitant te verzwaren.

$\mathrm{Na}$ de bespreking van de redenen waarom de beperking van aansprakelijkheid werd ingevoerd in het nuclcaire aansprakelijkheidsrecht, wordt hieronder aangegeven hoe deze beperking in het Verdrag van Parijs werd ingeschreven en tot welke bedragen deze aansprakelijkheid precies werd beperkt.

\subsubsection{Analyse van de bepalingen van het Verdrag van Parijs}

Artikel 7, b) van het Verdrag van Parijs beperkt het bedrag waarvoor de exploitant van een kerninstallatie aansprakelijk is: de exploitant is aansprakelijk tot maximaal 15 miljoen Bijzondere Trekkingsrechten (BTR). Omgerekend komt dit neer op 21,46 miljoen euro $(865,8$ miljoen BEF of 74,3 miljoen NLG). Toch zijn de desbetreffende Verdragsbepalingen voor interpretatie vatbaar: - volgens artikel 7 a) zal het totaal der vergoedingen waarvoor een exploitant aansprakelijk is, het vastgestelde maximumbedrag der aansprakelijkheid niet overschrijden;

- volgens artikel 7, b) bedraagt dit maximumbedrag 15 miljoen BTR, maar:

i) een Verdragsluitende Staat beschikt over de mogelijkheid om bij wet een hoger of een lager bedrag vast te stellen, met inachtneming van de mogelijkheden waarover de exploitant beschikt om een verzekering af te sluiten of een andere financiële zekerheid te verkrijgen;

ii) een Verdragsluitende Staat kan ook, gelet op de aard van de kerninstallatie, een lager bedrag vaststellen,

met dien verstande dat de aldus vastgestelde bedragen in geen geval lager mogen zijn dan 5 miljoen BTR. Dit laatste bedrag komt overeen met 7,15 miljoen euro $(288,4$ miljoen BEF of 15,7 miljoen NLG).

In het Verdrag zijn geen bepalingen opgenomen die voorzien in een periodieke wijziging van het bedrag van 15 miljoen BTR. Daarbij komt dat het Verdrag moeilijk te wijzigen is ${ }^{48}$. Nochtans werd bij de onderhandelingen van het Verdrag van Parijs overwogen om te voorzien in een periodieke revisie van het bedrag waarvoor de exploitant aansprakelijk kan worden gesteld ${ }^{489}$. Ook volgens de auteurs van het Harvard Rapport diende de aansprakelijkheidslimiet flexibel te zijn ${ }^{490}$.

Toch kan worden vastgesteld dat 15 miljoen BTR niet als een absoluut cijfer moet worden beschouwd: aan de Verdragsluitende Staten wordt de mogelijkheid gegeven om een hoger of lager

Piérard, J.P., "Responsabilité civile. Energie atomique et droit comparé", l.c., 113.

Volgens artikel 20 van het Verdrag van Parijs kan het Verdrag slechts worden gewijzigd met onderling goedvinden van alle Verdragsluitende Partijen. Bovendien worden deze wijzigingen pas van kracht indien zij door twee derde van de Verdragsluitende Partijen zijn bekrachtigd of bevestigd.

Cigoj, S., "Intemational Regulation of Civil Liability for Nuclear Risk", International and Comparative Law Quarterly, vol. 14, 1965, 837.

Harvard Rapport, 48. 
bedrag vast te stellen "met inachtneming" van de mogelijkheden welke de exploitant heeft om cen verzekering af te sluiten, overeenkomstig artikel 10 van het Verdrag ${ }^{491}{ }^{492}$. Het bedrag van 15 miljoen BTR is dus niet bindend. Ook de Bestuurscommissie van de NEA erkent dit: in 1990 heeft zij een aanbeveling uitgeschreven om de aansprakelijkheid vast te leggen op minimaal 150 miljoen BTR of 214,65 miljoen euro (8,6 miljard BEF of 473 miljoen NLG) ${ }^{493}$, ofwel een vertienvoudiging van het bedrag voorzien in artikel 7 van het Verdrag van Parijs ${ }^{494}$. Het doel van deze aanbeveling was te komen tot een harmonisatic van de aansprakelijkheidslimieten onder de nationale wetgeving op een niveau dat correspondeert met de evolutie van de verzekeringsmarkt.

Toch kan worden verwezen naar de bepalingen van het Verdrag van Wenen. Volgens artikel V van het Verdrag van Wenen kan de aansprakelijkheid van de exploitant worden beperkt tot een bedrag dat niet lager is dan 5 miljoen dollar. De limiet werd opzettelijk laag gehouden met tot doel om zoveel mogelijk landen aan te moedigen om tot het Verdrag toe te treden. Een te hoog bedrag zou de ontwikkelingslanden ervan weerhouden om het Verdrag van Wenen te tekenen en te ratificeren ${ }^{495} 496$.

Het grote verschil met de bepaling van het Verdrag van Parijs bestaat erin dat het Verdrag van Wenen enkel voorziet in een minimumlimiet, terwijl het Verdrag van Parijs het onmiskenbaar heeft over een maximumbedrag. Artikel 7 van het Verdrag van Parijs en artikel 3, c van het Aanvullend Verdrag van Brussel hebben het inderdaad expliciet over een maximumbedrag dat niet mag worden overschreden en over een maximumbedrag waarvoor de exploitant aansprakelijk is. Gedurende de onderhandelingen van het Verdrag van Wenen werd bij de bespreking van de beperking van aansprakelijkheid verwezen naar de bepalingen van het Verdrag van Parijs; dienaangaande werd gesteld dat het Verdrag van Parijs een plicht inhoudt voor Staten om de aansprakelijkheid te beperken ${ }^{497}$.

Aan de ene kant geeft het Verdrag van Parijs dus een vrij ruime vrijheid aan de Verdragspartijen om de hoogte van de aansprakelijkheid te bepalen; maar aan de andere kant geeft het Verdrag aan dat een maximumlimiet moet worden vastgelegd. Een stelsel van onbeperkte aansprakelijkheid is daarom moeilijk verenigbaar met artikel 7 van het Verdrag van Parijs; een onbeperkte aansprake-

Dit artikel voorziet in de congruentie tussen het bedrag waarvoor de exploitant wordt aansprakelijk gesteld en het bedrag waarvoor hij is gehouden om een financiële zekerheid te hebben en in stand te houden. Zie paragraaf 4 van dit hoofdstuk.

"A contracting Party may (...), taking into account the possibilities for the operator of obtaining the insurance (...) establish by special legislation a greater or lesser amount than 15 million" (Exposé des Motifs, 53).

Recommendation of the Steering Committee van 20 april 1990, Paris Convention. Decisions, Recommendations, Interpretations, Parijs, 1990, 13.

Bij de redactie van het Protocol van 1982 aan het Verdrag van Parijs is tevergeefs getracht om deze aansprakelijkheidslimiet op te trekken (Domsdorf, E.P.M.W., "Intemationaal Atoomenergierecht", l.c., 716).

Official Records Vienna Convention, 256 en 259. Onder meer de Verenigde Staten waren voorstander van een limiet van 70 miljoen dollar.

De kritiek dat het bedrag van 5 miljoen dollar te laag was, werd met name door de Sovjetrussische delegatie bestreden: het gevaar inzake het gebruik van kernreactoren zou zwaar worden overdreven, want de enige incidenten die zich tot dan toe hadden voorgedaan, hadden enkel schade veroorzaakt aan de installatie zelf. Het probleem van aansprakelijkheid tegenover derden was bijgevolg geen ernstig probleem en de som van 5 miljoen dollar zou makkelijk alle schade uit een kemongeval kunnen vergoeden, aldus de afgevaardigde van de voormalige Sovjet-Unie (Official Records Vienna Convention, 258). 
lijkheid impliceert namelijk dat aan de aansprakelijkhcid geen maximumlimiet wordt gesteld. De discussic met betrekking tot de verenigbaarheid van cen stelsel van onbeperkte aansprakelijkheid met het Verdrag van Parijs, moet echter ook worden gezien in het licht van een ander in het Verdrag neergelegde principe, namelijk het congruentievereiste. Deze vereiste wordt in $\$ 4$ besproken. Naast deze discussie dient nog op een aantal andere elementen te worden gewezen.

Over het algemeen wordt ervan uit gegaan dat de aansprakelijkheid van de exploitant is beperkt per ongeval en niet per installatie ${ }^{498}$. Dit wordt met name afgeleid uit artikel $V$ van het Verdrag van Wenen op basis waarvan de aansprakelijkheid van de exploitant mag worden beperkt tot niet minder dan 5 miljoen dollar "for any one muclear incident". Artikel 7 van het Verdrag van Parijs is minder duidelijk omdat wordt gesproken van schadc uit cen kernongeval in het algemeen ${ }^{459}$. Uiteraard zal, door de nauwe band in het Verdrag tussen de aansprakelijkheid en de dekking, een en ander afhangen van de door de verzekeraars ter beschikking gestelde dekking ${ }^{500}$.

Volledigheidshalve wordt erop gewezen dat de kosten en interesten die door de rechtbank worden toegekend naar aanleiding van de schade uit een kernongeval, niet worden beschouwd als schadevergoeding. Deze kosten zijn door de exploitant verschuldigd bovenop het bedrag waarvoor hij aansprakelijk is (artikel 7, g van het Verdrag van Parijs).

\subsubsection{Verband met de overheidstussenkomst ex Aanvullend Verdrag van Brussel}

In het nucleaire aansprakelijkheidsrecht, hangt de beperking van de aansprakelijkheid direct samen met de overheidstussenkomst. Uit de aansprakelijkheidsbeperking wordt de noodzaak afgeleid dat ook de Staat een deel van de schade voor haar rekening zou nemen ${ }^{501}$. Voor de meeste landen van het NEA-regime werd deze overheidstussenkomst ingevoerd in het Aanvullend Verdrag van Brussel van 1963. Het Aanvullend Verdrag van Brussel zou tot stand zijn gekomen onder druk van de Amerikaanse leveranciers die de beperkte aansprakelijkheid onder het Verdrag van Parijs dermate laag vonden, dat zij steeds vreesden te worden aansprakelijk gesteld niettegenstaande het principe van de kanalisatie van aansprakelijkheid ${ }^{5 i 2}$.

Op basis van artikel 3 van het Aanvullend Verdrag, zijn de Verdragsluitende Staten verplicht om ervoor zorg te dragen dat de schade uit een kernongeval tot een bedrag van 300 miljoen BTR of 429,31 miljoen euro (17,3 miljard BEF of 946 miljoen NLG) per kernongeval wordt vergoed ${ }^{503}$. Dit bedrag bestaat uit verschillende schijven:

- de eerste schijf van de aansprakelijkheid van de exploitant van tenminste 5 miljoen BTR (7, I5 miljoen euro);

Cigoj, S., "Intemational Regulation of Civil Liability for Nuclear Risk", o.c., 837; Picard, M., "The Convention on third party liability in the field of nuclear energy", Journal de Droit International, 1962, 359; Piérard, J.P., "Responsabilité civile. Energie atomique et droit comparén", l.c., 361.

Artikel 7, b van het Verdrag van Parijs luidt: "The maximum liability of the operator in respect of damage caused by a nuclear incident shall be $15 \operatorname{SDR}(\ldots)^{\prime \prime}$.

In $\$ 4.1 .5$ wordt de vraag beantwoord of de exploitant zijn aansprakelijkheid moet dekken per kernongeval, dan wel per kerninstallatie.

Piérard, J.P., "Responsabilité civile. Energie atomique et droit comparé", l.c., 113.

Doeker, G. en Gehring, T., "Private or International Liability for Transnational Environmental Damage - the precedent of conventional liability regimes", o.c., 10.

Benadrukt dient te worden dat de waarde van de verschillende beschikbare bedragen kan verschillen van dag tot dag. De juiste waarde van de BTR kan worden teruggevonden op de website van het Internationaal Muntfonds. Bij een kemongeval zal de waarde van de BTR worden genomen van de dag van het ongeval (artikel 3, g van het Aanvullend Verdrag van Brussel). 
- de tweede schijf bestaande uit de bijdragen van de installatiestaat, voor een bedrag van maximaal 170 miljoen BTR (243,27 miljoen euro) - of het verschil tussen 175 miljoen BTR en het bedrag, waarvoor de exploitant aansprakelijk is, maar dat hoger is dan (of gelijk aan) de cerste schijf;

- de derde schijf bestaande uit een solidaire bijdrage van de verschillende leden van het Aanvullend Verdrag van Brussel ten belope van 125 miljoen BTR $\left(178,88\right.$ miljoen euro) ${ }^{504}$.

Uit artikel 3 van het Aanvullend Verdrag van Brussel blijkt onmiskenbaar de plicht in hoofde van de Verdragsluitende Staten om te voorzien in een totaal beschikbaar bedrag per kernongeval van 429,31 miljoen euro. De Verdragspartijen beschikken evenwel over een zekere vrijheid om dit bedrag samen te stellen. De plicht van de Partijen strekt er enkel toe om ervoor te zorgen een bedrag varr $4.29,31$ miljoen euro beschikbaar is.

In zekere zin is de tussenkomst in de derde schijf bijzonder, met name ten aanzien van de andere landen dan het land waar het kernongeval heeft plaats gevonden. De verschillende Verdragsluitende Staten zijn ertoe gehouden om openbare middelen ter beschikking te stellen, terwijl zij de werking van de buitenlandse installaties niet hebben toegestaan en zij evenmin de bevoegdheid hebben om de installatie aan bepaalde normen en controles te onderwerpen ${ }^{505}$.

Een bijzondere vraag in verband met de toepassing van de verschillende schijven zoals voorzien in het Aanvullend Verdrag van Brussel, betreft de hypothese waarin de wetgeving van een land zou voorzien in een aanzienlijke tweede schijf waardoor deze tweede schijf meer zou bedragen dan 175 miljoen BTR. De vraag rijst of in deze hypothese de Verdragsluitende Staten nog gehouden blijven om tussen komen, dan wel of de verplichting van de Verdragsluitende Staten in de derde schijf sowieso slechts geldt na uitputting van de tweede schijf, zijnde de tussenkomst van de installatiestaat.

Een aanbeveling van de Raad van de OESO geeft een antwoord op deze vraag. Volgens deze aanbeveling kunnen de verschillende Verdragsluitende Staten een verklaring afleggen op basis waarvan zij er zich toe verbinden om hun bijdrage in de derde schijf ter beschikking te stellen indien de aansprakelijkheidsverzekering van de exploitant of een andere financiële zekerheid meer bedraagt dan 175 miljoen BTR $^{506}$. De landen die een dergelijke verklaring hebben afgelegd - waaronder België en Nederland - kunnen dus niet weigeren om hun bijdrage te leveren in de derde schijf, indien in de eerste en/of tweede schijf reeds aanzienlijke bedragen beschikbaar zijn.

Op welke wijze de beperking van de aansprakelijkheid van de exploitant van een kerninstallatie is ingeschreven in de Belgische en de Nederlandse nucleaire aansprakelijkheidswet, wordt in de paragrafen 3.1 .2 en 3.1 .3 besproken.

\subsubsection{Volgens de Belgische wet van 22 juli 1985}

Aangezien de wijzigingen die aan de Belgische nucleaire aansprakelijkheidswet van 22 juli 1985 werden aangebracht door de wet van 11 juli 2000 in belangrijke mate betrekking hebben op het bedrag waarvoor de exploitant aansprakelijk is, wordt eerst onderzocht wat de bepalingen waren

\footnotetext{
504

De precieze berekening van de bedragen die elke Staat zal moeten bijdragen, is bepaald in een verdeelsleutel. Cfr. supra, \$2.1.2.1 van hoofdstuk 2 . 
van de oorspronkelijke wet $(\S 3.1 .2 .1)$ en vervolgens welke de impact is van de wetswijziging (\$3.1.2.2).

\subsubsection{De aansprakelijkheidsbeperking in de oorspronkelijke wet van 22 juli 1985}

De Belgische wet van 22 juli 1985 heeft de aansprakelijkheid van de exploitant gebracht op 4 miljard $\mathrm{BEF}^{507}$. Het oorspronkelijke ontwerp van de wet van 1985 stelde de exploitant aansprakelijk tot een bedrag van 3 miljard BEF. Als tweede schijf zoals voorzien in het Aanvullend Verdrag van Brussel, zou daarboven de Staat 6 miljard BEF voor haar rekening nemen. De Regering had zich op drie criteria gebaseerd om het bedrag van drie miljard te verantwoorden. Ten eerste een vergelijking op internationaal vlak, ten tweede de beschouwing dat de toenmalige limiet van 1 miljard BEF absoluut onvoldoende was en ten derde de mogelijkheden van de verzekeringsmarkt $^{508}$.

Een van de meest gehoorde kritieken tijdens bespreking van dit artikel, was de wanverhouding tussen de schadevergoedingsplicht van de exploitant en die van de Staat ${ }^{50 ?}$. Meerdere commissieleden achtten het billijker dat een $50-50$ verhouding in acht zou worden genomen ${ }^{510}$, waarop de Minister antwoordde dat een stijging van ecn half miljard in 1966 tot 4 miljard in 1985 reeds buitengewoon was ${ }^{\text {s! }}$.

Op het regeringsvoorstel werden vier amendementen ingediend die ertoe strekten het bedrag waarvoor de exploitant aansprakelijk was, te verhogen. Deze amendementen gingen ervan uit dat de Staat cen te zware last op zich nam en stelden cen aansprakelijkheidsbedrag voorop variërend van 4,5 tot 9,1 miljard $\mathrm{BEF}^{512}$. Vooral opmerkelijk was het derde amendement dat de cxploitant onbeperkt aansprakelijk wilde stellen voor de schade veroorzaakt door een kernongeval, met de verplichting een verzekering te sluiten voor een minimumbedrag ${ }^{513}$.

Om de bijdrage van de Staat te kunnen dekken, werd tot twee maal toe een voorstel ingediend om een Fonds op te richten waaruit de Staat de nodige financiële middelen zou halen om haar verplichtingen na te komen. Het eerste voorstel was vrij vaag en bepaalde enkel dat de Staat een taks zou heffen waarvan de opbrengsten zouden gestort worden in een nog op te richten Fonds ${ }^{514}$. Het was echter niet duidelijk waarop deze taksen gebaseerd zouden worden. Het tweede voorstcl was concreter. Het beoogde de oprichting van een Interventiefonds door een heffing op elke Kwh geproduceerd in de kerncentrales. Indien bijvoorbeeld de heffing één centiem/Kwh zou bedragen, zou de jaarlijkse opbrengst van die heffing ongeveer 230 miljoen BEF bedragen ${ }^{515}$. De heffingen zouden ecn einde nemen op het tijdstip dat het Fonds de waarde van de bijdrage van de Staat zou

\footnotetext{
507 Op basis van de wet van 18 juli 1966 bedroeg de aansprakelijkheid van de exploitant van 500 miljoen $\mathrm{BEF}$. Bij KB van 13 mei 1980 werd dat bedrag verhoogd tot 1 miljard BEF.

sil Parlementaire Stukken, Senaat, GJ/983-1984,593/3, 37

Volgens de Minister is het immers niet mogelijk zich integraal tegen een kemramp te verzekeren (Parlementaire Stukken, Senaat, GZ/1983-1984, 593/3, 37).

Parlementaire Stukken, Senaat, GZ/1983-1984, 593/3, 35.

Dit zou de exploitant er moeten toc dwingen zeer werkzaam te zijn en alle mogelijke voorzorgen te nemen, dus de veiligheid van de bevolking beter te waarborgen (Parlementaire Stukken, Senaat, GZ/1983-1984, 593/3, 36). 
bereiken. Beide voorstelien werden afgevoerd omdat, volgens antwoord van de minister van Economische Zaken, geen belasting mag worden ingevoerd bij wege van delegatie aan de uitvoerende macht en omdat het voorstel in strijd zou zijn met het opzet van het ontwerp ${ }^{516}$. De minister gaf hierbij aan "dat er al fondsen genoeg zijn"

Het wetsvoorstel dat in België de aansprakelijkheid beperkte, werd onder meer onder vuur genomen omdat een dergelijke beperking van de aansprakelijkheid de concurrentie zou vervalsen. Bovendien, zo werd gesteld, was in vergelijking met de reële kostprijs van een kemongeval het beschikbare schadevergoedingsbedrag dermate klein "dat men eerder kan spreken van een aansprakelijkheidsvrijstelling dan van een aansprakelijkheidsbegrenzing"s18.

In het Parlement verdedigde de Minister van Economische Zaken de beperking van de aansprakelijkheid als volgt. Ten eerste verwees hij uitdrukkelijk naar een brief van SYBAN ${ }^{519}$ waarin wordt gesteld dat het maximum te verzekeren bedrag 3 miljard BEF bedraagt. Nochtans had SYBAN blijkbaar eerder verklaard in staat te zijn om een bedrag van 6 miljard te verzekeren ${ }^{520}$; later zou SYBAN zelfs niet meer akkoord zijn gegaan met een bedrag van 3 miljard ${ }^{521}$. Ten tweede wees hij op de mogelijkheid voorzien bij artikel 7, lid 2 van de wet dat aan de Koning de toelating geeft het aansprakelijkheidsbedrag te verhogen of te verlagen. En bovendien stelde hij dat de stap van 500 miljoen over 1 miljard naar 4 miljard BEF reeds bijzonder groot was ${ }^{522}$. Vooral het eerste argument leidde tot aanzienlijke discussies in het parlement; hierbij werd geoordeeld dat de verzekeringsmaatschappijen onder één hoedje zouden spelen met de elektriciteitsmaatschappijen ${ }^{523}$.

Uiteindelijk werd de aansprakelijkheid van de exploitant in artikel 7 vastgelegd op 4 miljard BEF. Voor de schade die hoger was dan dit bedrag, dienen de openbare middelen van de tweede en derde schijf van het Aanvullend Verdrag van Brussel worden ter beschikking gesteld (artikel 19 van de wet). De verschillende vergoedingsplafonds zoals voorgeschreven in de Belgische wet werden dus als volgt vastgelegd:

- eerste schijf ten laste van de exploitant: 4 miljard BEF (99,1 miljoen euro);

- tweede schijf van ongeveer 6,1 miljard $\operatorname{BEF}$ (151,35 miljoen euro) ten laste van de Belgische Staat;

- derde schijf van ongeveer 7,2 miljard (178,88 miljoen euro) ten laste de Verdragsluitende Staten.

Het totale beschikbare bedrag bij schade uit een kernongeval in België bedroeg dus, op basis van de oorspronkelijke wet van 22 juli 1985, ongeveer 17,3 miljard BEF (429,31 miljoen euro).

Het bedrag van 4 miljard BEF kan bij ministerieel besluit worden verhoogd of verlaagd "fen einde dit bedrag op een vast peil te handhaven of met inachtneming van het vermogen en de aard van de kerninstallatie, van de omvang van het vervoer of van iedere omstandigheid die de waarde kan beïnvloeden" ${ }^{1524}$. In de Memorie van Toelichting worden als redenen van een aanpassing van het

316 Parlementaire Stukken, Senaat, GZ/1983-1984, 593/3, 67

Parlementaire Handelingen, Senaat, Vergadering van 23 oktober 1984, 127.

Parlementaire Handelingen, Senaat, Vergadering van 23 oktober 1984, 106.

Synđicat Belge đes Assurances Nucléaires of de Belgische nucleaire verzekeringspool; cfr. infra, in $\S 3$ van hoofdstuk 6.

Parlementaire Sickken, Senaat, GZ/1984-1985, 593/3, 64.

Parlementaire Handelingen, Senaat, Vergadering van 23 oktober 1984, 112 en 116.

Parlementaire Handelingen, Senaat, Vergadering van 23 oktober $1984,116$.

Parlementaire Handelingen, Kamer, vergadering van 3 juli 1985, 3082.

Artikel $7,2^{\circ}$ lid van de wet van 22 juli 1985. Indien het bedrag wordt verlaagd, kan het evenwel nooit minder bedragen dan de minimumlimieten zoals neergelegd in het Verdrag van Parijs. 
bedrag onder meer aangegeven de aanpassing aan het inflatieritme, de dekkingsmogelijkheid die aan redelijke voorwaarden op de verzekeringsmarkt kan worden gevonden en de noodzaak om de bijdrage van de Staat en deze van de exploitant met elkaar in evenwicht te brengen ${ }^{525}$. Van deze mogelijkheid werd echter geen gebruik gemaakt. Nochtans had de Raad van State in haar advies reeds gewezen op de "feitelijke wanverhouding tussen de vergoedingsplicht van de exploitant en deze van de Staat" ${ }^{\prime 26}$.

Minder dan een jaar na het totstandkomen van deze wet, vond het kernongeval van Tsjernobyl plaats. In de nasleep hiervan werden enkele wetsvoorstellen ingediend die de positie van slachtoffers aanzienlijk wensten te verbeteren.

Een voorstel dat vrij snel na het ongeval tot stand kwam, voorzag in de invocring, naar Duits en Zwitsers model, van een onbeperkte aansprakelijkheid van de exploitant en in een verzekeringsplicht tot 500 miljard $\mathrm{BEF}^{527}$ (12,4 miljard euro). Op basis van ecn in 1988 ingediend voorstel bleef de aansprakelijkheid van de exploitant beperkt, maar werd het bedrag meer dan verdubbeld $^{528}$. Tegelijk werd voorzien in een aanvulling van het bestaande drietrapssysteem, door de invoering van twee bijkomende trappen. Deze trappen voorzagen in een verregaande tussenkomst van de Belgische Staat ${ }^{529}$, met dien verstande dat de exploitant hicrvoor een premie zou betalen aan een op te richten Openbaar Nucleair Rampenfonds en dat de Staat uit de middelen van dit Fonds zou kunnen putten. Tegelijk zou de Staat een bijzonder regresrecht kunnen instellen, niet alleen tegen de aansprakelijke exploitant, maar eveneens tegen alle erkende exploitanten in België.

Geen van beide "post-Tsjernobyl" voorstellen is wet geworden. De exacte reden waarom deze voorstellen het, zelfs eventueel onder gewijzigde vorm, nict hebben gehaald, is niet meteen duidelijk. Zonder twijfel was het eerste voorstel veel ambitieuzer dan het twcede, vooral omdat het voorstel De Batselier leidde tot een quasi onbeperkte Staatstussenkomst. Uiteindelijk zou de wet van 22 juli 1985 pas in 2000 worden gewijzigd.

\subsubsection{De aansprakelijkheidsbeperking volgens de gewijzigde wet.}

Bij wet van 11 juli 2000 werd het bedrag waarvoor de exploitant aansprakelijkheid is, verhoogd ${ }^{530}$. De aansprakelijkheid werd opgetrokken van 4 miljard BEF naar 12 miljard BEF $(297,4$ miljoen euro). Een dergelijke verhoging werd noodzakelijk geacht "als men de beperking ervan

Memorie van Toelichting, Parlementaire Stukken, Senaat, GZ/1983-1984, 593/1, 8.

Advies Raad van State, Parlementaire Stukken, Senaat, GZ/1983-1984, 593/I, 42.

Voorstel van wet tot wijziging van de wet van 22 juli 1985 betreffende de wettelijke aansprakelijkheid op het gebied van kemenergie, Parlementaire Stukken, GZ/1986-1987, 402/1, 4.

Dit wetsvoorstel, ingediend door dhr. De Batselier, wilde voorkomen dat de indirecte kosten verbonden aan het gebruik van kemenergie door de privé-exploitant worden afgewenteld op de gemecnschap. Het werd tegen clke economische logica geacht om één encrgiesector kunstmatig te bevourdelen cn competitief te houden door een aantal kosten af te wentelen op de gemeenschap (Parlementaire Stukken, Kamer, BZ/1987-1988, 416/4, 3-4).

Deze aansprakelijkheid ging vrij ver: in de vierde schijf was de Staat aansprakelijk voor con bedrag tussen 16 en 50 miljard BEF; boven dit laatste bedrag zou de Staat aansprakelijk zijn zonder maximumgrens.

Tegelijk wordt, net zoals in het oorspronkelijke artikel 7, ook onder de gewijzigde wet aan de Koning de mogelijkheid gegeven om het bedrag van de aansprakclijkheid de verhogen of te verlagen. Het nieuwe artikel 7 verschilt van het oude artikel 7 ondat het icts concreter is over de omstandighcden waarbij een dergelijke wijziging mogelijk is. Zic hicrover Vanden Borre, T., "Recente ontwikkelingen in het nucleaire aansprakelijkheidsrecht: innovatie of renovatie?", o.c., 47 e.v 
wil blijven rechtvaardigen door de objectieve en exclusieve aansprakelijkheid van de exploj$\operatorname{tant} t^{n 3 i}$. Hiermee heeft de Belgische wetgever uitvoering gegeven aan de reeds vermelde aanbeveling van de Bestuurscommissie van de NEA om te voorzien in een aansprakelijkheidsgrens van minstens 150 miljoen BTR of 214,65 miljoen euro. Het uiteindelijke bedrag waarvoor de exploitant aansprakelijk is op basis van de gewijzigde Belgische wet van 22 juli 1985, is zelfs hoger dan deze aanbeveling. Volgens de Memorie van Toelichting werd dit bedrag vastgelegd overeenkomstig de capaciteit van de verzekeringsmarkt ${ }^{532}$.

Tegelijk werd de tweede schijf zoals voorzien in het Aanvullend Verdrag van Brussel - de tussenkomst van i.c. de Belgische Staat - afgeschaft. Deze schijf werd opgeheven omdat de regering van oordeel was dat de Staat niet diende bij te springen voor vergoeding van schade ten gevolge van een privé-activiteit ${ }^{533}$. Volgens de Memorie van Toelichting worden door de wetswijziging ruimere onderhandelingsmarges geboden aan exploitanten en verzekeraars ${ }^{534}$. Het gevolg van de wetswijziging is dus dat op basis van het Belgische nucleaire aansprakelijkheidsrecht de totale schadevergoeding nog uit twee schijven bestaat: een eerste schijf van 12 miljard BEF, zijnde de aansprakelijkheidsverzekering van de exploitant van de keminstallatie en de tweede schijf van 6,5 miljard BEF zijnde de solidaire bijdrage van 125 miljoen BTR van de verschillende Verdragspartijen van het Aanvullend Verdrag van Brussel. Sinds het inwerking treden van deze nieuwe wet, op 1 januari 2001, bedraagt het totale beschikbare schadevergoedingsbedrag bijgevolg 18,5 miljard BEF (458,6 miljoen euro) ${ }^{535}$. In absolute cijfers impliceert dit dat de wetswijziging heeft geleid tot een verhoging van het totale beschikbare schadevergoedingsbedrag van 47 miljoen euro of 1,9 miljard BEF.

Toch is het vreemd om vast te stellen dat voor de wijziging van de aansprakelijkheidslimiet de toevlucht werd genomen tot een wetswijziging ${ }^{536}$. Artikel 7 van de oorspronkelijke wet varı 22 juli 1985 bepaalde reeds dat de Koning bij een in ministerraad overlegd besluit, het aansprakelijkheidsbedrag kon verhogen "teneinde dit bedrag op een vast peil te handhaven of met inachtneming van het vermogen en de aard van de kerninstallatie, van de omvang van het vervoer of van iedere andere omstandigheid die de waarde kan beïnvloeden". De vraag rijst of deze bepaling toelaat om het bedrag van de aansprakelijkheid op te trekken tot het bedrag dat op de verzekeringsmarkt beschikbaar is.

Uit een louter tekstuele analyse blijkt dat de omstandigheden die aanleiding kunnen geven tot het wijzigen van het aansprakelijkheidsbedrag, vrij ruim kunnen worden geïnterpreteerd: dit blijkt met name uit de bepaling "of iedere andere omstandigheid ...". In de Memorie van Toelichting van de oorspronkelijke wet is overigens aangegeven dat de bevoegdheid van artikel 7 ook kan worden aangewend ter zake van de dekkingsmogelijkheid die aan redelijke voorwaarden op de verzekeringsmarkt kan worden verkregen ${ }^{537}$. Door de nieuwe wet is artikel 7 lichtjes gewijzigd, in die zin dat werd toegevoegd dat het aansprakelijkheidsbedrag kan worden gewijzigd rekening

Verslag. 24 mei 2000, Parlementaire Stukken, GZ/1999-2000, 560/002, 3.

Memorie van Toelichting. Parlementaire Stukken, GZ/1999-2000, 560/001, 3-4.

Verslag, 24 mei 2000, Parlementaire Stukken, GZ/1999-2000, 560/002, 6. Zie ook de parlementaire bespreking: Parlementaire Handelingen, Kamer, 8 juni 2000.

Memorie van Toelichting, Parlementaire Stukken, GZ/1999-2000, 560/001, 4.

In de voorbereidende werken van de wetsuvijziging komen andere bedragen voor, maar dit heeft te maken met het feit dat voor de huidige analyse werd uitgegaan van een andere omrekeningskoers van de BTR. In de voorbereidende werken wordt een omrekeningskoers gehanteerd van I BTR = 1,293 euro $=52,16$ BEF (Verslag, 24 mei 2000, Parlementaire Stukken, GZ/1999-2000, 560/002, 4).

Vanden Borre, T., "Recente ontwikkelingen in het nucleaire aansprakelijkheidsrecht: innovatie of renovatie?", o.c., 47 .

Memorie van Toelichting, Parlementaire Stukken, Senaat, GZ/1984-1985, 593/1, 8. 
houdend met "de verplichtingen die voor België voortvloeien uit de internationale overeenkomsten en verdragen en uit aanbevelingen van de krachtens het Verdrag van Parijs bevoegde instellingen". Deze wijziging voegt weinig toe aan het oorspronkelijke artikel 7; het bedrag van de aansprakelijkheid kon dus ook worden gewijzigd op basis van de bevoegdheidsdelegatie van artikel 7, tweede lid van de oorspronkelijke wet van 22 juli 1985 .

De wetswijziging lijkt vooral om een andere reden noodzakelijk te zijn geweest: niet alleen werd de aansprakelijkheidslimiet opgetrokken, maar tegelijk werd artikel 4 van de wet vervangen. Oorspronkelijk bevatte dit artikel een bevoegdheidsdelegatie naar de Koning. Deze kon verscheidene kerninstallaties die zich op één site bevonden en die door een enkele exploitant worden uitgebaat, als één kerninstallatie beschouwen. Maar deze bevoegdheidsdelegatie was tcgelijk afgelijnd, in die zin dat indien de Koning van deze delegatie zou gebruik maken, het bedrag van de verzekering gelijk diende te zijn aan de som van de bedragen voor iedere kerninstallatie afzonderlijk.

Hoewel de Koning nooit van deze bevoegdheid heeft gebruik gemaakt, werd in de praktijk Electrabel er inderdaad toe verplicht om een dekking te nemen per kcrninstallatie. Concreet betckent dit dat de zeven reactoren die zich op twee reactorenparken bevinden (namelijk 4 reactoren in Doel en 3 in Tihange), elk voor 4 miljard BEF waren verzekerd. Bij de voorbereiding van de wijziging van de aansprakelijkheidslimiet in 2000 , bleek Electrabel niet akkoord te kunnen gaan met een verhoging van de limiet per kerninstallatie. Het stemde in met een verhoging van de limiet, op voorwaarde dat werd overgestapt naar een systeem van een verzekering per kerninstallatie naar een systeem van verzekering per nucleaire site. De regering is hierop ingegaan: op basis van het nieuwe artikel 4 van wet worden meerdere kerninstallaties die zich op eenzelfde vestigingsplaats bevinden en die door dezelfde exploitant worden uitgebaat, automatisch beschouwd als één kerninstallatie.

Er was dus een wetswijziging vereist om aan de Belgische exploitant te garanderen dat hij slechts een verzekeringsdekking diende te nemen voor de twee nucleaire sites en niet voor de zeven kerninstallaties $^{538}$. De verdrievoudiging van de aansprakelijkheidslimiet van 4 naar 12 miljard BEF moet dus in dit licht te worden begrepen. Indien per saldo wordt gerekend, dan kan worden geconcludeerd dat door de wetswijziging het verzekerde bedrag is gedaald van 28 miljard (7 reactoren aan 4 miljard dekking elk) naar 24 miljard BEF (2 reactorenparken aan 12 miljard dekking elk).

Op zich kan worden aanvaard dat het zinvol is om een reactorpark te verzekeren omdat ervan kan worden uitgegaan dat zodra zich een kernongeval voordoet in één reactor, ook de andere reactoren van dezelfde site zullen worden stilgelegd, waardoor er geen risico bestaat dat zich in deze andere reactoren een tweede kernongeval zou voordoen. Anderzijds is het twijfelachtig of de nieuwe wet leidt tot een reële verzwaring van de lasten in hoofde van Electrabel en of is gebruik gemaakt van de maximale verzekeringscapaciteiten van SYBAN.

Sinds 1998 wordt de eigenschadedekking van de Belgische exploitant - ten belope van 50 miljard BEF per site - namelijk niet meer verzekerd via SYBAN, maar via de Amerikaanse captive van de exploitanten (Nuclear Electric Insurance Limited, kortweg NEIL) ${ }^{539}$. Aangenomen mag worden dat SYBAN hierdoor een aanzienlijke bijkomende capaciteit ter beschikking kreeg die kon

Zie hierover Vanden Borre, T., "Recente ontwikkelingen in het nucleaire aansprakelijkheidsrecht: innovatic of renovatie?", o.c., 48 .

Over de term captive, zie hoofdstuk 11 ; over de Amerikaanse captive, zie hoofdstuk 13. 
worden aangewend ter dekking van de aansprakelijkheid van de exploitant. Indien zuiver cijfermatig wordt gerekend dan zou SYBAN een capaciteit ter beschikking kunnen stellen van minstens 100 miljard BEF over de twee sites. Het is uiteraard gevaarlijk om uitsluitend op basis van deze cijfermatige analyse conclusies te trekken. Het risico om schade te berokkenen aan derden wordt anders geèvalueerd dan de eigenschade van de exploitant. In ieder geval lijkt het aannemelijk om ervan uit te gaan dat het huidige bedrag waarvoor de exploitant op basis van de Belgische nucleaire aansprakelijkheidswet wordt aansprakelijk gesteld, niet correspondeert met de werkelijke capaciteit van $\mathrm{SYBAN}^{540}$. De voorbereidende werken van de wetswijziging bieden weinig transparantie over de mate waarin werd getracht om de werkelijke capaciteit van SYBAN te achterhalen. Dit doet vermoeden dat andere belangen dan deze van het slachtoffer een rol hebben gespeeld bij deze wetswijziging ${ }^{541}$.

Volledigheidshalve wordt erop gewezen dat de Belgische Staat is verplicht om, tot maximaal het bedrag waarvoor de exploitant aansprakelijk is, de schade te vergoeden die niet is vergoed door middel van verzekering of andere financiële zekerheid ${ }^{542}$. Het betreft een soort garantstelling vanwege de Staat.

\subsubsection{Volgens de Nederlandse WAKO}

De aansprakelijkheidslimiet zoals vastgelegd door artikel $5,1^{\circ}$ van de WAKO bedraagt momenteel 750 miljoen NLG (340,36 miljoen euro). Het bedrag wasrvoor de exploitant op basis van de WAKO aansprakelijk is, is in twintig jaar geëvolueerd van 100 miljoen NLG naar 750 miljoen $\mathrm{NLG}^{543}$. Volgens het tweede lid van artikel 5 kan dit maximumbedrag bij algemene maatregel van bestuur, en rekening houdend met de mogelijkheden tot het verkrijgen van dekking, worden. gewijzigd. Van deze mogelijkheid werd dus reeds, sinds de nieuwe WAKO van 1991, tweemaal gebruik gemaakt. Een onbeperkte aansprakelijkheid naar Duits voorbeeld werd niet haalbaar geacht wegens strijdigheid met het Verdrag van Parijs ${ }^{544} 545$.

Daar bovenop stelt de Nederlandse Staat, overeenkomstig artikel $18 \mathrm{WAKO}$, een bedrag van 5 miljard gulden ( 2,3 miljard euro) ter beschikking van de slachtoffers van een kemongeval. Deze bepaling is zonder twijfel een van de meest in het oog springende bepalingen van de WAKO en

Vanden Borre, $T$., "Recente ontwikkelingen in het nucleaire aansprakelijkheidsrecht: innovatie of renovatie?", o.c., 48.

54i Eerder reeds was aangetoond dat de oorspronkelijke wet van 22 juli 1985 tegemoet $k$ wam aan de cisefi van de industrie. Zie met name Faure, M. en Van den Bergh, R., "Liability for Nuclear Accidenis in Belgium from an Interest Group Perspective", International Review of Law and Economics, 1990, vol. $10,24 i-254$.

Artikel 22 van de wet van 22 juli 1985. Deze bepaling was reeds opgenomen in de oorspronkelijke wet.

De oorspronkelijke WAKO van 1979 voorzag in een bedrag van 100 miljoen gulden. Dat bedrag werd in 1984 verhoogd tot 200 miljoen en in 1987 tot 400 miljoen gulden. Zie hierover Van Maanen, G.E., "Wettelijke aansprakelijkheid voor kemcentrales", Nederlands Juristenblad, 1981, 286 e.v. De WAKO van 1991 heeft het bedrag opgetrokken tot 500 miljoen gulden. Bij Besluit van 14 december 1993 werd het bedrag opgetrokken tot 625 miljoen gulden; bij Besluit van 14 november 1997 tenslotte werd de aansprakelijkheid, met ingang van 1 januari 1998, opgetrokken tot 750 miljoen NLG (Stb., 1997, 577). Tweede Kamer, Vergaderjaar 1988-1989, 20025, nr. 8, 2.

s45 De reactie op de beperking van de aansprakelijkheid was in het Nederlandse Parlement bij wijlen bijzonder seherp: "Als de in geld om te rekenen schade als gevolg van een kernongeval zo groot is dat deze noch door de exploitant noch door een verzekering is af te dekken, dan is kernenergie eigenlijk niet exploitabel" (Tweede Kamer, 23 april 1991, 72-4054). 
vormt de reactie van de Nederlandse wetgever op het ongeval in Tsjernobyl ${ }^{546}$. Het aanvankelijke voorstel ging uit van een bedrag van 10 miljard gulden. Het gekozen bedrag van 5 miljard dient te worden beschouwd als een compromis tussen het door het initiatiefvoorstel genoemde bedrag on het regeringsvoorstel dat een Staatstussenkomst van 2 miljard vooropstelde ${ }^{547}$. Hoewel het bedrag van 5 miljard gulden hoog is in vergelijking met de andere leden van het Verdrag van Parijs, vond de oppositie dit bedrag veel te laag. Gesteld werd dat onderzoek uitwees dat een kernongeval kon leiden tot een schade van 30 miljard gulden en meer; zelfs de 10 miljard van het oorspronkelijke voorstel werd veel te laag geacht ${ }^{548}$. Hoe dan ook is de bijdrage van de Nederlandse Staat in het totale schadevergoedingsbedrag bijzonder hoog in vergelijking met de overheidstussenkomst in andere landen.

Het is dan ook niet verwonderlijk dat artikel 18 lid 4 de wederkerigheidsverciste ${ }^{549}$ invoert. Deze bepaling heeft tijdens de parlementaire voorbereiding aanleiding gegeven tot nadere toelichting van de minister van Financiën, met name betreffende de vraag wat er gebeurt indien schade wordt geleden in Nederland door een kernongeval in een Duitse kerninstallatic en vice versa ${ }^{550}$

Indien in Nederland schade wordt geleden door een in Duitsland gelegen kerninstallatie, dan zal de gehele schade - dus ook de in Nederland geleden schade - worden gedekt tot een bedrag van 1 miljard DM (het totale schadevergoedingsbedrag in Duitsland). Alle schade die hoger ligt dan dat bedrag, is niet gedekt. Indien een ongeval in een in Nederland liggende kerninstallatie schade veroorzaakt in Duitsland, zal de in Duitsland geleden schade door de reciprociteit in de WAKO slechts worden vergoed tot een bedrag van maximaal 1 miljard DM; voor de in Nederland geleden schade zal een bedrag van 5 miljard NLG ter beschikking staan.

Artikel 19 van de WAKO schrijft bovendien voor dat de Nederlandse Staat voor het ter beschikking stellen van het bedrag van 5 miljard gulden, aan de exploitant een vergoeding kan vragen. De Nederlandse Staat kan dus een premie vragen voor de garantstelling ${ }^{551}$. In de oorspronkelijke Belgische wet van 22 juli 1985 ontbrak een dergelijke bepaling. Door de afschaffing van de tweede schijf van de Staatstussenkomst bij wet van 11 juli 2000 is een dergelijke vergoeding in België niet meer relevant, tenminste voor wat betreft de ter beschikking stelling van overheidsgeld in de tweede schijf.

In vergelijking met de beschikbare bedragen in andere Europese landen, is het totale beschikbare schadevergoedingsbedrag in Nederland zonder enige twijfel zeer hoog, met name 5,75 miljard

346 In de literatuur kwam een eerste pleidooi om de wetgeving dienaangaande grondig aan te passen, er overigens snel (Van Maanen, G., "Pleidooi voor de verbetering van de rechtspositie van slachtoffers van kemongevallen", Nederlands Juristenblad, 1986, 1342-I345); op 8 december 1987 werd door Zijlstra een wetsvoorstel ingediend om de WAKO ingrijpend te wijzigen. Deze wijziging werd slechts 4 jaar later doorgevoerd.

Van Maanen, G., "De civielrechtelijke aansprakelijkheid voor kemongevallen naar Nederiands recht", in Faure, M. (red.), "Aansprakelijkheid voor het nucleaire risico", l.c., 24; Sluijter, J., "Aansprakelijkheid bij kernongevallen", Recht en Kritiek, 1988, 196-215. In het parlement werd het bedrag van 5 miljard verdedigd omdat dit zowel in het belang van de slachtoffers als in het belang van de "maatschappelijke constellatie" zou zijn (Tweede Kamer, 23 april 1991, 72-4048).

Zie de rede van de heer Tommel: "Meer principieel is de vraag, waarom de regering cen maatschappelijke activiteit waarvan de ongevallen niet te verzekeren zijn en waarvoor de overheid niet volledig garant wil staan, acceptabel vindt" (Tweede Kamer, 23 april 1991, 72-4050).

Cfr. supra, \$ 1.4 en $\$ 3.3$ van hoofdstuk 3.

Brief van de Minister van Financiën, Tweede Kamer, vergaderjaar 1990-1991, 21 917, nr. 6, 1.

Dit werd uitdrukkelijk bevestigd in de parlementaire bespreking (Tweede Kamer, 23 april 1991, 72 4047). 
NLG (2,61 miljard euro). Ook in Nederland blijft de beperking van aansprakelijkheid omstreden, al wordt aangegeven dat een verzekerde gelimiteerde vordering beter is dan een ongelimiteerde vordering die niet is gedekt ${ }^{552}$.

De drie schijven zoals voorzien in het Aanvullend Verdrag van Brussel, worden in Nederland bijgevolg als volgt samengesteld:

- eerste schijf ten laste van de exploitant: 750 miljoen gulden of 340,36 miljoen curo;

- tweede schijf ten laste van de Nederlandse Staat van 5 miljard gulden of 2,27 miljard euro;

- derde schijf ten laste van de verschillende verdragsluitende Staten ten belope van 394,2 miljoen NLG of 178,88 miljoen euro.

Vastgesteld dient te worden dat de Nederlandse tweede schijf aanzienlijk hoger is dan de grenzen van het Aanvullend Verdrag van Brussel, namelijk 2,27 miljard euro ten overstaan van maximaal 243,27 miljoen euro. Toch zal dit niet beletten dat de verschillende Verdragspartijen van het Aanvullend Verdrag van Brussel ertoe zullen gehouden zijn om hun bijdragen te leveren in de derde schijf, tenminste voor die landen die voortgaand op de aanbeveling van de OESO uit 1992, een verklaring in die zin hebben afgelegd ${ }^{553}$.

Bovendien moet rekening worden gehouden met de wederkerigheidsvereiste: een deel van de tussenkomst van de Nederlandse Staat zal voorbehouden blijven voor de in Nederland geleden schade. Het is bijgevolg niet makkelijk om op exacte wijze aan te geven hoeveel de totale in Nederland beschikbare schadevergoeding bedraagt. In de mate waarin andere Verdragspartijen van het Aanvullend Verdrag van Brussel geen verklaring hebben afgelegd overeenkomstig de OESO-aanbeveling, kan het zijn dat een aantal landen zal weigeren om hun bijdrage in de derde schijf te leveren; en door de wederkerigheidsvereiste zal slechts een deel van het bedrag kunnen worden toegepast voor schade die elders is geleden. Het lijkt dus voorzichtig om bij het bepalen van het totale op basis van de WAKO beschikbare schadevergoedingsbedrag niet zonder meer een optelling te maken van de sommen van de drie schijven.

\subsubsection{De beperking van het bedrag van de aansprakelijkheid naar toekomstig recht}

Eén van de belangrijkste elementen bij de wijzigingen die in 1997 werden aangebracht aan het internationale nucleaire aansprakelijkheidsrecht, betreft de verhoging van de beschikbare bedragen, c.q. het optrekken van de aansprakelijkheidsgrens van de exploitant van een kerninstallatic. Doordat de nucleaire aansprakelijkheidsverdragen nog steeds niet in werking zijn getreden, worden deze bepalingen besproken onder de noemer "toekomstig recht". Dit laat toe om niet enkel het Protocol van het Verdrag van Wenen $(\$ 3.1 .4 .1)$ en het Verdrag inzake Bijkomende Compensatie $(\$ 3.1 .4 .2)$ in de analyse te betrekken, maar eveneens de voorstellen bij de lopende revisie van het Verdrag van Parijs (§ 3.1 .4 .3$)$.

\subsubsection{Relevante bepalingen in het Protocol van het Verdrag van Wenen}

Meerdere bepalingen in het Protocol van het Verdrag van Wenen hebben betrekking op de beperking van het bedrag waarvoor de exploitant aansprakelijk is: een herziening van het bedrag waarvoor de exploitant kan worden aansprakelijk gesteld met daaraan gekoppeld de creatie van een mechanisme om geleidelijk aan hogere bedragen te genereren, een verduidelijking ten aanzien

Van Maanen, G., "De civielrechtelijke aansprakelijkheid voor kemongevallen naar Nederlands recht", in Faure, M. (red.), "Aansprakelijkheid voor het nucleaire risico", l.c., 33. 
van landen die een onbeperkte aansprakelijkheid invoeren en een bepaling die toelaat om de in het Verdrag aangegeven bedragen makkelijker te wijzigen.

Het verhogen van de aansprakelijkheid van de exploitant wordt beschouwd als een van de belangrijkste en meest ingrijpende wijzigingen van het Protocol van het Verdrag van Wenen ${ }^{5{ }^{4}}$. Uiteraard moet het optrekken van de aansprakelijkheidslimieten eveneens worden gezien in het licht van de andere wijzigingen die worden aangebracht, aangczien deze andere wijzigingen ertoe leiden dat meer slachtoffers een aanspraak zullen kunnen maken op de beschikbare bedragen.

Volgens artikel 7 van het Protocol van het Verdrag van Wenen mag de wetgeving van de installatiestaat de aansprakelijkheid van de exploitant beperken tot een bedrag dat nict lager is dan 300 miljoen BTR of 429,31 miljoen euro (17,3 miljard BEF of 946 miljoen NLG). In het oorspronkelijke Verdrag van Wenen was voorzien een aansprakelijkheidsgrens van 5 miljoen dollar. Eens het Protocol in werking zal zijn, zal deze limiet in beginsel stijgen tot 392,8 miljoen dollar, wat op zich kan worden beschouwd als een forse stijging. Een Stat mag evenwel de aansprakelijkheidsgrens beperken tot 150 miljoen BTR (214,5 miljoen euro), op voorwaarde dat tenminste tot het bedrag van 300 miljoen BTR publieke fondsen worden ter beschikking gesteld door de installatiestaat. Dit betekent dat het Protocol van het Verdrag van Wenen in beginsel een beschikbaar bedrag garandeert van 300 miljoen BTR, waarvan minstens de helft wordt bijgedragen door de exploitant van de kerninstallatie.

Op die manier wordt in het Verdrag van Wenen het principe aanvaard dat de installatiestaat een deel van de aansprakelijkheid van de exploitant voor haar rekening kan nemen ${ }^{555}$, wat een belangri.jk nieuw principe is in het IAEA-regime: het voorziet in een Staatstussenkomst, in analogie met de bepalingen van het Aanvullend Verdrag van Brussel onder het NEA-regime.

Gelet op de belangrijke stijging van deze bedragen in vergelijking met het oorspronkelijke Verdrag van Wenen ${ }^{556}$, laat het Protocol evenwel toe om in een overgangsperiode te voor 2 ien in een lager bedrag dan de minimumlimict van 150 miljoen BTR. Gedurende cen periode van 15 jaar vanaf het inwerking treden van het Protocol van het Verdrag van Wenen - deze overgangsperiode wordt het "phasing-in mechanism" genoemd - mag de aansprakelijkheid worden vastgelegd op 100 miljoen BTR (143,1 miljoen euro of 131 miljoen dollar). Het is aan landen zelfs toegelaten om gedurende deze periode een nog lagere limiet vast te leggen, op voorwaarde dat de Staat zal instaan voor het verschil tussen de lagere limiet en de 100 miljoen BTR. Dit mechanisme werd in het leven geroepen om de toetreding van bepaalde landen - hoofdzakelijk van het voomalige Oostblok - te vergemakkelijken ${ }^{557}$. Het probleem is namelijk het verschillende veiligheidsniveau in vergelijking met de westerse kerncentrales. Verzekeraars zijn dan ook zeer weigerachtig om

Lamm, V., "Le Protocole d'amendement de la Convention de Vienne de 1963", o.c., 1998, 16.

Suransky, F., "Increased liability amounts under the 1997 Vienna Protocol and elsewhere", in Reform of Civil Nuclear Liability, NEA-OECD, Parijs, 2000, 119.

Er wordt van uitgegaan dat deze verhoging van de limiet er ook toe zal leiden dat ook milieuschade zal worden gedekt, met dien verstande dat het aan de bevoegde rechter toekomt om te bepalen in welke mate milieuschade voor vergoeding in aanmerking komt (Gomez del Campo, J., "Working Group 2 Report. Report on Environmental Nuclear Damage", in "Nuclear Inter Jura 1999", l.c., 205-206, hierin bijgestaan door Blanchard, P., "Responsibility for Environmental Damage caused by Nuclear Accidents", in "Nuclear Inter Jura 1999", l.c., 286).

Suransky, F., "Increased liability amounts under the 1997 Vienna Protocol and elsewhere", in "Reform of Civil Nuclear Liability", l.c., 120. 
dekking te verlenen aan de centrales in het voormalige Oostblok, zolang deze niet voldoen aan de westerse normen $^{558}$.

Eens het Protocol van het Verdrag van Wenen in werking treedt, zal dus een minimumbedrag van 100 miljoen BTR - dat gedeeltelijk kan bestaan uit publieke fondsen - gegarandeerd zijn ${ }^{559}$. Vanaf 15 jaar na het in werking treden zal het minimale beschikbare bedrag 300 miljoen BTR bedragen, waarvan minstens de helft ten laste zal vallen van de exploitant van de kerninstallatie; de verdragsluitende Staten hebben bijgevolg 15 jaar de tijd om het beschikbare bedrag te verdrievoudigen. Het phasing-in mechanisme is uiteraard minder voordelig voor slachtoffers van een kernongeval; bovendien dreigt hierdoor de harmonisering van de in de verschillende landen beschikbare bedragen, in het gedrang te komen ${ }^{560}$

Het spreekt voor zich dat de bedragen die uiteindelijk werden aanvaurd, het resultaat zijn van een compromis waarover jarenlang werd onderhandeld. Enerzijds was er de betrachting van landen die geen keminstallaties hebben om zo hoog mogelijke bedragen te genereren en anderzijds werd geoordecld dat ook landen met weinig keminstallatics en beperkte verzekeringsmogelijkheden dienden te worden tocgelaten tot het internationaal-rechtelijke regime ${ }^{56 !}$.

Een tweede belangrijke bepaling van het Protocol van het Verdrag van Wenen geeft aan de verdragsluitende Staten de mogelijkheid om in het interne recht een systeem van onbeperkte aansprakelijkheid in te voeren. Artikel 9 van het Protocol voegt een bepaling toe aan artikel VII van het Verdrag van Wenen op basis waarvan een land waar de exploitant onbeperkt aansprakelijk is, een beperking mag stellen aan het bedrag waarvoor de exploitant wordt verplicht om een verzekeringsdekking te nemen. Dat bedrag mag echter niet lager zijn dan 300 miljoen BTR. Een voorstel, tijdens de onderhandelingen, om voor wat betreft letselschade, een onbeperkte aansprakelijkheid in te voeren, werd niet aanvaard ${ }^{562}$.

Tenslotte is van belang dat het Protocol een procedure in het leven roept die moet toelaten om de aansprakelijkheidslimiet makkelijker te wijzigen. Volgens artikel V D van het Protocol van het Verdrag van Wenen zal een bijeenkomst van de verdragsluitende Partijen worden samengeroepen om de aansprakelijkheidslimieten te wijzigen indien één derde van de verdragsluitende Staten daarom verzoekt. Een wijziging zal worden aangenomen indien bij de stemming cen quorum wordt bereikt van tenminste de helft van de Verdragpartijen en indien het voorstel met $2 / 3$ mecrderheid wordt goedgekeurd. Een aangenomen wijziging moet echter door de Directeur Generaal van het Internationaal Atoomagentschap ter goedkeuring worden genotificcerd aan alle verdragsstaten. Het amendement zal pas zijn aanvaard indien in de daarop volgende periode van 18 maanden tenminste één derde van de verdragsstaten hun akkoord met het amendement hebben mede-

Warren, G.C., "Vienna Convention revision: a review of the exercise and the insurance implications in the provisions under discussion", Nuclear Law Bulletin, $\mathrm{n}^{\circ} 55,1995,14$.

Al wordt erop gewezen dat het basisbedrag reeds veertig keer hoger is dan het bedrag zoals voorzien in het oorspronkelijke Verdrag van Wenen (Lamm, V., "Le Protocole d'amendement de la Convention de Vienne de 1963", o.c., 17); zie ook Horbach, N.L.J.T., "Lacunae of International Nuclear Liability Agreements", in Horbach, N.L.J.T. (ed.), "Contemporary Developments in Nuclear Energy Law", I.c., 66.

Reynters, P., "Modernisation du régime de responsabilité civile pour les dommages nucléaires: Révision de la Convention de Vienne et Nouvelle Convention sur la réparation complémentaire des dommages nucléaires", o.c., 1998, vol. 3, 755 .

US Non-Paper on an Approach to Revising the Vienna Convention to attract Broad Adherence, Standing Committee on Liability for Nuclear Damage, 10th session, Wenen, 31 oktober - 4 november 1994 , SCNL/10/INF.4, 18 november 1994, 104. 
gedeeld aan de Directeur Generaal. Bovendien zal een goedgekeurd amendement pas 12 maanden na de goedkeuring in werking treden, en dan nog enkel voor die landen die het amendement hebben aanvaard. Het is niet overdreven te stellen dat de procedure om de aansprakelijkheidslimieten te verhogen zeer zwaar is ${ }^{563}$ en dat het niet zeker is of deze formule soepeler zal zijn dan een gewone "conventionele" verdragswijziging. Doordat geen enkel land kan worden verplicht om een wijziging van de limieten te aanvaarden, valt daarenboven te vrezen dat van een harmonisatie van de bedragen op termijn nog nauwelijks sprake zal zijn.

Volledigheidshalve dient te worden vermeld dat in de loop van de onderhandelingen bij de revisie van het Verdrag van Wenen, werd voorgesteld om voor wat betreft de beperking van de aansprakelijkheid van de exploitant, de zgn. "breakability clause" in te voeren. Via een dergelijke clausule, die bijvoorbeeld is terug te vinden in het CLC-Verdrag van 1969, kan in een aantal specifieke gevallen de beperking van de aansprakelijkheid worden doorbroken ${ }^{564}$. Bij de revisie van het Verdrag van Wenen werd voorgesteld om een analoge clausule in te voeren in het nucleaire aansprakelijkheidsrecht: de exploitant van de kerninstallatie zou zich niet op de beperking van de aansprakelijkheid kunnen beroepen indien hij opzettelijk de toepasselijke veiligheidsvoorschriften niet zou hebben nageleefd ${ }^{565}$. In het Standing Committee werd dit voorstel bekritiseerd omdat het de afhandeling van de vorderingen zou vertragen en compliceren ${ }^{566}$; het werd uiteindelijk niet in het Protocol opgenomen.

\subsubsection{Relevante bepalingen in het Verdrag inzake Bijkomende Compensatie}

Het Verdrag inzake Bijkomende Compensatie van 1997 garandeert de beschikbaarheid van een bedrag van 600 miljoen BTR (858,63 miljoen euro, 34,6 miljard BEF of 1,8 miljard NLG). Dit bedrag wordt bijeengebracht voor de helft door de installatiestaat en voor de andere helft door bijdragen van de verschillende Verdragsluitende Staten.

De eerste schijf van 300 miljoen BTR wordt gegarandeerd door de Installatiestaat ${ }^{567}$ - dit bedrag correspondeert met de aansprakelijkheidslimiet onder het herziene Verdrag van Wenen ${ }^{568}$. Op welke wijze dit bedrag dient te worden samengesteld, wordt in het Verdrag niet gespecificcerd: aangenomen wordt dat dit zowel kan via private verzekering, een pool van exploitanten als via een regionaal verdrag ${ }^{569}$. Op zich leidt deze bepaling niet tot de verplichting van een gegeven Staat om publieke fondsen ter beschikking te stellen; dit zal slechts het geval zijn indien de andere middelen voor het samenstellen van de 300 miljoen BTR, hebben gefaald. Aan de vereisten van

Ook in đie zin Reyners, P., "Modemisation du régime de responsabilité civile pour les dommages nucléaires: Révision de la Convention de Vienne et Nouvelle Convention sur la réparation complémentaire des dommages nucléaires", o.c., 756.

Inzake de aansprakelijkheid voor schade door olieverontrciniging op zee is de scheepseigciaar niet gerechtigd zijn aansprakelijkheid te beperken indien de schade door verontreiniging het gevolg is van zijn persoonlijk handelen of nalaten, begaan hetzij met het opzet zodanige schade te veroorzaken, hetzij roekeloos en in de wetenschap dat zodanige schade er waarschijnlijk uit zou voortvloeien. Deze bepaling werd wel gewijzigd door het Protocol van 1992; cfr. infra, hoofdstuk 12.

Lopuski, J., "Civil liability for nuclear damage: selccted questions connected with the revision of the Vienna Convention", in "Nuclear Accidents. Liabilities and Guarantees", l.c., 204-205.

Lopuski, J., "Civil liability for nuclear damage: selected questions connected with the revision of the Vienna Convention", in "Nuclear Accidents. Liabilities and Guarantees", l.c., 206.

Artikel III, I van het Verdrag inzake Bijkomende Compensatic.

Boulanenkov, V., "Main features of the Convention on Supplementary Compensation for Nuclear Damage - an overview", in Reform of Civil Nuclear Liability, AEN-OECD, Parijs, 2000, 167.

McRae, B., "La Convention sur la réparation: sur la voie d'un régime mondial permettant de faire face à la responsabilité et à l'indemnisation des dommages nucléaires", o.c., 32
} 
het Verdrag zal zijn voldaan zodra bijvoorbeeld de installatiestaat de exploitant zou verplichten om een aansprakelijkheidsverzekering te hebben van 300 miljoen BTR. In dit geval zal de installatiestaat zelf niet meer worden verplicht om haar eigen publieke fondsen aan te spreken.

In een overgangsperiode tot 12 september 2007 is het voldoende dat een bedrag van 150 miljoen BTR wordt ter beschikking gesteld ${ }^{570}$. Voor wat betreft deze eerste schijf werd bijgevolg, net als bij het Protocol van het Verdrag van Wenen, voorzien in een phasing-in mechanisme. De bepalingen van het Verdrag inzake Bijkomende Compensatie zijn zo geformuleerd dat landen cen lagere aansprakelijkheidslimiet kunnen handhaven, op voorwaarde dat de Staat instaat voor het verschil tot een bedrag van 150 miljoen BTR. Dit is met name van belang voor landen van het voormalige Oostblok zoals Bulgarije en Litouwen waar een aansprakelijkheidsgrens geldt van 15 miljoen BTR (21,46 miljoen euro, 865,8 miljoen BEF of 47,3 miljoen NLG).

Het verschil tussen de grenzen in het Protocol van het Verdrag van Wenen en het Verdrag inzake Bijkomende Compensatie bestaat er bijgevolg in dat het beschikbare minimumbedrag onder het Verdrag inzake Bijkomende Compensatie één derde hoger ligt dan onder het Protocol van het Verdrag van Wenen. Indien een land zou toetreden tot beide Verdragen, dan zal de 150 miljoen BTR in de plaats komen van de 100 miljoen BTR die is voorgeschreven in het Protocol van het Verdrag van Wenen ${ }^{57 !}$.

De tweede schijf van eveneens 300 miljoen BTR, wordt gevormd door een internationaal publiek fonds, bestaande uit bijdragen van de verschillende Verdragsluitende Staten. Deze bijdragen worden berekend op basis van de nucleaire capaciteit van een Verdragsstaat enerzijds en een percentage van de bijdrage van de verschillende Staten tot de $\mathrm{UNO}^{572}$. De netto nucleaire capaciteit van cen installatiestaat wordt inderdaad vermenigvuldigd met $300 \mathrm{BTR}^{573}$. De formule is zo opgesteld dat minstens $90 \%$ van deze schijf wordt samengebracht door landen die over kerninstallaties beschikken. Aangezien de landen die over kerninstallaties beschikken ook meer bijdragen tot de UNO, betekent dit in de praktijk dat meer dan $98 \%$ van deze schijf zal worden samengebracht door de "genucleariseerde" landen ${ }^{574}$. Artikel IV. I, b bepaalt dat landen die de minimumbijdrage van de UNO betalen en die geen kernenergiepark bezitten, niet kunnen worden verplicht om een bijdrage in de tweede schijf te betalen.

Artikel III, 1 , a, ii) voorziet in een periode van 10 jaar te rekenen vanaf de dag dat het Verdrag werd opengesteld ter ondertekening.

Horbach, N.L.J.T., "Lacunae of International Nuclear Liability Agreements", in Horbach, N.L.J.T. (ed.), "Contemporary Developments in Nuclear Energy Law", l.c., 72.

Artikel IV, a) van het Verdrag inzake Bijkomende Compensatie luidt: "The formula for contributions according to which the Contracting Parties shall make available the public funds (...) shall be determined as follows: (i) the amount which shall be the product of the installed nuclear capacity of that Contracting Party multiplied by 300 SDR's per unit of installed capacity and (ii) the amount determined by applying the ratio between the United Nations rate of assessment for that Contracting Party as assessed for the year preceding the year in which the nuclear incident occurs, and the total of such rates for all Contracting Parties to $10 \%$ of the sum of the amounts calculated for all Contracting Parties under sub-paragragh (i)". Teneinde deze bijdragen te kunnen berekenen, is elk land dat tot het Verdrag toetreedt ertoe gehouden om een lijst op te geven van kerninstallaties (artikel VIII, 1 van het Verdrag inzake Bijkomende Compensatie).

Tijdens de onderhandelingen werden verschillende berekeningen gemaakt, uitgaande zowel van 100 , 250) als 350 BTR (SCNL/II/INF. I/MOD.I).

574 McRae, B., "La Convention sur la réparation: sur la voie d'un régime mondial permettant de faire face à la responsabilité et à l'indemnisation des dommages nucléaires", o.c., 32; zie ook Horbach, N.L.J.T., "Lacunae of International Nuclear Liability Agreements", in Horbach, N.L.J.T. (ed.), "Contemporary Developments in Nuclear Energy Law", l.c, 70. 
Er dient ook op te worden gewezen dat in principe de landen die reeds zijn toegetreden tot het Verdrag van Parijs en het Verdrag van Wenen en die de basisprincipes van deze verdragen reeds in hun inteme recht hebben omgezet, vrij kunnen toetreden tot het Verdrag inzake Bijkomende Compensatie, op voorwaarde uiteraard dat in de interne wetgeving voldoende bedragen beschikbaar zijn ${ }^{575}$.

Opmerkelijk is overigens de bepaling dat de uit de tweede schijf gegenereerde bedragen, voor de helft zullen worden gebruikt ter vergoeding van schade uit een kernongeval buiten de installatiestaat (grensoverschrijdende schade), voorzover deze schade niet werd vergoed onder de eerste schijf $^{576}$. Het is duidelijk de bedoeling geweest van deze bepaling om zoveel mogelijk landen, waaronder landen die niet over eigen kerninstallaties beschikken, aan te moedigen om tot het Verdrag toe te treden ${ }^{577}$. Hoewel het Verdrag inzake Bijkomende Compensatie de beschikbare fondsen verhoogt, blijft de situatie voor slachtoffers van de installatiestaat onveranderd ten aanzien van het Protocol van het Verdrag van Wenen, dat eveneens voorziet in een bedrag van 300 miljoen BTR. De verhoging van de beschikbare bedragen onder het Verdrag inzake Bijkomende Compensatie zal dan ook voomamelijk de slachtoffers van grensoverschrijdende schade ten goede komen $^{578}$. Volledigheidshalve wordt erop gewezen dat het reserveren van een deel van de tweede schijf voor grensoverschrijdende schade niet wordt verplicht gesteld zodra de installatiestaat 600 miljoen BTR (of meer) ter beschikking stelt ${ }^{579}$.

Een belangrijke vaststelling is dat beide schijven onder het Verdrag inzake Bijkomende Compensatie worden samengesteld uit fondsen die van de overheid afkomstig zijn. De gelijkenis met het Aanvullend Verdrag van Brussel van 1963 is dan ook treffend - al zijn er ook verschillen vast te stellen tussen het Verdrag inzake Bijkomende Compensatie en het Aanvullend Verdrag van Brus$\mathrm{se}^{580}$. Tijdens de onderhandelingen was initieel nochtans sprake van een collectieve bijdrage van de nucleaire sector. Verscheidene wijzen van pooling werden besproken, maar voomamelijk door de aanzienlijke verschillen inzake het veiligheidsniveau van de keminstallaties in de verschillende landen, werd de idee van een gemeenschappelijke bijdrage van de exploitanten verlaten ${ }^{58:} 582$.

Het Verdrag voorziet in een procedure voor het ter beschikking stellen van deze fondsen. Indien zich een kemongeval heeft voorgedaan, zal de Verdragsluitende Staat wiens rechtbanken bevoegd zijn, de andere Verdragsluitende Staten inlichten zodra de schade uit het kernongeval meer dreigt te bedragen dan de 300 miljoen BTR van de eerste schijf. Vervolgens zal aan de andere landen

\footnotetext{
575 McRae, B., "Overview of the Convention on Supplementary Compensation", in Reform of Civil Nuclear Liability, NEA-OECD, Parijs, 2000, 177-178.

576 Artikel $\mathrm{XI}, 1, \mathrm{~b}$ ) van het Verdrag inzake Bijkomende Compensatie.

s7 McRae, B., "La Convention sur la réparation: sur la voie d'un régime mondial permettant de faire face à la responsabilité et à l'indemnisation des dommages nucléaires", o.c., 33; McRae, B., "Overview of

578 the Convention on Supplementary Compensation", in "Reform of Civil Nuclear Liability", I.c., 181 . "Nuclear Inter Jura 1999", l.c., 207. Artikel XI, 2 van het Verdrag inzake Bijkomende Compensatie.

Reyners, P., "Modernisation du régime de responsabilité civile pour les dommages nucléaires: Révision de la Convention de Vienne et Nouvelle Convention sur la réparation complémentaire des dommages nucléaires", o.c., 760.

Er was onder meer sprake van een internationaal fonds dat door het IAEA zou worden beheerd en dat zou worden gespijsd door bijdragen van de exploitanten van de verschillende Verdragsluitende Staten (IAEA, GOV/2735, 3 juni 1994, 4). Met name landen uit het voormalige Oostblok leken gekant tegen een te zware aansprakelijkheid van de exploitant, aangezien hierdoor de investeringen in veiligheid in het gedrang konden komen (IAEA, GOV/2735, 3 juni 1994, 3). 
worden gevraagd om de fondsen uit de tweede schijf ter beschikking te stellen. Het Verdrag voorziet bijgevolg niet in een voorafgaandelijke bijdrage in het internationale fonds ${ }^{583}$.

Tot slot moet worden gewezen op artikel XXV van het Verdrag inzake Bijkomende Compensatie dat voorziet in een vereenvoudigde procedure tot wijziging van het Verdrag met betrekking tot de bedragen. Een wijziging kan plaatsvinden indien een derde van de Verdragspartijen daarom vraagt. Maar een amendement wordt pas aanvaard indien niemand tegenstemt; bovendien vereist het inwerking treden van een op deze wijze aanvaard amendement dat alle Verdragspartijen hun akkoord bevestigen in een periode van 36 maanden na notificatic. Bij gebrek aan een dergelijke bevestiging, wordt het amendement geacht te zijn verworpen (artikel XXV, lid 4).

\subsubsection{De voorstellen in het kader van de revisie van het Verdrag van Parijs}

$\mathrm{Na}$ de ondertekening van de nucleaire aansprakelijkheidsverdragen van de tweede generatie hebben do landen van de NEA zich ten overstaan van de leden van het Verdrag van Wenen ertoe geëngageerd om na de revisie van het Verdrag van Wenen ook snel werk te maken van de revisie van het Verdrag van Parijs ${ }^{584}$. In het licht hiervan heeft de NEA een studie laten uitvoeren omtrent de wenselijkheid om ook het Verdrag van Parijs en het Aanvullend Verdrag van Brussel aan te passen $^{58.5}$. Hoewel het Verdrag van Parijs desgevallend kan worden aangepast door middel van beslissingen en interpretaties van het Bestuurscomité, werd het, wegens het niet bindende karakter ervan, verkieslijk geacht om toch over te gaan tot een Verdragswijziging ${ }^{586}$. Tegelijk kan een toetreding van de leden van het Verdrag van Parijs tot het Verdrag inzake Bijkomende Compensatie leiden tot onduidelijkheden in verband met de relatie tot het Aanvullend Verdrag van Brus$\mathrm{sel}^{587}$.

Inmiddels is de werkgroep die zich over de revisie buigt reeds meermaals samengekomen. Eén van de belangrijkste thema's op de agenda is het bedrag van de aansprakelijkheid van de exploitant van een kerninstallatie. Hierbij wordt zowel onderhandeld over de hoogte van de aansprakelijkheid van de exploitant, over de "claims handling costs" en over het principe van de beperkte aunsprakelijkheid zelf.

Door de onmiskenbare band tussen de aansprakelijkheidslimiet van de exploitant en het bedrag van de verzekeringsplicht van de exploitant, hebben de Verdragsluitende Partijen bij de onderhandelingen een beroep gedaan op de verzekeringssector. Het is de bedoeling om de aansprakelijkheidsbeperking op te trekken in functie van de toegenomen capaciteit van de verzekeringsmarkt. Volgens de lopende voorstellen zou de aansprakelijkheidslimiet worden vastgesteld op een bedrag

Boulanenkov, V., "Main features of the Convention on Supplementary Compensation for Nuclear Damage - an overview", in "Reform of Civil Nuclear Liability", l.c., 196; Reyners, P., "Modernisation du régime de responsabilité civile pour les dommages nucléaires: Révision de la Convention de Vienne et Nouvelle Convention sur la réparation complémentaire des dommages nucléaires", o.c., 761. Reyners, P., "Modernisation du régime de responsabilité civile pour les dommages nucléaires: Révision de la Convention de Vienne et Nouvelie Convention sur la réparation complémentaire des dommages nucléaires", o.c., 763.

Aide Mémoire in Amendments to the Paris Convention of Third Party Liability in the Field of Nuclear Energy resulting from the proposed Revision of the Vienna Convention of Civil Liability for Nuclear Damage, $N E A / L E G / D O C(97) 4$ van 2 juni 1997. (ed.), "Contemporary Developments in Nuclear Energy Law", l.c., 77-78. 
tussen 300 en 600 miljoen BTR ${ }^{588} 589$. De exploitanten beschouwen cen limiet van 600 miljoen BTR als extreem zwaar ${ }^{590}$; volgens de onderhandelaars moet dit bedrag misschien nict volledig via de nucleaire verzekeringspools worden gedekt, maar zou ook de Staat bedragen ter beschikking kunnen stellen, mits hiervoor een bepaalde vergoeding wordt aangerekend ${ }^{591}$. Daarenboven wordt de mogelijkheid besproken om cen phasing-in mechanisme in te voeren, zoals in het Protocol van het Verdrag van Wenen en het Verdrag inzake Bijkomende Compensatie.

Van belang is ook dat het er sterk op lijkt dat de onderhandelaars hebben ingestemd met het principe dat Verdragsstaten de mogelijkheid zullen hebben om een onbeperkte aansprakelijkheid van de exploitant in te voeren ${ }^{592}$. Deze onbeperkte aansprakelijkheid zou dan worden gekoppeld aan een beperkte verzekeringsplicht.

Bijkomend wordt onderhandeld over de vraag of de kosten naar aanleiding van een aansprakelijkheidsvordering - claims handling costs - moeten zijn inbegrepen in het voorziene aansprakelijkheidsbedrag (zoals het geval is in de VS op basis van de Price-Anderson Act), dan wel of deze kosten moeten worden vergoed boven op de aansprakelijkheid van de exploitant. Vooral de verzekeraars dringen erop aan dat deze kosten zouden deel uitmaken van de aansprakelijkheidsdekking, zoniet zouden zij hun maximale risico moeilijk kunnen berekenen ${ }^{593}$. Tenslotte wordt ook de mogelijkheid besproken om een vereenvoudigde wijzigingsprocedure in het Verdrag in te schrijven. Volgens een bepaald voorstcl zou het NEA-Stccring Committee de bevoegdheid moeten krijgen om de bedragen te wijzigen; maar tegen dit voorstel bestaat aanzienlijke weerstand: tegenstanders wijzen op de vrijheid van de Verdragspartijen om de bedragen te wijzigen ${ }^{594}$.

In de bovenstaande paragrafen werd telkens gerefereerd aan de verschillende bedragen - zowel aansprakelijkheid van de exploitant als de tussenkomst van de Staat - en dit zowel in België, Nederland als op basis van de huidige en toekomstige nucleaire aansprakelijkheidsverdragen. Om de bedragen zelf in een juiste context te kunnen plaatsen, zal hieronder een overzicht worden gegeven van de bedragen die in een aantal landen beschikbaar zijn. Hier zal met name ook de vraag worden beantwoord welk element van doorslaggevende invloed is op het bedrag dat in een bepaald land kan worden verzekerd.

\subsubsection{Vergelijking van de bedragen in een aantal landen}

Uit de Preambule van het Verdrag van Parijs kan worden afgeleid dat het in de bedoeling ligt van de Verdragsluitende Staten om een zekere harmonisatie in de wetgeving van de verschillende landen te bewerkstelligen. Het Verdrag van Parijs voert een aantal limieten in; er kan dus worden

\footnotetext{
398 Rustand, H., "Paris Convention on Third Party Liability in the field of Nuclear Energy. Progress report on negotiations to revise the Convention", in "Reform of Civil Nuclcar Liability", l.c., 143.

589 Eighth Meeting of the Contracting Parties to revise the Paris Convention, NEA/LEG/CPPC(2000)15, 5 e.v.

$\$ 99$ Delpirou, D., "L'évolution des conventions sur la responsabilité civile nucléaire - enjeux pour Electricite de France", in Reform of Civil Nuclear Liability, NEA-OECD, Parijs, 2000, 136.

591 Eighth Meeting of the Contracting Parties to revise the Paris Convention, NEA/LEG/CPPC(2000) 15, 5 .

592 Delpirou, D., "L'évolution des conventions sur la responsabilité civile nucléaire - enjeux pour Electri-

393 cite de France", in "Reform of Civil Nuclear Liability", l.c., 144. Zie hierover ook Harbrücker, D., "Claims Settlement procedures and costs", in "Reform of Civil Nuclear Liability", l.c., 380.

Sบ4

Rustand, H., "Paris Convention on Third Party Liability in the field of Nuclear Energy. Progress report on negotiations to revise the Convention", in "Reform of Civil Nuclear I..iability", l.c., 145.
} 
verwacht dat de bedragen die in de verschillende landen beschikbaar zijn niet sterk verschillen. Bijkomend erkent het Verdrag ook de mogelijkheid voor de verschillende landen on bijkomende maatregelen te nemen die zij nodig achten ${ }^{595}$.

De vergelijking van de beschikbare bedragen wordt weergegeven in onderstaande tabel. Hierin wordt zowel het bedrag weergegeven van de aansprakelijkheidslimiet van de exploitant, als van de tussenkomst van de installatiestaat en van de tussenkomst van verschillende Verdragsluitende Staten ("Internationaal overheidsfonds"). Tegelijk wordt het totale beschikbare schadevergoedingsbedrag aangegeven.

\begin{tabular}{|c|c|c|c|c|}
\hline \multicolumn{5}{|c|}{ Verschillende bedragen (in miljoen euro) } \\
\hline & Aansprakelijkheid & $\begin{array}{l}\text { Installatie- } \\
\text { staat }\end{array}$ & $\begin{array}{l}\text { Internationaal } \\
\text { overheidsfonds }\end{array}$ & $\begin{array}{l}\text { Totaal beschik- } \\
\text { baar }\end{array}$ \\
\hline NEA-regime & 7,15 & 243,27 & 178,88 & 429,31 \\
\hline IAEA-regime: & 5,45 & - & - & 5,45 \\
\hline Protocol Wenen & 214,65 & 214,65 & - & 429,31 \\
\hline Bijk. Compensatie & $214,65^{\text {(a) }}$ & $214,65^{(a)}$ & $429,3 !$ & 858,63 \\
\hline Belgie $(7)^{(6)}$ & $\begin{array}{l}\text { Nieuw: } 297,47 \\
\text { Oud: } 99,16\end{array}$ & 151,27 & $\begin{array}{l}178,88 \\
178,88\end{array}$ & $\begin{array}{l}476,35 \\
429,31\end{array}$ \\
\hline Duitsland (19) & $\begin{array}{l}102,26^{(\mathrm{c})} \\
153,38^{(\mathrm{d})}\end{array}$ & 255,64 & 178,88 & 690,17 \\
\hline Frankrijk (59) & 91,47 & 158,96 & 178,88 & 429,31 \\
\hline Nederland (1) & 340,36 & $2.268,90$ & $(178,88)^{(\mathrm{c})}$ & $2.609,23$ \\
\hline $\begin{array}{l}\text { Verenigde Staten } \\
\text { (106) }\end{array}$ & $\begin{array}{l}218,77 \\
9.730^{(d)}\end{array}$ & - & - & 9.960 \\
\hline Zwitserland (5) & $323,64^{(\mathrm{c})}$ & 323,64 & - & 647,29 \\
\hline
\end{tabular}

De Preambule van het Verdrag van Parijs luidt: "Convinced of the need for unifying the basis rules applying in the various countries to the liability incurred for such damage, whilst leaving these countries free to take, on a national basis, any additional measures which they deem appropriate ...". 
(a) Deze twee bedragen maken de eerste schijf uit in het Verdrag inzake Bijkomende Compensatie; de wijze van verdcling tussen de exploitant en de installatiestaat wordt niet in het Verdrag geregeld. Wel moet in alle gevallen de ecrste schiff in totaal 429,31 miljoen euro bedragen.

(b) Dit cijfer is het aantal kernreactoren dat in het desbetreffende land op I jamuari 2000 operationeel was (bron: website van het LAEA).

(c) Het aangegeven bedrag voor Duitsland en Zwitserland is het bedrag van de verzekeringsplicht in beide landen. Hiermee wordt benadrukt dat in deze landen een onbeperkie aansprakelijkheid in voege is.

(d) Dit is de schijf die door de resp. Duitse en Amerikaanse exploitanten gezamenlijk wordt bijeengebracht.

(e) In Nederland wordt ook de derde schijf zoals voorzien in het Aanvullend Verdrag van Brussel ter beschikking gesteld. Maar door de wederkerigheidsvereiste word ervan uitgegaan dat een deel van de door de Nederlandse Staat ter beschikking gestelde fondsen enkel zal worden uitgekeerd voor wat betreft schade in Nederland en bijgevolg wordt het bedrag van de derde schijf niet opgeteld bij de andere bedragen.

Uit bovenstaande tabel blijkt dat in de verschillende landen een aanzienlijk verschil merkbaar is in de hoogte van zowel de bedragen waarvoor de exploitant aansprakelijk is, als inzake de totale beschikbare bedragen. Ook de nucleaire aansprakelijkheidsverdragen van het NEA- en van het IAEA-regime vertonen opvallende verschillen.

In een land als Frankrijk ligt de aansprakelijkheid van de exploitant vrij laag in vergelijking met Nederland, maar ook met België na de wetswijziging van 8 juni 2000. De aansprakelijkheid van de exploitant van een kerninstallatie in Nederland ligt ruim drie maal hoger dan in Frankrijk.

In Europa wordt een bijzondere plaats ingenomen door Duitsland en Zwitserland. In beide landen is immers een systeem in voege van onbeperkte aansprakelijkheid. In Duitsland is de exploitant sinds 1985 onbeperkt aansprakelijk voor de schade uit een kernongeval ${ }^{596}$. Aan deze onbeperkte aansprakelijkheid is een verzekeringsplicht gekoppeld van 500 miljoen DM $^{597}(255,64$ miljoen euro). Dit bedrag bestaat zelf uit twee schijven: de eerste schijf is de aansprakelijkheidsverzekering van de exploitant ten belope van een bedrag van 200 miljoen DM. Deze dekking kan worden verkregen bij de Duitse nucleaire verzekeringspool. De tweede schijf bestaat uit een systeem van onderlinge verzekering van de verschillende nucleaire exploitanten zelf ${ }^{58}$. Bovenop de aansprakelijkheid van de exploitant, stelt de Duitse Staat een som van eveneens 500 DM ter beschikking. Het totale in Duitsland beschikbare schadevergoedingsbedrag bedraagt dus 690,17 miljoen euro, met dien verstande dat de exploitant van de kerninstallatie ook aansprakelijk is voor de schade die dit bedrag te boven gaat.

Ook in Zwitserland wordt de onbeperkte aansprakelijkheid gekoppeld aan een beperkte verzekeringsplicht ${ }^{599}$. De exploitant is verplicht om zich te verzekeren tot een bedrag van 500 miljoen Zwitserse CHF $(323,64 \text { miljoen euro })^{600}$. Eenzelfde bedrag wordt door de Zwitserse Staat ter

$\S 31$ (1) van het Duitse Atomgesetz.

$\S 13$ (2) van het Duitse Atomgesetz.

Dangelmaier, P., "Nuclear Liability Insurance in the Federal Republic of Germany", in Nuclear Accidents. Liabilities and Guarantee", OECD-LAEA Helsinki Symposium, Paris, 1993, 428; Pclzer, N., "Unbegrenzte Haftung", l.c., 64.

Zie artikel 3 en artikel 11 van de Zwitserse nucleaire aansprakelijkheidswet van 18 maart 1983. De tekst van deze wet is gepubliceerd als supplement bij de Nuclear Law Bulletin, $\mathrm{n}^{\circ} 32,1983$.

De oorspronkelijke wet legde de verzekeringsplicht op 300 miljoen CHF, maar het bedrag werd inmiddels tweemaal verhoogd, telkens met een bedrag van 100 miljoen CHF. Respectievelijk bij Ordonnan- 
beschikking gesteld. Het totale beschikbare schadevergoedingsbedrag in Zwitserland bedraagt dus 1 miljard CHF (647,29 miljoen euro). Opvallend is ook dat de Zwitserse nucleaire aansprakelijkheidswet een bepaling bevat die de federale overheid verplicht om de verzekeringsdekking te verhogen zodra de verzekeringsmarkt tegen acceptabele voorwaarden een hogere dekking kan aanbieden $^{601}$. In de nabije toekomst zal de wet overigens opnieuw worden gewijzigd en zal de exploitant worden verplicht om zich te verzekeren tot een bedrag van 1 miljard CHF - ofwel een verdubbeling van het huidige bedrag. Uitgaande van de veronderstelling dat de hoogte van de Staatstussenkomst ongewijzigd blijft, zal dan een totaal bedrag van 970,93 miljoen euro beschikbaar zijn.

De achterliggende idee is dus in feite dat de aansprakelijkheid wordt beperkt tot het bedrag dat op de verzekeringsmarkt beschikbaar is. Zoals zal worden uiteengezet bij de analyse van verzekeringen, is de verzekering van het nucleaire risico per land in hoofdzaak geregeld via nationale nucleaire verzekeringspools ${ }^{602}$. Maar de capaciteit van deze pools lijkt geen verband te vertonen met het aantal kernreactoren in dat land. Op het eerste gezicht zou het namelijk logisch zijn dat hoe meer kerninstallaties worden verzekerd bij een nationale pool, hoe beter haar mogelijkheden tot risicospreiding. Uit bovenstaande cijfers kan worden afgeleid dat het aantal kernreactoren in een gegeven land geen invloed lijkt te hebben op de hoogte van de dekking die op de verzekeringsmarkt wordt geboden. Duitsland, Frankrijk en de Verenigde Staten, met respectievelijk 19, 59 en 106 operationele kemreactoren, scoren vrij laag wat betreft de door de nucleaire verzekeringspool aangeboden dekking - in de VS en in Duitsland is daarentegen een hoog bedrag beschikbaar via de captive van de exploitanten. In Zwitserland en Nederland, waar de verzekeringsindustrie zich traditioncel sterk heeft ontwikkeld en waar respectievelijk slechts vijf en éen reactor(en) operationeel zijn, is toch, in vergelijking met de andere landen, een vrij hoge aansprakelijkheidsdekking beschikbaar in de nationale nucleaire verzekeringspool. Het lijkt er dus inderdaad op dat de capaciteit op de nucleaire verzekeringsmarkt in belangrijke mate afhankelijk is van de verzekeringsmarkt in het desbetreffende land.

Op zich is deze vaststelling volledig in overeenstemming met de ratio legis van het Verdrag van Parijs. De idee was namelijk om de aansprakelijkheid te beperken op basis van een economisch criterium, namelijk de capaciteit van de nationale verzekeringsmarkt. Het is evenwel niet zeker of de verschillende bedragen van aansprakelijkheidsverzekering van de exploitant daadwerkelijk corresponderen met de capaciteit van de overeenstemmende verzekeringsmarkt. In Nederland lijkt het beleid inderdaad regelmatig de bedragen te verhogen, hierbij telkens kijkend naar dc capaciteit van de verzekeringsmarkt. In België lijkt dit niet of veel minder het geval te zijn: het heeft meer dan 15 jaar geduurd vooraleer het aansprakelijkheidsbedrag werd gewijzigd. Het lijkt dus een goed idee om naar Zwitsers voorbeeld de overheid te verplichten stelselmatig het bedrag op tc trekken $a$ rato van de gestegen verzekeringscapaciteit.

Voor wat betreft de hoogte van de bedragen waarvoor de exploitant aansprakclijk is, dient te worden vastgesteld dat de bedragen onvoldoende zijn om de kosten van een ernstig kemongeval te vergoeden ${ }^{603}$. Volgens bepaalde schattingen lopen de kosten van het kernongeval in Tsjernobyl, wanneer men uitsluitend de kosten in de voormalige Sovjet-Unie bekijkt, reeds op tot 15 miljard

tie van 2 december 1985 (Nuclear Law Bulletin, $n^{\circ} 37,1986,22$ ) en bij Ordonnantie van 24 oktober 1990 (Nuclear Law Bulletin, $n^{\circ} 47,1991,55-56$ ).

Artikel 11.2 van de Zwitserse nucleaire aansprakelijkheidswet.

Cfr. infra, in § 2 van hoofdstuk 6 .

Ook in die zin: Faure, M., "Economic Models of Compensation for Damage caused by Nuclear Accidents: Some Lessons for the Revision of the Paris and Viema Conventions", European Journal of Law" and Economics, 1995, 31 . 
dollar ${ }^{64}$ (16,4 miljard euro). Volgens de eerste beschikbare gegevens heeft het ongeval in Tokaimura van 1999 eveneens 10 miljard dollar (10,9 miljard euro) schade veroorzaakt ${ }^{605}$. De beschikbare cijfers voor de ongevallen in Tsjernobyl en Tokaimura laten onvoldoende toe om na te gaan. welk deel van het bedrag voortkomt uit vorderingen van derden en wat het aandeel is van de eigenschade van de exploitant; toch geven de cijfers aan dat de beschikbare bedragen ontoereikend zullen zijn.

De overheidstussenkomst in het nucleaire aansprakelijkheidsrecht werd steeds beschouwd als een tijdelijk fenomeen dat diende te worden afgebouwd naarmate de nucleaire industrie aan maturiteit zou winnen. Bijgevolg werd in de VS werd de overheidstussenkomst geleidelijk afgebouwd om in 1982 te worden afgeschaft ${ }^{606}$. De VS is met andere woorden trouw gebleven aan het pragmatische uitgangspunt van de overheidstussenkomst ${ }^{607}$, al moet worden erkend dat ook in de VS nog steeds de aansprakelijkheid van de exploitant wordt beperkt. Tegelijk dient te worden vastgesteld dat de Belgische wetgever consequent heeft gehandeld bij de wetswijziging van 8 juni 2000, in die zin dat de tussenkomst van de Belgische Staat in de tweede schijf van het Aanvullend Verdrag van Brussel, werd afgeschaft ${ }^{608}$. In Nederland daarentegen is de bereidheid van Staat om schadevergoeding uit te keren ten gevolge van een kernongeval in 1991 nog drastisch toegenomen.

Tot slot tonen de cijfers aan dat het enkele feit dat een land geen partij is bij het Verdrag van Parijs of van Wenen, op zich een onvoldoende reden is om de bescherming van slachtoffers van een kernongeval in vraag te stellen ${ }^{609}$. In de Verenigde Staten is het totale beschikbare schadevergoedingsbedrag immers het hoogst. Nochtans dient te worden gewaarschuwd voor een al te eenzijdige vergelijking van cijfers. Zij geven een indicatie, maar ook andere factoren die de bescherming van slachtoffers bepalen, dienen in aanmerking te worden genomen. Zo kan de positie van een slachtoffer aanzienlijk verschillen naargelang het in een gegeven land beschikbare sociale zekerheidssysteem; tegelijk zijn bijvoorbeeld de verjaringstermijnen van land tot land verschillend, wordt causaliteit verschillend geïnterpreteerd, etc. Tenslotte worden van land tot land verschillende dekkingssystemen gehanteerd ${ }^{610}$.

\subsubsection{Conclusie}

De beperking van het aansprakelijkheidsbedrag werd ofticieel ingevoerd in de betrachting om tezelfdertijd de kemenergie-industrie niet te belasten met potentiecl ruïneuze aansprakelijkheidsvorderingen en om slachtoffers te garanderen dat (beperkte) schadevergoedingsbedragen zouden beschikbaar zijn. Uit de analyse is gebleken dat slechts één criterium werd gebruikt ter beoordeling van het financiële risico van de nucleaire industrie, namelijk de capaciteit van de verzeke-

604

Cijfer geciteerd in Faure, M. en Skogh, G., "Compensation for Damages caused by Nuclear Accidents: a Convention as Insurance", The Geneva Papers on Risks and Insurance, vol. 17, n 65, 1992, 505.

Cijfer geciteerd in de voorbereidende werken van de wetswijziging van de Belgische wet van 22 juli 1985: Verslag, 24 mei 2000, Parlementaire Stukken, GZ/1999-2000, 560/002, 5.

Cfr. infra hoofdstuk 13.

Vanden Borre, T., "Dekking van het nucleaire risico op nationaalrechtelijke basis of via internationale Verdragen: de Verenigde Staten versus Europa", in Faure, M., Deketelaere, K. en Verhoosel, G., (red.), "Grensoverschrijdende milieuproblemen", l.c., 478.

Met dien verstande dat de Belgische Staat enkel nog ten dele zal bijdragen in de derde "solidariteitsschijf" van het Aanvullend Verdrag van Brussel.

Vanden Borre, T., "Dekking van het nucleaire risico op nationaalrechtelijke basis of via internationale Verdragen: de Verenigde Staten versus Europa", in Faure, M., Deketelacre, K. en Verhoosel, G., (red.), "Grensoverschrijdende milieuproblemen", l.c., 484.

Cfr. infra, in $\$ 4.1 .5$ van dit hoofdstuk. 
ringsindustrie. De aansprakelijkheidslimiet van de exploitant van een keminstallatie wordt dus in principe gekoppeld aan de verzekeringscapaciteit.

Maar op basis van de nucleaire aansprakelijkheidsverdragen bestaat er geen enkele garantie dat het bedrag waarvoor de exploitant aansprakelijk is, overeenstemt met de effectieve capaciteit van de desbetreffende nucleaire verzekeringspool. Men zou kunnen zeggen dat de koppeling tussen de aansprakelijkheidslimiet en de verzekeringscapaciteit op statische wijze in de Verdragen is ingeschreven. De achterliggende idee van de koppeling tussen limiet en capaciteit is namelijk niet met zoveel woorden opgenomen in de Verdragstekst. Het lijkt daarom nuttig dat een nationale wetgever de nucleaire verzekeringspools verplicht om periodiek te melden wat haar werkelijke verzekeringscapaciteit is en dat de aansprakelijkheidslimiet daaraan wordt aangepast ${ }^{611}$.

Zeker in het Verdrag van Parijs wordt de koppeling onmogelijk gemaakt: door ook een maximumlimiet vast te leggen kan de aansprakelijkheidsgrens eigenlijk onmogelijk de evolutie van de verzekeringsmarkt volgen. Hopelijk wordt van de revisie van het Verdrag van Parijs gebruik gemaakt om tenminste deze maximumaansprakelijkheid op te heffen. Een systeem dat de evolutie wil volgen van de verzekeringsmarkt dient logischerwijze een flexibele aansprakelijkheidslimiet te hanteren - hetgeen ook werd aangegeven door de auteurs van het Voorlopig Rapport ${ }^{612}$.

Het feit dat (de aansprakelijkheidslimiet van) de Verdragen van Wenen en Parijs nooit zijn gewijzigd, hoeft overigens niet te verbazen omdat onder beide Verdragen er geen bepaling voorhanden is die toelaat om het Verdrag, als was het maar inzake het bedrag van de aansprakelijkheid van de exploitant, op soepele wijze te kunnen wijzigen. In principe bevat zowel het Verdrag inzake Bijkomende Compensatie als het Protocol van het Verdrag van Wenen een procedure om de bedragen te wijzigen, maar de procedures blijven zeer ingewikkeld. Een verandering van de flexibiliteit van het bedrag van de aansprakelijkheid lijkt uitgesloten.

Meteen rijst de vraag naar de mate waarin de nucleaire aansprakelijkheidsverdragen van de tweede generatie erin slagen een werkelijke verandering op gang te brengen. Op het eerste gezicht lijken deze Verdragen inderdaad te leiden tot een aanzienlijke verbetering: op basis van het Protocol van het Verdrag van Wenen wordt de aansprakelijkheid van de exploitant opgetrokken tot 300 miljoen BTR en het Verdrag inzake Bijkomende Compensatie garandeert de beschikbaarheid van 600 miljoen BTR ( 858,63 miljoen euro). Ten aanzien van de bestaande toestand betekent dit inderdaad een verhoging van de beschikbare bedragen. Maar de nucleaire aansprakelijkheidsverdragen van de tweede generatie voorzien in een verregaande tussenkomst van de installatiestaat en van, voor wat betreft de tweede schijf in het Verdrag inzake Bijkomende Compensatie, de verschillende Verdragsluitende Staten ${ }^{613}$. Beide verdragen leggen dus vooral bijkomende verplichtingen op aan de verschillende staten. Het uitgangspunt van het Voorlopig Rapport, op basis waarvan de Staatstussenkomst als voorlopig dient te worden aanzien, is dus geheel verlaten. Bovendien blijven zelfs de gewijzigde bedragen zcer laag.

Voor België en Nederland zou een toetreding tot het Verdrag inzake Bijkomende Compensatie leiden tot een verhoging van het totale beschikbare schadevergoedingsbedrag, maar niet van de aansprakelijkheid van de exploitanten. In beide landen is namelijk reeds 300 miljoen BTR be-

Dit uiteraard op voorwaarde dat de gegevens die de verzekeraar ter beschikking stelt, betrouwbaar zijn. Met name op een gemonopoliseerde verzekeringsmarkt, kan de betrouwbaarheid van de cijfers worden in twijfel getrokken. Zie hierover verder, in $\$ 1.3 .2$ van hoofdstuk 15 .

613 Cfr. infra, in $\$ 1.3$ van hoofdstuk 13.

Vanden Borre, $T$., "Recente ontwikkelingen in het nucleaire aansprakelijkheidsrecht: innovatie of renovatic?", o.c., 49. 
schikbaar; het verschil zal er dus in bestaan dat beide landen in de tweede schijf van het Verdrag inzake Bijkomende Compensatie een beroep kunnen doen op bijkomende fondsen, maar dat zij er bij toetreding evenzeer zullen toe gehouden zijn een bijkomende bijdrage te leveren. Het lijkt overigens zeer twijfelachtig of België en Nederland, beiden lid van zowel het Verdrag van Parijs van 1960 als van het Aanvullend Verdrag van Brussel van 1963, snel geneigd zullen zijn om openbare middelen ter beschikking te stellen voor een kernongeval in bijvoorbeeld Oekraïne, waar de veiligheidseisen niet dezelfde zijn als in West-Europa. Het is bijgevolg hoogst twijfelachtig of de landen van het NEA-regime zullen geneigd zijn om toe te treden tot het Verdrag inzake Bijkomende Compensatie of het Protocol van het Verdrag van Wenen. De nucleaire aansprakelijkheidsverdragen van de tweede generatie slagen er evenmin als de aansprakelijkheidsverdragen van de eerste generatie in om de gevolgen op te vangen van een zwaar kernongeval ${ }^{614}$. Het lijkt er sterk op dat ook na het in werking treden van de nucleaire aansprakelijkheidsverdragen van de tweede generatie de bescherming van de kemenergie industrie primeert op de bescherming van het slachtoffer.

Bijkomend dient te worden vastgesteld dat de leesbaarheid van het internationale nucleaire aansprakelijkheidsrecht met de komst van de Verdragen van de tweede generatie er niet bepaald is op vereenvoudigd. Dit blijkt bijvoorbeeld indien een land van het NEA-regime zou toetreden tot het Verdrag inzake Bijkomende Compensatie. Dit zou betekenen dat dit land onder beide Verdragen en volgens verschillende verdeelsleutels zou worden verplicht om bij te dragen in het internationale publieke fonds. Terecht kan worden gesproken van een labyrint van internationale Verdragen inzake nucleaire aansprakelijkheid ${ }^{615}$. Ook de Verdragen van 12 september 1997 zelf zijn reeds moeilijk combineerbaar, met name inzake het verschillende startpunt van het phasing-in mechanisme ${ }^{616}$.

Het beperkte bedrag van aansprakelijkheid wordt vaak gezien als een subsidie aan de nucleaire industrie, aangezien hiermee de kosten van een kemongeval niet volledig worden geïntemali$\operatorname{seerd}^{617}$. Het is dan ook weinig verbazingwekkend dat met name de beperking van de aansprakelijkheid van de exploitant van de kerninstallatie, zwaar onder vuur wordt genomen ${ }^{618}$; landen als Zwitserland, Japan en Oostenrijk wensen niet toe te treden tot het internationale nucleaire aansprakelijkheidsrecht zolang het principe van de beperkte aansprakelijkheid in deze Verdragen behouden blijft.

\footnotetext{
614 Warren, G.C., "Nuclear Damage under the 1997 Protocol: Conventional Thinking?", in "Reform of Civil Nuclear Liability", l.c., 91 .

o15 Horbach, N.L.J.T., "Lacunae of International Nuclear Liability Agreements", in Horbach, N.L.J.T., (ed.), "Contemporary Developments in Nuclear Energy Law", l.c., 81. Horbach wijst erop dat minstens 16 verschillende scenario's kunnen worden onderscheiden.

616 Bij het Verdrag inzake Bijkomende Compensatie start het phasing-in mechanisme op de dag dat het Verdrag werd opengesteld ter ondertekening. Dit betekent dat deze fase hoe dan ook zal zijn afgelopen in september 2007. Onder het Protocol van het Verdrag van Wenen echter start het phasing-in mecha-

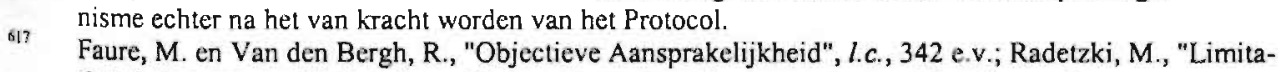

6!s tion de la responsabilité civile nucléaire: causes, conséquences et perspectives", o.c., 21 . Interest Group Perspective", International Review of Law and Economics, 1990, vol. 10, 241-254; Hohlefelder, W., "Reconsideration of the Principle of the Nuclear Operator's Limitation of Liability", o.c., 375; Pelzer, N., "Unbegrenzte Haftung", l.c., 35; Lopuski heeft het over "ridiculously low limits of the operator" (Lopuski, J., "Civil liability for nuclear damage: selected questions connected with the revision of the Vienna Convention", in "Nuclear Accidents. Liabilities and Guarantees", l.c., 203).
} 
Het feit dat het Protocol van het Verdrag van Wenen aan de Verdragsluitende toelaat om te kiezen tussen een systeem van onbeperkte dan wel beperkte aansprakelijkheid, is dus reeds een stap in de goede richting. Hopelijk zal de revisie van het Verdrag van Parijs tot eenzelfde resultaat leiden. Traditioneel wordt evenwel gesteld dat een onbeperkte aansprakelijkheid weinig zou toevoegen, omdat bij een faillissement van de exploitant een slachtoffer geen enkele compensatie van de geleden schade zouden kunnen bekomen. Uit de rechtseconomische analyse zal evenwel blijken dat een onbeperkte aansprakelijkheid bepaalde voordelen biedt en dat een beperkte aansprakelijkheid leidt tot een aantal economische neveneffecten ${ }^{619}$.

\subsection{Beperking van de aansprakelijkheid in de tijd}

De aansprakelijkheid van de exploitant werd niet enkel beperkt in bedrag, maar ook in de tijd. Hieronder worden de overeenstemmende bepalingen besproken van het Verdrag van Parijs $(\$ 3.2 .1)$, van de Belgische wet van 1985 (\$ 3.2.2) en van de Nederlandse WAKO (\$ 3.2.3). In $\S 3.2 .4$ wordt de beperking van de aansprakelijkheid in de tijd naar toekomstig recht besproken. Tenslotte worden in $\$ 3.2 .5$ enkele conclusies getrokken inzake de beperking van de aansprakelijkheid in de tijd in het nucleaire aansprakelijkheidsrecht.

\subsubsection{Volgens het Verdrag van Parijs}

Overeenkomstig artikel 8 van het Verdrag van Parijs vervalt het recht op vergoeding indien de rechtsvordering niet is ingesteld binnen de ticn jaar na de datum van het kernongeval. De onderhandelaars van het Verdrag van Parijs waren er zich van bewust dat een emstig kemongeval kon leiden tot nict eerder geziene vorderingen ${ }^{620}$. Indien bijgevolg de aansprakelijkheid van de exploitant niet cou worden beperkt, dan zou dit kunnen leiden tot het faillissement van de exploitant, hetgeen ook nudelig zou, ijn voor de slachtoffers van een kemongeval ${ }^{621}$.

Net zoals de beperking van het bedrag waarvoor de exploitant kan worden aansprakelijk gesteld, werd ook de beperking van de aansprakelijkheid in de tijd ingevoerd vanuit de dubbele beschermingsdoelstelling van het Verdrag. Indien geen beperking zou worden ingesteld in de tijd zou de verzekeraar van de exploitant ertoe gehouden zijn om gedurende een lange periode reserves aan te houden teneinde de uit een kernongeval voortkomende schade te dekken. Vooral na het verstrijken van de polis, zou dit voor de verzekeraar problematisch kunnen zijn. Anderzijds wilde men ook slachtoffers bij wie de schade zich slechts jaren na het kernongeval manifesteert het recht niet ontzeggen schadevergoeding te vorderen. In de Exposé des Motifs wordt overigens uitdrukkelijk gewezen op de mogelijke bewijsproblemen om te bewijzen of te ontkennen dat een gegeven schade door een kemongeval werd veroorzaakt ${ }^{622}$. Ook volgens de auteurs van het Harvard Rapport zou een snelle afhandeling van de schadegevallen en een kortere verjaringstermijn in het belang van de slachtoffers zijn: hoe langer de tijd tussen het kemongeval en het optreden van gezondheidsschade, hoe moeilijker het wordt de causaliteit tussen beide vast te stellen. Een kortere verjaringstermijn zou tegelijk de verzekeringspremies drukken waardoor een hogere aansprakelijkheidslimiet kan worden opgelegd ${ }^{623}$.

Zie met name hoofdstuk 15.

Exposé des: Motifs, 53.

Camier, M.C., "Responsabilité et Assurance du Risque Atomique", l.c., 92.

Exposé des Motifs, 55.

Harvard Rapport, 64 en 65. 
De beperking van de aansprakelijkheid van de exploitant van de kerninstallatie in de tijd is in feite ook een gevolg van het congruentievereiste ${ }^{624}$ : de verzekeringsindustrie was/is niet bereid om te voorzien in een langere dekkingsperiode dan 10 jaar na het kernongeval. De ratio legis van de beperking van de aansprakelijkheid in de tijd is dan ook grosso modo dezelfde als deze van de beperking van het bedrag van de aansprakelijkheid.

Aan de leden van het Verdrag wordt evenwel de mogelijkheid geboden een langere termijn vast te stellen dan een termijn van tien jaar, op voorwaarde dat de installatiestaat, voor de rechtsvorderingen die zijn ingesteld na de termijn van 10 jaar, "maatregelen heeft genomen om de aansprakelijkheid van die exploitant te dekken". Hieruit valt niet eenduidig af te leiden of het de bedoeling is dat de aansprakelijkheidsverzekering van de exploitant dient in te staan voor de aansprakelijkheid na 10 jaar na het kernongeval, dan wel of het bijvoorbeeld voldoende is dat de Staat in dergelijke gevallen zal tussenkomen. Over het algemeen wordt aangenomen dat de aansprakelijkheid van de exploitant na 10 jaar na het kernongeval, kan worden gedekt door de Staat ${ }^{625}$. Dit betekent niet noodzakelijk dat de Staat deze schade zal dienen te dragen, maar dat de Staat ervoor moet zorgen dat voor deze uitgebreide aansprakelijkheid ook een daadwerkelijke dekking voorhanden is ${ }^{626} 627$.

Eenzelfde termijn is voorzien in artikel 6 van het Aanvullend Verdrag van Brussel: enkel die rechten op schadevergoeding worden in aanmerking genomen, die binnen een termijn van 10 jaar worden te gelde gemaakt. Hierbij moet worden aangegeven dat de termijn zoals voorzien in het Verdrag van Parijs, een verschillende strekking heeft als deze in het Aanvullend Verdrag van Brussel. Artikel 8 van het Verdrag van Parijs is een vervaltermijn: vorderingen die na 10 jaar na het kernongeval worden ingediend kunnen niet meer worden uitgeoefend. Daarentegen heeft de temijn van artikel 6 van het Aanvullend Verdrag van Brussel enkel betrekking op de twee bijkomende schijven van het Aanvullend Verdrag van Brussel en valt deze niet te beschouwen als een vervaltermijn zoals in het Verdrag van Parijs. Het overschrijden van de termijn onder het Verdrag van Brussel heeft enkel tot gevolg dat de installatiestaat zich niet meer tot de andere Verdragsstaten (derde schijf) zal kunnen richten voor vorderingen ingediend 10 jaar na het ongeval ${ }^{628}$ en dat in principe ook de installatiestaat niet meer kan worden verplicht om haar bijdrage in de tweede schijf ter beschikking te stellen. Uiteraard kan, wat dit laatste betreft, de nationale wet hiervan afwijken.

Artikel $8, \mathrm{c}$ ) van het Verdrag van Parijs voorziet in de mogelijkheid om bij nationale wet een termijn van tenminste twee jaar vast te stellen als verjarings- of vervaltermijn ingaande op de dag dat het slachtoffer kennis had of redelijkerwijze kennis had moeten hebben van zijn schade en van de identiteit van de aansprakelijke exploitant. Na het verstrijken van deze periode van twee jaar kan het slachtoffer geen enkele vordering tot schadevergoeding indienen. Benadrukt dient te worden dat het een mogelijkheid betreft waarvan een Verdragsluitende Staat kan gebruik maken

\footnotetext{
624 Pelzer, N., "The present state of research carried out by the English speaking section of the Centre for Studies and Research", o.c., 278. Cfr. infra, in \$ 4.1.1 van dit hoofdstuk.

Picard, M., "The Convention on third party liability in the field of nuclear energy", o.c., 363.

Ook in die zin Piérard, J.P. "Responsabilité civile. Energie atomique et droit compare", l.c., 364

Dit wordt bevestigd in artikel VI van het Verdrag van Wenen op basis waarvan in een langere periode dan tien jaar kan worden voorzien indien het recht van de installatiestaat bepaalt dat de aansprakelijkheid van de exploitant is gedekt door diens aansprakelijkheidsverzekering, door een andere financieje zekerheid of door de Staat.

Bette, A. e.a., "La Réparation des Dommages Nucléaires en Europe", l.c., 34.
} 
Staten die eveneens lid zijn van het Aanvullend Verdrag van Brussel van 1963, die van deze mogelijkheid wensen gebruik te maken, kunnen enkel een verjaringstermijn van 3 jaar instellen. Artikel 7 van het Aanvullend Verdrag van Brussel bepaalt dat, wanneer een Staat gebruik maakt van de bevoegdheid zoals bepaald in artikel 8, c van het Verdrag van Parijs, de door haar bepaalde termijn een verjaringstermijn is van 3 jaar, die ingaat op de dag waarop de persoon die schade heeft geleden kennis draagt of redelijkerwijze geacht kan worden kennis te dragen van de schade en de aansprakelijke exploitant. Het doel van deze bepaling van het Aanvullend Verdrag van Brussel is om in de mate van het mogelijke te komen tot een harmonisatie van de termijnen ingevolge de mogelijkheid waarover de Verdragspartijen overeenkomstig artikel 8, c van het Verdrag van Parijs beschikken om te voorzien in een termijn die niet minder bedraagt dan 2 jaar ${ }^{629}$. Het beperkt de vrijheid van de Verdragspartijen om in een andere termijn te voorzien: ofwel bepalen zij geen enkele termijn, ofwel een verjaringstermijn van drie jaar.

De termijn van twee of drie jaar wordt ook de "discovery rule" ${ }^{n 30}$ of ontdekkingsregel genoemd. In ieder geval mogen de termijnen van artikel 8, a gecombineerd met 8, c van het Verdrag van Parijs in geen geval leiden tot een overschrijding van de termijn van 10 jaar. Indien bijgevolg een slachtoffer van een kernongeval er slechts na 9 jaar na het kemongeval achterkomt dat een bepaalde schade het gevolg is van dat kernongeval, beschikt hij slechts over één jaar om zijn vordering in te dienen tegen de exploitant.

Nochtans kunnen in drie gevallen vorderingen ook worden ingediend na de periode van 10 jaar. Ten eerste kan de nationale wet in cen langere periode voorzien, voorzover de aansprakelijkheid van de exploitant is gedekt ${ }^{631}$. Ten tweede kan het slachtoffer wiens schade is toegenomen ook na 10 jaar een bijkomende eis indienen, mits de bevoegde rechter nog geen eindvonnis heeft geveld ${ }^{632}$. En ten derde geldt een afwijkende termijn ingeval een kernongeval heeft plaatsgevonden doordat radioactieve producten, splijtstoffen of afvalstoffen werden gestolen of zijn verloren ${ }^{633}$. In dat geval wordt de termijn van 10 jaar berekend vanaf de dag van het kernongeval, met dien verstande dat de termijn in geen geval langer mag zijn dan 20 jaar te rekenen vanaf de datum van de diefstal of het verlies.

Tegelijk dient te worden vastgesteld dat de termijn waarvan sprake in het Verdrag een algemene termijn betreft, in die zin dat geen onderscheid wordt gemaakt tussen vorderingen ingesteld ter zake van zaakschade of letselschade. Nochtans werden voorstellen in die zin besproken ${ }^{634}$.

\subsubsection{Volgens de Belgische wet 22 juli 1985}

Overeenkomstig artikel $23, \S 1$ van de wet dienen vorderingen tot schadevergoeding tegen de exploitant op straffe van verval te worden ingesteld binnen 10 jaar na het kemongeval. Volgens de tweede paragraaf van hetzelfde wetsartikel is, indien de aansprakelijkheid voor een kemongeval dat op Belgisch grondgebied schade heeft veroorzaakt slechts komt vast te staan na de termijn

\footnotetext{
629 Bette, A. e.a., "La Réparation des Dommages Nucléaires en Europe", l.c., 34.

"Liability and Compensation for Nuclear Damage", l.c., 50.

Artikel 8, a) van het Verdrag van Parijs.

Artikel $8, e$ ) van het Verdrag van Parijs.

Artikel $8, b$ ) van het Verdrag van Parijs.

Zo werd door Zwitserland een voorstel ingediend dat een oplossing bood voor de schade die zich pas na 10 jaar na het kemongeval zou manifesteren. Het voorstel voorzag hiertoe in de oprichting van een "Fonds pour dommages atomiques différés" dat haar middelen zou putten uit bijdragen vanwege de gehele nucleaire sector (Camier, M.-C., "Responsabilité et Assurance du Risque Atomique", l.c., 112).
} 
van 10 jaar, de Staat gehouden deze schade ter vergoeden, voorzover nog geen dertig jaar zijn verstreken sinds het kernongeval heeft plaatsgevonden.

In ieder geval verjaart de vordering na drie jaar nadat het slachtoffer kennis heeft gehad of redelijkerwijze geacht kan worden kennis te hebben gehad van de schade en van de identiteit van de exploitant - dit zonder dat de termijnen van 10,20 of 30 jaar mogen overschreden worden. Zoals ook blijkt uit het Verdrag van Parijs is de termijn van drie jaar niét cumulatief toepasbaar met de termijn van 10 jaar. Tijdens de Parlementaire werken werd benadrukt dat de termijn van drie jaar betrekking heeft op de verjaring van de schadevordering; deze loopt pas vanaf het tijdstip waarop het slachtoffer de aansprakelijke kent ${ }^{635}$.

De bepaling op basis waarvan de Staat na 10 jaar de schadevergoeding voor haar rekening neemt ${ }^{636}$, werd ingevoerd na een door de Regering ingediend amendement. Deze redeneerde dat op basis van wetenschappelijke gegevens de vervaltermijn van 10 jaar te kort was; "om redenen

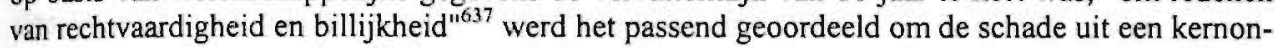
geval gedurende een voldoende lange periode ten laste te leggen van de Staat.

Gedurende de parlementaire bespreking van de wet van 1985 werden verschillende amendementen ingediend die ertoe strekten om de termijn van 10 jaar te vervangen door de gemeenrechtelijke verjaringstermijn van 30 jaar. Deze amendementen werden verworpen omdat een langere periode dan 10 jaar de verzekerbaarheid van het nucleaire risico in het gedrang zou brengen $^{638}$ en omdat de langere termijn een probleem zou kunnen opleveren inzake wederkerigheid ${ }^{639}$. Volgens de Minister zouden slachtoffers beter beschermd worden indien zij gedurende 20 jaar een beroep konden doen op de overheid in plaats van de exploitant, waarmee in dertig jaar "heel wat kan gebeuren" ${ }^{\prime 640}$. Artikel $23, \S 2$ is dus een soort garantiestelling vanwege de Staat voor schade die niet in de eerste 10 jaar na het kernongeval kon worden vastgesteld, maar die wordt vastgesteld vóór het verstrijken van een periode van 30 jaar na het kernongeval.

Het is echter niet meteen duidelijk hoe ver deze garantiestelling gaat; de vraag rijst namelijk of de Belgische Staat enkel verplicht is om na 10 jaar na het kernongeval tussen te komen ten belope van maximaal het bedrag van de aansprakelijkheid van de exploitant, dan wel of deze garantie ook betrekking heeft op de tweede schijf van het Aanvullend Verdrag van Brussel. Sinds 1 januari 2001 heeft deze vraag grotendeels haar relevantie verloren. Wel relevant is de vaststelling dat door de verhoogde aansprakelijkheid van de exploitant eveneens de garantieverplichting van de Staat, zowel ex artikel 22 als ex artikel $23, \S 2$ evenredig werd verhoogd. Overigens is het zo dat de Belgische wet geen bepaling bevat, die toelaat dat de wetgever de exploitant hiervoor een vergoeding aanrekent.

\subsubsection{Volgens de Nederlandse WAKO}

In uitvoering van het Verdrag van Parijs, bevat ook de WAKO een aantal bepalingen ter zake van de termijn wararbinnen een vordering dient te worden ingesteld. Deze worden in $\$ 3.2 .3 .1$ besproken. Maar de WAKO bevat ook een bijzonderheid, in die zin dat ter gelegenheid van de wijziging

Parlementaire Stukken, Senaat, GZ 1983-1984, 593/3, 60.

Zoals toegelaten in artikel 8 van hei Verdrag van Parijs.

Parlementaire Stukken, Senaat, GZ/1983-1984, 593/3, 64.

Parlementaire Stukken, Senaat, GZ/1983-1984, 593/3, 60.

Parlementaire Stukken, Senaat, GZ 1983-1984, 593/3, 20.

Parlementaire Siukken, Senaat, Vergadering van 23 oktober 1984, 129.
} 
van de WAKO in 1991, werd voorzien in een aantal procesrechtelijke bepalingen met tot doel een vlot of vlotter verloop van de procedure. Deze worden in $\$ 3.2 .3 .2$ aan de orde gesteld.

\subsubsection{Termijn voor het instellen van een vordering}

Volgens artikel 7 WAKO verjaart een rechtsvordering na verloop van drie jaren nadat het slachtoffer kennis had of redelijkerwijze kennis had moeten hebben van de schade en van de aansprakelijke exploitant. Tot zover zijn de WAKO-bepalingen dus gelijk aan de bepalingen van de Belgische nucleaire aansprakelijkheidswet.

De WAKO maakt echter wat vervaltermijnen betreft, een onderscheid tussen schade aan personen (termijn van 30 jaar) en alle andere schade waar een termijn van 10 jaar toepasselijk is. De lange termijn van 30 jaar is bedoeld om er zeker van te zijn dat gezondheidsschade die zich jaren na het kernongeval manifesteert, eveneens door de exploitant wordt vergoed. De kortere termijn van 10 jaar beoogt een spoedige afwikkeling van de schade ${ }^{641}$; gesteld werd dat de kans gering is dat zaakschade zich voor het eerst zal manifesteren na een termijn van 10 jaar $^{642}$.

Op basis van artikel 7, derde lid van de WAKO worden, voor wat betreft de vorderingen ingesteld na een periode van 10 jaar maar vóór een periode van 30 jaar na het kernongeval, door de minister van Financiën verzekeringsovereenkomsten aangegaan of andere garanties verstrekt. Dit betekent dus dat voor vorderingen inzake letselschade ingediend na 10 jaar niet de "gewone" aansprakelijkheidsverzekering van de exploitant zal tussenkomen, maar dat de Nederlandse Staat zal voorzien in een dekking. Artikel 7 van de WAKO verwijst in dat verband naar artikel 9. Aangezien op basis van dit artikel de Staat gemachtigd is om premies of vergoedingen te bepalen voor het feit dat zij hetzij verzekeringsovereenkomsten aangaat, hetzij zich garant stelt, kan ook worden gesteld dat indien de Nederlandse Staat bijvoorbeeld verzekeringsovereenkomsten zou afsluiten voor de dekking van letselschade die zich pas na 10 jaar na het kemongeval manifesteert, zij de exploitant hiervoor eveneens een bedrag kan aanrekenen.

Dit heeft wel tot gevolg dat na 10 jaar de vorderingen inzake zaakschade in het geheel niet meer voor vergoeding in aanmerking komen, terwijl voor vorderingen inzake letselschade de aansprakelijkheid na 10 jaar zal vallen ten laste van de dekking die door de Nederlandse Staat werd voorzien, maar waarvan de kosten - minstens ten dele - aan de Nederlandse exploitant kunnen worden doorgerekend. De Nederlandse wetgever oordeelde dat het zeer onwaarschijnlijk was dat zaakschade zich na 10 jaar na het kernongeval zou openbaren ${ }^{643}$.

De WAKO laat er weinig twijfel over bestaan dat de verval- en verjaringstermijnen enkel betrekking hebben op de aansprakelijkheid van de exploitant: artikel 7 valt namelijk onder het hoofdstuk II van de wet - uitvoering van het Verdrag van Parijs. Met betrekking tot de bijkomende schijven zoals voorzien in het Aanvullend Verdrag van Brussel, bevat hoofdstuk III van de WA$\mathrm{KO}$ geen bijzondere bepalingen inzake de verjarings- of vervaltermijnen. Dit betekent dus dat voor wat betreft de tussenkomst van de Nederlandse staat, eveneens de termijn geldt van 10 jaar, zoals bepaald in artikel 6 van het Aanvullend Verdrag van Brussel.

Volledigheidshalve moet erop worden gewezen dat bij de wijziging van de WAKO in 1991 is gepoogd om tegemoet te komen aan de causaliteitsproblematiek waarmee slachtoffers worden

641

642

643
Tweede Kamer, Vergaderjaar 1988-1989, 20 374, nr. 6, Memorie van Antwoord, 9.

Tweede Kamer, Vergaderjaar 1988-1989, 20 025, nr. 10, 2.

Memorie van Antwoord, Tweede Kamer, vergaderjaar 1988-1989, 20 374, nr. 6, 9. 
geconfronteerd. Op basis van het initiatiefvoorstel Zijlstra-Tazelaar zou een artikel 32 a in de WAKO worden ingevoerd in verband met niet individueel aanwijsbare schade ${ }^{644}$. Een commissie van deskundigen zou in deze gevallen een oordeel kunnen vellen ${ }^{645}$. Het is uitdrukkelijk de bedoeling geweest van de indieners van het voorstel om de bewijslast met betrekking tot de schade waarvan de causaliteit met een kernongeval moeilijk kan worden bewezen, niet eenzijdig te leggen bij individuele slachtoffers ${ }^{646}$. Dit voorstel tot invoering van artikel 32 a heeft het echter niet gehaald omdat de regering van oordeel was dat er geen wezenlijke behoefte bestond: via de voorziene procesrechtelijke bepalingen wordt vroegtijdig overleg tussen de verschillende betrokkenen mogelijk gemaakt ${ }^{647} 648$. Hierbij werd onder meer verwezen naar het feit dat causaliteit ook zonder het voorstel kan worden aangenomen op basis van statistische gegevens en dat de rechter op grond van de billijkheid de bewijslast anders kan verdelen. Tegelijk werd geoordeeld dat het beter zou zijn om de verdere ontwikkelingen van de rechtspraak af te wachten ${ }^{649}$. Op basis hiervan hebben de indieners van het initiatiefvoorstel hun wetsvoorstel ingetrokken ${ }^{650}$.

Hoewel dit voorstel het niet heeft gehaald, bestaat de verdienste van de indieners er zonder meer in dat werd gewezen op de mogelijke problemen bij de praktische afwikkeling van een kernongeval. Terecht werd gesteld dat een lange periode kan verstrijken vooraleer de eerste bedragen worden uitgekeerd ${ }^{651}$ : bij een aanzienlijk kernongeval in een land van het NEA-regime zal het niet eenvoudig zijn om snel de bedragen uit de drie verschillende schijven te kunnen genereren. Indien de totale schadevergoeding groter is dan het totale beschikbare schadevergoedingsbedrag (som van de drie schijven in het NEA-regime of de aansprakelijkheid van de exploitant in het IAEAregime), dan dienden de verschillende vorderingen op basis van de oude WAKO proportioneel te worden verminderd ${ }^{65}$. Maar er kan pas sprake zijn van een proportionele vermindering zodra de totale schadeomvang bekend is. Dit zal ontegensprekelijk tot een vertraging leiden. Een gevolg darvan is volgens de Nederlandse wetgever:

"Een goed deel van de winst dic voortvloeit uit de kanalisatie van de aansprakelijkheid (...) wordt door de gescheiden indiening van claims bij ener/ijds de exploitant en ander 2 ijds de overheid, op deze wijze weer teniet gedaan" ${ }^{1653}$.

Dit voorstel luidde: "Voorzover schade aan personen als gevolg van het vrijkomen van ioniserende straling niet per individu aanwijsbaar is, maar wel in medisch-statistisch verband met het ongeval staat, zal deze schade worden vastgesteld door de (...) commissie. Het door deze commissie vast te stellen bedrag zal daartoe worden uitgekeerd met name aan de daarvoor in aanmerking komende zicktekostenverzekeraars" (Voorstel van wet, Tweede Kamer, vergaderjaar 1986-1987, 20.025, nr. 2, 3). Het voorstel impliceerde dus geen omkering van de bewijslast zoals door Van Maanen wordt verdedigd (Van Maanen, G., "Pleidooi voor verbetering van de rechtspositie van slachtoffers van kemongevallen", o.c., 1343).

Memorie van Toelichting, Tweede Kamer, vergaderjaar 1986-1987, 20.025, nr. 3, 6-7.

Brief van de Minister van Financiën, Tweede Kamer, vergaderjaar 1988-1989, 20.025, nr. 10, 5; Tweede Nota van Wijziging, Tweede Kamer, vergaderjaar 1990-1991, 20.374, nr. 12, 4.

Over de politieke achtergronden bij het verwerpen van het voorstel, zie Van Maanen, G., "De civielrechtelijke aansprakelijkheid voor kemongevallen naar Nederlands recht", in Faure, M. (red.), "Aansprakelijkheid voor het nucleaire risico", l.c., 27.

Tweede Nota van Wijziging. Tweede Kamer, vergaderjaar 1990-1991, 20.374, nr. 12, 4.

Brief van het lid $\mathrm{K}$. Zijlstra en Swildens-Rozendaal houdende intrekking van het wetsvoorstel, Tweede Kamer, vergaderjaar 1990-1991, 20.025, nr. 12, 4.

Memorie van Toelichting, Tweede Kamer, vergaderjaar 1986-1987, 20.025, nr. 3, 3-4.

Artikel 15 van de WAKO van 17 maart 1979.

Memorie van Toelichting, Tweede Kamer, vergaderjaar 1986-1987, 20.025, nr. 3, 4. 
Voornamelijk dankzij het initiatiefvoorstel Zijlstra werd dus gewezen op de noodzaak om maatregelen uit te werken die een snelle en eenvoudige afhandeling van de vorderingen zouden bewerkstelligen. In de uiteindelijk goedgekeurde wettekst werden inderdaad bepalingen ingevoerd met het oog op de vereenvoudiging van de procesrechtelijke afwikkeling van schadegevallen.

\subsubsection{Procesrechtelijke bepalingen ter zake van de afwikkeling van schadegevallen}

De WAKO van 1979 bevatte reeds een aantal procesrechtelijke bepalingen; zo konden voorschotten worden gevraagd en kon aan de verzekeraar een tijdelijk betalingsverbod worden opgelegd ${ }^{654}$. Zodra de totale schade groter zou zijn dan het bedrag van de aansprakelijkheid van de exploitant, diende de wijze van afwikkeling van de schadevordering te worden geregeld bij wijze van algemene maatregel van bestuur ${ }^{655}$. Bij de totstandkoming van de WAKO van 1991 was de Nederlandse wetgever van oordeel dat een regeling omtrent het afwikkelen van de schade in feite ontbrak en dat een verdelingsregeling in de wet moest worden opgenomen ${ }^{656}$. In tegenstelling tot de oude WAKO, bevat de WAKO van 1991 dan ook een aantal artikelen die aangeven wie instaat voor de afwikkeling van de schade en hoe deze afwikkeling dient te geschieden ${ }^{65}$.

De Nederlandse wetgever heeft ervoor gekozen om de afwikkeling van een nucleair schadegeval in handen te leggen van een of meer onafhankelijke derden die onder toezicht staan van de rechter, met name de vereffenaar en rechter-commissaris ${ }^{68}{ }^{659}$. De in de WAKO uitgewerkte regels zijn opzettelijk niet bijzonder gedetailleerd maar verschaffen slechts een algemeen kader. Geoordeeld werd dat de omstandigheden van een kernongeval dermate gevarieerd kunnen zijn dat een te strakke regeling niet adequaat zou zijn ${ }^{660}$.

Overeenkomstig artikel $22,2^{\circ}$ lid van de WAKO, kan de rechtbank, zodra redelijkerwijze kan worden aangenomen dat het totaal der vorderingen het maximumbedrag van de aansprakelijkheid van de exploitant overtreft, een aantal maatregelen nemen. De rechtbank kan een verbod van betaling opleggen, een rechter-commissaris aanwijzen en een commissie van vereffenaars instellen. De taak van deze commissie heeft een "voorbereidend en praktisch karakter" ${ }^{1661}$.

De beschikking van de rechtbank waarbij deze maatregelen worden genomen, wordt terstond ter kennis gebracht van de exploitant en de verzekeraars of andere personen die een financiële zekerheid hebben gesteld. Betalingen die zijn verricht na deze kennisname, zijn van rechtswege nietig. Het is de bedoeling geweest van de Nederlandse wetgever om deze procedure uitsluitend toe te passen bij een zwaar kemongeval, waar een "verdelingsprobleem" zal ontstaan; als drempel om te bepalen of al dan niet sprake is van een verdelingsprobleem, wordt de overschrijding van de aansprakelijkheidslimiet gehanteerd. Dit blijkt zowel uit de bewoordingen van de wet zelf als uit de Memorie van Antwoord. Indien geen sprake is van een emstig kernongeval, zal de rechtbank

Respectievelijk artikel 31 en artikel 16 van de WAKO van 1979.

Artikelen 15 en 22 van de WAKO van 1979.

Memorie van Toelichting, Tweede Kamer, vergaderjaar 1987-1988, 20.374, nr. 3, 9.

Van Maanen, G., "De civielrechtelijke aansprakelijkheid voor kemongevallen naar Nederlands recht", in Faure, M. (red.), "Aansprakelijkheid voor het nucleaire risico", l.c., 25.

Memorie van Toelichting, Tweede Kamer, vergaderjaar 1987-1988, 20.374, nr. 3, 9.

De rechter-commissaris en de vereffenaar-curator zijn figuren die voortkomen uit de artikelen 64 e.v. de Nederlandse faillissementswet (Wet van den 30sten september 1893 op het faillissement en de surséance van betaling (Stb. 140, meermaals gewijzigd).

Memorie van Toelichting, Tweede Kamer, vergaderjaar 1987-1988, 20.374, nr. 3, 9.

Tweede Nota van Wijziging, Tweede Kamer, vergaderjaar 1990-1991, 20.374, nr. 12, 3. 
geen beschikking nemen, en zullen de algemene regels van burgerlijk procesrecht toepassing vin$\operatorname{den}^{662}$.

Belangrijk is vooral dat artikel $22,2^{\circ}$ lid in werking kan worden gesteld "op verzoek van een belanghebbende". Een slachtoffer van een kemongeval kan dus een vordering instellen bij de rechtbank teneinde de toepassing te verkrijgen van de voorziene maatregelen; nadat de exploitant en de minister van Financiën zijn gehoord, kan de rechtbank een verzoek in die richting al dan niet inwilligen. Weigert de rechter dit te doen, dan kan de belanghebbende hiertegen hoger beroep aantekenen. Omgekeerd is een hoger beroep tegen een beschikking die deze maatregelen uitvaardigt, uitdrukkelijk uitgesloten ${ }^{663} 664$.

Alle vorderingen tot vergoeding van de schade moeten ter verificatie worden ingediend bij de commissie van vereffenaars, die hiervan een afschrift stuurt naar de exploitant en de Minister van Financiën. Daarenboven kan de rechter-commissaris de exploitant, de verzekeraar of een andere persoon die een financiële zekerheid heeft gesteld, alsmede de Staat verplichten om de bedragen te storten. Op deze bedragen kan geen beslag worden gelegd.

Een bijzonder element in de procedure bestaat erin dat wordt voorzien in de mogelijkheid om snel met de belanghebbenden in overleg te treden en om deskundigen aan te wijzen ${ }^{665}$. Het overleg tussen slachtoffers en verzekeraars wordt gecoördineerd door de commissie van vereffenaars. Op basis van dit overleg en van de stukken die haar in dit kader worden overhandigd stelt de commissie een lijst op van de ingediende vorderingen; deze lijst kan door iedereen kosteloos worden ingekeken. De verificatie van de ingediende vorderingen gebeurt op de tijd en op de plaats die door de rechter-commissaris, in overleg met de commissie van vereffenaars, wordt vastgelegd. Deze verificatie kan inderdaad reeds in een vroeg stadium van de procedure plaatsvinden

Vorderingen die niet worden betwist, worden door de rechter-commissaris vastgesteld op het gevorderde bedrag ${ }^{666}$. Vorderingen die worden betwist, worden verwezen naar de rechtbank. Drie categoricën van personen kunnen volgens de Memorie van Toelichting de vordering betwisten: de schuldeisers (slachtoffers van het kemongeval kunnen belang hebben omdat de toewijzing van een vordering in hun nadeel kan werken doordat de totale schade de geldende limieten overschrijdt), de debiteuren (de exploitant, de verzekeraar of een andere persoon die een financiële zekerheid heeft gesteld en de Staat) en tenslotte ook de vereffenaar, uit hoofde van zijn ambt (bijvoorbeeld indien een ongegronde vordering werd ingediend die, bij gebrek aan betwisting, dreigt te worden aanvaard) ${ }^{667}$.

Memorie van Antwoord, Tweede Kamer, vergaderjaar 1987-1988, 20.374, nr. 6, 12.

Volgens artikel $31,1^{\circ}$ lid van de WAKO kan tegen een dergelijke beschikking geen hoger beroep, noch cassatieberoep worden ingesteld. In het Memorie van Antwoord lezen we dienaangaande dat: "... het belang dat wellicht is gemoeid met een eventuele vemietiging van een dergelijke beschikking, riet opweegt tegen het nadeel van de grote onzekerheid en de mogelijke chaos die kan ontstaan indien de mogelijkheid van vemietiging van een beschikking openstaat" (Memorie van Antwoord, Tweede Kamer, vergaderjaar 1987-1988, 20.374, nг. 6, 14).

Volgens de Memorie van Antwoord belet dit evenwel niet dat tegen een uitspraak over de vordering zelf en de omvang daarvan alle rechtsmiddelen openstaan, zoals voorzien in het Nederlands burgerlijke procesrecht (Memorie van Antwoord, Tweede Kamer, vergaderjaar 1987-1988, 20.374, nr. 6, 14).

Artikel $23,1^{\circ}$ lid van de WAKO.

Artikel $24,3^{\circ}$ lid van de WAKO

Memorie van Toelichting, Tweede Kamer, vergaderjaar 1987-1988, 20.374, nr. 3, 10.
} 
De staat van verdeling wordt na afloop van de zittingen van de rechtbank vastgesteld door de commissie van vereffenaars; deze wordt vervolgens door de rechter-commissaris goedgekeurd ${ }^{668}$. Zodra dit is gebeurd, ligt deze gedurende drie maanden gratis ter inzage op de griffie. Partijen kunnen gedurende deze termijn een met redenen omkleed bezwaarschrift indienen. Uiteindelijk zal de rechtbank hierover een beschikking vellen, die niet vatbaar is voor hoger beroep, noch voor beroep in cassatie ${ }^{669}$. Nadat deze verdeling is vastgesteld (hetzij door de rechter-commissaris, hetzij door de rechtbank) betaalt de commissie van vereffenaars de slachtoffers uit ${ }^{670}$. Voor alle duidelijkheid dient te worden onderstreept dat de definitieve afwikkeling veelal slechts na 10 of 30 jaar zal kunnen plaatsvinden en dat gedurende al die tijd vorderingen kunnen worden inge$\operatorname{diend}^{671}$.

De wetgever heeft dus van meet af aan erkend dat niettegenstaande deze procedure, de afwikkeling van een schadegeval meer dan een decennium kan duren; er werd op gewezen dat dit niet ligt aan de procedure zelf, maar aan het feit dat lang zal moeten worden gewacht op zekerheid omtrent de schadeomvang ${ }^{672}$. Volgens de Nederlandse wetgever is evenwel vooral van belang dat via de ingestelde commissie een vroegtijdig overleg plaatsvindt tussen de verschillende betrokkenen en dat de rechtbank slechts een rol heeft te vervullen indien geschillen overblijven ter zake van de schadeafwikkeling door de commissie ${ }^{673}$.

Net als onder de eerste versie van de WAKO, wordt ook hier, in artikel 30 , in de mogelijkheid voorzien om reeds voorschotten te verlenen gedurende de termijn die voorafgaat aan de vaststelling van de staat van verdeling; de rechter-commissaris kan op deze wijze een voorlopige staat van verdeling vaststellen ${ }^{674}$. De exploitant, de verzekeraar, een andere persoon die een financiële zekerheid heeft gesteld en de Staat kunnen worden verplicht tot betaling. Personen die een voorschot hebben verkregen, kunnen door de rechter-commissaris worden gevraagd om een door hem aan te wijzen vorm van zekerheid ter beschikking te stellen.

\subsubsection{De beperking van de aansprakelijkheid in de tijd naar toekomstig recht}

Op zich bevat het Verdrag inzake Bijkomende Compensatic niet meteen een bepaling inzake de aansprakelijkheid in de tijd. Het Verdrag voorziet enkel in een bijkomende schadevergoeding en voert als dusdanig geen verjarings- of vervaltermijnen in. Zoals reeds aangegeven kan een land toetreden tot het Verdrag indien het ofwel lid is van het Verdrag van Wenen of het Verdrag van Parijs, ofwel indien het in zijn interne wetgeving voldoet aan de voorwaarden zoals opgenomen in de Annex, c.q. indien het de grote principes van het nucleaire aansprakelijkheidsrecht heeft ingevoerd in het interne recht ${ }^{675}$. Artikel 9 van de Annex vermeldt uitdrukkelijk de vervaltermijn van 10 jaar en de ontdekkingsregel van 3 jaar. In beide hypothesen zal dus reeds een beperking van de aansprakelijkheid in de tijd in voege zijn, en daarom bevat het Verdrag inzake Bijkomende Compensatie hierover geen bijkomende bepalingen.

Artikel 26, $1^{\circ}$ lid van de WAKO.

Artikel $31,1^{\circ}$ lid van de WAKO.

Artike! 29 van de WAKO.

Memorie van Toelichting, Tweede Kamer, vergaderjaar 1987-1988, 20.374, nr. 3, 10.

Memorie van Antwoord, Tweede Kamer, vergaderjaar 1987-1988, 20.374, nr. 6, 15.

Tweede Nota van Wijziging, Tweede Kamer, vergaderjaar 1990-1991, 20.374, nr. 12, 4.

$\mathrm{Bij}$ (relatief) kleine schadevordering kan, volgens de Nederlandse wetgever, de definitieve afwikkeling een zuiver formele aangelegenheid blijven (Memorie van Toelichting, Tweede Kamer, vergaderjaar 1987-1988, 20.374, nr. 3, 12).

Cfr. supra, in $\S 2.2 .2 .2$ van hoofdstuk 2. 
De meest opvallende wijziging aangebracht door het Protocol van het Verdrag van Wenen inzake de beperking van de aansprakelijkheid in de tijd, is het onderscheid dat wordt gemaakt al naargelang het soort schade. Met name voor letselschade werd een andere termijn ingevoerd, namelijk 30 jaar na het kernongeval in plaats van 10 jaar. Voor alle andere schade blijft de termijn van 10 jaar onverkort gelden ${ }^{676}$. Volledigheidshalve wordt erop gewezen dat de bijzondere vervaltermijn van 20 jaar als voorzien in het Verdrag van Wenen, indien het kernongeval is veroorzaakt door gestolen of verloren splijtstoffen, wordt afgeschaft door het Protocol van het Verdrag van Wenen $^{677}$.

Het Protocol van het Verdrag van Wenen bevestigt dat een verlenging van de termijn waarbinnen een vordering kan worden ingediend enkel zinvol is indien deze is gedekt door een financiële zekerheid (verzekering, Staatstussenkomst, ...) (678 $^{679}$. Bij de onderhandelingen van het Protocol bleek dat met name de verzekeringsindustric was gekant tegen een aansprakelijkheidstermijn van meer dan 10 jaar $^{680}$. Hun bezorgdheid heeft vooral te maken met de onzekerheid inzake het causaliteitsbewijs en het daaruit voortvloeiende risico op speculatieve vorderingen ${ }^{681}$.

Bovendien kunnen de vorderingen inzake letselschade - of bij toepassing van de verlenging van de termijn ook inzake andere schade - die worden ingediend meer dan 10 jaar na het kernongeval, in geen enkel geval de rechten aantasten van personen die hun eis reeds hebben ingediend vóór het verstrijken van de periode ${ }^{682} 683$.

Het Protocol van het Verdrag van Wenen brengt ook een wijziging aan aan de ontdekkingstermijn van drie jaar. Op zich werd niet geraakt aan de termijn van drie jaar; maar onder het oorspronkelijke Verdrag van Wenen kon het toepasselijke recht voorzien in een periode van tenminste drie jaar (optioneel), terwijl onder het Protocol van het Verdrag van Wenen het recht op schadevergoeding komt te vervallen indien de vordering niet werd ingediend binnen de drie jaar nadat het slachtoffer kennis had of kennis behoorde te hebben van de schade en de aansprakelijke exploitant. Ook hier is uitdrukkelijk voorzien dat de termijn van 10 of 30 jaar in geen enkel geval kan worden overschreden ${ }^{684}$.

Artikel $8,1,1$, a) van het Protocol van het Verdrag van Wenen.

Artikel 8, 2 van het Protocol van het Verdrag van Wenen, schaft paragraaf 2 van artikel VI van het Verdrag van Wenen af.

678 Lamm, V., "Le Protocole d'amendement de la Convention de Vienne de 1963", o.c., 19.

57. Artikel 8 van het Protocol van het Verdrag van Wenen brengt op dit punt slechts een kleine redactionele wijziging aan aan de oorspronkelijk tekst van het Verdiag en brengt deze bepaling onder in cen afzonderlijke paragraaf.

6950 Dit blijkt uit een brief van British Insurance (Atomic Energy) Commitlce aan de NEA (Ruitsma, S.M.S. en Warren, G.C., "Vienna Convention on Civil Liability for Nuclcar Damage", British Insurance (Atonic Energy) Committee, London, januari 1995). Zie ook Warren, G.C., "Vienna Convention revision: a review of the exercise and the insurance implications in the provisions under discussion", o.c., 14.

651 Warren, G.C., "Nuclear Damage under the 1997 Protocol: Conventional Thinking?", in "Reform of Civil Nuclear Liability", l.c., 95-96; Warren, G.C., "Vienna Convention revision: a review of the exercise and the insurance implications in the provisions under discussion", o.c., 1995, 15; Lamm, V., "Le Protocole d'amendement de la Convention de Vienne de 1963", o.c., 19-20.

Artikel $8,1, c)$ van het Protocol van het Verdrag van Wenen.

Horbach, N.L.J.T., "Lacunae of Intemational Nuclear Liability Agreements", in Horbach, N.L.I.T. (ed.), "Contemporary Developments in Nuclear Energy Law", l.c., 67-68.

Artikel 8, 3 van het Protocol van het Verdrag van Wenen. 
Van belang is ook dat artikel 10 van het Protocol van het Verdrag van Wenen een regeling invoert inzake de prioritaire behandeling van letselschade en schade door overlijden. Deze voorrang wordt echter enkel verleend op voorwaarde dat het totale bedrag aan schadevorderingen het totale beschikbare schadevergoedingsbedrag dreigt te overtreffen, en op voorwaarde dat de vordering werd ingediend binnen de 10 jaar na het kernongeval ${ }^{685}$. Bij de onderhandelingen konden de verzekeraars zich moeilijk met deze bepaling verzoenen omdat dit tot de nodige problemen zou leiden voor wat de concrete afhandeling van de vorderingen betreft ${ }^{686}$.

Aansluitend hierbij werd in de loop van de onderhandelingen een voorstel besproken dat sterk door Nederland werd gesteund en dat voorzag in de oprichting van een nationale of internationale "Claims Commission"687. Uit bovenstaande analyse is inderdaad gebleken dat de Nederlandse WAKO een bijzondere procedure bevat ter zake van de afwikkeling van vorderingen na een kernongeval. Het voorstel bij de revisie van het Verdrag van Wenen hield in dat bij een kernongeval de verzekeraar ertoe zou gehouden zijn om meteen de volledige som zoals voorzien in de aansprakelijkheidspolis uit te keren aan de bijzondere Commissie, die zich vervolgens zou bezighouden met de verdeling van de fondsen.

De verzekeringsindustrie was voorstander van dit voorstel omdat in haar ogen het probleem van de kosten van een vordering (gerechtskosten, advocatenkosten etc.) niet op adequate wijze in het Verdrag wordt geregeld. Het probleem zou zich vooral situeren ten aanzien van vorderingen die langere tijd na het kemongeval zouden worden ingediend. Volgens de verzekeringsindustrie zou het aantal speculatieve vorderingen met de jaren toenemen ${ }^{688}$. Zij steunden zich met namen op cijfers naar aanleiding van het ongeval in Three Mile Island ${ }^{689}$.

Toch werd dit voorstel niet overgenomen in de definitieve tekst van het Protocol van het Verdrag van Wenen. Blijkbaar werd geoordeeld dat ook de Claims Commission bijzondere kosten met zich zou meebrengen.

Bij de besprekingen in het kader van de revisie van het Verdrag van Parijs liggen analoge thema's als deze in het Protocol van het Verdrag van Wenen ter tafel. Zo wordt de mogelijkheid besproken om de aansprakelijkheidslimiet uit te breiden tot 30 jaar voor wat betreft letselschade en om voorrang te geven aan vorderingen in verband letselschade ${ }^{6 \%}$. Ook wordt, eens te meer door de verzekeraars, veel aandacht besteed aan de kosten voor de afhandeling van de vorderingen ${ }^{691}$.

685 Lamm, V., "Le Protocole d'amendement de la Convention de Vienne de 1963", o.c., 21.

Warren, G.C., "Vienna Convention revision: a review of the exercise and the insurance implications in the provisions under discussion", o.c., 16.

687 "Liability and Compensation for Nuclear Damage", l.c., 129.

688 Warren, G.C., "Vienna Convention revision: a review of the exercise and the insurance implications in the provisions under discussion", o.c., 16.

Cfr. infra, in $\$ 3.2 .4$ van hoofdstuk 13.

Rustand, H., "Paris Convention on Third Party Liability in the field of Nuclear Energy. Progress report on negotiations to revise the Convention", in "Reform of Civil Nuclear Liability", l.c., 146; Warren, G.C., "Nuclear Damage under the 1997 Protocol: Conventional Thinking?", in "Reform of Civil Nuclear Liability", l.c., 94. 


\subsubsection{Conclusie}

Volgens het Verdrag van Parijs valt de schade uit een kernongeval enkel ten laste van de exploitant van de keminstallatie indien de vordering werd ingediend binnen een termijn van 10 jaar na het kernongeval. Toch kan de wetgeving van de Verdragsluitende Staten bepalen dat ook in de twintig daarop volgende jaren de schade zal worden gedekt.

Doordat de vervaltermijn eveneens is opgenomen in het Aanvullend Verdrag van Brussel, zal het verstrijken van een termijn van 10 jaar na het kernongeval tot gevolg hebben dat de tweede en derde schijf van het Verdrag in principe komen te vervallen. Na 10 jaar kunnen de Verdragsluitende Staten niet meer worden verplicht om hun bijdrage in de derde schijf te leveren. De interne wetgeving van een land kan uiteraard steeds bepalen dat zij ook na de periode van 10 jaar zal tussenkomen.

Op basis van de Belgische nucleaire aansprakelijkheidswet is de Staat ertoe gehouden om de schade te vergoeden die na 10 jaar wordt gevorderd - deze verplichting geldt slechts tot maximaal het bedrag waarvoor de exploitant aansprakelijk kan worden gesteld.

De Nederlandse WAKO verschilt van de Belgische nucleaire aansprakelijkheidswet omdat een onderscheid wordt gemaakt naargelang het type schade. Een vordering inzake zaakschade moet sowieso worden ingediend vóór het verstrijken van een termijn van tien jaar na het kemongeval, zoniet komt deze op basis van de WAKO niet in aanmerking voor vergoeding. Een vordering inzake letselschade daarentegen zal in de periode tot 10 jaar na het kernongeval ten laste vallen van de aansprakelijkheidsverzekering of financiële zekerheid van de exploitant; van dan af tot uiterlijk 30 jaar na het kernongeval zal deze schade ten laste vallen van de dekking waarvoor de Nederlandse overheid heeft gezorgd.

Inzake de beperking van de aansprakelijkheid in de tijd verschillen de Belgische en Nederlandse nucleaire aansprakelijkheidswet dus op twee punten van elkaar. Op basis van de Belgische wet komt zaakschade ook na 10 jaar na het kemongeval voor vergoeding in aanmerking, weze het dat deze ten laste valt van de Belgische Staat. Daarenboven kan de Belgische overheid op basis van de wet van 22 juli 1985 geen vergoeding aanrekenen voor de garantie die zij op deze wijze verschaft; dit is wel het geval voor de Nederlandse overheid. Anderzijds is de regeling in beide landen gelijk ter zake van de dekking van letselschade tussen 10 en 30 jaar na het kernongeval: de in die periode ingestelde vorderingen vallen ten laste van de overheid.

Doordat België en Nederland reeds gebruik hebben gemaakt van de in het Verdrag van Parijs geboden mogelijkheid tot uitbreiding van de vervaltermijn, kunnen zij op dit vlak probleemloos toetreden tot het Protocol van het Verdrag van Wenen. Ook daar wordt voorzien in ecn langere vervaltermijn mits een dekking beschikbaar is. Om helemaal correct te zijn kan echter niet worden gesproken van een verlenging van de aansprakelijkheid in de tijd, want deze blijft slechts gedurende de eerste 10 jaren ten laste van de exploitant. Het is juister te stellen dat op basis van het Verdrag de compensatieplicht wordt uitgebreid. Na 10 jaar na het kemongeval, en uiterlijk tot 30 jaar na het kernongeval, wordt deze plicht verschoven van de exploitant naar de overheid.

Naarmate een slachtoffer over een langere termijn beschikt om ccn vordering in te dienen, zal het evenwel onvoldoende zijn om eveneens in een dekking na 10 jaar te voorzien. Een groter probleem dan de dekking van de sommen die desgevallend na 10 inzake letselschade kunnen worden uitgekeerd, betreft het bewijzen van de causaliteit. $\mathrm{Na}$ langere tijd zal het voor slachtoffer namelijk zeer moeilijk worden om de causaliteit te kunnen aantonen tussen de door hem geleden scha- 
de en het kernongeval. Een verlengde vervaltermijn zal dus niet noodzakelijk de positie van slachtoffers verbeteren, indien niet wordt tegemoet gekomen aan de bewijsproblematiek inzake door de onmogelijkheid om de causaliteit te bewijzen ${ }^{62}$.

Hoewel in Nederland een poging werd ondernomen om tegemoet te komen aan de causaliteitsproblematiek, valt de WAKO ook op omdat wordt voorzien in een aantal procesrechtelijke bepalingen die tot doel hebben een geordende en sncllere afwikkeling van de vorderingen te bewerkstelligen. Opmerkelijk hierbij is vooral dat de rechtbank enkel als "last ressort" instantie zal worden ingeschakeld; er wordt naar gestreefd om de vordering zovecl als mogelijk in der minne te regelen in de schoot van een commissie van vereffenaars.

Ter afsluiting van de bespreking van de beperking van de aansprakelijkheid in de tijd, zoals ingevoerd in het internationale nucleaire aansprakelijkheidsrecht, dient opnieuw de aandacht te worden gevestigd op Zwitserland. In Zwitserland is in de eerste plaats een vervaltermijn van kracht van 30 jaar na het kernongeval; hierbij geldt evenwel de verjaringstermijn van drie jaar nadat het slachtoffer kennis had van zijn schade en van de aansprakelijke exploitant ${ }^{693}$. Maar artikel 13 bepaalt dat de Confederatie de schade zal dekken indien geen vergoeding meer kan worden verkregen door het verstrijken van de dertigjarige vervaltermijn. Met het oog hierop werd in Zwitserland de Nuclear Damage Fund opgericht, dat zijn middelen haalt uit heffingen die door de exploitant van de keminstallatie dienen te worden gedragen ${ }^{694}$. De middelen van dit Fonds worden aangewend niet alleen voor de verplichting van de Zwitserse Staat om een bedrag bovenop de aansprakelijkheidsverzekering van de exploitant ter beschikking te stellen, maar eveneens on vorderingen te vergoeden die na 30 jaar na een kernongeval worden ingediend.

\subsection{Conclusie}

De beperking van de aansprakelijkheid is een belangrijke afwijking van het gemene civiele aansprakelijkheidsrecht, op basis waarvan in principe de volledige schade dient te worden vergoed. In navolging van de analyse van het civiele aansprakelijkheidsrecht in hoofdstuk 1 , waaruit is gebleken dat een schade enkel wordt verschoven indien daartoe een goede reden bestaat, zou kunnen worden gezegd dat er een bijzonder goede reden dient te bestaan om de aansprakelijkheid te beperken.

In het nucleaire aansprakelijkheidsrecht werd de aansprakelijkheid beperkt omwille van verzekeringstechnische redenen. Bij de start van de nucleaire industrie waren onvoldoende gegevens beschikbaar om het nucleaire risico te kunnen inschatten. Uit de onmogelijkheid om een volledige dekking te krijgen, werd de noodzaak afgeleid om de aansprakelijkheid te beperken. De bijzonder goede reden om het slachtoffer van een kernongeval het recht op volledige schadeloosstelling te ontnemen is in het nucleaire aansprakelijkheidsrecht dan ook van zuiver economische aard: het dient de exploitant te beschermen tegen potentieel ruïneuze vorderingen.

De idee was dat de aansprakelijkheid diende te worden beperkt tot het bedrag dat op de verzekeringsmarkt beschikbaar is. Maar doordat nergens in de Verdragen de plicht is opgenomen om de

Ook in die zin Matthijs, J., "Aansprakelijkheid bij toepassing van kemenergie tot vreedzame doeleinden", o.c., 130.

${ }_{694}$ Zie hierover Bühlmann, W.A., "Assurance Responsabilité Civile complémentaire d'Etat: L'exemple de la loi suisse sur la responsabilité civiele en matière nucléaire", in Nuclear Accidents. Liabilities and Guarantees, OECD-IAEA, Paris, 1993, 434 e.v. 
aansprakelijkheidslimiet te laten mee evolueren met de capaciteit van de nucleaire verzekeringsmarkt en doordat de verzekerde bedragen slechts in geringe mate zijn gestegen, lijkt het er sterk op dat in de meeste landen in werkelijkheid een hogere capaciteit beschikbaar is dan de aansprakelijkheidslimiet van de exploitant. Er kan immers van uit worden gegaan dat na meer dan veertig jaar nucleaire activiteiten meer gegevens beschikbaar zijn en dat in dezelfde periode de capaciteit van de nucleaire verzekeraars is toegenomen.

Bijzonder is ook het feit dat deze Staatstussenkomst via het Aanvullend Verdrag van Brussel, verplicht wordt gesteld. Ook in het toekomstige nucleaire aansprakelijkheidsrecht 7al de overheid verplicht dienen tussenbeide te komen: het Protocol van het Verdrag van Wenen van 1997 en het Verdrag inzake Bijkomende Compensatie van 1997 voorzien in een tussenkomst vanwege de Staat. Het feit dat het inderdaad .een plicht betreft in hoofde van de Staat, heeft verregainde gevolgen: geeft de Staat geen gevolg aan haar plicht, dan kan haar aansprakelijkheid desgevallend in het gedrang komen.

Ingevolge de rol van de installatiestaat, zal een slachtoffer van een kernongeval in de meeste landen minstens twee schuldeisers hebben: de aansprakelijkheidsverzekcraar van de exploitant en de installatiestaat. Alleen al hieruit kan de nood worden afgeleid om con soepele regeling voor de schadeafwikkeling tot stand te brengen. Alvast via het Protocol van het Verdrag van Wenen is het niet gelukt om een internationale commissie op te zetten. De Nederlandse WAKO lijkt op dit punt een buitenbeentje. Waarschijnlijk zal de WAKO erin slagen om de proceskosten te beperken; maar of de beschikbare bedragen sneller zullen worden uitgekeerd ingevolge de specifieke procedure, is niet zeker.

Deze economische reden om de aansprakelijkheid te beperken, wordt ook ingeroepen in andere takken van het civiele aansprakclijkheidsrecht. Uit onderzoek blijkt dat de gocde redenen om de aansprakelijkheid te beperken in feite variaties zijn op eenzelfde thema, met name de onverzekerbaarheid $^{695}$ : onbeperkte risicoaansprakelijkheid zou onverzekerbaar zijn, elke aansprakelijkheid dient door een verzekering te zijn gedekt, onverzekerbare aansprakelijkheid is niet in het belang van het slachtoffer etc. komen.

Een essentiële vraag bij de discussie omtrent de beperkte aansprakelijkheid, is of elke aansprakelijkheid door een verzckering moet zijn gedekt, laat staan dat elkc aansprakelijkheid verzekerbaar moet zijn ${ }^{696}$. Door de aansprakelijkheid te beperken wordt namelijk een deel van de lasten afgewenteld op de gemeenschap ${ }^{697}$. In het nucleaire aansprakelijkheidsrecht krijgt deze vaststelling cen bijkomende dimensie. Uit de analyse is geleken dat het bedrag dat slachtoffers ter beschikking zullen hebben, afhangt van de verzekeringscapaciteit op de markt waar de exploitant zijn dekking kan kopen en van de bereidheid van de Staat om hetzij een deel van deze aansprakelijkheid voor zijn rekening te nemen, hetzij een bedrag te garanderen bovenop de aansprakelijkheid van de exploitant. Door de combinatie van de rol van de installatiestaat en de beperking van de aansprakelijkheid (waardoor een deel van de schade ten laste van de gemeenschap valt), draagt de Staat in het nucleaire aansprakelijkheidsrecht in feite op dubbele wijze bij ter zake van de compensatie van schade uit een kernongeval.

De Vries, F.J., "Wettelijke limitering van aansprakelijkheid", l.c., 26 e.v.

Faure, M.G. en Hartlief, T., "Gevolgen van de uitbreidende werkgeversaansprakelijkheid", in Faure, M.G. en Hartlief, T., (red.), "Verzekering en dc groeiende aansprakelijkheidslast", l.c., 314.

Memorie van Antwoord, Tweede Kamer, vergaderjaar 1990-191, 21 202, nr. 6, 24. 
Indien er een maatschappelijke consensus zou bestaan over de voordelen van de beperkte aansprakelijkheid en over de noodzaak dat ook de Staat een deel van de schade voortvloeiend uit een maatschappelijk nuttige activiteit vergoedt, dan dient deze afwijking van het gemene aansprakelijkheidsrecht te zijn gebaseerd op eenduidige criteria. Door de lastenverschuiving ingevolge de beperking van aansprakelijkheid, wordt de wetgever inderdaad aangezet tot een voorzichtige belangenafweging ${ }^{698}$. Hoewel de beperking van aansprakelijkheid ook is terug te vinden in de wetgeving inzake de aansprakelijkheid voor olieverontreiniging op zee, blijft een beperking van de aansprakelijkheid een uitzondering op de algemene regel ${ }^{699}$. Bij heel wat ongevallen zal de totale schade uit een ongeval hoger zal zijn dan de bedragen die op basis van de aansprakelijkheidsverzekering van de betrokken actoren beschikbaar zijn. In deze situatie zal de aansprakelijkheid niet noodzakelijk beperkt zijn, laat staan dat de Staat zal worden verplicht een deel van de niet-gedekte schade voor haar rekening te nemen.

Een zeker maar beperkt bedrag wordt in het nucleaire aansprakelijkheidsrecht hoger ingeschat dan een onbeperkte maar onzekere schadevergoeding ${ }^{700}$. Het belang dat wordt gehecht aan de zekerheid dat een slachtoffer een schadeloosstelling zal ontvangen, blijkt ook uit één van de andere grote basisprincipes van het nucleaire aansprakelijkheidsrecht: de verplichte dekking van de aansprakelijkheid. Dit principe wordt in de volgende paragraaf aan de orde gesteld.

\section{VERPLICHTE DEKKING VAN DE AANSPRAKELIJKHEID VAN DE EXPLOITANT}

Het vierde basisprincipe van het nucleaire aansprakelijkheidsrecht is de verplichte dekking van de aansprakelijkheid van de exploitant van de kerninstallatie. Eerder werd reeds besproken dat diens aansprakelijkheid berust op een regime van risicoaansprakelijkheid, dat de aansprakelijkheid naar de exploitant wordt gekanaliseerd en dat deze aansprakelijkheid zowel naar bedrag als in de tijd is beperkt. Hieronder wordt opnieuw de in de vorige delen van dit hoofdstuk gehanteerde indeling gevolgd. In eerste instantie worden de bepalingen besproken van het Verdrag van Parijs (\$4.1), vervolgens deze van de Belgische wet van 1985 ( $\$ 4.2$ ) en van de Nederlandse WAKO (\$4.3). Ook inzake de verplichte dekking van de aansprakelijkheid van de exploitant zal worden onderzocht of het toekomstige nucleaire aansprakelijkheidsrecht hierin een wijziging zal aanbrengen $(\$ 4.4)$. De bevindingen van de analyse worden samengevat in $\S 4.5$.

Voor de goede orde dient te worden aangegeven dat in deze paragraaf enkel de verplichte dekking wordt besproken zoals ingeschreven in het internationale nucleaire aansprakelijkheidsrecht. De wijze waarop deze dekking kan worden verkregen, wordt aangegeven in hoofdstuk 6, bij de analyse van de verzekering van het nucleaire risico.

698. De Vries, F.J., "Wettelijke limitering van aansprakelijkheid", l.c., 2; Faure, M.G. en Hartlief, T., "Gevolgen van de uitbreidende werkgeversaansprakelijkheid", in Faure, M.G. en Hartlief, T., (red.), "Verzekering en de groeiende aansprakelijkheidslast", l.c., 309-310.

Onderzoek heeft uitgewezen dat van een algemene beperking van milieuaansprakelijkheid, beroepsaansprakelijkheid en verkeersaansprakelijkheid vooralsnog geen sprake is (Faure, M.G. en Hartlief, T., "Gevolgen van de uitbreidende werkgeversaansprakelijkheid", in Faure, M.G. en Hartlief, T., (red.), "Verzekering en de groeiende aansprakelijkheidslast", l.c., 311; Hartlief, T. en Tjittes, R.P.J.L., "Verzekering en Aansprakelijkheid", l.c., 58).

Piérard, J.P., "Responsabilité civile. Energie atomique et droit comparé", l.c., 113; Van Maanen, G., "De civielrechtelijke aansprakelijkheid voor kemongevallen naar Nederlands recht", in Faure, M. (red.), "Aansprakelijkheid voor het nucleaire risico", l.c., 33. 


\subsection{Volgens het Verdrag van Parijs}

De bepalingen in het Verdrag van Parijs inzake de verplichte dekking van de aansprakelijkheid van de exploitant worden geanalyseerd aan de hand van vier thema's. In eerste instantie wordt het principe zelf van de verplichte dekking besproken (\$ 4.1.1). In tweede instantie wordt de rol van het congruentievereiste besproken in de discussie omtrent de toelaatbaarheid van een systeem van onbeperkte aansprakelijkheid ( $\$ 4.1 .2)$ Vervolgens worden de rol van de installatiestaat ( $\$ 4.1 .3)$ en van het bevoegde openbare gezag aan de orde gesteld ( $\$ 4.1 .4)$. Tenslotte wordt ook geanalyseerd of het Verdrag van Parijs de dekking verplicht stelt per installatie, dan wel per kernongeval $(\$ 4.1 .5)$.

\subsubsection{Verplichte dekking van de aansprakelijkheid: het congruentievereiste}

Artikel 10, a van het Verdrag van Parijs verplicht de exploitant van een kerninstallatie om, ter dekking van zijn aansprakelijkheid tegenover derden, een verzekering of andere financiële zekerheid te hebben en in stand te houden. Dit wordt het congruentievereiste genoemd ${ }^{701}$. Het komt erop neer dat tegenover elke aansprakelijkheid een financiële voorziening beschikbaar dient te zijn. Het congruentievereiste wil aan slachtoffers van een kernongeval de garantie geven dat - zij het beperkte - sommen beschikbaar zullen zijn ter compensatie van de geleden schade ${ }^{702}$. Slachtoffers worden via deze bepaling met andere woorden beschermd tegen de mogelijke insolvabiliteit van de exploitant ${ }^{703}$. Twee andere bcpalingen hebben tot doel deze zekerheid te "verstevigen".

Volgens artikel 10, b van het Verdrag van Parijs kan de verzekeraar of de persoon die een andere financiële zekerheid heeft gesteld, de verzekering niet opzeggen of schorsen dan nadat hij daarvan tenminste twee maanden van tevoren het bevoegde openbare gezag schriftelijk heeft op de hoogte gebracht; deze termijn kan door deze bevoegde autoriteit worden verlengd. Deze bepaling strekt er volgens het Exposé des Motifs toe om in de mate van het mogclijke te garanderen dat er nooit een periode zal zijn gedurende dewelke een geringer bedrag dan het totale bedrag van de aansprakelijkheid zal beschikbaar zijn ${ }^{704}$.

Artikel 10, c van het Verdrag van Parijs tenslotte bepaalt dat de bedragen die ingevolge de verzekering, herverzekering of andere financiële zekerheid ter beschikking staan, uitsluitend mogen worden aangewend voor vergoeding van de door een kernongeval veroorzaakte schade. Blijkbaar wil deze bepaling benadrukken dat de sommen die de exploitant ter beschikking heeft op basis van zijn verplichting in artikel 10 van het Verdrag van Parijs, enkel mogen worden aangewend ter vergoeding van schadc aan derden, en bijgevolg niet ter vergoeding van de eigenschade van de exploitant en dat deze sommen enkel kunnen worden aangewend bij een kernongeval.

Het congruentievereiste wordt in het Verdrag van Parijs niet enkel vermeld in artikel 10 , maar ook in de artikelen 7, b en 8 a, respectievelijk met betrekking tot de beperking van het bedrag van de aansprakelijkheid en de beperking van de aansprakelijkhcid in de tijd. Er wordt aangegeven dat de aansprakelijkheid van de exploitant mag worden verhoogd, op voorwaarde dat deze aansprakelijkheid is gedekt:

701

Domsdorf, E.P.M.W., "Internationaal Atoomenergierecht", I.c., 723; Pelzer, N., "Focus on the Future of Nuclear Liability Law", in "Reform of Civil Nuclear Liability", l.c., 433 e.v.

Camier, M.-C., "Responsabilité et Assurance du Risque Atomique", l.c., 159; "Liability and Compensation", l.c., 50 .

Official Records Vienna Convention, 81; Camier, M.-C., "Responsabilité et Assurance du Risque Atomique", l.c., 159.

Exposé des Motifs, 61 . 
De verplichting in hoofde van de exploitant van de kerninstallatie om bepaalde financiêle garanties te geven, vloeit rechtstreeks voort uit de conclusies van het Voorlopig Rapport ${ }^{705}$. Volgens dit rapport dient de exploitant te bewijzen dat hij over voldoende provisies beschikt zodat hij de door hem veroorzaakte schade aan derden kan vergoeden. Toch betekent dit volgens de auteurs van het Voorlopig Rapport niet dat hij moet worden verplicht om een verzekeringsdekking te kopen. $Z_{0}$ zou het volstaan dat de exploitant bewijst dat hij over voldoende eigen middelen beschikt ${ }^{706} 707$, of dat hij een andere financiële zekerheid stelt.

Dezelfde vrijheid waarover de exploitant beschikt om in een financiële dekking te voorzien, is terug te vinden in het Verdrag van Parijs. Volgens het Exposé des Motifs kan de financiële zekerheid iit een borgtocht of liquide middelen bestaan; ook een garantie van de Staat en een bankgarantie kunnen worden aanvaard, maar van in het begin was duidelijk dat voornamelijk verzekeringspolissen de aansprakelijkheid van de exploitant zouden dekken ${ }^{708}$. Het is de exploitant toegelaten om een verzekeringsdekking ${ }^{709}$ te combineren met andere financiële zekerheden, op voorwaarde dat te allen tijde het bedrag waarvoor hij aansprakelijk is, wordt gedekt ${ }^{710}$. Een exploitant heeft dus in principe de keuze om uit te maken via welke middelen zijn aansprakelijkheid tegenover derden zal worden gedekt. Aangezien de exploitant meerdere types van financiële zekerheid mag aanwenden, betekent de congruentie dus niet dat de aansprakelijkheid volledig door de exploitant zelf moet worden gedekt; van belang is dat tegenover het gelimiteerde aansprakelijkheidsbedrag een financiële voorziening beschikbaar is.

De vrijheid die aan de exploitant wordt gegeven, gaat zeer ver: op grond van de bepalingen van het Verdrag van Parijs is het perfect mogelijk dat een deel van de aansprakelijkheid van de exploitant wordt gedekt door een aansprakelijkheidsverzekering, terwijl voor het andere deel de installatiestaat instaat voor de dekking. Sterker nog: geen enkele bepaling in het Verdrag van Parijs staat eraan in de weg dat het gehele bedrag waarvoor de exploitant door het nationale recht wordt aansprakelijk gesteld, door de installatiestaat zou worden gedragen. In dat geval zal de exploitant immers, volledig conform artikel 10, een financiële zekerheid hebben ter grootte van zijn (beperkte) aansprakelijkheid.

Het congruentievereiste heeft ook een belangrijk gevolg voor de discussie met betrekking tot de toelaatbaarheid van een regime van onbeperkte aansprakelijkheid in het internationale nucleaire aansprakelijkheidsrecht. Eerder werd aangegeven dat artikel 7 van het Verdrag van Parijs ondub-

705 Cfr. supra, bij de bespreking van het ontstaan van de kanalisatie van aansprakelijkheid, $\$ 2.1 .2$ van hoofdstuk 4.

706 "To insist upon adequate provision by the operator is not, however, to require that he purchases insurance. If he can show that he is financially able to pay losses out of assets which are and will remain available for such purpose, he should be allowed to make his own decision with respect to insurance" (Voorlopig Rapport, 34).

De rol van de overheid met betrekking tot de aansprakelijkheid van de exploitant was volgens de auteurs van het Voorlopig Rapport: "(to) ... take affirmative steps to see that the operator has made adequate provisions to compensate those whom he may damage" (Voorlopig Rapport, 34). Exposé des Motifs, 57; Camier, M.-C., "Responsabilité et Assurance du Risque Atomique", l.c., 162. Het blijkt overigens de bedoeling te zijn geweest van de Verdragspartijen om deze dekkingsplicht op te leggen aan exploitanten van alle keminstallaties, ongeacht of kleinere onderzoeksreactoren betreft, dan wel commerciële elektriciteitsproducerende kerninstallaties. Geoordeeld werd dat aangezien de premies worden berekend aan de hand van het vermogen van de reactor en het type installatie, de premies van onderzoeksreactoren automatisch lager zullen liggen dan de premies van elektriciteitsproducerende reactoren (Carnier, M.-C., "Responsabilité et Assurance du Risque Atomique", l.c., 160). 
belzinnig een maximumlimiet plaatst op de aansprakelijkheid van de exploitant ${ }^{711}$. Gelet op het feit dat artikel 7 verwijst naar artikel 10, moet worden onderzocht in welke mate het congruentievereiste van belang is bij de discussie over de toelaatbaarheid van een regime van onbeperkte aansprakelijkheid in het Verdrag van Parijs.

\subsubsection{Rol van het congruentievereiste in de discussie omtrent de toelaatbaarheid van de onbeperkte aansprakelijkheid in het Verdrag van Parijs}

In de literatuur bestaat geen eensgezindheid met betrekking tot de vraag of een regime van onbeperkte aansprakelijkheid al dan niet strijdig is met de bepalingen van het Verdrag van Parijs. Eenzelfde vraag rijst voor wat betreft het IAEA-regime, vermits artikel VII van het Verdrag van Wenen het congruentievereiste invoert ${ }^{712} 713$

Ook in de praktijk is enige twijfel vast te stellen: Zwitserland en Japan weigeren lid te worden van een van de Verdragen (Parijs of Wenen), precies omdat zij oordelen dat de in hun interne wetgeving van kracht zijnde onbeperkte aansprakelijkheid niet in overeenstemming is te brengen met de desbetreffende Verdragsbepalingen ${ }^{714}$. Ook de recent gewijzigde nucleaire aansprakelijkheidswet in Oostenrijk heeft de beperking van de aansprakelijkheid opgeheven ${ }^{715}$. Duitsland is lid van het Verdrag van Parijs, maar heeft in haar Atomgesetz een onbeperkte aansprakelijkheid van de exploitant van de keminstallatie ingevoerd. De Duitse wet voorziet in een onbeperkte aansprakelijkheid maar koppelt hieraan een beperkte verzekeringsplicht.

Het wekt dan ook weinig verwondering dat met name in de Duitse literatuur ruim aandacht werd besteed aan de beperking van de aansprakelijkheid van de exploitant van de keminstallatie ${ }^{716}$. Een aantal Duitse auteurs is de mening toegedaan dat een opheffing van de beperking van de aanspra-

Cfr. supra, in $\$ 3.1 .1 .2$ van dit hoofdstuk.

Artikel VII van het Verdrag van Wenen luidt: "The operator shall be required to maintain insurance or other financial security covering his liability for nuclear damage (...)".

A contrario Pelzer, N., "Focus on the Future of Nuclear Liability Law", in "Reform of Civil Nuclear Liability", l.c., 434.

Zie voor wat Zwitserland betreft: Brunengo, C., "Cross Border Damage - Two Fiction Stories", AIDN/1NLA, Nuclear Inter Jura 91, Bath, 23 september - 26 september 1991, 217; Bủhlman, W., "Deux éléments nouveaux de la législation suisse sur la responsabilité civile en matière nucléaire", in Nuclear Third Party Liability and Insurance, AEN-OECD, Paris, 1985, 385-399; en voor wat Japan betreft: Dogauchi, M., "Transfrontier Nuclear Civil Liability without International Conventions", AIDN/INLA, Nuclear Inter Jura '91, Bath, 23 september - 26 september 1991, 209.

Hinteregger, M., "La nouvelle loi autrichienne sur la responsabilité civile pour les domrnages nucléaires", o.c., 30 e.v.

In de ogen van de voorstanders van de onbeperkte aansprakelijkheid, was de beperking van de aansprakelijkheid onlogisch: "Wer für unsere Energieversorgung die Energie von Kernkraftwerke bejaht, der sollte daher auch die volle finanzielle Versorgung der Mitbürger im nuklearen Schadensfalle bejahen" (Pfaffelhuber, J.K. en Kuckuck, B., "Reformüberlegungen zur Ausgestaltung der atornechtlichen Haftung", in Lukes, R. (herausg.), Sechstes Deutsches Atomrechts-Symposium, Carl Heymanns Verlag, Keulen, 1980, 383). 
kelijkheid van de exploitant strijdig is en blijft met het Verdrag van Parijs ${ }^{717}$. Ook de verzekeraars waren van oordeel dat het onmogelijk was om in een onbeperkte dekking te voorzien ${ }^{718}$.

De voorstanders van een systeem van onbeperkte aansprakelijkheid stelden dat op grond van de bepalingen van het Verdrag van Parijs de exploitant onbeperkt aansprakelijk kan worden gesteld voor de schade uit een kernongeval. Hun hoofdargument was dat enkel een onbeperkte aansprakelijkheid die zou leiden tot het faillissement van de exploitant, strijdig is met het Verdrag. Omgekeerd zou een onbeperkte aansprakelijkheid die niet ruïneus zou zijn voor de exploitant, in overeenstemming zijn met het Verdrag van Parijs ${ }^{719}$. De kernenergie-industrie zou volgens Pelzer door een onbeperkte aansprakelijkheid niet worden benadeeld of ontmoedigd indien voldoende voorzieningen werden getroffen ${ }^{720}$. Uit artikel 10 zou dus geen verplichting kunnen worden afgeleid om tegenover een onbeperkte aansprakelijkheid te voorzien in een onbeperkte dekking ${ }^{721}$. De congruentie zou enkel impliceren dat de exploitant ertoe gehouden is om voor het minimumbedrag van diens aansprakelijkheid een verzekeringsdekking te nemen ${ }^{722}$. Bijkomend zijn Pfaffelhuber en Kuckuck van oordeel dat een onbeperkte aansprakelijkheid misschien strijdig is met de verdragsbepalingen, maar het zou zeker strijdig zijn met de geest van het Verdrag om pogingen om de positie van het slachtoffer te verbeteren, in strijd met het Verdrag te verklaren ${ }^{723}$. Volledigheidshalve wordt erop gewezen dat in de Verenigde Staten de grondwettelijkheid van de beperkte aansprakelijkheid van de exploitant werd in vraag gesteld ${ }^{724}$. Ook Pelzer wijst erop dat in eender welk land bijvoorbeeld door een evolutie in de rechtspraak betreffende de interpretatie van een aantal grondwettelijke bepalingen, de grondwettelijkheid van de beperkte aansprakelijkheid in het gedrang kan komen ${ }^{725}$.

Deze argumenten nemen niet weg dat vanuit juridisch oogpunt een systeem van onbeperkte aansprakelijkheid niet mogelijk is onder het NEA-regime ${ }^{726}$. In ecrste instantie moet worden gewezen op de tekst van artikel 7 van het Verdrag inzake de beperking van het bedrag van de aansprakelijkheid van de exploitant van een kerninstallatie ${ }^{727}$. Maar vooral het congruentievereiste lijkt zich tegen een onbeperkte aansprakelijkheid te verzetten: volgens deze vereiste dient elke aansprake-

Bijvoorbeeld Schmidt, K., "Reformüberlegungen zur Ausgestaltung der atomrechtlichen Haftung", in Lukes, R. (herausg.), Sechstes Deutsches Atomrechts-Symposium, Carl Heymanns Verlag, Keulen, $1980,399$.

Zie bijvoorbeeld Breining, W., "Reformüberlegungen zur Ausgestaltung der atomrechtlichen Haftung" in Lukes, R. (herausg.), Sechstes Deutsches Atomrechts-Symposium, Carl Heymanns Verlag. Keulen, $1980,404$. Pelzer, N., "Unbegrenzte Haftung", l.c., 40-41.

De discussie met betrekking tot de hoogte van het bedrag waarvoor de exploitant aansprakelijk is, is nauw verbonden met de mate wasin ook de overheid een deel van de schadevergoeding voor schade uit een kernongeval, op zich neemt. De redenering hierbij is dat de Staat de bedragen die uitstijgen boven de aansprakelijkheidsverzekering van de exploitant, voor haar rekening neemt. Het voordeel hiervan bestaat erin dat slachtoffers steeds een aansprakelijke persoon tegenover zich hebben: hetzij de exploitant, hetzij de Staat (Pelzer, N., "Unbegrenzte Haftung", l.c., 22 en 54). Peizer, N., "Unbegrenzte Haftung", l.c., 58. Hohlefelder, W., "Reconsideration of the Principle of the Nuclear Operator's Limitation of Liability", in "Nuclear Third Party Liability and Insurance, l.c., 383. Pfaffelhuber, J.K. en Kuckuck, B., "Reformüberlegungen zur Ausgestaltung der atorrrechtichen Haftung", o.c., 389 Cfr. infra, in \$2.4.1.2 van hoofdstuk 13.

Pelzer, N., "Reformüberlegungen zur Ausgestaltung der atomrechtlichen Haftung", in Lukes, R. (Herausg.), "Sechstes Deutsches Atmrechts-Symposium", l.c., 419; Pelzer, N., "Unbegrenzte Haftung", l.c., 29 e.v

Ook in die zin Domsdorf, E.P.M.W., "Internationaal Atoomenergierecht", l.c., 674-681.

Cfr. supra, in § 3.1.1.2 van dit hoofdstuk. 
lijkheid namelijk te zijn gedekt door een verzekering of financiële zekerheid. Een onbeperkte dekking en een onbepeikte aansprakelijkheid zouden in de ogen van de Verdragspartijen leiden tot het faillissement van de exploitant waardoor de bescherming van het slachtoffer in het gedrang zou komen. Hierbij mag evenmin de context van het Verdrag van Parijs uit het oog worden verloren. Deze context is de samenhang van de verschillende basisprincipes en zeker de samenhang tussen artikel 7 en artikel 10 van het Verdrag. De stelling dat de congruentie de onbeperkte aansprakelijkheid niet in de weg staat, is een interpretatie die deze samenhang miskent. Uit het enkele feit, zoals betoogd door een deel van de Duitse rechtsleer, dat het absurd is om aan slachtoffers het voordeel van een onbeperkte aansprakelijkheid te ontzeggen, kan niet worden afgeleid dat een onbeperkte aansprakelijkheid conform is aan de verdragsbepalingen.

Concluderend kan worden gesteld dat het, volgens de huidige tekst van het Verdrag van Parijs, niet mogelijk is om een onbeperkte aansprakelijkheid in te voeren. Het is dan ook niet toevallig dat dit thema één van de discussiepunten is bij de revisie van het Verdrag van Parijs. Volgens de hangende voorstellen zouden de Verdragsluitende Staten de mogelijkheid krijgen om een onbeperkte aansprakelijkheid in hun nationale wetgeving in te voeren ${ }^{728}$. Dit veronderstelt evenwel zowel een wijziging van artikel 7 als van artikel 10 van het Verdrag.

Het is evident dat de congruentie zoals verwoord in artikel 10 van het Verdrag van Parijs, uitsluitend betrekking heeft op de aansprakelijkheid van de exploitant. Toch kan ook de installatiestaat een rol vervullen bij de dekking van deze aansprakelijkheid.

\subsubsection{Rol van de installatiestaat}

Ter zake van de bepaling van de dekking van de aansprakelijkheid van de exploitant bestaut een veischil in de tekst van het Verdrag van Parijs ten overstaan van de tckst van het Verdrag van Wenen. Artikel VII, 1, tweede zin van het Verdrag van Wenen bepaalt namelijk dat de installaticstaat de betaling van de vorderingen zal verzekeren indien de dekking van de exploitant niet toereikend of adequaat blijkt te zijn ${ }^{729}$. Uit deze bepaling wordt een dubbele verplichting afgeleid. Ten eerste rust op de exploitant de verplichting ervoor te zorgen dat hij een financiële zekerheid of verzekeringsdekking verkrijgt en heeft. Daarenboven hecft de installatiestaat de plicht crvoor tc zorgen dat een effectieve en adequate dekking in stand wordt gchouden, binnen de limieten van de aansprakelijkheid van de exploitant ${ }^{730}$.

Een analoge dubbele verplichting als deze vermeld in het Verdrag van Wenen, is niet expliciet terug te vinden in het Verdrag van Parijs. Er bestaat weinig twijfel over de verplichting van de exploitant om een dekking te hebben, maar de tekst van het Verdrag van Parijs bevat nict meteen een verplichting in hoofde van de installatiestaat om tussen te komen ingeval de dekking van de exploitant ontoereikend zou zijn. De rol van de installatiestaat is er, minsténs op het eerste gezicht, beperkt tot het vaststellen van de aard en de voorwaarden van financiële zekerheid.

\footnotetext{
mis

Rustand, H., "Paris Convention on Third Party Liability in the field of Nuclear Energy. Progress report on negotiations to revise the Convention", in "Reform of Civil Nuclear Liability", l.c., 144.

729 Dit artikel luidt: "The Installation State shall ensure the payment of claims for compensation for nuclear damage which have been established against the operator by providing the necessary funds to the extent that the yield of insurance or other financial security is inadequate to satisfy such claims, but not in excess of the limit, if any, established pursuant to article V". Tijdens de onderhandelingen werd benadrukt dat deze bepaling niet de verplichting inhield van de Staat om reeds op voorhand budgetten vrij te maken (Official Records Vienna Convention, 286).

Official Records Vienna Convention, 81.
} 
Toch lijkt het Exposé des Motifs te refereren aan een analoge plicht van de installatiestaat zoals voorzien in het Verdrag van Wenen. Blijkbaar werd tijdens de onderhandelingen erkend dat er steeds iets onverwacht kon gebeuren zoals het faillissement van de verzekeraar of de financiële waarborg ${ }^{731}$ :

"It was therefore recognised that these circumstances could not set aside the obligation of the operator under article 10 or that of the State which is required to ensure that the operator always holds financial security up to his maximum liability. The Contracting Parties may therefore be led to intervene in such a situation to avoid their international responsibilities being involved"732.

Hieruit kan worden afgeleid dat ook volgens het Verdrag van Parijs op de Staat een verplichting rust om te garanderen dat de exploitant steeds beschikt over een verzekering of andere financiële zekerheid. Bovendien wordt melding gemaakt van de mogelijke internationale aansprakelijkheid. Zoals verderop zal blijken, heeft ook de Belgische wetgever uit deze bepalingen de verplichting afgeleid van de Staat "om als borg tussen te komen"733; ook in Nederland wordt deze redenering gevolgd ${ }^{734}$.

Daarenboven moet worden onderstreept dat het Verdrag geen enkele verplichting bevat op basis waarvan de kosten van een door de overheid gestelde financiële zekerheid door de aansprakelijke exploitant moeten worden ten laste genomen. Nochtans was het volgens de auteurs van het Voorlopig Rapport de bedoeling dat de kosten van deze dekking ten laste zouden vallen van de explojtant van de kerninstallatie ${ }^{7.35}$.

De dubbele verplichting van de installatiestaat opent een aantal interessante perspectieven in de richting van de civielrechtelijke aansprakelijkheid van de installatiestaat indien zou blijken dat de exploitant geen of onvoldoende dekking hecft. Uit de niet beschikbaarheid of ontocreikendheid van de dekking zou kunnen worden afgeleid dat, behoudens bewijs van het tegendeel, de bevoegde autoriteiten hebben nagelaten voldoende controle uit te oefenen. Boyle beschouwt dit als een residuaire aansprakelijkheid van Staten om de schade voortvloeiend uit nucleaire activiteiten te vergoeden $^{736}$.

Het is onmiskenbaar de bedocling van het internationale nucleaire aansprakelijkheidsrecht om het slachtoffer niet alleen te beschermen tegen de mogelijke insolventie van de exploitant van de kerninstallatie, maar eveneens tegen de mogelijke insolventie van diens verzekcraar of van degene die een andere financiële zekerheid heeft verstrekt. In gevallen waar de financiële zekerheid van de exploitant faalt, zal het dus de installaticstaat zijn die verplicht moet tussenkomen. Het gaat misschien te ver om te spreken van een civielrechtelijke aansprakelijkheid van de installatiestaat; deze laatste moet in ieder geval fungeren als borg voor de financiële dekking van de exploitant van de kerninstallatic.

\section{Exposé des Molifs, 59.}

Exposé des Motifs, 59 (onze cursivering). Met "these circumstances" werd onder meer gerefereerd aan het faillissement van degene die de tinanciële zckerheid had gesteld.

Memorie van Toelichting, Senaat, Parlementaire Stukken, 1983-1984, 593/1, 15.

Dit zal verderop blijken, bij de bespreking van de WAKO. Zie ook Domsdorf, E.P.M.W., "Internationaal Atoomenergierecht", l.c., 724.

Yoorlopig Rapport, 34.

Boyle, A.E., "Nuclear energy and international law: an environmental perspective", o.c., 305. 
Tenslotte dient erop te worden gewezen dat, voor wat betreft de landen van het Verdrag van Parijs die eveneens zijn toegetreden tot het Aanvullend Verdrag van Brussel, de rol van de installatiestaat verder gaat dan alleen de eerste schijf. Hogerop werd rceds gesteld dat uit artikel 3 van het Aanvullend Verdrag van Brussel de plicht van een installaticstaat kan worden afgeleid om te voorzien in een totaal beschikbaar bedrag van 429,31 miljoen euro ${ }^{7.37}$.

\subsubsection{Rol van het bevoegde gezag}

Volgens artikel 10, a in fine van het Verdrag van Parijs worden de aard en de voorwaarden waaraan de dekking of de andere financiële zekerheid dient te beantwoorden, bepaald door het bevoegde openbare gezag. Dit betekent niet dat de Verdragsluitende Staten verplicht zijn om een controleorgaan op het verzekeringswezen in te stellen, maar dat zij moeten voorzien in een voldoende controle op de naleving van de Verdragsbepalingen. Zo dient het controleorgaan erop toe te zien dat de verzekeraar tegenover de slachtoffers geen verweermiddelen kan aanvvoeren, zoals de nietbetaling der premies ${ }^{738}$.

De rol van het bevoegde gezag houdt dan ook nauw verband met de autoriteit waarover zij beschikt om een bepaalde persoon als exploitant aan te wijzen. Hier dient de band te worden gelegd met de definitie van het begrip "exploitant" onder het Verdrag van Parijs: volgens artikel 1, a, vi is dit de persoon die door het bevoegde gezag is aangewezen of erkend als exploitant van een kerninstallatic.

In het nucleaire aansprakelijkheidsrecht wordt de verplichting tot het stellen van een financiële zekerheid gekoppeld aan de vergunningsplicht. Het bewijs van solvabiliteit is een van de essentiële vereisten voor het verkrijgen van een vergunning vanwege de bevoegde nationale autoritei$\operatorname{ten}^{739}$. Ook de koppeling van het bewijs van verzekering aan de erkenning of het verlenen van een vergunning voor het uitbaten van een kerninstallatie, vloeit voort uit het Voorlopig Rapport ${ }^{740}$; het wekt dan ook weinig verwondering dat eveneens onder de Price-Anderson Act de vergunningverlening afhangt - en steeds heeft afgehangen - van het bewijs voldoende te zijn verzckerd ${ }^{741}$.

Artikel 10 van het Verdrag van Parijs is vrij ruim gcformuleerd ter zake van de bevoegdheid van het openbare gezag. De tekst van het Verdrag stclt dat het bevoegde gezag mag oordelen over de aard en de voonwaarden van de dekking; maar nergens worden criteria aangereikt die deze beoordelingsbevoegdheid invullen. Een toetsingskader voor het openbare gezag ontbreekt evenals een aanduiding van wat precies dient te worden verstaan over de aard en de voorwaarden van een dekking. Dit impliccert bijgevolg dat het bevoegde gezag over een vrij ruime discretionaire bevoegdheid beschikt om te oordelen of een door de exploitant voorgestelde dekking al dan niet voldoet aan de voorwaarden van het Verdrag. Deze ruime bevoegdheid sluit uiteraard aan bij de ruime keuzemogelijkheden van de exploitant om een dekking te verschaffen. De werkelijke keuze warover een exploitant beschikt (verzekeringsdekking, financiële zekerheid etc.), zal ook in belangrijke mate afhangen van het beleid van de overheid. Naarmate ook nieuwere vormen van risicodekking beschikbaar zijn zal nict enkel het beleid van de instantie die de verzekeringsplicht controleert van belang zijn, maar bijvoorbeeld ook het fiscale beleid van de installatiestaat. $\mathrm{Zo}_{0}$

Cfr. supra, in \$ 3.1.1.2 van dit hoofdstuk.

Exposé des Motifs, 59.

Camier, M.-C., "Responsabilité et Assurance du Risque Atomique", l.c., 159-100.

Voorlopig Rapport, 35

Cfr. infra, in hoofdstuk 13. 
bestaat in België geen duidelijkheid over de fiscale impact van bepaalde vormen van onderlinge verzekeringsvormen, waarvan de captive er één is ${ }^{742}$.

\subsubsection{Dekking per installatie of per kernongeval?}

Bij de analyse van de beperking van het bedrag van de aansprakelijkheid overeenkomstig het Verdrag van Parijs, werd aangegeven dat het Verdrag uitgaat van een beperking van de aansprakelijkheid per ongeval en niet van een beperking per installatie.

Onder een systeem van aansprakelijkhcid per installatie zou een eerste ongeval reeds kunnen leiden tot een uitputting van de beschikbare bedragen, zelfs indien zich later nog een kernongeval in dezelfde installatie zou voordoen. Onder een systeem van aansprakelijkheid per ongeval daarentegen is er steeds een bedrag beschikbaar, ongeacht het aantal ongevallen ${ }^{743}$ : indien zich in korte tijd meerdere kernongevallen voordoen, dan impliceert dit dat het maximumbedrag waarvoor de exploitant aansprakelijk is, zal worden vermenigvuldigd a rato van het aantal kernongevallen $^{744}$

De Exposé des Motifs bevestigt dat de exploitant verplicht is om een dekking te hebben voor elk kernongeval. Maar er wordt aan toegevoegd dat in de praktijk een dekking waarschijnlijk per installatic en voor een bepaalde periode zal kunnen worden verkregen, eerder dan per kernonge$\mathrm{val}^{745}$. Ook uit het Harvard Rapport blijkt dat verzekeraars hun risico wensen te herevalueren na een ongeval dat op basis hiervan de polissen per installatie zouden worden uitgeschreven ${ }^{746}$.

Op voorwaarde dat de exploitant, nadat het bedrag van de dekking is verminderd of uitgeput na een eerste kernongeval, voor latere ongevallen beschikt over een financiële zekerheid ten belope van het maximumbedrag, is het volgens de Exposé des Motifs dus toegelaten dat wordt voorzien in een dekking per installatie. Hier wordt bijgevolg gesuggereerd dat een dekking per kerninstallatie is toegelaten onder het Verdrag van Parijs en dat verzekeraars de voorkeur zouden geven aan cen dekking per installatie in plaats van een dekking per ongeval ${ }^{747}$.

In de praktijk lijken de verzekeraars drie systemen van dekking te hanteren ${ }^{748}$ : een "lifetime"dekking per installatie, een jaarlijkse dekking en een dekking op een full reinstatement basis. Op basis van een verzekering op lifetime-basis, verleent de verzekeraar dekking voor de gehele levensduur van de installatie. Dit betekent dat na een eerste kemongeval niet meer het volledige bedrag van de dekking zal beschikbaar zijn voor latere kernongevallen in dezelfde installatie. Bij een verzekering met een jaarlijkse dekking wordt de verzekeraar verplicht om jaarlijks eenzelfde dekking ter beschikking te stellen; dit impliceert dat de verzekeraar gehouden is tot een gedeel-

Gysen, S., "Le traitement fiscal de cotisants et des membres-fondateurs des Associations d'assurance mutuelle", in L'Assurance Mutuelle en Belgique, Academia, Bruylant, Louvain-la-Neuve, Bruxelles, Collection Droit des Assurances $n^{\circ} 10,1999,328-329$. Het begrip captive wordt in $\$ 2.2$ van hoofdstuk 11 besproken.

Official Records Vienna Convention, 79.

Camier, M.-C., "Responsabilité et Assurance du Risque Atomique", l.c. , 94.

Expose des Motifs, 59.

Harvard Rapport, 47.

Volgens Hertel zou het voor de verzekeraars niet mogelijk zijn om een verzekeringsdekking aan te bieden per installatie (Hertel, G., "Basic principles of insurance for nuclcar risks", Insurance for $\mathrm{Nu}$ clear Installations, LAEA, Legal Series, $n^{\circ} 6$, Wenen, 1970.60). 
telijke reinstatement van de dekking ${ }^{749}$. Een verzekering op full reinstatement basis impliceert dat na een kernongeval waarbij de volledige dekking werd uitgekeerd, de verzekeraar ervoor moet zorgen dat voor het volgende kernongeval het volledige bedrag van de dekking opnieuw ter beschikking zal zijn. Voor de aansprakelijkheidsdekking bij kernongevallen is de verzekeraar dus niet verplicht tot automatische reinstatement ${ }^{750}$. Er bestaan dan ook vrij aanzienlijke verschillen in de wijze waarop de aansprakelijkheid in de verschillende landen van de NEA wordt gedekt ${ }^{751}$.

Tenslotte verleent het Verdrag van Parijs de vrijheid aan elke Verdragsstaat om te oordelen of de exploitant die meer dan één keminstallatie op dezelfde vestigingsplaats exploiteert, dient te beschikken over een verzekering voor elke installatie afzonderlijk, dan wel voor deze installaties samen $^{752}$.

$\mathrm{Na}$ de analyse van de bepalingen van het Verdrag van Parijs inzake het congruentievereiste, zullen hieronder de Belgische wet van 22 juli 1985 en de Nederlandse WAKO worden bestudeerd.

\subsection{Volgens de Belgische wet van 22 juli 1985}

Op basis van artikel 8 van de wet van 22 juli 1985 is de exploitant van een keminstallatie er overeenkomstig artikel $10 \mathrm{a}$ en b van het Verdrag van Parijs toc gehouden om ter dekking van zijn aansprakelijkheid een verzekering of andere financiele zekerheid, die door de minister passend wordt geoordeeld, te hebben en in stand te houden. De wet verwijst uitdrukkelijk ook naar artikel 10 , b van het Verdrag van Parijs zodat de verzekeraar de verzekering niet kan schorsen of beëindigen zonder het in acht nemen van een opzegtermijn van twee maanden. De opzegging van de verzekeringspolis dient te gebeuren bij de minister tot wiens bevoegdheid de verzekering inzake kemenergie behoort.

Artikel 8, eerste lid in fine voegt eraan toe dat indien zich een schadegeval heeft voorgedaan, de exploitant de verzekering dient te vernieuwen binnen zestig dagen na het schadegeval: in België wordt dus het systeem van de full reinstatement na een kernongeval gehanteerd. Deze alinea was niet voorzien in het oorspronkelijke wetsontwerp, maar werd in de wet ingeschreven na een amendement van de Regering. Het amendement werd verantwoord door het feit dat de verzekeringspolis door SYBAN kan worden opgezegd na een schadegeval ${ }^{753}$.

Het laatste lid van artikel 8 bepaalt dat de bedragen die voortkomen uit de verzekering, herverzekering of andere financiële zekerheid alleen mogen aangewend worden voor de vergoeding van de schade veroorzaakt door een kemongeval. Volgens de wetgever garandeert deze bepaling dat de bedragen van de verzekering of financièle zekerheid prioritair worden aangewend voor de schadeloosstelling van de slachtoffers en verhindert deze bepaling dat deze bedragen zouden worden aangewend voor de uitbetaling van de schuldeisers van de exploitant ${ }^{754}$.

\footnotetext{
749 Dit systeem veronderstelt echter geen volledig herstel van de dekking. De plicht tot herstel van het bedrag van de dekking, varieert van land tot land.

Dow, J.C., Nuclear Energy and Insurance, Witherby \& Co Ltd., London, 1989, 253.

Summary Record of the meeting held in Paris, 22-23 October 1998, NEA/SEN/LEG(99)1, 12.

Artikel I a, ii) van het Verdrag van Parijs. Een analoge bepaling is terug te vinden in artikel $I, j$, in fine van het Verdrag van Wenen.

Parlementaire Stukken, Senaat, GZ 1984-1985, 593/3, 40.

Parlementaire Stukken, Senaat, GZ 1984-1985, 593/3, 41.
} 
Artikel 22 van de wet van 1985 bevat een bepaling die aan slachtoffers garandeert dat indien de verzekering of financiële zekerheid niet in staat is om de aansprakelijkheid van de exploitant te dekken, de Staat dit bedrag voor haar rekening zal nemen. Op basis van deze bepaling is de Staat dus verplicht om, maximaal tot beloop van het maximumbedrag waarvoor de exploitant aansprakelijk is, de schade te vergoeden die niet wordt vergoed door middel van verzekering of andere financiële zekerheid ${ }^{755}$. Artikel 22 is ingegeven door de betrachting om elk juridisch vacuüm te vermijden en beoogt aan het slachtoffer een snelle en zekere schadeloosstelling te garanderen ${ }^{756}$. Ook de voorbereidende werken laten er weinig twijfel over bestaan dat kan worden gesproken van een plicht van de Belgische Staat om als borg tussen te komen bij de schadeloosstelling van slachtoffers en dit bij het faillissement van de exploitant van de kerninstallatie of van de persoon, die een financiële zekerheid heeft gesteld ${ }^{757}$. Dit wetsartikel ligt volledig in de lijn van de bepalingen van het Verdrag van Parijs ${ }^{788}$.

Opmerkelijk is wel dat in de Belgische wet geen bepaling is opgenomen die het de Staat mogelijk maakt om aan de exploitant een vergoeding aan te rekenen voor haar tussenkomst. Nochtans werd een amendement ingediend bij het wetsontwerp ter invoering van artikel 24bis in de wet van 1985, dat de Staat de mogelijkheid gaf taksen aan te rekenen aan exploitanten. Dergelijke taksen zouden worden gestort in een op te richten Fonds. Dit amendement werd verantwoord omdat het gezien de budgettaire moeilijkheden niet aangewezen leek dat de Staat zou moeten opdraaien voor de betaling van zware schadeloosstellingen ${ }^{759}$. Op vraag van de Minister werd dit amendement evenwel verworpen omdat het niet zou zijn aangewezen om via deze wet een nieuwe heffing in te voeren en omdat het amendement "afwijkt van de grondgedachte van het ontwerp" ${ }^{1760}$. Bij de Parlementaire bespreking werd in de Senaat een analoog voorstel ingediend: een Interventiefonds zou worden opgericht en worden gespijsd door een heffing op elke kilowattuur geproduceerd in de kerninstallaties. Volgens het voorstel mocht die heffing niet op de verbruiker worden verhaald. Net zoals wat betreft het eerste amendement was het met name de minister die felle kritiek uitte omdat er reeds fondsen genoeg zouden zijn ${ }^{761}$.

Uit de voorbereidende werken valt ook af te leiden dat de verplichting van de Staat bovenop de verplichting kwam om reeds in de tweede schijf tussen te komen ${ }^{762}$. Indien de verzekering van de aansprakelijkheid wegviel, was het in principe mogelijk dat de Belgische Staat de eerste én de tweede schijf moest betalen, dus tot cen bedrag van 9 miljard BEF. Doordat de tweede schijf van het Aanvullend Verdrag van Brussel door de wetswijziging van 8 juni 2000 werd afgeschaft, moet de Belgische Staat nog enkel tussenkomen voor wat betreft de eerste schijf - of in total voor 24 miljard BEF. Wel is het zo dat indien de Belgische Staat in deze eerste schijf dient tussen te komen, zij voor de uitgekeerde bedragen, in alle rechten en vorderingen van de slachtoffers treedt (artikel 22, in fine). Daarenboven wordt de Staat in dat geval, overeenkomstig artikel 25, $\S 1$

Deze verplichting doet geen afbreuk aan de verplichtingen van de Staat om tussen te komen ingevolge haar verplichtingen voortvloeiend uit het Aanvullend Verdrag van Brussel. Conruyt, H. en Rivalet, F., "Champ d'Application de la Législation belge sur la Responsabilité Civile Nucléaire", o.c., 67. Memorie van Toelichting, Senaat, Parlementaire Stukken, 1983-1984, 593/1, 15.

Cfr. surpa, bij de analyse van de rol van de installatiestaat, $\$ 4.1 .2$.

Parlementaire Siukken, GZ/1983-1984, 593/3, 65-66.

Parlementaire Stukken, GZ1983-1984, 593/3, 66.

Parlementaire Handelingen, Senaat, Vergadering van 23 oktober 1984, 127.

Artikel 22 van de wet luidt immers: "Onverminderd het bepaalde in artikel 19..." (onze cursivering). Zie ook Parlementaire Stukken, Senaat, GZ/1984-1985, 593/3, 58. 
gesubrogeerd in het verhaalsrecht tegen die personen die overcenkomstig artikel (o, f) van het Verdrag van Parijs kunnen worden aangesproken ${ }^{76 ?}$.

De definitie van het begrip exploitant is terug te vinden in artikel 3 van de wet: is een exploitant elke persoon die splijtstoffen, radioactieve producten of afvalstolfen in ecn keminstallatie in zijn bezit heeft of aanwendt, of die nucleaire stoffen welke voor zijn kerninstallatie bestemd zijn, in ontvangst neemt ${ }^{764}$. Essentieel om de hoedanigheid van exploitant overeenkomstig artikel 3 te verwerven, is dat de persoon die met kemmateriaal omgaat, in het bezit is van (of beschikt over) een kerninstallatie. Een terrorist die radioactieve producten in zijn bezit heeft, kan bijgevolg geenszins als een exploitant in de zin van de wet worden beschouwd, aangezien de vereiste band ontbreekt met een kerninstallatie. Indien echter een persoon dic wel cen band heeft met een kerninstallatie en splijtstoffen in zijn bezit heeft zonder door de Koning als exploitant te zijn erkend, kan hij tóch op basis van deze wet aansprakelijk gestcld worden. Door het invoeren van dczc bepaling werd "een op het bestaan van het nucleaire risico zelf stoelende definitie van de exploitant" ingevoerd zodat "clkeen die nucleair materiaal in zijn bczit heeft, automatisch is onderworpen aan de bepalingen van het Verdrag van Parijs" ${ }^{\text {765 }}$.

Artikel 9 van wet bepaalt dat het de exploitant van een kerninstallatie verboden is om splijtstoffen, radioactieve producten of afvalstoffen te bezitten of aan te wenden indien hij niet vooraf als exploitant is erkend. Deze erkenning wordt verleend nadat de aanvrager heeft aangetoond dat hij ter dekking van zijn aansprakelijkheid over een verzekering of andere financiële zekerheid beschikt.

In de voorbereidende werken is sprake van een "consecutief verband" tussen artikel 3 en artikel 9: de uitoefening van de bedrijvigheid vereist niet alleen de hoedanigheid van exploitant, maar ook de verplichting voor die exploitant om zich als dusdanig door de Koning te laten erkennen ${ }^{766}$. Gesteld kan worden dat zodra de beide betekenissen van het begrip "exploitant" niet samenvallen, de wet wordt overtreden: iemand die exploitant is in de zin van artikel 3 van de wet van 22 juli 1985, maar die niet door de Koning is erkend, zal ook strafrechtelijk aansprakelijk kunnen worden gesteld. Zowel artikel 35 van de wet van $1985^{767}$, als het Belgische strafwetboek ${ }^{768}$, voorzien in aanzienlijke strafsancties.

Memorie van Toelichting, Senaat, Parlementaire Stukken, 1983-1984, 593/1, 15.

Deze bepaling werd in de wet ingeschreven ondat de wetgever van oordeel was dat onder de wet van 18 juli 1966 en onder het Verdrag van Parijs deze materie gebrekkig is geregeld (Memorie van Toelichting, Senaat, Parlementaire Stukken, 1983-1984, 593/1, 5-6).

Memorie van Toelichting, Scnaat, Parlementaire Stukken, 1983-1984, 593/1, 6.

Parlementaire Stukken, Senaat, GZ 1984-1985, 593/3, 28.

Een overtreding van onder meer de artikelen 8 en 9 wordt gestraft met een gevangenisstraf van drie maanden tot vijf jaar en/of met een geldboete van 1.000 tot 50.000 frank (artikel 35 van de wet).

Artikel 488bis Sw luidt: "Hij die opzettelijk en zonder vergunning verleend door het bevoegd gezag, of niet op de voonwaarden daarin gesteld, zich kemmateriaal laat afgeven, dan wel zodanig materiaal verkrijgt, in zijn bezit houdt, gebruikt, verandert, afstaat, achterlaat, vervoert of verspreidt, wordt gestraft met opsluiting". Dit artikel voert de Belgisehe intemationale verplichtingen uit die voortvloeien uit het hoger genoemd Verdrag van New York van 3 maart 1980 betreffende de fysieke beseherming van kernmateriaal. Volgens het Belgische strafrecht is de duur van de opsluiting vijf tot tien jaar (art. 13 Sw.). Indien een persoon door het onwettig gebruik van kernmateriaal schade berokkent aan personen of goederen, kan de straf zelfs oplopen tot twintig jaar dwangarbeid. Artikel 488 bis zal vaak gehanteerd worden in combinatie met de artikelen 477 - 477sexies Sw. wanncer het gaat om gestolen kernmateriaal. 
Inzake de erkenning als exploitant zijn modaliteiten van toepassing die voomamelijk tot doel hebben erop toe te zien dat de exploitant ook daadwerkelijk een dekking van zijn aansprakelijkheid in stand houdt. De erkenning wordt verleend door de Koning nadat de aanvrager heeft aangetoond dat hij beschikt over een verzekering of andere financiële zekerheid ${ }^{769}$. De erkenning is met andere woorden de controleprocedure van de verzekeringsverplichting 770 .

Naar aanleiding van de per 1 januari 2001 van kracht geworden wijzigingen van de wet van 22 juli 1985 werden nieuwe erkenningen verleend aan de diverse exploitanten. Zo werd bij de KB's van 19 december 2000 Electrabel erkend als exploitant een kerninstallatie in Doel en Tihange ${ }^{771}$. Artikel I vasn deze KB's bepaalt uitdrukkelijk dat de kerninstallaties van Doel 1, 2, 3 en 4 als eén kerninstallatie worden beschouwd. Hetzelfde geldt voor de kerninstallatie Tihange 1, 2 en 3 .

\subsection{Volgens de Nederlandse WAKO van 1991}

In tegenstelling tot de Belgische wet van 1985, bevat de Nederlandse WAKO geen eigen definitie van het begrip "exploitant"; artikel I van de WAKO verwijst hiervoor uitdrukkelijk naar de definitie van exploitant in het Verdrag van Parijs. Uiteraard bevat de WAKO wel een aantal bepalingen betreffende de erkenning en betreffende de dekking van de aansprakelijkheid van de exploitant.

Voor wat betreft het congruentievereiste, verwijst artikel 10 van de WAKO naar artikel 10, a van het Verdrag van Parijs. Het bevoegde gezag dat naar Nederlands recht de erkenning als exploitant uitreikt, is de minister van Financiën ${ }^{72}$. Deze kan bepalen dat twee of meer kerninstallaties die door eenzelfde exploitant op hetzelfde terrein worden geëxploiteerd als één kerninstallatie worden beschouwd.

De WAKO voorziet ter zake van de dekking van de aansprakelijkheid van de exploitant, op dubbele wijze in een tussenkomst van de Staat: ten eerste wanneer een verzekeringsdekking slechts zeer moeilijk kan worden verkregen en in het tweede geval indien deze financiële zekerheid niet het gehele bedrag van de aansprakelijkheid dekt.

Overeenkomstig artikel 9 van de WAKO is de minister van Financiën gemachtigd om voor de Staat als verzekeraar verzekeringsovereenkomsten aan te gaan of om namens de Staat andere garanties te verstrekken wanneer geen of onvoldoende dekking kan worden verkregen, of wanneer deze dekking slechts tegen een onredelijke premie of vergoeding is te verkrijgen. De voorwaarden en de premies of vergoedingen waarmee dit zou gebeuren, worden eveneens door de minister bepaald. De bevoegdheid om verzekeringsovereenkomsten aan te gaan, werd door de Nederlandse wetgever "noodzakelijk geacht in verband met de feitelijke monopoliepositie die wordt ingenomen door de Nederlandse Atoompool" ${ }^{173}$. Eenzelfde bepaling was overigens reeds ingeschreven in artikel 13 van de wet van 27 oktober 1965 en in artikel 9 de WAKO van 1979.

Indien daarenboven de financiële zekerheid of de dekking ontoereikend is om het bedrag van de aansprakelijkheid van de exploitant te dekken, stelt de Nederlandse Staat aan dic exploitant open-

Artikel $10,1^{\circ}$ lid van de wet.

Memorie van Toelichting, Parlementaire Stukken, GZ 1983-1984, 593/1, 9.

B.S., 24 januari 2001 . Ook andere firma's en instellingen (waaronder het SCK te Mol) werden in dezelfde periode erkend als exploitant van een kerninstallatie.

Artikel 8 , lid 1 van de WAKO.

Memorie van Toelichting, Tweede Kamer, zitting 1975-1976, 13.928, nr. 5, 28. 
bare middelen ter beschikking tot het maximumbedrag van zijn aansprakelijkheid ${ }^{774}$. Ook deze bepaling is niet nieuw in de WAKO van 1991, al werd een kleine redactionele aanpassing aangebracht zodat ondubbelzinnig zou worden vastgesteld dat de "gehoudenheid van de Staat intreedt zodra de uit verzekering of andere financiële zekerheid voortkomende middelen onvoldoende zijn om de schade waarvoor de exploitant aansprakelijk is, te voldoen ${ }^{\text {775 }}$.

Indien blijkt dat het ontbreken van financiële zekerheid is te wijten aan de schuld van de exploitant, dan heeft de Staat recht van verhaal op de exploitant van de kerninstallatie. Tenslotte wordt eveneens voorzien in een subrogatie zoals bedoeld in artikel 6, $f$ ) van het Verdrag van Parijs. Hier bevat de WAKO evenwel een bijzonderheid: bij de uitoefening van dit subrogatierecht heeft de Staat voorrang boven verzekeraars of andere personen die een financiële zekerheid ter beschikking hebben gesteld ${ }^{776}$.

Volledigheidshalve wordt erop gewezen dat de niet-nakoming van de verzekeringsplicht niet in de WAKO strafrechtelijk wordt gesanctioneerd. Via een omweg wordt tot eenzelfde resultaat gekomen: artikel 15 van de Kemenergiewet stelt een verbod in om zonder voorafgaandelijke vergunning kernenergie te produceren. De vergunning kan enkel worden verkregen indien de exploitant bewijst over de vereiste verzekeringsdekking te beschikken. Een overtreding van artikel 15 van de Kemenergiewet, wordt strafbaar gesteld op basis van de Wet op de economische delic$\operatorname{ten}^{77}$.

\subsection{Wijzigingen naar toekomstig recht}

Bij de bespreking van de beperking van de aansprakelijkheid in paragraaf 3 werd aangegeven dat het Protocol van het Verdrag van Wenen en het Verdrag inzake Bijkomende Compensatic van 1997 leiden tot een verhoging van de voor slachtoffers beschikbare bedragen. Uitgaande van het congruentiebeginsel, implicecrt dit ook dat de beschikbare verzekeringsdekking evenredig dient te worden verhoogd, tenzij uiteraard afbreuk wordt gedaan aan de congruentie tussen aansprakelijkheid en dekking.

Geen van beide uit 1997 daterende Verdragen brengt hicraan een wijziging aan. De eerste zinsnede van artikel VII van het Verdrag van Wenen, dat de verplichte dekking invoert, wordt door het Protocol van het Verdrag van Wenen niet gewijzigd ${ }^{778}$. De bezorgdheid betreffende de beschikbaarheid van de minimumbedragen blijkt ook uit het reeds besproken artikel VII van het Verdrag van Wenen: in de mate waarin de verzekering van de exploitant niet adcquaat is om de 300 miljoen BTR te betalen, zal de installatiestaat dienen in te staan voor deze betaling.

Het Verdrag inzake Bijkomende Compensatic brengt evenmin een wijziging aan aan de verplichte dekking van de aansprakelijkheid van de exploitant van en kerninstallatie. Artikel 5 van de annex van het Verdrag schrijft voor dat de wetgeving van een land dat wenst toe te treden, (onder meer)

Artikel 10, eerste lid van de WAKO.

Memorie van Toelichting, Tweede Kamer, vergaderjaar 1987-1988, 20.374, nr. 3, 7.

Artikel $10,3^{\circ}$ lid in fine van de WAKO.

Wet van 22 juni 1950 houdende vaststelling van regelen voor de opsporing, de vervolging en de berechting van economische delicten, meermaals gewijzigd.

Artikel 9 van het Protocol van het Verdrag van Wenen voegt enkel een tweetal zinnen toe aan artikel VII van het Verdrag van Wenen. Een gecoördineerde tekst van het Verdrag van Wenen, zoals gewijzigd door het Protocol van het Verdrag van Wenen, is terug te vinden in Horbach, N.L.J.T. (ed.), "Contemporary Developments in Nuclear Energy Law", l.c., 557-573. 
het principe van de verplichte dekking van de aansprakelijkheid in de interne wetgeving dient te hebben ingeschreven.

Een van de redenen waarom de onderhandelingen slechts moeizaam tot enig resultaat hebben geleid, heeft precies te maken met de congruentie. Vanaf in het begin was duidelijk dat tegenover de verhoogde bedragen een evenredige verhoging van de beschikbare bedragen diende te staan. Maar doordat werd geoordeeld dat enerzijds de verzekeringsmarkten in de landen van het voormalige Oostblok onvoldoende waren ontwikkeld en dat anderzijds het niet haalbaar leek, ingevolge het grote verschil in veiligheid tussen de westerse kerninstallaties ten aanzien van deze in het voormalige Oostblok, om de exploitanten gezamenlijk de verhoogde aansprakelijkheid te laten dragen, werd ervoor geopteerd om de Staat te laten tussenkomen.

Gelet op het phasing-in mechanisme, is de rol van de installatiestaat gedurende de eerste 15 jaar van de nucleaire aansprakelijkheidsverdragen van de tweede generatie zonder meer aanzienlijk.

Aangezien bij de revisie van het Verdrag van Parijs de mogelijkheid wordt besproken om in de interne wetgeving een systeem van onbeperkte aansprakelijkheid in te voeren, wordt dus ook het congruentievereiste, minstens ten dele, in vraag gesteld.

\subsection{Conclusie}

Artikel 10 van het Verdrag van Parijs voert het congruentievereiste in in het nucleaire aansprakelijkheidsrecht. Op basis van deze vereiste dient de exploitant een dekking of een andere financiële zekerheid te hebben en in stand te houden ter grootte van het bedrag waarvoor hij aansprakelijk is. Het is duidelijk dat de verdragspartijen hebben gewild dat de exploitant voor de dekking van zijn aansprakelijkheid over zeer ruime keuzemogelijkheden zou beschikken en dat aan de installatiestaat een ruime vrijheid wordt gelaten om te oordelen welke type financiële dekking gepast is.

Op zich maakt het in eerste instantie nict uit door wie deze aansprakelijkheid zal worden gedekt. Via de congruentie werd de garantie gegeven aan slachtoffers dat bepaalde sommen in ieder geval beschikbaar zouden zijn. Dit impliceert dat niet kan worden gesproken van een verzekeringsplicht in hoofde van de exploitant; het lijkt correcter om te spreken van een dekkingsplicht. Deze plicht rust in de eerste plaats op de exploitant van de keminstallatie - die zich blootstelt aan aanzienlijke strafsancties indien hij deze plicht niet nakomt - en in de tweede plaats in hoofde van de installatiestaat. Niets in het Verdrag verplicht de Verdragspartijen ertoe om, indien een deel van de aansprakelijkheid door de Staat zou worden gedekt, de kosten van deze voorzieningen door te rekenen naar de exploitant van de keminstallatie.

Het Verdrag van Parijs maakt het bijgevolg mogelijk dat de bevoegde overheden van de installatiestaat een eigen beleid voeren. Niet alleen kunnen zij de aard en voorwaarden van de dekking bepalen, maar zij hebben ook een ruime vrijheid om te beslissen voor welk deel van de aansprakelijkheid de Staat borg zal staan en in welke mate de kosten hiervan zullen worden doorgerekend naar de exploitant.

Op dit punt verschilt de Nederlandse WAKO van de Belgische nucleaire aansprakelijkheidswet. In Nederland treedt de Staat in de regel op als verzekeraar en kunnen premies of vergoedingen worden gevraagd van de exploitant. In België ontbreekt een analoge bepaling.

Het congruentievereiste wil garanderen dat tegenover elke aansprakelijkheid ook daadwerkelijk financiële middelen staan. Het lijkt dan ook in de eerste plaats uiting te geven aan het Schutz- 
zweck van het nucleaire aansprakelijkheidsrecht. De garantie-idee in het nucleaire aansprakelijkheidsrecht gaat zelfs zo ver dat het slachtoffer niet alleen wordt beschermd tegen het faillissement van de exploitant van de kerninstallatie, maar ook tegen het faillissement van de verzekeraar.

Maar het congruentievereiste impliceert dat een aansprakelijkheid waar geen verplichte dekking tegenover staat, zinloos zou zijn. Ervan uitgaande dat de verzekeringsmarkt niet in staat is om een ongelimiteerde dekking van het nucleaire risico te verschaffen, belet het congruentievereiste in de internationale nucleaire aansprakelijkheidsverdragen de invoering van een onbeperkte aansprakelịkheid.

Nochtans zijn in het Burgerlijk Wetboek - zowel in België als in Nederland - heel wat voorbeelden te vinden van aansprakelijkheden waar geen dekkingsplicht tegenover staat. Het lijkt er zelfs op dat als dusdanig de verzekeringsplicht zoals die in mindere of meerdere mate is terug te vinden in het milieuaansprakelijkheidsrecht, een andere strekking heeft dan de dekkingsplicht van de exploitant van een kerninstallatie. In eerste instantie is er in het milieurecht geen bepaling opgenomen op basis waarvan de Staat ertoe gehouden is om zich borg te stellen indien de dekking van een verzekeringsplichtige zou falen. Ten tweede blijft in principe de aansprakelijkheid van de verzekeringsplichtige bovenop het bedrag waarvoor hij wordt verplicht om zich te verzekeren, ongemoeid gelaten.

De analyse van de bepalingen van het nucleaire aansprakelijkheidsrecht wordt afgerond door de bespreking van het vijfde basisprincipe: de exclusieve bevoegdheid van de rechter van de installatiestaat.

\section{EXCLISIEVE BEVOEGDHEID VAN ÉÉN RECHTBANK PER LAND}

Zodra zich een grensoverschrijdend kernongeval voordoet, zal de vraag rijzen hoe de uit het kernongeval voortvloeiende vorderingen ook processuecl kunnen worden geëffectuecrd. Zeker in een internationale context zullen in feite een drietal elementen het slachtoffer aanbelangen: de bevoegde rechtbank, het toepasselijke recht en de mate waarin een vonnis dat in een bepaald land is verkregen, kan worden ten uitvoer gelegd. Er zijn vaak meerdere mogelijkheden. Inzake de bevoegde rechtbank, zou het slachtoffer bijvoorbeeld een vordering kunnen indienen in de installatiestaat of in het land waar de schade is geleden ${ }^{779}$. Bij een grensoverschrijdend kernongeval zal er inderdaad een aanzienlijke kans bestaan dat het slachtoffer aan forum-shopping zal doen ${ }^{780}$. Een slachtoffer kan ertoe geneigd zijn en kan er belang bij hebben om een vordering in te dienen in een land met een gunstiger aansprakelijkheidregime. Om deze problemen het hoofd te bieden werden in het Verdrag van Parijs een aantal bevoegdheidsbepalingen ingeschreven. Het hoofdthema hierbij is de exclusieve bevocgdheid van de rechtbanken van één land om alle vorderingen te behandelen die uit een kemongeval voortkomen.

Ook in deze paragraaf wordt de eerder gehanteerde indeling gevolgd. In eerste instantic worden de bepalingen van het Verdrag van Parijs toegelicht ( $\$ 5.1$ ); vervolgens wordt geanalyseerd hoe deze bepalingen werden ingeschreven in de Belgische wet van $1985(\S 5.2)$ en in de Nederlandse

\footnotetext{
79 Krause-Ablass, W.-D., "Apportioning Liability for Transborder Damages", in Cameron, P., Hancher, L. en Kühn, W. (ed.), "Nuclear Energy Law after Chemobyl", l.c., 125.

780

Dat de kans op forum shopping niet ONdenkbeeldig is, is bijvoorbeeld gebleken in een vordering die in Ierland werd ingesteld tegen het Britse BNFL; zie de bespreking hiervan in Sands, P. en Galizzi, P., "The 1968 Brussels Convention and Liability for Nuclear Damage", in Reform of Civil Nuclear Liability, NEA-OECD, Parijs, 2000, 503 e.v.
} 
WAKO (\$ 5.3). De wijzigingen aan dit principe aangebracht door de nucleaire aansprakelijkheidsverdragen van 1997 zullen vooral van belang zijn bij een kernongeval tijdens transport van nucleair materiaal en worden in het kader van dit onderzoek niet besproken ${ }^{781}$. De conclusie van de analyse wordt weergegeven in $§ 5.4$.

\subsection{Volgens het Verdrag van Parijs}

Het Vcrdrag van Parijs bevat zowel bepalingen inzake de bevoegde rechtbank en de erkenning van een vonnis ( $\$ 5.1 .1)$ als inzake het op de vordering toepasselijke recht $(\$ 5.1 .2)$.

\subsubsection{Bevoegde rechtbank en erkenning van een vonnis}

Rechtsvorderingen ingevolge de artikelen 3, 4,6 a) en 6 e) van het Verdrag van Parijs kunnen uitsluitend worden ingesteld bij de bevoegde rechters van de Verdragsluitende Staat op wiens grondgebied het keminongeval heeft plaatsgevonden ${ }^{782}$; het betreft vorderingen die respectievelijk betrekking hebben op de aansprakelijkheid van de exploitant voor schade toegebracht aan personen en goederen, de aansprakelijkheid van de exploitant bij vervoer van nucleaire stoffen, de kanalisatie van aansprakelijkheid naar de exploitant van de keminstallatie en het subrogatierecht voor degene die schadevergoeding heeft betaald voor de schade uit een kemongeval dat plaatshad op een niet-Verdragsluitende Staat, of aldaar geleden schade. De achterliggende idee is een uniformiteit in de jurisprudentic te creëren.

Door de eenheid van rechtspraak wordt vermeden dat meerdere bevoegde rechtbanken in verschillende landen elk een schadevergoeding zouden toekennen waarvan de som het (beperkte) aansprakelijkheidsbedrag van de exploitant zou overtreffen. Volgens de Exposé des Motifs zou de billijke verdeling van het beschikbare schadevergoedingsbedrag onoplosbare problemen opleveren wanneer vorderingen betreffende hetzelfde ongeval aan verschillende rechters zouden worden voorgelegd ${ }^{783}$. De bevoegdheidsbepaling is dus onlosmakelijk verbonden met de beperking van de aansprakelijkheid en met de kanalisatie van aansprakelijkheid. Voor de slachtoffers van een kernongeval zou een exclusief bevoegde rechtbank het voordeel bieden dat zij snel weten tot welke rechtbank zij zich kunnen wenden ${ }^{784}$, c.q. in welk land zij hun vordering kunnen indienen.

Ook voor wat betreft dit basisprincipe van het nucleaire aansprakelijkheidsrecht, kan worden verwezen naar het Harvard Rapport ${ }^{7 s s}$. Een exclusief bevocgde rechtbank zou zowel voordelig zijn voor slachtoffers als voor de exploitanten:

Zie hierover evenwel Horbach, N.L.J.T, "Lacunae of International Nuclear Liability Agreements", in Horbach, N.L.J.T. (ed.), "Contemporary Developments in Nuclear Energy Law", l.c., 69; Brown, O.F. en Horbach, N.L.J.T, "Liability for International Nuclear Transport: an Overview", in "Reform of Civil Nuclear Liability", 1.c., 237-261; Magnus, U., "Intercontinental Nuclear Transport from the Private International Law Perspective", in Reform of Civil Nuclear Liability, NEA-OECD, Parijs, 2000, 263-284; Gioia, A., "Maritime Zones and the new Provisions on Jurisdiction in the 1997 Vienna Protocol and in the Convention on Supplementary Compensation", in Reform of Civil Nuclear Liability, NEA-OECD, Parijs, 2000, 299-322.

Artikel 13, a) van het Verdrag van Parijs; een analoge bepaling is terug te vinden in artikel XI van het Verdrag van Wenen, met dien verstande dat het Verdrag van Wenen geen verwijzing bevat naar andere artikelen uit het Verdrag.

783 Exposé des Motifs, 63.

784 Camier, M.-C., "Responsabilité et Assurance du Risque Atomique", l.c., 130-131.

785 Zie de bespreking van de kanalisatie van aansprakelijkheid, in $\$ 2.1 .3$ van dit hoofdstuk 
"... in reducing trial costs, simplifying evidentiary procedures, and permitting a more equitable distribution of the available funds" ${ }^{\prime 786}$.

Of tijdens de onderhandelingen van het Verdrag van Parijs een andere mogelijkheid dan de exclusief bevoegde rechtbank van één Verdragsstaat emstig werd in overweging genomen, is niet duidelijk. Er zijn aanwijzingen dat met name de mogelijkheid werd besproken om een vordering uit een kemongeval voor te leggen aan een internationale rechtbank of aan arbitrage te onderwer$\operatorname{pen}^{787}$

Artikel 13 van het Verdrag van Parijs bepaalt enkel dat de rechtbanken van één enkel land bevoegd zullen zijn. Hiermee is nog niet gezegd dat binnen deze Verdragsstaat slechts één enkele rechtbank zal bevoegd zijn. De Steering Committee van de NEA heeft met betrekking tot deze materie een aanbeveling uitgevaardigd waarbij de Verdragsstaten ertoe worden aangespoord om in de nationale wetgeving te voorzien dat slechts één enkele rechtbank bevoegdheid kan opnemen ter zake van de uit een kernongeval voortvloeiende schade ${ }^{788}$.

Het Verdrag bevat eveneens voorschriften voor het geval het ongeval plaats heeft buiten het grondgebied van een Verdragsstaat of voor het geval de plaats van het ongeval niet is vast te stellen. Hiermee wordt met name de hypothese beoogd van het transport van nucleair materiaal waarbij zich bijvoorbeeld een kernongeval voordoet in de volle zee of waar het kernongeval het gevolg is van een continue blootstelling aan radioactieve straling ${ }^{799}$. In beide gevallen zal de rechter van de plaats van de kerninstallatie van de aansprakelijke exploitant bevoegd zijn ${ }^{791}$. Tijdens de onderhandelingen voor het Verdrag werd beseft dat, in deze gevallen, de afstand tussen de slachtoffers en de bevoegde rechter kon leiden tot ernstige praktische bezwaren. Anderzijds leek een andere oplossing, die aan slachtoffers het recht zou geven om naar hun eigen rechtbanken te stappen en die tezelfdertijd de eenheid van rechtspraak zou garanderen, niet haalbaar te zijn $^{792}$.

Nochtans kunnen de in het Verdrag ingeschreven bevoegdheidsregels er toe leiden dat mecrdere rechters bevoegdheid opnemen. Ook deze situatie zou de eenheid van rechtspraak aantasten en bijgevolg bevat het Verdrag ook dienaangaande meerdere bepalingen. Met name wanneer een kemongeval deels buiten en deels binnen het grondgebied van de Verdragsluitende Partijen valt, zal de rechter van de Verdragsstaat bevoegd zijn. In elk ander geval zal het Tribunaal van het Europees Agentschap voor Kernenergie ${ }^{793}$ een Verdragsluitende Staat aanduiden die het nauwst bij het ongeval is betrokken ${ }^{794}$.

Harvard Rappor, 66.

Camier, M.-C., "Responsabilité et Assurance du Risque Atomique", l.c. 132.

Aanbeveling van 3 oktober 1990 NE/M(90)2, gepubliceerd in Paris Convention. Decisions, Recommendations, Interpretations, Parijs, NEA, 1990, 15.

Gecoördineerde versie van de Exposé des Morifs, 1988, nr. 55.

De desbetrefiende bepalingen van het Verdrag van Parijs werden overigens gewjjzigd door het Protocol van 1964.

Artikel 13, b) van het Verdrag van Parijs.

Exposé des Molifs, 63.

Overeenkomstig artikel 17 van het Verdrag beschikt dit Tribunaal over de bevoegdheid te oordelen over ieder geschil tussen twee of meer Verdragsluitende Partijen betreffende de interpretatie of uitvoering van het Verdrag. Het Tribunaal is opgericht door het Verdrag van 20 december 1957 inzake de instelling van een Veiligheidscontrole op het gebied van de Kemenergic.

Artikel 13, c, ii van het Verdrag van Parijs. 
Teneinde de tenuitvoerlegging van de rechterlijke uitspraak te vergemakkelijken bepaalt artikel 13, d) dat wanneer een op tegenspraak gewezen vonnis of een verstekvonnis door het recht van de krachtens het Verdrag bevoegde rechter uitvoerbaar is geworden, dit vonnis ook uitvoerbaar zal zijn op het grondgebied van elke andere Verdragsstaat zodra de vereiste formaliteiten zijn vervuld. Tenslotte kan een Verdragsluitende Staat die in een schadevergoedingsvordering wordt aangesproken, de onschendbaarheid ten aanzien van de rechtsvervolging die zij anders zou kunnen genieten, niet inroepen tenzij wat betreft de maatregelen inzake de tenuitvoerlegging ${ }^{795}$.

Uit de tekst zelf van artikel 13 vloeit een belangrijke nuance voort voor wat betreft de exclusiviteit van de rechtbank van de installatiestaat. Deze exclusiviteit wordt namelijk gekoppeld aan een aantal Verdragsbepalingen ${ }^{196}$; voor de verdragsbepalingen waaraan artikel 13 niet refercert en waar een geschil mogelijk is, zal deze exclusiviteit dus niet van toepassing zijn. De overeenkomstig het Verdrag aangeduide rechtbank, zal inderdaad exclusief bevoegd zijn voor alle vorderingen ingediend tegen de exploitant van een kerninstallatie. Deze vorderingen kunnen hetzij direct door een slachtoffer worden ingesteld, hetzij indirect - bij wijze van regres van andere personen die overeenkomstig internationale Verdragen ter zake van transport of overeenkomstig de wetgeving van een niet-Verdragsstaat, aansprakelijk kunnen worden gesteld ${ }^{797}$. Dit impliceert dat de bevoegdheid van de rechtbanken voor vorderingen ingesteld door de exploitant nict door het Verdrag van Parijs worden geregeld - denk bijvoorbeeld aan het door de exploitant overeenkomstig artikel 6, f) van het Verdrag uitgeoefende regresrecht. Toch bepaalt het Verdrag van Parijs dat, op alle materieelrechtelijke en procesrechtelijke materies die niet in het Verdrag worden geregeld, de nationale wet van toepassing zal zijn. Hoewel het Exposé des Motifs hierover geen verdere aanwijzingen bevat, impliceert dit dat bijvoorbeeld voor de vorderingen die de exploitant desgevallend wenst in te stellen, het recht van de installatiestaat indirect van toepassing zal zijn. Hiermee wordt bedoeld dat het internationaal privaatrecht van de installatiestaat zal bepalen welke rechtbank bevoegd zal zijn en welke wetgeving op deze vorderingen zal van toepassing zijn.

Indien de verzekeringsdekking van de exploitant niet alle schade zal kunnen vergoeden, zal eveneens een beroep worden gedaan op het Aanvullend Verdrag van Brussel en moet ook worden onderzocht welke bepalingen in het laatstgenoemde Verdrag ter zake zijn voorzien. Teneinde te vermijden dat slachtoffers die een beroep wensen te doen op de tweede en de derde schijf een vordering zouden moeten aanhangig maken bij de rechtbanken van verschillende landen, zijn de Verdragsluitende Staten ertoe verplicht, overeenkomstig artikel 9, b) van het Aanvullend Verdrag van Brussel, ervoor te zorgen dat slachtoffers hun recht op schadevergocding kunnen uitoefenen, zonder dat zij gedingen aanhangig hoeven te maken al naargelang de herkomst van de gelden. Bijgevolg zal de rechtbank die op basis van het Verdrag van Parijs bevoegd is, een uitspraak kunnen doen over de toewijzing van de vorderingen voor het gehele beschikbare schadevergoedingsbedrag, dat onder het NEA-regime uit drie schijven bestaat ${ }^{798}$.

Uiteraard zal de beoogde eenheid in rechtspraak in het gedrang kunnen komen ten aanzien van niet-Verdragsluitende Staten. In de mate waarin zich een kernongeval voordoet of schade wordt geleden in een land dat geen lid is van het Verdrag van Parijs of van het Verdrag van Wenen zullen de in dat land toepasselijke bevoegdheidsregels toepassing vinden ${ }^{799}$. Uit bovenstaande

Artikel 13, e) van het Verdrag van Parijs.

Met name aan de artikelen $3,4,6$ a) en 6 e) van het Verdrag van Parijs.

Exposé des Motifs, 65.

Bette, A. e.a., "La Réparation des Dommages Nucléaires en Europe", l.c., 79-80.

Volgens Sands en Galizzi zullen slachtoffers van een niet Verdragsstaat bij het Verdrag van Parijs er belang bij hebben om zich met name te beroepen op het Europese Executieverdrag van 1968 (Sands, P. 
analyse inzake de kanalisatie van aansprakelijkheid was reeds het belang gebleken van de IPRregels en van de toetreding van zoveel mogelijk landen tot de internationale nucleaire aansprakelijkheidsverdragen $^{800}$.

\subsubsection{Toepasselijk recht}

Naast de vraag naar de bevoegde rechtbank en de erkenning van buitenlandse vonnissen, dient ook de vraag te worden beantwoord naar het tocpasselijke recht. Het is perfect mogelijk dat, bij gebrek aan specifieke bepalingen ter zake, op eenzelfde schadegeval meerdere wetten van toepassing zouden zijn (bijvoorbeeld het recht van de plaats van het kernongeval, van de plaats waar de schade werd geleden, ...). Ook op dit vlak biedt het Verdrag van Parijs een oplossing. Overeenkomstig artikel 11 van het Verdrag van Parijs wordt de aard, vorm en omvang van de schadevergoeding, alsmede de billijke verdeling ervan, geregeld door de nationale wetten van de Verdragsluitende Partijen. Onder "nationale wet" wordt verstaan de nationale wet of nationale wetgeving van de rechter die overeenkomstig het Verdrag bevoegd is om kennis te nemen van de uit een kernongeval voortvloeiende rechtsvorderingen. Deze wet is van toepassing op alle materieelrechtelijke en procesrechtelijke aangelegenheden die niet uitdrukkelijk door het Verdrag worden geregeld $^{80 !}$.

De formeelrechtelijke bepalingen inzake de bevoegde rechtbank, zijn voor slachtoffers van een kernongeval van groot belang omdat zij ook hun invloed hebben op materieelrechtelijk vlak. Het spreekt voor zich dat al naargelang het op de zaak toepasselijke recht, bepaalde soorten schade in mindere of meerdere mate in aanmerking zullen worden genomen. Volledigheidshalve wordt erop gewezen dat het Verdrag een dubbele non-discriminatie clausule bevat. De bevoegde rechter moet zowel het Verdrag als zijn nationale recht en nationale wetgeving toepassen zonder onderscheid naar nationaliteit, woon- of verblijfplaats ${ }^{802}$.

De basisregel in het internationale nucleaire aansprakelijkheidsrecht is bijgevolg dat de rechtbank van de Verdragsluitende Staat exclusief bevoegd is om kennis te nemen van de uit een kernongeval voortvloeiende rechtsvorderingen en dat deze rechtbank de lex fora zal toepassen.

\subsection{Volgens de Belgische wet van 22 juli 1985}

De bespreking van de exclusieve bevoegdheid van één rechtbank wordt in eerste instantie toegelicht op basis van de bepalingen van de wet van 1985 (\$ 5.2.1). Vervolgens zal ook worden onderzocht of een kernongeval eveneens kan aanleiding geven tot een strafrechtelijke vordering $(\$ 5.2 .2)$.

en Galizzi, P.x "The ! 968 Brussels Convention and Liability for Nuclear Damage", in "Reform of Civil Nuclear Liability", l.c., 475-506; Galizzi, P., "Questions of jurisdiction in the event of a nuclear accident in a member state of the European Union", Journal of Environmental Law, vol. 8, $\mathrm{n}^{\circ} 1,1996,71$ 97).

Cfr. supra, in § 2.2 .8 van dit hoofdstuk.

Artikel 14, b) van het Verdrag van Parijs.

Artikel 14 a) en c) van het Verdrag van Parijs. 


\subsubsection{De bevougdheid overtenkomstig ariikel 26 van de wet}

Volgens artikel 26 van de Belgische wet van 22 juli 1985 , is de rechtbank van Brussel, zetelend in burgerlijke zaken, exclusief bevoegd om uitspraak te doen over vorderingen gebaseerd op het Verdrag van Parijs, het Aanvullend Verdrag van Brussel en op de wet.

De wil van de wetgever om de bevoegdheid exchsief bij de Brusselse rechtbank te leggen, blijk uit het feit dat artikel 26 van openbare orde is. Hiermee wilde men vermijden dat door een onderling akkoord tussen het slachtoffer en de exploitant na het kemongeval, de vordering zou worden ingeleid voor een andere rechibank ${ }^{803}$.

Dẹ optie om één enkele rechtbank exclusieve bevoegdheid te geven, werd in het Parlement gemotiveerd op basis van verschillende argumenten. Ten eerste diende de eenvormigheid van de rechtspraak te worden gegarandeerd. Ten tweede konden zich, indien het kernongeval overal in België slachtoffers maakte, talproblemen voordoen. Daamaast weten slachtoffers, dankzij deze exclusieve bevoegdheid, tot wie zij zich moeten richten om een klacht in te dienen. Tenslotte zouden er ook psychologische en sociologische redenen zijn om de rechtbank gelegen van het gerechtelijk arrondissement waar de kerninstallatie is gelegen, geen bevoegdheid toe te kennen ${ }^{804}$.

De reden waarom uitgerekend voor Brussel werd geopteerd als exclusieve rechtbank, kan onrechtstreeks uit deze laatste twee argumenten worden afgeleid. Brussel is een tweetalig gerechtelijk arrondissement en bovendien bevinden zich in dit arrondissement geen kerninstallaties zodat mogelijke psychologische elementen, volgens de Belgische wetgever, worden uitgesloten. Anderzijds was de discussic met betrekking tot de exclusieve bevoegdheid van de Brusselse rechtbank reeds gevoerd bij het totstandkomen van de wet van 1962 inzake de burgerrechtelijke aansprakelijkheid van het $\mathrm{SCK}^{805}$. Een bijkomend argument dat toen werd aangehaald om de bevoegdheid exclusief bij de Brusselse rechtbank te leggen, bestond erin dat slachtoffers een rechtstreekse vordering hadden tegen verzekeraars en dat de meeste verzekeraars hun hoofdzetel in Brussel hadden ${ }^{806}$.

Hoger werd reeds gewezen op het vonnis van de rechtbank van Turnhout van 14 februari 1969 , waar het slachtoffer van een kernongeval op het SCK de exploitant ook strafrechtelijk dagvaardde ${ }^{807}$. In dit vonnis nam de correctionele rechtbank van Tumhout eveneens bevoegdheid op voor de civielrechtelijke vordering. Maar de bevoegdheidsattributie aan de Brusselse rechter was onder de wet van 1962 van geheel andere aard dan deze zoals voorzien in de wet van 22 juli 1985 : onder de eerstgenoemde wet was de Brusselse rechtbank uitsluitend bevoegd indien het SCK er niet in zou zijn geslaagd of zou hebben nagelaten om een verzekeringsdekking af te sluiten. Onder de huidige wet is de Brusselse rechtbank exclusief bevoegd voor vorderingen voortvlociend uit een kemongeval. De vraag rijst wat de invloed is van de bepalingen van het Beigische strafrecht op de bevoegdheidsattributie die voortvloeit uit artikel 26 van de wet van 22 juli 1985.

Parlementaire Stukken, Senaat, G2/1983-1984, 593/3, 71.

Parlementaire Stukken, Senaat, GZ/1983-1984, 593/3, 71.

Cfr. supra, $\$ 3.3 .1 .5$ van hoofdstuk 2.

Parlementaire Stukken, Kamer, GZ/1961-1962, vergadering van 12 juli 1962, 51.

Cfr. supra, \$ 3.3.1.6 van hoofdstuk 2. Zie ook Bonotto, O. en Vanden Borre, T., "Problèmes de compétence judiciaire dans les procédures de droit pénal relatives aux accidents nucléaires. Les principes de droit pénal et l'article 13 de la Convention de Paris", in "Nuclear Inter Jura '97", l.c., 469 e.v. 


\subsubsection{Invloed van een mogelijke strafrechtelijke vordering overeenkonistig het Belgische strafrecht}

De initiële vraag, bij de bespreking van een mogelijke strafrechtelijke vordering, is uiteraard of iberhaupt een strafrechtelijke vordering mogelijk is naar aanleiding van een kernongeval en zo ja wat hiervan het belang van het slachtoffer is.

Naar Belgisch strafrecht kan met name het toebrengen van opzettelijke of onopzettelijke slagen en serwondingen aanleiding geven tot een strafrechtelijke vervolging ${ }^{808}$. Het is vrij aannemelijk om ervan uit te gaan dat een kernongeval op het strafrechtelijke vlak kan en zal worden gekwalificeerd als het toebrengen van onopzettelijke slagen en verwondingen. Op basis van het vonnis van de correctionele rechtbank van Tumhout werd inderdaad geoordeeld dat het kernongeval de strafrechtelijke aansprakelijkheid van een aantal betrokkenen in het gedrang bracht. Het niet naleven van de veiligheidsmaatregelen waardoor lichamelijk letsel werd veroorzaakt, werd beschouwd als het onopzettelijk toebrengen van slagen en verwondingen. Daarenboven kon er ook sprake zijn van de schending van een strafrechtelijk gesanctioneerde veiligheidsregulering. Een strafrechtelijke vervolging naar aanleiding van een kernongeval - of naar aanleiding van een ander ernstig industrieel ongeval - is bijgevolg niet ondenkbeeldig.

Een strafrechtelijke vordering kan naar Belgisch recht zowel worden opgestart door het Openbaar Ministerie als door een slachtoffer van een misdrijf ${ }^{809}$. Indien zich een kernongeval heeft voorgedaan, kan het Openbaar Ministerie autonoom oordelen dat er voldoende redenen voorhanden zijn om de dader strafrechtelijk te vervolgen. Een klacht of tussenkomst van een slachtoffer is niet vereist. Anderzijds kan het slachtoffer zelf, bij stilzitten van het Openbaar Ministeric, het initiatief nemen om een strafonderzoek op te starten. Het voordeel voor het slachtoffer bestaat erin dat het Openbaar Ministerie als het ware een deel van de bewijslast van het slachtoffer ovemeemt ${ }^{810}$. Bovendien laat een burgerlijke partijstelling het slachtoffer toe een actieve rol te spelen in de strafrechtelijke procedure. Een slachtoffer kan er dus belang bij hebben om de strafrechtelijke procedure op te starten of om zich als burgerlijke partij in het strafproces te voegen; zelfs indien het slachtoffer zou stilzitten, is een strafrechtelijke vervolging eveneens mogelijk op initiatief van het Openbaar Ministerie. Hiermee is nog niet de vraag beantwoord naar het verloop van cen dergelijke strafrechtelijke procedure en naar de invloed hiervan op het nucleaire aansprakelijkheidsrecht.

Op basis van het Belgische strafrecht zijn gelijkelijk bevoegd de rechtbank van de plaats waar het misdrijf werd gepleegd, de rechtbank van de plaats waar de verdachte verblijft en de rechtbank war de verdachte kan worden aangetroffen ${ }^{811}$. Deze bevoegdheidsattributie is van openbare orde. Het gevolg hiervan is dat in de mate waarin een kernongeval zowel leidt tot een civielrechtelijke als tot een strafrechtelijke vordering, naar Belgisch recht, twee afzonderlijke procesrechtelijke bepalingen van openbare orde - één op basis van de wet van 22 juli 1985 en één op basis van het strafprocesrecht - kunnen leiden tot een verschillende bevocgdheid ratione loci van de burgerlijke rechter enerzijds en de strafrechter anderzijds. De regels inzake de machten van de strafrechtbanken raken inderdaad de openbare orde, zowel wat de strafvordering als wat de burgerlijke

Artikel 418 e.v. van het Belgische Strafwetboek.

Respectievelijk de artikelen 1 en 3 van het Belgische Wetboek van Strafvordering.

Bonotto, $\mathrm{O}$. en Vanden Borre, T., "Problèmes de compétence judiciaire dans les procédures de droit pénal relatives aux accidents nucléaires. Les principes de droit pénal et l'article 13 de la Convention de Paris", in "Nuclear Inter Jura '97", l.c., 470-471.

Zie de artikelen 23, 24 en 62bis van het Belgische Wetboek van Strafvordering; zie hierover Van den Wyngaert, C., Strafrecht en strafprocesrecht in Hoofdlijnen, Maklu, Antwerpen-Apeldoorn, 1999; Bosly, H.-D. en Vandermeersch, D., Droit de la Procédure pénal, la Charte, Brugge, $2^{\text {de }}$ druk, 2000. 
vordering aangaat ${ }^{812}$. Indien zich bijgevolg een kernongeval voordoet in de kerninstallatie van Doel bij Antwerpen, vormt Antwerpen de lex loci delicti, hetgeen de bevoegdheid van de Antwerpse strafrechter tot gevolg heeft. Dit terwijl, wat de burgerlijke vordering betreft, de Brusselse rechtbank van eerste aanleg zetelend in burgerlijke zaken, exclusief bevoegd is.

Het gevolg hiervan is dat indien zich een kernongeval voordoet in een ander gerechtelijk arrondissement dan Brussel, er territoriaal een verschillende strafrechter en burgerlijke rechter bevoegd kunnen zijn. De bevoegdheidstoewijzing aan de Brusselse rechter, bij toepassing van artikel 26 van de wet van 22 juli 1985, verhindert dus geenszins de bevoegdheid van de strafrechter van de lex loci delicti op basis van het Wetboek van Strafvordering; dit kan leiden tot een aarizienlijke vertraging van de gehele afwikkeling van een rechtszaak gebaseerd op het nucleaire aansprakelijkheidsrecht.

In verband hiermee stelt artikel 4 V.T. Sv. dat de burgerlijke rechtsvordering tezelfdertijd en voor dezelfde rechters kan worden vervolgd als de strafvordering. Indien een slachtoffer zich met andere woorden tot de strafrechter van de lex loci delicti wendt, is deze verplicht bevoegdheid op te nemen. Deze bevoegdheid om een uitspraak te doen over de strafvordering, brengt in principe de bevoegdheid mee om eveneens uitspraak te doen over de civiclrechtelijke vordering. Maar ter zake van een kernongeval, dient de strafrechter rekening te houden met de exclusieve bevoegdheidstoewijzing van de civielrechtelijke vordering aan de Brusselse rechtbank overeenkomstig artikel 26 van de wet van 22 juli 1985. Indien bijgevolg een andere strafrechter dan deze uit Brussel bevoegdheid opneemt ingevolge een kemongeval, kan hij geen uitspraak doen over de door slachtoffers ingestelde eis tot schadevergoeding. Hij zal zich dus onbevoegd dienen te verklaren.

Dit leidt evenwel tot een tweede probleem. De Brusselse rechter kan geen uitspraak doen over de vordering uit schadevergoeding, zolang de strafrechter geen uitspraak heeft gedaan: overeenkomstig artikel 4 in fine VT Sv, is de burgerlijke vordering immers geschorst zolang niet definitief is beslist over de strafvordering die vóór of gedurende de burgerlijke vordering is ingesteld (le criminel tient le civil en état $)^{813}$. Ook deze bepaling wil garanderen dat een gelijkluidende uitspraak wordt bekomen van de strafrechter enerzijds en de burgerlijke rechter anderzijds.

Dit kan er dus toe leiden dat indien de strafzaak naar aanleiding van een kemongeval lang aansleept, het lang kan duren vooraleer een definitieve uitspraak kan worden gedaan over de vorderingen inzake schadevergoeding. Of de exclusieve bevoegdheid zoals voorzien in het Verdrag van Parijs en in de Belgische wet zal leiden tot een snelle rechterlijke uitspraak, is dus niet gegarandeerd.

\subsection{Volgens de Nederlandse WAKO}

Volgens artikel 22, eerste lid van de WAKO is in eerste aanleg uitsluitend de rechtbank te 'sGravenhage bevoegd. De WAKO van 1979 voorzag reeds in de bevoegdheid van dezc ruchtbank $^{814}$. Toen werd deze bepaling noodzakelijk geacht teneinde te garanderen dat alle vorderingen voor éénzelfde rechtbank zouden worden gebracht ${ }^{815}$.

Cass., 13 juni 1955, Pas, $1,1118$.

Artikel 4 in fine VT Sv:; ook in die zin: Veuchelen, L., "De civielrechtelijke aansprakelijkheid voor kemongevallen naar Belgisch recht", o.c., 48 .

Artikel 13 van de WAKO van 1979.

Memorie van Toelichting. Tweede Kamer, zitting 1975-1976, 13.928, nr. 5, 29. 
Nochtans dient een verschil te worden vastgesteld tussen de bepalingen van de WAKO van 1979 en deze van 1991. Artikel 13 van de oude WAKO luidde: "Als rechter in eerste aanleg in Nederland, bevoegd ingevolge artikel 13 van het Verdrag van Parijs, en als rechtbank, bedoeld in deze wet, wordt aangewezen de arrondissementsrechtbank te 's-Gravenhage". Onder de WAKO van 1991 luidt de bevoegdheidsattributie evenwel: "In cerste aanleg is bij uitsluiting bevoegd de rechtbank van 's-Gravenhage".

Het betreft een duidelijke redactionele wijziging die echter een invloed kan hebben. Bij de bespreking van de bepalingen van het Verdrag van Parijs is gebleken dat de bevoegdheidsattributie aan één exclusief bevoegde rechtbank enkel betrekking heeft op een aantal specifieke artikelen uit het Verdrag en dat deze attributie zich bijvoorbeeld niet uitstrekt ter zake van het regresrecht van de exploitant. Door de verwijzing, onder de WAKO van 1979, naar artikel 13 van het Verdrag van Parijs, werd voorzien in een aan het Verdrag van Parijs identieke bepaling. Ook onder de oude WAKO was de exclusieve bevoegdheid van de rechter van Den Haag niet absoluut. Maar door de algemene bewoordingen van artikel 22, eerste lid van de WAKO van 1991, en door het gebrek aan verwijzing naar het Verdrag van Parijs, lijkt het erop dat de bevoegdheidsattributie in het Nederlandse kernenergierecht dermate absoluut is dat ook de vorderingen van de exploitant zullen ressorteren onder de bevoegdheid van de rechtbank van 's-Gravenhage. Of dit ook de bedoeling is geweest van de Nederlandse wetgever, is niet meteen duidelijk.

Bovendien lijkt het aannemelijk om ervan uit te gaan dat ook in Nederland de civielrechtelijke procedure kan worden vertraagd door een strafrechtelijke vordering. Het Nederlandse Wetboek van Strafrecht bevat een bepaling die in sterke mate gelijkt op de bepaling ter zake van onopzettelijke slagen en verwondingen naar Belgisch strafrecht ${ }^{816}$; daarnaast voorziet artikel 16 lquinquies in een specifieke bepaling ingeval door iemands schuld mensen, dieren, planten of goederen aan ioniserende straling worden blootgesteld. Op het procedurele vlak is ook in Nederland de strafrechter van het rechtsgebied waar de feiten hebben plaatsgevonden bevoegd ${ }^{817}$, en kan degene die rechtstreeks schade heeft geleden door een strafbaar feit zijn vordering tot schadevergoeding als benadeelde partij voegen in het strafproces ${ }^{818}$. Hiermee is niet gezegd dat zich in Nederland precies dezelfde situatie kan voordoen als in België. Wel is hiermee aangetoond dat ook in Nederland de kans reëel is dat naar aanleiding van een kemongeval een strafonderzoek zal worden geïnitieerd en dat mogelijkerwijze de op de WAKO gebaseerde civielrechtelijke vordering zal worden vertraagd.

\section{S.4. Conclusie}

Via de exclusieve bevoegdheid van éćn rechtbank per Verdragsstaat wordt de eenheid in de rechtspraak bewerkstelligd. Het voomaamste punt lijkt hicr te zijn dat vermeden dient te worden dat door de bevoegdheid van mecrdere rechtbanken in verschillende landen de beperking en de kanalisatie van aansprakelijkheid zouden worden omzeild. Tegelijk zouden, via de exclusieve berocgdheid van één rechtbank, de proceskosten worden gereduceerd.

Uit de analyse is evenwel gebleken dat twee elementen de eenheid van rechtspraak in het gedrang kunnen brengen, of minstens de afwikkeling van schadevorderingen kunnen vertragen. In cerste instantic zal artikel 13 van het Verdrag van Parijs enkel kunnen worden ingeroepen ten aanzien van Verdragsstaten. Zodra een kernongeval dus schade veroorzaakt in een niet-Verdragsluitende

Met name artikel 307 en 308 van het Wetboek van Strafrecht.

Artikel $2,1^{\circ}$ eerste boek WbSV.

Artikel 5 I a eerste boek WbSV. 
Staat (of wanneer er een ander aanknopingspunt is met een niet-Verdragsluitende Staat) zal het systeem niet sluitend (meer) zijn ${ }^{819}$. In tweede instantie kan ook de territoriale bevoegdheid van de strafrechter tot vertraging van de rechtsgang leiden.

Hiermee wordt de analyse van de basisprincipes van het nucleaire aansprakelijkheidsrecht afgesloten. In de volgende twee hoofdstukken richt de aandacht zich (hoofdzakelijk) tot de aansprakelijkheidsverzekering. In hoofdstuk 5 worden de algemene aansprakelijkheidsverzekeringen aan de orde gesteld; in hoofdstuk 6 wordt de verzekering van het nucleaire risico besproken. 


\section{HOOFDSTUK 5}

\section{VERZEKERINGEN}

In de vier eerste hoofdstukken van dit onderzoek werd aandacht besteed aan het civiele aansprakelijkheidsrecht, de eerste pijler van het onderzoek. In de twee nu volgende hoofdstukken zal worden stilgestaan bij de tweede pijler, namelijk de verzekeringen: in hoofdstuk 5 en 6 worden verzekeringen vanuit juridisch perspectief geanalyseerd; in hoofdstuk 9 volgt een rechtseconomische analyse. Omdat dit proefschrift de aansprakelijkheid en de verzekering van kernongevallen als yoorwerp heeft, zal in dit hoofdstuk een centrale plaats toekomen aan de aansprakelijkheidsverzekering. Ook bij de bespreking van deze pijler wordt in eerste instantie aandacht besteed aan verzekeringen in het algemeen (hoofdstuk 5); de verzekering van het nucleaire risico wordt in hoofdstuk 6 aan de orde gesteld. Op deze wijze kan worden nagegaan hoe en op welke wijze de verzekeringsmechanismen die worden toegepast op "conventionele risico's" ook (kunnen) worden toegepast op de verzekering van het nucleaire risico.

In cerste instantie wordt het ontstaan van verzekeringen toegelicht in een historische context; vervolgens wordt weergegeven welke wezenlijke kenmerken hieruit voortvloeien en hoe het begrip "verzekeringsovereenkomst" kan worden gedefinieerd ( $\$ 2$ ). Na deze definiëring is het voor het onderzock van belang een onderscheid te maken tussen een aantal verschillende soorten verzekeringen $(\$ 3)$, met name privé- en sociale verzekeringen, verzekering tegen premie en onderlinge verzekering, vrijwillige en verplichte verzekeringen en grote en massarisico's. Na deze algemene bepalingen inzake verzekeringen, wordt in paragraaf 4 aandacht besteed aan de aansprakelijkheidsverzekering. Een bijzonder probleem dat bij de aansprakelijkheidsverzekering rijst en dat van groot belang is in het kader van dit onderzoek, namelijk de dekking van de aansprakelijkheid in de tijd, wordt afzonderlijk behandeld in $\S 5$.

\section{HISTORISCHE SCHETS VAN HET ONTSTAAN VAN VERZEKERINGEN}

Aan de basis van de verzekeringscontracten zoals wij die vandaag kennen ligt de idee van onderlinge bijstand en kredietverschaffing'. Dergelijke mutualiteiten of onderlinge verzekeringen bestonden reeds in Mesopotamië waar de kameeldrijvers onder elkaar de schade verdeelden voor het geval een bepaald lid van de groep zijn kamelen verloor ${ }^{2}$. Ten tijde van de Soemeriërs bestonden systemen van onderlinge verzekering en kredietverlening tegen het verlies van eetwaren die per karavaan werden vervoerd ${ }^{3}$. Een ander voorbeeld van mutualiteit is terug te vinden in het zeerecht ten tijde van de Pheniciërs in de lex Rhodia de jactu: indien een schip in nood verkecrde en een deel van de lading overboord werd gegooid tencinde het schip te redden, werd het verlics verdeeld tussen al degenen die hadden declgenomen aan de boottocht, de eigenaars van de verloren vacht, de eigenaars van de geredde vracht en de scheepscigenaar ${ }^{4}$. Dit systeem bestaat nog steeds in het huidige zeerecht, met name via het systeem van de avaries communes of gemeen-

Bigot, J., "Historique des entreprises d'assurance", Bigot, J, e.a., Traité de Droit des Assurances, Tome I, Entreprises et organismes d'assurance, 2ième édition, Librairie Générale de Droit et de Jurisprudence, Paris, 1996, 7 (hierna geciteerd als "Traité").

Fontaine, M., Droit des Assurances, 2ième édition, De Boeck \& Larcier, Bruxelles, 1996, 9; Fontaine, M., V'erekeringsrecht, De Boeck \& Larcier, Brussel, 1999, 5.

Bigot, J., "Historique des entreprises d'assurance", in Bigot, J., e.a., "Traité", l.c., 7.

liontaine, M., "Droit des Assurances", l.c., 9. 
schappelijke averij ${ }^{5}$. Ook het moderne fenomeen van verzekering vindt zijn wortels in de maritieme praktijk.

Geleidelijk zou niet de betrokken handelaar zelf, maar een derde de zeereis financieren. Bij behouden terugkomst in de thuishaven, diende de ontlener niet enkel het geleende bedrag, maar ook een vergoeding te betalen voor het door de geldschieter gelopen risico. Deze lening was reeds bekend ten tijde van de Romeinen ${ }^{6}$ (de Nauticum foenus of de lening op bodemerij) ${ }^{7}$. Hierbij nam een geldschicter het risico op zich voor de aan een zeereis verbonden gevaren; enkel indien het schip en/of de lading hun bestemming hadden bereikt, diende de lening (verhoogd met een rente) te worden terugbetaald. In een dergelijk geval kon de eigenaar van schip en/of lading de lening immers terugbetalen door de goederen te verkopen. De winst uit deze verkoop dekte niet enkel de kosten van de lening zelf, maar hield tegelijk een aanzienlijke risicopremie in (de bij dergelijke leningen gehanteerde tarieven schommelden tussen 30 en $50 \%$ ). Indien het schip zijn bestemming niet bereikte, verviel de terugbetalingsplicht van de eigenaar van het schip en/of van de goederen ${ }^{8}$. Het spreekt voor zich dat de geldschieter die op deze wijze aan een aanzienlijk risico werd blootgesteld, een zeer hoge rente aanrekende waardoor het voor de handelaar zelfs voordeliger werd de vracht verloren te laten gaan, hetgeen de deur openzette voor allerhande misbruiken.

De woekerleningen die werden gevraagd bij deze leningen op bodemerij, werden echter verboden door de decretale "Naviganti vel eunti ad nundinas" van paus Gregorius IX in 1234, met als gevolg dat werd gezocht naar allerlei mechanismen die aan de handelaren de zekerheid verschaften de risico's van een zeetocht niet alleen te moeten dragen. Ingevolge het verbod werd een nieuwe techniek toegepast op basis waarvan het schip of de vracht werden verkocht aan degene die bereid was het risico op zich te nemen, onder de ontbindende voorwaarde dat het schip zijn bestemming bereikte. De systemen die op deze wijze werden gecreëerd in het zeerecht liggen dan ook aan de basis van verzekeringen". De nood aan "beschermingsmechanismen" vergrootte uiteraard naargelang de belangen en de waarde van de goederen op een zeetocht toenamen ${ }^{10}$. Deze bescherming kreeg aanvankelijk gestalte via eenvoudige praktische maatregelen om de risico's van de zeetochten zoveel mogelijk te spreiden. In plaats van een lading op één enkel schip te laden, werd deze verdeeld over verschillende schepen die overigens meer en meer in konvooi voeren. Eenzelfde risicospreiding werd bereikt in hoofde van de scheepseigenaren door gezamenlijk meerdere schepen te kopen, waardoor bij verlies van een schip slechts een deel van de eigendom van één persoon verloren ging. Een verdere perfectionering van deze maatregelen leidde uiteindelijk tot het ontstasn van de maritieme verzekeringen in het begin van de 15 de eeuw om in de daarop volgende eeuw tot volle ontwikkeling te komen ${ }^{11}$. De eerste teksten waarin sprake is van cen juri-

De Smet, R., Droit maritime et droit flwvial belges, 1971, II, 639-737.

Tijdens het Romeinse keizerrijk stelde de overheid de reders die wapens en proviand aanvoerden ten behoeve van de Romeinse legioenen in de kolonies, garant voor schipbreuk en voor het geval de schepen in handen kwamen van de vijand. Het betreft een soort garantstelling van de overheid voor oorlogsschade. In de Franse literatuur de "prệt à la grosse aventure", Bigot, J., "Historique des entreprises d'assurance", in Bigot, J., e.a., "Traité", l.c., 7.

Rodière, R, "Droit Maritime", I.c., 29; van Huizen, P.H.J.G., Het Transporiverzekeringsbedrijf. Juridische en rechtsvergelijkende beschouwingen, diss., 1988, 21 e.v.

9 Wery. P. L., Hoofdzaken Verzekeringsrecht, Kluwer, Deventer, 1995, 1 (hicrna geciteerd als: Hoofdzaken).

10 Bijvoorbeeld de ontdekking van Amerika door Christoffel Columbus heeft aanleiding gegeven tot een aanzienlijke groei van het maritieme verkeer. Aangezien de schepen steeds groter werden en de waarde van de vracht enkel toenam, vergrootte meteen de noodzaak om commerciële zeereizen te beschermen tegen de inherente gevaren van dergelijke tochten. Rodière, R, "Droit Maritime", l.c., 7. 
disch kader voor maritieme verzekeringen zijn de tussen 1435 en 1461 tot stand gekomen Ordonnanties van Barcelona, waar sprake is van verzekcringspremics dic op voorhand dienden te worden betaald en van de geldigheid van te goeder trouw afgesloten veryekeringscontracten ${ }^{12}$.

De eerste overeenkomsten die min of meer kunnen worden beschouwd als verzekeringsovereenkomsten hadden betrekking op de gocderen van de handelaar die over zec werden vervoerd. Eveneens vanuit het zeerecht ontwikkelden zich andere verzekeringsvormen dan de eigenschadeverzekering van de handelaar. Ook de levensverzekering ontstond in het kader van de scheepvaart. Aanvankelijk dekte deze verzekering de losgelden die piraten eisten nadat zij een schip hadden gekaapt. Later werd deze dekking uitgebreid tot het leven an sich, buiten elk risico op zee. Deze verzekeringsvorm stuitte op heel wat weerstand omdat het verzekeren van een menselijk leven als immoreel werd beschouwd: zo verbood Filips II van Spanje in 1570 de levensverzekering, hoewel hij schoorvoetend maritieme verzekeringen had toegelaten.

De op kapitalistische leest geschoeide aandelenvennootschappen komen pas op het einde van de 18 de ceuw tot volle ontwikkeling ${ }^{13}$ : de verschillende bij de verzekering betrokken personen troffen elkaar in openbare plaatsen zoals in cafés om informatie uit te wisselen en zaken te doen. Ecn van die plaatsen waar reders, scheepsbevrachters, financiers en tussenpersonen samenkwa men was de taveme van Edouard Lloyd. Dit leidde uiteindelijk tot de oprichting van de bekende Lloyd's of London ${ }^{14}$, een groep van maritieme verzekeraars die 50 jaar na haar oprichting reeds $90 \%$ van de zeehandel verzekerde ${ }^{15}$. De techniek die deze verzekeraars gebruikten om de gedekte risico's optimaal te spreiden bestond in het verdelen van de eigendom van ecn schip over verschillende personen die elk voor hun deel van de eigendom een afzonderlijke verzekering afsloten met Lloyd's. Deze vorm van verzekering kreeg steeds gestalte op een ad hoc basis; voor een specifieke reis werd namelijk telkens een groep van mensen gevonden die bereid waren het risico te delen.

Aanvankelijk werden verzekeringen geassocieerd met misbruiken en fraude. Enkel door belangrijke ontwikkelingen op wetenschappclijk gebied die het kanskarakter en het gokclement in dergelijke contracten verminderden, verkregen verzekeringen hun legitimiteit. In de 17de eeuw legde Pascal de basis voor de probabiliteitenleer die toeliet op basis van de observatie van een groot aantal feitelijke gegevens bepaalde onzekere gebeurtenissen te voorspellen ${ }^{16}$; deze inzichten werden door anderen in een later stadium verder uitgewerkt waardoor bijvoorbeeld sterftetabellen konden worden opgesteld.

Niet alleen levensverzekeringen werden aanvankelijk als immoreel beschouwd: ook de aansprakelijkheidsverzekeringen die zich vanaf de 19 de eeuw ontwikkelden, stuitten aanvankelijk op aanzienlijke weerstand. Aansprakelijkheidsverzekeringen werden onverenigbaar geacht met moraal, godsdienst en rechtvaardigheid die alle uitgaan van de individuele verantwoordelijkheid van elkeen. De evolutie die de aansprakelijkheidsverzekering heeft gekend is zonder meer opmerkelijk te noemen: terwijl aanvankelijk de vraag werd gesteld of deze verzekeringsvorm moreel verantwoord was, wordt zij in de twintigste eeuw in verschillende domeinen verplicht opgelegd door

Voor meer details, zie Rodière, R., "Droit Maritime", l.c., 14 e.v.

De eerste aandelenvennootschappen waren weliswaar opgericht in de 13de eeuw, maar deze kwamen slechts in de $18 \mathrm{de}$ eeuw echt tot ontwikkeling (Bigot, J., "Historique des entreprises d'assurance", in Bigot, J., e.a., "Traité", l.c., 12).

1

Zie o.m. Hodgson, G., Llyod's of London. A Reputation at Risk, Londen, 1984; Nys, C., "De juridische natuur van de Lloyd's Syndicates en de wijze waarop haar leden in rechte optreden", Jura Falconis, 1989-90, 161-176.

Bigot, J., "Historique des entreprises d'assurance", in Bigot, J., e.a., "Traité", l.c., I I.

Fontaine, M., "Droit des Assurances", l.c., 12. 
de wetgever en wordt gesteld dat zij de technologische en economische vooruitgang heeft mogelijk gemaakt $^{17} 18$.

Dit blijkt uit de variatie in de thans in België beschikbare polissen ${ }^{19}$ : BA verzekering voor bepaalde beroepen (architecten, geneesheren, advocaten en notarissen) ${ }^{20}$, de BA exploitatie voor ondernemingen ${ }^{21}$, en naargelang de activiteit van de ondernemingen de $\mathrm{BA}$ na levering ${ }^{22}$ en de $\mathrm{BA}$ vervuiling. Met het oog op de bescherming van het slachtoffer, wordt de aansprakelijkheidsverzekering in een aantal gevallen verplicht gesteld. De beschikbaarheid van een verzekeringsdekking heeft ook de perceptie van het aansprakelijkheidsrecht danig veranderd ${ }^{23}$. De indruk ontstaat dat het aansprakelijkheidsrecht zou zijn geëvolueerd naar een soort schadevergoedingsrecht ${ }^{24}$; daarbij zou de vraag wie over een verzekeringsdekking beschikt belangrijker zijn dan de vraag wie juridisch aansprakelijk is voor de geleden schade ${ }^{25}$.

Ook de opkomst van het stelsel van sociale zekerheid, op basis waarvan een persoon recht heeft op de vergoeding van ziektekosten en inkomensderving, buiten elk foutelement om, heeft zonder twijfel bijgedragen tot de perceptie dat eender welk vermogensverlies zal worden vergoed. Toch blijven de principes van het aansprakelijkheidsrecht onverkort gelden en kan niet echt een tendens naar assurance oblige worden vastgesteld ${ }^{26}$.

Fontaine, M., "Droit des Assurances", l.c., 291-292.

18 Over de wisselwerking tussen aansprakelijkheid en verzekering, zie Cousy, $\mathrm{H}_{\text {., }}$ "Over aansprakelijkheidsrecht en verzekering: living together apart?", in "Liber Amicorum Walter van Gerven", l.c., 203222.

Bepaalde auteurs gaan zelfs zover te stellen dat zonder aansprakelijkheidsverzekering het aansprakelijkheidsrecht reeds lang zou zijn ineengestort en zijn vervangen door een ander, misschien efficiênter compensatiesysteem bij ongevallen (Fleming, J.G., "The Law of Torts", l.c., 11). Markesinis heeft het over "la perversion" van de aansprakelijkheid (Markesinis, B., "La perversion des notions de responsabilité civile délictuelle par la pratique de l'assurance", o.c., 1983, 301). D'Hondt, A., "Responsabilités et Assurances des professions libérales", in Les Assurances de l'Entreprise, Editions du jeune barreau de Bruxelles, 1999, 37-73.

Delvaux, P.H., "Le champ d'application matériel de l'assurance de la responsabilité civile exploitation", Recueil Générale des Assurances et des Responsabilités, 1989, $\mathrm{n}^{\circ}$ 11512; Delvaux, P.H., "Responsabilités et Assurances de l'Entreprise", in Les Assurances de Responsabilité, Editions du jeune barreau de Bruxelles, 1999, 1-36; Rogge, J., "L'assurances des risques d'exploitation", in Les Assurances de l'Entreprise, Bruxelles, Bruylant, vol. II, 1993, 175-214.

Cousy, H. en Claassens, H., Produkienaansprakelijkheid, veiligheid en verzekering, Maklu, Antwerpen, 1988; Moustic, K., "Verzekering van produktaansprakelijkheid", Tijdschrift voor Privaatrecht, 1988, 141-160; Van Aerschot, R., "Produktaansprakelijkheid, een verzekeringsproduct in beweging", Bulletin des Assurances, 1988, 224-231.

Zie o.m. Dekkers, R., "Aansprakelijkheid en Verzekering", o.c., 1545-1548; Schuermans, L., "Van foutaansprakelijkheid naar schadeverzekering", Tijdschrift voor Privaatrecht, 1967, 1-42; Schuernans, L., "Perspectieven in het verzekeringsrecht", Rechtskundig Weekblad, 1977-1978, 2249-2268; Tunc, A., "Responsabilité civile et assurance", o.c., 343-357; Van Gerven, W., "De invloed van de verzekering op het verbintenissenrecht", o.c., 777-792.

Dalcq, R.O., "Sécurité, assurance et solidarité", in "Responsabilité et réparation des dommages", lc., 327 e.v.; Daicq, R.O., "Réflexions sur le droit de la responsabilité civile", o.c., 157-159; Fagnart, J.L, "La socialisation des risques par les mécanismes de la responsabilité civile et de l'assurance", "Les Assurances de l'Entreprise", l.c., 419-448; Fagnart, J.L., "Recherches sur le droit de la réparation", in "Mélanges R.O. Dalcq", l.c., 1994, 135-157. Tunc, A., "La responsabilité civile", l.c., 73.

26 O.m. Hartlief, I. en Tjittes, R.P.J.L; "De invloed van verzekeringen op de civielrechtelijke aansprakelijkheid: privaatrechtelijke aspecten", in De invloed van verzekeringen op de civiele aansprakelijkheid. Preadviezen uitgebracht door de vereniging van burgerlijke recht, Vermande, Lelystad, 1990, 55-115; 
Tegelijk is het moderne verzekeringsrecht buiten het handelsrechtelijke kader getreden, in die zin dat een verzekering niet noodzakelijk meer wordt afgesloten tussen twee ondernemingen, maar heel vaak tussen een particulier en een verzckeringsmaatschappij ${ }^{27}$. Verder heeft de evolutic en de ontwikkeling van het verzekeringswezen ertoe geleid dat de eigenlijke verzekeringsovereenkomst wordt afgesloten met en dat het risico wordt gespreid ten overstaan van een verzekeringsonderneming die volkomen vreemd is aan het risico. De overgang van de onderlinge risicospreiding tussen zeehandelaren naar de risicospreiding door een derde betekende de start van het eigenlijke verzekeringswezen.

Er kan worden geconcludeerd dat het verzekeringswezen is ontstaan vanuit de pragmatische noodzaak tot bescherming van de toenemende handel. Aangezien de handel zich vooral hecft ontwikkeld dankzij de scheepvaart, vinden verzekeringen ook daar hun oorsprong. Aanvankelijk werd cnkel dekking verleend voor de eigenschade van handelaren die aan eenzelfde risico werden blootgesteld. Geleidelijk heeft het verzekeringswezen zich geprofessionaliseerd en werd het risico meer en meer gespreid tussen personen die geen enkele band hadden met het risico; in deze gevallen diende de verzekeringsnemer een premie te betalen in ruil voor de dekking. Al deze elementen zijn terug te vinden in de juridische definitie van het begrip "verzekeringsovereenkomst"; uit deze definitie kunnen de wezenlijke bestanddelen worden afgeleid.

\title{
2. DEFINIËRING EN WEZENLIJKE BESTANDDELEN VAN DE VERZEKERINGSOVEREENKOMST
}

In de Belgische wet van 25 juni 1992 op de landverzekeringsovereenkomst wordt een ver $\angle$ ekeringsovereenkomst als volgt omschreven (artikel 1.A):

\begin{abstract}
"een overeenkomst waarbij de ene partij, de verzekeraar, zich er tegen betaling van een vaste of veranderlijke premie tegenover een andere partij, de verzekeringsnemer, toe verbindt een in de overeenkomst bepaalde prestatie te leveren ingeval zich een onzekere gebeurtenis voordoet waarbij, naargelang het geval, de verzekerde of de begunstigde belang heeft dat die zich niet voordoet".
\end{abstract}

Deze definitie ontsnapt niet aan kritische bemerkingen vooral omdat deze definitie te zwaar en tegelijk onvolledig wordt bevonden ${ }^{28} 29$. Het is bijvoorbeeld vreemd dat de termen "verzekerde" en "derdebegunstigde" worden gedefinieerd, wat niet het geval is voor de termen "verzekeraar" en

Hartlief, T. en Tjittes, R.P.J.L., "Verzekering en Aansprakelijkheid", l.c., 22; Sinoens, D., "Ongevallenrecht: Grensgebieden van aansprakelijkheid, verzekcring en sociale zekerheid", o.c., 1984, 422. Voor een rechtseconomische benadering, zie bijvoorbeeld Faure, M.G., "The Influence of Insurance on Liability Issues", in McGee, A. en Heuscl, W. (ed.), "The Law and Practice of Insurance in the Single European Market", l.c., 190 e.v. Wory, P.L., "Hoofdzaken", l.c., 4.

35. Ook de definitie onder de oude wet van 11 juni 1874 was aan heel wat kritiek onderhevig. Zo heerst onduidelijkheid of een verzekeringsovereenkomst steeds een vergoedend karakter heeft en of de verzekeringstechniek (actuariële techniek) een essentieel bestanddeel vormt van de verzekeringsovereenkomst. In dit onderzoek wordt geen aandacht besteed aan deze discussie; voor een goed beeld ervan, kan worden verwezen naar Libert, P., Recht en Techniek van de Verzekering, Brussel, Bruylant, 1986, 16 en naar Fontaine, M., "Droit des Assurances", I.c., 83-95.

Vanuit verzekeringstechnisch oogpunt wordt verzekering omschreven als: "une opétation anti-aléatoire de lutte collective contre le hazard" "Lambert-Faive, Y., "Droit Des Assurances", $9^{\mathfrak{c}}$ editie, Dalloz, Parijs, 1995, 36). 
"verzekeringsnemer". Nochtans was de definitie van deze laatste uitgewerkt in een eerdere versie van artikel I van de wet ${ }^{30}$.

In de Memorie van Toelichting bij de Belgische wet wordt de verzekeringsverrichting omschreven als een "kansverrichting onder bezwarende titel betreffende een voor verzekering vatbare gebeurtenis, die niet wederkerig is wat het risico betreft en als een zelfstandige verrichting kan worden aangegaan ${ }^{31}$. Het betreft een overeenkomst onder bezwarende titel omdat de verzekeringsnemer een premie betaalt aan de verzekeraar, waarbij deze laatste als tegenprestatie voor de aan hem betaalde premie een prestatie levert voor het geval de in de verzekeringsovereenkomst beschreven onzekere gebeurtenis zich voordoet. Hierbij is een duidelijke band voorhanden tussen de premie, de prestatie en de toevallige gebeurtenis.

Daamaast steunt de verzekeringsovereenkomst op een voor verzekering vatbare gebeurtenis, dit wil zeggen dat de voor verzekering vatbare gebeurtenis hetzij schade berokkent aan het vermogen, hetzij het leven, de gezins- of lichaamstoestand van cen persoon raakt. De gebeurtenis kan zich zowel plots voordoen zoals bij een ongeval als langzaam, bijvoorbeeld in geval van ziekte.

De verzekeringsovereenkomst is niet wederkerig wat het risico betreft: door de overeenkomst zelf wordt het risico, dat bij afwezigheid van verzekeringsdekking ten laste zou vallen van de verzekerde of van de uitkeringsgerechtigde, overgedragen op de verzekeraar. Hierdoor bevat de verzekeringsovereenkomst in hoofde van de verzekeraar een speculatief element dat vergelijkbaar is met de weddenschap ${ }^{32}$.

Artikel 2:246 van het Nederlandse WvK definieert een verzckeringsovereenkomst als volgt:

\begin{abstract}
"assurantie of verzekering is een overeenkomst bij welke de verzekeraar zich aan den verzekerde, tegen genot eener premie, verbindt om denzelve schadeloos te stellen wegens een verlies, schade of gemis van verwacht voordeel, welke dezelve door een onzeker voorval zoude kunnen lijden".
\end{abstract}

Uit bovenstaande definiëring kunnen de wezenlijke bestanddelen van de verzekeringsovereenkomst worden afgeleid, met name het risico, het verzekerbaar belang, de premie en de verzekeringsprestatie ${ }^{33}$.

Het risico is een toevallige en onzckere gebeurtenis die leidt tot schade; doet de gebeurtenis zich voor, dan lijdt de verzekerde schade en zal deze worden vergoed onder een gegeven verzekeringspolis. Vandaar wordt de verzekeringsovereenkomst omschreven als een kanscontract zoals gedefinieerd in artikel 1964 van het Belgische BW: "een kanscontract is een wederkerige overeenkomst, waarvan de gevolgen, met betrekking tot winst en verlies, hetzij voor alle partijen, hetzij voor één of meer van hen, van een onzekere gebeurtenis afhangen. Van dien aard zijn het

Parlementaire Stukken, Kamer, GZ/990-1991, $n^{\circ} 1586 / 5,29$ en $n^{\circ} 1586 / 1,113$; in Cousy, H. en Schoorens, G., De nieuwe wet op de landverzekeringsovereenkomst. Parlementaire Voorbereiding van de wet van 25 juni 1992 en van de wijzigende wet van 16 maart 1994, Kluwer, Deurne, 1994, 47 (hierna geciteerd als: Cousy, H. en Schoorens, G., "Parlementaire Voorbereiding"). Kamer, GZ/1990-1991, nr. 1586/1, 10, in Cousy, H. en Schoorens, G., "Parlementaire Voorbereiding", l.c., 46 .

Memorie van Toelichting, Kamer, GZ/1990-1991, n 1586/1, in Cousy, H. en Schoorens, G., "Parlementaire Voorbereiding", l.c., 47. Antwerpen, 1994, 15 (hiema: "Algemene Beginselen"). 
verzekeringscontract, de bodemerij, spel en weddenschap en het contract van lijfrente". Een quasi identicke bepaling is terug te vinden in artikel 7A:1811 van het Nederlandse $\mathrm{BW}^{34}$; ook hier wordt de verzekeringsovereenkomst gekwalificeerd als een kanscontract. Een eerste essentieel kenmerk van een verzekeringscontract impliceert dat de verplichting van de verzekeraar om het verzekerde bedrag uit te keren, afhangt van een onzekere gebeurtenis ${ }^{35}$. Voor het afsluiten van een verzekeringscontract is het voldoende dat het onzeker is of een bepaalde gebeurtenis zich al dan niet zal voordoen. Doet deze gebeurtenis zich voor, dan zal schade worden geleden; deze schade wordt vervolgens door de verzekeraar vergoed hetzij aan de verzekerde, hetzij aan de derde begunstigde ${ }^{36}$.

Overeenkomstig artikel 1, A in fine van de Belgische wet op de landverzekeringsovereenkomst is het verzekerbaar belang het belang van de verzekeringsnemer of derde begunstigde dat het verzekerde risico zich niet voordoet. Bij afwezigheid van het verzekerbaar belang wordt een verzekeringsovereenkomst eerder een weddenschap en worden vrijwillige schadegevallen in de hand gewerkt $^{37}$. In Nederland wordt het belang omschreven als de voor de verzekerde bestaande mogelijkheid van kans op vermogensschade als gevolg van het onzekere voorval ${ }^{38}$. Het spreekt voor zich dat de verzekeringsnemer behalve zijn eigen belang ook het belang van een derde kan verzekeren (zgn. verzekering voor rekening van derden); in een dergelijk geval heeft niet de onderschrijver van de polis een verzekerbaar belang, maar wel de persoon voor wiens rekening hij handelt. Deze derde is dan de verzekerde als titularis van het verzekerde belang ${ }^{39}$.

Het derde wezenlijke bestanddeel van een verzekering is de premie. De premie is iedere vorm van vergoeding die door de verzekeraar wordt gevraagd als tegenprestatie van diens verbintenissen (art. 1, E wet op de landverzekeringsovereenkomst). Deze premie bestaat uit verschillende elementen $^{40}:$ de technische of pure premie ${ }^{41}$, de bedrijfs- en distributiekosten (vooral administratieve en beheerskosten) en de winst. Het spreekt voor zich dat de op basis van actuariële technieken berekende premie een voorname bron van inkomsten is voor de verzekeraar. Een correcte premiebepaling draagt in belangrijke mate bij tot de financiële gezondheid van de desbetreffende verzekeringsmaatschappij ${ }^{42}$. Over het algemeen dient de premie te worden betaald bij anvang van de verzekeringsovereenkomst en vervolgens periodiek op de tijdstippen en volgens de modaliteiten zoals overeengekomen in de verzekeringsovereenkomst. Dit impliceert dat de premie $a$

34 "Eene kans-overeenkomst is eene handeling, waarvan de uitkornsten, met betrekking tot voordeel en nadeel, het zij voor alle partijen, het zij voor eenige derzeive, van eene onzekere gebeurtenis afhangen".

35 De Belgische wet van 11 juni 1874 definieerde het risico als een bepaalde toevallige of uit overmacht ontstane gebcurtenis; de wet op de landverzekeringsovereenkomst van 25 juni 1992 daarentegen stelt de tussenkomst van de verzekeraar afhankelijk van een "onzekere gebeurtenis". In de literatuur wordt de nieuwe omschrijving aanbevolen omdat met name bij aansprakelijkheidsverzekeringen het risico van de verzekerde niet afhangt van gevallen van overmacht (Fontaine, M., "Droit des Assurances", I.c., 103).

In bepaalde gevallen zal het schadegeval zich niet manifesteren naar aanleiding van een plotselinge gebeurtenis, maar eerder ten gevolge van een geleidelijk proces dat meerdere maanden of zelfs jaren kan duren. Zie ook in $\$ 5$ van dit hoofdstuk, bij de bespreking van de dekking van een aansprakelijkheidsverzekering in de tijd.

Libert, P., Recht en Technick van de Verzekering, Bruylant, Brusse1, 1986, 25.

Wery, P.L., "Hoofdzaken", l.c., 25.

Libert, P., "Recht en Verzekering", l.c., 26-27.

Colle, Ph., Algemene Beginselen van het Belgisch Verzekeringsrecht, Bruylant, Maklu, BrusselAntwerpen, 1994, 15 (hierna: Algemene Beginselen).

Deze is gebaseerd op verschillende factoren zoals het verzekerde bedrag, de duur van de dekking, de probabiliteit en de eventuele toepassing van franchises of vrijstellingen.

Wery, P.L., "Hoofdzaken", l.c., 4. 
priori dient te worden betaald. In een aantal gevalien evenwel dient de premie a posteriori te worden betaald, of wordt de premie voldaan door een combinatie van een voorlopige $a$ priori premie en een a posteriori premie die, afhankelijk van de realisatie van de verzekerde onzekere gebeurtenis, de voorlopige premie zal corrigeren. Een dergelijke techniek wordt vaak gehanteerd in systemen van onderlinge verzekeringen.

De verzekeringsprestatie tenslotte is het bedrag of de dienst die door de verzekeraar is verschuldigd wanneer het risico zich voordoet. In bepaalde gevallen zal deze prestatie erin bestaan cen bepaalde som uit te keren; in andere gevallen houdt de prestatie het leveren van bepaalde diensten in zoals adviesverstrekking of pechverhelping.

In deze paragraaf werd een algemene definitie gegeven van de verzekeringsovereenkomst en werden de algemene bestanddelen ervan besproken. Vooraleer verder te gaan met de analyse van verzekeringen, is het voor de duidelijkheid aangewezen aandacht te besteden aan enkele verschillende soorten verzekeringen ${ }^{43}, \mathrm{c.q}$. om enkele begrippen toe te lichten die ook in het verdere onderzoek zullen worden gehanteerd.

\section{ONDERSCHEID TUSSEN VERSCHILLENDE SOORTEN VERZEKERINGEN}

In de praktijk zal het zelden voorkomen dat een persoon slechts één verzekeringsdekking heeft afgesloten, verzekerd is onder één enkele polis of slechts een beroep doet op één enkel type van verzekering. Een werknemer bijvoorbeeld die een wagen heeft zal in België en Nederland in de regel zowel via een stelsel van verplichte verzekering, als via een stelsel van onderlinge en sociale verzekering (bijvoorbeeld ziekte en invaliditeit) van verschillende dekkingen kunnen genieten. In deze paragraaf wordt het verschil besproken tussen privé- en sociale verzekeringen $(\S 3.1)$, tussen premieverzekeringen en onderlinge verzekering of mutualiteiten ( $\S 3.2$ ), tussen verplichte en vrijwillige verzekeringen $(\$ 3.3)$ en tussen grote risico's en massarisico's ( $\$ 3.4)$. Tenslotte wordt ook het verschil uiteengezet tussen verzekering, medeverzekering en herverzekering ( $\S 3.5$ ).

\subsection{Privé- en sociale verzekeringen}

Een onderscheid dient te worden gemaakt tussen sociale verzekeringen en privéverzekeringen, omdat de eerste vorm geen verzekeringen zijn in de echte zin van het woord. Hierbij denken we aan de uitkeringen in het kader van het sociaal zekerheidssysteem zoals bijvoorbeeld aan de ziekte- en invaliditeitsverzekering en werkloosheidsuitkeringen. Hoewel hier vaak de term "verzekering" wordt gebruikt, bestaat nochtans een aanzienlijk verschil met de privéverzekeringen omdat deze laatste gebaseerd zijn op de actuariële wetenschap, hetgeen niet in dezelfde mate het geval is voor sociale, verzekeringen.

Terwijl bij privéverzekeringen de bijdrage (premie) in functie staat van het gedekte risico, draagt bij sociale verzekeringen eenieder bij in functie van zijn inkomen. Daarenboven bestaan de inkomsten van sociale verzekeringen niet enkel uit bijdragen van de verzekerden maar ook uit bijdragen van werkgevers en van de overheid. Beide verzekeringsvormen zijn overigens aan duidelijk onderscheiden regels onderworpen, met name aan het sociaal zekerheidsrecht en de

Het is niet de bedoeling van het overzicht om een volledig beeld te geven van de verschillende soorten verzekeringen, maar enkel om die verschillen toe te lichten die van belang zijn voor dit onderzoek. Voor een volledig overzicht, zie Fontaine, M., "Verzekeringsrecht", l.c., 33 e.v. 
wetgeving inzake private verzekeringen ${ }^{44}$. Nochtans moet deze stelling, zeker wat België betreft, worden gerelativeerd aangezien de arbeidsongevallenverzekering ${ }^{45}$ valt onder de wetgeving inzake privéverzekeringen en niet onder het sociale zekerheidsrecht. Tenslotte dient voor ogen te worden gehouden dat een aantal privéverzekeringen, zoals de groepsverzekeringen, tot doel hebben de waarborgen van het sociale zekerheidsstelsel aan te vullen.

\subsection{Verzekering tegen premie en onderlinge verzekering}

Bij verzekeringen tegen premie is de verzekeraar een derde ten overstaan van het risico. De verzekerde betaalt een premie aan de verzekeraar die het risico overneemt. Net als bij elke andere commerciële onderneming, is het doel van de verzekeringsondememing om winst te halen uit haar activiteiten, uit de verschillende in haren hoofde afgesloten verzekeringscontracten. De klanten van deze onderneming (de verzekerden) hebben geen enkele band met de eigenaars van de ondememing (vaak aandeelhouders indien de verzekeraar een aandelenvennootschap is). Hetzelfde geldt voor de relatie tussen de verzekerden onderling: bij premieverzekeringen zijn de verschillende verzekerden - die onderling zijn gegroepeerd - doorgaans derden ten opzichte van elkaar.

Geheel anders is het systeem van onderlinge verzekering. Hier spreidt een bepaalde groep personen of ondernemingen onder elkaar een gemeenschappelijk risico. Om dit doel te verwezenlijken wordt doorgaans een afzonderlijke vereniging of rechtspersoon gecreëerd. De eigenaren van deze vereniging zijn vaak tegelijk de verzekerden. Dit betekent dat de verzekeraar geen derde is ten aanzien van het gedekte risico, maar dat de verschillende leden van de groep optreden als elkaars verzekeraar. Een dergelijke vereniging streeft op zich geen winst na, maar wil enkel de verliezen spreiden onder de leden van de groep. Deze betalen elk een deel van de geleden schade, waarbij eerder sprake is van een bijdrage dan van een verzekeringspremie in de echte betekenis van het woord. In bepaalde gevallen wordt deze bijdrage slechts opeisbaar nadat een schadegeval zich heeft voorgedaan (a posteriori), terwijl bij "klassieke" verzekeringen in de regel de premie $a$ priori dient te worden betaald.

Verschillende systemen van onderlinge verzekeringen hanteren echter een gemengd systeem in die zin dat op voorhand een bepaalde bijdrage wordt gevraagd en dat bij een schadegeval bijkomende bijdragen dienen te worden betaald. Omgekeerd zal bij de afwezigheid van schade in een gegeven periode, een deel van de bijdrage worden terugbetaald aan de verschillende leden ${ }^{46}$. Dit is bijvoorbeeld het geval met de mutualiteit inzake eigenschadeverzekeringen van kerninstallaties in de Verenigde Staten: NEIL (Nuclear Electric Insurance Limited) heeft in de loop der jaren voldoende reserves opgebouwd waardoor (een deel van) haar leden jaarlijks een terugbetaling genieten, die groter is dan de jaarlijks te betalen bijdrage ${ }^{47}$.

Over de gelijkenissen tussen beide verzekeringsvormen, zie bijvoorbeeld Waleffe, F., "Assurances sociales, assurances privées", Revue belge de Sécurité Sociale, 1963, 46-67.

Nochtans wordt de door de wet van 10 april 1971 aangebrachte wijziging over het algemeen beschouwd als een stap in de richting van het sociaal zekerheidsrecht (Van Crombrugghe, B., "L'assurance contre les accidents du travail: un modèle d'avenir", Bulletin des Assurances, 1995, 206240).

Colle, Ph., "Algemene Beginselen", l.c., 16; Fontaine, M., "Droit des Assurances", l.c., 48-49; Fontaine, M., "Verzekeringsrecht", l.c., 38.

Zie hoofdstuk 13. 
Bij modemere vormen van onderlinge verzekering treedt een zgn. waarborgmaatschappij op als verzekeraar ${ }^{48}$. Deze nnaatschappij heeft tot doel met haar leden verzekeringsovereenkomsten af te sluiten met het oog op het verzekeren van de (vaak specifieke) risico's van haar leden.

Het grote verschil tussen premieverzekeringen en klassieke systemen van onderlinge verzekeringen ligt op het niveau van de eigendom van de verzekeringsinstantie en het nastreven van winst, of de bestemming van deze winst. Bij een klassieke verzekeringsmaatschappij zal de winst in de regel worden verdeeld onder personen die geen enkele band hebben met de verzekerden; bij cen onderlinge verzekering zal de winst vaak ten goede komen van de verzekerden zelf.

Maar tegelijk dient te worden gewaarschuwd voor een ongenuanceerd gebruik van de term onderlinge verzekering, omdat verschillende soorten van onderlinge verzekering bestaan ${ }^{49}$. Zo kunnen mutualiteiten, captives en verzekeringspools onder bepaalde voorwaarden worden beschouwd als systemen van onderlinge verzekering ${ }^{50}$. Volgens Wery is het onderscheid tussen premieverzekering en onderlinge verzekering misleidend omdat de bijdrage bij bepaalde vormen van onderlinge verzekeringen - zoals bij captives - ook kan worden beschouwd als een premie ${ }^{51}$. Een aantal van dergelijke verzekeringsvormen zal worden besproken in hoofdstuk 11.

\subsection{Vrijwillige en verplichte verzekeringen}

Volgens een algemeen principe van het contractenrecht is eenieder vrij al dan niet een contract af te sluiten. Hetzelfde geldt in principe voor wat betreft het afsluiten van verzekeringscontracten. Zoals zal worden aangegeven in de rechtseconomische analyse van verzekeringen, zal iemand een verzekering nemen als reactie op zijn risicoaversie ${ }^{52}$.

In bepaalde gevallen is het afsluiten van een verzekeringscontract, hetzij via contractuele bepaling hetzij via een wettelijke bepaling, evenwel verplicht gesteld. Een bekende wettelijke verplichting betreft die ter zake van de civielrechtelijke aansprakelijkheid bij auto-ongevallen ${ }^{53}$. Door het verplicht stellen van verzekeringen wil de wetgever garanderen dat slachtoffers niet worden geconfronteerd met insolvabele daders. Ook inzake het nucleaire risico, is de exploitant verplicht diens aansprakelijkheid tegenover derden te verzekeren, of tenminste om te voorzien in cen dekking van zijn aansprakelijkheid ${ }^{54}$.

\subsection{Grote risico's en massarisico's}

Naarmate in het kader van verzekeringen de noodzaak duidelijk werd om de consument te beschermen, is het onderscheid tussen grote en massarisico's tot stand gekomen.

48

Wery, P.L., "Hoofdzaken", l.c., 13.

De term onderlinge verzekering of mutualiteit is in bepaalde gevallen evenwel misleidend en ambigu omdat elke vorm van verzekering sensu lato is gebaseerd op een onderlinge verdeling of spreiding van de risico's. Zie onder meer: Bigot, J., "Traité de Droit des Assurances", l.c., 95.

Peck, B. en Blackman, R.L., "Captives, mutuals and pools: an overview of Australian Regulation", International Journal of Insurance Law, 1996, 157 e.v.

Wery, P.L., "Hoofdzaken", l.c., 14.

Zie hoofdstuk 10.

Zie hiervoor in Belgiē de wet van 21 november 1989; in Nederland wet van 30 mei 1963. Beide wetten werden meermaals gewijzigd. Voor verschillende bijdragen inzake verkeersaansprakelijkheid, zic Faure, M. en Hartlief, T. (red.), Verkeersaansprakelijkheid in België en Nederland, Intersentia, Antwerpen, 1998.

Cfr. supra, in $\$ 4$ van hoofdstuk 4. 
Grote risico's zijn risico's van ondememingen met een bepaalde omvang. Massarisico's zijn de risico's met grote spreiding. Dit onderscheid is trouwens terug te vinden in meerdere Europese richtlijnen inzake verzekeringen ${ }^{55}$. Het onderscheid is gebasecrd op de omzet van de onderneming en de aard van de verzekeringsdekking ${ }^{56}$.

\subsection{Verzekering, medeverzekering en herverzekering}

De essentie van het verzekeringswezen is risicospreiding. Een verzekeringsmaatschappij zal deze spreiding in de eerste plaats bewerkstelligen door verzekeringstechnische middelen die berusten op mathematische regels.

Uitgangspunt van de mathematische verzekeringstechniek is de berekening van de kans dat het risico zich voordoet, waarbij bijzondere aandacht wordt besteed aan een correcte statistische berekening en aan een correcte selectie van risico's. Hoe groter het aantal leden van eenzelfde risicogroep, hoe meer de mogelijke verliezen optimaal kunnen worden gespreid en hoe constanter de bijdragen van de verschillende leden kunnen worden gehouden. Deze techniek is een toepassing van de wet der grote getallen, die aan de basis ligt van de statistiek. Op basis van een groot aantal feitelijke gegevens van soortgelijke risico's, kan immers de kans worden bepaald. Hct spreekt voor zich dat een dergelijke statistische berekening tegelijk de kracht en de achillespees van het verzekeringswezen is: indien wordt uitgegaan van onvoldoende, onvolledige of onjuiste parameters of indien uit een hoeveelheid gegevens verkeerde resultaten worden afgeleid, wordt vertrokken van een verkeerde probabiliteit, en wordt een verkeerde premie aangcrekend, hetgeen leidt tot de nodige gevaren, zowel voor de verzekerde als voor de verzekeraar. Verzekering impliceert bijgevolg het correct afbakenen van de verschillende risicogroepen om op deze basis een correcte premic te kunnen aanrekenen ${ }^{57}$.

De door een verzekeraar gedekte risico's worden evenwel niet alleen intern, dit wil zeggen binnen de onderneming gespreid. In vele gevallen, met name bij grote risico's, zal de verzckeraar een beroep doen op andere verzekeraars, door middel van medeverzekering of herverzekering ${ }^{58}$.

Medeverzekering houdt in dat voor de dekking van eenzelfde risico, een verzekeringsmaatschappij een beroep doet op andere verzekeringsmaatschappijen die elk een overeengekomen deel van het risico dekken ${ }^{59}$. Elke medeverzekeraar engageert zich voor zijn deel rechtstreeks tegenover de verzekerde, waarbij in de regel de medeverzekeraars niet hoofdelijk zijn gehouden tot betaling van het geheel. Niettegenstaande verschillende maatschappijen aldus eenzelfde risico dekken, treedt slechts één van hen op als mandataris (apériteur of eerste verzekeraar) naar de verzekerde

Zie hierover Levie, G., Droit européen des Assurances, Travaux de la Faculté de Droit de l'Univcrsité Catholique de Louvain, Bruxelles, Bruylant, 1992, 220-221.

Fontaine, M., "Droit des Assurances", l.c., 51.

Zie ook in het rechtseconomische deel, bij de bespreking van averechtse selectic ( $\$ 2.3$. van hoofdstuk 9).

Lambert-Faivre, Y., "Droit des Assurances", l.c., 40 e.v.; Fontaine, M., "Droit des Assurances", l.c., 351 e.v.

Delvaux, Ph., "La coassurance et ses surprises", Mélanges Roger O. Dalcq. Responsabilités et assurances, Larcier, Bruxelles, 1994, 97-110; Lambert-Faivre, Y., "Risques et Assurances des entreprises", l.c., 196 e.v. 
toe ${ }^{60}$. Meestal zal de verzekerde onderhandelen met de ccrste verzekeraar die dan op zoek gaat naar andere verzekeraars ${ }^{61}$.

Bij herverzekering zal een verzekeringsmaatschappij zich bij een andere verzekeraar verzekeren voor een al dan niet groter deel van de door haar gedekte risico's ${ }^{62}$. De verzekerde zelf blijft geheel buiten de relatic tussen zijn verzekeraar en de herverzekeraar. Er worden twee vormen van herverzekering onderscheiden ${ }^{63}$ : een proportionele herverzekering of sommenherverzekering enerzijds en een niet-proportionele herverzekering of een schadeherverzekering anderzijds.

Bij een proportionele herverzekering neemt de herverzekeraar een deel van het risico voor zijn rekening, ongeacht de omvang van de schade. Het lot van de herverzekeraar is dan ook verbonden met het lot van de verzekeraar: indien deze laatste moet tussenkomen, zal eveneens de herverzekeraar gehouden zijn. Het risico van de herverzekeraar - en diens premie - kan een bepaald percentage bedragen van het risico (quote-part). Een tweede mogelijkheid bestaat erin dat zijn tussenkomst vereist zal zijn voor het deel van het risico dat een bepaalde som te boven gaat (sommen-cxcedent $)^{64}$.

Bij een niet-proportionele herverzekering dekt de herverzekeraar een bepaald deel van het schadegeval voor zijn rekening. Ook hier worden twee vormen onderscheiden. Bij een systeem van "excess loss" neemt de herverzekeraar dat deel van de schade voor zijn rekening dat een bepaald bedrag overtreft. Onder een systeem van "stop loss" wordt de herverzekering niet afgesloten per schadegeval, maar heeft deze betrekking op de gezamenlijke schadegevallen in een bepaalde periode $^{65}$. Overschrijdt de totale schadelast in een vooraf overeengekomen periode een bepaald grensbedrag, dan zal de herverzekeraar dienen tussen te komen.

Herverzekering is dus een techniek waardoor de spreiding van risico's wordt vergroot; zeker door de combinatie van medeverzekering en herverzekering wordt de last van grote risico's verdeeld over verzekeraars over de gehele wẹreld ${ }^{66}$. Een dergelijke verdeling is vooral noodzakelijk inzake natuurrampen ${ }^{67}$ en inzake de verzekering van grote industriële risico's.

Naast de herverzekering zoals net beschreven, worden catastrofale risico's ook gedekt door de creatie van verzekeringspools gespecialiseerd in de dekking van een bepaald risico, waar een maximale verzekeringscapaciteit wordt gegenereerd door een combinatie van medeverzekering en herverzekering ${ }^{68} 69$.

Het aanduiden van een eerste verzekeraar is onder artikel 28 van de Belgische wet op de landverzekeringsovereenkomst verplicht.

Colle, Ph., "Algemene Beginselen", l.c., 78.

62 Lambert-Faivre, Y., "Droit des Assurances", l.c., 41 e.v.; Fontaine, M., "Droit des Assurances", l.c., 356 e.v.; Hagopian, M., "Réassurance", Jurisclasseur Responsabilité civile et assurances, fasc 120, 1988; speciale editie van Risques, nr. 9, jan. 1992, 7-158 en nr. 15, juli 1992, 123-152. Lambert-Faivte, Y., "Risques et Assurances des entreprises", l.c., 100-104. Lambert-Faivre, Y., "Risques et Assurances des entreprises", l.c., 102.

Lambert-Faivre, Y., "Droit des Assurances", l.c., 44.

Fontaine, M., "Droit des Assurances", l.c., 357.

Zie hierover de verschillende bijdragen in: Cousy, H. en Claassens, H. (ed.), Natuurrampen en Verzekering, Maklu, Antwerpen-Apeldoom, 1995.

Zie ook verderop in hoofdstuk 13. 


\section{DE AANSPRAKELIJKHEIDSVERZEKERING - ALGEMENE KENMERKEN}

In dit onderdeel wordt in eerste instantie het wettelijke kader geschetst dat op aansprakelijkheidsverzekeringen van toepassing is $(\$ 4.1)$. Vervolgens worden de verschillende elementen van de aansprakelijkheidsverzekering zoals het verzekerbaar belang, het gedekte risico en het schadegeval toegelicht ( $\$ 4.2$ ). In $\S 4.3$ wordt de duur van de aansprakelijkheidsverzekering besproken. Tenslotte zullen ecn aantal andere voor het onderzoek relevante bepalingen uit de Belgische wet op de landverzekeringsovereenkomst worden besproken ( $\$ 4.4)$.

\subsection{Definiêring - wettelijk kader}

Bij de bespreking van het wettelijke kader dat van toepassing is op aansprakelijkheidsverzekeringen, wordt zowel de situatie naar Belgisch $(\S 4.1 .1)$ als naar Nederlands recht $(\S 4.1 .2)$ belicht.

\subsubsection{Naar Belgisch recht}

De Belgische wet op de landverzekeringsovereenkomst van 1992 is van toepassing op aansprakelijkheidsverzekeringen. Deze wet is er overigens onder meer gekomen omdat de oude wet nauwelijks aandacht besteedde aan aansprakelijkheidsverzekeringen ${ }^{70} 71$.

De wet op de landverzekeringsovereenkomst bevat een afzonderlijk hoofdstuk inzake aansprakelijkheidsverzekeringen dat van toepassing is op "de verzekeringsovereenkomsten dic ertoe strekken de verzekerde dekking te geven voor alle vorderingen tot vergoeding wegens het voorvallen van de schade die in de overeenkomst is beschreven, en zijn vermogen binnen de grenzen van de dekking te vrijwaren tegen alle schulden uit een vaststaande aansprakelijkheid" (artikel 77 van de wet op de landverzekeringsovereenkomst) ${ }^{72}{ }^{73}$. De wetgever geeft inderdaad geen definiëring van

Voor meer details over het totstandkomen van deze wet, zie Fontaine, M., "Droit des Assurances", l.c., 52 e.v.; Fontaine, M., "Le droit nouveau du contrat d'assurance terrestre (Loi du 25 juin 1992)", Annales de Droit de Louvain, 1993/3, 367; Fontaine, M., "Présentation générale. Dispositions préliminaires et finales", in La loi du 25 juin 1992 sur le contrat d'assurance terrestre, Recyclage organisé par le Centre de droit des obligations et la licence en droit et économie des assurances de l'UCL, Louvain-laNeuve et Bruxelles, 1993, 19-49; Schuermans, L., "De nieuwe wet op de landverzekeringsovereenkomst van 25 juni 1992", Rechtskundig Weekblad, 1992-1993, nr. 21 en nr. 22, 689 e.v.

De wet op de landverzekeringsovereenkomsten is van toepassing op alle landverzekeringen voorzover in geen afwijkende bepaling wordt gegeven door bijzondere wetten (artikel $2, \S 1$, lid I van de wet op de landverzekeringsovereenkomsten). Voorbeelden van verzekeringsovereenkomsten die aan bijzondere bepalingen zijn onderworpen zijn onder meer de brandverzekering, de motorrijtuigenverzekering, de levensverzekering en de rechtsbijstandverzekering. Voor deze verzekeringsovereenkomsten blijft de wet op de landverzekeringsovereenkomsten evenwel van belang voorzover de bijzondere reglementering geen uitdrukkelijke bepalingen bevat. Zie over deze bijzondere voorschriften: Colle, Ph., Bijzonder gereglementeerde verzekeringscontracten in hoofdlijnen, Antwerpen, Maklu, 1993. De Belgische wet op de landverzekeringsovereenkomst is niet van toepassing op verzekeringen van goederenvervoer (met uitzondering van bagage- en verhuisverzekeringen), noch op herverzekering. Zowel zeeverzekeringen, als verzekeringen inzake het vervoer te land, over water en in de lucht blijven beheerst door de wet van 11 juni 1874, behoudens andersluidende bepaling in bijzondere wetten.

De Belgische wet op de landverzekeringsovereenkomst wordt gekenmerkt door het dubbele onderscheid tussen enerzijds schadeverzekeringen en personenverzekeringen en tussen anderzijds vergoedende en sommenverzekeringen. Volgens artikel 1, G van de wet op de landverzekeringsovereenkomst, is een schadeverzekering de verzekering waarbij de verzekeringsprestatie afhankelijk is van een onzeker voorval dat schade veroorzaakt aan iemands vermogen. Een persoonsverzekering daarentegen is de verzekering waarbij de verzekeringsprestatie of de premie afhankelijk is van een onzeker voorval 
het begrip "aansprakelijkheidsverzekering" maar heeft zich beperkt tot het omschrijven van het toepassingsgebied in het desbetreffende hoofdstuk van de wet. Het essentiële element hierbij is dat deze verzekeringsvorm strekt tot vergoeding van het vermogen van de verzekerde die gehouden is tot het betalen van een schadevergoeding ${ }^{74}$. Hierbij wordt het gehele vermogen van de verzekerde beschermd en niet slechts bepaalde goederen uit diens vermogen. Uit artikel 77 in fine vloeit voort dat de verzekeraar ertoe gehouden is het vermogen van de verzekerde te vrijwaren tegen potentiële aanspraken van derden tegen de verzekerde.

De meest voorkomende vorm van aansprakelijkheidsverzekering dekt de extracontractuele aansprakelijkheid van de verzekerde; nochtans zal in bepaalde gevallen ook dekking worden geboden voor de contractuele aansprakelijkheid, bijvoorbeeld de door de huurder af te sluiten brandverzekering. Ook een aantal op de markt beschikbare polissen inzake productaansprakelijkheid dekken zowel de contractuele als de extracontractuele aansprakelijkheid van de producent van een gebrekkig product.

In theorie kan een onderscheid worden gemaakt tussen een onbeperkte aansprakelijkheidsdekking en een beperkte aansprakelijkheidsdekking. Overeenkomstig het gemene recht is de aansprakelijkheid van een persoon in de regel onbeperkt. In een aantal gevallen heeft de wetgever evenwel de aansprakclijkheid van een aantal actoren beperkt, zoals bij de exploitant van een kerninstallatic: zoals reeds besproken is de verzekeringsdekking van de exploitant precies gelijk aan diens wettelijk gelimiteerde aansprakelijkheid ${ }^{75}$. Terwijl een persoon wettelijk onbeperkt aansprakelijk is, zal de verzekeraar in de meeste gevallen evenwel beperkingen inbouwen in de polis, waardoor tegenover de onbeperkte aansprakclijkheid een beperkte verzekeringsdekking staat. Zo zal de verzekeraar vaak zijn tussenkomst tot een maximumbedrag beperken. Het deel van de schade dat op deze wijze niet is verzekerd, zal bij een onbeperkte aansprakelijkheid door de verzekerde zelf dienen te worden vergoed. Voor het deel van de niet-gedekte schade, staat de verzekerde aldus bloot aan een eigen risico.

dat iemands leven, fysieke integriteit of gezinstoestand aantast. De wet op de landverzekeringsovereenkomst makt in titel II aangaande schadeverzekeringen een onderscheid tussen zaakverzckeringsovereenkomsten (artikelen 53-76), aansprakelijkheidsverzekeringen (artikelen 77-89) en rechisbijstandverzekeringen (artikelen 90-93). Volgens artikel 1, I van de wet op de landverzekeringsovereenkomsten is de verzekering tot vergoeding van schade de verzekering waarbij de verzekeraar er zich toe verbindt de prestatie te leveren die nodig is om de schade die de verzekerde heeft geleden of waarvoor hij aansprakelijk is, geheel of gedeeltelijk te vergoeden. Een verzekering tot uitkering van een vast bedrag (of forfaitaire verzekering) daarentegen is de verzekering waarbij de prestatie van de verzekering niet afhankelijk is van de omvang van de schade. Het dubbele onderscheid is van kapitaal belang omdat de wet zelf specifieke regels voorschrijft al naargelang de categorie: de wet stelt inderdaad dat specifieke regels van toepassing zijn op verzekeringen tot vergoeding van schade (artikelen 37-47) enerzijds en op verzekeringen tot uitkering van een vast bedrag (artikel 48-50) anderzijds. Zo wordt inzake verzekeringen tot vergoeding van schade de verzekeraar gesubrogeerd in de rechten van de verzekerde tegen aansprakelijke derden, hetgeen niet het geval is bij verzekeringen tot uitkering van een vast bedrag.

Dit hoofdstuk inzake aansprakelijkheidsverzekeringen is terug te vinden onder titel II van de wet inzake schadeverzekeringen. Zoals hierboven reeds aangegeven, zijn aansprakelijkheidsverzekeringen verzekeringen tot vergoeding van schade. Vandaar zijn zowel de bepalingen betreffende alle verzekeringsovereenkomsten, betreffende de verzekeringen tot vergoeding van schade en betreffende schadeverzekeringen, van toepassing op aansprakelijkheidsverzekeringen. Daarenboven zijn aansprakelijkheidsverzekeringen ook onderworpen aan een aantal specifieke regels.

Fagnart, J.L., "Les assurances de responsabilité dans la loi du 25 juin 1992", in Questions de droit des assurances, Editions du jeune barreau de Liège, 1996, 351; Fontaine, M., "Droit des Assurances", l.c., 295-296. 


\subsubsection{Naar Nederlands recht}

In Nederland bestaat geen specifieke wettelijke bepaling betreffende aansprakelijkheidsverzekeringen; de wettelijke bepaling ter zake gaat terug op het Wetboek van Koophandel van 1838, thans Titel 9 van het cerste boek van het Wetboek van Koophande ${ }^{76}$. Vandaar wordt de invulling van de bepalingen inzake de dekking van de aansprakelijkheidsverzekering volledig overgelaten aan de wil van de contractpartijen. Deze vrijheid wordt in de praktijk gerelativeerd in die zin dat voor de meeste vormen van aansprakelijkheidsverzekering een uniforme polis werd opgesteld. Hierbij wordt een onderscheid gemaakt tussen de bedrijfsaansprakelijkheidsverzekering (AVBpolis) en de particuliere aansprakelijkheidsverzekering (AVP-polis). In deze polissen staat de aansprakelijkheid voor door derden geleden schade centraal ${ }^{77}$. Gezien de afwezigheid van een specifieke wetsbepaling ter zake, dient voor de vaststelling van de aansprakelijkheid en de omvang van de schadevergoedingsplicht te worden teruggegrepen naar het aansprakelijkheidsrecht (zowel wettelijke bepalingen als de invulling daarvan door de rechtspraak) en naar de verzekeringsovereenkomst zelf.

\subsection{Voornaamste elementen in aansprakelijkheidsverzekering}

Bij de bespreking van de definitie van de verzekeringsovereenkomst in het algemeen werden reeds de wezenlijke bestanddelen besproken van elk verzekeringscontract. In deze paragraaf wordt besproken hoe de begrippen verzekerbaar belang ( $\$ 4.2 .1$ ), een gedekt risico $(\S 4.2 .2)$, en een schadegeval ( $\$ 4.2 .3$ ) worden ingevuld in het kader van een aansprakelijkheidsverzekering. Aangezien deze begrippen naar Belgisch recht wettelijk verankerd liggen, vertrekt deze analyse van de Belgische wet op de landverzekeringsovereenkomst; het spreekt echter voor zich dat ook. in Nederland de aansprakelijkheidsverzekering grosso modo dezelfde elementen bevat.

\subsubsection{Verzekerbaar belang}

Met betrekking tot het verzekerbaar belang bij verzekeringen tot vergoeding van schade dient artikel 37 van de wet op de landverzckeringsovereenkomst ${ }^{78}$ te worden gelezen samen met artikel 77 van dezelfde wet op basis waarvan de verzckeraar ertoc gehouden is het vermogen van de verzekerde te beschermen tegen "alle schulden uit cen vaststaande aansprakelijkheid".

Aansprakelijkheidsver/ekeringen strekken ertoe het vermogen van de verzekerde te vrijwaren tegen de schulden die deze laatste oploopt tengevolge van het vaststaan van diens aansprakelijkheid. Het verzekerbaar belang bij een aansprakelijkheidsverzekering bestaat er bijgevolg in dat het vermogen van de verzekerde niet wordt aangetast door een aansprakelijkheidsvordering. Het verzekcrbaar belang bij cen aansprakelijkheidsverzekering vloeit direct voort uit dese definiëring:

In het kader van de invoering van het Nieuwe Burgerlijk Wetboek was nochtans voorzien dat de verzekeringsovereenkomst een afzonderlijke plaats kreeg in titel 17 boek 7 (Wansink, J.H., De Algemene Aansprakelijkheidsverzekering. Een hernieuwde verzekeringsrechtelijke en verzekeringstechnische beschouwing, W.E.J. Tjeenk Willink, Zwolle, 1994, 8 e.v., hierna geciteerd als "Aansprakelijkheidsverzekering"). Voor een vergelijking tussen Belgisch en Nederlands recht, zie Wansink, J.H., "Enige rechtsvergelijkende beschouwingen over titel 7.17 en de Belgische Wet op de landverzekeringsovereenkomst van 1992", in In volle verzekerdheid, Opstellen aangeboden aan Prof. mr. A.J.O. baron van Wassenaer van Catwijck, W.E.J. Tjeenk Willink, Zwolle, 1993, 379-393.

Wansink, J.H., "Aansprakelijkheiđsverzekering", l.c., 21.

"De verzekerde moet kunnen aantonen dat hij een in geld waardeerbaar belang heeft bij het behoud van de zaak of bij de gaafheid van zijn vermogen". 
aangezien deze verzekeringsvorm strekt tot vrijwaring van het vermogen van de verzekerde, is het moeilijk aan te nemen dat deze laatste geen belang zou hebben bij de dekking ${ }^{79}$.

\subsubsection{Gedekt risico}

Het gedekte risico bij een aansprakelijkheidsverzekering is de uit een aansprakelijkheid voortvloeiende schuld. Fontaine omschreef het gedekte risico bij een aansprakelijkheidsverzekering als volgt:

"l'éventualité pour l'assuré de causer par ses actes un dommage à un tiers, d'être à raison de ce dommage l'objet d'une réclamation amiable ou judiciaire et, en conséquence de cette réclamation, de voir son patrimoine grevé d'une dette d'indemnité" ${ }^{80}$.

Deze omschrijving geeft duidelijk de verschillende etappes weer naar aanleiding van een aansprakelijkheid, met name de aan een derde veroorzaakte schade, de eis vanwege de derde tot vergoeding van de schade en de vaststelling van het schadevergoedingsbedrag, hetzij door onderlinge overeenkomst hetzij door een rechterlijke beslissing. Het is inderdaad in de eerste plaats de uit aansprakelijkheid vaststaande schuld van de verzekerde die het risico vormt bij een aansprakelijkheidsverzekering ${ }^{81}$.

Overeenkomstig de oorspronkelijke versie van de wet op de landverzekeringsovereenkomst werd dekking verleend voor vorderingen tot vergoeding wegens een "schadeverwekkende gebeurtenis die in de overeenkomst is beschreven". Dit aan een aantal verzekeringspolissen ontleende begrip ${ }^{82}$ gaf echter aanleiding tot verwarring wat betreft de toepassing van artikel 78, dat de term "schadeverwekkende gebeurtenis" hanteerde. De onduidelijkheid omtrent de vraag of de schadeverwekkende gebeurtenis betrekking had op de fout die de schade veroorzaakte, dan wel het zich manifesteren van de schade leidde tot opschudding in verzekeringsmiddens, vooral vanuit de hoek van de herverzekeraars die er zelfs mee hebben gedreigd de Belgische markt te verlaten ${ }^{83}$.

Teneinde de kritiek het hoofd te bieden, werden de artikelen 77 en 78 gewijzigd bij wet van 16 maart 1994: dekking wordt verleend "tegen alle vorderingen tot vergoeding wegens het voorvallen van de schade die in de overeenkomst is beschreven". Hierbij wordt geoordeeld dat het begrip "voorvallen van schade" minder verwarrend en onduidelijk is dan het begrip "schadeverwekkende gebeurtenis" ${ }^{84}$. Het probleem is evenwel dat de wetgever heeft nagelaten om aan te geven wat wordt bedoeld met "voorvallen van schade". Dat dit nog steeds aanleiding geeft tot de nodige problemen, zal hieronder worden toegelicht.

Deze nieuwe bepaling belet evenwel op geen enkele wijze dat in een verzekeringscontract wordt overeengekomen dat enkel accidentele schade wordt vergoed. In vele gevallen beperken verzekeraars hun tussenkomst inderdaad tot gevallen waar de aansprakelijkheid voortvloeit uit cen ongeval, namelijk een plotseling en onvrijwillig voorval. Geleidelijk werd dit begrip vervangen

79 Dalcq, R.O., "Les assurances de responsabilité. Questions générales", in La loi du 25 juin 1992 sur le contrat d'assurance terrestre, Acadernia-Bruylant, Louvain-la-Neuve en Brussel, 1993, 189. Fontaine, M., Droit des Assurances, Précis de la Faculté de droit de l'UCL, Larcier, 1975, nr. $39,153$. Janssens-Brigode, A., L'assurance de responsabilité, Larcier, 1971, 29.

Fontaine, M., "Droit des Assurances", l.c., 299.

Fagnart, J.L., "Les assurances de responsabilité dans la loi du 25 juin 1992", in "Questions de droit des Assurances", l.c., 352. 
door de dekking van de aansprakelijkheid uit een schadeverwekkend feit, waarbij het plotselinge element niet langer was vereist. In een groot aantal dekkingen betreffende schade uit milieuverontreiniging, blijft echter vereist dat de schade voortvloeit uit een accidentele verontreiniging. Indien de schade is veroorzaakt door graduele vervuiling, wordt geen dekking verleend ${ }^{85}$.

\subsubsection{Schadegeval}

Bij aansprakelijkheidsverzekcringen rijst de vraag op welk moment precies er sprake is van schade, op welk moment de aansprakelijkheid - overeenkomstig artikel 77 wet op de landverzekeringsovereenkomst in fine - van de verzekerde vaststaat. In vele gevallen kan het immers langere tijd duren vooraleer deze aansprakelijkheid daadwerkelijk vaststaat, bijvoorbceld omdat het slachtoffer zich nog nict bewust is van de opgelopen schade. Nochtans is het bepalen van het tijdstip van het schadegeval van primordiaal belang omdat hieruit belangrijke juridische verplichtingen voortvloeien: een contract waarbij het schadegeval zich recds hecft voorgedaan op het moment van het afsluiten van het contract, is nietig ${ }^{86}$; de verzekerde dient alle redelijke maatregelen te nemen om de gevolgen van het schadegeval te voorkomen en te beperken ${ }^{87}$ (deze verplichting vangt bijgevolg aan zodra de schade zich manifesteert); de verzekeraar van zijn kant is verplicht zich achter de verzekerde te stellen vanaf het ogenblik dat hij gehouden is tot het geven van de dekking ${ }^{88}$. Deze bepaling dient niet letterlijk te worden geïnterpretecrd omdat de verzekeraar slcchts gehouden zal zijn na de vaststelling, vaak langs rechterlijke weg, van de aansprakelijkheid van de verzekerde. Vandaar is de verzekeraar verplicht de verzekerde te beschermen zodra de kans bestaat dat hij zal gehouden zijn dekking te verlenen ${ }^{89}$, met andere woorden zodra op hem ecn beroep wordt gedaan.

Vanuit de praktijk wordt vaak voorgehouden dat inzake aansprakelijkheidsverzekeringen sprake is van een schadegeval op het moment waarop de verzekerde door het slachtoffer wordt aangesproken ter vergoeding van de door hem geleden schade ${ }^{90}$. Artikel 77 van de oorspronkelijke versie van de wet op de landverzekeringsovereenkomst leek dit te bevestigen vermits dekking werd verleend "tegen alle vorderingen tot vergoeding wegens een schadeverwekkende gebeurtenis die in de overeenkomst is beschreven". Deze interpretatie werd bevestigd door artikel 1, G dat een schadeverzekering definieert als een verzekering waarbij de verzekeringsprestatie afhankelijk is van een onzeker voorval dat schade veroorzaakt aan iemands vermogen. Het vermogen van de verzekerde wordt in een aansprakelijkheidsverzekeringpolis immers slechts bedreigd indien de vordering wordt ingediend, ook al heeft het slachtoffer reeds schade geleden ${ }^{91}$. Maar deze interpretatie werd tegengesproken door het oorspronkelijke artikel 78 op basis waarvan de verplichting van de verzekeraar zich uitstrekte tot vorderingen die na het einde van de verzekeringsovereenkomst werden ingediend, op voorwaarde dat de schadeverwekkende gebeurtenis zich had voorgedaan in de loop van de overeenkomst. Volgens de oorspronkelijke versie van de wet op de landverzekeringsovereenkomst was er dus slechts sprake van schade indien de schadeverwekkende gebeurtenis zich had voorgedaan tijdens de looptijd van de polis.

Cfr. infra, in $\$ 1$ van hoofdstuk 11.

Artikel 24, $\$ 1$ wet op de landverzekeringsovereenkomst.

Artikel 20 wet op de landverzekeringsovereenkomst.

Artikel 79, lid 1 wet op de landverzekeringsovereenkomst.

Fontaine, M., "Droit des Assurances", l.c., 301.

Deschamps, B., "Claims-made: l'altemative?", Recueil Générale des Assurances et des Responsabilités, 1988, 11335.

91

Fagnart, J.L. en Rogge, J., "Les Assurances de responsabilití dans la loi du 25 juin 1942". Bulletin des Assurances, Dossier, 1993, 102-102. 
Dit had tot gevolg dat de verzekerde zich verplicht zou hebben gezien zijn verzekeraar ten tijde van de schadeverwekkende gcbeurtenis aan te spreken. In een aantal gevallen zou het evenwel nagenoeg onmogelijk zijn de schadeverwekkende gebeurtenis exact te dateren; het was dus lang niet zeker of de verzekerde na al die jaren zijn polis zou terugvinden en of de toenmalig overeengekomen dekking nog toereikend zou zijn ${ }^{92}$.

In het licht van deze bezwaren werd vrij snel duidelijk dat de wet diende te worden aangepast, hetgeen zowel de belangen van het slachtoffer, de verzekerde als van de verzekeraar zou dienen 94

\subsection{Duur van de aansprakelijkheidsverzekering}

In het verleden werden verzekeringscontracten afgesloten voor langere tijd (vaak van vijf tot tien jaar) om op die manier verzekerden voor een gegarandeerde periode te binden aan de verzekeringsmaatschappij. Voor verzekeraars leidde de relatief lange duur van deze overeenkomsten tot een zekere stabiliteit van de verzekeringsportefeuilles. Deze binding van de verzekerden werd bovendien versterkt door het feit dat in de meeste gevallen de verzekeringsovereenkomsten stilzwijgend werden verlengd. Het nadeel van de langere duur van de verzekeringscontracten was dat de concurrentie deels buiten werking werd gesteld: verzekerden die in de loop van het contract ontevreden waren, konden moeilijk naar een andere verzekeringsmaatschappij overstappen. Om hieraan tegemoet te komen legt de Belgische wet op de Iandverzekeringsovereenkomst beperkingen op aan de duur van de verzekeringsovereenkomst.

Artikel 30 van de wet bepaalt dat de duur van verzekeringsovereenkomsten niet langer mag zijn dan één jaar. Het betreft hier een regel van dwingend recht ${ }^{95}$. De wetgever heeft hierbij nagelaten aan te geven of deze periode een aanvang neemt op het moment van het sluiten van de overeenkomst, dan wel op het moment van het in werking treden ervan. Het verdient zonder meer aanbeveling dat de termijn van één jaar aanvangt op het moment dat de overeenkomst in werking treedt $^{96}$. Daarnaast voorziet de wet in de mogelijkheid tot stilzwijgende verlenging indien de overeenkomst niet door één der partijen werd opgezegd ten minste drie maanden vóór de vervaldag van de overeenkomst.

De Koning kan evenwel uitzonderingen aanbrengen aan de principieel éénjarige duur van de verzekeringsovereenkomsten ${ }^{97} 98$. Het KB van 24 december 1992 houdende de uitvoering van de

92

Fagnart, J.L. en Rogge, J., "Les Assurances de responsabilité dans la loi du 25 juin 1992", o.c., 106107.

Fagnart, J.L. en Rogge, J., "Les Assurances de responsabilité dans la loi du 25 juin 1992", o.c., 107. Deze aanpassing werd doorgevoerd bij wet van 16 maart 1994 en wordt hieronder besproken. Cfr. infra, in $\S 5.3$ van dit hoofdstuk.

Artikel 3 van de wet. Zie hierover Cousy, H., "Dispositions in communes: modification du risque, duree et fin du contrat, prescription. Coassurance et arbitrage", La loi du 25 juin 1992 sur le contrat d'assurance terrestre, Academia-Bruylant, Louvain-la-Neuve, 1993, 99. In de rechtsleer worden de nodige vraagtekens geplaatst bij artikel 3. 7.ie o.m. Schuermans, L., "De nieuwe wet op de landverzekeringsovereenkomst van 25 juni 1992", o.c., 692.

Ook in die zin: Fontaine, M., "Droit des Assurances", l.c., 323.

Artikel $30, \S 2$ wet op de landverzekeringsovereenkomst.

Daarnaast zijn ook andere uitzonderingen mogelijk, bijvoorbeeld bij verzekeringsovereenkomsten waarvan de duur korter is dan één jaar (art. 30, § 3 wet op de landverzekeringsovereenkomst). Deze laatste bepaling is toegevoegd bij wet van 16 maart 1994. De oorspronkelijke versie van de wet op de landverzekeringsovereenkomst leidde inderdaad tot problemen voor contracten van zeer korte duur, 
wet op de landverzekeringsovereenkomst, zoals gewijzigd bij KB van 29 december $1994^{99}$ geeft een opsomming van een aantal risico's waarvan de dekking niet onderhevig is aan de principieel éénjarige duur van de verzekeringsovereenkomst. Inzake aansprakelijkheidsverzekeringen zijn enkel van dwingend recht de in het KB van 29 december 1994 limitatief opgesomde verzekeringen, met name de "risico's van burgerrechtelijke aansprakelijkheid inzake motorrijtuigen, de risico's van burgerrechtelijke aansprakelijkheid buiten overeenkomst met betrekking tot het privéleven en de risico's van burgerrechtelijke aansprakelijkheid met betrekking tot de brandverzekering, eenvoudige risico's alsmede de risico's van dezelfde aard die op aanvullende of bijkomende wijze gedekt worden in een andere verzekeringsovereenkomst".

\subsection{Overige relevante bepalingen in de Belgische wet op de landverzekeringsovereenkomst}

Het is niet de bedoeling om in het kader van het gevoerde onderzoek alle bepalingen van de Belgische wet op de landverzekeringsovereenkomst te bestuderen. Wel wordt aandacht besteed aan die aspecten die ook van belang zijn bij schade uit een kernongeval, met name de mogelijkheid tot opzegging na een schadegeval $(\$ 4.4 .1)$, de dekking van de reddingskosten $(\$ 4.4 .2)$ en de dekking van interesten en (gerechts)kosten $(\$ 4.4 .3)$.

\subsubsection{Opzegging na schadegeval}

De verzekeraar kan zich het recht voorbehouden de verzekeringsovereenkomst op te zeggen na een schadegeval; maar in een dergelijk geval is hij verplicht hetzelfde recht toe te kennen aan de verzekerde $^{100}$. De verzekeringsovereenkomst dient ten laatste één maand na de uitbetaling of de weigering tot uitbetaling van de schadevergoeding te worden opgezegd.

Deze opzeggingsmogelijkheid biedt voordelen voor de verzekeraar en voor de verzekerde. De verzekeraar kan zich ontdoen van slechte risico's, terwijl de verzekerde diens verzekeraar kan "sanctioneren" indien hij niet tevreden is over de manier waarop de verzekeraar het schadegeval heeft opgevolgd ${ }^{101}$. De kern van deze bepaling betreft de wederkerigheid van de mogelijkheid tot opzegging na een schadegeval. In de traditionele polissen bestond deze mogelijkheid enkel in hoofde van de verzekeraar.

De Koning kan bepalen dat deze wederkerige opzeggingsmogelijkheid niet zal bestaan wat betreft een aantal door hem te bepalen risico's ${ }^{102}$, met dien verstande dat de risico's met grote dekking niet van deze mogelijkheid kunnen worden uitgesloten. Het KB van 22 december 1992, zoals gewijzigd door het KB van 29 december 1994, bevat de lijst van risico's waarop artikel $31, \S 1$ niet van toepassing is. Het betreft dezelfde lijst als die inzake de duur van de overeenkomsten ${ }^{103}$.

zoals bijvoorbeeld bij bepaalde reisverzekeringen (zie hierover Cousy, H., "Dispositions communes: modification du risque, durée et fin du contrat, prescription. Coassurance et arbitrage", o.c., 97).

B.S., 27 januari 1995.

Artikel $31, \$ 1$ wet op de landverzekeringsovereenkomst.

Memorie van Toelichting, Parlementaire Stukken, Kamer, GZ/1990-1991, nr. 1586/, 33.

Het betreft een door de wet van 16 maart 1994 gewijzigde bepaling; onder de oorspronkelijke versie van de wet op de landverzekeringsovereenkornst waren niet onderworpen aan de bepalingen van artikel $31, \S 1$ de verzekeringsovereenkomsten gesloten met ondememingen die hun jaarrekening niet volgens het verkorte schema mogen opstellen overeenkomstig artikel 12 van de wet van 17 juli 1975 .

Cfr. supra, in $\S 4.3$ van dit hoofdstuk. 


\subsubsection{Reddingskosten}

De verplichtingen betreffende de door de verzekerde te nemen maatregelen naar aanleiding van een schadegeval, wordt in de wet op de landverzekeringsovereenkomst opgesplitst in de algemene verplichting de gevolgen van een schadegeval te beperken (artikel 20) en in een bepaling betreffende de in het kader hiervan gemaakte kosten (artikel 52).

De verzekerde is er bij verzekeringen tot vergoeding van schade toe gehouden alle redelijke maatregelen te nemen om de gevolgen van het schadegeval te voorkomen en te beperken. Deze bepaling wordt beschouwd als zijnde van openbare orde, net zoals een analoge bepaling in de vroegere wet van 11 juni $1874^{104} 105$.

Overeenkomstig artikel $52, \S 1$ vallen de reddingskosten ten laste van de verzekeraar bovenop de dekking van de verzekerde som ${ }^{106}$. Het betreft kosten die voortvloeien uit maatregelen die de verzekeraar heeft gevraagd om de gevolgen van een schadegeval te voorkomen of te beperken en de kosten voortvloeiend uit dringende en redelijke maatregelen die de verzekerde uit eigen beweging heeft ondernomen om bij nakend gevaar een schadegeval te voorkomen, of, zodra de schade is ontstaan, kosten om de gevolgen ervan te voorkomen of te beperken. De door de verzekerde genomen maatregelen dienen evenwel met de zorg van een goed huisvader te zijn uitgevoerd. De wet specificeert dat deze kosten ten laste vallen van de verzekeraar, zelfs indien de pogingen om de schade of de gevolgen te voorkomen vruchteloos zijn geweest. Het is de bedocling van deze bepaling om verzekerden aan te moedigen de schade te voorkomen of te beperken.

Het betreft kosten die zijn gemaakt voor maatregelen met tot doel een toekomstig maar zeker schadevoorval te voorkomen dan wel de gevolgen ervan te beperken; zonder de maatregelen zou het schadegeval zich ongetwijfeld hebben voorgedaan ${ }^{107}$. Enkel de dringende en redelijk gemaakte kosten dienen door de verzekeraar te worden vergoed ${ }^{108}$, hetgeen uiteraard in de praktijk aanleiding kan geven tot de nodige betwistingen.

104 Fontaine, M., "Droit des Assurances", l.c., 154-155.

105 Over het regime onder de oude wet, zie Piedboeuf, F., "Les frais de prévention et de retrait", in Les Assurances de l'enireprise, Bruxelles, Bruylant, vol. I, 1988, 167-194.

106 In verband met artikel 52, zie o.m. Claassens, H., "Assurances indemnitaires, assurances de dommages et assurances des choses", in Fontaine, M. en Binon, J.M. (ed.), La loi du 25 juin 1992 sur le contrat d'assurance terrestre, Bruxelles, Bruylant, 1993, 126-128; Fagnart, J.L. en Rogge, J., "Les assurances de responsabilité dans la loi du 25 juin 1992", o.c., 114-119; Schuermans, L., "De nieuwe wet op de landverzekeringsovereenkomst van 25 juni 1992", o.c., 706-707; Van Schoubroeck, C. en Schoorens, G., "De aansprakelijkheidsverzekering: a never ending story", Tijdschrift voor Belgisch Handelsrecht, $1995,640-643$.

107 Zie o.m. Rutsaert, J., "Le débat sur l"article 17 de la loi du 11 juin 1874 (1"obligation pour l"assuré de prévenir le dommage)", De Verz., 1984, 43 e.v.; Vernimmen, G., "Obligation de prévention et de sauvetage et prise en charge des frais par l"assureur (article 17 de la loi du 11 juin 1874)", Receuil Générale des Assurances et des Responsabilités, 1977, 79-93; Colle, Ph., "Recente wijzigingen in de verzekeringswetgeving", Rechtskundig Weekblad, 1995, 1996, 1364.

Zie hierover Fagnart, J.L., "L'étendue de la garantie", in La loi du 25 juin 1992 sur le contrat d'asstrance terrestre, Recyclage organisé par le jeune barreau de Bruxelles, 1995, 47; Delvaux, P.H., "Les assurances de responsabilité: questions spéciales", in Fontaine, M. en Binon, J.M. (éd.), La loi du 25 juin 1992 sur le contrat d'assurance terrestre, Bruxelles, Bruylant, 1993, 217-218. 
Overeenkomstig artikel $52^{109}$ kunnen evenwel, voor aansprakelijkheidsverzekeringen andere dan de verplichte aansprakelijkheidsverzekering inzake motorrijtuigen en voor zaakverzekeringsovereenkomsten, grenzen worden gesteld aan de dekking van de reddingskosten boven de verzekerde som. Het KB van 24 december 1992, zoals gewijzigd bij KB van 29 december 1994, geeft weer hoe de grenzen dienen te worden berekend warbinnen de verzekeraar verplicht is de reddingskosten te vergoeden bovenop het verzekerde totalbedrag 11011.

\subsubsection{Dekking van interesten en (gerechts)kosten}

Overeenkomstig artikel 82 van de wet op de landverzekeringsovereenkomst is de verzekeraar ertoc gehouden, zelfs boven de dekkingsgrenzen, de interesten op de in hoofdsom verschuldigde schadevergoeding te betalen, evenals de kosten betreffende burgerlijke rechtsvorderingen, alsook de honoraria van de advocaten en deskundigen. Hij dient deze kosten enkel te dekken boven de overeengekomen dekkingsgrenzen indien de kosten door hem of met zijn toestemming zijn gemakt of, in geval van belangenconflict dat niet te wijten is aan de verzekerde, voorzover die kosten niet onredelijk zijn gemaakt.

Dit artikel wordt gerechtvaardigd omdat de aansprakelijkheidsverzekeraair overeenkornstig artikel 79 de leiding heeft van het geschil; vandaar kan de verzekeraar zich al dan niet verzetten tegen de door een slachtoffer gemaakte aanspraken en bepaalt hij mee de omvang van de interestlast en van de gerechtskosten ${ }^{112}$. Net zoals dit het geval is bij de reddingskosten, kan ook inzake interesten en gerechtskosten, de Koning de tussenkomst van de verzekeraar bovenop de verzekerde hoofdsom beperken. Aan deze bepaling werd uitvoering gegeven door artikel 6ter van het KB van 24 december $1992^{113}$.

109 Zoals gewijzigd bij wet van 16 maart 1994. Zie hicrover Schoorens, G., "Op zoek naar de beschermingsbehoeftige consument na enkele recente wijzigingen in het verzekeringsrecht", D.C.C.R., 1994$1995,394$.

"§ 1. Voor de verzekeringen inzake burgerrechtelijke aansprakelijkheid worden de in artikel 52 van de wet bedoelde reddingskosten integraal door de verzekeraar gedragen, voorzover het geheel van de schadeloosstelling en van de reddingskosten per verzekeringsnemer en per schadegeval het verzekerde maximumbedrag niet overschrijdt. Boven het verzekerde totaalbedrag kunnen de reddingskosten beperkt worden tot: $1^{\circ}$ ) 20 miljoen frank wanneer het verzekerde totaalbedrag lager is dan of gelijk is aan 100 miljoen frank; $2^{\circ}$ ) 20 miljoen frank plus $20 \%$ van het verzekerde totaalbedrag wanneer dit tussen 100 en 500 miljoen frank ligt; $3^{\circ}$ ) 100 miljoen frank plus $10 \%$ van het deel van het verzekerde totaalbedrag boven 500 miljoen frank, met een maximumbedrag van 400 miljoen frank reddingskosten.

$\$ 2$. Voor de zaakverzekeringen zijn de reddingskosten bedoeld in $\$ 1$ gelijk aan het verzekerd bedrag, maar zijn kunnen beperkt worden tot een maximumbedrag van 750 miljoen frank.

$\S 3$. De bedragen bedoeld bij $\S \S 1$ en 2 zijn gekoppeld aan het indexcijfer der consumptieprijzen met als basisindexcijfer dat van november 1992, namelijk 113,77 (basis $1988=100$ )" (artikel 4 van het KB van 24 december 1992).

De tekst van het $\mathrm{KB}$ is nogal chaotisch opgesteld: Fontaine, $M$. en Delvaux, P.H., "Le nouveau régime du contrat d'assurance terrestre. Loi du 25 juin 1992, loi modificative du 16 mars 1994, arrêtés d'exécution", Journal des Tribunaux, 1995, 336.

Fagnart, J.L., "L'étendue de la garantie", in "La loi du 25 juin 1992 sur le contrat d'assurance terrestre", l.c., 49; Delvaux, P.H., "Les assurances de responsabilité: questions spéciales", in Fontaine, M. en Binon, J.M. (éd.), l.c., 226 e.v.

Het desbetreffende artikel bepaalt drie schijven in verband met de verzekerde som: " $\left.1^{\circ}\right) 20$ miljoen frank wanneer het verzekerde totaalbedrag lager is dan of gelijk is aan 100 miljoen frank; $2^{\circ}$ ) 20 miljoen frank plus $20 \%$ van het verzekerde totaalbedrag wanneer dit tussen 100 miljoen en 500 miljoen frank ligt; $3^{\circ}$ ) 100 miljoen frank plus $10 \%$ van het deel van het verzekerde totalbedrag boven 500 miljoen frank, met een maximumbedrag van 400 miljoen frank intresten en kosten. De bedragen zijn ge- 
De ratio legis voor de beperking van zowel de reddingskosten als de interest- en gerechtskosten is dezelfde: bij een onbeperkte dekking van deze kosten boven de verzekerde som zou voor bepaalde risico's geen dekking meer kunnen worden verkregen. Hierbij werd gedacht aan risico's in de nucleaire, scheikundige en farmaceutische sector en aan exportrisico's naar de VS en Canada ${ }^{1 / 4}$.

\section{DEKKING VAN DE AANSPRAKELIJKHEID IN DE TIJD}

Een bijzonder probleem bij aansprakelijkheidsverzekeringen betreft de dekking in de tijd. Deze dekking vormt een uitermate belangrijk element in de discussie rond de vraag of een gegeven risico al dan niet verzekerbaar is. Het spreekt voor zich dat deze discussie vooral met betrekking tot langetermijnaansprakelijkheden van belang is. Bij langetermijnaansprakelijkheden kan geruime tijd verstrijken tussen de gebeurtenis die aan de oorsprong van de schade ligt, en het zich manifesteren van de schade en dus van het indienen van de eis tot schadevergoeding. Het probleem hierbij is dat de verzekeringsovereenkomst intussen ten einde kan zijn gekomen, waardoor de schadeverwekkende gebeurtenis zich heeft voorgedaan tijdens de looptijd van de verzekeringsovereenkomst, maar waar de schade zelf zich pas na het einde van deze overeenkomst heeft gemanifesteerd. De vraag rijst hierbij of het voldoende is dat de schadeverwekkende gebeurtenis zich heeft voorgedaan tijdens de looptijd van de verzekeringsovereenkomst opdat de verzekeraar zou gehouden zijn dekking te verschaffen. Indien deze vraag zonder meer positief zou worden beantwoord, dan zou dit meteen betekenen dat de verzekeraar gedurende jaren na het einde van de overeenkomst reserves in stand dient te houden ter dekking van het aansprakelijkheidsrisico.

In eerste instantie wordt het probleem van de dekking in de tijd nader toegelicht (\$ 5.1). Met betrekking tot de dekking in de tijd worden verschillende dekkingsgrondslagen of "triggers" gehanteerd, namelijk act-committed, loss-occurrence en claims-made. De inhoud en strekking van deze verschillende dekkingsgrondslagen worden in $\$ 5.2$ besproken. Deze bespreking zal toelaten te onderzoeken welke dekkingsgrondslag wordt gehanteerd en/of toegelaten onder de Belgische wet op de landverzekeringsovereenkomst $(\$ 5.3)$ en onder de Nederlandse AVB, AVP en MASpolissen $(\$ 5.4)$. De conclusie uit de analyse wordt gebundeld in $\S 5.5$.

\subsection{Probleemstelling}

De tussenkomst van een verzekeraar naar aanleiding van een vaststaande aansprakelijkheid van zijn verzekerde, is de laatste fase van een langdurig proces.

Wansink onderscheidt hierbij zes fasen ${ }^{115}$ :

a. een onrechtmatige gedraging van de verzekerde of een gedraging die wanprestatie oplevert;

b. de eigenlijke gebeurtenis waarvan de schade het gevolg is;

c. de inwerking van geweld of van de schadelijke omstandigheden op de persoon of op de zaak;

d. het zich manifesteren van de schade (letselschade of zaakschade);

e. het aansprakelijk stellen van de verzekerde door de benadeelde;

f. de melding van de verzekerde aan de verzekeraar dat zijn aansprakelijkheid in het gedrang komt.

koppeld aan het indexcijfer der consumptieprijzen met als basisindexcijfer dat van november 1992 , namelijk 113,77".

IIs Wansink, J.H., "Aansprakelijkheidsverzekering", l.c., 97. 
In bepaalde schadegevallen zullen de verschillende fasen van dit proces elkaar zeer snel opvolgen, zoals bij een auto-ongeval waarbij de onrechtmatige gedraging (bijvoorbeeld het niet verlenen van voorrang) leidt tot een ongeval waaruit onmiddellijk schade voortvloeit. De problematische schadegevallen zijn die waar een grote tijdspanne kan verlopen tussen de gedraging van de verzekerde of de schadeverwekkende gebeurtenis en het zich manifesteren van de schade. Dit is met name het geval bij milieuschade, en des te meer bij schade uit kernongevallen, waar een kanker zich slechts jaren na het ongeval kan manifesteren.

De hamvraag vanuit verzekeringsstandpunt is welke fase binnen de duur van de verzekeringsovereenkomst dient te vallen opdat de verzekerde dekking kan genieten c.q. opdat de verzekeraar verplicht wordt dekking te verlenen. De fase die bepalend is, wordt in de Amerikaanse verzekeringsliteratuur de trigger genoemd. In de loop der jaren werden verzekeringspolissen ontwikkeld waarbij gebruik wordt gemaakt van verschillende triggers: de schadeverwekkende gebeurtenis (act committed), het schadevoorval (loss occurrence) of het instellen van de aansprakelijkheidsvordering (claims made). Aansprakelijkheidsverzekeringen gingen traditioneel uit van een act-committed dekking; vanaf de jaren zeventig wordt meer gebruikt gemaakt van loss-occurrence polissen, terwijl de laatste jaren vooral de claims-made polis aan belang wint en wordt beschouwd als de dekkingsgrondslag van de toekomst ${ }^{116}$.

\subsection{Mogelijke dekkingsgrondslagen}

Vaak wordt de keuze van de verschillende dekkingsgrondslagen overgelaten aan de vrijheid van de partijen. In andere gevallen schrijft de wet voor welke grondslagen dienen te worden gebruikt bij bepaalde soorten verzekeringen.

Hieronder worden de dric traditionele triggers besproken, namelijk act-committed ( $\$ 5.2 .1$ ), lossoccurrence $(\$ 5.2 .2)$ en claims-made $(\$ 5.2 .3)^{117}$.

\subsubsection{Act-committed}

Bij een dekking op basis van een act-committed systeem dient de (schadeverwekkende) gebeurtenis te hebben plaatsgevonden tijdens de duur van de verzekeringsovereenkomst ${ }^{118}$. Teruggrijpend naar de verschillende fasen van Wansink impliceert dit dat de fasen a tot en met c zich tijdens de verzekerde periode moeten hebben voorgedaan. Het inlooprisico is geheel uitgesloten en in de regel is het narisico volledig gedekt. Het is hierbij met andere woorden niet van belang of de schade pas is ontstaan na het einde van de overeenkomst of dat de vordering tot schadevergoeding werd ingesteld na het einde van de verzekeringsovereenkomst ${ }^{119}$.

De volledige dekking van het narisico biedt voor slachtoffers het voordeel dat er nog steeds een dekking voorhanden is nadat de verzekeraar en de verzekerde hun overeenkomst hebben opgezegd. Het voordeel voor de verzekerde bestaat erin dat de verzekeraar zal dienen tussen te komen

Spier, J. en Haazen, O.A., Aansprakelijkheidsverzekeringen op claims-made grondslag in rechtsvergelijkend perspectief, Kluwer, Deventer, 1996, 1 (hiema: Aansprakelijkheidsverzekeringen).

Zie ook Schoorens, G. en Vanderspikken, A., "De verkorting van de verjaringstermijnen en de verzekerbaarheid van langetermijnaansprakelijkheden", in Liber Amicorum Hubert Claassens, Maklu, Academia-Bruylant, Antwerpen, 1998, 181 e.v.

Faure, M.G. en Hartlief, T., "De gevolgen van de uitbreidende werkgeversaansprakelijkheid: beleidsconsequenties voor verzekeraars?", in Faure, M.G. en Hartlief, T., "Verzekering en de groeiende aansprakelijkheidslast", l.c., 330 .

Wansink, J.H., "Aansprakelijkheidsverzekering", l.c., 100.
} 
tot op het moment waarop zijn vordering is verjaard ${ }^{120}$. Dit betekent echter niet dat gedurende al die tijd "volledige dekking" is gegarandeerd: de omvang van de dekking wordt vaak bepaald door het verzekerde bedrag ten tijde van het veroorzaken van de schade. Indien de vordering derhalve wordt ingediend meerdere jaren na het einde van de verzekeringsovereenkomst, is de kans reëel dat ingevolge inflatie het verzekerde bedrag ontoereikend zal zijn ter compensatie van alle scha$\mathrm{de}^{121}$.

Het voordeel voor de verzekerde impliceert een aanzienlijk risico voor de verzekeraar die bijvoorbeeld twintig jaar na het einde van het verlenen van een dekking, kan gehouden zijn om tussen te komen. Indien de polis daarenboven geen of onvoldoende beperkingen bevat ter zake van de omvang van de tussenkomst, loopt de verzekeraar het risico te moeten tussenkomen voor een veel hoger bedrag dan hij destijds kon voorzien. Mede onder invloed van de internationale herverzekeraars zijn de act-committed polissen nagenoeg verdwenen en vervangen door lossoccurrence polissen ${ }^{122}$.

\subsubsection{Loss-occurrence}

Onder een dekking op basis van een loss-occurrence systeem is bepalend dat de schade zich heeft voorgedaan tijdens de duur van de verzekeringsovereenkomst - de vierde fase volgens Wansink. Hierbij is het irrelevant of de schadeverwekkende gebeurtenis, die aan de basis van de schade ligt, zich al dan niet tijdens de looptijd van het contract heeft voorgedaan. Behoudens gevallen van verzwijging is het inlooprisico bij een loss-occurrence systeem dus volledig gedekt ${ }^{123}$. Op voorwaarde dat de schade tijdens de duur van de overeenkomst is ontstaan, is bij deze trigger eveneens het narisico gedekt ${ }^{124}$.

De verzekeringspolissen op basis van het loss-occurrence systeem hebben als nadeel dat zij de verzekeraar voor ernstige problemen kunnen stellen bij sluipende schade of een ver in het verleden veroorzaakte schade waar de causaliteit moeilijk kan worden vastgesteld ${ }^{125}$. In deze gevallen is het moment van het ontstaan van de schade zeer moeilijk te achterhalen. Dergelijke langetermijnrisico's confronteren de verzekeraars zowel met een problcem inzake anterioriteitsdekking (inlooprisico) als inzake posterioriteitsdekking (narisico). Ook onder dit systeem lopen verzekeraars met andere woorden het risico om zelfs jaren na de afloop van het verzekeringscontract, te moeten tussenkomen ${ }^{126}$.

120 Faure, M.G. en Hartlief, T., "De gevolgen van de uitbreidende werkgeversaansprakelijkheid: beleidsconsequenties voor verzekeraars?", in Faure, M.G. en Hartlief, T., "Verzekering en de groeiende aansprakelijkheidslast", l.c., 330.

121 Wansink, J.H., "Aansprakelijkheidsverzekering", l.c., 102.

122 Spier, J. en Haazen, O.A., "Aansprakelijkheidsverzekeringen", l.c., 3; Faure, M.G. en Hartlief, T., "De gevolgen van de uitbreidende werkgeversaansprakelijkheid: beleidsconsequenties voor verzekeraars?", in Faure, M.G. en Hartlief, $T$., "Verzekering en de groeiende aansprakelijkheidslast", l.c., 331. Wansink, J.H., "Aansprakelijkheidsverzekering", l.c., 103.

124 Haazen, O.A. en Spier, A., "Feitelijke ontwikkelingen en verzekerbaarheid", preadvies van Bolt, A.T. en Spier, J., "De uitdijende reikwijdte", l.c., 51.

i2s Haazen, O.A. en Spier, A., "Feitelijke ontwikkelingen en verzekerbaarheid", preadvies van Bolt, A.T. en Spier, J., "De uitdijende reikwijdte", l.c., 54.

126 Faure, M.G. en Hartlief, T., "De gevolgen van de uitbreidende werkgeversaansprakelijkheid: beleidsconsequenties voor verzekeraars?", in Faure, M.G. en Hartlief, T., "Verzekering en de groeiende aansprakelijkheidslast", l.c., 331. 
Op basis van de loss-occurrence polissen werden verzekeraars geconfronteerd met onvoorzienbare vorderingen uit het verleden ${ }^{127}$. De in verband hiermee in de literatuur aangehaalde klassieke voorbeelden hebben vaak betrekking op de asbestgevallen zoals die zich met name in de Verenigde Staten hebben voorgedaan. Verschillende fabrikanten van asbest werden door hun werknemers en door derden voor de rechter gedaagd omdat de blootstelling aan asbest tijdens een langere periode bij deze mensen had geleid tot longkanker. Gedurende deze periode waren de fabrikanten echter verzekerd bij andere verzekeraars zodat de vraag rees welke verzekeraar tussenbeide diende te komen ${ }^{128}$. Bij dergelijke schadegevallen kunnen verschillende gebeurtenissen deels tot de schade hebben bijgedragen ${ }^{129}$. Vanuit de loss-occurrence grondslag rijst hierbij de vraag of elk van deze gebeurtenissen kan worden gekwalificeerd als een "occurrence".

Het spreekt voor zich dat de problemen bij loss-occurrence polissen evenzeer rijzen bij schade uit kernongevallen: het moment waarop de schade is ontstaan is veelal moeilijk vast te stellen. Met name door een kernongeval veroorzaakte letselschade manifesteert zich slechts na een zekere incubatieperiode, zekere bij lagere stralingsdoses.

De geschetste problemen maken het uitermate moeilijk het risico op adequate wijze in te schatten. Dit geldt met name bij gevallen van causaliteitsonzekerheid waarin de rechter de aansprakelijkheidslast legt bij de ondememer en dus bij diens verzekeraar ${ }^{130}$. Illustratief in dit verband is het in Nederland beroemde DES-arrest uit $1992^{131}$.

Gedurende de jaren vijftig en zestig gebruikten zwangere vrouwen DES-pillen waarvan pas gedurende de jaren tachtig is gebleken dat deze pillen schadelijke gevolgen hadden op de gezondheid van de dochters van deze vrouwen. De causale relatie tussen het innemen van het geneesmiddel DES door de moeder en de afwijkingen bij de dochter, stond vast. De DES-dochters hebben de verschillende producenten van het geneesmiddel voor de rechter gebracht, hoewel reeds meerdere jaren waren verstreken tussen de inname van het geneesmiddel door hun moeder en hoewel niet kon worden aangetoond welke producent precies het schadelijke geneesmiddel op de markt had gebracht ${ }^{132}$. Hier rees met andere woorden het probleem dat niet precies kon worden vastgesteld

127 Er kan worden gesproken van een niet voorzienbare uitbreiding van de aansprakelijkheid; met een dergelijke retroactieve aansprakelijkheid werd geen rekening gehouden bij de berekening van de premie die noodzakelijkerwijze wordt bepaald bij het begin van de verzekeringsovereenkomst. Deze tendens tot retroactieve aansprakelijkheid betekent voor verzekeraars dan ook een rečel gevaar (Faure, M.G., Geers, A.J.C.M. en Hartlief, T., "Juridische aspecten van het beroepsziektenonderzoek: mogelijke toename van claims op de werkgever?", Faure, M.G. en Hartlief, T., "Verzekering en de groeiende aansprakelijkheidslast", l.c., 23).

Wansink, J.H., "Aansprakelijkheidsverzekering", l.c., 106.

Deze problematiek wordt ook de deelschade-problematiek genoemd; zic Akkermans, A.J., "Veroorzaking van deelschade", Weekblad voor Privaatrecht, Notariaat en Registratie, 6043, 1992, 249 e.v.; Akkermans, A.J., Proportionele aansprakelijkheid bij onzeker causaal verband. Een rechtsvergelijkend onderzoek naar wenselijkheid, grondslagen en afgrenzing van aansprakelijkheid a rato van veroorzakingswaarschijnlijkheid, Deventer, Tjeenk Willink, Zwolle, 1997.

Faure, M.G., Geers, A.J.C.M. en Hartlief, T., "Juridische aspecten van het beroepsziektenonderzoek: mogelijke toename van claims op de werkgever?", Faure, M.G. en Hartlief, T., "Verzekering en de groeiende aansprakelijkheidslast, l.c., 24; Frenk, N., "Toerekening naar kansbepaling", Nederlands Juristenblad, 1995, 482-491.

HR, 9 oktober 1992, Nederlandse Jurisprudentie, 1994, 535; Tijdschrift voor Milieu-aansprakelijkheid, 1993, 15, met noot Van Dunné, J.M., Milieu \& Recht, 1992, 668, met noot Kottenhagen-Edzes, P.A.

Hoofdzakelijk om die reden hadden de rechtbank en het Hof van Amsterdam de vordering eerder afgewezen (vonnis dd. 25 mei 1988, TvC, 1988, 274 met noot Hondius, E; arrest dd. 22 november 1990, Tijdschrift voor Milieuaansprakelijkheid, 1991, 338, met noot Spier, J.). 
welke fabrikant het geneesmiddel aan een bepaald slachtoffer had verstrekt ${ }^{133}$. Het voorwerp van discussie in deze zaak betrof inderdaad de verdeling van aansprakelijkheid tussen verschillende mogelijke schadeveroorzakers.

De eiseressen steunden hun vordering op artikel 6:99 $\mathrm{BW}^{134}$ inzake schade die het gevolg is van meerdere gebeurtenissen. De Hoge Raad volgde de redenering van de eiseressen en stelde dat de gedaagde fabrikant kon worden aansprakelijk gesteld voor de gehele schade ${ }^{135}$, hoewel niet alle producenten van de DES-pil waren gedagvaard én hoewel het onzeker is of de veroordeelde fabrikant diegene was die de schadelijke pil heeft geproduceerd. Op deze wijze maakte de Hoge Raad in deze zaak toepassing van de alternatieve causaliteit ${ }^{136}{ }^{137}$. De leer van de alternatieve causaliteit vergemakkelijkt de positie van slachtoffers omdat deze laatsten niet moeten bewijzen wie precies uit de kring van potentieel aansprakelijke personen, de schade werkelijk heeft veroorzaakt $^{138}$. Het slachtoffer kan derhalve aantonen wat de schade heeft veroorzaakt, maar niet wie uit een grotere groep van potentieel aansprakelijke personen, daaraan precies ten oorsprong ligt ${ }^{139}$; bijgevolg kan een "DES-dochter" schadevergoeding vorderen van elke gedaagde producent van de pillen ${ }^{140}$. De uitspraak van de Hoge Raad komt in feite neer op het toepassen van een hoofdelijke aansprakelijkheid in hoofde van de verschillende producenten ${ }^{141}$ en dit leidt ertoe, dat de causaliteitsonzekerheid wordt afgewenteld op deze producenten ${ }^{142}$; indien deze lijn bijvoorbeeld bij kernongevallen zou worden doorgetrokken, is het niet ondenkbaar dat verzekeraars meteen

Van Maanen, G.E., "De civielrechtelijke aansprakelijkheid voor kernongevallen naar Nederlands recht", in Faure, M., (red.), "Aansprakelijkheid voor het nucleaire risico", l.c., 30.

Artikel 6:99 BW luidt: "Kan de schade een gevolg zijn van twee of meer gebeurtenissen voor elk waarvan een andere persoon aansprakelijk is en staat vast dat de schade door tenminste één van deze gebeurtenissen is ontstaan, dan rust de verplichting om de schade te vergoeden op ieder van deze personen, tenzij hij bewijst dat deze niet het gevolg is van een gebeurtenis waarvoor hijzelf aansprakelijk is".

Er dient op te worden gewezen dat in dit arrest geen uitspraak werd gedaan over de onrechtmatigheidsvraag.

Volgens Van is sprake van alternatieve causaliteit "wanneer twee of meer verzamelingen van noodzakelijke voorwaarden zijn aan te wijzen die elk op zichzelf reeds voldoende zouden zijn geweest om de volledige schade te doen ontstaan" (Van, A., Onzekerheid over daderschap en causaliteit, Gouda Quint, Amhem, 1995, 93 e.v.).

Bergkamp, L., "'Wie van de Drie' en 'Alles of Niets': Nederlandse toestanden?", Nederland's Juristerblad, 1993, 100-103; Dommering Van Rongen, L., "Het DES-arrest: geen marktaandeelaansprakelijkheid, maar aansprakelijkheid voor de gehele markt", Weekblad voor Privaatrech, Notariaal en Registratie, 6089, 276-282; Ekering. J., "Several Theories on Liability in the Dutch DES Case", in Transnational Environmental Liability and Insurance, Graham \& Trotman, Londen, 1993, 58-66; Hartlief, T., "Altematicve causaliteit". Tijdschrift voor ondernemingsrecht en rechispersonen, jrg. 35 , 1992, 308-314; Spier, J., "De DES-dochters", Nederlands Tijdschrift voor Burgerlijk Recht, 1992, 193198; Van Dunné, J.M., noot onder de DES-zaak, Tijdschrifi voor Milieu-aansprakelijkheid, 1993/1, 20 e.v.; Hulst, E.H., "Grondslagen van milieu-aansprakelijkheid", l.c., 510. Kottenhagen-Edzes, P.A., noot onder de DES-zaak, Milieu \& Recht, 1992/12, 672.

Van, A., "Onzekerheid", l.c., 94.

Faure, M.G., Geers, A.J.C.M. en Hartlief, T., "Juridische aspecten van het beroepsziektenonderzoek: mogelijke toename van claims op de werkgever?", in Faure, M.G. en Hartlief, T., "Verzekering en de groeiende aansprakelijkheidslast", l.c., 24.

141 Spier, J., "How to keep liability within reasonable limits? A brief outline of Dutch law", in Spier, I., The Limits of Liability. Keeping the Floodgates Shut, Kluwer Law International, Den Haag, 1996, 123 124; Spier, J. en Wansink, J.H., "Joint and Several Liability of DES-manufacturers: a Dutch Court Crisis", International insurance Law Review, 1993, 176.

${ }_{142}$ Faure, M.G., Geers, A.J.C.M. en Hartlief, T., "Juridische aspecten van het beroepsziektenonderzoek: mogelijke toename van claims op de werkgever?", in Faure, M.G. en Hartlief, T., "Verzekering en de groeiende aansprakelijkheidslast", l.c., 26. 
zullen wijzen op de gevolgen op het vlak van de verzekerbaarheid. Wil de gedaagde ontsnappen aan aansprakelijkheid, dan dient hij het (nagenoeg onmogelijke) bewijs te leveren dat hij de schade niet heeft veroorzaakt ${ }^{143}$.

De problematiek waarbij benadeelden niet precies kunnen aanwijzen wie daadwerkelijk hun schade heeft veroorzaakt, rijst ook buiten gevallen van productaansprakelijkheid en met name bij milieuaansprakelijkheid. Hier rijst de vraag of de oplossing van de DES-zaak zonder meer kan worden getransponeerd naar gevallen van milieuaansprakelijkheid. De meningen hierover zijn verdeeld. Terwijl van Dunnél ${ }^{\prime 4}$ duidelijke voordelen ziet in de gecombineerde toepassing van artikel 6:99 en de hoofdelijkheid ex artikel 6:102, wordt over het algemeen aangenomen dat het DES-arrest niet kan worden toegepast buiten produktaansprakelijkheid ${ }^{145}$.

Dekkingen op basis van de loss-occurrence trigger stellen de verzekeraar dus voor de nodige problemen, met name wat betreft het vergroten van het narisico. Daar komt bij dat de schade zich veel later kan manifesteren dan de schadeverwekkende gebeurtenis zelf. Nochtans zullen bij een loss-occurrence polis de op dat moment geldende polisvoorwaarden bepalen of en tot welke hoogte dekking dient te worden verleend. Hierbij loopt de verzekeraar het risico gehouden te zijn tot een hogere dekking dan initieel kon worden ingeschat ${ }^{146}$. Een analoog probleem rijst voor herverzekeraars die het risico lopen meerdere malen te moeten tussenkomen voor hetzelfde risico. Deze problemen hebben in de VS geleid tot de introductie van een nieuwe trigger: de claimsmade polis. Ook in Europa wordt meer en meer dekking verleend op basis van een claims-made polis $^{147}$.

\subsubsection{Claims-made}

Bij een claims-made polis dient de vordering te worden ingediend tijdens de looptijd van de polis. Dergelijke polis kent een aantal varianten: in bepaalde claims-made polissen is bepalend dat het slachtoffer tijdens de contractduur de verzekerde aansprakelijk stelt, terwijl in andere claimsmade polissen de vordering tijdens de looptijd van de polis moet zijn ingediend tegen de verzekeraar. Hierbij is het inlooprisico in beginsel gedekt, terwijl - althans bij zuivere claims made polissen - het narisico volledig wordt uitgesloten: de verzekeraar weet dat zodra het contract ten einde is, hij niet meer kan worden aangesproken ${ }^{148}$. Eens de verzekeringsovereenkomst ten einde, kan de verzekerde geen enkele aanspraak meer maken op de dekking uit deze overeenkomst, tenzij anders is overeengekomen.

Faure, M. en Hartlief, T., "Towards an Expanding Enterprise Liability in Furope". How to analyze the Scope of Liability of Industrial Operators and their Insurers", Maastricht Journal of European and Comparative Law, 1996, vol. 3, 250. Van Dunné, J.M., noot onder de DES-zaak, o.c., 24.

Kottenhagen-Edzes, P.A., noot onder de DES-zaak, o.c., 673; Bolt, A.T. en Spier, J., "De uitdijende reikwijdte", l.c., 35.

Haazen, O.A. en Spier, A., "Feitelijke ontwikkelingen en verzekerbaarheid", preadvies van Bolt, A.T. en Spier, J., "De uitdijende reikwijdte", l.c., 55.

Haazen, O.A. en Spier, A., "Feitelijke ontwikkelingen en verzekerbaarheid", preadvies van Bolt, A.T. en Spier, J., "De uitdijende reikwijdte", l.c., 56.

Frame, C., "'Claims-made' Liability Insurance: Closing the gaps with retroactive coverage", Temple Law Quarterly, vol. 60, 1987, 178-179. 
Haazen en Spier onderscheiden twee soorten inloop ${ }^{149}$. Bij "veroorzakingsinloop" is de schade gedekt die is ontstaan tijdens de duur van de overeenkomst, maar waarvan de oorzaak ligt in een gebeurtenis die dateert van vóór deze overeenkomst. Bij een "occurrence-inloop" is gedekt de schade die is ontstaan vóór de looptijd van de polis, waarbij de verzekerde nog geen weet heeft van deze schade. Bij een zuivere claims-made polis is enkel het tijdstip van het indienen van de vordering determinerend; of de schade zich reeds voor de looptijd van de polis heeft voorgedaan, is van geen belang. Dit element kan worden beschouwd als een belangrijk voordeel voor de verzekerde.

Claims-made polissen bieden daarnaast het voordeel dat de erkende vorderingen worden beheerst door een polis die vaak is afgesloten geruime tijd nadat de schade is ontstaan. Hierdoor zijn de claims-made polissen in staat een afdoende dekking te geven. Doordat het inlooprisico is gedekt, rijst het probleem van inflatie die zich heeft voorgedaan in de periode tussen de schadeverwekkende gebeurtenis of de schade enerzijds en het indienen van de vordering anderzijds, hier niet ${ }^{150}$. Het spreekt voor zich dat een nagenoeg volledige anterioriteitsdekking zich ongetwijfeld zal vertalen in de premie. Omgekeerd, zal de premie van een claims-made polis met beperkte anterioriteitsdekking over het algemeen lager zijn. Het is overigens zeer de vraag of de langetermijnaansprakelijkheid van een ondememing beter kan worden ingeschat via de claims-made grondslag ${ }^{151}$ : op basis van de onder dergelijke polis betaalde premie kan de verzekerde immers moeilijk zijn potentiële toekomstige aansprakelijkheid inschatten.

Logischerwijze zal onder een claims-made polis de schade die ontstaat na het einde van de verzekeringsovereenkomst, niet gedekt zijn; in dat geval zal er namelijk geen vordering zijn ingediend tijdens de polislooptijd. Door de uitsluiting van de posterioriteitsdekking dient de verzekeraar niet te vrezen dat hij jaren na het einde van de polis nog zal worden geconfronteerd met schadevorderingen. Gevallen waar de schade slechts optreedt wanneer de duur van de polis reeds (lang) is verstreken, leiden bijgevolg niet tot problemen van posterioriteitsdekking bij de verzekeraar met wie de "laatste" overeenkomst intussen ten einde is gekomen, maar leiden tot problemen van anterioriteitsdekking bij de volgende verzekeraar ${ }^{152}$.

Zodra bij het verstrijken van de duur van de polis geen vordering werd ingesteld, heeft de verzekeraar in de regel niets te vrezen. Diens verplichtingen in de tijd zijn vanuit dit perspectief dus begrensd waardoor bepaalde risico's verzekerbaar en de premies betaalbaar blijven. Bij de premieberekening onder een dergelijke polis hoeft geen rekening te worden gehouden met vorderingen die na het einde van de polis worden ingediend, zelfs indien de schadeverwekkende gebeurtenis of de schade zich heeft voorgedaan tijdens de looptijd ervan. Indien tijdens de polisduur vorderingen worden ingediend, kan de verzekeraar overigens het volgende jaar de nodige maatregelen nemen en de premie aanpassen. Zodra een vordering is aangemeld, kan de verzekeraar inschatten tot welk bedrag hij desgevallend zal gehouden zijn en kan hij hiertoe de nodige reserves aanleggen $^{153}$.

Haazen, O.A. en Spier, A., "Feitelijke ontwikkelingen en verzekerbaarheid", preadvies van Bolt, A.T. en Spier, J., "De uitdijende reikwijdte", $l c ., 58$.

Dit in tegenstelling tot met name verzekeringsdekking op basis van de act-committed grondslag, cfr. supra.

151 Spier, J. en Haazen, O.A., "Aansprakelijkheidsverzekeringen", l.c., 26.

152 Haazen, O.A. en Spier, A., Feitelijke ontwikkelingen en verzekerbaarheid", preadvies van Bolt, A.T. en Spier, J., "De uitdijende reikwijdte", l.c., 59. en Spier, J., "De uitdijende reikwijdte", l.c., 61. 
Teneinde tegemoet te komen aan de voor de verzekerden zware gevolgen van de claims-made polis, met name op het vlak het uitsluiten van het narisico, wordt vaak toch een beperkte posterioriteitsdekking geboden ${ }^{154}$. Afhankelijk van het te dekken risico, zal de verzekeraar hiervoor al dan niet een bijkomende premie aanrekenen. Deze methodes om de voor de verzekerde nadelige gevolgen van de claims-made polis te verzachten zijn meestal beperkt, in die zin dat de schade waarvoor de vordering slechts in de uitloopperiode wordt ingediend, toch dient te zijn ontstaan tijdens de duur van de intussen afgelopen polis ${ }^{155}$.

Over het algemeen wordt gesteld dat een claims-made polis in de eerste plaats de belangen dient van de verzekeraar ${ }^{156}$. Illustratief is dat het Franse Hof van Cassatie de claims-made polissen heeft nietig verklaard ${ }^{157}$, waardoor Franse verzekeringsmaatschappijen bepaalde risico's niet meer verzekeren en waardoor de premies aanzienlijk zijn gestegen ${ }^{158}{ }^{159}$. Ook in België bleek uit de oorspronkelijke versie van de wet op de landverzekeringsovereenkomst de huiverigheid om een claims-made polis toe te laten; daarin is verandering gekomen door de in 1994 aangebrachte wijzigingen. De wijzigingen die in 1994 aan de wet op de landverzekeringsovereenkomst werden aangebracht worden hieronder aan de orde gesteld.

In de volgende paragrafen wordt onderzocht welke dekkingsgrondslag over het algemeen wordt gehanteerd in België ( $\$ 5.3)$ en in Nederland ( $\$ 5.4$ ).

\subsection{Dekking in de tijd volgens de Belgische wet op de landverzekeringsovereenkomst}

Voor wat betreft de overgang van de act-committed naar de loss-occurrence en de claims-made trigger is de evolutic van de Belgische wet op de landverzekeringsovereenkomst uitermate interessant. Zeer kort na het afkondigen van deze wet in 1992 gingen de eerste stemmen op tot wijziging ervan: de wet zou er namelijk toe leiden dat onder meer risico's inzake milieuaansprakelijkheid en productaansprakelijkheid niet meer verzekerbaar zouden zijn ${ }^{160}$. De bij wet van 16 maart 1994 doorgevoerde wijziging had in belangrijke mate betrekking op de dekkingsgrondslag. Gelet op het belang van de dekkingsgrondslag in het kader van dit onderzoek, wordt onderzocht waarom deze wijzigingen werden doorgevoerd ( $\$$ 5.3.1) en welke de strekking is van het inloop- en narisico volgens de gewijzigde wet op de landverzekeringsovereenkomst ( $\$ 5.3 .2$ ).

144 Onderzoek ter zake van de werkgeversaansprakelijkheid voor langetermijnrisico's en retroactieve aansprakelijkheid komt tot de conclusie dat de nadelige gevolgen voor verzekerden kunnen worden opgevangen door het verlenen van een zekere posterioriteitsdekking (Faure, M.G. en Hartlief, T., "De gevolgen van de uitbreidende werkgeversaansprakelijkheid: beleidsconsequenties voor verzekeraars?", in Faure, M.G. en Hartlief, T., "Verzekering en de groeiende aansprakelijkheidslast", l.c., 334).

iss Wansink, J.H., "Aansprakelijkheidsverzekering", l.c., 112

1s6 Faure, M.G. en Hartlief, T., "De gevolgen van de uitbreidende werkgeversaansprakelijkheid: beleidsconsequenties voor verzekeraars?", in Faure, M.G. en Hartlief, T., "Verzekering en de groeiende aansprakelijkheidslast", l.c., 332; Wansink, J.H., "Aansprakelijkheidsverzekering", l.c., 110.

157 Sprakelijkheidslast", l.c., 332; Wansink, J.H., "Aansprakelijkheidsver

198 Agard-Peano, M.A., "Rapport français concernant l'assurance de la responsabilité civile: couverture dans le temps", in Cousy, H. en Claassens, H., Aansprakelijkheidsverzekering: dekking in de tijd, Maklu, Academia, Bruylant, Antwerpen, Apeldoom, 1997, 121.

Zie over de Franse aansprakelijkheidsverzekeringen: Lambert-Faivre, Y., "Droit des assurances", l.c., 464 e.v.

160 Van Schoubroeck, C. en Schoorens, G., "De aansprakelijkheidsverzekering: a never ending story", o.c., 643. 


\subsubsection{Noodzaak tot wijziging van de wet op de landverzekeringsovereenkomst: van act- committed naar loss-occurrence}

De oorspronkelijke regeling van artikel $78, \S 1$ van de Belgische wet op de landverzekeringsovereenkomst van 25 juni 1992 luidde dat de verzekeringswaarborg zich uitstrekte tot vorderingen die na het einde van de overeenkomst worden ingediend, wanneer de schadeverwekkende gebeurtenis zich in de loop van de overeenkomst heeft voorgedaan. Het begrip "schadeverwekkende gebeurtenis" diende overeenkomstig de parlementaire voorbereiding te worden gelezen als "het feit waaruit de schade is ontstaan"161 162 . Niettegenstaande de onduidelijkheid in verband met het begrip "schadeverwekkende gebeurtenis" werd ervan uitgegaan dat de Belgische wetgever had gekozen voor de act-committed dekkingsgrondslag ${ }^{163}$.

Doordat artikel 78 zo algemeen was geformuleerd werd het voor verzekeraars onmogelijk om de in de praktijk reeds gehanteerde claims-made polissen verder aan te bieden ${ }^{164}$. Bovendien zagen de verzekeraars zich geconfronteerd met lange verjaringstermijnen (inzake verzekering en inzake aansprakelijkheid, respectievelijk artikel 34 wet op de landverzekeringsovereenkomst en art. 2260 e.v. B.W.), zodat hij zich moeilijk kon verweren indien meerdere jaren na het einde van de verzekeringsovereenkomst aanspraak werd gemaakt op de verzekeringswaarborg ${ }^{165}$. Door dit nagenoeg onbeperkte narisico waren verzekeraars en herverzekeraars van oordeel dat de verzekerbaarheid van risico's inzake milieuaansprakelijkheid, productaansprakelijkheid en beroepsaansprakelijkheid in het gedrang $\mathrm{kwam}^{166}$.

Daarom werd onder meer artikel 78 van de wet op de landverzekeringsovereenkomst van 1992 bij wet van 16 maart $1994^{167}$ (grondig) gewijzigd ${ }^{168}$; het doel van deze wijziging bestond erin een

Memorie van Toelichting, in Cousy, H. en Schoorens, G., "Parlementaire Voorbereiding", l.c., 258.

Fagnart en Rogge hebben op basis van verschillende interpretatiemechanismen (grammaticale, systematisch en teleologische interpretatie) onderzocht of het begrip "schadeverwekkende gebeurtenis" duidelijk kon worden afgelijnd; geen van de genoemde mechanismen gaf evenwel uitsluitsel (Fagnart, J.L. en Rogge, J., "Les Assurances de responsabilité dans la loi du 25 juin 1992", o.c., 110-114).

Van Schoubroeck, C. en Schoorens, G., "De aansprakelijkheidsverzekering: a never ending story", o.c., 645 .

Denoél, N., "Les Assurances de responsabilité et la loi du 25 juin 1992", in Les Assurances de Responsabilité, Editions du jeune barreau de Bruxelles, 1999, 117; Denoël, N., "La couverture dans le temps des contrats d'assurance de responsabilité civile", Journal des Tribunaux, 1997, 249.

Rekening houdend met de mogelijke schorsing of stuiting van de verjaringstermijnen, kon de verzekeraar in bepaalde gevallen tot 33 jaar na het einde van de verzekeringsovereenkomst worden aangesproken Zie hierover Schoorens, G. en Vanderspikken, A., "De verkorting van de verjaringstermijnen en de verzekerbaarheid van langetermijnaansprakelijkheden", in "Liber Amicorum Hubert Claassens", l.c., 179-20i. Colle, Ph., "Recente wijzigingen in de verzekeringswetgeving", o.c., 1365; Fagnart, J.L. en Rogge, J., "Les Assurances de responsabilité dans la loi du 25 juin 1992", o.c., 105; Van Schoubroeck, C. en Schoorens, G., "De aansprakelijkheidsverzekering: a never ending story", o.c., 645.

Delvaux, Ph., "Les assurances de responsabilité: questions spéciales", Fontaine, M. en Binon, J.M. (ed.), "La loi du 25 juin 1992 sur le contrat d'assurance terrestre", l.c., 209 e.v.; Fontaine, M., "Claims made policies under Belgian law", International Journal of Insurance Law, 1994, 128-129; Van Schoubroeck, C. en Schoorens, G., "De aansprakelijkheidsverzekering: a never ending story", o.c., 643: Denoël, N., "Les Assurances de responsabilité et la loi du 25 juin 1992", in "Les Assurances de Responsabilité", I.c., 117.

B.S., 4 mei 1994.

Voor de impact van deze wijzigingen op de verzekeringspremies, zie Beckers, Y. en Hofman, P., "La loi du 25 juin 1992 a-t-elle eu un impact sur le coût des primes des assurances de la responsabilité civile professionnelle et sur le coût potentiel de la sinistralité?", in Les Assurances de Responsabilité, Editions du jeune barreau de Bruxelles, 1999, 207-247. 
algemene regel in te voeren betreffende de dekking van het narisico, met dien verstande dat ook moest worden voorzien in een systeem dat het hoofd zou bieden aan uitzonderingsgevallen ${ }^{169}$.

Op basis van artikel $78, \S 1$ van de gewijzigde wet slaat de verzekeringswaarborg op de schade voorgevallen tijdens de duur van de overeenkomst en strekt de waarborg zich uit tot vorderingen die na het einde van de overeenkomst worden ingediend (loss-occurrence). De onbeperkte posterioriteitsdekking blijft dus behouden als regel, evenwel op voorwaarde dat de schade is voorgevallen tijdens de duur van de overeenkomst ${ }^{170}$. De wet op de landverzekeringsovereenkomst ging dus in zijn oorspronkelijke versie uit van de act-committed dekkingsgrondslag, terwijl de gewijzigde wet uitgaat van de loss-occurence trigger ${ }^{17 !}$. Vermits de eerste paragraaf van artikel 78 geldt als algemene regel, volgt hier impliciet uit voort dat claims-made dekkingen in beginsel zijn verboden ${ }^{172}$. Indien bijgevolg het feit dat aanleiding geeft tot aansprakelijkheid plaatsheeft binnen de looptijd van de polis, terwijl de schade zich voordoet na het einde van de polis, zal geen dekking worden verleend onder de gewijzigde wet, hetgeen wel het geval was onder de oorspronkelijke wet.

Nochtans kunnen partijen, overeenkomstig artikel 78, $\S 2$, voor bepaalde takken van de burgerrechtelijke aansprakelijkheid overeenkomen dat de verzekeringswaarborg alleen slaat op de vorderingen die schriftelijk worden ingesteld tegen de verzekerde of tegen de verzekeraar tijdens de duur van de overeenkomst voor schade voorgevallen tijdens dezelfde duur. Als algemene regel geldt bijgevolg de loss-occurrence trigger, tenwijl in cen aantal uitzonderingsgevallen toepassing mag worden gernaakt van de claims-made trigger ${ }^{173}$.

De in artikel $78, \S 2$ bedoelde uitzonderingen laten een claims-made polis toe voor bepaalde takken van de algemene burgerrechtelijke aansprakelijkheid, andere dan de burgerrechtelijke aansprakelijkheid inzake motorrijtuigen, die door de Koning worden bepaald. Overeenkomstig artikel 6 bis van het $K B$ van 24 december $1992^{174}$ zijn derhalve claims-made polissen toegelaten voor alle civielrechtelijke aansprakelijkheidsverzekeringen "met uitsluiting van de risico's van burgerrechtelijke aansprakelijkheid buiten overeenkomst met betrekking tot het privéleven en de risico's van burgerrechtelijke aansprakelijkheid met betrekking tot brandverzekering - eenvoudige risico's alsmede risico's van dezelfde aard die op aanvullende of bijkomende wijze gedekt worden in een andere verzekeringsovereenkomst".

En verzekeringsovereenkomst op basis van de claims-made trigger, is echter aan een aantal beperkingen onderhevig. Artikcl $78 \S 2,2^{\circ}$ lid van de wet op de landverzekeringsovereenkomst

Verslag Senaatscommissie. Artikelsgewijze bespreking, in Cousy, H. en Schoorens, G., "Parlementaire Voorbereiding", l.c., 261.

Voorstanders van een nieuwe wetswijziging wijzen er dan ook op dat het begrip "voorvallen van de schade" minder bescherming biedt dan de notie "schadeverwekkende gebeurtenis". (Dubuisson, B., "Rapport belge concernant l'assurance de la responsabilité civile", in Cousy, $\mathrm{H}$. en Claassens, $\mathrm{H}$, "Aansprakelijkheidsverzekering: dekking in de tijd", l.c., 73).

Cousy, H. en Claassens, H., "Van aansprakelijkheid naar verzekering en terug? Enkele orienterende beschouwingen", in Cousy, $\mathrm{H}$. en Claassens, H., Aansprakelijkheidsverzekering: dekking in de tijd, Maklu en Academia-Bruylant, Antwerpen, Louvain-la-Neuve, 1997, 19; Van Schoubroeck, C. en Schoorens, G., "De aansprakelijkheidsverzekering: a never ending story", o.c., 645.

Dubuisson, B., "Rapport belge concernant l'assurance de la responsabilité civile", in Cousy, H. en Claassens, H., "Aansprakelijkheidsverzekering: dekking in de tijd", l.c., 70.

Van Schoubroeck, C. en Schoorens, G., "De aansprakelijkheidsverzekering: a never ending story", o.c., 646-647.

Zoals gewijzigd door het KB van 29 december 1994 (B.S., 27 januari 1995). 
verplicht de verzekeraar om een posterioriteitsdekking te bieden van 36 maanden te rekenen vanaf het einde van de overeenkomst, voor de vorderingen die betrekking hebben op:

- schade die zich tijdens de duur van deze overeenkomst heeft voorgedaan indien bij het einde van de overeenkomst het risico niet door een andere verzekeraar wordt gedekt;

- daden of feiten die aanleiding kunnen geven tot schade, die tijdens de duur van deze overeenkomst zijn voorgevallen en aan de verzekeraar zijn aangegeven.

Het uitzonderingssysteem combineert bijgevolg de claims-made en de loss-occurrence trigger ${ }^{175}$.

De Belgische wet op de landverzekeringsovereenkomst, zoals gewijzigd, kan als volgt worden samengevat. Voor alle verzekeringsovereenkomsten betreffende de risico's met grote spreiding (de: door de consument afgesloten verzekeringscontracten) geldt de loss-occurence grondslag. Voor andere verzekeringscontracten kunnen partijen overeenkomen dat de dekking zal worden verleend op basis van de claims-made grondslag, op voorwaarde dat de schade is voorgevallen tijdens de looptijd van de polis.

Hiermee is de discussie omtrent de omvang van de verzekeringswaarborg niet ten einde omdat, door de onduidelijke wetsbepalingen en de daaruit voortvloeiende discussies in de literatuur, geen eensgezindheid bestaat omtrent de strekking van het inloop- en narisico.

\subsubsection{Strekking van inloop- en narisico in de gewijzigde wet}

De genoemde onzekerheden aangaande de strekking van het inloop- en narisico vloeien voort uit twee tekortkomingen van de wet op de landverzekeringsovereenkomst. In de eerste plaats rijst de vraag of uit het stilzwijgen van de wet ter zake van de anterioriteitsdekking een verbod dan wel een toelating tot het verlenen van een inlooprisico kan worden afgeleid. Hierbij is met name relevant dat de Belgische wet op de landverzekeringsovereenkomst van dwingend recht is. Bijgevolg zullen het inloop- en narisico worden geïnterpreteerd in het licht van de dwingende bepalingen van de wet op de landverzekeringsovereenkomst ( $\$$ 5.3.2.1). Nochtans zal deze interpretatie niet toelaten alle onzekerheden met betrekking tot het inloop- en narisico weg te nemen. Welke deze onzekerheden zijn, wordt in $\$$ 5.3.2.2 aan de orde gesteld. Teneinde de genoemde onzekerheden beter te illustreren, wordt nadien een kernongeval als voorbeeld genomen $(\S 5.3 .2 .3)$.

\subsubsection{Interpretatie van het in-en narisico in het licht van het dwingende karakter van de wet}

De bepalingen van artikel 78 hebben volgens de bewoordingen door de wet zelf gebruikt, betrekking op de verplichtingen van de partijen na het einde van de overeenkomst, met andere woorden op de dekking van het narisico. In de gevallen waar claims-made polissen zijn toegelaten, is de verzekeraar verplicht een dekking van het narisico van 36 maanden te verlenen. Gelet op het feit dat de wet van dwingend recht is, rijst hierbij zowel de vraag of de verzekeraar gehouden is tot het verlenen van een dekking van het inlooprisico, als de vraag of een langer narisico kan worden gedekt.

Met betrekking tot de eerste vraag dient te worden vastgesteld dat de wet geen bepalingen bevat in verband met het inlooprisico. Uit het stilzwijgen van de wet wordt over het algemeen afgeleid dat de dekking van het inlooprisico wordt overgelaten aan de contractvrijheid van de partijen ${ }^{176}$;

Colle, Ph., "Recente wijzigingen in de verzekeringswetgeving", o.c., 1365.

Dubuisson, B., "Rapport belge concernant l'assurance de la responsabilitẻ civile", in Cousy, H. en Claassens, H., "Aansprakelijkheidsverzekering: dekking in de tijd", I.c., 72. Nochtans plaatst Fagnart de nodige vraagtekens bij de geldigheid van het verlenen van een dekking van het inlooprisico bij con- 
uit het feit dat de wet het enkel heeft over de verplichtingen van de verzekeraar na het einde van de overeenkomst, wordt terecht afgeleid dat het niet de bedoeling van de wetgever kan zijn geweest de dekking van het inlooprisico te verbieden. Vandaar kan worden aangenomen dat partijen vrij zijn al dan niet dekking te verschaffen indien het schadeverwekkend feit of de schade voortkomen uit de periode voorafgaand aan de looptijd van de polis.

Of het narisico ook na 36 maanden kan worden gedekt, hangt af van het antwoord op de vraag of het de bedoeling van de wetgever is geweest de belangen van de verzekerden en van de slachtoffers dan wel de belangen van de verzekeraars te beschermen. Een langere narisicodekking dient de belangen van de verzekerde, c.q. benadeelde, en betekent in principe dat aan de verzekeraar zwaardere verplichtingen worden opgelegd ${ }^{177}$. Uit het feit dat de wet op de landverzekeringsovereenkomst in niet onbelangrijke mate tegemoet komt aan de belangen van de verzekerde ${ }^{178}$, kan dan inderdaad worden afgeleid dat partijen een langer narisico kunnen overeenkomen ${ }^{179}$. Het dwingend karakter van de wet moet immers worden beschouwd als cen middel om de consument te beschermen bij toetredingscontracten en niet als een doel op zich ${ }^{180}$.

Deze interpretatie laat evenwel niet toe alle onzekerheden in verband met de wet op de landverzekeringsovereenkomst op te lossen.

\subsubsection{Onopgeloste vragen onder de nieuwe wet op de landverzekeringsovereenkomst}

Hoger werd reeds aangegeven dat het begrip "schadeverwekkende gebeurtenis" in de oorspronkelijke versie van de wet op de landverzekeringsovereenkomst werd vervangen door "voorvallen van schade". Eén van de onopgeloste vragen in verband met de nieuwe wet heeft met name betrekking op de gevolgen van de afwezigheid van definitie van dit begrip ${ }^{181}$.

Teruggrijpend naar de door Wansink onderscheiden fasen ${ }^{182}$, kan de schade immers op verschillende ogenblikken voorvallen, namelijk hetzij:

- op het moment van de gebeurtenis waarvan de schade het gevolg is;

- op het moment van het inwerken van de schade zonder dat dezc zichtbaar is;

- op het moment dat de schade zich manifesteert.

tracten "de grande diffusion". De formulering van artikel $78 \S \mathrm{l}$ en het dwingende karakter van deze bepaling zou de wettelijkheid van een inlooprisico in het gedrang kunnen brengen (Fagnart, J.L., "L'étendue de la garantie", o.c., 43).

in Uiteraard zullen deze zwaardere verplichtingen hun weerslag hebben op de door de verzekeringsnemer te betalen premie.

178 De wet op de landverzekeringsovereenkomst van 1992 wordt inderdaad beschouwd als een consumentvriendelijke wet hetgeen blijkt uit verschillende bepalingen, onder meer inzake de dekkingsmogelijkheid van de grove schuld, de bevrijdende betaling van de premie aan een tussenpersoon, de verzwaring van het risico, de duur van de verzekeringsovereenkomst en de opzeggingsmogelijkheid na een schadegeval. De bedoeling om de consument te beschermen komt eveneens tot uiting door het feit dat deze wet van dwingend recht is, tenzij uit de bewoordingen van sommige bepalingen zelf blijkt dat ervan mag worden afgeweken. Door dit dwingende karakter en de daaruit voortvloeiende beperking van de contractvrijheid wordt de consument immers beschermo tegen abusieve clausules in het verzekeringscontract. Ook uit de voorbereidende werken blijkt duidelijk dat het de bedoeling van de wetgever is geweest in de eerste plaats de belangen van de verzekerde te beschermen.

159 Fagnart, J.L., Droit privé des Assurances, Story-Scientia, Gent, 1998, 250.

180 Van Schoubroeck, C. en Schoorens, G., "De aansprakelijkheidsverzekering: a never ending story?", o.c., 654 .

${ }_{182}^{131}$ Uit de oorspronkelijke versie vloeide dus een nagenoeg onbeperkte posterioriteitsdekking voort

Wansink, J.H., "Algemene Aansprakelijkheidsverzekering", l.c., 97. Zoals besproken in $\S 5.1$. 
De lacune in de wet wordt door de meeste verzekeraars opgevangen door dit begrip in de verzekeringspolis te definiëren als het feit dat aanleiding geeft tot de civielrechtelijke aansprakelijkheid. Een dergelijke definitie neemt dus het feit of de gebeurtenis als uitgangspunt, hetgeen zonder meer restrictieve interpretatie is van het begrip "voorvallen van de schade". Het is hierbij zeer de vraag of de verzekeraar een dergelijke interpretatie kan opleggen en of deze door de rechter zal worden aanvaard ${ }^{183}$. Volgens Van Schoubroeck en Schoorens is de verzekerde gerechtigd vergoeding te vorderen van de verzekeraar bij wie hij op één van deze momenten is verzekerd ${ }^{184}$. Indien de verzekerde gedurende deze verschillende fasen verzekerd was bij verschillende verzekeraars, zou bijgevolg elk van hen tot vergoeding gehouden zijn ${ }^{185}$ - met dien verstande uiteraard dat de benadeclde in geen geval aanspraak kan maken op een cumulatieve dekking en meerdere keren uitkering zou kunnen verkrijgen.

De hamvraag in de gehele discussie is nochtans eenvoudig: wanneer is de schade voorgevallen? Voor wat betreft het antwoord op deze vraag, dient te worden teruggegrepen naar de invulling van het begrip "schadegeval" bij aansprakelijkheidsverzekeringen. Aangezien overeenkomstig artikel 77 van de wet op de landverzekeringsovereenkomst een aansprakelijkheidsverzekering ertoe strekt het vermogen van de verzekerde te vrijwaren tegen diens schuld uit een vaststaande aansprakelijkheid, wordt de verzekerde in een aansprakelijkheidspolis geconfronteerd met een schade vanaf het moment waarop een slachtoffer een beroep doet op de aansprakelijkheid van de verzekerde. Dit betekent noodzakelijkerwijze dat de schade zich reeds heeft gemanifesteerd aan het slachtoffer. Enkel nadat deze schade zichtbaar is geworden, is het slachtoffer zich bewust geworden van de door hem geleden schade en is hij op zoek gegaan naar de oorzaak van de schade. De "voorgevallen schade" kan dus niets anders betekenen dan schade die zich reeds heeft gemanifesteerd ${ }^{186}$ - met andere woorden in de laatste fase van de hierboven weergegeven verschillende fasen van verwezenlijking van de schade.

Indien de voorgevallen schade wordt ondergebracht bij een van de daaraan voorafgaande fasen, wordt hierbij de bepalende dekkingsgrondslag miskend. In de discussie omtrent de merites en tekortkomingen van de gewijzigde wet op de landverzekeringsovereenkomst, wordt inderdaad onvoldoende onderscheid gemaakt tussen de kenmerken van de verschillende dekkingsgrondslagen. Het is immers zo dat wanneer "voorvallen van schade" wordt gekwalificeerd als het moment van de gebeurtenis die aanleiding geeft tot aansprakelijkheid, men gevaarlijk dicht in de buurt komt van de act-committed dekkingsgrondslag. Er kan bezwaarlijk worden volgehouden dat het feit dat aanleiding geeft tot aansprakelijkheid een andere betekenis heeft dan de schadeverwekkende gebeurtenis onder de oorspronkelijke wet.

Een restrictieve interpretatie van het begrip "voorvallen van de schade", leidt ertoe dat de desbetreffende polis eerder is gebaseerd op de act-committed dan op de loss-occurrence dekkingsgrondslag, terwijl de wetswijziging precies voorzag in de introductie van de loss-occurrence dekkingsgrondslag ten nadele van de act-committed dekkingsgrondslag. Het lijkt dan ook logisch dat de restrictieve interpretatie niet kan worden aanvaard en dat het begrip "voorvallen van schade" dient te worden geïnterpreteerd als het moment waarop de schade zich manifesteert aan het slachtoffer. Dit betekent dat de gebeurtenis zich noodzakelijkerwijze heeft voorgedaan vóór de

Dubuisson, B., "Rapport belge concemant l'assurance de la responsabilité civile", in Cousy, H. en Claassens, H., "Aansprakelijkheidsverzekering: dekking in de tijd", l.c., 73.

Van Schoubroeck, C. en Schoorens, G., "De aansprakelijkheidsverzekering: a never ending story?". o.c., 649.

Ibidem.

186

Ook in die zin: Colle, Ph., "Recente wijzigingen in de verzekeringswetgeving", o.c., 1366. 
schade, en dat voor de verzekerde het risico slechts ontstaat op het moment waarop de schade zichtbaar wordt.

In het licht van bovenstaande beschouwingen, kunnen de verplichtingen van de verzekeraar met betrekking tot het inloop- en narisico, zoals die voortvloeien uit de vernieuwde wet op de landverzekeringsovereenkomst, als volgt worden geresumeerd.

Voor wat betreft de verzekeringsovereenkomsten met grote spreiding die overeenkomstig artikel $78 \S 1$ de loss-occurrence dekkingsgrondslag hanteren, is de verzekeraar verplicht het inloop- en narisico te dekken. Aangezien het "voorvallen van schade" dient te worden gekwalificeerd als het zich manifesteren van de schade is het inlooprisico onbeperkt gedekt; het schadeverwekkend feit kan zich zowel tijdens als vóór de looptijd van de desbetreffende polis hebben voorgedaan. Het narisico is enkel gedekt op voorwaarde dat de schade zich tijdens de polis heeft gemanifesteerd.

Voor wat betreft de andere verzekeringsovereenkomsten die voorkomen in de lijst van het KB van 24 december 1994 waar partijen kunnen kiezen voor de claims-made dekkingsgrondslag, zijn de verplichtingen van de verzekeraar als volgt. Het inlooprisico is beperkt ingevolge de wettelijke voorwaarde dat de schade dient te zijn voorgevallen tijdens de overeenkomst; daarenboven is de verzekeraar ertoe gehouden gedurende drie jaar na het einde van de overeenkomst een narisicodekking te verlenen. De claims-made grondslag onder de Belgische wet op de landverzekeringsovereenkomst beperkt met andere woorden het inlooprisico, en voorziet in een uitbreiding van het narisico ${ }^{187}$.

Volledigheidshalve dient erop te worden gewezen dat een aantal auteurs de mogelijkheid om te kiezen voor een claims-made grondslag afwijst en een wijziging van artikel 78 voorstelt waarbij het narisico volledig is gedekt ${ }^{\text {88 }}$.

\subsubsection{Ter illustratie: een kernongeval}

Bovenstaande problematiek kan worden toegelicht door een kernongeval als voorbeeld te nemen, waarbij een persoon na een relatief langere tijdspanne kanker ontwikkelt en de exploitant hiervoor aansprakelijk stelt. Volgende fasen kunnen worden onderscheiden:

1. Kernongeval;

2. Vrijkomen van radioactiviteit in de lucht;

3. Radioactieve regen of fall-out (neerkomen en verspreiden van de radioactiviteit in bepaalde gebieden);

4. Inwerking van de radioactiviteit op de persoon;

5. Ecrste gezondheidsklachten worden door het slachtoffer vastgesteld;

6. Kanker wordt vastgesteld door de arts;

7. Vordering tegen verzekerde (exploitant);

8. Vordering tegen verzekeraar.

Terwijl uit deze verschillende fasen een min of meer duidelijk onderscheid blijkt voor wat betreft het feitenverloop, is het antwoord op de vraag welke van deze verschillende fasen vanuit juridisch

\footnotetext{
187 Onder een zuivere claims-made grondslag is het inlooprisico onbeperkt (ook dekking indien de schade zich reeds vroeger heeft gemanifesteerd) en wordt in het geheel geen dekking verleend voor het narisico.

Van Schoubroeck, C. en Schoorens, G., "De aansprakelijkheidsverzekering: a never ending story?", o.c., 656 .
} 
oogpunt relevant is voor het bepalen de dekkingsgrondslag, uitermate delicaat. De verschillende elementen van het schadeverloop dienen onder gelijk welke grondslag duidelijk te worden onderscheiden. Onderzocht dient te worden welke van de fasen bij het kemongeval juridisch kunnen worden gekwalificeerd als de schadeverwekkende gebeurtenis, het schadevoorval en het instellen van de vordering.

Ten eerste dient te worden nagegaan wat de schadeverwekkende gebeurtenis is van het kemongeval. Zowel het ongeval zelf als het vrijkomen van de straling en de radioactieve fall-out kunnen als een schadeverwekkende gebeurtenis worden aanzien. Naar onze mening kunnen de bovengenoemde fasen I tot en met 4 redelijkerwijze niet van elkaar worden onderscheiden. Het lijkt weinig zinvol en vanuit praktisch oogpunt weinig steekhoudend om één enkel element van deze fasen als schadeverwekkende gebeurtenis te kwalificeren. De schadeverwekkende gebeurtenis is de ondeelbare aaneenschakeling van gebeurtenissen die de oorzaak vormen van de later optredende schade - in ons voorbeeld het kernongeval, het vrijkomen van radioactiviteit in de lucht, de radioactieve fall-out en de inwerking ervan op de gezondheid van een persoon. Deze verschillende elementen kunnen niet worden gescheiden omdat bij afwezigheid van één fase, er geen gebeurtenis is die aanleiding kan geven tot schade. Het is mogelijk dat een gegeven persoon in een gebied woont waar de radioactieve neerslag is terechtgekomen (fasen 1 tot en met 3) maar dat de straling niet is ingewerkt bij de persoon die in het gebied woont, bijvoorbeeld omdat hij langere periode in het buitenland heeft verbleven. Het is ook mogelijk dat zich een kemongeval heeft voorgedaan waarbij geen straling is vrijgekomen in de lucht; ook in dat geval is er een duidelijke onderbreking in de aaneenschakeling van elementen waardoor geen sprake kan zijn van een schadeverwekkende gebeurtenis.

Zoals hoger weergegeven is het moment waarop de schade is voorgevallen het moment waarop de schade zich aan het slachtoffer manifesteert; in ons voorbeeld zijn dat de fasen 5 en 6 . Het laatstgenoemde element (instellen van de vordering) levert uiteraard het minste problemen op.

Overeenkomstig deze beschouwingen kan vervolgens de vraag worden beantwoord welke elementen zijn gedekt bij toepassing van de wet op de landverzekeringsovereenkomst. Deze wet biedt bij kernongevallen de mogelijkheid om te kiezen tussen een loss-occurrence en een claimsmade dekkingsgrondslag.

Bij keuze voor de loss-occurrence polis dient de schade zich te manifesteren tijdens de looptijd van de polis. Hierbij is het irrelevant dat de schadeverwekkende gebeurtenis zich al dan niet heeft voorgedaan tijdens de polis. Wanneer de schade zich voordoet onder een gegeven polis, zal ook het ongeval in die periode hebben plaatsgevonden omdat de exploitant is verplicht zijn aansprakelijkheid jegens derden te verzekeren van bij de aanvang van de nucleaire activiteiten ${ }^{189}$. Ook het narisico is gedekt, op voorwaarde dat de schade zich heeft gemanifesteerd tijdens de polis. Stel dat een slachtoffer zich na een kernongeval laat behandelen wegens klachten aan zijn gezondheid, dat de exploitant alle nucleaire activiteiten en dus ook zijn verzekeringspolis stopzet, dan kan het slachtoffer nadien nog steeds een vordering indienen.

Indien exploitant en verzekeraar evenwel hebben gekozen voor een claims-made polis, dan is de uitloop slechts gedekt tot 3 jaar na het einde van de polis. Het feit dat onder het Belgische systeem de inloop wordt beperkt, heeft verder geen invloed op de positie van het slachtoffer omdat, zoals 
hierboven aangegeven, door de verplichte aansprakelijkheidsverzekering van de exploitant, de schade noodzakelijkerwijze zal zijn voorgevallen tijdens de polis.

De wijze van verzekeren van het nucleaire risico, wordt in hoofdstuk 6 aan de orde gesteld; ook daar zal de dekkingsgrondslag in de aansprakelijkheidsverzekering van de exploitant worden toegelicht. Hieronder wordt eerst aandacht besteed aan de dekking in de tijd volgens de Nederlandse AVB-, AVP- en MAS-polis.

\subsection{Dekking in de tijd onder de Nederlundse AI'B-, AI'P-en MAS-polis}

In tegenstelling tot in België, bestaat in Nederland geen wet waarin de aansprakelijkheidsverzekering op systematische wijze wordt behandeld, laat staan dat de wet het hanteren van een bepaalde dekkingsgrondslag verplicht stelt. Partijen beschikken dan ook in ruime mate over de vrijheid om contractueel te bepalen welke dekkingsgrondslag zal worden gehanteerd.

De door de consumenten afgesloten particuliere aansprakelijkheidsverzekeringen (AVP-polis) zijn gebascerd op een gecombineerde grondslag: dekking wordt verleend indien de schade $\vdots ;$ veroorzaakt of ontstaan tijdens de ver/ekeringsduur. Aldus worden de act committed en de lossoccurrence dekkingsgrondslag gecombineerd. Hierbij worden in de regel zowel het inloop- als het narisico gedekt.

In de jaren vijftig en zestig ging de bedrijfsaansprakelijkheidsverzekering (AVB-polis) uit van de act-committed dekkingsgrondslag: de schade diende zich te hebben voorgedaan tijdens de contractduur ${ }^{i 90}$. Vanaf de jaren zeventig werd meer en meer een beroep gedaan op de loss-coccurrence dekkingsgrondslag: dekking werd verleend indien het letstel, de aantasting van de gezondheid of de zaakbeschadiging is ontstaan binnen de looptijd van de polis ${ }^{191}$. Vanaf 1997 hanteert deze polis evenwel de claims-made grondslag. De specifieke milieu-aansprakelijkheidspolis zoals op de markt gebracht door de MAS-pool in 1985, was eveneens gebaseerd van in het begin op de claims-made dekkingsgrondslag ${ }^{192}$.

Het claims-made systeem wordt dus gehanteerd zowel wat betreft de algemene bedrijfsaansprakelijkheidsverzekering (AVB polismodel 1996) als wat betreft de milieuaansprakelijkheidsverzekering. Onder de AVB 96 wordt dekking verleend indien de aanspraak tot schadevergoeding tijdens de looptijd van de polis zowel werd ingesteld tegen de verzekerde als tegen de verzekeraar. Onder de MAS-polis dient de aanspraak te zijn ontvangen tijdens de duur van de overeenkomst ${ }^{193}$.

Terwijl onder een claims-made stelsel het narisico in beginsel niet is gedekt, bevat het polismodel AVB96 toch twee aanvullingen, met name de nameldingsdekking en de omstandighedendekking.

190 Faure, M.G. en Hartlief, T., "De gevolgen van de uitbreidende werkgeversaansprakelijkheid: beleidsconsequenties voor verzekeraars?", in Faure, M. G. en Hartlief, T., "Verzekering en de groeiende aansprakelijkheidslast", lc., 330.

Wansink, J.H., "Rapport voor Nederland inzake aansprakelijkheidsverzekering: dekking in de tijd", in Cousy, H. en Claassens, H. (ed.), "Aansprakelijkheidsverzekering: dekking in de tijd", l.c., 130; Faure, M.G. en Hartlief, T., "De gevolgen van de uitbreidende werkgeversaansprakelijkheid: beleidsconsequenties voor verzekeraars?", in Faure, M.G. en Hartlief, T., "Verzekering en de groeiende aansprakelijkheidslast", l.c., 331.

Wansink, J.H., "Rapport voor Nederland inzake aansprakelijkheidsverzekering: dekking in de tijd", in Cousy, H. en Claassens, H. (ed.), "Aansprakelijkheidsverzekering: dekking in de tijd", I.c., 132. 
De nameldingsdekking luidt als volgt: "indien de verzekeraar van haar recht gebruik maakt de verzekering te beëindigen, heeft de verzekeringsnemer het recht de termijn van aanmelden met 1 jaar te verlengen voor aanspraken, die voortvloeien uit een handelen of nalaten, dat heeft plaatsgevonden vóór de beëindigingdatum, doch terzake waarvan aanspraken schriftelijk bij de verzekeraar worden gemeld binnen één jaar na deze beëindiging". Deze verlengde mogelijkheid tot melding na het einde van de overeenkomst biedt evenwel in bepaalde gevallen geen afdoende dekking, met name in de hypothese dat de verzekeringsovereenkomst bijna ten einde is en waarbij de verzekerde weliswaar op de hoogte is van feiten waaruit schade kan voortvloeien, maar waar deze schade zich nog niet heeft gemanifesteerd.

Daarom werd in een tweede aanvullende regeling voorzien, met name de omstandighedendekking. Op basis van deze aanvullende regeling wordt de vordering geacht te zijn ingediend tijdens de looptijd van de polis indien de verzekerde de verzekeraar tijdens de looptijd van de polis in kennis stelt van feiten waarvan in redelijkheid kan worden aangenomen dat zij zullen leiden tot een vordering.

Onder de AVB96-polis is, zoals in het algemeen bij een claims-made polis, het inlooprisico volledig gedekt ${ }^{194}$. Deze polis verschilt op dit punt van de MAS-polis waar in beginsel geen dekking wordt verleend voor milieuaantasting die zijn oorzaak vindt in een handelen of nalaten vóór de aanvang van de dekking ${ }^{195}$.

Via de overgang van het systeem van loss-occurrence naar claims-made in Nederland, net zoals in andere landen, wordt aangenomen dat langetermijnrisico's makkelijker verzekerbaar worden ${ }^{1 \%}$. Door de invoering van de claims-made dekkingsgrondslag in het polismodel AVB96, wordt het langetermijnrisico nu ook in Nederland meer verzekerbaar geacht. Dit nieuwe polismodel werd opgesteld omdat voornamelijk de risico's inzake productaansprakelijkheid, milieuaansprakelijkheid en werkgeversaansprakelijkheid onder de loss-occurrence trigger van de "oude" AVB-polis onverzekerbaar werden geacht ${ }^{197}$. Zo bleek uit onderzoek naar de aansprakelijkheid van de werkgever voor bedrijfsongevallen en beroepsziekten dat de verzekeringsindustrie met name inzake werkgeversaansprakelijkheid, in de komende jaren zou worden geconfronteerd met een dramatische stijging van de schadelast ${ }^{198}$.

Kenmerkend bij het nieuwe polismodel is dat de aangeboden polis toelaat rekening te houden met de specifieke risico's van het bedrijf ${ }^{199}$ : het model omvat afzonderlijke rubrieken voor het algemene aansprakelijkheidsrisico (exclusief werkgevers- en milieuaansprakelijkheid), het risico inzake werkgeversaansprakelijkheid, het risico inzake plotselinge milieuaantasting en het risico inzake geleidelijke milieuaantasting. Inmiddels is in Nederland reeds een alternatief voor de milieuaansprakelijkheidsverzekering beschikbaar, met name de milieuschadeverzekering. In hoofdstuk 1 I wordt hieraan verder aandacht besteed

194 Van der Schaaf, F.A., "Voor- en narisico in het polismodel AVB96", Aansprakelijkheid \& Versekering, 1996/6, 122.

Wansink, J.H., "Rapport voor Nederland inzake aansprakelijkheidsverzekering: dekking in de tijd", in Cousy, H. en Claassens, H. (ed.), "Aansprakelijkheidsverzekering: dekking in de tijd", l.c., 136.

Zie bijvoorbeeld Wansink, J.H., "De aansprakelijkheidsverzekering en de dekking voor 'long-tail'risico's", Aansprakelijkheid \& Verzekering, 1995/1, 1-6.

Haazen, O.A. en Spier, J., "Amerikaanse toestanden en de nieuwe aansprakelijkheidsverzekering voor bedrijven en beroepen", Nederlands Juristenblad, 1996, af1. 2, 45.

Faure, M.G. en Hartlief, T. (red.), "Verzekering en de groeiende aansprakelijkheidslast", l.c.

Wansink, J.H., "Het polismodel AVB96 en de dekking voor "long-tail'-risico's", Aansprakelijkheid \& Verzekering, 1996/6,121. 


\subsection{Conclusie}

Een delicaat probleem bij aansprakelijkheidsverzekeringen is de dekking in de tijd. Centraal hierbij staat de vraag hoe lang de verzekeraar ertoe kan worden verplicht om dekking te verlenen. Bijvoorbeeld bij een kernongeval kunnen namelijk meerdere jaren zijn verstreken tussen het ongeval, het zich manifesteren van de schade en het indienen van de vordering.

In de praktijk werden in de loop der jaren verschillende dekkingsgrondslagen ontwikkeld. In België en Nederland kan een analoge evolutie worden vastgesteld, in die zin dat bijvoorbeeld voor milieurisico's meer en meer een beroep wordt gedaan op de claims-made dekkingsgrondslag. Voorheen werd dekking verleend op basis van de act-committed of de loss-occurrence grondslag. Over het algemeen worden de gevolgen van de loss-occurrence en de claims-made grondslag verzacht doordat ook dekking kan worden verleend voor het in- en uitlooprisico.

Een opvallend verschil tussen de situatie in België en Nederland, heeft betrekking op de wettelijke basis van deze dekkingsgrondslagen. In Belgjẻ is heel wat te doen geweest over de gevolgen van de wet op de landverzekeringsovereenkomst van 25 juni 1992; hoofdzakelijk omwille van de onduidelijkheden inzake de toepasselijke dekkingsgrondslag, werd deze wet vrij snel gewijzigd. In Nederland daarentegen bestaat geen analoge wettelijke regeling inzake de dekkingsgrondslag voor de aansprakelijkheidsverzekering. De wijziging in de dekkingsgrondslag die zich ook in Nederland heeft voltrokken, is tot stand gekomen via de door de verzekeraars uitgebrachte polismodellen. De wijziging in de dekkingsgrondslag is dus in Nederland tot stand kunnen komen zonder tussenkomst van de wetgever.

De discussie met betrekking tot de dekkingsgrondslag van de aansprakelijkheidsier/ckering heeft overigens in essentie te maken met de verzekerbaarheid van aansprakelijkheid. Precics omdat de verzekeraars oordeelden dat bijvoorbeeld met betrekking tot milieuaansprakelijkheid de lossoccurrence grondslag zou leiden tot de onverzekerbaarheid van dergelijke risicu's, werd de claims-madc grondslag geïntroduceerd. De discussie in/ake de verzekerbudrheid van een risicu en de invloed van de dekkingsgrondslag hierop, wordt besproken in de rechtseconomische analyse. In het volgende hoofdstuk wordt aandacht besteed aan de verzekering van het nucleaire risico. 



\section{HOOFDSTUK 6}

\section{VERZEKERING VAN HET NUCLEAIRE RISICO}

$\mathrm{Na}$ de analyse, in de vorige hoofdstukken, van de civielrechtelijke aansprakelijkheid, de nucleaire aansprakelijkheid en verzekeringen in het algeimeen, wordt in dit hoofdstuk aandacht besteed aan de verzekering van het nucleaire risico.

Hierbij zal in eerste instantie de vraag worden beantwoord, hoe de nucleaire verzekeringsmarkt is ontstaan en zal worden aangegeven waarom het nucleaire risico op een andere wijze werd verzekerd dan een "conventioneel" nieuw risico $(\$ 1)$. In paragraaf 2 worden de nucleaire verzekeringspoois besproken; zowel hun ontstaan en hun werking, als de aangeboden dekking zullen worden toegelicht. De werking van een nucleaire verzekeringspoul wordt vervolgens toegelicht aan de hand van de analyse van de Belgische nucleaire verzekeringspool, Syndicat Belge des Assurances Nucléaires of SYBAN ( $\$ 3$ ). In paragraaf 4 wordt bestudeerd in welke mate de (nucleaire) verzekeringspools verenigbaar zijn met het Europese concurrentierecht. Dit hoofdstuk wordt afgesloten met een conclusie ( $(5)$.

\section{HET NUCLEAIRE RISICO VANUIT HET OOGPUNT VAN DE VERZEKERINGSINDUSTRIE}

Van bij de aanvang van de onderhandelingen van het Verdrag van Parijs werd het nucleaire risico door de verzekeraar als een bijzonder risico gekwalificeerd, in die zin dat de in het Verdrag van Parijs bepaalde dekking van 5 miljoen BTR door de verzekeraars als een "catastrofe" werd beschouwd ${ }^{1}$. Zoals is gebleken bij de bespreking van de verplichte dekking van de aansprakelijkheid van de exploitant, is de verzekering van het nucleaire risico nauw verbonden met de beperking van de aansprakelijkheid: het bedrag waarvoor de exploitant aansprakelijk is, weerspiegelt althans in theoric - het bedrag dat op de verzekeringsmarkt beschikbaar is. Dat de Europese verzekeraars een sterke invloed hebben gehad op de beperking van het bedrag waarvoor de exploitant van een keminstallatie kon worden aansprakelijk gesteld, blijkt uit cen uiteenzetting door de directeur van het Centre d'Etudes de la Commission Permanente du Risque Atomique (CERA):

"Les assureurs européens (...) ont lutté et continueront à lutter pour que la limite de la responsabilité civile ne dépasse pas 5 millions d'unités de compte (...) car ils estiment qu'un dommage d'un montant supérieur causé à des tiers est une catastrophe, et cette catastrophe, la Convention de Paris n'a jamais voulu la couvrir!"2.

De vraag rijst op welke basis een bijzondere regeling voor de verzekering van het nucleaire risico noodzakelijk werd geacht. Hieronder wordt eerst uiteengezet waarom de verzekering van het nucleaire risico door de verzekeringsindustrie als bijzonder werd beschouwd $(\$ 1.1)$. Nadien wordt aangegeven op welke wijze aan deze problemen, volgens de verzekeringsindustrie, het hoofd kon worden geboden $(\S 1.2)$.

Bēlser, W.E., "Les tâches et les possibilités de l'assurance face aux développement de l'énergie nucléaire", Quatrième colloque sur l'assurance du risque nucléaire, Euratom, EUR 2642, 1966, 41.

Ibidem. 


\subsection{Specifieke kenmerken van het nucleaire risico}

Het enkele feit dat de kernenergic-industric op het einde van de jaren vijftig en in het begin van de jaren zestig een totaal nieuwe industrie was, volstond niet om het nucleaire risico vanuit verzekeringsoogpunt als bijzonder of afwijkend te kwalificeren. Elke nieuwe technologische ontwikkeling stelt de verzekeringsindustrie voor een uitdaging en leidt tot een nieuwe verzekeringsvraag: in de regel zullen de producenten, de invoerders etc. van het nieuwe product of van de nieuwe dienstverlening of de exploitanten van de activiteit zich willen indekken tegen risico's die, zeker bij aanvang van de desbetreffende activiteiten, nauwelijks bekend zijn ${ }^{3}$. Door de industriële revolutie en dic hieraan verbonden nieuwe uitvindingen (bijvoorbeeld stoommachines, vliegtuigen, gas, olictankers en auto's) zag de verzekeringsindustrie zich de afgelopen eeuw meermaals geconfrontecrd met de vraag naar de dekking van deze nieuwe risico's.

Toch drong met name de verzekeringsindustrie aan op een bijzondere benadering van de verzekering van het nucleaire risico. In eerste instantic beschouw(d)en verzekeraars het nucleaire risico als een catastroferisico doordat een kemongeval niet enkel zou leiden tot een aanzienlijke eigenschade van de exploitant, maar ook tot een enorme schade aan derden. Ten tweede kon de potentieel te betalen schadevergoeding de capaciteit van een of meerdere verzekeraars overschrijden. Tenslotte waren, door het geringe aantal kerninstallaties, de mogelijkheden tot risicospreiding uitermate gering ${ }^{4}$.

Eén van de hoofdbckommernissen van de verzekeraars en exploitanten was dat een ongeval met ernstige schade aan derden automatisch impliceert dat eveneens zware vernieling is toegebracht aan de reactor en de installatie zelf. Dit kan leiden tot een cumulatie van schade in de verschillende door de exploitant afgesloten verzekeringspolissen ${ }^{5}$. De eigenschade van een exploitant bij een ernstig kernongeval beperkt zich niet tot de materiële schade, maar heeft eveneens betrekking op het door het stilliggen van de reactor veroorzaakte inkomstenverlies ${ }^{6}$. Nochtans is een combinatie van eigenschade en schade aan derden zeker niet eigen aan een kernongeval. Waarschijnlijk zal zelfs bij de meeste ongevallen zowel de schadeveroorzaker zelf als een derde schade lijden; dit geldt voor auto-ongevallen maar ook bijvoorbeeld voor "conventionele" industriële ongevallen.

Het tweede specifieke element van het nucleaire risico bestaat in de onzekerheden met betrekking tot de vaststelling van de schade: zowel de causaliteitsonzekerheid als het feit dat schade wit een kernongeval zich pas jaren nadien kan manifesteren, leidden tot de nodige problemen op verzekeringsvlak. Het vrcedzame gebruik van kemenergie creëert in hoofde van de verzekeraars verschillende risico's ${ }^{7}$ : de gevaren verbonden aan de verschillende ioniserende stralingen, het gevaar van

Belser, W.E., "Examen des solutions apportées par les lois nationales et les conventions internationales sur la responsabilité dans le domaine de l'énergie nucléaire aux problèmes posés aux assureurs pour la couverture de cette responsabilité", in Albonetti, A., Belser, W.E., c.a., Droit Nucléaire Européch, Colloque de Droit nucléaire européen, Presses universitaires de France, Paris, 1968, 69. Besson, A., "L’énergie atomique et le droit des assurances", Rapports généraux au Vième Congres international de droit comparé, Brussel, Bruylant, 1960, 461; Devrient, J.N., La responsabilité civile et l'assurance à raison du risque nucléaire, Imprimerie de la Tribune de Genève, Genève, 1964, 71. Belser, W.E., "Examen des solutions apportées par les lois nationales et les conventions internationales sur la responsabilité dans le domaine de l'énergie nucléaire aux problèmes posés aux assureurs pour la couverture de cette responsabilité", in "Droit Nucléaire Européen", l.c., 71. De redenering hierbij is dat een gebrek aan elektriciteit aanzienlijke schade kan veroorzaken aan bedrijven buiten de besmette zone.

Voor een bijdrage waarin de gevaren worden weergegeven van de verschillende toepassingen van kemenergie, zie bijvoorbeeld Chenu, C.-A., "Les dangers atomiques et leur assurance", in Puget, H. (éd.), Apects du droit de l'énergie atomique, 1967, 151-156. 
radioactieve besmetting en de gevaren verbonden aan de criticiteit, namelijk de aan een kernreactie verbonden gevaren. Bijna bij alle soorten van schade leidt het fenomeen "radioactiviteit" tot de nodige problemen omdat radioactieve straling niet zintuiglijk kan worden waargenomen en omdat de schade zich in een aantal gevallen slechts vele jaren na een opgelopen stralingsdosis manifesteert. Gezondheidsschade verschilt naar gelang van de soort opgelopen straling. Een persoon kan worden blootgesteld zowel aan inwendige als aan uitwendige besmetting. Afhankelijk van de opgelopen soort straling en de stralingsdosis kan dit aanleiding geven tot de ontwikkeling van een bepaalde ziekte. Daarenboven leidt een gegeven straling niet tot een welbepaalde specifiek aan kernenergie verbonden ziekte, maar kan een dergelijke straling leiden tot een ziekte die ook daar andere factoren kan worden veroorzaakt. Zo kan leukemie door een te hoge stralingsdosis worden veroorzaakt, maar ook door verschillende andere factoren. Hieruit vloeit eveneens voort dat een verzekeraar het risico loopt om vele jaren na een kemongeval te worden aangesproken ter vergoeding van de opgelopen schade.

Tenslotte impliceert een risico-inschatting in hoofde van de verzekeraar ook de mogelijkheid tot een afdoende risicospreiding tussen verschillende verzekerden. Een risico is makkelijker verzekerbaar naarmate meer risico's worden gedekt; in een dergelijk geval kan het risico op voldoende wijze worden gespreid. Ook op dit vlak stelde de dekking van het nucleaire risico de verzekeringsmarkt voor de nodige problemen omdat slechts geleidelijk aan kerninstallaties werden gebouwd en het risico bijgevolg slechts over een relatief klein aantal reactoren en exploitanten kon worden gespreid. Daarenboven werden in de beginfase van de ontwikkeling van kernenergie heel wat reactoren uitgebaat door de Staat, waarvan een aantal niet werden verzekerd ${ }^{9}$.

Concluderend kan worden gesteld dat het nucleaire risico door de verzekeraars vanaf het begin als een bijzonder risico werd beschouwd ${ }^{10}$. De aan de vreedzame toepassingen van kernenergie verbonden gevaren konden een schade veroorzaken die de capaciteit van de internationale verzekeringsmarkt te boven ging. Het nucleaire risico werd dan ook a priori als onverzekerbaar beschouwd".

\subsection{Oplossing van de bijzondere problemen}

Om het hoofd te bieden aan de specifieke kenmerken van de verzekering van het nucleaire risico, werd in de jaren vijftig door verzekeraars in verschillende landen onderzoek verricht naar de

Een radioacticve besmetting is uitwendig bij contact tussen radioactieve deeltjes met de huid. Er is sprake van een inwendige besmetting indien deze dee!tjes in het lichaam komen, bijvoorbeeld door het inademen of inslikken van deze deeltjes. De invloed van deze besmetting is sterk afhankelijk van de soort opgelopen straling. Er zijn drie soorten stralen met elk sterk verschillende eigenschappen: alfa-, beta- en gammastralen. Alfastralen zijn relatief grote en zware energiedecltjes, die precies dooi hun massa, makkelijk kunnen worden tegengehouden. Betastralen zijn lichtere energiedeeltjes (elektronen) die kunnen worden tegengehouden door bijvoorbeeld een aluminiumplaat met een dikte van enkele millimeter. Gammastralen tenslotte zijn electromagnetische golven zonder massa en kunnen enkel door zware stoffen worden tegengehouden.

Martin, G., "L'assurance de risques nucléaires", Annales de Sciences économiques appliquées, UCL, août 1962, n 3, 277; Sacerdoti, P., "The role of Insurance", in Weinstein, J.L. (ed.), Law and Administration, vol. 3 Nuclear Liability, Pergamon Press, Oxford, 1962, 213.

Devrient, J.N., "La responsabilité civile et l'assurance à raison du risque nucléaire", l.c., 70-71.

Belser, W.E., "Examen des solutions apportées par les lois nationales et les conventions internationales sur la responsabilité dans le domaine de l'énergie nucléaire aux problèmes posés aux assureurs pour la couverture de cette responsabilité", in "Droit Nucléaire Européen", l.c., 74-75. 
mogelijkheid tot het verzekeren van het nucleaire risico ${ }^{12}$. Teneinde dit onderzoek te bevorderen werd een institutioneel kader gecreëerd: de verzekeraars organiseerden zich door de oprichting van de "Permanente Commissie van het Atoomrisico" ${ }^{13}$. Deze Commissie had als opdracht de verzekering van het nucleaire risico te bestuderen, de nodige informatie hierover te verzamelen en te verspreiden, de ontwikkeling van doze verzekering te bevorderen, en de nucleaire verzekeraars te vertegenwoordigen bij de ter zake bevocgde internationale organisaties (voomamelijk de AEN en het IAEA). Uiteindelijk heeft de Permanente Commissie van het Atoomrisico een gemeenschappelijk standpunt van de verzekeraars geformuleerd dat van grote invloed is geweest bij de bespreking van het Verdrag van Parijs ${ }^{14} 15$

Tegelijk organiseerden de verzckeraars regelnatig congressen waar de verzekeringsproblemen aan de orde worden gesteld ${ }^{16}$. Het docl van het ondcrzoek was aan te geven welke precies de risico's waren verbonden aan het gebruik van kernenergie, op welke verzekeringspolissen deze risico's een invloed konden hebben en hoe een voldoende verzekeringscapaciteit kon worden gegenereerd.

De rode draad van deze verschillende studies was dezelfde: geen enkele verzekeringsmaatschappij waar ook ter wereld was in staat om dekking te verlenen boven haar financiële capaciteiten. Voor de dekking van het nucleaire risico had niet alleen de verzekeringsindustrie zelf, maar door de onverzekerbaarheid van het risico, ook de Staat een bijzondere rol te vervullen ${ }^{17}$. De uitzonderlijke omvang van de potentiële schade en het relatief kleine aantal kerncentrales hebben tot gevolg dat, steeds in de visie van de verzekeraars, de normale verzekeringstechnieken niet konden toegepast worden ter dekking van het nucleaire risico ${ }^{18}$ en dat specifieke maatregelen waren vereist. De belangrijkste van deze maatregelen waren de aanpassing van de conventionele verzekcringscontracten $(\S 1.2 .1)$, de creatie van nucleaire verzekeringspools $(\S 1.2 .2)$ en het tot stand brengen van een bijzondere wetgeving $(\S 1.2 .3)$.

\subsubsection{Aanpassen van bestaande verzekeringspolissen en creëren van nieuwe polissen}

Het nieuwe soort schade waartoe het gebruik van kernenergie kon leiden, stelde de verzekeraars in de jaren vijftig voor de nodige problemen omdat deze, bij afwezigheid van andersluidende bepalingen in de toenmalige verzekeringsovereenkomsten, was gedekt onder verschillende "conventionele" verzekeringscontracten. Het gebruik van kernenergie leidde tot risico's die een aanzienlijke invloed hadden op de bestaande persoonsverzekeringen (levensverzekering, ongevallenverzekering, ziekteverzekering en arbeidsongevallenverzekering), de schadeverzekeringen (brand-

Zie bijvoorbeeld: Belser, W.E., L'Assurance des Risques Nucléaires. Ses problèmes dans les domaines technique, administratif et législatif, Rapport préliminaire présent au Groupe de Sous-Comité des Assurances de l'Organisation Européenne de Coopération Economique, februari 1957, 39 e.v.

Dit was een afzonderlijke commissie in de schoot van het Europees Comité van Verzekeringen. Zie hierover Lacroix, F., "Insurance against Nuclear Risks in Europe", in Nuclear Law for a Developing World, IAEA, Wenen, 1969, 164-165.

De Kernverzekeringen in België sinds 1957, SYBAN, 1990, 8.

Sinds 1982 is de taak van de permanente Commissie overgenomen door de Algemene Commissie voor de Verzekering van het Atoomrisico; deze commissie vertegenwoordigt bijvoorbeeld de belangen van de verzekeraars in de groep van regeringsexperten in het kader van de revisie van de internationale nucleaire verdragen. Voor een gedetailleerd overzicht van deze besprekingen, zie Dow, J.C., Nuclear Energy and Insuran$c e$, Witherby \& Co Ltd., London, 1989, 169 e.v.

17 Besson, A., "L'énergie atomique et le droit des assurances", in "Rapports généraux", l.c., 460.

is B. Lacroix, F, De nucleaire verzekeringen, Technisch rapport van de Commissie van Beraad inzake kernenergie, 1 . 
verzekering, verzekering tegen ontploffing en de verzekering tegen machinebreuk), de verzekeringen inzake aansprakelijkheid tegenover derden (BA-bedrijven en BA-producten) en de transportverzekeringen (zowel transport over land, zeetransport als luchttransport). Zonder wijziging van deze polissen zou de verzekeringsindustrie in haar geheel worden blootgesteld aan de uit het gebruik van kemenergie voortvloeiende gevaren: in geen enkele polis werd de schade uit een kernongeval uitgesloten, waardoor dit risico in principe was gedekt via de klassieke polissen. Vandaar werd in alle toenmalige verzekeringscontracten een clausule ingelast op basis waarvan het nucleaire risico werd uitgesloten ${ }^{19}$. Een dergelijke ingreep was vooral nodig voor bepaalde eigenschadepolissen, brandpolissen en aansprakelijkheidspolissen. Indien bijvoorbeeld een kemongeval schade veroorzaakte aan een auto van een derde komt de eigenschadeverzekering van de eigenaar niet (meer) tussen indien de schade is veroorzaakt door een kernongeval. In een dergelijk geval zal niet meer de eigenschadeverzekering van de eigenaar de schade vergoeden, maar de ansprakelijkheidsverzekering van de exploitant.

Er dient op gewezen te worden dat de aanpassing van de polissen ook diende te gebeuren in landen die geen beroep deden op kernenergic en waar geen nucleaire verzekeringspool werd opgericht $^{20}$; ook in de niet genucleariseerde landen kon immers schade uit een kernongeval worden veroorzaakt.

Omdat in alle polissen een uitsluitingsclausule werd ingelast ${ }^{21}$, dienden ook nieuwe polissen te worden gecreëerd met het oog op het dekken van de eigenschade van de exploitant (deze polis diende zowel de schade aan de installatie te dekken als de schade aan zaken die zich op de nucleaire site bevinden), de schade die werknemers van de exploitant kunnen lijden (ziekte- en arbeidsongevallenpolis) en uiteraard een polis ter dekking van de aansprakelijkheid van de exploitant tegenover derden. Vooral wat betreft de laatstgenoemde polis kon het verzekeringswezen enkel dekking verschaffen rekening houdend met has financiële en technische capaciteiten. Gelet op de potentiële omvang van de schade uit een kernongeval, diende voor het gebrek aan capaciteit een bijzondere oplossing te worden gevonden.

\subsubsection{Creatie van verzekeringspools}

Uit berekeningen van verzekeraars in de jaren vijftig bleek dat via een beroep op de klassieke verzekeringsmechanismen maximaal een verzekeringscapaciteit kon worden bereikt van 2,5 miljoen BTR, terwijl de in het Verdrag van Parijs neergelegde bedragen het zesvoudige bedroegen $^{22}$. Geoordeeld werd dat het nucleaire risico niet kon worden gedekt door de gangbare methodes van verzekering en herverzekering ${ }^{23}$

Volgens de verzekeraars kon een voldoende capaciteit enkel worden gegenereerd door middel van de oprichting van nationale nucleaire verzekeringspools; dit zijn verenigingen van verschillende verzekeringsmaatschappijen van eenzelfde land waarbij elke maatschappij een deel van het nucleaire risico dekt. Via dergelijke medeverzekeringspools kon een maximale capaciteit worden ge-

Sacerdoti, P., "The role of Insurance", in Weinstein, J.L. (ed.), "Law and Administration", l.c., 225.

Warren, G., "Insurance for the Nuclcar Industry", in Horbach, N.L.J.T. (ed.). "Conternporary Developments in Nuclear Energy Law", l.c., 342.

Besson, A., "L'énergie atomique et le droit des assurances", o.c., 462-463. Zie voor wat Frankrijk betreft: Lambert-Faivre, Y., Risque et assurances des entreprises, $3^{\circ}$ editie, 1991, 593-594.

Belser, W.E., "Les tâches et les possibilités de l'assurance face aux développment de l'énergie nucléaire", o.c., 41.

Belser, W.E., "Über die Zweckmäßigkeit der Poolung von Atomrisiken", Versicherungswirtschaft, nr. 18, 14. Jahrg, september 1959,572 . 
genereerd. op de nationale markt. Bovendien werd een ongekende cumulatie van risico's ${ }^{24}$ tegengegaan doordat de pools zich enkel bij de andere pools zouden herverzekeren, eerder dan via de klassieke herverzekeringsmarkt. Door het mechanisme van de nucleaire verzekeringspools konden verzekeraars speciale provisies aanleggen voor de hoge verzekerde sommen; tegelijk kon, aldus Dow, op die manier een staat zijn nucleaire exploitanten verplichten hun aansprakelijkheid te dekken via verzekering.

"... faced with the very serious responsibilities insurers decided that they would pool their resources on a non-competitive basis" ${ }^{25}$.

De creatie van de verzekeringspools op nationale basis had evenwel tot gevolg dat een exploitant zich enkel tot de nationale nucleaire verzekeringspool kon/kan richten ter dekking van zijn aansprakelijkheid tegenover derden. Precies door de uitschakeling van de concurrentie ${ }^{26}$ werd de nodige kritiek geuit op de creatie van de pools, met name door de Europese Commissie, door exploitanten die vreesden hierdoor te hoge premies te betalen en door de verzekeringsmakelaars wier activiteiten grotendeels zijn gebaseerd op de concurrentie op de verzekeringsmarkt. Meermaals werd herhaald dat de creatie van nucleaire verzekeringspools een absolute noodzaak. was; tegelijk toonden de verzekeraars zich bereid af te zien van deze poolingtechniek zodra dit tot de mogelijkheden behoorde ${ }^{27}$.

In 1966 erkende een vertegenwoordiger van Euratom dat in de aanvangsfase moeilijk sprake kon zijn van concurrentie bij gebrek aan voldoende verzekeringscapaciteit. Op een conferentie in Berlijn riep hij de verzekeringswereld op een groter deel van het nucleaire risico te onderschrij$v_{e n}{ }^{28}$. Voor de premies betreft stelde hij voor een analoog systeem in te voeren als in de Verenigde Staten, waar een deel van de premie werd gereserveerd en na afwezigheid van schadegevallen gedurende een zekere periode, dat deel van de premie werd teruggestort ${ }^{29}$. Euratom trachtte dus de verzekeringswereld tot meer soepelheid te bewegen, hetgeen zou resulteren in lagere premies.

Hoewel de pools garant zouden staan voor een maximale verzekeringscapaciteit, zou geen enkele pool in staat zijn de gehele schade van een zwaar kernongeval te verzekeren. Daarom diende de door de pools verschafte dekking door wetgevend ingrijpen te worden beperkt tot cen bepaald bedrag ${ }^{30}$. De verzekeringswereld benadrukte dat de door hen zelf genomen praktische maatregelen - het uitschrijven van nieuwe polissen en de creatie van nucleaire verzekeringspools - alleen niet volstonden om een zekere nucleaire verzekeringscapaciteit te kunnen genereren.

Met name de cumulatie van de eigenschade van de exploitant en diens aansprakelijkheid tegenover derden.

Dow, J.C., "Nuclear Energy and Insurance", l.c., 178.

26 Verder wordt teruggekomen op de verenigbaarheid van de nucleaire pools met het Europese concurrentierecht, zie $\S 4$ van dit hoofdstuk.

27 Belser, W.E., "Les tâches et les possibilités de l'assurance face aux développment de l'énergie nucléaire", o.c., 39.

28 Von Gelderen, E.R., "Le développement de l'énergie nucléaire et la collaboration entre Euratom, l'industrie nucléaire, les producteurs d'électricité et les assureurs", Quatrième colloque sur l'assurance du risque nucléaire, Euratom, EUR 2642, 1966, 32-33. Dhr. Von Gelderen was directeur-generaal van het departement industrie en economie van Euratom. Een dergelijk systeem waarbij een deel van de premie wordt terugbetaald, wordt in de VS nog steeds toegepast door ANI. Cfr. infra, in $\$ 3.2 .3$ van hoofdstuk 13.

Belser, W.E., "Examen des solutions apportées par les lois nationales et les conventions internationales sur la responsabilité dans le domaine de l'énergie nucléaire aux problèmes posés aux assureurs pour la couverture de cette responsabilité", in "Droit Nucléaire Européen", I.c., 78. 


\subsubsection{Tot stand komen van bijzondere wetgeving}

De bijzondere wetgevende maatregelen die in de ogen van de verzekeraars noodzakelijk waren, zijn precies dezelfde als de maatregelen die voortvloeien uit het Harvard Rapport. Deze maatregelen dienden de aansprakelijkheid van de exploitant te beperken in bedrag en in de tijd, een overheidstussenkomst te voorzien voor alle schade die niet kon worden verzckerd, de aansprakelijkheid te kanaliseren naar de exploitant, uitzonderingen te bevatten voor bepaalde gevallen van overmacht en diende tenslotte de tussenkomst van de verzekeraar te beperken. Vandaar hebben de verzekeraars een grote rol gespeeld bij de beperking van de aansprakelijkheid van de exploitant en bij het totstandkomen van de kanalisatie van aansprakelijkheid ${ }^{31}$. Geoordeeld werd dat dankzij deze kanalisatie van aansprakelijkheid de verzekeringsproblematiek werd vereenvoudigd ${ }^{32} 33$.

De conclusie van de verschillende door verzekeraars uitgevoerde studies was dat het nucleaire risico diende te worden verzekerd door enerzijds het nucleaire risico uit de conventionele verzekeringsmarkt te halen, door nieuwe polissen uit te schrijven die werden verzekerd door mididel van nationale verzekeringspools en door de creatie van een bijzondere wetgeving ${ }^{34}$. Het spreekt voor zich dat de ontwikkeling van de nucleaire aansprakelijkheidsrecht hand in hand is gegaan met de creatie van de nucleaire verzekeringspools: vóór de ondertekening van het Verdrag van Parijs waren verzekeraars in 12 Europese landen reeds in staat om een dekking te verschaffen ${ }^{35}$. Hieronder wordt uiteengezet wat een nucleaire verzekeringspool precies is, hoe een dergelijke pool functioneert en welke de kenmerken van de pool zijn.

\section{DE NUCLEAIRE VERZEKERINGSPOOLS}

Aangezien het verzekeringsaspect, samen met het aansprakelijkheidsvraagstuk, een centrale plaats inneemt in dit onderzoek wordt meer in detail aandacht besteed aan de nucleaire vercekeringspools. In eerste instantie wordt het ontstaan van deze pools toegelicht $(\$ 2.1)$. Vervolgens wordt een definitie van de nucleaire verzekeringspool gegeven $(\$ 2.2)$ en word de werking ervan aan de orde gesteld ( $\$ 2.3$ ). Op basis hiervan worden in $\$ 2.4$ de kenmerken van een dergelijke pool aangegeven en zal worden onderzocht welke dekking een nucleaire verzekeringspool verleent $(\$ 2.5)$.

\subsection{Ontstaan}

De creatie van de nucleaire verzekeringspools vloeit rechtstreeks voort uit de conclusies van bovengenoemde rapporten van de verzekeraars, waarin het gebrek aan verzekeringscapaciteit äls éen van de voomaamste problemen werd beschouwd. De nucleaire verzekeringspool biedt een! oplossing voor dit probleem: doordat meerdere verzekeringsmaatschappijen elk een deel van het

Zie hierboven, in $\S 2$ van hoofdstuk 4 voor meer details.

Sacerdoti, P., "The role of Insurance", in "Law and Administration", I.c., 224.

Voor een kritische analyse, zie $\$ 1.1 .3$ van hoofdsiuk 15 .

Volgens de verzekeringsindustrie konden enkel op deze wijze zowel de belangen van de bevolking (oescherming tegen de door kernongevallen veroorzaakte schade) als de nationale econornische industriële - belangen worden gevrijwaard: "Denn es wăre sinnlos, bei der Entwicklung der Kemenergie, welche für die Menschheit so große Bedeutung erlangen kann, die Geführdung, eines Wirtschaftszweiges zuzulassen, der durch Schutzgewährung als wirtschaftliche Funktion für die gewaltige industrielle Entwicklung der letzten 100 jahre Wesentliches geleistelt hat" (Belser, W.E., "Öber die Zweckmäßigkeit der Poolung von Atomrisiken", o.c., 584).

Deprimoz, J., "International Co-operation in providing insurance cover for nuclear damage to third parties and for damage to nuclear installations", Nuclear Law Bulletin, $\mathrm{n}^{\circ} 32,1983,35$. 
risico dekken en dus elk een bepaalde capaciteit ter beschikking stellen wordt een grotere verzekeringscapaciteit op de nationale markt beschikbaar ${ }^{36}$. Omgekeerd impliceert een dergelijke pool dat het nucleaire risico wordt verdeeld over de verschillende verzekeraars van één land ${ }^{37}$.

De eerste nucleaire verzekeringspool werd in 1956 opgericht in de Verenigde Staten door de Joint Stock Insurance Companies. Deze pool omvatte twee afzonderlijke syndicaten, namelijk Nuclear Energy Liability Insurance Association (NELIA) en Nuclear Energy Property Insurance Association (NEPIA). In dezelfde periode richtten de mutual insurance companies MAERP en MAELU op (respectievelijk Mutual Atomic Energy Reinsurance Pool en Mutual Atomic Energy Liability Underwriters $)^{38}$.

In 1957 werden in de meeste landen die zich toelegden op de productie van kemenergie, naar Amerikaans voorbeeld soortgelijke pools opgericht ${ }^{39}{ }^{40}$. De oprichting van deze Europese pools gebeurde in internationaal overleg om een optimale harmonisatie van de verzekeringen ${ }^{41}$ en de wetgeving inzake nucleaire aansprakelijkheid te bewerkstelligen. Het is uiteraard niet toevallig dat de pools werden opgericht gedurende de onderhandelingen die leidden tot de ondertekening van het Verdrag van Parijs.

De noodzaak tot oprichting van deze nucleaire verzekeringspools werd ook aangegeven in de Exposé des Motifs van het Verdrag van Parijs:

"... the possible magnitude of a nuclear incident requires intemational collaboration between national insurance pools. Only an effective marshalling of the resources of the European insurance market by co-insurance and reinsurance will enable sufficient financial security to be made available to meet possible compensation claims ${ }^{\prime \prime 2}$.

Vanaf de eerste jaren van hun bestaan deden de pools wereldwijd een beroep op elkaar; een internationale samenwerking tussen de pools was vooral opvallend binnen de Euratom-lidstaten maar situeerde zich duidelijk niet enkel in de Europese context. In 1965 participeerden de pools van de

Devrient merkte in 1964 reeds op dat deze capaciteit nog kan worden uitgebreid door de creatie van internationale of mondiale pool (Devrient, J.N., "La responsabilité civile et l'assurance à raison du risque nucléaire", l.c., 72).

Camier, M.-C., "Responsabilité et Assurance du Risque Atomique", l.c., 183.

Cfr. infra bij de bespreking van de dekking van het nucleaire risico in de VS (hoofdstuk 13).

39 Het gaat met name om Belgiě, Denemarken, Finland, Frankrijk, Duitsland, Italię, Noorwegen en Zwitserland; gevolgd door Nederland in 1958, Oostenrijk in 1959 en Japan in 1960. Ze hierover Deprimoz, J., "International Co-operation in providing insurance cover for nuclear damage to third parties and for damage to nuelear installations", o.c., 38; Mosthaf, H.D., "Haftung und Versicherung für Kernrisiken in der Europäischen Gemeinschaft", Zeitschrift für Kerntechnik, oktober 1964, 280. Over de Belgische pool, zie o.m. Faure, M. en Van den Bergh, R., "Objectieve Aansprakelijkheid", l.c., 320 e.v, Claassens, H., "Kemenergie en aansprakelijkheidsverzekeringen", Verzekeringswereld, 1984, afl. 258, 35-36; voor Nederland: Van Maanen, G.E., "Wettelijke aansprakelijkheid voor kerncentrales", Nederlands Juristenblad, 1981, afl. 11, 286-292; Hamburger, M., "De aansprakelijkheidsverzekering in Nederland voor schade door kemongevallen in West-Europa", Nederlands Juristenblad, 1986, afl. $42,1335-1341$.

4i Opvallend hierbij is de rol van Euratom die verschillende initiatieven nam met het oog op een zekere harmonisatie van de verzekeringspolissen. Zo publiceerde Euratom een kaderpolis inzake civielrechtelijke aansprakelijkheid voor kernongevallen (Euratom, Directoraat-Generaal Industrie en Economie, Voornaamste bepalingen voor een verzekeringscontract betreffende wettelijke aansprakelijkheid van vaste kerninstallaties, EUR 3127, 1966). 
Euratomlidstaten bijvoorbeeld in de Amerikaanse, Zwitserse, Scandinavische, Oostenrijkse, Turkse en Japanse pools ${ }^{43}$. Vandaag bestaan er wereldwijd 28 van dergelijke pools; deze pools zijn echter nog steeds niet in staat om de exploitant een volledige risicodekking te verschaffen waarbij alle schade uit een kernongeval zou worden vergoed ${ }^{44}$. Het aantal kernreactoren is op mondiaal niveau gestegen van 15 in 1959 tot ongeveer 440 in 1992. Ongeveer de helft van deze reactoren wordt door de overheid uitgebaat en is niet verzekerd ${ }^{45}$.

In 1992 participeerden wereldwijd naar schatting meer dan 1000 verzekeringsmaatschappijen in nationale nucleaire pools ${ }^{46}$ en had de nucleaire verzekeringsindustrie een gecumuleerde ervaring van meer dan 5.000 reactorjaren $^{47}$ opgebouwd, waardoor toch meer gegevens bekend zijn betreffende de verzekering van het nucleaire risico. Sinds hun ontstaan is de capaciteit van de pools aanzienlijk gestegen. Bijvoorbeeld in Frankrijk is de capaciteit gestegen van 7 miljoen FF in 1957 naar 157 miljoen FF in $1987^{48}$; in de periode 1957-1990 is de capaciteit in de VS vertwaalfvoudigd $^{49}$. Op het einde van 1998 zou de wereldwijde capaciteit van de nucleaire verzekeringspools ongeveer 2 miljard dollar bedragen ${ }^{50}$.

Sinds hun ontstaan werden de pools slechts één enkele keer geconfronteerd met een zwaar verlies, met name door het ongeval in Three Mile Island in 1979. De exploitant van TMI had bij twee Amerikaanse pools een polis afgesloten ter dekking van materiële schade (eigenschadeverzekering). Deze dekking was beperkt tot een bedrag van 300 miljoen dollar $^{51}$; het was meteen het grootste bedrag dat ooit door de verzekeringsindustrie diende te worden uitbetaald. Bovendien waren de twee Amerikaanse pools waarbij de exploitant van TMI was aangesloten herverzekerd bij de meeste andere pools in de wereld. Vandaar dat heel wat verzekeringsmaatschappijen wereldwijd - waaronder Belgische en Duitse verzekeraars - zijn moeten tussenkomen als herverzekeraar $^{52}$. Ook aan derden werden aanzienlijke bedragen uitgekeerd ${ }^{53}$.

\subsection{Definiëring van een nucleaire verzekeringspool of van een syndicaat}

Een verzekeringspool is in essentie een mechanisme op basis waarvan een aantal verzekeraars overeenkomt om voor bepaalde activiteiten en bepaalde risico's hun middelen te bundelen ${ }^{54}$, in

43

De Mori, B., "Rapport sur l'état actuel de l'assurance nucléaire dans la Communauté", Quatrième colloque sur l'assurance du risque nucléaire, Euratom, EUR 2642, 1966, 16-17.

Nuclear Power. Insurance and the Pooling System, Special Edition of the Nuclear Pools' Bulletin, 1992 en Reitsma, S.M.S., "Nuclear Insurance Pools: History and Development", Nuclear Accidents. Liabilities and Guarantees, Helsinki symposium 1992, 346.

"Kernverzekeringen in Belgiè sinds 1957", l.c., 5; "Liability and Compensation for Nuclear Damage", l.c., 32.

Dow, J.C., "Nuclear Energy and Insurance", l.c., 232.

De kernverzekeringen in Belgiê sinds 1957, l.c., 5

"Liability and Compensation for Nuclear Damage", l.c., 32.

O'Connell, J.M., "Curtent Operating Practices of Nuclear Insurance Pools", in Nuclear Accidents Liabilities and Guarantees, NEA-lAEA, Paris, 1993, 351.

Warten, G., "Insurance for the Nuclear Industry", in Horbach, N.L.J.T. (ed.), "Contemporary Developments in Nuclear Energy Law", l.c., 345.

Dow, J.C., "Nuclear Energy and Insurance", l.c., 228.

Dow, J.C., "The Organisation and Development of International Liability Capacity and National Market Pools with Special Reference to New Nuclear Countries", in Nuclear Third Party Liability and Insurance. Status and Prospects, Paris, OECD-NEA, 1985, 172-182.

Cfr. infra, in $\$ 3.2 .4$ van hoofdstuk 13.

Warren, G., "Pooling operations: how nuclear insurance works", Nuclear Engineering International, 1995, 30; Warren, G., "Insurance for the Nuclear Industry", in Horbach, N.L.J.T. (ed.), "Contemporary Developments in Nuclear Energy Law", l.c., 342. 
die zin dat elke participerende verzekeraar een deel van het risico voor zijn rekening neemt. Naargelang de pool optreedt als verzekeraar of als herverzekeraar wordt gesproken van een medeverzekeringspool of een herverzekeringspool.

Een verzekeringspool kan worden beschouwd als een vereniging van commerciële en onafhankelijke verzekeraars (zowel private verzekeraars als systemen van onderlinge verzekering) die contractueel overeenkomen een bepaald risico te dekken ${ }^{55}$. Hierbij behoudt elk lid van de pool zijn juridische en economische onafhankelijkheid en heeft het mechanisme enkel en alleen betrekking op de dekking van het specifieke contractucel overeengekomen risico ${ }^{56}$. Het doel van een dergelijke pool is dus niet noodzakelijk het creëren van een verhoogd rendement, maar veeleer de creatie van een welbepaalde verzekeringscapaciteit. Over het algemeen wordt een dergelijke pool in het leven geroepen indien de mogelijkheden tot risicospreiding beperkt zijn, indien voor een gegeven risico een capaciteit is vereist die de middelen van de individuele leden (zelfs indien verenigd bij wijze van klassieke medeverzekering) te boven gaat of indien het een risico betreft met bijzondere gevaren, waardoor een dekking ervan via klassieke methoden nagenoeg is uitgesloten $^{57}$. Door middel van medeverzekering van het risico in een verzekeringspool kan op de markt een dekking worden aangeboden die de capaciteit van een individueel lid van de pool te boven gaat $^{58}$.

De benaming nucleaire verzekeringspool wordt in het algemeen gebruikt als de vereniging van verzekeringsmaatschappijen die dekking aanbieden zowel voor de aansprakelijkheid tegenover derden als voor de eigenschade van de exploitant. Niettegenstaande een aantal identieke kenmerken, verschillen de nucleaire verzekeringspools van elkaar, met name op het vlak van de relatie tussen de pool en de verzekerden. Er wordt dan ook een onderscheid gemaakt tussen een pool en een syndicaat.

In de VS en het Verenigd Koninkrijk wordt gesproken van een "pool" omdat de polissen worden uitgeschreven in naam van de pool zelf en dit voor rekening van haar leden ${ }^{59}$.

De meeste pools in Europa daarentegen functioneren op een andere manier. De polissen worden niet uitgeschreven door de pool zelf, maar door een of meer van haar leden. Eén van die leden treedt op als "fronting company" en schrijft de polis uit in naam van de verschillende leden; vervolgens wordt deze verzekering voor $100 \%$ overgedragen aan de pool die de dekking herverdeelt overeenkomstig het door ieder lid onderschreven deel. Het is dus deze fronting company die de directe contacten legt met de verzekerden (exploitanten), die de premies int, de verzekeringspolis uitschrijft en eventuele vorderingen afhandelt. De benaming "syndicaat" wordt gebruikt voor deze laatste manier van verzekeren ${ }^{60}$; een syndicaat kan immers zelf geen verzekeringspolissen uitschrijwen bij gebrek aan rechtspersoonlijkheid. Syndicaten worden ook beschouwd als herverzekeringspools omdat hun functie er in essentie op is gericht de fronting company voor $100 \%$ te herverzekeren. Het is bijgevolg voomamelijk de fronting company die de pool beheert en de administratieve functies voor haar rekening neemt ${ }^{61}$.

55 Belser, W.E., "Über die Zweckmäßigkeit der Poolung von Atomrisiken", o.c., 573.

Devrient, J.N., "La responsabilité civile et l'assurance à raison du risque nucléaire", l.c., 73.

Warren, G., "Pooling operations: how nuclear insurance works", o.c., 30.

"Liability and Compensation for Nuclear Damage", l.c., 32.

Dow, J.C., "Nuclear Energy and Insurance", I.c., 210.

Dow, J.C., "Nuclear Energy and Insurance", l.c., 210.

Volgens Dow kan een syndicaat niet op efficiènte wijze worden beheerd. Daarenboven dient de fronting company steeds toe te zien op haar eigen zakenbelangen waardoor zij kwetsbaar wordt voor in- 
Afhankelijk van de wijze van contracteren is dus een duidelijk verschil merkbaar in de contractuele relatie tussen de pools enerzijds en de exploitanten anderzijds ${ }^{62}$. Een pool staat in direct contact met de exploitanten; de polis wordt door de pool uitgeschreven in naam van haar leden die optreden als medeverzekeraar. Een syndicaat daarentegen treedt in de regel enkel op als herverzekeraar van haar fronting company.

\subsection{Werking van de pools}

De pools schrijven polissen uit op collectieve basis, waardoor elke verzekeraar die een deel van het nucleaire risico op zich neemt, slechts aansprakelijk is voor het deel waartoe hij zich verbonden heeft. Jaarlijks verklaart elk lid van de pool voor welk bedrag het bereid is dekking te verlenen en voor welke risico's (eigenschade, aansprakelijkheid tegenover derden en herverzekering van buitenlandse pools $)^{63}$. Het vermogen van de pool wordt gevormd door de som van de bijdragen van de verschillende leden ${ }^{64}$. Ten overstaan van de verzekerden fungeren de leden van de pool als medeverzekeraar. Een nucleaire verzekeringspool is dan ook in de regel een medeverzekeringspoo $l^{65}$. Elk lid is slechts gehouden tot de vooraf overeengekomen bedragen; tussen de verschillende leden is geen sprake van hoofdelijke aansprakelijkheid ${ }^{66}$. Op het moment waarop uitkering dient te geschieden, zal elk lid van de pool dienen bij te dragen a rato van zijn participatie zoals contractueel met de pool werd overeengekomen. Teneinde zijn verplichtingen na te komen, zal elk lid daartoe de nodige reserves opbouwen ${ }^{67}$. Indien één lid zijn verplichtingen niet kan nakomen, wordt diens deel omgeslagen op de andere leden van de pool.

Er dient op te worden gewezen dat in vele landen een exploitant niet rechtstreeks met een nucleaire pool in contact treedt, maar dat dit veelal gebeurt door middel van een verzekeringsmakelaar; deze laatste zal contact opnemen met een van de leden van de pool, bijvoorbeeld de fronting company, teneinde te onderhandelen over voorwaarden en premies ${ }^{68}$.

Eén van de voornaamste elementen in de werking van een nucleaire verzekeringspools is dat de verzekering geschiedt op net-line retention basis ${ }^{69}$. Dit houdt in dat het de individuele leden van een pool niét is tocgelaten om zelf in te staan voor de herverzekering van het door hen onderschreven deel van het risico. Door te participeren in een nucleaire verzekeringspool ontzegt een

vloeden uitgaande van haar cliënten en verzekeringsmakelaars, terwijl dergelijke invloeden nagenoeg onmogelijk zijn bij een onafhankelijke en zelfstandige pool (Dow, J.C., "Nuclear Energy and Insurance", l.c., 210).

Nuclear Power. Insurance and the Pooling System, Special Edition of the Nuclear Pools' Bulletin, $1992,7$.

"Liability and Compensation", l.c., 33

O'Connell, J.M., "Current Operating Practices of Nuclear Insurance Pools", in "Nuclear Accidents Liabilities and Guarantees", I.c, 349.

Camier, M.-C., "Responsabilité et Assurance du Risque Atomique", l.c., 188.

Devrient, J.N., "La responsabilité civile et l'assurance à raison du risque nucléaire", l.c., 73.

Op aanbeveling van het Europese Comité der Verzekeraars dienden voor het nucleaire risico, naast de reserves zoals gebruikelijk voor eender welk ander risico, ook speciale veiligheidsreserves te worden opgebouwd ingeval de werkelijke kosten van een kemongeval groter zouden blijken dan de aangelegde provisies ("Détermination des reserves techniques en matière d'assurance des risques atomiques", Comité Européen des Assurances, Insurance for Nuclear Installations, LAEA, Legal Series $\mathrm{N}^{\circ} 6$, Wenen, $1970,113-114)$. Deprimoz, J., "Régime Juridique des Assurances contre les Risques Nucléaires", Editions du JurisClasseur, Fasc. 55, 1995, 20.

Dow, J.C., "Nuclear Energy and Insurance", l.c., 249; Warten, G., "Pooling operations: how nuclear insurance works", o.c., 30. 
verzekeraar zich bijgevolg het recht op herverzekering van het risico; dit betekent dat elke verzekeringsmaatschappij die deelneemt aan een van de pools precies weet tot welk maximum hij zal zijn gehouden, met name tot de omvang van zijn participatie in de pool $^{70}$.

Daarnaast gebeurt de herverzekering van het nucleaire risico tussen de pools onderling; dit wordt common account reinsurance genoemd ${ }^{71}$. Volgens de verzekeraars levert deze werkwijze een dubbel voordeel op. Doordat elk lid van de pool precies weet tot welk bedrag hij gehouden is, zal hij bereid zijn een groter deel van het nucleaire risico te verzekeren dan bij conventionele industriële risico's. Daarenboven geschiedt herverzekering in de regel op directe wijze tussen de verschillende nationale pools, zonder tussenpersonen, waardoor de kosten tot een minimum kunnen worden beperkt. Tussen de pools wordt geen commissie gevraagd voor de herverzekering; er wordt enkel een deel van de kosten aangerekend, gemiddeld $7,5 \%$ tegenover een commissic van gemiddeld $30 \%$ op de conventionele herverzekeringsmarkt ${ }^{72}$. Er wordt van uitgegaan dat de herverzekering bij buitenlandse pools, de verzekeringscapaciteit ten goede komt ${ }^{73}$. De risico's die bijvoorbeeld door Amerikaanse nucleaire pools worden onderschreven, werden in het begin van de jaren negentig voor $72 \%$ herverzekerd ${ }^{74}$. Het gevolg hiervan is dat een nationale pool in eigen land slechts een gering deel van het nucleaire risico van de "eigen" installaties draagt ${ }^{75}$.

Het spreekt evenwel voor zich dat het aanvaarden van een deel in herverzekering geen verplichting is voor een van die andere pools. Elke pool blijft volkomen vrij al dan niet in te gaan op een van een andere pool uitgaande vraag tot herverzekering. Deze vaststelling werd door de pools zelf van belang geacht in de discussie rond de strijdigheid van de pools met de Europese concurrentieregels $^{76}$.

De wijze waarop de pools op elkaar een beroep doen voor herverzekering, geschiedt grotendeels op basis van een standaarddocument: Standard Rules for the Transaction of Facultative Reinsurance between Nuclear Pools. Dit document bevat een aantal praktische richtlijnen, bijvoorbeeld met betrekking tot de betaling van de premies en verliezen, verdeling van kosten etc., al beschikt een pool over de mogelijkheid om hiervan af te wijken ${ }^{77}$.

De samenwerking tussen de pools wordt ook vergemakkelijkt doordat elke pool in een standaarddocument ("Basis of Operations") informatie over de wijze van werken, de polisvoorwaarden, de leden etc. aan de andere verspreidt ${ }^{78}$. Ook in relatie tot de landen van het voormalige Oostblok wordt de dekking verleend op basis van een aantal standaarddocumenten ${ }^{79}$.

"Liability and Compensation for Nuclear Damage", l.c., 33.

"Nuclear Power. Insurance and the Pooling System", l.c., 1992; Reitsma, S.M.S., "Nuclear Insurance Pools: History and Development", o.c., 345.

De Mori, B., "Rapport sur l'état actuel de l'assurance nucléaire dans la Communauté", o.c, 16

"Liability and Compensation for Nuclear Damage", l.c., 34.

O'Connell, J.M., "Current Operating Practices of Nuclear Insurance Pools", in "Nuclear Accidents. Liabilities and Guarantees", l.c, 350.

De Mori, B., "Rapport sur l'état actuel de l'assurance nucléaire dans la Cornmunauté", o.c., 17.

O'Connell, J.M., "Current Operating Practices of Nuclear Insurance Pools", in "Nuclear Accidents. Liabilities and Guarantees", l.c, 354.

De pool vormt het forum bij uitstek waar gegevens worden uitgewisseld inzake technische en veiligheidsmaatregelen en ongevallenstatistieken.

"Nuclear Power. Insurance and the Pooling System", l.c., 1997; Warren, G., "Insurance for the Nuclear Industry", in Horbach, N.L.J.T. (ed.), "Contemporary Developments in Nuclear Energy Law", l.c, 347. 
Een bijkomend opvallend element in de werking van de nucleaire verzekeringspools, is dat een lid van de pool dat rechtstreeks of onrechtstreeks (via een verzekeringsmakelaar) een vraag tot dekking van een nucleair risico ontvangt, verplicht is om deze vraag aan de pool voor te leggen ${ }^{80}$. Het komt vervolgens toe aan de pool om te beslissen of hij het risico al dan niet zal dekken; enkel wanneer hij beslist geen dekking te verlenen, zal het lid van de pool zelf een voorstel kunnen formuleren.

De pool creëert de mogelijkheid voor verzekeringsmaatschappijen om deel te nemen aan een markt waar zij anders door gebrek aan financiële capaciteit, aan technische kennis en expertise, niet aan zouden kunnen deelnemen. Het feit dat ook kleine(re) verzekeringsmaatschappijen een deel van het nucleaire risico kunnen verzekeren wordt over het algemeen gezien als één van de grote voordelen van dergelijke pools ${ }^{81}$. Ook kleine verzekeringsmaatschappijen kunnen bijgevolg een deel van het nucleaire risico verzekeren, zonder hun eigen capaciteit in gevaar te brengen. Door middel van deze pools kan inderdaad elke verzekeringsmaatschappij die dat wenst een contract afsluiten met de pool waarin wordt afgesproken welk deel van de dekking die maatschappij voor haar rekening neemt. Het nucleaire risico wordt op deze wijze gespreid tussen de verschillende bijdragende leden (dit wil zeggen die leden van de pool die elk een deel van het risico onderschrijven) en herverzekeraars die een deel van het risico van de pool overnemen.

Ook in landen die geen eigen kerninstallaties hebben, bestaan nucleaire verzekeringspools, zoals Denemarken en Portugal. Het doel van deze pools bestaat erin om de andere pools herverzekeringscapaciteit aan te bieden. Bijgevolg kan worden gesteld dat elke nucleaire pool optreedt als herverzekeraar, maar dat niet alle pools optreden als verzekeraar ${ }^{82}$.

\subsection{Kenmerken van de nucleaire verzekeringspools}

Hoewel de werking en de organisatie van de verschillende pools onderling sterk kunnen verschillen, vertonen de pools een aantal gemeenschappelijke kenmerken ${ }^{83}$.

Een eerste kenmerk is dat de nucleaire verzekeringspools nationaal zijn georganiseerd. Dit betekent dat in principe enkel nationale verzekeringsmaatschappijen lid kunnen worden van de pool en dat de exploitant van een keminstallatie enkel dekking kan verkrijgen bij de nucleaire verzekeringspool van zijn land. Bij de start van de kemenergie-industrie werd geoordeeld dat de omvang van het nucleaire risico een dergelijke monopolisering van de beschikbare middelen rechtvaardigde ${ }^{84}$.

Elke pool verschaft bijgevolg dekking voor een welbepaalde nationale markt: zo verschaft SYBAN (Syndicat Belge des Assurances Nucléaires) dekking voor het nucleaire risico op de Belgische nucleaire verzekeringsmarkt; de "Nederlandse Pool voor Verzekering van Atoomrisico's" doet hetzelfde op de Nederlandse markt ${ }^{85}$. Wat betreft zijn verplichte verzekeringsdekking, kan een Belgische exploitant zich enkel wenden tot de Belgische pool, kan de Nederlandse exploitant

Camier, M.-C., "Responsabilité et Assurance du Risque Atonique" "l.c., 189.

Dow, J.C., "The organisation and development of intemational liability capacity and national market pools, with special reference to new nuclear countries", in "Nuclear third party liability and insurance", l.c., 173.

O'Connell, J.M., "Current Operating Practices of Nuclear Insurance Pools", in "Nuclear Accidents. Liabilities and Guarantees", l.c, 355.

Belser, W.E., "Über die Zweckmäßigkeit der Poolung von Atomrisiken", o.c., 573-575.

Faure, M. en Van den Bergh, R., "Objectieve aansprakelijkheid", l.c., 320.

Domsdorf, E.P.M.W., "Internationaal Atoomenergierecht", l.c., 717. 
zich enkel richten tot de Nederlandse pool, enz. Het nationale karakter van deze pools leidt dus tot een uitschakeling van de concurrentie tussen nucleaire verzekeraars. De totale capaciteit van een pool kan nochtans aanzienlijk verschillen van land tot land ${ }^{86}$. Socio-economische factoren evenals verschillen in technical risk assessment zouden hieraan ten grondslag liggen ${ }^{87}$.

Tegenover deze nationale werking van de pools, staat een nauwe internationale samenwerking, met name op het vlak van de herverzekering, wat kan worden beschouwd als een tweede belangrijk kenmerk van de nucleaire verzekeringspools. Aangenomen wordt dat in dit marktsegment de samenwerking tussen verschillende verzekeringsmaatschappijen groter is dan voor klassieke verzekeringsdekkingen ${ }^{88}$. Volgens de verzekeringsindustrie heeft het systeem van de in de jaren vijftig opgerichte pools duidelijk zijn nut bewezen. Deze samenwerking neemt verschillende vormen aan: jaarlijkse vergadering van de poolmanagers, driejaarlijkse vergadering van de voorzitters van de pools, bijeenkomsten van ad-hocwerkgroepen die voor een specifieke reden werden of worden opgericht en regelmatige bilaterale contacten tussen twee pools ${ }^{89}$.

Tenslotte blijken ook de bilaterale verhoudingen en het bilaterale vertrouwen een bijzondere plaats in te nemen in de werking van de nucleaire verzekeringspool ${ }^{90}$.

Dankzij de pools geniet de kernenergie-industrie een ruimere verzekeringsdekking dan eender welke andere industrietak en dit tegen premies die aantrekkelijker zijn dan in andere verzekeringstakken. Gesteld wordt dat de door de exploitanten betaalde premies nagenoeg zuivere premies zijn omdat slechts een klein deel van de premie wordt gebruikt ter dekking van operationele en administratieve kosten ${ }^{91}$. Naarmate de nucleaire verzekeringsmarkt groeide, waren de pools eveneens in staat de door hen gevraagde premies geleidelijk te verminderen. Naarmate meer reactoren operationeel waren, konden de risico's beter worden gespreid en konden de premies geleidelijk dalen. Vandaar werd geoordeeld dat een groter aantal te verzekeren kerninstallaties het algemene belang zou dienen ${ }^{42}$. De premievermindering was evenwel niet alleen het gevolg van het toegenomen aantal kerninstallaties; met name de nucleaire exploitanten hebben de monopoliepositie van de nucleaire verzekeringspools meer en meer in vraag gesteld ${ }^{93}$.

\subsection{Verleende dekking}

Zoals hierboven werd uiteengezet, is de nuclcaire verzekeringsmarkt volledig anders georganiseerd dan de conventionele verzekeringsmarkt; toch tracht de nucleaire verzekeringsindustrie eenzelfue dekking te bieden als de conventionele verzekeringsmarkt ${ }^{94}$. De exploitant van ecn kerninstallatie kan via de nucleaire verzekeringspool in de regel een dekking kopen voor machi-

Cfr. supra, bij de bespreking van de beperking van de aansprakelijkheid van de exploitant, $\$ 3.1 .5$ van hoofdstuk 4: vergelijking tussen enkele bedragen.

"Nuclear Power. Insurance and the Pooling System", l.c., 5.

Zo houden de pools om de twee à drie jaar bijeenkomsten waar ervaringen en gegevens worden uitgiwisseld. Ook informeel bestaan er vrij verregaande kontakten tussen de verschillende nationale pools. O'Connell, J.M., "Current Operating Practices of Nuclear Insurance Pools", in "Nuclear Accidents. Liabilities and Guarantees", l.c, 353.

O'Connell, J.M., "Current Operating Practices of Nuclear Insurance Pools", in "Nuclear Accidents. Liabilities and Guarantees", I.c., 349.

"Nuclear Power. Insurance and the Pooling System", l.c., 3.

De Mori, B., "Rapport sur l'état actuel de l'assurance nucléaire dans la Communauté", o.c., 16.

Dit wordt verder besproken in $\$ 4.4 .1$ van dit hoofdstuk.

Warten, G., "Insurance for the Nuclear Industry", in Horbach, N.L.J.T. (ed.), "Contemporary Deve'opments in Nuclear Energy Law", l.c., 343. 
nebreuk, inkomensderving, transportverzekering, etc. De meeste pools verschaffen dus meerdere dekkingen: de aansprakelijkheid tegenover derden (zowel bij transport als bij de vaste kerninstallatie), eigenschade van de exploitant, de verzekering tegen arbeidsongevallen, etc.

De (verplichte) aansprakelijkheidsverzekering van de exploitant dekt over het algemeen de geldelijke gevolgen van de buitencontractuele aansprakelijkheid van de exploitant van een kerninstallatie voor schade veroorzaakt door een kernongeval, zelfs indien het kemongeval te wijten is aan een uitzonderlijke natuurramp. Deze dekking van de exploitant sluit uiteraard aan bij de vereisten van de internationale en nationale nucleaire aansprakelijkheidswetgeving ${ }^{95}$.

Over het algemeen zal de verleende dekking onder de aansprakelijkheidspolis iets hoger liggen dan het overeenkomstig de nationale wetgeving vereiste bedrag. Dit is ingevoerd ondat de meeste polissen die de dekking verlenen, voorzien in een maximale tussenkomst gedurende de looptijd van een polis, terwijl de Verdragen uitgaan van een aansprakelijkheidslimiet per ongeval. Bijgevolg voorzien de polissen over het algemeen niet in een automatisch herstel van de dekking na een ongeval, maar zal een uitbetaalde vordering leiden tot een vermindering van de beschikbare dekking gedurende de looptijd van de polis (over het algemeen één jaar). Hiermee wordt vermeden dat de maximale tussenkomst van een verzekeraar per jaar en per risico zou worden overschreden $^{96}$. Toch kunnen op dit vlak verschillen bestaan in de polissen van de verschillende pools 97 .

Gewapende conflicten en oorlogen vormen ook in de nucleaire aansprakelijkheidspolis cen klassieke uitsluitingsgrond. Daarentegen wordt in bepaalde landen dekking verleend indien het kernongeval is veroorzaakt door een emstige natuurramp of door opstand of burgeroorlog. Daarentegen is schade door kernproeven en kernwapens steeds uitgesloten ${ }^{98}$. Hiermee sluit deze dekking aan op de bepalingen van het Verdrag van Parijs: dit biedt de mogelijkheid om de exploitant aansprakelijk te stellen voor schade veroorzaakt door een natuurramp ${ }^{99}$. Tegelijk is het Verdrag uitsluitend van toepassing op kerninstallaties voor vreedzaam gebruik ${ }^{100}$.

De aansprakelijkheidspolis moet duidelijk worden onderscheiden van de eigenschadeverzekering van de exploitant. Deze dekking beantwoordt aan de vraag van de exploitanten om hun enorme investering in een kerninstallatie te beschermen ${ }^{|0|}$. Onder de eigenschadeverzekering worden verschillende risico's gedekt: niet alleen de klassieke brandverzekering, verzekering tegen machinebreuk ${ }^{102}$ of verzekering tegen extra-bedrijfskosten, maar ook specifiek "nucleaire schade" wordt verzekerd (bijvoorbeeld het ontsmetten van de site na cen kernongeval) ${ }^{103}$.

Het beschikbare bedrag voor de eigenschadeverzekering van een exploitant is evenwel veel hoger dan diens aansprakelijkheidsverzekering. De redenering van de verzekeraars is dat een nucleair

95

Lagorce, M., "Problèmes pratiques de responsabilité et d'assurance nucléaires vus par un exploitant français", Insurance for Nuclear Installations, LAEA, Legal Series Nº, Wenen, 1970, 103.

"Liability and Compensation for Nuclear Damage", l.c., 36.

Over het algemeen worden drie systemen onderscheiden. Deze werden besproken in $\S 4.1 .5$ van hoofdstuk 4.

"Liability and Compensation for Nuclear Damage", l.c., 37.

Cfr. supra, in \$ 1.1.2 van hoofdstuk 4.

Cfr. supra, in $\$ 1.1 .2 .3$ van hoofdstuk 3 .

"De kernverzekeringen in Belgiê sinds 1957", l.c., 29.

Zie hierover o.m. Lacroix, F., "L'assurance 'bris de machines' dars les installations nueléaires", in Insurance for Nuclear Installations, LAEA, Legal Series $\mathrm{N}^{\circ} 6$, Wenen, 1970, 105-110.

"Liability and Compensation for Nuclear Damage", l.c., 39. 
ongeval eerst schade zal berokkenen aan de installatie zelf en slechts in tweede instantie aan derden $^{104}$. Een aantal exploitanten heeft echter de eigenschade zelf verzekerd via zogenaamde "captives"; dit is een onderlinge verzekering van nucleaire exploitanten, buiten de nucleaire verzekeringspools $^{105}$.

Bij nagenoeg alle pools worden conventionele en nucleaire risico's binnen eenzelfde polis verzekerd omdat in een gegeven schadegeval het onderscheid tussen beide soorten risico's moeilijk kan worden gemaakt. Eenzelfde oorzaak kan immers tot conventionele en nucleaire schade leiden ${ }^{106}$.

Door de steeds strenger wordende veiligheidsvoorschriften is de waarde van de eigen installaties van de exploitant door de jaren heen blijven stijgen. Dit heeft ertoe geleid dat de pools in het algemeen niet zozeer de dekking van de aansprakelijkheid tegenover derden als problematisch beschouwen, maar wel de dekking van de eigenschade van de exploitant ${ }^{107}$. In de wetgeving van de meeste landen wordt aansprakelijkheid tegenover derden ofwel de verzekeringsplicht immers beperkt.

\section{De Belgische Nucleaire verzekeringspool: Syndicat Belge des Assurances Nu- CLEATRES (SYBAN)}

Ter illustratie van de werking van de nucleaire verzekeringspools wordt de Belgische pool als voorbeeld genomen. SYBAN of Syndicat Belge des Assurances Nucléaires is de vereniging van verzekeringsmaatschappijen waarop de Belgische exploitanten een beroep kunnen doen ter dekking van zowel hun eigenschade als de verzekering van hun aansprakelijkheid ${ }^{108}$. In eerste instantie wordt nagegaan hoe en wanneer SYBAN werd opgericht $(\$ 3.1)$. Vervolgens worden de toetredingsmodaliteiten tot SYBAN aan de orde gesteld ( $\$ 3.2)$. Nadien worden de polis aansprakelijkheid $(\$ 3.3)$ en de eigenschadepolis $(\$ 3.4)$ geanalyseerd. Tenslotte wordt de positie van SYBAN op het einde van de jaren negentig besproken $(\$ 3.5)$.

\subsection{De oprichting van $S Y B A N$}

De oprichting van SYBAN is te situeren in de periode waar de eerste kernreactor in België operationeel werd. De eerste kritische reactor in België was de onderzoeksreactor van het Studiecentrum voor Kernenergie (SCK/CEN) te Mol, die op 11 mei 1956 de fase van criticaliteit bereikte. In november van datzelfde jaar vergaderden verschillende verzekeringsmaatschappijen teneinde de mogelijkheden te bestuderen om de risico's van nucleaire aard te dekken. Op die vergadering werd beslist twee comités op te richten met als taak na te gaan welke vorm de te creëren pool diende aan te nemen, de statuten ervan op te stellen, het bepalen van het eigen behoud van de verschillende leden van de pool en het aanknopen van onderhandelingen met buitenlandse pools met het oog op internationale samenwerking. Uiteindelijk werden de statuten van SYBAN goed-

104 Müller, W., "The Role of the Insurance Industry in Covering Nuclear Third Party Liability Risks", Nuclear Third Party Liability and Insurance, München symposium, NEA-IAEA, 1984, 171.

105 De reactic van enkele nucleaire exploitanten op de monopoliepositie van de nucleaire verzekeringspools wordt besproken in $\$ 4.4 .1$ van dit hoofdstuk.

io6 Hertel, G., "Basic principles of Insurance for Nuclear Risks", in "Insurance for Nuclear Installations", l.c., 59.

307 Dow, J.C., "Nuclear Energy and Insurance", I.c., 249; Müler, W., "The Role of the Insurance Industry in Covering Nuclear Third Party Liability Risks", o.c., 171.

108 Zie ook onze eerdere analyse: Vanden Borre, $T$., "Dekking van het nucleaire risico op nationaalrechtelijke basis of via internationale Verdragen: de Verenigde Staten versus Europa", in Faure, M., Deketelaere, K. en Verhoosel, G., (red.), "Grensoverschrijdende milieuproblemen", l.c., 472. 
gekeurd op 23 juli 1957; op die datum sloten 56 verzekeringsmaatschappijen onmiddellijk aan bij SYBAN en gaven 46 andere maatschappijen hun principieel akkoord onder voorbehoud van latere bevestiging ${ }^{109}$. Toen na een jaar bleek dat de statuten een soepele en doeltreffende werking in de weg stonden, werden de statuten aangepast; deze vernieuwde statuten werden van kracht op 1 september 1959. Niettegenstaande enkele kleine wijzigingen, bepalen deze statuten nog steeds de werking van SYBAN.

\subsection{Toetredingsmodaliteiten en werking van $S Y B A N$}

Een verzekeringsmaatschappij die een deel van het nucleaire risico wenst te onderschrijven, sluit een overeenkomst met het syndicaat, waarbij de Statuten worden aanvaard. De toetreding tot SYBAN is voorbehouden aan Belgische verzekerings- of herverzekeringsmaatschappijen en aan de Belgische zetels of agentschappen van buitenlandse verzekeringsondernemingen ${ }^{10}$. Een kandidaat-lid geeft aan voor welke categorieën risico's het wil bijdragen aan de pool en hoe groot deze bijdrage is voor elk van die categorieèn. Het maximum aan eigen behoud van een lid moet een veelvoud zijn van 1 miljoen BEF (24.800 euro) ${ }^{111}$.

De leden worden verplicht SYBAN te raadplegen inzake elke vraag naar verzekering van nucleaire aard ${ }^{112}$. Dit betekent dat wanneer een lid van SYBAN vanuit de markt wordt gevraagd een risico van nucleaire aard te dekken, deze maatschappij verplicht is deze vraag aan SYBAN voor te leggen. Ofwel zal SYBAN in een dergelijk geval beslissen de polis uit te schrijven, ofwel zal SYBAN te kennen geven dat zij zulks niet wenst te doen, in welk geval het desbetreffende lid van SYBAN zich dient te houden aan de door het syndicaat opgelegde voorwaarden en premies. Op dit vlak verliest een lid van SYBAN dus een deel van zijn autonomie op het terrein van de dekking van risico's van nucleaire aard, zelfs indien SYBAN het desbetreffende risico niet wil dekken.

De leden van SYBAN verbinden zich ertoe om wat betreft hun aandeel in de onderschreven risico's zich niet elders te herverzekeren, noch rechtstreeks, noch onrechtstreeks ${ }^{113}$. Deze bepaling sluit aan bij wat reeds hoger werd aangegeven, met name dat de leden van een nucleaire pool zich niet zelf mogen herverzekcren, maar dat de herverzekering in ruime mate gedragen wordt door de andere nucleaire verzekeringspools.

Niettegenstaande de term "syndicaat" treedt SYBAN evenwel zelf op naar de verzekerden toc, tenwijl bij cen syndicaat in de regel een bepaald lid van de pool optreedt als "fronting company". SYBAN houdt dus het midden tussen een echt syndicaat en een zuivere pool naar Amerikaans model. De Duitse pool kan worden beschouwd als een syndicaat in de echte zin van het woord omdat één van de leden van de pool er optreedt als fronting company. Dit neemt niet weg dat een aantal verzekeraars-leden een grote invloed uitoefenen op SYBAN. Drie Belgische verzekeringsmatschappijen leveren de belangrijkste bijdrage aan SYBAN: Royal Belge, AG Fortis en de $\mathrm{KBC}$. In 1997 bedroeg het aantal leden van SYBAN 34 verzekeringsmaatschappijen, hetgeen nominaal een daling is ten aanzien van het aantal leden in 1957. Deze daling is echter het gevolg van verschillende fusies die zich hebben voorgedaan op de Belgische bank- en verzekerings-

"De kernverzekeringen in Belgiê sinds 1957", l.c., 2-3.

Artikel 3 van de statuten van SYBAN.

Artikel 8 van de statuten van SYBAN.

Artikel 5 van de statuten van SYBAN.

Artikel 7 van de statuten van SYBAN. 
markt ${ }^{1 / 4}$ en is dus niet toe te schrijven aan het feit dat bepaalde maatschappijen de pool zouden hebben verlaten ${ }^{115}$.

\subsection{De aansprakelijkheidsverzekeringspolis van de exploitant van een kerninstallatie}

Inzake de civielrechtelijke aansprakelijkheid voor kernongevallen, biedt SYBAN twee polissen aan, met name een polis inzake de aansprakelijkheid van exploitanten van een kerninstallatie en een polis inzake de aansprakelijkheid voor het vervoer van nucleaire stoffen. In het kader van dit onderzoek wordt enkel de eerstgenoemde polis besproken.

De aansprakelijkheidspolis van SYBAN bevat een dekking voor conventionele of niet-nucleaire risico's en voor nucleaire risico's. Dit is een bewuste keuze omdat in de praktijk moeilijk een onderscheid kan worden gemaakt tussen nucleaire en niet-nucleaire of conventionele schade. De leden van SYBAN zijn van oordeel dat door de groepering van beide soorten risico's leemten in de dekking worden vermeden ${ }^{i 16}$. De aansprakelijkheidspolis van SYBAN is dan ook onderverdeeld in drie titels: gemeenschappelijke bepalingen voor de verzekering van nucleaire risico's en niet-nucleaire risico's, bijzondere bepalingen met betrekking tot de verzekering van nucleaire risico's en bijzondere bepalingen met betrekking tot de verzekering van niet-nucleaire risico's. De dekking inzake niet-nucleaire risico's is in grote lijnen gelijklopend met de traditionele polis BAuitbating.

De polis heeft enkel betrekking op kerninstallaties in de zin van het Verdrag van Parijs. Het wekt dan ook weinig verwondering dat deze polis geregeld verwijst naar het Verdrag en naar de Belgische uitvoeringswet van 22 juli 1985 . Het heeft weinig zin deze bepalingen hier te herhalen omdat deze werden bestudeerd in hoofdstuk 4 . Hier worden slechts die aspecten van de polis besproken die van bijzonder belang zijn in het kader van het gevoerde onderzoek.

Met betrekking tot de vraag of zowel dekking wordt verleend voor accidentele als voor graduele schade, bevat de polis geen bijzonderheden. De polis neemt letterlijk de definitie van het begrip "kernongeval" over van het Verdrag van Parijs. Uit deze eerdere analyse van deze bepalingen bleek dat dit begrip zowel accidentele als graduele schade omvatte ${ }^{117}$.

Uitdrukkelijk uitgesloten zijn de schade veroorzaakt door een kernongeval tijdens transport van nucleaire stoffen, schade veroorzaakt door wapens, schade aan de nucleaire installatie zelf en aan gocderen die zich op het terrein van deze installatie verbinden en waarvan het gebruik verband houdt met de installatie zelf en de schade voortvloeiend uit een kemongeval te wijten aan gewapende conflicten, vijandelijkheden, burgeroorlog en oproer.

De premie van SYBAN houdt rekening met de volgende factoren: het vermogen van de reactor, de inplanting daarvan, de veiligheid op het gebied van beheer en beleid en seismologische factoren. In nomale gevallen wordt in de berekening van de premie met de verwachte schade rekening gehouden, maar gezien een beperking van aansprakelijkheid tot 12 miljard BEF geldt, is de omvang van het potentieel verlies gekend. De premie is volledig vooraf betaalbaar.

\footnotetext{
114 Zo zijn de Generale en de ASLK gefuseerd tot de Fortis-groep en zijn de Kredietbank, Cera en ABB gefuseerd tot de KBC Bank en Verzekeringen.

I15 Gesprek met dhr. V. Verbraeken, directeur van SYBAN, 10 december 1997.

116 "De Kernverzekeringen in België sinds 1957", l.c., 22.

117 Cfr. supra, in $\$ 1.1 .1 .3$ van hoofdstuk 3.
} 
De verzekeringswaarborg is enkel van toepassing "op schade voortvloeiend uit kernongevallen die zich voordoen tijdens de waarborgperiode, dit wil zeggen vanaf de aanvangsdatum van de overeenkomst en vóór de datum waarop de opzegging van de overeenkomst van kracht wordt" "18. Bovendien is de waarborg slechts van kracht als de schade het voorwerp uitmaakt van een eis tot schadeloosstelling ingediend binnen een termijn van ten hoogste 10 jaar vanaf de dag van het kemongeval, en van drie jaar vanaf ofwel de datum waarop het slachtoffer kennis heeft gehad van de schade en van de identiteit van de exploitant, ofwel de datum waarop hij redelijkerwijze geacht kan worden hiervan kennis te hebben gehad. Ook deze bepaling sluit aan bij de bepalingen van het Verdrag van Parijs.

Uit de geciteerde bepaling van de aansprakelijkheidspolis van SYBAN valt evenwel niet eenduidig af te leiden of toepassing wordt gemaakt van de act-committed, dan wel van de loss-occurrence dekkingsgrondslag. Het is onduidelijk of uit artikel 17 van de polis moet worden afgeleid dat het kernongeval (als schadeverwekkende gebeurtenis) dan wel de schade zich moet hebben voorgedaan tijdens de waarborgperiode. Aangezien de polis is onderworpen aan de bepalingen van de Belgische wet op de landverzekeringsovereenkomst ${ }^{19}$, kan enkel een loss-occurrence dekkingsgrondslag worden gehanteerd ${ }^{120}$. De regel in deze wet is namelijk dat de schade zich tijdens de waarborgperiode moet hebben voorgedaan; voor bepaalde risico's zoals catastroferisico's kan evenwel de claims-made grondslag worden gehanteerd.

Het lijkt aannemelijk om ervan uit te gaan dat de polis van SYBAN de loss-occurence grondslag hanteert, evenwel met een beperking van het inloop- en van het uitlooprisico. Indien zich tijdens de waarborgperiode een schade zou voordoen ingevolge cen kemongeval van vóór het in werking treden van de polis, dan zal geen dekking worden verleend ${ }^{12 !}$. Ook het narisico wordt beperkt: een slachtoffer beschikt slechts over een beperkte termijn om zijn vordering in te dienen. Op deze wijze wordt in feite een combinatie gemaakt tussen een loss-occurrence en een claims-made dekkingsgrondslag. Toch gaat de beperking in de polis vrij ver: SYBAN verleent enkel dekking indien de vordering werd ingediend binnen een termijn van 10 jaar na het kernongeval, dit ongeacht het feit of de polis intussen al dan niet is verstreken. Deze bepaling vloeit voort uit de beperking van de aansprakelijkheid van het Verdrag van Parijs ${ }^{122}$.

De hoogte van de dekking verleend onder de aansprakelijkheidsverzekeringspolis wordt bepaald door het bedrag dat door of krachtens de wet van 22 juli 1985 werd vastgesteld, zijnde 4 miljard $\mathrm{BEF}$ onder de oorspronkelijke wet en 12 miljard BEF onder de gewijzigde wet.

Volledigheidshalve wordt erop gewezen dat in 2000 SYBAN werk heeft gemaakt van een Claims Handling Procedure ${ }^{123}$. De bedocling is om zo efficiënt mogelijk de kosten naar aanleiding van een schadegeval onder controle te houden. In deze context dient te worden herinnerd aan de wet

Artikel 17 van de aansprakelijkheidsverzckeringspolis.

Artikel 2, b van de aansprakelijkheidspolis van SYBAN verklaart uitdrukkelijk dat de wet op de iandverzekeringsovereenkomst van toepassing is op de polis, in zoverre er in de algemene voorwaarden niet van wordt afgeweken krachtens de wet van 22 juli 1985. Een dergelijke afwijking betreft met name de duur van de verzekeringsovereenkomst. Daarnaast verwijst de polis in verschillende gevallen uitdrukkelijk naar de wet op de landverzekeringsovereenkomst (inzake opzegging, inzake de verplichtingen bij schadegeval en inzake de cumulatie van verzekeringen); inzake de wijziging van het risico worden de wetsbepalingen overgenomen.

Cfr. supra, $\$ 5.3 .1$ van hoofdstuk 5 .

Het spreekt voor zich dat dit een louter theoretische hypothese is, aangezien SYBAN "van in het begin" de aansprakelijkheid van de verschillende Belgische exploitanten heeft gedekt.

Cfr. supra, in $\$ 3$ van hoofdstuk 4.

Gesprek met de heer V. Verbraeken, Directeur van SYBAN, 5 september 2000. 
op de landverzekeringsovereenkomst op basis waarvan de aansprakelijkheidsverzekeraar - en dus ook SYBAN -verplicht is om bovenop het bedrag van de aansprakelijkheid een bedrag te reserveren voor de kosten naar aanleiding van een schadegeval. Overeenkomstig de bepalingen van de wet op de landverzekeringsovereenkomst worden de gerechtskosten en interesten en de reddingskosten tengevolge van een kernongeval gedekt bovenop het bedrag van de aansprakelijkheid van de exploitant ${ }^{124}$.

\subsection{Eigenschadeverzekering van de exploitanten}

De wetgeving inzake civielrechtelijke aansprakelijkheid voor kernongevallen en de hierboven besproken aansprakelijkheidsverzekeringspolis van de exploitant zijn niet van toepassing op schade die werd toegebracht aan de installatie, zelfs indien de exploitant geen eigenaar is van de installatie.

Gelet op de enorme investeringen van de exploitant bij de bouw en het onderhoud van de kerninstallatie, worden zeer hoge bedragen verzekerd in de eigenschadeverzekering van de exploitant. Door de tussenkomst van SYBAN bereikte de verzekerde waarde van Doel 4 en Tihange 3 in I997 60 miljard BEF per eenheid. In datzelfde jaar was deze dekking gekoppeld aan een vijstelling van 600 miljoen BEF; voorheen bedroeg de vrijstelling 50 miljoen BEF per eenheid, maar deze is op uitdrukkelijke vraag van Electrabel opgetrokken tot 600 miljoen BEF. Het verzekerde bedrag werd vrij overeengekomen tussen SYBAN en Electrabel (de exploitant), hetgeen resulteerde in een premiedaling voor Electrabel.

Ter dekking van de eigenschade, schrijft SYBAN drie polissen uit: verzekering tegen stoffelijke schade, verzekering tegen machinebreuk en verzekering van extra-bedrijfskosten. De polis stoffelijke schade kan worden vergeleken met de brandverzekeringspolis op de conventionele markt, en hetzelfde geldt voor de polis ter dekking van machinebreuk.

De door SYBAN uitgeschreven polis inzake stoffelijke schade dekt:

- basisgevaren: accidentele radioactieve besmetting, accidentele bestraling en overdreven temperatuur met een accidenteel karakter;

- bijkomende gevaren: brand, ontploffing, blikseminslag, orkaan, storm, vorst en water - behalve overstroming;

- bijzondere gevaren of gevolgen van bepaalde tussenkomsten of incidenten zoals: inzetten van hulpdiensten, sloping, instorten van gebouwen, rook, corrosiedampen, aanslagen, vandalisme, kwaadwilligheid, arbeidsconflicten;

- ontsmettingskosten om niet-accidentele radioactieve besmetting te verminderen of te verwijderen voor herstelling of vervanging van de beschadigde goederen.

De belangrijkste uitsluitingen van deze polis zijn:

- schade veroorzaakt door wapens of tuigen die bestemd zijn om door structuurwijziging van de atoomkern tot ontploffing te komen;

- schade die ontstaat gedurende proefnemingen of herstellingswerken, die gepaard gaan met uitschakeling van de essentiële regelings- of veiligheidssystemen;

- de graduele radioactieve besmetting voortvloeiend uit de normale werking van de reactor;

- schade die voortvloeit uit een bedrijfsonderbreking ten gevolge van een staking van het personeel. 
Belangrijk is dat de vergoeding van de schadegevallen gebeurt op basis van de nieuwwaarde van de beschadigde goederen en dat de verzekeraars afstand doen van elk recht van verhaal tegen de verzekerden, hun aangestelden, hun deelgenoten, hun onderaannemers, hun leveranciers en dienstverleners, tegen elke natuurlijke en rechtspersoon die zich op verzoek of met de toelating van de exploitant binnen de omheining van de kerninstallatie bevindt.

Wat betreft de polis machinebreuk dient te worden opgemerkt dat de herstelling of vervanging van voonwerpen die door een kernongeval werd beschadigd, in een aantal gevallen een voorafgaandelijke ontsrnetting vereist. Door de radioactieve omgeving dienen bijzondere behandelingstechnieken te worden aangewend, hetgeen aanzienlijke bijkomende kosten met zich meebrengt. Vandaar dekt de machinebreuk-polis naast de vergoeding van de breuk aan de machines zelf, ook de terugbetaling van deze bijkomende kosten, met dien verstande dat op de verzekering tegen machinebreuk in de zone van hoge radioactiviteit een belangrijk eigen risico van toepassing is en dat ook de premie vrij hoog is.

Tenslotte biedt SYBAN ook een polis aan voor de verzekering van extra-bedrijfskosten. Het betreft onrechtstreekse verliezen die de exploitant kan lijden ingevolge een kemongeval: vaste kosten, financiële gevolgen van de bedrijfsonderbreking en winstderving ${ }^{125}$. Deze polis dekt de bijkomende bedrijfskosten van de kerninstallatie, met name de uitgaven die werden gedaan om de gevolgen van elke totale of gedeeltelijke onderbreking van de activiteit te beperken.

\subsection{Positie van SYBAN op het einde van de jaren negentig}

Naar het einde van de jaren negentig is de positie van SYBAN emstig bemoeilijkt, met name omdat de grootste exploitant in België, Electrabel, op zoek ging naar concurrentie op de nucleaire verzekeringsmarkt.

In eerste instantie werd via een verzekeringsmakelaar een buitenlandse verzekeraar bereid gevonden om een verzekeringsdekking inzake aansprakelijkheid te verschaffen ${ }^{126}$. Nadat Electrabel zijn polis met SYBAN had opgezegd, heeft SYBAN zijn tarieven herzien. Doordat de premies met $25 \%$ werden verminderd besliste de exploitant om toch bij SYBAN te blijven. Terwijl Electrabel in het midden van de jaren negentig jaarlijks ongeveer 800 miljoen BEF aan premies betaalde, leidde de concurrentie op de verzekeringsmarkt tot een premiebesparing van 100 miljoen per jaar. Deze cijfers dienen echter te worden gerelativeerd omdat Electrabel de vrijstelling had opgetrokken van 50 miljoen naar 600 miljoen BEF en deze vrijstelling via cen eigen captive verzekerde.

In 1998 ging Eletrabel nog een stap verder en werd voor de eigenschadeverzekering per 1 januari 1999 overgestapt naar NEIL, de Amerikaanse captive van de nucleaire exploitanten. Blijkbaar biedt NEIL cen bredere dekking én wordt de eigenschadeverzekering gedekt onder één enkele polis, wat nict het geval is bij SYBAN. Meteen is de dekking zelf opgetrokken tot 80 miljard BEF per ongcval ${ }^{127}$. Deze overstap had voor SYBAN ernstige financiële gevolgen omdat meteen zijn

\footnotetext{
125 "De kemverzekeringen in Belgiê sinds 1957", l.c., 33.

126 Gesprek op 22 december 1997 met dhr. A. van den Abeele, Directeur van het Departement Verzekeringen en Risicobeheer van Tractebel.

Met dien verstande dat een dekking wordt geboden van 60 miljard BEF per site en per ongeval en dat daar bovenop een dekking wordt verleend van 20 miljard voor de twee sites van Electrabel samen (Gesprek op 5 september 2000 met dhr. A. van den Abeele, Directeur van het Departement Verzekeringen en Risicobeheer van Tractebel).
} 
omzet werd gehalveerd ${ }^{128}$. Inzake eigenschade werd nog enkel dekking verleend aan Belgoprocess en Belgonucleaire.

Electrabel heeft ook in 2000 de concurrentie willen bevorderen door het uitschrijven van een openbare aanbesteding ter zake van de dekking van de aansprakelijkheid tegenover derden ${ }^{129}$. Deze aanbesteding had betrekking op de "nieuwe" aansprakelijkheid van de exploitant overeenkomstig de gewijzigde wet van $1985^{130}$. Uiteindelijk heeft een drietal verzekeraars ingeschreven op deze aanbesteding ${ }^{131}$ en heeft Electrabel de aansprakelijkheidsdekking aan SYBAN toegewezen.

Deze verschillende ontwikkelingen geven aan dat tenminste een aantal nucleaire exploitanten steeds meer op zoek gaat naar concurrentie op de nucleaire verzekeringsmarkt ${ }^{132}$. In de onderstaande paragraaf wordt nader ingegaan op de verenigbaarheid van de (nucleaire) verzekeringspools met het Europese mededingingsrecht.

\section{VERENIGBAARHEID VAN DE (NUCLEAIRE) VERZEKERINGSPOOLS MET HET EUROPESE CON- CURRENTIERECHT}

Uit de vorige hoofdstukken blijkt dat de poolvorming op de nucleaire verzekeringsmarkt de concurrentie op deze markt sterk kan beperken: de nucleaire verzekeringspools zijn immers per land georganiseerd. In Europa bestaat er slechts één nucleaire verzekeringspool per land; een explojtant kan geen dekking verkrijgen bij een andere nucleaire verzekeringspool dan de eigen nationale pool. Dit doet vragen rijzen naar de verenigbaarheid van de nucleaire verzekeringspools met het communautaire mededingingsrecht.

Eerst worden de grote lijnen van het EG-concurrentierecht, en met name de artikelen 8I en 82 van het EG-Verdrag besproken ( $\$ 4.1$ ); nadien wordt het algemene communautaire concurrentierecht toegepast op de verzekeringssector ( $\$ 4.2$ ). Het EG-concurrentiebeleid ter zake van de gemeenschappelijke dekking van bepaalde risico's wordt in $\$ 4.3$ aan de orde gesteld. In de laatste paragraaf tenslotte worden deze regels specifiek toegepast op de nucleaire verzekeringspools $(\$ 4.4)$.

\subsection{Het Europese concurrentierecht}

Eén van de basisdoelstellingen van het Verdrag van Rome is het tot stand brengen van een gemeenschappelijke interne markt waar de concurrentie niet wordt vervalst ${ }^{133}$. Zoals bekend vormen

In 1996 had SYBAN cen jaaromzet van 1 miljard BEF. In 1996 ontving SYBAN een totaal van 785 miljoen BEF aan premies van haar klanten (Belgische exploitanten) en 205 miljoen BEF als herverzekeraar. Voor de bedragen die SYBAN zelf herverzekerde bij de andere pools betaalde het, eveneens in 1996, 600 miljoen aan premies in herverzekering. Het totale bedrag dat onder de leden werd herverdeeld bedroeg 393 miljoen BEF (Verslag van de Algemene ledenvergadering van SYBAN in mei 1997). Nadat Electrabel de eigenschadeverzekering via NElL ging dekken, bedroeg de omzet nog een half miljard BEF (Gesprek op 5 september 2000 met de heer V. Verbraeken, Directeur van SYBAN). De aankondiging van deze aanbesteding werd gepubliceerd in het Publicatieblad van de Europese Gemeenschap (PB, 12 mei 2000, S/91, 060634).

130 Cfr. supra, in \$3.1.2.2 van hoofdstuk 4 .

131 Gesprek op 5 september 2000 met dhr. A. van den Abeele, Directeur van het Departement Verzekeringen en Risicobeheer van Tractebel.

132 In \$ 4.4.1 van dit hoofdstuk wordt teruggekomen op de reactie van enkele exploitanten op de monopoliepositie van de nucleaire verzekeringspools. 
de artikelen 81 en 82 van het EG-Verdrag de basis van het Europese concurrentierecht ${ }^{134}$. Hieronder zal de structuur van artike] 81 worden besproken: zowel het principiële kartelverbod (4.1.1), de sanctie (4.1.2), de vrijstellingsvoorwaarden (4.1.3) als de strekking van artikel 82 (4.1.4) worden aan de orde gesteld.

Voor de toepassing van de artikelen 81 en 82 van het EG-Verdiag, is Veroidening $17^{135}$, die aangeeft over welke bevoegdheden de Commissie ter zake beschikt, van belang. Deze Verordening wordt als dusdanig niet afzonderlijk besproken, maar een aantal inhoudelijke bepalingen wordt incidenteel aan de orde gesteld. Hier wordt niet stilgestaan bij de verhouding tussen de bevoegdheden van de Commissie en de nationale kartelautoriteiten ${ }^{136}$ en evenmin bij de Europese regelgeving inzake concentraties van ondernemingen. De in het kader van dit onderzoek relevante concurrentiebeperkende maatregelen zijn vooral de kartelafspraken tussen verzekeringsondernemingen die leiden tot de creatie van nucleaire verzekeringspools.

\subsubsection{Artikel 81, lid 1: kartelverbod (ex artikel 85)}

Artikel 81, lid I van het EG-Verdrag verbiedt afspraken tussen ondernemingen, besluiten van ondememingsverenigingen, en onderling afgestemde feitelijke gedragingen die de handel tussen lidstaten ongunstig kunnen beïnvloeden en ertoe strekken of ten gevolge hebben dat de mededinging binnen de gemeenschappelijke markt wordt verhinderd, beperkt of vervalst.

Artikel 81 , lid 1 vindt een ruime toepassing doordat zowel het ondernemingsbegrip als het begrip "overeenkomst" ruim worden geïnterpreteerd. Ook dienstverlenende entiteiten en fysieke personen die een vrij beroep uitoefenen vallen onder het begrip onderneming ${ }^{137}{ }^{138}$. Daarnaast vallen zowel bilaterale afspraken, gentlemen's agreements als aanbevelingen van bepaalde verenigingen onder het principiële verbod, zelfs indien niet alle leden van die vereniging de aanbeveling volgen $^{139}$.

Voorwaarde is wel dat het kartel een impact heeft of kan hebben op het intracommunautaire handelsverkeer. Een kartel is enkel verboden indien het de handel tussen lidstaten ongunstig kan beïnvloeden en indien het kartel ertoe strekt of tot gevolg heeft dat de mededinging binnen de gemeenschappelijke markt wordt verhinderd, beperkt of vervalst. Hierbij is het voldoende dat de verwezenlijking van de gemeenschappelijke markt wordt bemoeilijkt of dat de concurrentiestructuur wordt aangetast ${ }^{j 40}$. Het spreekt voor zich dat een dergelijke aantasting in de meeste gevallen voorhanden zal zijn indien het kartelafspraken betreft tussen ondernemingen in verschillende lidstaten. Ook kartelafspraken gemaakt tussen ondernemingen binnen eenzelfde lidstaat

De vroegere artikelen 85 en 86 van het Verdrag.

Raadsverordening van 6 februari 1962, $P B, 21$ februari 1962, 204/62, meermaals gewijzigd.

Zie over de verhouding tussen de Europese Commissie en de Belgische karteloverheder o.m. Stuyck, J., "Europees en nationaal concurrentierecht in de verzekeringssector", in Het Europees Concurrentiebeleid in de Verzekeringssector, Academia-Bruylant, Louvain-la-Neuve, 1994, 89-119.

Marescau, M., Van den Bossche, A.M. en Tison, M., Europees Gemeenschapsrecht. Bronnenboek II. Europees kartelrecht, Story Scientia, Brussel, 1992, 9.

Wel is een voldoende graad van onafhankelijkheid vereist tussen de verschillende ondememingen: zo is artikel 81 niet van toepassing op afspraken tussen moeder- en dochterondememingen indien de dochteronderneming haar beleid niet volledig zelf kan bepalen (H.v.J., 11 april, 1989 "zaak 66/86, Ahmeed Saeed tegen Zentrale, Jur., 1989, 848).

Zaak 39-40/92, Groupement des Cartes Bancaires 'CB' en Eurocheque International tegen de Commissie, 1994.

Zie bijvoorbeeld HvJ, 4 mei 1988, zaak. 30/87, Bodson t. Pompes funèbres, Jur., 1988, 2479. 
kunnen onder het kartelverbod vallen omdat deze afspraken de toegang tot de markt waarin het kartel van kracht is, ernstig kunnen bemocilijkcn ${ }^{141}$. Zelfs kartelafspraken van ondernemingen buiten de Gemeenschap, en zonder dochterondememingen binnen de EG, maar die actief zijn op de EG-markt, worden geviseerd ${ }^{142}$.

\subsubsection{Artikel 81, lid 2: sanctie}

Lid 2 van artikel 81 verklaart dat verboden kartels van rechtswege nietig zijn. Deze nietigheid kan enkel door de nationale rechter worden uitgesproken en dus niet door de Europese Commissie of het Europees Hof.

\subsubsection{Artikel 81, lid 3: ontheffing}

Overecnkomstig artikel 81 lid 3 kan een vrijstelling of ontheffing worden verleend; dit artikel maakt het dus mogelijk dat kartels die onder het principiële verbod van lid 1 vallen, worden vrijgesteld van tocpassing van het verbod. Op basis van Verordening 17 kan een vrijstelling enkel worden verleend door de Europese Commissie ${ }^{1+3}$.

De voomaamste technieken op basis waarvan vrijstelling of ontheffing kan worden verleend zijn de individuele ontheffing en de groepsvrijstelling. Teneinde te kunnen genieten van een individuele ontheffing dient een kartelovereenkomst te worden aangemeld. Een dergelijke aanmelding is niet verplicht maar biedt de partijen twee duidelijke voordclen: enkel aangemelde overeenkomsten komen in aanmerking voor vrijstelling onder de voorwaarden van paragraaf 3 en zodra de overecnkomst is aangemeld kan de Commissie vanaf de dag van de aanmelding geen boete opleggen aan de betrokken partijen. Bedrijven worden dus niet gesanctioneerd voor inbreuken gepleegd tijdens de periode van aanmelding. Dergelijke individuele ontheffingen worden steeds verleend voor een bepaalde duur, die evenwel kan worden verlengd.

In andere gevallen vaardigt de Commissie een Verordening uit waarin een groepsvrijstelling wordt aanvaard. De bedocling van een dergelijke groepsvrijstelling is een efficiëntere toepassing van artikel 81 , lid 3 gelet op het grote aantal aanmeldingen. Dergelijke groepsvrijstellingen bestaan bijvoorbeeld in het kader van de intellectucle eigendom (knowhow-overeenkomsten, licentie-overeenkomsten), in de transportsector en in de verzekeringssector. Deze groepsvrijstellingen bevatten een lijst met contractclausules die weliswaar de concurrentie kunnen beperken, maar die toch worden aanvaard. Indien bepaalde afspraken tussen ondernemingen onder de groepsvrijstelling vallen, dient geen aanmelding te gebeuren. Overeenkomstig artikel 2 van Verordening 17 kan de Commissie vaststellen dat niet is voldaan aan de voorwaarden van artikel 81 , $\S 1$ en dat daarom niet dient te worden opgetreden tegen de desbetreffende afspraken tussen ondernemingen (negatieve verklaring) ${ }^{1 / 4}$.

Essentieel is evenwel dat vrijstelling enkel kan worden verleend indien is voldaan aan vier cumulatieve voorwaarden:

14

Onder meer HvJ, 11 juli 1985, zaak 42/84, Remia t. Commissie, Jur., 1985, 2545; HvJ, 11 juli 1989, zaak 246/86, Belasco t. Commissie, Jur., 1989, 2117.

De gekende Woodpulp-zaak: HvJ, 27 september 1988, zaak 125-129/85, Houtslijp t. Commissie, Jur, $1988,5193$.

Fitzsimmons, A., Insurance Competition Law, Graham \& Trotman, Londen, 1994, 52-53.

Over de procedure omtrent het bekomen van een negatieve verklaring, zie o.m. Fitzsimmons, $A$, "Insurance Competition Law", l.c., 100 e.v. 
- het kartel dient bij te dragen tot de verbetering van de productie of de distributie van de producten of tot verbetering van de technische of economische vooruitgang;

- een billijk deel van de uit het kartel voortvlociende voordelen dient aan de gebruikers ten goede te komen;

- de beperking van de mededinging dient onmisbaar te zijn voor het bereiken van het beoogde doel en

- de mededinging mag niet voor een wezenlijk deel worden uitgeschakeld.

Artikel 8, lid 1 van Verordening 17 bepaalt dat deze vrijstelling wordt verleend voor een bepaalde termijn en koppelt hieraan een aantal voorwaarden en verplichtingen. Indien de voorwaarden van artikel 81, lid 3 van het EG-Verdrag vervuld blijven, kan de beschikking op verzoek worden verlengd. De Europese Commissie beschikt overigens over de bevoegdheid om haar beschikking te wijzigen of in te trekken of zij kan bepaalde handelingen verbieden, bijvoorbeeld indien de feitelijke omstandigheden op een wezenlijk punt zijn gewijzigd, of indien de betrokkenen zich gedragen in strijd met een bij de beschikking opgelegde verplichting ${ }^{145}$. Over het algemeen worden vrijstellingen in de verzekeringssector verleend voor een - vernieuwbare - periode van vijf tot tien jaar $^{146}$.

\subsubsection{Artikel 82: misbruik van machtspositie (ex artikel 86)}

Artikel 82 verbiedt een onderneming om misbruik te maken van haar machtspositic; hierop zijn geen vrijstellingen of uitzonderingen mogelijk. Analoog aan de toepassing van artikel 81, lid 1 wordt als criterium gehanteerd de beperking van het intercommunautaire handelsverkecr. Van een machtspositie is sprake indien een onderneming door haar positie op de markt de concurrentie beperkt en zich jegens haar afnemers en de consument in belangrijke mate onafhankclijk ge$\operatorname{draggt}^{147}$.

Bij de beoordeling of sprake is van misbruik van machtspositie wordt rekening gehouden met het desbetreffende product, met het geografjsch gebied waar de machtspositie ${ }^{148}$ bestaat en met de vraag of de machtspositie van tijdelijke dan wel permanente aard is ${ }^{149}$.

De artikelen 81 en 82 , zoals hierboven kort besproken, vormen de ruggengraat van het Europese mededingingsrecht. In het kader van dit onderzoek dient vervolgens de vraag te worden beantwoord of deze principes ook op de verzekeringssector kunnen worden toegepast.

\subsection{Europees concurrentierecht toegepast op de verzekeringssector ${ }^{150}$}

Van bij het in werking treden van het Verdrag van Rome betwistte de verzekeringssector de toepasselijkheid van de artikelen 81 en 82 van het EG-Verdrag op verzekeringsovereenkom-

Artikel $8,3^{\circ}$ lid van de Kartelverordening.

Fitzsimmons, A., "Insurance Competition Law", l.c., 106

HvJ, 3 oktober 1985, zaak 311/85, CBEM t. CLT en IPB, Jur., 1985, 3261.

Zie bijvoorbeeld HvJ, 21 februari 1973, zaak 6/72, Continental Can t. Commissic, Jur, 215; HvJ, 14 februari 1978, United Brands t. Commissie, zaak 27/76, Jur., 1978, 207.

Merkin, R. en Rodger, A., EC Insurance Law, Longman, London, 1997, 165.

Zie o.m. Bigot, J., "Traité", l.c., 713 e.v.; Fitzsimmons, A., "Insurance Competition Law", l.c., 311; Fitzsimmons, A., "The Application of EC-Anti-Trust Law to the Insurance Industry", in McGee, A. en Heusel, W. (ed.), The Law and Practice of Insurance in the Single European Market, Academy of European Law in Trier, Bundesanzeiger, 1995, Keulen, 25-39. 
$\operatorname{sten}^{151}$. De verzekeringssector argumenteerde dat het communautaire concurrentierecht niet van toepassing was op de sector, gelet op de specifieke kenmerken van de sector, die erin bestaat dat de prestatie van één der contractanten afhangt van een grote onzekerheidsfactor, en dat een onbeperkte mededinging in het verzekeringswezen zou kunnen leiden tot de ondergang van heel wat verzekeringsondernemingen ${ }^{152}$. Bovendien achtte de sector het verbod van artikel 81 niet van toepassing zolang de Raad, overeenkomstig artikel 87, lid 2, geen specifieke uitvoeringsmaatregelen had uitgevaardigd.

In 1984 verklaarde de Europese Commissie in de Nuovo Cegam zaak ${ }^{153}$ dat artikel 81 (85 oud) wel degelijk van toepassing was op de verzekeringssector. Deze visie werd later bevestigd door het Europees Hof in de zaak Verband der Sachversicherer ${ }^{154}$. Het Hof stelde dat wanneer het Verdrag bepaalde activiteiten aan de toepassing van de mededingingsregels heeft willen onttrekken, het ter zake een uitdrukkelijke uitzondering heeft voorzien en dat een dergelijke uitzondering niet voorhanden is voor de verzekeringssector. Uit het arrest kunnen een aantal krachtlijnen worden afgeleid. Ten eerste ontsnapt een afspraak niet aan de toepassing van artikel 85 (oud) omdat nationale kartelautoriteiten deze hebben goedgekeurd. Ten tweede kan ook cen aanbeveling die geen enkel dwingend karakter heeft een verboden afspraak zijn indien het de bedoeling is van de vereniging om het beleid van haar leden op elkaar af te stemmen. Tenslotte kan een aanbeveling van een nationale vereniging van verzekeraars het intercommunautaire handelsverkeer belemmeren in de mate waarin deze aanbeveling zich ook richt to de lokale vestiging (dochterondememing) van een onderneming in een andere lidstaat.

Vandaar was het Hof van oordeel dat het EG-concurrentierecht, inzonderheid de artikelen 81 en 82 en Verordening 17, onbeperkt gelden voor de verzekeringssector ${ }^{155}$. Dit betekent evenwel niet dat gecn rekening mag worden gehouden met de bijzondere kenmerken van bepaalde economische sectoren. Op basis van de bevocgdheid van de Commissie om ex artikel 81 , lid 3 vrijstellingen te verlenen, kon rekening worden gehouden met de bijzondere aard van bepaalde economische sectoren en de aldaar optredende moeilijkheden, aldus het Hof.

Als gevolg van de beslissing van het Europces Hof gingen verzekeraars en hun federaties over tot aanmelding van bestaande afspraken, om op deze wijze een vrijstelling of een negatieve verklaring te verkrijgen ${ }^{156}$. Tegelijk werd vanaf juli 1987 overleg gepleegd tussen de Europese Commissie en het Comité Européen des Assurances (CEA) ${ }^{157}$. Het doel van dit overleg was drievoudig: het toelaten dat de op dat moment bestaande afspraken tussen verzekeringsondernemingen werden aangemeld, het uitloggen van de specifieke technische aspecten van het verzekeringswezen

[5!

I52

153

154

Bigot, J., "Traité", l.c., 715; Merkin, R. en Rodger, A., "EC Insurance Law", l.c., 167.

Dit argument werd ook gehanteerd in de zaak Verband der Sachversicherer, punt 7.

Nuovo Cegam, $P B, \mathrm{~L}$ 99/29, paragraaf 12 .

HvJ, 27 januari 1987, Verband der Sachversicherer tegen Commissie, zaak 45/85, Jur., 1987, 405. Het Verband der Sachversicherer was een vereniging met als taak het behartigen en bevorderen van de beroepsbelangen en het beschermen van de verzekeraars die bedrijvig zijn in de industriële brand- en bedrijfsonderbrekingsverzekering en die in de Bondsrepubliek Duitsland tot het verzekeringsbedrijf zijn tocgelaten.

Verband der Sachversicherer, punt $14 \mathrm{en} 15$.

Van Miert, K., "La politique Européenne de la Concurrence en matière d'Assurances", in Het Europees Concurrentiebeleid in de Verzekeringssector, Academia-Bruylant, Louvain-la-Neuve, 1994, 25-26; Rutsaert, J.M., "European Competition Law in Insurance", in Huybrechts, M.A. (ed.), Marine Insurance at the turn of the Millennium, Volume 1, Intersentia, Antwerpen, Groningen, 1999, 162.

Over de rol van de CEA bij de eenmaking van de verzekeringsmarkt, zie Rutsaert, J.M., "De rol van het 'Comité Européen des Assurances'", in Liber Amicorum Hubert Claassens. Verzekering: theorie en praktijk, Maklu, Academia-Bruylant, Antwerpen, 1998, 393-407. 
aan de Commissie en het opstellen van een groepsvrijstelling van toepassing op verzekeringen ${ }^{158}$. Door de Verordening van 31 mei $1991 \mathrm{kreeg}$ de Commissie de bevoegdheid om een vrijstellingsverordening inzake verzekeringen uit te vaardigen ${ }^{159}$. Volgens artikel 1 van deze Verordening mag de Vrijstellingsverordening betrekking hebben op samenwerking ten aanzien van:

a) gemeenschappelijke risicopremietarieven die op collectief opgestelde statistieken of op het aantal schadegevallen berusten;

b) gemeenschappelijke standaardpolisvoorwaarden;

c) het gemeenschappelijk verzekeren van bepaalde standaardrisico's;

d) de schadeafwikkeling;

e) het onderzoek en de goedkeuring van veiligheidsvoorzieningen;

f) registers van en informatie omtrent verhoogde risico's, op voorwaarde dat het bijhouden van deze registers en de behandeling van deze informatie zodanig gebeurt dat de vertrouwelijkheid wordt beschermd.

De vrijstellingsverordening voor verzekeringen kwam een jaar later tot stand en was deels gebaseerd op een aantal zaken waarover het Hof en vooral de Commissie reeds eerder een uitspraak hadden gedaan. Overeenkomstig Verordening $3932 / 92^{160}$ geniet de verzekeringssector van een groepsvrijstelling voor bepaalde overeenkomsten inzake premieberekening, standaardpolisvoorwaarden voor directe verzekering, gemeenschappelijke verzekering van bepaalde categorieën risico's en overeenkomsten tot de vaststelling, erkenning en bekendmaking van veiligheidsvoorzieningen $^{161} 162$

Afspraken tussen verzekeringsondernemingen die onder het toepassingsgebied van de Verordening vallen, dienen niet te worden aangemeld; vallen de afspraken buiten het toepassingsgebied van de Verordening, dan is een individuele vrijstelling vereist. Daarenboven wordt het voordeel van een automatische vrijstelling overeenkomstig artikel 17 van de Verordening opgeheven indien de vrijgestelde overeenkomst niettemin gevolgen heeft die onverenigbaar zijn met de vrijstellingscriteria ex artikel 81 , lid 3 van het EG-Verdrag.

158 Lohéac, F., "Le point de vue des Assureurs", in Levie, G. en Cousy. H. (ed.) Het Europees Concurren" tiebeleid in de Ferzekeringssector, Academia-Bruylant, Lovain-la-Neuve, 1994, 71 e.v.

159. Verordening (EEG) nr. 1534/91 van de Raad van 31 mei 1991 betreffende de toepassing van artikel 85 , lid 3 van het Verdrag op bepaalde groepen van overeenkomsten, besluiten en onderling afgestemde feitelijke gedragingen in de verzekeringssector, $P B, 7$ juni 1991, L 143/1.

Verordening van 21 december 1992, PB, 1992, L. 398/7 (ter uitvoering van de Raadsverordening $1534 / 91, P B, 1991, \mathrm{~L} \mathrm{143/1)}$; de Verordening is in werking getreden op I april $1993 \mathrm{en}$ blijf van kracht tot 31 maart 2003.

Twee domeinen waar regelmatig afspraken worden gemaakt tussen verzekeringsondernemingen, met name inzake de gemeenschappelijke afhandeling van vorderingen en inzake het verschaffen van informatie over zware risico's, vallen niet onder de Verordening omdat de Commissie van oordeel was dat wegens gebrek aan ervaring op dit vlak, geen algemene principes konden worden vooropgesteld (Chance, C., Insurance Regulation in Europe, Lloyd's List Practical Guides, Lloyd's of London Press, London, 1993, 79).

152 Voor een scherpe kritiek op deze Verordening, zie met name Faure, M. en Van den Bergh, R., "Het toelaten van kartels op de Europese verzekeringsmarkt", Nederlands Juristenblad, 1993, 261-267; Fauге, M., "Regulering en concurrentie op verzekeringsmarkten in Europa", De Vrijbrief, juni/juli 1993, 12-20; Faure, $M$ en Van den Bergh, R., "Restrictions of competition on insurance markets and the applicability of EC antitrust law", Kyklos, vol. 48, 1995, 65-85. 
Het zou te ver gaan om in het kader van dit onderzoek de verschillende elementen van de Vrijstellingsverordening in detail te bestuderen ${ }^{163}$. Vooral relevant zijn de bepalingen inzake de gemeenschappelijke dekking van bepaalde risico's. Deze problematiek wordt hieronder aan de orde gesteld.

\subsection{Gemeenschappelijke dekking van bepaalde risico's}

In het kader van dit ondercoek zijn vooral de bepalingen inzake de gemeenschappelijke verzekering van bepaalde risico's van belang omdat deze bepalingen met name relevant zijn voor verzekeringspools. In eerste instantie worden de desbetreffende bepalingen van de Vrijstellingsvordering inzake verzekeringen besproken ( $\$ 4.3 .1$ ). Nadien wordt de visie van de Commissie belicht aan de hand van de bespreking van de zaak van de P\&I Clubs (\$ 4.3.2). Vervolgens worden enkele algemene elementen van het EG-beleid belicht ( $\$ 4.3 .3$ ); tenslotte wordt aandacht besteed aan het toekomstige EG-beleid inzake de gemeenschappelijke dekking van bepaalde risico's $(\$ 4.3 .4)$.

\subsubsection{Volgens de Vrijstellingsverordening inzake verzekeringen}

Artikel 10 van de Verordening laat verzekeraars en herverzekeraars toe zich te groeperen in medeverzekerings- en medeherverzekeringspools ${ }^{164}$. Onder medeverzekeringsgroepen wordt verstaan groepen gevormd door verzekeringsondernemingen die zich ertoe verplichten namens en voor rekening van alle deelnemers verzekeringen van een bepaalde categorie af te sluiten of die het afsluiten en het beheer van de verzekering van een bepaalde categorie risico's op hun naam en voor hun rekening aan één van hen, aan een gemeenschappelijke makelaar of aan een daartoe opgericht gemeenschappelijk orgaan opdragen. Medeherverzekeringsgroepen zijn groepen die bestaan uit verzekeringsondernemingen, eventueel in samenwerking met een of meer herverzekeringsondememingen teneinde onderling alle of cen deel van hun verplichtingen betreffende een bepaalde categorie risico's te herverzekeren en teneinde, namens en voor rekening van alle deelnemers, de herverzekering van dezelfde categorie risico's te aanvaarden.

Ad hoc-overeenkomsten tussen verzekeraars om bepaalde risico's mede te verzekeren, vallen buiten het toepassingsgebied van de Verordening. $\mathrm{Zij}$ is enkel van toepassing op langere-termijnovereenkomsten ${ }^{165}$.

Overeenkomstig artikel 10 , lid 3 is het de leden van een medeverzekeringspool toegelaten dat ufspraken worden gemaakt inzake de aard en de kenmerken van het gedekte risico, de voorwaarden voor lidmaatschap en ontslag, de individucle aandelen voor eigen rekening van de declnemers in de medeverzekerde of medeherverzekerde risico's en de manier waarop de pool functioneert en wordt beheerd. Naast deze verplichtingen, mogen aan de ondernemingen die deelnemen in een medeverzekeringsgroep geen andere concurrentiebeperkingen worden opgelegd dan ${ }^{165}$ :

a) de verplichting, teneinde voor medeverzekering door de groep in aanmerking to komen,

- met preventieve maatregelen rckening te houden;

Zie hierover met name meerdere bijdragen in Levie, G. en Cousy, H. (red.), Het Eurapees Concurrentiebeleid in de Verzekeringssector, Academia, Bruylant, Louvain-la-Neuve, 1994. In 1999 heeft de Commissie een verslag opgestuurd naar de Raad inzake de toekomst van de Vrijstellingsverordening voor de verzekeringen. Dit verslag wordt besproken in \$ 4.3.2.4 van dit hoofdstuk. Merkin, R. en Rodger, A., "EC Insurance I aw", l.c., 177.

Artikel 12 van de Verordening. 
- algemene of bijzondere, door de groep geaccepteerde voorwaarden toe te passen;

- door de groep vastgestelde commerciële premies toe te passen;

b) de verplichting elke afwikkeling van een schadegeval betreffende een medeverzekerd risico voor goedkeuring aan de groepering voor te leggen;

c) de verplichting om onderhandelingen over herverzekeringsovereenkomsten voor gemeenschappelijke rekening door de groep te laten voeren;

d) het verbod het individuele aandeel in het medeverzekerde risico te herverzekeren.

Artikel 10, lid 4 laat toe dat in het kader van medeherverzekeringspools afspraken worden gemaakt inzake de delen van de gedekte risico's die de deelnemers niet voor herverzekering afstaan, de kosten van de medeherverzekeringen en de kosten van het functioneren van de groep. Hier dient de aandacht te worden gevestigd op het feit dat in herverzekeringspools afspraken mogen worden gemakt inzake premiebepaling die verder gaan dan de pure premie: ook afspraken over de kosten van een dergelijke pool zijn toegelaten. Naast deze verplichtingen mogen aan de ondernemingen die deelnemen in een medeherverzekeringsgroep geen andere concurrentiebeperkingen worden opgelegd dan ${ }^{167}$.

a) de verplichting, teneinde deel te kunnen nemen aan de medeherverzekering,

- met preventieve maatregelen rekening te houden;

- algemene of bijzondere, door de groep geaccepteerde voorwaarden toe te passen;

- een door de groep vastgestelde gemeenschappelijke risicopremie voor directe verzekeringen, gebaseerd op de waarschijnlijke kosten van de dekking van het risico, te hanteren of, bij afwezigheid van voldoende ervaring, een risicopremie te hanteren die door de groep is goedgekeurd;

- deel te nemen in de kosten van medeherverzekering;

b) de verplichting de afwikkeling van schadegevallen betreffende de medeherverzekerde risico's die een bepaald bedrag overtreffen voor goedkeuring voor te leggen aan de groep of haar het onderzoek van deze schadegevallen op te dragen;

c) de verplichting om de onderhandelingen over retrocessie-overeenkomsten voor gemeenschappelijke rekening door de groep te laten voeren;

d) het verbod de individuele retentie te herverzekeren of het individuele aandeel te retrocederen.

Van groot belang is echter artikel 11 van de vrijstellingsverordening, die de verkregen vrijstelling verbindt aan twee voorwaarden: een voorwaarde met betrekking tot het marktaandeel van de pool en een voorwaarde met betrekking tot de mogelijkheid tot uittreden uit de pool. Overeenkomstig artikel 11, a) mogen medeverzekeringsgroepen niet meer dan $10 \%$ van de markt in handen hebben en medeherverzekeringsgroepen niet meer dan $15 \%$ van de markt. De vrijstellingsverordening is dus niet van toepassing indien de pool een aanzienlijk deel van de markt in handen heeft ${ }^{168}$. Bovendien moet elke deelnemende onderneming het recht hebben om de groep te verlaten met een opzegtermijn van maximaal zes maanden.

Voor catastroferisico's en verhoogde risico's ligt de drempel op $10 \%$, respectievelijk $15 \%$ op de verzekeringsproducten die in de groep zijn ondergebracht ${ }^{169}$. Dit betekent dat enkel moet worden

Artikel 13 van de Verordening.

Fitzsimmons, A., "The Application of EC-Anti-Trust Law to the Insurance Industry", in "The Law and Practice of Insurance in the Singele European Market", l.c., 35.

169 Deze laatste afwijking is alleen mogelijk op voorwaarde dat geen van de betrokken ondernemingen deelneemt in een andere groep die risico's op dezelfde markt verzekert; wat groepen betreft die verhoogde risico's verzekeren, mogen de in de groep ingebrachte verzekeringsproducten niet meer dan $15 \%$ vertegenwoordigen van alle identieke of gelijksoortige producten die door de deelnemende on- 
rekening gehouden met de activiteiten van de pool zelf ${ }^{170}$. De Verordening maakt inderdaad een onderscheid tussen "catastroferisico's" enerzijds en "verhoogde risico's" anderzijds. Catastroferisico's worden beschouwd als risico's waarbij de schade uiterst zelden voorkomt en van grote omvang is; verhoogde risico's zijn risico's waarbij, vanwege het karakter van het verzekerde risico's, de waarschijnlijkheid van schadegevallen hoger is ${ }^{171}$.

De: Vrijsteilingsverordening gaat er dus van uit dat elke geïnstitutionaliseerde samenwerking tussen verzekeraars de concurrentie beperkt en dat het voordeel van de groepsvrijstelling enkel wordt verleend indien het marktaandeel van de deelnemers of van de groep onder de genoemde drempels blijft.

De drempels in de Verordening liggen relatief laag waardoor mag worden aangenomen dat veruit de meeste medeverzekerings- en herverzekeringspools niét van de vrijstelling kunnen genieten ${ }^{172}$. Daarnaast worden in de Verordening nauwelijks aanwijzingen gegeven met betrekking tot het bepalen van de relevante markt, in die zin dat zowel het begrip verzekeringsproduct als de geografische markt moeilijk vast te stellen zijn ${ }^{173}$. Toch heeft de Commissie in een mededeling aangegeven dat de productmarkt de producten omvat waarvan een concurrentiebeperking op het betrokken product uitgaat ${ }^{174}$. De drie belangrijkste beperkingen zijn volgens de Commissie: de substitueerbaarheid aan de vraagzijde, de substitueerbaarheid aan de aanbodzijde en de potentiële concurrentie. Vooral de substitueerbaarheid aan de aanbodzijde speelt in de ogen van de Commissie een bijzonder grote rol bij de definitie van de markten in het verzekeringswezen ${ }^{175}$.

Poolingovereenkomsten die de drempels van de vrijstellingsverordening overschrijden dienen te worden aangemeld en kunnen desgevallend een individuele vrijstelling genieten (artikel $81, \S 3$ EG-Verdrag juncto Verordening 17). Een dergelijke individuele vrijstelling kan enkel worden verkregen indien daar een specifieke reden voor bestaat. Vanuit de verzekeringswereld wordt geoordeeld dat de nood aan individuele vrijstellingen de rechtszekerheid in gevaar brengt en zelfs strijdig is met het doel van de vrijstellingsverordening ${ }^{176}$.

In ieder geval kan de Commissie bepalen dat de verordening niet meer van toepassing is op een vrijgestelde overeenkomst indien de kartelafspraak gevolgen geeft die onverenigbaar zijn met de voorwaarden van artikel 81 , lid 3 , en met name indien de deelnemende leden geen aanzienlijke moeilijkheden ondervinden om zich zonder de groep te organiseren, indien één van de leden een overheersende invloed uitoefent op het commerciële beleid van meer dan één groepering op dezelfde markt, indien de poolingovereenkomst dreigt te leiden tot een verdeling van de markt, of

dernemingen zelf of voor hun rekening worden aangeboden op dezelfde markt (Artikel 11, $2^{\circ}$ lid, 2 van de Verordening).

Van Miert, K., "La politique Européenne de la Concurrence en matière d'Assurances", in "Het Europees Concurrentiebeleid in de Verzekeringssector", l.c., 27.

Artikel $11,2^{\circ}$ lid, 1 van de Verordening.

Deze drempels worden door de verzekeringssector bekritiseerd omdat deze zo laag zijn gelegd dat nagenoeg alle pools deze drempels overschrijden (Von Fürstenwerth, F., "European Competition rules in the Insurance Sector", in Het Europees Concurrentiebeleid in de Verzekeringssector, AcademiaBruylant, Louvain-la-Neuve, 1994, 69). Chance, C., "Insurance Regulation in Europe", l.c., 81; Fitzsimmons, A., "Insurance Competition Law", l.c., 89-90. Mededeling van de Commissie over het begrip relevante markt in het kader van het communautaire mededingingsrecht, $P B, C 372,9$ december 1997. Rapport over de Vrijstellingsverordening inzake verzekeringen", l.c., 13.

176 Von Fürstenwerth, F., "European Competition rules in the Insurance Sector", in "Het Europees Concurrentiebeleid in de Verzekeringssector", l.c., 68 e.v. 
indien - wat de verhoogde risico's betreft - door de gezamenlijke sterkte van de leden het voor de verzekeringsnemer moeilijk wordt om elders een verzekeringsdekking te verkrijgen ${ }^{i 77}$.

Na de bespreking van de bepalingen van de Vrijstellingsverordering op verzekeringspools, wordt hieronder een concrete zaak besproken, met name de verzekeringspool van de verschillende P\&I Clubs.

\subsubsection{Visie van de Commissie ten aanzien van verzekeringspools: de zaak van de P\&I Clubs}

De discussie omtrent de "Protection and Indemnity Clubs" (P\&I Clubs) heeft te maken met de verzekeringen die worden afgesloten in de zeetransportsector ${ }^{178}$. Deze Clubs bieden een breed gamma van dekking aan aan hun leden: het element protection verwijst naar de risico's van het schip zelf, terwijl de indemnity betrekking heeft op de exploitatierisico's van het schip ${ }^{179}$. Wat betreft de eigenschadeverzekering doen scheepseigenaren hoofdzakelijk een beroep op commerciële verzekeraars ${ }^{180}$. Inzake de aansprakelijkheidsverzekering wordt een beroep gedaan op de Protection and Indemnity Clubs. Een P\&I Club is een onderlinge verzekering zonder winstoogmerk die een aansprakelijkheidsverzekering aanbiedt aan zijn leden, de scheepseigenaren. Via de P\&I Club wordt zowel persoonsschade als zaakschade gedekt als schade aan schepen ingevolge aanvaringen, schade aan haveninstallaties, schade aan de vracht, schade door vervuiling etc ${ }^{181}$. Al deze elementen worden vaak in één enkele polis aangeboden.

Teneinde het hoofd te kunnen bieden aan zware aansprakelijkheidsvorderingen, hebben verschillende P\&I Clubs een herverzekeringspool opgericht, de International Group of P\&I Clubs ${ }^{182}$. Deze pool treedt op als herverzekeraar van haar leden; de pool zelf doet voor herverzekering een beroep op de wereldmarkt. De discussie voor de Europese Commissie had betrekking op twee overeenkomsten die in het kader van de internationale groep van P\&I Clubs waren afgesloten, namelijk enerzijds de International Group Pooling Agreement en anderzijds de International Group Agreement ${ }^{183}$. Het waren dus niet de P\&I Clubs zelf die ter discussie stonden, maar wel de in het kader van de Internationale Groep van P\&I Clubs afgesloten overeenkomsten. In het kader van deze bijdrage wordt enkel stilgestaan bij de afspraken gemaakt in het kader van de poolingovereenkomst.

In de loop der jaren heeft de Europese Commissie twee formele beschikkingen getroffen waarbij een vrijstelling werd verleend aan deze overeenkomsten: de eerste beschikking die dateerde van

Artikel 17 van de Vrijstellingsverordening; Merkin, R. en Rodger, A., "EC Insurance Law", 1.c., 178. De wetgeving inzake de aansprakelijkheid voor schade door olieverontreiniging op zee, wordt in hoofdstuk 12 aan de orde gesteld.

Dieryck, C., Van Havre, P., "Les assurances P\&I(Protection and Indemnity Clubs)", in L'Assurance Mutuelle en Belgique, Collection Droit des Assurances, Academia, Bruylant, Bruxelles, 1999, 382.

Zie hierover onder meer de bijdragen van Huybrechts, M., Dieryck, C., Themas, R. en ter Meer, J., in Huybrechts, M.A. (ed.), Marine Insurance at the turn of the Millennium, Volume 1. Intersentia. Antwerpen, Groningen, 1999, 432.

Voor een overzicht van de verschillende elementen die in een dergelijke polis kunnen worden gedekt, zie Dieryck, C., Van Havte, P., "Les assurances P\&l (Protection and Indemnity Clubs)", in "L'Assurance Mutuelle en Belgique", l.c., 382. Zie ook verderop, in $\S 5$ van hoofdstuk 12.

Hazelwood, S.J., Pd I Clubs. Law and Practice, Lloyd's of London Press, $2^{\circ}$ druk, London, 1994,359 e.v.; Dieryck, C., Van Havre, P., "Les assurances P\&l (Protection and Indernity Clubs)", in "L'Assurance Mutuelle en Belgique", l.c., 392-393.

Hierna genoemd respectievelijk de poolingovereenkomst en de IGA. 
$1985^{184} 185$ liep tot 1995. Een tweede beschikking volgde in $1999^{186}$. Beide beschikkingen zijn tot stand gekomen na moeizaam overleg tussen de Clubs en de Commissie ${ }^{187}$.

Vier elementen van de poolingovereenkomst werden door de Commissie onderzocht: de overeenkomst tot het omslaan van schadevorderingen, het gemeenschappelijke minimum dekkingsniveau, de goedkeuring van de clubvoorwaarden en de regels inzake herverzekering ${ }^{188}$.

De overeenkomst tot het omslaan van schadevorderingen voorziet in verschillende schijven:

- tot 4,57 miljoen euro valt een vordering ten laste van de club wiens lid de schade heeft veroorzaakt ("franchiseschijf");

- tussen 4,57 en 27,42 miljoen euro wordt een vordering omgeslagen over de verschillende clubs;

- tussen 27,42 miljoen euro en 1,8 miljard euro wordt een vordering gedekt door het algemene herverzekeringscontract van de gтоep ("General Excess Loss Reinsurance Contract");

- tussen 1,8 miljard euro tot ongeveer 3,9 miljard euro wordt de vordering opnieuw omgeslagen over de verschillende clubs ("Overspill")

Volgens de Commissie is het eigen aan elke overeenkomst inzake het omslaan van schadevorderingen dat de leden op zijn minst gezamenlijk de polisvoonwaarden en het geboden dekkingsniveau vaststellen. Een dergelijke overeenkomst is niet strijdig met het concurrentierecht indien het omslaan van de vorderingen noodzakelijk is om de leden in staat te stellen een soort verzekering aan te bieden die zij alleen niet zouden kunnen aanbieden ${ }^{189}$. Daarenboven is de Commissie van oordeel dat het omslaan van de schadevorderingen de enige beschikbare mogelijkheid is om een dekking tot ongeveer 3,9 miljard euro aan te bieden. Uit onderzoek van de Commissie was namelijk gebleken dat geen enkele entiteit of groep in staat was om een dergelijk bedrag aan te bieden ${ }^{190}$.

De inherente beperkingen van de regeling inzake het omslaan van de schadevorderingen moeten bijgevolg, volgens de Commissie, als verenigbaar worden beschouwd met artikel 81 , lid 1 van het EG-Verdrag ${ }^{19}$. Deze aan de poolingovereenkomst verbonden inherente beperkingen zijn het minimum dekkingsniveau, de gezamenlijke goedkeuring van voorwaarden en boekhoudkundige praktijken en de gezamenlijke herverzekering.

Beschikking van de Commissie van 16 december 1985 inzake een procedure op grond van de artikelen 85 en 86 van het EG-Verdrag en de artikelen 53 en 54 van de EER-Overeenkomst, $P B$ L 376/2 van 3 ! december 1985. Zie hierover Merkin, R. en Rodger, A., "EC Insurance Law", l.c., 171-172. Voor een kritische analyse van de beschikking van 1985 inzake de P\&l Clubs, zie Faure, M. en Van den Bergh, R., "Objectieve Aansprakelijkheid", l.c., 331-336. Beschikking van de Commissie van 12 april 1999 inzake een procedure op grond van de artikelen 85 en 86 van het EG-Verdrag en de artikelen 53 en 54 van de EER-Overeenkomst, $P B$, L $125 / 12$ van 19 mei 1999.

Gyselen, L., "P\&I Insurance: the European Commission's Decision concerning the Agreement of the International Group of P\&I Clubs", in Huybrechts, M.A. (ed.), Marine Insurance at the turn of the Millennium, Volume 1, Intersentia, Antwerpen, Groningen, 1999, 181. Voor meer details, zie Gyselen, L., "P\&I Insurance: the European Commission's Decision conceming the Agreement of the Intermational Group of P\&I Clubs", in "Marine Insurance at the turn of the Millennium", l.c., 188 e.v. Overwegingen 65 en 66 van de Beschikking van de Commissie dd. 12 april 1999. Er zou meer dan $50 \%$ van de mondiale tonnage zijn vereist om een bedrag te kunnen dekken van meer dan 2,75 miljard euro. Overweging 72 van de Beschikking van de Commissie dd. 12 april 1999. Overweging 74 van de Beschikking van de Commissie dd. 12 april 1999. 
Het minimum dekkingsniveau van de poolingovereenkomst houdt in dat de P\&I Clubs die aan de pooling deelnemen verplicht zijn om bij te dragen tot een bepaald bedrag. Dit bedrag werd in 1998 aangepast in functie van de opmerkingen van de Commissie en werd van 16,5 miljard euro gebracht op 3,9 miljard euro. Bovendien staat het de Clubs vrij om buiten de poolingovereenkomst hogere dekkingen aan te bieden. De overeenkomst van de Clubs slaat dus enkel op het verschaffen van een minimumdekking en om die reden is de Commissie van oordeel dat deze geen beperking inhoudt van de mededinging in de zin van artikel 81 , lid $1^{192}$.

De poolingovereenkomst bevat een bepaling op basis waarvan de verzekeringspolissen van elke club dienen te worden goedgekeurd door de andere leden van de poolingovereenkomst. Zowel de polisvoorwaarden als de boekhoudkundige methoden moeten door drie vierde van de leden worden goedgekeurd. Volgens de Commissie is deze afspraak noodzakelijk voor de werking van de afspraken van de IG inzake het omslaan van de schadevorderingen ${ }^{1 \%, 3}$.

In de derde schijf van de poolingovereenkomst wordt de schade gedekt door een algemeen herverzekeringscontract. Dit contract werd door de clubs gezamenlijk afgesloten met een aantal commerciële herverzekeraars. Elke Club kan dus niet individueel zijn eigen aandeel herverzekeren.

Naast de bepalingen van de poolingovereenkomst heeft de Commissie ook enkele bepalingen van de International Group Agreement (IGA) getoetst aan de verenigbaarheid met het concurrentierecht. Voornamelijk de bepalingen inzake de procedure voor offertes als de offerte voor tankers werden hierbij onderzocht.

De IGA beperkt de vrijheid van de P\&I Clubs om aan reders bepaalde tarieven aan te bieden om hen als klant te winnen. Volgens de IGA mag cen Club geen lager tariel aunbieden dan het turief dat wordt gehanteerd door de Club waar het schip momenteel is virckcrd, tenzij cen commissie van deskundigen oordeelt dat het tarief van deze club onredelijk hoog is ${ }^{194}{ }^{195}$. Vanaf 20 februari 1999 is de procedure voor offertes niet meer van toepassing op alle kostenclementen van een P\&I Club, maar enkel op de kosten van de vorderingen en de herverzekering. De interne beheerskosten van een Club vallen dus niet meer onder de procedure voor offertes.

De IGA bevat bijzondere regels inzake offertes voor tankers. Zo bepaalt de IGA onder meer dat bij offertes voor tankers op eerlijke wijze en in voldoende mate moet worden rekening gehouden met alle relevante kostenfactoren. In overcenstemming met de wijzigingen van de offerteprocedure, zal de IG voortaan voorschrijven dat bij offertes voor tankers op eerlijke wijze en in voldoende mate moet worden rekening gehouden met alle relevante kostenfactoren, behalve met de interne beheerskosten.

Het ligt duidelijk in de bedoeling van de Commissie om de concurrentie tussen de Clubs aan te moedigen, met name op het vlak van het beheersen van de kostenstructuur van de Clubs en de wijze waarop deze worden geleid. Toch lijkt de Commissie te aanvaarden dat moet worden voor-

\footnotetext{
192

193 Overweging 79 van de Beschikking van de Commissie dd. 12 april 1999.

14 Overweging 81 van de Beschikking van de Commissie dd. 12 april 1999.

194 Dit wordt de "20 februari-procedure" genoemd omdat het polisjaar steeds een aanvang neemt op die dag.

Op verzoek van de Commissie werd in 1985 de procedure verfijnd in die zin dat de nieuwe club een lager tarief mag toepassen indien hij vóór 30 september een bindende overeenkomst sluit met een reder en de huidige club daarvan in kennis stelt. De huidige Club kan beroep aantekenen indien hij van oordeel is dat het tarief van de nieuwe club onredelijk laag is.
} 
komen dat een club waanmee schadevorderingen worden gedeeld, een lager bod doet door de kosten van de vorderingen lager in te schatten. Wel is de Commissie van oordeel dat de offerteprocedure verder gaat dan strikt noodzakelijk voor de kosten die niét over de verschillende Clubs worden omgeslagen (bovengenoemde eerste "franchise-schijf" van vorderingen beneden 4,57 miljoen euro).

De Europese Commissie heeft in haar Beschikking van 12 mei 1999 een individuele vrijstelling verleend ten aanzien van beide elementen ${ }^{196}$. De Commissie is namelijk van oordeel dat de beschikbaarheid tot een bedrag van 3,9 miljard euro de reders ten goede komt, dat deze beperking onmisbaar is ingevolge de mocilijkheid om de franchisekosten te scheiden van de andere kosten en dat niettegenstaande het feit dat de IG ongeveer $89 \%$ van de wereldmarkt dekt, er mededinging is tussen de P\&I Clubs.

De vrijstelling die de Commissie op deze wijze heeft verleend kan worden ingetrokken "wanneer de leden van de IG gezamenlijk een marktaandeel hebben dat groter is dan tweemaal de minimumomvang die economisch is vereist om het op enig ogenblik in de IG overeengekomen dekkingsniveau te verschaffen". De Commissie is van oordeel dat in dat geval twee marktdeelnemers kunnen ontstaan en dat de poolingovereenkomst niet meer noodzakelijk zal zijn ${ }^{197}$

De beschikking van de Commissie is opmerkelijk te noemen, aangezien zij van oordeel is dat de afspraken die zijn gemaakt tussen concurrenten die $90 \%$ van de markt in handen hebben, niet worden geacht om een concurrentiebeperkende werking te hebben. Een aantal afspraken inzake het beperken van de onderlinge concurrentie werd weliswaar strijdig geacht met artikel 81 , maar daarvoor werd een vrijstelling verleend.

Een vrijstelling werd eerder ook reeds verleend in de zaak Assurpol ${ }^{198}$. Assurpol dekt specifieke milieurisico's van ondernemingen. Ook in deze zaak is de Commissie van oordeel dat de pool tot gevolg heeft dat de mededinging ten dele wordt beperkt omdat de leden van de pool niet meer vrij zijn om de algemene voorwaarden en de nettopremies vast te stellen en omdat ook de keuzevrijheid op het punt van het afsluiten van herverzekeringsovereenkomsten wordt beperkt. Ook de gebruikers genieten van de voordelen van de pool omdat het verzekeringsproduct in ruimere mate beschikbaar wordt, terwijl een dergelijke dekking buiten de landsgrenzen niet eenvoudig zou zijn te verkrijgen. Tegelijk bevat de pool volgens de Commissie geen beperkingen die onmisbaar zijn voor het beoogde doel en leidt de samenwerking in de pool niet tot een volledige uitschakeling van de concurrentie. Wat dit laatste element betreft stipt de Commissie aan dat de leden verzekeraars de autonomie behouden om het verzekeringsproduct Assurpol aan te bieden tegen verschillende brutopremies, dat de leden verzekeraars over de vrijheid beschikken de risico's tegen andere voorwaarden te dekken met herverzekering buiten de pool en dat een aangesloten verzekeraar zich zonder specifieke moeilijkheden uit de pool kan terugtrekken. De Commissie acht het aldus belangrijk dat potentiële concurrenten niet van soortgelijke mogelijkheden worden beroofd en dat partijen na het opzeggen van de overeenkomst over alle concurrentiële middelen beschikken "zodat een toename van de concurrentie tussen de partijen in de lijn der verwachtingen ligt".

Zie hicrover Deprinoz, J., "Régime juridique des assurances contre les risques d'atteinte à l'environnoment", Juris-Classeurs Responsabilité Civile, fasc. 58-1-1, 1994, 19. 
De redenering van de Commissie in de zaak Assurpol en in de recentere zaak van de P\&I Clubs is interessant in het kader van de analyse, omdat daaruit de krachtlijnen voortvloeien van het EGbeleid. Hieronder worden eerst de algemene elementen van dat beleid belicht $(\$ 4.3 .3)$; vervolgens wordt ook de toekomst van het EG-beleid besproken $(\$ 4.3 .4)$.

\subsubsection{Algemene elementen van het EG-beleid}

Uit de verschillende zaken die door de Commissie ${ }^{199}$ werden behandeld en uit de Vrijstellingsverordening kan worden afgeleid dat verzekeringspools, onder welbepaalde voorwaarden, kunnen worden toegelaten en zelfs aangemoedigd, zelfs indien de concurrentie hierdoor wordt beperkt ${ }^{200}$. De oprichting van deze pools kan volgens de Commissie een antwoord bieden op een capaciteitstekort op de traditionele verzekeringsmarkt ten aanzien van moeilijk te verzekeren risico's. In de Tekozaak werd gesteld dat zonder de afspraken de ondernemingen niet in staat zouden zijn een verzekering inzake machine- en bedrijfsonderbreking aan te bieden ${ }^{201}$. Ook in de zaak van de P\&I Clubs was de Commissie van oordeel dat een pooling noodzakelijk is om de vereiste verzekeringscapaciteit te kunnen genereren.

Tegelijk erkende de Commissie dat door de creatie van een dergelijke pool ook kleinere verzekeringsondernemingen cen risico konden dekken en dus toegang kregen op een markt waarvan zij onder de normale marktomstandigheden zouden zijn uitgesloten. Het feit dat de verzekeringspools het voorwerp uitmaken van een groepsvrijstelling toont dan ook aan dat de Commissie ervan is overtuigd dat de pools een positieve invloed kunnen hebben op de concurrentie ${ }^{202}$.

Inzake moeilijk te verzekeren risico's heeft de Commissie aanvaard dat poolingovereenkomsten tussen verzekeringsmaatschappijen de productie en distributie van verzekeringen kunnen bevorderen. Zo erkende de Commissie in de zaak Assurpol dat door de samenwerking tussen verzekeraars en herverzekeraars de bekendheid met risico's uit milieuverontreiniging kan worden verbeterd, dat een financiële capaciteit wordt gecreëerd en dat een technische know-how wordt ontwikkeld $^{203}$.

De Commissie is van oordeel dat de samenwerking tussen verzekeringsondernemingen het mogelijk maakt de kennis van de risico's te verbeteren en dat het voor individuele ondernemingen makkelijker wordt om de risico's te waarderen ${ }^{204}$. De oprichting van medeverzekerings- of medeherverzekeringspools wordt positief beoordeeld voorzover een groter aantal ondernemingen toegang krijgt tot de markt en daardoor de capaciteit toeneemt om vanwege hun schaal, zeldzaamheid of hun onbekendheid moeilijk verzekerbare risico's te verzekeren. Geoordeeld wordt dat de oprichting en het functioneren van dergelijke pools afspraken tussen de verschillende deelnemende verzekeraars vereisen. Bij afwezigheid van dergelijke afspraken zou geen enkel lid van de pool

Over de rol van de nationale kartelautoriteiten, zie Gyselen, L., "Antitrust law in the area of financial services. The cause of subsidiarity diagnosed", in Raffaelli, E.A. (ed.), Antitrust between EC Law and national Law, Bruylant, Bruxelles, 1998, 439-448; over het Belgische en Nederlandse kartelrecht, zie Ottervanger, T.R., Steenbergen, J. en Van der Voorde, S.J., Competition Law of the European Union, the Netherlands and Belgium, Loeff Legal Series, Kluwer, Den Haag, 1998, 166.

Fitzsimmons, A., Insurance Competition Lawn, l.c., 85.

Teko, overweging 20.

Soussan, G., "Les accords sur la couverture en commun de certains types de risques", in Het Europees Concurrentiebeleid in de Verzekeringssector, Academia-Bruylant, Lovain-la-Neuve, 1994, 56.

Fitzsimmons, A., "Insurance Competition Law", l.c., 56. Assurpol, overweging 38; P\&I Clubs overweging 32 en 33; Teko, overweging 26 en 27 en Concordato overweging 24 en 25.

Overwegingen van de vrijstellingsverordening. 
bereid zijn een overeengekomen deel van het risico te dekken ${ }^{205}$. Zodra blijkt dat de vorming van een pool de enige manier is om voor een gegeven risico de vereiste capaciteit te genereren, zijn de beperkingen geen beperkingen in de zin van artikel $81, \S 1$ van het EG-Verdrag ${ }^{206}$. Ook het Europees Hof is van oordeel dat bepaalde concurrentiebeperkingen niet onder het toepassingsgebied vallen van artikel $81 \S 1$ omdat deze beperkingen ondergeschikt zijn aan het nastreven van een doel dat wenselijk is vanuit het oogpunt van de concurrentie ${ }^{207}$. Het vastleggen door een pool van de premies en van de dekkingsvoorwaarden wordt vanuit concurrentie-oogpunt als neutraal beschouwd omdat een pool een risico dekt waarvoor op de traditionele verzekeringsmarkt geen dekking kan worden verkregen ${ }^{208}$.

Maar het is uiteraard niet omdat de Commissie de voordelen van poolvorming in welomschreven gevallen aanvaardt, dat meteen ook alle pools in overeenstemming kunnen worden geacht met het EG-concurrentierecht of dat alle elementen van de samenwerking de toets zullen doorstaan. Ook dit is duidelijk gebleken uit de zaak van de P\&I Clubs: de Commissie leek terecht vooral vragen te hebben inzake de beperking inzake prijszetting en inzake het uitbrengen van offertes. Niet eender welke voorwaarden die de pool aan haar werking en oprichting verbindt, worden door de Commissie aanvaard. Elke samenwerking tussen (her)verzekeraars zal daarom moeten worden onderzocht. Op deze wijze weegt de Commissie de voordelen van de poolvorming - de beschikbaarheid van een dekking voor moeilijk te verzekeren risico's en de mogelijkheid van kleinere ondememingen om een deel van een gegeven risico te dekken - af tegen de nadelen in termen van de beperkingen die uit een dergelijke poolvorming voortvloeien ${ }^{209}$.

Zodra sprake is van een afspraak tussen verzekeringsondememingen waarvoor een vrijstelling wordt gevraagd, zal moeten worden aangetoond dat ook de consument voordeel haalt uit de samenwerking tussen verschillende verzekeraars.

Het in de context van kartels tussen verzekeringen gehanteerde concept "consument" is uiteraard niet hetzelfde als de betekenis die hieraan in het algemeen wordt gegeven ${ }^{210}$. Zo oordeelde de Commissie in de Assurpol-zaak dat door de samenwerking tussen verzekeringsondememingen het verzekeringsproduct in bredere mate beschikbaar wordt en beter aansluit op de behoeften van bedrijven in industric en handel. Het zijn deze bedrijven die in de context van het EG-concurrentierecht worden beschouwd als consumenten ${ }^{211}$. Indien evenwel, zoals bij systemen van onderlinge verzekering, de verzekeraar tegelijk de verzekerde is, volstaat het in de visie van de Commissie niet om te besluiten dat de gebruiker voordelen haalt uit de samenwerking. In cen dergelijk geval dient te worden aangetoond dat ook andere personen voordelen halen uit de gemaakte overeenkornsten ${ }^{212}$.

Zo werd geoordeeld dat een billijk aandeel van de verbetering van de producten de gebruiker ten goede komt indien:

Soussan, G., "Les accords sur la couverture en commun de certains types de risques", o.c., 56. Soussan, G., "Les accords sur la couverture en commun de certains types de risques", o.c., 58. Zaak 42/84 van 11 juli 1985, Remia tegen Commissic, Rec, 1987, 2545; zaak 166/84, 28 januari 1986, Pronuptia tegen Schilgallis, rec, 1986, 353.

Soussan, G., "Les accords sur la couverture en commun de certains types de risques", o.c., 58.

Fitzsimmons, A., "Insurance Competition Law", l.c., 85.

Zie hierover bijvoorbeeld Rinkes, J.G.J., "The Consumer Perspective on the Completion of the Single Market of Insurance", in McGee, A. en Heusel, W. (ed.), The Low and Practice of Insurance in the Single European Market, Academy of European Law in Trier, Bundesanzeiger, 1995, Keulen, 11-24. Assurpol, overweging 39 .

P\&I Clubs, overweging 41 .
} 
- door de samenwerking het verzekeringsproduct in bredere mate beschikbaar wordt ${ }^{213}$;

- een grotere capaciteit beschikbaar is dankzij de samenwerking tussen verzekeringsondernemingen $^{214}$;

- de samenwerking aanleiding geeft tot lagere premies ${ }^{215}$;

- de afhandeling van vorderingen wordt versneld ${ }^{216}$;

- de verzekeringsdekking gepaard gaat met preventieve maatregelen ${ }^{217}$.

Bij de beoordeling van de vermelde zaken ging de Commissie uiteraard ook na of de beperkingen onmisbaar waren voor het bereiken van het beoogde doel en of de concurrentie niet geheel werd uitgeschakeld. Over het algemeen kan worden gesteld dat de Commissie de beperkingen als onmisbaar beschouwt zodra blijkt dat de samenwerking leidt tot een verbetering van de productie en distributie van verzekeringen en zodra blijkt dat de leden nog over de vrijheid beschikken om de premies zelfstandig vast te leggen ${ }^{218}$ of om zich elders te herverzekeren of wanneer de premies van de pool een louter indicatieve waarde hebben ${ }^{219}$. De concurrentie wordt niet geheel uitgeschakeld indien een aangesloten verzekeraar zich zonder veel moeilijkheden kan terugtrekken, indien de leden over de vrijheid beschikken risico's tegen andere condities te dekken met herverzekering buiten de pool ${ }^{220}$ of indien er voldoende concurrentie bestaat van derde ondernemingen ${ }^{221}$.

Het beleid van de Europese Commissie inzake verzekeringen heeft meermaals geleid tot zware kritieken in de literatuur. Zowel de Vrijstellingsverordening als bijvoorbeeld de Beschikking van de Commissie inzake de P\&I Clubs werden onder vuur genomen ${ }^{222}$. In een aantal gevallen is het namelijk onzeker in welke mate de concurrentiebeperkende maatregelen die een pool oplegt, wel strikt noodzakelijk zijn ${ }^{223}$.

\subsubsection{De toekomst van het $\mathrm{EG}$-beleid}

Twee documenten kunnen inzicht verschaffen in het beleid dat de Europese Commissie in de toekonst zal ontwikkelen inzake mededinging. In eerste instantie werd een Witboek opgesteld ter zake van de modernisering van het algemene mededingingsrecht; in tweede instantic heeft de Commissie aan de Raad een verslag uitgebracht over de werking van de Vrijstellingsverordening inzake verzekeringen.

Assurpol, overweging 39 .

Assurpol, overweging 39 en P\&I Clubs, overweging 46.

P\&l Clubs, overweging 43 en Teko, overweging 28.

Assurpol, overweging 38.

Assurpol, overweging 39.

Assurpol, overweging 40.

Teko, overweging 30.

Assurpol, overweging 41 .

Teko, overweging 31 .

Faure, M. en Van den Bergh, R., "Het toclaten van kartels op de Europese verzekeringsmarkt", o.c., 261-267; Faure, M., "Regulering en concurrentie op verzekeringsmarkten in Europa", o.c., 12-20; Faure, $M$ en Van den Bergh, R., "Restrictions of competition on insurance markets and the applicability of EC antitrust law", o.c., 65-85; Faure, M. en Van den Bergh, R., "Objectieve Aansprakelijkheid", Lc., 33!-336.

Bovendien staat de overheid die wordt geconfronteerd met cen monopolistische speler; bloot aan een probleem van informatieasymmetrie. Cfr. infra, in $\$ 1.3 .2$ van hoofdstuk 15 . 
Op 28 april 1999 heeft de Europese Commissie het "Witboek betreffende de modernisering van de regels inzake de toepassing van de artikelen 85 en 86 van het EG-Verdrag" uitgevaardigd ${ }^{224}$. Het uitgangspunt van de Commissie is dat zij, onder het huidige systeem, van haar eigenlijke taak wordt afgeleid en wordt overspoeld met aanmeldingen waardoor het haar onmogelijk is om de tussen ondernemingen gesloten overeenkomsten aan een emstig onderzoek te onderwerpen. In de periode 1988-1998 is slechts 13\% van de nieuwe zaken op gang gebracht door een ambtshalve tussenkomst van de Commissie ${ }^{225}$. Bovendien stelt de Europese Commissie dat Verordening 17 niet meer is aangepast aan de evolutie van de ondernemingswereld en aan de uitgebreide Gemeenschap 226 .

De door de Commissie naar voren geschoven opties voor de modernisering van haar mededingingsbeleid bestaan uit drie pijlers ${ }^{227}$ : de afschaffing van het systeem van machtiging en aanmelding, de gedecentraliseerde toepassing van de mededingingsregels en de versterking van de controle achteraf.

De afschaffing van het systeem van machtiging en aanmelding zou nodig zijn omdat dit voor de ondernemingen leidt tot zware kosten en zou wegen op hun commercieel beleid. In plaats van de aanmelding zou een regime wettelijke uitzondering in het leven worden geroepen. Onder cen dergelijk systeem geldt het verbod op concurrentiebeperkende maatregelen niét indien de overeenkomsten voldoen aan bepaalde, bij wet vastgestelde voorwaarden. Dit impliceert meteen dat artikel 81 een rechtstreeks toepasselijke bepaling zou worden, dat afspraken tussen ondememingen die aan deze voorwaarden voldoen, rechtsgeldig zijn vanaf het ogenblik van de totstandkoming en dat geen voorafgaande beschikking is vereist. De controle op deze mededingingsbeperkende afspraken zou achteraf plaatsvinden ${ }^{228}$.

Hierbij aansluitend heeft de Europese Commissie haar intentie te kennen gegeven om een nieuw type vrijstellingsverordening vast te stellen: hierbij zal een algemene vrijstelling gelden voor alle overeenkomsten en alle contractbepalingen die tot een bepaalde categorie behoren. Het voordeel van de algemene vrijstelling zal uitsluitend worden begrensd door een zwarte lijst van verboden beperkingen en verboden toepassingsvoorwaarden en door een marktaandeelcriterium dat het voordeel van de vrijstelling beperkt ${ }^{23 !}$.

Door middel van een gedecentraliseerde toepassing van het mededingingsrecht wil de Commissie afstand doen van haar ontheffingsmonopolie. Ook nationale kartelautoriteiten zouden de bevōegdheid moeten krijgen om te onderzoeken of aan de voorwaarden van ontheffing is voldaan en om desgevallend het voordeel van een groepsvrijstelling op te heffen. Op deze wijze wil de Commissie komen tot de complementariteit van haar eigen bevoegdheden en die van de nationale kartelautoriteiten en tot een "netwerk" van nauw' samenwerkende autoriteiten ${ }^{230}$.

Tot stand gekomen in het kader van het Programma van de Commissie nr. 99/027. Hiema genocmd: "Witboek inzake mededingingsbeleid ' 99 ".

225 Witboek inzake mededingingsbeleid' '99, 24.

226 Witboek inzake mededingingsbeleid '99, 56.

227 Witboek inzake mededingingsbeleid' '99, 35-55.

228 Witboek inzake mededingingsbeleid' '99, 27 en 32.

229 Witboek inzake mededingingsbeleid '99, 33.

Witboek inzake mededingingsbeleid '99, 39. Hierbij stelt de Commissie een aantal maatregelen voor die de coherentie en de samenwerking moeten garanderen. 
Het verbeteren van de controle achteraf kan worden bereikt door het versterken van de onderzoeksbevoegdheden van de Commissie, door het vergemakkelijken en aanmoedigen van het indienen van klachten en door het verhogen van de sancties.

Naast deze algemene beleidsopties van de Commissie ter zake van het concurrentierecht, werd eveneens in 1999 een verslag opgestuurd naar de Raad inzake de toekomst van de Vrijstellingsverordening voor de verzekeringen. Overeenkomstig artikel 8 van de machtigingsverordening van de Raad ${ }^{231}$, diende de Commissie binnen de 6 jaar aan de Raad een verslag uit te brengen over de werking van de vrijstellingsverordening inzake verzekeringen. Dit verslag, door de Europese Commissie uitgebracht in mei $1999^{232}$, bespreekt onder meer de tockomstverwachtingen voor elke categorie zoals opgenomen in de Vrijstellingsverordening.

Ter zake van de gemeenschappelijke dekking van bepaalde categorieën risico's, gaat de Commissie verder op de ingeslagen weg. De rechtmatigheid van een verzekeringspool zal worden beoordeeld aan de hand van drie vragen. In eerste instantie wordt onderzocht of de pool en de leden ervan voldoen aan de bepaling inzake marktaandeel.

Worden deze drempelwaarden overschreden, dan zal moeten worden nagegaan of de groep noodzakelijk is om de deelnemers in staat te stellen om actief te zijn op de desbetreffende markt ${ }^{233}$. Indien de verzekeringspool noodzakelijk is om een bepaalde dekking aan te bieden die de leden van de pool anders niet op de markt zouden kunnen brengen, gaat de Commissie ervan uit dat deze niet binnen het toepassingsgebied vallen van artikel 81 en dit ongeacht de omvang van het marktaandeel van de betrokken pool ${ }^{234}$.

Indien een pool nict nood/akelijk blijkt te zijn voor het verzekeren van een bepaald risico, wordt een derde vraag beantwoord, namelijk of de deelnemers zich al dan niet contractucel hebben verbonden om hun overeenkomsten betreffende het verzekerde risico gcheel of gedeeltelijk in de groep in de brengen. Als de leden van de pool daartoe worden verplicht, is volgens de Commissic artikel 81 van toepassing.

De Commissie is zelf van oordeel dat door het toetsen of de vorming van een verzekeringspool noodzakelijk is, artikel 11 van de Vrijstellingsverordening het effect krijgt van een de minimis-regel $^{235}$. Toch kan zich volgens de Commissie de situatie voordoen waarbij de vorming van een verzekeringspool op een gegeven moment noodzakelijk is, maar dat na verloop van tijd de verzekeraars een voldoende minimumcapaciteit of voldoende deskundigheid hebben opgebouwd zodat een lid van de pool het risico alleen kan verzekeren. Bovendien kan de situatie zich voordoen dat de pool zo groot is geworden dat hij kan worden vervangen door twee of meer andere pools die

Verordening nr. 1534/91 van 31 mei 1991 (PB, nr. L 143, van 7 juni 1991); in deze Verordening heeft de Raad de Europese Commissie de machtiging gegeven om de vrijstellingsverordening inzake verzekeringen vast te stellen.

"Verslag aan het Europese Parlement en aan de Raad over de werking van Verordening (EEG) nr. $3932 / 92$ van de Commissie van 21 december 1992 betreffende de toepassing van artikel 81 , lid 3 van het Verdrag (ex-artikel 85, lid 3) op bepaalde groepen van overeenkomsten, besluiten en onderling af gestemde feitelijke gedragingen in de verzekeringssector", COM(1999)/192 (geciteerd als "Rapport over de Vrijstellingsverordening inzake verzekeringen").

"Rapport over de Vrijstellingsverordening inzake verzekeringen", l.c., 14.

"Rapport over de Vrijstellingsverordening inzake verzekeringen", l.c., 14.

"Rapport over de Vrijstellingsverordening inzake verzekeringen", l.c., 15 
met elkaar kunnen concurreren. De Commissie laat er geen twijfel over bestaan dat in een dergelijk geval de voorkeur wordt gegeven aan het creëren van concurrentie ${ }^{236}$.

Tenslotte dient erop te worden gewezen dat de Europese Commissie blijkbaar in 1999 een onderzoek is gestart naar de nucleaire verzekeringspools ${ }^{237}$. In het algemeen wenst de Commissie overigens prioritair haar aandacht te richten tot de medeverzekerings- en medeherverzekeringspools ${ }^{238}$.

$\mathrm{Na}$ de bespreking van het communautaire concurrentiebeleid inzake verzekeringen in het algemeen, zal hieronder de verenigbaarheid worden geanalyseerd van de nucleaire verzekeringspools met het EG-concurrentierecht.

\subsection{De nucleaire verzekeringspools en het EG-concurrentierecht}

In het licht van de werking van de nucleaire verzckeringspools en van de bepalingen van dc vrijstellingsverordening, wordt hier de vraag beantwoord in welke mate de nucleaire verzekeringspools in overeenstemming zijn met het communautaire mededingingsrecht. In eerste instantie wordt aandacht besteed aan de reactie van enkele nucleaire exploitanten op de monopoliepositie van de nucleaire verzekeraars $(\$ 4.4 .1$ ). Vervolgens wordt aandacht besteed aan de houding van de Europese Commissie ten aanzien van de nucleaire verzekeringspools ( $\$ 4.4 .2$ ).

\subsubsection{Reactie van enkele exploitanten van een kerninstallatie op de monopoliepositie van de nucleaire verzekeringspools}

In de jaren zeventig heeft een aantal nucleaire exploitanten een eigen initiatief genomen naar aanleiding van de monopolicpositie van de nucleaire verzekeringspools. Deze ontwikkeling heeft zich zowel in de VS als in Europa voorgedaan. De exploitanten zijn namelijk overgegaan tot de oprichting van een eigen systeem van onderlinge verzekering, een zogenoemde captive ${ }^{239}$.

In 1973 hebben 14 Amerikaanse exploitanten van een kerninstallatie een captive opgericht, namelijk Nuclear Mutual Limited (NML). Na het ongeval in Three Mile Island werd overigens beslist een tweede captive op te richten, namelijk Nuclear Electric Insurance Limited (NEIL) ${ }^{240}$. Inmiddels is NML gefuseerd met NEIL.

De oprichting van NML had tot doel om een alternatief te bieden voor de verzekering die via de Amerikaanse nucleaire verzekeringspools werd aangeboden ${ }^{241}$. In zekere zin was het merkwaardig dat uitgerekend in de VS om die reden werd overgegaan tot de oprichting van de captive. De VS was namelijk het enige land waar twee verzekeringspools actief waren ${ }^{242}$; sinds 1998 is de

"Rapport over de Vrijstellingsverordening inzake verzekeringen", l.c., 18.

"Rapport over de Vrijstellingsverordening inzake verzekeringen", l.c., 17.

"Rapport over de Vrijstellingsverordening inzake verzekeringen", l.c., 25.

In $\S 2.2$ van hoofdstuk 11 wordt besproken wat een captive is, wordt een overzicht gegeven van de verschillende soorten captives etc.

Vanden Borre, T., "Dekking van het nucleaire risico op nationaalrechtelijke basis of via internationalc Verdragen: de Verenigde Staten versus Europa", in Faure, M., Deketelacre, K. en Verhoosel, G., (red.). "Grensoverschrijdende milieuproblemen", l.c., 470 e.v.; zie ook verderop in hoofdstuk 13.

Dow, J.C., "Nuclear Energy and Insurance", l.c., 267-268.

In 1956 werden twee nucleaire verzekeringspools opgericht in de VS: Nuclear Energy Liability Insurance Association (NELIA), bestaande uit commerciële verzekeraars en Mutual Atomic Energy Liability Underwriters (MAELU), bestaande uit onderlinge verzekeringsmaatschappijen. Inmiddels is de 
enige pool American Nuclear Insurers (ANI). Het dient te worden benadrukt dat de activiteiten van NEIL in hoofdzaak betrekking hebben op de verzekering van de eigenschade van de exploitanten.

Het gevolg van de oprichting van de captive op de mededinging was aanzienlijk: tussen 1957 en 1972 was de dekking inzake eigenschade gestegen van 60 miljoen dollar naar 84 miljoen dollar; tussen 1973 en 1979 daarentegen was de dekking verdrievoudigd ${ }^{243}$. In 1997 bedroeg de dekking die door NEIL kon worden aangeboden ongeveer 3 miljard dollar. In de VS is het zelfs zo dat ANI en NEIL concurrenten zijn voor een deel van de dekking van de aansprakelijkheid van de exploitant ${ }^{244}$.

Eenzelfde reactie vanwege de exploitanten heeft zich in Europa voorgedaan. In 1978 werd European Mutual Association for Nuclear Insurance, kortweg EMANI, opgericht ${ }^{245}$ met tot doel extra capaciteit te genereren die de nationale pools niet steeds kunnen leveren ${ }^{246}$, de premies van de leden te drukken en druk uit te oefenen op de nationale verzekeringspools. EMANI is een captive naar Belgisch recht, met zetel te Brussel en kan worden beschouwd als de Europese tegenhanger van NEIL in de Verenigde Staten. De werkwijze van beide captives is grotendeels gelijklopend, a] is het zo dat enkel nucleaire elektriciteitsproducenten deel uitmaken van NEIL, terwijl ook niet elektriciteitproducerende nucleaire exploitanten (zoals een producent van splijtstoffen, een nucleaire opwerkingsfabriek etc.) lid zijn van EMANI.

Ook EMANI biedt in hoofdzaak dekking voor de eigenschade van de exploitanten, al treedt zij ook op als medeverzekeraar inzake aansprakelijkheid en als herverzekeraar voor haar leden ${ }^{247}$. EMANI biedt dus het voordeel dat bijkomende of alternatieve capaciteit wordt aangeboden voor de dekking van eigenschade én om bijkomende dekking aan te bieden inzake aansprakelijkheid, hetzij als medeverzekeraar, hetzij als herverzekeraar.

De capaciteit van EMANI die aanvankelijk 360 miljoen BEF bedroeg, was in 1991 evenwel slechts gestegen tot ongeveer 6,3 miljard $\mathrm{BEF}^{248}$. EMANI kende tot in het begin van de jaren negentig inderdaad een beperkt succes. Een belangrijke oorzaak van dit beperkte succes lijkt de gebrekkige solidariteit te zijn tussen de Europese nucleaire exploitanten ${ }^{249}$; een aantal Europese exploitanten is niet meteen geïnteresseerd in een participatie aan EMANI, omdat zij hun eigenschade niet verzekeren ${ }^{250} 25$ ! Sinds 1997 kan evenwel een aanzienlijke stijging van de capaciteit

naam van NELIA gewijzigd in ANI en hebben de onderlinge verzekeringsmaatschappijen zich in 1998 teruggetrokken uit de nucleaire verzekeringsmarkt, in hoofdzaak door de concurrentie van de captive. Cfr. infra, in $\$ 3.2 .3$ van hoofdstuk 13 .

Lederer, P.D., "Nuclear Risks - whose Risks are they?", AIDN/INLA, Nuclear Inter Jura '89, "Nuclear Law for the 1990's", Tokyo, september 1989, Il-5.

Zie hierover Vanden Borre, T., "Dekking van het nucleaire risico op nationaalrechtelijke basis of via internationale Verdragen: de Verenigde Staten versus Europa", in Faure, M., Deketelaere, K. en Verhoosel, G., (red.), "Grensoverschrijdende milieuproblemen", l.c., 471; zie ook verderop in hoofdstuk 13.

EMANI werd erkend bij KB's van 20 oktober 1978 en 7 oktober 1999.

Dow, J.C., "Nuclear Energy and Insurance", l.c., 269.

De herverzekering staat enkel open voor de eigen leden; EMANI is namelijk een gesloten captive (zie $\$ 2.2 .3$ van hoofdstuk 11 ).

EMANI, Annual Report 1991, 14.

Debaets, M., "Insurance of Nuclear Power Stations", Nuclear Inter Jura '91, AIDN/INLA, Bath, september 1991, 196.

Dow, J.C., "Nuclear Energy and Insurance", l.c., 270. 
van EMANI worden vastgesteld. In 1999 bedroeg de capaciteit 17,5 miljard BEF (433,8 miljoen euro) en telde EMANI 35 leden $^{252}$.

De twee besproken voorbeelden tonen aan dat zowel in de VS als in Europa de nucleaire verzekeringspools onder grote druk staan, in eerste instantie wat betreft de dekking van de eigenschade. De verzekeraars zelf lijken er inmiddels van uit te gaan dat dankzij het succes van de captives van de exploitanten, de nucleaire verzekeringspools niet meer de enigen zijn die dekking kunnen verlenen voor de eigenschade van de exploitant ${ }^{253}$. De vraag rijst dus welke positie de Europese Commissie aanneemt ten aanzien van deze pools.

\subsubsection{Houding van de Europese Commissie ten aanzien van de nucleaire verzekerings- pools}

De nucleaire verzekeringspools werden opgericht ten tijde van de ondertekening van het Verdrag van Rome. Op het einde van de jaren vijftig bevond de nucleaire industrie zich nog in een beginfase, waardoor ook op verzekeringsvlak de nodige onzekerheid bestond over de werking en de samenstelling van de nucleaire verzekeringspools. In bijkomende orde bestond onduidelijkheid aangaande de toepassing van artikel 81 (oud 85) van het EG-Verdrag op verzekeringen in het algemeen.

Een opvallende vaststelling is dat de nucleaire verzekeringspools hun afspraken hebben aangemeld aan de Commissie, hoewel de Commissie en het Europees Hof slechts veel later hebben geoordeeld dat het communautaire concurrentierecht eveneens van toepassing was op verzekeringen. Geheel conform de bepalingen van Verordening 17, verstuurde SYBAN op 30 oktober 1962, in eigen naam en in naam van de Franse, Nederlandse, Italiaanse en Duitse pool, een aanmeldingsdossier naar de Commissie teneinde een negatieve verklaring te bekomen ${ }^{254}$.

In het begin van de jaren negentig heeft de Franse pool (Assuratome) haar werkwijze deels veranderd, in die zin dat bij voorstellen tot verzekering die aan een exploitant worden overgemaakt, enkel nog rekening wordt gehouden met de zuivere premie; de commissies van de tussenpersonen en de algemene beheerskosten van de verzekeraars worden niet meer in rekening gebracht ${ }^{255}$. Dit zou, volgens Deprimoz, voldoende moeten zijn opdat de nucleaire verzekeringspools van dezelfde tolerantie zouden genieten als Assurpol inzake de dekking voor milieuverontreiniging ${ }^{256}$.

Op dit vlak is overigens de nauwe samenwerking tussen de industriële nucleaire sector en Euratom opvallend. In het begin van de zestiger jaren werd een groot aantal congressen georganiseerd onder auspiciën van Euratom; op deze congressen werd onder meer de positie van de Commissie ten overstaan van de nucleaire verzekeringspools aan de orde gesteld. De verzekeraars waren

251 Opvallend is ook dat de Belgische elektriciteitsproducerende exploitant en mede-oprichter van EMANI, Electrabel, deze captive heeft verlaten (Gesprek op 22 december 1997 met dhr. A. van den Abeele, Directeur van het Departement Verzekeringen en Risicobehcer van Tractebel). Sinds 1999 wordt de eigenschade van Electrabel zelfs verzekerd in de Amerikaanse captive. EMANI, Annual Report, 1999, 13. In 1999 telde EMANI leden uit Belgiě, Finland, Frankrijk, Duitsland, Nederland, Zuid-Afrika, Zweden, Zwitserland en het Verenigd Koninkrijk. Warren, G., "Insurance for the Nuclear Industry", in Horbach, N.L.J.T. (ed.), "Contemporary Developments in Nuclear Energy Law", l.c., 346. Blijkbaar werd een negatieve verklaring bekomen (zie Deprimoz, J., "Régime Juridique des Assurances contre les Risques Nucléaires", o.c., 21). Deprimoz, J., "Régime Juridique des Assurances contre les Risques Nucléaires", o.c., 22-22. Deprimoz, J., "Régime Juridique des Assurances contre les Risques Nucléaires", o.c., 22. 
zelfs van oordeel dat de algemene taak van Euratom ex artikel 98 van het Euratom-Verdrag om de ontwikkeling van het vreedzame gebruik van kernenergie te bevorderen, ook impliceerde dat Euratom als taak had de ontwikkeling van de verzekering van het nucleaire risico te bevorderen. Euratom stelde dat verzekeringspools noodzakelijk waren om capaciteit te genereren en dat in de aanvangsfase moeilijk sprake kon zijn van concurrentie ${ }^{257}$. Vandaar legden de verzekeraars de nadruk op de noodzaak tot samenwerking voor het geval de Commissie vragen had over werking van pools en de gevolgen daarvan op het vlak van de mededinging. Hierbij maakten de verzekeraars de kanttekening dat het voor functionarissen bijzonder moeilijk is om te kunnen inschatten in welke mate deze afspraken tussen verzekeringsondernemingen de concurrentie beperk$\operatorname{ten}^{258}$.

In de discussie omtrent de verenigbaarheid van de nucleaire pools met het communautaire mededingingsrecht was het hoofdargument van de verzekeraars dat zonder de oprichting van de pools, bij gebrek aan ervaring met dergelijke risico's, de verzekering van het nucleaire risico onmogelijk zou zijn ${ }^{259}$. Daarbij werd toegegeven dat na verloop van tijd dergelijke pools eventueel minder noodzakelijk konden worden.

De pools waren van oordcel dat het net-line retention-systecm, en de geregelde contacten tussen de pools over de inhoud van de polissen inderdaad kartelafspraken waren, maar dat deze afsprakicn noodzakelijk waren voor het functioneren van het poolsystecm ${ }^{260}$. Daarenboven was een min uf meer verregaande gelijkenis van de polisbepalingen normaal, gelet op de harmonisatic van de wetgeving in de Euratom lidstaten, met name door hun toetreding tot het Verdrag van Parij ${ }^{201}$.

Er kan weinig twijfel over bestaan dat door de monopoliepositic van de nucleaire verzekeringspools op de nationale markt, zij niet in aanmerking komen om desgevallend te kunnen genieten van de vrijstellingsverordening: ze hebben duidelijk meer dan 10 of $15 \%$ van de relevante markt in handen. Er zal desgevallend een individuele vrijstelling moeten worden verlecnd. In welke mate de verschillende pools een dergelijke vrijstelling hebben aangevraagd, is niet meteen duidelijk.

Er kan niet worden ontkend dat de creatie van de nucleaire verzekeringspools heeft geleid tot het creëren van een bepaalde verzekeringscapaciteit. Maar het is zeer de vraag of een dergelijke pool, zeker na 40 jaar, nog wel de enige manier is tot dekking van het nucleaire risico. Vooral doordat de pools nationaal zijn georiënteerd, is er overigens sprake van een verdeling van de markt tussen de verschillende pools.

Het probleem met de nucleaire verzekeringspools ligt zich niet zozeer op het vlak van de samenwerking op nationaal niveau van verschillende verzekeringsondememingen. Ook de Commissie heeft in de zaken Assurpol en P\&I Clubs erkend dat een van de voordelen van een dergelijke samenwerking erin bestaat dat ook kleinere verzekeringsondernemingen dekking kunnen verlenen

Von Gelderen, E.R., "Le développement de l'énergie nucléaire et la collaboration entre Euratom, l'industrie nucléaire, les producteurs d'électricité et les assureurs", o.c., 32-33.

Basyn, M., "L'Assurance des Risques Atomiques devant les Règles de Concurrence", Colloquizm Euratom. Verzekeringmaatschappijen over de actuele problemen voor het verzekeren van nucleaire risico's, Firenze, december 1962, 42; Basyn, M., "Les Pools et la Réglementation Européenne de la Concurrence", Derde Colloquium over de verzekering van nucleaire risico's, EUR 2464, Aix-enProvence, mei 1964, 92-93. 
voor een deel van het moeilijk te verzekeren risico. Het probleem ligt zich eerder bij de verregaande concurrentiebeperkingen die een gevolg zijn van de werking van de pools, in die zin dat een Belgische exploitant zich enkel kan verzekeren bij de Belgische pool, een Nederlandse exploitant enkel bij de Nederlandse pool enz. Dit maakt elke concurrentie tussen de nucleaire pools onmogelijk.

Zelfs indien exploitanten pogingen hebben ondemomen om een verzekeringsvoorstel te verkrijgen bij een buitenlandse pool, werden zij telkens verwezen naar de nationale pool. Volgens de informatie die gedurende het onderzoek werd verzameld, bestaan tussen de verschillende nucleaire verzekeringspools geen schriftelijke afspraken analoog aan de poolingovereenkomst of de IGA van de International Group van P\&I Clubs. Theoretisch is er geen enkcl letsel dat bijvoorbeeld een Duitse pool dekking zou verschaffen voor een Nederlandse exploitant; toch waagt geen enkele pool het om in het buitenland dekking te verlenen. Dit zou kunnen wijzen op een feitelijke gedraging die met een verboden kartelafspraak gelijkstaat.

Ook de verzekeringsmakelaars hebben de positie van de nucleaire verzekeringspools reeds in vraag gesteld. Wijzend op de nood om de aansprakelijkhcidsdekking op te trekken werd hierbij gesuggereerd dat de dekking van de eigenschade van de cxploitant via de gewone verzekeringsmarkt kon worden geregeld ${ }^{262}$.

Het feit dat enkele nucleaire exploitanten zijn overgegaan tot de oprichting van een captive voor de dekking van de eigenschade, toont onmiskenbaar aan dat er nood is aan concurrentie op de nucleaire verzekeringsmarkt. Momenteel zijn er slechts twee nucleaire captives actief; dit volstaat duidelijk niet om te kunnen spreken van een volwaardige concurrentie op de nucleaire verzekeringsmarkt. Misschien moet worden gekeken naar manieren om exploitanten aan te moedigen om bijkomende captives op te richten.

Het is aannemelijk om ervan uit te gaan dat de nucleaire verzekeringspools ook bij het begin van de éénentwintigste eeuw nog steeds noodzakelijk zijn om een verzekeringscapaciteit voor het nucleaire risico te genereren. Maar of de hiermee samenhangende afspraken of feitelijke gedragingen inzake premieberekening en gemeenschappelijke polisvoorwaarden nog steeds kunnen worden gerechtvaardigd, is zeer de vraag. Zeker ten aanzien van de dekking van de eigenschade zijn de pools niet meer de enige mogelijkheid om capaciteit te genereren. De onmogelijkheid om de nucleaire pools te laten concurreren, lijkt steeds moeilijker houdbaar.

Het wordt dus de hoogste tijd dat de Europese Commissie de werking van deze pools aan een kritisch onderzoek onderwerpt. Uiteraard moeten alle dekkingen in verband met nucleaire activiteiten in het onderzoek worden betrokken (zowel de dekking van de aansprakelijkheid tegenover derden, de arbeidsongevallendekking als de dekking tegen machincbreuk, brand, etc.). Het valt niet uit tc sluiten dat de pools enkel nog een noodzaak zijn voor zeer specifieke dekkingen, terwijl voor andere dekkingen misschien voldoende verzekeringscapaciteit voorhanden is buiten de pools. Ook de gehele nucleaire verzekeringsmarkt zelf moet in de analyse worden betrokken. De captives van de exploitanten hebben al hun nut bewezen voor de exploitanten zelf; hiermee is niet gezegd dat deze voordelen worden doorgegeven aan de consument. Bovendien moet worden onderzocht in welke mate de samenwerking tussen de twee captives onderling en tussen de captives en de nucleaire verzekeringspools transparant is. 1984; weergegeven in Nuclear Third Party Liability and Insurance. Status and Prospects, OECD, Paris, $1985,192$. 
Een dergelijk onderzoek is geen makkelijke taak; in de zaak van de P\&I Clubs heeft de Commissie er meerdere jaren over gedaan om tot een uitspraak te komen. Hierbij wordt zij geconfronteerd met de moeilijkheid dat zij bij de beoordeling van de verschillende elementen van het dossier nagenoeg volledig afhankelijk is van de verklaringen van een monopolistische verzekeraar ${ }^{263}$.

\section{CONCLUSIE}

De nucleaire verzekeringspools werden opgericht omdat in de jaren vijftig onvoldoende informatie beschikbaar was omtrent de dekking van het nucleaire risico en vooral omdat grote onzekerheid bestond over de mogelijke uit een kernongeval voortvloeiende schade.

Om aan het verzekeringsprobleem tegemoet te komen, werden meerdere maatregelen genomen: een bijzondere wetgeving werd gecreëerd, in de algemene verzekeringspolissen werd een clausule toegevoegd die de schade door een kernongeval uitsluit en er werd overgegaan tot de oprichting van nucleaire verzekeringspools.

Deze pools organiseren de dekking van het nucleaire risico op nationale basis. Dit impliceert dat nationale verzekeringsondernemingen die dat wensen, een deel van het nucleaire risico kunnen dekken. Hoewel de pools een aantal gemeenschappelijke kenmerken vertonen, verschilt de werking van deze pools naargelang het een echte pool betreft die rechtspersoonlijkheid heeft, dan wel een syndicaat waarbij een lid van de pool optreedt als fronting-company.

Deze pools verlenen dekking voor zowel de eigenschade van de exploitant als de aansprakelijkheid tegenover derden. Door de evolutie van de verzekeringsmarkt en door de grotere maturiteit dic de nucleaire scctor dankzij een halve eeuw ervaring heeft weten op to bouwen, blijken anno 2000 wel degelijk alternatieven te bestian. Zo blijkt bijvoorbeeld dat de eigenschadeverzekering, of delen daarvan (machinebreuk, brandverzekering) ook via andere wegen, bijvoorbeeld via een door de exploitanten opgezette captive, kan worden gedekt.

Een bijkomend element is dat in de loop der jaren het aantal verzekeraars is verminderd door fusies van bank- en verzekeringsgroepen. In de mate waarin verschillende verzekeraars in een pool participeren, heeft een fusie uiteraard gevolgen voor de (machts)positie van de verzekeraar binnen de pool en van de pool zelf. Met name het feit dat concurrentie tussen de pouls onmogelijk is, maakt het voor de exploitanten nagenoeg onmogelijk om verzekeringsdekking te krijgen buiten de nationale pool om.

Een belangrijk element voor de Commissie om de vorming van verzekeringspools toe te laten, bestaat in het feit dat op deze wijze ook kleine verzekeringsondernemingen een deel van het risico kunnen dekken. Deze vaststelling is inderdaad niet onbelangrijk. De gemeenschappelijke dekking van bepaalde risico's is volgens de verzekeringsindustrie noodzakelijk om bepaalde grote "onverzekerbare" risico's het hoofd te bieden. In een aantal gevallen kan een vorm van medeverzekering of medeherverzekering in een zogenaamde verzekeringspool inderdaad efficięnt zijn ${ }^{264}$. Door een systeem van pooling zullen immers ook een aantal kleinere verzekeringsmaatschappijen in staat worden gesteld om dekking te bieden voor een bepaald risico waraan ze anders nooit zouden

Faure, M.G., "De verzekering van het nucleaire risico", in in volle Verzekerdheid, W.E.J. Tjeenk Willink, Zwolle, 1993, 254. Cfr. infra, in hoofdstuk 15. 
kunnen participeren. Hierdoor vergroot ook meteen de verzekeringscapaciteit, wat bijvoorbeeld bij de dekking van het nucleaire risico noodzakelijk kan zijn ${ }^{265}$.

Anderzijds is het zeer de vraag of in het licht van de vele jaren ervaring die de pools intussen hebben opgebouwd, het niet dringend tijd wordt dat concurrentie tussen de pools wordt toegelaten. Niet de verschillende pools op zich vormen een probleem, maar eerder de uitschakeling van concurrentie tussen de verschillende pools. Het lijkt er sterk op dat een uitschakeling van de concusrentie niet (meer) noodzakelijk is met het oog op het dekken van het nucleaire risico, zeker bijvoorbeeld ten aanzien van de dekking van de eigenschade en ten aanzien van de verzekering van de werknemers van de exploitant.

Met deze analyse wordt het eerste deel van dit boek afgerond. De conclusies met betrekking tot de juridische analyse van de aansprakelijkheid en verzekering van de bestaande wetgeving, worden weergegeven in hoofdstuk 14. In deel 2 wordt de rechtseconomische analyse aan de orde gesteld. 


\section{DEEL 2}

\section{RECHTSECONOMISCHE ANALYSE}

Bij de hierboven uitgevoerde analyse van het (kern)ongevallenrecht werden reeds enkele conclusies geformuleerd; toch werd ook aangegeven dat deze conclusies enkel verder kunnen worden getoetst en verfijnd aan de hand van de rechtseconomische analyse. Uitgangspunt van dit onderzoek is dat de rechtseconomische benadering in belangrijke mate de problematiek en de analyse van de aansprakelijkheid en verzekering voor schade uit kernongevallen, kan verrijken.

In de inleiding van dit boek werd de keuze voor de rechtseconomische analyse reeds gemotiveerd. Samenvattend kan worden gesteld dat rechtseconomic in het algemeen ertoe strekt om rechtsregels te verklaren aan de hand van begrippen uit de economie en dat het recht wordt beschouwd als een mechanisme dat het gedrag van individuen zal sturen of beïnvloeden. Specifiek met betrekking tot het aansprakelijkheidsrecht is in de rechtseconomische analyse de vraag aan de orde hoe de maatschappelijke kosten van een ongeval kunnen worden geminimaliseerd. Het ongevallenrecht wordt onder deze benadering gezien als een systeem dat prikkels geeft aan potentiële schadeveroorzakers en op die manier de preventie van ongevallen ten goede komt '. Zoals verder zal blijken is een maatschappij niet te allen prijze bereid ongevallen te vermijden. Dit impliceert: dat niet alleen wordt rekening gehouden met de kosten van een ongeval, maar eveneens met de kosten om een ongeval te voorkomen (preventiekosten). Rechtseconomen zullen inderdaad een gegeven situatie eerder ex ante bekijken en niét ex post ${ }^{2}$. Uit de benadrukking van de preventieve functie van het aansprakelijkheidsrecht blijkt dat ook rechtseconomen zijn geïnteresseerd in slachtofferbescherming omdat zij aangeven hoe slachtoffers kunnen worden vermeden, eerder dan slachtoffers post factum te "beschermen" via het toekennen van een schadevergoeding. Zoals door Faure en Van den Bergh wordt gesteld: liever geen slachtoffer dan een (door het recht) beschermd slachtoffer ${ }^{3}$.

De rechiseconomische benadering van het ongevallenrecht richt de aandacht vooral op de preventie, en op de reductie van andere kosten naast de strikte compensatie van slachtoffers. Dit laat met name toe om de interactic te onderzoeken van regelgeving terzake van aansprakelijkheid, verzekering en veiligheidstegulering. Uit de positiefrechtelijke analyse is gebleken dat het nucleaire aansprakelijkheidsrecht bepalingen bevat uit elk van deze gebieden.

Het rechtseconomische model waarop de conclusies deels zullen worden gebaseerd, wordt stapsgewijs uiteengezet. Zo zal doorheen de gehele rechtseconomische analyse worden gesproken over het ongevallenrecht; de rechtseconomische analyse van het kernongevallenrecht wordt, als bijzondere vorm van ongevallenrecht, op het einde van het uitgebouwde model bestudeerd. Het kernongevallenrecht kan immers enkel economisch worden benaderd nadat een theoretisch model van het ongevallenrecht in het algemeen werd toegelicht.

Veljanovski, C.G., "The Economic Theory of Tort Liability - toward a Corrective Justice Approach", in Burrows, P. en Veljanovski, C.G. (eds.), The Economic Approach to Law, Butterworths. London, 1981, 127 (hierna genoemd: "Corrective Justice"). Ook Posner (vooral in zijn artikel "The Concept of Corrective Justice in Recent Theories of Tort Law", Journal of Legal Studies, 1981, 201 maar ook in zijn boek The Economics of Justice, Harvard University Press, Cambridge, 1981, 75) en Calabresi (zic $\$ 4$ van dit hoofdstuk) besteedden ruim aandacht aan de economische doelsteling van het ongevallenrecht. diair, 18 december 1987. 
Het is van belang erop te wijzen dat in dit deel de rechtseconomische analyse beperkt blijft tot een positieve rechtseconomische benadering; de normatieve rechtseconomische analyse wordt in deel vier uiteengezet ${ }^{4}$. Een economische analyse biedt het voordeel dat zowel aan efficiëntie- als aan effectiviteitonderzoek kan worden gedaan. Een effectiviteitonderzoek zoekt een verklaring voor het bestaan van bepaalde rechtsregels en onderzoekt de neveneffecten van deze regels (positieve economische analyse), terwijl bij de normatieve economische analyse rechtsregels kritisch getoetst worden op hun efficiëntie. De positieve economische analyse van het recht stelt zich als doel het bestaan en ontstaan van bepaalde rechtsregels te verklaren. Het recht wordt beschreven zoals het is en niet zoals het zou moeten zijn; aan deze verklaring wordt geen normatieve waarde gekoppeld ${ }^{5}$. Nagegaan wordt of een rechtsregel het vooropgestelde doel bereikt. Indien een bepaalde wet bijvoorbeeld pretendeert de consument te beschermen tegen bepaalde handelspraktijken, of pretendeert slachtoffers van een kernongeval te beschermen, kan via de positieve economische analyse worden onderzocht of dit doel wordt bereikt en of de desbetreffende regels leiden tot bepaalde neveneffecten.

In een normatieve economische analyse van het recht daarentegen worden rechtsregels getoetst op hun efficiëntie: een rechtsregel zal van de hand worden gewezen indien hij verspilling in de hand werkt. Zo kan via een dergelijke analyse worden aangetoond dat de maatschappij met het invoeren van een bepaalde rechtsregel een bepaald doel heeft bereikt, maar dat andere regels, of eventueel de afwezigheid van rechtsregels, tegen geringere kosten tot hetzelfde resultaat kunnen leiden. Dit betekent evenwel niet dat, zoals vaak wordt beweerd, rechtseconomie automatisch zal opteren voor deregulering; in bepaalde gevallen zal regulering de meest efficiënte manier zijn om het vooropgestelde doel te bereiken ${ }^{6}$.

De positieve rechtseconomische analyse wordt opgebouwd aan de hand van zes hoofdstukken. In hoofdstuk 7 worden bij wijze van inleiding een aantal rechtseconomische concepten en uitgangspunten van de rechtseconomische analyse van het ongevallenrecht verduidelijkt. Het rechtseconomisch model van het ongevallenrecht wordt uiteengezet in hoofdstuk 8 . Dit model zal in de twee daaropvolgende hoofdstukken worden verfijnd door ook verzekeringen en veiligheidsregulering in de rechtseconomische analyse te betrekken (rcspectievelijk hoofdstuk 9 en 10).

Cir. infra, in hoofdstuk 15.

Faure, M. en Van den Bergh, R., "Objectieve Aansprakelijkheid", l.c., 26 e.v.; Van den Bergh, R. en Heremans, D., "Recht en economie", Tijdschrift woor Economie en Management, 1987, 139-164; Van den Bergh, R., "Wat is rechtseconomie?", in "Rechtseconomie en Recht", l.c., 13. 


\section{HOOFDSTUK 7}

\section{INLEIDING RECHTSECONOMIE}

Bij wijze van inleiding wordt in dit hoofdstuk nagegaan hoe de rechtseconomie is tot stand gekomen en welke de uitgangspunten zijn van de rechtseconomische analyse. In eerste instantie wordt hier de historische ontwikkeling van de rechtseconomie in de Verenigde Staten en in Europa geschetst $(\S 1)$. Vervolgens worden een aantal door de rechtseconomie gehanteerde concepten zoals de homo economicus, economische efficiëntic en "property rights" toegelicht $(\$ 2)$. Nadien zullen de uitgangspunten van de rechtseconomische analyse van het ongevallenrecht worden besproken ( $\$ 3$ ) en worden de ideeën van Coase en Calabresi, twee grondleggers van de economische analyse van het recht, aan de orde gesteld $(\S 4)$.

Het is overigens niet onze bedocling om in dit hoofdstuk cen nicuwe inleiding in de rechtseconomic te schrijven; een aantal rechtseconomische concepten wordt toegelicht teneinde de loser vertrouwd te maken met het begrippenapparaat dat in dit deel zal worden gehanteerd.

\section{HISTORISCHE ONTWIKKELING VAN DE RECHTSECONOMIE}

Terwijl de economie in feite bestudeert hoe individuen en organisaties zich op de markt gedragen, hanteert de rechtseconomie het door de economische wetenschap aangeboden analytisch kader om het gedrag te bestuderen van organisaties en individuen die buiten de markt senso stricto actief zijn. Het uitgangspunt is dan ook dat mensen rationele wezens zijn. Dit uitgangspunt is niet zo irreëel als op het eerste gezicht misschien lijkt: indien mensen zich rationeel gedragen op de markt, waarom zouden zij zich dan niet-rationeel gedragen bij eender welke andere activiteit in hun leven?' ${ }^{1}$ Ook voor Adam Smith ${ }^{2}$ en voor Jeremy Bentham was de link tussen economie en andere sociale wetenschappen - waaronder met name het recht - duidelijk ${ }^{3}$.

Smith heeft aangetoond dat de economische ontwikkeling wordt bepaald door een reeks "natuurwetten": zonder overheidstussenkomst heerst er een natuurlijke orde. Een invisible hand regelt telkens weer het economische evenwicht. Jeremy Bentham verdedigde reeds vurig de stelling dat mensen rationele wezens waren die enkel beslissingen nemen indien zulks een nut vertoont. Zo bepleitte Bentham een codificatie van het Engelse recht waarbij een norm slechts zou worden behouden indien deze norm een praktisch nut vertoont voor mens en samenleving ${ }^{5}$. Hoewel het belang van diens werk aanvankelijk niet werd onderkend, had Benthams werk wel degelijk een invloed op het strafrecht ${ }^{6}$. Later zouden recht en economie meer worden gescheiden. Mackaay

Posner, R., "The Economics of Justice", l.c., 1.

"Vader van de economie" door zijn boek The Inquiry into the Nature and the Causes of the Wealth of Nations, verschenen in 1776.

Zo gedragen burgers zich bij hoge pakkans rationeel indien zij niet door het rode licht rijden omdat zij weten dat deze overtreding zal leiden tot een geldboete.

Dit is het zgn. utilitarisme. Bentham was de auteur van o.m. A fragment on government (1776), Principles of Morals and Legislation, (1789) en Codification Proposals (1823).

Van Caenegem, R.C., "Geschiedkundige Inleiding tot het Privaatrecht", l.c., 146 e.v.

Posner, R., "The Economics of Justice", l.c., 2. 
ziet de poging tot "verwetenschappelijking" van recht en economie als voornaamste oorzaak van deze scheiding ${ }^{7}$.

De eerste wetenschappelijke werken inzake nieuwe rechtseconomie situeren zich op het einde van de jaren vijftig en het begin van de jaren zestig in de VS. Vooral Ronald Coase en Guido Calabresi moeten worden gezien als pioniers inzake de economische benadering van het ongevallenrecht. Ook James Buchanan en Gordon Tullock kunnen tot de grondleggers van de rechtseconomie worden gerekend ${ }^{\mathrm{g}}$. Door de evolutie die de rechtseconomie inmiddels heeft gekend, wordt een onderscheid gemaakt tussen de oude en nieuwe rechtseconomie.

De "oude" rechtseconomische analyse bestudeert de traditionele raakvlakken tussen recht en economie. Daar worden met name die rechtsregels geanalyseerd die betrekking hebben op de productie en consumptic van goederen en diensten. Verder dan het toetsen van rechtsregels in materies die traditioneel tot de economie thuishoren gaat de analyse niet. Onder de oude rechtseconomische benadering doet de jurist een beroep op de econoom teneinde een invulling te geven aan een juridische vraag die economische raakvlakken kent, bijvoorbeeld wat betreft de invulling van de notie "werkzame mededinging" in het EG-concurrentierecht". Ook voor het berekenen van de juiste omvang van een schade, doet de jurist een beroep op een econoom. Onder de Old Law and Economics helpt de economie de jurist bij de oplossing van een gegeven juridische vraag.

In een New: Law and Economics benadering ${ }^{10}$ wordt onderzocht hoe het rechi kan bijdragen aan het maximaliseren van de maatschappelijke welvaart, aan het optimaal toewijzen van schaarse middelen. In de nieuwe rechtseconomie fungeert de economie niet meer als een hulpwetenschap, maar worden recht en economic op gelijke voet behandeld ${ }^{1 i}$. De "nieuwe" economische analyse van het recht analyseert materies die niet behoren tot het klassieke terrein van de econoom, zoals het personen- en familierecht, het staatsrecht, het strafrecht of het aansprakelijkheidsrecht.

De rechtseconomische benadering van het ongevallenrecht werd verder uitgebouwd door mensen als Richard Posner ${ }^{12}$, John Brown, Peter Diamond, Steven Shavell en George Priest - de verdienste van de twee laatstgenoemde auteurs situeert zich tevens in de rechtseconomische analyse van het verzekeringsrecht. Het in dit boek uiteengezette rechtseconomische model bouwt grotendeels voort op de idecën van deze auteurs. Een groot aantal auteurs is in de Verenigde Staten reeds gedurende een drietal decennia actief op rechtseconomisch terrein; de rechtseconomic heeft bijgevolg een aanzienlijke evolutie ondergaan waardoor het op het einde van de jaren zeventig

? Mackaay, E., "Het recht bezien door de bril van een economist", Rechisgeleerd Magazijn Themis, 1988,412 .

8 Traditioneel worden zij tot de zgn. Public Choice economen gerekend. Zie hierover Farber, A. en Frickey, P.P., Law and Public Choice. A Critical Introduction, The University of Chicago Press, Chicago, 1991. Het werk van verschillende Chicago economen werd bekroond met de Nobelprijs Economie (Buchanan, Coase, Becker en Stigler). Van den Bergh, R., "Wat is rechtseconomie?", in "Rechtseconomie en Recht", l.c., 12. Voor een uitgebreidere analyse van het mededingingsrecht zie Van den Bergh, R., Economische Analyse van het Mededingingsrecht. Een terreinverkenning, Gouda Quint, Amhem, 1993.

Over de begrippen "New" en "Old" Law and Economics, zie o.m. Faure, M. en Van den Bergh, R., "Maakt Economie recht wat krom is ...", Inermediair, nr. 41, 20 november 1987, 45 e.v.; Veljanovski, C.G., The New Law-and-Economics. A Research Review, Oxford, Centre for Socio-Legal Studies, 1982,5 e.v.

"Van den Bergh, R., "Wat is rechtseconomie?", in "Rechtseconomie en Recht", l.c., 13.

12 Zie diens standaardwerk The Economic Analysis of Law, Little, Brown and Company, Boston and Toronto, 5th Edition, Apsen Law \& Business, New York, 1998, 572. 
reeds is ingeburgerd in de VS, en waar het sindsdien verplichte materie is geworden in de juristenopleiding.

Geleidelijk aan groeide ook in Europa de interesse voor economische analyse van het recht. Deze interesse kwam evenwel vrij laat op gang ${ }^{13}$; tegelijk lijkt de scepsis waarmee rechtseconomic in Europa te kampen heeft groter dan in de VS. In België zijn vooral Bouckaert, De Geest, Faure en Van den Bergh actief op rechtseconomisch terrein ${ }^{14}{ }^{15}$. De Nederlandse interesse voor de rechtseconomie vindt haar oorsprong bij Mackaay, Holzauer en Teijl, Hondius, Schippers en Siegers ${ }^{16}$. De samenwerking tussen de Nederlandstalige rechtseconomen vindt niet enkel haar wecrslag in gezamenlijke publicaties zoals het aangehaalde "Rechtseconomie en Recht", maar ook in organisatie van symposia. Tegelijk hebben de Europese rechtseconomen zich onder impuls van Faure en Van den Bergh verenigd in de European Association of Law and Economics.

\section{VERSCHILLENDE CONCEPTEN ZOALS GEHANTEERD IN DE RECHTSECONOMIE}

Voor een goed begrip van de verdere analyse is het aangewezen een aantal concepten toe te lichten die door de rechtseconomie worden gebruikt. In deze paragraaf zal met name worden aangegeven wat wordt verstaan onder "homo economicus" ( $\$ 2.1)$ en "efficiëntie" ( $\$ 2.2$ ). Dit zijn een aantal kembegrippen van de rechtseconomie in haar geheel; de uitgangspunten die specifiek worden gebruikt in de economische analyse van het ongevallenrecht, worden in paragraaf 3 besproken.

In Australiě, Canada en het Verenigd Koninkrijk vanaf de jaren zeventig; op het Europese vasteland vanaf de tweede helft van de tachtiger jaren.

Een handig overzicht van de literatuur is te vinden bij Bouckacrt, B. en De Geest, G. (ed.), Encyclopedia of Law and Economics, Edward Elgar, Northampton, MA, USA, 2000. Zie verder o.m. volgende werken: Bouckaert, B., "L'analyse économique du droit: vers un renouveau de la science juridique?", Revue interdisciplinaire d'études juridiques, 1987-88, 47-61; Bouckaent, B., "Efficiéntie of rechtvaardigheid: het onvermijdelijk dilemma?", Tijdschrift voor Sociale Wetenschappen, 1984, 101-133; De Geest, G.s "Public Choice en rechtseconomic. Aers Aequi, 1990. 666-673; De Gecst, G., (diss.), Economische Analyse van het Contracten en Quasi-contractenrecht. Een onderzoek naar de wetenschappelijke waarde van de rechtseconomie, Maklu, Antwerpen, Apeldoom, 1994, 568; Faure, M., "Rechtseconomie en Privaatrecht: kunnen rechtsregels bijdragen tot de reductie van ongevalskosten?", in "Rechtseconomie en Recht", l.c., 51-93; Faure, M. en Van den Bergh, R., Objectieve aansprakelijkheid, Verzekering en Veiligheidsregulering, Maklu, Antwerpen, Apeldoom, 1989, 386; Van den Bergh, R., Economische Analyse van het Mededingingsrecht. Een terreinverkenning, Gouda Quint, Amhem, 1993, 120.

Bekend is vocral de harde discussie tussen Kruithof enerzijds en Van den Bergh en Heremans anderzijds Kruithof, R. "Leven en dood van het contract", Rechiskundig Weekblad, 1985-86, 2761-2768; Van den Bergh, R. en Heremans, D., "Over krommen rechten. Een reactie op de kritiek van Kruithof ten aanzien van de economische analyse van het recht", Rechtskundig Weekblad, 1986-87, 1649-1668; Kruithof, R., "Naschrift", Rechtskundig Weekblad, 1986-87, 1669-1680.

Mackaay, E.J.P., "Veranderingen in het stelsel van vergoeding en verhaal van schade", Nederlands Juristenblad, 1980, 813-825; Mackaay, E.J.P., "Het recht bezien door de bril van de economist. Een gestileerd overzicht van de rechtseconomie", Rechtsgeleerd Magazijn Themis, 1988, 411-452; Holzhauer, R.W. en Teijl, R. e.a., Inleiding Rechtseconomie, Gouda Quint, Amhem, 1989, 345; Holzhauer, R.W. en Teijl, R., "Rechtseconomie in Nederland", Ars Aequi, 1989, 248-252; Hondius, E.H., Schippers, J.J. en Siegers, J.J. (red.), Rechtseconomie en Recht; kennismaking van een vakgebied in opkomst, W.E.J. Tjeenk Willink, Zwolle, 1991. 


\subsection{Homo economicus}

Economie heeft te maken met een efficiënt gebruik van de beschikbare schaarse middelen; met een keuze tussen verschillende mogelijke opties. Het is precies deze keuze die de basis vormt van de economische wetenschap. De economie gaat ervan uit dat elke persoon emaar streeft zijn nut te maximaliseren ${ }^{17}$; het beschouwt de mens als homo economicus, als een rationeel individu dat reageert op prikkels vanuit zijn omgeving ${ }^{18}$. Onder een economische benadering wordt de welvaart gemaximaliseerd indien ieder individu een rationele keuze maakt ter bevrediging van zijn behoeften. Een keuze is rationeel te noemen indien zij in de gegeven omstandigheden te verkiezen is boven de beschikbare alternatieven ${ }^{19}$.

Niet alleen in economische processen wordt rationeel gehandeld, maar ook individuen in het alledaagse leven handelen (vaak) rationeel; in de regel zullen ook individuen slechts een beslissing nemen na een kosten-baten analyse van de mogelijke alternatieven. Stel dat een persoon een computer wil kopen. Hij zal kunnen kiezen tussen verschillende merken en tussen verschillende types computers. Zo stelt de persoon zich de vraag of het de moeite is 100 euro méér te betalen voor een snellere computer enz. Het afwegen van voor- en nadelen is niets anders dan een kostenbatenanalyse. Tegelijk weet de persoon dat op zich het vergaren van informatie over computers ook kosten veroorzaakt. Zo zou het inefficiënt zijn in alle computerwinkels van Nederland de prijs te vragen van een bepaald type computer, vermits hiermee eveneens kosten (zgn. zoekkosten) gepaard gaan ${ }^{20}$

Ook ten aanzien van de houding tegenover juridische normen kan rationeel gedrag worden verondersteld. Het menselijk gedrag krijgt immers bepaalde prikkels via het opleggen van ge- of verboden. Dit blijkt zeer duidelijk uit voorschriften uit de economische sfeer, bijvoorbeeld het heffen belastingen. Indien bijvoorbeeld in het kader van de milieubescherming een bepaalde verpakking schadelijk is voor het milieu, kan het economisch zinvoller zijn een belasting te heffen op die bepaalde verpakking waardoor de aankoop van dat product minder aantrekkelijk wordt, dan wel te verbieden die verpakking te produceren. Een goed geïnformeerde homo economicus zal automatisch zijn gedrag aanpassen en zal het product in een andere verpakking aankopen. Maar ook andere regels uit andere rechtstakken sturen het menselijk gedrag. Het verbod om door het rode licht te rijden bijvoorbeeld geeft in principe een prikkel om niet door het rode licht te rijden.

Hier moet wel worden benadrukt dat de behoeftes van elke persoon en dus de invulling van de nutsmaximalisatie sterk kunnen verschillen. Zo is het mogelijk dat voor de ene persoon een boete van 200 euro zo hoog is dat hij bij elk rood licht zal stoppen; een andere persoon, die er een immens genoegen in schept om door het rode licht rijden, zal dan weer onverschillig staan tegenover de boete. Indien hij door het rode licht heeft kunnen rijden, stoort het hem niet noodzakelijk om hiervoor 200 euro te moeten betalen. Ook deze laatste persoon handelt als een homo economicus; als een individu dat zijn nut maximaliseert.

Posner omschrijft economie als "the science of human choice in a world in which resources are limited in relation to human wants" (Posner, R., "Economic Analysis of Law", l.c., 3).

"If a person's surroundings change is such a way that he could increase his satisfactions by altering his behaviour, he will do so" (Posner, R., "Economic Analysis of Law", l.c., 4).

Holzhauer, R.W., Teijl, R., e.a., "Inleiding Rechtseconomie", l.c., 25.

20 Eveneens volgens een homo-economicus benadering kan het perfect rationeel zijn bepaalde goederen steeds in dezelfde winkel te kopen (niettegenstaande dezelfde of gelijkaardige goederen elders goedkoper te verkrijgen zijn), vermits dit een aanzienlijke besparing oplevert in zoekkosten; tegelijk kan op die manier een vertrouwensband ontstaan tussen consument en verkoper, wat opnieuw een in de kosten-batenanalyse in aanmerking te nemen voordeel oplevert. 


\subsection{Efficiëntie}

In een rechtseconomische benadering wordt de in de economie gehanteerde efficiëntie toegepast op rechtsregels. Een situatie is efficiënt te noemen wanneer zij vanuit economisch oogpunt optimaal is, namelijk wanneer een vooropgesteld doel wordt gerealiseerd met een minimum aan middelen. Om deze optimaliteit te bepalen werden meerdere criteria ontwikkeld, waarbij het Pareto en het Kaldor-Hicks-criterium het meest besproken zijn ${ }^{21}$. Hierbij wordt bewust niet stilgestaan bij de kritieken op het efficiëntiecriterium; anderen hebben hierover reeds uitvoerig geschre$v^{22}{ }^{22}$. Onderstaande toelichting beoogt enkel duidelijkheid te verschaffen voor de verdere analyse.

\subsubsection{Pareto-efficiëntie}

Een maatschappelijke toestand $(\mathrm{t} 1)$ is Pareto-superieur in vergelijking met een andere toestand ( $\mathrm{t}$ 2) indien niemand in $t 1$ slechter af is ten aanzien van $t 2$, en indien tenminste één persoon beter af is in $t 1$ dan in $t 2$. Anders geformuleerd luidt het dat $t 1$ superieur is aan $t 2$ indien niemand $t 2$ verkiest én indien tenminste één persoon t 1 verkiest. Een verandering is bijgevolg Pareto-superieur indien deze verandering de welvaart van één of meerdere partijen verhoogt zonder schade toe te brengen aan de welvaart van cen ander individu. Dit efficiëntieconcept laat een verandering alleen toe wanneer er winnaars zijn; zodra een gewijzigde situatie bij enkelen de welvaart doet afnemen is deze nieuwe situatie volgens de Paretiaanse visie inefficiënt.

Voortbouwend op het criterium van de Pareto-superioriteit, wordt gesteld dat een toestand Paretoefficiënt is indien er geen nieuwe situatie $t 2$ mogelijk is die Pareto-superieur is aan $t 1^{23}$. Als dusdanig bestaat Pareto-efficiëntie uit een efficiënte productie, een efficiënte consumptie en een efficiënte productiestructuur ${ }^{24}$. Hierbij dient te worden onderstreept dat Pareto-efficiëntie en Paretosuperioriteit twee onderscheiden begrippen zijn.

Maar de Pareto-efficiëntie gaat uit van een initiële verdeling van arbeid en kapitaal en is dus per definitie een contextgebonden begrip ${ }^{25}$; het vertoont met andere woorden een aantal belangrijke tekortkomingen. Aangezien het moeilijk is het nut van een situatie weer te geven, kan Paretosuperioriteit enkel worden aangetoond indien iedereen die door de maatregel wordt getroffen, daarin heeft toegestemd. Indien persoon A voor 10 euro een appel verkoopt aan B, dan kan worden aangenomen dat voor $A$ de 10 euro een groter nut heeft dan de appel en omgekeerd, ook al kan niet precies worden begroot met hoeveel het nut van beide personen is gestegen door de transactie. Bovendien gaat dit uit van de assumptie dat de transactie geen gevolgen heeft voor derden $^{26}$. Hierdoor is het Pareto-criterium ongeschikt om een uitspraak te doen over beleidskwesties. Zo levert het criterium geen antwoord op de vraag welke situatie nu de meest efficiënte

Dit blijkt duidelijk uit het aantal publicaties over economische efficiêntie, zie Teijl, R., "620 Efficiency", in Bouckaert, B en De Geest, G. (ed.), Bibliography of Law and Economics, Boston, Kluwer Academic Publishers, 1992, 85-88. Met name Posner, R., "Utilitarism, Economics and Legal Theory", Journal of Legal Studies, 1979. 105; De Geest, G., "Economische Analyse", l.c., 479 en 504; Faure, M. en Van den Bergh, R., "Objectieve Aansprakelijkheid", l.c., 42 e.v. De Geest, G., "Economische Analyse", l.c., 470.

Zie hierover Schäfer, H.-B en Ott, C., Lehrbuch der ökonomischen Analyse des Zivilrechts, Berlin, Springer, 1986, 25-27. Faure, M. en Van den Bergh, R., "Objectieve Aansprakelijkheid", l.c., 39.

Posner noemt dit "the absence of third-party effects" (Posner, R., "The Economics of Justice", l.c., 8889). 
is: een vrije markt waar appels worden verkocht, dan wel een markt waar een maximumprijs werd opgelegd. Indien de maximumprijs wordt afgeschaft, zal de prijs van de appels op de vrije markt stijgen, zullen meer appels worden geproduceerd, zal de prijs van de gronden waar appels worden geteeld stijgen, enz. Onder een Pareto-efficiëntie benadering kan met deze effecten geen rekening worden gehouden.

Een tweede voorbeeld kan dit verduidelijken. Stel dat een bedrijf besluit haar vestiging in stad A te sluiten en op te starten in stad B en dat het bedrijf op geen van beide locaties negatieve externe effecten veroorzaakt. Een dergelijke herlocatie kan een invloed hebben op de waarde van de gronden in beide steden, respectievelijk een daling en een stijging. Deze verandering zal dus niet Pareto-superieur zijn, vermits landeigenaars in A slechter af zijn. Als dusdanig veroorzaakt deze herlocatie enkel een verandering of verschuiving in de vraag, eerder dan te leiden tot gewijzigde consumptie van schaarse goederen ${ }^{27}$. De "third party effects" hebben bijgevolg geen invloed op de welvaart van de maatschappij in haar gehee ${ }^{28}$. Vanuit Paretiaans standpunt is dit echter irrelevant, vermits ten minste enkelen slechter af zijn in de nieuwe situatie.

Een overgang van een inefficiënte naar een efficiënte maatschappelijke toestand leidt dus niet noodzakelijkenwijze tot een Pareto-superioriteit ${ }^{29}$. Terecht moet worden gewezen op de mogelijke distributionele gevolgen van verschillende efficiënte situaties. Doordat de overgang van een inefficiënte naar een efficiënte situatie veelal ook distributionele gevolgen heeft (verslechtering van de toestand van tenminste één persoon), voldoet het Pareto-criterium niet helemaal.

\subsubsection{Het Kaldor-Hicks-criterium}

De Pareto-efficiëntie werd verfijnd door het Kaldor-Hicks-criterium ${ }^{30}$, doordat ook rekening wordt gehouden met de distributionele gevolgen van een transactie. Op basis van het KaldorHicks-criterium wordt een verandering efficiënt genoemd indien het totale saldo van de verandering positief is. Volgens dit criterium is een maatschappelijke toestand $t 1$ efficiënter dan $t 2$, zelfs indien onder $t 2$ een aantal personen slechter af is dan onder $t 1$; essentiële voorwaarde is wel dat degenen die winst halen uit $\mathrm{t} 1$ het nadeel van de personen onder $\mathrm{t} 2$ compenseren zonder het voordeel volledig teniet te doen ${ }^{3 !}$. Indien met andere woorden de winst van de winnaars groot genoeg is om het verlies van de verliezers te compenseren en indien na dergelijke compensatie de winnaars nog steeds een positief saldo overhouden, is een toestand volgens het Kaldor-Hickscriterium efficiënt te noemen ${ }^{32.33}$.

Zoals zuivere lucht. Immers, noch op locatie A, noch op locatie B veroorzaakt het bedrijf negatieve exteme effecten zoals milieuvervuiling.

Posner, R., "The Economics of Justice", l.c., 90.

De Geest, G., "Economische Analyse", l.c., 470; Faure en Van den Bergh, "Objectieve aansprakelijkheid", l.c., 39.

Kaldor, N., "Welfare Propositions of Economics and Interpersonal Comparisons of Utility", Economic Journal, Macmillan, London, Vol. 49, 1939, 549-552 en Hicks, J., "The Valuation of Social Income", Economica, Vol. 7, 1940, 696-712.

Schåfer, H.-B en Ott, C., "Lehrbuch", l.c., 30-32; Veljanovski, C.G., "New Law and Economics", l.c.

Faure en Van den Bergh, "Objectieve aansprakelijkheid", l.c., 39-40.

Onder dit criterium is daadwerkelijke compensatic niet noodzakelijk; het is voldoende dat de mogelijkheid daartoe bestaat. Vandaar wordt het Kaldor-Hicks-criterium ook het hypothetische compensatie-criterium of het potentiële Pareto-superioriteitscriterium genoemd (Posner, R., "The Economics of Justice", l.c., 91). 
Het feit dat bij een Kaldor-Hicks-efficiênte situatie een aantal personen er minder goed aan toe is, betekent geenszins dat deze situatie inefficiënt is; gekeken moet worden naai de maatschappelijke welvaart. Indien de schaarse middelen optimaler worden verdeeld, is sprake van een stijging van de efficiëntie.

Uitgaande van het Kaldor-Hicks-criterium heeft Posner zijn wealth maximization principle ontwikkeld. Op basis hiervan dient een maatschappelijke toestand te worden nagestreefd die leidt tot een maximalisatie van de beschikbare middelen. Vanuit economische hoek heeft een handeling nut indien zij bijdraagt tot het verhogen van de maatschappelijke welvaart, tot een efficiënter gebruik van de beschikbare schaarse middelen. Deze welvaart wordt gemeten aan de hand van de willingness to pay ${ }^{34}$. De willingness to pay - die een functie is van een brede waaier elernenten, waaronder de distributie van inkomen en rijkdom - geeft weer wat mensen bereid zijn voor een goed te betalen of, indien zij het goed reeds in hun bezit hebben, tegen welke prijs zij van het goed afstand wensen te doen ${ }^{35}$. Het bedrag dat zij wensen neer te tellen geeft een indicatie van het nut dat personen aan dat goed of aan die dienst hechten. Een bepaald recht zal daarom worden toegekend aan degene die bereid is er de hoogste prijs voor te betalen ${ }^{36}$. Op basis van deze ideeën van Poisner, kan ook het recht worden beschouwd als een middel om de welvaart te verhogen: een efticiènt recht zal de burgers aanzetten tot een gedrag waardoor de rijkdom van de maatschappij in haar geheel zo groot mogelijk wordt ${ }^{37}$.

Concluderend kan worden gesteld dat het Kaldor-Hicks-criterium de theoretische basis is voor een kosten-baten analyse; deze zal positief zijn indien de winst van de winnaars groter is dan het verlies van de verliezers. Een maatschappelijke toestand zal efficiënt zijn indien hierbij de beschikbare middelen worden gemaximaliseerd.

Uit de vorige paragrafen van dit hoofdstuk werd duidelijk wat het rechtseconomische denken in het algemeen precies inhoudt, namelijk wat wordt bedcelủ met rationeel gedrag en efficiëntie. Het komt er vervolgens op aan om na te gaan hoe het algemene rechtseconomische denken kan worden "vertaald" naar het ongevallenrecht toe.

\section{UITGANGSPUNTEN VAN DE ECONOMISCHE ANALYSE VAN HET ONGEVALLENRECHT}

De uitgangspunten van de economische benadering van het ongevallenrecht bouwen vanzelfsprekend voort op de door de rechtseconomie gehanteerde concepten; het komt er in deze paragraaf op aan bovenvermelde concepten toe te passen op het ongevallenrecht.

Uitgaande van de ideeën van Adam Smith, zal ook het ongevallenrecht dienen aan te geven hoe mensen het beste een bepaalde keuze maken en hoe mensen ertoe kunnen worden gebracht deze keuze ook daadwerkelijk te maken. Het uitgangspunt hierbij is dat ongevallen maatschappelijke kosten veroorzaken (zowel voor slachtoffers, daders als voor derden en de maatschappij in haar geheel). Deze kosten moeten echter zoveel mogelijk worden vermeden, want deze kosten vereisen de inzet van schaarse middelen die in een welvaartmaximaliserende visie optimaal dienen te worden aangewend. Stel bijvoorbeeld dat zich een milieuramp voordoet en dat hierdoor zowel schade aan personen, aan goederen en aan het milieu werd toegebracht. Een dergelijk ongeval veroorzaakt heel wat kosten: zo zal het stelsel van de sociale zekerheid dienen tussen te komen,

Posner, "Economic Analysis of Law", l.c., 10.

Posner, R., "Utilitarism, Economics and Legal Theory", o.c., 119 e.v.

Posner, "Economic Analysis of Law", l.c., 10 e.v.

Mackaay, E., "Het recht bezien door de bril van een economist", o.c., 431. 
zal een rechtbank moeten worden ingeschakeld, zullen verzekeringsmaatschappijen een deel van de schade moeten uitbetalen etc. Het geheel van al deze door het ongeval veroorzaakte tussenkomsten leidt tot aanzienlijke kosten die misschien een optimale verdeling van de beschikbare middelen in de weg staan en aldus tot inefficiënties leiden. Misschien had het ongeval kunnen worden voorkomen door een aantal eenvoudige preventiematregelen, misschien heeft de exploitant van de betrokken installatie een onvoldoende prikkel om efficiënte zorg aan te wenden, misschien wordt het "billijk" geacht dat een overheidsfonds een deel van de schade voor haar rekening zou nemen, etc.

Volgens de rechtseconomische analyse moet het aansprakelijkheidsrecht worden beschouwd als een geheel van regels met als doel de maatschappelijke kosten van een ongeval te minimaliseren. Een aansprakelijkheidsregel zal aan de verschillende betrokken actoren een prikkel geven om zorgvuldig te handelen. Een rechtsregel zal dan ook efficiënt zijn indien deze erin slaagt om de maatschappelijke kosten van een ongeval te minimaliscren.

Een rechtseconomische analyse van het ongevallenrecht maakt naast het efficiëntieonderzoek ook uitspraken mogelijk over de effectiviteit van een bepaalde rechtsregel of van een combinatie van rechtsregels ${ }^{38}$. Doordat de aandacht gaat naar de door een ongeval veroorzaakte maatschappelijke kosten, kunnen ook de neveneffecten (ook derdepartij-effecten of oversijpelingseffecten genoemd) van de rechtsregels worden geanalyseerd ${ }^{39}$. Uit het hierboven aangehaalde voorbeeld blijkt immers dat een ongeval niet enkel de ongevalspartijen raakt (dader en slachtoffer), maar ook algemene kosten veroorzaakt en op deze wijze een aanzienlijke invloed heeft op de optimale toewijzing van schaarse middelen en dus op de maatschappelijke welvaart.

Ook in de economische analyse van het ongevallenrecht wordt ervan uitgegaan dat alle betrokkenen rationeel handelen (homo economicus) en dat zij bijgevolg zullen reageren op de prikkels die uitgaan van het aansprakelijkheidsrecht. Dit maakt het mogelijk het gedrag te onderzoeken van individuen al naargelang hun aansprakelijkheid is gebaseerd op foutaansprakelijkheid dan wel risicoaansprakelijkheid en al naargelang zij zijn verzekerd voor de geleden schade (en dit zowel op basis van een first party of een third party verzekering). Dit sluit aan bij de ex ante benadering van de rechtseconomie. Individuen reageren op prikkels waardoor zij mogelijke schadegevallen zullen anticiperen. Dit betekent dat zij hun gedrag zullen afstemmen op het verwachte verlies en op het ongevalrisico. Is de som van dit verlies en risico groter dan het nut dat zij uit de activiteit halen, zal een individu de goedkoopste manier zoeken om deze kosten te minimaliseren. Dit kan inhouden dat een andere activiteit zal worden uitgevoerd - voorzover een dergelijk altematief tegen een redelijke prijs beschikbaar is - of dat bij dezelfde activiteit veiligheidsmechanismen zullen worden in acht genomen.

Critici betwisten dat mensen hun gedrag aanpassen aan het recht; zij stellen dat zelfs indien mensen rationeel zouden handelen, zij onvoldoende kennis hebben aangaande het risico en de verwachte schade ${ }^{40}$. Aan de rechtseconomie wordt dus verweten dat zij geen rekening houdt met deze informatieproblemen. Het grootste deel van deze kritiek bekritiseert niet enkel de economische benadering van het ongevallenrecht, maar trekt het afschrikkend effect van het recht in het algemeen in twijfel. Indien evenwel het recht geen enkel afschrikkend effect heeft, kan de vraag worden gesteld waarom mensen contracten naleven indien zij daar geen voordeel (meer) uit halen, waarom mensen stoppen voor een rood licht en wat er hen van weerhoudt iemand met een

\footnotetext{
38 Zie hierover de ideeën van Calabresi, in $\S 4.1$ van dit hoofdstuk.

39 Faure, M. en Van den Berghe, R., "Objectieve Aansprakelijkheid", l.c., 34.

40 Zie wat Belgie betreft Kruithof, R., "Naschrift", o.c., 1673-1674.
} 
andere mening te vermoorden ${ }^{41}$ en waarom verzekeringsmaatschappijen de polissen indelen via een bonus-malus systeem ${ }^{42}$. Bovendien heeft uitgebreid empirisch onderzoek de prikkclfunctie van het ongevallenrecht aangetoond ${ }^{43}$.

Wat het informatieprobleem betreft, dient te worden gesteld dat dit probleem niet eigen is aan de rechtseconomie, en dat de rechtseconomie bovendien rekening houdt met dergelijke problemen. Deze problematiek wordt ook verderop aan de orde gesteld ${ }^{44}$.

\section{Twee grondleggers: Guido Calabresi en Ronald CoAse}

$\mathrm{Na}$ de verduidelijking van een aantal sleutelbegrippen van de rechtseconomische analyse, wordt hieronder specifiek de aandacht gericht op twee grondleggers van de rechtseconomische analyse van ongevallenrecht, met name Guido Calabresi ( $\S 4.1$ ) en Ronald Coase ( $\S 4.2$ ) De analyse wordt bewust beperkt tot Coase en Calabresi omdat zij in feite kunnen worden beschouwd als de voorlopers van de eigenlijke rechtseconomische analyse van het aansprakelijkheidsrecht. De ideeên van andere grote rechtseconomische denkers zoals Richard Posner en Steven Shavell, die in het volgende hoofdstuk aan bod komen, bouwen in belangrijke mate voort op de inzichten van Calabresi en Coase.

\subsection{Guido Calabresi}

In meerdere artikels ${ }^{45}$ en vooral in zijn boek The Cost of Accidents ${ }^{46}$ legde Guido Calabresi de basis van de rechtseconomische analyse van het aansprakelijkheidsrecht. Aanleiding tot het schrijven van het boek, was de vernieuwde belangstelling voor het ongevallenrecht in de jaren zestig, het steeds toenemend aantal verkecrsongevallen en de daaraan gekoppelde reactie van de verzekeringsmaatschappijen. Volgens Calabresi werden heel wat voorstellen geschreven teneinde het ongevallenrecht te hervormen, maar waren de meeste van deze voorstellen niet voorzien van een adequate theoretische onderbouw. Met zijn boek en aansluitende artikelen, heeft hij de aanzet gegeven van het rechtseconomisch denken terzake van het aansprakelijkheidsrecht.

Volgens Calabresi moet het ongevallenrecht de som van de ongevalskosten en de preventiekosten zo laag mogelijk houden. Deze doclstelling kan op haar beurt worden onderverdeeld in drie sub-

Voor een economische benadering van het strafrecht zie o.m.: Ehrlich, I., "The Deterrent Effect of Capital Punishment: A Question of Life and Death", American Economic Review, 1975, 397-417; Polisnky, M., "Private versus Public Enforcement of Fines", Journal of Legal Studies, 1980, 105-127; Polinsky, M. en Shavell, S., "The Optimal Trade-off between the Probability and Magnitude of Fines", American Economic Review, 1979, 880-891; Shavell, S., "Criminal Law and the Optimal use of NonMonetary Sanctions as a Deterrent", Columbia Law Review, 1985, 1232-1262.

Zie de bespreking van verzekeringen, meer in het bijzonder het "moral hazard"-probleem, cf. infra, bij de bespreking van de rechtseconomische analyse van verzekeringen in hoofdstuk 9.

Empirisch onderzoek werd o.m. verricht door Chelius, J., "Liability for Industrial Accidents: A Comparison of Negligence and Strict Liability Systems", Journal of Legal Studies, 1976, 293-309 en door Landes, E., "Insurance, Liability and Accidents: A Theoretical and Empirical Investigation of the Effect of No-Fault Accidents", Journal of Law and Economics, 1982, 49-65. Cfr infra, \& 3 van hoofdstuk 8.

4s O.m. Calabresi, G., "Some Thoughts on Risk Distribution and the Law of Torts", Yale Law Journal., 1961, 499-551; Calabresi, G., "The Decision for Accidents. An Approach to Non Fault Allocation Costs", Harvard Law Review, 1965, 713-745; Calabresi, G., "Transaction Costs. Resource Allocation and Liability Rules. A Comment", Journal of Law and Economics, 1968, 677-73.

The Cost of Accidents. A Legal and Economic Analysis, New Haven, Yale University Press, 1970, 340 (hierna: The Cost of Accidents). 
doelstellingen, die aansluiten bij het door Calabresi naar voren geschoven onderscheid tussen drie categorieën ongevalskosten: primaire, secundaire en tertiaire ongevalskosten ${ }^{47}$.

Primaire ongevalskosten zijn de kosten veroorzaakt door het aantal ongevallen en de ernst daarvan. Hiermee wordt met andcre woorden de eigenlijke door een ongeval veroorzaakte schade bedoeld, namelijk het vermogensnadeel van slachtoffer en dader. Deze kosten kunnen worden gereduceerd door het aantal ongevallen en de emst van deze ongevallen terug te dringen.

Met secundaire ongevalskosten bedoelt Calabresi de kosten die ongevallen veroorzaken aan de maatschappij in haar geheel, de kosten van het spreiden van de geleden schade ${ }^{48}$. Bijvoorbeeld verzekeringskosten worden gezien als secundaire ongevalskosten. Deze secundaire ongevalskosten kunnen worden gereduceerd door een betere spreiding van de schade te bewerkstelligen. Verliezen veroorzaakt door een ongeval zullen geringer zijn indien deze verliezen door meerdere personen worden gedragen en indien deze verliezen in de tijd gespreid worden (interpersonele en intertemporele spreiding). Spreiden van het verlies bouwt in feite voort op de theorie van het afnemend marginale nut ${ }^{49}$ : een schade van 5 dollar gedragen door één enkele persoon brengt meer schade toe dan wanneer 10 personen elk een halve dollar voor hun rekening nemen ${ }^{50}$.

Tertiaire ongevalskosten zijn de kosten die gepaard gaan met het afhandelen van ongevallen, ook wel administratieve kosten genoemd ${ }^{51}$. Deze kosten omvatten zowel de tijd en de inspanningen van slachtoffers, advocaten, daders en verzekeraars om hun vordering te regelen. De reductie van de tertiaire ongevalskosten is mede gericht op de reductie van de primaire en secundaire ongevalskosten. Bijgevolg dient bij de reductie van primaire en secundaire ongevalskosten steeds te worden nagegaan of deze reductie niet meer administratieve kosten veroorzaakt dan ze opbrengt ${ }^{52}$.

Een efficiënt ongevallenrecht moet ernaar streven om de som van de primaire, secundaire en tertiaire ongevalskosten zo laag mogelijk te houden. Het spreekt voor zich dat in bepaalde gevallen het moeilijk zal zijn uit te maken of bepaalde kosten tot de primaire dan wel tot de secundaire ongcvalskosten behoren. Stel bijvoorbeeld dat het beleid in een bepaald land erop gericht is motorongevallen te reduceren en dat vervolgens wordt beslist in dat land geen motoren meer te fabriceren en dat de producenten bijgevolg worden verplicht hun onderneming te sluiten. Deze sluiting leidt tot werkloosheid, wat eveneens een kost is voor de maatschappij. De vraag rijst of het hier gaat om primaire ongevalskosten (reductie van het aantal ongevallen) dan wel om secundaire ongevalskosten. De discussie omtrent het onderscheid tussen deze verschillende soorten van kosten is geenszins een academische discussie, maar heeft wel degelijk zijn nut: de methodes om de drie soorten ongevalskosten te vermijden, verschillen immers grondig. Door het onderscheid te

Calabresi, G., "The Cost of Accidents", l.c., 26.

Dit betckent evenwel niet dat deze kosten van minder belang zouden zijn dan de primaire ongevalskosten; de kosten veroorzakt aan de maatschappij zijn enkel secundair in die zin dat ze slechts relevant zijn nadat de primaire preventiemaatregelen hebben gefaald.

Zoals Calabresi zelf aangeeft verliest deze theorie in bepaalde gevallen haar geldigheid. Indien bijvoorbeeld een relatief klein inkomensverlies gepaard gaat met verlies van sociale statuspositie, kan dit kleinere inkomensverlies zwaardere gevolgen hebben dan cen hoger inkomensverlies. Toch behoudt de theorie van het atinemend grensnut haar geldigheid met betrekking tot het nut van spreiding van verlies. De schade zal uiteraard bepalend zijn bij de graad van risicoaversie, cfr infra, in $\$ 1$ van hoofdstuk 9 . Faure, M. en Van den Bergh, R., "Objectieve Aansprakelijkheid", l.c., 98.

Zoals Calabresi opmerkt, is het perfect mogelijk dat bij het streven naar reductie van secundaire ongevalskosten de doelstellingen inzake reductie van primaire ongevalskosten in gedrang komen. 
maken kan bijgevolg accuraat worden nagegaan hoe de ongevalskosten voor een bepaald type van ongeval optimaal kunnen worden gereduceerd.

De meest voor de hand liggende manier om ongevalskosten te vermijden, is het ontmoedigen van risicovolle ${ }^{53}$ activiteiten door deze op een veiligere manier uit te voeren of door ze te vervangen door andere, minder risicovolle activiteiten. Nochtans heeft ook het voorkomen van ongevallen een prijs; een maatschappij wil nooit te allen prijze ongevallen vermijden ${ }^{54}$. Anders gezegd: de matschappij aanvaardt een bepaalde schadeomvang, die het resultaat is van een kosten-batenanalyse $^{55}$. Alhoewel bijvoorbeeld auto-ongevallen heel wat kosten met zich meebrengen, wordt er van uit gegaan dat deze kosten niet opwegen tegen de voordelen van het autoverkeer.

De maatschappij heeft steeds twee benaderingswijzen gehanteerd ter reductie van de primaire ongevalskosten. Ten eerste de "general or market approach" of algemene afschrikking en tcn tweede de "specific deterrence or collective approach" of specifieke afschrikking.

Onder de general deterrence-benadering wordt getracht om het aantal ongevallen en de emst van deze ongevallen terug te dringen door mogelijke schadeveroorzakers af te schrikken door een bervep te doen op de markt.

Calabresi gaat hierbij uit van het postulaat dat niemand beter weet wat goed is voor individuen dan het individu zelf. Zolang individuen voldoende geïnformeerd zijn aangaande de alternatieven en zolang de kosten van een activiteit worden doorgerekend aan het individu, is hij de best geplaatste persoon om te beoordelen wat hij al dan niet wenst ${ }^{56}$.

Ongevalskosten worden in deze general deterrence-benadering beschouwd net zoals alle andere kosten van de desbetreffende activiteiten ${ }^{57}$. Indien in elke activiteit de ongevalskosten ervan worden weerspiegeld, is elk individu in staat te bepalen of de voordelen van de activiteit opwegen tegen de ongevalskosten. Indien individuen een welbepaalde activiteit wensen uit te voeren, worden zij genoodzaakt rekening te houden met de door de activiteit veroorzaakte ongevalskosten (internalisatie van kosten). Onder de "general deterrence"-benadering zullen de vrije markt en het prijsmechanisme deze keuze helpen bepalen: doordat de totale kostprijs van een activiteit ook de ongevalskosten omvat, zal een gevaarlijke activiteit duurder worden, hetgeen automatisch het aantal ongevallen zal reduceren. Liggen deze kosten te hoog dan zullen deze personen ervoor opteren andere en veiliger activiteiten uit te voeren. Het geheel van deze keuzes zal leiden tot de

Met risicovolle activiteiten worden hier bedoeld activiteiten die het risico inhouden een ongeval te kunnen veroorzaken ("aceident prone activities" zoals Calabresi ze noemt).

"Most activities can be carried out safely enough or be sufficiently enough reduced in frequency so that there is a point at which their worth outweighs the costs of the accidents they cause" (Calabresi, G., "The Cost of Accidents", l.c., 68).

Faure, $M$ en Van den Bergh, "Objectieve aansprakelijkheid", l.c., 51-52.

Calabresi argumenteert dat de algemene afschrikking nuttig is ter reductie van de ongevalskosten, zelfs in maatschappijen waar het postulaat dat mensen het best weten wat goed voor ze is niet opgaat, maar waar ervan uitgegaan wordt dat de Staat beter geplaaist is. Stel bijvoorbeeld dat de collectieve beslissing wordt genomen slechts een beperkt aantal auto's te produceren omdat een groter wagenpark te hoge ongevalskosten zou veroorzaken. Dan nog wordt aan de markt overgelaten welk type auto's geproduceerd zal worden, of overdag dan wel 's nachts gereden wordt e.d.m. Dit laat niet alleen toe dat nog steeds rekening wordt gehouden met individuele smaken en verschillen, maar dit zorgt er ook voor dat de beslissingsinstantie geinformeerd wordt over de mate waarin individuele wensen beperkt worden door een bepaalde collectieve beslissing.

Bij auto's bijvoorbeeld worden de ongevalskosten evenzeer in rekening gebracht als de kosten van de verschillende onderdelen, werkuren, enz. 
best beschikbare combinatie en zal bepalen in welke mate risicovolle activiteiten worden uitgevoerd, op welke wijze dit gebeurt en wie deze activiteiten zal ondernemen. Indien de ongevalskosten niet worden doorberekend in de prijs zullen meer risicovolle activiteiten leiden tot meer ongevallen dan men bereid is te aanvaarden.

Nochtans kent deze methode van algemene afschrikking ook enkele beperkingen. Zo is algemene afschrikking niet de optimale methode in een situatie waar verkopers zich in een monopoliepositic bevinden. Monopolisten verkopen immers met een hogere winstmarge dan op een competitieve markt. Hierdoor is de vraag op een monopolistische markt lager, wat leidt tot een misallocatie van de beschikbare middelen. Zodra er sprake is van monopolievorming, gaat bijgevolg de stelling niet meer op dat mensen het best weten wat ze willen op basis van de totale kosten van een product. Tegelijk wordt ervan uit gegaan dat individuen perfect geïnformeerd zijn - ook over de ongevalskosten - en bijgevolg de juiste keuze maken.

De tweede benadering ter reductie van de primaire ongevalskosten, specifieke afschrikking, veronderstelt dat alle kosten en alle baten van elke activiteit gezamenlijk worden geèvalueerd en dat een collectieve - politieke - beslissing moet worden genomen met betrekking tot de vraag hoe on in welke mate een bepaalde activiteit doorgang kan vinden. Onder de specific deterrencebenadering worden activiteiten als gewenst of ongewenst beoordeeld en worden deze activiteiten respectievelijk gesubsidieerd, dan wel gepenaliseerd.

Volgens Calabresi kunnen verschillende redenen een specific deterrence-benadering van het ongevallenrecht rechtvaardigen. Zo is het ten eerste lang niet zeker dat individuen weten wat het beste voor ze is. Uitgangspunt hierbij is dat een collectieve beslissing beter kan zijn dan een reeks individuele beslissingen. Daamaast wordt bij de afweging van kosten en baten van een potentieel gevaariijke activiteit rekening gehouden met niet in geld waardecrbare kosten zoals pijn en lijden. Calabresi stelt dat activiteiten ook niet in geld waardeerbare voordelen opleveren; zo vergroot het autoverkeer de mobiliteit van de maatschappij. Een politieke beslissing hierover dient al deze waarden in aanmerking te nemen. Ten derde vereisen de beperkingen van de theorie van optimale allocatie van middelen een collectieve beslissing. Het is immers perfect mogelijk dat de beste manier om een bestaande misallocatie van de beschikbarc middelen te bestrijden, erin bestaat dat meer of minder risicovolle activiteiten worden toegelaten dan het aantal dat door de markt zou zijn bepaald ${ }^{58}$.

Net zoals de algemene afschrikking, heeft ook de specifieke afschrikking benadering haar beperkingen. Een dergelijke beperking vindt onder meer haar oorzaak in de onmogelijkheid om politicke beslissingen te nemen: elke beslissing impliceert immers een keuze tussen een minder veilige en een veilige activiteit. Dit veronderstelt niet alleen dat voldoende informatie beschikbaar is, maar impliceert tegelijk dat een moeilijke keuze dient te worden gemaakt over een deel van een bepaalde activiteit. Indien bijvoorbeeld uit de algemene afschrikking blijkt dat teveel mensen nalaten de veiligheidsriem te gebruiken in de auto, zal voor het autorijden een collectieve beslissing noodzakelijk zijn. Specifieke afschrikking kan dus de primaire ongevalskosten reduceren door meer gedetailleerde activiteiten te bereiken dan bij algemene afschrikking ${ }^{59}$. Ecn tweede beperking ligt in het feit dat individuen niet al hun handelingen kunnen controleren; deze handelingen kunnen weliswaar het beste via specifieke afschrikking worden benaderd, maar het is van belang 
te weten in welke mate mensen hun gedrag onder controle hebben (bijvoorbeeld verstrooid zijn bij het autorijden $)^{60}$.

Calabresi wijst er overigens op dat de marktbenadering en de collectieve benadering van het ongevallenrecht elkaar in belangrijke mate aanvullen. Zodra een collectieve beslissing is genomen om een bepaalde activiteit aan te moedigen of te ontmoedigen zal de markt hierop reageren ${ }^{61}$. Tegelijk is het zo dat een regulering veel of weinig ruimte kan overlaten aan het marktmechanisme ${ }^{62}$. Concluderend kan worden gesteld dat in de visie van Guido Calabresi de keuze om bepaalde activiteiten al dan niet uit te voeren, via een combinatie van marktgebonden factoren en via een collectieve beslissing kan worden gemaakt. Meer in het bijzonder omtrent deze keuze, zijn de inzichten van Ronald Coase van groot belang geweest voor de rechtseconomie.

\subsection{Het Coase-theorema}

Onder een traditionele benadering van het aansprakelijkheidsrecht wordt enkel nagegaan wie aansprakelijk is voor een gegeven; de vraag of deze aansprakelijkheidsstelling economisch zinvol is, wordt niet expliciet gesteld. De vergoeding van het slachtoffer primeert hierbij.

Als standaardvoorbeeld kan de volgende situatie worden genomen: een fabriek veroorzaakt rookuitstoot die tot schadelijke effecten leidt op naburige eigendommen. In een klassieke analyse waren meerdere oplossingen mogelijk voor dit probleem: ofwel diende de eigenaar van de fabriek aansprakelijk te worden gesteld voor de door de rook veroorzaakte schade, ofwel diende een belasting te worden geheven op de fabriek a rato van de hoeveelheid rookuitstoot, ofwel diende de fabriek in kwestie te worden verwijderd uit de residentiewijken. De klassieke analyse gaat er bijgevolg van uit dat A schade berokkent aan B en dat moet worden gekeken hoe A ertoe kan worden gebracht om geen schade aan B meer te veroorzaken.

Coase heeft er evenwel op gewezen dat de fabriek in kwestie misschien maatschappelijk zinvolle activiteiten verricht en dat het sluiten van de onderneming kan leiden tot een daling van de maatschappelijke welvaart. Het is de verdienste geweest van Ronald Coase om te wijzen op de wederkerigheid van een gegeven schade ${ }^{63}$.

De echte vraag is dan ook: mag A schade berokkenen aan B of mag B A belemmeren in zijn vrijheid om een bepaalde activiteit uit te oefenen (en op deze wijze schade berokkenen aanı A)? Immers, ook door het opleggen van schadevergoeding of door het op een andere wijze beperken van de activiteiten van een activiteit ontstaan kosten.

Dezc visie sluit aan bij de door Calabresi en Melamed opgebouwde classificatie van rechten en met name bij de stclling dat elk juridisch systeem cen fundamentele normatieve keuze moet ma-

Calabresi wijst cr overigens op dat indien enkel toepassing zou worden gemaakt van de specific deterrence, dat zou betekenen dat elke beslissing met betrekking tot een gedraging of activiteit collectief zou moetcn worden genomen, hetgeen onmogelijk en onwenselijk is. In een dergelijke samenleving zouden in principe geen secundaire ongevalskosten bestaan omdat voor de toegelaten activiteiten fondsen beschikbaar zullen zijn. Maar doordat mensen bepaalde gedragingen niet meer mogen stellen, zal dit verbod (bijvoorbceld op autorijden) kosten meebrengen (namelijk niet meer mogen autorijden), hetgeen vergelijkbaar is met de secundaire ongevalskosten (Calabresi, G., "The Cost of Accidents", l.c., 111). Calabresi, G., "The Cost of Accidents", l.c., 113.

Faure, M. en van den Bergh, R., "Objectieve Aansprakelijkheid", l.c., 53.

Coase, R., "The Problem of Social Cost", Journal of Lmw and Economics, october 1960, 1-44. 
$\mathrm{ken}^{64}$ : aan wie moet een bepaald recht worden toegekend en hoe moet dit recht worden beschermd? Elk rechtssysteem dient een keuze te maken die vervolgens dient te worden afgedwongen. Het recht steit zich als doel een evenwicht te vinden tussen de verschillende in de samenleving conflicterende belangen. Een dergelijk evenwicht wordt gevonden door op een gegeven moment een recht toe te kennen aan bepaalde personen. Dit wordt rechtseconomisch gezien als de "entitlement of property rights" ${ }^{65}$. Het spreekt voor zich dat de toewijzing van rechten een aanzienlijke invloed heeft op de inkomensverdeling van een gegeven maatschappij. Naargelang van de toewijzing, zal ook de inkomensverdeling verschillend zijn. Met andere woorden: voor elke toewijzing zal een andere allocatie van middelen leiden tot een efficiënt resultaat ${ }^{66}$.

Dit blijkt bijvoorbeeld duidelijk bij het verlenen van een milieuvergunning, waar een keuze moet worden gemaakt tussen enerzijds de belangen van het milieu en anderzijds het maatschappelijke belang om al dan niet te voorzien in bepaalde producten en diensten. Indien aan een exploitant een vergunning wordt verleend om bepaalde activiteiten uit te oefenen, impliceert dit dat ervoor werd gekozen om een zekere vorm van milieuhinder toe te laten - ervan uitgaande dat zelfs indien een exploitant alle milieunormen strikt respecteert, er toch een zekere milieuhinder zal zijn (immers, ook bijvoorbeeld het veroorzaken van geluid onder de geluidsnormen kan als een hinder worden beschouwd). Het afdwingen van deze beslissing gebeurt door middel van een wet inzake milieuvergunningen en door de mogelijkheden waarover de overheid beschikt om zowel strafrechtelijk als bestuursrechtelijk op te treden. Indien in een omgekeerde situatie zou worden beslist om géén milieuvergunning toe te kennen, impliceert dit dat in het concrete geval de opbrengst van een activiteit niet opweegt tegen de mogelijke milieu-impact (en andere mogelijke kosten) ervan. Dit voorbeeld toont aan dat de economische analyse in staat is te wijzen op het feit dat bij de toekenning van rechten keuzes werden gemaakt ${ }^{67}$.

Deze inzichten sluiten aan bij wat Coase de wederkerige natuur van de keuze heeft genoemd. Ook bij een schadegeval heeft immers een toewijzing van rechten plaatsgehad. Indien een persoon de door hem geleden schade kan verhalen op de dader, betekent dit dat het recht ervoor heeft gekozen de schade in dergelijke gevallen ten laste te leggen van de dader. De vraag waarop het recht hier een antwoord heeft gegeven is: "wie mag schade berokkenen aan wie?".

De kern van het Coase-theorema wordt verduidelijkt aan de hand van diens bekende voorbeeld van de vee- en de graanboer. De eigendom van een veeboer en van een graanboer grenzen aan elkaar. Een deel van het vee brengt schade toe aan het graan. Indien bijgevolg de veestapel asngroeit, zal een groter deel van het graan verloren gaan. Gezien het schaarsteprobleem, moet ook hier een keuze worden gemaakt: vee of graan. Het uiteindelijke doel bestaat erin de situatie te vinden waar de verdeling tussen vee- en graanproductie optimaal is. Indien de veeboer een vergoeding betaalt aan de graanboer voor de schade die het vee heeft aangebracht aan het graan, zullen zijn productiekosten stijgen en zal hij automatisch zijn veestapel verminderen. In de omgekeerde situatie betaalt de graanboer de veeboer met het oog op het beperken van de schade en dus op het verminderen van de veestapel. Het resultaat op productieniveau is in beide gevallen gelijk: de veestapel vermindert. Er zal wel een verschil ontstaan op inkomensniveau: in het eerste geval betaalt de veeboer en blijft het inkomen van de graanboer gelijk (juridisch vertaald betekent dit

Calabresi, G. en Melamed, A.D., "Property nules, Liability Rules and Inalienability: one View over the Cathedral", Harvard Law Review, Vol. 85, 1972, 1.089-1128 (hiema geciteerd als: "Property Rules"). Aan het begrip "property rights" komt in de rechtseconomie een bijzondere plaats toe; met dit begrip worden niet de gemeenrechtelijke eigendomsrechten bedoeld, maar wel de toewijzing van rechten. Veljanovski, C.G., "The Economic Theory of Tort Liability - toward a Corrective Justice Approach", o.c., 134.

Faure, M. en Van den Bergh, R., "Objectieve Aansprakelijkheid", l.c., 64. 
dat de veeboer aansprakelijk is); in het tweede geval betaalt de graanboer en blijft het inkomen van de veeboer gelijk.

Hieruit kan worden geconcludeerd dat in een goed functionerende markt de uiteindelijke omvang van de productie niet zal afhangen van de initiële toewijzing van rechten. Er is geen overheidstussenkomst vereist om een efficiënt resultaat te bekomen: uit het voorbeeld van Coase blijkt immers dat de veeboer niet hoeft aansprakelijk te worden gesteld om een optimaal resultaat te bereiken.

In feite kan het Coase-theorema op verschillende wijzen worden geformuleerd ${ }^{68}$. De neutraliteitsversie luidt dat indien de markt perfect functioneert en indien er geen transactiekosten zijn, een rechtsregel geen invloed heeft op de efficiënte allocatie van de beschikbare middelen. Volgens de efficiëntieversie wordt allocatieve efficiëntie bereikt zonder overheidstussenkomst. Er is weliswar een inkomensverschil maar de uiteindelijke toewijzing van middelen is dezelfde, waardoor dit verschil geen invloed heeft op de allocatieve efficiëntie.

Een economie die enkel zou bestaan uit de graan- en veeboer zou elke rechtsregel overbodig ${ }^{69}$ maken, aangezien de efficiënte situatie in ieder geval wordt bereikt. Het uitgangspunt is immers dat het marktmechanisme perfect werkt en bijgevolg zullen partijen net zo lang onderhandelen tot wanneer de efficiënte situatie is bereikt. Belangrijk is inderdaad dat Coase ervan uitgaat dat deze onderhandelingen kosteloos kunnen plaatshebben, de zogenaamde zero transaction cost assumption.

Vooral het lage realiteitsgehalte van deze zero transaction cost assumptie gaf aanleiding tot heel wat kritiek op het Coase-theorema. Afwezigheid van transactiekosten veronderstelt immers dat partijen elkaar kennen en dat het sluiten van een overeenkomst geen kosten met zich meebrengt; dit impliceert ook dat van beide partijen een coöperatieve geest wordt gevraagd. Indien dit niet het geval is, is er sprake van strategisch gedrag en is het theorema niet van toepassing. Aan de hand van de invulling van het begrip transactiekosten, zal hieronder worden getracht weer te geven wat met strategisch gedrag wordt bedoeld.

Veljanovski wijst er in zijn kritick op het Coase-theorema op dat onzekerheid bestaat betreffende de inhoud van het begrip "transactiekosten" ${ }^{70}{ }^{71}$, dit terwijl het theorema uitgaat van de afwezigheid van transactiekosten ${ }^{72}$.

68 Veljanovski, C.G., "The Coase Theorems and the Economic Theory of Markels and Law", Kyklos, Vol. 35, 1982. 54 e.v.

Ook in die zin: Faure, M. en Van den Bergh, R., "Objectieve aansprakelijkheid". i.c., 65.

Zie o.m. Veljanorski, C.G., "The Coase Theorems and the Economic Theory of Markets and Law", o.c., 57.

De Geesik schuift volgende definitie naar voren: "de informatiekosten die gemaakt worden voor het tot stand en tot uitvoering brengen van transacties, evenals de kosten van strategisch gedrag bij het tot stand brengen van een transactie" (De Gcest, G., Economische analyse", l.c., 45). Nogg volgens dezelfde auteur zijn de kosten van strategisch gedrag niets anders dan prikkelkosten: indien het voor een van de partijen beter is dat de onderhandelingen afspringen, bestaan er wat De Geest noemt "preferentierelevantieproblemen". Dit betekent dat een partij bij de onderhandeiingen geen informatie vrijgeeft betreffende haar voorkeuren.

Mackaay stelt zelfs dat door de onzekerheid inzake het begrip "transactiekostert" het efficientiecriterium een tautologic wordt; indien in een gegeven situatie geen efficiëntie wordt bereikt, kan immers steeds als uitvlucht worden aangevoerd dat onvermoede transactiekosten in het geding zijn (Mackasy, E.J.P., "Het recht bezien door de bril van de economist", o.c., 436). 
Maar de aanwezigheid van strategisch gedrag in bepaalde gevallen, betekent evenwel niet meteen dat het Coase-theorema niet meer geldig zou zijn; empirisch onderzoek toont immers aan dat bij geringe onderhandelings-, handhavings- en informatiekosten het Coase-theorema zijn volledige geldigheid behoudt ${ }^{73}$.

Naast het in twijfel trekken van de zero transaction cost assumption, wordt het Coase-theorema ook bekritiseerd omdat de inkomensverschillen op lange termijn toch de allocatie van middelen zouden beïnvloeden ${ }^{74}$. Het Coase-theorema zou bijgevolg enkel geldig zijn op korte termijn. Zo stelde Calabresi aanvankelijk dat op lange termijn aansprakelijkheidsregels wel degelijk een invloed zouden hebben op het gevoerde aantal activiteiten ${ }^{75}$. Indien de veeboer op korte termijn niet aansprakelijk wordt gesteld, zullen op lange termijn meer mensen vee gaan telen. Later kwam Calabresi hier echter op terug ${ }^{76}$. Hij stelde dat hetzelfde mechanisme dat mogelijke misallocaties op korte termijn wegwerkt, er ook in zal slagen misallocaties op langere termijn weg te werken. Doordat meer mensen vee gaan telen, is de schade aan de graanoogst groter en bijgevolg zullen de graanboeren de veetelers afkopen, met als gevolg dat de veestapel opnieuw afneemt. Ook op lange termijn wordt dus de optimale allocatie bereikt, onafhankelijk van een tussenkomst van het recht.

Bovenstaande kritieken ondermijnen echter geenszins de verdiensten van het Coase-theorema. Het is inderdaad niet omdat slechts in een beperkt aantal gevallen geen transactiekosten aanwezig zijn dat het theorema zijn nut en geldigheid zou verliezen. Van belang is het inzicht dat de tussenkomst van het recht een keuze vooronderstelt en dat een schade in feite als wederkerig kan worden beschouwd.

Het Coase-theorema kan ook worden toegepast op het aansprakelijkheidsrecht: hierbij zal dan worden aangegeven hoe, ongeacht de keuze van de aansprakelijkheidsregel, de maatschappelijke kosten van een ongeval zullen worden geminimaliseerd. Wel is het zo dat aan heel wat voorwaarden moet zijn voldaan vooraleer een efficiënte maatschappelijke toestand zal worden bereikt zonder tussenkomst van de overheid, c.q. zonder aansprakelijkheidsregel.

Het is vrij duidelijk dat in het ongevallenrecht de transactiekosten vaak prohibitief hoog zullen zijn. In de meeste ongevalsituaties zullen ex ante onderhandelingen onmogelijk zijn omdat de ongevalspartijen vreemden zijn voor elkaar. Een tussenkomst van het recht zal dan noodzakelijk zijn om een maatschappelijk efficiënte toestand te bewerkstelligen. Indien daarentegen schade

73. De experimenten vonden plaats in groepen van 20 personen. Hoffrman, E. en Spitzer, M.L., "The Coase-Theorem: some experimental Test", Joumal of Law and Economics, 1982, 73-98; Hoffnan, E. en Spizer, M.L., "Experimental Tests of the Coase-Theorem with Large Bargaining Groups", Journal of Law and Economics, 1986, 149-171.

In het voorbeeld van de graan- en de veeboer was het zo dat bij afwezigheid van rechtsregels de graanboer de veeboer zou betalen en dat een rechtsregel daarentegen de veeboer aansprakelijk zou stellen, hetgeen uiteindelijk tot hetzelfde resultaat leidde, maar een verschil in inkomensverdeling tot gevolg had.

Calabresi, G., "The Decision for Accidents: An Approach to Nonfault Allocation of Costs", Harvard Law Review, vol. 78, 1965, 730, voetnoot 28.

Calabresi, G., "Transaction Costs, Resource Allocation and Liability Rules - A Comment", Journal of Law and Economics, 1968, 67-73. 
wordt veroorzaakt tussen twee contractpartijen, is de kans veel groter dat een efficiënte situatie kan worden bereikt, zonder tusserikomst van het recht ${ }^{77}$.

$\mathrm{Na}$ deze inleidende toelichting op de rechtseconomische analyse, wordt in het volgende hoofdstuk het rechtseconomische model van het ongevallenrecht uiteengezet.

In \$ุ 1.1.3.1 van hoofdstuk 15 zal het Coase-theorema worden toegepast op de relatie tussen đe. exploi$\tan t$ van een kerninstallatie en diens leverancier. 



\section{HOOFDSTUK 8}

\section{HET RECHTSECONOMISCHE MODEL VAN HET ONGEVALLENRECHT}

Uit het vorige hoofdstuk onthouden we dat bij de meeste ongevallen de transactiekosten prohibitief hoog zijn, waardoor enkel een tussenkomst van het recht zal leiden tot een efficiënte allocatie van de beschikbare middelen. In dit hoofdstuk wordt het ongevallenrecht rechtseconomisch bestudeerd, vanuit de veronderstelling dat geen verzekering beschikbaar is en dus zonder rekening te houden met de invloed van verzekering op de aansprakelijkheidsprikkel; de rechtseconomische benadering van verzekeringen wordt in hoofdstuk 9 aan de orde gesteld.

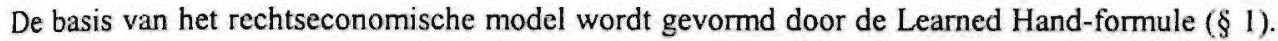
In paragraaf 2 wordt het eigenlijke rechtseconomische model uiteengezet, volgens een aantal vaste parameters en veronderstellingen. Dit model zal vervolgens worden verfijnd, met name door rekening te houden met de invloed van informatietekorten ( $\$ 3$ ).

\section{DE LEARNED HAND-FORMULE}

In het begin van de jaren zeventig heeft Richard Posner, een van de grondleggers van de economische analyse van het ongevallenrecht, onderzoek gedaan naar de theoretische grondslag van foutaansprakelijkheid. Hiertoe heeft hij ongeveer 1.500 Amerikaanse aansprakelijkheidscases onderzocht. Als uitgangspunt van dit onderzoek stelde Posner dat foutaansprakelijkheid reeds gedurende anderhalve eeuw de basis vormt van het aansprakelijkheidsrecht, terwijl nooit werd gezocht naar een theoretische onderbouw van het foutconcept ("negligence concept"). De resultaten van dat onderzoek heeft Posner gepubliceerd in een artikel dat geldt als een van de standaardbijdragen inzake de rechtseconomische analyse van het ongevallenrecht'.

In de verschillende onderzochte aansprakelijkheidscases is volgens Posner een methode te onderkennen die werd weergegeven door een zaak die door Judge Leamed Hand werd behandeld. Het betrof een zaak waar een in een storm losgeslagen duwvaartbak schade had veroorzaakt ${ }^{2}$. Volgens rechter Learned Hand moeten in een aansprakelijkheidsvordering drie elementen in aanmerking worden genomen: de grootte van de schade, de probabiliteit dat zich een schadegeval voordoet en de lasten veroorzaakt door het nemen van preventiemaatregelen. Op basis van deze dric elementen kan worden beoordeeld of een bepaalde gedraging al dan niet foutief was: indien de preventiekosten kleiner zijn dan de ongevalskosten, dan zal de gedraging als foutief worden beschouwd. In een dergelijk geval had de auteur van de gedraging voldoende voor/nrgsmaatregelen mocten nemen teneinde geen ongeval te veroorzaken - of een ongeval met geringure schade.

In formulevorm weergegeven luidt het ( $\mathrm{K}$ zijn de kosten van voorzorg of preventickosten; $\mathrm{P}$ is de probabiliteit en $\mathrm{S}$ de schade): $\mathrm{K}<\mathrm{P} . \mathrm{S} \rightarrow$ fout $\rightarrow$ aansprakelijkheid.

In de zaak van de losgeslagen duwvaartbak oordeelde rechter Leamed Hand dat de preventickosten (kosten nodig om te voorkomen dat de bak zou loskomen) kleiner waren dan P.S en bijgevolg dat de eigenaar van de bak aansprakelijk was.

Posner, R., "A Theory of Negligence", Journal of Legal Studies, 1972, 29-96.

United States v. Carroll Towing Co., 159 F.2d 169 (2d Cir. 1947). Zie ook Faure en Van den Bergh,

"Objectieve aansprakelijkheid", l.c., 56. 
Hieruit volgt dat het, indien de preventiekosten groter zijn dan P.S, vanuit economisch oogpunt efficiënter zal zijn geen voorzorgen te nemen en de ongevalsschade te vergoeden. Indien in een dergelijk geval toch voorzorgen zouden worden genomen, zal de economische welvaart immers afnemen. Volgens dezelfde redenering zou het economisch weinig zinvol zijn om de auteur van de schade aansprakelijk te stellen indien het slachtoffer tegen lagere kosten het ongeval kan vermijden $^{3}$.

Aanvankelijk maakte Posner een onderscheid tussen twee categorieën ongevallen: ongevallen tussen vreemden en ongevallen tussen personen dic een of andere - contractuele - band hebben met elkaar. De functie van het (fout)aansprakelijkheidsrecht bij ongevallen tussen vreemden (bijvoorbeeld verkeersongevallen) is duidelijk: de partijen hebben geen enkele band met elkaar, waardoor de transactiekosten prohibitief hoog zijn ${ }^{4}$ en waardoor de markt onmogelijk het economisch optimale niveau van ongevallen en veiligheid kan aangeven. Aangezien het onrealistisch is crvan uit te gaan dat onderhandelingen zullen plaatsvinden tussen de ongevalspartijen, is volgens Posner de economische rol van het recht duidelijk: het geeft hetzelfde niveau van ongevallen en veiligheid aan dat via de markt zou worden bereikt indien transacties tussen de ongevalspartijen zouden mogelijk zijn ${ }^{5}$.

Een voorbeeld kan dit verduidelijken. Stel dat er een kans van één op honderd bestaat dat een verkeersongeval tussen een voetganger en een auto een schade van 1.000 euro veroorzaakt, dat de goedkoopste manier om het ongeval te vermijden erin bestaat dat de chauffeur minder hard rijdt en dat de kosten van het trager rijden 8 euro bedragen. Aangezien beide partijen vreemden zijn voor elkaar, zullen geen onderhandelingen plaatsvinden; bij een ongeval zal een schade van 1.000 euro ontstaan. Het recht zal hier moeten tussenkomen door de chauffeur aansprakelijk te stellen. Volgens de Learned Hand-formule zal de chauffeur aansprakelijk zijn indien de preventiekosten (8 euro) lager zijn dan het product van de ongevalschade en de probabiliteit $(0,01 \times 1.000$ euro); 8 $<10$ en dus zal de chauffeur aansprakelijk worden gesteld. De chauffeur zal trager rijden omdat hij dan geen ongeval zal veroorzaken.

In de tweede categorie bevinden partijen zich in een contractuele relatie, waardoor zij in principe ex ante afspraken kunnen maken inzake aansprakelijkheid en de in acht te nemen veiligheid. Maar ook in een dergelijk geval kunnen de transactiekosten aanzienlijk zijn omdat de kosten van het afsluiten van een expliciete overeenkomst in de gegeven situatie hoog kunnen oplopen. Temand die bijvoorbeeld een buskaartje koopt, kan in principe onderhandelingen aanknopen betreffende de uit te keren schadevergoeding indien de bus bij een ongeval betrokken raakt. Dit zal in de regel te veel tijd in beslag nemen en bijgevolg te duur zijn.

De rechtbank zal na een ongeval beslissen welke veiligheidsmaatregelen de partijen zouden overeengekomen zijn indien ex ante onderhandelingen hadden plaatsgevonden. Deze onderhandclingen zouden automatisch hebben geleid tot een efficiënt niveau van zorg; de rechter zal moeten nagaan of het niveau van zorg dat op de markt zou zijn tot stand gekomen ook in het concretc geval werd toegepast. Ook hier moet de rechtbank oordelen of optimale veiligheid werd aangewend, waardoor het vanuit het oogpunt van de foutstandaard geen verschil uitmaakt of ongevallen

Posner, R., "A Theory of Negligence", o.c., 33.

Dit betekent dat onderhandelingen tussen partijen onmogelijk zijn of enkel mogelijk zijn tegen te hoge kosten. Zie de bespreking van het Coase-theorema, cfr. supra, $\$ 4.2$ van hoofdstuk 7 .

Posner, R., "A Theory of Negligence", o.c., 37. 
plaatsvinden tussen vreemden dan wel tussen personen met een zekere contractuele band, aldus Posner ${ }^{6}$.

Brown heeft er evenwel voor gewaarschuwd dat een te strikte interpretatie van de Leamed Handformule leidt tot een inefficiënt resultaat ${ }^{7}$. Hij maakt een onderscheid tussen de letterlijke Learned Hand en de marginale Learned Hand-formule ${ }^{8}$. Onder de letterlijke Learned Hand worden de totale preventickosten vergeleken met de verwachte ongevalskosten. De marginale Learned Handformule daarentegen houdt rekening met de marginale kosten van voorzorg en de marginale opbrengsten. Zolang een bijkomende eenheid zorg leidt tot een vermindering van de verwachte ongevalschade, zal deze zorg efficiënt zijn. Indien enkel rekening wordt gehouden met de totale kosten, kan het effect van de extra eenheid zorg niet worden gemeten, hetgeen kan leiden tot inefficiënte zorg (namelijk overdreven zorg waar slechts uiterst geringe reductie van ongevalskosten tegenover staat). Bij toepassing van de Incremental Learned Hand-formule zal een ongevalspartij aansprakelijk zijn zolang de marginale kosten van zorg lager zijn dan de marginale opbrengst in de vorm van een reductie van de verwachte schade.

Bovendien wijst Brown erop dat beide ongevalspartijen de ongevalskosten kunnen beïnvloeden; beide moeten dus inspanningen leveren teneinde de ongevalskosten te drukken.

\section{RECHTSECONOMISCH MODEL VAN HET AANSPRAKELIJKHEIDSRECHT}

Op basis van de inleidende beschouwingen in de vorige paragraaf en gebruik makend van de in het vorige hoofdstuk gehanteerde begrippen, wordt hieronder het rechtseconomisch model van het aansprakelijkheidsrecht uiteengezet. Dit model is voomamelijk gebaseerd op de inzichten van Posner, Brown en Shavell ${ }^{10}$. Vooraleer het model toe te lichten, wordt aangegeven op welke veronderstellingen het model is gebaseerd $(\S 2.1)$. In tweede instantie wordt besproken wat, volgens de rechtseconomische analyse, het economische optimum is $(\$ 2.2)$; wanneer met andere woorden de maatschappelijke kosten van ongevallen kunnen worden geminimaliseerd. Het onderscheid tussen bilaterale en unilaterale schadegevallen wordt aangegeven in paragraaf 2.3.

De uiteenzetting van de veronderstellingen van het rechtseconomische model, de toclichting van het economische optimum en het onderscheid tussen de verschillende ongevalsituaties zal vervolgens toelaten om het rechtseconomische model verder uit te bouwen. Daarbij zal worden onderzocht welke aansprakelijkheidsregel efficiënt is bij unilaterale schadegevallen $\left(\begin{array}{l}\S \\ 2.4\end{array}\right)$ en zal worden nagegaan wat de invloed is van het activiteitsniveau op de efficiënte aansprakelijkheidsregel $(\$ 2.5)$. In de laatste paragraaf zullen enkele conclusies worden geformuleerd $(\$ 2.6)$.

\subsection{Veronderstellingen}

In dit proefschrift gaat de aandacht centraal uit naar de civielrechtelijke aansprakelijkheid voor schade uit kemongevallen. In het uitgebouwde model wordt ervan uitgegaan dat de exploitant

Posner, R., "A Theory of Negligence", o.c., 38.

Brown, J.P., "Toward an Economic Theory of Liability", Journal of Legal Studies, 1973, $323 \cdot 349$.

Of de "lncremental" Leamed Hand zoals Brown het noemt.

Brown, J.P., "Toward an Economic Theory of Liability", o.c., 332-335.

Brown, J.P., "Toward an Economic Theory of Liability", o.c., 323-349; Posner, R., "Economic Analysis of Law", l.c.; Landes, W.M en Posner, R.A., "The Positive Economic Theory of Tort L.aw", Georgia Law Review, vol. 15, 1981, 865 (hiema: "Theory of Tort Law"); Landes, W.M. en Posner, R.A., The Economic Structure of Tort Law, Harvard University Press, Cambridge, Massachusetts, 1987, 54 e.v. (hiema: "Structure of Tort Law"); Shavell, S., "Accident Law", l.c. 
enkel prikkils krijgt vanuit het civiele aansprakelijkheidsrecht. De mate waarin desgevallend ook vanuit hot strafrecht of het administratieve recht prikkels worden gegenereerd, worden in eerste instantie buiten beschouwing gelaten ".

In dit deel van het onderzoek, waar nog geen verzckeringen in de analyse worden betrokken, wordt er bovendien van uitgegaan dat iedereen onverschillig is ten aanzien van een risico (assumptie van risiconeutraliteit) ${ }^{12}$. Op basis van het rechtseconomische model van het aansprakelijkheidsrecht, zullen individuen een keuze maken tussen verschillende altematieven. Het probleem is evenwel dat in vele gevallen deze keuze wordt bemoeilijkt omwille van de onzekerheid hetreffende de economische waarde en betreffende de welvaartsimplicaties van die keuze. Welke situatie dient men bijvoorbeeld te verkiezen: een kans van $10 \%$ om 50 euro te winnen, een kans van $25 \%$ om 20 euro tc winnen, dan wel een kans van $100 \%$ om 5 euro te winnen; of nog $10 \%$ risico om 500 euro te verliezen aan schade, dan wel de zekerheid te hebben 50 euro schade te Jijden?

Vanuit economisch oogpunt werd de theorie van het verwachte nut ontwikkeld om de keuze toe te laten, ook bij onzekerheid. Deze theorie vertrekt vanuit de basisveronderstelling dat een individu onzekere gebeurtenissen en activiteiten rangschikt volgens het verwachte nut van deze activitei$\operatorname{ten}^{13}$ en dat het individu, als homo economicus, de activiteit zal kiezen die voor hem het grootste verwachte nut heeft. Onder de assumptie van risiconeutraliteit, is het verwachte nut gelijk aan het verwachte inkomen. Dat betekent dan ook dat een individu indifferent is wat betreft de keuze tussen de hierboven geschetste situaties. Er wordt voorts van uitgegaan dat dit nut enkel afhangt van het inkomen van het individu. Het nut is bijgevolg gelijk aan het inkomen: $N=I$. Dit impliceert dat het economisch optimum zal worden bereikt op het punt waar het totale inkomen het hoogst is ${ }^{14}$.

Indien de persoon schade lijdt, zal dit resulteren in een verlies van een aantal eenheden van het inkomen. Een individu verkiest een hoger inkomen boven een lager inkomen; het marginale nut van inkomen is derhalve positief. Veronderstel dat de wereld bestaat uit twee landen: Ongevallenland en Niet-Ongevallenland; beide landen hebben een bepaald inkomen, respectievelijk $I^{\circ}$ en $I^{\text {nv; }}$; de kans dat zich een ongeval voordoet is $\mathrm{p}$; de kans dat geen ongeval plaatsheeft is dan $1-p$. Het totale nut in die wereld bedraagt dus: $\mathrm{N}^{\mathrm{w}}=\mathrm{pN}\left(\mathrm{I}^{\circ}\right)+(1-\mathrm{p}) \mathrm{N}\left(\mathrm{I}^{\mathrm{no}}\right)$.

Het verwachte nut in deze situatie kan vervolgens worden vergeleken met andere inkomens of andere ongevalsprobabiliteiten. Een rationeel individu zal telkens kiezen voor de situatic waarin zijn verwacht nut het hoogste is. In ongevalsituaties hangt het verwachte nut bovendien af van de houding van het individu ten aanzien van het risico. In de rechtseconomische literatuur worden grosso modo drie houdingen ten aanzien van een risico ondersçheiden: een individu kan risicoavers, risiconeutraal of risicozoekend zijn ${ }^{15}$. In het hieronder gehanteerde model wordt voorlopig uitgs-

Bij de uitbouw van het rechtseconomische model van het kernongevallenrecht in hoofdstuk 15, wordt ook besproken in welke mate bijvoorbeeld het strafrecht prikkels geeft aan de exploitant van een keminstallatie.

Bij de rechtseconomische analyse van verzekeringen (hoofdstuk 9) wordt de assumptie van risiconeutraliteit verlaten en wordt rekening gehouden met de verschillende houdingen ten aanzien van een risico. 
gaan van risiconeutraliteit omdat dit een fijnere rechtseconomische analyse toelaat; vaak zullen mensen immers, indien zij volledig zijn verzekerd, handelen alsof zij risiconeutraal zijn ${ }^{16}$.

Het economische model inzake ongevallenrecht gaat ook uit van een samenleving waar slechts twee mensen wonen, namelijk het slachtoffer (A) en de dader (B). Indien bijgevolg een ongeval plaatsheeft, zal dit ongeval geen gevolgen hebben voor andere personen. Het maatschappelijke nut is dus gelijk aan het gezamenlijke inkomen van A en B.

Verder wordt ervan uitgegaan dat zowel $A$ als $B$ een invloed kunnen uitoefenen op de verwachte ongevalskosten, dat schade enkel door B aan A kan worden toegebracht en dat de inspanningen om de ongevallen te verminderen, in geld waardeerbaar zijn. De schade (S), de probabiliteit $(p)^{17}$ en de handelingen of inspanningen die de ongevalsschade beïnvloeden ( $\mathrm{x}$ en $\mathrm{y}$ ) worden eveneens weergegeven. Deze inspanningen worden weergegeven door $\mathrm{x}$ wat het slachtoffer betreft en door y wat de dader betreft. De kosten die het slachtoffer besteedt aan zorg worden weergegeven door $\mathrm{A}(\mathrm{x})$; die van de dader door $\mathrm{B}(\mathrm{y})$. Hoe meer zorg de partijen besteden, hoe lager de probabiliteit. Er wordt met andere woorden uitgegaan van een omgekeerd evenredige relatie tussen preventiekosten en ongevalsprobabiliteit, annex verwachte ongevalskosten. Anders gezegd: meer zorg zal steeds het ongevalsrisico doen dalen ${ }^{18}$.

Op basis van deze uitgangspunten kan worden onderzocht wat in de rechtseconomische analyse van het ongevallenrecht wordt verstaan onder het economisch optimum.

\subsection{Het economisch optimum}

In een efficiëntieanalyse wordt ernaar gestreefd om het gezamenlijke inkomen van dader en slachtoffer te maximaliseren. Of het slachtoffer al dan niet wordt vergoed, is in eerste instantie van ondergeschikt belang, aangezien dit betrekking heeft op de distributie van het inkomen en niet op de optimalisatie daarvan. Centraal in de rechtseconomische analyse van het ongevallenrecht staat de verhoging van de maatschappelijke welvaart. Uitgaande van de in bovenstaande paragraaf vooropgestelde uitgangspunten, betekent dit de optimalisatie van het inkomen van A en B.

Het komt er vervolgens op aan te bepalen wat het gezamenlijke inkomen van dader en slachtoffer precies inhoudt. Aangezien wordt uitgegaan van risiconeutraliteit is het verwachte nut gelijk aan het inkomen. Het vertrekpunt is dus het inkomen van het slachtoffer. Dit inkomen dient te worden verminderd met de verwachte schade (p.S) en met de kosten van voorzorg. Indien zich geen ongeval voordoet $(l-p)$, spreekt het voor zich dat het slachtoffer geen schade zal lijden. Diens inkomen wordt enkel verminderd met de preventiekosten. Het verwachte nut van het slachtoffer is dus: $N(A)=p[I a-S-A(x)]+(1-p)[I a-A(x)] ;$ of nog: Na $=I a-p . S-A(x)$.

Ook het verwachte nut van de dader kan in formulevorm worden weergegeven; zowel wanneer zich een ongeval voordoet als bij afwezigheid van ongeval zal het nut van $\mathrm{B}$ bestaan uit diens inkomen verminderd met de door hem uitgeoefende kosten van voorzorg ${ }^{19}$. Het verwachte nut van de dader is: $N(B)=p[I b-B(y)]+(1-p)[I b-B(y)]$. Of nog: $N b=I b-B(y)$.

Landes, W. en Posner, R., "Structure of Tort Law", l.c., 58.

De kans dat zich geen ongeval voordoet, wordt als $(1-p)$ aangegeven.

Faure, M. en Van den Bergh, R., "Objectieve Aansprakelijkheid", l.c., 69.

In het huidige stadium van de analyse wordt ervan uitgegaan dat geen rechtsregei beschikbaar is die de schade ex post verschuift. 
De efficiëntieanalyse gaat uit van het gezamenlijke inkomen van dader en slachtoffer, dus: $\mathrm{Na}+$ $\mathrm{Nb}=\mathrm{Ia}+\mathrm{Ib}-\mathrm{p}(\mathrm{x}, \mathrm{y}) \mathrm{S}-\mathrm{A}(\mathrm{x})-\mathrm{B}(\mathrm{y})$.

inkomen van dader (la)

$+\quad$ inkomen van slachtoffer (Ib)

- $\quad$ verwachte ongevalskosten $[\mathrm{p}(\mathrm{x}, \mathrm{y}) \mathrm{S}]$

- $\quad$ kosten van voorzorg van dader en slachtoffer $[A(x)$ en $B(y)]$

$=\quad$ totale maatschappelijke nut $(\mathrm{Nm})$

Uitgaande van de risiconeutraliteit is het gezamenlijke inkomen van A en B gelijk aan het maatschappelijke inkomen of het maatschappelijke nut. Het totale maatschappelijke nut $(\mathrm{Nm})$, kan dan ook worden beschouwd als het verschil tussen het maatschappelijke inkomen en de maatschappelijke ongevalskosten $(\mathrm{K})$, namelijk de som van de verwachte ongevalskosten en de voorzorgskosten van de twee ongevalspartijen: $N(m)=I m-K$, waarbij $K=p(x, y) S+A(x)+B(y)$.

Hieruit blijkt dat het totale maatschappelijke nut wordt gemaximaliseerd door de maatschappelijke ongevalskosten zo laag mogelijk te houden. In ecn dergclijk geval is het maatschappelijke inkomen namelijk het grootst.

De vraag rijst bijgevolg hoe de maatschappelijke kosten van het ongeval zo laag mogelijk kunnen worden gehouden. Dit impliceert dat een antwoord wordt gegeven op de vraag tot welk punt een activiteit wordt toegelaten, welke veiligheidsmaatregelen dienen te worden genomen etc. Dat preventiemaatregelen moeten worden genomen, is duidelijk, de vraag is echter hoe ver deze maatregelen dienen te gaan, rekening houdend met de kosten van deze maatregelen en de baten in termen van reductie van verwachte ongevalskosten.

In het gehanteerde rechtseconomische model, wordt gekeken naar de impact van een bijkomende eenheid zorg op de ongevalskosten; op basis hiervan wordt aangegeven tot op welk punt het efficiënt is om bijkomende eenheden zorg te spenderen.

De ongevalspartijen dienen bijkomende eenheden zorg besteden tot op het punt waar de reductie van de verwachte ongevalskosten gelijk is aan de marginale kosten van de laatste eenheid $z^{2} \mathrm{org}^{20}$. Anders gezegd: bijkomende zorg zal worden besteed zolang deze bijkomende eenheid zorg leidt tot een grotere reductie van de verwachte ongevalskosten. De zorg is met andere woorden optimaal op het punt waar de marginale kosten van zorg gelijk zijn aan de marginale opbrengst ervan (reductie van de verwachte ongevalsschade). Méér zorg besteden zou resulteren in een geringere reductie van de verwachte ongevalskosten; minder zorg zou betekenen dat relatief goedkope middelen om de ongevalskosten te verminderen, niet worden gebruikt en dat te veel ongevallen zouden plaatshebben.

Het aanwenden van zorg is dus efficiënt zolang de marginale kosten van zorg kleiner zijn dan de marginale opbrengst in reductie van de verwachte schade. Efficiënte zorg is daarom niet hetzelfde als een zo hoog mogelijke zorg; een optimaal niveau van zorg is dus evenmin het niveau waar de verwachte schade het laagst is. Dit blijkt ook uit onderstaand cijfervoorbeeld. 
Tabel $1^{21}$

\begin{tabular}{|l|c|c|c|c|c|}
\hline $\begin{array}{l}\text { Niveau van } \\
\text { zorg }\end{array}$ & $\begin{array}{l}\text { Kosten van } \\
\text { zorg }\end{array}$ & $\begin{array}{l}\text { Verwachte } \\
\text { schade }\end{array}$ & $\begin{array}{l}\text { Maatschappe- } \\
\text { lijke kosten }\end{array}$ & $\begin{array}{l}\text { Marginale } \\
\text { opbrengst }\end{array}$ & $\begin{array}{l}\text { Marginale } \\
\text { kosten }\end{array}$ \\
\hline Geen & 0 & 10 & 10 & - & - \\
\hline Gemiddeld & 1 & 5 & 6 & 5 & 1 \\
\hline Hoog & 5 & 2 & 7 & 3 & 4 \\
\hline Zeer hoog & 8 & 0 & 8 & 2 & 3 \\
\hline
\end{tabular}

Dit voorbeeld toont aan dat de situatie waarbij geen schade meer optreedt, niet noodzakelijk de maatschappelijke welvaart verhoogt. Indien in een maatschappij ervoor zou worden gekozen geen enkel ongeval toe te laten, zal dit dus niet leiden tot het minimaliseren van de maatschappelijke ongevalskosten, gelet op de hoge preventiekosten. Deze analyse sluit ook aan bij de stelling van Calabresi dat ook voorzorgsmaatregelen tot kosten leiden die in de kosten-baten-analyse moeten worden in overweging genomen en dat een maatschappij niet bereid is om te allen prijze een ongeval te vermijden. Omgekeerd kan worden gesteld dat elke maatschappij bereid is om een bepaald aantal ongevallen te aanvaarden.

De efficiënte situatie zal in bovenstaand voorbeeld erin bestaan dat gemiddelde zorg wordt uitgeoefend. Enkel in dat geval zijn de marginale opbrengsten (5) groter dan de marginale kosten (1). Door gemiddelde zorg te besteden kan mits een relatief kleine inspanning een verhoudingsgewijs grotere reductie van de ongevalskosten worden bereikt ${ }^{22}$. Het aanwenden van méér dan gemiddelde zorg zal resulteren in een verlies aan maatschappelijke welvaart: de maatschappelijke kosten zijn in dat geval immers hoger dan bij het besteden van gemiddelde zorg. Efficiënte zorg betekent dus niet noodzakelijk het niveau van zorg waar de verwachte schade het laagst is ${ }^{23}$.

Uit dit cijfervoorbeeld blijkt het belang van het in aanmerking nemen van de marginale kosten en opbrengsten bij de reductie van de ongevalskosten. De letterlijke Learned Hand-formule stelt de dader aansprakelijk indien de preventiekosten lager zijn dan de verwachte schade. Zelfs indien de dader sterke zorg aanwendt, zal hij volgens de Leamed Hand-formule worden aansprakelijk worden gesteld, aangezien 8 kleiner is dan 10. De Incremental Leamed Hand-formule daarentegen houdt rekening met de marginale waarden van opbrengsten en kosten.

Uit deze paragraaf onthouden we dat het totale maatschappelijke nut wordt gemaximaliseerd door het uitoefenen van optimale zorg. Van optimale zorg is sprake indien de marginale opbrengst van zorg gelijk is aan de marginale kosten ervan. Het zal daarom zinvol zijn om een bijkomende eenheid zorg te spenderen zolang de marginale opbrengst daarvan groter is dan de marginale kosten. Optimale zorg betekent dus niet dat zoveel mogelijk zorg moet worden uitgeoefend, noch dat de verwachte schade zo laag mogelijk moet zijn.

21 De maatschappelijke kosten zijn de som van de kosten van voorzorg en van de verwachte schade; de marginale opbrengst is het verschil in de verwachte schade bij het besteden van een bijkomende cenheid zorg; de marginale kosten zijn de kosten veroorzaakt door het spenderen van een bijkomende eenheid van zorg. Als uitgangspunt werd er immers van uitgegaan dat de maatschappij risiconeutraal is; gesteld dat deze risicoavers zou zijn, kan toch het uitoefenen van een hoog of zelfs van een zeer hoog niveau van zorg 


\subsection{Unilaterale versus bilaterale ongevalsituaties}

In de rechtseconomische analyse van het ongevallenrecht wordt een onderscheid gemaakt tussen bilaterale en unilaterale ongevalsituaties. Met bilaterale ongevalsituaties wordt bedoeld dat zowe] de dader als het slachtoffer een invloed hebben op het ongevalsrisico. Auto-ongevallen zijn in de regel bilaterale ongevallen: zowel de ene als de andere bestuurder of zowel de bestuurder als de fietser/voetganger beïnvloeden het ongevalsrisico.

In een unilaterale ongevalsituatie heeft enkel de dader een invloed op het risico. Dit is bijvoorbeeld het geval bij industriële ongevallen zoals een kernongeval. In principe zal enkel de exploitant het risico beinvloeden; omwonenden hebben geen directe impact op het risico ${ }^{24}$. Voor alle duidelijkheid dient te worden benadrukt dat dit onderscheid betrekking heeft op het ongevalsrisico (p) en dus niet op de verwachte ongevalskosten (S). In het kader van dit proefschrift zal een rechtseconomisch model worden uitgebouwd dat uitgaat van een unilaterale ongevalsituatie.

In het hieronder gehanteerde model moeten daders (bij unilaterale ongevallen) twee beslissingen nemen die een invloed zullen hebben op de ongevalskosten. Vooreerst dienen zij te beslissen een bepaalde activiteit al dan niet uit te oefenen: fietsen of niet, autorijden of niet. Dit wordt het activiteitsniveau genoemd. Hoe meer een risicovolle activiteit wordt uitgeoefend, hoe meer kans iemand loopt bij een ongeval te worden betrokken ${ }^{25}$. Daarnaast moeten zij beslissen welke zorg zij hierbij zullen aanwenden: $50 \mathrm{~km} / \mathrm{u}$ dan wel $20 \mathrm{~km} / \mathrm{u}$ rijden; al dan niet een helm opzetten bij het fietsen, etc.

Hieronder wordt eerst nagegaan welke aansprakelijkheidsregel leidt tot het bereiken van het economisch optimum $(\S 2.4)$; later zal ook het activiteitsniveau worden besproken $(\S 2.5)$.

\subsection{Efficiënte aansprakelijkheidsregels bij unilaterale ongevallen}

Ook hier wordt uitgegaan van twee partijen, namelijk de dader en het slachtoffer. Beide partijen maken hun beslissingen op basis van het verwachte nut ("expected utility"). Indien een partij de keuze heeft tussen verschillende activiteiten of gedragingen, wordt aangenomen dat hij dic gedraging zal aannemen waarvan hij verwacht dat die voor hem het grootste nut oplevert. Analoog kan worden geredeneerd dat een persoon die gedraging zal aannemen met het geringste verwachte verlies (zijnde de grootte van de schade vermenigvuldigd met de probabiliteit). Voorlopig wordt ervan uitgegaan dat de houding van personen enkel afhangt van dit verwacht verlies en dus niet van de potentiële schadeomvang. In eerste instantie wordt tegelijk verondersteld dat daders enkel door het uitoefenen van zorg het ongevalsrisico kunnen beïnvloeden; het activiteitsniveau wordt constant geacht. De analyse zal rekening houden met drie verschillende situaties: in een eerste situatie bestaat geen aansprakelijkheidsregel $(\$ 2.4 .1)$; in een tweede situatie is de dader aansprakelijk op basis van een regime van risicoaansprakelijkheid. In de derde situatie tenslotte is de dader aansprakelijk voor de door hem begane fout $(\$ 2.4 .3)$.

Bewust spreken we over geen "directe" impact; in de mate waarin omwonenden bijvoorbecld bepaalde veiligheidstekortkomingen van de exploitant aan de kaak zouden kunnen stellen, kan worden aangenomen dat zij een indirecte impact kunnen hebben. Hoewel hier zeker geen sprake is van een lineaire relatie tussen het aantal deelnames aan het verkeer en de probabiliteit, omdat ook nog andere factoren meespelen. Een persoon die zeer regelmatig met de auto rijdt, heeft meer ervaring en zal daarom in bepaalde gevallen minder risico lopen bij een ongeval te worden betrokken. 


\subsubsection{Geen aansprakelijkheidsregel (in juridische zin)}

Bij afwcrigheid van aansprakelijkheidsrecht, zal de schade ten laste van het slachtoffer blijven; de wettelijke mogelijkheden om deze schade te verschuiven ontbreken in dit geval ${ }^{26}$.

Het nut van het slachtoffer bestaat uit diens inkomen verminderd met de verwachte ongevalsschade en met de door het slachtoffer genomen kosten van voorzorg. Het nut van B zal echter volledig gelijk zijn aan zijn inkomen. Aangezien hij niet aansprakelijk kan worden gesteld, zou het in beginsel zinloos zijn dat hij voorzorgsmaatregelen neemt: $N(B)=I(B)$.

Dit betekent dat zodra de dader een invloed heeft op het ongevalsrisico, het niet aansprakelijk stellen van de dader niet efficiënt is, omdat hij geen enkele prikkel zal hebben om zelfs maar de kleinste zorg te besteden. Omgekeerd kan worden gesteld dat indien de dader géén invloed kan uitoefenen op het ongevalsrisico, de afwezigheid van een aansprakelijkheidsregel wel efficiënt zal zijn. Calabresi wees er reeds op dat enkel indien het slachtoffer het best geplaatst is om door het uitoefenen van zorg het ongeval af te wenden, de afwezigheid van een aansprakelijkheidsregel efficiënt zal zijn ${ }^{27}$. Ook hier kan een tabel verduidelijking verschaffen ${ }^{28}$.

Tabel 2

\begin{tabular}{|l|l|c|c|c|}
\hline Niveau van zorg & $\begin{array}{l}\text { Kosten van zorg } \\
(\mathbf{y})\end{array}$ & Probabiliteit (p) & $\begin{array}{l}\text { Verwachte } \\
\text { schade (p.S) }\end{array}$ & $\begin{array}{l}\text { Maatschappelij- } \\
\text { ke kosten }\end{array}$ \\
\hline Geen & 0 & $80 \%$ & 80 & 80 \\
\hline Gemiddeld & 20 & $40 \%$ & 40 & 60 \\
\hline Sterk & 50 & $20 \%$ & 20 & 70 \\
\hline
\end{tabular}

Bij afwezigheid van een aansprakelijkheidsregel, zal de dader geen enkelc zorg aanwenden, waardoor de maatschappelijke kosten hoger zijn dan bij het uitoefenen van gemiddelde zorg, namelijk 80 tegenover 60 . In dit voorbeeld zou nochtans het uitoefenen van een gemiddelde $/$ org efficiënt zijn: in dat geval is de marginale opbrengst (vermindering van de verwachte schade met 40) immers groter dan de marginale kosten (20).

Ook een niet cijfervoorbeeld kan duidelijkheid verschaffen. Stel bijvoorbeeld dat het risico dat een auto tegen een huis rijdt wordt geëvalueerd. Het betreft een unilaterale ongevalsituatie, aangezien enkel de chauffeur een invloed heeft op het ongevalsrisico. Indien er geen aansprakelijkheidsregel in voege is waarbij de schade wordt verschoven van het slachtoffer naar de dader, zal de chauffeur geen cnkele prikkel hebben om trager te rijden. Omgekeerd zal de eigenaar van het huis misschien maatregclen nemen om zijn huis te beschermen ${ }^{29}$, bijvoorbeeld door het plaatsen van reflectoren op de muren, of door het huis niet te dicht bij een wcg te bouwen. In een dergelijk geval is de kans reëel dat de door de huiseigenaar uitgeoefende zorg een stuk hoger zal liggen dan

In economische zin is hier wel degelijk sprake van een aansprakelijkheidsregel, aangezien ook het ontbreken van een juridische aansprakelijkheidsregel het gedrag van de ongevalspartijen zal beinvloeden (zie Landes, W en Posner, R., "Structure of Tort Law," l.c., 62).

Calabresi, G., "Optimal Deterrence", o.c., 657. Hierin wordt hij overigens bijgetreden door Landes, W. en Posner, R., "Structure of Tort Law", l.c., 62.

Tabel overgenomen uit Faure, M. en Van den Bergh, R., "Objectieve Aansprakelijkheid", l.c., 74.

In dat geval oefent de eigenaar geen invloed uit op het ongevalsrisico (probabiliteit, of p), maar enkel op de grootte van de verwachte schade $(S)$. 
de optimale zorg. Het mag duidelijk zijn dat dit een optimale reductie van de ongevalskosten in de weg staat en bijgevolg leidt tot een verlies van welvaart.

Heel vaak zal een ongeval echter niet enkel schade veroorzaken aan het slachtoffer, maar ook aan de dader. In bovenstaand voorbeeld zal de wagen van de chauffeur die tegen het huis rijdt eveneens beschadigd zijn. Hetzelfde kan worden gesteld bij een kernongeval: een kernongeval zal ook schade veroorzaken aan de eigen installatie van de exploitant zelf. Dit leidt tot een zekere nuancering van bovenstaande stelling, maar doet geen afbreuk aan de geldigheid ervan. Immers, in de huidige analyse wordt uitgegaan van de risiconeutraliteit van partijen; indien de dader daarentegen risicoavers is, zal hij zijn eigenschade laten verzekeren en zal hij maar een zeer klein deel van de eigenschade moeten dragen ${ }^{30}$. Indien de dader dus een eigenschadeverzekering heeft, doet dit nauwelijks afbreuk aan de stelling dat hij bij afwezigheid van een aansprakelijkheidsregel geen prikkel tot het uitoefenen van zorg zal hebben.

Zodra de dader door het uitoefenen van zorg een invloed kan uitoefenen op de ongevalskosten, zal dus een rechtsregel noodzakelijk zijn teneinde de maatschappelijke kosten van cen ongeval te minimaliseren. Het doel van de aansprakelijkheidsregel is het verschuiven van de schadelast waardoor de dader wordt gedwongen rekening te houden met de negatieve gevolgen van zijn gedrag op anderen. Bij risicoaansprakelijkheid zal de dader aansprakelijk zijn zodra er bij een ongeval überhaupt negatieve externe effecten optreden; bij foutaansprakelijkheid zal hij enkel aansprakelijk zijn indien hij onvoldoende zorg heeft besteed.

\subsubsection{Risicoaansprakelijkheid}

Onder een regime van risicoaansprakelijkheid krijgt het slachtoffer steeds zijn volledige schade vergoed. Het nut van het slachtoffer is gelijk aan zijn inkomen: $N(A)=I(A)$. In een unilateraal schadegeval, zal het slachtoffer immers geen voorzorgen nemen. De voorwaarde hierbij is wel dat de uitgekeerde schadevergoeding precies gelijk is aan de reëel geleden schade. Deze situatie is dus volledig omgekeerd van de vorige; bij afwezigheid van een aansprakelijkheidsregel was immers het nut van de dader gelijk aan het inkomen van de dader.

Voor de dader impliceert een regime van risicoaansprakelijkheid dat hij alle schade zal moeten compenseren én alle kosten van voorzorg zal moeten dragen. Diens totale kosten zullen dus gelijk zijn aan de totale ongevalskosten. Hierdoor zijn de kosten van de dader gelijk aan de maatschappelijke kosten ${ }^{31}$. Dit impliceert ook dat de negatieve externaliteiten volledig zullen worden geïnternaliseerd $^{32}$. Een rationele dader zal ernaar streven zijn totale kosten te minimaliseren, waardoor hij meteen ook zal trachten de totale ongevalskosten te minimaliseren. Hierdoor zal de dader automatisch de juiste prikkel hebben om het optimale niveau van zorg uit te oefenen, want op het punt waar optimale zorg wordt uitgeoefend worden de totale ongevalskosten geminimaliseerd en meteen ook zijn eigen totale kosten. Een risiconeutrale dader zal bijgevolg niet méér zorg besteden dan de optimale zorg omdat anders de marginale opbrengst van een bijkomende eenheid zorg kleiner is dan de marginale kosten.

Bijvoorbeeld de vrijstelling die desgevallend van kracht is onder de verzekeringspolis of het deel van de eigenschade dat om een andere reden niet door de polis is gedekt. Polinsky, A.M., "Strict Liability versus Negligence in a Market Setting", American Economic Review, 1980, 364; Shavell, S., "Strict Liability versus Negligence", Journal of Legal Studies, 1980, 11; Shavell, S., "Accident Law", I.c., 8. Faure, M. en Van den Bergh, R., "Objectieve Aansprakelijkheid", l.c., 75. 
Het spreckt voor zich dat de dader enkel de juiste prikkel krijgt indien de schadevergoeding die hij krachtens de aansprakelijkheidsregel moet uitkeren, ook overeenstemt met de werkelijk geleden schade. Zoniet zal ofwel een deel van de schade onvergoed blijven, waardoor het negatief extern effect niet volledig werd geïnternaliseerd; ofwel zal teveel schade worden vergoed, wat eveneens een optimale allocatie van de middelen in de weg staat.

\subsubsection{Foutaansprakelijkheid}

Bij een regime van foutaansprakelijkheid zal de dader enkel aansprakelijk zijn indien hij onvoldoende zorg heeft aangewend. Op voorwaarde dat de rechtbanken voldoende zorg gelijk stellen aan optimale zorg, zal de dader enkel worden aansprakelijk gesteld indien hij minder zorg hecft besteed dan het niveau van de optimale zorg.

Een rationele dader zal ernaar streven zijn totale kosten zo laag mogelijk te houden, dus zal hij ook niet méér zorg besteden dan nodig om aansprakelijkheid te vermijden. Voortbouwend op tabel 2 , kan dit worden verduidelijkt aan de hand van volgende tabel.

Tabel 3

\begin{tabular}{|l|c|c|c|c|}
\hline Niveau van zorg & $\begin{array}{l}\text { Kosten van zorg } \\
\text { (y) }\end{array}$ & $\begin{array}{l}\text { Aansprakelijk- } \\
\text { heid }\end{array}$ & $\begin{array}{l}\text { Verwachte } \\
\text { schade (p.S) }\end{array}$ & $\begin{array}{l}\text { Maatschappe- } \\
\text { lijke kosten }\end{array}$ \\
\hline Geen & 0 & Ja & 80 & 80 \\
\hline Gemiddeld & 20 & Neen & 0 & 20 \\
\hline Hoog & 50 & Neen & 0 & 50 \\
\hline
\end{tabular}

In bovenstaande tabel zal de dader gemiddelde zorg aanwenden omdat hij niet aansprakelijk zal worden gesteld. Evenmin zal de dader hoge zorg besteden omdat dit enkel zijn kosten verhoogt, terwijl hij niet "minder aansprakelijk" wordt gesteld ${ }^{33}$; tegenover de extra kosten van zorg staan geen opbrengsten in termen van daling van de verwachte kosten van aansprakelijkheid. Indien hij bijgevolg hoge zorg zou aanwenden, zou dit niet leiden tot een minimalisatie van de maatschappelijke kosten.

Of de maatschappelijke ongevalskosten inderdaad dankzij foutaansprakelijkheid worden geminimaliseerd, hangt in eerste instantie af van de mate waarin het rechtssysteem erin slaagt de juridisch redelijke zorg te vertalen naar en gelijk te schakelen met efficiënte zorg. Van de dader may immers worden verwacht dat hij als nutsmaximaliseerder correct reageert op de prikkels van het rechtssysteem. Stel dat de rechter de efficiënte zorg te hoog of te laag inschat, dan zal dat respectievelijk betekenen dat de dader toch het hoge niveau van zorg zal aanwenden of dat nict alle negatieve externe effecten worden geïnternaliseerd. In beide gevallen wordt het economisch optimum niet bereikt en zal een welvaartsverlies optreden.

\subsection{Activiteitsniveau}

Het uitoefenen van zorg is een eerste manier om ongevallen te vermijden; de maatschappelijke ongevalskosten worden evenwel ook bcïnvloed door het activiteitsnivcau, namelijk het aantal keren dat een activiteit wordt verricht. De vraag rijst of het recht naast het uitoefenen van zorg

Shavell, S., "Accident Law", l.c., 8 
ook het activiteitsniveau van de dader kan beïnvloeden - of het recht met andere woorden de dader op tweeërlei wijze een prikkel kan geven teneinde een optimale reductie van de ongevalskosten te bewerkstelligen.

Alvorens deze vraag te beantwoorden, dient nader te worden toegelicht wat wordt bedoeld met het activiteitsniveau. In heel wat gevallen nemen rechters enkel de foutstandaard of het niveau van zorg mee in hun appreciatie; het activiteitsniveau wordt hierbij niet beoordeeld. Hoe moeilijk de vaststelling van het activiteitsniveau ook is, toch is zij van belang ${ }^{34}$. Een verkeersongeval wordt niet enkel beïnvloed door een aantal duidelijk vast te stellen factoren zoals door het rode licht rijden en het verlenen van voorrang (wat duidelijk valt onder het uitoefenen van zorg), maar ook door factoren die in de appreciatie van de zorgstandaard worden opgenomen, zoals het defensieve rijgedrag van de chauffeur ${ }^{35}$. Het activiteitsniveau dient bijgevolg breed te worden geïnterpreteerd en omvat alle elementen die de ongevalskosten beïnvloeden en die niet in aanmerking worden genomen door de rechter bij het vaststellen van een fout ${ }^{36}$.

In het hieronder geschetste model wordt uitgegaan van twee assumpties. Ten eerste leidt een verhoging van het activiteitsniveau tot een proportionele verhoging van de verwachte ongevalsschade en ten tweede zal een hoger activiteitsniveau het nut van de dader verhogen ${ }^{37}$.

Tabel 4

\begin{tabular}{|c|c|c|c|c|}
\hline Activiteitsniveau & Totale nut & $\begin{array}{l}\text { Kosten van } \\
\text { voorzorg }\end{array}$ & $\begin{array}{l}\text { Totale verwachte } \\
\text { ongevalskosten }\end{array}$ & Sociaie weivaart \\
\hline 1 & 20 & 2 & 5 & 13 \\
\hline 2 & 40 & 4 & 10 & 26 \\
\hline 3 & 55 & 6 & 15 & 34 \\
\hline 4 & 65 & 8 & 20 & 37 \\
\hline 5 & 70 & 10 & 25 & 35 \\
\hline 6 & 72 & 12 & 30 & 30 \\
\hline 7 & 69 & 14 & 35 & 20 \\
\hline
\end{tabular}

In dit voorbeeld ervaart de dader die eenmaal een activiteit stelt hierdoor een nut van 20, terwijl hij 2 aan voorzorg besteedt en de totale ongevalskosten 5 bedragen. Indien hij de activiteit tweemaal stelt, zal hij het dubbele aan voorzorg spenderen en zullen de verwachte ongevalskosten eveneens het dubbele bedragen; stelt hij de activiteit driemaal, zullen de preventie en totale ongevalskosten het drievoud bedragen, etc. In het begin leidt een hoger activiteitsniveau tot een proportioneel hoger nut, en dit op basis van de theorie van het afnemend grensnut. Eénmaal met de auto rijden wordt als heel leuk ervaren en levert een groot nut op, maar indien een persoon ontzettend veel met de auto rijdt, zal hij daar steeds minder nut van ervaren.

Shavell, S., "Strict Liability versus Negligence", o.c., 22.

Hiermee wordt een rijgedrag bedoeld waarbij de chauffeur de fouten van andere chauffeurs tracht te anticiperen en aldus ongevallen te vermijden. Indien een chauffeur op een voorrangsweg rijdt, houdt defensief rijgedrag bijvoorbeeld in dat hij er toch rekening mee houdt dat een andere chauffeur ervan uitgaat dat hij voorrang van rechts heeft. Omdat de eerste chauffeur voorbereid is op de fout van de andere, kan hij tijdig remmen en een ongeval vermijden. 
De optimale situatie zal erin bestaan dat de persoon de activiteit op activiteitsniveau vier zal uitoefenen omdat de totale welvaart in dat geval het hoogste is. Telkens wanneer de dader de activiteit éénmaal uitvoert, zullen de totale ongevalskosten met $2+5=7$ toenemen $^{38}$. Vandaar zal de maatschappelijke welvaart toenemen zolang het marginale nut van het extra uitoefenen van de activiteit, groter is dan 7 . Indien in het voorbeeld de dader de activiteit uitoefent op activiteitsniveau 4, is zijn marginaal nut 10 (namelijk 65-55); indien hij de activiteit uitoefent op activiteitsniveau 5, bedraagt het marginale nut slechts 5 (namelijk 70-65).

Indien de dader niet aansprakelijk wordt gesteld voor de door hem aangebrachte schade, zal hij geen zorg uitoefenen en zal hij bovendien te vaak de activiteit uitvoeren. De dader zal zijn activiteitsniveau immers blijven verhogen zolang hij hieruit enig nut haalt. In bovenstaand voorbeeld zal hij de activiteit uitoefenen op activiteitsniveau 6; pas vanaf dit activiteitsniveau vermindert zijn nut.

Bij risicoaansprakelijkheid zal de dader ertoe gehouden zijn alle schade te vergoeden; zijn nut zal bijgevolg gelijk zijn aan de maatschappelijke welvaart omdat hij enerzijds het nut van de activiteit ervaart en omdat hij anderzijds moet opdraaien voor de hierdoor ontstane kosten en de preventiekosten. Dit is precies hetzelfde als de sociale welvaart; het nut van de dader zal dus gelijk zijn aan de sociale welvaart en die is het grootst bij activiteitsniveau 4. Onder risicoaansprakelijkheid zal een dader het niveau van optimale zorg breed interpreteren. Hij is geïnteresseerd in elke maatregel die zijn verwachte schade meer reduceert dan de kosten ervan; deze maatregel kan zowel betekenen dat hij veiliger materiaal $/$ al gebruiken als dat hij zijn activiteitsniveau aanpast.

Bij foutaansprakelijkheid zal de dader vrijuit gaan zodra hij het niveau van optimale zorg naleeft - op voorwaarde uiteraard dat de rechtbanken de in het recht betamelijke zorg invullen als optimale zorg in rechtseconomische zin. Voor alle ongevalsschade die daar bovenop wordt toegebracht, zal hij niet aansprakelijk worden gesteld. De foutstandaard voldoet bijgevolg niet indien enkel rekening wordt gehouden met de uitgeoefende optimale zorg ${ }^{39}$. De dader zal geen reden hebben om rekening te houden met zijn activiteitsniveau. Zodra hij niet meer aansprakelijk word't gesteld, zal hij zijn activiteitsniveau verhogen tot op het punt waar hij geen nut meer haalt uit de toegenomen activiteit ${ }^{40}$

Bijgevolg kan, in een unilaterale ongevalsituatie waarin de fout enkel wordt beoordeeld aan de hand van de uitgeoefende zorg, een regime van foutaunsprakclijkheid leiden tot een inefficiënte maatschappelijke toestand. Bij risicoaansprakelijkheid daarentegen zal de dader ook een prikkel hebben om het activiteitsniveau in acht te nemen.

\subsection{Conclusie}

Volgens het uitgebouwde rechtseconomische model kan het aansprakelijkheidsrecht bịjdragen tot een verhoging van de maatschappelijke welvaart door de maatschappelijke kosten van ecn ongeval zo laag mogelijk te houden. Onder deze benadering wordt het maatschappelijke nut gemaximaliseerd door optimale zorg uit te oefenen; van optimale zorg is sprake indien de marginale kosten van zorg gelijk zijn aan de marginale opbrengst ervan.

De som van de totale verwachte ongevalskosten en de kosten van voorıorg stijgen telkens met 7 eenheden.

Shavell, S., "Strict Liability versus Negligence", o.c., 12.

Shavell, S., "Accident Law", l.c., 23-24. 
In dit onderzoek gaat de aandacht met name uit naar unilaterale ongevalsituaties, dit wil zeggen ongevallen waarbij enkel de dader een invloed heeft op het ongevalsrisico. Uit de analyse is gebleken dat in dergelijke gevallen een aansprakelijkheidsregel is vereist. $\mathrm{Bij}$ afwezigheid van een dergelijke regel zal de dader immers geen enkele prikkel hebben om zelfs maar de geringste zorg te besteden.

Een prikkel tot het uitoefenen van zorg zal daarentegen wel voorhanden zijn bij een regime van foutaansprakelijkheid of bij risicoaansprakelijkheid. Het grote verschil tussen beide aansprakelijkheidsregimes bestaat erin dat bij risicoaansprakelijkheid de rechter enkel de grootte van de schade dient vast te stellen en dat de uitgekeerde schadevergoeding dient overeen te stemmen met de werkelijk geleden schade, terwijl bij foutaansprakelijkheid de rechter het niveau van optimale zorg moet berekenen en moet bepalen of de dader dit niveau van zorg heeft besteed. Onder de gestelde voorwaarden leiden zowel foutaansprakelijkheid als risicoaansprakelijkheid tot een efficiënt resultaat.

Rekening houdend met het activiteitsniveau, bestaat; in unilaterale ongevalsituaties een voorkeur voor risicoaansprakelijkheid omdat in een dergelijk geval de dader niet alleen optimale zorg zal uitoefenen, maar tegelijk ook het juiste activiteitsniveau zal aanhouden. Bij foutatansprakelijkheid wordt enkel gekeken of de dader voldoende zorg heeft aangewend en niet of hij het optimale activiteitsniveau heeft aangehouden.

Het hierboven uiteengezette model bleef vrij eenvoudig. In de onderstaande paragraaf wordt met name de invloed bestudeerd van informatieproblemen op de geldigheid van het uitgebouwde model.

\section{DÉ INVLOED VAN INFORMATIEPROBLEMEN - HET MODEL VERFIJND}

Het bovenstaande rechtseconomische model gaat uit van een aantal basisverondeistellingen waaraan in de realiteit niet altijd zal zijn voldaan. Zo werd er inzake van de foutaansprakelijkheid van uitgegaan dat de rechter het niveau van efficiënte zorg hanteert als fouteriterium. De kans bestaat dat de rechter over onvoldoende informatie beschikt om inderdaad de fout vast te leggen op het niveau van efficiënte zorg. In deze paragraaf worden bijkomende elementen in het hierboven uiteengezette rechtseconomische model geïntroduceerd. Vooral de invloed van informatieproblemen staat hierbij centraal $\left.\right|^{41}$.

In het kader van het onderzoek inzake de aansprakelijkheid voor schade uit kernongevallen, richt onze aandacht zich in het bijzonder tot informatieproblemen inzake het bepalen van de fout $(\$$ 3.1), inzake het vaststellen van de causaliteit (\$ 3.2) en inzake de begroting van de schadeomvang \$3.3). Op hun beurt leiden deze informatieproblemen tot een aantal administratieve kosten. De Invloed daarvan op het rechtseconomische model, wordt in $\$ 3.4$ aan de orde gesteld. De conclusies van deze analyse worden gebundeld in $\S 3.5$. Theory of Liability", o.c., 327; Calabresi, G., "Optimal Deterrence and Accidents", o.c., 658; Chelius, J.R., "Liability for Industrial Accidents: A Comparison of Negligence and Strict Liability Systems", Journal of Legal Siudies, 1976, 293-309; Winter, H., "Sequential Torts with Imperfect Information", International Review of Law and Economics, 1994, vol. 14, 35-40. 


\subsection{Problemen bij het bepalen van de fout}

Eén van de basisveronderstellingen van het hierboven geschetste rechtseconomische model, is dat de ongevalspartijen in alle gevallen zullen trachten hun nut te maximaliseren, en dat zij bijgevolg gepast zullen reageren op de prikkels die zij ontvangen uit hun omgeving. Het probleem is echter dat in de appreciatie van de fout vergissingen kunnen worden begaan door de dader, het slachtoffer en door de rechter en dit op verschillende niveaus, namelijk zowel bij het bepalen van de uitgeoefende zorg als bij het bepalen van de efficiënte zorg.

Een eerste magelijke vergissing bestaat erin dat de rechter de daadwerkelijk door de ongevalspartijen uitgeoefende zorg foutief inschat ${ }^{42}$. De kans zal dan reëel zijn dat - bij unilaterale onge. vallen - de dader méér dan betamelijke zorg zal uitoefenen om te vermijden toch aansprakelijk te worden gesteld ${ }^{43}$. Is de dader van oordeel dat het uitoefenen van bijkomende zorg geen invloed heeft op de mogelijke vergissing van de rechter, dan zal hij gewoon optimale zorg bijiven uitoefenen.

Ook een vergissing bij het bepalen van de efficiěnte zorg kan đe optimale verdeling van de beschikbare middelen in het gedrang brengen ${ }^{44}$. Dit zal met name het geval zijn inzake van activiteiten waar een beschikbare technologie verandert; hierdoor zal onduidelijk zijn welke voorzorgsmastregelen de dader $\mathrm{kan} /$ moet nemen ${ }^{45}$. Ook deze situatie zal de dader ertoe aanzetten om meer dan optimale zorg te besteden. Dit zal zeker het geval zijn voor cen dader wiens activiteiten gepaard gaan met technologische procédés waarmee voor een buitenstaander het niveau van efficiënte zorg slechts uiterst moeilijk kan worden bepaald ${ }^{46}$. In een dergelijk geval valt bijvoorbeeld niet uit te sluiten dat verschillende door een rechtbank geconsulteerde experts tot een andere bevinding zullen komen. Een ongevalspartij die weet heeft van een mogelijks meningsverschil tussen deskundigen, zal meer of minder zorg uitoefenen dan het niveau van optimale zorg.

Een derde mogelijke vergissing kan erin bestaan dat de rechter het niveau van de in het recht betamelijke zorg verkeerd inschat en dat dus een verschil ontstaat met het niveau van optimale zorg ${ }^{47}$. Indien de betamelijke zorg lager wordt ingeschat dan de optimale zorg, zal de dader slechts het niveau van betamelijke zorg uitoefenen, zelfs indien via een geringe kost de verwachte schade zou dalen. Immers, zodra hij de betamelijke zorg uitoefent, zal hij niet worden aansprakelijk. gesteld. Dit betekent dat indien er bijvoorbeeld een goedkoop veiligheidsmechanisme voorhanden. is met een aanzienlijke invloed op de verwachte schade, de dader dit toch niet zal installeren.

Indien de betamelijke zorg hoger wordt ingeschat dan de optimale zorg, dan zall de dader geen andere keuze hebben dan deze betamelijke zorg aan te wenden. Dit impliceert bijvoorbeeld dat een zeer duur veiligheidsmechanisme met geringe impact op de verwachte ongevalskosten, toch zal worden geìnstalleerd ${ }^{48}$. Op een gegeven moment kan het echter voorkomen dat deze kosten zo, aanzienlijk zijn, dat de dader geen voorzorgen meer zal nemen en verkiest toch aansprakelijk te: worden gesteld.

Posner, R., "Economic Analysis", o.c., 243.

Shavell, S., "Aceident Law", l.c., 80-81.

Landes, W en Posner, R., "Theory of Tort Law", o.c., 880.

Faure, M. en Van den Bergh, R., "Objectieve Aansprakelijkheid", l.c., 92.

Shavell, S., "Accident Law", l.c., 82.

Faure, M. en Van den Bergh, R., "Objectieve Aansprakelijkheid", l.c., 92.

Shavell, S., "Accident Law", l.c., 83. 
De geschetste problemen bij het vaststellen van de foutstandaard lijken te impliceren dat in de gevallen waar inderdaad problemen zijn te verwachten, een regime van risicoaansprakelijkheid efficiënter zal zijn. Toch zal ook een regime van risicoaansprakelijkheid leiden tot bepaalde administratieve kosten. Deze problematiek wordt later aan de orde gesteld. Eerst zullen twee bijzonder problemen worden bestudeerd, met name de gevolgen van de causaliteitsonzekerheid en van de omvang van de schade, op de efficiëntie van het ongevallenrecht.

\subsection{Problemen bij causaliteitsonzekerheid}

In de juridische literatuur maar ook in de rechtseconomie is reeds veel geschreven over causaliteit bij het leerstuk van de onrechtmatige daad ${ }^{49}$. Een specifiek probleem bij de schade veroorzaakt door kernongevallen, is de causaliteitsonzekerheid ${ }^{50}$.

Indien de aansprakelijkheid bij causaliteitsonzekerheid stelselmatig toch zou worden toegewezen aan een potentiële dader, zal dit de efficiëntie van het ongevallenrecht in het gedrang brengen. Dit zou immers impliceren dat een persoon aansprakelijk wordt gesteld voor schade die hij niet heeft veroorzaakt, en bijgevolg zal hij de desbetreffende activiteit, die maatschappelijk misschien wenselijk was, stopzetten. Het investeren in maatschappelijk wenselijke activiteiten zal hierdoor worden ontmoedigd. Om een mogelijke "crushing liability"s1 te vermijden, moet de aansprakelijkheid inderdaad worden beperkt tot de schade die een persoon daadwerkelijk heeft veroorzaakt. Dit impliceert dat een potentiële dader enkel aansprakelijk kan worden gesteld voor het door hem veroorzaakt verhoogde risico en niét voor het omgevingsrisico ${ }^{52}$. Het spreekt voor zich dat indien een potentiële dader in een dergelijk geval toch aansprakelijk zou worden gesteld, dit zal leiden tot een inefficiënte situatie. De potentiële dader zal meer voorzorgen nemen, bijvoorbeeid door het installeren van bijkomende veiligheidsmechanismen, zonder dat dit zal leiden tot een (significante) beperking van het verhoogde risico. Omgekeerd, zullen degenen die een invloed kunnen hebben op het omgevingsrisico ${ }^{53}$, geen prikkel meer hebben om voorzorgen te nemen en dus bijvoorbeeld om niet meer te roken. De vraag rijst dus hoe het recht, volgens de rechtseconomie, dient om te gaan met deze onzekerheid omtrent het causaal verband.

Een eerste mogelijkheid zou erin bestaan om een bedrijf inderdaad aansprakelijk te stellen, en het te verplichten tot integrale schadeloosstelling, ook al was er slechts een kans van bijvoorbeeld

Wat de rechtseconomische literatuur betreft, zie o.m. Calabresi, G., "Conceming Cause and the Law of Torts", University of Chicago Law Review, 1975, 69-108; Landes, W. en Posner, R., "Causation in Tort Law: an Economic Approach", Journal of Legal Siudies, 1983, 109-134; Landes, W en Posner, R., "Structure of Tort Law", l.c., 228-255; Posner, R., "Economic Analysis", l.c., 167-171; Kaye, D., "The limits of the Preponderance of the Evidence Standard: Justifiably Naked Statistical Evidence and Multiple Causation", American Bar Foundation. Research Journal, 1982, 487-516; Rosenberg, D., "The Causal Connection in Mass Exposure Cases: a 'Public Law' Vision of the Tort System", Harvard Law Review, 1984, 851-929; Shavell, S., "Uncertainty over Causation and the Determination of Civil Liability", Journal of Law and Economics, 1985, 587-609; Shavell, S., "An Analysis of Causation and the Scope of Liability in the Law of Torts", Journal of Legal Studies, 1980, 463-519; Shavell, S., "Accident Law", l.c., 105-126. Voor een Nederlandstalige bijdrage hierover, zie vooral Faure, M., (G)een schijn van kans. Beschouwingen over het statistisch causaliteitsbewijs bij milieugezondheidsschade, oratie, Maklu, Antwerpen, 1993, 31.

Algemeen juridisch, zie o.m. Akkermans, A.J., "Proportionele aansprakelijkheid", l.c.; Van, A.J., Onzekerheid over daderschap en causaliteit, Gouda Quint, Amhem, 1995; van Dam, C.C., "Aansprakelijkheidsrecht", l.c., 809.

In onze visie dient bijvoorbeeld het roken tot een element van het omgevingsrisico worden gerekend 
$20 \%$ dat het de schade effectief heeft veroorzaakt. Vanuit rechtseconomisch oogpunt is dit een inefficiënte oplossing omdat het bedrijf schade zal moeten vergceden die voor $80 \%$ door een onbekende factor is veroorzaakt (door een andere dader, door bijvoorbeeld de voorbestemdheid van het slachtoffer, ...). Zelfs als het bedrijf efficiënte zorg aanwendt, dan nog loopt het een aanzienlijk risico om aansprakelijk te worden gesteld.

Betreffende deze problematiek hebben Landes en Posner een voorbeeld uitgewerkt voor de schade veroorzaakt door ioniserende straling ${ }^{54}$. Er wordt verondersteld dat een kerninstallatie wederrechtelijk een aantal omwonenden blootstelt aan ioniserende straling en dat door deze straling het aantal kankerdoden in de komende 20 jaar zal stijgen van 100 naar 111 . Volgens een strikt eco. nomische benadering impliceert dit dat de keminstallatie aansprakelijk moet worden gesteld voor 11 gevallen van kanker. Het probleem is evenwel dat niet met zekerheid kan worden vastgesteld wie de 11 personen zijn die precies door de emissie van de ioniserende straling kanker hebben gekregen. De kans dat de kanker door de straling is veroorzaakt, bedraagt bijgevolg net geen $10 \%$. Ook hieruit blijkt dat het inefficiènt is om de exploitant van de kerninstallatie te laten opdraaien voor alle 111 kankergevallen. Vandaar bestaat de meest efficiënte oplossing er volgens Landes en Posner in - abstractie makend van de administratieve kosten - dat elk slachtoffer 10\% van zijn schade van de exploitant kan vorderen ${ }^{55}$.

Deze stelling sluit nauw aan bij de in het recht verdedigde oplossing van de proportionele aansprakelijkheid ${ }^{56}$. Aan de hand van de "probability of causation", zal de dader een proportioneel deel van de schade moeten vergoeden. Indien er $30 \% \mathrm{kans}$ is dat de schade van het slachtoffer is veroorzaakt door de radioactieve uitstoot, dan zal de dader $30 \%$ van de schade moeten vergoeden. Dit zal erop neerkomen dat het bedrijf $30 \%$ zal betalen van de schade van alle slachtoffers - een analoog resultaat aan wat er zou gebeuren, indien het bedrijf de gehele schade zou betalen van 30 van de 100 kankergevallen ${ }^{57}$. Op deze wijze zal de dader enkel instaan voor het verhoogde risico en niet voor het omgevingsrisico ${ }^{58}$. Dit impliceert in de visie van Shavell dat de dader zich zal gedragen alsof er geen onzekerheid bestaat omtrent de causaliteit ${ }^{59}$; bijgevolg geeft de proportionaliteitsregel een optimale prikkel tot schadepreventie ${ }^{60}$.

Benadrukt dient te worden dat onder de proportionaliteitsregel de correctheid van de rechtseconomische analyse in ruime mate wordt bepaald door natuurwetenschappelijke gegevens. De probability of causation vormt met name het onderzoeksterrein van wetenschappers in de nucleaire sector. Deze formule - die zowel toelaat na te gaan aan welke stralingsdoses mensen kunnen worden blootgesteld, als te onderzoeken welke de kans is dat in een gegeven geval een bepaalde aandoening werd veroorzaakt door radioactieve besmetting - werd overigens in de Verenigde Staten aanvaard teneinde een uitspraak te kunnen doen of een gegeven ziekte door radioactieve straling werd veroorzaakt ${ }^{61}$. Niettegenstaande de bewijsmoeilijkheden vanuit wetenschappelijk

Landes, W en Posner, R., "Structure of Tort Law", l.c., 123-124; Posner, R., "Economic Anałysis", l.c., 168.

Landes, W en Posner, R., "Siructure of Tort Law", Ic., 124.

Voor een enthousiast positiefrechtelijk pleidooi voor proportionele ansprakelijkneid, zie Akkermans, A.J., "Proportionele Aansprakelijkheid", l.c., 451-462.

Shavell, S., "Accident Law", l.c., 116.

Faure, M. "(G)een schijn van kans", l.c., 37.

Shavell, S., "Accident Law", l.c., 115 ; Robinson, G.O., "Probabilistic Causation and Compensation for Tortious Risk", Journal of Legal Studies, 1985, 798.

Shavell, S, "Accident Law", l.c., 116.

National Council on Radiation, Protection and Measurements Statement $N^{\circ} 7,30$ september 1992; zie Bond, V., "The Cancer Risk Attributable to Radiation Exposure: Some Practical Problems", Health 
oogpunt, kan dus in individuele gevallen de kans worden berekend dat een bepaalde opgelopen straling een bepaalde aandoening heeft veroorzaakt ${ }^{62} 63$

Een andere mogelijkheid om tegemoet te komen aan causaliteitsonzekerheid, bestaat in het toepassen van een drempelwaarde; zodra een gegeven drempelwaarde wordt overschreden, zou het slachtoffer integraal recht hebben op schadeloosstelling ${ }^{64}$. Indien de drempelwaarde bijvoorbeeld wordt vastgesteld op 50\% krijgt een slachtoffer alle schade vergoed indien er meer dan $50 \% \mathrm{kans}$ bestaat dat zijn aandoening is veroorzaakt door i.c. een blootstelling aan radioactieve straling ${ }^{65}$. Een drempelregel is evenwel vrij ongenuanceerd, in die zin dat zodra de kans lager ligt dan de drempelwaarde, er geen schadeloosstelling zal volgen. Dit impliceert automatisch dat indien de dader een aantal kankergevallen heeft veroorzaakt dat beneden de drempelwaarde ligt - bijvoorbeeld 30 kankergevallen op 100 - hij niet aansprakelijk zal worden gesteld, met alle negatieve gevolgen op het vlak van de preventie van ongevallen ${ }^{66}$. Daarenboven zal het zeer moeilijk zijn om een correcte drempelwaarde vast te stellen.

Bij een proportionele aansprakelijkheid zullen meer zaken voor de rechtbank worden gebracht dan bij een drempelregeling. In het laatste geval zal immers enkel bij overschrijding van de drempel een vordering worden ingediend. Bij zeer hoge causaliteitsonzekerheid is er meer kans op overdreven en onvoldoende aansprakelijkheid; het zoeken naar de feitelijke oorzaak kan dermate duur zijn, dat het welvaartsverlies ingevolge de "error-costs" te prefereren zal zijn boven de administratieve kosten ingevolge het zoeken naar de feitelijke oorzaak. Zeker indien een rechtbank en de partijen verschillende experts zullen aanstellen, zal dit aanleiding geven tot aanzienlijke kosten zonder enig evenredig voordeel in termen van correcte vaststelling van de causaliteit: de kans op onenigheid tussen experts is niet ondenkbeeldig.

Toch pleiten Shavell en Faure voor een proportionele aansprakelijkheid ${ }^{67}$, zeker in gevallen waar grote causaliteitsonzekerheid bestaat: in dat geval zijn volgens beide auteurs de negatieve gevolgen van de drempelregel op preventief vlak het sterkst. Deze stelling kan in die zin worden verfijnd dat het nadeel van de drempelregel op preventief vlak op een gegeven moment lager zal liggen dan de administratieve kosten onder de proportionaliteitsregel. Indien het bijgevolg uitermate moeilijk is om in een concreet geval de causaliteit vast te stellen, zal de proportionaliteitsregel de

Physics, 1981, 108-111: Ketchum, L., "Epidemiologic tables Law Groundwork fọ Future Rađiogenic Cancer Claims", The Journal of Nuclear Medicine, 1985, 967-972.

Faure, M. "(G)een schijn van kans", l.c., 36.

Specifiek voor wat Belgie betreft, wordt uitgebreid epidemiologisch onderzoek verricht door het Studiecentrum voor Kemenergie in Mol.

Onder meer Kaye is voorstander van de drempelwaarde (Kaye, D., "The limits of the Preponderance of the Evidence Standard: Justifiably Naked Statistical Evidence and Multiple Causation", o.c., 487 e.v.). De redenering van Kaye is gebaseerd op de assumptie dat de kosten van een vergissing ("error costs") moeten worden geminimaliseerd. Onder vergissingskosten wordt hier verstaan de som van het bedrag dat een potentiele dader dient te betalen voor gevallen waarin hij in feite de schade niet heeft veroorzaakt en van het bedrag dat hij niet heeft mocten betalen voor gevallen waarin hij in feite de schade wel degelijk had veroorzaakt. De vergissingskosten kunnen in deze context ook de kosten van overdreven aansprakelijkheid en van onvoldoende aansprakelijkheid worden genoemd. Shavell, S., "Accident Law", l.c., 115

Shavell, S., "Accident Law", l.c., 115.

Op basis van natuurwetenschappelijke gegevens dient eerst de probabiliteit te worden bepaald dat een schade door een radioactieve uitstoot werd veroorzaakt; de dader zal gehouden zijn tot schadeloosstelling van dat deel van de schade dat hij volgens de natuurwetenschappelijke gegevens heeft veroorzaakt. Concreet betekent dit dat de probabiliteit wordt vermenigvuldigd met de individueel geleden schade (Shavell, S., "Accident Law", l.c., 117 en Faure, M. "(G)een schijn van kans", l.c., 38). 
voorkeur hebben zolang de impact van de administratieve kosten geringer is dan het welvaartsverlies op het vlak van de geringere prikkelwerking bij toepassing van een andere regel.

Hiermee is echter niet gezegd dat bij zeer hoge administratieve kosten van cen proportionaliteitsregeling automatisch een andere regeling dient te worden toegepast. De administratieve kosten kunnen ook door eenvoudige maatregelen worden teruggedrongen, bijvoorbeeld indien de rechtbank de taak om een oordeel te vellen over de causaliteitsproblematiek toevertrouwt aan een wetenschappelijke onderzoekscommissie, eerder dan de verschillende partijen toe te laten elk een expert aan te duiden. Het is naar alle waarschijnlijkheid zo dat het functioneren van een dergelijke commissie op zich een duurder'systeem zal zijn dan het aanstellen van experts; anderzijds zal hierdoor het welvaartsverlies ingevolge een overdreven of onvoldoende aansprakelijkheid aanzienlijk kunnen worden teruggedrongen. In deze context kan het nuttig zijn om bijkomend onderzoek te verrichten naar andere mogelijkheden om de administratieve kosten van de proportionaliteitsregeling terug te dringen. Het mag duidelijk zijn dat indien deze kosten inderdaad worden beperkt, de voorkeur voor deze regeling nog meer aan kracht wint.

\subsection{Problemen bij onzekerheid over de schadeomvang}

In het rechtseconomische model dat totnogtoe werd uitgebouwd, werd uitgegaan van de assumptie dat de verwachte schade gelijk was aan het verwachte verlies. In een aantal gevallen zal echter onzekerheid bestaan omtrent schade en verlies, wat uiteraard een impact heeft op de optimale allocatie van middelen tengevolge van het aansprakelijkheidsvraagstuk. In dit verband zal zowel de hypothese worden besproken waarbij de rechtbank een schatting maakt van de schade ( $\$ 3.3 .1)$ als de hypothese dat ook economische schade werd veroorzaakt ( $\$ 3.3 .2)$.

\subsubsection{Schatting van de schade door de rechtbank}

Vaak zullen rechtbanken een schadevergoeding toekennen op basis van een geschat verlies. Stel bijvoorbeeld dat de verwachte schade 100 bedraagt en dat de rechtbank in $50 \%$ van de gevallen het verlies correct inschat op $100^{68}$. Maar in $25 \%$ van de gevallen schat de rechtbank de schade te laag (op 50) en in het resterende geval schat de rechtbank de schade te hoog (op 150). De verwachte schatting van de rechtbank is dan $(50 \% \times 100)+(25 \% \times 50)+(25 \% \times 150)=100$. In dit geval zal het geschatte verlies precies gelijk zijn aan de werkelijk geleden schade en zal de dader bijgevolg een juiste prikkel hebben om optimale zorg aan te wenden.

De onzekerheid waarmee de rechtbank wordt geconfrontecrd, kan zich met name voordoen in gevallen waarbij het niet zeker is of een bepaalde schade zich in de toekomst manifesteert. Op het vlak van de efficiëntie is dat op zich geen probleem, op voonwaarde echter dat de gemiddelde schatting van de rechtbank correct is ${ }^{69}$, dit wil zeggen dat het aantal keren dat de rechtbank de schade te hoog inschat wordt gecompenseerd door het aantal keren dat de rechtbank de schade te laag inschat.

Zodra de rechtbank zich gemiddeld vergist, zal een welvaartsverlies optreden. Indien de schattingen systematisch lager liggen dan de wcrkelijke schade, zal de dader een onvoldoende prikkel hebben en zal een deel van de externaliteit niet worden geïnternaliscerd. Omgekeerd zal bij con te hoge schatting de dader inefficiënt hoge zorg aanwenden. 
De vraag rijst dan of en in welke mate deze foute schattingen dienen te worden gecorrigeerd. Hierbij moet worden voor ogen gehouden dat een dergelijke correctie ook administratieve kosten zal teweegbrengen. Indien het onzeker is of een bepaalde schade zich zal voordoen of indien de grootte van een schade moeilijk kan worden ingeschat (bijvoorbeeld morele schadevergoeding wegens pijn en lijden), zal het vanuit welvaartsoogpunt beter zijn om deze schade niet in de totale schadeomvang op te nemen, op voorwaarde uiteraard dat de waarschijnlijke grootte van deze schade en de daarmee samenhangende invloed op de preventieve werking, niet te groot is ${ }^{70}$. Er zal met andere woorden een kosten/batenanalyse moeten worden gemaakt aangaande het nut om bijkomend onderzoek in te stellen aangaande de waarschijniijkheid van een bepaalde schade.

\subsubsection{Economische schade}

Onzekerheid met betrekking tot de grootte van de schade kan evencens voorhanden zijn bij zogenaamde economische schade ${ }^{71}$. Hoewel op zich de begroting van een economische schade niet meteen problematisch is, is het vanuit een economische benadering niet eenvoudig om in te schatten welke invloed economische schade heeft op de maatschappelijke welvaart ${ }^{72}$. In dit verband dienen twee vragen te worden beantwoord. In eerste instantie moet worden onderzocht wat de maatschappelijke kosten zijn van een ongeval dat economische schade veroorzaakt; in tweede instantie zal de relatie tussen de maatschappelijke kosten en economische verliezen aan de orde worden gesteld.

Een economische schade kan optreden indien door een ongeval een bepaald goed niet meer kan worden geproduceerd of indien een bepaalde dienst niet meer kan worden verstrekt of indien de verkoop van het goed in het gedrang wordt gebracht (bijvoorbeeld doordat de toegang tot de plaats van verkoop volledig is geblokkeerd). Verschillende elementen veroorzaken in dit geval maatschappelijke kosten.

Bepaalde verkopen zullen niet kunnen doorgaan, waardoor de verkoper, maar ook de koper, die uit de aankoop een nut zou hebben gehaald, economische verlies lijdt; dit kan resulteren in een welvaartverlies. Een bijkomend element is dat alternatieven misschien niet meteen beschikbaar zijn. Is een alternatief beschikbaar, dan zullen de maatschappelijke kosten duidelijk worden gereduceerd: de koper kan een bepaald nut halen uit de aankoop van het substituut; de producent van dat substituut ziet zijn omzet stijgen. In een extreem geval zal er zelfs helemaal geen welvaartsverlies optreden ${ }^{73}$, hoewel er wel degelijk sprake kan zijn van een economisch verlies in hoofde van een bepaalde onderneming.

De beschikbaarheid van een alternatief zal in een aantal gevallen evenwel bijkomende maatschappelijke kosten veroorzaken. Dit zal bijvoorbeeld het geval zijn indien het substituut minder aan de eisen van de aankoper voldoet; hij zal dan minder nut halen uit de aankoop van dit substituut in vergelijking met het nut dat hij zou halen uit de aankoop van het "originele" product.

Uit deze beschouwingen kan worden afgeleid dat indien geen substitutiegoederen beschikbaar zijn, de maatschappelijke kosten groter zullen zijn dan het economisch verlies. Het zal in dit geval

\section{Ibidem.}

In het algemeen wordt hiermee het verlies aan inkomen en/of winst bedoeld.

Zie hierover Bishop, W., "Economic Loss in Tort", Oxford Journal of Legal Studies, 1982, 1-29; Rizzo, M., "A Theory of Economic Loss in the Law of Torts", Journal' of Legal Studies, 1982, 281310.

Shavell, S., "Accident Law", l.c., 136. 
wenselijk zijn om de dader ook aansprakelijk te stellen voor economische verliezen. Zijn er daarentegen wel substitutiegoederen beschikbaar, dan zullen de maatschappelijke kosten kleiner zij.jn dan het economisch verlies. Indien in dit geval de dader eveneens aansprakelijk zou zijn voor economisch verlies, zal hij presteren op een geringer dan het optimale activiteitsniveau en zal hij tevens te veel zorg aanwenden ${ }^{74}$ : hij zal immers méér moeten vergoeden dan er strikt genomen aan schade is geleden. De cconomische voordelen van de beschikbaarheid van substitutiegoederen worden als het ware niet in mindering gebracht van zijn aansprakelijkheid.

Vanuit rechtseconomische optiek is het bijgevolg weinig zinvol om op ongenuanceerde wijze een dader aansprakelijk te stellen voor economisch verlies dat hij heeft veroorzaakt. Dit heeft te maken met het verband tussen het economisch verlies en de maatschappelijke kosten van een ongeval dat leidt tot economisch verlies. Uit de analyse is gebleken dat het aansprakelijk stellen van de dader voor het door hem veroorzaakte economisch verlies enkel zal leiden tot een optimaal resultat indien er geen substitutiegoederen beschikbaar zijn. Een veralgemeende aansprakelijkheid voor economisch verlies, zou bovendien een belangrijk neveneffect hebben: het aantal vorderingen zal toenemen, met een verhoging van de administratieve kosten tot gevolg. Dat hierdoor het welvaartsverlies nog zal toenemen, is duidelijk.

In deze context dient er tevens op te worden gewezen dat het in heel wat gevallen geen sinecure zal zijn om de economische verliezen te begroten. Dit heeft te maken met het feit dat in een aantal gevallen het antwoord op de hypothetische vraag welke de winst zou zijn geweest bij afwezigheid van een ongeval, niet eenvoudig zal kunnen worden gegeven. Dit zal met name het geval zijn bij ondememingen met een wisselende maandelijkse omzet of een seizoensgebonden omzet (bijvoorbeeld de horeca aan de kust), of bij beginnende ondememingen. Dit neemt niet weg dat geen bijzonder ingewikkelde mechanismen moeten worden aangewend om een ruwe schatting te kunnen maken, hetzij op basis van de ornzet van de jaren voorafgaand aan het jaar van het ongeval, hetzij op basis van eigen schattingen van de onderneming bij contacten met klanten, leveranciers, etc.

\subsection{Administratieve kosten}

Toegepast op het ongevallenrecht omvatten de administratieve kosten alle kosten ten laste van partijen om de uit een gegeven ongeval gerezen geschillen op te lossen. Dit betekent dat onder het begrip "administratieve kosten" wordt verstaan het geld en de tijd van slachtoffers, daders, advocaten en verzekeraars (zowel bij een geschil voor de rechtbank als bij onderhandelingen met het oog op een minnelijke schikking), en de kosten van de rechtszaak. Het betreft met andere woorden de wat Calabresi heeft genoemd tertiaire ongevalskosten ${ }^{75}$.

Voorafgaandelijk dient te worden benadrukt dat administratieve kosten veel meer zijn dan de gerechtskosten; het is aannemelijk om ervan uit te gaan dat de administratieve kosten tengevolge van een ongeval de som zijn van de gerechtskosten (deze zijn afhankelijk van het aantal rcchtsgcdingen) ener $\measuredangle i j d s$ en de informatiekosten anderzijds (dit zijn de kosten om ecn aansprakelijkheidsgeschil op te lossen $)^{76} 77$. Elk van deze kosten varieert al naargelang de gekozen rechtsregel.

Shavell, S., "Accident Law", l.c., 137.

C.fr. supra, paragraaf 2 van hoofdstuk 7.

Faure, M. en Van den Bergh, R., "Objectieve Aansprakelijkheid", l,c., 98. 
De informatiekosten zullen bij een regime van foutaansprakelijkheid hoger ligger dan bij risicoaansprakelijkheid, omdat bij foutaansprakelijkheid de rechtbank moet nagaan of de door de dader verrichte zorg gelijk is aan de optimale zorg. Bij risicoaansprakelijkheid daarentegen zal de rechtbank in een unilaterale ongevalsituatie in principe enkel de omvang van de schade van het slachtoffer moeten nagaan; bijgevolg zullen de gemiddelde administratieve kosten per vordering lager liggen bij risicoaansprakelijkheid ${ }^{78}$. Boven werd reeds gewezen op het risico en de gevolgen van een foute inschatting van de foutstandaard; de hiermee gepaard gaande kosten kunnen duidelijk worden vermeden bij een regime van risicoaansprakelijkheid.

Volgens Faure en Van den Bergh zullen de gerechtskosten een omgekeerde trend vertonen ${ }^{79}$. Zij gaan ervan uit dat bij risicoaansprakelijkheid elk ongeval aanleiding geeft tot een rechtsgeding, tenminste indien het verlies van het slachtoffer groter is dan zijn kosten om een vordering in te leiden. Bij foutaansprakelijkheid zou een slachtoffer slechts naar de rechtbank stappen indien de zorg die de dader heeft besteed lager ligt dan het niveau van optimale zorg.

Hieruit kan worden afgeleid dat onder foutaansprakelijkheid de informatiekosten hoger zijn, terwijl bij risicoaansprakelijkheid de gerechtskosten hoger zijn. Indien er bijvoorbeeld middelen worden gevonden om deze gerechtskosten terug te dringen, kan de voorkeur voor een regime van risicoaansprakelijkheid behouden blijven. Deze discussie toont het cruciale belang aan van de beschikbaarheid van correcte informatie en de kosten die gepaard gaan met het verkrijgen van deze informatie.

\subsection{Conclusie}

Uit bovenstaande analyse is gebleken dat wanneer onzekerheid bestaat over het bepalen van de fout, ever de causaliteit of over de schadeomvang, dit een weerslag kan hebben op de keuze van de meest efficiënte rechtsregel.

Zodra er problemen kunnen worden verwacht bij het bepalen van de fout, zal een regime van risicoaansprakelijkheid efficiënter zijn dan foutaansprakelijkheid.

Wat betreft gevallen van causaliteitsonzekerheid dient een belangenafweging te worden gemaakt tussen enerzijds het feit dat de drempelwaarde nefaste gevolgen heeft op de prikkelwerking, en anderzijds het feit dat via een systeem van proportionele aansprakelijkheid meer zaken voor de rechtbank worden gebracht. Aangezien het aannemelijk is om ervan uit te gaan dat de geringe prikkelwerking bij een drempelwaarde enkel mits aanzienlijke administratieve kosten kan worden opgevangen, zal een voorkeur ontstaan voor proportionele aansprakelijkheid.

Indien er grote onzekerheid bestaat over de schade, dan kan deze worden geschat. Bij grote onzekerheid is de kans dat de schade te hoog of te laag wordt ingeschat zeer aanzienlijk. In beide gevallen zal een welvaartsverlies optreden: in het ene geval zal de dader teveel zorg uitoefenen en in het andere geval zullen niet alle kosten worden geïnternaliseerd. Het kan dan ook zinvol zijn om een "vermoedelijke" schade niet te aanvaarden omdat het welvaartverlies van het toelaten van deze schade groter kan zijn dan het welvaartverlies ingevolge het niet toelaten. Enkel wanneer het

77 Over informatietekorten bij unilaterale schadegevallen, zie Ordover, J.A., "On the Consequences of Costly Litigation in the Model of Single Activity Accidents: Some new Results", Journal of Legal Studies, 1981, 269-291.

78 Shavell, S., "Accident Law", l.c., 264.

79 Faure, M. en Van den Bergh, R., "Objectieve Aansprakelijkheid", l.c., 98-99. 
niet in aanmerking nemen van een bepaalde schade een belangrijke invloed heeft op de prikkelwerking, zal het zinvol zijn om deze schade te schatten en in de totale schadeomvang op te nemen.

Specifiek met betrekking tot economische schade geldt dat het enkel zinvol is om de dader aansprakelijk te stellen voor economisch verlies dat hij heeft veroorzaakt indien er geen substitutiegoederen beschikbaar zijn.

Tenslotte hebben de administratieve kosten een invloed op de efficiëntie van de aansprakelijkheidsregel. Er bestaat een voorkeur voor risicoaansprakelijkheid omdat de informatiekosten lager liggen dan bij foutaansprakelijkheid, zeker indien de gerechtskosten in de hand kunnen worden gehouden. 



\section{HOOFDSTIK 9}

\section{RECHTSECONOMISCHE ANALYSE VAN VERZEKERINGEN}

In het vorige hoofdstuk werd het rechtseconomisch model van het aansprakelijkheidsrecht uiteengezet. In dit hoofdstuk worden ook verzekeringen in de analyse betrokken. Precies deze rechtseconomische analyse van verzekeringen zal een toetsingskader aanreiken op basis waarvan een aantal vragen kan worden beantwoord die in het kader van dit onderzoek relevant zijn. Zo zal de invloed van verzekeringen worden besproken op de prikkelwerking uit het aansprakelijkheidsrecht, zal het nut van een verplichte verzekering vanuit economische hoek worden bestudeerd en zal worden onderzocht welke elementen een invloed hebben op de verzekerbaarheid van een risico. Ook zal worden gewezen op het belang van een competitieve verzekeringsmarkt.

In hoofdstuk 8 werd uitgegaan van de risiconeutraliteit van dader en slachtoffer. In dit hoofdstuk wordt bestudeerd of en in welke mate het risico een invloed kan uitoefenen op het gedrag van dader en slachtoffer. Hierbij zullen in de eerste plaats de verschillende houdingen ten aanzien van risico worden besproken, namelijk risiconeutraliteit, risicoaversie en risicozoekend gedrag. Vervolgens wordt weergegeven in welke mate verzekeringen een antwoord kunnen bieden op risicoaversie ( $(2)$. Nadien wordt bestudeerd welke de gevolgen zijn van het verplicht stellen van een aansprakelijkheidsverzekering $(\S 3)$ en wordt aangegeven wat in de economische literatuur wordt verstaan onder de (on)verzekerbaarheid van een risico ( $\S 4$ ). In $\S 5$ worden enkele conclusies geformuleerd

\section{HoOfdLIJNEN VAN DE ECONOMISCHE RISICOTHEORIE}

De economische risicotheorie is gebaseerd op de houding die ongevalspartijen kunnen aannemen ten aanzien van een risico $(\$ 1.1)$; overeenkomstig deze houding zullen partijen het risico wensen te spreiden en/of te verschuiven. In welke mate risicospreiding en risicoverschuiving bijdragen tot een verhoging van de maatschappelijke welvaart, wordt in $\$ 1.2$ besproken. In paragraaf 1.3 tenslotte worden de conclusies van de analyse gebundeld.

\subsection{Verschillende houdingen ten aanzien van risico}

Zeer in het algemeen kan een verzekering worden omschreven als de dekking voor een bepaald risico. Essenticel voor de analyse van verzekeringen is dat duidelijkheid bestaat over het begrip "risico".

In de rechtseconomie worden grosso modo drie houdingen ten aanzicn van een risico onderscheiden: een persoon kan risicoavers, risiconeutraal of risicozoekend zijn.

De houding ten aanzien van een risico kan makkelijk worden weergegeven bij een kansspel. Stel dat een persoon voor de keuze staat om ofwel 1.000 euro te krijgen, ofwel om een krabbiljet van de loterij te ontvangen waarbij $10 \%$ kans bestaat om 10.000 euro te winnen; in beide gevallen is de economische waarde gelijk, namelijk 1.000 .

Is de persoon risiconeutraal, dan makt het hem in principe niks uit welke van de twee situaties hij zal verkiezen, vermits de economische waarde dezelfde is. Een risicoaverse persoon zal de situatie verkiezen waarin hij zeker is van zijn opbrengst en zal dus de 1.000 euro aannemen. Hij neemt met andere woorden het zekere voor het onzekere. Een risicozoekend persoon zal daaren- 
tegen uen gok wagen en redeneren dat hij misschicn 10.000 euro kan winnen, ook al bestaat er slechts 1 kans op 10 dat hij dit bedrag zal winnen.

Precies dczelfdc redenering kan worden toegepast op verwachte verliezen. Nemen we de volgende situatie: in situatie A bestaat er een kans van 10\% om een schade van 100.000 te lijden en in situatie B is er een kans van $25 \%$ om 40.000 schade te lijden (ook in dit geval is de economische waurde van beide situaties dezelfde, namelijk 10.000). Iemand die risicoavers is, zal kiezen voor de situatie met de laagste absolute schade, dus voor situatie B. Een risicoaverse persoon maximaliseert zijn nut niet alleen door rekening te houden met de verwachte rekenkundige uitkomst van een gegeven situatic, maar ook met de absolute waarde van het risico'. Een risicozoekend persoon ral opteren voor situatie A en cen risiconeutrale persoon tenslotte is algeheel onverschillig met betrekking tot de keuzc yan én van beide situaties.

Met andere woorden: de absolute warde van het risico weegt door, behalve bij risiconeutraliteit; bij risicoaversic en bij voorkeur voor risico bepaalt de absolute waarde van het verlics weike houding ten aanzien van het risico wordt aangenomen ${ }^{2}$.

Het spreekt evenwel voor zich dat vele gradaties kunnen bestaan in de genoemde houdingen ten aanzien van het risico: een persoon kan eerder risicozockend, cerder risicoavers of zeer risicoavers zijn. Bepaalde mathematische modellen laten zelfs toe deze gradaties te meten ${ }^{3}$. Tegelijk zal de houding ten aanzien van het risico afhangen van de grootte van het verwachte verlies (of de verwachte winst) en van het inkomen van de persoon. Terwijl cen bepaalde persoon in bovengenoemd voorbeeld van het loterijbiljet liever 1.000 euro met zekerheid ontvangt - en dus risicoavers is - is het perfect mogelijk dat hij onverschillig - risiconeutraal - wordt met betrekking tot de keuze 10 euro met zekerheid te winnen of een kans van 1 op 10 om 100 euro te winnen. Deze keuze zal trouwens deels worden bepaald door het inkomen van de persoon. Terwijl ienand met een groot inkomen onverschillig zal zijn om al dan niet 1000 euro te winnen dan wel een kans yan $10 \%$ te hebben om 1 miljoen te winnen, zal een persoon met een laag inkomen de situatie kiezen die de meeste zekerheid biedt; hij zal de 1000 euro aannemen ${ }^{4}$.

In onze analyse gaan we ervan uit dat de meeste mensen risicoavers zijn, omdat reeds intuitief kan worden aangevoeld dat de meeste mensen zekerheid verkiezen boven onzekerheid met gelijke economische waarde; dit geldt des ter meer wanneer de onzekerheid een verwacht verlies betreft. Wanneer iemand bijvoorbeeld een nieuwe wagen heeft gekocht, komt zijn risicoaversie tot uiting in het feit dat hij een eigenschadeverzekering voor de wagen afsluit. De persoon in kwestie verkiest de zekerheid om een kleinere som geld te "verliezen", met name het betalen van de verzekeringspremie, cerder dan het risico te lopen om bij een ongeval een veel hogere schade te moeten lijden. Dit voorbeeld sluit meteen aan bij mechanismen die het risico kunnen spreiden of verschuiven.

\section{Polsinsky, "Introduction", l.c., 51.}

Faure, M. en Van den Bergh, R., "Objectieve aansprakelijkheid", I.c., 105.

Zie bijvoorbeeld het door Arrow uitgewerkte model: Arrow, K., Aspects of the Theory of Risk-Bearing, Helsinki, Yrjö Johnsonin Sătio, 1965, 28 (hiema geciteerd als "Risk Bearing").

Zie meer in detail: Arrow, K., "Risk Bearing", l.c., 34 en Pratt, J., "Risk Aversion in the Small and in the Large", Econometrica, 1964, 122-136. 


\subsection{Verspreiden of verschuiven van risico}

In rechtseconomische termen vormen onzekerheid en risico een kostenfactor omdat voor de meeste individuen het verwachte nut bij zekerheid groter is dan bij onzekerheid. Vandaar wordt gezocht naar mechanismen die de kosten van de onzekerheid minimaliseren. Dit betekent uiteraard niet dat een risicoavers individu automatisch een verzekering zal afsluiten; er zijn meerdere manieren om de risicoaversie van een persoon weg te nemen. Een persoon die een portable computer heeft en die wil vermijden dat de pc wordt gestolen, kan zelf de nodige maatregelen nemen om zijn risicoaversie te minimaliseren. Zo kan hij er bijvoorbeeld op letten dat hij steeds de kamer afsluit waarin de computer zich bevindt, of dat hij die computer niet in zijn wagen laat liggen. Een andere mogelijkheid bestaat erin dat die persoon een verzekering afsluit tegen diefstal. Het individu zal de maatregelen kiezen die de kosten van zijn onzekerheid het meest minimaliseren ${ }^{5}$. Het spreekt voor zich dat de ene maatregel de andere niet uitsluit en dat een persoon vaak tegelijk zelf voorzorgsmaatregelen zal nemen en het overblijvende deel van het risico zal trachten te verschuiven of te spreiden.

Uitgaand van de veronderstelling dat de maatschappelijke welvaart de som is van het verwachte nut van alle leden van de maatschappij, zal de welvaart toenemen indien het risico wordt verschoven van een persoon die risicoavers is naar een risiconeutrale persoon. In deze hypothese wordt minstens één van de partijen in een betere positie geplaatst, zonder dat de situatie van de ander verslechtert - in de economische literatuur wordt dit een Pareto-verbetering genoemd ${ }^{6}$. Indien de risiconeutrale persoon bovendien nog wordt betaald om het risico over te nemen, dan zullen beide partijen er beter aan toe zijn dan vóór het verschuiven van het risico: de risicoaverse persoon heeft zijn aversie afgewenteld op de risiconeutrale persoon die hiervoor een vergoeding ontvangt'.

Ook de spreiding van het risico over verschillende personen die een afkeer van risico hebben, doet de maatschappelijke welvaart toenemen. Dit blijkt met name uit het feit dat twee risicoaverse partijen met een gelijk inkomen hun nut kunnen maximaliseren door ex ante het risico te spreiden ${ }^{3}$. In dit geval daait de omvang van de potentiële schade voor elk individu en bijgevolg neemt hct verwachte nut toe?

Het spreiden of verschuiven van een risico zal in een aantal gevallen worden doorgevoerd omdat dit economisch zinvol is. Door het verschuiven of het spreiden van een risico wordt de risicoaversie van een persoon weggenomen of daalt deze risicoaversie. Hierdoor zal de maatschappelijke welvaart toenemen. Risicospreiding verhoogt bovendien ook op indirecte wijze de maatschappelijke welvaart omdat risicoaverse personen toch een prikkel krijgen tot het verrichten van risico-

Een klassiek voorbeeld betreft de mogelijke maatregelen om een brandrisico te reduceren. De risicoaverse perscoon kan speciale brandbesiendige elektriciteitsleidingen laten leggen, kan een dure sproeiinstallatie installeren, of kan voor dit risico een verzekeringscontract afsluiten (Mackaay, E., Economics of Information and Law, Boston, Kluwer, 1982, 175). In de praktijk zal zelis vaak een combinatie van deze maatregelen verkozen worden.

Cfr. supra, in $\$ 2.2 .1$ van hoofdstuk 7.

Shavell, S., "Accident Law", I.c., 190.

Shavell, S., "Accident Law", l.c., 191-192.

Faure, M. en Van den Bergh, R., "Objectieve aansprakelijkheid", l.c., 110. 
volle maar maatschappelijk nuttige activiteiten. Dankzij risicospreiding zal toch worden geìnvesteerd in gevaarlijke activiteiten ${ }^{10}$.

\subsection{Conclusie}

In grote lijnen kunnen drie houdingen ten aanzien van een risico worden onderscheiden. Een persoon kan risiconeutraal, risicoavers of risicozoekend zijn. Bij toepassing van de economische risicotheorie op een verwacht verlies, dan zal voor een risicoaverse en een risicozoekende persoon de absolute waarde van het risico doorslaggevend zijn: zij zullen het risico respectievelijk niet en wel nemen.

Voor risicoaverse personen zal het verwachte nut groter zijn bij zekerheid en bijgevolg zal worden gezocht naar manieren om het risico af te wentelen. Zowel het spreiden als het verschuiven van het risico kunnen het risico afwentelen en zullen de maatschappelijke welvaart verhogen. Deze stelling zal verder worden toegelicht aan de hand van de economische analyse van verzekeringen.

\section{ECONOMISCHE ANALYSE VAN VERZEKERING}

Op basis van de analyse van de houding ten aanzien van het risico, kan worden bestudeerd in welke mate verzekeringen bijdragen tot een verhoging van de maatschappelijke welvaart. De beginselen van de economische analyse van verzekeringen worden uiteengezet in paragraaf 2.1. Vervolgens wordt bestudeerd in welke mate het voorhanden zijn van een verzekeringsdekking de van het aansprakelijkheidsrecht uitgaande prikkels beïnvloedt, hetzij omwille van het morele risico (\$ 2.2 ), hetzij omwille van het probleem van averechtse selectie ( $\$ 2.3$ ). De invloed van een aansprakelijkheidsverzekering op de maatschappelijke welvaart, wordt in $\$ 2.4$ besproken. Nadien worden de economische gevolgen toegelicht van onvoldoende concurrentie op de verzekeringsmarkt $(\$ 2.5)$. De conclusie van de analyse wordt weergegeven in $\$ 2.6$.

\subsection{Beginselen}

Er bestaan verschillende vormen van risicospreiding of risicoverschuiving. Een dergelijke spreiding of verschuiving hoeft niet noodzakelijk te kaderen in de activiteiten van een verzekeringsonderneming sensu stricto. Een bezitter van een schilderij van Picasso kan zijn risico overdragen op een andere persoon door bijvoorbeeld het schilderij in bewaring te geven bij een daartoc gespecialiseerde veiligheidsonderneming. Bij traditionele vormen van verzekering zal het risico worden overgenomen door een derde die bereid is om tegen betaling het risico over te nemen. Dit hoeft evenwel niet noodzakelijk een derde te zijn: bij systemen van onderlinge verzekering ${ }^{\text {II }}$ wordt het risico in principe gespreid tussen verschillende personen die aan bepaalde risico's worden blootgesteld.

Verzekering is een methode die, zoals gezegd, de risicoaversie van een persoon kan wegnemen: een verzekeringsmaatschappij neemt tegen betaling een risico geheel of ten dele over van een bepaald individu. Wanneer degene die het risico ovemeemt beter in staat is het risico te dragen 1963, 946; Easterbrook, F. en Fischel, D., "Limited Liability and the Corporation", University of Chicago Law Review, 1985, 89-117; Shavell, S., "Accident Law", l.c., 189. 
dan die risicoaverse persoon, dan stijgt de maatschappelijke welvaart ${ }^{12}$. Een verzekeringsmaatschappij ontvangt premies voor het overnemen van het risico; daarnaast vergroot ook het nut van het risicoaverse individu omdat deze zijn verwacht verlies nu perfect kent: zijn enige "verlies" is het betalen van de verzekeringspremie.

Bij de economische analyse van verzekeringen wordt uitgegaan van een economisch optimale verzekeringsmarkt, hetgeen veronderstelt dat de verzekeraar actief is op een volkomen concurrentiêle markt en dat de verzekeraar beschikt over volledige informatic aangaande het gedekte risico. In dit deel van de analyse gaan we er bovendien van uit dat de verzekerde het risico niet zelf kan beïnvloeden. Tenslotte wordt verondersteld dat verschillende risicoaverse verzekerden worden geconfronteerd met identieke en onafhankelijke risico's en dat de verzekeringsoperatie geen aanleiding geeft tot zware administratieve kosten ${ }^{13}$.

In een economisch optimale verzekeringsmarkt zal een verzekeringsmaatschappij een volledige dekking verlenen tegen een premie die gelijk is aan de verwachte ongevalskosten, met name p.S of de probabiliteit vermenigvuldigd met de verwachte schade ${ }^{14}$. Een voorbeeld kan dit illustreren: een risicoavers persoon heeft $20 \%$ kans dat hij 10.000 euro zal verliezen. De verwachte ongevalskosten bedragen met andere woorden 2.000 euro. Op een volledig transparante verzekeringsmarkt zal de premie eveneens gelijk zijn aan 2.000 euro (dit wordt de actuaricel eerlijke premie genoemd $)^{15}$. In de praktijk zal dit bedrag evenwel iets hoger liggen omdat een deel van de administratieve kosten van de verzekeringsmaatschappij worden verrekend in de premie.

Bij de rechtseconomische analyse van verzekeringen wordt een onderscheid gemaakt tussen twee situaties: in de eerste situatic kan de verzekerde zelf geen invloed uitoefenen op het risico (zoals bijvoorbeeld het geval is bij bliksemschade ${ }^{16}$ ); in de tweede situatie heeft de persoon wel degelijk een invloed op het risico. Dit onderscheid is van groot belang omdat de beschikbaarheid van een verzekeringsdekking het risico kan beïnvloeden.

Indien de verzekerde geen invloed heeft op het risico, spreekt het voor zich dat enkel het verlenen van volledige dekking optimaal is: wanneer minder dan volledige dekking gegeven wordt, wordt de risicoaversie van het individu niet volledig weggenomen. Vandaar wordt het nut van cen risico-avers individu dat het risico /elf niet kan beïnvloeden gemaximaliseerd indien hem volledige dekking wordt verleend ${ }^{17}$.

Faure, M. en Van den Bergh, R., "Objectieve Aansprakelijkheid", l.c., 111.

Shavell, S., "Accident Law", l.c., 192.

Faure, M.G., "Ongevallenpreventie door efficiênte aansprakelijkheidsregels en verzekeringspolissen op competitieve verzekeringsmarkten", Het Verzekeringsarchief, deel 70, 1993-1,8.

Faure, M. en Van den Bergh, R., "Objeetieve Aansprakelijkheid", l.c., 112.

Ehrlich, J. en Becker, G., "Market Insurance, Self Insurance and Self-Protection", Journal of Political Economy, vol. 80, 1972, 638 .

Voorwaarde hierbij is wel dat wordt uitgegaan van een competitieve verzekeringsmarkt waar de verzekeraar over perfecte informatie beschikt over het gedekte risico. Gebrekkige informatie aangaande een risico kan de maatschappelijke welvaart verminderen: zowel verzekerde als de verzekeraar kunnen het risico te hoog of te laag inschatten. Indien de verzekerde zijn risico te hoog inschat, zal hij ertoe geneigd zijn een te hoge dekking te kopen en omgekeerd zal de verzekerde een te beperkte dekking kopen indien hij zijn risico onderschat. Indien de verzekeraar het risico onderschat zal de premie die hij aanrekent te laag liggen (Shavell, S., "Accident Law", l.c., 98). 
In een tweede situatie wordt ervan uitgegaan dat de verzekerde wel degelijk het risico kan beinvloeden, hetgeen vanuit economisch oogpunt een aantal vragen oproept. Deze situatie wordt hieronder besproken.

\subsection{Moral hazard of het morele risico}

In gevallen waar de verzekerde een invloed heeft op het risico - hetgeen in de meeste verzekeringsvormen het geval is - staat de vraag centraal in welke mate het kopen van een verzekeringsdekking de prikkels van de verzekerde om schadeverwekkend gedrag te vermijden, kan aantasten.

Stel bijvoorbeeld dat iemand een antieke kast heeft gekocht en deze wenst te verzekeren tegen brandgevaar. In dit geval kan de verzekerde een invloed uitoefenen op het risico door bijvoorbeeld een brandblusser te plaatsen in de buurt van de kast. Omgekeerd bestaat het gevaar dat hij tegenover de verzekeringsmaatschappij de waarde van de kast te hoog zal schatten, waardoor hij zelfs belang krijgt bij een schadegeval, bijvoorbeeld indien de kast een werkelijke waarde heeft van 100.000 euro maar deze is verzekerd tot een bedrag van 150.000 euro. Het probleem dat de beschikbaarheid van een verzekeringsdekking het risico, en dus de prikkel tot het uitoefenen van optimale zorg, kan beïnvloeden wordt in de rechtseconomische literatuur het moral hazardprobleem (of morele risico) genoemd.

In de literatuur is het moral hazard-probleem vooral met betrekking tot aansprakelijkheidsverzekeringen besproken, in de bekommernis ervoor te zorgen dat verzekering niet elke door het aansprakelijkheidsrecht gegeven prikkel tot het vermijden van ongevallen wegneemt ${ }^{18}$. Om deze reden was in bepaalde rechtsstelsels verzekering van aansprakelijkheid zelfs verboden ${ }^{19}$. Hierboven werd aangetoond dat indien een persoon aansprakelijk wordt gesteld voor schade voortvloeiend uit een bepaalde activiteit, hij een prikkel zal hebben om geen schade te berokkenen. Wanneer die persoon voor die activiteit een verzekering heeft afgesloten, dan weet hij dat niet hijzelf maar de verzekeringsmaatschappij de schade zal moeten vergoeden. Vanuit rechtseconomisch oogpunt betekent dit dat door verzekering de prikkels tot het nemen van zorg kunnen verminderen of verdwijnen. Hierdoor stijgt de verwachte schade, zonder een aangepaste stijging van de premie. De premie is op dat moment dus niet meer gelijk aan de verwachte schade ${ }^{20}$.

Of een gegeven verzekeringsdekking leidt tot een moreel risico hangt vooral af van de beschikbaarheid van informatie voor de verzekeraar ${ }^{21}$. Indien de verzekeraar geen kosten moet maken om over perfecte informatie te beschikken aangaande risicoreducerend gedrag van de verzekerde, zal er geen moreel risico bestaan. In dit geval kan de verzekeraar zijn tussenkomst in de polis afhan-

Zo wijst Snijders erop dat een aansprakelijkheidsverzekering vanuit preventie-oogpunt in beginset contraproductief is (Snijders, W, "Aansprakelijkheid voor milieuverontreiniging: het verzekeringsaspect", Aansprakelijkheid \& Verzekering, 1993, 2).

Dit is met name het geval in bepaalde delen van de voormalige Sovjet-Unie; ook bij ons was dergelijke verzekering aan het begin van deze eeuw ondenkbaar en immoreel (Shavell, S., "Accident Law", l.c., 215; Shavell, S., "On liability and Insurance", Bell Journal of Economics, Vol. 13, 1982, 120). Shavell, S., "On liability and Insurance", o.c., 120.

21 De omvang van het morele risico hangt af van de elasticiteit van de vraag (Faure, M. en Van den Bergh, R., "Objectieve Aansprakelijkheid", l.c., 115). De prijselasticiteit van de vraag duidt in het algemeen op de relatie tussen de prijs van een goed of van een dienst en de hoeveelheid: indien de prijs van een goed zeer sterk afhangt van de beschikbare hoeveelheid, is er sprake van een elastische vraag. Toegepast op de problematiek van het morele risico, kan worden gesproken van elasticiteit indien de vraag naar een bepaalde verzekering wordt beïnvloed door de prijs op de markt. Volgens Faure en Van den Bergh doet niet de verzekering op zichzelf het morele risico ontstaan, maar wel de elasticiteit van de vraag naar het verzekerde risico. 
kelijk stellen van welbepaalde risicoreducerende acties zoals het installeren van brandblusapparaten; dergelijke acties kunnen bovendien worden beloond via de premie. Voorwaarde hierbij is uiteraard dat de kosten van deze acties niet groter zijn dan de daling van het verwachte verlies door de acties ${ }^{22}$.

Hieruit kan eveneens worden afgeleid dat het verwachte nut van de verzekerde het hoogst zal zijn indien de verzekeraar over informatie beschikt omtrent de risicoreducerende acties van de verzekerde omdat in dit geval volledige dekking mogelijk blijft. In die zin kan de verzekerde belang hebben bij het feit dat de verzekeraar informatie inwint bijvoorbeeld door middel van inspecties en dat de verzekerde zelfs bereid zal zijn de kosten van deze inspecties te dragen, hetzij door een hogere premie te betalen, hetzij door deze kosten direct te betalen ${ }^{23}$.

Indien daarentegen onvoldoende informatie beschikbaar is, of indien deze informatie enkel tegen hoge kosten kan worden verkregen, kan de verzekeraar in de polis zijn tussenkomst niet afhankelijk stellen van bepaalde risicoreducerende acties, en kan een daling van premie geen bijkomende prikkel geven tot risicoreductie. Een uitstekend voorbeeld van risicoreducerende acties vinden we bijvoorbeeld terug bij auto-ongevallen waar het dragen van de veiligheidsgordel een middel bij uitstek is om de omvang van de schade na een ongeval terug te dringen. Het dragen van deze veiligheidsgordel betekent voor de verzekerde slechts een zeer geringe kost, maar vanuit het oogpunt van de verzekeraar is dit nagenoeg onmogelijk te controleren.

Dit is vooral problematisch indien volledige dekking wordt geboden omdat de verzekerde in dit geval nog weinig redenen zal hebben om verliezen te vermijden. Hierdoor wordt duidelijk dat het moral hazard-probleem kan worden geremedieerd door de verzekerde zelf voor een deel bloot te stellen aan het risico; door met andere woorden geen volledige dekking te verschaffen. Tot op welk niveau dekking zal worden verleend, zal afhangen van de prikkel die wordt gecreëerd dooir de gedeeltelijke blootstelling aan de schade. Deze prikkel is op zijn beurt afhankelijk van de kosten van de voorzorgsmaatregelen. Zijn deze kosten zeer gering, dan zal de optimale dekking sterk aanleunen bij een volledige dekking ${ }^{24}$.

Uiteraard zal de beschikbaarheid van een verzekeringsdekking niet noodzakelijk alle prikkels tot het uitoefenen van zorg aantasten. In de eerste plaats zal in vele gevallen de verzekerde zelf ook schade lijden uit een ongeval. Daarnaast kunnen vanuit andere mechanismen prikkels worden gecreêerd zoals uit het administratieve recht inzake vergunningverlening of uit het strafrecht. Stel bijvoorbeeld dat een bedrijf schade berokkent aan derden omdat het een giftige stof heeft geloosd in een rivier. In dit geval lijdt de verzekerde zelf geen schade, maar loopt hij het risico dat zijn vergunning wordt ingetrokken en dat hij strafrechtelijk zal worden vervolgd.

Uit bovenstaande beschouwingen kan worden afgeleid dat grosso modo twee mechanismen het morele risico kunnen beperken. Ten eerste kan de verzekeringsmaatschappij het gedrag van de verzekerde controleren; in functie hiervan kunnen de premie en/of de polisvoorwaarden worden aangepast ${ }^{25}$. Ten tweede kan het individu zelf gedeeltelijk aan het risico worden blootgesteld ${ }^{26}$. Er

Shavell, S., "Accident Law", l.c., 195.

Shavell, S., "Accident Law", l.c., 197.

Shavell, S., "On Moral Hazard and Insurance", Quarterly Journal of Economics, 1979, 341.

Polinsky, "Introduction", l.c., 54.

Zie uitgebreid Faure, M. en Van den Bergh, R., "Objectieve Aansprakelijkheid", l.c., 114-122. 
zijn verschiliende manieren om de verzekerde aan een deel van het risico bloot te stellen ${ }^{27}$ en op deze wijze aan te sporen tot schadevermijdend gedrag. De meest voor de hand liggende manier is dat de verzekeraar slechts uitkeert tot een bedrag dat lager ligt dan de werkelijke schade; daarnaast kan de polis bepalen dat de verzekeraar slechts zal tussenkomen indien de schade een bepaald bedrag te boven gaat en tenslotte kan worden bepaald dat de verzekerde, ongeacht de omvang van de schade, een bepaald deel van de schade zelf zal dienen te dragen. In de mate waarin controle van het gedrag van de verzekerde of van de verzekeringsnemer mogelijk is, zal het efficiënt zijn om de poliswoorwaarden aan te passen. Uiteraard zal een tailormade-polis vooral zinvol zijn bij bepaalde bedrijfspolissen; voor de consumenten worden in de regel standaardpolissen gehanteerd ${ }^{28}$.

Hierboven is aangegeven dat de meest efficiënte situatie deze is, waarin volledige dekking wordt verleend. Daarom geniet vanuit nutsmaximaliserend oogpunt de controle van de verzekeraar met aanpassing van de premie de voorkeur boven de gedeeltelijke blootstelling van de verzekerde. Het spreekt voor zich dat niet eender welke risicoreducerende acties economisch zinvol zijn; voorwaarde blijft dat de kosten van zorg lager blijven dan de voordelen voortvloeiend uit een reductie van de verwachte schade $e^{29}$.

Vaak zullen echter de kosten van een dergelijke controle heel aanzienlijk zijn ${ }^{30}$, of zal controle gewoon onmogelijk zijn, zodat enkel het verlenen van een gedeeltelijke blootstelling aan het risico het morele risico zal kunnen remediëren. De kosten van controle worden onder meer beïnvloed door het tijdstip waarop deze controle wordt uitgevoerd. Een controle kan zowel ex ante als ex post worden uitgevoerd. Stel dat de controle plaatsheeft op het moment van het ondertekenen van de polis. In dat geval kan de verzekeraar nagaan of naast de antieke kast een brandblusapparaat werd geïnstalleerd. Het is evident dat deze controles dienen te worden opgevolgd omdat de verzekerde te allen tijde het brandblusapparaat kan weghalen. Bovendien dienen bij ex ante controles alle polishouders te worden gecontroleerd. Bij ex post controles zal de verzekeraar na een schadegeval nagaan of de polisvoorwaarden werden nageleefd. Hier dienen enkel die polishouders te worden gecontroleerd die een vordering indienen. Vandaar zullen ex post controles in de meeste gevallen goedkoper zijn dan ex ante controles, waardoor enkel voor ex ante controles wordt geopteerd indien daartoe specifieke redenen bestaan ${ }^{31}$.

De verschillende besproken mechanismen (eigen risico, inbouwen van vergoedingsplafonds, individuele polisvoorwaarden) strekken er in feite toe om de prikkelwerking uit het aansprakelijkheidsrecht, die door de beschikbaarheid van een verzekeringsdekking negatief wordt beînvloed, te herstellen. Het verzekerde individu zal vanuit de prikkelwerking van de verzekeringspolis ertoe worden aangezet om (opnieuw) zorgvuldig te handelen. In zekere zin heeft de verzekeraar de preventieve functie van het aansprakelijkheidsrecht overgenomen ${ }^{32}$.

Pauly, M., "The Economics of Moral Hazard: Comment", American Economic Review, vol. $58,196 \overline{8}$, 535-536; Raviv, A., "The Design of an Optimal Insurance Policy", American Economic Review, vol. 69, 1979, 84-96. Faure, M.G., "Over beschermde slachtoffers, vrijgevige rechters en zuchtende verzekeraars", o.c., 1230.

Shavell, S., "Accident Law", l.c., 197.

Marshall, J., "Moral Hazard", American Economic Review, 1976, 880-890.

Shavell, S., "On Moral Hazard and Insurance", o.c., 550-551.

Shavell, S., "Accident Law", l.c., 195-199; Faure, M., "Rechtseconomie en Privaatrecht", in "Rechtseconomie en recht", l.c., 82 . 
Volledigheidshalve wordt erop gewezen dat de term "moreel risico" zoals die in de verzekeringsliteratuur wordt gehantecrd niet volledig accuraat is. Deze term veronderstelt dat het gedrag van de verzekerde immorcel is wanncer hij zijn gedrag aanpast in functie van de beschikbaarheid van een verzekering. Nochtans is het gedrag van de verzekerde niet immoreel: hij reagcert op de prikkels die hij uit zijn omgeving ontvangt en is er enkel op uit om zijn nut te maximaliseren ${ }^{13}$.

\subsection{Averechtse selectie}

Een goed begrip van de economische analyse van verzekeringen veronderstelt na de toelichting van het morele risico, eveneens een verduidelijking inzake de risicoaversie van de verzekeraar. Hierboven werd betoogd dat het afsluiten van een verzekeringsdekking de maatschappelijke welvaart verhoogt omdat de risicoaversie van een bepaalde persoon wordt weggenomen. Hiermee is echter niet gezegd dat de verzekeringsmaatschappij niet risicoavers zou zijn, wel integendeel. Er kan van worden uitgegaan dat ook een verzekeringsmaatschappij risicoavers is: zij zal te allen prijze vermijden dat zij meer schadegevallen zal moeten uitkeren dan het bedrag dat zij binnenkrijgt aan verzekeringspremies.

Een verzekeraar zal zijn risicoaversie verkleinen door gelijkaardige risico's in te delen in verschillende groepen. Door de wet op de grote getallen verkleinen het totale risico en het risico per verzekerde ${ }^{34}$.

Voor een verzekeraar is een correcte indeling van de door hem gedekte risico's in groepen van essentieel belang. Daartoe verzamelt een verzekeraar verschillende niet verbonden risico's en brengt deze onder in risicogroepen. Dergelijke risicogroepen bestaan uit gelijkaardige risico's waarvoor in de regel dezelfde premie wordt aangerekend. Bij het bepalen van deze groepen is het voor de verzekeraar van belang dat de gedekte risico's onafhankelijk zijn ten aanzien van elkaar ${ }^{3.5}$ en dat de risicogroepen zo eng mogelijk dienen te worden omschreven. Een enge omschrijving van de risico's zal ertoe leiden dat de verschillen tussen de goede en de slechte risico's binnen een risicogroep beperkt blijven. Het is immers zo dat binnen één enkele risicogroep zich zowel goede als slechte risico's bevinden en dat de premic voor alle leden van de risicogroep dus een gemiddelde premie is. Goede risico's zijn risico's die lager zijn dan het gemiddelde en slechte risico's zijn risico's die hoger liggen dan het gemiddelde.

Indien de risicogroepen te breed zijn omschreven, zal een aanzienlijk verschil bestaan tussen de goede en de slechte risico's. De goede risico's zullen een te hoge premie betalen en de slechte risico's zullen een te lage premie betalen. Als gevolg hiervan zullen de goede risico's de groep verlaten en zal de verzekeraar enkel nog de slechte risico's behouden. Dit probleem noemt men

\footnotetext{
3 Pauly, M., "The Economics of Moral Hazard: Comment", o.c., 531-537; Faure, M.G., "OngevalIenpreventie door efficiënte aansprakelijkheidsregels en verzekeringspolissen op competitieve verzekeringsmarkten", o.c., 9.

Pauly, M., "The Economics of Moral Hazard: Comment", o.c., 531; Faure, M. en Van den Bergh, R. "Objectieve Aansprakelijkheid", l.c., 122; Wils, W.P.J., "Insurance Risk Classification in the EC: Regulatory Outlook", Oxford Journal of Legal Studies, 1994, 450.

Dit betekent dat de verzekeraar moet vermijden dat de verwezenlijking van een gegeven risico zou leiden tot de verwezenlijking (als een gevolg hiervan) van andere risico's. Het gevaar bestaat anders dat één schadegeval een cascade aan andere schadegevallen met zich zal meebrengen. Klassiek voorbeeld is hier de brandverzekering waar de verzekeraar zal vermijden in één straat een hele rij huizen te verzekeren (Faure, M. en Van den Bergh, R. "Objectieve Aansprakelijkheid", l.c., 122-123).
} 
averechtse selectie ${ }^{36}$. In essentie is averechtse selectie een probleem van informatieasymmetrie tussen verzekerde en verzekeraar.

De: basis van de leer van de informatieasymmetrie werd gelegd door Akerlof die bestudeerde waarom goederen van slechte kwaliteit zich op de markt weten te handhaven, terwijl op basis van het gewone prijsmechanisme deze goederen van de markt zouden verdwijnen ${ }^{37}$. De leer van de informatieasymmetrie stelt dat deze goederen ${ }^{38}$ zich weten te handhaven door een informatietekort bij de koper: wanneer onvoldoende of onjuiste gegevens voorhanden zijn aangaande de kwaliteit van bepaalde goederen, zal het informatietekort het marktmechanisme verstoren en zal een optimale allocatie van de beschikbare middelen worden belemmerd.

Akerlof heeft zijn stelling onderbouwd door de verkoop van tweedehandse auto's als voorbeeld te nemen. Deze auto's zijn ervaringsgoederen ("experience goods"), hetgeen betekent dat informatie aangaande de kwaliteit van de gekochte goederen enkel kan worden verkregen op basis van de opgedane ervaring na de aankoop ${ }^{39}$. Immers, wie een tweedehandse auto koopt, kan op het moment van de aankoop niet beoordelen of het een goede of slechte auto betreft. Slechts nadat de koper de wagen enkele maanden heeft gebruikt, zal hij zich een oordeel kunnen vormen over de kwaliteit van de wagen. Van de verkoper mag worden aangenomen dat hij op het moment van de verkoop wel op de hoogte was van de kwaliteit van de wagen en vandaar is er sprake van asymmetrische informatie. Het gevolg hiervan is dat het prijsmechanisme wordt verstoord: de koper denkt een goede wagen te kopen waardoor de prijs van een goede tweedehandse auto gelijk zal zijn aan de prijs van een slechte tweedehandse auto. Geleidelijk aan zullen enkel nog wagens van gemiddelde kwaliteit worden aangeboden die zullen worden verkocht tegen een gemiddelde prijs. Gclet op de gemiddelde prijs zal de eigenaar van een goede tweedehandse auto geen prikkel meer hebben om zijn auto op de markt aan te bieden. Naar verloop van tijd zullen de slechte tweedehands auto's de goede auto's van de markt verdringen. Het resultaat van een asymmetrische informatic is dus cen cumulatief proces van kwaliteitsvermindering ${ }^{40}$.

Slechte producten gaan dus goede producten van de markt verdringen indien bij de aankoop de kwaliteit van de aangekochte goederen of diensten niet is gekend. Maar deze stelling zal enkel opgaan indien het voor de koper moeilijk of onmogelijk is om zijn aankoopgedrag aan te passen om op deze wijze de verkoper te straffen voor de slechtere kwaliteit ${ }^{41}$. De mate waarin een verkoper kan gestraft worden zal bijvoorbeeld afhangen van de substitueerbaarheid van de goederen.

Het probleem van averechtse selectie is ook van belang bij verzekeringen: de verzckeraar kan worden vergeleken met de koper die onvoldoende informatie heeft. Hij weet niet of het risico waarvoor hij dekking verleent een goed of een slecht risico is, terwijl de verzekerde over het algemeen wel over de juiste informatie beschikt. Ook in deze situatie zal een gemiddelde prijs worden

Priest, G., "The Current Insurance Crisis and Modern Tort Law", Yale Law Journal, 1987, 1540-1541. Akerlof, G., "The Market of the Lemons: Quality Uncertainty and the Market Mechanism", Quarterly Journal of Economics, vol. 84, 1970, 488-500.

Deze goederen noemt hij lemons of citroenen, namelijk nagenoeg onbruikbare producten die niet voor consumptie zijn geschikt.

Ervaringsgoederen staan tegenover zoekgoederen (search goods) waar de koper de nodige productinformatie kan verkrijgen teneinde het informatietekort van zijn koopbeslissing te minimaliseren. De termen zoekgoederen en ervaringsgoederen zijn ontleend aan Nelson, P., "Information and Consumer Behaviour", Journal of Political Economy, vol. 78, 1970, 311; Nelson, P., "Advertising as Information", Journal of Political Economy, vol. 82, 1974, 729.

Faure, M. en Van den Bergh, R., "Objectieve Aansprakelijkheid", l.c., 124.

Faure, M. en Van den Bergh, R., "Objectieve Aansprakelijkheid", l.c., 125. 
berekend met als gevolg dat vooral slechte risico's een verzekeringsdekking zullen nemen - voor hen is de gemiddelde premie immers laag - terwijl omgekeerd voor de goede risico's de gemiddelde premie te hoog zal zijn. De goede risico's zullen zich niet meer verzekeren ${ }^{42}$ en bijgevolg zal de verzekeraar enkel nog slechte risico's in zijn portefeuille overhouden.

Hier kan het verband worden gelegd tussen het probleem van de averechtse selectie en het morele risico. In de literatuur wordt het morele risico beschouwd als een bijzondere vorm van averechtse selectie $^{43}$. Zoals weergegeven leidt het morele risico ertoe dat de loutere beschikbaarheid van een verzekeringsdekking het risico doet stijgen. Dit betekent dat ook de premie zal stijgen waardoor de goede risico's precies de groep zullen verlaten en de verzekeraar voornamelijk nog slechte risico's zal overhouden. Op deze manier bemoeilijkt het morele risico de vereiste nauwe indeling in risicogroepen ${ }^{44}$.

Het probleem van de averechtse selectie toont duidelijk de noodzaak aan van een enge omschrijving van de risicogroepen in hoofde van de verzekeraar. Immers, wanneer de risicogroepen te breed zijn omschreven, zullen enkel de slechte risico's overblijven; de verzekeraar kan hicrop reageren door de premie verder te verhogen, maar daardoor zullen nog meer mensen de groep verlaten en neemt het probleem enkel toe. Het probleem van averechtse selectie kan zelfs de verzekerbaarheid van een risico in het gedrang brengen ${ }^{45}$.

Doordat averechtse selectie wordt veroorzaakt door een informatieprobleem bij de verzekeraar, kan aan dit probleem tegemoet worden gekomen door bijkomende informatie te verzamelen en door de risicogroepen in functie van deze bijkomende informatie, beter te omschrijven. De nauwe omschrijving in risicogroepen blijkt met name duidelijk inzake autoverzekeringen ${ }^{46}$ waar jonge chauffeurs die een hoger risico vormen, in een aparte risicocategorie worden ondergebracht. Een enge(re) omschrijving van de risicogroepen zal evenwel niet volstaan omdat eveneens binnen de groep jonge chauffeurs aanzienlijke verschillen kunnen bestaan. Zijn de verschillen te groot, dan zal sprake zijn van een kruiselingse subsidiëring van de slechte risico's door de goede risico's ${ }^{47}$. Een verdere versmalling van de groep zal zich opdringen. Zo kan een verder onderscheid worden gemaakt naar gelang van het type wagen, het al dan niet frequente gebruik ervan enz. Maar een versmalling van de risicogroep kan niet eindeloos worden doorgetrokken omdat zowel de kosten van het verzamelen van informatie als de administratieve kosten ter implementatie van deze informatie hoog kunnen oplopen.

Ook andere technieken kunnen worden gehanteerd om goede risico's aan te sporen binnen de risicogrocp te blijven. Zowel het verhogen van franchises (of het eigen risico), het verlagen van de verzekerde bedragen als het opnemen van uitsluitingen in de polis ${ }^{48}$ zijn geschikt om goede risico's in de groep te houden en op die manier de averechtse selectic tegen te gaan. Voor icmand dic een goed risico vertegenwoordigt zal bijvoorbeeld een franchise minder nadelen vertonen dan voor een slecht risico.

42

Pauly, M., "The Economics of Moral Hazard: Comment", o.c., 531-537; Arrow, K., "The Economics of Moral Hazard: Further Comment", American Economic Review, vol. 58, 1968, 537-539.

Priest, G., "The Current Insurance Crisis and Modern Tort Law", o.c., 1547-1548.

Zie bijvoorbeeld de verzekeringscrisis in de Verenigde Staten (Priest, G., "The Current Insurance Crisis and Modem Tort Law", o.c., 1540-1541). Cfr. infra, in $\$ 4.3 .1$ van dit hoofdstuk.

Mackaay, E., Economics of Information and Law, Boston, Kluwer, 1982, 178.

Faure, M. en Van den Bergh, R., "Objectieve Aansprakelijkheid", l.c., 127.

Priest, G., "The Current Insurance Crisis and Modem Tort Law", o.c., 545-1546. 


\subsection{De invloed van de aansprakelijkheidsverzekering op de maatschappelijke welvaart}

In het rechtseconomische model van het aansprakelijkheidsrecht, zoals besproken in hoofdstuk 8 , werd uiteengezet dat zowel foutaansprakelijkheid als risicoaansprakelijkheid de maatschappelijke welvaart kunnen verhogen. Deze conclusie was gebaseerd op de assumptie dat de ongevalspartijen risiconeutraal zijn en dat geen verzekeringsdekking voorhanden is. In deze paragraaf wordt deze assumptie verlaten en wordt nagegaan wat de invloed is van een aansprakelijkheidsverzekering op de maatschappelijke welvaart. Ook hier wordt de situatie besproken bij een regime van risicoaansprakelijkheid $(\$ 2.4 .1)$ en bij een regime van foutaansprakelijkheid $(\S 2.4 .2)$. De conclusie van de analyse wordt weergegeven in $\$ 2.4 .3$.

\subsubsection{Onder een regime van risicoaansprakelijkheid}

Eerder is reeds gesteld dat bij risicoaansprakelijkheid de dader efficiënte zorg zal aanwenden indien de door de dader te betalen schadevergoeding gelijk is aan het verwachte verlies. Omdat in deze hypothese de schade van het slachtoffer steeds wordt vergoed, zal het slachtoffer geen verzekeringsdekking kopen. Onder een regime van risicoaansprakelijkheid zullen risicoaverse slachtoffers dus worden verzekerd door de dader ${ }^{49}$.

Afhankelijk van zijn houding ten aanzien van het risico zal dus enkel de dader een verzekering nemen. Op het eerste gezicht zou kunnen worden geconcludeerd dat een risicoaverse dader inderdaad een aansprakelijkheidsverzekering zal afsluiten. Maar dit kan leiden tot een moreel risico: een volledige dekking kan immers de prikkels tot het uitoefenen van zorg aantasten. Dit betekent dus dat een aansprakelijkheidsverzekering enkel tot het maatschappelijk optimum zal leiden indien de verzekeraar in staat is om de door de dader uitgeoefende zorg correct in te schatten, c.q. te controleren ${ }^{50}$. In deze hypothese zal de premie namelijk kunnen worden aangepast in functic van de door de dader ondemomen voorzorgsacties.

Kan de verzekeraar daarentegen de door de dader aangewende zorg niet controleren, dan zal geen volledige verzekeringsdekking beschikbaar zijn voor de risicoaverse dader. Een volledige dekking zou in dit geval een moreel risico veroorzaken. Omdat de dader dus nog voor een deel aan het risico blijft blootgesteld, wordt zijn risicoaversie niet helemaal weggenomen, maar behoudt hij anderzijds een prikkel om schade te vermijden. Indien de dader toch een volledige dekking zou krijgen, dan zal dit zijn prikkels tot het aanwenden van zorg aantasten. Vandaar wordt in deze hypothese een suboptimale maatschappelijke welvaart bereikt ${ }^{5 !}$. Er moet een afweging worden gemaakt tussen ofwel een optimale risicospreiding (en dus volledige dekking) ofwel het geven van optimale prikkels voor het aanwenden van efficiënte zorg (onvolledige dekking) ${ }^{52}$.

\subsubsection{Onder cen regime van foutaansprakelijkheid}

Onder een regime van foutaansprakelijkheid zal de dader de juiste prikkels hebben indien de door het recht vereiste betamelijke zorg gelijk is aan het niveau van efficiënte zorg. De dader zal dan ook aan aansprakelijkheid ontsnappen zodra deze efficiënte zorg aan de dag legt. Indien de dader in deze situatie een verzekeringsdekking zou kopen, ontstaat een moral hazard-probleem omdat hij weet dat hij niet aansprakelijk is zodra hij efficiënte zorg uitocfent. De verzekeringspremie zal

Fuure, M. en Van den Bergh, R., "Objectieve Aansprakelijkheid", l.c., 132.

Shavell, S., "Accident Law", l.c., 211 .

Shavell, S., "Accident Law", l.c., 211.

Ook in die zin Faure, M. en Van den Bergh, R., "Objectieve Aansprakelijkheid", l.c., 134. 
in dat geval gelijk zijn aan de verwachte ongevalskosten ${ }^{53}$. Het uitoefenen van efficiënte zorg zal voor de dader goedkoper zijn dan deze premie te betalen ${ }^{54}$. Slachtoffers van hun kant zullen in deze situatie een first-party insurance kopen indien zij risicoavers zijn.

Maar ook inzake foutaansprakelijkheid zal het resultaat afhangen van de beschikbaarheid van correcte informatie, namelijk over het uit te oefenen niveau van efficiënte zorg. Dit betekent dat de dader toch het risico loopt om aansprakelijk te worden gesteld, zelfs indien hij efficiënte zorg aanwendt. Een risicoaverse dader zal zich hiervoor verzekeren. Nochtans zal in dit geval de verzekeringsdekking er enkel toe strekken om de gevolgen van een foute vaststelling van de foutstandaard op te vangen. Een dergelijke dekking zal de dader nooit in die mate beschermen dat hij onzorgvuldig zal gaan handelen ${ }^{55}$.

\title{
2.4.3. Conclusie
}

In het algemeen is gebleken dat de beschikbaarheid van een aansprakelijkheidsverzekering vanuit welvaartsoogpunt zinvol is. Het maatschappelijke nut van risicoaverse daders zal namelijk verhogen omdat het risico wordt weggenomen en omdat zij anders een te hoog niveau van zorg zouden uitoefenen ${ }^{56}$. Bovendien zal de beschikbaarheid van een verzekeringsdekking niet noodzakelijk de prikkels voor het uitoefenen van zorg wegnemen. Een aansprakelijkheidsverzekering wijzigt weliswaar deze prikkels, maar daartegenover staat dat een dergelijke dekking, indien gekocht op een competitieve markt, equivalente prikkels in het leven roept $t^{57}$.

Wordt de verzekeringsdekking gekocht op een competitieve verzekeringsmarkt, waar de verzekeraar over perfecte informatie beschikt en aldus controle kan uitoefenen, dan geldt precies dezelfde conclusie als in hoofdstuk 8. In unilaterale schadegevallen zal een voorkeur bestaan voor risicoaansprakelijkheid omdat dit niet enkel resulteert in een optimale prikkelwerking, maar eveneens in een optimaal activiteitsniveau. Bij risicoaansprakelijkheid zal de dader een aansprakelijkheidsverzekering afsluiten.

De situatie verandert indien de verzekeraar geen optimale controle kan uitoefenen op het niveau van zorg van de ongevalspartijen: hier zal foutaansprakelijkheid de voorkeur genieten. Omdat in deze gevalien het slachtoffer vaak slechts een geringe invloed zal hebben op het ongevalsrisico, zal tegelijk een voorkeur ontstaan voor een first party dekking omdat in de huidige hypothese het morele risico bij cen first party verzekering kleiner is dan bij bijvoorbeeld een aansprakelijkheidsverzekering ${ }^{58}$.

Vandaar kan worden geconcludeerd dat de beschikbaarheid van een aansprakelijkheidsverzekering geen nadelige invloed heeft op de prikkelwerking uitgaande van de aansprakelijkheidsregels, op voorwaarde dat problemen inzake moral hazard en averechtse selectie onder controle kunnen worden gehouden. Indien een verzekeringsdekking beschikbaar is, zal de risicoaverse dader een dekking nemen onder een regime van risicoaansprakelijkheid en het risicoavers slachtoffer bij een regime van foutaansprakelijkheid. Bij risicoaansprakelijkheid zal een aansprakelijkheidsverzeke-

\author{
Shavell, S., "Accident Law", l.c., 212. \\ Faure, M. en Van den Bergh, R., "Objectieve Aansprakelijkheid", l.c., 134. \\ Shavell, S., "Accident Law", l.c., 212-213. \\ Shavell, S., "Accident Law", l.c., 213. \\ Shavell, S., "On Liability and Insurance", o.c., 121-122. \\ Faure, M. en Van den Bergh, R., "Objectieve Aansprakelijkheid", l.c., 136.
}


ring de maatschappelijke welvaart verhogen en bij foutaansprakelijkheid een first party verzekering.

\subsection{Economische gevolgen van onvoldoende concurrentie op de verzekeringsmarkt}

Op verscheidene plaatsen in dit onderzoek werd reeds gewezen op de noodzaak van concurrentie op de verzekeringsmarkten. Hieronder wordt besproken in welke mate een daadwerkelijke con. currentie op de verzekeringsmarkt kan bijdragen tot een verhoging van de maatschappelijke welvaart.

Net zoals op eender welke andere markt, worden de prijzen op de verzekeringsmarkt bepaald door het spel van vraag en aanbod. Hierbij is het aanbod van verzekeringen zeer prijselastisch, voomamelijk voor die verzekeringstakken met eenvoudige kostenstructuur, waar met andere woorden de gemiddelde kosten per overeenkomst constant zijn of zelfs een licht dalende trend vertonen ${ }^{59}$. De prijselasticiteit impliceert dat wanneer de vraag naar verzekeringsdekking stijgt, een uitbreiding van het aanbod mogelijk is zonder stijging van de premie ${ }^{60}$. Vandaar zal op een competitieve markt een stijging van de premie niet kunnen worden verklaard door een toegenomen vraag. Enkel indien de verwachte schade verhoogt, zal dit leiden tot een hogere premie ${ }^{61}$.

Op een competitieve verzekeringsmarkt zal de actuariële premie nagenoeg gelijk zijn aan de verwachte schade, vermeerderd met de administratieve kosten ${ }^{62}$. A contrario vloeit hieruit voort dat bij onvoldoende competitie er een groter verschil zal bestaan tussen de premie en de verwachte schade, waardoor de verzekeraar hoge winsten kan opstrijken. Hierboven werd reeds gesteld dat de beschikbaarheid van een aansprakelijkheidsverzekering geen nadelige invloed heeft op de prikkelwerking uitgaande van de aansprakelijkheidsregels. Een aansprakelijkheidsverzekering wijzigt weliswaar deze prikkels, maar daartegenover staat dat een dergelijke dekking, indien gekocht op een competitieve markt, equivalente prikkels in het leven roept. Enkel bij informatieasymmetrie zal het morele risico een efficiënte oplossing in de weg staan. De vraag rijst hier welke invloed concurrentie op de verzekeringsmarkt heeft op de negatieve gevolgen van het morele risico.

Zoals eerder betoogd, kan het morele risico worden beperkt door de verzekerde deels zelf aan het risico bloot te stellen. De meest efficiënte situatie is evenwel die waarin volledige dekking wordt verleend. Daarom geniet vanuit nutsmaximaliserend oogpunt de controle van de verzekeraar met aanpassing van de premie de voorkeur boven de gedeeltelijke blootstelling van de verzekerde. Precies op dit punt kan de concurrentie op de verzekeringsmarkt leiden tot het wegwerken van de negatieve gevolgen van het morele risico. De concurrentie zal ertoe leiden dat de verschillende verzekeraars verschillende reducties toestaan naar gelang van de door de verzekerde uitgcoefende zorg.

De mogelijkheid waarover de verzekeraar beschikt om het niveau van efficiënte zorg te bepalen speeit hier een belangrijke rol. In het algemeen wordt aangenomen dat het makkelijker is de premie te laten fluctueren a rato van de genomen voorzorgsmaatregelen bij grote risico's dan bij

Faure, M. en Van den Bergh, R., "Objectieve Aansprakelijkheid", l.c., 326.

6o Adams, M., "Gefährdungs- und Verschuldenshaftung", l.c., 215-216; Frech, III, F.E. en Samprone, J., "The Welfare Loss of Excess Non-Price Competition: the Case of Property Liability Insurance", Journal of Law and Economics, 1980, 429 e.v.

61 Faure, M. en Van den Bergh, R., "Objectieve Aansprakclijkheid", l.c., 326.

62 Op een compctitieve markt zullen ook deze kosten tot een minimum worden teruggebracht aangezien deze kostenbeheersing een element bij uitstek kan zijn waar de ene verzekeraar zich kan onderscheiden van de andere. 
massarisico's ${ }^{63}$. Bij massarisico's zijn de kosten van ex ante controles immers dermate hoog dat het enkel efficiënt is ex post controle uit te voeren ${ }^{64}$, met name na een schadegeval ${ }^{65}$.

De traditionele manier om bij consumentenverzekeringen de verzekerde te belonen voor het in acht nemen van efficiënte zorg, is de premie te bepalen op basis van een bonus-malus systeem (ex post controle van het gedrag van de verzekeringsnemer). Uiteraard is ook een ex ante controle niet uitgesloten; dit kan er bijvoorbeeld in bestaan dat bij verandering van verzekeringsmaatschappij de nieuwe verzekeraar een attest vraagt waaruit de bonus-malus graad van de verzekerde blijkt. Een goed werkend bonus-malus systeem zal voor een goed risico direct resulteren in een reductie van de premie ${ }^{66}$. Indien de verzekeraar onvoldoende informatie heeft over de wijze waarop de verzekerde het risico kan beïnvloeden, kan het zinvol zijn een franchise (eigen risico) of vrijstelling in te bouwen.

Uit de beschrijving van het bonus-malus systeem en de franchise, kan het belang worden afgeleid van concurrentie op de verzekeringsmarkt. De factor waarmee de basispremie wordt vermenigvuldigd, kan enkel verschillen van verzekeraar tot verzekeraar indien op dit vlak concurrentie mogelijk is. Bij onvoldoende concurrentie zal het gedrag van een voorzichtige verzekerde onvoldoende worden beloond en zal de prikkel om schadeverwekkend gedrag te vermijden verminderen of teloor gaan. Hetzelfde kan worden gezegd inzake het hanteren van een franchise. Is er onvoldoende concurrentie op de verzekeringsmarkt, dan zal de hoogte van de vrijstelling onvoldoende worden gerelateerd aan de premievermindering. Dit leidt ook tot de nodige problemen op het vlak van de risicospreiding. Indien een bepaalde persoon zo sterk risicoavers is dat hij geen enkel deel van het risico zelf wil dragen en overeenkomstig de graad van zijn risicoaversie bereid is hiervoor de premie te betalen, dan kan dit onmogelijk zijn op een niet-concurrentiële verzekeringsmarkt, waar een monopolistische verzekeraar enkel dekkingen zal aanbieden met een bepaalde vrijstelling.

Uit deze elementen kan worden afgeleid dat het concurrentierecht dat mededinging op de verzekeringsmarkt toelaat, meteen ook in staat zal zijn de negatieve gevolgen van informaticasymmetrie (minstens ten dele) op te vangen. Een concurrentiële verzckeringsmarkt geeft met andere woorden een prikkel aan de verzekeraar om correcte informatie te verzamelen en om het gedrag van de verzekerde nauw op te volgen. Het mededingingsrecht, dat kartelvorming tegengaat, kan dus een efficiënt ongevallenrecht ondersteunen ${ }^{67}$.

Immers, bij gebrek aan concurrentie verliest de verzekeringsnemer minstens een deel van de prikkel om schadeverwekkend gedrag te vermujden: hij wordt onvoldoende beloond voor de door hem genomen voorzorgmaatregelen. Dit zal zich vertalen in een hoger aantal ongevallen en dus een verhoging van het ongevalrisico. Tegelijk zullen de premies niet meer beantwoorden aan de ac tuarieel eerlijke premie; deze zal een stuk hoger liggen dan de venwachte ongevalkosten en de

Faure, M. en Van den Bergh, R., "Objectieve Aansprakelijkheid", l.c., 327.

Adams, M., "Gefährdungs- und Verschuldenshaftung", l.c., 227.

Zo zal na een auto-ongeval de verzekeraar bijwoorbeeld onderzoeken of de verzekerde zijn autogordel om had; voor de verzekeraar is het onmogelijk om dat ex ante te controleren.

Volgens het bonus-malus systeem wordt de basispremie berekend - in functie van leeftijd, type wagen etc, - en vermenigvuldigd met een bepaalde factor. Stel dat de basispremie 100 bedraagt, dan zal de premie van een voorzichtige verzekeringsnemer worden vermenigvuldigd met factor 0,9 ; bij een minder voorzichtige verzekerde bij wie zich meerdere schadegevallen hebben voorgedaan, zal de premie bijvoorbeeld worden vermenigvuldigd met factor 1,5 . De premie van de voorzichtige verzekerde zal 90 bedragen; deze van de minder voorzichtige verzekerde 150.

Faure, M. en Van den Bergh, R., "Objectieve Aansprakelijkheid", l.c., 328-329. 
administratieve kosten. De door de verzekeraars geïnde premies zullen te hoog liggen waardoor de verzekeraar extra winst kan opstrijken.

\subsection{Conclusie}

De risicoaversie van een persoon kan worden weggenomen door het afsluiten van een verzekeringscontract. Dit geldt ook voor een aansprakelijkheidsverzekering. Toch dient aan een aantal voorwaarden te zijn voldaan vooraleer verzekeringen ook de maatschappelijke welvaart zullen verhogen. In de eerste plaats dient de verzekeringsmarkt competitief te zijn; daarnaast moeten zowel het morele risico als de averechtse selectic onder controle blijven.

Van een moreel risico is sprake wanneer de loutere beschikbaarheid van een verzekeringsdekking het gedrag van de verzekerde zal wijzigen, wat resulteert in een toename van het risico. Door de verzekerde gedeeltelijk zelf bloot te stellen aan het risico of door het gedrag van de verzekerde te controleren met een eventuele aanpassing van de premie, kan het morele risico worden uitgesloten of beperkt. Aangezien het maatschappelijke nut in principe wordt geoptimaliseerd door het verlenen van een volledige dekking, zal het de voorkeur genieten om de premie aan te passen in functie van de controle van het gedrag van de verzekeringsnemer of van de verzekerde. Indien er onvoldoende informatie beschikbaar is over het gedrag van deze personen, zal het aangewezen iijn om het morele risico in te perken via gedeeltelijke blootstelling aan het risico.

In de mate waarin de verzekeraar over onvoldoende informatie beschikt (in rechtseconomische termen wordt dan gesproken van een informatieasymmetrie in hoofde van de verzekeraar), kan het probleem van de averechtse selectie opduiken. Onvoldoende informatie van de kant van de verzekeraar zal leiden tot een te brede omschrijving van de risicogroepen, waardoor de goede risico's de groep zullen verlaten. Dit zal het geval zijn zodra de gemiddelde premie van een risicogroep te hoog wordt in de ogen van de personen die een goed risico vertegenwoordigen. De beste remedie tegen het probleem van de averechtse selectie is een strakke omschrijving van de verschillende risicogroepen.

Een voldoende concurrentie op de verzekeringsmarkt is in dit kader van groot belang aangezien zij een antwoord zal kunnen bieden op de informatieasymmetrie in hoofde van de verzekeraar en aangezien het gedrag van een voorzichtige verzekeringsnemer zal worden beloond. Gebrekkige concurrentie zal voorzichtig gedrag niet (voldoende) belonen, waardoor het ongevalrisico verhoogt.

\section{ECONOMISCHE ANALYSE VAN EEN VERPLICHTE VERZEKERING}

Uit de analyse in vorige paragrafen van dit hoofdstuk is gebleken dat verzekering de maatschappelijke welvaart kan verhogen en werd het belang aangetoond van een competitieve verzekeringsmarkt. In deze paragraaf wordt nagegaan of het verplicht stellen van cen (aansprakelijkheids)verzekering de maatschappelijke welvaart kan verhogen $(\$ 3.1$ ). Met name wordt onderzocht of twee klassieke argumenten om een aansprakelijkheidsverzekering verplicht te stellen - bescherming van het slachtoffer tegen mogelijke insolventie van de dader en remedie tegen een probleem van informalicasymmetrie - vanuit rechtseconomisch perspectief verantwoord zijn. Deze twee argumenten worden respectievelijk in paragrafen 3.2 en 3.3 aan de orde gesteld. Een evaluatic van de verplichte verzekering wordt gegeven in paragraaf 3.4 . 


\subsection{Verplichte aansprakelijkheidsverzekering en de maatschappelijke welvaart}

Een verzekering zal de maatschappelijke welvaart verhogen door een risico weg te nemen van een risicoaverse dader en het over te dragen naar een verzekeraar die dat risico beter kan spreiden. Op het vlak van de maatschappelijke welvaart impliceert dit niet alleen dat het verwachte nut van de dader toeneemt, maar ook dat hij het zal wagen om bepaalde risicovolle en maatschappelijk nuttige activiteiten uit te voeren - die hij bij afwezigheid van verzekering misschien niet zou uitvoeren.

De beschikbaarheid van een verzekeringsdekking zal in een aantal gevallen de prikkelwerking van het aansprakelijkheidsrecht beïnvloeden; maar bijvoorbeeld via de aanpassing van de polisvoorwaarden zal de verzekeraar de prikkelfunctie overnemen. Toch is het zo dat zelfs indien een ansprakelijkheidsverzekering tot een moreel risico leidt, de stelling blijft gelden dat een verzekeringsdekking de maatschappelijke welvaart zal verhogen. Een volgend element in de analyse is dan ook de vraag of een verplichte verzekering eenzelfde gunstige invloed heeft.

Hierboven werd reeds aangetoond dat niettegenstaande in sommige gevallen een moreel risico kan ontstaan, een aansprakelijkheidsverzekering de maatschappelijke welvaart verhoogt. Indien bijgevolg voldoende concurrentie aanwezig is op de verzekeringsmarkt en het morele risico onder controle kan worden gehouden, bestaat er geen economische reden voor de overheid om hierin tussen te komen ${ }^{68}$. De risicoaversie van de verschillende personen en bedrijven varieert en dus is ook de vraag naar verzekeringsdekking verschillend.

Het is zonder meer de verdienste van de rechtseconomische analyse om een duidelijke scheiding te maken tussen een vraag naar verzekering en de noodzaak om aansprakelijkheidsverzekering ook verplicht te stellen. In tegenstelling tot wat vaak wordt aangenomen, leidt een vraag naar een verzekeringsdekking er niet noodzakelijkerwijze toe dat een verplichte verzekering zinvol zou zijn. Met andere woorden, het is niet omdat de markt automatisch een vraag zal genereren en omdat verzekeringen kunnen leiden tot een verhoging van de maatschappelijke welvaart, dat meteen het kopen van een dergelijke verzekeringsdekking verplicht dient te worden gesteld.

Laten we uitgaan van de veronderstelling dat een potentiële dader niet verplicht is om een aansprakelijkheidsverzekering af te sluiten. De vraag naar verzekering zal dan afhangen van zijn houding ten aanzien van het risico. Indien de dader sterk risicoavers is, zal enkel een volledige dekking zijn welvaart maximaliseren; is de risicoaversie evenwel niet zo sterk, dan zal dat individu kiezen voor gedeeltelijke dekking. Uiteraard zal de vraag naar verzekering ook in sterke mate afhangen van de prijs die moet worden betaald om de risicoaversie weg te nemen, namelijk de hoogte van de verzekeringspremie. Het spreekt voor zich dat op dit vlak een hoge concurrentic tussen verzekeraars een gunstige invloed zal uitoefenen op deze premie.

Is de persoon risiconeutraal, dan zal er in die hypothese geen vraag naar verzekering bestaan. Bij een relaticf geringe risiconeutraliteit kan de optimale situatie voor de dader erin bestaan voor het deel waarin hij aan het risico blijft blootgesteld, een beroep te doen op andere mechanismen dan een aansprakelijkheidsverzekering, bijvoorbeeld door een vorm van onderlinge verzekering.

Indien een goed geïnformeerde dader geen verzekering wenst te kopen, of indien hij slechts een gedeeltelijke dekking zou kopen, dan zal het verplicht stellen van de verzekering de maatschappelijke welvaart niet verhogen. Hierbij rijst de vraag of de overheid die de dekking verplicht stelt

Shavell, S., "On liability and insurance", o.c., 121-122. 
over betere informatie beschikt over de risicoaversie van de dader dan de dader zelf. Het gevaar bij een verplichte verzekering is dat de hoogte van deze verplichte dekking weinig ruimte laat voor nuances, hetgeen zeker bij een gemiddelde risicoaverse dader (die zou verkiezen deels aan het risico blootgesteld te blijven) de maatschappelijke welvaart zal verminderen. Indien de dader wordt verplicht een hogere dekking te nemen dan de dekking die hij zou wensen te kopen a rato van zijn houding ten aanzien van het risico, betekent dat meteen dat hij een relatief hoge premie zal betalen. Deze premie zal in ieder geval hoger liggen dan zijn verwacht nut ${ }^{69}$. Zeker bij hoog gespecialiseerde industricén kan crvan worden uitgegaan dat vooral de dader over voldoende informatie beschikt aangaande zijn risico en dat de dader zelf zijn risicoaversie perfect kan inschatten.

Daarenboven veroorzaakt een verplichte verzekering administratieve kosten met betrekking tot de goedkeuring en de controle van de dekking. Een dader die een verzekeringsdekking kan kopen op een competitieve markt zal daarom, wil hij bijvoorbeeld van verzekeraar veranderen, bijkomcnde administratieve kosten moeten maken. Het is hierbij lang niet zeker of deze extra kosten ook voordelen met zich meebrengen.

Tenslotte kan ook worden geargumenteerd dat het verplicht stellen van een verzekering een negatieve invloed kan hebben op de concurrentie en vanuit die optiek ook een welvaartsverlies kan veroorzaken. Stel bijvoorbeeld dat op een gegeven lokale markt 10 bedrijven actief zijn, waarvan 5 grote bedrijven en 5 kleine familiale ondernemingen. Het lijkt redelijk om ervan uit te gaan dat de kosten van een verzekeringsdekking voor de grote ondememing makkelijker te dragen zijn, dan voor de kleine ondernemingen. De impact van het verplicht stellen van een verzekeringsdekking die voor alle ondernemingen dezelfde is, zal voor de kleine ondernemingen relatief belangrijker en moeilijker om dragen zijn dan voor de grote ondernemingen. Het is overigens niet uitgesloten dat voor precies eenzelfde te dekken bedrag, de premie voor de kleine ondernemingen, die slechts een beperkt aantal polissen hebben afgesloten, hoger zal liggen dan voor de grotere onderneming. Op deze manier kan een stijging van de kosten ingevolge een verplichte verzekering het aantal concurrenten op een markt beperken.

Er kan worden geconcludeerd dat het enkele feit dat er in een bepaalde situatie een vraag naar verzekering zal bestaan, geen valabel argument is om de verzekering meteen verplicht te stellen. Eens die vraag er is zal de werking van het marktmechanisme automatisch tot de meest efficiënte oplossing leiden. Indien uit het feit dat in een gegeven situatie een vraag van verzekeringsdekking bestaat, wordt afgeleid dat deze dekking ook dient te worden verplicht gesteld, wordt voorbijgegaan aan de negatieve gevolgen op het vlak van het welvaartsverlies.

Vaak wordt evenwel aangevoerd dat de verzekering wordt verplicht gesteld om slachtoffers te beschermen tegen de mogelijke insolventie van de dader of omdat de dader niet over voldoende informatie beschikt. Beide argumenten worden hieronder besproken.

\subsection{Verplichte verzekering als antwoord op mogelijke insolventie van de dader}

In het uitgebouwde rechtseconomische model werd uitgegaan van de veronderstelling dat alle schade werd vergoed, dat met andere woorden de negatieve effecten van de activiteit volledig worden geïntemaliseerd. Onderzocht dient te worden of dezc stelling ook opgaat indien de schade groter zal zijn dan het vermogen van de dader; wanneer met andere woorden de totale schade dermate groot kan zijn, dat dit de insolventie van de dader tot gevolg kan hebben. 
Ervan uitgaande dat het aansprakelijkheidsrecht aan de dader een prikkel geeft tot zorgvuldig gedrag, kan worden gesteld dat zodra de verwachte schade groter is dan het vermogen van de dader, hij geen optimale zorg meer zal aanwenden. Het deel van de schade dat het vermogen van de dader overtreft, zal door de gemeenschap worden gedragen waardoor niet alle kosten worden geïnternaliseerd ${ }^{70}$. De dader zal als maximale aansprakelijkheid de grens van zijn eigen vermogen in aanmerking nemen. Een potentiële schade die groter is dan het eigen vermogen van de dader heeft dan ook eenzelfde effect als een beperkte aansprakelijkheid: de dader weet dat hij sowieso slechts een deel van de schade zal dienen te vergoeden. Hij zal minder zorg besteden dan bij volledige aansprakelijkheid omdat hij weet dat het aanwenden van meer zorg niet zal resulteren in een geringere aansprakelijkheid.

Indien een dader een vermogen heeft van 100.000 euro, maar een schade kan veroorzaken van 500.000 euro, zal hij handelen alsof de schade maximaal 100.000 euro bedraagt. Het gevolg hiervan is dat de dader te veel risicovolle activiteiten zal uitvoeren en dat hij onvoldoende prikkels zal hebben om zorg uit te oefenen ${ }^{7 !}$. Tegelijk zal de dader minder geneigd zal zijn om een volledige aansprakelijkheidsverzekering te kopen: een deel van de premie zou dienen om schade te vergoeden waarvoor hij sowieso niet zou moeten instaan. Het kan met andere woorden voor de dader rationeel zijn om geen volledige dekking te kopen of zelfs om zich helemaal niet te verzekeren. Een beperkte aansprakelijkheid zal niet alleen leiden tot een probleem van "underdeterrence", maar zal ook vanuit het standpunt van de distributieve efficiëntie negatieve gevolgen hebben: niet alle schade van slachtoffers zal worden vergoed. Hieronder wordt eerst dit laatste element aan de orde gesteld; nadien wordt aandacht besteed aan de gebrekkige prikkelwerking van het aansprakelijkheidsrecht.

Er kan worden vastgesteld dat met name vanuit het standpunt van de distributieve efficiëntie een verplichte verzekeringsdekking wel degelijk zinvol kan zijn, voorzover een reẻel insolventiegevaar van de dader bestaat. Bij een zware milieuramp is het bijvoorbeeld niet uitgesloten dat ook een aanzienlijk deel van het vermogen van de dader zal zijn teloor gegaan, waardoor meteen ook de beschikbare bedragen voor de slachtoffers van een dergelijke ramp - die geen bevoorrechte schuldeiser zijn - afnemen. Bij reëel insolventiegevaar van de dader zal een verzekeringsdekking fungeren als een soort "garantiefonds"; hiermee wordt bedoeld dat via een verzekeringsdekking bij een afzonderlijke persoon (namelijk de verzekeraar) middelen worden gereserveerd die geen invloed zullen ondervinden van een eventueel faillissement van de dader. Uiteraard zal het nemen van een verzekeringsdekking niet de enige manier zijn om een aantal middelen te "reserveren" voor slachtoffers. Er kan worden gedacht aan een bankgarantie, of aan het verstrekken van een andere financiële zekerheid.

Een tweede thema dat in dit kader dient te worden bestudeerd, heeft betrekking op de gebrekkige prikkelwerking. De vraag rijst of, in gevallen waar de prikkels van de dader zijn aangetast omdat hij maximaal ten belope van zijn gchele vermogen aansprakelijk is, een verplichte verzekeringsdekking deze gebrekkige prikkelwerking kan remediëren.

De mate waarin een dader een verzekeringsdekking zal kopen, zal afhangen van een aantal factoren. De meest determinerende factoren zijn uiteraard zijn risicoaversie en de relatic tussen de

Posey, L.L., "Limited Liability and Incentives when Firms can inflict Damages Greater than Net Worth", International Review of Law and Economics, 1993, vol. 13, 325.

Shavell, S., "The Judgment Proof Problem", International Review of Law and Economics, 1986, 43. 
grootte van zijn vermogen en de verwachte schade ${ }^{72}$. Precies de correcte inschatting hiervan, is voor de wetgever een uiterst moeilijke taak.

In eerste instantie kan worden aangenomen dat de risicoaversie van een hele groep van daders exploitanten onmogelijk door de wetgever in het algemeen kan worden bepaald. Daarnaast is het niet uitgesloten dat binnen eenzelfde onderneming waarvan de activiteiten zich over verschillende sites uitstrekken, de risicoaversie zal verschillen van site tot site. Factoren zoals de nabijheid van andere gevaarlijke industrieën, het risico om getroffen te worden door overstroming, etc. hebben zeker een effect op de risicoaversie ${ }^{73}$.

In tweede instantie moet ermee rekening worden gehouden dat het vermogen van elke dader verschilt en dat zelfs het vermogen van eenzelfde onderneming - zeker van een beursgenoteerde vennootschap - kan variëren. Het lijkt dus weinig zinvol om de hoogte van de verzekeringslimiet in een wet of in een verdrag op te nemen. Doordat onvoldoende kan worden ingespeeld op de eigenheid van elke dader, treedt een aanzienlijk welvaartsverlies op. Er kan bijvoorbeeld voor worden gepleit dat de hoogte van de te kopen dekking wordt bepaald door de vergunningverlenende overheid.

Zoals eerder aangegeven, kan de loutere beschikbaarheid van een verzekeringsdekking de prikkels van de dader aantasten (moreel risico). Dit geldt uiteraard evenzeer in gevallen waarin het nemen van een verzekeringsdekking verplicht wordt gesteld. Indien de verzekeraar over voldoende informatie beschikt en de premie kan aanpassen in functie van de door de dader in acht genomen voorzorgsmaatregelen, zal geen moral hazard-probleem rijzen. In dit geval zal de verzekeraar de preventieve functie van het aansprakelijkheidsrecht overnemen. Een controle vanwege de vurzekuraar zal dan ook invol zijn omdat dit het risico tot minder zorgvuldig gedrag zal vermin$\operatorname{deren}^{74}$.

Muar indien het voor verzekeraars onmogelijk of te duur is om het gedrag van de verzekeringsnemer te controleren, zal een verplichte verzekeringsdekking het effect van de gebrekkige prikkelwerking ingevolge het beperkte vermogen van de dader, alleen maar versterken ${ }^{75}$. In gevallen waar een verplichte verzekering het morele risico in de hand werkt, kan het verplicht stellen van een verzckering het insolventierisico van de dader niet opvangen. De mogelijkheid tot het beheersen van het morele risico zal dus een belangrijk element zijn om al dan niet over te gaan tot het invoeren van een verzekeringsplicht.

Meteen is ook duidelijk waarom met name de combinatie tussen een verplichte verzekering en het beperken van de aansprakelijkheid tot het bedrag van de verzekeringslimiet nadelige economische gevolgen kan hebben: omdat het nict mogelijk is om de dader zelf gedeeltelijk aan het risico bloot te stellen, zal het morele risico enkel via de polisvoorwaarden kunnen worden beperkt ${ }^{76}$. Kan het gedrag van de verzekeringsnemer niet worden gecontroleerd, dan kan het in een aantal situaties zelfs aangewezen zijn om een verbod tot het nemen van een aansprakelijkheidsverzekering op te

Shavell, S., "Accident Law", l.c., 241.

Het zijn in ieder geval factoren die een invloed zullen hebben op de door de verzekeringsnemer te betalen verzekeringspremie.

Jost, P.J., "Limited Liability and the Requirement to Purchase Insurance", International Review of Law and Economics, 1996, 263.

Shavell, S., "Accident Law", l.c., 241.

Faure, M.G. en Hartlief, T. (red.), "Verzekering en de groeiende aansprakelijkheidslast", l.c., 308. 
leggen ${ }^{77}$. Uiteraard moet rekening worden gehouden met het feit dat een dergelijk verbod tot welvaartsverlies kan leiden: door het verbod zal de dader meer zorg aanwenden.

Indien wordt aangenomen dat het morele risico kan worden beperkt en indien er ook andere redenen zouden bestaan om een verzekering verplicht te stellen, dan nog dient de vraag te worden bcantwoord tot op welk niveau de dekking dient te worden verplicht gesteld.

Wordt de grens van de verzekeringsplicht gelegd in de buurt van het vermogen van de dader, dan zal dit in principe weinig toevoegen aan de gebrekkige prikkelwerking. Minstens is vereist dat de dader deels aan een eigen risico wordt blootgesteld om bijkomende prikkels in het leven te roepen.

Het kan evenwel ook zinvol zijn om de dader te verplichten een dekking te nemen die hoger ligt dan het eigen verrnogen. Dit zal met name het geval zijn voor daders met een hoge graad van risicoaversie. Het is bijvoorbeeld niet ondenkbaar dat een hoog niveau van zorg zal worden aangewend door een onderneming waarvan het eigen vermogen sterk afhangt van externe factoren. Dit zal met name het geval zijn voor beursgenoteerde vennootschappen waarvan de aandelen in belangrijke mate in handen zijn van niet-institutionele beleggers. Aangenomen mag worden dat kleinere aandeelhouders vrij sterk reageren op negatieve berichten zodat de geringste fout van de ondememing wordt afgestraft. Voor een dergelijke onderneming zal de reputatie van het bedrijf uitermate belangrijk zijn; hoewel in een aantal gevallen overdreven zorg zal worden aangewend, zal dit niet opwegen tegen de positieve gevolgen in termen van ongevallenpreventie.

Uit bovenstaande analyse kan dus worden afgeleid dat een verplichte verzekering de geringere prikkel van de dader - veroorzaakt door het feit dat hij niet alle schade kan vergoeden - kan herstellen op voorwaarde dat het gedrag van de verzekerde kan worden gecontroleerd tegen redelijke kosten ${ }^{78}$, dat deze dekking kan worden gekocht op een competitieve verzekeringsinarkt en dat de dader in alle gevallen voor een deel zelf aan het risico blijft blootgesteld.

Dit neemt niet weg dat er ook andere manieren bestaan om een eventuele gebrekkige prikkelwerking van de dader op te vangen. Vooral de keuze voor een aansprakelijkheidsregel kan hier een belangrijke rol spelen. Bij foutaansprakelijkheid zal de dader namelijk hoe dan ook efficiënte zorg aanwenden omdat hij daardoor aan aansprakelijkheid kan ontkomen. Bij risicoaansprakelijkheid daarentegen zal de dader onvoldoende zorg besteden zodra de potentiële schade groter is dan zijn vermogen ${ }^{79}$. Zodra de totale verwachte schade toch hoger ligt dan het vermogen van de dader, zal hij bij risicoaansprakelijkheid een te laag niveau van zorg aanwenden. In deze hypothese zal het verwachte verlies immers maximaal gelijk zijn aan zijn vermogen, terwijl de schade veel groter zal zijn. Vandaar kan het bij mogelijke insolventie van de dader efficiënter zijn om een regime van foutaansprakelijkheid in te voeren ${ }^{80}$.

Daamaast kan het ook zinvol zijn om de mogelijkheid om risicovolle activiteiten te verrichten, te verbinden aan bepaalde minimumeisen inzake eigen vermogen. Dit kan vrij makkelijk worcien

Shavell, S., "Accident Law", l.c., 242.

In recentere publicaties wordt de noodzaak benadrukt on te investeren in veiligheid en om het gedrag van de potentięle dader te controleren door de overheid. Zie met name Boyd, J. en Ingberman, D.E., "Noncompensatory Damages and Potential Insolvency", Jounnal of Legal Siudies, 1994, 895-910; Jost, P.J., "Limited Liability and the Requirement to Purchase Insurance", o.c., 259-276;

Faure, M. en Van den Bergh, R., "Objectieve Aansprakelijkheid", l.c., 306.

Landes, W. en Posner, R., "Tort Law as a Regulatory Regime for Catastrophic Personal Injuiies", Journal of Legal Studies, 1984, 417-434. 
geregeld in de milieuvergunning van de desbetreffende activiteit. Tegelijk zou de toezichthoudende overheid over de mogelijkheid moeten kunnen beschikken om bijvoorbeeld de vergunning in te trekken zodra het eigen vermogen onder een bepaald niveau daalt.

Het verplicht stellen van een aansprakelijkheidsverzekering is bijgevolg niet de enige manier om het insolventierisico van de dader op te vangen. Een algemene plicht voor grote groepen van daders zal evenwel uit den boze zijn. Indien er voor de verplichte verzekering wordt gekozen, dan dient deze nauw te beantwoorden aan de risicoaversie van de dader en dient ook rekening te worden gehouden met diens vermogen. De vergunningverlenende overheid kan hier een zeer belangrijke rol spelen.

\subsection{Verplichte verzekering als antwoord op een informatieasymmetrie}

Verzekering wordt ook vaak verplicht gesteld als remedie tegen een informatietekort van de dader. Deze kan zijn houding ten aanzien van het risico verkeerd inschatten of kan niet op de hoogte zijn van het feit dat een bepaalde verzekeringsdekking voorhanden is. In feite kan deze problematiek zowel worden beschouwd als een gebrekkige vraag vanwege de dader of als het gevolg van een informatieasymmetrie tussen dader en verzekeraar.

Indien wordt geoordeeld dat de dader zijn risicoaversie verkeerd inschat, dan impliceert dit meteen dat hij een verkeerd beeld heeft van zijn vraag naar verzekering. Er zou kunnen worden geargumenteerd dat in gevallen waar de dader een verzekering zou moeten hebben, maar waar hij dit niet doet, het verplicht stellen van een dekking hieraan tegemoet kan komen. Maar dit veronderstelt dat de reguleerder (meestal de wetgever) beter in staat is om de risicoaversie van de dader of van een hele sector in te schatten dan de dader of een groep van daders. Het is zeer de vraag of dit een realistische assumptie is. Daarenboven rijst de vraag waarom uitsluitend een informatieasymmetrie ten aanzien van de vraag naar verzekeringen moet worden gecorrigeerd. Aangenomen mag worden dat een onderneming evenzeer bij andere beslissingen niet altijd over de juiste of volledige informatie beschikt. Er kan omgekeerd worden aangenomen dat wanneer een ondernemer weet dat er een risico op informatieasymmetrie bestaat, hij precies een prikkel zal hebben om de nodige informatie in te winnen.

Eerder werd besproken dat averechtse selectie in wezen het gevolg is van een informatieasymmetrie tussen de verzekeraar enerzijds en de dader anderzijds. De kern van de geschetste problematiek is dat de dader vaak beter weet dan de verzekeraar of hij een goed dan wel een slecht risico is en dat de dader zijn graad van risicoaversie vrij goed weet in te schatten. De verzekeraar zal in dat geval de verzekerde in een "verkcerde" groep indelen waardoor de vastgestelde gerniddelde premie voor een goed risico te hoog zal zijn en waardoor deze de groep zal verlaten. Het verplicht stellen van een verzekering zou een oplossing kunnen bieden omdat de goede risico's worden verplicht om in de groep te blijven, ook al is de gemiddelde premie voor hen te hoog ${ }^{81}$. Uiteraard leidt deze oplossing tot een welvaartsverlies omdat de goede risico's de slechte risico's dan als het ware subsidiëren. Dit zal een negatieve invloed hebben op de prikkels van de goede risico's.

Ook hier kan worden gesteld dat een verplichte verzekering de prikkel in hoofde van de verzekeraar, om zoveel mogelijk informatie in te winnen over het risico van zijn verzekerde, kan aantasten. Nochtans kan worden aangenomen dat op een competitieve markt de verzekeringsnemer en 
de verzekeraar belang zullen hebben bij een goede samenwerking en dus een uitwisseling van informatie: dit zal een gunstig effect hebben op de premie.

Een aantal economen schuift als oplossing voor de averechtse selectie naar voren dat, indien de overheid tegen lagere kosten de informatie kan verkrijgen dan de verzekeraar, het efficiënt kan zijn om de verzekering door de overheid ter beschikking te stellen ${ }^{82}$ of om deze informatie door te geven aan de verzekeraars ${ }^{83}$. Op basis van deze theorieën kan een verplichte aansprakelijkheidsverzekering dienen als een remedie tegen averechtse selectie, op voorwaarde dat er effectief sprake is van informatieasymmetrie. Het is echter zeer de vraag of, zeker wat grote industriële activiteiten betreft, de overheid over betere informatie beschikt dan de dader en of de overheid deze informatie tegen een lagere kost kan verkrijgen.

\subsection{Conclusie}

Een verzekeringsdekking zal bijdragen tot een verhoging van de maatschappelijke welvaart in de mate warin deze dekking de risicoaversie van de dader wegneemt en in de mate waarin deze dekking kan worden aangekocht op een competitieve verzekeringsmarkt. De kans dat een verplichte verzekering precies die dekking verplicht stelt die de dader zou nemen bij afwezigheid van een verplichte dekking is klein, wat een welvaartverlies tot gevolg heeft.

Wat zware milieurisico's betreft, lijkt enkel het insolventierisico van de dader een valabel argument om een aansprakelijkheidsverzekering verplicht te stellen. Immers, bij faillissement van de dader zullen slachtoffers als niet-bevoorrechte schuldeisers weinig kans maken om de door hen geleden schade terug te vorderen. Indien kan worden gesproken van een reëel insolventierisico, betekent dit dat het vermogen van de dader niet zal volstaan om alle schade te vergoeden; er is met andere woorden sprake van een beperkte aansprakelijkheid.

Een verplichte dekking die evenredig is aan de risicoaversie van de dader en aan diens vermogen, kan wel degelijk dienen als remedie tegen de gebrekkige prikkelwerking van een beperkte aansprakelijkheid.

Het tweede klassieke argument voor de rechtvaardiging van een regime van verplichte verzekering, namelijk als remedie tegen een informatieasymmetrie, lijkt weinig aannemelijk. Zeker ten aanzien van zware milieurisico's is het belangrijk dat de verschillende betrokken partijen de nodige prikkels behouden om informatie in te winnen over de activiteiten, het risico etc.

Ook hier is dus het belang aangetoond van voldoende concurrentie op de verzekeringsmarkt. Het welvaartsverlies op een niet-competitieve verzekeringsmarkt, zal inderdaad ncgatief worden beïnvloed indien het kopen van een verzekeringsdekking verplicht wordt gesteld. Hoewel op zich een verplichte verzekering een antwoord kan bieden op het insolventierisico van de dader, zal een verzekeringsplicht leiden tot nog meer welvaartverlies bij gebrekkige concurrentie ${ }^{84}$. In de eerste plaats zal een beperkte concurrentie leiden tot inefficiënt hoge premies. Door het beperkte aantal actoren aan de aanbodzijde van verzekeringen, zal de verzekeringsnemer er niet in slagen enige bargaining power te gebruiken. Het zal met andere woorden zeer moeilijk zijn om offertes van

Pauly, M., "Overinsurance and Public Provision of Insurance: the Rules of Moral Hazard and Adverse Selection", Quartely Journal of Economics, 1974, 44-62.

Rothshild, M. en Stiglitz, J., "Equilibrium in Competitive Insurance Markets: An Essay on the Economics of Imperfect Information", Quarterly Journal of Economics, 1976, 629-649.

Faure, M. en Van den Bergh, R., "Objectieve Aansprakelijkheid", l.c., 330. 
verschillende verzekeraars te bekomen om op basis hiervan de prijzen te drukken. Tegelijk zal de verzekeraar geen enkele reden meer hebben om de verzekerde te belonen voor risico vermijdend gedrag $^{85}$.

Indien een verzekering wordt verplicht gesteld als remedie tegen insolventie, dan moet er in ieder geval over worden gewaakt dat het morele risico kan worden in de hand gehouden. Dit zal mak. kelijker zijn wanneer het bedrag waarvoor de verzekeringsplicht geldt individueel, dit wil zeggen per industriële site, wordt vastgesteld.

\section{DE VERZEKERBAARHEID VAN DE AANSPRAKELIJKHEID ${ }^{86}$}

In dit onderzock werd eerder reeds gewezen op een aantal ontwikkelingen in het recht die leiden tot het verzwaren van de civielrechtelijke aansprakelijkheid, bijvoorbeeld inzake milieuschade. Onder meer toenemende regels van risicoaansprakelijkheid in het internationale en het nationale recht, een grotere claimbewustheid van het slachtoffer, en een stijging van de toegekende schadevergoeding liggen hieraan ten grondslag ${ }^{87}$. Aangenomen kan worden dat de stijgende aansprakelijkheidslast van bedrijven, zal leiden tot een (min of meer) parallelle stijging van de verzekeringsvraag. Op verschillende niveaus wordt inderdaad opgeroepen om meer een beroep te doen op de private verzekeringsmarkt - bijvoorbeeld inzake de privatisering van de sociale zekerheid ${ }^{85}$ terwijl verzekeraars niet meteen geneigd of in staat lijken te zijn, om een bijkomende dekking ti verlenen, of om een volledige dekking aan te bieden ${ }^{89}$.

Specifiek met betrekking tot milieurisico's zijn momenteel op de markt verschillende polissen beschikbaar ${ }^{90}$ ter dekking van graduele vervuiling, maar deze polissen zijn aan belangrijke beperkingen onderworpen, zowel inzake uitsluitingsgronden als inzake het verzekerde bedrag ${ }^{91}$. In de mate waarin vaker vorderingen worden ingediend en in de mate waarin rechtbanken ook hogere

85 Adams, M., "Gefährdungs- und Verschuldenshaftung", l.c., 227.

86 De analyse in deze paragraaf beperkt zich inderdaad tot de verzekerbaarheid van het aansprakelijkheidsrisico: in het kader van dit onderacek zou het te ver voeren om de analyse uit te breiden naar de verzekerbaarheid van andere risico's.

Voor een onderzock naar de elementen die in deze van invloed zijn, zie onder meer Faure, $M$. en Hartlief, T., "Towards an Expanding Enterprise Liability in Europe? How to analyze the Scope of Liability of Industrial Operators and their Insurers?", Maastricht Journal of European and Comparative Law, $n^{\circ} 3$, 1996, 235-270; Hartlief, $T$., "leder draagt zijn eigen schade", l.c., Cfr. supra, in hoofdstuk 1 en de aldaar gecitecrde literatuur.

Zie over deze discussie onder meer Kessler, D., "Social Security and Private Insurance: the great changes". The Genewa Papers on Risk and Insurance, vol. 24, $\mathrm{n}^{\circ} 4,1999,439-447$; Heubeck, K.; "Some Observations concerning the Privatization of social security systems", The Geneva Papers on Risk and Insurance, vol. 24, $\mathrm{n}^{2} 2$ 2, 1999, 163-166; Faure, M.G., "The applicability of the Principles of Private Insurance to Social Health Insurance seen from a Law and Economics Perspective", The Geneva Papers on Risk and Insurance, vol. 23, $\mathrm{n}^{\circ} 87,1998,265-293$. Corby, B., "On Risk and Uncertainty in Modern Society", The Geneva Papers on Risk and' Insurance, 1994, vol. $19, n^{\circ} 6,235-243$. Cfr. infra, in \$ I van hoofdstuk 11.

Zie hierover met name Abraham, K.S., "Environmental Liability and the limits of insurance", Columbia Law Review, 1988, 942-988; Katuman, M.T. "Pollution Insurance and Catastrophic Environmental Risk", The Journal of Risk and Insurance, 1988, 75-100. 
bedragen toekennen, gaan verzekeraars ervan uit dat dergelijke dekkingen steeds moeilijker te verkrijgen zullen zijn ${ }^{92}$.

Uit onderzoek is gebleken dat in de Verenigde Staten een aantal belangrijke wijzigingen in het aansprakelijkheidsrecht en de daaruit voortvloeiende verzekeringscrisis, hebben geleid tot aanzienlijke prijsstijgingen en zelfs tot het verdwijnen van bepaalde producten uit de markt ${ }^{93}$. Inzake verzekeringspolissen voor natuurrampen worden in de VS beperkingen gesteld aan de hoogte van de premies, waardoor een aantal verzekeraars ertoe geneigd is zich uit bepaalde delen van de markt terug te trekken, voornamelijk in gebieden die vaak door natuurrampen zijn getroffen ${ }^{94}$. Doordat zij slechts in beperkte mate premies kunnen innen, wordt het risico voor hen onverzekerbaar. Hoewel over het algemeen wordt aangenomen dat een analoge aansprakelijkheids- en verzekeringscrisis zoals in de Verenigde Staten niet meteen in Europa valt te verwachten ${ }^{95}$, woedt ook in Europa, ingevolge de verzwarende aansprakelijkheidslast, de discussie met betrekking tot het beperken van de aansprakelijkheidslasten ${ }^{96}$ en de verzekerbaarheid van een (aansprakelijkheids)risico ${ }^{6}$.

Zo heeft in Europa de discussie inzake de aansprakelijkheidsgrondslag, en met name het toenemend beroep op de claims-made grondslag, eveneens betrekking op de verzekerbaarheid van de desbetreffende risico's ${ }^{98}$. Ook de wetgever is in een aantal gevallen voorzichtig bij de invoering van nieuwe aansprakelijkheden. In Nederland bijvoorbeeld werd de verzekerbaarheidsproblematiek aan de orde gesteld bij de invoering van de nieuwe kwalitatieve aansprakelijkheden in het $\mathrm{BW}$, in die zin dat werd gesteld dat "een niet verzekerbare aansprakelijkheid vanuit het oogpunt van de slachtofferbescherming goede zin mist" ${ }^{n 9}$. Het lijkt erop dat de gedachte veld wint dat een aansprakelijkheid enkel zin heeft wanneer deze verzekerbaar is en dat de grens van de verzekerbaarheid de grens van de aansprakelijkheid bepaalt ${ }^{100}$. Nauw hiermee verbonden is het matigingsen limiteringsrecht dat in het Nederlandse BW is toegekend aan respectievelijk de rechter en de wetgever $^{10 !}$. Of de rechter de omvang van een schade zal kunnen matigen, hangt in belangrijke

Dincler, G., "Insurability of Environmental Risks", Conferentie Verzekering van Industriële risico's, Antwerpen, 1995, 15; Faure, M., "The limits to Insurability form a Law and Economics Perspective", Geneva Papers on Risk and Insurance, $\mathrm{n}^{\circ} 76,1995,455$.

Priest, G. L., "The current Insurance Crisis and Modern Tort Law", o.c., 1521-1590.

Kunreuther, H., "Rethinking Socicty's Management of Catastrophic Risks", The Geneva Papers On Risk and Insurance, vol. 22, n' $83,1997,163-164$.

Vooral door het contingency-fee systeem, door de juryrechispraak in aansprakelijkheidsvorderingen en door de mogelijkheid in de wetgeving van sommige Amerikaanse staten om punitive damages toe te kennen, is het zeer moeilijk om de conclusies die gelden voor het Amerikaanse rechi zomaar te transponeren naar het "Europese" aansprakelijkheidsrecht. Zie met name de verschillende bijdragen in Spier, J. (ed.), The Limits of Liability. Keeping the Floadgates shut, Kluwer, Deventer, 1996.

Spier, J., "De (on)verzekerbaarheid van aansprakelijkheden", in "van Dunné bundel", l.c., 409 e.v.; Holsboer, J.H., "Insurability and Uninsurability: an Introduction", The Geneva Papers On Risk and Insurance, vol. 20, $\mathrm{n}^{\circ}$ 77, 1995, 408 e.v.; Vermaat, A.J., "Uninsurability: a Growing Problem", The Geneva Papers On Risk and Insurance, vol. 20, $n^{\circ} 76,1995,446-453$.

Cfr. supra, $\$ 5$ van hoofdstuk 5.

Memorie van Toelichting, Tweede Kamer, 21 202, nr. 3, 27.

Hartlief, T. en Tjittes, R.P.J.L., "Verzekering en Aansprakelijkheid", l.c., 32-33.

Artikel 6:109 NBW luidt: "Indien toekenning van volledige schadevergoeding in de gegeven omstandigheden waaronder de aard van de aansprakelijkheid, de tussen partijen bestaande rechtsverhouding en hun beider draagkracht, tot kennelijk onaanvaardbare gevolgen zouden leiden, kan de rechter een wettelijke verplichting tot schadevergoeding matigen. De matiging mag niet geschieden tot een lager bedrag dan waarvoor de schuldenaar zijn aansprakelijkheid door verzekering heeft gedekt of verplicht was te dekken". Artikel 6:110 NBW luidt: "Opdat de aansprakelijkheid die terzake van schade kan ont- 
mate af van de verzekeringspositie van dader en slachtoffer; bij limitering zal de verzekerbaarheid van de schade een belangrijke rol spelen ${ }^{102}$.

In deze paragraaf wordt op basis van de rechtseconomische benadering onderzocht welke elementen een invloed hebben op de verzekerbaarheid van een risico. Hieronder wordt in eerste instantie aangetoond dat een essentieel element van de verzekerbaarheid van een risico de voorzienbaarheid van dat risico is $(\$ 4.1)$ en dat een gebrek aan statistische gegevens op zich onvoldoende is om te besluiten tot de onverzekerbaarheid van het risico (\$ 4.2). In $\$ 4.3$ worden verschillende elementen besproken die de verzekerbaarheid van een risico wel degelijk in het gedrang kunnen brengen. Nadien wordt de vraag beantwoord of de dekkingsgrondslag een invloed kan hebben op de verzekerbaarheid van een risico $(\$ 4.4)$ en wordt onderzocht in welke mate het beperken van de aansprakelijkheid een remedie kan zijn tegen onverzekerbaarheid $(\S 4.5)$.

\subsection{Voorzienbaarheid van een risico}

In het algemeen kan worden gesteld dat de inschatting van een risico door de verzekeraar betrekking heeft op twee elementen, namelijk de schadeomvang $(S)$ en de probabiliteit $(p)^{103}$. Op een concurrentiële markt zal de door de verzekeringsnemer te betalen premie gelijk zijn aan de verwachte ongevalschade (p.S), eventueel vermeerderd met een aantal administratieve kosten. Een goed verzekerbaar risico veronderstelt een relatief hoge schadefrequentie en een lage gemiddelde schade. In dit geval zijn voldoende gegevens voorhanden om een correcte actuariële berekening te maken, om de premies te berekenen en om de nodige reserves op te bouwen.

Dit betekent meteen dat een wijziging in het aansprakelijkheidsrecht niet noodzakelijk de verzekerbaarheid van een risico in het gedrang brengt. Door een wijziging in het aansprakelijkheidsrecht kan zowel de probabiliteit (p) wijzigen (bijvoorbeeld ingevolge de evolutie van foutaansprakelijkheid naar risicoaansprakelijkheid), als de grootte van de toegekende bedragen (S). Aangezien de premie in principe ongeveer gelijk zal zijn aan de verwachte ongevalskosten, zal een toenemende aansprakelijkheid enkel leiden tot een hogere premie of tot een aanpassing van de polis ${ }^{104}$. Zo komen de wijzigingen die het civiele aansprakelijkheidsrecht sinds de jaren zestig heeft ondergaan, neer op een uitbreiding van de aansprakelijkheid, maar dat dit niet heeft geleid tot onoverkomelijke problemen inzake verzekerbaarheid ${ }^{105}$. In feite heeft de toenemende aansprakelijkheid zelfs geleid tot nieuwe opportuniteiten en nieuwe markten voor verzekeraars.

staan niet hetgeen redelijkerwijs door verzekering kan worden gedekt, to boven gaat, kunnen bij algemene maatregel van bestuur bedragen worden vastgesield, waarboven de aansprakelijkheid zich niet uitstrekt. Afzonderlijke bedragen kunnen worden bepaald naar gelang van onder meer de aard van de gebeurtenis, de aard van de schade en de grond van aansprakelijkheid".

Volledigheidshalve wordt erop gewezen dat de toepassing van het matigings- en limiteringsrecht in het Nederlandse civiele aansprakelijkheidsrecht beperkt is, ondat het een uitzondering betreft op de algemene regel dat eenieder recht heeft op volledige compensatic (Hartlief, T. en Tjittes, R.P.J.L., "Verzekering en Aansprakelijkheid", l.c., 60).

Faure, M.G. en Hartlief, T. (red.), "Verzekering en de groeiende aansprakelijkheidslast", I.c., 12; Faure, M. en Hartlief, T., "Remedies for expanding liability", Oxford Journal of Legal Studies, vol. 18, 1998, 685 .

Uiteraard dienen ook de overige voorwaarden te zijn vervuld om het risico verzekerbaar te maken. Zo zal onder meer dienen te worden nagegaan of het aansprakelijkheidsrisico nauwkeurig is afgelijnd en ingeperkt.

Faure, M.G., "Over beschermde slachtoffers, vrijgevige rechters en zuchtende verzekeraars", o.c, 1230. 
Uiteraard dienen deze wijzigingen voorzienbaar te zijn. Ten aanzien van wijzigingen in de wetgeving, zijn toch een aantal gevallen bekend van voorzienbare nieuwe aansprakelijkheden in de Europese rechtsorde. Een treffend voorbeeld betreft de mogelijke invoering in de EU, van een min of meer algemene aansprakelijkheid voor milieuschade. Het is bekend dat de Europese Commissie reeds geruime tijd werkt aan de invoering van een risicoaansprakelijkheid terzake: in februari 2000 werd het lang verwachte Witboek van de Europese Commissie inzake milieuaansprakelijkheid $^{106}$ - dat verder bouwt op het Groenboek inzake herstel van milieuschade van 1993 - uitgebracht. Hier kan worden gesteld dat, indien bijvoorbeeld in de toekomst een Europese richtlijn inzake milieuaansprakelijkheid zou worden uitgevaardigd, dit voor verschillende lidstaten een uitbreiding van de aansprakelijkhcid tot gevolg zal hebben, maar dat deze wijziging in ruime mate voorzienbaar was voor de verzekeraars. Nu reeds kunnen deze wijzigingen worden geanticipeerd en kunnen bijvoorbeeld de polissen worden aangepast ${ }^{107}$.

In een meerderheid van gevallen is een wetgevend initiatief het gevolg van cen langere voorbereiding. Dit zal des te meer het geval zijn ten aanzien van nationale wetgeving die haar oorsprong vindt in het internationale recht: aan de totstandkoming van verdragen gaat in de regel een lange onderhandelingsperiode vooraf. Zo heeft de wijziging aan de nucleaire aansprakelijkheidsverdragen meer dan 10 jaar in beslag genomen - en het zal nog enige tijd duren vooraleer deze verdragen in werking zullen treden - zodat zeker kan worden gesproken van een voorzienbare wijziging. Ook wat EG-richtlijnen betreft, geven zowel de totstandkoming als de implementatie in de nationale wetgeving de nodige tijd om een ontwikkeling in het recht te voorzien. Het spreekt voor zich dat deze factoren, althans wat het aspect van de wetswijziging betreft, de voorzienbaarheid van een risico ten goede komt.

Indien verzekeraars daarentegen worden geconfronteerd met een onvoorzienbare aansprakelijkheid, of wanneer de verzekeraar het gedrag van de verzekerde of verzekeringsnemer niet kan controleren of bijsturen, zal mogelijks een probleem van onverzekerbaarheid rijzen. Dit impliceert meteen dat te allen tijde het morele risico onder controle moet worden gehouden ${ }^{108}$.

In cen aantal gevallen zal het voor verzekeraars niet eenvoudig zijn om, bij gebrek aan betrouwbare statistische gegevens, de probabiliteit en de verwachte schade in te schatten. Dit zal met name het geval zijn voor ongevallen met een lage frequentie en een hoge verwachte schade, of de zgn. catastroferisico's. Hieronder wordt onderzocht of een gebrek aan gegevens een voldoende reden is om tot de onverzekerbaarheid van een risico te besluiten.

\subsection{Invloed van gebrekkige statistische gegevens op de verzekerbaarheid}

In de discussie met betrekking tot de invloed van beperkte statistische gegevens op de verzekerbaarheid van een risico, staan de zgn. catastroferisico's centraal. In het algemeen wordt een catastroferisico omschreven als een risico met lage probabiliteit en een hoge verwachte schade ${ }^{109}$. Hoe minder statistische gegevens voorhanden zijn, hoe moeilijker het is voor de verzekeraar om

${ }_{107}$ Witboek betreffende milieuaansprakelijkheid, 9 februari 2000, COM(2000) $66 \mathrm{def}$.

Ook de mate waarin een regime van foutaansprakelijkheid wordt vervangen door een regime van risicoaansprakelijkheid en de daaruit voortvioeiende toenemende vraag naar aansprakelijkheidsverzekeringen - en afname van de vraag naar first party dekkingen - is voorzienbaar en heeft op zich geen invloed op de verzekerbaarheid.

ius De invloed van het morele risico en van averechtse selectie op de verzekerbaarheid van cen risico, wordt in $\$ 5.3 .1$ van dit hoofdstuk besproken.

Zeckhauser, R., "19th Annual lecture of the Geneva Association. Insurance and Catastrophes", The Geneva Papers on Risk and Insurance, vol. $21, \mathrm{n}^{\circ} 78,1996,3$. 
dat risico in te schatten. Tegelijk zal het vaak zo zijn dat het aantal potentiële daders is beperkt, waardoor de wet der grote getallen geen effect kan hebben en waardoor ook de mogelijkheid tot risicospreiding beperkt is. Voor verzekeraars is het risico van een aardbeving evenzeer een catastroferisico als het risico dat bijvoorbeeld plots massaal vorderingen worden ingediend ingevolge het gebruik van asbest, bodemverontreiniging, etc.

Hoewel het verzekeringswezen in ruime mate is gebaseerd op de actuariële wetenschap, toch bestaat er op zich geen wiskundige formule die kan bepalen of een bepaald risico verzekerbaar is. Wel werden pogingen ondermomen om een aantal criteria te ontwikkelen. Berliner onderscheidt negen criteria die de verzekerbaarheid van een risico bepalen ${ }^{10}$ :

1. kan het verlies redelijkerwijze op basis van empirische gegevens worden ingeschat?;

2. wat is het maximale verlies? (capaciteit van de markt);

3. wat is, voor het gedekte risico, het geschatte gemiddelde verlies per incident?;

4. wat is de gemiddelde periode tussen twee opeenvolgende verliezen?;

5. hoe hoog dient de verzekeringspremie te zijn, hoe dient deze te worden samengesteld en kan de grootte van deze premie worden bepaald?;

6. wat is de invloed van het morele risico?;

7. zijn er beperkingen door het overheidsbeleid?;

8. bestaan er andere juridische beperkingen?;

9. welke zijn a priori de maximale dekkingslimieten onder een gegeven polis?

Ook het Nederlandse Verbond der Verzekeraars heeft getracht een objectieve definitie te geven van een onverzekerbaar risico: van onverzekerbaarheid is sprake indien een potentiële polishouder niet de dekking kan kopen die hij redelijkerwijze nodig heeft om de nadelige gevolgen op te vangen wanneer een onzekere gebeurtenis schade veroorzaakt ${ }^{111}$. Er zou dus sprake zijn van een onverzekerbaar risico indien een verzekeringsproduct niet kan worden verkregen, indien slechts cen gedeeltelijke dekking beschikbaar is of indien de prijs van het verzekeringsproduct te hoog ligt ${ }^{112}$.

In de visie van Berliner is een risico niet verzekerbaar indien niet is voldaan aan een van deze criteria; indien met andere woorden de uitkomst van één van deze criteria onzeker is. De vijf eerste criteria van Berliner verwijzen naar de actuariële wetenschap (de beschikbaarheid van empirische gegevens, het maximale verlies, het gemiddelde verlies per incident, de gemiddelde periode tussen opeenvolging van incidenten en de hoogte van de verzekeringspremie). Overeenkomstig dezc visie wordt gesteld dat risico's onverzekerbaar zijn zodra statistische gegevens over de probabiliteit en de mogelijke schadeomvang ontbreken. De hamvraag is dus of er sprake is van een onverzekerbaar risico zodra een verzekeraar wordt geconfronteerd met moeilijkheden inzake de toepassing van actuariële technieken.

Voor het antwoord op deze vraag dient in de eerste plaats te worden vastgesteld dat de bereidheid van verzekeraars een belangrijk element is bij de verzekerbaarheid. Of een verzekeringsdekking kan worden verkregen en tegen welke voorwaarden, hangt in belangrijke mate af van de bereidheid van verzekeraars en herverzekeraars om het risico onderling te spreiden. Naarmate minder statistische gegevens beschikbaar zijn, zal een verzekeraar meer moeten interpreteren en zal automatisch de subjectiviteit bij de beslissing om al dan niet dekking te verlenen, toenemen. Het is

Berliner, B., Limits of Insurability of Risks, Englewood Cliffs, 1982.

Holsboer, J.H., "Insurability and Uninsurability: an Introduction", o.c., 407

Ibidem.
} 
aannemelijk om ervan uit te gaan dat een verzekeraar voor de dekking van een nieuw risico voortbouwt op de ervaringen van een naar zijn mening vergelijkbaar risico. Zowel deze vergelijking als de daarop gebaseerde beslissing om al dan niet dekking te verlenen, zijn in ruime mate subjectief. Nochtans kunnen zelfs zeer subjectieve gegevens aangaande een risico een voldoende basis vormen om een premieberekening toe te laten, op voorwaarde evenwel dat de verzekeringsdekking ondubbelzinnig is beschreven of precies kan worden omlijnd ${ }^{13}$. Door deze bijna onvermijdbare subjectiviteit is het zo dat verzekerbaarheid in feite wordt bepaald door de markt en de verzekeraars zelf ${ }^{114}$.

Het spreekt voor zich dat de bereidheid om een risico te verzekeren in ruime mate zal afhangen van de risicoaversie van de verzekeraar en van diens insurer's ambiguity ${ }^{115}$. Met dit laatste wordt de onzekerheid bedoeld omtrent de correctheid van de risico-inschatting; naarmate deze onzekerheid - die bij elk risico aanwezig is, zoniet hebben we niet meer te maken met een risico - toeneemt, zal de verzekeraar een grotere aversie vertonen. Naarmate een verzekeraar dus meer risicoavers en "ambigu-avers" is, zal de veiligheidsbuffer (security loading) die hij wenst in te bouwen, stijgen ${ }^{116}$. Het is dan ook normaal dat hoe minder gegevens voorhanden zijn betreffende het te dekken risico, hoe groter de buffer zal zijn die de verzekeraar in zijn premie wenst in te bouwen. Zeker voor zware risico's bouwen verzekeraars speciale reserves op die toelaten de verwezenlijking van deze risico's het hoofd te bieden. Hoe zwaarder het risico, hoe groter het deel van de premie dat zal worden aangewend om in die reserves te worden gestort. Een redelijk voorzienbare wijziging van het risico ex post is dus niet meteen problematisch voor de verzekeraar ${ }^{117}$.

Het voomaamste gevolg van het feit dat elke verzekeraar extra reserves dient aan te leggen, heeft uiteraard betrekking op de door de verzekerde te betalen premie. Vandaar kan worden gesteld dat een risico objectief te verzekeren kan zijn, maar dat de premie dermate hoog wordt, dat de verzekerde niet meer bereid is om tegen die premie zijn risico over te dragen of te spreiden. De willingness to pay van de verzekerde zal afhangen van diens risicoaversie en van mogelijke beschikbare alternatieven. Kan de risicoaversie tegen lagere kosten worden weggenomen door altematieve technieken, dan zal hij afzien van het kopen van een verzekeringsdekking op de klassieke verzekeringsmarkt. Steun voor deze visie vinden we bij Gollier ${ }^{118}$ die er eveneens van uitgaat dat objectief gezien een dekking beschikbaar kan zijn, maar dat deze een of beide partijen bij de verzekeringsovereenkomst, geen voldoening schenkt.

Een zeer hoge schade is op zich evenmin een voldoende reden om een risico als onverzekerbaar te beschouwen. In de verzekeringsindustrie werden verschillende technieken ontwikkeld om hicraan minstens ten dele het hoofd te bieden ${ }^{119}$. Dankzij medeverzekering, herverzekering en het poolen

113 Karten, W.T., "How to Expand the Limits of Insurability?", The Geneva Papers On Risk and Insurance, vol. $22, \mathrm{n}^{\circ} 85,1997,518$.

114 Faure, M., "The Limits to Insurability from a Law and Economic Perspective", The Geneva Papers On Risk and Insurance, vol. 20, $\mathrm{n}^{\circ} 76,1995,459$.

115 Zie hierover met name Kunreuther, H., Hogarth, R. en Mesaros, J., "Insurer Ambiguity and Market Failure", Journal of Risk and Uncertainty, 1993, 71-81.

116 Faure, M. en Fenn, P., "Retroactive Liability and the Insurability of Long-tail Risks", International Review of Law and Economics, vol. 19, 1999, 491.

Faure, M., "Is aansprakelijkheid 'met terugwerkende kracht' efficiënt en verzekerbaar?", Aansprakelijkheid \& Verzekering, 1998/1, 10.

Hij beschouwt een risico als onverzekerbaar indien "given the economic environment, no mutually advantageous risk transfer can be exploited by the consumer and the suppliers of insurance" (Gollier, C., "About the Insurability of Catastrophic Risks", The Geneva Papers On Risk and Insurance, vol. 22, $\left.\mathrm{n}^{\circ} 83,1997,177\right)$.

Faure, M. en Hartlief, T., "Remedies for expanding liability", o.c., 695. 
van risico's kan ook een verzekeraar zijn risico spreiden en kan een dekking worden verleend die de capaciteit van een individuele verzekeraar te boven gaat.

Dit neemt uiteraard niet weg dat rekening moet worden gehouden met de werkelijke capaciteit van de verzekeringsmarkt. Aangezien per definitie de financiële middelen van een verzekeraar net zoals van elke onderneming - beperkt zijn, kan hij ook slechts tot op een bepaald niveau verbintenissen op zich nemen. De daadwerkelijke capaciteit van één welbepaalde verzekeraar zal niet alleen afhangen van de eigen middelen, maar eveneens van de mogelijkheden waarover hij op de herverzekeringsmarkt beschikt, om zijn risico verder te spreiden. Deze mogelijkheden hangen opnieuw af van de bereidheid van verzekeraars en herverzekeraars om het risico te spreiden. Het is met andere woorden zeer moeilijk om op objectieve wijze de capaciteit van de verzekeringsmarkt te bepalen en dus om de verzekerbaarheid van een risico in te schatten ${ }^{120}$; het is bovendien zo dat deze capaciteit in de realiteit aan belangrijke wijzigingen onderhevig kan zijn. Een gebrek aan statistische gegevens of een zeer hoge schade zijn niet voldoende om een risico als onverzekerbaar te beschouwen.

Concluderend kan worden gesteld dat problemen inzake de actuariële berekening aanleiding kunnen geven tot de onverzekerbaarheid van een risico indien de verzekeringsvraag en het verzekeringsaanbod elkaar niet "vinden". Dit zal met name het geval zijn indien de ambigü̈teitsaversie van de verzekeraar hem ertoe brengt om hetzij geen dekking te verlenen, hetzij om dermate aanzienlijke veiligheidsbuffers in de premie op te nemen, dat de verzekerde niet meer bereid is om een dekking aan te kopen.

\subsection{Elementen die kunnen leiden tot onverzekerbaarheid}

Een belangrijk element bij de verzekerbaarheid van een risico heeft te maken met de mogelijkheden waarover een verzekeraar beschikt om het gedrag van de verzekerde bij de sturen of de polis aan te passen. Hiermee wordt gerefereerd aan het morele risico en de averechtse selectic. De invloed daarvan op de verzekerbaarheid wordt in $\S 4.3 .1$ besproken.

Ook een wijziging in het aansprakelijkheidsrecht gedurende de looptijd van cen gegeven polis, door een verandering van de aansprakelijkheidsregel $(p)$ en/of door een groter wordende schade (p), kan de verzekerbaarheid van het risico in het gedrang brengen in de mate waarin deze wijzigingen niet konden worden voorzien. In een dergelijk geval zal de aangerekende premie immers te laag zijn en heeft de verzekeraar onvoldoende reserves om een schadegeval te dekken. Twee tendensen in het aansprakelijkheidsrecht kunnen de voorzienbaarheid van het risico in het gedrang te brengen, met name in gevallen van retroactieve aansprakelijkheid en bij onzekere causaliteit. In de nucleaire aansprakelijkheidsverdragen wordt niet voorzien in een retroactieve aansprakelijkheid. Toch is ook hier sprake van een lange termijn risico ${ }^{121}$ en kan een verzekeraar wel degelijk worden geconfronteerd met een retroactieve aansprakelijkheid indien een vordering zou worden ingediend nadat de kerninstallatie is stilgelegd of ontmanteld, of indien de exploitant in de loop der jaren van verzekeraar is veranderd. Ook de invloed van retroactieve aansprakelijkheid $(\$ 4.3 .2)$ en van onzekere causaliteit $(\S 4.3 .3)$ op de verzekerbaarheid van een risico, worden hieronder besproken.

Faure, M., "The Limits to Insurability from a Law and Economic Perspective", o.c., 459; Holsboer, J.H., "Insurability and Uninsurability: an Introduction", o.c., 408.

121 Over de zgn. lange termijn risico's, zie onder meer Spier, J., "De (on)verzekerbaarheid van aansprakelijkheden", in "van Dunné bundel", l.c., 409-422; Dommering-van Rongen, L., "Risico's met een lange staart", in "van Dunné bundel", l.c., 27-39. 


\subsubsection{Moreel risico en averechtse selectie}

Economen beschouwen een risico alleen onverzekerbaar wanneer het morele risico en averechtse selectie niet ingedijkt kunnen worden ${ }^{122}$; een hoog schadebedrag of onvoldoende gegevens op zich leiden niet tot onverzekerbaarheid van een risico ${ }^{123}$.

De analyse van het morele risico heeft aangetoond dat de houding (en dus de prikkels) van de verzekerde kunnen wijzigen door het enkele feit dat hij over een verzekeringsdekking beschikt ${ }^{124}$. Het risico stijgt waardoor de premie niet meer is aangepast. Enkel indien de verzekeraar over de mogelijkheid beschikt om het gedrag van de verzekerde te controleren kan aan het morele risico worden verholpen.

De verzekeraar beschikt inderdaad over een aantal technieken die het morele risico kunnen beperken. Ten eerste kan de verzekerde voor een deel blootgesteld blijven aan het risico, bijvoorbeeld door de introductic van een franchise of door het verzekerde bedrag te beperken. Het kan met andere woorden zinvol zijn am de dekking te beperken en aldus het morele risico in te dijken, ook al bestaat op de markt voldoende capaciteit om het gehele risico te dekken. Daarnaast kan het morele risico ook worden beperkt indien de verzekeraar over voldoende mogelijkheden beschikt om het gedrag van de verzekerde te controleren en de premie en de polisvoorwaarden in die zin an te passen. In een dergelijk geval zal de verzekerde dezelfde prikkel behouden als bij afwezigheid van verzekeringsdekking ${ }^{125}$.

Ook het probleem van averechtse selectie kan de verzekerbaarheid van een risico in het gedrang brengen. Bestaat een informatieasymmetric ten gevolge waarvan de verzekerde beter weet of hij een goed dan wel een slecht risico vormt, dan kan dit ertoe leiden dat de goede risico's de groep verlaten. De verzekeraar zal een onvoldoende onderscheid kunnen maken in de premieberekening, waardoor goede risico's een te hoge en slechte risico's een te lage premie betalen. Bij averechtse selectie worden goede risico's dus niet meer beloond omdat ze een te hoge gemiddelde premie betalen; enkel een correcte risicodifferentiatie kan het probleem van averechtse selectie tegengaan.

In de mate van het mogelijke dienen dus verschillende risico's van elkaar te worden onderscheiden en zullen de premie- en de polisvoorwaarden de verschillen tussen een goed en een slecht risico weerspiegelen. Op deze wijze zal verzekering met name ook voor goede risico's aantrekkelijk worden gemaakt ${ }^{126}$. Doordat de goede risico's zullen worden beloond voor hun voorzichtig gedrag, is ook het effect op de reductie van de maatschappelijke kosten duidelijk.

Niet ten aanzien van alle risico's zal een doorgedreven risicodifferentiatie echter zinvol zijn, gelet op de ermee gepaard gaande kosten ${ }^{12}$. Ten aanzien van consumentenverzekeringen zal het nagenoeg onmogelijk zijn om zo specifiek mogelijke polissen op te stellen; geheel anders is de situatie ten aanzien van zware industriële risico's, waar een verzekeraar in principe geen dekking verleent zonder een voorafgaand bezoek aan de verzekeringsnemer, of zonder veiligheids- en milieuaudit.

Pauly, M., "The Economics of Moral Hazard: Comment", o...n 531.

Priest, G., "The Current Insurance Crisis and Modern Tort Law", o.c., 1521-1590.

Cfr. supra, \$2.2 van dit hoofdstuk.

Faure, M., "The Limits to Insurability from a Law and Economic Perspective", o.c., 457.

Faure, M.G. en Hartlief, T., "Verzekering en de groeiende aansprakelijkheidslast", l.c., 316-319.

Zie hierover Borenstein, S., "The economics of costly risk sorting in competitive insurance markets", International Review of Law and Economics, 1989, 25-39; Wils, W.P.J., "Insurance Risk Classification in the EC: Regulatory Outlook", Oxford Journal of Legal Studies, 1994, 449-467. 
Daarenboven kan de verzekeraar makkelijk informatie bekomen ten aanzien van vergunningsplichtige activiteiten. De bijzondere voorwaarden die in de vergunning desgevallend worden opgelegd, en de naleving daarvan door de verzekeringsnemer, zijn een belangrijke indicatie die tegen geringe kosten kunnen worden verkregen.

Een aangepaste risicodifferentiatie is bijgevolg een belangrijk clement bij de verzekerbaarheid van een risico, omdat risicodifferentiatie een adequate oplossing vormt voor het morele risico en omdat ook averechtse selectie wordt tegengegaan. Tegelijk zal een gedegen risicodifferentiatie de prikkels van de exploitant positief beïnvloeden.

Gesteld dat in een gegeven situatie het morele risico en de averechtse selectie inderdaad kunnen worden gecontroleerd, dan nog kunnen andere factoren de verzekerbaarheid alsnog in het gedrang brengen. De invloed van retroactieve aansprakelijkheid en van causaliteitsonzekerheid worden hieronder besproken.

\subsubsection{Retroactieve aansprakelijkheid}

Er is sprake van retroacticve aansprakelijkheid indien de verzekeringsnemer of de verzekerde aansprakelijk wordt gesteld voor risico's die ten tijde van het afsluiten van de verzekeringsovereenkomst niet te voorzien waren ${ }^{128}$; indien met andere woorden de juridische aansprakelijkheidscriteria zijn verzwaard ten opzichte van het verleden en indien vandaag iemand wordt aansprakelijk gesteld op basis van deze criteria, ten gevolge van een gedraging in het verleden ${ }^{129}$. Zeker bij bepaalde vormen van milieuschade is het niet ondenkbaar dat gevallen die vandaag aanleiding geven tot aansprakelijkheid, in het verleden niét tot aansprakelijkheid zouden hebben geleid.

Vanuit rechtseconomisch oogpunt kan retroactieve aansprakelijkheid tot problemen leiden ${ }^{130}$ omdat een gedrag dat voorheen geen aanleiding gaf tot aansprakelijkheid - en dus waar de explojtant geen prikkel had zijn gedrag aan te passen - plots wel aanleiding geeft tot aansprakelijkheid. Indien bijvoorbeeld na meerdere jaren van exploitatie een gevarlijke activiteit wordt stopgezet en indien later zou blijken dat deze installatie een bepaalde schade heeft veroorzaakt, is het risico van een retroactieve aansprakelijkheid niet denkbeeldig. Met name in gevallen van "deep-pocket" kan de verleiding van de rechtbank groot zijn om de aansprakelijkheid ten laste te leggen van het fonds dat de verzekeraar in de loop der jaren heeft opgebouwd en dat hij eventueel nog in stand houdt.

Ook vanuit het standpunt van de verzekeraar leidt dit tot de nodige problemen omdat de premie niet is aangepast en er dus geen reserves zijn opgebouwd om deze nicuwe vorderingen te dekken, en omdat in de polis geen preventiemechanismen zijn opgenomen om dergelijke schade te minimaliseren of te vermijden. Nochtans is het zo dat in een aantal gevallen de evolutie van een gegeven schade niet geheel onvoorzienbaar was. De kern van de activiteiten van een verzekeraar heeft betrekking op de inschatting van de evolutie van onzekerheden. De ontwikkeling van het aansprakelijkheidsrecht kan als één van deze onzekerheden worden beschouwd en kan bijgevolg tot

Faure, M. en Hartlief, T., "Remedies for expanding liability", o.c., 687

Faure, M. en Fenn, P., "Retroactive Liability and the Insurability of Long-Tail Risks", o.c., 488.

Voor meer details zie onder meer Faure, M. en Fenn, P., "Retroactive Liability and the Insurability of Long-tail Risks", o.c., 487-500; Faure, M., "Is aansprakelijkheid 'met terugwerkende kracht' efficiênt en verzekerbaar?", o.c., 1-11; Hartlief, T. en Spier, J., "Verzekering en aansprakelijkheid met terugwerkende kracht", Aansprakelijkheid \& Verzekering, 1994, 24; Haazen, O.A., Bolt A.T. en Spier, J., "De uitdijende reikwijdte", l.c., 45-46. 
op zekere hoogte ex ante worden ingeschat ${ }^{131}$. In de mate waarin een verzekeraar de evolutie van het aansprakelijkheidsrecht kan inschatten, ligt het in de lijn van het basisactiviteiten dat deze evolutie wordt behandeld als eender welk ander risico waarvoor dekking kan worden verleend. De probabiliteit van de evolutie kan inderdaad worden geschat en dienovereenkomstig kan een afzonderlijke risicopremie worden aangerekend.

Anderzijds is het zo dat de nadelen verbonden aan een retroactieve aansprakelijkheid niet als alibi mogen dienen om geen voorzorgsmaatregelen meer te nemen of om niet meer te investeren in betere en veiliger technieken. Vanuit maatschappelijk oogpunt kan het inderdaad uitermate zinvol zijn om ervoor te zorgen dat een exploitant de nodige prikkels zal hebben om onderzoek te verrichten naar de risico's van zijn activiteit ${ }^{132}$. Via de wetgeving inzake de vergunningsplicht van gevaarlijke activiteiten kan hieraan worden tegemoet gekomen, met name bij toepassing van de stand der technick. Hierbij kan worden opgemerkt dat een foute inschatting van de stand der techniek vanwege de rechter of de verzekeraar, kan leiden tot een soort retroactieve aansprakelijkheid, of tot een resultaat dat daarmee gelijkstaat. Ook voor de verzekeraar zal het nuttig zijn om de evolutie van de verschillende bestaande technicken op te volgen en om de verzekeringsnemer via risicodifferentiatie aan te zetten tot zorgvuldig gedrag. Wordt in een aansprakelijkheidsvordering hiemee geen rekening gehouden, dan kan de voorzienbaarheid en dus ook de verzekerbaarheid in het gedrang komen.

\subsubsection{Onzekere causaliteit}

Een andere tendens in het recht kan de voorzienbaarheid van een risico bemoeilijken, met name in de gevallen waarin een persoon wordt aansprakelijk gesteld, indien onzekerheid bestaat omtrent de causaliteit ${ }^{133}$; indien met andere woorden niet kan worden bewezen dat degene die aansprakelijk wordt gesteld de schade daadwerkelijk heeft veroorzaakt. In vele gevallen wordt op deze wijze de aansprakelijkheidslast verschoven naar bedrijven en hun verzekeraars ${ }^{134}$.

Een bekend voorbeeld van causaliteitsonzekerheid is de Nederlandse DES-zaak waar de leer van de alternatieve causaliteit werd toegepast en waar in feite het causaliteitsprobleem werd doorgeschoven naar de onderneming voor wie het bewijs van het tegendeel nagenoeg onmogelijk is ${ }^{135}$.

Ook in andere landen en in andere domeinen dan in de hierboven besproken zaak, worden rechtbanken geconfronteerd met causaliteitsonzekerheid. In het Verenigd Koninkrijk bijvoorbeeld werd door een nabestaande van een kankerpatiënt en door een kankerpatiënt een vordering ingediend tegen de exploitant van de nabijgelegen keminstallatie van Sellafield ${ }^{136}$. Belangrijk in dezo

In $\S 4.2$ werd reeds gerefereerd aan de "insurer ambiguity".

Calabresi, G. en Klevorick, A.K., "Four tests for Liability in Torts", Journal of Legal Studies, vol. 15, 1985, 585-627; Shavell, S., "Liability and the incentive to obtain information about risk", Journal of Legal Studies, vol. 21, 1992, 259-270.

Zie hierover met name Akkermans, A.J., Proportionele ansprakelijkheid bij onzeker causaol verband. Een rechisvergelijkend onderzoek naar wenselijkheid, grondslagen en afgrenzing van äansprakelijkheid naar rato van veroorzakingswaarschijnlijkheid, diss., Deventer, Tjeenk Willink, Zwolle, 1997 en Faure, M.G., (G)een schijn van kans. Beschouwingen over het statistisch causaliteitsbewijs bij milieugezondheidsschade, Maklu, Antwerpen, 1993.

Faure, M. en Hartlief, T., "Remedies for expanding liability", o.c., 690.

Cfr. supra, in $\$ 5.2 .2$ van hoofdstuk 5.

Zie ook Van, A.J., "Statistisch bewijs van causaal verband. Bespreking van High Court of Justice 8 October 1993 (Sellafield claims)", Tijdschrift voor Milieuaansprakelijkheid, 1994, 109-1 18; Van A., "Onzekerheid over dadersehap en causaliteit", l.c., 145-154. 
zaak was de discussie omtrent de causaliteit. Enerzijds stelde het onderzoeksverslag, het zgn. Gardner-Rapport, vast dat er een statistische relatie bestond tussen het hoge aantal kankergevallen bij kinderen rond Sellafield en het feit dat de vaders van deze kinderen in Sellafield hadden gewerkt en aan straling hadden blootgestaan ${ }^{137}$. Mar uit ander wetenschappelijk onderzoek kwam naar voren dat leukemie ook kon zijn veroorzaakt door factoren die volledig losstaan van de keminsta!latie, bijvoorbeeld door een virus. Omdat vanuit medisch-wetenschappelijk oogpunt niet kon worden bewezen wat nu precies de oorzaak was van de kankergevallen, heeft de rechtbank de causaliteit niet aangenomen.

Voornamelijk in gevallen waar de oorzaak van een ziekte of aandoening moeilijk kan worden toegewezen aan één welbepaalde factor of activiteit - bijvoorbeeld bij de ontwikkeling van kanker - is het causaliteitsbewijs niet eenvoudig. Van Maanen heeft voorgesteld om bij causaliteitsonzekerheid bij kernongevallen de bewijslast om te keren ${ }^{138}$; het zal met andere woorden aan de exploitant van de kerninstallatie toekomen om te bewijzen dat een bepaalde straling niet de oorzaak is van een welbepaalde kanker. Maar indien niet onomstootbaar kan worden bewezen welke gevallen van kanker precies door de straling van de keminstallatie is veroorzaakt en welke gevallen een andere oorzaak hebben, dan zal het nagenoeg onmogelijk zijn om aan aansprakelijkheid te ontsnappen. In de praktijk zou dat erop neerkomen dat de exploitant ook moet opdraaien voor kankergevallen die hij niet heeft veroorzaakt.

Vanuit rechtseconomische hoek zijn heel wat bezwaren geformuleerd tegen de verschuiving van de aansprakelijkheid, bij causaliteitsonzekerheid, ten nadele van de exploitant ${ }^{139}$. Wordt de aansprakelijkheid niet beperkt tot de gevallen die de exploitant daadwerkelijk heeft veroorzaakt, dan zal de dader worden geconfronteerd met een veel te zware aansprakelijkheid en zal hij misschien zijn activiteiten staken, waardoor een maatschappelijk nuttige activiteit zal verdwijnen ${ }^{140}$.

Vanuit het standpunt van de verzekeraar leidt het toewijzen van aansprakelijkheid bij causaliteitson rekerheid crtoe dat de dckking automatisch wordt uitgebreid tot schade berokkend door andere personen dan de verzekerde ${ }^{141}$. Ook dit fenomeen brengt de voorzienbaarheid van een risico in het gedrang. Bovendien lijkt het risico reëel dat wanneer bij causaliteitsonzekerheid de aansprakelijkheid toch wordt gelegd bij een verzekerde onderneming dit zal leiden tot strategisch gedrag van

Hierbij werd vastgesteld dat door de opgelopen straling het genetisch materiaal van de zaadcellen van de vaders was beschadigd wat leidde tot een bepaalde voorbestemming voor de ontwikkeling van leukemie en lymfklierkanker bij de kinderen van deze vaders. Gardner, M., "Results of a case-control study of leukaemia and lymphoma among young people near the Sellafield nuclear plant in West Cumbria", British Medical Journal, 1990, 423-434.

Van Maanen, G.E., "De civielrechtelijke aansprakelijkheid voor kernongevallen naar Nederlands recht", in "Aansprakelijkheid voor het nucleaire risico", l.c., 29-32.

Zie onder meer Calabresi, G., "Concerning Cause an the Law of Torts", University of Chicago Law Review, 1975, 69; Shavell, S., "An analysis of Causation and the Scope of Liability on the Law of Torts", Journal of Legal Studies, 1980, 463-516; Landes, W. en Posner, R., "Causation in Tort law: an Economic Approach", Journal of Legal Studies, 1983, 109-134; Landes, W. en Posner, R., "Economic Structure of Tort Law", l.c., 228-255; Kaye, D., "The Limits of the Preponderance of the Evidence standard: Justifiably Naked Statistical Evidence and Multiple Causation", American Bar Foundation, Research Journal, 1982, 487-516. 
derden $^{142}$. Dit betekent dat wanneer potentiële slachtoffers weten dat zij schadevergoeding zullen krijgen niettegenstaande causaliteitsonzekerheid, heel wat fictieve vorderingen zullen worden ingediend. Allerlei vermeende anormaliteiten van de gezondheid zullen op die manier worden toegeschreven aan de activiteiten van de onderneming; zo zal ieder geval van kanker worden toegeschreven aan de onderneming, ook al is het "slachtoffer" in kwestie bijvoorbeeld een kettingroker. Het betreft een risico dat uitermate ernstig is omdat het volledig buiten de controle valt van de verzekerde en de verzekeraar.

Tot op zekere hoogte zijn de problemen inzake causaliteitsonzekerheid te vergelijken met die veroorzaakt door retroactieve aansprakelijkheid. In beide gevallen valt namelijk niet uit te sluiten dat de schade werd veroorzaakt door een andere persoon dan de verzekerde. Ook bij retroactieve aansprakelijkheid bestaat het risico dat de verzekerde wordt aansprakelijk gesteld ondat hij op het ogenblik van het indienen van de vordering zeggenschap heeft over de onderneming, terwijl de schade evengoed kan zijn veroorzaakt door vorige eigenaren of exploitanten. Hoe verder retroactieve aansprakelijkheid teruggaat in de tijd, hoe meer ook de causaliteitsonzekerheid zal toenemen.

Indien bijgevolg iemand wordt aansprakelijk gesteld voor een schade die hooguit waarschijnlijk verband houdt met zijn activiteiten of georag, dan is het risico van onverzekerbaarheid reëel. De door de verzekeraar geinde premies kunnen hier namelijk onmogelijk mee rekening houden ${ }^{143}$. Weliswaar krijgt het slachtoffer misschien zijn schade vergoed, maar doordat een voorzichtige dader niet meer wordt beloond voor de door hem genomen preventieve maatregelen, zal dit dan weer een negatieve invloed hebben op het ongevalrisico en bijgevolg ook op de verzekerbaarheid.

\subsection{Invloed van de dekkingsgrondslag op de verzekerbaarheid}

Ten aanzien van aansprakelijkheidsverzekeringen kunnen verschillende dekkingsgrondslagen worden onderscheiden ${ }^{144}$. Bij een act-committed grondslag wordt dekking verleend indien de schadeverwekkende gebeurtenis in de looptijd van de polis valt; bij een loss-occurrence grondslag dient de schade zijn voorgevallen tijdens de looptijd van de polis; bij cen claims-made grondslag darentegen dient de vordering te zijn ingediend tijdens de looptijd van de polis.

Grotendeels omwille van problemen van verzekerbaarheid werd overigens in de loop der jaren afgestapt van de act-committed grondslag ten voordele van loss-occurrence; in de jaren negentig werd meer en meer gebruik gemaakt van de claims-made dekkingsgrondslag. De reclenering hierbij was dat zowel de act-committed als de loss-occurrence dekkingsgrondslag konden leiden tot problemen ten aanzien van lange termijn risico's ${ }^{145}$. Bij claims-made polissen, waar de vordering tijdens de looptijd van de polis moet worden ingediend, zal er geen lange termijn risico bestaan in hoofde van de verzekeraar.

De invloed van de dekkingsgrondslag op de verzekerbaarheidsproblematick heeft dan ook in hoofdzaak betrekking op de verplichtingen van de verzckeraar verschillende jaren na het einde van de polis. Doordat de polis is verstreken, kunnen geen nieuwe inkomsten uit het innen van pre-

In de literatuur wordt dit aangeduid met de term public moral hasard, maar wij verkiezen de term strategisch gedrag omdat moral hazard is gebaseerd op informatiessymmetric, hetgem niet meteen het geval is in de besproken situatie.

Faure, M., "The Limits of Insurability from a Law and Economics Perspective", o.c, 455-456.

Cfr. supra, in $\$ 5.2$ van hoofdstuk 5.

Faure, M. en Hartlief, T., "Remedies for expanding liability", o.c., 700. 
mies worden gegenereerd, laat staan dat het gedrag van de verzekerde nog zou kunnen worden beinvloed. Daamaast is het niet ondenkbaar dat de verzekeringsnemer na vele jaren niet meer bestaat of niet meer kan worden teruggevonden, zodat ook een eventueel regresrecht van de verzekeraar van tevoren is uitgehold.

Op zich vormen de verplichtingen van een verzekeraar om onder een gegeven polis het in- en/of uitlooprisico te dekken niet meteen een probleem, in die zin dat een meer uitgebreide in- en uitloopdekking een onmiddellijke weerslag zal hebben op de te betalen premie; op basis hiervan kan de verzekeraar de nodige reserves aanleggen. De verzekeraar zal inderdaad een additionele risicopremie in rekening brengen in de mate waarin de verzekeringsnemer een dekking wenst voor inen/of uitloop. Bij een act-committed grondslag zal een risicopremie worden in aanmerking genomen ten aanzien van het uitlooprisico; bij een loss-occurrence grondslag zal een risicopremie worden in aanmerking genomen ten aanzien van het in- en uitlooprisico en bij een claims-made grondslag ten aanzien van het inlooprisico.

Bijgevolg kan worden gesteld dat, indien ex ante voldoende informatie beschikbaar is omtrent het risico op retroactieve aansprakelijkheid en indien het inlooprisico eenzelfde risico vertegenwoordigt als het uitlooprisico, het verschil tussen een loss-occurrence of een claims-made dekkingsgrondslag weinig terzake doet ${ }^{146}$. Of voor de ene dan wel voor de andere grondslag wordt gekozen, zal sowieso worden gereflecteerd in de te betalen premie: deze zal lager liggen bij de claimsmade dekkingsgrondslag omdat de verzekeraar geen bijkomende risicopremie in rekening zal brengen voor de toekomstige evoluties van het recht ${ }^{147}$.

Deze stelling gaat evenwel enkel op voorzover ex ante informatie beschikbaar is over het risico dat het aansprakelijkheidsregime in de toekomst zal wijzigen. In deze hypothese zal de verzekeraar er niet meer in slagen om via een additionele risicopremie aan zijn ambiguilteit het hoofd te kunnen bieden. Het beperken of het geheel uitsluiten van een uitlooprisico kan dan een oplossing bieden.

De stelling dat de keuze voor de ene of voor de andere dekkingsgrondslag slechts een geringe invloed heeft op de verzekerbaarheid, gaat evenmin op indien het uitlooprisico moeilijker is in te schatten dan het inlooprisico. Uit de voorkeur vanwege de verzekeringsindustrie voor een claimsmadc dekking, kan inderdaad worden afgeleid dat de dekking van een uitlooprisico problematischer wordt geacht dan de dekking van het inlooprisico. Toch is het zo dat een volledige inloop zelden of nooit zal worden geboden ${ }^{148}$. De inloop kan in de tijd worden begrensd, met name ten aanzicn van gebeurtenissen of schade die zich in een bepaalde tijd vóór het afsluiten van de verzekeringspolis hebben voorgedaan. Er kan worden gesteld dat het inlooprisico makkelijker kan worden verzckerd omdat in feite een risico uit het verleden wordt geëvalueerd aan de hand van de nieuwstc technicken en de meest recente evolutie van de wetgeving, met name op het moment van het afsluiten van de polis. Indien zich bijvoorbeeld inmiddels een wijziging heeft voorgedaan in het recht, dan kan de verzekeraar hiermee rekening houden bij de berekening van de premie. Anderzijds zal een claims-made dekking geen antwoord bieden op plotse wijzigingen in het aan-

\footnotetext{
146 Faure, M. en Fenn, P., "Retroactive Liability and the Insurability of Long-Tail Risks", o.c., 493.

147 Het is dan aan de verzekerde om te beslissen of hij bereid is om meer te betalen voor een ruimere dekking onder de loss-occurrence dekkingsgrondslag.

I48 Spier, J. en Haizen, O.A., "Aansprakelijkheidsverzekeringen op claims-made grondslag", l.c., 30-31.
} 
sprakelijkheidsrecht: een onvoorzienbare wijziging zal er namelijk toe leiden dat het inlooprisico veel $z$ waarder is dan initieel ingeschat ${ }^{149}$.

Vanuit deze optiek kan worden aangenomen dat het inlooprisico makkelijker kan worden verzekerd dan het uitlooprisico, en dat bijgevolg de claims-made dekkingsgrondslag gunstiger is vanuit het standpunt van de verzekerbaarheid. Toch moet voor ogen worden gehouden dat een claimsmade polis ook negatieve effecten kan hebben. Ten eerste zal het slachtoffers ertoe aanzetten om veel sneller een vordering in te dienen. Ten tweede zal, met name ten aanzien van letselschade, bij een claims-made grondslag de kans op causaliteitsonzekerheid toenemen. Immers, hoe langer de temijn tussen de gebeurtenis en schade enerzijds en het indienen van de vordering anderzijds, hoe moeilijker het slachtoffer de causaliteit zal kunnen bewijzen. In die optiek is het onzeker of een claims-made dekkingsgrondslag erin zal slagen om de insurer ambiguity weg te nemen. Ten derde kan een claims-made dekking, of de overgang van de ene naar de andere dekkingsgrondslag, de vrijheid van de verzekeringsnemer om de polis op te zeggen, beperken. Zeker wanneer de verzekeringsnemer de concurrentie tussen aantal verzekeraars uitspeelt en van verzekeraar wenst te veranderen, kunnen beperkingen op de in- en uitloop ertoe leiden dat de verzekeringsnemer slechts over een beperkte mogelijkheid beschikt om van verzekeraar te veranderen ${ }^{150}$. In de mate waarin het veranderen van verzekeraar zal leiden tot een vacuüm in de dekking, zal in feite een drempel worden gecreëerd om van verzekeraar te veranderen. Tenslotte zal bij een schadegeval de verzekeraar ertoe geneigd zijn de polis op te zeggen, om te vermijden dat vorderingen nog tijdens de polis worden ingediend ${ }^{|5|}$. Zeker wanneer een claims-made dekkingsgrondslag wordt aangeboden in het kader van een verzekeringsplicht, kan dit voor de verzekeringsnemer tot ernstige gevolgen leiden: de exploitant zal misschien geen andere keuze hebben dan zijn activiteiten te staken.

Het lijkt daarom in een aantal gevallen aangewezen om toch in een zekere uitloop te voorzien. Zo verplicht de Belgische wet op de landverzekeringsovereenkomst de verzekeraar ertoe om een uitloop te bieden van 36 maanden. Ook onder de MAS-polis in Nederland is een dekking uitloop verkrijgbaar $^{152}$. Een andere mogelijkheid is de omstandighedendekking. Dit impliccert dat het volstaat dat tijdens de dekkingsperiode bepaalde omstandigheden aan de verzekeraar worden gemeld, ook al wordt de vordering zelf pas na het einde van de dekkingsperiode ingediend ${ }^{153}$.

Concluderend kan worden gesteld dat de dekkingsgrondslag een invloed kan hebben op de verzekerbaarheid in gevallen waar ex ante nauwelijks informatie beschikbaar is over het risico op ex post wijzigingen (uitlooprisico). Anderzijds dient te worden vastgesteld dat ook de claims-made grondslag leidt tot een aantal negatieve economische gevolgen. Het grootste bezwaar tegen de claims-made grondslag, is de precaire situatie van de verzekeringsnemer wanneer de verzekeraar de polis opzegt na een schadegeval en het door de opzegging veroorzaakte dekkingsvacuüm.

\footnotetext{
49 Faure, M., "Is aansprakelijkheid 'met terugwerkende kracht' efficiënt en verzekerbaar?", o.c., 11.

Over de overgangsproblemen bij verandering van verzekering, zie meer in detail Spier, J. en Haazen, O.A., "Aansprakelijkheidsverzekeringen op claims-made grondslag", l.c., 147-151.

is Uiteraard beschikt de verzekeraar in principe onder gelijk welke dekkingsgrondslag over de mogelijkheid om de polis op te zeggen; maar bij een claims-made dekkingsgrondslag leidt de opzegging ertoe dat de verzekerde over geen enkele dekking meer beschikt ten aanzien van toekomstige vorderingen.

Wansink, J.H., "Aansprakelijkheidsverzekering", l.c., 111-112.

Voor meer details, zie Spier, J. en Haazen, O.A., "Aansprakelijkheidsverzekeringen op claims-made grondslag", l.c., 81 e.v.
} 


\subsection{Beperking van de aansprakelijkheid als remedie tegen onverzekerbaarheid?}

Bij ongevallen waarbij de potentiële aansprakelijkheid zeer hoog kan zijn, en waar het onzeker is of dit risico verzekerbaar is, wordt in een aantal gevallen - zoals terzake van het nucleaire risico de beperking van de aansprakelijkheid als remedie naar voren geschoven en wordt tegelijk de verplichting opgelegd om deze beperkte aansprakelijkheid te verzekeren.

Voor de potentiële dader is het voordeel van de beperkte aansprakelijkheid duidelijk: hij weet perfect wat het bedrag is dat hij maximaal dient te vergoeden. Ook verzekeraars lijken belang te hebben bij een beperking van de aansprakelijkheid: ze hebben zekerheid over de schade (S) en in die zin wordt de premieberekening vergemakkelijkt. Het Witboek inzake milieuaansprakelijkheid gaat er bijvoorbeeld van uit dat de kans op een snelle ontwikkeling van de verzekeringsmarkt zal toenemen wanneer een maximumgrens voor de aansprakelijkheid wordt vastgesteld ${ }^{154}$.

Vanuit rechtseconomisch perspectief zal het aansprakelijkheidsrecht aan de dader de nodige prikkels geven om de maatschappelijke kosten van een ongeval te minimaliseren. Dit impliceert dat hij optimale zorg zal aanwenden; naarmate de potentiële schade groter is, zal de marginale opbrengst van de zorg die hij besteedt, eveneens hoger zijn en zal hij dan ook meer preventieve maatregelen dienen te nemen ${ }^{155}$. Bij een beperkte aansprakelijkheid daarentegen zal de dader een geringere prikkel hebben om optimale zorg aan te wenden. Een rationele dader zal in dit geval handelen alsof de maximaal te verwachten schade gelijk is aan het bedrag van de beperkte aansprakelijkheid. Hij zal met andere woorden minder preventieve maatregelen nemen en de kans is reëel dat het optimale activiteitsniveau niet wordt gehandhaafd. Hij zal geen bijkomende zorg aanwenden omdat dit niet resulteert in een geringere aansprakelijkheid. Zodra het bedrag van de beperkte aansprakelijkheid dus lager is dan de totale schade, is deze beperking vanuit rechtseconomisch oogpunt inefficiënt.

Het is overigens niet duidelijk waarom uit de beperkte beschikbaarheid van een verzekeringsdekking moet worden afgeleid dat de aansprakelijkheid dient te worden beperkt. Omgekeerd dient te worden vastgesteld dat er vele gevallen bestaan waar een beperkte beschikbaarheid van verzekeringen niét leidt tot een beperking van de aansprakelijkheid; waar met andere woorden de wetgever een beperkte beschikbaarheid van verzekeringsdekking een onvoldoende reden vindt om de aansprakelijkheid te beperken. Hierbij kan bijvoorbeeld worden gedacht aan de aansprakelijkheid van de exploitant van een stortplaats: zowel naar Belgisch als naar Nederlands recht geldt een onbeperkte aansprakelijkheid, hoewel op de verzekeringsmarkt geen ongelimiteerde dekking voorhanden lijkt te zijn.

Zeker indien de aansprakelijkheid wordt beperkt tot een bepaald bedrag en indien de betrokkene wordt verplicht om zich precies voor dat bedrag te verzekeren, zijn negatieve gevolgen op de prikkels van de dader niet uitgesloten ${ }^{156}$. De verzekeraar beschikt dan namelijk niet meer over de mogelijkheid om het morele risico in te dijken via blootstelling aan het eigen risico. In dergelijke gevallen is het onzeker of alleen de polisvoorwaarden de prikkels kunnen "herstellen". Een onbeperkte aansprakelijkheid dient dan ook de belangen van de verzekeraar omdat meteen het morele

is4 "Witboek betrefiende milieuaansprakelijkheid", l.c., 25.

155 Zie hierover Landes, W. en Posner, R., "Tort law as a regulatory regime for catastrophic injuries", Journal of Legal Studies, 1984, 417.

156 Ook in die zin, terzake van de aansprakelijkheid van werkgevers: Faure, M.G. en Hartlief, T., "Verzekering en de groeiende aansprakelijkheidslast", l.c., 308. 
risico beter onder controle kan worden gehouden. Er kan dan ook worden gepleit voor de loskoppeling van de aansprakelijkheid van de vraag naar verzekeringen ${ }^{157}$.

Tegelijk blijkt hieruit dat het bepcrken van de aansprakclijkheid en de invoering van een verzekeringsplicht tot de wettelijke limiet weinig zinvol is ${ }^{158}$. Indien toch om de cen of andere reden $z o-$ wel een beperking van de aansprakelijkheid als een verzekeringsplicht noodzakelijk wordt geacht, verdient het veeleer de voorkeur om de aansprakelijkheidslimiet een stuk hoger to leggen dan de verzekeringsplicht.

Tenslotte zal een beperking van de aansprakclijkheid ook vanuit het oogpunt van slachtofferbescherming ongunstige gevolgen hebben: wanneer de schade hoger ligt dan het bedrag van de beperkte aansprakelijkheid, zal een deel van de schade ten laste blijven van het slachtoffer.

Er zijn bijgevolg heel wat bezwaren tegen de beperking van de aansprakelijkheid. Zeker wanneer de beperkte aansprakelijkheid wordt gekoppeld aan een verplichte verzekeringsdekking, wordt de onverzekerbaarheid zelfs in de hand gewerkt. Het eventuele insolventiegevaar kan eveneens worden vermeden door het opleggen van een beperkte verzekeringsplicht, terwijl het principe van de onbeperkte aansprakelijkheid behouden blijft ${ }^{159}$.

\section{Conclusie}

Vanuit rechtseconomisch oogpunt zal de houding ten aanzien van een risico bepalen of een verzekering al dan niet zinvol is. Voor een risicoaverse persoon kan het zinvol zijn om het risico te spreiden of te verschuiven.

Een verzekeringsdekking kan de maatschappelijke welvaart verhogen omdat de risicoaversie van een persoon wordt weggenomen. Hierbij is wel van belang dat er op de markt voldoende concurrentie is. Enkel in dat geval kan aan het morele risico en aan het probleem van de averechtse selectie het hoofd worden geboden. Indien dit niet het geval is, zijn problemen van onverzekerbaarheid niet uit te sluiten.

Het is niet eenvoudig om een eenduidige en alomvattende omschrijving te geven van een verzekerbaar risico. Theoretisch kunnen alle risico's worden verzekerd, op voorwaarde dat deze voorzienbaar zijn, dat het morele risico en het probleem van de averechtse selectie onder controle kunnen worden gehouden en dat voldoende capaciteit op de verzekeringsmarkt ${ }^{160}$ aanwezig is.

Uitgaande van de vaststelling dat in toenemende mate een beroep wordt gedaan op het aansprakclijkheidsrecht, kan ook worden verwacht dat in toenemende mate een beroep zal worden gedaan op verzekeringen (zowel first als third party-verzekeringen). Op zich is deze vaststelling niet problematisch, wel integendeel: indien de uitbreiding voorzienbaar is, leidt de uitgebreide belangde Vries, F.J., "Wettelijke limitering van aansprakelijkheid", l.c., 225-237; Faure, M.G. en Hartlief, T., "Verzekering en de groeiende aansprakelijkheidslast", o.c., 308. Shavell, S., "The Judgment Proof Problem", o.c., 43-58.

Faure, M.G., "The Influence of Insurance on Liability Issues", in McGee, A. en Heusel, W. (ed.), "The Law and Practice of Insurance", l.c., 186.

160 Giarini, O., "Insurability and the Economic Relevance of Insurance: a Historical Economic Perspective", The Geneva Papers On Risk and Insurance, vol. 20, $n^{\circ} 77,1995,422$.
} 
stelling voor aansprakelijkheidsverzekeringen tot een grotere vraag en tot nieuwe markten ${ }^{161}$. Stijgt de vraag naar aansprakelijkheidspolissen, dan zal de verzekeraar nieuwe polissen afsluiten en dus ook nieuwe inkomsten genereren waarmee de nieuwe verliezen kunnen worden gedekt.

Een zeer hoge verwachte schade of een moeilijk in te schatten probabiliteit zijn geen voldoende reden om te besluiten tot de onverzekerbaarheid van een risico. Niet alleen heeft de verzekeringsindustrie allerlei technieken ontwikkeld (herverzekering, verzekeringspools, etc.) om ook aan grote risico's het hoofd te bieden, bovendien zal hiermee rekening worden gehouden bij het bepalen van de premie. Zolang veranderingen in $\mathrm{p}$ en $\mathrm{S}$ voorzienbaar zijn en zolang de verzekeraar de premie en de polis dienovereenkomstig kan aanpassen, blijft dat risico verzekerbaar. Indien de voor de verzekeraar beschikbare gegevens moeilijk zijn in te schatten, is sprake van insurer's ambiguity. Deze verzekeraar zal hieraan tegemoet komen door een risicopremie in aanmerking te nemen.

Moeilijker wordt het wanneer de voorzienbaarheid van het risico in het gedrang komt, met name wanneer de verzekeraar wordt geconfronteerd met causaliteitsonzekerheid of retroactieve aansprakelijkheid. De verschillende elementen die leiden tot de onverzekerbaarheid van een risico hebben in feite te maken met een informatietekort, hetzij in hoofde van de verzekerde, hetzij in hoofde van de verzekeraar, hetzij in hoofde van de rechter.

Uit de analyse is ook gebleken dat een verplichte verzekering een remedie kan zijn tegen het insolventiegevaar van de dader, maar dat de combinatie tussen een verzekeringsplicht en een beperkte aansprakelijkheid tot hetzelfde bedrag, economisch nadelig is. Het wordt voor de verzekeraar namelijk moeilijk om het gedrag van de verzekerde te controleren; het morele risico wordt in de hand gewerkt, hetgeen kan leiden tot problemen inzake verzekerbaarheid.

16t Faure, M.G., "Over beschermde slachtoffers, vrijgevige rechters en zuchtende verzekeraars", o.c.. 1230-1231. 


\section{HOOFDSTUK 10}

\section{ECONOMISCHE ANALYSE VAN VEILIGHEIDSREGULERING}

In heel wat terreinen van het recht treedt de overheid regulerend op teneinde een gegeven doel tc bereiken. Zo worden voor bepaalde goederen vaste prijzen opgelegd die enkel via een beslissing van een overheidsorgaan kunnen worden gewijzigd; zo worden aan verschillende gevaarlijke activiteiten strikte veiligheidsnormen opgelegd die bij overtreding tot sancties kunnen leiden (geldboetes, administratieve boctes, strafsancties, ...).

Vanuit rechtseconomisch perspectief roept regulering vanwege de overheid de vraag op of, cn zo ja in welke mate en onder welke voorwaarden, regulering bijdraagt tot een verhoging van de maatschappelijke welvaart. In dit hoofdstuk wordt onder veiligheidsregulering verstaan de door de overheid opgelegde en afdwingbare geboden, verboden, instructies, toegangsvoorschriften en andere maatregelen van aard het marktmechanisme te beïnvloeden'.

Veiligheidsregulering moet immers worden gezien als één middel om een economische activiteit te beïnvloeden. Een ander middel bij uitstek is met name het aansprakelijkheidsrecht. In dit hoofdstuk zal dan ook aandacht worden besteed aan het gecombineerde gebruik van aansprakelijkheidsregels en veiligheidsregulering.

Vitgangspunt hierbij is dat overheidsregulering tot een ander resultaat leidt dan door de "perfecte" werking van de markt. Wanneer met andere woorden een gegeven activiteit onderworpen is aan enige vorm van overheidstussenkomst, betekent dit dat het aldus bekomen resultaat wordt verkozen boven het resultaat dat zou worden bereikt zonder een dergelijke tussenkomst. Daarom mout in eerste instantie worden gezocht naar verklaringen voor overheidsinterventie. Deze verklaringen worden geboden door een aantal theorieën inzake overheidsregulering; deze theorieën tonen aan wclke van de actoren op de markt de vruchten zullen plukken en welke actoren de lasten zullen dragen van een bepaalde regulering, welke vorm de regulering aanneemt en welke de gevolgen zijn van deze regulering op de maatschappelijke welvaart ${ }^{2}$

\section{VERKLARINGEN VOOR OVERHEIDSREGULERING}

Grosso modo worden in de literatuur twee stromingen onderscheiden die een gegeven overheidsoptreden verklaren ${ }^{3}$. Volgens een eerste stroming dient de overheid het algemeen bclang en komt zij tussen om een vermeende marktfaling te corrigeren en om, via de ingreep, een economisch optimale situatie te bewerkstelligen (Public Interest theorie). Een dergelijke marktfaling kan door verschillende factoren worden veroorzaakt: door concurrenticbeperkende situatics (gaande van prijsafspraken tot oligopolies of zelfs monopolies), door het bestaan van externaliteiten, door een informatietekort (asymmetrische informatic) en door de consumptic van publiekc goederen.

Daarnaast kan overheidsinterventie ook worden verklaard vanuit de Private Interest theorie. Deze theorie stelt dat de overheid niet het algemeen belang dient, maar dat de wetgever onder druk staat van verschillende belangen- en pressiegroepen die elk het inkomen van hun respectieve leden

Definitie ontleend aan Faure en Van den Bergh, "Objectieve Aansprakelijkheid", I.c., 143 en aan Posner, R.A., "Theories of economic Regulation", The Bell Journal of Economics, 1974, 335 e.v.

Stigler, G.J., "The Theory of economic regulation", The Bell Journal of Economics, 1971, 3.

Zie vooral Ogus, A., Regulation. Legal Form and Economic Theory, Clarendon Piess, Oxford, 1994, 3 e.y. 
trachten te maximaliseren ${ }^{4}$. Volgens deze visie is de wetgever een politieke ondernemer die zijn eigen nut maximaliseert met het oog op herverkiczing: bij toczeggingen aan bepaalde groepen hoopt de politicus dat de leden van die groep bij volgende verkiezingen op hem of voor zijn partij zullen stemmen. Beide theorieën worden hieronder verder toegelicht.

\subsection{Public interest}

Onder ten public interest benadering dient de overheid het algemeen belang'; zij zal enkel tussenkomen indien door het vrije spel van het marktmechanisme bepaalde factoren de economische optimale situatie in de weg staan. De overheid zal op deze wijze als deus ex machina marktfalingen corrigeren.

Overheidsregulering kan in eerste instantie zijn aangewezen in monopolistische situaties waar een suboptimale allocatie der middelen tot economisch nadelige gevolgen leidt voor de maatschappij in haar gehecl ${ }^{6}$. Een monopolist zal hogere winsten behalen dan in een open marktsituatie: de consumenten zullen een hogere prijs betalen en de producent zal minder produceren dan technisch mogelijk is ${ }^{7}$. Een dergelijke monopolistische situatie leidt tot cen daling van de maatschappelijke welvaart. Op voorwaarde dat de wetgever een wetgevend kader creëert dat de toegang tot en de werking van de vrije markt vergemakkelijkt ${ }^{8}$ en dat concurrentiebeperkende afspraken sanctioneert, kan een overheidsinterventie door het voeren van een mededingingsbeleid gewenst zijn. Via economische regulering ${ }^{9}$ wordt de marktfaling weggewerkt en wordt de maatschappelijke welvaart verhoogd ${ }^{10}$. De klassieke welvaartstheorie biedt inderdaad een verklaring voor bijvoorbeeld de Europese concurrentieregels ${ }^{11}$.

In tweede instantie kan overheidsinterventie zijn aangewezen indien een bepaalde economische activiteit leidt tot neveneffecten of overzijpelingseffecten of externaliteiten. Hierbij kunnen negaticve en positieve neveneffecten worden onderscheiden. Er is sprake van een negaticve externaliteit indien de externe kosten van een activiteit niet (volledig) worden geïnternaliseerd. Zo is bijvoorbecld bij milieuhinder sprake van een negatieve extemaliteit indien de schadeveroorzaker niet alle schade dient te vergoeden die door zijn activiteit wordt veroorzaakt. De kostprijs van de goederen of diensten die op de markt worden gebracht zal onder de werkelijke maatschappelijke kostprijs liggen. Indien de productie van een chemisch product schade veroorzaakt die slechts voor de helft wordt vergoed, betekent dit dat enkel die helft wordt doorberekend in de kostprijs wat kan leiden tot overproductie of overconsumptie ${ }^{12}$. De andere helft van de schade wordt niet door de desbetreffende producent, maar door het slachtoffer of door de maatschappij in haar geheel - de belastingbetaler - gedragen. Hier is sprake van een negatief extern effect.

Posner, R.A., "Theorics of economic Regulation", o.c, 335 c.v.

Voor meer details zie Ogus, A., "Regulation", l.c., 29-54.

Bowles, R., Law and the Economy, Martin Robertson, Oxford, 1982, 165.

Immers, indien hij zijn productie zou uitbreiden tot op het punt waar zijn gemiddelde totale kosten worden geminimaliseerd, betekent dit dat hij een lagere prijs krijgt voor zijn goed en een kleinere winst heeft (Vañdewalle, G. en Van den Broeck, J., Algemene Economie, Kluwer, Antwerpen, 1987, 149).

Posner, R.A., Antitrust Law. An Economic Perspective, Chicago, University of Chicago Press, 1976.

Ogus, A., "Regulation", l.c., 5.

Voor meer details zie o.m. Van den Bergh, R., Economische Analyse van het Mededingingsrecht. Een terreinverkenning, Gouda Quint, Amhem, 2) druk, 1997.

Bowles, R., "Law and the Economy", l.c., 165-175.

Pigou, A.C., The Economics of Welfare, London, Mac Millan, 4th edition, 1932, 183; Veljanovski,

"New Law and Economics", l.c., 44-45. 
Van een positieve externaliteit is sprake indien een product of een dienst vrij circuleert op de markt en waardoor de producent niet van iedere gebruiker van dat goed of dienst een prijs kan vragen. Een aantal gebruikers beschikt op deze wijze gratis over een product of geniet van een dienst waar anderen voor betalen. Nochtans zou de producent gerechtigd zijn om van elke gebruiker een vergoeding te ontvangen. Een klassiek voorbeeld is hier het vrij circuleren van informatic: de producent zal zijn informatie niet spontaan vrijgeven wat kan leiden tot onderproductie of onderconsumptie ${ }^{13}$.

Overheidsregulering kan een oplossing bieden voor het geschetste externaliteitenprobleem: het kan de verschillende partijen er met name toe aanzetten een verdeling der middelen to bewerkstelligen die dichter ligt bij het sociale optimum. Dit kan worden bercikt door het oplcggen van cen taks of van een reglementering. Indien een producent bijvoorbeeld onbeperkt aansprakclijk wordt gesteld voor de door hem aangerichte milieuschade, worden de negatieve externe effecten volledig geïnternaliseerd. Het spreekt voor zich dat een dergelijke overheidstussenkomst in bepaalde gevallen technisch niet haalbaar is of dat de kosten van het opleggen en afdwingen ervan prohibitief hoog zijn.

Een marktfaling kan ook worden veroorzaakt door het bestaan van een informatietekort (asymmetrische informatie). Dit betekent dat een gebrek aan informatie een optimale verdeling van de middelen in de weg staat. Indien een consument bijvoorbeeld een koelkast wenst te kopen wordt hij, gezien het ruime aanbod op de markt, geconfronteerd met een informatieprobleem. Dit informatieprobleem staat uiteraard in directe correlatie tot de eigen preferenties van de desbetreffende consument. Stel dat de consument milieubewust is en een koelkast wenst te kopen die weinig elektriciteit verbruikt en die geen CFK's bevat. Indien de overheid de producenten aanmoedigt of verplicht dergelijke informatie aan te brengen op het desbetreffende product, zal de keuze voor de consument een stuk makkelijker zijn. Dit probleem is niets anders dan een probleem inzake transactiekosten: indien dergelijke informatie niet aanwezig is zal de consument hetzij zelf mocten onderzoeken welk product het best beantwoordt aan zijn verlangens (wat in rechtseconomische termen betekent dat kosten noodzakelijk zijn om de beoogde transactie tot stand te kunnen brengen), hetzij een product aankopen waarvan hij vermoedt dat het aan zijn verwachtingen beantwoordt. In beide gevallen is sprake van een welvaartsverlies ${ }^{14}$. Indien de ovcrheid de industrie verplicht bepaalde informatie duidelijk aan te brengen op het product of indien een bepaalde activiteit slechts mag worden uitgeoefend mits erkenning vanwege de overheid, kunnen de transactiekosten worden verkleind, wat een gunstige invloed kan hebben op een bestaande informatieasymmetrie ${ }^{15}$.

De theorie die overheidsregulering verklaart als middel ter correctie van marktfalingen is evenwel niet alleenzaligmakend. In bepaalde gevallen dient zelfs te worden vastgesteld dat regulering cen marktfaling in de hand werkt. Hier kan worden voortgebouwd op wat hierboven werd gesteld

Ibidem.

Benadrukt dient te worden dat in deze overheidsregulering niet de enige of alleenzaligmakende manier kan zijn om het informatieprobleem op te lossen. Volledig losstaand van het reguleringsvraagstuk, kan het voor de consument efficient zijn zich te abonneren op een tijdschrift van een consumentenvereniging waar regelmatig verschillende producten en diensten worden getest. Door een abonnement te kopen op een dergelijk tijdschrift verlaagt de consument aanzienlijk zijn informaticprobleem; meteen zijn de transactiekosten relatief laag: het volstaat de prijs van het abonnement te betalen en het tijdschrift te lezen. In vele gevallen zullen deze kosten veel lager en betrouwbaarder zijn dan wanneer de consument zelf op onderzoek gaat en zal tegelijk het risico een verkeerd product te kopen, worden geminimaliseerd.

De regulering die de informatieasymmetric en extemaliteiten, wordt sociale regulcring genmemd (Ogus, A., "Regulation", l.c., 5). 
inzake informatietekorten in hoofde van consumenten. Een regulering die de toegang tot informatie beperkt, kan moeilijk worden gezien als een maatregel met als doel een marktfaling op te heffen. Indien bijvoorbeeld een wet een verbod instelt op vergelijkende reclame en op prijsvergelijkingen wordt de koopbeslissing van de consument bemoeilijkt: wil hij prijsbewust kopen, dan dient hij zelf verschillende handelaars te bezoeken wat aanzienlijke transactiekosten veroorzaakt, terwijl hierboven werd aangetoond dat precies deze transactiekosten leiden tot een marktfaling ${ }^{16^{\prime}}$. Terwijl de public interest theorie geen verklaring biedt voor een dergelijke regulering, is dat wel het geval voor de private interest theorie.

\subsection{Private interest}

Volgens deze theorie is een bepaalde overheidsinterventie het resultaat van de tussenkomst en druk van belangengroepen ${ }^{17}$. Deze groepen streven ernaar de kosten voor concurrenten te verhogen. Het gevolg van dergelijke regulering is dat de concurrentie wordt beperkt in het belang van de eigen groep. Verschillende theorieën bieden verklaringen voor het feit dat overheidstussenkomst het resultaat is van belangengroepen: de captatietheorie, die verder werd uitgebouwd door de Public Choice-economen en de economische reguleringstheorie.

De visie volgens welke wetgeving enkel dient ter behartiging van private belangen, staat bekend als de captatietheorie. Volgens de capatatietheorie komen overheidsorganen die zijn opgericht met het oog op het behartigen van het algemeen belang, na verloop van tijd in de ban van degenen die zij moeten reguleren. In vele gevallen is de regelgever immers aangewezen op informatie van de te reguleren persoon; het gevaar bestaat dan dat de te reguleren persoon eenzijdige informatie doorspeelt en deze informatie dermate formuleert dat uiteindelijk het overheidsorgaan wordt gemanipuleerd. Op die manier beschikt het overheidsorgaan nog over weinig middelen om zich te onttrekken aan de macht van de te reguleren persoon. Uiteindelijk wordt niet meer het algemeen belang gediend, maar wel het private belang van de te reguleren persoon of industrietak.

Hier dient te worden benadrukt dat het feit dat het overheidsorgaan informatie inwint bij de te réguleren persoon, geen waardeoordeel impliceert betreffende de goede of kwade trouw van dat overheidsorgaan. Gelet op de vaak ingewikkelde productieprocessen, is het vaak de enige manier om aan informatie te kunnen geraken.

Deze captatietheorie is aanvankelijk ontwikkeld door politieke wetenschappers. Op basis van deze inzichten hebben met name de Public Choice-economen ${ }^{18}$ gezocht naar een theoretische onderbouw van dexe theorie. Terwijl onder de klassieke welvaartstheorie het marktfalen centraal staai, onderzoekt de Public Choice-theorie de oorzaken van het falen van de overheidstussenkomst. Onderzocht wordt waarom de overheid, die wordt geacht het algemene belang te dienen, in bepaalde gevallen private belangen gaat dienen.

Public Choice-economen zien de wetgever als een politiek ondernemer die zijn nut maximaliseert door het beogen van herverkiezing. Voor elke politicus zal een welbepaalde groep kiezers een

Zie voor meer details Van den Bergh, R., "Economische Analyse van het Mededingingsrecht", I.c., 59 e.v.

Voor meer details zie Ogus, A., "Regulation", l.c., 55-75.

18 We denken hier in de eerste plaats aan Buchanan, Tullock en Olson. Zie o.m. Buchanan, J.M., The Calculus of Consent. Logical Foundations of Constitutional Democracy, Ann Arbor, University of Michigan Press, 1962; Olson, M., The Logic of Collective Action. Public Goods and the Theory of Groups, Cambridge, Harvard University Press, 1965, 186; De Geest, G., "Public Choice en rechtseconomie", Ars Aequi, 39, 1990, 666-673; De Geest, G., "Economische Analyse", I.c., 269 e.v. 
centrale rol spelen bij diens herverkiezing; hij zal zijn nut maximaliseren indien hij zich inzet om de belangen van deze groep te behartigen. In dat geval weet hij immers dat hij bij de volgende verkiezingen kan rekenen op de stem van de mensen van die welbepaalde groep.

De ideeën van de Public Choice-economen passen de klassieke economische theorieën toe op overheidsregulering: op de politieke markt is vraag naar bepaalde overheidstussenkomsten. Deze vraag komt van bepaalde belangengroepen die elkaar beconcurreren ${ }^{19}$. Het voordeel voor verschillende ondernemingen om zich te organiseren in professionele groepen of verenigingen bestaat erin dat dit leidt tot een vermindering van de informatie- en transactiekosten. Het is veel efficiënter om samen met bedrijven met analoge belangen naar de reguleerder te stappen, dan indien elke onderneming dat voor zich zou moeten doen. Dit verklaart bijvoorbeeld het succes van de beroepsverenigingen die het forum bij uitstek zijn om bij de reguleerder bepaalde voordelen te bekomen. Bij groepen die beter georganiseerd zijn zullen daarom de kosten van het inwinnen van informatie en het bekomen van bepaalde voordelen, lager zijn dan bij minder goed georganiseerde groepen.

De aanbodzijde van het reguleringsproces wordt gevormd door politici voor wie het efficiënt is de belangen te behartigen van groepen die hun stemmen kunnen opleveren. Een groep die erin slaagt om een regulering door te drukken, zal bovendien ook geneigd zijn actievere steun te verlenen aan de politicus (of aan diens partij) in de vorm van financiering van de verkiezingscampagne.

Naast de capatatietheorie en de daarop voortbouwende visie van de Public Choice-economen, biedt ook de door Stigler ontwikkelde economische reguleringstheorie ${ }^{20}$ een verklaring voor de rol van belangengroepen bij overheidstussenkomst. In de visie van Stigler zal een vraag bestaan naar overheidsregulering indien dit voor de belangengroepen die dergelijke overheidstussenkomst vragen, de beste manier is om een bepaald resultaat te bereiken. In bepaalde gevallen zal het voor ondernemingen inderdaad minder kosten en efficiënter zijn een beroep te doen op de overheid dan bijvoorbeeld het maken van kartelafspraken met concurrenten. Bij kartelafspraken rijst immer het free-rider-probleem. Stel dat twee benzinehouders in dezelfde straat afspraken maken om de brandstofprijzen op een bepaalde niveau te handhaven. Dit kan voor hen efficiënt zijn omdat zij op die manier beiden extra winst opstrijken in plaats van met elkaar een prijzenoorlog te voeren. Deze afspraken beletten evenwel niet dat in een straat in de buurt een andere pomphouder de prijzen wel degelijk laag houdt. In dergelijke situatie kan het voor pomphouders efficiënter zijn van de reguleerder te bekomen dat de toegang tot de markt wordt bemoeilijkt door middel van vestigingswetgeving.

Bovenstaande theorieën verklaren dus waarom de overheid in bepaalde gevallen in plaats van het algemene belang eerder het belang van welbepaalde en goed georganiseerde groepen dient. Zowel voor de politicus als voor deze groepen is het afkondigen van regulering efficiënt: voor de politicus omdat hij tegen geringe kosten de kansen op herverkiezing vergroot en voor de belangengroepen omdat de aldus tot stand gekomen regulering bepaalde voordelen oplevert.

Op basis van deze algemene beschouwingen, is het interessant na te gaan waarom, bijvoorbeeld terzake van milieurisico's, de overheid zich niet beperkt tot het uitvaardigen van een specifieke aansprakelijkheidsregel, maar ook nog veiligheidsregulering uitvaardigt. Deze problematiek wordt hieronder aan de orde gesteld.

Becker, G., "A Theory of Competition among Pressure Groups for Political Influence", Quarterly Joumal of Economics, 1983, 371 e.v.

Stigler, G., "The Theory of Economic Regulation", Bell Journal of Economics, 1971, 3-21. 


\section{VEILIGHEIDSREGULERING EN HET AANSPRAKELIJKHEIDSRECHT}

In feite heeft veiligheidsregulering eenzelfde preventief effect als het aansprakelijkheidsrecht. Het preventieve aspect inzake aansprakelijkheid bestaat erin dat een dader die weet dat hij een bepaalde schade zal dienen te vergoeden, geen schade zal berokkenen. Daarnaast heeft ook veiligheidsregulering een preventief effect omdat door de opgelegde veiligheidsmaatregelen de kans verkleint dat zich een ongeval voordoet, of tenminste omdat de verwachte schade afneemt. De vraag rijst wat de voordelen zijn van veiligheidsregulering $(\$ 2.1)$ en waarom in bepaalde gevallen wordt geopteerd voor een gecombineerd gebruik van deze afschrikkingstechnieken $(\$ 2.2)$.

\subsection{Gevallen waar het gebruik van veiligheidsregulering nuttig kan zijn}

Baanbrekend werk op dit terrein werd verricht door Guido Calabresi die ervan uitgaat dat eik ongevallenrecht zowel elementen van general deterrence als van specific deterrence bevat ${ }^{21}$. Beide vormen van afschrikking zijn van belang omdat de tekorten op het vlak van general deterrence kunnen worden opgevangen door mechanismen inzake specific deterrence en omgekeerd ${ }^{22}$. De ideeën van Calabresi werden verder uitgewerkt door Shavell en Wittman die een aantal criteria hebben naar voren geschoven op basis waarvan kan worden beslist of een beroep dient te worden gedaan op veiligheidsregulering, op het aansprakelijkheidsrecht, dan wel op een combinatie van beide technieken ${ }^{23}$. Deze criteria zijn de informatiekosten $(\$ 2.1 .1$ ), de onmogelijkheid alle schade te vergoeden ( $\S 2.1 .2$ ), het gebrek aan dreiging van de aansprakelijkheidsvordering ( $\S$ 2.1.3) en de administratieve kosten ( $\$ 2.1 .4$ ). Deze worden hieronder besproken.

\subsubsection{Informatiekosten}

Zeker inzake complexe industriële activiteiten, kan ervan worden uitgegaan dat de potentiële dader over meer informatie beschikt betreffende de risico's van deze activiteiten. Voor de overheid die op dit terrein regulerend wenst op te treden zal het moeilijk zijn dezelfde informatie te verkrijgen: niet alleen zal het vergaren van de nodige informatie leiden tot aanzienlijke kosten; daarnaast is de kans op vergissingen van de overheid zeer groot. In gevallen waarin de kans op foute inschattingen van het risico door de overheid reëel is, verdient het vanuit welvaartseconomisch oogpunt de voorkeur een beroep te doen op het aansprakelijkheidsrecht.

Anders wordt het risico hetzij onderschat, hetzij overschat, waardoor respectievelijk te weinig en te veel zorg zal worden besteed. Enkel indien de overheid over correctere informatie beschikt ten aanzien van de te reguleren activiteit, zal het nuttig zijn een beroep te doen op rechtstreekse veiligheidsregulering ${ }^{24}$.

\subsubsection{Onmogelijkheid om alle schade te vergoeden}

Rechtstreekse regulering van veiligheid kan ook zinvol zijn indien de potentiële schade groter is dan het vermogen van de dader. Indien het insolventiegevaar reëel is, zal de dader handelen alsof zijn vermogen de maximale schade is, waardoor hij een onvoldoende prikkel kan hebben. Deze gebrekkige prikkel kan inderdaad worden opgevangen door middel van overheidsregulering zools het uitvaardigen van veiligheidsmaatregelen.

$21 \quad$ Cfr. supra.

22 Calabresi, G., "The Cost of Accidents", l.c., 74-277.

23 Shavell, S., "Liability for Harm versus Regulation of Safety", Journal of Legal Studies, 1984, $357-374$.

24 Shavell, S., "Liability for Harm versus Regulation of Safety", o.c., 359-360. 
Het voordeel van regulering zal afhankelijk zijn van de verhouding tussen het vermogen van de dader en de verwachte ongevalskosten; hoe meer de verwachte ongevalskosten het vermogen van de dader overtreffen, hoe meer voordelen kunnen worden gehaald uit veiligheidsregulering ${ }^{25}$.

\subsubsection{Gebrekkige dreiging uitgaande van de aansprakelijkheidsvordering}

In bepaalde gevallen zal de prikkel uitgaande van het aansprakelijkheidsrecht onvoldoende zijn, bijvoorbeeld indien de dader van een bepaalde schade maar moeilijk kan worden geidentificeerd of indien lange tijd verloopt tussen het schadegeval en het optreden van de schade. In een dergelijk geval zal het de voorkeur genieten om een beroep te doen op veiligheidsregulering ${ }^{26}$.

\subsubsection{Administratieve kosten}

Tenslotte kan een voorkeur bestaan voor het opleggen van veiligheidsregulering indien de kosten van regulering lager liggen dan de kosten van het afdwingen van het aansprakelijkheidsrecht. De administratieve kosten van het aansprakelijkheidsrecht kunnen in een aantal gevallen aanzienlijk zijn, gelet op de duur van een proces, de advocatenkosten enz. Hoe meer partijen bij een proces betrokken zijn, hoe hoger de administratieve kosten van het aansprakelijkheidsrecht zullen zijn. Hieruit kan een sterk argument worden afgeleid inzake het gebruik van het aansprakelijkheidsrecht voor grote risico's.

Nochtans biedt het aansprakelijkheidsrecht belangrijke voordelen: de kosten hiervan worden verhaald op de aansprakelijke dader, die dus een extra prikkel zal hebben om schadegevallen te vermijden. Aldus worden de ongevalskosten geïntemaliseerd. De kosten van het opleggen, controleren en afdwingen van veiligheidsregulering daarentegen worden betaald door de belastingbetaler en dus door de gehele gemeenschap ${ }^{27}$.

\subsection{Gecombineerd gebruik van veiligheidsregulering en aansprakelijkheidsrecht}

Vaak wordt risicoaansprakelijkheid gecombincerd met het opleggen van veiligheidsregulering omdat wordt geoordeeld dat dit het slachtoffer beter beschermt: zelfs indien de dader prikkels heeft vanuit het aansprakelijkheidsrecht, wordt het noodzake]ijk geacht de dader door middel van veiligheidsregulering te verplichten bijkomende voorzorgsmaatregelen te nemen.

Veiligheidsregulering wordt in bepaalde gevallen afgekondigd als antwoord op mogelijke insolventie van de dader. Niet alleen wordt hierbij uit het oog verloren dat veiligheidsregulering enkel zinvol is indien de overheid over betere informatie beschikt dan de potentiële dader, tevens dient erop te worden gewezen dat bij mogelijke insolventie het efficiënter kan zijn een beroep te doen op foutaansprakelijkheid en niet op risicoaansprakelijkheid. Bovendien wordt reeds getracht het insolventieprobleem te verhelpen door het verplicht stellen van een aansprakelijkheidsverzekering. Het is daarom zeer de vraag waarom het insolventieprobleem nog eens extra dient te worden opgelost door middel van veiligheidsregulering on of het gecombineerd gebruik van risicoaanBergh, R., "Objectieve Aansprakelijkheid", l.c., 155.

Shavell, S., "Liability for Harm versus Regulation of Safety", o.c., 363.

Shavell, S., "Liability for Harm versus Regulation of Safety", o.c., 363-364.
} 
sprakelijkheid, veiligheidsregulering en verplichte verzekering niet zullen leiden tot inefficiënt hoge administratieve kosten ${ }^{28}$.

Indien veiligheidsregulering daarentegen wordt gecombineerd met foutaansprakelijkheid, zullen deze kosten een stuk lager liggen, met name indien het insolventierisico bestaat. Bij foutaansprakelijkheid zal de dader zorg aanwenden zolang deze kosten lager zijn dan zijn vermogen. Vanuit de kant van slachtoffers volstaat het om aan te tonen dat de dader de veiligheidsvoorschriften niet heeft nageleefd. Het grote voordeel hierbij is dat slachtoffers via deze weg voldoende prikkels krijgen om op te treden als handhavers van de veiligheidsregulering.

Hiermee wordt de rechtseconomische analyse afgesloten. In het volgende deel van dit boek wordt aandacht besteed aan enkele compensatiemechanismen inzake schade veroorzaakt door catastroferisico's. De conclusies uit de rechtseconomische analyse, en met name het toetsen van de analyse uit dit deel met de analyse van het nucleaire aansprakelijkheidsrecht, gebeurt in deel 4. 


\section{DEEL 3}

\section{ANDERE COMPENSATIEMECHANISMEN}

In de eerste twee delen van dit onderzoek werd respectievelijk aandacht besteed aan de juridische analyse van het nucleaire aansprakelijkheidsrecht en aan de rechtseconomische analyse. In dit deel worden enkele andere vergoedingssystemen ter zake van milieuschade bestudeerd. Dit kan namelijk nuttige inzichten verschaffen voor de dekking van het nucleaire risico, al dan niet via de klassieke verzekeringsmechanismen. Net als het nucleaire risico wordt het milieuaansprakelijkheidsrisico vaak omschreven als een catastroferisico, dat door de combinatie van potentieel zeer hoge schade en moeilijk in te schatten probabiliteit als onverzekerbaar wordt beschouwd. In dit hoofdstuk richt de aandacht zich op enkele andere moeilijk verzekerbare risico's en wordt bestudeerd op welke wijze wordt voorzien in de compensatie van de door deze risico's veroorzaakte schade.

In hoofdstuk 11 wordt onderzocht op welke wijze catastroferisico's in het algemeen worden verzekerd of gedekt. Hierbij zal zowel de dekking van algemene milieurisico's als de compensatie van luchtverontreiniging in Nederland worden besproken. Tegelijk zullen, voor wat betreft de dekking van de algemene milieuaansprakelijkheid, de vourstellen worden besproken van de Interuniversitaire Commissie voor Herziening van het Milieurecht in het Vlaamse Gewest; ter yake van de dekking van het nucleaire risico worden eveneens twee eerder in de literatuur gelanceerde voorstellen besproken. In hoofdstuk 12 wordt geanalyseerd hoe de aansprakelijkheid is geregeld voor schade door olieverontreiniging op zee en wordt besproken welke compensatiemechanismen instaan voor de vergoeding van dergelijke schade. Tenslotte wordt besproken hoe in de Verenigde Staten het nucleaire risico wordt verzekerd en op welke beginselen de aansprakelijkheid van de exploitant van een kerninstallatie er berust (hoofdstuk 13). 



\section{HOOFDSTUK 11}

\section{DEKKING VAN CATASTROFERISICO'S}

In hoofdstuk 9 werden catastroferisico's omschreven als risico's waarbij een verzekeraar slechts over beperkte statistische gegevens beschikt, wat de inschatting en de voorzienbaarheid van de risico ernstig kan bemoeilijken. Ook bij milieurisiso's is het vaak niet makkelijk om het risico op adequate manier in te schatten; toch zijn er ten aanzien van milieurisico's bepaalde dekkingen op de klassieke verzekeringsmarkt beschikbaar. Tegelijk werden ook minder traditionele compensatiemechanismen gecreëerd. Een aantal van deze mechanismen en dekkingen wordt in dit hoofdstuk besproken'.

Het is hierbij niet de bedoeling om een alomvattend overzicht te geven van de verschillende bestaande of mogelijke dekkingsmechanismen. In feite richt de aandacht zich in dit hoofdstuk enerzijds op de dekking van milieuschade via de klassieke verzekeringsmarkt; anderzijds worden twee alternatieve compensatiemechanismen besproken, met name schadefondsen en de captive. Hierbij moet voor ogen worden gehouden dat de aandacht van dit onderzoek zich in hoofdzaak tot Nederland en Belgie richt; vandaar worden de in deze landen voomaamste compensatiemechanismen (of voorstellen tot oprichting van een dergelijk mechanisme) aan de orde gesteld, zowel op de klassieke verzekeringsmarkt als daarbuiten ${ }^{2}$. Daarnaast bestaan er, zoals zal blijken, vele verschillende soorten fondsen evenals verschillende types van captives. De functie van de verschillende fondsen en captives verschilt vrij grondig zodat een onderzoek van deze twee mechanismen toch een vrij brede analyse toelaat. In ieder geval zullen uit de analyse een aantal krachtlijnen worden afgeleid waaraan elk compensatiemechanisme dient te voldoen.

In eerste instantie wordt bestudeerd welke dekkingen beschikbaar zijn op de "klassieke" Belgische en Nederlandse verzekeringsmarkt $(\$ 1)$. In paragraaf 2 worden twee alternatieve compensatiemechanismen besproken. In paragraaf 3 worden twee voorstellen besproken inzake de dekking van het nucleaire risico. De conclusie van de analyse wordt weergegeven in paragraaf 4.

\section{DEKKING VAN MILIEI SC'HADE VIA DE KLASSIEKE VERZEKERINGSMARKT}

Indien wordt gesproken van de dekking van milieuschade wordt uiteraard in de eeiste plaats gedacht aan een aansprakelijkheidsverzekering. Een persoon die een gevaarlijke en risicovolle activiteit uitvoert, zal een verzekeringsdekking kopen voor de schade die hij aan derden zou kunnen veroorzaken; in een aantal gevallen zal hij zelfs worden verplicht om een dergelijke dekking te kopen ${ }^{3}$. Daarnaast is het uiteraard ook mogelijk dat een slachtoffer zelf (deels) is verzekerd voor milieuschade, via een eigenschadeverzekering. Dit zal vaak het geval zijn voor letselschade of schade door overlijden (bijvoorbeeld via een levensverzekering). Tenslotte mag niet uit het oog worden verloren dat ook de dader zelf een directe verzekering kan afsluiten ten behoeve van het slachtoffer. Aangezien al deze verzekeringsvormen op de "klassieke" verzekeringsmarkt worden aangeboden, worden zij in deze paragraaf besproken.

Het aansprakelijkheidsrecht als compensatiemechanisme ter zake van milieuschade komt hier niet aan de orde omdat dit reeds in het eerste hoofdstuk van dit boek werd besproken.

Hiermee wordt dezelfde indeling aangehouden als in het eerste deel van dit boek.

Met name in een aantal internationale Verdragen wordt de aansprakelijkheidsverzekering verplicht gesteld. Zie hierover bijvoorbeeld Sandvik, B. en Suikkari, S., "Harm and Reparation in International Treaty Regimes: an overview", in Wetterstein, P. (ed.), Harm to the Environment. The Right to Compensation and the Assessment of Damages, Clarendon Press, Oxford, 1997, 57-71. 
Eerst wordt specifiek aandacht besteed aan de milieuaansprakelijkheidsverzekering $(\$ 1.1)$. Nadien wordt de directe verzekering ten behoeve van derden aan de orde gesteld $(\$ 1.2)$, evenals de eigenschadeverzekering $(\S 1.3)^{4}$.

Voor een goed begrip van de verdere analyse in dit hoofdstuk moet ook duidelijkheid bestaan over de gehanteerde begrippen. In het kader van dit boek wordt onder een first party dekking verstaan de polis die door een persoon wordt gekocht voor de dekking van zijn eigenschade (eigenschadeverzekering). Onder een directe verzekering ten behoeve van derden wordt verstaan een verzekering die door de "dader" wordt afgesloten, waarbij het slachtoffer begunstigde is en waarvan de schadeafwikkeling plaatsvindt buiten het aansprakelijkheidsrecht. Een third party dekking tenslotte is een aansprakelijkheidsverzekering.

\subsection{De dekking van milieuaansprakelijkheid}

Volgens de klassieke verzekeringsmechanismen wordt het milieurisico als onverzekerbaar beschouwd; verzekeraars voeren aan dat het risico onvoldoende kan worden gespreid en dat zij worden geconfronteerd met een vorm van anti-selectie.5. Toch is de verzekeringsindustrie in de loop der jaren erin geslaagd om polissen aan te bieden ter dekking van milieuaansprakelijkheid, hetzij als een afzonderlijke polis, hetzij als deel van een bestaande verzekeringspolis.

In de loop der jaren kan een opmerkclijke evolutie op de markt worden vastgesteld. Terwijl aanvankelijk het milieuaansprakelijkheidsrisico ter zake van accidentele schade in de regel was gedekt door een algemene aansprakelijkheidspolis, werd over het algemeen de aansprakelijkheid ingevolge graduele verontreiniging niet gedekt. Inmiddels werden meer en meer afzonderlijke polissen milieuaansprakelijkheid gecreëerd, waarbij dekking wordt verleend, zowel ten aanzien van graduele als van accidentele milieuverontreiniging, uiteraard rekening houdend met een aantal beperkingen ${ }^{7}$. Het spreekt voor zich dat er van land tot land verschillen zijn vast te stellen: zo wordt in België een milieuaansprakelijkheidspolis uitsluitend aangeboden door de gewone commerciële verzekeraars, terwijl in Nederland (en Frankrijk) een pool werd opgericht voor de dekking van dergelijke risico's. Hieronder wordt aandacht besteed aan de dekking van milicuaansprakelijkheid in België $(\S 1.1 .1)$ en in Nederland $(\S 1.1 .2)^{8}$.

Hier wordt in herinnering gebracht dat de analyse in dit onderzoek zich richt op ongevallen vanaf een vaste locatic; aansprakelijkheid voor of dekking van schade ingevolge transport wordt hier niet aan de orde gesteld.

5 Van de Poele, $A$., "Ervaringen van een verzekcraar inzake de selectie van de verzekerde risico's met betrekking tot milieuschade", in Bocken, H. en Ryckbost, D. (ed.), "Verzekering van Milieuschade", l.c., 310 .

- Zie hierover met name Ranson, D., "Verzekering van milieuaansprakelijkheid", Milieu- en Energierecht. 2000, nr. 3-4, 66-73.

7 Voor een overzicht van de beschikbare dekkingen in een aantal Europese landen, zie Insuring enmironmental impairment liability, Swiss Reinsurance Company, 1999, 23 p. Deze brochure is beschikbaar op het Internet, op de website van SwissRe (www.swissre.com). Zie ook de verschillende rapporten in Fitzsimmons, A. (cd.), Pollution Law and Insurance. A Comparison of the Legal Regimes of European States and the USA, AIDA, Kluwer Law International, London, 1997. name Deprimoz, J., "Régime juridique des assurances contre les risques d'atteinte à l'environnement", Juris-Classeurs Responsabilité Civile, fasc. $581-1,1994$. 


\subsubsection{In België}

De aansprakelijkheid voor milieurisico's wordt in Belgie over het algemeen verzekerd als een bijzondere dekking binnen de door ondernemingen afgesloten aansprakelijkheidspolis BAuitbating. Deze polis dekt de civielrechtelijke aansprakelijkheid van de verzekerde ter zake van de uit de uitoefening van de bedrijfsactiviteiten voortvloeiende schade aan derden. Over het algemeen wordt milieuaansprakelijkheid beschouwd als een bijzondere waarborg - met name accidentele milieuverontreiniging - binnen de polis BA-uitbating. Sommige verzekeraars sluiten echter milieuaansprakelijkheid uitdrukkelijk uit van de dekking, tenzij de verzekerde kan bewijzen dat het een accidentele milieuschade betreft ${ }^{10}$. Het belang van dit verschil mag duidelijk zijn: in het eerste geval zal de verzekeraar moeten aantonen dat het geen accidentele milieuschade betreft wil hij vermijden om dekking te moeten verlenen; in het tweede geval zal de verzekerde dit bewijs moeten leveren, zoniet zal hij niet van de dekking kunnen genieten ${ }^{11}$. Ook de manier waarop deze risico's worden omschreven verschilt al naargelang de verzekeringsmaatschappij: bepaalde verzekeraars definiëren het milieurisico, anderen geven een opsomming van fenomenen waarvan wordt verondersteld dat zij schade toebrengen aan het milieu (bijvoorbeeld emissies, rook, trillingen e.d.m.). De verschillende polissen hebben evenwel gemeen dat zij enkel dekking verlenen voor schade die het gevolg is van een ongeval; een ongeval wordt dan beschouwd als een plotselinge gebeurtenis die voor de verzekerde onvrijwillig, toevallig en onvoorzienbaar is. Graduele vervuiling wordt in de regel uitgesloten ${ }^{12}$.

In het begin van de jaren negentig wenste een aantal grote verzekeraars over te gaan op het uitschrijven van een polis BA-vervuiling (ook wel "BA-milieu" genoemd). De bereidheid van verzekeraars om de risico's uit milieuaansprakelijkheid te dekken liep evenwel sterk terug door het afkondigen van de nieuwe wet op de landverzekeringsovereenkomst op 25 juni $1992^{13}$. Zoals reeds besproken, liet de oorspronkelijke wet niet toe dat dekkingen werden uitgeschreven op claims-made basis waardoor de herverzekeraars zich van de Belgische markt zouden terugtrekken. Bij wet van 16 maart 1994 werd de situatie rechtgezet en dus zijn claims-made dekking wel degelijk toelaatbaar in de Belgische rechtsorde ${ }^{14}$.

Deketelacte, M., "Recente ontwikkelingen inzake de aansprakelijkheid voor en verzekering vañ milicuschade", Jura Falconis, 1990-1991, 553; Deketelaere, M., "Deel VIII. Milieu en verzekeringsrecht", in Deketelaere, K. (ecl.), "Handboek Milieurecht", I.c., 1200-1203; Rogge, J., "Assurance des dommages causés par la pollution. Les garantics usuelles accordées sur le marché belge", in "Verzekering van Milieuschade", l.c., 21 e.v.; Rogge, J., "De dekking van schade door milieuaantasting in het kader van de verzekering BA-exploitatie", De Verz, 1987, n² 281, 543; Rogge, J. en Moustie, K., "Belgium", in Pfennigstorl, W. (cd.), Pollution Insurance. International Survey of Covernges and Exclusions, Graham \& Trotman/Martinus Nijhoff, Londen, 1993, 29-32; Kerremans, H., "Aansprakelijkheid voor milicuschade en verzekeringsmogelijkheden", in Milieuzorg in de Onderneming. Deel 1. Juridische, financiële en organisatorische aspecten, Standaard Uitgeverij, 1999, 560 .

Zie hierover Cousy, H., "Recent Developments in Environmental Insurance", in Abraham, F. Deketelaere, K. en Stuyck, J., (eds.), "Recent Economic and Legal Developments in European Environmental Policy", l.c., 233-234.

Rogge, J., "L'assurance des risques d'exploitation", in Les Assurances de l'entreprise", Bruxelles, Bruylant, vol. II, 1993, 193; Kerremans, H., "Aansprakelijkheid voor milieuschade en verzekeringsmogelijkheden", in "Milieuzorg in de Ondememing", l.c., 560.

Ranson, D., "Verzekering van milieuaansprakelijkheid", o.c., 67.

Bocken, H., "L'assurance responsabilité civile pour dommages causés par la pollution", in "Les Assurances de l'entreprise", l.c., 241.

Cfr. supra, in $\S 5.3 .1$ van hoofdstuk 5. 
In België werden de eerste specifieke milieupolissen dan ook aangeboden rond 1996 ${ }^{15}$; deze dekking is bijgevolg vrij nieuw op de Belgische markt. Zeker in de aanvangsfase werd deze dekking voornamelijk gekocht door grote bedrijven ${ }^{16}$. Momenteel bieden vier verzekeraars een BAmilieu dekking aan ${ }^{17}$.

Een specifieke verzekeringspolis voor milieuschade krijgt in België dus slechts langzaam vorm ${ }^{18}$ De meest voorkomende vormen van milieuaansprakelijkheidspolissen zijn: de beroepsaansprakelijkheid van milieuconsulenten, de milieuaansprakelijkheid van aannemers, en de locatiegebonden milieuverzekering ${ }^{19}$. Gelet op de mogelijke risico's die de verzekeraar onder dergelijke polissen loopt en de beperkte capaciteit van de verzekeringsmarkt blijft deze onderhevig aan verschillende beperkingen, zowel wat betreft de financiële tussenkomst van de verzekeraar ${ }^{20}$, als de uitsluiting van bepaalde soorten schade ${ }^{21}$ als algemene uitsluitingen ${ }^{22}$. Daamaast worden alle polissen in verband met de aansprakelijkheid uit milieuschade uitgeschreven op een claims-made basis ondat de keuze van een andere trigger in de ogen van verzekeraars en herverzekeraars technisch en financieel niet haalbaar is ${ }^{23}$.

\subsubsection{In Nederland}

In de op de Nederlandse verzekeringsmarkt beschikbare traditionele bedrijfsaansprakelijkheidspolis (AVB-polis) van vóór 1970 werd niet specifiek gesproken van milieurisico's. In

Deketelaere, M., "Milieu-aansprakelijkheid. Burgerrechtelijke aansprakelijkheid voor milieuschade, strafrechtelijke aansprakelijkheid voor milieumisdrijven, administratieve sancties en veiligheidsmaatregelen en verzekering van milieuschade", in "Milieurecht in België. Status Questionis 1997", l.c., 705; Dubuisson, B., "Les assurances des atteintes à l'environnement: réalités et perspectives d'avenir", De Verz., 1996, 411; Rogge, J., "De dekking van schade door milieuaantasting in het kader van de verzekering BA-exploitatie", o.c., 543.

Rogge, J., "Les Assurances en matière d'environnement", Kluwer, Diegem, Coll. Env, 1997/2.0, 36.

Voor een vergelijkend overzicht van de polissen van deze vier verzekeraars, zie Kerremans, H., "Aansprakelijkheid voor milieuschade en verzekeringsmogelijkheden", in "Milieuzorg in de Onderneming", l.c., $570-575$.

Morrow, J.C., Pfennigstorf, W. en Wansink, J.H., "General Report", in Pfennigstorf, W. (ed.), Pollution Insurance. International Survey of Coverages and Exclusions, Graham \& Trotman/Martinus Nijhoff, Londen, 1993, 153.

Ranson, D., "Verzekering van milieuaansprakelijkheid", o.c., 68 e.v.

De tussenkomst van de verzekeraar is beperkt per vordering, waarbij vaak per verzekeringsjaar een absoluut maximum wordt gesteld aan de totale tussenkomst van de verzekeraar (Wansinsk, J.H., "Environmental Liability Insurance: Tour d'Horizon in Europe", Transnational Environmental Liability and Insurance, Graham \& Trotman, Londen, 1993, 17).

Worden over het algemeen uitgesloten: zuiver economisch verlies, ecologische schade (in die zin dat de polis enkel de schade dekt aan goederen in private eigendom), genetische schade. Er worden ook vaak beperkingen gesteld aan de door de verzekeraar gedragen clean-up kosten.

Zie hierover met name Hupin, G., "La pollution, risque assurable", in Les Assurances de l'Entreprise, Bruxelles, Bruylant, vol. I, 1, 1988, 243-263; Pfennigstorf, W., "Policy considerations for insurers engaging in environmental liability insurance", in Bocken, H. en Ryckbost, D. (ed.), "Verzekering van Milieuschade", l.c., 271-287; Pfennigstrof, W., "Limited Insurability of Unlimited Liability: Serial Claims aggregates and altematives. The continental view", in Kröner, R.P., Transnational Environmental Liability and Insurance, Graham \& Trotman, Kluwer Academic Publishers, London, [993, 159-165; Kerremans, H., "Aansprakelijkheid voor milieuschade en verzekeringsmogelijkheden", in "Milieuzorg in de Onderneming", l.c., 569 e.v.

Hellebuyck, A.D. en Deketelaere, M., "Verzekering en leefmilieu. Een internationaal overzicht van de ervaringen van de verzekeraars inzake de burgerrechtelijke aansprakelijkheid voor aantastingen van het leefmilieu", in Morrens, P. (red.), Milieurecht voor bedrijfsleiders en hun adviseurs, Mys \& Breesch, Gent, $1993,154$. 
principe was de aansprakelijkheid voor milieuschade dan ook gedekt ${ }^{24}$, voorzover deze betrekking had op personenschade of zaakschade. Na een aanbeveling van de Nederlandse Vereniging van Algemene Aansprakelijkheidsverzekeraars werd de AVB-polis in 1971 aangepast ${ }^{25}$. Volgende uitsluiting werd in de polis opgenomen:

"Uitgesloten is schade in verband met verontreiniging en/of aantasting van de bodem, water of lucht, tenzij deze verontreiniging en/of aantasting het gevolg is van een plotselinge onzekere gebeurtenis".

Er werd bijgevolg enkel dekking verleend voor milieuschade ten gevolge van accidentele verontreiniging. Graduele pollutie werd uitgesloten. Zo bleef de AVB-polis inzake milieuschade aan een aantal beperkingen onderhevig ${ }^{26}$. De AVB-polis sloot geleidelijk ontstane schade uit, bood enkel dekking van schade tengevolge van zaakbeschadiging, letsel of dood, en beperkte de dekking van de reddingskosten. Naar het einde van de jaren zeventig bood een aantal verzekeraars de mogelijkheid om ook graduele pollutie te verzekeren (MAV-polis). De "oude" MAV dekte geleidelijk ontstane milieuschade (en dus geen plotselinge schade) maar evenals alle opruimingskosten. Terwijl de AVB-polis was gebaseerd op de loss-occurrence trigger, ging de MAV-polis uit van de claims-made trigger. Toch heeft deze MAV-polis nooit echt succes gekend, onder meer omdat in die tijd het Nederlandse bedrijfsleven blijkbaar het belang van de milieurisico's nog onvoldoende wist in te schatten ${ }^{27}$.

In 1981 publiceerde de Nederlandse Vereniging van Algemene Aansprakelijkheidsverzekeraars een rapport inzake milieuaansprakelijkheidsverzekering waarbij werd gesteld dat de verzekeringsindustric haar rol slechts kon vervullen ten aanzien van de milieuaansprakelijkheid indien de markt een voldoende omvang had en dat dit kon worden bewerkstelligd door het instellen van een wettelijke verzekeringsplicht ${ }^{28}$. Het voorstel om de verzekering verplicht te stellen werd afgewezen omdat een te grote invloed werd gevreesd van de verzekeraars ${ }^{29}$. Anderzijds werd wel de noodzaak onderkend om voldoende capaciteit op de Nederlandse markt te genereren. Een aantal Nederlandse verzekeraars heeft zich daarom verenigd in het Milieu Aansprakelijkheid Samenwerkingsverband (MAS), een pool waarin de aangesloten verzekeraars elkaar herverzekeringsdekking verlenen ${ }^{30}$. Deze vereniging bood vanaf 1 maart 1985 de MAS-dekking aan ${ }^{31}$. Van belang is dat, zeker bij de aanvang van het samenwerkingsverband, MAS geen monopoliepositie bekleedde. Het stond de verzekeraars die niet declnamen aan de pool in principe vrij om eigen

Wansink, J.H., "De nieuwe milieuaansprakelijkheidsverzekering", Milieu en Recht, 1985/4, 98.

Zie ook van Acht, R.J.J. en Bauw, E., "Milieuprivaatrecht", l.c., 171 e.v.

Robesin, M.A., "Aansprakelijkheid voor Milieuschade en Verzekering", in Koeman, N.S.J., Ouwerkerk, W.J. en van Dunné, J.M., Civielrechtelijke aansprakelijkheid voor milieuschade, Vereniging voor Milieurecht, W.E.J. Tjeenk Willink, Zwolle, 1989, 143-144; Tonnaer, F.P.C.L., "Handboek Nederlands Milieurecht", l.c., 974-975.

Wansink, J.H., "De nieuwe milieuaansprakelijkheidsverzekering ", o.c., 99; Robesin, M.A., "Aansprakelijkheid voor Milieuschade en Verzekering", in "Civielrechtelijke aansprakelijkheid voor milieuschade", l.c., 144.

Robesin, M.A., "Aansprakelijkheid voor Milieuschade en Verzekering", in "Civielrechtelijke aansprakelijkheid voor milieuschade", l.c., 144.

Tonnaer, F.P.C.L., "Handboek Nederlands Milieurecht", l.c., 976-977.

Wansink, J.H., "De nieuwe milieuaansprakelijkheidsverzekering ", o.c., 100.

Zie ook Hulst, E.H., "Grondslagen van milieuaansprakelijkheid", l.c., 541-543; Wurfbain, J.W., "De verzekerbaarheid van aansprakelijkheid, een terreinverkenning", in Raaijmakers, M.J.G.C., van Rooij, R. en Spier, J., Aansprakelijkheden, Kluwer, Deventer, 1990, $235-244$. 
"milieupolissen" aan te bieden. Volledigheidshalve wordt erop gewezen dat inmiddels de naam van het samenwerkingsverband is veranderd in Nederlandse Milieupool ${ }^{32}$.

De dekking die door MAS wordt aangeboden, makt niet het voorwerp uit van een afzonderlijke polis, maar is een uitbreiding van de AVB-polis. Deze laatste werd inderdaad aangepast tot een zgn. "rubriekenpolis". De rubrieken A en B vormen de traditionele AVB-polis; degene die een meer uitgebreide dekking wenst, kan eveneens rubriek $\mathrm{C}$ meeverzekeren. Rubriek $\mathrm{C}$ dekt de aansprakelijkheid voor schade als gevolg van het vrijkomen van milieugevaarlijke stoffen rechtstreeks vanaf de verzekerde locatie, ook als dit vrijkomen een plotseling en onzeker karakter heeft. Er bestaat dus een gedeeltelijke overlapping tussen de rubrieken B en C indien het gaat om milieuaantasting die plaatsvindt vanaf de verzekerde locatie ${ }^{33}$. De MAS-polis is inderdaad zeer locatie gebonden, in die zin dat enkel dekking wordt verleend voor graduele verontreiniging op de door de verzekeraar van tevoren goedgekeurde locatie ${ }^{34}$.

Een belangrijk element in de polis is het schadebegrip. De MAS-polis is ruimer dan de AVB-polis omdat in beginsel eveneens gevolgschade is gedekt. Zowel aantasting van de economische gebruikswaarde van stoffelijke goederen als schade door het verontreinigd of vuil worden van oppervlaktewater zijn gedekt. Tegelijk wordt eveneens dekking verleend voor de kosten van onderzoek en opruiming en voor de preventiekosten ${ }^{35}$.

Het spreekt voor zich dat ook de MAS-polis aan een aantal beperkingen is onderworpen. In de eerste plaats is de MAS-polis van toepassing op milieuaantasting. Hiermee wordt grosso modo bedoeld het vrijkomen van bepaalde stoffen die een verontreinigende werking hebben. Het gaat dus om een emissie - trillingen en geluidshinder zijn bijvoorbeeld niet onder deze polis gedektdie leidt tot een verontreiniging. In tweede instantie is ook het verzekerde bedrag beperkt, in principe tot 5 miljoen gulden per vordering per jaar. Van belang is tenslotte dat de MAS-polis dekking verleent indien de vordering werd ingediend tijdens de dekkingsperiode. De MAS-polis hanteert inderdaad de claims-made dekkingsgrondslag ${ }^{36}$. De verzekeraar zal enkel dekking verlenen indien de vordering is ingesteld tijdens de looptijd van de polis; wel bestat de mogelijkheid om het uitlooprisico gedurende één jaar na het einde van de polis te dekken ${ }^{37}$. Tegelijk wordt in de regel ook het inlooprisico beperkt, en dit om te vermijden dat een vordering zou worden ingediend ter vergoeding van in het - verre - verleden veroorzaakte milieuschade.

In 1996 werd het polismodel van de AVB aangepast. In de eerste plaats werd de polis in meerdere rubrieken opgedeeld, waardoor een betere risicodifferentiatie en een aan de specifieke risico's van het bedrijf aangepaste polis kon worden aangeboden ${ }^{38}$. Daarenboven werd in de nieuwe polis de claims-made dekkingsgrondslag geïntroduceerd, wat impliceert dat het inlooprisico onbeperkt wordt gedekt, maar dat geen dekking wordt verleend voor het uitlooprisico ${ }^{39}$. Wel wordt, via de

Telefonisch gesprek met dhr. Bos van de Nederlandse Milieupool op 20 oktober 2000.

Wansink, J.H.., "Verzekering van aansprakelijkheid voor gevaarlijke stoffen in het NBW", Tijdschrijt voor Miliewaansprakelijkheid, 1990/3, 65-66; Wansink, J.H., "De nieuwe milieuaansprakelijkheidsverzekering", o.c., 100.

Wansink, J.H.., "Verzckering van aansprakelijkheid voor gevaarlijke stoffen in het NBW", o.c., 68.

Wansink, J.H., "Verzekering van aansprakelijkheid voor gevaarlijke stoffen in het NBW", o.c, 69.

Wansink, J.H., "De Algemene Aansprakelijkheidsverzekering", l.c., 114-115.

Wansink, J.H., "De nieuwe milieuaansprakelijkheidsverzekering", o.c., 102.

Wansink, J.H., "Het polismodel AVB 1996 en de dekking voor 'long-tail risico's"', Aansprakelijkheid d Verzekering, 1996/6, 121.

Tjoeng, L.M., "Het polismodel AVB 96 en de overgang van occurrence naar claims made", Aansprakelijkheid \& Verzekering, 1996/6, 127 e.v. 
nameldings- en de omstandighedendekking, voorzien in een veraachting van het gebrek aan dekking van het uitlooprisico. Een nameldingsdekking houdt in dat een aanspraak na het einde van de dekking kan worden ingediend, op voorwaarde dat de aanspraak betrekking heeft op een handelen of nalaten dat heeft plaatsgehad vóór de beëindigingsdatum van de polis ${ }^{40}$. Bij een omstandighedendekking wordt de mogelijkheid geboden dat voorvallen worden gemeld die zich tijdens de looptijd van de polis hebben voorgedaan, maar die nog niet tot een aanspraak hebben geleid. Het grote verschil tussen de nameldings- en de omstandighedendekking bestaat erin dat de namelding over het algemeen geldt voor een periode van 1 of 3 jaar, terwijl de omstandighedendekking, eens een voorval of een feit werd aangemeld, in beginsel een onbeperkte uitloopdekking verleent ${ }^{41}$. Precies dezelfde mogelijkheid is voorzien in de MAS-polis ${ }^{42}$, zodat de AVB 96 en de MAS-polis eenzelfde dekkingsgrondslag hanteren.

De MAS-polis biedt dus dekking voor een aantal gevallen van milieuschade; door de beperkingen ervan, bieden zij slechts in beperkte mate de zekerheid dat de door het slachtoffer geleden schade wordt gecompenseerd ${ }^{43}$. Inmiddels heeft de MAS-polis een nieuwe evolutie ondergaan, in die zin dat het Nederlands Verbond der Verzekeraars heeft aanbevolen om een bijkomende beperking in te bouwen ten aanzien van milieuaansprakelijkheid ${ }^{44}$. Uit het begrip "zaakschade" wordt uitgesloten schade aan de bodem, het oppervlaktewater of enig(e) al dan niet ondergronds(e) water(gang). Concreet betekent dit dat onder de AVB en de MAS-polis geen dekking meer wordt verleend ten aanzien van verontreiniging van bodem en water en de daaruit voortvloeiende zaakschade.

In de plaats van de dekking onder de MAS-polis, is op de Nederlandse verzekeringsmarkt sinds begin 1998 een bijzondere milieuschadeverzekering (MSV-polis) beschikbaar ${ }^{45}$. Deze polis biedt een dekking voor milieuschade, met name bij verontreiniging van bodem of water. Het centrale aanknopingspunt van de milieuschadeverzekering is de locatie van de verzekeringsnemer. Belangrijk is vooral dat niet enkel schade op de eigen locatie, maar eveneens schade die door de eigen locatie aan naburige percelen is veroorzaakt, wordt verzekerd ${ }^{46}$. Op deze wijze wordt een schade, die traditioneel via een aansprakelijkheidspolis zou worden gedekt, verzekerd via een directe verzekering. Deze directe verzekering bevat zowel elementen ter dekking van de eigenschade van de verzekeringsnemer als ter dekking van de schade aan derden.

\footnotetext{
* Van der Schaaf, F.A., "Voor- en narisico in het polismodel AVB 96", Aansprakelijkheid \& Verzekering, 1996/6, 124.

41 Van der Schaaf, F.A., "Voor-en narisico in het polismodel AVB 96", o.c., 214.

2. Wansink, J.H., "De ansprakelijkheidsverzekering en de dekking van 'long-tail risico's'", Aansprakelijkheid \& Verzekering, 1995/1, 5.

43 Ook in die zin, Hafkamp, W.A., Gilhuis, P.C., Hofland, J., Verschuuren, J.M en de Putter, P.J., Een Milieuschadefonds in Nederland: een onderzoek naar de mogelijkheden, VROM, Publikatiereeks milieubcheer, nr. 1994/3, 32.

Wansink, J.H., "Verzekering en milieuschade als gevolg van vervoer/opslag van gevaarlijke stoffen", Tijdschrift woor Milieuaansprakelijkheid, 1999/3, 79.

Drion, P.J.M., "Milieu onder één dak: milieuschadeverzekering (MSV)", Verzekeringsrechtelijke Berichten, 1998/2, 19-21; Niezen, G.J., "Aansprakelijkheid voor Milieuschade in de Europese Unie. Over de slak en de bonte specht", in Niezen, G.J., Raaijmakers, M.J.G.C. en Tervoort, A.J.S..M., Ongebonden recht bedrijven, Kluwer, Deventer, 2000, 178.

Zogenaamde "inkomende verontreiniging" op de eigen locatie is dus niét gedekt; enkel schade op de eigen locatie veroorzaakt en de schade die aan de naburige percelen is veroorzaakt, vallen onder de MSV-polis. Zie hierover "Duurzame ondememing straks goed verzekerd", Bondig Dossier, Verbond der Verzekeraars, juni 1997, 3.
} 
Het is de bedoeling dat deze MSV-polis uiteindelijk de bestaande dekkingen voor milieuschade zal gaan vervangen ${ }^{47}$. Geoordeeld wordt namelijk dat de reeds bestaande milieupolissen zoveel mogelijk in één polis dienen te worden geïntegreerd, dat de lacunes in de bestaande dekking zoveel mogelijk dienen te worden aangevuld en dat de verzekerde een keuze moet hebben betreffende de omvang van de verzekeringsdekking ${ }^{48}$. Ter zake van milieuaansprakelijkheid is de MSV-dekking van groot belang omdat een derde die schade heeft geleden, direct een beroep kan doen op de verzekeraar, buiten het aansprakelijkheidsvraagstuk om. De MSV-polis is dus niet beperkt tot een directe verzekering voor eigenschade, maar is tegelijk een directe verzekering ten behoeve van derden. Daar wordt in de volgende paragraaf op teruggekomen.

Hiermee is aangegeven dat milieuschade niet alleen via een aansprakelijkheidsverzekering (third party insurance), maar eveneens via een directe verzekering (direct insurance) kan worden gedekt. Een directe verzekering of schadeverzekering kan verschillende vormen aannemen, in die zin dat zowel de dader als het slachtoffer een dergelijke dekking kunnen afsluiten. Hieronder wordt eerst de situatie besproken waarbij de dader een directe verzekering afsluit ten behoeve van het slachtoffer $(\$ 1.2)$. Vervolgens wordt de hypothese belicht waarbij het slachtoffer zelf een schadeverzekering afsluit, via een zgn. first party insurance $(\S 1.3)$.

\subsection{Directe verzekering ten behoeve van derden}

Voor de dekking van een (milieu)risico kan een dader ten voordele van het slachtoffer niet alleen een aansprakelijkheidsverzekering, maar eveneens een schadeverzekering afsluiten. Dit betekent dat de potentiële schadeveroorzaker een polis aanschaft voor de vergoeding van de schade die hij aan derden berokkent ${ }^{49}$. Bij een dergelijke polis betaalt de verzekeraar een bepaalde vergoeding uit aan slachtoffers, en dit buiten het aansprakelijkheidsrecht om. Hiermee is meteen gewezen op een aanzienlijk voordeel van deze vorm van directe verzekering, met name een daling van de administratieve kosten en een vereenvoudiging van de afhandeling van een schadegeval. Precies om die reden pleitte Bigot reeds in het verleden voor de introductie van een dergelijke polis ${ }^{50}$.

Het Zweedse systeem voor verzekering van slachtoffers van milieuschade kan worden beschouwd als een voorbeeld van een dergelijke directe verzekering ${ }^{51}$. Op basis van de wetgeving inzake milieuaansprakelijkheid van 1989 is een exploitant van een hinderlijke inrichting er verplicht om een verzekeringsdekking te hebben voor slachtoffers van milieuschade. Deze polis dekt met name letselschade en zaakschade in gevallen waar slachtoffers geen beroep kunnen doen op het aansprakelijkheidsrecht, bijvoorbeeld bij insolventie van de dader, wanneer de dader niet kan worden geidentificeerd etc. In dergelijke gevallen is een slachtoffer er niet toe gehouden om cen causaal verband aan te tonen tussen de door hem geleden schade en een welbepaalde activiteit ${ }^{52}$. Vorde-

Drion, P.J.M., "Milieu onder één dak: milieuschadeverzekering (MSV)", o.c., 19.

"Duurzame onderneming straks goed verzekerd", Bondig Dossier, Verbond der Verzekeraars, juni 1997, 1.

Bocken, H., "Rechtstreekse verzekeringen ten behoeve van derden en andere wisseloplossingen voor aansprakelijkheid en aansprakelijkheidsverzekering. Een typologie", in "Liber Amicorum René Van Gompl!", l.c., 32-33; Bocken, H., "Systemes altematifs pour l'indemnisation des dommages dus à la pollution", Revue Générale des Assurances et des Responsabilités, 1990, 11714, 11 e.v.

Bigot, J., "Compensation for pollution damage and insurance", in Compensation for pollution damage, OECD, Parijs, 1981, 141-142.

Bocken, $H_{\text {, }}$ "Rechtstreekse verzekeringen ten behoeve van derden en andere wisseloplossingen voor aansprakelijkheid en aansprakelijkheidsverzekering. Een typologie", in "Liber Amicorum René Van Gompel", l.c., 35.

Bocken, H., "Systèmes altematifs pour l'indemnisation des dommages dus à la pollution", o.c., 11714, 2. 
ringen die worden ingediend worden dan ook niet behandeld via de gewone rechtbanken, maar via een arbitrageprocedure ${ }^{53}$. Toch rijst de vraag of deze Zweedse milieuverzekering wel als een directe verzekering kan worden gekwalificeerd omdat een slachtoffer eerst een vordering kan indienen bij de verzekeraar nadat het aansprakelijkheidsrecht heeft gefaald. Het lijkt er dan ook op dat dit Zweedse systeem veel kenmerken vertoont van een privaat beheerd garantiefonds ten voordele van slachtoffers.

De Nederlandse MSV-polis daarentegen bevat wel degelijk een luik dat is te beschouwen als een directe verzekering ten behoeve van derden. In feite zijn er drie polismodellen beschikbaar, al naar gelang de activiteiten van de verzekeringsnemer en verzekerde. Het betreft ten cerste de rubrickenpolis milieuschadeverzekering ${ }^{\text {ss }}$ (voor bedrijven die op een vaste locatic zijn gevestigd), de bij-derdenpolis (voor bedrijven die op steeds wisselende locaties werkzaamheden uitvoeren) en de tijdelijk vastpolis (voor bedrijven die gedurende een zekere periode hun werkzaamheden uitvoeren op een vaste locatie). Uitgangspunt van de rubriekenpolis is de locatie waar het bedrijf is gevestigd. Op basis van deze polis zijn in de eerste plaats gedekt de kosten van sanering van deze locatic. Daamaast dekt de MSV rubriekenpolis ook de saneringskosten van naburige percelen, voorzover deze percelen werden verontreinigd door een verzekerd gevaar dat zich op de verzekerde locatic heeft voorgedaan. De bij-derden polis en de tijdelijk vast polis hebben betrekking op de saneringskosten van de werklocatie, evenals de kosten van sanering van naburige percelen, voorzover deze percelen werden verontreinigd door een verzekerd gevaar dat zich op de verzekerde locatie heeft voorgedaan ${ }^{56}$.

Elk van de drie beschikbare polissen voorziet in een derdenbeding. Een derde maakt aanspraak op vergoeding indien de verzekeringsnemer hem daartoe toestemming verleent ${ }^{57}$. De dekking bij de rubriekenpolis heeft betrekking op de kosten van sanering van een locatie bij het behoud waarvan een derde belang heeft uit hoofde van eigendom of enig ander zakelijk recht dan wel voor het behoud waarvan hij risico draagt en op andere zaakschade van een derde, inclusief de daaruit voortvloeiende schade, voorgevallen buiten de verzekerde locatie. Als uitsluitingen zijn in de polis onder meer opgenomen: schade veroorzaakt door gewapend conflict, burgeroorlog of opstand, schade tengevolge van een "atoomkernreactie", of ten gevolge van aardbeving of overstroming; merkelijke schuld; de kosten veroorzaakt uit verontreiniging die reeds aanwezig is op het

Oldertz, C., "Swedish Environmental Damage Insurance. A new concept of insuring injuries or property damages, caused by environmental disturbances", in Bocken, H. en Ryckbost, D. (ed.), "Verzekering van Milieuschade," l.c., 371.

Volledigheidshalve wordt erop gewezen dat de dekking die op dezé wijze wordt verleend, ook aan beperkingen is onderworpen: lichamelijke schade wordt beperkt tot 5 miljoen kronen per persoon; zaakschade tot 50 miljoen SEK per vordering en per schadeoorzaak.

Deze polis wordt opgebouwd aan de hand van een aantal rubrieken. Onder de basisrubriek wordt dekking voor milieuschade verleend als gevolg van brand, blikseminslag en ontploffing. De uitgebreide evenementenrubriek bicdt ook dekking bij onder meer aanrijding, braak, vandalisme en het breken of barsten van een ondergrondse tank door van buiten komend onheil. De toprubriek tenslotte biedt dekking tegen alle milieuschade ten gevolge van een van buiten komend onheil en dekking voor eigen gebrek. Zie hierover ook Janssen, C.A., "Aansprakelijkheid voor milieuschade en financięle zekerheid naar toekomstig recht: nieuwe oplossingen. Nederlands recht", in Wiggers-Rust, L.F. en Deketelaere, $\mathrm{K}$., (red.) Aansprakelijkheid voor milieuschade en financiële zekerheid. Een vergelijking van Nederlands, Belgisch en Europees recht, Die Keure, Koninklijke Vermande, Brugge, Lelystad, 1998, 111 112.

Zie hierover Wansink, J.H., "Verzekering en milieuschade als gevolg van vervoer/opslag van gevaarlijke stoffen", o.c., 79-80.

Drion, P.J.M., "Milieu onder één dak: milieuschadeverzekering (MSV)", o.c., 20. 
moment waarop het verzekerde gevaar zich verwezenlijkt ("oud zeer"); genetische schade; overtreding van overheidsvoorschriften.

Een derde die schade heeft geleden zal zich dus op de MSV-polis kunnen beroepen ter compensatie van de door hem geleden schade. Een slachtoffer zal enkel het causale verband moeten bewijzen tussen de door hem geleden schade en de oorzaak daarvan ${ }^{58}$ en hij zal geen beroep op het aansprakelijkheidsrecht moeten doen. Dit neemt uiteraard niet weg dat een slachtoffer geen plich heeft om zich op de MSV-polis te beroepen; het staat hem dan ook vrij om de onder deze dekking beschikbare bedragen niét aan te wenden en zich tot de rechtbank te richten. Ook in de mate waarin de uitgekeerde bedragen onder deze polis ontoereikend zijn, zal hij zich nog steeds op het aansprakelijkheidsrecht kunnen beroepen.

De verschillende MSV-polissen beperken het verzekerde bedrag tot een bepaald bedrag en voorzien ook in een eigen risico. Er wordt dekking verleend mits het verzekerde gevaar zich op de verzekerde locatie heeft verwezenlijkt tijdens de looptijd van de verzekering en mits binnen één jaar na verwezenlijking van het verzekerde gevaar een aanspraak op vergoeding is ingediend.

Tenslotte moet er ook op worden gewezen dat de integratie in de MSV-polis van zowel het element eigenschadeverzekering als directe verzekering voor derden voordelen oplevent indien het verzekerde bedrag van het ene luik niet en van het andere luik wel wordt overschreden. De MSVpolis voorziet namelijk in een "overloop"-clausule. Deze clausule houdt in dat wanneer het voor derden beschikbare verzekerde bedrag niet toereikend is en het voor de verzekerde locatic verzekerd bedrag nog niet (geheel) is aangewend, het restant van het verzekerde bedrag ten goede komt aan het verzekerde bedrag voor derden. Eenzelfde clausule is voorzien voor de omgekeerde situatie, met name wanneer het verzekerde bedrag voor derden niet geheel is uitgeput, dan kan het restant worden aangewend voor de dekking van schade op de eigen locatie ${ }^{59}$.

\subsection{Eigenschadeverzekering}

Hoewel vooral ter zake van milieuschade hoofdzakelijk wordt gesproken van aansprakelijkheidsverzekeringen - dit wil zeggen een dekking die door de schadeveroorzaker wordt afgesloten ten voordele van de schadelijder - is het perfect mogelijk dat een slachtoffer zich wenst te verzekeren tegen de schade die hij kan lijden door een ongeval.

Bij dergelijke polissen zal een verzekerde die schade lijdt, zich meteen tot de verzekeraar kunnen wenden, en dit onafhankelijk van de vraag of iemand aansprakelijk is voor de schade ${ }^{60}$.

In een aantal landen is milieuschade als het ware indirect verzekerd bij eigenschadeverzekeringen van het slachtoffer ${ }^{6 !}$, en dit zowel ter zake van zaakschade als personenschade. Zo is via de brandverzekering de schade veroorzaakt door rook gedekt; bij een ziekteverzekering is de licha-

58 "Durzame ondememing straks goed verzekerd", Bondig Dossier, Verbond der Verzekeraars, juni 1997, 3.

59 Of werklocatie, al naargelang het gaat om de rubriekenpolis, de bij-derdenpolis dan wel de tijdelijk vast polis.

60 Zie hierover Wetterstein, P., "Les dommages causés par les catastrophes intemationales à la lumière du droit de la responsabilité civile et du droit des assurances", in Les dommages causés par les catastrophes internationales. Le contrôle financier des compagnies d'assurances, AIDA, Kopenhagen, 1990. 211 e.v.

61 Bocken, H., "Systèmes altematifs pour l'indemnisation des dommages dus à la pollution", o.c., I1714, 1. 
melijke schade verzekerd, zelfs indien deze schade bijvoorbeeld is veroorzaakt door een emissie in de lucht.

Een eerste belangrijke stap in de richting van een eigenschade-milieupolis, is uiteraard het eerste luik van de MSV-polis. Deze polis is in die zin beperkt dat deze betrekking heeft op de kosten van sanering van bodem en water. Eigenschade ingevolge luchtverontreiniging of radioactieve uitstoot is bijvoorbeeld niet gedekt.

Tot op vandaag is voorzover bekend geen algemene first party milieuschadeverzekering op de markt beschikbaar. Nochtans kan een first party polis bijdragen tot een verhoging van de maatschappelijke welvaart. Dit wordt verder uitgediept, bij de vergelijking tussen schadefondsen en een first party dekking ${ }^{62}$.

De in deze paragraaf besproken verzekeringsdekkingen kunnen worden beschouwd als traditionele vormen van verzekering omdat een beroep wordt gedaan op de klassieke verzekeringsimarkt, zelfs indien bijvoorbeeld voor wat Nederland betreft, cen aantal verzekeraars zich in een pool heeft verenigd om een specifieke milieudekking te kunnen aanbieden. In onderstaande paragrafen zal aandacht worden besteed aan meer alternatieve compensatiemechanismen. In paragraaf 2 staan compensatiemechanismen voor de dekking van milieuschade centraal. In paragraaf 3 zal aandacht worden besteed aan de dekking van het nucleaire risico.

\section{ALTERNATIEVE COMPENSATIEMECHANISMEN VOOR DE DEKKING VAN MILIEUSCHADE}

Inzake milieuschade wordt door de nationale en internationale wetgever meer en meer een beroep wordt gedaan op risicoaansprakelijkheid, omdat hiermee wordt tegemoet gekomen aan de bewijslast van slachtoffers ${ }^{63}$. Toch is gebleken dat, zelfs in gevallen waar een regime van risicoaansprakelijkheid werd ingevoerd, de compensatie van slachtoffers uitbleef. Gebleken is namelijk dat bepaalde problemen die rijzen onder een regime van foutaansprakelijkheid evenzeer rijzen bij een regime van risicoaansprakelijkheid. Ter zake van de aansprakelijkheid voor milieuschade kunnen als belangrijkste problemen worden aangehaald het feit dat de dader onvindbaar is, het faillissement van de dader (of diens verzekeraar) en de onmogelijkheid om causaliteit tussen de dader en de geleden schade aannemelijk te maken ${ }^{64}$. Spccifiek met betrekking tot ecologische schade, lijkt risicoaansprakelijkheid evenmin een duidelijkc oplossing te bieden.

Zelfs indien de problemen van het aansprakelijkheidsrecht zijn overwonnen, zal het vaak van de beschikbare verzekeringsdekking afhangen of de geleden schade effectief wordt vergoed. Uit de rechtseconomische analyse van verzekeringen is gebleken dat slachtoffers ook op dit terrein met de nodige problemen worden geconfronteerd: in een aantal gevallen kan een risico onver/ckerbaar worden, of is er bijvoorbeeld onvoldoende capaciteit beschikbaar. Zcker ten aanzicn van massaschade wordt zelfs geoordeeld dat een cumulatie van vorderingen niet te rijmen valt met het spreidingsprincipe van verzekeringen ${ }^{65}$. Het civiele aansprakelijkheidrecht en de aansprakelijk-

Cfr. infra, $\$ 2.1 .5 .3$ van dit hoofdstuk.

Cfr. supra, hoofdstuk 1.

Voor meer details, zie Kottenhagen-Edzes, P.A., "Onrechtmatige daad en milieu", l.c., 57 e.v.; Dekettlaere, M., "Deel VII. Milieu en burgerlijk aansprakelijkheidsrecht", in Deketelacre, K. (ed.), "Handboek Milieurecht", l.c., $1176 \mathrm{c.v}$.

Kamp, P.A.J., "Massaschades en verzekering", in Massaschade. Vergt de behandeling van massale schade een bijzondere benadering?, Koninklijke Vermande, Lelystad, 1996, 65. 
heidsverzekering zijn blijkbaar niet in staat om te voorzien in een afdoende systeem ter vergoeding van milieuschade ${ }^{66}$, noch wat betreft individuele schade, noch wat betreft. collectieve schade.

Een bijzonder probleem bij zware industriële ongevallen en milieurampen is het beheer van de verschillende vorderingen. Zeker bij een grensoverschrijdend ongeval is de kans groot dat zich al gauw honderden of duizenden mensen als slachtoffer zullen aandienen ${ }^{67}$. Hierbij moet dan worden getracht om op snelle en efficiënte wijze compensatie uit te keren. In deze gevallen komen de grenzen van het privaatrecht snel in zicht ${ }^{68}$ en is het niet evident om aan de slachtoffers binnen cen redelijke termijn genoegdoening te schenken.

Teneinde de problemen inzake aansprakelijkheid en de daaraan gekoppelde idee van de onverzekerbaarheid van deze aansprakelijkheden het hoofd te bieden, werden in de literatuur verschillende maatregelen gesuggereerd: het beperken van de aansprakelijkheid ${ }^{69}$, het verplicht stellen van een (milieu)aansprakelijkheidsverzekering ${ }^{70}$, de oprichting van verzekeringspools zoals de Nederlandse Milieupool en de Franse ASSURPOL ${ }^{71}$, en de oprichting van private en of publieke schadefondsen ${ }^{72}$. Vaak wordt ook gewezen op de noodzaak tot internationale samenwerking, zeker in

Bocken, H., "Deficiencies of the system of liability and liability insurance as a mechanism for the indemnification of environmental damage suffered by individual victims", in Bocken, H. en Ryckbost, D. (ed.), "Verzekering van milieuschade", l.c., 139; Bocken, H., "Systèmes alternatifs pour l'indemnisation des dommages dus à la pollution", o.c., 11698 en 11714 .

Zie bijvoorbeeld Sellschopp, H.D., "Multiple Tort Feasors/Combined Polluter Theories, Causality and Assumption of Proof, Technical Insurance Aspects", in Kröner, R.P., Transnational Environmental Liability and Insurance, Graham \& Trotman, Kluwer Academic Publishers, London, 1993, 51-57.

Bauw, E., "Tussen traditie en efficiëntie. Naar een wettelijke regeling van de afwikkeling van massaschade", Nederlands Juristenblad, 1995, 622.

Viney pleit voor een beperking en matiging van aansprakelijkheden en schadevergoedingen; zij gaat ervan uit dat bij de aansprakelijkheid eveneens rekening moet worden gehouden met de mogelijkheid tot verzekering omdat een niet-verzekerde zware aansprakelijkheid aanleiding geeft tot faillissementen en werkloosheid. Het is volgens haar logischer dergelijke beperking in te voeren bij een regime van risicoaansprakelijkheid dan bij een regime van foutaansprakelijkheid (Viney, G., "Modération et limitation des responsabilités et des indemnisations", in Spier, J., "The Limits of Liability", l.c., 127 e.v.). Zie bijvoorbeeld Wetterstein, P., "Les dommages causés par les catastrophes internationales à la lumière du droit de la responsabilité civile et du droit des assurances", in "Les dommages causés par les catastrophes internationales", l.c., 194 e.v.; Cowell, J., "Compulsory environmental liability insurance", in Bocken, H. en Ryckbost, D. (ed.), "Verzekering van milieuschade", l.c., 319 e.v.; Hulst. H.E, "Grondslagen milieuaansprakelijkheid", l.c., 556 en 563; Tenière-Buchot, P.F., Clave, A. en Hetzel, I, "Méthodologies et pratiques d'indemnisation des dégâts provoqués par les pollutions accidentelles", in in La réparation des dommages catastrophiques. Les risques technologiques majeurs en droit internttional et en droit communautaire. Travaux des XIIles Joumées d'études juridiques Jean Dabin, Bruxelles, Bruylant, 1990, 199.

ASSURPOL dekt zowel de schade accidentele als niet accidentele verontreiniging en is de opvolger van GARPOL. ("Groupement d'Assurance et de Réassurance Pollution"). Zie hierover onder meer Hupin, G., "La pollution, risque assurable", in "Les Assurances de l'Entreprise", l.c., 256; Deprimoz, J., "France", in Pfennigstorf, W. (ed.), Pollution Insurance. International Survey of Coverages and Exclisions, Graham \& Trotman/Martinus Nijhoff, Londen, 1993, 54; Deprimoz, J., "Régime juridique desi assurances contre les risques d'atteinte à l'environnement", o.c., 581-1; Hulst, E.H., "Grondslagen van milieuaansprakelijkheid", l.c., 543

Zie o.m. Bocken, H., "Complementary compensation mechanisms. A general environmental damage fund?", in Bocken, H. en Ryckbost, D. (ed.), "Verzekering van milieuschade", 427-433; Collart, J., "La. capacité financière du maché des assurances", in Bocken, H. en Ryckbost, D. (ed.), "Verzekering van. milieuschade", 296-297; Smets, H., "Pour une indemnisation garantie des victimes de pollution accidentelle", in Bocken, H. en Ryckbost, D. (ed.), "Verzekering van milieuschade", l.c., 399-419; Thiern, V., "Environmental Damage Funds", in Compensation for Pollution Damage, OECD, Parijs, 1981, 144-180. 
gevallen van grensoverschrijdende schade ${ }^{73}$; bepaalde auteurs gaan er ook van uit dat de overheid die bepaalde activiteiten toelaat en noodzakelijk acht voor de ontwikkeling van het land, een verantwoordelijkheid op dit vlak heeft ${ }^{74}$. Een aantal van deze thema's is reeds in de vorige hooffstukken aan bod gekomen: met name in de rechtseconomische analyse werd de invloed bestudeerd van de beperking van aansprakelijkheid en van het verplicht stellen van een aansprakelijkheidsverzekering op de maatschappelijke welvaart.

In deze paragraaf staan een aantal alternatieve compensatiemechanismen centraal. Met "alternatief" wordt bedoeld dat het mechanismen betreft die niet echt tot de klassieke verzekeringsproducten (aansprakelijkheidsverzekering, schadeverzekering etc.) kunnen worden gerekend. Toch zal blijken dat alternatieve mechanismen zoals fondsvorming en captives in mindere of meerdere mate een beroep doen op de verzekerings- en/of herverzekeringsmarkt. In een aantal gevallen zullen zelfs deze mechanismen niet in staat zijn om voldoende capaciteit te genereren. Vandaar werden inmiddels ter zake van de dekking van natuurrampen mechanismen gecreëerd die een beroep doen op de kapitaalmarkt.

Er wordt voor gekozen om twee alternatieve compensatiernechanismen te bespreken en om bijkomend ook te wijzen op een recentere evolutie, met name de risicotransfer op de kapitaalmarkt. In eerste instantie zal aandacht worden besteed aan schadefondsen inzake milieuschade $(\S 2.1)$. Dit is een actueel thema in Belgiẻ en Nederland omdat in beide landen voorstellen werden gelanceerd die de oprichting van een fonds bepleitten. In tweede instantic wordt een bijzondere vorm van verzekering belicht, namelijk de dekking van een catastroferisico via een captive. Dit is een relatief onbekend mechanisme dat, zoals in hoofdstuk 13 zal blijken, in de Verenigde Staten een belangrijke positie inneemt voor de dekking van het nucleaire risico. In paragraaf 2.2 wordt een algemene omschrijving gegeven van de captive en worden enkele verschillende soorten captives belicht. Tenslotte wordt in $\S 2.3$ de trend besproken om natuurrampen te verzekeren door een beroep te doen op de kapitaalmarkt.

\subsection{Fondsvorming}

Reeds geruime tijd staat de creatie van schadefondsen in de belangstelling, zeker in verband met de compensatie van milieuschade ${ }^{75}$. Verschillende onderzoeken ter zake van de compensatie voor

3 Dupuy, P. en Smets, H., "Compensation for damage due to transfrontier pollution", in Compensation for Pollution Damage, OECD, Parijs, 1981, 181 e.v.

74 Bijvoorbeeld: Dupuy, P.M., "Le rôlê de l'état danș l'indemnisation des dommages catastroṛhiques intemationaux", in La réparation des dommages catasirophiques. Les risques teclinologiques majears en droit international et en droit communautaire, Travaux des XIlles Journées d'études juridiques Jean Dabin, Bruxelles, Bruylant, 1990, 219-245.

Zie wat Nederland betreft onder meer De Groot, G.J., "Schadefondsen. Tussen toen en toekomst?", Nederlands Juristenblad, 1980, 269-276; Bröring, H.E., "Fondsvorming en financiele ackerheden", in Koeman, N.S.J., Ouwerkerk, W.J. en van Dunné, J.M., "Civielrechtelijke aansprakelijkheid voor milieuschade", l.c., 151-168; Hustinx, J.P. en Stolker, C.J.J.M., "Massaschade en fondsvorming", Verzekeringsarchief, 1997, 58-66; Faure, M.G. en Hartlief, T., "Een schadefonds als alternatief voor aansprakelijkheid en verzekering?", Rechtsgeleerd Magazijn Themis, 1998/7, 211 -228; Faure, M.G. en Hartlief, T., "Een asbestfonds als alternatief voor de aansprakelijkheid van de werkgever?", Sociaal Rechl, 1996-2, 37-43. Voor wat Belgie betreft, zie vooral Bocken, H., "Complementary compensation mechanisms. A general environmental damage fund?", in Bocken, H. en Ryckbost, D. (ed.), "Verzekering van milieuschade", 427-433; Bocken, H., "Systèmes alternatifs pour l'indemnisation des dommages dus à la pollution", o.c., 11714,2 e.v.; Bocken, H., "Alternatives to liability and liability insurance for the compensation of pollution damages", Tijdschrift voor Milieuaansprakelijkheid, 1987/4, 83-87 en 1988/1, 3-10. 
milieuschade, pleiten in de richting van de oprichting van een milieuschadefond ${ }^{76}$. Ook de wetgever van een aantal landen heeft geoordeeld dat de oprichting van een fonds zinvol kan zijn ${ }^{77}$. Bekend in dit verband zijn bijvoorbeeld de Amerikaanse CERCL. ${ }^{78}$ en het Nederlandse Fonds Luchtverontreiniging. Inzake de olieverontreiniging op zee is vooral het IOPC-Fonds bekend ${ }^{\text {Th }}$.

Over het algemeen wordt ervan uit gegaan dat de problemen waarmee slachtoffers in het aansprakelijkheidsrecht worden geconfronteerd, kunnen worden geremedieerd via een fonds ${ }^{80}$. In deze paragraaf worden enkele fondsen en voorstellen voor de oprichting van een fonds besproken en wordt geanalyseerd wat de voor- en nadelen hiervan zijn. Het is niet de bedoeling om in dit kader een alomvattend overzicht te geven van de bestaande fondsen die als compensatiemechanisme zijn in het leven geroepen, naast of in plaats van het aansprakelijkheidsrecht. Wel wordt voor een goed begrip voor de verdere analyse in eerste instantie een algemeen overzicht gegeven van een aantal verschillende soorten fondsen $(\S 2.1 .1)$.

In het kader van dit proefschrift, gaat onze aandacht vooral uit naar Belgiê en Nederland. Vandaar worden de voorstellen besproken van de Commissie Bocken (§ 2.1.2), en wordt ook het Nederlandse Fonds Luchtverontreiniging bestudeerd (\$ 2.1.3). Aangezien, zoals zal blijken, dit fonds misschien zal worden vervangen door een algemeen milieuschadefonds, wordt cok daaraan aandacht besteed $(\$ 2.1 .4)$. In $\S 2.1 .5$ tenslotte zal worden geëvalueerd wat de voordelen zijn van een fonds ten overstaan van andere compensatiemechanismen.

\subsubsection{Voornaamste soorten fondsen}

In feite kunnen meerdere soorten fondsen worden onderscheiden, al naargelang de functie die aan het Fonds wordt toegemeten. Het zou te ver voeren om in het kader van dit onderzoek een alomvattend overzicht te geven van de verschillende soorten fondsen; de aandacht beperkt zich tot de fondsen die relevant zijn voor de verdere analyse ${ }^{81}$. De belangrijkste soorten fondsen in het kader van dit onderzoek zijn: een beperkingsfonds, een voorschotfonds, een waarborgfonds en een fonds ter vervanging van aansprakelijkheid en verzekering ${ }^{82}$. Meteen moet worden aangegeven dat het onderscheid tussen deze verschillende soorten fondsen in de praktijk minder strak is dan

Zie bijvoorbeeld Carette, A., "Herstel van en vergoeding voor aantasting aan niet-toegeëigende milieubestanddelen", l.c., 492-500 en Kottenhagen-Edzes, P.A., "Onrechtmatige daad en milieu", l.c., 297. Zie ook Smets, H., "COSCA: A Complementary System for Compensation of Accidental Pollution Damage", in Wetterstein, P., "Harm to the Environment", l.c., 223-248.

De in opdracht van het Nederlandse Ministerie VROM uitgevoerde onderzoeken, worden in $\$ 2.1 .4$ besproken.

Zie hierover o.m. Carette, A., "Herstel van en vergoeding voor aantasting aan niet-toegeéigende milieubestanddelen", l.c., 326 e.v.; Jacus, J.R. en Miller, D.C., "Coming Full CERCLA: An Update on Superfund Developments", Environmental Liability, vol. 3, 1999, 77-80. De wetgeving en de compensatiemechanismen inzake de olieverontreiniging op zee, worden in hoofdstuk 12 aan de orde gesteld. Hartlief, $\mathrm{T}$., "leder draagt zijn eigen schade", l.c., 60 .

81 Voor een uitstekende analyse van een aantal bestaande fondsen, zie Thiem, V., "Environmental Damage Funds", in "Compensation for Pollution Damage", l.c., 144-180.

Faure, M.G. en Hartlief, T., "Een schadefonds als alternatief voor aansprakelijkheid en verzekering?", o.c., 211 e.v. Faure, M.G. en Hartlief, T., "Compensation Funds versus Liability and Insurance for Remedying Environmental Damage", Review of European Community \& International Environmental Law, vol. 5, nr. 4, 1996, 32 l e.v. 
op het eerste gezicht misschien zou blijken. In de praktijk heeft een bepaald fonds vaak meer dan één functie $e^{83}$.

Er wordt gesproken van een beperkingsfonds in gevallen waar de persoon die aansprakelijk wordt gesteld, een bepaalde som vrijmaakt die uitsluitend wordt aangewend ter vergoeding van de slachtoffers, met dien verstande dat de aansprakelijkheid wordt beperkt tot het vrijgemaakte bedrag $^{84}$. Een beperkingsfonds strekt er in de eerste plaats toe om de beschikbare middelen te verdelen onder de vele slachtoffers. Benadrukt dient te worden dat een beperkingsfonds uitsluitend door de aansprakelijke wordt gevoed en dat er bijgevolg geen sprake is van risicospreiding. Het is dan ook een fonds dat functioneert binnen het aansprakelijkheidsrecht. In zekere zin kan het gehele systeem van het nucleaire aansprakelijkheidsrecht, zoals ingevoerd door het Verdrag van Parijs van 1960 en het Verdrag van Wenen van 1963, worden beschouwd als een beperkingsfonds.

Het voordeel van een beperkingsfonds bestaat crin dat aan de exploitant, bij de start van zijn activiteiten, kan worden gevraagd om ex ante cen belangrijke financiële bijdrage te storten, die kan worden gebruikt zodra zich een milicuschade zou voordoen ${ }^{85}$. De voorstellen van de Commissie Bocken gaan eveneens in dezelfde richting ${ }^{86}$.

Een tweede type fonds is het voorschotfonds. Ecn voorschotfonds tracht tegemoet te komen aan gevallen waar een lange tijd kan verlopen tussen een voorval of ecn schade enerzijds en de definitieve toewijzing van aansprakelijkheid en de uitbetaling van schadevergoeding anderzijds. Een dergelijk fonds zal, in afwachting van een definitieve uitspraak over de aan de zaak verbonden fundamentele juridische vraagstukken, reeds een bcpaald voorschot toekennen. Anderzijds kan een slachtoffer dat een voorschot heeft ontvangen, maar dat er nict in slaagt een aansprakelijkheidsvordering tot een goed einde te brengen, ertoe worden verplicht om het voorschot alsnog terug te betalen. Een voorbeeld van een dergelijk fonds is terug te vinden in de Belgische federale en gewestelijke grondwaterwetgeving ${ }^{87}$.

Als derde kunnen waarborgfondsen of garanticfondsen worden onderscheiden. De functic van een waarborgfonds bestaat erin om tussen te komen indien de oorspronkelijke schuldenaar in gebreke blijtt (degene die aansprakelijk is of diens verzckeraar). Van belang is vooral dat dit fonds pas zal tussenkomen indien andere compensatiemechanismen hebben gefaald ${ }^{88}$. Het geeft met andere woorden bescherming tegen mogelijke insolventie van dader en/of diens verzekeraar, of bij gebrek aan voldoende verzekeringsdekking ${ }^{89}$. Een waarborgfonds zal alleen maar zinvol zijn indien

Bocken, H., "Alternatives to liability and liability insurance for the compensation of pollution damages", o.c., 1988, 4.

Zie voor meer details Frenk, N., "Afwikkeling van massaschade", Nederlands Tijdschrift voor Burgerlijk Recht, 1993, 89; Dommering-van Rongen, L., Schade vergoeden door Fondsvorming, Deventer, Kluwer, 1996.

3) Faure, M.G. en Hartlief, T., "Compensation Funds versus Liability and Insurance for Remedying Environmental Damage", o.c., 322.

Cfr. infra, in paragraaf 2.1.2 van dit hoofdstuk.

Zie hierover in detail Bocken, H., "Het proces zonder einde: aansprakelijkheid voor schade veroorzaakt door grondwaterwinning en bronbemaling", Tijdschrift voor Privaatrecht, 1995, 1633-1662.

Faure, M.G. en Hartlief, T., "Een schadefonds als altematicf voor aansprakelijkheid en verzekering?", o.c. 213.

Bocken, H., "Alternatives to liability and liability insurance for the compensation of pollution damages", o.c., 4 . 
ten aanzien van de verschillende potentiële insolvente daders een verzekeringsplicht wordt ingesteld $^{90}$.

Een dergelijk garantiefonds bestaat reeds in het Waalse Gewest, ten aanzien van de vergoeding van schade veroorzaakt door afval. Artikel 44 van het Waalse afvalstoffendecreet bepaalt dat degene die in Wallonië door afval schade heeft geleden, een vordering tot compensatie kan indienen bij de regering ${ }^{\text {"1. }}$. Deze vordering kan worden ingediend wanneer degene die de schade heeft veroorzaakt niet of moeilijk kan worden geïdentificeerd, wanneer de aansprakelijkheid niet of moeilijk kan worden vastgesteld of wanneer de aansprakelijke niet solvabel is of over onvoldoende middelen beschikt. Een uitkering die op deze basis plaatsvindt, komt ten laste van het Fonds pour la Gestion des Déchets ${ }^{92}$. Dit Fonds wordt gevoed door de heffingen die in Wallonië op afval worden geheven, krachtens een decreet van $1991^{93}$. De compensatieregeling is verder uitgewerkt in een Besluit van 5 november $1998^{94}$. Een vraag tot uitkering dient te worden ingediend bij het Office Wallon des Déchets dat eveneens instaat voor de afhandeling van het dossier. Het is evenwel de Waalse minister van Leefmilieu die de beslissing neemt. Volledigheidshalve wordt erop gewezen dat de bedragen die worden uitgekeerd, beperkt zijn: 1 miljoen BEF ten aanzien van letselschade en $600.000 \mathrm{BEF}$ ten aanzien van zaakschade ${ }^{95}$. Tegelijk zal geen vergoeding worden uitgekeerd indien de schade is gedekt door verzekering ${ }^{96}$ en zal het slachtoffer steeds cen eigen risico moeten dragen van $50.000 \mathrm{BEF}^{97}$.

Andere voorbeelden van een garantiefonds zijn het Nederlandse Waarborgfonds Motorrijtuigen, het Belgische Motorwaarborgfonds of het IOPC-Fonds.

In deze context dient erop te worden gewezen dat er in de literatuur blijkbaar geen eensgezindheid bestaat over de terminologie en de indeling van de verschillende soorten fondsen. Zo kwalificeert Bocken het Motorwaarborgfonds als een "invallerfonds", in die zin dat dit fonds invalt wanneer de aansprakelijke heeft nagelaten om een verzekeringsdekking te onderschrijven of wanneer de verzekeraar niet solvabel is ${ }^{98}$.

Tenslotte kan ook een fonds ter vervanging van aansprakelijkheid en verzekering worden onderscheiden. Een dergelijk fonds zou volledig in de plaats komen van het aansprakelijkheidsrecht en van een verzekeringsdekking; gesproken kan worden van een autonoom schadefonds ${ }^{99}$. In dit

Faure, M.G. en Hartlief, T., "Een schadefonds als alternatief voor aansprakelijkheid en verzekering?", o.c., 214.

Decret du 27 juin 1996 relatif aux déchets, B.S., 2 augustus 1996, meermaals gewijzigd.

Dit Fonds vormt in feite het centrale budget van de Waalse overheid ter zake van haar afvalbeleid, gaande van de oprichting van installaties voor afvalbeheer, over voorlichting inzake afvalpreventie tot de uitkering van compensatie bij schade veroorzaakt door afval. Zie met name artikel $1, \$ 2$ van het afvalstoffenheffingendecreet van 1991.

Deeret du 25 juillet 1991 relatif à la taxation des déchets en Région wallonne, B.S., 20 november 199l, meernaals gewijzigd.

Arreté du gouvemement Wallon du 5 novembre 1998 relatif aux règles d'indemnisation par la Région wallonne des dommages causées par des déchets, B.S., 18 december 1998.

Artikel 5 van het Besluit.

Artikel 44, $\$ 2$, lid 2 van het Waalse afvalstoffendecreet.

Artikel $44, \S 3$ van het Waalse afvalstoffendecreet.

Bocken, H., "Rechtstreekse verzekeringen ten behoeve van derden en andere wisseloplossingen vwor aansprakelijkheid en aansprakelijkheidsverzekering. Een typologie", in "Liber Amicorum René Van Gompel", l.c., 29.

Bocken, H., "Altematives to liability and liability insurance for the compensation of pollution damages", o.c., 5. 
geval hoeft het slachtoffer enkel te bewijzen dat hij schade heeft geleden en dat het desbetreffende fonds dat type schade dekt; het slachtoffer is met andere woorden verlost van de noodzaak om (zware) procedures in te stellen. De uiteindelijke compensatie van het slachtoffer zal dan ook hoofdzakelijk worden bepaald door het type schade dat door het fonds wordt vergoed ${ }^{100}$.

Na deze algemene analyse van een aantal verschillende type fondsen, wordt in de volgende paragrafen aandacht besteed aan de voorstellen van de Interuniversitaire Commissie tot Herziening van het Milieurecht in het Vlaamse Gewest ( $\$ 2.1 .2)$, aan het Nederlandse Fonds Luchtverontreiniging ( $\$ 2.1 .3)$ en aan de voorstellen, eveneens in Nederland, voor de introductie van een algemeen milieuschadefonds ( $(2.1 .4)$.

\subsubsection{De voorstellen van de Commissie Bocken}

Hierboven werden de voorstellen van de Interuniversitaire Commissie tot Herziening van het Milieurecht in het Vlaamse Gewest (beter bekend onder de naam "Commissie Bocken") reeds besproken, ten aanzien van het aansprakelijkheidsregime ${ }^{101}$. De Commissie Bocken heeft ook voorstellen uitgewerkt ten aanzien van de compensatie van milieuschade ${ }^{102}$.

Een nieuw mechanisme voor schadevergoeding van milieuschade dient volgens de Commissie Bocken te voldoen aan een aantal objectieven: de oplossing van het insolventieprobleem, de opvulling van mogelijke tekorten van het aansprakelijkheidsrecht, de creatie van procedures voor de snelle en goedkope afhandeling van vorderingen en de bescherming van bedrijven door het spreiden van de verliezen voortvloeiend uit milieuongevallen ${ }^{103}$.

Voor de uitwerking van deze objectieven baseert de Commissie Bocken zich op een aantal algemene beleidsopties. Ten eerste dient de vergoeding van slachtoffers van milieuverontreiniging te worden gegarandeerd; de Commissie acht het billijk dat de schade wordt gedragen door degene die het risico creëert. De aansprakelijkheidsregel moet in de tweede plaats garanderen dat de schade, overeenkomstig het vervuiler-betaalt beginsel, wordt toegerekend aan de vervuiler en niet ten laste valt van de gemeenschap. Ten derde dient een schadevergoedingssysteem de exploitant te goeder trouw in staat te stellen om de financiële gevolgen van zijn aansprakelijkheid te behecrsen; ook met de belangen van de vervuiler dient bijgevolg rekening te worden gehouden ${ }^{104}$. De Commissie Bocken heeft deze opties ingevuld door een brede waaier aan voorstellen uit te wer$k{ }^{105}$. Deze voorstellen hebben zowel betrekking op het toepasselijke aansprakelijkheidsregime als op het ter beschikking stellen van financiële zekerheden.

Er wordt voorgesteld om een stelsel van foutloze aansprakelijkheid in te voeren voor schade of milieuverstoring veroorzaakt door emissie van verontreinigende stoffen, organismen en energie (art. 9.1.3). Zoals blijkt neemt de Commissie de emissie van verontreinigingsfactoren als aankno-

106)

Bocken, H., "Alternatives to liability and liability insurance for the compensation of pollution damages", o.c., 5 .

10i Zie \$2.3.1.2 van hoofodstuk 4 .

Het onderzoekswerk werd gebundeld in Bocken, H., Ryckbost, D. en Deloddere, S., "Voorontwerp Decreet Milieubeleid", l.c.; zic ook Bocken, H., "The Compensation of Ecological Damage in Belgium", in Wetterstein, P., "Harm to the Environment", l.c., 143-158.

103

Bocken, H., "Deficiencies of the system of liability and liability insurance as a mechanism for the indemnification of environmental damage suffered by individual victims", o.c., 141 .

Bocken, H., Ryckbost, D. en Deloddere, S., "Voorontwerp Decreet Milieubeleid", l.c., 840.

Bocken, H., Ryckbost, D. en Deloddere, S., "Voorontwerp Decreet Milieubeleid", l.c., 842 e.v. 
pingspunt ${ }^{106}$. Tegelijk word̉t een onderscheid gemaakt tussen schade aan individuele belangen en schade aan collectieve goederen (milieuverstoring) ${ }^{107}{ }^{108}$. Indien meerdere personen aansprakelijk zijn voor eenzelfde schade of milieuverstoring, zijn zij hoofdelijk aansprakelijk (art. 9.1.9). Degene die de schade van het slachtoffer heeft vergoed, beschikt desgevallend over een regresrecht tegen de medeveroorzakers. De aansprakelijkheid is niet exclusief in die zin dat geen afbreuk wordt gedaan aan de rechten die de schadelijder op een andere rechtsgrond kan uitoefenen tegen de aansprakelijke of tegen derden (art. 9.1.13) ${ }^{109}$.

Teneinde de mogelijke insolvabiliteit van de aansprakelijke op te vangen, wordt aan bepaalde exploitanten de verplichting opgelegd om een financiële zekerheid te stellen, tot waarborg van diens aansprakelijkheid (art. 9.1.16). Zonder een voorkeur te uiten voor de ene of andere vorm stelt de Commissie verschillende mogelijkheden voor ${ }^{110}$ :

- financiële zekerheden uit het eigen vermogen van de verzekerde: bewijs van gezonde financiële situatie van het bedrijf, zakelijke zekerheden, de consignatie van een borgsom;

- financiële zekerheden waarbij beroep wordt gedaan op de financiële middelen van een derde: borgstelling en bankgarantie;

- spreiding van de financiële lasten over verschillende potentiële vervuilers: de aansprakelijkheidsverzekering en een garantiefonds (naar het model van het IOPC-Fonds) ${ }^{111}$;

- vergoeding ten laste van de overheid ${ }^{\mathrm{t} 2}$.

De auteurs van het voorontwerp stellen dat geen verplichte aansprakelijkheidsverzekering wordt ingevoerd omdat weliswaar de financiële zekerheid verplicht is maar dat deze van uiteenlopende aard kan zijn. Verzekering is hierbij slechts één van de vele mogelijkheden ${ }^{113}$.

Een belangrijk nieuw element dat door de Commissie Bocken expliciet werd voorgeschreven, is de mogelijkheid tot het stellen van een borgsom bij wijze van financiële zekerheid. Hier wordt overigens voorzien in de oprichting van de Waarborgkas Milieuschade; deze kas wil tegemoet komen aan de geringe beschikbaarheid of de beperkingen van bijvoorbeeld een klassieke aansprakelijkheidsverzekering. $\mathrm{Bij}$ het in 1998 uitgevoerde onderzock naar de haalbaarheid van een nieuw vergoedingssysteem voor milieuschade is wel gebleken dat de bedrijfswereld niet meteen

Een emissie wordt gedefinieerd als "elke inbreng door de mens van verontreinigingsfactoren in de atmosfeer, de bodem of het water"; onder verontreinigingsfactoren wordt verstaan: "vaste stofien, vloeistoffen, gassen, mirco-organismen, energievormen zoals warmte, stralingen, geluid en andere trillingen" (artikel 1.1.2 van het voorontwerp).

Het belang van het onderscheid bestaat erin dat ten aanzien van individuele schade zowel het herstel in natura als schadevergoeding kan worden gevorderd; bij milieuverstoring kunnen enkel de kosten van het herstel in natura worden gevorderd (zie de artikelen 9.1 .7 en 9.1 .8 van het voorontwerp decret). Bij ecn vervolgonderzoek, uitgevoerd in 1998, werd erop gewezen dat in de praktijk het belang van het begrip milieuverstoring, althans wat het Vlaamse Gewest betreft, beperkt zal zijn. Zie Schutyser, F., Deketelaere, M. en Deketelaere, K., "Onderzoek naar de opportuniteit en de haalbaarheid van een vernieuwd vergoedingssysteem voor milieuschade", Milieu- en Energierecht, 1999, nr. 6-7, 149.

Zoals eerder reeds aangetoond verwarren de auteurs de begrippen "kanalisatie van aansprakelijkheid" en "risicoaansprakelijkheid". Cfr. supra bij de bespreking van de kanalisatie van aansprakelijkheid, in $\$ 2.3 .1 .2$ van hoofdstuk 4.

Enkel in bepaalde gevallen, met name betreffende de bodemsaneringverplichting stelt de Commissie dat de warborgsom de meest aangewezerı oplossing is (Bocken, H., Ryckbost, D. en Deloddere, S., "Voorontwerp Decreet Milieubeleid", l.c., 966). Cfr. infra in $\$ 3$ van hoofdstuk 12.

112 Hierbij verwijst de Commissie uitdrukkelijk naar de nucleaire aansprakelijkheidswetgeving, met nane naar het Aanvullend Verdrag van Brussel (Bocken, H., Ryckbost, D. en Deloddere, S., "Voorontwerp Decreet. Milieubeleid", l.c., 965-966). 
gewonnen is om een bankgarantie te stellen als vorm van financiële zekerheid is, gelet op de hiermee gepaard gaande kosten ${ }^{114}$.

Wat ook opvalt, is dat de Commissie zich niet op algemene wijze heeft uitgesproken over de hoogte van de door de exploitant te stellen financiële zekerheid. Het komt toe aan de Vlaamse Regering om, in functie van de gevaren voor mens en milieu, de hoogte van deze bedragen vast te leggen.

Onder bepaalde voorwaarden kan een bona fide exploitant zijn aansprakelijkheid beperken, met name indien hij door de oprichting van of de toetreding tot een vrijwillig garantiefonds de zekerheid biedt dat slachtoffers effectief zullen worden vergoed (art 9.1.24) ${ }^{115}$. Deze situatie komt erop neer dat in feite een beperkingsfonds in het leven wordt geroepen. Bij de aanvang van elk kalenderjaar zal de exploitant dienen te bewijzen dat hij over een fonds beschikt ter dekking van zijn aansprakelijkheid, vooraleer hij zich op een beperking van de aansprakelijkheid zal kunnen beroepen. Dit zou een stimulans moeten leveren voor de exploitanten om bijkomende onderlinge verzekeringsmechanismen te creëren ${ }^{16}$. De voorstellen die de Commissie hier heeft uitgewerkt, zijn in belangrijke mate geïnspireerd op de compensatiemechanismen ter zake van schade door olieverontreiniging op zee (met name TOVALOP en CRISTAL) ${ }^{117}$.

Voor gevallen waarin het slachtoffer zijn schade niet kan verhalen op de aansprakelijke, bijvoorbeeld omdat deze niet kan worden geïdentificeerd of omdat hij insolvabel is, voorziet de Commissie Bocken in een oplossing buiten het civiele aansprakelijkheidsrecht ${ }^{118}$ : overeenkomstig artikel 9.2.2 van het voorontwerp decreet milieubeleid kan het slachtoffer in bepaalde gevallen aanspraak maken op een vergoeding van het Fonds voor Preventie en Sanering inzake Leefmilieu en Natuur (MINA-fonds) ${ }^{119}$. Op deze manier wordt volgens de Commissie Bocken de vergoeding ten laste gelegd van deze vervuilers die door het betalen van heffingen bijdragen hebben betaald aan het MINA-Fonds ${ }^{120}$. Opvallend is vooral dat uitdrukkelijk wordt gekozen voor een soepele procedure: een slachtoffer zal een rechtstreekse vordering kunnen indienen bij het Vlaamse Gewest indien bij de behandeling van zijn vordering voor de rechtbank een aanzienlijke vertraging is te verwachten. Artikel 9.2.2 van het Voorontwerp verwoordt dit als volgt: "... voorzover niet binnen redelijke termijn vergoeding kan worden bekomen ...". Uiteraard zijn de vorderingen die via deze weg kunnen worden ingediend aan beperkingen onderworpen. Zo is de jaarlijkse tussenkomst die het Vlaamse Gewest uitkeert, beperkt is tot 500 miljoen BEF en wordt geen schadevergoeding toegekend voor schade van minder dan $10.000 \mathrm{BEF}^{121} 122$.

114 Schutyser, F., Deketelaere, M. en Deketelaere, K., "Onderzoek naar de opportuniteit en de haalbaarheid van een vernieuwd vergoedingssysteem voor milieuschade", o.c., 161.

115 Op deze wijze wordt volgens de auteurs van het voorontwerp ook rekening gehouden met de belangen van de aansprakelijke (Bocken, H., Ryckbost, D. en Deloddere, S., "Voorontwerp Decreet Milieubeleid", l.c., 928).

Bocken, H., Ryekbost, D. en Deloddere, S., "Voorontwerp Decreet Milieubeleid", l.c., 932.

Deze mechanismen werden inmiddels opgedoekt, cfr. supra, in $\S 4$ van hoofdstuk 12.

Bocken, H., Ryckbost, D. en Deloddere, S., "Voorontwerp Decreet Milieubeleid", I.c., 935.

Dit Fonds heeft als doel het hergroeperen van de geldmiddelen die het Vlaams Gewest aanwendt voor haar beleid te zake van de preventic, de bescherming, de administratie, het beheer en de sanering van het leefmilieu (De Pue, E., Lavrysen, L. en Stryckers, P., "Milicuzakboekie 2000", l.c. , 26,3). Dit Fonds werd opgericht bij Decreet van 23 januari 1991 (B.S., 2 februari 1991, meermaals gewijzigd). Verder uitvoering aan dit decreet werd gegeven in het Besluit van 24 juli 1991 (B.S. 27 november 1991, meermaals gewijzigd).

Bocken, H., Ryckbost, D. en Deloddere, S., "Voorontwerp Decreet Milicubeleid", I.c., 844.

Artikel 9.2.2, $\$ \S 3$ en 5 van het Voorontwerp Decreet Milieubeleid. 
De voorstellen van de Commissie Bocken ter zake van de compensatie van schade die niet via het aansprakelijkheidsrecht kan worden vergoed, zijn ten dele geïnspireerd op het Nederlandse Fonds Luchtverontreiniging. Dit zal blijken uit onderstaande analyse.

\subsubsection{Het Nederlandse Fonds Luchtverontreiniging}

Op basis van de Nederlandse Wet Luchtverontreiniging van 26 november 1970 werd het Fonds voor Luchtverontreiniging opgericht. De directe aanleiding voor de oprichting van dit fonds was de schade die een aantal tuinders had geleden door smog ${ }^{123}$. Later werd het Fonds overgenomen door de Wet Algemene Bepalingen Milieuhygiëne (WABM) ${ }^{124}$, die inmiddels heeft plaats gemaakt voor de Wet Milieubeheer ${ }^{125}$. De huidige juridische bepaling van het Fonds is dan ook terug te vinden in artikel 15.25 van de Wet Milieubeheer. Op het Fonds kan een beroep worden gedaan door:

"... een ieder dic ten gevolge van plotseling optredende luchtverontreiniging schade heeft geleden welke redelijkerwijs niet of niet geheel tc zijnen laste behoort te blijven ...".

Uit deze omschrijving kunnen reeds een aantal voorwaarden worden afgeleid ten aanzien van het toepassingsgebied van het Fonds. Ten eerste moct sprake zijn van luchtverontreiniging. Schade door verontreiniging van water of bodem kan niet via deze weg worden gecompenseerd. Ten tweede moet deze verontreiniging plotseling zijn opgetreden. Dit is de zogenaamde evenementsvereiste van het Fonds Luchtverontreiniging. Schade ingevolge ecn continue blootstelling komt bijgevolg niet in aanmerking. Ten derde zal in principe alleen schade die redelijkerwijs niet ten laste van het slachtoffer dient te vallen, voor vergoeding in aanmerking komen. Het is dan ook mogelijk dat het Fonds slechts een gedeeltelijke schadeloosstelling zal betalen en dat een deel van de schade ten laste van het slachtoffer zal blijven ${ }^{126}$. Daarenboven bepaalt artikel $15.26 \mathrm{Wm}$ dat de geleden schade minimaal 500 gulden moet bedragen. In een maximumlimiet is niet voorzien.

Van belang is dat het Fonds een subsidiair karakter heeft ${ }^{127}$. Schade door luchtverontreiniging dient in eerste instantie te worden verhaald op degene die aan de oorzaak ligt van de verontreiniging. Enkel indien de veroorzaker niet kan worden gevonden, of indien om andere juridische reden geen vergoeding mogelijk is via het aansprakelijkheidsrecht, kan een beroep worden gedaan op het Fonds Luchtverontreiniging ${ }^{128}$.

Tegelijk zal geen vordering lastens het MINA-fonds mogelijk zijn indien, ter zake van schade tengevoige van dood en lichamelijk letsel, aanspraak kan worden gemaakt op cen uitkering overeenkomstig de wet op de arbeidsongevallen, de wet op de beroepsziekten of de wet op de ziekte- en invaliditeilsverzekering (artikel 9.2.2, $\$ 6$ van het Voorontwerp Decreet Milieubeleid). Ook een regres lastens het MINA-Fonds van een uitkering op basis van de genoemde wetten, zal niet mogelijk zijn. Tenslotte zal geen vordering bij het MINA-Fonds kunnen worden ingediend indien een vordering openstaat ingevolge de toepassing van intemationale verdragen.

Bakker, M.H.C., "Het Fonds Luchtverontreiniging", in Bocken, H. en Ryckbost, D. (ed.), Verzekering van milieuschade, Gent, Story Scientia, 1991, 347.

Wet van 13 juni 1979, Stb., 442.

Wet van 2 juli 1992, Stb., 414.

Bakker, M.H.C., "Het Fonds Luchtverontreiniging", in Bocken, H. en Ryckbost, D. (ed.), "Verzekering van milieuschade", l.c., 349-350.

127 Hulst, E.H., "Grondslagen van milieuaansprakelijkheid", l.c., 540.

128 Bakker, M.H.C., "Het Fonds Luchtverontreiniging", in Bocken, H. en Ryckbost, D. (ed.), "Verzekering van milieuschade", l.c., 350. 
Ten aanzien van verzekeringen werd het volgende systeem uitgewerkt ${ }^{129}$. Een persoon die een verzekeringsdekking heeft afgesloten dient zich in eerste instantie tot zijn verzekeraar te richten. Het deel van de schade dat niet via deze dekking wordt vergoed, komt in aanmerking voor vergoeding door het Fonds - uiteraard op voorwaarde dat de drempel van 500 gulden wordt bereikt en dat eveneens aan de andere voorwaarden is voldaan. Een persoon die niet is verzekerd, kan zich rechtstreeks tot het Fonds richten, ook al had hij zich kunnen verzekeren. Verzekeraars daarentegen kunnen geen beroep doen op het Fonds.

Volledigheidshalve wordt crop gewezen dat het Fonds regres kan uitoefenen tegen de dader, maar dat het van deze mogelijkheid alsnog geen gebruik heeft gemaakt ${ }^{130}$.

Tot 1992 haalde het Fonds haar inkomsten voornamelijk uit heffingen op brandstof ${ }^{i 31}$; in feite was het Fonds dan ook een toepassing van het beginsel dat de vervuiler betaalt. $\mathrm{Na}$ de invoering van de verbruiksbelasting op milieugrondslag wordt het Fonds gefinancierd uit algemene midde$\operatorname{len}^{132} 133$.

Het is opmerkelijk dat van in het begin discussie heeft bestaan over de rechtsgrond en de functie van het Fonds Luchtverontreiniging: bepaalde auteurs zijn van mening dat het Fonds een uitgesproken privaatrechtelijke grondslag heeft ${ }^{134}$; andere dichten het Fonds een publiekrechtelijke grondslag to $e^{135}$ en nog anderen spreken van een gemengd karakter ${ }^{136}$. Doordat het Fonds een aanvulling vormt op het aansprakelijkheidsrecht, ligt het op het eerste gezicht voor de hand dat een privaatrechtelijke grondslag wordt aanvaard. Anderzijds wordt door de evenementsvereiste en door de uitsluiting van de verzekerde schade niet alle schade vergoed, wat eerder duidt op een publiekrechtelijke grondslag. Aan deze discussie wordt in dit kader geen verdere aandacht gegeven; hier wordt volstaan met de kanttekening dat de onzekerheden die uit de discussie voortkomen een consistent beleid zeker niet ten goede komen ${ }^{137}$.

Uit een recente studie in opdracht van het Ministerie van de VROM is gebleken dat het Fonds voornamelijk uitkeringen heeft verricht ten gevolge van schade geleden door de agrarische sec$\operatorname{tor}^{138}$. De meerderheid van de ingediende vorderingen (met name $55 \%$ ) had namelijk betrekking

129 Faure, M., Hartlief, T. en Hertoghs, M., Evaluatie van het Fonds Luchtverontreiniging. Op verzoek van het Ministerie van Volkshuisvesting. Ruimtelijke Ordening en Milieubeheer, Sdu Uitgevers, Den Hasg, 2000,31 .

130 Ibidem, 69 .

131 Bocken, H., "Systèmes alternatifs pour l'indemnisation des dommages dus à la pollution", o.c., 11714 , 5.

132 Wet van 24 juni 1992, Stb., 317, vervangen door de Wet belastingen op milieugrondslag van 23 december 1994, Stb., 923.

i3 Overeenkomstig artikel $15.24 \mathrm{Wm}$ worden de inkomsten van het Fonds aangevuld door het batig saldo van de laatste rekening van het Fronds en door andere inkomsten.

134 Polak, J.M., "Vergoeding van schade door luchtverontreiniging", in Hijmans van den Bergh, L.J. en Van Zeben, C.J. (red.), Met eerbiedigende werking. Hijmans van de Bergh bundel, Kluwer, Deventer, 1971, 203 e.v.

Stroink, F., "Nogmaals het Fonds luchtverontreiniging", Milieu en Rechl, 1974, 122; Poortinga E. en Poortinga, G., "Het Fonds Luchtverontreiniging en zure regen", Milieu en Recht, 1986, 135 e.v.

Langelaar, K., "Het Fonds Luchtverontreiniging", Milieu en Recht, 1974, 76.

Ook in die zin Faure, M., Hartlief, T. en Hertoghs, M., "Evaluatie van het Fonds Luchtverontreiniging", l.c., 42.

Faure, M., Hartlief, T. en Hertoghs, M., "Evaluatie van het Fonds I_uchtverontreiniging", l.c, 140. Een samenvatting van de conclusies van dit rapport is verschenen in Milieu en Rechl, 2000, nr. 3, 6469. 
op gewasschade; $37 \%$ van de ingediende vorderingen had betrekking op lakschade ${ }^{139}$. De vorderingen inzake gewasschade waren overigens vrij succesvol, aangezien op de 602 ingediende vorderingen er 438 of $72 \%$ werden toegewezen ${ }^{140}$. Deze cijfers geven meteen een zeer belangrijke indicatie met betrekking tot de door het Fonds uitgekeerde schadesoort. Zuiver ecologische schade komt niet voor vergoeding in aanmerking ${ }^{141}$; gezondheidsschade al evenmin. Het Fonds Luchtverontreiniging is dus geen milieuschadefonds, noch een algemeen fonds ter bescherming van slachtoffers. De conclusie van het onderzoek is dan ook dat het Fonds kan worden beschouwd als een agrarisch fonds ${ }^{142}$ en dat het enkel welbepaalde soorten van schade vergoedt.

Ten aanzien van de bedragen die door het Fonds worden beheerd en uitgekeerd, dient te worden vastgesteld dat het Fonds slechts een bescheiden impact heeft. Gemiddeld is jaarlijks iets meer dan 200.000 NLG uitgekeerd (3,6 miljoen BEF of 91.000 euro $)^{143}$. Dit lage cijfer heeft een allesbehalve positieve invloed op de kosten-batenanalyse van het Fonds: aangezien ook de administratieve kosten van het Fonds ongeveer 200.000 NLG per jaar bedragen, betekent dit dat voor elke gulden die werd uitbetaald, er eenzelfde bedrag voor de administratieve afwikkeling in rekening dient te worden gebracht. Van belang hierbij is vooral dat de gemiddelde afwikkeling van een dossier door het Fonds Luchtverontreiniging twee jaar in beslag neemt ${ }^{144}$. Het is met andere woorden lang niet zeker of het Nederlandse Fonds Luchtverontreiniging erin slaagt een snel en efficiënt alternatief compensatiemechanisme te bieden in vergelijking met het aansprakelijkheidsrecht. De knelpunten die een vergoeding van de geleden schade door het Fonds in de wey staan, zijn precies dezelfde als de problemen van het aansprakelijkheidsrecht ${ }^{145}$.

De discussie met betrekking tot het nut van het Fonds Luchtverontreiniging is in Nederland uitermate actucel, aangezien wordt gedacht aan de creatie van een meer algemeen milieuschadefonds. Eén van de opties die in het Evaluatierapport inzake het Fonds Luchtverontreiniging worden naar voren geschoven om de effectiviteit ervan te verhogen, is namelijk de integratie van het Fonds Luchtverontreiniging in een algemeen milieuschadefonds.

\subsubsection{De toekomst: naar een algemeen milieuschadefonds?}

In 1994 werd in opdracht van het Ministerie VROM onderzoek verricht over de wenselijkheid en de mogelijkheid tot invoering van een algemeen milieuschadefonds ${ }^{146}$. De hoofdconclusie van dit rapport luidt dat er een rol is weggelegd voor een algemeen milieuschadefonds, dat als vangnet dient op te treden voor slachtoffers van milieuschade die deze schade niet via een andere wcg kunnen verhalen. Naast deze vangnetfunctie zou een dergelijk fonds twee andere doelen hebben:

Deze cijfers hebben betrekking op de periode 1972-1998 en zijn weergegeven in het evaluaticrapport (Faure, M., Hartlief, T. en Hertoghs, M., "Evaluatic van het Fonds Luchtverontreiniging", l.c., 65). Inzake lakschade werd $37 \%$ van de vorderingen toegewezen.

141 Carette, A., "Herstel van en vergoeding voor aantasting aan niet-toegeëigende milieubestanddelen", l.c., 476 c.v.

Faure, M., Hartlief, T. en Hertoghs, M., "Evaluatie van het Fonds Luchtverontreiniging", l.c. 95.

Faure, M., Hartlief, T. en Hertoghs, M., "Evaluatie van het Fonds Luchtverontreiniging", l.c., 62-63.

Slechts $17 \%$ van de dossiers wordt binnen een jaar afgehandeld; $36 \%$ van de dossiers wordt binnen de twee jaar afgehandeld; $13,5 \%$ binnen 3 jaar en $24,4 \%$ binnen vier jaar.

Faure, M.G. en Hartlief, T., "Een schadefonds als altematief voor aansprakelijkheid en verzekering?", o.c., 227.

146

Hafkamp, W.A., Gilhuis, P.C., Hofland, J., Verschuuren, J.M. en de Putter, P.J., Een Milieuschadefonds in Nederland: een onderzoek naar de mogelijkheden, VROM, Publikatiereeks milieubeheer, nr. 1994/3. 
het zou kunnen fungeren als aanvulling op het bestaande milieubeleidsinstrumentarium en het fonds zou een signaleringsfunctie kunnen hebben voor de overheid ${ }^{147}$.

Het rapport maakt ten aanzien van milieuschade een onderscheid tussen schade aan het milieu en schade via het milieu. Met schade aan het milieu wordt de milieukwaliteitsvermindering bedocld; met schade via het milieu wordt de schade bedoeld die via verontreiniging aan de mens en zijn bezittingen wordt veroorzaakt ${ }^{148}$. Volgens het rapport kan een algemeen milieuschadefonds een rol vervullen ten aanzien van schade aan het milieu waarvoor via de rechtbank geen compensatie kan worden verkregen. Het betreft gevallen waar de schade niet individualiseerbaar is, wanneer geen economisch nadeel wordt geleden en wanneer de schade niet of nauwclijks is tc herstel$\mathrm{len}^{149}$. Met name ecologische schade (schade aan het milieu) komt op deze wijze voor vergoeding in aanmerking ${ }^{150}$. Maar het fonds dient volgens het rapport eveneens tussen te komen in gevallen waar schade via het milieu, niet kan worden vergoed.

Volgens het rapport moeten zowel natuurlijke personen als rechtspersonen vorderingen kunnen indienen bij het milieuschadefonds, inclusief de overheid en milieuorganisaties. Voor zuivere ecologische schade kunnen milieuorganisaties enkel een vordering indienen indien zij reeds meer dan vijf jaar bestaan ${ }^{151}$. Daarentegen is het volgens de auteurs van het rapport niet wenselijk dat verzekeringsmaatschappijen en andere partijen die van het verzekeren van milieuschade hun bedrijf maken, een beroep zouden kunnen doen op het fonds.

Voor wat de financiering van een in te voeren algemeen milieuschadefonds betreft, stelt de studic dat de financiële lasten bij voorkeur dienen te worden gedragen door de potentiële veroorzakers van de schade. Maar omdat uiteindelijk iedereen veroorzaker is van de schade die aan het milieu ontstaat, dient het fonds in hoofdzaak te worden gefinancierd door algemene middelen. Aangezien dit een beperking inhoudt op het beginsel dat de vervuiler betaalt, zou dit via een actief verhaalsbeleid kunnen worden gecorrigeerd ${ }^{152}$. Daarnaast zouden ook rente van het vermogen van het fonds, de opbrengsten uit dwangsommen en bestuurlijke boetes en de premies voor een verplichte milieuaansprakelijkheidsverzekering als bijkomende financieringsmechanismen kunnen worden aangewend ${ }^{153}$. De onderzoekers pleiten er inderdaad voor om naar het voorbeeld van het Waarborgfonds Motorverkeer een verplichte milieuaansprakelijkheidsver/ckering in te voeren, waarbij een deel van de te betalen premie in het algemene milieuschadefonds wordt gestort.

Toch blijken nog heel wat vragen open omtrent de invoering van dit fonds. Met name de verhouding tussen een algemeen milieuschadefonds en andere compensatiemechanismen is in de studie niet meteen aan bod gekomen. Hierop is gewezen zowel tijdens een symposium dat naar aanleiding van het onderzoeksrapport werd georganiseerd ${ }^{154}$, als door Hulst ${ }^{155}$.

167 Hafkamp, W.A. e.a., "Een Milieuschadefonds in Nederland", l.c., 115

Zie ook Koeman, N.S.J., Ouwerkerk, W.J. en van Dunné, J.M., "Civielrechtelijke aansprakelijkheid voor milieuschade", l.c., 38.

149 Hafkamp, W.A. e.a., "Een Milieuschadefonds in Nederland", l.c., 37

130 Het rapport onderscheidt schade aan de res communes, schade aan de res nullius, schade door vermindering van de biodiversiteit en schade door aantasting van de intrinsieke waarde van het milieu (Hafkamp, W.A. e.a., "Een Milieuschadefonds in Nederland", l.c. 49).

Hafkamp, W.A. e.a., "Een Milieuschadefonds in Nederland", l.c., 72-75.

Hafkamp, W.A. e.a., "Een Milieuschadefonds in Nederland", l.c., 99-100.

Hafkamp, W.A. e.a., "Een Milieuschadefonds in Nederland", l.c., 101.

Ministerie van Volkshuisvesting, Ruimtelijke Ordening en Milieubeheer, Symposium Milieuschadefonds, Publikatiereeks Milieubeheer, nr. 1996/3. 
In een vervolgstudie werd de totale schade aan het Nederlandse milieu geschat op ten minste 200 miljoen NLG $\left(90,76\right.$ miljoen euro) ${ }^{156}$. Alleen al de kosten voor het bestrijden van verzuring, verrnesting en verdroging zouden oplopen tot meer dan 100 miljoen NLG ${ }^{157}$. Omdat hiervoor aanzienlijke financiële middelen nodig zijn, wordt aanbevolen dat de tussenkomst in eerste instantie wordt voorzien voor particulicren en voor bos- en natuurbeheerders.

Een essenticel punt bij de discussie omtrent het nut van een (milieu)schadefonds heeft betrekking op de voordelen die aan een Fonds worden toebedeeld. Uit het evaluatieonderzoek van het Nederlandse Fonds Luchtverontreiniging is alvast gebleken dat er ook belangrijke nadelen aan een fonds kunnen zijn verbonden. Hieruit kan uiteraard niet worden afgeleid dat een schadefonds in het algemeen geen nut kan of zal hebben; hiermee is enkel het nut aangetoond van een zorgvuldige belangenafweging vooraleer over te gaan tot de introductie van een schadefonds. In onderstaande paragraaf wordt een schadefonds vergeleken met andere compensatiemechanismen.

\subsubsection{Fonds ten aanzien van andere compensatiemechanismen}

Centraal in de rechtseconomische analyse van het ongevallenrecht staat de gedragsbeïnvloeding van de dader. De vraag rijst dan ook of de prikkelwerking die uitgaat van het aansprakelijkheidsrecht, behouden blijft dan wel wordt aangetast indien wordt gekozen voor een ander compensatiemechanisme. Bijkomend rijst de vraag welk compensatiemechanisme de voorkeur wegdraagt ter zake van de schade veroorzaakt door een catastroferisico: een schadefonds, een aansprakelijkheidsverzekering dan wel een first party dekking.

Het antwoord op deze vragen wordt hieronder gegeven door in eerste instantie stil te staan bij de invloed van collectieve compensatiemechanismen op de prikkels tot preventief gedrag $(\S 2.1 .5 .1)$. Vervolgens worden de voordelen van een fonds en van een aansprakelijkheidsverzekering tegen elkaar afgewogen $(\S 2.1 .5 .2)$ en wordt gekeken welke de voordelen zijn van een first party dekking en van een directe verzekering $(\$ 2.1 .5 .3)$. De conclusie van de analyse wordt weergegeven in $\$ 2.1 .5 .4$.

\subsubsection{Invloed van collectieve compensatiemechanismen op de preventie van ongevallen}

Het aansprakelijkheidsrecht genereert prikkels in hoofde van potentiële schadeveroorzakers in de mate waarin het erin slaagt om het gedrag van deze daders te beïnvloeden. Dit zal met name het geval zijn wanneer de dader daadwerkelijk de kosten van de door hem veroorzaakte schade zal moeten dragen ${ }^{158}$. Worden de ongevalskosten ten laste gelegd van een ander, dan zal dit een negatieve invloed hebben op de prikkelwerking. Dit impliceert dat wanneer een schadefonds dienst doet als compensatiemechanisme, dit mechanisme eenzelfde prikkelwerking moet genereren opdat geen afbreuk zou worden gedaan aan de preventieve werking van het aansprakelijkheidsrecht. Met andere woorden: een schadefonds zal eveneens de preventie van ongevallen kunnen bewerkstelligen op voorwaarde dat het erin slaagt om de kosten van het schadeverwek-

155 Hulst, E.H., "De werkelijkheid rondom een algemeen milieuschadefonds, een commentaar", Tijdschrift voor Milieuaansprakelijkheid, 1995-6, 167 e.v.

156 Ministerie van Volkshuisvesting, Ruimtelijke Ordening en Milieubeheer, Milieuschade in Nederland. Een onderzoek naar de mogelijkheden en de noodzaak van een voorziening ter financiering van het herstel van ecologische schade, Publicatiereeks Milieubeheer, nr. 1998/9. Ministerie van Volkshuisvesting, Ruimtelijke Ordening en Milieubeheer, "Milieuschade in Nederland", l.c., 59. 
kend gedrag te leggen bij de persoon die een invloed heeft op het ongevalsrisico ${ }^{159}$. Dit betekent dat uitsluitend de potentiële daders een financiële bijdrage tot het fonds zullen moeten leveren ${ }^{160}$.

Doordat in onze analyse de preventiegedachte centraal staat, kunnen ook weinig argumenten worden gevonden om, ten aanzien van schade uit het verleden waarvoor geen voorzieningen waren getroffen, een beroep te doen op een collectief compensatiemechanisme. Het is evident dat eender welk mechanisme dat schade uit het verleden wil compenseren, geen enkele invloed meer kan uitoefenen op preventief vlak ${ }^{161}$. Indien de lasten uit het verleden worden ten laste gelegd van een bepaalde groep, dan impliceert dit een zekere vorm van willekeur: immers, het gedrag van degene die door de wetgever of door de rechter zou worden aangeduid om de schade uit het verleden ten laste nemen, houdt per definitie geen enkel verband met de schade. Op het eerste gezicht kan het verleidelijk zijn om, vanuit compensaticoogpunt, de schade uit het verleden ten lastc te leggen van een onderneming die veel winst maakt (deepest pocket-effect). Op deze wijze wordt een herverdeling van de rijkdom bewerkstelligd. Of dit ook vanuit maatschappelijk oogpunt zinvol is, is een andere zaak. Het is namelijk alsof bedrijven die inspanningen doen on die via een gedegen bedrijfsvoering zeer rendabel zijn, worden gestraft voor deze inspanningen. Omgekeerd zal de eigenlijke vervuiler die toevallig minder winstgevend is in principe geen enkele reden hebben om zijn gedrag te wijzigen. Indien de schade uit het verleden wordt ten laste gelegd van een specifieke groep, zal geen sprake zijn van een internalisering van de kosten, maar van een willekeurige herverdeling van de beschikbare middelen. Door deze herverdeling zullen negatieve economische neveneffecten ontstaan die niet opwegen tegen de mogelijke baten voortvloeiend uit de compensatie of het herstel van deze schade. Vandaar zal de minst slechte oplossing erin bestaan om de kosten voor schade uit het verleden waarvoor niemand aansprakelijk kan worden gesteld, ten laste te nemen van de algemene middelen en dus van de gehele bevolking ${ }^{162}$.

Een schadefonds dat aanknoopt bij het gedrag van een (groep) potentiële dader(s), zal daarom enkel betrekking kunnen hebben op toekomstige schade. Op dit vlak heeft een schadefonds cen nadeel ten overstaan van het aansprakclijkheidstecht. Het voordeel van het aansprakelijkheidsrecht bestaat erin dat het per definitie een "individueel mechanisme" is. Hiermee wordt bedocld dat in een gegeven ongevalsituatie de dader in principe een prikkel heeft om de maatschappelijke kosten van de door hen veroorzaakte ongevallen te vermijden. Hij zal niet moeten instaan voor het ongevalsrisico van anderen. Een schadefonds daarentegen is een collectief mechanisme. De vraag rijst bijgevolg of een collectief mechanisme erin zal slagen om eenzelfde, op het daadwerkelijke risico van elke individuele dader afgestemde, prikkel in het leven te roepen.

Deze problematiek is analoog aan de problemen waarmee een verzekeraar wordt geconfronteerd: het ter beschikking stellen van een verzekeringsdekking kan de prikkel van de dader aantasten. Teneinde problemen inzake onverzekerbaarheid te voorkomen, dienen het morele risico en de averechtse selectie te worden beperkt ${ }^{163}$. Bij een verzekeringsdekking dragen de correctiemechanismen van de verzekeraar (blootstelling aan eigen risico, risicodifferentiatie, ...) ertoe bij dat de verzekerde een voldoende prikkel heeft tot preventief gedrag. Dankzij dezc mechanismen wordt in feite weer aangekoppeld bij het individuele gedrag van de dader - wat essentieel is in het licht van de prikkelwerking van het aansprakelijkheidsrecht. Doordat schadefondsen net als verzeke-

Faure, M.G. en Hartlief, T. (red.), "Verzekering en de groeiende aansprakelijkhoidslast", l.c., 292.

Faure, M.G. en Hartlief, T., "Een schadefonds als altematief voor aansprakelijkheid en verzckering?", o.c., 215.

Faure, M.G. en Hartief, T. (red.), "Verzekering en de groeiende aansprakelijkhcidslast", l.c., 292-293.

Ook in die zin: Faure, M.G. en Hartlief, T. (red.), "Verzekering en de groeiende aansprakclijkheidslast", l.c., 300.

Cfr. supra, in $\S \S 2.2$ en 2.3 van hoofdstuk 9. 
ringen de collectivisering van het risico tot gevolg hebben, rijzen hier dezelfde problemen. Het is met andere woorden van belang dat een dader enkel bijdraagt tot het fonds in de mate waarin hij effectief tot het risico heeft bijgedragen. Indien een dader teveel moet bijdragen tot het fonds in verhouding tot zijn daadwerkelijke risico, dan zullen de goede risico's het fonds verlaten. Tegelijk zullen de inspanningen van voorzichtige daders niet worden beloond, wat uiteraard een negatieve invloed heeft op preventief vlak. Een positieve invloed op de prikkels veronderstelt tegelijk dat de potentiële daders die adequate preventiemaatregelen nemen hiervoor worden beloond en dat, omgekeerd, de "slechte risico's" méér zullen moeten bijdragen.

Een optimale preventie van een collectief vergoedingsmechanisme veronderstelt dus dat de bijdrageplicht wordt gekoppeld aan de mate waarin de bijdrageplichtige tot het risico heeft bijgedragen $^{164}$. Een dergelijke "fijn afgestemde" bijdrage veronderstelt op zijn beurt dat de instantie die instaat voor de collectivisering over voldoende informatie beschikt om een adequate risicodifferentiatie te kunnen doorvoeren, én dat deze differentiatie kan worden bereikt tegen zo laag mogelijke kosten. In de twee volgende subparagrafen worden enkele compensatiemechanismen met elkaar vergeleken, met name inzake de preventieve werking, de mogelijkheid tot het verzamelen van correcte informatie en de beheersing van de administratieve kosten.

\subsubsection{Schadefonds versus aansprakelijkheidsverzekering}

Aangezien een collectief compensatiemechanisme de maatschappelijke welvaart slechts zal verhogen indien het erin slaagt om een voldoende risicodifferentiatie door te voeren, en aangezien deze differentiatie op zijn beurt afhangt van de vraag wie over de juiste informatie beschikt, rijst de vraag welk compensatiemechanisme geacht kan worden over de juiste informatie te beschikken, c.q. deze informatie tegen de geringste kosten kan verwerven.

In het algemeen mag worden aangenomen dat degene die in de eerste plaats over de juiste informatie beschikt, de potentiële dader zelf is. Dit zal zeker het geval zijn voor wat betreft hoogtechnologische risico's.

Ook de verzekeraar zal uiteraard over de nodige informatie dienen te beschikken. Het behoort tot de kern van de verzekeringsactiviteit om informatie in te winnen, statistieken op te maken en hieraan de juiste consequenties te koppelen in termen van risicodifferentiatie en premieberekening. Een verzekeraar die zich op dat punt onderscheidt van andere verzekeraars, zal meteen over een competitief voordeel beschikken. Het is zeer twijfelachtig of een publiek fonds in staut zal zijn om dezelfde technieken te hanteren en of een fonds even bedreven is in het doorvoeren van een risicodifferentiatic. In de literatuur wordt dan ook over het algemeen aangenomen dat ter zake van informatieverwerving en de daarop gebaseerde risicodifferentiatie, er op een competitieve verzekeringsmarkt een voordeel bestaat in hoofde van de verzekeraar ${ }^{165}$. Dit betekent meteen dat wanneer er een aansprakelijkheidsverzekering beschikbaar is, er niet meteen een reden kan worden gevonden om te kiezen voor de creatie van een publiek beheerd fonds ${ }^{166}$.

Een schadefonds kan wel een oplossing bieden indien de verzekeringsmarkt onvoldoende concurrentieel is. In deze hypothese zal er slechts een beperkt aanbod zijn, en zullen de aangerekende premies te hoog liggen.

Faure, M., Hartlief, T. en Hertoghs, M., "Evaluatie van het Fonds Luchtverontreiniging", l.c., $10-11$. Faure, M.G. en Hartlief, T., "Een schadefonds als altematief voor aansprakelijkheid en verzekering?", o.c., 2.15-216.

Faure, M., Hartlief, T. en Hertoghs, M., "Evaluatie van het Fonds Luchtverontreiniging", l.c., 12-13. 
Met name inzake gespecialiseerde of hoog technologische risico's, zal het in een aantal gevallen ook voor de verzekeraar niet eenvoudig zijn om de juiste informatie in te winnen en vooral om het gedrag van de verzekerde te controleren. In dergelijke gevallen zullen de exploitanten zelf over de juiste informatie beschikken en zullen zij beter in staat zijn om elkaar te controleren en dus om het morele risico te beheersen ${ }^{167}$. In de praktijk bestaan er inderdaad mechanismen waarbij exploitanten elkaar controleren: ter zake van de aansprakelijkheid voor olieverontreiniging op zee nemen bijvoorbeeld de Protection and Indemnity Clubs een centrale positie in. In de Verenigde Staten heeft NEIL (Nuclear Electric Insurance Limited) eveneens een systeem uitgewerkt van wederzijdse controle ${ }^{168}$. Ervan uitgaande dat bijvoorbeeld bij het nucleaire risico de exploitanten beter in staat zijn om informatie te verwerven en uit te wisselen, werd in de literatuur door Faure en Skogh het voorstel geformuleerd om tussen de exploitanten een risicospreidingsovereenkomst af te sluiten ${ }^{169}$.

Wat de kostenbeheersing betreft, kan ervan worden uit gegaan dat een verzekeraar beter in staat zal zijn om de kosten van zijn compensatiemechanisme te beheersen. In de eerste plaats kan hij namelijk de kosten spreiden over gelijkaardige risico's. Daarenboven kan van een verzekeraar worden verwacht dat hij zijn kosten zo laag mogelijk zal willen houden, wil hij concurrentieel blijven. Een overheidsfonds zal niet tegen dezelfde lage kosten kunnen werken. De studie van het Nederlandse Fonds Luchtverontreiniging heeft bijvoorbeeld aangetoond dat voor elke uitgekeerde gulden, er eenzelfde bedrag aan administratieve kosten diende te worden in rekening gebracht ${ }^{170}$. Het is dan ook weinig aannemelijk om ervan uit te gaan dat de administratieve kosten van een overheidsfonds lager zouden liggen dan deze van een private verzekeraar ${ }^{171}$. Er kan dus worden aangenomen dat de transactiekosten van een verzekeraar lager zullen liggen ${ }^{172}$.

Vanuit economisch oogpunt zal er enkel een voorkeur bestaan voor compensatiefondsen indien de private verzekeringsmarkt niet of tegen minder gunstige voorwaarden in staat is om te voorzien in een vergoedingsregeling ${ }^{173}$. Indien de dekking in kwestie kan worden aangekocht op een competitieve verzekeringsmarkt, dan zullen er weinig redenen bestaan om alsnog een beroep te doen op een schadefonds. Voor een overheid zal het niet eenvoudig zijn om tegen geringe kosten de nodige informatie en expertise te verwerven. Een treffend voorbeeld hiervan werd gegeven in Zweden waar, ten tijde van het tot stand komen van de wet inzake milieuaansprakelijkheid van 1989 aanvankelijk was voorzien in de oprichting van een overheidsfonds ${ }^{174}$. Onder meer omwille van de expertise van verzekeraars, werd geoordeeld dat het zinvoller zou zijn dat een beroep werd ge-

Faure, M.G. en Hartief, T., "Compensation Funds versus Liability and Insurance for Remedying Environmental Damage", o.c., 323.

Beide mechanismen worden in de twee volgende hoofdstukken aan de orde gesteld.

Dit voorstel wordt afzonderlijk besproken in $\$ 3.2$ van dit hoofdstuk.

Cfr. supra, in $\$ 2.1 .3$ van dit hoofdstuk.

Faure, M.G. en Hartlief, T. (red.), "Verzekering en de groeiende aansprakelijkheidslast", I.c., 295.

Zie hierover Skogh, G., "The Transaction Cost Theory of Insurance: Contracting Impediments and Costs", Journal Of Risk and Insurance, 1989, 726-732.

Faure, M.G. en Hartlief, T. (red.), "Verzekering en de groeiende aansprakelijkheidslast", l.c., 293.

Zie met name Oldertz, C., "Swedish Environmental Damage Insurance. A new concept of insuring injuries or property damages, caused by environmental disturbances", in Bocken, $H$. en Ryckbost, D. (ed.), "Verzekering van Milieuschade," l.c, 367 c.v.; Andersson, U., "The Swedish Environmental Damage Insurance. Viewpoint of the government", in Bocken, H. en Ryckbost, D. (ed.), Verzekering van Milieuschade, Verslagboek van het Internationaal Colloqium gehouden te Gent op 14 en $15 \mathrm{de}$ cember 1989, Story Scientia, Gent, 1991, 388. 
daan op de verzekeringsmarkt, eerder dan een toevlucht te moeten nemen tot een overheidsfonds ${ }^{175}$.

Enkel in gevallen waar de dader zelf het beste in staat is om zijn risico te beoordelen, en waar het ook voor de verzekeraar niet eenvoudig zal zijn om tegen geringe kosten informatie te verwerven over het risico, kan het zinvol zijn dat de daders een collectief compensatiemechanisme in het leven roepen.

Omgekeerd kan worden geredeneerd dat ten aanzien van een onverzekerbaar risico en dus bij afwezigheid van een beschikbare aansprakelijkheidsdekking, de creatie van een fonds een goed alternatief zou kunnen bieden. Toch dient in eerste instantie in herinnering te worden gebracht dat het zeer moeilijk is om een objectieve kwalificatie te geven van een onverzekerbaar risico ${ }^{176}$. Daarenboven veronderstelt de keuze voor een fonds dat de traditionele problemen waarmee cen aansprakelijkheidsverzekeraar wordt geconfronteerd - zoals de causaliteitsproblematiek - niet aan de orde zijn bij een schadefonds, dan wel adequaat kunnen worden opgelost.

Problemen inzake causaliteitsonzekerheid kunnen leiden tot de onverzekerbaarheid van een risico. Het risico bestaat immers dat een persoon wordt aansprakelijk gesteld voor een schade die hij niet heeft veroorzaakt en waarvoor geen premie in rekening werd gebracht. Doordat er ook bij een fonds cen nauwe band dient te bestaan tussen de bijdrageplicht van de dader en het daadwerkelijke risico dat hij vertegenwoordigt, rijst hier dus hetzelfde probleem. Ook op dit punt is niet meteen duidelijk waarom een fonds een betere oplossing zou bieden dan het civiele aansprakelijkheidsrecht of dan een aansprakelijkheidsverzekering. Met name inzake milieurisico's zal een compensatiemechanisme dat is gerelateerd aan het aansprakelijkheidsrecht, uiteraard te kampen hebben met dezelfde problemen als het aansprakelijkheidsrecht zelf. Daarenboven kunnen misschien in het aansprakelijkheidsrecht zelf oplossingen worden gevonden, eerder dan meteen een fonds als altematief te introduceren. Zo kan bijvoorbeeld bij causaliteitsonzekerheid de invoering van een proportionele aansprakelijkheid een oplossing bieden ${ }^{177}$.

In deze paragraaf werd een schadefonds enkel afgewogen tegen een aansprakelijkheidsverzekering, dit wil zeggen een door de dader afgesloten verzekeringsdekking. Toch moet ermee rekening worden gehouden dat enerzijds het slachtoffer een verzekeringsdekking kan afsluiten (first party insurance) en dat anderzijds ook de dader een directe verzekeringsdekking kan kopen.

\subsubsection{First party verzekering en directe verzekering}

Een van de grote problemen bij een aansprakelijkheidsverzekering of een schadefonds, is de beheersing van het morele risico en van de averechtse selectie. Een remedie tegen dergelijkc problemen kan - deels - worden geboden door een first party verzekering.

Bij een first party dekking zal het voor de verzekeraar eenvoudiger zijn om het risico in te schatten omdat de begunstigde van de verzekeringsdekking de partij is waarmee de verzekeraar het verzekeringscontract heeft afgesloten. Dit betekent dat de verzekeraar op vrij eenvoudige wijze informatie zal kunnen vergaren over het te verzekeren risico. Er kan namelijk van uit worden gegaan dat de verzekeringsnemer degene is die de verzekeraar juist kan en moet informeren over

Zie hierover ook Carette, A., "Herstel van en vergoeding voor aantasting aan niet-toegeẻigende milieubestanddelen", l.c. $472-475$.

176 Cfr. supra, in $\$ 4$ van hoofdstuk 9.

177 Cfr. supra, in $\$ 3.2$ van hoofdstuk 8. 
de factoren die zijn risico beïnvloeden ${ }^{178}$; dit zal dan tuiteraard bij de premieberekening in aanmerking worden genomen. Dit impliceert tegelijk dat de verzekeraar in de mogelijkheid wordt gesteld om een voldoende risicodifferentiatic door te voeren ${ }^{179}$ en hierdoor het antiselectie probleem tegengaat. Een first party insurance kan dus een antwoord bieden op problemen van antiselectie ${ }^{180}$.

Het voordeel van een first party dekking ten aanzien van schade veroorzaakt door een industrieel ongeval, bestaat erin dat de verzekeraar informatie zal hebben over de potentiële schade (S) aangezien dit vaak een unilateraal ongeval is, kan ervan worden uitgegaan dat enkel de exploitant de probabiliteit zal kunnen beïnvloeden. Indien de verzekeraar er dan ook in slaagt om een correcte inschatting te maken van de probabiliteit, dan zal de premie de verwachte ongevalskosten zeer dicht benaderen.

Bij een third party insurance ontbreekt de mogelijkheid om op eenzelfde wijze een verfijnde polis uit te schrijven: de begunstigde van polis is voor de verzekeraar per definitie een derde. Bij het afsluiten van het verzekeringscontract is het niet mogelijk om informatie in te winnen over het risico dat deze derde vormt. Op zich kan de verzekeraar op statistische basis informatie inwinnen over het risico, maar het zal voor de verzekeraar nagenoeg onmogelijk zijn om het gedrag van de begunstigde te beïnvloeden. Volgens deze visie is het voor de verzekeraar ex ante moeilijk om in te schatten of deze derde een goed dan wel een slecht risico vormt ${ }^{181}$; bijgevolg bestaat er bij third party dekkingen een aanzienlijk risico dat de risicogroepen te groot worden, met alle gevolgen van dien op het vlak van de beheersing van de averechtse selectie.

Bij een directe verzekering die door de dader wordt afgesloten ten behoeve van derden, wordt ten dele tegemoet gekomen aan de problemen waarmee een aansprakelijkheidsverzekeraar wordt geconfronteerd. Centraal bij een aansprakelijkheidsverzekering staat de vaak moeilijk in te schatten evolutic van het aansprakelijkheidsrecht evenals de kosten van het afhandelen van de vorderingen (langdurige processen, hoge advocatenhonoraria etc.). Met name op dit punt kan een directo verzekering ten behoeve van derden een oplossing bieden: niet meer het aansprakelijkheidsrecht, maar wel de inhoud van de polis zal determinerend zijn bij de vraag of de verzekeraar een uitkering zal dienen te verrichten, c.q. of de schade van het slachtoffer zal worden gecompenseerd.

Zeker directe verzekeringen met een relatief beperkt toepassingsgebied - zoals de MSV polis kunnen voordelig zijn. Met een beperkt tocpassingsgebied wordt bedoeld dat deze polis enke] betrekking heeft bijvoorbeeld op de kosten van sanering aan de nabijgelegen percelen. Dit impliceert namelijk dat de verzekeraar niet enkel informatic kan inwinnen over de "dader" maar eveneens over het risico van de mogelijke slachtoffers. Naarmate de dekking van een directe verzekeringspolis algemener wordt, zal deze verzekeringsvorm worden geconfronteerd met analoge problemen als deze van de aansprakelijkheidsverzekeraar.

Zie ook, ten aanzien beroepsziekten Faure, M.G. en Hartlief, T. (red.), "Verzekering en de groeiende aansprakelijkheidslast", l.c., 302.

18 Faure, M., Hartlief, T. en Hertoghs, M., "Evaluatie van het Fonds Luchtverontreiniging", 1.c., 17-18.

180 Niet toevallig wordt er in Nederland bijvoorbeeld gepleit voor de invoering van een stelsel van firstparty verzekeringen ten aanzien van verkeersongevallen. Verkeersongevallen vormen cen schoolvoorbeeld van een bilaterale ongevalssituatie aangezien zowel dader als slachtoffer een invloed uitoefenen op het ongevalsrisico. Zie hierover verder Hartlief, T., "leder draagt zijn eigen schade", l.c., 68.

Faure, M., Hartlief, T. en Hertoghs, M., "Evaluatie van het Fonds Luchtverontreiniging", l.c., 18-19. 
Directe verzekeringen zullen in de regel tailor made polissen zijn. Dit impliceert dat nauw wordt aangesloten bij het daadwerkelijke risico van de verzekeringsnemer; de verzekeraar zal het gedrag van de verzekeringsnemer kunnen inschatten en dus ook kunnen beïnvloeden.

Het verschil tussen een directe verzekering en een aansprakelijkheidsverzekering enerzijds en een first party clekking anderzijds, bestaat erin dat bij de eerstgenoemde verzekeringsvormen degene die doorgaans als "dader" wordt beschouwd premieplichtig zal zijn, terwijl bij een first party dekking het "slachtoffer" de premie zal dienen te betalen.

Precies om die reden wordt een first party dekking soms als onrechtvaardig of onbillijk beschouwd $^{182}$. Het feit dat het slachtoffer de schade zal dienen te betalen heeft vanuit rechtseconomische optiek uitsluitend een invloed op de herverdeling van de beschikbare middelen; wat telt is dat er best hypotheses mogelijk zijn waarbij de maatschappelijke welvaart zal stijgen dankzij de introductie van een first party dekking.

Tegelijk zou kunnen worden betoogd dat een first party dekking ook vanuit rechtseconomische hoek niet zinvol zou zijn omdat het niet leidt tot een internalisatie van de negatieve externe effecten. Het is inderdaad correct dat het vanuit preventief oogpunt belangrijk is dat degene die een rechtstreekse invloed heeft op het ongevalsrisico, de nodige prikkels krijgt tot preventief gedrag. Maar het is uiteraard niet omdat een first party dekking wordt aangekocht door de slachtoffers dat dit meteen de onverantwoordelijkheid van de "dader" tot gevolg heeft. Een first party dekking stelt het aansprakelijkheidsrecht op geen enkele wijze buiten werking: een slachtoffer zal nog steeds over de mogelijkheid beschikken om de dader alsnog voor de rechtbank te brengen. Daarnaast zal de first party verzekeraar over een regresrecht tegen de dader beschikken. Tenslotte zullen ook het administratieve recht (vergunningverlening) en het strafrecht een positieve invloed kumnen uitoefenen op de prikkels tot preventief gedrag.

\subsubsection{Conclusie}

Concluderend kan worden gesteld dat schadefondsen die aansluiten op het aansprakelijkheidsrecht met dezelfde problemen kampen als het aansprakelijkheidsrecht en de aansprakelijkheidsverzekering. Het is dan ook onduidelijk wat op dit terrein de voordelen zouden zijn van een schadefonds vergeleken met een verzekeringsdekking.

Centraal in de discussie over het nut van een fonds ten overstaan van verzekeringen, staan de informatie en de kosten van het desbetreffende compensatiemechanisme. Enkel in een zeer beperkt aantal gevallen zal een fonds over betere informatie beschikken dan een op een competiticve markt actieve verzekeraar. Zelfs indien er bijvoorbeeld een gebrek aan concurrentie is op de verzekeringsmarkt, moet misschien eerst worden gekeken of het niet efficiënter is om concumentiebevorderende maatregelen te nemen, veeleer dan meteen een schadefonds in het leven te roepen.

Tegelijk mogen de voordelen van een first party dekking ten aanzien van de mogelijkheden tot risicodifferentiatie, niet uit het oog worden verloren. Het grote voordeel van een first party dekking bestaat erin dat de verzekeraar ex ante - en dus tegen geringe kosten - informatie kan inwin-

182. Indien slachtoffers een eigenschadeverzekering voor milieuschade zouden afsluiten, dan zou dit volgens Bockent onrechtvaardig zijn en strijdig met het beginsel van de vervuiler betaalt (Bocken, H., "Alternatives to liability and liability insurance for the compensation of pollution damages", o.c., 83; Boc. ken, H., "Systèmes alternatifs pour l'indemnisation des dommages dus à la pollution", o.c., 2). 
nen over het te dekken risico en dat hij dus relatief makkelijk de goede van de slechte risico's kan onderscheiden. Omdat bij third party dekkingen de verzekeraar per definitie nauwelijks gegevens in handen heeft over het risico, wordt de indeling in risicogroepen een stuk moeilijker.

Zowel een aansprakelijkheidsverzekering als een fonds dat aansluit op het aansprakelijkheidsrecht blijven hoogdrempelige mechanismen die een nadelige invloed hebben op de tertiaire ongevalskosten. Een directe verzekering of een first party verzekering kan daarentegen een handig middel zijn om bijkomende informatie in te winnen én om deze tertiaire ongevalskosten te drukken. Beiden hebben onmiskenbaar een gunstige invloed op de snelle afhandeling van de vorderingen. Voor wat betreft het terugdringen van de tertiaire ongevalskosten, zal vooral de first party dekking een oplossing kunnen bieden. Een directe verzekering zal enkel dit voordeel hebben indien de groep van begunstigden van deze dekking niet te groot is.

Indien er toch redenen zouden zijn voor de invoering van een fonds, is het zeer belangrijk dat initieel het aansprakelijkheidsrecht ongemoeid wordt gelaten, zodat de prikkels die van daaruit ontstaan, intact blijven. Vandaar kan voornamelijk een fonds met een waarborgfunctie zinvol zijn. In een aantal gevallen zal overigens de combinatie van een waarborg- en een voorschotfonds zinvol zijn ${ }^{183}$.

In deze paragraaf werd aandacht besteed aan de voor- en nadelen van een schadefonds als aanvulling op of als vervanging voor het aansprakelijkheidsrecht. Een tweede alternatief compensaticmechanisme dat zal worden besproken is de captive.

\subsection{De captive}

Een relatief nieuw compensatiemechanisme is de captive. De captives kwamen tot volle ontwikkeling in de VS gedurende de jaren vijftig, waar zij hoofdzakelijk worden gebruikt als een methode om risico's beter te kunnen financieren ${ }^{184}$. In 1994 bestonden wereldwijd ongeveer 3.000 captives $^{185}$; Van deze 3.000 captives waren er 700 van Europese oorsprong ${ }^{186}$. De captive begint ook op het Europese vasteland aan belang te winnen, hetgeen blijkt uit het feit dat meer en meer (relatief) grote Europese ondememingen die moeite hebben om bepaalde risico's op de conventionele verzekeringsmarkt te dekken, een eigen captive oprichten. Enkele voorbeelden daarvan zijn onder meer BMW, Lufthansa, Krupp en Siemens (in Duitsland) en Petrofina, Vandemoortele, Tractebe $^{187}$ (in België). In vergelijking met de VS is de markt voor captives in Europa nog relatief klein, maar zal deze markt de komende jaren ten volle tot ontwikkeling komen ${ }^{188}$.

Hieronder wordt in eerste instantic de captive gedefinieerd ( $\$ 2.2 .1)$ en worden de verschillende soorten captives besproken ( $\$ 2.2 .2$ ). Vervolgens worden de voor- en nadelen van de captive aan de orde gesteld $(\S 2.2 .3)$. Nadien wordt nagegaan welke impact een captive kan hebben op de

Faure, M. en Hartlief, T., "Een asbestfonds als alternatief voor de aansprakelijkheid van de werkgever?", o.c., 41.

Bawcut, P.A., Captive Insurance Companies. Establishmeni, Operation and' Management, 3 th edition, Woodhead-Faulkner, New York, 1991, 2.

Andere aantrekkelijke landen voor captives zijn de Cayman-eilanden, Guemsey, Vermont, Luxemburg. Barbados, het eiland Man, Ierland, Singapore en Hawai.

"Captives in Europe - from strength to strength", in Risk Financing Options, Risk and Insurance Research Group, 1994, 21.

Van den Abeele, Ph., "Doe het zelf", Belgian Business \& Industrie, oktober 1994, 29.

Bawcut, P.A., "Captive Insurance Companies", l.c., 9. 
conventionele verzekeringsmarkt $(\$ 2.2 .4)$. De conclusie van de analyse wordt weergegeven in $\S 2.2 .5$.

\subsubsection{Definiëring}

Een captive wordt over het algemeen gedefinieerd als een ondememing die als doel heeft om bepaalde of alle risico's van de moedermaatschappij of zusteronderneming te verzekeren of te herverzekeren ${ }^{189}$. De captive is dus een onderneming die wordt opgericht door een of meerdere commerciële of industriële moederondernemingen die actief zijn buiten de verzekeringssector, met het oog op het dekken van bepaalde of alle risico's van het moederbedrijf of van andere zustermaatschappijen van de industriële groep.

Een captive is bijgevolg een vorm van eigen verzekering omdat de eigenaar van de captive (cen deel van) haar cigen risico's verzekert en hierbij in mindere of meerdere mate beroep doet op de klassieke verzekerings- en/of herverzekeringsmarkt. Toch is het niet eenvoudig om een captive te omschrijven. Dit heeft voornamelijk te maken met het feit dat er vele verschillende soorten captives bestaan. waarvan het doel sterk kan variëren. De belangrijkste soorten captives worden hieronder besproken.

\subsubsection{Belangrijkste soorten captives}

In de literatuur wordt een onderscheid gemaakt tussen verschillende soorten captives al naargelang de grootte (paper-captive, small scale captive, en full scale captive), de eigendom (single parent dan wel multiple captive), de gedekte risico's (pure captive dan wel open market captive), de locutic (on-shore of offshore captive), de activiteiten en de vorm ${ }^{190}$. Het belangrijkste, en voor dit onderzoek meest relevante criterium is het onderscheid op basis van de activiteiten en de vorm van de captive. Volgende soorten captives kunnen worden onderscheiden: de herverzekeringscaptive ( $\$ 2.2 .2 .1$ ), de directe verzekcringscaptive ( $\$ 2.2 .2 .2$ ) en de rent-a-captive ( $\$ 2.2 .2 .3$ ).

\subsubsection{De herverzekeringscaptive}

Een herverzekeringscaptive herverzekert (een deel van) de risico's van de moederonderneming via een (andere) verzekeringsmaatschappij die de polis uitschrijft. Dit betekent dat de moederonderneming een polis onderschrijft op de conventionele verzekeringsmarkt en dat deze verzckeraar zich voor een belangrijke deel herverzekert bij de captive van haar cliënt; op deze wijze is de moedermaatschappij minder afhankelijk van de traditionele herverzekeringsmarkt ${ }^{191}$. Een klassieke verzekeraar treedt dus op als fronting company. In de meeste gevallen onderschrijft de

189 Bawcut, P.A., "Captive Insurance Companies", l.c.,1; Barile, A.J., The captive insurance company...an emerging profit center, Interstate Service Corporation, 1979, 3; Dowding, T., Global Developmenis in Captive Insurance, FT Financial Publishing, London, 1997, 7; Captive Insurance: a Threat to the Global Insurance Industry?, Datamonitor, FT Insurance Report, Pearson Professional Ltd., London, 1995, 7 (hierna geciteerd als "Captive Insurance: a Threat"); Corroon Europe, W., "Characteristics of association captives", in Risk Financing Options, Risk and Insurance Research Group, 1994, 9. Voor details kan worden verwezen naar Bawcut, P.A., "Captive Insurance Companies", l.c., 31 e.v.; Corroon Europe, W., "Characteristics of association captives", o.c., 9 e.v.; Lindrea, P.N., "The role of group and association captives", in Risk Financing Options, Risk and Insurance Research Group, 1994. 11-13.

191 Windibank, T. en Rodger, A., "Reinsuring captives", in Risk Financing Options, Risk and Insurance Research Group, 1994, 19; Barile, A.J., "The captive insurance company... an emerging profit center", l.c. 22 
fronting company $100 \%$ van het risico dat hij voor $90 \%$ herverzekert bij de captive. Het is ook de fronting verzekeraar die de polissen uitschrijft en instaat voor de afhandeling van de vorderingen. Het voordeel van een dergelijke structuur is dat de fronting company optreedt als buffer tussen de regulerende overheid en de moederonderneming ${ }^{192}$; deze laatste dient in deze structuur niet zelf te voldoen aan de wettelijke eisen inzake solvabiliteit e.d.m. waaraan verzekeringsondernemingen dienen te voldoen. Het is dan ook logisch dat het makkelijker is en minder tijd in beslag neemt om een herverzekeringscaptive op te richten ${ }^{193}$; hoofdzakelijk om die reden zijn de meeste captives herverzekeringscaptives ${ }^{194}$.

Via herverzekeringscaptives kan de moedermaatschappij ook de risico's van haar buitenlandse filialen dekken zonder ertoe gehouden te zijn om in de landen waar haar filialen opereren telkens een verzekeringsmaatschappij te moeten oprichten; de fronting verzekeraar zal zorgen voor de nodige vergunningen in de verschillende landen waar een filiaal van de moeder actief is.

Een herverzekeringscaptive wordt door een aantal bedrijven ook beschouwd als cen middel om fiscaal gunstige voorzieningen te creëren ${ }^{195}$; om dus bepaalde reserves aan te leggen. Toch wordt er over het algemeen van uit gegaan dat een captive enkel zinvol is indien het erin slaagt om een dekking te bieden voor een reële risico's van een onderneming ${ }^{196}$.

\subsubsection{De directe verzekeringscaptive}

Bij een directe verzekeringscaptive wordt geen beroep gedaan op een externe fronting company, maar wordt het gehele risico onderschreven binnen en door (een afdeling binnen) de eigen grocp. Hierdoor dienen geen commissies te worden betaald aan verzekeringsmakelaars, noch aan de fronting company, waardoor de directe verzekeringscaptive op een kostenefficiënte manier de risico's van de gehele groep kan beheren ${ }^{197}$.

Geoordeeld wordt dat een directe verzekeringscaptive voor ondernemingen actief binnen de Europese Unie aantrekkelijk kan zijn ${ }^{198}$. Een moederondememing met risico's in verschillende EU-lidstaten kan een captive oprichten met zetel binnen één EU-lidstaat teneinde de risico's van haar filialen binnen de gehele EU te dekken ${ }^{199}$. In Europa is vooral Dublin een populaire locatie voor de directe verzekeringscaptives, terwijl Luxemburg de thuisbasis is van verschillende herverzekeringscaptives. In die zin kan het voor een onderneming aantrekkelijk zijn een directe

Dowding, T., "Global Developments in Captive Insurance,", l.c. 37.

X., "Captive Insurance: a Threat", l.c., 49.

Bawcut, P.A., "Captive Insurance Companies", l.c., 33. Zie ook Ranson, D., "Verzekering van milieuaansprakelijkheid", o.c., 71.

Haelterman, A., "De herverzekeringscaptive: verzekeringsrealiteit of fiscale trukendoos?", Directetir. Nieuwsbrief voor Bedrijfsleiders, editie 40, 15 oktober 1994, 1. Zo heeft de Vlaamse Televisiemaatschappij (VTM) een herverzekeringscaptive opgericht ("VTM heeft ook in lerland een herverzekeringsmaatschappij", De Financieel-Economische Tijd, 11 augustus 1995).

Ook in die zin Haelterman, A., "De herverzekeringscaptive: verzekeringsrealiteit of fiscale trukendoos?", o.c., 5; "Herverzekeringscaptive niet enkel om fiskale redenen aantrekkelijk", De FinancieelEconomische Tijd, 25 oktober 1988.

X., "Captive Insurance: a Threat", l.c., 51.

Dowding, T., "Global Developments in Captive Insurance,", l.c., 36.

$X$., "Captive Insurance: a Threat", l.c., 51-52.
} 
verzekeringscaptive op te richten in Dublin die zich herverzekert bij haar herverzekeringscaptive in Luxemburg ${ }^{200}$.

\subsubsection{De rent-a-captive}

Voomamelijk omwille van de aan de oprichting van een captive verbonden kapitaalvereisten, laat de grootte van een aantal ondernemingen niet toe een eigen of een gezamenlijke captive op te richten. Voor dergelijke ondernemingen kan de rent-a-captive structuur een oplossing bieden omdat het een tussenweg biedt tussen de traditionele verzekeringsdekking en de pure captive ${ }^{201}$.

Een rent-a-captive is cen captive die is opgericht met als doel verzekeringspolissen uit te schrijven en die in de regel niet de risico's van haar eigenaar(s) dekt. Eigen aan deze vorm van captive is dat als het ware de captive structuur wordt gehuurd van de eigenaar en dat de verzekerde geen eigenaar is van de captive. Het in cen dergelijke captive aanwezige kapitaal wordt ter beschikking gesteld van ondernemingen die zichzelf via een captive structuur willen verzekeren. Een rent-acaptive kan zowel de vorm aannemen van de directe als van een herverzekeringscaptive.

Elke verzekerde in een dergelijke structuur betaalt een bijdrage in een afzonderlijk fonds (aparte "unit") dat enkel dient voor de uitbetaling van de vorderingen die in de desbetreffende polis zijn gedekt; een deel van de premie wordt gebruikt als bijdrage in de kosten van de gehele rent-acaptive structuur. De verschillende units in een rent-a-captive zijn onafhankelijk van elkaar zodat het verlies in een bepaalde unit de fondsen in een andere unit niet zal aantasten. Mogelijke verliezen van andere bedrijven binnen eenzelfde rent-a-captive tasten bijgevolg de fondsen van een ander bedrijf niet aan, hetgeen wel het geval kan zijn bij multiple captives. Doordat het geheel aan fondsen opgebouwd in een dergelijke captive fors kan oplopen, heeft dit een positieve invloed op het investeringsinkomen van de captive. Dergelijke vorm van captive kan aantrekkelijk zijn voor bedrijven die een certificaat dienen te hebben om te bewijzen dat zij voor bepaalde risico's over een verzekeringsdekking beschikken. Het is immers onzeker of de door een zuivere eigen captive uitgereikte certificaten aanvaardbaar zijn, terwijl dergelijke certificaten bij een rent-a-captive worden uitgereikt door een onderneming die een derde is ten aanzien van de verzekerde ${ }^{202}$.

\subsubsection{Voor-en nadelen van captives}

Een van de grote voordelen van de oprichting van een eigen verzekeringscaptive is de directe toegang tot de herverzekeringsmarkt. Herverzekeraars opereren immers tegen veel lagere kosten dan directe verzekeraars wier taak als verzekeraar een uitgebreide dienstverlening omvat zowel wat betreft hun industriële als hun niet-industriële klanten.

In tweede instantie biedt de captive het voordeel dat het een gunstige invloed hecft op de cashflow aangezien de aan de captive betaalde premie binnen de onderneming blijft.

Daamaast biedt een captive het voordecl dat de eigenaar van de captive zelf kan beslissen welke risico's hij bij de captive kan plaatsen en voor welk deel hij beroep zal (blijven) doen op de conventionele verzekeringsmarkt. Zo kunnen de meer rendabele risico's binnen de groep worden X., "Captive Insurance: a Threat", l.c., 52.

201 Taft, W. A, "Rent-a-captive - not a halfway housc", in Risk Financing Options, Risk and Insurance Research Group, 1994, 15. 
gehouden, terwijl de mindere rendabele risico's worden geplaatst op de conventionele verzekeringsmarkt ${ }^{203}$.

Een captive kan ook een antwoord bieden voor de dekking van risico's die op de conventionele verzekeringsmarkt niet of slechts beperkt kunnen worden gedekt ${ }^{204} 205$. Een verzekeringsdekking op de conventionele verzekeringsmarkt is in een aantal gevallen vrij duur en bovendien dienen de premies in het algemeen op voorhand te worden betaald waardoor de verzekeringsmaatschappij aanzienlijke inkomsten kan genereren door deze premies te investeren en te beleggen.

De captive biedt tegelijk de nodige flexibiliteit ${ }^{206}$ in die zin dat een tailor-made polis kan worden aangeboden die perfeet aansluit aan de behoefte tot dekking van een gegeven risico. De captive en de verzekerde moeder- of dochtermaatschappij kunnen inderdaad een polis uitschrijven volledig conform de eigen behoeften. Dit is niet altijd het geval bij klassieke verzekeringen, waar een tailor-made polis, indien überhaupt beschikbaar, in vele gevallen onbetaalbaar zal zijn. De captive kan ook op andere manieren aan de moedermaatschappij de nodige flexibiliteit bieden, met name wanneer wijzigingen optreden aan de vereiste dekking.

Deze anpassing wordt mogelijk gemaakt omdat, zeker wat betreft ondememingen die opereren in specifieke industriële activiteiten, deze onderneming vaak beter dan een verzekeraar in staat is haar eigen risico in te schatten. De oprichting van de captive kan dan ook worden verbonden aan het door het moederbedrijf gevoerde risicobeheer ("risk management"). De meeste captives worden opgericht door ondernemingen die worden blootgesteld aan specifieke risico's waarvan de dekking op de conventionele verzekeringsmarkt moeilijk of enkel tegen een te hoge prijs kan worden verkregen. Vandaar zal de beslissing van een onderneming om over te gaan tot de oprichting van cen captive kaderen in een breder preventiebeleid en een gestructureerd riskmanagement ${ }^{207}$.

Het voor de hand liggend nadeel van de captive in verhouding tot een directe klassieke verzekeringsmaatschappij is het feit dat deze laatste veel beter in staat is het risico te spreiden. Een captive kan enkel het risico spreiden indien het een voldoende deel van het risico kan plaatsen bij een herverzekeringsmaatschappij, waardoor de kosten van deze herverzekering voor de captive zeer hoog kunnen oplopen.

Een tweede nadeel voor de captive is de vaak uitermate strenge wetgeving op de controle op verzekeringsondememingen inzake solvabiliteitsgaranties, vereist kapitaal en controle op internationale transacties. In het kader van dergelijke controle dient de maatschappij continu de nodige statistische gegevens over haar werking, calculatie van reserves etc. over te maken aan de overheid. In die optiek kan het zinvol zijn een offshore-captive op te richten, maar ook hier kunnen de autoriteiten van het land van oorsprong allerhande beperkingen instellen en controles verrichten.

Vaak wordt onderschat hoeveel tijd is vereist om de captive te beheren. De kosten verbonden aan het beheer van een captive kunnen inderdaad dermate aanzienlijk zijn dat deze niet opwegen tegen de mogelijke voordelen van de captive. Een bijkomend probleem bestaat erin dat het loutere

Bawcut, P.A., "Captive Insurance Companies", l.c., 25-26.

Hierbij wordt met name gedacht aan risico's inzake productaansprakelijkheid en milieuaansprakelijkheid; cfr. infra.

Bawcut, P.A., "Captive Insurance Companies", l.c., 13.

Bibbings, T. en Brining, W.D., "Considering a captive? Consider financial insurance or reinsurance", in Risk Financing Options, Risk and Insurance Research Group, 1994, 25.

Bawcut, P.A., "Captive Insurance Companies", l.c., 3. 
feit dat een grote onderneming een eigen captive heeft, kan leiden tot een soepelere toekenning van bepaalde vorderingen ${ }^{208}$. Dit kan worden opgevangen indien de captive, zoals vaak het geval is, niet door de moedermaatschappij wordt beheerd, maar door een onafhankelijke beheersmaatschappij of door een verzekeringsmakelaar.

Tenslotte kan een captive uitermate nadelig blijken voor de moedermaatschappij indien de onderneming of de groep plots wordt geconfronteerd met een aanzienlijk aantal verliezen of met een zwaar schadegeval. Zeker bij de aanvang van de captive kan haar positie zeer kwetsbaar zijn omdat de tot dan toe in de captive opgebouwde reserves onvoldoende zullen zijn om een zware schadelast te dekken.

\subsubsection{Impact op de traditionele verzekeringsmarkt}

Aanvankelijk werden captives opgericht met het oog op het dekken van de eigenschade van de onderneming, bijvoorbeeld ter dekking van machinebreuk. Geleidelijk aan hebben ondernemingen ook andere risico's verzekerd via captives, en met name de moeilijk te verzekeren risico's. Het is logisch dat ondernemingen wier risico's op de markt haast onverzekerbaar en de premies onbetaalbaar werden, op zoek zijn gegaan naar andere manieren om die risico's te dekken ${ }^{209}$. De captive kan bijgevolg worden opgericht ter dekking van eender welk risico van de moederonderneming; gelet op de problemen op de conventionele verzekeringsmarkt worden meer en meer captives opgericht die een polis uitschrijven inzake milieuaansprakelijkheid.

Zonder enige twijfel kan het succes van captives (groten)deels worden toegeschreven aan de toenemende langtermijn risico of long-tail risks. Zeker in de VS heeft de tendens in de rechtspraak om inzake verschillende vormen van aansprakelijkheid zeer hoge schadevergoedingen toe te kennen, mede geleid tot de groei van het aantal captives wat een zware impact zal hebben op de commerciële verzekeringssector ${ }^{210}$. De gevaren voor de verzekeringssector werden bijvoorbeeld duidelijk naar aanleiding van de vorderingen inzake asbest. Het gevolg van de potentieel zware tussenkomsten was dat verzekeraars immense reserves dienden aan te leggen wat voor de verzekerden heeft geleid tot nagenoeg onbetaalbare premies. Doordat aansprakelijkheidsverzekeringen onbetaalbaar werden, heeft een aantal grote ondernemingen de conventionele verzekeringsmarkt verlaten om een captive op te richten ${ }^{211}$.

De evolutie in de VS brengt ook in Europa enige reactie teweeg. Zo hebben de drie grootste Duitse chemiebedrijven (Hoechst, Bayer en BASF) gezamenlijk Indurisk Re opgericht, een captive die enkel is gericht op de dekking van hun risico's inzake milieuaansprakelijkheid. De captive kan zeker in de beginperiode kwetsbaar zijn indien zij wordt geconfronteerd met een aantal aanzienlijke schadegevallen. In vele gevallen zal het risico uit milieuaansprakelijkheid slechts nadat de captive enkele jaren functioneert en reeds voldoende reserves heeft opgebouwd, in de captive worden ondergebracht ${ }^{212}$.

Bawcut, P.A., "Captive Insurance Companies", l.c., 29.

Powell, C.W., "The importance of captive management in an increasingly difficult insurance market", in Risk Financing Options, Risk and Insurance Research Group, 1994, 24; Haelterman, A., "De herverzekeringscaptive: verzekeringsrealiteit of fiscale trukendoos?", o.c., 5 .

X., "Captive Insurance: a Threat", l.c., 19.

X., "Captive Insurance: a Threat", l.c., 20.

Dequae, M., "Ervaringen op het vlak van milieu en verzekering binnen de Bekaertgroep", in Bocken, H. en Ryckbost, D. (ed.), "Verzekering van Milieuschade," l.c., $26 \mathrm{l}$. 
De captive kan bijgevolg voor een aantal ondememingen een altematief bieden voor de beperkingen die inherent lijken te zijn aan de dekkingen die op de commerciële verzekeringsmarkt beschikbaar zijn. Nochtans is de ontwikkeling van de captives moeilijk denkbaar zonder de steun van de traditionele verzekeringsmarkt. Een groot deel van de nood aan herverzekering wordt inderdaad ingevuld door directe verzekeraars die binnen hun onderneming departementen hebben opgericht die zijn gespecialiseerd in het begeleiden en/of beheren van captives ${ }^{213}$.

Deze tendens naar het beheer van de eigen risico's kadert tegelijk in het stijgende belang voor riskmanagement in ondernemingen met aanzienlijke (aansprakelijkheids)risico's.

\subsubsection{Conclusie}

Er bestaan verschillende soorten captives, die elk een hun eigen kenmerken hebben. De activiteit van bepaalde captives beperkt zich tot het reserveren van een bepaalde som op fiscaal gunstige wijze. Maar de werking van bijvoorbeeld open captives vertoont aanzienlijke analogieën met een "traditionele" verzekeraar in die zin dat ook sprake is risicospreiding onder de leden van de captive en op de herverzekeringsmarkt. Gelet op de vele verschijningsvormen van de captive, moet geval per geval worden bekeken of de activiteiten van de captive zich beperken tot een louter risicobeheer, dan wel of ook daadwerkelijk kan worden gesproken van een daadwerkelijke risicospreiding.

In het kader van deze analyse is vooral belangrijk te onthouden dat bepaalde soorten captives een alternatief kunnen bieden voor een gebrekkige capaciteit van de verzekeringsmarkt. Tenslotte zal het voor een verzekeringsnemer gunstig zijn dat de premies of bijdragen die worden betaald aan de captive economisch gezien niet in handen komen van een andere onderneming maar binnen de eigen groep blijven. Indien de captive winst makt zal bovendien die winst in mindere of meerdere mate de verzekeringsnemer ten goede komen.

Hier moet worden benadrukt dat een captive in de praktijk niet wordt gehanteerd in een "alles-ofniets" benadering. Hiermee wordt bedoeld dat een exploitant zelden zijn volledige risico, maar eerder een beperkt deel van het risico via een captive zal dekken. Zo komt het vaak voor dat op de klassieke verzekeringsmarkt een dekking wordt aangekocht, maar dat het eigen risico van de exploitant via een captive wordt gedekt. In de praktijk wordt inderdaad meer en meer gewerkt met dergelijke gemengde verzekeringspakketten ${ }^{214}$.

Voor bepaalde risico's zullen de reeds besproken mechanismen geen afdoende bescherming bieden, in die zin dat de capaciteit die wordt gegenereerd nog steeds onvoldoende zial zijn. Ook indien een dekking kan worden verkregen door bijvoorbecld een combinatie van eigenschadeverzekering, captive, verzekeringspool etc. dan nog betekent dit geen garantie dat metecn alle schade kan worden vergoed. Vandaar werden in de Verenigde Staten ten aanzien van de schade door natuurrampen systemen uitgewerkt waarbij wordt getracht om de capaciteit uit te breiden door cen beroep te doen op de kapitaalmarkt.

\subsection{Dekking van natuurrampen via de kapitaalmarkt}

Voor een aantal risico's waarvoor op de traditionele verzekeringsmarkt capaciteitsproblemen dreigen, wordt inderdaad een beroep gedaan op een alternatieve risico-overdracht naar de kapi-

X., "Captive Insurance: a Threat", l.c., 62.

Ranson, D., "Verzekering van milieuaansprakelijkheid", o.c., 72. 
taalmarkt ${ }^{215}$. Dit is bijwoorbeeld het geval bij de dekking van natuurrampen. Volgens bepaalde schattingen bedroeg de capaciteit van de Amerikaanse verzekeringsmarkt, ter zake van de dekking van natuurrampen, in 1997 ongeveer 200 miljard dollar ${ }^{216}$. In de wetenschap dat een emstige natuurtamp 50 miljard dollar schade kan veroorzaken, is het duidelijk dat de capaciteit te beperkt is. De beurskapitalisatie van de Amerikaanse financiële markt zou, eveneens in 1997, 19.000 miljard dollar bedragen ${ }^{217}$.

De bestaande ART-mechanismen (Alternative Risk Transfer) maken gebruik van afgeleide financiële beleggingsproducten (zgn. insurance derivates) zoals options en swaps ${ }^{218}$. Er wordt van uitgegaan dat vóór het ontstaan van deze nieuwe produkten investeerders sowieso reeds participeerden in catastroferisico's, met name in de mate waarin zij aandeelhouder waren van een verzekeringsondememing ${ }^{219}$. De nieuwe mechanismen hebben enkel tot gevolg dat er een nauwere band ontstaat tussen de belegger en het catastroferisico ${ }^{220}$. Andere financiële mechanismen zoals de Catex (Catastrophe Risk Exchange) in New York, voorzien in de uitwisseling van bepaalde pakketten catastroferisico' ${ }^{221}$. Meer en meer worden ook obligaties uitgeschreven ("bonds") waarbij de ontvangen rente varieert in functie van het risico ${ }^{222}$. Een extreme vorm is met name de Act of God Bonds waarbij de terugbetaling van het kapitaal in (zeer) belangrijke mate afhangt van het zich al dan niet verwezenlijken van het catastroferisico ${ }^{223}$.

Een tweede element van deze ART-mechanismen bestaat erin dat een beroep wordt gedaan op de veel grotere capaciteit van de financielle markten. Grosso modo is het de bedoeling van deze alternatieve mechanismen om een verzekeringsrisico om te zetten in een financieel risico ${ }^{224}$. Geoordeeld wordt dat indien meer kapitaal beschikbaar is om verzekeringsrisico's te dekken, dit een gunstige invloed zal hebben op de verzekeringscapaciteit ${ }^{225}$. Er wordt met andere woorden

Cousy, H., "Over de verzekering van het onverzekerbare", in "Liber Amicorum Prof. Dr. Roger Blanpain", l.c., 708 e.v.

Zech, J., "Will the Intemational Insurance Market replace Traditional Insurance Products", The Geneva Papers on Risk and Insurance, vol. 23, $\mathrm{n}^{\circ}$ 89, 1998, 492.

De Varenne, F., "Techniques alternative de couverture", Risques, n³4, 1998, 53.

Zie met name Clow, R., "Coping with catastrophe", Institutional Investor, december 196, 143-150.

Gollier, C., "About the insurability of catastrophic risks", o.c., 177.

Cousy, H., "Over de verzekering van het onverzekerbare", in "Liber Amicorum Prof. Dr. Roger Blanpain", l.c., 708-709.

Zie hierover onder meer De Varenne, F., "Techniques alternative de couverture", o.c., 56-57; Kieholz, W. en Durrer, A., "Insurance Derivatives and Securization: New Hedging Perspectives for the US Cat Insurance Market", The Geneva Papers on Risk and Insurance, vol. 22, n० 82, 1997, 3-16; Smith, R.E., Canelo, E.A. en Di Dio, A., "Reinventing Reinsurance Using the Capital Markets", The Geneva Papers on Risk and Insurance, vol. 22, $\mathrm{n}^{\circ}$ 82, 1997, 26-37; Shimpi, P., "The context of Trading Insurance Risks", o.c., 17-25.

Zie bijvoorbeeld Radetzki, M. en Radetzki, M., "Private Arrangements to Cover Large-Scale Liabilities Caused by Nuelear and Other Industrial Catastrophes", The Geneva Papers on Risk and Insurance, vol. $25, \mathrm{n}^{\circ} 2,2000,189$.

Cousy wijst erop dat deze Act of God Bonds veel gemeen hebben met de eerste vormen van verzekering zoals de bodemerij en de foenus nauticum (Cousy, H., "Over de verzekering van het onverzekerbare", in "Liber Amicorum Prof. Dr. Roger Blanpain", l.c., 711-712.). Cfr. supra, bij de bespreking van het historische schets van verzekeringen, in $\$ 1$ van hoofdstuk 5.

Shimpi, P., "The context of Trading Insurance Risks", The Geneva Papers on Risk and Insurance, vol. $22, n^{\circ} 82,1997,19$. 
buiten de verzekeringsmarkt gezocht naar bijkomende capaciteit voor de dekking van catasiroferisico's ${ }^{226}$.

Het ligt uiteraard niet binnen het bestek van deze analyse om hierop verder op in te gaan. Hoe dan ook bevindt de ontwikkeling van deze mechanismen zich, zeker in Europa, nog in een beginstadi$u m^{227}$. Van belang is de vaststelling dat zich een evolutie voordoet waarbij op de kapitaalmarkt wordt gezocht naar bijkomende capaciteit. Met name voor verzekeraars is dit belangrijk aangezien deze financiële producten in feite neerkomen op een uitbreiding van de herverzekeringscapaciteit ${ }^{228}$.

In de toekomst kan het aangewezen zijn om verder onderzoek te doen naar de mate waarin verzekeringen en dergelijke ART-oplossingen elkaar desgevallend kunnen aanvullen en om na te gaan in welke mate de mechanismen die reeds in de VS worden toegepast ten aanzien van natuurrampen, ook zullen worden gehanteerd ten aanzien van andere moeilijk verzekerbare risico's. Volgens verzekeraars kunnen deze systemen slechts een zeer beperkt deel van de capaciteitsproblemen ondervangen ${ }^{229}$. Het valt uiteraard niet uit te sluiten dat naarmate meer ervaring wordt opgedaan met dergelijke financiële instrumenten, en naarmate meer onderzoek is verricht, de mogelijkheden ervan zullen toenemen.

Na de bespreking van de dekking van milieuschade via de klassieke verzekeringsmarkt en van de mogelijkheden om alternatieve compensatiemechanismen in het leven te roepen, worden hieronder twee voorstellen besproken voor wat betreft de dekking van het nucleaire risico.

\section{TWEE VOORSTELLEN TER ZAKE VAN DE DEKKING VAN HET NUCLEAIRE RISICO}

In de vorige paragraaf van dit hoofdstuk richtte de aandacht zich op altematieve compensatiemechanismen voor de dekking van milieuschade in het algemeen. Hieronder worden twee altematieve voorstellen bestudeerd die in de literatuur werden gelanceerd met betrekking tot de dekking van het nucleaire risico.

Het eerste voorstel, van de hand van Tyran en Zweifel, doet een beroep op de kapitaalmarkt en wil via deze markt de internalisatie van de kosten bewerkstelligen. De naam van het voorstel luidt Environmental Risk Internalisation through Capital Market, kortweg ERICAM (\$ 3.1). Het tweede voorstel werd gelanceerd door Faure en Skogh en houdt in dat tussen verschillende exploitanten een risicospreidingsovereenkomst wordt afgesloten $(\bar{\S} 3.2)$.

\subsection{Environmental Risk Internalisation through Capital Market (ERICAM) ${ }^{230}$}

Volgens Tyran en Zweifel is de beperkte beschikbaarheid van nucleaire aansprakelijkheidsverzekeringen toe te schrijven aan de nationale kartelvorming van de nucleaire verzekeringspools ${ }^{231}$.

Wagner, F., "Risk Securitization. An Alternative of Risk Transfer of Insurance Companies", The Geneva Papers on Risk and Insurance, vol. 23, n 89, 1998, 575.

Smith, R.E., Canelo, E.A. en Di Dio, A., "Reinventing Reinsurance Using the Capital Markets", o.c. 31.

Wagner, F., "Risk Securitization. An Alternative of Risk Transfer of Insurance Companies", o.c., 577 e.v.

Zech, J., "Will the International Insurance Market replace Traditional Insurance Products", o.c., 494.

Tyran, J.R. en Zweifel, P., "Environmental Risk Intemalization through capital markets (ERICAM): the Case of Nuclear Power", International Review of Law and Economics, 1993, vol. 13, nr. 4, 431444. 
Zij stellen dan ook voor om te voorzien in een bijkomende dekking door een beroep te doen op de kapitaalmarkt.

Concreet bevat hun voorstel de volgende elementen. Teneinde dekking te verkrijgen richt de exploitant van een keminstallatie zich niet meer tot de nucleaire verzekeringspools, maar zal hij daarentegen risk participation shares uitschrijven op de kapitaalmarkt. Investeerders kunnen dan op dergelijke shares intekenen; in ruil voor deze deelname zullen zij een financiële portefeuille moeten afgeven die als garantie (warrant) zal dienen voor de exploitant van hun keuze. Deze warrant is voorwaardelijk en kan door het agentschap uitgevoerd worden wanneer zich een schadegeval voordoet. Zolang zich geen schadegeval voordoet blijven de investeerders dus eigenaar van de door hen neergelegde portefeuille en kunnen zij ook nog steeds de opbrengsten ervan genieten $^{232}$. Hier bovenop zullen ze een vergoeding krijgen als risicopremie voor de door hen neergelegde garantie.

Een dergelijk systeem zal uiteraard een invloed hebben op het gedrag van verschillende betrokkenen. In de eerste plaats zullen de verschillende exploitanten een aanbod doen aan potentiële investeerders. Hier staan de exploitanten dus in directe competitie met elkaar. In een dergelijke situatie zal het voor een slecht risico nagenoeg onmogelijk zijn om op deze markt een dekking te kopen $^{233}$. Hij zal dus zijn aanbod aantrekkelijker moeten maken, door bijvoorbeeld bijkomend in veiligheid te investeren. Indien hij er niet in slaagt deze dekking te vinden, dan zal de overheid de bevoegdheid hebben om de desbetreffende installatie te sluiten. Investeerders zullen moeten beslissen of zij al dan niet een risk share zullen kopen en zullen dus op zoek gaan naar de meest aantrekkelijke aanbiedingen op de markt. Dit systeem leidt er volgens Tyran en Zweifel toe dat de exploitanten elkaar beconcurreren voor het bekomen van dekking en dat de nucleaire pools en de investeerders elkaar beconcurreren voor wat de premies betref $\mathrm{f}^{234}$. Er zal dus een marktprijs voor het nucleaire risico ontstaat; het nucleaire risico zal als een financieel risico worden beschouwd. Het spreekt voor zich dat via ERICAM de investeerders een aanzienlijke prikkel zullen hebben om over correcte informatie te beschikken aangaande het risico dat de betreffende kerninstallatie vormt.

Volgens Tyran en Zweifel zal ERICAM er ook toe leiden dat rekening zal worden gehouden met de inplanting van de kerninstallatie (de locatie waar een dergelijke installatie wordt gebouwd) en zal het bijdragen tot een optimale keuze van energiebronnen. Doordat de kosten van een kernongeval volledig worden geïnternaliseerd, zal het makkelijker zijn om een correcte vergelijking te maken met de mogelijke impact van andere energiebronnen ${ }^{235}$.

Ook dit systeem heeft sterke en zwakke punten. Het grote voordeel van dit systeem is dat enerzijds de nucleaire verzekeringspools aan concurrentie worden blootgesteld en dat anderijds cen aanzienlijke vraag zal bestaan naar correcte informatie.

231 Tyran, J.R. en Zweifel, P., "Environmental Risk Internalization through capital markets (ERICAM): the Case of Nuclear Power", o.c., 434-435.

Bovendien beschikken de beleggers over de mogelijkheid om de inhoud van hun portefeuille te wijzigen, op voorwaarde dat de totale waarde van de portefeuille gelijk blijf. Tyran, J.R. en Zweifel, P., "Environmental Risk Internalization through capital markets (ERICAM). the Case of Nuclear Power", o.c., 438. Ibidem.

235 Tyran, J.R. en Zweifel, P., "Environmental Risk Internalization through capital markets (ERICAM): the Case of Nuclear Power", o.c., 439. 
Het voomaamste nadeel van ERICAM heeft te maken met de instabiliteit van de kapitaalmarkt. In heel wat gevallen zal namelijk onzekerheid bestaan over de echte waarde van de portefeuille die door de belegger wordt aangeboden om te participeren in het systcem. Indien bijvoorbeeld aandelen in deze portefeuille zitten, dan kan een beurscrash de waarde ervan zeer negatief beïnvloeden. Ook bij een kemongeval kan ervan worden uit gegaan dat niet enkel de beurswaarde van de exploitant drastisch zal afnemen; het is niet uitgesloten dat ook de waardering van andere nutsbedrijven en zelfs de beurs in het algemeen in de klappen zullen delen. Concreet zal dit betekenen dat wanneer de risk shares na een kernongeval te gelde zouden worden gemaakt, de reële compensatie van slachtoffers in het gedrang kan komen.

Het is bovendien zeer de vraag of een financiële markt, die telkens op korte termijn fluctueert, geschikt is voor de verzekering van lange termijnrisico's. Bijvoorbeeld inzake het nuclcaire risico zal een deel van de schade zich slechts na een lange periode na het ongeval manifesteren; in dc mate waarin investeerders zich bijvoorbeeld na een ongeval massaal hebben teruggetrokken, is niet meteen duidelijk in welke mate nog fondsen ter beschikking zullen zijn.

\subsection{Risicospreidingsovereenkomst}

Het uitgangspunt van het door Faure en Skogh gelanceerde voorstel ${ }^{236}$ is dat de huidige bedragen voor de dekking van het nucleaire risico zelfs ontoereikend zijn om de schade uit kleinere kernongevallen te vergoeden. Deze auteurs stellen dat mogelijke problemen met catastroferisico's niet beletten dat deze risico's via ex ante afspraken zouden worden verdeeld en dat cr reeds voorbcelden van bestaan in de praktijk ${ }^{237}$. Verwezen wordt daarbij naar de afspraken in het kader van de Protection and Indemnity Clubs inzake de dekking van schade voor olieverontreiniging op zee.

Uitgaande van de mogelijkheid tot het maken van ex ante afspraken, hebben Faure en Skogh dan ook een voorbeeld uitgewerkt voor de dekking van schade uit kemongevallen. De basisidee in dit voorstel is dat via een ex ante risicospreidingsovereenkomst het nucleaire risico, dat niet of nauwelijks op de markt te verzekeren is, wordt verdeeld tussen zoveel mogelijk exploitanten. Dit veronderstelt dat verschillende exploitanten overeenkomen om lid te worden van een wederzijds garantiefonds, waarbij elke exploitant een vooraf bepaalde bijdrage levert. Indien bijvoorbeeld de maximale aansprakelijkheid 100 miljard euro zou bedragen en indien 100 cxploitanten in een dergelijk systeem zouden stappen, dan zal volgens het voorstel elke exploitant 1 miljard euro moeten bijdragen ${ }^{238}$. Voor de dekking van deze bedragen zal een beroep moeten worden gedaan op de internationale verzekerings- en herverzekeringsmarkt. Hicrbij kan het volgens Faure en Skogh zijn aangewezen dat de Staat optreedt als herverzckeraar ${ }^{239}$.

Belangrijk is ook dat een dergelijke risicospreidingsovereenkomst dient te worden afgesloten in een internationale context, zodat exploitanten van verschillende landen kunnen participeren.

Faure, M. en Skogh, G., "Compensation for damages caused by nuclear accidents: a convention as insurance", The Genera Papers on Risk and Insurance, $n^{\circ}$ 65, 1992, 499-513; Faure, M., "Naar een nieuw model van vergoeding van nucleaire schade", in Faure, M. (red), "Aansprakelijkheid voor het nucleaire risico", l.c., 141-175.

${ }^{3.37}$ Faure, M. en Skogh, G., "Compensation for damages caused by nuclear accidents: a convention as insurance", o.c., 508-509.

23. Er moet op worden gewezen dat er in 2000 ongeveer 430 keminstallaties in gebruik waren over de gehele wereld, waarvan ongeveer 150 in West-Europa. De schatting van een 100-tal deelnemende exploitanten is in die zin dan ook realistisch te noemen. 
Indien er dan een ongeval plaatsvindt, zal elke exploitant slechts voor een deel moeten tussenkomen. Indien zich dan in Nederland een ongeval voordoet dat een totale schade veroorzaakt van 60 miljard euro, dan zal - bij de risicospreidingsovereenkomst waaraan 100 exploitanten participeren - iedere exploitant 600 miljoen euro moeten bijdragen.

Maar aangezien in de praktijk één enkele exploitant meerdere kerninstallaties uitbaat, kan het onder een dergelijk systeem voorkomen dat een exploitant zeer aanzienlijke bijdragen moet leveren. In België bijvoorbeeld is Electrabel uitbater van 7 kerninstallaties; in Frankrijk baat Electricité de France (EDF) 55 kerninstallaties uit. Op basis van het voorstel van Faure en Skogh, zouden zij respectievelijk 4,2 miljard euro en 33 miljard euro moeten bijdragen. De auteurs zijn evenwel van mening dat precies omwille van de hoge sommen, een groot deel van dit bedrag sowieso door de respectievelijke landen zou worden herverzekerd ${ }^{240}$.

Precies omdat in dit voorstel nog in ruime mate een beroep wordt gedaan op de Staat, is er kritick geleverd op dit voorstel; het zou namelijk de subsidie in hoofde van de kemenergie-industrie in stand houden ${ }^{24 !}$. In de mate waarin de Staat een reële vergoeding zal aanrekenen voor haar tussenkomst, lijkt deze kritiek niet gegrond.

Dit voorstel kan ook worden onder vuur genomen omdat de bijdragen van één exploitant in én jaar zeer hoog kunnen oplopen. Er kan evenwel worden vastgesteld dat in de Verenigde Staten een sterk analoog systeem van risicospreiding wettelijk verplicht is. De aanzienlijke bijdrage van de exploitant is op jaarbasis geplafonneerd. De Amerikaanse Price-Anderson Act voorziet inderdaad in een gemeenschappelijke bijdrage van de verschillende exploitanten. Dit systeem wordt in hoofdstuk 13 bestudeerd.

Op zich is het voorstel voor de introductie van een risicospreidingsovereenkomst een eenvoudig systeem dat als bijkomend voordeel biedt dat, teneinde het morele risico en de averechtse selectie onder controle te houden, de verschillende leden van de groep elkaars installaties zullen inspecteren. Er wordt met andere woorden optimaal gebruik gemaakt van het feit dat ter zake van hoogtechnologische risico's, de potentiële daders zelf de juiste informatie hebben over het risico. In die zin wordt dus tegemoet gekomen aan de problemen van informatieasymmetrie.

\section{Conclusie}

In dit hoofdstuk werden inzake de dekking van catastroferisico's of moeilijk verzekerbare risico's verschillende compensatiemechanismen bestudeerd.

Er zijn enkele opmerkelijke verschillen vast te stellen voor wat betreft de dekking van milieurisico's op de Belgische en de Nederlandse markt. De grootste Nederlandse verzekeraars hebben zich aangesloten in een samenwerkingsverband, met name de Nederlandse Milieupool. Deze pool is in feite de opvolger van het Milieu Aansprakelijkheid Samenwerkingsverband of MAS. Aanvankelijk bood deze pool de specifieke MAS-polis aan, ter dekking van milieuaansprakelijkheid. Inmiddels is sinds 1998 ook een geïntegreerde milieuschadeverzekering (MSV-polis) beschikbaar. Deze polis draagt elementen in zich van een eigenschadeverzekering, maar is daarenboven

Faure, M. en Skogh, G., "Compensation for damages caused by nuclear accidents: a convention as insurance", 510 .

241

Radetzki, M. en Radetzki, M., "Private Arrangements to Cover Large-Scale Liabilities Caused by Nuclear and Other Industrial Catastrophes", o.c., 188. 
ook een directe verzekering ten behoeve van derden. Deze directe verzekering biedt het voordeel dat een vordering kan worden afgehandeld buiten het aansprakelijkheidsrecht om.

Een analoge geïntegreerde milieupolis is niet beschikbaar op de Belgische markt. Wel zijn sinds 1996 afzonderlijke polissen inzake milieuaansprakelijkheid beschikbaar. Deze polis wordt in tegenstelling tot Nederland, niet aangeboden door een samenwerkingsverband van verzekeraars, maar door een viertal verschillende grotere verzekeringsondernemingen. Een aanzienlijk deel van de dekking van milieurisico's is dan ook hetzij niet gedekt, hetzij gedekt als een bijzondere waarborg onder de algemene polis BA-uitbating.

Naast de aansprakelijkheidsverzekering en de directe verzekering ten behoeve van derden, werd ook de eigenschadeverzekering (of first party insurance) als mogelijkheid naar voor geschoven. Voorzover bekend wordt een first party dekking op de markt niet op algemene wijze aangeboden ter zake van de dekking van milieuschade. Nochtans kan deze verzekeringsvorm een aantrekkelijk alternatief vormen op de aansprakelijkheidsverzekering omdat beter kan worden tegemoet gekomen aan de problemen van antiselectie. Een first party verzekering zal het inderdaad mogelijk maken om informatie in te winnen van de verzekeringsnemer (geen probleem van informatieasymmetrie) en dus zullen de goede van de slechte risico's kunnen worden onderscheiden. Een first party dekking en een directe verzekering kunnen daarenboven een positieve invloed hebben op de tertiaire ongevalskosten.

In dit hoofdstuk werden ook de voor- en nadelen bestudeerd van een schadefonds. Uit de analyse is gebleken dat de verschillende schadefondsen niet zonder meer een oplossing bieden voor problemen uit het aansprakelijkheidsrecht (annex aansprakelijkhcidsverzekering).

Net als bij een aansprakelijkheidsverzekering zal het ook voor een fondsbeheerder niet eenvoudig zijn on antiselectie en het morele risico tegen te gaan. Tegelijk zijn twijfels gerezen bij de stelling dat een fonds goedkoper en efficiënter zou werken dan een commerciële verzekeringsmaatschappij. De ervaring met van het Nederlandse Fonds Luchtverontreiniging bevestigt die twijfels.

In de loop der jaren werden zowel in België (Vlaanderen) als in Nederland reeds verschillende onderzoeken uitgevoerd naar de haalbaarheid van een alternatief compensatiemechanisme. In geen van beide landen werd al effectief over gegaan tot de implementatie van de gelanceerde voorstellen: totnogtoe hebben nog de voorstellen van de Interuniversitaire Commissie tot Herziening van het Milieurecht in het Vlaamse Gewest (Commissie Bocken), noch de voorstellen gelanceerd naar aanleiding van het rapport over een milieuschadefonds tot concrete resultaten geleid. Hiermee wordt op geen enkele wijze een oordeel gegeven over de waarde van deze onderzoe$\mathrm{ken}^{242}$. De Belgische en Nederlandse voorstellen ter zake bevatten een aantal uitermate waardevolle elementen.

Bij de voorstellen van de Commissie Bocken springt in het oog dat aan de exploitant een brede waaier aan mogelijkheden wordt geboden ter dekking van zijn aansprakelijkheid. Ook de idee om de exploitant de mogelijkheid te bieden om zijn aansprakelijkheid te beperken in ruil voor deelname aan een vrijwillig compensatiemechanisme is uitermate waardevol. De Nederlandse voorstellen inzake de creatie van een algemeen milieuschadefonds zijn vooral opmerkelijk aangezien dit fonds erop gericht zou zijn voor de compensatie van ecologische schade.

\footnotetext{
Het feit dat anno 2000 nog niet werd overgegaan tot de implementatie heeft meer dan waarschijnlijk te maken met de complexiteit van de problematiek. Het is voor beleidsmakers blijkbaar niet makkelijk om concrete knopen door te hakken.
} 
Tenslotte kan uit dit hoofdstuk worden onthouden dat blijkbaar op verschillende fronten word gezocht naar alternatieve oplossingen. Commerciële verzekeraars bundelen hun krachten in samenwerkingsverbanden; bijzondere geïntegreerde polissen worden gecreëerd; "daders" gaan op zoek naar manieren om zelf een deel van het risico te verzekeren; verzekeraars gaan op hun beurt op zoek om via de kapitaalmarkt de herverzekeringscapaciteit te verhogen. Het lijkt er dan ook op dat het onmogelijk is om een enige en zaligmakende oplossing voor de dekking van een catastroferisico - zoals het nucleaire risico - te vinden en toe te passen. Er moet meer worden gedacht in de vorm van gemengde mechanismen. In die zin bevatten de besproken voorstellen inzake de dekking van het nucleaire risico waardevolle elementen, maar zullen deze in een groter geheel moeten worden geïntegreerd. 


\section{HOOFDSTUK 12}

\section{AANSPRAKELIJKHEID VOOR SCHADE DOOR OLIEVERONTREINIGING OP ZEE}

$\mathrm{Na}$ een algemene bespreking van een aantal mogelijkheden voor de dekking van een catastroferisico in het vorige hoofdstuk, worden in de hoofdstukken 12 en 13 twee bestaande compensatiemechanismen meer in detail besproken, respectievelijk de wetgeving en het daarop geënte compensatiemechanisme ter zake van schade door olieverontreiniging op zee enerzijds en ter zake van het nucleaire risico in de Verenigde Staten anderzijds.

De vergelijking tussen de aansprakelijkheid van een exploitant van een kerninstallatie bij kernongevallen, en de aansprakelijkheid van de eigenaar van een olietanker bij olieverontreiniging op zee ligt voor de hand. Uit de analyse zal blijken dat ook ter zake van de aansprakelijkheid voor schade door olieverontreiniging op zee internationale verdragen van kracht zijn, die basisprincipes introduceren die sterk gelijken op die van het Verdrag van Parijs van 29 juli 1960. Anderzijds vertoont het systeem voor de dekking van schade door olieverontreiniging op zee een bijzonderheid, met name ten aanzien van de dekking door de Protection and Indemnity Clubs.

In eerste instantie wordt een kort overzicht gegeven van het ontstaan van de maritieme aansprakelijkheidswetgeving $(\S 1)$. Vervolgens worden de twee Verdragen aan de orde gesteld die centraal staan in de analyse, met name het CLC-Verdrag ( $\$ 2$ ) en het Oliefondsverdrag ( $\$ 3$ ). In de daarop volgende paragrafen wordt aandacht besteed aan de specifieke dekkingsmechanismen in het maritieme recht, namelijk de vrijwillige compensatiemechanismen TOVALOP en CRISTAL die gedurende meerdere decennia een belangrijke rol hebben gespeeld $(\S 4)$ en de Protection and Indemnity Clubs $(\S 5)$. De conclusie van het onderzoek wordt weergegeven in $\S 6$.

\section{ONTSTAAN VAN DE MARITIEME AANSPRAKELIJKHEIDSWETGEVING}

De eerste pogingen tot het opstellen en afsluiten van een internationale regeling inzake olievervuiling door olie, dateren van het interbellum. Een van de eerste internationale Verdragen inzake zeerecht was het in 1924 in Brussel gesloten "Internationaal Verdrag voor de eenmaking van zekere regels betreffende de beperking van de aansprakelijkheid van eigenaren van zeeschepen" op basis waarvan de eigenaar van een schip zijn aansprakelijkheid kon beperken tot de waarde van het schip, de vracht en het toebehoren'. Dit Verdrag beoogde een evenwicht te vinden tussen de belangen van de schipper, de scheepseigenaai, de passagier en de verzekeraar ${ }^{2}$. De aansprakelijkheid van de eigenaar was beperkt tot de waarde het schip, met dien verstande dat deze waarde niet hoger kon zijn dan $8 £$ per ton ${ }^{3}$. Slechts een gering aantal landen heeft dit Verdrag geratificeerd omdat enerzijds de aansprakelijkheidsgrens vrij laag lag en omdat anderzijds enkel de eigenaar zijn aansprakelijkheid kon beperken, waardoor bijvoorbeeld charteraars onbeperkt aansprakelijk waren.

Tegelberg, G.G.A., Olie op de Golven, W.E.J. Tjeenk Willink, Zwolle, 1984, 48; Cleton, R., De Beperkte Aansprakelijkheid van de Scheepseigenaar, W.E.J. Tjeenk Willink, Zwolle, 1990, 23.

Zie hierover ook Wu, C., La pollution du fait du transport maritime des hydrocarbures. Responsabilité et Indemnisation des Dommages, Pedone, Monaco, 1994, 1 e.v.

De manier waarop de ansprakelijkheid werd beperkt, getuigde van een compromis tussen het continentale systeem dat was gebaseerd op de waarde van het schip en het Britse systeem, gebaseerd op een vast bedrag per ton (Tegelberg, G.G.A., "Olie op de golven", l.c., 48). 
In 1926 onderzochten experts in Washington het probleem van de olieverontreiniging door stookolie; hierbij werden maritieme zones bepaald waarbinnen het storten van stookolie werd verboden ${ }^{4}$. De experts bleven het evenwel oneens betreffende de grootte van deze zones en betreffende de invloed van het lozen van olie in volle zee.

Een belangrijke stap in de ontwikkeling van de internationale wetgeving inzake de aansprakelijkheid van scheepseigenaren werd gezet door het Verdrag van Brussel inzake de beperking van de aansprakelijkheid van eigenaren van zeeschepen van $1957^{5}$. Dit Verdrag bouwt voort op het eerder genoemde Verdrag van 1924. Overeenkomstig artikel I diende de eigenaar van een schip een bedrag ("limitation fund"), gebaseerd op het scheepstonnage, in te leveren bij de bevoegde gerechtelijke instantie. Bij zaakschade bedroeg de aansprakelijkheidsgtens 1.000 Poincaréfranken per ton; bij personenschade 3.100 Poincaréfranken per ton; en bij een combinatie van zaak en personenschade 2.100 Poincaréfranken per ton wat betreft de personenschade en 1.000 Poincaréfranken per ton wat betreft de zaakschade ${ }^{6}$. Dit systeem van goudfranken was sterk gekoppeld aan het in Bretton Woods opgestelde internationale monetaire systeem.

Door de verzwakking van de Amerikaanse dollar en het tengevolge hiervan geïntroduceerde systeem van de zwevende munten leidde de omrekening van de goudfranken in nationale munt tot aanzienlijke problemen. Dit, samen met de sterke inflatie in de jaren zestig, leidde ertoe dat de in 1957 vastgestelde limieten zeer laag kwamen te liggen ${ }^{7}$. De aansprakelijkheidsgrens en de manier warop die werd bepaald, diende bijgevolg grondig te worden herzien.

In maart 1967 leidde het ongeval met de Torrey Canyon tot een zware verontreiniging van de Britse en Franse kusten. Dit leidde op 29 november 1969) tot de adoptie van twee Verdragen. Het betreft in eerste instantie het "Verdrag betreffende maatregelen in volle zee bij een ongeval dat olicverontreiniging tot gevolg kan hebben"8. Op basis van deze interventieconventie kunnen kuststaten actie ondernemen ter voorkoming of eliminatie van ernstige en onmiddellijke gevaren voor hun kust tengevolge van cen ongeval op volle zee. Dit Verdrag is zowel van toepassing op olietankschepen als op andere schepen?.

Eveneens op 29 november 1969 kwam het Verdrag inzake de burgerlijke aansprakelijkheid voor schade veroorzaakt door verontreiniging door olie tot stand ${ }^{10}$ (beter bekend als het CLC-Verdrag). Dit Verdrag werd aangevuld door het Internationaal Verdrag ter oprichting van een Internationaal fonds voor vergoeding van schade door verontrciniging door olie van 18 december 1971. Aan deze beide Verdragen wordt in de volgende paragraaf uitgebreider aandacht besteed.

Massart, A., "De bezoedeling van oceanen en zccën", Rechiskundig Weekblad, 1968, 1466.

Trb., 1958, 46.

Artikel 3 van de Conventie van 1957.

Tegelberg, G.G.A., "Olie op de golven", l.c., 33 en 37.

In Belgiê werd dit Verdrag goedgekeurd bij wet van 29 juli 1971 (B.S., 2 februari 1972); in Nederland werd dit Verdrag goedgekeurd via de Wet olieverontreiniging zeewater; deze wet werd nadien vervangen door de wet verontreiniging zeewater (Wet van 5 juni 1975, Stb., 352) en de wet voorkoming verontreiniging door schepen (Stb. 1983, 683). Zie Havekes, H.J.M., "Wetgeving op de waterkwaliteit", in Brussaard, W, Drupsteen, Th. e.a. (red.), Milieurecht, W.E.J. Tjeenk Willink, Zwolle, vierde druk, 1996, 317 e.v.

Zie o.m. Sands, Ph., "Principles of International Environmental Law", l.c., 333; Cleton, R., "Civil Liability for Oil Pollution Damage caused by sea-going ships", Tijdschriff voor Milieuaansprakelijkheid, 1989, 109.

Gold, E., Handbook on Marine Pollution, Arendal, Gard, 1985, 23-32. 
Op 19 november 1976 kwam het Verdrag inzake de beperking van aansprakelijkheid voor maritieme vorderingen" tot stand. Dit Verdrag kan worden beschouwd als de opvolger van het Verdrag van Brussel van 1957 inzake de aansprakelijkheid van eigenaars van zeeschepen. Het Verdrag van 1976 introduceerde een nieuw element in de bepaling van de aansprakelijkheidsgrens: de ansprakelijkheid diende te worden beperkt tot het bedrag waarvoor de scheepseigenaar tegen redelijke kosten een verzekeringsdekking kon krijgen ${ }^{12}$. Meteen werden de aansprakelijkheidsgrenzen aanzienlijk opgetrokken - nochtans bleef en blijft het gehele systeem gerelateerd aan het scheepstonnage. De wijze waarop de aansprakelijkheidsgrens wordt berekend, is evenwel vrij ingewikkeld. Het Verdrag stelt in de artikelen 6 en 7 meerdere beperkingsfondsen in: een personenfonds, een zakenfonds en een passagiersfonds. Voor elk van deze fondsen zijn schalen vastgesteld, gebaseerd op de tonnage van het schip; binnen elke schaal geldt een vast bedrag per ton ${ }^{13}$. Op deze wijze bedraagt bijvoorbeeld het personenfonds voor een schip met een bruto inhoud van 90.000 ton 23,9 miljoen BTR $^{14}$.

Van groot belang is artikel 3 van het Verdrag inzake de beperking van maritieme vorderingen dat stelt dat het Verdrag niet van toepassing is indien schade veroorzaakt door verontreiniging door olie onder het toepassingsgebied van het C.LC-Verdrag valt ${ }^{15}$. Indien met andere woorden een schadevordering onder het CLC-Verdrag valt, kan een eigenaar de beperking van de Conventie van 1976 niet inroepen ${ }^{16}$.

In 1978 leidde het ongeval met de Amoco Cadiz tot een vervuiling van de Bretoense kusten. Naar aanleiding hiervan startten onderhandelingen voor de revisie van het CLC-Verdrag en het Oliefondsverdrag. In $1984 \mathrm{kwamen}$ twee Protocollen tot stand, respectievelijk het Protocol van het CLC-Verdrag en van het Oliefondsverdrag. Toen, tenslotte, na het ongeval met de Exxon Valdez in 1989 bleek dat deze Protocollen nog steeds niet in werking waren getreden, werd gewerkt aan de redactie van twee nieuwe Protocollen die in 1992 zijn tot stand gekomen en die jets later van kracht zijn geworden. Inhoudelijk zijn de Protocollen van 1992 nagenoeg identiek aan die van 1984; de voornaamste aanpassing in de Protocollen van 1992 heeft betrekking op de bepalingen inzake de inwerkingtreding ${ }^{17}$.

11 Ook bekend als de LLMC Conventie (Convention on the Limitation of Liability for Maritime Claims); van kracht vanaf 1 december 1986.

12 Abecassis, D., "The Framework of Liability in International Law", chapter 9, Abecassis, (ed.), Oil Pollution from Ships, London, Stevens and Sons, 1985, 186.

13 Zo bijwoorbeeld wat betreft het personenfonds, wordt het beperkingsfonds als volgt vastgesteld: 333.000 rekeneenheden voor een schip van een tonnage van niet meer dan 500 ton; voor een schip met een groter tonnage wordt daar telkens volgend bedrag bijgeteld: per ton tussen 501 en 3.000 ton: 500 rekeneenheden; per ton tussen 3.001 en 30.000 ton: 333 rekeneenheden; per ton tussen 30.001 en 70.000 ton: 250 rekeneenheden en per ton boven 70.000 ton: 167 rekeneenheden. Zie voor meer details: Cleton, R., "De Beperkte Aansprakelijkheid van de scheepseigenaar", l.c., 82 e.v.

Voorbceld overgenomen uit Cleton, R., "De Beperkte Aansprakelijkheid van de scheepseigenaar", l.c. 83.

Over de verhouding tussen het CLC-Verdrag en de hoger genoemde Converitie inzake de beperking van de aansprakelijkheid van eigenaren van zeeschepen van 1957, zie Vincineau, M., "Un Imbrogolio juridique: la loi du 20 juillet 1976 portant approbation et exécution de la Convention Internationale sur la responsabilité pour les dommages dus à la pollution des Hydrocarbures, faite à Bruxelles le 29 novembre 1969", Revue Belge de Droit International, 1978-79, 700 e.v.

Selvig, E., "The 1976 Limitation Convention and Oil Pollution Damage", Lloyds Maritime and' Commercial Law Quarterly, 1979, 21.

Cfr. infra, in $\$ 2.1$ van dit hoofdstuk. 
Volledigheidshalve dient erop te worden gewezen dat ter zake van aansprakelijkheid voor schade op zee, op 3 mei 1996 de International Convention on Liability and Compensation for Damage in Connection with the Carriage of Hazardous and Noxious Substances by Sea ("HNS-Verdrag") is tot stand gekomen ${ }^{1819}$. Dit Verdrag vertoont sterke gelijkenissen met het systeem zoals uitgewerkt in het CLC-Verdrag en het Oliefondsverdrag. In de eerste plaats hanteert het dezelfde basisprincipes zoals de risicoaansprakelijkheid van de scheepseigenaar, de beperking van diens aansprakelijkheid en de verplichte verzekering daarvan ${ }^{20}$. Daamaast hanteert het HNS-Verdrag een systeem bestaande uit twee dekkingslagen. De eerste laag bestaat uit de verplichte aansprakelijkheidsdekking van de scheepseigenaar. De tweede laag wordt gevormd door een nog op te richten HNSFonds ${ }^{21}$.

In de besproken periode kwamen ook een aantal Verdragen tot stand die de nadruk leggen op het beperken van de activiteiten die kunnen leiden tot de verontreiniging van de zee. In 1972 werden twee Verdragen gesloten met het oog op het beperken van zeeverontreiniging door het dumpen van gevaarlijke stoffen in zee. Het gaat om het "Verdrag van Oslo ter voorkoming van verontreiniging van de zee ten gevolge van het storten uit schepen en vliegtuigen" van 15 februari 1972 (of de Oslo Dumping Convention) en het "Verdrag van Londen ter voorkoming van de verontreiniging van de zee ten gevolge van het storten van afval en andere stoffen" van december 1972 (of de London Dumping Convention) $)^{22}$.

In 1973 werd het "Internationaal Verdrag ter preventie van olieverontreiniging op zee" of MARPOL-Verdrag afgesloten ${ }^{23}$. Het doel van MARPOL $73 / 78^{25}$ is het beperken van alle vormen van

19 Zie hierover o.m. Göransson, M., "Liability for damage to the Marine Environment", in Boyle, A. en Freestone, D., (ed.), International Law and Sustainable Developments. Past Achievements and Future Challenges, Oxford University Press, Oxford, 1999, 353 e.v.; de Boer, J.E., "Internationale aansprakelijkheidsverdragen inzake olieverontreiniging en het zeevervoer van gevaarlijke stoffen", Tijdschrift voor Milieuaansprakelijkheid, 1999/4, $106 \mathrm{e.v}$.

Over de problemen bij de totstandkoming van dit Verdrag, zie Wetterstein, P., "Trends in maritime environmental impairment liability", Lloyds Maritime and Commercial Law Quarterly, 1994, 232; Abecassis, D., "Risk Sharing in LNG shipping - some aspects of the relationships between owners and charterers of LNG ship and third parties", Lloyd's Maritime and Commercial Law Quarterly, 1982, 148; Cleton, R., "Liability and Compensation for Maritime Carriage of Hazardous and Noxious Substances (HNS)", in De la Rue, C.M., (ed.), Liability for Damage to the Marine Environment, Llyod's of London, 1993, 173-188.

Artikel 13 van het HNS-Verdrag. Zie hierover Brans, E.H.P., van der Veen, G.A., "Publiek domein en aansprakelijkheid voor milieuschade veroorzaakt door milieuverontreiniging: de Patmos en de Haven", Tijdschrift voor Milieuaansprakelijkheid, 1999/4, 106.

Beide Verdragen beogen het voorkomen of beperken van zeeverontreiniging door het lozen van bepaalde stoffen te verbieden of te reglementeren; terwijl het Verdrag van Oslo een regionale werkingssfecr heeft, heeft het Verdrag van Londen een mondiale werkingssfeer. Zie hierover o.m. Timagenis, G.J., International Control of Marine Pollution, Oceana Publications, 1980, 124 e.v.

Dit is de opvolger van het in 1954 tot stand gekomen "International Convention for the Prevention of Oil Pollution" (OlLPOL-Verdrag). Zie hierover Massart, A., "De bezoedeling der zeeên en oceanen", o.c., 1468.

In Nederland is dit Verdrag uitgewerkt in de Wet voorkoming verontreiniging door schepen (Wws, Stb. 1983, nr. 683); in Belgie werd het Verdrag goedgekeurd bij wet van 17 januari 1984 (Wet tot goedkeuring van het Verdrag tot voorkoming van de verontreiniging van de zee door schepen, B.S., 24 mei 1984) en uitgevoerd bij wet van 6 april 1995, B.S., 27 juni 1995.

Door de wijziging van het Verdrag in 1978, wordt naar deze Conventie verwezen als MARPOL $73 / 78$. Zie o.m. Birubaker, D., Marine Pollution and International Law, Belhaven Press, London and Florida, 1993, 122 e.v.; Sands, Ph., "Principles of International Environmental Law", l.c., 326 e.v.; Tegelberg, G.G.A., "Olie op de Golven", l.c., 12 e.v. 
zeeverontreiniging, zowel door olie als andere gevaarlijke stoffen, zowel door opzettelijke als accidentele lozingen. Meteen is dit Verdrag een van de belangrijkste Verdragen met betrekking tot de preventie van zeeverontreiniging door schepen ${ }^{26}$. In december 1982 werd het VN-Verdrag inzake het recht van de zee (beter bekend als UNCLOS) gesloten ${ }^{27}$. Het UNCLOS, dat van kracht is sinds 16 november 1994, heeft als basis gediend voor de redactie van een aantal regionale Verdragen ter bescherming van de zee en voor verschillende internationale Verdragen terzake ${ }^{28}$. Krachtens UNCLOS zijn Staten ertoe gehouden zeeverontreiniging te voorkomen, te beperken en te controleren. In 1992 kwamen een aantal nieuwe of "tweede generatie"-zeerechtverdragen tot stand. Het belangrijkste Verdrag in dit verband is het Verdrag van Parijs ter voorkoming en beperking van zeeverontreiniging in de Noordelijke Atlantische Oceaan van 22 september $1992^{29}$. Dit "nieuwe" Verdrag van Parijs is van tocpassing op de Noordzee en op het noordoostelijke deel van de Atlantische Oceaan en stelt een verbod in tot het dumpen van afvalstoffen vanaf schepen, een verbod tot het dumpen van kernafval en het bevat een aantal regels die gelden voor booreilanden.

Uit bovenstaande gegevens blijkt dat verschillende intemationale Verdragen van toepassing zijn op de olieverontreiniging op zee. Een groot aantal van deze Verdragen, waarvan MARPOL 73/78 en UNCLOS de belangrijkste zijn, beogen de preventie van zeeverontreiniging. Tegelijk zijn gedurende de twintigste eeuw meerdere Verdragen tot stand gekomen die de beperking van de aansprakelijkheid van scheepseigenaren beogen: het Verdrag van Brussel van 1924 voor de eenmaking van zekere regels betreffende de beperking van de aansprakelijkheid van eigenaren van zeeschepen, het Verdrag van Brussel van 1957 nopens de beperking van de aansprakelijkheid van eigenaren van zeeschepen en het Verdrag van Londen van 1976 inzake de beperking van aansprakelijkheid voor maritieme vorderingen. Deze Verdragen moeten worden gezien als een essentieel onderdeel van andere intermationale Verdragen inzake aansprakelijkheid voor olieverontreiniging waarvan de CLC- en het Oliefondsverdrag de belangrijkste zijn ${ }^{30}{ }^{31}$. In dit hoofdstuk wordt dan ook met name aan deze Verdragen aandacht besteed.

\footnotetext{
26 Brubaker, D., "Marine Pollution and International Law", l.c., 122; Sands, Ph., Principles of International Environmental Law", l.c., 327.

Als afkorting van de Engels titel van het Verdrag: "United Nations Convention on the Law of the Sea", tot stand gekomen in Montego Bay. Zie o.m. Timagenis, G.J., "International Control of Marine Pollution", l.c., 577 e.v.; Sands, Ph., "Principles of Intemational Environmental Law", l.c., 293 e.v., Tonnacr, F.P.C.L, "Handboek van het Nederlands Milieurecht", l.c., 252.

Zie hierover Carette, A., "Herstel van en vergoeding voor aantasting aan niet-toegeêigende milieubestanddelen", l.c., 220 e.v.; Anderson, D.H., "Legal Implications of the Entry into force of the UN Convention on the Law of the Sea", International and Comparative Law Quarterly, vol. 44, 1995, 313 326.

29 Trb. 1993, nr. 16; het Verdrag dat weliswaar door Belgiê en Nederland werd ondertekend, is evenwel nog niet van kracht. Het Verdrag vervangt de bovengenoemde Verdragen van Oslo en van Parijs. Abecassis, D., "The Framework of Liability in International Law", chapter 9, Abecassis, (ed.), Oil Pollution from Ships, London, Stevens and Sons, 1985.

Het samengaan van enerzijds de Conventies van 1969 en 1971 en van de drie andere Verdragen anderzijds, leidt tot een complex geheel van regels waar de aansprakelijkheid van verschillende actoren (scheepseigenaren, reders, scheepsbouwers etc.) is gebaseerd op verschillende regels, waardoor meteen de mogelijkheid van deze actoren om de aansprakelijkheid te beperken en vooral de hoogte van deze beperking, sterk kan verschillen (Abecassis, D., "The Framework of Liability in International Law", o.c., 186).
} 


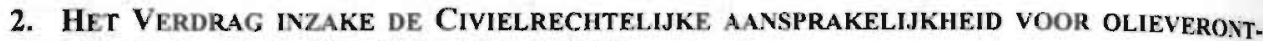
REINIGING OP ZEE VAN 29 NOVEMBER 1969

In eerste instantie wordt toelichting verschaft bij het tot stand komen van het CLC-Verdrag en de wijzigingen aan dit verdrag $(\$ 2.1)$. Nadien wordt aandacht besteed aan het territoriaal toepassingsgebied $(\$ 2.2)$ en worden de basisprincipes van dit Verdrag besproken ( $\$ 2.3)$.

\subsection{Tot stand komen van het Verdrag en van de wijzigingen}

Op 29 november 1969 kwam in Brussel "The International Convention of Civil Liability for Oil Pollution Damage" - of het CLC-Verdrag - tot stand. Dit Verdrag werd afgesloten in de schoot van de IMCO (Intergovernmental Maritime Consultative Organisation), thans de IMO (International Maritime Organisation).

Het CLC.Verdrag werd - net zoals het Oliefondsverdrag - reeds driemaal gewijzigd, met name door de Protocollen van 1976, 1984 en 1992. Terwijl het eerste Protocol voomamelijk als doel had de goudfranken om te zetten in rekeneenheden van het Internationaal Muntfonds, leidde vooral het Protocol van 1984 tot aanzienlijke wijzigingen in het vigerende stelsel. Het hoofddoel van het Protocol was het optrekken van de aansprakelijkheidslimieten, zowel van het C.LC-als van het Oliefondsverdrag ${ }^{32}$. Deze limieten waren te laag geworden tengevolge van de zware inflatie sinds het in werking treden van beide Verdragen; tegelijk had het ongeval met de Amoco Cadiz aangetoond dat de bestaande limieten ontoereikend waren ${ }^{33}$.

Van meet af aan was echter reeds duidelijk dat het Protocol van 1984 nooit in werking zou treden. Het Protocol van 1984 zou slechts in werking zijn getreden wanneer de grootste olie-importeurs ter wereld (met name de Verenigde Staten en Japan) tot het Verdrag toetraden ${ }^{34}{ }^{35}$. Daarenboven wachtten andere Staten totdat de VS zouden toetreden vooraleer zelf de Protocollen te ondertekenen $^{36}$. Onder president Bush waren de Verenigde Staten nochtans bereid toe te treden tot het CLC-Verdrag, maar tengevolge van het ongeval met de Exxon Valdez in 1989 oordeelde het Amerikaanse Congres dat de aansprakelijkheidslimieten onder het CLC-Verdrag te laag waren en dat het in de toekomst moeilijk zou zijn deze limieten te verhogen ${ }^{37}$. Tegelijk vreesden de Vere-

Abecassis, D., "International Conventions on Civil Liability for Oil Pollution Damage", o.c, 239; Göransson, M., "The 1984 and 1992 Protocols to the Civil Liability Convention, 1969 and the Fund Convention, 1971", in De la Rue, C.M., (ed.), Liability for Damage to the Marine Environment, Lyod's of London, 1993, 72.

Göransson, M., "The 1984 and 1992 Protocois to the Civil Liability Convention, 1969 and the Fund Convention, 1971", o.c., 72; Rémond-Gouilloud, M., "The Future of the Compensation System established by International Convention", in De la Rue, C.M., (ed.), Liability for Damage to the Marine Environment, Llyod's of London, 1993, 89.

Op basis van artikel 13 van het CLC-Protocol van 1984 treedt het Protocol in werking twaalf maanden nadat tien landen, inclusief zes landen met een groter tonnage dan 1 miljoen tonnage-eenheden, zjn toegetreden.

Zie hierover Oosterveen, W.J.G., "Verbeterde mogelijkheden voor vergoeding van schade door ongevallen met olietankers", Ars Aequi, 1997, nr. 6, 424. Gorransson, M., "The 1984 and 1992 Protocols to the Civil Liability Convention, 1969 and the Fund Convention, 1971 ", o.c., 74.

De Verenigde Staten hebben het Protocol weliswaar ondertekend, maar ze hebben het nooit geratificeerd (Van Hanswyck, B., "The 1984 Protocols to the International Convention on Civil Liability for Oil Pollution Damages and the International Fund for Compensation for Oil Pollution Damages: An Option for Needed Reform in United States Law", The International Lawyer, 1988, vol. 22, 323). Zie hierover ook Wu, C., "La pollution du fait du transport maritime des hydrocarbures", l.c., 289 e.v. 
nigde Staten dat de ratificatie van het Verdrag afbreuk zou doen aan de onbeperkte aansprakelijkheid van de scheepseigenaar zoals neergelegd in de wetgeving in enkele $\operatorname{Staten}^{38}$ en dat een toetreding tot het Verdrag zou verseisen dat het recht van de verschillende Staten, met name inzake de kanalisatie van aansprakelijkheid, zou moeten worden gewijzigd ${ }^{39}$. Om die reden hebben de Verenigde Staten het CLC-Verdrag niet geratificeerd en hebben zij door middel van de Oil Pollution Act (OPA) van 1990 voorzien in een federale wetgeving terzake ${ }^{40}$. De Protocollen van 1984 zijn dan ook nooit in werking getreden.

In november 1992 werd vervolgens opnieuw een diplomatieke Conferentie samengeroepen teneinde de bepalingen inzake de inwerkingtreding van de Protocollen van 1984, te herzien ${ }^{41}$. Op deze wijze kwamen de Protocollen van 1992 tot stand. Vier jaar later, op 30 mei 1996, zijn de Protocollen in werking getreden. Inhoudelijk zijn de Protocollen van 1992 quasi identick aan die van 1984, op de bepalingen inzake het in werking treden $\mathrm{na}^{42}$. Volledigheidshalve moet erop worden gewezen dat de Protocollen van 1992 die van 1984 vervangen en niet wijzigen ${ }^{43}$.

Het Protocol voert in de eerste plaats een specifieke aansprakelijkheidslimict in voor kleinere schepen en het verhoogt de reeds bestaande aansprakelijkheidslimieten. Tegelijk werd de tussenkomst van het IOPC-Fonds verhoogd. Daarnaast leidt het Protocol tot een uitbreiding van het territoriale toepassingsgebied tot de exclusieve economische zone zoals gedefinieerd onder UNCLOS. Zelfs indien geen olieverontreiniging plaatsvindt worden preventieve maatregelen vergoed, op voorwaarde weliswaar dat er sprake is van een ernstige dreiging. Tenslotte wordt een nieuwe definitie gegeven van schade door verontreiniging, waarbij de kosten veroorzaakt door het herstellen van het milieu in zijn oorspronkelijke staat, worden gedekt.

In België en Nederland werden het CLC-Verdrag en het Protocol goedgekeurd, wat België betreft bij wet van 20 juli $1976^{44}$ en bij wet van 11 april 198945; in Nederland werd het CLC-Verdrag

Sturms, W. W., "Internationale ontwikkelingen met betrekking tot aansprakelijkheid voor milieuschade", X., Risicoaansprakelijkheid voor milieuschade, Vereniging voor milieurecht, W.E.J. Tjeenk Willink, Zwolle, 1992, 147.

Zie hierover in detail Wu, C., "La pollution du fait du transport maritime des hydrocarbures", l.c., 288. Brans, E.H.P., "Liability for Leological Damage under the 1992 Protocols to the Civil Liability Convention and the Fund Convention, and the Oil Pollution Act of 1990", Tijdschrift voor Milieuaansprakelijkheid, 1994, afl. 3,64.

¿1 Wetterstein, P., "Trends in maritime environmental impairment liability", Lloyd's Maritims' and ( ommercial Law Quarterly, 1994, 231.

Brails, E.H.P., "Liability for Ecological Damage under the 1992 Protocols to the C'ivil Liability Convention and the Fund Convention, and the Oil Pollution Act of 1990", o.c., 64; Goransson, M., "I he 1984 and 1992 Protocols to the Civil Liability Convention, 1969 and the Fund Convention, 1971 ", o.c., 78 .

4 Göransson, M., "The 1984 and 1992 Protocols to the Civil Liability Convention, 1969 and the Fund Convention, 1971", o.c., 79. De Protocollen van 1984 blijven weliswaar formeel bestaan, maar Staten worden aangemoedigd om enkel tot die van 1992 toe te treden; Staten die toch al de Protocollen van 1984 hadden geratiticeerd worden aangemocdigd om deze ratificatie ongedaan te maken.

4 Wet tot goedkeuring en uitvoering van het Verdrag inzake de burgerlijke aansprakelijkheid voor schade veroorzaakt door olieverontreiniging, B.S, 13 april 1977: zie o.m. Maes, F., "De burgerrechtelijke aansprakelijkheid van de scheepseigenaar voor schade ontstaan door olieveronirciniging: ein verduidelijking bij de toepasselijke Verdragen en contracten", Revue Belge de Droit International, 1988/1, 97-128; Faure, M. en Van den Bergh, R., "Objectieve Aansprakelijkheid", l.c, 270 e.v.

Artikel 1, b) van de wet van 11 april 1989 houdende goedkeuring en uitvoering van diverse Internationale Akten inzake de zecvaart, $B . S, 6$ oktober 1989; deze wet werd op haar beurt uitgevoerd bij KB van 27 november 1989 , B.S., 1 december 1989. 
goedgekeurd bij wet van 11 juni $1975^{46}$; op 4 september 1996 kwam in Nederland een wet tot stand waarbij de Wet aansprakelijkheid olietankschepen in overeenstemming wordt gebracht met de door het Protocol van 1992 aangebrachte wijzigingen ${ }^{47}$. Deze wet is in werking getreden op 15 november $1997^{48}$. In België werd het Protocol van 1992 goedgekeurd bij wet van 10 augustus $1998^{49}$; deze wijzigingen werden van kracht met ingang van 1 februari $2000^{50 ~} \mathrm{sI}$.

Op 30 september 2000 waren 64 landen lid geworden van het vernieuwde CLC-Verdrag ${ }^{52}$. Voor de volledigheid wordt erop gewezen dat door de toetreding van België en Nederland tot het nieuwe CLC-Verdrag (en het Oliefondsverdrag) beide landen hun lidmaatschap aan deze "oorspronkelijke" verdragen hebben opgezegd ${ }^{53}$

\subsection{Territoriaal toepassingsgebied}

Het CLC-Verdrag is enkel van toepassing op schade door olieverontreiniging veroorzaakt op het grondgebied van een Verdragsluitende Staat (inclusief de territoriale zee) en op preventieve maatregelen ter voorkoming of beperking van zodanige schade ${ }^{54}$. Het aanknopingspunt in het Verdrag is dus de plaats waar de schade is geleden, en dit ongeacht de plaats waar het olielek dat tot de schade heeft aanleiding gegeven, zich heeft voorgedaan ${ }^{55}$.

Onder het schadebegrip vallen verlies of schade buiten het olievervoerende schip, inclusief de kosten van preventieve maatregelen ${ }^{56}$. Sinds het in werking treden van het Protocol van 1992, is

Wet aansprakelijkheid olietankschepen (Waot), Stb. 1975, nr. 321, nadien gewijzigd. Voor een bespreking van deze wet zie Tonnaer, F.P.C.L., "Handboek van het Nederlands Milieurecht", l.c., 1233 e.v. Wet tot wijziging van de Wet aansprakelijkheid olietankschepen, Stb., 1996, 461.

Artikel 1 van het Besluit van 17 april 1997, houdende vaststelling tijdstip inwerkingtreding van de wet van 4 september 1996 tot wijziging van de Wet aansprakelijkheid olietankschepen en van de wet van 26 juni 1996 tot wijziging van de Wet schadefonds olietankschepen, Stb., 1997, 167.

Wet houdende goedkeuring van het Protocol van 1992 tot wijziging van het Internationaal Verdrag van Brussel inzake de burgerlijke aansprakelijkheid voor schade door verontreiniging door olie, van 1969 en de Bijlage, gedaan te Londen op 27 november 1992 (B.S.,16 maart 1999).

$\mathrm{KB}$ van 26 juni 2000 tot vaststelling van de datum van inwerkingtreding van de wet van 10 augustus 1998 houdende instemming met het Protocol van 1992 tot wijziging van het Intemationaal Verdrag van Brussel inzake de burgerlijke aansprakelijkheid voor schade door verontreiniging door olie, 1969 en de Bijlage, gedaan te Londen op 27 november 1992 (B.S., 5 oktober 2000). Eerder had Belgiê op 6 oktober 1998 het CLC-Verdrag van 1969 opgezegd (B.S., 16 maart 1999).

Zie over dit verdrag: Carette, A., "Herstel van en vergoeding voor aantasting aan nict-toegeetigende milieubestanddelen", l.c., 242-266; Swinnen, J., "Burgerlijke ansprakelijkheid voor milieuschade door olieverontreiniging afkomstig van schepen: recente ontwikkelingen", Milieu- en Energierecht, 1999, nr. 3, 75-79.

Bron: website van de International Maritime Organisation op 15 oktober 2000 (www.imo.org).

Wat Belgiê betreft: zie "Internationaal Verdrag inzake de burgerlijke aansprakelijkheid voor schade door verontreiniging door olie en bijlage, opgemaakt te Brussel op 29 november 1969. Internationaal Verdrag ter oprichting van een Internationaal Fonds voor vergoeding van schade door verontreiniging door olie, opgemaakt te Brussel op 18 december 1971. Opzegging door België", B.S. 16 maart 1999; wat Nederland betreft: Oosterveen, W.J.G., "Verbeterde mogelijkheden voor vergoeding van schade door ongevallen met olietankers", o.c., 429; de Boer, J.E., "Internationale aansprakelijkheidsverdragen inzake olieverontreiniging en het zeevervoer van gevaarlijke stoffen", o.c., 106. Artikel 2 van het CLC-Verdrag.

Wu, C., "La pollution du fait du transport maritime des hydrocarbures", l.c., 55.

Dit zijn "alle na het voorval door een persoon genomen redelijke maatregelen ter voorkoming of beperking van de verontreiniging" (artikel 1 , alinea 7 van het CLC-Verdrag). 
het territoriale toepassingsgebied uitgebreid tot de exclusieve economische zone ${ }^{57}$ van een Verdragsluitende Staat. Een dergelijke territoriale uitbreiding van het CLC-Verdrag was een van de grote discussiepunten bij de redactie en de onderhandelingen van het Protocol van 1976. Tegenstanders vreesden dat een dergelijke uitbreiding zou leiden tot exorbitant hoge vorderingen ${ }^{58}$. Of dit argument werkelijk van waarde is, valt te bezien. Het overgrote deel van olievervuiling vindt immers plaats in de territoriale zee van een Staat, met name voor de kust en vlakbij een haven.

Het zou te ver voeren om uitgebreid stil te staan bij het begrippenarsenaal van het CLC-Verdrag. Hiervoor kan worden verwezen naar de verdragsbepalingen zelf en naar de literatuur ${ }^{s 9}$. In het kader van dit proefschrift zijn met name de basisprincipes van het CLC-Verdrag van belang.

\subsection{Basisprincipes van de wetgeving inzake de aansprakelijkheid vor schade door oliever- ontreiniging op zee}

Van groot belang voor dit onderzoek, is uiteraard de analyse van de basisprincipes die door het CLC-Verdrag worden gehanteerd. Dit zal met name toelaten om een vergelijking te maken met de basisprincipes van het nucleaire aansprakelijkheidsrecht. Alleen al het overzicht van de basisprincipes van het CLC-Verdrag wijst op een sterke gelijkenis tussen beide. Ook in het CLC-Verdrag is sprake van risicoaansprakelijkheid $(\S 2.3 .1)$, kanalisatie van aansprakelijkheid $(\S 2.3 .2)$, beperking van de aansprakelijkheid ( $\$ 2.3 .3$ ) en verplichte verzekering van de aansprakelijkheid $(\$ 2.3 .4)$; tenslotte worden eveneens een aantal procesrechtelijke bepalingen ingevoerd $(\S 2.3 .5)$.

\subsubsection{Risicoaansprakelijkheid}

Artikel 3, $1^{\circ}$ van het CLC-Verdrag van 1969 voert een risicoaansprakelijkheid in in hoofde van de eigenaar van het schip:

"de eigenaar van het schip op tijdstip van het voorval (...) is aansprakelijk voor schade door verontreiniging, veroorzaakt door olie welke tengevolge van het voorval uit het schip is ontsnapt of weggevloeid".

Blijkbaar werd gekozen voor een risicoaansprakelijkheid, omdat dit voor slachtoffers de meest rechtvaardige oplossing zou zijn. Een regime van foutaansprakelijkheid zou aanleiding geven tot

De tweehonderdmijlszone, zoals ingesteld door UNCLOS. Zie Abecassis, D., "International Conventions on Civil Liability for Oil Pollution Damage", o.c., 234; Van Hanswyck, B., "The 1984 Protocols to the International Convention on Civil Liability for Oil and Pollution Damages and the International Fund for Compensation for Oil Pollution Damages: An Option for Needed Reform in United States Law, o.c., 324 .

Abecassis, D., "Intemational Conventions on Civil Liability for Oil Pollution Damage", o.c., 235.

Zie met name Abecassis, D., "International Conventions on Civil Liability for Oil Pollution Damage", o.c., 230 e.v.; Cleton, R., "Civil Liability for Oil Pollution Damage caused by Sea-going Ships", o.c., 117 e.v.; Wu, C., "La pollution du fait du transport maritime des hydrocarbures", l.c., 189 e.v.; Brans, E.H.P., "Liability for Ecological Damage under the 1992 Protocols to the Civil Liability Convention and the Fund Convention, and the Oil Pollution Act of 1990", o.c., 63; Brans, E.H.P., van der Veen, G.A., "Publiek domein en aansprakelijkheid voor milieuschade veroorzaakt door milieuverontreiniging: de Patmos en de Haven", o.c., 109-118; Jacobsson, M., "The Intemational Conventions on Liability and Compensation for Oil Pollution Damage and the Activities of the Internationa! Oil Pollution Compensation Fund", in De la Rue, C.M., (ed.), "Liability for Damage to the Marine Environment", l.c., 1993, 51 e.v.; Rémond-Gouilloud, M., "The Future of the Compensation System established by International Convention", in De la Rue, C.M., (ed.), "Liability for Damage to the Marine Environment", i.c., 92 e.v. 
langdurige processen waardoor slachtoffers aanzienlijke kosten zouden moeten maken teneinde compensatie voor de geleden schade te kunnen verkrijgen ${ }^{60}$. Bij de onderhandelingen van het Verdrag, drongen de vertegenwoordigers van het Verenigd Koninkrijk nochtans sterk aan op de introductie van een foutaansprakelijkheid, met omkering van de bewijslast; een regime van risico. aansprakelijkheid zou namelijk leiden tot een verdubbeling van de verzekeringspremies ${ }^{6 !}$.

Artikel 4 van het CLC-Protocol van 1992 heeft artikel 3, $1^{\circ}$ alinea gewijzigd. Voortaan is de eigenaar van het schip op het tijdstip van het voorval aansprakelijk voor schade door verontreinjging veroorzaakt door het schip als gevolg van het voorval ${ }^{62}$. Deze wijziging heeft vooral betrekking op de wijziging van het begrip "voorval" zoals hierboven besproken. Onder het oorspronkelijke CLC-Verdrag was de scheepseigenaar enkel aansprakelijk nadat olie uit het schip was ontsnapt of weggevloeid. Vandaar werd deze bepaling aangepast: ook indien nog geen olie is ontsnapt uit het schip kan de scheepseigenaar aansprakelijk worden gesteld voor de kosten van de preventieve maatregelen. De aanpassing van artikel 3 van het CLC-Verdrag moet bijgevolg worden gezien als een logisch gevolg van de nieuwe definitie van het begrip voorval.

Zowel in het oorspronkelijke als onder het nieuwe CLC-Verdrag is dus geen fout in hoofde van de scheepseigenaar vereist opdat deze aansprakelijk zou kunnen worden gesteld. De aansprakelijkheid onder het CLC-Verdrag kan worden beschouwd als een vorm van risicoaansprakelijkheid $^{63}$, met dien verstande dat het slachtoffer steeds zal moeten aantonen dat sprake is van een verontreiniging door olie en van een dreiging van zulke verontreiniging.

De eigenaar is niet aansprakelijk indien hij bewijst dat de schade ${ }^{64}$ :

- het gevolg is van cen oorlogsdaad, vijandelijkheden, burgeroorlog of een natuurverschijnsel van uitzonderlijke, onvermijdelijke en onweerstaanbare aard;

- geheel en al werd veroorzaakt door het opzettelijke handelen of nalaten van derden met de bedoeling de schade te veroorzaken;

- geheel $\mathrm{cn}$ al werd veroorzaakt door onzorgvuldigheid of een andere onrechtmatige handeling van een regering of andere overheid, verantwoordelijk voor het onderhoud van lichten of andere hulpmiddelen bij de navigatie in de vervulling van die taak.

Daarenboven zal de eigenaar niet of slechts gedeeltelijk aansprakelijk zijn indien hij bewijst dat de schade door verontreiniging geheel of gedeeltelijk is veroorzaakt door het slachtoffer ${ }^{65}$. Het spreekt voor zich dat deze exoneratie enkel geldt ten aanzien van het slachtoffer in kwestic en niet ten aanzien van alle slachtoffers.

\subsubsection{Kanalisatie van aansprakelijkheid}

Gelet op de centrale positie die het thema kanalisatie van aansprakelijkheid inneemt in dit onderzoek, wordt hieronder niet enkel aandacht besteed aan de verdragsbepalingen zelf $(\$ 2.3 .2 .1)$,

Wu, C., "La pollution du fait du transport maritime des hydrocarbures", l.c., 70.

$\mathrm{Wu}, \mathrm{C}$., "La pollution du fait du transport maritime des hydrocarbures", l.c., 7 l.

Onze cursivering.

63 Faure, M. en Van den Bergh, R., "Objectieve Aansprakelijkheid", l.c., 273; Tegelberg, G.G.A., "Olie op de golven", l.c., 54; Vincineau, M., "Un Imbrogolio juridique: la loi du 20 juillet 1976 portant approbation et exécution de la Convention Internationale sur la responsabilité pour les dommages dus à la pollution des Hydrocarbures, faite a Bruxelles le 29 novembre 1969", o.c., 698. Artikel 3, $2^{\circ}$ lid van het CLC-Verdrag; niet gewijzigd door het Protocol van 1992.

Artikel $3,3^{\circ}$ lid van het CLC-Verdrag.
} 
maar eveneens aan de uitwerking ervan in het Belgische en Nederlandse maritieme recht (respectievelijk $\S 2.3 .2 .2$ en $\S 2.3 .2 .3$ ).

\subsubsection{Volgens hel Verdrag}

Overeenkomstig de eerdere analyse van het begrip kanalisatic van aansprakelijkheid, vloeit cen deel van de kanalisatie in het maritieme aansprakelijkheidsrecht voort uit de gekozen juridische grondslag: uit artikel $3,1^{\circ}$ volgt reeds dat de eigenaar van het schip aansprakelijk is.

Bij de onderhandelingen van het CLC-Verdrag is veel gedebatteerd omtrent de vraag wie aansprakelijk diende te worden gesteld voor schade door verontreiniging: de eigenaar van het schip, de exploitant van het schip, dan wel de eigenaar van de lading. Uiteindelijk werd de aansprakelijkheid gelegd bij de eigenaar omdat dit om praktische reden de meest eenvoudige oplossing zou $z_{i j n}{ }^{66}$. Het zou voor slachtoffers veel moeilijker zijn om op zoek te gaan naar de eigenaar van de lading. Bovendien moet de keuze om de aansprakelijkheid te leggen bij de eigenaar van het schip, worden gezien in samenhang met het Oliefondsverdrag dat voorziet in een financiële bijdrage vanwege de olie-industrie.

Maar het CLC-Verdrag gaat - net als het Verdrag van Parijs van 29 juli 1960 inzake de civiele aansprakelijkheid bij kemongevallen - een stuk verder. Artikel 3, 4${ }^{\circ}$ van het CLC-Verdrag doet namelijk ook een uitspraak over de andere juridische grondslagen op basis waarvan de eigenaar van het schip desgevallend kan worden aansprakelijk gesteld.

Onder het CLC-Verdrag van 1969 werd de kanalisatic van aansprakelijkheid als volgt omschreven:

"Geen vordering tot vergoeding van schade door verontreiniging door olie kan tegen de eigenaar worden ingesteld anders dan in overeenstemming met dit Verdrag. Noch op grond van dit Verdrag, noch op enige andere grond, kan een vordering tot vergoeding van schade door verontreiniging door olie worden ingesteld tegen de aangestelden of lasthebbers van de eigenaars".

Ingevolge deze bepaling geniet de eigenaar van het schip van de beschermende of exonererende werking van de kanalisatie ${ }^{67}$ : de eigenaar kan enkel op basis van dit Verdrag aansprakelijk worden gesteld. De immuniteit van de aangestelden of lasthebbers van de eigenaars gaat nog een stuk verder, omdat zij noch op basis van het CLC-Verdrag, noch op een andere juridische grondslag kunnen worden aansprakelijk gesteld. Volledigheidshalve wordt erop gewezen dat ook in het door de vertegenwoordigers van het Verenigd Koninkrijk ingediende voorstel - waar werd uitgegaan van cen regime van foutaansprakelijkheid met omkering van de bewijslast - in eenzelfde kanalisaticclausule was voorzien ${ }^{68}$.

De redenen waarom de kanalisatie van aansprakelijkheid werd ingevoerd, liggen voor de hand. Kanalisatie zou voor slachtoffers grote voordelen bieden omdat ze weten van wie schade-

Zie hievover Wu, C., "La pollution du fait du transport maritime des hydrocarbures", l.e, 62 e.v.

Cif. supra, in \$2.4. I van hoofdstuk 4.

Wu, C., "La pollution du fait du transport maritime des hydrocarbures", l.c., 215. 
vergoeding kan worden gevorderd; tegelijk wordt vermeden dat meerdere personen zich zouden verzekeren voor hetzelfde risico ${ }^{69}$.

Door het. CLC.Protocol van 1992 werd de kanalisatie uitgebreid tot een aantal andere categorieên van mogelijke betrokkenen, met name: de loods, de bevrachter, de persoon die met instemming van de eigenaar of in opdracht van een bevoegde overheidsinstantie hulpverleningswerkzaarnheden heeft verricht, de persoon die preventieve maatregelen neemt en de ondergeschikten of lasthebbers van al deze personen ${ }^{70} 71$. Tegenover de genoemde categorieën van personen kan het gemene aansprakelijkheidsrecht bijgevolg niet meer worden ingeroepen. De bedoeling van deze uitbreiding was deze personen te beschermen tegen vorderingen voor schade veroorzaakt door deze preventieve maatregelen ${ }^{72}$.

Een vordering tot schadevergoeding door olieverontreiniging kan tegen de eigenaar enkel worden ingesteld overeenkomstig het Verdrag ${ }^{73}$. Gemeenrechtelijke vorderingen tegen andere personen zoals de scheepsbouwer blijven, zelfs na de verstrakking van de kanalisatie door het Protocol van 1992 , evenwel mogelijk ${ }^{74}$. Personen die niet voorkomen in de lijst van artikel $3,4^{\circ}$ kunnen inderdaad op basis van het gemene aansprakelijkheidsrecht worden aansprakelijk gesteld ${ }^{75}$. Tegenover de personen die wél op de lijst voorkomen, kan enkel het Verdrag als juridische grondslag worden aangewend.

Bij de bespreking van het Protocol van 1984 werd op basis van de ervaringen met de Amoco $\mathrm{Cadiz}^{76}$ voorgesteld een algehele kanalisatie van aansprakelijkheid in te voeren, waarbij een vordering tot schadevergoeding door olieverontreiniging enkel op grond van een Verdrag kon worden ingesteld tegen de scheepseigenaar ${ }^{77}$. Het doortrekken van de kanalisatie van aansprakelijkheid zou een overlappende verzekeringsdekking door verschillende potentiële aansprakelijke personen - naast de scheepseigenaar - overbodig maken, waardoor een grotere capaciteit op de verzekeringsmarkt zou ontstaan. De uitbreiding van de kanalisatie van aansprakelijkheid tot andere personen dan de eigenaar, zoals tot stand gekomen in het Protocol van 1984, was eng verbonden met de discussie betreffende het optrekken van de aansprakelijkheidsgrens: een aantal Verdragsluitende Staten stelde het optrekken van de aansprakelijkheidslimieten als voorwaarde voor

Oosterveen, W.J.G., "Verbeterde mogelijkheden voor vergoeding van schade door ongevallen met olietankers", o.c., 427; Wu, C., "La pollution du fait du transport maritime des hydrocarbures", l.c., 216-217.

Volgens Rémond-Gouilloud gaat deze lijst te ver. De lijst omvat drie verschillende categorieén personen zonder enige nuanceringsmogelijkheid (Rémond-Gouilloud, M., "The Future of the Compensation System established by International Convention", in "Liability for Damage to the Marine Envionment", l.c., 95). Het Verdrag definieert niet wat onder lasthebbers of aangestelden dient te worden verstaan; deze begrippen zullen bijgevolg worden ingevuld overeenkomstig nationaalrechtelijke bepalingen.

Abecassis, D., "Intemational Conventions on Civil Liability for Oil Pollution Damage", o.c., 233.

Merk op dat indien de geleden schade niet door olieverontreiniging werd veroorzaakt, de kanalisatie van aansprakelijkheid niet zal gelden; in een dergelijk geval zal de aansprakelijkheid en de mogelijke beperking daarvan, worden bepaald door bijvoorbeeld de LLMC-Conventie van 1976. Daarom wordt deze beperkte kanalișatie geacht van slechts geringe waarde te zijn (Rémond-Gouilloud, M., "The Future of the Compensation System established by Intemational Convention", o.c. 95). Ook in die zin Abecassis, D., "International Conventions on Civil Liability for Oil Pollution Damage", o.c., 233; Tegelberg, "Olie op de golven", l.c., 55.

Dubais, B.A., "Some Legal Aspects of the Amoco Cadiz Incident", Lloyds Maritime and' Commercial Law Quarterly, 1979, 292 e.v.

Cleton, R., "Civil Liability for Oil Pollution Damage caused by Sea-going Ships", o.c., 117; Popp, A.H.E., "Liability and Compensation for Pollution Damage caused by Ships Revisited - Report on an important International Conference", Lloyd's Maritime and Commercial Law, 1985, 120. 
het uitbreiden van de kring van personen die zich konden beroepen op de bescherming geboden door de kanalisatie van aansprakelijkheid ${ }^{78}$.

Artikel 3, alinea 5 tenslotte, stelt dat het Verdrag geen inbreuk maakt op enig recht van verhaal van de eigenaar tegenover derden. Het Protocol heeft hieraan geen wijzigingen aangcbracht omdat werd geoordeeld dat een wijziging van de regresrechten in bepaalde landen zou kunnen leiden tot constitutionele problemen ${ }^{79}$. Er kan bijgevolg worden gesproken van een partiele kanalisalie van aansprakelijkheid ${ }^{80}$.

Volledigheidshalve kan hier worden verwezen naar de rechtszaak naar aanleiding van het ongeval met de Amoco Cadiz. Een aantal slachtoffers van dit ongeval is erin geslaagd om het systeem van de kanalisatie van aansprakelijkheid te omzeilen: Franse eisers (Frankrijk is lid van het CLCVerdrag) hebben toen de beheerders van het schip voor de rechter gebracht in de Verenigde Staten - deze beheerders hadden in de VS hun maatschappelijke zetel, terwijl de VS niet waren toegetreden tot het CLC-Verdrag ${ }^{81}$.

Uit deze analyse blijkt dat de kanalisatie van aansprakelijkhcid onder het C.LC-Verdrag minder strak wordt doorgetrokken dan onder de nucleaire aansprakelijkheidswetgeving. Het CLCVerdrag kent inderdaad geen exclusieve kanalisatie van aansprakelijkheid. Ten eerste kunnen andere personen dan de scheepseigenaar buiten het Verdrag om worden aangesproken. En ten tweede laat het Verdrag de regresrechten van de scheepseigenaar intact ${ }^{82}$.

\subsubsection{Volgens de Belgische wet}

Artikel l van de wet van 20 juli $1976^{83}$ bepaalt dat het C.LC-Verdrag volkomen uitwerking zal hebben. Wat betreft de regeling van de kanalisatie van aansprakelijkheid, wordt dus verwezen naar de Verdragstekst. Nochtans voorzag het oorspronkelijke wetsontwerp in een uitbreiding van de kanalisatie van aansprakelijkheid, in die zin dat ook de berger, de loods en diegenen die preventieve maatregelen hebben genomen, de door de kanalisatie geboden bescherming konden genieten. Volgens de Raad van State is kanalisatie een dusdanig ingrijpende afwijking van het gemene recht dat het beperkend dient te worden geïnterpreteerd. Vandaar diende de uitbreiding van de kanalisatie zoals bepaald in het oorspronkelijke wetsontwerp te worden geschrapt teneinde

\% Abecassis, D., "Intemational Conventions on Civil Liability for Oil Pollution Damage", o.c., 202 en 233; Van Hanswyck, B., "The 1984 Protocols to the Intemational Convention on Civil Liability for Oil and Pollution Damages and the International Fund for Compensation for Oil Pollution Damages: An Option for Needed Reform in United States Law", o.c., 325; Wu, C., "La pollution du fait du transport maritime des hydrocarbures", l.c., 217 e.v.

Popp, A.H.E., "Liability and Compensation for Pollution Damage caused by Ships Revisited - Report on an important International Conference", o.c., 121

Wu, C., "La pollution du fait du transport maritime des hydrocarbures", l.c., 218.

Cfr. supra bij de bespreking van de kanalisatie van aansprakelijkheid in het kemenergierecht $(\$ 2.2 .8$ van hoofdstuk 4).

Precies daarom werd dit systeem in de literatuur onder vuur genomen. Lucchini stelt dat de Conventie "organise ses propres funerailles en ouvrant les voies pour éliminer son application" (Lucchini, I.., "Le procès de l'Amoco Cadiz: présent et voies du futur", Annuaire Français de Droit International, 1985, 767).

Wet houdende goedkeuring en uitvoering van het Internationaal Verdrag inzake de burgerlijke aansprakelijkheid voor schade door verontreiniging door olie en van de Bijlage, opgemaakt te Brussel op 29 november 1969, B.S., 13 april 1977. 
mogelijke verwarring tegen te gaan ${ }^{84}$. Vandaar werd de redenering aangehouden dat de berger en de loods aangestelden of lasthebbers zijn van de scheepseigenaar.

Het wetsontwerp sloot ook alle regresvorderingen van de scheepseigenaren tegen de genoemde personen uit, terwijl het CLC-Verdrag diens regresrechten tegenover derden intact laat. Ook tegen deze bepaling maakte de Raad van State bezwaar omdat het niet aan de nationale wetgever zou toekomen om een restrictieve interpretatie te geven aan internationaal-rechtelijke bepalingen ${ }^{85}$.

De Belgische wet die het CLC-Verdrag uitvoert, bevat bijgevolg inzake de kanalisatie van aansprakelijkheid naar de scheepseigenaar geen afwijkende bepalingen ten overstaan van de Verdragsbepalingen.

\subsubsection{Volgens de Nederlandse wet}

Artikel 3, lid 4 tot en met 7 van de Nederlandse Wet aansprakelijkheid Olietankschepen (Waot) bevat bepalingen inzake de kanalisatie van aansprakelijkheid naar de scheepseigenaar. Allereerst kan de scheepseigenaar niet uit anderen hoofde worden aangesproken. Daarnaast kunnen noch uit hoofde van de wet, noch uit anderen hoofde worden aangesproken: de loods, degenen die preventieve maatregelen nemen en ondergeschikten, vertegenwoordigers of lasthebbers van deze personen $^{87}$.

Op basis van artikel $1, \mathrm{G}$ van de wet tot wijziging van de Waot ${ }^{88}$ kunnen noch uit hoofde van de Waot, noch uit anderen hoofde volgende personen worden aangesproken:

a. de ondergeschikten, vertegenwoordigers of lasthebbers van de eigenaar of de leden van de bemanningen;

b. de loods of enige andere persoon die, zonder lid te zijn van de bemanning, diensten voor het schip verricht;

c. een bevrachter (hoe ook omschreven, met inbegrip van de rompbevrachter), beheerder of degene in wiens handen de exploitatie van het schip is gelegd;

d. personen die met instemming van de eigenaar of in opdracht van een bevoegde overheidsinstantie hulpverleningswerkzaamheden verrichten;

e. personen die preventieve maatregelen nemen;

f. alle ondergeschikten, vertegenwoordigers of lasthebbers van personen genoemd onder b, $c, d$ en e;

tenzij de schade het gevolg is van hun persoonlijk handelen of nalaten, hetzij met het opzet zodanige schade te veroorzaken, hetzij roekeloos en in de wetenschap dat zodanige schade er warschijnlijk uit zou voortvloeien.

Zowel het Nederlandse als het Belgische maritieme civiele aansprakelijkheidsrecht hanteren dus de kanalisatie van aansprakelijkheid zoal gewijzigd door het CLC-Verdrag van 1992.

Advies Raad van State, Parlementaire Stukken, Kamer, 1974-1975, nr. 646/1, 11.

Zie ook Maes, F., "De burgerlijke aansprakelijkheid van de scheepseigenaar en de vergoeding voor schade ontstaan door olieverontreiniging: een verduidelijking bij de toepasselijke Verdragen en contracten", o.c., 104 en Vincineau, M., "Un Imbrogolio juridique: la loi du 20 juillet 1976 portant approbation et exécution de la Convention Internationale sur la responsabilité pour les domrnages dus à la pollution des Hydrocarbures, faite à Bruxelles le 29 novembre 1969", o.c., 698.

Stb. 1975, nr. 321.

Artikel 3, lid 6 Waot.

Wet van 4 september 1996 tot wijziging van de Waot, Stb. 1996, nr. 461. 


\subsubsection{Beperking van de aansprakelijkheid}

Op basis van artikel 5 het CLC-Verdrag van 1969 kon de eigenaar van een schip zijn aansprakelijkheid beperken tot een bedrag van 2.000 goudfranken voor elke ton van de tonnage van het schip. Het bedrag kon evenwel in geen geval 210 miljoen goudfranken te boven gaan. Door het Protocol van 1976 werden deze bedragen omgezet in rekeneenheden van het Internationaal Muntfonds; de bedragen werden als volgt gewijzigd: 133 BTR per ton zonder evenwel 14 miljoen BTR te boven te gaan ${ }^{89}$. Deze bedragen betekenden een verdubbeling van de aansprakelijkheidsgrens zoals neergelegd in het Verdrag van $1957^{90}$.

Over het algemeen wordt de beperking van de aansprakelijkheid van het CLC-Verdrag beschouwd als de tegenhanger van de risicoaansprakelijkheid ${ }^{9 !}$.

De scheepseigenaar zal zich evenwel enkel kunnen beroepen op de beperking van zijn aansprakelijkheid indien hij een fonds heeft gevormd tot een bedrag gelijk aan diens aansprakelijkheid ${ }^{92}{ }^{93}$. Het is wel van groot belang te onderstrepen dat het beperkingsfonds van het CLC-Verdrag enkel van toepassing is ten aanzien van schade door verontreiniging ${ }^{94}$; bovendien zal een scheepseigenaar deze beperking niet kunnen inroepen ten aanzien van schade in een niet-verdragsluitende Staat ${ }^{95}$. Scheepseigenaren zullen er bijgevoig belang bij hebben dat zoveel mogelijk landen toetreden tot hei Verdrag.

Opmerkelijk is overigens artikel $5,8^{\circ}$ van het CLC-Verdrag. Op basis van deze bepaling worden de door de eigenaar gedane uitgaven tot voorkoming of beperking van schade door verontreiniging op gelijke voet behandeld met de vorderingen van derden. Concreet leidt deze bepaling ertoe dat de kosten van de preventiemaatregelen die door de eigenaar werden gemaakt voor het behoud van het schip, op gelijke voet worden behandeld als de preventiemaatregelen die door andere personen dan de eigenaar werden genomen. Artikel 5, $8^{\circ}$ van het CLC-Verdrag wordt bijkbaar beschouwd als een middel om de eigenaar ertoe aan te zetten om eveneens preventiemaatregelen te nemen ${ }^{96}$.

Het wekt weinig verbazing dat de besprekingen inzake de verhoging van de aansprakelijkheidslimieten vrij moeizaam verliepen. De voomaamste oorzaak hiervan was het belangenconflict tussên de olie-industrie aan de ene kant en de scheepseigenaren en P\&I Clubs aan de andere kant. Dit betekende dat werd gediscussieerd over de wisselwerking tussen het CLC - en het Oliefondsverdrag, die respectievelijk de aansprakelijkheid van de scheepseigenaren en van de olie-industrie aangeven. De spanningen kwamen duidelijk naar voren in de discussie rond de beperking van de aansprakelijkheid voor kleinere schepen ${ }^{97}$. De olie-industrie was het er enkel mee eens dat de tussenkomst van het IOPC-Fonds zou worden verhoogd op voorwaarde dat voor alle schepenook schepen met een kleiner tonnage - de aansprakelijkheidsgrens aanzienlijk zou worden ver-

Artikel 5 van het CLC-Verdrag, zoals gewijzigd door het Protocol van 19 november 1976.

Abecassis, D., "International Conventions on Civil Liability for Oil Pollution Damage", o.c. 215.

Wu, C., "La pollution du fait du transport maritime des hydrocarbures", l.c., 76.

Artikel 5, derde alinea van het nieuwe CLC-Verdrag.

Dit fonds kan zowel worden gevormd door het storten van een geldsom of van een bankgarantic, als door iedere andere financiële zekerheid die wordt aanvaard door de Verdragsluitende Staat waar het fonds wordt gevormd.

Abecassis, D., "International Conventions on Civil Liability for Oil Pollution Damage", o.c., 217-218.

Wu, C., "La pollution du fait du transport maritime des hydrocarbures", l.c., 79.

Wu, C., "La pollution du fait du transport maritime des hydrocarbures", l.c., 80.

Cleton, R., "Civil Liability for Oil Pollution Damage caused by Sea-going Ships", o.c., 118. 
hoogd. Volgens de olie-industrie was het Fonds in het verleden te vaak tussengekomen voor schade door olieverontrciniging veroorzaakt door kleinere schepen ${ }^{98}$. Het doel van het Fonds zou er volgens hen in bestaan enkel tussen te komen bij gevallen van zware olieverontreiniging".

De scheepseigenaren en de P\&I Clubs vonden dat een dergelijke stellingname de oorspronkelijke lastenverdeling, zoals necrgelegd in het CLC- en Oliefondsverdrag, op de helling zette. Volgens hen leidden ongevallen met kleinere schepen tot geringere schade: een ongeval met een schip van minder dan 1.000 ton kostte maximaal 3 miljoen dollar, terwijl de schade veroorzaakt door grote schepen kon oplopen tot meer dan 7,5 miljoen dollar ${ }^{101}$. Na moeizame besprekingen werd uiteindelijk volgend compromis bereikt.

De aansprakelijkheidslimieten werden als volgt verhoogd door het Protocol van 1984: voor een schip van 5.000 ton bedraagt de grens 3 miljoen BTR (4,29 miljoen euro); voor elk groter schip wordt dit bedrag per bijkomende ton verhoogd met 420 BTR (60l euro), zonder dat evenwel het totale bedrag 59,7 miljoen BTR (85,44 miljoen euro) kan overstijgen ${ }^{101}$. Exact dezelfde limieten werden vastgesteld door het Protocol van 1992.

De verhoging van de aansprakelijkheidslimieten moet samen worden gezien met de wijziging van artikel 5, $2^{\circ}$ van het CLC-Verdrag. In het CLC-Verdrag van 1969 was inderdaad voorgeschreven dat de beperking van de aansprakelijkheid kon worden doorbroken indien het voorval het gevolg was van de persoonlijke schuld van de scheepseigenaar. Bij de onderhandelingen van het Protocol van 1984 werd geoordeeld dat via deze bepaling de beperking van aansprakelijkheid in heel wat gevallen kon worden opgeheven; bovendien zou het beoordelen van een persoonlijke schuld leiden tot vertraging bij het toekennen van schadevergoeding aan de slachtoffers en zou de verschillende interpretatie van dit begrip van land tot land, kunnen leiden tot een ongelijke behandeling tussen slachtoffers ${ }^{102}$.

Artikel 5, $2^{\circ}$ werd door het Protocol van 1992 gewijzigd in die zin dat de eigenaar niet gerechtigd is zijn aansprakelijkheid te beperken indien de schade door verontreiniging het gevolg is van zijn persoonlijk handclen of nalaten, begaan hetzij met het opzet zodanige schade te veroorzaken, hetzij roekeloos en in de wetenschap dat zodanige schade er waarschijnlijk uit zou voortvloeien. Doordat onder het CLC-Verdrag van 1992 opzet (of roekeloosheid in de wetenschap dat schade zal ontstaan) in hoofde van de scheepseigenaar moet worden bewezen, wordt het moeilijker de aansprakelijkheidslimiet te doorbreken. Het optrekken van de aansprakelijkheidslimiet was inderdaad slechts mogelijk indien deze quasi absoluut zou zijn. Doordat de scheepseigenaren slechts in extreme gevallen onbeperkt aansprakelijk zullen zijn, hebben zij ingestemd met de hogere aansprakelijkheidslimieten $^{103}$.

Ibidem.

Bovendien moet voor ogen worden gehouden dat de bijdragen aan het Fonds enkel wetden betald door enkele grote olie-importerende staten, waaronder Japan, Italië, Frankrijk en Nederland.

Cleton, R., "Civil Liability for Oil Pollution Damage caused by Sea-going Ships", o.c., 118.

Dit maximale bedrag wordt bereikt bij schepen met een bruto-tonnage van 140.000 ton (Oosterveen, W.J.G., "Verbeterde mogelijkheden voor vergoeding van schade door ongevallen met olietankers", o.c., 427).

Wu, C., "La pollution du fait du transport maritime des hydrocarbures", l.c., 221-222.

Popp, A.H.E., "Liability and Compensation for Pollution Damage caused by Ships Revisited - Report on an important International Conference", o.c., 121; Tegelberg, G.G.A., "Olie op de golven", l.c., 73; Wu, C., "La pollution du fait du transport maritime des hydrocarbures", l.c., 228-229. 


\subsubsection{Verplichte verzekering van de aansprakelijkheid}

Ter dekking van diens aansprakelijkheid, is elke eigenaar van een schip dat meer dan 2.000 ton olie in bulk als lading vervoert, verplicht een verzekering of andere financiële zekerheid als een bankgarantie of een door een international vergoedingsfonds afgegeven certificaat, te hebben ${ }^{104}$.

Door deze verplichte verzekeringsdekking worden in de eerste plaats kleinere maatschappijen met een beperkte vloot beschermd omdat hun vermogen onvoldoende is om alle schade door olieverontreiniging te dekken.

Het certificaat wordt aan elk schip afgegeven nadat de bevoegde autoriteit van de Verdragsluitende Staat heeft vastgesteld dat aan de verzekeringsplicht werd voldaan. Het Protocol van 1992 heeft een bepaling toegevoegd betreffende de uitgifte van een dergelijk certificaat door een Verdragspartij voor een schip van een niet-Verdragsluitende Staat dat de haven van een andere Verdragsluitende Staat wil aandoen ${ }^{105}$. Daarnaast dient het certificaat zich aan boord van het schip te bevinden en een afschrift daarvan moet worden neergelegd bij de overheden die het register houden waarin het schip staat te boek gesteld, of indien het schip niet in een Verdragsluitende Staat is te boek gesteld, bij de autoriteiten van de Staat die het certificaat afgeeft ${ }^{106}$.

De verzekering van olieschade onder het CLC-Verdrag wordt geregeld door de zogenaamde Protection and Indemnity Clubs (P\&I Clubs), een vereniging van de scheepseigenaars die zich op mutualistische basis verzekeren. Herverzekering geschiedt door middel van "the International Group of the P\&I Clubs".

Over het algemeen wordt aangenomen dat de risicoaansprakelijkheid, de hoge aansprakelijkheidslimieten en de verplichte verzekering van de aansprakelijkheid van de scheepseigenaar (en de daaraan gekoppelde directe vordering tegen de verzekeraar) in aanzienlijke mate de positie van slachtoffers verbeteren ${ }^{107}$.

\subsubsection{Procesrechtelijke bepalingen}

Een vordering tot schadevergoeding kan enkel worden ingesteld bij de rechter van de Verdragsluitende Staat op wiens grondgebied een voorval schade door verontreiniging heeft veroorzaakt ${ }^{108}$. Het CLC-Verdrag knoopt bijgevolg aan bij de plaats waar de schade is geleden. De nationaliteit of de woonplaats van het slachtoffer of van de eigenaar van het schip, zijn niet relevant. In de mate waarin een ongeval schade heeft veroorzaakt in meerdere landen, zullen de rechtbanken van elk land bijgevolg bevoegd zijn ${ }^{109}$.

Anderzijds dient voor ogen te worden gehouden dat, overeenkomstig artikel $9,3^{\circ}$ van het CLCVerdrag, zodra de scheepseigenaar een fonds heeft gevormd, uitsluitend de rechter van de Staat waar dat fonds is gevormd, bevoegd zal zijn te beslissen in alle aangelegenheden betreffende de

Artikel 7 van het CLC-Verdrag.

Artikel 7 van het CLC-Protocol van 1992.

Deze laatste zinsnede werd eveneens toegevocgd door het Protocol van 1992.

Jacobsson, M., "The International Conventions on Liability and Compensation for Oil Pollution Damage and the Activities of the International Oil Pollution Compensation Fund", in De la Rue, C.M., (ed.), "Liability for Damage to the Marine Environment", l.c., 41.

Artikel $9,1^{\circ}$ van het CLC-Verdrag.

Wu, C., "La pollution du fait du transport maritime des hydrocarbures", l.c., 89-90. 
toedeling en verdeling van het fonds. Deze bepaling kan ertoe leiden dat bij een ongeval waarbij schade wordt veroorzaakt in verschillende landen, meerdere rechtbanken bevoegd zullen zijn ten aanzien van de aansprakelijkheidsvraag, terwijl - in de hypothese waarin alle landen waar schade is geleden eveneens lid zijn van het CLC-Verdrag - slechts één rechtbank bevoegd zal zijjn wat betreft de toekenning van schadevergoeding uit het beperkingsfonds van de scheepseigenaar.

Het recht om een vordering tot schadevergoeding in te dienen vervalt indien zij niet is ingesteld binnen een periode van drie jaar vanaf de datum waarop de schade is ontstaan. Een vordering kan in geen geval worden ingestcld indien zes jaren zijn verstreken vanaf de datum van het voorval dat de schade heeft veroorzaakt ${ }^{110}$. Door het Protocol van 1992 werd aan deze bepaling geen wijziging aangebracht.

\section{HET VERdRAG TOT OPRICHTING VAN EEN INTERNATIONAAL FONDS YOOR VERGOEDING VAN SCHADE DOOR VERONTREINIGING DOOR OLIE VAN 18 DECEMBER 1971}

Bij de analyse van de internationale regelgeving inzake aansprakelijkheid voor schade door olieverontreiniging op zee dient naast het CLC-Verdrag, ook het Oliefondsverdrag in de analyse te worden bctrokken. In eerste instantie worden het tot stand komen en de wijzigingen van het Oliefondsverdrag besproken $(\$ 3.1)$ en wordt het toepassingsgebied besproken $(\S 3.2)$. Nadien wordt de vraag beantwoord wie financiële bijdragen levert tot het Fonds $(\$ 3.3)$ en in welke gevallen hel Fonds tussenbeide komt ( $\$ 3.4$ ). Tenslotte wordt aandacht besteed aan de afwikkeling van de procedures tegen het IOPC-Fonds (\$3.5).

\subsection{Algemeen}

Op 18 december 197」 kwam een tweede Verdrag inzake de schade door olieverontreiniging op zec tot stand, met name de International Convention on the Establishment of an International Fund for Compensation for Oil Pollution Damage (hierna genoemd: het Oliefondsverdrag). De totstandkoming van het Oliefondsverdrag maakte deel uit van het compromis dat was bereikt tijdens de redactie van het C.LC-Verdrag van 1969: de eigenaars van tankers waren enkel bereid het CLC-Verdrag te tekenen op voorwaarde dat ook andere partijen die belang hadden bij het olievervoer, cen decl van de aansprakelijkheid zouden dragen ${ }^{111}$. Vandaar voorzag het Oliefondsverdrag in de oprichting van het "International Fund for Compensation of Oil Pollution Damage" (hierna genoemd: IOPC-Fonds), dat zijn inkomsten grotendeels haalt uit bijdragen van de olicindustric. Door de wisselwerking tussen het CL.C-Verdrag en het Oliefondsverdrag is sprake van een lastenverdeling tussen rederijen en de olie-industrie ${ }^{132} 113$. Het IOPC-Fonds stelt zich namelijk

III Abecassis, D., "IMO and liability for Oil Pollution from Ships: a Retrospective", Lloyd 's Maritime ani Commercial Law Quarterly, 1983, 47; Maes, F., "De burgerlijke aansprakelijkheid van de schecpselgenaar en de vergoeding voor schade ontstaan door olieverontreiniging: een verduidelijking bij de toepasselijke Verdragen en contracten", o.c., 99.

Abecassis, D., "IMO and liability for Oil Pollution from Ships: a Retrospective", o.c., 47; Bongaerts, J. en Debièvre, A., "Insurance for Civil Liability for Marine Oil Pollution Damages", Geneva Papers on Risk and Insurance, 1987, 147; Gold, E., "Handbook on Marine Pollution", l.c., 24; Wu, C., "La pollution du fait du transport maritime des hydrocarbures", l.c., 96-97.

Volgens Jacobsson wijst het grote aantal landen dat lid is van de Conventies - per september 1992 waren 74 landen lid van het CLC-Verdrag en 49 Staten waren toegetreden tot het Oliefondsverdragerop dat heel wat landen beide Conventies zien als een aanvaardbare lastenverdeling (Jacobsson, $M_{\text {, }}$ "The International Conventions on Liability and Compensation for Oil Pollution Damage and the Activities of the International Oil Pollution Compensation Fund", in De la Rue, C.M., (ed.), "Liability for Damage to the Marine Environment", l.c., 40). 
als doel om vergoeding te verlenen voor schade door verontreiniging voorzover het CLC-Verdrag onvoldoende bescherming biedt ${ }^{114}$.

In 1984 kwam ook voor het Oliefondsverdrag een Protocol tot stand, waarbij het oorspronkelijke toepassingsgebied van het Oliefondsverdrag van 1971 grotendeels hetzelfde bleef. Ook dit Proto$\mathrm{col}$ is nooit in werking getreden; gekeken moet worden naar de wijzigingen aangebracht door het Protocol van 1992. Ook hier - net zoals bij de Protocollen van 1984 en 1992 van het CLCVerdrag - geldt dat het Fonds-Protocol van 1992 vrijwel identiek is aan het Protocol van 1984. Het is van groot belang erop te wijzen dat door het nieuwe Oliefondsverdrag een totaal nieuw IOPC-Fonds is opgericht, met name "het International Fonds voor vergoeding van schade door verontreiniging door olie, 1992", dat meteen ook een nieuwe juridische entiteit is, los van het oorspronkelijke IOPC-Fonds ${ }^{115}$. Het doel van dit Fonds bestaat erin de schade te vergoeden voorzover het CLC-Verdrag van 1992 ontoereikend is.

In België is het Oliefondsverdrag van 1971 goedgekeurd bij wet van 6 augustus $1993^{116}$ en (uitgevoerd bij KB van 19 juli 1994), hoewel een wetsontwerp reeds in 1975 werd neergelegd ${ }^{117}$. Het Oliefondsverdrag van 1992 werd in België goedgekeurd in $1998^{118}$; het "nieuwe" IOPC-Fonds geldt in België vanaf 6 oktober $1999^{119}$. In Nederland wordt het Oliefondsverdrag ingevoerd in de nationale rechtsorde door de Wet schadefonds olietankschepen van $1981^{120}$. Het Protocol van 1992 werd ingevoerd in $1996^{121}$ en werd van kracht op 15 november $1997^{122}$. Op 30 september 2000 waren 61 landen toegetreden tot het Oliefondsverdrag ${ }^{123}$.

\subsection{Toepassingsgebied}

Enkel Staten die lid zijn van het CLC-Verdrag, kunnen toetreden tot het Oliefondsverdrag ${ }^{124}$.

\section{Artikel $2,1^{\circ}$ van het Oliefondsverdrag; cfr infra.}

115 Het IOPC-Fonds is een volledig onafhankelijke organisatie, een afzonderlijke juridische entiteit, los van het IMO; het is evenmin een gespecialiseerde VN-organisatic (Jacobsson, M., "The International Conventions on Liability and Compensation for Oil Pollution Damage and the Activities of the International Oil Pollution Compensation Fund", in De la Rue, C.M., (ed.), "Liability for Damage to the Marine Environment", l.c., 45).

116 Wet houdende goedkeuring en uitvoering van het Internationaal Verdrag ter oprichting van een international Fonds voor vergoeding van schade door verontreiniging door olie en van het Protocol (B.S., 5 november 1993).

117 Parlementaire Stukken, Kamer, 1974-1975, 645/1, 3-4.

10 Wet van 10 augustus 1998 houdende instemming met het Protocol van 1992 tot wijziging van het Internationaal Verdrag van 1971 ter oprichting van een Internationaal Fonds voor vergoeding van

119 Schade door verontreiniging door olie, gedaan te Londen op 27 november 1992, B.S., 16 maart 1999 . wet van 10 augustus 1998 houdende instemming met het Protocol van 1992 tot wijziging van het Internationaal Verdrag van 1971 ter oprichting van een International Fonds voor vergoeding van schade door verontreiniging door olie, gedaan te Londen op 27 november 1992, B.S., 26 oktober 1999.

Wet van 14 mei 1981 houdende uitvoering van het op 18 december 1971 te Brussel tot stand gekomen Internationaal Verdrag ter oprichting van een intemationaal Fonds voor vergoeding van schade door verontreiniging door olie, Stb., 1981, 294.

Wet van 26 juni 1996 tot wijziging van de Wet schadefonds olietankschepen, Sib., 1996, 462.

Artikel 2 van het Besluit van 17 april 1997, houdende vaststelling tijdstip inwerkingtreding van de wet van 4 september 1996 tot wijziging van de Wet aansprakelijkheid olietankschepen en van de wet van 26 juni 1996 tot wijziging van de Wet schadefonds olietankschepen, Stb., 1997, 167.

Bron: website van de International Maritime Organisation op 15 oktober 2000 (www.imo.org).

Artikel $37,1^{\circ}$ van het Oliefondsverdrag. 
In tweede instantie is, ten aanzien van de compensatie van slachtoffers, het territoriale toepassingsgebied van het Oliefondsverdrag hetzelfde als dat van het CLC-Verdrag. Bepalend is bijgevolg dat schade door verontreiniging (of door preventiemaatregelen) is geleden in een Verdragsluitende Staat. Opdat het IOPC-Fonds tussenbeide komt voor de vergoeding van slachtoffers is dus niet vereist dat de olie die tot de verontreiniging heeft geleid, bijdraagt tot het Fonds; de vraag of de vlaggestaat lid is van het Verdrag is evenmin aan de orde ${ }^{125}$. Het Oliefondsverdrag biedt vanuit die optiek duidelijke voordelen voor de verschillende landen die tot het Verdrag toetreden.

Volledigheidshalve wordt erop gewezen dat ten aanzien van de tussenkomst van het IOPC-Fonds ten voordele van de scheepseigenaar, het Oliefondsverdrag in bijkomende voorwaarden voorzag; maar aangezien dit tweede doel is opgeheven door het Protocol van 1992, wordt dit aspect niet verder belicht.

Doordat het Oliefondsverdrag aansluit bij het CLC-Verdrag, spreekt het voor zich dat dezelfde definities worden gehanteerd in beide Verdragen: artikel $1,2^{\circ}$ van het Oliefondsverdrag verwijst uitdrukkelijk naar de definities van het CLC-Verdrag ${ }^{126}$.

\subsection{Bijdrage aan het IOPC-Fonds}

Vooraleer verder in te gaan op de vraag welke personen recht hebben op een uitkering vanwege het IOPC-Fonds, is het voor een goed begrip van de verdere analyse van belang dat wordt aangegeven welke personen gehouden zijn om een bijdrage te leveren tot het Fonds.

De basisidee zoals neergelegd in het Oliefondsverdrag is dat enkel de invoerders van over zee vervoerde olie bijdrageplichtig zijin ${ }^{127}$. De personen die olie uitvoeren, zijn niét gehouden tot het. leveren van een financiële bijdrage. Toch moeten niet alle invoerders van olie een financiële bijdrage leveren, aangezien het Oliefondsverdrag een drempel heeft ingebouwd.

Volgens artikel 10 van het Verdrag moeten aan het Fonds bijdragen worden betaald door "iedere persoon die bijdragende olie heeft ontvangen in hoeveelheden die in totaal meer dan 150.000 ton bedragen". Het betreft zowel bijdragende olic die over zee is aangevoerd in havens of laad-en Josinstallaties op het grondgebied van die Staat en bijdragende olie die is ontvangen in enige installatie op het grondgebied van een Verdragsluitende Staat. Het begrip "bijdragende olie" wordt gedefinieerd in artikel 1, alinea 3 van het Oliefondsverdrag: het gaat om ruwe olie en stookolie ${ }^{128}$.

$125 \mathrm{Wu}, \mathrm{C}$., "La pollution du fait du transport maritime des hydrocarbures", I.c., 99.

126 Het Oliefondsverdrag van 1971 beperkte wel de definitie van het begrip "olie" tot bestendige minerale olięn (koolwaterstoffen). Doordat evenwel ook onder het CLC-Verdrag van 1992 dit begrip werd gewijzigd, hanteren beide Verdragen ook ter zake van "olie" dezelfde definitie. Abecassis, D., "The 1971 Fund Convention and the IOPC-Fund", o.c., 278; Wu, C., "La pollution du fait du transport maritime des hydrocarbures", le., 118.

Onder "ruwe olie" wordt verstaan: elk vloeibaar mengsel van koolwaterstoffen dat in natuurlijke staat in de aarde voorkomt en dat al dan niet is behandeld om het geschikt te maken voor vervoer. Tevens wordt onder "ruwe olie" begrepen: ruwe olie waarvan bepaalde distillaatfracties zijn onttrokken (soms aangeduid als "afgetopte olie" of "topped crude") of waarvan bepaalde distillaatfracties zijn toegevoegd (soms aangeduid als "gereconditioneerde ruwe olie" of "reconstituted crude"). Onder stookolie wordt verstaan: distillaten of residuen van ruwe olie of mengsels van zodanige producten, bestemd om als brandstof te worden gebruikt voor de opwekking van warmte of energie, van een kwaliteit welke overeenkomt met de specificatie van de "American Society for Testing Materials" voor "Number Four Fuel Oil (Designation D 396-69)" of zwaarder (artikel 1, alinea 3, sub a) en b) van het Oliefondsver- 
Personen die minder dan 150.000 ton olie ontvangen, moeten bijgevolg geen bijdrage leveren tot het IOPC-Fonds. Het is dus mogelijk dat een land met een kleine import van ruwe olie en stookolie lid wordt van het Oliefondsverdrag, hierdoor ten volle van de tussenkomst van het IOPC-Fonds kan genieten, zonder dat enige persoon in het land een bijdrage aan het Fonds heeft geleverd. Vandaar dat meer dan $90 \%$ van de totale bijdragen in 1991 werd betaald door maatschappijen in 10 van de 49 Verdragsluitende Staten ${ }^{129}$.

Het oorspronkelijke Oliefondsverdrag voorzag in een eenmalige aanvangsbijdrage en in een jaarlijkse bijdrage. Door het Protocol van 1992 werd de aanvangsbijdrage afgeschaft. Deze was immers vrij hoog en bemoeilijkte de ratificatie van het Oliefondsverdrag ${ }^{130}$.

Tenslotte dient de rol van de Staat inzake de bijdragen tot het IOPC-Fonds to worden tocgelicht. Overeenkomstig artikel 15 van het Oliefondsverdrag moet elke Verdragsluitende Staat aan het IOPC-Fonds melden wanneer een persoon op zijn grondgebied bijdragende olie ontvangt in zodanige hoeveelheden dat hij verplicht is aan het Fonds bij te dragen. Op deze wijze weet het Fonds van welke personen het een gegeven bijdrage kan vragen. Het Protocol van 1992 voegt hier een bepaling aan toe op basis waarvan de Verdragsluitende Staat die niet aan deze verplichting voldoet, een door het Fonds geleden financieel verlies moet vergoeden.

\subsection{Doel van het Fonds en niveaus van tussenkomst}

Aangezien door het Protocol van 1992 het doel van het IOPC-Fonds is gewijzigd, wordt hieraan afzonderlijk aandacht besteed $(\$ 3.4 .1)$. Vervolgens wordt de tussenkomst van het IOPC-Fonds ten voordele van slachtoffers van verontreiniging door olie geanalyseerd $(\$ 3.4 .2)$; tenslotte wordt aangegeven tot op welk niveau het Fonds tussenbeide komt $(\$ 3.4 .3)$.

\subsubsection{Wijziging door het Protocol van 1992}

Het Oliefondsverdrag van 1971 streefde volgens artikel 2 een dubbel doel na. Ten eerste diende de door slachtoffers uit olieverontreiniging op zee veroorzaakte schade volledig te worden gecompenseerd en ten tweede ondersteunde het Fonds de op de scheepseigenaar gelegde financiële lasten ${ }^{131}$. Vandaar dat zowel slachtoffers van schade uit olieverontreiniging als de eigenaar van het schip dat de schade heeft veroorzaakt een vordering konden indienen bij het IOPC-Fonds.

Artikel 5 van het Oliefondsverdrag van 1971 voorzag inderdaad in een systeem waarbij de financiêle lasten van de scheepseigenaar werden verlicht. Het IOPC-Fonds kwam namelijk tussenbeide indien de aansprakelijkheid van de scheepseigenaar ingevolge het CLC-Verdrag een bepaald bedrag te boven ging. Het systeem kwam erop neer dat de scheepseigenaar een daadwerkelijke aansprakelijkheid voor olieverontreiniging had ten belope van 1.500 goudfranken per ton of 125 miljoen goudfranken indien dit laatste bedrag kleiner is. De rest van diens aansprakelijkheid werd gedekt door het IOPC-Fonds, tot het maximum van de aansprakelijkheidsgrens onder het CLC-

drag). Deze bepaling werd niet gewijzigd door het Protocol van 1992. Voor wat betreft de definities van de begrippen "schip", "persoon", "eigenaar", "olie", "schade door verontreiniging", "preventieve maatregelen" en "voorval" werd het Oliefondsverdrag in die zin gewijzigd dat wordt verwezen naar de definities van het CLC-Verdrag van 1992 (artikel 2, derde alinea van het Fonds-Protocol van 1992). Jacobsson, M., "The International Conventions on Liability and Compensation for Oil Pollution Damage and the Activities of the International Oil Pollution Compensation Fund", in De la Rue, C.M., (ed.), "Liability for Damage to the Marine Environment", l.c., 46.

Abecassis, D., "The 1971 Fund Convention and the IOPC-Fund", o.c., 297.

Abecassis, D., "The 1971 Fund Convention and the IOPC-Fund", o.c., 253. 
Verdrag. Artikel 5 van het Oliefondsverdrag van 1971 werd evenwel geschrapt door artikel 7 van het Protocol van $1992^{132}$. Hierdoor heeft het "IOPC-Fonds 1992" als enige functie de compensatie van schade door olieverontreiniging voorzover de door het CLC-Verdrag geboden bescherming onvoldoende is ${ }^{133}$. Door de afschaffing van artikel 5 vervalt de functie van het Fonds waar het de financiële lasten van de scheepseigenaren ondersteunt.

Het Protocol van 1992 moet dan ook worden gezien als een herschikking van de lasten tussen enerzijds de scheepseigenaren en anderzijds de petroleumindustrie ${ }^{134}$. Deze laatste vond haar bijdrage bij een schadegeval door olieverontreiniging te zwaar in vergelijking met de bijdrage van de scheepseigenaren ${ }^{135}$. Doordat de scheepseigenaren geen beroep meer kunnen doen op het IOPC-Fonds dragen zij een groter deel van de financiële lasten van hun aansprakelijkheid voor schade door olieverontreiniging op $7 \mathrm{c}^{136}$. Dit impliceert dat het IOPC-Fonds bijna uitsluitend bestemd is voor de compensatie van slachtoffers en dat de vorderingen van slachtoffers niet meer moeten "concurreren" met de vorderingen van de scheepseigenaar, behalve wat betreft de door hem genomen preventieve maatregelen ${ }^{137}$.

\subsubsection{Compensatie van slachtoffers}

Het principiële uitgangspunt van het Oliefondsverdrag is dat de tussenkomst van het IOPC-Fonds begint waar de aansprakelijkheid op basis van het CLC-Verdrag eindigt. Belangrijk is inderdaad dat het Oliefondsverdrag geen aansprakelijkheid van het IOPC-Fonds in het leven roept, maar wel een vergoedingsplicht ${ }^{138}$.

Het Fonds komt enkel tussenbeide indien de schade niet is gedekt onder het CLC-Verdrag of indien de onder het CLC-Verdrag beschikbare bedragen ontoereikend zijn. Op deze manier bestaat het totale compensatiesysteem ter zake van olieverontreiniging op zee uit een combinatie van fondsvorming en verzekering ${ }^{139}$.

Volgens artikel 4, eerste alinea van het Oliefondsverdrag, is het Fonds er in drie gevallen toe gehouden schadevergoeding te betalen aan iedere persoon die schade door verontreiniging heef geleden en die op basis van het CLC-Verdrag geen volledige en passende vergoeding van die schade heeft bekomen.

Ten eerste zal het Fonds tussenkomen indien uit het CLC-Verdrag geen aansprakelijkheid in hoofde van de scheepseigenaar voortvloeit ${ }^{140}$. Dit zal met name het geval zijn indien de eigenaar gec̈xonereerd is van aunsprakelijkheid overecnkomstig het CLC-Verdrag, bijvoorbeeld bij overmacht.

Ook het Protocol van 1984 schafte artikel 5 van het oorspronkelijke Oliefondsverdrag af. Abecassis, D., "The 1971 Fund Convention and the IOPC-Fund", o.c., 287.

De combinatie het CLC- en het Oliefondsverdrag beoogt immers een evenwicht te creëren tussen de belangen van de olie-industrie en die van de scheepseigenaren.

Abecassis, D., "IMO and Liability for Oil Pollution from Ships: a Retrospective", o.c., 48.

Popp, A.H.E. "Liability and Compensation for Pollution Damage caused by Ships Revisited - Report on an important International Conference", o.c., 124.

Wu, C., "La pollution du fait du transport maritime des hydrocarbures", l.c., 236.

Wu, C., "La pollution du fait du transport maritime des hydrocarbures", l.c., 97.

Bongaerts, J. en Debièvre, A., "Insurance for Civil Liability for Marine Oil Pollution Damages", oct. 148.

Artikel 4, 1, a, van het Oliefondsverdrag. 
Daamaast kan volledige schadevergoeding uitblijven omdat de eigenaar die overeenkomstig het CLC-Verdrag aansprakelijk is, financieel niet in staat is om aan zijn verplichtingen te voldoen en de financiële zekerheid geen dekking geeft of ontoereikend is. In deze hypothese is de eigenaar insolvent, is hij niet verzekerd of blijkt de verzekeringsdekking slechts een fractie van zijn (beperkte) aansprakelijkheid te dekken. Zo is het mogelijk dat de verzekeringsmaatschappij op basis van de polisvoorwaarden weigert uit te betalen, bijvoorbeeld omwille van het gedrag van de verzekerde. Wel dient te worden verduidelijkt dat het IOPC-Fonds slechts tussenbeide zal komen indien het slachtoffer redelijkerwijze alles heeft gedaan om zijn aanspraken overeenkomstig het CLC-Verdrag geldend te maken ${ }^{141}$. In zekere zin zal het IOPC-Fonds, wanneer het een vergoeding uitkeert op basis van artikel $4,1^{\circ}$, b van het Oliefondsverdrag, de functie vervullen van een garantiefonds. De petroleumindustrie zal als het ware optreden als verzekeraar van de maritieme transport- en verzekeringsindustrie ${ }^{142}$.

Ten derde kan een volledige en passende schadevergoeding uitblijven omdat de totale schade het bedrag van de beperkte aansprakelijkheid van de scheepseigenaar, ingevolge het C.LC-Verdrag of een ander Verdrag, overtreft. Veruit de meeste vorderingen tegen het Fonds totnogtoe betroffen deze hypothese ${ }^{143}$. Het IOPC-Fonds komt in dit geval in feite tussen als een aanvulling op het CLC-Verdrag ${ }^{144}$.

Volgens artikel 4, tweede lid van het Oliefondsverdrag is het IOPC-Fonds echter niét verplicht om schadevergoeding uit te betalen indien de schade het gevolg is van oorlogshandelingen, vijandelijkheden, burgeroorlog of opstand of indien de schade werd veroorzaakt door wegvloeien van olie uit een oorlogsschip ${ }^{145}$. Het Fonds zal evenmin kunnen worden aangesproken indien de schuldeiser niet kan bewijzen dat de schade is veroorzaakt door een voorval waarbij een of meerdere schepen waren betrokken.

Het Fonds is wel verplicht tussenbeide te komen in volgende gevallen: wanneer de schacie het gevolg is van een natuurverschijnsel van een uitzonderlijke, onvermijdelijke en onweerstaanbare aard; indien de schade geheel en al werd veroorzaakt door een opzettelijk handelen of nalaten van derden met de bedoeling schade te veroorzaken; of indien de schade geheel en al werd veroorzaakt door onzorgvuldigheid of een andere onrechtmatige handeling van een regering of andere overheid, verantwoordelijk voor het onderhoud van lichten of andere hulpmiddelen bij de navigatie in de vervulling van die taak.

Naast de hierboven vermelde twee gevallen waarbij het Fonds niet kan worden aangesproken overigens om dezelfde reden waarom de scheepseigenaar niet aansprakelijk is krachtens het CLCVerdrag - is het Fonds ontheven van haar verplichting vergoeding van schade door verontreiniging uit te betalen indien het bewijst dat deze schade geheel of gedeeltelijk het gevolg is van een handelen of nalaten van de persoon die de schade heeft geleden met het opzet schade te veroorza-

14. Artikel 4, 1, b, in fine van het Oliefondsverdrag.

143 $\quad \mathrm{Wu}, \mathrm{C}$., "La pollution du fait du transport maritime des hydrocarbures", l.c., 101.

Abecassis, D., "The 1971 Fund Convention and the IOPC-Fund", o.c., 256; Jacobsson, M., "The International Conventions on Liability and Compensation for Oil Pollution Damage and the Activities of the Intemational Oil Pollution Compensation Fund", De la Rue, C.M., (ed.), "Liability for Damage to the Marine Environment", l.c., 42. Van de 61 incidenten waar het 1OPC-Fonds per september 1992 was tussengekomen, vielen 58 in deze categorie. Zo keerde het Fonds tengevolge van het ongeval met de. Tanio 40 miljoen dollar uit aan benadeelden.

14 Wu, C., "La pollution du fait du transport maritime des hydrocarbures", l.c., 102.

Precies in deze gevallen is de scheepseigenaar op basis van de artikelen 3.2 en 9.1 van het CLCVerdrag niet aansprakelijk.
} 
ken. Deze exoneratie in hoofde van het Fonds is evenwel enkel van toepassing op schade door verontreiniging en niet op preventieve maatregelen ${ }^{146}$. Vaak zal het echter moeilijk zijn om precies uit te maken welke schade een preventieve maatregel is en welke schade een vorm van schade door verontreiniging is.

Tenslotte moet worden gewezen op artikel 4, eerste alinea in fine dat stelt dat alle door de eigenaar vrijwillig en binnen de grenzen der redelijkheid genomen maatregelen ter preventie van olieverontreiniging, eveneens worden beschouwd als schade door verontreiniging. In de mate waarin de door hem genomen preventieve maatregelen niet kunnen worden vergoed door zijn eigen beperkingsfonds, beschikt de scheepseigenaar dus over een vordering tegen het IOPCFonds. In de praktijk zullen de preventieve maatregelen worden gedekt door de verzekering van de scheepseigenaar, namelijk de Protection and Indemnity Clubs ${ }^{147}$.

\subsubsection{Niveau van tussenkomst van het IOPC-Fonds}

Nadat de vraag werd beantwoord in welke gevallen het IOPC-Fonds een vergoeding zal uitkeren, dient te worden bestudeerd tot op welke hoogte het Fonds zal tussenbeide komen.

Op basis van het Oliefondsverdrag van 1971 bedroeg de tussenkomst van het IOPC-Fonds bij schade door verontreiniging door olie 675 miljoen goudfranken ${ }^{145}$. Indien de schade werd veroorzaakt door een natuurverschijnsel van een uitzonderlijke, onvermijdelijke en onweerstaanbare aard, was de tussenkomst van het IOPC-Fonds beperkt tot 450 miljoen goudfranken.

Door het Protocol van 1976 werden de bedragen in goudfranken omgezet in speciale trekkingsrechten van het Internationaal Monetair Fonds. Tengevolge van deze omzetting bedroeg de tussenkomst van het IOPC-Fonds maximaal 45 miljoen BTR (30 miljoen BTR indien de schade werd veroorzaakt door een natuurramp).

De grenzen van de mogelijke uitkering van het IOPC-Fonds werden vervolgens aanzienlijk verhoogd door het Protocol van 1992. Volgens artikel 6, derde alinea van dat Protocol bedraagt de maximale bijdrage van het IOPC-Fonds 135 miljoen BTR (193,2 miljoen euro) per voorval, ook indien de schade door verontreiniging door olie werd veroorzaakt door een natuurramp.

Het maximumbedrag dat het Fonds per voorval moet uitkeren bedraagt evenwel 200 miljoen BTR $(286,21$ miljoen euro) indien de totale hoeveelheid bijdragende olie die in drie Verdragsluitende Staten werd ontvangen in het afgelopen kalenderjaar 600 miljoen ton of meer bedraagt. Deze bijkomende dekking zal enkel kunnen worden geboden indien de Verenigde Staten en tenminste twee andere grote olie-ontvangende landen toetreden tot het Fonds ${ }^{149}$.

Artikel 4 , alinea 3 van het Oliefondsverdrag.

Abecassis, D., "The 1971 Fund Convention and the IOPC-Fund", o.c., 258.

Artikel 4, alinea 4 van het Oliefondsverdrag; aanvankelijk bedroeg de grens 450 miljoen gondfranken, maar door een beslissing van de Algemene Vergadering van het IOPC-Fonds, genomen overeenkomstig de zesde alinea van artikel 4, werd dat bedrag per 20 april 1979 opgetrokken tot 675 miljoen goudfranken.

Abecassis, D., "The 1971 Fund Convention and the IOPC-Fund", o.c., 292; Cleton, R., "Civil Liability for Oil Pollution Damage caused by Sea-going Ships", o.c., 119. 
Indien de totale schade door verontreiniging deze limieten overschrijdt, zullen de vorderingen van de verschillende schuldeisers pro rata de respectievelijke grootte van de vorderingen worden toegekend $^{i 50}$.

In de periode 1978-1991 heeft het IOPC-Fonds 57 aanvragen tot uitkering ontvangen en heeft het voor in total 70 miljoen dollar uitgekeerd ${ }^{\mathrm{j} 51}$. Enkel de schade veroorzaakt door de Tanio gingen. de limieten van het Fonds te boven. Uit cijfers van de P\&I Clubs blijkt dat de nieuwe limieten zullen toelaten quasi alle schade uit verontreiniging door olie te compenseren ${ }^{152}$.

\subsection{Afwikkeling van procedures tegen het Fonds}

Overeenkomstig artikel 7 van het Oliefondsverdrag dient een vordering tegen het Fonds aanhangig te worden gemaakt bij dezelfde rechter die bevoegd is kennis te nemen van vorderingen tegen de eigenaar op basis van het CLC-Verdrag. In de mate waarin het land van de rechter dus lid is van het Oliefondsverdrag, rijzen er dus geen problemen, aangezien dat land automatisch ook lid is van het CLC-Verdrag.

Indien voor deze rechter het Oliefondsverdrag niet van toepassing is, moet de vordering tegen het Fonds, volgens keuze van de eiser, gebracht worden hetzij voor de rechter van de Staat waar het IOPC zijn hoofdkantoor heeft (zijnde het Verenigd Koninkrijk), hetzij voor de rechtbank van een Verdragsluitende Staat die wel lid is van het Oliefondsverdrag ${ }^{153}$.

De termijnen waarover de eiser beschikt om een vordering in te stellen tegen het Fonds zijn dezelfde als de termijnen van het CLC-Verdrag: 3 jaar na de datum waarop de schade is ontstaan; in geen geval kan een vordering worden ingesteld na verloop van zes jaar na de datum van het voorval dat de schade heeft veroorzaakt ${ }^{154}$.

Er moet ook op worden gewezen dat het IOPC-Fonds over een subrogatierecht beschikt: voor elk bedrag dat het heeft uitbetaald, treedt het Fonds in de rechten die de persoon wiens schade is vergoed, op grond van het CLC-Verdrag, zou hebben kunnen doen gelden ten aanzien van de eigenaar of zijn garant ${ }^{155}$.

In de afwikkeling van vorderingen tegen het Fonds, werken het Fônds en de P\&I Club vañ de scheepseigenaar nauw samen op basis van een voor elk schadegeval ad hoc opgestelde overeenkomsi $^{156}$. De bedoeling van deze samenwerking is om vorderingen toe te kennen zodra het Fonds en de P\&I Club daarover een akkoord hebben bereikt. Het resultaat hiervan is dat eisers slechts eenmaal een vordering moeten indienen, in plaats van een vordering tegen de eigenaar en een vordering tegen het Fonds. De eiser ontvangt dus in de regel een eenmalige schadeloosstelling: de precieze verdeling van de aansprakelijkheid wordt overgelaten aan de P\&I Club en aan het Fonds.

Artikel 4, alinea 5 van het Oliefondsverdrag van 1971; bevestigd in het Protocol van 1992.

Wu, C., "La pollution du fait du transport maritime des hydrocarbures", l.c., 127.

Abecassis, D., "International Conventions on Civil Liability for Oil Pollution Damage", o.c., 293.

Artikel $7,3^{\circ}$ van het Oliefondsverdrag. Zie hierover ook Wu, C., "La pollution du fait du transpori maritime des hydrocarbures", l.c., 124-125.

Artikel 6, eerste alinea van het Oliefondsverdrag.

Artikel 9, $1^{\circ}$ van het Oliefondsverdrag, zoals gewijzigd door het Protocol van 1992.

Abecassis, D., "The 1971 Fund Convention and the IOPC-Fund", o.c., 272; Jacobsson, M., "The International Conventions on Liability and Compensation for Oil Pollution Damage and the Activities of the International Oil Pollution Compensation Fund", De la Rue, C.M., (ed.), "Liability for Damage to the Marine Environment", l.c., 47. 
Vóór het in werking treden van het Protocol van 1992 betaalde het Fonds in de regel bovenop de door de scheepseigenaar betaalde bedragen. Daarom kon het Fonds de precieze grootte van zijn eventuele bijdrage enkel berekenen nadat het limitatiefonds werd samengesteld. Toch kon het IOPC-Fonds een provisionele som uitkeren of kon het krediet verschaffen aan een eiser die preventieve maatregelen wenste te nemen. Deze bepaling werd gewijzigd door het Protocol van 1992: in uitzonderlijke gevallen kan het Fonds overgaan tot vergoeding, zelfs indien de eigenaar van het schip geen fonds heeft gevormd ${ }^{157}$. Een procedure tegen het nieuwe Fonds kan bijgevolg flexibeler en sneller worden afgewerkt.

$\mathrm{Na}$ de juridische analyse van het CLC-Verdrag en van het Oliefondsverdrag, wordt in de volgende paragrafen aandacht besteed aan twee dekkingsmechanismen die eigen zijn aan het maritieme recht. Het spreekt voor zich dat deze mechanismen nauw aansluiten op de regels zoals neergelegd in de besproken Verdragen.

\section{DE VRIJWILLIGE COMPENSATIEMECHANISMEN: TOVALOP EN CRISTAL}

Naar aanleiding van de redactie van het CLC-Verdrag van 1969 en het Oliefondsverdrag van 1971, hebben de olie- en tankerindustrie twee vrijwillige compensatiemechanismen in het leven geroepen: TOVALOP dat aansluit bij het CLC-Verdrag en CRISTAL dat aansluit bij het Oliefondsverdrag ${ }^{158}$.

Op 7 januari 1969 kwam de Tanker Owners Voluntary Agreement Concerning Liability for Oil Pollution (afgekort tot TOVALOP) tot stand. Bijna alle grote zeeschepen die olie vervoeren op zee waren toegetreden tot TOVALOP ${ }^{159}$.

De oorspronkelijke bedoeling van TOVALOP was reeds in enige bescherming te voorzien tot wanneer het CLC-Verdrag van kracht zou worden. Het C.LC-Verdrag werd inderdaad slechts van kracht op 19 juni $1975^{160}$. Toch was TOVALOP ook nadien nog van belang, aangezien het voorzag in additionele compensatie voor schade die niet onder het CLC-Verdrag was gedekt, bijvoorbeeld indien de schade groter was dan de beperkte bedragen of indien het land van het slachtoffer geen lid was van het CLC-Verdrag ${ }^{161}$.

Het uitgangspunt van TOVALOP bestond erin dat wanneer uit een participerende tanker persistentie olie wegvloeide of dreigde weg te vloeien, de scheepseigenaar diegene vergoedt die redelijke kosten heeft gemaakt teneinde de gevolgen van het olieverlies te minimaliseren, of diegene dic

157 Artikel 4, zesde alinea van het Oliefondsverdrag van 1992.

158 Zie hierover ook Carette, A., "Herstel van en vergoeding voor aantasting aan niet-toegeeigende milieubestanddelen", i.c., 266 e.v.; Wu, C., "La pollution du fait du transport maritime des hydrocarbures", l.c., 129 e.v.

TOVALOP trad in werking op 6 oktober 1969. In 1992 waren ongeveer 6.600 tankers lid (White, I.C., "The Voluntary Oil Spill Compensation Agreements - TOVALOP and CRISTAL", in De la Rue, C.M. (ed.), Liability to the Marine Environment, Lloyd's of London Press, 1993, 57-58). Zie ook: Abecassis, D., "Voluntary Compensation Schemes", chapter 12 in Abecassis, D., o.c., 304; Sturms, W.W., "internationale ontwikkelingen met betrekking tot ansprakelijkheid voor milieuschade", o.c., 147.

Krachtens artikel XV van het CLC-Verdrag, trad het Verdrag in werking 90 dagen nadat 8 regeringen de Conventie hadden ondertekend, waarbij tenminste vijf Staten elk niet minder dan 1 miljoen bruto ton aan tankercapaciteit.

Dit op voorwaarde, uiteraard, dat de eigenaar van de tanker lid is van TOVALOP. 
schade door verontreiniging heeft geleden ${ }^{162}$. Een van de belangrijkste elementen van TOVALOP - dat kon worden aangesproken voor een maximum bedrag van 70 miljoen dollar ${ }^{163}$ - bestond erin dat het dekking verleende voor situaties waar verontreiniging door olie dreigde te ontstaan ${ }^{164}$. In 1987 en 1990 werd TOVALOP uitgebreid in die zin dat zuiver economische verliezen en de kosten voor het herstel van de natuurlijke rijkdommen die een direct gevolg waren van het weglekken van olie, waren gedekt ${ }^{165}$.

Een maatschappij die op vrijwillige basis verplichtingen aanging onder TOVALOP, was verplicht zich voor de aangegane verbintenissen te verzekeren, hetgeen over het algemeen geschiedde via de P\&I Clubs. TOVALOP kwam niet tussenbeide indien de schade voortvlocide uit een van de omstandigheden zoals omschreven in artikel 3, alinea 2 van het CLC-Verdrag of indien de scheepseigenaar aansprakelijk was overeenkomstig de bepalingen van het CL,C-Verdrag. Beide instrumenten, TOVALOP en het CLC-Verdrag, sloten elkaar inderdaad uit.

Terwijl TOVALOP fungeerde als aanvulling van het CLC-Verdrag, vulde CRISTAL (Contract Regarding an Interim Supplement to Tanker Liability for Oil Pollution) ${ }^{166}$ het Oliefondsverdrag aan. CRISTAL werd van kracht in 1971; hiermee was reeds enige bescherming voorhanden, omdat het Oliefondsverdrag pas in 1978 van kracht werd.

CRISTAL streefde dan ook hetzelfde doel na als het Oliefondsverdrag: het compenseerde zowel slachtoffers als de scheepseigenaren zelf. CRISTAL was als het ware de laatste mogelijkheid van partijen om schadevergoeding te verkrijgen - de tussenkomst van CRISTAL lag tussen 36 en 135 miljoen dollar ${ }^{167}$. Enkel indien andere mechanismen ontoereikend waren, en indien een slachtoffer alle nodige en redelijke stappen hadden genomen om deze middelen uit te putten, kwam CRISTAL tussenbeide ${ }^{168}$. Ook hier gold dat CRISTAL niet tussenbeide kwam indien de schade door het IOPC-Fonds was gedekt. Net als TOVALOP werd CRISTAL ingevolge de Protocollen van 1984 ingrijpend gewijzigd.

CRISTAL kwam enkel tussenbeide indien het incident werd veroorzaakt door het weglekken van persistente olie uit een tanker met een olielading die eigendom is van een lid van CRISTAL. De eigendom waarvan sprake werd breed geïnterpreteerd en impliceerde niet het bezit van wettelijke titel van de lading.

Als reactie op de ondertekening van de Protocollen van 1984, werd in 1985 een nieuw vrijwillig compensatiesysteem in het leven geroepen ter vervanging van TOVALOP, nameiijk PLATO (Pollution Liability Agreement among Tank Owners). CRISTAL werd herzien tot. CRISTAL

White, I.C., "The: Voluntary Oil Spill Compensation Agreements - TOVALOP and CRISTAI.", o.c., 58.

16.

Sturms, W.W., "Internationale ontwikkelingen met betrekking tot aansprakelijkheid voor milieuschade", o.c., 147.

Dergelijke "pure threat situations" vielen inderdaad buiten het CLC-Verdrag van 1971. Merk op dat deze situaties wel degelijk zijn gedekt onder het CLC-Verdrag van 1992. Cfr. supra bij de bespreking van het begrip "voorval" onder de nieuwe CLC-Conventie.

White, I.C., "The Voluntary Oil Spill Compensation Agreements - TOVALOP and CRISTAL", o.c., 59.

166 De overeenkomst werd gesloten op 14 januari 1971 en werd van kracht op I april van datzelfde jaar. Sturms, W.W., "Internationale ontwikkelingen met betrekking tot aansprakelijkheid voor milieuscha. de", o.c., 147.

Om die reden kan het vrij lang duren vooraleer door CRISTAL, een vordering zal worden toegekend. 
Revised '85. Doordat deze Protocollen nooit in werking zijn getreden werden PLATO en CRIS. TAL Revised '85 evenwel nooit operationeel ${ }^{169}$.

De: Protocollen van 1992 hebben de situatie nog grondiger gewijzigd in zoverre zelfs dat de vrijwillige compensatiemechanismen werden opgeheven per 20 februari $1997^{170}$. Het verder bestaan ervan zou immers de ratificatie van de Protocollen van 1992 aanzienlijk kunnen vertragen ${ }^{17 !}$.

In de praktijk waren zowel publieke regelingen (CLC-Verdrag en Oliefondsverdrag) als private overeenkomsten (TOVALOP en CRISTAL.) van belang bij schadevergoeding veroorzaakt door olieverontreiniging op zee ${ }^{172}$. Beide mechanismen die waren bedoeld als tijdelijke mechanismen, hebben intussen veel langer bestaan dan oorspronkelijk de bedoeling was. Het belang van beide mechanismen verminderde ook gaandeweg wanneer meer Staten toetraden tot de Verdragen ${ }^{173}$.

Geoordeeld werd dat het naast elkaar bestaan van publieke en private overeenkomsten de ratificatie van de Protocollen kon bemoeilijken ${ }^{174}$. Door lid te worden van het nieuwe CLC- en Oliefondsverdrag kunnen Staten hun onderdanen een voldoende compensatie voor schade door verontreiniging garanderen; dit in tegenstelling tot de vrijwillige mechanismen waar schadevergoeding afhing van het lidmaatschap van de scheepseigenaar van TOVALOP of CRISTAL. Vanaf 20 februari 1997 kunnen personen die schade lijden door olieverontreiniging op zee zich bijgevolg nog enkel beroepen op het nieuwe CLC - en Oliefondsverdrag ${ }^{175}$.

Toch werd het nuttig geacht orn deze compensatiemechanismen hier te bespreken, omdat hiermee wordt aangesloten op de voorstellen van de Commissie Bocken: één van de voorstellen strekt er namelijk toe om de exploitant toe te laten zijn aansprakelijkheid te beperken, op voorwaarde dat hij toetreedt tot een vrijwillige compensatiemechanisme. In deel 4 van dit boek wordt hierop teruggekomen.

\section{De Protection and Indeminity Clubs}

In cleze paragraaf wordt eerst omschreven wat een Protection and Indemnity C.lub is ( $\$ 5.1$ ). Nadien wordt besproken welke dekking door een dergelijke Club wordt verleend $(\$ 5.2)$ en op welke wijze de bijdragen of premies worden geïnd $(\$ 5.3)$. Tenslotte wordt aandacht aan het beheer van een P\&I Club ( $\$ 5.4)$ en aan de Internationale Groep van P\&I Clubs ( $\$ 5.5)$.

CRISTAL Revised '85 zou slechts in werking treden op het moment dat ook PLATO van kracht zwu worden (Abecassis, D., "Voluntary Compensation Schemes", chapter 12 in Abecassis, D., o.c., 319 ; Brubaker, D., "Marine Pollution and International Law", l.c., o.c., 16). Voor meer details, zie Wu, C., "La pollution du fait du transport maritime des hydrocarbures", l.c., 241 e.v. Zie hicrover de website van de IMO (www.imo.org).

171 White, I.C., "TOVALOP and CRISTAL give way to the Legal Regimes - the Continuing Role of ITOPF", ongepubliceerd, 1996, 1. Bongaerts, J en Debièvre, A., "Insurance for Civil Liability for Marine Oil Pollution Damages", o.c., 148; Faure, M. en Van den Bergh, R., "Objectieve Aansprakelijkheid", l.c., 271. White, I.C., "TOVALOP and CRISTAL give way to the Legal Regimes - the Continuing Role of ITOPF", ongepubliceerd, 1996, 2. met olietankers", o.c., 431 . 


\subsection{Omschrijuing van een P\&I Club}

Een Protection and Indemnity Club (P\&I Club) is een vereniging waarbij een aantal scheepseigenaren op mutualistische basis aan elkaar verleent. Het element Protection verwijst naar de risico's verbonden van de eigendom van het schip; het element Indemnity verwijst naar de cxploitaticrisico's van het schip ${ }^{176}$. Toch is de dekking die een P\&I Club verleent nog ruimer dan deze elementen.

Het basisprincipe is dat alle leden van de Club bijdragen leveren voor vorderingen waaraan andere leden zijn blootgesteld. Dit betekent dat de leden van een P\&I Club tegelijk verzekeraar en verzekerde zijn. De P\&I Club moet worden gezien als een onderlinge en wederzijdse financiële verbintenis waar alle scheepseigenaren de kosten delen van een aansprakelijkheidsvordering tegen een van hun collega's - leden van de desbetreffende Club. Vanuit die optiek vervult een Club een duale rol: ten eerste als vertegenwoordiger van de verzekerde scheepsbelangen en ten tweede als verzekeraar $^{177}$. De P\&I Club is met andere woorden een soort captive ${ }^{178}$.

P\&I Clubs zijn bijgevolg geen klassieke verzekeringsmaatschappijen maar organisaties ter behartiging van de belangen van haar leden - in de eerste plaats schecpseigenaren, maar ook charteraars ${ }^{179}$. Geheel in dezelfde lijn verschilt het contract dat een scheepseigenaar afsluit met de P\&I Club van een traditionele verzekeringspolis; indien een scheepseigenaar lid wil worden van een bepaalde P\&I Club, moet hij een formulier invullen en ondertekenen. Indien de Club het lidmaatschap aanvaardt, schrijft het meteen een toetredingscertificaat uit waarin het schip, de schepen of de vloot staan vermeld en waarin wordt weergegeven welke risico's zijn gedekt. Bovendien is het zo dat indien een scheepseigenaar voldoet aan bepaalde basisvereisten inzake veiligheid e.d., hij relatief makkelijk door een Club als lid zal worden opgenomen, zonder dat hierbij ingewikkelde aanvaardingsprocedures moeten worden gevôlgd $^{180}$.

Dit getuigt van een zekere soepelheid vanwege de P\&I Clubs. Deze soepelheid blijkt bijvoorbeeld ook uit de "omnibusclausule" die een optimale dekking garandeert. Deze dekking komt aan bod in de volgende paragraaf.

\subsection{Dekking verleend door een P\&I Club}

De door een P\&I Club verleende dekking is zeer ruim en verschilt van club tot club ${ }^{181}$. Zoals reeds aangegeven verwijst de benaming van de P\&I Club enerzijds naar de eigendomrisico's en anderzijds naar de exploitatierisico's. Dit onderscheid blijkt in de praktijk nict strikt te (kunnen)

Dieryck, C en Van Havre, P., "Les Assurances P\&l (Protection and Indemnity Clubs)", in L'Assurance Mutuelle en Belgique, Academia, Bruylant, Bruxelles, 1999, 382.

in Aspden, P., "Oil Pollution Legislation and its consequences. A P\&I Club View", in Shipping Law Faces Europe: European Policy, Competition and Environment, Maklu, Antwerpen-Apeldoon, Bruylant, Brussel, 1995, 143.

ins Over dit begrip, cfr. supra, in $\$ 2.2$ van hoofdstuk 11.

Coghlin, T.G., "Protection and Indemnity Clubs", Lloyds Maritime and Commercial Law Quarterly, 1984,411

is Aspden, P., "Oil Pollution Legislation and its consequences. A P\&I Club View", in "Shipping Law Faces Europe", l.c., 143.

Hardy lvamy, E. R., Marine Insurance, London, Butterworths, 4th edition, 1985, 215 e.v. 
worden gevolgd; een P\&I Club dekt zowel aansprakelijkheidsrisico's als bepaalde contractuele verplichtingen van zijn leden ${ }^{182}$.

Over het algemeen worden de door een P\&I Club gedekte risico's onderverdeeld tussen enerzijds algemene of gewone maritieme risico's en anderzijds de aanverwante maritieme risico's. Tol de gewone risico's behoren onder meer: aanvaringen, vorderingen ten aanzien van de lading, verlies van of schade aan goederen aan boord, aansprakelijkheid voor schade door overlijden en letsel. schade en door schade aan goederen, clandestiene passagiers, aansprakelijkheid van de bemanning, aansprakelijkheid opgelopen ingevolge een reddingsoperatie, verontreiniging, ... De aanverwante risico's zijn onder meer het corlogsrisico, risico op staking, verzekering van tussenpersonen $^{183}$. Vooral wat deze laatste risico's betreft, verschilt de verleende dekking van Club tot Club.

De P\&I Club biedt dus ook verzekeringsdekking voor de potentiële aansprakelijkheid van de scheepseigenaar tegenover derden. Dekking voor de schade aan het schip zelf wordt in de regel gedekt door scheepsrompverzekeraars ${ }^{184}$. Toch zullen de laatsten bij aanvaring van de verzekerde met een ander schip niet alle eigenschade vergoeden. Zo worden de kosten voor het lichten van het scheepswrak, schade aan de vracht aan boord van het schip en aansprakelijkheid ingevolge contractuele verplichtingen niet gedekt door de scheepsrompverzekeraars, waar wel door de P\&] Club.

De tussenkomst van een gemiddelde P\&I Club over de verschillende verleende dekkingen, is sterk verschillend. Een belangrijk deel van de door de P\&I Club verleende dekking (namelijk $34 \%{ }^{185}$ ) betreft de vracht van het schip. Daarnaast verleent de P\&I Club dekking voor letselschade of overlijden van de bemanning, stuwadoors, passagiers en andere personen die zich om de een of andere reden aan boord van het schip bevinden (22\%). De aansprakelijkheid die de scheepseigenaar kan oplopen voor zeeverontreiniging door olie, bedraagt $16 \%$ van de totale tussenkomst: van de $\mathrm{Club}^{186}$. Deze aansprakelijkheid viel vroeger onder TOVALOP, met dien verstande dat de aldaar aangegane verbintenissen in de P\&I Club werden verzekerd ${ }^{187}$. Tenslotte bevat de P\&I Club-polis een clausule op basis waarvan ook dekking kan worden verleend voor vorderingen die niet expliciet zijn gedekt door de polis (zgn. omnibus clausule of catch all rule ${ }^{188}$. De bedoeling van deze omnibusclausule is om snel tegemoet te komen aan de noden van de leden van de Club, indien een exccptioneel ernstig incident heeft plaatsgehad of indien een nieuw risico opduikt ${ }^{189}$.

Een bepaald lid van de Club is niet verplicht om voor alle risico's die door de Club kunnen worden gedekt, een dekking te nemen. De scheepseigenaar kan enkel voor een bepaald aantal risico's

Dieryck, C. en Van Havre, P., "Les Assurances P\&l (Protection and Indemnity Clubs)" in "L'Assnrance Mutuelle en Belgique", l.c., 382.

Dieryck, C. en Van Havre, P., "Les Assurances P\&I (Protection and Indemnity Clubs)", in "LAsslrance Mutuelle en Belgique", l.c., 383. Coghlin, T.G., "Protection and Indemnity Clubs", o.e., 405.

185 De cijfers geven het aandeel weer van een bepaalde dekking tegenover het geheel van uitgekeerdi vorderingen, in termen van de waarde van elke respectievelijke vordering. Aspden, P., "Oil Pollution Legislation and its consequences. A P\&I Club View", in "Shipping Law Faces Europe", l.c., 139. Coghlin, T.G., "Protection and Indemnity Clubs", o.c., 409; Aspden, P., "Oil Pollution Legislation and its consequences. A P\&l Club View", in "Shipping Law Faces Europe", l.c., 140. rance Mutuelle en Belgique", l.c., 381. 
dekking vragen; tegelijk mag hij, volledig conform zijn eigen wensen, een grotere of kleinere vijstelling bij elk van die risico's bedingen.

\subsection{Bijdragen van de leden van de Club - "premie"}

De P\&I Club is zoals gezegd een captive, die enkel het belang van zijn leden dient - scheepseigenaren en charteraars. De premie die aan de leden wordt gevraagd, stelt de Club enkel in staat de potentiële vorderingen te voldoen en de administratieve kosten te dekken; het is niet meteen de bedoeling om winst te maken.

De aangerekende premie is geen vaste verzekeringspremie zoals bij een klassieke verzekeringsovereenkomst. De jaarlijkse bijdrage van elk lid is opgesplitst in twee delen. Een eerste deel wordt betaald bij de aanvang van elk jaar; een tweede deel wordt opgevraagd zes maanden nadat het jaar is verstreken. De som die wordt betaald aan het begin van het jaar wordt de voorafgaande bijdrage of advance call genoemd; het tweede deel van de premie is de bijkomende bijdrage of supplementary call ${ }^{190}$

Het spreekt voor zich dat niet alle vorderingen kunnen worden betaald binnen de zes maanden na elk jaar en dat de grootte van de bijkomende bijdrage soms heel moeilijk kan worden ingeschat. Indien bijgevolg de ieeds betaalde voorafgaande en bijkomende bijdragen ontoereikend zijn, is het mogelijk dat de leden bovenop de eerder betaalde bijkomende bijdrage opnieuw een bijkomende bijdrage dienen te betalen. Indien in de omgekeerde situatie, de bijkomende bijdrage hoger was dan de uitbetaalde vorderingen, kan een deel van de bijdrage worden terugbetaald of gereserveerd. In het algemeen bedraagt de voorafgaande bijdrage tussen $75 \%$ en $80 \%$ van de geanticipeerde fotale vorderingen - gebaseerd op de ervaring in de vorige jaren - die een Club dat jaar zal moeten uitbetalen

Toch kunnen de vorderingen die een P\&I Club in een gegeven jaar moet uitbetalen onderhevig zijn aan aanzienlijke schommelingen, met name indien een van hun leden werd getroffen door een zwaar verlies. Door dergelijke schommelingen kunnen de leden van de Club ertoe gehouden zijn een aanzienlijke bijkomende bijdrage te betalen. Teneinde deze onpopulaire bijkomende bijdragen tot een minimum te beperken, hebben de meeste Clubs een systeem ontwikkeld waarbij de overschotten van een bepaald jaar worden gereserveerd waardoor de grootte van een bijkomende bijdrage in een slecht jaar, kan worden beperkt. Een zekere stabiliteit in de jaarlijkse totale bijdrage van elk lid wordt op deze wijze bewerkstelligd.

De grootte van de voorafgaande bijdrage die een bepaald lid moet betalen, is afhankelijk van het risico dat hij vertegenwoordigt en van andere factoren zoals de vlagstaat, het scheepstype, en uiteraard de hoogte van de vrijstellingen en de uitgestrektheid van de dekking zoals dat lid is overeengekomen met de Club. De grootte van de voorafgaande bijdrage wordt bepaald door de Club-managers; de grootte van de bijkomende bijdrage wordt bepaald door de directeuren van de Club, volgens hetzelfde percentage als de voorafgaande bijdrage. Indien een lid van de Club met andere woorden in een bepaald jaar aanzienlijke verliezen heeft geleden, zal dit zonder invloed zijn op de grootte van diens bijkomende bijdrage voor datzelfde jaar. Uiteraard kan de grootte van zijn voorafgaande bijdrage voor het volgende jaar worden aangepast ${ }^{\text {i9! }}$. Tegelijk kan een lid uit de Club worden gezet indien hij een te groot risico vertegenwoordigt.

Coghlin, T.G., "Protection and Indemnity Clubs", o.c., 415.

Coghlin, T.G., "Protection and Indemnity Clubs", o.c., 416. 
Voor een aantal scheepseigenaren en voor de meeste charteraars zal toch een klassieke vaste premie worden aangerekend, in plaats van het dubbele systeem van voorafgaande en bijkomende bijdragen. Deze premie wordt berekend op basis van wat deze leden anders zouden betalen aan voorafgaande en bijkomende premie, rekening houdend met een bepaalde marge om mogelijke bijkomende bijdragen het hoofd te bieden. Maar de leden van de Club die een vaste premie betalen, kunnen geen eventuele terugbetalingen genieten na een "goed jaar"; bovendien is de dekking die zij genieten, in tegenstelling tot de andere Clubleden, beperkt tot een bepaalde som.

\subsection{Internationale Groep van P\&I Clubs}

De meeste P\&I Clubs zijn op hun beurt lid van de "International Group of P\&I Clubs" waar een deel van de door elke afzonderlijke club verleende dekking wordt herverzekerd ${ }^{192}$. Deze herverzekeringspool treedt op als herverzekeraar van de P\&I Clubs. In Europa was in 1998 het volledige scheepstonnage gedekt via deze pool. Het is dan ook niet verwonderlijk dat de Europese Commissie de nodige vraagtekens heeft geplaatst bij de werking van deze pool ${ }^{193}{ }^{194}$.

Ingevolge de opmerkingen van de Commissie, bedraagt het minimale dekkingsniveau 3,9 miljard euro (eerder bedroeg deze 16,5 miljard euro)

\subsection{Beheer en bestuur van de P\&I Club}

Elke P\&I Club wordt bestuurd en gecontroleerd door een comité van directeurs, dat door de leden van de jaarlijkse Algemene Vergadering wordt gekozen. De dagelijkse leiding van de Club wordt gedelegeerd aan managers die verantwoording dienen af te leggen tegenover het comité van directeurs.

Een belangrijke taak van deze managers is bijstand te verlenen aan de leden van de Club op het moment waarop deze met een vordering tot schadeloosstelling worden geconfronteerd. Voor deze taak worden de managers in havens overal ter wereld bijgestaan door een netwerk van correspondenten. Daarom is na een ongeval een snelle en correcte evaluatie van de grootte van het ongeval en van de oorzaken ervan, van uitermate groot belang.

De Clubmanagers geven ook advies aan de Clubleden inzake preventie van verliezen en van aansprakelijkheidsvorderingen en helpen hen op juridisch vlak (onder meer bij het voorbereiden van verschillende scheepvaartdocumenten $)^{195}$.

\section{Conclusie}

Lit de bespreking van de internationale Verdragen in 2 ake aansprakelijkheid voor olieverontreiniging op 7ee, blijkt in eerste instantie dat deze Verdragen inhoudelijk vijj gelijklopend zijn met de nucleaire aansprakelijkheidsverdragen, in die zin dat dezelfde basisprincipes kunnen worden teruggevonden: risicoaansprakelijkheid, kanalisatie van aansprakelijkheid, verplichte verzekering vun aansprakelijkheid en beperking van de aansprakelijkheid.

192

Aspden, P., "Oil Pollution I egislation and its consequences. A P\&I Club View", "Shipping Law Faces T:urope", l.c., 140.

Cir. supra, \$ 4.3 .2 van hoofdstuk 6 .

Zie hiernier mk Dieryck, $C$. en Van Havre, P., "I es Assurances P\&I (Protection and Indernity Clubs)", in "I 'Assurance Mutuelle en Belgique", l.c., 392 e.v.

Coghlin, I.G., "Protection and Indemnity Clubs", o.c., 414. 
Onder het CLC-Verdrag kan een exploitant zich echter enkel op deze beperking beroepen indien hij een fonds heeft gevormd, gelijk aan het bedrag waarvoor hij aansprakelijk is. Het maximale bedrag waarvoor de eigenaar aansprakelijk is op basis van het CLC-Verdrag, bedraagt 88,44 miljoen euro. In het maritieme aansprakelijkheidsrecht onder het CLC-en het Oliefondsverdrag wordt de aansprakelijkheid daarenboven verdeeld tussen de verschillende partijen die belang hebben bij het transport. Naast de aansprakelijkheid van de scheepseigenaar, voorziet het IOPCFonds in een maximale uitkering per voorval van 193,2 miljoen euro. In een aantal gevallen kan deze uitkering zelfs oplopen tot 286,21 miljoen euro. In het nucleaire aansprakelijkheidsrecht wordt er geen lastenverdeling ingevoerd met andere private actoren. Bij transport van olie kan inderdaad worden aangenomen dat twee duidelijk onderscheiden partijen belang hebben bij het transport en dat bijgevolg beiden een inspanningen dienen te leveren. Bij de productic van kernenergie ligt eenzelfde lastenverdeling niet meteen voor de hand. De rol die de Staat op zich neemt in het nucleaire aansprakelijkheidsrecht kan niet als een analoge lastenverdeling worden beschouwd. De staatstussenkomst werd namelijk initieel in het kemenergierecht ingeschreven wegens de beperkte gegevens inzake de dekking van het nucleaire risico.

Recent hebben zich op het terrein van de aansprakelijkheid voor olieverontreiniging op zee een aantal opmerkelijke en ingrijpende veranderingen voorgedaan. De belangrijkste wijziging betreft het optrekken van de aansprakelijkheid van de verschillende actoren door de nieuwe CLC- en Oliefondsverdragen. Tegelijk werden de vrijwillige afspraken tussen scheepseigenaren opgedoekt. Blijkbaar is de industric van oordeel dat de compensatiemechanismen die in de Verdragen zijn uitgewerkt afdoende bescherming bieden. Een quasi analoge lastenverdeling tussen de verschillende belanghebbenden van het transport, is ook doorgetrokken in het in mei 1996 tot stand gekomen HNS-Verdrag.

Weliswaar worden de nieuwe aansprakelijkheidslimieten van het CLC-Verdrag en van het Oliefondsverdrag hoog genoeg geacht om quasi alle schade door oljeverontreiniging op zee te dekken, en is het de hoofdbedoeling van deze Verdragen om de wetgeving van de Verdragsstaten te harmoniseren, maar toch blijven door het belang van de lex fora aanzienlijke verschillen mogelijk voor wat betreft het al dan niet toekennen van een vordering en de omvang daarvan.

De dekking van de schade door olieverontreiniging op zee gebeurt via de P\&I Club. Dit is een captive van de scheepseigenaren. In tegenstelling tot de captive van de exploitanten van een keminstallatie in de VS, verzekert deze Club zowel de extracontractuele en de contractuele aansprakelijkheid als de eigenschade ${ }^{196}$. Tussen deze Protection and Indemnity Clubs bestaat ook concurrentie, zodat de verschillende betrokken partijen een keuze hebben om zich bij een welbcpaalde Club aan te sluiten. Het is logisch dat de bevoegdheid van het clubbeheer om een lid uit te club te zetten, met name de preventie van ongevallen ten goede komt. Toch heeft de Europese Commissie heel wat vraagtekens geplaatst bij de werking van de P\&I Club en met name bij de wijze van herverzekering via de International Group of P\&I Clubs. De Commissie heeft de Clubs verplicht om belangrijke wijzigingen aan te brengen aan de wijze van herverzekeren.

De bedragen die door de Clubs worden verzekerd, liggen overigens zeer hoog in vergelijking met de bedragen die door de Belgische en de Nederlandse nucleaire pool worden verzekerd. Via de P\&I Clubs worden bedragen verzekerd die kunnen oplopen tot 16,5 miljard euro of meer (zowel aansprakelijkheid als de dekking van de eigenschade). In de nucleaire sector liggen de bedragen opmerkelijk lager, met name ongeveer 300 miljoen euro wat betreft de aansprakelijkheid cn, wat

Cfr. infra, in hoofdstuk 13. NEIL verzekert hoofdzakelijk de eigenschade van de exploitant, maar treedt sinds kort op als belangrijke herverzekcraar van de Amerikaanse nucleaire verzekeringspool. 
de eigenschade van de Belgische exploitant betreft, 1,24 miljard euro. Bijzonder is dan ook de vaststelling dat deze zeer hoge bedragen in de maritieme sector volledig worden gefinancierd dooi private fondsen, terwijl wat het nucleaire risico, in de landen van het NEA-regime, en met name in Nederland, de installatiestaat instaat voor een aanzienlijk deel van de schade.

Zowel in het maritieme recht als in het nucleaire recht wordt dus naast de aansprakelijkheid van de scheepseigenaar en de exploitant van de kerninstallatie (respectievelijk het CLC-Verdrag van 1969 en het Verdrag van Parijs van 1960) ook voorzien in bijkomende compensatie. Maar in het maritieme recht bestaat de aanvullende compensatie uit private middelen (Oliefondsverdrag), terwijl in het kernenergierecht de verschillende verdragsluitende Staten van het Aanvullend Verdrag van Brussel van 1963 publieke fondsen ter beschikking stellen. 


\section{HOOFDSTUK 13}

\section{AANSPRAKELIJKHEID EN VERZEKERING VAN HET NUCLEAIRE RISICO IN DE VERENIGDE STATEN}

Hierboven werd bij de bespreking van de invoering van kanalisatie van aansprakelijkheid reeds aangegeven dat de Europese wetgeving inzake civielrechtelijke aansprakelijkheid voor kemongevallen, in ruime mate is geïnspireerd op het Amerikaanse kemenergierecht. Vandaar is het zonder meer nuttig na te gaan hoe de aansprakelijkheid van de exploitant van een kerninstallatie is geregeld in het Amerikaanse kernenergierecht en via welke mechanismen het nucleaire risico in de VS wordt verzekerd. In dit hoofdstuk wordt eerst een beknopt overzicht gegeven van het ontstaan van het Amerikaanse kernenergierecht $(\S 1)$. In paragraaf 2 wordt aandacht besteed aan de Amerikaanse wet inzake aansprakelijkheid voor het nucleaire risico - de Price-Anderson Act - en vervolgens wordt bestudeerd hoe in de VS zowel de eigenschade als de aansprakelijkheid tegenover derden wordt verzekerd $(\$ 3)$. In paragraaf 4 tenslotte zullen een aantal conclusies worden getrokken.

\section{BEKNOPT OVERZICHT VAN HET AMERIKAANSE NUCLEAIRE AANSPRAKELIJKHEIDSRECHT}

Het totstandkomen van het Amerikaanse nucleaire aansprakelijkheidsrecht werd reeds aan de orde gesteld bij de bespreking van het ontstaan van de kanalisatie van aansprakelijkheid'. Hier worden enkel de hoofdlijnen kort in herinnering gebracht.

Het Amerikaanse nucleaire aansprakelijkheidsrecht is gebaseerd op de Atomic Energy Act. De oorspronkelijke versie van deze wet dateert van 1946, toen de Amerikaanse overheid een monopolie had over het gebruik en het aanwenden van kernenergie. Private ondernemingen konden onder deze wet participeren in nucleaire activiteiten, evenwel onder controle en onder de verantwoordelijkheid van de Staat. Eens de VS niet meer beschikten over het feitelijke monopolie van het gebruik van kemenergie, belemmerde het monopolie de ontplooiing van de nucleaire industrie. De Atomic Energy Act werd daarom in 1954 gewijzigd - opheffing van het overheidsmonopolie - maar al gauw bleek dat de industrie huiverachtig stond tegenover de aanzienlijke aansprakelijkheden die uit de nucleaire activiteiten konden voortvloeien.

Daarom liet de nucleaire industrie onderzoek verrichten naar manieren om zowel de belangen van slachtoffers als de belangen van exploitanten veilig te stellen. Volgens de auteurs van het Voorlopig Rapport werd een evenwicht tussen beide belangen bereikt door de exploitant te verplichten om een financiële zekerheid te nemen - met dien verstande dat zijn aansprakelijkheid tot dit bedrag zou worden beperkt - en doordat eveneens de overheid een dcel van dc compensatieplicht op zich zou nemen ${ }^{2}$. Deze principes werden vervolgens ingeschreven in de Amerikaanse nucleaire wetgeving met name toen de Atomic Energy Act werd gewijzigd door het Price Anderson Amendment van $1957^{3}$.

Cfr. supra, in \$ 2.1.1 van hoofdstuk 4.

Cfr. supra, in \$ 2.1.2 van hoofdstuk 4.

Brown, O.F., II, "Legislative History of Government Indemnification Under the Price Anderson Act", paper gepresenteerd voor The Price-Anderson Contractors Policy Issues Study, september 1984, 4-5; Stason, E.B., Estep, S.D. en Pierce, W.J., Atoms and the Law, University of Michigan Law School, 1959,572 . 


\section{De Price-ANDERSon ACT}

Voortbouwend op de ideeën van het Voorlopig Rapport ${ }^{4}$ worden hieronder in eerste instantie een aantal van de belangrijkste wetsvoorstellen besproken die uiteindelijk hebben geleid tot de adoptie van de Price-Anderson Act ( $\$ 2.1$ ). Vervolgens wordt weergegeven welk doel de Amerikaanse wetgever wenste te bereiken via de adoptie van de Price-Anderson Act ( $\$ 2.2$ ). In $\S 2.3$ wordt een overzicht gegeven van de verschillende wijzigingen die deze wet sinds 1957 heeft ondergaan. De voornaamste bepalingen van de Price-Anderson Act anno 2000, worden besproken in paragraaf 2.4. Tegelijk wordt ook vooruit geblikt op de wijziging van de Price-Anderson Act in 2002 $(\$ 2.5)$.

\subsection{Wetsvoorstellen}

In het licht van de terughoudendheid van de Amerikaanse nucleaire industrie zoals hierboven beschreven, diende de Atomic Energy Act zodanig te worden gewijzigd dat enerzijds de nucleaire industrie niet langer zou zijn afgeschrikt om te investeren en anderzijds dat slachtoffers van een kernongeval afdoende zouden worden beschermd. Met dit doel voor ogen werden verschillende wetsvoorstellen ingediend ${ }^{5}$. Een eerste voorstel, gelanceerd door Melville Price ${ }^{6}$, hield in dat de USAEC de exploitant zou vrijwaren tegen alle uit een kernongeval voortvloeiende vorderingen, op voorwaarde evenwel dat de exploitant over een verzekeringsdekking zou beschikken, tot een bedrag waarvan de USAEC oordeelde dat het redelijkerwijze voldoende was ${ }^{7}$. Daamaast werd een voorstel ingediend door Stirling Cole ${ }^{89}$ dat stelde dat de aansprakelijkheid van de personen betrokken bij de realisatie, constructie en uitbating van de keminstallatie zou worden beperkt tot de gevallen waar het kemongeval was veroorzaakt door het slecht functioneren van de reactor. Het bedrag van de aansprakelijkheid zou volgens het voorstel van Cole maximaal het dubbele bedragen van de globale kost van de keminstallatie ${ }^{10}$.

Beide voorstellen werden in het Amerikaanse Congres emstig bekritiseerd. Bij het voorstel van Cole was onduidelijk of het slecht functioneren van de installatie impliceerde dat de exploitant enkel aansprakelijk was indien hem een fout kon worden verweten. Het voorstel van Price werd onder vuur genomen omwille van de onbeperkte verplichtingen van de Staat, die alle schade boven de verzekeringsdekking van de exploitant zou dienen te vergoeden. Niettegenstaande deze kritieken, bevatten de genoemde voorstellen twee principes die zouden worden overgenomen in

Cfr. supra, in \$2.1.2 van hoofdstuk 4.

Voor meer details, zie Mazuzan, G.T. en Walker, J.S., "Controlling the Atom", l.c., 105 e.v.; Brom, O.F., II, "Legislative History of Government Indemnification Under the Price Anderson Act", paper gepresenteerd voor The Energy Contractors Price-Anderson Group, Washington, 1998, 19 e.v. House of Representatives, 9701, 84th Congress, 2d Session, 1956.

$7 \quad$ "(...) the AEC shall, upon request, indemnify each owner, operator, manufacturer, designer and builder of a production or utilization facility (...) and each supplier of equipment, material or services for such facility $(.$.$) against uninsured liability (. .$.$) , subject to the condition that primary non-governmental in-$ surance against such liability has been procured in amounts deemed reasonably adequate by the Commission (...)" (House of Representatives, 970, 84th Congress, 2d Session, 1956).

Zowel Price als Cole waren lid van de Joint Committee on Atomic Energy, een parlementaire comnissie die de werkzaamheden van de AEC controleerde. House of Representatives, 9802, 84th Congress, 2d Session, 1956.

"(...) the liability of those persons responsible for the design, construction, or operation of such facilities shall be limited in the case of damages caused by the malfunctioning of such facility". "The licensee of a production or utilization facility shall not be liable in damages for the malfunctioning (...) in in aggregate amount more than twice the original capital cost of such facility" (House of Representativey, 9802,84 th Congress, 2d Session, 1956). 
de uiteindelijke Amerikaanse nucleaire aansprakelijkheidswet, met narne de beperking van de aansprakelijkheid van de exploitant en de overheidstussenkomst.

Als antwoord op deze kritieken werden nieuwe wetsvoorstellen ingediend, waarvan vooral het door senator Anderson uitgewerkte voorstel ${ }^{11}$ van belang is geweest. Het voorstel bevatte volgende principes: beperking van de aansprakelijkheid van de exploitant tot het bedrag dat op de verzekeringsmarkt beschikbaar was, de verplichte verzekering van de aansprakelijkheid, en een beperking van de overheidstussenkomst tot een bedrag van 500 miljoen dollar. Dit voorstel, dat de basis vormde van de uiteindelijk goedgekeurde wet, voorzag bijgevolg in de introductie van een systeem van twee lagen: de eerste schijf betrof de (verplichte) aansprakelijkheidsverzekering van de exploitant en de tweede schijf voorzag in een (veel hogere) overheidstussenkomst.

Uit de voorbereidende werken van de Price-Anderson Act blijkt dat de hoogte van de staatstussenkomst weinig aanleiding heeft gegeven tot discussie: het door senator Anderson voorgestelde bedrag van 500 miljoen dollar werd overgenomen in de uiteindelijk goedgekeurde wet. Dienaangaande werd enkel gesteld dat dit bedrag het overheidsbudget niet te zwaar zou belasten, dat het waarschijnlijk genoeg zou zijn om de meeste schade te vergoeden en dat het bedrag laag genoeg was "not to frighten the country or Congress to death"12.

Uiteindelijk werd de Price-Anderson Act aangenomen waarin zowel de idee van de verplichte verzekeringsdekking zoals voorgesteld door Price, als de beperking van de staatstussenkomst tot een bedrag van 500 miljoen dollar zoals uitgewerkt door Anderson, zijn terug te vinden.

\subsection{Doelstelling}

De Price-Anderson Act werd ingeschreven als Section 170 van de Atomic Energy Act en had cen dubbel doel: ten eerste ervoor zorgen dat de deelname van de privé-sector aan de groei van de kernenergie-industrie niet werd afgeremd door de potentieel extreem hoge aansprakelijkheidsvordering bij een zwaar kemongeval en ten tweedc garanderen dat voldoende fondsen beschikbaar waren voor slachtoffers van een kernongeval ${ }^{13}$. Het evenwicht tussen de belangen van slachtoffers en van de industrie bestond erin dat enerzijds publieke fondsen zouden worden vrijgemaakt voor de compensatie van slachtoffers en dat anderzijds de aansprakelijkheid van degenen dic voor een dergelijke schade aansprakelijk zijn, zou worden beperkt ${ }^{14}$.

Volgens de Price Anderson Act wordt - conform de conclusies van het Voorlopig Rapport - het nucleaire risico verdeeld tussen de private industrie die het risico creëert en de natie die voordelen halt uit de ontwikkeling van kemenergie. Deze lastenverdeling werd als volgt bewerkstelligd. Ten eerste werd degene die van de AEC een vergunning kreeg, verplicht om tot cen bepaald bedrag cen verzekeringsdekking te nemen tot het bedrag waarvoor op de private verzekeringsmarkt dekking voorhanden was (op dat moment 60 miljoen dollar) ${ }^{15}{ }^{16}$. De Price-Anderson Act

Senate 4112, 84th Congress, 2d Session, 1956.

Hearings Before the Joint Committee on Atomic Energy on Governmental Indemnity, 84th Congress; 2d Session, 123.

is "The Price-Anderson Act - The Third Decade", U.S. Nuclear Regulatory Commission, Washington DC, Report to Congress, November 1983, I-1.

Section 2. Findings, f en i. 42 USC 2012.

42 USCS $\$ 2210$ (b).

Het bedrag van deze aansprakelijkheid bedroeg einde 1997, volgens NRC-regulering, 200 miljoen dollar (10 CFR \$ 140.11) 
introduceerde dus een systeem van beperkte aansprakelijkheid van de exploitant van een keminstallatie.

Ten tweede werd de industrie door middel van publieke fondsen schadeloos gesteld voor alle schade die het bedrag van de verzekeringsdekking te boven gaat. Het principe hierbij was dat de AEC de licentiehouder schadeloos zou stellen voor schade dic dat bedrag te boven ging. De schadeloosstelling kreeg vorm in een zgn. Indemnity Agreement tussen de AEC en de licentiehouder. Op voorwaarde dat de licentiehouder een verzekeringsdekking nam tot een bedrag van 60 miljoen dollar, bood de Amerikaanse regering (in hoofde van de AEC) een bescherming tot maximaal 500 miljoen dollar ${ }^{17}$; het totale schadevergoedingsbedrag bedroeg bijgevolg 560 miljoen dollar ${ }^{18}$

\section{In miljoen dollar}

560

Overheidstussenkomst of

Government Indemnity

60
Aansprakelijkheidsverzekering van de exploitant

Via deze Indemnity Agreement ontsloeg de AEC haar leveranciers van een groot deel van de schadevergoedingsverplichting, zelfs tegenover derden, tengevolge van een kernongeval ${ }^{19}$. Vandaar introduceerde de Price-Anderson Act een mechanisme op basis waarvan de totale schadevergoeding uit een kernongeval wordt beperkt tot de som van de publieke fondsen en de private verzekeringsdekking van de exploitant. Deze som bestond uit twee lagen (zie schema): de cerste schijf van 60 miljoen dollar was de verzckeringsdekking van de exploitant en de tweede schijf bestond uit de overheidstussenkomst (500 miljoen dollar).

Hier dient evenwel te worden opgemerkt dat reeds vóór er sprake was van kernenergie er voorbeelden te vinden zijn van een beginnende industrie die actief door de overheid werd gesteund, bijvoorbeeld in de sector van de telegrafie, zeevervoer en commerciële luchtvaart ${ }^{20}$. Inzake kemenergie werd door middel van de inbreng van privé-kapitaal steun gegeven aan militaire activitejten die nadien voor vredelievende doeleinden werden aangewend. Een analoge evolutie had zich eerder voorgedaan op het terrein van bijvoorbeeld dieselmotoren en inzake luchtyaart ${ }^{21} 22$.

19 Hennessey, J.F., "Indemnification of the US Atomic Energy Commission's Contractors against Liability for Nuclear Accidents", in Weinstein, J.L. (ed.), "Progress in Nuclear Energy", l.c., 55; Lowenstein, R., "Indemnification against Liability for Nuclear Incidents in Licensed Atomic Energy Activities", in Weinstein, J.L. (ed.), "Progress in Nuclear Energy", l.c., 245; Stason, E.B., Estep, S.D. en Pierce, W.J, "Atoms and the Law", l.c., 583.

Ondertussen is de Price Anderson Act meermaals ingrijpend gewijzigd. Cfr. infra, $\S 2.3$ van dit hooflstuk.

Isenbergh, M., "La loi américaine sur l'énergie atomique", in Puget, H., Aspects de droit de lénergie atomique, tome II, Centre français de droit comparé, Paris, 1967, 283. Fischer, G., "Energie Atomique et les Etats-Unis", l.c., 88-89.

Fischer, G., "Energie Atomique et les Etats-Unis", l.c., 90.

Nadat de overheid zich als financier had teruggetrokken werden de desbetreffende industrieetn overgens gereglementeerd door diezelfde overheid (Fischer, G., "Energie Atomique et les Etats-Unis", lic. 89) 
In tegenstelling tot de bevindingen van het Voorlopig Rapport, werd wel degelijk een bepaling ingelast op basis waarvan de NRC een vergoeding van 30 dollar per 1000 kilowatt kon vragen van de exploitant, in ruil voor de overheidstussenkomst ${ }^{23}$.

Voor de dekking van hun aansprakelijkheid tegenover derden laat de Price-Anderson Act de exploitanten duidelijk de keuze tussen een aantal alternatieven ${ }^{24}$; daarnaast kan de NRC bepalen dat voor een gegeven reactor een lagere aansprakelijkheidsdekking volstaat, rekening houdend met de kosten van een private verzekeringsdekking, het type, de grootte en de locatie van de reactor en de aard en het doel van de vergunde installatie. Opmerkelijk is in ieder geval dat de mogelijkheid de aansprakelijkheid tegenover derden te verzekeren door middel van een onderlinge dekking via de "captives" ${ }^{25}$ expressis verbis wordt vermeld in de Price-Anderson Act. Daar wordt op teruggekomen bij de bespreking van de verzekering van het nucleaire risico in de VS.

\subsection{Wijzigingen aangebracht aan de Price-Anderson Act}

De in de loop der jaren aan de Price-Anderson Act aangebrachte wijzigingen staan in direct verband met een opvallend kenmerk van deze wet: de Price-Anderson Act wordt telkens afgesloten voor een beperkte termijn. Vandaar werden reeds wijzigingen aangebracht in 1966, 1975 en 1988. Bij deze verlengingen wordt telkens gekeken of de doelstellingen van de wet niet dienen te worden bijgestuurd. De huidige Price-Anderson Act is geldig tot 1 augustus $2002^{26}$. Als voorbereiding voor de verlenging bracht de NRC in 1998 verslag uitbrengen aan het Amerikaanse Congres $^{27}$

De wijzigingen die na het uitvaardigen van de Price-Anderson Act werden aangebracht, zijn terug te brengen tot één enkel thema, met name de verbetering van de positie van slachtoffers ${ }^{28}$. Zonder enige twijfel slaagde de eerste versie van de Price-Anderson Act er vooral in de industrie aan te moedigen te investeren in kernenergie, terwijl slachtoffers van een kernongeval geconfronteerd bleven met het probleem dat slechts beperkte bedragen inzake schadevergoeding beschikbaar waren $^{29}$.

Een verbetering van de positie van slachtoffers kwam tot stand doordat in toenemende mate de financiële verantwoordelijkheid van de nucleaire sector werd verzwaard. De verschillende etappes van deze verbetering worden hieronder besproken. Zo werd de positie van slachtoffers verbeterd door de amendementen van 1966 door megelijke juridische obstakels die in de oorspronkelijke versie van de Price-Anderson Act de compensatie in de weg stonden, ongedaan te maken (\$ 2.3.1). De meest ingrijpende wijziging vond plaats in 1975: door de introductie van een tweede

42 USCS $\$ 2210, f$.

"Such primary financial protection may include private insurance, private contractual indemnities, selfinsurance, other proof of financial responsibility, or a combination of such measures $(. . .)^{n} 42$ USCS $\S$ 2210 (b) (1).

Over dit begrip cfr. supra, in 2.2 van hoofdstuk 11.

42 USC $\$ 2210$ (c) en (d).

The Price-Anderson Act - Crossing the Bridge to the Next Century: A Report to Congress, NRC, Washington, 1998, 152 p.

Vanden Borre, T., "Dekking van het nucleaire risico op nationaalrechtelijke basis of via internationale Verdragen: de Verenigde Staten versus Europa", in Faure, M., Deketelaere, K. en Verhoosel, G., (red.), "Grensoverschrijdende milieuproblemen", l.c., 452 e.v.

Financial Protection against Nuclear Hazards: Thirty Years Experience under the Price Anderson-Act, The Legislative Drafting Research Fund of Columbia University; januari 1984, 16-17 (hierna geciteerd als: Columbia Rapport). 
schijf boven de (beperkte) aansprakelijkheid van de exploitant werd de voorheen aanzienlijke financiële tussenkomst van de federale regering afgebouwd $(\$ 2.3 .2$ ). Ook bij de in 1988 aangebrachte amendementen werden de beschikbare bedragen aanzienlijk verhoogd $(\S 2.3 .3)$.

\subsubsection{In 1966}

In 1966 was de kemenergie-industrie reeds in volle ontwikkeling in de Verenigde Staten; nochtans oordeelde de Joint Committee dat slachtoffers van een kernongeval geconfronteerd bleven met verschillende problemen inzake snelle en adequate compensatie van slachtoffers ${ }^{30}$. Geoordeeld werd dat de Price-Anderson Act erin slaagde de industrie te beschermen tegen al te zware aansprakelijkheidslasten, terwijl het zeer de vraag bleef of deze wet ook in staat was om het publiek te beschermen.

Vooral het feit dat aanzienlijke verschillen bestaan in het civiele aansprakelijkheidsrecht van de verschillende Staten, werd beschouwd als een voomame bron van rechtsonzekerheid ${ }^{31}$. In het toenmalige recht waren reeds verschillende leerstukken ${ }^{32}$ voorhanden op basis waarvan de exploitant van een keminstallatie buiten het bewijs van een fout kon worden aansprakelijk gesteld, maar de mate waarin deze leerstukken zouden worden toegepast bleef in ruime mate onzeker ${ }^{33}$. Het was met andere woorden onduidelijk of de verschillende staten in de VS risicoaansprakelijkheid dan wel foutaansprakelijkheid zouden toepassen bij schade uit een kernongeval. Tegelijk oordeelde de AEC dat een uniforme basis voor de aansprakelijkheid een gelijke behandeling van slachtoffers zou bevorderen ${ }^{34}$ en dat de adoptie van risicoaansprakelijkheid in de Price-Anderson Act desgevallend de toetreding van de Verenigde Staten tot de bestaande internationale Conventies zou vergemakkelijken ${ }^{35}$.

Terwijl eensgezindheid bestond met betrekking tot de noodzaak de bewijslast van slachtoffers te verlichten door de introductie van risicoaansprakelijkheid, concentreerde de discussie zich op de vraag of risicoaansprakelijkheid diende te worden geïntroduceerd via een federale aansprakelijkheidswet, dan wel via andere wegen. Deze discussie getuigt van een grote terughoudendheid om het federale parlement de mogelijkheid te bieden een wet te stemmen inzake aansprakelijkheid. Opvallend in deze gehele discussie was dat pogingen om inzake kernongevallen in de VS risicoaansprakelijkheid in te voeren, waren mislukt. Geen enkele Staat had de "Model Nuclear Facilities Liability Act" aanvaard. Deze Act die in 1961 was opgesteld door de National Conference of Commissioners on Uniform Siate Laws, voorzag onder meer in risicoaansprakelijkheid, kanalisatie van aansprakelijkheid en een beperking van de aansprakelijkheid in de tijd ${ }^{36}$.

Hearings voor de Joint Committee on Atomic Energy, 89 th Congress, 2d Session, 1966.

Columbia-Report, 1984, 17.

In de literatuur werd verwezen naar verschillende doctrines waaronder de doctrine van Rylands is. Fletcher, ultra hazardous activity, trespass, nuisance en res ipsa loquitur. Zie hicrover o.m. Cavers, D.F., "Improving Financial Protection of the Public against the Hazards of Nuclear Power", Harvard Law Review, vol. 77:644, 1964, 650-656; Piérard, J.P., "Responsabilité civile. Risque Atomique", l.c., 294 e.v.; Stason, E.B., Estep, S.D. en Pierce, W.J., "Atorns and the Law", l.c, 635 e.v. AEC-Study of the Price-Anderson Indemnity ACt, 15 februari 1965, 89th Congress, Ist Session, 1965, 33 (hierna geciteerd als: $A E C$-Study).

"AEC-Study", l.c., 33.

35 "AEC-Study", l.c., 4; Cavers, D.F., "Improving Financial Protection of the Public against the Hazands of Nuclear Power", o.c., 648. 
Uiteindelijk werd ervoor gekozen geen federale wet inzake risicoaansprakelijkheid voor kernongevallen in te voeren omdat dit werd beschouwd als een gevaarlijk precedent ${ }^{37}$, omdat een dergelijke wet afbreuk kon doen aan de flexibiliteit van het common law systeem en omdat de federale regering via wetgevende weg niet diende tussen te komen in domeinen waar de Staten de nodige middelen ter beschikking hebben om zelf op te $\operatorname{treden}^{38}$. Risicoaansprakelijkheid zou worden ingevoerd via een andere weg dan door een bepaling in de federale Price-Anderson Act die expliciet een dergelijke aansprakelijkheid invoerde.

De techniek die uiteindelijk tot hetzelfde resultaat leidde, bestond erin dat de exploitant bij een zwaar kernongeval - een Extraordinary Nuclear Occurence - door de AEC (nadien de NRC) kon worden verplicht afstand te doen van bepaalde verweermiddelen ("waiver of defenses") waarover hij krachtens federale of staatswetten zou beschikken ${ }^{39}{ }^{40}$. Een van de voornaamste verweermiddelen i.c. is het gebrek aan bewijs van fout ${ }^{41}$. In het midden van de zestiger jaren kon een exploitant aan aansprakelijkheid ontsnappen door aan te voeren dat geen fout in zijnen hoofde kon worden bewezen. Ingevolge de wijziging van de Price-Anderson Act in 1966 zou de exploitant dit verweermiddel niet meer kunnen inroepen zodra sprake zou zijn van een ENO. De facto kwam dit neer op de invoering van een systeem van risicoaansprakelijkheid bij zware kernongevallen: bij een ENO dient een slachtoffer enkel het causaal verband tussen zijn schade en het ongeval en de grootte van zijn schade te bewijzen. Het gedrag van het slachtoffer of van de gevrijwaarde personen doet hierbij geen afbreuk aan de schadeloosstelling ${ }^{42}$.

\section{Een Extraordinary Nuclear Occurence (ENO) ${ }^{43}$ wordt als volgt gedefinieerd:}

"any event causing a discharge or dispersal of source, special nuclear, or byproduct material from its intended place of confinement in amounts offsite, or causing radiation levels offside which the Nuclear Regulatory Commission determines to be sub-

"It might well lead to further Federal invasion of areas which have traditionally been left to the States and the private economy" ("AEC-Study", l.c., 36).

"AEC-Study", l.c., 36.

Senate Report $\mathrm{n}^{\circ} 1605,1966,3209$.

Zo zou de exploitant kunnen aanvoeren dat het slachtoffer er niet in slaagde te bewijzen dat de exploitant een fout heeft begaan bij het kernongeval of zou de vordering kunnen worden afgewezen indien zij niet binnen een specifieke termijn werd ingediend. "The Commission may incorporate provisions in indemnity agreements with licencees and contractors (...) which waive:

(i) any issue or defense as to the conduct of the claimant or fault of persons indemnified,

(ii) any issue or defense as to the charitable or governmental immunity, and

(iii) any issue or defense based on any statute of limitations if suit is instituted within three years from the date on which the claimant first knew, or reasonably could have known, of his injury or damage and the cause thereof" (42 USC $\$ 2210$ (n)). De "foutvereiste" wordt hier ais voorbeeld genomen; ook de andere, hierboven aangehaalde verweermiddelen konden bij een ENO niet meer worden ingeroepen. Volledigheidshalve dient erop te worden gewezen dat lid iii) van 42 USC $\$ 2210$ (n) geen beperking van de aansprakelijkheid in de tijd inhield; de enige bedoeling van deze bepaling was kortere aansprakelijkheidstermijnen zoals van kracht in bepaalde Staten, opzij te schuiven (Columbio Report, 18). Ook hier betrof het met andere woorden een verweermiddel dat de exploitant niet meer kon inroepen teneinde aan zijn aansprakelijkheid te ontsnappen. De aansprakelijkheid kon maximaal worden beperkt tot drie jaar vanaf de dag van het ongeval of vanaf de dag waarop het slachtoffer kennis had of redelijkerwijze kennis had moet hebben van diens schade. Dollar Question", Harvard Environmental Law Review, vol. 13, n 1, 1989, 13.

42 USC § 2014 (j). 
stantial, and which the Commission determines has resulted or will probably result in substantial damages to persons offsite or property offsite".

De bevoegdheid om uit te maken of een gegeven kernongeval al dan niet een extra-ordinary nuclear occurrence is, ligt in handen van de $\mathrm{NRC}^{44}$ die hiervoor een procedure ${ }^{45}$ en een reeks van criteria heeft opgesteld die de leidraad vormen bij de vraag of een gegeven kemongeval als cen ENO kan worden gekwalificeerd. De genoemde criteria worden onderverdeeld in criteria I en criteria II. De criteria I bepalen wanneer een vrijgekomen hoeveelheid straling substantieel is; de criteria II bepalen wanneer schade veroorzaakt aan personen of goederen buiten de nucleaire site substantieel is ${ }^{46}$. Enkel indien aan criteria I is voldaan, kan een beroep worden gedaan op criteria II. Wat betreft de criteria I, hanteert de NRC een aantal niveaus van stralingsdosis. Worden deze niveaus overschreden, dan wordt nagegaan of substantiěle schade werd geleden. Hierbij worden parameters gehanteerd a rato van de grootte van de schade ${ }^{47}$ en het aantal personen dat dergelijke schade heeft geleden.

Tot nog toe diende de NRC zich in één enkel geval te buigen over de vraag of een gegeven ongeval een ENO was, met name na het ongeval van Three Mile lsland. De NRC was van oordeel dat aan het eerste criterium niet was voldaan en dat onvoldoende informatie beschikbaar was om te bepalen of substantiële schade werd geleden door personen buiten de nucleaire site; daarom werd dit ongeval niet gekwalificeerd als een extraordinary nuclear occurrence. Tengevolge van deze beslissing werden beide criteria ernstig in vraag gesteld ${ }^{48}$.

Hier weze evenwel benadrukt dat de bepaling van een ENO volkomen los staat van de toepasselijkheid van de Price-Anderson Act of van de tussenkomst van de verzekering. Het is niet omdat een kernongeval niet wordt gekwalificeerd als een ENO, dat de Price-Anderson Act niet van. toepassing is. Het enige gevolg van een ENO is dat bepaalde verweernnechanismen die onder het recht van een bepaalde Staat de aansprakelijkheid van de exploitant, c.q. de schadevergoeding in de weg zouden kunnen staan, niet kunnen worden ingeroepen. Via de invoering van het begrip Extraordinary Nuclear Occurrence werd dus in het Amerikaanse nucleaire aansprakelijkheidsrecht een systeem van risicoaansprakelijkheid gecreëerd, zonder een federale aansprakelijkheids-

Het Amerikaanse Congres was van oordeel dat het aanbeveling verdiende de AEC (nu NRC) deze bevoegdheid te geven, eerder dan te trachten deze term bij wet te definiëren. Blijkbaar wilde mert vooral vernijden dat een rechter zou dienen te beslissen over de interpretatie van deze term. Geheel in dezelfde lijn werd daarom gesteld dat de beslissing van de Commissic of een gegeven ongeval al dar niet een ENO is, riet voor de rechtbank kan worden angevochten. Dit zou immers leiden tot langdurige procesvoering, terwijl het precies de bedoeling moet zijn om na een kemongeval alle tijdverlies te vermijden (Senate Repori $n^{\circ}$ 1605, 1966, 3211-3212).

Een procedure kan worden ambtshalve worden opgestart door de NRC of door andere getrofferist: "The Commission may initiate, on its own motion, the making of a determination as to whether or not there has been an extraordinary nuclear occurrence. In the event the Commission does not so initiate the making of a determination, any affected person, or any licensee or person with whom an indemnity agreement is executed or a person providing financial protection may petition the Commission for a determination of whether or not there has been an extraordinary nuclear occurrence" (I0 CFR \& 140.82)

$46 \quad 10$ CFR. $\S \S 140 . \overline{8} 1-140.85$

47. Dit begsip wordt als volgt gedefinieerd: "Damage shall be that arising out of or resulting from the radioactive, toxic, explosive or other hazardous properties of source, special nuclear, or byproduct material and shall be based upon estimates of one or more of the following: total cost necessary to put affected property back into use; loss of use of affected property; value of affected property where not practical to restore to use; financial loss resulting from protective actions appropriate to reduce or avoid exposure to radiation or to radioactive materials" (10 CFR $\$ 140.85$ (b)). 
wet te "moeten" afkondigen ${ }^{49}$. Zoals het begrip zelf aangeeft, wordt een ENO enkel voorbehouden voor zwaardere kernongevallen; het Congres heeft deze bepaling niet op alle kernongevallen willen toepassen uit vrees het indienen van aansprakelijkheidsvorderingen aan te moedigen ${ }^{50}$, zeker indien slachtoffers zouden weten dat ze zouden genieten van een regime van risicoaansprakelijkheid, gekoppeld aan de beschikbaarheid van een fonds van 560 miljoen dollar ${ }^{51}$.

Sinds de invoering van dit begrip in de Price-Anderson Act, is het belang crvan sterk gereduceerd. In de loop der jaren werd in het aansprakelijkheidsrecht van de mecste Staten van VS sowicso cen regime van risicoaansprakelijkheid geïntroduceerd ${ }^{52}$. Met andere woorden: zelfs indien een ongeval niet als een ENO zou worden gekwalificeerd, is de kans reëel dat een exploitant zal worden aansprakelijk gesteld buiten elk foutbewijs om.

\subsubsection{In 1975}

De belangrijkste wijziging die in 1975 aan de Price-Anderson Act werd aangebracht, betrof een aanzienlijke verandering in de fondsvorming bij civielrechtelijke aansprakelijkheid voor zware kemongevallen. Uitgangspunt van deze wijziging was dat het totale beschikbare schadevergoedingsbedrag ongewijzigd bleef, met name 560 miljoen dollar, maar dat de exploitanten zelf dit bedrag dienden samen te brengen, terwijl voorheen de Staat door middel van de government indermity, het grootste deel van dit bedrag voor zijn rekening nam ${ }^{53}$.

Het Joint Committee on Atomic Energy oordeelde dat naarmate meer reactoren een vergunning zouden krijgen, de kemenergie-industrie beter in staat zou zijn de aan een kernongeval verbonden financiële risico's te dekken. De meest effectieve manier om de industrie haar financiële verantwoordelijkheid te laten opnemen, was het overhevelen van de lasten van de ovcrheid naar de industrie, aldus het Joint Committee ${ }^{54}$. Geoordeeld werd dat in de beginjaren van de kernencrgieindustrie, deze niet in staat was het nucleaire risico te dragen, maar dat zij na verloop van enkele jaren evenwel meer verantwoordelijkheid op zich diende te nemen ${ }^{55}$. Deze redenering was overigens volledig in overeenstemming met het hierboven besproken Voorlopig Rapport dat stelt dat de tegemoetkoming van de overheid sowieso tijdelijk zou zijn. Tegenstanders van de government indemnity waren daarenboven van oordeel dat de nucleaire industrie dankzij deze overheidstussenkomst een ongeoorloofde subsidic kon genieten ${ }^{56}$.

Dece lastenverschuiving werd bewerkstelligd door de introductie van een nieuwe schijf tussen de aansprakelijkheidsverzekering van de exploitant en de overheidstusscnkomst. De eerste schijf -

Shapar, H.K., "La législation rclative à l'indemnisation des dommages nucléaires aux Etats-Unis", Bulletin de Droit Nucléaire, $n^{\circ} 15,1975,57$.

Brown, O.F., "Nuclear Liability Coverage Developments in the United States of America", INLA Conference Rio de Janeiro, Nuclear Inter Jura 1993, II.5.6, 4.

$\because \quad$ Verklaring van James, T. Ramey, Hearings before the Joint Committee on Atomic Energy on Proposed Amendments to Price-Anderson Act Relating to Waiver of Defenses, 89th Congress, 2d Session 3, 1966.

Rockett, L.R., "Financial Protection against Nuclear Hazards", l.c., 47-48.

Berkovitz, D., "Price-Anderson Act: Model Compensation Legislation? - The Sixty-Three Million Dollar Question", o.c., 14.

Senate Rep. $N^{\circ} 454,99$ th Congress, 1st Session, 1975, 10

Report $N^{0}$ 94-648, House of Representatives, 1975, 9-10.

Zie hierover Lowenstein, R., "The Price-Anderson Act an imaginative Approach to Public Liability Concerns", Forum, 1977, vol. 12(2), 594 e.v.; Wilson, R., "Nuclear Liability and the Price Anderson Act", Forum, 1977, v 12(2), 612 e.v. 
de aansprakelijkheidsverzekering van de exploitant - bleef ongewijzigd. Indien de schade uit een kernongeval echter groter was dan de 60 miljoen dollar van de aansprakelijkheidsverzekering diende voortaan een beroep te worden gedaan op een nieuwe schijf die gezamenlijk door alle exploitanten diende te worden betaald.

De exploitant diende inderdaad naast zijn aansprakelijkheidsdekking van de eerste schijf een retroactieve bijdrage

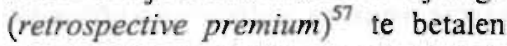
van 5 miljoen dollar per kerninstallatie. Deze nieuwe schijf werd zoals gezegd gecreěerd tussen de aansprakelijkheidsverzekering van de exploitant (60 miljoen dollar van de eerste schijf) en de vrijwaring door de overheid (500 miljoen dollar van de tweede schijf). De nieuwe schijf bestond uit een vaste bijdrage van 5 miljoen dollar die elke exploitant diende te betalen indien de schade uit een kemongeval groter is dan de 60 miljoen dollar van de aansprakelijkheidsverzekering.
Situatie in 1975

In miljoen dollar

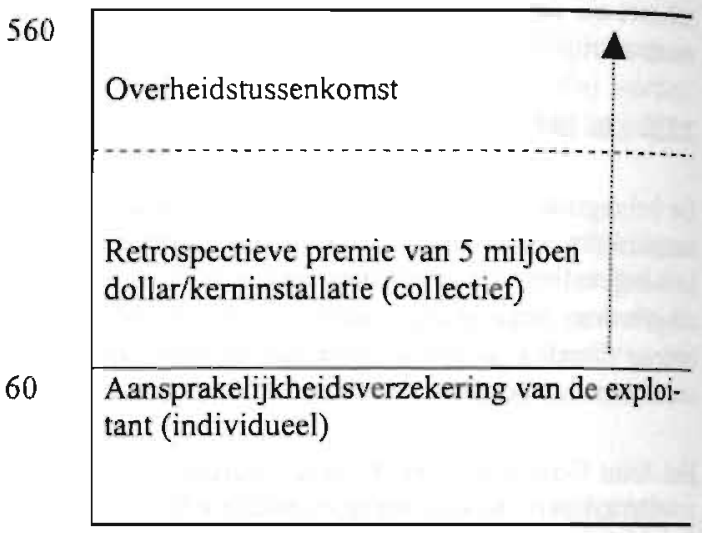

Aangezien bij een zwaar kernongeval elke exploitant, naast zijn "individuele" aansprakelijkheidsverzekering, eveneens moet voorzien in een som van 5 miljoen dollar per kerninstallatie, hangt het total van de beschikbare fondsen in de tweede schijf af van het aantal reactoren, c.q. van het aantal exploitanten en kon de staatstussenkomst worden afgebouwd naarmate meer reactoren operationeel zouden worden ${ }^{58}$. Zolang de exploitanten niet het gehele schadevergoedingsbedrag voor hun rekening namen, betekende dit dat overheidstussenkomst gelijk was aan het verschil tussen 560 miljoen dollar en het beschikbare schadevergoedingsbedrag (aansprakelijkheidsdekking plus retroactieve premie).

Een voorbeeld kan dit verduidelijken: op een gegeven moment hadden 70 exploitanten een vergunning. De eerste schijf bleef ongewijzigd, met name 60 miljoen dollar. De in de nieuwe tweede

57 De NRC kreeg de bevoegdheid de hoogte van deze premie te bepalen; deze premie mocht minstens twee: en maximum vijf miljoen dollar bedragen. Doordat de NRC uiteindelijk een retroactieve premie van vijf miljoen USD eiste, werd de afbouw van de overheidstussenkomst sneller bereikt dan verwachi, met name reeds in 1982, terwijl dit aanvankelijk was voorzien in 1985 (Report No 94-648, "Amentments to the Price-Anderson provisions of the Atomic Energy Act of 1954, as amended, to provide for the phaseout of governmental indernnity, and related matters", House of Representatives, 94th Con:gress, 1st Session, 10 november 1975, 10; Columbia-Report, 19). Nochtans waren bij de redactie van het wetsvoorstel dat leidde tot de verlenging van de Price-Anderson Act, weinig gegevens voorhanden die het mogelijk maakten in te schatten wanneer de overheidstussenkomst zou worden opgeheven; wolgens sommigen zou dat meteen gebeuren bij het van kracht worden van de nieuwe regeling; anderen waren van mening dat zulks slechts zou gebeuren in 1985 (Shapar, H.K., "La législation américaine relative à l'indemnisation des dommages nucléaires aux Etats-Unis", o.c., 64)

Met de pijl in het schema wordt aangegeven dat de tweede schijf die gezamenlijk door de exploitanter wordt bijeen gebracht, geleidelijk aan steeg, met name naarmate meer keminstallaties operationecl werden. 
schijf beschikbare fondsen bedroegen in dat geval 350 miljoen dollar (met name 70 kerninstallaties die elk 5 miljoen dollar dienden bij te dragen). In dit voorbeeld zou de overheidstussenkomst nog 150 miljoen dollar bedragen. Naarmate meer reactoren operationeel werden, werd de overheidstussenkomst dus geleidelijk verminderd. Bij de adoptie van de Price-Anderson Act in 1957 bedroeg de tussenkomst van de Amerikaanse Staat 500 miljoen dollar; tien jaar later bedroeg deze tussenkomst maximaal 486 miljoen dollar; in 1977 daalde de tussenkomst vanwege de Amerikaanse regering tot 110 miljoen dollar.

De amendementen van 1975 voerden niet alleen een nieuwe schijf in; tegelijk werd gesteld dat de eerste schijf (aansprakelijkheidsverzekering van de exploitant) diende te evolueren a rato van de nieuwe mogelijkheden op de nucleaire verzekeringsmarkt. Naarmate deze markt een groter bedrag kon dekken dan de initiële 60 miljoen dollar, verminderde ook op deze wijze het aandeel van de Amerikaanse overheid. Zo bedroeg in 1975 de verzekeringscapaciteit, wat de aansprakelijkheid van de exploitant betreft, 110 miljoen dollar.

Op 15 november 1982, toen de tachtigste reactor operationeel werd, participeerde een voldoende aantal reactoren zodat de Amerikaanse Staat geen enkele financiële verantwoordelijkheid meer droeg bij een kernongeval. Op dat moment was 160 miljoen dollar beschikbaar op de verzekeringsmarkt en 400 miljoen dollar door het systeem van retroactieve premies. Dit betekent dat in 1982 hetzelfde bedrag werd gedekt als onder de oorspronkelijke Price-Anderson Act van 1957, maar zowel via het stelsel van de retroactieve premie als door de verhoogde capaciteit op de nucleaire verzekeringsmarkt, stond de Amerikaanse nucleaire sector volledig zelf in voor de dekking van het beschikbare schadevergoedingsbedrag van 560 miljoen dollar ${ }^{5960}$.

De wijzigingen die in 1975 aan de Price-Anderson Act werden aangebracht hebben geleid tot een geleidelijke lastenverschuiving van de overheid naar de Amerikaanse privé-industrie ${ }^{61}$, en dus tot een verzwaring van de lasten van de industrie. Deze lastenverschuiving doet zich op twee niveaus voor. Enerzijds is de individuele aansprakelijkheidslast van elke exploitant gestegen (stijging van het bedrag waarvoor een aansprakelijkheidsverzekering diende te worden afgesloten); anderzijds is de lastenverschuiving gepaard gegaan met een soort van collectivisering van de aansprakelijkheidslasten in hoofde van alle exploitanten.

Indien de totale schade minder bedraagt dan 560 miljoen dollar, maar meer dan de aansprakelijkheidsdekking, zal elke exploitant een premie dienen te betalen die zijn pro rata deel vormt van de schade boven het bedrag van de beperkte aansprakelijkheid.

Tegelijk werd aan het Amerikaanse Congres de bevoegdheid gegeven om bij een zwaar kernongeval waarvan de schade groter is dan de aansprakelijkheid van de exploitant, het ongeval te onderzoeken en alle maatregelen te nemen om het publiek te beschermen tegen de gevolgen van een ramp van die grootte ${ }^{62}$. Hierbij aansluitend oordeelde het Joint Committee dat een verhoging

Marrone, J., "The Price-Anderson Act: the Insurance Industry's view", Forum, Chicago, 1977, v. 12 (2), 609 .

Enkel in bepaalde gevallen zal de Staat zich garant stellen voor leveranciers van de exploitant, waarbij de Staat nadien uitdrukkelijk regres zal uitoefenen op de exploitant of diens verzekeraar.

a De Amerikaanse wetgever heeft bewust gekozen voor een geleidelijke vermindering van de overheidstussenkomst omdat in 1975 slechts 54 kerninstallaties een vergunning hadden, terwijl 64 reactoren in aanbouw waren (Report $\left.N^{\circ} 94-648,1975,10\right)$.

Pub. L. $N^{\circ} 94-197, \S 6,89$ Stat. 1111 ; gecodificeerd als 42 USC $\$ 2210$ (e) (2). 
of een verlaging van de aansprakelijkheidslimiet niet noodzakelijk was aangezien het Congres, na het ongeval te hebben onderzocht, de aansprakelijkheidslimiet kon herzien ${ }^{63}$.

\subsubsection{In 1988}

Per 1 augustus 1987 was de Price-Anderson Act opnieuw aan verlenging to $e^{64}$. Ter voorbereiding van de discussies ter zake in het Amerikaanse Congres, overhandigde de NRC in december 1983 een rapport aan het Congres. Hierbij suggereerde de NRC meerdere opties, waaronder het beëin. digen van de Act, het uitbreiden van het systeem van retroactieve premies en het ongewijzigd. verlengen van de Act.

De NRC was voorstander van de verlenging van de Price-Anderson Act, met dien verstande dat de nadruk diende te worden gelegd op de verbetering van de positie van slachtoffers ${ }^{65}$. Zij was van oordeel dat de nucleaire industrie sinds de jaren vijftig een aanzienlijke ontwikkeling heeft gekend waardoor eenzelfde bescherming als geboden door de Price-Anderson Act misschien niet meer noodzakelijk was ${ }^{66}$. Door het systeem van snelle compensatic van schade uit kernongevallen, bood de Price-Anderson Act anderzijds wel duidelijke voordelen voor het publiek ${ }^{67}$. De voomaannste kritiek van de NRC betrof de beperkte aansprakelijkheid waardoor niet gedekte schade ten laste viel van de slachtoffers of van de federale regering ${ }^{68}$.

Teneinde deze kritiek het hoofd te bieden, stelde de Commissie een vernieuwing voor aan het toenmalige systeem. De absolute beperking van de aansprakelijkheid in de tweede schijf zou worden vervangen door een jaarlijkse aansprakelijkheidslimiet van 10 miljoen dollar ${ }^{69}$. Volgens de berekeningen van de NRC zou een jaarlijkse bijdrage van 10 miljoen dollar de jaarlijkse kosten van de exploitanten slechts doen stijgen met twee procent. In ruil voor de ruimere fondsen, zouden de exploitanten blijven genieten van de bescherming van de Price-Anderson Act ${ }^{70}$. In plats van een eenmalige retroactieve premie te betalen, zouden de exploitanten jaarlijks een bijdrage moeten betalen tot wanneer alle aansprakelijkheidsvorderingen uit een kernongeval zijn betaald. Op deze wijze zou er geen beperking bestaan op het totale schadevergoedingsbedrag tengevolge van een kernongeval, maar enkel een beperking van de jaarlijks te betalen som.

Op basis van deze door de NRC gelanceerde voorstellen, werd in het Amerikaanse Congres een groot aantal wetsvoorstellen ingediend met zeer uiteenlopende strekking: van slechts minimale wijzigingen in het niveau van de retroactieve premies tot het opheffen van de aansprakelijkheids-

Berkovitz, D., "Price-Anderson Act: Model Compensation Legislation? - The Sixty-Three Million Dollar Question", $0 . c .16$.

De uiteindelijke wet die de Price Anderson Act opnieuw verlengde, werd slechts op 20 augustus 1988 getekend; meer dan een jaar na het verstrijken van de termijn vooropgesteld bij de verlenging van. 1975. Merk op dat een niet-verlenging van de Prrice-Anderson Act tot gevolg had dat voor nieuw te bouwen reactoren geen vergunning kon worden verkregen; het regime bleef van kracht voos reeds vergunde kerninsta!laties.

US Nuclear Regulatory Commission, The Price-Anderson Aci - The Third Decade (Report to the Congress), NUREG-0957, 1983, IV-2 (hierna genoemd: "NRC-Rapport 1983")

"NRC-Rapport 1983", l.c., IV-3.

"NRC-Rapport 1983", l.c., IV-8.

"NRC-Rapport 1983", l.c., IV-5.

"NRC-Rapport 1983", l.c., IV-8-9.

Hearing before the Subcommission on Energy and the Environment of the House Comm. on Interior and insular Affairs, 99th Congress, 1st Session, 1985, 194 en 201. 
limiet $^{71}$. Voorstanders van een onbeperkte aansprakelijkheid waren van oordeel dat de nucleaire industrie sinds haar ontstaan voldoende was gegroeid om deze onbeperkte aansprakelijkheidslast te dragen en dat een beperkte aansprakelijkheid een ongeoorloofde subsidie betekende aan de nucleaire industrie ${ }^{72}$. Senator Hart stelde dat een beperking van de aansprakelijkheid de prikkel wegnam die uitgaat van het gewone aansprakelijkheidsrecht om zo veilig mogelijk met kernenergie om te gaan $^{73}$.

Vooral de kemenergie-industrie was fel gekant tegen alle voorstellen die in mindere of meerdere mate leidden tot de opheffing van de beperkte aansprakelijkheid. Voor hen was en blijft de beperkte aansprakelijkheid de quid pro quo voor het opheffen van een aantal obstakels die in het gewone aansprakelijkheidsrecht de compensatie van slachtoffers zouden verhinderen, zoals de introductie van risicoaansprakelijkheid. Bovendien was een beperking van de aansprakelijkheid noodzakelijk om weer te geven dat de beschikbare fondsen beperkt waren, aldus de industrie $\mathrm{e}^{74}$. Elke verhoging van de aansprakelijkheid zou volgens de kernenergie-industrie het in de PriceAnderson neergelegde evenwicht tussen hun eigen belangen enerzijds en die van de slachtoffers anderzijds verstoren ${ }^{75}$.

Tengevolge van de felle tegenstand van de industrie en van de verzekeringssector, werd het aanvankelijke voorstel van de NRC afgezwakt tot een compromis. Enerzijds bleef de beperking van de aansprakelijkheid behouden; anderzijds werd het bedrag van de retroactieve premies aanzienlijk verhoogd van 5 miljoen dollar tot 63 miljoen dollar per reactor, met dien verstande dat de jaarlijkse bijdrage niet meer kan bedragen dan 10 miljoen dollar. Deze bepaling reflecteert duidelijk de voorstellen van de NRC, met name een beperking van de jaarlijks te betalen deferred premium tot 10 miljoen dollar. Anderzijds werd de totale bijdrage van de exploitanten in de tweede schijf verhoogd tot 63 miljoen dollar per reactor.

\section{In miljoen dollar}

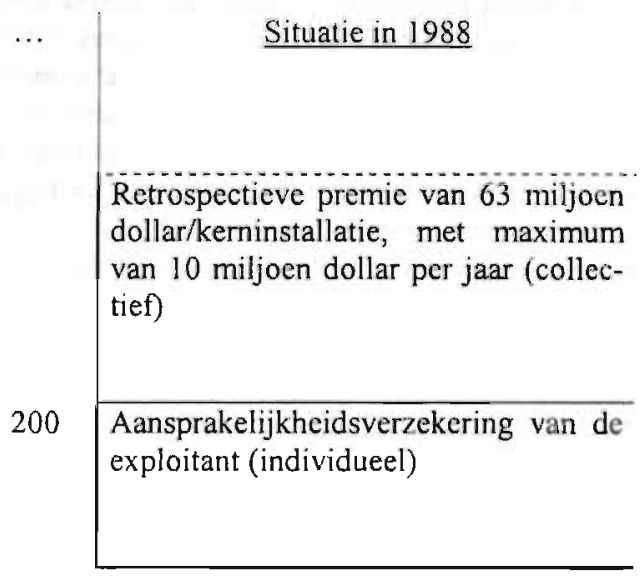

Concreet betekent dit dat indien zich een zwaar kernongeval voordoet, een exploitant die niet aansprakelijk is voor dat ongeval, er toch toe zal gehouden zijn om tussen te komen in de tweede collectieve schijf. Opmerkelijk is ook dat het maximumbedrag van de standard deferred premium ten minste om de vijf jaar dient te worden aangepast volgens de evolutie van de index cler con-

Voor meer bijzonderheden: zie Berkovitz, D., "Price-Anderson Act: Model Compensation Legislation? - The Sixty-Three Million Dollar Question", o.c., 19 e.v.

Hearing before the Subcommission on Energy and the Environment of the House Comm. on Interior and Insular Affairs, 99th Congress, Ist Session, 1985, 564.

Reauthorization of the Price-Anderson Act, 1985: hearings before the Subcomm. on Nuclear Regulation of the Senate Comm. on Environment and Public Works, 99th Congress, Ist Session, 14-15.

Reauthorization of the Price-Anderson Act, 1985: hearings before the Subcomm. on Nuclear Regulation of the Senate Comm. on Environment and Public Works, 99th Congress, Ist Session, 237.

Berkovitz, D.M., "Price-Anderson Act: Model compensation Legislation? The sixty-three million dollar question", o.c., 24. 
sumptieprijzen $^{76}$. Respectievelijk in 1993 en in 1998 werd de premie aangepast; de exploitant is verplicht om per installatie 83,6 miljoen dollar bij te dragen - het maximum van 10 miljoen dollar per jaar blijft behouden.

De door de NRC geformuleerde voorstellen leidden in ieder geval tot een aanzienlijke verbetering van de positie van slachtoffers: de beschikbare fondsen werden ongeveer vertienvoudigd tot 7 miljard dollar ${ }^{77}$.

Hocwel de bescherming voor exploitanten dus bleef bestaan na de amendementen van 1988, nam het Congres zich voor de snelle en volledige schadevergoeding te garanderen ${ }^{78}$. Er blijkt weinig twijfel tc bestaan aangaande de strekking van dcze bepaling: na een ongeval waarbij de totale schade groter is dan het beschikbare schadevergoedingsbedrag (aansprakelijkheid van de exploitant plus retroactieve dekking), zal het Amerikaanse parlement bekijken hoe een volledige schadeloosstelling kan worden bereikt ${ }^{79}$.

In het licht hiervan werd de Presidential Commission on Catastrophic Nuclear Accidents gecreeerd $^{80}$, die via aanbevelingen diende aan te geven hoe een dergelijke volledige schadeloosstelling kon worden bereikt. In het algemeen wilde deze commissie tegemoet komen aan de toenemende vrees dat de bestaande rechtsregels moeilijk konden worden toegepast op grote catastrofen zoals een ernstig kemongeval ${ }^{81}$. Op 20 augustus $1990^{82}$ bracht de presidentiële commissie een rapport uit met aanbevelingen omtrent een drietal thema's:

- inzake civielrechtelijke procedures en aansprakelijkheid teneinde alle gegronde vorderingen op een evenwichtige, snelle en efficiënte wijze toe te kennen;

- inzake procedures die de prioriteiten vastleggen voor het geval de totale schade de beschikbare fondsen dreigt te overschrijden;

- en inzake procedures of normen op basis waarvan kan worden beslist of schadevergoeding wordt toegekend voor latente letselschade ${ }^{83}$.

In het kader van dit onderzoek zou het te ver voeren dit lijvige rapport in detail te bespreken, mede gelet op het feit dat het slechts om aanbevelingen gaat. Van belang is dat deze presidentiele commissie aanbevelingen heeft geformuleerd met het oog op de snelle afhandeling van rechtszaken in rake kemongevallen. Het is de bedoeling dat de regels van het aansprakelijkheidsrecht

42 USCS $\$ 2210(t)$

Price-Anderson Amendments Act of 1988, Pub. L., $N^{\circ} 100-408,1988,102$ Stat. 1067.

"In the event of a nuclear incident involving damages in excess of the amount of aggregate public liability (...), the Congress will thoroughly review the particular incident (...) and will take (...) whatever action is determined to be necessary (including approval of appropriate compensation plans and appropriation of funds) to provide full and prompt compensation to the public for all public liability claims resulting from a disaster of such magnitude" 42 USC $\$ 2210$ (e) (2) (onze cursivering).

Heimann, F.F., "The U.S. Liability protection system for nuclear power plants", Nuclear Accidenis. Liabilities and Guarantees, OECD/NEA-IAEA, Helsinki, 1993, 419; Saltzman, J., "Conclusions of the Presidential Commission on Catastrophic Nuclear Accidents", Nuclear Accidents. Liabilities and Guarantees, OECD/NEA-IAEA, Helsinki, 1993, 267.

42 USC $\$ 2210$ (1). Zoals de naam van de commissie suggereert, werden de leden ervan benoemd door de president. In feite bestaat (bestond) de commissie uit vertegenwoordigers van de regering, de industrie, ingenieurs, verzekeraars en advocaten met ervaring in aansprakelijkheidsvorderingen.

Saltzman, J., "Conclusions of the Presidential Commission on Catastrophic Nuclear Accidents", o.c., 269.

Namelijk uiterlijk twee jaar na het van kracht worden van de Price-Anderson Amendementen van 1988.

42 USC \& 2210 (I), (3). 
worden aangevuld door een aantal maatregelen die een efficiënt beheer beogen van de voor slachtoffers beschikbare fondsen. Zo is in maatregelen voorzien om enerzijds zeer snel grote bedragen te genereren en anderzijds om bepaalde delen van deze fondsen achter de hand te houden voor later vast te stellen schade.

Andere wijzigingen doorgevoerd in 1988 houden in dat ook de kosten van preventieve evacuaties en de gerechtskosten onder de aansprakelijkheidsdekking vallen. Tenslotte moet de NRC binnen de 90 dagen nadat een rechtbank heeft vastgesteld dat de aansprakelijkhcid van één enkel kemongeval het bedrag van de beperkte dekking overtreft, een "comprchensive compensation plan" voorleggen aan het Congres.

$\mathrm{Na}$ de bespreking van de doelstelling van de Price-Anderson en de wijzigingen die inmiddels aan deze wet werden aangebracht, worden hieronder de voomaamste bepalingen van de PriceAnderson Act anno 2000 besproken.

\subsection{Voornaamste bepalingen van de Price-Anderson Act anno 2000}

De Price-Anderson Act regelt de aansprakelijkheid en schadevergoeding indien een kernongeval ${ }^{84}$ plaatsvindt tengevolge van activiteiten van NRC-vergunninghouders en van contractpartners van de DOE. Met NRC-vergunninghouders ("NRC licensees") worden in de eerste plaats de grote commerciële elektriciteit producerende keminstallaties bedoeld ${ }^{55}$. De activiteiten van contractanten van DOE omvatten onderzoek, ontwikkeling en testen van kernwapens, de ontwikkeling en onderzoek van kernenergie en activiteiten verbonden met radioactief afval ${ }^{86}$. De Price-Anderson Act is enkel van toepassing op kernongevallen die zich op het grondgebied voordoen van de Verenigde Staten, zelfs indien een dergelijk ongeval eveneens schade veroorzaakt buiten de $\mathrm{VS}^{87}$.

In eerste instantie worden in deze paragraaf de grote basisprincipes besproken van de PriceAnderson Act ( $\$ 2.4 .1$ ). Na de analyse van deze basisprincipes wordt de bijzondere rol belicht van de Amerikaanse Nuclear Regulatory Commission ( $\$ 2.4 .2$ ).

\subsubsection{Basisprincipes}

Een aantal basisprincipes van de Price-Anderson Act is gelijklopend met die van het internationale nucleaire aansprakelijkheidsrecht; ook in het Amerikaanse kermenergierecht wordt een systeern van risicoaansprakelijkheid gehanteerd $(\$ 2.4 .1 .1)$ en wordt de aansprakelijkheid van de exploitant van de kerninstallatie beperkt $(\$ 2.4 .1 .2)$. Daarentegen is geen sprake van juridische

Deze term wordt als volgt gedefinieerd: "the term 'Nuclear Incident' means any occurrence, including an extraordinary nuclear occurrence, within the United States causing, within or outside the United States, bodily injury, sickness, disease, or death, or loss of or damage of property, or loss of use of property, arising out of or resulting from the radioactive, toxic, explosive, or other hazardous properties of source, special nuclear or byproduct material" 42 USC $\$ 2014$ (q).

Ook bepaalde installaties waar kernbrandstof wordt aangemaakt en onderzoeksreactoren die niet aan DOE toebehoren vallen onder deze regeling; deze zijn echter van minder belang in het kader van dit onderzoek.

McNett, "Nuclear Indemnity for Government Contractors Under the Price Anderson-Act", Public Contract Law Journal, vol. 14, $\mathrm{n}^{\circ} 1,1983$.

Lowenstein, R., "The United States Indemnity Program for Atomic Energy Activities within the United States", in Mayda, J. (ed.), Atomic Energy and Law, Interamerican Symposium, School of Law, University of Puerto Rico, 1959, 128 (hierna genoemd: Atomic Energy and Law). 
kanalisatie van aansprakelijkheid, maar wel van economische kanalisatie ( $\$ 2.4 .1 .3)$. Tenslotte worden enkele andere elementen van de Price-Anderson Act besproken $(\S 2.4 .1 .4)$.

\subsubsection{Risicoaansprakelijkheid}

Zoals reeds aangegeven komt het in 1966 ingevoerde begrip "Extraordinary Nuclear Occurrence" neer op een regime van risicoaansprakelijkheid. Zodra de NRC, op basis van enkele voorafgaandelijk vastgestelde criteria oordeelt dat een kernongeval een ENO is, kan de exploitant bepaalde verweermiddelen waarover hij beschikt overeenkomstig het aansprakelijkheidsrecht van de Staat wiens recht op de zaak van toepassing is, niet inroepen. Belangrijk hierbij is het feit dat de Price-Anderson Act als dusdanig geen wijzigingen aanbrengt aan het aansprakelijkheidsrecht van de verschillende staten ${ }^{88}$ omdat werd geoordeeld dat een federale tussenkomst op dit vlak ongewenst was, gelet op het feit dat het aansprakelijkheidsrecht tot de bevoegdheid van de verschillende staten behoort.

In de mate waarin de aansprakelijkheidswetgeving van de Staat in kwestie een algemene risicoaansprakelijkheid oplegt aan de exploitant van een kerninstallatie, is deze bepaling van de PriceAnderson Act minder relevant geworden.

\subsubsection{Beperking van de aansprakelijkheid en verplichte verzekering}

Ten tweede wordt ook onder de Price-Anderson Act de aansprakelijkheid beperkt, met dien verstande dat het totale beschikbare bedrag voor slachtoffers uit twee schijven wordt samengesteld: de aansprakelijkheidsdekking van elke individuele exploitant enerzijds en het collectieve systeem van retroactieve premies anderzijds.

De exploitant is verplicht een aansprakelijkheidsverzekering af te sluiten voor een bedrag dat beschikbaar is op de private verzekeringsmarkt (200 miljoen dollar in het jaar 2000). Dit bedrag vormt dus de cerste schijf van het totale beschikbare schadevergoedingsbedrag. Het bedrag van 200 miljoen dollar is niet vastgelegd in de Price-Anderson Act. De NRC pleegt regelmatig overleg met de verzekeringsindustrie; zodra deze meldt dat er bijkomende capaciteit beschikbaar is, vaardigt de NRC een verordening uit waarbij de exploitanten worden verplicht om zich vour dit nieuwe bedrag te verzekeren.

Indien de schade uit een kernongeval dat bedrag te boven gaat, treedt het in 1975 ingevoerde en in 1988 gewijzigde systeem van bijkomende financiële bescherming (retrospective rating plan) in werking, hetgeen inhoudt dat elke cxploitant die van de NRC een vergunning heeft gekregen, verplicht is een retroactieve premie te betalen gelijk aan diens proportionele deel van het bijkomende verlies. Sinds de aanpassing aan de inflatie in 1998, bedraagt de bijdrage in de tweede schijf 83,9 miljoen dollar per reactor $(91,77 \text { miljoen euro })^{89}$ met een maximum van 10 miljoen dollar per jaar (10,93 miljoen euro).

88 Report $N^{0}$ 2298, Senate, 84th Congress, 2d Session, Amending the Atomic Energy Act, 22 juni 1956. 6; Lowenstein, R., "The United States Indemnity Progamme for Atomic Energy Activities within the United States", in Mayda, J. (ed.), "Atomic Energy and Law", l.c., 127; Murphy, A.W., "Principles of United States Law governing Liability for Nuclear Accidents", in Mayda, J. (ed.), "Atomic Energy and Law", l.c., 121 .

42 USCS $\$ 2210$ (b) (1): "The Commission shall require licensees that are required to have and maintain primary financial protection equal to the amount of liability insurance available from private 
Einde 2000 participeerden 106 reactors in het systeem van bijkomende financiële bescherming. In de tweede collectieve schijf was bijgevolg 8,89 miljard dollar of 9,73 miljard euro beschikbaar. Rekening houdend met de aansprakelijkheidsverzekering van de exploitant, namelijk 200 miljoen dollar bedroeg, op het einde van het jaar 2000, het totale beschikbare schadevergoedingsbedrag in de Verenigde Staten 9,11 miljard dollar of 9,96 miljard euro (401,78 miljard BEF of 21,95 miljard NLG). Dit bedrag is dus meteen het bedrag van de maximale aansprakelijkheid van de cxploitant van een kerninstallatie in de VS. Boven dit bedrag zal noch hij, noch een andere persoon aansprakelijk kunnen worden gesteld ${ }^{90}$.

Hier moet er wel aan worden herinnerd dat het bedrag dat de exploitant in de tweede schijf moet ter beschikking moet stellen, jaarlijks niet meer mag bedragen dan 10 miljoen dollar. Bij een zeer emstig kemongeval dat bijvoorbeeld een schade van 10 miljard dollar veroorzaakt, zullen alle exploitanten dus gedurende negen jaar na het ongeval jaarlijks hun bijdrage moeten leveren ${ }^{91}$.

Zelfs indien de totale schade van een kemongeval het totale beschikbare bedrag zou overtreffen, schrijft de Price-Anderson Act voor dat het Congres het ongeval zal beoordelen en de nodige maatregelen zal nemen om snelle en volledige compensatie van schade te bereiken ${ }^{92}$. Hiertoe is de regering gemachtigd een belasting kan heffen ten laste van de exploitanten, waarvan de opbrengst zal dienen om de schade die groter is dan 9,11 miljard dollar te vergoeden.

Niettegenstaande de wijzigingen die de Price-Anderson Act heeft ondergaan sinds 1957, werd door tegenstanders van de Price-Anderson Act de grondwettelijkheid van beperkte aansprakelijkheid van de exploitant in vraag gesteld. In 1973 daagde de Carolina Environmental Study Group de bouwer van twee kerninstallaties (Duke Power Company) ${ }^{93}$ voor de rechter, waarbij de eisers aanvoerden dat de beperking van de aansprakelijkheid onder de Price-Anderson Act ongrondwettelijk was. Het District Court van Noord-Carolina stelde de eisers in het gelijk omdat de beperking van de aansprakelijkheid strijdig werd geacht met de due process-bepaling van het Vijfde Amendement. De rechter oordeelde dat het beschikbare schadevergoedingsbedrag niet op rationele wijze de mogelijke schade reflecteerde, dat de Price-Anderson Act onverantwoordelijk gedrag inzake veiligheid en milieubescherming aanmoedigde en dat er geen redenen voorhanden waren die de beperking van de aansprakelijkheid konden rechtvaardigen. Tezelfdertijd oordeelde de rechter dat de Price-Anderson Act strijdig was met het gelijkheidsbeginsel aangezien de kosten van de productie van kemenergie werden gelegd op de schouders van een op arbitraire wijze gekozen segment van de maatschappij, namelijk de slachtoffers van een kemongeval.

Duke Power maakte vervolgens de zaak aanhangig bij het Supreme Court ${ }^{94}$ dat op 26 juni 1978 de eerdere uitspraak ongedaan maakte door te verklaren dat de Price-Anderson Act wel degelijk in overeenstemming was met de Amerikaanse grondwet. Het Hof steunde zich hierbij voorname-

sources to maintain, in addition to such primary financial protection, private liability insurance available under an industry retrospective rating plan providing for premium charges deferred in whole or major part until public liability from a nuclear incident exceeds or appears likely to exceed the level of the primary financial protection required of the licensee involved in the nuclear incident".

Marrone, J., "Closing the circle of Protection for the Public - the Evolution of the System in the United States", in "Nuclear Accidents. Liabilities and Guarantees", l.c., 376-377.

9 Uiteraard zal daamaast op ook de aansprakelijkheidsverzekering dienen tussen te komen van de exploitant in wiens installatie het ongeval heeft plaatsgevonden.

42 USCS \& 2210 (e) (2).

Carolina Environmental Study Group Inc. vs. United States Atomic Energy Commission, 431 F. Supp. 203 (W.D.N.C. 1977).

Duke Power Co. vs Carolina Environmental Study Group Inc, 438 US 59 (1978). 
lijk op de ratio legis van de Price-Anderson Act en oordeelde dat het volkomen legitiem was de aansprakclijkheid te bepcrken met het oog op het aanmoedigen van de privé-industrie. Het Hof beschouwde de beperking van de aansprakelijkheid als een klassiek voorbeeld van economische regulering waarbij een evenwicht werd gevonden tussen de lasten en de voordelen van economische expansie; op een dergelijke regulering rustte een vermoeden van grondwettigheid. Het enkele feit dat de schade uit een kemongeval veel hoger kon zijn dan het bedrag van 560 miljoen dollar, betekende volgens het Supreme Court niet dat dit bedrag op arbitraire wijze zou zijn gekoren ondat bij schade die dit bedrag overtreft, het Congres de nodige maatregelen kan nemen om het publiek op adequate wijze te beschermen. Verder oordeelde het Hof dat de Price-Anderson Act geen aanleiding gaf tot onverantwoordelijk gedrag, gelet op de uitgebreide en strenge verplichtingen van de exploitant bij de vergunningverlening en gelet op het feit dat de exploitant zelf aanzicnlijke schade kan lijden bij een kemongeval.

De Duke Power-zaak is opmerkelijk te noemen omdat het een van de enige zaken is waar de grondwettigheid van de beperking van de aansprakelijkheid ter discussie werd gesteld. Zonder de argumenten van het Supreme Court op haar merites of tekorten te willen beoordelen, is het ons inziens van belang te wijzen op het tijdstip waarop de beslissing is tot stand gekomen. De zaak is aanhangig gemaakt in 1973, toen de geloofwaardigheid van de USAEC emstig ter discussie stond - cen jaar later zouden de taken van de USAEC worden verdeeld over de Nuclear Regulatory Commission (NRC) enerzijds en de Energy Research and Development Administration (ERDA) anderzijds ${ }^{95}$. Daarnaast velde het Hof zijn arrest in een periode toen de veiligheid van kerninstallaties nauwelijks ter discussie stond en de kans dat zich een ernstig kernongeval voordeed nagenoeg onmogelijk werd geacht. Toch is de Duke Power-zaak belangrijk omdat de rechtbank van een deelstaat heeft aanvaard dat een federale wet een aansprakelijkheidsbeperking invoert.

\subsubsection{Economische kanalisatie}

In hoofdstuk 4 werd reeds aangegeven dat het Amerikaanse nucleaire aansprakelijkheidsrecht een systeem hanteert van economische kanalisatie, en niet van juridische kanalisatie van aansprakelijkheid zoals in de verdragen van Parijs en Wenen en zoals ingevoerd in het Belgische en Nederlandse nucleaire aansprakelijkheidsrecht.

In essentie voorziet de Price-Anderson Act in een compensatiesysteem bij kemongevallen. De exploitanten zijn verplicht om zowel een eigen aansprakelijkheidsverzekering af te sluiten als om te participeren in de collectieve schijf (retrospectieve premie per keminstallatie). Dit compensatiesysteem, dat volledig door de exploitanten wordt gespijsd, is echter niet enkel van toepassing op de exploitant van de kerninstallatie, maar op elke "person indemnified" ${ }^{16}$. Dit impliceert dat elke persoon die naar aanleiding van een kernongeval zou worden aansprakclijk gesteld, het voordeel kan genieten van de via de Price-Anderson Act ter beschikking gestelde fondsen. Personen die bijvoorbeeld onderdelen hebben geleverd of onderhoudswerkzaamheden hebben uitgevoerd kunnen weliswaar worden aansprakelijk gesteld, maar zij zullen het genot kunnen hebben van deze fondsen. Dit systeem wordt ook omschreven als een "omnibus dekking". In deze context dient te worden benadrukt dat dit betekent dat de beperkte aansprakelijkheid ook geldt voor deze andere personen.

Cfr. infra, in $\$ 2.4 .3$ van dit hoofdstuk.

Dit begrip omvat volgens artikel 42 USCS $\$ 2014$, immers niet alleen de persoon met wie een indermity agreement is afgesloten of de persoon die is verplicht een financiele zekerheid in stand te houden. maar ook elke persoon die aansprakelijk kan worden gesteld. 
Met het begrip "person indemnified" wordt dus niet het slachtoffer van een kemongeval bedoeld ${ }^{97}$, maar elke persoon die geniet van de door de exploitant afgesloten verzekeringsdekkingen (zowel in de eerste als in de tweede schijf). Ook al heeft een ander daadwerkelijk het ongeval veroorzaakt, toch zal de verzekering van de exploitant dienen tussen te komen; onder de PriceAnderson Act wordt de (beperkte) schadevergoedingsplicht dus gekanaliseerd naar de exploitant van de keminstallatie ${ }^{98}$.

Toen bij de voorbereiding van de wijziging van de Price-Anderson Act van 1966 de vraag aan de orde werd gesteld of een systeem van juridische kanalisatie diende te worden geïntroduceerd, werd geoordeeld dat een adequate bescherming van het publiek ook kon worden verwezenlijkt zonder een dergelijke verregaande ingreep in het aansprakelijkheidsrecht ${ }^{99}$. Uit de eerdere analyse is reeds gebleken dat de VS, ook bij de aanvang van de ééncntwintigste eeuw, vasthouden aan deze economische kanalisatie en dat zij niet bereid zijn om een systeem van juridische kanalisatie van aansprakelijkheid in te voeren.

\subsubsection{Overige bepalingen}

In deze paragraaf wordt een overzicht gegeven van enkele bepalingen van de Price-Anderson Act die niet in detail zullen worden besproken. Het betreft voornamelijk regels van procesrechtelijke aard.

In de eerste plaats vallen de "legal costs" van aansprakelijkheid binnen de aansprakelijkheidslimiet van de Price-Anderson Act. Dit impliccert dat de kosten die een exploitant moet maken om zich te verdedigen, deel uitmaken van de aansprakelijkheidslimiet. De verzekeraar dient geen bijkomende sommen ter beschikking te stellen.

De Price-Anderson Act bevat ook een bevoegdheidsbepaling: bevoegd is het United Status District Court van het district waar het kemongeval heeft plaatsgevonden, ongeacht de nationaliteit van de klager en ongeacht het bedrag van de vordering ${ }^{100}$.

Indien wordt vastgesteld dat de schade uit een kernongeval het totale beschikbare schadevergoedingbedrag dreigt te overtreffen, zal de NRC een rapport dienen op te stellen dat de nodige maatregelen voorstelt teneinde de nodige fondsen te vinden voor dat deel van de schade dat het totale schadevergoedingsbedrag overtreft ${ }^{10 !}$.

Bovendien wordt uitdrukkelijk gesteld dat ook de kosten van preventieve evacuatie vallen onder de ansprakelijkheidsdekking van de Price-Anderson Act, zelfs indien later wordt vastgesteld dat

Gautron wees reeds op de mogelijke verwarring van deze tcrm: Gautton, R., "La responsabilité civile et la protection financière en raison des risques atomiques aux Etats-Unis", in Puget, H., a.c., 72.

Brown, O. F. II, "Nuclear Liability Coverage Developments in the United States of America", Nuclcar Inter Jura '93, AIDN/INLA, Rio, 11.5.6-2; Brown, O.F. II, "Recent Developments in the Areas of Nuclear Liability Coverage in the United States of America and International Regimes", PATRAM "95, 2; Shapar, H.K., "La législation relative à l'indemnisation des dommages nucléaires aux Etats-Unis", o.c., 55; NRC-Report 1998, 3.

42 USCS $\$ 2210$ (n), (2).

Een dergelijk rapport wordt een "compensation plan" genoemd, zie 42 USCS $\S 2210$ (i). 
geen kernongeval heeft plaatsgevonden. Tenslotte wordt een beperking aangebracht aan het aantal gevallen waarin een rechtbank punitive damages kan toekennen ${ }^{102}$.

De bespreking van de voornaamste bepalingen van de Price-Anderson Act wordt afgerond door stil te staan bij de rol van de Nuclear Regulatory Commission.

\subsubsection{De Nuclear Regulatory Commission (NRC)}

De $\mathrm{NRC}$ is de opvolger van de Atomic Energy Commission. Reeds van bij haar oprichting stond de rol van de USAEC ter discussie omdat de USAEC zowel een controlerende als cen promotio. nele functie had. Doordat beide functies verenigd waren in een enkel agentschap kwam haar geloofwaardigheid met betrekking tot haar veiligheidsprogramma in het gedrang. De USAEC werd in 1974 opgeheven door de Energy Reorganisation Act ${ }^{103}$ en haar bevoegdheden werden verdeeld over twee nieuwe agentschappen: de Nuclear Regulatory Commission (NRC) en de Energy Research and Development Administration (ERDA). Later werd de ERDA opgenomen in het Department of Energy (DOE). De NRC heeft de licentiefunctie van de USAEC overgenomen, terwijl het DOE als taak heeft meegekregen kernenergie te promoten.

Van belang is het feit dat de NRC een onafhankelijk regelgevend orgaan is met eigen rechtspersoonlijkheid dat ter uitvoering van haar taken over uitgebreide bevoegdheden beschikt inzake regelgeving ${ }^{104}$. De NRC bestaat uit vijf leden waarvan de voorzitter wordt aangeduid door de President van de Verenigde Staten. Jaarlijks overhandigt de NRC aan de President een verslag van haar werkzaamheden. Hoewel de NRC in de beginjaren een aarzelend beleid voerde, maakte zij na het ongeval in Three Mile Island ten volle gebruik van haar bevoegdheden en heeft zij sindsdien een stevige reputatie verworven als onafhankelijk regulerend orgaan op het gebied van veiligheidsaspecten bij het gebruik van kemenergie ${ }^{105}$. De door de NRC uitgevaardigde regulering wordt gepubliceerd in titel 10 van de United States Code of Federal Regulations (CFR).

\subsection{De verwachte wijzigingen in 2002}

De Atomic Energy Act verplicht de NRC om ter voorbereiding van een wijziging aan de PriceAnderson Act, een rapport in de dienen bij het Amerikaanse Congres. Een belangrijk deel van een dergelijk rapport zijn de aanbevelingen van de Nuclear Regulatory Commission. In augustus 1998 werd het rapport gepubliceerd dat betrekking heeft op de vraag of de Price-Anderson Act in 2002 al dan niet zal worden verlengd. Hieronder worden de belangrijkste elementen van dat rapport besproken.

Eén van de belangrijkste uitdagingen van het Price-Anderson systeem naar de toekomst, is dc vraag wat er dient te gebcuren met de bedragen beschikbaar in de tweede schijf. Aangezien deze bedragen afhankelijk zijn van het aantal reactoren valt een ernstige daling van de beschikbare bedragen te verwachten naarmate ook het aantal kerninstallaties afneemt. Zo wordt verwacht dat tegen 2013 ongeveer 34 kerninstallaties zullen zijn stilgelegd ${ }^{106}$ - deze installaties zullen dan gedurende 40 jaar operationeel zijn geweest. Indien geen bijkomende kerninstallaties worden gebouwd en indien de levensduur van de huidige installaties niet wordt verlengd, dan zal de laats-

102

103

104

105

106

42 USCS $\$ 2210(\mathrm{~s})$.

Afgekondigd op 11 oktober 1974, 42 USC 5801 .

42 USC 5801 en 5841.

Website van NRC: http://www.nrc.gov: "A short history of Nuclear Regulation, 1946-1992".

NRC Report 1998, 29. 
te reactor in de VS worden stilgelegd in 2035; dan zullen in de tweede schijf geen fondsen meer beschikbaar zijn.

De NRC heeft berekend dat, indien het bedrag van de eerste schijf en de retrospectieve premie van de tweede schijf gelijk blijven, in 2013 in totaal nog 4,48 miljard dollar beschikbaar zal $z i j n^{107}$. Een behoud van het huidige totale beschikbare bedrag tegen 2008 vereist dat het bedrag van de tweede schijf stijgt met 10 à $28 \%$; tegen 2013 is zelfs een stijging nodig tot $120 \%{ }^{108}$. In het licht hiervan heeft de NRC volgende aanbevelingen geformuleerd.

In de eerste plaats stelt de NRC een verdubbeling voor van de jaarlijkse limiet in de tweede schijf - dus van 10 naar 20 miljoen dollar per jaar. Dit heeft geen effect op het totale beschikbare bedrag in de tweede schijf, maar zal ervoor zorgen dat na een kemongeval de bedragen sneller ter beschikking zullen worden gesteld. Concreet betekent dit dat de totale bijdrage van een exploitant (83,9 miljoen dollar per instal!atie) uiterlijk na iets meer dan vier jaar na het kernongeval beschikbaar moet zijn - in plaats van na negen jaar.

Door de mogelijke aanzienlijke daling van het aantal kerninstallaties en de daaraan gekoppelde daling van de beschikbare bedragen in de tweede schijf, luidt de tweede aanbeveling van de NRC dat in 2002 de Price-Anderson Act slechts voor 10 jaar zou worden verlengd en niet voor 15 jaar zoals in $1988^{109}$.

Een reële verhoging van het beschikbare bedrag moet volgens de NRC vooral komen van een verhoging van de eerste schijf; het bedrag van de aansprakelijkheidsverzekering is inderdaad lange tijd constant gebleven. Het bedrag werd niet aan de inflatie aangepast; de limiet van 200 miljoen dollar is inderdaad reeds van kracht sinds de laatste wijziging van de Price-Anderson Act in $1988^{110}$. Daarom spoort de NRC de nucleaire verzekeringspool ertoe aan te onderzoeken in welke mate de aansprakelijkheidsverzekering aanzienlijk kan worden verhoogd ${ }^{111}$. American Nuclear Insurers (ANI) lijkt in te stemmen met een aanzienlijke verhoging van de aansprakelijkheidslimiet, bij de aanpassing van de Price-Anderson Act in $2002^{112}$.

Tenslotte stelt de NRC voor dat wijzigingen die aan de Price-Anderson Act zullen worden aangebracht, consistent zijn met de verplichtingen van de Verenigde Staten, zodra zij het Verdrag inzake Bijkomende Compensatie zullen hebben geratificeerd ${ }^{113}$. Grosso modo kunnen de VS dit Verdrag ratificeren zonder grote wijzigingen te moeten aanbrengen aan de Price-Anderson Act; voornamelijk inzake het territoriale toepassingsgebied lijkt een aanpassing aangewezen ${ }^{1 / 4}$. Bij de voorbereiding van de ratificatie van dit Verdrag door de VS, lijken evenwel heel wat discussies te bestaan over de vraag wie uiteindelijk zal moeten instaan voor de bedragen uit de tweede schijf van het Verdrag inzake Bijkomende Compensatie. Volgens dit Verdrag moeten de verdragspartijen namelijk publicke fondsen ter beschikking stellen. De ratificatie van het Verdrag inzake Bij-

NRC Report 1998, 36.

NRC Report 1998, 35.

NRC Report 1998, 131 .

Indien het bedrag zou zijn aangepast aan de inflatie, dan zou de limiet in 1998 zijn gestegen naar 275 miljoen dollar (NRC Report 1998, 98).

NRC Report 1998, 131.

Quattrochi, J.L., "The Pricc-Anderson A.ct in the New Millennium. An Insurer's Perspective", in "Nuclear Inter Jura 1999", l.c., 255.

NRC Report 1998, 123-124 en 132.

Het Verdrag inzake Bijkomende Compensatie is namelijk eveneens van toepassing in de Exclusieve Economische Zone. 
komende Compensatie door het Amerikaanse Congres, kan er dus toe leiden dat de overheidstussenkomst, die sinds 1982 werd stop gezet, opnieuw wordt ingevoerd ${ }^{115}$.

De aanbeveling van de NRC luidt dan ook dat in 2002 de Price-Anderson Act met 10 jaar kan worden verlengd, gelet op de belangrijke voordelen van het huidige systeem voor slachtoffers van een kernongeval ${ }^{116}$.

$\mathrm{Na}$ de bespreking van de Amerikaanse aansprakelijkheidswetgeving, zal vervolgens aandacht worden besteed aan de verzekering van het nucleaire risico in de VS. Het spreekt voor zich dat deze verzekeringsdekking een parallelle evolutie heeft ondergaan als de Price-Anderson Act zelf.

\section{VERZEKERING VAN hET NUCLEAIRE RISICO IN DE VERENIGdE STATEN}

De bepaling in de Price-Anderson Act die de exploitant verplicht een verzekeringsdekking te nemen inzake diens aansprakelijkheid tegenover derden, heeft aanleiding gegeven tot het ontstaan van een nucleaire verzekeringscapaciteit. Hier wordt nagegaan hoe deze capaciteit is ontstaan en hoe die is geëvolueerd in de loop der jaren, mede in het licht van de hierboven besproken wijzigingen die aan de Price-Anderson Act werden aangebracht. Eerst wordt het ontstaan toegelicht van de Amerikaanse pools ( $\$ 3.1$ ) en nadien worden de twee pools besproken die in 1997 op de markt opereren, met name American Nuclear Insurers (\$ 3.2) en Nuclear Electric Insurance Limited $(\S 3.3)$

\subsection{Ontstaan van de Amerikaanse nucleaire verzekeringspools}

Zoals hierboven weergegeven, maakte de Atomic Energy Act van 1954 een einde aan het overheidsmonopolie en werden private ondernemingen aangemoedigd in deze nieuwe industrie te investeren. In maart 1955 liet de USAEC door een adviescomité inzake verzekeringen onderzoek verrichten naar aansprakelijkheids- en verzekeringsproblemen betreffende het vreedzame gebruik van kernenergie. Ten aanzien van werknemers verwachtte men weinig problemen omdat aan deze risico's via de reeds bestaande verzekeringsdekkingen het hoofd konden worden geboden. Daar tegenover stond dat geen enkele individuele verzekeraar dekking kon verlenen voor het nucleaire aansprakelijkheidsrisico tegenover derden. Vandaar verkoos de verzekeringsindustrie on de krachten te bundelen in een verzekeringspool ${ }^{117}$.

In de VS werden in 1956 twee nucleaire verzekeringspools opgericht: Nuclear Energy Liability Insurance Association (NELIA) en Mutual Atomic Energy Liability Undenwriters (MAELU) ${ }^{118}$.

NELIA bestond uit 141 private verzekeringsmaatschappijen die uitsluitend een aansprakelijkheidsdekking verschaften van 47,5 miljoen dollar per ongeval. Daarnaast richtten de privéverzekeringen ook NEPIA (Nuclear Energy Property Association) op. De namen en het bestuur van deze samenwerkingsverbanden zijn in de loop der jaren evenwel gewijzigd. De twee privéverzekeraars, NEPIA en NELIA, functioneerden aanvankelijk volledig onafhankelijk van elkaar,

115 Uiteraard wordt onderhandeld over de wijze waarop de Amerikaanse overheid een regres kan instellen indien zij zou worden verplicht om deze fondsen ter beschikking te siellen.

ii6 NRC Report $1998,128$.

117 Cfr. supra, in $\$ 2.1$ van hoofdstuk 6.

18 Zie hierover ook Dow, J.C., "Nuclear Energy and Insurance", l.c., 209; Boylan, F., "United States System. Insurance/Indemnity Protection. Nuclear Energy Risks", Alexander \& Alexander, mei 1989, onuitg., 1. 
maar worden sinds 1978 bestuurd door American Nuclear Insurers (ANI) ${ }^{119}$. In de loop van de jaren zeventig zijn NELIA en NEPIA samengevoegd tot ANI ${ }^{i 20}$.

MAELU daarentegen werd opgericht door een aantal onderlinge verzekeringsmaatschappijen; zij richtten overigens ook MAERP op (Mutual Atomic Energy Reinsurance Pool) dat dekking verleende voor de eigenschade van de exploitant ${ }^{121}$. In 1998 hebben de onderlinge verzekeringsmatschappijen zich evenwel teruggetrokken uit de nucleaire verzekeringsmarkt ${ }^{122}$. De reden warom deze beslissing werd genomen, zal verderop in dit hoofdstuk worden besproken.

De gezamenlijke aansprakelijkheidsdekking van NELIA en MAELU bedroeg in het midden van de jaren vijftig 60 miljoen dollar. Analoog aan de evolutie van de vereiste dekking onder de PriceAnderson Act, is deze capaciteit intussen verhoogd tot 200 miljoen dollar. De dekking van ANI richt zich hoofdzakelijk tot de aansprakelijkheid van de exploitant van een kerninstallatie en is dus volledig geënt op de Price-Anderson $\mathrm{Act}^{123}$.

Inmiddels is ANI niet meer de enige verzekeraar die actief is op de Amerikaanse nucleaire verzekeringsmarkt; in de loop van de jaren zeventig hebben de exploitanten namelijk een systeem opgezet van onderlinge verzekering. Dit systeem wordt in $\$ 3.3$ besproken; eerst wordt bestudeerd welke dekkingen beschikbaar zijn via de "klassieke" Amerikaanse nucleaire verzekeringspool.

\subsection{American Nuclear Insurers (ANI)}

Hoewel de Price-Anderson Act voor de dekking van hun aansprakelijkheid tegenover derden de exploitanten duidelijk de keu\%s laat tussen cen aantal alternaticven, waaronder private ver $/ 2-$ kering en onderlinge verzekering, hebben quasi alle cxploitanten gekozen voor een dekking via de private verzekeringsmarkt. De USAEC meldde dat in 1958 slechts één exploitant had verkn/en zich te verzekeren buiten de private ver/ckeringsmarkt om ${ }^{124}$.

ANI is de uit private (Amerikaanse) verzekeraars samengestelde nucleaire pool. De pool is een samenwerkingsverband van ongeveer 150 Amerikaanse verzekeringsmaatschappijen. In 1996 was ANI voor $50 \%$ herverzekerd bij de andere nucleaire verzekeringspools, bij Lloyds en bij enkele kleinere herverzekeraars $^{125}$.

Tencinde een globaal beeld te schetsen van de verzekering van het nucleaire risico in de VS, worden in eerste instantie de werkzaamheden van ANI toegelicht ( $\$ 3.2 .1$ ). Nadien wordt bestudeerd welke polissen door ANI worden uitgeschreven $(\$ 3.2 .2)$ en wordt een overzicht gegeven van de evolutie van de premies in de loop der jaren $(\$ 3.2 .3)$. Tenslotte wordt besproken hoe ANI is tussengekomen tengevolge van het ongeval in Three Mile Island ( $\$ 3.2 .4$ ).

\footnotetext{
119 De facto werden NEPLA en NELIA in juni 1974 werden samengevoegd tot NELPLA (Nuciear Energy Liability - Property Insurance Association). Als dusdanig bestuurt ANI enkel NELPLA.

120 Rockett, L.R., "Financial Protection against Nuclear Hazards", l.c., 23.

Toll, D.R., "Liability: Insurance and Legislative Aspects", Mayda, J. (Ed.), Atomic Energy and Law, Interamerican Symposium, Puerto Rico, November 1959, School of Law, University of Puerto Rico, 133.

122 NRC Report 1998, 74.

Boylan, F., "United States System. Insurance/Indemnity Protection. Nuclear Energy Risks", o.c., 1.

Stason, E.B., Estep, S.D. en Pierce, W.J., "Atoms and the Law", l.c., 593.

Annual Report ANI, 1996, 2.
} 


\subsubsection{Werkzaamheden van ANI}

ANI is een vereniging van verzekeraars die optreedt als beheerder van de verschillende leden; de vereniging zelf heeft geen rechtspersoonlijkheid. In die hoedanigheid exploiteert ANI drie verschillende syndicaten van verzekeraars. De winsten die in het kader van haar activiteiten worden geboekt, worden verdeeld tussen de leden, afhankelijk van hun deeinemingspercentage in de verschillende syndicaten.

Het eerste syndicaat is het "Domestic Liability Syndicate", dat nucleaire-aansprakelijkheidsdek. king aanbiedt aan Amerikaanse exploitanten van keminstallaties, installaties waar splijtstoffen worden gemaakt, installaties voor laagradioactief afval en andere nucleaire installaties. Via de gezamenlijke capaciteit van dit syndicaat kan een aansprakelijkheidsdekking worden geboden tot het wettelijk vereiste niveau van 200 miljoen dollar, zoals voorzien in de Price-Anderson Act.

Daamaast omvat ANI een syndicaat dat een eigenschadedekking aanbiedt aan de exploitanten ("Domestic Property Syndicate"). Door de gezamenlijke capaciteit in dit syndicaat kunnen polissen worden uitgeschreven tot 500 miljoen dollar per keminstallatie. Een dergelijke dekking kan zowel als primaire of als bijkomende dekking worden gekocht. ANI biedt eveneens een bijkomende dekking aan tot een bedrag van 600 miljoen dollar via het "Supplemental Excess Syndica. te".

Het derde syndicaat in de schoot van ANI, het "Foreign Syndicate" biedt herverzekeringscapaciteit aan voor buitenlandse nucleaire pools. De via dit syndicaat aangeboden dekking bedraagt maximaal 140 miljoen doliar per site (zowel eigenschade als aansprakelijkheid tegenover derden).

\subsubsection{ANI-polissen}

In 1997 bood ANI vier verschillende polissen aan. De eerste is de "Facility Form Policy" en dient uitsluitend ter dekking van letselschade en schade aan eigendommen van derden. Deze polis is met andere woorden direct verbonden met de verplichte aansprakelijkheidsdekking van de exploitant onder de Price-Anderson Act. De tweede polis, de "Secondary Financial Protection" of SFPpolis, dient ter dekking van de tweede schijf onder de Price-Anderson Act, met name de retrospectieve premie. De derde polis richt zich tot bedrijven die goederen of diensten leveren aan keminstallaties in de VS en wordt de "Suppliers and Transporters Policy" genoemd. Tenslotte biedt ANI ook een polis aan voor werknemers van kerninstallaties (Facility Worker Form) ${ }^{126}$. De inhoud van deze laatste polis spreekt voor zich.

De belangrijkste elementen van de Facility Form-polis kunnen als volgt worden samengevat.

a. De polis is enkel van toepassing op nucleaire aansprakelijkheid voortkomend uit de gevaarlijke eigenschappen van nucleair materiaal dat zich op de site bevindt of in bepaalde transportmiddelen.

b. De verzekerde is elkeen die aansprakelijk kan worden gesteld voor de uit een kemongeval voortvloeiende schade (de zgn. omnibusdekking).

c. De dekking is enkel van toepassing op letselschade, schade aan eigendommen of schade aan het milieu veroorzaakt door een kernongeval tijdens de polisdekking, indien deze schade werd sing was voor werknemers die na 1 januari 1988 in dienst zijn gekomen bij een kerninstallatie. Per einde 1997 werd deze polis vervangen door een programma voor alle werknemers van de gehele kernenergie-industrie (ANI, Annual Report 1996,5). 
vastgesteld en een vordering werd ingediend tegen de verzekerde, ten laatste 10 jaar na het einde van de polisdekking. Hierbij wordt de eigenschade binnen de site van de exploitant uitdrukkelijk uitgesloten.

d. De polis is enkel van toepassing op accidentele schade, en dus niet op graduele schade.

e. Kosten tot herstel van het milieu (clean-up) tengevolge van richtlijnen vanwege de overheid, zijn eveneens uitgesloten.

Geheel overeenkomstig de Price-Anderson Act bevat deze polis een afzonderlijke bepaling - de Waiver Of Defenses Endorsement - op basis waarvan zowel de verzekeraar (ANI) als de verzekerde (de exploitant) bij een extraordinary nuclear occurrence een aantal verweermiddelen niet zullen inroepen.

De SFP-polis wordt van belang zodra het bedrag dat: onder de Facility Form polis ontoereikend is; het dekt met andere woorden het stelsel van de retrospectieve premies van de Price-Anderson Act. De jaarlijkse limiet die onder deze polis wordt uitgekeerd is gelijk aan het bedrag dat de exploitant maximaal jaarlijks ter beschikking moet stellen (momenteel 10 miljoen dollar per jaar).

De Suppliers and Transporters Policy biedt een aanvulling voor die gevallen waar de PriceAnderson Act niet van toepassing is, bijvoorbeeld bij vervoer van bepaalde stoffen die niet onder het toepassingsgebied van deze wet vallen.

\subsubsection{Premies}

Bijzondere aandacht dient vervolgens te worden besteed aan de manier waarop de premies worden aangerekend, c.q. de verschillende soorten premies die de exploitanten betalen. In de beginjaren van de kemenergie-industrie waren weinig gegevens voorhanden die het mogelijk maakten de door de verzekeringspools onderschreven risico's in te schatten; dit betekende meteen dat het voor de pools, zcker in de aanvangsfase, nagenoeg onmogelijk was de actuariële premie te berekenen.

Daarom werd voor de Facility Form Polis, de Suppliers \& Transporters-polis en de werknemerspolis een "Industry Credit Rating Plan" ${ }^{127}$ gecreëerd. Volgens dit plan werd een groot deel van de aangerekende premie - variërend tussen $65 \%$ en $75 \%$ - in een speciaal fonds gestort. Dit geld dient om toekomstige verliezen te dekken; bij afwezigheid van verliezen gedurende tien jaar, kan een deel van dit fonds worden terugbetaald aan de verzekerden ${ }^{128}$. Het kredietplan voorziet met andere woorden in een soort retroactieve reductie van de premie indien zich geen schadegevallen hebben voorgedaan in de afgelopen 10 jaar. Dergelijke premieatanpassingen weerspiegelen de ervaring van alle polishouders gezamenlijk vanaf de start van de werkzaamheden in $1957^{129}$. Dankzij dit Industry Credit Rating Plan werd gedurende deze eerste tien jaar na het ter beschikking stellen van de eerste polis, een bedrag van 12,7 miljoen dollar gereserveerd; ondat zich in die periode geen schadegevallen voordeden, werd een bedrag van 9,7 miljoen dollar aan de exploitanten geretournecrd ${ }^{130}$.

Hiema genoemd "het kredietplan".

Toll, D.R., "Liability: Insurance and Legislative A.spects", a.c, 136.

Boylan, F.X., "United States System. Insurance/Indemnity Protection. Nuclear Energy Risks", o.c., 11

Einde 1976 bedroeg dit fonds 45 miljoen dollar, waarmes hêt voor sommigen duidelijk was dat de nucleaire industrie en de overheid erin slaagden een effectief preventiebeleid te voeren (Marrone, J.,

"The Price-Anderson Act: the Insurance Industry"s View", o.c., 609). 
Een bijkomend voorbeeld kan de werking en het doel van het kredietplan verduidelijken: in 1968 verzamelden de pools ongeveer 3,1 miljoen dollar aan premies. Van dit bedrag werd 2,2 miljoen dollar gereserveerd om schadegevallen te betalen, of om terug te geven aan de polishouders. Tien jaar later, in 1978 , betaalden de pools $99 \%$ van de 2,2 miljoen dollar van deze reservepremie terug. Het spreekt voor zich dat een dergelijke gunstige evolutie zich enkel kan voordien bij afwezigheid van schadegevallen. Doordat ANI is tussengekomen bij het ongeval van Three Milc Island ${ }^{131}$, bedroeg de teruggave van de reservepremie in 1989 slechts $54 \%$ van de tien jaar eerder betaalde reservepremies ${ }^{132}$. Cumulatief werd in de periode 1957 tot 1987 door verzekeraars 209 miljoen dollar, ofwel $66 \%$ van de totale reservepremies terugbetaald aan de exploitanten ${ }^{133}$.

De premie die door een exploitant dient te worden betaald hangt in de eerste plaats af van de risicoanalyse van een ploeg van ingenieurs die de veiligheid van de kerncentrale evalueren en waarbij rekening wordt gehouden met verschillende risicofactoren zoals de locatie van de installatie en de grootte van de reactor. ANI onderscheidt grosso modo drie verschillende premies. De standaardpremie is de gewone premie die per kalenderjaar wordt aangerekend overeenkomstig de door ANI gehanteerde parameters. De voorschotpremie ("advance premium") is de geschatte standaardpremie voor een gegeven kalenderjaar. De reservepremie tenslotte is het deel van de standaardpremie bestemd voor het Industry Credit Rating Plan.

De voorschotpremie dient in het begin van elk kalenderjaar te worden betaald ter dekking van het desbetreffende jaar. Na dat kalenderjaar berekent ANI de standaardpremie van het afgelopen kalenderjaar. Indien de standaardpremie lager is dan de voorschotpremie, krijgt de verzekerde het verschil uitbetaald; is de standaardpremie hoger dan de voorschotpremie, dan dient de verzekerde het verschil bij te passen. Dankzij het systeem van het Industry Credit Rating Plan was het tot nog toe niet nodig om een dergelijke aanpassing te vragen. Het reservefonds dat door middel van het kredietplan wordt gecrec̈erd, fungeert inderdaad als een soort buffer tussen het geleden verlies en de tussenkomst van de deelnemende bedrijven: alle vorderingen werden uit het fonds betaald ${ }^{134}$. In 1996 bedroeg het reservefonds 300 miljoen dollar. Het aanzienlijke inkomen dat via beleggingen door het fonds wordt gegenereerd, wordt verdeeld tussen de deelnemende bedrijven van het syndicaat en de herverzekeraars ${ }^{135}$.

Sinds januari 1997 bedraagt het reservefonds 400 miljoen dollar. Als een gevolg hiervan kon de premie onder de Facility Form polis in dat jaar en in 1998 met telkens $15 \%$ worden verlaagd ${ }^{136}$. Ingeval door een emstig verlies het fonds minder bedraagt dan de vooropgestelde 400 miljoen dollar, zullen de premies opnieuw worden opgetrokken ${ }^{1.37}$.

ANI heeft ook een systeem opgezet waarbij de door een individuele exploitant te betalen premic varieert a rato van de door hem veroorzaakte verliezen en de veiligheid van zijn reactor. Het Individual Risk Credit Program voorziet in een korting van $9 \%$ indien zich gedurende acht jaar geen schadegeval heeft voorgedaan en in een additionele korting van $6 \%$ indien de exploitant de door ANI voorgeschreven technische aanbevelingen implementeert ${ }^{138}$.

Cfr. infra, in \$ 3.2.4 van dit hoofdstuk.

Boylan, F.X., "United States System. Insurance/Indemnity Protection. Nuclear Energy Risks", o.c., 11. NRC Report 1998, 82.

Annual Report ANI, 1996, 6.

Annual Report ANI, 1996, 7.

NRC Report 1998, 95.

Annual Report ANI, 1996, 7.

Annual Report ANI, 1996, 9. 
De gemiddelde premie die ANI in 1998 aanrekende voor de aansprakelijkheidsdekking in de eerste schijf bedroeg 2.050 dollar per miljoen aan geboden dekking, ofwel 410.000 dollar voor de volledige dekking van 200 miljoen dollar ${ }^{139}$. Een vrij aanzienlijke variatie in de hoogte van de premies kan worden vastgesteld naargelang de keminstallatie zich in een afgelegen dan wel in een stedelijk gebied bevond ${ }^{140}$. Zoals reeds aangegeven, is de hoogte van deze premie aanzienlijk gedaald sinds het kredietfonds meer dan 400 miljoen dollar bedraagt: in 1995 bedroeg de gemiddelde standaardpremie nog 536.000 dollar, terwijl die in 1998 was gedaald tot 410.000 dollar.

De algemene daling van de premie kan echter niet alleen worden toegeschreven aan het feit dat het kredietfonds sinds 1997 voldoende omvangrijk is. Met name in 1988 bedroeg de standaardpremic die werd aangerekend - in dat jaar werd voor het eerst een dekking aangeboden van 200 miljoen dollar - gemiddeld 735.000 dollar per jaar ${ }^{141}$, terwijl die in 1998 zoals gezegd was gedaald tot gemiddeld 410.000 dollar per jaar. Dit impliceert dat de premie in 10 jaar tijd met meer dan $40 \%$ is gedaald. Deze premiedaling moet ook worden gezien in het licht van de toenemende concurrentie van NEIL, de captive van de exploitanten ${ }^{142}$. Het is overigens de forse premiedaling die ertoe heeft geleid dat MAELU/MAERP heeft besloten zich uit de markt terug te trekken ${ }^{143}$.

De premie die in 1998 werd aangerekend onder de SFP-polis, bedroeg 7.500 dollar per verzekerde reactor. De totale geïnde premies onder deze polis bedroegen dan ook 825.000 dollar - toen waren in de VS 110 reactoren operationeel ${ }^{144}$.

Ten aanzien van de eigenschadeverzekering tenslotte, verleende ANI in 1997 een dekking van 500 miljoen dollar per installatie; de gemiddelde jaarlijkse premie voor deze dekking bedroeg in 1996 ongeveer 1,3 miljoen dollar.

Volledigheidshalve dient te worden aangegeven dat ANI onder druk van de nucleaire exploitanten een belangrijk deel van de aansprakelijkheidsverzekering in herverzekering heeft gecedeerd aan NEIL. In 1997, 1998 en 1999 werd telkens 15\% overgedragen aan NEIL. Dit impliceert dat NEIL voor $45 \%$ optreedt als herverzekeraar van $\mathrm{ANI}^{145}$; bij een kernongeval zal NEIL dus moeten instaan voor 90 miljoen dollar van de totale schijf van 200 miljoen dollar.

\subsubsection{Tussenkomst van ANI ingevolge Three Mile Island}

Op 28 maart 1979 vond in de kerninstallatie van Three Mile Island (TMI) een ongeval plaats wair aanzienlijke schade aan de installatie werd veroorzaakt, en waar een beperkte hoeveelheid radioactiviteit in de atmosfeer is terechtgekomen. Op 30 maart 1979 gaf de gouverneur van Pennsylvania het bevel om de bevolking die in de vijf mijlszone rond de reactor woonde, te evacucren ${ }^{146}$. ANI betaalde in totaal 1,4 miljoen dollar voor deze evacuatiekosten ${ }^{147}$.

NRC Report 1998, 81 .

De premie bedroeg respectievelijk 190.500 dollar en 722.500 dollar (NRC Report 1998, 81).

NRC Report 1998, 83.

Cfr. infra, in $\$ 3.3$.

NRC Report 1998, 95.

NRC Report 1998, 82.

NRC Report 1998, 95.

$\mathrm{Na}$ deze beslissing werden nảar sehatting 140.000 mensen geëvacueerd.

Columbia Rapport, 1984, 29. 
Vanaf 2 april was in Harrisburg ANI's claims office operationeel en werden de eerste betalingen verricht ${ }^{148}$. Deze eerste uitkeringen dekten de kosten van herlocatie, eten, dringende medische kosten etc. Over het algemeen dienden de slachtoffers hun identiteit te bewijzen waardoor ze konden aantonen dat ze in de geëvacueerde zone woonden, en dienden ze een ontvangstbewijs te tekenen. Na het ongeval werden meerdere vorderingen, waaronder enkele massavorderingen, ingediend tegen de exploitant en tegen een aantal leveranciers van TMI ${ }^{149}$. Twee van deze vorderingen werden buiten de rechtbank geregeld. In 1981 werd een dading afgesloten voor het econo. misch verlies van bedrijven en individuen die zich binnen een straal van 25 mijl rond de installatie bevonden: ANI keerde 20 miljoen dollar uit. Deze overeenkomst schreef ook voor dat bovenop deze som 5 miljoen dollar moest worden betaald met het oog op de oprichting van een gezondheidsfonds dat de gevolgen zou bestuderen van de gezondheidsimpact van het ongeval op de omwonenden. Vervolgens werd in 1985 14,25 miljoen dollar uitgekeerd aan 280 mensen ingevolge letselschade en "emotional distress"150.

In totaal heeft ANI dus ongeveer 40,65 miljoen dollar (44,46 miljoen euro) uitgekeerd tengevolge van het TMI-ongeval. Maar kort nadat bekend raakte dat een dading was bereikt met een aantal slachtoffers, werden 2.200 nieuwe vorderingen ingediend. De slachtoffers beweerden eveneens letselschade en schade ingevolge emotional distress te hebben opgelopen. Het eerder bereikte akkoord heeft dus een aantal andere mensen aangemoedigd om eveneens een vordering in te dienen. ANI beschouwt haar beslissing waarbij ze akkoord ging om buiten de rechtbank cen bepaalde schadevergoeding te betalen, dan ook als een vergissing ${ }^{151}$. Het wekt dan ook weinig verbazing dat de proceskosten naar aanleiding van het ongeval in TMI, zeer omvangrijk zijn: naast de 40 miljoen dollar uitgekeerde schadevergoeding naar aanleiding van TMI, heeft ANI tot in 1998 reeds 28 miljoen dollar gespendeerd aan de verdediging tegen de verschillende vorderin$\operatorname{gen}^{152}$.

Overigens werden in de periode 1956-1999 bij ANI ongeveer 200 vorderingen ingediend ${ }^{153}$. In die periode werd een totaal bedrag uitgekeerd van 157 miljoen dollar, waarvan 45 miljoen dollar aan schadevergoeding en 112 miljoen dollar (122,5 miljoen euro) aan proceskosten ${ }^{154}$. Het wekt dan ook weinig verbazing dat de Amerikaanse nucleaire verzekeringspool hamert op het feit dat deze proceskosten deel uitmaken van de aansprakelijkheidsdekking, en dus niet moeten worden betaald bovenop de som van 200 miljoen dollar ${ }^{155}$. Onder de Price-Anderson Act maken deze kosten inderdaad deel uit van de verleende dekking.

Quattrochi, J.L., "The Price-Anderson Act in the New Millemium. An Insurer's Perspective", in "Nuclear Inter Jura 1999", i.c., 251; Marrone, J., "The Liability Claims Experience of the American Nuclear Pools and their Response to the Three Mile Island Accident", in "Nuclear Third Party Liability and Insurance", l.c., 202.

Columbia Rapport, 1984, 29.

Quattrochi, J.L., "The Price-Anderson Act in the New Millennium. An Insurer's Perspective", in "Nuclear Inter Jura 1999", l.c., 251.

Quattrochi, J.L., "The Price-Anderson Act in the New Millennium. An Insurer's Perspective", in "Nuclear Inter Jura 1999", l.c., 251.

NRC Report 1998, 93.

Een beknopt overzicht van deze vorderingen kan worden geraadpleegd in NRC Report 1998, 85-91.

Voor de openstaande vorderingen werd een totaal bedrag gereserveerd van 321 miljocn dollar (Quattrochi, J.L., "The Price-Anderson Act in the New Millennium. An Insurer's Perspective", in "Nuciear Inter Jura 1999", l.c., 252-253).

Quattrochi, J.L., "The Price-Anderson Act in the New Millennium. An Insurer's Perspective", in "Nuclear Inter Jura 1999", l.c., 253. 


\subsection{Nuclear Electric Insurance Limited (NEIL) en Nuclear Mutual Limited (NML)}

NEIL en NML zijn captives van de Amerikaanse nucleaire exploitanten. Alle activiteiten van NEIL en NML worden geredigeerd vanuit hun filiaal in Wilmington, Delaware. Deze captives zijn opgericht met als doel te voorzien in een kostenbesparende verzekeringsvorm, het genereren van een voldoende capaciteit en het opstellen van pertinente technische normen op basis waarvan de risico's van de verschillende leden kunnen worden ingeschat ${ }^{156}$.

Hieronder wordt eerst de totstandkoming van NEIL en NML weergegeven ( $\$ 3.3 .1$ ), nadien wordt de door de NRC ingevoerde property rule besproken (\$ 3.3.2) en wordt aangegeven welke dekking inzake eigenschadeverzekering op de markt in de VS beschikbaar is ( $\$ 3.3 .3$ ); tenslotte wordt weergegeven welke premies de exploitanten dienen te betalen ( $\$ 3.3 .4$ ).

\subsubsection{Totstandkoming NEIL en NML}

Vóór 1972 werd door de Amerikaanse traditionele verzekeringspools (toen nog NEPIA) ten aanzien van de eigenschadeverzekering van de exploitanten geen systeem toegepast waarbij een deel van de premie kon worden terugbetaald indien zich gedurende een zekere tijd geen schadegeval had voorgedaan. Dit leidde tot emstige kritieken vanwege de exploitanten die besloten een systeem op te zetten van onderlinge verzekering ("captive") ${ }^{157}$ met het oog op het dekken van de eigenschade.

NML werd inderdaad door enkele Amerikaanse exploitanten opgericht in 1973 omwille van de hoge kosten van nucleaire verzekering, het gebrek aan verzekeringscapaciteit en onvoldoende technische controles vanwege de nucleaire verzekeraars. Aanvankelijk werden dan ook enkel de kerninstallaties van de eigen leden verzekerd ${ }^{158}$. In het begin van de jaren ' 70 bedroeg de eigenschadepremie voor een kerninstallatie 1,25 miljoen dollar voor een dekking van 100 miljoen dollar (zijnde de maximum capaciteit van de markt). Dit terwijl voor eenzelfde dekking van een conventionele installatie een premie werd aangerekend van 120.000 dollar. Niet alleen was de premie voor de dekking van de eigenschade van een kerninstallatie zeer hoog, bovendien was de dekking beperkt tot 100 miljoen dollar, terwijl de waarde van een kerninstallatie meer dan 400 miljoen dollar bedroeg ${ }^{159}$.

NEIL werd opgericht als respons op het ongeval in Three Mile Island. Het was de bedoeling dat door het oprichten van een duidelijk van NML afgescheiden entiteit een verlies van NEIL nooit de reserves van NML zou kunnen aantasten. De eerste door NEIL aangeboden polis betrof een dekking van de kosten van replacement power. Toen evenwel duidelijk werd dat de zwaarste door een kemongeval veroorzaakte kosten de kosten van ontsmetting waren, bood NEIL II vanaf 1981 bijkomende dekking van eigenschade. In 1994 was de door NEIL II aangeboden dekking opgelopen tot 1,4 miljard dollar ${ }^{160}$. Vanaf 15 november 1994 bood NEIL een nieuwe bijkomende dekking (NEIL III) aan van 850 miljoen dollar, wat de totale capaciteit van NEIL bracht op 2,2 miljard dollar. De noodzaak om de limieten van de aangeboden polissen te verhogen wordt regelmatig bestudeerd door het directiecomité van NEIL.

\footnotetext{
156

Nuclear Electric Insurance Limited, Information Brochure, December 1994, 2; Nuclear Mutual Limited, Information Brochure, December 1994, 2.

Over dit begrip, cfr. supra in $\$ 2.2$ van hoofdstuk 11 .

Dow, J.C., "Nuclear Energy and Insurance", l.c., 267.

Nuclear Mutual Limited, Information Brochure, December 1994, 2.

Nuclear Eleciric Insurance Limited, Information Brochure, December 1994, 2.
} 
Volledigheidshalve wordt erop gewezen dat sinds einde 1998 de activiteiten van beide captives zijn samengevoegd. Polissen worden sinds die datum uitsluitend uitgeschreven door NEIL.

\subsubsection{De "property-rule" van NRC}

Vóór het ongeval van. TMI achtte de NRC het niet nodig om regels uit te vaardigen in verband met de eigenschadeverzekering omdat werd geoordeeld dat deze schade enkel betrekking had op de schade binnen de site en daarom geen gevaar opleverde voor de veiligheid en de gezondheid van de bevolking.

Toen evenwel duidelijk werd dat de eigenschade veroorzaakt door TMI ruimschoots de dekking van 300 miljoen dollar van de exploitant zou overschrijden, oordeelde de NRC dat dit kon leiden tot een vertraging van het ontsmetten van de site, wat wel degelijk een gevaar opleverde voor de bevolking. De NRC concludeerde dat de sommen die beschikbaar waren via de eigenschadeverzekering van de exploitant in de eerste plaats dienden te worden gebruikt voor de ontsmetting van de nucleaire site en voor de stabilisatie van de reactor. Om die reden voerde de NRC de property rule in, op basis waarvan elke exploitant ertoe gehouden is:

"take reasonable steps to obtain insurance available at reasonable costs and on reasonnable terms from private sources or to demonstrate to the satisfaction of the Commission that is possesses an equivalent amount of protection covering the licencee's obligation, in the event of an accident at the licencee's reactor, to stabilize and decontaminate the reactor and the reactor station site at which the reactor experiencing the accident is located".

De exploitant is met andere woorden verplicht een verzekering of een andere financiële dekking ${ }^{161}$ te kopen teneinde de reactor te stabiliseren en de site te ontsmetten. Via deze bepaling wil de NRC er zeker van zijn dat de exploitant onmiddellijk na een ongeval voldoende financiële middelen ter beschikking hecft om de gevolgen van het ongeval te beperken, wat duidelijk in het voordeel is van potentiële slachtoffers van het kemongeval. De NRC heeft een verordening uitgevaardigd op basis waarvan deze dekking ten minste 1,06 miljard dollar (1,16 miljoen euro) dient te bedragen ${ }^{162}$. De NRC eist bovendien dat de verzekeringspolis uitdrukkelijk aangeeft dat uitkeringen onder deze polis in eerste instantie dienen te worden aangewend voor het stabiliseren van de reactor, vervolgens voor de ontsmetting van de reactor en van de site. Een verzekeraar mag dus slechts overgaan tot de vergoeding van de eigenschade aan goederen van de exploitant nadat de ontsmetting van de site is beëindigd.

De door de NRC uitgevaardigde property rule leidt er dus toe dat de eigenschadeverzekering van de exploitant (first party dekking) ook positieve gevolgen kan hebben voor derden. Hoe sneller de radioactieve besmetting is weggenomen van de site, hoe beperkter de straling zal zijn waaraan omwonenden worden blootgesteld.

\subsubsection{Op de markt beschikbare dekking}

De dekking van de eigenschade geschiedde in 1997 nagenoeg volledig door middel van de captive. Net zoals de dekking inzake aansprakelijkheid tegenover derden, bestaat ook de dekking van de eigenschade van de exploitant uit meerdere schijven.

161

162
Waarbij de NRC zal oordelen of de dekking afdoende is.

10 CFR $50.54(w)$. 
Enkel voor de eerste en de tweede schijf werd eveneens dekking verleend door de traditionele Amerikaanse nucleaire verzekeringspool (ANI). De in de VS in 1997 beschikbare dekking voor eigenschade zag er als volgt uit. De eerste schijf bedroeg 500 miljoen dollar; zowel ANI als NML boden een dergelijke polis aan. Vervolgens waren twee bijkomende dekkingen mogelijk: een dekking van 600 miljoen dollar (ANI) en een dekking van 2,75 miljard dollar (aangeboden door NEIL). Vandaar kon een exploitant zich voor de dekking van de eigenschade aan de installatie verzekeren tot een bedrag van 3,85 miljard dollar (4,21 miljard euro).

\begin{tabular}{|l|}
\hline $\begin{array}{l}\text { Dekking van eigenschade in } 1997 \\
\text { (in miljoen dollar) }\end{array}$ \\
\hline 500 ANI/NEIL \\
600 supplementary excess ANI \\
2.750 excess NEIL \\
\hline 3.850 in totaal \\
\hline
\end{tabular}

Uit bovenstaande tabel kan worden afgeleid dat in de eerste schijf van de dekking van eigenschade, ANI en NEIL concurrenten zijn. Van de 70 nucleaire sites die midden 1997 in de VS in deze eerste schijf waren verzekerd, waren 50 verzekerd bij NEIL en 20 bij ANI $^{163}$.

Hier weze herinnerd aan het feit dat de kerninstallaties in de VS voor de dekking van de eigenschade verplicht zijn te voldoen aan de property rule van de NRC. Voor het overige zijn de exploitanten geheel vrij hun eigenschade al dan niet te verzekeren. Nochtans koopt het overgrote deel van de Amerikaanse exploitanten de volledige dekking van 3,85 miljard dollar.

Deze dekking voor eigenschade dekt zowel schade aan goederen, ontsmetting van de reactor, onbeschadigde goederen, economisch verlies en machinebreuk. In Europa wordt machinebreuk niet gedekt door de pools omdat dit via de conventionele markt wordt gedekt.

Opvallend bij de dekking voor eigenschade in de VS is dat zij aan een bepaalde franchise ("eigen risico") is onderworpen. De franchise varieert van 1 tot 2,5 miljoen dollar. Deze franchise wordt door de exploitant gedekt op basis van eigen financiële middelen.

Tenslotte wordt eraan herinnerd dat in 1999, betreffende de aansprakelijkheidsverzekering in de eerste schijf van de Price-Anderson Act, NEIL optrad als een belangrijke herverzekeraar van ANI. Het nam inderdaad $45 \%$ van de herverzekering voor zijn rekening.

\subsubsection{Premie bij NEIL}

De verzekerden van de eigenschadedekking betalen jaarlijks een bijdrage aan NEIL. Deze bijdrage wordt geplaatst in een soort garantiefonds. Belangrijk is dat een bijdrage "eigendom" blijft van het desbetreffende lid. Indien er zich een schadegeval voordoet, zullen dus in eerste instantie deze fondsen worden aangesproken. Is de schade groter dan deze reserve, dan zullen de verschillende herverzekeraars worden aangesproken.

Aangezien NEIL ecn captive is van de nucleaire exploitanten, vloeit een deel van de winst. naar hen terug. In 1996 waren de reserves van NEIL/NML dermate gegioeid dat aanzienlijke uitkeringen aan de verschillende leden kon geschieden, in die mate zelfs dat ongeveer de helft van de 
leden de facto geen bijdrage diende te betalen, maar geld terug kreeg: de door hen te ontvangen retributie of dividend werd gecompenseerd met de te betalen bijdrage. Zo werd in 1996 in total 210 miljoen dollar aan de leden terugbetaald ${ }^{164}$.

\section{Conclusie}

Hierboven werd het ontstaan van het Amerikaanse nucleaire aansprakelijkheidsrecht in het algemeen en van de Price-Anderson Act in het bijzonder onderzocht en werd weergegeven hoe de verzekeringsindustrie de vanuit die hoek ontstane vraag naar verzekering voor het nucleaire risico, heeft beantwoord. In deze paragraaf worden uit deze analyse enkele conclusies getrokken, zowel ten aanzien van de Price-Anderson Act zelf $(\S 4.1)$, als ten aanzien van het Europese nucleaire aansprakelijkheidsrecht $(\$ 4.2)$.

\subsection{De Price-Anderson Act}

Centraal in het Amerikaanse nucleaire aansprakelijkheidsrecht staat de Price-Anderson Act van 1957. Deze wet heeft een aantal belangrijke principes geintroduceerd in de Atomic Energy Act.

Het doel van de Price-Anderson Act was het vinden van een evenwicht tussen de belangen van de industrie en de belangen van slachtoffers van kernongevallen. Deze wet hecf sinds haar ontstaan in 1957 een zeer grondige evolutie gekend. Belangrijk hicrbij is dat deze wet steeds wordt afgesloten voor een beperkte periode omdat wordt geoordeeld dat het een uitzonderingsregime betreft; bij elk van deze verlengingen werd telkens de vraag gesteld of de doelstellingen van de wet afdoende werden bereikt. Periodick wordt de wet dus opnieuw voorgelegd aan het Amerikaanse Congres, dat moet oordelen of er een voldoende evenwicht wordt bereikt tussen de belangen van de industrie en de belangen van slachtoffers van een kemongeval.

Zonder enige twijfel kan worden gesteld dat de Price-Anderson Act in haar oorspronkelijke versie vooral de Amcrikaanse nucleaire industrie beschermde. Het overgrote deel van de schadevergoeding (500 miljoen dollar) viel ten laste van de overheid; de industrie diende zich te verzekeren voor een bedrag dat op de markt beschikbaar was (60 miljoen dollar). Belangrijk voor de verhoging van de financiële lasten van de exploitant, was de introductie van een nieuwe schijf in het compensatiesysteem van de Price-Anderson Act in 1975. Deze schijf werd gevormd door een collectieve bijdrage van alle Amerikaanse exploitanten. Naarmate meer kerninstallaties een vergunning kregen, namen de beschikbare fondsen in deze schijf toe en werd de overheidstussenkomst opgeheven. Een transfer van financiële verantwoordelijkheid van de overheid naar de industrie is in de VS dan ook consequent doorgevoerd, met dien verstande dat het totale beschikbare schadevergoedingsbedrag en de aansprakelijkheid van de exploitant beperkt blijven. Bij de wijzigingen in 1988 stelde de NRC voor deze beperking op te heffen, hetgecn nict is doorgevoerd onder druk van de nucleaire industrie.

Toch heeft het al bij al vrij lang geduurd vooraleer het zover was. Pas in 1982, ofwel 25 jaar na de adoptic van de Price-Anderson Act, was de overheidstussenkomst volledig afgebouwd. Bovendien was het totale beschikbare bedrag toen nog steeds ongewijzigd - namelijk 560 miljoen dollar. Een substantiële verhoging van het schadevergoedingsbedrag werd bewerkstelligd door de wijzigingen die in 1988 aan de Price-Anderson Act werden aangebracht, en dan met name door een aanzienlijke verhoging van de bijdragen in de tweede schijf. Belangrijk is ook dat de bijdragen van deze eerste schijf elke vijf jaar worden aangepast aan de index. Het is onduidelijk war- 
om een dergelijke aanpassing nict is ingebouwd ten aanzien van de individuele aansprakelijkheidsverzekering van de cxploitanten.

Via de combinatie van de individucle cerste schijf en de collectieve tweede schijf, is de PriceAnderson Act inderdaad in staat om vrij hoge bedragen te genereren: in 2000 bedroeg het totale beschikbare schadevergoedingsbedrag 9,11 miljard dollar, of 9,96 miljard euro. Dit is ongevecr het viervoudige van het bedrag dat in Nederland beschikbaar is en het twintigvoudige van de in België beschikbare schadevergoeding ${ }^{165}$.

Dit is echter meteen ook de achillespecs van het systeem: naarmatc minder reactoren operationecl zullen zijn, zal het totale schadevergoedingsbedrag drastisch afnemen. Tot nog toe hecft de NRC nog geen pasklaar antwoord op de vraag hoe kan worden voorkomen dat in 2035 het totalc schadevergoedingsbedrag lager zou uitvallen dan het bedrag onder de initiële Price-Anderson Act. Voor de wijziging in 2002 lijkt de NRC aan te sturen op een aanzienlijke verhoging van de aansprakelijkheidsverzekering van de exploitant.

De evolutie van het Amerikaanse nucleaire aansprakelijkheidsrecht kan niet los worden gezien van de rol die de Nuclear Regulatory Commission ter zake vervult. De voorganger van de NRC, de Atomic Energy Commission, werd opgeheven in 1974 omdat ernstige vragen werden gesteld bij de rol die de AEC speelde bij de ontwikkeling van civiele toepassingen van kernenergie. Vooral het feit dat de AEC zowel een promotionele als een controlerende functic had, gaf aanleiding tot ernstige kritieken. Daarom werd de NRC opgericht als een onafhankelijke instelling die enkel verantwoording verschuldigd is aan de President van de Verenigde Staten. Precies deze onafhankelijkheid van de NRC is een belangrijke factor geweest in de evolutie van de PriceAnderson Act. Dat de NRC reeds verschillende jaren haar onafhankelijkheid doordrukt in haar beleid, blijkt uit verschillende elementen.

De NRC kreeg in 1975 de bevoegdheid de hoogte te bepalen van de retrospective premiums die de exploitanten dienden te betalen; deze premies konden variêren tussen 2 en 5 miljoen dollar. Meteen legde de NRC de exploitanten de verplichting op bij te dragen ten belope van het maximale bedrag, namelijk 5 miljoen dollar. Daamaast is eveneens de respons van de NRC op het ongeval in Three Mile Island opvallend. Toen duidelijk werd dat de kosten voor decontaminatie van de site zeer hoog konden oplopen, voerde de NRC de property rule in en werd bij de eerstvolgende verlenging van de Price-Anderson Act in 1988, het schadevergoedingsbedrag vertienvoudigd.

De Price-Anderson Act geeft overigens aan de NRC regelmatig de mogelijkheid om haar bevoegdheden uit te oefenen, met name bij de tienjaarlijkse verlengingen. Deze verlengingen blijken een adequaat middel om op geregelde tijdstippen de vigerende wetgeving te evalueren.

De evolutie die zich in de VS heeft voorgedaan, verliep parallel met de evolutie op de Amerikaanse nucleaire verzekeringsmarkt. Onmiddellijk na de invoering van het stelsel van retroacticve premies, bood ANI de daartoe noodzakelijke dekking aan. Hetzelfde geldt na het afkondigen door de NRC van de property rule. Het proactieve beleid van de Amerikaanse nucleaire industrie dateert overigens van vóór het van kracht worden van de property rule. Toen de exploitanten van keminstallaties in 1972 oordeelden dat de kosten voor de eigenschadeverzekering te hoog opliepen, richtten zij een eigen captive op (NML). In 1981 werd daarenboven, als rcactic op het onge-

Met dien verstande dat het overgrote deel van het totale beschikbare bedrag in Nederland door de Staat wordt ter beschikking gesteld. 
val van Three Mile Island, een tweede captive opgericht. In 1997 boden de verschillende polissen een gecombineerde dekking aan van 3,85 miljard dollar. Dankzij de werking van de captives van de Amerikaanse nucleaire exploitanten, werden aanzienlijke reserves opgebouwd, waardoor de bijdragen van de meeste leden kleiner zijn dan de retributie die ze jaarlijks terugkrijgen.

\subsection{Vergelijking met het Europese nucleaire aansprakelijkheidsrecht}

Het Europese nucleaire aansprakelijkheidsrecht is duidelijk verwant met de Amerikaanse PriceAnderson Act. Ook in het Verdrag van Parijs wordt een regime van risicoaansprakelijkheid gehanteerd, wordt de aansprakelijkheid van de exploitant beperkt en wordt de exploitant verplicht om deze aansprakelijkheid te verzekeren. Daarenboven voorzag ook de oorspronkelijke PriceAnderson Act in een overheidstussenkomst. Deze verwantschap is ook nict verwonderlijk, aangezien beide systemen voortbouwen op de conclusies van het Voorlopig Rapport ${ }^{166}$. Bij het totstandkomen van het Verdrag van Parijs, drie jaar na de Price-Anderson Act, vertoonden beide systemen evenwel ook een tweetal verschillen.

Het belangrijkste inhoudelijke verschil tussen beide systemen heeft betrekking op de juridische kanalisatie van aansprakelijkheid. In de VS kunnen verschillende personen die diensten of producten hebben geleverd aan de exploitant, worden gedagvaard door de slachtoffers van een kemongeval. De leveranciers zijn evenwel economisch gedekt via de omnibus-dekking in de aansprakelijkheidsverzekering van de exploitant (economische kanalisatie).

Het tweede verschil was dat de aansprakelijkheidslimiet van de exploitant in Europa aanzienlijk lager was dan in de VS. Overeenkomstig het Verdrag van Parijs, was de exploitant aansprakelijk tot een bedrag van 15 miljoen dollar ${ }^{167}$. De door het Verdrag van Brussel geîntroduceerde bijkomende schijven van staatsaansprakelijkheid en van solidariteit tussen de verdragsluitende staten, voorzagen in een bijkomende dekking van respectievelijk 70 en 50 miljoen dollar $^{168}$. Onder de Price-Anderson Act van 1957 bedroeg de aansprakelijkheid van de exploitant daarentegen 60 miljoen dollar.

In 2000 is de situatie in die zin veranderd dat de aansprakelijkheidslimiet van de exploitant in België en Nederland hoger ligt dan de eerste schijf van de Price-Anderson Act. Sinds 1988 bedraagt de aansprakelijkheidsverzekering onder de Price-Anderson Act 200 miljoen dollar of 218,77 miljoen euro. Dit bedrag is vrij laag: in Nederland bedraagt de aansprakelijkheidsverzekering 340,36 miljoen euro en in België 297,47 miljoen euro. De individuele aansprakelijkheid van de Amerikaanse exploitant is dus eerder gering; daar staat tegenover dat via de collectieve bijdrage de exploitanten in belangrijke mate instaan voor het nucleaire risico.

In de loop der jaren zijn aanzienlijke verschillende ontstaan tussen beide systemen, hoofdzakelijk omwille van de periodieke aanpassing van de Price-Anderson Act. In de VS wordi de PriceAnderson Act periodick ter beoordeling aan het parlement voorgelegd. Bovendien is aan een onafhankelijk orgaan de bevoegdheid gegeven om regulerend op te treden, bijvoorbeeld ter zake van de verhoging van de aansprakelijkheidslimiet. In België en Nederland daarentegen is telkens

166 Cfr. supra, in $\$ 2.1 .2$ van hoofdstuk 4.

167

Deze bedragen zijn de omrekening van de Bijzondere Trekkingsrechten overeenkomstig het Verdrag van Parijs; deze omrekening is gebaseerd op de wisselkoersen in 1964 (bron: Cavers, F.D., "Improving Financial Protection of the Public against the Hazards of Nuclear Power", o.c., 680).

168 De aansprakelijkheid van de exploitant onder het Verdrag van Wenen, was nog lager dan diens aansprakelijkheid onder het Verdrag van Parijs, namelijk 5 miljoen dollar. 
een tussenkomst van de regering vereist alvorens de limieten kunnen worden opgetrokken, en wordt de nucleaire aansprakelijkheidswet niet periodiek aan het parlement voorgelegd.

De aanpassing van de Price-Anderson Act heeft geleid tot een belangrijk verschil wat betreft de samenstelling van de collectieve schijf. Beide stelsels voorzien, naast deze individuele aansprakelijkheid van de exploitant, in bijkomende financiële middelen. In de landen van de NEA zijn dit evenwel middelen die door de overheid worden ter beschikking gesteld (met name via het Aanvullend Verdrag van Brussel van 1963); terwijl in de VS een collectief mechanisme van de exploitanten deze bijkomende fondsen genereert. In de VS kwam initieel de Staat eveneens tussenbeide, maar van de periodieke wijzigingen van de Price-Anderson Act werd gebruik gemaakt on deze tussenkomst op te heffen. In Europa en in het nucleaire aansprakelijkheidsrecht heeft men duidelijk uit het oog verloren dat de overheidstussenkomst in het Voorlopig Rapport als een tijdelijke maatregel werd beschouwd.

Daarnaast ligt de totale beschikbare schadevergoeding in Europa ecn stuk lager dan de in de VS uit private middelen beschikbare schadevergoeding. Zelfs met de overheidstussenkomst blijven de bedragen die op basis van het internationale nucleaire aansprakelijkheidsrecht - onder het Aanvullend Verdrag van Brussel van 1963 en onder van het Verdrag inzake Bijkomende Compensatie van 1997 - beschikbaar zijn, vrij bescheiden. Het gevolg hiervan was dat na de wijzigingen van de Price Anderson Act in 1988, de onder het Verdrag van Parijs beschikbare bedragen minder dan $10 \%$ bedroegen dan de in VS beschikbare fondsen ${ }^{169}$. Nederland vormt hier een notoire uitzondering op.

Hieruit kan worden geconcludecrd dat de positie van slachtoffers in de VS een stuk beter is vergeleken met Europa. De wetgeving van een land dat nog niet is toegetreden tot het intemationale nucleaire aansprakelijkheidsrecht biedt, in vergelijking met het Verdrag van Parijs, meer garanties dat de schade uit een kernongeval zal worden gecompenseerd. Een internationaal Verdrag betekent dus niet noodzakelijk dat aan slachtoffers een ruimere bescherming wordt geboden ${ }^{170}$. Opvallend is wel dat de VS vrij snel het Verdrag inzake Bijkomende Compensatie van 1997 hebben ondertekend. Hierboven werd reeds besproken wat de achtergrond is van deze toetreding ${ }^{171}$.

Een bijkomend verschil tussen beide systemen bestaat erin dat de gerechtskosten in de VS deel uitmaken van de aansprakelijkheidsverzekering van de exploitant, terwijl in het Verdrag van Parijs deze bedragen door de verzekeraar dienen te worden betaald bovenop het bedrag van de dekking.

Tot slot kan erop worden gewezen dat een opvallende gelijkenis tussen de situatie in Europa en de VS erin bestaat dat de traditionele nucleaire verzekeringspools onder zware druk staan van de exploitanten. Zowel ANI als SYBAN verliezen, zeker voor de dekking van de eigenschade, steeds meer marktaandeel, ten voordele van de captives van de nucleaire exploitanten (NEIL in de VS en EMANI in Europa) ${ }^{172}$

Heimann, F.F., "The U.S. Liability System for Nuclear Power Plants", o.c., 423.

Vanden Borre, T., "Dekking van het nucleaire risico op nationaairechtelijke basis of via intemationale Verdragen: de Verenigde Staten versus Europa", in Faure, M., Deketelaere, K. en Verhoosel, G., (red.), "Grensoverschrijdende milieuproblemen", l.c., 483. 
Met deze analyse wordt deel 3 van dit boek afgesloten. In het volgende en laatste deel worden een aarital conclusies en aanbevelingen geformuleerd. 


\section{DEEL 4}

\section{CONCLUSIES EN AANBEVELINGEN}

In het laatste deel van dit onderzoek worden de inzichten van de verschillende hoofdstukken gecombineerd. In de vorige hoofdstukken is reeds naar voren gekomen dat het nucleaire aansprakelijkheidsrecht op bepaalde punten tekort schiet en dat niettegenstaande de sterke verwantschap, er anzienlijke verschillen zijn vast te stellen tussen het Europese en het Amerikaanse nucleaire aansprakelijkheidsrecht enerzijds en tussen het nucleaire aansprakelijkheidsrecht en de wetgeving inzake de aansprakelijkheid voor schade door olieverontreiniging op zee anderzijds. De vraag die in dit deel aan de orde komt, is dan ook welke de voornaamste tekortkomingen zijn van het huidige nucleaire aansprakelijkheidsrecht, en hoe deze kunnen worden verklaard.

In hoofdstuk 14 komen de conclusies van de juridische analyse uit het eerste deel van het boek aan bod; de rechtseconomische conclusies worden in hoofdstuk 15 aan de orde gesteld. Daarnaast zal worden aangegeven op welke wijze aan de vastgestelde tekortkomingen kan worden tegemoet gekomen. De centrale vraag van dit onderzoek was immers hoe de compensatie voor slachtoffers van kemongevallen kan worden verbeterd. Het antwoord op deze vraag wordt gegeven in de aanbevelingen (hoofdstuk 16). 


\section{HOOFDSTUK 14}

\section{CONCLUSIES UIT DE JURIDISCHE ANALYSE}

De conclusies uit de juridische analyse hebben in eerste instantie betrekking op het nucleaire aansprakelijkheidsrecht $(\S 1)$. Dit zal toelaten om een antwoord te geven op de vraag in welke mate het nucleaire aansprakelijkheidsrecht afwijkt van andere takken van het civiele aansprakelijkheidsrecht. Vervolgens wordt ook aangegeven welke lessen hieruit kunnen worden getrokken voor het milieuaansprakelijkheidsrecht ( $\$ 2$ ).

\section{VOOR WAT BETREFT HET NUCLEAIRE AANSPRAKELIJKHEIDSRECHT}

Het Verdrag van Parijs van 29 juli 1960 inzake de civiele aansprakelijkheid voor schade uit kemongevallen is opgesteld in de betrachting om een evenwicht tot stand te brengen tussen de belangen van de exploitanten (Förderungszweck) en de belangen van slachtoffers van een kernongeval (Schutzzweck). In het Verdrag werd een geheel van samenhangende regels uitgewerkt dat een weerspiegeling zou vormen van dit evenwicht. De basisidee van het evenwicht bestond erin dat werd voorzien in een beperkt maar gegarandeerd compensatiesysteem. Het slachtoffer van een kemongeval zou beter gediend zijn met de garantie dat een deel van zijn schade zou worden vergoed, dan te worden geconfronteerd met een insolvente nucleaire exploitant en het risico te lopen dat zijn schade in het geheel niet wordt gecompenseerd.

De vraag rijst dus in welke mate, vanuit juridisch oogpunt, het nucleaire aansprakelijkheidsrecht inderdaad als evenwichtig kan worden beschouwd. Het antwoord op deze vraag wordt gegeven door in eerste instantie na te gaan of de basisprincipes van het nucleaire aansprakelijkheidsrecht erin slagen het slachtoffer van een kernongeval te beschermen $(\$ 1.1)$. Nadien worden de gevolgen besproken van het feit dat een aantal tijdelijke principes werden ingeschreven in het internationale nucleaire aansprakelijkheidsrecht $(\$ 1.2)$ en van de organisatie van de nucleaire verzekeringsmarkt ( $\S 1.3)$. De conclusies worden weergegeven in $\S 1.4$.

\subsection{De basisprincipes van het nucleaire aansprakelijkheidsrecht}

Hieronder worden de conclusies inzake de verschillende basisprincipes van het nucleaire aanspra-kelijkheidsrecht aan de orde gesteld: de beperking van de aansprakelijkheid (§ 1.1.1), de verplichte verzekeringsdekking $(\$ 1.1 .2)$, het regime van risicoaansprakelijkheid $(\S 1.1 .3)$, de kanalisatie van aansprakelijkheid naar de exploitant $(\$ 1.1 .4)$ en de exclusieve bevoegdheid van één rechter (\$ 1.1 .5$)$.

\subsubsection{Beperking van de aansprakelijkheid}

Traditioneel wordt ervan uitgegaan dat het in het nucleaire aansprakelijkheidsrecht geldende regime van risicoaansprakelijkheid, de kanalisatie van aansprakelijkheid naar de exploitant en de plicht van de exploitant om zich te verzekeren in het voordeel zijn van het slachtoffer. Voor de exploitant is met name de beperking van de aansprakelijkheid voordelig.

De idee achter de beperking van de aansprakelijkheid van de exploitant van een keminstallatie was de beperkte beschikbaarheid van een verzekeringsdekking. De idee achter de verplichte dekking (het congruentievereiste) was dat dit een garantie gaf aan slachtoffers van een kernongeval dat in ieder geval een deel van hun schade zou worden gecompenseerd. Het congruentievereiste in 
het Belgische en het Nederlandse recht gaat zelfs zover dat indien de financiële zekerheid van de exploitant in gebreke zou blijven, de Staat hiervoor optreedt als garant. Op deze wijze leidt het nucleaire aansprakelijkheidsrecht ertoe dat het slachtoffer niet enkel wordt beschermd tegen het faillissement van de exploitant, maar eveneens tegen het faillissement van de verzekeraar of van degene die een financiële zekerheid heeft gesteld.

Nochtans is in de nucleaire aansprakelijkheidsverdragen geen enkele verplichting opgenomen op basis waarvan de verplichte dekking automatisch de capaciteit van de verzekeringsmarkt zou volgen. Het Belgische en het Nederlandse nucleaire aansprakelijkheidsrecht bevatten evenmin een dergelijke bepaling. De respectievelijke nucleaire aansprakelijkheidswetten bepalen enkel dat de regering het aansprakelijkheidsbedrag kan verhogen. Van enige verplichting tot systematische verhoging in functie van de capaciteit van de verzekeringsmarkt, is geen sprake. Overigens heett totnogtoe enkel de Nederlandse regering op geregelde tijdstippen het bedrag gewijzigd; in België heeft het 15 jaar geduurd vooraleer het bedrag werd aangepast. Bovendien werd overgestapt van een dekking per installatie naar een dekking per site. Op zich is dat geen onoverkomelijk probleem in de mate waarin na een kernongeval ook de andere reactoren van hetzelfde reactorenpark worden stilgelegd; maar er kan niet worden gesproken van een reële lastenverhoging in hoofde van de Belgische exploitant'.

De totale schade bij een zwaar kernongeval kan oplopen tot ongeveer 100 miljard dollar of 110 miljard euro ${ }^{2}$. Op basis van het huidige nucleaire aansprakelijkheidsrecht, is slechts een vel beperkter bedrag beschikbaar. In totaal was in 2000 de exploitant van een keminstallatie aansprakelijk tot veel beperktere bedragen: in de VS tot 8 miljard euro, in Nederland tot 340 miljoen euro $\mathrm{en}$ in België tot 300 miljoen curo. Indien evencens wordt rekening gehouden met de bedragen die beschikbaar zijn via de openbare middelen van het Aanvullend Verdrag van Brussel, dan was op het einde van het jaar 2000 in Nederland ongeveer 6 miljard euro en in België nog geen half miljard euro beschikbaar ${ }^{3}$.

Zelfs indien rekening zou worden gehouden met een "gemiddeld" kernongeval dat een schade zou veroorzaken van 40 miljard euro, dan nog dient te worden vastgesteld dat de exploitant slechts voor een klein deel aansprakelijk is voor de schade die hij aan derden veroorzaakt. Behalve in enkele uitzonderingsgevallen (Duitsland, Zwitserland, Oostenrijk en Japan) kan de exploitant boven deze bedragen niet aansprakelijk worden gesteld. Er moet worden erkend dat het zeer moeilijk is om louter op basis van bedragen gefundeerde uitspraken te doen over de merites van het compensatiesysteem van een land. De mate waarin een slachtoffer wordt beschermd, hangt namelijk niet uitsluitend af van deze cijfers. Eveneens het in een gegeven land aanwezige stelsel van sociale zekerheid en de interpretatie van bepaalde juridische begrippen zijn elementen die bepalend zijn voor de bescherming van een slachtoffer. Daamaast worden door de verzekeraars verschillende dekkingssystemen gehanteerd ${ }^{4}$. Dit neemt niet weg dat de geciteerde cijfers cen belangrijke indicatie bieden voor de sommen die, buiten sociale zekerheid, beschikbaar zijn voor de slachtoffers van een kernongeval.

Vanden Borre, T., "Recente ontwikkelingen in het nucleaire aansprakelijkheidsrecht: innovatie of renovatie?", o.c., 48. Radetzki, M. en Radetzki, M., "Private Arrangements to Cover Large-Scale Liabilities Caused by Nuclear and Other Industrial Catastrophes", o.c., 184. Voor een overzicht van de verschillende beschikbare bedragen, cfr. supra, in $\$ 3.1 .5$ van hoofdstuk 4 . Cfr. supra, in $\$ 4.1 .5$ van hoofdstuk 4 . 
Tenslotte is het ook vreemd dat zowel de internationale Verdragen als de uitvoeringswetten een algemene dekkingslimiet invoeren die dus van toepassing is op alle kerninstallaties van het land. Er wordt met andere woorden geen verschillende limiet opgelegd in functie van het type reactor, de ligging van de reactor etc. Verzekeraars daarentegen hanteren voor hetzelfde dekkingsbedrag verschillende premies. Dit wijst erop dat rekening wordt gehouden met bijvoorbeeld de ligging van de reactor; dat verzekeraars dus een zekere graad van risicodifferentiatie doorvoeren. Door evenwel één enkel dekkingsbedrag in de wet vast te leggen wordt de risicodifferentiatie ernstig bemoeilijkt ${ }^{5}$.

\subsubsection{Verplichte dekking van de aansprakelijkheid}

Het congruentievereiste duidt op de garantie-idee in het nucleaire aansprakelijkheidsrecht: het biedt aan slachtoffers de garantie dat na een kernongeval bepaalde fondsen zullen ter beschikking staan van slachtoffers. Het Verdrag van Parijs gaat zelfs zover om te stellen dat elke aansprakelijkheid van de exploitant dient te zijn gedekt door een financiële zekerheid. Het congruentievereiste verhindert bijgevolg dat een land dat lid is van het Verdrag van Parijs een regime van onbeperkte aansprakelijkheid zou invoeren ${ }^{6}$. In een dergelijk geval zou namelijk een deel van de aansprakelijkheid niet zijn gedekt door enige financiële zekerheid.

\subsubsection{Risicoaansprakelijkheid}

Het nucleaire civiele aansprakelijkheidsrecht heeft een regime van risicoaansprakelijkheid in hoofde van de exploitant van de kerninstallatie geïntroduceerd. De belangrijkste reden hiervoor was dat het slachtoffer is bevrijd van de last om een fout te bewijzen ${ }^{7}$. Een regime van risicoaansprakelijkheid wordt vaak ingevoerd samen met een beperking van de aansprakelijkheid. De prijs die het slachtoffer dient te betalen voor het vermeende voordeel om geen fout te moeten bewijzen, bestaat erin dat hij slechts een deel van de door hem geleden schade kan verhalen op de aansprakelijke exploitant. Bij de voorbereiding van het Verdrag van Wenen werden risicoaansprakelijkheid en de beperking van aansprakelijkheid duidelijk aan elkaar gekoppeld; het is niet meteen duidelijk of dit ook het geval was in het Verdrag van Parijs.

In het nucleaire aansprakelijkheidsrecht wordt soms ook gesproken van een absolute aansprakelijkheid; hiermee wordt aangegeven dat de exploitant van een kerninstallatie zich niet kan beroepen op een aantal klassieke gevallen van overmacht. Op basis van het Belgische en het Nederlandse nucleaire aansprakelijkheidsrecht zal de exploitant bijvoorbeeld ook aansprakelijk. zijn voor schade uit een kemongeval dat door een emstige natuurramp van uitzonderlijke aand is veroorzaakt.

Toch is de nucleaire industrie onderworpen aan vrij gedetailleerde veiligheidsregulering inzake stralingsbescherming, nucleaire veiligheid etc. Deze regulering voert normen in dic dienen te worden in acht genomen, zowel bij het ontwerp, bij de bouw als bij de eigenlijke uitbating van de kerninstallatie. Zowel naar Belgisch als naar Nederlands recht vorrnt de schending van een wettelijke bepaling een civielrechtelijke fout ${ }^{9}$; het is dus nog maar de vraag of een regime van risico-

\footnotetext{
De gevolgen hiervan worden in hoofdstuk 15 belicht.

Cfr. spura, in $\$ 4.1 .2$ van hoofdstuk 4.

Cfr. supra, in $\$ 1$ van hoofdstuk 4 .

Cfr. supra, in \$3.1.1.1 van hoofdstuk 4.

Cfr. supra, in hoofdstuk 1.
} 
aansprakelijkheid daadwerkelijk tegemoet komt aan de belangen van het slachtoffer en een snellere compensatie van de geleden schade mogelijk maakt ${ }^{10}$. Immers, het bewijs van de fout bij kemongevallen vormt wellicht niet het belangrijkste obstakel; in een aantal gevallen zal het niet eenvoudig zijn om de schade en de causaliteit te kunnen bewijzen. Het is dus twijfelachtig of risicoaansprakelijkheid bij kernongevallen de positie van slachtoffers substanticel verbetert.

\subsubsection{Kanalisatie van aansprakelijkheidsrecht naar de exploitant van de kerninstallatie}

Officieel dient ook de juridische kanalisatie van aansprakelijkheid de belangen van het slachtoffer. In het onderzoek is evenwel naar voren gekomen dat deze kanalisatie van aanş̧rakelijkheid werd ingevoerd onder druk van de Amerikaanse leveranciers van nucleair materiaal. Met name doordat de kanalisatie van aansprakelijkheid aan het slachtoffer een aantal rechtsgronden ontneemt, werd dit principe - terecht - onder vuur genomen in de Duitse literatuur en heeft de Oostenrijkse wetgever dit principe met ingang van 1 januari 1999 uit de nucleaire aansprakelijkheidswet geschrapt ${ }^{1 !}$.

In de nucleaire aansprakelijkheidsverdragen van de tweede generatie werd niet geraakt aan de juridische kanalisatie van aansprakelijkheid naar de exploitant van een kerninstallatie; het is evenmin een thema bij de onderhandelingen voor de revisie van het Verdrag van Parijs. Nog steeds wordt de stelling verdedigd dat de kanalisatie van aansprakelijkheid voordelig is voor zowel de slachtoffers, de exploitanten als voor de leveranciers van nucleair materiaal en de dienstverleners van de nucleaire industrie ${ }^{12}$. Of de kanalisatie van aansprakelijkheid erin slaagt de proces- en verzekeringskosten terug te dringen, is overigens nog maar de vraag ${ }^{13}$.

Het is in ieder geval uitermate vreemd dat in de Verenigde Staten een compensatiesysteem in voege is - dat overigens hogere bedragen genereert dan in Europa - dat niet ingrijpt in het gemene aansprakelijkheidsrecht en dat geen rechtsgronden buiten werking stelt. Hetzelfde geldt voor de aansprakelijkheid van de scheepseigenaar onder het CLC-Verdrag, waar een veell lichtere vorm van kanalisatie van kracht is.

\subsubsection{Exclusieve bevoegdheid van één rechter per land}

Om de eenheid van rechtspraak te waarborgen, en om dus om te vermijden dat meerdere rechtbanken een schadevergoeding zouden tockennen waarvan de som het beperkte bedrag van de aansprakelijkheid van de exploitant zou overtreffen, is in het Verdrag van Parijs één enkele rechter bevoegd om kennis te nemen van de vorderingen voortvloeiend uit een kemongeval.

De analyse heeft echter aangetoond dat deze exclusiviteit niet in alle gevallen zal gewaarborgd zijn. Met name indien ook schade is geleden in een niet-verdragsstaat, kunnen slachtoffers er belang bij hebben om elders een vordering in te dienen. Ten tweede is het niet uitgesloten dat, tenminste in een aantal landen, het kemongeval ook zal leiden tot een strafvordering wat de afwikkeling van de civielrechtelijke vorderingen emstig kan vertragen.

Ook in die zin: Faure, M., "Economic Models of Compensation for Damage caused by Nuclear Accidents: some Lessons for the Revision of the Paris and Vienna Conventions", o.c., 27. Cfr. supra, in \$2.2.6.2 van hoofdstuk 4 .

12 Kolehmainen, H., "The Modemisation of the International Nuclear Third Party Liability Regime Does Exclusive Liability still make sense?", in "Reform of Civil Nuclear Liability", l.c., 456.

Zie hierover verder bij de rechtseconomische toets in $\$ 1.1 .3$ van hoofdstuk 15 . 


\subsection{Inschrijven van tijdelijke principes in het internationale nucleaire aunsprakelijk- heidsrecht}

Een belangrijk probleem van het nucleaire aansprakelijkheidsrecht, is dat verschillende maatregelen waarvan het de bedoeling was dat zij slechts tijdelijk van toepassing zouden zijn, in een moeilijk te wijzigen verdrag zijn ingeschreven ${ }^{14}$.

Ten eerste moet worden gekeken naar de oorsprong van de kanalisatic van aansprakelijkheid naar de exploitant van een kerninstallatie. Deze kanalisatie is, zoals uit de historische totstandkoming bleek, een opgewaardeerde contractuele clausule. In feite werd een Amerikaanse vrijwaringsclausule (hold harmless clause), die werd gehanteerd in de jaren veertig en vijftig, en die uitdrukkelijk als een tijdelijke maatregel werd beschouwd zodat de nucleaire industrie zich op de vrije markt zou kunnen voorberciden, in het internationale nucleaire aansprakelijkheidsrecht ingeschreven. Blijkbaar werd de oorsprong van de kanalisatie van aansprakelijkheid uit het oog verloren, waardoor dit principe niet meer in vraag werd gesteld. Door de kanalisatie van aansprakelijkheid op deze wijze aan te wenden in het nucleaire aansprakelijkheidsrecht, kreeg het in feite een permanent karakter.

Ten tweede was ook de tussenkomst van de overheid als cen tijdelijke maatregel bedoeld. Ook dit principe zou worden afgebouwd naarmate de nucleaire sector meer ervaring kreeg zodat kon worden overgeschakeld naar het vrije markt mechanisme, zonder subsidiëring van de industrie. In het Voorlopig Rapport werd ondubbelzinnig gesteld dat de overheidstussenkomst stelselmatig zou worden afgebouwd. Andere industrieën waaronder de luchtvaartindustrie konden overigens initieel van een analoge tussenkomst genieten, maar deze tussenkomst werd na de ontwikkelingsfase systematisch afgebouwd.

Toch werd ook de overhcidstussenkomst, althans in het NEA-regime, in een internationaal Verdrag verankerd. Volledigheidshalve moet eraan worden tocgevoegd dat strikt genomen het Aanvullend Verdrag van Brussel van 1963 de Staten enkel verplicht om tussenbeide te komen in de derde schijf; voor wat de eerste twee schijven betreft, is het voldoende dat de Staat garandeert dat de nodige fondsen beschikbaar zijn. Bijvoorbeeld in België werd de tussenkomst van de Staat in de tweede schijf afgeschaft met ingang van 1 januari 2001. In Nederland daarentegen komt de Staat tussenbeide voor een zeer hoog bedrag.

De VS hebben zich wel aan hun initiële uitgangspositie gehouden (slechts staatssteun voor een opstartende industrie): de wijzigingen die de Price-Anderson Act in de loop der jaren heeft ondergaan, strekten er in eerste instantie toe om de lasten die initieel grotendeels door de overheid werden gedragen, naar de exploitanten te verschuiven. Deze lastenverschuiving was wel een proces van lange adem, in die zin dat het een kwarteeuw heeft geduurd vooral de overheidstussenkomst volledig was opgeheven ${ }^{15}$.

Van een analoge vaste wil om ook in Europa de overheidstussenkomst af te bouwen, lijkt voorlopig nog geen sprake, wel integendeel. Zowel het Protocol van het Verdrag van Wenen als het

Zowel de Belgische als de Nederlandse wetgever hebben vervolgens deze principes in een nationale wet vastgelegd.

De Price-Anderson Act kwam namelijk tot stand in 1957; de overheidstussenkomst werd opgeheven in 1982. 
Verdrag inzake Bijkomende Compensatie voorzien in een (belangrijke) tussenkomst van de over. heid.

Paradoxal genoeg lijkt de overheidstussenkomst zoals voorzien in het Aanvullend Verdrag van Brussel, te zijn ingegeven door de Verenigde Staten, met name omdat zij het bedrag van de beperkte aansprakelijkheid in het Verdrag van Parijs als onvoldoende beschouwden ${ }^{16}$. Er kan in ieder geval worden vastgesteld dat de aansprakelijkheid van de exploitant onder de Price-Anderson Act van 195760 miljoen dollar bedroeg, terwijl het Verdrag van Parijs slechts voorag in een aansprakelijkheidslimiet van 15 miljoen dollar ${ }^{17}$.

Ook de nucleaire verzekeringspools, die op nationale basis een monopolie creëren, werden bsschouwd als een tijdelike maatregel. Doordat de werking van deze pools niet als basisprincipe in het internationale nucleare aansprakelikheidsrecht werd ingeschreven, worden zij hieronder afzonderlijk besproken.

\subsection{Organisatie van de nucleaire verzekeringsmarkt}

De idee was - niet geheel ten onterechte - dat er in de jaren vijftig onvoldoende gegevens en onvoldoende verzekeringscapaciteit beschikbaar waren en dat daardoor een dergelyk monopolie gerechtvaardigd was. Het lijkt evident dat vijtig jaar later deze stelling niet meer, althans niet meer in dezelfde mate, opgaat.

Het is dan ook niet verwonderlijk dat dit monopolie de exploitanten een doom in het oog is. Zj hebben een mogelijke wijziging in het beleid ten anzien van de nucleaire verzekeringspools nict afgewacht en hebben naar alternatieven gezocht, tenminste voor wat betreft de eigenschadeverzekering. Met name de onderlinge verzekeringsmechanismen (captives) van de exploitanten lijken momenteel sterk in trek. Andere risico's die vroeger ook door de nucleaire verzekeringspools werden verzekerd, zoals de verzckering van de werknemers van de nucleaire sector, kunnen zelts buiten de pools en buiten de captives worden verzekerd. Het leidt dan ook geen twijfel dat de capaciteit op de verzekeringsmarkt sterk is gestegen en dat het twijfelachtig is of de monopoliepositie van de nucleaire pools nog kan worden gerechtvaardigd.

Hiermee is niet gezegd dat de nucleaire verzekeringspools geen reden van bestaan meer hebben. Het is aannemelijk om ervan uit te gaan dat deze pools nog steeds noodzakelijk zijn om een capaciteit te kunnen genereren, met name ten aanzien van de aansprakelijkheid tegenover derdin: maar het gebrek aan concurrentie tussen de pools lijkt niet langer houdbaar.

Door de koppeling van de bedragen die op de markt beschikbaar zijn en de monopoliepositic van de nucleaire verzekeraars én exploitanten, is ook deze maatregel niet meteen voordelig voor do positie van slachtoffers.

Arangio-Ruiz, G., "Some Intemational Legal Problems of the Civil Uses of Nuclear Energy", o.c.. 544: Doeker, G. en Gehring, T., "Private or International Liability for Transnational Environmental Damuk' - the precedent of conventional liability regimes", o.c., 10 Cavers, F.D., "Improving Financial Protection of the Public against the Hazards of Nuclear Power". o.c., 680 . 


\subsection{Conclusie}

Concluderend kan worden gesteld dat het nucleaire aansprakelijkheidsrecht drie kenmerken vertoont die afwijken van andere takken van het civielrechtelijke aansprakelijkheidsrecht. De belangrijkste afwijking is de strenge kanalisatie van aansprakelijkheid, ofwel de exclusieve aansprakelijkheid van de exploitant van een keminstallatie. In tweede instantie wordt in het kernenergierecht al gedurende bijna een halve eeuw de aansprakelijkheid van een privé-persoon aangevuld door de overheid. Er zijn niet meteen andere rechtstakken bekend waar in een analoge, in een verdrag vastgelegde, overheidstussenkomst voor de compensatie van schade aan derden is voorzien. Op een aantal andere punten ligt het nucleaire aansprakelijkheidsrecht duidelijk in de lijn van de evolutie van andere takken van het civiele aansprakelijkheidsrecht: ook elders wordt de aansprakelijkheid beperkt, is de rechter van één land exclusief bevoegd om kennis te nemen van de vordering en wordt uitgegaan van een regime van risicoaansprakelijkheid.

Wat overigens opvalt bij de studie van het Harvard Rapport en van het totstandkomen van het nucleaire aansprakelijkheidsrecht, zijn de inspanningen die men heeft gedaan om te voorkomen dat slachtoffers buiten het compensatiesysteem van het Verdrag een vordering zouden indienen. De rol die de VS hebben gespeeld bij het tot stand komen van het Verdrag inzake Bijkomende Compensatie van 1997 valt grotendeels te verklaren vanuit de schrik om in het nucleaire aansprakelijkheidsrecht te worden geconfronteerd met het "Amoco-Cadiz"-scenario ${ }^{18}$. Blijkbaar vinden slachtoffers van een kernongeval dus dat het nucleaire aansprakelijkheidsrecht onvoldoende bescherming biedt. Immers, indien een afdoende compensatiesysteem zou worden geboden, dan zouden slachtoffers er alle belang bij hebben om hun vordering binnen dat systeem in te dienen.

Vandaag lijkt het er eerder op dat slachtoffers die worden geconfronteerd met schade uit een kemongeval er belang bij hebben om het Verdrag van Parijs - of het Verdrag van Wenen - te omzeilen, bijvoorbecld door een vordering in te leiden in een land dat voldoende aanknopingspunten heeft met het kernongeval ${ }^{19}$ en dat geen lid is van het Verdrag.

Het internationale nucleaire aansprakelijkheidsrecht bevindt zich in feite in een paradoxale toestand: de bedragen waarvoor de exploitant aansprakelijk wordt gesteld, worden bewust laag gehouden om landen niet te zeer af te schrikken om tot het Verdrag toe te treden. Anderzijds weigert een aantal andere landen om tot het Verdrag toe te treden ingevolge de beperkte aansprakelijkheid en/of de lage beschikbare bedragen. Een internationaal Verdrag biedt dus niet steeds de beste garanties voor slachtoffers ${ }^{20}$.

Uit de juridische analyse blijkt dus dat ernstige vraagtekens kunnen worden geplaatst bij het "evenwicht" in het nucleaire aansprakelijkheidsrecht, met name bij de positie van slachtoffers van een kernongeval. In de mate waarin andere rechtstakken de/elfde principes hanteren als het nucleaire aansprakelijkheidsrecht, zullen de conclusies uit deze paragraaf evenzeer gelden voor het algemene milieuaansprakelijkheidsrecht.

18

19 Cfr. supra, $\$ 2.2 .8 .2$ van hoofdstuk 4 .

Hierbij wordt met name gedacht aan een land waar de exploitant of de leverancier van de exploitant omvangrijke bczittingen heeft.

Zie onze eerdere analyse Vanden Borre, T., "Dekking van het nucleaire risico op nationaalrechtelijke basis of via internationale Verdragen: de Verenigde Staten versus Europa", in Faure, M., Deketelaere, K. en Verhoosel, G., (red.), "Grensoverschrijdende milieuproblemen", I.c., 482. 


\section{VOOR WAT BETREFT HET ALGEMENE MILIEUAANSPRAKELIJKHEIDSRECHT}

Gelet op de plaats die de kanalisatie van aansprakelijkheid inneemt in dit onderzoek, kunnen enkele conclusies worden getrokken over de toepassing van de kanalisatie van aansprakelijkheid in het milieuaansprakelijkheidsrecht.

Risicoaansprakelijkheid wordt steeds geassocieerd met kanalisatie van aansprakelijkheid en met een gekwalificeerde aansprakelijkheid. Zowel de "klassieke" gevallen van risicoaansprakelijkheid onder het Belgische en Nederlandse BW, als de nieuwere gevallen van risicoaansprakelijkheid leggen de aansprakelijkheid bij een persoon die een bepaalde hoedanigheid bezit; in al deze gevallen wordt de aansprakelijkheid naar deze persoon gekanaliseerd.

Dit betekent dat in één klap twee zaken worden geregeld: er wordt een bijzondere aansprakelijkheidsgrondslag gecreëerd ${ }^{21}$ en er wordt een uitspraak gedaan over een mogelijk samenloopprobleem. Zodra een aansprakelijkheidsgrondslag inzake milieuschade een regime van risicoaansprakelijkheid introduceert én deze aansprakelijkheid kanaliseert naar een bepaalde persoon, kan niet echt worden gesproken van een algemene risicoaansprakelijkheid voor milieuschade. De desbetreffende grondslag zal namelijk uitsluitend kunnen worden ingeroepen ten aanzien van de personen naar wie de aansprakelijkheid wordt gekanaliseerd.

Uit het onderzoek is ook naar voren gekomen dat kanalisatie van aansprakelijkheid in verband staat met het aantal personen naar wie de aansprakelijkheid wordt gekanaliseerd, met het regresrecht van deze persoon of personen en met de vraag of het gemeen recht intact wordt gelaten hiermee wordt bedoeld dat bepaalde juridische grondslagen van het gemeenrechtelijke aansprakelijkheidsrecht worden buiten werking gesteld.

Wanneer de aansprakelijkheid slechts naar één persoon wordt gekanaliseerd, wanneer deze wes geen enkel regresrecht beschikt en wanneer het gemene aansprakelijkheidsrecht buiten werking wordt gesteld, kan worden gesproken van een exclusieve aansprakelijkheid. De aansprakelijkheid van de exploitant van een kerninstallatie kan als een exclusieve aansprakelijkheid worden beschouwd, met dien verstande dat de exploitant in een beperkt aantal gevallen over een regresrecht beschikt.

Het moet ook duidelijk zijn dat niets de wetgever belet om ook bij een regime van foutaansprakelijkheid deze aansprakelijkheid naar bepaalde personen te kanaliseren, c.q. om een gekwalificeerde foutaansprakelijkheid in te vocren.

Mogelijke rechtsdogmatische bezwaren tegen de kanalisatie van aansprakelijkheid zullen met name aan de orde zijn zodra de kanalisatie ertoe leidt dat het gemene aansprakelijkheidsrecht buiten werking wordt gesteld, hetzij door een beperking van het regres, hetzij door bepaalde juridische grondslagen uit te schakelen. In een dergelijk geval zullen slachtoffers slechts een beperkt aantal personen kunnen aanspreken voor de compensatie van de door hen geleden schadc; dan zal de kanalisatie van aansprakelijkheid namelijk een beschermende of exonererende werking hebben ten aanzien van een aantal potentiële schadeveroorzakers. 
Indien dus het begrip "kanalisatie van aansprakelijkheid" wordt gehanteerd, dient daar bijgevolg omzichtig mee te worden omgesprongen en verdient het de aanbeveling om telkens de drie genoemde variabelen af te wegen. Bijkomend onderzoek lijkt aangewezen om uit te maken of ook in andere takken van het recht gebruik wordt gemaakt van een (soort van) kanalisatie van aansprakelijkheid.

Een tweede conclusie in verband met het "algemene" milieuaansprakelijkheidsrecht houdt verband met het feit dat grote delen van het milieuaansprakelijkheidsrecht eveneens zijn gesteund op intemationale verdragen. Deze Verdragen pogen in hoofdzaak een zekere harmonisatie tot stand te brengen. Het nadeel van een verdrag is uiteraard dat het niet eenvoudig is om dit te wijzigen. Totnogtoe werd het Verdrag van Parijs nog niet ingrijpend gewijzigd. Ook de wijziging van het CLC-Verdrag was niet eenvoudig: het Protocol van 1984 is nooit in werking getreden. Enkel na nieuwe onderhandelingen kon een akkoord worden bereikt over het Protocol van 1992, dat in 1996 in werking is getreden ${ }^{22}$.

Daarnaast bestaat de kans dat bij het totstandkomen van een Verdrag een land het internationale forum aanwendt om de belangen van de eigen nationale industrie veilig te stellen, eerder dan oog te hebben voor de belangen van slachtoffers van een kernongeval. Dit is met name het geval voor de rol die de VS hebben gespeeld bij het totstandkomen van de nucleaire aansprakelijkheidsverdragen van de eerste én van de tweede generatie. Hetzelfde kan overigens worden gezegd voor een aantal westerse landen ten aanzien van de landen van het voormalige Oostblok en ten aanzien van een aantal Aziatische landen. 


\section{HOOFDSTUK 15}

\section{RECHTSECONOMISCHE CONCLUSIES}

Zoals in de inleiding werd aangegeven, was het de ambitie van dit onderzoek om de nucleaire aansprakelijkheidswetgeving in België en Nederland te toetsen, zowel aan de hand van de rechtseconomische analyse als op basis van enkele rechtsvergelijkende beschouwingen.

In de vorige hoofdstukken werd reeds een algemeen rechtseconomisch model van het ongevallenrecht aan de orde gesteld. Hieronder zal in eerste instantie het rechtseconomische model van het kernongevallenrecht worden uitgebouwd ( $\S 1$ ). In paragraaf 2 zullen ook de inzichten vanuit de rechtsvergelijkende analyse aan dit model worden getoetst. De conclusie wordt weergegeven in paragraaf 3 .

\section{RECHTSECONOMISCH MODEL VAN HET KERNONGEVALLENRECHT}

Het rechtseconomisch model van het kernongevallenrecht dient in feite te worden opgebouwd door eerst de basisprincipes van het nucleaire aansprakelijkheidsrecht rechtseconomisch te toetsen ( $\$ 1.1$ ). Derhalve zal eerst worden nagegaan hoe de basisprincipes van het nucleaire aansprakelijkheidsrecht die in het eerste deel van dit boek werden besproken, zich verhouden tot de rechtseconomische uitgangspunten van het ongevallenrecht. Op basis van deze analyse wordt de vraag beantwoord in welke mate het toekomstige nucleaire aansprakelijkheidsrecht de maatschappelijke welvaart zal doen toenemen ( $(1.2)$. Vervolgens wordt ook de verzekering van het nucleaire risico rechtseconomisch benaderd $(\S 1.3)$. Tenslotte wordt getracht om een verklaring te geven voor het huidige nucleaire aansprakelijkheidsrecht (\$1.4).

\subsection{De basisprincipes van het nucleaire aansprakelijkheidsrecht}

In eerste instantie wordt de vraag beantwoord of een regime van risicoaansprakelijkheid een betere bescherming biedt aan de slachtoffers van een kernongeval dan foutaansprakelijkheid $(\$ 1.1 .1)$. In tweede instantie wordt bestudeerd wat de economische gevolgen zijn van de beperking van de aansprakelijkheid van de exploitant $(\S 1.1 .2)$ en van de juridische kanalisatie van de aansprakelijkheid naar de exploitant van de kerninstallatic $(\S 1.1 .3)$. In $\$ 1.1 .4$ worden de gevolgen van de verplichte aansprakelijkheidsverzekering aan de orde gesteld. Vervolgens wordt onderzocht wat vanuit rechtseconomisch oogpunt het nut is van één exclusief bevoegde rechtbank (\$ 1.1.5). Tenslotte wordt aangegeven of het zinvol is om, naast deze verschillende maatregelen betreffende de civielrechtelijke aansprakelijkheid van de exploitant van een kerninstallatie, bijkomende veiligheidsregulering op te leggen $(\S 1.1 .6)$.

\subsubsection{Risicoaansprakelijkheid versus bescherming van slachtoffers van een kernongeval}

Het doel van het ongevallenrecht is volgens de rechtseconomische analyse het minimaliseren van de maatschappelijke ongevalskosten. De initiële vraag die aan de orde is, is of een tussenkomst van het recht is vereist om een dergelijke optimale allocatie van de beschikbare middelen te bewerkstelligen. Ronald Coase heeft aangetoond dat indien de markt perfect functioneert en indien er geen transactiekosten zijn, een rechtsregel geen invloed heeft op de efficiënte allocatie van de 
beschikbare middelen ${ }^{1}$. Een kernongeval daarentegen zal leiden tot massaschade; de exploitant wordt dus geconfronteerd met een zeer grote groep van slachtoffers. Deze slachtoffers zijn per definitie vreernden voor de exploitant. Bijgevolg zijn de transactiekosten prohibitief hoog, zullen ex ante geen onderhandelingen kunnen plaatshebben, en zal een tussenkomst van het recht vereis zijn om te leiden tot een optimale verdeling van de beschikbare middelen. De vraag rijst welké aansprakelijkheidsregel dit doel zal bereiken.

Kernongevallen zijn unilaterale ongevallen, aangezien enkel de dader (en niet het slachtoffer) een invloed heeft op het ongevalsrisico. Een slachtoffer kan hooguit indirect, en dan nog slechts tot op beperkte hoogte, de omvang van de schade beïnvloeden? ${ }^{2}$.

Daarenboven zal een stelsel van risicoaansprakelijkheid er evenmin als een stelsel van foutaansprakelijkheid in slagen om het hoofd te bieden aan een aantal klassieke problemen van het aansprakelijkheidsrecht bij milieuschade: ook bij risicoaansprakelijkheid moet de causaliteit worden bewezen, en kunnen de administratieve kosten van het ongeval hoog oplopen.

Vanuit rechtseconomische hoek bestaat er bij unilaterale ongevalsituaties, inzake de aansprakelijkheid voor milieuschade in het algemeen, een voorkeur voor een regime van risicoaansprakelijkheid. Bij risicoaansprakelijkheid zal de dader namelijk niet alleen optimale zorg aanwenden; hij zal eveneens een optimaal activiteitsniveau aanhouden. Bovendien zal de dader ook al die preventieve maatregelen nemen die niet in de betamelijke zorg van de foutstandaard kunnen worden geïncorporeerd. Het is niet zeker of de rechtseconomische voorkeur voor risico. aansprakelijkheid bij kemongevallen kan worden gemotiveerd door dit argument van het activiteitsniveau. Bij kemongevallen kan namelijk moeilijk worden gesproken van een optimaal activiteitsniveau: of een keminstallatie I $\mathrm{kWh}$, dan wel $1000 \mathrm{kWh}$ aan elektriciteit produceert, heef immers nauwelijks een invloed op het ongevalsrisico. Dit is geheel anders bij bijwoorbeeld autoongevallen, waar kan worden uitgegaan van een relatie tussen het aantal gereden kilometers en de kans op een ongeval. Zodra een kerninstallatie kritisch is - dit betekent dat een kemreactic op gang kan worden gebracht - bestaat het risico van een kernongeval. Wol kan ervan worden uitgegaan dat er een zeker verband bestaat tussen het vermogen van een reactor en de potentiële schadeomvang. Het is weinig waarschijnlijk dat een regime van risicoaansprakelijkheid tot gevolg heeft dat exploitanten kleinere kerninstallaties zouden bouwen. Het aannemen van het juiste activiteitsniveau kan dus moeilijk worden beschouwd als criterium om te kiezen voor een stelsel van risicoaansprakelijkheid in het kernenergierecht. Echter, er zijn wel andere argumenten waruit een voorkeur blijkt voor risicoaansprakelijkheid bij kernongevallen.

Bij een regime van foutaansprakelijkheid zal de dader aansprakelijk zijn indien hij onvoldoende zorg heeft aangewend; de dader zal dus enkel worden aansprakelijk gesteld indien hij minder zorg heeft besteed dan het niveau van de optimalc zorg. ${ }^{3}$. Maar een belangrijke randvoorwaarde bij decc stelling, is dat de rechter erin slaagt de juridische redelijke zorg te vertalen naar en gelijk te schakelen met het niveau van efficiënte zorg. De informatiekosten ter zake kunnen voor de rechter zeer hoog zijn. Inzake kemongevallen is het niet ondenkbeeldig dat het voor een rechter moei-

$1 \quad$ Cfr. supra, $\$ 4.2$ van hoofdstuk 7.

2 Hier moet voor ogen worden gehouden dat bij een kernongeval de schade aan derden nict noodzakelijk $z$ al worden veroorzaakt in de buurt van de keminstallaties. Door de weersomstandigheden bij het on. geval (voomamelijk dan in functie van de neerslag en de windrichting) kan de schade het grootst ajn op een aanzienlijke afstand van de installatie. 
lijk zoniet onmogelijk zal zijn om het niveau van betamelijke zorg correct in te schatten. Met andere woorden: in het nucleaire aansprakelijkheidsrecht kan een informatietekort in hoofde van de rechter leiden tot een aanzienlijk welvaartverlies. Bij hoge onzekerheid over de vraag wie de schade heeft veroorzaakt, is het overigens niet ondenkbeeldig dat het deepest pocket effect zal spelen en dat de exploitant de schade zal moeten vergoeden omdat hij hiervoor is verzekerd. De kans is reëel dat ofwel de exploitant niet aansprakelijk zal worden gesteld voor schade die hij heeft veroorzaakt (wat leidt tot een belangrijk probleem van externalisatie), ofwel dat hij wordt ansprakelijk gesteld voor schade die hij niet heeft veroorzaakt (waardoor hij een te hoog niveau van zorg zal aanwenden). Risicoaansprakelijkheid heeft het voordeel dat de beslissing over de te nemen zorg naar de dader wordt verschoven. Deze heeft vermoedelijk betere informatie over de optimale preventieve maatregelen ter voorkoming van nucleaire ongevallen dan de rechter ${ }^{4}$. Dit informatievoordeel in hoofde van de exploitant van een kerninstallatie, is dus een belangrijk argument voor risicoaansprakelijkheid.

Daarenboven heeft de foutaansprakelijkheid als nadeel dat deze regel de exploitant alleen prikkels zal geven om die preventieve maatregelen te nemen die de rechter kan herkennen bij het beoordelen van de betamelijke zorg. Het is goed mogelijk dat de exploitant ook andere efficiënte preventieve maatregelen zou kunnen nemen ter reductie van het ongevalsrisico. Foutaansprakelijkheid biedt daartoe geen prikkels, terwijl de exploitant onder een regime van risicoaansprakelijkheid alle efficiënte preventieve maatregelen zal nemen, ongeacht de vraag of de rechter deze al dan niet zal herkennen. Dit vormt een belangrijk aanvullend argument ten voordele van een regime van risicoaansprakelijkheid in het nucleaire aansprakelijkheidsrecht.

Tenslotte dienen de administratieve kosten die gepaard gaan met het bewijzen van een fout in aanmerking te worden genomen. Vanwege de complexiteit van het nucleaire risico kunnen de administratieve kosten van de foutbeoordeling zeer hoog oplopen.

Vandaar verdient het toch de voorkeur om bij kernongevallen het regime van risicoaansprakelijkheid te behouden, zelfs indien het onzeker is in welke mate de risicoaansprakelijkheid in het kernenergierecht een invloed kan hebben op het activiteitsniveau. De andere argumenten pro risicoaansprakelijkheid zijn evenwel doorslaggevend. Hiermee is niet gezegd dat uitsluitend een regime van risicoaansprakelijkheid in staat is om de administratieve kosten van een kernongeval optimaal te reduceren. Weliswaar komen de kosten voor het bewijzen van een fout te vervallen; onder een regime van risicoaansprakelijkheid echter leidt elk ongeval tot een procedure. Gelet op het grote aantal potentiële slachtoffers bij een kemongeval kunnen de kosten van de administratieve afhandeling van een (risico)aansprakelijkheid toch ook zecr hoog oplopen.

\subsubsection{Beperking van de aansprakelijkheid van de exploitant van de kerninstallatie en ter beschikking stellen van openbare middelen}

Een tweede belangrijk principe in het nucleaire aansprakelijkheidsrecht is de beperking van de aansprakelijkheid van de exploitant van een kerninstallatie ( $\$ 1.1 .2 .1)$; daarenboven stelt, tenminste wat de verdragspartijen van het Aanvullend Verdrag van Brussel betreft, de overheid ook publieke fondsen ter beschikking van de exploitanten ( $\S$ 1.1.2.2).

Cooter, R., "Prices and Sanctions", Columbia Law Review, n 84, 1984, 1523. 


\subsubsection{Beperking van de aansprakelijkheid van de exploitant}

De beperking van het bedrag van de aansprakelijkheid lijkt haaks te staan op de economische uitgangspunten van het ongevallenrecht. Een eerste gevolg van de beperkte aansprakelijkheid is uiteraard dat zodra de schade van het kernongeval groter is dan dit bedrag, aan slachtoffers het recht op volledige schadevergoeding wordt ontzegd. Dit betekent dat niet alle negatieve exteme effecten van het gebruik van kernenergic worden geïnternaliseerd. Dit leidt tot een overconsumptie van kernenergie voor wat betreft de productie van elektriciteit. Een deel van de kosten van het nucleaire risico wordt door de limitering op de gemeenschap en dus op de belastingbetaler afgewenteld. Er kan dan ook worden gesproken van een subsidie aan de nucleaire industrie: de nucleaire sector moet niet alle kosten dragen van het door haar gecreëerde risico.

Dit kan ook een belangrijk aspect zijn in het kader van de liberalisering van de elektriciteitsmarkt $^{5}$ : er zal slechts sprake zijn van een eerlijke concurrentie tussen de producenten indien de verschillende energiebronnen de volledige kosten van het productieproces in rekening moeten brengen. Het hoeft dan ook niet te verbazen dat bijvoorbeeld in België, graag wordt uitgepakt met het argument dat kernenergie zeer goedkoop is in vergelijking met andere energiebronnen ${ }^{6}$. Van een correcte vergelijking tussen de verschillende prijzen aan de consument kan-evenwel slechts sprake zijn indien de negatieve externe effecten van de productie van kernenergie ten volle worden geinternaliseerd.

Vanuit de optiek van het rationeel energiegebruik is het ook belangrijk dat alle energiebronnen volledig de negatieve effecten internaliseren: enkel indien de burger de volledige kosten van de elektriciteitsproductie moet dragen, kan hij een rationele beslissing nemen over zijn consumptiapatroon. Hiemee is niet gezegd dat kemenergie de enige energiebron is die wordt gesubsidieerd; bijkomend onderzoek zal moeten uitwijzen of aan andere energiebronnen niet evenzeer een subsidie wordt gegeven ${ }^{7}$.

Zelfs. zonder de wettelijke beperking van de aansprakelijkheid van de exploitant van de kerninstallatie, kan worden aangenomen dat de facto de aansprakelijkheid van de exploitant zal zijn beperkt tot maximaal zijn gehele vermogen. Er mag worden aangenomen dat de door een zwar kernongeval veroorzaakte schade groter zal zijn dan het vermogen van de exploitant. Dit impliceert dat, zelfs indien een stelsel van onbeperkte aansprakelijkheid zou gelden, deze aansprakelijkheid de facto zou zijn begrenșd. In rechtseconomische termen betekent dit dat er in het nucleaire aansprakelijkheidsrecht een probleem rijst van underdeterrence. De exploitant zal hande-

Richtlijn nr. 96/92/EG van het Europees Parlement en de Raad van de Europese Unie van 19 december 1996 betreffende gemeenschappelijke regels voor de inteme markt voor elektriciteit (PB, 1997, L 27). Omgezet in Nederlands recht bij wet van 2 juli 1998, houdende regels met betrekking tot de productic, het transport en de levering van elektriciteit (Stb., 1998, 427). Omgezet in Belgisch recht bij wet van 29 april 1999 betreffende de organisatie van de elektriciteitsmarkt (B.S. 11 mei 1999) en Decreet van 17 juli 2000 houdende organisatie van de Belgische elektriciteitsmarkt (B.S., 22 september 2000). Zie hierover Deketelacre, K., De Cock, K., Deridder, L. en Verhoosel, G., Handboek Energierech, Intersentia, Antwerpen-Groningen, 2001, 91 e.v.

Zie bijvoorbeeld het dossier in Knack nr. 44 van november 2000, 35, waar wordt aangegeven dat de kostprijs (uitgedrukt in BEF/kWh) voor kemenergie 1 i 2 frank bedraagt, tegenover 4 frank voor hydraulische energie en 4,5 frank voor wiridmolens.

Onderzoek heeft aangegeven dat ook in de Verenigde Staten de kemenergie-industric van een subsidie kan genieten (Heyes, A. en Liston-Heyes, C., "Capping Environmental Liability: the Case of North American Nuclear Power", The Geneva Papers on Risk and Insurance, vol. 25, $\mathrm{n}^{6} \mathrm{2}, 2000,196-202$ ). 
len alsof zijn maximale schade gelijk is aan de wettelijke beperking of aan de feitelijke aansprakelijkheidsbeperking. De eenvoudige conclusie is dan ook dat de beperking van aansprakelijkheid in de nucleaire aansprakelijkheidswetgeving een negatieve invloed heeft op de prikkels tot het nemen van preventieve maatregelen. In de rechtseconomische literatuur is immers aangetoond dat cen risicoaansprakelijkheid alleen efficiënt is wanneer de dader ertoe gehouden wordt om de totale schade integraal te vergoeden ${ }^{8}$. Er is bijgevolg nood aan een model dat de gevolgen van deze underdeterrence opvangt en dat wel in staat is om ervoor te zorgen dat de exploitant van een. kerninstallatie, evenals de andere personen die een invloed hebben op het nucleaire risico - zoals de leveranciers van de exploitant - voldoende prikkels hebben om preventieve maatregelen te nemen.

In het nucleaire aansprakelijkheidsrecht wordt de aansprakelijkheid van de exploitant van de keminstallatie ook beperkt in de tijd. Ook op dit vlak verschilt de Nederlandse WAKO van de Belgische nucleaire aansprakelijkheidswet. In de WAKO wordt een onderscheid gemaakt al naargelang de vorderingen betrekking hebben op letselschade (vervaltermijn van 30 jaar) dan we! zaakschade (vervaltermijn van 10 jaar). In België wordt dit onderscheid niet gemaakt en vervalt de aansprakelijkheid van de exploitant 10 jaar na het kernongeval. In beide landen is eenzelfde: verjaringstermijn van kracht: zodra een slachtoffer weet heeft of redelijkerwijze weet kan hebben van de schade, beschikt hij maximaal over een periode van drie jaar om zijn vordering in te dienen. Na de periode van 10 jaar stelt de Belgische Staat zich kosteloos garant; de Nederlandse Staat zal optreden als verzekeraar of als garant, maar kan hiervoor wel degelijk een vergoeding vragen.

Met name ten aanzien van letselschade zal het, naarmate meer tijd verstrijkt tussen het ongeval en het indienen van de vordering, moeilijker worden om de causaliteit vast te stellen tussen de schade en het kernongeval. Dit is problematisch, zowel vanuit het standpunt van de exploitant als vanuit het standpunt van het slachtoffer. Voor deze laatste wordt het nagenoeg onmogelijk om het bewijs aan te brengen dat zijn schade door het kemongeval is veroorzaakt; de exploitant loopt het risico dat een foutieve rechterlijke beslissing hem aansprakelijk zal stellen voor een schade die hij niet heeft veroorzaakt ${ }^{9}$. Aangezien de exploitant van een kerninstallatie op basis van het huidige nucleaire aansprakelijkheidsrecht niet aansprakelijk is voor schade die zich na 10 jaar of na 30 jaar manifesteert, wordt slechts een deel van de reële schade geïntemaliseerd.

Het nucleaire aansprakelijkheidsrecht zoals neergelegd in het Verdrag van Parijs van 1960 (en het Aanvullend Verdrag van Brussel van 1963) leidt evenwel tot een dubbele subsidiëring van de kernenergie-industrie. Naast de wettelijke beperking van de aansprakelijkheid, stellen de verschillende verdragsluitende staten geld ter beschikking ingeval de schade groter is dan het beperkte bedrag van aansprakelijkheid van de exploitant.

Cooter, R., "Prices and Sanctions", a.c., 1523.

Het spreekt voor zich dat het achterhalen van de causaliteit ook zal leiden tot een aanzienlijke verhoging van de tertiaire ongevalskosten. 


\subsubsection{Ter beschikking stellen van openbare fondsen}

In de landen die zijn toegetreden tot het Aanvullend Verdrag van Brussel en die zullen toetreden tot de nucleaire aansprakelijkheidsverdragen van de tweede generatic ${ }^{i 0}$, wordt de subsidie versterkt omdat tegelijk wordt voorzien in een Staatstussenkomst. Op dit punt valt een opmerkelijk verschil vast te stellen tussen het Belgische en het Nederlandse nucleaire aansprakelijkheidsrecht.

In Belgiê werd de overheidstussenkomst in de tweede schijf van het Aanvullend Verdrag van Brussel afgeschaft door de wet van 11 juli 2000. Onder de oorspronkelijke versie van de wet van 22 juli 1985 was wel degelijk voorzien in een tussenkomst van de Belgische Stat als installatiestaat - namelijk voor een bedrag van 151,27 miljoen euro. Eén van de opvallendste elementen van de Nederlandse WAKO is de zeer hoge staatstussenkomst ( 5 miljard gulden of 2,27 niljard euro) als installatiestaat. Toch kan niet echt worden gesproken van een subsidie aangezien de WAKO voorziet in de mogelijkheid dat de Nederlandse Staat aan de exploitant een vergoeding vraagt voor het ter beschikking stellen van dit bedrag ". In welke mate de Nederlandse Stat inderdaad een vergoeding aanrekent aan de exploitant, is echter niet duidelijk.

Dit neemt echter niet weg dat, ten aanzien van de derde schijf van het Aanvullend Verdrag van Brussel (collectieve schijf van de verschillende verdragsluitende Staten), de tussenkomst van zowel Belgie als Nederland behouden blijft en dat nergens in het Verdrag bepalingen zijn opgenomen om hiervoor aan de exploitanten een vergoeding aan te rekenen. Hetzelfde geldt voor het Verdrag inzake Bijkomende Compensatie. Op basis van het Aanvullend Verdrag van Brussel bedraagt de bijdrage waarop de exploitant kan rekenen 178,88 miljoen euro en onder het Verdrag inzake Bijkomende Compensatie 429,31 miljoen euro - dit uiteraard in de veronderstelling dat de schade groter is dan het bedrag dat beschikbaar is op basis van de aansprakelijkheidsverzekering van de exploitant.

Vanuit rechtseconomisch oogpunt valt de tussenkomst van de verschillende verdragsluitende Staten in 1963 te verklaren vanuit een probleem van informatieasymmetrie: de overheidstussenkonst in de jaren zestig was uitdrukkelijk bedoeld om het informatietekort in hoofde van de verzekeraars tegen te gaan. Er waren nauwelijks gegevens voorhanden die toelieten om het nucleaire risico in te schatten. Bij de aanvang van de eenentwintigste eeuw daarentegen zijn reeds heel wat gegevens beschikbaar die de inschatting van de actuariële premie een stuk minder problematisch maakt dan in 1960 . Het is met andere woorden zeer de vraag of de informatieasymmetrie even acuut is als in de jaren vijftig. Toch heeft de overheid geen blijk gegeven van de intentic om de dubbele subsidiëring van de kernenergie-industrie af te bouwen: het in werking treden van het Verdrag inzake Bijkomende Compensatie zal integendeel leiden tot een bestendiging van dit beleid.

Door de afschaffing van de tussenkomst als installaticstaat kan België als een uitzondering worden aanzien; maar indien België bijvoorbeeld zou toetreden tot het Verdrag inzake Bijkomende Compensatic, moet erover worden gewaakt dat deze tussenkomst niet opnieuw wordt ingevoerd.

Dit geldt in ieder geval voor het Verdrag inzake Bijkomende Compensatie; voor wat betreft het Proticol van het Verdrag van Wenen, beschikt een land over de mogelijkheid om zelf overheidsfondsen ter beschikking te stellen.

"I In de Belgische wet van 22 juli 1985 is een dergelijke mogelijkheid niet opgenomen. 


\subsubsection{Juridische kanalisatie van aansprakelijkheid naar de exploitant van een kerninstal- latie}

De aansprakelijkheid zoals die is ingevoerd in het internationale nucleaire aansprakelijkheidsiecht werd officieel ingevoerd om piramidale verzekeringskosten te vermijden. Uit de juridische analyse van de kanalisatie van aansprakelijkheid is gebleken dat de kanalisatie in feite is bedoeld als bescherming van de Amerikaanse nucleaire toeleveringsindustrie ${ }^{12}$. In deze paragraaf wordt bestudeerd in welke mate de kanalisatie inderdaad leidt tot een reductie van de piramidale verzekeringskosten en welke, meer in het algemeen, de gevolgen zijn van deze juridlische kanalisatie of exclusieve asnsprakelijkheid van de exploitant.

Hieronder wordt in eerste instantie bestudeerd of het Coase-theorema kan worden toegepast op de kanalisatie van aansprakelijkheid (§ 1.1.3.1). Vervolgens wordt de kanalisatie van aansprakelijkheid bestudeerd vanuit de Calabresiaanse visie $(\S 1.1 .3 .2)$ en worden, vanuit een rechtseconomische benadering, de functie en de gevolgen belicht van de juridische kanalisatie van aansprakelijkheid $(\$$ 1.1.3.3).

\subsubsection{Invloed van de kanalisatie van aansprakelijkheid op de toepassing van het Coase- theorema.}

In deze paragraaf wordt bestudeerd in welke mate - inzake de juridische kanalisatie van aansprakelijkheid - in het nucleaire aansprakelijkheidsrecht toepassing kan worden gernaakt van het Coasetheorema. Deze vraag is met name aan de orde met betrekking tot de positie van de leveranciers van de exploitant. Hieronder wordt zowel de relatie tussen de exploitant van de kerninstallatie en zijn leverancier, als tussen de leverancier en de slachtoffers van een kernongeval aan de orde gesteld. Voor wat de eerstgenoemde relatie betreft, moet zowel de toepassing van het Coase-theorema ten aanzien van de schade aan derden, als ten aanzien van de eigenschade van de exploitant worden besproken.

De exploitant van een keminstallatie en zijn leverancier staan in cen contractuele relatic, zodat mag worden aangenomen dat de transactiekosten niet prohibitief hoog zijn. Op voonwaarde dat de markt voldoende concurrentieel is, zal geen tussenkomst van het recht vereist zijn teneinde te komen tot een optimale allocatie van de beschikbare middelen. Dit zou impliceren dat het van geen belang is of de leveranciei dan wel de exploitant uiteindelijk de schade zal moeten dragen ${ }^{13}$.

In deze hypothese kunnen de exploitant en de leverancier in principe vooraf afspreken wie de schade bij een kemongeval zal vergoeden. De uitkomst van deze onderhandelingen zal meteen een invloed hebben op de prijs van het geleverde materiaal: indien de leverancier de schade moet vergoeden, zal hij dit in aanmerking nemen bij de prijsberekening. In de meest eenvoudige vorm neemt hij hiervoor een verzekering en de premie berekent hij door in de prijs van het geleverde materiaal. Indier de exploitant de schade dient te vergoeden, zal het materiaal goedkoper zijn en kan hij eventueel een verzekeringscontract afsluiten. Op het eerste gezicht kan dus in het nucleaire aansprakelijkheidsrecht in cen contractuele relatie informatie worden doorgegeven via het prijsmecharisme. Tegelijk zou

Cfr. supra, in $\S 2$ van hoofdstuk 4.

Zie onzc ecrdere analyse Vanden Borre T., "Transplantatie van kanalisatie van aansprakelijkheid van het kernenergierecht naar het milieu(aansprakelijkheids-)recht: een goede of een gebrekkige zaak?", in Faure, M. en Deketelaere, K., (red.), "Ius Commune en Milieurecht", l.c., 364 e.v. 
kunnen worden afgesproken dat de exploitant in bepaalde gevallen over een regresrecht beschikt tegen de leverancier.

Maar in het nucleaire aansprakelijkheidsrecht wordt het regresrecht van de exploitant ten aanzien van de door hem aan slachtoffers betaalde schadevergoeding beperkt, in die zin dat het regres enkel kan worden uitgeoefend indien dit contractueel werd overeengekomen. Dit impliceert een beperking van de onderhandelingspositie van de exploitant ten aanzien van het gemene aansprakelijkheidsrecht. In het gemene aansprakelijkheidsrecht zal in de regel een regresrecht openstaan, tenzij contractueel anders werd overeengekomen. In het nucleaire aansprakelijkheidsrecht is deze situatie precies omgekeerd. Wordt niets afgesproken tussen de exploitant van de keminstallatie en zijn leveranciers, dan zal de exploitant - of zijn verzekeraar - geen regresrecht kunnen instellen. In de praktijk blijken de overeenkomsten inderdaad niet in een regresrecht te voorzien.

Tegelijk moet worden vastgesteld dat slechts een beperkt aantal leveranciers van nucleair materiaal op de markt actief is. Dit was zeker zo bij de totstandkoming van de Verdragen van Parijs en Wenen: toen hadden de VS een monopolie op nucleaire kennis. Precies dankzij dit monopolie zijn zij erin geslaagd om een invloed uit te oefenen op de verdragsteksten: via de kanalisatie van aansprakelijkheid wordt niet alleen ingegrepen in de exteme relatie (leverancier-derden), maar eveneens in de inteme relatie (leverancier-exploitant). Er kan dan ook worden gesteld dat in het nucleaire aansprakelijkheidsrecht de voor de toepassing van het Coase-theorema vereiste vrije onderhandelingen reeds van tevoren zijn beperkt. De spelregels van de onderhandelingen zijn opgesteld ten voordele van de leveranciers. Dit kan worden aanzien als een transactiekost, wat de toepasbaarheid van het Coasetheorema in de relatie tussen de exploitant en zijn leverancier beperkt, ten minste ten aanzien van de aan derden veroorzaakte schade.

Een tweede element in de relatie tussen de exploitant en zijn leverancier, is de eigenschade van de exploitant. Een kernongeval zal in de eerste plaats schade toebrengen aan de keminstallatie zelf. Op deze hypothese is het Verdrag van Parijs niet van toepassing, zodat de spelregels niet van tevoren werden aangepast. Bij toepassing van het Coase-theorema kan de exploitant dus ex ante met zijn leverancier afspreken wie de gevolgen zal moeten dragen van de schade aan de keminstallatic, indien deze schade het gevolg is van een gebrek waarvoor de leverancier moet instaan (gebrekkig onderhoud, gebrek in een onderdeel van de reactor, etc.).

In de relatie tussen de leverancier en het slachtoffer zullen de transactiekosten prohibitief hoog zijn, zodat een tussenkomst van het recht zal nodig zijn. In de veronderstelling dat de aansprakelijkheid niet zou worden gekanaliseerd, betekent dit dat de leverancier ten aanzien van het slachtoffer over een prikkel zal beschikken om schade te vermijden. Maar precies deze situatie is in het nucleaire aansprakelijkheidsrecht onmogelijk gemaakt: door de aansprakelijkheid exclusief naar de exploitant van de kerninstallatie te kanaliseren, is de leverancier ten aanzien van het slachtoffer juridisch volledig geëxonereerd. De leverancier zal bijgevolg ten aanzien van het slachtoffer geen prikkel hebben vanuit het extracontractuele aansprakelijkheidsrecht.

Tot op zekere hoogte kan worden aangenomen dat de leverancier, zelf bij een systeem van kanalisatie van aansprakelijkheid naar de exploitant van een kerninstallatie, een prikkel zal hebben ten aanzien van het slachtoffer van een kernongeval, met name via de doorwerking van de contractuele 
prikkel voor wat betreft de eigenschade van de exploitant ${ }^{14}$. Maar deze stelling gaat enkel op ten aanzien van de eigenschade die door een kernongeval wordt toegebracht aan de exploitant. Het is zeer aannemelijk om ervan uit te gaan dat deze eigenschade een stuk lager zal liggen dan de totale schade van een kemongeval. Het doorwerken van de contractuele prikkel zal dus slechts een beperkte correctie aanbrengen aan de stelling dat de leverancier geen prikkel heeft ten aanzien van slachtoffers van een kemongeval.

\subsubsection{Reductie van de ongevalskosten volgens Calabresi}

Guido Calabresi onderscheidt de primaire, de secundaire en de tertiaire ongevalskosten ${ }^{15}$. De primaire ongevalskosten zijn de kosten veroorzaakt door het aantal ongevallen en van de emst daarvan. Met secundaire ongevalskosten bedoelt Calabresi de kosten van schadespreiding. Tertiaire kosten zijn de kosten die gepaard gaan met het afhandelen van ongevallen. De reductie van de tertiaire ongevalskosten beoogt in feite de reductie van de primaire en de secundaire ongevalskosten. Een efficiënt ongevallenrecht moet ernaar streven de totale ongevalskosten zo laag mogelijk te houden. De vraag rijst hoe dit zich verhoudt tot het nucleaire aansprakelijkheidsrecht.

In de visie van Calabresi worden de primaire ongevalskosten gereduceerd door het uitoefenen van optimale zorg. Een persoon zal zorgvuldig handelen, voorzover hij hiertoe een prikkel krijgt. De vaagt rijst dan ook wat de invloed is van de kanalisatie van aansprakelijkheid op de prikkels van de exploitant van de kerninstallatie en van diens leveranciers.

In onze analyse wordt ervan uitgegaan dat grosso modo twee personen een invloed kunnen hebben op het ongevalsrisico (dat er met andere woorden slechts een tweetal potentiële daders zijn): in de eerste plaats de exploitant zelf, en in de tweede plaats de leveranciers van de exploitant. Hiermee worden ook degenen bedoeld die bij de bouw of tijdens de exploitatie bepaalde onderdelen leveren of die onderhoudswerkzaamheden uitvoeren.

Op basis van het nucleaire aansprakelijkheidsrecht, is de exploitant aansprakelijk ten overstaan van de slachtoffers van het kernongeval. Dit betekent dat, in de visie van Calabresi, de exploitant een prikkel zal hebben om de primaire ongevalskosten te reduceren. De leverancier van de exploitant daarentegen is niét aansprakelijk ten aanzien van derden. De leverancier heeft dan ook vanuit het extracontractuele aansprakelijkheidsrecht geen prikkel tegenover een slachtoffer om veilig materiaal te leveren.

Hieruit volgt dat diegenen die ten aanzien van het slachtoffer genieten van de beschermende werking van de kanalisatie van aansprakelijkheid, een onvoldoende prikkel hebben om optimale zorg uit te oefenen ${ }^{16}$ waardoor het ongevalsrisico toeneemt en de primaire ongevalskosten stijgen. De kanalisatie van aansprakelijkheid past derhalve niet in de Calabresiaanse visie inzake de reductie van de primaire ongevalskosten.

Niet alleen de primaire ongevalskosten, maar ook de secundaire ongevalskosten dienen in een rechtseconomische benadering van het ongevallenrecht te worden gereduceerd. Kosten om een

Vanden Borre T., "Transplantatie van kanalisatie van aansprakelijkheid van het kernenergierecht naar het milieu(aansprakelijkheids-)recht: een goede of een gebrekkige zaak?", in Faure, M. en Deketelaere, K., (red.), "Ius Commune en Milieurecht", l.c., 365.

Cfr. supra, in $\$ 4.1$ van hoofdstuk 7.

Ook in die zin Faure, M. en Van den Bergh, R., "Objectieve Aansprakelijkheid", l.c., 353. 
optimale schadespreiding te realiseren zoals verzekeringskosten, worden beschouwd als secun. daire ongevalskosten. Officieel werd de kanalisatie van aansprakelijkheid in het kernenergierecht ingevoerd met het oog op de reductie van de verzekeringskosten. Door kanalisatie zouden piramidale verzekeringskosten worden vermeden: toegepast op het nucleaire aansprakelijkheidsrecht betekent dit dat indien alle leveranciers van de exploitant van een kerminstallatie elk een dekking zouden moeten nemen voor de uit een kernongeval voortvloeiende schade, dit zou leiden tot hoge premies, zonder enig evenredig voordeel voor het slachtoffer.

De stelling dat de kanalisatie van aansprakelijkheid (of de exclusieve aansprakelijkheid) zou bijdragen tot de reductie van de verzekeringskosten gaat uit van de veronderstelling dat de verzekeringskosten stijgen indien meerdere personen een dekking nemen voor eenzelfde risico. De vraag rijst uiteraard of dit argument correct is. Er moet namelijk worden vastgesteld dat dit argument enkel in het nucleaire aansprakelijkheidsrecht wordt gehanteerd. In andere takken van he: civiele aansprakelijkheidsrecht wordt ofwel de aansprakelijkheid niet gekanaliseerd, ofwel word: slechts een lichte vorm van kanalisatie ingevoerd ${ }^{17}$. De vraag moet dus worden beantwoord of in alle situaties waarin meerdere personen het ongevalsrisico kunnen beïnvloeden (c.q. dader kunnen zijn), de verzekeringskosten kunnen worden gedrukt indien slechts één van de mogelijke aan te spreken personen zich voor het bewuste risico verzekert.

Het feit dat meerdere personen zich voor eenzelfde risico verzekeren betekent niet dat hierdoor de verzekeringskosten stijgen. Er kan in tegendeel vanuit worden gegaan dat de gemiddelde kosien van een bepaalde verzekeringsdekking afnemen naarmate meer polissen worden afgesloten. Bovendien zal ook het premievolume toenemen naarmate meer personen een verzekeringsdekking wensen aan te schaffen.

In het nucleaire aansprakelijkheidsrecht daarentegen moet de exploitant zich echter niet alleen verzekeren voor het risico dat hijzelf vertegenwoordigt, maar eveneens voor het risico dat door zijn leverancier(s) wordt veroorzaakt. Voor een verzekeraar is het echter niet makkelijk om het risico in te schatten van andere personen dan de verzekeringsnemer, zeker ten aanzien van een kernongeval. De verzekeraar kan namelijk het gedrag van zijn eigen verzekeringsnemer controleren; het is veel moeilijker om ook het gedrag te controleren van personen waarvoor zijn verzekeringsnemer moet instaan, met name wanneer deze personen een invloed hebben op het ongevalsrisico (i.c. de leveranciers van de exploitant).

Het essentiële punt bij de exclusieve aansprakelijkheid in het intemationale kemenergierecht is dat de exploitant niet over de mogelijkheid beschikt om via onderhandelingen met de leveranciers af te spreken wie het uiteindelijke risico zal dragen. Indien de exploitant over een regresrecht zou beschikken, dan kan ex ante worden afgesproken wie de uiteindelijke ansprakelijkheidslast zal dragen. Dit zal zijn weerslag hebben op de prijs van het geleverde materiaal.

Precies op dit punt verschilt het Europese van het Amerikaanse nucleaire aansprakelijkheidsrecht. Aangezien in de Verenigde Staten het gemene aansprakelijkheidsrecht intact is gelaten, kunnen leveranciers en exploitanten van tevoren onderhandelen over de aansprakelijkheidslast. De aansprakelijkheid van de leverancier is gedekt via de omnibuspolis van de exploitant van de kerninstallatic; dit zal een weerslag hebben op de prijzen van de geleverde goederen en diensten. In de landen die lid zijn van de internationale nucleaire aansprakelijkheidsverdragen is de situatie anders. De juridische kanalisatie van aansprakelijkheid in het nucleaire aansprakelijkheidsrecht lciơt 
tot een welvaartsverlies, omdat de mogelijkheden om belangrijke signalen door te geven via het prijzenmechanisme worden ontnomen. Met name het beperken van het regresrecht van de cxploitant en de aansprakelijkheidsexclusiviteit blijken dus zeer nadelig te zijn.

De stelling dat de kanalisatie van aansprakelijkheid naar de exploitant van een kerninstallatie leidt tot een reductie van de secundaire ongevalkosten, is derhalve niet correct.

De kosten die gepaard gaan met het afhandelen van aansprakelijkheidsvorderingen, worden in de rechtseconomische literatuur "administratieve kosten" genoemd ${ }^{18}$. Deze kosten omvatten zowel de tijd en de inspanningen door slachtoffers, daders, hun advocaten en verzekeraars om de vordering te regelen, hetzij onderling, hetzij voor de rechtbank. Ook de kosten die met de onderlinge regeling gepaard gaan en de proceskosten maken in deze visie deel uit van de administratieve kosten. Posner wijst er terecht op dat administratieve kosten, en meer in het bijzonder informatiekosten een belangrijke rol spelen bij het formuleren van efficiënte aansprakelijkheidsregels ${ }^{12}$. De in het Harvard rapport aangehaalde procesrechtelijke reden ter invoering van de kanalisatie beoogde een reductie van deze tertiaire ongevalskosten (met name de kosten veroorzaakt door de moeilijkheden en het tijdverlies bij internationale procesvoering).

De kanalisatie van aansprakelijkheid moet hier worden gezien in samenhang met één van de andere basisprincipes van de nucleaire aansprakelijkheidswetgeving, namelijk de exclusieve bevoegdheid van één rechter per land. Het feit dat een slachtoffer weet welke rechter bevoegd zal zijn, biedt een aanzienlijke rechtszekerheid en bespaart hem de moeite vruchteloos in het buitenland te procederen. Ook de directe vordering van het slachtoffer tegen de verzekeraar van de exploitant, is hierbij belangrijk.

Een snelle afhandeling van de vordering is vanuit economisch oogpunt zinvol omdat het de maatschappelijke kosten van een kemongeval in belangrijke mate reduccert, met name de tertiaire ongevalskosten: de procedure zelf zal minder kosten en voor slachtoffers leidt dit ertoe dat $z i j$ geringere advocatenkosten zullen dienen te dragen en dat hun schadc sneller wordt gecompenseerd. Het argument dat de kanalisatie van aansprakelijkheid de kosten van de procesvoering reduceert is dus correct: slachtoffers zullen slechts de exploitant van de kerninstallatie (of diens verzekeraar) dagvaarden en deze zal slechts in bepaalde gevallen een regresrecht kunnen uitoefenen.

De immuniteit van de leveranciers leidt er evenwel toe dat de reductie van deze kosten gepaurd gaat met belangrijke negatieve effecten wat betreft de preventie van kernongevallen. Het is met andere woorden onzeker of de daling van de proceskosten een voldoende opbrengst is voor slachtoffers wiens vorderingsrechten zwaar zijn beperkt. Deze problematiek wordt hieronder aan de orde gesteld bij de analyse van de functie en de gevolgen van de kanalisatie van aansprakelijkheid vanuit rechtseconomische hoek.

Shavell, S., "Accident Law", l.c., 262 e.v.; Faure, M. en Van den Bergh, R., "Objectieve Aansprakelijkheid", l.c., 98.

Posner, R., "Fconomic Analysis of Law", l.c., 167. 


\subsubsection{Functie en gevolgen van de kanalisatie van aansprakelijkheid vanuit rechtseconomische hoek}

De kanalisatie van aansprakelijkheid werd in het nucleaire aansprakelijkheidsrecht ingevoerd om de proceskosten van een ongeval terug te dringen ${ }^{20}$. De redenering hierbij was dat een exclusieve aansprakelijkheid in hoofde van de exploitant van de kerninstallatie blijkbaar een aantal voordelen oplevert. De vraag rijst evenwel of de beperking van het aantal schuldenaars - hiermee words bedoeld het aantal personen dat kan worden aangesproken voor de vergoeding van de schade uit een kernongeval - voordelen biedt voor slachtoffers van een kernongeval, dan wel voor de potentiële daders, of voor allebei.

Een rechtszaak naar aanleiding van een kernongeval is een vorm van zogenaamde massaschade ${ }^{21}$ : voor één enkele rechtbank zullen duizenden slachtoffers trachten compensatie te krijgen van de door hen geleden schade. Op het eerste gezicht lijkt het aannemelijk om. ervan uit te gaan dar de rechtsgang versnelt en de administratieve kosten dalen, wanneer het aantal personen dat tot de rechtbank wordt toegelaten, wordt beperkt. Hier moet in eerste instantie worden aangegeven dat het probleem bij massavorderingen zich niet zozeer situeert aan de kant van de verweerders (exploitant en zijn leveranciers), maar aan de kant van de eisers (slachtoffers van een kernongeval), Het is namelijk zeer de vraag of de administratieve kosten van het proces aanzienlijk dalen doordat de slachtoffers slechts tegen én verweerder een vordering kunnen indienen, in plaats van tegen twee of drie verweerders.

Verder kan worden gesteld dat door het afschaffen van samenloop als gevolg van de kanalisatie het aantal potentiële schuldenaars voor de slachtoffers verkleint, terwijl het voor deze laatsten precies voordelig kan zijn meerdere personen aan te spreken, zoals bijvoorbeeld bij een vordering inzake productaansprakelijkheid. De vraag naar de voordelen van de juridische kanalisatie van aansprakelijkheid is daarom terug te voeren naar de belangenafweging tussen de voordelen op het gebied van de reductie van de administratieve kosten en de nadelen veroorzaakt door de afbreuk aan de verhaalspositie. Het is evenwel lang niet zeker of de marginale opbrengsten van kanalisatie (vermijden van samenloop) opwegen tegen de marginale kosten van de verminderde verhaalspositie voor benadeelden en van preventie. Men kan overigens ook de vraag stellen of het beperken van de samenloop voor slachtoffers een voordeel dan wel een nadeel is: is een slachtoffer beter gediend bij een brede waaier van aanspreekbare personen, dan wel bij één enkele - duidelijk. aanwijsbare - aan te spreken persoon?

Het feit dat bij een massaschade meerdere verweerders tegenover de massa eisers staan, hoeft niet meteen problematisch te zijn. In de eerste plaats zal de snelheid en de efficiëntie waarmee een zaak wordt behandeld in belangrijke mate worden bepaald door een goede organisatie van de rechtbank. In de tweede plaats kan ook het recht hieraan tegemoet komen. Zo wordt in het Verdrag van Parijs zelf reeds een belangrijke maatregel genomen die bijdraagt tot cen reductie van de tertiaire ongevalskosten: in het systeem van het Verdrag, is er in principe slechts één rechter bevoegd. Zeker bij een grensoverschrijdend kemongeval zal het inderdaad uitermate zinvol zijn dat partijen niet meer kunnen twisten over de bevoegdheidsvraag. Daarnaast lijkt het niet uitge-

Dit blijkt met name uit een onderzock van de Exposê des Motifs van het Verdrag van Parijs en uit de voorbereidende werken van het Verdrag van Wenen.

211 Zie hierover verschillende bijdragen in Massaschade. Vergt de behandeling van massale schade een bijzondere benadering?, Inleidingen gehouden op het symposium van de Vereniging van Letselschade Advocaten 1996, Koninklijke Vermande, Lelystad, 1996. 
sloten dat een advocaat meerdere eisers vertegenwoordigt. In Nederland bijvoorbeeld trad op I april 1995 een nieuw artikel in het BW in werking, dat collectieve acties toelaat ${ }^{22}$. Wel moet erop worden gewezen dat deze regeling de uitkering van schadevergoeding in geld uitdrukkelijk uitsluit $^{23}$. Ook in België is voorzien in een regeling voor de vorderingsrechten van bijvoorbeeld milieuorganisaties ${ }^{24}$.

Vanuit het oogpunt van de administratieve kosten van een rechtszaak, kan inderdaad worden aangenomen dat deze kosten stijgen naarmate samenloop is toegelaten. Maar vanuit het oogpunt van het slachtoffer impliceert een samenloop dat meerdere personen kunnen worden aangesproken voor eenzelfde schade; in de mate waarin bijvoorbeeld ook twee onderscheiden personen de schade hebben veroorzaakt en hiervoor worden aansprakelijk gesteld, betekent dit een toename van de kans dat de geleden schade zal worden gecompenseerd. Via de sannenloop van schuldenaars, beschikken de schuldeisers dus over een groter onderpand. Dit kan vanuit het perspectief van de schadespreiding en de preventie worden beschouwd als een voordeel. Hiermee wordt immers in de eerste plaats bereikt dat alle personen die een bepaalde schade hebben veroorzaakt, een prikkel zullen hebben om dergelijke schade in de toekomst te vermijden. Daamaast is het wenselijk vanuit het perspectief van de schadespreiding om de verhaalsmogelijkheden van het slachtoffer niet a priori te beperken. Dit geeft aan dat samenloop wel degelijk als een maatschappelijk voordeel kan worden beschouwd, en dit zowel vanuit compensatie- als vanuit preventicoogpunt.

Vanuit het standpunt van slachtoffers heeft samenloop van vorderingen natuurlijk meer voordelen, althans deze overstijgen ruimschoots de vermeende nadelen. Overigens gaat het argument dat kanalisatic het voordeel biedt dat het slachtoffer niet moet uitzoeken wie hij kan dagvaarden, niet echt op. Een slachtoffer zal immers een beroep doen op gespecialiseerde juridische bijstand (advocaat) voor wie de samenloop geen probleem mag opleveren ${ }^{25}$.

Inzake de organisatie van de advocatuur is wel een aanzienlijk verschil vast te stellen tussen grosso modo - het Amerikaanse en het Europese recht. In de VS worden advocaten in de regel vergoed op basis van een no cure no pay systeem én op een percentage van de verkregen schadevergoeding. Het is niet ondenkbeeldig dat een dergelijk systeem leidt tot onnodige proceskosten. Maar doordat in Europa een ander systeem wordt gehanteerd, is het risico dat samenloop tot onoverkomelijke problemen leidt, veel geringer ${ }^{26}$.

Artikel 3:305a, lid I BW luidt: "Een stichting of vereniging met volledige rechtsbevoegdheid kan een rechisvordering instellen die strekt tot bescherming van gelijksoortige belangen van andere personen, voorzover zij deze belangen ingevolge haar statuten behartigt". Zie hierover met name Frenk, N., "Kollectieve akties in het privaatrecht", l.c., 105 c.v.

Artikel 3:305a, lid 3 BW luidt: "Een rechtsvordering als bedoeld in lid I kan niet strekken tot schadevergoeding te voldoen in geld". Deze regeling lijkt dan ook in hoofdzaak te zijn bedoeld voor acties van algemeen belang. Zie hierover Stolker, C.J.J.M., "U bent met te veel, dus u krijgt niets!" Amerikaanse ervaring met collectief schadeverhaal", in "Massaschade. Vergt de behandeling van massale schade een bijzondere benadering?", l.c., 43 e.v.

Zie hierover vooral Carette, A., "Herstel van en vergoeding voor aantasting aan niet-toegeěigende milieubestanddelen", l.c.

Tjittes, R.J., "Centralisering van aansprakelijkheden", o.c., 280.

Over de zogenaamde claimcultuur, zie Spier, J., "Claimcultuur en aansprakelijkheidsrecht", in Niezen, G.J. Raaijmakers, M.J.G.C. en Tervoort, A.J.S.M. (red.), Ongebonden Recht Bedrijven. Bedrijfsjuridische opstellen op de grens van het derde millennium bij gelegenheid van het 70-jarig bestaan van het 
Tenslotte mag ook de rol van de verzekeraar niet worden uit het oog verloren. Zoals blijkt drukt bijvoorbeeld de Amerikaanse nucleaire verzekeringspool (ANI) de administratieve kosten en maakt het een snelle uitkering van de beschikbare bedragen mogelijk door haar personeel in die zin op te leiden. Dat is gebleken na het ongeval in Three Mile Island ${ }^{27}$.

Het terugdringen van de administratieve kosten van een massavordering kan bijgevolg worden bereikt zonder de juridische kanalisatie van aansprakelijkheid; en dus door maatregelen buiten het aansprakelijkheidsrecht. Bovendien is kanalisatie van aansprakelijkheid niet de enige maatregel die tot geringere kosten leidt; ook ingrepen in het procesrecht zoals de exclusieve bevoegdheid van een rechter per land, een efficiënte organisatie van de rechtbank en een vlotte afwikkeling van schadedossiers door de verzekeraar leiden tot een daling van de administratieve kosten ${ }^{28}$.

\subsubsection{Conclusie}

De kanalisatie van aansprakelijkheid in het nucleaire aansprakelijkheidsrecht beperkt de samenloop. Vanuit economisch oogpunt levert dit slechts een beperkt voordeel op.

Door aan slachtoffers de mogelijkheid te geven om meerdere personen aan te spreken (samenloop), kan een stijging van de administratieve kosten worden verwacht, maar deze stijging wcegt niet op tegenover de opbrengsten in de vorm van preventie en van compensatic van de slachtoffers.

Daarenboven moet worden aangegeven dat, aangenomen dat de kanalisatie van aansprakelijkheid voordelen oplevert inzake de reductie van de tertiaire ongevalskosten, de afschaffing misschien niet de enige maatregel is die een dergelijke reductie kan bewerkstelligen.

Ook vanuit de rechtseconomische analyse blijkt het belangrijk om een onderscheid te maken tussen de verschillende variabelen die de kanalisatie van aansprakelijkheid bepalen. Trebilcock en Winter stellen namelijk dat door de beperking van aansprakelijkheid van de exploitant, meteen ook de aansprakelijkheid van de gehele groep worden beperkt ${ }^{29}$. Deze stelling houdt evenwel onvoldoende rekening met de verschillende variabelen die in de kanalisatie van aansprakelijkheid zitten vervat. In dit onderzoek werden drie variabelen geïdentificeerd: het aantal personen waarnaar de aansprakelijkheid wordt gekanaliseerd, de mogelijkheid voor de aansprakelijke om regres uit te oefenen en tenslotte de mate waarin het gemene aansprakelijkheidsrecht wordt intact gela$\operatorname{ten}^{30}$. Naar onze mening is het eerder de uitschakeling van de andere juridische grondslagen en de beperking van het regres van de exploitant die de leveranciers civielrechtelijke immuniteit verlenen. Zelfs indien in het nucleaire aansprakelijkheidsrecht de exploitant onbeperkt aansprakelijk zou zijn, dan nog zouden de leveranciers in het geheel niet aansprakelijk zijn.

Nederlands Genootschap van Bedrijfsjuristen, Kluwer, Deventer, 2000, 223-231; Faure, M. en Hartlief, T., "Enkele opmerkingen naar aanleiding van de brief van het kabinet over de Claimcultuur", Aansprakelijkheid \& Verzekering, 1999/4\&5, 75-84; Bauw, E. en Barendrecht, J.M. (red.), Het aansprakelijkheidsrecht in de $21^{\text {ste }}$ eeuw, Kluwer, Deventer, 1999.

Cfr. supra, in \$ 3.2 .4 van hoofdstuk 13.

Ook de Amerikaanse Price Anderson Act bevat bepalingen die het voor slachtoffers makkelijker maken compensatie te krijgen voor letsel- en zaakschade en maakt het mogelijk dat een rechter bevoegd is te oordelen, over alle vorderingen uit hetzelfde kernongeval (AEN/NEA, Nuclear Legislation. Analytical Study, Regulatory and Institutional Framework for Nuclear Activities, OECD, Paris, 1996). Trebilcock, M. en Winter, R.A., "The Economics of Nuclear Accident Law", o.c., 233. Cfr. supra, in $\$ 2.4 .2$ van hoofdstuk 4. 
Wel is het zo dat de combinatie van de kanalisatie van aansprakelijkheid en de beperking van aansprakelijkheid leidt tot een stijging van de negatieve effecten (de kosten) van de kanalisatie. Door de exclusieve aansprakelijkheid, wordt het onderpand waarover slachtoffers van een kernongeval kunnen beschikken, gereduceerd. Wanneer - zoals in het nucleaire aansprakelijkheidsrecht - ook dit onderpand nog eens wordt beperkt, dan leidt de kanalisatie als het ware tot een dubbele beperking van de verhaalsmogelijkheden.

\subsubsection{Verplicht stellen van de aansprakelijkheidsverzekering}

In de rechtseconomische analyse van verplichte aansprakelijkheidsverzekering is naar voren gekomen dat er weinig redenen bestaan om deze dekking verplicht te stellen, of tenminste dat enkel in een beperkt aantal gevallen een verplichte aansprakelijkheidsverzekering economisch zinvol zal zijn ${ }^{3 !}$. Het is namelijk niet omdat in een gegeven situatie een persoon spontaan een aansprakelijkheidsverzekering zal wensen aan te schaffen, dat deze dekking meteen ook moet worden verplicht gesteld. Daarenboven kan worden aangenomen dat de potentiële dader het beste in staat is om zijn eigen graad van risicoaversie in te schatten.

In het algemeen wordt een verplichte aansprakelijkheidsverzekering voorgesteld als remedie tegen de mogelijke insolventie van de dader. Hoewel in de literatuur vraagtekens werden geplatst bij de vraag of inzake kemongevallen sprake is van een ernstig insolventierisico ${ }^{32}$, lijken de cijfers toch in die richting te wijzen. Het is namelijk niet omdat de schade aan de eigen keminstallatie is verzekerd voor een hoger bedrag dan de aansprakelijkheid tegenover derden, dat het insolventierisico beperkt zou zijn. Vanuit actuarieel oogpunt is het logisch dat de eigenschade gemakkelijker verzekerbaar is, in die zin dat voor de schade aan de keminstallatie een correctere inschatting kan worden gemaakt van de probabiliteit en de omvang van de schade. Ten aanzien. van de schade aan derden is dit een stuk moeilijker. In België wordt de eigenschade aan de installatie verzekerd voor een bedrag van 1,24 miljard euro; in de VS wordt de eigenschade verzekerd voor een bedrag van 4,21 miljard euro. In deze landen bedraagt de "individuele" aansprakelijkheidsverzekering respectievelijk 297,47 miljoen euro en 182,84 miljoen euro. Aangezien de totale schade van een kernongeval een veelvoud kan zijn van het verzekerde bedrag van de eigenschade van de exploitant, biedt de eigenschadeverzekering de exploitant geen bescherming tegen insolventie. In het nucleaire aansprakelijkheidsrecht is het insolventierisico dus reëel.

Indien er een reëel insolventiegevaar bestaat, dan kan het zinvol zijn om een verzekeringsplicht in te voeren omdat slachtoffers hierdoor, minstens ten belope van het verzekerde bedrag, de garantie hebben dat hun schade wordt vergoed. Indien ervoor zou worden gekozen om een verzekeringsplicht in te voeren, dan dient het bedrag waarvoor cen dekking dient te worden aangekocht, zo dicht mogelijk bij de verwachte schade te liggen. In het nucleaire aansprakelijkheidsrecht is het de bedoeling geweest om het bedrag waarvoor de exploitant wordt verplicht om zich te verzekeren, te koppelen aan de capaciteit op de verzekeringsmarkt. Dit veronderstelt evenwel dat het bedrag van de verzekeringsplicht evolueert samen met de capaciteit van de verzekeringsmarkt ${ }^{33}$. Zoals aangegeven is in het Verdrag geen enkele verplichting in die zin opgenomen.

Cfr. supra, in $\$ 3$ van hoofostuk 9.

Zie met name Faure, M. en Van den Bergh, R., "Liability for Nuclear Accidents in Belgium from an Interest Group Perspective", o.c., 246.

Cfr. infra, in $\$ 1.3$ bij de bespreking van de economische analyse van het nucleaire risico. 
Maar zelfs indien er op de markt slechts een beperkte dekking voorhanden is, dan nog is het volstrekt onduidelijk waarom dan ook meteen de aansprakelijkheid tot dit bedrag moet worden beperkt. Het is vanuit economisch oogpunt veel zinvoller om de verzekerde voor een deel zelf nog aan het risico te laten blootstaan: dit zal hem een prikkel geven om geen schade te veroorzaken (reductie van het morele risico) ${ }^{34}$. Doordat in het nucleaire aansprakelijkheidsrecht de exploitant zich moet verzekeren tot precies het bedrag van zijn beperkte aansprakelijkheid, wordt het voor de verzekeraar niet eenvoudig om het morele risico te controleren. Nicts belet om een verzekeringsplicht in te voeren voor een bedrag waarvoor dekking kan worden verkregen op de markt, maar om de exploitant onbeperkt aansprakelijk te stellen.

Daarenboven is het beter om voor de omvang van deze verzekeringsplicht geen algemeen bedrag vast te leggen in de wetgeving, maar om per kerninstallatie een bedrag vast te stellen. In de praktijk kan dit door bijvoorbeeld deze bevoegdheid te geven aan het bevoegde gezag of aan een onafhankelijk regulerend orgaan. Een algemeen bedrag houdt namelijk onvoldoende rekening met de risicoaversie van de dader en met de verschillende sites waarover de exploitant desgevallend beschikt. Nagenoeg alle exploitanten van een kerninstallatie beschikken inderdaad over meerdere sites en zelfs over meerdere types reactoren.

Het verplicht stellen van een aansprakelijkheidsverzekering is echter niet de enige manier om het insolventiegevaar tegen te gaan. Als andere mogelijkheden werden in de literatuur naar voren geschoven het verplicht stellen van een first-party verzekering voor de slachtoffers van een kemongeval, het oprichten van een garantiefonds, of het invoeren van een regime van foutaansprakelijkheid. Door een mogelijk probleem van informatietekort in hoofde van de rechter, zal zoals gezegd een regime van foutaansprakelijkheid niet meteen een goede oplossing bieden. De twee andere mogelijkheden worden aan de orde gesteld bij de normatieve rechtseconomische analyse van de rechtsvergelijkende inzichten ${ }^{35}$.

\subsubsection{Eén exclusief bevoegde rechtbank per land}

Vanuit rechtseconomisch oogpunt beoogt het idee van één exclusief bevoegde rechtbank een reductie van de administratieve ongevalskosten, en dan met name de proceskosten. Op zich is dit een zeer valabel argument. Aangenomen mag worden dat, zeker bij een grensoverschrijdend kernongeval, de proceskosten zeer hoog kunnen oplopen.

In de loop van het gevoerde onderzoek is evenwel naar voren gekomen dat door de mogelijke combinatie van een civielrechtelijke met cen strafrechtelijke vordering, de effectiviteit van deze maatregel in het gedrang dreigt te komen. Deze stelling gaat in ieder geval op voor wat betreft het Belgische rechi ${ }^{36}$. Het lijkt niet uitgesloten dat in Nederland of in andere landen waar een kemongeval plaatsheeft, evencens een strafrechtelijke procedure zal worden gestart. Daarbij kan onduidelijkheid rijzen over de mogelijke cumulatie van de civiele en strafrechtelijke vordering bij dezelfde rechter. In Nederland is dat namelijk bepaald niet gebruikelijk. Het strafproces kan derhalve de exclusieve bevoegdheid soms doorkruisen. Dit zal de snelheid van de afhandeling van de vordering niet ten goede komen en kan leiden tot een stijging van de proceskosten (advocatenkosten, administratieve kosten voor de werking van de rechtbank, etc.).

Cfr. supra, in $\$ 2.2$ van hoofdstuk 9 .

Cfr. infra, in \$ 2 van dit hoof dstuk.

Cfr. supra, in $\S 5$ van hoofdstuk 4. 
De effectiviteit van deze maatregel komt ook in het gedrang in de mate waarin bepaalde landen deze verwijzingsregel niet erkennen en zolang slachtoffers zullen geneigd zijn of er belang bij hebben om een vordering in te leiden voor een andere rechtbank dan de rechtbank die overeenkomstig het intemationale nucleaire aansprakelijkheidsrecht bevoegd zou zijn. Hiermee wordt met name gerefereerd naar het risico van een Amoco-Cadiz scenario in het kernenergierecht. Slachtoffers kunnen trachten om de beperking van de aansprakelijkheid te omzeilen door te dagvaarden in een land waar de beperking niet geldt.

In de huidige stand van de wetgeving is het immers niet ondenkbaar dat slachtoffers van een kernongeval in België en Nederland, wier schade niet wordt gecompenseerd ingevolge de beperkte beschikbare bedragen, zullen trachten om bijvoorbeeld in de VS een vordering in te leiden tegen de Amerikaanse leveranciers van de kerninstallatie waar het ongeval heeft plaatsgevonden. Hiermee is niet gezegd dat een dergelijke vordering succesvol zal zijn; wel blijkt hieruit dat de procesrechtelijke regeling van het Verdrag van Parijs inzake een exclusief bevoegde rechtbank, haar effect dreigt te missen.

\subsubsection{Nut van veiligheidsregulering}

Naast de toepassing van het nucleaire aansprakelijkheidsrecht, is de exploitant van een kerninstallatie eveneens onderworpen aan gedetailleerde veiligheidsmaatregelen. Deze maatregelen worden, voor wat België en Nederland betreft, opgelegd via Euratom-richtlijnen en vervolgens omgezet in nationaal recht ${ }^{37}$.

In het algemeen zal het opleggen van veiligheidsregulering zinvol zijn indien de administratieve kosten van het aansprakelijkheidsrecht hoog oplopen, indien sprake is van hoge informatiekosten bij de inschatting van het risico en indien het risico bestaat dat een aansprakelijkheidsvordering geen preventief effect zal hebben. Ook het insolventierisico kan de effectiviteit van het aansprakelijkheidsrecht belemmeren en vormt derhalve een argument voor regulering.

In het nucleaire aansprakelijkheidsrecht wordt getracht om aan het insolventierisico tegemoet te komen door de combinatie van de beperkte aansprakelijkheid en de verplichte verzekering. Het is daarom zeer de vraag waarom het insolventieprobleem nog eens extra dient te worden opgelost door middel van veiligheidsregulering en of het gecombineerd gebruik van risicoaansprakelijkheid, veiligheidstegulering en verplichte verzekering niet zal leiden tot inefficiént hoge administratieve kosten. In bepaalde gevallen kan het gecombineerd gebruik van risicoaansprakelijkheid en veiligheidsregulering maatschappelijke inefficiënties zelf in de hand werken ${ }^{38}$.

Vanuit rechtseconomisch oogpunt kan het echter zinvol zijn om, met name in gevallen waar de dader niet in staat is om alle schade te vergoeden en indien er onvoldoende dreiging uitgaat van een civiele aansprakelijkheidsrecht, bijkomende veiligheidsregulering op te leggen. Een uitermate belangrijk criterium hierbij is de vraag of de reguleerder over betere informatie beschikt over het ongevalsrisico dan de dader. Inzake kernongevallen is het niet zeker of aan deze laatste voorwaarde is voldaan. Echter, bij kemongevallen bestaat het risico dat aan aansprakelijkheidswordering niet zal worden ingesteld bijvoorbeeld omdat de letselschade zich lang na de blootstelling mani-

Cfr. supra, in hoofdstuk 2.

Faure, M. en Van den Bergh, R., "Negligence, Strict Liability and Regulation of Safety under Belgian Law: An Introductory Economic Analysis", Geneva Papers of Risk and Insurance, 1987, 110-111; Faure, M. en Van den Bergh, R., "Objectieve Aansprakelijkheid", l.c., 156 e.v. 
festeert. Ex ante veiligheidsregulering dient derhalve te worden gebruikt om, onafhankelijk van de aansprakelijkheidsvraag, een behoorlijk niveau van preventieve zorg af te dwingen. In die zin kan veiligheidsregulering dus voor een deel tegemoet komen aan de gebrekkige prikkelwerking vanuit het aansprakelijkheidsrecht.

\subsection{Het toekomstige nucleaire aansprakelijkheidsrecht}

Bij de analyse van de basisprincipes van het nucleaire aansprakelijkheidsrecht in hoofdstuk 4 werd ook aandacht besteed aan de wijzigingen die door het Verdrag inzake Bijkomende Compensatie en het Protocol van het Verdrag van Wenen aan het nucleaire aansprakelijkheidsrecht werden aangebracht en aan de lopende onderhandelingen met het oog op de revisie van het Verdrag van Parijs.

Vanuit rechtseconomisch oogpunt hebben de nucleaire aansprakelijkheidsverdragen van de tweede generatie weinig bijgedragen tot de verbetering van de situatie: de aansprakelijkheid blijf beperkt tot een zeer laag bedrag en de kanalisatie van aansprakelijkheid wordt intact gelaten ${ }^{39}$. Uitsluitend vanuit het oogpunt van de compensatie van slachtoffers kan worden gesproken van een uiterst bescheiden verbetering, in die zin dat de aansprakelijkheidslimiet van de exploitant is opgetrokken. Deze stap is inderdaad uiterst bescheiden omdat de nieuwe limiet die door het Protocol van het Verdrag van Wenen naar voren wordt geschoven (214 miljoen euro) lager is dan de huidige aansprakelijkheidslimiet in België en Nederland (respectievelijk 297 en 340 miljoen euro).

De compensatie van slachtoffers wordt ook lichtjes verbeterd via het Verdrag inzake Bijkomende Compensatie dat voorziet in een bijkomende tussenkomst door de overheid. In de mate waarin de overheid hiervoor geen vergoeding zal vragen, zal de externalisatie van de negatieve exteme effecten van een kernongeval worden doorgezet. Het in werking treden van het Verdrag inzake Bijkomende Compensatie zal dan leiden tot een bestendiging van de subsidie aan de nucleaire industrie. Het is dus van groot belang dat een land dat op basis van het Verdrag inzake Bijkomende Compensatie of van het Protocol van het Verdrag van Wenen overheidsfondsen ter beschikking stelt, hiervoor een vergoeding vraagt van de exploitanten.

Het valt nog af te wachten of de revisie van het Verdrag van Parijs wel tot aanzienlijke veranderingen zal leiden. Volgens de huidige ontwerpteksten lijkt het ęr niet op dat een substantiële inhoudelijke verandering in het verschiet ligt: voor een groot deel zal de wijziging leiden tot een gelijkschakeling met het Protocol van het Verdrag van Wenen en met het Verdrag inzake Bijkomende Compensatie.

Op één punt kan wel een belangrijke verandering worden bereikt, met name inzake de revisie van het Aanvullend Verdrag van Brussel van 1963. In de loop van de onderhandelingen is namelijk voorgesteld om de tussenkomst van Staat te vervangen door een collectieve schijf naar het voorbeeld van de Price-Anderson Act. Dit zou kunnen leiden tot een substantiële verhoging van de bijdragen van de exploitanten van een kerninstallatie in Europa. Uiteraard kan de uitkomst van de onderhandelingen moeilijk worden voorspeld. Het feit dat ook gedurende de onderhandelingen over de revisie van het Verdrag van Wenen aanvankelijk. was voorgesteld om een soort collectie-

Vanden Borre, T., "Recente ontwikkelingen in het nucleaire aansprakelijkheidsrecht: innovatic of renovatie?", o.c., 49 . 
ve schijf in te voeren, maar dat daarover in de uiteindelijk goedgekeurde tekst niets meer is terug te vinden, geeft aan dat er weinig reden is voor optimisme.

Na de rechtseconomische analyse van het huidige en toekomstige nucleaire aansprakelijkheidsrecht, dient ook de tweede pijler van het onderzoek in de analyse te worden betrokken. Hieronder wordt de verzekering van het nucleaire risico vanuit economische hoek bestudeerd.

\subsection{Economische analyse van de verzekering van het uucleaire risico}

In deze paragraaf wordt de verzekering van het nucleaire risico bestudeerd vanuit rechtseconomische hoek. Hierbij wordt in de eerste plaats de vraag beantwoord of het nucleaire risico verzekerbaar is $(\$ 1.3 .1)$. Nadien worden de gevolgen bestudeerd van de gebrekkige concurrentie op de nucleaire verzekeringsmarkt $(\$ 1.3 .2)$. Tenslotte wordt het belang aangetoond van een tailormade polis ( $\S 1.3 .3)$.

\subsubsection{Verzekerbaarheid van het nucleaire risico}

Het nucleaire risico kan worden beschouwd een typevoorbeeld van een catastroferisico: het is namelijk een risico met een geringe maar moeilijk in te schatten probabiliteit en met een zeer hoge verwachte schade. Deze beide elementen volstaan evenwel niet om het nucleaire risico als onverzekerbaar te beschouwen.

Het nucleaire risico zal enkel onverzekerbaar zijn indien het niet voorzienbaar is, indien het morele risico en problemen van averechtse selectie niet kunnen worden vermeden of indien er onvoldoende capaciteit op de verzekeringsmarkt beschikbaar is ${ }^{40}$.

Voor wat de voorzienbaarheid betreft van het nucleaire risico, kan worden vastgesteld dat in de jaren vijftig de inschatting van het risico inderdaad problematisch was. Maar inmiddels heeft de verzekeringssector op dit vlak een aanzienlijke ervaring opgebouwd. Er kan moeilijk worden ontkend dat de inschatting van het nucleaire risico bij de aanvang van de éénentwintigste eeuw een stuk eenvoudiger zal zijn dan in 1960. Bovendien dient een verzekeraar geen statistisch perfect voorzienbare inzichten te hebben om een risico te kunnen verzekeren. Bij insurer's ambigui$t y$, kan namelijk een risicopremie worden toegevoegd om rekening te houden met deze onzekerheid in hoofde van de verzekeraar ${ }^{41}$.

Een uitermate belangrijk element bij de verzekerbaarheid van het nucleaire risico, is de beschikbaarheid van correcte informatie. In essentic zijn het morele risico en het probleem van averechtse selectie het gevolg van een informatieasymmetrie. Indien de verzekeraar er niet in slaagt: om via de premies en de poliswoorwaarden prikkels te geven aan de exploitant om preventief te handelen, kan dit leiden tot onverzekerbaarheid. In de praktijk blijkt dat de nucleaire verzekeringspools regelmatig inspecties laten uitvoeren en dat de premie varieert in functie van het type installatie, de ligging van de installatie etc. Dit duidt op een zekere premiedifferentiatie. Verder zal echter blijken dat door de beperkte concurrentie op de nucleaire verzekeringsmarkt de exploitanten slechts in beperkte mate worden beloond voor de door hen genomen preventieve maatregelen. 
Een bijzonder probleem voor wat betreft de dekking van het nucleaire risico, is uiteraard de beschikbare capaciteit. In 1995 werd de totale beschikbare verzekeringscapaciteit inzake eigenschade en aansprakelijkheidsverzekering voor de OESO-landen geschat op 500 miljard dollar ${ }^{42}$. Anderzijds zou volgens schattingen een zeer zwaar kernongeval een schade kunnen veroorzaken van 100 miljard dollar ${ }^{43}$. Los van de discussie of de verzekeringscapaciteit al dan niet is beperkt, dient te worden vastgesteld dat de verzekerbaarheid in belangrijke mate afhangt van de bereidheid van een verzekeraar om een risico al dan niet te dekken. Deze bereidheid is per definitie een subjectief gegeven ${ }^{44}$. Toch hebben de traditionele verzekeraars door middel van de creatie van verzekeringspools het capaciteitsprobleem minstens ten dele weten op te vangen.

In de loop der jaren werd evenwel door de exploitanten gezocht naar bijkomende verzekeringscapaciteit: in de jaren zeventig heeft een aantal onder hen namelijk een eigen systeem opgezet van onderlinge verzekering. In de nucleaire sector werden in de VS en in Europa respectievelijk NEIL en EMANI opgericht. De beperkte concurrentie op de nucleaire verzekeringsmarkt was een belangrijk element dat heeft geleid tot de oprichting van deze onderlinge verzekeringsmatschappijen door de exploitanten (ook aangeduid als "captives").

Tenslotte wordt de laatste jaren via nieuwe financiële instrumenten meer en meer een beroep gedaan op de veel hogere capaciteit van de financiële markt om de capaciteit van de verzekeringsmarkt te verhogen ${ }^{45}$.

\subsubsection{Gebrekkige concurrentie op de nucleaire verzekeringsmarkt}

De nucleaire verzekeringen zijn georganiseerd in nationale verzekeringspools. De reden waarom een dergelijke pool is opgericht, is duidelijk: de schade uit een kemongeval gaat de middelen van een individuele verzekeraar te boven. Een verzekeringspool is er dus op gericht om de verzekeringscapaciteit te verhogen. Tegelijk leidt een nucleaire verzekeringspool tot een verbetering van het aantal marktdeelnemers: via het poolingsysteem kunnen kleinere verzekeraars ook een deel van het nucleaire risico verzekeren. Zonder de oprichting van een pool zouden zij niet over deze mogelijkheid beschikken. Ook de Europese Commissie heeft gewezen op de mogelijke voordelen van de gemeenschappelijke dekking van met name catastroferisico's ${ }^{46}$.

Doordat de nucleaire verzekeringspools echter nationaal zijn georganiseerd, bieden zij enkel dekking voor het nucleaire risico van de "eigen" nationale exploitant. Deze laatste beschikt niet over de mogelijkheid om zich tot een buitenlandse pool te richten: elke concurrentie tussen de verschillende nucleaire verzekeringspools is uitgesloten. Dit gebrek aan concurrentie heeft duidelijk een aantal negatieve gevolgen.

Uit het onderzoek is meermaals de uitgebreide betrokkenheid van de verzekeringsindustrie naar voren gekomen bij het tot stand komen van de nucleaire aansprakelijkheidswetgeving. Telkens vraagt de wetgever aan de nucleaire verzekeringspool tot welk bedrag de pool dekking kan verle-

Radetzki, M. en Radetzki, M., "Private Arrangements to Cover Large-Scale Liabilities Caused by Nuclear and Other industrial Catastrophes", o.c., 184.

lbidem.

Cfr. supra, in $\S 5$ van hoofdstuk 9.
Cousy, H., "Over de verzekering van het onverzekerbare", in "Libur Amicorum Prof. Dr. Roger Blarlpain", l.c., 708.

Cfr. supra, in $\$ 4.3$ van hoofdstuk 6 . 
nen. Maar door het monopolie van de nucleaire verzekeringspools is de wetgever in zeer belangrijke mate afhankelijk van de verklaringen van een monopolist en is hij met andere woorden kwetsbaar voor beïnvloeding ${ }^{47}$. Dit wordt nog versterkt doordat in verschillende landen ook de exploitant zich in een monopoliepositie bevindt; ook de informatie die van die kant aan de wetgever wordt doorgeven, kan door de wetgever zeer moeilijk worden getoetst. De monopolievorming in de nucleaire sector creëert met andere woorden een ernstig probleem van informatieasymmetrie in hoofde van de wetgever. Dit geldt ook op internationaal vlak: zowel de exploitanten als de verzekeraars nemen via internationale belangengroeperingen deel aan de onderhandelingen bij het totstandkomen van de verdragen ${ }^{48}$.

Zoals elke nutsmaximaliseerder zal ook de nucleaire verzekeringspool die zich in een monopoliepositie bevindt, ernaar streven om monopoliewinsten te boeken, met alle negatieve gevolgen van dien op de door de exploitant te betalen premies ${ }^{49}$. Het is uiteraard niet evident om in het algemeen uitspraken te doen over de premies die de nucleaire exploitanten dienen te betalen of over enig misbruik van de concurrentiepositie. Toch bleek bijvoorbeeld dat de nucleaire verzekeringspools in het verleden nauwelijks bereid waren om enige premiereductie toe te staan indien de exploitant een grotere vrijstelling op zich wou nemen ${ }^{50}$. Een bijzonder negatief gevolg van de wijze waarop het nucleaire risico wordt verzekerd, is de onmogelijkheid voor exploitanten on de concurrentie uit te spelen. Precies daarom is een aantal nucleaire exploitanten over gegaan tot de oprichting van een eigen captive, met dien verstande dat de activiteiten van deze captives hoofdzakelijk zijn gericht op de dekking van de eigenschade.

De laatste jaren zijn de nationale nucleaire verzekeringspools inderdaad in toenemende mate onder druk komen te staan van de verschillende exploitanten. Doordat de concurrentie op de elektriciteitsmarkt toeneemt, lijken de exploitanten van een keminstallatic niet langer geneigd om de negatieve gevolgen van de beperkte concurrentie te aanvaarden. Over het algemeen is op de nucleaire verzekeringsmarkt sprake van een bilateraal monopolie: zowel de aanbodzijde (pools) als de vraagzijde (exploitanten) wordt gevormd door monopolisten ${ }^{52}$. Hoewel in de literatuur onenigheid bestaat over de vraag of de negatieve effecten van een dergelijk bilateraal monopolie elkaar opheffen dan wel versterken, kan, althans wat de productie van kemenergie betreft, worden vastgesteld dat de exploitanten van een kerninstallatie het monopolie van de verzekeraars meer in vraag zijn gaan stellen naarmate het eigen elektriciteitsmonopolie afbrokkelde.

De vraag rijst dan ook of anno 2001, de nucleaire verzekeringspools de toets met het Europees. concurrentierecht kunnen doorstaan. Het uitgangspunt van de analyse van de EG-Commissie blijft klaarblijkelijk dat een verzekeringspool de enige manier mag zijn om een capaciteit te kunnen genereren. Vastgesteld dient te worden dat de nucleaire verzekeringspools nog slechts gedeeltelijk

Ook in die zin: Faure, M., "Vergoeding van nucieaire schade: verzekeringskartels of vergoeding van risico's via de markt?", o.c., 9.

4 Dit geldt zowel voor de nucleaire aansprakelijkheidsverdragen van de eerste als van de tweede generatie.

Zie over de negatieve gevolgen van kartelvorming met name. Faure, M. en Van den Bergh, R., "Het toelaten van verzekeringskartels op de Europese verzekeringsmarkt", o.c., 266 e.v.

Debaets, M., "Insurance of Nuclear Power Stations", in Nuclear Inter Jura "91, Bath, AIDN/INLA, $1991,197$.

s. Op een competitieve markt zal de premie inderdaad worden beïnvloed door het eigen risico waaraan de verzekerde blijft blootgesteld. Een hogere vrijstelling zou impliceren dat de verzekeraar minder heeft te vrezen van het morele risico, waardoor de premie in beginsel kan worden verlaagd.

Zie bijvoorbeeld "Power Play. Hoe Electrabel de liberalisering afremt", Trends, oktober 2000, 24-29. 
aan dit criterium beantwoorden. Het succes van de captives van de Amerikaanse exploitanten en de toenemende belangstelling voor EMANI in Europa tonen aan dat, tenminste voor wat betreft de dekking van de eigenschade van de exploitant, de nucleaire verzekeringspools niet langer noodzakelijk zijn om capaciteit te genereren, of tenminste niet meer als enige capaciteit kunnen genereren.

Daarmee is ook aangegeven dat het onzeker is of de nucleaire verzekeringspools voldoen aan het tweede criterium van de EG-Commissie. De vraag rijst inderdaad of en in welke mate een billijk aandeel van de verbetering van de producten aan de gebruiker ten goede komt: de reactie van de exploitanten op de monopoliepositie van de verzekeraars geeft aan dat de nucleaire verzekerings. pools niet leiden tot een verlaging van de premies.

Zelfs indien wordt aangenomen dat, met name ter zake van de dekking van de aansprakelijkheid van de exploitant, de nucleaire verzekeringspools noodzakelijk zijn om een bepaalde capaciteit te genereren, dan nog is het niet zeker of alle ermee gepaard gaande concurrentiebeperkingen onmisbaar zijn om het beoogde doel te bereiken. Bijvoorbeeld in België wordt de vrijheid van een verzekeraar die participeert in SYBAN, om zelf het nucleaire risico (of een deel daarvan) te verzekeren, ernstig beperkt. Zelfs al zou een deel worden verzekerd door een lid van de pool - en dus niet door de pool zelf - dan nog zal SYBAN de premie bepalen. Naar aanleiding van de zaak Assurpol is echter gebleken dat de Commissie terecht veel belang hecht aan de vrijheid van de verschillende leden om zelf de premie te kunnen bepalen. Omdat de leden van de nucleaire verzekeringspools zich ertoe hebben verbonden om hun overeenkomsten betreffende het verzekerde risico geheel of gedeeltelijk in de groep onder te brengen, lijkt de toepassing van het Europese mededingingsrecht onafwendbaar. Daarenboven moet grondig worden onderzocht of een aantal nucleaire verzekeringspools inmiddels niet zo groot is geworden dat cen splitsing zich opdringt. Omgekeerd lijkt niets uit te sluiten dat enkele kleinere pools nauwer zouden gaan samenwerken.

Ook kunnen vragen worden gesteld naar de gevolgen van de intensieve internationale samenwerking tussen de nucleaire verzekeringspools. Meerdere keren per jaar worden samenkomsten georganiseerd tussen de managers van deze pools. Dit zou onder meer noodzakelijk zijn omdat de pools elkaar herverzekeringsdekking verschaffen; een dergelijke dekking zou een regelmatig overleg vereisen. Bij de oprichting van de nucleaire verzekeringspools werd het noodzakelijk geacht dat de verschillende leden van de pool niet zelf hun deel van het risico zouden herverzekeren, maar dat uitsluitend de pool dat zou doen. Op deze wijze zou worden verhinderd dat een participerende verzekeraar het risico zou lopen om meerdere keren te moeten tussenkomen naar aanleiding van eenzelfde kernongeval. Door het gebrek aan ervaring en kennis bij de start van de kernenergie-industrie en door de geringe verzekeringscapaciteit in die tijd, kon deze maatregel inderdaad worden verantwoord. Maar aangenomen mag worden dat in de afgelopen veertig jaar de herverzekeringscapaciteit drastisch is gestegen, zodat het onzeker is of ook deze maatregel nog steeds noodzakelijk is.

Deze stelling wordt bijvoorbeeld bevestigd door de analyse van de Amerikaanse nucleaire verzekeringsmarkt. Tot 1997 deed ANI voor herverzekering in ruime mate een beroep op de andere nucleaire pools. Maar geleidelijk aan werd een groter deel herverzekerd bij NEIL, de captive van de exploitanten - einde 1999 werd zelfs $45 \%$ van de aansprakelijkheidsdekking herverzekerd bij NEIL. Dit impliceert dat de herverzekeringscapaciteit van de nucleaire verzekeringspools is tocgenomen en dat de nucleaire pools niet meer de enige manier vormen om herverzekering aan te bieden. Ook in Europa biedt EMANI herverzekeringscapaciteit aan. Daarnaast kan worden vastgesteld dat bijvoorbeeld EMANI en NEIL op dezelfde markt actief zijn en bijgevolg concurrenten zijn. Uit het onderzoek is naar voren gekomen dat de eigenschadeverzekering van Electrabel niet via de Europese maar wel via de Amerikaanse captive is gedekt. Het lijkt dus niet uitgesloten dat 
de captives op termijn volwaardige concurrenten worden van elkaar en van de nucleaire verzekeringspools. De nucleaire verzekeringsmarkt lijkt daarmee minstens van een zuiver monopolie naar een oligopolie te transformeren. Het ideaal van de volkomen concurrentie is evenwel nog lang niet bereikt.

Het feit dat de nucleaire exploitanten meer en meer zijn gaan zoeken naar een verzekeringsdekking buiten de traditionele verzekeringspools, duidt erop dat de exploitanten de monopoliepositie van de nucleaire verzekeringspools niet langer houdbaar achtten.

Vandaag lijkt het er overigens op dat de traditionele nucleaire verzekeringspools moeite hebben om zich in dit concurrentiële veld te bewegen tegenover de goed georganiseerde captives van de exploitanten. Het succes van de nieuwe vormen van dekking, zoals de captives, is overigens ook niet verwonderlijk: door het gebrek aan concurrentie gedurende vele jaren, hadden de pools geen enkele prikkel om bijvoorbeeld een behoorlijke kostenreductie na te streven.

Het is niet gemakkelijk om dergelijke zware conclusies te trekken voor het functioneren van alle nucleaire verzekeringspools voor de verschillende landen. In dit onderzoek werd enkel aandacht besteed aan de Belgische pool (SYBAN) en aan de Amerikaanse pool (ANI). Een opvallend verschil tussen beiden wat de aansprakelijkheidsdekking betreft, is dat ANI een systeem hanteert waarbij een deel van de risicopremie via het Industry Credit Rating Plan gedurende 10 jaar wordt gereserveerd en bij afwezigheid van schadegevallen wordt teruggestort aan de exploitant. Een analoog systeem is in België niet voorhanden. Dit verklaart ten dele ook de populariteit van de captives: de premie die aan de nucleaire pool wordt betaald blijft, wanneer het risico zich niet realiseert, behouden voor de pool, terwijl de premie bij een onderlinge verzekeringsmaatschappij - of tenminste de opbrengsten daaruit - kan terugvloeien naar de exploitanten.

Het systeem waarbij de nucleaire verzekeringspools per land zijn georganiseerd, heeft een bijkomend nadeel, met name voor de exploitanten van een klein land. Het betekent namelijk dat de mogelijkheden van de verzekeraar of de pool orn het risico te spreiden, uitermate beperkt zijn. In België kan het risico slechts worden gespreid over 7 kerninstallaties voor de productie van elektriciteit; in Nederland is er slechts één kerninstallatie. De risicospreiding moet dus in belangrijke mate worden verwezenlijkt via herverzekering. Indien er daarentegen een verzekeringssysteem op Europees (of mondiaal) niveau zou worden opgebouwd, dan zou dit meteen de mogelijkheden tot risicospreiding doen toenemen.

\subsubsection{Tailor-made polis}

Een derde belangrijk element bij de rechtseconomische analyse van het nucleaire risico bestaat uit de voordelen van een tailor made polis. Het geldende nucleaire aansprakelijkheidsrecht biedt niet meteen een stimulans voor het afsluiten van een op de noden van de exploitant afgestemde polis. Vanuit economisch oogpunt biedt een dergelijke tailor-made polis nochtans duidelijke voordelen.

In eerste instantie sluit een op maat gemaakte polis nauw aan bij de verlangens van de individuele exploitant, en met name op zijn graad van risicoaversie. Volgens de rechtseconomische analyse zal een verzekeringsdekking bijdragen tot een stijging van de maatschappelijke welvaart indien het erin slaagt om de risicoaversie van de betrokken persoon op optimale wijze te reduceren. $\mathrm{Bij}$ kerninstallaties kan worden gesteld dat de risicoaversie van exploitant tot exploitant zal verschillen en zelfs dat de risicoaversie van eenzelfde exploitant die een kerninstallatie uitbaat in verschillende regio's, verschillend zal zijn. 
In tweede instantie is een op maat gemaakte polis van groot belang omdat dit de verzekeraar zal helpen om problemen van averechtse selectie, evenals het morele risico in te dijken. Indien deze beide problemen niet onder controle kunnen worden gehouden, kan dit namelijk leiden tot de onverzekerbaarheid van het nucleaire risico. Ook de exploitant zelf heeft hier dus belang bij: het risico blijft verzekerbaar, en daarenboven wordt hij beloond voor zijn preventief gedrag. In concreto betekent een "maatpolis" dat een dekking wordt geboden die qua inhoud en qua omvang aansluit bij de graad van risicoaversie van de desbetreffende exploitant (er kan bijvoorbeeld een voorkeur bestaan voor een hoog eigen risico, waarbij de verzekeraar alleen voor het excess-risico tussenkomt) en bij de verwachte schade - hoewel dat laatste, door de beperking van de bedragen in het nucleaire aansprakelijkheidsrecht alleen theorie is. De bedragen waarvoor de exploitant vandaag aansprakelijk is weerspiegelen immers geenszins de verwachte schade.

Het spreekt voor zich dat de technische onderzoeken die vooraf gaan aan het uitschrijven van een tailor made polis vrij uitgebreid zijn en dus vrij hoge kosten met zich meebrengen. Bij een gemiddelde consumentenverzekering zullen de kosten dan ook niet opwegen tegen de voordelen. Daar wordt dan ook geen tailor-made polis, maar een standaardpolis uitgeschreven. Toch zullen bij de nucleaire aansprakelijkheidsverzekering deze kosten ruimschoots worden gecompenseerd door de eruit voortvloeiende baten: er wordt een polis aangeboden die aansluit bij de risicoaversie van de exploitant. Doordat de exploitant wordt beloond voor het nemen van preventieve maatregelen, mogen ook de voordelen op het vlak van de ongevallenpreventie niet uit het oog worden verloren. Bij de nucleaire aansprakelijkheidsverzekering is dan ook het maatpak van de geïndividualiseerde polis op zijn plaats eerder dan de standaardpolis.

\subsection{Verklaring van het huidige nucleaire aansprakelijkheidsrecht}

De overheid heeft het nodig geacht om tussen te komen in het nucleaire aansprakelijkheidsrecht: België en Nederland hebben inderdaad de principes van het Verdrag van Parijs van 29 juli 1960 in het interne recht ingevoerd. Een dergelijkc tussenkomst kan vanuit twee gezichtspunten worden benaderd. In eerste instantie van een Public Interest benadering ( $\S 1.4 .1$ ) en vervolgens vanuit een Private Interest benadering $(\S 1.4 .2)$.

\subsubsection{Vanuit een Public Interest benadering}

In de rechtseconomische analyse wordt aanvaard dat er goede redenen kunnen bestaan om een overheidsinterventic te rechtvaardigen. In dit onderzoek werd aangegeven dat een dergelijke interventic kan worden verklaard met het oog op het verhelpen van de negatieve gevolgen voor de maatschappelijke welvaart ingevolge de monopoliepositie van een marktspeler, ingevolge negatieve externe effecten en ingevolge het bestaan van een informatieasymmetrie ${ }^{53}$.

Voor wat betreft het nucleaire aansprakelijkheidsrecht, kan moeilijk worden verdedigd dat het Verdrag van Parijs en de daarop gebaseerde Nederlandse WAKO en de Belgische wet van 22 juli 1985 de monopoliepositie van een aantal marktspelers wensten aan te pakken. De overheid heeft in de meeste landen van Europa integendeel toegelaten dat per land een monopolie van verzekeraars tot stand is gekomen evenals een monopolie van de elektriciteitsproducenten. In de loop van de jaren negentig werden evenwel, via de regelgeving inzake de vrije elektriciteitsmarkt, concrete stappen gezet om het monopolie van de producenten te doorbreken. Deze laatste interventie kan 
dus worden verklaard vanuit de betrachting om de negatieve economische gevolgen van een monopolie ongedaan te maken, of minstens te verzachten.

Op het eerste gezicht kan de tussenkomst van de overheid in het nucleaire aansprakelijkheidsrecht worden verklaard vanuit een poging om de negatieve externe effecten van een kernongeval tegen te gaan. Het staat buiten kijf dat de nucleaire aansprakelijkheidsverdragen werden opgesteld met als motivering dat een beperkt maar gegarandeerd systeem beter was dan een onvolkomen systeem, zonder enige garantics. Het risico dat een slachtoffer van een kernongeval geen schadevergoeding zou bekomen ingevolge de insolventie van de exploitant, werd tegengegaan door het invoeren van een beperkte, gekanaliseerde risicoaansprakelijkheid met een verplichte verzekering voor de exploitant van een keminstallatic. Maar uit het onderzoek is naar voren gekomen dat de bedragen die op basis van het huidige nucleaire aansprakelijkheidsrecht worden gegenereerd, eerder de externaliteit bestendigen dan deze weg te werken.

Belangrijk is wel de vaststelling dat er misschien redenen bestaan om een beginnende industrie te ondersteunen - hetgeen ook is gebeurd voor andere sectoren zoals de luchtvaartindustrie - maar het nucleaire aansprakelijkheidsrecht springt in het oog doordat het gedurende meer dan veertig jaar ongewijzigd is gebleven. Ook al worden de Verdragen van 1997 van kracht, dan nog zal dit cen bestendiging van de bescherming van de nucleaire industrie tot gevolg hebben. Vandaag lijkt er uiteraard geen reden meer te bestaan om de nucleaire industrie via een aansprakelijkheidsbeperking een bijzondere bescherming te bieden.

De tussenkomst van de wetgever kan misschien worden verklaard om een bestaande informatieasymmetrie tegen te gaan. Het leidt weinig twijfel dat, zoals aangegeven in het Voorlopig Rapport, de overheidstussenkomst in de jaren zestig diende om het informatietekort in hoofde var de verzekeraars tegen te gaan. Er waren nauwelijks gegevens voorhanden die toelicten om het nucleaire risico in te schatten. Maar deze stelling gaat niet meer op veentig jaar na de start van de; nucleaire activiteiten.

De Public Interest theorie kan bijgevolg niet verklaren waarom het nucleaire aansprakelijkheidsrecht nog steeds niet fundamenteel werd gewijzigd. Derhalve dient te worden onderzocht of een verklaring kan worden gevonden via de private interest benadering of de theorie van de belangengroeperingen.

\subsubsection{Vanuit een Private Interest benadering}

Eén van de meest fundamentele kenmerken van het nucleaire aansprakelijkheidsrecht, de juridische kanalisatie van aansprakelijkheid naar de exploitant, kan inderdaad vanuit de theorie van de belangengroeperingen worden verklaard. Uit het onderzoek is gebleken dat de kanalisatic van aansprakelijkheid is ingevoerd vanuit de betrachting om de Amerikaanse leveranciers van de Europese exploitanten te beschermen. Dit duidelijk private belang heef dus geprimeerd bij de totstandkoming van het Verdragen van Parijs en Wenen. Zowel vanuit rechtsdogmatisch oogpunt als vanuit rechtseconornisch oogpunt is deze kanalisatie nochtans nadelig. Kanalisatie beperkt immers de rechten van slachtoffers van kemongevallen en heeft derhalve ook een nadelige invloed op de prikkels tot preventie.

De Amerikaanse leveranciers zijn niet de enigen die erin zijn geslaagd om hun stempel te drukken op het nucleaire aansprakelijkheidsrecht. Ook de verzekeringsindustrie en de nucleaire exploitanten zelf hebben een duidelijk belang bij (het behoud van) het huidige systeem. De klassieke verzekeringsindustrie immers heeft via de nucleaire verzekeringspools gedurende vele jaren 
kunnen participeren in de dekking van het nucleaire risico. Het leidt weinig twijfel dat het verschaffen van een dergelijke dekking in het begin van de jaren zestig niet eenvoudig was en dat de creatie van samenwerkingsverbanden tussen verzekeraars de enige manier was om de nodige capaciteit te genereren. Maar ook op dit punt geldt dat het nucleaire aansprakelijkheidsrecht niet is geëvolueerd: het dekkingsniveau is niet gestegen in verhouding tot de toegenomen verzekeringscapaciteit. Er is dus een zekere stijging van de bedragen vast te stellen, maar deze staat niet in verhouding tot de reële stijging van de capaciteit. De nucleaire verzekeringspoolsi zijn immers duidelijk niet meer de enige manier om een verzekeringscapaciteit te creëren. Hiermee is niet gezegd dat deze pools geen nut meer zouden hebben, wel integendeel. Niet de pools zelf leiden vandaag tot een aanzienlijk welvaartsverlies, maar wel de daarmee gepaarde gaande beperkende maatregelen, zoals het gebrek aan concurrentie tussen de pools en de onmogelijkheid voor explojtanten om zich bij een andere dan de eigen nationale pool te verzekeren.

Tenslotte leidt het geen twijfel dat ook de nucleaire exploitanten zelf belang hebben bij het huidjge systeem: zij zijn slechts tot op zeer beperkte hoogte aansprakelijk voor het door hen gecreëerde risico. Dit levert hen, zoals hierboven werd toegelicht, een belangrijk economisch voordeel (een subsidie) op.

De invloed van de belangengroepentheorie is in Belgiê ook aan de orde geweest bij de wijziging die bij wet van 11 juli 2000 aan de nucleaire aansprakelijkheidswet werd aangebracht. Niet alleen bleef de beperking van de aansprakelijkheid behouden; de verhoging van het aansprakelijkheidsbedrag correspondeert niet met de werkelijke verzekeringscapaciteit van de Belgische nucleaire verzekeringspool ${ }^{54}$. De lobby van de Belgische exploitant lijkt dus een stuk efficiënter te functioneren dan deze van de Belgische nucleaire verzekeringspool.

In zekere zin heeft het nucleaire aansprakelijkheidsrecht ertoe geleid dat de overheid zichzelf tot gijzelaar heeft gemaakt van de verschillende belangengroepen. Uiteraard is er niks op tegen dat een overheid, die een goede reden heeft om in te grijpen in het marktproces, informatie inwint bij de verschillende actoren op de markt. Inzake kernenergie had de overheid echter te maken met twee grote monopolies, zodat de overheid wel moest vertrouwen op de verklaringen van deze monopolisten. Hierdoor heeft de overheid zichzelf de mogelijkheid ontnomen om de infornatie die via deze weg werd verkregen, kritisch te toetsen. Dit is overigens geen typisch national probleem: de verschillende nationale monopolies hebben ook op internationaal vlak de krachten gebundeld en slagen erin om ook op internationaal niveau de regelgeving naar hun hand te zetten.

In de loop der jaren zijn tussen de verschillende belangengroepen inzake kemongevallen evenwel nieuwe machtsverhoudingen zichtbaar geworden. In de jaren vijftig waren de verzekeraars de bondgenoten van de leveranciers van de exploitant: onder het mom van het vermijden van piramidale verzekeringskosten werd de juridische kanalisatic van aansprakelijkheid ingevoerd. Het beperken van de aansprakelijkheid was dan weer zowel in het belang van de exploitanten als van de verzekeraars: geen van beiden werd aan een te groot risico blootgesteld. Maar doordat het monopolie van de exploitanten langzaam afbrokkelt, zijn er meer tegenstellingen gegroeid met de verzekeraars. De traditionele verzekeringspools lijken vrij machteloos tegenover het streven van een groot aantal exploitanten om zich te organiseren in eigen systemen van onderlinge verzekering. Zowel in Europa als in de VS staan de pools onder zeer zware druk. Het gevolg daarvan was dan ook de opkomst van collectieve compensatiemechanismen van de exploitanten. nucleaire aansprakelijkheidsrecht: innovatie of renovatie?", o.c., 47-48. 
Inmiddels heeft een aantal Europese exploitanten gelijklopende belangen met de Amerikaanse leveranciers van nucleair materiaal omdat ook zij leverancier zijn geworden. Voor beiden is het belangrijk dat met name ten aanzien van landen in Oost-Europa en in Azië, waar een aanzienlijke groei van de nucleaire industrie in het verschiet ligt, de juridische kanalisatie van aansprakelijkheid behouden blijft.

\section{NORMATJEVE RECHTSECONOMISCHE ANALYSE VAN DE RECHTSVERGELIJKENDE INZICHTEN}

In dit boek werden op meerdere wijzen rechtsvergelijkende elementen in het onderzoek betrokken. De rechtsvergelijking had zowel betrekking op de vergelijking van het nucleairc aansprakelijkheidsrecht van een aantal landen (met name België, Nederland en de Verenigde Staten), als op de vergelijking tussen het nucleaire aansprakelijkheidsrecht en het civielrechtelijke aansprakelijkheidsrecht voor schade door olieverontreiniging op zee. Tegelijk werden ook enkele alternatieve compensatiemechanismen bestudeerd.

Hieronder wordt nagegaan in welke mate het zinvol is om mechanismen die buiten het kernenergierecht worden toegepast, in het nucleaire aansprakelijkheidsrecht in te voeren. Daarbij passeren de volgende mechanismen de revue: een first party dekking $(\$ 2.1)$, een nucleair schadefonds ( $\$$ 2.2) en een collectief mechanisme van de exploitanten ( $\$ 2.3)$.

\subsection{First party dekking}

Uit de rechtseconomische analyse is naar voren gekomen dat bij risico's waarbij problemen van antiselectie moeilijk onder controle zijn te houden, een first party dekking een aantrekkelijk alternatief kan bieden voor de "klassieke" aansprakelijkheidsverzekering, en dat een first-party ver $<$ kering een antwoord zou kunnen bieden voor het insolventierisico van de exploitant van de kerninstallatie.

Het theoretische voordeel van een first party dekking is dat deze verzekeringsvorm de verzekeraar beter in staat stelt om voldoende informatie in te winnen over de verzekeringsnemer. Hierdoor kan de verzekeraar de goede van de slechte risico's onderscheiden en kan hij een adequate risicodifferentiatie doorvoeren.

Toegepast op het nucleaire risico, zou dit impliceren dat personen die eventueel een schade kunnen lijden ingevolge een kernongeval, hiervoor een specifieke dekking kopen. De verzekeraar zal dan rekening kunnen houden met een aantal spccifieke elementen, zoals de gezondheid van de verzekeringsnemer, het feit of hij al dan niet rookt, etc. Een medisch onderzoek kan deze gegevens verder onderbouwen; op basis daarvan kan de premic worden berekend en kunnen de goede van de slechte risico's worden van elkaar onderscheiden. Ten aanzien van zaakschade kan rekening worden gehouden met de waarde van onroerende goederen, etc.

Doordat een eigenschadeverzekering wordt afgesloten, worden de problemen van het aansprakelijkheidsrecht en van de aansprakelijkheidsverzekering vermeden. Het slachtoffer zal enkel dienen te bewijzen dat hij schade heeft geleden en dat deze schade wordt gedekt onder de desbetreffende polis. Bijvoorbeeld ten aanzien van letselschade is de causaliteitsvereiste in de relatie tussen verzekeraar en verzekerde niet aan de orde. Dit betekent dan ook dat de administraticve ongevalskosten kunnen worden gercducecrd.

Een stelsel waarbij slachtoffers een first party verzekering zouden afsluiten, mag uiteraard niet leiden tot een afbreuk van de prikkels waarover een exploitant dient te beschikken. Van een af- 
breuk zou sprake zijn indien de exploitant weet dat slachtoffers sowieso verzekerd zijn en dat weinig te vrezen valt van het regres van de first party verzekeraars. In dit systeem is het dus zeer belangrijk dat een afschrikkende werking uitgaat van deze regresvordering. Indien zou blijken dat bij een first-party insurance de kansen van een regres zeer beperkt zijn, dan zullen ook in deze situatie de negatieve effecten van het kernongeval worden afgewenteld op andere personen. Voor slachtoffers leidt dit systeem er uiteraard wel toe dat zijn schade wordt vergoed.

Volledigheidshalve wordt erop gewezen dat indien slachtoffers een eigenschadeverzekering zouden afsluiten, in zekeте zin kan worden gesproken van een verplaatsing van de administratieve kosten van het kernongeval. Deze kosten zullen niet meer rijzen bij de uitbetaling van de vordering van de verzekeringsnemers ${ }^{55}$, maar vooral bij de uitoefening van het regres van de verzekeraars.

Of mogelijke slachtoffers vandaag zullen geneigd zijn om een first party dekking aan te kopen, zal in belangrijke mate worden bepaald door hun graad van risicoaversie. Deze risicoaversie zal uiteraard grotendeels afhangen van de beschikbaarheid van een aansprakelijkheidsverzekering van de exploitant. Bovendien hangt het ervan af of een deel van de schade reeds wordt gedekt, hetzij via het sociale zekerheidssysteem, hetzij via de aansprakelijkheidsverzekering van de exploitant.

Een andere mogelijke oplossing kan erin bestaan dat de exploitant van een kerninstallatie geen aansprakelijkheidsverzekering meer afsluit, maar wel een directe verzekering ten behoeve van de slachtoffers. Hierdoor worden mogelijke problemen van bewijs van aansprakelijkheid etc. vermeden en worden met andere woorden de proceskosten aanzienlijk gereduceerd. In deze hypothese dient echter te worden vermeden dat de exploitant zal moeten instaan voor schade dic hij niet heeft veroorzaakt. Het kan niet de bedoeling zijn dat door een stelsel van directe verzekering ten behoeve van de slachtoffers van een kemongeval, de exploitant de schade moet vergoeden van een longkanker die door het roken is veroorzaakt. Er dienen met andere woorden heldere causaliteitscriteria te worden gesteld.

De praktijk wijst evenwel uit dat directe verzekering vooral nuttig is indien de schade die kan worden veroorzaakt geografisch kan worden beperkt. Ook de Nederlandse MSV-polis bijvoorbeeld is enkel van toepassing op schade aan naburige percelen. Naarmate de dekking van cen directe verzekeringspolis algemener wordt, wordt de directe verzekering ten behoeve van derden geconfronteerd met analoge problemen als deze van de aansprakelijkheidsverzekeraar ${ }^{56}$. Doordat de schade bij een kemongeval geografisch nagenoeg niet kan worden afgebakend, is het moeilijk om deze toe te passen inzake het nucleaire risico.

\subsection{Schadefonds}

Een belangrijk probleem dat in de loop van het onderzoek naar voren is gekomen, heeft betrekking op de causaliteitsproblematiek en op de beschikbaarheid van voldoende fondsen. De verleiding is dan ook groot om, zoals ten aanzien van andere gevallen van milieuaansprakelijkheid werd bepleit, een nucleair schadefonds in het leven te roepen. Maar een dergelijk Nucleair Fonds

Deze kosten hoeven niet zeer hoog te zijn. Ook bij de uitbetaling van de schadeloosstelling van siachtoffers in het kader van een first party dekking komen enkele administratieve kosten om de hoek kijken, zij het dai deze vermoedelijk beperkter zullen zijn dan bij een aansprakelijkheidsverzekering. 
moet ook omzichtig worden benaderd. Het is immers niet duidelijk waarom een dergelijk fonds in staat zou zijn orn eventuele problemen die rijzen in het aansprakelijkheidsrecht op te lossen.

Een goed functionerend schadefonds veronderstelt dat de probilemen van averechtse selectic en het morele risico onder controle kunnen worden gehouden. Dit veronderstelt dan weer dat de bijdrage van de exploitant tot het fonds precies is afgestemd op de mate waarin elke exploitant tot het risico heeft bijgedragen; dat er met andere woorden een voldoende graad van risicodifferentiatie tussen de verschillende installaties kan worden toegepast.

Ten tweede is de kans reëel dat een fonds dat door de overheid wordt beheerd vrij duur is; uit onderzoek is gebleken dat dit met name het geval is voor het Nederlandse Fonds Luchtverontreiniging ${ }^{57}$. De toekomst van dit Fonds is zelfs onzeker geworden.

Een derde reden waarom weinig vertrouwen kan worden gesteld in een algemeen Nucleair Schadefonds heeft betrekking op de informatieproblematiek. Er is ontegensprekelijk een aanzienlijke kennis aanwezig op de huidige nucleaire verzekeringsmarkt, zelf́s indien de werking van deze markt, ingevolge de beperkte concurrentie, voor verbetering vatbaar is. De klassieke verzekeringsmaatschappijen zijn gespecialiseerd in het inschatten van de risico's en in het aanpassen van de premie aan het gedrag, van de verzekerde. De specialisatie en het belang van de kennis worden nog versterkt via het succes varı de captives van de nucleaire exploitanten.

Het is dus gevaarlijk om ervan uit te gaan dat een nucleair schadefonds erin zal slagen om een aantal problemen van het nucleaire aansprakelijkheidsrecht het hoofd te bieden, zeker indien dit door de overheid zou worden beheerd. Doordat er op de markt reeds een nucleaire aansprakelijkheidsdekking beschikbaar is, is het inderdaad onduidelijk in welke mate een algemeen nucleaire schadefonds beter en tegen geringere kosten in staat zou zijn om een aansprakelijkheidsdekking te verlenerı. Daarvoor zou alleen cen argument bestaan als kan worden betoogd dat de beheerders van het Fonds beter in staat zouden zijn om het nucleaire risico te controleren dan de verzekeraar. $\mathrm{Nu}$ de nucleaire aansprakelijkheidsverzekering wordt aangeboden door nucleaire pools die juist in dit risico zijn gespecialiseerd, lijkt dat weinig realistisch.

Anderzijds blijft overeind dat zelfs indien de werking van de nucleaire verzekeringsmarkt wordt verbeterd, ет nog steeds problemen kunnen rijzen ten aanzien van de compensatic van Jetselschade. Zeker indien meerdere jaren zijn verstreken tussen het kemongeval en het optreden van de schade, c.q. het indienen van een vordering kan de causaliteit nog maar moeilijk worden vastgesteld. Bovendien kan de nucleaire verzekeringsmarkt nog steeds geen integrale schadeloosstelling waarborgen. Een nucleair schadefonds zou dus zinvol kunnen zijn als een vangnet om schadegevallen op te vangen die buiten het aansprakelijkheidsrecht vallen.

De bijdrage tot het Nucleaire Schadefonds, zou dan kunnen bestaan in een procentuele taks op de premie die de exploitant betaalt aan zijn verzekeraar. Omdat in onze visie een op maat gemaakte polis dient te worden uitgeschreven, kan ervan worden uitgegaan dat - in de toekomst - op cen competitieve verzekeringsmarkt de premie rekening zal houden met het preventieve gedrag van de exploitant. Toch moet worden benadrukt dat wij in een ideal model van compensatie voor schade veroorzaakt door kernongevallen slechts een beperkte rol zien weggelegd voor een fonds. Immers, om de aangegeven redenen zullen andere compensatiemechanismen doorgaans effectie- 
ver zijn dan fondsen, zeker wanneer hierbij aan een fonds wordt gedacht dat onder publiek beheer staat. Het fonds krijgt derhalve slechts een beperkte functie toebedeeld als vangnet, specifiek voor gevallen waarbij bijvoorbeeld een lange tijd na het kernongeval nog schade zou blijken. Dit beperkt vangnet- of garantiefonds wordt gefinancierd op basis van heffingen die zijn gekoppeld aan de financiële zekerheid die de exploitant dient te verschaffen. Bijgevolg kan via deze bepaling van de financieringsbijdrage toch een zekere risicodifferentiatie worden gerealiseerd.

Bijkomend kan een Nucleair Schadefonds dienst doen als voorschotfonds. Met het oog op het terugdringen van de administratieve kosten, kan het zinvol zijn dat het Fonds reeds bepaalde voorschotten toekent, met name ter zake van letselschade. Voorwaarde is wel dat het Fonds de uitgekeerde voorschotten integraal kan terugvorderen van de exploitant.

\subsection{Collectieve compensatiemechanismen van de exploitanten}

In het kader van dit onderzoek werden de collectieve compensatiemechanismen in twee verschillende rechtstakken bestudeerd, met name in het nucleaire aansprakelijkheidsrecht en in het maritieme aansprakelijkheidsrecht. Zoals aangegeven gaan beide rechtstakken tot op zekere hoogte uit van dezelfde basisprincipes.

Voor wat betreft de dekking van de aan de activiteiten verbonden risico's, is opgevallend dat zowel in de nucleaire als in de maritieme sector systemen van onderlinge verzekering in voege zijn. De P\&I Clubs kunnen worden vergeleken met de captives in de nucleaire sector. De gelijkenis tussen beide systemen bestaat erin dat de P\&I Clubs verenigingen zijn die een onderlinge verzekering aanbieden aan deelnemende leden. De winsten van Clubs en de captives komen aan de leden ten goede, dus respectievelijk de scheepseigenaren en de exploitanten van een kerninstallatie.

De bijdragen die de leden van de P\&I Clubs moeten betalen, bestaat uit twee schijven, namelijk een voorafgaandelijke bijdrage en een bijkomende bijdrage. Al naargelang een aantal leden al dan niet een verlies heeft geleden, zal worden bepaald of een bijkomende bijdrage is verschuldigd. Bij de nucleaire captives wordt voorzover bekend slechts een jaarlijkse bijdrage gevraagd; wel is ecn ristorno voor de in het verleden betaalde bijdragen mogelijk. Voor een aantal leden van NEIL is het bijvoorbeeld zelfs zo dat de ristorno groter is dan de te betalen bijdrage.

Anderzijds bieden de P\&I Clubs een veel ruimere dekking: naast de eigenschade van de scheepseigenaren worden eveneens de aansprakelijkheid tegenover derden en zclfs de contractuele aan. sprakelijkheid van de scheepseigenaar gedekt.

De exploitanten hebben duidelijk belang bij een participatie in een captive van verschillende nucleaire exploitanten. In eerste instantie om zuiver financiële redenen: in de mate waarin de captive winstgevend is, zal deze winst de leden van de captive, en dus de exploitanten ten goede komen. Dit kan zelfs zo ver gaan dat de jaarlijks te betalen bijdrage geringer is dan het uit te keren dividend ${ }^{58}$. Indien de exploitanten uitsluitend een beroep doen op de klassieke nucleaire verzekeringspool, zullen de premiewinsten enkel de verzekeraars te goede komen. Het spreekt voor zich dat er slechts van winst belegt op de beurs. 
sprake zal zijn indien er zich geen (ernstige) schadegevallen hebben voorgedaan. Dit geldt zowel voor de leden van de nucleaire verzekeringspool als voor de leden van de captive.

De activiteiten van NEIL en EMANI zijn zo opgebouwd dat de bijdrage die een bepaald lid betaalt; in een bijzonder fonds blijft gereserveerd en dat elk lid in principe eigenaar blijft van de door hem betaalde bijdragen. Deze captives bieden dus in feite twee diensten aan: een reservering van de bijdragen en een risicospreiding dankzij de toegang tot het herverzekeringsmarkt. Met name ten aanzien van een catastroferisico, is het dan ook duidelijk waar de voordelen van de captive liggen: hoe moeilijker een risico via de traditionele verzekeringstechnieken kan worden gedekt, hoe hoger de risicopremie zal zijn die door een klassieke verzekeringsmaatschappij in rekening wordt gebracht. Op een gegeven moment zal het voor de verzekerde interessant worden om zelf in te staan voor de verzekering, omdat de opbrengsten van de risicopremie, bij afwezigheid van schadegevallen, hem ten goede zullen komen. Er wordt als het ware een positieve prikkel gecreëerd: de verschillende leden - en dus de exploitanten - hebben er belang bij dat er zich geen schade voordoet.

Vanuit rechtseconomisch oogpunt leidt een captive er ook toe dat de informatie wordt gecentraliseerd. Een essentieel element in de verzekerbaarheid van het nucleaire risico heeft inderdaad betrekking op de kennis van het risico en op mogelijke problemen van informatieasymmetrie. Er kan van worden uitgegaan dat de exploitant degene is die het risico het best kan inschatten; indien bijgevolg meerdere exploitanten zich organiseren om een eigen verzekeringssysteem op te zetten, kan worden aangenomen dat nog meer kennis beschikbaar wordt en dat deze tegen relatief geringe kosten kan worden uitgewisseld. Voor het uitvoeren van de veiligheidscontroles doet NEIL bijvoorbeeld geen beroep op externe competentie: in de schoot van deze captive is een onafhankelijke technische commissie opgericht die instaat voor de controle van de kerninstallaties.

Een risicospreiding via een collectiviteit heeft ook als groot voordeel dat ex ante geen precieze actuariële informatie beschikbaar dient te zijn over het ongevalsrisico. Er werd reeds op gewezen dat verzekering veronderstelt dat $e x$ ante steeds premies worden betaald. Daartoe is derhalve actuariële en dus statistische - informatie over het ongevalsrisico vereist. Juist dat is een zwak punt bij het nucleaire risico. Die onzekerheid kan weliswaar, zoals aangegeven, deels worden gecompenseerd door een additionele risicopremie in rekening te brengen ${ }^{59}$. Maar ook die additionele risicopremie kent zijn beperkingen. Juist bij onbekendheid betreffende het risico kan een risicospreiding door exploitanten een uitkomst bieden. In de literatuur is er immers op gewezen dat daartoe ex ante geen statistische informatie is vereist. Er wordt immers geen premie geheven. Er is alleen vereist dat de exploitanten elkaar wederzijds kunnen controleren en wederzijds preventieve maatregelen kunnen opleggen $^{60}$. De schadeverdeling daarentegen kan ex post plaatsvinden op basis van cerı vooraf afgesproken verdeelsleutel.

Het rechtsvergelijkend onderzoek heeft ook een aantal interessante elementen opgeleverd voor de principes van het nucleaire aansprakelijkheidsrecht. Met name via de collectieve schijf in de Amerikaanse Price-Anderson Act, worden de exploitanten verplicht om aanzienlijke bedragen te genereren. De analyse van de Verdragen inzake de aansprakelijkheid voor schade door olieverontreiniging op zee heeft aangetoond dat een minder strikte vorm van kanalisatie van aansprakelijkheid dan deze in het kemenergierecht, de maatschappelijke welvaart kan doen toenemen.

Kunreuther, H., Hogarth, R. en Mesaros, J., "Insurer Ambiguity and Markct Failurc", Journal of Risk and Uncertainty, 1993, 71-81.

Skogh, G., "Development Risks, Strict Liability, and the Insurability of Industrial Hazards", The Geneva Papers on Risk and Insurance, vol. 23, $\mathrm{n}^{\circ} 87,1998,253$ e.v. 


\section{Conclusie.}

Een model dat op efficiënte wijze schade door kemongevallen wil voorkomen en wil voorzien in een adequaat compensatiesysteem, moet dus met bovenvermelde elementen rekening houden.

Dit betekent in de eerste plaats dat de aansprakelijkheid van de exploitant in principe onbeperkt dient te zijn. Daarnaast dient ook de congruentieplicht te worden afgeschaft; op deze wijze zal de exploitant steeds aan een eigen risico worden blootgesteld, wat zowel op het vlak van de preventie als voor de bestrijding van het morele risico voordelen oplevert. In derde instantie dient de juridische kanalisatic van aansprakelijkheid te worden afgeschaft - of een systeem wordt gehanteerd van economische kanalisatie wordt in beginsel overgelaten aan de onderhandelingen tussen de exploitant en zijn leveranciers.

Inzake de dekking van het nucleaire risico bieden collectieve systemen van de exploitanten aanzienlijke voordelen, met name voor het vermijden van problemen van informatieasymmetrie. De werking van de traditionele nucleaire verzekeringspools daarentegen is aan grondige herziening toe. Tenslotte lijkt cen voorschot- en een garantiefunctie weggelegd voor een Nucleair Schadefonds.

Deze normatieve rechtseconomische conclusies zullen thans met de juridische conclusies worden gecombineerd voor het formuleren van enkele aanbevelingen. 


\section{HOOFDSTUK 16}

\section{AANBEVELINGEN: NAAR EEN VERBETERD MODEL INZAKE, COMPENSATIE VAN SCHADE DOOR KERNONGEVALLEN}

Een verbeterd model voor de compensatie van schade veroorzaakt door kernongevallen kan worden bereikt indien een verschillende maatregelen worden ingevoerd. In eerste instantie worden de uitgangspunten van het model toegelicht $(\S 1)$. Vervolgens wordt, ten laste van de exploitant, een vijftrapssysteem ingevoerd voor de compensatie van de schade uit een kernongeval $(\hat{2} 2)$ en wordt aan de exploitant een beperking opgelegd om de eigenschade te verzekeren $(\$ 3)$.

\section{UITGANGSPUNTEN}

Het model is gebaseerd op drie uitgangspunten. In eerste instantie is het de bedoeling dat het model, zeker in de aanvangsfase, tot stand komt via een regionaal Verdrag dat telkens slechts geldig is voor een periode van tien jaar $(\$ 1.1)$. Vervolgens moet het model zo worden opgebouwd dat een deel van de bedragen snel beschikbaar is en dat de bedragen gespreid in de tijd ter beschikking worden gesteld $(\S 1.2)$. Een bijzondere rol is weggelegd voor een onafhankelijk en regulerend orgaan $(\$ 1.3)$.

\subsection{Regionaal Verdrag met duur van telkens 10 jaar}

Een nationaal compensatiesysteem voor een risico zoals het nucleaire risico, kan in West-Europa maar een beperkt succes hebben. Zo zijn de mogelijkheden tot risicospreiding evenals de verzekeringsmogelijkheden binnen één enkel land, zeer beperkt. Anderzijds heeft een mondiaal Verdrag tot gevolg dat voor een aantal landen de erin neergelegde principes niet ver genoeg gaan. Het eerste belangrijke uitgangspunt bestaat erin dat het model op beperkte internationale schaal' wordt toegepast. Het model moet tot stand komen in regio's met gelijklopende sociaal-economische achtergrond, waar ook de veiligheidsnormen waaraan de kerninstallaties voldoen, gelijklopend zijn. Een ideaal kader wordt bijvoorbeeld gevormd door de landen van Euratom, of de landen van West-Europal.

Voor de verschillende regio's in de wereld moet een dergelijk model op poten worden gezet. Het komt dan toe aan het IAEA om te waken over de coherentie tussen de verschillende bestaande systemen.

\subsection{Beschikbaarheid van bedragen: snel en gespreid in de tijd}

Het model wordt op een manier uitgebouwd dat niet alle fondsen meteen beschikbaar worden gesteld, maar dat integendeel gedurende meerdere jaren bedragen zullen beschikbaar zijn. Onder het huidige stelsel is het risico namelijk reëel dat enkel de schade zal worden vergoed van de slachtoffers die als eerste een vordering indienen, of dat jaren moet worden gewacht vooraleer een eerste uitkering zal kunnen worden verricht. Twee maatregelen komen hieraan tegemoet. Ten

Indien bijwoorbeeld Belgie (7), Finland (4), Frankrijk (59), Duitsland (19), Nederland (1), Spanje (9), Zweden (11), Zwitserland (5) en het Verenigd Koninkrijk (35) tot dit Verdrag toetreden, dan zullen precies 150 keminstallaties onder dit compensatiesysteem vallen. Het cijfer tussen haakjes geeft het aantal reactoren weer per land. 
eerste worden de bedragen die in de tweede trap worden gegenereerd, geleidelijk aan ter beschikking gesteld, naar het voorbeeld van de retrospective premiums van de exploitanten onder de Price-Anderson Act. Indien deze bedragen niet volstaan om de eerste vorderingen te compenseren, zal het Nucleair Schadefonds voorschotten kunnen verstrekken, die evenwel integraal kunnen worden teruggevorderd. Dit wordt hieronder meer in detail uiteengezet.

Van groot belang is ook dat de juridische kanalisatie van aansprakelijkheid wordt afgeschaft. Vanuit rechtseconomische hoek leidt de kanalisatie tot onoverkoombare negatieve economische effecten. Met name het feit dat de personen die een invloed hebben op het risico immuun zijn ten aanzien van de slachtoffers, is zeer nadelig. Ook vanuit rechtsdogmatisch standpunt lijkt het moeilijk verdedigbaar om een slachtoffer een aantal rechtsgronden voor de compensatie van geleden schade te ontnemen.

\subsection{Onafhankelijk regulerend orgaan}

In het model worden regulerende bevoegdheden toegekend aan een onafhankelijk functionerend orgaan, naar het voorbeeld van de Amerikaanse Nuclear Regulatory Commission. Het is onzeker of bijvoorbeeld het IAEA of Euratom deze taken zouden kunnen vervullen, aangezien beide instanties zowel controlerende als promotionele taken hebben ten aanzien van kernenergic. Ook de vroegere Amerikaanse Atomic Energy Commission had deze taken; om moeilijkheden te vermijden werd deze gesplitst en werden de controlerende en regulerende taken toegewezen aan de NRC ${ }^{2}$.

Dit orgaan reikt de vergunningen uit, en bepaalt de hoogte van de verzekeringsplicht van elke exploitant. Dit hangt ook samen met de visie dat de verzekeringsdekking en de omvang van de verzekeringsplicht veeleer een maatpak dient te vormen dan de confectie van de algemene wettelijke beperkingen of de standaard verzekeringspolis. In de schoot van dit orgaan zullen wetenschappelijke commissies worden opgericht die advies uitbrengen, bijvoorbeeld over het causaliteitsvraagstuk. Makkelijkheidshalve wordt dit orgaan - West-Europa als voorbeeld nemend - het European Nuclear Regulatory Agency (ENRA) genoemd.

\section{INVOERING VAN EEN VIJFTRAPSSYSTEEM}

Het is zinvol om het totale beschikbare schadevergoedingsbedrag in vijf schijven of trappen onder te verdelen (zie onderstaand schema): een eerste trap bestaande uit de onbeperkte aansprakelijkheid van de exploitant, gekoppeld aan het stellen van een "individuele" financiële zekerheid ( $(2.1)$. In de tweede trap dragen verschillende exploitanten collectief bij tot de schade $(\$ 2.2)$. 
In de derde trap zullen de deelnemende landen optreden als herverzekeraar ( $\$ 2.3$ ). De vierde trap wordt gevormd door een Nucleair Schadefonds ( $§ 2.4$ ). De vijfde trap tenslotte is een facultatieve trap, in die zin dat de exploitanten en de leveranciers die participeren in een vrijwillig compensatiemechanisme, gerechtigd zijn om hun aansprakelijkheid te beperken. Dit mechanisme draagt de naam Voluntary Liability Agreement of Nuclear Operators and Suppliers, kortweg VLANOS ( $\$ 2.5$ ).

\begin{tabular}{|c|l|}
\hline \multicolumn{2}{|c|}{ Vijftrapssysteem } \\
\hline 1 & $\begin{array}{l}\text { Individuele aansprakelijkheidsverzeke- } \\
\text { ring van de exploitant }\end{array}$ \\
\hline 2 & $\begin{array}{l}\text { Risicospreidingsovereenkomst - collec- } \\
\text { tieve bijdrage alle exploitanten }\end{array}$ \\
\hline 3 & Herverzekering door de Staat \\
\hline 4 & Nucleair Schadefonds \\
\hline 5 & VLANOS \\
\hline
\end{tabular}

De precieze strekking van elk van deze trappen wordt in de onderstaande paragrafen verder toegelicht.

\subsection{Eerste trap: onbeperkte aansprakelijkheid met beperkte verzekeringsplicht}

Het uitgangspunt in het nucleaire aansprakelijkheidsrecht moet zijn dat de exploitant in beginsel onbeperkt aansprakelijk is voor de door hem aan derden veroorzaakte schade. Gelet op het reële insolventierisico, dienen echter garanties te worden geleverd dat een financiële zekerheid beschikbaar is, ten belope van cen minimaal bedrag. De exploitant mag zelf kiezen welke financiële zekerheid hij hiervoor zal aanwenden: borgstelling, bankgarantie, aansprakelijkheidsverzekering, directe verzekering of financiële instrumenten. Het model veronderstelt ook dat voldoende concurrentie aanwezig is ter dekking van de financiële zekerheid van de exploitant van de kerninstallatie.

Het bedrag van deze zekerheid zal worden bepaald door de ENRA, rekening houdend met verschillende factoren. De ENRA zal ook de door de exploitant voorgelegde financiële zekerheid beoordelen. Het is hierbij de bedoeling dat wordt nagegaan of er een garantie bestaat dat de bedragen ook zullen beschikbaar zijn wanneer het risico zich realiseert.

Aan de verschillende spelers op de nucleaire dekkingsmarkt wordt de plicht opgelegd om jaarlijks een overzicht te geven van de evolutie van de capaciteit en van de elementen die een invloed hebben op de markt en om dit aan de ENRA te melden. Jaarlijks kunnen dan ook de bedragen waaryoor de exploitanten worden verplicht om een dekking te nemen, worden aangepast.

Een exploitant die bijkomende veiligheidsinvesteringen heeft gedaan, za! met de ENRA kunnen onderhandelen om het bedrag dat in de eerste trap moet ter beschikking staan te verlagen. Uitcraard moet in ieder geval de minimumlimiet worden gerespecteerd. Hier dient erop te worden gewezen dat de ENRA alleen het minimumbedrag bepaalt waarvoor de exploitant in de eerste schijf een financiële zekerheid dient te verschaffen; hij blijft echter in beginsel onverkort onbeperkt aansprakelijk voor de gehele schade.

Op voonwaarde dat deze instantie onafhankelijk en autonoom kan optreden, kan deze werkwijze ertoe leiden dat inderdsad een financiële zekerheid wordt verleend tot het bedrag dat op de financierings- en verzekeringsmarkt beschikbaar is en dat dit bedrag regelmatig kan worden aangepast. Aangezien ons model eveneens veronderstelt dat er concurrentie mogelijk is tussen de verschil- 
lende vormen van financiële zekerheid, zoals tussen de nucleaire verzekeringspools en tussen de captives van de nucleaire exploitanten, zal deze instantie niet om de tuin kunnen worden geleid door eenzijdige verklaringen van een exploitant of van een monopolistische verzekeraar. Essentieel is immers dat het controleorgaan de financieringscapaciteiten kan beoordelen aan de hand van verschillende beschikbare verzekerings- en financiële mechanismen. Deze zijn voor alle duidelijkheid niet beperkt tot de nucleaire verzekeringspools.

Maar zelfs indien de ENRA erin slaagt om stelselmatig de capaciteit van de markt tot verschaffing van financiële zekerheid "op te volgen", dan nog zal het probleem van underdeterrence en van ondercompensatie niet van de baan zijn. Het is aannemelijk om te stellen dat het bedrag dat kan worden gedekt indien de maximale financierings- en verzekeringscapaciteit wordt gebruikt, nog steeds onvoldoende zal zijn om alle schade te compenseren die door een kernongeval kan worden veroorzaakt. De door de financiële zekerheid beschikbare bedragen zullen vermoedelijk nog steeds een stuk lager liggen dan de waarde van het totale vermogen vañ de exploitant, en zeker dan de schade uit een kernongeval.

\subsection{Tweede trap: collectieve aansprakelijkheid van de exploitanten}

Naast de individuele aansprakelijkheid van de exploitant, dient een collectieve aansprakelijkheidsschijf te worden ingevoerd naar het voorbeeld van de Price-Anderson $\mathrm{Act}^{3}$. Dit impliceert dat elke exploitant toetreedt tot een risicospreidingsovereenkomst ${ }^{4}$ : van tevoren spreken de verschillende exploitanten af dat elk per kerninstallatie een bepaald bedrag zal dienen bij te dragen, met dien verstande dat de maximale jaarlijkse bijdrage eveneens wordt beperkt. Het lijkt bijvoorbeeld zinvol om het totale bedrag van deze schijf in 10 te delen, zodat wordt gegarandeerd dat gedurende 10 jaar na het kernongeval fondsen zullen beschikbaar zijn.

Indien een dergelijk systeem zou worden geïntroduceerd in West-Europa dan betekent dit dat een bijdrage in de tweede schijf dient te worden geleverd door de exploitanten van 150 kerninstallaties - dit is een groter aantal installaties dan in de tweede schijf van de Price-Anderson Act. Indien bijvoorbeeld alle exploitanten per kernongeval 100 miljoen euro zouden bijdragen, dan betekent dit dat via de risicospreidingsovereenkomst in totaal 15 miljard euro zou beschikbaar zijn; een bedrag dat gedurende 10 jaren wordt opgebouwd (jaarlijks 10 miljoen euro per kerninstallatie).

De meest geëigende juridische vorm voor de creatie van een dergelijke risicospreidingsovereenkomst, is een systeem van onderlinge verzekering van de exploitant; een captive naar het voorbeeld van NEIL en EMANI. In feite kan het onderschrijven van de risicospreidingsovereenkonst deel uitmaken van de toetreding tot de captive.

Ook hiervoor geldt dat deze risicospreiding door de exploitanten wordt aangegaan, én dat daartoe ook een plicht bestaat. Gelet op het publieke belang dat hiermee gepaard gaat, lijkt het aangewezen om de risicospreiding weliswaar door de exploitanten te laten uitvoeren, maar om de uitvoering van deze risicospreidingsovereenkomst door het onafhankelijk orgaan te laten controleren.

Cfr. supra, in \$2.4.1.2 van hoofdstuk 13.

$4 \quad$ Faure, M. en Skogh, G., "Compensation for damages caused by nuclear accidents: a convention as insurance", The Geneva Papers on Risk and Insurance, ${ }^{\circ}$ 65, 1992, 499-513; Faure, M., "Naar een nieuw model van vergoeding van nucleaire schade", in Faure, M. (red), "Aansprakelijkheid voor het nucleaire risico", l.c., 141-175. Zoals besproken, in $\$ 3.2$ van hoofdstuk 11 . 
Hiertoe dient een administratief kader te worden uitgewerkt. Dit kan de hierboven besproken ENRA zijn, maar dat hoeft niet. Wel dient de bijdrage van de exploitant aan de risicospreidingsovereenkomst uiteraard rekening te houden met de financiële zekerheid die reeds in het kader van de eerste schijf werd verschaft.

\subsection{Derde trap: de verschillende landen als herverzekeraar}

Het lijkt ook zinvol om de verschillende deelnemende landen te laten optreden als herverzekeraar. Dit betekent dat zij dus fondsen ter beschikking stellen in ruil voor een premie die de exploitanten dienen op te brengen. Het voornaamste gevolg van deze derde trap zal erin bestaan dat de globale capaciteit zal toenemen.

Deze maatregel komt in feite neer op een herziening van het systeem van het Aanvullend Verdrag van Brussel en het Verdrag inzake Bijkomende Compensatie, in die zin dat de Stat een vergoe-ding vraagt voor de ter beschikking gestelde fondsen. Deze vergoeding zal de gangbare tarieven op de verzekeringsmarkt dienen te benaderen. Door een vergoeding te vragen voor deze herverzekeringsfunctie, wordt de huidige impliciete subsidie aan de nucleaire industrie beëindigd en zal de prijs van kernenergie beter het reële risico reflecteren.

\subsection{Vierde trap: Nucleair Schadefonds}

De exploitanten dienen ook verplicht bij te dragen tot een Nucleair Schadefonds dat wordt gespijsd door een verplichte heffing ten laste van de exploitanten. Zoals reeds aangegeven kan het zinvol zijn om een procentuele taks te heffen op de premie die de exploitant aan zijn verzekeraar betaalt. Ervan uitgaande dat de verzekering kan worden verkregen op een competitieve markt en dat een tailor made polis werd uitgeschreven, is voldaan aan de vereiste dat de exploitant slechts cen bijdrage tot het Fonds levert in de mate waarin hij tot het risico heeft bijgedragen ${ }^{5}$.

Dit fonds heeft een dubbele functie: een vangnetfunctie en een voorschotfunctie ${ }^{6}$. De fondsen die in deze schijf beschikbaar zijn, zullen in essentie worden gebruikt voor de uitkering van de bedragen die niet via de vorige trappen voor vergoeding in aanmerking zijn gekomen. Maar daarnaast kan het fonds tot maximaal $30 \%$ van de beschikbare middelen uitkeren bij wijze van voorschot. Doordat de bedragen van de tweede trap bijvoorbeeld pas vrijkomen in jaar 4 , zal het fonds iceds cen voorschot kunnen uitkeren. Het sprcekt voor zich dat dit voorschot nadien kan worden teruggevorderd zodra het geld in de tweede trap beschikbaar is.

\subsection{Vijfde trap: Voluntary Liability Agreement of Nuclear Operators and Suppliers (VLANOS)}

Tenslotte worden de exploitanten en de leveranciers aangemoedigd om te participeren in cen vrijwillig compensatiesysteem, VLANOS ${ }^{7}$.

Cfr. supra, in $\S 2.2$ van hoofdstuk 15 .

Cfr. supra, in $\S 2.1 .5$ van hoofdstuk 11; zo ook Faure, M. en Hartlief, T., "Een asbestfonds als alternatief voor de aansprakelijkheid van de werkgever?", o.c., 41 .

Naar het voorbeeld van TOVALOP en CRISTAL. 
De exploitanten kunnen bijdragen tot een dergelijk systeem, bijvoorbeeld door een deel van de ristorno's die zij jaarlijks terugkrijgen van de captive, in het systeem te storten. Alleen de exploitanten die in een dergelijk systeem participeren, zijn gerechtigd om hun aansprakelijkheid te beperken ${ }^{8}$. Tegelijk zijn zij gerechtigd om de kosten van verdediging via dit fonds terug te vorderen. De hoogte van deze beperking wordt vastgesteld door de ENRA. Ook de leveranciers van de nucleaire industrie die in een dergelijk systeem participeren, kunnen hun aansprakelijkheid beperken. Doordat in het voorgestelde model er geen beperking wordt gesteld aan het aantal personen dat door slachtoffers kan worden gedagvaard, kunnen ook de leveranciers door de slachtoffers worden aangesproken ter compensatie van de door hen geleden schade?.

Hier dient het uitgangspunt tc zijn dat de administratieve overheid verwacht dat het via VLANOS ter beschikking gesteld bedrag, samen met de bedragen uit de eerdere schijven ex ante in beginsel kan worden geacht dekking te bieden voor de schade veroorzaakt door de exploitant. Juist omdat dit bedrag ro hoog is, en het de lege lata niet eens wordt benaderd, rechtvaardigt dit de beperking van de aansprakelijkhcid.

De beperking van aansprakelijkheid kan evenwel worden opgeheven indien zou blijken dat de exploitant de toepassclijke veiligheidsregulering niet heeft nageleefd.

\section{BEPERKTE MOGELIJKHEID OM DE EIGENSCHADE TE VERZEKEREN, MET "DECONTAMINATIF- DEKKING"}

Omdat zelfs met het vijftrapssysteem het underdeterrence-probleem wellicht niet volledig zal zijn aangepakt ${ }^{10}$, kan eraan worden gedacht om de exploitant beperkingen op te leggen ten aanzien van de mogelijkheid tot het verzekeren van zijn de schade aan de keminstallatie. Een kernongeval zal immers in eerste instantie emstige schade berokkenen aan de keminstallatie zelf. Indien de exploitant een bijkomende prikkel zou krijgen om geen schade aan zijn eigen installatie te veroorzaken, dan zal deze prikkel automatisch ook de potentiële slachtoffers van een kernongeval ten goede komen. Bovendien is in het huidige verzekeringssysteem het nadeel dat veel hogere bedragen ter beschikking staan voor de dekking van de installatie dan voor derden. De eigenschadeverzekering van de exploitant beperkt bijgevolg de capaciteit voor de dekking van aansprakelijkheid tegenover derden. Wanneer de eigenschadeverzekering wordt beperkt, neemt de capaciteit voor de aansprakelijkheidsdekking dus automatisch toe. Het lijkt dus om meerdere redenen aangewezen om de mogelijkheden ter dekking van de eigenschade aan de installatie te beperken of zelfs uit te sluiten.

De vraag hierbij rijst hoe ver een dergelijke beperking dient te gaan. Zoals aangegeven is gebleken dat in de onderzochte landen de eigenschade van de exploitanten is verzekerd voor een veel hoger bedrag dan de aansprakelijkheid tegenover derden. In België is bijvoorbeeld vandaag het vijfroudige beschikbaar voor de eigenschade van de exploitant dan voor de aansprakelijkheidspolis. Indien zonder meer zou worden besloten dat een exploitant in het geheel géén eigenschadeverzekering meer zou mogen nemen, dan zal dit wellicht ook leiden tot een welvaartsverlies. Ten eerste wordt de risicoaversie van de exploitant niet meer weggenomen en ten tweede

Naar het voorbeeld van de voorstellen van de Commissie Bocken, cfr. supra, in $\$ 2.1 .2$ van hoofustuk 11. Uiteraard geldt ook hier dat de leverancier enkel dan aansprakelijk mag worden gesteld indien hij daadwerkelijk aan de oorzaak ligt van de schade. 
kunnen mogelijke investeerders in de nucleaire sector worden afgeschrikt. Het is onzeker of de baten die voortvloeiend uit de gunstige prikkel van een beperking, zullen opwegen tegen de maatschappelijke kosten ervan.

De meest geëigende manier om ervoor te zorgen dat de exploitant van een kerninstailatie, via cen doorwerking van de prikkel om geen eigenschade te lijden, eveneens ertoe zal geneigd zijn om geen schade aan derden te veroorzaken, is uiteraard door de exploitant voor een deel zelf te laten blootstaan aan de eigenschade.

Zo kan worden bepaald dat een exploitant slechts een verzekeringsdekking mag nemen voor de schade die een bepaald bedrag te boven gaat, en dat hij zich niet mag verzekeren voor deze eerste schijf. Dit bedrag moet hoog genoeg zijn om een voldoende prikkel te genereren om geen eigenschade te veroorzaken; anderzijds mag het niet te hoog zijn om potentiële investeerders niet te zeer af te schrikken. Een andere maatregel kan erin bestaan dat de exploitant zijn eigenschade slechts tot een bepaald bedrag mag verzekeren. Alle eigenschade die groter is dan dit bedrag zal hij uit cigen middelen moeten betalen.

De meest aangewezen oplossing bestaat erin om een koppeling te maken tussen het bedrag van de aansprakelijkheidsverzekering en de eigenschade verzekering van de exploitant. In het verleden is het aansprakelijkheidsbedrag laag gehouden onder druk van de lobby van de nucleaire exploitanten. Indien de verzekering van de eigenschade en de aansprakelijkheidsverzekering op de één of andere wijze worden verbonden, kan een dergelijke druk in de toekomst misschien worden vermeden. Zo kan worden bepaald dat de dekking van de eigenschade verzekering van de exploitant nooit méér mag bedragen dan de aansprakelijkheidsdekking. Via deze maatregel zal een exploitant die in hoge mate risicoavers is ten aanzien van schade aan de eigen installatie, een prikkel hebben om te voorzien in een afdoende aansprakelijkheidsdekking, volgens het hierboven ontwikkelde model.

Indien deze maatregel in het jaar 2000 zou worden ingevoerd, dan heeft dit een aanzienlijke daling van de verzekering van de eigenschade tot gevolg. Deze exploitant die een hogere eigenschadedekking wenst, zal ook op zoek moeten gaan naar een hogere aansprakelijkheidsdekking. Op deze wijze zal de exploitant zelf mee helpen zoeken naar additionele verzekeringscapaciteit. Zodra deze is gevonden, moet de exploitant worden verplicht om zich voor dit hogere bedrag te verzekeren; pas dan kan de exploitant eveneens zijn dekking voor de eigenschadeverzekering verhogen.

Tenslotte wordt de exploitant wél verplicht om - naar het voorbeeld van de property rule van de NRC - een "decontaminatiedekking" voor de eigen site af te sluiten. De bedoeling hiervan is dat de exploitant na een kernongeval prioritair de eigen site ontsmet; dit \%al namelijk leiden tot een daling van de totale ongevalskosten. De verzekeraar mag slechts overgaun tot uitkering van de eigenschade aan goederen van de exploitant nadat de ontsmetting van de site is beëindigd.

Een model dat al deze elementen omvat zal in staat zijn om op efficiënte wijze bij te dragen tot de preventie van een kernongeval en zal kunnen voorzien in een adequate compensatie van de door cen kernongeval veroorzaakte schade. In de mate waarin andere catastroferisico's analoge kenmerken vertonen, kan dit model (of delen daarvan) ook buiten het nulceaire aansprakelijkheidsrecht worden gehanteerd. 



\section{SAMENVATTING}

In dit boek wordt aan de hand van een juridische, een rechtseconomische en een rechtsvergelijkende analyse onderzocht hoe de aansprakelijkheid voor schade door catastroferisico's op efficiënte wijze kan worden geregeld en op welke wijze kan worden voorzien in een compensaticsysteem. Het risico van een kernongeval en dus het nucleaire civielrechtelijke aansprakelijkheidsrecht worden hierbij als voorbeeld genomen. In dit onder $/$ oek worden het civielrechtelijke aansprakelijkheidsrecht, het verzekcringsrecht en milieuaansprakelijkheidsrecht aan de orde gesteld.

Dit boek bestaat uit vier delen: de analyse van het civielrechtelijke (nuclcaire) aansprakelijkheidsrecht, de rechtseconomische analyse, de analyse van enkele andere compensaticmechanismen en tenslotte de conclusies en aanbevelingen.

\section{DeEl 1 - ANALySE VAN HET CIVIELRECHTELIJKE, (NUCLEAIRE) AANSPRAKELIJKHEIDSREChT}

\section{TOEPASSING VAN HET CIVIELRECHTELIJKE AANSPRAKELIJKIIEIDSRECHT OP MILIEUSCHADE}

Het uitgangspunt van het Belgische en Nederlandse civielrechtelijke aansprakelijkheidsrecht is hetzelfde: in principe draagt iedereen zijn eigen schade, tenzij er een goede reden bestaat om deze schade te verschuiven. De meest traditionele reden tot schadeverschuiving is iemands fout. Anders gezegd: wanneer iemand onrechtmatig heeft gehandeld jegens een ander, dan zal deze persoon de door de andere geleden schade dienen te compenseren.

In de loop der jaren werden zowel door de rechter als door de wetgever een aantal nuanceringen aan de foutvereiste aangebracht. De invoering van aansprakelijkheidsgrondslagen die van de fout afwijken (bepaalde vormen van risicoaansprakclijkheid) heeft evenwel geen goede diensten bewezen aan de coherentie van de wet civielrechtelijke aansprakelijkheidsrecht. Er bestaat onduidelijkheid betrekkelijk een groot aantal begrippen, het onderscheid tussen de begrippen en de precieze draagwijdte daarvan.

Aangezien in dit onderzoek in belangrijke mate wordt gebruik gemaakt van een aantal begrippen uit het aansprakelijkheidsrecht, dient duidelijkheid te bestaan met betrekking tot de precicze inhoud van deze begrippen. Voor de eenduidigheid van de analyse betekent "foutaansprakelijkheid" in dit boek elke vorm van aansprakelijkheid voor eigen fouten; "risicoaansprakelijkheid" daarentegen is een aansprakelijkheid op grond van andere criteria dan de fout.

Een belangrijke factor die zowel de door de rechtspraak gecreëerde uitdijing van het aansprakelijkheidsrecht heeft mogelijk gemaakt, als de door de wetgever ingevoerde risicoaansprakelijkheden, is het ontstaan van verzekeringen. Zeker bij een stclsel van sociale zekerheid, maar ook onder invloed van de aansprakelijkheidsverzekering, wordt de indruk gewekt dat in bepaalde gevallen een aansprakelijkheidsrecht niet meer van belang is. De opkomst van andere compensatiemechanismen dan het aansprakclijkheidsrecht hebben de illusie gecreëerd dat het uitgangspunt van het aansprakelijkheidsrecht werd gewijzigd.

In Nederland werd in 1970 een Nieuw Burgerlijk Wetboek van kracht en werden in 1995 belangrijke nieuwe kwalitatieve aansprakelijkheden toegevoegd. Wel hanteert het Nederlandse BW cen aantal termen die niet in het Belgische BW voorkomen (met name relativiteit). De verschillen tussen het Belgische en het Nederlandse BW zijn echtcr in belangrijke mate terug te vocren tot verschillen in terminologie. Inhoudelijk worden via andere concepten en begrippen vaak analoge resultaten bereikt. 
Het gemene aansprakelijkheidsrecht biedt in een aantal gevallen een voldoende grondslag voor de aansprakelijkheid voor milieuschade. Het Belgische en Nederlandse BW bieden zowel een juridische grondslag op basis van de klassicke foutaansprakelijkheid als op basis van verschillende risicoaansprakelijkheden. Toch lijden beide stelsels aan belangrijke tekortkomingen die bijvoorbeeld te maken hebben met discussies omtrent de begrippen "gebrek" en "bijzonder gevaar".

\section{ONTSTAAN EN OVERZICHT VAN HET INTERNATIONALE EN NATIONALE KERNENERGIERECHT}

Het kemenergierecht is een uitgesproken intemationale rechtstak. Deze internationale dimensie is makkelijk te verklaren, ten eerste door de inspanningen op internationaal vlak om te verhinderen dat kernenergie ook voor militaire doeleinden wordt aangewend. Ten tweede vereist het aanwenden van kernenergie dat men beschikt over een aanzienlijke technologische uitrusting, over de juiste knowhow en over voldoende financiële middelen. Een dergelijke uitwisseling van wetenschappelijke kennis en financiële ondersteuning wordt bevorderd door middel van internationale samenwerking. Tenslotte zou met name de veiligheidsregulering weinig zinvol zijn indien door de verschillende landen verschillende standaarden zouden worden gehanteerd. De internationale dimensie van het kernenergierecht uit zich bijgevolg vrij sterk inzake de harmonisatie van de wetgeving in het algemeen en de inspanningen die de verschillende internationale organisaties ter zake leveren. Van groot belang voor het internationale kernenergierecht zijn met name: het Internationaal Atoomagentschap van Wenen, het Energie-agentschap van de OESO en Euratom. Nochtans kan enkel Euratom juridisch dwingende maatregelen opleggen aan de verschillende lidstaten. De afdwingbaarheid van de verschillende intermationale Verdragen is overigens de achillespees van het internationale kernenergierecht.

In het intemationale kemenergierecht werd een onderscheid gemaakt tussen de Verdragen van de eerste en die van de tweede generatie. De "demarcatielijn" was het ongeval in Tsjemobyl. Dit ongeval was een stimulans voor het kemenergierecht in de mate waarin het heeft geleid tot internationale afspraken omtrent nieuwe thema's: onderlinge bijstand, vroegtijdige kennisgeving en nucleaire veiligheid. Tegelijk werden ook de nucleaire aansprakelijkheidsverdragen aan een revisie onderworpen. Dit revisieproces is slechts gedeeltelijk ten einde, in die zin dat de revisie van het Verdrag van Parijs in 2000 nog lang niet was afgerond.

Het is overigens zeer de vraag of de nucleaire verdragen van de tweede generatie veel toevoegen aan het internationale kemenergierecht: de weinige verdragen met echt juridische verplichtingen zullen waarschijnlijk nooit in werking treden (Verdrag inzake Bijkomende Compensatie en het Protocol van het Verdrag van Wenen van 12 september 1997). De overige Verdragen van de tweede generatie zijn zo algemeen dat hieruit geen juridisch bindende verplichtingen kunnen worden afgeleid. Of het ongeval van Tsjernobyl heeft geleid tot een werkelijke breuk met het verleden, is dus zeer twijfelachtig.

De belangrijkste juridische instrumenten die in het kader van dit onderzoek worden gehanteerd zijn het Verdrag van Parijs van 29 juli 1960 inzake de wettelijke aansprakelijkheid op het gebied van de kemenergie, de Belgische wet van 22 juli 1985 betreffende de wettelijke aansprakelijkheid op het gebied van de kemenergie en de Nederlandse Wet Aansprakelijkheid Kemongevallen (WAKO) van 17 maart 1979 (ingrijpend gewijzigd in 1991). Dit Verdrag en deze wetten voorzien in een regeling indien derden schade lijden door cen kemongeval.

Ook van belang is het Aanvullend Verdrag van Brussel van 1963, dat de verschillende Verdragsluitende Staten verplicht om een deel van de wit een kernongeval geleden schade te compenseren. Ook in het toekomstige nucleaire aansprakelijkheidsrecht zal de overheid verplicht dienen tussen 
te komen: het Protocol van het Verdrag van Wenen van 1997 en het Verdrag inzake Bijkomende Compensatie van 1997 voorzien in een tussenkomst vanwege de Staat.

Het Belgische en het Nederlandse kernenergierecht dragen duidelijk de sporen van het internationale kader van deze rechtstak. Inzake safeguards zijn Belgiẻ en Nederland niet alleen een Euratomlidstaat, maar bovendien zijn zij Partij bij het Non-Proliferatieverdrag van 1969. Inzake safety zijn de Euratomverplichtingen en het Verdrag van Parijs van 29 juli 1960 inzake de wettelijke aansprakelijkheid op het gebied van kemenergie relevant. Inzake security hebben beide landen de Conventie van New York en Wenen van 3 maart 1980 inzake de fysieke bescherming van kernmateriaal getekend en geratificeerd.

De invloed van het ongeval in Tsjernobyl is, wat het nationale Belgische kemenergierecht betreft, niet meteen waarneembaar. Weliswaar werd in 1994 een wet aangenomen inzake de gevaren voortspruitend uit ioniserende straling en is het de bedoeling dat hiermee de wet van 1958 wordt vervangen, maar in oktober 2000 was deze wet slechts zeer partieel in werking getreden. Ook de wet op de nucleaire aansprakelijkheid werd niet gewijzigd naar aanleiding van het ongeval in Tsjernobyl. Na twee mislukte pogingen om de wet van 22 juli 1985 op de civiele aansprakelijkheid voor kernongevallen te wijzigen in 1986 en 1988, werd de wet uiteindelijk gewijzigd bij wet van 11 juli 2000. Deze wijzigingen zijn van kracht geworden op 1 januari 2001.

In Nederland daarentegen kan tot op zekere hoogte wél worden gesproken van een duidelijke wijziging na het ongeval in Tsjernobyl. In 1991 werd de WAKO ingrijpend gewijzigd door de invoering van de Staatstussenkomst van 5 miljard gulden. In 1994 werd de Kernenergiewet aanzienlijk uitgebreid.

\section{TOEPASSINGSGEBIED VAN DE NUCLEAIRE AANSPRAKELIJKHEIDSWWETGEVING}

Het toepassingsgebied van het Verdrag van Parijs van 29 juli 1960 is ruim omdat het in principe voldoende is dat het feit of de schade voortkomt uit de gevaarlijke eigenschappen van radioacticve stoffen, omdat niet noodzakelijk een vrijkomen van radioactiviteit is vereist en omdat evenmin een plotselinge gebeurtenis is vereist. Het toepassingsgebied is daarentegen beperkt in die zin dat bepaalde fabrieken of inrichtingen niet onder het Verdrag vallen, net zo min als bepaalde radioactieve stoffen (zoals medische isotopen in ziekenhuizen).

Het Verdrag van Parijs laat een bepaalde vrijheid aan de verschillende Verdragsluitende Staten ten aanzien van het territoriale toepassingsgebied. Zowel België als Nederland hebben van deze mogelijkheid gebruik gemaakt. Het Verdrag van Parijs is enkel van toepassing op een kemongeval dat zich heeft voorgedaan op het grondgebied van een verdragsluitende Staat en op de aldaar gcleden schade.

Een specifiek probleem met betrekking tot de beoordeling van de Verdragen van het NEA-regime heeft betrekking op een aantal onduidelijkheden ingevolge de wisselwerking tussen het Verdrag van Parijs en het Aanvullend Verdrag van Brussel. In de analyse werden verschillen vastgesteld in het territoriale toepassingsgebied en met betrekking tot de vraag of ook kerninstallaties voor vreedzaam gebruik onder het NEA-regime vallen.

Via de analyse van het Belgische en Nederlandse nucleaire aansprakelijkheidsrecht is gebleken dat de toepassing van de verschillende Verdragen tot complexe situaties én tot aanzienlijke verschillen aanleiding kan geven. Doordat Nederland lid is van het Gemeenschappelijk Protocol van 1988, zullen Nederlandse slachtoffers van een kernongeval in Hongarije - dat lid is van het Ver- 
drag van Wenen en van het Gemeenschappelijk Protocol - een beroep kunnen doen op de bepalingen van het Verdrag van Wenen. Doordat België niet is aangesloten bij het Gemeenschappelijk Protocol, zullen Belgische slachtoffers geen beroep kunnen doen op het Verdrag van Wenen.

\section{BASISPRINCIPES VAN HET NUCLEAIRE AANSPRAKELIJKHEIDSWETGEVING}

De basisprincipes van het nucleaire aansprakelijkheidsrecht zijn: risicoaansprakelijkheid van de exploitant, kanalisatie van deze aansprakelijkheid naar de exploitant van een kerninstallatie, beperking van de aansprakelijkheid, verplichte dekking van de aansprakelijkheid en de exclusieve bevoegdheid van één rechtbank.

Het Verdrag van Parijs voert een regime in van risicoaansprakelijkheid in hoofde van de exploitant van een kerninstallatie. Deze vorm van risicoaansprakelijkheid gaat echter verder dan een aantal andere vormen van risicoaansprakelijkheid, waar de aansprakelijke zich kan beroepen op de klassieke gevallen van overmacht of op een vreemde oorzaak. De aansprakelijkheid van de exploitant is dus vrij absoluut; geheel absoluut kan diens aansprakelijkheid niet worden genoemd, omdat bijvoorbeeld een burgeroorlog een geval van overmacht kan uitmaken. Vereist is wel dat de burgeroorlog rechtstreeks het kernongeval heeft veroorzaakt. De aansprakelijkheid van de exploitant strekt zich ook uit tot het transport van nucleair materiaal van en naar zijn site.

In het internationale kernenergierecht worden twee vormen van kanalisatie onderscheiden: de economische kanalisatie en de juridische kanalisatie van aansprakelijkheid. De Amerikaanse Price-Anderson Act hanteert een systeem van economische kanalisatie; de internationale Verdragen gaan uit van een juridische kanalisatie van aansprakelijkheid waarbij zowel wordt ingegrepen in het extracontractuele aansprakelijkheidsrecht (uitsluiten van andere rechtsgronden) als in het contractuele aansprakelijkheidsrecht (regresrecht van de exploitant ten opzichte van zijn leveranciers).

Volgens het zogenaamde Harvard Rapport van 1959 (gemaakt in opdracht van de Amerikaanse nucleaire toeleveringsindustric) was de kanalisatie van aansprakelijkheid naar de exploitant van de kerninstallatie noodzakelijk om drie redenen. Door kanalisatie zou ten eerste een dubbele verzekeringsdekking worden vermeden. Indien zowel de exploitant als diens leverancier voor hetzelfde risico een veizekeringsdekking moeten nemen, zou dit resulteren in hogere verzekeringskosten zonder evenredig voordeel voor slachtoffers. Vervolgens wordt ook het beperken van de samenloop als voordeel gezien omdat een slachtoffer eenvoudig kan achterhalen wie hij precies moet aanspreken bij cen vordering tot schadevergoeding. Tenslotte zou het onredelijk zijn de leverancier van cen klein onderdeel van de reactor aansprakelijk te stellen voor alle schade uit cen kernongeval. Daarbij, zo werd geredeneerd, zou het voor slachtoffers weinig zin hebben deze kleine bedrijven aan te spreken omdat die onvoldoende middelen hebben om aan alle uit een kernongeval voortvloeiende vorderingen het hoofd te bieden. Op basis van deze argumenten werd de kanalisatie van aansprakelijkheid ingeschreven in het Verdrag van Parijs van 29 juli 1960 en het Verdrag van Wenen van 21 mei 1963 inzake de civiele aansprakelijkheid bij kemongevallen: precies dezelfde redenen als aangegeven in het Harvard Rapport zijn terug te vinden in het Exposé des Motifs van het Verdrag van Parijs en bij de voorbereidende werken van het Verdrag van Wenen.

Het meest opvallende, en meteen vernieuwende element van de kanalisatie van aansprakelijkheid in het kernenergierecht, bestaat in de combinatie van het dirigeren van de aansprakelijkheid naar de exploitant van de kerninstallatie met het beperken van diens regresrechten en het buiten werking stellen van het gemene aansprakelijkheidsrecht. 
Van meet af aan werd erkend dat de kanalisatie van aansprakelijkheid zoals verwoord in het internationale kernenergierecht een drastische ingreep was in het civiele aansprakelijkheidsrecht, aangezien dit leidt tot de immuniteit van de leveranciers van de exploitant van de kerninstallatie; anderzijds werd ook gewezen op de voordelen ervan. Voorstanders van de kanalisatie in het kernenergierecht benadrukken dat de afschaffing van de gemeenrechtelijke vorderingen bij een kernongeval kadert in een geheel van maatregelen dat zowel de belangen van de industrie als de belangen van de slachtoffers dient. De discussie omtrent het nut, de merites en de tekortkomingen van de kanalisatie van aansprakelijkheid in het kernenergierecht, is nog steeds actueel. Getuige daarvan het feit dat Oostenrijk in 1999 de kanalisatie van aansprakelijkheid in het kernenergierecht heeft afgeschaft.

Het belang dat met name de VS hechten aan de bescherming van de nucleaire industrie, is ook gebleken naar aanleiding van hun inspanningen bij de onderhandelingen van het Verdrag inzake Bijkomende Compensatie. Toen in de rechtszaken naar aanleiding van de ongevallen met de Amoco Cadiz en in Bhopal bleek dat de Amerikaanse leveranciers kwetsbaar waren voor vorderingen in eigen land voor schade uit een kemongeval elders in de wereld en dat de oorzaak hiervan was te vinden in het feit dat de VS geen lid waren van het internationale nucleaire aansprakelijkheidsrecht, hebben de VS actief deeigenomen aan de onderhandelingen. Het resultaat is dat zodra het Verdrag inzake Bijkomende Compensatie in werking zal zijn getreden, de Amerikaanse rechter de zaak in principe zal doorverwijzen naar de rechtbank van de installatiestaat.

Ook buiten het nucleaire aansprakelijkheidsrecht wordt de term kanalisatie gehanteerd, maar het moet duidelijk zijn dat de kanalisatie van aansprakelijkheid in het nucleaire aansprakelijkheidsrecht en in het (milieu)aansprakelijkheidsrecht aanzienlijk van elkaar verschillen. Kanalisatie in het kernenergierecht gaat duidelijk een stuk verder: het beperkt de mogelijkheden van de slachtoffers om zich op een andere rechtsgrond te baseren enerzijds en anderzijds kan degene die wordt aansprakelijk gesteld slechts in een beperkt aantal gevallen een regresrecht uitoefenen.

Het gebruik van deze term buiten het kernenergierecht gaat echter vaak gepaard met heel wat verwarring; zo wordt risicoaansprakelijkheid in een deel van de Belgische doctrine ten onrechte beschouwd als een synoniem voor kanalisatie van aansprakelijkheid. Deze verwarring heeft voor een groot deel te maken met het feit dat in de praktijk risicoaansprakelijkheid en kanalisatie nagenoeg steeds samen voorkomen. Uit de analyse is evenwel gebleken dat de samenloopvraag dogmatisch duidelijk dient te worden onderscheiden van aansprakelijkheidsgrondslag.

Kanalisatie van aansprakelijkheid is een begrip dat in essentie een uitspraak doet over samenloopproblemen: het kiest uit een grote groep personen dic personen uit die op basis van een specifieke juridische grondslag aansprakelijk kunnen worden gesteld. Het kanaliseren van aansprakelijkheid betekent dat de aansprakelijkheid in een gegeven schadegeval, via een wettelijke bepaling wordt gedirigeerd naar een bepaalde persoon. Dit houdt in dat in een potentieel kluwen van rechtsverhoudingen door de wetgever een welbepaalde persoon wordt aangeduid die - naargelang de vorm van kanalisatie - hetzij mogelijk, hetzij in ieder geval, hetzij als enige, hetzij samen met anderen aansprakelijk zal worden gesteld.

De "strengheid" van cen bepaalde vorm van kanalisatie van aansprakelijkheid zal afhangen van drie factoren: het aantal personen naar wie de aansprakelijkheid wordt gekaraliseerd, het al dan niet intact laten van de regresvorderingen van de gekanaliseerde en het al dan niet intact laten van het gemene aansprakelijkheidsrecht voor slachtoffers van de schade. Teneinde absolute duidelijkheid te hebben bij de verschillende vormen van kanalisatie lijkt het aangewezen dat de wetgever, telkens wanneer hij gebruik wenst te maken van de kanalisatie van aansprakelijkheid, steeds de 
drie criteria voor ogen houdt én motiveert waarom hij voor een strengere dan wel voor een lichtere vorm kiest van de kanalisatie van aansprakelijkheid.

Het derde basisprincipe van het nucleaire aansprakelijkheidsrecht is de beperking van de aansprakelijkheid van de exploitant van een kerninstallatie. Deze beperking werd ingevoerd op grond van verzekeringstechnische redenen. $\mathrm{Bij}$ de start van de nucleaire industrie waren onvoldoende gegevens beschikbaar om het nucleaire risico te kunnen inschatten. Uit de onmogelijkheid om een volledige dekking te krijgen, werd de noodzaak afgeleid om de aansprakelijkheid te beperken. De bijzonder goede reden om het slachtoffer van een kernongeval het recht op volledige schadeloosstelling te ontnemen is in het nucleaire aansprakelijkheidsrecht dan ook van zuiver economische aard: het dient de exploitant te beschermen tegen potentieel ruïneuze vorderingen.

Het idee was dat de aansprakelijkheid diende te worden beperkt tot het bedrag dat op de verzekeringsmarkt beschikbaar is. Maar doordat nergens in de Verdragen de plicht is opgenomen om de aansprakelijkheidslimiet mee te laten evolueren met de capaciteit van de nucleaire verzekeringsmarkt lijkt het er sterk op dat in de meeste landen in werkelijkheid een hogere capaciteit beschikbaar is dan de aansprakelijkheidslimiet van de exploitant. Er kan immers van uit worden gegaan dat na meer dan veertig jaar nucleaire activiteiten meer gegevens beschikbaar zijn en dat in dezelfde periode de capaciteit van de nucleaire verzekeraars is toegenomen.

De economische reden om de aansprakelijkheid te beperken, wordt ook ingeroepen in andere takken van het civiele aansprakelijkheidsrecht. Uit onderzoek blijkt dat de goede redenen om de aansprakelijkheid te beperken in feite variaties zijn op eenzelfde thema, met name de onverzekerbaarheid: onbeperkte risicoaansprakelijkheid zou onverzekerbaar zijn, elke aansprakelijkheid dient door een verzekering te zijn gedekt, onverzekerbare aansprakelijkheid is niet in het belang van het slachtoffer etc.

Een essentiële vraag bij de discussie over de beperkte aansprakelijkheid, is of elke aansprakelijkheid door een verzekering moet zijn gedekt, laat staan dat elke aansprakelijkheid verzekerbaar moet zijn. Door de aansprakelijkheid te beperken wordt namelijk een deel van de lasten afgewenteld op de gemeenschap. In het nucleaire aansprakelijkheidsrecht krijgt deze vaststelling een bijkomende dimensie. Uit de analyse is gebleken dat het bedrag dat slachtoffers ter beschikking zullen hebben, afhangt van de verzekeringscapaciteit op de markt waar de exploitant zijn dekking kan kopen en van de bereidheid van de Staat om hetzij een deel van deze aansprakelijkheid voor zijn rekening te nemen, hetzij een bedrag te garanderen bovenop de aansprakelijkheid van de exploitant. Door de combinatie van de rol van de installatiestaat en de beperking van de aansprakelijkheid (waardoor een deel van de schade ten laste van de gemeenschap valt), draagt de Staat in het nucleaire aansprakelijkheidsrecht in feite op dubbele wijze bij ter zake van de compensatie van schade uit een kernongeval.

Het vierde basisprincipe is de verplichte dekking van de aansprakelijkheid. Artikel 10 van het Verdrag van Parijs voert het congruentievereiste in in het nucleaire aansprakelijkheidsrecht. Op basis van deze vereiste dient de exploitant een dekking of een andere financiële zekerheid te hebben en in stand te houden ter grootte van het bedrag waarvoor hij aansprakelijk is. Het is duidelijk dat de verdragspartijen hebben gewild dat de exploitant voor de dekking van zijn aansprakelijkheid over zeer ruime keuzemogelijkheden zou beschikken en dat aan de installatiestaat een ruime vrijheid wordt gelaten om te oordelen welk type financielle dekking gepast is.

Het congruentievereiste wil garanderen dat tegenover elke aansprakelijkheid ook daadwerkelijk financiêle middelen staan. Het lijkt dan ook in de eerste plaats uiting te geven aan het Schutzzweck van het nucleaire aansprakelijkheidsrecht. De garantie-idee in het nucleaire aansprakelijk- 
heidsrecht gaat zelfs zo ver dat het slachtoffer niet alleen wordt beschermd tegen het faillissement van de exploitant van de kerninstallatie, maar ook tegen het faillissement van de verzekeraar.

Maar het congruentievereiste impliceert dat een aansprakelijkheid waar geen verplichte dekking tegenover staat, zinloos zou zijn. Ervan uitgaande dat de verzekeringsmarkt niet in staat is om een ongelimiteerde dekking van het nucleaire risico te verschaffen, belet het congruentievereiste in de internationale nucleaire aansprakelijkheidsverdragen de invoering van een onbeperkte aansprakelijkheid.

Nochtans zijn in het Burgerlijk Wetboek - zowel in België als in Nederland - heel wat voorbeelden te vinden van aansprakelijkheden waar geen dekkingsplicht tegenover staat. Het lijkt er zelfs op dat als dusdanig de verzekeringsplicht zoals die in mindere of meerdere mate is terug te vinden in het milieurecht, een andere strekking heeft dan de dekkingsplicht van de exploitant van een kerninstallatie. In eerste instantie is er in het milieurecht geen bepaling opgenomen op basis waarvan de Staat ertoe gehouden is om zich borg te stellen indien de dekking van een verzekeringsplichtige zou falen. Ten tweede wordt in principe de aansprakelijkheid van de verzekeringsplichtige bovenop het bedrag waarvoor hij verplicht wordt om zich te verzekeren, ongemoeid gelaten.

De exclusieve bevoegdheid van één rechtbank tensiotte wil de eenheid in rechtspraak garanderen. Indien meerdere rechtbanken in verschillende landen bevoegd zouden zijn, dan bestaat namelijk het risico dat elk van deze rechtbanken een schadevergoeding toekennen waarvan de som het bedrag van de beperkte aansprakelijkheid (en de corresponderende beperkte dekking) van de exploitant zou overtreffen. Ook dient via deze bepaling te worden vermeden dat de kanalisatie van aansprakelijkheid kan worden omzeild.

Zodra echter ook schade wordt geleden in een land dat geen lid is van de internationale nucleaire aansprakelijkheidsverdragen, kan deze exclusieve bevoegdheid in het gedrang komen. Ook de mogelijkheid tot het instellen van een strafvordering naar aanleiding van cen kernongeval, kan de exclusieve bevoegdheid in het gedrang brengen en kan aldus de afwikkeling van de schadevorderingen emstig vertragen.

\section{S. VERZEKERINGEN}

De belangrijkste verzekering in het kader van dit onderzoek is de aansprakelijkheidsverzekering. Een delicaat probleem bij aansprakelijkheidsverzekeringen is de dekking in de tijd. Centraal hierbij staat de vraag hoe lang de verzekeraar ertoe kan worden verplicht om dekking te verlenen. Bijvoorbeeld bij een kernongeval kunnen namelijk meerdere jaren zijn verstreken tussen het ongeval, het zich manifesteren van de schade en het indienen van de vordering.

In de praktijk werden in de loop der jaren verschillende dekkingsgrondslagen ontwikkeld. In België en Nederland kan een analoge evolutie worden vastgesteld, in die zin dat bijvooibeeld voor milieurisico's een beroep wordt gedaan op de claims-made-dekkingsgrondslag. Voorheen werd dekking verleend op basis van de act-committed of de loss-occurrence-grondslag. Over het algemeen worden de gevolgen van de loss-occurrence en de claims-made-grondslag verzacht doordat ook dekking kan worden verleend voor het in- respectievelijk het uitlooprisico.

Een opvallend verschil tussen de situatie in België en Nederland heeft betrekking op de wettelijke basis van deze dekkingsgrondslagen. In Belgie is heel wat te doen geweest over de gevolgen van de wet op de landverzekeringsovereenkomst van 25 juni 1992; hoofdzakelijk ornwille van de 
onduidelijkheden inzake de toepasselijke dekkingsgrondslag, werd deze wet vrij snel gewijzigd. In Nederland daarentegen bestaat geen analoge wettelijke regeling inzake de dekkingsgrondslag voor de aansprakelijkheidsverzekering. De wijziging in de dekkingsgrondslag die zich ook in Nederland heeft voltrokken, is tot stand gekomen via de door de verzekeraars uitgebrachte polismodellen. De wijziging in de dekkingsgrondslag is dus in Nederland tot stand kunnen komen zonder tussenkomst van de wetgever.

De discussie met betrekking tot de dekkingsgrondslag van de aansprakelijkheidsverzekering heeft overigens in essentie te maken met de verzekerbaarheid van aansprakelijkheid. Precies omdat de verzekeraars oordeelden dat bijvoorbeeld met betrekking tot milieuaansprakelijkheid de lossoccurrence-grondslag zou leiden tot de onverzekerbaarheid van dergelijke risico's, werd de claims-made-grondslag geïntroduceerd.

\section{VERZEKERING VAN HET NUCLEAIRE RISICO}

De nucleaire verzekeringspools werden opgericht omdat in de jaren vijftig onvoldoende informatie beschikbaar was omtrent de dekking van het nucleaire risico en vooral omdat grote onzekerheid bestond over de mogelijke, uit een kemongeval voortvloeiende schade. Deze pools organiseren de dekking van het nucleaire risico op nationale basis. Dit impliceert dat nationale verzekeringsondernemingen die dat wensen, een deel van het nucleaire risico kunnen dekken. Hoewel de pools een aantal gemeenschappelijke kenmerken vertonen, verschilt de werking van deze pools naargelang het een echte pool betreft die rechtspersoonlijkheid heeft, dan wel een syndicaat waarbij een lid van de pool optreedt als fronting-company.

Deze nucleaire verzekeringspools verlenen zowel dekking voor de eigen schade van de exploitant als voor de aansprakelijkheid tegenover derden. Door de evolutie van de verzekeringsmarkt en door de grotere maturiteit die de nucleaire sector, dankzij een halve eeuw ervaring heeft weten op te bouwen, blijken anno 2000 wel degelijk alternatieven te bestaan. Zo blijkt bijvoorbeeld dat de eigen schadeverzekering, of delen daarvan (machinebreuk, brandverzekering) ook via andere wegen, bijvoorbeeld via een door de exploitanten opgezette captive, kan worden gedekt.

Een bijkomend element is dat in de loop der jaren het aantal verzekeraars is verminderd door fusies van bank- en verzekeringsgroepen. In de mate waarin verschillende verzekeraars in een pool participeren, heeft een fusie uiteraard gevolgen voor de (machts)positie van de verzckeraar binnen de pool en van de pool zelf. Met name het feit dat concurrentie tussen de pools onmogelijk is, maakt het voor de exploitanten nagenoeg onmogelijk om verzekeringsdekking te krijgen buiten de nationale pool om.

Een belangrijk argument voor de Commissie om de vorming van verzekeringspools toe te laten, bestaat in het feit dat op deze wijze ook kleine verzekeringsondernemingen een deel van het risico kunnen dekken. De gemeenschappelijke dekking van bepaalde risico's is volgens de verzekeringsindustrie noodzakelijk om bepaalde grote "onverzekerbare" risico's het hoofd te bieden. In een aantal gevallen kan een vorm van medeverzekering of medeherverzekering in een zogenaamde verzekeringspool inderdaad efficiënt zijn. Door een systeem van pooling zullen immers ook een aantal kleinere verzekeringsmaatschappijen de mogelijkheid krijgen om dekking te bieden voor een bepaald risico waaraan ze anders nooit zouden kunnen participeren. Hierdoor vergroot ook meteen de verzekeringscapaciteit, wat bijvoorbeeld bij de dekking van het nucleaire risico noodzakelijk kan zijn. 
Anderzijds is het zeer de vraag of in het licht van de vele jaren ervaring die de pools intussen hebben opgebouwd, het niet dringend tijd wordt dat concurrentie tussen de pools wordt toegelaten. Niet de verschillende pools op zich vormen een probleem, maar eerder de uitschakeling van concurrentie tussen de verschillende pools. Het lijkt er sterk op dat een uitschakeling van de concurrentie niet (meer) noodzakelijk is met het oog op het dekken van het nucleaire risico, zeker bijvoorbeeld ten aanzien van de dekking van de eigen schade en ten aanzien van de verzekering van de werknemers van de exploitant.

\section{DEEL 2. RECHTSECONOMISCHE ANALYSE}

\section{EN 8. INLEIDING + RECHTSECONOMISCH MODEL VAN HET ONGEVALLENRECHT.}

Volgens het uitgebouwde rechtseconomische model kan het aansprakelijkheidsrecht bijdragen tot een verhoging van de maatschappelijke welvaart door de maatschappelijke kosten van een ongeval zo laag mogelijk te houden. De maatschappelijke welvaart wordt gevormd door het gezamenlijke inkomen van dader en slachtoffer; de ongevalskosten zijn de kosten van voorzorg en de verwachte ongevalskosten. Onder deze benadering wordt het maatschappelijke nut gemaximaliseerd door optimale zorg uit te oefenen; van optimale zorg is sprake indien de marginale kosten van zorg gelijk zijn aan de marginale opbrengst ervan.

In dit onderzoek gaat de aandacht met name uit naar unilaterale ongevalsituaties - dat wil zeggen ongevallen waarbij enkel de dader een invloed heeft op het ongevalsrisico. Uit de analyse is gebleken dat in dergelijke gevallen een aansprakelijkheidsregel is vereist. Bij afwezigheid van een dergelijke regel zal de dader immers geen enkel prikkel hebben om zelfs maar de geringste zorg te besteden. Het Coase-theorema is dus niet van toepassing gelet op de prohibitief hoge transactiekosten.

Een prikkel tot het uitoefenen van zorg zal daarentegen wel voorhanden zijn bij een regime van. foutaansprakelijkheid of bij risicoaansprakelijkheid. Het grote verschil tussen beide aansprakelijkheidsregimes bestaat erin dat bij risicoaansprakelijkheid de rechter enkel de grootte van de schade dient vast te stellen en dat de uitgekeerde schadevergoeding dient overeen te stemmen met de werkelijk geleden schade, terwijl bij foutaansprakelijkheid de rechter het niveau van optimale zorg moet berekenen en moet bepalen of de dader dit niveau van zorg heeft besteed. Onder de gestelde voorwaarden leiden zowel foutaansprakelijkheid als risicoaansprakelijkheid tot een. efficiènt resultaat.

Rekening houdend met het activiteitsniveau, bestaat in unilaterale ongevalsituaties een voorkeur voor risicoaansprakelijkheid omdat in een dergelijk geval de dader niet alleen optimale zorg zal uitoefenen, maar hij tegelijk het juiste activiteitsniveau zal aanhouden. Bij foutaansprakelijkheid wordt enkel gekeken of de dader voldoende zorg heeft aangewend en niet of hij het optimale: activiteitsniveau heeft aangehouden.

Indien onzekerheid bestaat over de causaliteit of over de schadeomvang, dan kan dit een weerslag, hebben op de keuze van de meest efficiënte rechtsregel.

Wat gevallen van causaliteitsonzekerheid betreft dient een belangenafweging te worden gernaakt tussen enerzijds het feit dat de drempelwaarde nefaste gevolgen heeft op de prikkelwerking, en anderzijds het feit dat via een systeem van proportionele aansprakelijkheid meer zaken voor de rechtbank worden gebracht. Aangezien het aannemelijk is om ervan uit te gaan dat de geringe 
prikkelwerking bij een drempelwaarde enkel tegen aanzienlijke administratieve kosten kan worden opgevangen, zal een voorkeur ontstaan voor proportionele aansprakelijkheid.

Indien er grote onzekerheid bestaat over de schade, dan kan die worden geschat. Bij grote onzekerheid is de kans dat de schade te hoog of te laag wordt ingeschat zeer aanzienlijk. In beide gevallen zal een welvaartsverlies optreden: in het ene geval zal de dader teveel zorg uitoefenen en in het andere geval zullen niet alle kosten worden geïnternaliseerd. Het kan dan ook zinvol zijn om een "vermoedelijke" schade niet te aanvaarden omdat het welvaartverlies door het toelaten van deze schade groter kan zijn dan het welvaartverlies ingevolge het niet toelaten. Enkel wanneer het niet in aanmerking nemen van een bepaalde schade een belangrijke invloed heeft op de prikkelwerking, zal het zinvol zijn om deze schade te schatten en in de totale schadeomvang op te nemen.

Tenslotte hebben de administratieve kosten een invloed op de efficiëntie van de aansprakelijkheidsregel. Er bestaat cen voorkeur voor risicoaansprakelijkheid omdat de informatiekosten lager liggen dan bij foutaansprakelijkheid, zekcr indien de gerechtskosten in de hand kunnen worden gehouden.

\section{ECONOMISCHE ANALYSE VAN VERZEKERINGEN}

Vanuit rechtseconomisch oogpunt zal de houding ten aanzien van een risico bepalen of een verzekering al dan niet zinvol is. Voor een risicoaverse persoon kan het zinvol zijn om het risico te spreiden of te verschuiven.

Verzekeringen kunnen de maatschappelijke welvaart verhogen omdat een verzekeringsdekking de risicoaversic van een persoon wegneemt. Wanneer degene die het risico overneemt beter in staat is om het risico te dragen, dan stijgt de maatschappelijke welvaart. Toch dient aan een aantal voorwaarden te zijn voldaan vooraleer verzekeringen ook de maatschappelijke welvaart verhogen. In de eerste plaats dient de verzekeringsmarkt competitief te zijn; daarnaast moeten zowel het morele risico als de averechtse selectie onder controle blijven.

Van een morcel risico is sprake wanneer de loutere beschikbaarheid van een verzekeringsdekking het gedrag van de verzekerde zal wijzigen, wat resulteert in een toename van het risico. Door de verzekerde gedeeltelijk zelf bloot te stellen aan het risico of door het gedrag van de verzekerde te controleren met een eventuele aanpassing van de premie, kan het morele risico worden uitgesloten of beperkt. Aangezien het maatschappelijke nut in principe wordt geoptimaliseerd door het verlenen van een volledige dekking, zal het de voorkeur verdienen om de premie aan te passen in functie van de controle van het gedrag van de verzekeringsnemer of van de verzckerde. Indien er onvoldoende informatie beschikbaar is over het gedrag van deze personen, zal het aangewezen zijn om het morele risico in te perken via gedeeltelijke blootstelling aan het risico.

In de mate waarin de verzekeraar over onvoldoende informatie beschikt (in rechtseconomische termen wordt dan gesproken van een informaticasymmetrie in hoofde van de verzekeraar), kan het probleem van de averechtse selectie opduiken. Onvoldoende informatie van de kant van de verzekeraar zal leiden tot een te brede omschrijving van de risicogroepen, waardoor de goede risico's de groep zullen verlaten. Dit zal het geval zijn zodra de gemiddelde premie van een risicogroep te hoog wordt in de ogen van de personen die een goed risico vertegenwoordigen. De bestc remedic tegen het probleem van de averechtse selectie is een strakke omschrijving van de verschillende risicogroepen. 
Een voldoende concurrentie op de verzekeringsmarkt is in dit kader van groot belang, aangezien het een antwoord zal kunnen bieden op de informatieasymmetrie in hoofde van de verzekeraar en aangezien het gedrag van een voorzichtige verzekeringsnemer zal worden beloond. Gebrekkige concurrentie zal voorzichtig gedrag niet (voldoende) belonen, waardoor het ongevalrisico verhoogt.

Het is echter niet omdat in een gegeven situatic een vraag naar een bepaalde dekking bestaat, dat het zinvol zou zijn om deze dekking verplicht te stellen. De kans dat een verplichte verzekering precies die dekking verplicht stelt die de dader zou nemen bij afwezigheid van een verplichte dekking is klein, wat een welvaartverlies tot gevolg heeft. Traditioneel worden twee argumenten ingeroepen om een verzekering verplicht te stellen: het risico van insolventie van de dader of het bestaan van een informatieasymmetrie.

Wat zware milieurisico's betreft lijkt enkel het insolventierisico van de dader een valabel argument om een aansprakelijkheidsverzekering verplicht te stellen. Immers, bij faillisscment van de dader zullen slachtoffers als niet-bevoorrechte schuldeiser weinig kans maken on de door hen geleden schade terug te vorderen. Indien kan worden gesproken van een reëel insolventierisicu. betekent dit dat het vermogen van de dader niet zal volstaan om alle schade te vergoeden; er is met andere woorden sprake van een beperktc aansprakelijkheid. Een verplichte dekking die beantwoordt aan de risicoaversie van de dader en rekening houdt met diens vermogen, kan wel dus dienen als remedie tegen de gebrekkige prikkelwerking van een beperkte aansprakelijkheid. Indien een verzekering wordt verplicht gesteld als remedic tegen insolventie, dan moet er in ieder geval over worden gewaakt dat het morele risico in de hand kan worden gehouden. Dit zal makkelijker zijn wanneer het bedrag waarvoor de verzekeringsplicht geldt individueel, dit wil zeggen per industriële site, wordt vastgesteld.

Het tweede klassieke argument ter rechtvaardiging van een regime van verplichte verzekering, namclijk als remedie tegen een informatieasymmetrie, lijkt weinig aannemelijk. Zeker ten aanzien van zware milieurisico's is het belangrijk dat de verschillende betrokken partijen de nodige prikkels behouden om informatie in te winnen over de activiteiten, het risico etc.

Een bijzonder element in het onderzoek vormt de verzekerbaarheid van een risico. Het is niet eenvoudig om een eenduidige en alomvattende omschrijving te geven van een verzekerbaar risico. Theoretisch kunnen alle risico's worden verzekerd, op voorwaarde dat ze voorzienbaar zijn, dat het morele risico en het probleem van de averechtse selectie onder controle kunnen worden gehouden en dat voldoende capaciteit op de verzekeringsmarkt aanwezig is.

Uitgaande van de vaststelling dat in toenemende mate een beroep wordt gedaan op het aansprakelijkheidsrecht, kan ook worden verwacht dat in toenemende mate een beroep zal worden gedaan op verzekeringen (zowel first als third party-verzekeringen). Op zich is deze vaststulling niet problematisch, wel integendeel: indien de uitbreiding voorzienbaar is, leidt de uitgebreide belangstelling voor aansprakelijkheidsverzekeringen tot een grotere vraag en tot nieuwe markten. Stijgt de vraag naar aansprakelijkheidspolissen, dan zal de verzekeraar nieuwe polissen afsluiten en dus ook nieuwe inkomsten genereren waarmee de nieuwe verliezen kunnen worden gedekt.

Ecn zeer hoge verwachte schade of een moeilijk in te schatten probabiliteit zijn geen voldoende reden om te besluiten tot de onverzekerbaarheid van een risico. Niet alleen heeft de verzekeringsindustrie allerlei technicken ontwikkeld (herverzekering, verzekeringspools, etc.) om ook aan grote risico's het hoofd te bieden, bovendien zal hiermee rekening worden gehouden bij het bepalen van de premie. Zolang veranderingen in $p$ en $S$ voorzienbaar zijn en zolang de verzckeraar de premie en de polis dienovereenkomstig kan aanpassen, blijft dat risico verzekerbaar. Indien de 
voor de verzekeraar beschikbare gegevens moeilijk zijn in te schatten, is sprake van insurer's ambiguity. Deze verzekeraar zal hieraan tegemoet komen door een additionele risicopremie in aanmerking te nemen.

Moeilijker wordt het wanneer de voorzienbaarheid van het risico in het gedrang komt, met name wanneer de verzekeraar wordt geconfronteerd met causaliteitsonzekerheid of retroactieve aansprakelijkheid. De verschillende elementen die leiden tot de onverzekerbaarheid van een risico hebben in feite te maken met een informatietekort, hetzij in hoofde van de verzekerde, hetzij in hoofde van de verzekeraar, hetzij in hoofde van de rechter.

Uit de analyse is ook gebleken dat een verplichte verzekering een remedie kan zijn tegen het insolventiegevaar van de dader, maar dat de combinatie tussen een verzekeringsplicht en een beperkte aansprakelijkheid tot hetzelfde bedrag, economisch nadelig is. Het wordt voor de verzekeraar namelijk moeilijk om het gedrag van de verzekerde te controleren; het morele risico wordt in de hand gewerkt, hetgeen kan leiden tot problemen inzake verzekerbaarheid.

\section{ECONOMISCHE ANALYSE VAN VEILIGHEIDSREGULERING}

Vaak wordt risicoaansprakelijkheid gecombineerd met het opleggen van veiligheidsregulering omdat wordt geoordeeld dat dit noodzakelijk is om een optimale preventie te bewerkstelligen: zelfs indien de dader prikkels heeft vanuit het aansprakelijkheidsrecht, wordt het noodzakelijk geacht de dader door middel van veiligheidsregulering te verplichten bijkomende voorzorgsmaatregelen te nemen.

Veiligheidsregulering wordt in bepaalde gevallen afgekondigd als antwoord op mogelijke insolventie van de dader. Niet alleen wordt hierbij uit het oog verloren dat veiligheidsregulering enkel zinvol is indien de overheid over betere informatic beschikt dan de potentiële dader, daarnaast dient erop te worden gewczen dat bij mogelijke insolventie het efficiënter kan zijn een beroep te doen op foutaansprakelijkheid en niet op risicoaansprakelijkheid. Bovendien wordt reeds getracht het insolventieprobleem te verhelpen door het verplicht stellen van een aansprakelijkheidsverzekering. Het is daarom zeer de vraag waarom het insolventieprobleem nog eens extra dient te worden opgelost door middel van veiligheidsregulering en of het gecombineerd gebruik van risicoaansprakelijkheid, veiligheidsregulering en verplichte verzekering niet zal leiden tot inefficiënt hoge administratieve kosten.

Indien veiligheidsregulering daarentegen wordt gecombineerd met foutaansprakelijkheid, zullen deze kosten een stuk lager liggen, met name indien er een insolventierisico bestaat. Bij foutaansprakclijkheid zal de dader zorg aanwenden zolang deze kosten lager zijn dan zijn vermogen. Vanuit de kant van slachtoffers volstaat het om aan te tonen dat de dader de veiligheidsvoorschriften niet heeft nageleefd. Het grote voordeel hierbij is dat slachtoffers via deze weg voldoende prikkels krijgen om op te treden als handhavers van de veiligheidsregulering.

\section{DEEL 3. ANDERE COMPENSATIEMECHANISMEN}

\section{DEKKING VAN CATASTROFERISICO'S}

Er zijn enkele opmerkelijke verschillen betreffende de dekking van milieurisico's op de Belgische en de Nederlandse markt. De grootste Nederlandse verzekeraars hebben zich aangesloten bij een samenwerkingsverband, met name de Nederlandse Milieupool. Deze pool is in feite de opvolger van het Milieu Aansprakelijkheid Samenwerkingsverband of MAS. Aanvankelijk bood deze pool 
de specifieke MAS-polis aan, ter dekking van milieuaansprakelijkheid. Inmiddels is sinds 1998 ook een geïntegreerde milieuschadeverzekering (MSV-polis) beschikbaar. Deze polis draagt elementen in zich van een eigen schadeverzekering, maar is daarenboven ook een directe verzekering ten behoeve van derden. Deze directe verzekering biedt het voordeel dat een vordering kan worden afgehandeld buiten het aansprakelijkheidsrecht om.

Een analoge geïntegreerde milieupolis is niet beschikbaar op de Belgische markt. Wel zijn sinds 1996 afzonderlijke polissen inzake milieuaansprakelijkheid beschikbaar. Deze polis wordt in tegenstelling tot in Nederland, niet aangeboden door een samenwerkingsverband van verzekeraars, maar door een viertal verschillende grotere verzekeringsondernemingen. Een aanzienlijk deel van de dekking van milieurisico's is dan ook hetzij niet gedekt, hetzij gedekt als een bijzondere waarborg onder de algemene polis BA-uitbating.

Naast de aansprakelijkheidsverzekering en de directe verzekering ten behoeve van derden, werd ook de eigen schadeverzekering (of first party insurance) onderzocht. Voor zover bekend wordt een first party-dekking op de markt niet op algemene wijze aangeboden ter zake van de dekking van milieuschade. Nochtans kan deze verzekeringsvorm een aantrekkelijk altematief vormen voor de aansprakelijkheidsverzekering omdat beter kan worden tegemoet gekomen aan de problemen van antiselectie. Een first party-verzekering zal het inderdaad mogelijk maken om informatie in te winnen van de verzekeringsnemer (minder probleem van informatieasymmetrie) en dus zullen de goede risico's beter van de slechte kunnen worden onderscheiden. Een first party dekking en een directe verzekering kunnen daarenboven een positieve invloed hebben op de tertiaire ongevalskosten.

Uit het onderzoek blijkt ook dat schadefondsen die aansluiten op het aansprakelijkheidsrecht met dezelfde problemen kampen als het aansprakelijkheidsrecht en de aansprakelijkheidsverzekering. Het is dan ook onduidelijk wat op dit terrein de voordelen zouden zijn van een schadefonds vergeleken met een verzekeringsdekking. Centraal in de discussie over het nut van een fonds vergeleken met verzekeringen, staan de informatic en de kosten van het desbetreffende compensatiemechanisme. Enkel in een zeer beperkt aantal gevallen zal een fonds over betere informatie beschikken dan een op een competitieve markt actieve verzekeraar. Zelfs indien er bijvoorbeeld een gebrek aan concurrentie is op de verzekeringsmarkt, moet misschien eerst worden gekeken of het niet efficiënter is om concurrentiebevorderende matregelen te nemen, veeleer dan meteen een schadefonds in het leven te roepen. Net als bij een aansprakelijkheidsverzekering zal het ook voor een fondsbeheerder niet eenvoudig zijn om antiselectic en het morele risico tegen te gaan. Tegelijk zijn twijfels gerezen bij de stelling dat een fonds goedkoper en efficiënter zou werken dan een commerciële verzekeringsmaatschappij. De ervaring met van het Nederlandse Fonds Luchtverontreiniging bevestigt die twijfels.

Tegelijk mogen de voordelen van een first party dekking ten aanzien van de mogelijkheden tot risicodifferentiatie, niet uit het oog worden verloren. Het grote voordeel van een first partydekking bestaat erin dat de verzekeraar ex ante - en dus tegen geringe kosten - informatie kan inwinnen over het te dekken risico en dat hij dus relatief makkelijk de goede van de slechte risico's kan onderscheiden. Omdat bij third party-dekkingen de verzekeraar per definitie nauwelijks gegevens in handen heeft over het risico, wordt de indeling in risicogroepen cen stuk moeilijker.

Zowel een aansprakelijkheidsverzekering als een fonds dat aansluit op het aansprakelijkheidsrecht blijven hoogdrempelige mechanismen die een nadelige invloed hebben op de tertiaire ongevalskosten. Een directe verzekering of een first party-verzekering kan daarentegen een handig middel zijn om bijkomende informatie in te winnen én om deze tertiaire ongevalskosten te drukken. Beiden hebben onmiskenbaar een gunstige invloed op de snelle afhandeling van de vorderingen. 
Wat het terugdringen van de tertiaire ongevalskosten betreft, zal vooral de first party-dekking een oplossing kunnen bieden. Een directe verzekering zal enkel dit voordeel hebben indien de groep van begunstigden van deze dekking niet te groot is.

Indien er toch redenen zouden zijn voor de invoering van een fonds, is het zeer belangrijk dat initieel het aansprakelijkheidsrecht ongemoeid wordt gelaten, zodat de prikkels die van daaruit ontstaan, intact blijven. Vandaar kan voomamelijk een fonds met een waarborgfunctie zinvol zijn. In een aantal gevallen zal overigens de combinatie van een waarborg- en een voorschotfonds zinvol zijn.

In de loop der jaren werden zowel in België (Vlaanderen) als in Nederland reeds verschillende onderzoeken uitgevoerd naar de haalbaarheid van een alternatief compensatiemechanisme. Bij de voorstellen van de Interuniversitaire Commissie tot Herziening van het Milieurecht in het Vlaamse Gewest (Commissie Bocken) springt in het oog dat aan de exploitant een brede waaier aan mogelijkheden wordt geboden ter dekking van zijn aansprakelijkheid. Ook de idee om de exploitant de mogelijkheid te bieden om zijn aansprakelijkheid te beperken in ruil voor deelname aan een vrijwillig compensatiemechanisme is uitermate waardevol. De Nederlandse voorstellen inzake de creatie van een algemeen milieuschadefonds zijn vooral opmerkelijk aangezien dit fonds gericht zou zijn op de compensatie van ecologische schade.

Tenslotte is gebleken dat blijkbaar op verschillende fronten wordt gezocht naar alternatieve oplossingen. Commerciële verzekeraars bundelen hun krachten in samenwerkingsverbanden; bijzondere geïntegreerde polissen worden gecreëerd; "daders" gaan op zoek naar manieren om zelf een deel van het risico te dekken; verzekeraars gaan op hun beurt op zoek om via de kapitaalmarkt de herverzekeringscapaciteit te verhogen. Het lijkt er dan ook op dat het onmogelijk is om een enige en zaligmakende oplossing voor de dekking van een catastroferisico - zoals het nucleaire risicote vinden en toe te passen. Er moet meer worden gedacht aan gemengde mechanismen. In die zin bevatten de besproken voorstellen inzake de dekking van het nucleaire risico waardevolle elementen, maar ze zullen in een groter geheel moeten worden geïntegreerd.

\section{AANSPRAKELIJKHEID VOOR SCHADE DOOR OLIEVERONTREINIGING OP ZEE}

Uit de bespreking van de internationale Verdragen inzake aansprakelijkheid voor olieverontreiniging op zee, blijkt in eerste instantie dat deze Verdragen inhoudelijk vrij gelijklopend zijn met de nucleaire aansprakelijkheidsverdragen, in die zin dat dezelfde basisprincipes kunnen worden teruggevonden: risicoaansprakelijkheid, kanalisatie van aansprakelijkheid, verplichte verzekering van aansprakelijkheid en beperking van de aansprakelijkheid.

Onder het CLC-Verdrag kan een exploitant zich echter enkel op deze beperking beroepen indien hij een fonds heeft gevormd, gelijk aan het bedrag waarvoor hij aansprakelijk is. In het maritieme aansprakelijkheidsrecht onder het CLC- en het Oliefondsverdrag wordt de aansprakelijkheid daarenboven verdeeld tussen de verschillende partijen die belang hebben bij het transport. In het nucleaire aansprakelijkheidsrecht wordt er geen lastenverdeling ingevoerd met andere private actoren. Bij transport van olie kan inderdaad worden aangenomen dat twee duidelijk onderscheiden partijen belang hebben bij het transport en dat bijgevolg beiden een inspanningen dienen te leveren. Bij de productie van kernenergie ligt cenzelfde lastenverdeling niet meteen voor de hand. De rol die de Staat op zich neemt in het nucleaire aansprakelijkheidsrecht kan niet als een analoge lastenverdeling worden beschouwd. De staatstussenkomst werd namelijk initieel in het kernenergierecht ingeschreven wegens de beperkte gegevens inzake de dekking van het nucleaire risico. 
Recent hebben zich op het terrein van de aansprakelijkheid voor olieverontreiniging op zee; een aantal opmerkelijke en ingrijpende veranderingen voorgedaan. De belangrijkste wijziging betreft het optrckken van de aansprakelijkheid van de verschillende actoren door de nieuwe CLC- en Oliefondsverdragen. Tegelijk werden de vrijwillige afspraken tussen scheepseigenaren opgedoekt. Blijkbaar is de industrie van oordeel dat de compensatiemechanismen die in de Verdragen zijn uitgewerkt afdoende bescherming bieden.

De dekking van schade door olieverontreiniging op zec gebeurt via de Protection \& Indemnity Club. Dit is een captive van de scheepseigenaren. In tegenstelling tot de captive van de exploitanten van een kerninstallatie in de VS, verzekert deze Club zowel de extracontractuele, de contractuele aansprakelijkheid als de eigen schade. Tussen deze Protection and Indemnity Clubs bestaat ook concurrentie, zodat de verschillende betrokken partijen een keuze hebben om zich bij een welbepaalde Club aan te sluiten. Het is logisch dat de bevoegdheid van het clubbcheer om een lid uit de club te zetten, met name de preventie van ongevallen ten goede komt. Toch heeft de Europese Commissie heel wat vraagtekens geplaatst bij de werking van de P\&I Club en met name bij de wijze van herverzekering via de Intemational Group of P\&I Clubs. De Commissie heeft de Clubs verplicht om belangrijke wijzigingen aan te brengen aan de wijze van herverzekeren.

Zowel in het maritieme recht als in het nucleaire recht wordt dus naast de aansprakelijkheid van de scheepseigenaar en de exploitant van de kerninstallatic (respectievelijk het CLC-Verdrag van 1969 en het Verdrag van Parijs van 1960) ook voorzien in bijkomende compensatie. Maar in het maritieme recht bestaat de aanvullende compensatie uit private middelen (Oliefondsverdrag), terwijl in het kemenergierecht de verschillende verdragsluitende Staten van het Aanvullend Verdrag van Brussel van 1963 publieke fondsen ter beschikking stellen.

\section{AANSPRAKELIJKHEID EN VERZEKERING VAN HET NUCLLAIRE RISICO IN DE VHRLNIGNE STATEN}

Centraal in het Amerikaanse nucleaire aansprakelijkheidsrecht staat de Price-Anderson Act van 1957. Deze wet heeft een aantal belangrijke principes geïntroduceerd in de Atomic Encrgy Act. Het doel van de Price-Anderson Act was het vinden van een evenwicht tussen de belangen van de industrie en de belangen van slachtoffers van kemongevallen. Deze wet heeft sinds haar ontstaan in 1957 een zeer grondige evolutie gekend. Belangrijk hierbij is dat deze wet steeds wordt afgesloten voor een beperkte periode omdat wordt geoordeeld dat het een uitzonderingsregime betreft; bij elk van deze verlengingen werd telkens de vraag gesteld of de doelstellingen van de wet afdoende werden bereikt. Periodiek wordt de wet dus opnieuw voorgelegd aan het Amerikaanse Congres, dat moet oordelen of er een voldoende evenwicht wordt bereikt tussen de belangen van de industrie en de belangen van slachtoffers van een kernongeval.

Zonder enige twijfel kan worden gesteld dat de Price-Anderson Act in haar oorspronkelijke versie vooral de Amerikaanse nucleaire industrie beschermde. Het overgrote deel van de schadevergoeding (500 miljoen dollar) viel ten laste van de overheid; de industrie diende zich te verzekeren voor een bedrag dat op de markt beschikbaar was (60 miljoen dollar). Belangrijk voor de verhoging van de financiële lasten van de exploitant, was de introductie van een nieuwe schijf in het compensatiesysteem van de Price-Anderson Act in 1975. Deze schijf werd gevormd door een collectieve bijdrage van alle Amerikaanse exploitanten. Naarmate meer kerninstallaties waren vergund, namen de beschikbare fondsen in deze schijf toe en werd de overheidstussenkomst opgeheven. Een transfer van financiële verantwoordelijkheid van de overheid naar de industrie is in de VS dan ook consequent doorgevoerd, met dien verstande dat het totale beschikbare schadevergoedingsbedrag en de aansprakelijkheid van de exploitant beperkt blijven. Bij de wijzigingen in 1988 stelde de NRC voor deze beperking op te heffen, hetgeen niet is doorgevoerd onder druk van de nucleaire industrie. 
Een substantiële verhoging van het schadevergoedingsbedrag werd echter pas doorgevoerd door de wijzigingen die in 1988 aan de Price-Anderson Act werden aangebracht, en dan met name door een aanzienlijke verhoging van de bijdragen in de tweede schijf. Belangrijk is ook dat de bijdragen van deze eerste schijf elke vijf jaar worden aangepast aan de index.

Via de combinatie van de individuele eerste schijf en de collectieve tweede schijf, is de PriceAnderson Act inderdaad in staat om vrij hoge bedragen te genereren: in 2000 bedrocg het totale beschikbare schadevergoedingsbedrag 9,11 miljard dollar, of 9,96 miljard euro. Maar naarmate minder reactoren operationeel zullen zijn, zal het totale schadevergoedingsbedrag drastisch afnemen.

De evolutie van het Amerikaanse nucleaire aansprakelijkheidsrecht kan niet worden los gezien van de rol die de Nuclear Regulatory Commission ter zake vervult. De voorganger van de NRC, de Atomic Energy Commission werd opgeheven in 1974 omdat ernstige vragen werden gesteld bij de rol dic de AEC speelde bij de ontwikkeling van civiele toepassingen van kernenergie. Vooral het fcit dat de AEC zowel een promotionele als een controlerende functie had, gaf aanleiding tot emstige kritick. Daarom werd de NRC opgericht als een onafhankelijke instelling die enkel verantwoording verschuldigd is aan de President van de Verenigde Staten. Precies deze onafhankelijkheid van de NRC is een belangrijke factor geweest in de evolutie van de PriceAnderson Act.

De evolutie die zich in de VS heeft voorgedaan, verliep parallel met de evolutie op de Amerikaanse nucleaire verzekeringsmarkt. Onmiddellijk na de invoering van het stelsel van retroactieve premies, bood ANI de daartoe noodzakelijke dekking aan. Hetzelfde geldt na het afkondigen door de NRC van de property rule. Het proactieve beleid van de Amerikaanse nucleaire industrie dateert overigens van vóór het van kracht worden van de property rule. Toen de exploitanten van kerninstallaties in 1972 oordeelden dat de kosten voor de eigen schadeverzekering te hoog opliepen, richtten zij een eigen captive op (Nuclear Mutual Limited). In 1981 werd daarenboven, als reactie op het ongeval van Three Mile Island, een tweede captive opgericht. In 1997 boden de verschillende polissen een gecombineerde dekking aan van 3,85 miljard dollar. Dankzij de werking van de captives van de Amerikaanse nucleaire exploitanten, werden aanzienlijke reserves opgebouwd, waardoor de bijdragen van de meeste leden kleiner zijn dan de retributie die ze jaarlijks terugkrijgen.

Het Europese nucleaire aansprakelijkheidsrecht is duidelijk verwant met de Amerikaanse PriceAnderson Act. Ook in het Verdrag van Parijs wordt een regime van risicoaansprakelijkheid gehanteerd, wordt de aansprakelijkheid van de exploitant beperkt en wordt de exploitant verplicht om deze aansprakelijkheid te verzekeren. Daarenboven voorzag ook de oorspronkelijke PriceAnderson Act in een overheidstussenkomst. Deze verwantschap is ook niet verwonderlijk aangezien beide systemen voortbouwen op de conclusies van het Voorlopig Rapport. Op eén fundamenteel punt verschillen beide systemen evenwel van elkaar, met name inzake de juridische kanalisatie van aansprakelijkheid. In de VS kunnen verschillende personen die diensten of producten hebben geleverd aan de exploitant, worden gedagvaard door de slachtoffers van een kernongeval. De leveranciers zijn evenwel economisch gedekt via de omnibusdekking in de aansprakelijkheidsverzckering van de exploitant (economische kanalisatie).

De aanpassing van de Price-Anderson Act heeft geleid tot een belangrijk verschil wat de samenstelling van de collectieve schijf betreft. Beide stelsels voorzien, naast deze individuele aansprakelijkheid van de exploitant, in bijkomende financiële middelen. In de landen van de NEA zijn dit cvenwel middelen die door de overheid worden ter beschikking gesteld (met name via het Aanvullend Verdrag van Brussel van 1963); terwijl in de VS een collectief mechanisme van de ex- 
ploitanten deze bijkomende fondsen genereert. In de VS kwam initieel de Staat eveneens tussenbeide, maar van de periodieke wijzigingen van de Price-Anderson Act werd gebruik gemaakt om deze tussenkomst op te heffen. In het Europese nucleaire aansprakelijkheidsrecht heeft men duidelijk uit het oog verloren dat de overheidstussenkomst in het Voorlopig Rapport als een tijdelijke maatregel werd beschouwd.

Daarnaast ligt de totale beschikbare schadevergoeding in Europa een stuk lager dan de in de VS uit private middelen beschikbare schadevergoeding. Zelfs met de overheidstussenkomst blijven de bedragen die op basis van het internationale nucleaire aansprakelijkheidsrecht - onder het Aanvullend Verdrag van Brussel van 1963 en onder het Verdrag inzake Bijkomende Compensatie van 1997 - beschikbaar zijn, vrij bescheiden.

\section{DeEl 4. Conclusies EN AANBEVELINGEN}

\section{CONCLUSIES UIT DE JURIDISCHE ANALYSE}

In de nucleaire aansprakelijkheidsverdragen is geen enkele verplichting opgenomen op basis warvan de verplichte dekking automatisch de capaciteit van de verzekeringsmarkt zou volgen. Het Belgische en het Nederlandse nucleaire aansprakelijkheidsrecht bevatten evenmin een dergelijke bepaling. De respectievelijke nucleaire aansprakelijkheidswetten bepalen enkel dat de regering het aansprakelijkheidsbedrag kan verhogen. Van enige verplichting tot systematische verhoging in functie van de capaciteiten van de verzekeringsmarkt, is geen sprake.

Zelfs indien rekening zou worden gehouden met een "gemiddeld" kernongeval, dan nog dient te worden vastgesteld dat de exploitant slechts voor een klein deel aansprakelijk is voor de schade die hij aan derden veroorzaakt. Behalve in enkele uitzonderingsgevallen (Duitsland, Zwitserland, Oostenrijk en Japan) kan de exploitant boven deze bedragen niet aansprakelijk worden gesteld. Er moet worden erkend dat het zeer moeilijk is om louter op basis van bedragen gefundeerde uitspraken tc doen over de merites van het compensatiesysteem van een land. De mate waarin een slachtoffer wordt beschermd, hangt namelijk niet uitsluitend af van deze cijfers. Eveneens het in een gegeven land aanwezige stelsel van sociale zekerheid en de interpretatie van bepaalde juridische begrippen zullen bepalend zijn voor de mate van slachtofferbescherming. Daarnaast worden door de verzekeraars verschillende dekkingssystemen gehanteerd. Dit neemt niet weg dat de cijfers met betrekking tot de aansprakelijkheidsbedragen een belangrijke indicatic bieden voor de sommen die, buiten sociale zekerheid, beschikbaar zijn voor de slachtoffers van een kernongeval.

Het is ook vreemd dat zowel de internationale Verdragen als de uitvoeringswetten een algemene dekkingslimiet invoeren die dus van toepassing is op alle kerninstallaties van het land. Er wordt met andere woorden niet cen verschillende limiet opgelegd in functie van risicobepalende factoren, zoals bijvoorbeeld het type reactor, de ligging van de reactor etc. Verzekeraars daarentegen hanteren voor hetzelfde dekkingsbedrag verschillende premies. Dit wijst erop dat rekening wordt gehouden met bijvoorbeeld de ligging van de reactor. Verzekeraars voeren dus een zekere graad van risicodifferentiatie door. Door evenwel één enkel dekkingsbedrag in de wet vast te lcggen dat dus van toepassing is op verschillende types reactoren met een verschillende ligging - wordt de risicodifferentiatie emstig bemoeilijkt.

De nucleaire industrie is onderworpen aan vrij gedetailleerde veiligheidsregulering inzake stralingsbescherming, nucleaire veiligheid etc. Deze regulering voert normen in die dienen tc worden in acht genomen, zowel bij het ontwerp, bij de bouw als bij de eigenlijke uitbating van de keminstallatie. Zowel naar Belgisch als naar Nederlands recht vormt de schending van een wettelijke 
bepaling een civielrechtelijke fout; het is dus nog maar de vraag of een regime van risicoaansprakelijkheid daadwerkelijk tegemoet komt aan de belangen van het slachtoffer en een snellere compensatie van de geleden schade mogelijk maakt. Immers, het bewijs van de fout bij kernongevallen vormt wellicht niet het belangrijkste obstakel; in een aantal gevallen zal het niet eenvoudig zijn om de schade en de causaliteit te kunnen bewijzen. Het is dus twijfelachtig of risicoaansprakelijkheid bij kernongevallen de positie van slachtoffers substantieel verbetert.

Officieel dient ook de juridische kanalisatie van aansprakelijkheid de belangen van het slachtoffer. In het onderzoek is evenwel naar voren gekomen dat deze kanalisatie van aansprakelijkheid werd ingevoerd onder druk van de Amerikaanse leveranciers van nucleair materiaal. Met name doordat de kanalisatie van aansprakelijkheid aan het slachtoffer een aantal rechtsgronden ontneemt, werd dit principe - terecht - onder vuur genomen in de Duitse literatuur en heeft de Oostenrijkse wetgever dit principe met ingang van 1 januari 1999 uit de nucleaire aansprakelijkheidswet geschrapt. Wat overigens opvalt bij de studie van het Harvard Rapport en van het totstandkomen van het nucleaire aansprakelijkheidsrecht, zijn de inspanningen die men heeft gedaan om te voorkomen dat slachtoffers buiten het compensatiesysteem van het Verdrag een vordering zouden indienen. De rol die de VS hebben gespeeld bij het tot stand komen van het Verdrag inzake Bijkomende Compensatie van 1997 valt grotendeels te verklaren vanuit de schrik om in het nucleaire aansprakelijkheidsrecht te worden geconfronteerd met het "Amoco-Cadiz"-scenario. Blijkbaar vinden slachtoffers van een kernongeval dus dat het nucleaire aansprakelijkheidsrecht onvoldoende bescherming biedt. Immers, indien een afdoend compensatiesysteem zou worden geboden, dan zouden slachtoffers er alle belang bij hebben om hun vordering binnen dat systeem in te dienen.

Een belangrijk probleem van het nucleaire aansprakelijkheidsrecht, is dat verschillende maatregelen waarvan het de bedoeling was dat zij slechts tijdelijk van toepassing zouden zijn, in een moeilijk te wijzigen verdrag zijn ingevoerd. Dit geldt met name ten aanzien van de kanalisatie van aansprakelijkheid en van de overheidstussenkomst in het Aanvullend Verdrag van Brussel.

De nucleaire verzekeringspools werden opgericht omdat er in de jaren vijftig onvoldoende gegevens en onvoldoende verzekeringscapaciteit beschikbaar waren. Daardoor was destijds een dergelijk monopolie wellicht gerechtvaardigd. Het lijkt evident dat vijftig jaar later dit argument (noodzaak van concurrentie-uitsluiting om meer capaciteit te genereren) niet meer, of althans niet meer in dezelfde mate, opgaat.

Het is dan ook niet verwonderlijk dat dit monopolie de cxploitanten een doom in het oog is. Zij hebben een mogelijke wijziging in het beleid ten aanzien van de nucleaire verzekeringspools niet afgewacht en hebben naar alternatieven gezocht, tenminste wat de eigen schadeverzekering betreft. Met name de onderlinge verzekeringsmechanismen (captives) van de exploitanten lijken momenteel sterk in trek. Andere risico's die vrocger ook door de nucleaire verzekeringspools werden verzekerd, zoals de verzekering van de werknemers van de nucleaire sector, kunnen zelfs buiten de pools en buiten de captives worden verzekerd. De capaciteit op de verzekeringsmarkt is onmiskenbaar sterk gestegen en derhalve is het twijfelachtig of de monopoliepositie van de nucleaire pools vandaag nog kan worden gerechtvaardigd.

Hiermee is niet gezegd dat de nucleaire verzekeringspools geen reden van bestaan meer hebben. Het is aannemelijk om ervan uit te gaan dat deze pools nog steeds nuttig zijn om een hogere capaciteit te kunnen genereren, met name ten aanzien van de aansprakelijkheid tegenover derden; het gebrek aan concurrentie tussen de pools lijkt echter niet langer houdbaar. 
Gelet op de plaats die de kanalisatie van aansprakelijkheid inneemt in dit onderzoek, kunnen enkele conclusies worden getrokken over de toepassing van de kanalisatie van aansprakelijkheid in het milieuaansprakelijkheidsrecht.

Risicoaansprakelijkheid wordt steeds geassocieerd met kanalisatie van aansprakelijkheid en met een gekwalificeerde aansprakelijkheid. Zowel de "klassieke" gevallen van risicoaansprakelijkheid onder het Belgische en Nederlandse BW, als de nieuwere gevallen van risicoaansprakelijkheid leggen de aansprakelijkheid bij een persoon die een bepaalde hoedanigheid bezit; in al deze gevallen wordt de aansprakelijkheid naar deze persoon gekanaliseerd.

Dit betekent dat in één klap twee zaken worden geregeld: er wordt een bijzondere aansprakelijkheidsgrondslag gecreëerd en er wordt een uitspraak gedaan over een mogelijk samenloopprobleem. Zodra een aansprakelijkheidsgrondslag inzake milieuschade een regime van risicoaansprakelijkheid introduceert én deze aansprakelijkheid kanaliseert naar een bepaalde persoon, kan niet echt worden gesproken van een algemene risicoaansprakelijkheid voor milieuschade. De desbetreffende grondslag zal namelijk uitsluitend kunnen worden ingeroepen ten aanzien van de personen naar wie de aansprakelijkheid wordt gekanaliseerd. Indien dus het begrip "kanalisatie van aansprakelijkheid" wordt gehanteerd, dient daar bijgevolg omzichtig mee te worden omgesprongen en verdient het de aanbeveling om telkens de drie genoemde variabelen af te wegen. Bijkomend onderzoek lijkt aangewezen om uit te maken of ook in andere takken van het recht dan het civiele aansprakelijkheidsrecht gebruik wordt gemaakt van een (soort van) kanalisatie van aansprakelijkheid.

Een tweede conclusie in verband met het "algemene" milieuaansprakelijkheidsrecht houdt verband met het feit dat grote delen van het milieuaansprakelijkheidsrecht eveneens zijn gesteund op internationale verdragen. Deze Verdragen pogen in hoofdzaak een zekere harmonisatie tot stand te brengen. Het nadeel van een verdrag is uiteraard dat het niet eenvoudig is om dit te wijzigen. Totnogtoe werd het Verdrag van Parijs nog niet ingrijpend gewijzigd. Ook de wijziging van het CLC-Verdrag was niet eenvoudig: het Protocol van 1984 is nooit in werking getreden. Enkel na nieuwe onderhandelingen kon een akkoord worden bereikt over het Protocol van 1922, dat in 1996 in werking is getreden.

Daarnaast bestaat de kans dat bij het totstandkomen van een Verdrag een land het internationale forum aanwendt om de belangen van de eigen nationale industrie veilig te stellen, eerder dan oog te hebben voor de belangen van slachtoffers van een kernongeval. Dit is met name het geval voor de rol die de VS hebben gespeeld bij het tot stand komen van de nucleaire aansprakelijkheidsverdragen van de eerste én van de tweede generatie. Hetzelfde kan overigens worden gezegd voor een aantal westerse landen ten aanzien van de landen van het voormalige Oostblok en ten aanzien van een aantal Aziatische landen.

\section{RECHTSECONOMISCHE CONCLUSIES}

Kernongevallen zijn unilaterale ongevallen, aangezien enkel de dader (en niet het slachtoffer) een invloed heeft op het ongevalrisico. Een slachtoffer kan hooguit indirect, en dan nog slechts tot op beperkte hoogte, de omvang van de schade beïnvloeden. Hieruit kunnen enkele conclusies worden getrokken inzake de basisprincipes van het nucleaire aansprakelijkheidsrecht en inzake de wijze van verzekering van het nucleaire risico en kan het belang worden ingeschat van enkele alternatieve compensatiemechanismen. 
Indien in het nucleaire aansprakelijkheidsrecht zou worden uitgegaan van een regime van foutaansprakelijkheid, dan kan een informatietekort in hoofde van de rechter leiden tot een aanzienlijk welvaartsverlies. Bij kernongevallen is het niet ondenkbeeldig dat het voor een rechter moeilijk zoniet onmogelijk zal zijn om het niveau van betamelijke zorg correct in te schatten. De kans is reëel dat ofwel de exploitant niet aansprakelijk zal worden gesteld voor schade die hij heeft veroorzaakt (wat leidt tot een belangrijk probleem van externalisatie), ofwel dat hij wordt aansprakelijk gesteld voor schade die hij niet heeft veroorzaakt (waardoor hij een te hoog niveau van zorg zal aanwenden). Risicoaansprakelijkheid heeft het voordeel dat de beslissing over de te nemen zorg naar de dader wordt verschoven. Deze heeft vermoedelijk betere informatie over de optimale preventieve maatregelen ter voorkoming van nucleaire ongevallen dan de rechter. Dit informatievoordeel in hoofde van de exploitant van een kerninstallatie, is dus een belangrijk argument voor risicoaansprakelijkheid.

De beperking van het bedrag van de aansprakelijkheid lijkt haaks te staan op de economische uitgangspunten van het ongevallenrecht. Een eerste gevolg van de beperkte aansprakelijkheid is uiteraard dat zodra de schade van het kernongeval groter is dan dit bedrag, aan slachtoffers het recht op volledige schadevergoeding wordt ontzegd. Dit betekent dat niet alle negatieve externe effecten van het gebruik van kernenergie worden geïnternaliseerd. Dit leidt tot een overconsumptie van kernenergie voor de productie van elektriciteit. Een deel van de kosten van het nucleaire risico wordt door de limitering op de gemeenschap en dus op de belastingbetaler afgewenteld. Er kan dan ook worden gesproken van een subsidie aan de nucleaire industrie: de nucleaire sector moet niet alle kosten dragen van het door haar gecreëerde risico.

Het nucleaire aansprakelijkheidsrecht zoals neergelegd in het Verdrag van Parijs van 1960 (en het Aanvullend Verdrag van Brussel van 1963) leidt evenwel tot een dubbele subsidiëring van de kernenergic-industrie. Naast de wettelijke beperking van de aansprakelijkheid, stellen de verschillende verdragsluitende staten geld ter beschikking ingeval de schade groter is dan het beperkte bedrag van aansprakelijkheid van de exploitant.

De kanalisatie van aansprakelijkheid in het nucleaire aansprakelijkheidsrecht beperkt de samenloop. Vanuit economisch oogpunt levert dit slechts een beperkt voordeel op. Door aan slachtoffers de mogelijkheid te geven om meerdere personen aan te spreken (samenloop), kan een stijging van de administratieve kosten worden verwacht, maar deze stijging weegt niet op tegenover de opbrengsten in de vorm van preventie en van compensatie van de slachtoffers. Daarenboven moet worden aangegeven dat, aangenomen dat de kanalisatie van aansprakelijkheid voordelen oplevert inzake de reductie van de tertiaire ongevalskosten, de afschaffing misschien niet de enige maatregel is die cen dergclijke reductie kan bewerkstelligen.

De vraag naar de voordelen van de kanalisatie van aansprakelijkheid is daarom terug te voeren naar de belangenafiweging tussen de voordelen op het gebied van de reductie van de administratieve kosten en de nadelen veroorzaakt door de afbreuk aan de verhaalspositie. Het is cvenwel lang niet zeker of de marginale opbrengsten van kanalisatie (vermijden van samenloop) opwegen tegen de marginale kosten van de verminderde verhaalspositie voor benadeelden en van preventie. Men kan overigens ook de vraag stellen of het beperken van de samenloop voor slachtoffers een voordeel dan wel een nadeel is: is een slachtoffer beter gediend bij een brede waaier van aanspreekbare personen, dan wel bij én enkele - duidelijk aanwijsbare - aan te spreken persoon?

Indien er een reëel insolventiegevaar bestaat, dan kan het zinvol zijn om een verzekeringsplicht in te voeren omdat slachtoffers hierdoor, minstens ten belope van het verzekerde bedrag, de garantie hebben dat hun schade wordt vergoed. Aangezien de totale schade van een kernongeval een veelvoud kan zijn van het verzekerde bedrag van de eigen schade van de exploitant, biedt de eigen scha- 
deverzekering de exploitant geen bescherming tegen insolventie. In het nucleaire aansprakelijkheidsrecht is het insolventierisico dus reëel. Doordat in het nucleaire aansprakelijkheidsrecht de exploitant zich moet verzekeren tot precies het bedrag van zijn aansprakelijkheid, wordt het voor de verzekeraar niet eenvoudig om het morele risico te controleren. Niets belet om een verzekeringsplicht in te voeren voor een bedrag waarvoor dekking kan worden verkregen op de markt, maar om de exploitant onbeperkt aansprakelijk te stellen.

Vanuit rechtseconomisch oogpunt kan het zinvol zijn om, met name in gevallen waar de dader niet in staat is om alle schade te vergoeden en indien er onvoldoende dreiging uitgaat van een civiele aansprakelijkheidsrecht, bijkomende veiligheidsregulering op te leggen. Een uiternate belangrijk criterium hierbij is de vraag of de reguleerder over betere informatie beschikt over het ongevalsrisico dan de dader. Inzake kernongevallen is het niet zeker of aan deze laatste voorwaarde is voldaan. Echter, bij kernongevallen bestaat het risico dat een aansprakelijkheidsvordering niet zal worden ingesteld bijvoorbeeld omdat de letselschade zich lang na de blootstelling manifesteert. Ex ante veiligheidsregulering dient derhalve te worden gebruikt om, onafhankelijk van de aansprakelijkheidsvraag, een behoorlijk niveau van preventieve zorg af te dwingen. In die zin kan veiligheidsregulering dus voor een deel tegemoet komen aan de gebrekkige prikkelwerking vanuit het aansprakelijkheidsrecht.

De rechtseconomische conclusies inzake de verzekering van het nucleaire risico kunnen als volgt worden samengevat. Het nucleaire risico zal enkel onverzekerbaar zijn indien het niet voorzienbaar is, indien het morele risico en problemen van averechtse selectie niet kunnen worden vermeden of indien er onvoldoende capaciteit op de verzekeringsmarkt beschikbaar is. Een uitermate belangrijk element bij de verzekerbaarheid van het nucleaire risico, is de beschikbaarheid van correcte informatie. In essentie zijn het morele risico en het probleem van averechtse selectie het gevolg van een informaticasymmetrie. Indien de verzekeraar er niet in slaagt om via de premies en de polisvoorwaarden prikkels te geven aan de exploitant om preventief te handelen, kan dit leiden tot onverzekerbaarheid.

Precies op dit punt leidt de organisatie van de nucleaire verzekeringspools tot een aantal problemen. Door het monopolie van de nucleaire verzekeringspools is de wetgever in zeer belangrijke mate afhankelijk van de verklaringen van een monopolist en is hij met andere woorden kwetsbaar voor beïnvloeding. Dit wordt nog versterkt doordat in verschillende landen ook de exploitant zich in een monopoliepositie bevindt; ook de informatie die van die kant aan de wetgever wordt doorgegeven, kan door de wetgever zeer moeilijk worden getoetst. De monopolievorming in de nucleaire sector creëert met andere woorden een ernstig probleem van informatieasymmetrie in hoofde van de wetgever. Dit geldt ook op internationaal vlak: zowel de exploitanten als de verzekeraars nemen via internationale belangengroeperingen deel aan de onderhandelingen voor de revisie van het Verdrag van Parijs.

De vraag rijst dan ook of anno 2000 , de nucleaire verzekeringspools de toets met het Europees concurrentierecht kunnen doorstaan. Het uitgangspunt van de analyse van de EG-Commissie blijft klaarblijkelijk dat een verzekeringspool de enige manier zou zijn om een capaciteit te kunnen genereren. Vastgesteld dient te worden dat de nucleaire verzekeringspools nog slechts gedeeltelijk aan dit criterium beantwoorden. Het succes van de captives van de Amerikaanse exploitanten en de toenemende belangstelling voor EMANI in Europa tonen echter aan dat, tenminste wat de dekking van de eigen schade van de exploitant betreft, de nucleaire verzekeringspools niet langer noodzakelijk zijn om capaciteit te genereren, of tenminste niet meer als enige capaciteit kunnen genereren. 
Daarmee is ook aangegeven dat het onzeker is of de nucleaire verzekeringspools voldoen aan het tweede criterium van de EG-Commissie. De vraag rijst inderdaad of en in welke mate een billijk aandeel van de verbetering van de producten aan de gebruiker ten goede komt: de reactie van de exploitanten op de monopoliepositie van de verzekeraars geeft aan dat de nucleaire verzekeringspools niet leiden tot een verlaging van de premies.

Inzake de verzekering van het nucleaire risico, is ook van belang dat de aan de exploitant ter beschikking gestelde dekking een tailor-made polis is. Een op maat gemaakte polis is van groot belang omdat dit de verzekeraar zal helpen om problemen van averechtse selectie, evenals het morele risico in te dijken. Indien deze beide problemen niet onder controle kunnen worden gehouden, kan dit namelijk leiden tot de onverzekerbaarheid van het nucleaire risico. Ook de exploitant zelf heeft hier dus belang bij: het risico blijft verzekerbaar, en daarenboven wordt hij beloond voor zijn preventief gedrag. In concreto betekent een "maatpolis" dat een dekking wordt geboden die qua inhoud en qua omvang aansluit bij de graad van risicoavcrsie en corresponderende vraag naar verzckering van de desbetreffende exploitant (er kan bijvoorbeeld een voorkeur bcstaan voor een hoog eigen risico, waarbij de verzekeraar alleen voor het excess-risico tussenkomt) en bij de verwachte schade - hoewel dat laatste, door de beperking van de bedragen in het nucleaire aansprakelijkheidsrecht alleen theorie is. De bedragen waarvoor de exploitant vandaag aansprakelijk is weerspiegelen immers geenszins de verwachte schade.

Wat betreft de mogelijke alternatieve compensatiemechanismen, kan worden vastgesteld dat een first party-dekking inzake de schade uit kernongevallen niet meteen voor de hand ligt. Of mogelijke slachtoffers vandaag geneigd zullen zijn om een first party-dekking aan te kopen, zal in belangrijke mate worden bepaald door hun graad van risicoaversic. Deze risicoaversie zal uiteraard in belangrijke mate worden bepaald door de beschikbaarheid van een aansprakelijkheidsverzekering van de exploitant.

Een andere mogelijke oplossing kan erin bestaan dat de exploitant van een kerninstallatie geen aansprakelijkheidsverzekering meer afsluit, maar wel een directe verzekering ten behoeve van de slachtoffers. De praktijk wijst evenwel uit dat directe verzekering vooral nuttig is indien de schade die kan worden veroorzaakt geografisch kan worden beperkt. Ook de Nederlandse milieuschadeverzekeringspolis bijvoorbeeld is enkel van toepassing op schade aan naburige percelen. Naarmate de dekking van een directe verzekeringspolis algemener wordt, wordt de directe verzekering ten behoeve van derden geconfronteerd met analoge problemen als die van de aansprakelijkheidsverzekeraar.

Een algemeen Nucleair Schadefonds kan evenmin worden beschouwd als de ideale oplossing omdat een dergelijk fonds vrij duur is en omdat het onzeker is of een dergelijk Fonds erin zal slagen om de problemen van averechtse selectie en van het morele risico in te dijken. Anderzijds kan de nucleaire verzekeringsmarkt nog steeds geen integrale schadeloosstelling waarborgen. Een nucleair schadefonds zou dus zinvol kunnen zijn als een vangnet om schadegevallen op te vangen dic buiten het aansprakelijkheidsrecht vallen.

Inzake de dekking van het nucleaire risico bieden collectieve systemen van de exploitanten aanzienlijke voordelen. De exploitanten hebben duidelijk belang bij een participatie in een captive van verschillende nucleairc exploitanten. In cerste instantie om zuiver financiële redenen: in de mate waarin de captive winstgevend is, zal deze winst de leden van de captive, en dus de exploitanten ten goede komen. Dit kan zelfs zo ver gaan dat de jaarlijks te betalen bijdrage geringer is dan het uit te keren dividend. Vanuit rechtseconomisch oogpunt leidt een captive er ook toe dat de informatie wordt gecentraliseerd. Een essentieel element in de verzekerbaarheid van het nucleaire risico heeft inderdaad betrekking op de kennis van het risico en op mogelijke problemen van informatieasymme- 
trie. Er kan van worden uitgegaan dat de exploitant degene is die het risico het best kan inschatten; indien bijgevolg meerdere exploitanten zich organiseren om een eigen verzekeringssysteem op te zetten, kan worden aangenomen dat nog meer kennis beschikbaar wordt en dat die tegen relatief geringe kosten kan worden uitgewisseld.

\section{AANBEVELINGEN}

Het naar voren geschoven model inzake compensatie van schade door kernongevalien is gebaseerd op drie uitgangspunten. Ten eerste wordt het model op beperkte internationale schaal toegepast. Het model moet tot stand komen in regio's met gelijklopende sociaal-economische achtergrond, waar ook de veiligheidsnormen waaraan de kerninstallaties voldoen, gelijklopend zijn. Voor de verschillende regio's in de wereld moet een dergelijk model op poten worden gezet. Het komt dan toe aan het IAEA om te waken over de coherentie tussen de verschillende bestaande systemen. Ten tweede wordt het model op een manier uitgebouwd dat niet alle fondsen meteen beschikbaar worden gesteld, maar dat integendeel gedurende meerdere jaren bedragen beschikbaar zullen zijn. Dit doel wordt bereikt doordat de bedragen die in de tweede trap worden gegenereerd, geleidelijk aan ter beschikking worden gesteld, naar het voorbeeld van de retroactieve premies van de exploitanten onder de Price-Anderson Act. Indien deze bedragen niet volstaan om de eerste vorderingen te compenseren, zal het Nucleair Schadefonds voorschotten kunnen verstrekken, die evenwel integraal kunnen worden teruggevorderd. Het derde uitgangspunt is dat regulerende bevoegdheden worden toegekend aan een onafhankelijk functionerend orgaan, naar het voorbeeld van de Amerikaanse Nuclear Regulatory Commission. Dit orgaan reikt de vergunningen uit, en bepaalt de hoogte van de verzekeringsplicht van elke exploitant. Mmakkelijkheidshalve wordt dit orgaan - West-Europa als voorbeeld nemend - het European Nuclear Regulatory Agency (ENRA) genoemd.

Van groot belang is ook dat de juridische kanalisatie van aansprakelijkheid wordt afgeschaft. Vanuit rechtseconomische hoek leidt de kanalisatie tot onoverkoombare negatieve economische effecten. Met name het feit dat de personen die een invloed hebben op het risico, immuun zijn ten aanzien van de slachtoffers, is zeer nadelig.

Het uitgebouwde model bestaat uit een vijftrapssysteem:

1. Het uitgangspunt in het nucleaire aansprakelijkheidsrecht moet zijn dat de exploitant in beginsel onbeperkt aansprakelijk is voor de door hem aan derden veroorzaakte schade. Gelet op het reële insolventierisico, dienen garanties te worden geleverd dat een financiële zekerheid beschikbaar is, ten belope van een minimaal bedrag.

2. Naast de individuele aansprakelijkheid van de exploitant, dient cen collectieve aansprakelijkheidsschijf te worden ingevoerd naar het voorbeeld van de Price-Anderson Act. Dit impliceert dat elke cxploitant toetreedt tot een risicospreidingsovereenkomst: van tevoren spreken de verschillende exploitanten af dat elk van hen per keminstallatie een bepaald bedrag zal dienen bij te dragen, met dien verstande dat de maximale jaarlijkse bijdrage eveneens wordt beperkt. De meest geëigende juridische vorm voor de creatie van een dergelijke risicospreidingsovereenkomst, is een systeem van onderlinge verzekering van de exploitant; een captive naar het voorbeeld van NEIL en EMANI. In feite kan het onderschrijven van de risicospreidingsovereenkomst deel uitmaken van de toetreding tot de captive.

3. Het lijkt ook zinvol om de verschillende deelnemende landen te laten optreden als herverzekeraar. Dit betekent dat zij dus fondsen ter beschikking stellen in ruil voor een premie die de exploitanten dienen op te brengen. Het voomaamste gevolg van deze derde trap zal erin bestaan dat de globale capaciteit zal toenemen.

4. De exploitanten dienen ook verplicht bij te dragen tot een Nucleair Schadefonds dat wordt gespijsd door een verplichte heffing op de exploitanten. Dit fonds heeft een dubbele functie: 
een vangnetfunctie en een voorschotfunctie. De fondsen die in deze schijf beschikbaar zijn, zulien in essentie worden gebruikt voor de uitkering van de bedragen die niet via de vorige trappen voor vergoeding in aanmerking zijn gekomen. Maar daarnaast kan het fonds ook middelen uitkeren bij wijze van voorschot.

5. Tenslotte worden de exploitanten en de leveranciers aangemoedigd om te participeren in een vrijwillig compensatiesysteem, de Voluntary Liability Agreement of Nuclear Operators and Suppliers (VLANOS). De exploitanten kunnen bijdragen tot een dergelijk systeem, bijvoorbeeld door een deel van de restorno's die zij jaarlijks terugkrijgen van de captive, in het systeem te storten. Alleen de exploitanten die in een dergelijk systeem participeren, zijn gerechtigd om hun aansprakelijkheid te beperken.

Omdat zelfs met het vijftrapssysteem het underdeterrence-probleem wellicht niet volledig zal zijn aangepakt, kan eraan worden gedacht om de exploitant beperkingen op te leggen ten aanzien van de mogelijkheid tot het verzekeren van zijn de schade aan de kerninstallatie. Bijkomend wordt de exploitant verplicht om - naar het voorbeeld van de property rule van de NRC - een "decontaminatiedekking" voor de eigen site af te sluiten. De bedoeling hiervan is dat de exploitant na een kernongeval prioritair de eigen site ontsmet; dit zal namelijk leiden tot een daling van de totale ongevalskosten. 


\section{SUMMARY}

As the title of this $\mathrm{PhD}$-research (Efficient prevention and compensation of catastrophic risks the example of nuclear accidents) already indicates, this book deals with the liability for damage due to catastrophic risks. The nuclear liability law serves as an example of such a catastrophic risk. The question that we tried to answer is what an efficient compensation scheme for catastrophic risks should look like. This question is dealt with both from a law and an economic point of view and from a comparative point of view. The main element in comparing the laws in different countries is the comparison between Belgian and Dutch civil (nuclear) liability law. But also American nuclear liability law is part of the analysis (the Price-Anderson Act).

The book consists of four parts: (nuclear) civil liability law, legal and economic approach, analysis of other compensation systems and conclusions. The big themes in this book are therefore eivil (nuclear) liability law, insurance law and environmental liability law.

\section{PART 1 - ANALYSIS OF THE CIVIL (NUClEAR) LIABILITY LAW}

\section{THE APPLICABILITY OF CIVIL LIABILITY LAW TO ENVIRONMENTAL DAMAGE}

The basic principle of Belgian and Dutch civil liability law (both based on the code nupoleon) is the same: everyone has to bear the damage he suffered, unless there is a good reason for shifting the damage. The most traditional reason to shift the damage to someone else is a fault (tort). When someone acted wrongfully towards someone else, then he needs to compensate the damage suffered by that person.

In the course of time, both the judge and the legislator have made some differentiations in the meaning of the word "tort". New types of liability that are no longer based on tort (several types of strict liability) were indeed introduced. But those new types of liability were never adopted in a coherent and structured manner. Even for a lawyer it has become quite difficult to assess the exact content of several notions as well as the consequences thereof. It is therefore not surprising that in a given liability case, it will not be easy to determine the relevant clue. This holds true both for the Belgian and for the Dutch Civil Code. In this book, we use the words fault liability for determining a liability based on tort, whereas strict liability will mean a liability based on another criterion than tort.

The evolution in law and jurisprudence was made possible by the success of different types. of insurance. Fspecially in a social security system, but also in a liability insurance policy, people get the impression that the question of who is finally liable is no longer at stake. The success of other compensation schemes has created the illusion that the basic principles of civil liability law have been changed.

At first glance, it is not easy to compare Dutch and Belgian civil liability law. First of all, a new Dutch Civil Code was adopted in the seventies. Secondly, some important new liabilities were introduced in the Dutch Civil Code in 1995. Thirdly, some notions used in the Dutch Civil Code appear to be quite different from the Belgian Civil Code (e.g. "relativity"). However, those differences do not reflect major differences between both legal systems; very often, similar results will be obtained via other notions or concepts. 
Both Dutch and Belgian eivil liability law offer a legal basis for the liability for environmental damage, basing on both tort and strict liability. However, in an important number of cases, tort liability will not be able to compensate the damage suffered by the victims of an accident.

\section{OVERVIEW OF INTERNATIONAL AND NATIONAL NUCLEAR LAW}

This international dimension of nuclear law is easy to explain. First of all, a lot of efforts were (and are) being made in order to prevent nuclear energy being used for military purposes. Secondly, the use of nuclear energy presupposes that a country has sufficient technological equipment, know-how and financial means. Finally, the use of safety regulation only makes sense if different countries apply the same standards and rules. The international dimension of nuclear law becomes evident in the different efforts to harmonise nuclear law and in the activities of some important international organisations. Of major importance for nuclear law are the International Atonic Energy Agency (IAEA, Vienna), the Nuclear Energy Agency (NEA, Paris) and Euratom. However, only Euratom can take legally binding decisions. The enforcement of the different international treaties in nuclear law is indeed the weak point of intemational nuclear law.

As for as nuclear liability law is concerned, two regimes exist. The first regime is the NEARegime. This regime consists of the Paris Convention on Third Party Liability in the Field of Nuclear Energy (July 29th, 1960) and the Brussels Supplementary Convention of (January 31st, 1693). The Paris Convention introduced the five principles of nuclear liability law (cf. infra). The Brussels Supplementary Convention obliges the Contracting Parties to guarantee the availability of certain amounts, including public funds. Belgium and the Netherlands are Contracting Party of the two treaties of the NEA regime; they have introduced the legal principles of the treaties by law of July 22nd, 1985 (Belgium), and by law of March 17th, 1979 (the Netherlands). The IAEA regime consists of only one treaty, being the Vienna Convention on Civil Liability for Nuclear Damage (May 21st, 1963). Therefore, there is no obligation to make available public funds under the IAEA-regime.

In international nuclear law, a distinction can be made between the treaties of the first and second generation. The Chernobyl accident can be seen as the dividing line. This accident has indeed served as a stimulus for international nuclear liability law, because treaties on new issues (early notification and assistance, nuclear safety) were concluded shortly after the accident or as a consequence of it. At the same time, a revision process of the nuclear liability treaties was initiated. This revision exercise was only partially terminated in the beginning of 2001: in September 1997 two new treatics have been opened for signature (Protocol to the Vienna Convention and Convention on Supplementary Funding), but none of those treaties have yet come into effect. At the same time, the revision of the Paris Convention was still ongoing.

It is also important that in 1988 an agreement was reached concerning the Joint Protocol relating to the Application of the Vienna Convention and the Paris Convention. This Convention in fact makes a bridge between the geographical scope of the Paris and the Vienna Convention.

The influence of the Chemobyl accident is not directly clear in Belgian nuclear (liability) law. Although in 1994 a new law concerning the protection of the public and the workers against the consequences of ionising radiation was voted, this law has only partially come into effect. After two failed attempts in 1986 and 1988, the Belgian Nuclear Liability Act was changed on July 11 th, 2000. Those changes became effective on January 1st, 2001. 
As far as the Dutch nuclear liability Act is concerned, one could speak of a certain "Chemobyl effect". The Act indeed has been substantially changed in 1991, by making available considerable amounts of public funds ( 5 billion Dutch guilders or 2,7 billion EUR).

\section{SCOPE OF APPLICATION}

In fact, the scope of application of the Paris Convention is quite wide, because it is enough that the fact or the damage is the consequence of the dangerous properties of radioactive substances or material. The release of radiation is not necessary, nor is a sudden event. On the other hand, the scope of application is rather limited because the Convention does not apply to certain installations where nuclear materials are present (e.g. medical isotopes used in hospitals).

The Paris Convention offers a certain freedom to the Contracting States as far as the territorial scope is concerned. Basically, the Paris Convention is not applicable to a nuclear accident that occurred on the territory of a Contracting State, nor does it apply to the damage suffered in such a State. Both the Belgian and the Dutch Nuclear Liability Act have used the freedom to extend the scope.

But the application of the different nuclear liability conventions will often not be very easy, even in the NEA regime. This is mainly due to the fact that only few countries of the Paris Convention are also member of the Joint Protocol of 1988. Once the nuclear liability treaties of the second generation will come into effect, those problems will only get worse.

\section{BASIC PRINCIPLES OF NUCLEAR LIABILITY LAW}

The Paris Convention introduces the following principles: strict liability, channelling of liability to the nuclear operator, limitation of his liability, compulsory insurance and the exclusive competence of the courts of one country.

The Paris Convention makes the nuclear operator strictly liable for damage caused by a nuclear incident. This type of strict liability is however more severe than a classical type of strict liability, because the nuclear operator cannot invoke some classical types of force majeure. Whether one could qualify this liability as an absolute liability is questionable, because the operator will not be liable if the nuclear incident was caused by e.g. a civil war.

In nuclear liability law two types of channelling are distinguished: economic and legal channelling. The American Price-Anderson Act applies the system of economic channelling whereas the Paris and Vienna Convention apply legal channelling. Legal channelling means that changes are made to the ordinary civil law rules, i.e. it excludes the use of legal rules that might be available under common civil law. At the same time legal channelling limits the contractual liability: the operator has a right of recourse - mainly towards his suppliers - only in a limited number of cascs.

According to the Harvard Report of 1959 (ordered by the American nuclear suppliers), it was necessary to channel all liability to the nuclear operator for the following reasons. Channelling would avoid pyramiding insurance costs, meaning that if both the nuclear operator and his supplier should buy an insurance coverage this would only increase the insurance costs without any benefit for victims of a nuclear incident. Secondly, channelling offers the advantage that the victim knows exactly against whom he should file his claim. Finally, it would be unreasonable if the supplier of a small part of a nuclear reactor were held liable for the entire damage of a nuclear 
incident. Based on those arguments, legal channelling was introduced in the Paris and the Vienna Convention. It is interesting to note that exactly the arguments of the Harvard Report can be found in the Exposé des Motifs of the Paris Convention and in the Official Records of the Vienna Convention.

A new element in this channelling of liability in nuclear energy law is the combination of directing the liability to the nuclear operator whilst limiting his right of recourse and whilst excluding any application of ordinary civil law. From the beginning, the channelling of liability was being considered as a novel principle in civil liability law, because it leads to the immunity of the suppliers of the nuclear operator. Those in favour of legal channelling tend to say that the channelling of liability is part of a bigger entity, i.e. that one has to consider the principles of nuclear liability law as a whole and that this whole serves both the interests of victims and the industry. But the discussion about legal channelling has never really ceased. On the contrary, it is still very vivid. Austria for example has recently abolished legal channelling. The analysis of the Harvard Report showed however that channelling was, in fact, introduced with the aim of protecting the American nuclear industry.

In the course of the lawsuits in the Bhopal and the Amoco Cadiz cases, the American suppliers realised that they were still vulnerable to lawsuits in their own country for a nuclear accident elsewhere in the world. The major problem was that the US is not a party of the international nuclear liability conventions and that the rules of international private law of the Paris Convention are thus not applicable in the US. Those rules aim at guaranteeing that a lawsuit based on a nuclear accident is only filed in a court and according to the law of a State that has accepted the principles of nuclear liability law. This explains the role the US has played during the negotiations of the Supplementary Funding Convention. Once this Convention will come into effect, an American court will refer to the court of the place where the accident took place.

The notion of "legal channelling" has also been used outside nuclear liability law, i.e. in environmental liability law. However, both types of channelling are quite different. Channelling in nuclear liability law is much more severe than channelling in environmental liability law, since the right of recourse of the operator is limited and since it excludes the application of legal bases in common liability law.

The use of the channelling concept outside nuclear liability law has however led to considerable confusion; several authors consider channelling as a synonym of strict liability. This confusion is caused by the fact that in practice, channelling has always been used together with a strict liability regime. Our analysis has shown that a clear distinction needs to be made between the concurrence of lawsuits and the legal basis of liability.

Basically, the channelling of liability is a concept that deals with problems of concurrence of lawsuits: out of a bigger group of potentially liable persons, it singles out one or several persons who may be liable for a certain damage. In fact, a channelled liability implies that a liability is directed to e.g. the operator of dangerous activities. When the legislator introduces channelling, it means that in a tangle of potential claims, the person who is deemed to be liable (either alone or together with other persons) is pointed out.

The severity of the type of channelling used, will depend on three elements: the number of persons to whom the liability is channelled, the extent to which the right of recourse of the person liable is limited and the extent to which victims of the accident still can call upon the legal bases of common liability law. In order not to create confusion in using the channelling of liability, the 
legislator should take into account those three criteria and he should clearly motivate why such a type of channelling is used.

The third basic principle of nuclear liability law is the limitation of the nuclear operator's liability. This limitation was introduced because of insurance reasons. At the start of the nuclear industry in the fifties, there were no sufficient data available allowing insurance to assess the nuclear risk. At the same time, there was not enough capacity available on the insurance market. The nuclear operator could not obtain full insurance coverage and it was therefore deemed necessary to limit his liability. The limitation of liability is thus protecting the operator against ruinous claims.

The idea was that the nuclear operator's liability needs to be limited to the amount available on the insurance market. But none of the existing nuclear liability treaties impose a legal duty according to which the liability amounts evolve in step with the increasing capacity of the nuclear insurance market. One can easily argue that after forty years of nuclear activities, the knowledge about the nuclear risk and the insurance capacity have considerably increased.

In fact, the reasons for limiting someone's liability all have to do with the same issue, being the insurability of a certain risk: an unlimited liability is deemed to be uninsurable, every liability needs to be covered by an insurance coverage; an uninsured liability is not in the best interests of a victim etc.

Due to the limitation of liability, part of the burden of liability is shifted to the community as a whole (no internalisation of external costs). In nuclear liability law, there is in fact a double shift to the community because - under the NEA regime - the installation states pay part of the darnage of a nuclear accident.

The fourth basic principle is the compulsory financial coverage of liability. Article 10 of the Paris Convention indeed introduces what is called the congruence principle. This implies that the nuclear operator is obliged to have and maintain coverage (insurance or other financial security) for the amount for which he is liable. A nuclear operator is clearly free to determine the kind of coverage he sees fit.

The congruence principle wants to guarantee that any liability is covered by insurance. In fact, it aims to protect the victims against a possible bankruptcy of the operator (Schutzzweck of nuclear liability law). But the protection under the Paris Convention goes beyond that since it also wants to protect victims against bankruptcy of the insurer or the person that has given a financial security. On the other hand, the congruence principle implies that a liability without cover is useless. Taking into account that the insurance market is not able to provide full coverage, the congruence principle does not allow unlimited liability.

Finally, the exclusive liability of one court wants to guarantee unity in jurisprudence. If several courts were competent to deal with lawsuits following a nuclear incident, and if each court granted compensation, than it might well be that the total amount of compensation granted exceeds the amount of limited liability and thus of insurance cover. At the same time, the exclusive liability needs to guarantee that the channelling of liability is not by-passed.

But whenever damage is suffered outside a Contracting State, this exclusive liability might be put in jeopardy. Also the possibility to start criminal investigations can seriously retard the final settlement of all claims. 


\section{INSURANCE}

The type of insurance coverage that is most relevant to our analysis is liability insurance. A delicate problem of liability insurance is the coverage in time. The major question with this is how long after the expiry of the policy the insurer can be obliged to offer coverage. In case of a nuclear incident it may take several years before the consequences of radiation become evident (e.g. latent effects of cancer).

In practice, several triggers have been developed. In Belgium and the Netherlands - as elsewhere in the world - a similar evolution has taken place. Initially insurance coverage was granted on an act-committed trigger, meaning that the act leading to the damage must have taken place during the duration of the policy; gradually the act-committed trigger was replaced by the loss-occurrence trigger, meaning that the loss must have taken place during the policy duration. Under a loss-occurrence trigger both the "in-risk" and "out-risk" are covered. As far as environmental risks are concerned, a new trigger has been developed, namely claims-made insurance policies. Under such a policy, a claim must be filed during the duration of the policy; a claims-made insurance basically excludes any coverage after the duration of the policy.

The discussion concerning the relevant trigger in a liability insurance coverage has a major impact on the issue of the insurability of a certain risk. It is indeed because insurance claimed that the use of the loss-occurrence trigger in covering environmental risks would lead to the uninsurability of those risks, that the claims-made trigger has been introduced.

\section{INSURANCE OF THE NUCLEAR RISK}

The nuclear insurance pools were created in the fifties because there was not enough information available concerning the coverage of nuclear incidents. Although the existing nuclear pools have several characteristics in common, their way of working can vary considerably. Some pools are to be considered as entirely independent legal entities whercas other pools work via an existing insurer that acts as a fronting company. In the latter case, the pool is called a syndicate. The nuclear insurance pools offer coverage for the nuclear operator's own damage as well as for his third party liability.

These pools offer coverage for the nuclear risk on a national basis. This means that the insurance companies of a given country that wish to insure part of the nuclear risk, can do so. This also means that the nuclear operator can only buy coverage with "his" national insurance pool. This, of course, is a serious limitation of competition, which was perhaps necessary at the start of the nuclear industry.

But thanks to the evolution of the insurance market and the increased strength of the nuclear industry, there appear to exist altcmatives to the nuclear insurance pools. Especially for the coverage of own darnage, a captive insurance company owned by the nuclear operators appears to be quite a valid alternative.

Additionally, due to several mergers and acquisitions in the insurance and banking sector, the number of insurance companies has decreased over the past few years. Thus, it is not excluded that the power of one insurer inside a specific nuclear insurance pool has become bigger and bigger. One could therefore seriously question the conformity of those practices with European competition law. 
An important motive for the European Commission to allow insurance pools, is the fact that a pool allows smaller insurance companies to participate in the coverage of a big risk. The insurance world claims that the common coverage of certain risks is necessary to keep the risk insurable. It is clear that in a certain number of cases, insurance and rcinsurance pools are necessary to offer a specific coverage.

However it remains questionable whether the experience the insurance business has gathered in the last 50 years still necessitates a complete lack of competition between the nuclear insurance pools. It seems that especially the lack of competition between the pools is no longer necessary in covering (parts of) the nuclear risk, e.g. as far as an operator's own damage is concerned.

\section{PaRt 2. Legal AND ECONOMIC APProACH}

\section{AND 8. INTRODUCTION AND ECONOMIC ANALYSIS OF ACCIDENT LAW}

The basic assumption under the law and economic approach is that the law (and thus also liability rules) gives an incentive to potential parties of an accident to behave carcfully and that, more generally, legal rules influence human behaviour. According to a law and economic approach, accident law can contribute to an increase of social welfare by lowering the social costs of accidents. Social welfare consists of the joint income of victims and injurers; the costs of accidents are the prevention costs and the expected costs of an accident. Under this approach, social welfare is maximised by applying optimal care. This means applying a level of care at which the marginal costs of care equal the marginal benefits thereof.

Our attention is primarily aimed at unilateral accidents, meaning accidents in which only the injurer has an influence on the accident risk. In our case, a liability rule is necessary because the Coase-theorem cannot be applied to nuclear accidents: the transaction costs are too high.

The economic approach of law tends to favour strict liability in unilateral accidents because the injurer will not only have to exercise optimal care, but he will also have to apply the optimal level of care. Under fault liability rule, he will not have the incentive to apply the optimal activity level. It is also important that from an economic point of view strict liability is preferable in cases in which it is difficult to assess the magnitude of the damage. Under fault liability rule, the judge needs to estimate the optimal level of care and he has to assess whether or not the injurer applied this level of care. Under strict liability rule on the other hand, the judge will only have to assess the magnitude of the damage. Thus, the information costs and the error risk is much more remote under a strict liability regime.

\section{ECONOMIC ANALYSIS OF INSURANCE}

From an economic viewpoint the attitude towards risk will determine whether insurance increases social welfare. For a risk-averse person it will be efficient to spread or shift the risk. Insurance can indecd increase social welfare if it takes away the risk aversion from a person. Especially when the person who is taking over the risk is in a better position to bear the risk, social welfare will increase.

But a certain number of conditions need to be fulfillcd. First of all, the insurance market needs to be competitive; secondly moral hazard and adverse selection need to be kept under control. 
Moral hazard means that the availability of insurance cover influences the incentive to avoid any damage inducing behaviour. The problem of moral hazard can be dealt with by exposing the insured partially to the risk or by controlling the insured's behaviour while adjusting the premium he has to pay. Since social utility is optimised by granting full coverage, it will be preferable to have full coverage by adapting the premium accordingly. However, if there is too little information available about his behaviour, then the first solution will be preferable.

A situation where the insurer has insufficient information, can lead to adverse selection. When he has not got enough information, the risk categories will be too broad. This means that the average insurance premium will be too high for the good risks within the group, causing the good risks to leave. In the end, the insurer will only have bad risks left. The best remedy against adverse selection is a nartow definition of the different risk groups.

It is also important that there is enough competition on the insurance market, because this can be an answer to a possible information asymmetry of the insurer. Insufficient competition will not sufficiently award careful conduct, which will lead to an increase of the accident risk.

A legal and economic analysis also offers some interesting views concerning compulsory insurance. According to this analysis, the advantage of a compulsory insurance cover is not very obvious. The likelihood that an obligation to insure will precisely match the insurance that the insured would take without any compulsory insurance, is very small. Traditionally there are two arguments favouring compulsory insurance: the insolvency risk of the injurer and the problem of information asymmetry.

As far as environmental risks are concemed, only the insolvency risk seems to be a valid argument for introducing a compulsory liability insurance coverage. If the injurer goes bankrupt the victims of the accident will have little or no chance of having their damage compensated. In those cases a compulsory insurance might increase social welfare if the obligation meets the risk aversion of that person as closely as possible and if moral hazard can be controlled. This will be easier if the amount of coverage is fixed on an individual basis (thus varying from one industrial site to another).

It seems very unlikely that concerning environmental or nuclear risks compulsory insurance is able to meet a problem of information asymmetry. Especially concerning such type of risks it is crucial that the different partics involved still have an incentive to gather enough information about the risk.

Another important element in this book is the insurability of a risk. It is not easy to give an exact definition of an insurable risk. Theoretically any risk can be insured, if it is foreseeable and if problems of moral hazard and adverse selection can be controlled. This analysis also presupposes that there is sufficient competition on the insurance market.

As such, a risk is not uninsurable if there is a very high potential damage or if it is very difficult to assess the probability. The insurance business has developed several techniques (co-insurance, insurance pools etc.) allowing to deal with big risks. The key is that changes of the probability or the damage need to be foreseeable allowing the insurer to adapt the premium and the policy accordingly. If the insurer encounters major difficulties in interpreting the available data, we can speak of insurer's ambiguity. The insurer will deal with this problem by taking into account an additional risk premium. 
The insurability of a risk will really become a problem in case the foreseeability of the risk is at stake, e.g. in cases of retroactive liability. Basically, the different elements in the insurability of a risk all have to do with a lack of information with either the insured or the insurer or the judge.

Finally it is important to note that the combination of a duty to insure and a limited liability to the same amount is detrimental to social welfare. In those cases it will be very difficult for an insurer to control the insured's behaviour, leading to a moral hazard problem.

\section{ECONOMIC ANALYSIS OF SAFETY REGLIATION}

Whilst aiming at the increased protection of accident victims, strict liability is often introduced together with safety regulation. Even if liability law gives the injurer incentives to avoid damage, it is deemed that safety regulation gives additional incentives.

In a number of cases, safety regulation is used as a remedy to possible insolvency of the injurer. It is however questionable whether the government has more or better information than the potential injurer. Moreover, the insolvency problem can also be dealt with by introducing a compulsory insurance. It seems however that even given a certain problem of information asymmetry, it can be efficient to have additional safety regulation in cases where liability law is unable to give sufficient incentives to act carefully (the so-called problem of underdeterrence of liability law).

\section{PART 3. OTHER COMPENSATION SYSTEMS}

\section{COVERAGE OF CATASTROPHC RISKS}

The coverage of environmental risks is quite different on the Belgian and Dutch insurance market. The biggest Dutch insurance companies have indeed joined their forces in the Dulch Environmental Pool ("Nederlandse Milieupool"), formerly the Environmental Liability Co-operation ("Milieuaansprakelijkheid Samenwerkingsverband" or MAS). Initially this pool offered a specific policy for environmental liability but since 1998 the pool also offers an integrated environmental damage policy. This policy is partially an insurance for own damage but contains also elements of a direct insurance of victims. This direct insurance has the advantage that a claim can be dealt with outside liability law. A similar policy is not available on the Belgian insurance market. Where the biggest insurance companies offer a specific environmental liability policy. In other cases, environmental liability is (partially) covered as a part of a company's more general third party liability policy.

As such, the market in both countries does not seem to offer a first party insurance for covering environmental damage. Yet, such a policy can be a valid altemative to liability insurance because problems of adverse selection can be better dealt with. For the insurer it will indeed be easier to obtain information about the insured enabling him to clearly divide good and bad risks. Additionally, a first party insurance and a direct insurance will have a positive influence on the tertiary accident costs. Hence, the positive effects of direct insurance on tertiary accident costs will only be substantial if the group of persons who benefit from the cover is not too large.

As far as compensation funds are concerned, it seems that a fund that is linked to liability law, faces the same problems as liability law and third party liability insurance. An important element in assessing pros and cons of a compensation fund, is the information as well as the costs of the system. Only in a very limited number of cases a fund will have better information than an insurer active on a competitive market. Even for the administrator of the fund it will not be easy to tackle 
adverse selection and moral hazard. On top of that, it is highly doubtful whether a fund will be cheaper and more efficient than a commercial insurance company. The experience with the Dutch Fund on Air Pollution ("Fonds Luchtverontreiniging") seems to confirm this.

A first party insurance also offers advantages in terms of risk differentiation. A first party insurer can gather information ex ante about the risk more easily and thus he will be in a better position to distinguish good and bad risks. By definition the third party insurer has hardly any data available, making it quite difficult to distinguish good and bad risks.

If there are sufficient reasons to create a compensation fund, it is very important that liability law is left intact, allowing the incentives of it untouched. Therefore a fund will mainly offer advantages if it acts as a guarantee fund or as an advance fund.

During the past few years, both in Flanders and in the Netherlands, research has been carried out into finding an alternative compensation system. The proposal made by the Flemish Interuniversity Commission for Revising Environmental Law ("Interuniversitaire Commissie tot Herziening van het Milieurecht in het Vlaamse Gewest") also known as the "Bocken Commission", offer the operators of dangerous activities a wide variety of methods to cover their liability. Especially the idea that the operator should be allowed to limit his liability if he takes part in a voluntary compensation system, is quite valuable. Also remarkable are the Dutch proposals concerning the creation of a bigger environmental fund, because this fund would offer compensation for ecological damage.

Finally it seems that solutions are being searched for on different levels. Commercial insurers join their forces in insurance pools; they also offer specific policies. Potential injurers are looking for ways to insure (a part of) the risk themselves. Recently insurers are using alternative mechanisms of risk transfer using the capacity of the financial market in order to increase their insurance capacity. It seems however that none of these mechanisms can function independently from each other; it seems more realistic to have a compensation system mixing several of the discussed mechanisms.

\section{LIABILITY' FOR DAMAGE CAUSED BY OIL POLLUTION AT SEA}

The Convention on Civil Liability for Oil Pollution Damage of November 29th, 1969 introduces a liability system that is quite similar to the system laid down in the nuclear liability conventions. Basically the same principles are being used: strict liability, channelling of liability to the owncr of the ship, limitation of liability, and compulsory insurance.

According to the Convention on the Establishment of an International Fund for Compensation of Oil Pollution Damage of December 17th, 1971, the liability of oil pollution damage is split between the different parties involved in the transport of oil. Whereas the CLC- Convention deals with the liability of the ship-owner, the Fund Convention deals with the liability of the oil company that is transporting the oil. Thus, in maritime law the burden of liability for oil pollution damage is borne by all those having an economic interest in oil transportation. There is no similar spread liability in nuclear liability law.

In the nineties both oil pollution damage conventions have been changed. The liability limits have been increased and the then existing voluntary agreements between ship-owners (TOVALOP and CRISTAL) have been shut down. Apparently the compensation systems in the conventions seem to offer sufficient protection to victims. 
Protection and Indemnity Clubs, being captives of the ship-owners, cover the oil pollution damage. Contrary to the captive of nuclear operators in the US, the P\&I Clubs offer coverage both for contractual liability, tort liability and proper damage. There is sufficient competition amongst the P\&I Clubs, so that a ship owner has a certain choice of joining one of the Clubs. Hence, the European Commission raised serious doubts whether certain practices between the different Clubs were compatible with European competition law. The Clubs were forced to change the way they were seeking reinsurance.

As is the case in nuclear liability law, also maritime law provides for additional compensation. But whereas this additional compensation in maritime law consists of private funds (IOPCConvention), the Contracting Parties of the 1963 Brussels Supplementary Convention make available public funds.

\section{LIABILITY AND INSURANCE OF THE NUCLEAR RISK IN THE UNITED STATES}

The American Price-Anderson Act of 1957 aimed at finding an equilibrium between the interests of victims of a nuclear incident and the interests of nuclear industry. An important element is the fact that the Price-Anderson Act is only valid for a 10-years period; at each renewal the American Congress assesses the necessity to extend the Act, i.e. it assesses whether there still is a sufficient equilibrium between the victims' interests and those of nuclear industry.

Without any doubt the initial Price-Anderson Act of 1957 mainly protected the nuclear industry: the major part of the compensation made available ( 500 million dollars) consisted of public funds. The industry was obliged to insure 60 million dollars. The financial burden of the nuclear operator was considerably increased in 1975 by introducing a collective layer in which all American nuclear operators had to contribute by way of retroactive premiums. Gradually the financial burden was entirely shifted from the government to the industry, although also in the US the liability of the operator is still limited. The amount of the retroactive premiums was raised dramatically in 1988.

The evolution of the American nuclear liability law is closcly linked to the role of the Nucleur Regulatory Commission (NRC). Especially the independence of the NRC' has contributed to the positive evolution of the Price-Anderson Act.

Initially, the nuclear risk in the US was covered by an insurance pool similar to the one in Europe. But as the nuclear operators deemed that the costs for insuring their own installations was becoming too high, they established their own captive Nuclear Mutual Limited (NML). As a reaction to the Three Mile Island incident, a second captive was established in 1981. In the meantime, the captive of the American nuclear operators (NEIL) also offers liability insurance coverage and thus has become a competitor of the American nuclear insurance pool.

The European nuclear liability law clearly is similar to the American Price-Anderson Act: also under the Paris Convention it limits the liability of the nuclear operator and obliges him to buy an insurance or other financial security. Moreover, the Price-Anderson Act in its first version introduced a layer of public funds.

The similarity between the two systems is not surprising, since they are both based on the conclusion of the Preliminary Report. However, they differ on one fundamental issue, being the legal channelling of liability. In the US persons who have delivered products or services to a nuclear operator can be held liable for the damage of a nuclear incident. Those suppliers are covered 
thanks to the so-called omnibus cover of the third party liability insurance of the nuclear operator (economic channelling).

However, due to the evolution of the Price-Anderson Act, the similarities between the American and European systern have decreased. Although both systems provide for additional financial compensation beyond the liability insurance of the nuclear operator (second layer), this layer consists of public funds under the NEA regime but consists of private funds in the American system (collective layer of the nuclear operators). Apparently, the European nuclear liability legislator has forgotten that government intervention had to be considered as a temporary measure. Apart from that, it is striking that the amounts available in Europe, even including State intervention, are much lower than those available in the US.

\section{Part 4. Conclusions and recommendations}

\section{CONCLUSTONS FROM THE LEGAL ANALYSTS}

Despite the different measures in the nuclear liability conventions, the nuclear operator is only partially liable for the darnage of a nuclear incident. Above the amounts available, the operator cannot be held liable (although some countries have a system of unlimited liability).

Secondly, there is no systematic obligation in the nuclear liability conventions according to which the amount of insurance is systematically adapted to the increasing capacity of the insurance market. It is also strange that the conventions as well as the nuclear liability laws in most countries introduce a general coverage, applicable to all the nuclear installations of that country. The limit does not vary according to the reactor type or other parameters. This seriously hinders the possibility of the insurer to differentiate the different risks.

Officially the legal channelling serves the interest of victims of a nuclear incident. However, our research has revealed that channelling has been introduced in trying to protect American suppliers of nuclear material. Legal channelling in nuclear liability law is specifically criticised because it deprives victims from legal bases available under common liability law. Very striking are the efforts in the 1959 Harvard Report to prevent victims from a nuclear incident in Europe to file a claim in another country than the country of the operator liable. The role the US has played during the negotiations of the 1997 Supplementary Funding Convention can mainly be explained by the fear of the American nuclear industry to be confronted with an "Amoco Cadiz" scenario. In that case American companies were held liable in the US for damage suffered elsewhere in the world and according to a system under which liability was also channelled.

An important problem in nuclear liability law is that measures that were originally intended to apply only temporarily, have been introduced in a convention. It is well known that it is difficult to change such a convention.

As far as the nuclear insurance pools are concerned, it is highly questionable whether their monopoly can still be justified after more than fifty years of experience. As such not the pools create problems, but mainly the lack of competition between them. Also the nuclear operators tend to attack this monopoly more and more, since they have been looking for alternatives. This certainly holds true for the American operators who have established their captive (NEIL). Also in Europe, the nuclear operators become more and more interested in similar insurance schemes; it is in this respect that EMANI has been established. Consequently, risks that were previously covered by 
the pools are now covered by other insurance mechanisms (mainly property damage). At least for those risks alternatives to the nuclear insurance pools do exist.

This does, however, not mean that the nuclear insurance pools are not useful anymore. They still are necessary in order to generate more capacity. If competition between the pools were allowed, this would surely enhance their search for additional capacity.

\section{CONCLUSIONS FROM A LAW AND ECONOMIC APPROACH}

According to a law and economic approach, the major reason for introducing strict liability has to do with a problem of information asymmetry. Under a fault liability regime, it is quite likely that the judge will make mistakes concerning the optimal level of care. This mistake can be avoided under a strict liability system where it is the potential injurer who has to decide to what extent he will take preventive measures.

The limitation of liability should be abolished since it is contrary to the basic principles of the economic analysis. If the total damage of a nuclear incident exceeds the amount of the operator's limited liability (and the public funds available), then all negative external effects are not internalised. Part of the cost of the nuclear risk is thus shifted to the taxpayer; one can indeed say that the nuclear industry is being subsidised because it must only bear a fraction of the total damage it causes. In fact, the system laid down in the NEA-regime offers a double subsidy since the 1963 Brussels Supplementary Convention makes available public funds if the damage is higher than the limited amount of the nuclear operator's liability insurance.

The channelling of liability offers only limited economic advantages. Basically the channelling limits potential problems of concurrence of lawsuits. This can be regarded as beneficial from an economic viewpoint because it decreases the administrative costs. But granting victims the possibility to sue different persons for a given damage offers far greater economic benefits in terms of prevention and compensation of victims. It is indeed highly questionable whether the marginal benefits of channelling (limiting the concurrence of lawsuits and thus the administrative costs) outweigh the economic costs (limitation of lawsuits for victims and lower incentives for potential injurers). A similar reduction of tertiary accident costs is obtained in the US, thanks to the umbrella coverage of the nuclear operator. Also economic channelling can thus contribute to the limitation of tertiary accident costs.

Since there is a serious insolvency risk of the nuclear operator, there is a good reason to introduce compulsory insurance cover. But in order to enable the insurer to limit moral hazard, the operator needs to remain liable for all damage exceeding the amount for which he can obtain coverage.

Finally one can argue that despite the liability of the operator, there will still be a problem of underdeterrence. Therefore it can be useful to introduce $e x$ ante safety regulation, although it is not sure whether the government has more and better information about the risk than the operatur.

The conclusion concerning the insurance of the nuclear risk can be summarised as follows. The nuclear risk will only be uninsurable if the risk is not foresecable, if moral hazard and adverse selection cannot be controlled and if there is no sufficient capacity on the insurance markct. An extremely important element in the discussion about the insurability of a risk is the information available. In essence moral hazard and adverse selection are the consequences of information asymmetry. If by adapting the premiums and the policy conditions, the insurer does not succed in giving incentives to the nuclear operator, this can lead to the uninsurability of the nuclear risk. 
Precisely on this point the organisation of the nuclear insurance pools can cause severe problems. Due to the monopoly of the pools, the legislator depends to a large extent on the declarations of a monopolistic insurer, making the legislator vulnerable to influencing. This holds true both on a national and international level.

It is also important that the insurance cover of the operator must be a tailor-made policy. This will enable the insurer to attack problems of adverse selection and moral hazard. This is also important for the operator: the risk remains insurable and he will be rewarded for his preventive behaviour. This means that the terms and conditions of the operator's policy fit closely his degree of risk aversion.

It is also obvious that collective systems of operators (captives) offer great advantages. From a financial point of view, it can be tempting because any profit of the captive will be returned to its owners, being the nuclear operators. This can even lead to the fact that the return of profit exceeds the annual contribution they have to pay. Secondly a captive will also offer the advantage that all information about the nuclear risk is centralised. One can easily argue that the operators can best assess the risks they represent; if therefore several operators organise their own insurance system, more knowledge will become available at low cost.

Finally, it is highly doubtful whether a general Nuclear Damage Fund can be considered as a perfect solution. The administration of such a fund will be quite expensive and it is not sure whether it will be able to deal with moral hazard and adverse selections problems. Therefore, a Nuclear Fund will mainly be useful by way of guarantee or advance fund.

\section{RECOMMENDATIONS}

Our proposed compensation system for nuclear damage is based on three assumptions. Firstly, the system is to be applied on a limited international basis. This means that regional conventions need to be established in regions with similar economic and social backgrounds and where the safety of nuclear installations is similar. The IAEA will have to guarantee the coherence between the different regional systems. Secondly, the system is conceived in such a way that enough funds will be available over a certain lapse of time (e.g. 10 or 15 years). This goal will be achieved by making the funds of the second layer only gradually available (like the retrospective premiums in the Price-Anderson Act). If the funds of the first years are not enough, than a Nuclear Damage Fund will be entitled to grant advances to victims. Thirdly, regulatory power needs to be given to an independent regulatory body having similar functions as the NRC. This body will deliver permits and will determine the amounts for which the operator is obliged to take insurance coverage. In Europe, we can call this body the European Nuclear Regulatory Agency (ENRA).

The proposed system consists of five layers.

1. The nuclear operator is in principle liable for the damage he causes to third parties without any limit. Given the insolvency risk, the availability of minimal amounts needs to be guaranteed.

2. On top of the individual liability of the nuclear operator, a collective layer needs to be introduced (just like the second layer of the Price-Anderson Act). This implies that the nuclear operator becomes part of a risk spreading agreement: the operators agree beforehand upon the amount every operator has to make available, although the yearly maximum contribution is limited. The most convenient way of introducing such a system would be the creation of additional captives.

3. It also seems useful that the different participating countries would act as a re-insurer. This means that they would make available certain amounts. Of course, the operator needs to pay a premium for this. 
4. The nuclear operators are also obliged to contribute to a Nuclear Damage Fund, which receives its funds from a tax paid by the nuclear operators. This Fund has a double function: guarantee and advance fund. The amounts available in the Fund will basically be used to compensate the damage that has not been compensated by the former layers. But the Fund can also award advances.

5. Finally, the operators and suppliers will be encouraged to participate in a voluntary compensation system, the Voluntary Liability Agreement of Nuclear Operutors and Suppliers (VLANOS). The operators can contribute to such a system, e.g. by using the profit of their captive.

It is, however, likely that even in such a five-layer system, there still will be a problem of underdeterrence. It can therefore be wise to limit the possibility of the nuclear operator to insure the damage to his own nuclear installation. In addition, the operator would be obliged to have a policy covering the decontamination of his site (similar to the property rule of the NRC). The aim of this cover is that after an accident, the nuclear operator will make efforts in order to decontaminate his own site. This will in turn lead to lower accident costs. 


\section{TREFWOORDENREGISTER}

Aansprakelijkheid van de leverancier $250 ; 253$

Aansprakelijkheid van de Staat..

Aansprakelijkheid van rechtswege

$69 ; 219$

Aansprakelijkheid voor gebrekkige zaken

Aansprakelijkheid voor gevaarlijke stoffen

Aansprakelijkheidsgrondslag ...

Aansprakelijkheidslimiet

Aansprakelijkheidsvermoeden

Aansprakelijkheidsverzekering 384: 393; 394; 4012, 414; 435: 438

Aanvullend Verdrag van Brussel $108 ; 159 ; 183 ; 188 ; 319 ; 333 ; 704$

Absolute aansprakelijkheid $70 ; 211 ; 679$

Accident Compensation Commission 80

Accidentele vervuiling

Act-committed

Activiteitsniveau $498 ; 688$

Actuariële premie 524

Actuariële technieken.

Adam Smith

Administratieve kosten $507 ; 689 ; 697$

Advance call

Akerlof

Algemeen milieuschadefonds

Algemene afschrikking

Alternaticve causaliteit.

Altemative Risk Transfer

Amoco Cadiz

$269 ; 278 ; 290 ; 311 ; 607 ; 616$

ANI $461 ; 661 ; 708$

Artikel 29 bis van de Belgische WAM-wat $70 ; 74$

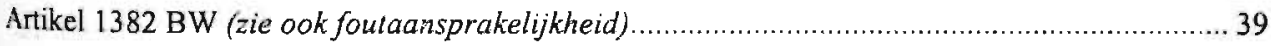

Artikel 1384 BW

Artikel 1403 oud BW

Artikel 544 BW

Artikel 6:173 NBW

Artikel 6:175 NBW

Assistentie bij kemongevallen 
Assurance oblige

Assurpol $454 ; 708$

Asymmetrie $114 ; 130$

Atomic Energy Act $91 ; 142 ; 227 ; 232 ; 280$

Atomic Energy Commission.

Atoms for Peace

Autonoom schadefonds. 576

Avaries communes

AVB 96

AVB-polis/AVP

Averechtse selectie

Baruch

BA-uitbating

BA-vervuiling .

Bedrijtsmatige gebruiker of bezitter.

Belangengroepen.

Beperking van de aansprakelijkheid.

Beperkingsfonds 575

Berging van radioactief afval . 182

Beschermende werking 305

Bevoegde gezag 363

Bhopal $271 ; 311$

Bijkomende fondsvorming. 133

Bijstand bij kernongevallen 121

Bilateraal monopolie 707

Bilaterale ongevalsituaties 494

Bodemvervuiling. 47

Bonus-malus systeem. .525

Breakability clause 331

BTR 13

Burenrecht.

Calabresi

Capaciteit $339 ; 422 ; 425 ; 430 ; 598$

Capaciteit van de verzekeringsmarkt $313 ; 324 ; 334 ; 338 ; 339 ; 597 ; 678 ; 701$

Captatietheorie 


\section{Captives}

$390 ; 460 ; 592 ; 633 ; 707 ; 708 ; 716 ; 722$

Carolina Environmental Study Group

Cascade-vergoedingsregeling

Catastroferisico $7 ; 422 ; 449 ; 537 ; 561 ; 705$

Catastrophe Risk Exchange. 598

Causaliteit $45 ; 82 ; 265 ; 346 ; 353 ; 543 ; 691 ; 713$

Causaliteitsbewijs $.76 ; 263 ; 351$

Causaliteitsonzekerheid $405 ; 422 ; 588$

Centralisering van aansprakelijkheid 300

Claims Commission 352

Claims handling $335 ; 439$

Claims-made $407 ; 535 ; 564 ; 565 ; 566$

Clause des droits acquis 284

CLC-Verdrag $269 ; 273 ; 331 ; 610$

Coase $481 ; 687 ; 693$

Code Napoléon 34

Collectieve compensatiemechanismen 584

Combined Development Agency

Commissie van vereffenaars 348

Common account reinsurance 432

Compensatiemechanismen 585

Concentreren van aansprakelijkheid

Concurrentie op de verzekeringsmarkt. $426 ; 441 ; 455 ; 524$

Congo $91 ; 141$

Congruentievereiste $343 ; 357 ; 370$

CRISTAL

Cumulatieve centralisering. 301

Cyclotrons.

De vervuiler betaalt $81 ; 210 ; 577$

Decontaminatiedekking

Deepest pocket

Decltjesversnellers

Dekking.

Dekking per installatie $325 ; 364$

Dekking per ongeval 319

Dekking per site 


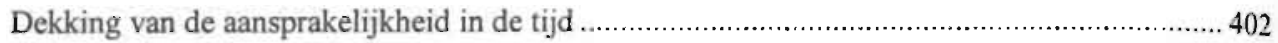

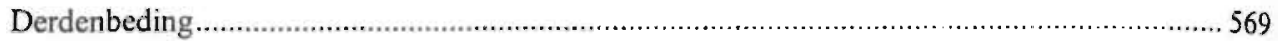

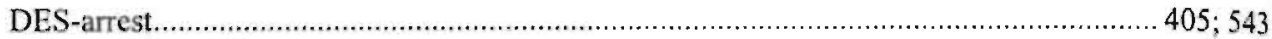

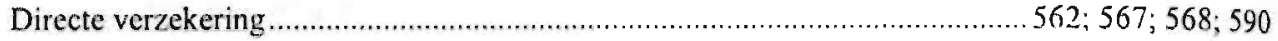

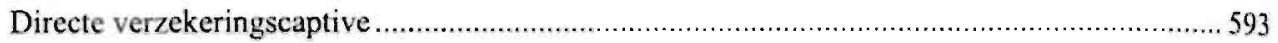

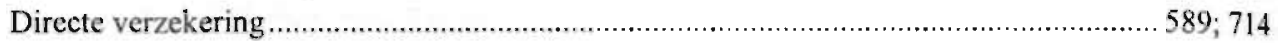

Dirigeren van een aansprakelijkheid ............................................................ 300; 305

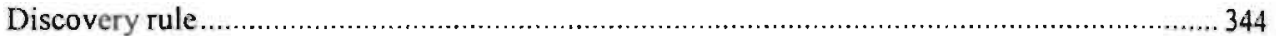

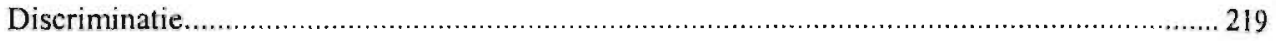

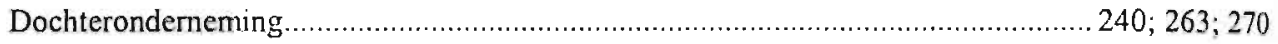

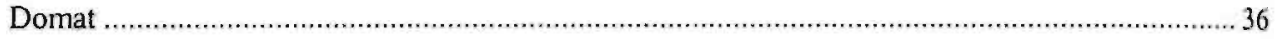

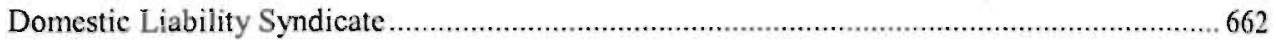

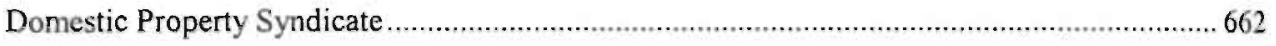

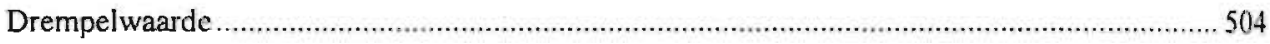

Dubbele verzekeringsdekking (zie ook piramidale verzekeringskosten) ............................... 300

Duitsland ....................................................................... 195; 206; 250: 261; 337; 359

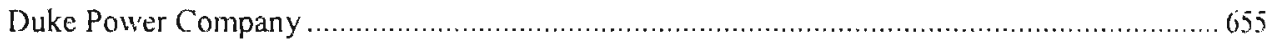

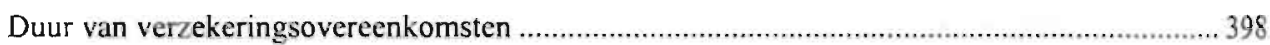

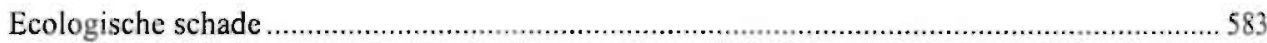

Economische kanalisatie .......... 157; 170;240;243;248;252;259;276;281;289;301;310;656

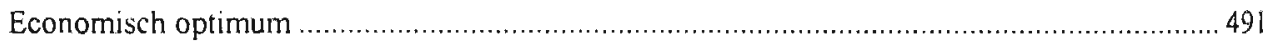

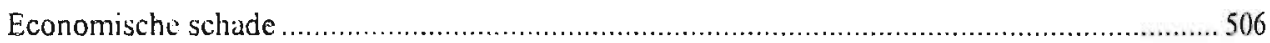

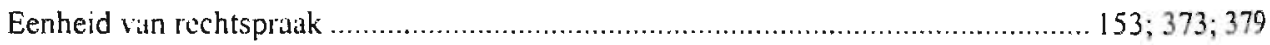

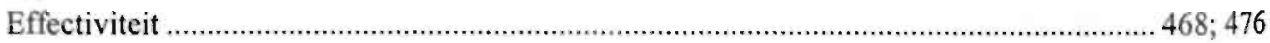

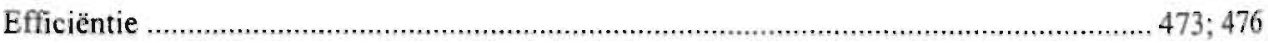

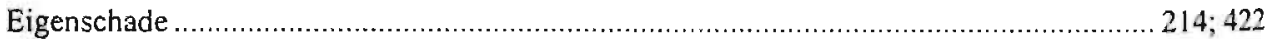

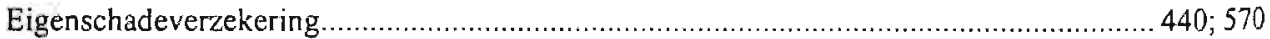

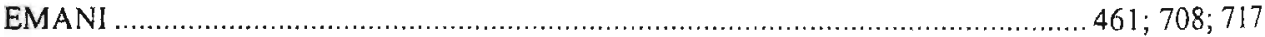

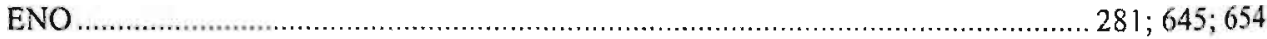

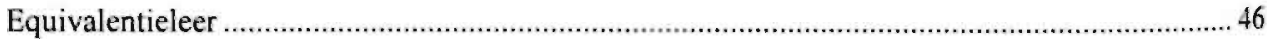

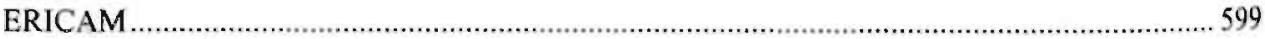

Erkenning van de exploitant............................................................................ 192; 367

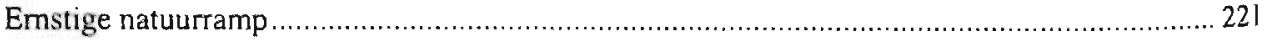

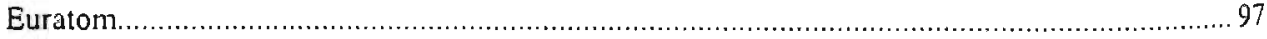

Europese concurrentierecht ..................................................................... 443; 445

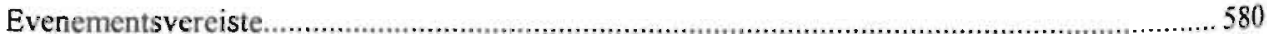


Evenwichtsleer

Excess loss

Exclusieve aansprakelijkheid

$219 ; 230 ; 289 ; 308 ; 684$

Exclusieve bevoegdheid.

$374 ; 376$

Exclusieve centralisering

Exclusieve en exhaustieve karakter van het nucleaire aansprakelijkheidsrecht

Exoneratie van aansprakelijkheid.

Exploitant $367 ; 368$

Externaliteiten

Exxon Valdez.

Facility Form Policy

Faillissement van de exploitant (zie ook insolvabiliteit) $361 ; 371$

Federaal Agentschap voor Nucleaire Controle.

First party milieuschadeverzekering $562 ; 571 ; 588$

First-party verzekering $84 ; 713$

Fonds $321 ; 590$

Fonds Luchtverontreiniging 580

Fonds pour la Gestion des Déchets 576

Fonds ter vervanging van aansprakelijkheid en verzekering 576

Förderungszweck $107 ; 313 ; 677$

Foreign Syndicate 662

Forum non conveniens $238 ; 270 ; 271 ; 275$

Forum-shopping. $243 ; 371$

Fossiele brandstoffen

Fout

$36: 38 ; 42 ; 87$

Foutaansprakelijkheid $39 ; 70 ; 87 ; 147 ; 497$

Fout van anderen. 216

Fout van het slachtoffer. 217

Franse Revolutie

Fronting company

Full reinstatement basis

Garantiefonds.

Garantstelling.

Gardner-Rapport

Gebrek aan voorzichtigheid 
Gebrek in de zaak. .58

Gedekte risico 396

Gedragscode voor het civiele gebrek van kemenergie

Gemeenschappelijk Protocol van 21 september 1988

Gemeenschappelijk Verdrag inzake de veiligheid van het

beheer van gebruikte splijtstoffen en radioactief afval. 125

General deterrence

Gesegmenteerde aansprakelijkheid

Goiânia.

Governmental hold harmless

Government indemnity

Graduele vervuiling

Grandfather clause 284

Grensoverschrijdend

Grensoverschrijdend kemongeval

Gensoverschrijdende schade

Grondwettelijkheid van de beperkte aansprakelijkheid

Grote risico's.

Guido Calabresi

Harvard Rapport $237 ; 256 ; 274 ; 285 ; 289 ; 299 ; 310 ; 315 ; 372 ; 427 ; 683 ; 697$

Herverzekering $392 ; 432 ; 434 ; 594$

Herverzekeringscaptive

HNS-Verdrag

Hold harmless clausule. $146 ; 228 ; 230 ; 240 ; 248 ; 309 ; 681$

Homo economicus

IAEA $8 ; 94$

IAEA-regime

ICHM. $81 ; 295 ; 306 ; 577$

ICRP

Immuniteit van de leveranciers

Inbreuk op een subjectief recht $40 ; 52 ; 54$

Indemnity Agreement $280 ; 642$

Indemnity Programm $236 ; 246$

Indurisk $\mathrm{Re}$. 596

Industry Credit Rating Plan. $663 ; 709$ 
Informatieasymmetrie $520 ; 532 ; 541 ; 602 ; 692 ; 705 ; 707 ; 711 ; 717$

Informatiekosten 688

Informatieplicht... 120

Informatieproblemen. 500 Inlooprisico $403 ; 404 ; 407 ; 412$

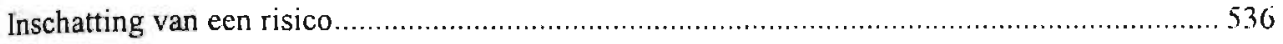

Insolvabiliteit van de exploitant (zie ook faillissement) ................................................. 357

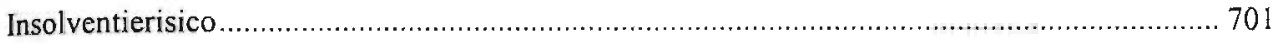

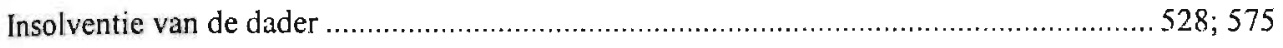

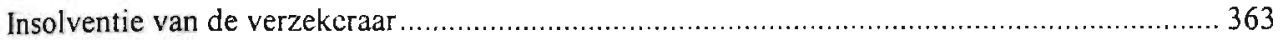

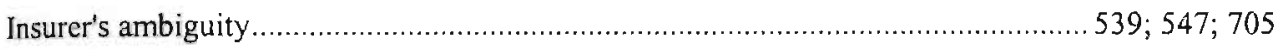

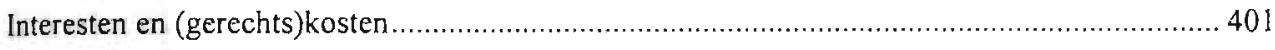

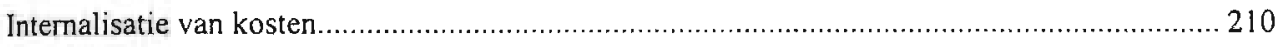

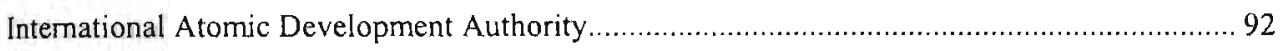

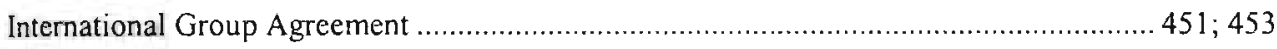

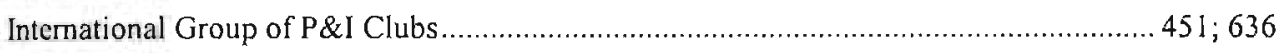

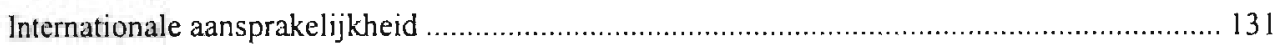

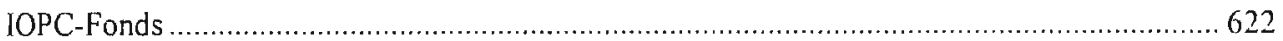

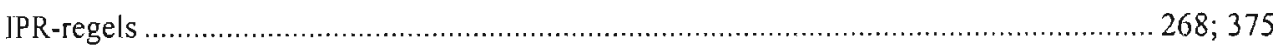

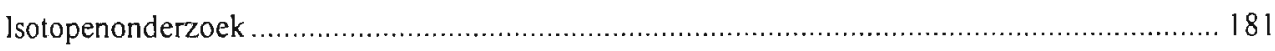

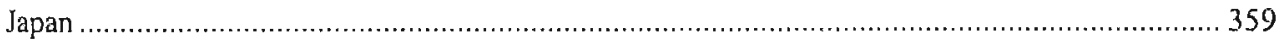

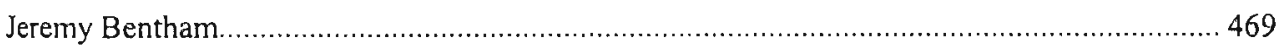

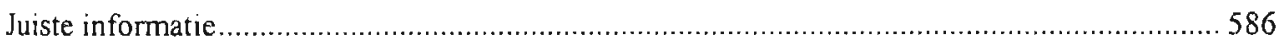

Juridische kanalisatie ...........................................248; $251 ; 283 ; 289 ; 301 ; 310 ; 680$

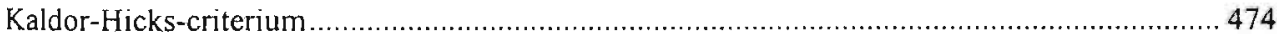

Kanalisatie van aansprakelijkheid .............................148;150;185;216;244;295;316;614

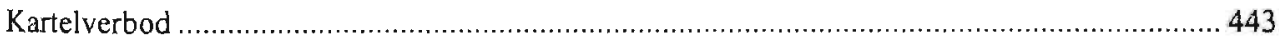

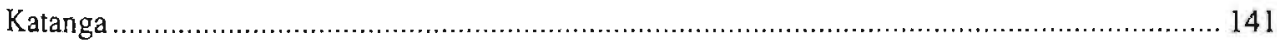

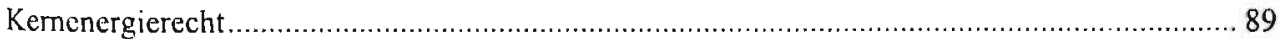

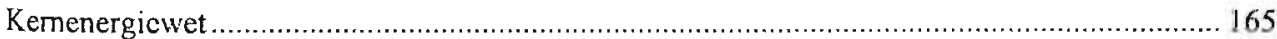

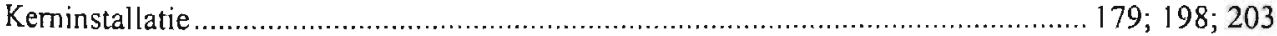

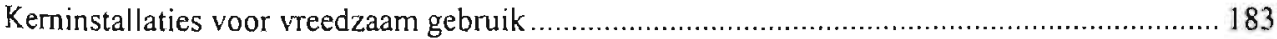

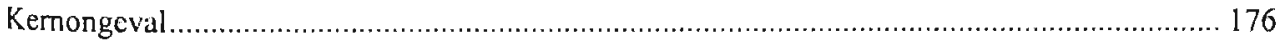

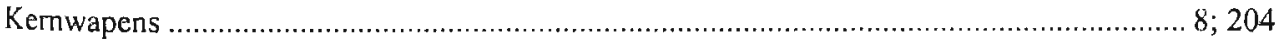

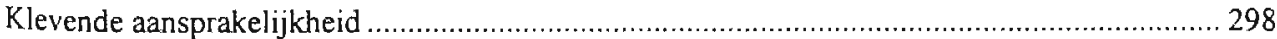


Klimaatverandering

Kwalitatieve aansprakelijkheid $63 ; 297 ; 302 ; 305 ; 684$

Langetermijnaansprakelijkheden 402

Langetermijnrisico's

Learned Hand.

Le criminel tient le civil en état

Lening op de bodemerij

Leverancier $149 ; 152 ; 157 ; 170 ; 216 ; 236 ; 238 ; 250 ; 260 ; 271 ; 273 ; 275 ; 279 ; 288$

Levy-draft

Lex fora $221 ; 226 ; 268 ; 273 ; 276$

Lex loci delicti $272 ; 275 ; 276 ; 378$

Lex specialis $267 ; 289$

Liberalisering van de elektriciteitsmarkt 690

Licentieovcreenkomst 233

Lifetime-dekking. 364

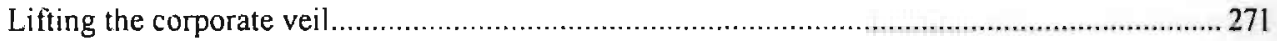

L.loyd's of London.

Loss-occurence $404 ; 439 ; 656$

Maatregelschade 168

Maatschappelijke welvaart.

MAELU $428 ; 660 ; 661$

MAERP $428 ; 661$

MARPOL 608

Manhattan Engineer District $90 ; 227$

Marginale kosten van zorg.

Marginale opbrengst 492

Maritiem transport 114

MAS. 565

MAS-polis. 417

Massarisico's 391

Massaschade 698

Maximumbedrag van aansprakelijkheid 318

May-Johnson Bill.

MeMahon Bill. 228

Medeherverzekeringspools 
Medeverzekering.

Medeverzekeringspool 448

Medische isotopen 181

Melville Price. 640

Milieuaansprakelijkheid $76 ; 371 ; 407 ; 410 ; 596$

Milieuaansprakelijkheidsverzekering. 584

Milieuschade $55 ; 59 ; 265 ; 267 ; 289 ; 303$

Milieuschadefonds 574

Milieuschadeverzekering 567

Militaire installaties $184 ; 204$

MINA-fonds. 579

Minimumlimiet 318

Misbruik van machtspositie 445

Modemisering 131

Moedermaatschappij 272

Monopolie $229 ; 259 ; 289 ; 682 ; 694 ; 707 ; 710$

Morele risico $.516 ; 541 ; 585 ; 587 ; 702 ; 710$

MSV-polis

Mutualiteiten $381 ; 390$

Narneldingsdekking $417 ; 567$

Narisico $403 ; 404 ; 407 ; 412$

Natuurramp $213 ; 221 ; 223 ; 535$

NEA

NEA-regime 105

Nederlandse Milicupool 566

Negatieve verklaring 444

NEIL $325 ; 389 ; 441 ; 460 ; 587 ; 667 ; 708 ; 717$

NELIA $428 ; 432 ; 660$ NEPIA $428 ; 432 ; 660$

Net-line retention basis $431 ; 463$

New Law and Economics

Niet uitzonderlijke risico's $180 ; 186$

NML $465 ; 667$

Non-discriminatie $130 ; 194 ; 460$

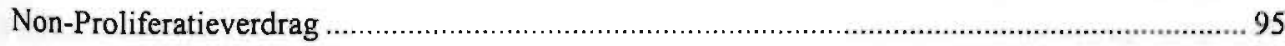

Normatieve economische analyse ................................................................................. 468 
Normbestemmingsleer

NRC

Nucleaire risico

Nucleair schadefonds

Nucleaire schepen

Nucleaire stoffen: zeevervoer

Nucleaire veiligheid

Nucleaire veiligheidscultuur

Nucleaire verzekeringspool.

Nuclear Damage Fund 354

Nuclear Safety Standards-Programme

Objectieve aansprakelijkheid $70 ; 292$

Occurrence-inloop 408

Oil Pollution Act 611

Old Law and Economics 470

Omnibusdekking $248 ; 251 ; 280 ; 656 ; 696$

Omstandighedendekking $417 ; 567$

Onbeperkte aansprakelijkheid. $195 ; 315 ; 318 ; 323 ; 330 ; 335 ; 337 ; 359$

Onbeperkte aansprakelijkheidslast

Underlinge verzekering

Ondernemingssluier (zie ook lifting the corporate veil). 273

Onder/oekslaboratoria 181

Ongevallenbestrijding....

Onopzettelijke slagen en verwondingen.

Onrechtmatigheid.

Ontdekkingsregel .

Ontheffing

Ontmanteling $181 ; 193 ; 198$

Onverzekerbaar risico $355 ; 585 ; 588$

Oostenrijk $259 ; 262 ; 359$

Openbare middelen (zie ook staatstussenkomst, overheidstussenkomst) $110 ; 130 ; 368$

Oprichting van nucleaire verzekeringspools $425 ; 427 ; 436$

Opwerking van gebruikte splijtstoffen

Opzegging

Overheidsmonopolic.

Overheidsregulering 
Overheidstussenkomst (zie ook openbare middelen en staatstussenkomst) $275 ; 333$

Overloop-clausule 570

Overmacht.

Pareto-superioriteit 473

Peer reviews 124

Permanente Commissie van het Atoomrisico. 424

Person indemnified $280 ; 656$

Phasing-in mechanisme $329 ; 332 ; 335$

Piramidale verzekeringskosten $239 ; 696$

PLATO 631

Plotselinge gebeurtenis 179

Pool $430 ; 432$

Pool-draft

Pooling van de exploitanten

$134 ; 137 ; 333$

Positieve economische analyse 468

Premie $327 ; 387 ; 663$

Presidential Commission on Catastrophic Nuclear Accidents 652

Preventieve maatregelen 168

Price-Anderson Act $157 ; 236 ; 248 ; 258 ; 276 ; 280 ; 310 ; 363 ; 641 ; 681 ; 722$

Primaire ongevalskosten $478 ; 695$

Private Interest $551 ; 554$

Private Verzekering 79

Privéverzekeringen 388

Probability of causation 503

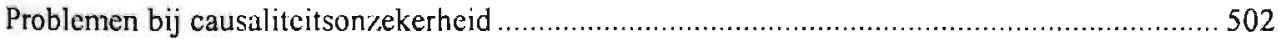

Problemen bij het bepalen van de fout ........................................................................ 501

Problemen bij onzekerheid over de schadeomvang ...................................................... 505

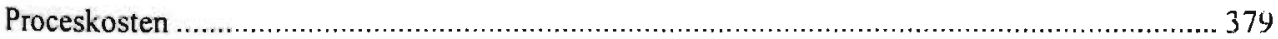

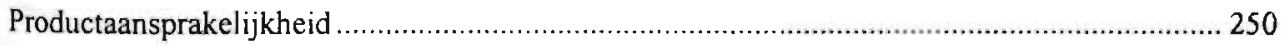

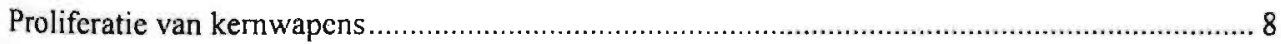

Property-rule

Proportionele aansprakelijkheid $504 ; 588$

Protection and Indemnity Clubs $451 ; 587 ; 633$

Protocol bij het Verdrag van Parijs

Protocol van het Verdrag van Wenen $134 ; 224 ; 328 ; 351 ; 369 ; 681 ; 704$

Public Choice 
Public Interest theoric

Publieke fondsen.

Quasi-risicoaansprakelijkheid

Quote-part

Radioactief afval.

Radiotherapeutische bestraling

Rationeel gedrag

Rechter-commissaris.

Rechtmatigheid van een verzekeringspool

Reciprociteit (zie wederkerigheid)

Reddirgskosten.

Regresrecht

Regulering.

Relativiteitsleer.

Rent-a-captive.

Retroactieve aansprakelijkheid

Retrospective premium

Revisie van het Verdrag van Parijs $136 ; 174 ; 197 ; 254 ; 334 ; 704$

Revisie van het Verdrag van Wenen. $282 ; 285$

Risico 386

Risicoaansprakelijkheid $68 ; 87 ; 209 ; 292 ; 316 ; 496 ; 571 ; 613 ; 654 ; 679$

Risicoavers 511

Risicoaversie van de verzekeraar 519

Risicodifferentiatie $541 ; 586 ; 590$

Risicogroepen 519

Risicoleer 210

Risiconeutraal $490 ; 511$

Risicopremie 717

Risicospreiding $382 ; 391 ; 422 ; 514$

Risicospreidingsovereenkornst $601 ; 722$

Risicoverschuiving. 514

Risicozoekend 511

Rubriekenpolis 
Safeguardssysteem

Safety.

Samenloop

$294 ; 300 ; 304 ; 309 ; 684 ; 698$

Schadegeval $397 ; 414$

Schade uit het verleden 585

Schadevergoedingsrecht. 384

Schadeverwekkende gebeurtenis. $396 ; 403 ; 410 ; 413 ; 416$

Schutznorm-theorie.

Schutzzweck $107 ; 313 ; 370 ; 677$

Secondary Financial Protection 662

Secundaire ongevalskosten $478 ; 695$

Security

Security loading 539

Sellafield 543

Semi-absolute aansprakelijkheid 219

Sociaal zekerheidsstelsel $.75 ; 77 ; 79 ; 84 ; 218 ; 221 ; 223 ; 388$

Sociale verzekeringen 388

Soft law 139

Solidaire bijdrage 110

Solidariteit. $139 ; 183$

Sommen-excedent. 392

Specifieke afschrikking 480

Speculatieve vorderingen. 352

Spreiden of verschuiven van een risico 513

Staatshervorming

Staatstussenkomst (zie ook openbare middelen en overheidstussenkomst)

Standing Committee on Liability for Nuclear Damage.

Stigler

Stirling Cole.

Stop loss

Strafrechtelijke bevoegdheid.

Strafrechtelijke vordering

Stralingsbescherming . $97 ; 124 ; 144$

Studiccentrum voor Kemenergie $143 ; 436$

Studiecentrum voor Toepassingen van de Kemenergie $143 ; 146$

Subrogatie $149 ; 369$

Subsidie. 
Supplementary call.

SYBAN. $322 ; 325 ; 433 ; 436 ; 440 ; 441 ; 708$

Syndicaat. $430 ; 437$

Systeem van imputatie 218

Systeem van subrogatie. 218

Systemen van dekking van nucleaire aansprakelijkheid 364

Tailor made polis $518 ; 590 ; 595 ; 709$

Ten behoeve van derden 589

Tenzijformule. $65 ; 69$

Territoriaal toepassingsgebied $129 ; 186 ; 199 ; 205$

Tertiaire ongevalskosten $478 ; 591$

Theorie van de belangengroeperingen 711

Third party dekking. 562

Three Mile Island $4 ; 281 ; 429 ; 646 ; 665$

Torrey Canyon 606

Toerckening 41

TOVALOP. 630

l'ransport van nucleair materidal $215 ; 373$

'l'rigger

Tsjemobyl $4 ; 117 ; 129 ; 159 ; 167 ; 173 ; 287 ; 327 ; 338$

Tussenkumst van de Staat 108

Uitsluitingsgronden. 212

Uitzonderingsregime. 184

Umbrella Convention. 133

UN Atomic Energy Commission

UNCLOS

Underdeterrence. 6)0; 722

Unilaterale ongevalsituatie. 494

Union Carbide Corporation.

Unit 594

United Nations Scientific Committee on the Effects of Atomic Radiation

Veiligheidscultuur. 128

Veiligheidsregulering. 


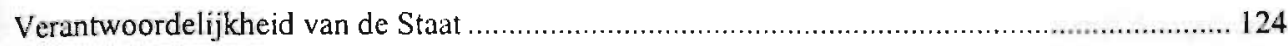

Verdrag inzake Assistentie bij kernongevallen ............................................................. 119

Verdrag inzake Bijkomende Compensatie .........................135; 224; 279; 284; 369; 682; 704

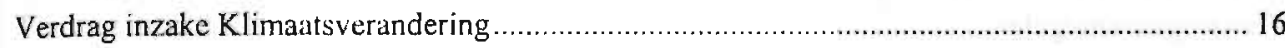

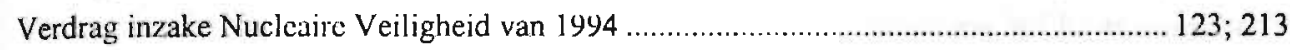

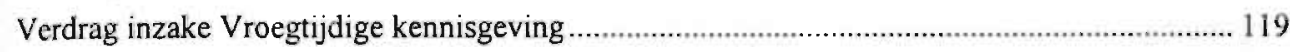

Verdrag van Brussel van 31 januari 1963: ontstaan ......................................................... 103

Verdrag van Brussel van 1957 inzake de aansprakelijkheid van eigenaars van zeeschepen ....... 607

Verdrag van Parijs van 29 juli 1960: ontstaan...................................................................... 103

Verdrag van Wenen van 21 mei 1963: ontstaan ........................................................... 103; 111

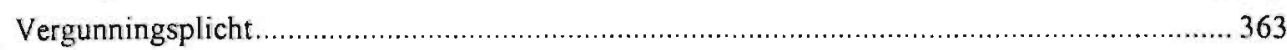

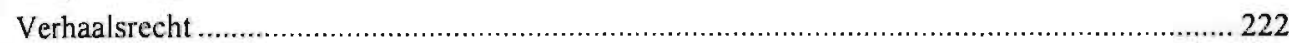

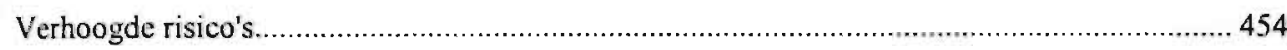

Verjaring

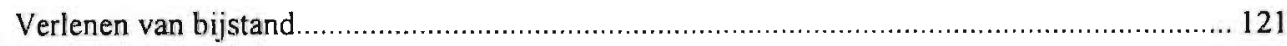

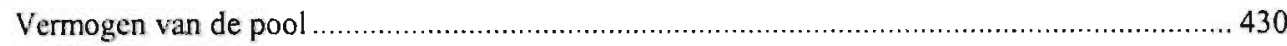

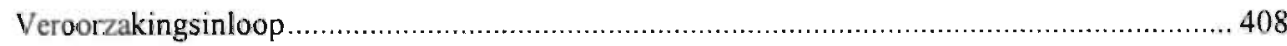

Verplichtc aansprakelijkheidsver/ckering …......................................................... 527; 621

Verplichte milicuaanspralelijkheidsverzekering ………….............................................5 583

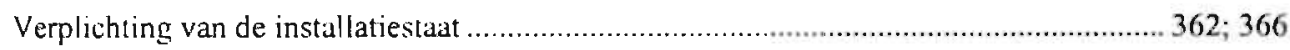

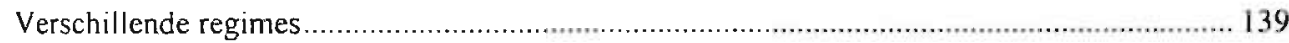

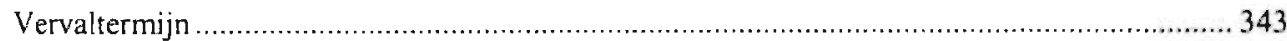

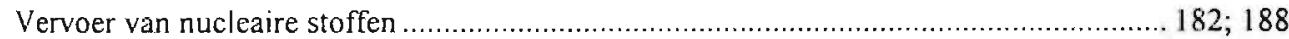

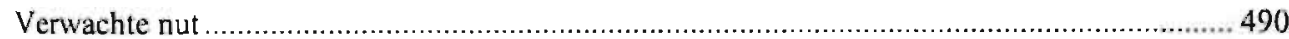

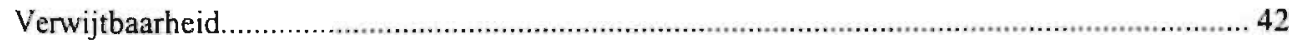

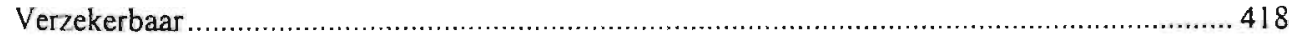

Verzekerbaar belang ................................................................................ $387 ; 395$

Verzekerbaarheid ................................................................

Verzekerbaarheid van het nucleaire risico ………………................................................. 705

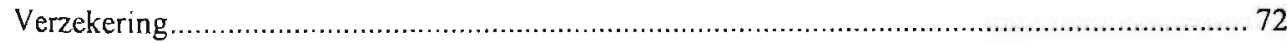

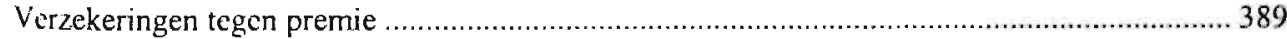

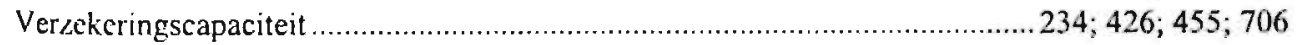

Verzekcringsovereenkomst........................................................................... 385; 386

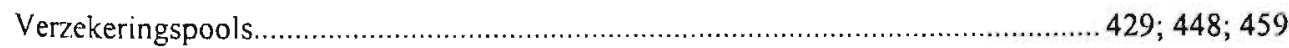

Vlaamse Voorontwerp Decreet Milieubeleid (zie ook ICHM) …........................................... 308

Vonnis Correctionele Rechtbank Turnhout.............................................................. 154; 376

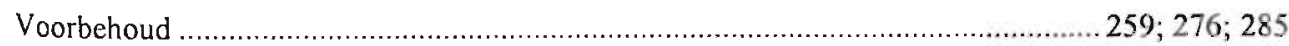


Voorlopig Rapport $233 ; 358 ; 362 ; 363 ; 640 ; 681$

Voorschotfonds $575 ; 716$

Voorvallen van schade 414

Voorzorgsmaatregelen 213

Voorzienbaarheid van een risico 536

Vrijstelling $444 ; 451$

Vrijstellingsverordening voor verzekeringen

Vrijwaring (zie ook hold harmless). $226 ; 246 ; 681$

Vrijwillig garantiefonds. 579

Vroegtijdige kennisgeving bij kemongevallen.

Waarborgfonds. 575

Waarborgkas Milieuschade. 578

Warrant 600

Wederkerigheid. $193 ; 202 ; 206 ; 223 ; 327$

Wet Mac Mahon 91

Wet Milieugevaarlijke Stoffen. .66

Wettelijke exoneratie 305

Wettelijke uitzondering 458

Willingness to claim 77

Willingness to pay. $475 ; 539$

Witboek betreffende de modernisering van de regels inzake de toepassing van de artikelen 85 en 86 van het EG-Verdrag. 457

Witboek van de Europese Commissie inzake milieuaansprakelijkheid. $81 ; 537$

Working Group on Liability for Nuclear Damage

Zeevervoer van nucleaire stoffen 116

Zero transaction cost assumption 483

Zorgvuldigheidsnorm. $40 ; 53 ; 56 ; 62$

Zweden 587

Zweedse milieuverzekering 569

Zwitserland $337 ; 354 ; 359$ 


\section{LITERATUIRLIJST}

\section{Boeken}

Abecassis, D. (ed.), Oil Pollution from Ships, London, Stevens and Sons, 1985.

Adams, M., Okonomische Analyse der Gefährdungs- und Verschuldenshaftung, Heidelberg, R.v. Decker's Verlag, 1985.

Adede, A.O., The IAEA Notification and Assistance Conventions in Case of a Nuclear Accident. Landmarks in the Multilateral Treaty-Making Process, Graham and Trotman, London-Dordrecht, 1987.

Akkermans, A.J., Proportionele aansprakelijkheid bij onzeker causaal verband. Een rechtsvergelijkend onderzoek naar wenselijkheid, grondslagen en afgrenzing van aansprakelijkheid naar rato van veroorzakingswaarschijnlijkheid, diss., Deventer, Tjeenk Willink, Zwolle, 1997.

Akkermans, A.J., Faure, M. en Hartlief, T., Proportionele aansprakelijkheid, Boom Juridische Uitgevers, Den Haag, 2000.

Albonetti, A., Belser, W.E., e.a., Droit Nucléaire Européen, Colloque de Droit nucléaire européen, Presses universitaires de France, Paris, 1968.

Alen, A., België: een tweeledig en centrifugaal federalisme, Ministerie van Buitenlandse Zaken, Buitenlandse handel en Ontwikkelingssamenwerking, Brussel, 1990.

Arrow, K., Aspects of the Theory of Risk-Bearing, Helsinki, Yrjö Johnsonin Säätiō, 1965.

Barile, A.J., The captive insurance company ... an emerging profit center, Interstate Service Corporation, 1979. Bauw, E. en Barendrecht, J.M. (red.), Het aansprakelijkheidsrecht in de $2 I^{\text {ste }}$ eeuw, Kluwer, Deventer, 1999.

Bauw, E., Buitencontractuele aansprakelijkheid bij bodemverontreiniging, diss., Kluwer, Deventer, 1994.

Bawcut, P.A., Captive Insurance Companies. Establishment, Operation and Management, 3th edition, Woodhead-Faulkner, New York, 1991.

Bergkamp, L., De Vervuiler Betaalt Dubbel: over de Verhouding tussen Privaat en Publiek Milieurecht, oratie, Intersentia, Astwerpen, Groningen, 1998.

Berliner, B., Limits of Insurability of Risks, Englewood Cliffs, 1982.

Bette, A., Didier, J.M., Fornasier, R., Stein, R.M., La Réparation des Dommages Nucléaires en Europe. Régime instauré par la Convention de Briexelles du 31 janvier 1963, Brussel, 1965.

Bigot, J., (dir.), Traité de Droit des Assurances, Tome I, Entreprises et organismes d'assurance, 2ième édition, Librairie Générale de Droit et de Jurisprudence, Paris, 1996.

Bocken, H., Het aansprakelijkheidsrecht als sanciie tegen verstoring van het leefmilieu, diss., Brussel, Bruylant, 1979.

Bocken, H. en Ryckbost, D. (ed.), Verzekering van Milieuschade, Verslagboek van het Intemationaal Colloqium gehouden te Gent op 14 en 15 december 1989, Story Scientia, Gent, 1991.

Bocken, H., Rycbost, D. en Deloddere, S., Voorontwerp Decreet Milieubeleid, Interuniversitaire Commissie tot Herziening van het Milieurecht in het Vlaamse Gewest, Die Keure, Brugge, 1995.

Bolt, A.T. en Spier, J., De uitdijende reikwijdte van de aansprakelijkheid uit onrechtmatige daad, W.E.J. Tjeenk Willink, Zwolle, 1996.

Bosly, H.D. en Vandermeersch, D., Droit de la procédure pénale, $2^{\circ}$ druk, Brugge, Die Keure, 2000.

Bouckaert, B. en De Geest, G. (ed.), Encyclopedia of Law and Economics, Edward Elgar, Northampton, MA, USA, 2000.

Bowles, R., Law and the Economy, Martin Robertson, Oxford, 1982. 
Boylan, F., United States System. Insurance/Indemnity Protection. Nuclear Energy Risks, Alexander \& Alexander, mei 1989 , onuitg.

Braams, W. Th., Buitencontractuele Aansprakelijkheid voor gevaarlijke stoffen. Rechtsvergelijkende beschouwingen naar aanleiding van het wetsvoorstel ter aanvulling van de boeken 3, 6 en 8 van het Nieuw $B W$ met regels betreffende de aansprakelijkheid voor gevaarlijke stoffen en verontreiniging van lucht, water of bodem, Kluwer, Deventer, 1989.

Brownlie, I., Principles of Public International Law, Clarendon Press, Oxford, 5th edition, 1998.

Brubaker, D., Marine Pollution and International Law, Belhaven Press, London and Florida, 1993.

Buchanan, J.M., The Calculus of Consent. Logical Foundations of Constitutional Democracy, Ann Arbor, University of Michigan Press, 1962.

Burrows, P. en Veljanovski, C.G., The Economic Approach to Law, Butterworths, London, 1981.

Calabresi, G., The Cost of Accidents. A Legal and Economic Analysis, New Haven, Yale University Press, 1970.

Cameron, P., Hancher, L., Kühn, W. (ed.), Nuclear Energy Law afier Chernobyl, Graham and Trotman, London-Dordrecht, 1988.

Camier, M.-C., Responsabilité el Assurance du Risque Aiomique dans les Droits Européens, Centre français de droit comparé, Paris, 1960.

Carchon, R., De non-proliferatie van kernwapens en internationale controle, SCK/CEN, NN-3605, 1995.

Carette, A., Herstel van en vergoeding voor aantasting aan niet-toegeëigende milieubestanddelen, diss., Intersentia, Antwerpen, 1997.

Carreau, D., Droit International, Pedone, $6^{\circ}$ druk, Parijs, 1999.

Carson, P., Het fraaie gelaat van Vlaanderen, Lannoo, Tielt, 1995.

Chance, C., Insurance Regulation in Europe, Lloyd's List Practical Guides, Lloyd's of London Press, London, 1993.

Cleton, R., De Beperkte Aansprakelijkheid van de Scheepseigenaar, W.E.J. Tjeenk Willink, Zwolle, 1990.

Coenraets, Ph., Les Responsabilités en matière d'environnement, Kluwer, 1997/1.0.

Cogen, M., Handboek Internationaal recht, tweede uitgave, Mys \& Breesch, Gent, 1998.

Colie, Fh., Bijzonder gereglementeerde verzekeringscontracten in hoofdlijnen, Antwerpen, Makiu, 1993.

Coile, Ph., Algemene Beginselen van het Belgisch Verzekeringsrecht, Bruylant, Maklu, Brussel-Antwerpen, 1994.

Cooter, R. en Ulen, T., Law and Economics, Scott, Foresman and Company, Illinois, 1988.

Cornelis, L., Beginselen van het Beigische buitencontractwele aansprakelijkheidsrecht. De onrechtmatige dand, MAKLU, ced.samson, Antwerpen, 1989.

Cousy, H., Produkienaansprakelijkheid, Veiligheid en Verzekering, Maklu, Antwerpen-Apeldoorn, 1988.

Cousy, H. en Claassens, H. (ed.), Natuurrampen en Verzekering, Verslagboek van de Negende Leuvense Verzekeringsdagen, Maklu, Antwerpen-Apeldoom, 1995.

Cousy, H. en Claassens, H. (ed.), Aansprakelijkheidsverzekering: dekking in de tija, Maklu, AcademiaBruylant, Antwerpen, Apeldoom, 1997.

Cousy, H. en Schoorens, G., De nieuwe wet op de landverzekeringsovereenkomst. Parlementaire Voorbereiding van de wet van 25 juni 1992 en van de wijzigende wet van 16 maart 1994, Kluwer, Deume, 1994. 
Daillier, P. en Pellet, A., Droit International Public, Librairie Générale de Droit et de Jurisprudence, Paris, 1999.

Däuber, W., Haftung für gefährliche Technologien. Das Beispiel Atomrecht, C.F. Müller Juristischer Verlag, Heidelberg, 1988.

De Geest, G., Economische Analyse van het Contracten en Quasi-contractenrecht. Een onderzoek naar de wetenschappelijke waarde van de rechtseconomie, diss., Maklu, Antwerpen, Apeldoom, 1994.

De Groot, G.R., Vergelijkt alles en behoudt het goede. Beschouwingen over onderwijs en onderzoek op het gebied van rechtsvergelijking, oratie, Rijksuniversiteit Limburg, 5 oktober 1989, Kluwer, Deventer, 1989.

Deketelaere, K. (red.), Milieurecht in België. Status Questionis Anno 1997, Die Keure, Brugge, 1997.

Deketelaere, K., Faure, M. en Verhoosel, G. (red.), Grensoverschrijdende milieuproblemen: uitdagingen voor de nationale en de internationale rechtsorde, Intersentia, Antwerpen, Groningen, 1998.

Deketelaere, K. en Wiggers-Rust, L.F. (red.), Aansprakelijkheid voor milieuschade en financiële zekerheid. Een vergelijking van Nederlands, Belgisch en Europees recht, Die Keure, Brugge, 1998.

Deketelaere, K. en Deketelaere, M. (eds.), Jaarboek Milieurecht 1998, Leuvem, Milieurechtstandpunten 13, Brugge, Die Keure, 1999.

Deketelaere, K. en Deketelaere, M. (eds.), Jaarboek Milicurecht 1999, Leuvem, Milieurechtstandpunten 14, Brugge, Die Keure, 2000.

Deketelaere, K. en Deketelaere, M. (eds.), Jaarboek Milieurecht 2000, Leuvem, Milieurechtstandpunten 15 , Brugge, Die Keure, 2001.

Deketelaere, K., De Cock, K., Deridder, L. en Verhoosel, G., Handboek Energierecht, Reeks Energic \& Recht, Intersentia, Antwerpen-Groningen, 2001.

Deketelaere, K., Handboek Milieurecht, Die Keure, Brugge, 2001.

De la Rue, C.M., (ed.), Liability for Damage to the Marine Environment, Lloyd's of London, 1993.

De Page, H., Traité de Droit Civil, Bruxelles, Bruylant, 1962.

De Pue, E., Lavrysen, L. en Stryckers, P., Milieuzakboekje, editie 2000, Kluwer, Antwerpen, 2000.

De Smet, R., Droit maritime et droit fluvial belges, 1971.

Devrient, J.N., La responsabilité civile et l'assurance à raison du risque nucléaire, ('icnìve, Imprimerie de la Tribune de Genève, 1964.

De Vries, F.J., Wettelijke limitering van aansprakelijkheid, diss., W.E.J. Tjeenk Willink, Zwolle, 1990.

Dommering-Van Rongen, L., Produktenaansprakelijkheid. Een nieuwe Europese privaatrechtelijke regeling vergeleken met de produktenaansprakelijkheid in de Verenigde Staten, Kluwer, Deventer, 1991.

Dommering-van Rongen, L., Schade vergoeden door Fondsvorming, Deventer, Kluwer, 1996.

Domsdorf, E.P.M.W., Internationaal Atoomenergierecht. De betrokkenheid van Nederland bij meer dan 100 verdragen, W.E.J. Tjeenk Willink, Zwolle, 1993.

Dow, J.C., Nuclear Energy and Insurance, Witherby \& Co Ltd., London, 1989.

Dowding, T., Global Developments in Captive Insurance, FT Financial Publishing, London, 1997.

Drupsteen, Th.G. en Koeman, N.S.J. (red.), Wet Milieubeheer. Tekst \& Commentaar, Kluwer, Devcntur, 1996 .

Erauw, J., Beginselen van Internationaal Privaatrecht, Story, Gent, 1985.

Fagnart, J.L., Droit privé des Assurances, Story-Scientia, Gent, 1998. 
Farber, A. en Frickey, P.P., Law and Public Choice. A Critical Introduction, The University of Chicago Press, Chicago, 1991.

Faure, M. en Van den Bergh, R., Objectieve aansprakelijkheid, Verzekering en Veiligheidsregulering, Maklu, Antwerpen, Apeldoom, 1989.

Faurc, M., (red.), Aansprakelijkheid voor het nucleaire risico, Maklu, Antwerpen-Apeldoom, 1993.

Faure, M., (G)een schijn van kans. Beschouwingen over het statistisch causaliteitsbewijs bij milieugezondheidsschade, oratie, Maklu, Antwerpen, 1993.

Faure, M.G. en Hartlief, T., Verzekering en de groeiende aansprakelijkheidslast. Een juridisch. gezondheidskundig en economisch onderzoek naar ontwikkelingen met betrekking tot de aansprakelijkheidslast en de consequenties voor verzekeraars naar aanleiding van de werkgeversaansprakelijkheid voor bedrijfsongevallen en beroepsziekten, Kluwer, Deventer, 1995.

Faure, M. en Deketelaere, K., (red.), Ius Commune en Milieurecht. Actualia in het Milieurecht in België en Nederland, Intersentia, Antwerpen, Groningen, 1997.

Faure, M. en Hartlief, T. (red.), Verkeersaansprakelijkheid in Belgie en Nederland, Intersentia, Antwerpen, Groningen, 1998.

Faure, M., Hartlief, T. en Hertoghs, M., Evaluatie van het Fonds Luchtverontreiniging. Op verzoek van het Ministerie van Volkshuisvesting, Ruimtelijke Ordening en Milieubeheer, Sdu Uitgevers, Den Haag, 2000.

Fischer, G., L'Energie atomique et les Etats Unis. Droit Interne et droit International, Paris, Pichon et Durand-Auzias, 1957.

Fischer, G., La non-prolifération des armes nuclénires, Paris, Pichon et Durand-Auzias, 1969.

Fischerhof, H., Deutsches Atomgesetz und Strahlenschutzrecht, Verlag August Lutzeyer, Baden-Baden, 1962.

Fitzsimmons, A., Insurance Competition Law, Graham \& Trotman, Londen, 1994.

Fitisimmons, A. (cd.), Pollution Law and Insurance. A Comparison of the Legal Regimes of European States and the (/SA, NIDA, Kluwer Law International, London, 1997.

Fontaine, M., Droit des .Assurances, Précis de la Faculté de droit de l'UCL, I arcier, 1975.

Fontaine, M. en Binon, J.M. (éd.), La loi du 25 juin 1992 sur le contrat d'assurance terrestre, Bruxelles, Bruylant, 1993.

liontaine, M., Droit des Assurances, 2ième édition, De Boeck \& I arcier, Bruxelles, 1996.

Fontaine, M. (dir.), L'Assurance Mutuelle en Belgique, Academia Bruylant, Louvain-la-Neuve, 1999.

Fontaine, M., Verzekeringsrecht, De Boeck \& Larcier, Brussel, 1999.

Francioni, F. en Scovazzi, T., (ed.), International Responsibility for Environmental Harm, Graham and Trotman, Martinus Nijhoff, 1991.

Frenk, N., Kollektieve akties in het privaatrecht, diss, Kluwer, Deventer, 1994.

Gillon, L., De kwestie kernenergie, Standaard Uitgeverij, Antwerpen, 1986.

Gillon, L., Après l'accident de Tchernobyl. Le nucléaire en question, Duculot, 1986.

Gold, E., Handbook on Marine Pollution, Arendal, Gard, 1985.

Goldblatt, J., Twenty years of the non-proliferation Treaty. Implementation and Prospects, Intemational Peace Research Institute, Oslo, 1990.

Hädrich, H., Europäische Atomverträge. Kommentar, Nomos, Baden-Baden, 1966.

Hafkamp, W.A., Gilhuis, P.C., Hofland, J., Verschuuren, J.M. en de Putter, P.J., Een Milieuschadefonds in Nederland: een onderzoek naar de mogelijkheden, VROM, Publikatiereeks milieubeheer, nr. 1994/3. 
Hăndll, G. en Lutz, R.E., Transferring Hazardous Technologies and Substances. The International Legal Challenge, Graham \& Trotman, Martinus Nijhoff, London, 1989.

Hardy Ivamy, E.R., Marine Insurance, London, Butterworths, 4th edition, 1985.

Hartkamp, A.S., Asser's handleiding tot de beoefening van het Nederlands Burgerlijk recht. Verbintenissenrecht. Deel III, De verbintenis uit de wet, W.E.J. Tjeenk Willink, Zwolle, 10de druk, 1998.

Hartlief, T., leder draagt zijn eigen schade. Enige opmerkingen over de fundamenten van en ontwikkelingen in het aansprakelijkheidsrecht, oratie, Kluwer, Deventer, 1997.

Hartlief, T. en Tjittes, R.P.J.L., Verzekering en Aansprakelijkheid, Kluwer, Deventer, $2^{\text {de }}$ druk, 1999.

Hazelwood, S.J., P\&I Clubs. Law and Practice, Lloyd's of London Press, $2^{\circ}$ druk, London, 1994.

Hodgson, G., Llyod's of London. A Reputation at Risk, Londen, 1984.

Holzhauer, R.W. en Teijl, R. e.a., Inleiding Rechtseconomie, Gouda Quint, Amhem, 1989.

Hondius, E.H., Schippers, J.J. en Siegers, J.J. (red.), Rechtseconomie en Recht; kennismaking van een vakgebied in opkomst, W.E.J. Tjeenk Willink, Zwolle, 1991.

Horbach, N.L.J.T., Liability versus Responsibility under International Law, Amsterdam, 1996.

Horbach, N.L.J.T. (ed.), Contemporary Developments in Nuclear Energy Law. Harmonising Legislation in CEEC/NIS, Kluwer Law International, Den Haag, Boston, 1999.

Huls, N.J.H., Recht in de risicomaatschappij, Delft University Press, Delft 1997.

Hulst, E.H., Grondslagen van milieu-aansprakelijkheid, diss., Gouda Quint, Amhem, 1993.

Huybrechts, M.A. (ed.), Marine Insurance at the turn of the Millennium, Volume l, Intersentia, Antwerpen, Groningen, 1999.

Kaiser, K. en Lindemann, B. (herausg.), Kernenergie und Internationale Politik, R. Oldenbourg Verlag. München, 1975.

Kelly, P. en Attree, R., European Producl Liability, London Butterworths, 1992.

Klaassen, C.J.M., Risicoaansprakelijkheid. De afdelingen 6.3 .2 en 6.3 .3 NBW alsmede art. 31 Wegenverkeersrecht, Tjeenk Willink, Zwolle, 1991.

Knottenbelt, J., Hoofdstukken produkıaansprakelijkheid: buitencontractuele aansprakelijkheid van de producent van een gebrekkig produkt voor persoonschade, Tjeenk Willink, Zwolle, 1991.

Koeman, N.S.J., Ouwerkerk, W.J. (red.), in Civielrechtelijke Aansprakelijkheid voor Milieuschade, Vereniging voor Milieureeht, W.E.J. Tjeenk Willink, Zwolle, 1989.

Koeman, N.S.J., (ed.), Environmental Law in Europe, Kluwer Law Intemational, Den Haag 1999.

Kottenhagen-Edzes, P.A., Onrechtmatige Daad en Milieu. Het gebruik van het privaatrecht bij het voorkomen van milieu-aantassing en het verhaal van milieuschade, diss., Gouda Quint, Amhem, 1992.

Kottenhagen-Edzes, P. (red.), Immaterièle schade: tendensen en wensen, Boekenrceks lus Commune, nr. 33, Intersentia, Antwerpen, Apeldoom, 2000.

Krầmer, L., EEC Treaty and Environmental Protection, London, Sweet \& Maxwell, 1997.

Krämer, L., Focus on European Environmental Law, London, Sweet \& Maxwell, 1998.

Kröner, R.P., Transnational Environmental Liability and Insurance, Graham \& Trotmān, Kluwer Academic Publishers, London, 1993.

Lambert-Faivre, Y., Risques et Assurances des entreprises, $3^{\circ}$ editie, Dalloz, Paris, $199 \mathrm{i}$.

Lambert-Faivre, Y., Droit des Assurances, $9^{\circ}$ editie, Dalloz, Paris, 1995. 
Lamm, V., The Utilization of Nuclear Energy and International Law, Akadémiai Kiadó, Budapest 1984.

Landes, W.M. en Posner, R.A., The Economic Structure of Tort Law, Harvard University Press, Cambridge, Massachusetts, 1987.

Lankhorst, G.H., De relativiteit van onrechtmatige daad, Kluwer, Deventer, 1992.

Lavrysen, L., De ontwikkeling van het Europese, Belgische en Vlaamse milieurecht in een wijzigende institutionele context. Onderzoek naar de ontwikkeling van het milieurecht vanuit een publiekrechtelijke invalshoek, Kluwer, Antwerpen, 1998.

Leclercq, J., L'ère nucléaire: le monde des centrales nucléaires, Hachette, 1986.

Levie, G. en Cousy, H. (red.), Het Europees Concurrentiebeleid in de Verzekeringssector, Academia, Bruylant, Louvain-la-Neuve, 1994.

Levie, G., Droit européen des Assurances, Travaux de la Faculté de Droit de l'Université Catholique de Louvain, Bruxelles, Bruylant, 1992.

Libert, P., Recht en Techniek van de Verzekering, Bruylant, Brussel, 1986.

Lopuski, J., Liability for Nuclear Damage. An international perspective, National Atomic Energy Agency, Warschau, 1993.

Lukes, R. (herausg.), Fünftes Deutsches Atomrechts-Symposium, Carl Heymans Verlag, Keulen, 1977.

Lukes, R. (herausg.), Sechtstes Deutsches Atomrechts-Symposium, Carl Heymans Verlag, Keulen, 1980.

Lukes, R. (herausg.), Siebtes Deutsches Atomrechts-Symposium, Carl Heymans Verlag, Keulen, 1983.

Lukes, R. en Birkhofer, A. (herausg.), Achtes Deutsches Atomrechts-Symposium, Carl Heymans Verlag, Keulen, 1989.

Lukes, R. en Birkhofer, A. (herausg.), Neuntes Deutsches Atomrechts-Symposium, Carl Heymans Verlag, Keulen, 1991.

Lukes, R. (herausg.), Reformüberlegungen zum Atomrecht, Carl Heymans Verlag, Keulen, 1991.

Mackaay, E., Economics of Information and Law, Boston, Kluwer, 1982.

Marescau, M., Van den Bossche, A.M. en Tison, M., Europees Gemeenschapsrecht. Bronnenboek II. Europees kartelrecht, Story Scientia, Brussel, 1992.

Markesinis, B.S. en Deakin, S.F., Tort Law, 3rd eđition, Clarendon Press, Oxford, 1994.

Mayda, J., (ed.), Aiomic Energy and Law, School of Law, Puerto Rico, 1959.

Mazeaud, H.\&L. en Tunc, A., Traité théorique et pratique de la responsabilité délictuelle el contractuelle, Moncrétien, Paris, $6^{\circ}$ édition, 1932.

Mazeaud, H.\&L en Tune, A., Leçons de Droit Civil, Tome II, Moncrétien, Paris, 1969.

Mazuzan, G.T. en Walker, J.S., Controlling the Atom. The Beginnings of Nuclear Regulation 1946-1962, University of Califomia Press, Los Angeles, 1984.

Merkin, R. en Rodger, A., EC Insurance Law, Longman, London, 1997.

Messer, E.A., Risicoaansprakelijkheid voor milieuverontreiniging in het BW, diss., Arnhem, Gouda Quint, 1994.

Michiels, F.C.M.A., De wet milieubeheer, W.E.J. Tjeenk Willink, Zwolle, tweede druk, 1994.

Milo, J.M., Het rechtsvergelijkende argument in de ontwikkeling van het Nederlandse vermogensrecht 1838 1940: aansprakelijkheid voor zaken, artikel 2014, publiek domein en de relativiteit van de onrechtmatige daad, diss., Intersentia, Antwerpen-Groningen, 1997. 
Moerenhout, R. en Smets, J., De samenwerking tussen de federale Staat, de Gemeenschappen en de Gewesten, Kluwer, Deume, 1994.

Mohr, P.C., Die Kanalisierung der Haftung unter besondere Berücksichtigung des Atomrechts, Berlin, Walter de Gruyter \& Co, 1970.

Morrens, P. (red.), Milieurecht voor bedrijfsleiders en hun adviseurs, Mys en Breesch, Gent, 1993.

Naveau, J. en Godfroid, M., Précis de Droit Aérien, Bruylant, Bruxelles, 1988.

Niezen, G.J., Raaijmakers, M.J.G.C. en Tervoort, A.J.S.M. (red.), Ongebonden Recht Bedrijven. Bedrijfsjuridische opstellen op de grens van het derde millennium bij gelegenheid van het 70-jarig bestaan van het Nederlands Genootschap van Bedrijfsjuristen, Kluwer, Deventer, 2000.

Nguyen Quoc, D., Daillier, P. en Pellet, P., Droit International Public, 5 druk, LGDJ, Parijs, 1994.

Ogus, A., Regulation. Legal Form and Economic Theory, Clarendon Press, Oxford, 1994.

Olson, M., The Logic of Collective Action. Public Goods and the Theory of Groups, Cambridge, Harvard University Press, 1965.

Ottervanger, T.R., Steenbergen, J. en Van der Voorde, S.J., Competition Law of the European Union, the Netherlands and Belgium, Loeff Legal Series, Kluwer, Den Haag, 1998.

Pascal, M. (ed.), Droit Nucléaire, CEA, Paris, Eyrolles, 1979.

Pelzer, N., Begrenzte und unbegrenzte Haftung im deutschen Atomrecht, Nomos, Baden-Baden, 1982.

Pelzer, N., (herausg.), Friedliche Kernenergienülzung und Staatsgrenzen in Mitteleuropa, Tagungsbericht der AIDN/INLA Regionaltagung in Regensburg 1986, Nomos, Badan-Baden, 1987.

Pelzer, N., (herausg.), Deutsches Atomenergierecht im internationalen Rahmen, Nomos, Baden-Baden, 1992.

Pelzer, N., (herausg.), Neues Atomenergierecht - Internationale und nationale Entwicklungen, Tagungsbericht der AIDAN/INLA Regionaltagung in Regensburg 1994, Nomos, Badan-Baden, 1995.

Pfennigstorf, W. (ed.), Pollution Insurance. International Survey of Coverages and Exclusions, Graham \& Trotman, Martinus Nijhoff, Dordrecht, 1993.

Piérard, J.P., Responsabilité civile. Energie atomique et droit comparé, Centre universitaire de droit comparé, Bruxelles, Bruylant, 1963.

Pigou, A.C., The Economics of Welfare, London, Mac Millan, 4th edition, 1932.

Pirotte, O., Girerd, P., Marsal, P. en Morson, S., Trente ans d'expérience Euratom. La naissance d'une Europe nucléaire, Bruxelles, Bruylant, 1988.

Posner, R., Antitrust Law. An Economic Perspective, Chicago, University of Chicago Press, 1976.

Posner, R., The Economics of Justice, Harvard University Press, Cambridge, 1981.

Posner, R., The Economic Analysis of Law, Apsen Law \& Business, New York, Sth edition, 1998.

Puget, H., Aspects du droit de lénergie atomique, tome II, Editions du centre national de la recherche scientifique, Paris, 1967.

Rainaud, J.M., L'Agence Internationale de l'Energie Atomique, Colin, Paris, 1953.

Rainaud, J.M., Le droit nucléaire, Que sais-je?, Presses Universitaires de France, 1994.

Rigaux, F. en Fallon, M, Droit International Privé, Tome II, Droit positif belge, Larcier, Bruxelles, 1993.

Rockett, L.R., Financial Protection against Nuclear Hazards: Thirty Years' Experience ander the PriceAnderson Act, The Legislative Drafting Research Fund of Columbia University, 1984.

Sands, Ph., (ed.), Chernobyl: Law and Communication, Grotius Publications Limited, Cambridge, 1988. 
Sands, Ph., Principles of International Environmental Law, Manchester University Press, Manchester, 1995. Schäfer, D., Soziale Schäden, Soziale Kosten und Soziale Sicherung, Berlijn, 1972.

Schäfer, H.-B. en Ot, C., Lehrbuch der okonomischen Analyse des Zivilrechts, Berlin, Springer, 1986.

Schamps, G., La mise en danger: Un concept fondateur d'un principe général de responsabilité. Analyse de droit comparé, Bruylant, L.G.D.J., Brussel, 1998.

Scheinman, L., The International Atomic Energy Agency and the World Nuclear Order, Resources for the Future, 1987.

Schirmeister, F.C., Amerikaanse toestanden in hel schadevergoedingsrecht? De vergoeding van letselschade in de Verenigde Staten, Koninklijke Vermande, Lelystad, 1996.

Schut, G.H.A., Onrechtmatige Daad, W.E.J. Tjeenk Willink, Zwolle, $5^{\circ}$ druk, 1997.

Seerden, R. en Heldeweg, M., Comparative Environmental Law in Europe. An Introduction to Public Environmental Law in the EU Member States, Maklu, Antwerpen, Apeldoom, 1996.

Shavell, S., Economic Analysis of Accident Law, Harvard University Press, Cambridge Massachusetts, 1987.

Sieburgh, C.H., Toerekening van een Onrechtmatige Daad, diss., Kluwer, Deventer, 2000.

Simoens, D., Buitencontractuele Aansprakelijkheid, Deel II, Schade en schadeloosstelling, Story Scientia, 1999.

Sinninghe Damsté, W.A., Regres bij onrechtmatige Daad, Koninklijke Vermande, Lelystad, 1999.

Smyth, H.D., Atomic energy for military purposes. The official report on the Development of the Atomic Bomb under the auspices of the U.S. government, Princeton, 1946.

Spier, J., De maalstroom van het aansprakelijkheidsrecht, Houthoff-lezing, maart 1992.

Spier, J. en Sterk, C.H.W.M., Aansprakelijkheid voor gevaarlijke stoffen. Gevaarlijke sioffen, stortplaatsen, boorgaten en vervoer van gevaarlijke stoffen, Kluwer, Deventer, 1995.

Spier, J. (ed.), The Limits of Liability. Keeping the Floodgates Shut, Kluwer, Deventer, 1996.

Spier, J. en Haazen, O.A., Aansprakelijkheidsverzekeringen op claims-made grondslag in rechtsvergelijkend perspectief, Kluwer, Deventer, 1996.

Spier J., Hartlief, T., Van Maanen G.E. en Vriesendorp, R.D., Verbintenissen uit de wet en schadevergoeding, Kluwer, Deventer, 1997.

Spier, J., Een nieuwe dageraad voor het aansprakelijkheidsrecht?, Rede uitgesproken bij het afscheid van het ambt van gewoon hoogleraar in het privaatrecht aan de Katholieke Universiteit Brabant op vijjag 26 maart 1999, W.E.J. Tjeenk Willink, Deventer, 1999.

Stanners, D. en Bourdeau, Ph., (ed.), Europe's Environment. The Dobris Assessment, Report on the State of the pan-European environment, European Environment Agency, Copenhagen, 1995.

Stason, E.B., Estep, S.D. en Pierce, W.J., Atoms and the Law, Ann Arbor, University of Michigan Law School, 1959.

Sterk, C.H.W.M., Verhoogd gevaar in het aansprakelijkheidsrecht. Een rechtsvergelijkend onderzoek naar aansprakelijkheid voor zaken, stoffen en motorrijtuigen, diss., Kluwer, Breda, 1994.

Street, H. en Frame, F.R., Law relating to nuclear energy, London, Butterworths, 1966.

Suy, E., Corpus Iuris Gentium. A Collection of Basic Texts on Modern Interstate Relations, Acco, Leuven, 1996.

Tegelberg, G.G.A., Olie op de Golven, W.E.J. Tjeenk Willink, Zwolle, 1984.

Timagenis, G.J., International Control of Marine Pollution, Oceana Publications, 1980. 
Tonnaer, F.P.C.L., Handboek van het Nederlands Milieurecht, Lemma, Utrecht, 1994.

Tunc, A., La responsabilité civile, Economica, Paris, 1981.

Van, A., Onzekerheid over daderschap en causaliteit, diss., Gouda Quint, Amhem, 1995.

Van Acht, R.J.J., Burenrecht, Kluwer, Deventer, 1990.

Van Acht, R.J.J. en Bauw, E., Milieuprivaatrecht, W.E.J. Tjeenk Willink, Zwolle, tweede druk, 1996.

Van Boom, W.H., Hartlief, T. en Spier, J., Regresrechten. Afschaffen, handhaven of uitbreiden?, W.E.J. Tjeenk Willink, Deventer, 1996.

Van Caenegem, R.C., Geschiedkundige inleiding tot het privaatrecht, Story Scientia, 1985.

Van Dam, C.C., Zorgvuldigheidsnorm en Aansprakelijkheid. Een rechtsvergelijkend onderzoek naar plaats, inhoud en functie van de zorguuldigheidsnorm bij de ansprakelijkheid voor letsel- en zaakschade, diss., Kluwer, Deventer, 1989.

Van Dam, C.C., Aansprakelijkheidsrechi. Een grensoverschrijdend handboek, Boom Juridische uitgevers, Den Haag, 2000.

Van den Bergh, R. (ed.), Verslagboek Eerste Werkvergadering Recht en Economie, Antwerpen, Handelshogeschool, 1986.

Van den Bergh, R., Economische Analyse van het Mededingingsrecht. Een terreinverkenning, Gouda Quint, Amhem, 2) druk, 1997.

Vandenberghe, H., Kernenergie in België, SCK/CEN, ENE.RA95xx, april 1995 (niet gepubliceerd).

Van den Wijngaert, C., Strafrecht en Strafprocesrecht in hoofdlijnen, Maklu, Antwerpen-Apeldoom, 1999.

Vandewalle, G. en Van den Broeck, J., Algemene Economie, Kluwer, Antwerpen, 1987.

Van Dunné, J.M., (red.), Civielrechtelijke aansprakelijkheid voor milieuschade, Vereniging voor Milieurecht, W.E.J. Tjeenk Willink, Zwolle, 1989.

Van Dunné, J.M., Verbintenissenrecht Deel 2. Onrechtmatige Daad. Overige Verbintenissen, Kluwer, Deventer, derde herziene druk, 1997.

Van Hecke, G. en Lenaerts, K, Internationaal Privaatrecht, Story, Gent, 1989.

Van Huizen, P.H.J.G., Het Transportverzekeringsbedrijf. Juridische en rechisvergelijkende beschouwingen, diss., 1988.

Van Maanen, G.E., Onrechtmatige Daad: Aspekten van de ontwikkeling en struktuur van een omstreden leersink, dissertatie, Deventer, Kluwer, 1986.

Veljanovski, C.G., The New Law-and-Economics. A Research Review, Oxford, Centre for Socio-Legal Studies, 1982.

Viney, G., Traité de Droit (ivil. Les Obligations. La responsabilité: conditions, L(ID), Paris, 1982.

Wansink, J.H., De algemene aansprakelijkheidsverzekering. Een hernieuwde verzekeringsrechteiijke en verzekeringstechnische beschouwing, W.E.J. Tjeenk Willink, Zwolle, 1994.

Weinstein, J.L., (ed.), Progress in Nuclear Energy. Law and Administration, vol. 3, Nuclear Liability, Oxford, Pergamon Press, 1962.

Wery, P.L., Hoofdzaken Verzekeringsrecht, Kluwer, Deventer, 1995.

Wetterstein, P. (ed.), Harm to the Environment. The Right to Compensation and the Assessment of Damages, Clarendon Press, Oxford, 1997.

Wiggers-Rust, L.F. en Deketelaere, K., (red.) Aansprakelijkheid voor milicuschade en financiële zekerheid. Een vergelijking van Nederlands, Belgisch en Europees recht, Die Keure, Koninklijke Vermande, Brugge, Lelystad, 1998. 
Wu, C., La pollution du fait du transport maritime des hydrocarbures. Responsabilité et Indemnisation des dommages, diss., Pedone, Monaco, 1994.

X., A Forum Report. The New Atomic Energy Law - What is means to Industry, Atomic Industrial Forum, New York, 1954.

X., A Shorl History of Nuclear Regulation, 1946-1992, NRC.

X., AEN/NEA, Nuclear Legislation. Analytical Study, Regulatory and Institutional Framework for Nuclear Activities, OECD, Paris, 1996.

X., Annual Report ANI, Washington, 1996.

X., Annual Report 1996, Nuclear Mutual Limited/Nuclear Electric Insurance Limited.

X., Annual Report 1999, LAEA, Wenen.

X., Captive Insurance: a Threat to the Global Insurance Industry?, Datamonitor, FT Insurance Report, Pearson Professional Lto., London, 1995.

X., Compensation for Pollution Damage, OECD, Parijs, 1981.

X., De kernverzekeringen in België sinds 1957, SYBAN, 1990.

X., EMANI, Annual Report, Brussel, 1991.

X., EMANI, Annual Report, Brussel, 1999.

X., Future Financial Liabilities of Nuclear Activities, OECD-NEA, Parijs, 1996.

$\mathrm{X}$, Insurance for Nuclear Installations, IAEA, Legal Series $\mathrm{n}^{\circ}$ 6, Vienna, 1970.

X., Insuring environmental impairment liability, Swiss Reinsurance Company, 1999.

X., International Problems of Financial Protection against Nuclear Risk, Harvard Law School, 1959.

$\mathrm{X}$., In volle verzekerdheid, Opstellen aangeboden aan Prof. $\mathrm{mr}$. A.J.O. baron van Wassenaer van Catwijck, W.E.J. Tjeenk Willink, Zwolle, 1993.

X., Les Assurances de Responsabilité, Editions du jeune barreau de Bruxelles, Bruxelles, 1994.

$\mathrm{X}$, La Réparation des dommages catastrophiques. Les risques technologiques majeurs en droit international et en droit communautaire, Travaux des XIIles Joumées d'études juridiques Jean Dabin, Bruxelles. Bruylant, 1990.

X., Liability and Compensation for Nuclear Damage. An international overview, OECD-NEA, Parijs, 1994.

$\mathrm{X}$. Massaschade. Vergt de behandeling van massale schade een bijzondere benadering?, Inleidingen gehouden op het symposium van de Vereniging van Letselschade Advocaten 1996, Koninklijke Vermande, Lelystad, 1996.

X., Ministerie van Volkshuisvesting, Ruimtelijke Ordening en Milieubeheer, Symposium Milieuschadefonds, Publikatierceks Milieubeheer, nr. 1996/3.

X., Nuclear Accidents: Liabilities and Guarantees, OECD-IAEA Helsinki Symposium, Paris, 1993.

X., Nuclear Electric Insurance Limited, Information Brochure, December 1994.

X., Nuclear Inter Jura 1993, Verslagboek van het Tweejaarlijkse Congres van de International Nuclear Law Association (INLA/AIDN), Rio de Janeiro, 1993.

X., Nuclear Inter Jura 1995, Verslagboek van het Tweejaarlijkse Congres van de International Nuclear Law Association (INLA/AIDN), Helsinki, Finland, 1995.

X., Nuclear Inter Jura 1997, Verslagboek van het Tweejaarlijkse Congres van de Intemational Nuclear Law Association (INLA/AIDN), "Le Droit Nucléaire: du XX' au XXI siècle", Société de Législation Comparée, Paris, 1998. 
X., Nuclear Inter Jura 1999, Verslagboek van het Tweejaarlijkse Congres van de International Nuclear Law Association (INLA/AIDN), Washington, 1999.

X., Nuclear Law for a Developing World, IAEA, Wenen, 1969.

X., Nuclear Mutual Limited, Information Brochure, December 1994.

X., Nuclear Power. Insurance and the Pooling System, Special Edition of the Nuclear Pools' Bulletin, 1992.

X., Nuclear Third Party Liability and Insurance. Status and Prospects, AEN-OECD Munich Symposium, Paris, 1985.

$\mathrm{X}$, Official Records Vienna Convention, Vienna, 1963.

X., Paris Convention. Decisions, Recommendations, Interpretations, Parijs, NEA, 1990.

X, Reform of Civil Nuclear Liability, International Symposium, Budapest 1999, OECD, Parijs, 2000.

X., The Manhattan Project. Making the Atomic Bomb, United States Department of Energy, Energy History Series, september 1994.

X., The Price-Anderson ACt - Crossing the Bridge to the Next Century: A Report to Congress, NRC, Washington, 1998.

$\mathrm{X}$, US Nuclear Regulatory Commission. The Price-Anderson Act - The Third Decade (Report to the Congress), NUREG-0957, 1983.

X., The United Nations and Nuclear Non-Proliferation, United Nations Blue Books Series, New York, vol. 3, 1995.

$\mathrm{X}$, Witboek beireffende de modernisering van de regels inzake de toepassing van de artikelen 85 en 86 van het EG-Verdrag, Commissie van de Europese Gemeenschappen, Brussel, 1999.

X., Witboek betreffende milieuaansprakelijkheid, Commissie van de Europese Gemeenschappen, Brussel, 9 februari $2000, \operatorname{COM}(2000) 66$ def:

Zweigert, K. en Kötz, H., An Introduction to Comparative Law, Clarendon Press, Oxford, $2^{\circ}$ druk, 1987.

\section{Artikelen}

Abecassis, D., "Risk Sharing in LNG shipping - some aspects of the relationships between owners and charterers of LNG ship and third parties", Lloyd's Maritime and Commercial Law Quarterly, 1982, 138-151.

Abecassis, D., "IMO and liability for oil pollution from ships: a retrospective", Lloyd's Maritime and Commercial Law, 1983, 45-59.

Abraham, K.S., "Environmental Liability and the linits of insurance", Columbia Law Review, 1988, 942-988,

Agard-Peano, M.A., "Rapport français concernant l'assurance de la responsabilité civilê: couverture dans le temps", in Cousy, H. en Claassens, H. (ed.), Aansprakelijkheidsverzekering: dekking in de tijd, Maklu, Academia-Bruylant, Antwerpen, Apeldoom, 1997, 107-127.

Akerlof, G., "The Market of the Lemons: Quality Uncertainty and the Market Mechanism", Quarterly Journal of Economics, vol. 84, 1970, 488-500.

Akkermans, A.J., "Veroorzaking van deelschade", Weekblad voor Privaatrecht, Notariaat en Registratie, $6043,1992,249-255$.

Akkermans, A.J., "Statistisch causaliteitsbewijs bij toxische schadeveroorzaking", Verzekeringsarchief, 1995, nr. 2, 44-53.

Akkermans, A.J., "Proportionele schadevergoeding: onbekend maakt onbemind?", Verkeersrecht, 1999, 6569. 
Alen, A. en Peters, P., "Belgie op zoek naar een coöperatief federaal staatsmodel. Over de samenwerking tussen de Staat, de Gemeenschappen en de Gewesten na de derde staatshervorming", Tijdschrift voor Belgisch Publiekrecht, 1989, 344-345.

Alexander, W., "Wettelijke aansprakelijkheid bij toepassing van kemenergie", Nederlands Juristenblad, 1961, 841-848 en 865-872.

Alexander, W., "La législation nucléaire aux Pays-Bas", in Puget, H. (éd.), Aspects du droit de l'énergie atomique, Tome II, Editions du centre national de la recherche seientifique, Paris, 1967, 347-356.

Anderson, D.H., "Legal Implications of the Entry into force of the UN Convention on the Law of the Sea", International and Comparative Law Quarterly, vol. 44, 1995, 313-326.

Andersson, U., "The Swedish Environmental Damage Insurance. Viewpoint of the government", in Bocken, H. en Ryckbost, D. (ed.), Verzekering van Milieuschade, Verslagboek van het International Colloqium gehouden te Gent op 14 en 15 december 1989, Story Scientia, Gent, 1991, 385-391.

Arangio-Ruiz, G., "Some Preliminary reflections on the international responsibility of States for nuclear damage", in Weinstein, J.L., (ed.), Progress in Nuclear Energy. Law and Administration, vol. 3 Nuclear Liability, Oxford, Pergamon Press, 1962, 228-235.

Arangio-Ruiz, G., "Indemnification against liability for nuclear incidents in licensed atomic energy activities", in Weinstein, J.L., (ed.), Progress in Nuclear Energy. Law and Administration, vol. 3 Nuclear Liability, Oxford, Pergamon Press, 1962, 237-251.

Arangio-Ruiz, G., "Some International Legal Problems of the Civil Uses of Nuclear Energy", Recueil des Cours, Académie de Droit International, 1962, tome 107 de la Collection, A.W. Sijthoff, Leiden, 1963, 503633.

Arpel, J.D., "Environment and Insurability. The Application of Risk Managment Principles to Running an Insurance Company", The Geneva Papers of Risk and Insurance, vol. 20, n 76, 195, 374-392.

Arrow, K, "Uncertainty and the Welfare Economics of Medical Care", American Economic Review, 1963, 941-973.

Arrow, K., "The Liconomics of Moral Hazard: Further Comnent", American Economic Review, vol. 58, 1968, 537-539.

Aspden, P., "Oil Pollution Legislation and its consequences. A P\&I Club View", in Shipping Law Faces Europe: European Policy. Competition and Environment, Maklu, Antwerpen-Apeldoom, Bruylant, Brussel, $1995,135-154$.

Avossa, G., "Trends in nuclear third party liability law", ALDN/INLA, Nuclear Inter Jura '91, "Nuclear law and nuclear energy for the future", Bath, 23-26 september 1991, 199-203.

Bakker, M.H.C., "Het Fonds Luchtverontreiniging", in Bocken, H. en Ryckbost, D. (ed.), Verzekering van Milieuschade, Verslagboek van het Internationaal Colloqium gehouden te Gent op 14 en 15 december 1989 , Story Scientia, Gent, 1991, 345-357.

Ballarino, T., "La réparation des dommages catastrophiques. Problèmes de droit international privé", in $L a$ Réparation des dommages catastrophiques. Les risques technologiques majeurs en droit international et en droit communautaire, Travaux des XIIles Joumées d'études juridiques Jean Dabin, Bruxelles, Bruylant, 1990, $59-100$.

Barraclough, I. en Camino, A., "Safety culture. Keys for sustaining progress", IAEA Bulletin, vol. 40/2, 1998, 27-30.

Basyn, M., "L'Assurance des Risques Atomiques devant les Règles de Concurrence", Colloqium Euratom. Verzekeringmaatschappijen over de actuele problemen voor hot verzekeren van nucleaire risico's, Firenze, december $1962,41-46$.

Basyn, M., "Les Pools et la Réglementation Européenne de la Concurcnce", Derde Collogium over de verzekering van nucleaire risico's, EUR 2464, Aix-en-Provence, mei 1964, 84-94. 
Basyn, M., "L'assurance des risque nucléaires et l'application de l'article 85 du traité de Rome", Revue: Générale des Assurances Terrestres, 1963, $\mathrm{n}^{\circ} \mathrm{I}-2,106-122$.

Basyn, M., "Energie nucléaire et problèmes juridiques", Journal des Tribunaux, 1957, 345-346.

Bauer, R., "Les projets de I'OECD et de l'Euratom relatifs à une convention sur la responsabilité civile dans le domaine de l'énergie atomique", in Puget, H. (red.), Aspects du droit de l'énergie atomique, tome II, Centre français de droit comparé, Parijs, 1967, 81-92.

Bauw, [:., "Tussen traditie en efficiëntie. Naar een wettelijke regeling van de afwikkeling van massaschade", Nederlands Juristenblad, 1995, 622-630.

Baxter, M.S., "Environmental radioactivity: a perspective on industrial contributions", IAEA Bulletin, 2/1993. 33-38.

Becker, G., "A Theory of Competition among Pressure Groups for Political Influence", Quarrerly" Journal of Economics, 1983, 371-400.

Belser, W.E., "Ŭber die Zweckmäßigkeit der Poolung von Atomrisiken", Versicherungswirtschaft, nr. 18, 14.Jahrg., september 1959, 572-584.

Belser, W.E., "Atomversicherungsrechtliche Fragen unter Berücksichtigung der internationalen Konventionen", in Erler, G. (herausg.), Beiträge zum internationalen Wirtschaftsrecht und Atomenergierecht, Verlag Otto Schartz \& Co, Göttingen, 1963, 51-84.

Belser, W.E., "Aktuelle Probleme der Versicherung von Atomrisiken", Die Versicherungstundschau, 20. Jrg., 1965, Heft 9/10, 265-283.

Belser, W.E., "Les tâches et les possibilités de l'assurance face aux développment de l'énergie nucléaire", Quatrième colloque sur l'assurance du risque nucléaire, Euratom, EUR 2642, 1966.

Belser, W.E., "Examen des solutions apportées par les lois nationales et les conventions internationales sur la responsabilité dans le domaine de l'énergie nucléaire aux problèmes posés aux assureurs pour la couverture de cette responsabilité", in Albonetti, A., Belser, W.E., e.a., Droit Nucléaire Européen, Colloque de Droit nucléaire européen, Presses universitaires de France, Paris, 1968, 65-109.

Belser, W.E., L'Assurance des Risques Nucléaires. Ses problèmes dans les domaines technique, administratif et législatif, Rapport préliminaire présenté au Groupe de Sous-Comité des Assurances de l'Organisation Européenne de Coopération Economique, februari 1957, 32-63.

Berger, R., "Ist die Kanalisierung der Haftung auf den Betreiber einer Kernanlage nicht dogmatisch zu begründen?", Versicheringsrecht, 1967, Hen 5, 114-115.

Bergkamp, L., "'Wie van de Drie' en 'Alles of Niets': Nederlandse toestanden?", Nederlands Juristenblad, 1993, 100-103.

Bergkamp, L., "A Future Environmental Liability Regime", European Environmental Law Review', 1998, 200 204.

Berkovitz, D., "Price-Anderson Act: Model Compensation Legislation" - The Sixty-Three Million Dollar Question", Harvard Emironmenial Law Review, vol. 13, n 1, 1989, 1-68.

Bertel, E. en Van de Vate, J., "Nuclear energy and the environmental debate: the context of choices", IAEA Bulletin, 4/1995, 2-7.

Besson, A., "L'énergie atomique et le droit des assurances", Rapports Généraux au V Vongrès intirnational de droit comparé, Intenuniversitair Centrum voor Rechtsvergelijking, Brussel, Bruylant, 1960, 459-467.

Betlem, G., "It's no use crying over spilt chemicals. House of Lords, Cambridge Water Co. V. I:ustem Counties ple.", Maastricht Journal of European and Comparative Law, 1995, vol. 2, n 3, 289-305.

Beyens, M., "Les dommages aux biens sur le site", in Reform of Civil Nuclear Liability, International Symposium, Budapest 1999, OECD, Parijs, 2000, 507-526. 
Bibbings, T. en Brining, W.D., "Considering a captive? Consider financial insurance or reinsurance", in Risk Financing! Options, Risk and Insurance Research Group, 1994, 25-27.

Bierbooms, P. en Brans, E., "Milieuschade en civiele aansprakelijkheid voor olielozingen. Entering the Ecological Warzone'?", Nederlands Juristenblad, 1993, 85-91.

Bierbooms, P.F.A. en Taams, R.A., "Aansprakelijkheid voor bodemvervuiling in het verleden en in de toekomst", Nederlands .Juristenblad, 1994, 1339-1345.

Bierbooms, P. en Brans, E., "Het EU Witbock Milieuaansprakelijkheid: de vage contouren van een toekomstig aansprakelijkheidssregime", Milieu en Recht, 2000, nr. 7/8, 182-188.

Biezup, J.T. en Abeel, T.J., "The Limitation Fund and its distribution", Tulane Law Review, vol. 53, 1979, 1185-1204.

Bigot, J., "Compensation for pollution damage and insurance", in Compensation for pollution damage, OECD, Parijs, 1981, 124-143.

Billiet, C., "BAT et BATNEEC: quelques faits et réflexions", Aménagement-Envrionnement, 1995/2, 71-77.

Bishop, W., "Economic Loss in Tort", Oxford Journal of Legal Studies, 1982, 1-29.

Blanchard, P., "The Risk of Civil Nuclear Liability for Foreign Contractors in Central and Eastern Europe and the NIS", in Horbach, N.L.J.T. (ed.), Contemporary Developments in Nuclear Enengy Law. Harmonising Legislation in CEEC/NIS, Kluwer Law Intemational, Den Haag, Boston, 1999, 523-551.

Blanchard, P., "Responsibility for Environmental Damage caused by Nuclear Accidents", in Nuclear Inter Jura 1999, AIDN/INLA, Washington, 1999, 283-296.

Blix, H., "The dual challenge of a nuclear age", IAEA Bulletin, 1/1993, 32-39.

Blix, H., "The LAEA, United Nations and the new giobal nuclear agenda", IAEA Bulletin, 3/1995, 3-7.

Bloembergen, A.R., "De invloed van verzekeringen", Nederlands Juristenblad, 1980, 174-183.

Bocken, H., "Van fout naar risico. Een overzicht van de objectieve aansprakelijkheidsregeling naar Belgisch recht", Tijdschrifi voor Privatrecht, 1984, 329-416.

Bocken, H., "Aansprakelijkheid voor milieuschade", Rechtskundig Weekblad, 1987-1988, 1269-1280.

Bocken, H., "Alternatives to liability and liability insurance for the compensation of pollution damages", Tijdschrift voor Miliewaansprakelijkheid, 1987/4, 83-87 en 1988/1, 3-10.

Bocken, H., "Enkele hoofdthema's van de eausaliteitsproblematiek", Tijdschrift voor Belgisch Burgerlijk Recht, 1988. 268-296.

Bocken, H., "Complementary compensation mechanisms. A general environmental damage fund?", in Bocken. H. en Ryckbost, D. (ed.), Verzekering van milieuschade, Gent Story Scientia, 1989, 427-437.

Bocken, H., "Systèmes alternatifs pour l'indemnisation des dommages dus à la pollution", Revie Générale des Assurances et des Responsabilités, 1990, 11.698 en 11.714.

Bocken, H., "Milieuwetgeving en onroerende goederen. Aansprakelijkheid voor de kosten van bodemsanering", Tijdschrift voor Privaatrecht, 1992, 7-83.

Bocken, H., "Aansprakelijkheid voor milieuschade: een nieuw en belangrijk bedrijfsrisico", in Morrens, P. (red.), Milieurecht voor bedriffsleiders en hun adviseurs, Mys en Breesch, Gent, 1993, 53-80.

Bocken, H. en De Sacgher, T., "Aansprakelijkheid en financiele zekerheden na VLAREM II", Fijdschrift voor Milieurecht, 1993,81-89.

Bocken, H., "L'assurance responsabilité civile pour dommages causés par la pollution", in Les Assurances de l'Entreprise, Bruxelles, Bruylant, volume II, 1993, 239-280.

Bocken, H., "Het proces zonder einde: aansprakelijkheid voor schade veroorzaakt door grondwaterwinning en bronbemaling", Tijdschrift voor Privaatrecht, 1995, 1633-1678. 
Bocken, H. en Geerts, I., "De vergoeding van letselschade en schade doot overlijden bij verkeersongevallen in het Belgisch recht", Tijdschrift voor Privaatrecht, 1996, 1250-1255.

Bocken, H., "Compensation of Ecological Damage in Belgium", in Wetterstein, P. (ed.), Harm to the Environment: the right to Compensation and the assessment of Damages, Oxford, Clarendon Press, 1997, 143-158.

Bocken, H., "Rechtstreekse verzekeringen ten behoeve van derden en andere wisseloplossingen voor aansprakelijkheid en aansprakelijkheidsverzekering. Een typologie", in Liber Amicorum René Van Gompel, Story Scientia, Kluwer, Deurne, 1998, 23-37.

Bocken, H., "Nog iets over inbreuk op recht?", in Liber Amicorum Walter van Gerven, Kluwer, Deurne, 2000, 183-202.

Bond, V., "The Cancer Risk Attributable to Radiation Exposure: Some Practical Problems", Health Physics, $1981,108-111$

Bongaerts, J. en Debièvre, A., "Insuranee for Civil Liability for Marine Oil Pollution Damages", The Geneva Papers on Risk and Insurance, 1987, 145-157.

Bonotto, O. en Vanden Borre, T., "Problèmes de compétence judiciaire dans les procédures de droit pénal relatives aux accidents nucléaires. Les principes de droit pénal et l'article 13 de la Convention de Paris", in Le droit nucléaire: du XXe au XXTe Sciècle. Nuclear Inter Jura '97, Société de Législation Comparée, Paris, $1998,467-471$.

Bonte, E., "Aansprakelijkheidsbeperking der eigenaars en exploitanten van konventionele en kernenergetische schepen", Rechtskundig Weekblad, 1963-64, 145-182.

Borden, W.L., "Financing Future Development", in A Forum Report. The New Atomic Energy Law - What is means to Industry, Atomic Industrial Forum, New York, 1954, 59-62.

Borenstein, S., "The economics of costly risk sorting in competitive insurance markets", International Review of Law and Economics, 1989, 25-39.

Bouckaert, B., "Efficientie of rechtvaardigheid: het onvermijdelijk dilemma?", Tijdschrift voor Sociale Wetenschappen, 1984, 101-133.

Bouckaert, B., "L'analyse économique du droit: vers un renouveau de la science juridique?", Revue interdisciplinaire d'ctudes juridiques, 1987-88, 47-61

Boulanenkov, V. en Brands, B., "Nuclear Liability: Status and Prospects", IAEA Bulletin, 4/1988, 5-9.

Boulanenkov, V., "Main Features of the Convention on Supplementary Compensation for Nuclear Damage an Overview", in Reform of Civil Nuclear Liability, International Symposium, Budapest 1999, OECD, Parijs, $2000,161-170$.

Boustany, K., "Reflection on the Development of Nuclear Law", Nuclear Law Bulletin, vol. 51, 1993, 7.25.

Boustany, K., "Le developpement de la normativité nucléairte uu l'art de l'évasion juridique", Bulléin de' Lroit Nucléaire, $\mathrm{n}^{\circ} 61,1998,43-58$.

Boyd, J. en Ingberman, D.E., "Nonconpensatory I)amages and Potential Insolvency", Journal of legal Situdies, 1994, 895-910.

Boyd, J. en Ingberman, D.E., " The "'Polluter Pay Principle": Should Liability be Extended when the Polluter Cannoy pay?", The Geneva Papers on Risk and Insurance, vol. 21, n 79, 1996, 182-203.

Braams, W., Th., "Over de rol van schuld bij milieu-aansprakelijkheid", in Koeman, N.S.J., Ouwerkerk, W.J. (red.), in Civielrechtelijke Aansprakelijkheid voor Milieuschade, Vereniging voor Milieurecht, W.E.J. Tjeenk Willink, Zwolle, 1989, 46-78.

Brans, E.H.P., "Liability for Ecological Damage under the 1992 Protocols to the Civil Liability Convention and the Fund Convention, and the Oil Pollution Act of 1990", Tijdschrift voorMilieu-Aansprakelijkheid, 1994, $61-67$ en 85-91. 
Brans, E.H.P., van der Veen, G.A., "Publiek domein en aansprakelijkheid voor milieuschade veroorzaakt door milieuverontreiniging: de Patmos en de Haven", Tijdschrift voor Milieunansprakelijkheid, 1999/4, 109-118.

Breining, W., "Reform of liability in Nuclear Law (unlimited liability does not automatically create unlimited cover)", Nuclear Law Bulletin, $\mathrm{n}^{\circ} 25,1980,76-79$.

Breining, W., "Reformüberlegungen zur Ausgestaltung der atomrechtlichen Haftung", in Lukes, R. (herausg.), Sechstes Deutsches Atomrechts-Symposium, Carl Heymanns Verlag, Keulen, 1980, 403-406.

Brodecki, Z., "New definition of Pollution Damage", Lloyd's Maritime and Commercial Law, 1985, 382-391.

Brodecki, Z., "The Polish-Soviet Disputes arising from the Chemobyl Accident - A hypothetical legal analysis", in La réparation des dommages catastrophiques. Les risques technologiques majeurs en droit international et en droit communautaire, Travaux des XIlles Joumées d'études Jean Dabin, Bruxelles, Bruylant, 1990, 249-262.

Bröring, H.E., "Fondsvorming en financiële zekcrheden", in Koeman, N.S.J., Ouwerkerk, W.J. (red.), in Civiolrechtelijke Aansprakelijkheid voor Milieuschade, Vereniging voor Milieurecht, W.E.J. Tjeenk Willink, Zwolle, 1989, 15!-168.

Brown, E.D., "Making the Polluter pay for Oil Pollution Damage to the Environment. A note to the Zoe Colocotroni Case", Maritime and Commercial Law Quartcrly, 1981, 323-334.

Brown, J.P., "Toward an Economic Theory of Liability", Journal of Legal Studies, 1973, 323-349.

Brown, O.F., "Legislative History of Government Indemnification Under the Price Anderson Act", paper gepresenteerd voor The Price-Anderson Contractors Policy Issues Study, september 1984, 1-22.

Brown, O. F., "Nuclear Liability Coverage Developments in the United States of America", in Nuclear Inter Jura '93, AIDN/INLA, Rio de Janeiro, 1993, Il.5.6-2.

Brown, O.F., "Recent Developments in the Areas of Nuclear Liability Coverage in the United States of Amerlca and International Regimes", PATRAM '95, 1-9.

Brown, O.F., "Litigation persists from the 1979 Three Miles Island Accident", Nuclear Law Bulletin, vol. 57, $1996,67-69$.

Brown, O.F., "Legislative History of Government Indemnification Under the Price Anderson Act", paper gepresenteerd voor The Energy Contractors Price-Anderson Group, Washington, 1998, 1-50.

Brown, O.F., "International Nuclear Liability Developments from the USA Perspective", in Le droit nucléaire: du XXe au XXle Sciècle. Nuclear Inter Jura '97, Société de Législation Comparée, Paris, 1998, 473-475.

Brown, O.F., "Recent Developments from the Perspective of the United States", in Horbach, N.L.J.T. (ed.), Contemporary Developments in Nuclear Energy Law. Harmonising Legislation in CEECNIS, Kluwer Law International, Den Haag, Boston, 1999, 481-488.

Brown, O.F. en Horbach, N.L.J.T., "Liability for Intcrnational Nuclear Transport", in Reform of Civil Nuclear Liability, Intemational Symposium, Budapest 1999, OECD, Parijs, 2000, 237-261.

Brunengo, C., "Cross Border Damage - Two Fiction Stories", AIDN/INLA, Nuclear Inter Jura '91, Bath, 23 september - 26 september 1991, 215-224.

Buglass, L. J., "Limitation of liability from a marine insurance viewpoint", Tulane Law Review, vol. 53, 1979, 1364-1394.

Bühlman, W., "Deux êléments nouveaux de la législation suisse sur la responsabilité civile en matière nucleaire", in Nuclear Third Party Liability and Insurance, AEN-OECD, Paris, 1985, 385-399.

Bühlmann, W.A., "Assurance Responsabilité Civile complémentaire d'Etat: L'exemple de la loi suisse sur la responsabilité civiele en matière nuclėaire", in Nuclear Accidcnts. Liabilities and Guaraniees, OECD-LAEA, Paris, 1993, 434-446. 
Calabresi, G. en Klevorick, A.K., "Four tests for Liability in Torts", Journal of Legal Studies, vol. 15, 1985, 585-627.

Calabresi, G. en Melamed, A.D., "Property rules, Liability Rules and Inalienability: one View over the Cathedral", Harvard Law Review, Vol. 85, 1972, 1089-1128.

Calabresi, G., "Concerning Cause and the Law of Torts", University of Chicago Law Review, 1975, 69-108.

Calabresi, G., "Some Thoughts on Risk Distribution and the Law of Torts", Yale Law Journal, 1961, 499-551.

Calabresi, G., "The Decision for Accidents. An Approach to Non Fault Allocation Costs", Harvard Law Review, 1965, 713-745.

Calabresi, G., "Transaction Costs, Resource Allocation and Liability Rules - A Comment", Journal of Law and Economics, 1968, 67-73.

Cameron, P., "The Vienna Conventions on early notification and assistance", in Cameron, P, Hancher, I.,, Kühn, W. (ed.), Nuclear Energy Law after Chernobyl, Graham and Trotman, London-Dordrecht, 1988, 19-32.

Carette, A., "Op zoek naar de inhoud en de draagwijdte van BAT(NEEC)", Tijdschrift voor Milieurecht, 1996, 310-328.

Carette, A., "Wet betreffende een vorderingsrecht inzake bescherming leefmilieu", Rechtskundig Weckblad, 1992-1993, 1392-1400.

Cavers, D.F., "Improving Financial Protection of the Public against the Hazards of Nuclear Power", Harvard Law Review, vol. 77:644, 1964, 650-656.

Chandelle, J.M., "La réparation du dommage en matière de troubles de voisinage", Annales de la Faculté de Droit de Liège, 1980, 85-126.

Charlier, R.E., "Questions juridiques soulevées par l'évolution de la scicnce atomique", Recueil des Cours, Académie de Droit International, 1957, tome 91 de la Collection, A.W. Sijthoff, Leiden, 1958, 217-349.

Chelius, J., "Liability for Industrial Accidents: A Comparison of Negligence and Strict Liability Systenss", Journal of Legal Studies, 1976, 293-309.

Chenu, C.-A., "Les dangers atomiques et leur assurance", in Puget, H. (éd.), Apects du droit de l'énergie atomique, tome II, Centre français de droit comparé, Paris, 1967, 151-156.

Cigoj, S., "International Regulation of Civil Liability for Nuclear Risk", International and Comparative Law' Quarterly, vol. 14, 1965, 809-844.

Claassens, H., "Kernenergie en aansprakelijkheidsverzekeringen", Verzekeringswereld, 1984, afl. 258, 35-36.

Claassens, H. en Van Schoubroeck, C., "Praktische ervaring met de Beigische schadevergoedingsregeling voor zwakke weggebruikers in de autoverzekering", in Faure, $M$. en Hartlief, $T$. (red.), Verkecrsaansprakelijkheid in België en Nederland, Intersentia, Antwerpen, Groningen, 1998, 75-111.

Clement, D., "Environment and Insurability. Strengths in Insurance?", The Geneva Papers of Risk and Insurance, vol. $20, n^{\circ} 76,348-373$.

Clerens, A., "Burgerrechtelijke aansprakelijkheid inzake schade aan derden op het aardoppervlak toegebrachi door luchtvaartuigen. De Verdragen van Rome van 1933 en 1952", Rechiskundig Weekblad, 1958-59, 1377. 1414.

Cleton, R., "Civil Liability for Oil Pollution Damage caused by Sea-going Ships", Tijdschrift voor Milieuaansprakelijkheid, afl. 4, 1989, 109-122.

Cleton, R., "Aansprakelijkheid en schadevergoeding als nasleep van luchtvaartongevallen", Nederlands Juristenblad, 1993, afl. 17, 621-629.

Cleton, R., "Liability and Compensation for Maritime Carriage of Hazardous and Noxious Substances (HNS)", in De la Rue, C.M., (ed.), Liability for Damage to the Marine Environment, Llyod's of London, 1993, 173-188. 
Clow, R., "Coping with catastrophe", Institutional Investor, december 196, 143-150.

Coase, R., "The Problem of Social Cost", Journal of Law and Economics, october 1960, 1-44.

Coenraets Ph., "Responsabilité du fait des choses et responsabilités objectives en droit de l'environnement", Revue Générale des Assurances et des Responsabilités, 1993, $\pi^{\circ}$ 12.213, l-70.

Coghlin, T.G., "Protection and Indemnity Clubs", Lloyds Maritime and Commercial Law Quarterly, 1984, 403-416.

Collart, J., "La capacité financière du marché des assurances", in Bocken, H. en Ryckbost, D. (ed.), Verzekering van Milieuschade, Verslagboek van het Internationaal Colloqium gehouden te Gent op 14 en 15 december 1989, Story Scientia, Gent, 1991, 296-297.

Colle, Ph., "Recente wijzigingen in de verzekeringswetgeving", Rechtskundig Weekblad, 1995-1996, 13611370 .

Collins, D.L., "What the Industry sers ahead", in A Forum Report. The New Atomic Energy Law - What is means to Indusiry, Atomic Industrial frorum, New York, 1954, 63-66.

Conruyt, H. en Rivalet, F., "Champ d'application de la législation belge sur la responsabilité civile nucléaire", Bulletin de Droit Nucléaire, $\mathrm{n}^{\circ} 37,1986,63-71$.

Conruyt-Angenent, H., "L'évolution en droit belge de la réparation des dommages nucléaires à la lumière des conventions internationales", in Liber Amicorum René Van Gompel, Story Scientia, Kluwer, Deurne, 1998, 77-108.

Cnoter, D., "Komhauser, L. en Lane, D., "Liability Rules, Limited Information and the Role of Precedent", Bell Journal of Economics, 1979, 366-373.

Cooter, R., "The Cost of Coase", Journal of Legal Situdies, 1982, 1-33.

Cooter, R., "Prices and Sanctions", Columbia Law Review, n 84, 1984, 1523-1560.

Corby, B., "On Risk and Uncertainty in Modem Society", The Geneva Papers on Risk and Insurance, 1994, vol. $19, \mathrm{n}^{\circ} 76,235-243$.

Comelis, L., "Extra-contractuele aansprakelijkheid voor zaken. Het gebrek van de zaak en de causalitcitsbeoordeling", Tijdschrift voor Privaatrecht, 1984, 299-327.

Comelis, L., "Aansprakelijkheid voor gevaarlijke produkten", Rechtskundig Weekblad, 1987-1988, I1391159.

Comelis, L., "De aansprakelijkheid voor gebrekkige zaken in België en Nederland (art. 6.3.2.5 NBW)", Rechtgeleerd Magazijn Themis, 1987, 165-179.

Comelis, L., "De objectieve aansprakelijkheid voor motorrijtuigen", Rechtskundig Weekblad, 1998-1999, 521537.

Corroon Europe, W., "Characteristics of association captives", in Risk Financing Options, Risk and Insurance Research Group, 1994, 9-10.

Courades, J-M.. "The New 96/29/Euratom Directive on Basic Safety Standards for the Protection of Workers and the Gtmeral Public Against Ionising Radiation, Nuclear Law Bulletin, vol. 58, 1996, 49-53.

Cousy, H., "Een nicuwe vorm van schuldloze aansprakelijkheid - Aansprakelijkheid voor schade veroorzaakt door het vreedzaam gebruik van kernenergie", Jura Falconis, 1974-1975, 35-51.

Cousy, H., "L'adaptation du droit belge à la directive sur la responsabilité du fait des produits défectueux", in Les Assurances de l'Entreprise, vol. I, Bruylant, Bruxelles, 1988, 93-139.

Cousy, H., "Nieuwe wetgeving i.v.m. aansprakelijkheidsverzekering (wet van 25 juni 1992 en wet van 21 november 1989)", in Storme, M. (red.), Recht halen uit Aansprakelijkheid, Postuniversitaire cyclus Willy Delva, 1992-1993, Mys en Breesch, Gent, 1993, 269-301. 
Cousy, H., "Recent Developments in Environmental Insurance", in Abraharn, F. Deketelaere, K. en Stuyck, J., (eds.), Recent Economic and Legal Developments in European Environmental Policy, Leuven University Press, 1995, 227-241.

Cousy, H., "The Implementation of Directives in Belgium", in McGee, A. en Heusel, W., (ed.), The Law and Practice of Insurance in the Single European Market, Bundesanzeiger, Keulen, 1995, 97-103.

Cousy, H., "Panta Rei: een kortbericht over de wijziging van de gewijzigde wetgeving inzake verzekeringer", Tijdschrift voor Belgisch Handelsrecht, 1995, 464-471.

Cousy, H., "Enkele beschouwingen over de systematiek van de stelsels van foutloze aansprakelijkheid", in Liber Amicorum Jacques Putzeys. Etudes de Droit des Transports, Bruylant, Bruxelles, 1996, 37-51.

Cousy, H. en Claassens, H., "Van aansprakelijkheid naar verzekering en terug? Enkele oriěnterende beschouwingen", in Cousy, H. en Claassens, H., Aansprakelijkheidsverzekering: dekking in de tijd, Maklu en Academia-Bruylant, Antwerpen, Louvain-la-Neuve, 1997, 11-21.

Cousy, H., "De grote oriêntaties van het verzekeringsrecht", in Liber Amicorum René Van Gompel, Story Scientia, Kluwer, Deume, 1998, 129-155.

Cousy, H., "Over de verzekering van het onverzekerbare", in Liber Amicorum Prof. Dr. Roger Blanpuin, Dic Keure, Brugge, 1998, 695-713.

Cousy, H., "Over aansprakelijkheidsrecht en verzekering: living together apart?", in Libir Amicurum W'all'r van Gerven, Kluwer, Deume, 2000, 203-222.

Cowell, J., "Compulsory environmental liability insurance", in Bocken, H. en Ryckbost, D. (ed.), Verzekering van Milieuschade, Verslagbock van het Internationaal Colloqium gehouden te Gent op 14 en 15 december 1989, Story Scientia, Gent, 1991, 317-330.

Dabin, J., "Les thèses du Procureur Général Leclercq en matière de responsabilité civile", Revue Générale des Assurances et des Responsabilités, 1933, nr. 1315.

Daleq, R.O., "Sources et Finalités du Droit de la responsabilité ouu de la responsabilité poru faute à la responsabilité objective", in Responsabilité Professionnele et Assurance du Risque, Larcier, Bruxelles, 1975, $21-38$.

Daleq, R.O., "Les assurances de responsabilité. Questions ginérales", in La loi du 25 juin 1992 sur le contrat d'assurance terrestre, Academia-Bruylant, Louvain-la-Neuve en Brussel, 1993, 185-234.

Dalcq, R.O., "Réflexions sur le droit de la responsabilité civile", Journal des Tribunaux, 1982, 157-159.

Dalcq, R.O., "Sécurité, assurance et solidarité", in Responsabilité et réparation des dommages, Bruxelles, Jeune Barreau, 1983, 327-344.

Dalcq, R.O., "Les responsabilités de l'entreprise: de la faute au risque", in Les Assurances de l'Entreprise, Bruxelles, Bruylant, vol. I, 1988, 3-23.

Daleq, R.O., "Le risque des produits et des services", in Les Assurances de l'Entreprise, Bruxelles, Bruylant, vol. II, 1993, 215-280.

Dalcq, R.O., "L'indemnisation des dommages corporels des piètons et des cyclistes", Journal des Tribunaux, $1994,665-672$.

Dalcq, R.O. en Schamps, G., "Examen de jurisprudence (1987 à 1993), La responsabilité délictuelle et quasidélictuelle", Revue Critique de Jurisprudence Belge, 1995, 525-637.

Dangelmaier, P., "Nuclear Liability Insurance in the Federal Republic of Germany", in Nuclear Accidents. Liabilities and Guarantees", OECD-LAEA Helsinki Symposium, Paris, 1993, 425-446.

Davies, L.M. en Boothroyd, A.D., "L'énergie nucléaire: option toujours valable", AlEA Bulletin, 2/1995, 1417.

Debaets, M., "Insurance of Nuclear Power Stations", in Nuclear Inter Jura '91, Bath, AIDN/INLA, 1991, 195198. 
De. Boer, J.E., "Internationale aansprakelijkheidsverdragen inzake olieverontreiniging en het zeevervoer van gevaarlijke stoffen", Tijdschrift voor Milienaansprakelijkheid, 1999/4, 105-108.

De Boer, J.E., "Risicoaansprakelijkheid voor gevaarlijke stoffen en milieuverontreiniging", Nederlands Juristenblad, 1993, 225-231.

Decroïs, A., "De vergoeding van de zwakke weggebruikers (art. 29 bis WAM-wet)", Rechtskundig Weelkblad, 2000-2001, 1257-1267.

De Dekker, H. en Schautteet, M., "De objectieve aansprakelijkheiủ naar Duits en Belgisch recht - Een rechtsvergelijkende studie", in Wie zal dat betalen?, Antwerpen, Kluwer, 1983, 69-117.

De Geest, G., "Public Choice en rechtseconomie, Aers Aequi, 1990, 666-673.

De Groot, G.J., "Schadefondsen. Tusse, toen en toekomst?", Nederlands Juristenblad, 1980, 269-276.

De Kageneck, A. en Pinel, C., "La Convention commune sur la sûreté de la gestion du combustible usé et sur la sûreté de la gestion des déchets radioactifs: champ d'application et contexte conventionnel existant", in Le droit nucléaire: du XXe an XXIe Sciècle. Nuclear Inter Jura '97, Société de Législation Comparée, Paris, $1998,509-526$.

Deketelaere, K., "De voorstellen van de interuniversitaire Commissie tot Herziening van het Milieurecht in het Vlaamse Gewest inzake de ansprakelijkheid voor milieuschade", in Deketelacre, M. (red.), Recente Ontwikkelingen inzake de aansprakelijkheid voor milieuschade, Milieurechtstandpunten 3, Brugge, Die Keure, 1993, 77-100.

Deketelaere, K., "Het juridisch kader inzake duurzame ontwikkeling in België", in Faure, M. en Deketelaere, $\mathrm{K}$, (red.), hus Commune en Milieurecht. Actualia in het Milieurecht in België en Nederland, Intersentia, Antwerpen-Groningen, 1997, 93-129.

Deketelaere, K., "Public Environmental Law in Belgium in general and in the Flemish Region in particular", in Seerden en Heldeweg. M. (eds.), Comparative Environmental Law in Europe. An Introduction to Environmental Law in the EU, Maklu, Antwerpen-Apeldoorn, 1996, 33-71.

Deketelaere, K., "Evolutie en krachtlijnen van het milieurecht in het Vlaamse Gewest", in Milieurecht in België. Status Questionis 1997, Leuvem, Milieurechtstandpunten nr.10, Brugge, Die Keure, 1997, 1.49.

Deketelaere, K., Deketelaere, M. en Schutyser, F., "Onderzoek naar de opportuniteit en de haalbaarheid van een Vernieuwd Vergoedingssysteem voor Milieuschade", Instituut voor Milieu- en Energierecht, KUL, december 1998.

Deketelaere, M., "Civielrechtelijke aansprakelijkheid voor milieuschade als instrument voor Europees milieubeleid: het groenbock inzake herstel van milieuschade van de Commissie van de Europese Gemeenschappen", in Deketeleare, M., (red.), Recente ontwikkelingen inzake hat herstel voor milieuschade, Leuvern, Milieurechtstandpunten nr. 3, Brugge, Die Keure, 1993, 99-125.

Deketelaere. M., "Burgerrechtelijke aansprakelijkheid voor milieuschade, strafrechtelijke aansprakelijkheid voor milieumisdrijven, administratieve sancties en veiligheidsmaatregelen, en verzekering van milieuschade", in Milieurecht in Belgie. Status Questionis Anno 1997, Die Keure, 1997, 671-714.

Deketelaere, M., " Deel VII. Milieu en burgerlijk aansprakelijkheidsrecht", in Deketelaere, K. (ed.), Handboek Milieurecht, Brugge, Die Keure, 2001, 1157-1193.

Deketelaere, M., "Deel VIII. Milieu en verzekeringsreeht", in Deketelaere, K. (ed.), Handboek Milieurecht, Brugge, Die Keure, 2001, 1195-1208.

De la Fayette, $L$., "Vers un nouveau régime de responsabilité de l'Etat visant les activités nucléaires", Bulletin de Droit Nucléaire, $\mathrm{n}^{\circ}$ 50, 1992, 7-39.

De la Fayette, L., "Nuclear Liability Revisited", Review of European Community and International Environmental Law, 1992, vol. 1, $n^{\circ} 4,443-452$. 
Delpirou, D., "La contribution de l'industrie au financement complémentaire du risque nucléaire. Le point de vue commun de deux organisations d'exploitants: OPEN et l'UNIPEDE", in Nuclear Accidents. Liabilities and Guarantees, OECD-NEA, 1993, 464-470.

Delpirou, D., "L'évolution des Conventions sur la responsabilité civile nucléaire: les enjeux pour Electricité de France", in Reform of Civil Nuclear Liability, International Symposium, Budapest 1999, OECD, Parijs, 2000, 131-137.

Delvaux, P.H., "Le champ d'application matériel de l'assurance de la responsabilité civile exploitation", Recueil Générale des Assurances el des Responsabilités, 1989, n 11512.

Delvaux, P.H., "Les assurances de responsabilité: questions spéciales", in Fontaine, M. en Binon, J.M. (éd.), La loi du 25 juin 1992 sur le contrat d'assurance terrestre, Bruxelles, Bruylant, 1993, 217-218.

Delvaux, P.H., "Responsabilités et Assurances de l'Entreprise", in Les Assurances de Responsabilité, Editions du jeune barreau de Bruxelles, 1999, 1-36.

Delvaux, Ph., "La coassurance et ses surprises", in Mélanges Roger O. Dalcq. Responsabilités et Assurances, 1994, 97-110.

De Mori, B., "Bericht über den derzeitigen Stand der Nukleare Versicherung in der Gemeinschaft", in Viertes Kolloqium über die Versicherung von Kernrisiken, Euratom, EUR 2642.d, 1966, 15-21.

Demoures, Y., "La responsabilité de l'exploitant nucléaire au regard de la réglementation française de la responsabilité civile", in Albonetti, A., Belser, W.E., e.a., Droit Nucléaire Européen, Colloque de Droit nucléaire européen, Presses universitaires de France, Paris, 1968, 121-132.

Denoël, N., "Les Assurances de responsabilité et la loi du 25 juin 1992", in Les Assurances de Responsabilité, Editions du jeune barreau de Bruxelles, 1999, 75-133.

Denoël, N., "La couverture dans le temps des contrats d'assurance de responsabilité eivile", Journal des Tribunaux, 1997, 249-250.

Deprimoz, J., "Rapport du pool français", in Colloque Euratom/Assureurs sur les problèmes actuels de l'assurance des risques nucléaires, Euratom, 1962, EUR 486, 23-28.

Deprimoz, J., "International Co-operation in providing insurance cover for nuclear damage to third parties and for damage to nuclear installations", Nuclear Law Bullelin, $n^{\circ} 32,1983,33-49$.

Deprimoz, J., "La notion de dommage nucléaire appliquée au coût des mesures préventives en cas de menace imminente de dommages aux tiers", Nuclear Third Party Liability and Insurance. Status and Prospects, Munich Symposium, OECD-NEA, LAEA, 1985, 214-230.

Deprimoz, J., "Cross Fronticr Nuclear Incidents. How and to what extent can Insurers inform Foreign Victims and Compensate their Damage", in Nuclear Inter Jura '89, AIDN/INLA, Japan, II-33-II-39.

Deprimoz, J., "France", in Pfennigstorf, W. (ed.), Pollution Insurance. International Survey of Coverages and Exclusions, Graham \& Trotman, Martinus Nijhoff, Dordrecht, 1993, 51-57.

Deprimoz, J., "Relations des exploitants et de leurs assureurs avec les organismes de protection sociale au cours des procédures d'indemisation des dommages aux personnes", in Nuclear Inter Jura "93, AIDN/INLA, Rio de Janeiro, II.5.3-1 - 5.3-18.

Deprimoz, J., "Régime juridique des assurances contre les risques d'atteinte à l'environnement", JurisClasseurs Responsabilité Civile, fasc. 581-1, 1994, 1-25.

Deprimoz, J., "Régime juridique des Assurances contre les Risques Nucléaires", Editions du Juris-Classeur, Fasc. 55, 1995/5, 1-24.

Deprimoz, J., "Risques liés a la production et aux utilisations industrielles et medicales des radioisotopes", in Le Droit Nucléaire: du XX' au XXI siècle. Nuclear Inter Jura '97, AIDN/INLA, Tours, Société de Législation Comparée, Paris, 1997, 337-350.

De Putter, P. en Verschuuren, J., "Een milieuschadefonds in Nederland?", Milieu en Recht, 1995, nr. 5, 96-99. 
Deridder, L, "Energie", in Van Haegendoren, G. en Suetin, B., (eds.), De bevoegdheidsverdeling in het federale, België, Brugge, Die Keure, 2000, 1-99.

De Sadeleer, N., "La répartition des compétences en matière đ'environnement: les upports de la loi spéciale du 16 juillet 1993 visant à achever la structure fédérale de l'Etat", in Milieubeleid in het federale België anno 1993, Belgische Vereniging voor Milieurecht, Story Scientia, Gent, 1994, 1-28.

De Sadeleer, N., "Les transferts de compétences aux entités fëdérées: l'environnement, l'agriculture et le pénal" ${ }^{n}$, Administration Publique, 1994, 181-193.

Deschamps, B., "Claims-made: l'alternative?", Recueil Générale des: Assurances et des Responsabilités, 1988 , 11335.

De Varenne, F., "Techniques altemative de couverture", Risques, $\mathrm{n}^{\circ}$ 34, 1998, 53-61.

De Vries, C., "Aansprakelijkheid voor milieuschade en financiële zekerheid naar toekornstig recht: nieuwe oplossingen - Europees recht", in Deketelaere, K. en Wiggers-Rust, L.F. (red.), Aansprakelijkheid voor milieuschade en financiële zekerheid. Een vergelijking van Nederlands, Belgisch en Europees recht, Die Keure, Vermande, Brugge, 1998, 141-147.

D'Hondt, A., "Responsabilités et Assurances des professions libérales", in Les Assurances de Responsabilité, Editions du jeune barreau de Bruxelles, 1999, 37-73.

Dieryck, C. en Van Havre, P., "Les Assurances P\&I (Protection and Indemuity Clubs)", in L'Asswance. Mutuelle en Belgique, Academia, Bruylant, Bruxelles, 1999, 373-395.

Doeker, G. en Gehring, T., "Private or International Liability for Transnational Environmental Damage - the precedent of conventional liability regimes", Journal of Environmental Law, vol.2, n 1, 1990, 1-16.

Dogauchi, M., "Transfrontier Nuclear Civil Liability without Intemational Conventions", in Nuclear Inter Jura '91, Bath, 23 september - 26 september 1991, AIDN/INLA, 205-214.

Dommering-van Rongen, L., "Het DES-arrest: geen marktaandeelaansprakelijkheid, maar aansprakelijkheid voor de gehele markt", Weekblad voor Privaatrecht, Notariaat en Registratie, 6089, 276-282.

Dommering-van Rongen, L., "Risico's met een lange staart", in Miscellanea Jurisconsulto vero Dedicata (van Duriné-bundel). Deventer, 1997, 27-39.

Domsdorf, E.P.M.W., "Kemenergie en wetgever", Nederlands Juristenblad, 1960, 793-834.

Donald Etienne, A., "Claim of the reactor insurer against the supplier of nuclear cquipment", Atomic Energy Law Joumal, vol. 3, nr. 3, 1961, 239-271.

Dopehic, H., "La Réglementation nucléaire en Belgique", in, Govaerts, P., Jaumotte, A. en Vanderlinden, J., Un demi-siècle de nucléaire en Belgique. Témoignages, Belgian Nuclear Society, Presses Universitaires Européennes, Bruxelles, 1994, 301-352.

Dow, J.C., "The Organisation and Development of Intemational Liability Capacity and National Market Pools with Special Reference to New Nuclear Countries", in Nuclear Third Party Liability and Insurance. Status and Prospects, Paris, Munich Symposium, OECD-NEA, 1985, 172-182.

Drion, P.J.M., "Milieu onder één dak: milieuschadeverzekering (MSV)", Verzekeringsrechtelijke Berichten, 1998/2, 19-21.

Drupsteen, Th.G., "Relativiteit per 1 januari 1975", Nederlands Juristenblad, 1992, afl. 25, 786-791.

Dubais, B.A., "Some Legal Aspects of the Amoco Cadiz Incident", Lloyds Maritime and Commercial Law Quarterly, 1979. 292-296.

Dubais, B.A., "La réparation du dommage en cas de pollution résultant de l'exploration et l'exploitation des hydrocarbures en mer", in Dupuy, R.J., Le pétrole et la mer, Presses Universitaires de France, Paris, 1976, 119-147.

Dubuisson, B., "Développements récents concemant les reponsabilités du fait des choses (choses, aninaux, bâtiments), Revue Générale des Assurances et des Responsabilités, 1997, n 12729. 
Dubuisson, B., "Les assurances des atteintes à l'environnement: réalités et perspectives d'avenir", De Verz., $1996,377-419$.

Dupuy, P.M., "Le rôle de l'état dans l'indemnisation des dommages catastrophiques intemationaux", in $L a$ réparation des dommages catastrophiques. Les risques technologiques majeurs en droit international et en droit communautaire, Travaux des XIIles Joumées d'études juridiques Jean Dabin, Bruxelles, Bruylant, 1990 , 219-245.

Dupuy, P. en Smets, H., "Compensation for damage due to transfrontier pollution", in Compensation for Pollution Damage, OECD, Parijs, 1981, 181-208.

Easterbrook, F. en Fischel, D., "Limited L.iability and the Corporation", University of Chicago Law Review, $1985,89-117$.

Easey, J. en Molina, P., "Regional cooperation in Asia and the Pacific: energy, electricity, and nuclear power planning", IAEA Bulletin, 4/1993, 8-12.

Ehrlich, I., "The Deterrent Effect of Capital Punishment: A Question of Life and Death", American Economic Review, 1975, 397-417.

Ehrlich, J. en Becker, G., "Market Insurance, Self Insurance and Self-Protection", Journal of Political Econo$m y$, vol. 80, 1972, 623-648.

Ekering, J., "Several Theories on Liability in the Dutch DES Case", in Transnational Environmental Liability and Insurance, Graham \& Trotman, Londen, 1993, 58-66.

El Baradei, M., Nwogugu, E. en Rames, J., "International law and nuclear energy: Overview of the legal framework", IAEA Bulletin, 3/1995, 16-25.

Engelhard, E.F.D. en van Maanen, G.E., "Naar een gedifferentieerd vergoudingsregime voor verkeersslachtoffers; een nieuw wetsvoorstel", Verkeersrecht, 1999, nr. 5, 135-137.

Fagnart, J.L., "La socialisation des risques par les mécanismes de la responsabilité civile et ed l'assurance", in Les Assurances de l'Entrcprise, vol. I, Bruxelles, Bruylant, 1988, 419-448.

Fagnart, J.L., "La responsabilité du fait des produits à l'approche du Grand Marché", Droit des Afjaires, 1990 , $n^{\circ} 17,9-40$.

Fagnart, J.L. en Rogge, J., "Les Assurances de responsabilité dans la loi du 25 juin 1992", Bulletin des Assurances, Dossier, 1993, 10 1-123.

Fagnart, J.L., "L'indemnisation des victimes d'accidents de la circulation après la réforme baclée du 30 mars 1994, Revue Générale des Assurances el des Responsabilités, 1994, nr. 12388.

Fagnart, J.L., "L'interprétation de l'article 1384, alinéa ler, du Code Civil en droit belge", in Les Obligations en droit français et en droit belge. Convergences et Divergences, Bruylant, Bruxelles, 1994, 281 -296.

Fagnart, J.L., "Recherches sur le droit de la réparation", in Mélanges Roger O. Dalcq. Responsabilités et Assurances, Larcier, Bruxelles, 1994, 135-157.

Fagnart, J.L., "L'étendue de la garantie", in La loi du 25 juin 1992 sur le contral d'assurance terrestre, Recyclage organisé par le jeune barreau de Bruxelles, 1995, 23-71.

Fagnart, J.L., "Les assurances de responsabilité dans la loi du 25 juin 1992", Questions de droit des assurances, Editions du jeune barreau de Lic̀ge, 1996, 343-387.

Fallon, M., "L'adaptation de la responsabilité du fait des produits à la directive européenne du 25 juillet 1985", Revue Générale des Assurances et des Responsabilités, 1987, n 11245.

Fallon, M., "La loi du 25 février 1991 relative à la responsabilité du fait des produits défectueux", Journal des Tribunaux, 1991, 465-473.

Faure, M. en Van den Bergh, R., "Liever geen slachtoffer dan een beschermd slachtofter", Intermediair, 18 december 1987. 
Faure, M. en Van den Bergh, R., "Maakt Economie recht wat krom is ...", Intermediair, nr. 41, 20 november 1987.

Faure, M. en Van den Bergh, R., "Negligence, Strict Liability and Regulation of Safety under Belgian Law: An Introductory Economic Analysis", The Geneva Papers of Risk and Insurance, 1987, 95-114.

laaure, $M$. en Van Buggenhout, W., "Produktenaansprakelijkheid. De Europese richtlijn: harmonisatie en consumentenbescherming?", Rechtskandig Weekblad, 1987-1988, 1 c.v.

Faure, M. en Van den Bergh, R., "Liability for Nuclear Accidents in Belgium from an Interest Group Perspective", International Review of Law and Economics, 1990, vol. 10, 241-254.

Faure, M., "Rechtseconomie en privaatrecht: kunnen rechtsregels bijdragen tot de reductie van ongevalskosten?", in Hondius, E.H., Schippers, J.J. en Siegers, J.J., Rechtseconomie en Recht. Een k'nnismaking met een rechtsgebied in opkomst, W.E.J. Tjeenk Willink, Zwolle, 1991, 51-93.

Faure, M. en Skogh, G., "Compensation for damages caused by nuclear accidents: a convention as insurance", The Geneva Papers on Risk and Insurance, vol. 17, $\mathrm{n}^{\circ} 65,1992,499-513$.

Faure, M.G., "De verzekering van het nucleaire risico", in In volle Verzekerdheid, W.E.J. Tjeenk Willink, Zwolle, 1993, 247-260.

Faure, M.G., "Ongevallenpreventie door efficiënte aansprakelijkhcidsregcls en verzekeringspolissen op competitieve verzekeringsmarkten", Het Verzekeringsarchief, deel 70, 1993-1, 3-22.

Faure, M., "Regulering en concurrentie op vetzekeringsmarkten in Europa", De Vrijbrief, juni/juli1993, 12-20.

Faure, M., "Naar een nieuw model van vergoeding van nucleaire schade", in Faure, M. (red.), Aansprakelijkheid voor het nucleaire risico, Maklu, Antwerpen-Apeldoom, 1993, 141-175.

Faure, M. en Van den Bergh, R., "Ilet toelaten van kartels op de Europese verzekeringsmarkt", Nederlands Juristcnblad, 1993, 261-267.

Faure, M., "The limits to Insurability form a Law and Economics Perspective", The Geneva Papers on Risk and Insurance, $\mathrm{n}^{\circ} 76,1995,454-462$.

Faure, M., "Economic Models of Compensation for Damage caused by Nuclear Accidents: Some Lessons for the Revision of the Paris and Vienna Conventions", European Journal of Law and Economics, 1995, $21-43$

Faure, M., "Over beschermde slachtoffers, vrijgevige rechters en zuchtende verzekeraars", Nederlands Juristenblad, 1995, 1227-1235.

Faure, M.G., "The Influence of Insurance on Liability Issues", in McGee, A. en Heusel, W., (ed.), The Law and Practice of Insurance in the Single European Market, Bundesanzeiger, Keulen, 1995, 179-204.

Faure, M., "Vergoeding van Nucleaire Schade: Verzekeringskartels of Pooling van risico's via de Markt?", De Vrijbrief, 1995/3, 4-12.

Faure, $M$ en Van den Bergh, R., "Restrictions of competition on insurance markets and the applicability of EC antitrust law", Kyklos, vol. 48, 1995, 65-85.

Faure, M., "Economic aspects of environmental liability: an introduction", European Review of Private Lan, vol. $4,1996,85-110$.

Faure, M. en Hartlief, T., "Towards an Expanding Enterprise Liability in Europe? How to analyze the Scope of Liability of Industrial Operators and their Insurers?", Maastricht Journal of European and Comparative Law, $\pi^{\circ} 3,1996,235-270$.

Faure, M.G. en Hartlief, T, "Compensation Funds versus Liability and Insurance for Remedying Environmental Damage", Review of Europe'an Community \& International Environmental Law, vol. 5, nr. 4, $1996,321-327$.

Faurc, M.G. en Hartlief, 'T., "Een asbestfonds als altematief voor de aansprakelijkheid van de werkgever?", Sociaal Recht, 199t1-2, 37-43. 
Faure, M. en Hartlief, T., "Remedies for expanding liability", Oxford Journal of Legal Studies, vol. 18, 1998, 681-706.

Faure, M., "Is aansprakelijkheid 'met terugwerkende kracht' efficiënt en verzekerbaar?", Aansprakelijkheid \& Verzekering, 1998/1, 1-11.

Faure, M.G. en Hartlief, T., "Een schadefonds ais alternatief voor aansprakelijkheid en verzekering?", Rechtsgeleerd Magazijn Themis, 1998/7, 211-228.

Faure, M.G., "The applicability of the Principles of Private Insurance to Social Health Insurance seen from a Law and Economics Perspective", The Geneva Papers on Risk and Insurance, vol. 23, n 87, 1998, 265-293.

Faure, M. en Fenn, P., "Retroactive Liability and the Insurability of Long-tail Risks", International Review of Law and Economics, vol. 19, 1999, 487-500.

Faure, M. en Hartlief, T., "Enkele opmerkingen naar aanleiding van de brief van het kabinet over de Claimcultuur", Aansprakelijkheid \& Verzekering, 1999/4 \& 5, 75-84.

Faure, M., Hartlief, T. en Hertoghs, M., "Evaluatie van het Fonds Luchtverontreiniging", Milieu en Recht, nr. $3,2000,64-69$.

Feldmann, F.J., "Reciprocity within the Framework of Nuclear Civil Liability Law", in Pelzer, N., (ed.), International Harmonisation in the Field of Nuclear Energy Law, Nuclear Inter Jura '85, Nomos, Baden Baden, 1986, 311-319.

Ferguson, E.E., "Liability for Nuclear Hazards: international Problems and Progress", in Mayda, J., (ed.), Atomic Energy and Law, School of Law, Puerto Rico, 1959, 140-149.

Fischer, G., "La coopération internationale en matière d'utilisation pacifique de l'énergie atomique", Annuaire Français de Droit International, 1955, 228-257.

Fischer, G., "L'Agence Internationale de l'Energie Atomique", Annuaire Français de Droit International, $1956,616-634$.

Fischer, G., "Nuclear Energy Liability Insurance in the United States of America", in Nuclear Law for a Developing World, LAEA, Wenen, 1969, 167-174.

Fischerhof, H., "Das Problem einer dogmatischen Begründung der rechtlichen Kanalisierung der Hattung auf den Betrieber einer Kernanalage", Energiewirtschafiliche Tagesfragen, Ileft 156, 1966, 278-281.

Fischerhof, H., "Essai d'une théorie juridique de la canalisation de la responsabilité sur l'exploitant d'une installation nucléaire", in Albonetti, A., Belser, W.E., e.a., Droil Nucléaire Européen, Colloque de Droit nucléaire européen, Presses universitaires de France, Paris, 1968, 11 1 1-120.

Fitzsimmons, A., "The Application of EC-Anti-Trust Law to the Insurance Industry", in McGee, A. en Heusel, W., (ed.), The Law and Practice of Insurance in the Single European Market, Academy of European Law in Trier, Bundesanzeiger, 1995, Keulen, 25-39.

Flakus, F.N., "Les rayonnements sous leur vrai jour: les risques doivent être mieux compris", AlEA Bulletin, 2/1995, 7-13.

Fontaine, E., "The French experience: Tanio and Amoco Cadiz incidents compared", in De la Rue, C.M. (ed.), Liability for Damage to the Marine Environment, Lloyd's of London Press Ltd., 1993, 101-108.

Fontaine, M., "Le droit nouveau du contrat d'assurance teтrestre (Loi du 25 juin 1992)", Annales de Droit de Louvain, 1993/3, 367.

Fontaine, M., "Présentation générale. Dispositions préliminaires et finales", in La loi du 25 juin 1992 sur le contrat d'assurance terresire, Recyclage organisé par le Centre de droit des obligations et la licence en droit et économie des assurances de 1'UCL, Louvain-la-Neuve et Bruxelles, 1993, 19-49.

Fontaine, M., "Claims made policies under Belgian law", International Journal of Insurance Law, 1994, 128. 129. 
Fontaine, M. en Delvaux, P.H., "Le nouveau régine du contrat d'assurance terrestre. Loi du 25 juin 1992, loi modificative du 16 mars 1994, arrêtés d"exécution", Journal des Tribunaux, 1995, 336.

Frame, C., "'Claims-made' Liability Insurance: Closing the gaps with retroactive coverage", Temple Law Quarterly, vol. 60, 1987, 165-187.

Freeman, A.V., "The development of international co-operation in the peaceful use of atomic energy", American Journal of International Law, vol. 54, 1960, 383-392.

Frenk, N., "Afwikkeling van massaschade", Nederlands Tijdschrift voor Burgerlijk Recht, 1993-5, 89-94.

Frenk, N., "Toerekening naar kansbepaling", Nederlands Juristenblad, 1995, 482-491.

Galizzi, P., "Questions of jurisdiction in the event of a nuclear accident in a member state of the European Union", Journal of Environmental Law, vol. 8, n 1, 1996, 71-97.

Gardner, M., "Results of a case-control study of leukaemia and lymphoma amoung young people near the Sellafield nuclear plant in West Cumbria", British Medical Journal, 1990, 423-434.

Gauci, G.M., "Protection of the Marine Environment through the International Ship-Source Oil Pollution Compensation Regimes", Review of European Community and International Environmental Law, vol. 8, $n^{\circ} 1$, 1999, 29-36.

Gautron, R., "La responsabilité civile et la protection financière en raison des risques atomiques aux EtatsUnis", in Puget, H., Aspects de droit de l'énergie atomique, tome II, Centre français de droit comparé, Paris, $1967,59-80$.

Gautron, R., "La responsabilité du constructeur de centrales nucléaires", in Puget, H., Aspects de droit de l'énergie atomique, tome II, Centre français de droit comparé, Paris, 1967, 105-120.

Gautron, R., "Réflexions sur le monopole d'assurance des risques atomiques", in Puget, H., Aspects de droit de l'énergie atomique, tome II, Centre français de droit comparé, Paris, 1967, 167-179.

Gehr, W., "The Question of Exclusive liability - Austria's Response", in Reform of Civil Nuclear Liability, International Symposium, Budapest 1999, OEC.D, Parijs, 2000, 463-473.

Giarini, O., "Insurability and the Economic Relevance of Insurance: a Historical Economic Perspective", The Geneva Papers On Risk and Insurance, vol. 20, $\pi^{\circ} 77,1995,422-423$.

Gijssels, J., "L'accord entre Euratom et l'AIEA en application du Traité de non-prolifération des armes: nucléaires", Annuaire Français de Droit International, 1972, 837-863.

Gill, M., "The expansion of liability and the role of insurance. Who is the chicken?", The International Journal of Insurance Law, 1999, 27-40.

Gilliams, H., "Horizontale werking van richtlijnen: dogna's en realiteit", in Liber Amicorum Walier van Gerven, Kluwer, Deume, 2000, 223-245.

Gillon, L., "L'approvisionnement en uranium", in L'énergie Nucléaire en Europe: des Origines à Eurutom, Actes de joumées d'études de Louvain-la-Neuve 18-19 november 1991, Petér Lang, Bern, 1994, 11-34.

Glaesner, H.J., "The European Atomic Energy Community (Euratom)", in Nuclear Law for a Developing World, LAEA, Wenen, 1969, 39-45.

Glaize, G., "Cadre Général des Conventions intemationales relatives à la Notification des Incidents ou Accidents et a l'Assistance Mutuelle en cas d'Accident Nucléaire", in Nuclear Inter Jura '87, AIDN/INLA, Antwerpen, 1987, C.23-C.40.

Gnam, P., "Die nukleare Zulieferindustrie im Haftungsfreiraum der rechtlichen Kanalisierung", in Drittes Deutsches Atomrechis Symposium, Carl Heymans Verlag, 1975, 223-240.

Goldie, L.F.E., "Liability for damage and the progressive development of international law", International and Comparative Law Quarterly, vol. 14, 1965, 1189-1264. 
Gollier, C., "About the Insurability of Catastrophic Risks", The Geneva Papers On Risk and Insurance, vol. $22, n^{\circ} 83,1997,177-186$.

Gomez del Campo, J., "Report on Envirunmental Nuclear Damage", in Nuclear Inter Jura 1999, AIDN/INLA, Washington, 1999, 203-247.

Gonzílez, A.J., "Global levels of radiation exposure: latest international findings", LAEA Bulletin, 4/1993, 4951.

González, A.J, "Chernobyl - ten years after", LAEA Bulletin, 3-1996, 2-13.

González, A.J., "Towards an International Regime on Radiation and Nuclear Safety", IAEA Bullctin, 1998/2, $2-4$.

Göransson, M., "Liability for damage to the Marine Environment", in Boyle, A. en Frecstone, D., (ed.), International Law and Sustainable Development. Past Achievements and Future Challenges, Oxford University Press, Oxford, 1999, 347-358.

Gorransson, M., "The 1984 and 1992 Protocols to the Civil Liability Convention, 1969 and the Fund Convention, 1971", in De la Rue, C.M., (ed.), Liability for Damage to the Marine Environment, Llyod's of London, 1993, 71-82.

Goulandris, P.J., "TOVALOP and CRISTAL give way to the Protocols", Ocean Orbil, juni 1996

Govaerts, P., "Stralingsbescherming na Chemobyl", Energie, 1988, nr. 4, 159-162.

Govaerts, P. "Economische aspecten van emstige nucleaire ongevallen", in Faure, M. (red.), Aansprakelijkheid voor het nucleaire risico, Maklu, Antwerpen-Apeldoom, 1993, 177-207.

Govaerts, P., Jaumotte, A. en Vanderlinden, J. (eds.), Un demi-scièle de nucléaire en Belgique. Témoignages, Belgian Nuclear Society, Presses universitaire européennes, Bruxelles, 1994, 201-297.

Gyselen, L., "Antitrust law in the area of financial services. The cause of subsidiarity diagnosed", in Raffaelli, E.A. (ed.), Antitrust between EC Law and national Law, Bruylant, Bruxelles, 1998, 439-448.

Gyselen, L., "P\&I Insurance: the European Commission's Decision concerning the Agreement of the International Group of P\&I Clubs", in Huybrechts, M.A. (cd.), Marine Insurance at the turn of the Millennium, Volume 1, Intersentia, Antwerpen, Groningen. 1999, 181-202.

Gysen, S., "Le traitement fiscal de cotisants et des membres-fondateurs des Associations d'assurance mutuelle", in L'Assurance Mutuelle en Belgique, Academia, Bruylant, Louvain-la-Neuve, Bruxelles, Collection Droit des Assurances n ${ }^{\circ} 10,1999,328-329$.

Haazen, O.A. en Spier, J., "Amerikaanse toestanden en de nieuwe aansprakelijkheidsverzekering voor bedrijven en beroepen", Nederlands Juristenblad, 1996, afl. 2, 45-50.

Haelterman, A., "De herverzekeringscaptive: verzekeringsrealiteit of fiscale trukendoos?", Directeur. Niemsbricf voor Bedrijfsleiders, editie 40, 15 oktober 1994, 1-5.

Häfele, W., "Die historische Entwicklung der fricdlichen Nützung der Kemenergic", in Kaiser, K. en Lindemann, B. (herausg.), Kernenergie und Internationale Politik, R. Oldenbourg Verlag, München, 1975, 43-63.

Hagopian, M., "Réassurancc", Jurisclasseur Responsabilité civile et assurances, fasc 120, 1988; speciale editie van Risques, nr. 9, jan. 1992, 7-158 en nr. 15, juli 1992, 123-152.

Hamburger, M., "De aansprakelijkheidsverzekering in Nederland voor schade door kemongevallen in WestEuropa", Nederlands Juristenblad, 1986, afl. 42, 1335-1341.

Hanak, K., "Dic Kanalisierung der Haftung. Zur Weiterentwicklung des Haftpflichtrechts durch dic Atomgesetzgebung", Juristische Blatter, Heft 20/21, 1961, 537-542.

Hancher, L., "1992 and Accountability Gaps: the Transniklear Scandal: a Case Study in European Regulation", The Modern Law Review, 1990, vol. 53, 669-684. 
Handl, G., "State liability for accidental transnational environmental damage by private persons", The American Journal of International Law, vol. 74, 1980, 525-565.

Handl, G., "Transboundary Nuclear Accidents: the Post-Chemobyl Multilateral Legislative Agenda", Ecology Law Quarterly, vol. 15:203, 1988, 203-247.

Handl, G., "Après Tchernobyl: quelques réflexions sur le programme législatif multilatéral à l'ordre du jour", Revue Générale de Droit International Public, tome 92, 1988, 5-62.

Handl, G., "Towards a Global System of Compensation for Transboundary Nuclear Damage: Reflexions on the Interrelationship of Civil and Intemational State Liability", in Nuclear Accidents. Liabilities and Guarantees, OECD, Paris, 1993, 497-520.

Harbrücker, D., "Claims Settlement procedures and costs", in Reform of Civil Nuclear Liability, International Symposium, Budapest 1999, OECD, Parijs, 2000, $371-381$.

Hardy, M.J.L "Nuclear Liability: the general principles of law and further proposals", British Yearbook of International Law, 1960, 223-249.

Hartlief, T. en Tjittes, R.P.J.L., "De invloed van verzekeringen op de civielrechtelijke aansprakelijkheid: privaatrechtelijke aspecten", De invloed van verzekeringen op de civiele aansprakelijkheid. Preadviezen uitgebracht door de vereniging van burgerlijke recht, Vermande, Lelystad, 1990, 55-115.

Harilief, T., "Atiernatieve causaliteit", Tijdschrift voor ondernemingsrecht en rechtspersonen, jrg. 35, 1992, 308-314.

Hartlief, T. en Spier, J., "Vurakering en aansprakelijkheid met terugwerkende kracht", Aansprukelijkheid \& Verzekering, 1994, 24-33.

Hartlief, T. en van Maanen, G.E., Hoe werkt de onrechtmatige daad? Of het paard van de professor en andere aangrijpende verhalen, Ars Aequi Cahiers Privaatrecht, deel 5, Amhem, 1995.

Hartlief, T., "Het aansprakelijkheidsrecht en de macht van het getal", Nederlands Juristenblad, 1995, 118 125

Hébert, J, "Problèmes pratiques posés à EDF par la responsabilité en Matière nucléaire", in Puget, H., Aspects de droit de l'énergie atomique, tome II, Centre français de droit comparé, Paris, 1967, 121-129.

Hébert, J., "Application aux cas particuliers des dommages subis par l'enfant conçu et des dommages génétiques d'origine nucléaire", in Albonetti, A., Belser, W.E., e.a., Droit Nucléaire Européen, Colloque de Droit nucléaire européen, Presses universitaires de France, Paris, 1968, 21-39.

Hébert, J., "Observations sur l'établissement du lien de causalité entre le 'fait ou la succession de faits de même origine' et les 'dommages' nécessaire à la mise en oeuvre de la Convention sur la responsabilité civile dans le domaine de l'énergie nucléaire", in Nuclear Third Party Liability. Status and Prospects, Munich Symposium, OECD-NEA, Paris, 1985, 241-261.

Hébert, J., " Nucléaire", Juris Ciasseur Responsabilitié Civile, fasc. 425-1, 1986, 1-40.

Hébert, J., "Analyse des conditions d'application pratiques du régime intemational de responsabilité civile nucléaire à un accident nucléaire en Europe", in Nuclear Accidents. Liabilities and Guarantees, OECD/NEALAEA, Helsinki, 1993, 92-141.

Heimann, F.F., "The U.S. Liability protection system for nuclear power plants", in Nuclear Accidents. Liabilities and' Guarantees, OECD/NEA-LAEA, Helsinki, 1993, 418-424.

Heldeweg, M., Hertoghs, M. en Seerden. R., "Besluitvorming rond de lokalisatie van kemcentrales", in Faure. M. (red.), Aansprakelijkheid voor het nucleaire risico, Maklu, Antwerpen-Apeldoom, 1993, 119-140.

Hellebuyck, A.D. en Deketelaere, M., "Verzekering en leefmilieu. Een internationaal overzicht van de ervaringen van de veizekeraars inzake de burgerrechtelijke aansprakelijkheid voor aantastingen van het leefmilieu", in Morrens, P. (red.), Milieurecht voor bedrijfsleiders en hun adviseurs, Mys \& Breesch, Gent, 1993, 143-165. 
Helmreich, J.E., "The Uranium Negotiations of 1944" in Le Congo Belge durant la seconde Guère Mondiale, Brussels, Royal Academy for Overseas Studies, 1983, 253-283.

Helmreich, J.E., "Belgium, Britain, the United States and Uranium, 1952-1959", Studia Diplonatica, $n^{\circ} 3$, $1990,27-81$.

Hennessey, J.F., "Indemnification of the US Atomic Energy Commission's Contractors against Liability for Nuclear Accidents", in Weinstein, J.L. (ed.), Progress in Nuclear Energy, Law and Administration, Vol. 3, Nuclear Liability, Oxford, Pergamon Press, 1962, 252-271.

Herrero de la Fuente, A., "The legal force of international rules relating to nuclear risks", Nuclear Law Bulletin, vol. 30, 1982, 47-59.

Herron, L.W., "Le point de vue d'un juriste sur les garanties et la non-prolifération", AIEA Bulletin, 1982/3, vol. $24,32-38$.

Hertel, G., "Basic principles of Insurance for Nuclear Risks", in Insurance for Nuclear Installations, IAEA, Legal Series $n^{\circ} 6$, Vienna, 1970, 59-61.

Herzog, P., "La théorie du forum non conveniens en droit anglo-américain: un aperçu", Revue Critique de Droit International Privé, 1976, 1-41.

Heubeck, K., "Some Observations concerning the Privatization of social security systems", The Geneva Papers on Risk and Insurance, vol. 24, $\mathrm{n}^{\circ} 2,1999,163-166$.

Heyes, A. en Liston-Heyes, C., "Capping Environmental Liability: the Case of North American Nuclear Power", The Geneva Papers on Risk and Insurance, vol. 25, $\mathrm{n}^{\circ} 2,2000,196-202$.

Hicks, J., "The Valuation of Social Income", Economica, Vol. 7, 1940, 696-712.

Hildebrand, J.E., "The Three Mile island unit 2 recovery: a decade of challenge", in Recovery operations in the event of a nuclear accident or radiological emergency, LAEA, Vienna, 1990, 65-77.

Hillsinger-Costanzo, P.C., "Civil Consequences of Nuclear Power", Insurance Law Journal, 1978, 727-747.

Hinteregger, M., "La nouvelle loi autrichienne sur la responsabilité civile pour les dommages nucléaires", Bulletin de Droit Nucléaire, vol. 62, 1998, 27-34.

Hoffman, E. en Spitzer, M.L., "The Coase-Theorem: some experimental Test", Journal of Law and Economics, 1982, 73-98.

Hoffman, E. en Spitzer, M.L., "Experimental Tests of the Coase-Theorem with Large Bargaining Groups", Journal of Law and Economics, 1986, 149-171.

Hofman, P., "La loi du 25 juin 1992 a-t-elle eu un impact sur le coût des primes des assurances de la responsabilité civile professionnelle et sur le coût potentiel de la sinistralité?", in Les Assurances de Responsabilité, Editions du jeune barreau de Bruxelles, 1999, 207-247.

Hohlefelder, W., "Reconsideration of the Principle of the Nuclear Operator's Limitation of Liability", in Nuclear Third Party Liability and Insurance, AEN-OECD, Paris, 1985, 372-384.

Hollis, E. L., "The New Law in General", in A Forum Report. The New Atomic Energy Law. What it means to industry, Atomic Industrial Forum Inc, New York, november 1954, 1-9.

Holsboer, J.H., "Insurability and Uninsurability: an Introduction", The Geneva Papers On Risk and Insurance, vol. $20, n^{\circ} 77,1995,407-413$.

Holzhauer, R.W. en Teijl, R., "Rechtseconomie in Nederland", Ars Aequi, 1989, 248-252.

Horbach, N.L.J.T., "Nuclear Protocol of the Energy Charter Treaty", Journal of Energy and Natural Resources Law, vol. 13, n 3, 1995, 163-177.

Horbach, N.L.J.T., "Lacunae of Intemational Nuclear Liability Agreements", in Horbach, N.L.J.T. (ed.), Contemporary Developments in Nuclear Energy Law. Harmonising Legislation in CEEC/NIS, Kluwer Law International, Den Haag, Boston, 1999, 43-85. 
Horbach, N.L.J.T., "Nuclear Energy Law and Regulation in Central and Eastem Europe", in Horbach, N.L.J.T. (ed.), Contemporary Developments in Nuclear Energy Law. Harmonising Legislation in CEEC/NIS, Kluwer Law International, Den Haag, Boston, 1999, 139-236.

Horbach, N.L.J.T., "Nuclear Liability entering a New Millennium", in Nuclear Inter Jura 1999, AIDN/INLA, Washington, 1999, 259-271.

Hughes, L.N., "The shipowners' right to a limitation of liability adrift on a sea of tort changes", Lloyds Maritime and Commercial Law Quarterly, 1988, 517-527.

Hughlo, C., "La pratique de la réparation en matière de dommages catastrophiques", in La réparation des dommages catastrophiques. Les risques technologiques majeurs en droit international et en droit communautaire, Travaux des XIIles Journées d'études juridiques Jean Dabin, Bruxelles, Bruylant, 1990, 145 155.

Hulst, E.H., "De werkelijkheid rondom een algemeen milieuschadefonds, een commentaar", Tijdschrift voor Milieuaansprakelijkheid, 1995-6, 167-173.

Hulst, E.H., "Zorgvuldigheidsnormen en bewijslastverdeling bij medische aansprakelijkheid en nilieuaansprakelijkheid vergeleken", Tijdschrift voor Milieuaansprakelijkheid, 1999-1, 3-14.

Hulst, E.H., "Actualiteiten milieuaansprakelijkheid. Schadelijk water en schadefonds, pleidooi voor adequate oplossingen", Tijdschrifi voor Milieuaansprakelijkheid, 1999-2, 33-36.

Hulst, E.H. en Klinge-van Rooij, I., "Het Europese milieu-groenboek: ecologie of economie?", Tijdschrift voor Milieuansprakelijkheid, 1994-1, 8-18.

Hupin, G., "La pollution, risque assurable", in Les Assurances de l'Entreprise, vol. I, Bruxelles, Bruylant, 1988, 243-263.

Hustinx, J.P. en Stolker, C.J.J.M., "Massaschade en fondsvorming", Verzekeringsarchief, 1997, 58-66.

lansiti, If. en Niehaus, F., "Impact of energy production on atmospheric concentration of greenhouse gases", IAEA Bulletin, 2/1989, 12-20.

Ilyin, L.A. en Pavlovskij, O.A., "Radiological Consequences of the Chemobyl Accident in the Soviet Union and measures taken to mitigate their impact", IAEA Bulletin, 4/1987, 17-24.

Islam, S. en Lindgren, K., "How many reactor accidents will there be?", Nature, 21, augustus 1986.

Iscnburgh. M., "Là loi Anciricaine sur l'énergie atomique", in Puget, H., Aspects de droil de l'énergie atomique, tome II, Centre français de droit comparé, Paris, 1967, 279-288.

Jacobsen, D.A. en Yellen, J.D., "Oil Pollution: the 1984 London Protocols and the Amoco Cadiz", Journal of Maritime Law and Commerce, vol. 15, $n^{\circ} 4,1984,467-488$.

Jacobsson, M., "State financial cover for nuclear incidents", in Nuclear Third Party Liability and Insurance. Status and Prospects, Paris, Munich Symposium, OECD-NEA, 1985, 141-145.

Jacobsson, M. en Trotz, N., "The Definition of Pollution Damage in the 1984 Protocols to the 1969 Civil Liability Convention and the 1971 Fund Convention", Journal of Maritime Law and Commerce, vol. $17, \mathrm{n}^{\circ} 4$, $1986,467-491$.

Jacobsson, M., "The regime of compensation for oil pollution damage and the Conventions on nuclear third party liability - a comparison", in Nuclear Inter Jura '89, AIDN/INLA, Tokyo, 1989, II-81-II-100.

Jacobsson, M., "The International Conventions on Liability and Compensation for Oil Pollution Damage and the Activities of the Intemational Oil Pollution Compensation Fund", in De la Rue, C.M., (ed), Liability for Damage to the Marine Environment, Lloyd's of London Press, London, 1993, 39-55.

Jacus, J.R. en Miller, D.C., "Coming Full CERC.LA: An Update on Superfund Developments", Environmental Liability, vol. 3, 1999, 77-80.

Jankowitsch, O., "La Convention sur la Sûreté nucléaire", Bulletin de Droit Nucléaire, $\pi^{\circ}$ 54, december 1994, 9-23. 
Jankowitsch, O. en Flakus, F.-N., "La Convention internationale sur la Sûreté Nucléaire marque une étape en droit", AIEA Bulletin, 3/1994, 36-40.

Jankowitsch, O., "Convention on Nuclear Safety: Status, Structure and Contents", in Nuclear Inter Jura 1995, Verslagboek van het Tweejaarlijkse Congres van de International Nuclear Law Association (INLA/AIDN), Helsinki, Finland, 1995, 687-690.

Jankowitsch, O., "La Convention Commune sur la sûreté de la gestion du combustible usć et sur la sûreté de la gestion des déchets radioactifs", in Le droit nucléaire: du XIe au XXIe sciécle. Nuclear Inter Jura '97, Société de Législation Comparée, AIDN/INLA, Paris, 1998, 539-542.

Janssen, C.A., "Aansprakelijkheid voor milieuschade en financiële zekerheid naar toekomstig recht: nicuwe oplossingen. Nederlands recht", in Wiggers-Rust, L.F. en Deketelaere, K., (red.) Aansprakelijkheid voor milieuschade en financiële zekerheid. Een vergelijking van Nederlands, Belgisch en Europees recht, Die Keure, Koninklijke Vermande, Brugge, Lelystad, 1998, 97-120.

Jessurun D'Oliviera, M.U., "IPR en Tsjemobyl. Privaatrechtelijke aansprakelijkheid voor grensoverschrijdende kemrampen", Nederlands Juristenblad, afl. 42, 1986, 1331-1334.

Joirysch, A. en Supataeva, O., "Compensation for damage caused by the Chemobyl accident", in Nuclear Accidents. Liabilities and Guarantees, OECD, Paris, 1993, 70-79.

Joirysch, A. en Supataeva, O., "The problem of the Russian Legislation on Liability for Nuclear damage", in Nuclear Accidents. Liabilities and Guarantees, OECD, Paris, 1993, 80-91.

Jones, B., "Remedying environmental damage: the European Commission's Green Paper", Tijdschrift voor Milieuaansprakelijkheid, 1994-1, 1-7.

Jones, B., "Deterring, Compensating, and Remcdying Environmental Damage: the Contribution of Tort Liability", in Wctterstein, P. (ed.), Harm to the Environment. The Right to Compensation and the Assessment of Damages, Clarendon Press, Oxford, 1997, 11-27.

Jones, P.M.S., "Cost of nuclear and conventional baseload electricty generation", IAEA Bulletin, 3/1990, 1824.

Jorgensen, S., "The Decline and Fall of the Law of Torts", The American Journal of Comparative Law, 1970, vol. $18,39-53$.

Jost, P.J., "Limited Liability and the Requirement to Purchase Insurance", International Review of Law and Economics, vol. 16, 1996, 259-276.

Juhn, P.E. en Kupitz, J., "Nuclear power beyond Chemobyl: a changing international perspective", IAEA Bulletin, 1-1996, 2-7.

Kagramanian, V., Kononov, S. en Rogner, H.-H., "Climate Change driving forces. Nuclear energy and the latest IPCC emission scenarios", IAEA Bulletin, vol. 42, $\mathrm{n}^{\circ} 2,2000,31-35$.

Kaldor, N., "Welfare Propositions of Economics and Interpersonal Comparisons of Utility", Economic Journal, Macmilian, London, Vol. 49, 1939, 549-552.

Kamp, P.A.J., "Massaschades en verzekering", in Massaschade. Vergt de behandeling van massale schade een bijzondere benadering?, Koninklijke Vermande, Lelystad, 1996, 55-66.

Kapteyn, P., "Vergoeding schade Tsjemobyl. Volkenrechtelijke Aspecten", Nederlands Juristenblad, afl. 42, 1986, 1329-1330.

Karten, W.T., "How to Expand the Limits of Insurability?", The Geneva Papers On Risk and Insurance, vol. $22, n^{\circ} 85,1997,515-522$.

Katzman, M.T. "Pollution Insurance and Catastrophic Environmental Risk", The Journal of Risk and Insurance, 1988, 75-100.

Kaufman, O., "State control and liabiilty in the nuclear industry", in Weinstein, J.L. (ed.), Progress in Nuclear Energy. Law and Administration, vol. 3 Nuclear Liability, Pergamon Press, Oxford, 1962, 66-74. 
Kaye, D., "The Limits of the Preponderance of the Evidence standard: Justifiably Naked Statistical Evidence and Multiple Causation", American Bar Foundation, Research Journal, 1982, 487-516.

Kende, C.B., "Liability for pollution damage and legal assessment of damage to the marine environment", Journal of Energy and Natural Resoucres Law, 1993, vol. 11, nr. 2, 105-119.

Kerremans, H., "Aansprakelijkheid voor milieuschade en verzekeringsmogelijkheden", in Milieuzorg in de Onderneming, Deel l. Juridische, financiële en organisatorische aspecten, Standaard Uitgeverij, 1999, 539583.

Kessler, D., "Social Security and Private Insurance: the great changes", The Geneva Papers on Risk and Insurance, vol. 24, n 4, 1999, 439-447.

Ketchum, L., "Epidemiologic tables Law Groundwork for Future Radiogenic Cancer Claims", Thie Journal of Nuclear Medicine, 1985, 967-972.

Kieholz, W. en Durrer, A., "Insurance Derivatives and Securization: New Hedging Perspectives for the I.s' Cat Insurance Market", The Geneva Papers on Risk and Inswance, vol. 22, $\mathrm{n}^{\circ}$ 82, 1997, 3-16.

Kirkpatrick, R., "La responsabilité objective en matière d'accidents d'aviation et de roulage", Revue Générale des Assurances et des Responsabilités, 1933, 1341.

Kiss, A., "L'accident de Tchemobyl et ses conséquences au point de vue du droit international", Annuaire Français de Droit International, 1986, 139-152.

Klarr, H., "Current Problems of Nuclear Insurance from the point of view of Industry", in Insurance for Nuclear Installations, LAEA, Wenen, 1970, Legal Series $n^{\circ}$ 6, 63-70.

Kolehmainen, H., "The Modemisation of the Intemational Nuclear Third Party Regime - does Exclusive Liability still make Sense?", in Reform of Civil Nuclear Liabilitu, International Symposium, Budapest 1999, OECD, Parijs, 2000, 453-461.

Kooymans, P.H., "The Peaceful Application of Nuclear Power and the Non-Ptoliferation System", in Proliferation and the Safeguarding of the Peaceful Application of Nuclear Power, Koninklijk Instituut van Ingenieurs Kerntechniek, The Hague Symposium, 9 december 1976.

Kottenhagen-Edzes, P.A., "De elementaire vragen van de onrechtmatige daad", in Koeman, N.S.J., Ouwerkerk en van Dunné, I.M., Civielrechtelijke aansprakelijkheid voor milieuschade, W.E.J. Tjeenk Willink, Zwolle, 1989, 35-45.

Kottenhagen, R.J.P. en Kottenhagen-Edzes, P.A., "Enkele nieuwe schadesoorten, ontstaan tengevolge van milieu-aantasting", in Miscellanea Jurisconsulto vero Dedicata (van Dunné-bundel), Deventer, 1997, 229253.

Kovan, D., "Nuclear insurance and indemnity", Nuclear Engineering International, 1976, 51 -53.

Krause-Ablaß, W.D., "Zulicfererhaftung trotz rechtlicher Kanalisierung?", in Pelzer, N. (ed.), Friedliche Kernenergienutzung und Staatsgrenzen in Mitteleuropa, Baden Baden, Nomos, 1987, 308-321

Krause-Ablaß, W.D., "Apportioning liability for transborder damages", in Cameron, P., Hancher, L. en Kühn, W. (eds.), Nuclear Energy Law after Chernobyl, Graham and Trotman, London-Dordrecht, 1988, 125-140.

Kremen, D., "Transboundary Damage. Carpe Solutionem", in Nuclear Inter Jura 1999, AIDN/INI.A, Washington, 1999, 273-275.

Kronenberg, W., "The Environmental Insuranfe Markets in the U.S. and Western Europe: A U.S. Underwriter's Observations", The Geneva Papers of Risk and Insurance, vol. 20, n 76, 1995, 336-347.

Kruithof, R. "Leven en dood van het contract", Rechtskundig Weekblad, 1985-86, 2761-2768.

Kruithof, R., "Naschrift", Rechtskundig Weekblad, 1986-87, 1669-1680.

Kuckuck, B., "Für eine Normalisierung der atomrechtlichen Haftung", Zeitschriff für Rechtspolitik, 1981, Heft $8,186-189$. 
Kühn, W., "Liability of suppliers to nuclear power plants in Western Europe", in Carneron, P., Hancher, L. en Kühn, W. (eds.), Nuclear Energy Law after Chernobyl, Graham and Trotman, London-Dordrecht, 1988, 115124.

Kunreuther, H., "Rethinking Society's Management of Catastrophic Risks", The Geneva Papers On Risk and Insurance, vol. $22, \mathrm{n}^{\circ} 83,1997,151-176$.

Kunreuther, H., Hogarth, R. en Mesaros, J., "Insurer Ambiguity and Market Failure", Journal of Risk and Unceriainty, 1993, 71-81.

Lacroix, $\mathrm{F}_{\mathrm{n}}$ "Insurance against Nuclear Risks in Europe", in Nuclear Law for a Developing World, LAEA, Wenen, 1969, 159-166.

Lacroix, F., "L'assurance 'bris de machines' dans les installations nucléaires", Insurance for Nuclear Installations, LAEA, Legal Series n 6, Wenen, 1970, 105-110.

Lagorce, M., "Etude comparative des Conventions OCDE et AIEA sur la responsabilité civile dans le domaine de l'énergie nueléaire", in Puget, $H$. (éd.), Aspects du droit de l'énergie atomique, Centre national de la recherche scientifique, Paris, 1967, 93-102.

Lagorce, M., "The Brussels Supplementary Convention and its Joint Intergovernmental Security Fund", in Nuclear Law for a developing world, LAEA, Vienna, Legal Series $n^{\circ} 5,1969,143-148$.

Lagorce, M., "Problèmes pratiques de responsabilité et d'assurance nucléaires vus par un exploitant français", in Insurance for Nuclear Installations, IAEA, Legal Series $N^{\circ} 6$, Wenen, 1970, 99-103.

Lagoree, M., "Bilan et analyse critique de la Convention de Paris et de la Convention complémentaire de Bruxelles après les Protocoles de 1982", in Nuclear Third Party Linbility. Status and Prospects, Munich Symposium, Paris, 1985, 24-42.

Lamm, V., "Status of the Revision of the Vienna Convention", in Nuclear Accidents. Liabilities and Guarantees, OECD, Paris, 1993, 170-180.

Lamm, V., "Le Protocole d'amendement de la Convention đe Vieme de I963", Bulletin de Droit Nucléaire, $\mathrm{N}^{\circ} 61,1998,7-26$.

Larmuseau, I., "Het voorzorgsbeginsel geintroduceerd in de Belgische iechtspraak: zoveel hoofden, zoveel zinnen?", Tijdschrift voor Milieurecht, 2000, 24-32.

Landes, W.M. en Posner, R.A., "The Positive Economic Theory of Tort Law", Georgia Law Review, vol. 15, $1981,851-924$.

Landes, E., "Insurance, Liability and Accidents: A Theoretical and Empirical Investigation of the Effect of No-Fault Accidents", Journal of Law and Economics, 1982, 49-65.

Landes, W. en Posner, R., "Causation in Tort Law: an Economic Approach", Journal of Legal Studies, 1983" 109-134.

Landes, W. en Posner, R., "Tort Law as a Regulatory Regime for Catastrophic Personal Injuries", Journal of Legal Studies, 1984, 417-434.

Lang, W., "Le droit intemational de l'environnement face aux défits du 2lème siècle", in Deketelaere, K. Faure, M. en Verhoosel, G. (red.), Grensoverschrijdende milieuproblemen: zitiagingen voor de nationale en internationale rechtsorde, Intersentia, Antwerpen-Groningen, 1998, 39-55.

Langelaar, K., "Het Fonds Luchtverontreiniging", Milieu en Recht, 1974, 69-80.

Lavrysen, L.., "De bevoegdheidsverdeling tussen Staat en Gewesten inzake leefmilieu na de tweede fase van de Staatshervorming 1988-1989", in De bevoegdheden inzake milieubeheer, Story Scientia, Gent, 1990, 1. 225.

Lavrysen, L., "Judicial respsonses in the nineties to Dutch (and German) Shipments of Waste to Belgium in the eighties", Maastricht Journal of European and Comparative Law, 1995, 219-243. 
Lecomte, J.F., "La nouvelle directive communautaire sur les normes de base en matière de radioprotection", in Le droit nucléaire: dn XXe au XXIe Siècle. Nuclear Inter Jura '97, Société de Législation Comparée, Paris, $1998,155-161$.

Lederer, P.D., "Nuciear Risks - whose Risks are they?", AIDN/INLA, Nuclear Inter Jura '89, "Nuclear Law for the 1990's", Tokyo, september 1989, II-3-[I-13.

Leigh, W.J., "The Nuclear Liability Convention - the only World on Liability?", in Horbach, N.L.J.T. (ed.), Contemporary Developments in Nuclear Energy Law. Harmonising Legislation in CEECNIS, Kluwer Law Intemational, Den Haag, Boston, 1999, 509-519.

Liénard, R., "Energie nucléaire et responsabilité civile", Revue de Droit International et de Droit Comparé, $1958,659-670$.

Lindemann, C., "Die Nukleare Sicherheitskonvention - Bestătigung deutschen und Fortschreibung internationalen Rechts?"', in Pelzer, N., (herausg.), Neues Atomenergierecht - Internationale und nationale Entwicklungen, Tagungsbericht der AIDN/INLA Regionaltagung in Regensburg 1994, Nomos, Badan-Baden, $1995,47-81$.

Lindrea, P.N., "The role of group and association captives", Risk Financing Options, Risk and Insurance Research Group, 1994, 11-13.

Lochard, J. en Boehler, M.C., "Les bases éthiques et juridiques du principe d'optimisation de la radioprotection", Bulletin de Droit Nucléaire, $\mathrm{n}^{\circ}$ 52, 1993, 9-28.

Lohéac, F., "A propos du marché unique de l'assurance et de quelques questions connexes", Revue du Marché Commun et de l'Union Européenne, ${ }^{\circ} 362,1992,781-787$.

Lohéac, F., "Le point de vue des Assureurs", in Levie, G. en Cousy, H. (eds.), Het Europees Concurrentiebeleid' in de Verzekeringssector, Academia-Bruylant, Lovain-la-Neuve, 1994, 71-78.

Lonergan, S.C. en Goble, R.L., "Estimating the financiai consequences of a severe nuclear accident in Canada", Energy, vol. 15, nº 6, 1990, 507-522.

Lopuski, J., "Civil liability for nuclear damage: selected questions connected with the revision of the Vienna Convention", in Nuclear Accidents. Liabilinies and' Guarantees, Helsinki symposium, OECD, 1993, 181-216.

Lorgé, M. "Rapport du pool belge", in Colloque Euratom/Assureurs sur les problèmes actuels de l'assurance des risques nucléaires, Euratom, 1962, EUR 486, 31-33.

Lowenfeld, A.F., "International Litigation and the Quest for Reasonableness", Recueil des Cours, Academy of International Law, Tome 245, Martinus Nijhoff Publishers, Den Haag, 1995, 9-320.

Lowenstein, R., "The United States Indemnity Progam for Atomic Energy Activities within the United States", in Mayda, J. (ed.), Atomic Energy and Law, Interamerican Symposium, School of Law, University of Puerto Rico, 1959, 125-132.

Lowenstein, R. "Indemnification against Liability for Nuclear Incidents in Licensed Atomic Energy" Activities", in Weinstein, J.L. (cd.), Progress in Nuclear Energy, Law and Administration, vol. 3 Nuclear Liability, Pergamon Press, Oxford, 1962, 237-251.

Lowenstein, R., "The Price-Anderson Act an imaginative Approach to Public Liability Concerns", Forum, 1977, vol. 12(2), 594-604.

Lucchini, L., "Le procès de l'Amoco Cadiz: présent et voies du Futur", Annuaire Français de Droit International, 1985, 762-782.

Mackaay, E.I.P., "Veranderingen in het stelsel van vergoeding en verhaal van schade", Nederlands Juristenblad, 1980, 813-825.

Mackaay, E., "Het recht bezien door de bril van een economist", Rechtsgeleerd Magazijn Themis, 1988, 411 452.

Mackaay, E., "Het aansprakelijkheidsrecht", Ars Aequi, 1990, vol. 39, n 10, 141-147. 
Maes, F., "De burgerrechtelijke aansprakelijkheid van de scheepseigenaar voor schade ontstaan door olieverontreiniging: een verduidelijking bij de toepasselijke Verdragen en contracten", Revue Belge de Droit International, 1988/1, 97-128.

Maffei, M.C., "The Compensation for Ecological Damage in the "Patmos" case", in Francioni, F. en Scovazzi, T., (ed.), International Responsibility for Environmental Harm, Graham and Trotman, Martinus Nijhoff, 1991, 381-394.

Markesinis, B., "La perversion des notions de responsabilité civile délictuelle par la pratique de l'assurance", Revue Internationale de Droit Comparé, 1983, 301-317.

Marrone, J., "The Price-Anderson Act: the Insurance Industry's view". Forum, Chicugo, 1977, v. 12 (2), 605 611 .

Marrone, J., "L'assurance de la responsabilité civile nucléaire: le régime de réparation des dommages en vertu de la loi Price-Anderson et l'expérience acquise par l'industrie nucléaire en matière de demandes en réparation", Bulletin de Droit Nucléaire, $\mathrm{n}^{\circ} 33,1984,47-55$.

Marrone, J., "The liability claims experience of the American Nuclear Pools and their response to the Three Mile Island accident", in Nuclear Third Party Liability and Insurance. Status and Prospects, OECD, Paris, $1985,197-205$.

Martone, J., "US Commission Recommendations ... compensation plan for nuclear catastrophes - an insurer's perspective", in Nuclear Jura '91, Bath, AIDN/INLA, 1991, 265-282.

Marrone, J., "Boucler le système de protection du public - l'évolution du régime aux Etats-Unis", in Nuclear Accidents. Liabilities and Guarantees, OECD-NEA, 1993, 361-380.

Martin, G., "L'assurance de risques nucléaires", Annales de Sciences économiques appliquées, UCL, août $1962, n^{\circ} 3,275-294$.

Martin, G., "Rapport du pool belge", in Troisième Colloque sur l'Assurance du Risque Nucléaire, Euratom, Aix-en-Provence, 1964, 101-125.

Martinez-Favini, J., "Application de la Convention de Vienne et mise en pratique au niveau mondial des principes de la responsabilité civile en matière nucléaire", in Nuclear Third Party Liability and Insurance. Status and Prospects, Paris, Munich Symposium, OECD-NEA, 1985, 43-59.

Marshall, J., "Moral Hazard", American Economic Revie"1", 1976, 880-890.

Massart, A., "De bezoedeling van oceanen en zecën", Rechiskundig Weekblad, 1968, 1466-1476.

Matte, N.M., "International Air Transport", International Encyclopaedia of Comparative Law, vol. XII, 6-3 6-176.

Matthijs, J., "Aansprakelijkheid bij toepassing van kernenergie tot vтeedzame doeleinden", Rechiskundig Weekblad, 1962, 113-146.

McCaffrey, S.C., "Expediting the Provision of Compensation to Accident Victims", in Händ, (i. en Lutz, R.E., Transferring Hazardous Techmologies and Substances. The International Legal Challenge, Graham \& Trotman, Martinus Nijhoff, London, 1989, 199-239.

Mc Cormick, N.J., "Changes in the nuclear power industry after TMI", Progress in Nuclear Energy, 1982, Vol. 10, 245-248.

McNett, "Nuclear Indemnity for Government Contractors Under the Price Anderson-Act", Public Cuntract Law Journal, vol. 14, $\mathrm{n}^{\circ} \mathrm{1}, 1983,40-57$.

McRae, B., "La Convention sur la réparation: sur la voie d'une régime mondial permettant de faire face à la responsabilité et à l'indemnisation des dommages nucléairess", Bulletin de Droit Nuclénire, n 61, 1998, $27-41$.

McRae, B., "Nuclear Liability from the Pcrspective of the United States", in Nuclear Inter Jura 1999, AIDN/INLA, Washington, 297-302. 
McRae, B., "Overview of the Convention on Supplementary Compensation", in Reform of Civil Nuclear Liability, International Symposium, Budapest 1999, OECD, Parijs, 2000, 171-183.

Melber, B.D., "The impact of TMI upon the public acceptance of nuclear power", Progress in Nuclear Energy, 1982, Vol. 10, 387-398.

Miles, A.C., "Nuclear Installations. Insurance problems", in Nuclear Law for a Developing World, Legal Series $n^{\circ}$ 5, LAEA, Vienna, 1969, 149-158.

Moerenhout, R, "De samenwerking tussen de federale Staat, de Gemeenschappen en de Gewesten - recente ontwikkelingen", Tijdschrift voor Belgisch Publiekrecht, 1996, 27 I-283.

Morrow, J., Pfennigstorf, W. en Wansink, J.H., "General Report", in Pfennigstorf, W. (ed.), Pollution Insurance. International Survey of Coverages and Exclusions, Graham \& Trotman/ Martinus Nijhoff, Londen, $1993,129-154$.

Mosthaf, H.D., "Haftung und Versicherung für Kemrisiken in der Europäischen Gemeinschaft", Zeitschriji für Kerntechnik, oktober 1964, 276-281.

Mosthaf, H.D., "Wirtschaftlich oder rechtlich kanalisieren? Eine Streitfrage der Kemhaftung", Vorsicherungsrcecht, maart 1967, Heft 9, 197-202.

Moustie, K., "Verzckering van produktaansprakelijkheid", Tijdschrift voor Privaatrecht, 1988, 141-160.

Müller, W., "Huttpflichtversicherungen für Kemenergieanlagen", Allianzberichte für Betriebstechnik und Schadenverhütung, 1967, Heft 4, 29-34.

Müller. W., "The Role of the Insurance Industry in Covering Nuclear Third Party Liability Risks", in Nuclear Third Party linbility and Insurance, München symposium, NEA-LAEA, 1985, 166-171.

Murase, S., "Perspectives from International Economic Law on Transnational Environmental lssucs", Recueil des Cours, Academy of International Law, Tome 253, Martinus Nijhoff Publishers, Den Haag, 1996, 286-425

Murphy, A.W., "Principles of United States law governing Liability for Nuclear Accidents", in Mayda, J., (ed.), Atomic Energy and Law, School of Law, Puerto Rico, 1959, 119-125.

Murphy, A.W., "Third Party Liability of Suppliers in Intemational Nuclear Transactions", in Weinstein, J.L., (ed.), Progress in Nuclear Energy. Law and Administration, vol. 3, Nuclear Liability, Oxford, Pergamon Press, 1962, 166-186.

Murtagh, H., "The Oil Pollution Act of 1990 (OPA) and the Comprehensive environmental response. compensation and liability Act (CERCLA)", in De la Ruc, C.M. (ed.), Liability to the Marine Environment, Lloyd's of London Press, 1993, 169-172.

Nanda, V.P. en Bailey, B.C., "Nature and Scope of the Problem", in Händl, G. en Lutz, R.E., Transferring Hazardous Technologies and Substances. The International Legal Challenge, Graham \& Trotman, Martinus Nijhoff, Landon, 1989, 4-39.

Nelson, P., "Information and Consumer Behaviour", Journal of Political Economy, vol. 78, 1970, 311.

Nieuwenhuis, J.H., "De tuinman en de dood", Rechtsgeleerd Magazijn Themis, 1989, 193-201.

Niezen, G.J., "Aansprakelijkheid voor Milieuschade in de Europese Unie. Over de slak en de bonte specht", in Niezen, G.J. Raaijmakers, M.J.G.C. en Tervoort, A.I.S.M. (red.), Ongebonden Recht Bedrijven. Bedrijfsjuridische opstellen op de grens van het derde millennium bij gelegenheid van het 70 -jarig bestaan van het Nederlands Genootschap van Bedrijfsjuristen, Kluwer, Deventer, 2000, 165-179.

Nocera, F., Boehler, M.C. e.a., "Radiation Protection Legislation in the European Union: the Imperative of Uniformity, related initiatives and problems", in Nuclear Inter Jura '99, INLAAIDN, Washington, 1999, 5575 .

Nys, C., "De juridische natuur van de Lloyd's Syndicates en de wijze waarop haar leden in rechte optreden", Jura Falconis, 1989-90, 161-176. 
O'Connell, J.M., "Current Operating Practices of Nuclear Insurance Pools", in Nuclear Accidents. Linbilities and Guaramecs, NEA-IAEA, Paris, 1993, 348-360.

Oldertz, C., "Swedish Environmental Damage Insurance. A new concept of insuring injuries or property damages, caused by environmental disturbances", in Bocken, H. en Ryckbost, D. (ed.), Verzekering van Milieuschade, Verslagbock van het Internationaal Colloqium gehouden te Gent op 14 en 15 december 1989, Story Scientia, Gent, 1991, 363-373.

Olson, L.K., "The existing Legal Framework in the United States", in Mayda, J. (ed.), Atomic Energy and Law, School of Law, Pucrto Rico, 1959, 159-166.

Oosterveen, W.J.G., "Verbeterde mogelijkheden voor vergocding van schade door ongevallen met olietankers", Ars Aequi, 1997, nr. 6, 423-431.

Orban de Xivry, E., "Jurisprudence de la Cour d'Arbitrage et droit de l'environnement", in De bevoegdheden inzake Milieubeheer, Story Scientia, Gent, 1990, 227-25\%.

Ordover, J.A., "On the Consequences of Costly Litigation in the Model of Single Activity Accidents: Some new Results", Joumal of Legal Sludies, 1981, 269-291.

Oulahan, C., "United States Atomic Energy Commission Licensing", in Weinstein, J.L. (ed.), Progress in Nuclear Energy. Law and Administration, Pergamon Press, Oxford, 1962, 35-65.

Pauly, M., "Overinsurance and Public Provision of Insurance: the Rules of Moral Hayard and Adverse Selection", Quartely Journal of Economics, 1974, 44-62.

Pauly, M., "The Economics of Moral Hazard: Comment", American Economic Review, vol. 58, 1968, 535536.

Peck, B. en Blackman, R.L., "Captives, mutuals and pools: an overview of Australian Regulation", International Journal of Insurance Law, 1996. 157-I62.

l'elzer, N., "Die rechtliche Kanalisierung der I Iaftung auf den Inhaber einer Atomanlage - ein juristischer und wirtschaftlicher Fehlgriff?", Versicherungsrecht, 1966, 1010-1020.

Pelzer, N., "Opferschutz im Haftungsverband nach den europäischen Alomhaftungsübercinkommen Bemerkungen zu einigen Problemen bei der Durchsetzung von Ersatzansprüchen", in Drittes Deutsches Atomsrechts-Symposium, Carl Heymans, 1975, 251-258.

Pelzer, N., "Reformüberlegungen zur Ausgestaltung der atomrechtlichen Haftung", in Lukes, R. (herausg.), Sechstes Deutsches Atomrechts-Symposium, Carl Heymanns Verlag, Keulen, 1980, 407-425.

Pelzer, N., "The nature and scope of international co-operation in connection with the peaceful uses of nuclear energy and its limits - an assessment", Nuclear Law Bulletin, vol. 27, 1981, 34-49

Pelzer, N., "La responsabilité civile dans le domaine nucléaire au lendemain de l'accident de Chernobyl", Bulletin de Droit Nucléaire, 1987, $0^{\circ} 39,69-79$.

Pelzer, N., "Aktuelle Probleme des Atomhaftungsrechts nach Tchernobyl", Energiewirtschaftliche Tagesfragen, 1987, $\mathrm{n}^{\circ} 1,81-85$.

Pelzer, N., "Concepts of Nuclear Liability Revisited: A Post-Chemobyl Assessment of the Paris and the Vienna Conventions", in Cameron, P., Hancher, L. en Kühn, W. (eds.), Nuclear Energy Law after Chernobyl, Graham and Trotman, London-Dordrecht, 1988, 97-114.

Pelzer, N., "Überlegungen zur Novellierung des atomrechtlichen Haftungs- und Deckungsrechts in den 90er Jahren", in Lukes, R. (herausg.), Reformüberlegungen zum Atomrecht, Carl Heymans Verlag, Keulen, 1991, 456-503.

Pelzer, N., "The present state of research carried out by the English speaking section of the Centre for Studies and Rescarch", in The hazards arising out of the peaceful use of nuclear energy', Centre for Studies and Research in International Law and International Relations, Hague Academy of International Law, Kluwer Academic Publishers, Dordrecht, 1993, 207-300. 
Pelzer, N., "Inadequacies in the Civil Nuclear Liability Régime evident after the Chemobyl Accident: the Response of the Joint Protocol of 1988", in Nuclear Accidents. Liabilities and Guarantees, Helsinki symposium 1992, IAEA-NEA, Parijs, 1993, 155-169.

Pelzer, N., "Iinternationales Atomrecht im Wandel - Auf dem Wege zu einer Nuklearen Sicherheitskonvention und zur Verbesserung des internationalen Atomhaftungsrecht", in Jahrbuch des Umwelt- und Technikrechts, Decker's Verlag, Heidelberg, 1994, 639-681.

Pelzer, N., "Channelling: Concept and Policy under the Paris and the Vienna Conventions", Joint CEC/LAEA/NEA Training Seminar on Nuclear Law, Bratislava, 30 augustus - 2 september 1994, 1-10.

Pelzer, N., "Focus on the Future of Nuclear Liability Law", in Reform of Civil Nuclear Liability, International Symposium, Budapest 1999, OECD, Parijs, 2000, 421-451.

Pfaffelhuber, J.K. en Kuckuck, B., "Reformüberlegungen zur Ausgestaltung der atomrechtlichen Haftung", in Lukes, R. (herausg.), Sechstes Deutsches Atomrechts-Symposium, Carl Heymanns Verlag, Keulen, 1980, 383391.

Pfaffelhuber, J.K. en Kuckuck, B., "Standard rules for liability and cover for nuclear installations", Nuclear Law Bulletin, $\mathrm{n}^{\circ} 25,1980,70-75$.

Pfennigstorf, W., "Policy considerations for insurers engaging in environmental liability insurance", in Bocken, H. en Ryckbost, D. (ed.), Verzekering van Milieuschade, Verslagboek van het Intemationaal Colloqium gehouden te Gent op 14 en 15 december 1989, Story Scientia, Gent, 1991, 269-287.

Pfennigstorf, W., "Limited Insurability of Unlimited Liability: Serial Claims aggregates and alternatives. The continental view", in Kröner, R.P., Transnational Environmental Liability and Insurance, Graham \& Trotman, Kluwer Academic Publishers, London, 1993, 159-165.

Pfennigstorf, W., "How to deal with damage to natural resources: solutions in the German Environmental Liability Act of 1990", in Wetterstein, P. (ed.), Harm to the Environment. The Right to Compensation and the Assessment of Damages, Clarendon Press, Oxford, 1997, 131-142.

Philippe, D.-M., "La théorie de la relativité aquilienne", in Mélanges Roger O. Dalcq. Responsabilités et Assurances, Larcier, Bruxelles, 1994, 484-485.

Philippe, D., "A propos du lien causal en matière de responsabilité civile nucléaire", in Le droit nucléaire: du XXe au XXIe Sciècle. Nuclear Inter Jura '97, Société de Législation Comparée, Paris, 1998, 431-444.

Philips, R.O., "Charterer's point of view", in De la Rue, C.M. (ed.), Liability to the Marine Environmont, Lloyd's of London Press, 1993, 155-167.

Picard, M., "The Convention on third party liability in the field of nuclear energy", Journal de Droit International, 1962, 345-367.

Piedboeuf, F., "Les frais de prévention et de retrait", in Les Assurances de l'entreprise, Bruxelles, Bruylant, vol, 1, 1988, 167-194.

Piérard, J.P., "La réparation des dommages futurs provoqués par l'énergue nucléaire", Revue de Droit International Comparé, 1962, 676-691.

Pinel, C., "La Convention sur la Sûreté Nucléaire adoptée le 17 juin 1994: amélioration ou détérioration de la règle de droit? La confiance en question", in Nuclear Inter Jura 1995, Verslagboek van het Tweejaarlijkse Congres van de International Nuclear Law Association (INLA/AIDN), Helsinki, Finland, 1995, 671-677.

Polbom, M.K., "Mandatory Insurance and the Judgment-Proof Problem", International Review of Law and Economics, vol. 18, 1998, 141-146.

Polak, J.M., "Vergoeding van schade door luchtverontreiniging", in Hijmans van den Bergh, L.J. en Van Zeben, C.J. (red.), Met eerbiedigende werking, Hijmans van den Bcrgh bundel, Kluwer, Deventer, 1971, 203208.

Polinsky, A.M., "Strict Liability versus Negligence in a Market Setting", American Economic Review, 1980, 363-367. 
Polinsky, M. en Shavell, S., "The Optimal Trade-off between the Probability and Magnitude of Fines", American Economic Review, 1979, 880-891.

Polinsky, M., "Private versus Public Enforcement of Fines", Journal of Legal Studies, 1980, 105-127.

Politi, M., "International and civil liability for nuclear damage: some recent developments of state practice", in La réparation des dommages catastrophiques. Les risques technologiques majeurs en droit international et en droit communautaire, "Travaux des XIIles Journées d'études juridiques Jean Dabin, Bruxelles, Bruylant, 1990, 319-337.

Poortinga, E. en Poortinga, G., "Het Fonds Luchtverontreiniging en zure regen", Milieu en Recht, 1986, 134141.

Popp, A.H.E., "Liability and Compensation for Pollution Damage caused by Ships Revisited - Report on an important International Conference", Lloyd's Mariime and Commercial Law, 1985, 118-131.

Popp, A.H.E., "A North American perspective on liability and compensation for oil pollution caused by ships", in De la Rue, C.M. (ed.), Liability to the Marine Environment, Lloyd's of London Press, 1993, 109130 .

Posch, W., "New developments in the Law of Civil Liability for Nuclear Damage Spearheaded by Austria: from Privileges for the Nuclear Industry to a true Protection of Mankind and the Environment", Environmental Liability, 1999, vol. 3, 81-83.

Posey, L.L., "Limited Liability and Incentives when Firms can inflict Damages Greater than Net Worth", International Review of Law and Economics, 1993, vol. 13, 325-330.

Posner, R., "A Theory of Negligence", Journal of Legal Siudies, 1972, 29-96.

Posner, R.A., "Utilitarianism, Economics and Legal Theory", Journal of Legal Studies, 1979, 103-140.

Posner, R.A., "The Concept of Corrective Justice in Recent Theories of Tort Law", Journal of Legal Studies, $1981,187-206$.

Posner, R.A., "Theories of economic Regulation", The Bell Journal of Economics, 1974, 335-358.

Postma, H., "Bericht des Niederländischen Pool", in Colloque Euratom/Assureurs sur les problèmes actuels de l'assurance des risques nucléaires, Euratom, 1962, EUR 486, 19-20.

Powell, C.W., "The importance of captive management in an increasignly difficult insurance market", in Risk Financing Options, Risk and Insurance Research Group, 1994, 23-24.

Pratt, J., "Risk Aversion in the Small and in the Large", Econometrica, 1964, 122-136.

Priest, G., "The Current Insurance Crisis and Modern Tort Law", Yale Law Journal, 1987, 1521-1590.

Priest, G., "The Invention of Enterprise Liability: A Critical History of the Intellectual Foundations of Modem Tort Law", Journal of Legal Studies, 1985, 461-527.

Priest, G., "The American Legal System and the Insurability of Environmental Damage and Catastrophic Loss", The Geneva Papers of Risk and Insurance, vol. 22, n 83, 1997, 190-193.

Prince, P., "Bhopal, Bougainville and Ok Tedi: Why Australia's forum non conveniens Approach is better", International and Comparative Law Quarterly, vol. 47, 1998, 573-598.

Quattrochi, J.L., "The Price-Anderson Act in the New Millennium. An Insurer's Perspective", in "Nuclear Inter Jura 1999", AIDN/INLA, Washington, 1999, 249-257.

Quattrochi, J.L., "Nuclear Liability Insurance in the United States: an Insurer's Perspective", in Reform of Civil Nuclear Liability, Intemational Symposium, Budapest 1999, OECD, Parijs, 2000, 383-398.

Radetzki, M., "Limitation de la responsabilité civile nucléaire: causes, conséquences et perspectives", Bulletin de Droit Nucléaire, $\mathrm{n}^{\circ}$ 63, 1999, 7-25.

Radetzki, M. en Radetzki, M., "Private Arrangements to Cover Large-Scale Liabilities Caused by Nuclear and Other Industrial Catastrophes", The Geneva Papers on Risk and Insurance, vol. 25, n² 2, 2000, 180-195. 
Ranson, D., "Verzekering van milieuaansprakelijkheid", Milieu- en Energierecht, 2000, nr. 3-4, 66-73.

Raviv, A., "The Design of an Optimal Insurance Policy", American Economic Review, vol. 69, 1979, 84-96.

Rehbinder, E., "Towards a Community Environmental Liability Regime: the Commission's White Paper on Environmental Liability", Environmenial Liability, vol. 8, $\mathrm{n}^{\circ} 3,2000,85-90$.

Rehmann, J., "Ciaims expenses and limits of liability in third party liability insurances", in Nuclear Inter Jura 91, AIDN/INLA, Bath, 1991, 293-311.

Rehmann, J., "Claims expenses and insurance capacity in third party liability insurance", in Nuclear Accidents. Liabilities and Guarantees, Helsinki symposium 1992, OECD-LAEA, Paris, 1993, 381-406.

Reitsma, S.M.S., "Nuclear Insurance Pools: History and Development", in Nuclear Accidents. Liabilities and Guarantees, Helsinki symposium 1992, OECD-IAEA, Paris, 1993, 341-347.

Reitsma, S.M.S., "An Equitable Distribution of Compensation: Realistic or Wishful Thinking?", in Reform of Civil Nuclear Liability, International Symposium, Budapest 1999, OECD, Parijs, 2000, 347-361.

Rémond-Gouilloud, M., "Compensating victims of Pollution Damage caused by Activities at Sea", in Compensation for Pollution Damage, OECD, Parijs, 1981, 59-92.

Rémond-Gouilloud, M., "The Future of the Compensation System established by International Convention", in De la Ruc, C.M., (ed.), Liability for Damage to the Marine Environment, Llyod's of London, 1993, 83-99.

Rémond-Gouilloud, M., "L'expérience du FIPOL - une hybridation réussie", Risques, n 30, 1997, $101-105$.

Renard, C., "Le dynamisme de la théorie des troubles de voisinage: le cas du locataire", Revue Critique de Jurisprudence Belge, 1975, 360-369.

Rest, A., "Tschernobyl und die internationale Haftung - Volkerrechtliche Aspekte", Versicherungsrecht, 1986, Heft $25,609-620$.

Reygaerts, M., "Le droit nucléaire belge", in Puget, H., Aspects de droit de lénergie atomique, tome II, Centre français de droit comparé, Paris, 1967, 263-276.

Reyners, P., "Compensation for nuclear damage in the OECD member countries", in Compensation for Pollution Damage, OECD, Parijs, 1981, 93-123.

Reyners, P. en Lellouche, "Regulation and Control by Intemational Organisations in the Context of a Nuclear Accident: the International Atomic Energy Agency and the OIECD Nuclear Energy Agency", in Cameron, $P$. Hancher, L. en Kühn, W. (eds.), Nuclear Energy Law after Chernobyl, Graham and Trotman, LondonDordrecht, 1988, 1-17.

Reyners, P. en von Busekist, O. "The Joint Protocol relating to the application of the Vienna and Paris Conventions - One step towards the necessary modemisation of the international nuclear civil liability regime", in Nuclear Inter Jura '89, AIDN/INLA, Tokyo, 1989. II-63 - II-80.

Keyners, P., "Civil Liability versus State Liability in case of a Nuclear Incident - Some Thoughts inspired by the Vienna Convention Revision Exercise", in Niaclear Inter Jura '91, AIDN/INLA, Bath, 1991, 225-255.

Reyners, P., "Le Régime Intenational de Responsabilité civile Nucléaire. Perspectives d'évolution", in L'option Nucléaire. L'Ethique et le Droit, Colloqium mei 1994, Société Française d'Energie Nucléairc, 1994, 245-269.

Reyners, P., "Modernisation du régime de responsabilité civile pour les dommages nucléaires: révision de la Convention de Vienne et nouvelle Convention sur la réparation complémentaire des dommages nucléaires", Revue Générale de Droit Iniernational Public, 1998/3, 747-763.

Rice, P., "From Lugano to Brussels via Arhus: Environmental Liability White Paper Published", Environmental Liability, vol. 2, 2000, 39-45.

Rinkes, J.G.J., "The Consumer Perspective on the Completion of the Single Market of Insurance", in McGee, A. en Heusel, W., (ed.), The Law and Practice of Insurance in the Single European Market, Academy of European Law in Trier, Bundesanzeiger, 1995, Keulen, 11-24. 
Rizzo, M., "A Theory of Economic Loss in the Law of Torts", Joumal of Legal Siudies, 1982, 281-310.

Robesin, M.A., "Aansprakelijkheid voor milieuschade en verzekering", in Koeman, N.S.J., Ouwerkerk en van Dunné, J.M., Civielrechtelijke aansprakelijkheid voor milieuschade, W.E.J. Tjeenk Willink, Zwolle, 1989, 133-150.

Robinson, G.O., "Probabilistic causation and compensation for tortious risk", Journal of Legal Studies, 1985, 779-798.

Rodière, R., "Responsabilité civile et risque atonique", in Puget, $\mathrm{H}$., Aspects de droit de l'énergie atomique, tome II, Centre français de droit comparé, Paris, 1967, 2-17.

Rogers, W.V.H., Spier, J. en Viney, G., "Preliminary Observations", in Spier, J., The Limits of Liability. Keeping the Floodgates Shut, Kluwer Law International, Den Haag, 1996, 1-15.

Rogge, J., "Assurance des dommages causés par la pollution. L.es garantics usuelles accordćes sur le marché belge", in Bocken, H. en Ryckbost, D. (ed.), Vercekcring van Milicuschade, Verslagbock van het Intemationaal Colloqium gehouden te Gent op 14 en 15 december 1989, Story Scientia, Gent, 1991, 15-43.

Rogge, J. en Moustie, K., "Belgium", in Pfennigstorl, W. (cd.), Pollution Insurance. International Survey of Coverages and Exclusions, Graham \& Trotman/ Martinus Nijhoft, Londen, 1993, 29-32.

Rogge, J., "De dekking van schade door milieuaantasting in het kader van de verzekering BA-exploitatie", $D e$ Verz, $1987, n^{\circ} 281,542-552$.

Rogge, J., "L'assurances des risques d'exploitation", in Les Assurances de l'Entreprise, Bruxelles, Bruylant, vol. II, 1993, 175-214.

Rogge, J., "Les Assurances en matière d'environnement", Kluwer, Diegem, Coll. Env., 1997/2.0, 1-51.

Rogner, H.-H., "Kyoto's flexible mechanisms and nuclear power. Rethinking the options", LAEA Bulletin, vol. $42, n^{\circ} 2,2000,25-30$.

Rosenberg, D., "The Causal Connection in Mass Exposure Cases: a 'Public Law' Vision of the Tort System", Harvard Law Review, 1984, 851-929.

Roser, T., "Plea for European Price Anderson legislation", in Nuclear Inter Jura '91, AIDN/INLA, Bath, $1991,257-263$.

Rothshild, M. en Stiglitz, J., "Equilibrium in Competitive Insurance Markets: An Essay on the Economics of Imperfect Information", Quarterly Journal of Economics, 1976, 629-649.

Rustand, $\mathrm{H}$., "Updating the Concept of damage, particularly as regards environmental damage and preventive measures, in the context of the ongoing negotiations on the revision of the Vienna Convention - some comparative aspects", in Nuclear Accidents. Liabilities and Guarantees, OECD/NEA-LAEA, Helsinki, 19933, 218-238.

Rustand, H., " Paris Convention on Third Party Liability in the Field of Nuclear Energy. Progress Report on Negotiations to Revise the Convention", in Reform of Civil Nuclear Lialility, International Symposium, Budapest 1999, OECD, Parijs, 2000, 139-146.

Rutsaert, J.M., "De rol van het 'Comite Européen des Assurances'", in Liber Amicorum Huberl Claassens. Verzekering: theorie en prakiljk, Maklu, Academia-Bruylant, Antwerpen, 1998, 393-407.

Rutsaert, J.M., "European Competition Law in lnsurance", in Huybrcchts, M.A. (ed.), Marine Insurance at the turn of the Millennium, Volume 1, Intersentia, Antwerpen, Groningen, 1999, 161-179.

Sacerdoti, P., "The role of Insurance", in Weinstein, J.L. (cd.), Progress in Nuclear Energy. Law and Administration, vol. 3. Nuclear Liability, Pergamon Press. Oxford, 1962, 209-227.

Saltzman, J., "Conclusions of the Presidential Commission on Catastrophic Nuclear Accidents", in Nuclear Accidents. Liabilities and Guarantees, OECD/NEA-IAEA, Helsinki, 1993, 265-277. 
Sands, P., "Liability for nuclear damage: financial and definitional limitations with particular reference to the EEC rules prohibiting subsidies and anti-competitive practices and agreements", in Nuclear Inter Jura '91, AIDN/INLA, Bath, 1991, 283-291.

Sands, P. en Galizzi, P., "The 1968 Brussels Convention and Liability for Nuclear Damage", in Reform of Civil Nuclear Liability, International Symposium, Budapest 1999, OECD, Parijs, 2000, 475-506.

Sandvik, B. en Suikkari, S., "Harm and Reparation in International Treaty Regimes: an overview", in Wetterstein, P. (ed.), Harm to the Environment. The Right to Compensation and the Assessment of Damages, Clarendon Press, Oxford, 1997, 57-71.

Schäfer, A., "Die Nukleare Sicherheitskonvention mit den Augen eines Naturwissenschaftlers gesehen", in Pelzer, N, (herausg.), Neues Atomenergierecht - Internationale und nationale Entwicklungen, Nomos, BadenBaden, ! $995,38-39$.

Schenke!, W., "Catastrophic Effects of Environmental Damage and the Consequences", The Geneva Papers of Risk and Insurance, vol. 24, $\mathrm{n}^{\circ} 3,1999,397-406$.

Schmidt, K., "Reformüberlegungen zur Ausgestaltung der atomrechtlichen Haftung", in Lukes, R. (herausg.), Sechstes Deutsches Atomrechts-Symposium, Carl Heymanns Verlag, Keulen, 1980, 393-401.

Schoorens, G. en Vanderspikken, A., "De verkorting van de verjaringstermijnen en de verzekerbaarheid van langetermijnaansprakelijkheden", in Liber Amiconum Hubert Claassens, Maklu, Academia-Bruylant, Antwerpen, 1998, 179-201.

Schoorens, G., "Verkeersongevallen met 'zwakke weggebruikers': het nieuwe vergoedingssysteem van art. 29 bis WAM-wet. Het kwalificatieprobleem", Revue Générale des Assurances et des Responsabilités, 1995, nr. 12443.

Schuermans, L., "Van foutaansprakelijkheid naar schadeverzekering", Tijdschrift voor Privaatrecht, 1967, 142.

Schuermans, L., "Perspectieven in het verzekeringsrecht", Rechtskundig Weekblad, 1977-1978, 2249-2268.

Schuermans, L., "De nieuwe wet op de landverzekeringsovereenkomst van 25 juni 1992", Rechtskundig Weekblad, 1992-1993, nr. 21, 689-722 en nr. 22, 729-751.

Schuermans, L., "Het verzekeringsrecht: bron en smeltkroes van het verbintenissenrecht", in Mélanges Roger O. Dalcq. Responsabilités el Assurances, Larcier, Bruxelles, 1994, 553-556.

Schutyser, F., Deketelaere, $M$ en Deketelacre, K, " Onderzoek naar de opportuniteit en de haalbaarheid van een Vernieuwd Vergoedingssysteem voor Milieuschade", Milieu- en Energierecht, 1999, nr. 6-7, 146-174.

Schutyser, F., "Aansprakelijkheid voor milieuschade en financiële zekerheid naar toekomstig recht: nieuwe oplossingen", in Deketelaere, K. en Wiggers-Rust, L.F. (red.), Aansprakelijkheid voor milieuschade en financiële zekerheid. Een vergelijking van Nederlands. Belgisch en Europees recht, Die Keure, Vermande. B̂rugge, $1998,121-140$.

Schwartz, J., "Diplomatic conference convened to adpot a protocol to amend the Vienna Convention on civil liability for nuclear damage and to adopt a Convention on supplementary compensation for nuclear damage", in Le droit nucléaire: du XXe au XXYe Sciècle. Nuclear Inter Jura '97, Société de Législation Comparéc, Paris, 1998, 427.429.

Scovazzi, T., "Industrial Accidents and the Veil of Transnational Corporations", in Francioni, F. en Scovazzi, T., (ed.), International Responsibility for Environmental Harm, Graham \& Trotman, London, 1991, 395-427.

Sellschopp, H.D., "Multiple Tort Feasors/Combined Polluter Theories, Causality and Assumption of Proof, Technical Insurance Aspects", in Kröner, R.P., Transnational Environmental Liability and hnsurance, Graham \& Trotman, Kluwer Academic Publishers, London, 1993, 51-57.

Selvig, E., "The 1976 Limitation Convention and Oil Pollution Damage", Lloyds Maritime and Commercial Law Quarterly, 1979, 21-25. 
Shapar, H., "L'Agence pour l'énergie nucléaire de l'OCDE: nouvelles orientations", AIEA Bulletin, vol. $25, \mathrm{n}^{\circ}$ $1,1983,23-25$.

Shapar, H.K., "La législation relative à l'indemnisation des dommages nucléaires aux Etats-Unis", Bulletin de Droit Nucleaire, $\mathrm{n}^{\circ} 15,1975,54-69$.

Shavell, S., "On Moral Hazard and Insurance", Quarterly Journal of Economics, 1979, 54 1-562.

Shavell, S., "Strict Liability versus Negligence", Journal of Legal Studies, 1980, I-25.

Shavell, S., "An Analysis of Causation and the Scope of Liability in the Law of Torts", Journal of Legal Studies, 1980, 463-519.

Shavell, S., "On Liability and Insurance", Bell Journal of Economics, Vol. 13, 1982, 120-132.

Shavell, S., "Liability for Harm versus Regulation of Safety", Journal of Legal Studies, 1984, 357-374.

Shavell, S., "Criminal Law and the Optimal use of Non-Monetary Sanctions as a Deterrent", Columbia Law Review, 1985, 1232-1262.

Shavell, S., "Uncertainty over Causation and the Determination of Civil Liability", Journal of Law and Economics, 1985, 587-609.

Shavell, S., "The Judgment Proof Problem", International Review of Law and Economics, 1986, 43-58.

Shavell, S., "Liability and the incentive to obtain information about risk", Journal of Legal Studies, vol. 21, 1992, 259-270.

Shavell, S., "On the social function and the Regulation of Liability Insurance", The Geneva Papers on Risk and Insurance, vol. $25, \mathrm{n}^{\circ} 2,2000,166-179$.

Shiane di Pepe, L., "The International Oil Pollution Compensations Funds: the Transitional Period and Beyond", Environmental Liability, 1998, $\mathrm{n}^{\circ}$ 3, 85-94.

Shimpi, P., "The context of Trading Insurance Risks", The Geneva Papers on Risk and Insurance, vol. 22, $\mathrm{n}^{\circ}$ $82,1997,17-25$.

Sieburgh, C.H., "Wat is rechtsinbreuk?", Nederlands Juristenblad, 1997, 628-635.

Simoens, D., "Hoofdlijnen in de evolutie van het aansprakelijkheidsrecht", Rechtskundig Weekblad, 19801981, 1962-2036.

Simoens, D., "Ongevallenrecht: grensgebieden van aansprakelijkheid, verzekering, en sociale zekerheid", Tijdschrif voor Privaatrecht, 1984, 417-460.

Simoens, D., "De gewijzigde vergoedingsregel ten voordele van voetgangers, fietsers en passagiers", Rechtskundig Weekblad, 1995-1996, 218-223.

Simoens, D., "De nieuwe verkeersongevallenwet: contouren van een genereus vergoedingsprincipe". Tijdschrift voor Belgisch Burgerlijk Recht, 1997, 54-57.

Skogh, G., "The Transaction Cost Theory of Insurance: Contracting Impediments and Costs", Journal Of Risk and Insurance, 1989, 726-732.

Skogh, G., "Development Risks, Strict Liability, and the Insurability of Industrial Hazards", The Geneva Papers of Risk and Insurance, vol. 23, $\mathrm{n}^{\circ} 87,1998,247-264$.

Sluijter, J., "Aansprakelijkheid bij kemongevallen", Recht en Kritiek, 1988, nr. 3, 196-199.

Smets, H., "Indemnisation des dommages à l'environnement causés par les activités industrielles autres que nucléaires", in Nuclear Third Party Liability and Insurance. Status and Prospects, Paris, Munich Symposium, OECD-NEA, 1985, 64-96.

Smets, H., "Le cout des pollutions accidentelles", in La réparation des dommages caiastrophiques. Les risques technologiques majeurs en droit international et en droit communautaire, Travaux des XIIIes Journées d'études juridiques Jean Dabin, Bruxelles, Bruylant, 1990, 23-46. 
Smets, H., "COSCA: a Complementary System for Compensation of Accidental Pollution Damage", in Wetterstein, P. (ed.), Harm to the Environmen:. The Right to Compensation and the Assessment of Damages, Clarendon Press, Oxford, 1997, 223-249.

Smith, H., "The International Commission on Radiation Protection: historical overview", IAEA bulletin, $1988 / 3,42-44$.

Smith, R.E., Canelo, E.A. en Di Dio, A., "Reinventing Reinsurance Using the Capital Markets", The Geneva Papers on Risk and Insurance, vol. 22, $\mathrm{n}^{\circ} 82,1997,26-37$.

Snijders, H.J., "Aansprakelijkheidsrecht na Gouderak en Spier", Weekblad voor Privaatrecht. Notariaat en Registratie, 1995, in. 6180, 303-306 en 6181, 319-322.

Soussan, G., "Les accords sur la couverture en commun de certains types de risques", in Het Europees Concurrentiebeleid in de Verzekeringssector, Academia-Bruylant, Lovain-la-Neuve, 1994, 55-63.

Spadaro, J.V., Langlois, L. en Hamilton, B., "Greenhouse gas emissions of electricity generation chains. Assessing the Difference", IAEA Bulletin, vol. 42, $\mathrm{n}^{\circ} 2,2000,19-24$.

Spier, J. en Sterk, C.H.W.M., "Van...naar risicoaansprakelijkheid", Tijdschrift voor Milieuaansprakelijkheid, 1990/3, 73-78.

Spier, J. en Sterk, C.H.W.M., "Noot 3. Naar risicoaansprakelijkheid voor gevaarlijke stoffen", Tijdschrift voor Milieuaansprakelijkheid, 1991/6, 164-167.

Spier, J., "De DES-dochters", Nederlands Tijdschrift voor Burgerlijk Recht, 1992, 193-198.

Spier, J. en Wansink, J.H., "Joint and Several Liability of DES-manufacturers: a Dutch Court Crisis", International Insurance Law Review, 1993, 176.

Spier, J., "De macht van het toeval", Weekblad voor Privaatrecht, Notariaat en Registratie, 1995, nr. 6205, 847-849.

Spier, J., "How to keep liability within reasonable limits? A brief outline of Dutch law", in Spier, J., The Limits of Liability. Keeping the Floodgates Shut, Kluwer Law International, Den Haag, 1996, 93-126.

Spier, J., "De (on)verzekerbaarheid van aansprakelijkheden", in Miscellanea Jurisconsulto vero Dedicata (van Dunné-bundel), Deventer, 1997, 409-422.

Spier, J., "Long Tail (Liability) Risks and Claims Made Policies", The Geneva Papers of Risk and Insurance, vol. $23, \mathrm{n}^{\circ} 87,1998,152-168$.

Spier, J., "Claimcuituur en aansprakelijkheidsrecht", in Niezen, G.J. Raaijmakers, M.J.G.C. en Tervoort, A.J.S.M. (red.), Ongebonden Recht Bedrijven. Bedrijfsjuridische opstellen op de grens van het derde millennium bij gelegenheid van het 70 -jarig bestaan van het Nederlands Genootschap van Bedrijfsjuristen, Kluwer, Deventer; 2000, 223-231.

Stein, R.M., "La nouvelle Législation Américaine relative à la propriété privée des matières nucléaires", in Puget, H., Aspects de droil de l'énergie atomique, tome II, Centre français de droit comparé, Paris, 1967, 28829 i.

Stein, R.M., "The European Nuclear Energy Agency", in Nuclear Law for a Developing World, Legal Series $n^{\circ}$ 5, IAEA, Vienna, 1969, 21-32.

Sterk, C.H.W.M., "De aansprakelijkheid voor gevaarlijke stoffen en afvalstoffen", Weekbiad voor Privatrecht, Notariaat en Registratie, 1991, 5991, 73-84 en 5992, 89-94.

Stigler, G. "The Theory of Economic Regulation", Bell Journal of Economics, 1971, 3-21.

Stoiber, C., "The Convention on Nuclear Safety - an Introduction", in Nuclear Inter Jura 1905, Verslagboek van het Tweejaarlijkse Congres van de International Nuclear Law Association (INLA/AIDN), Helsinki, Finland, 1995, 655-669.

Stoiber, C., "The Peer Review Process of the Nuclear Safety Convention", in Pelzer, N., (herausg.), Neues Atomenergierecht - Internationale und nationale Entwicklungen, Nomos, Baden-Baden, 1995, 41-46. 
Stoiber, C., "International Convention in Nuclear Safety: National Reporting as the Key to Effective Implementation", in Horbach, N.L.J.T. (ed.), Contemporary Developments in Nuclear Energy Law. Harmonising Legislation in CEEC/NIS, Kluwer Law International, Den Haag, Boston, 1999, 97-113.

Stolker, C.J.J.M., "U bent met te veel, dus krijgt u niets! Amerikaanse ervaring met collectief schadeverhaal", in Massaschade. Vergt de behandeling van massale schade een bijzondere benadering?, Inleidingen gehouden op het symposium van de Vereniging van Letselschade Advocaten 1996, Koninklijke Vermande, Lelystad, 1996, 39-53.

Strohl, $\mathrm{P}$., "La Convention de 1971 relative à la responsabilité civile dans le domaine du transport maritime de. matières nucléaires", Annuaire Français de Droit International, 1972, 755-760.

Strohl, P. "Chemobyl et le problème des obligations intemationales relatives aux accidents nucléaires", Revue de Politique Etrangère, $1986, \mathrm{n}^{\circ} 4$.

Strohl, P., "Code de bonne conduite pour les utilisations pacifiques de l'énergie nucléaire", L'option nucléaire. L'éthique et le droit, conferentie 12-13 mei 1994, Tunis, 286-302.

Strohl, P.,"Bilan de Recherches de la Section de langue française du Centre d'étude et de recherche de l'Académie", in Les Risques Résultant de l'Utilisation Pacifique de l'Energie Nucléaire, Académie de droit international de La Haye, Centre d'étude et de recherche de droit international et de relations internationales, Kluwer Academic Publishers, Dordrecht, 1993, 15-206.

Strohl, P., "La Convention sur la sûreté nucléaire", Annuaire Français de Droit International, 1994, 804-822.

Strohl, P., "The originality of nuclear law and its future", in Le droit nucléaire: du XXe au XXIe Sciècle. Nuclear Inter Jura 97, Société de Législation Comparée, Paris, 1998, 571-583.

Stroink, F., "Nogmaals het Fonds luchtverontreiniging", Milieu en Recht, 1974, 121-124.

Suransky, F., "Increased Liability Amounts under the 1997 Vienna Protocols and elsewhere", in Reform of Civil Nuclear Liability, International Symposium, Budapest 1999, OECD, Parijs, 2000, 115-123.

Sturms, W.W., "Internationale ontwikkelingen met betrekking tot aansprakelijkheid voor milieuschade", X., Risicoaansprakelijkheid voor milieuschade, Vereniging voor milieurecht, W.E.J. Tjeenk Willink, Zwolle, 1992, 124-149.

Sturms, W.W., "Internationale ontwikkelingen met betrekking tot aansprakelijkheid voor milieuschade", Tijdschrift voor Milieuaansprakelijkheid, 1992/5, 155-166.

Sturms, W.W. en Sinha, S., "Nuclear Third Party Liability", Nuclear Engineering International, 1995, 32-34.

Swinnen, J., "Burgerlijke aansprakelijkheid voor milieuschade door olieverontreiniging afkomstig van schepen: recente ontwikkelingen", Milieu- en Energierecht, 1999, ni. 3, 75-79.

Stuyck, J., "Europees en nationaal concurrentierecht in de verzekeringssector", in Het Europees Concurrentiebeleid in de Verzekeringssector, Academia-Bruylant, Louvain-la-Neuve, 1994, 89-1 19.

Suontausta, T., "L'exclusion de la responsabilité en cas ce qui concernent les dommages à l'installation ellemême et aux biens qui se trouvent sur le site de cette installation", in Nuclear Inter Jura '73, AIDN/INLA, Karlsruhe, 1973, 79-83.

Taft, W.A, "Rent-a-captive - not a halfway house", in Risk Financing Options, Risk and Insurance Research Group, 1994, 15-17.

Tenière-Buchot, P.F., Clave, A. en Hetzel, J., "Méthodologies et pratiques d'indemnisation des dégâts provoqués par les pollutions accidentelles", in La réparation des dommages catastrophiques. Les risques technologiques majeurs en droit international et en droit communautaire, Travaux des XIlies Journées d'études juridiques Jean Dabin, Bruxelles, Bruylant, 1990, 183-205.

Theunis, J., "Bevoegdheden en bevoegdheidsgrenzen inzake leefmilieu: een stand van zaken", in Deketelaere, K. (red.), Milieurecht in Belgie. Status Questionis Anno 1997, Die Keure, Brugge, 1997, 51-81.

Thiem, V., "Environmental Damage Funds", in Compensation for Pollution Damage, OECD, Parijs, 1981, 144-180. 
Thorstensen, S. en Chitumbo, K., "Safeguards in the European Union: the New Partnership Approach", IAEA Bulletin, $\mathrm{N}^{\circ} 1,1995,25-28$.

Tjittes, R.P.J.L., "Centralisering van aansprakelijkheden", Nederlands Juristenblad, 1995, 274-282.

Tjoeng, L.M., "Het polismodel AVB 96 en de overgang van occurrence naar claims made", Aansprakelijkheid \& Verzekering, 1996/6, 127-133.

Toll, D.R., "Liability: Insurance and Legislative Aspects", in Mayda, J. (Ed.), Atomic Energy and Law, Interamerican Symposium, Puerto Rico, November 1959, School of Law, University of Puerto Rico, 133-140.

Tonhauser, W., "The Joint Convention on the Safety of the Spent fuel Management and on the Safety of Radioactive Waste Management", in Le droit nucléaire: du XXe au XXIe sciècle. Nuclear Inter Jura '97, Société de Législation Comparée, AIDN/INLA, Paris, 1998, 535-539.

Trebilcock, M. en Winter, R.A., "The Economics of Nuclear Accident Law", International Review of Law and Economics, vol. 17, 1997, 215-243.

Trevor, J.P.H., "Principles of civil liability for nuclear damage", in Nuclear Law for a developing world, IAEA, Vienna, Legal Series $n^{\circ} 5,1969,109-115$.

Trevor, J.P.H., "Third party liability. The intemational legal fiamewordk and its transposition into national legislation", in Insurance for Nuclear Installations, LAEA, Legal Series $N^{\circ}$ 6, Vienna, 1970, $41-47$.

Tromas, S., "Multinational Companies and Environmental Liability", Environmental Liability, vol. 3, 1998, $71-80$.

Tunc, A., "Les problèmes contemporains de la responsabilité civile délictuelle", Revue Internationale de Droit Comparé, $1967,757-777$.

Tunc, A., "Machine et protection de l'homme", in Keller, M. (herausg.), Revolution der Technik. Evolutionen des Rechts. Festgabe zum 60. Geburtsiag von Karl Ofinger, Zürich Schultess \& Co, 1969, 311-320.

Tune, A., "Responsabilité civile et assurance", Hommage à R. Dekkers, Bruxelles, Bruylant, 1982, 343-357.

Tyran, J.R. en Zweifel, P., "Environmental Risk Internalization through capital markets (ERICAM): the Case of Nuclear Power", International Review of Law and Economics, 1993, vol. 13, nr. 4, 431-444.

Ungerer, W., "Die Rolle intemationaler Organisationen bei der Verhinderung mißbräuchlicher Verwendung der Kernenergie", in Kaiser, K. en Lindennann, B. (herausg.), Kernenergie und Internationale Politik, R. Oldenbourg Verlag, München, 1975, 153-226.

Vaísse, M., "La coopération nucléaire en Europe (1955-1958)", in L'énergie Nucléaire en Europe: des Origines à Euratom, Actes de journées d'études de Louvain-la-Neuve 18-19 november 1991, Peter Lang, Bern, 1994, 99-110.

Van, A.J., "Statistisch bewijs van causaal verband. Bespreking van High Court of Justice 8 October 1993 (Sellafield claims)", Tijdschrift voor Milieuaansprakelijkheid, 1994, 109-118.

Van Aerschot, R., "Produktaansprakelijkheid, een verzekeringsproduct in beweging", Bulletin des Assurances, $1988,224-231$.

Van Crombrugghe, B., "L'assurance contre les accidents du travail: un modèle d'avenir", Bulletin des Assurances, 1995, 206-240.

Van Dam, C.C., "Het wetsvoorstel verkeersongevallen. Verzekeringsdekking voor personenschade in het verkeer", Verkeersrecht, 1997, nr. 12, 353-358.

Van den Bergh, R. en Faure, M., "De invloed van verzekeringen op de civiele aansprakelijkheid, een rechtseconomische analyse", in Preadviezen uitgebracht voor de l'ereniging voor Burgerlijk Recht, Lelystad, Vermande, 1990, 9-53.

Van den Bergh, R., "Wat is rechtscconomie?", in Hondius, E.H., Schippers, J.J. en Siegers, J.J. (red.), Rechtseconomie en Recht. Een kennismaking met een rechtsgebied in opkomst, W.E.J. Tjeenk Willink, Zwolle, 1991, 9-49. 
Van den Bergh, $R$, "Automatische vergocding van schade geleden door zwakke verkeersdeelnemers: een rechtseconomische kritiek", in Faure, M. en Hartlief, T. (red.), Verkeersaansprakelijkheid in België en Nederland, Intersentia, Antwerpen, Groningen, 1998, 27-74.

Van den Bergh, R. en Heremans, D., "Over krommen rechten. Een reactie op de kritiek van Kruithof ten aanzien van de economische analyse van het recht", Rechtskundig Weekblad, 1986-87, 1649-1668.

Van den Bergh, R. en Heremans, D., "Recht en Economie", Tijdschrift voor Economie en Management, 1987, 139-164.

Vandenberghe, H., Van Quickenborne, M. en Hamelinck, P., "Aansprakelijkheid uit onrechtmatige daad (1964-1978)", Tijdschrift voor privaatrecht, 1980, 1139-1142.

Vandenberghe, H., Van Quickenbome, M., Geelen, K. en Decoster, S., "Overzicht van rechtspraak (19791984). Aansprakelijkheid voor onrechtmatige daad", Tijdschrift voor Privaatrecht, 1987, 1255-1615.

Vandenberghe, H., Van Quickenborne, M. en Wynant, L., "Overzicht van rechtspraak (1985-1993). Aansprakelijkheid uit onrechtmatige daad", Tijdschrift voor Privaatrecht, 1995, 1115-1534.

Vanden Borre, T., "Liability for Isotopes used in Radioatherapy", Nuclear Inter Jura 1995, Verslagboek van het Tweejaarlijkse Congres van de International Nuclear Law Association (INLA/AIDN), Helsinki, Finland, $1995,209-272$.

Vanden Borre, T., "Preventing the Proliferation of Nuclear Weapons: 50 Years of Aroms for Peace", Nuclear Law Bulletin, 1996, vol. 57, 23-52.

Vanden Borre, T., "Transplantatie van 'kanalisatie van aansprakelijkheid' van het kemenergierecht naar het milieu(aansprakelijkheids)recht: een goede of een gebrekkige zaak?", Faure, M. en Deketelaere, K., Ius Commune en Milieurecht. Aciualia in het Milieurecht in België en Nederland, Intersentia, Antwerpen, Groningen, 1997, 331-382.

Vanden Borre $T$., "Dekking van het nucleaire risico op nationaalrechtelijke basis of via internationalc Verdragen: de Verenigde Staten versus Europa", Deketelaere, K., Faure, M. en Verhoosel, G. (red.), Grensoverschrijdende milieuproblemen: uitdagingen voor de nationale en de internationale rechtsorde, Intersentia, Antwerpen, Groningen, 1998, 443-490.

Vanden Borre, T., "Channelling of Liability: a Fex Juridical and Economic Views on an Inadequate Legal Construction", Horbach, N.L.J.T. (ed.), Contemporary Developments in Nuclear Energy Law. Harmonising Legislation in CEEC/NIS, Kluwer Law Intemational, Den Haag, Boston, 1999, 13-39.

Vanden Borre, T., "Recente ontwikkelingen in het nucleaire aansprakelijkheidsrecht: innovatie of renovatie?", Milieu- en Energierecht, 2001-1, 25-49.

Van de Poele, A., "Ervaringen van een verzekeraar inzake de selectie van verzckerde risico's met betrekking tot milieuschade", in Bocken, H. en Ryckbost, D. (ed.), Verzekering van Milicuschade, Verslagboek van het Internationaal Colloqium gehouden te Gent op 14 en 15 december 1989, Story Scientia, Gent, 1991, 301-310.

Van der Mensburgghe, Y., "Le droit international de l'environnement marin", in Shipping Law Faces Europe: European Policy, Competition and Environment, Maklu, Antwerpen-Apeldoom, Bruylant, Brussel, 1995, 123-133.

Van der Schaaf, F.A., "Voor- en narisico in het polismodel AVB96", Aansprakelijkheid \& Verzekering, $1996 / 6,122-126$.

Van Dunné, J.M., "De rechtspraak inzake milieuaansprakelijkheid uit onrechtmatige daad: van schuldbeginsel naar risicobeginsel", Tijdschrift voor milieuaansprakelijkheid, 1987-1, 3-9.

Van Dunné, J.M., "Een kamikaze-aktie op de Rotte. De visie van Vranken op de aansprakelijkheid uit artikel $1401 \mathrm{BW}$, in het bijzonder bij bodemvervuiling uit het verleden", Weekblad voor Privaatrecht, Notariaat en Registratie, 1990, 5976.

Van Dunné, J.M., "Wie sterk is mag dom zijn. De uitspraken van de Hoge Raad, andermaals als wetgeverplaatsvervanger, inzake grootschalige milieuvervuiling in het verleden door Shell, Philips-Duphar en Fasson", Nederlands Juristenblad, 1994, 1329-1338. 
Van Dunné, J.M., "Alternatieve causaliteit: de DES-regel toegepast bij milieuaansprakelijkheid", Tijdschrift voor milieuaansprakelijkheid, 1997, 51-55.

Van Dunné, J.M. en Smale, L.J., "Aansprakelijkheid voor milieuschade en financięle zekerheid naar huidig recht: knelpunten en gerealiseerde oplossingen - Nederlands recht", in Wiggers-Rust, L.F. (red.), Aansprakelijkheid voor milieuschade en financiële zekerheid. Een vergelijking van Nederlands, Belgisch en Europees recht, Die Keure, Vermande, Brugge, 1998, 15-61.

Van Dunné, J.M., "Causaliteitsproblemen in het milieu-aansprakelijkheidsrecht: alternatieve causaliteit en res ipso loquitur", Tijdschrifi voor Milieuaansprakelijkheid, 1999-4, 119-125 en 1999-5, 145-157.

Van Gelein Vitringa, J., "Openbaarheid van den weg en burgerlijk recht", Rechtsgeleerd Magazijn Themis, $1919,23-50$.

Van Gerven, W., "De invloed van de verzekering op het verbintenissenrecht", Rechiskundig Weekblad, 1962 $1963,777-792$.

Gerven, W., "Non-contractual Liability of Member States, Community Institutions and Individuals for Breaches of Community Law with a View to a Common Law for Europe", Maastricht Journal of European and Comparative Law, 1994, afl. 1, 6-41.

Van Gerven, W., "Bridging the unbridgeable: community and national tort laws after Francovich and Brasserie", International and Comparative Law Quarterly, vol. 45 1996, 507-544.

Van Gerven, W., " The ECJ's Recent Case-Law in the Field of Tort Liability; Towards a European Ius Commune? ", in Jansen, R., Koster, D., Van Zutphen, R. (ed.), European Ambitions of the National Judiciary, Kluwer Law International, Den Haag, 1997, 91-110.

Van Gijn, S.H., "Liability and insurance aspects of international transport of nuclear materials", in Nuclear Third Party Liability. Status and Prospects, Munich Symposium, Paris, 1985, 183-190.

Van Hanswyck, B., "The 1984 Protocols to the International Convention on Civil Liability for Oil Pollution Damages and the International Fund for Compensation for Oil Pollution Damages: An Option for Needed Reform in United States Law", The International Lawyer, 1988, vol. 22, 319-343.

Van Hecke, S., "Drie jaar vorderingsrecht inzake bescherming leefmilieu": analyse van de eerste rechtspraak", Tijdschrift voor Milieurecht, 1996, 2-18.

Vanheusden, B., "Het Federale Plan inzake Duurzame Ontwikkeling: de impact op het Belgische bedrijfsleven via productnormen, verhandelbare emissierechten en milieuheffingen", in Deketelaere, $K$. en Deketelaere, M. (eds.), Jaarboek Milieurecht 2000, Leuvern, Milieurechtstandpunten 15, Brugge, Die Keure, 2001, 185-246.

Van Leeuwen, M., "Nuclear Protiferation in the Middle-East", in van Leeuwen, M. (ed.), The Future of the Internatianal Nuclear Non-Proliferation Regime, Martinus Nijhoff Publishers, Dordrecht, 1995, 125-153.

Van Maanci, G.E., "Wettelijke aansprakelijkheid voor kemcentrales", Nederlands Juristenblad, 1981, 286292.

Van Maanen, G.E., "De mythe rond het actest Lindenbaum-Cohen (31 januari 1919)", Recht en Kritiek, 1983 , 51-87.

Van Maanen, G.E., "Onrechtmatige Daad tussen BW en NBW. Overeenkomsten en verschillen in de wettelijke struktuur van de art!. 1401 en 1402 BW 1838 en art. 6.3.1.1 NBW", Groninger opmerkingen en mededelingen. Magazijn voor Leerstellige Rechtsvergelijking op Historische Grondslag, II, 1985, 156.

Van Maanen, G.E., "Pleidooi voor verbetering van de rechtspositie van slachtoffers van kemongevallen", Nederlands Juristenblad, 1986, 1342-1345.

Van Maanen, G.E., Spier, J. en Sterck, C.H.W.M., "Van schuld naar risico. Enkele opmerkingen over ontwikkelingen in het aansprakelijkheidsiecht", in Raaijmakers, M.J.G.C., Van Rooij, Spier, J., Aansprakelijkheden. Opstellen rond her thema ontwikkelingen in het aansprakelijkheidsrecht bij gelegenheid van het 60-jarig bestaan van het Nederlands Genootschap van Bedrijfsjuristen, Kluwer, Deventer, 1990, 65143. 
Van Maanen, G.E., "Aansprakelijkheid voor schade door gevaarlijke stoffen en verontreiniging van lucht, water of bodem", Weekblad voor Privaatrecht, Notariaat en Registratie, 1990, 5946, 55-62.

Van Maanen, G.E., "De civielrechtelijke aansprakelijkheid voor kemongevallen naar Nederlands recht", in Faure, M. (red.), Aansprakelijkheid voor het nucleaire risico, Maklu, Antwerpen-Apeldoom, 1993, 19-35.

Van Maanen, G.E., "Bodemsanering na Duphar, Fasson en Gouderak", Aansprakelijkheid en Verzekering, $1994 / 6,139-143$.

Van Maanen, G.E., "Kroniek van het vermogensrecht", Nederlands Juristenblad, 1995, 338-346.

Van Maanen, G.E., "De relativiteit als onlosmakelijk bestanddeel van de onrechtmatigheidsvraag", in Miscellanea Jurisconsulto vero Dedicata (van Dunné-bundel), Deventer, 1997, $255-272$.

Van Miert, K., "La politique Européenne de la Concurrence en matière d'Assurances", in Het Europees Concurrentiebeleid in de Verzekeringssector, Academia-Bruylant, Lovain-la-Neuve, 1994, 23-28.

Van Oevelen, A., "Enige bedenkingen van een jurist bij de economische analyse van het aansprakelijkheidsrecht", in Van den Bergh, R. (ed.), Verslagboek Eerste Werkvergadering Recht en Economie, Antwerpen, Handelshogeschool, 1986, $21-30$.

Van Oevelen, A., "Objectieve aansprakelijkheid voor schade veroorzaakt door milieuverontreiniging volgens het Belgische recht", Preadvies voor de Vereniging voor Milieurecht, Risico-aansprakelijkheid voor Milieuschade, W.E.J. Tjeenk Willink, Zwolle, 1992, 81-124.

Van Oevelen, A., "La modération de la réparation du dommage dans le droit belge de la responsabilité civile extra-contractue!le", in Spier, J., The Limits of Liability. Keeping the Floodgates Shut, Kluwer Law Intemational, Den Haag, 1996, 65-74.

Van Schoubroeck, C. en Schoorens, G., "De aansprakelijkheidsverzekering: a never ending story?", Tijdschrift voor Belgisch Handelsrecht, 1995, 636-663.

Van Schoubroeck, C. en Schoorens, G., "De aansprakelijkheidsverzekering: HST of ontsporing?", in Landverzekering en motorrijtuigenverzekering. Een kritische commenataar bij recente wetswijzigingen, Centrum voor Verzekeringswetenschap, Leuven, 1995, 155-186.

Van Schoubroeck, C., "Wetgeving en praktijk inzake natuurrampen en verzekering in enkele Europese landen", in Cousy, H. en Claassens, H. (ed.), Natuurrampen en Verzekering, Verslagboek van de Negende Leuvense Verzekeringsdagen, Maklu, Antwerpen-Apeldoorn, 1995, 79-120.

Van Schoubroeck, C. en Schoorens, G., "Dekking in de tijd: een vergelijkend overzicht van de regeling in enkele Europese landen", in Cousy, H. en Claassens, H. (ed.), Aansprakelijkheidsverzekering: dekking in de tijd, Maklu, Academia-Bruylant, Antwerpen, Apeldoorn, 1997, 205-240.

Van Schoubroeck, C., "Legislation and practice concerning natural disasters in insurance in a number of European countries", The Geneva Papers of Risk and Insurance, 1997, $n^{\circ} 83.238-267$.

Vansweevelt, T., "Onderzoek naar de grondslag en de begrenzing van de aansprakelijkheid voor dieren", Rechtskundig Weekblad, 1985-1986, 2187-2214.

Vansweevelt, T., "Les risques de développement", in Les Assurances de l'Entreprise, vol. II, Brussel, Bruylant, 1993, 317-358.

Vedel, G., "Un problème difficile: la responsabilité des fournisseurs envers les exploitants d'installations nucléaires en cas de dommage nucléaire imputable au fait de ceux-ci", Cahiers Juridiques de l'électricité et de $g a z, 1973,249-263$.

Veljanovski, C.G., "The Economic Theory of Tort Liability - toward a Corrective Justice Approach", in Burrows, P. en Veljanovski, C.G. (eds.), The Economic Approach to Law, Butterworths, London, 1981, 125150 .

Veljanovski, C.G., "The Coase Theorems and the Economic Theory of Markets and Law", Kykios, Vol. 35, 1982, 53-74. 
Verhoeven, J., "Une réparation communautaire ou internationale des catastrophes? Conclusions", in $L a$ réparation des dommages catastrophiques. Les risques technologiques majeurs en droit international et en droil communaulaire, Travaux des XIlles Joumées d'études juridiques Jean Dabin, Bruxelles, Bruylant, 1990, $457-491$.

Vermaat, A.J., "Uninsurability: a Growing Problem", The Geneva Papers On Risk and Insurance, vol. 20, ${ }^{\circ}$ $76,1995,446-453$.

Vernimmen, G., "Obligation de prévention et de sauvetage et prise en charge des frais par l"assureur (article 17 de la loi du 11 juin 1874)", Receuil Générale des Assurances el des Responsabilités, 1977, 79-93.

Veuchelen, L., "De civielrechtelijke aansprakelijkheid voor kernongevallen naar Belgisch recht", in Faure, M. (red.), Aansprakelijkheid voor het nucleaire risico, Maklu, Antwerpen-Apeldoorn, 1993, 37-64.

Vincineau, M., "Un Imbrogolio juridique: la loi du 20 juillet 1976 portant approbation et exécution de la Convention Internationale sur la responsabilité pour les dommages dus à la pollution des Hydrocarbures, faite à Bruxelles le 29 novembre 1969", Revue Belge de Droit International, 1978-79, 693-716.

Viney, G., "Modération et limitations des responsabilités et des indeminsations", in Spier, J., The Limits of Liability. Keeping the Floodgates Shut, Kluwer Law International, Den Haig, 1996, 127-136.

Visscher, L.T. en Kerkmeester, H.O., "Kenbaarheidsvereiste en gewoonte als verweren tegen een aansprakelijkheidsactie: een rechtseconomische benadering", Tijdschrift voor Milieunansprakelijkheid, $1996 / 3,48-56$.

Von Bar, C., "Environmental Damage in Private International Law", Recueil des Cours, Academy of International Law, 1997, Tome 268, Martinus Nijhoff Publishers, Den Haag, 1999, 291-411.

Von Busekist, O., "Le Protocole Commun relatif à l'application de la Convention de Vienne et de la Convention de Paris: Une passerelle entre les deux Conventions sur la responsabilité civile pour les dommages nucléaires", Bulletin de Droit nucléaire, nr. 43, juni 1989, 10-45.

Von Busekist, O., "Haftungsprobleme im Verhälnis zwischen Vertragsstaaten des Pariser und des Wiener Atomhaftungsubereinkommens", in Pelzer, N., (herausg.), Friedliche Kernenergienutzung und Staatsgrenzen in Mitteleuropa, Nomos, Baden-Baden, 1987, 271-303.

Von Busekist, O., "The Joint Protocol Relating to the Application of the Vienna and the Paris Conventions One Step towards the Necessary Modernisation of the Intemational Nuclear Civil Liability Regime", in Nuclear Inter Jura '89, AIDN/INLA, 1989, II-69.

Von Caemerer, E., "La responsabilité du fait des choses inanimées et le risque atomique", in Puget, H., Aspects de droit de l'énergie alomique, tome II, Centre français de droit comparé, Paris, 1967, 19-29.

Von Fürstenwerth, F., "European Competition rules in the Insurance Sector", in Het Europees Concurrentiebeleid in de Verzekeringssector, Academia-Bruylant, Louvain-la-Neuve, 1994, 65-70.

Von Gelderen, E.R., "Le développement de l'énergie nucléaire et la collaboration entre Euratom, l'industric nucléaire, les producteurs d'électricité et les assureurs", Quatrième colloque sur l'assurance du risque nucléaire, Euratom, EUR 2642, 1966, 32-33.

Von Welck, S., "La troisième Conférence des Nations Unies sur le droit de la mer et l'utilisation de l'énergie nucléaire", Bulletin de Droit Nucléaire, $\mathrm{n}^{\circ} 15,1975,70-79$.

Vranken, J.B.M., "Zorgvuldigheidsnorm en aansprakelijkheid voor bodemverontreiniging uit het verleden", Weekblad voor Privaatrecht, Notariaat en Registratie, 1990, 5953, 177-181; 5954, 193-199; 5955, $211-216$.

Waelbroeck, D., "An Introduction ro European Competition Rules and their impact on Shipping Law", in Shipping Law Faces Europe: European Policy, Competition and Environment, Maklu, Antwerpen-Apeldoom, Bruylant, Brussel, 1995, 157-172.

Wagner, F., "Risk Securitization. An Alternative of Risk Transfer of Insurance Companies", The Geneva Papers on Risk and Insurance, vol. 23, n 89, 1998, 540-607.

Waleffe, F., "Assurances sociales, assurances privées", Revue belge de Sécurité Sociale, 1963, 46-67. 
Wansink, J.H., "De nieuwe milieuaansprakelijkheidsverzekering", Milieu en Recht, 1985/4, 98-105.

Wansink, J.H., "Verzekering van aansprakelijkheid voor gevaarlijke stoffen in het NBW", Tijdschrift voor Milicuaansprakelijkheid, 1990/3, 65-71.

Wansink, J.H., "Enige rechtsvergelijkende beschouwingen over titel 7.17 en de Belgisehe wet op de landverzekeringsovereenkomst van 1992", in In volle Verzekerdheid, W.E.J. Tjeenk Willink, Zwolle, 1993, $379-393$.

Wansinsk, J.H., "Environmental Liability Insurance: Tour d'Horizon in Europe", Transnational Environmental Liability and Insurance, Graham \& Trotman, Londen, 1993, 1-20.

Wansink, J.H., "Het DES-arrest in het perspectief van verzekerbare slachtofferbescherming", Aansprakelijkheid \& Verzekering, 1993, 7-12.

Wansink, J.H., "Gradual pollution and retrospective liability", Pollution and Insurance Bulletin, AIDA, nr. 10, $1995,19$.

Wansink, J.H., "Claims made policies and the test of legality in Europe", Pollution and Insurance Bulletin, AIDA, nr. 10, 1995, 3-4.

Wansink, J.H., "De aansprakelijkheidsverzekering en de dekking van 'long-tail risico's"', Aansprakelijkheid \& Verzekering, 1995/1, 1-6.

Wansink, J.H., "Het polismodel AVB 1996 en de dekking voor 'long-tail risico's"', Aansprakelijkheid \& Verzekering, 1996/6, 120 122.

Wansink, J.H., "Rapport voor Nederland inzake aansprakelijkheidsverzekering: dekking in de tijd", in Cousy, H. en Claassens, H. (ed.), Aansprakelijkheidsverzekering: dekking in de tijd, Maklu, Academia-Bruylant, Antwerpen, Apeldoorn, 1997, 129-152.

Wansink, J.H., "Hoe plotseling en onzeker is de verzekeringsdekking voor milieuaansprakelijkheidsrisico's?", in Miscellanea Jurisconsulto vero Dedicata (van Dunné-bundel), Deventer, 1997, 451-460.

Wansink, J.H., "Verzekering en milieuschade als gevolg van vervoer/opslag van gevaarlijke stoffen", Tijdschrift voor Milieuaansprakelijkheid, 1999/3, 77-82.

Warren, G.C., "Nuclear legislation and practical difficulties in settling claims", in Nuclear Jura ' 91 , Bath, AIDAN/INLA, 1991, 335-351.

Warren, G.C., "Vienna Convention revision: a review of the exercise and the insurance implications in the provisions under discussion", Nuclear Law Bulletin, $\mathrm{n}^{\circ} 55,1995,9-17$.

Warren, G.C., "Pooling operations: how nuclear insurance works", Nuclear Engineering International, 1995, $30-32$.

Warren, G.C., "Insurance for the Nuclear Industry", in Horbach, N.L.J.T. (ed.), Contemporary Developments in Nuclear Energy Law. Harmonising Legislation in CEEC/NIS, Kluwer Law Intemational, Den Haag, Boston, 1999, 341-348.

Warren, G.C., "Nuclear Damage under the 1977 Protocol: Conventional Thinking?", in Reform of Civil Nuclear Liability, International Symposium, Budapest I999, OECD, Parijs, 2000, 85-97.

Warrikoff, A., "Soll Deutschland die Pariser Atomhaftungskonvention ratifizieren?", Atomwirtschaft, maart $1965,129-131$.

Wetterstein, P., "Trends in maritime environmental impairment liability", Lloyd's Maritime and Commercial Law Quarterly, 1994, 230-247.

Wetterstcin, P., "Les dommages causés par les catastrophes internationales à la lumière du droit de la responsabilité civile et du droit des assurances", in Les dommages causés par les catastrophes internationaies. Le contrôle financier des compagnies d'assurances, AIDA, Kopenhagen, 1990, 163-265.

White, I.C., "The Voluntary Oil Spill Compensation Agreements - TOVALOP and CRISTAL", in De la Rue, C.M. (ed.), Liability to the Marine Environment, Lloyd's of London Press, 1993, 57-69. 
White, LC., "TOVALOP and CRISTAL give way to the Legal Regimes - the Continuing Role: of ITOPF", ongepubliceetd, 1996.

Windibank, T. en Rodger, A., "Reinsuring captives", in Risk Financing Options, Risk and Insurance Research Group, 1994, 19-20.

Wils, W.P.J., "Insurance Risk Classification in the EC: Regulatory Outlook", Oxford Journal of Legal Studies, 1994, 449-467.

Wilson, R., "Nuclear Liability and the Price Anderson Act", Forum, 1977, v 12(2), 612-621.

Winter, H., "Sequential Torts with Imperfect Information", International Review of Law and Economics, 1994, vol. 14, 35-40.

Wiwen-Nilsson, T., "Memorandum. Liability of Suppliers and Contractors for nuclear damage to on-site property under the Vienna Convention for Nuclear Damage 1963", NEA/LEG/DOC(97)5.

Wurtbain, J.W., "De verzekerbaarheid van asnsprakelijkheid, een terreinverkenning", in Raaijmakers, M.J.G.C., Van Rooij, R. en Spier, J., Aansprakelijkheden, Kluwer, Deventer, 1990, 235-244.

X., "Champ d'Application des Conventions Nucléaires", Bulletin de Droit Nucléaire, n 5, 1970, 25-31.

X., "Détermination des reserves techniques en matière d'assurance des risques atomiques", Comité Européen des Assurances, Insurance for Nuclear Insiallations, IAEA, Legal Series No $^{\circ}$, Wenen, 1970, 113-114.

X., "Duurzame onderneming straks goed verzekerd", Bondig Dossier, Verbond der Verzekeraars, juni 1997.

$\mathrm{X}$., Nuclear Power and Health. The implications for health of nuclear power production, WHO Regional Publications, European Series, $n^{\circ} 51,1994$.

X., "One decade after Chernobyl: the basis for decisions", IAEA Bulletin, 3/1996, 14-23.

X., "Outlook on International Nuclear Liability", Nucleonics Week, 29 september 1994, 1-24.

X., "Post-Chemobyl scientific perspectives: Reports on topics addressed at technical sessions of the International Conference convened in Vienna 10 years after the Chemobyl accident", IAEA Bulletin, 3-1996, 24-47.

X., "Potential Liabity of Contractors working on Nuclear Safety improvement Projects in Central and Eastem Europe", Nuclear Law Bulletin, $\mathrm{n}^{\circ}$ 53, 1994, 36-43.

X., "Power Play. Hoe Electrabel de liberalisering afremt", Trends, oktober 2000, 24-29.

X., "Radiation levels: WHO reports on Chernobyl", met aansluitend "Nationai Reports", in IAEA Bulletin, autumn 1986, 27-39.

X., "Questions soulcvées par l'application des Conventions sur la responsabilité civile nucléaire aux installations d'évacuation des déchets radioactifs", Bulletin de Droit Nucléaire, n 55, juni 1995, 19-24.

$X$., "Tasten in het duister", dossier kemenergie, Knack nr. 44 van november 2000, 28-35.

$\mathrm{X}$, Tchernobyl. Dix ans déjà. Impact radiologique ei sanitaire, Evaluation établie par le Comité de protection radiologique et de sante publique de l'AEN, OECD-AEN, Paris, 1996.

X., "Voomaamste bepalingen voor een verzekeringscontract betreffende de wettelijke aansprakelijkheid van vaste keminstallaties", kaderpolis Euratom, EUR 3127.n, 1966.

Zahariev, K., "Nuclear Liability from the Perspective of the European Bank for Reconstruction and Development", in Nuclear Inter Jura 1999, AIDN/INLA, Washington, 1999, 277-282.

Zeckhauser, R., "19th Annual lecture of the Geneva Association. Insurance and Catastrophes", The Geneva Papers on Risk: and Insurance, vol. 21, $\mathrm{n}^{\circ}$ 78, 1996, 3-21.

Zech, J., "Will the International Insurance Market replace Traditionai Insurance Products", The Geneva Papers on Risk and Insurance, vol. $23 n^{\circ} 89,1998,492-495$. 


\section{CURRICULUM VITAE}

Tom Vanden Borre werd geboren op 25 december 1969 te Gent (België). Hij studeerde rechten aan de Universiteit Gent (diploma behaald in 1992) en vervolgens aan de Université Catholique de Louvain (Louvain-La Neuve) waar hij zich specialiseerde in internationaal en Europees recht (diploma behaald in 1993). Van 1993 tot 1997 was hij als bedrijfsjurist werkzalam bij het Studiecentrum voor Kernenergie te Mol; tegelijk startte hij de voorbereiding van zijn promotie aan Instituut METRO van de Universiteit Maastricht. Van 1997 tot 2001 werkie hij als bedrijfsjurist bij Biffa Waste Services België. Sinds juli 2001 werkt hij als consultant bij Deloitte \& Touche (email: tvandenborre@deloitte.com).

Tom Vanden Borre is lid van de Werkgroep Aansprakelijkheid en Verzekering evenals van de Werkgroep Grensoverschrijdend Milieurecht van de Ius Commune Onderzoeksschool (een samenwerkingsverband tussen de juridische faculteiten van de Universiteit Maastricht, Katholieke Universiteit Leuven en Universiteit L/trecht). 
In dit boek wordt onderzocht hoe de aansprakelijkheid voor schade door catastroferisico's op efficiente wijec kan worden geregeld en op welke wijze kan worden voorzien in een adequaat compensatiesysteem. Uitgaande van de nucleaire civic/rechtelijke aansprakefijkheid en de verzekering van het nucleaire risico, wordt aandacht besteed aan de aansprakelijkheid en verzekering van milieuschade en aan andere compensatiemechanismen. Een centraal thema in de analyse van het aansprakelijkheidsrecht vormt de kanalisat ic van nansprakelijklecid en dit zowel in het nucleaire als in het milieuaansprakelijkheidsrecht: Eveneens alternatieve compensatiemechanismen ter dekking van milieuschade (waaronder het Nederlandse Fonds I uchtverontreiniging en captives), de alasprakelijkheid voor en dekking van het nucleaire risico in de Verenigde Staten (Price-Anderson Act) en de wetgeving inzake de aansprakelijkheid voor schade door olieverontreiniging op see komen aan bod.

Deze thema's worden benaderd vanuit een rechtseconomische en vanuit een rechtsvergelijkende analyse. Vía de rechtseconomie wordt de problematick van aansprakelijkheid en verzekering van catastroferisico's multidisciplinair benaderd. Hierbif richt de aandacht zich ook tot de efficiènte werking van de verzekeringsmarkten en verzekeringspools. De rechtsvergelifkende aanpak blijkt met name uit het feit dat het Belgisehe en het Nederlandse nucleaire en milieuaansprakelijkheidsrecht evenals de verzekering van milieuschade op een systematische wijze naast elkaar worden geplaatst. 